


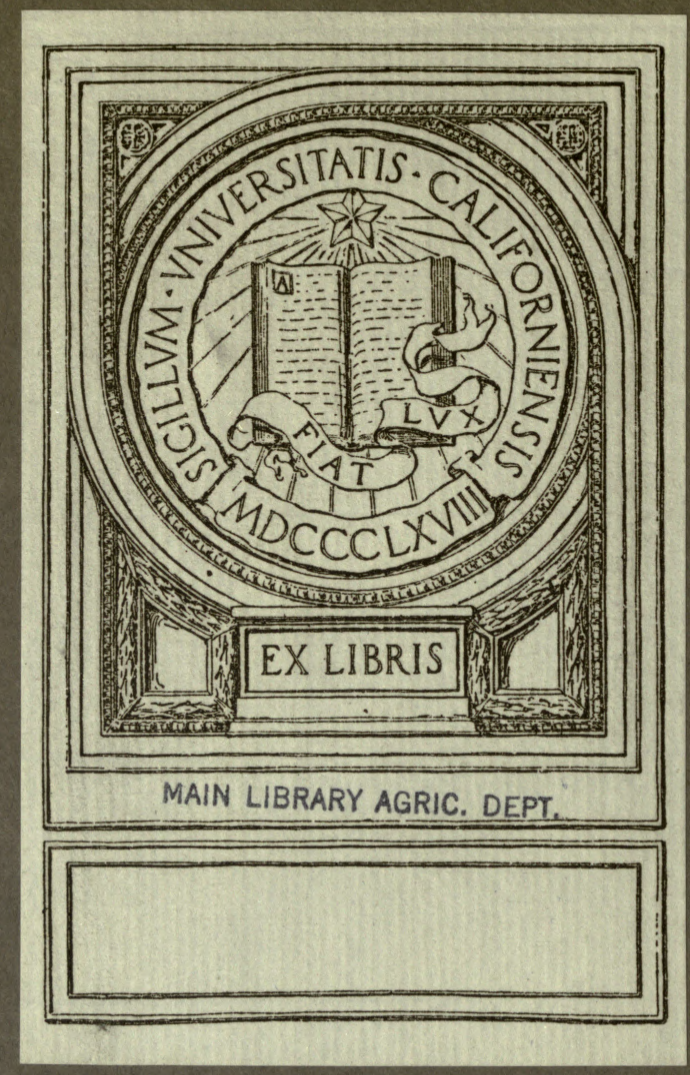





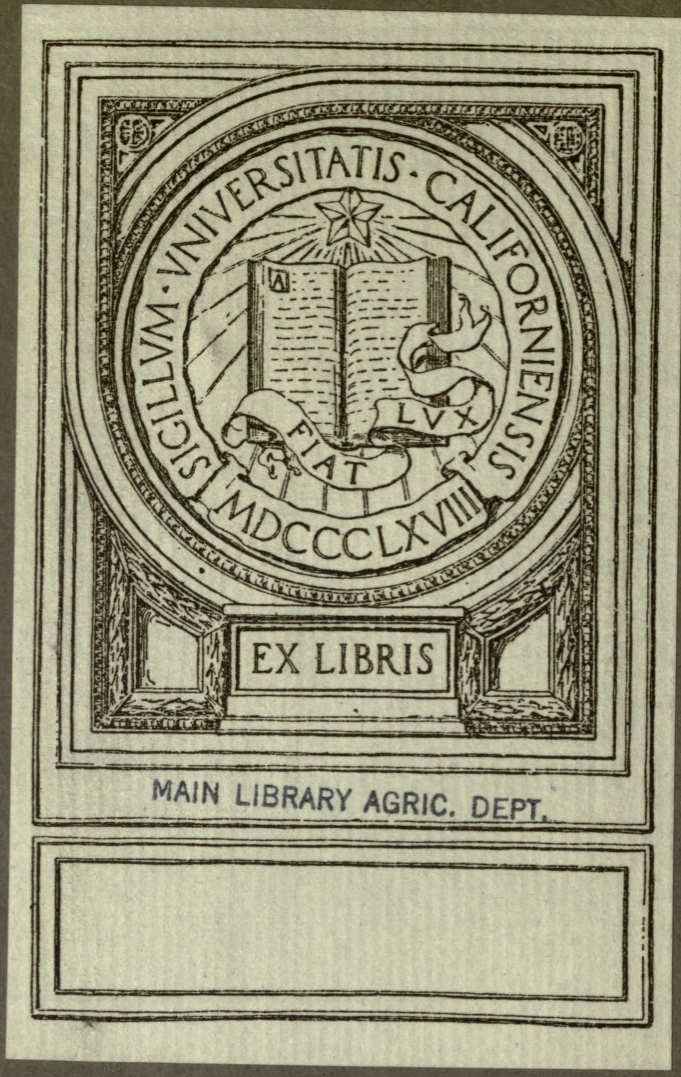





CYCLOPEDIA OF AMERICAN HORTICULTURE 



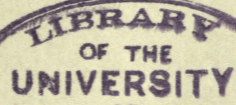

CALIFORNIA 


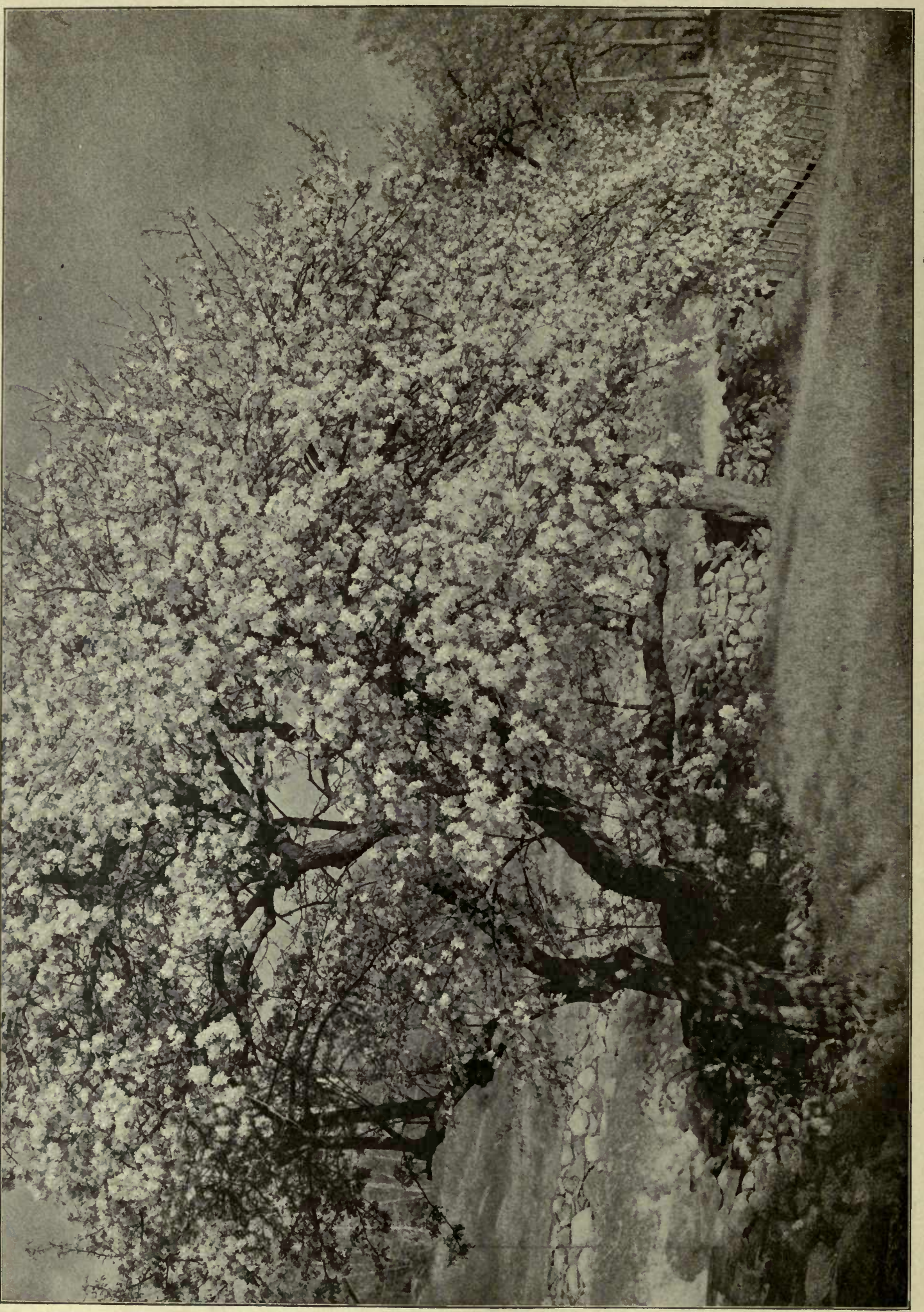




\section{CYCLOPEDIA OF}

\section{AMERICAN HORTICULTURE}

COMPRISING SUGGESTIONS FOR CULTIVATION OF HORTICULTURAL PLANTS, DESCRIPTIONS OF THE SPECIES OF FRUITS, VEGETABLES, FLOWERS AND ORNAMENTAL PLANTS SOLD IN THE UNITED STATES AND CANADA, TOGETHER WITH GEOGRAPHICAL AND BIOGRAPHICAL SKETCHES

BY

\section{H. BAILEY \\ Professor of Horticulture in Cornell University}

ASSISTED BY

WILHELM MILLER, PH.D.

Associate Editor

AND MANY EXPERT CULTIVATORS AND BOTANISTS

\section{IIlustrated with}

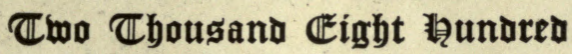

Driginal Ẽngrabingg

$$
\begin{aligned}
& \text { IN FOUR VOLUMES } \\
& \text { VOL. } I-A-D
\end{aligned}
$$

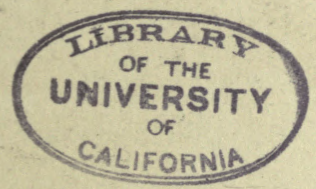

SIXTH EDITION

Jim 罗ork

THE MACMILLAN COMPANY

LONDON : MACMILLAN \& CO., LTD.

1909 

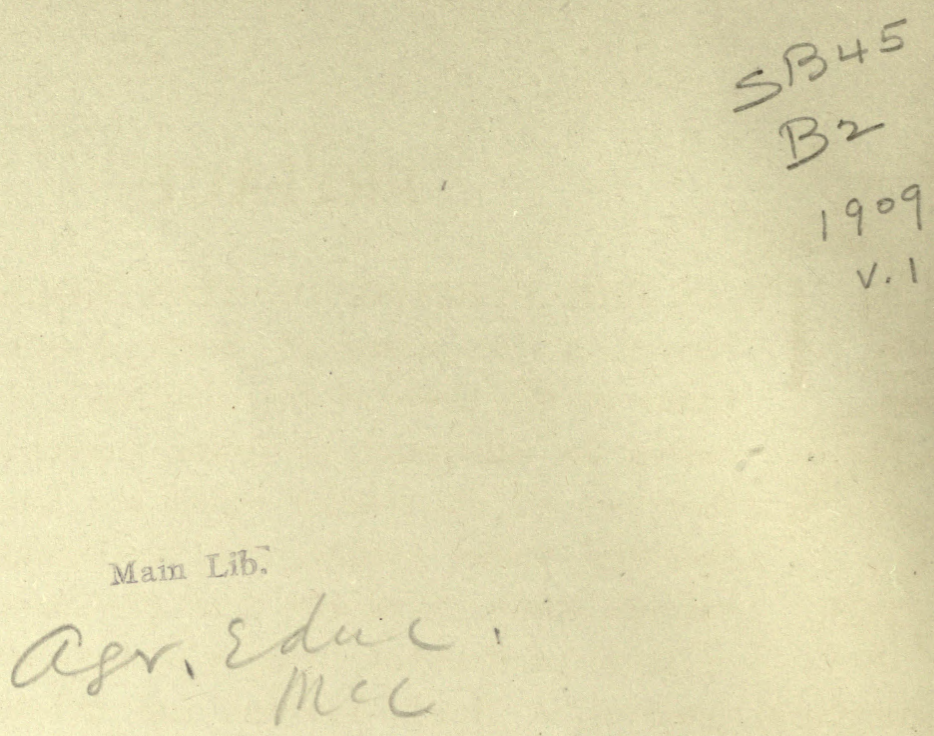

COPYRIGHT, 1900

BY THE MACMILLAN COMPANY

Set up and electrotyped, January, 1900

Reprinted July, 1903, May, 1904, January, 1906 April, 1909 


\section{PREFACE}

T IS THE PURPOSE OF THIS WORK to make a complete record of the status of North American horticulture as it exists at the close of the nineteenth century. The work discusses the cultivation of fruits, flowers and garden vegetables, describes all the species which are known to be in the horticultural trade, outlines the horticultural possibilities of the various states, territories and provinces, presents biographies of those persons not living who have contributed most to the horticultural progress of North America, and indicates the leading monographic works relating to the various subjects.

It has been the dream of years to close the century with a comprehensive index to American horticulture, and for a long period the Editor, therefore, has collected notes, books, plants and information for the furtherance of the work. Before the active preparation of the manuscript was begun, a year was expended in making indexes and references to plants and literature. Every prominent plant and seed catalogue published in the United States and Canada has been indexed, and the horticultural periodicals have been explored. A dozen artists have beên employed in various horticultural centers to draw plants as they grow. Expert cultivators and botanists have contributed on their various specialties. All the important articles are signed, thus giving each author full credit for his work, and holding him responsible for it.

The work is made first-hand, from original sources of information. So far as possible, the botanical matter has been newly elaborated from the plants themselves; and in all cases it is specially prepared directly for this Cyclopedia, and is not the work of copyists nor of space-writers. In many of the most important subjects, two authors have contributed, one writing the culture and the other the botany; and in some cases the culture is presented from two points of view. When it has been necessary to compile in comparatively unfamiliar groups, the greatest pains has been taken to select authentic sources of information; and the proofs always have been submitted to recognized specialists. In fact, 
proufs of every article in the work have been read by experts in that subject.

Every effort has been made to present a truthful picture of American horticulture, by describing those plants which are or lately have been in the trade, and by giving cultural directions founded upon American experience. Therefore the Old World cyclopedias, which represent other horticultural floras and other methods of cultivation, have not been followed. Species which are commonly cultivated in the Old World, or which are mentioned prominently in horticultural literature, but which are not known to be in North American commerce, are briefly recorded in smaller type in supplementary lists. The object has been to make the work essentially American and wholly alive.

Particular attention has been given to the tropical and sub-tropical plants which are now being introduced in southern Florida and southern California. These plants already represent the larger part of the cultivated tropical flora; and a knowledge of them will be of increasing interest and importance with the enlargement of our national sphere. The work is intended to cover the entire field from Key West and the Rio Grande to Quebec and Alaska.

North America is a land of outdoor horticulture, and the hardy fruits, trees, shrubs and herbs are given the prominence which they deserve. In most works of this character, the glasshouse and fanciers' plants receive most emphatic attention.

Since it is hoped that the work will be of permanent value, descriptions of varieties are not included; for such descriptions would increase the bulk of the work enormously, and the information would be out of date with the lapse of a few months or years. If the work finds sufficient patronage, it is hoped that a small supplemental volume may be issued annually, to record the new species and varieties and the general progress of horticultural business and science.

The illustrations have been made under the personal supervision of the Editor so far as possible, and, with few exceptions, they are owned and controlled by the publishers. No trade cuts have been purchased. In various confused groups, copies have been made of old prints for the purpose of showing the original or native form of a plant, and thereby to illustrate the course of its evolution; but credit is given to the source of the illustration.

The point of view is the garden, not the herbarium. The herbarium 
is the adjunct. In other words, the stress is laid upon the plants as domesticated and cultivated subjects. Special efforts have been made to portray the range of variation under domestication, and to suggest the course of the evolution of the greatly modified forms. Garden plants are worthy subjects of botanical study, notwithstanding the fact that they have been neglected by systematists. It is desired to represent the plants as living, growing, varying things, rather than as mere species or bibliographical formulas.

The Editor desires to say that he considers this book but a beginning. It is the first complete survey of our horticultural activities, and it is published not because it is intended to be complete, but that it may bring together the scattered data in order that further and better studies may be made. A first work is necessarily crude. We must ever improve. To the various articles in the work, the teacher of horticulture may assign his advanced students. The Editor hopes that every entry in this book will be worked over and improved within the next quarter century.

Horticultural Depártment,

L. H. BAILEY.

College of Agriculture of Cornell University,

ITHACA, New YoRk, December S0, 1899.

\section{NOTE TO THE SECOND EDITION}

In the second edition several changes have been made for the purpose of reducing typographical errors and inconsistencies, a class of shortcomings which is to be found chiefly in the first volume. Perhaps a half-dozen changes have been made in statements of fact in the first volume. There has been no attempt at a revision, since it is the purpose of the Editor, as explained in the preface to Vol. IV of the original issue, to let the work stand as an expression of American horticulture at the time it was made. This expression is very imperfect, as the Editor is well aware, but it cannot be greatly improved by mere changes in the plates. Therefore, Cratægus and other subjects which recently have been much studied are left as they were understood by their authors in 1900 .

In typographical matters the Editor desired to use such forms as he thought would help the reader in consulting the articles, without making 
any strenuous effort at mere uniformity or so-called consistency in the various entries. For example, the entry-word or caption is usually capitalized in its own article, as Cabbage in the article Cabbage, Strawberry in the article Strawberry. This enables the reader readily to eatch the word-and therefure the leading thought-wherever it occurs. In other articles in which the same word occurs, but when it is a minor note, it is not capitalized. In some instances of general-language terms which are used repeatedly, this rule is not followed (except, perhaps, at the beginning of the article), as it would be of no distinct service to the reader. The article Bulbs is an example. In general, generic names of plants, when used in a semitechnical or botanical sense, have been capitalized; when used in a generallanguage or incidental way they have not been capitalized. In all cases, mere rules have been considered to be of very secondary importance, and they have been broken whenever the interest of the reader seemed to demand it.

The Editor cannot hope that all the errors and shortcomings have been eliminated in this second edition. He will be glad to have readers advise him of needed corrections.

L. H. BAILEY

August 12, 1902. 


\section{COLLABORATORS}

\section{PARTIAL LIST OF CONTRIBUTORS TO THE CYCLOPEDIA}

The asterisk designates the contributors to the first volume. Many of the contributors have also assisted in reading rroofs and in other ways.

Adams, Geo. E., Asst. Horticulturist, R. I. Exp. Sta., Kingston, R. I. (Rhode Island.)

*Ames, OAKes, Asst. Dir. Botanic Garden, and Instructor in Botany in Harvard Univ., Cambridge, Mass. (Many genera of Orchids.)

*Arnold, Jr., Geo., Florist, Rochester, N. Y. (China Asters.)

Arthur, Prof. J. C., Purdue Univ., Lafayette, Ind. (Physiology of Plants.)

Atrinson, Geo. F., Prof. of Botany, Cornell Univ., Ithaca, N. Y. (Mushrooms.)

Balmer, Prof. J. A., Horticulturist, Wash. Exp. Sta., Pullman, Wash. (Washington.)

*Barclay, F. W., Gardener, Haverford, Pa. ( Native Asters. Various hardy plants.)

Barnes, Charles R., Prof. of Plant Physiology, Univ. of Chicago, Chicago, Ills. (Fertilization. Flower.)

Bayersdorfer, H., Dealer in florists' supplies, Philadelphia, Pa. (Everlasting flowers.)

${ }^{*}$ Beach, Prof. S. A., Horticulturist, N. Y. Exp. Sta., Geneva, N. Y. (Corn. Thinning.)

*Beadle, C. D., Botanist and horticulturist, Biltmore, N. C. (Bamboos.)

Beal, Prof. W. J., Mich. Agric. College, Agricultural College, Mich. (Article "Grasses.")

*Beckert, Theo. F., Florist, Allegheny City, Pa. (Bougainvillea.)

Berckmans, P. J., Pomologist and nurseryman, Augusta, Ga. (Kaki. Has read proof of various groups of importance in the South.)

Blair, Prof. J. C., Horticulturist, Ill. Exp. Sta., Champaign, Ills. (Glass. Illinois.)

*Bruckner, Nichol N., Dreer's nursery, Riverton, N. J. (The article "Ferns." Many groups of tender ferns.)

Buffum, Prof. B. C., Horticulturist, Wyo. Exp. Sta., Laramie, Wyo. (Tyoming.)

Burnette, Prof. F. H., Horticulturist, La. Exp. Sta., Baton Rouge, La. (Louisiana.)

Bush And Sons and Meissner, Bushberg, Mo. (Grape Culture in the Prairie States.)

*Butz, Prof. Geo. C., Asst. Horticulturist, Pa. Exp. Sta., State College, Pa. (Carnation. Pennsylvania.)
*Cameron, Robert, Gardener, Botanic Garden of Harvard Univ. (Various articles and much help on rare plants. Alpinia. Campanula, etc.)

*Canning, Edward J., Gardener, Smith College, Botanic Gardens, Northampton, Mass. (Many articles and much help on rare piants. Anthurium, Gloxinia, etc.)

${ }^{*}$ Card, Prof. Fred. W., Horticulturist, R. I. Exp. Sta., Kingston, R. I. (Nebraska. Botany and culture of many bush fruits. Amelanchier. Berberis. Blackberry. Buffalo Berry. Currant.)

Clinkaberry, Henry T., Gardener, Trenton, N. J. (Certain orchids, as Latia, Lycaste.)

${ }^{*}$ Cook, O. F., Div. of Botany, Section of Seed and Plant Introduction, Dept. of Agric., Washington, D. C. (Coffee.)

Corbett, Prof. L. C., Horticulturist, W. Va. Exp. Sta., Morgantown, W. Va. (West Tirginia.)

*Coulter, JoHn M., Professor and Head of the Dept. of Botany, Univ. of Chicago, Chicago, Illinois.

*Craig, Prof. John, Horticulturist, Ia. Exp. Sta., Ames, Ia. (Canada. Gooseberry.)

*Craig, Robert, Florist, Philadelphia, Pa. (Araucaria. Ardisia. Codiceum.)

Craig, W. N., Taunton, Mass.

*Crandall, Prof. C. S., Horticulturist, Colo. Exp. Sta., Fort Collins, Colo. (Colorado.)

Cushman, E. H., Gladiolus specialist, Euclid, Ohio. (Gladiolus.)

*Davis, K. C., Science teacher, Ithaca, N. Y. (Ranunculaceo.)

* Davy, J. Burtw, Assistant Botanist, Univ. of Calif. Agric. Exp. Sta., Berkeley, Calif. (Acacia. Eucalyptus. Myrtacea.)

*Dorner, Fred., Carnation specialist, Lafayette, Ind. (Carnation.)

Dorsetr, P.H., Associate Physiologist and Pathologist Dept. of Agric., Washington, D. C. (Violet.)

Duggar, B. M., formerly Asst. Cryptogamic Botanist, Cornell Exp. Sta., Ithaca, N. Y. (Pollen.)

*Earle, Prof. F. S., Horticulturist, Ala. Polytechnic Institute, Auburn, Ala. (Alabama.)

Earle, Parker, Horticulturist, Roswell, N. M. (New Mexico.) 
*Eisele, J. D., Foreman Dreer's Nursery, Riverton, N. J. (Cordyline.)

*Elliotr, William H., Florist, Brighton, Mass. (Asparagus plumosus.)

Emery, S. M., Director Mont. Exp. Sta., Bozeman, Mont. (Montana.)

*Endicotr, W. E., Teacher, Canton, Mass. (Achimenes. Acidanthera.)

*Evans, Walter H., Office of Exp. Stations, Dept. of Agric., Washington, D. C. (Alaska.)

*Fawcetr, WM., Dir. Dept. Public Gardens and Plantations, Kingston, Jamaica. (Tropical fruits, as Cherimoya, Mangosteen, etc.)

*Fernow, Prof. B. E., Dir. College of Forestry, Cornell Univ., Ithaca, N. Y. (Conifers. Forestry.)

*Finlayson, Kenneth, Gardener, Brookline, Mass. (Diosma.)

*Fletcher, S. W., Horticulturist, Ithaca, N. Y. (Convolvulacece. Helianthus. Papaver.)

*Franceschi, Dr. F., Manager S. Calif. Acclimatizing Ass'n, Santa Barbara, Calif. (Rare plants of S. Calif., as Dasylirion, etc.)

GARFIELD, C. W., Horticulturist, Grand Rapids, Mich. (Michigan.)

*Gerard, J. N., Elizabeth, N. J. (Many articles, especially on bulbous plants, as Crocus, Iris, Narcissus.)

GilleTt, Edward, Nurseryman, Southwick, Mass. (Hardy Ferns.)

GoFf, Prof. E. S., Horticulturist, Wis. Exp. Sta., Madison, Wis. (Wisconsin.)

*Gould, H. P., Asst. Entomologist and Horticulturist, Maryland Exp. Sta., College Park, Md. (Brussels Sprouts. Celeriac.)

Green, Prof. S. B., Horticulturist, Minnesota Exp. Sta., St. Anthony Park, Minn. (Minnesota.)

Green, WM. J., Horticulturist, Ohio Exp. Sta., Wooster, Ohio. (Ohio. Sub-irrigation.)

${ }^{*}$ Greiner, T., Specialist in vegetables, La Salle, N. Y. (Garden vegetables, as Artichoke, Asparagus, Bean, Cress.)

*Grey, Robert M., Gardener, North Easton, Mass. (Cypripedium and other orchids.)

Groff, H. H., Simcoe, Ont. (Gladiolus.)

*Gurnex, JAmes, Gardener, Mo. Botanical Garden, St. Louis, Mo. (Cacti.)

${ }^{*}$ Hale, J. H., Nurseryman and pomologist, South Glastonbury, Conn. (Connecticut.)

*Halsted, Prof. B. D., Rutgers College, New Brunswick, N. J. (Diseases. Fungi.)

Hansen, Geo., Landscape architect and botanist, Berkeley, Calif. (Epidendrum.)

Hansen, Prof. N. E., Horticulturist, S. Dak. Exp. Sta., Brookings, S. Dak. (South Dakota.)
Hasselbring, H., Instructor in Botany, Cornell Univ., Ithaca, N. Y. (Iris and certain orchids, as Gongora, Odontoglossum.)

*Hastings, G. T., Asst. in Botany, Cornell Univ., Ithaca, N. Y. (Some tropical piants, as Berria, Bertholletia.)

Hatfield, T. D., Gardener, Wellesley, Mass. (Gesnera and various articles.)

Hedrick, U. P., Asst. Prof. of Horticulture, Agricultural College,Mich. (Evaporated Fruits.)

*Henderson \& Co., Peter, Seedsmen, 37 Cortlandt St., New York, N. Y. (B்ulbs.)

*Herrington, A., Gardener, Florham Farms, Madison, N. J. (Chrysanthemum coccineum.)

Hexamer, Dr. F. M., Editor American Agriculturist, New York, N. Y. (A. S. Fuller.)

Hicks, G. H., late of Dept. of Agric., Washington, D. C. (Seed Testing.)

${ }^{*}$ Hill, E. G., Florist, Richmond, Ind. (Begonia.)

Hoopes, Josiah, Nurseryman, West Chester, Pa. (Hedges.)

*Horsford, Fred. H., Nurseryman, Charlotte, Vt. (Alpine Gardens. Has read proof of many articles on native plants.)

Hunn, Charles E., Gardener, Cornell Exp. Sta., Ithaca, N. Y. (Forcing of vegetables.)

Huntlex, Prof. F. A., Idaho Exp. Sta., Moscow, Idaho. (Idaho.)

Hutchins, Rev. W. T., Sweet Pea specialist, Indian Orchard, Mass. (Sweet Pea.)

${ }^{*}$ IrIsh, H. C., Horticulturist, Mo. Botanical Garden, St. Louis, Mo. (Capsicum.)

*Jackson \& Perkins Co., Nurserymen, Newark, N. Y. (Clematis.)

Jordan, A. T., Asst. Horticulturist, New Brunswick, N. J. (New Jersey.)

*KaIns, M. G., Div. of Botany, Dept. of Agric., Washington, D. C. (Minor vegetables. Pot Herbs. Importations.)

*Keller, J. B., Florist, Rochester, N. Y. (Many groups of hardy herbaceous perennials.)

Kelsey, Harlan P., Landscape architect, Boston, Mass. (North Carolina plants, as Galax and Leucothö̈.)

*Kennedy, P. Beveridge, Div. of Agrostology, Dept. of Agric., Washington, D. C. (Many genera of grasses. Begonia.)

KerR, J. W., Nurseryman, Denton, Md. (Maryland.)

*Kift, Robert, Florist, Philadelphia, Pa. (Cutflowers.)

KIng, F. H., Prof. of Agricultural Physics, Madison, Wis. (Irrigation.)

*Kinney, L. F., Horticulturist, Kingston, R. I. (Celery.)

*Lager \& Hurrell, Orehid cultivators, Summit, N. J. (Cattleya.) 
CAAKE, Prof. E. R., Horticulturist, Ore. Exp. Sta., Corvallis, Ore. (Oregon.)

LAUMaN, G. N., Instructor in Horticulture, Cornell Univ., Ithaea, N. Y. (Geranium. Pelargonium.)

*Lonsdale, Edwis, Florist, Chestnut Hill, Philadelphia, $\mathrm{Pa}$. (Conservatory.)

LORD \& BURNHAM Co., Horticultural architects and builders, Irvington-on-Hudson, N. Y. (Greenhouse Construction.)

*Lothrop \& Higgins, Dahlia specialists, East Bridgewater, Mass.

*Mannine, J. Woodward, Nurseryman, Reading, Mass. (Pyrethrum. Has read proof of many groups of herbaceous perennials.)

MANNING, WARREN H., Landscape architect, Boston, Mass. (Article, "Herbaceous Perennials.")

Massey, Prof. W. F., Horticulturist, N. C. Exp. Sta., Raleigh, N. C. (Figs. North Carolina.)

Mathews, Prof. C. W., Horticulturist, Ky. Exp. Sta., Lexington, Ky. (Kentucky.)

*Mathews, F. Schurler, Artist, 2 Morley St., Boston, Mass. (Color.)

Maynard, Prof. S. T., Horticulturist, Mass. Hatch Exp. Sta., Amherst, Mass. (Massachusetts.)

McDowell, Prof. R. H., Reno, Nev. (Nevada.)

* McFarland, J. Horace, Horticultural printer and expert in photography, Harrisburg, Pa. (Border.)

*McWilliam, Geo., Gardener, Whitinsville, Mass. (Dipladenirı.)

*Mead, T. L., Horticulturist, Oviedo, Fla. (Crinu $n$. Has helped in matters of extreme southern horticulture.)

Morris, O. M., Asst. Horticulturist, Okla. Exp. Sta., Stillwater, Okla. (Oklahoma.)

Moon, Samuel C., Nurseryman, Morrisville, Pa. (Trees for ornament.)

Munson, T. V., Nur'seryman and grape hybridist, Denison, Tex. (Grape culture in the South.)

Munson, Prof. W. M., Horticulturist, Me. Exp. Sta., Orono, Me. (Maine.)

*Newell, A. J., Gardener, Wellesley, Mass. (Certain orchids.)

Norton, J. B. S., Botanical Assistant, Mo. Botanical Garden, St. Louis, Mo. (Euphorbia.)

*Oaston, Colis, Gardener, Kimball Conservatories, Rochester, N. Y. (Dendrobium.)

*Oliver, G. W., Gardener, U. S. Botanic Gardens, Washington, D. C. (Many articles on palms, aroids, succulents and rare plants, and much help on proofs. Alstromeria. Amaryllis.)

*Orpet, Edward O., Gardener, So. Lancaster, Mass. (Many articles. Border. Cyclamen. Dianthus, and certain orchids.)
*Peacock, Lawrence K., Dahlia specialist, Atco, N. J. (Dahlia.)

*Powell, Prof. G. Haruld, Horticulturist, Del. Exp. Sta., Newark, Del. (Cherry. Delaware.)

Price, Prof. R. H., Horticulturist, Tex. Exp. Sta., College Station, Tex. (Texas.)

*Purdy, Carl, Specialist in California bulbs, Ukiah, Calif. (Californian native plants, as Brodiae, Calochortus, Fritillaria.)

Rane, Prof. F. W., Horticulturist, N. H. Exp. Sta., Durham, N. H. (New Hampshire.)

*Rawson, W. W., Seedsman and market-gardener, Boston, Mass. (Cucumber.)

*Reasoner, E. N., Nurseryman and horticulturist, Oneco, Fla. (Many articles, and much help on extreme southern horticulture. Casalpinia. Cocos.)

*Rehder, Alfred, Specialist in hardy trees and shrubs, Jamaica Plain, Mass. (Botany and culture of most of the hardy trees and shrubs.)

*Roberts, Prof. I. P., Dir. College of Agric., Cornell Univ., Ithaea, N. Y. (Drainage. Fertility. Potato.)

Rolfs, Prof. P. H., Horticulturist, S. C. Exp. Sta., Clemson College, S. C. (Florida. Eggplant.)

*Rose, J. N., Asst. Curator, U. S. Nat. Herb., Smithsonian Inst., Washington, D. C. (Agave.)

Rose, N. J., Landscape gardener to New York City Parks, New York, N. Y.

*Rowlee, Prof. W. W., Asst. Prof. of Botany, Cornell Univ., Ithaca, N. Y. (Nymphoea. Narcissus. Salix. Definitions.)

*Sargent, Prof. C. S., Dir. Arnold Arboretum, Jamaica Plain, Mass. (Abies.)

${ }^{*}$ Scotr, Wm., Florist, Buffalo, N. Y. (Acacia. Cytisus. Convallaria. Cyclamen. Smilax, etc.)

*Scotr, Wm., Gardener, Tarrytown, N. Y. (Bertolonia and other dwarf tender foliage plants.)

* Semple, James, Specialist in China Asters, Bellevue, Pa. (Aster.)

*Shinn, Charles H. , Inspector of Experiment Stations, Univ. of Calif., Berkeley, Calif. (California. Fig, etc.)

*Shore, Robert, Gardener, Botanical Dept., Cornell Univ., Ithaca, N. Y. (Various articles, as Acalypha, Bedding, Marguerites, Dichorisandra, Fittonia.)

*Siebrecht, Henry A., Florist and nurseryman, New York and Rose Hill Nurseries, New Rochelle, N. Y. (Dracona and various articles. Much help on rare greenhouse plants, particularly orchids.)

Simonds, O.C., Supt. Graceland Cemetery, Buena Ave., Chicago, Ill. (Cemeteries, in article on Lxndscape Gardening.) 
Slingerland, Prof. M. V., Asst. Prof. Economic Entomology, Cornell Univ., Ithaca, N. Y. (Insects. Insecticides.)

*Smith, A. W., Cosmos cultivator, Americus, Ga. (Cosmos. Moonflower.)

*Smith, Elmer D., Chrysanthemum specialist, Adrian, Mich. (Chrysanthemum.)

${ }^{*}$ Smith, Jared G., Div. of Botany, Dept. of Agric., Washington, D. C. (Nearly all palms and various genera, as Centaurea,Cerastium, Cotyledon.)

Spencer, JoHn W., Fruit-grower, Westfield, Chautauqua Co., N. Y. (Grapes. Help on important fruits.)

Starnes, Prof. Hugh N., Horticulturist, Ga. Exp. Sta., Athens, Ga. (Georgia.)

*Stinson, Prof. John T., Dir. Mo. Fruit Exp. Sta., Mountain Grove, Mo. (Arkansas.)

TAFT, Prof. L. R., Horticulturist, Mich. Agric. Coll., Agricultural Collège, Mich. (Heating. Hotbeds.)

*Taplin, W. H., Specialist in palms and ferns, Holmesburg, Philadelphia, Pa. (Culture of many palms, ferns and foliage plants.)

*Taylor, WM. A., Asst. Pomologist, Div. of Pomology, Dept. of Agric., Washington, D. C. (Nuts.)

*Thompson, C. H., Assistant Botanist, Mo. Botanical Garden, St. Louis, Mo. (Many genera of Cacti.)

*Toumer, Prof. J. W., Biologist, Ariz. Exp. Sta., Tueson, Ariz. (Arizona. Date.)

Tracy, S. M., Biloxi, Miss. (Mississippi.)

*Tracy, Prof. W. W., Seedsman, Detroit, Mich. (Cabbage.)

*Trelease, Dr. WM., Dir. Mo. Botanical Garden, St. Louis, Mo. (Aloe. Apicra. Gasteria. Haworthia.)

*Tricker, WM., Specialist in aquaties, Dreer's Nursery, Riverton, N. J. (Aquarium. Aquatics. Nymphaea. Nelumbium. Victoria, etc.)

Troop, Prof. J AMEs, Horticulturist, Ind. Exp. Sta., Lafayette, Ind. (Indiana.)

Turner, WM., Gardener, Tarrytown, N. Y. (Forcing Fruits.)
*Tutrue, H. B., Cranberry grower, Valley Junction, Wis. (Cranberry.)

*Underwood, Prof. L. M., Columbia University, Now York, N. Y. (Botany of all ferns.)

*Van Deman, H. E., Pomologist, Parksley, Va. (Date.)

VAUghaN, J. C., Seedsman and florist, Chicago and New York. (Christmas Greens.)

Voorhees, Prof. Edward B., Dir. N. J. Exp. Sta., New Brunswick, N. J. (Fertilizers.)

Waldron, Prof. C. B., Horticulturist, N. Dak. Exp. Sta., Fargo, N. Dak. (North Dakota.)

${ }^{*}$ Walker, Ernest, Horticulturist, Arkansas Exp. Sta., Fayetteville, Ark. (Annuals. Basket Plants. Watering.)

Watrous, C. L., Nurseryman, Des Moines, Ia. (Iowa.)

*Watson, B. M., Instructor in Horticulture, Bussey Inst., Jamaica Plain, Mass. (Colchicum. Cuttage. Forcing. House Plants.)

Watrs, R. L., Horticulturist, Tenn. Exp. Sta., Knoxville, Tenn. (Tennessee.)

*Waugh, Prof. F. A., Horticulturist, Vt. Exp. Sta., Burlington, Vt. (Beet. Carrot. Cucumber. Lilium. Pentstemon. Salad Plants. Fermont.)

*Webber, H. J., In charge of Plant Breeding Laboratory, Div. of Veg. Phys. and Path., Dept. of Agric., Washington, D. C. (Citrus.)

Whitney, Prof. Milton, Chief Div. of Soils, Dept. of Agric., Washington, D. C. (Soil.)

Whitren, Prof. J. C., Horticulturist, Mo. Exp. Sta., Columbia, Mo. (Missouri.)

${ }^{*}$ Wickson, Edward J., Prof. of Agricultural Practice, Univ. of Calif., and Horticulturist, Calif. Exp. Sta., Berkeley, Calif. (Almond, Apricot, Cherry, Grape, etc., in California.)

*Wiegand, K. M., Instructor in Botany, Cornell Univ., Ithaca, N. Y. (Coreopsis. Cordyline. Cyperus. Draccena.)

*Wrman, A. P., Asst. to Olmsted Bros., Landscape Architects, Brookline, Mass. (Dirca, Epigae, Halesia and other hardy trees and shrubs.)

\section{PARTIAL LIST OF THOSE WHO HAVE ASSISIED BY READING PROOF, AND IN OTHER WAYS}

ANdRews, D. M., Nurseryman, Boulder, Colo. (Native western plants, especially new hardy Cacti.)

BALL, C. D., Wholesale florist, Holmesburg, Philadelphia, Pa. (Palms. Ferns. Foliage Plants.)

BARKer, Michael, Editor "American Florist," 324 Dearborn St., Chicago, Ill. (Many suggestions.)
BassetT, Wm. F., \& SoN, Hammonton, N. J. (Hibiscus and other plants.)

Berger \& Co., H. H., New York, N. Y. (Japanese and Californian plants.)

Blanc, A., Seedsman and plantsman, Philadelphia, Pa. (Cacti. Novelties.)

Breck \& Sons, Joseph, Seedsmen, Boston, Mass. (Portrait of Joseph Breck.) 
Budlong Bros., Pickle makers, Providence, R. I. (Cucumber.)

Clark, Miss Josephine A., Asst. Librarian, Dept. of Agric., Washington, D. C. (Information as to species since Index Kevensis )

Coates, Leonard, Napa City, Calif. (Fruit Culture in California.)

Coville, Frederick V., Botanist, Dept. of Agric., Washington, D. C. (Suggestions as to contributors.)

Cowen, J. H., Horticulturist, Ithaca, N. Y. (Colorado.)

DAY, Miss MARY A., Librarian, Gray Herbarium of Harvard Univ., Cambridge, Mass. (Rare books.)

Deane, Waltek, Cambridge, Mass. (Various botanical problems.)

Devron, Dr. G., Amateur in Bamboos, New Orleans, La. (Bamboos.)

Dоск, Miss M. L., Harrisburg, Pa. (Bartram.)

Dreer, H. A., Seedsmen and plantsmen, Philadelphia, $\mathrm{Pa}$. (Many and varied services, especially in aquatics, ferns, foliage plants and rare annuals.)

EgAN, W. C. Amateur, Highland Park, Ills. (Plants of exceptional hardiness.)

EllwaNger \& BarRy, Nurserymen, Rochester, N. Y. (Hardy plants.)

Ganong, W. F., Prof. of Botany, Smith College, Northampton, Mass. (Cacti.)

Hallidar Bros., Baltimore, Md., Florists. (Azalea. Camellia.)

Lupton, J. M., Market-gardener, Gregory, L. I. (Cabbage.)

Makepeace, A. D., Cranberry grower, West Barnstable, Mass. (Cranberry.)

Manda, W. A., Nurseryman, South Orange, N. J. (Orchid pictures.)

Manning, Јасов W., Nurseryman, Reading, Mass. (Dried specimens of herbaceous perennial plants.)

Manning, Robert, Sec. Mass. Hort. Soc., Boston, Mass. (Biographical sketches.)
Mathews, WM., Florist, Utica, N. Y. (Orchids.)

MaY, Jонм N., Florist, Summit, N. J. (Florists' flouers.)

Meehan \& Sons, Thos., Nurserymen, Germantown, Pa. (Hardy plants.)

Pierson, F. R., Nurseryman, Tarrytown-onHudson, N. Y. (Bulbs.)

Powell, Geo. T., Pomologist, Ghent, N. Y. (Important fruits.)

Rider, Prof. A. J., Trenton, N. J. (Cranberry.)

Robinson, Dr. B. L., Curator Gray Herbarium of Harvard Univ., Cambridge, Mass. (Various articles.)

Scoon, C. K., Fruit-grower, Geneva, N. Y. (Cherry.)

Sears, Prof. F. C., Wolfville, Nova Scotia. (Canada.)

Shady Hill Nursery Co., Boston, Mass. (Herbaceous perennials.)

Slaymaker, A. W., Fruit-grower, Camden, Del. (Delaware.)

Storrs \& Harrison, Nurserymen, Painesville, Ohio. (Various plants.)

Suzuki \& IIdA, Yokohama Nursery Co., 11 Broadway, New York, N. Y. (Japanese plants.)

Thorburn \& Co., J. M., Seedsmen, New York, N. Y. (Numerous important and rare plants, especially annuals.)

Todd, Frederick G., Landscape architect, Montreal, P. Q. (Hardy trees and shrubs.)

VICK's Sons, JAMEs, Seedsmen, Rochester, N. Y. (Various plants.)

WARD, C. W., Florist, Cottage Gardens, Queens, L. I. (Carnation.)

Webb, Prof. Wesley, Dover, Del. (Delaware.)

White, J. J., Cranberry grower, New Lisbon, N. J. (Cranberry.)

Willard, S. D., Nurseryman, Geneva, N. Y. (Important fruits, as Cherry.)

Wood, E. M., Florist, Natick, Mass.

Wright, Charles, Horticulturist, Seaford, Del. (Delaware.) 


\section{EXPLANATIONS}

Horticulture is the art of raising fruits, vegetables, flowers and ornamental plants. The lines of demarcation between it and the art of agriculture on the one hand and the science of botany on the other, are purely arbitrary. In this work, the word horticulture has been interpreted liberally. Herein are included discussions of landscape gardening, and brief notes of such important agricultural subjects as Coffee, Cotton, Flax, and such economic subjects as Cinchona, India Rubber. Forage and medicinal plants are mentioned only incidentally.

\section{WHAT IS MEANT BY "THE TRADE"}

It is the design of the Cyclopedia to describe fully all those species of plants which are in the American trade,-that is, the species that are bought and sold. In order to determine what species are in the trade, catalogues of nurserymen, seedsmen and florists have been indexed, and other commercial literature has been consulted; in addition to this, specialists have been consulted freely for lists of plants. The work includes the plants offered by foreign dealers who have American agents, and who circulate in America catalogues printed in the English language: therefore, the work will be found to include many species offered by the bulb growers of Holland, and by most other large European concerns. The purpose is to make a live record of the real status of our horticulture, rather than a mere compilation from the other literature. However, important plants which are not in the American trade are mentioned, for they may be expected to appear at any time: but these plants are in supplementary lists in smaller type. Thus, the size of type indicates that Abobra viridiflora is in the trade, whereas Abroma augusta is not. It will no doubt be a surprise to the reader, as it has been to the Editor, to discover the great wealth of American horticulture in species of plants.

\section{NOMENCLATURE}

The Editor has desired to be conservative on the vexed question of nomenclature. This effort is particularly important in the discussion of cultivated plants, because names become established in the trade and are worth money. A plant sells under a familiar name, but it may be a commercial failure under a new or strange one. Since plants belong as much to the horticulturist as to the botanist, it is only fair that the horticulturist be consulted before wholesale changes are made in nomenclature.

It is well to bear in mind that changes in the names of plants proceed from two general causes, (1) from new conceptions respecting the limits of genera, species, varieties, and (2) from new ideas in the merely arbitrary fashions or systems of nomenclature. Changes of the former kind are usually welcomed by horticulturists, because they elucidate our understanding of the plants, but changes of the latter kind are usually deplored. At the present moment, there is the greatest unrest in respect to systems of nomenclature. This unrest is, to be sure, in the interest of the fixity or permanency of names, but there is no guarantee-if, indeed, there is any hope-that the system which may be adopted to-day will be accepted by the next generation. In fact, the very difficulty of arriving at a common understanding on the question is itself the strongest evidence that the systems dc not rest on fundamental or essential principles, but upon expediency and personal preference. There is no evidence that names which are making to-day will persist any longer than have those which they are supplanting.

So-called reforms in nomenclature are largely national or racial movements, often differing widely between different peoples : consequently it is impossible to bring together under one system of nomenclature the cultivated plants of the world without making wholesale changes in names. Therefore, the Editor has accepted the most tenable names which the plants bring, without inquiring into the system under which they are given. In general, however, he believes that the technical name of a plant is comprised of two words, and that the first combination of these two parts should be accepted as the name. Such double names as Catalpa Catalpa and Glaucium Glaucium are the results of carrying arbitrary rules to the utmost limit, but their ugliness and arbitrariness condemn them. It is to be expected that in the names of plants, as in everything else, the race will not long tolerate inflexibility. 
In generic names, the system of Bentham and Hooker (Genera Plantarum) has been followed. This system makes fewer changes in accepted horticultural names than any other, and this is considered to be a distinct merit. The chief reason for adopting the British ideas of genera, however, is that Index Kewensis affords a complete finding-list of species under those genera. It would be impossible, in a work like the present, to follow the more recent system of Engler and Prantl (Die Natürlichen Pflanzenfamilien), because there is no index or finding-list for the species under those genera, and to make the proper combinations of generic and specific names for horticultural plants would necessitate a compilation practically equivalent to Index Kewensis. However, the various contributors have been at liberty to adopt their own ideas of generic limitations, so that the work will be found to occupy a somewhat middle ground between the British and German ideas of genera.

\section{CHIEF LITERARY AIDS.}

In the compilation of this work, the Editor has had access to most of the important world-floras, and to the leading geographical floras. In the systematic botany, the greatest help has been derived from the following great general works : Bentham and Hooker, Genera Plantarum (18621883 ) ; Hooker \& Jackson, Index Kewensis (18931895); DeCandolle's Prodromus -(1824-1873) • DeCandolle's Monographiæ Phanerogamarum (1878-1896, and continuing); Engler and Prantl, Die Natürlichen Pflanzenfamilien (begun 1889); Botanical Magazine (1786 to the present, and continuing); Botanicàl Register (1815-1847); Revue Horticole, Paris (1829 to the present, and continuing) ; Gardeners' Chronicle, London (1841, and continuing); Garden, London (1871, and continuing); Loddiges's Botanical Cabinet, London (1817-1833); Flore des Serres, Ghent (1845-1880); L'Illustration Horticole, Ghent (1854-1896) ; Gartenflora, Berlin (1852, and continuing); Garden and Forest, New York (1888-1897) ; Nicholson's Illustrated Dictionary of Gardening, London (1884-1887); Mottet's translation of Nicholson, Paris (1892-1899) ; Siebert and Voss, Vilmorin's Blumengärtneri (1890).

\section{HOW TO USE THE KEYS}

In order to facilitate the study of the plants, the species have been arranged systematically, under the genus, rather than alphabetically. However, in all genera which contain $\mathbf{1 5}$ or more species, an alphabetical index has been supplied for purposes of rapid reference. The grouping of the species is founded preferably on horticultural rather than on botanical characters, so that the arrangement does not always express botanical relationships. The grouping and the keys are arranged primarily to aid the gardener in making determinations of species. Every effort is made sharply to contrast the species rather than to describe them. A word of explanation will facilitate the use of the keys. The species are arranged in coördinate groups of various ranks, and groups of equal rank are marked by the same letter. Thus, group $\mathrm{A}$ is coördinate with $\mathrm{AA}$ and with $\mathrm{AAA}$, and B with $\mathrm{BB}$ and $\mathrm{BBB}$. Moreover, whenever possible, the coördinate keys begin with the same catchword : thus, if A begins "flowers," so do AA and $\triangle A A$; and this catchword is not used for keys of other rank. As an example, refer to Acer, page 12. Look first at A, beginning "foliage;" then at AA (p. 15), also beginning "foliage." Under A are the coördinate divisions $\mathrm{B}$ and $\mathrm{BB}$, each with "bloom" for the catchword. Under B there are no subdivisions, but under $\mathrm{BB}$ there are divisions c, cc and ccc, each with "fls." for a catchword. Under $\mathrm{C}$ there are no subdivisions, but $\mathrm{CC}$ has four coördinate divisions, D, DD, DDD, DDDD, each with "lvs." for a catchword, and so on. In other words, if the plant in hand does not fall under A, the inquirer goes at once to AA. If it falls under $A$, then he determines whether it belongs to $B$ or to $\mathrm{BB}$, and so on.

A diagrammatic display of a scheme would stand as follows:

A. Leaves, etc.

B. Flowers, etc.

c. Fruits, etc.

c. Fruits, etc.

BB. Flowers, etc.

AA. Leaves, etc.

B. Roots, etc.

c. Flowers, etc.

D. Margins of leaves, etc.

DD. Margins of leaves, etc.

c. Flowers, ete.

BB. Roots, etc.

BBB. Roots, etc.

AAA. Leaves, etc.

\section{PRONUNCIATION}

Accent marks are used to aid the reader in pronouncing the name. The accent designates (1) stress, or the emphatic syllable, and (2) the length of the emphatic vowel. Following the American custom, as established by Gray and others, a grave accent (, ) is employed to designate a long vowel, and an acute accent (') a short vowel. Thus, officinàle is pronounced offici-nay-li ; microcárpus is pronounced microcarp' -us. Ordinarily in diphthongs the mark is placed over the second letter. Thus, in aùrea the $a u$ is meant to have its customary long sound, as if written awe. Double vowels take their customary English sounds, as $e e$ and 
oo. Thus, the oo in Hodkeri is to be pronounced as in hook. In most cases, the letters oi (from the Greek, meaning like to) are to be pronounced separately : if the $i$ is the penultimate syllable (next to the last), it is long, as in yuccot-des; if the $i$ is the antepenultimate syllable (third from the end) it is short, as in rhomboi-dea. In dioicus and monoicus, however, the oi is a true diphthong, as in moist. It should be remembered that the final $e$ terminates a separate syllable, as commù-ne, vulgà-re, gran'-de. This final $e$ takes the short sound of $i$, as in whip.

These pronunciations follow, in general, the common English method of pronouncing Latin names. However, many of the Latinized forms of substantive and personal names are so unlike Latin in general construction that the pronunciation of them cannot follow the rule. As a matter of fact, biological nomenclature is a language of itself thrown into a Latin form, and it should not be a source of regret if it does not closely follow classical rules in its pronunciation. It has seemed best to make an exception to the literary rules in the case of personal commemorative names in the genitive: we retain, so far as possible, the pronunciation of the original name. Thus, a plant named for Carey is called $\boldsymbol{C} \grave{a}-r e y i$, not Carèy-i; for Sprenger, Spréng-eri, not Sprengèr-i. The original spelling (as written by the author of the name) of the masculine genitive ending is usually retained, whether $i$ or $i i$, but the syllable is usually pronounced as if the $i$ were single. Whether one $i$ or two is used in the making of a masculine genitive, is largely a matter of euphony and personal preference.

It may be well to add what are understood to be the long and short sounds of the vowels.

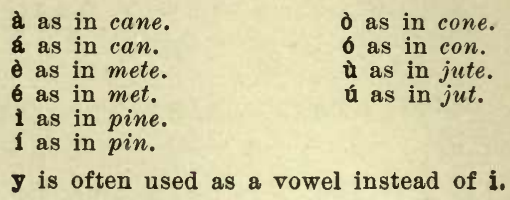

\section{SPELLING}

The original spelling of generic and specific names is preferred. In some instances this original orthography does not conform to the etymology of the name, particularly if the name is made from that of a person. Such a case is Diervilla, named for Dierville. Ideally, the name should be spelled Diervillea, but Tournefort and Linnæus did not spell it so, and a name is a name, not primarily a monument to a man.

In accordance with the best authorities, the digraph $a$ is used in the words cærulea, cærulescens, cæspitosa, cæsia; $\propto$ is used in cœlestis and cœlestinum.

Digraphs $\alpha$ and $\alpha$ have been dropped from Latinmade names which have come into the vernacular. Thus, as a common or English name, Spiræa becomes spirea, Pæonia becomes peonia or peony, Bougainvillæa becomes bougainvillea. 


\section{ABBREVIATIONS}

\section{OF GENERAL EXPRESSIONS}

cult. . . . . . . . cultivated, etc.

diam. ........ diameter

E. . . . . . . . . east.

ft............ feet.

in. .......... inches.

N. . . . . . . . . north.

S........... south.

trop............. tropies, tropical.

W........... . west.

\section{OF BOTANICAL TERMS}

f............... flower.

fls, .............. flowers.

fld. . . . . . . . . . . flowered.

fr. . . . . . . . . . . fruit.

h.............. height.

lf. ............. leaf.

lft. . . . . . . . . . . leaflet.

lvs............... . . leaves.

st................. stem.

sts. . . . . . . . . . . stems.

syn............... . . synonym.

var............. . . variety.

\section{OF BOOKS AND PERIODICALS}

To aid the student in the verification of the work, and to introduce him to the literature of the various subjects, eitations are made to the portraits of plants in the leading periodicals to which the American is most likely to have access. These references to pictures have been verified as far as possible, both in the MS. and in the proof. A uniform method of citation is much to be desired, but is extremely difficult, because periodicals rarely agree in methods. With great reluctance it was decided to omit the year in most cases, because of the pressure for space, but the student who lacks access to the original volumes may generally ascertain the year by consulting the bibliographical notes below.

An arbitrary and brief method of eitation has been chosen. At the outset it seemed best to indicate whether the cited picture is colored or not. This accounts for the two ways of eiting certain publications containing both kinds of pictures, as The Garden, Revue Horticole, and Gartenflora.
The figures given below explain the method of citation, and incidentally give some hints as to. the number of volumes to date, and of the number of pages or plates in one of the latest volumes.

A few works of the greatest importance are mentioned elsewhere by way of acknowledgment (p. xv.). The standard works on the bibliography of botany are Pritzel's Thesaurus and Jackson's Guide to the Literature of Botany; also, Jackson's. Catalogue of the Library of the Royal Botanic. Gardens, Kew.

A. F. . . The American Florist. Chicago. A trade. paper founded August 15, 1885. The volumes end with July. Many pictures repeated in "Gng." (14:1524=vol. and page).

A. G. . American Gardening. New York. Represents. 14 extinct horticultural periodicals, including The American Garden (1888-1890). Founded 1879? (20:896=vol. and page.)

B. . . . The Botanist. Edited by Maund. No years. on title pages. Founded 1839. 8 vols., 50 colored plates in each vol. $(8: 400=$ vol. and col. plate.) Cumulative index.

B. B. . . Britton \& Brown. An Illustrated Flora of the Northern U. S., etc. New York. 1896-1898. (3:588= vol. and page. $)$

B. H. . . La Belgique Horticole. Ghent. 35 vols. (1851-1885.)

B. M. . . Curtis' Botanical Magazine. London. Founded 1787. The oldest current periodical devoted to garden plants. The. vol. for 1899 is vol. 125 of the whole work. Index to first 107 volumes by $\mathrm{E}$. Tonks. London. $(7690=$ col. plate. $)$

B. R. . . Botanical Register (1815-1847). Vols. 1-14 edited by Edwards: vols. 15-33 by Lindley. In vols. 1-23 the plates are numbered from 1-2014. In vols. 24-33 they are numbered independently in each vol. There are 688 plates in vols. 24-33. "An Appendix to the First Twenty-three Volumes" (bound separately or with the 25th vol.), contains an index to the first 23 vols. An index to vols. 24-31 may be found in vol. 31 . $(33: 70=$ vol. and col. plate.)

D. . . Dana. How to Know the Wild Flowers. New York. 1893. (298= page.)

Em. . Emerson, G. B. Trees and Shrubs of Massachusetts. Boston. 2 vols. 149 plates.

F. C. . . Floral Cabinet. Knowles \& Westcott. London. 1837-1840. 3 vols., 4 to.

F. E. . . The Florists' Exchange. New York. A trade paper, whose pictures sometimes are repeated in "A.G." Founded Dec. 8, 1888. (11:1298 = vol. and page.)

F. M. . . Floral Magazine. London. Series I. 18611871, 8vo. Series II. 1872-1881, 4to. (1881:450 = year and col. plate.)

F. R. . . Florists' Review. Chicago. A trade paper. Vol. 1, Dec. 2, 1897, to May 26, 1898. Two vols. a year. $(4: 660=$ vol. and page.) 
F.S. . . Flore des Serres. Ghent. (1845-1880.) Inconsistent in numbering, but the plate numbers are always found on the plate itself or on the page opposite. Valuable but perplexing indexes in vols. 15 and 19. (23:2481 = vol. and col. plate.)

G. C. . . The Gardeners' Chronicle. London. Series I. (1841-1873) is eited by year and page. Series II. or "Now Series" (18741886), is cited thus: II. $26: 824=$ series, volume and page. Series III. is cited thus: III. $26: 416$. Two vols. a year, beginning 1874. A select index is scattered through 1879 and 1880 . Consult II. 12: viii (1879), and similar places in subsequent rols.

C. F. . . Garden and Forest. New York. 1888-1897. $(10: 518=$ vol. and page. $)$

G. M. . . Gardeners' Magazine. London. Ed. by Shirley Hibberd. Founded 1860. Vols. 31-42 are cited. $(42: 872=$ vol. and page. $)$

Gn. . . . The Garden. London. Founded 1871. Two vols. a year. $(56: 1254=$ vol. and col. plate. 56, p. $458=$ vol. and page containing black figure.) An Index of the first 20 vols. was separately published. Complete Index of Colored Plates to end of 1888 in vol. 54 , p. 334 .

Gng. . . Gardening. Chicago. Founded Sept. 15, 1892. Vols. end Sept. 1 . $(7: 384=$ vol. and page.)

Gt. . . Gartenflora. Berlin. Founded 1852. (Gt. $48: 1470=$ vol. and col. plate. Gt. 48 , p. $670=$ vol. and page containing black figure).

G. W. F. . Goodale's Wild Flowers of America. Boston, 1886. $(50=$ col. plate. $)$

HBK. . Humboldt, Bonpland \& Kunth. Nova Genera et Species, etc. Paris. 1815-25. 7 vols. Folio.

I. H. . . L'Illustration Horticole. Ghent. (1854-1896.) (43:72 = vol. and col. plate. $)$ The volumes were numbered continuously, but there were 6 series. Series I. $=1854-63$. Se. ries II. $=1864-69$. Series III. $=1870-80$. Series IV. $=1881-86$. Series $\bar{V}_{.}=1887-$ 93. Series VI. $=1894-96$. The plates were numbered continuously in the first 16 vols. from 1 to 614 : in vols. $17-33$ they run from 1 to 619 : in series $V$. from 1 to 190 : in Series VI. they begin anew with each vol. Valuable indexes in vols. 10 and 20 . Series V. in 4 to, the rest $8 \mathrm{vo}$.

J. H. . . Journal of Horticulture. London. Founded in 1848 as The Cottage Gardener. Series III. only is cited, beginning 1880. (III. 39:504 = series, vol., page.)

L. . . . In vol. 1 of this work, sometimes means Lindenia, sometimes Lowe's Beautiful Leaved Plants. See "Lind." and "Lowe."

L. B. C. . The Botanical Cabinet. Loddiges. 181733. 100 plates in each vol. Complete index in last rol. $(20: 2000=$ vol. and col. plate.)

Lind. . . Lindenia. Ghent. Founded 1885. Folio. Devoted to orchids.

Lowe. . Beautiful Leaved Plants. E. J. Lowe and Howard. London. 1864. $(60=$ col. plate. $)$

M. . . A. B. Freeman-Mitford. The Bamboo Garden. London. 1896. $(224=$ page. $)$

M. D. G. . Möller's Deutsche Gärtner-Zeitung. Erfurt. Founded 1886. (1897:425 = year and page.)

Mn. . . Meehan's Monthly. Germantown, Philadelphia. Founded 1891. $(9: 192=$ vol. and page opposite col. plate.)

N. . . Nicholson. Dictionary of Gardening. Vols. 1-5 (1884-1901).
P. F. G. . Lindley \& Paxton. Flower Garden. London. 1851-53. 3 vols. 4 to.

P. G. . . Popular Gardening. Buffalo. 1885-90. $(5: 270=$ vol. and page. $)$

P. M. . . Paxton's Magazine of Botany. London. 1834-49. (16:376 = vol. and page opposite col. plate.) Vol. 15 has index of first 15 vols.

R. . . Reichenbachia. Ed. by Fred.Sander. London. Founded 1886. Folio.

R. B. . . Revue de l'Horticulture Belge et Etrangère. Ghent. Founded 1875 ? (23: $288=$ vol. and page opposite col. plate.) In the first vol. of the CYCLOPEDIA "R.B." sometimes means Belgique Horticole, but the confusion is corrected in later vols., where Belgique Horticole is abbreviated to "B.H."

R.H. . . Revue Horticole. Dates from 1826, but is now considered to have been founded in 1829. (1899:596 = year and page opposite col. plate. 1899, p. $596=$ year and page opposite black figure.)

S. . . Schneider. The Book of Choice Ferns. London. In 3 vols. Vol. 1, 1892. Vol. 2, 1893.

S. B. F.G. . Sweet British Flower Garden. London. Series I., 1823-29, 3 vols. Series II., 1831-38, 4 vols

S. H. . . Semaine Horticole. Ghent. Founded 1897. (3:548 = year and page.)

S. M. . . Semaine Horticole. Erroneously cited in this fashion a few times in first vol.

S. S. . . Sargent. The Silva of North America. 13 vols. Vol. 1, 1891. Vol. 12, 1898. (12:620 = vol. and plate, not colored.)

S. Z. . . Siebold \& Zuccarini. Flora Japonica. Vol. $1,1835-44$. Vol. 2 by Miquel, 1870. (2:150 = vol. and plate. $)$

V. or V.M. Vick's Magazine. Rochester, N.Y. Founded 1878. Vols. numbered continuously through the 3 series. Vols. begin with Nov. (23:250 = vol. and page.) Sometimes cited as "Vick."

\section{OF AUTHORS OF PLANT NAMES}

By common consent, the Latin name of a plant, in order to be considered by botanists, must first be regularly published by a reputable author in a reputable book or periodical. As an index to this name, the name of its author is published with it whenever an accurate account of the species is given. Thus, Abelia Chinensis, R. Br., means that this name was made by Robert Brown. This eitation at once distinguishes Robert Brown's Abelia Chinensis from any other Abelia Chinensis; for it is possible that some other author may have given this name to some other plant,-in which case the older name must stand. Thus, the Abelia serrata of Siebold \& Zuccarini is not the $A$. serrata of Nicholson. In some cases, the fact that there are two plants passing under one name is indicated in the citation: Abelia rupestris, Hort., not Lindl., means that the rupestris of horticulturists is not the rupestris of Lindley. "Hort." means that the particular name is one in use amongst horticulturists, - that it is a garden name.

The citation of authorities gives a elue to the time and place of publication of the species. It is 
an index to the literature of the subject. It is no part of the idea merely to give eredit or honor to the man who made the name. It is held by some that the authority is an integral part of the name, and should always go with it; but common usage dictates otherwise, for the authority is never pronounced with the Latin words in common speech. The authority is a matter of bibliography, not of language.

It remains to be said (as already explained under the discussion of Nomenclature, page xiv.) that the Editor holds that the name of a plant is of two coördinate words. Therefore, it is the habit of this vorik to eite the author who first made the combination of the two, not the one who first invented the specific name. Thus, Linnæus called a certain plant Eupatorium colestinum ; De Candolle, however, prefers to put this plant in the genus Conoclinium, and calls it Conoclinium colestinum. For the name in Eupatorium, Linnæus is cited: for the name in Conoclinium, De Candolle is cited. Some writers would cite both authors under Conoclinium, thus: Conoclinium colestinum, (Linn.) DC. The authority in parentheses is the one who invented the specific name itself: the other is the one who made the particular combination. This double citation is bungling, particularly for a horticultural work. Its merit is the fact that it suggests the history of the name; but it is not complete in this respect, for the name may have been used in other combinations, of which the citation gives no hint. The full history of a name can appear only in the synonymy.

Adans. Michael Adanson, 1727-1806. France.

AIt. William Aiton, 1731-1793. England.

AIT. f. William Townsend Aiton, the son, 1766-1849. England.

AuL. Carlo Allioni, 1725-1804. Italy.

ANDr. Henry C.Andrews, botanical artist and engraver, conducted The Botanists' Repository from 1799-1811, and illustrated books on heaths, geraniums and roses.

ANDre. Edouard André, once editor of Illustration Horticole, now editor-in-chief of Revue Horticole.

ARN. George Arnold Walker Arnott, 1799-1868. Scotland.

BAILL. H. Baillon, author of the great natural history of plants in French.

BAKER. John Gilbert Baker, formerly keeper of the Herbarium of the Royal Gardens, Kew, England.

BALt. Charles Baltet, frequent contributor to Revue Horticole.

BEan. W. J. Bean, recent writer from Kew in Gard. Chron. on bamboos.

Beauv. Ambroise Marie François Joseph Palisot de Beauvois, 1755-1820. France.

Brisss. L. Beissner, Inspector of the Botanic Gardens at Bonn, and Instructor at Poppelsdorf, pub. Handbuch der Nadelholzkunde.

Benth. George Bentham, 1800-1884, one of England's most distinguished botanists.
Benth. \& Hook. George Bentham and J. D. Hooker, authors of Genera Plantarum. England.

BERnH. Johann Jacob Bernhardi, 1774-1850. Germany.

Bert. Carlo Giuseppe Bertero, 1789-1831. Died between Tahiti and Chile.

Bieb. Friedrich August Marschall von Bieberstein, 1768-1826. German botanist; lived later in Russia.

Bigel. Jacob Bigelow, 1787-1879. Massachusetts.

BL. See Blume.

Blume. Karl Ludwig Blume, b. 1796 at Braunschweig, d. 1862 at Leyden. Wrote much on Javan plants.

Borss. Edmond Boissier, 1810-1886. Switzerland.

BoJER. W. Bojer, 1800-1856, author of a Flora of Mauritius. Austria.

BritTon. Nathaniel Lord Britton, Director New York Botanic Garden, New York, N. Y.

BrongN. Adolphe Théodore Brongniart, 1801-1876. France.

BuLL. William Bull, plant merchant, London.

BuLl. Pierre Bulliard, 1742-1793, author of the great Herbier de la France in 12 folio vols., with 600 plates.

BuNGE. Alexander von Bunge, 1803-1890. Russia.

BuRM. Johannes Burmann, 1706-1779, Prof. at Amsterdam, wrote on plants of Ceylon and Malabar.

BuRM. f. Nickolaus Laurens Burmann, 1734-1793. Son of Johannes.

CARr. Elie Abel Carrière, 1818-1896, distinguished French botanist and horticulturist, editor of Revue Horticole.

Cass. Alexandre Henri Gabriel Cassini, Comte de, 1781-1832. France.

Cav. Antonio José Cavanilles, 1745-1804. Spain.

Cerv. Vicente Cervantes, 1759 ( $१$ )-1829. Mexico.

Cнам. Adalbert von Chamisso, poet and naturalist, 1781-1838. Germany.

CHAPM. Alvan Wentworth Chapman, 1809-1899, author of Flora of the Southern United States.

Chors. Jacques Denys Choisy, 1799-1859. Switzerland.

Cuns. Richard Cunningham, 1793-1835. Colonial botanist in Australia.

Cunv., A. Allan Cunningham, b. 1791, Scotland, d. 1839, Sidney, Australia. Brother of Richard.

CurT. William Curtis, 1746-1799. England. Founder of the Botanical Magazine, now known as Curtis' Botanical Magazine.

Curtis. Moses Ashley Curtis, 1808-1873. North Carolina.

DC. Augustin Pyramus De Candolle, 1778-1841, projector of the Prodromus, and head of a distinguished family. Alphonse De Candolle, the son (1806-1893), and Casimir De Candolle, the grandson, are also quoted in this work.

Decne. Joseph Decaisne, 1809-1882. France.

DESF. René Louiche Desfontaines, 1750-1833. France.

DEsv. Augustin Nicaise Desvaux, 1784-1856. France.

DeVr. Willem Hendrik de Vriese, 1807-1862, Prof. of Botany at Leyden. Wrote on medical plants and plants of the Dutch East Indies.

Dicks. James Dickson, 1738-1822, Scotch writer on flowerless plants.

Dipp. Dr. L. Dippel, of Darmstadt, Germany. Dendrologist; pub. Handbuch der Laubholzkunde. 
D. Dos. David Don, brother of George, 1800-1841. Scotland.

DoN. George Don, 1798-1856. England.

DoNs. James Donn, 1758-1813, author of Hortus Cantabrigiensis. England.

Douglas. David Douglas, 1799-1834, collector in northwestern America. Scotland.

Drude. Prof. O. Drude, of Dresden, Germany.

Duchesne. Antoine Nicolas Duchesne, 1747-1827. France.

DưnoRT. Barthélemy Charles Dumortier, 1797-1878. Belgium.

Dunal. Michel Felix Dunal, 1789-1856. France.

DYer. IV. T. Thistleton-Dyer, Director of Kew Gardens, present editor of the Flora of Tropical Africa, etc.

EAton, A. Amos Eaton, 1776-1842, author of a Manual of Botany for North America, 1st ed. 1817, 8th ed. 1841.

Eaton, D. C. Daniel Cady Eaton, Prof. at Yale College, and writer on ferns.

EhrH. Friedrich Ehrhart, 1742-1795. Germany.

ELL. Stephen Elliott, 1771-1830. South Carolina.

Ellis. John Ellis, 1711-1776. England.

ENDL. Stephan Ladislaus Endlicher, 1804-1849, Prof. at Vienna. Numerous works.

ENGelm. George Engelmann, 1809-1884. Missouri.

ExGler. Prof. A. Engler, of Berlin, joint author of Engler and Prantl's Natürlichen Pflanzenfamilien.

F. C. LeHM. See Lehm., F. C.

FÉe. Antoine Laurent Apollinaire Fée, 1789-1874. France.

Fisch. Friedrich Ernst Ludwig von Fischer, 1782-1854. Russia.

ForB. John Forbes, catalogued heaths, willows, conifers, and other plants at Woburn Abbey.

Forsk. Pehr Forskal, 1736-1768, collected in Egypt and Arabia.

Forst. Johann Reinhold Forster, 1729-1798. Germany. (Also Georg Forster, the son.)

Fraser. John Fraser, 1750-1811, traveled in America 1785-96. Had a son of same name.

Frce. Joseph Aloys Frœlich, 1766-1841. Germany.

F. v. M. Ferdinand von Mueller, Royal botanist of Australia, author of many works on economic plants. See Muell.

GaERTN. Joseph Gaertner, 1732-1791. Germany.

Gaud. Charles Gaudichaud-Beaupré, 1789-1864. France.

Gawl. See Ker.

GMeL. Samuel Gottlieb Gmelin, 1743-1774. Russia.

GokPP. Heinrich Robert Goeppert, 1800-1884, Prof. at Breslau. Wrote much on fossil botany.

Gond. George Gordon, 1806-1879, author of the Pinetum, London, 1858.

Gray. Asa Gray, 1810-1888, Harvard University, Massachusetts. America's most noted botanist.

GreenM. J. M. Greenman, writes from Harvard University on Mexican plants.

Griseb., Gris. Heinrich Rudolph August Grisebach, 1814-1879. Germany.

HAssk. Justus Karl Hasskarl, 1811- . Germany.

Hayne. Friedrich Gottlob Hayne, 1763-1832, Prof. at Berlin. Medicinal plants; trees and shrubs.
HAw. Adrian Hardy Haworth, 1772-1833. England.

HBK. Friedrich Alexander von Humboldt, 1796-1859. Germany. Aimé Bonpland, 1773-1858. France. Karl Sigismund Kunth, 1788-1850. Germany. Authors of a great work on plants of the New World.

HemsL. W. Botting Hemsley, Keeper at Kew, has written many reviews of genera of horticultural value in Gard. Chron. and elsewhers.

Herb. William Herbert, 1778-1847. England.

Носніт. Christian Friedrich Hochstetter, 1787-1860, described many African plants.

HoFFM. Georg Franz Hoffmann, 1761-1826. Germany. Ноок. William Jackson Hooker, 1785-1865. England.

Ноок. f. Joseph Dalton Hooker, the son, 1817England.

HoRT. Hortorum, literally of the gardens. Placed after names current among horticulturists, but not necessarily all horticulturists. Often used with less exactness than names of authors. Frequently indicates garden or unknown origin. Many of these plants have never been sufficiently described.

JACQ. Nicolaus Joseph Jacquin, 1727-1817. Austria.

Juss. Antoine Laurent Jussieu, 1748-1836, the first to introduce the natural families of plants. France.

KARw. Wilhelm Karwinsky von Karwin, d. 1855, collector in Brazil.

KaUlF. Georg Friedrich Kaulfuss, Prof. at Halle, d. 1830. He described the ferns collected by Chamisso.

KER. John Bellenden Ker, 1765 (?)-1871, botanist, wit and man of fashion. First known as John Gawler. In 1793 was compelled to leave army because of sympathy with French Rev. His name was changed in 1804 to John Ker Bellenden, but he was known to his friends as Bellenden Ker. First editor of Edwards' Botanical Register.

Ker-Gawl. See Ker.

KLAtт. Friedrich Wilhelm Klatt, a contemporaneous botanist. Germany.

Kцотzsch. Johann Friedrich Klotzsch, 1805-1860, curator of Royal herbarium at Berlin, monographer of Begoniaceæ.

Косн. Karl Koch, 1809-1879. Germany.

Koenne. Emil Koehne, Prof. at Berlin. Pub. Deutsche Dendrologie.

Kотsсhy. Theodor Kotschy, Asst. curator at Vienna, 1813-1866. Wrote on oriental plants.

KranzL. F. Kränzlin, Berlin, writes on orchids in The Gardeners' Chronicle. .

Kunth. See HBK.

LAG. Mariano Lagasca, 1776-1839, one of Spain's most distinguished botanists.

LAM. Jean Baptiste Antoine Pierre Monnet Lamarck, 1744-1829, author of the Lamarckian philosophy of organic evolution. France.

LaNGS. Georg Heinrich von Langsdorf, 1774-1852, Russian consul-general in Brazil.

LAUTh. Thomas Lauth, 1758-1826, Prof. of Anatomy at Strassburg, wrote a 40-page monograph on Acer in 1781.

LeCQ. Henry Lecoq, b. 1802, once Prof. at ClermontFerrand, wrote an elementary botany, a dictionary of botanical terms, a book on hybridization, etc.

LeConte. John Eaton LeConte, 1784-1860. Pennsylvania. 
LEDEB. Karl Friedrich von Ledebour, 1785-1851. Russia.

LEHM. Johann Georg Clristian Lehmann, 1792-1860, Prof. at Hamburg, wrote several monographs, and described many new plants.

LeHм., F. C. F. C. Lehmann, living German collector in South America.

Leicht. Max Leichtlin, horticulturist, Baden-Baden, Germany.

LEM. Charles Lemaire, 1800-1871. Belgium.

L'Her. C. L. L'Héritier de Brutelle, 1746-1800. France.

Livv. \& Rov. L. Linden and E. Rodigas, once administrator and editor, respectively, of L'Illustration Horticole.

Lisdex. J. Linden, 1817-1898. Belgium. For many years director of L'Illustration Horticole.

Lrsp., L. Lucien Linden, associated with J. Linden for some years on L'Illustration Horticole.

Lixpl. John Lindley, 1799-1865, one of the most illustrious of English horticulturists.

Lisk. Heinrich Friedrich Link, 1767-1851. Germany.

Liss. Carolus Linnæus (Carl von Linné), 1707-1778, the "Father of Botany," and author of binomial nomenclature. Sweden.

Liss. f. Carl ron Linné, the son, 1741-1783. Sweden.

LoDD. Conrad Loddiges, nurseryman near London, conducted Loddiges' Botanical Cabinet from 1817-33, 20 rols., 2,000 colored plates.

LoIsel. Jean Louis Auguste Loiseleur-Deslongchamps, 1774-1849. France.

Lovd. John Claudius Loudon, 1783-1843, an extremely prolific English writer.

Lorr. Juan Loureiro, 1715-1796, missionary in China. Portugal.

Marsh. Humphrey Marshall, 1722-1801. Pennsylvania.

MART. Karl Friedrich Philipp von Martius, 1794-1868, Prof. at Munich, monographer of palms, founder of the great Flora Brasiliensis, and author of many works.

Mast. Maxwell T. Masters, editor of The Gardeners' Chronicle, wherein he has described great numbers of new plants of garden value; author of Vegetable Teratology, etc.

Max. or Maxn. Karl Johann Maximowicz, 1827-1891, one of the most illustrious Russian systematic botanists; wrote much on Asian plants.

Medic. Friedrich Casmir Medikus, 1736-1808, director of the garden at Mannheim, wrote a book of 96 pages in German on North American plants in 1792.

MeIss. Karl Friedrich Meisner, 1800-1874. Switzerland.

METT. Georg Heinrich Mettenius, 1823-1866, Prof. at Leipzig, wrote on flowerless plants.

MEx. Ernst Heinrich Friedrich Meyer, 1791-1851. Prussia.

Mex., C. A. Carl Anton Meyer, 1795-1855, director botanic garden at St. Petersburg, wrote on Russian botany.

Michx. André Michaux, 1746-1802. France, but for ten years a resident of North America.

Michx. f. François André Michaux, the son, 1770-1855. France.
MrLL. Phillip Miller, 1691-1771, of Chelsea, England, author of a celebrated dictionary of gardening, which had many editions.

MıQ. Friedrich Anton Wilhelm Miquel, 1811-1871. Holland.

Mitrond. A. B. Freeman-Mitford, English amateur, author of The Bamboo Garden.

Moench. Konrad Moench, 1744-1805. Germany.

MöNch. See Moench.

Moore. Thomas Moore, 1821-1887, curator of Chelsea Botanic Garden, author of Index Filicum, and other well known works.

MoQ. Alfred Moquin-Tandon, 1804-1863. France.

Morken. Charles Jacques Edouard Morren, of Ghent. 1833-1886.

Motт. S. Mottet, frequent contributor to Revue Horticole, translator of Nicholson's Dictionary of Gardening.

Muell. ArG. Jean Mueller, of Aargau, wrote for De Candolle's Prodromus, vol. 16.

Muell., C. Carl Mueller, 1817-1870, who edited vols. 4-6 of Walpers' Annals.

Muell., F. Ferdinand ron Mueller, Royal botanist at Melbourne, has written much on Australian and economic botany.

Murl. Henry Ludwig Muhlenberg, 1756-1817. Pennsylvania.

MURR. Johann Andreas Murray, 1740-1791. Germany.

MURr., A. Andrew Murray, 1812-1878, author of The Pines and Firs of Japan. London, 1863.

NAUD. Charles Naudin, 1815-1899, botanist, frequent contributor to Revue Horticole.

NDs. See Naud.

N.E. BR. N. E. Brown describes many new plants in Gardeners' Chronicle.

NeEs. Christian Gottfried Nees von Esenbeck, 17761858. Prussia.

Nichols. George Nicholson, Curator at Kew, author of The Dictionary of Gardening.

Nutr. Thomas Nuttall, 1786-1859. Massachusetts.

O'Brien. James O'Bricn, current writer on orchids in Gardeners' Chronicle.

OuIv. Daniel Oliver, once Curator at Kew, and founder of the Flora of Tropical Africa.

ORPH. Theodor Georg Orphanides, Prof. of Botany at Athens. D. 1886.

Ortega, Ort. Casimiro Gomez Ortega, 1740-1818. Spain.

Oтто. Friedrich Otto, 1782-1856. Germany.

Pall. Peter Simon Pallas, 1741-1811, professor and explorer in Russia. Germany.

Pax. Ferdinand Pax, German botanist. Breslau.

Paxt. Joseph Paxton, 1802-1865. England.

Pers. Christian Hendrick Persoon, 1755-1837. Germany.

Planch. Jules Émile Planchon, professor at Montpellier. France.

PoHL. Johann Emmanuel Pohl, 1782-1834, Prof. at Vienna, wrote a large book on travels in Brazil.

PoIr. Jean Louis Marie Poiret, 1755-1834. France.

Presl. Karel Boriweg Presl, 1794-1852. Bohemia.

Pursh. Frederick T. Pursh (or Pursch), 1774-1820. Siberia, but for 12 years in the United States. 
RADDI. Giuseppe Raddi, 1770-1829. Italy.

RAF. Constantino Samuel Rafinesque-Schmaltz, 17841842. Prof, of Nat. Hist. Transylvania Univ., Lexington, $\mathrm{Ky}$.

R. BR. Robert Brown, b. Scotland, 1773, d. London, 1858. Author of many important works.

REGEL. Eduard von Regel, 1815-1892, German, founder of Gartenflora; Dir. Bot. Garden at St. Petersburg.

REICH. Heinrich Gottlieb Ludwig Reichenbach, 17931879. Germany.

Rеich. f. Heinrich Gustar, 1823-1889, son of the preceding. Orchids.

RICH. John Richardson, 1787-1865. Scotland. [France. RICHARD. Louis Claude Marie Richard, 1754-1821.

RIDDELL. John Leonard Riddell, 1807-1865, Prof. of Chemistry in Cincinnati and New Orleans.

Rов. Dr. B. L. Robinson, Director Gray Herbarium of Harvard Univ., is editing The Synoptical Flora of North America.

RoD. Émile Rodigas, for some years connected with L'Illustration Horticole.

RoEM. Johann Jacob Roemer, 1763-1819. Switzerland. Also M. J. Roemer.

Roscoe. William Roseoe, 1753-1831. England.

Rose. J. N. Rose, Asst. Curator, U. S. Nat. Herb., Smithsonian Institution. Mexican plants.

Rотн. Albrecht Wilhelm Roth, 1757-1834, Physician at Vegesack, near Bremen.

RoxвG. William Roxburgh, 1759-1815. India.

Royue. John Forbes Royle, b. 1800 at Cawnpore, d. London, 1858. Prof. in London. Plants of India.

Rurz \& PAv. Hipolito Ruiz Lopez, 1764-1815, and José Pavon, authors of a Flora of Peru and Chile. Spain.

RUPR. Franz J. Ruprecht, 1814-1870. Russia.

S. \& Z. See Sieb. \& Zucc.

Sabine. Joseph Sabine, 1770-1837. England. [land.

SalisB. Richard Anthony Salisbury, 1761-1829. Eng-

Salm-Drck. Joseph, Prince and High Count SalmReifferscheidt-Dyck, b. at Dyck, 1773, d. 1861. Wrote on Aloe, Cactus, Mesembryanthemum.

SARG. Prof. Charles Sprague Sargent, Dir. Arnold Arboretum, author of Silva of North America.

Scherdw. Michael Joseph Scheidweiler, 1799-1861, Prof. of Bot. and Hort. at Hort. Inst. of Ghent.

Schlecht. Diedrich Franz Leonhard von Schlechtendahl, 1794-1866. Prof. at Halle, wrote several memoirs in Latin and German.

ScHLdL. See Schlecht.

Schотт. Heinrich Wilhelm Schott, 1794-1865, wrote much on Aroids with Nyman and Kotschy.

Schrad. Heinrich Adolph Schrader, 1767-1836. Germany.

Schw., Schwein. Lewis David von Schweinitz, 17801834. Pennsylvania.

Schwer. Graf Schwerin, German authority on Acer. Scop. Johann Anton Scopoli, 1723-1788. Italy.

SEEM. Berthold Seemann, Hanover, 1825-1872, wrote on palms, and botany of the voyage of the Herald.

SiвTH. John Sibthorp, 1758-1796, author of a Flora of Greece. England.

Sieb. \& Zucc. Philipp Franz von Siebold, 1796-1866, and Joseph Gerhard Zuccarini, 1797-1848. Germany.
Siebert. A. Siebert, Dir. of the Palm Gard. at Frankfurt, joint author of Vilmorin's Blumengärtnerei.

Srms. John Sims, 1792-1838. England, for many years editor of Curtis' Botanical Magazine.

Sмiтн. James Edward Smith, 1759-1828. England.

Sol., Soland. Daniel Solander, 1736-1782. England. SPACH. Eduard Spach, b. Strassburg, 1801, d. 1879. Author of Histoires Naturelle des Vegetaux.

Spaeth. L. Spaeth, Berlin, nurseryman.

SPRENG. Kurt Sprengel, 1766-1833. Germany.

Steud. Ernst Gottlieb Steudel, 1783-1856. Germany. STEv. Christian Steven, 1781-1863. Russia.

ST. HIL. Auguste de Saint Hilaire, 1779-1853. France. Swartz. Olof Swartz, 1760-1818. Sweden.

SwEET. Robert Sweet, 1783-1835, author of many well known works, as Geraniaceæ, British Flower Garden. Swz. See Swartz.

Thore. Jean Thore, 1762-1823, physician at Dax.

Thunb. Carl Peter Thunberg, 1743-1822. Sweden.

TorR. John Torrey, 1796-1873. New York. [setts. Tuскм. Edward Tuckerman, 1817-1886. MassachuUNDERW. Prof. Lucien M. Underwood, Columbia Univ., New York, N. Y., has written much on ferns, etc.

VAHL. Martin Vahl, 1749-1804. Denmark.

VAN Houtre. Louis Van Houtte, 1810-1876, founder and publisher of Flore des Serres.

VerTch. John Gould Veitch, 1839-1867, and successors, horticulturists at Chelsea, England.

VENT. Etienne Pierre Ventenat, 1757-1808. France.

VERL. B. Verlot, contributor to Revue Horticole.

VERSCH. Ambroise Verschäffelt, 1825-1886, founder and publisher of L'Illustration Horticole at Ghent, Belgium.

VILL. Dominiaue Villars, 1745-1814. France.

VILM. Several generations of the family of Vilmorin, Paris, seedsmen and authors of many books and memoirs on botany and horticulture. Pierre Philippe André Leveque de Vilmorin, 1746-1804. Pierre Vilmorin, 1816-1860. Henry L. de Vilmorin, d. 1899.

Voss. A. Voss, author of botanical part of Vilmorin's Blumengärtnerei.

Waнl. Georg Wahlenberg, 1781-1851. Sweden.

WaLL. Nathanael Wallich, b. Copenhagen 1786, d. London 1854, wrote on plants of India and Asia.

WALP. Wilhelm Gerhard Walpers, 1816-1853.

WALT. Thomas Walter, about 1740-1788, author of Flora Caroliniana. South Carolina.

WaNG. Friedrich Adam Julius von Wangenheim, 17471800. Germany.

WATS. Sereno Watson, 1826-1892. Harvard University.

Wedp. H. A. Weddell, wrote for De Candolle's Prodromus, vol. 16 , etc.

Wendu., H. Hermann Wendland, Dir. Royal Bot. Garden at Herrenhausen, one of the chief writers on palms.

WiLld. Karl Ludwig Willdenow, 1765-1812. Germany. With., Wither. William Withering, 1741-1799. Eng. WiтTM. Max Karl Ludwig Wittmack, editor of Gartenflora. Prof. at Berlin.

Wood. Alphonso Wood, 1810-1881. Of his Class-Book of Botany, 100,000 copies have been sold in Amer.

Zucc. Joseph Gerhard Zuccarini, 1797-1848, Prof. at Munich. 


\section{Cyclopedia of American Horticulture}

ABELIA (after Dr. Clarke Abel, d. 1826) C Caprifolidcea. Small shrubs: lvs. opposite, small, petioled and mostly dentate: fls. tubular, unequally 5-lobed, in axillary,1-3-fld.cymes, sometimes forming terminal panicles: fr. a dry, leathery berry. E. A sia, Himalay as and Mexico. Free-flowering low shrubs for cool greenhouse or outdoor cultivation. The Japanese and Chinese species are the hardiest, but in the north require some protection during the winter. The Mexican species are hardy only south. If potted, a sandy compost of peat and loam will suit them; in the open they grow best in sandy soil in a sunny position. Prop. by greenwood cuttings in summer or by layers in spring.

Chinénsis, R. Br. (A. rupéstris, Lindl.). Lvs. ovate, rounded at the base, serrate, hairy on the midrib beneath and sometimes with scattered hairs above, deciduous: fls. in terminal panicles, white, $1 / 2$ in. long; sepals 5 ; stamens exserted. Summer. China. B.R. 32:8. Gn. 27, p. 424.

floribúnda, Decaisne. Shrub, 4 ft.: Ivs. persistent, oval, crenate-serrate, ciliate: peduncles axillary, 1-3-fld.; corolla rosy purple, 2 in. long; sepals 5 . Summer. Mex. B.M. 4316. F.S. 2:5. R.B. $23: 157$.

grandiflòra, Hort. (A. Chinénsis $\times$ uniflòra, A. rupés tris, Hort., not Lindl. A. rupéstris, var. grandiflora, André. A. uniflora, Hort., not Turez.). Lvs. otate, rounded or attenuate at the base, serrate, shining above, nearly glabrous, half-evergreen: fls. in terminal panicles, white flushed pink, over $3 / 4$ in. long; sepals $2-5$; stamens not exserted. Of garden origin. Gt. 41:1366.- One of the hardiest and most free-flowering Abelias; it flowers continuously from June to Nov.

A. biflòra, Turez. Lvs. ovate-lanceolate, hairy, coarsely serrate, deciduous : fls. white: sepals 4. Manchuria, N. China.A. serràta, Sieb. \& Zuce. Allied to A. biflora. Sepals 2. Japan. S. Z 1:34, - A spathulàta, Sieb.\&Zuce. Allied to A. biflora. Lvs. ovate: fls. ove $1 \mathrm{in}$. long, white tinged yellow in throat; sepals 5. Japan. S. Z 1:34, B.M 6601 - A triftora R. Br. Lvs. persistent, Japan. S.Z.1:34. B.M.6601.-A.triftora, R. Br. Lvs. persistent, sep. 5, linear, long, hairy. Himal. P.F.G. 3: 91. R.H. 1870: 511. sep. 5, linear, long, hairy. Himal. P.F.G. 3: 91. R.H. 1870: 511.-
A. unifiora, R.Br. (A. serrata, Nichols., not S.\&Z.). Lus. persistent, ovate-lanceolate : fls. rosy white with yellow in throat; sepals 2. China. B.M. 4694. Gn. 27, p.425. AlFred ReHder.

AB ĖRIA (Mt. Aber). Bixinacea. The Kei Apple of the Cape of Good Hope; a spiny plant grown S. for hedges, but killed in Fla. by freeze of 1893; is considered promising for S. Calif. and S. Fla. as a fruit plant. Int. 1891. Fresh fruit used as pickles.

Cáffra, Hook.f. \& Harv. Thorny, glabrous : lvs. obovate, obtuse, cuneate at base, entire: fls. diœcious, apetalous. G.C. III. 18: 737 .

ABIES (derivation doubtful). Coniferce. Fir. Tall, pyramidal trees: lvs. lanceolate or oblanceolate, entire, sessile, persistent for many years; on young plants and lower sterile branches flattened, usually deep green and lustrous above and silvery white below from the presence of many rows of stomata, rounded and variously notched at the apex, appearing 2-ranked by a twist at their base; on upper fertile branches crowded, more or less erect, often incurved or falcate, thickened or quadrangular, obtuse or acute : fis. axillary, appearing in early spring from buds formed the previous summer on branchlets of the year, surrounded by involucres of the enlarged scales of the flower-buds; staminate fls. pendent on branches above the middle of the tree; pistillate fls. globular, ovoid or oblong, erect on the topmost branches: fr. an erect, ovoid or oblong cylindrical cone, its scales longer or shorter than their bracts, separating at maturity from the stout, persistent axis. Northern and mountainous regions of the northern hemisphere, often gregarious. Twenty-three species are distinguished; greatest segregation on the Cascade Mountains of Ore- gon, in the countries adjacent to the Mediterranean, and in Japan. All the species produce soft, perishable wood, sometimes manufactured into lumber, and balsamic exudations contained in the prominent resin vesicles in the bark characteristic of the genus. Handsome in cultivation, but usually of short-lived beauty. Moist, welldrained soil. Prop. by sowing and by grafts. Seeds are usually kept dry over winter and planted in frames or seed-beds in spring. Young plants usually need shade. Most species can be grafted with comparative ease; A. Picea and A. balsamea are commonly used for

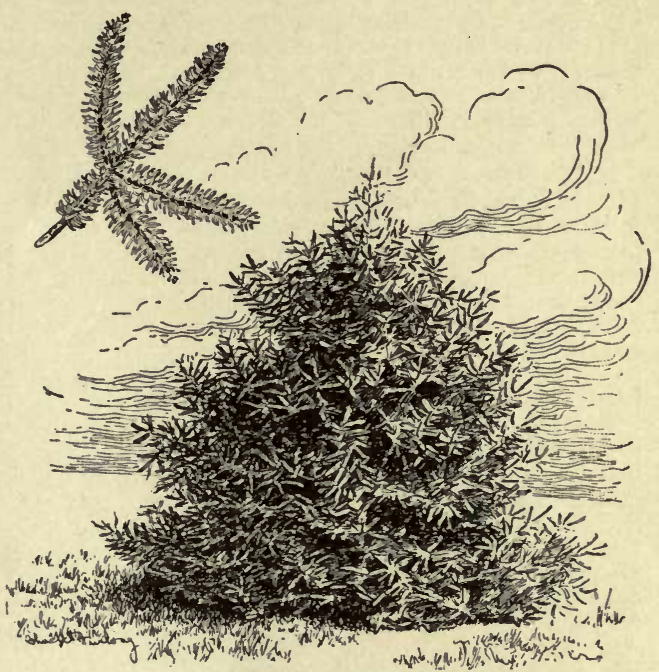

1. Spanish Fir.-Abies Pinsapo.

stocks. Many species which have been referred to Abies are now included in Picea. S. S. 12. Heinrich Mayr, Monographie der Abietineen des Japanischen Reiches. Gn. 11, pp. 280, 281. See Conifers.

The following species, in the American trade, are here described, the synonyms being in italies: amabilis, Nos. 4, 8; Apollinis, 12; balsamea, 6; brachyphylla,11; Cephalonica, 12; Cilicica, 3; concolor, 9; Fraseri, 7; Gordoniana, 8; grandis, 8; homolepis, 11; Hudsonia, 6; Lou $i$ ana, 9 ; magnifica, 15; nephrolepis, 10 ; nobilis, 14; Nordmanniana, 2; Parsonsiana, 9; pectinata, 1; Picea, 1; Pichta, 5; Pinsapo, 13 ; Shastensis, 15 ; Sibirica, 5 ; Veitchii, 10. See supplementary list, p. 3, for other cultivated species.

A. Euabies. Leaves flat, grooved on the upper surface, only occasionally stomatiferous above on upper fertile branches.

B. Leaf blunt.

c. Foliage essentially green,-the leaves green above and whitish only beneath.

D. Cones usually upwards of $4 \mathrm{in}$. long.

1. Picea, Lindl. (A. pectinata, DC.). Silver Fir. Fig. 2,c. Tree 100-200 ft.: trunk 6-8 ft. in diam.: Ivs. flat, distichously spreading, dark green and lustrous above, silvery white below: cones slender, cylindrical, light green to dark purple, 5-6 in. long ; bracts slightly longer than their scales. Mountains of central and southern Europe, often gregarious. - Wood esteemed and much used; yields Strasburg turpentine. Dwarf forms, with erect and pendulous and with much abbreviated branches, are common in gardens. 
2. Nordmanniàna, Spach. Fig. 2, e. Tree 100-150 ft.: trunk 4-6 ft. in diam. : lvs. flat, crowded, dark green and very lustrous above, silvery white below: cones oblongcylindrical or ellipsoidal, dark orange-brown,4-6 in. long; bracts as long as or slightly longer than their scales. Mountains south and southeast of the Black Sea, and western spurs of the Caucasus. B.M. 6992. Gng. 6:51.-Very hardy; one of the most desirable firs in northern states.

3. Cilícica, Carrière. Tree 45-60 ft.: trunk 2-3 ft. in diam.: lvs. narrow, flat, dark green above, silvery white below: cones stout, cylindrical, orange-brown, 5-6 in. long; bracts rather shorter than their scales. At high elevations on the Anti-Taurus of Asia Minor, and on the Lebanon. A. G. 16:255. Gng. 4:113.-Begins to grow early in the spring and is often injured by late frosts; hardy and desirable in the northern states.

4. amábilis, Forb. White Fir. Tree 100-150 ft. : trunk 4-6 ft. in diam.: lvs. crowded, dark green and very lustrous above, silvery white below, occasionally stomatiferous on the upper surface: cones oblong, dark purple, $3 \frac{1}{2}-6$ in. long; bracts much shorter than their scales Cascade Mountains of Washington and Oregun, and Coast Ranges from Vancouver Island to Oregon.-One of the handsomest of the genus, often forming groves at high elevations; in cultivation grows slowly, and is not very satisfactory.

DD. Cones usually under $4 \mathrm{in.}$ long.

5. Sibírica, Ledeb. (A. Pichta, Forbes). Tree 60-100 ft.: trunk 2-4 ft. in diam.: 1vs. crowded, dark yellow-green: cones cylindrical, slender, brownish yellow, $2 \frac{1}{2}-3$ in. long; bracts much shorter than their scales. Northern and eastern Russia to Kamtschatka and Mongolia,gregarious on the Altai Mountains. - Very hardy, the early growth often injured by late frosts ; in cult. soon becomes thin and loose in habit.

6. balsàmea, Mill. Balsam Fir. Fig.2, $b$. Tree 50-80 ft.: trunk 17-30 in.in diam. :lvs. dark green and lus-

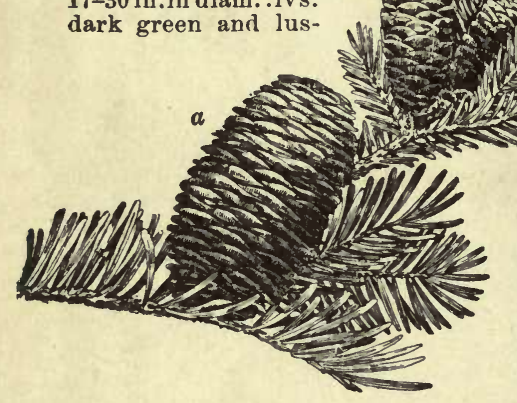

2. Abies or Fir.

a. A. grandis; $b$. A. balsamea ; $c$. A. Picea; $d$. A. concolor; $e$. A. Nordmanniana; $f$. A. magnifica.

Eastern North America from Labrador and the valley of the Athabasca to Iowa and the mountains of Virginia. S. S. 12:610. G.C. III. 17: 423, 425, 431.-Wood occasionally used for lumber; Canadian Balsam, or Balm of Fir, is obtained from bark ; in cult. loses its beauty early.

Var. Hudsònia, Engelm. (A. Hudsónica, Hort.), is a dwarf form.

7. Fràseri, Poir. She Balsam. T'ree 30-50 or even 70 ft.: trunk reaching $2 \frac{1}{2} \mathrm{ft}$. in diam.: lvs. flat, obtusely short-pointed, twisted at the base so as to appear to be crowded on the upper side of the branches, dark green and lustrous : cones oblong-ovate or nearly oval, rounded at the slightly narrower apex, $21 / 2 \mathrm{in}$. long and 1 in. thick, the scales dark purple, twice as wide as long and at maturity nearly half covered by pale reflexed bracts or points. Mountains of Va., Tenn., and N. C. S. S. 12:609.-Too much like the balsam fir to be prized as an ornamental

tree. Trees sold under this name are nearly always forms of $A$. balsamea.

8. grándis, Lindl. (A. amábilis, Murr., not Forbes. A. Gordonidna, Carr.). Fig. 2, $a$. Tree 200-300 ft., becoming $4 \mathrm{ft}$. in diam.: Ivs. thin and flexible, deeply grosved, very dark green above and silvery white beneath: cones cylindrical, 2-4 in. long, rounded or retuse at the apex, the broad scales somewhat squarrose and irregularly serrate and furnished with a short point. Coast of northern California to Vancouver Island and to the western slopes of the Rocky Mountains of Montana. S.S.12: 612. Gn. 38, p.291. R.H.1894, p.274. - Occasional specimens are seen in parks and choice grounds, but

it rarely thrives in eastern states.

$$
\text { cc. Foliage pale blue or }
$$

glaucous.

9. cóncolor, Lindl.\& Gord.

(A. Lowidna, A. Murr. A. Parsonsiana,

Hort.).WHITE

FIR. Fig. 2, d.
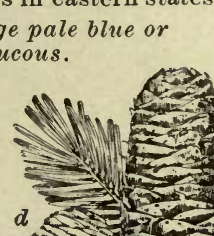

\begin{abstract}
.
\end{abstract}


13. Pinsàpo, Boiss. Spanish Fir. Fig. 1. Tree 70-80 ft.: trunk 4-6 ft. in diam.: lvs. short, broad, rigid, sharp-pointed, bright green, spreading from all sides of the stiff branchlets : cones cylindrical, slender, graybrown, 51/2-6 in. long; bracts shorter than their scales. Mountains of central and southern Spain, often gregarious. G.C. III. 21:407. - Not very hardy north of the Middle states.

AA. Nobiles. Leaves blue-green, often glaucous, stomatiferous on both surfaces, flut or 4-sided on sterile branches; 4-sided, acute, incurved and crowded on fertile branches.

14. n6bilis, Lindl. ReD FIR. Tree 150-250 ft. : trunk 6-8 ft. in diam.: lvs. on lower branches grooved above, rounded and emarginate at the apex: cones oblong-cylindrical, purplish or olive-brown, 4-6 in. long; bracts much longer, thin and covering the scales, strongly reflexed, pale green. Cascade and Coast Mountains of Washington and Oregon, often gregarious. S.S. 12:617. G. C. III. 20:275.-There is a var. glauca in the trade.

15. magnifica, A. Murr. RED FIr. Fig. $2, f$. Tree $200-250 \mathrm{ft}$.: trunk $6-10 \mathrm{ft}$. in diam. : lvs. quadrangular, bluntly pointed on sterile and acute on fertile branches: cones oblong-cylindrical, purplish brown, 6-9 in. long; bracts much shorter than the scales. Sierra Nevada of California; gregarious and forming great forests. S.S. 12:618. Gn. 37, p. 591.-Wood occasionally manufactured into lumber. Less hardy in the eastern states than $\boldsymbol{A}$. nobilis.

Var. Shasténsis, Lemm., of southern Oregon and northern California, cones somewhat smaller, with bracts as long as or longer than the scales. S.S. 620.

A. Albertiàna, Murr.=Tsuga hetero phylla.-A. Baborénsis, Let. Lvs. dark silvery below, very numerous, $1 / 2-1$ in. long: cones 4 or 5 together, reaching 7 or 8 in. long and 1 in. diam. N. Africa. R.H. 1866 , p. 106.-A. bifida, Sieb. $\&$ Znce. $=$ A. firma. $-A$. bracteàta, Hook. \& Arn. =A. vennsta. $-A$. Can adénsis, Michx $=$ Tsuga Canadensis. Canadensis. $-A$. firma. Sieb. \& Zuce. $=$ A. Mome Sieb. Lvs. thick and rigid lin.long: cones cylindrica often 6 in.long, with keeled seales. Japan. Promising for S. - A. Hookeriàna. Iurr $=$ Tsuga Mertensiana.-A.lasiocárpa, Nutt.

Lvs. blue-green and glaucous: cones $3 \mathrm{in}$. long, with very broad spineless scales. Western U.S.Gng.4:373. S.S.12:611. - A.macrocárpa, Vasey=Pseudotsuga macrocarpa. - A. Màriesii, Mast. Small tree with crowded branches and short, dark foliage which is pale below: cones large, dark purple. N. Japan. - A. Merten. siàna, Lindl. =Tsuga heterophylla. - A. Numidica, DeLannoy $=$ A. Baborensis. - A.Pindrovo, Spach., is a form of A. Webbiana, but has longer leaves and smaller cones. Himalayas. $-A$. Reginoe A málioe $=\mathrm{A}$. Cephalonica, var. Appolinis, $-A$. religidsa, Lindl. Long, slender, drooping branches: lvs. silvery below: cones 5 in. long. Mex. B.M.6753. - A.Sachalinénsis, Mast. Tall tree, with pale bark, white buds, and long, slender, dark green lvs.: cones 3 in. long. E. Asia. - A. subalpina, Engelm =lasiocarpa. - $A$ venùsta, Koch. Lvs. acuminate, dark yellow, green above and silvery below: cones 4 in. long, with long, slender bracts. California. S. S. $12: 615,616$, B. M. 4740, $-A$. Webbiàna, Lindl. Lvs. 1-21/2in. long, flat, silvery below: cones cylindrical, 6 or $7 \mathrm{in}$. long. Himalayas. See Picea for $A$. Ajanensis, alba, Alcockiana, Engelmanni, excelsa, Gregoriana, miniata, Morinda, nigra, obovata, orientalis, pendula, polita, pungens, Schrenkiana, Smithiana. See, also, Pseudotsuga and Tsuga.

$$
\text { C. S. SARGENT. }
$$

ABOBRA (Brazilian name). Cucurbitdcece. Greenhouse climber, cult. for its numerous small, showy fruits: grows rapidly, and may be planted out in summer. The tuberous roots are stored like dahlias. Prop. by seeds or rarely by soft cuttings.

viridiflora, Naudin. Height $10-15 \mathrm{ft} .: 1 \mathrm{rs}$. much divided: fls. small, pale green, fragrant: fr. a scarlet gourd. Brazil. R.H. 1862: 111 .
ABROMA (from $a$, not, and broma, food). Sterculidcere. Greenhouse evergreen trees. Prop. by seeds or by cuttings in spring from half-ripened wood under glass.

A. augústa, Linn. f. Lower lvs. cordate, 3-5-lobed; upper lvs. ovate-lanceolate. Trop.As. B.R. 518. - A . fastud̀sa, R.Br. Lower Ivs. cordate, 5-lobed; upper lvs. ovate: fls. dark purple. Trop. As., Austral.

ABRONIA (from abros, delicate, referring to involucre). Nyctagindcece. Trailing plants, with fragrant verbena-like flowers suitable for baskets and rockeries; commonly treated as hardy annuals. Mostly tender perennials from Calif. Height 6-18 in. For early and continuous summer bloom, seeds may be sown in pots of sandy soil the previous autumn and wintered in a frame. Peel off the husk before sowing seed. Cf. Sereno Watson, Bot. Calif. 2:3-5.

\section{A. Flowers yellow}

latifolia, Esch. Fig. 3. Plant very viscid-pubescent: ivs. thick, broadly ovate or reniform, obtuse, on distinct petioles: root stout, fusiform. $A$. are ndria, Menzies, is probably the same, but is considered distinct by some. B.M. 6546. G.C.II. $16: 365$.

AA. Flowers pink or rose.

umbellàta, Lam. Whole plant viscid-puberulent : lvs. typically narrower than the above, oval or oblong: fls. pink. F. S. 11: 1095. P. M. 16: 36. Var. grandiflora, Hort., has larger fls. and broader lvs.

villosa, Watson. Smaller and slenderer than the last and covered with a glandular-villous pubes-

\section{Abronia latifolia $\left(X_{1 / 2}\right)$.}

cence: Ivs. rarely 1 in. long: fis. 5-15 in a cluster, rose. Not common in cult. Int. 1891.

$$
\text { AAA. Flowers white. }
$$

mellifera, Dougl. Stouter than A. umbellata: involucre larger, scarious: lvs. longer and narrower. B.M. 2879. Int. 1891.

fràgrans, Nutt. Lvs. larger than in A. umbellata, broader at the base and more tapering: fls. night-blooming. B.M. 5544

A. pulchélla, Nicholson. Fls. pinkish rose.-A. ròsea, Hartweg. =nmbellata

$$
\text { W. M. }
$$

ABRUS (from $a b r o s$, soft, referring to leaves). Legumindsa. Deciduous greenhouse climber, or used S. outdoors for screens. Roots have virtues of licorice. Needs strong heat for indoor culture. Prop. by seeds or by cuttings under glass in sand.

precatorius,Linn. CraB'S-EYE VINE. WeAthrir-PLANT. Height 10-12 ft.: leaflets oblong, in numerous pairs: $\mathrm{fls}$. varying from rose to white: seeds bright scarlet, with a black spot, used by Buddhists for rosaries, and in India as standards of weight. Tropics. - The absurd claims made for its weather-prophesying properties are exposed by Oliver in Kew Bull. Jan. 1890.

ABÙTA (native name). Menispermacea. Greenhouse evergreen climber. Prop. by cuttings under glass with bottom heat. $-A$. ruféscens, Aubl. Lvs. ovate: fls, dark purple within. S. Am. Unimportant. 
ABÙTILON (name of obscure origin). Malvacece. Flowering MAPle. Attractive coolhouse shrubs and window plants. Lvs. long-stalked, often maple-like: fls. with naked 5-cleft calyx, 5 separate obovate petals. many stamens united in a column about the many-branched

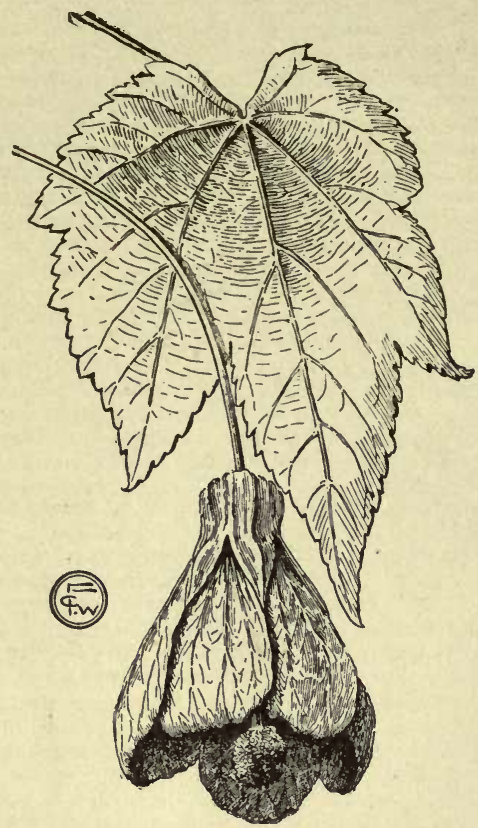

4. Abutilon striatum $(\times 1 / 2)$.

style. Of very easy culture in conditions which are suitable for geraniums or fuchsias. Usually grown in pots, but sometimes bedded out in summer. Dwarf and compact varieties suitable for bedding are becoming popular. The tall varieties are adaptable to growing on rafters or pillars. $A$. striatum and $A$. Thompsoni are the commonest type forms. Prop. by greenwood cuttings at any season, preferably in late winter or early spring; also freely by seeds. Many horticultural varieties, some of them no doubt hybrids, are in common cultivation. Following are well known: Arthur Belsham, red, shaded gold. Boule de Neige, pure white, very free. Eclipse, foliage marbled green and yellow: fls. of fair size; sepals scarlet; petals orange-buff : suited for baskets and vases: a form of $A$. megapotamicum (another Eclipse is known). Erecta, pink orange-veined erect fls. Golden Bell, deep yellow, free-flowering. Golden Fleece, pure yellow, free-flowering. Mary Miller, deep rose pendulous fls. Mrs. John Laing, purplish rose. Rosæflora, pinkish rose. Royal Scarlet, rich, shining scarlet. Santana, deep red. Savitzii, dwarf, with white-edged foliage: useful for bedding. Snow Storm, semi-dwarf, pure white. Souvenir de Bonn, lvs, large, deep green, not mottled, but edged with a broad white margin: distinct and striking: a.useful bedding plant. Splendens, bright red.

A. Leaves prominently lobed, mostly maple-like or vine-like.

B. Corolla widely open or spreading.

Dárwini, Hook. f. Strong pubescent shrub 3-5 ft.: Ivs. velvety pubescent beneath, thickish, 5-9-ribbed, the lower ones lobed to the middle, the upper ones shallow3-lobed: fls. 1-3 at a place, orange with blood-red veins. Brazil. B.M. 5917. - Blooms in both winter and summer. Much hybridized with other species. A.grandifiorum and $A$. compáctum are garden forms ; also A. floribundum, Hort., R. H. 1881: 350 .

BB. Corolla mostly longer and contracted at the mouth.

striatum, Dicks. Fig.4. Glabrous throughout: Ivs.thin, deeply 5-lobed, the lobes long-pointed, rather closely serrate, sometimes small-spotted: fls. rather small and slender, hanging on peduncles 4-6 in. long, red or orange, with brown-red veins, the stamens scarcely or not at all exserted. Brazil. B.M.3840. P.M. 7:53.-One of the hardiest species, blooming continuously.

Thompsoni, Hort. Fig. 5. Graceful but strong-growing plant: lvs.vine-like, mostly 3 -lobed, the middle lobe longpointed, thin and usually glabrous, mottled with green and yellowish blotches: fls. medium size, yellow or orange with red veins, the column of stamens conspicuously exserted in the single forms. R.H. 1885:324. G.W. $70: 133$. - Blooms in summer and winter. An offshoot of $A$. striatum, or a hybrid with that species. In the doublefld. form, the fls. are open-spreading. Cions often convey the variegation to the stock. Common and valuable.

vendsum, Lemaire. Very strong grower: lvs. large, deeply palmate-lobed and strongly toothed: fls. large, 3 in. long, on peduncles 10-12 in. long. Mex. B.M. 4463. -A showy species.

AA. Leaves not lobed, cordate, but prominently toothed, sometimes angled.

B. Corolla wide-spreading.

insigne, Planchon. (A. igneum, Hort.). Lvs. medium size, crenate-dentate, acuminate, villous pubescent underneath: fls. large, flaring-mouthed, white with very heavy and rich veining and markings of purple and red, on slender hanging peduncles. New Granada. B.M. 4840. Gn. 18:263.-Very showy; common.

longicúspe, Hochst. White-canescent shrub, with longacuminate, broad-cordate and blunt-toothed long-stalked lvs., felt-like below: blue veiny wide-open fls. on mostly many-branched axillary peduncles. Abyssinia. - Recently introduced by S. Cal. Acclimatizing Assoc, from seed collected by Schweinfurth and distributed from Berlin in 1893 . 
Peru. - A. Bedfordiànum, St. Hil. Lvs. lobed: fls. yellow with red: very tall. Brazil. - A. globiflorum, Don. Fls. large, creamcolored Mauritins -A integerrimum, Hooker \& Jackson, colored. Maritis. A .integer date, tomentose below : fls. large, yellow, flaring. New Granada. - A.pconiaflòm, Walpers. Fls, rather small, pink. Brazil.

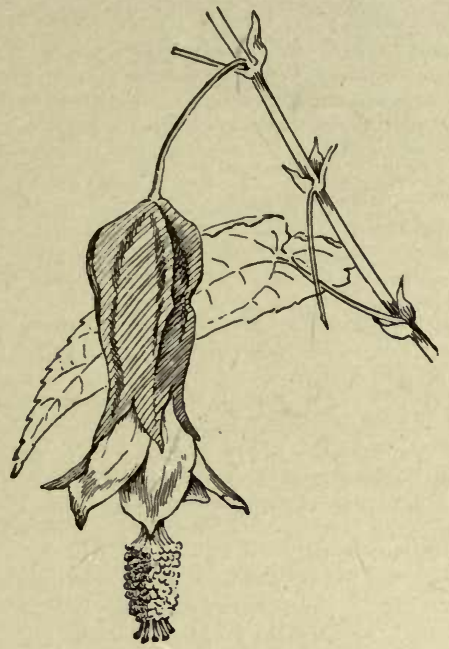

6. Abutilon megapotamicum $(\times 1 / 2)$.

- A. pulchéllum, Sweet, and $A$. púlchrum, Don.=Plagianthus pulchellus. $-A$. vitifolium, Pres]. Lvs. Jobed: fls. wide-spreading, light blue (a white-flowered var.): plant one of the hardiest. Chile. B.M.4227, 7328. Gn. 51:1117.

L. H. B.

ACACIA (ancient name). Leguminòsa, tribe Mimòsea. Shrubs or trees: lvs. twice-pinnate, of many leaflets, or reduced to phyllodia or leaf-like petioles, as in Figs. 8 and 9 (except the earlier lvs. of young seedlings, and occasionally those on robust shoots): fis. yellow or white, minute, in conspicuous globular heads or cylindrical spikes, axillary, solitary or fasciculate, or diffusely paniculate at the ends of the branches; stamens very many, exserted. Australia (chiefly); a few in N. and S. America, N. and $\mathbf{S}$. Africa and Asia. Ours Australian unless otherwise stated. Prop. by seeds sown under glass as soon as ripe, or by cuttings of half-ripened wood taken with a heel, in summer; the seeds should first be placed in hot water and left to soak 24 hours. The bark of most of the Australian and of some other species (especially A.pycnantha, A. mollissima and $A$. decurrens) abounds in tannins, which may eventually make their cultivation profitable in the southwest. For outdoor planting in Calif. and the S., keep in pots until large enough to place in permanent quarters, for they do not transplant well. Several African species yield the gum arabic of commerce, especially $\boldsymbol{A}$. Senegai. Monographed in part by Baron von Muller in his Iconography of Australian Acacias, cited here as F. v. M. Icon.

\section{J. Burtt DAvy.}

Of several hundred known kinds, not more than $\mathbf{5 0}$ are in cultivation, and a dozen species will cover those deserving of greenhouse culture, but these few are gems. All of this most important section thrive in a winter temperature ranging from $40^{\circ}$ to $50^{\circ}$; in fact, little above the freezing point is sufficient. They do not like heat, and consequently are not adapted for forcing. If wintered cool and allowed to come along naturally with the increasing heat and light of the spring, they will flower in March and April, a season when their graceful beauty is appreciated in the private conservatory or is valuable to the commercial florist. The prevailing color of all the Australian species is yellow, varying from pale lemon to deep orange. The tall-growing kinds, or rather those inclined to make long, straight shoots, make excellent subjects for planting permanently against a glass partition of a conservatory, or against a pillar. There is scarcely a more beautiful plant than $A$. pubescens, with its slightly drooping, yellow racemes. It deserves a favored place in every cool conservatory. The Acacias are of easy culture. If planted permanently in the border, provision for drainage should be made. A good, coarse, turfy loam, of not too heavy texture, is all they want, with the addition of a fifth part of leaf-mold or wellrotted spent hops. Few of our greenhouse pests trouble them. Water in abundance they like at all times, and in their growing season, which is the early summer months, a daily syringing is necessary. Several of the species of bushy habit are very largely grown as pot-plants in Europe, and are now largely imported and sold for the eastern trade. A. armata and $A$. Drummondii are good species for this purpose. We believe, with our hot summers, the commercial man will do better to import than to attempt to grow them from cuttings. The Acacias need pruning, or they will soon grow straggling and unshapely; more especially is this true of those grown in pots. After flowering, cut back the leading shoots rather severely. Shift into a larger pot if roots demand it, and encourage growth by a genial heat and syringing, giving at same time abundance of light and air. They should be plunged out-of-doors as soon as danger of frost is past, and removed to the greenhouse before any danger of early fall frosts. Cuttings root surely but not quickly. The best material is the side shoots from a main stem in the condition that florists call half-ripened-that is, not green and succulent as for a verbena, nor as firm and hard as the wood of a hybrid perpetual rose in Nov. The wood or shoot will be in about the right condition in June. No bottom heat is needed, but the cuttings should be covered with a close frame and kept moderately moist and cool by shading. The following spring these young plants can be either planted out-of-doors, where there is a good chance to keep them well watered, or grown on in pots, as described above. A few of the finest species are $A$. pubescens, suitable for training on pillars; $\boldsymbol{A}$. Riceana makes a bush or can be trained; A. longifolia, an erect species, deserves a permanent position in the greenhouse border. Of all the species best adapted for medium-sized, compact pot-plants, $A$. armata and $A$. Drummondii are the best. The former has small, simple, dark green lvs. and globular, pure yel low fls. A. Drummondii has drooping, eylindrical, pale lemon fls. As both these flower in March without any forcing in our northern greenhouses, they are very valuable acquisitions to our Easter plants. The Acacia has two distinctive charms: the foliage is either small, simple and glaucous, as in A.armata, or much divided, graceful and fern-like, as in $A$. pubescens. All the Acacias are among the freest-flowering of our hard-wooded plants. Cult. by William ScotT.

The species in the American trude are here described under the following numbers: A. acinacea, 7 ; aneura, 38; angustifolia, 16; Arabica, 49; argyrophylla, 15; armata 5; Baileyana, 45; brachybotrya, 15; calamifolia, 3 ; Catechu, 52 ; Cavenia, 48; celastrifolia, 16; cinerascens, 39 ; cultrata, 12; cultriformis, 12 ; cuspidata, 1 ; cyanophylla, 20; Cyclops, 32; dealbata, 43; decurrens, 41; diffusa, 1 ; dodonæifolia, 10; Drummondii, 53; extensa, 4; falcata, 17; falciformis, 18; Farnesiana, 47; flicina, 50; genistoefolia, 1; glabra, 15; glaucescens, 39; glaucophylla, 15; grandis, 46; Greggii, 51; harpophylla, 29; hispidissima, 46; holosericea, 40; implexa, 30; juncifolia, 2; Latrobei, 7; leptophylla, 47; leucophylla, 40; linearis, 37 ; lineata, 6; linifolia, 14 ; longifolia, 36 ; longissima, 37 ; lunata, 11 ; Meissneri,9; melanoxylon, 31 ; mollissima,42; myrtifolia, 16 ; neriifolia, 22 ; normalis, 16,41 ; obliqua, 8 ; obtusata, 21; olecefolia, 11; Oswaldi, 27; oxycedrus, 33 ; paradoxa, 5 ; pendula, 28; penninervis, 18 ; pentodra, 4 ; pinifolia, 2 ; pravissima, 13 ; prominens, 14 ; pubescens, 44 ; pul. chella, 46; pycnantha, 23 ; retinodes, 22 ; Riceana, 35 ; rostellifera, 25; rotundifolia, 8; salicina, 24; saligna, 19 ; Sophoræ,36; suaveolens, 26 ; undulata, 5; verticillata,34.

A. Lv's. simple; that is, reduced to phyllodia (except the earlierlvs. of young seedlings, and occasionally those of robust shoots). Figs. 7, 8 and 9.

B. Fls. in globular heads.

c. Phyll. terete, or only slightly flattened.

1. diffùsa, Lindl. (A. genistoefòlia, Link.). A tall, glabrous shrub: branches angular: phyll. $8 / 4-1$ in. long, 
1-11/2 line's widle, quadrangular-linear, 1-nerved: fl. hds. solitary, or 2 or 3 together; peduncles short; fls. yellow, May. B.M. 2417. B.R. 634 .

Var. cuspidata, Benth. (A. cuspidata, Cunn.). Phyll. $3 / 4$ to rarely 2 in. long, slender, often not broader than thick.

¿. juncifolia, Benth. (A. pinifòtia, Benth.). Tall, glabrous shrub: branches slender, quite terete: phyll. $3-6$ in. long, often nearly tetragonous, linear-subulate, with a scarcely prominent nerve on each side: fl. hds. solitary or in pairs; peduncles short. F.v.M.Icon. 2: 8 .

3. calamifdlia, Sweet. Broom WAtrle. Tall shrub 6-10 f.. : phyll. 3-4 in. long, linear-subulate, slightly flattened, with 1 nerve prominent or indistinct; point fine, recurved cr simply oblique: fl. hds. 3 or 4 , shortly racemed in the axils of the terminal phyll.; calyx shortly toothed or lobed. Feb. B.R. 839.

4. exténsa, Lindl. (A. pentâdra, Regel). Shrub : branches angular or sometimes winged: phyll. 3-4 or even 8 in. long, slender, linear-subulate, almost tetragonous, with a prominent nerve on each side: peduncles 1-headed or rarely irregularly racemose in the axils of the terminal phyll.: calyx triangular, truncate. Mar.

\section{cc. Phyll. vertically flattened.}

D. Veins of phyll. 1, or very rarely 2 .

E. Fl. heads solitary or in pairs or clusters.

F. Length of phyll. 1 in. or less.

G. Stipules persistent as slender spines.

5. armàta, R. Br. (A. unduldta, Willd. A. paradoxa, DC. Mimosa paradoxa, Poir.). Kangaroo ThorN. Fig. 7. Spreading shrub, 6-10 ft. high: branches pubescent: phyll. 1 in. long, semi-ovate, undulate, obtuse, or with a short, oblique point: heads solitary: peduncles axillary, equaling the phyll., borne all along the branches: fls. fragrant. Feb. B.M. 1653. F.E. 9: 401, 431.-Good hedge shrub. Grown also for spring bloom.

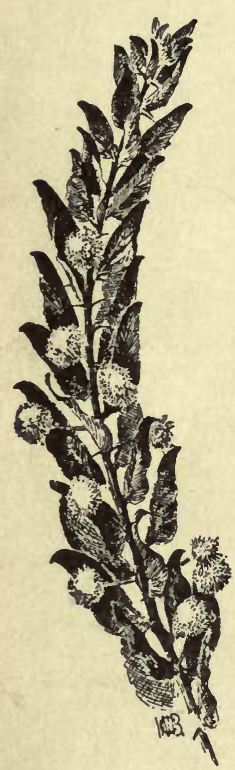

GG. Stipules small, deciduous, or 0 .

6. lineàta, Cunn. Bushy shrub: branches pubescent, terete: phyll. $1 / 2-8 / 4$ in. long, broadly linear; point small, hooked : peduncle solitary, axillary, very slender, equaling or exceeding the phyll., glabrous: fls. rich yellow. Mar. B.M. 3346.

7. acind̀cea, Lindı. (A. Latròbei, Meissn.). Shrub : branches glabrous, angular: phyll. 1/2-3/4in. long, about 3 lines wide, obliquely oblong or somewhat falcate, obtuse, with a small, recurved point: peduncles slender, about equaling the phyll. Mar. F.v.M. Icon. 4:7.

8. obliqua, Cunn. (A. rotundifolia, Hook.). Shrub: branches glabrescent : phyll. $1 / 4$ to nearly $1 / 2$ in. long, obliquely obovate or orbicular; mid-nerve terminating in a minute,recurved point: peduncles very slender, mostly exceeding the phyll. Mar. B.M. 4041.

9. Meissneri, Lehm. Tall shrub: young branches glabrous, acutely angular: phyll. $1 / 2-1$ in. long, $2-4$ lines broad, obovate-oblong or obliquely cuneate, obtuse, or with a small, hooked point: peduncles shorter than the phyll.: fis. yellow. May.

FF. Length of phyll. 11/2-4 in.

10. dodonæifolia, Willd. Tall shrub, very resinous, shining : phyll. 2-4 lines wide, oblong-linear or lanceolate, mostly obtuse, 1-nerved, lateral veins prominent and anastomosing: stipules 0 : peduncles solitary or in pairs, ahout $1 /$ in. long. Mar.
EE. Fl. heads in axillary racemes (rarely reduced to a solitary head).

F. Phyll. 2 in. or less long, broad.

G. Racemes much exceeding the phyll.

11. Iundta,Sieb.(A.olecefolia,Cunn.). Glabrous shrub: phyll. less than 1 in. long, obliquely-lanceolate or elliptical-cuneate, obtuse, or with a minute, oblique or recurved point: fls. yellow: pods linear-elliptical, 3-4 lines broad; seeds placed close to the upper suture. Apr. B.R. 1352. -Without the fruit this may easily be mistaken for $A$. linifolia var. prominens.

12. cultrifórmis, Cunn. (A. cultrdta, Ait.). Tall shrub, glaucous with wax when young : phyll. $1 / 2-3 / 4$ in. long, falcate-ovate or almost triangular, mucronulate, with thickened margins and usually a marginal gland at the angle on the convex side: fl. heads in axillary racemes much exceeding the phyll. : pods flat, about 3 lines broad; seeds placed close to the upper suture. Mar. R.H. 1896, p. 503. J.H. III. $34: 131$.

13. pravissima, F.v.M. Tall shrub or small tree; glabrous: phyll. mostly 3-5 lines long, obliquely falcateobovate, or almost trapezoid, recurved, imperfectly 2 veined; marginal gland much below the angle on the convex side: $\mathrm{fl}$. heads in handsome axillary racemes much exceeding the phyll.: pods flat, about 3 lines broad; sceds placed along the center of the pod.

GG. Racemes not, or only slightly, exceeding the phyll.

14. linifolia, Willd. Tall shrub: phyll. 1-11/2in. long, linear to linear-lanceolate, straight, rather thin; marginal gland small, near the base: fl. heads in slender, axillary racemes about equaling the phyll.: pods linear, very flat, 4-6 lines broad; seeds placed along the center. B.M. 2168. See No. 11.

Var. próminens, Moore (A. próminens, Cunn.). Phyll. broader, linear-lanceolate to oblong-falcate; marginal gland prominent, distant from the base. B.M. 3502 .

15. brachybotrya, Benth. Tall shrub: phyll. $1 / 2-1 \frac{1}{2}$ in., rarely, in luxuriant specimens, 2 in. long, obliquely obovate or oblong, firm, rather broad, obtuse or mucronulate: fl. heads few, in short, axillary racemes, about equaling the phyll., or rarely reduced to 1 head: fls 2050 in a head: pods flat, linear to narrow-elliptical.

Var. argyrophylla, Benth. (A. argyrophýlla, Hook.). Silvery-silky, turning sometimes golden yellow: phyll. mostly 3/4-11/2in. long: fl. heads often solitary. B.M. 4384.

Var. glaucophylla, Benth. Glaucous and more or less pubescent: phyll. mostly $1 / 2-3 / 4$ in. long: fl. heads mostly $2-5$, shortly racemose.

Var. glàbrà, Benth. Quite glabrous: phyll. small and narrow: fl. heads small.

16. myrtifollia, Willd. Shrub, rarely tall: phyll. 1-2 in. long, very variable, firm, usually acute or mucronate and narrowed at base, with thickened, nerve-like mar gins, and a marginal gland below the middle: fl. heads several, in short, axillary racemes about equaling the phyll.: fls. 2-4 in a head, rather large: pods linear, thick, curved, with very thick margins, $2-3$ lines broad. B.M. 302, as Mimosa myrtifolia.

Var. celastrifłlia, Benth. (A. celastrifòlia, Benth.). Phyll. mostly $1 \frac{1}{2}-2$ in. long and often 1 in. broad. B.M. 4306 .

Var. normàlis, Benth. Phyll. mostly 1-2 in. long and about $1 / 2 \mathrm{in}$. broad.

FF. Phyll. 2-6-12 in. long (sometimes only $1 \frac{1}{2} \mathrm{in}$. in A. obtusata).

Var. angustifolia, Benth. Phyll. mostly $2-4$ in. long, 2-4 lines broad

G. The phyll. distinctly penniveined.

17. falcàta, Willd. Tall shrub or small tree; glabrous: branches angular: phyll. 3 to above 6 in. long, lanceolate. falcate, acuminate, much narrowed to the base; marg. nal gland close to the base or 0 : sepals free, narrow: pods rather narrow; funicle encircling the seed.

18. penninérvis, Sieb. Tree; glabrous: branches angular: phyll. 3 to above 6 in. long, oblong to lanceolatefalcate, acuminate, much narrowed to the base; margins nerve-like; gland distant from the base or 0 : pods broad; funicle encircling the seed. Mar. B.M. 2754. 
Var. falciformis, Benth. (A. falciformis, DC.). Phyll. mostly larger and more falcate: young shoots and inflorescence minutely hoary or golden-pubescent: pod nearly $3 / 4$ in. broad.

19. salígna, Wendl. Shrub 6-10 ft.: branchlets angular: phyll. $4-6$ in. long, falcate-lanceolate or oblanceolate, narrowed to the base, rather obtuse, glaucous and smooth, the lateral veins but little conspicuous: racemes short; peduncles short: $\mathrm{fl}$. heads few, large. Mar.

20. cyanophýlla, Lindl. Blue-Leaved Wattle. Tall shrub $18 \mathrm{ft}$.; stoloniferous: branches drooping: lower phyll. about 12 in. long; upper 6 in. or less and narrower, linear-oblong to lanceolate-falcate, much narrowed toward the base, glabrous and often glaucous: peduncles $1 / 4-1 / 2$ in. long: fl. heads 3-5, large, golden yellow. Mar. Gn. 52 , p. 99.

21. obtusàta, Sieb. Tall, glabrous shrub: phyll. 11/2-3 in. long, oblong-linear, or almost spatulate, usually almost straight, rather obtuse, point not curved, thick, rigid, with thickened, nerve-like margins; marginal gland 1 , distant from the base, not prominent: racemes about $3 / 4$ in. long, with densely packed heads; fls. 30 or more. Mar.

GG. The phyll. thick, usually with inconspicuous lateral veins (conspicuous in A. pycnantha).

22. neriifdlia, Cunn. (A. retinddes, Schlecht. A. retinddes, var. floribúnda, Hort.). Fig. 8. Tall, handsome shrub or small tree: branchlets slender: phyll. 3-5 in. long, 2-5 lines wide, linear-lanceolate, falcate, much narrowed to the base: racemes 1-21/2in. long; peduncles about 2 lines long : fls. bright yellow. Mar. F.v.M.Icon. 5:9. R.H. 1896, p. 505. A.F. 13:880.-Useful as a street tree in Calif.

23. pycnántha, Benth. GoLden Watrue. Small tree: phyll, 3-6 in. long, lanceolate to oblanceolate, or, on vigorous shoots, even obovate-falcate, obtuse or acutish, distinctly penniveined, with a conspicuous marginal gland near the base: fl. heads in axillary racemes, on short peduncles, large, fragrant: funicle scarcely folded. Feb. R.H. 1896, p. 504. - Very variable in shape and size of phyll.

24. salicina, Lindl. Small tree : branches drooping: foliage pale: phyll. $2-5$ in. long, $21 / 2-6$ lines wide, oblong-linear or lanceolate, narrowed at base, thick, rigid, with a curved point; midrib and marginal veins scarcely prominent: racemes short, often reduced to 2 or 3 heads, or even only 1: peduncles slender: fls. about 20 in the head: pods straight; funicle scarlet, folded under the seed.

25. rostellifera, Benth. Tall shrub, perhaps only a variety of $A$. salicina, but, according to Bentham, different in aspect and the nerve of the phyll. much more prominent: phyll. linear-lanceolate, with an oblique or recurved callous point.

26. suavèolens, Willd. Shrub 3-6 ft. high, glabrous: branches acutely angled: phyll. $3-6$ in. long, 2-4 lines wide, narrowly lanceolate to linear; margins thickened: racemes about $3 / 4 \mathrm{in}$. long before opening, inclosed in large, imbricate bracts: fls. 6-10 in a head. Apr.

DD. Veins of phyll. several (rarely only 2), longitudinal.

27. Oswaldi, F. v. M. Tall shrub: phyll. $1 \frac{1}{2}-2$ in. long, falcate-oblong to linear, rigid, mostly mucronate, finely striate, twisted, mostly 3 or 4 lines broad. F. v. M. Icon. $6: 10$.

28. péndula, Cunn. Weeping Mrall. Handsome small tree: branches pendulous: foliage pale or ash-colored, with minute pubescence: phyll. $1 \frac{1}{2}-2 \frac{1}{2}$ in. long, narrowly lanceolate or almost linear-falcate, ending in a curved cusp; nerves few, indistinct: racemes very short, sometimes reduced to a solitary head; peduncles 5-6 lines long. F. v. M. Icon. $6: 8$.

29. harpophłlla, F.v.M. Tree: branchlets slightly angular: phyll. 6-8 in. long, lanceolate, very falcate, narrowed at the end but obtuse, much narrowed at the base, coriaceous, pale or glaucous; nerves several, fine; reticulate veins few and indistinct: peduncles slender, mostly clustered in the axils: funicle short. F. v. M. Icon. $6: 9$.
30. implexa, Benth. Glabrous tree: branchlets nearly terete: phyll. $3-6$ in. long, $2 \frac{1}{2}-5$ lines wide, lanceolate and very falcate-acuminate, with a short, hooked point, rather thin; reticulate veins numerous and distinct: peduncles few, in a very short raceme, long and slender: fls. pale yellow or dirty white: pods rather narrow, biconvex, curved or twisted, slightly constricted between the seeds; funicle yellow, folded at the end of the seed but not encircling it. F. r. M. Icon. 8:2.

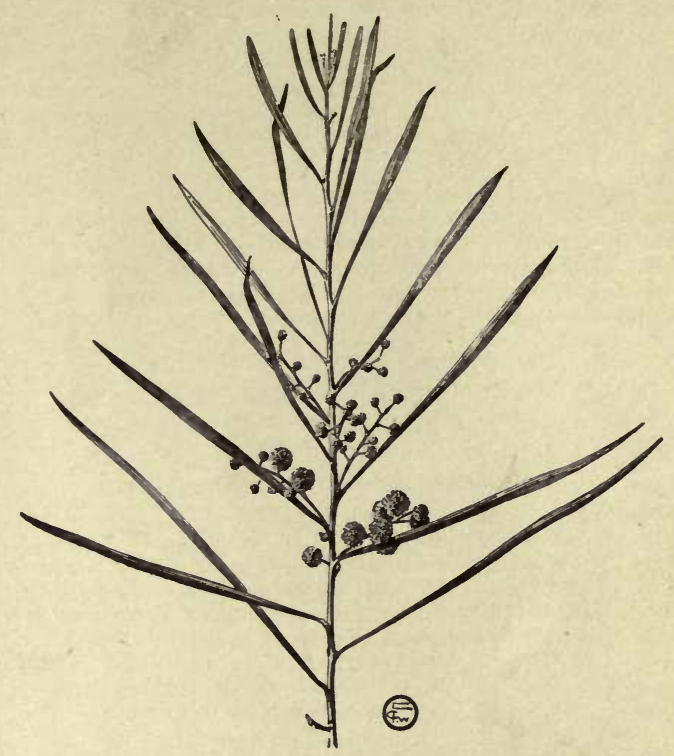

8. Acacia neri:folia, narrow-leaved form.

31. melanóxylon,R. Br. Australian Blackwood. Tall tree, usually pyramidal, glabrous: branchlets slightly angular: phyll. mostly 3 or 4 in. long, $1 / 2-1$ in. wide, narrowly lanceolate to falcate-oblong, or even falcate-oblanceolate, much narrowed to the base, very obtuse, thick and stiff; reticulate veins numerous: racemes oc casionally reduced to 1 or 2 heads; peduncles short, stout : fls. pale yellow or dirty white ; petals connate above the middle: pods flat, 3-4 lines broad, of ten curved in a circle; funicle bright red, doubly encircling the seed. Mar. B.M. 1659

32. Cỳclops, Cunn. Shrub 6-10 ft. : branchlets angular: phyll, 11/2-3 in. long, nearly straight, narrow-oblong, obtuse, rigid: racemes short, occasionally reduced to 1 or 2 heads : fls. yellow; petals smooth, free : pods flat, 4-6 lines wide, curved or twisted; funicle richly colored, doubly encircling the seed. Apr. F. v. M. Icon. 8: 3 .

BB. Fls. in cylindrical, or rarely oblong, spikes.

C. Phyll. narrow, pungent-pointed, $1 / 2-1$ in. long.

33. oxycèdrus, Sieb. Tall, spreading shrub: phyll. $1 / 2-3 / 4$, or rarely 1 in. long, narrowly lanceolate, acuminate, scattered, very rigid, striate, with 3 or 4 prominent nerves on each side; stipules small, often spinescent: spikes often above 1 in. long. B.M. 2928.

34. verticillata, Willd. (Mimosa verticillata, L'Her.). Bushy, spreading shrub: phyll. 1/2-3/4in. long, linearsubulate to lanceolate or oblong, mostly whorled, rigid, with 1 prominent central nerve; stipules minute: spikes $1 / 2-1$ in. long, dense ; fls. deep yellow. Apr. B. M. 110.

35. Riceana, Hensl. Tall shrub or small tree, handsome,dark greén: phyll. 1/2-3/4in. long, linear or subulate, sometimes very narrow and 1-11/2in. long, scattered or whorled, 1-nerved; stipules minute: spikes interrupted, slender, often above 1 in. long; fls. pale yellow. Apr. N. $1: 7$. 
cc. Phyll. broader, less rigid, not pungent-pointed, $11 / 2-6$ in. long.

36. longifòlia, Willd. Sydney Golden Wattle. Fig. 9. Tall, handsome shrub: phyll. 4-6 in. long, oblonglanceolate, acuminate; longitudinal veins several, prominent: spikes 1 in. long, loose, axillary, mostly in divergent pairs; fls. golden yellow. Mar. B.R. 362. B.M. 2166. R.H. 1896, p. 504. - Useful as a street tree in Calif.

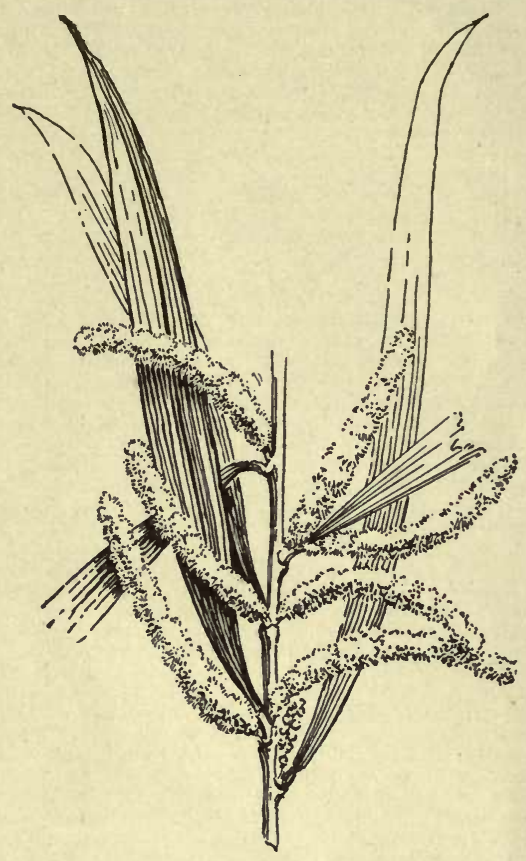

9. Phyllodia and racemes of Acacia longifolia.

Var. Sophòræ, F.v. M. (A. Sophòra, R. Br.). Phyll. 2-3 in. long, 5-8 lines wide, broadly oblong, obtuse.

37. lineàris, Sims. (A. longissima, Wendl.). Shrub: phyll. 4-6 in. long, linear, with 1 prominent longitudina nerve: spikes 1-2 in. long, loose and interrupted, slender: fis. pale yellow or dirty white. B.M. 2156. B.R. 680.Valued as a street tree in Calif.

38. aneùra, F. v. M. MUlGa. Shrubby; often hoary, with minute pubescence : phyll. $1 \frac{1}{2}-3$ in. long, $1-1 \frac{1}{2}$ lines wide, narrowly linear, without prominent nerves but minutely striate, rigid: spikes short and dense on short peduncles: pods broad, flat, short. F. v. M. Icon. 10:8.

39. glaucéscens, Willd. (A.cineráscens, Sieb.). Glaucous tree $50 \mathrm{ft}$. or more high: phyll. 4-6 in. long, 5-12 lines broad at the middle, linear-lanceolate, narrowed at both enas, falcate, striate, and with 3-5 more prominent nerves, all free from the lower margin: spikes in pairs, 1-2 in. long: pods narrow-linear, biconvex, irregularly twisted. Mar. B.M. 3174 .

40. holosericea, Cunn. (A. leucophýlla, Lindl.). Shrub or small tree 10-20 ft., white, silky : phyll. 4-6 in. long, 1-3 in broad, oblong-lanceolate, with 3 or 4 prominent nerves confluent with the lower margin at the base: spikes mostly in pairs, sessile, about 2 in. long. Mar.

$$
\begin{aligned}
& \text { AA. Lvs. all bipinnate. } \\
& \text { B. Fls. in globular heads. }
\end{aligned}
$$

C. Heads in terminăl-axillary panicles or racemes: stipules small or 0.

D. Trees: pinnoe in 8-15 pairs, $f$. heads panicled.

41. decúrrens, Willd. GREeN WATtLE. Branchlets with very prominent angles decurrent from the petioles; glabrous, or the young shoots slightly tomentose-pubescent: leaflets 1-2 lines long, narrow, rather distant: fls. whitish yellow: pods mostly less than 4 lines wide, flat, more or less contracted between the seeds. Mar.May.

Var. normàlis, Benth. Leaflets $3-4$ lines long.

42. mollíssima, Willd. (A. decúrrens var. móllis, Lindl.). BLACK WA'rTLE. Branchlets with decurrent angles only slightly prorninent: foliage and branchlets pubescent, the young shoots of a yellowish or golden tinge; leaflets 2-3 lines long, narrow, crowded: fls. fragrant: pods mostly less than 4 lines wide, flat, more or less contracted between the seeds. Dec.-Mar. B.R. 371.-The names of this and of the next species are often interchanged in gardens and even in herbaria.

43. dealbàta, Link. SiLver Wattue. Branchlets with decurrent angles only slightly prominent : foliage and branchlets very glaucous or hoary, with a fine pubescence, the young shoots whitish; leaflets $2-3$ lines long, narrow, crowded : pods mostly more than 4 lines wide. flat, hardly constricted between the seeds. Mar. A.F. 13: 880. R.H. 1896, p. 502 .

DD. Shrubs or small trees: pinnce mostly in 2-8 pairs: $f$. heads racemed.

44. pubéscens, R. Br. Hairy Wattrle. Shrub 6-10 ft.: branches and petioles hirsute: pinnæ inostly 3-8 pairs; leaflets 6-20 pairs, 1-2 lines long, crowded, linear, glabrous: racemes slender, longer than the lvs. Mar. B.M. ]263. F.R. 1: 733 .

45. Baileyd̀na, F.v.M. Small,handsome tree: branches and foliage glabrous and glaucous: pinnæ 2-3 pairs leaflets about 13 pairs, 11/2-21/2 lines long, crowded, linear: racemes 3-4 in. long. Jan. F. v. M. Icon. 12:5. G.C. III. 15: 37 .

cc. Heads on simple, solitary, or clustered peduncles: stipules often spinescent.

46. pulchélla, R. Br. Elegant shrub: branches slender, glabrous or hirsute, usually armed with subulate axillary spines : pinnæ 1 pair ; leaflets 4-7 pairs, 1-2 lines long, obtuse: fl. heads solitary; fls. yellow. Apr.

Var. grándis, Hort. (A. grándis, Henfr.). Shrub $6 \mathrm{ft}$, glabrous: leaflets 8-10 pairs, longer: fls. yellow. Feb.May. J.H. III. 35: 369 (1897).

Var. hispidíssima, Hort. (A. hispidissima, DC.). Branches very hirsute, with long, spreading hairs leaflets narrow: fls. white. B.M. 4588.

47. Farnesiàna,Willd.(A. leptophýlla, DC.). Popinac. Opopanax. Cassie. Huisache. Much branching shrub, 6-10 ft.: stipules straight, slender, sometimes minute spines; pinnæ 5-8 pairs; leaflets mostly 10-25 pairs, $1-2$ lines long, narrow, linear, glabrous: peduncles 2 or 3 in the older axils: fil. heads large, globular, deep yellow, very fragrant: pods almost terete, indehiscent, at length turgid and pulpy. Feb.-Mar. Tex., Mex., Asia, Afr. and Austral. Grown in S. France for perfumery.

48. Cavènia, Bertero. Espino. Cavan. Height $20 \mathrm{ft}$.: spines stout: leaflets scabrous, scabious-pubescent. Otherwise near to A. Farnesiana, of which it is sometimes considered a mere variety. Chile. $-A$ good hedge plant.

49. Arábica, Willd. GuM Arabic Tree. Fig. 10. Small tree, with spiny stipules : pinnæ 3-6 pairs, each with 40 or less very narrow leaflets : fls. white, in globular, pedunculate heads, which are usually in 3's. Arab. and Eu.

50. filicina, Willd. Unarmed shrub : pinnæ 2-15 pairs; leaflets $20-50$ or more pairs (rarely 10-15), very small: fl. heads globular: pods linear, straight, flat, not pulpy. Tex. and Mex.

$$
\text { вв. F'ls. in cylindrical spikes. }
$$

51. Gréggii, Gray. Small tree 10-20 ft., pubescent, often with scattered, short, stout, hooked prickles : pinnæ 2-4 pairs, $1 / 2-1$ in. long; leaflets $3-5$ pairs, 2 or 3 lines long, oblong or oblong-obovate, thick, and with 2 or 3 straight nerves: peduncles $1 / 2-1$ in. long. Apr. Tex., S. Calif. and Mex.

52. Cátechu, Willd. Tree: pinnæ 8-10 pairs, each bearing 100 or less linear, pubescent leaflets : fis. yellow; spikes solitary or in 2's or 3's. E. Ind. - Yields Catechu, a valuable tannin. 
53. Drúmmondii, Benth. Bush or small tree: pinnæ 2-4 pairs, each with 4-10 linear, very obtuse glabrous. leaflets: fls. pale lemon-yellow, in dense, solitary, drooping spikes $1-1 \frac{1}{2}$ in. long. Austral. B.M. 5191.-Handsome, and popular for spring bloom, as at Easter.

In the following supplementary list, the heights given are those attained by the plants under glass in N. Europe; in the open air in the southwest U.S. they often grow much taller. and sometimes flower 2 months earlier. Except when otherwise stated, the flowers are yellow. Those marked (*) are considered most desirable. Those marked "stove" need hothouse treatment; the others ean be grown in a coolhouse, or in the open in California. A, abietina, Willd =linifolia - A acan thocárpa Willd $=$ irimosa acanthocarpa $-A$ A capulcénsis. Kunth.=Lysiloma Acapulcensis. - A aciculàris, "Needle-leaved Acacia," $4 \mathrm{ft}$. - A. aff inis, Sweet. $=$ dealbata. $-A$. alàta, R.Br., 6 ft. May. B.R. 396. - A amoena, Wendl., $3 \mathrm{ft}$. May. Near to heterophylla. $-A$. angulàta, Desv.=discolor. $-A$. angustifòlia Lodd.=longifolia, var. floribunda. $-A$. argyrophýlla, Hook. brachybotrya, var. argyrophylla. $-A$. áspera, Lindl. (A. Aus feldii, Regel. A. densifolia, Benth.). $4 \mathrm{ft}$. May.-A. A usféldii, Regel.=aspera. $-A$. Bancroftiàna, Bert. $=$ Cæsalpinia bijuga.A. Bartheriana, Hort. = Berteriana? $-A$. Berlandieri, Benth. Fls.? Mexico. $-A$. Berteriàna, Balb. $=$ Pithecolobium fragrans. brachyacántha, Humb. \& Bonpl.=Mimosa acanthocarpa.-A brevifolia, Lodd. =lunata. $-A$. brévipes, Cunn. =melanoxylon.A. Burmanniana, DC. Fls.? $6 \mathrm{ft}$. Ceylon. Stove. $-A$.buxifò lia, Cunn. $4 \mathrm{ft}$. A pr. Hook. Icon. 164. - A. caesia, Wight \& Arn. (A. Intsia, Willd.). $20 \mathrm{ft}$. E. Indies. Stove. $-A$. celastrifolia, Benth.=myrtifolia, var. celastrifolia.-A. centrophýlla, DC. 20 fì.; white. Jamaica. Stove. - A.Ceratomia, Willd.=Mimosa Ceratonia. $-A$. chrysóstachys, Hort. $=$ Piptadenia chrysostachys. $-A$. ciliàta, R. Br. =strigosa. -A. cineráscens; Sieb.=glaucescens. $A$. cochleàris, Wendl. $4 \mathrm{ft}$. Apr. to May. $-A$. concinna, DC. 2 ft.; fls. white. E. Indies. Stove. $-A$. Concordiàna, Loud.=Pithe colobium umbellatum. $-A$. conférta, Cunn. A pr. $-A$. cordàta, a trade name, probably belongs to some other species. $-A$. coriacea, DC. $5 \mathrm{ft}$. May. $-A$. cornigera, Willd.=spadicigera. $-A$. coronillaefólia, Desf. $10 \mathrm{ft}$. N. Africa. Stove-A. crassicárpa, coronillaefolia, Desf. $10 \mathrm{ft}$. N. Arrica. Stove.-A. crassicarpa, Cunn. $6 \mathrm{ft}$. May. $-A$. cultrata, Hort. $=$ eultriformis. $-A$. cune-
àta, Benth. Apr. $-A$. cuspidàta, Cunn $=$ diffusa, var. cuspidata. àta, Benth. Apr.-A. cuspidàta, Cunn. =diffusa, var, cuspidata.
$-A$. cycnòrum, Hook.=obscura. $-A$. daviesioefolia, Cunn. $6 \mathrm{ft}$ June.-A decipiens, var. proemórsa, Hort.* 3 ft. May. B.M. 3244 $-A$.decurrens, var. mólis, Benth. $=$ mollissima. $-A$. densifolia Benth. $=$ aspera. $-A$. dentifera, Benth. Apr. B.M. 4032. $-A$. de péndens, Cunn. $=$ longifolia, var.mucronata. - A détinens, Burch. $3 \mathrm{ft}$. May. S. Afr. $-A$. díptera, Willd.=Prosopis juliflora. $-A$. diptera Lindl Shrub: fls ?-A, diptera var erióptera, Gra ham. Sept. B.M. 3939. - A discolor, Willd. (A. angulata, Desv.) $10 \mathrm{ft}$. May. $-A$. divaricàta, Willd.=Lysiloma Schiedeana. $-A$. Donkelaarii is a trade name. $=$ Mimosa? $-A$. doratóxylon, ${ }^{*}$. Currawang," a beautiful small tree : fls. golden yellow. -A.dumòsa, Wight \& Arn. =latronum. - A.ebúrnea, Willd. $5 \mathrm{ft}$. E.Ind. Stove. -A.echínula, DC.=juniperina.-A. édulis, Humb. \& Bonpl.= Farnesiana - A elàta, -* "Pepper-tree Wattle"-A elongàta. Sieb.* $6 \mathrm{ft}$. May. B.M. 3337. Especially suitable for damp sandy land. $-A$. emarginàta, Wendl. $=$ stricta. $-A$. erioclàda, Benth. June-A. Esterhàzia, Mackay. $4 \mathrm{ft}$. May. $-A$. falciformis, DC.=penninervis, var. falciformis. $-A$. ferruginea, DC. $\mathrm{E}$ Indies. Fls.? Stove. $-A$. flexicaùlis, Benth.=Pithecolobinm flexicaule, Coulter. $-A$. floribuinda, Willd.=longifolia, var, floribunda. $-A$. Aoribunda, Hort. = neriifolia. $-A$. formdsa, Kunth. $=$ Calliandra formosa. $-A$. frondòs $a$. Willd =Leucæna glauca.A. fruticosa, Mart.=Piptadenia latifolia. $-A$. genistaefolia, Link = diffusa. $-A$. giráffoe. Willd "Camel-thorn" $40 \mathrm{ft}$. S. Afr. Fls. ? Stove. $-A$. glaùca, Monch. $=$ Lencæna glauea. $-A$ glaùca, Hort.=A. glancescens. $-A$. grándis, Henfr.=pulchella var. grandis. $-A$. gràta, Willd = Piptadenia macrocarpa. A. gravèolens, Cunn.=verniciflua. $-A$. Guayaquilénsis, Desf. =Mimosa Guayaquilensis. $-A$. Guianénsis, Willd.=Stryph nodendron Guianense. $-A$. gummifera, Willd. $30 \mathrm{ft}$. Guinea. Fls. ? - A. Hamatóxylon, Willd. $20 \mathrm{ft}$. Fls. yellow or white. S. Afr. Stove-A. hastuldta, Sm, $4 \mathrm{ft}$. May. B.M. 3341-A heteracántha Burch $15 \mathrm{ft}$ : fls. S S Afr $-A$. hetero phýlla, Willd. $5 \mathrm{ft}$. May. Mascarene Isls. $-A$. híspida. Hort. =Robinia hispida. $-A$. hispidissima, DC. $=\mathrm{A}$. pulchella, var. hispidissima. - A. homalophýlla, " "Yarran."-A. homomálla, Wendl.=glaucescens. $-A$. Huegélii, Benth.* Pale yellow. Feb. A. humifüsa, Cunn. Anstral-A. hỳbrida, Lodd.=armata.$A$. intermedia, Cunn. =longifolia, var. floribunda. $-A$. intertéxta, Sieb.=longifolia. $-A$. Intsia, Willd = cresia. $-A$. Julibrissin, Willd =Albizzia Julibrissin.-A juniperina, Willd* (A. echinula, DC.) $6 \mathrm{ft}$ : near to verticillata $-A$. Kalkdra, G. Don = Albizzia Julibrissin. $-A$ Koa, Gray. Fls ? Hawaiian Isls. Stove. $-A$. Lambertiàna, D. Don.=Calliandra Lambertiana.A. lanigera, Cunn. $6 \mathrm{ft}$. Apr. B.M. 2922.-A. latisíliqua, Willd.= Lysiloma latisiliqua. $-A$. Latròbei, Meissn. =acinacea. $-A$. la trònum, Willd. (A. dumosa, Wight \& Arn.). $20 \mathrm{ft}$.; fls. ? E. In dies. Stove.-A. laurifôlia, Willd. $4 \mathrm{ft}$. May. Pacific Islands. Stove.-A. Lébbeck, Willd.=Albizzia Lebbek. $-A$. leiophýlla, Benth=saligna $-A$, lentiscifôlia, Desf, $20 \mathrm{ft}$. Fis, I Mexico. Stove-A Seuro - Sentiscifolia, Dess. $20 \mathrm{ft}$. Fls. Mexico. Stove. -A. lepròsa, Sieb.* May. B.R. 1441. "Graceful, linear
leaves, and habit of $a$ willow."-A lepròsa,var. tenuifólia, Benth. leaves, and habit of a willow." $-A$. lepròsa, var tenuifolia, Benth. Stove. $-A$. leptocárpa, Cunn. $6 \mathrm{ft}$. Apr. $-A$. leptoneùra, Benth
$6 \mathrm{ft}$. Apr. B.M. $4350 .-A$. leptophýlla, DC. = Farnesiana. $-A$. leucophliea, Willd. $12 \mathrm{ft}$.; pale yellow. Tropical Asia. Stove.A. leucophýlla, Colvill =holosericea $-A$, ligulàta Cunn $=\mathrm{sali}$ cina $-A$ longifòlia, var, floribúnda, $\mathrm{F}, \mathrm{v}, \mathrm{M}$ (A floribunda Willd. A. intermedia, Cunn.). $6 \mathrm{ft}$. Apr. B.M. 3203.-A. longi fòlia, var. mucronàta, F. v. M. (A. dependens, Cunn. A. mucronata, F.v. M.). Mar. B.M. 2747.-A. longissima, Wendl =linearis. $-A$. lophätha, Willd=Albizzia lophantha. $-A$. lophántha, var. gigantèa, Hort.=Albizzia lophantha, var. gigan. tea. $-A$. lùcida, Baill=Albizzia lucida.-A. Mángium Willd. $10 \mathrm{ft}$. Molucea Isls. Stove.-A. microphylla, Willd.Piptadenia peregrina $-A$ mollis, Wall = Albizzia Julibrissin $\boldsymbol{A}$. Nèmu, Willd =Albizzia Julibrissin, $-\boldsymbol{A}$, neurocárpa, Cunn $=$ holosericea. $-A$. nigricans, R. Br. $6 \mathrm{ft}$. Apr. B.M. 2188. - A nudiftòra, Willd. (A.Rohriana, DC.). $30 \mathrm{ft}$.; white. W. Indies. Stove. - A obscùra, A.DC. (A. eyenorum, Hook.). $21 / 2$ ft. B.M. 4653. - A. odoratísima, Willd = Albizzia odoratissima. $-A$. oleaefolia, Cunn. =lunata.-A. oligophýlla, Hoffmgg. $4 \mathrm{ft}$. Habitat? Stove.-A. ornata is a namein the trade, probably of some wellknown species. $-A$. paradòxa, DC. =armata. $-A$. pentadenia Lindl. $10 \mathrm{ft}$. May. B.R. 1521. - A pinifólia, Benth.= juncifolia. -A. pinnàta, Link.=tamarindifolia. $-A$. platyphýlla, Sweet $10 \mathrm{ft}$. June.-A. plumòsa, Lowe. $20 \mathrm{ft}$. Brazil. B.M. 3366. A stove climber.-A, podalyriafolia, Cunn.* Tall shrub. G.C. III. 15, p.39. - A polybòtrya, Benth.* A beautiful pinnate-leaved species. $-A$. Portoricénsis, Willd. =Calliandra Portoricensis.A.prismática, Hoffmgg. $6 \mathrm{ft}$. Habitat? Stove.-A próminens, Cunn =linifolia, var prominens $-A$. Pseudacácia. Hort =Rohinia Pseudacacia.-A pulchérrima Willd = Stryphnodendron floribundum. - A. quadrangulàris, Link $=$ Calliandra tetragona - A. retinòdes, Schlecht.=neriifolia. -4 . ripària, $\mathrm{HBK}$. (A. sarmentosa, Griseb.). $10 \mathrm{ft}$. W. Indies. A stove climber.-A. Rohriàna, DC. $=$ nudiflora. $-A$. ròsea, Hort. = Robinia hispida.A. ruscifolia, Cunn.=verticillata, var. latifolia.-A. sarmentòsa, Griseb.=riparia. $-\boldsymbol{A}$. scándens, Willd. = Entada scandens. $-A$ semicordata, Roxb. $40 \mathrm{ft}$.; fls. ? E. Indies. Stove.-A. Sénegal, Willd. $30 \mathrm{ft}$; ; fls. white. Tropical W. Afr. Stove.-A. sericàta, Cunn. Apr-A. Símsii, Cunn. Apr-A. Sophdrae, R. Br= longifolia, var. Sophoræ.-A. spadićgera, Ch. \& Schl. (A. cornigera, Willd.). $15 \mathrm{ft}$. pale yellow. Jamaica. B. M. 7395. Stove.-A. speciosa, Willd.=Albizzia Lebbek. $-A$. spectábilis, Cunn.* Apr. B.R. 1843: 46. Remarkably beautiful.-A. Spini, Balb. $15 \mathrm{ft}$; red and yellow. Guadeloupe Isl. Stove.-A. squamáta, Lindl. Apr. Hook. Icon. Plant. 367. - A stenophýlla, Cunn. Mar.-A. stipulàta. DC.=Albizzia stipulata. $-A$. stricta, Willd. (A. emarginata, Wendl.), 2 ft. Mar. B.M. 1121.-A. strigdsa Link. (A. ciliata, R. Br.). $4 \mathrm{ft}-\mathrm{A}$. strombulifera, Willd.= Prosopis strombulifera. - A. subulàta, Bonpl. $4 \mathrm{ft}$. May. $-A$ sulcàta, R. Br. 2 ft. July. B.R. 928. - A. Süma, Gurz. $10 \mathrm{ft}$. fls. ? E. Indies. Stove. $-A$. tamarindifolia, Willd. (A. pinnata) $4 \mathrm{ft}$.; white. S. Amer. Stove. $-A$. taxifolia, Lodd.=Riceana.$A$. tomentòsa, Willd. $20 \mathrm{ft}$.; fls. ? E. Indies. Stove. $-A$. trichòdes, Willd =Leucæna trichodes. $-A$. trinervàta, Sieb. $6 \mathrm{ft}$. Apr.-A. tristis, Graham=armata.-A umbellàta. Cunn. Apr. $-A$. uncinàta, Lodd $=$ undulrefolia $-A$, undulcefòlin (A, uncinata, Lodd). 4 ft. May. B.M. 3394. - A. urophýlla, Benth. Palo

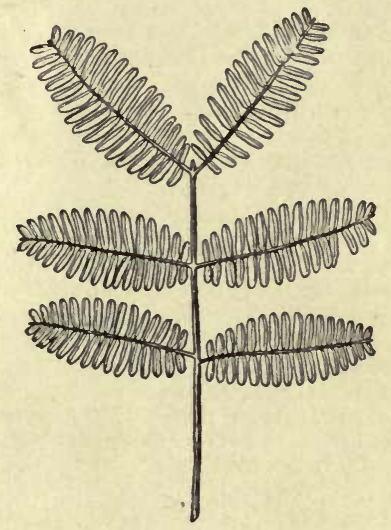

10. Acacia Arabica.

yellow. Apr. B.M.4573.-A. vdga, Willd. $40 \mathrm{ft}$.: white. Brazil. Stove. $-A$. venùsta. Willd $=$ Calliandra Portoricensis. $-A$. vèra Willd. $=$ Arabica. $-A$. verniciflua, Cunn. (A.graveolens, Cunn. A.virgata,Lodd.) 6 ft. Apr. B.M. 3266.3279.-A verticillàta, var. angústa, Hort. $10 \mathrm{ft}$. Apr.-A verticillàta, var. latifòlia, Benth. (A. ruscifolia, Conn. A moesta, Lindl.), $10 \mathrm{ft}$. Apr. B.M 3195. B.R. 1846: 67-A. vestita, Ker-Gawl* 6 ft. June. B.R. 698. $-A$ viminàlis, Ait. A pr- - A vviréscens, DC. $20 \mathrm{ft}$. S. Amer. Stove.$A$. virgàta, Lodd.=verniciflua. $-A$. viridiràmis, Burch $=$ Xero cladia Zeyheri. - A. viscidula, Cunn. 6 ft. Feb. Gt. 1109. Apr.-A. Wallichiána. DC.=Catechu. ${ }^{\text {J }}$ J. BURTT DAVY. 
ACACIA, FALSE. See Robinia Pseudacacia.

ACACIA, ROSE. See Robinia hispida.

ACENA (from akaina, thorn). Rosacea. Dwarf, hardy perennial sub-shrubs with inconspicuous green flowers, cultivated in rockeries for their showy crimson spines, which are borne on the calyx; 1-12 in. As groundwork for dwarf, spring-flowering bulbs, as trilliums, they are unsurpassed. Useful in protecting native orchids and bog plants. Prop. by cuttings, creeping rootlets, divisions and seeds. Monogr. by T.Citerne, in Revue des Sciences Naturelles de l'Ouest, 1871, Nos. 1, 2, 3.

microphýlla, Hook. f. Lvs. evergreen, pale, pinnate, serrate : spines attractive all summer and autumn. N. Zeal. - Grows well in either wet or dry soils.

ovalifolia, Ruiz \& Pav. Lvs. a little larger than the latter; leaflets oblong, subcuneate. Chile. Gn. 52, p. 46.

A. argéntea, Ruiz \& Pav. Lvs. silvery. Chilean Andes. $-A$. adscéndens, Vahl. Austral.-A. cuneàta, Hook. \& Arn., is a good species according to some, but may $=$ A. sericea. Magellan. $-A$. millefòlia, Nicholson. Fruit not in globular heads. Hab. ?A. myriophýlla, Lindl. Fern-like. Chile. Gn. 37, p. 177.-A. Nova-Zealándiae, T. Kirk. Good species according to some, but may = A. microphylla. $-A$. ovina, A. Cunn. Austra]. $-A$. pinnatifida, Ruiz \& Pav. Chile.-A. pulchélla, Nicholson. Lvs. bronzy. - A. Sanguisórba, Vahl. N.Zeal.-A. sarmentdsa, Carmich.=A. Sanguisorbæ.-A. serícea, Jacq. f. Mex.-A. spléndens, Hook. \& Arn. Chile.

\section{J. B. KELLER.}

ACALYेHA (a name given by Hippocrates to a nettle). Euphorbidcea. Tender foliage plants much used for greenhouse ornament, and especially for bedding. out. For the latter purpose it is desirable to have strong, well hardened plants in 5-in. pots, which should be set out the last week in May, and grown in a rich soil without check. Prop. by cuttings, chiefly in three ways: (1) in fall from outdoor bedded plants ; (2) from plants lifted in fall, cut back, and kept for spring stock ; (3) from stock plants in pots reserved from the previous season. The well ripened wood of these last is a great advantage, and gives cuttings that may

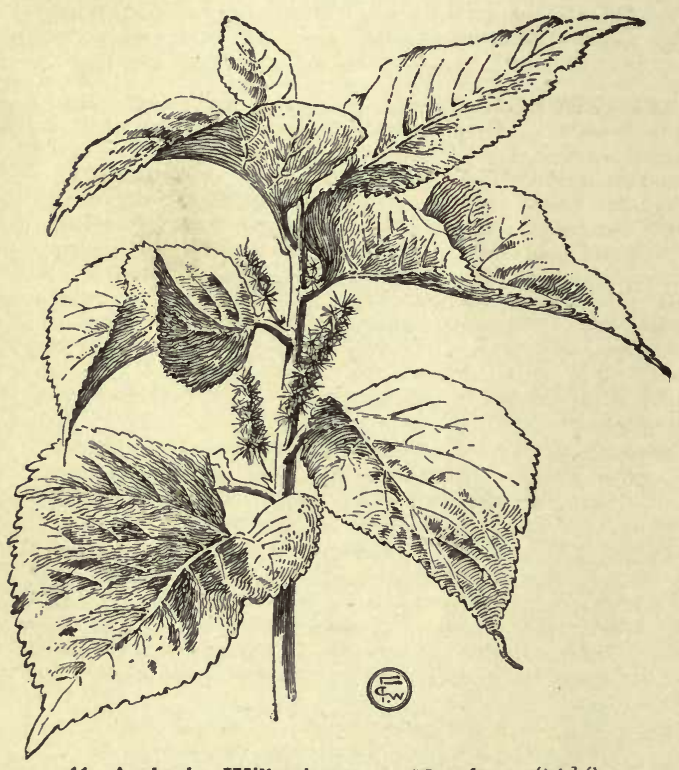

11. Acalypha Wilkesiana, var. Macafeana $(\times 1 / 3)$.

be taken with a heel. A mature stem will furnish several beside the top one. This is the best method for general purposes. Cuttings are taken below joints, and require mild bottom heat. For greenhouse ornament in fall and winter, excellent specimens may be secured from cuttings made in summer from such stock plants.

Cult. by ROBERT SHORE.
Wilkesiàna, Muill. Arg. (A. trícolor, Hort. ex Seem.). Lvs. ovate-acuminate, bronzy green, variously mottled with red: fls. inconspicuous. S. Sea Islands. Var. Macafeàna, Hort. Fig. 11. Lvs, red, marked with crimson and bronze. Perhaps the commonest variety. R.H. 1882: 288. Var. marginata, Hort. Lvs. with a crimson margin. F.M. 1875:156. Gn. 7, p. 521. Var. musaica, Hort. Lvs green, with orange and red markings. Var. obovata, Hort. Lvs. obovate, green, edged white when young, changing to bronzy green with rosy pink margins. Var. triúmphans, Hort. (A.triúmphans, Lind. \& Rod.). Lvs. large, spotted with crimson, green, and brown. I.H. 35 : 55 (1888).

Godseffiàna, Mast. Lvs. ovate or ovate-lanceolate, green, with ereamy margin: fls. unknown. G.C. III. 28:242. Gng. 6:278. F.E. 10:554. A.F. 13: 1286.

híspida, Burm. f. (A. Sánderi, N. E. Brown). Fig. 12. Cult. chiefly for its long red, amarantus-like spikes of flowers : lvs. green. E. Ind. Burm. Fl. Ind., p. 303, t. 61 , f. 1. A.F. $13: 1285$. A.G. $19: 453,827$. F.E. $10: 554$. G.C. III. 23:248. Gt. 47:276. Gn. 54:1180. Gng. 6:279. -The leading novelty of 1899 . Called by various names, as Chenille Plant, Philippine Medusa, and others.

A. coloràta, Spreng.=A. integrifolia. $-A$. Commersoniàna Baill = A integrifolia. A. macrophýlla. Hort not HBK =A Wilkesiana, var. macrophylla. $-A$. marginàta, Hort., not Spreng. $=$ A. Wilkesiana, var. marginata. - A.obovata, Hort., not Benth.=A. Wilkesiana, var. obovata. $-A$. integrifolia, Willd. 4-7 ft.: lvs. thick, glabrous, oblong, green above, colored below. Madagascar. Other trade names are A. Hamiltoniàna (Int. 1893), A. Miltoniàna, and A. tórta.

W. M.

ACÁMPE (named from the brittle nature of the flowers). Orchiddcea. Greenhouse epiphyte.

A. longifolia, Lindl. (Vánda longifolia, Lindl.). E. Ind. A species of little decorative value, said to be sold by its synonym.

ACANTHEPHIPPIUM (meaning unknown). Often spelled Acanthophippium. Orchiddcece. Terrestrial stove orchids. Fls. rather large, racemose, few ; sepals combined to form a broad pitcher. They do best in a compost of loam and leaf-mold. Being natives of the hottest, moist, densely shaded jungles, they require much heat and moisture during the growing period. Good drainage is essential. Prop. by dividing the pseudobulbs as soon as growth begins. Cult. by E. O. ORPET.

Javánicum, Blume. Fls. yellow and red, with distinct longitudinal stripes. Java. B. M. 4492 .

A.bicolor, Lindl. Fls. purple and yellow. $-A$. Cúrtisii, Reichb. f. Fls. many colored. Distinguished by the five keels between the side laciniæ. Malay Arch. G.C.II. $25: 169 .-A$. Sylheténse, Lindl. Fls. white, much spotted. Himalayas.

\section{ACANTHODIUM. See Blepharis.}

ACANTHOLIMON (akanthos, spine, and limon, sea lavender). Syn.,Armeriastrum. Plumbagindcea. Hardy evergreen perennials; dwarf, tufted, with sharp-pointed, rigid leaves; less common than Statice and Armeria. An oriental genus of slow-growing and sun-loving plants for rockeries. Prop. by seeds (which germinate slowly) sown carefully on a warm but somewhat shaded border, and transplanted when plants are large enough to handle; by cuttings made in late summer and wintered in a frame; by very carefully made divisions. Boissier describes 74 species in the Flora Orientalis. See A. Bunge, Die Gattung Acantholimon, St. Petersburg, 1872.

glumàceum, Boiss. Height 6 in.: lvs. green : fls. small, rose, on one-sided, spicate racemes, 6-9 in each short, dense spikelet. July-Sept. Armenia. F. S. 7:677. Gn. 31: 592. R. H. 1891, p. 489.

venùstum, Boiss. (Armeriástrum dianthifòlium, O. Kuntze). About 8 in.: lvs. grey-green, very stiff : fls. larger than the last, rose, 12-20 in each long, loose spikelet. July-Sept. Asia Minor. R.H. 1866:450. Gn. 13:117. B. M. 7506. Gn. 53, p. 405

J. B. Keller and W. M.

acanthomfntha. Labiatoe. Thorny Mint. Ten. der annual, with the habit of Lamium. Its chief interest is botanical, the nearest relative of the genus being the Brazilian genus Glechon. Only two species known. Prop. by seeds in spring under glass. 
ilicifolia, Gray. Height 6 in.: Ivs. petioled, orate, bluntly toothed: fls. $3-8$ in a whorl, chiefly purple, with yellow and white marks. Calif. B.M. 6750. Int. 1891. -Less desirable than Lamium, which see.

ACANTHOPANAX (a thorny Panax-like plant). Aralidcea. Hardy ornamental trees and shrubs: lvs. alternate, long-petioled, lobed or digitate, deciduous: fls, in-

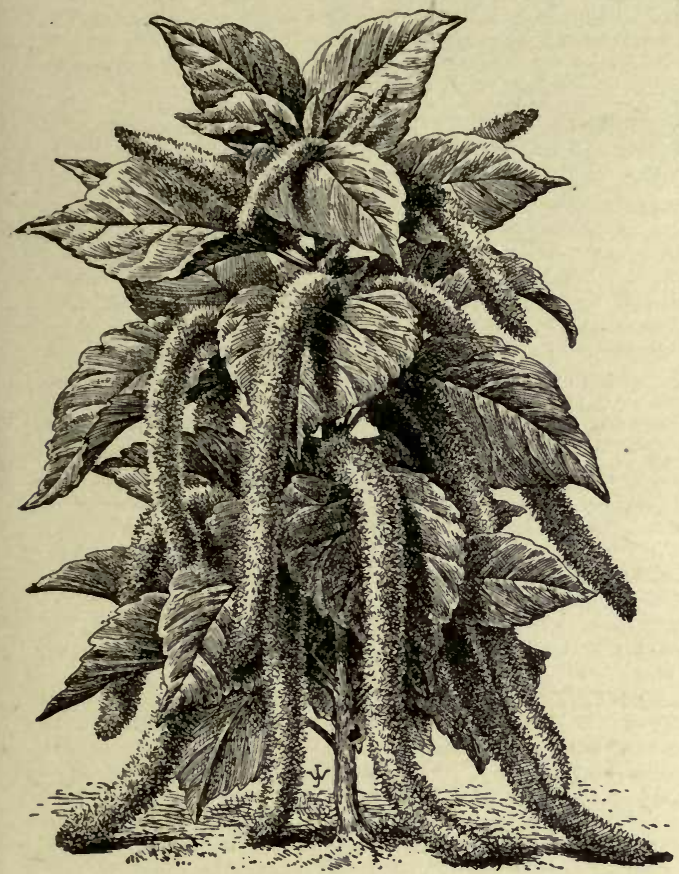

12. Acalypha hispida (A. Sanderi).

conspicuous, in umbels ; petals and stamens 5 : fr. a black 2-5-seeded berry. Cent. Asia and Himalayas. Prop. by seeds or by root-cuttings; $A$. pentaphyllum also by hardwood cuttings.

A. Lvs. simple, palmately lobed.

ricinifdlium, Seem. (Ardlia Maximowiczii,Hort. Kalopanax ricinifolium, Miq.). Tree, $80 \mathrm{ft}$.: branches with numerous stout prickles: lvs. deeply 5-7-lobed, 9-14 in. in diam., downy beneath when young; lobes oblonglanceolate, serrate : inflorescense terminal, large, compound. Japan. F.S. 20:2067. - A very ornamental tree of striking subtropical effect. A new form from Japan has the lvs. less downy beneath and with short, broad lobes.

$$
\text { AA. Lvs. digitate. }
$$

sessiliflorum, Seem. (Panax sessiliflòrum, Rupr. \& Max.). Shrub, 12 ft.: branches with only few prickles: leaflets mostly 3 , obovate-lanceolate or oblong-lanceolate, cuneate, acuminate, 4-7 in. long, irregularly crenate-serrate, nearly smooth: fls. dull purplish, sessile, in globular heads on stout, downy peduncles. Manchuria, N. China. G.C. III. 22:339. Gt. 11:369.-The freely produced heads of black berries are decorative.

pentaphýllum, Marsh. (A. spinòsum, Hort., not Miq. A ralia pentaphylla, Thunb.). Shrub, 5-10 ft.: branches long and slender, with few compressed, straight prickles: leaflets 5-7, oblong-obovate or oblong-lanceolate, cuneate, acute, $3 / 4-11 / 2$ in. long, crenate-serrate, smooth: fis. green, in long and slender-peduncled umbels; styles 5 , connate. Japan.-A graceful shrub, with arching branches and bright green, shining foliage, excellent on rocky banks and slopes. Var. variegàtum, Hort. Lvs. edged white. F.S. 20:2079.

A. aculeàtum, Seem. Spiny shrub: leaflets $3-5$, shortly petioied, glabrous. Himalayas.-A. divaricatum, Seem. Allied to
A. sessiliflorum. Lvs. hairy beneath: fls. pedicelled. Japan.A. innovans, Franch. et Sav. Unarmed small tree: lvs. fascieulate: leaflets $3-5$, nearly sessile, glabrous. Japan. $-A$. 8 ciadophylloides. Franch, et Sav. Unarmed tree, $40 \mathrm{ft}$.: leaflets 5 , photiolulate, long petiolulate, glabrous. Japan. - A. senticosum, Harms. pentaphyllum. Lvs. often sparingly appressed-setose above: peduncles shorter than petioles; styles 2, separate. China.

\section{ALFRED REHDER.}

ACANTHOPHIPPIUM. See Acanthephippium.

ACANTHOPHÒNIX (akantha, thorn, and phonix, a date palm). Palmacea, tribe A rècece. Tall palms, spiny, with the stout trunk ringed: lvs. terminal, equally pinnatisect, more or less armed with long slender spines, the narrow segments linear-lanceolate, acuminate, scaly below, midrib and nerves prominent, the thickened margins recurved at the base, rachis somewhat 3 -sided, sheath long, smooth or spiny: spadix twice branched, pendent, with a short, thick peduncle, glabrous or tomentose, smooth or spiny, the branches slender or thick and twisted : spathes 2, compressed, deciduous : fis. red or orange: fr. black, scarcely longer than a grain of wheat. Species 3 or 4 . Madagascar.

They need a temperature of $70^{\circ}-90^{\circ} \mathrm{F}$.; never less than $60^{\circ}$. The rooting medium should be somewhat light, with a quantity of crushed charcoal. Drainage should be very carefully arranged, as they demand an abundance of moisture. Prop. only by seeds, which may remain two or three years in the seed-pan before germinating. For general cult., see Palms and Areca.

crinita, H.Wendl. (A rèca crinita, Bory). Trunk 50-60 ft.: lvs. 7-13 ft. long; petiole densely tomentose, 4-8 in. long ; leaf-sheath $2 \frac{1}{2}-4 \frac{1}{2} \mathrm{ft}$. long, thickly covered with short brown bristles and spines; segments silvery white beneath. Mauritius. F.S. 16:1706. F.R. 2:201.-Young plants have pale, yellowish green lvs.

rùbra, H. Wendl. (A rèca rubra, Bory). Trunk $60 \mathrm{ft}$.: lvs. 6-12 ft. long; petiole glabrous, 2-4 in. long; leafsheath $21 / 2-41 / 2 \mathrm{ft}$. long, thickly covered with long brownblack spines; pinnæ slightly glaucous beneath: fr. globose, $1 / 3-3 / 8$ in. in diam., with a prominent ridge extending from the stigma to the base. Mauritius and Isl. Bourbon.- Young plants have dark green lvs. with red veins.

JARED G. SMith and G. W. Oliver.

ACANTHORHIZA (akantha, thorn, and rhiza, root). Palmacea, tribe Coryphea. Spineless palm, with a rather robust caudex, densely clothed with the bases of the deac sheaths ; roots spinescent at the base: lvs. terminal, the orbicular blade deeply cut into 3- to many-parted cuneiform segments, glaucous below, without any rachis; petiole flattened or convex above, smooth on the margins: sheath short, fibrous: spadix compressed : the short peduncle and spreading thickened branches white: bracts and spathes elongated toward the base of the branches, coriaceous, deciduous; bractlets bristly, deciduous. Species 2 or 3. Cent. Amer. About one-fourth of the soil given them should be vegetable mold. Prop. by seeds in bottom heat.

aculeàta, H.Wendl. (Cha maerops stauracaintha,Hort.). St. spiny at base : lvs, orbicular, with a narrow sinus at the base, whitish beneath. Mex. I.H. 26:367. B.M. 7302. - Succeeds in an intermediate house.

Chùco, Drude (Thrinax Chuco, Mart.). St. smooth, about $30 \mathrm{ft}$. high, 9-10 in. in diam., slender, flexuous: lvs. orbicular, with a narrow sinus at the base; petioles slender, 3-6 ft. long, smooth; blade $6 \mathrm{ft}$. in diam., divided to or beyond the middle; segments 15-20, lanceolate, acute, 1-2 in. wide, dark green above, paler and glandular below. Braz.

The following species are rarely seen outside of botanic gar dens, and need stove temperature: $\boldsymbol{A}$. Wállisi, H. Wendl. Hab. ?-A. Warscewiczii, H. Wendl. Panama.

\section{JARed G. SMith and G. W. Oliver.}

ACANTHUS (akanthos, thorn). A canthdcece. BEAR's BREECH. Mostly hardy herbaceous perennials of vigorous growth and broad foliage, suitable for backgrounds of borders and subtropical effects. The acanthus leaf is one of the commonest of art forms. The ornamentation of the Corinthian column is said to have been suggested by $A$. spinosus. Height $3-4 \mathrm{ft}$. : spikes $1-1 \frac{1}{2} \mathrm{ft}$. long: 
fls. duli white to rose or purplish. Mostly southern Europe. A. mollis may have suggested the more conventionalized acanthus leaf of Roman architecture. Must be deeply mulched $\mathrm{N}$. in winter. They need a rich, light, well-d rained soil and much sunshine. Excessive moisture is fatal, especially in winter and spring. Fall-planted stock should always be protected for the winter by long

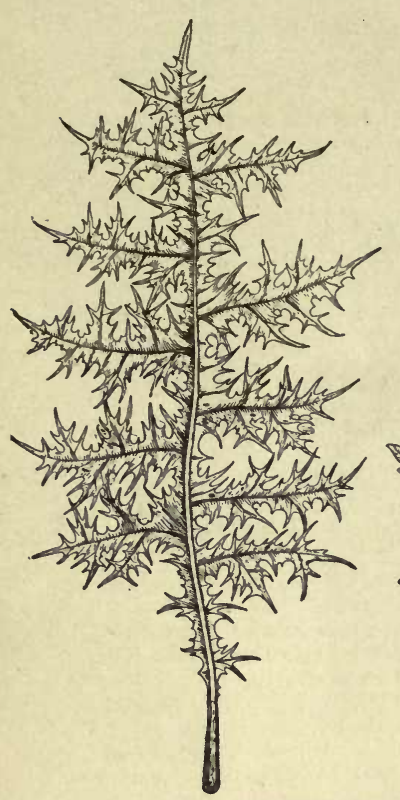

13. Acanthus spinosissimus.

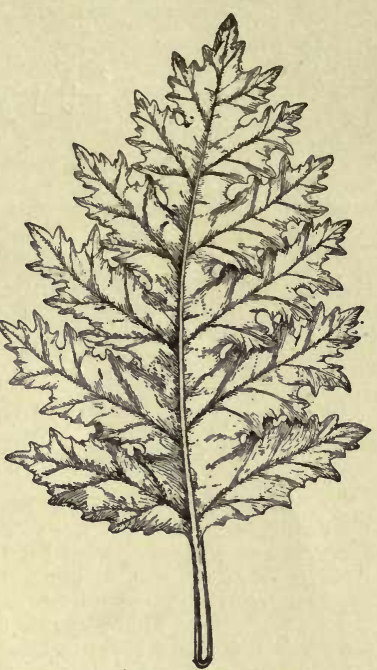

14. Acanthus mollis. litter or evergreen boughs, even where established plants are hardy. Prop. by division in spring or early autumn, and by seeds.

Cult. by J. B. KeLler.

A. Lvs. spiny.

spinosíssimus, Desf. Fig. 13. Lvs. dark green, pthnately parted; spines glistening: fls.infrequent; autumn; spikes loose, pilose or glabrescent: spines of the bracts recurved.

spindsus, Linn. Lvs. lanceolate, pinnatifid, pubescent; spines short, whitish: fls. smaller than in the last; summer; spikes dense, slightly villous. B. M. 1808. Gn $8: 147$.

$$
\text { AA. Lvs, not spiny. }
$$

mollis, Linn. Fig. 14. Lvs. 2 x $1 \mathrm{ft}$., cordate, sinuately pinnatifid, mostly radical: fls. summer; spikes loose, pubescent. Gn. 52, p. 239. - Also recommended as a window plant. Var. latifolius, Hort. (A. latifolius, Hort. A. Lusitanicus, Hort.) is larger and hardier. Gn. 1, p.303.

longifolius, Poir. Lvs, radical, longer and narrower than in A. mollis, bright green: fls. June. - Though said to be a stove species in Eu., it is the hardiest of all at Cambridge, Mass.

A. Cároli-Alexándri, Hausskn. 9-18 in. Lrs. fow, radical, in a lax rosette, lanceolate, spiny; spikedense. Greece.-A. cardui fòlius, Linn.= Blepharis earduifolia. $-A$. ilicifolius (Dilivaria ilicifolia, Juss.). Smooth greenhouse sub-shrub with leaves resembling Ilex aquifolium, the Eu. Holly. Prop. by cuttings under glass, E. Asia.-A montanus, T. Anders. Lvs. pinnatifid or sinuate-spinose. W. Afr. B.M. 5516. Stove species.

ACER (classical Latin name). Sapindacea. MAPLE. Trees, rarely shrubs: lvs. opposite, long petioled, simple and mostly palmately lobed, or 3-5-foliolate, deciduous: fls. small, in racemes or corymbs; petals generally 5 ; stamens 4-12, mostly 8: fr. compound of two longwinged nutlets called samaras. Asia, especially E. Asia, N. Amer., Europe. Monograph by Pax in Engler's Bot. Jahrb., 6:287, and 8: 177 (1885 and 1886), suppl. in the same, 16: 393 (1893), and Hook. Ic. Plant. 19, t. 1897
(1889). The maples are among our most ornamental and valuable trees for park and street planting. Nearly all assume a splendid color in autumn, especially the species of N. Amer, and E. Asia, which surpass by far the European maples. Many of them are valuable timber trees, and some American species, especially $\boldsymbol{A}$. saccharum, produce sugar. For purposes of shade, the common sugar maple is best and most popular. The Norway maple makes a very dense and round head, and is excellent for lawns, but it is too low-headed for the streets. The silver maple, $A$. saccharinum and its vars., is also popular where quick-growing trees are desired. The Japanese maples are among the most striking and showy exotic small trees, and are adapted for fine grounds and for growing in pots. Prop. by seeds sown in autumn, or stratified and sown in spring. The early ripening species, like $A$. saccharinum and $A$.rubrum must be sown soon after maturity; the varieties and rare species may be budded in summer on the typical forms or allied common kinds; some shrubby species, as $A$. palmatum, also $A$. cissifolium and $A$. lietum, var. rubrum. may be propagated by layers or half-ripened greenwood cuttings in summer. Fancy maples are readily winter-grafted by the veneer method, the stocks being grown in pots. The Japanese kinds are usually worked on imported stocks of $A$. palmatum. Monograph of the garden forms and varieties by Graf Schwerin in Gt., 1893; see, also, G.C. II. 16:75. About 100 species.

The following species of maple are cult. in this country: campestre, No. 8; carpinifolium, 28; circinatum, 15 ; cissifolium, 30 ; dasycarpum, 1; Floridanum, 5 ; Ginnala, 24; glabrum, 14 ; grandidentatum, 6 ; Heldreichi, 20; insigne, 22; Italum, 7; Japonicum, 17; $1 æ-$ tum, 12; macrophyllum, 18; Monspessulanum, 9; Ne gundo, 31 ; nigrum, 4; Nikoense, 29; palmatum (polymorphum), 16; Pennsylvanicum, 27; pictum, 11; platanoides, 13; Pseudo-platanus, 19; rubrum, 2; rufinerve. 26 ; saccharinum, 1; saccharum, 3 ; spicatum, 25; Tataricum, 23; Trautvetteri, 21; truncatum, 10.

A. Foliage of simple, mostly palmate lvs. (occasionally s-foliolate in No. 14); fls. polygamous or monocious.

B. Bloom appearing long before the lvs. in dense lateral clusters: lvs. 5-lobed: fr. ripening in May or June.

1. saccharinum, Linn. (A. dasycárpum, Ehrh. A. eriocárpum, Michx.). SILver MaPLe. Fig. 15. Large tree, $120 \mathrm{ft}$.: $1 \nabla \mathrm{s}$. deeply 5 -lobed to 5-cleft, 4-6 in. long, green above, silvery white beneath; lobes deeply and doubly serrate: fls. greenish yellow, apetalous: fr. pu bescent when young. E. N. Amer. S.S. 2:93. G.C. II. 1:137. Em. 556.-Ornamental tree, with wide-spreading, slender branches, growing best in rich and moist soil, but succeeds almost anywhere. Lvs. turn clear yellow in fall. Many yarden forms: Var. Wièri, Schwer. ( var. Wieri laciniatum, Hort.). Branches pendulous: l:s. deeply cleft, with dissected lobes. A graceful variety, remarkable for its drooping branches and finely divided foliage. Var. heterophýllum, Hort. (var. heterophyllum laciniatum, Hort.). Upright: lvs. deeply cut or lobed. Var. tripartitum, Hort. Upright: lvs. 3parted. Var. lutéscens, Hort. Lvs. yellow, bronze-colored when unfolding. Var. albo-variegatum, Hort. (var. Jïhlkei, Hort.). Lvs. spotted with white or rosy pink. Var. crispum, Hort. Lvs. deeply cut and crimped. - Linnæus evidently supposed this species to be the sugar maple, and named it accordingly. He did not know the true sugar maple.

2. rùbrum, Linn. RED or Scarlet MAPLe. Fig. 16. Large tree, $120 \mathrm{ft} .:$ lvs. 3-5-lobed, 3-4 in. long, green above, pale or glaucous beneath; lobes unequally and crenately serrate: fls. red or scarlet, rarely yellowish; petals 5: fr. glabrous. E. N. Amer. S.S. 2:94. Em. 557. G.C. II. 1:173. - Very valuable tree for street and park planting; attractive at every season from its excellent habit, earliness of the scarlet fls., bright red fruits in late spring, and the beautiful foliage, which turns bright scarlet or orange in autumn. Var. Columnare, Rehd. Of upright, columnar habit. Var. globdsum, Hort. Dwarf, compact: Ivs. glaucous beneath: fls. bright searlet. Var. Drúmmondi, Sarg. I A. Drummondi, Hook. \& Arn.). Lvs. large, mostly 3-lobed, tomentose beneath. fr. bright scarlet. S. states. S.S. 2:95. Var. tomento 
sum, Arb. Musc. (A. tomentòsum, Desf. A. rùbrum,var. fulgens, Hort.). Of moderate growth: lvs. 5-lobed, pubescent beneath: fls. bright red.

Bв. Bloom appearing with or after the lvs., distinctly stalked.

c. Fls, on long, pendulous, mostly hairy pedicels, in almost sessile corymbs, appearing with the ivs., apetalous; sepals connate.

3. sáccharum, Marsh. (A. saccharinum, Wangh., not Linn. A. barbatum, Michx.). Sugar or Rock Maple. Fig. 17. Large tree, $120 \mathrm{ft}$., with gray bark : lvs. 3-5lobed, cordate, 3-6 in. long, with narrow and deep sinuses; lobes acuminate, sparingly dentate, usually glaucous and glabrous beneath : fr. mustly with spreading wings. E. N. Amer. S.S. 2: 90. Em. 558.-An excellent street and shade tree of upright, dense growth, turning bright yellow and scarlet in autumn. It does well in almost every soil. Var. Rugéli (A. Rugéli, Pax., A. síccharum, var. barbatum, Trel.). Lvs. 3-lobed, generally broader than long, $2-5$ in. across, pale green or glaucous beneath, and at leugth mostly glabrous, coriaceous; lobes nearly entire. Centr. states. S.S. 2:91, as var. nigrum.

4. nigrum, Michx. (A. saccharinum, var. nìgrum, Torr. \& Gray. A. sáccharum, var. nigrum, Britt.). Black Maple. Fig. 18. Large tree, $120 \mathrm{ft}$., with black bark: lvs. cordate, with the sinus mostly closed, generally 3-lobed, with broad sinuses, the sides of the blade mostly drooping, green and pubescent beneath; lobes acute, entire or obtuselv toothed: fr. with variable wings. Centr. states. - Similar to A. saccharum, but of duller appearance and less dense habit. Var. monumentale (A. saccharinum var. monumentàle, Temple). Of upright, columnar habit.

5. Floridànum, Chapm. (A. barbatum, var. F'loridd num, Sarg.). Tree, rarely $50 \mathrm{ft}$. : lvs. mostly truncate at the base, 3 -lobed, $1 \frac{1}{2}-3$ in. across, glaucous beneath and mostly tomentose; lobes obtuse, entire or slightly 3 lobed. Gulf states. S.S. 2:91. G.F. 4: 148.

6. grandidentàtum, Nutt. Tree, $40 \mathrm{ft}$.: petioles comparatively short; lvs. slightly cordate 3-5-lobed, with broad sinuses, $2-3$ in. across, pubescent beneath, coriaceous; lobes acute or obtuse, entire or slightly 3-lobed: corymbs few-flowered, short-stalked. Rocky Mts. S.S. $2: 92$.

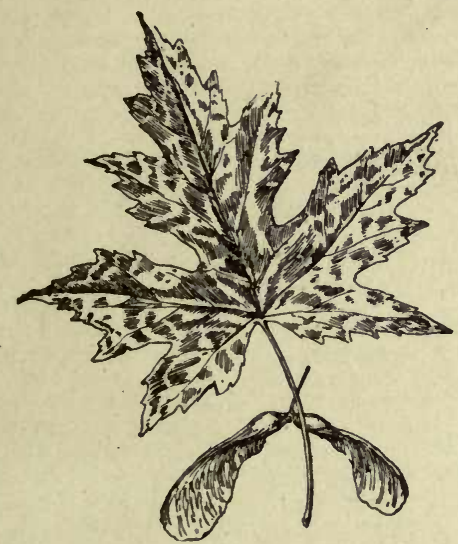

15. Acer saccharinum (or A. dasycarpum).

cc. Fls. in distinctly peduncled corymbs or short umbellate racemes, mostly erect, with petals and distinct sepals.

D. Lvs. 3-5-lobed, with obtuse, entire or obtusely toothed lobes: corymbs short-stalked : ovary pubescent: uinter-buds with several outer scales.

7. Italum, Lauth. Small tree, $30 \mathrm{ft}$.: lvs. 5-lobed, 3-5 in. long, glaucous beneath and at length glabrous; lobes obtusely dentate. the middle ones often 3 -lobed: corymbs somewhat drooping : fr. with slightly spreading wings. S. Eu., Orient. - A variable species, similar to a smallleaved syeanore maple. Var. Hyrcanum, Pax. ( $A$. Hyrcàum, F.\& M. A. Taùricum, Hort. A.trilobatum, Hort., not Lam.). Petioles very slender, red, 2-4 in. long; segments of the lvs. 3-lobed, with straight margins.

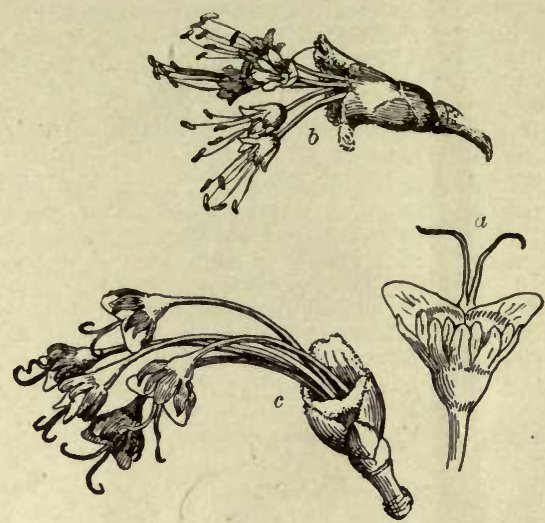

16. Red Maple.-Acer rubrum

$b$, staminate flowers; $a, c$, pistillate flowers.

* 8. campéstre, Linn. Shrub or tree, occasionally $50 \mathrm{rt}$, with corky branches : lvs. 3-5-lobed, 11/2-31/2in. long, green and pubescent beneath or nearly glabrous; lobes entire or the middle ones slightly 3 -lobed : corymbs erect, hairy : fr. with horizontally spreading wings. Eu., W. Asia. - Shrub or tree of moderate, dense growth, with dull green foliage, valuable for planting as undergrowth and on dry ground. Many varieties and garden forms : Var. argénteo-variegàtum, Hort. Lvs. with large white blotehes. Var. pulveruléntum, Hort. Lvs. sprinkled with white. Var. Austriacum, DC. Usually a tree : lvs. 5-lobed, with acute, nearly entire lobes. Var. Tauricum, Booth. Shrub: lvs. 5-lobed; small, lobes 3lobed. Var. hebecárpum, DC. Fr. and generally the lvs. beneath pubescent.

9. Monspessulànum, Linn. (A. trilobàtum, Lam.). Shrub or small tree, $25 \mathrm{ft}$.: 1vs. 3-lobed, coriaceous, 1-3 in. across, shining above, glaucous and glabrous beneath ; lobes entire or with few obtuse teeth : corymbs erect: fr, with slightly spreading wings. S. Eu., N. Afr., W. Asia. - Shrub or small tree of slow growth, with a dense, rounded head and in temperate regions nearly evergreen foliage, thriving well in dry situations. Var. Ibèricum, Koch. (A. Ibèricum, Bieb.). Lrs. larger, the inner lobes usually slightly 3 -lobed, obtuse.

DD. Lvs. 5-or 7-lobed, green on both sides; lobes pointed, entire or with few pointed teeth: ovary glabrous: winter-buds with several outer scales.

10. truncàtum, Bunge. Tree: Ivs. deeply 5-lobed and mostly truncate at the base, $2 \frac{1}{2}-4$ in. across, glabrous; lobes acuminate, setosely pointed, sometimes the middle ones 3-lobed : fr. with short, diverging yellow wings. N. China. - Hardy tree, with handsome, dense foliage.

11. pictum, Thunb. Tree, $60 \mathrm{ft}$.: Irs. 5- or 7-lobed, 3-7 in. across, usually pubescent beneath when young; lobes entire, acuminate, sometimes very broad and short: fls. yellow: wings of the fr. upright, brown or brownisb yellow, hardly twice as long as the nutlets. Manchuria, Japan. Handsome tree, with bright green foliage. Var. Mono, Maxim. Lvs. more cordate : wings of the fr. reflexed.

12. læ̇tum, C. A. Mey. Tree, $50 \mathrm{ft}$ : lvs. 5-7-lobed, mostly cordate, 3-6 in. across, giabrous; lobes entire. acuminate : fls. greenish yellow: wings 2-3 times as long as the nutlets. Orient, Himalayas. - Much resembling $A$. pictum, but Ivs. lighter green and of more membraneous texture Var, rubrum, Hort. (A. Cb́lchicum, var. rùbrum, Hort.). Lvs. dark blood-red when 
unfolding. Var. tricolor, Hort. Lvs. dark blood-red, sprinkled with rosy pink when young. These two beautiful forms usually remain shrubby.

13. platanoldes, Linn. Norway Maple. Fig. 19. Large tree, $100 \mathrm{ft}$. : 1vs. 5-lobed, cordate, 4-7 in. across, glabrous; lobes pointed, remotely serrate: fls. yellowish green : fr. with horizontally spreading wings. Eu., Caucasus. - Large, handsome tree, with round, spreading head, resembling somewhat $A$. saccharum. The lvs. turn pale yellow in autumn. Many garden forms, some of which are here arranged in two groups: the first being chiefly remarkable for the manner in which the lvs. are cut; the second being chiefly remarkable for their coloring.

(1) Var. cucullàtum, Nichols. Lvs. irregularly and shortly lobed, crimpled, light green. Var. disséctum, Jacq. Similar to var. Lorbergi, but with darker foliage and of slower growth. Var. globòsum, Hort. Forming a globose head. Var. laciniatum, Ait. Lvs. irregularly divided, the divisions bending downwards : growth upright. Var. Lórbergi, Van Houtte. Lvs. divided nearly to the base, divisions deeply lobed.

2) Var. álbo-variegàtum, Nichols. Lvs. with large white blotches. Var, aureo-marginatum, Pax. Lvs. with yellow margin, somewhat irregularly lobed. Var.

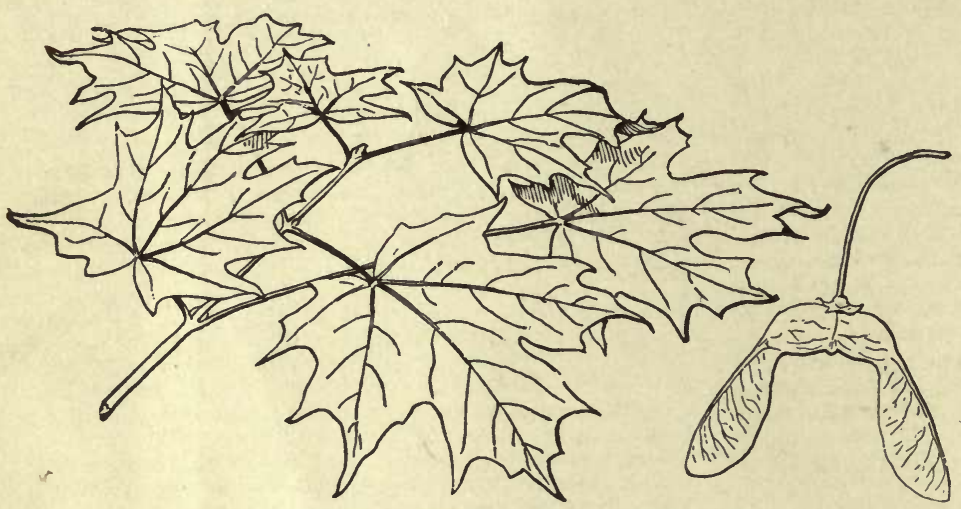

17. Common Sugar Maple.-Acer saccharum $\left(X_{1 / 2}\right)$.

Reitenbachi, Nichols. Lvs. greenish red when unfolding, turning dark blood-red in late summer. Var. Schwédleri, Koch. Lvs. bright red when young, changing to dark green.

DDD. Lis. 3-5-lobed or 3-foliolate, doubly serrate: winter-buds small, with 2 valvate scales.

14. glàbrum, Torr. (A. Doùglasi, Hook.). Shrub or small tree, $25 \mathrm{ft}$., quite glabrous : petioles bright red; 1vs. deeply 3-5-lobed or 3-parted, 1-5 in. across, dark green and shining above, pale or glaucous beneath; lobes doubly serrate. W. N. Amer. S.S. 2:89.-Handsome shrubby maple, with graceful, shining foliage, contrasting well with the red petioles and branches: fr. often rose-colored. Var. tripartitum, Pax. (A. tripartitum, Nutt.). Lrs. small, usually 3 -foliolate.

DDDD. Lvs. 5-11-lobed, lobes serrate: corymbs long, peduncled: winter-buds with 2 valvate scales.

15. circinàtum, Pursh. Small tree, rarely $40 \mathrm{ft}$. : petioles and peduncles glabrous; 1vs. 7-9-lobed, $2-7$ in. across, glabrous; lobes acute, doubly serrate: fls. in drooping corymbs, with purple sepals. W. N. Amer. S.S. 2: 87. - Hand some, round-headed tree or shrub, beautiful with its delicate light green foliage, red fls, rosecolored fr., and its orange and scarlet fall coloring.

16. palmàtum, Thunb. (A. polymórphum, S. \& Z.). JAPAN MAPLE. Shrub or small tree, $20 \mathrm{ft}$. : petioles and peduncles glabrous; 1vs. 5-9-lobed or divided, 2-4 in. across, glabrous, lobes oblong, acuminate, doubly serrate or incised: corymbs few-fiowered, erect, with small purple fls. Japan. S.Z. 1: 145, 146. A.F. 12:11. - This species and $A$. Japonicum are known as Japanese maples. They are extremely handsome shrubs of dense though graceful habit, and with elegant foliage, beautiful especially in spring for its delicate shades of green and red, and again in autumn, when the lvs. assume the most striking tints. Some of the more vigorous-growing varieties, like atropurpureum, dissectum, ornatum, and the typical forms, are hardy even in New England, while the most variegated forms are more tender. They grow best in partly shaded situations and in well drained, rich soil. There are many varieties, mostly introduced from Japanese gardens, of which the following are some of the best. They may be divided into 5 groups, representing various degrees of dissection of the leaves

(1) A. palmàtum, var. Thúnbergi, Pax. (A. palmatum, Thunb.). Ivs. deeply 5-9-lobed or cleft; iobes oblong-lanceolate, coarsely and doubly serrate or incised. Var. atropurpùreum, Van Houtte. Fig. 20, c. Lvs. dark purple, coarsely doubly serrate. F.S. 12:1273. Var. sanguineum, Hort., is brighter, and var. nigrum, Hort., darker red than var. atropurpureum. Var. bicolor, Koch. (var. atropurpùreum variegdtum, Hort.). Lvs. dark purple, with large carmine blotches, the lobes half purple and half carmine. Var. aùreum, Nichols. Lvs. yellow. Var. versícolor, Van Houtte. Lvs. bright green, with large white spots. F.S. 14:1498. Var. ròseo-marginàtum, Van Houtte. Lvs. small, deeply cut, with narrow pink margin. Var. críspum, André. Fig. 20, e. Lvs. small, with involute margins; of distinctly upright growth. I.H. 13: 43 .

(2) Var. septémlobum, Koch (A. septémlobum, Thunb.). Lvs. mostly 7-lobed; lobes broad, equally doubly serrate. Var. rùbrum Schwer. Lvs. large, deep red when young, becoming almost green later. Var. reticulàtum, André. Fig. 20 $a$. Lvs. greenish yellow, with green margin and dark green veins. I.H. 13:18. Var. trícolor, Hort. Lvs. with red, pink and white spots.

(3) Var. linearilobum, S. \& Z. (var. scolopendrifòlium, Hort.). Lvs. divided nearly to the base; lobes linear, remotely serrate or nearly entire. Var. atrolineàre, Schwer. (var. linearilobum atropurpùreum, Nichols., var. pinnatifòlium atropurpùreum, Hort.). Lvs. dark red.

(4) Var. dissèctum, Koch (A. polymórphum, var. decompositum, S. \& Z, . Fig, 20, f. LYs divided to the base in 5-9 pinnatifid lobes. S.Z. 1:146. Var. ornàtum, Carr. (var.disséctum atropurpùreum, Hort.). Fig.20.d. Lvs. deeply cut, deep red. Var. Frederici-Guilélmi, Carr. (var. pinnatífiaum ròseo-píctum, Lem.). Lvs. finely cut, green, with white and pink spots. I.H. 14: 523. R.H. 1867: 391 .

(5) Var. sessilifolium, Maxim. Lvs. deeply cut, with very short petioles. G.C. II. 16. Of little decorative value.

17. Japonicum, Thunb. Fig. 20, b. Small tree or shrub: petioles and peduncles downy when young; lvs. 7-11lobed, cordate, $3-6$ in. across, light green, with silky hairs when unfolding; lobes ovate, doubly serrate: fis. large, purple. Japan. S.Z. 1: 144. Var. macrophyllum, Van Houtte. Lvs. large, light green. Var, aùreum, Hort. Lvs. yellow. Var. Pársonsi, Veitch. (var. fiticifòlium, Hort.). Lvs. large, divided nearly to the base in 9-11 pinnatisect segments.

ccc. Fls, in elongated, distinctly peduncled racemes or panicles.

D. Lvs. distinctly 5-lobed, large.

18. macrophyllum,Pursh. LARgE-LEA ved MAPLE. Tree, 100 feet high: lvs. cordate, deeply 3-5-lobed or cleft, pubescent when young, pale green beneath, 8-12 in. across: middle lobe mostly 3 -lobed: racemes pendulous : fr, with yellow, bristly hairs, largely winged. W. N. Amer. S.S. $2: 86,87$. - Handsome round-headed tree, remarkable for its large foliage; not hardy in the North. 
19. Pseùdo-plátanus, Linn. Sycamore Maple. Tree, $70 \mathrm{ft}$. high: lvs. 5-lobed, coarsely crenate-serrate, $3 \frac{1}{2}-7$ in. across, deep green above, glaucous and mostly glabrous beneath : racemes pendulous : fr. glabrous. Eu., Caucasus. - Large tree of vigorous growth, with large, spreading head; thrives well even in exposed situations. Many varieties and garden forms: Var. villossum, Prsl. Lvs. chartaceous, pubescent beneath. Var. purpuráscens, Pax. (vars. purpùreum and atropurpüreum, Hort.). Lvs. purplish red beneath; of robust growth. Var.Handjèryi,Späth. (var. Prinz Handjery, Hort.). Lvs. purplish beneath, bright red when unfolding. Var. Worleei, Hort. (var. lutéscens, Hort.). Lvs. yellow. Var. álbo-variegatum, Hort. Lvs. with white blotehes and spots. Var. trícolor, Hort. Lvs. spotted with recl, changing to white.

20. Héldreichi, Orph. Tree: lvs. 5-lobed, the middle incisions reaching nearly to, the outer half way to the base, 3-5 in. across, glabrous, dark green and shining above, glaucous beneath; lobes coarsely and doubly serrate: panicle erect, long-stalked, ovate. S. E. Eu. Gt. $34: 1185$. G.C. II. $16: 141$.

21. Traùtvetteri, Medw. (A. velùtinum, Hort., not Boiss.). Lvs. slightly cordate, deeply 5-lobed, 5-7 in. across, glaucous beneath and pubescent when young; lobes coarsely crenate-serrate: panicle erect, ovate. Caueasus. Gt. 40 , pp. 264-266. B.M. 6697. - Similar to $A$. insigne, but hardier and with smaller leaves.

22. insigne, Boiss. \& Buhse. Large tree: lvs. 5-lobed, deeply cordate, $5-10$ in. across, bright green above, glaucous beneath; lobes broad, coarsely crenate-serrate : panicles large, erect. Caucasus, N. Persia. G.C. III. 10: 189. - Remarkable for its large, handsome foliage; not hardy in the North. May be divided into two varieties: Var. Van Volxemi, Pax. (A.Van Volxemi, Mast.). Lvs. at length glabrous beneath. Var. velùtinum, Boiss. Lvs. densely pubescent beneath.

DD. Lvs. mostly 3-lobed or without lobes, green beneath.

23. Tatáricum, Linn. Shrub or small tree, $20 \mathrm{ft}$.: lvs. roundish oval or oblong, cordate, sometimes slightly lobed, 2-4 in. long, doubly serrate, nearly glabrous: fls. in long peduncled panicles, white. S. E. Eu., Orient. -Round-headed small tree, growing best in somewhat moist soil.

24. Ginndla, Max. (A. Tatáricum, var. Ginnala, Hort.). Fig. 21. Shrub or small tree, $20 \mathrm{ft}$.: lvs. 3-lobed, $11 / 2-3 \frac{1}{2}$ in. long glabrous, the terminal lobe elongated, doubly serrate: fls. in long peduncled panicles, yel lowish, fragrant. Manchuria, N. China, Japan. Gt. 1877 : 308. - Graceful shrub, with handsome foliage, turning bright red in autumn; may be used as a substitute for the Japanese maples where these are not hardy. Var. Semendvi, Pax. (A. Semendvi, Regel.). Shrub: lvs. smaller, deeply 3- or nearly 5-lobed. Turkestan.

25. spicàtum, Lam. Mountain Maple. Shrub or small tree, rarely $30 \mathrm{ft}$.: lvs. 3 - or slightly 5-lobed, coarsely serrate, pubescent beneath, $2 \frac{1}{2}-41 / 2$ in. long: racemes rather dense, long, upright: $\mathrm{fr}$. with diverging wings, bright red in summer. E. N. Am. S.S. 2: 82,83 . - Valuable as undergrowth; lvs. turn yellow and scarlet in fall.

26. rufinérve, S. \& Z. Tree with striped bark : branches glaucous when young: lvs. rounded at the base, 3-lobed, 3-5 in. long, doubly serrate, ferrugineously pubescent beneath when young: racemes ferrugineously pubescent. Japan. S.Z. 2:148. Var. álbo-limbatum, Hook. Lvs, edged with white. B.M. 5793.

27. Pennsylvánicum,Linn. (A.striatum, Dur). STRIPED MaPle. Moosewood. Tree, rarely $40 \mathrm{ft}$.: bark greenish, striped with white lines: lvs. slightly cordate, roundishobovate, 3 -lobed at the apex, 6-8 in. long, finely serrate, ferrugineously pubescent beneath when young: racemes glabrous, drooping. E. N. Amer. S.S. $2: 84,85$, Michx. Hist. Arb. 2:17. Em. 566. - Handsome medium-sized tree of upright, dense habit, with bright green, large foliage, turning clear yellow in autumn, and attractive even in winter from its smooth, greenish bark, striped with white. 
long, upright racemes, with petals. Japan.- Handsome, round-headed tree, with slender, spreading branches and graceful bright green foliage, turning orange-yellow and scarlet in autumn; hardy.

31. Negúndo, Linn. (Negúndo fraxinifolium, Nutt. $N$. aceroides, Mönch.). Ash-LEaved MAPLe. Box Elder. Large tree, $70 \mathrm{ft}$ : : livs. pinnate; leaflets $3-5$, ovate or oblong-lanceo. late, coarsely serrate or 3-lobed, mostly glabrous, $2-5$ in. long: fis. before the lvs.; staminate fls. in pendulous corymbs, pistillate fis. in pendulous racemes. E. N. Amer. S. S. 2: 96. Michx. Hist. Aro,

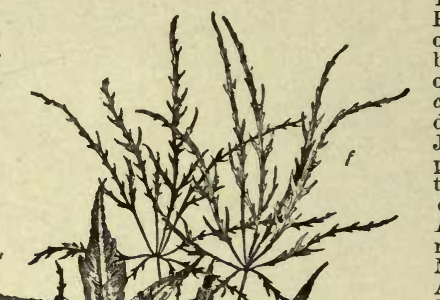
Probably hybrid, A. Monspessulanum $\times$ Lataricum. $-A$. Call fórnicum, Dietr. =A. Negundo, var. Californicum. -A. Califór nicum, Hort. =A. Negundo, var. violaceum. - A. capillipes, Max. Allied to A rufinerve. Lvs. 3-lobed, glabrous. Japan. $-A$. cau dàtum, Wall. =A. acuminatum. $-A$. cineráscens, Boiss. Shrub or small tree: lvs. 3-lobed, $1 / 2-2$ in. long. Similar to A. Monspessulanum. Persia. $-A$. coriàceum, Tsch. (A. Creticum Tratt A. polymorphum, Spach.). Probably A. CreticumX Pseudo-platanus. - A cratcegifolium, S. \& Z. Tree: lvs. oblong. ovate, often slightly 2 -lobed at the base, inequally serrate, glabrous. Japan. S.Z. 1: 147. Hardy.-A. Oréticum, Linn. =A orientale.-A.Créticum, Tratt. = A.coriaceum, Tsch.-A.diabólicum, Blume. Tree, $30 \mathrm{ft}$ : lvs. 5-lobed, 3-6 in. across, coarsely dentate, green beneath and pubescent when young: fls, greenish. Japan. G.C. II. 15:533.-A. Diecki, Pax. Probably A. LobeliX platanoides. $-A$. disséctum, Thunb. =A. palmatum, var. dissectum.-A. distylum, S. \& Z. Tree: lvs. ovate, 5-7 in. long, coarsely crenate-serrate, glabrous. Japan. G.C. II. 15: 499-A. Doúglasi, Hook.=A. glabrum. -A. Drúmmondi, Hook.=A. rubrum, var. Drummondi. $-A$. Durétti, Pax. Probably A. Ionspessulanum $\times$ Pseudo-platanus. $-A$. eriocárpum, Michx. $=$ A. dasycárpum.-A. glaùcum, Marsh.=A. dasycarpum $-A$. heterophýllum, Willd.=A. orientale. $-A$. Hodkeri, Miq. Tree, $60 \mathrm{ft}$. : lvs. cordate-oblong, serrate, 4-6 in. long. Himalayas, China.-A. Hyrcanum, F.\& M.=A. Italum, var. Hyreanum.A. hỳbridum, Spach. Probably A. Italum XPseudo-platanus.A. hỳbridum, Baudr. =A. Boscii. $-A$. Ibéricum, Bieb $=\mathbf{A}$. A. hybridum, Baudr. =A. Boscii. - A. Ibéricum, Bieb.=A. Monspessulanum, var. Ibericum.-A. laevigatum, Wall. Small tree: lvs. oblong, nearly entire, attenuate at the base, green be-
neath. Himalayas. $-A$. loevigatum, Hort.=A. acuminatum.A. laurifòlium, Don. =A. oblongum.-A. leucodérme, Small. (A. Floridanum, var. acuminatum, Trel.). Allied to A. saccharum. Small bushy tree with white bark: lvs. mostly 3-lobed, 3-4 in. across, greenish and finely pubescent beneath; lobes acuminate, nearly entire: corymbs glabrous. N. C., Ala. - A. Lobéli, Ten. Allied to A. lotum. Branches glaucous : lvs, rounded at the base; lobes mostly undulated, abruptly pointed. Italy. $-A$. Mexicanum, $\mathrm{Pax}$, not Gray. $=\mathrm{A}$. serratum. $-A$. micránthum, S. \& Z. Shrub or small tree: lvs. 5-7-lobed; lobes ineised and doubly serrate, glabrous : fls. and fr. small. S.Z. 1:141. -A. Miyábei, Max. Tree, $40 \mathrm{ft}$.: branches corky: ivs. 3-5-lobed, pubescent and pale green beneath, 4-6 in. long; lobes slightly lobed. Japan. G.F. 3: 143.-A. montànum, Ait.=A. spicatum. - A.Neapolitànum, Ten $=$ A. obtusatum - - . negléctum, Lange. Probably A. campestreXLobeli. $-A$, oblóngum, Wall. Tree, 50 ft.: lvs. ovate-lanceolate, entire, quite glabrous, glaucous beneath, coriaceous. Himalayas.-A. obtusàtum, Waldst. \& Kit. Allied to A. Italum. Small tree : lvs. tomentose beneath ; lobes short, rounded: peduncles hairy. S. Eu., N. Afr. $-A$. Opalus. Ait. $=\mathrm{A}$. Italum. $-A$. opulifolium, Vill. $=\mathrm{A}$. Italum. $-A$. orientàle, Linn. (A. Creticum, Linn. A. sempervirens, Linn. A. heterophyllum, Willd.). Shrub, 4 ft.: lvs. nearly evergreen. orbicular or oval, entire or $3-$ lobed, $1 / 2-1 \frac{1}{2}$ in. long glabrous. Orient-A palmifolium, Borkh =A, saccharum $-A$ pectina. tum, Wall. Tree: lvs. 3-lobed, coarsely serrate, the middle tum, Wall. Tree : lvs. 3-lobed, coarsely serrate, the middle
lobe elongated, acuminate. Himalayas. G.C. II. 15: 365. -A. polymórphum, S. \& Z.=A. palmatum -A. polymórphum, Spach =A. coriaceum. - A. purpuráscens, Franch. Very similar to A. diabolicum. Fls. purple. Japan.-A. Rùgeli, $\mathrm{Pax}=\mathrm{A}$. saccharum, var. Rugeli. $-A$. saccharinum, Linn. =A. dasyearpum. $-A$. saccharinum, Wangh.=A.saccharum. - A.saccharinum, var. $n i$ grum, Torr. \& Gray=A. nigrum. - A. sáccharum, var columnàre, Temple, A nigrum var, - saccharum, var. columnare, Temple $=\mathbf{A}$. nigrum var. monumentale.-A. sáccna-
rum, var. nigrum, Britt. $=$ A. nigrum. $-\mathbf{A}$. Schwerini, Pax. rum, var. nigrum, Britt. =A. nigrum.-A. Schwerini, Pax. beneath, 5-7 in. long. Himalayas. $-A$. Semendvi, Regel.=A. Ginnala, var. Semenovi.-A. sempérvirens, Linn.=A. orientale. -A. septemlobum, Thunb.=A. palmatum, var. septemlobum-A. serratum, Pax (A. Mexicanum, Pax, not A. Gray). Allied to A. Negundo. Leaflets 3, pubescent, equally serrate. Mex.A Sieboldiànum Miq. Allied to A. Japonicum, Lvs, 9-11lobed, serrate: fls. small, yellowish. Japan-A. Sikkiménse, lobed, serrate : fls. small, yellowish. Japan.-A. Sikhiménse,
Miq. Tree : lvs. cordate-ovate, entire or serrate, quite glaMiq. Tree : lvs. cordate-ovate, entire or serrate, quite gla-
brous, coriaceous. Himalayas. $-A$. striatum, Dur.=A. Pennsylvanicum.-A. Tatáricum, var. Ginnala, Hort.=A. Ginnala.A. Tatáricum, var. laciniàtum, Regel.=A. Ginnala.-A. Tauricum, Hort. $=$ A. Italum, var. Hyrcanum or A. campestre, var. Tauricum.-A. tegmentòsum, Max. Allied to A. Pennsylvanicum. Lvs, 3-4 in. long, glabrous beneath ; lobes short: fis. small. Manchuria. G.C.II. 15: 75, -A. trifidum, Hook. \& Arn. Small. Manchuria. G.C. I1. 15: 75.-A. trifidum, Hook. \& Arn. Small tree: lvs. cuneate-obovate, 3-lobed, small, glabrous; lobes
entire. China, Japan. S.Z. 2: 143. - A. trilobatum, Lam.=A. entire. China, Japan. S.Z. 2: 143. - A. trilobàtum, Lam.=A.
Monspessulanum. $-\mathbf{A}$. trilobàtum, Hort.=A. Italum, var. Hyrcanum.-A. tripartìtum, Nutt. $=$ A. glabrum, var. tripartitum.-A. Tschonóskii, Max. Small tree: lvs. 5-7-lobed, cordate, 2-31/2in. long, glabrous; lobes incised-serrate. Japan. Graceful, hardy, shrubby tree.-A. Ukurunduénse, F.\& M. (A. spicatum, var. Ukurunduense, Max.). Allied to A spicatum. Small tree: lvs. 5-7-lobed, pubescent beneath, 4-5 in. long; lobes elongated, lvs. 5-7-lobed, pubescent beneath, 4-5 in. long; lobes elongated, deeply serrate. Manchuria, Japan. G.C. II. 15: 172.-A. Van
Vólxemi, Mast. $=$ A. insigne, var. Van Volxemi. $-A$. velútinum. Vólxemi, Mast. $=$ A. insigne, var. Van Volxemi. $-\boldsymbol{A}$. velùtinum.
Boiss.=A. insigne, var. velutinum. $-A$. velutinum, Hort. $=\mathrm{A}$. Trautvetteri. $-A$. villosum, Wall. Tall tree: lvs. 5-lobed, cordate, 6-8 in. across, tomentose below, coarsely serrate. Himalayas.-A. Virginiànum, Mill.=A. dasycarpum. $-A$. Zoeschénse Pax.=A. neglectum, Lange. 
ACERANTHUS (a flower without horns). Berberi. ddcece. Slender, hardy, herbaceous perennial.

A diphýllus, Morr. \& Decne. (Epimèdium diphýllum. Lodd.). Plant rhizomatous : leaflets obliquely cordate, green above, glaucous beneath : fls. small, bluish white. Japan. B.M.3448. L.B.C. $19: 1858$.

\section{ACHANIA. See Malvaviscus.}

ACHILLEA (its virtues said to have been discovered by Achilles). Compósitoe. Includes Ptarmica. Hardy herbaceous border and alpine plants of easy culture. Dwarf kinds make earpets in dry, sunny places. Large kinds suitable for wild gardens. Lvs. simple, compound or ternate: $\mathrm{fl}$.-heads small, corymbose.- Prop. in spring by division, cuttings and seeds; chiefly by the tirst method.
A. Rays about 5, except in double forms, half as long as the ovate-ublong involucre; fls. white, red, or yellow

$$
\text { B. Fls, white or red. }
$$

Millefolium, Linn. Milfoil. YarRow. Height 1-3 ft.: 1vs. bi-pinnately parted, segments linear, 3-5 cleft: fls. in flat corymbs. June-Oct. Eu., Asia, Amer. Common in pastures. D. 95. - Less commonly cult. than vars. mebrum and roseum, with red or purple fls.

$$
\text { вв. Fls. yellow. }
$$

Tournefortii, DC. (A. Ágyptiaca, Linn.). Height 12 18 in. : lvs. pinnatisect; segments roundish, coarsely toothed : fls. pale yellow. June-Oct. Greece.

filipendulina, Lam. (A. Eupatorium, Bieb.). Height 4-5 ft.: stem erect, furrowed, almost hairy: fls. in dense, convex compound corymbs, often 5 in. across. JuneSept. Orient. - Needs staking.

tomentòsa, Linn. A woolly, earpet-like plant for rockeries. Height 8-10 in. Eu., Orient, N. Am. B.M. 498. Gn. 52, p. 421.

AA. Rays 6-20, as long as or longer than the rotund or campanulate involucre; fls. white.

\section{B. Lvs. not divided.}

Ptármica, Linn. Sneezewort. Height 1-2 ft.: lvs. serrate: fls. in loose corymbs; all summer. N. Temp.

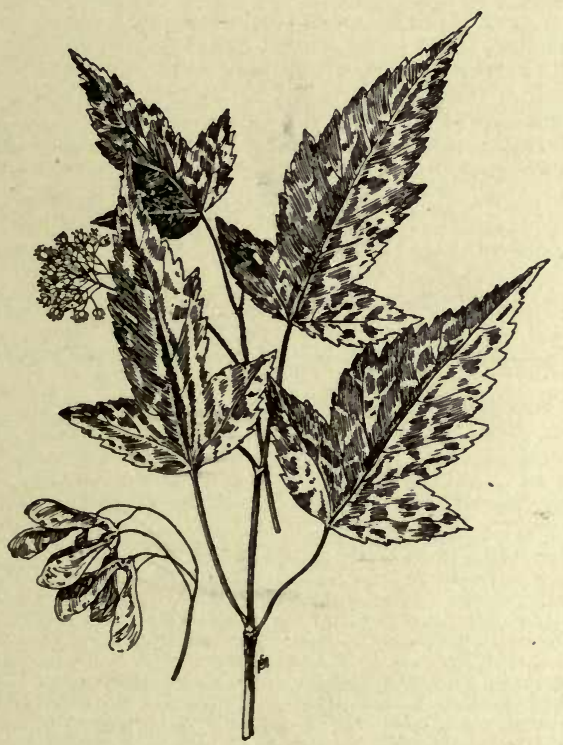

21. Acer Ginnala.

Reg.-Its full-double var., the Pearl, Fig. 22, is much used for cut-flowers and in cemeteries, and is one of the most popular of all hardy herbaceous plants. There are other varieties.
Sibirica, Ledeb. (A. Mongdlica, Fisch. A. ptarmi coides, Maxim.). Denser than the last, more erect and rigid: height $1 \frac{1}{2}-2 \mathrm{ft}$. : fls. larger and in more com. pact corymbs. July-Sept.

$$
\text { вв. Lvs. deeply divided. }
$$

macrophýlla, Linn. Height $3 \mathrm{ft}$ : lvs. long, broad. July. Alps. Gn. 52, p. 421. - Better suited to shrubbery than herbaceous border.

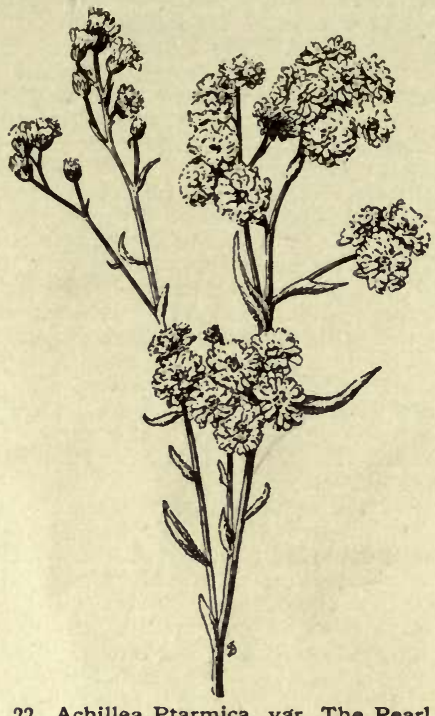

Clavénæ, Linn. (Commonly spelled A. Clavennae. A. argéntea, Hort., not Lam.). Dwarf, tufted, hoary alpine plant: height 10 in.: lvs. dentate at apex; segments obtuse: fls. spring and summer. Eu. B.M. 1287. Gn. 52, p. 421. - Thrives in sand.

A. Ageràtum, Linn. Fls. yellow. Eu.-A ageratifòtia, Benth. \& Hook (Anthemis Aizoon). Tufted, woolly, silvery gray: fls. white. May-June. Greece.-A. alpina, Linn. Lvs. pinnatifid: fls. white. May-June. Alps. $-A$. asplenifolia, Vent. Lrs. pin nate, smooth: fls. white. There is a red-flowered form. Hab. - A. atràta, Linn. Dwarf, tufted, aromatic: radical lvs. petiolate; cauline lvs. pinnatisect: fls, white. Alps. - A. decolòrans, Schrad Lys, undivided: fls pale yellow. July. En -A Herbaròta All Dwarf tufted, aromatic, alpine: lvs, undivided serrota, Al. Dware, tarted, arorate: fis. White. May-June.-A. Lngustica, All. Lrs. pinnatifid: fls. white. Eu., Orient. - A. moschata, Jacq. Lvs. smooth, pinnately parted, lobes uncut : fis. white. Eu.-A. nana, Linn. Spring. Eu. Used in making Chartreuse- $-A$. odoràta, Linn. Lvs. pinnatisect; lobes cut : fls. white-A. pectinàta, Willd. Fls. pale yellow - A rupéstris, Huter. Lvs. 1/2 in. long, linearspatulate, entire. S. Italy. B.M. 6905.-A santolinotdes, Lag. $1 \mathrm{ft}$. lvs, pinnatisect, hairy-woolly: fls. white. July. Spain. 1 ft.: 1vs. pinnatisect, hairy-wooly: Hs. white. white. Siberia? A. serrata, Retz. Lvs. pinnatifi, woolly: fls. white. Siberia? A. umbellata, Sibth. Very woolly rock plant, $4-5$ in.: lvs. pinJune. Greece.-A. Valesiaca, Stein. Lvs. pinnately parted: fls. white. June-Aug. Eu.

W. M.

ACHIMEN ES (Greek, cheimaino, to suffer from cold). Gesnerdcece. Greenhouse herbs, allied to gloxinias, native to tropical Amer. Fls. axillary; the 5 calyx lobes narrow and short; the corolla tube cylindrical and limb spreading; anthers 4, connivent in the corolla tube, and a rudiment of a fifth stamen; style long, usually exserted, the stigma dilated or obscurely 2 -lobed.

The rhizomes of Achimenes should be potted about the flrst of April, in soil which has been made loose and open by the addition of about one-third leaf-mold. Six or seven of these in a 5-inch pot, or nine or ten in a 6-inch one, make specimens of the most convenient size. The young growth appears in about eighteen days, and from that time onward great pains should be takeu to keep the soil moist, for a single severe drying will ruin the plants. Liquid manure should be given twice 
a week after flowering begins, i.e, toward the end of May. The plants are generally tied up to slender supports as growth advances, and, so treated, make surprisingly effective specimens. They may also be allowed to grow naturally, when they will droop over the sides of the pots and flower profusely. Still another way is to pinch off the tops of the growing plants when they are 4 or 5 inches high. As this produces a branching growth, a smaller number of rhizomes should be allowed to each pot. The flowers of Achimenes are produced for several months without cessation, i.e., until Oct., and sometimes still later if the small-flowered kinds are used. As soon as blossoming comes to an end, the plants should be cut off level with the tops of the pots, which should then be stored away, putting a reversed pot on the top of each one that stands on its base, for otherwise mice may destroy all the roots. Achimenes are propagated usually by means of the natural increase of the rhizomes, but all kinds may be grown from cuttings. Another way, which produces many though weak plants, is to rub off the scales and sow them as if they were seeds. The roots should be separated from the soil during the winter, and care should be taken that they do not decay from getting too wet in the moist air of greenhouse or cellar. Some of the best species are $A$. long $i-$ flora, purplish blue; $A$. longiflora var. alba maxima, the best white kind; $A$. patens var. major, a large flower of purplish rose; $A$. pedunculata, orange; $A$. heterophylla, tubular, a fiery orange at one end and blazing yellow at the other. Some of the best varieties are Ambroise Verscheffelt, white, with a network of violet lines; Chirita, deep, intense violet-blue with white throat; Dazzle, small, vivid scarlet, and late-blooming; Lady Littleton, rich crimson; Masterpiece, rosy violet with white throat; Mauve Queen, a very large and substantial variety of A. longiflora, pale purple; Rose Queen, rich, rosy lake; Nisida, lavender, shading to white; Trevi-

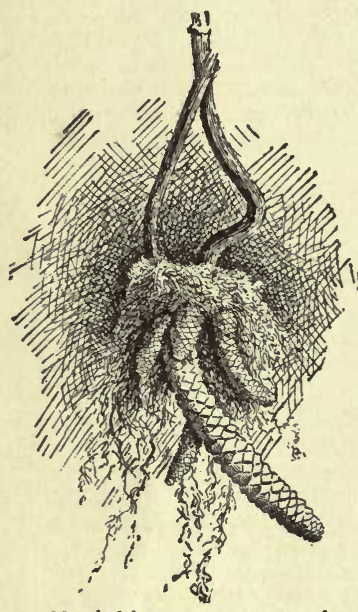

23. Achimenes; tubers of the coccinea section. rana rosea, like Dazzle, except in color. For other points in the culture of Achimenes, see G.F. 7: 456, 477, 506, $518 ; 8: 16$. In the grandiflora group the tubers or bulbs are clustered; in the longiflora group the tubers are pear-shaped bodies, growing on the ends of root-like rhizomes. The coccinea and hirsuta groups (Fig. 23) are late bloomers.

Cult. by W. E. EndicotT.

The garden Achimenes are much confused by hybridization, and it is doubtful if any of the pure species are in general cultivation in this country. Years ago, the small red-flowered types (of the coccinea section) were frequent, but modern evolution has proceeded from the broad-flowered purple species. The following first six species seem to have contributed most largely to the present garden forms.

A. Fls. colored, the tube usually not more than twice the length of the limb.

B. Blossoms small, red or scarlet.

ocellata, Hook. Roots small and tuberous : st. 1-2 ft.: lvs. rich green above and purple beneath, ovate, strongly serrate, with conspicuous purplish petioles : fls. small, 1 in. long, broad-tubed, spotted with black and yellow, the lobes short and obtuse and well separated, drooping on reddish peduncles. Panama. B.M. 4359.Fine for foliage.

coccinea, Pers. Height, 1-2 ft.: st. reddish: lvs. 3whorled or opposite, green, ovate-acuminate, serrate: fls. small, scarlet the corolla twice longer than the erect lanceolate parted, calyx on short peduncles. Minute lvs. often borne in the axils. Blooms late. Jamaica.- One of the older types. See Fig. 23. heterophýlla, DC. (A. ignéscens, Lem. A. Ghiès brechtii, Hort.). Root fibrous : st. 1 ft. or less, dark purple, somewhat hairy: Ivs. ovate-acuminate, stalked, serrate, the two of each pair usually unequal in size: fls. solitary, on peduncles somewhat longer than the leafstalks, long-tubular and slightly curved, with a narrow, nearly equal flaring limb, rich scarlet, yellow within. Mex. B.M. 4871. - This species has tubers like those of the grandiflora section.

pedunculatta, Benth. St. 11/2-2 ft., hairy, reddish: lvs. opposite, small, ovate, sharply serrate, green, hairy, on short reddish stalks : fls. medium size, drooping and dilated upwards, yellow-red with dark markings and a yellow throat, the limb comparatively short; on long (4-5 in.) bracted stems. Guatemala. B.M. 4077.-Stem produces tubers.

\section{BB. Blossom large, with wide limb, blue, violet} or purple.

longiflora, DC. Fig. 24. The root-like rhizomes producing pear-shaped tubers at their ends: st. 1-2 ft.,

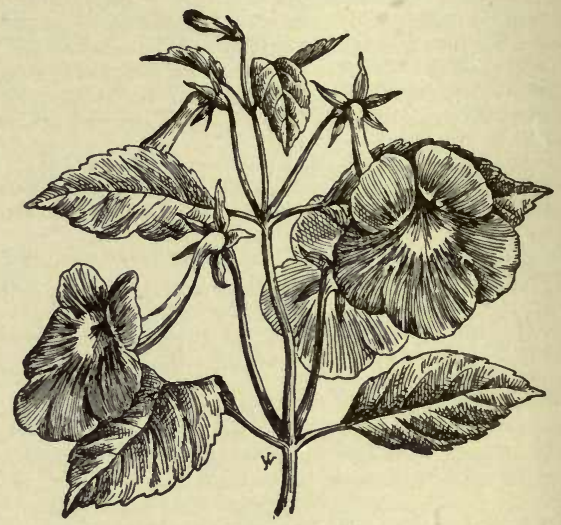

24. Achimenes longiflora $\left(X^{1 / 2}\right)$.

hairy: lvs. opposite or 3-4-whorled, ovate-oblong, serrate, hairy, sometimes colored beneath: fls. solitary, the corolla salver-shaped, with a long and graceful tube; the limb very large and widely spreading, violet-blue and whitish beneath, the lowest segment sometimes divided. Guatemala. B.M. 3980. P.M. 9:151.-A popular type.

grandiflora, DC. Lvs. mostly larger than in last, rusty below, often oblique at base: Hs. very large, dis tinctly red-tinged. Mex. B.M. 4012.- Popular type.

pàtens, Benth. Height, 1-11/2 ft.: 1vs. unequal, ovateacuminate, hispid and serrate: fls. violet-blue, with downy calyx, tube shorter than spreading crenate limb. Mex.

AA. Fls. pure white, the tube s-4 times the length of the limb.

tubiflora, Nicholson, Suppl. p. 483 (Gloxinia tubiflora, Hook. Dolichodèira tubiflòra, Hanst.). St. short, with opposite oblong-acuminate, crenate, short-petioled lvs.: fls. 4 in. long, curved, gibbous at the base, the tube downy, the pedicels opposite and 2 in. long. Argentina. B.M. 3971.-Tubers solid, much like a potato.

A. amábilis, Decne. $=$ Nøgelia multiflora. $-A$. atrosanguinea, Lindl. $=A$. foliosa. $-A$. cándida, Lindl. $=$ Dicyrta candida. $-A$. cupreàta, Hook. = Episcea cupreata. $-A$. foliòsa. Morr. Lvs. cordate, unequal: fls. erimson, with saccate tube $1 \frac{1}{2}$ in. long, with narrow limb. Guatemala.-A. gloxiniceflòra, Forkel.=Gloxinia glabrata.-A. hirsuta, DC. Loose grower : st. bulbiferous : fls. rather large, with swollen tube and oblique limb, rose, with yelrather large, with swollen tube and oblique limb, rose, with yelOnce popular.-A. Jaureguia, Warsez, =A. longiflora.-A.Kleei, Once popular.-A. Jaureguia, Warsez. $=$ A. longiflora. $-A . K l e e ̀$,
Paxt. Dwarf: fls. pink-purple. P.M. $16: 289$. Form of A. longiPaxt. Dwarf: fls. pink-purple. P.M. 16: 289 . Form of A. longi-
flora?-A. multiflora, Gardn. Hairy: lvs. broad-ovate: fls. blue, fringed. Brazil. B.M. 3993.-A. picta, Benth.=Tydøa picta.A. rosea, Lindl. Fls. pink or rose, the peduncles many-flowered. Guatemala.-A. Skinneri, Gordon, =A. hirsuta.-Garoien forms and hybrids are Escherii, floribúnda, intermèdia, Jayii, Mountfórdii, naegeliòdes, nína, venústa (P.M. 15:121), Verschafféltii.

L. H. B. 
ACHLYS (the goddess of obscurity). Berberidicea. Hardy herbaceous perennial. Fls. minute, numerous, spicate, on a slender scape.

triphylla, DC. Root-stock terminated by a strong, scaly winter-bud: lvs. 1 or 2 ; leaflets 3 , fan-shaped, sinuate-dentate, $2 \frac{1}{2} \times 5$ in.: scape $1 \mathrm{ft}$. long: spike 1 in. long. Spring. W. N. Amer.-An interesting and delicate plant. Int. 1881.

\section{ACHRAS. See Sapodillo.}

\section{ACHYRÁNTHES. See Iresine.}

ACIDANTHERA (pointed anthers). Iriddcece. Tender herbaceous perennials, intermediate between Gladiolus and Ixia. Lvs. many, linear ensiform, 1-11/2ft. long: spikes 3-6-flowered, simple, lax : fls. long-tubed, somewhat pendulous : corms roundish, flattened, covered with a matted fiber. - Prop. by seed or by the numerous corms.

bicolor, Hachst. St. 15-18 in.: fls. creamy white, blotched chocolate brown within, fragrant : corms $1 / 2-1$ in. in diam. Abyssinia. G.F. 1:486, 487. Gn. 47:1014. G.C. III. 20:393. Mn. 8:11. - Requires a somewhat stiffer soil than the tender species of Gladiolus. May be grown in a tub outdoors during summer, and flowered within during Oct. Several corms in a large pot give good results. Corms should be dried as soon as lifted, to prevent rot.

A, aquinoctidlis, Baker. St. 3-4 ft., stout, stiffly erect: lvs. strongly ribbed: fis. white, blotched erimson or purple within: corms large. Sierra Leone. B.M. 7393. May be a stronger growing and more tropical form of the above.

$$
\text { W. E. ENDicotт and W. M. }
$$

ACIN EेTA (immovable, the lip being jointless). Orchidacea. Stout epiphytes with interesting pendent scapes. Pseudobulbs conspicuously furrowed, slightly compressed : leaf-blades smooth, conspicuously veined, plaited and pliable : fls. globose. As a genus it is too near to Peristeria and Stanhopea. The species are rarely seen, as they are less conspicuous in their coloring than many orchids. They require a warm house and plenty of moisture during the growing season, with a decided rest, to make them flower. Use baskets, not pots, as the flower-spikes are produced from the base of the bulbs, as in Stanhopea, and should have free egress or they will be lost. Cult. by E. O. ORPET.

Bárkeri, Lindl. (Peristèria Bárkeri, Batem.). Pseudobulbs sub-conic, about 5 in.: leaf-blades longer than in A. Humboldtii: fls. 12 or more, in pendent racemes, golden yellow spotted with brown. Mex. B.M. 4203. I.H. 2: 44. Gn. 54 , p. 332 . P.M. $14: 145$.

Húmboldtii, Lindl. Pseudobulbs ovate, about 3 in.: leaf-blades about $1 \mathrm{ft}$. long, lanceolate, acute: scapes pendent, 2 ft. long; fls. 6 or more, chocolate colored, about 2 in. in diam. Ecuador, high elevations. Gn. $3: 11$.

A. chrysántha, Lindl. Racemes pendent; fls. golden yellow, with whitish labellum and crimson or purplish column; labellum furnished with a long, blunt, papillose horn. Mex.-A. dénsa, Lindl. (A. Warscewiczii, Klotzsch). Fls. subglobose, fragrant, pale yellow, spotted externally with reddish brown; labellum yellow, spotted with reddish brown. Costa Rica.-A. Hrubyàna, Reichb. f. Fls, ivory white, in loose racemes; lip spotted purple, with erect sidelobes. New Grenada. - A sulcàta, Reichb.f. purple, with erect sidelobes. New Grenada.-A sulcata, Reich
Similar to A. Humboldtii. Fls. yellow. OAKES AMES.

ACOKANTHERA (mucronate anthers). A pocyndcea. Tender shrubs, cult. in greenhouses North, and outdoors in Fla. and Calif. Fls. with the odor of jasmine, lasting.

spectábilis, G. Don. (Toxicophlòa spectábilis, Sond. T. Thúnbergii, Hort., not Harv.). Lvs. 3-5 in. long, short petiolate, leathery, elliptic, acute, shining above: fls. numerous, in dense axillary, branched, short cymes, pure white, very sweet scented. Natal. B.M. 6359. R.H. 1879:270. G.F.6:185. G.C. 1872: 363. - Poisonous. The plants cult. under this name are said by trade catalogues to bave pink or violet flowers.

venenàta, G. Don. (Toxicophlóa cestroides, DC. T. Thùnbergii, Harv., not Hort.). Fls. white or rose. Differs from the above in the well marked venation of the leaves, its flowers a third smaller, its calyx not pubescent, and its corolla-limb less widely spreading.

ACONITE, WINTER. See Eranthis.
ACONITUM. Ranunculdcece. Aconite. Monkshood. WOLFSBANE. A genus of hardy ornamental, perennial herbs, much used in borders, etc. Many species are planted in European gardens, but only nine have been much used in America. The number of species varies from 18 to 80 , with different botanists. Native in mountain regions of Europe, temperate A sia, and five in $\mathrm{N}_{\text {. }}$ Amer. Root tuberous, turnip-shaped, or thick fibrous: st. tall or long, erect, ascending or trailing: lvs. palmately divided or cleft and cut-lobed: fls. large, irregular, showy; sepals 5, the large upper sepal in shape of a hood or helmet; petals 2-5, small; stamens numerous; carpels 3-5, sessile, many-ovuled, forming follicles when ripened. The following species do well in any garden soil, but rich preferred; they thrive in open sun, but flowers last longer in shaded places. Aconites should never be planted in or too near the kitchen garden or the children's garden, as the roots and some of the flowers have a deadly poison. Prop. easily by division. Reichenbach Monographia Generis Aconiti, Leipsic, 1820,2 vols., folio. Reichenbach Illustratio Specierum Aconiti, Leipsic, 1822-7, folio.

\section{A. Roots globular-tuberous.}

B. Lvs. deeply cut, but not to the base.

Físcheri, Reichb. (A. Columbianum, Nutt. A. Californicum, Hort.). Stems 4-6 ft.: lvs. large, smooth, 3parted, attractive; segments much cut and divided: fls. numerous, pale blue, panicled, pedicels pubescent; helmets hemispherico-conical. Autumn. N. Amer. and Asia. Int. 1889. B.M. 7130.

Cammàrum, Linn. (A. décorum, Reichb.). St. 3-4 ft.: lvs. with short, bluntish lobes: fls. purple or blue; panicles or loose spikes few-flowered ; helmet hemispherical, closed. July-Sept. Hungary. Int. 1889. A. Storkidnum, Reichb., is a dwarf form of this, with fewer flowers and somewhat fibrous roots.

uncinàtum, Linn. WILd Monkshood. St. slender, 3-5 ft., inclined to climb: Ivs. thick, deeply cut into 3-5 cut-toothed lobes : fls. loosely panicled, but crowded at the apex; blue, pubescent, 1 inch broad ; helmet erect, nearly as broad as long, obtusely conical: follicles 3 . June-Sept. Low grounds of Penn. S. and W., Japan. Mn. 4: 81.-Much planted now.

$$
\text { BB. Lvs. divided to the base. }
$$

variegàtum, Linn. Erect, 1-6 ft.: lvs. variously divided into usually broad lobes and cut divisions; lower petioles long, others short or none: fls. in a loose panicle or raceme, blue, varying to whitish, rather smooth; helmet higher than wide, top curved forward; visor pointed, horizontal or ascending. July. Europe. $\boldsymbol{A}$. álbum, Ait., is a pure white-flowered form of this, with rather fibrous roots.

\section{AA. Roots long-tuberous. \\ B. Carpels usually 5.}

Japonicum, Decne. St. erect, 3-4 ft., smooth : lvs. dark green, shining, petioled; lobes $2-3$ times cut, the parts blunt and deeply toothed: fls. large, deep blue or violet, tinged with red, on loose panicles with ascending branches; helmet conical ; beak abruptly pointed : follicles 5. July-Sept. Japan. Int. 1889. R.H. 1851, p. 475. Var. cærùleum, Hort. Fls, very abundant; panicles shortened.

$$
\text { BB. Carpels } 3 \text { or } 4 .
$$

Napéllus, Linn.(A. Taúricum, Jacq. A. pyramidale, Mill.). True Monkshood. Officinal Aconite. Fig. 25. The best known and most poisonous species, and used in medicine. Sts, erect, 3-4 ft.: lvs. divided to the base, and cleft 2-3 times into linear lobes: fls. blue, in a raceme; peduncles erect, pubescent; helmet broad and low, gaping, smoothish: fr. 3-4-celled. June-July. Gn. 12, p. 362. - Very many varieties, differing in shade of flowers, often mottled or lined with white. Var. álbum is nearly white. Var. bícolor and var. versícolor, much used in gardens for the large blue and white flowers. Reichenbach has divided this species into 20-30 species. AAA. Roots in the form of a scaly, elongated bulb, or somewhat fibrous.

B. Sepals deciduous.

autumnàle, Reichb. Autums Aconite. Fig. 26. St. 3-5 ft.: lvs. pedately 5-lobed: fls. in a simple spike, be- 
coming a panicle; blue, lilac or whitish; helmet closed. Sept.-Nov. N. China.

Lycóctonum, Linn. (A. barbàtum, Patr. A. squarròsum, A. ochroleúcum, Willd.). PALE Yellow WolfsBANE. St. slender, simple, 3-6 ft.: lvs. deeply cut into
25. Aconitum Napellus $(\times 1 / 4$.

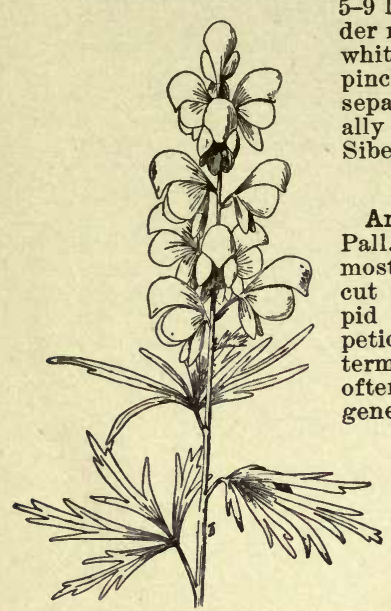
5-9 lobes ; long petioles and under ribs pubescent : fis. yellow or whitish, in racemes; helmet a. pinched elongated cone ; middle sepals usually bearded : fr. usually 3-celled. June-Sept. Eu., Siberia. B.M. 2570. G.M. 34: 124 .

\section{BB. Sepals persistent.}

Anthòra, Linn. (A.Pyrendicum, Pall.). St. 1-2 ft.: lvs. parted almost to the base, parts deeply cut and lobed, more or less hispid beneath, smoothish above; petioles long : fls. in lateral and terminal racemes, pale yellow, often large; racemes or panicles generally pubescent; spur bent back or hooked; helmet arched, but cylindrical at base: follicles 5. June-July. S. Eu. B. M. 2654.-Several varieties.

A. Chinènse, Sieb. Deep blue spike of fls. from the axil of every leaf : foliage bold and every leaf : foliage bold and
handsome. B.M. 3852. P.M. 5:3. $-A$. delphinifolium, DC. Allied to A. Napellus. $-A$. heterophýllum, Wall. Fis. yellow and violet. Used as a tonic medicine in India. B.M. 6092. $-A$. Noveboracénse, Gray. Probably =A. paniculatum. - A. paniculàtum, Lam. (A. toxicum, Reichb.). Has bluo fls. L.B.C. 9:810. latum, Lam. Gray, of the Alleghanies, with white fls. and large lvs., is worth cult. - A. septentrionàle, var. Carpáticum, Sims, is a beautiful purple kind, closely related to A. Lycoctonum. B.M. 2196.-A. tortuosum. Willd. Once listed in the trade; not now found.

K. C. Davis.

ÁCORUS (ancient name of unknown meaning). A roidece. Hardy, herbaceous water-loving plants. Lvs. sword-shaped, erect; spadix appearing lateral, with no true spathe: fls. inconspicuous. They thrive best in moist soil, and may be grown in shallow water or on dry land. Prop. easily in spring or autumn by division.

Cálamus, Linn. Sweet FraG. Height $2 \mathrm{ft}$ : rootstock horizontal, pungent, aromatic. Fls. early summer. N. Amer., Eu. Var. variegatus, Hort. Lvs. striped deep yellow when young, fading to a paler color later in summer. Eu. - Commoner in cult. than the type.

gramineus, Soland. Height 8-12 in. Much smaller than A. Calamus, forming compact, grassy tufts. Japan. Var.variegatus, Hort. Lvs. striped white. Used in hanging baskets, vases, rockeries and for cutting. Often grown indoors. J. B. KeLler.

\section{ACROCLINIUM. See Helipterum.}

ACROCOMIA (name means a tuft of leaves at the top). Palmacece, tribe Cocoinece. Spiny tropical American palms: caudex erect, solitary, ringed and swollen at the middle, densely spiny: lvs. terminal, pinnately cut; segments narrowly linear-lanceolate, long, obliquely acuminate, the naked margins recurved at the base; midnerves, rachis and petiole with long spines: fr. globose or oblong, glabrous or prickly; black or brown. Species 8 , mostly difficult to distinguish; allied to Cocos. They need a rich, sandy loam. The chief danger with young plants is overpotting, as few leaves are on a plant at a time, and the roots are not abundant.

sclerocárpa, Mart. (A. aculedta, Lodd.). Height 30$45 \mathrm{ft}$.: trunk cylindrical, about $1 \mathrm{ft}$. thick, with black spines 2-4 in. long: lvs. 12-15 ft. long; segments in irregular groups of 2 or $3,2-3 \mathrm{ft}$. long, $3 / 4-1$ in. wide, smooth and shining above, whitish, appressed-pilose below, entirely free of spines, except along the midrib. Braz. to W. Ind. I.H. 15:547. - Not hardy at Onéco, Fla. Cult. in Calif. "Gru-gru" and "corojo" are native names.
Havanénsis, Hort. A slow-growing, thorny plant, of which little is known. Trade name.

\section{JAREd G. Smith and G. W. Oliver.}

\section{ACROPERA. See Gongora.}

ACROPHYLLUM (Greek, top and leaf). Saxifragdcece. One Australian evergreen shrub, A. venosum, Benth. (A. verticillatum, Hook.), excellent for spring flowering in the coolhouse. Prop. by cuttings in early summer. Let the plant rest during summer. Do not expose to frost. It produces many pinkish fls. in dense spicate whorls near the top of the branches. Lvs. in 3 's, sessile, dentate: fis. with 5 petals and 10 stamens. 4-6 ft. B.M. 4050 .

ACROSTICHUM (derivation obscure). Polypodiaceo. Greenhouse ferns. Includes plants of great diversity of foliage, which are often referred to many genera. Sori spread in a layer over the entire under surface of the leaf or of certain of the upper pinnæ, rarely over both surfaces. Foliage rather coarse, the leaves simple or pinnate, rarely forked. All the 140 species are plants of tropical regions, two species growing in S. Fla. Some kinds are adapted to covering walls, columns, trunks of tree ferns, etc. The kinds with long fronds are excellent for hanging baskets. As all kinds require an abundance of water at the roots, the compost should be very porous.

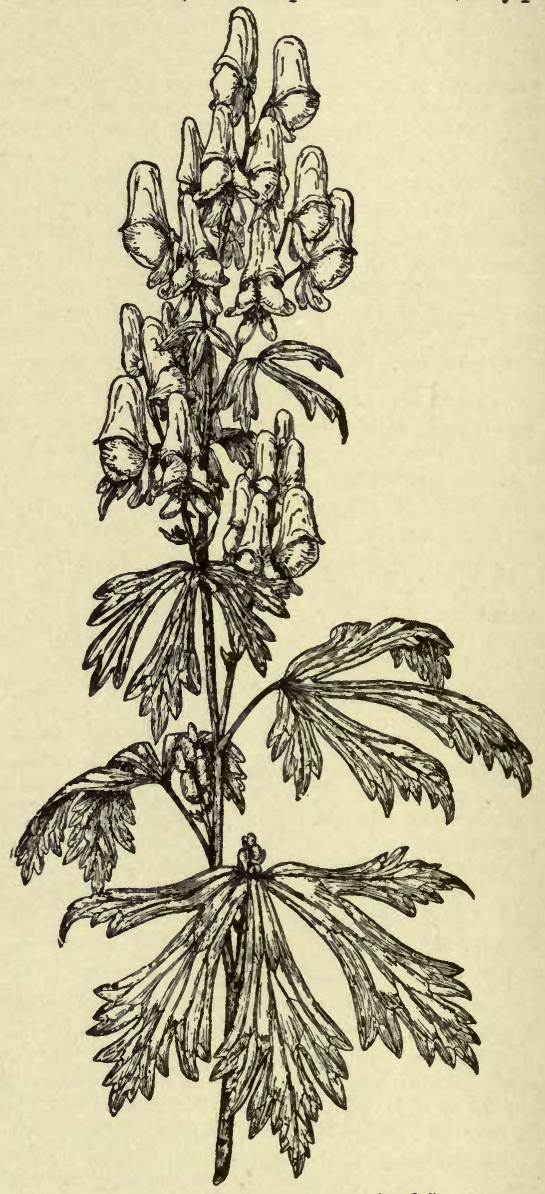

26. Aconitum autumnale $\left(\times \frac{1}{2}\right)$.

A mixture of two parts fibrous peat, one of chopped sphagnum, and one of coarse silver sand is recommended. For general culture, see Ferns.

The following species are cult. in Amer.: alienum, No. 15 ; aureum, 17; cervinum, 14 ; conforme, 7 ; crim- 


\section{ACROSTICHUM}

tum 9; flaccidum, 8; gorgoneum, 11; lomarioides, 18; muscosum, 3 ; nicotianæfolium, 16; osmundaceum, 19; peltatum, 20 ; pilosum, 5 ; reticulatum, 10 ; scandens, 12 simplex, 6 ; sorbifolium, 13; squamosum, 2; villosum, 1; viscosum, 4

A. Les. simple, less than 2 in. wide; veins free: (Eluphoglossum.)

B. Surface of les. densely scaly throughout. c. Texture thin, flaccid.

1. villosum, Swz. Fig. 27. Sterile lvs. 6-9 in. long; fertile lvs. scarcely more than half as large, both with abundant slender, dark-brown scales. Mex. and W. Ind. -Dwarf, variable. cc. Texture thick, leathery.

2. squamosum, Swz. Lvs. 6-12 in. long, the fertile narrower, on longer stems; both surfaces matted with bright reddish brown linear or lanceolate scales. Tropics of both hemispheres.

3. muscosum, Swz. Sterile lvs. 6-12 in. long, fertile much shorter; upper surface slightly scaly, the lower densely matted with ovate, rusty scales. Tropics of both hemispheres. S. 1:211.-Very distinct in habit. BB. Surface of lvs. slightly scaly.

4. viscòsum, Swz. Sterile lvs. 6-12 in. long, narrowed gradually at the base; the fertile shorter, on longer stems; texture leathery, the surfaces somewhat viscid. Tropies of both hemispheres.

5. pildsum, HBK. Lvs. flexuous, 6-8 in. long, 3/4in. wide, with tufts of star-like scales beneath; texture herbaceous. Mex. to Columbia. - Chiefly of botanical interest.

ВвВ. Surface of lvs. not scaly; texture leathery. D. Margins of le's. thick, cartilaginous.

6. símplex, Swz. Sterile lvs. 4-12 in. long, with a very acute point, the lower portion gradually narrowed into a short, somewhat margined stem. W. Ind. to Brazil.

7. conforme, Swz. Sterile Ivs. 2-9 in. long, with a bluntish point and wedge-shaped or spatulate base; fertile lvs. narrower. Tropics of both hemispheres.

DD. Margins of leaves not thickened.

8. fláccidum, Fée. Sterile lvs. 6-12 in. long, with very acute point, the lower portion gradually narrowed to the short stem; fertile lvs. on a stem 3-4 in. long. S. Amer. -Of botanical interest only.

AA. Lvs. simple; veins uniting to form a network.

B. Surface of lvs. densely clothed with narrow scales. (Hymenodium.)

9. crinitum, Linn. ELEPHANT-EAR FERN. Lvs.10-18 in long, 4-8 in. wide, on densely scaly stems ; fertile lvs. smaller, on shorter stems. W. Indies. F.S. 9:936, as $H$. crinitum.-Omit sand in potting, and avoid overwatering.

BB. Surface of les. mostly smooth, 6-15 in. long.

10. reticulàtum, Kaulf. Lvs. on distinct stems, with wedge-shaped bases, $11 / 2$ in. wide; veins forming copious meshes. (Chrysodium.) Hawaiian Islands. - Of botanical interest only.

11. gorgòneum, Kaulf. Lvs. tapering gradually downward to the short stem, 2-3 in. wide; veins forming meshes only near the margin. (Aconiopteris.) Hawaiian Isl. - Of little decorative value.

\section{AAA. Lis. pinnate.}

B. Ferns climbing with narrow, fertile pinna.

12. scándens, J. Smith. Rootstock widely climbing : lvs. 1-3 ft. long, with pinnæ 4-8 in. long; fertile pinnæ slender, 6-12 in. long; texture leathery. (Stenochlana.) India. S. 1:224. $-\mathrm{A}$ vigorous grower and coarse feeder, much used in cooler houses of large ferneries.

13. sorbifolium, Linn. Rootstock climbing, often prickly: lvs. 12-18 in. long, 6-12 in.wide, with close veins; fertile pinnæ 2-4 in. long, narrow. (Lomariopsis.) E. and W. Ind. to Braz.

BB. Ferns with creeping rootstocks and scattered lvs. C. Veins united only near the margin; fertile lvs. bipinnate.

14. cervinum, Swz. Fig. 28. Lvs, 2-4 ft. long, with pinnæ 4-9 in. long, 1-2 in. wide; fertile pinnæ slender, narrow, 4-8 in. long. (Olfersin.) Mex. and Cuba to Braz. S. 1: 192.

cC. Veins forming meshes everywhere. (Gymnopteris.)

15. aliènum, Swz. Sterile lvs. 1-2 ft. long, triangular, with the upper pinnæe decurrent, and the lower at least sinuate or even incised ; fertile lvs. smaller, with narrow pinnæ, the upper decurrent. Cuba and Mex. to Braz.

16. nicotianæfolium, Swz. Sterile lvs. with 3-7 pinnæ which are 6-12 in. long and 2-3 in. wide, with nearly entire edges; fertile lvs. smaller, with 3-7 pinnæ 3-4 in. long, 1 in. wide. W. Ind. to Braz.

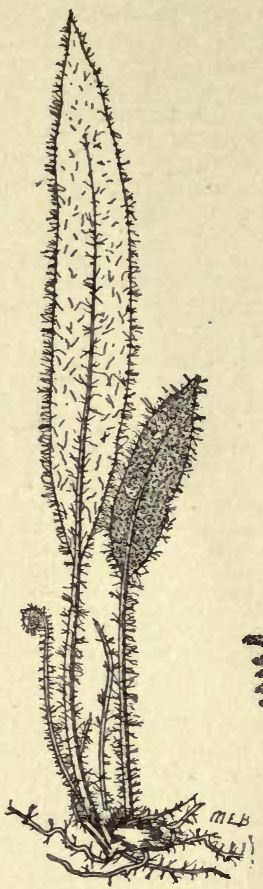

27. Acrostichum villosum $(\times 1 / 3)$. See No. 1 .

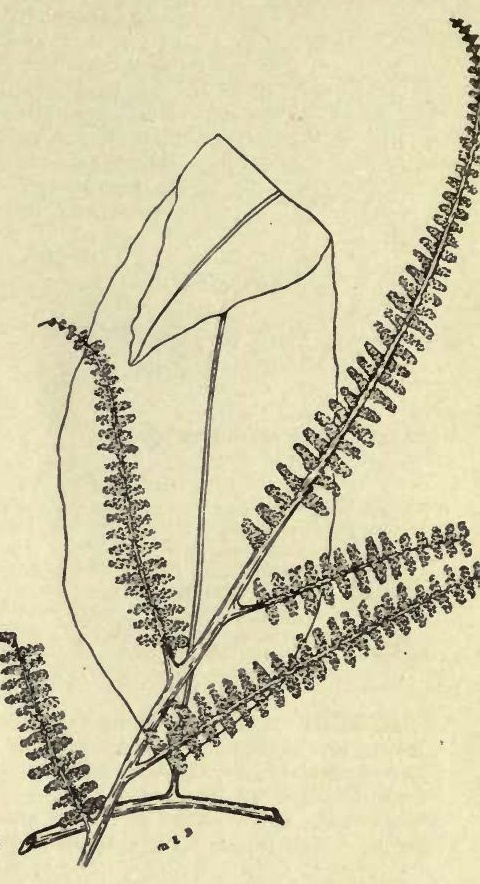

28. Acrostichum cervinum $(\times 1 / 3)$. See No. 14
BBB. Ferns of swampy places, growing in crowns from erect rootstocks.

17. aúreum, Linn. Lvs. fertile only in the upper pinnæ, 3-6 ft. long, with pinnæ 6-10 in. long, short stalked, coriaceous. Fla. to Braz. and in the tropies of the old world. S. 1: 187.-Strong-growing. One of the best. Should be treated as an aquatic.

18. lomarioides, Jenman. Sterile and fertile lvs. distinct, the sterile shorter and spreading, the fertile taller and more erect in the center of the cluster; pinnæ 9-14 in. long, almost sessile. Fla. to Braz.

AAAA. Lvs. bipinnatifid or bipinnate; veins free. (Polybotra.)

19. osmundàceum, Hook. Rootstock wide, climbing, with long, linear scales : sterile lvs. 2-3 ft. long, the lower pinnæ 8-10 in. long, with numerous slightly stalked segments; fertile lvs. tripinnate, with the lower pinnæ 1-2 ft. long, 4-8 in. wide, with narrow, cylindric segments $1 / 4-3 / 4$ in. long. W. Ind. to Braz. - Probably the handsomest of the climbing kinds.

AAAAA. Lv's palmate from creeping rootstocks: plants small.

20. peltàtum, Swz. Lvs. 1-2 in. each way on slender stems, repeatedly forked into very narrow divisions; fertile lvs. $1 / 4-1 / 2$ in. wide, circular, or somewhat 2 -lobed. (Rhipidopteris.) Mex. and W. Ind. to Braz. - A delicate and distinct plant, needing moisture all the year round, 
especially in the air. Avoid unnecessary disturbances of roots. Use some partly decayed leaf-mold.

A. acuminàtum, Hook., S. 1: 182, A. canaliculàtum, and A.caudatum, Hook., all from S. Amer., related to A. osmundaceum.A.flagelliferum, Wall. Rooting at apex of terminal pinna. E.Ind. S. 1:201.-A. foeniculàceum, Hook. Allied to A. peltatum. Ecuador.-A. Herminieri, Bory. Lvs, simple. Allied to A. sim plex. W. Ind. to Braz. -A. heteromórphum, Klotzsch. Lvs. simple, $1 \frac{1}{2-2}$ in. long. S. Amer.-A. latifòlium, Swz. Lvs. simple, 9-18 in. long. Allied to A. conforme. Mex. to Braz.-A. lepidòtum, Willd. Allied to A. villosum. Andes.-A.quercifòlium, Retz. Allied to A flagelliferum. Ind-A. serratifolium, Mert. Pinnate, with lvs. 1-2 ft. long. Allied to A. aureum. Mex. to Braz.-A spicatum Linn. Simple, with sori on long contracted apex. (Hymenolepis.) E. Ind. - A. taccefolium, Hook. Allied to A. flagelliferum. Philippines. $\quad$ L. M. UNDERWOOD.

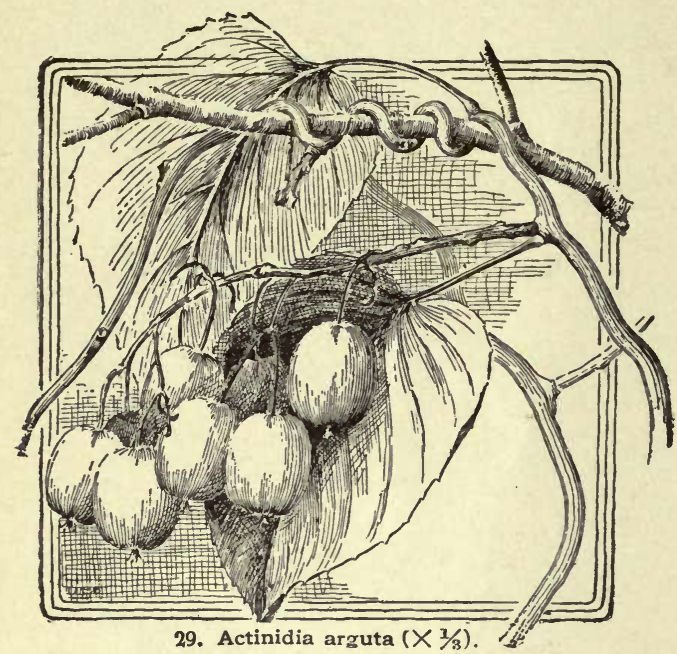

ACT Es A (ancient name of the elder, transferred by Linnæus). Ranunculdcece. Native hardy herbaceous perennials, with showy spikes of small fls. and handsome clusters of berries in autumn. Leaflets of the twice- or thrice-ternate lvs. ovate, sharply cleft, and cuttoothed. They like rich woods and shade. Useful for rockery and wild garden. Prop. by seeds and by rootdivision in spring.

álba, Mill. (A. rùbra, Bigel.). White BaneberRy. Height, 1-1 $1 / 2$ ft.; much like $A$. spicata, but the leaflets more cut, teeth and points sharper; plant smoother: fls. white, in an oblong raceme, and a week or two later: pedicels in fr. very thick, turning red : berries white, ovate-oblong, often purplish at the end. N. states. D. 53 .

spicàta, Linn. Cohosh. Herb-Christopher. Plant 1-2 ft.: lvs. bi- or triternate, serrated : fls. white or bluish, in ovate racemes: berries purplish black, oblong. Apr.-June. Eu.,Jap. - Less cult.than the red-fruited var.

Var. rùbra, Ait. (A. rùbra, Willd.). RED BANEBERRY. Rather taller than $A$, alba: lvs. bi- or triternate, serrated : fl. cluster white, larger than in A. spicata: berries bright red, very handsome. Apr.-June. Northern states.

K. C. Davis.

ACTINELLA (Greek, small-rayed). Compósitoe. Hardy perennials from W. N. Amer., for cult. in alpine gardens. Height 6-12 in.: fls. yellow, summer. Of easy cult. in light soil. Prop. by division or by seeds.

grandiflora, Torr. \& Gray. Plant densely woolly: lower lvs. pinnately or bipinnately parted, with margined petioles from broad, scarious bases; upper cauline lvs. simple or sparingly divided: fls. $2-3$ in. wide, summer. $-A$ pretty alpine plant.

scapòsa, Nutt. Plant villous: Ivs, radical, linear-spatulate, 2-3 in. long, punctate, entire: fls. 1 in. wide; scapes single, leafless, 1-fld., 3-9 in. long.

A. landta, Pursh. $=$ Eriophyllum cæspitosum.

J. B. KELLER and W. M.
ACTINIDIA (aktin, ray; referring to the radiate styles). Ternstromidceo. Hardy climbing deciduous shrubs, strong-growing and excellent for covering arbors, screens, trellises, walls and low buildings. Remarkably free from insects and fungi. Lvs. alternate, long-petioled, serrate: fls. axillary, single or in corymbs, polygamous, white, cup-shaped, 1/2-3/4in. in diam.; sepals and petals 5 ; stamens and stigmas numerous: berry many-seeded, about 1 in. long, edible. E. Asia, Himalayas. Prop. by seeds, by greenwood cuttings in summer, or by hardwood cuttings; also by layers. Monograph by Maximowicz in Diagn. Plant. As. Nov. 6: 422.

A. Lvs. dark green, shining, chartaceous.

argùta, Miq. (A. polýgama, Hort., not Miq. A. volùbilis, Hort., not Miq.). Fig. 29. Petioles mostly setose: lvs. 4-5 in. long, broad-elliptic, cuneate to subcordate at the base, abruptly acuminate, smooth except the setose midrib beneath, setulosely appressed serrate: fls. 3 or more, greenish white; anthers dark purple: fr. greenish yellow, with fig-like flavor. June. Japan, Saghalin, Manchuria. A.G. 1891:142.

AA. Lvs. bright green, dull, membranaceous, sometimes becoming in the summer handsomely variegated above the middle: fls, fragrant: not climbing high.

polýgama, Miq. Lvs. 3-4 in. long, broad-ovate or ovateoblong, cuneate to subcordate at the base, appressedserrate, mostly setose at the nerves on both sides: fls. $1-3,3 / 4$ in. in diam.; stigmas on a short, thick style; fr. yellow. July. Japan, Saghalin, Manchuria. B.M. 7497. -The plant attracts cats like valerian.

Kolomikta, Maxim. Petioles not setose ; lvs. downy beneath when young, 4-6 in. long, ovate-oblong, rounded or cordate at the base, unequally setulosely serrate, sparsely setose beneath: fls. 1-3, 1/2in. in diam.; stigmas sessile. July. Japan, Saghalin, Manchuria. R.H.1898:36.

A. callosa, Lindl. Allied to A. arguta. Lvs. mostly acute at both ends. Himalayas.

ALFRED REHDER.

ACTINOLEPIS (Greek, a scale-like ray). Compósita. Hardy annuals from Calif.; freely branching, and mostly yellow-flowered.

coronària, Gray (Shórtia Californica, Hort. Baria corondria, Gray). Figs. 30, 31. Lvs. opposite, except

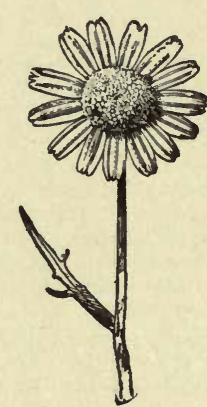

30. Actinolepis coronaria. Nearly natural size. the upper ones, 2 in. or more long, deeply pinnatifid; lobes 5-7, distant, linear, entire. B.M. 3828, as Hymenóxys Californica. - One of the prettiest of annual flowers, and deserving of greater popularity. Excellent for edging. An everlasting.

\section{Shortia Californica.}

31. Actinolepis coronaria. Known to the trade a
ACTINÓMERIS (from Greek aktis, ray, and meris, part, alluding to the irregularity of the rays). Compositoe. Native hardy herbaceous perennials suitable for wild gardens and shrubbery. Tall, branching. Cult. like Helianthus. Prop. by division.

squarròsa, Nutt. Height 4-8 ft.: lvs. lance-oblong, acuminate, subpetiolate, tapering to both ends: fls. numerous, corymbed, yellow; rays 4-10, irregular. Autumn.

A. helianthioides, Nutt. Lvs. silky-villous underneath: rays about 8 , usually more than in A. squarrosa. Mn. 4:129.-A. procera, Steud., is only a taller form of A. squarrosa.

\section{J. B, KeLLER.}


LCTINOPTERIS (aktin, ray, and pteris: the fronds radiately eut). Syn., Actiniopteris. Polypodiàcea. Greenhouse ferns from India, resembling miniature fan. palms. The sori are linear-elongate and submarginal, and covered with indusia. A. radidta, Link, is the only recognized species.

L. M. UNDERWOOD.

ADA (a complimentary name). Orchiddcece; tribe Vándece. A genus of epiphytes containing two species. Petals and sepals slightly spreading from half their length; labellum parallel with the column and united to its base. Found at high elevations on the Colombian Andes. Useful for the coolhouse, where they may be grown together with Odontoglossums, blooming in no definite season.

aurantlaca, Lindl. Fig. 32. Pseudobulbs 2-3 in., ovate to ovate-oblong, subcylindrical or slightly compressed, tapering toward the summits, bearing 1-3 narrow leaf-blades 6-12 in. long: petals and sepals narrow, pointed, channeled; labellum half as long as the petals: scape drooping, bearing racemes of cinnabar-red fls.

Léhmanni, Rolfe. Leaves marbled with gray : labellum white. - Not much in cultivation. A recent species.

OAKES AMES.

The Adas grow at the altitude of $8,500 \mathrm{ft}$. To grow them successfully, a house that can be kept very cool in summer is necessary, one having a northern exposure, such as is constructed for Odontoglossums being best, as the two plants are found growing together. Shading will be found necessary in summer during the hottest weather, preferably by roller shades, that can be rolled up in dull weather, as by this means a current of cool air is constantly passing over the glass. The temperature inside the structure can be kept below that outside in hot weather by careful airing and spraying. A. au rantiaca is the best known, and is much valued for its bright orange-colored spikes of bloom, which last a long time. A. Lehmanni is very rare in cultivation, and is listinguished, among other characteristics, by its white ip and by being a summer-blooming plant, while its companion species flowers early in spring. The usual fern fiber and sphagnum moss compost will be found best suited for their cultivation, taking care that the plants are never dry at the roots, either in summer or winter.

E. O. ORPET.

ADAM-AND-EVE. See Sempervivum tectorum, and Aplectrum hyemale.

ADAMIA. See Dichroa.

ADAM'S APPLE. See Citrus Limetta, Musa paradisiaca, and Tabernamontana coronaria.

\section{ADAM'S NEEDLE. See Yucca.}

ADANSONIA (named after M. Adanson, French botanist). Malvacea. The Baobab is said to have the thickest trunk of any tree in the world. Adansonia has few congeners familiar to the horticulturist: fls. large, pendulous ; petals 5 , white, obovate - stamens numerous ; ovary 5-10-celled : fr. oblong, woody, indehiscent, filled with a mealy pulp in which are numerous seeds.

digitàta, Linn. BAOBAB TrEe. Height not more than $60 \mathrm{ft}$; diam. said to be sometimes $30 \mathrm{ft}$. or more : lvs. palmate, with 3 leaflets in young plants, and 5-7 in older ones: fls. 6 in. across, with purplish anthers on long axillary, solitary peduncles. Africa. B.M. 2791.-Rarely cultivated in extreme S. Fla., where fr. is 9-12 in. long, and called "Monkey's Bread."

\section{ADDER'S-TONGUE. See Erythronium.}

\section{ADDER'S-TONGUE FERN. See Ophioglossum.}

ADENANDRA (from the glandular anthers). Rutdeece. Small summer-flowering, tender shrubs from the Cape of Good Hope. Lvs. alternate, small, leathery, subsessile, entire, glandular-dotted : fls. white or rosy; petals obovate. Prop. by cuttings from the ripened wood.

fragrans, Roem. \& Schult. (Diósma frdgrans, Sims). BReath of Heaven. Height 2-3 ft.: lvs. oblong, obtuse, dark green above, whitish beneath, with a glandular, denticulate margin: fls. rosy. B.M. 1519.-A favorite in Calif.
ADENANTHERA (from the deciduous pedicillate gland on each anther). Legumindsce. Tender, unarmed evergreen tree, cult. in greenhouses only for its eco. nomic interest, and also in Calif. in the open air. Prop. by seeds, which should be softened in hot water previous to sowing.

Pavonina, Linn. Red Sandal-wood Tree. Leaflets about 13: fls. in an axillary spike. Trop. Asia, where it grows to a tree of great size. -The red lens-shaped "Circassian Seeds" are curiosities with travelers, and are used for necklaces, etc.

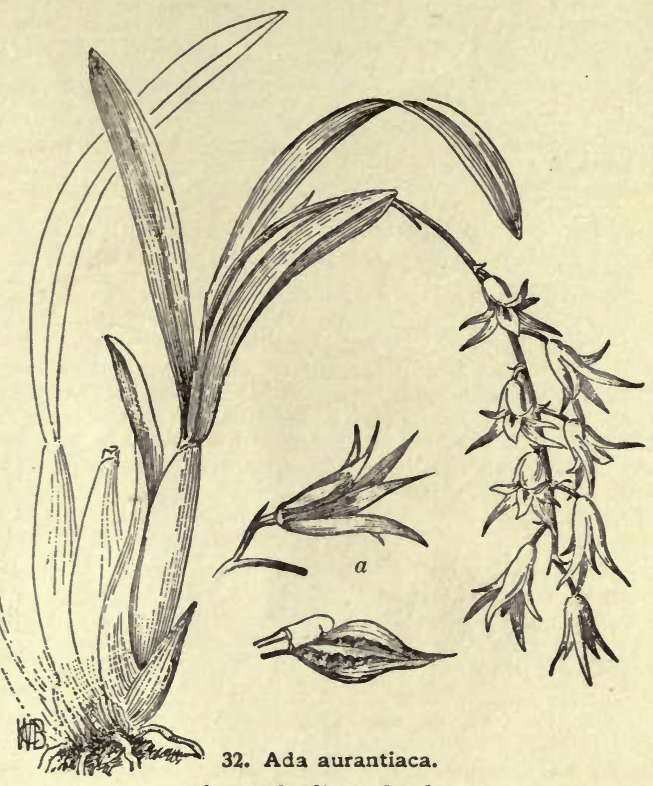

$a$ shows the lip and column.

ADENOCALYMNA (glandular covering; referring to leaves, etc.). Bignonidcece. Tender climbing shrub, closely allied to Bignonia. Grown in hothouses, requiring considerable moisture. Prop. by cuttings in frames.

comosum, DC. St. rough, punctate: lvs. opposite, trifoliolate; petioles thickened at junction with the blades: racemes so densely clothed at first with large bracts as to suggest the aments of the hop-vine ; fls. 2 in. across, brilliant yellow, trumpet-shaped; upper lip of 2 , and lower lip of 3 rounded, waved lobes. Braz. B.M. 4210.

ADENOCARPUS (from the glandular pod, which easily distinguishes it from allied genera). Legumindsce. Shrubs, rarely small trees, more or less pubescent: Ivs. alternate, trifoliolate, small: fls. papilionaceous, yellow, in terminal racemes; calyx 2-lipped: fr. a glandular pod, oblong or linear, compressed. About 14 species in $\mathrm{S}$. Eu., Asia Minor, N. and W. Afr., Canary Isl. Low shrubs, rarely more than $3 \mathrm{ft}$., of spreading habit, with handsome fls. produced profusely in spring ; very attractive when in full bloom. They require a sunny position and well drained soil. They are especially adapted for temperate regions, but do not bear transplanting well, and should be grown in pots until planted. They are also handsome greenhouse shrubs, and grow best in a sandy compost of peat and loam. Prop. by seeds and greenwood cuttings in spring; sometimes also by layers and grafting.

frankenioldes, Choisy. (A. anagỳrus, Spreng.). Branches pubescent : lvs. persistent, crowded ; leaflets linear-oblong, complicate: fls. crowded, in short racemes; calyx glandular, the lateral segments of the lower lip longer than the middle one, exceeding the upper lip. Teneriffe.

intermeddius, DC. Branches villous: lvs, deciduous, grouped; leaflets obovate or oblong-lanceolate: fls. in elongated racemes; calyx glandular, middle segment of 
the lower lip longer than the lateral ones, much exceeding the upper lip. Italy, Spain, Sicily.

decórticans, Boiss. (A. Boissièri, Webb). Shrub or small tree, 15-25 ft.: branches tomentose : lvs. crowded, persistent; leaflets linear, pubescent : racemes short, compact : calyx villous, segments nearly equal. Spain. R.H. 1883: 156. G.C. II. 25: 725. Gn. 30:572.-Resembles English Gorse, but is thornless. Bark peels naturally. Thrives in poor, sandy soil.

A. anagỳrus, Spreng. $=$ A. frankenioides $-A$. Boissieri, Webb =A. decorticans. $-A$. complicàtus, Gay. (A. parvifolius, DC.) Branches nearly glabrous : racemes elongated; calyx glandular. S. W. France, Spain. B.M. 1387, as Cytisus divaricatus.A. commutàtus, Guss. (A. Telonensis, DC.). Branches villous, pubescent : racemes loose; calyx villous. Spain Orient. $-A$. di varicatus, Boiss. $=\mathrm{A}$. intermedius when held to include $\mathrm{A}$. com varicatus, Boiss. $=$ A. intermedius when held to include A. comcrowded, villous : racemes compact, many-flowered ; calyx villous. Canary Isl.-A. grandiflorus, Boiss. Branches and lvs. glabrous : racemes few-flowered; calyx pubescent. S. France, Spain.-A. Hispánicus, DC. Branches velvety-pubescent : lvs. tomentose beneath : racemes dense, many-flowered; calyx glandular. Spain $-A$. parvifòlius, DC, $=$ A. complicatus, Gay. $-A$ Telonénsis, DC. $=\mathrm{A}$. commutatus. $-A$. Telonénsis, Nicholson= Telonénsis, DC. $=$ A. commutatus. $-A$. Telonensis, Nicholson
A. grandiflorus.
ALFrED REHDER.

ADENOPHORA (gland-bearing; referring to the cylindrical nectary which surrounds the base of the style). Campanuldcece. A genus of hardy herbaceous perennials separated from Campanula only by minor characters, as the trilocular ovary and cylindrical nectary. Fls. blue, nodding, on short pedicels, produced freely in midsummer in slender but stiff, erect panicles or loose racemes. For culture, see Campanula. Prop. by seeds or cuttings in spring. The plants do not take kindly to division or other disturbance of the roots. Many other species than those in the trade are worthy.

communis, Fisch. (A. lilifldra, Schur. A. F'ischeri, G. Don. A. liliifòlia, Ledeb.). Radical lvs. petiolate, ovaterotund, cordate, crenate-dentate; cauline lvs. sessile, ovate-lanceolate, coarsely serrate: fls. numerous, in a pyramidal panicle; lobes of the calyx triangular ; style exserted.

Lamárckii, Fisch. Lvs. ovate-lanceolate, sharply serrate, ciliate: fls. racemose; lobes of the calyx lanceolate style not exserted.

Potanini, Hort. Shrubby: spikes 2-3 ft. high: fls. 11/4 in. across, light blue. July-Aug. Int. 1899.

J. B. KELLER and W. M.

ADENOSTOMA (aden, gland, stoma, mouth ; calyx with 5 glands at the mouth). Rosdcece. Shrubs, rarely small trees : lvs. linear, small : fls. white, about 1-5 in. broad, in terminal panicles; petals 5 , stamens 10-15: fr. a small akene. Two species in Calif. Heath-like evergreen shrubs; very handsome when in full bloom. They may be cult. in temperate regions in a sunny position and well drained soil. A. fasciculatum stands many degrees of frost. Prop. by seeds and greenwood cuttings in spring.

fasciculàtum, Hook. \& Arn. Shrub, 2-20 ft.: 1vs. fasciculate, linear: panicles rather dense, $2-4$ in. long: fls. nearly sessile. May-June. Ranges northward to Sierra Co. The characteristic shrub of the chaparral or chamisal regions of the coast ranges of Calif. Int. 1891.

sparsifolium, Torr. Shrub or small tree, 6-12 ft., rarely $30 \mathrm{ft}$., resinous : lvs. alternate : panicles loose; fls. pedicelled, larger, fragrant. S. and Lower Calif. Int. 1891

AlFRED REHDER.

ADESMIA (not bound; referring to the free stamens). Legumindsa. Tender shrubs from Chili.

A. balsámica, Bertero. Lrs. $1-1 \frac{1}{2}$ in. long; leaflets $10-16$ in pairs : racemes 3-8 fld.; fls. $2 / 3$ in. across, golden yellow. B.M. 6921. - Has the odor of balsam. Not in Amer. trade.

ADHATODA (native name). Acanthdcece. Tender shrubs, distinguished from Justicia by the less spurred anthers, and often by the habit and calyx. For culture, see Justicia.

cydoniæfolia, Nees. Lvs. opposite on short petioles, ovate; lower lip broadly obovate, purple Brazil. B.M. 4962. F.S. $12: 1222$. R.H. 1873:110. - Cult. in Calif.

4. Vasica, Nees. Lvs. ovate-lanceolate, acuminate: fls. white, streaked red. Ceylon. B.M. 861 as Justicia Adhatoda.
ADIÁNTUM (Greek, unwetted). Polypodidcere. MAIDENHAIR FERN. A large genus of widely distributed ferns of tropical countries largely, with polished black or purplish stems, mostly smooth foliage to which water will not adhere, and marginal sori attached underneath an inrolled portion of the segment, which thus forms a protecting in dusium. The requirements of cultivation are plenty of space, good drainage, and a compost of peat, loam and sand. Of the one hundred or more species, five are natives, of which $A$ vedatum is the best known.

L. M. UNDERWOOD.

The genus Adiantum furnishes us some of the most useful and popular species of commercial ferns. They are easy of cultivation. They need a slightly shaded position, moderately moist atmosphere, and a temp. of $60-65^{\circ} \mathrm{F}$. The soil should be composed of rich loam and leaf-mold in equal parts, and should be kept moderately moist. Some of the most useful ones for general purposes (given under their trade names) are: $A$. cemulum, grows about 12-15 in. high, and has very graceful dark green fronds; $\boldsymbol{A}$. bellum, a dwarf, very compact species 6-8 in.; A . cuneatum, A. cuneatum var. grandiceps, with long, heavily-crested, drooping fronds; $A$. cuneatum var. variegatum makes a neat specimen; $A$. concinnum, gracefully drooping dark green fronds 15 in. long, with overlapping pinnæ; $A$. concinnum var. latum, of upright growth, is 24 in. high; $A$. decorum is very useful, 12-15 in., and has young fronds of a pleasing metallic tint; A. excisum var. multifidum; A. formosum; A. Fergusonii; A. fragrantissimum; A. pubescens; A. tenerum and var. roseum; A. Wiegandi; A.LeGrandi, very dwarf; $A$. mundulum, a very neat, dwarf species ; $A$. rubellum, a dwarf species with mature fronds light green, young fronds of a deep ruby tint. The abore may easily be grown from spores, if sown on a compost consisting of half each of finely screened, clean soil and leaf-mold or peat, and placed in a moderately moist and shady place in the greenhouse in a temp. of $60^{\circ} \mathrm{F}$. To be grown most economically, they should be transplanted in clumps of 3 or 4 plants as soon as the first pinnæ have appeared, and, as soon as strong enough, potted off, either in clumps or singly.

Some very desirable species to grow into large, tall specimens are: A. Athiopicum, A.Bausei, A. Collisii, A. Fergusoni, A. formosum, A. Lathomii, A. Peru vianum, $A$. princeps, $A$. rhomboideum, A. Sancto Catharina, A. trapeziforme, and $A$. Williamsii. The following are also recommended for special purposes: for fern-dishes, A fulvum; for cutting, $A$. gracillimum. The following kinds are economically prop. by division, temp. $65^{\circ}$ F.: A. Farleyense, the different varieties of Capillus-Veneris, A. rhodophyllum, A. assimile, etc. Some kinds, as $A$. dolabriforme, $A$. caudatum and $A$. $E$ dgeworthii, form small plants on the ends of fronds, which may be detached and potted separately, and if

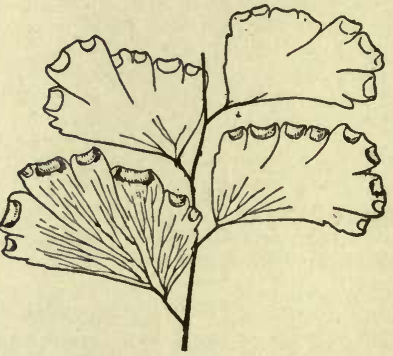

33. Fruiting pinnuics of Adiantum pedatum.

$k \in p t$ in a close atmosphere will in a short time grow into choice little plants. Temp. $65-70^{\circ} \mathrm{F}$. The last three kinds are adapted for hanging baskets.

NICHOL N. BRUCKNER.

The following species are in the American trade, the names in italies being synonyms: (A.roseum is an undetermined horticultural name, possibly referable to $A$. 
AAAAs. Fronds at least bipinnate, often tripinnate or quadripinnate, with numerous rather small fan-shaped or wedge-shaped leaflets with veins radiating from the base.

B. Leaflets an inch or less across.

C. Edges deeply cut into a series of narrow lobes.

18. Farleyénse, Moore. Fig. 34. Fronds often reaching 15-24 in. in length, forming a rich profusion of

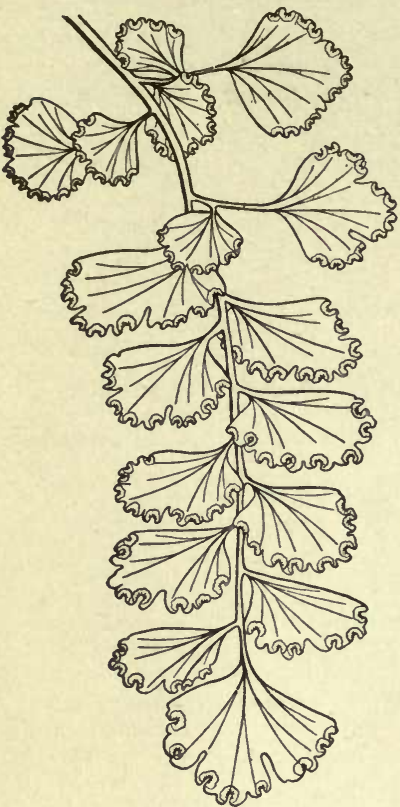

35. Pinna of Adiantum concinnum. Natural size. closely overlapping pinnæ, light green; leaflets more or less wedgeshaped at base, with curved sides and the outer margin rounded and deeply cut into 10-15 narrow lobes, which rarely bear sori. Barbadoes. I.H. 19: 92. - Said to be a garden variety of $A$. tenerum, but apparently a good species.

cc. Edges not laciniately cut.

19. ténerum, Swartz. Fronds deltoid, 12-15 in. long, two-thirds as wide, the terminal leaflets equally, the lateral unequally wedge-shaped at base, all of them rhombic and deciduous when dry, with 10 or less small sori on the outer and inner margins. A. Lathomi, $A$. Victòria, $A$. rhodophýllum, $A$. princeps, and $A$. Baùsei are horticultural forms. Fla. and Trop. Amer.

20. Jordani, C. Muell. (A. emarginatum, D. C. Eaton, not Hook.). Fronds $1 \mathrm{ft}$. or more long, 6 in. wide, mostly twice pinnate, with nearly semicircular leaflets; sori elongate, the indusium almost continuous around the margin of the leaflet. Calif. and Oreg.

21. Williamsii, Moore. Fronds triangular, nearly $1 \mathrm{ft}$. high; leaflets nearly semicircular, 3-4-lobed on the outer margin, bearing 5-8 sori covered with oblong indusia. Peru. - Similar in habit to the last, but smaller and with more numerous sori.

BB. Leaflets mostly less than a half inch across.

c. Fronds at least quadripinnate, broader than long.

22. Collisii, Moore. Fronds $1 \mathrm{ft}$. or more long, very broad, the black rachises apparently repeatedly forking; leaflets rhombic-ovate or cuneate, those towards the outer portions longer and larger than those nearer the base.Of garden origin, possibly a hybrid.

cc. Fronds mostly triangular or oblong, longer than broad.

D. Shape of leaflets rhombic, the indusia kidney-shaped or nearly circular.

23. concinnum, HBK. Fig. 35. Fronds 2-3-pinnate, 12-18 in. long, 6-9 in. wide, on rather stout bluck stalks; leaflets rhombic-oblong, slightly lobed; sori 4-8 on each leaflet, usually set close together. Mex. to Braz.

DD. Shape of leaflets roundish with obtuse base, small or medium size.

24. Ethiopicum, Linn. (A. assimile, Swartz). Fronds $1 \mathrm{ft}$. or more long on slender stalks, 2-3-pinnate, rather narrow; leaflets roundish or obscurely 3 -lobed, the margin finely serrulate; sori 2-3 to a leaflet, with oblong or kidney-shaped indusia. Afr. and Austral.

25. excisum, Kunze. Fronds 2-3-pinnate, 6-12 in. long, 3-4 in. wide; leaflets about $1 / 4 \mathrm{in}$. wide, roundish, with the margin cut into small rounded lobes; sori large, 2-4 to each leaflet, kidney-shaped or circular. Chile.
DDD. Shape of leaflets distinctly cuneate at the base. E. Indusia oblong or indistinctly lunate.

26. Capillus - Véneris, Linn. (A. Férgusoni, A. Mairisii, Moore). Fig. 36. Fronds 2-3-pinnate, 6-20 in. long, 3-8 in. wide; leaflets nearly $1 / 2$ in. wide, more or less irregularly lobed at the outer margin; sori $1-3$ to each leaflet, with oblong or more or less elongate narrow indusia. Native southward, and widely distributed throughout the Old World. - Exists in many varieties, some of them deeply lobed, like A. Farleyense; a compact imbricated form is very effective.

27. béllum, Moore. Small, 3-8 in. high, bipinnate; leaflets with the outer margin erose and often divided into 2-3 shallow lobes ; sori 2-3 to each leaflet, rather long and broad or somewhat lunate. Bermuda.

EE. Indusia nearly circular, with a narrow sinus.

28. cuneàtum, Langs. \& Fisch. (A. ámulum, A. múndulum, Moore. A. Versaillénse, A. fragrantissimum, Hort.). Fronds 3-4-pinnate, deltoid, 6-15 in. long, 5-9 in. wide; leaflets numerous, obtuse or broadly wedge-shaped at base, the margin rounded and more or less crenately lobed; sori 3-5 to each segment, with rather small rounded indusia. Braz. - Runs into many forms, of which $A . v a$ riegatum is one.

29. Moòrei, Baker (A. amábile, Moore, not Liebm.). Fronds 2-3-pinnate on long slender stalks, 6-15 in. long; leaflets $1 / 4-1 / 2$ in. long, rhomboidal, with wedge-like base, deeply lobed; sori of medium size, 4-6 to each leaflet. Peru.

30. Wágneri, Mett. (A. décorum, A. Wiègandi, A. élegans, A. Oweni, A . cyclosorum, Moore). Fronds 2-3-pinnate, 6-9 in. long, 4-6 in. wide; lateral leaflets rhomboid, the terminal cuneate, slightly lobed or incised ; sori 4-6 to each leaflet, with very large membranous circular indusia. Peru. - A. Sièbrechtii, Hort., "supposed to be a cross between $A$. decorum and $A$. Williamsii," has strong, graceful fronds thickly set with round pinnules of firm texture.

31. rubéllum, Moore. Fronds 4-6 in. long, deltoid, bipinnate; texture membranous, bright green, reddish when young; leaflets $1 / 2$ in. wide, deltoid or the lower rhomboid, the outer margin deeply lobed and the lobes finely toothed; sori round at the apices of the lobes. Bolivia.

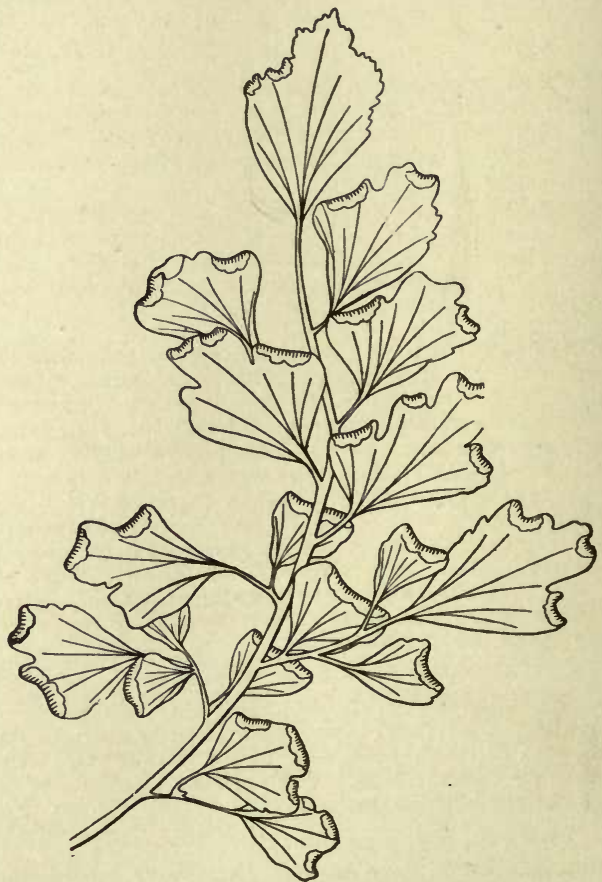

36. Pinna of Adiantum Capillus-Veneris. Natural sice 
32. monochlámys, D. C. Eaton. Fronds ovate-deltoid, 6-12 in. long, tripinnate ; leaflets $1 / 4 \mathrm{in}$. wide, cuneate at the base, the upper edge rounded, slightly toothed, with a single sorus or rarely two in a decided hollow at the npper edge. Jap.

33. venùstum, Don. Fronds ovate-deltoid, tri-quadripinnate, $6-12 \mathrm{in}$. long; leaflets cuneate at the base, $1 / 4 \mathrm{in}$. wide, with the upper edge irregularly rounded or with 3 indistinct lobes, finely toothed, bearing 1-3 sori in distinct hollows. Ind.

Ввв. Leaflets minute, innumerable; fronds 4-6-pinnate.

34. gracíllimum, Hort. Fronds $1 \mathrm{ft}$. or more long, nearly as wide, 4-6-pinnate, with innumerable very small leaflets, which are $1 / 8-1 / 4 \mathrm{in}$. wide and usually bear a single sorus or rarely two.-Dense, compact forms are in cult. under the name of $A$. Le Grándi.

AAAAAA. St. climbing, several ft. long, 3-4-pinnate.

35. digitàtum, Presl. (A. speciòsum, Hook. A. palmatum, Moore). Fronds 2-3 ft. long on a stalk 18 in. or more long, with palmately lobed leaflets 1 in. or more wide. S. Amer.

L. M. UNDERWOOD.

ADLUM, JOHN. Plate II. Grape experimenter, and author of "Memoir on the Cultivation of the Vine," 1823 and 1828, the first separately published American grape book. Born in York, Pa., Apr. 29, 1759. Died at Georgetown, D. C., Mar. 1, 1836. He was a soldier in the Revolution, major in the provisional army in the administration of the elder Adams, and later a brigadier-general in the militia of Pennsylvania. He was also a surveyor and civil engineer. He also held an associate judgeship in Lycoming county, Pennsylvania, having been appointed by Gov. Mifflin. He was a friend of Priestly, and endeavored to apply the seientific knowledge of his time to agriculture. He early became interested in the amelioration of the native grapes, and established an experimental vineyard in the District of Columbia. He endeavored, but without success, to secure the use of certain public land in Washington for the purpose of "cultivating an experimental farm." He brought the Catawba grape to public notice. He was a pioneer in the awakening industrial activity of our new country. The botanist, Rafinesque, commemorated his name in the pretty genus Adlumia; but otherwise he has remained practically unknown until very recently. For further information, see Bailey, "Evolution of our Native Fruits."

L. H. B.

ADLÙMIA (from John Adlum). Fumaridece. A hardy biennial vine, which climbs over high bushes in our moist woods. Sow seed in spring in a damp, cool place. Transplant in fall, if possible, if transplanted at all. It flowers the first season.

cirrhòsa, Raf. Climbing Fumitory. Mountain Fringe. Alleghent Vine. Figs. 37, 38. Climbs by the slender young leaf-stalks. Lvs. thrice pinnate; leaflets cutlobed, delicate : fls. white or purplish, in ample panicles. G.W.F. 13 .

ADONIS (a favorite of Venus, after his death changed into a flower). Ranunculdcea. Hardy annual and perennial herbs with showy flowers. Six well known species, natives of temperate regions of Eu. and Asia. Fls. solitary, terminal ; petals 5-16, yellow or red ; carpels many: st. about $\boldsymbol{l}$ foot high, very leafy: lvs. alternate, cut into very narrow divisions: fr. an akene. Culture easy in any good soil, light, moist earth preferred. They thrive in full sun or partial shade; the perennial species well suited for rockwork, borders, etc. Annuals prop. by the seeds, which are slow-germinating, sown in autumn or earliest spring; perennials by seeds or root divisions.

\section{A. Annuals : fls. crimson or scarlet.}

B. St. simple except at top: center of fl. yellow.

æstivalis, Linn. Pheasant's ExE. Stems erect, often branched at top: fls. crimson; petals flat, obtuse, half longer than calyx. June. Var. citrina, Hoffm., is a garden variety with citron-yellow fls.

Bв. St. branched: center of $f l$. dark.

antumnàlis, Linn. Flos AdoNis. Fig. 39. St. branched: fls. small, crimson, with dark center, globose; petals
6-8, concave, slightly larger than calyx. May-July, Gn 12, p. 131.-Sparingly naturalized.

AA. Perennials: fls. yellow.

B. St. not branched.

vernàlis, Linn. (A. A pennina, Jacq. A. Davùrica, Reichb.). SPRING Adonis. St. simple: lower lvs. scale

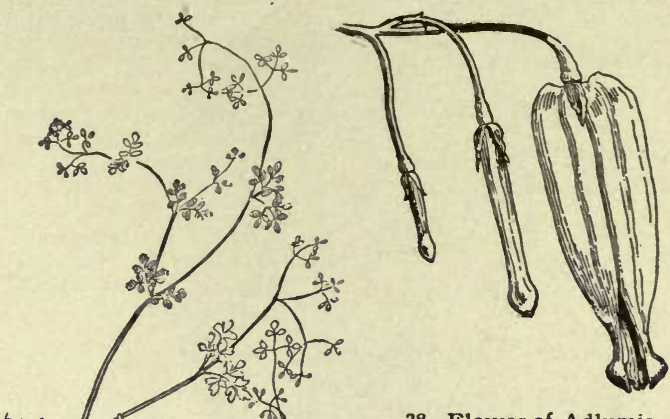

38. Flower of Adlumia Natural size.

like, others with lobes numerous, entire: fls. large; petals $10-15$, lanceolate, slightly toothed; sepals smooth. Early spring. Gn. 5, p. $519 ; 39: 797$. A.distorta, Tenore, from Italy ; a form with later fls.

Apennina, Linn. ( $A$. vernalis, var. Sibirica, DC. A. Sibirica, Patrin.). This species is much like A.vernalis : fls. larger : lower lvs. sheath-like. Apr. Siberia.

Bв. St. branched.

Pyrenàica, DC. St. branched: petals $8-10$, obtuse, smaller than in A. vernalis: lower lvs. with long branched petioles; upper ones sessile, the numerous lobes always entire. July.Gn. 39,p. 269. A.Ircutiana, DC., a form with some radical leaves; lobes dentate.

37. Adlumia cirrhosa.

Volgénsis, Stev. (A. Wolgénsis, Hort.) Much like A. vernalis, but st. branched: lvs. scale-like at base, petioled or sessile above: fls. like $A$. Pyrenaica, but sepals pubescent on under side. Apr. Volga region.

A. Amurénsis, Regel \& Radde, a beantiful species, with broad yellow fis.; not much cult. in Amer.; has many Japanese varieties. B.M.7490. G.M. 40: 169. Gn. 52: 1125.-A.microcárpa, DC. is a pale-flowered variation of A. mstivalis.-A.parviflora, Fisch. Allied to A, restivalis.

K. C. Davis.

ECHMìA (from aichme, point; referring to the rigid points on the calyx). Bromelidceo. The Atchmeas are closely allied to the Billbergias, from which they are distinguished by smaller flowers, which are little exserted from the calyx and not widely expanding, short filaments and small anthers, sharp-pointed sepals and conspicuous sharp-pointed flower-bracts. They are epiphytic herbs, of about 60 species, natives of Trop. S. Amer. Flowercluster arising from a cluster or rosette of long, hard leaves, which are usually serrate; petals 3, tongueshaped, obtuse or pointed, 2-3 times the length of the spine-pointed calyx-lobes; stamens 6 , shorter than the 
petals : ovary inferior, 3-celled. The flowers are subtended by (in the axils of) flower-bracts; the entire head or flower-cluster is often reinforced or subtended by conspicuous leaf-bracts; in the compound-inflorescence types, the individual branches are usually subtended by branch-bracts. In some species, as $A$. Lalindei and $A$. Marice-Regince, the large colored leaf-bracts are the most conspicuous part of the plant. In others, as $A$. Veitchii, the entire head is the showy part. Monograph

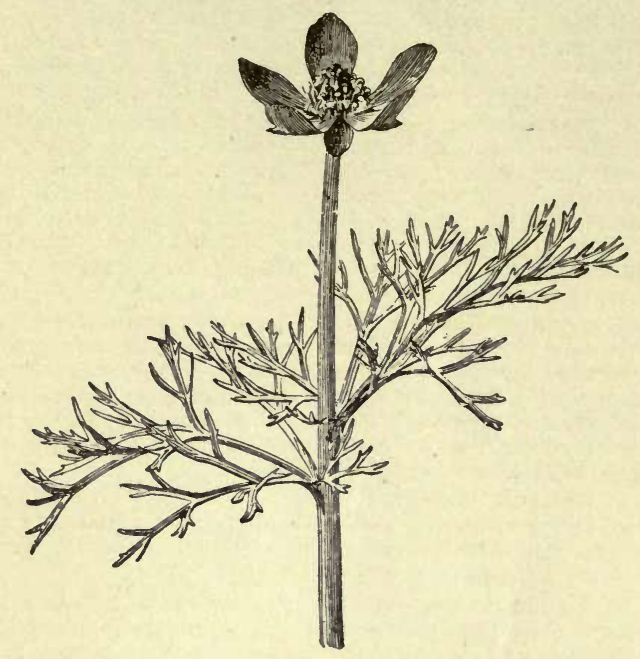

39. Adonis autumnalis.

by Baker, Journ. Bot. 1879: 129, 161, 226. Includes $C a$ nistrum, Echinostachys, Hohenbergia, Hoplophytum, Lamprococcus, Pironneava, Pothuava; and some of the species have been referred to Billbergia, Cryptanthus, Guzmannia, Tillandsia, Chevaliera, etc. For culture, see Billbergia.

A. Fls. 2-ranked on the branchlets.

distichántha, Lemaire. Lvs. 2-3 ft. long, with a dilated base $4-5 \mathrm{in}$. long and half as wide, the blade rigid and channelled, edges prickly: scape 1-11/2 ft.: fls. in a bipinnate panicle 4-7 in. long and half as wide, the petals tongue-shaped and red-purple, longer than the obtuse-cuspidate sepals : fl.-bract pocket-like, $1 / 4 \mathrm{in}$. long. Braz. B.M. 5447.

AA. Fls. multifarious, -in several or many rows on the spike or branchlets.

B. Inflorescence simple.

c. Ovary compressed or flattened.

Lalindei, Lind. \& Rod. Large (3-4 ft.), with long and broad spine-edged lvs.: spike very dense, greenish white, from the color of the aggregated calices, the fls. subtended by many deflexed, showy red, long-pointed, entire bract-lvs.: corolla not exserted. New Granada. I.H. $30: 481$. - Striking.

Mariæ-Reginæ, Wendl. Smaller than the last in all its parts: petals blue-tipped when young, fading to crimson like the bracts, half as long again as the mealy cuspidate sepals ; fl.-bracts entire, small, not showy: bract-lvs. toothed. Costa Rica. B.M. 6441.-One of the best species.

Veitchii, Baker. Lvs. spotted, serrate : petals pale, a little longer than the sepals: fl.-bracts conspicuous, toothed, scarlet: bract-lvs, greenish, erect, serrate, not encompassing the inflorescence. S. Amer. B.M. 6329.Referred to Ananas by Benthain \& Hooker.

$$
\text { cc. Ovary terete (cylindrical). }
$$$$
\text { D. Head oblong. }
$$

Líndeni, Koch (Hoplophỳtum Lindeni, Morr.). Lvs. dilated and entire at base, the blade minutely toothed and 2-3 ft. long, the tip broad-rounded and short-cuspidate: petals lemon-yellow, twice as long as sepals. Braz. B.M. 6565 .

\section{DD. Head globose.}

calyculàta, Baker (Hoplophỳtum calyculatum, Morr.). Lvs.about $1 \mathrm{ft}$. long, with an oblong, dilated base, the blade minutely toothed and rounded at the tip, but terminated with a minute cusp: scape shorter than the lvs., with several deciduous lanceolate bract-lvs.: petals tongueshaped, not half an inch long, bright yellow: fl.-bracts small, entire, reddish. S. Amer.

fasciàta, Baker (Billbérgia fasciàta, Lindl. B. rhodocydnea, Lemaire). Lvs. 1-2 ft. long, with an oblong entire clasping base, the blade strongly toothed and the back marbled with whitish cross-lines, the tip rounded and mucronate : scape $1 \mathrm{ft}$. high, floccose, the several bract-lvs. pale red and erect; petals $3 / 4$ in. long, pink. Braz. B.M. 4883. B.R. 1130. F.S. 3:207.-Inflorescence sometimes forked.

BB. Inflorescence branched (or compound).

c. Calyx and ovary not longer than the fl.-bract.

glomeràta, Hook. Lvs. strongly toothed, 11/2-2 ft. long: fls. in dense, rounded spikes disposed in a narrow panicle $1 \mathrm{ft}$. long; petals blue or violet, longer than the calyx : fl.-bracts long, pointed, scarlet (in one variety whitish). Braz. B.M. 5668

cc. Calyx prominently longer than the fl.-bract.

D. Panicle large, s-pinnate; petals bright red.

spectábilis, Brongn. Lvs. 2-21/2 ft. long, minutely serrate : fl.-bracts very small; petals twice as long as sepals. Guatemala. R.H. 1875: 310.

DD. Panicle 1-or 2-pinnate; petals blue or violet. E. F'ls. pedicellate.

cæruléscens, Hort. Lrs. 11/2-2 ft. long, with small prickles: panicle 4-5 in. long, 2-pinnate, with lax fewfld. crowded branches; petals bluish red, $1 / 3$ in. long: fl. bracts none or minute. S. Amer. Gt. 1871:694. - Produces white berries.

EE. Fls, sessile.

cœléstis, Baker. Lvs. much as in the last: panicle deltoid, 3-5 in. long, 2-pinnate, floccose, the lower branches subtended by red branch-bracts 1 in. lor.g; petals nearly balf an inch long, blue. S. Amer.

fúlgens, Brongn. ( $A$. discolor, Hort.). Lvs. broad, with small distant teeth, with a broad cuspidate end: panicle large, simple above, branched below, glakrous, bearing numerous fls.; petals blue-tipped, exceeding the rich red calyx; fl.-bracts minute or none: branch-bracts yellowish. S. Amer. B.M. 4293.

Weilbachii, F. Didr. Lvs. rather short, overtopped by the red-stemmed and red-bracted scape: panicle narrow, 1-pinnate, the fls. rather crowded, blue and red. S.Amer. R.H. 1871:170.

Var. Leodiénsis, André. Lvs. violet and spotted : fls. shorter. Braz.

Z2. augústa, Baker. Allied to E. Mariæ-Reginæ. Plant large: fls small, rose; petals short-protruded; panicle $1 \mathrm{ft}$.high, deltis. small, rose; petals short-protruded; pania ferruginea), $-A B$. toid. Braz. R.H. 1881, p. 437 (as Hohenbergia ferruginea).aurantiaca, Baker. Pl. vigorous :
fls. yellow, 2 in. long. S. Amer. B.H. 1873:15 (as Canistrum aufls. yellow, 2 in. long. S. Amer. B.H. 1873:15 (as Canistrum au-
rantiacum). - A . Bárleei, Baker. Fls. 2-ranked; corolla pale yel low. Honduras. - E. Brasiliénsis, Regel. Lvs. much dilated a base, whitish below, black-toothed: petals light blue, calyx and rachis red: panicle branched. Braz. Gt.1885:1202, $-A$. bromelioefòlia, Baker. Dense spike : lvs. whitish below, 3-4 ft. long, serrate or spinescent: fls. light vellow. S. Amer.-AE.Cornù $i$, Carr. rate or spinescent: fls. light yellow. S. Amer. - AE. Cornui, Carr. tate: spike simple and lax; fls. long-tubular, light blue; bracts tate : spike simple and lax; fls. long-tubular, light blue; bracts
and ovaries coral-red: berries rose, becoming blue. S. Amer.
R.H. 1888, p. 401.-AE. exsúdans, Morr. Lvs. whitish below : spike globular and dense, mucilaginous : petals yellow. Braz L.B.C.9:801. B.H. 1878:303.- - A. Fúrstenbergii, Morr.=Streptocalyx Furstenbergii. $-\not E$ ferruginea, Carr $=\not A$, augusta. $-\not E$. Hystrix, Morr. Lvs. lepidote, whitish, crowded : spike oblong, dense - fls purple, tomentose Guaiana - $A$, macracántha, dense : fls. purple, tomentose. Mruaiana. - At. Macracantha, Brongn. $=2$. Schiedeana. -2 . M elinonii, Hook. Panicle 3-pin nate, dense ; petals bright red : lvs. spiny, $112-2 \mathrm{ft}$. Guaiana.
B.M. 5235. - $A$. Mexicàna, Baker. Lvs. long and large, finetoothed: panicle 3-pinnate, long and lax, the peduncles mealy petals crimson. Mex. $-\not E$. miniàta, Hort.= Billbergia thyr soidea? - $A$. myriophyllla, Morr. Allied to A. distichantha. Lvs narrow, 2-3 ft, spiny, silvery-scaly on the back: fls. red, the Letich priseb. s. long and straight, brown-toothe : brabtending : spike large, brilliant red ; petals yellow. Trop. Amer. denser spike).-AE. paniculigera, Griseb. Lvs. large and long: 
panicle 1-2 ft. long, with few-flowered branches: scape tall. panicle 1-2 ft. long, with few-flowered branches: Schiedeana. reddish, downy : Ats. purple. Trop. Amer. - E. Schiedeana, Schlecht. (A.macracantha, Brongn.). Lvs. large, rigid, strongly
armed : paniele 3-pinnate, pubescent ; fls. pale yellow. Mex. Gt. 1894:175.-AE. zebrina is Billbergia zebrina. L. H. B.

ஷ̀GE (from Egle, one of the Hesperides). Rutd cea, tribe Aurantieue. Small, strongly spinose trees, with alternate, trifoliolate leaves. Distinguished from the nearly related genus Citrus (particularly $C$. trifoliata) by the hard, gourd-like rind of its fruit and its viscous, woolly seeds.

Mármelos, Correa. Elephant Apple. Maredoo. Bengal Quince. Bhel Fruit. Small tree: fr. large, 2-4 in. in diam., round or pear-shaped. Trop. Asia.-Cult. in S. Fla. and Calif., and in hothouses. The wood is valued for its strength, and the sweet, aromatic pulp is used medicinally in India for diarrhœe and dysentery, and also as a lemonade and conserve.

\section{H. J. WebBer.}

-EGOPODIUM (aix, goat, and podion, a little foot; probably from the shape of the leaflets). Umbellifera. GoutweEd. Coarse, hardy herbaceous perennial, with creeping rootstocks, biternate lvs., sharply toothed, ovate leaflets, and white tls. in umbels.

Podogrària, Linn., var. variegàtum, is a variegated form of this European weed, which makes attractive mats of white-margined foliage. Common in yards.

\section{AERANTHUS. Consult Angracum.}

A ËRIDES(Greek, air-plant).Orchiddceo, tribe Vándea. Epiphytes: stems erect, roundish : lvs. distichous, strapshaped and spreading, coriaceous, deeply channeled ut the base, obtuse: peduncles from the axils of the Irs.; fls. in loose or dense racemes; petals narrower than the sepals. A genus of remarkably beautiful plants, which develop well under cultivation. Species confined to the tropics of the Old World. The genus Aërides, though not in general cultivation, has many sterling qualities to recommend it. Some of the species produce dense racemes of great beauty, which emit a pleasing fragrance, and for decorative purposes have few if any rivals in the Orchid family. The genus offers no exceptional difficulties to the horticulturist.

All the species of Aërides are of easy culture in the warmest greenhouse-one that has a minimum temperature of $65^{\circ} \mathrm{F}$. in winter being best. They should be kept constantly moist, well shaded, and warm, with fresh live sphagnum round the roots at the base of the stems. $A$. odoratum is perhaps the best known. Other favorites are $A$. Lawrencioe and $A$. Fieldingii; the latter often has racemes 18 inches or more long, of a beautiful rose color.

Cult. by E. O. ORPET.

Following are in the American trade: A. affine, No. 11 ; Amesianum, 9; Augustianum, 8; Ballantineanum, 4 ; Bermanicum, 1; crassifolium, 15; crispum, 14; cylin. dricum, 18; Dayanum, 2; Ellisii, 2; expansum, 10; falcatum, 10; Fieldingii, 13; Godefroyanum, 11; Houlleti. anum, 10; Japonicum, 16; Larpenta, 10; Lawrenciæ, 9; Leeanum, 6; Leonæi, 10; Lindleyanum, 14 ; Lobbii, 11 ; maculosum, 12 ; majus, 1 ; maximum $=$ ? ; mitratum, 19 multiflorum, 11; odoratum, 1; pallidum $=$ ?; purpurascens, 1 ; quinquevulnerum, 5 ; radicosum, 17 ; Reichen bachii, 4; Robelenii, 5 ; Rohanianum, 4; roseum, 11 ; Sanderianum, 9; Savageanum, 3; suavissimum, 4 ; Thibautianum, 7; vandarum, 18; virens, 2; Warneri, 14.

\section{A. Odoratum section: middle lobe of labellum} narrow-oblong.

1. odoràtum, Lour. Lvs. 6-8 in. long, 1-11/4in. wide, nnequal at apices, deep green: peduncles not branched, pendulous ; fls. numerous, crowded; racemes cylindrical, as long as or longer than the lvs.; lateral sepals ovate; petals obovate-lanceolate, white, with a carmine apical spot; labellum trilobed, midlobe magenta, side lobes white, dotted with magenta; spur recurved, green1sh or white. Cochin China. B.M.4139. Gn.49, p. 158. Gt. 8: 273. B.R. 18:1485. Var. Bermánicum, Reichb. $f$ Fls. smaller than in the type, the apices of the petals with mauve lines and dashes instead of blotches. Var. purpuráscens, Hort. Produces large racemes, sepals and petals tipped with pale amethyst. Var. majus, Hort. Fls. larger; racemes longer.

2. virens, Linil. Peduncles $12-15$ in. long, 15-20 fld.; spur dotted with magenta; petals and sepals tipped with magenta. Java. P.M.14:197. B.R. $\checkmark$ : 41. - This species is very similar to $A$.odoratum, of which it is considered by some to be a geographical form. Var. Ellisii, Hort. (A. Ellisii, Hort.). Sepals and petals white, suffused with rose, tipped with amethyst-purple. Var. Dayànum, Hort. Racemes, very long ; fls. bright, large.

3. Savageanum, Hort. Sepals white at base, dotted with purple, otherwise crimson-purple; petals similar, narrower; labellum crimson-purple, with a greenish, straight spur ; midlobe denticulate on the margin.

4. suavissimum, Lindl. (A. Reichenbachii, Linden. A. Rohanianum, Reichb. f.). Plant robust, more lax in hubit than type: fls. $20-30,1 \frac{1}{2}$ in. across; petals and sepals white, suffused with carmine at apices ; labellum trilobed, yellowish dotted and suffused with carmine ; apex of spur white. Straits of Malacca. Var. Ballantineanum. Racemes shorter; blooms earlier; sepals and petals tipped with amethyst-purple.

5. quinquevúlnerum, Lindl. Racemes $1 \mathrm{ft}$. long; fls. crowded; dorsal sepal and petals equal, lateral sepals orbicular, all tipped with magenta; midlobe of labellum magenta. P.M. 8:241. Var. Rœbelenii (A. Robelenii, Reichb. f.). Sepals and petals shading to green at bases, petals denticulate; lobes of the labellum lacerated, midlobe rose-colored. Manila.

6. Leeànum, Reichb. f. Peduncles much longer than the lvs.: pedicels rose-color ; sepals rose-purple, white at base ; petals similarly colored; labellum small ; midlobe deep purple; spur green tipped. India.

7. Thibautiànum, Reichb. f. Racemes pendulous, longer than the lvs.; sepals and petals rose-color; labellum amethyst-purple; midlobe narrow, acute. Malaya.

8. Augustiànum, Rolfe. Petals and sepals shaded with rose; spur long, straight. Philippine Isls. G.C. III. $7: 233$.

9. Láwrenciæ, Reichb. (A. Lawrenciànum, Hort.). Largest species of the section. Fls. $20-30,13 \frac{1}{4}-2$ in. in diam.; sepals and retals flushed with amethyst-purple at the apices; labellum yellowish ; midlobe amethystpurple. Philippine Isls. Gn. 35: 702. Var. Amesiànum,

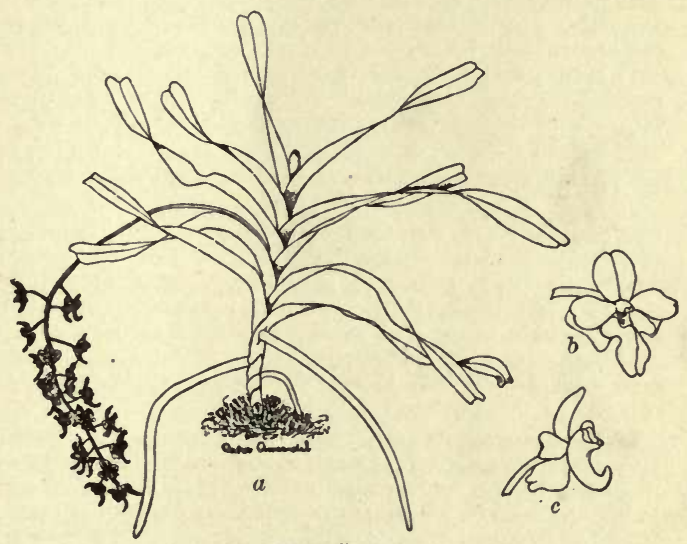

40. Aërides.

$a$. A. Lawrenciø; $b$. flower of multiflorum section; c. flower of odoratum section.

Kranzl. More robust: fls. more intense in color. Var. Sanderianum, Hort. Lvs. narrow : fls. yellowish, with amethyst on face of spur, otherwise like the species.

\section{AA. Falcatum section: lateral lobes of}

labellum falcate.

10. falcàtum, Lindl. \& Pax. (A. Larpèntce, Hort. A expánsum, Reichb. f.). Lvs. loosely arranged, 6-8 in. long, $11 / 2$ in. broad : tls. loosely arranged on racemes If $f$ : 
long, $1 \frac{1}{4}$ in. in diam.; sepals and petals white, tipped with amethyst; side lobes of labellum falcate, pale amethyst; front lobe convex, denticulate, keeled above, amethyst in center, margined with white and barred with rose; spur short. Upper Burmah. Var. Houlletiànum (A. Houlletianum, Reichb. f.). Fls. large, 11/4in. in diam.; petals and sepals pale buff, magenta apical blotch; labellum ereamy white; side lobes penciled with magenta, front lobe keeled. Cochin China. R.B. 21: 205 . R. H. 1891: 324. Var. Lednæi (A. Ledncei, Reichb. f.). Side lobes blunt and retuse.

\section{AAA. Multiflorum section: apicul lobe of labellum hastate.}

B. Peduncles not ascending.

11. multiflòrum, Roxb. (A. affine, Wall. A. ròseum, Lodd.). Plant compact, dwarf : lvs. stout, leathery, 6-10 in. long, dotted with brown (?): scapes 15-20 in. long, often branching: fls. small and erowded; petals and dorsal sepals ovate, equal in length, rose-colored shading to white at the base, dotted and spotted with crimson, inferior sepals pale, less spotted; labellum cordate-rhomboid at right angles, with other segments scarcely trilobed, deep rose; spur compressed, very short. India. B.M. 4049. Gt. 8:267. Var. Lobbi ( $A$. Lóbbii, Hort.). Lvs. erowded: peduncles more branching: fls. more intensely colored; very distinct. I. H. 15:559. Var. Godefroyànum, Hort. (A. Godefroydnum, Reichb. f.). Fls. larger than in type and more brilliant in color. R.B. 17: 169. This is the most widely distributed of the East Indian species, if we except $A$. odoratum.

12. maculdsum, Lindl. Plant compact: lvs. dark spotted : racemes pendent, sometimes branching; sepals and petuls pale rose, dotted with purple; anterior lobe rose-purple, white at base. India.

13. Fieldingii, Lodd. Fox-Brush Orchid. Tall: Ivs. glossy, 7-10 in. long: peduncles pendulous, branched near the base, 18-24 in. long : fls. crowded, petals and sepals white, suffused and dotted with rose ; labellum scarcely trilobed, white suffused with rose. Sikkim, Assam.

14. críspum, Lindl. St. brownish : lvs, rigid, 5-8 in. long: peduncle often branched, pendulous ; fls. not dense, large; petals and sepals white, flushed with rosecrimson, deeper colored on dorsal surfaces; lip trilobed, side lobes small, midlobe rose-amethyst. S. Ind. B.M. 4427. F.S. 5: 438. Gn. 4, p. 85. B.R. 28:55. Var. Lindleyànum, Hort. Larger: fls. paler, racemes branching. Var. Wárneri, Hort. Dwarf: fls. smaller and paler than in type.

15. crassifolium, Par. \& Reichb. f. Compact in growth: lvs. $6-10$ in. long: fls. 11/2in. in diam.; petals and sepals bright rose-magenta, shading off towards bases; labellum trilobed, side lobes subfalcate, rose-magenta, front lobe ovate, deeper colored. Burma.

16. Japonicum, Reichb. f. Smallest species of the genus in cult.: lvs. $3-4$ in. long, linear oblong : fls. few : peduncles loosely racemose; sepals and smaller petals greenish white, lateral sepals barred with amethystpurple; labellum crenate, ridged, dark violet, with 2 erect lobules. Japan. B.M. 5798. - This interesting species marks the N. limit of the genus Aërides. Requires eooler treatment than the other species.

$$
\text { Bв. Peduncles ascending. }
$$

17. radicosum, Reichb. Lvs. 8 in. long, 1 in. wide: peduncles ascending, 8-10 in. long, sometimes branching near the base: fls. $3 / 4$ in. across, purplish ; sepals and petals pale rose, verging on crimson; column winged. India.

AAAA. Vandarum section : lip various : lvs. terete.

18. vandárum, Reichb. f. (A. cylíndricum, Hook.). St. slender: lvs.4-6 in. long, channeled above, clasping at bases, alternate: peduncles $2-3$ fld.: fls. $13 / 4-2$ in. in diam.; segments undulate; sepals white, lanceolate ; petals white, irregularly obovate; lip trilobed, nearly divided in front, dentate, sides erect. Sikkim Himalaya, 4,000-5,000 ft. B.M. 4982. J.H. III. 34:417.-Much like Vanda teres in foliage. Subtropical species.

19. mitràtum, Reichb. f. Lvs. semi-terete : racemes many-fd.; sepals and petals white; labellum rose-purple. Burma. B.M. 5728.

OAKES AMES.
EERVA (name of no signification). Amarantaceo. Tender herbs or shrubs, allied to Achyranthes. Lanate plants of Trop. Asia and Afr., with perfect or imperfect fls., the perianth segments short and hyaline: stamens 5 or 4 , sterile filaments intervening: fls. very small, usually in clusters, white or rusty.

sanguinolénta, Blume (A. sanguinea, Hort.). Lvs. $1 \frac{1}{2}-2 \frac{1}{2}$ in. long, opposite or alternate, ovate, acuminate, soft, pubescent, pale beneath. Java.-Cult. for its dark red leaves.

ESCHYNÁNTHUS (aischuno, ashamed, ugly, and anthos, flower; probably referring to the wide-mouthed gaping of the fis.). Gesnerdcece. About 40 species of tropical Asian twining or rambling parasitic small shrubs, bearing very showy, more or less fleshy tubular fls., and cult. in warm houses (stoves): lvs. opposite or verticillate, thick, or even fleshy: perfect stamens 4 , ascending under the upper part of the imperfectly 2lobed corolla; stigma entire : capsule 2 -valved.

Nearly all the species of this exceedingly interesting genus are from the hot, tropical forests of Java and Borneo, where they grow in company with orchids and other plants on the trunks of trees. The fls., which are produced in the axils of the lvs. and at the ends of the shoots, last a long time in perfection. Being epiphytal under natural conditions, they should be put in a rooting medium which will require renewal not oftener than once in two years. They must have perfect drainage, as they suffer from stagnant moisture, but during the period of growth they must have copious supplies of water. Prop. by seeds, cuttings, and division. Cuttings are the most satisfactory in building up a flowering plant from the beginning. Seeds are slow, and divided pieces, unless their roots are in a good condition previous to the operation, do not make as good plants as cuttings. Cuttings should be taken early in the spring, and kept close until they are rooted and established in small pots. During the first year they should not be allowed to bloom, but encouraged to make growth by pinching out the ends of the shoots and shifting into larger pots as they require it. Most of the kinds look their best when grown as basket plants suspended from the roof of the stove. Wire baskets are best. In preparing them, first put in a lining of moss, next a goodly quantity of rough cinders, and the rooting material may consist of chopped fibrous peat, sphagnum, charcoal, and small pieces of pots or bricks, with a little coarsegrained sand. For a basket 12 in. across, several small plants out of 3-inch pots may be used, and in a hot, hu-

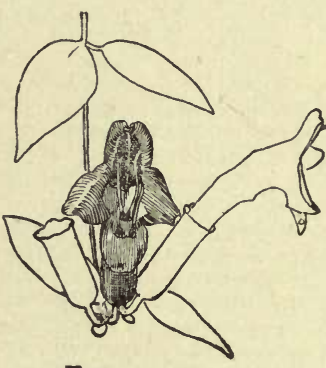

41. Eschynanthus pulchra $(\times 1 / 3)$. mid atmosphere the growth is encouraged until the sides of the receptacle are covered. During winter they should be rested by withholding water to a certain extent, and decreasing the temperature considerably. A good method of growing the scandent kinds, where facilities are at hand, is to start the small plants on blocks of wood, attach these to damp but warm walls, to which they will cling by means of the roots thrown out from every leaf joint.

Cult. by G. W. OLIver.

A. Calyx deeply 5-parted, the lobes acute.

grandiflora, Spreng. St. ereeping, mostly herbaceous, 4-5 ft.: lvs. lanceolate, acuminate, 4-5 in. long, repandserrate, fleshy: fls. aggregated; calyx fleshy and short; corolla arched-tubular, 2-3 in. long, downy, orange-scarlet. E. Ind. B.M. 3843. P.M.5:241.-Will succeed in an intermediate house.

AA. Calyx tubular, entire or shortly 5-toothed.

púlchra, Don (AE. púlcher, DC.). Figs. 41, 42. Trailing : lvs. broadly ovate, distantly small-toothed : corolla glabrous, brilliant scarlet, 3 times longer than the glabrous greenish calyx. Java. B.M. 4264. R.B. 18:13. R.H. 1883: 204. P.M. 16:161. 
Lobbiàna, Hook. The commonest species in cult. in this country: differs from $\boldsymbol{E}$. pulchra in narrower and nearly entire lvs., corolla downy and projecting only twice or less the length of the purple downy calyx. Java. B.M. 4260, 4261.

E. Boschiàna, De Vr. = ¿. Lamponga. - AE. fúlgens, Wall. Lvs. lanceolate: calyx tubular, short-toothed, glabrous: corolla about 2 in. long, orange-red, pubescent. E. Ind. B.M. 4891.AE. Javanica, Hook. Allied to $\mathbb{E}$. pulchra: differs in pubescent

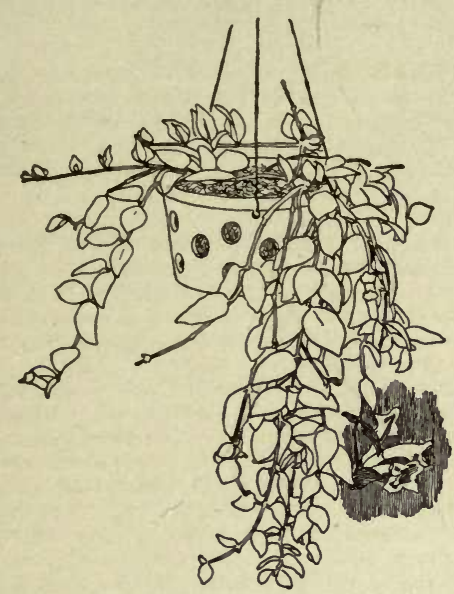

42. Eschynanthus pulchra.

Calyx and corolla. B.M. 4503. F.S. 6:558.- X. Lampónga, Miq Lvs. ovate or elliptic, obtusish, entire: calyx eylindrical, gla-
brous: corolla twice as long (2 in.), pubescent, scarlet. Sumatra. brous: corolla twice as long (2 in.), pubescent, scarlet. Sumatra. calyx deeply eut, the divisions linear-subulate: corolla tubular, scarlet, very long: fls. fascicled. Java. B.M. 4328. P.M. 15: 25 . $-Z$. miniata, Lindl. Fls. vermilion, in 3 's in the axils of the oval or elliptic entire lvs.: corolla pubescent. Java, Borneo. P.M. 16: 65- - E. speciosa, Hook. Branches knotty: lvs. large oval-lanceolate, nearly sessile, the upper ones verticillate or in oval-lanceolate, nearly sessile, the upper ones verticillate or in
3 's : fls, fascicled, numerous ; calyx with linear-subulate divi3's : fls. fascicled, numerous; ; calyx with linear-subulate divi-
sions; corolla large, orange-red, curved. Java. B.M.4320. P.M. 14:199. Gn. 51:1109. - E. spléndens, Lindl.\& Paxt.= Æ. speciosa. - AE. splendida, garden hybrid, with scarlet-spotted black fls., in terminal fascicles. - $2 E$. tricolor, Hook. Lvs. small, oval or lanceolate, hairy at the base: calyx obconic, pubescent: corolla small, pubescent, blood-red, throat orange, npper lobes striped black pr purrele: fls. mostly twin. Borneo, B.M. 5031. R.B.10:7. I.H. 5:169. F.S. 13:1384. J.H. III. 35:571.

L. H. B.

ÁSCULUS (ancient name of some oak, or mast-bearing tree). Sapindacea. Horse-CHESTNUT. BUCKEYE. Deciduous trees and shrubs: lvs. opposite, long-petioled, digitate ; leaflets 5-7, large, serrate : fls. symmetrical in terminal, showy panicles; petals 4-5, stamens 5-9: fr. a large trilocular capsule with 1-6 seeds. N. Amer., E. Asia, Himal., N. Greece. Ornamental trees and shrubs with handsome fls.; hardy except the Californian and Himalayan species, growing best in moist and loamy soil. The larger-growing species are excellent shade trees, and the fls. are showy and interesting. The fr. is not edible. Prop. by seeds, to be sown in the fall or stratified, or by grafting and budding on common species, and the shrubby forms also by layers. E. parviflora prop. also by root-cuttings.

A. Winter-buds resinous: claws of the petals not longer than the calyx; stamens exserted.

B. Petals 4-5; calyx campanulate, 5-lobed; stamens 5-8: fr. globular. (Hippocastanum.)

Hippocástanum, Linn. Comon Horse-Chestnut. Fig. 43. Large tree, $60-80 \mathrm{ft}$.; leaflets 5-7, sessile, cuneate-obovate, acuminate, obtusely serrate, nearly glabrous : panicles 8-12 in. long, very showy; fls. white, tinged with red: fr. echinate. May. From Himalayas to N. Greece. - Many garden forms, as var. flòre plèno, with double fls.; bears no fr. I.H. 2:50. Var. pùmila, Dipp. Dwarf form. Var. umbraculifera, Hort., with compact, roundish top. Var. laciniata, Dipp. (var dissecta, Hort., var. heterophylla, Hort.), leaflets laciniate. Var. Mém- mingeri, Hort., leaflets dotted with white. Some other variegated forms. The horse-chestnut is one of the most popular of shade trees on the continent of Europe, and is also much planted along roads and in parks and private grounds in this country. It is particularly adaptable for bowers and places where seats are desired, as the top stands heading-in and makes a very dense shade. Hardy in the N. states.

turbinàta, Blume (E. Sinénsis, Hort., not Bunge.). Tree, $30 \mathrm{ft}$.: petioles pubescent; leaflets $5-7$, nearly sessile, cuneate-obovate, erenate-serrate, pubescent beneath when young: panicles 6-10 in. long, dense and rather narrow ; fls. yellowish white, smaller than those of A. Hippocastanum : fr. rugose. June. N. China, Japan. G.C. III. 5: 717.

cárnea, Hayne (A. Hippocástanum $\times$ Pàvia. A. rubi. cúnda, Loisel.). Tree, $20-40 \mathrm{ft}$.: leaflets mostly 5, nearly sessile, cuneate-obovate, crenate-serrate, nearly glabrous: panicles 5-8 in. long; fls, varying from flesh. color to scarlet: fr. with small prickles. B.R. 1056. L.B.C. 13:1242. F.S. 2229-30.-Many garden forms, according to the different shades in coloring, and one with double fls. Commonly planted in parks and on road. sides. Handsome and desirable.

BB. Petals 4, white or pale rose-colored; calyx 2-lipped; stamens 7-9: fr. pear-shaped, smooth. (Calothyrsus.)

Californica, Nutt. Tree with broad top, 30-40 ft.: leaflets 5-7, petioled, oblong-lanceolate, cuneate or obtuse at the base, sharply serrate, smooth: panicles 3-8 in. long, rather dense. Calif. B.M. 5077. R.H. 1855, p. 150. Gn. 49 , pp. 490,492 . S.S. $2: 71,72$. F.S. $13: 1312$.

AA. Winter-buds not resinous: claws mostly longer than the 5-toothed calyx.

B. Petals 4, yellow to scarlet; stamens included or somewhat exserted: leaflets petioled. (Pavia.)

glàbra, Willd. (AE. Ohioènsis, Michx. Pàvia glàbra, Spach. $P$. pállida, Spach.). Small tree 15-30 ft.: leaflets 5 , oval or cuneate-obovate, finely serrate, smooth: panicles 5-6 in. long; fls. greenish yellow; claws as long as the calyx; stamens exserted : fr. echinate. May. N.Amer. B.R.24:51. S.S.2:67,68. Var. argùta, Robins. (A. argùta, Buckl.) Shrub: leaflets 6-7, obovate-lanceolate, unequally serrate.

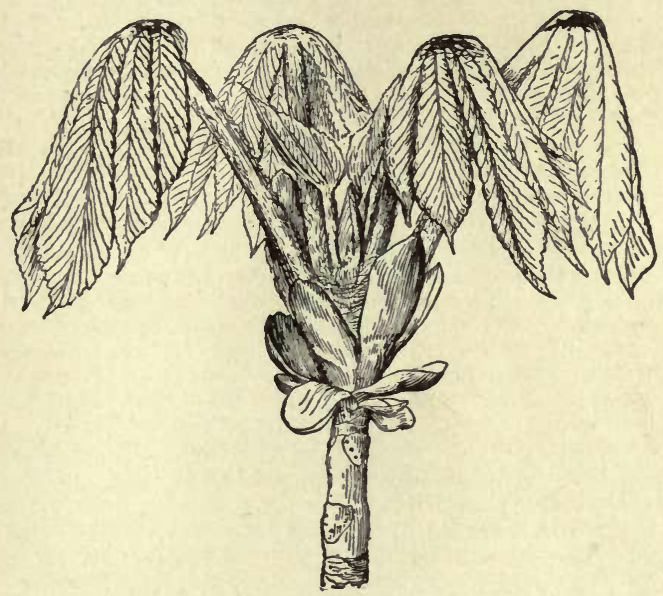

43. Opening foliage of Esculus Hippocastanum.

octándra, Marsh. (AE. fldva, Ait. AE. lùtea, Wangh. Pàvia lùtea, Poir.). Large tree, 40-90 ft.: leaflets 5, oblong-obovate or elliptical, cuneate, equally serrate, smooth or pubescent beneath : panicles 4-6 in. long; petals yellow, very dissimilar; stamens 7 , shorter than the petals : fr. smooth. May-June. N. Amer. L.B.C. $13: 1280$. S. S. 2:69, 70. Var. díscolor (var. hyेbrida, Sarg. A. flava, var. purpuráscens, Gray. A. díscolor, Pursh. A. Micha ѝxi, Hort.). Lvs. tomentose beneath: fls. red or purple. B.R. 310. An intermediate form is A. neglécta, Lindl. B.R. 1009. 
versícolor,Dipp. (AE.octándra $\times$ Pàvia. P’via hỳbrida, Spach. $\mathscr{E}$. or $P$. Lỳoni, Hort.). Intermediate between A. octandra and A. Pavia. Lrs. pubescent beneath: fls. yellow, tinged with red or nearly red.

Pàvia, Linn. (Pàvia rùbra, Poir. P. Michaùxi, Spach.). Shrub or small tree, 4-20 ft.: leaflets oblong or elliptical, acute at both ends, finely serrate, smooth or pubescent beneath : panicles 4-7 in. long, loose ; fls. purplish to dark red; petals very dissimilar; stamens mostly 8 , nearly as long as the petals : fr. smooth. May-June. N. Amer. B.R. 993. L.B.C. 13:1257. Var. hùmilis (A. hùmilis, Lodd.). Low shrub, $2-4 \mathrm{ft}$. leaflets coarsely and unequally serrate, tomentose beneath : fls. red, tinged with yellow; calyx dark red. B.R. 1018. - Many garden forms, as var. cárnea, Hort. Fls. flesh-colored. Var. atrosanguinea, Hort. Fls. very dark red. Var. Whitleyi, Hort. Fls. brilliant red. Var. péndula, Hort. (P. pùmila, var. péndula, Hort.). Dwarf form, with pendulous branches: lvs. smooth. Some forms with variegated lvs.

Bв. Fls. pure white, small; petals 4-5; stamens more than twice as long as the petals. (Macrothyrsus.)

parviflora, Walt. (AE. macrostàchya, Michx. Pàvia álba, Poir.). Shrub, 3-10 ft.: leaflets 5-7, elliptical or oblong-ovate, nearly sessile, finely serrate, pubescent beneath : panicles 8-16 in. long, narrow ; fr. smooth. July-Aug. S. states. B. M. 2118. Gng. 7:81. - One of the handsomest plants for a lawn clump.

AE. Chinénsis, Bunge. Allied to A. turbinata. Leaflets dis-

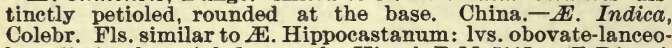
late, distinctly petioled, smooth. Himal. B.M. 5117.- AE.Párryi, Gray. Similar to A. Californica. Leaflets small, obovate, canescent-tomentose beneath : calyx 5-lobed. Calif. G.F. 3: 356 .

\section{ALFRED REHDER.}

EETHIONEMA (aitho, scorch, and nema, filament; probably referring to appearance of stamens). Crucif erce. Dwarf shrubs for the hardy herbaceous border or rockery. Less common than Iberis. The genus differs from Iberis in having all its petals equal, and from Lepidium in having its four stamens longer, winged and toothed. Fls. various shades of pink and purple. W. B. Hemsley, in Gn. 9, pp. 108, 109.

They dislike a moist or stiff soil or shady places; but in light, sandy loam, on dry and sunny slopes, they are compact and branchy, and when once fairly established will last for many successive years without replanting or renewal, while under the opposite conditions the plants grow feeble and lanky, and may die after a year or two. They keep fully as well as the Candytufts in water, and can be cut with longer and straighter stems. Prop. by seeds in spring or by cuttings in summer; annual and biennial kinds by seeds.

\section{J. B. KeLLeR.}

coridifòlium, DC. (Ibèris jucuinda, Schott \& Kotschy). Branches numerous, thick, 4-6 in. high : lvs. crowded, short, nerveless, linear or linear-oblong, acute or obtuse: fls. smaller and later than in the next, in dense, short, rounded racemes. Chalky summits of Lebanon and Taurus. B.M. 5952.- Good for edging. A. pulchéllum was sold under this name for many years.

grandiflorum, Boiss. \& Hohen. Branches 1-11/2 ft.: lvs. usually longer than in $\boldsymbol{A}$. coridifolium, more linear and more acute: fls. as large as those of Arabis alpina, in slender, elongated racemes; petals 4 times as long as the sepals. Persia. Gn. 9:5.

Pérsicum, Hort. Stout, erect, shrubby, dwarf. Fls. deep rose. Best of dwarfs. Int. 1892, by J.W. Manning.

pulchellum, Boiss. \& Huet. Similar to A coridifolium, but more diffuse and trailing. Fls. smaller and brightercolored; petals $2 \frac{1}{2}$ times as long as the sepals. Persia. Gn. 25: 436 .

W. M.

AGALMỲLA (agalma, ornament, and hule, wood; an ornament to the woods in which they grow wild). Ges nerdcea. Tender climbers from Java, which may be grown in a basket like Eschynanthus.

A. longistyla, Carr., is considered a synonym of the next. R.H. 1873: 270.-A. staminea, Blume St rooting from the lower sur face: lvs. alternate, with an abortive one opposite the base of each ; petioles 4-8 in. long; blade as long, ovate, serrate : fls. in large axillary sessile fascicles of 12-14; stamens exserted. B. M. 5747. P.M.15:73, F.S. 4:358
AGANISIA (Greek aganos, desirable). A small genus of tropical American epiphytal orchids, little cult. in N. Amer. Botanically allied to Warrea and Zygopetalum. Need a humid atmosphere. Grown on blocks in high temp. Prop. by dividing pseudobulbs.

trícolor, N. E. Brown. Fls. in a raceme; sepals whit ish; petals light blue; lip in the form of a saddle, marked with orange-brown. S. Amer.

pulchella, Lindl. Fls. white, blotched yellow on the lip, in a racemose spike from the base of the bulb. S. Amer.

The above species are the only ones known to have been offered in the Amer. trade. There are 5 or 6 others. A coerùlea, Reichb.t. Fls. in axillary peduncles, blue-blotehed, the lip bristled. Braz. -A. cyànea, Benth. \& Hook. (not Reichb., which=Acacaulis cyanea). Much like A. tricolor, the lip blue and undulate at the tip. B.R. 1845: 28, as Warrea cinerea, Lindl.; also, W. cyanea, Lindl. (see Rolfe., G.C. III. 6. p. 492).

AGAPANTHUS (agape, love, and anthos, flower). Lilidcece. Conservatory plants, with tuberous rootstocks, tall simple scape, and 2-bracted umbel of handsome fls.: perianth with 6 wide-spreading divisions, nearly regular: pod many-seeded; seeds flat, winged above: foliag $\Theta$ evergreen.

In this country, Agapanthuses are usually grown in tubs (the roots are apt to burst pots), and are flowered in late spring or early summer in the conservatory, window garden, or living room. The plant is kept dormant during winter, as in a frame or light cellar, only enough life being maintained to prevent the lvs. from falling (the var. albidus usually loses its leaves). When in bloom, give abundance of water. Plants will bloom many years if given a large enough tub, not allowed to become overerowded in the tub, and supplied with manure water, sending up many clusters each year. Good results can also be obtained in single pots. It forces well. If kept dormant until spring, they may be bedded in the open, or massed in vases, for summer bloom. Prop. by divid ing the roots (and rarely by seeds). Old roots break up more easily if soaked in water a few hours. When dormant, the plant will stand a few degrees-usually $10^{\circ}$ or less- of frost.

umbellàtus, L'Her. African Lily. Lily of the Nile. Fig. 44. Lrs. $2 \mathrm{ft}$. long and numerous, thick, narrow:

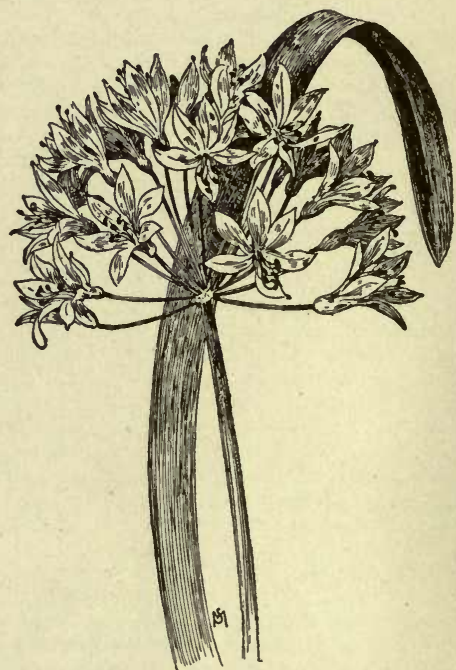

44. Agapanthus umbellatus.

scape rising 2-3 ft. from the leaf-rosette, bearing an umbel of 20-50 handsome blue fls.; perianth funnel-shaped, with a short tube. Cape of Good Hope. B.M. 500.- One of the best known of half-hardy liliaceous plants. There are white-flowered varieties (the best known is var. albidus /; dwarfs, as var. minor and var. Moorednus, both with blue fls.; giant forms, as var. máximus (both blue 
and white-fld.), with seape $4 \mathrm{ft}$. high; double-fld. variety variegated-lvd. varieties, as var. aureus and var. variegatus; var. Leichtlinii, a compact-trussed blue form ; and others.

AGÁRICUS. A genus of fleshy fungi, considered under Mushroom.

\section{AGATH良A. See Felicia.}

AGATHIS (agathis, glome; the fls. in clusters). Tender Australian conifers, allied to Araucaria, yielding Dammar resin. Cones axillary, globular or short.

robústa, Hook. (Dámmara robústa, C. Moore). Branches somewhat verticillate, horizontal : ivs. broad, oval-lanceolate, obtuse: tree reaching 130 feet in Austral. - Cult. in Calif.

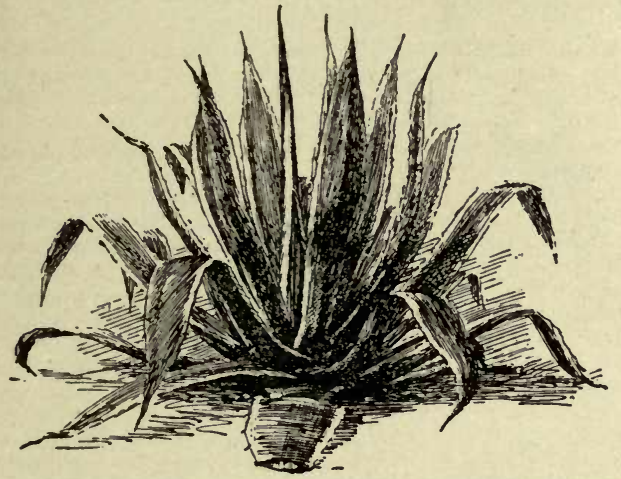

45. Agave Americana, as commoniy grown in greenhouses.

AGAVE (Greek, agauas, admirable). Amaryllidacece. Importunt decorative and economic plants from hot American deserts, the most familiar of which is $A$. A mericana, the American Century Plant. St. short or wanting: lvs, mostly in a close rosette, mostly stiff and more or less fleshy, persisting from year to year, the margins mostly armed with teeth and the apex tipped with a more or less pungent spine: fls. in spikes or panicles; perianth 6-parted, more or less funnel-shaped stamens 6 , mostly long-exserted; style 1 ; ovary inferior, 3-celled; seeds numerous, flat, thin, triangular, black. Some species flower but once and die, others occasionally, while others flower from year to year. The number of species is about 150 , although more than 325 have been described. One of the largest collections is at Kew, where there are 85 named species. The largest collections in the United States are at the Botanical Garden of Washington and the Missouri Botanical Garden, where there are about 75 species each. Amateurs often cultivate a greater number of species than are described in this account. Agaves are essentially fanciers' or amateurs' plants. This noble group of plants has never received the attention it deserves, and yet no genus of plants in America furnishes so many suitable decorative plants. Sir Joseph Hooker places it next to the palm and aloe, but the former is a great family of 1,100 species. While in the United States we think of the Agaves only as decorative plants, yet in Mexico, their native home, they are the most useful of plants. Many species furnish fiber, others soap, while still others produce the two great Mexican drinks, Pulque and Mescal. Pulque, which is a fermented drink, is obtained from several species, especially $A$. atrovirens. Mescal, which is a distilled drink, is usually not obtained from the same species as Pulque, although there is a general belief to the contrary. The species from which is made most of the Mescal used in Mexico is unknown. The species vary so much in size and form that they can be used in a great many ways. Some of the smaller species are suitable for the house, and eren some of the larger species are so used. The larger species are well adapted for vases in large gardens and grounds, along walks, terraces, etc. These plants, coming, as they do, from arid or even desert regions, where they have a hard struggle to exist, can be grown with little or no care, but they respond very quickly to good treatment. The species are propagated in various ways; some produce suckers at the base or even underground shoots ; others give off buds from the stem, which fall off and take root, or may be detached and planted; while not a few produce bulblets in the flower-clusters, and sometimes in great abundance, while all may be produced from seed. But as most of the species flower only after a long interval, and many have not yet been known to flower in cultivation, this latter means of propagation can not be relied upon. In cultivation, fruit is set very sparingly or not at all without artificial pollination, although this can be accomplished with very little trouble. Monograph by J. G. Baker, Amaryllider, 1888 .

J. N. Rose.

None of the Agaves are at all difficult to grow. The soil should be principally loam and sand, and if any vegetable soil be given it should be in small quantities. Good drainage and firm potting are necessary. To grow small plants of the large-leaved kinds into good-sized specimens quickly, they should be plunged out in a sunny spot in spring, taking care that the pots are large enough so that they will not require repotting in the fall. Nearly all of the large-growing kinds are easily increased from suckers, which, when the plants are grown in a pot-bound condition, are produced very readily. They should "only be taken off from the parent plant when furnished with sufficient roots to give them a start. Some kinds are raised only from seeds, which, when freshly gathered, germinate in a few weeks.

Cult. by G. W. OLIVER.

The classification of the Agaves is a very difficult one. This is partially owing to the great number of species, to the difficulty of preserving study material, and to the infrequency of flowering in many species. In fact, many species have never been known to flower. The most usable characters for classification are to be found in the leaves, and, although such an arrangement is more or less artificial, it is certainly the most satisfactory in naming a collection. From a botanical point of view, however, the inflorescence shows the true relationship of the species. In this way the genus is usually divided into three groups or subgenera. These are: First, the Euagave, having a paniculate inflorescence, with candelabra-like branches. Second, the Littoea, having a dense spike of flowers. (The section Littoea has been considered by some a good genus, but it seems to connect with the first section through certain species.) The third section, Mranfreda, is very differert from the above, and is considered by the writer as a distinct generic type, although treated here in accordance with general usage. Manfredas are all herbaceous, appearing each year from a bulbous base, the lvs. are soft and weak, dying down annually, while the inflorescence is a slender open spike, with solitary fls. from the axils of bracts.

The following Agaves are here described : albicans, No. 30 ; Americana, 1 ; Amurensis, 27 ; angustifolia, 3 ; applanata, 7 ; atrovirens, 5; attenuata, 19 ; Beaucarnei, 28 . Botteri, 29; brachystachys, 40 ; Candela.brum, 3 ; Celsii, 31 ; coarctata, 5 ; cochlearis, 6 ; dasylirioides, 36 ; densiflora, 32; Deserti, 10; echinoides, 34; Elemeetiana, 20 ; ensiformis, 34 ; flifera, 13 ; geminiflora, 16; Gilbeyi, 26 ; glaucescens, 19 ; heteracantha, 22; horrida, 26 ; ixtliondes, 3 ; Kerchovei, 28 ; Kochii, 27; latissima, 5 ; Lecheguilla, 23; Lehmanni, 5 ; macracantha. 8 ; macu- 
lata, 39 ; maculosa, 38 ; Mexicana, 2 ; micracantha, 33 ; mitis, 33; mitrceformis, 5; Nissoni, 25; potatorum, 11; Fotosina, 41; Pringlei, 4; recurva, 34 ; Richardsii, 34; rigida, 3 ; rigidissima, 28; Salmiana, 5 ; schidigera, 14; Scolymus, 11; Schottii, 18; Shawii, 9; Sisalana, 3; striata, 34 ; stricta, 34 ; Taylori, 17 ; Thuacanensis, 5 ; univittata,21; Utahensis, 12; vestita, 15; Victoriæ-Reginæ, 24; Virginica, 37; xylonacantha, 27; yuccæfolia, 35.

A. Foliage persisting from year to year: inflorescence dense, many-fld.: plants flowering after a more or less long interval, often but once, in others occasionally.

B. Infloresence a compact panicle; fls. borne in clusters near the ends of horizontal branches. (Euagave.)

1. Americàna, Linn. Common Century Plant. Figs. 45, 46. Plants becoming very large : lvs. 40-50, either straight or the tips recurved; the margin scalloped between the sharp teeth: fl. 3 in. long, yellow. The most common species in cult. A.F. 7:503. Gn. 12, p. 397. G.C. III. 19:17. Gn. 47, p. 59. F.E. 10:595. Trop. Amer. Several varieties, of which var. pícta, var. variegàta (B. M. 3654) and var. recurvàta are the best known. - Some forms have lvs. striped, and others bordered with yellow. This species is the one which is commonly grown as a tub plant by florists, being used out-of-doors in the summer for lawn and porch decoration.

2. Mexicàna, Lam. Plants becoming very large : lvs. 20-30 ; similar to $\boldsymbol{A}$. Americana. Common in Eu. Int. about 1817, from Mex. G.C. II. 19:149.

3. rigida, Miller. St. wanting or sometimes $4 \mathrm{ft}$. long: 1vs. thin, narrow, elongated; the margin either smooth or toothed. S. Mex. Perhaps more than one species included under this name. A. angustifòlia, Haw., seems to belong here. B.M. 5893, as A.ixtlioides. Gng. 5: 89 .

Var. elongàta, Baker (A. Candeldbrum, Todaro). St. inuch elongated.

Var. Sisalàna, Engelm. Sisal HeMP. Margin of the lvs. fntire. Yucatan. Naturalized on Fla. keys.-Recommended for cult. on a large scale in certain cheap lands of Fla. Largely grown in Yucatan as a fiber plant, the fiber being exported to U.S. and used in making cheap cordage.

4. Prínglei, Engelm. Lvs, sword-like, very stiff, 18 in. or less long, narrowed from near the base to the sharp tip, the margin with small, hooked, brown prickles: fl. 11/2in. long, yellow. Lower Calif.

5. atròvirens, Karw.(A. Thuacanénsis, Karw. A.Salmidna, Otto). Often attaining a great size: lvs. few, 10-30, becoming 9 in. broad and 7-9 ft. long. very thick at base and glaucous throughout, tipped wath a stout spine; the upper part of the margin horny: fl. 4 in. long Mex. G.C. II. 8:177. - Several species have passed under this name.

Var. latíssima (A. latíssima, coarctàta. Lèhmanni, and mitrofórmis, Jacobi). Lvs. broader, oblong-spatulate (8-9 in. broad above the middle).

6. cochleàris, Jacobi. Pulque Plant of W. Mex. Very similar to the above, but lvs. longer and a foot wide, not glaucous. Int. about 1867 , but rare in collections.

7. applanàta, Lem. Stemless : lvs. sometimes 150 , $3-3 \frac{1}{2}$ in. broad, stiff and glaucous, with long, pungent end spine: $\mathrm{fl} .3$ in. long, greenish yellow. $-\mathrm{A}$ beautiful species from Mex. Int. about 1862.

8. macracántha, Zuce. Small, stemless, compact: lvs. about 50, a foot long, very stiff and pungent, glaucous: fls. in a lax raceme. Int. about 1830 , from central Mex. G.C. II. 8:137.

9. Sháwii, Engelm. Stemless : Ivs, 50-60 or even more, oblong-spatulate, 8-10 in. long, dull green and slightly glaucous, with a brown tip-spine an inch long, the edge with upturned brown teeth $1 / 2$ in. or less long: fls. $3-3 \frac{1}{2}$ in. long, greenish yellow. S. Cal. Int. about 1875 .

10 Desérti, Engelm. Stemless : lvs. few, in a rosette, oblanceolate, a foot or less long, deep concave above, very glaucous, tip-spined, the lower half of the blade with hooked prickles : fl. yellow, 2 in. or less long. S. Cal. Int. about 1875 .
11. Scólymus, Karw. Lvs. 20-40, 9-18 in. long, 3-6 in. wide, glaucous; the margin indented between the teeth: fl. 2-3 in. long, yellowish. Mex. Gn. 12, p. 397. Int. about 1880.-Said to be common, with several varieties. A. potatorum, Zucc., may be only a form of the above.

12. Utahensis, Engelm. Stemless : lvs. sword-like, 1 ft. or less long, thick and rigid, the sharp tip-spine an inch long, the margin with triangular teeth, glaucous : t. an inch long. Utah and Ariz.

BB. Inflorescence a dense, cylindrical spike; fls. usually borne in twos. (Littaa.)

c. Margins of lvs, not toothed.

D. Lvs. linear, stiff, smooth, with the margins splitting off into fine threads.

13. filifera, Salm-Dyck. Plant small, compact, about $1 \mathrm{ft}$. in diam.: lvs. about 100, linear, stiff, 9 or 10 in. in diam., light green in color, with a very pungent tip: fi. 2 in. long, brownish: stalk 5-8 ft. long. Mex. G.C. III.

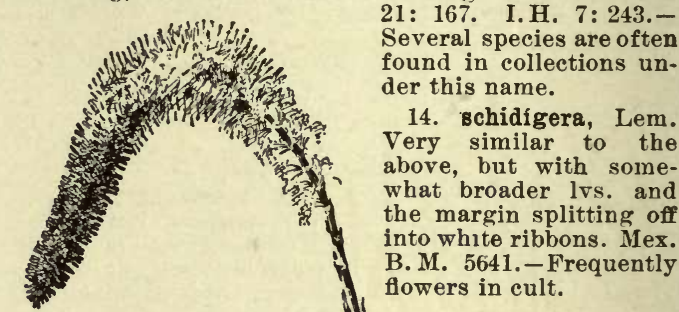
flowers in cult.

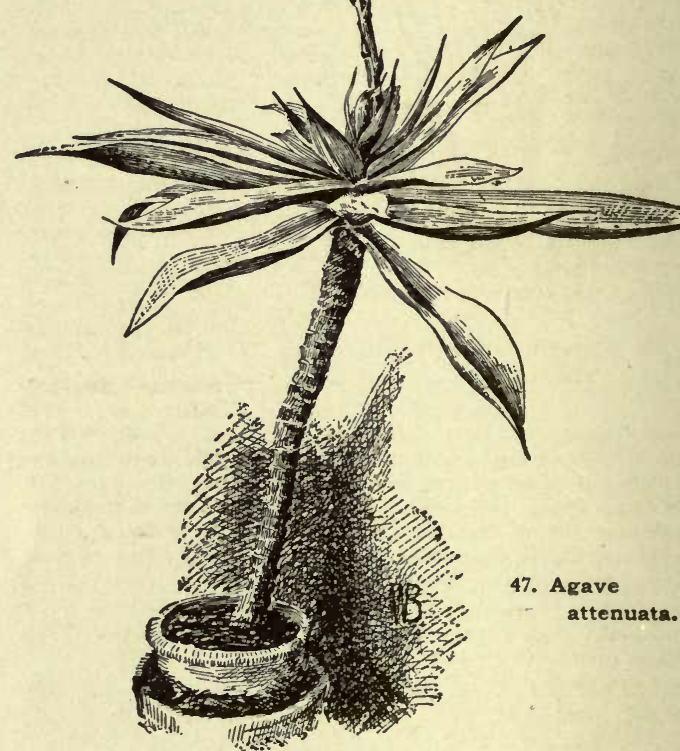

15. vestita, Watson, also of the type of $A$. filifera, is a very recently described and introduced species. Lvs. more bronzy than that species. Mex. table lands. A.G. 1892: 609. - It deserves a place in any large Agave col lection.

16. geminiflòra, Ker-Gawl. (Bonapártea júncea, Haw.). Lvs. often 200-300, narrowly linear, somewhat recurved, $1 \frac{1}{2}-2 \mathrm{ft}$. long, somewhat convex on both sides: flower stalk sometimes $25 \mathrm{ft}$. long. Mexico,where it grows commonly along streams. B.R. 1145. F.S. 7, p.6. - Very common.

17. Tàylori, Hort. A garden hybrid of A.geminiflora and A. densiflora is often seen in cult. Mn. 7:111 G.C. II. $8: 621$.

18. Schóttii, Engelm. (A, yemniflòra var. Sonòrce, Torr.). Stemless : lvs. linear, $1 \mathrm{ft}$. or less long and only $1 / 8$ in. broad, flat or concave, very rigid, sharp-tipped, the margin usually with white threads: fls. 1/2in. long S. Ariz. B.M. 7567 . 
DD. Li's. broad and fleshy.

19. attenuàta, Salm-Dyck (A. glaucéscens, Hook.). Figs. 47-49. St. 4-5 ft., crowned by a great mass of lvs. sometimes $6 \mathrm{ft}$. in diam.: lvs. about 20, 2-3 ft. long, 6-8 in. broad at the widest point, very glaucous on both sides: $\mathrm{fl}$.-spike $5 \mathrm{ft}$. long; fl. 2 in. long, greenish yellow. G.F. $10: 95$. G.C.II, $2: 218,223$. G.C. III. $17: 4 \overline{5} 5,457$ B.M. 5333. Gn. 51,p.407.-This is one of the most majestic of the Agaves. It has flowered only twice in the United States, - in the Washington Botanical Garden, in 1897 and 1898.

20. Elemeetiana, Koch. Very near the above, but stemless: lvs. about $25,1 \frac{1}{2}-2 \mathrm{ft}$. long, $4 \frac{1}{2}-6$ in. wide pale. B.M. 7027. G.C. II. 8:749. - A var. subdentàta is sometimes sold.

Cc. Margins of lvs. more or less toothed.

D. Border of lvs. horny throughout.

21. univittàta, Haw. Stemless: lvs. about 50, rigid,

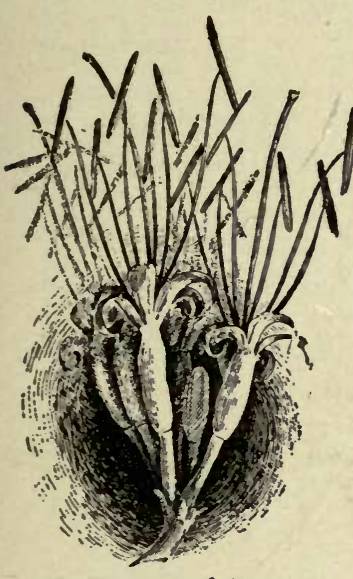

48. Flowers of Agave attenuata. $2-21 / 2$ ft. long, dark green except a pale band down the center: fls. yellowish. Mex. B. M. 6655. - Int. about 1830 .

22. heteracántha, Zucc. Very common. Forms seen in collections show a very polymorphous species. Stemless : lvs. about 20, with a pale band down the center; teeth widely separated, never banded, 12 in. long, 2 in. broad. Mex.Numerous varieties. Int. 1862.

23. Lechegúlla, Torr. Rather common in collections, but usually passing as $\boldsymbol{A}$. heteracantha. Seemingly a good species, though referred by Baker to $A$. heteracantha. Lvs. not banded, and spine very long. W. Tex. and N. Mex.

24. Victòriæ - Reginæ, Moore. Stemless : Ivs. sometimes 200 , very compact, rigid, 6-8 in. long, $11 / 2 \mathrm{in}$. broad, the margin and bands on the back white, obtuse at apex, tipped with a small spine. Mex. Gn. 8, p. 351 . G.C. II. $4: 485$; II.18:841. I.H.28:413. - A very remarkable species. Int. in 1872, but now seen in all collections. Probably more cult. than any other kind except $A$. A mericana.

25. Nissoni, Baker. A small species usually growing in clumps; especially desirable for large vases. Lvs. 5-6 in. long, with a pale band down the center. Mex. - Not known to have flowered.

26. horrida, Lem. Stemless : lvs. about 40, compact, rigid, with a very stout end spine, not striped: fls. nearly 2 in. long, yellowish. Mex. B.M. 6511.-Many forms.

Var. Gílbeyi, Baker. Lvs. with a pale stripe down the center. G.C. I. 33:1305. Gt. 1874, p. 84 .

27. xylonacántha, Salm-Dyck. Stout-stemmed: lvs.20 or less, sword-like, $3 \mathrm{ft}$. or less long, with a sharp brown point, slightly glaucous green, with a few darker green lines on the back, the margin with a few large teeth: fls. $11 / 2$ in. or less long, greenish yellow. Mex. B.M. 5660 . G.C. II. $7: 523 .-A$. Amurénsis and A. Kòchii, Jacobi, are forms of this species.

28. Kerchdvei, Lem. (A. Beaucárnei, Lem. A. rigidissima, Jacobi). Stemless: lvs. 20-30, sword-like, a foot or less long, rigid, dull green with a pale central band above, not dark-lined below, with lanceolate curved teeth: fls. 11/2in. long. Mex. G.C. II. 7: 523.- Many forms, as diplacántha, macrodónta, pectindata.

DD. Border of les. not horny.

E. Lv's.oblong, with smull teeth.

29. B6tteri, Buker. Stemless: lvs. 50, $2 \mathrm{ft}$. long, broad, pale green; triangular teeth on margin, crowded and black. Mex. B.M. 6248. - A very beautiful species.
30. álbicans, Jacobi. Stemless: Ivs. about 30, in a dense cluster, $15 \mathrm{in}$. or so long, $3-3 \frac{1}{2} \mathrm{in}$. wide, tapering to a weak spine, glaucous on both sides, the margin lined with small black teeth: spike of fls. about 15 in. long; fls. yellowish. Mex. B.M. 7207. G.C. II. 8:717.-This is one of the smaller Agaves. It does not die down after flowering. A form with variegated lvs.

31. Célsii, Hook. (A.Celsidna, Jacobi). Stemless: lvs. 20-30, oblong-spatulate, $2 \mathrm{ft}$. or less long, not strongly spine-tipped, the marginal lanceolate spines unequal, glaucous: fls. 2 in. or less long, purplish green, the tube very short. Mex. B.M. 4934.

32. densiflora, Hook. Stemless: Ivs. 30-40, oblunceolate-spatulate, $3 \mathrm{ft}$. or less long, glaucous when young but becoming green, the end-spine $1 / 2 \mathrm{in}$. long, the marginal deltoid prickles 1 line or less long: fls. 2 in. or less long, greenish brown. Mex. B.M. 5006.

33. mitis, Salm-Dyck. Short-stemmed: Ivs. 30, oblanceolate, 15 in. or less long, 3 in. at broadest part, tipspine weak, the teeth very small and green or only obscurely brown-tipped, green : fls. 2 in. long. Mex. - A. micracantha, Salm-Dyck, is very similar.

EE. Lvs. very narrow, weak, the surface mostly ribbed: the margin minutely serrulate

34. striata, Zucc. Stemless or nearly so: lvs. 150-200, linear from a wide base, $2 \frac{1}{2} \mathrm{ft}$. or less long, scabrous on the edge, sharp-tipped, glaucous-green, and ribbed on both surfaces: fl. 11/2in. long, brown-green. Mex. B.M. 4950. Cult. under several forms, as var. recúrva, Baker. Lvs. larger and more falcate, not sharp-tipped. Var. stricta, Baker (A. stricta, Salm-Dyck). Dwarf : lvs. very stiff, $1 \mathrm{ft}$. long. Var. echinoldes, Baker (A. echinoides, Jacobi. A . ensiformis and $\boldsymbol{A}$. Richardsii, Hort.). Dwarf and stiff: lvs. only $1 / 2 \mathrm{ft}$.long.

35. yuccæfolia, DC. St. short: lvs.20-40, much nerved, linear and recurved, with a pale center, entire or nearly so. Mex. B.M. 5213. - Int. about 1800 .

36. dasylirioldes, Jacobi. Stemless : lvs, about 100 , linear, stiff, very glaucous, serrulate, finely striate vertically on both faces: fl. nearly 2 in. long, yellow. Mex. B.M. 5716.

AA. Foliage weak and soft, dying down annually : inflorescence a slender open raceme or spike: st. arising from true bulbs. (Manfreda.)

37. Virgínica, Linn. Lvs. few, green, 6-20 in. long, spreading, lanceolate; pale green or brown mottled, with a narrow white and nearly entire margin: stalk 3-6 ft. high: fls. greenish. S. states. B.M. 1157.

Var. tigrina, Engelm., a form from South Carolina and Missouri, has spotted lvs.

38. maculdsa, Hook. Fig. 50. Basal lvs. 6-10, blotched with brown or green, soft and fleshy, somewhat recurved, the margin serrulate: st. 15-25 in. high, bearing a few scattered lvs. or leaf-like bracts: fls. 10-25, nearly sessile, 2 in. long, purplish; stamens a little longer than the segments of the fl. S. Tex. B.M.5122. - Generally labelled A. maculata.

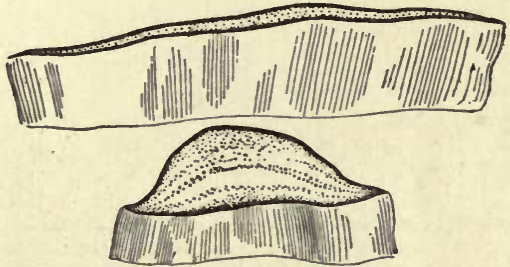

49. Cross-sections of leaf of Agave attenuata.

39. maculata, Regel. A name commonly used for the above, but a very uncertain species. It is probably $\boldsymbol{A}$. protuberans, Engelm.

40. brachystachys, Cav. Lvs. lanceolate, green with a pale nearly entire edge: fls. reddish. B.R. 25:55. - Rare in collections, but a very important plant in Mexico, furnishing much of the "amole" of the natives. 
41. Potosina, Rob. \& Greenm. An odd little species, resembling very much $A$. Virginica. Sometimes met with under the name of Delpinoa gracillima.

The gardener may find the following names (those marked * are or have been offered by American dealers): A. Bonnetiàna, Peacock, is considered by J. G. Baker to be a form of A. ferox.* A. Boùchei, Jacobi. Fls. in spikes : lvs. oblanceolate, glaucous when young, brown-toothed. Int. 1864. G.C. III. 21:166, 167. B.M. 7558. - *A. Cariboea, Baker. Fls. in spikes: lvs. lanceolate, with very minute and close teeth. Isle of Martinique. - *A.calciàna Hort. - *A. chloracántha. Salm-Dyck. Fls, in spikes : ciana, Hort. - A. chloracantha, Salm-Dyck. In. In spikes : lvs. oblanceolate, bright green, weak-spined. Int. about 1860.-
A. coccinea. Roezl. Has never fld. Apparently common in Europe, with at least one variety. Lvs. spatulate, dark green repand-prickly. - A.coeruléscens, Salm-Dyck, is a glaucous-leaved variety of A. lophantha. $-* A$. Córderoyi, Baker. Has never fld. in cult.: lvs. sword-like, rigid and spreading, channelled, spineedged.-*A. decipiens. "Tall-growing: lvs. dark green. Fla."A. Engelmanni, Trelease. A.F. 8:109.-*A. erubéscens, Hort.$*_{A}$. ferox, Koch. Said to be not uncommon in eult., but it has never fld: lvs, slightly glaucous, the brown teeth 1/in. long. never fld.: 18s, slightly glaucous, the brown teeth $1 / 2$ in. long. G.C. III. 20: 525. - *A. Franzdsini. "Large-growing, of peculiar
blue color." $*$ A. Gauliniàna, Hort. $-* A$. Ghiesbreghtii, Koch. Int. about 1862 . Several varieties. Lvs. glossy green, minutetoothed. It has never fld. Some plants eirculated under this name are $\mathrm{A}$. pruinosa $-A$. grandidentàta, $\mathrm{Jacobi}$, is a var, of $\mathrm{A}$ horrida.-A. Gustavidana, Hort. Considered by Baker as belonging to A. Maximiliana. Lvs. slightly glaueous, with brown prickles.-*A. Henriguèsi. Baker. Fls. in spikes : Ivs. lanceoprickles.-*A. Henriquesi, Baker. Fls. in spikes: Ivs. lanceoJacobi. Has never fld. in eult. Lvs. oblanceolate, not spiny.A.Jacquiniàna, Schult. Now considered a variety of A. lurida. Lvs. oblanceolate, very glaucous, with black prickles. B.M. 5097. -*A. Margaritoe. "Dwarf, very compact and prickly. Lower Calif."-*A. marmoràta, Roezl. Fls. in panicles: lvs. glaucous, repand-prickly. $-* A$. Mesotillo. "Pale stripe down the center of the leaf : similar to A. Lecheguilla, but of larger and stouter growth."-*A. micracántha, Salm-Dyck. A small-spined form of growth."-*A. micracántha, Salm-Dyck. A small-spined form of lanceolate, the prickles very small. $-*_{A}^{*}$. Níckelsii. "Similar in appearance to A. Vietoriø-Reginæ, except that it is of much more robust growth, the lvs. being thicker and the white markings on same being broader and more distinct." F.E. $7: 618$. A. Ousselghemiàna, Jacobi $=$ A. albicans. $-{ }^{*} A$.Pálmeri, Engelm. A beautiful species from Ariz. and Mex. Stemless: lvs. oblanceolate, glaucous, repand-prickly. $-A$. Párryi, Engelm. Now considered as a variety of A applanata. - *A. polyacántha, Haw. sidered as a variety of A. applanata.-*A. polyacantha, Haw. toothed. Int. about 1820.-A . pruinosa, Lem., see Ghiesbreghtii. $-{ }^{*}$ A pulchérrima, Hort. $-A$. Regeliàna, Jacobi $=$ A. horrida."A. Robini, Hort. -*A. rupicola, Regel. Fls. in spikes : lvs. ob lanceolate, bright green, Jagged.-*A. Simaron. "Resembling A. Americana, but ashy gray in color, and of smaller growth: thorns on points of lvs. much longer." Calif.-A. Símorri. Hort. Same as above? $-* A$. spectábilis, Todaro. Lvs. nearly 200, lan ceolate, very glaucous, brown-toothed. $-A$. subulàta, Hort. $*_{A}^{*}$ sylvéstris, Hort. $-{ }^{*}$. Tollinénsis, Hort. $-{ }^{*}$. Vanderwinneni,
Jacobi. Lvs. oblong-spatulate, dull green, brown-edged and toothed. $-\boldsymbol{A}$. Verschafféttii, Lem. Is usually considered a form of A. Scolymus. I.H. 15: $564 .-^{*}$ A. Whldingii, Todaro. Lvs. few, oblong, bright green, with small brown teeth. J. N. Rose.

AGDESTIS (a mythical hermaphrodite monster, the genus being an anomalous one in its order). Phytolaccacece. A monotypic genus. Tender climbing shrub from Mex. Cult. in Calif.

clematfdea, Moç. \& Sesse. Lrs, alternate, petiolate, cordate: fls, axillary or in terminal, branched, racemose cymes, white, star-shaped; sepals 4 ; petals 0 .

AGERATUM (Greek for not growing old, probably applied first to some other plant). Compósitoe. About 40 species of trop. Amer. herbs, with opposite stalked lvs. and blue or white fls. in small terminal cymes or panicles.

conyzoldes, Linn. (A. Mexicanum, Sims, and Hort.). Fig. 51. Annual and pubescent: lvs. ovate-deltoid, crenate-serrate : fls. blue or white, or varying to rose. Ordinarily a rather loose-growing plant a foot or two high, but there are dwarf and compact forms ; also variegated forms. Trop. Amer. B.M. 2524. - This is the common ageratum of gardeners and florists. It is easily grown from seeds, sown in the border where the plants are to stand, or started in the house or hotbed. If the plants are to be usted for bedding, they should be placed a foot or less apart. They thrive in any garden soil and exposure. They bloom all summer; and if sown in late summer or fall, they give winter bloom under glass.

The plant sold as $\boldsymbol{A}$. conspicuum is an Eupatorium; and that sold as A. Lasseduxii is a Conoclinium.

L. H. B.
AGLAIA (Greek, splendor; from the order and general appearance). Melidceo. Tender tree from China, with minute, yellow, fragrant fls., said to be used in perfuming certain teas. Prop. by cuttings.

odoràta, Lour. Lvs. alternate, 5-7 pinnate : fls. in axillary, branching panicles. Cult. sparingly in Calif.

AGLAON ÈMA (Greek, bright thread). A roidece. About 15 species, of trop. Asia and Africu, allied to Arum, Alocasia and Dieffenbachia, and requiring essentially the same treatment as those genera. Evergreen, often beautifully variegated. Aglaonema may be divided, or cuttings may be taken from plants that become too tall and weak. In either case the cuttings and divisions should be put into the sand-bed pre. vious to potting, to develop new roots. All of the kinds will succeed in fibrous loam enriched with rotted manure, with the addition of a moderato quantity of leaf-mold, sand. and some crushed charcoal.

Cult. by G. W. Oliver.

píctum, Kunth. Dwarf : lvs. somewhat unequilateral,oblong or elliptic, ovate (4-7 in. long and 2-3 in.wide), very dark green, blotched with white, the central markings usually extending the whole length of the midrib : spathe white or whitish, 1-1 1/2in. long. Sumatra. I.H. $29: 445$.

nebuldsum, N, E. Brown, Somewhat larger: lvs. narrower (5-8 in. long, $1 \frac{1}{2}$ in. or less widel, more acuminate, the markings rather more broken and not so continuous along the midrib. I.H. 1887:24. A.G. 16 : 361, and F.E. 7:961, as A.pictum.-This and $A$. pictum are confused in the trade. Both species deserve more attention than they have received in this country.

costàtum, Veitch. Very dwarf and compact: lvs.heart-shaped, thick, 3 in. wide, onethird longer than wide, seldom ex ceeding 5 in

long, dark,

shining green, with midrib ivory-white and scattering blotehes of white. Holds its tufted lvs. through the winter. Moluccas.

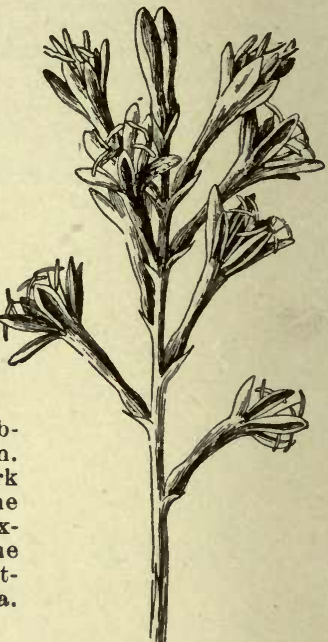

A. commutàtum, Schott. $=$ Scindapsus Cuscuaria.-A. Róeblinii, Hort., is " a fine decorative plant, with thick, leathery foliage" (Manda). - A. versícolor, Hort., is probably a form of either A. pictum or A. nebulosum.

L. H. B.

AGRIMONIA (old name of obscure meaning). Rosdcece. AGRIMony. Hardy native herbs, with interruptedly pinnate lvs. and small, numerous, yellow fls., produced through summer. Lvs. aromatic, astringent. Sometimes cult. in shrubbery and wild gardens.

Eupatoria, Linn. (A. officinalis, Lam.). СоммоN AGRIMONy. Fig. 52. Petals twice as long as calyx, latter making a small, lightly adhering bur. Cult. in herb gardens to make a tonic tea, also in wild borders. Common in woods; also native to Eu. Grows 2-3 ft. high, in little clumps, from a short rootstock. 
odoràta, Mill. Lfts. narrower than in A. Eupatoria; leaflets pubescent: lobes more deeply crenate-dentate: perals more than twice as long as the calyx. Italy. Occasionally cult. in Am.

J. B. KELLER and W. M.

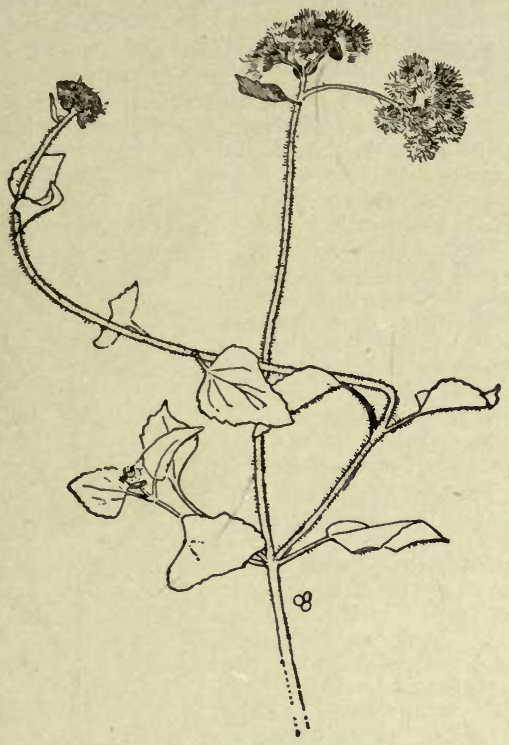

51. Ageratum conyzoides.

AGROPYRUM (Greek for field and wheat). Graminece. Perennials or annuals, with leaf-blades flat or convolute : spike terminal, usually stiff ; spikelets large, 3-8fld., compressed, sessile at each joint of the simple spike, the side of the spikelet placed next the axis. Species about 30. Temperate regions of Amer. and Eu.

rèpens, Beauv. Quack Grass. Covch Grass. QUick Grass. Quitch Grass. A smooth, pale green or glaucous perennial, very variable, with the internodes of the rootstock long. In many places it has become one of the worst weeds, spreading inveterately by its underground stems. Fig. 53. It may be destroyed by constant and thorough tillage. Often valuable to hold loose lands. Considered by some stock raisers as a valuable hay grass.

\section{AGROSTEMMA. See Lychnis.}

AGROSTIS (agros, field ; the place of growth). Graminece. BENT GRAss. A genus containing many useful grasses for lawns, pastures and bouquets. Panicles variable, usually spreading: spikelets very small, awnless or occasionally a short awn present. Species about 100 , distributed over the entire globe; about 9 useful in cult. Some species are much confused with Aira. In Agrostis the spikelets are 1-fld.; in Aira 2- to sereral-fld.
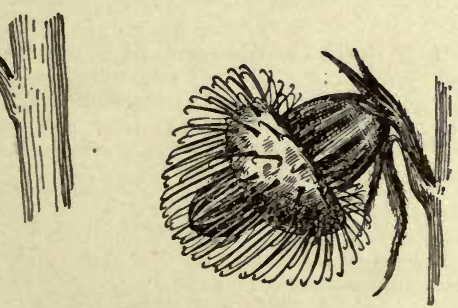

52. Agrimonia Eupatoria $(\times 3)$. Flower and bur.
A. Spikelets about 1 line long: panicle-branches short. Perennial lau'n and pasture grasses.

$$
\text { B. Awnless spikelets. }
$$

álba, Linn. Creeping Bent Grass. A well known perennial, creeping or stoloniferous, 1-3 ft.: sheaths smooth: leaf-blade linear or narrowly lanceolate, 4-8 in. long, scabrous: panicle open, 4-10 in. long, the branches sometimes widely spreading: spikelets about 1 line long: ligula 1-4 lines long. - Suitable for meadows, pasture mixtures, or exclusively for lawn-making.

Var. vulgàris, Thurb. (A.vulgd̀ris, With.). RED-TOP. Fine Bent Grass. Distinguished from the type by the smaller ligule, which is truncate, and less than \& line long. - Commoner in cult. than the type.

Var. stolonffera, Linn. ( A . stolonifera, Linn.). Panicle contracted linear; culms extensively creeping or stoloniferous: ligule 1-4 lines long.

\section{Bв. Auned spikelets.}

canina, Linn. Brown or Dog's Bent Grass. Rhode Is I.AND Bent Grass. Slender, creeping, 1-2 ft.: panicle pyramidal, 4-6 in. long: spikelets near the ends of the branches, very small, 1-9 of an in. long: small bent awn on back of flowering glume. Int. from Eu.-Makes a close sod.

AA. Spikelets about $1 / 2$ line long; panicle-branches long and hair-like. Annual ornamental grasses.

B. Culms, lvs, and panicle-branches smooth.

nebulossa, Boiss \& Reut. (A. capillaris, Hort.). Cr.oud Grass. Fig. 54. A low grass, with extremely delicate, feathery-like panicle and small spikelets: lvs. few and very small. Spain. -Very useful for vases and bouquets

minutiflora, Hort. Very similar to A. nebulosa, but smaller. with fewer lvs. and shorter panicles. - Useful for vases and bouquets.

BB. Culms, lv's. and panicle-branches scabrous.

scàbra, Willd. Rough-Bent. Tickle Grass. Flyaway Grass. Hair Grass. Silk Grass. Hair-like, delicate, with widely spreading, capillary panicles, which at maturity break away from the culm and fly about in the wind: spikelets very small, clustered at the ends of

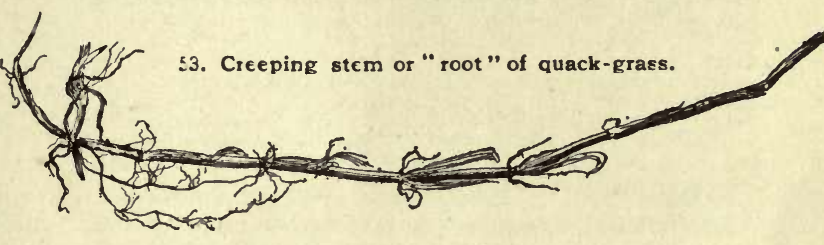

the branches.-Before panicle expands it is often sold in the vicinity of large towns for dry bouquets.

A. élegans, Hort., not Thore, and A.pulchélla, Hort. These names are applied by florists to Aira elegans and Aira caryophyllea, which see.

P. B. KENNEDY.

\section{AgUACATE, ALLIGATOR PEAR, AVOCADO. See} Persea.

AILANTHUS (from its native name Ailanto, meaning Tree of Heaven). Simarubdcece. Large trees: lvs. alternate, large, pinnate, deciduous : fls. small, in large terminal panicles, polygamous ; petals 5; stamens 10 ; fr. consisting of $1-5$ distinct samaras. Five species in Cent, and S. Asia and N. Austral.-Large, ornamental trees of loose and somewhat spreading habit, with elegant, feathery foliage. Very rapid growers. Good for smoky cities. Suckers from the roots. Prop. by seeds and root cuttings.

glanduldsa, Desf. (A. Japónica, Hort.). Tree of HeAven. Tree, $60 \mathrm{ft}$. : lvs. odd-pinnate, 11/2-2 ft. long ; leaflets 13-25, petiolulate, ovate-lanceolate, nearly glabrous near the base, with $2-4$ coarse teeth, each with a large gland beneath: fls. greenish: samaras 11/2in. long. June. China, cult. in Japan. - Valuable tree for street planting, much used in the temperate regions and naturalized in some localities; somewhat tender north in 
a young state. For street planting, the fertile plant only should be used, because the male exhales a disagreeable odor when flowering, and the pollen is said to cause catarrhal troubles. It grows in almost any soil, but best in a light and somewhat moist one, and stands dust and smoke well. Var. erythrocárpa ( $A$. erythrocárpa, Carr. A. rùbra, Hort.). Lvs. darker green above and more glaucous beneath : fr. bright red, very effective in late summer and autumn. Var. pendulifolia, Carr. Lvs. very large, drooping. - The Ailanthus foliage gives a tropical effect when the growth is very strong. If plants are cut back to the ground after they have become established (in two or three years after planting), they will throw up very strong shoots and make an excellent screen, as shown in Fig. 55. This practice may be repeated year after year. Sumacs, paulownias, basswoods, mulberries, and other fast-growing things may be treated in this way. The Ailanthus foliage is very like that of the Cedrela (which see for illustration of differences).

A. excélsa, Roxbg. Tall tree: lvs. $3 \mathrm{ft}$. long, abruptly pinnate; leaflets 20-28, teeth without glands. India. Can be grown only in tropical regions or in the hothouse. $-A$. flavéscens, Carr. = Cedrela Sinensis.

54. Agrostio nebulosa.

AlFRed ReHDER.

AtRA (an ancient Greek name for Darnel). Gramínece. HAIR Grass. A genus containing delicate annual grasses, with slender, loose panicle-branches: spikelets very small, of two perfect contiguous flowers: flowering glume acutely 2-cleft at the apex, bearing a slender twisted awn below the middle. Eu., N. Afr.-This genus is much confused with Agrostis by florists. Nat. from Eu. and cult. for dry bouquets.

caryophyllèa, Linn. (Agróstis élegans, Hort., not Guss.). A slender and elegant tufted annual, 10-20 in. high, bearing a very diffuse panicle of purplish and at length silvery scarious spikelets.

élegans, Gaud. (Agróstis élegans, Hort., not Guss.). A slender, erect and very pretty annual, from a few inches to a foot high, with widely spreading capillary panicles of many small spikelets.

A. coespitosa, Linn.= Deschampsia cæspitosa.-A. corrùlea, Linn. $=$ Molinia coerulea, Mönch. $-A$. flexuosa, Linn. $=$ Deschampsia flexuoss.

P. B. KenNedY.

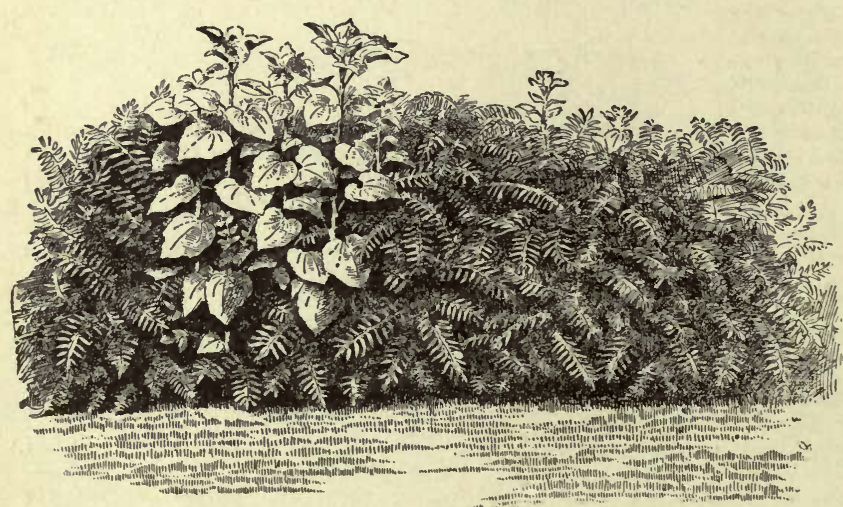

55. Ailanthus shoots; with a few sunflower plants.
AIR-PLANT, In common speech, any plant which grows on the trunk or in the top of another plant is called an air-plant. The proper term is epiphyte (that is, growing on a plant). In horticulture, the term air-plant is usually applied to epiphytal orchids, tillandsias, and the like. Most of these grow upon old bark, perhaps deriving some of their nourishment from the bark, but most of it from the air and rain. They are not parasites, - do not derive their support from the juices of the host.

AJÜGA (not yoked; the calyx not bilabiate). Labiatce. BUGLE WEED. Hardy herbaceous European perennials, creeping by stolons. Height 6-12 in.: fls. numerous, in whorls, normally blue or purple, with rosy or white varieties. Prop. by division or seeds.

Genevénsis, Linn.(A.rugdsa, Hort. A. alpina, Hort.) St. erect: cauline lvs. oblong-elliptic or obovate, narrowed at the base ; lower ones petiolate ; floral lvs. ovate or wedge-shaped, coarsely toothed, sparsely hairy: upper fl.-whorls spicate; lower whorls distant.

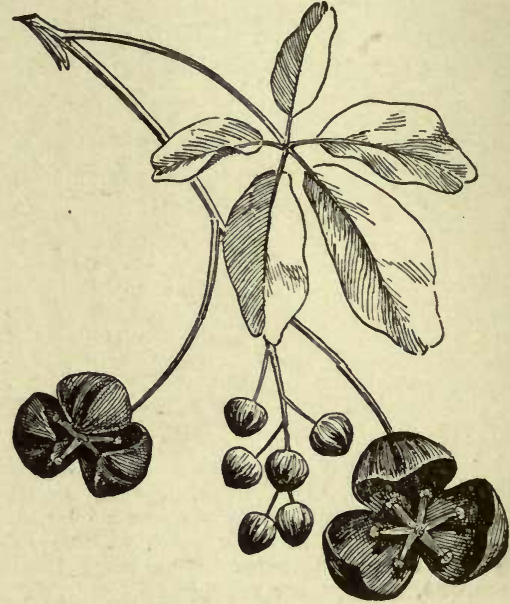

56. Akebia quinata.

The expanded flowers are pistillate; the others are staminate.

pyramidalis, Linn. St. erect: cauline Ivs. obovate, hardly petiolate, in a 4-sided pyramid; floral lvs. broadly ovate, the highest often colored ; all lvs. entire: $f$ l. whorls usually all spicate.

réptans, Linn. St. prostrate : lvs. ovate or obovate, entire or sinuate, shiny. - A low, dense, fast-spreading creeper, excellent for covering shady slopes. The typical and white-fid. forms are less cult. than the following: Var. rùbra, Hort. More valued for its dark purple Ivs. than its blue fls. Var. variegata, Hort. Lvs. splashed and edged creamy yellow.

metállica var. críspa, Hort., int. by Henderson, 1899, is described as dwarf (4-5 in.), with curled, metallic glossy and blue fls. in a pyramidal spike. A bedding plant, int. from Germany.

\section{J. B. KELLER and W. M.}

AKEेBIA (from Akebi, its Japanese name). Berberiddcec. Twining glabrous shrubs: lvs. long-petioled, digitate, coriaceous: fls. monœcious in axillary racemes, pistillate at the base, staminate at the end of the raceme; sepals 3 : fr. consisting of one or more very large, oblong berries with numerous seeds. Two species in Japan and China. Very ornamental, hardy climbing shrubs of graceful appearance, especially adapted for places in which very dense shade is not wanted. They require a sunny position and well drained soil; also valuable in the cool greenhouse for covering pillars and walls, growing best in a sandy compost of loam, leaf soil 
and peat. In Japan the fr., which is very showy, but with us rarely produced, is eaten, and the stems are much used for wicker-work. Prop. by seeds, by greenwood or hardwood euttings, and also by root division and layers.

quinàta, Decaisne. Figs. 56, 57. Climbing $12 \mathrm{ft}$. or more: leaflets 5 , oval or oblong-obovate, entire, emarginate, 1-2 in. long: fls. fragrant, the pistillate purplish brown, about 1 in. broad, the staminate smaller, rosy purple, in early spring: berry oblong, 3-5 in. long, dark purple with glaucous bloom, seeds black. - Hardy, handsome, not attacked by insects or fungi. Very graceful and desirable. China, Japan. B.R. 33 : 28. B.M. 4864. G.F. 4:137. A.G. March, 1891, Figs. 5, 7, and plate. R.H. 1853:141. S.Z. 77 .

lobàta, Decaisne. Leaflets 3 , broadly ovate, coarsely crenate : fls. in long racemes, smaller than those of A. quinata. Japan, China. B.M. 7485. A.G. March, 1891, p. 140. S.Z. 1: 78. - A clematifolia and A. quercifolia, Sieb. \& Zucc., are probably only varieties of this species.

\section{AlFRED REHDER.}

ALABAMA HORTICUL. TURE IN. Fig. 58. Commercial horticulture has not assumed the proportions in Alabama that it has in the neighboring southern states. This must be largely due to accidental causes, since in soils, climate and transportation facilities the state presents conditions fully equal to any of the others. At present the most important horticultural centers are at the extreme northern and southern ends of the state. Mobile has long been known as one of the chief sources of supply for early vegetables for the northern and western markets, and the truck business is gradually extending from Mobile county to the adjoining counties of Baldwin and Washington. Early cabbage and Irish potatoes are the most important crops, though snap beans, peas, radishes, and many other vegetables are grown in considerable quantities. The tomato, so important a market crop in many southern localities, is very little grown bere, owing largely to the prevalence of bacteriosis, often called southern tomato blight.

Huntsville, in northern Alabama, has a large and flourishing nursery business. Several large wholesale establishments are located there, and the fertile Tennessee River Valley lands prove to be admirably adapted to the growth of a good quality of nursery stock. Over 1,300 acres are now devoted to this business in this neighborhood, the annual shipments fill 150 cars, including $1,500,000$ fruit trees, besides roses and other ornamentals; and the sum of $\$ 40,000$ is paid out annually for labor.

Beginnings have been made in fruit and vegetable growing at various other points in the state, particularly at Cullman, Montgomery, and Evergreen, on the Louisville and Nashville railroad, and at Fruithurst, in northeastern Alabama, on the Southeru railway. No data have been secured as to the total shipment from these various points, but the combined amount is very small, as compared with those from the Mobile region. One road, the
Mobile and Ohio, torwarded 343 cars of home-grown fruits and vegetables from the Mobile depot during 1897. These figures do not include the shipments from other stations on this line, nor those carried by the Louisville and Nashville.

Such, in brief, is the present status of commercial horticulture in Alabama. In attempting to outline the possibilities of its future development, it will be necessary to glance at some of the more prominent topographical features of the state. For our purpose, it may be roughly divided into four regions. First, at the north is the Tennessee River region, or, as it is often called, the grain belt (Fig. 58, A). Its strong clay soils produce abundant crops of corn, wheat, clover and timothy, and were originally covered by a heavy growth of hardwood timber. Next comes the mineral belt (B), including the mountain region of northeast Alabama, and extending in an irregular way nearly across the state to its western border. This is a large region, containing a great variety of soils, ranging from rich creek and river bottoms, and the fertile red soils characteristic of the Piedmont region of Georgia, to barren sands and sterile, rocky hillsides. The surface is very much broken, and great areas are still covered with the original forests of mixed pine and hard woods. Below the mountain country, and forming an irregular belt or girdle across the middle of the state, is the prairie region (Fig. 58, C). This is narrow at the east, where the mountains press farthest southward, but broadens out toward the western border. The soil varies, in some places being light and sandy, but for the most part it is a dark, retentive loam, resembling that of the northern prairies. While cotton is a staple crop in all parts of the state, this is preëminently the cotton belt. Below the prairie comes the timber belt (D), covering the southern third of the state, and extending to the Gulf. Before the advent of the lumberman this extensive re-

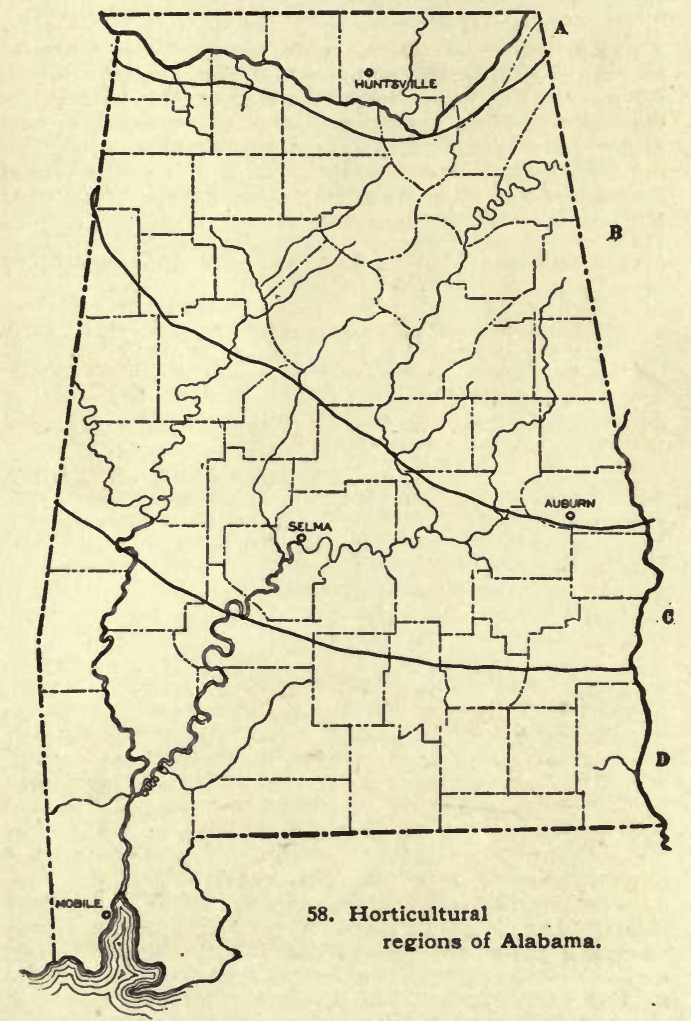

gion was an unbroken forest of long-leaf yellow pine, with magnolias and other broad-leaved evergreens bordering the water courses. The surface is rolling, or in 
some parts very hilly. The soil is a light, sandy loam, usually underlaid with red or yellow clay. It is naturally poor, being deficient in potash and phosphoric acid, and yields only scanty crops without fertilizers. It can, however, be made very productive by judicious manuring, and it builds up rapidly under intelligent intensive farming. This region is well adapted, both by soil and climate, to the production of early vegetables, and it seems probable that the business of truck-farming will ultimately spread widely from its present center at Mobile. Among fruits most promising for this region are grapes, oriental pears, figs, Japanese persimmons and strawberries. Satsuma oranges on hardy trifoliata stocks can be safely planted at the extreme south, and peaches and Japanese plums in the more northerly portion. Pecans thrive admirably, and the better kinds should be widely planted.

The soils of the prairie region, being mostly rather cold and wet in the spring, are not $\dot{w}$ ell adapted to early vegetables. Their fruit-growing capacity has not been fully tested, cotton claiming almost universal attention. Peaches and plums will thrive on some of the lighter soils, though the trees are usually short-lived. Apple trees grow well on the heavier prairie soils, and it seems probable that with a proper selection of varieties and due attention to spraying, their cultivation would prove profitable.

The mineral or mountain region presents so great a variety of soils and conditions that it is hard to characterize it as a whole. Some portions present almost ideal conditions for peaches, plums and grapes, and in the moister, heavier lands apples thrive and yield abun dantly. If the people of Alabama ever interest themselves in fruit-growing as their neighbors in Georgia do at the present day, then these choice mountain locations will certainly be covered with orchards and vineyards, and this mountain region will advance to the first place in the magnitude of its horticultural interests.

The northern region already has its well established nursery business, which seems destined to increave. Owing to late spring frosts, peach and plum crops are too uncertain here to make commercial plantings advisable. It is, however, a promising apple country, and strawberries, raspberries and blackberries succeed well. An undeveloped but promising industry for this region would seem to be the growing of late crops of cabbage and Irish potatoes for the southern market. The alluvial soils found here seem well adapted for this purpose, and all the southern towns and cities offer a near and ready market.

F. S. EARLE.

ALANGIUM (from the Malabar name). Cornacere. A few species of shrubs or small trees of the Old World tropics, with alternate entire evergreen lvs. and small, perfect purple fls. in axillary clusters. Rarely cult. in Old World stoves, but probably not in the Amer. trade.

ALASKA, HORTICULTURE IN. Fig. 59. When considered from a horticultural or agricultural point of view, Alaska may be very conveniently divided into two divisions, the southern coast region and the interior. These two regions differ very materially in their climate, and may be ultimately found as unlike in their possibilities. The climate of the coast region, which extends from Dixon's Entrance on the southeast to Unalaska on the southwest, is characterized by a heavy rainfall, a great preponderance of cloudy weather, and a rather low sum mer temperature, with little or no diurnal variation in the readings of the thermometer. The winter temperature is not excessively cold, zero weather being selrom experienced, while in the summer it is seldom high. The average rainfall, as shown by data from the Government Weather Service, varies from 55.9 inches at Killisnoo to 92.1 at Unalaska, about one-third of the precipitation falling during the growing period, from May to September. The data concerning the interior portion of the country are mainly from along the Yukon River, that being the great thoroughfare of the region. Here the rainfall is slight, and during summer clear skies are the rule. The intense cold of winter is followed by comparativels wirm tem perature in the summer, with a growing period of about four months, although occasional frosts have been reported from the upper part of the valley during the summer months.
The soils of the two regions are very similar, being largely of vegetable origin overlying rock or glacial deposits. In the coast region arable areas are confined to rather narrow valleys and the slopes along the sea. In the interior are reported more extensive areas of comparatively level land. Of the coast region, the most extensive area of land adapted to cultivation is that on the Kenai Peninsula, and, extending across Cook Inlet, is continued up the Sushitna River. This region, on account of its position relative to ocean currents, partakes more of the climatic characteristics of the interior, although still somewhat modified.

The accompanying map shows regions where some attempts have been made in gardening, from which definite reports have been secured. From the data at hand

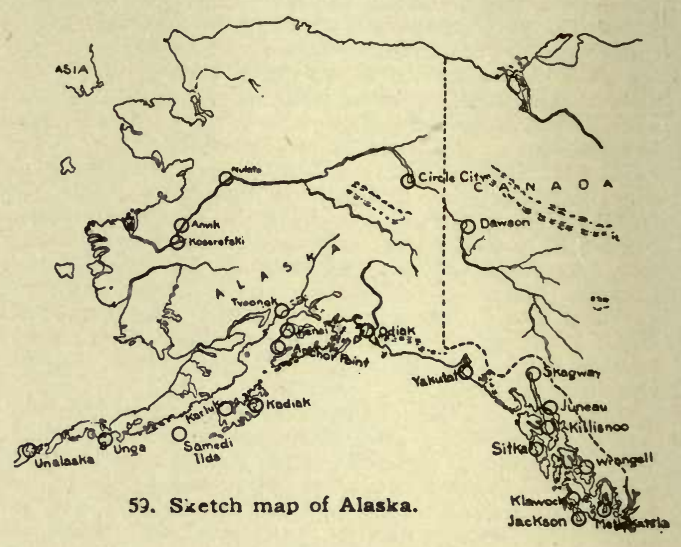

it seems probable that the local supplies of hardy vegetables might be produced nearer at hand than the Puget Sound. This is undoubtedly true of the southeastern portion of the country, where the production need be limited only by the demand for such supplies and the ability to secure arable lands at a cost that will permit the producer to compete with the Sound country. For some time certain economic features will enter into the subject of extensive horticulture. Among these are the high price of labor, the standard being at present determined by the wages paid for gold mining, the question of transportation, and the rather limited markets.

As it exists at the present time, horticulture in Alaska. is of a very primitive type. A few gardens here and there. with perhaps a row of berries along the side and an occasional fruit tree, represents nearly all that is done along this line. Near Juneau and at Killisnoo are market-gardens of considerable importance, but elsewhere only small areus are cultivated.

It has been said that during the Russian occupancy of the country many attempts were made to cultivate gardens and fields, but the data are often so meager and contradictory as to throw doubt upon the sincerity of the endeavor. In the accompanying account, it is desired to place on record some of the horticultural achievements as gathered from reports from gardeners in many places, as well as the personal observations of the writer during two seasons in the country

Fruits. - The great abundance both in kind and quantity of native fruits, especially berries, has doubtless contributed to the delay in the attempted introduction and cultivation of other sorts. Some effort has been made in this line, as is shown by the presence at Sitka of a number of old apple trees, remnants of the Russian days, which bear a very inferior fruit. A few young bearing trees of unknown variety are grown at the same place. At Wrangell there are apple trees of what are thought to be the Red June variety in bearing, and young thriving trees are known to be at Juneau and Metlakahtla. Plum and cherry trees have been recently planted in several places, but so far have not fruited. The mountain ash (Sorbus sambucifolia) is grown as an ornamental tree in a number of places. Currants flourish wherever planted, and gooseberries bave been seen, but they were usually 
badly mildewed. Cuthbert raspberries do exceedingly well at Wrangell and Sitka, the fruit being of fine size and quality. The same is true of strawberries at the several places where they are cultivated. Attempts have been made at a number of places to cultivate some of the indigenous fruits, and the dewberry or "knesheneka" (Rubus stellatus), wild currants (Ribes rubrum and $R$. bracteosum), and the strawberry (Fragaria Chiloensis?) have all been domesticated, and their fruit is fully equal, if not superior, to the wild product.

VEGETA BLES. - More attempts have been made to grow vegetables than fruits, and some definite data have been obtained, showing what varieties are known to be arlapted to Alaskan conditions. Most of these data have been secured from Sitka and Wrangell, in the southeastern part of the country, and from the Holy Cross Mission, near Koserefski, on the lower Yukon. A recent report from the latter place states that potatoes of fine quality, weighing $1 \frac{1}{4}$ pounds, and turnips weighing $5 \frac{1}{2}$ pounds, were grown during the summer of 1898 . In addition, notes were given of some of the varieties of vegetables adapted to the region, as follows: Cabbage-Early Jersey Waketield, Flat Dutch, and Drumhead; cauliflower-Early Snowball, Early Dwarf Erfurt ; turnips - Early Flat Dutch, Yellow Globe, and Extra Early Milan ; rutabagas-Improved American; radish-French Breakfast and Chartier; onions - Extra Early Red and Yellow Danvers; lettuce - Golden Heart; peas-American Wonder and Early Alaska; beets-Eclipse and Edmand's Blood Turnip; carrot-Oxheart ; parsley-Extra Early Double Curled; celery-White Plume, Giant Pascal; rhubarb - Victoria.

The same varieties, with numerous additions, have succeeded in the coast region. Snap beans, Challenge Black Wax and Golden Wax, have done fairly well at Sitka, where some experiments were conducted by the United States Department of Agriculture during 1898, a:d the English Windsor is quite in its element. At this place the Philadelphia Butter and San Francisco Market lettuce made fine beads of a most superior quality. Parsnips and carrots grow well, and salsify and spinach were successfully grown at Sitka for perhaps the first time. Peas were found to grow and yield well, and in addition to the varieties above given, some of the dwarfs and the Norwegian Sugar peas continued to produce their crop until cut off by the frost. The blood beets, Extra Blood Turnip and Extra Early Egyptian, grew well at Sitka, but in many places beets are a failure on account of their tendency to run to seed. This undesirable trait on the part of biennial plants is shared by other vegetables, principally turnips, although cabbage and cauliflower have bren reported as doing likewise. It is believed by some growers that the flat type of turnip is more subject to run to seed than the globe type. Celery of exceedingly fine quality has been grown at a number of places, although at Kadiak specimens were seen in which the central axis was greatly elongated. The leafstalks were also lengthened in about the same proportion, and this trait was not considered undesirable.

Potatoes are more extensively grown than any other crop, and the quality varies with the variety, locality, season, and culture. Usually little choice is exercised in the matter of varieties, but Polaris, Beauty of Hebron, and Early Rose appear well adapted to the conditions existing in this region. The two last are the most extensively known varieties, and very favorable reports have been received from a few trials of the Polaris. Season and method of planting undoubtedly exert a strong influence on the crop. If the soil, which usually contains a high proportion of organic matter and moisture, is well drained or thrown up into beds, as is the custom in many places, good potatoes can be grown in the average season. In some parts of the country, especially from Cook Inlet westward, the natives cultivate a small round potato, called the Russian, that seems to be well suited to the country. It is said to have been brought from Siberia fifty or more years ago. Close planting of potatoes, as well as almost every other regetable, is the rule, and often to this fact alone may be attributed many failures. The object seems to be to grow a large crop by planting an abundance of seed. The result is a large growth of tups that completely shade the ground, thinning being seldom or never practiced. Along the coast, where cloudy weather is the rule, it is safe to say tnat the sun's rays never strike the ground after the growing season has become well adranced. Under such conditions it is not an uncommon sight to see a crop of small potatoes borne in the axils of the leaves above ground, no tubers being formed below the surface.

In general, considerable judgment is shown in the choice of garlen sites. A southwestern slope is always preferred, and if well drained the garden is usually a thrifty one. In many places the earth is thrown up into beds 4 or 5 feet wide and the crop planted crosswise the beds. Where it can be easily obtained, sand is added to warm and to lighten the soil. Kelp is extensively employed as a fertilizer in some places, but its value when added to a soil already largely composed of vegetable debris is questionable. Gardens have been successfully maintained at Dawson, Circle City, and other of the great mining centers of the upper Yukon, and the dirt roof of the miner's cabin is frequently utilized for early gardens, the heat from within supplying the necessary warmth required for growing early radishes, onions, lettuce, turnips, etc.

WILD BERRIES. - The abundance of native fruits, especially of berries, has already been mentioned, and an enumeration of some of them would seem not out of place. Of widest distribution are the salmonberries (Rubus spectabilis, Fig. 60), two so-called cranberries (Viburnum pauciflorum and Vaccinium Vitis-Idcea). currants (Ribes rubrum, $R$.bracteosum, and $R$. laxiflorum), crowberries (Empetrum nigrum), huckleberries (Vaccinium uliginosum and its var. mucronatum), blueberries ( $\boldsymbol{V}$. ovalifolium), red huckleberries ( $V$. parviflorum), the molka or baked-apple berry (Rubus Chamamorus) improperly called salmonberry in the interior, and raspberries (Rubus strigosus). Of less general distribution, yet very abundant in places, may be mentioned straw berries bus stellatus), thim
ble berries $(R$. par II III) viflorus), salal(Gaulcranberries (Vaccin-
ium Oxycoccus), bearb- 1 -

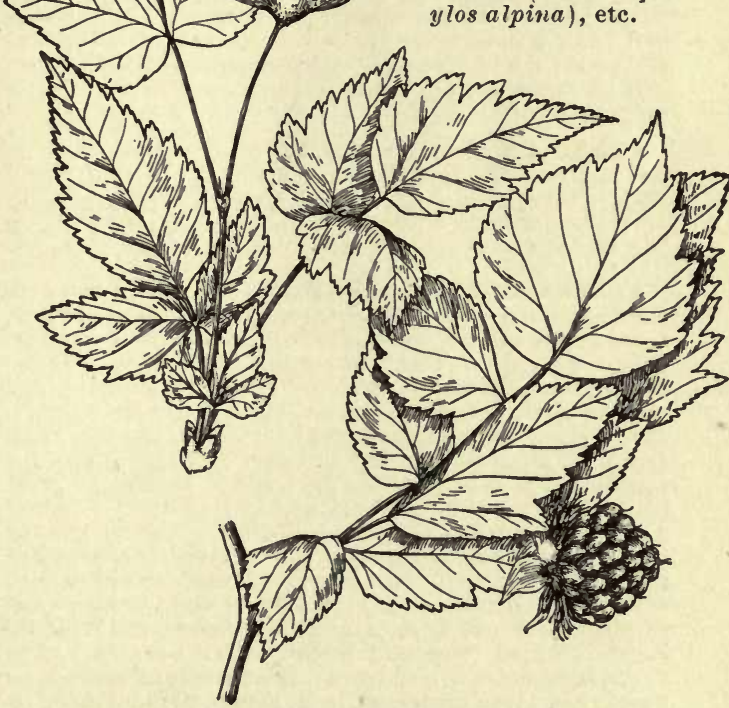

60. Salmonberry, one of the wild fruits of Alaska.

FLORICULTURE. - This branch of horticulture is rot wholly neglected in Alaska, although but few data are available. Many of the hardier plants of the old-fashioned flower garden are to be seen. Pansies of great size and brilliant color are common, and they remain in flower all summer. In some parts of the country sweet peas do well, and poppies, nasturtiums, mignonette, 
sweet alyssum, chrysanthemums, stock, candytuft, verbenas, and marigolds are not uncommon where any attempt is made to grow flowers. Window gardens and boxes add many sorts to the list already given.

A single season's experimentation at Sitka, under the direction of the Office of Experiment Stations, United States Department of Agriculture, has shown that much can be accomplished in horticulture if rational methods of culture and a proper selection of varieties and seed be followed.

WALter H. Evans.

For further information, consult Yearbook of Dept. of Agric. for 1897, and Bulletin 48, Office Exp. Sta., Dept. Agric.

L. H. B.

ALBERTA (from Albertus Grotus, commonly known as Albertus Magnus). Rubiáca. Tender evergreen shrub from Natal, suitable for greenhouse. Little known in commerce in this country.

mágna, E. Mey. Bark pale : lvs. 4-5 in. long, obovateoblong, obtuse, entire, narrowed into a short, stout petiole ; midrib stout: pan icle terminal, erect, 6 in. high and nearly as broad at the base ; corolla tube 1 in. long, slightly swelling in upper part; lobes 5, small, triangular, recurred. B.M. 7454. G.C. III. 22: 416. Gn. 53:1171.

ALBIZZIA (after Albizzi, an Italian naturalist). Leguminòsœ. Trees or shrubs, unarmed : lvs. alternate, bipinnate ; leaflets small, oblique : fls. in axillary, peduncled spikes or globular heads; calyx and corolla tubular and 5-lobed; stamens long, exserted: fr. a large strap-shaped pod. Twenty-five species in trop. and subtrop. regions of Asia, Afr. and Austral. Ornamental trees and shrubs with graceful, feathery foliage and yellowish, white or red fls. in summer. For cult., see Acacia.

$$
\begin{aligned}
& \text { A. Fls. in cylindrical axillary spikes : lvs. } \\
& \text { semi-persistent. }
\end{aligned}
$$

lophántha, Benth. (Acdeia lophántha, Willd.). Shrub or small tree, 6-20 ft.: lvs. with 14-24 pinnæ, each with 40-60 leaflets, about 5 lines long, linear, obtuse : spikes mostly 2, about 2 in. long, yellowish. S. W. Australia. B.M. 2108. B.R. 5:361. L.B.C. 8:716. - Sometimes cult. as greenhouse shrub and flowering in spring, and in the open in the S. Often known as Acacia speciosa. There is a var. gigantè in the trade.

AA. Fls. in globular heads : lvs, deciduous.

\section{B. Stamens united only at the base.}

c. Leaflets ovate or oblong, obtuse.

Lébbek, Benth. (Acàcia Lébbek, Willd. A. speci. $\delta s a$, Willd.). Tall tree : lvs. with 4-8 pinnæ, each with 10-18 leaflets, obliquely oblong or oval, 1-11/2in. long, nearly sessile: fls. greenish yellow, in short-peduncled, axillary heads, 3-4 together. Trop. Asia, N. Austral.

occidentàlis, Brandeg. Small tree, 15-25 ft.: lvs. with 8 pinnæ, each with $6-10$ leaflets, oblique-oval, $8 / 4-1 \frac{1}{2} \mathrm{in}$. long, glabrous: fls. Jellowish, in axillary heads. JuneJuly. Mex., Low. Calif.-Perhaps only a variety of $A$. Lebbek, and not indigenous.

odoratíssima, Benth. (Acacia odoratissima, Willd.). Tall tree: lvs. with downy rachis; pinnæ 6-14, each with 16-50 leaflets, oblique-oblong, $3 / 4-1$ in. long, glaucous beneath: heads few-fld., numerous, greenish white, forming large, terminal panicles. E. Ind.

pròcera, Benth. (Acacia pròcera, Willd.). Tall tree: lvs. with nearly glabrous rachis; pinnæ 6-10, each with 12-16 leaflets, oblique-oblong, 1-11/2in. long, glabrous: heads few-fld., greenish white, forming large, terminal panicles. Trop. Asia, Austral.

Moluccàna, Miq. Tree : rachis of the lvs. with many glands; pinnæ 14, each with 12-40 leaflets, obliquely elliptic-oblong, glaucous and pubescent beneath. Moluccas. cc. Leaflets falcate, with the midrib close to the upper edge, acute.

Julibrissin, Durazz. (Acdcia Julibrissin, Willd. A. Nèmu, Willd. Albizzia ròsea, Carr.). Tree, 30-40 ft.: rachis of the lvs. with a small gland at the base; pinnæ 8-24, with numerous leaflets, falcate-oblong, $1 / 4 \mathrm{in}$. long: heads pink, crowded on the upper end of the branches.
Trop. and subtrop. Asia and Afr. R.H. 1870:490. F.S. 21:2199. - This plant is the hardiest species, and will stand many degrees of frost. Hardy as far north as Washington.

Var. mollis, Benth. (A. mollis, Boiss. Acdcia mollis, Wall.). Leaflets broader, densely pubescent.

stipulàta, Boiss. (Acacia stipulata, DC.). Tall tree : young branches with large, persistent stipules: rachis of the lvs. with many glands, pubescent; pinnæ 12-40, with numerous leaflets, oblong-linear, 1/4-1/3in. long, pubescent beneath: heads in axillary simple or terminal compound racemes. Trop. Asia.

BB. Stamens connate into a long, narrow tube.

fastigiàta, Oliv. (Zýgia fastigiàta, E. Mey.). Tree : branches and petioles rusty-pubescent ; pinnæ 8-14, each with 16-30 leaflets, trapezoid-oblong, $1 / 3-1 / 2$ in. long, pubescent beneath: heads in terminal corymbs on the end of the branches. Trop. Afr. AlFred ReHDER.

ALBƯCA (whitish; the color of the first-described species). Lilidcece. Tender bulbs from the Cape of Good Hope allied to Ornithogalum, and treated in the same way. Prop. by offsets or seeds.

aurea, Jacq. Bracts yellow : fls. 10-30, pale yellow, upright.

màjor, Linn. Bracts red : fls. 6-15, greenish yellow, nodding. B.M. 804 . L.B.C. 12: 1191 .

ALCHEMILLA (from an Arabic name). Rosacea. Hardy herbaceous perennials with corymbose, inconspicuous fls., suitable for rockeries and front rows of borders. Of easiest culture. Height 6-8 in. Prop. by division or seeds. Native in Eu., and A.arvénsis is sparingly naturalized in this country. There are also tropical species.

alpina, Bieb. Lvs, digitate, 5-7 cut ; leaflets usually 7, lanceolate-cuneate, obtuse, serrate at apex, silky hairy beneath, shiny. Eu.

sericea, Willd. Lvs. larger than in A. alpina, 5-7 nerved, digitate; leaflets 7 , lanceolate, acute, deeply serrate from the middle to apex, downy beneath. Caucasus.

vulgàris, Linn. (A. montana, Schmidt). LAdY's MANTLE. Lvs. 7-9 nerved, 7-9 cut ; reniform, plicate-concave. N. Temp. Zone.

\section{ALDER. See Alnus.}

J. B. KELLER.

ALETRIS (Greek word for female slave who ground corn; alluding to apparent mealiness of the fls.). $H_{0 e}$ madoracece. Hardy perennial, smooth, stemless, bitter herbs. Lvs. thin, flat, lanceolate, grass-like, in a spreading cluster: fls. small, in a spiked raceme, terminuting a slender scape 2-3 ft. high; perianth not woolly. but wrinkled and roughened with thick set points which give a mealy appearance. July-Aug. They like a moist but sunny situation. Prop. slowly by division or seeds.

aurea, Walt. Fls. bell-shaped, fewer and shorter than in $A$. farinosa, yellow; lobes short, ovate. Eastern N. Amer. B.M. 1418, erroneously as $\boldsymbol{A}$. farinosa.

farindsa, Linn. Fls. longer and more tubular than in A. aurea, white ; lobes lanceolate-oblong. N. Amer. L.B.C. $12: 1161$.

Japónica, Hort. Fls. reddish or deep purple, in long spikes.

J. B. KELLER.

ALEURITES (Greek : farinose or floury). Euphorbidcece. Half dozen or less tropical species of evergreen trees, with small monœcious white fls. in terminal, lax cymes and alternate, entire or 3 -lobed lvs. with 2 glands at the top of the petiole.

tríloba, Forst. Candlenut, or Candleberry Trek. Small tree, with 3-5-lobed pubescent lvs, originally from the eastern tropics, but now widely distributed : cult. for its edible nut, which is spheroidal, nearly 2 in. in diam., 2-loculed, each compartment containing a walnutlike seed. The dried kernels are burned for illumination by natives. The nuts yield oil which is used in food or as a dryer in paint. The oil is variously known as Indian Walnut Oil, Kekune Oil, Kukui Oil. Sparingly cult. in S. Calif. and S. Fla. Fruits in S. Calif. 
cordàtı, Steud. Lrs. broadly ovate, acuminate, deeply cordate, $3-5$ cuspidate or lobed. S. China. - Yields an excellent lac varnish.

L. H. B.

ALFALFA, LUCERNE (Medicago sativa, Linn.). A deep-rooted perennial forage plant of the Leguminosa. The plant grows a foot or two high, bears pinnate lvs. with 3 ovate-oblong toothed leaflets, and small head-like racemes of purple clover-shaped fls. It is native to Eu. In the arid parts of the U.S. it is the staple hay and forage plant, and it is also grown to a considerable extent in the E. Two to six mowings may be made each year from established meadows. Fifteen to $20 \mathrm{lbs}$. of seed are sown to the acre; and the seed is preferably sown alone, without another crop. Alfalfa should not be pastured the first year. In two or three years it becomes thoroughly established and productive, and it should continue for many years. June grass often runs it out in a cool, moist climate. Alfalfa often becomes a weed in waste places.

ALFILERIA. The West American or Spanish name for E'ròdium cicutdrium, L'Her, Geranidcea. A hairy annual which is used for pasture in dry regions.

ALGA, plural ALGE. A general name for chlorophyll-bearing thallophytes. They are flowerless plants, allied to the fungi, and generally inhabit water. Those occurring in salt water are known as seaweeds. None are cultivated. The green "moss" on flower-pots is made up of algæ.

\section{ALGAROBA is the fruit of Ceratonia siliqua}

ALHAGI (its Mauritanian name). Leguminòsa. Low, spiny, much branched shrubs: lvs. oblong, small, obtuse, entire, alternate : fls. papilionaceous, in few-fld. racemes. Summer. Three closely allied species from Greece and Egypt to Himalayas, producing the Persian or Alhagi Manna. They may be cult. in temperate regions in dry and sunny positions and prop. by seeds and greenwood cuttings under glass with a little bottom heat.

A. camelorum, Fisch. CAMEL's Thorn. Glabrons at length: ovary glabrous. Cau. to Himal.-A. mauròrum, DC. Pubescent : ovary pubescent. Egypt to Persia, $-A$, graecòrum, Boiss. Very spiny and more densely pubescent : ovary pubescent. Greeee.

\section{ALFRED REHDER.}

ALIsma (derivation doubtful). Alismacece. Hardy aquatics, with small white or pale rose fls. on scapes with whorled, panicled branches. Perennial by a stout proliferous corm. Useful in ponds. Prop. by division or seeds.

Plantago, Linn. Water Plantain. Lrs. variable, but usually broadly cordate-ovate; thinner and narrower when growing under water. Panicle 1-2 ft. long. Common in swales and still waters in U.S.; also in Eu.

A. nàtans, Linn., is now referred to the monotypic genus Elisma (E. natans, Buch.). It is native to Eu., and is offered in foreign eatalogues. Fl. white, single, on a long peduncle: float ing lvs. elliptic and obtuse.

\section{ALKÁNNA, ALRANET. See Anchusa.}

\section{ALKEKENGI. See Physalis.}

ALLAMÁNDA (Dr. Allamand, Leyden). A pocyndceae. Greenhouse shrubs, mostly elimbers. Lvs. entire, whorled: fls. terminal, large and funnel-shaped, with \& flat-spreading or reflexed limb, the tube inflated below the throat: ovary 1-loculed: stamens 5, the flaments very short.

Allamandas are of easy culture. They are usually grown in the ground or in large tubs, and trained on the rafters. For best results, they should have plenty of sun. The bushy kinds, as $A$. neriifolia, $A$. grandiflora and $\boldsymbol{A}$. Williamsi, may be grown as specimen plants in pots. The strong kinds, as $\boldsymbol{A}$. Schottii, are sometimes used as stocks upon which to graft the weaker ones, particularly if root plants are desired. Prop. by cuttings of growing wood in a bottom heat of $75^{\circ}$; also by layers. The species are much confused.

$$
\text { A. F'ls. purple. }
$$

Blanchétii, DC. (A violdeea, Gardn.). irs, in 4's, hairy on both sides: Hs. in terminal clusters, 3 in. across, salmon-purple: habit of A. cathartica. Brazil. B.M. 7122. Int. into U. S. in 1893.

$$
\text { AA. Fls. yellow or orange. }
$$

B. Corolla with a swollen or bulb-like base.

neriifolia, Hook. A stocky, bushy grower, useful for pots, although it usually needs to be staked or grown against a support if allowed to take its full course: lvs. in 3's-5's, glabrous, oblong or elliptic, acuminate : corolla smaller than $A$. Schottii or A. Hendersoni, deeper yellow, streaked with orange. S. Amer. B.M. 4594. - Early and profuse bloomer.

BB. Corolla tube long, slender and stem-like.

C. Lvs. and calyx more or less hairy.

nobilis, Moore. A strong, tall climber, with purple twigs: lrs. in 3 's or 4's, large, acuminate, very shortstalked: fls, very large (4-5 in. across), nearly circular in outline of limb, bright, clear yellow, with magnolialike odor. Finest fls. in the genus. Braz. B.M. 5764 .

cc. Lvs. and calyx glabrous (except perhaps in $A$. Williamsi).

D. Plant tall-climbing.

cathártica, Linn. Lvs, rather small, obovate, usually in 4's, and more or less wavy-margined, thin, acuminate: fls. golden yellow, white-marked in the throat, the lobes acuminate on one angle, 3 in. or less across, the tube gibbous or curved. S. Amer. B.M. 338. P.M. 8: 77. - The species first described, but now rarely seen in cultivation.

Schóttii, Pohl. Strong-growing, suitable for rafters: young shoots and petioles slightly pubescent, the older stems warty: lvs, in 3's or 4's, broadly lanceolate and acuminate: corolla large, rich yellow, the throat darker and beautifully striped. Braz. B.M. 4351 , but this portrait is considered by Index Kewensis to belong to $A$. cathartica. A. magnifica, introduced into the U. S. in 1893 , is probably a form of this species.

Héndersoni, Bull. (A. Wardleyd̀na, Lebas.). Fig. 61 Tall and vigorous, free-flowering, excellent for roofs:

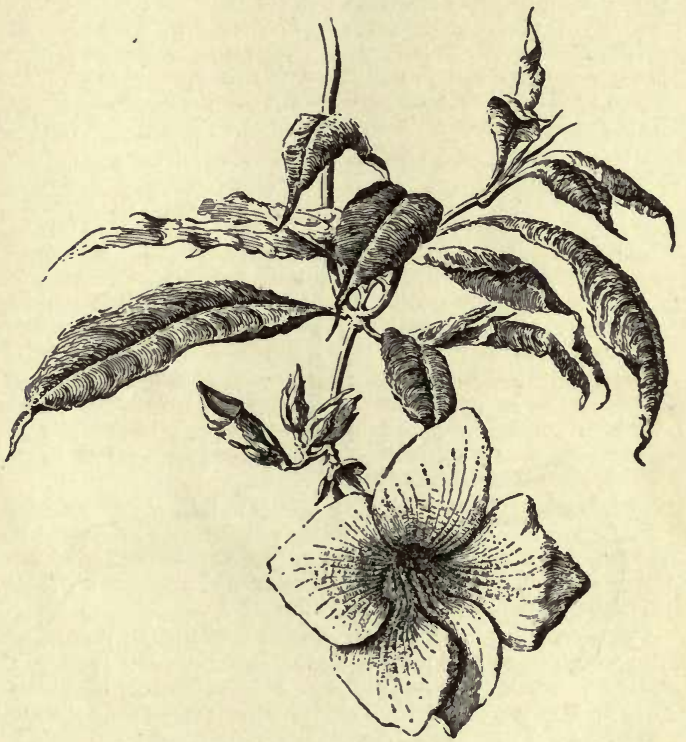

61. Allamanda Hendersoni $(\times 1 / 2)$

glabrous: lvs. large, elliptic-ovate, thick and leathery, in 4's: fis. large, yellow-orange, with 5 light spots in the throat, the corolla of thick substance, purplish on the exterior when in bud. Gn, 29:542. I.H. 12:452, - The commonest Allamanda in this country. By some authorities considered to be a variety of $A$. cathartica; by others referred to $A$. Schottii. Int. from Guiana by Henderson \& Co., St. John's Wood, England, and distributed by Bull about 1865 . 
DD. Plant erect-bushy.

grandiflora, Lam. St. thin and wiry: Ivs. thin, ovatelanceolate, pointed, usually in '3's : fls. somewhat smaller than those of $\boldsymbol{A}$. Hendersoni but larger than A. eathartica, lemon- or primrose-yellow. Braz. Gn. 39:794. P.M.12: 79. - Thrives well when grafted on stronger kinds.

Williamsi, Hort. Very dwarf: lvs. and young growth generally somewhat pubescent, the lvs. lonu and narrow, acuminate: usually in 4's : fls. in continuous clusters, rather smaller than those of $A$. Hendersoni and of better substance, fragrant. Gn. 40:832.-Certificated in Eng. in 1891 by B. S. Williams \& Son, and int. in U. S. in 1893. Supposed to be a hybrid. Promising for pots.

L. H. B.

ALL-HEAL. See Brunella vulgaris.

ALLIGATOR PEAR, ÁGACATE, AVOCÁdo. See Persea.

ALLIUM (ancient Latin name). Lilidcece. Bulbous plants, mostly cult. in the open; but a few, of which $A$. Neapolitanum is an example, are oftener grown indoors. Fls. in a simple umbel, from a 1-2-lvd. usually scarious spathe; stamens and perianth segments 6; style slender, the stigma either entire or parted.

Alliums are of the easiest cult., for which consult BuLBS. For the vegetable-garden members of the genus, see Chrves, Garlic, Leek, Onion, Shallot. Allium vineale, a bad weed in parts of the northeastern states, has a slender scape sheathed below with hollow threadshaped Ivs., and greenish rose-colored fls. (or bulblets in the place of fls.).

The following species are known to be in the Amer. trade : acuminatum, No. 4 ; anceps, 26 ; attenuifolium, 21; Bidwelliæ, 23; Bolanderi, 17; cernuum, 9; Cusickii, 16; falcifolium, 25; fimbriatum, 24; Geyeri, 13; hæmatochiton, 11; Hermettii, 3; madidum, 15; Moly, 1; Nea-

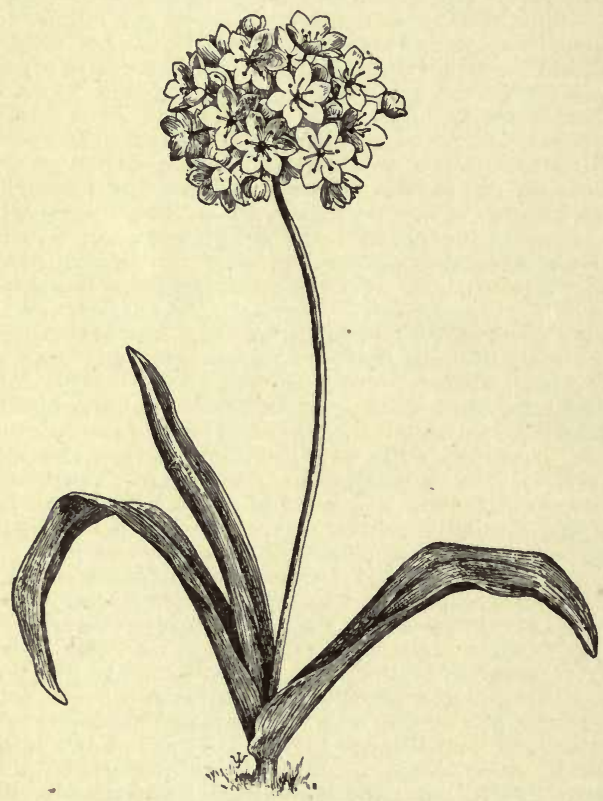

62. Alliım Neapolitanum.

politanum, 3 ; platrcaule, 27 ; reticulatum, 12 ; roseum, 5 ; Sanbornii, 20; scaposum, 14; Schœnoprasum, 8 ; senescens, 6 ; serratum, 22 ; stellatum, 19 ; tricoccum, 7 ; unifolium, 18 ; validum, 10 ; Victorialis, 2.

A. Camptcháticum, catalogued by Meehan, is perhaps a form of some other species. It is described as "dull pink. July. $1 \frac{1}{2} \mathrm{ft}$."
I. Exotic garden Alliums.

$$
\text { A. F'ls, yellow. }
$$

1. Mòly, Linn. Lvs. flat, broad : fls. numerous, in a dense umbel, in early spring. S. Eu. B.M.499.-Well known, and a favorite for massing. Hardy in the N.

$$
\begin{aligned}
& \text { AA. Fls, white or whitish. } \\
& \text { B. Lvs, very broad, obtuse. }
\end{aligned}
$$

2. Victorialis; Linn. Tall : lvs, ovate or broad-oblong, short: fls. greenish white, in large heads. Spring. Siberia. B.M. 1222. - Hardy.

BВ. Lvs. narrow, acute or tapering.

3. Neapolitanum, Cyr. Fig. 62. Lvs. long and rather narrow, loose-spreading, shorter than the scape: fls. large, pure white, with colored stamens on long pedicels. Eu. - Needs protection if grown outdoors. Much used for cut-flowers in winter and spring. The most popular species, A. Herméttii grandiflorum, recently introduced from Holland, is a clear white odorous variety, well adapted to forcing.

AAA. Fls. pink, rose, or lilac.

B. Segments with recurved tips.

4. acuminàtum, Hook. Scape 4-10 in.: lvs. 2-4, not longer than the scape, very narrow : umbel many-fll.: perianth segments a third longer than the stamens, the inner ones serrulate. W. Amer.

BB. Segments not recurved.

5. ròseum, Linn. Scape 12-18 in.: Ivs. narrow, with inrolled tips: Hs. few (10-12), on long pedicels in an open umbel. S. Eu. B.M. 978

6. senèscens, Linn. Scape 1-2 ft.: lvs. narrow, erect, often twisted: fls. rather small, numerous, in a rather dense head. Eu. B.M. 1150.

II. The above species comprise those which are in general cultivation in this country. Aside from these there are various native species, mostly from western America, which are offered by dealers in American plants. These are recorded below. Monograph of American Alliums by Sereno Watson,in Proc.Amer.Acad. Sci. 14: 226.

A. Bulbs clustered, narrowly oblong; scape terete. B. Lvs.elliptic-lanceolate, 2 or 3.

7. tricóccum, Ait. Common Wild Leek. Fls. greenish white on scape 4-12 in. high in early spring. Grows in clumps. N. Eng. to Wis. and N. C.

$$
\text { BB. Lvs. terete and hollow, several. }
$$

8. Schœnoprasum, Linn. Cives or Chives. Fls. rosecolor, in dense little heads: lvs. short, in dense mats. N. U. S. and Eu.

BBB. Lvs. linear, flat or channelled.

9. cérnuum, Roth. Fls. rose-colored or white, in open, nodding umbels. Alleghanies W.

10. válidum, Wats. Fls. rose-colored or nearly white, in dense erectish umbels : scape $1-2 \frac{1}{2} \mathrm{ft}$., very stout. Nev., Cal., Or.

11. hæmatochiton, Wats. Fls. deep rose, in a small, erect umbel : bulb-coats deep red : scape $1 \mathrm{ft}$. or less high. Cal.

AA. Bulbs usually solitary, globose to ovate: scape terete or nearly so.

B. Coats of bulbs fibrous.

12. reticulàtum, Fraser. Scape 3-8 in.: fls. white to rose, with thin segments. W. Amer. B.M. 1840, as $A$. stellatum.

13. Geyeri, Wats. A foot high : fls. rose, with broad acute segments. W. Amer.

\section{BB. Coats of bulbs not fibrous.}

c. Lvs. 2 or several.

D. Ovary with only 3 crests, or none at all.

14. scapdsum, Benth. Fls. white, red-veined, in a loose, few-fld. umbel : bulbs dark : scape $1 \mathrm{ft}$. or more. W. Amer.

15. mádidum, Wats. Fls. white or nearly so, in a manyfld. umbel: bulbs white: scape less than $1 \mathrm{ft}$, angled. Or.

16. Cùsickii,Wats. Fls. rather numerous, nearly white: lvs. 2, 1/4 in. wide: scape 3-4 in. Or. 
17. Bolánderi, Wats. Fls. rose, few, the segments serrulate: scape 4-10 in. Calif.

18. unifòlium, Kellogg. Lvs. several, narrow and flat: scape stout, 1-2 ft.: fls. rose, 10-30, the segments ovatelanceolate, exceeding stamens and style. Calif.

DD. Ovary distinctly G-crested; fls. usually rose-colored.

E. Scape usually more than 6 in. high (in the wild).

19. stellatum, Fraser. Bulb-coats reddish : scape 6-18 in.; pedicels $1 / 2-3 / 4$ in. long; stamens and styles exserted. W. Amer. B.M. 1576.

20. Sánbornii, Wood. Bulb-scales white: scape 12-24 in.; pedicels shorter; umbel densely many-fld.; stamens and styles exserted. Calif.

21. attenuifolium, Kellogg. Lvs. channelled: scape slender, 6-15 in., leafy below; umbel dense ; fls. nearly white. W. Amer.

EE. Scupe usually less than 6 in. high (in the wild).

22. serratum, Wats. Lvs. very narrow: flaments broadened at the base. W. Amer.

23. Bídwelliæ, Wats. Scape $2-3$ in.: umbel few-fld., the pedicels $1 / 2$ in. long: filaments fliform. Calif.

cc. Lf. solitary, linear or filifor m: scape 2-5 in. high: capsule 6-crested.

24. fimbriàtum, Wats. Lf. filiform and revolute scape 3 in.: fls. deep rose, stigma 3-cleft. S. Calif.

AA. Bulbs mostly solitury: scape stout, z-winged: lvs. 2, broad.

B. Stumens not exserted.

25. falcifolium, Hook. \& Arn. Fls. rose, the segments minutely glandular-serrate and twice longer than stamens : scape $2-3$ in. W. Amer.

26. ánceps, Kellogg. Fls. white, with purplish veins, the segments little longer than stamens. Calif., Or. BB. Stamens exserted.

27. platycaule, Wats. Fls, rose, the segments longacuminate; scape $3-5$ in. Calif. B.M. 6227 , as $A$. anceps.

L. H. B.

ALLOPLECTUS (diversely plaited; referring to appearance of the calyx). Gesnerdcece. Tender tropical evergreen shrubby plants, with tubular yellowish axillary fls., borne singly, to be grown in hotrouses and given the treatment required by Gesneras.

A. repens, Hook. Trailing by means of roots thrown out between the pairs of lvs.: lvs, ovate, coarsely serrate, hairy or smooth: calyx pale green, blotched with purple; corolla yellow, tinged red, gaping; tubeswollen at the base; limb of four spreadtinged red, gaping; tube swollen at the base; limb of four spreading segments, the uppermost being twice cut. E. Ind. B.M. 4250. - A. sparsiflorus, Mart. Erect: lvs.ovate-oblong, acute entire; petiole and nerves beneath often red: calyx of 5 cordate or triangular dark blood or purple sepals, forming a striking contrast to the yellow club-shaped densely hairy corolla; limb of corolla of 5 equal segments. Braz. B. M. 4216, erioneously as A. dichrous.

ALLSPICE. The dry berry of the Pimento (Piménta officindlis, Lindl.), an evergreen tree of the Myrtacea. The tree grows in the W. Indies. Jamaica yields much of the product. The fresh berry is about the size of a pea. It is borne in clusters. The word allspice is also applied to various plants with aromatic fragrance, as Calycanthus.

ALMOND. A name given to the tree and fruit of Prunus A mýgdalus, Baill. (A mýgcialus commùnis, Linn.), of the Rosdcex. It is also applied to certain $d w a r f$ ornamental trees or bushes, as Flowering Alnond (see Prunus). The Almond has been cultivated from time immemorial. It is thought to be native to the Meditcrranean basin. Some enquirers have supposed it to be the original of the peach, but this idea is evidently untenable. The flowers are peach-like and handsome (Fig. 63). The Almond nut of commerce is the pit or stone of a peachlike fruit (Fig. 64). The fleshy part, which is so thick and edible in the peach, is thin and hard, and it splits at maturity. There are two general tribes or races of Almonds, - the bitter and the sweet. The former has a bitter kernel, which is used in the manufacture of flavoring extracts and prussic acid. It is grown mostly in Mediterranean countries. Of the sweet or edible Al- monds, there are two classes, - the hard-shell and the soft-shell. The former is of intle value, and is not grown to any extent. The soft-sbell type produces the edible Almonds of commerce. Some of the thinnest-shelled forms are known as Paper-shells. It was once thought that almond-growing could be successfully practiced in the peach-growing sections of the East, but vagaries of late spring frosts, and other difficulties, have caused the effort to be abandoned commercially. Individual Almond trees are occasionally seen, and they frequently bear profusely. They are nearly as hardy as the peach. The commercial cultivation of the Almond is confined to western America, and the remainder of this account is, therefore, written from the California standpoint.

L. H. B.

Almond-growing in California has received the attention of horticulturists for nearly half a century, and during the whole of its course the industry has been marked by vicissitudes which, it must be admitted, are

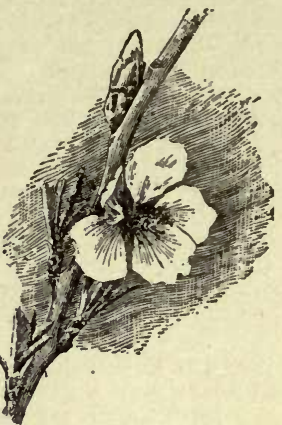

63. Flower of common

Almond $(X 1 / 2)$ not yet ended. Two chief sources of difficulty are now clearly discerned to have attended the effort from its beginning, and present knowledge may enable planters to avoid, in the future, errors which have led to much disappointment and loss - the vestiges of which still encumber the ground, though clearing is proceeding rapidly. Thus far the Almond tree has yielded more firewood than any other single fruit tree which has been largely planted in California, and yet planting bas continued, in the hope of better results, until in 1897 there were about $1,500,000$ trees included in the reports of the county assessors, of which number about two-thirds had attained bearing age at that date. The product of 1897 was 218 carloads, and the competition in the eastern markets with imported Almonds was so grievous that prices fell below what is considered a profitable return. In 1898, because of untimely frosts, the product fell to 25 carloads, which is counted about equal to the local consumption of the $\mathrm{Pa}$ cific coast. At the present time, 1899 , planting has prac tically ceased, and a considerable acreage of thrifty trees cf bearing age is being cleared for other purposes, because growers in certain places are out of patience with the Almond. In spite of these facts, the Almond will re main an important California product, through the satisfactory performance of trees enjoying favorable environment.

The two chief sources of failure with the Almond are the sterility of many varieties without cross-pollination, and the extreme propensity of the tree for early bloom ing, with the consequent destruction of the bloom or the young fruit by temperature very little below the freezing point. These two evils have been singularly associated historically, and only lately have they been shown to be independent factors and both of them demanding the closest attention from planters. At first it was thought that the wide planting of self-sterile varieties by themselves was the cause of disappointment, because, after years of chopping-out or grafting-over old, unproductive trees to the Prune d'Agen, for which it is an excellent stock, it was observed, by chance, that the Languedoc variety adjacent to Drake's seedling, of local origin, was heavily laden with nuts when it was sterile without such association. Attention was then directed to the growth of seedlings, and a large lot of seedlings of the bitter Almond, grown by A. T. Hatch, exhibited such satisfactory bearing habit and such striking variation toward new types of the soft-shell sweet Almond that the growth of new, selected California seedlings was seized upon as a panacea for the previously experienced troubles with the Almond. These new varieties were conceired to be not only self-fertile but hardy, and large plantations were made without due regard to the frosty character of the locations. Low valley lands of great area, and some extent of high plateaux, were planted. Fine, large trees grew only to lose their crops year after year by frosts 
from February to April, until the growers cast the trees upon the wood-pile. As a deduction of the experience of several decades, we have arrived at what seems now to be the proper conception of the situation of the Almond in California, which is, that the most prolific varieties must be chosen, must be associated for purposes of crosspollination, and must be planted in places of least liability to frost. There is a factor of some moment in the late-blooming habit of some varieties, which will be considered presently.

The soil best suited to the Almond is a light, welldrained loam. The tree makes a strong and rapid rootgrowth, and is more tolerant of drought than any other of our leading deciduous fruit trees. For this reason, as well as to avoid frost, it is often desirable to place the Almond on the higher and drier lands of the valleyproviding the soil is not heavy and too retentive of surplus water in the rainy season. The root is most intolerant of standing water, and will quickly die if exposed to it. Because of its thrift in light, dry soils the Almond root is used rather largely as a stock for the Prune d'Agen, and to some extent for the peach in the dry valleys.

Almond trees are grown by budding into seedlings grown from either the sweet or the bitter hard-shell Almonds, the bud being set during the first summer's growth of the seedling, and then either planted out as a dormant bud the following winter or allowed to make one season's growth on the bud in the nursery. The tree grows so rapidly, both in root and top, that only yearling trees are used.

At transplanting, the young trees are cut back so as to form a low head with only about a foot of clear trunk. They are allowed to make free growth during the following summer, and in the following winter are cut back so as to encourage branching on the main limbs within a foot of their attachment to the trunk. At the same time the branches are reduced to 4 or 5 in number, symmetrically arranged around the stem and at good distance from each other, so that they shall not unduly crowd each other as they enlarye. Another full growth during the following summer and another cutting back the following winter give the trees the vase-form on the outside, with enough interior branches to fill the inside of the tree without crowding. Thus the tree is systematically pruned after each of its first two years' growth in the orchard. After that, shortening-in of the branches usually ceases, and the third summer's growth is allowed to stand for fruit-bearing, with only thinning-out of growth to prevent crowding. This thinning-out has to be done from time to time in later years, otherwise the tree becomes too thick, and interior branches dwindle for lack of light. The amount of thinning varies in the different climates of the state: the greater the heat, the denser the tree for its own protection. With the proper adjustment of heat and light, fresh bearing wood may be encouraged in the lower part of the tree, otherwise it becomes umbrella-shaped, with the fruit wood at the top and bare poles below.

The Almond is the earliest bloomer of our common fruits. It puts forth flowers sometimes as early as Janu-

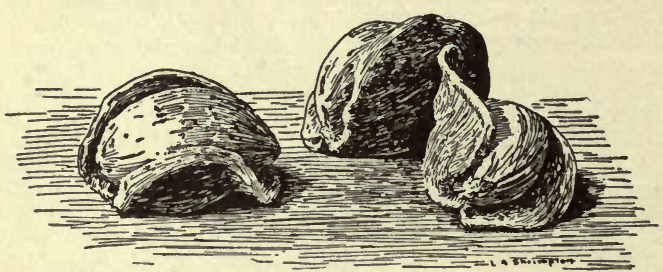

64. Almond nuts $(\times 1 / 3)$.

ary, but the usual date is about February 10 for the earliest bloomers in the warmer parts of the state, with the later bloomers at intervals thereafter until April 1. Records of full bloom of a number of varieties widely grown in California, which have been kept at the University of California sub-station, situated in the Sierra foot-hill region, show the following succession: Commercial, February 27 ; Sultana and Paper-shell, March 10 ;
King and Marie Duprey, March 11 ; IXL, March 12 ; Languedoc, March 19; Nonpareil, March 20; Routier Twin, March 24; Pistache, March 25; Drake Seedling, April 2. Obviously the late bloomers have greater chance of escaping frost, and there is at present some disposition to make this a consideration in selecting varieties for planting. The dates just given show an extreme variation in time of blooming. Some years the intervals are much shorter, but the relation seems to be constant. The crop ripens from August 15 to October 1 , according to locality. Early maturity does not follow early blooming - that is, as with other fruits, the first to bloom are not necessarily the first to ripen.

Not less than 25 varieties of Almonds have been grown to a greater or less extent in California. Varieties of foreign origin have almost wholly given place to selected seedlings of local origin, and of these a very few constitute the main crop at present. These are named in the order of their acreage, as follows : IXL, Nonpareil, Ne Plus Ultra, Drake, Paper-shell, Languedoc. Of these, the IXL and Nonpareil occupy not less than threefourths of the acreage.

In handling the crop the local climate modifies methods somewhat, and the growth-habit is also involved. In regions very free from atmospheric humidity in the summer, the hull opens readily and discloses a clean, bright nut, which can be marketed without treatment. Where this is not the case, and the nut is more or less discolored, bleaching in the fumes of sulfur has to be practiced. The nut must be dry before sulfuring, or the fumes will penetrate and injure the flavor of the kernel. Sulfured nuts also lose largely in power of germination. The practice is to gather the nuts, dry for a few days in the sun, then spray with water very lightly, so that only the surface of the shell is moistened, and then use the sulfur. In this way a light color can be secured without penetration of the fumes. The nuts. can usually be gathered from the ground as they naturally fall, or can be brovght down by shaking or the use of light poles. Some varieties are more easily harvested than others, and the same variety falls more readily in some localities than in others. A greater or less percentage, according also to variety and locality, will have adhering hulls, and for clearing them locally-invented machines, called almond hullers, are used. Early rains in some localities are apt to stain the nuts. Such stains cannot be removed by sulfuring, and the nuts have to be crushed and the product marketed as kernels for the use of confectioners. Machinery is also used for this operation, and a considerable fraction of the product reaches the market in this form.

The standard of excellence in the Almond, from a commercial point of view, as learned by the experience of California producers, is that the kernel must be as smooth, symmetrical and plump as possible. The twinning of kernels, welcome as it may be to searchers for philopenas, results in misshapen kernels, which are very objectionable to the confectioners, who are very large users of Almonds. Constancy to single kernels is therefore a good point in a variety.

Large proportion of kernel to shell by weight is also, obviously, an important point to almond buyers. At the same time, the shell may be so reduced in strength as to break badly in shipping in sacks and in subsequent handling. Incomplete covering also exposes the kernel to the sulfur and to loss of flavor. The illeal is such degree of thinness of shell as can be had with complete covering of the kernel and durability in handling.

Careful comparison of the proportion of kernel weight to gross weight of the popular California varieties, as compared with a leading imported variety, was made by a committee of the California Horticultural Society, with the following result: From one pound of each of the following varieties the net weight of kernels in ounces was: Imported Tarragona, 6 2-5; California Languedoc, $7 \frac{1}{2}$; El Supremo, $7 \frac{1}{2} ;$ Drake, $83 / 4$; IXL, 9 ; Commercial, 91/4; La Prima, 91/2; Princess, 91/2: Ne Plus Ultra, 10; King, 10; Paper-shell, 11; Nonpareil, 11 to 13.

EDWARD J. Wickson.

ALMOND, DEMERARA. See Terminalia Catappa.

ALMOND, FLOWERING. See Prunus 
ALNUS (the ancient Latin name). Cupulfferce, subfamily Betuldcea. ALDER. Trees or shrubs: lvs. alternate, shortly petioled, deciduous: fls. apetalous, monocious in catkins, staminate ones elongated and pendulous, pistillate ones erect, short, developing into an ovoid, ligneous cone with persistent scales: fr. a small nutlet. Twenty species in the northern hemisphere, in America south to Peru. Hardy ornamental trees and shrubs, suitable for planting on damp soil, where they grow very rapidly, but $A$. cordata, firma, Japonica, and also A.tinctoria prefer somewhat drier soil. The profuse male catkins are pleasing in early spring. The wood is valuable for its durability in water. Usually prop. by seeds gathered in the fall and well dried: sown in spring with but slight covering, and kept moist and shady, they germinate soon ; a slight covering with moss, taken off when the seedlings appear, will be useful. At the end of the same year or the following spring the seedlings are transplanted, usually into rows 1-2 ft. apart and 6 in. from each other. After two years they can be planted where they are to stand. The shrubby species, also A. glutinosa, grow from hardwood cuttings placed in moist and sandy soil, also from layers and $A$. incana from suckers. Rarer kinds are grafted on common potted stock in early spring in the propagating house; grafting out-of-doors is rarely successful.

Index : aurea, No. 10 ; cordata, 5 ; cordifolia , 5 ; denticulata, 10; firma, Sieb.\& Zucc., 2 and 4; glauca, 6; glutinosa, 10; imperialis, 10; incana, 6 ; incisa, 10 ; Japonica, 4 ; laciniata, 6 and 10 ; maritima, 3 ; multinervis, 2 ; oblongata, 3 and 10 ; Oregana, 8 ; pyrifolia, 5 ; rubra, 8 ; rubrinerva, 10 ; rugosa, 9 ; serrulata, 9 ; Sibirica, 1 ; tiliacea, 5 ; tiliafolía, 5 ; tinctoria, 7 ; viridis, 1.

A. Fls. opening in the spring with the lvs.; pistillate ones enclosed in buds during the winter: fr. with broad membraneous wings. Alnobetula.

1. víridis, DC. GReen ALder. Shrub, 3-6 ft.: lvs. usually rounded at the base, round-ovate or oval, sharply serrate, $11 / 2-4$ in. long, pale green and pubescent on the veins beneath: cones $3-4$, oblong, slender peduncled. Northern hemisphere, in the mountains, in different varieties. - Hardy low shrub with handsome foliage, of very pleasant effect on rocky streamlets, with its long, male catkins in spring. Var. Sibirica, Regel. (A. Sibirica, Hort.). Sometimes tree, 25 ft.: lvs. larger, cordate-ovate.

2. fírma, Sieb. \& Zucc. Tree, to $30 \mathrm{ft}$.: lvs. oblonglanceolate or ovate-lanceolate, sharply and doubly serrate, with 10-15 pairs of veins, $2-4$ in. long, often nearly glabrous beneath: cones 2-4, peduncled. Japan.

Var. multinérvis, Regel. Lvs. with 14-24 pairs of veins, thicker.-Handsome tree with dark green lvs., growing on dry and rocky soil; quite hardy.

AA. Fls. opening in the fall from catkins of the same year: lvs. not plicately folded in the bud.

3. marítima, Nutt. (A. oblongata, Regel., not Ait. nor Willd.). Tree, to $30 \mathrm{ft}$. : ivs. cuneate, oblong or obovate, shining above, pale green beneath, glabrous, remotely and crenately serrate, $2-4$ in. long: cones $2-4$, large, on short, stout peduncles. Del., Md. S.S. 9:458. G.F. 4:269. Nutt. N. Am. S. 1: 10.- Ornamental shrub or small tree with handsome shining foliage, attractive in autumn with its male catkins.

AAA. F'ls.opening in early spring before the lvs., from catkins formed the previous year and remaining naked during the winter.

B. Lvs. not plicate in the bud, green beneath, veins arcuate, ending mostly in the incisions: female catkins usually solitary in the axils.

4. Japónica, Sieb. \& Zucc. (A. fírma, Hort., not S. \& Z.). Tree, 50-80 ft.: lvs. cuneate, oblong-lanceolate, acuminate, sharply and irregularly serrulate, glabrous at length, bearded in the axils of the veins beneath, 2-6 in. long: cones 3-6, peduncled. Japan. G.F. 6:345. -Tall, pyramidal tree with dark green foliage; the largest and perhaps the most beautiful of all Alders.

5. cordàta, Desf. (A. cordifolia, Ten. A. tilidcea, Hort. ). Small tree, 20-50 ft. : lvs. cordate, ovate or roundish, acuminate, $2-4$ in. long, bearded in the axils beneath, glandular when young : cones 1-3, peduncled. Italy, Caucasus. L.B.C. $13: 1231$. G.C. II. $19: 285$. - Roundheaded tree with handsome, distinct foliage, changing orange yellow in autumn, resembling that of a linden or pear, therefore sometimes as A. tiliafòlia, or A. py rifolia, in gardens. Not quite hardy North.

BB. Lvs. plicate in the bud, the veins going straight to the points of the larger teeth: female catkins $8-6$ in every axil.

c. Under side of lvs. glaucous; not bearded.

6. incàna, Willd. Shrub or tree, to $60 \mathrm{ft}$. : branches pu. bescent: lvs. oval or oblong-ovate, acute, $1 \frac{1 / 4-4}{\text { in. long, }}$

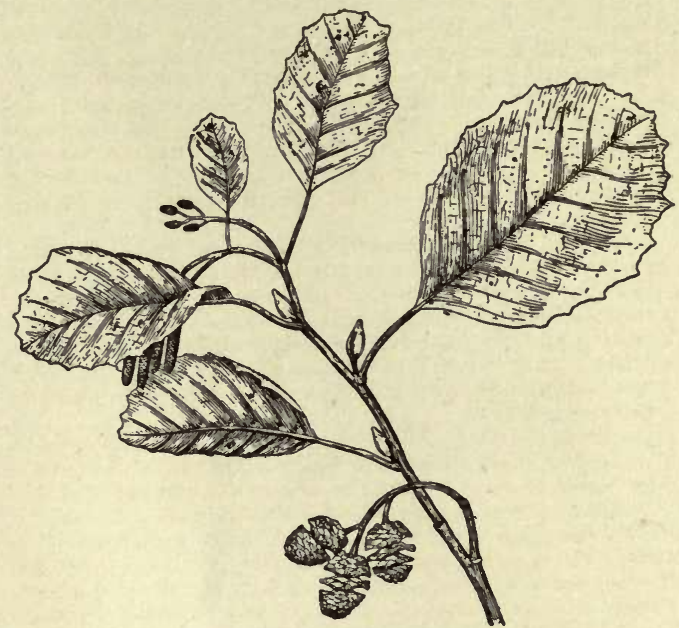

65. Alnus glutinosa $(\times 1 / 2)$

doubly serrate, pubescent or nearly glabrous beneath: cones 4-8, mostly sessile, $1 / 2 \mathrm{in}$. long. Northern hemisphere, in different varieties.

Var. glaùca, Ait. (A. glaùca, Michx.). Shrub, to $12 \mathrm{ft.:}$ lvs. often nearly glabrous beneath. N. Amer., Eu. Em. 251.

Var. vulgàris, Spach. Tree, to $50 \mathrm{ft}$.: lvs. usually densely pubescent beneath: cones 1 in. long. Eu., A sia.

Var. pinnatifida, Spach. (var. lacinidta, Hort.). Lvs. pinnately lobed or cleft, with dentate lobes.

7. tinctoria, Sargent (A. incdna, var. tinctòria, Hort.). Tree, to $60 \mathrm{ft}$.; lvs. broadly ovate, 4-6 in. long, membra. naceous, coarsely doubly serrate, slightly lobed, glaucous and rufously pubescent on the veins beneath. Japan. G.F. 10:473.- Handsome ornumental tree of very vigorous growth, with large foliage.

8. rùbra, Bong. (A. Oregdna, Nutt.). Tree, 40-50 ft. : lvs. oblong-ovate, 3-5 in. long, crenate-serrate, slightly lobed, revolute on the margin, nearly glabrous beneath; petioles and veins orange colored: cones $6-8$, oblong. W. N. Amer. S.S. 9:454. Nutt. N. Amer. S. 1:9.

cC. Under side of lvs. green or brownish green; usually bearded.

9. rugòsa, Spreng. (A. serruldta, Willd.). Shrub, to 25 ft.: lvs. usually cuneate, obovate or elliptic, acute or rounded at the apex, 2*5 in. long, finely serrate, usually pubescent on the veins beneath: cones short-stalked. E. N. Amer., from Mass. south. Em. 248.

10. glutinòsa, Gærtn. Black Alder. Fix. 65. Tree, to $70 \mathrm{ft}$.: lvs. orbicular or obovate, rounded or emarginate at the apex, 2-5 in. long, irregularly obtusely serrate, with 5-7 pairs of veins, nearly glabrous beneath, glutinous when unfolding: cones distinctly peduncled. Eu., N. Afr., Asia, naturalized in some localities in N. Amer. - A vigorously growing tree with dark green, dull foliage, valuable for planting in damp situations. Commonly planted in many forms : Var. aurea, Versch. Lvs, yellow. 1. H. 13:490. Var. denticulata, Ledeb. (A.oblongdta, Willd.). Lvs. usually cuneate, serrulate. 
S. Eu. Var. imperialis, Desf. Fig. 66. Lvs. deeply pinnately lobed with lanceolate or nearly linear lobes. Var. incisa, Willd.(var. oxyacanthifolia, Spach.). Lvs. small, deeply incised, like those of Cratoegus oxyacantha. Var. laciniata, Willd. Lrs. pinnately lobed; lobes oblong.

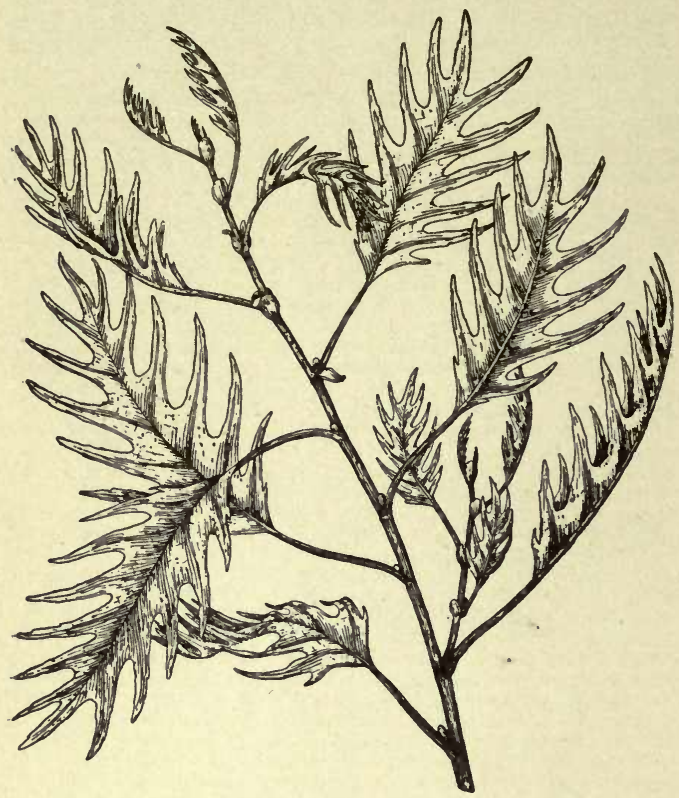

66. Alnus glutinosa, var. imperialis $(\times 1 / 2$.

Var. rubrinérvia, Dipp. Lvs. large and shining, with red nerves and petioles ; pyramidal tree of vigorous growth, very handsome.

A. acuminàta, HBK. Tree: lvs. usually ovate and pubescent beneath, doubly serrate. C. Amer., north to Ariz. $-A$. Alnobét ula, Hort. $=$ A. viridis. $-A$. barbata, C. A. Mey. Allied to A glutinosa. Lvs. pubeseent on the veins beneath, ovate. Caucasus. Perhaps hybrid of A. glutinosa Xsubeordata.-A. Canadénsis, Hort. $=$ A. rugosa. $-A$. communis, Desf. $=$ A. glutinosa.A. cordifolia, Ten. =A. cordata. $-A$. crispa, Pursh=A. viridis. A. cordifolia, $\mathrm{Ten} .=\mathrm{A}$. cordata. $-A$. crispa, Pursh $=\mathrm{A}$. viridis.
$-A$. fírma, Hort $=\mathrm{A}$. Japonica or $\mathrm{A}$. subeordata. $-A$. glaùca,

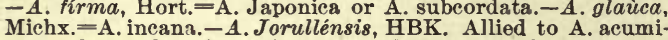
Michx. $=$ A. incana. $-A$. Jorullénsis, HBK. Allied to A. acumi-
nata: lvs. oblong-lanceolate, coarsely dentate. C. Amer. $-A$. macrocárpa, Lodd., not Regel.=A. glutinosa var. $-A$. macro phýlla, Hort. $=\mathrm{A}$. subcordata. $-A$. oblongàta, Willd. $=$ A. gluti nosa, var. denticulata $-A$. oblongdta, Regel $=$ A. maritima. $-A$ oblongifolia, Torr. Tree, 20-30 ft.: lvs. oblong.ovate, cuneate doubly serrate, 2-3 in. long: strobiles $1 / 2-1$ in. long, peduncled. N. Mex. and Ariz. S.S. 9: 457-A. Oregàna, Nutt=A. rubra.A. orientàlis, Docaisne=A. subeordata. - A. pubéscens, Tsch. (A. A. orientalis, Doeaisne $=$ A. subeordata. $-A$.pubéscens, Tsch. (A.
glutinosa $X$ incana). Lvs. roundish-ovate or obovate, irregularly serrate, pubescent beneath. Natural hybrid. $-A$. rhombifolia, Nutt. Tree, $60-80 \mathrm{ft}$.: lvs. cuneate, oval or ovate, $2-3 \frac{1}{2} \mathrm{in}$. long finely serrate, yellowish green and puberulous beneath: strobiles oblong, peduncled. W. N. Amer. S.S. 9:456.-A. serrulàta, Willd. $=A$, rugosa. $-A$. Sibirica, Hort., not Fiseh. $=A$. viridis Sibirica.-A sinuàta, Rydb. Allied to A. viridis: Shrub, 3-16 ft.: lvs. slightly lobed, serrulate, glabrons, thin. W. N. Amer. - A. subcordata, C. A. Mey. (A. orientalis, Decaisne. A. firma Hort., not, S. \& Z. A. macrophylla, Hort.). Tree, 30-50 ft.: lvs. rounded at the base, ovate or oblong, $2-6$ in. long, erenately serrate, often pubescent beneath. Allied to A. cordata. Caucasus, Asia Minor. $-A$. subrotúnda, Hort.=A. glutinosa var. denticulata.-A tenuifòlia, Nutt. (A. incana, var, virescens, Wats. A. occidentalis, Dipp) Small treo, oceasionally $30 \mathrm{ft}$. lvs. ovate, (1) ovate, , glabrous beneath. W. N. Amer. S.S. 9:455.-A. undulàta, Willd. $=\mathrm{A}$. viridis.

Alfred Rehder.

ALOCASIA (name made from Colocasia). Aroidece. Stove foliage plants, of 30 or more original species, from trop. Asia and the Malayan Isls. Closely allied to Caladium and particularly to Colocasia, which see. These three genera differ chiefly in characters of fruit. Monogr. by Engler in DeCandolle's Monographiæ Phanerogamarum, Vol. 2. In 1890, 52 species and specific- ally named hybrids were in cult. (Bergman, Jour. Soc. Nat. Hort. France. I.H. 37:80).

Alocasias are propagated by suckers or cuttings of the rhizomes, placed in small pots containing a mixture of light, fibrous peat and sand in equal proportions, and plunged in a close frame or propagating box with bottom heat. They may also be grown from seeds sown in 4 -inch pots, in a light, peaty soil in a temperature of $75^{\circ} \mathrm{F}$. The month of March is the best time for propagating. The evergreen species (as A.cuprea, longiloba, Lowii, Regina) thrive best in a compost of two parts fibrous peat and sphagnum moss and one part lumps of fibrous loam, to which should be added a sprinkling of silver sand and a few nodules of charcoal to keep the whole sweet. The herbaceous species (as A. macrorhiza) do best in good fibrous loam to which $1 / 3$ of well-rotted cow-manure or pulverized sheep-manure has been added. Perfect drainage of the pots is absolutely necessary, and in potting, the evergreen species should be coned up two or three inches above the rim of the pot, and finished off with a surfacing of live sphagnum moss. The season of active growth commences about the first of March, when they should be given a temperature of $70^{\circ}$ at night, with a rise of $15^{\circ} \mathrm{by}$ day, and the atmosphere must be kept in a humid condition. They should be given a position free from draughts and direct sunlight. They require an abundance of water at the roots as the leaves develop, and are greatly benefited by an occasional watering of clear liquid sheep or cow-manure water. To obtain the best develonment of the leaves, heavy syringing should be avoided, but frequent spraying on all fine days with an atomizer sprayer is very beneficial. Towards winter the humidity of the atmosphere and the supply of water to the roots should be reduced with the evergreen species, and gradually withheld altogether as the leaves mature with the herbaceous species. The temperature during winter should not fall below $60^{\circ}$.

Cult. by E. J. CANNing.

The propagation of most of the Alocasias consists of cutting up the stems, so that each piece will have at least one dormant bud. The pieces should be placed amongst moss, in a hot propagating frame, where they vegetate quickly. Such kinds as $\boldsymbol{A}$. Sanderiana, $\boldsymbol{A}$ macrorhiza, var.variegata, and $A$. Jenningsii (Colocasia) have creeping rhizomes, at the ends of which small resting tubers are formed. These should be carefully collected, and the two first named started in a propagating frame in a pan of moss and sand. A. Jenningsii roots readily in ordinary soil. Most of the kinds require a soil which is very fibrous, with a little moss added. The pots should be half filled with potsherds as drainage.

Cult. by G. W. Oliver.

A. Lvs. dislinctly notched or undulate on the margin.

prínceps, Nicholson. Lvs. sagittate, the basal lobes narrow and spreading, the margins deep-sinuate; upper surface olive-green, with darker veins, the under lighter colored, with brown veins and margin; petioles brownspotted, slender. E. Ind.

Sanderiàna, Bull. Fig. 67. Lvs. long-sagittate, with deeply notched margin, the basal lobes wide-spreading; deep glossy green with metallic reflection, with prominent white margins and veins; petioles brownish and striped. Philippines. Gng. 1897: 84.- One of the best of recent introductions. Runs into various forms, and has entered largely into cultivated hybrids.

\section{AA. Lvs. plane and entire on the margin.}

B. Markings chiefly on the petioles, the blades green.

zebrina, Koch \& Veitch. Lvs. triangular-sagittate ; petioles beautifully marked with large zigzag bands of green. Philippines. F.S. 15:1541-2.

Villeneúvei, Lind. \& Rod. Lvs. sagittate-ovate, the veins of lighter green and prominent, basal lobes very unequal; petioles spotted with chocolate-brown. Large. Borneo. I.H.34:21. - Named for de Villeneuve, Brazilian ambassador to Belgium.

вв. Markings or coloration chiefly on the leaf-blades. c. Veins and midrib light yellow.

Líndeni, Rod. Lvs. cordate-ovate, long-pointed, 8-12 in. long, bright green, with yellowish veins curving off 
from the midrib and vanishing near the margin; petioles nearly white. New Guinea. 1.H.33:603.-Bruised lvs. emit a strong odor.

cc. Veins and midrib wite or silvery.

longiloba, Miq. (A. gigantèa, Hort.). Petioles $2 \mathrm{ft.}$, greenish white, mottled purple; blade sagittate, 18 in. long, the basal lobes very long and erect, the upper surface green, with silvery or gray bands along veins and midrib, the under surface light purple. Java.

Putzèysi, N. E. Brown. Much like A. longiloba : lvs. broader (oval-sagittate), dark metallic green, prominently veined and bordered white, the petioles pale redpurple, under surface dark purple. Sumatra. I.H. $29: 439$. - More brilliant than $A$. longiloba, and has wider spaces between the veins.

Thibautiàna, Mast. Petioles $3 \mathrm{ft}$, greenish ; blade $2 \mathrm{ft}$. long and 18-20 in. broad, ovate-cordate, the basal lobes broad and rounded, olive-green, with broad silvery veins and rib, the under surface deep purple. Borneo. G.C. III. 17: 485 . I.H. $28: 419$.

Ldwii, Hook. Petioles 2-3 ft., rose-color ; blade narrow-ovate, 18 in. long and a third as wide, long-pointed, the basal lobes long-acute, upper surface olive-green, with very distinct silvery bands, under surface rich purple. Borneo. B. M. 5376. A.F. 1895:559 as var. grandis. Var. picta, Hook. (B.M. 5497), has surface covered with small white reticulations. This var. is A. Vèitchii, Schott. (var. Vèitchii, Engler).

ccc. Veins uhite and leaf blotched and mottled.

macrorhiza, Schott. Large, reaching 10 or $15 \mathrm{ft}$. : leafblades $3 \mathrm{ft}$.long, long-sagittate and pointed, the lobes short and obtuse, margin often somewhat wavy, the midrib very broad and conspicuous, the blotches or patches of green and white (in the var. variegdta, which is the common form) very striking. Ceylon. I. H. 8: 305.- One of the commonest species. Lvs. sometimes almost white.

cccc. Veins dark or purple, or the leaf dark-colored.

cùprea, Koch (A. metállica, Schott.). Petioles $2 \mathrm{ft}$. or less long, green; blade ovate and peltate, 18 by 12 in. notched at the base and cuspidate at the point, dark metallic green with darker rib and veins, the under side rich purple. Borneo. B. M. 5190. I. H. 8: 283. Lowe, 60. Gn. 50:336. - One of the best, and common.

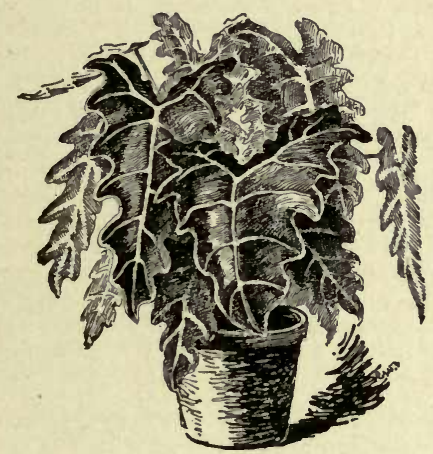

67. Alocasia Sanderiana.

Regina, N.E. Brown. Lvs. thick, ovate-cordate, obtuse or cuspidate, the basal lobes short and nearly or quite obtuse, the ribs and veins beneath pubescent, somewhat fleshy, dark green above with darker veins and brown-purple beneath; petioles terete, pubescent, spotted purple. Borneo. I.H. 32:544.

Several cult. varieties and hybrids are in the trade in this country: $A$. argyrea, hybrid of longiloba $\times$ Pucciana; Bataviénsis, petiole dark purple; lf.-blade dark green; Chantrièri (raised by Chantrier Bros., Mortefontaine, France), hyb. of cuprea $\times$ Sanderiana, with long wavy Ivs., purple below and prominently white-veined (I.H. 35: 64. R.H. 1887, p. 465); Chélsoni, cuprea $\times$ longiloba, with irs. purple below and green above; gigas, much like Villeneuvei ; intermèdia, hybrid by Veitch 25 years ago; La Salliana; Luciana, Thibautiana $\times$ Putzeysi, with lvs. dark green above and whitish veins and margins, purple beneath (I.H. 44:27); Mortefontainènsis, Lowii $\times$ Sanderiana; Puccidna, Putzeysi $\times$ Thibautiana; Sèdeni, cuprea $\times$ Lowii, with ovate-pellate lrs. purple beneath and white veined above (I.H. 24:292); Vun Hoúttei.

The following names are also in our trade: A. illús. tris=Colocasia antiquorum; Jénningsii=Colocasia af finis ; Jóhnstonii =Cyrtosperma Johnstoni : Marchállii = Colocasia Marchalli; violdcea = Colocasia antiquorum?

The following may be expected to appear in the American trade: A. A ugustiniàna, Lind. \& Rod. Lvs. peltate and wavy, green above and below, with pale nerves, the petioles brownspotted; allied to A. zebrina. I.H. 33: 593. New Guinea? - A Cúrtisi, N. E. Brown. Petioles $3 \mathrm{ft}$. or less, purple-barred : lf. blade 20 in. or less, and half as wide, shining green and greyribbed above, deep purple beneath. Penang.-A.éminens, N.E. Brown. Lvs. peltate, the blade $2 \mathrm{ft}$. or less long and nearly half as broad, purple beneath, green and light-veined above: petias broad, purple beneath, green and light-veined above; petiLarge : lvs. $2 \mathrm{ft}$. or less long, ovate-sagittate, half as broad, black.green below, bright green above; petioles $4 \mathrm{ft}$. or less, blackish. E. Ind.-A. guttàta, N. E. Brown. var. imperiàlis, N. E. Brown. Lvs. sagittate, acute, $1 \frac{1}{2} \mathrm{ft}$. or less long and half as broad, purple beneath, brown-green and dark-blotched above. Borneo. I.H. 31: 541.-A. Indica, Schott. St. $6 \mathrm{ft}$. or more, stout and fleshy:- lvs, very large (often $3 \mathrm{ft}$ across), ovate-cordate,

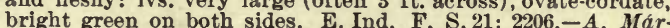
garito Lind \& Rod Lvs, slightly peltate, wavy, shining, green garitoe, Lind. \& Rod. Lvs, slightly peltate, wavy, shining, green
with blackish midrib, the veins and brownish petioles pubeswith blackish midrib, the veins and brownish petioles pubescome from Braz. Lvs. 2 ft. or less long and very broad, slightly wavy, rounded and short-pointed, pale green, striped and mot tled with purple; petioles brown-marked.-A plúmbea, Hort. =grandis? $-A$. revérsa, N. E. Brown. Dwarf and compact, the petioles 6 in. long, blade less than $1 \mathrm{ft}$. long, bright green, with rib and nerves olive-green. B.M 7498. Philippines, $-A$, Rodirib and nerves olive-green. B.M. 7498. Philippines.-A. RodiGasiàna, André. Thibautiana $\times$ Regina.-A. Sanderiàna, var. beneath. I.H. 43: 55.-A. scabriùscula, N. E. Brown. LVs. spreading, not deflexed, sagittate and not peltate, shining green above and paler beneath. Borneo.-A. sinudta, N. E. Brown. Lvs. sagittate and sinuate, dark green above with lighter areas, and whitish green below. Philippines - $A$. Watsonidna, Hort. $=$ Punis gr. Wavrinit Patzeyst. sagittate, lanceolate and long-pointed, dark green ; petioles
purple-spotted, winged. G.C. III. 23:243. F.E. 10:886. Gn. purple-spotted, winged. G.C. III. $23: 243$. F.E. $10: 886$. G
55:183. Celebes.

ALOE (Arabic name). Liliàce , tribe Aloíneœ. Acaulescent or variously caulescent succulents : Ivs. often large, usually crowded in rosettes or along end of st. : fls. red or yellow, often paler-striped, straight, tubular, with short, straight limb, equaled or surpassed by the stamens. Afr., especially in the Cape region, one species about the Mediterranean and extensively nuturalized in all warmer parts of the world, and one in China. Plants of the coolhouse, best planted out in a well-drained place in summer, when they flower prettily. Prop. by seed, which usually is not true to name, and by suckers or cuttings well dried-off. Branching for this purpose may be induced by searing the crown of old plants. Hybrids are said to occur with Gasteria (A. Bedinghausii $=A$. aristuta $\times$ G. nigricans $; \boldsymbol{A}$. Beguini=A. aristata $\times$ G. verrucos $a ; A$. Lapaixii=A. aristata $\times$ G. maculata; A. Lynchii $=A$. striata $\times$ G. verrucos $a$, and $A$. Nowotny $i$ $=A$. aristata $\times)$, and with Lomatophyllum $(A$. Hoyeri= $A$. serrata $\times$ L. sp.). J. G. Baker, in Jour. Linn. Soc. Bot. 18, pp. 152-182.

William Trelease.

Old plants of Aloe will keep healthy for several years in the same pots without a renewal of soil, and flower freely at the same time. The soil most suited to their needs is sandy loam three parts, lime rubble and broken brick one part, with a little decayed manure to strengthen the mixture. Very firm potting is necessary. Drainage is a more important item than soil, and must be perfectly arranged to enable the surplus water to run freely from the soil. Broken bricks are preferable to pieces of pots, large pieces for the bottom of the pot or tub, and smaller pieces above, till the last layer is quite fine. Some of the species need freer rooting conditions than others. A. ciliaris will grow from 5-7 ft. in a season. A. Abyssinica is of robust growth, and differs from most others in the color of the flowers, which are pure 
yellow, most of the others being orange and orangescarlet. $A$, plicatilis makes an ornamental tub plant when 4 or $5 \mathrm{ft}$. high. Except during the period in which the species are in active growth, they need very little water, the principal idea being to keep the soil sweet and porous even when in growth. At all times the air of the house should be as dry as possible, full sunshine not hurting them. Prop. by seeds, suck ers and cuttings. The arborescent kinds should be rooted after they have completed growth. Dust over the cut part of the cutting with powdered charcoal and dry in sunshine before putting it in to root. Insert singly in as small pots as they will go into, and plunge in a sand bed. Very little moisture is necessary while rooting.

G. W. OLIVER.

The generic or scientific name Aloe is a Latinized form of an Arabic name. As an English word it is pronounced in two syllables, thus, $A^{\prime}$-loe. Popularly this word is loosely used, the common American Aloe being Agave Americana, the commonest "Century Plant." The "bitter aloes" of commerce is a resinous juice much used as a laxative. The best quality is called "Socotrine or Zanzibar Aloes," a product of A. Perryi, which was known by the Greeks of the Fourth century B.C. to come from the island of Socotra. The "Barbadoes Aloes" is the product of $A$. vera, a species much planted in the West Indies. Genera allied to Aloe are Apicra, Gasteria, Haworthia, Pachidendron, and Phylloma. The group is an extremely difficult one for the botanist, there being few authentic specimens in the herbaria, because of the large size of the plants, the infrequent flowering, and the difficulty of suitably drying them.

Aloes are much cultivated as decorative plants, being amongst the most popular of desert and succulent plants for their stiff, harsh and rugged habit. They are often grouped about large public buildings, where they emphasize certain architectural features. Large collections are to be seen only in botanic gardens and in the collections of a few fanciers. The largest dealer has nearly a hundred kinds, but grows only five or six kinds in quantity. For index to the following species, see supplementary list, p. 51.

W. M.

A. Arrangement of lvs. spiral (except in seedlings).

B. Form of lvs. broadly lanceolate, acute: size of lvs. moderately large.

c. Border of lvs. thin, horny: margin entire or denticulate.

D. Color of lvs. grayish: shape of lvs. flattened.

1. striàta, Haw. (A. paniculdata, Jacq. A. álbo-cincta, Hort.). Caulescent : lvs. at length large, finely dark-

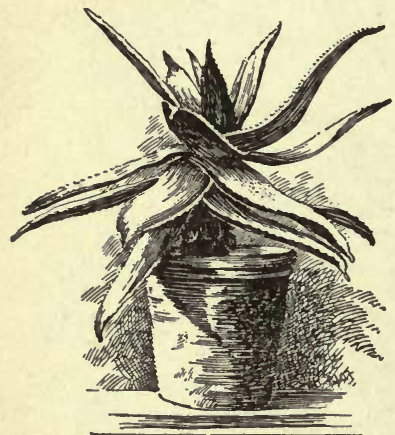

68. Aloe serrulata. lined, scarcely mottled, with entire white border: inflorescence compound, broadly eymose : fls. red, constricted above the ovary. Cape. B. M. 5210. Hybrids with $A$. serrulata and $A$. grandidentata oc cur, having toothed lvs.

Var. rhodocíncta (A. rhodocincta, Hort. $A$. Hanburidna,Naud.). Lvs. purplish, very glaucous, with entire reddish border.

2. serrulàta, Haw. Fig. 68. Lvs. less striate, obscurely mottled, the white border denticulate : inflorescence less cymose. Cape. B.M. 1415.

DD. Color of lvs. clearer green: shape of lvs. more concave: teeth small and cut nearly through the border.

3. macrocárpa, Tod. Lvs. interruptedly green-lined, more evidently mottled: inflorescence branched with elongated racemes. Abyssinia.

4. Schímperi, Tod. Lvs. coarsely green-lined, scarcely mottled: racemes short and cymose. Abyssinia, China?

\section{cc. Border of lvs. usually only near the apex:} mottling present.

5. saponària, Haw. (A. dísticha, Mill., not Linn. nor Thunb. A. umbellata, DC.). Shortly caulescent: lvs. somewhat gray-green or purplish, the small teeth remote : racemes short and compact. Cape. B.M. 460. - Varies into many forms.

Var. lùteo-striàta, Haw. Lvs. concave, coarsely pale-lined.

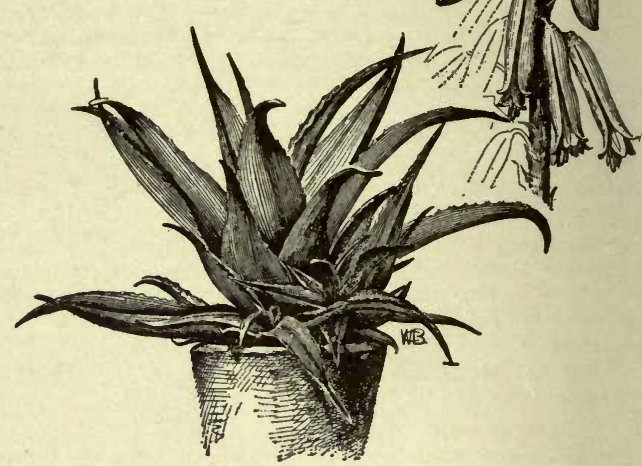

69. Aloe heteracantha.

6. Iatifdlia, Haw. (A. saponàia, var. latifdlia, Hort.). Lvs. apple-green, thick and broad, concuve, the con spicuous pale blotches irregularly transversely confluent; teeth large, mostly curved, rather remote: racemes short and dense. Cape. B.M. 1346.

7. commutata, Tod. Lvs, rather thinner: racemes several, somewhat elongated. Abys.

8. obscùra, Mill. (A. picta, Thunb.). Lvs. rather nar rower and thinner: racemes elongated. Cape. B. M. 1323.

9. grandidentàta, Salm. Lvs. and racemes still more elongated. Cape.

ccc. Border of lvs. nearly absent : mottling scarcely present: lvs. involute at tip.

10. glaùca, Mill. (A. rhodacántha, DC.). Caulescent: lvs.not mottled, very glaucous, the irregular red or brown teeth subconfluent: inflor. simple, densely racemose; fls. red, scarcely constricted above the ovary. Cape. B.M. 1278. A hybrid with $A$.humilis, var. incurva, is A. cyanea.

Var. muricata, Sch. Lvs. glaucous, with large teeth, those on the keel or apex more developed.

11. heteracántha, Bak. (A. inérmis, Hort.. not Forsk.). Fig. 69. Nearly stemless, often densely cespitose : Ivs. lark green, sometimes with a few obscure yellowish green spots, slightly striate at base, entire or with a few remote small teeth. Cape? B.M. 6863.

BB. Form of lvs. ovate-lanceolate, acute, thick, mostly tuberculate on the back: size of lis.large.

12. fèrox, Mill. (A. muricata, Schult. A. hórrida, Haw. Pachidéndron fèrox, Haw.). Caulescent, unbranched: lvs. crowded at summit, glaucous, the margin and both surfaces remotely coarsely pungently toothed: inflor. branched, with elongated very dense racemes; fls. reddish, with stamens twice as long as the perianth Cape. B.M. 1975. G.C. II. 3:243. - Varies into several less muricate forms.

13. mitriformis, Mill. (A. mitroeformis, Willd., not DC. nor Haw. A. Commélyni, Willd. A. spinulòsa, Salm. A. pachyphýlla, Hort. A. xanthacaintha, Willd.). Fig.70. Somewhat branching: lvs. spaced along the stem above, dark green, with strong, separated marginal teeth, both faces usually muricate: inflor. sometimes branched, with short, compact racemes: stamens not exserted. Cape. B.M. 1270. - Varies into numerous forms. 
Ввв. Form of 7rs. elongated, gradually tapering: size of lvs. large: border absent: teeth usually course.

14. Bànesii, Dyer. (A. Bárberce, Dyer.). A very large forking tree, in cultivation becoming tall, though at first slender : lvs. very concave, dark green, remotely dentate, spaced along the stem above, with white-margined sheathing base : inflor. short and compact, the reddish fls. tumid. S. Afr. G.F. 3:115. G.C. II. 19, pp. 566-571, ff. $117,119,120,122$. B.M. 6848 .

15. vèra, Linn. (A. vulgdris, Lam. A. Barbadénsis, Mill.). Low or small, slender tree: lvs. broader, less channeled, pale gray-green, coarsely dentate, not sheathing: fls. yellow. Suckers, freely produced in cultivation, have clear apple-green mottled linear lvs. Mediterranean region, and naturalized through the warmer parts of the world. - The oldest known and probably the commonest species.

Var. officinàlis, Forsk. (A. rubéscens, DC. A. Indica, Royle). Lvs. purplish: fls, red-orange. Orient.

16. Succotrina, Lam. (A . sinudta, Thunb., not Willd.). Related to the last : Ivs. relatively narrower, dark green, coarsely serrate : fls. red, variously tipped and striped. Cape. B.M. 472. Gn. 45, p. 303.-A hybrid with A. ciliaris is $A$. de Laetii.

Var. purpuráscens, Gawl. (A. purpuráscens, Haw. A. ramòsa, Haw.). Lvs. purplish. B.M. 1474.

17. arboréscens, Mill. (A. fruticòsa, Lam.). Low, slender tree: st. roughened by old leaf bases : lvs. dark green, glaucescent, coarsely green-dentate to hooked serrate when separated, with whitish sheathing bases: fls. red. Cape. B.M. 1306.

Var. frutéscens, Salm.iA.frutéscens, Salm.). Snaller, suckering freely: lvs. blue-glaucous, the sheathing bases coarsely green-striate.

ВвВв. Form of lvs. lanceolate, acute, flat: size of lvs. small: border absent: teeth ciliate: mottling absent: lvs.sheathing, with perfoliate margin.

18. ciliàris, Haw. St.elongated, very slender,branched: lvs. dark green, the slender white teeth longer about the base: infior. axillary, somewhat elongated, loosely fewfld.: fls. red. Cape.

ВвввВ. Form of lvs. various, thick, plano-convex: size of li's. small: border absent: mostly toothed on the back: mottling absent: lvs.crowded.

19. brevifolia, Mill. (A. prolifera, Haw.). Shortstemmed: Ivs. spreading, broadly lanceolate, acute, shortly and pungently white-toothed; a few similar teeth occasionally on both surfaces. Cape. B.R.996.

20. hùmilis, Mill. (A. echinàta, Willd. A. suberécta, Haw A. subtuberculàta, Haw.). Acaulescent: Ivs. ascending, lanceolate, gradually attenuate, loosely softserrate, both surfaces coarsely tuberculate or echinate: raceme somewhat elongated, loosely fld: fls, red. Cape. - An extremely variable species, of the habit of certain Haworthias.

Var. Candollei, Bak. L.B.C. 15:1481. Var. incúrva, Haw. B.M. 828. Var. acuminata. B.M. 757 . L.B.C. 16:1504. Var. minor, Hort., is in cult.

21. aristàta, Haw. (A. longiaristàta, Schult.). Lvs. as cending, attenuate into a long bristle. Cape.

AA. Arrangement of lv's.3-ranked: lvs.rather small.

22. variegàta, Linn. Short-stemmed: lvs. erect, v-shaped, acute, with finely warty horny white margin and keel, mottled, the pale blotches variously trans versely confluent: raceme short, rather loose: fls, reddish. Cape. B.M.513. F.E. 8:98.-Common.

AAA. Arrangement of lvs. 2-ranked: lv's. elongated.

23. Coòperi, Bak. (A. Schmidtidna, Regel.). Acaulescent: Irs. suberect, linear-oblong, sharply-grooved and keeled, niottled, faintly striate, the small white teeth subconfluent: inflor. subcymose: fls. reddish or brownish, tumid below. Cape. B.M. 6377. Gt. 970 .

24. plicátilis, Mill. (Rhipidodéndron plicátile, Haw.). Becoming tall and stout, branching : Ivs. glaucous, flat, lingulate, obtuse, serrulate and bordered at least near the apex: inflor. shortly racemose: fis. reddish, the petals wearly free within the tube. Cape. B.M. 457 .

\section{WILLIAM TRELEASE.}

In the following alphabetic list are included (1) the more important species (which are numbered, and have been fully described previously), (2) synonyms of the above (which are followed by the sign of equality and a number), (3) the less important species (which are briefly described in the present list, but not previously). Those marked with an asterisk (*) are advertised in the catalogues: A. Abyssinica, Lam.,var Peacockii Bak. Lvs, 20-30 in a dense sessile rosette, 11/2ft. long, 5-6 in. broad at base, glaucous green, not mottled, the margins with broad at base, glaucous green, not mottled, the margins with close, spreading, deltoid spines, with horny reddish brown tips:
inflor. as long as the lvs., a 6-8-branched panicle. B.M. 6620.$*_{A}$. A fricàna, Mill. St. stout, marked with scars of fallen lvs.: lvs. alternate, st.-embracing, concave; teeth conical, reddish orange at tip: seape bearing a dense many-fld. spike of long eylindrical fls. B.M. 2517. -A. agavafolia, Tod. Allied to A. tricolor. St. short: lvs. dense, copiously white spotted, lanceolate; color. St. short: lvs. dense, copiously white spotted, lanceolate; A. arboréscens, 17. $-A$. aristàta , 21. $-A$. Barbadénsis $=15 .-A$ Báinesii, 14. - A. Bárbera $=14 .-A$. brachýstachys, Bak. Allied to A. Abyssinica. St. long, slender : lvs. ensiform, in a dense rosette at the top of the st., all drooping, except the youngest, 11/2-2 $\mathrm{ft}$. long, 2 in. broad above the dilated base, bright green, not mottled; marginal prickles deltoid, not brown: peduncle flexuose; raceme dense; bracts with 5-7 distinct brown stripes. flexuose; raceme dense; bracts with 5 - disttinct brown stri lied to A. Abyssinica. Lvs. $15-20$ in a sessile rosette, $1 / 2-1 \mathrm{ft}$. Iong lied to A. Abyssinica. Lvs. $15-20$ in a sessile rosette, $1 / 2-1 \mathrm{ft}$. long, green: scape simple, $1 \frac{1}{2} \mathrm{ft}$. long; bracts few, distant, smali, deltoid. B.M. 6301. Hab.? -*A. ciliaris, 18.-A. Commélyni=13.A. commutàta, 7. -A. Cò̀peri, 23. - A. cyánea $=10 .-A$. dichb́toma, Linn. f. Allied to A.Bainesii. Arborescent: st. tall, much branched: lvs. in dense rosettes at the tops of branches, lanceolate, 8-12 in. long. Namaqua-land. G.C. 1873:713, f. 1371. 1874, $567,571, f, 118,121-A$, distans, Haw, (A mitrgerormis, $v a r$ brevifolia). St. 3 or more ft. high: lvs ovate-acuminate, concave, scattered along the st., with a few white spots on the back teeth short, distant: fls. red, tipped green. S. Afr. B.M. 1362 - A. distich $a=5 .-A$. echinàta $=20 .-A$. élegans, Tod. Little

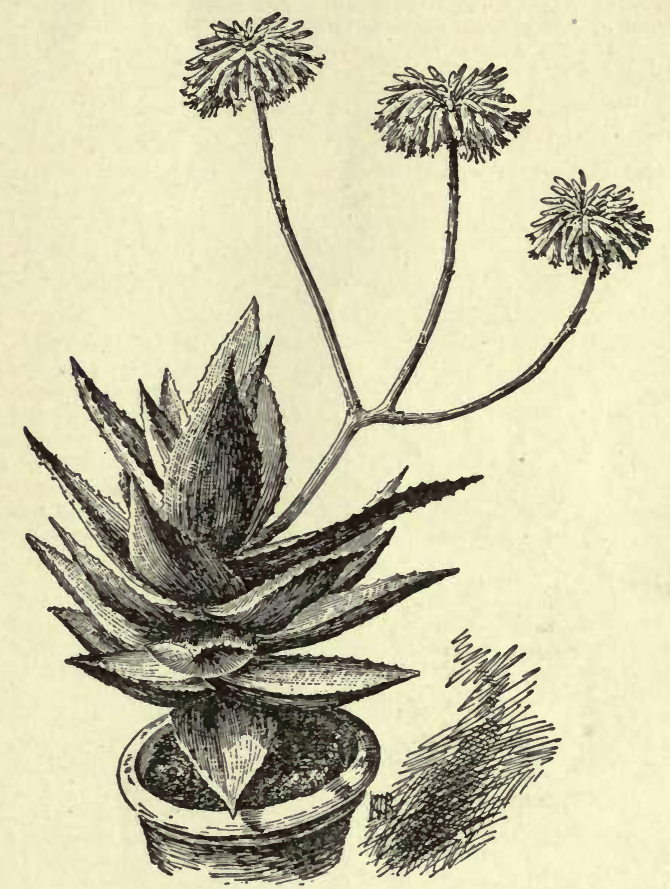

70. Aloe mitriformis.

known. Not mentioned by Baker. Hab.1-A. fèrox, 12.-*A. frutéscens. Salm $=17 . *_{A}^{*}$. fruticòs $a=17-A$. glaùca, 10.-A. grácilis, Haw. Allied to A. arborescens. St. long : lvs, loosely arranged, 6-10 in. long, 1 in. wide at the base, ensiform, acumi nate, not lined or spotted; prickles minute, spreading, tipped brown : fls, yellow, tube with long lanceolate segments. - *A. grandidentate, 0 - Greènei. Bak in the Picto gronp, is readily distinguished by the elongated racemes and the strong 
constriction of the perianth below the middle. Lvs. 12-15, in lense rosette, lanceolate, channelled, bright green; prickles connected by a narrow horny line: tls. pale salmon; bracts awl shaped, heteracántha, 11. - A. Hildebrándtii, Bak. St. 11/2-2 ft.; interheteracántha, 11. - A. Hildebrándtii, Bak. St. 11/2-2 ft.; inter-
nodes spotted white: lvs. loosely arranged, 6-10 in. long, glaucous green; teeth small, ascending : inflor. a lax panicle, $1 \frac{1}{2} \mathrm{ft}$ long, with 10-12 branches : remarkably prolific of fis. B.M. 6981 $-A$.hórrida $=12 . *^{*}$ A. hùmilis, $20-A$. Indica $=15 .-A$. inérmis, 11. - A. insignis, Brown. A bybrid of A. drepanophylla XA. echinata. G.C.II. 24: 41.-A. Kirkii, Bak. St. very short: lvs. 30-40, in a dense rosette, green, not spotted; teeth large: inflor. $2 \mathrm{ft}$. in a dense rosette, green, not spotted; teeth large: inflor. 2 ft. long, 3-branched; fls. red. Zanzibar. B.M. 7386.-A kniphofioides, Bak. Acaulescent: lvs. linear, rigid, serrulate: inflor. an
elongated raceme. Hook. Icon. 1939. $-A$. de Lotii $=16$. $*_{A}$. latifòlia $=6$. - A. longiaristàta $=21 .-A$. Lúntii, Bak. A very distine species with no marginal prickles: st. short: lvs. $7-8$, in a dense rosette, $1 \mathrm{ft}$. long, 2 in. wide at base, pale green, not spotted: peduncle much longer than lvs: panicle of 4-5 long, lax racemes; a marked character. B.M. 7448, - A macracántha, Bak. St. 2-3 ft.: lvs. $20-30$, in a dense rosette, lanceolate, bright green, much lined, prickles large, brown and horny in upper half : inflor, a dense corymb; fls. yellow, tinged red; tube constricted infor. a dense corymb; fls. Yellow, tinged red; tube constricted
above the globose base. B.M. 6580 . Said to be the finest of all spotted Aloes. -*A. macracárpa,3.-A. médica, Hort. Alverson ? ?-A. micracántha, Haw. Lvs. linear, 1/2ft. long, 11/2in. wide at base, deeply ehannelled, mottled; spines very minute, white fls. greenish red, in a lax umbel-like raceme; bracts large, ovatescuminate, striate. S. Afr. B.M.2272.-A. minima, Bak. Hook. Icon. 2423. A recent and little known species. ${ }^{*} A$. mitrofórmis $=13$ - * A mitrifórmis, 13, $A$, muricàta $=12,-A$. nóbilis, Haw. Allied to A. distans and A. mitriformis. Sts. long: lvs. loosely disposed, not spotted, ovate-lanceolate : fls. red. S. Afr. $-A . o b$ scùra, 8. - A. pachyphýlla $=13 .{ }^{*}$ A. paniculàta $=1 .-A$. per cássa, Tod.=A. Abyssiniea.-A. Pérryi, Bak. St. $1 \mathrm{ft}$. long: lvs 12-20, in a dense rosette, laneeolate, $1 \mathrm{ft}$.long, 3 in. wide at base, dull green, tinged red near the base, channelled: prickles $1 / 4 \mathrm{in}$. apart: peduncle purplish : racemes oblong-cylindrieal, 3-6 in. long; fls. red. Socotra. B.M. 6596.-*A pict $a=8,-A$. plicátilis, 24.-A.praténsis, Bak. Allied to A. humilis. St. none: lvs. 60-80, not spotted; spines large, red-brown, horny: pedunele $1 \mathrm{ft}$. long, stout ; bracts many. B.M. 6705.-A. prolifer $a=19 .-A$. purpu ráscens $=16 .-A$. ramòs $a=16 . *^{*} A$. rhodacánth $a=10 . *_{A}^{*}$. rho docinct $a=1 .-* A$. ròsea-cinct $a$, Hort. Blane $=?-A$. rubéscens $=$ 15. **A.saponària, 5. - A. Schímperi, 4. - A. Schmidtiàna $=23 .-$ A. Scilliaris, Hort. Alverson. Typographical error for A. ciliaris? - *A. scopelània, Hort. T. B. Shepherd $=?-A$. Sérra, DC. arls? - $A$. scopelania, Hort. $\mathrm{A}$. B. Shepherd $=$ - $A$. Sérra, DC.

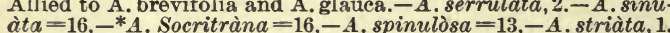
$-A$. suberéct $a=20 .-A$. subtuberculàt $a=20 .-A$. Succotrina, 16 . -A.trícolor, Bak. Differs from A. saponaria by its racemos (not capitate) inflorescence, and tube constricted in the middle white spots very numerous, oblong, in single or double lateral rows : fl. tube spotted white at base. B.M.6324.-A. umbellàta

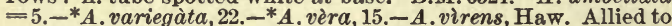
A. humilis. Stemless: lvs. $30-40$, lanceolate, white spotted, channelled, not lined; prickles green: racemelax, 15-18, in. long; fls. nelled, not lined; prickles green: racemelax, 15-18, in. lon
red. B.M. 1355. -*A. vulgáris, 15. - A. xanthacántha $=13$.

ALONSOA (Alonzo Zanoni, Spanish botanist). Serophularideece. Trop. Amer. plants, cult. as annuals in the open, or rarely grown in pots. They are tender, and need protection from frost. Seeds are usually started under glass in the N., although plants bloom well from seeds sown directly in the open. Use only finely prepared soil. Fls. showy; plant of good habit. The corolla is 'very irregular and turned upside down by the twisting of the pedicel, bringing the larger lobe uppermost: stamens 4 : Ivs. (at least below) opposite or in 3's. Cult. species mostly from Peru and Mex.

incisifdlia, Ruiz \& Pav. (A. urticafollia, Hort. Célsia urticafòlia, Sims, B.M. 417). About $2 \mathrm{ft}$. high, erect : Ivs. ovate to oval-lanceolate, long-stalked, deeply cuttoothed: fls. nearly $1 / 2 \mathrm{in}$. across, very irregular (somewhat hood-shaped), scarlet, with protruding organs, on slender axillary peduncles. Also a white-fld. var.-Annual; but perennial in warm countries or under glass.

Var. Warscewiczii, Boiss. (A. Warscewiczii, Regel. A. grandiflòra, Hort.). Fls. larger (often 1 in. across), rose-red, the plant more herbaceous and more perfectly annual. Also white-fld.-The commonest form in our gardens.

myrtifolia, Roezl. Plant 2-3 ft.: 1vs. broad-lanceolate, canaliculate, prominently serrate: fls. large, scarlet (a white var.).-Perennial under glass. Useful for wintergrowing in pots.

linifolia, Roezl. Plant 11/2ft. or less high: 1vs. lanceolate or narrower, entire: fls. bright scarlet.

A. acutifolia, Ruiz \& Pav. Lvs. less cut than in A. incisifolia: scarlet. - A. caulialàta, Ruiz \& Pav. Lvs. less cut than in incisi- folia : fls. smaller : st. 4-angled.-A.lineàris, Ruiz \& Pav. Lvs. linear, entire or very nearly so, often fascicled: fls. scarlet. Greenhouse.-A. Màthewsii, Benth. Lvs. lanceolate, toothed: fls. scarlet, in terminal racemes. Greenhouse.

L. H. B.

\section{ALOYSIA. See Lippia.}

ALPINE GARDENS. In the successful culture of alpine plants, the most important point is to give them as near their natural alpine conditions as possible. So far as soil is concerned this is not difficult, but when it comes to moisture with good drainage and surrounding atmospheric conditions, especially in the dryer atmos. phere of some of our western states, we have a more difficult task. In their natural homes, many of the alpines are found growing under very similar conditions to our bog plants, and the two classes, for the most part, may be brought together in cultivation. Of course, the mountain Prinula might never withstand the stagnation to which the roots of the water Arum (Peltandra Virginica) penetrate in the wet bog, nor should we expect the Peltandra to survive the wintry blasts to which the Primula is exposed, but the two may be grown together with very good results in a moist, springy situation, iu the same bed and soil. Any light, sandy soil, well drained, but through which water is constantly passing in and out, so that there is no stagnation and always a little moisture on the surface (which makes it cooler from the evaporation), will answer for most of the boo plants and the majority of the alpines also. There should be a natural slope to the surface of the ground for such conditions, and if the surface is undulating, so as to make some parts drier than others, those plants which require the most moisture can go into the wettest places. Alpines like a deep soil, into which their roots can penetrate. Leaf-mold should be used in place of any manure, and if the soil is a very fine one a mixture of grarel should be introduced. Shade and sun are rather necessary, as some of the alpines would hardly stand the full scorching sun of our hottest days in summer, even though the surface of the soil were moist, while others require full sun. Alpines have been successfully grown in sphagnum moss. This is done with best results in the rockery, where the various pockets are filled with the fresh moss and the plants set in it. Water should be supplied often enough to keep the moss always moist. The evaporation from the wet moss creates a cool atmosphere around the plants, thus giving them a condition somewhat like that which they have in alpine regions, surrounded by mountain fogs, or in the moist bog. Many alpine-garden plants are not confined to alpine situations. They grow in moist places in much lower altitudes as well. Such species as Houstonic carulea, Parnassia Caroliniana, and Smilacina stellata may be mentioned among these. Most of the alpines, when set in the fresh, damp sphagnum, do nicely in full sun, but for the alpine ferns shade should be given. Those which grow in drier places, like the little Woodsia glabella or $W$. hyperborea, need less shade and moisture, while Asplenium viride and A. Trichomanes want more moisture about their roots, and deep shade.

\section{F. H. HorsFord.}

ALPINIA (Prosper Alpinus, an Italian botanist). Scitaminacece. Stove herbs, cult. both for lvs. and the racemes or panicles of fls. The fl. has 3 exterior parts and 4 interior parts. The lowermost part is lobed or tubular. Stamens with petal-like filament. They need high temperature, much water, light soil, and abundance of room. After flowering, allow them to rest in heat, but do not dry them off. Prop. by dividing the gingerlike roots.

Alpinia contains many handsome species, but only a few are common in cultivation. They are tropical plants, and require a moist air and a temp. of $55^{\circ}$ to $60^{\circ} \mathrm{F}$. A mixture of 2 parts loam, 1 part leaf-mold, and 1 part dried cow-manure forms an excellent compost. While growing, they need an abundance of water, and the largegrowing kinds require large pots or tubs. The plants are prop. by division in the spring. A. nutans is grown for its handsome fls., and attains a height of 12 or $13 \mathrm{ft}$. $A$. vittata is popular c $n$ account of its variegated foliage. A. mutica has very showy fls., but is probably not in the American trade. Cult. by RoBert CAMEron. 
nùtans, Roscoe. Shell-FLower. Striking plant, reaching 10-12 ft., with long, lanceolate glabrous long-reined lvs.: fls. orchid-like, yellow with pink, sweet-scented, in a long, drooping, terminal, spike-like raceme. E. Ind. G.C.III. 19:301. I.H. 43:259. B.M. 1903. P.M. 13:125. R.H. 1861, 51.-Fine for foliage masses, and an old favorite.

vittàta, Hook. (Amдmum vittàtum, Hort.). Lower: Ivs. in tufts, lanceolate, with whitish bars or stripes between the nerves: fls. red, in axillary spikes. South Sea Islands. A.F. 8: 787. Gn. 4, p. 25.
71. Pinna of

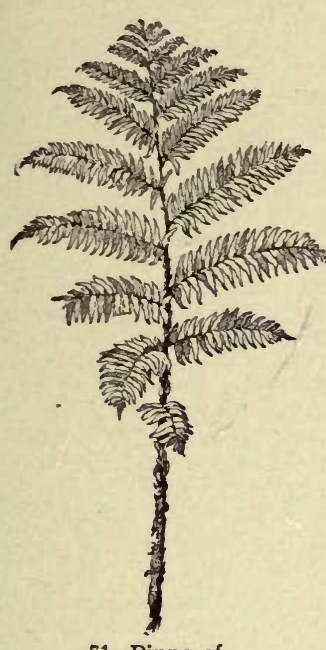

Alsophila australis.

álbo-lineàta, Hort. A plant 3-4 ft.high, with broad bands of white and pale green on the elliptic-lanceolate Ivs. Probably a form of some other species.

Other species are A.Allughas, Roscoe,fls. in terminal panicles, white and rose; A. magnifica, Roscoe= Amomum; A. Japónica, Miq., once int. into U.S. by Pitcher \& Manda; $A$. mútica Roxbg., fls. white and yellow, with erimson veins, in spicate racemes.

\section{H. B.}

ALSEÚ́SMIA (alsos, grove, and euosme, fragrance). Caprifolidacere. Tender greenhouse shrub from New Zealand.

A. macrophýlla, A. Cunn. Ls. 3-6 in. long, elliptic or oblanceolate, acute, serrate: fls. in small axillary clusters, drooping, $1 \frac{1}{2}$ in. long, creamy with dull red streaks; corolla lobes fimbriate. B.M. 6951.

ALSIKE. See Clover and Trifolium.

ALSÓPHILA (Greek, grove-loving). Cyathedcece. A genus of tropical tree ferns, with simple or forked free veins, round sori, and no indusia. Numerous species are found in the tropical regions of both hemispheres.

Of the different species of Alsophila, only one is in general commercial use. A. australis is a very graceful and rapidly growing tree fern, with finely divided fronds of a pleasiug shade of light gre $\in$, with the stipes thickly covered with light brown, hairy scales. It is grown from spores, which can only be obtained from old and large specimens, and which, like the spores of most commercial terns, will germinate very freely if sown on a compost consisting of finely sereened soil, leaf-mold and sand in equal parts. To develop a good crown of fronds in old specimen plants which may look starved, the stem may be covered to any thickness consistent with good appearance with green moss, which may be attached with thin copper wire, and which, if kept continually moist, will soon be thickly covered with fine roots. Al sophilas should be grown in a temperature of $60^{\circ} \mathrm{F}$. and the soil should never be allowed to become very dry.

$$
\text { Cult. by Nichol N. Bruckner. }
$$

A. Lvs.bipinnate; rachises merely fibrillose.

Rebéccæ, F. Muell. Lrs. ample, from a caudex 8 in. or so high; pinnæ $12-15$ in. long, with $20-30$ pinnules on each side, which are 2-3 in. long and serrate or crenate throughout. Australia.

\section{AA. Lvs.tripinnatifid or tripinnate; rachises armed} with spines.

B. Segments long, strongly curved; pinnules tapering to a slender point.

excélsa, R. Br. Lvs, coriaceous, with more or less woolly rachises; pinnæ 6-10 in. wide, with crowded pinnules, which are provided with about 20 pairs of segments, which are strongly eurved and more or less enlarged at the ends. Norfolk Is. - Said to have a trunk 60-80 ft. high.

Cooperi, Hook. Smaller than the last: rachises with pale brown scales: pinnæ spear-shaped, with linear pinnules 4-5 in. long. Queensland. lunulàta, R. Br. Lrs, rather thick herbaceous, from smooth rachises; pinnules close, 5-6 in. long, with 20-30 pairs of segments, which are finely serrate throughout.

$$
\text { BB. Segments } 1 / 2 \text { in. or less long. }
$$

austràlis, R. Br. Fig. 71. Rachises straw-colored ; lvs. ample, with primary pinnæ $18 \mathrm{in}$. long, $6-10$ in. wide; pinnules deeply pinnatifid, with segments broadest at the base, ovate-oblong and sharply serrate. Tasmania and Australia.

fèrox, Presl. (A.aculedta, J. Sm.). Rachises brownish; pinnæ 12-18 in. long; pinnules narrow, 3-4 in. long, $1 / 2-1 / 2$ in. wide, with $15-18$ pairs of segments, which are narrow and slightly serrate. Trop. Amer.

$$
\text { AAA. Lvs. quadripinnatifid. }
$$

oligocárpa, Fee. Fig. 72. Rachises smooth, grayish straw-colored; pinnules $1 \frac{1}{2}-2 \mathrm{ft}$. long, the segments ligulate, deeply pinnatifid, with blunt lobes; sori median, 4-6 on the lower lobes. Columbia.

ALSTONIA (Dr. Alston, once professor of botany at Edinburgh). A pocyndcece. Between 30 and 40 species of trees or shrubs of E. Ind. and Australia, with small wh te fls, in terminal cymes, and simple.entire Ivs, in whorls or opposite. A. scholdris, R. Br., is the Deviltree or Pali-mara of India, the bark of which is medicinal. Trees yield cuoutchouc.

macrophylla, Wall. A tall tree, with milky juice, sparingly cult. in S. Fla., and perhaps in S. Calif.

ALSTROEMERIA (Baron Alstrœmer, friend of Linnæus). Amaryllidacea. Coolhouse and stove plants, with tuberous roots, treated as bulbs. Fls. small ( 2 in. or less long), comparatively narrow, with 6 segments, parted nearly or quite to the ovary, often irregular; stamens mostly declined; stigma 3-cleft ; sts. slender and leafy, weak, or even disposed to climb. Monogr. by Baker, Handbook of the Amaryllider.

Some of the Alstromerias have survived the winters in Washington of late years only when a heavy mulch has been giren, as A. aurantiaca and its form A. aurea,

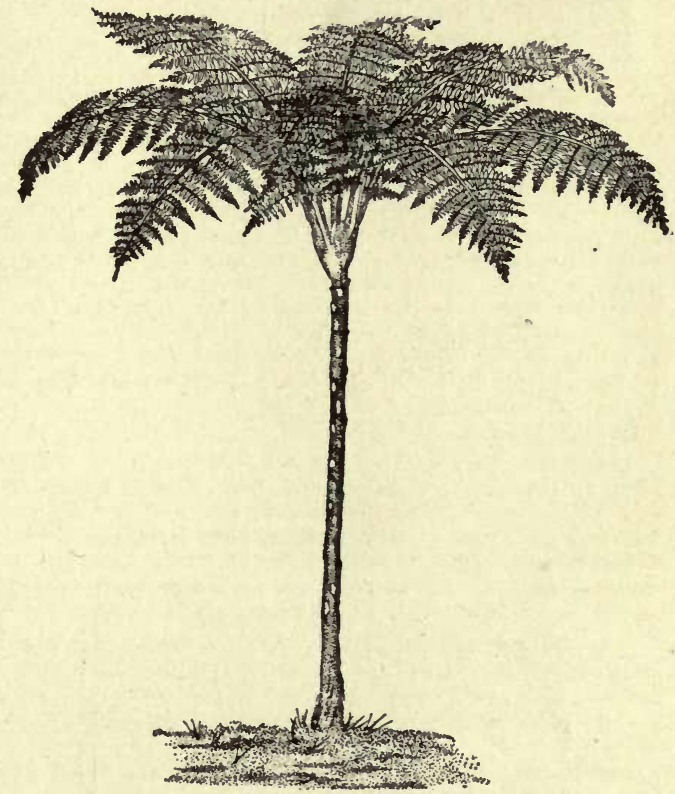

72. Alsophila oligocarpa

A. Chilensis and its forms. Evidently among the hardiest are $\boldsymbol{A}$. Brasiliensis and $\boldsymbol{A}$. pulchella, although some of the others have not been tried. For outdoor planting, Alstromerias are at their best in a partly shaded posi- 
tion, and at all times during their growth the roots must have an abundance of water. In fact, there is little use in attempting their cultivation out-of-doors where these conditions cannot be given. In colder climates, the Alstromerias can be grown very successfully by plantingout in spring, and, as soon as they die down, lift, und keep over winter in a place from which frost is excluded. An annual lifting, or, when grown in pots, an annual shaking-out, should be given, because they increase to such an extent that the younger and smaller crowns are apt to take the nourishment from the large, flowering crowns. The largest ones ought to be separated from the smaller ones, and either grown in pots or planted outside when the proper time arrives. In this way the genus will become much more popular than it now is, either for cutting or for the decoration of the border. The soil best suited to their requirements is largely composed of regetable humus; when this is not to be had, old, well-decayed cow or stable manure should be inco:porated with the soil. When they are planted outside, the tubers should be put deep in the ground, and the soil should be well worked for at least 15 inches. The tubers are slightly egg-shaped, attached to a common stem; the roots are made from the ends of the tubers, and also from near the growing points of the crowns.

One of the best for greenhouse work is A. Pelegrina, var. alba. Other kinds which may be considered tender north of Washing. ton are $A$. hremantha, $\boldsymbol{A}$. versicolor (or Peruviana) and its forms, A. Hookerii and $A$. violacea. Some of the Van Houtte hybrids, raised from Hookerii and hæmantha, are extremely pretty, but, with the others, they are rather unsuitable for potculture, owing to the peculiar formation of the roots.

The species are easily raised from seeds, which should be sown rather thinly in deep pans, and allowed to renain without pricking off or shifting for the first season. Cult. by G. W. Oliver,

A. Lvs. of fl. stem (or scape) broad, oblong or oblong-spatulate.

pulchélla, Linn. f. (A. psittacina, Lehm.). Sterile st. a foot or less long, with aggregated petioled lvs.: flowering st. 2-3 ft., with seattered lvs.: fls. in a simple umbel, on pedicels $1-1 \frac{1}{2}$ in. long, long funnel-shaped,the segments unequal, dark red and tipped with green and spotted inside with brown; stamens nearly as long as limb. Brazil. Fig. 73 is a copy of the A. psittacina, B.M. 3033.-An old garden plant.

Chilénsis, Cree. Stout, 2-4 ft.: lvs. scattered, obovate or spatulate, or the upper becoming lanceolate, twisted at the base, fringed, somewhat glaucous: fls. large, rose or red (or varying to whitish), the two lower segments longer and straighter: umbel with 5 or 6 2-fld. peduncles. Chile.

\section{AA. Lvs. of fl. st. lanceolate (at least the lower ones). B. Fls. purplish or red.}

Pelegrina, Linn. Fl. st. stout, a foot or less high: lvs. about 30 , thin, ascending, 2 in. or less long and $1 / 2$ in. or less wide: fl. 2 in. or less long, lilac, the outer segments broad and cuspidate, the inner ones spotted red-purple: nmbel few-rayed, normally simple, but becoming com pound in cult. Also a pure white var. Chile. B.M. 139. Gn. 46, p. 472. L.B.C. 13: 1295 .

hæmántha, Ruiz \& Pav. (A. Simsii, Spreng.). Fl. st. 2-3 ft.: Ivs. crowded and thin, somewhat stalked, 3-4 in. long and $3 / 4$ in. or less long, the upper becoming linear, glaucous beneath : fls. 2 in. or less long, bright red tipped green, the inner ones with red-purple spots on a red-yellow ground: umbel very compound, the branches
4-6 in. long. A white-fld. variety is cult. Chile. B.M. 2353, as A. pulchella.

Bв. Fls. yellow or yellowish.

aurantiàca, Don. Fl. st. 2-4 ft. high : lvs. nearly 50, thin, somewhat petiolate, slightly glaucous below, $3-4 \mathrm{ft}$. long and $1 / 2 \mathrm{in}$. wide: fls. $10-30$, in a compound umbel, the perianth bright yellow, outer segments tipped green and inner ones spotted brown. There is a form with pale, unspotted fls. Chile. B.M. 3350, as A. aurea. Gn. $26: 472$.

Brasiliénsis, Spreng. St. 3-4 ft.: Ivs. remote, thickish, oblong-lanceolate, 2 in. long: fl. $11 / 4$ in. long, in a 5 -rayed umbel (each ray bearing 1-3 fls.), the segments oblongspatulate and reddish Jellow, the inner ones spotted brown; stamens shorter than segments. Brazil.

AAA. Lvs, of flower stem linear.

versícolor, Ruiz \& Pav. (A. Peruviana, Van Houtte. $A$. sulphìrea and $A$. tigrina, Hort.). Fl. st. short (1 ft. or less high); lvs. many, the lower ones about 1 in. long : fis. 1 in. long, in a nearly simple umbel, yellow spotted purple, the segments all oblanceolate and acute. A marginate var. Chile.

Lígtu, Linn. FI. st. 11/2-2 ft.: lvs, $20-30$, thin, the lowermost becoming lanceolate, $2-3$ in. long: fls. $1 \frac{1}{2}$ in. long, in a nearly or quite simple umbel, whitish, lilac or pale red, streaked purple, the nner segments often obtuse. Var. púlchra, Baker (A. púlchra, Sims, B.M. 2421. A. Flós-Mártini, Ker.), has narrower and longer lvs., and all the segments acute or cuspidate. Chile. Common and variable in cult. A. Hodkeri, Lodd., is a form of A. Ligtu.

The A. Ligtu of B.M. 125 is A. caryophyllè , Jacq., with long-clawed, very unequal segments in two sets or lips, red and red-striped. Brazil.

violàcea, Phill. St. 1-2 ft.: Ivs. scattered and spreading, 1 in. or less long, those on sterile shoots larger, ovate-oblong and 5nerved: tls. on forked pedicels in a 5-rayed umbel, $1 \frac{1}{2}-2$ in. long, bright lilac, the outer segments obovate, truncate and with a short cusp, the inner oblong-acute, spotted. Chile.

L. H. B.

\section{ALTERNANTHERA. See Telanthera.}

ALTHAेA (Greek, to cure). Malvdceo. Tall biennial or perennial herbs, of the warm-temperate regions of the Old World, of about a dozen species. Fls. axillary, solitary, or racemose in the axils or at the summit of the stem, with 6-9 bracts below the calyx. $A$. frùtex and $\boldsymbol{A}$. coelèstis, Hort., are Hibiscus Syriacus.

officinàlis, Linn. Marsh MaLLOW. Downy: lvs. ovate, often heart-shaped or 3-lobed, frequently undivided, tomentose: fls. 1 in. across, blush or rose, clustered in the axils of the lvs. Perennial. E. Eu. - Root used for mucilage and for other purposes; also medicinal. The root of commerce has its brown outer covering removed. Rarely cult., but occasionally escaped in marshes near the coast.

ròsea, Cav. HolLyноск, which see for culture. St. strict and spire-like, hairy: lvs, large and rough, rounded-heart-shaped, wavy-angled or loued: fls, large and nearly sessile, in a long wand-like raceme or spike, in many forms and colors. Biennial. China. B.M. 3198

ficifdlia, Cav. Biennial, 5-8 ft.: lvs. 7-lobed, toothed. fl. yellow or orange, large, in terminal spikes, showy. Eu. Int. by Franceschi, Cal., as A. sidoefolia.

ALUM ROOT. See Heuchera.
L. H. B. 
ALYSSUM (classical name). Cruciferce. Low plants, mostly perennials and used for rockwork. The Sweet Alyssum is one of the commonest annuals, grown both

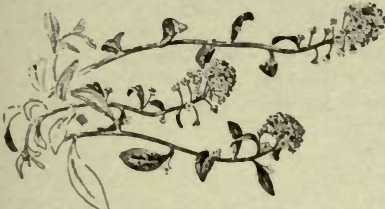

74. Sweet alyssum $(\times 1 / 4)$. in the open and forced in benches, beds or pots. It is of the easiest culture, either indoors or out. The com. pact vars, are most prized for pot-culture. Under glass, requires temperature of a car nation house. It will stand considerable frost in the open, and may be sown early; it blooms all summer, and until killed by winter. Useful for window gardens and baskets. For winter bloom, sow seeds late in Aug. or in Sept. When blooms begin to fail, cut back the plant, and it will bloom again. The perennial species are usually prop. by dividing the roots; also by cuttings and seeds.

$$
\text { A. F'ls, white. }
$$

marítimum, Lam. (A.odordtum, Hort.). SweET Alyssum. Fig. 74. A low, spreading, light green annual, with lanceolate or linear entire lvs., tapering to the base, and small honey-scented fls. in terminal clusters, which become long racemes. Eu. Many cult. vars.: Bénthami or compáctum, a dwarf and compact form, not over 6 in. high ; variegàtum, with pale white-edged Ivs.; giganteum, robust, broad-lvd.; procúmbens, of spreading habit; and various horticultural forms with trade names.

spinjsum, Linn. A woody-stemmed little perennial, with lanceolate acute silvery lvs., spiny fl. branches, and very small numerous fls. En. Rockwork; 3-6 in.

$$
\begin{aligned}
& \text { AA. Fls.yellow: perennials. } \\
& \text { B. Lvs. } 1 / 2 \text { in. or less long. }
\end{aligned}
$$

serpyllifolium, Desf. (A. alpéstre, Linn.?). Dwarf (3-4 in. high), somewhat woody at the base, with rough hoary Ivs., and pale yellow fls. in racemes. Eu. Int.1892

\section{BB. Lvs. 1 in. or more long.}

saxátile, Linn. GoLden-TUFT. A foot high, woody at base : Ivs. oblanceolate or ovate-lanceolate, entire or wavy, hoary-tomentose : fis. golden yellow, numerous, in little compact clusters. Eu. B.M. 159. A.F. 5:37. - Common in rockwork, making a spreading mat, blooming in early spring. There is a dwarf var. (compdctum and a pretty variegated variety sold as $A$. variegdtum.

Gemonénse, Linn. Less hardy than the last: lvs. lanceolate, velvety : fls. lemon-yellow: st. usually more woody at base. Eu.

rostràtum, Stev. (A. Wièrzbickii, Heuff.). About 20 in.: lvs. 2 in. long, broad-oblong, pointed, hairy: fls. deep yellow, in dense heads, in summer. Asia Minor.

argénteum, Vitm. Dwarf and dense grower, 15 in. or less: lvs. oblong-spatulate, silvery beneath: fls. yellow in clustered heads, all summer. Eu.

L. H. B.

AMANITA. See Mushroom.

AMARABOYA (native name). Melastomacece. A genus of only three species of tender shrubs from New Grenada, which are showy both in foliage and flower. Lvs. large, opposite, sessile, with three prominent nerves, brownish red beneath: fls. large, cymose; petals usually 6; stamens 12-15. For cult., see Pleroma. Not known to be in American trade.

A. amábilis, Linden. Fls. white, margined carmine; stamens white; style red, exserted. I.H. 34: 9. - A princeps, Linden Fls. carmine; stamens white; styles white. I.H. $34: 4 .-A$ spléndida, Linden. Fls. $6 \frac{1}{2}$ in. across; petals narrower at the base than in the other species; stamens yellow; style red, exserted. I.H. 34: 34 .

AMARÁNTUS (Greek, unfading). Amarantdece. AMARANTH Coarse annual plants, grown for foliage and the showy fl.-clusters. Related to the Cockscomb. The Amaranths are usually treated as open-air annuals. They thrive best in a hot and sunny situation. In very rich soil the Ivs. become very large but usually lack in bright coloring. Seeds may be sown in the open or in frames. The dwarf and compact vars., which often have beautifully variegated foliage, may be grown in pots or used for bedding. Give plenty of room.

A. Lvs. linear-lanceolate, long and drooping.

salicifolius, Veitch. Graceful pyramidal habit, 3ft.: lvs. 5-8 in. long and $1 / 4 \mathrm{in}$. wide, wavy, bronze-green, changing to orange-red. Philippines. G.C.I. 1871:1550. F.S. 19: 1929 .

$$
\text { AA. Lvs. broad, mostly ovate. }
$$

$$
\text { B. Spikes drooping. }
$$

caudàtus, Linn. Love-Lies-BLeEdiNG. Fig. 75. Tall and diffuse $(3-5 \mathrm{ft}$.$) : lvs. ovate to ovate-oblong, stalked,$ green : spikes red, long and slender, naked, in a long and drooping panicle, the terminal one forming a long, cord-like tail. Also vars. with yellowish and whitish panicles. India. G.W. 6:709.-Common, and an old favorite.

atropurpureus, Hort. Foliage blood-red. Probably a form of A.caudatus. Perhaps the same as Roxburgh's A. atropurpureus from India.

\section{Bв. Spikes erect.}

hypochondriacus, Linn. Prince's Feather. Tall and glabrous : Ivs. oblong-lanceolate, acute: spikes blunt, aggregated into a thick, lumpy terminal panicle, of which the central part is elongated: bracts long-awned.-An old garden plant, with the heavy heads variously colored, but mostly purple. Lvs. mostly purple or purplegreen. Probably Asian. Cult. also as A.cruéntus and A. atropurpùreus. Sometimes a weed in cult. grounds.

paniculàtus, Linn. St. usually pubescent : lvs. usually broader than in the last, and spikes acute or acutish, and in an open, more graceful terminal panicle: bracts awn-pointed.-Common, and sometimes a weed. LVs. usually green, but often blotched or bright purple. A showy form is A. speciosus, Sims, B.M. 2227. Cult. also as A.sanguineus. Probably originally Asian.

Gangetticus, Linn. (A.melanchólicus, Linn.). Usually a lower plant, $3 \mathrm{ft}$. or less and often only $1 \mathrm{ft}$., with thin, ovate-pointed Ivs., and fls, in short, glomerate, interrupted spikes, both terminal and axillary.-Very variable. Cult. by Amer. Chinese (Fig. 76) as a pot-herb under the name of Hon-toi-moi, with green lvs. (Bailey, Bull. 67. Cornell Exp. Sta.). A form used for bedding, with foliage red, yellow and green, is JOSEPH's COAT, or A tricolor (G.W. 6: 709). A form with fiery red lvs. is known as $A$. hicolor. Various dwarf and compact bedding forms. Used more for foliage than for fl. panicles. Asian.

Other garden Amaranthuses are A. Abyssinicus, dark red; A.gibbdsus, Hort., a form of $A$. paniculatus; A. Hénderi, probably a hybrid with A.salicifolius, or a

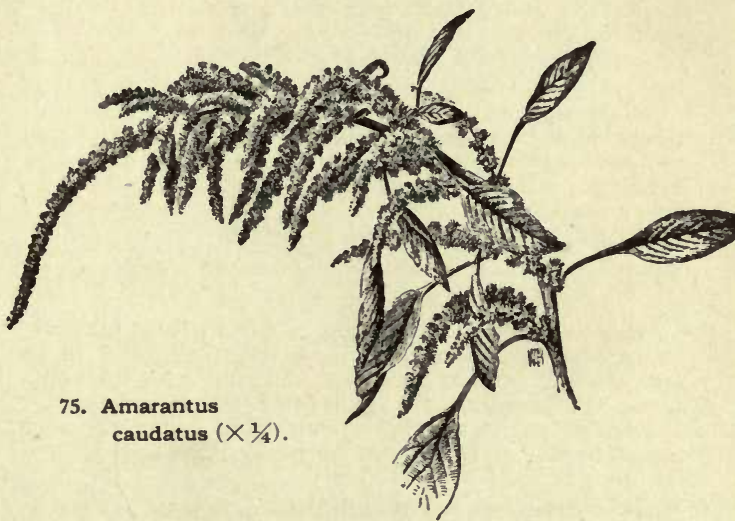

var. of it, with long-drooping, orown lvs., and tall, pyramidal stature; $\boldsymbol{A}$. Górdoni, or Sunrise, with bronzy banded Ivs. and brilliant scarlet Ivs. on top; $\boldsymbol{A}$. supérbus, int. 1893. Other Amaranthuses are common weeds: $\boldsymbol{A}$. 
retrofléxus, Linn., A. chloróstachys, Willd., A. álbus, Linn., A. blitò̀des, Wats., A. spinòsus, Linn. The two first are known as pigweeds and beet-roots; the third is a common tumbleweed.

L. H. B.

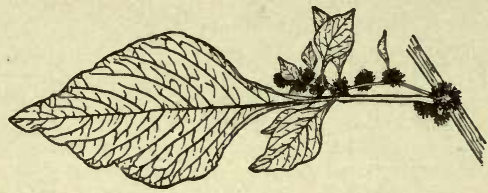

76. Amarantus Gangeticus $(\times 1 / 4)$.

AMARYLLIS (classical name). Amaryllidacece. Bulbous plants from Cape of Good Hope, flowering in late summer or in fall, the lvs. appearing later. Perianth with a short ribbed tube, the divisions oblong or lanceolate, the filaments distinct and no scales between them, fis. 5-12, in an umbel, on a tall scape. Monogr. by Herbert, Amaryllidaceæ, 1837 ; and by Baker, Handbook of the Amaryllideæ.

In dealing with the culture of Amaryllis, it is customary to speak of the genus in its horticultural sense, - to include Hippeastrum and related things. Such is the understanding in the following cultural directions. There are two widely differing methods of cultivating the Amaryllis to produce showy flowers in the spring months, - the border method and the pot method. Any one trying both of these methods will soon come to the conclusion that they differ not only in method, but in flower-producing results. The first method is to plant the bulbs out in a prepared border after they are done flowering, say about the middle of May. The border selected should have perfect drainage, and, if convenient, be situated on the south side of a house or wall, fully exposed to the sun during the greater part of the day. The bulbs are set out in rows, necessarily with as little disturbance of the roots as possible, because if they are bulbs which have undergone similar treatment the previous year, by the middle of May they have made a considerable number of new roots; besides, the foliage also has gained some headway, and may be considered in the midst of actual growth. In planting, carefully firm the soil around the old balls, give one watering, and on the succeeding day, after the surface of the soil has been raked over, cover to the depth of 2 inches

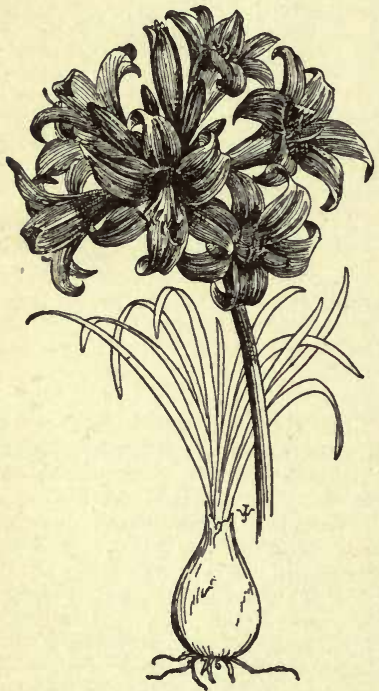

77. Amaryllis Belladonna. with half-decaved cowmanure. With frequent waterings during the summer and the removal of weeds, they will need no more attention until the approach of cool weather, when they should be lifted, sized, and potted; however, at this season, if wet weather has predominated, some of the bulbs will be in a semi-dormant state, while the majority will yet be in active growth. Here is the drawback to this method : the roots are large and fleshy, they take up considerable room in a 6- or 7 -inch pot, and the soil cannot be evenly distributed amongst them, neither can it be made as firm as it should be. The result is the partial decay of the roots and leaves, and in the spring, when the flower scapes appear, they are developed at the expense of the bulh, through having insufficient roots to take up nourishment from the soil. The flowers which are produced ure small, few in number, and do not show what the
Amaryllis is capable of. To partly ameliorate these conditions, the bulbs in active growth at lifting time may be heeled-in on a greenhouse bench until they gradually ripen, taking care that some of the soil is retained on the roots; otherwise the ripening process is altogether too rapid, so that the roots and leaves suddenly lose their robust nature, become flabby, and eventually die. For this method, it can be said that a larger number of bulbs can be grown with less trouble than by the pot method, but neither bulbs nor flowers compare in size with those kept in pots the year round. For the purpose of simply increasing stock, the outdoor method is to be preferred. Most of the kinds are naturally evergreen; potting under those conditions is best done either after the plants have made their growth in the fall or after they have finished flowering in April. When done in the fall, they are allowed to remain rather dry during the winter; this will keep the soil of the original ball in a sweet condition until the time arrives to start them into growth, which may be anywhere after the 1st of January, or even earlier if necessary. They will winter all right, and keep their foliage, in a brick frame in which the temperature is not allowed to fall below $45^{\circ} \mathrm{F}$. By the beginning of February, in a structure of this sort, they will be showing flower-scapes, and should then be taken to a position where more heat and light can be given. A weak solution of cow-manure will much help the development of the flowers. When in bloom, a greenhouse temperature, with slight shade, will prolong the flowering period. After flowering, the greatest care should be taken of the plants, as it is from that period till the end of summer that the principal growth is made. A heary loam, enriched with bone-dust and rotted cow-manure, suits then well. The seeds of Hippeastrums should be sown as soon as ripe, covered very lightly with finely sifted leaf-mold, and if this shows a tendency to dry too quickly, cover with panes of glass until germination takes place. As soon as the first leaves are developed, they should be potted in the smallest sized p ts and kept growing. In the propagation of varieties, it will be found that the large bulbs make two or more offsets each season; these should not be detached until it is certain that they hare enough roots of their own to start with after being separated from the parent. If a well-flowered specimen clump is desired, the offsets may be allowed to remain attached to the parent; they will, in most cases, flower the second year under generous treatment. A maryllis $B$ Blladonna and the plant known as $A$. longiflora (really a Crinum) are hardy in the District of Columbia; $A$. longiflora thrives even in damp, heavy soils, with no protection, and flowers abundantly each year. The seeds are about the size of a chestnut, and if not gathered as soon as ripe, they are apt to germinate on the surface of the ground during the next rainy spell succeeding the ripening. A.Belladonna needs a warm, sheltered spot, with deep planting.

Cult. by G. W. Oliver.

Belladónna, Linn. Belladonna Lily. Fig. 77. Scape 2-4 ft., with a 2-lvd. dry spathe or involucre just underneath the umbel: fls. lily-like, short-tubed, and' flaring, with pointed segments and style, and 6 stamens deflexed, on short pedicels, fragrant, normally rose-color; scape solid : lvs. strap-shaped, canaliculate and acute. B.M. 733. Gn. $33: 641,47$, p. 46,49, p. $276,54: 414$. G.C. III. 24:315. An old favorite. There are varieties ranging from white to red, and varying in shape and size of $\mathrm{fls}$. A. blánda, Gawl (B.M. 1450), is a large form, with white fls., fading to blush. A. Hállii, Hort., said to be from N. China, and reported as hardy in New England, is apparently a Lycoris. For var. ròsea perfécta, see Gt. 45 , p. 443 ; spectábilis trícolor, 45 , p. 358. See Brunsvigia for A. gigantea and orientalis; Crinum for A.longifolia and ornata ; Hippeastrum for A. aulica, equestris, fulgida, Johnsoni, Leopoldii, pardina, procera, Regina, reticulata, vittata; Lycoris for $A$. aurea; Nerine for A. Nerine; Sprekelia for A.formosissima; Sternbergia for $A$. lutea; Vallota for A purpurea; Zephy. ranthes for $A$. Atamasco and candida. The following trade names probably belong to other genera, most likely to Hippeastrum : A. cròcea, Gravedna, macrántha, refúlgens. A. erubéscens, of Horsford's Cat., 1899 (by mistake printed crubescens), is Zephyranthes erubescens, Wats. It is not now offered.

L. H. B 
AMASONIA (after Thomas Amason, early American traveler). Verbendcece. Greenhouse shrub from Trinidad, with long, tubular, hairy yellow fls. and bright red bracts, which remain attractive two or three months at a time.

calycina, Hook. f. (A. punicea, Hort. not Vahl.). Lrs. 6-12 in. long, elliptic, acuminate, coarsely irregularly toothed or sinuate, glabrous, except the floral ones: fls. $11 / 2-2$ in. long, drooping; calyx nearly 1 in. long, red. B.M. 6915. Gn. 27: 479. R.B. 20: 13.

AMBRostNIA (Giacinti Ambrosini, an Italian). A roidece. A dwarf, perennial, tuberous herb of Italy and Algeria. Half-hardy; planted in the open or in pots, and blooms in the fall. A single species.

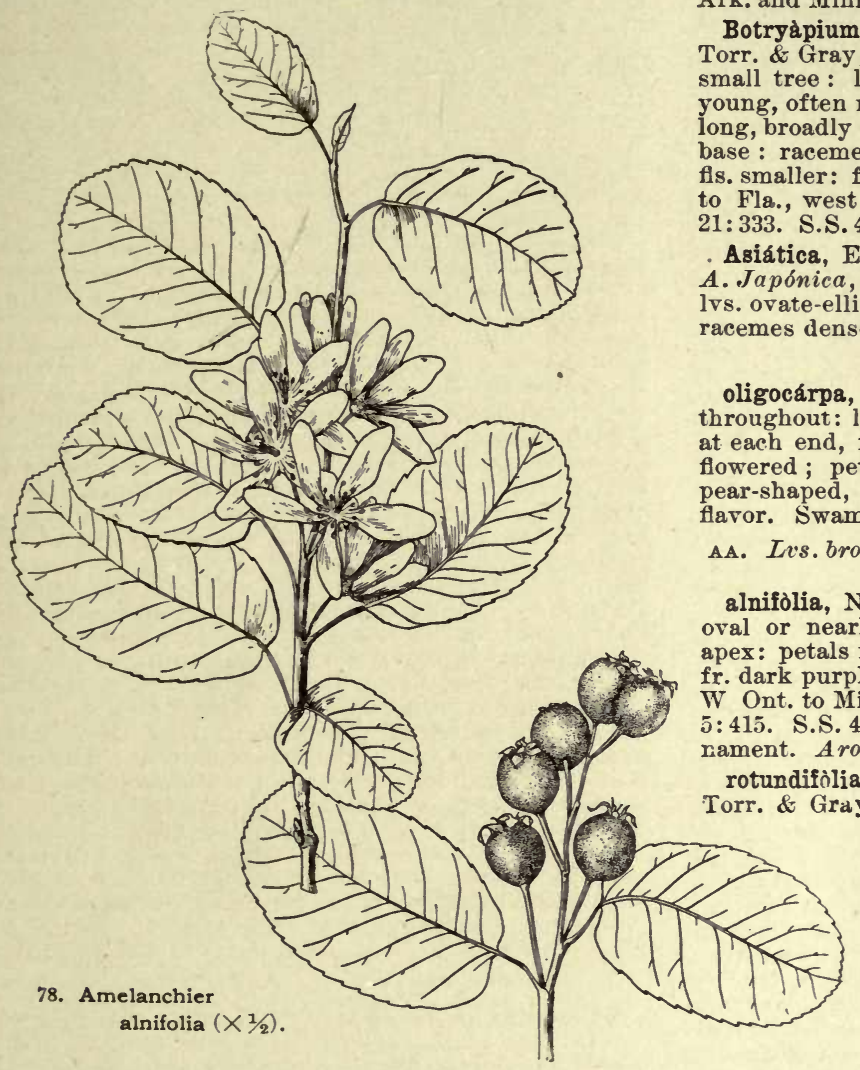

Bássii, Linn. Three or 4 inches : lvs. 2 or 3, overtopping the spathe, the leaf-blade ovate or ovate-elliptic, obtuse, often retuse: spathe $3 / 4 \mathrm{in}$. long, tipped with a brown tail, divided lengthwise, the anthers being in one compartmeut (which has a hole to admit insects), and the solitary ovary in the other, thus preventing automatic close pollination. B.M. 6360.-Prop. by seeds started inside or in frames, or by division in spring. There is a narrow-leaved form (var, angustifolia, Guss.), a spotted-leaved form (var. maculdta, Engler), and a form with pale green reticulations (var. reticuldta, Engler).

L. H. B.

AMELÁNCHIER (Savoy name). Rosàcece. Shrubs or small trees of Eu. A sia and Amer. lvs. alternate, simple, usually serrate: fls. white, in racemes, rarely solitary; calyx tube campanulate, 5 -lobed, lobes narrow, reflexed, persistent; petals 5 ; orary $2-5$-celled, each subdivided and containing 2 ovules: berry round or oblong, with prominent cavity, red or dark purple, sweet, juicy. Temperate regions around the globe. Species few and closely related. Desirable for ornament, the dwarf varieties also valuable as fruit-bearing plants.
Bloom very early in spring, often before lvs. appear. They thrive upon a variety of soils and over a wide range, succeeding well in dry climates. Prop. by seeds or suckers. A. ovdlis and A. alpina of horticulturists, sometimes purporting to come from Eu., are our native Pyrus nigra, which see. Seo Juneberry.

A. Lvs. acute or acuminate, finely serrate.

B. Petals narrow, lanceolate. oblanceolate or spatulate.

Canadénsis, Medic. Common SHAD-Bush. Tree, 25-40 ft., upright, narrow, oblong, round-topped : trunk tall, straight: branches small, spreading: lvs. oval or ovate, acute or acuminate, rounded or cordate at base, sharply and finely serrate, soon becoming glabrous : fruit globose. Early summer. Newfoundland to Fla., west to Ark. and Minn. S.S. 4: 194.

Botryàpium, DC. (A. Canadènsis, var. oblongifòlia, . \& Gray). Common Dwarf JUNEBERRy. Bush or lvs, and flower-stalks whitish woolly when young, often nearly or quite glabrous when old; lvs. obelliptical, seldom cordate, often pointed at. - racemes dense, shorter than in $A$. Canadensis; s. smaller: fr. juicy, of good flavor. New Brunswick. Fla., west to Mo. and Minn. B.M. 7619. G.C. III. S.S. 4:195, as A.Canadénsis var.obovallis, Sarg. siática, Endl. (A.Canadénsis, var. Japónica, Miq. a ónica, Hort.). Small tree with slender branches: vs. ovate-elliptical, acute, densely woolly wheu young: eompound. China and Jap.

Bв. Petals broad, obovate.

2oem. Low shrub 2-9 ft., nearly glabrous. hroughout: lvs. thin, narrowly ovate or oblong, pointed. at each end, finely and sharply serrate : racemes fewpear-shaped, with heavy bloom, sweet, of pronounced. flavor. Swamps, Lab. to N. Y. G.F. 1:247.

A. Lvs. broader, obtuse or rounded at apex, coarsely serrute or dentate.

Nutt. Fig. 78. Shrub : lvs. thick, broad, oval or nearly circular, coarsely toothed toward the apex: petals narrowly obovate or oblanceolate, cuneate: fr. dark purple or blue, with bloom, large, sweet, juicy. W Ont. to Mich., New Mex. and westward. G.F. 1:185; $5: 415$. S.S. $4: 196$. - A raluable species for fruit or or Aronia alnifolia of some lists.

rotundifòlia, Roem. (A. Canadensis, var. rotundifòlia. Torr. \& Gray). Low, stragglish bush: lvs. rounded, coarsely serrate : fr. ripening after $A$. Canadensis. N. Brunswick to Minn.

spicata, Dec. Small bush 1-3 ft.: 1rs. elliptic or oval, rounded at both ends or somewhat cordate at base : fls in numerous 4-10-fld. racemes: plant woolly on young growths, but becoming glabrous. Dry, rocky places. Pa. and N.J.

vulgàris, Mönch. Service-BerRY. Dwarf: shrub: lvs. roundish, coarsely serrate, woolly beneath when young : racemes short; petals longnarrowly oblanceolate : fr. blue-black. Cent. Eu. - Cult. for ornament ; also for fr. under the name of European. Juneberry.

Fred T. CARD.

AMES, FREDERICK LOTHROP (June 8, 1835-Sept. 13,1893 ), of the fourth generation of a family distinguished in the history of Massachusetts enterprise, was. born in North Easton, in that state. He was graduated from Harvard College in the class of 1854 , and devoted his life to the management of great commercial and industrial interests. Business did not occupy all his attention; he was a Fellow of Harvard College, a trustee of the Massachusetts Society for Promoting Agriculture, and of the Museum of Fine Arts; and an active and faithful director of charitable and benevolent institutions. A munificent patron of arts and sciences, he was successful in stimulating the increase of knowledge in many fields of human research. Devoted through his whole life to horticulture, he gained distinction for his wide and accurate knowledge of tropical orchids and their cultivation, and his collection of these plants at his country place in his native town was the most complete 
in the New World. His important services to botany and horticulture are commemorated in Laelia Amesiana, Loelia anceps var. Amesiana, Phalcenopsis F'. L. Ames, Cypripedium Amesianum, Cypripedium insigne var. Amesianum, Vanda Amesiana, Stanhopea Amesiana, Miltonia vexillaria var. Amesiana, Odontoglossum Rossia var. Amesiana, and Cattleya Hardyana var. Amesiana.

C. S. SARgENT.

AMHERSTIA (Countess Amherst and her daughter, Lady Amherst, promoters of botany in India). Legumindsce. One of the noblest of flowering trees, native to India, where it reaches a height of $40 \mathrm{ft}$. and more. Gaudy red fls. 8 in. long, with wide-spreading petals, the upper ones gold-tipped, and colored petal-like bracts, in long, hanging racemes : lvs. pinnate, nearly $3 \mathrm{ft}$. long. The tree first flowered in Eng. in 1849. It requires hothouse treatment. The fls. last only 2 or 3 days. Demands rich, loamy soil, and abundant moisture during the growing season, after which the wood must be ripened firm. B.M. 4453. F.S. 5: 513-516.

\section{AMIÁNTHIUM. See Zygadenus.}

AMMOBIUM (Greek, living in sand). Compositoe. Hardy herb, cult. as an everlasting or immortelle. Florets perfect, yellow, surrounded by a dry, silvery white involucre, and subtended by chaffy scales; pappus of 2 bristles and 2 teeth. Commonly treated as an annual, but seeds are sometimes sown in Sept., and the plant treated as a biennial. Of easiest culture, the seeds being sown where the plants are to grow. In the N., sow seeds in spring. Cut the fls. before they are fully expanded, and hang in a dry, shady place. They will then remain white.

alàtum, R. Br. Three ft. or less high, erect and branchy, white-cottony, the branches broadly winged: early root-lvs. ovate at the ends and long-tapering below (javelin-shaped); st.-lvs. linear or linear-lanceolate, entire or nearly so : heads 1-2 in. across, the involucre becoming pearly white. Australia. A large-headed form is var. grandiflorum.

L. H. B.

AMMOCHARIS (ammos, sand; charis, beauty). Amaryllidacees. Greenhouse bulb from Cape of Good Hope. J. G. Baker, Amaryllideæ, p. 96. For cult., see Bulbs.

falcàta, Herb. Bulb ovoid, sometimes 6-9 in. in diam. with brown tunies: lvs. 1-2 ft. long, 1 in. wide, strap shaped, spreading, produced before the lvs.: fls, 20-40, in an umbel, bright red, fragrant. Winter. Probably the fruit figured in B.M. 1443 is that of a Brunsvigia, mismatched with the flowers.

Ammocharis falcata requires rich, loamy soil. It starts to grow in the spring. Give plenty of water during growing season in summer. It can be cultivated out-ofdoors. When perfected and finished in autumn, the bulb can be put under the greenhouse bench ; keep moderately dry in sand or earth ; can be potted in January, after which it will soon throw out its fine, fragrant blooms.

Cult. by H. A. Siebrecht.

AMMONIACAL CARBONATE OF COPPER. See Fungicide.

AMMÓPHILA (Greek, sand-loving). Graminece. A coarse perennial, with long, hard rootstocks. Spikelets 1-fid., in large, spike-like panicles, jointed above the empty glumes: flowering glume surrounded at the base by a tuft of hairs: axis of spikelet terminating in a small bristle-like rudiment. Species one. Eu. and N. Amer.

arenària, Link. (A. arundind̀cea, Host.). BEACH Grass. Marram Grass. Abundant along the sandy coasts of the Atlantic, and the great lakes. Adapted for binding drifting sands of coasts.

\section{P. B. KENNEDY.}

AMOMUM (Greek-made name). Scitamindcece. Hothouse ginger-like herbs, with narrow entire lvs., and fls. in dense cone-like spikes, which are usually near the base of the plant or on a scape. Closely allied to Alpinia (which see for culture).

Cárdamon, Linn. Cardamon. Thick, spiey, lanceolate lvs.: plant 4-8 $\mathrm{ft}$ : : fls. brownish, in a recumbent compound spike. E. Ind. Produces the Cardamon seeds of commerce. Not to be confounded with Elettaria Carda. momum (which see).

Other species are $A$. angustifòlium, Sonner, with linear-lanceolate lvs. and yellow fls., Madag.; A. Dánielli, Hook., lvs. lanceoblong and fl.large, red and yellow, Afr.; A. Granum-Paradisi, Linn. (A. grandiflorum, Smith), with colored stems and whitetinted fls., Afr.; A. magnificum, Benth. \& Hook. (Alpinia magnifica, Roscoe), 10-12 ft., fls. very numerous, in a gaudy bracted head, large, red, Mauritius, B.M. $3192 ; A$. vittàtum, Hort. $=\mathrm{Al}$ pinia vittata ; $A$. vitellinum, Lindl., with oval lvs. and yellow fls., E. Ind. L. H. B.

AMORPHA (Greek amorphos, deformed; the fls. are destitute of wings and keel). Legumindsa. Shrubs: lvs. alternate, odd-pinnate, deciduous, with entire leaflets : fls. in dense, terminal spikes, small, papilionaceous, but without wings and keel; stamens exserted: pod short, slightly curved, with 1-2 seeds. Eight species, 6 in N. Amer. Hardy flowering shrubs, with graceful foliage, well adapted for small shrubberies, especially in somewhat dry and sunny situations. Prop. usually by seeds ; also by greenwood cuttings under glass in early summer, or by hardwood cuttings, placed in sheltered situations early in fall and left undisturbed till the following autumn. They may be grown, also, from layers and suckers.

canéscens, Nutt. Lead Plant. Low shrub, 1-3 ft., densely white-canescent: 1vs. sessile, $2-4$ in. long, leaflets $21-49$, nearly sessile, oval or ovate-lanceolate, 4-7 lines long: fls. blue, the spikes crowded into terminal panicles. June. S. states. Mn. 5:707. B.M.6618. R.H. 1896:280 - Handsome free-flowering shrub of dense habit, well adapted for rockeries and borders of shrubberies in sunny and well-drained situations.

fruticòsa, Linn. BASTARD INdigo. Shrub, 5-20 ft.: lvs. petioled, 6-16 in. long, leaflets 11-21, oval or elliptic mostly obtuse and mucronulate : spikes dense, $3-6$ in. long, usually in panicles; fls. dark purple. From Wis. and Pa. south. B.R. 5: 427. - Interesting ornamental shrub of spreading habit, with fine, feathery foliage ; remarkable for the unusual color of its dark violetpurplish fls. A very variable species; slightly differing forms have been described, and are cult. under many different names, as, e. g.: A. Caroliniana, Croom ; croceolanata, Wats.; dealbata, Hort. ; elata, Hort. ; fragrans, Sweet; glabra, Desf.; lavigata, Nutt.; Lewisi, Lodd.; Ludoviciana, Hort. ; mimosifolia, Hort, ; ornata, Wend.; paniculata, Torr. \& Gr. ; Tennesseensis, Shuttlew.; Texana, Buckl.

A. Califórnica, Nutt. Allied to A. fruticosa. Pubescent : sts. and leaf-stalks furnished with prickly glands : spikes usually single. Calif. $-A$. herbàcea, Walt. (A. pubescens, Willd.), $2-4 \mathrm{ft}$. lvs. nearly sessile, pubescent or glabrous ; leaflets with black glands beneath : spikes mostly panicled ; fls. blue or white. S. states. L.B.C. 7: 689.-A microphýlla, Pursh. (A. nana, Nutt.) One ft high. leaflets small, 1/in. long crowded glandular beRocky Mts.-A, virgàta, Small. Allied to A. fruticosa. Perennial, 2-6 ft., sparingly branched: leaflets broad, coriaceous: spikes single or few. S. states.

ALFRED REHDER.

AMORPHOPHÁLLUS (Greek-made name). A roìdex. Giant aroids, from the eastern tropics, grown as curiosities in hothouses. Spathe (or "flower") springing from the great bulb-like tuber in advance of the lvs., the latter usually pedately compound: differs from Arum and related genera by technical characters. Monogr. by Engler in De Candolle's Monographiæ Phanerogamarum, vol.2, 1879.

Amorphophalluses are propagated by offsets of the tubers. Towards the end of March the plants should be taken from their winter quarters and placed on the stages of a moderately warm greenhouse and kept moist, where, if the tubers are strong enough, they will soon flower. The leaves begin to grow immediately after the flowering season. Towards the end of May they should be planted out in the open ground, or they may be used in subtropical bedding. Plants should be lifted in the fall, before frost, and potted in any good, rich soil, and placed in a warm greenhouse to ripen off the leaves, after which they may be stored away under the greenhouse stages, or any convenient place where the temperature does not fall below $50^{\circ}$, giving just sufficient moisture to keep the tubers from shriveling.

Cult. by EDward J. Cannine. 
Rivièri, Dur. Devil's Tongue. SNake Palm. Fig. 79. Scape (sent up in early spring) preceding the lvs., 3-4 $\mathrm{ft}$., lark colored and speckled with light red: If. often $4 \mathrm{ft}$. across, pedately decompound, the petiole mottled, standing on a stalk like an umbrella: spathe rosy, calla-like, with a long-projecting and slender dark red slightly curved spadix, the whole "flower" often measuring $3 \mathrm{ft}$. long. Cochin China. R.H. 1871, p. 573. - The best known species in Amer. gardens. Has a strong and disagreeable odor.

campanulàtus, Blume. Stanley's WASH TUB. Scape lower $(2 \mathrm{ft}$. or less): spathe nearly or quite $2 \mathrm{ft}$. broad and 15 in. high, with a horizontal, spreading fluted border(not calla-like), red-purple on the margin and grayish spotted white lower down, and becoming purple in the center : spadix 10-12 in. high the purple top enlarged and convoluted: If. much as in $A$. Rivieri: tuber weighing 8-10 lbs., shape of a flat cheese. An old garden plant from E. Ind. B.M. 2812. F.S. 15:1602-3. G.C. $1872: 1720,1721$; III. 5:755.

gigantès, Blanc. "Fl. larger than A. campanulatus (often 2 ft. across) and much more pleasing in color, shading from deep red to cream color towards the center. The club-shaped spadix is dark maroon, with yellow and red base. After flowering, the foliage - stem appears, $-a$ stout foliage - stem appears, - a stout with gray. After growing at the

79. Inflorescence and bit of leaf of Amorphophallus Rivieri. rate of several inches a day, it ex pands into a large palm-like leaf, of a rich, dark green color, often measuring $5 \mathrm{ft}$. across." Blane, 1892, received "under this name from India." $\boldsymbol{A}$. campanulatus? Probably not the A.giganteus of Blume.

Simlénse, Blanc. "Fl. 15 in. long, the inside of peculiar golden color, spotted purple; the back is metallic brown. Fine palm-like foliage." The cut in Blanc's catalogue shows a spathe produced into a long foliaceous summit, and a long, slender, recurved spadix. Probably of some other genus : very likely an Arisæma.

A. Afzelii, Hort. (Corynophallus Azelii, Schott) $=$ Hydrosme Leonensis. - A. Eichleri, Hook. f. Spathe 2 in. across, purple and white : spadix 5 or 6 in. high, thick, brown: if. single, much divided. W. Afr. B.M. 7091.-A. Lacoùrii, Linden. (Pseudodracontium Lacourii, N.E.Br.). Petioles barred with yellow; blades much cut, green, spotted white. Cochin China. I.H. 25: 316.A.Leopoldianus, Nicholson (Hydrosme Leopoldiana, Masters). Spathe reddish, long acuminate on one side, with undulate margins: spadix $2-3 \mathrm{ft}$., terete, recurved: If. $2-3 \mathrm{ft}$. across. Congo. gins : spadix $2-3 \mathrm{ft}$., terete, recurved: 1f. $2-3 \mathrm{ft}$ across. Congo. tium asperum. $-A$. Titànum, Beccari. One of the most remarktium asperum. - A. Titànum, Beccari. One of the most remark$45 \mathrm{ft}$. in circ.: spathe $3 \mathrm{ft}$. in diam.: spadix $6 \mathrm{ft}$. high. Bloomed at Kew in 1890 , the tuber dying thereafter. Sumatra. B.M. 7153-5. G.C. III. 5:748.

L. H. B.

AMPELOPSIS (Greek ampelos, vine, and opsis, likeness). Vitacea. Shrubs, climbing by tendrils opposite the lvs.: lvs. alternate, petioled, digitate, bipinnate or simple : corymbs opposite the lvs. or terminal ; fls. perfect, greenish and small ; petals and stamens usually 5 : fr. a 1-4-seeded berry. Allied to Vitis, but easy to distinguish, even in the winter state, by its bark bearing lenticels and the white pith of the branches, while Vitis has a shredding bark and brownish pith. About 20 species in N. Amer., E. Asia and Himal. Hardy and ornainental climbing vines, thriving in almost any soil. Prop. by seeds and by hardwood or greenwood cuttings. A. quinquefolia is usually increased by hardwood cuttings, while $\boldsymbol{A}$. tricuspidata grows best from seeds nlanted under glass or out-of-doors; also from greenwood cuttings in spring or early summer, under glass. Layers also root readily. All species may be prop. by cuttings with a good eye placed in sandy soil under bellglasses in Sept. Monogr. by Planchon in De Candolle, Monographiæ Phanerogamarum, 5:447-463. Cf. Cissus.

A. Tendrils mostly disk-bearing: berries dark purple with blue bloom, pea-sized. (Parthenocissus.)

quinquefolia, Michx. (A. hederdcea, DC. Natis quinque. fòlia, Lam.). Virginia CreEPER. Fig. 80. High-climbing: Ivs. digitate; lfts. usually 5, elliptic or oblong-obovate, coarsely serrate. N.Amer. Em. 2: 5335. Var. Iadicantíssima, Rehder. Young branches and lfts. beneath pubescent: tendrils with many ramifications and well developed disks. Var. murorum, Rehder. (A. hederàcea, var. muròrum, Focke. A. muròrum and murd̀lis, Hort.). Inflorescence and tendrils like the former; lfts. glaucous and glabrous beneath. Var. Engelmanni, Hort. Similar to the last, with smaller and more dense foliage. Var. latifolia, Dipp. (ARóylei, Hort.). Of vigorous growth : lvs, very large, shining. Var. Græbbneri, Rehder. Pubes cent, intense scarlet in fall. Gt. 48: 1462. Var. vitàcea, Knerr. Aërial roots none, and the tendrils scarcely disebearing: berries large and early. Mich, to Kans. Does not cling to walls. - A very valuable climber of vigorous growth, coloring bright scarlet in autumn; the varieties radicantissima and murorum well adapted for covering walls, clinging firmly, growing more straight upward than the following species.

tricuspidàta, Sieb. \& Zucc. (A. Vèitchi, Hort. A. Roylei, Hort. Vitis incónstans, Miq.). JaPANESE Ivy. Boston Ivy. Figs. 81, 82. High-climbing, with short and disciferous tendrils: lvs. 3-lobed or 3-foliolate, coarsely and remotely dentate, shining and glabrous on both sides: racemes short-stalked. China, Jap. R.B. 1877:11. Gng. 4:353, 1:373. - A hardy and very useful climber, clinging firmly and covering walls densely; the glossy foliage stands dust and smoke well, and turns to a brilliant orange and scarlet in fall. Probably the favorite of all hardy vines in cities.

\section{AA. Tendrils without disks: not climbing very high.}

B. Lvs. not lobed or rarely tricuspidate.

cordàta, Michx. (Vitis indivisa, Willd. Cissus Am. pelópsis, Pers.). Nearly glabrous : lvs. cordate, roundish-ovate, acuminate, acutely serrate : berries bluish or greenish. From Ill. and Ohio south.

\section{BB. Lvs. 3-5-lobed or divided.}

heterophylla, Sieb. \& Zucc. Lvs. cordate, slightly 3. or deeply 3-5-lobed, nearly glabrous and shining beneath, lobes serrate or incised : berries light blue, punc-

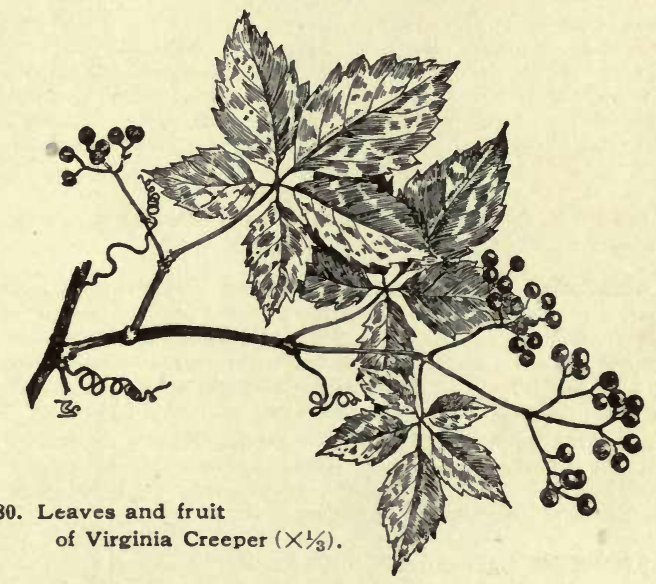

tate. E. Asia. B.M. 5682. Gt. 1873: 765. - Well adapted for covering rocks and low trellis work; handsome in autumn, with its freely produced light blue berries.

Var. élegans, Koch (A. trícolor, Hort.). Lvs blotehed and striped with white, flushed pink when young : slow-growing and tender. Gn. 54,p. 5. 
aconitifollia, Bunge. (A.quinquefòlia, var. aconitifòlia, Hort.). Lvs. 3 - or 5 -cleft, the middle lobe often pinnately lobed, shining and nearly glabrous beneath: berries small. yellow. N. China. Var. dissécta, Koehne ( $A$. dissecta, Carr. A. affinis, var. dissecta, Hort.). Lvs. 5-parted, the middle or the three inner lobes pinnatifid. R.H. 1883, p. 318. Gn. 5, p. 523. - Graceful climber for trellis work.

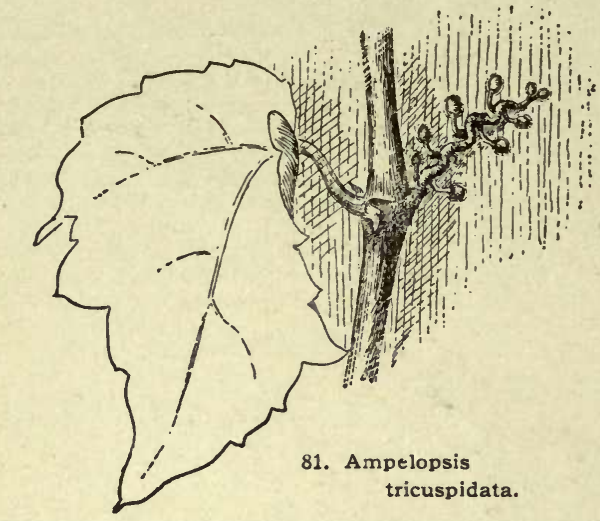

Showing a young leaf and the disks on the tendrils by which the plant is attached to walls.

serjaniæfolia, Bunge. Roots tuberous : lvs.3-5-parted or digitate, chartaceous, shining and dark green above, the divisions pinnate, with winged rachis, the pinnæ separate from the wings : berry small, blue, punctate. Jap., N. China. Gt. 16:531. R.H. 1870,p. 17.

ввв. Lvs. bipinnate, leaflets distinctly stalked.

arbòrea, Koehne (Vitis bipinnàta, Torr. \& Gr. Cissus stáns, Pers.). St. erect or somewhat climbing: pinnæ and leaflets usually 5 ; leaflets ovate or cuneate-obovate, coarsely toothed, $1 / 2-1 \frac{1}{2}$ in. long : berries dark purple. S. states, Mex.

A. bipinnàta, Michx.=A. arborea.-A. brevipedunculàta, Koehne $=$ A. heterophylla, var. $-A$. citrulloides, Hort. $=$ heterophylla - A. Davidiàna, Mottet=Vitis Pagnucei-A, dissécta, Hort. $=\mathrm{A}$. aconitifolia, var. dissecta $-\mathbf{A}$. hederàcea, $\mathrm{DC} .=\mathrm{A}$. quinquefolia $-A$. hederàcea, Hort. $=$ A. quinquefolia, var. muroquinquefolia $-A$, hederàcea, Hort $=\mathrm{A}$. quinquefolia, var. muro-
rum. $-A$. Hóggi, Hort. $=\mathrm{A}$. tricuspidata. $-A$.humulifolia. Bunge. $\Rightarrow$ A. heterophylla var. $-A$.incónstans. Miq. $=A$. trieuspidata. $A$. Japónica, Hort. $=$ A. tricuspidata. $-A$. lùcida, Carr. $=$ A. aco nitifolia.-A.napifórmis, Carr. =A.serjaniæfolia $-A$.orientàlis, Planch. Allied to A. arborea. Petloles longer; Ivs. ovate-elliptic, quite glabrous: petals and stamens 4. Orient.-A. Róylei, $\mathrm{Hort}=\mathrm{A}$. quinquefolia, var. latifolia or A. trieuspidata. $-\boldsymbol{A}$. $r u$ bricaúlis, Carr.=A. aconitifolia.-A sempérvirens, Hort. $=$ Cisbricautis, Carr. $=\mathrm{A}$. aconitifolia. $-\mathrm{A}$. sempervirens, Hort. $=$ Cis-
sus striata. $-\mathrm{A}$.Sièboldi, Hort. $=\mathrm{A}$. heterophylla, var. elegans.$A$. tripartìta, Carr. $=\mathrm{A}$. aconitifolia. $-A$. trilobàta, Carr $=\mathrm{A}$. aconitifolia.-A tuberòsa, Carr. =A. serjaniæfolia. $-A$. Vetchi, Hort. $=$ A. tricuspidata. $-A$. Virginiàna, Hort. =A.quinquefolia. ALFRED REHDER.

AMPELOVITIS. See Vitis.

AMPHICARP is A (Greek, alluding to the two kinds of fruits). Legumindso. A half-dozen little herbaceous vines of E. Amer. and Himalayas, bearing subterranean cleistogamous fls.: lvs. pinnate, of 3 leaflets: fls. small, purplish. Two common species are $A$. monoica, Nutt., and $A$. Pitcheri, Torr. \& Gray (also known as Falcata comosa and $\boldsymbol{F}$. Pitcheri). Not known to be in cult.

AMPHICOME (amphi, both, and kome, hair ; the seeds having a tuft of hair at both ends). Bignonidceoe. Greenhouse herbaceous rockery plants from the Himalayas, with large, rosy, funnel-shaped, 5-lobed fls.

A. argùta, Royle. Height $3 \mathrm{ft}$ : leaflets in 3-4 pairs, sessile, lanceolate, acuminate, deeply serrate: fls. in terminal racemes, fewer than in the next; corolla tube not orange-colored: calyx lower than in the next; ; corolla tube not orange-colored; calyx $11 / 2^{-3} \mathrm{ft}$.: leaflets in 5-7 pairs, cordate-ovate, obtuse, shortly petiolulate, margin erenate-lobate : fls. at first corymbose; corolla tube and throat orange: calyx lobes short, thick, fleshy. B.M. 4890. Gn. 8, p. 25. Gn. 38, p. 458. F.S. 11:1109.
AMSONIA (named for Charles Amson). Called also Ansonia. A pocynàcer. Tough-barked perennial herbs of eastern N. Amer. and Jap., with terminal panicles of blue or bluish narrow-limbed small fis. in May and June, the inside of the corolla tube bearing reflexed hairs. Grown in the hardy border, mostly with shrubbery. Prop. mostly by dividing the clumps; also by seeds and by cuttings in summer.

Tabernæmontàna, Walter (A. latifòlia, Michx, A.salicifòlia, Pursh. Taberncemontàna Amsònia, Linn.). Glabrous or nearly so, 2-3 ft. : lvs. willow-like, ovate to lanceolate, acuminate, alternate, short-petioled : fls. many, with lanceolate spreading lobes, succeederl by slender, milkweed-like follicles or pods $2-3$ in. long. Holds its foliage late. N.C. to Tex. B.M. 1873 . L.B.C. 592. B.R. 151. G.W.F. 48

angustifolia, Michx. (A. ciliata, Walt.). Villous when young, the stem $1-3 \mathrm{ft}$. : lvs. linear to lance-linear, an inch or two long, much crowded, margins becoming revolute: corolla lobes ovate-oblong to linear-oblong. S. states. Int. 1883.

L. H. B.

\section{AMYGDALÓPSIS. See Prunus.}

AMÝGDALUS (Greek-made name, referring to the furrowed pit). Rosacea. A name given to the peaches, apricots and their kin, but here treated as a section of the genus Prunus, which see.

ANACAMPSEROS (Greek-made name). Portulacàceœ. Succulent herbs, of a dozen species, from the Cape of Good Hope, but not grown in this country except in botanic gardens. They are greenhouse plants, with ovate fleshy lvs., fls. expanding in the sun; prop. by seeds or by cuttings of stems or leaves.

ANACÁRDIUM (name refers to the heart-shaped character of the nut). Anacardidcece. Eight or ten species native to the Amer. tropies, of which one is widely cult.:

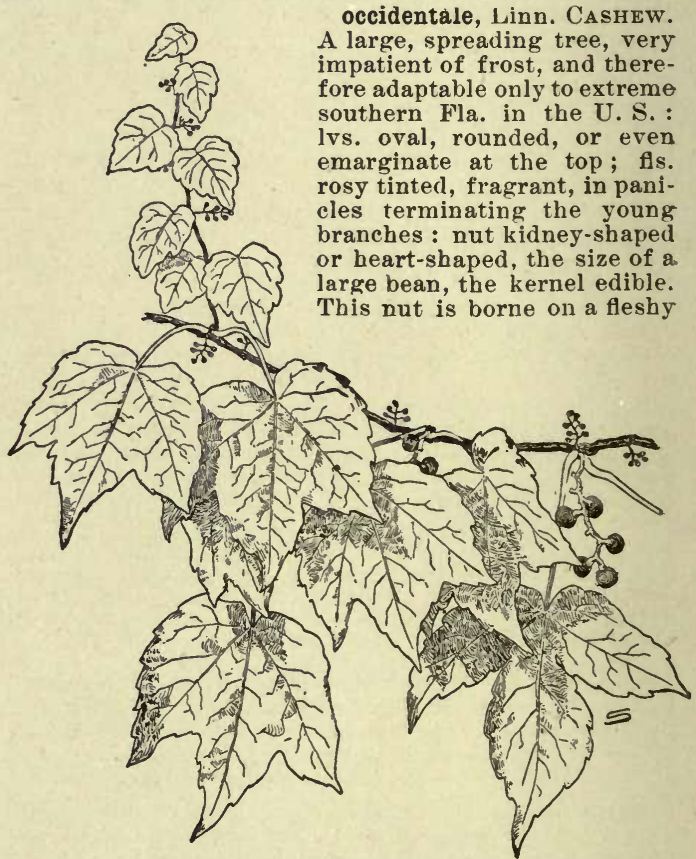

82. Ampelopsis tricuspidata.

receptacle (the cashew apple) which varies from the size of a cherry to that of a pear, from white to yellow and red, and is acid and edible. Gn. 11, p. 211.-A vinous liquor is made from the apple. The kernel of the nut yields oil, and is edible when roasted; the shell of the nut is exceedingly acrid, even the fumes from the 
roasting being highly irritant. The tree yields a gum which is the basis of a varnish, being used to protect books and woodwork from the rarages of white ants and other insects. The tree grows 20-40 ft. high. L. H. B.

ANAGÁLLIS (Greek, meaning delightful). Primuld̀cex. PIMPERNel. Annual, bienuial or perennial herbs cult. in the open. In Amer. only the annual species are generally known. Fls. axillary : 1rs. in pairs or 3's. These are easily grown in a warm soil, the seed usually being sown where the plants are to grow. The perennials are prop. by division and are grown in glass houses, or well protected if grown in the open.

arvénsis, Linn. Poor Man's Weather-glass. Spreading and low : lvs. ovate, pale, shorter than peduncles: fls. small, red to white, the petals fringed with glandular teeth. Annual. Eu.-Often runs wild. Fls. said to close on the approach of rain:

Yar. cærùlea, Neilr. (A. carìlea, Lam.). Blue fls. Supposed to be more tender.

linifolia, Linn. More upright, a foot high : lvs. linear or lanceolate : fls. 1/2in. in diam., blue. Many named varieties, in various colors and habits. Biennial or perennial, but most of the annual Anagallises of gardens are supposed to be forms of it, as A. grandiflora, Andrews (blue annual); $\boldsymbol{A}$. collina, Schousb. (vermilion, greenhouse); $\boldsymbol{A}$. Morélli, Linn. (blue, greenhouse); A. Wilmoredna, Hook (purple). S. Eu. and N. Afr. B.M. 319,831 (as A. fruticosa), 3380.-The biennial forms often cult. in cool greenhouses.

L. H. B.

ANANAS (modified from aboriginal S. Amer. name). Written also Ananassa. Bromeliacece. Stove herbs, allied to the Billbergias, and demanding the same general treatment. As ornamental subjects, grown mostly for the rosette of rigid lvs. and the strange often colored Lead of fleshy fls., which are 6-cleft, with 6 stamens and one style. The ripe head is composed of the thickened rachis, in which the fleshy berry is imbedded, and the fleshy persistent bracts ; in the pineapple, the fls. are abortive. Prop. by the leafy crown or topknot, by stroug suckers, or by small offisets from the base : these are treated as cuttings, being rooted in sand with bottom heat, or in the S. set directly in the field. Monogr. by Mez, DC., Monogr. Phaner. 9.

sativus, Schult. f. Pineapple, which see for field culture, Fig. 83. Plant producing a single shaft $2-4 \mathrm{ft}$. high, and when 12-20 mos. old bearing a head or pineapple, on the top of which is a rosette of stiff lvs.: lvs. long and sword-shaped, stiff, more or less rougli-edged. The same stalk does not bear a second time, but a new shoot may arise from the same root and bear another. Better results are usually secured by severing the sucker or crown, and growing a new plant. Amer. tropics. B.M. 1554. B.R. 1081-There is a common cult. form (var. variegdta or stratifòlia), with striped lvs. Gn. 51, p. 57. A. Portednus, Koch, is a form of A. sativus, with olive-green, sharp-spined lvs. with a yellow central band. A. Cochinchinénsis, Hort., is another form (introduced by Pitcher \& Manda, 1891).

$A$.bracteatus, Schult. $f$., is a showy species with red heads, all the bracts being elongated, spiny and prominent, Braz. B.M. 5025. Regarded by Mez as a form of A. sativus. - A. macrodóntes, E. Morr., like a Bromelia, has large toothed bracts. Braz. - A. Mordilònus, Hort., a form of A. sativus probably, has variegated spineless lvs.

L. H. B.

ANAPHALIS (Greek name of a plant). Compdsitoe. Everlastivg. Much like Antennaria, but differs in the pappus-bristles of the staminate fls. not being thickened (these are thickened upwards in that genus) and the st. leafy. Hardy border plant; useful for immortelles.

margaritàcea, Benth. \& Hook. A foot or two high, with many corymbose heads, white : lvs. sessile, linearlanceolate, long-pointed : involucre pearly white, hence the value of the plant as an everlasting. N. states.

ANARRHINOM (snoutless). Scrophulariacece. A dozen biennials and perennials of $\mathrm{S}$. Eu. and N. Afr. Allied to Antirrhinum, but not cult. in this country. Fls. small, in spike-like racemes, white or blue.

ANASTÁtICA. See Resurrection Plants.
ANCHÙSA (anchousa, a paint for the skin). Boragindcec. Alkanet. Hardy plants, with fls. blue or purple, in panicled scorpioid racemes, the corolla trumpetshaped and the throat closed by scales. Of easy cult. in sunny position. Prop. by seed generally.

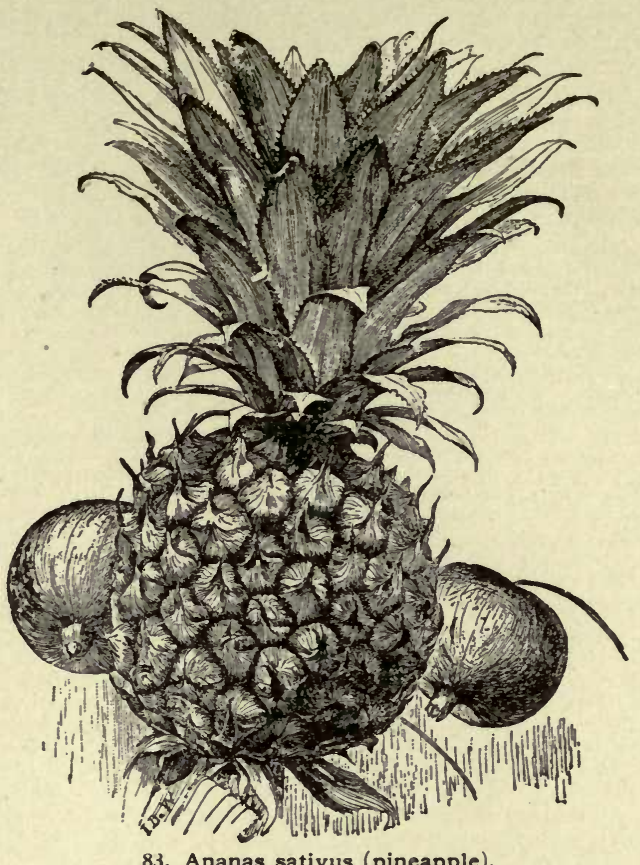

83. Ananas sativus (pineapple).

A. Fls. small, like forget-me-nots.

Barrelièri, Vilm. Perennial : height $2 \mathrm{ft}$. : Ivs. ovatelanceolate, smaller and shorter than in A. Italica: fls. with a white tube and pink throat. May. Eu. and Asia Minor. B.M. 2349. - Valued for its earliness, and for cut fls. The least common of the three species.

Capénsis, Thunb. Biennial : height $1 \frac{1}{2} \mathrm{ft}$.: lvs. narrowly lanceolate and less hispid than in A.Italica: Hs. red-margined, with a white throat; buds red; calyx inflated after the fl. has withered ; divisions short, obtuse. June-Sept. Cape of Good Hope. B.M. 1822. - Fine for cut fls. Often winter-killed, but seeds itself freely.

$$
\text { AA. F'ls. large. }
$$

Itálica, Retz. Perennial : height 3-5 ft.: lvs. largest of the three species here contrasted, ovate-lanceolate, rough, shining; radical ones sometimes $2 \mathrm{ft}$. long. Mediterranean. B.M. 2197. L.B.C. 14: 1383.-If not allowed to go to seed, will bloom continuously from June to Sept. Commonest and perhaps best species.

A. Agárdhii, Lehm. Lvs. linear. Siberia. Rare.-A. myosotidiflora, Lehm. Lvs. large ; radical ones long-petiolate, cordatereniform : cauline ones sessile, oval. Siberia, Caucasus. $-A$. officinàlis, Linn. Lvs. lanceolate; radical ones clustered : fls. opening in pairs. June-Oct. Eu. B.M. 1897 is A. officinalis var. angustifolia. $-A$. sempérvirens, Linn. LVs. broadly ovate; lower ones petiolate : racemes short, generally bracted at the base. Eu. Esteemed in France. J. B. KeLLER and W. M.

ANDtRA (Brazilian name). Leguminòsce. Nearly 30 species of tropical Amer. trees, with conspicuous fls. in racemes. Two or three species are sometimes cult. in hothouses in the Old World.

ANDROMEDA (Greek mythological name). Ericàcea. Low shrub, quite glabrous: lvs. small, evergreen, entire, short-petioled: fls. pedicelled, in terminal umbels; carolla globose-urceolate, with 10 included stamens: capsule splitting into 5 carpels, with numerous very small seeds. One species through the northern hemisphere; in America from Penn. northward, and Alaska. Low, 
evergreen shrub, with delicate fls., growing best in peaty or sandy soil. Prop. by seeds, sown thinly soon after maturity, in pots or pans of sandy peat soil, placed in a coolframe. They germinate easily if sown in cut sphagnum, but must be pricked into boxes as soon as they can be handled. Cuttings from mature wood, placed in sand under glass in fall, and kept in a cool greenhouse during the winter, will root easily; also increased by layers. See, also, Leucothoë, Chamodaphne, Pieris and Zenobia.

polifỏlia, Linn. (A. rosmarinifòlia, Pursh). One-half to 2 ft.: lvs. oblong-lanceolate or linear, $3 / 4-1 \frac{1}{2}$ in. long, whitish-glaucous beneath, with strongly revolute margins : fls. nodding, white or pink. June. L.B.C. $6: 546$, $16: 1591,18: 1714$. - There are a number of forms, differing in the color and size of the fls. and'shape of the lvs.

A. acuminàta, Ait.=Leucothoë populifolia.-A arbòrea, Linn = Oxydendrum arboreum $-A$, axillàris, Michx. = Leucothoê Catesbæi. - A. axillàris, Lam = L. axillaris, $-A$. calyculàta, Linn.= Chamædaphne calyeulata. $-A$. campanulàta, Niq. Linn. $=$ Chamædaphne calyeulata. $-A$. campanulàta, Miq.
Enkianthus campanulatus. $-\boldsymbol{A}$. cándida, Hort.=Zenobia pul verulenta. - A. cassiniafólia, Vent. $=\mathrm{Z}$. pulverulenta. $-A$. Cátes bae, Walt. = Leucothoë Catesbæi. $-A$. cérnua, Miq. =Enkianthus cernuus. $-A$. dealbàta, Lindl. = Zenobia pulverulenta. $-A$. fas tigiàta, Wall.= Cassiope fastigiata. $-A$. ferrugínea, Walt. = Lyonia ferruginea. $-A$. floribúnda, Pursh $=$ Pieris floribunda. A. formòsa, Walt. = Pieris formosa. - A. glaùca, Hort.=Zenobia pulverulenta $-A$. Japónica, Thunb. = Pieris Japonica - A ligus

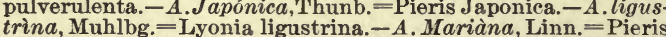
trìna, Muhlbg. = Lyonia ligustrina. $-A$. Mariàna, Linn $=$ Pieris
Mariana. $-A$. nítida, Bartr. = Pieris nitida. $-A$. ovalifòlia, Wall. - Pieris ovalifolia. - A. paniculàta, Ait.=-Lyonia ligustrina.A. parabólica, Duh.= L. ligustrina. $-A$. populifòlia, Lam. $=\mathrm{Leu}$ cothoë populifolia.-A. pulverulénta, Bartr.=Zenobia pulverulenta.-A. racemòsa, Linn. = Leucothoë racemosa. $-A$. speciòsa, Mi $=$. tetragona. $-A$. tomentòsa. Hort., not Dum.-Cours. = Lyonia ligustrina pubescens.

AlFRED REHDER.

ANDROPOGON (Greek-made name, referring to the bearded flowers). Graminea. A polymorphous genus, spread over all parts of the world in the tropical and temperate zones. The species prefer dry places, especially plains. Lvs. usually long and narrow: spikes terminal and axillary; spikelets in pairs at each node of the jointed hairy branches, one sessile and perfect; the other with a pedicel and either staminate, empty, or reduced to a single scale: a straight or twisted awn present. Species, about 180 . Includes many species of useful pasture grasses. Two or three species are grown occasionalky for ornament. They are of easiest culture, either from seeds or division of clumps.

argénteus, DC. Silver BEard-Grass. A stout, tall grass, 2-4 ft. high, with a distinct ring of white hairs at the nodes: panicles narrow, silver-bearded: lf.-blades long: spikelets covered with long white hairs at the base : awn 1 in. long. $-A$ handsome ornamental grass. Probably a form of $A$. saccharoides, Swartz, of Trop. Amer.

Halepénsis, Brot. Johnson Grass. A stout perennial, with smooth, erect culms, 3-6 ft. high, and strong, creeping rootstocks: panicles variable, more or less drooping, exserted, rays mostly in whorls of 4, rarely 2-6; sessile spikelets variable; pedicellate spikelets staminate or neutral, much narrower than the sessile ones. S. Eu., S. Amer., Australia. Gn. 13, p. 305.-Abundantly grown in the southern states for hay, where it makes a very rapid growth. When once it has become established it is exceedingly difficult to eradicate, and hence it has become a very troublesome weed in some parts. Much admired in Eu. as an ornamental grass, and sometimes cult. in the $N$. for that purpose.

Schœnánthus, Linn. (A. formòsus. A citràtus, Hort.). LEMON GRAss. A very handsome tropical grass, growing in fine clumps 5-6 ft. high; effective for borders and as single lawn specimens. S. Asia, Japan, and Trop. Africa. Gn. 10 , p. 605; 12, p. 495. - Cult. in India and Ceylon. Yields a fragrant oil, called both oil of verbena and lemongrass oil. Used as a stimulant and antispasmodic for neuralgia and rheumatism, and also in the adulteration of attar of roses.

A. Nárdus, Linn. Citronella Grass. Cult.in Ceylon. Yields the citronella oil, which is used for scenting soap and perfumery Forty thousand pounds of oil distilled annually from this grass S. Asia and N. Australia. Gn. 12, p. 495. - A. Sórghum, Brot (Sorghum vulgare, Linn.). Includes all the varieties of cultivated Sorghum; of great economic value for sugar, brooms, brushes, fodder, alcoholic drinks. Seed prized for poultry. E. Ind - A squarròsus, Linn. Rhizomes fragrant, ITsed in Indi for thatching, weaving into mats, fans, brushes. Roots said to keep garments free from insects. Sold by druggists in Europe under the name of Radix anatheri. Introduced into Louisiana. India, W. Ind. Is., and Brazil.

P. B. KenNeDY.

ANDROSACE (Greek-made name). Primulacea. Rock JASMiNe. Small tufted plants cult. in the alpine garden, those known in Amer. being perennials. Fls. constricted at the throat, primula-like, in umbels, on short leafless scapes. Fl. in very early spring. Many species are known in European gardens, but alpine-gardening is little known in this country, and only those species which have been found to succeed, and are in the trade, need to be mentioned.

A well-drained soil, partial shade, free circulation of air, frequent waterings during our dry summer months, and protection from heavy fall and spring rains, will lead to success with these charming alpines. A heavy shading of evergreen boughs in winter will be found of great benefit. Close covering is not to be recommended, because it smothers the plants. A great many species have been tried in this country, with variable and not very encouraging results, but in a few instances, with extra care, plants have done well. The northern aspect of a steep rockery seems to be the most favorable position for them. Prop. by division, seeds or cuttings. Plants should be kept in pots until thoroughly established.

Cult. by J. B. KeLler.

lanuginòsa, Wall. Lvs. scattered, oblong-obovate, acute, 1 in. long, silky-hairy : fls. rose-purple with yellow eye, the mouth contracted with a crenated ring, in a dense umbel : plant 6-10 in. high, with many trailing shoots, making a good drapery for rocks. Himal. B.M. 4005. Gn. 49, 287.

sarmentosa, Wall. Lvs. oblanceolate or spatulate, silky-hairy on the edges, in rosettes : plant producing many pink runners, which root freely : fls. in umbels of 10-20, pink with white eye. Himal. B.M. 6210. Gn. 54, p. 128 .

cárnea, Linn. Lvs, very narrow and pointed : fls. a half dozen, flesh-color, with yellow eye. Switz.

Var. exímea, Hook. Lvs. less rigid, strongly recurved: fls. larger ( $1 / 3$ in. across). Switz. B.M. 5906. L.H.B.

ANDROSTEPHIUM (Greek-made name, referring to the corona). Lilidcea. Small genus of S. W. United States, with funnel-shaped, spreading-limbed, 6-lobed perianth, 6 stamens, and 3-angled ovary, and a corona or crown at the mouth: lvs. linear, radical : scape simple, leafless. Plant in a sunny place in sandy soil, placing the bulbs 4-6 ft. deep ; protect in winter. Prop. by division of the bulbs and by seeds.

violàceum, Torr. Slender, 6-10 in.: fl. blue, 1 in. long, $3-6$ in loose umbel. Blooms in spring ; pretty.

ANEILEMA (Greek ; no involucre). Commelinàcea. Sixty tropical perennials, of which $\boldsymbol{A}$. biflòum, R. Br., and $\boldsymbol{A}$. Sínicum, Lindl., are sometimes cult. in Old World hothouses. These species are blue-fld., diffuse or trailing plants.

ANEMIA (Greek, naked; the panicles deroid of sporangia). Schizodcec. A genus of tropical ferns, with the lower pair of pinnæ elongate and bearing the sporangia in panicles at their extremities. Of the 40 species, two are found in the southern states, and a few are occasionally in cult.

L. M. UNDERWOOD.

Anemias are dwarf, compact ferns, suited for shelves, or for growing near the glass in warm pits or low houses. They prefer being grown in small pots to being planted out in the fernery. Their growth is too slow to make them popular decorative ferns for general purposes. Prop. by spores, which germinate freely : tufted kinds by division between Mar. 15 and Apr. 30.-Schneider, Book of Choice Ferns.

A. Leaf 2-3-pinnate, with narrow divisions.

adiantifòlia, Swz. Leaf 6-9 in. long on a stalk often twice as long, the ultimate divisions oblong or linearcuneate, with the outer margin toothed. S. Fla. and tropics. 
AA. Leaf only once pinnate with broad pinnae.

$$
\text { B. Veins free. }
$$

Mexicàna, Klotzsch. Leaf 6-9 in. long, with 4-6 pinnæ on either side, which are distinctly stalked, ovate-lanceolate and rounded on both sides at the base : panicles 3-4 in. long, dense. Tex. and Mex.

collina, Raddi. Plants a foot high, on hairy stalks ; 1vs. with about 10 leaflets on each side, which are rounded at the outer ends and truncate at the upper side at the base : panicles about $1 \frac{1}{2}$ in. long, dense. Braz. S. $1: 384$.

BB. Veins anastomosing (munning together).

Phyllitidis, Swz. (A. lanceolata, Lodd. A. longifolia, Link. Anemidíctyon Phyllitidis, Willd.). Leaf 4-12 in. long, with 4-12 pairs of sessile pinnæ, with a crenulate margin and a rounded or unequal base; veins forming long, narrow areolæ: panicle 3-9 in. long, dense. Cuba and Mex. to Braz. S. 1: 390 . L. M. Unnerwood.

\section{ANEMIDICTYON. See Anemia.}

ANEMONE (Greek, wind). Ranunculdcen. ANEMONE, or ANEMONY. WINDFLOWER. A genus of about 85 species, with many handsome garden forms; all hardy perennials : chiefly native of the north temperate and mountainous regions. Stems usually erect, with great variation in height. Basal leaves lobed, divided or dissected, those of the stem forming an involucre near to, or remote from, the flower. Sepals few or many, petallike; no true petals. Stamens many, shorter than sepals. Carpels numerous; fruit a 1-seeded akene.

The plants thrive best in a fresh, rather rich, sandy loam, well drained; but most of the species will do well in any good garden soil. The tuberous species are suitable for hardy borders, while most of the others prefer a place in a rockery, and some are partial to shady places. A. hortensis, coronaria, fulgens and others will well repay the littie indoor or greenhouse care they require for producing winter blossoms. They require essentially the same handlirg as tulips and hyacinths, and are usually classed with bulbous plants. Tubers placed in pots in Sept. or Oct. bring forth a beautiful show of bloom by Jan. or March. For this purpose they should be well

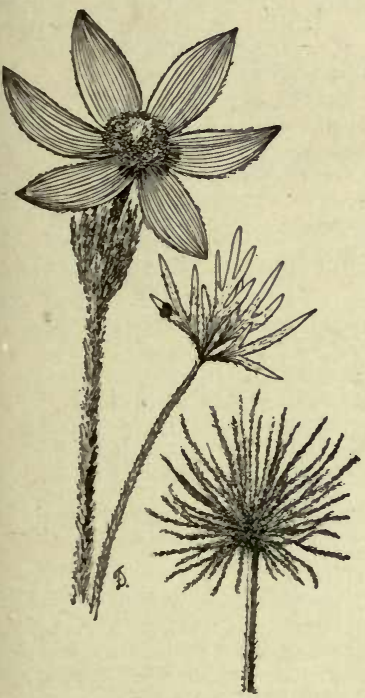

84. Anemone patens, var. Nuttalliana $(\times 1 / 3)$. rained, and not kept very wet or too warm before the growth is well started they prefer more moisture at flowering time. Nearly all the species can be readily propagated by both root division and seed. The season for both out and indoor planting will directly influence the flowering season. Good seasons for outdoor planting are Sept., Oct., Nov., Dec., Feb. and March. As a rule, the tuberous Anemones will blossom at any time desired, being influenced by the time they are kept out of the ground. The bulbs may be ripened after flowering time by being taken from the ground to dry, or by covering the bed to keep out rains. $A$. Japonica is one of the finest of all fall-blooming herbs. Pritzel, Revision of Anemone, in Linnæa 15: 498 (1811). Britton, N. Amer. Anemone, in Ann. N. Y. Acad. Sci. 6: 217 (1891-92).

Alphabetical list of species described below (synonyms in italics): A. acutipetala, Hort., 6 ; acutipetala, Schl., 4 ; alpina, Linn., 6 ; alpina, Hort., 5 ; apennina, 13 ; blanda, 14 ; Canadensis, 23 ; Caroliniana, 11 ; coronaria, 7; decapetala, 11; deltoidea, 17; dichotoma, 23; fulgens, 8 ; Grayi, 19 ; Halleri, 2 ; hortensis, Linn., 9 ; hortensis, Thore., 8; Japonica, 21 ; multifida, 22 ; narcissiflora, 24 ; nemorosa, 15 ; nemorosa, var. quinquefolia, 16 ; occidentalis, 5 ; Oregana, 19 ; palmata, 10 ; patens, 3 ; Pavoniana, 8 ; Pennsylvanica, 23 ; Pulsatilla, 4 ; quinquefolia, 16 ; ranunculoides, 18 ; rubra, 4 ; stellata, 9; sulphurea, 1 ; sylvestris, 12 ; umbellata 24 ; vernalis, 1 ; Virginiana, 20. See supplementary list.

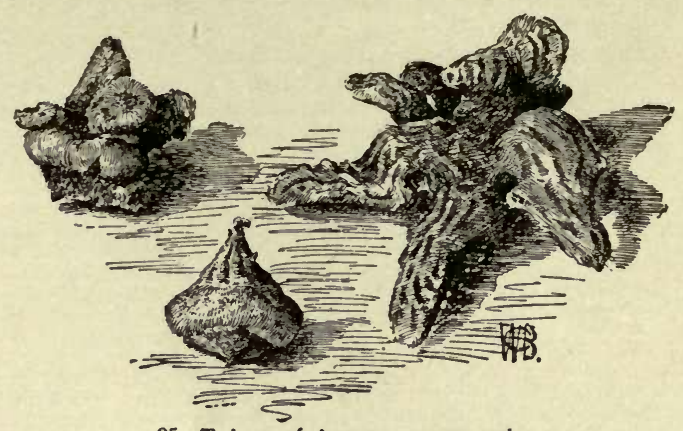

85. Tubers of Anemone coronaria.

A. Akenes uith long styles, which may become feather like on ripening; fls. solitary.-Pulsatilla sec tion.

B. Involucre bell-shaped, dissected into numerous linear equal lobes.

1. vernàlis, Linn. (Pulsatilla vernalis, Mill, As sul. phùrea, All.). Very shaggy, 6 in. high or less: lvs. pin nately parted, segments trifid: fls. purple without, whit ish within, and smoothish ; erect, on very short pedun. cles; sepals 6, rarely spreading. Apr. Cool, moist places. Eu. 1896. J. H. III. 32: 223. Gn. 25: 436.

2. Hálleri, All. Villous, 6 in. or less in height; simple: lvs. pinnately divided with segments $3-4$ parted; the lesser divisions lanceolate-linear ; involucre of long narrow segments, sessile : fls. large, erect, whitish purple ; sepals 6 ; anthers yellow. Apr. Sunny places. Switzerland. 1889. L.B.C. 10:940.

3. pattens, Linn. Much like the first variety below, which is more common in Amer, but differs in it broader and shorter leaf-segments and smaller fls. Eu.

Var. Nuttalliàna, Gray (Pulsatilla hirsutissima, Brit.). Wild Patens. American Pasque Flower. Fig. 84. Villous, with long, silky hairs, 4-9 in. high : radical lvs. petioled, others sessile, all much divided into narrow, linear, acute lobes : fls. appearing before the root-lvs., bluish purple or whitish, erect, seldom nodding : akenes silky : styles plumose, becoming 2 in. long; peduncle elongates several inches after flowering. Apr. Low ground. N. central states and Siberia.

Var. ochroleùca, Sims. Fls. creamy white, appearing at same time as basal lvs. Mar.-Apr. J.H. III. 30: 343. B. M. 1994 .

4. Pulsatílla, Linn. (Pulsatílla vulgàris, Mill. A. acutipétala, Schl.). PASQUe Flower of Europe. Villous, hairy, rising $3 / 4-1 \mathrm{ft}$. : basal $1 \mathrm{vs}$. finely thrice-pinnately divided, on slender petioles ; involucre sessile, deeply cut into long narrow lobes : fls. blue to reddish purple, $1 \frac{1}{2}-2 \frac{1}{2}$ in. across. Apr. Well-drained soil or stony places. Eu. Gn. 32:623. L. B. C. 18: 1704. Var. rùbra, Hort. (A. rùbra, Lam.). Dwarfer: fls. always erect. Var. variegata, Hort. Fls. pale, appearing in M̆ay.

Bв. Involucral leaves 3 , on short petioles, sheathing the stem.

5. occidentàlis, Tats. (A. alpina, Hook., not Linn.). Silky-hairy, $1 / 2-11 / 2 \mathrm{ft}$. high, simple : lvs. 2-parted, the divisions deeply pinnatifid into usually incised linear, acute lobes; involucre short-petioled; basal lvs. longpetioled : fls. solitary, white or purple, varying, 1-2 in. across; receptacle conic, sometimes much elongated : akenes pubescent: plumose styles reflexed; peduncle becoming much elongated after sepals fall. May. Calif. to Brit. Columbia. Int. 1892. 
6. alpìna, Linn. (A. acutipétala, Hort.). Closely allied to the above. Stem $3 / 4-1 \frac{1}{2} \mathrm{ft}$. high, from thick, strong roots : lvs. large, finely divided, cut and serrated, smooth or hairy ; lvs. of involucre similar : fls. few, in an umbel or solitary, 2-3 in. in diam., creamy white inside, purple outside, but varying much; anthers yellow. Mountain sides. Eu. May-June. L.B.C. 17: 1617. B.M. 2007 (var. major). Var. sulphùrea, Hort. Fls. a delicate sulfur yellow, larger, downy beneath : lvs. larger. Moist, rich soil. 1882. Gn. 35: 682 .

AA. Akenes woolly or smoothish, with short styles. (Anemone proper.)

B. Peduncle 1 (rarely 2); involucre mostly 3-leaved. c. Head of fr. cylindric; akenes woolly.

D. Roots tuberous; involucre usually sessile.

7. coronària, Linn. PopPy-FLOwERed A. Figs. 85, 86, 87. One-half to $1 \mathrm{ft}$. high, from tuberous roots:

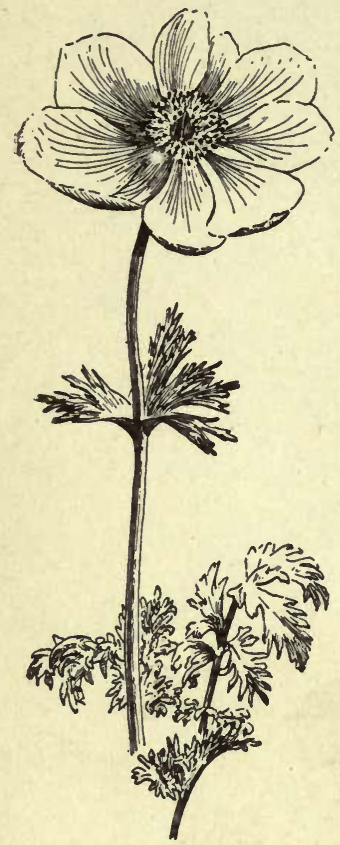

86. Anemone coronaria single-fld. form $\left(X^{1} / 3\right)$. lvs. cut into many fine lobes and lobules; involucral lvs. ses. sile, 3-4-parted, deeply cut : fls. $1 \frac{1}{2}-2 \frac{1}{2}$ in. across, poppy-like, of many colors and mixtures of red, blue, white, etc.; stamens blue. Early in spring to June. Meadows Mediterranean region. Vick's Mag. 11:257. B.M. 841 . Gn. $50: 1073 ; 16$, p. 111 . R.H.

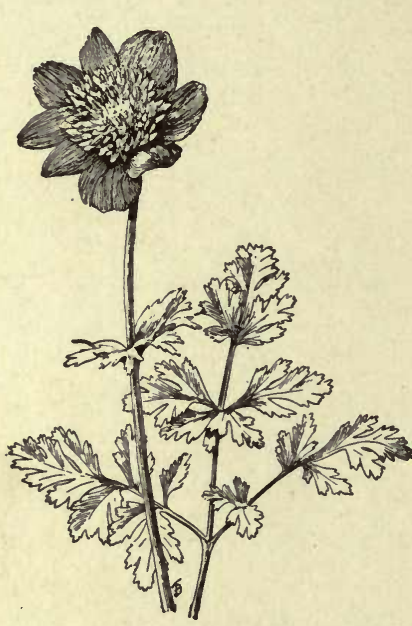

87. Anemone coronaria, doublefld. form $\left(X^{1 / 4}\right)$.
1893: 232. Caen, Scarlet, The Bride, St. Brigid, Victoria Giant, etc., are some of the trade names given to the single forms. Var. flore-plèno, Hort. Fls. double, as shown in Fig. 87, by the pistils becoming petal-like, the stamens mostly remaining perfect ; many colors, scarlet being the most common at present. F.S. 16:1678. Var. chrysanthemiflora, Hort. A seedling variety produced in 1848 , and introduced many years later. Fls. more completely doubled than the above variety, by the stamens all becoming petal-like. A dozen forms, beautiful, selfcolored, as deep red, sky-blue and even pure white, have been fixed and named. Useful as cut fis. Gn. 30:564. R.H. 1887:36; 1897, pp. 418-19. R.B. 21:260-1.

8. fúlgens, Gay (A. Pavoniana, var. fúlgens, DC. A.horténsis, Thore.). Fig. 88 . One ft. high, simple: basal lvs. 3-5-lobed, with rounded outline, followed later by deeply cut lvs.; sessile involucre several inches below the solitary fl.: fls. vivid scarlet, 2 in. across; stamens black. May and June. France. Sometimes called a variety of $A$. hortensis, Linn., from which it may have descended. Several garden forms, as annuata-grandiflora, multipetala, and Southern Star. Gn. 11:65. Gt. 27: 66 . R.B. $21: 262-3$. R.H. 1877:270.

9. horténsis, Linn. (A. stellata, Lam.). BROADLraved Garden A. Fig. 89. St, simple, erect, $10 \mathrm{in.}$ high: basal lvs. lobed and eut irregularly : involucre small, 3-5-lobed, usually 3 or more in. below the fl.; fls. red, rosy purple, or whitish, single, $1 \frac{1}{2}$ in. across ; stamens brownish violet. Rich, light soil. S. Eu. May.This differs from $A$. coronaria in its coarse, broad lvs. and its elongated, rather narrow-pointed sepals. Garden names are given to the forms with different coloration. B.M. 123, from which Fig. 89 is taken.

10. palmàta, Linn. St. 6-9 in. high from tuberous root: basal lvs. leathery, 3-5-lobed, cordate, toothed ; involucral lvs. 3-parted : fls. golden yellow, solitary or in 2's ; sepals 10 or more. May-June. Deep, light soil, Mediterranean region. B.R. 200.-Three good varieties in the trade. Var. flore-pleno, Hort., with double yellow or white fls. Var. álbida, Sims (var. alba, Hort.). Fls. white: basal ivs. lobed. B.M. 2079. L.B.C. 2: 175. Gn. 22:364. Var. lutea, Lodd., like the last, but with yellow fls. L.P.C. 17: 1660 .

11. Caroliniàna, Walt. (A. decapétala, Amer. authors, not Ard.). St. simple, slender, $1 / 2-1 \mathrm{ft}$. high, arising from a large tuber: Ivs. of involucre sessile, with 3 wedgeshaped clefts ; basal lvs. thrice divided, and much lobed and parted, slender-petioled : solitary fl. erect, $1-1 \frac{1}{2}$ in. broad, creamy white or purple ; sepals often numerous : akenes densely woolly. April-May. Open places. U.S.

DD. Rootstock creeping: lvs. of involucre petioled.

12. sylvéstris, Linn. St. 1-11/2 ft., simple, or branched

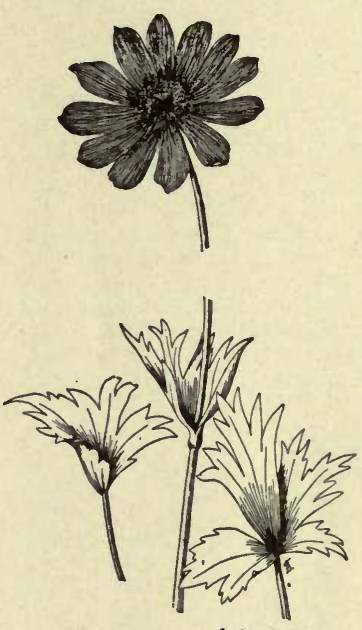

88. Anemone fulgens $(\times 1 / 4)$.

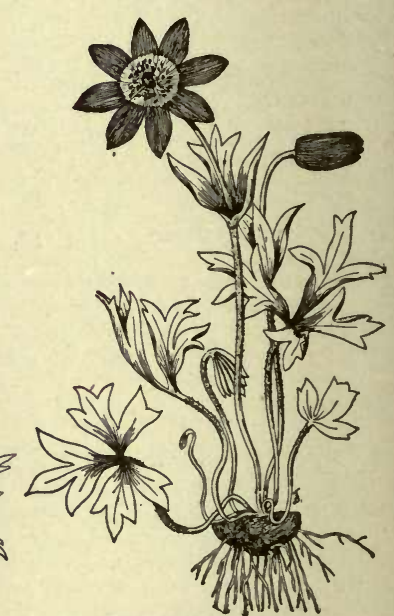

89. Anemone hortensis.

Feduced from an old cut, to show once at involucre, from a creeping rootstock : lvs. 3-4parted, deeply cut at top, hairy beneath : involucre petioled; fls. solitary or in 2's, pure white, $1 \frac{1}{2} \mathrm{in}$. across, nodding, sweet-scented; sepals 6. May-July. Wooded places, Eu. and Liberia. B.M. 54. Gn. 18, p. 561 ; 30, p. 173. L.B.C. 18: 1739. Var.flore-plèno,Hort. Double SNowdrop A. Has large, white, double tls. G.C. III. $19: 739$.

\section{cc. Head of fruit hemispherical; akenes} silky-pubescent.

D. Roots tuberous.

13. Apennina, Linn. St. simple, slender, 4-9 in.: lvs. twice-divided and lobed, much toothed: fls. skyblue, $11 / 2$ in. across ; sepals $10-12$, elongated, obtuse ; anthers white. Mar.-Apr. Woods, Italy. Gn. 46:975. -This and a form with whitish fls., both well suited for shady nooks in clumps of shrubbery, etc.

14. blánda, Schott \& Kotschy. St. 4-6 in. high, from a cylindrical rootstock: lvs. like $A$. apennina, but harder and smoother, and principal divisions sessile : fls. intense sky-blue, differing from above species in being larger, more finely rayed, styles black-pointed, and sepals smooth on the outside; opens in earliest spring or mild winter weather. From Taurus Mts. and Greece. Rocky places, Int. 1898. Gn. $14: 143 ; 46$, p. 152. 
DD. Rootstock slender, creeping, cylindrical.

15. nemoròsa, Linn. Wood A. St. simple, $3-8$ in., nearly smooth : rootstock horizontal, $3-4$ times the st. in diameter : lvs. of involucre petioled, 3-5-parted ; basal lvs. appearing after the fl. st., 5-parted, divisions wedge-shaped, toothed : fls. white or purplish, solitary, 1 in. across : akenes pubescent; styles hooked. Apr.May. Eu. and Siberia. Three or more horticultural rarieties. Var. álba, Hort. (var. flore-pleno, Hort.). Fls. larger, pure white, and abundant. Int. 1883. Gn. 32: 618 . D. 25. Var. Robinsoniana, Hort. (var. carulea, Hort.). A robust form, 6-12 in., with broader and thicker lrs., and large fls., becoming blue. Sometimes given as a separate species. Mar.-Apr. Gn. 46, p. 153; 32:618: p. 345. Var, ròsea, Hort. (var. mibra flore-pleno, Hort.). Fls. a reddish purple; now much used.

16. quinquefollia, Linn. (A. nemoròsa, var. quinquefòlia, Gray). This American species differs from A. nemorosa in having smaller fls., involucral lvs. less lobed, foliage paler, and much more slender st, and petioles. The common Windflower or Spring Anemone, formerly called $A$. nemorosa.

17. deltoidea, Dougl. St. simple, slender, 6-12 in. high, from a slender rootstock : lvs. trifoliate, basal ones petioled, others nearly sessile, coarsely crenated, often incised : fls. solitary, white, rather large: akenes several, densely pubescent; style very short. Spring. Pacific slope.

DDD. Rootstock horizontal, fleshy or someuhat tuberous.

18. ranunculoides, Linn. Yellow Wood A. St. 3-8 in., from elongated, somewhat tuberous rootstock : lvs. 3-5̄-parted, divisions deeply cut and serrated : fls. golden yellow, usually solitary, single or semi-double. Mar. and Apr. Rich, light soil in open places and woods. Eu. and Siberia. Gn. 35: 699. L.B.C. 6: 556.

19. Gràyi, Behr. (A. Oregdna, Gray). St. slender, 3-12 in. high, from a fleshy, brittle rootstock: basal lvs. slender-petioled, 3-parted, coarsely serrate ; involucral lvs petioled, trifoliate, the parts 2-3-lobed, much toothed . sepals blue or purplish: akenes pubescent, in a globose head. Moist, shady slopes. Oreg. and Wash. In gardens west of the Rockies. Int. 1892.

\section{Bв. Peduncles 2-5 (mostly 3).}

c. Fruits (akenes) woolly or very silky; secondary involucre present.

20. Virginiàna, Linn. Plant hairy, 2-3 ft. high, stout, branching at the involucre: the petioled involucral lis. 3-parted, the leaflets eleft and lobed; basal lvs. similar, broader than long, on long petioles: fl. peduncles naked (or the lateral ones 2-lvd.): : fls. greenish or white, 1-11/2ln. across: akenes woolly, in an oblong head; styles short, awl-shaped. June-Aug. Woods and meadows. U.S. and Canada. G.M. 33:763.

21. Japónica, Sieb. \& Zucc. Fig. 90. Stately, branching st., 2-3 ft. high : plant soft and downy, with short hai1 3 : lvs. ternate, much lobed and toothed : fls. rosy purple or carmine; 1-3 whorls of sepals, $2-3$ in. in diam., on long peduncles from leafy involucre; stamens yellow: akenes silky. A very useful species for mixed borders or for pot culture. Hardy in N. states. Sept. to late frosts. Rich soil, China and Japan. 1844. Gn. 30:558. B. M. 4341. P. M. 14:25. A. G. 19:305. Gng. 1:221; 3:131. G.C.III.16:661. A.F.12:29. F.S. $2: 74$. Var. álba, Hort. Honorine Jobert. The Bride. WhiRLwiNd, etc. Two or three whorls of large, white sepals: fls. 2-3 in. across, lasting until hard frosts. Vick's Mag. 14: 47. Gng. 5:117. R.H. 1867:11. Var. hybrida, Hort. (vars. rosea and elegans, Hort.). Radical lvs. 5-lobed, often cordate; lobes twice serrate: fls. somewhat paler, earlier; sepals rather broader. Said to be a hybrid of $\boldsymbol{A}$. Japonica and A. vitifolia; produced in Royal Gardens, 1848. G.M.B. 1:17. Var. rubra, Hort. LADY ARdilaun. Probably the same as the type, but having lvs. and fls. with a waxy gloss: plant 4-5 ft. high.

22. multifida, Poir. Plant silky - hairy, somewhat branched, $1 / 2-1 \frac{1}{2} \mathrm{ft}$. high, from a branched, upright rootstock : main involuere 2-3-1vd., others 2-lvd. or naked, short petioles, similar to the root lvs., 2-3 times 3-parted and cleft, divisions linear: fls. $1 / 2-1$ in. across, red, varying to white or yellow: akenes very woolly. Early summer. Rocks and uplands. Middle states to Hudson Bay.

$$
\text { cc. Fruits (akenes) glabrous at first; fls. white, }
$$
someuhat umbellate.

23. Canadénsis, Linn. (A. Pennsylvánica, Linn. A. di. chótoma, Am. Auth. \& Michx., not Linn.). Hairy, stout, 1-2 ft. high, branching at or above the involucre: the 3 Ivs. of main involucre sessile, 3-eleft; upper involucres each 2-lvd.; basal lvs. broader than long, much divided, cleft and toothed; petioles long: fls. white, 1-2 in. across: akenes wing-margined, naked, becoming pubescent, grouped into a spherical head. Summer. In shaded woods and open meadows. N. Amer. Gng. 2: 21 .

24. narcissiflòra, Linn. (A.umbellata, Lam.). St. erect, rather stout, $1 / 2-11 / 2 \mathrm{ft}$. high : lvs. of involucre sessile; basal lvs. petioled, 3-5-parted, divisions deeply cut: fls white, $1 / 2-1$ in. across, several in an umbel ; anthers yellow: akenes smooth, with short style. May-July. Mountainous regions. Northern hemisphere. Gn. 30, p. 173. B.M. 1120.

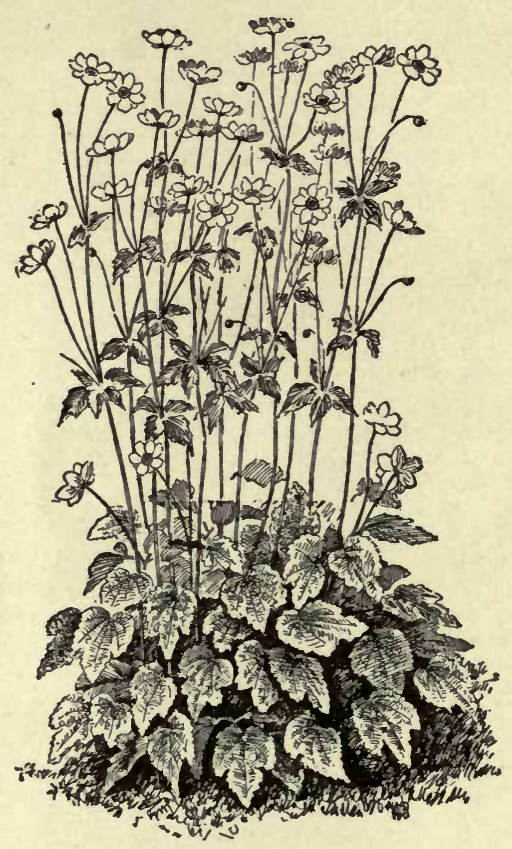

90. Anemone Japonica.

A. alba, Juss. Allied to A. sylrestris, if not the same. L.B.C. 4: 322. B.M. 2167.-A. cylíndrica, Gray. A tall native species, used for beauty of foliage and fruit. $-A$. decapétala, Ard. (A. trilobata, Juss. A. heterophylla, Nutt.). Native and culti(A. trilobata, Juss. A. heterophyla, Nutt.). Native and cultiin. across: $5 \mathrm{ft}$. high: lvs. $1 \mathrm{ft}$. across. B.M. 6958. Gn. 34: 664.A. parviflora, Michx. Pretty white fis. Native of N. states and Canada.-A. polyánthus, Don. Allied to A. narcissiflora. B.M. 6840. J.H. III. 32: 259 -A praténsis, Linn. Allied to A. Pulsatilla. L.B.C. 9: 900.-A. praténsis, var. obsoleta, Sims. Fls. pale: leaflets terminated with a sort of bristle. B.M. 1863. A. sphenophýlla Poepp. Fls. blne. S. W. U. S.-A. trifolia, Linn. Lvs. phyla, Poepp. Fls. flue. S. W. 1 in. across. Two blue vars. B.M. beautifully regular: fls. white, 1 in. across. Two blue vars. B.M.
$6846 .-A$. vitifolia, Ham. Allied to A. Japonica. Has cordate. 5-7-parted lvs. B.M. 3376.

K. C. Davis.

ANEMONELLA. See Syndesmon.

ANEMONOPSIS (Anemone-like). Ranunculacea. A monotypic genus from Japan, now much planted in American gardens. A beautiful hardy plant for border purposes. Perennial herb, with erect stems; radical and stem lvs, rather large, ternately compound and 
much incised, similar to Actæa: sepals many (often only 9), regular, petal-like, deciduous; petals many (often 12), short, sessile, with nectariferous impression at the base; carpels few (3-4), forming many-seeded follicles. In general appearance similar to the Japanese Anemones, but smaller in all its parts, and with numerous drooping fls., about $1 \frac{1}{2} \mathrm{in}$. across, of pale purple color. Thrives well in rich, deep loam, in well-drained situatinns in partial shade. Prop. by division or seed, in late fall or early spring.

macrophylla, Sieb. \& Zucc. (A. Califórnica, Hort.). The only known species. The petals, instead of spreading, form a half-closed bud-like cone within the sepals.

ANEMOPÉGMA. Consult Bignonia.

K. C. Davis.

ANEтTHOM. See Dill and Peucedanum; also Fennel.

ANGELICA (supposed to have angelic healing virtues). Umbellíferce. A large genus in temperate regions, widely distributed. A number of them are native to N. Amer. See also Archangelica.

Cúrtisii, Buckley. Stout perennial, 2-5 ft., glabrous : Ivs. 2-ternate, with quinate divisions, the leaflets thin, ovate-lanceolate, irregularly sharp-toothed. Pa. to N. C. - Grown for the subtropical effect of its finely cut, ample foliage. Int. by H. P. Kelsey, 1891.

hirsùta, Muhl. (Archangélica hirsùta, Torr. \& Gray). Pubescent above: 1vs. twice pinnately or ternately divided, the leaflets thickish and serrate. E. states. Int. 1892 by $\mathrm{H}$. P. Kelsey.

ANGELONIA (South American name). Scrophularidcece. Perennial herbs or sub-shrubs, with pretty, irregular 2-lipped axillary fls., in a long, leafy terminal raceme: lvs. opposite, long: branches 4-sided. Grown as pot plants in warm glass-houses, and prop. by seeds or softwood cuttings.

salicariæfòlia, Humb. \& Bonpl. Three ft. or less: lvs. lanceolate to ovate-lanceolate, sessile, toothed, closely pubescent : fls. deep blue. S. Amer. B.M. 2478. P.M. 5:75. B.R. 415 .

Gárdneri, Hook. Lvs. linear-lanceolate, more strongly toothed throughout their length : fl. purple, white-centered, handsome : plant pubescent-glandular and aromatic. S. Amer. B.M. 3754.-The plant sold in this country as $A$.grandiflora probably belongs here. The A. grandiflora introduced by Benary in 1897 (a good annual), however, is represented as an entire-lvd. pot plant : see the picture in Gt. 46, p. 612 ; G.C. III. $22: 307$; Gn. 52, p. 461 ; R.B. 23: 272.

L. H. B.

ANGIÓPTERIS (Greek, vessel-fern). Marattidcea. An Old World genus of coarse greenhouse ferns, with twice- or thrice-pinnate lvs., and the sporangia arranged in boat-shaped marginal conceptacles. In cultivation, requires plenty of room and abundant drainage. The only recognized species is

evécta, Hoffm. Growing from an erect caudex, 2-6 ft. high : lvs. 6-15 ft. long, mostly bipinnate, with swollen rachises; leaflets $4-12$ in. long, $1 / 2-1 \frac{1}{2} \mathrm{in}$. wide, the margin entire or slightly toothed. India and Jap. to Madagascar and Queensland. S. 1:399.-Known under various names in cultivation, as $A$. longifolia, ete. The trade names, which appear to indicate species, may be regarded as varieties.

L. M. UNDERWOOD.

Angiopteris grows wild in swampy places, and is of robust habit. If grown in pots, the pots may stand in 2 or 3 in. of water. Although spores are freely produced, no seedlings are on record. Easily prop. by the fleshy scales at the base of each frond. Each scale contains at least two dormant buds, and should not be divided. They may be laid in sand, covered with sphagnum, and kept in a close case for $3-5$ months. They start quicker in early spring. - Schneider, Book of Choice Ferns.

ANGOPHORA (vessel-bearing; Greek, in allusion to shape of fruit). Myrtacea. Five or six Australian trees or shrubs, sometimes cult. in glass houses in the Old World. but not known to the trade in this country.
ANGREACUM (Malayan name). Orchiddcea, tribe Vándece. Epiphytes. Lvs. variably distichous, coriaceous : racemes few- to many-flowered, produced from the axils of the lvs.: labellum exserted into a conspicuous spur, sometimes many inches long. Trop. and S. Afr., Madagascar and Jap. With exception of $A$. falca: tum, the species of this genus require high temperatures in order to develop satisfactorily. For culture, see Orchids. Prop. by removing upper portion and planting separately. It should include a few roots.

Angræcums are valued for their winter-flowering and lasting qualities. The compost found most suitable is fresh-growing sphagnum moss, no earthy matter being desirable, as most of the roots are seen striking out into the atmosphere for their needs, and do not take kindly to confinement in pots. Moisture is essential at all times, as Angræcums do not have bulbs to fall back on for their sustenance during rest or blooming, in which respect they resemble the Aërides, Vandas and Saccolabiums. The moss must not be allowed to become deeayed, but kept living by renewal when seen to be necessary, usually in springtime. Some of the favorite species are A. Ellisii, superbum, sesquipedale, Humblotii and falcatum. Cult. by E. O. ORPET.

Alphabetical list of American favorites: A. articulatum, 6 ; citratum, 9 ; distichum, 4 ; eburneum, 12 ; Ellisii, 7 ; falcatum, 3; Humblotii, 1: A. Leonis, 1; modestum, 8 ; pertusum, 11 ; Sanderianum, 8 ; Scottianum, 5 ; sesquipedale, 2 ; superbum, 12 ; virens, 12.

\section{A. Pedicels winged.}

1. Humblòtii, Reichb. f. (A. Leònis, Hort. Aeränbhus theòis. Reichb. f.). Lvs. sword-shaped, equitant, about 8 in. long: Hs. few, white; spur longer than winged pedicel ; petals and sepals lanceolate ; labellum rotund. Comoro 1sls.

\section{AA. Pedicels not winged.}

B. F's. rarely more than 6 .

2. sesquipedale, Thouars (Aeránthes sesquipedalis, Lindı.). Lvs. coriaceous, oblong, about $1 \mathrm{ft}$. in length, 2 in. wide, bluntly bilobed at the summits, dark green : fls. fleshy, 7 in. across, ivory-white; petals and sepals similar ; labellum ovate, serrate in part, acuminate ; spur nearly $1 \mathrm{ft}$. long. Madagasear, in low, hot districts. A.G. 1892:217. A.F. 7: 831. Gn. 2, p. 5. F.S. 14: 1413. B.M.5113. - Noblest of Angræcums.

3. falcàtum, Lindl. Lvs. linear-lanceolate, about 2 in. long: fls. whitish, about $1 / 2$ in. across ; sepals and petals linear, acute or nearly so ; labellum trilobed; spur as long as pedicel. China.-One of the first brought into cultivation.

4. dístichum, Lindl. Plants rarely exceeding $5 \mathrm{in.} \mathrm{in}$ height : lvs. short, those below clasping those above at base : fls. inconspicuous, white, borne singly. Sierra Leone. - Not worth cultivating.

5. Scottiànum, Reichb. f. Lvs. terete : peduncles slender; fls. inverted, pale yellow. Comoro Isls.

$$
\text { вв. F'ls. numerous. }
$$

C. Color white or yellowish.

6. articulàtum, Reichb. f. Dwarf: lvs. oblong-cuneate, 4-5 in. long, unevenly bilobed : fls. white, in pendent racemes. Madagascar. R. 55. -A pretty species, difficult to grow.

7. Ellisii, Reichb. f. St. stout: lvs. oblong: peduncles pendulous; fls. white. Madagascar. Often confused with $A$. articulatum, but distinguished from it by its orange-colored spurs. L. 92.

8. modéstum, Hook. f. (A. Sanderidnum, Reichb. f.). Dwarf : lvs. elliptical, coriaceous : fls. whitish, in pendent racemes. Madagascar. R.H. 1888: 516. R.B. 15:217.

9. citràtum, Thouars. Lvs. oblong-lanceolate, 4-5 in. long, $1 \mathrm{in}$. wide: racemes of yellowish fls. Madagascar, in vicinity of swamps. B.M. 5624. L. 238. I.H. 33: 592 .

10. pertùsum, Lindl. Lvs. ligulate : peduncles about 6 in. long ; fls. small, white. Bourbon. B.M. 4782.

$$
\text { cc. Color of fls. green. }
$$

12. supérbum, Thouars (A. ebúrneum, Lindl.). Lrs. coriacecus, striated, 2 in. wide, over $1 \mathrm{ft}$. long, strapshaped, light green, unequal at the summits : reduncle 
from near the base of the st.; fls. large, green and white, placed alternately back to back; sepals and petals spreading, green ; labellum whitish, round, thickish ; spur green. Valuable; grows to enormous proportions. Madagascar. B.M. 4761. B.R. 1522. L. 236. Var. virens, Hort. (A. virens, Lindl.). Fls. smaller ; labellum tinged with green. B.M. 5170 .

OAKES AMES.

ANGULOA (dedicated to Don Franciseo de Angulo). Orchidàcea, tribe Vándea. Pseudobulbs rather tall (when old), spinose at the summits with the remnants of leaf veins : leaf-blades 1-2 ft. long, prominently nerved, as in Acineta, Stanhopea and Lycaste : fls. large, subglobular, on erect scapes : habit similar to Lycaste, which is a member of the same sub-tribe. The Anguloas grow under shade of trees in leaf-mold. Some growers find that they do well when placed under vines. They are coolhouse orchids, but require a moderate rise in temperature during the growing season. OAKES AMES.

Anguloa is a very interesting genus of cool orchids that thrive well in an ordinary greenhouse temperature, in which a minimum of $50^{\circ}$ can be maintained. They are natives of the Andes of Colombia and Peru. The popular name of "Boat Orchid" somewhat suggests their shape and general appearance, the lip, being delicately hinged at its base, allowing this organ to oscillate when shaken. A. Clowesii is the best known as well as the most decorative species, its color being clear yellow. A. Ruckeri is similar in structure, but the fls. are chocolate-brown, with a decided aromatic fragrance, resembling Anise. There is also a white variety of $\boldsymbol{A}$. Clowesii, but it is very rare in cultivation, as are all of the white forms of well known orchids, this making them very valuable commercially. A.uniflora is also a pretty plant, with white flowers, spotted with pink. Pot culture is best, as they require similar treatment to Lycaste Skinneri.

E. O. ORPET.

uniflora, Ruiz \& Pavon. (A. virginalis, Hort.). Pseudobulbs about 6 in. high ( sometimes considerably higher): leaf-blades $1 \frac{1}{2}-2 \mathrm{ft}$. long, lanceolate : fls. whitish, sometimes spotted within, or the labellum streaked with rose. Colombia. G. C. III. 19: 423. A. F. 6: 607.-There is a white-fld. var.

Clowesii, Lindl. Larger in every way than the above: fls. lemon-yellow, labellum tending toward white, marbled with orange. Colombia.

Rúckeri, Lindl. Smaller than A. Clowesii: fls. yellow, spotted with crimson. A variety has been figured with the crimson or red color predominant (var. sanguinea, A.F. 6:607). Colombia.

ebúrnea, Nicholson. Similar to $A$. Clowesii, but sepals and petals pure white and lip spotted pink. New Granada.

OAKES AMEs.

ANHALONIUM (name of no significance). Cactàcece. Top-shaped succulent desert plants, mostly buried in the ground, the flat aërial portion covered with angular tubercles bearing no spines. A genus of 4 or 5 species, manni) crosses the Rio Grande into Texas. It is referred to Mamillaria by some. For A. Williamsii and $A$. Lewinii, see under Echinocactus, section Lophophora. For culture, see Cactus.

A. Upper surface of tubercle with a broad and deep wool bearing longitudinal groove, which widens below.

Engelmanni, Lem. (A. fissuratum, Engelm.). Living Rock. The flat tubercle-covered top 2-5 in. across, tapering below into a thick root: tubercles imbricated and appressed, triangular in outline, $1 / 2-1$ in. long and about as wide at base, the upper surface variously fissured, even to the edges, presenting an irregular warty appearance : fls. central, about 1 in. long and broad, shading from whitish to rose. On limestone hills in the "Great Bend " region of the Rio Grande in Texas, and extending into Mexico. I.H. 16, p. 73, and fig.

Kotchùbeyi, Lem. (A. sulcatum, Salm-Dyck). This appears as a trade name, but the form is very uncertain, as no type seems to be in existence. According to the description, it is very much like the preceding species, except that the upper surface of the tubercle is not irregularly fissured, but is smooth, at least at the edges, except for the central furrow.

\section{B. Upper surface of tubercle not grooved.}

prismáticum, Lem. The fiat top 3-8 in. across: tubercles imbricate, but squarrose-spreading, sharply triangular-pyramidal and very acute, with a sharp, cartilaginous tip, which usually disappears with age and leaves the older tubercles blunt or retuse, $8 / 4-1$ in. long and about as wide at base, the upper surface almost plane and smooth, except that it is more or less pulverulent, and often bears a small tomentose tuft just behind the clawlike tip: fls.rose color. Mts.of Mex.-Resembles an Aloe.

JohN M. COULTER.

ANIGOZANTHUS (Greek, expanded-flower). Hamodoràcece. Eight or 10 species of Australian greenhouse or half-hardy perennials, with greenish, yellow or purple fls. and sword-like lvs., cult. in Europe, but unknown to the Amer. trade.

ANISACANTHUS (Greek, unequal acanthus). Acanthàcece. A genus of six species of Mexican and American shrubs, with mostly lanceolate, entire, petioled lvs., and loosely spicate or scattered red fls. an inch or more long; corolla lobes 4 ; stamens 2, equaling or exceeding the corolla lobes.

Wrightii, Gray. Height, 2-4 ft.: lvs. 1-2 in. long, oblong- or ovate-lanceolate, acute or acuminate. S. and W. Tex.-Once sold by John Saul, Washington, DC.

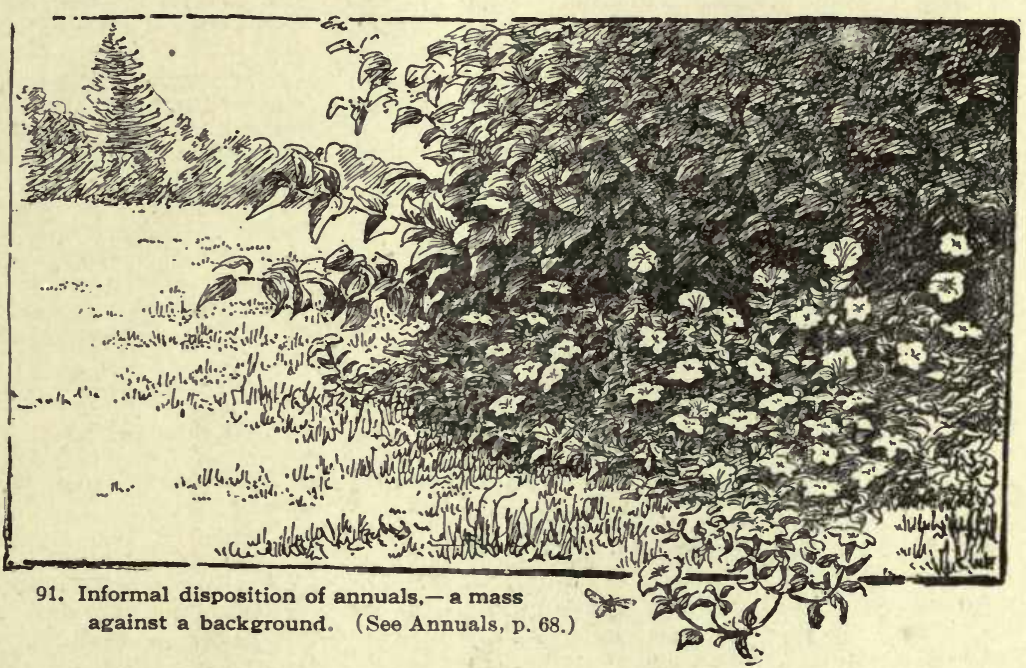

ANISE. Umbelliferce. An aromatic condimental and medicinal herb (Pimpinélla Anisum, Linn.) of the Orient. It is an annual, and is easily grown from seeds in any warm and mellow soil. The seeds are commonly sown where the plants are to stand. The seeds are used in medicine and in cookery, and for flavoring liquors. They yield a highly perfumed essential oil. They are mostly grown in Mediterranean countries. The leaves are also used as seasoning and garnishing. The plant reaches a height of $2 \mathrm{ft}$., bears twice-pinnate lvs. and small yellowish white fls. in large, loose umbels. The seeds are oplong and curved, ribbed on the convex side, grayish, 
the size of caraway seed. In common with all umbelliferous seed, Anise seed does not retain its viability long, the normal longevity being 1 to 3 years.

ANNUALS. Plants which, in cultivation, are preferably grown from seeds euch year are commonly classed as Annuals. More strictly, Annuals are plants which normally live but a single season. Among Annuals are found a number of the most showy flowers. As a rule, they are easily grown, producing quick results and affording a variety of brilliant colors. The class is, therefore, one of the greatest value. Some of the Annuals last only a few weeks in bloom, others continue throughout the summer. There are trailers and climbers, $d w a r f s$ and tall growers. By a judicious selection and arrangement of kinds, the handsomest effects may be produced. Many of the showy kinds are adapted to mass effects, while the dwarf-growing sorts make fine flowering edgings for beds or walks. With the latter, handsome ribbon-beds are possible, but this requires care in the selection of kinds, and as the use of the trimming shears is almost precluded it is best to limit oneself to simple designs. Annuals are well adapted to the covering of bare spots of ground in the border. Annuals, like other flowers, show off best when seen against a background of foliage. See Figs. 91, 92. The tall and leafy kinds make excellent covers for unsightly objects; see Screens. For climbing and twining kinds, see Vines. See, also, Everlastings and Grasses.

In the case of others than the continuous bloomers, a succession of sowings or plantings is desirable to provide for a continuous display; then as a kind begins to fail its place may be filled with young plants of the same or other species. The usual method of securing succession is to sow the secds in tiats, or beds, and trans. plant the seedlings first to pots. The potted plants may be set out at any time, with but little check to growth.

Most Annuals prefer an open, sunny situation, but pansies, forget-me-nots, and some others, thrive where they get the full sunshine for only half the day. In all cases the best results are obtained only when the soil is well enriched and thoroughly prepared previous to sowing or planting ; and it is far better to make this preparation a fortnight or more in advance. A considerable proportion of humus in the soil is desirable, rendering it less subject to baking and drying out. Cow-manure, stable-manure or leaf-mold, worked in liberally, will supply this. Beds should be spaded thoroughly and at least a foot deep. If the surface is then again worked over to half this depth, better results will be obtainable. The soil should not be disturbed, however, unless it pulverizes readily. For the reception of seeds, the surface should be mellow and smooth. The seeds are sown in drills or concentric circles, according to the method of planting decided upon. Taller growing kinds are sown

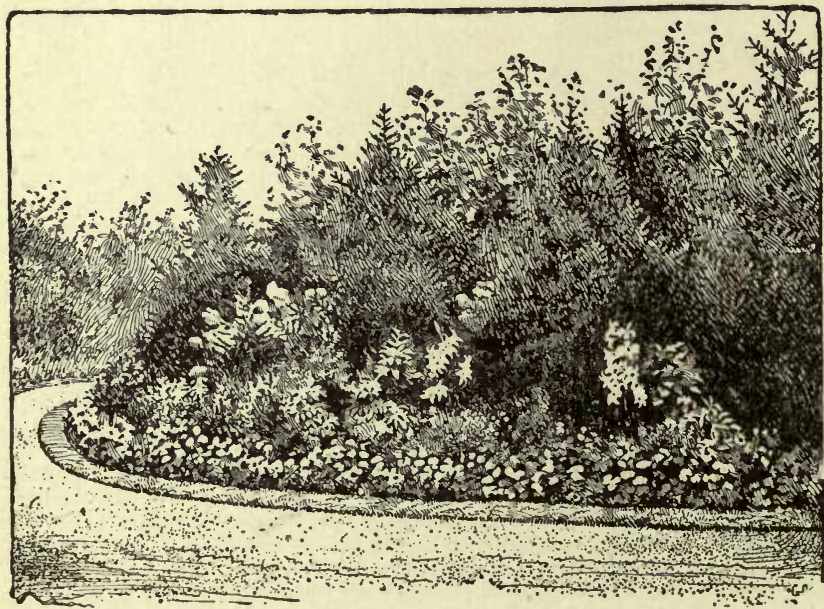

92. Annuals filling the formal space between a drive and a tree-group. torvard the center or back of the bed. Only the best seeds should be purchased, and it is generally best to get the colors in separate packets. In the open ground, seeds may be covered to a depth of four or five times their own thickness, but when sown indoors in trays or pots, the rule is to cover them to about their own thickness. The position of each row or kind should be marked, so that when weeds and flowers spring up there will be no trouble in separating the sheep from the goats. After covering, the soil should be pressed firmly over the seed with a board or hoe, or the feet. In soils which are inclined to bake, a sprinkling of sand or fine litter over the surface after sowing will remedy this evil. Evergreen boughs placed over the beds until the seedlings have appeared will afford useful shelter from beating rains. It is desirable to sow the seeds thickly. When up, the plants may be thinned to their proper distances. Particular care should be given to this matter, and to keeping down weeds, or the plants may become weak, spindling and valueless. No seed pods should be allowed to form, else the vitality of the plants will be exhausted. The flowers may be freely gathered with advantage to the flowering.

It is customary to divide Annuals into three classes: (1) Hardy Annuals are those which are sown directly in the open ground where they are to grow. They are vitally strong, developing without artificial heat, and may be sown from February to May, according to the season and latitude. Some of them, as sweet peas, may be sown even in the fall. For this class, a well prepared border on the south side of a fence or wall, or other sheltered place, is usually preferred for early sowings. From here the secdlings are transplanted later where they are to grow. Some sorts, however, do not bear transplanting well, consequently must be sown in the places they are to occupy. Among such are poppies, eschscholtzia, bartonia, Venus' looking-glass, lupine, malope, and the dwarf convolvulus. (2) Half-hardy Annuals are usually sown in February or March in the window or a warm frame. The season is usually not long enough to enable them to reach full development in the open. In the early stages of growth, they need protection and warmth. Such kinds are sometimes sown in the fall and wintered over in a coldframe. When once established, they are hardy with slight protection. Pansies and some other kinds are grown to their greatest perfection only in this way. (3) Tender Annuals require still more warmth, and are started from January to May in the greenhouse or other suitable place. They commonly need a temperature of from $60^{\circ}$ to $70^{\circ}$. The danger with early grown seedlings, especially those started in the window, is crowding and want of light. As soon as erowding begins, the plants should be thinned out or transplanted to other trays, or into pots, and reset from time to time, as they need: frequent transplanting is usually an advantage. The last transplanting is preferably into small pots, as then the seedlings may be readily set out in the open ground at the proper time, with little or no check to growth.

Some of the staple or general-purpose types of Annuals in the North are the following: Petunias, phloxes, pinks or dianthuses, larkspurs or delphiniums, calliopsis or coreopsis, pot marigolds or calendula, bachelor's buttons or Centaurea Cyanus, (larkias, zinnias, marigolds or tagetes, collinsias, gilias, California poppies or eschscholtzias, verbenas, poppies, China asters, sweet peas, nemophilas, portulacas, silenes, candytufts or iberis, alyssum, stocks or matthiolas, morning-glories, nasturtiums or tropæolums. Other species are mostly of special or particular use, not general-use types. In the South, and occasionally at the North, some of the Annuals come up voluntarily year after year from self-sown seeds. Petunias, phloxes and morning-glories are examples.

For further suggestions, see Seedage. For an annotated list of Annuals suited for northern climates, see Bull. 161, Cornell Exp. Sta.

ERNEST WALKER. 
ANECTOCHILUS (Greek, open lip). Orchidldcen, tribe Neottice. A genus eultivated for the beautifully reticulated lvs., which are oval or ovate, membranaceous and diversely colored. Fls. small, not ornamental. The known species belong to India and the Malay Archipelago. Although many methods have been adopted for the suceessful cultivation of the best species and varieties, failure has been the general rule, so that at the present time few Amer. collections contain even a single specimen. "For a time-it may be two, or even five years - they will grow and remain in health, and then suddenly they go wrong, the plants perishing one after the other, in spite of all one can do."-W. Watson.

Búlleni, Low. Lvs. about 2 in. long, bronze-green, with 3 longitudinal bands of copper-red. Borneo.

regalis, Blume. One of the most attractive species of the group: lvs. oval, large, bronze-green netted, veined with gold, the surface of the lvs. like velvet. Java. B.M. 4123. F.S. 2: 79 as A. setdceus.-Several good varieties exist.

Roxburghii, Lindl. Lvs. ovate, median line of pale green, reticulated and veined with gold. Java and Ind.

Many species are described and figured in foreign publications, but they are all fanciers' plants. Other names which ap. pear in the Amer. trade are: $A$. Dayàn $a=?-A$. Dáwsoni (Davsoniànus) $=$ Hæmaria $-A$. Lowvii, $\cdot$ Hort $=$ Dossinis $-A$. Petòla, Hort.=Macodes. $-A$. Veitchiànus, Hort.=Macodes.

OAKES AMES.

\section{ANOMATHECA. See Lapeirousia.}

ANONA (aboriginal name). Anondcece. CUSTARD. APPLE. Tropical trees and shrubs, cult. for their large, fleshy fruits, and for ornament. Fls. perfect, solitary, terminal or opposite the lvs.: petals typically 6 , but half of them sometimes reduced to small scales or even wanting: pistils many, each with one erect ovule, united into a fleshy fruit-like body or syncarpium. Small trees or shrubs, over 50 in number, of Tropical America, and a few in Africa and Asia. Some of the species have been introduced into southern Florida, but they are generally imperfectly known, both to horticulturists and botanists. Aside from the species deseribed below, various other Anonas have beeen introduced into southern Florida, but their botanical status is unknown and some of them are probably forms of old species. Amongst these names are $A$. Mexicana, which was a catalogue name used by Loddiges, the species never having been fully described; $\boldsymbol{A}$. A fricana, a very obscure species founded by Linnæus upon an American specimen, with lanceolate pubescent lvs.; A.trilobata is undoubtedly Asimina triloba: A. aurantiaca, A. macrocarpa, A. maritima, $A$. reniformis, and A. suavissima are either horticultural names, or belong to other genera ; the Beribá, introduced by Reasoner Bros., from Brazil, is evidently a Rollinia, possibly $\boldsymbol{R}$. orthopetala. For A. longifolia, see Duguetia, and for A.muscosa, see Rollinia. Some of the species are imperfectly evergreen. See Artabotrys.

Anonas are of easy culture, requiring no special treatment in frostless countries. They propagate readily by seeds, and are usually thus grown; also, by ripened cuttings under glass. In the U.S. they are sometimes grown under glass as ornamental subjects. They should then be kept fairly dry in winter, for at that time they assume a semi-dormant condition. They thrive best in heavy loam.

A. Petals corlate-ovate or obovate, the inner ones conspicuous.

B. Exterior petals plainly acute, inner ones obtuse.

$$
\text { c. Fruit bearing weak spines. }
$$

muricàta, Linn. (A. Asicítica, Linn.). Sour-Sop. Guanabena. Corresol. Surraak. Susakka. Small tree, the size of a peach tree, evergreen, the young growth scurfy-pubescent: exterior petals scarcely exceeding the interior ones, 1-2 in. long, and yellowish or greenish,the inner ones yellow or red: lvs. elliptic and pointed, varnished above and rusty beneath, but becoming glabrous: fr. very large (6-8 in. long and weighing from 1-5 lbs.), oblong oriconical and blunt, dark green, the skin rough and spiny; pulp soft, white and juicy, subacid, with a turpentine-like flavor. West Indies, where it is a popu- lar fruit. - It is grown with especial excellence in Porto Rico, and is common in the markets of Key West, whither it is shipped from the islands to the southward. A favorite drink is made from the juice. It is one of the tenderest trees of the genus, and thrives only in extreme southern Florida and California. Introduced in the Old World.

cc. Fruit nearly or quite smooth (or in A.pyriformis undescribed).

glàbra, Linn. (A. laurifòlia, Dunal). Pond-Apple. MAMON. Fig. 93. Small nearly evergreen tree, with smooth growth: exterior petals somewhat exceeding the

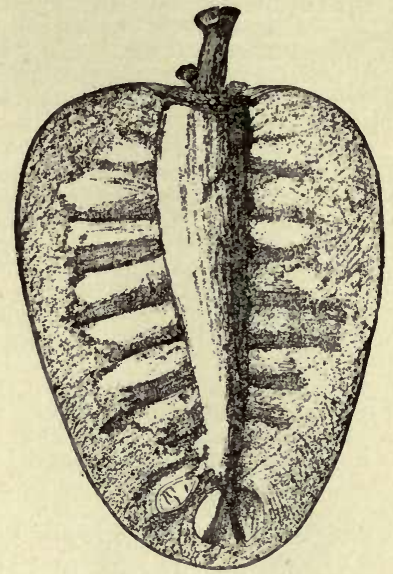

93. Anona glabra. Nearly $1 / 2$ uatural size.

interior ones, greenish : lvs. oblong-ovate or long-ovate, pointed, green on both sides and glossy above : fr. the size and shape of a Bellflower apple or an ox's heart, yellow or brownish yellow, smooth, the stem pulling out of the fruit at maturity and leaving a very deep cavity; pulp cream-colored and very fragrant, fair in quality. Native in swamps, both salt and fresh, in southern Florida, and on the Indian River; also, in the West Indies. B.R. 1328. SS. 1:17, 18. - The fruit, although acceptable to many people, is not generally prized.

pyriformis, Bojer. Climbing, glabrous : petals of the two series nearly equal, oblong-spatulate or obovate (about 2 in. long), flat, the outer ones hooded or cucullate at the top : sepals joined half their length : lvs. nearly oblong (3-6 in. long), obtuse or acutish, thick and rigid, somewhat shining and glaucous. Mauritius.- Said to have been introduced into southern Florida recently, but it is imperfectly known.

BB. Exterior petals obtuse or nearly so.

palústris, Linn. Alligator-APPLE. CORK -WoOd. MoNkey-APple. BunYa. Tree, 10-15 ft. high, the young growth smooth: exterior petals ovate, exceeding the oblong inner ones, a half-inch or more long, and yellow, with a red spot at the base within, the interior red inside: Ivs. ovate-elliptic or oblong, with a short, narrow point (or occasionally bluntish), smooth on both sides, rather thick, and more or less evergreen: fr. 2 in. in diam., yellow, and somewhat roughened or scaly. Cuba to Rio Janeiro ; also, in Africa. B.M. 4226.-Introduced in southern Florida, but imperfectly known in cultivation. Unless improved by cultivation, the fruit is probably unworthy of cultivation.

Ввв. Exterior and interior petals all acute.

paludòsa, Aubl. Shrub, with rusty-villous branches: outer petals acute, twice longer than the canescent inner ones: lvs. oblong-acute, rounded at the base, sparsely pubescent above and tomentose beneath : fr. ovate and tuberculate, pubescent when young. Guiana.-Introduced into southern Florida, where it is yet very littlo known. 
AA. Petals (exterior) linear or oblong, the inner ones minute lor conspicuous in A. muscosa).

B. Fruit smooth or very nearly so (in A. amplexicaulis undescribed).

c. Lvs. velvety beneath.

Cherimolia, Miller (A.tripétala, Aiton). Cherlmoyer, or Cherimoya. Jamaica-ApPle. Tree, 15-20 ft. high, with young growth scurfy-pubescent: fls. opposite the lvs., greenish, and fragrant, the exterior petals oblong-linear and keeled on the inner side, velvety : lvs. ovate or oblong (about 3 in. long), obtuse or scarcely acute, dark green, and sparsely hairy above and velvety beneath : fr. very large (from the size of a large apple to 8 in. or more in diam.), spherical or slightly flattened at the ends, nearly smooth, brownish yellow, sometimes with a red cheek, the flesh soft and rich. Peru and adjacent regions northward, but naturalized in Central America and Mexico, the West Indies and parts of the Old World. B.M. 2011. - It is a well-known fruit of the tropics, and it thrives upon the Florida keys and the adjacent coasts. It is also grown to a limited extent in southern California. Fruit will stand transportation if picked green. Possibly the plants sold as A. macrocárpa and A. suavissima are forms of the Cherimoyer. See Cherimoyer.

$$
\text { cc. Lvs. not velvety. }
$$

reticulàta, Linn. Custard-ApPle. Bullock's-Heart. Fruta DE CoNDE. A tree, 15-25 ft. high, with growth smooth or nearly so: fls. with the exterior petals oblonglinear and keeled on the inside, acute, greenish, with purple spots at the base : lvs. lanceolate or oblong and pointed, glabrous above and rough beneath, but becoming smooth: fr. 3-4 in. in diam., smooth, with small depressions, in various shades of yellow or even russet, with a soft yellow cream-like pulp next the skin, and a white pulp at the middle, sweet and excellent. West Indies, where it is a very popular fruit. It thrives in southern Florida, where it has lately been introduced. B.M. 2911, 2912.

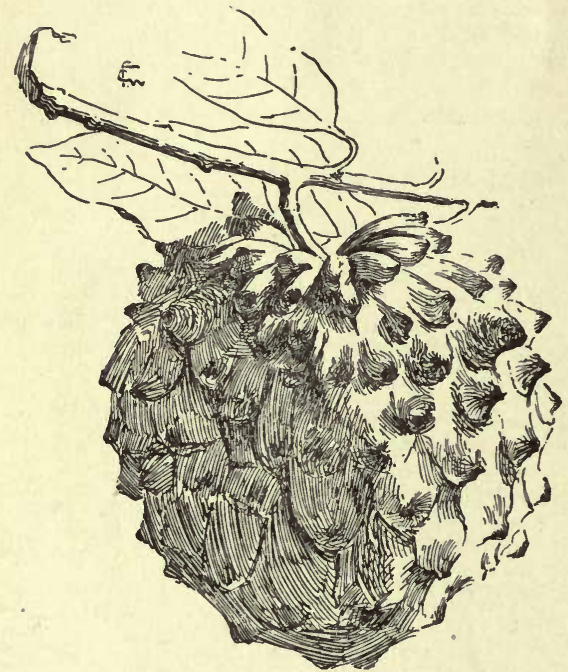

94. Anona squamosa, grown in Bermuda $\left(\times \frac{1}{2}\right)$.

amplexicaùlis, Lam. Erect shrub, glabrous : outer petals oblong and obtuse (11/2in. long), the inner very much shorter and lanceolate and pointed: Ivs.oblong or ovate, obtuse or acute (4-6 in. long), thick and rigid, glaucous and somewhat shining, deeply cordate-clasping at the base. Mauritius and Madagascar.-Said to have been lately introduced into southern Florida. Little known.

Bв. Fruit tuberculate.

squamòsa, Linn. (A. cinèrea, Dunal). SweEt-Sop. SugAr-Apple. Fig. 94. Diffuse small tree, or a shrub, 10-20 ft. high: fls. with the outer petals oblong-linear and blunt, keeled on the inner side, greenish: lvs, thin, ob long-ovate, very sparsely hairy on both sides, but often becoming smooth, glaucous: fr. egg-shaped, or of the form of a short pine cone, 3-4 in. in diam., yellowish green, and tuberculate (each carpel forming a protuberance); the pulp creamy yellow and custard-like, very sweet. West Indies to Brazil. B.M. 3095.-Much prized in the tropics, and considerably grown on the Florida keys, and extending north, with some protection, nearly to the middle of the state; also cultivated in Califoruia. Introduced in the Old World. Lvs., green frs., and seeds said to be used for destroying vermin.

L. H. B.

ANSÉLLIA (John Ansell, African explorer). Orchidacece, tribe Vándece. Inflorescence terminal : stems tufted, jointed, nodes conspicuous : lvs. lanceolate, alternate toward the summit of the stems, visibly nerved, about 6 in. long. The species require high temperatures for successful development. Epiphytes. For further culture, see Orchids.

Africana, Lindl. Plants $2 \mathrm{ft}$. or more high : stems cylindrical : fls. numerous (40-80), yellowish, verging on green, marked with curiously oblong, brown-purple spots; labellum yellow, 3-lobed. Sierra Leone. B.M. 4965. - This is undoubtedly the type, all other forms so far known being departures from it of horticultural merit only.

gigantèa, Reichb.f. (Cymbídium Sándersoni, Harv.). Habit as above. Sepals and petals sparingly, if at all, spotted. Natal?

OAKes Ames.

\section{ANSONIA. See Amsonia.}

ANTENNARIA (pappus likened to antennoe). Compósitoe. Everlasting. Cat's-Ear. Small, white-woolly perennial herbs, with spatulate or obovate root-lvs., and mostly leafless scapes, bearing small gray or white heads which remain stiff and dry. They are interesting for rockwork and the edges of borders, and for this purpose have been sparingly introduced in the last few years. They are perfectly hardy, and thrive in poor soil. The fls. are often cut before fully mature and dried (and often dyed) as everlastings. Several species grow wild. Prop. mostly by division of the mats; also by seeds. Allied to Anaphalis and Gnaphalium. Diœcious. See Everlastings.

A. Pappus of sterile fls. not thickened at the tip, minutely roughened.

dimórpha, Torr. \& Gray. Tufted with spatulate Ivs. and a sparsely-leaved fl.-st. an inch or less high, from a stout, much-branched caudex. Neb. west.

\section{AA. Pappus of sterile fls. thickened at the top.}

\section{B. Not spreading by stolons.}

Geỳeri, Gray. Stout, thick-woolly, from a woody base: fl.-st. 3 in. or more high, very leafy to the top : pistillate heads narrow : involucre with rose-purple or ivorywhite tips to the inner scales. Cal. $\mathrm{N}$.

$$
\text { Bв. Spreading by stolons. }
$$

C. Heads solitary or in a cymose cluster.

diolca, Linn. Basal Ivs. 11/2 in. or less long, 1-nerved or only indistinctly 3 -nerved : st. 2-12 in.: involucral bracts all light green or light brown, with white or pinkish tips. N. states and Eu.-The plant in the trade as $A$. tomentòsum is probably a form of this species. Also in cult. under the proper name, $\boldsymbol{A}$. dioica.

alpina, Gærtn. Plant 1-4 in.: involucral bracts in fertile heads, dark brownish green, acute. Canada, Rocky Mts., Sierra Nevadas.

plantaginifòlia, Rich. Basal lvs. 11/2 in. or more long, distinctly 3-nerved : st. 6-18 in. high. Stoloniferous, making broad patches. Common in fields and old pastures. Perhaps not in cult.

\section{cc. Heads loosely panicled.}

racemosa, Hook. Light-woolly, 6-20 in. high, the sts. sparsely leafy, the heads mostly on slender peduncles : involuere brownish. Rocky Mts.

L. H. B. 


\section{ANTHEMIS}

ANTHEMIS (Greek name of the cha nomile). Composite. CHAMOMLE. Pyrethrum-like heavy-scented plants, annual, biennial or perennial, members of a large, Old World temperate-region genus. Heads manytlowered, the disk yellow, the rays white and yellow and (lowered, the disk yellow, the rays white and yellow and conical and chaffy, the akenes terete or ribbed, and either naked or bearing a minute crown : lvs. pinnately dissected. Two or three of the species are weeds. Others are excellent border plants. The true chamomile is a medicinal plant. The hardy perennial species, which alone are grown in this country, are easily handled in the border, where they bloom from midsummer till frost. They thrive in almost any soil, but need full exposure to sun. Prop. by seeds or division of the clumps, usually the latter.

\section{A. Rays normally yellow.}

tinctoria, Linn. Golden Marguerite. Of bushy habit, 2-3 ft, with ancular st, and pinnately divided, and again piunatifid or cut-toothed lvs., and large, daisylike, golden yellow fls. (1-2 in. across). A. Kéluayi, Hort. (or var. Kélu'ayi, Hort.), has finer-cut foliage and deeper yellow fls. There is also a pale-rayed var. Gn. 52: 1149. - An excellent hardy border plant, and useful at the same time for cut fls.

$$
\text { AA. Rays white. }
$$

B. Perennial; cultivated.

nóbilis, Linn. ChамомıLe. Half-spreading and muchbranched, downy, the lvs. very finely dissected : pappus wanting, chaff of the receptacle blunt.-A pleasantscented herb, sometimes escaped from cult. It yields the medicinal chamomile fls. of commerce. For medicinal purposes, the heads (the single preferred) are cut as soon as fully expanded, and dried. Cult. also as a hardy border plant; often double.

BB. Biennial or annual; weeds.

arvénsis, Linn. Pubescent, notill-scented; lvs. rather ooarsely 1-2 pinnately parted : pappus a minute border: heads 1 in. or more across : rays pistillate. - Not common.

Cótula, DC. MAY-WEed. A common weed along roadsides, ill-scented, growing a foot or two high, with finely dissected lvs., neutral rays, and many aster-like fls. 1 in. across.

A. Aizoon, Griseb. $=$ Achillea ageratifolia. $-A$. Arábica, Linn. -Cladanthus. $-A$. coronària, Hort.=Chrysanthemum coronarium.

L. H. B.

\section{ANTHER. See Flower.}

ANTHERICUM (Greek, flower hedge). Includes Phalangium. Lilidcea. Herbs, with tuber-like rhizomes, and racemes of rather small, white, deep-cut fls.: perianth rotate ; anthers attached between their basal lobes, and the locules many-ovuled-in these characters differing from Paradisea. Grown in borders, where the roots should have a cover of leaves or litter in winter; also in pots and under benches in coolhouses. Useful for lawn vases. Prop. naturally by stolons ; increased also by division and seeds. Of easiest culture. Give plenty of water when in bloom. A. Liliastrum, St. Bruno's Lily, will be found under Paradisea. A picturatum, $v a$ riegatum and vittatum will be found under Chlorophytum. A. Californicum of some catalogues perhaps belongs to Chlorophytum.

Liliàgo, Linn. St. Bernard's LiLy. Fig. 95. Stem simple, $2-3 \mathrm{ft}$. high, bearing an open raceme of open spreading fis. 1 in. or less across, the segments linearoblong : lvs. long and narrow. S. Eu. and N. Afr. B.M. 914. Var. màjor, Sims, is larger in all its parts. B.M.1635.

ramòsum, Linn. (A. graminifolium, Hort.). Stem branched : fls. somewhat smaller. Eu. B.M. 1055.

\section{H. B.}

ANTHOLYZA (name from the Greek, of no particular application). Iriddcece. About 20 Cape and Trop. African cormous plants, with linear or sword-shaped lvs, and bright fls. in 2-sided spikes. Perianth long tubular, curved, dilated above, the uppermost segments largest: stamens 3: style branched : ovary 3-loculed. Cult. the same as gladioli, being taken up in the fall. The tubers are often started in a frame or in the house before planting in the open. See Baker, Irideæ.
A. Perianth red, segments very unequal.

Cunonia, Linn. Corm small : st. simple, 1-11/2 ft.: lvs. about 4 , linear, $1 \mathrm{ft}$. or less long: fls, $4-6$, in a lax spike, bright red, an inch long, the stamens reaching to the tip of the upper segment. Cape. L.B.C. 20:1971.

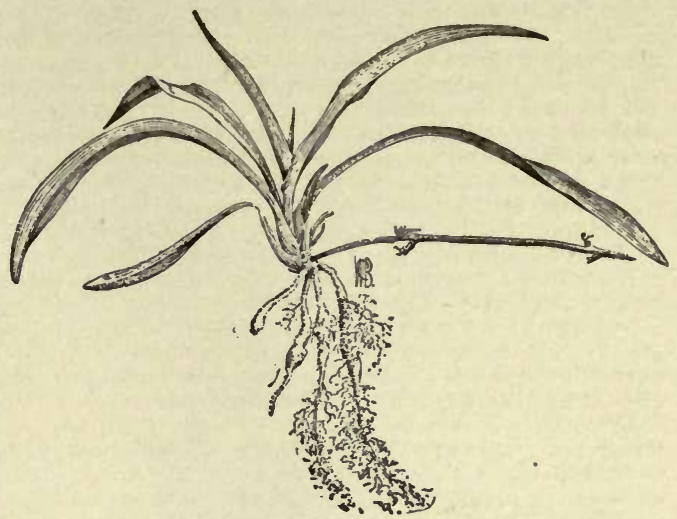

95. Stolon of Anthericum Liliago.

Cáffra, Banks. Corm large : st. 2 ft. or less : lvs. narrow-linear, $1 \mathrm{ft}$.: fls.12-20, in a lax spike, bright red, 1-11/4 in. long, stamens not quite reaching tip of upper segment. Cape.- Has been hybridized with gladiolus.

AA. Perianth red and yellow, segments less unequal.

Exthiopica, Linn. Corm large : st. branched, 3-4 ft.: lvs. several, sword-shaped, 1 in. broad and $1-1 \frac{1}{2} \mathrm{ft}$. long: spike 6-9 in. long, rather dense : fls. $1 \frac{1 / 2-2}{\mathrm{in}}$. long, red and yellow; stamens reaching to the tip of the upper segment. Cape. B.M. 561 .

Var. minor, Lindl. (A. bicolor, Gasp.). Dwarf : lvs. narrow : fls. red at top, pale yellow below.

Var. vittígera, Baker (var. ringens, Nichols.). Tall as the type : fls. bright yellow, striped red. B.M. 1172.

Var. immarginàta, Baker. Fls, red, with dull yellow.

L. H. B.

ANTHOXANTHOM (yellow-flower, from the Greek). Graminea. A.odordtum, Linn., of the temperate part3 of the Old World, is the Sweet Vernal Grass. It is a perennial, of low growth very early bloom, and sweet odor when mown. It is used in mixtures of pasture grasses, and is also spontaneous in the $\mathbf{E}$. states in pastures, meadows, and along roads. $A$. Puélii, Lec. \& Lamotte is an annual species, of smaller size, sometimes used in forage mixtures.

\section{ANTHÙRIUM (Greek,} tail-flower). A roide a. Tropical herbs, of 200 or more species, cult. mostly in stoves, grown for the showy spathes and spadices or for foliage. Spathe usually spreading or even reflexed, only rarely partially enclosing the spadix. Differs from Alocasia and allied genera in technical characters. Monogr. by Engler in DeCandolle's Monographiø Phanerogamarum, Vol. 2 (1879).

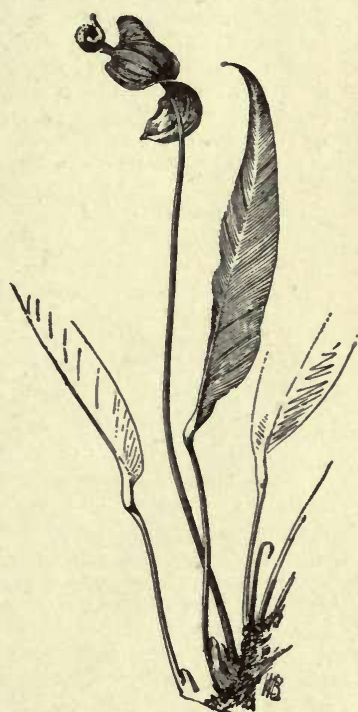

96. Anthurium Scherzerianum.

Propagation is effected by suckers or cuttings of the rhizome inserted in small pots containing a mixture of peat fiber, chopped sphagnum moss and silver sand in 
equal proportions, and plunged in a propagating box in a temperature of $75^{\circ}$ to $80^{\circ}$, with bottom heat. About the end of January is the most suitable time to take the cuttings. Anthuriums may also be propagated by seeds sown in a mixture of very fine fibrous peat and chopped sphagnum moss in 4-inch pots. The seeds should be lightly covered with sphagnum and the pots placer either in a propagating case or under bell glasses, where a temperature of $80^{\circ}$ can be maintained. A coustant humid atmosphere is very necessary to induce the seeds to germinate. The compost in which Anthuriums thrive best is a mixture of one-third fern root, or the fiber of peat with the dust shaken out, one-third sphagnum moss and one-third broken crocks and charcoal. The pots must be well drained, and the plants should be coned up 2 or 3 inches above the rim of the pots, and finished off with a surfacing of live sphagnum moss.

Established plants will only need repotting once in 2 or 3 years, but should have a fresh top-dressing every year ; the best time to overhaul them is about the end of January, or before active growth commences. They should be given a shaded position, free from draughts of cold air, and ordinary stove temperature.

Like most evergreen aroids, they require a copious supply of water at the roots and a humid atmosphere during the spring and summer months, and at no season of the year must the plants be allowed to become dry. Care must also be taken not to mar the leaves by hard spraying. The temperature during winter should not fall below $55^{\circ}$.

Cult. by Edward J. Canning.

Anthuriums such as $A$. Andra nnum, A. ornatum, and their numerous hybrid progeny, require at all times a high and humid atmosphere. Under those conditions and in a good rooting medium, they ought to be continually in flower. A bloom is produced from the axil of each leaf, and immediately beneath this leaf a new root is produced, thick and succulent at first, becoming tough with age, and, if not allowed to bury itself among the compost in which the plant grows, it eventually hardens and is of no help in the sustenance of the plant. Therefore, the growing point of the specimens should not be allowed to get too high, or the flowers will be few and poor. When the plant forms stems above the pot, the compost should either be built up around the stem, to catch the roots, or the plant may be cut over, rooted afresh in sand, and given a new start in a pot. The two ornamental-leaved species, $A$. Veitchii and $A$. Warocqueanum, should be treated in the same manner. When eut down, we may look for the old stocks to send out small growths, which in course of time may be taken off and put in small pots. All of the above are such free-rooting kinds that they may, with the addition of some rotted manure, be grown in sphagnum moss. A good mixture is as follows: Sphagnum, chopped not too fine, one part; fern or kalmia roots, chopped up and the fine substance removed, one part; another part to be made up equally of sand and rotted manure. With well-drained pots, this forms an admirable rooting substance. Most of the other

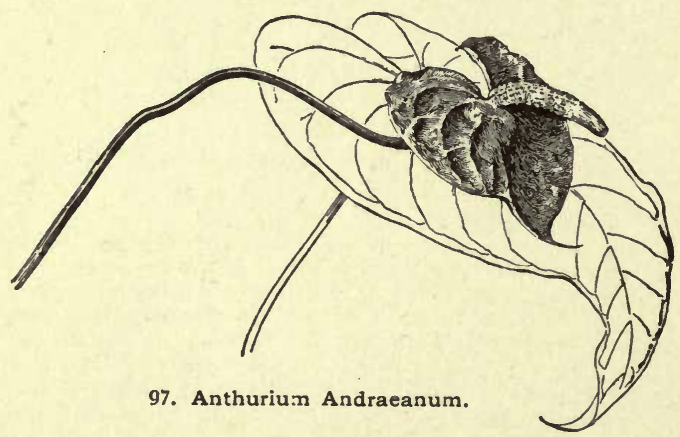

species and their forms, including $A$. Scherzerianum and $A$. crystallinum, will thrive better in material mainly composed of rough, fibrous loam and peat with the fine material sifted from it. This rough, fibrous material should be mixed witb a small quantity each of sphagnum, charcoal and sand. Good drainage, and less water than is needed for the Andreanum section, will be necessary. $A$. Scherzerianum, although thriving well in the hottest house, will succeed in an intermediate house. Seeds are obtained by pollinating the flowers, the stigmas of which become mature long before the anthers. The seeds

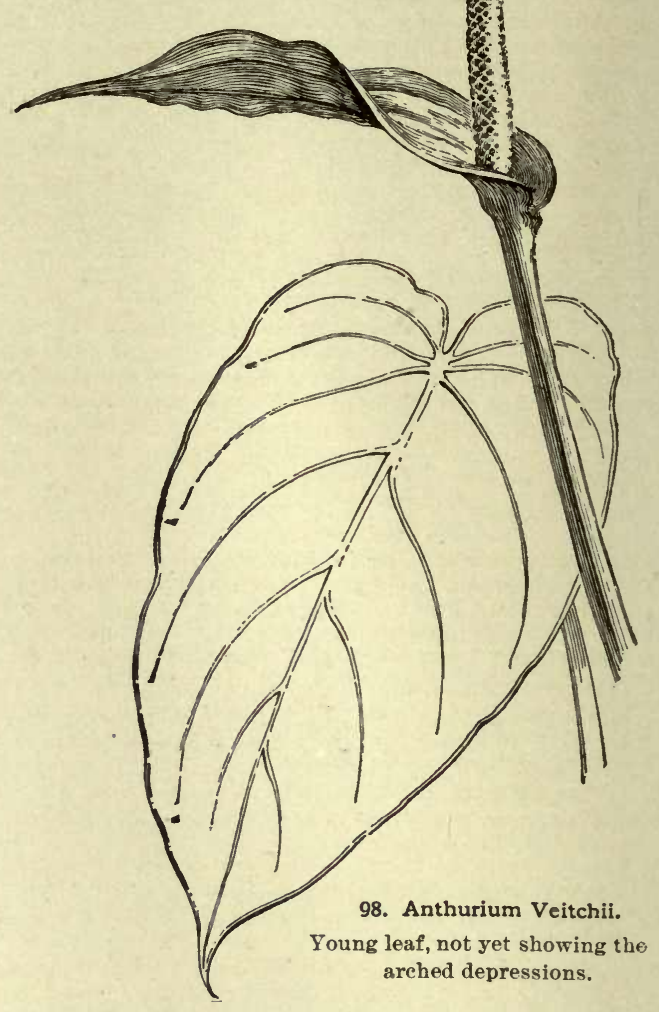

should be sown on the surface of a pan of chopped moss and sand covered with glass; they sometimes show signs of germinating almost before being gathered, so that it is dangerous to keep them any length of time before sowing. To prevent damping, the seedlings should be pricked off round the edge of a 3-inch pot as soon as the first leaf is large enough to handle. Seeds of such kinds as crystallinum and regale will germinate well on the moss of nepenthes baskets.

Cult. by G. W. Oliver.

\section{A. Lis. plain green : grown mostly for the shou'y}

Scherzeriànum, Schott. Fig. 96. A foot or two high, evergreen : lvs. long-lanceolate (the blade $1 \mathrm{ft}$. or more long and petiole of nearly equal length), thick, usually somewhat revolute, with a strong vein parallel with each edge and close to it, and many cross-veins : scape long and slender (1-2 ft.), red: spathe ovate-oblong, 3-4 in. long, spreading or deflexed, intense red (sometimes double, I.H. 37: 67) : spadix slender, often curled, yellow. Central Amer. B.M. 5319. R.B. 22:121. A.F. 6:569 (in variety). - An old farorite. Runs into many forms : Spathe white, vars. álbum, álbum magníficum, lácteum, máximum álbum, Williamsii, Verì̃neum ; spathe parti-colored, vars. Andegavénsis (scarlet on the back, white and scarlet spotted above), mutábile (white-bordered), nebuldsum (double, white spotted rose), Rothschildidnum (scarlet mottled white, Gn. 30:570), Warocquednum (not $A$. Warocquednum) (white spotted red); spathe very large, vars. gigantèum, máximum, Wárdii, Woddbridgei. Very dwarf is var. pýgmoum; rose-salmon spathe and orange spadix is var. Parisiénse; sharp pointed lvs. and spathes is var. Bénrettii. 
Spathiphyllum, N. E. Brown. Two ft. or less, stemless or nearly so: leaf-blarle $2 \mathrm{ft}$. or less, narrow-lanceolate, attenuate in a straight line from the middle to the base, acuminate, bright green above and grayish beneath, with prominent midrib : spathe 2 in. or less long and a half or more as wide, erect, boat-shaped, pale green or whitish : spadix 1 in. long and very blunt, pale yellow. Trop. Amer.

Andræanum, Lind. Fig. 97. Low species, with leafblades drooping like an Alocasia and cordate ovate-lanceolate : spathe cordate-ovate, thick in texture, 6-10 in. long, orange-red, widely open-spreading : spadix 3-4 in. long, yellowish, with white band marking the zone in which the stigmas are receptive. Colombia. B.M. 6616. A.F. $6: 569 ; 10: 1065$. Gt. $38: 1293$. I.H. $24: 271 ; 37: 105$. - Beautiful and popular. Runs into muny varieties, some with very large spathes and others with white ones. Also hybridized with other species.

AA. Lvs. prominently marked with white or colors, or with deep bands of green: cult. mostly for foliage. B. Markings green or greenish.

Vèitchii, Mast. Fig. 98. Tall and robust species (st. 2-3 ft.): If.-blades pendent, like a fine Alocasia, often 3-4 ft. long, cordate or eared at base, metallic green, but marked by deep-sunk nerves, which arch off the midrib: spathe $1 \mathrm{ft}$. long, horizontal, green : spadix 6-8 in. long, straw-color. Colombia. G.C.II. 6: 773. B.M. 6968. Mn. 8: 187.-Striking.

BB. Markings white or essentially so.

Warocqueànum, Moore. Fig. 99. Very vigorous: Irs. oblong-lanceolate, long-tapering, hanging, 2-4 ft. long, deep velvety green, with rib and principal veins of a prominently lighter shade, making handsome contrasts. Colombia:-A handsome and striking foliage plant.

magnificum, Lind. Leaf-blade deep cordate, oval, $2 \mathrm{ft}$. long, upper surface olive-green with white nerves; petiole 4-angled : spathe small, oblong, green : spadix green, cylindrical. Colombia.

crystallinum, Lind. \& André. Like A. magnificum : differs in petiole terete or only very imperfectly ang?ed, sinus of blade smaller, veins wide-banded and whiter and very regular : leaf-blade ovate-cordate, short, deep, velvety green, with the midrib and two consecutive bands crystal white : spathe linear-oblong, acuminate, green. Peru. I.H.20:128. G.C.III.24:417(var.illustre).

regàle, Lind. Leaf-blade cordate-oblong, long-cuspidate, $3 \mathrm{ft}$. or less, at first tinged rose, but becoming dull green and marked with white veins; petiole nearly terete: spathe broad-lanceolate, greenish. Peru.

Various horticultural forms and hybrids are in cult. in this country: A. amábile. Lvs. soft rose : crystallinum $\times$ magnificum. $-A$. cárneum is a hybrid of Andræanum and ornatum. $-A$. Chantrièri. Lvs. triangular, with wide-spreading basal lobes : spathe ivory-white, erect : nymphæfolium $\times$ subsignatum. - A. Clarkidnum. Lvs. large and broad: spathe resembling that of Andræanum but salmon-rose.-A. Ferrierénse. Lvs. large, cordate : spathe cordate, brilliant red : ornatum $\times$ Andræanum. - A. floribúndum, Linden and André=Spathiphyllum floribundum. $-A$. Frobelii. Lvs. large and cordate : spathe deep carmine: Andræanum $\times$ ornatum. A. gránde = magnificum. $-A$. hỳbridum. Lvs. large, lobed at base, obtuse, green.-A. musdicum. $-A$ orndtum. Lvs. oval or oblong, cordate : spathe linear-oblong, white, purple-tinted. $-\boldsymbol{A}$.Reynoldsianum, various forms: Ferrierense $\times$ Andræanum ?-A. Siebrechtidnum. Lrs. much as in magnificum, rich, velvety green, with thick margins : spathe light green shading to cream : spadix large, crimson. - A triúmphans. Lvs.long-heart-shaped, bright green with lighter veins : spathe narrow, green: spadix greenish white.

A. acùtum, N. E. Brown. Lvs. 8-10 in. long, triangular and long-acuminate, green : spathe reflexed, green : spadix deep green. Braz. - A. Allendórfii : Andreanum $\times$ Grusoni. $-A$.
Bàkeri, Hook. Lvs. elliptic-lanceolate or linear, green : spathe small, reflexed, green : spadix 3 in. long, yellowish green, becoming longer and red and drooping in fruit, - the chief merit of the plant. Costa Rica. B.M. 6261.-A. Bogoténse, Schott. Lvs. with a very broad halberd-shaped base and a long-acuminate middle lobe, dark green. Gt. 46, p. 525.-A. brevilobum, $\mathrm{N}$. E. Brown. Lvs. oval-acuminate, cordate, 8-10 in paper-like, green : spathe lanceolate, purplish : spadix purplish brown.-
A. Chàmberlaini, Masters. Lvs. $4 \mathrm{ft}$. long, broadly cordate-ovate. and narrowly long-pointed, green : spathe erect, boat-shaped, 8-9 in. long, purplish outside, crimson inside, partially inclosing the purplish spadix. Venezuela. G.C.III. 3: 465. I.H. 35:62. B.M. 7297.-A. Glaziovii, Hook. Leaf-blade obovate-oblong, not hanging tapering to petiole, green and strongly light-veined: ante spathe linear-oblong, often twisted, purple as is also the spadix). Braz. B.M. 6833. - A. insigne, Masters. G.C. 11.6: 365 =Philodendron tripartitum.-A. Kalbrèyeri, Hort. Climbing: Koch. Spathe white: spadix purple. Veneznela.-A.purpùreum, N. E. Brown. Lrs. oblong-lanceolate, thick, green : spathe and spadix purple. Braz.-A.signatum, Koch. Lvs. 3-lobed, deep green Venezuela - A spléndidum, Bull. Lvs. ovate-cordate, (1) tled green $1 \mathrm{ft}$ or less long: spathe lancoolate, white: spadix tled green, $1 \mathrm{ft}$. or less long: spathe lancoolate, white : spadix green, becoming yellow and brick red : peduncles winged. S.
Amer. G.C. 1883, 1:381. B.M. 6878. Gt. 33: 145, 146. I.H.31:510. - A. trifidum, Oliver. B.M. $6339=$ signatum. I. H. B.

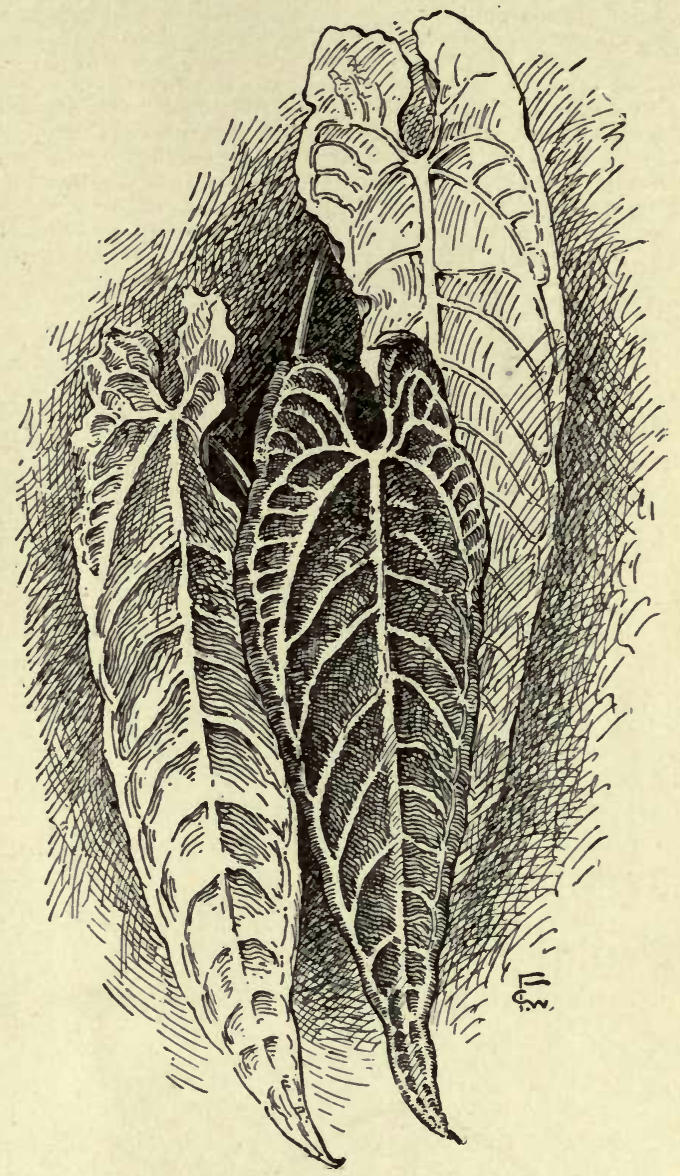

99. Anthurium Warocqueanum.

ANTHYLLIS (Greek, meaning downy flowers). KIDNEY VETCH. Leguminosse. Perennial herbs, or somewhat shrubby, prized for their spikes or heads of yellow, purple or white fls. and usually silky pinnate foliage; also for forage. In the Old World, prized mostly for rockwork. The cult. is the easiest, as the plants thrive even in poor soil. Prop. by seeds or division, or, rarely, by soft cuttings. Not generally known in U.S.

Vulnerària, Linn. SAND Clover. WOUNDWORT. A foot high : lfts. 5 or more : fls. normally yellow, but there are red and white varieties. Ev.-A deep-rooted, clover-like, hardy plant, excellent for sandy and light lands. Useful for forage, and, for that purpose, occasionally grown in this country. Requires $20 \mathrm{lbs}$. of seed to the acre. 
montàna, Linn. A foot or less high, silky-hoary; lfts. numerous: fls. purple. Herbaceous. Eu. L.B.C.6:578.

Bárba-Jòvis, Linn. JUPITER's BEARD. Glasshouse silky evergreen, 3-8, or even $12 \mathrm{ft}$. high, with several to many pairs of narrow, pointed lfts.: fls. straw-colored or whitish, in clover-like heads. S. Eu. B.M: 1927.-In frostless countries, endures sea-winds and salt spray.

\section{H. B.}

ANTInRIS toxicària, Lesch. Urticàcece. UPAS TREE of Java. The juice and gum are virulently poisonous, and it was once supposed that no life could exist in the neighborhood of the tree, but this is false. The tree has been grown in botanic gardens. See Hooker, in Companion to Botanical Magazine. Gn. 12, p. 407 .

ANTIDESMA (Greek, for and band, the bark of $A$. Bunius being used for cordage). Euphorbidcea. Tropical tree or shrubs, with simple, entire lvs. and inconspicuous unisexual fls., in spikes: fr. a 1-seeded little drupe.

Bùnius, Spreng. A tree with dark green foliage and small, round berries of a subacid taste, much used for preserves: the bark yields a fiber. Adapted to S. Calif. and S. Fla. Malay.-Cult. in S. Calif.

ANTIGONON (name from the Greek). Polygondcen. Tropical tendril-climbers: sepals 5 , colored and petallike, the 2 interior ones narrower; stamens 8 ; styles 3 , and ovary 3-angled: lvs. alternate and entire: fls. in racemes, which end in branching tendrils.

léptopus, Hook. \& Arn. Mountain Rose. Rosa DE Montana. San Miguelito. Probably the only species cult. in this country. Stem slender and tall, glabrous, or nearly so: lvs. cordate and acuminate, or hastate-

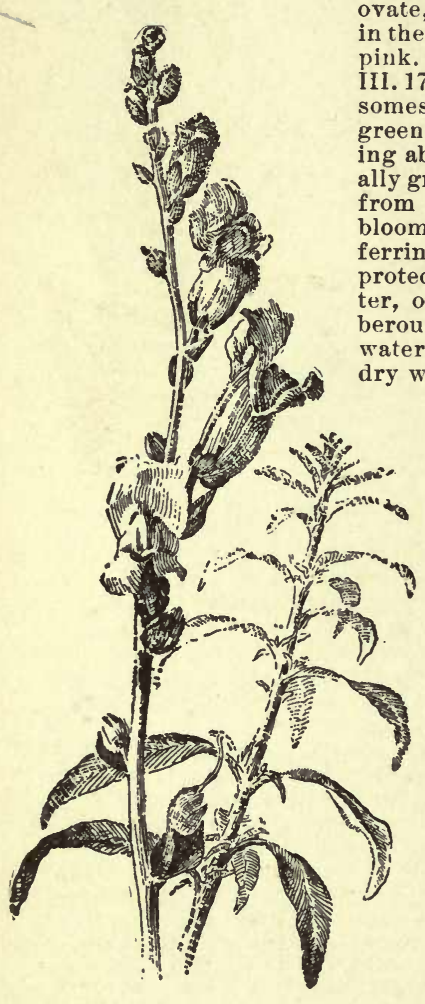

100. Young spike of a dwarf form of Antirrhinum majus ( $X 1 / 8)$. ovate, 3-5 in. long: fls. 6-15 in the raceme, handsome rosepink. Mex. B.M.5816. G.C III. 17:797.- One of the handsomest summer - blooming greenhouse climbers, requiring abundance of light; usually grown from seeds, but also from cuttings. In the $\mathrm{S}$. it blooms freely in the open, preferring sunny and lot places; protect the root well in winter, or plant deep. It is tuberous rooted. Give plenty of water when in fl., but keep ry when at rest.

Guatemalénse,Meissn. (A. insigne, Mast.). Pubescent: lvs. broader: fls.more numerous, the sepals nearly twice longer ( 1 in. long) than in the last. Guatemala. G.C. II. 7:789.

$$
\text { L. H. B. }
$$

A N T I R R H I UM (Greek, snout-flower). Scrophularidceo. Snapliragon. Over 60 species of herbs, natives to the Old and New World, in warm temperate regions. Lvs. usually opposite below and generally entire, never compound : corolla saccate or gibbous at base, but not spurred, personate or closed at the throat: stamens 4 . Closely allied to Linaria, from which it differs in the spurless fis.

Snapdragons are flowered either in the open or under glass. The common varieties are forms of $A$. majus, and are perennial, although the first crop of bloom is usually the only one which is desired. Most of the varieties of this species are hardy in the $\mathrm{N}$. if well covered during winter. Seeds sown very early in the spring, especially under frames, and transplanted, produce blooming plants the same season. It is usual, however, if early bloom is desired, to sow the seeds in Aug. or Sept., and cover

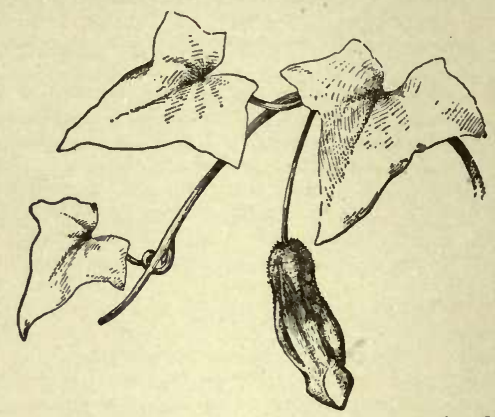

101. Antirrhinum maurandioides, in bud $(X 1 / 2)$.

the plants with a mulch on the approach of cold weather. These fall-sown plants may be transplanted into pots (or grown in them from the first) and flowered in the house. For forcing in this way, Snapdragons are very satisfactory. The temperature and treatment required for geraniums and carnations suit them well. Dwarf vars. are used for edgings.

\section{A. Common Snapdragon, strictly erect.}

màjus, Linn. CoMmon or LARGE SNAPDragon. Fig. 100. Perennial, or practically a biennial under cult.: 1-3 ft., not downy except in the fl.-cluster : lvs. oblong or lanceolate, entire, sometimes variegated : fls. large, long tubular, with spreading, very irregular lobes, in an elongated terminal spike or raceme. In many colors and varieties (ranging from red and purple to white), in forms both tall and dwarf. Mediterranean region; sometimes running wild about gardens. A.F. 9:909; 13:949. I.H. $41: 22$. A.G. $17: 379$, F.E. $7: 711$ - There are double forms. Some of the varietal names used by horticulturists are álbum, bicolor, coccíneum, variegàtum.

Oróntium, Linn. Small Snapdragon. A low, slender annual, with linear lvs. and small fls. purple or white ( $1 / 3$ in. long) in the axils. An occasional weed in cult. grounds, 6 in. or less high; not cult.

AA. Native species, produring tendril-like branches in the inflorescence.

Orcuttiànum, Gray. Slender, 2-4 ft., glabrous : corolla $1 / 3$ in. long, white or violet, lower lip not much larger than the upper: lower lvs. spatulate-lanceolate, the upper linear. Annual. Lower and S. Calif. Int. by Orcutt in 1891 .

\section{AAA. Climbing vine.}

maurandioldes, Gray (Maurandia antirrhiniflora, Wild.). Fig. 101. Climbing 2-6 ft. by means of the coiling petioles and peduncles: Ivs. 3-lobed, halberdshape : fls. axillary, 1 in. or more long, violet or purple, handsome. Tex. to Calif. B.M. 1643.-Attractive plant for the window, cool greenhouse or conservatory. Suitable for baskets.

L. H. B.

ANTROPHYUM (Greek, growing in caverns). Polypodidcea. A genus of inconspicuous, simple-leaved ferns rarely found in cultivation. Require high temp.

APERA (Greek, undivided). Graminece. One or two European and Asian grasses of the tribe Agrostidea. $A$. arundindcea, Hook, is a tender grass from New Zealand, of erect habit and exceedingly long, pendulous panicles, grown under glass; but it really belongs to the genus Stipa. G.C. III. 22: 283. Likely to come into Anierican trade.

APHANANTHE (Greek, aphanes, inconspicuous, and anthe, flower). Urticacece. Trees or shrubs: lvs. alternate, petiolate, serrate: fls. monœcious, inconspicuous; staminate in corymbs; pistillate single, axillary: 
fr. a drupe. Three species in Jap. and Austral. Prop. by seeds or perhaps in the same way as Celtis, and also by grafting on Celtis.

áspera, Planch. Small tree : Ivs. ovate, oblique, acuminate, serrate, $21 / 2-4$ in. long, rough to the touch : fls. greenish, with the 1vs.: drupe globular, black, slenderstalked. Jap.-Not hardy N., with slender branches, not much different in appearance from Celtic occidentalis. Little known in this country. AlFred REHDER.

APHELANDRA (Greek-made name). Acanthàcea. Nearly 70 species of evergreen tropical American shrubs, grown in hothouses for the fine foliage and showy 4 -sided terminal spikes of red or yellow gaudy-bracted fls. Of easy culture, if given plenty of diffused light in the growing season, and plants are not allowed to become tall and leggy. It is well to grow new plants frequently. Prop. by seeds when obtainable, or by cuttings of partially ripened wood at any season. They bloom in autumn, but ean readily be brought into flower at other seasons. When done blooming, the plants should be rested in an intermediate temperature, kept rather dry, but not allowed to wilt or shrivel. Require treatment of Justicias, and thrive along with Allamandas and Poinsettias.

L. H. B.

All Aphelandras like a stovehouse temperature and a light leaf-mold, with a liberal proportion of sand. They should not be kept very wet in winter. They propagate readily from cuttings and seeds. The leading trade names are A aurantiaca, chrysops, Fascinator, Rozlii. A. chrysops is one of the handsomest of the group.

H. A. Siebrecht.

A. Fls. in shades of yellow.

Chamissoniàna, Nees. (A. punctata, Bull). Lvs. oblong-lanceolate or elliptic-lanceolate, acuminate, the center banded with white, and white dots running off towards the margin, the midrib green : fls. and spiny bracts bright yellow. S. Amer. I.H. 29:457. B.M. 6627.

squarròsa, Nees. (A. Lèopoldi, Hort. A. chrỳsops, Hort.). Lvs. large, ovate to ovate-elliptic, acuminate, dark green above (pale below), with white rib and main veins : fls. bright yellow and much exserted beyond the yellow crenate-dentate bracts. Braz. A.squarròsa itself is probably not in cult., the showy plant in the trade (and described above) being called A. squarròsa var. Lèopoldi by Van Houtte (F.S. 9: 889).-One of the most showy.

Blanchetiàna, Hook. f. (A. amòna, Bull). St. thick and stout: lvs, ovate-acuminate, with many pairs of conspicuous nerves, green, the midrib, and often the main veins, white: fls. dark yellow, exceeding the long, entire, cusp-pointed red scales: spike sessile. Braz. B.M. 7179. - Known in the trade as $A$. amoena, having been described under that name before it had flowered in cult.

$$
\text { AA. F's, orange, verging to scarlet. }
$$

aurantiaca, Lindl. Lvs. ovate-elliptic, deep green above, light green below, strongly veined, but not particolored, slightly wavy edged: fls. orange, with a tinge of scarlet, the spreading limb overhanging the greenish sharp-toothed scales. Mex. B.M. 4224. B.R.31: 12.

Var. Rœ̀zlii, Nicholson (A. Róezlei, Carr.). Fls, with more scarlet: lvs. twisted, with silvery hue between the veins. Mex.-Showy and good. Not so tall as A. aurantiaca.

$$
\text { AAA. F'ls, red. }
$$

Fascinàtor, Lind. \& André. Lvs. ovate to ovate-elliptic, the rib and veins widely margined with interlocking bands of white, the under surface purple: fls. large, brilliant vermilion, obscuring the inconspicuous bracts. New Granada. I.H. 21:164. - Very showy and desirable.

A. atrovirens, N. E. Brown. Dwarf : lvs. very dark green above and purplish beneath : fls. yellow, 1 in. long. Braz. I.H. 31: 527. - A. cristàta, R. Br. Lvs. ovate-elliptic, green: fls. dark red, very long and eurving, 2-3 in. Long known. W. Ind. B.M. $1578,-A$. Liboniàna, Linden. Dwarf: lvs ovate and long-M. minate, with a white rib, green below : fls. deep yellow, small, scarcely exserted beyond the red bracts. Braz? B.M. 5463.A. Macedoidana Lind. \& Rod. Said to be a form of A. atroviA. Macedoiana, Lind. \& rod. Said white rib and main veins. Braz of A. atrovirens. Lvs. with white rib and main veins. Braz. I.H. 33: 583 . white, purple below : fls. yellow, the bracts strong-toothed.
Once catalogued by John Saul. Braz. G. C. III. 2:585.-A. nìtens, Hook. Compact : lvs. ovate, thick, shining green above, dark purple beneath : fls. vermilion-scarlet, large, the bracts rot showy. New Granada. B.M. 5741. Gn. 48:1027. - A, orientàlis, offered in America, is possibly a form of some well known species.

$$
\text { L. H. B. }
$$

APICRA (not bitter, from the Greek). Lilideea, tribe Aloinea. Shortly caulescent small succulents: lvs. spirally arranged or crowded along the stem : fls. greenish, often striped with white, straight, tubular or prismatic, with short, flat or spreading white limb surpassing the stamens. Cape region. Agave house or cactus house; suitable for rockeries during the summer. Prop. like Aloe. Monogr. by Baker. G.C.II. 11: 717 (1879); Journ. Linn. Soc. Bot. 18: 216.

A. Lvs. as broad as long, acuminate, horizontal.

folioldsa, Willd. (Alde foliolòsa, Haw. Hawórthia folio$l \grave{s} a$, Haw.). Lvs. densely crowded, thin-margined, very acuminate, smooth, serrulate: fls. smooth. Cape. B.M. 1352.

AA. Lvs. more elongated, thick, acute, erect or ascending, except in age.

B. Fls. smooth.

áspera, Willd. (Alde áspera, Haw. Hawórthia áspera, Haw.). Lrs. small, crowded, finely tuberculate, roughened on the back and margin, only the uppermost erect. Cape.

pentágona, Willd. (Alde pentágona, Haw., not Jacq. Hawórthia pentágona, Haw.). Fig. 102. Lvs. larger, from slightly concave and angled becoming biconvex; 5 -ranked ; finely pale-tuberculate on back and margin. Cape. B.M. 1338. - Includes several forms : Var. Wildenovii, Baker; var. bullulàta, Willd. (A lde bullulata, Jacq.); var. spirélla, Baker (Alde spirélla, Salm. Hawórthia spirélla, Haw.).

вв. Fls. rough-tuberculate. spiràlis, Bak. (A. imbricata, Willd. Alde spiraltis, Linn., not Haw. Hawór thia imbricata, Haw.). Lvs. small, irregularly dispersed, smooth, the margin and keel denticulate. Cape. B. M. 1455.

Other species are: A. bicarinàta, Haw. (Aloe bicarinata, Spreng.); A.congésta,Bak.(Aloe congesta, Salm.); A. deltoidea Bak. (Aloe deltoidea, Hook. f.). Bak. (Aloo d

William Trelease.

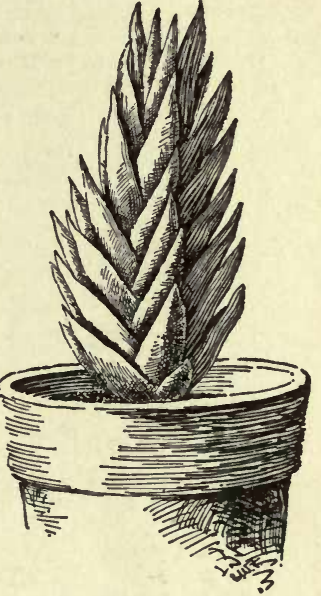

102. Apicra pentagona.
APIOS (pear, from the Greek, alluding to the shape of the tubers). Legumindsa. Perhaps half a dozen species in N. Amer. and Asia, of twining, tuberous-rooted pinnate-leaved herbs. Fls. in dense, short racemes : pod linear and flat, several-seeded. A light soil and sunny place are essential to free growth. Under these conditions, the plant covers a trellis or other support in a comparatively short time.

tuberòsa, Mönch. Groundnut. Wild Bean. Four to $8 \mathrm{ft}$., climbing over bushes : root bearing strings of edible tubers, 1-2 in. long: leaflets 5-7, ovate-lanceolate: fls. fragrant, chocolate-brown, the standard very broad and turned back, the keel long, incurved and of scytheshape. July-Aug. G.W.F. 44.-Common in low grounds. The fruit often fails to mature. Prop. by the tubers, 2 to 4 of which should be planted together at a depth of 3 or 4 inches; also, by seeds. Grows well in the wild border, in any loose, rich soil. Likely to become a weed in rockeries.

A. Fórtunei, Maxim., is occasionally eult. in Japan for its small, ovate, edible tubers. A.G. 1892:77.-A. Priceana, Robinson, native to Kentucky, may be expected to appear in the trade. The root is a single large tuber, becoming 6 or 7 in. in diam. fls. greenish white, tinged with rose-purple or magenta. A vig. orous elimber, first described in 1898 (Bot, Gaz 25: 451, with illustration).

J. B. KELLER and L. H. B 
APIUM. See Celery.

APLECTRUM (Greek, with no spur). Orchiddceœ. A small orchid, with smallish dull-colored fls. in a raceme, on a leafless scape, which springs from a large corm-like tuber. Single species, in woods in the N. states.

hyemàle, Nutt. Putty Root. Adam-And-Eve. Fig. 103. Sends up a pointed green lf. 2-6 in. long, which lasts through the winter, and in spring a stalk about a foot high, bearing a raceme of rather large greenish a raceme of rather large greenish
brown fls., which are succeeded by hanging, oblong-pointed pods (Fig. 103). Hardy. May be grown in rich, loamy borders. Interesting, but not showy.

APLOPAPPUS (Greek, simple pappus). Syn., Haplopappus. Compositoe. About 115 species, mostly from California and Chili. Fls. yellow, in summer and autumn. The only species known to be in American trade is

lanuginòsus, Gray. Hardy alpine herb, woolly, 4 in. high, from creeping rootstocks : lvs. soft, narrowly spatulate, or upper linear, 1-2 in. long: rays 15-20. Mts. of Wash. and Mont. Int. 1889, by F. H. Horsford.

A. ericoides, Hook. \& Arn. Shrub, 2-5 ft. high : lvs. very numerous, filiform, those of the dense fascicles 2 or 3 lines long: fls.very numerous. G.C. III. 20: 301.

APOCYNUM (Greek for dog-bane). Apocynàceo. DOG-BANE. INDIAN HEMP. Tough perennial herbs, chiefly of N. Temp. zone, with oblong or ovate opposite lvs., milkweed-like fls. in small cymes, and slender follicles or pods. About 25 species, 3 or 4 native to N. Amer.

androsæmifolium, Linn. Three ft. or less high, usually glabrous, the branches spreading : lobes of corolla revolute and tube of corolla longer than the calyx: Ivs. oval or ovate, short-petioled: cymes loose: fls. belllike, white or pink. N. states : common. B. M. 280. D. 189, - Sold by dealers in native plants. Useful for the hardy border.

cannábinum, Linn. Branches erect or nearly so: lobes of corolla nearly erect, the tube not longer than calyx: lvs. ovate to lance-oblong, shortpetioled : cymes dense: fis. greenish white. N. states : common. - Not known to be in the trade, but apt to be confounded with the above.

APONOGETON (Greek name, referring to its habitat in the water). Naiaddcea. About 20 tropical or subtropical water plants. Fls. in twin terminal spikes, wholly naked, but subtended by a double row of petallike bracts. trum hyemale.

Nearly natural size.

distàchyum, Thunb. CAPE Ponn-weed. Water HawTHORN (from the fragrance). Forked spikes 4-8 in. long, with several pairs of pure white bracts, borne on the emersed ends of long scapes: fls. very fragrant, with purple anthers : lvs. with very long petioles, the blade floating, oblong-lanceolate, round-based, parallel-veined, 3-6 in. long. Cape of Good Hope. B.M. 1293. F.R. 1:463. P.G. 4: 106.-A charming and interesting plant. In a protected pool, especially if it can be covered in winter, the plant is hardy in the N., blooming nearly all summer. Removed to tubs in the fall, it blooms nearly all winter ; or it can be grown permanently in tubs or deep pans in the house. Requires about $2 \mathrm{ft}$. of water, or out-of-doors it may have twice that depth. Prop. chiefly by seeds, but fis. should be pollinated and kept above water at least 24 hours afterwards, and seeds not be allowed to become dry. Var. Lagràngei, Hort. ( $\boldsymbol{A}$. Lagràngei, Hort.), is a rare and beautiful variety, with violet bracts and lvs, violet beneath. It props. slowly. R.H. 1895 : 380.

L. H. B.

APPLE. Rosicen. TheApple is native to southwestern Asia and adjacent Europe. It has been cultivated from time immemorial. Charred remains of the fruit are found in the prehistioric lake dwellings of Switzerland. Now widely cultivated and immensely rariable, it is grown in every temperate climate, and is the most important commercial pomological fruit.

The Apple has come from two original stems. All the common Apples are modifications of Pyrus Malus (see Pyrus), a low round-headed tree, with thick and fuzzy, irregularly dentate, short-stemmed leaves and fairly compact clusters of woollystemmed flowers. The crabapples are derived from Pyrus baccata, commonly known as the Siberian crab. This species is probably of more northern or eastern origin than the other. It is of smoother and more wiry growth, with narrower and thinner essentially glabrous long-stemmed leaves, and more open clusters of glabrous-stemmed flowers. The fruit is small and hard, and the calyx-lobes fall at maturity, leaving the eye or basin of the fruit smooth and plain. Hybrids between these species have given the race of large-fruited

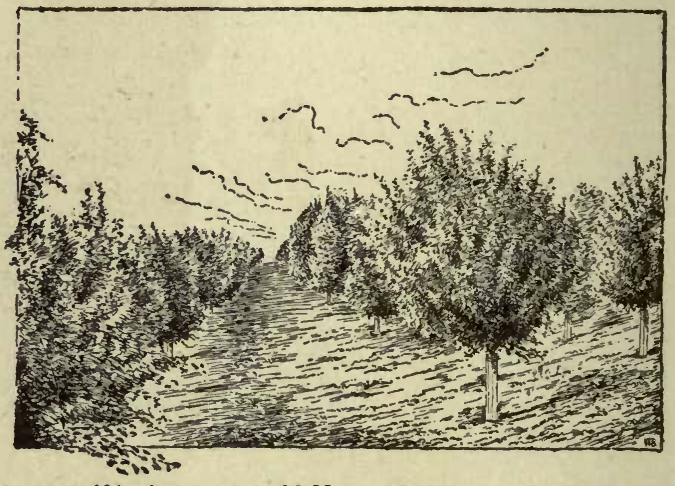

104. A ten-year-old Nebraska Apple orchard.

The trunks are protected from the sun by board jackets.

crab-apples, of which the Transcendent and Hyslop are examples. This race is known to botanists as Pyrus prunifolia. Certain Apples are native to North America. Two species, Pyrus Ioensis and $P$. coronaria, are of interest to the pomologist. The former is the prairiestates crab, and is the more promising. In characters of growth, leaves and flowers, it bears a striking resemblance to forms of Pyrus Malus. The fruit is spherical or spherical-oblong, short-stemmed, very hard, and remains green-colored. The fruit of the eastern-states crab, Pyrus coronaria, is distinctly flattened endwise, and is long-stemmed. The leaves are deep-cut and often three-lobed. There are no improved varieties of this eastern species, and no authentic hybrids between it and the common Apples. The fruit is sometimes used by settlers, but it has little comestible value. Pyrus Ioensis has produced a number of promising hybrids with the common Apple, and this mongrel race is known as Pyrus Soulardi. The Soulard crab is the best known of these. Its value lies only in its extreme hardiness. The pomological value of the native crabs is prospective. For a completer account of the native Apples, see Bailey "Evolution of our Native Fruits."

The most perfect Apple region of this country-consid ering productiveness, quality, long-keeping attributes, longevity of tree - is that which begins with Nova Scotia and extends to the west and southwest to Lake Michigan. Other important regions are the Piedmont country of Virginia and the highlands of adjacent states, the Plains regions, the Ozark and Arkansas region, and the Pacific 


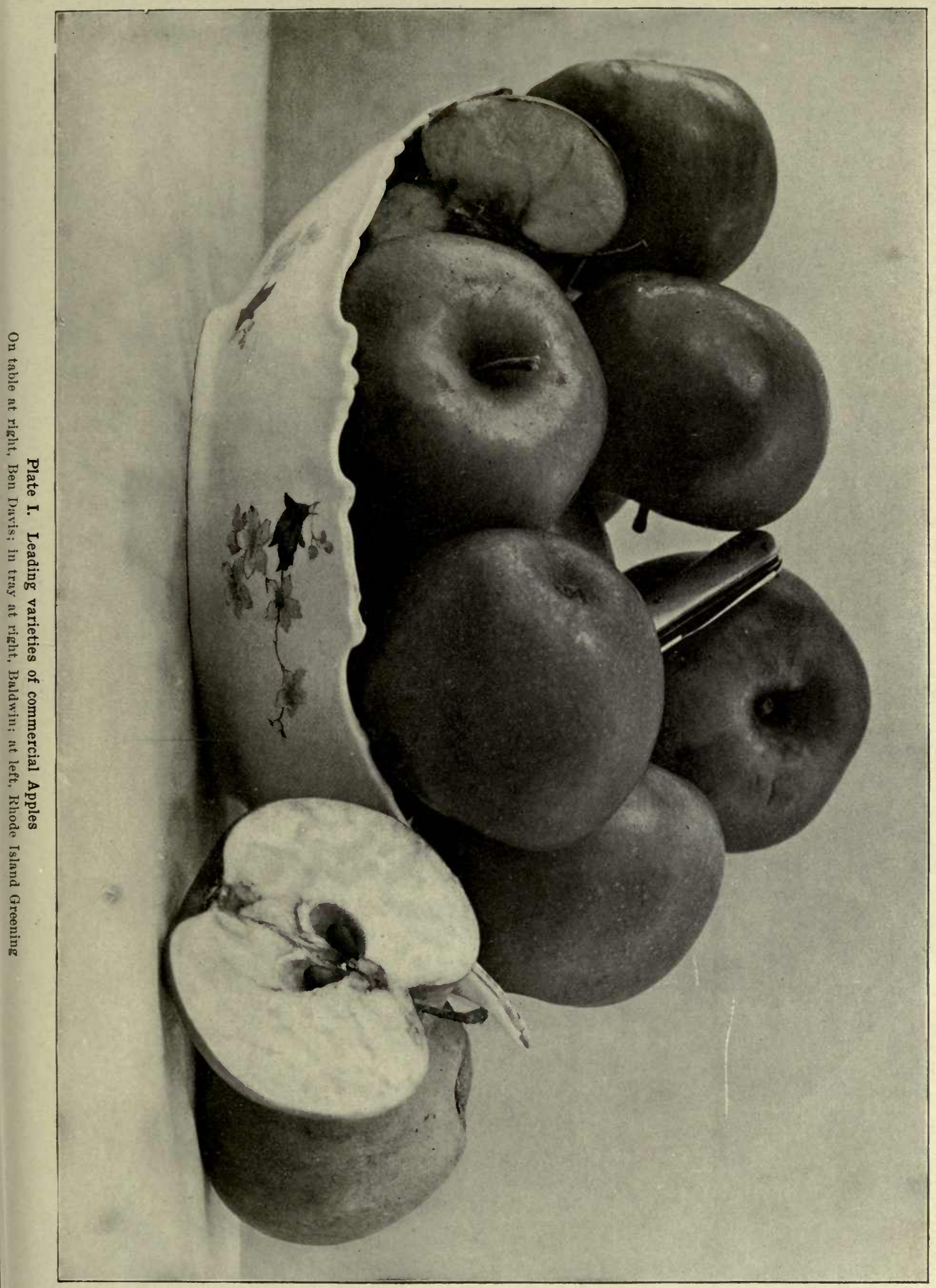


IIBRARP

OF THE
UNIVERSITY
OF

CALIFORNIA 
region, the last comprising the foothills in Califcrnia and the country to the northward. All parts of the United States north of Florida and the Gulf borders, and excluding the warm-temperate parts of the Southwest and the Pacific coast, are adapted to the Apple in greater or lesser degree. North America is the leading Apple-growing country of the world. A full crop for the United States and Canada, of all kinds and grades, is probably not less than $100,000,000$ barrels. The Apple is a cosmopolitan fruit ; and since it thrives almost anywhere, it is commonly neglected. The plants which are most difficult to cultivate are the ones which are best cultivated.

The Apple was early introduced into this country. In the early days it was prized chiefly for cider. It is an ancient and common notion that any Apple is good enough for cider ; and this is one reason for the neglect in which the Apple plantation is commonly allowed to stand. The best results in Apple-growing are to be expected when the land is tilled. The reasons for tilling the orchard are those which apply to other crops, - to make plant-food available, to extend the area in which the roots can grow, to conserve moisture. It is especially important, in our hot and sunny country, that the roots extend deep enough to escape the disastrous effects of drought. The ideal treatment of orchard land is to fit the ground deep before the trees are planted, to plow deep for a year or two or three in order to force the roots down and to thoroughly ameliorate the soil, and to practice shallow tillage in order to conserve moisture. (See Tillage.) Since trees make

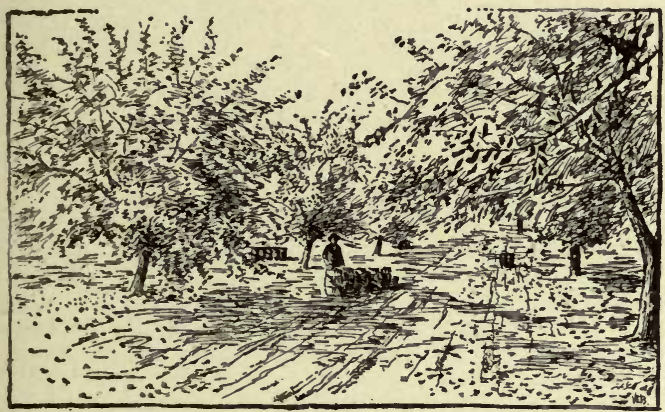

105. A good New York Apple orchard at 25 years.

most of their growth early in the season, the tillage should be begun as soon as the laud is fit in spring; and it may be discontinued by midsummer or August. This cessation of the tillage allows of the growing of some cover crop or eatch crop (see Cover-crops) late in the season, in order to secure humus and to improve the physical texture of the soil. If the land is well handled in the first few years, it will not be necessary to turn a furrow in the orchard thereafter, but merely to loosen the surface in the spring with a spading harrow, spring-tooth harrow, or otber tool, in order to reëstablish the surface mulch. The only reasons for turning a furrow will occur when the land is so hard that the surface tools cannot mellow the surface, or when it is desirable to turn under a greenmanure crop. Even hard lands may be got in such con. dition, by means of tillage and green-manures, that they may be worked up with harrow tools when the orchard comes into bearing. Plowing the orchard, therefore, has two legitimate objects : to mellow and ameliorate the land to a considerable depth, so that the roots may forage deep ; to turn under a cover crop. The former purpose should not be necessary after the first few plowings. An incidental object of plowing is to facilitate the inaking of the annual surface mulch; and this mulch is to save the moisture.

The Apple thrives in a variety of soils, but it is most productive and longest-lived on land which has a considerable original admixture of clay: that is, in a clay loam. I ands which yield good crops of wheat and corn may be expected to be good Apple lands, if other conditions are right. Rolling, inclined, or somewhat elevated lands are generally considered to be most desirable.
Their value lies in the better drainage of water and air The trees may be set in either fall or spring. Forty feet apart each way is the standard distance for Apple trees . but some varieties, as the Wagener and the crabs, may be set closer. In the South and on the Plains, trees may be set closer, as they do not attain such great size as in the, northeastern states. In general, it is best to devote the land to Apples alone; but persons who are willing to give the plantation the best of care may plant other trees between the Apples, as fillers. The more diverse the kinds of trees which are planted together, the more difficult it is to give the proper care to each. Some

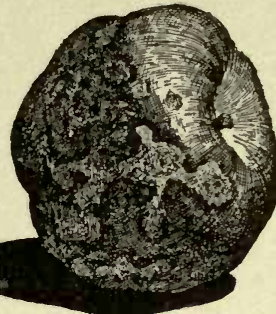

106. Apple badly attacked by the scab. of the shorter-lived varieties of Apples make excellent fillers in the Apple orchard : and in special cases dwarf Apples may be used.

It should be the general purpose to till the Apple orchard throughout its life; but whenever the trees seem to be growing too rapidly, the plantation may be seeded down for a time. That is, tillage is the general practice; seeding down is the special practice. For the first few years, annual crops may be grown in tha Apple orchard; but every year a more generous open space should be left about the trees. Till as often as the land becomes crusted or baked. On strong soils which are well handled, it is rarely necessary to apply concentrated fertilizers until the trees are old enough to bear. What fertilizers are then needed, and how much to apply, are to be determined by the behavior of the trees. If the trees are making insufficient growth, and the foliage lacks color, one or all of three things may be the trouble : the trees may need water; they may be suffering from insects or disease ; they may lack nitrogen. If it is thought that they lack nitrogen, this material may be supplied in the form of nitrate of soda, sulfate of ammonia, or the unburned animal substances, as blood and tankage. Two to three hundred pounds to the acre of the nitrate of soda or sulfate of ammonia are liberal applications on welltilled lands. If the trees are making vigorous growth, the probability is that they are not in need of more nitro-. gen. Potash and phosphoric acid may then be applied. Three hundred pounds of muriate of potash, or other concentrated material, should be sufficient for an acre, under ordinary conditions. As a rule, all orchards in full bearing should have a liberal annual application of fertilizing materials. In the East, Apple trees should be in profltable bearing at 10 years from planting, and should continue in that condition for 30 years.

The two staple enemies of the Apple are the appleworm (the larva of the codlin-moth), and the apple-scab (Flg. 106). These are readily held in check by spraying, - with arsenical poisons for the worm, and with Bor. deaux mixture for the scab. (See Spraying.) Spraying for the worm should be performed as soon as the last

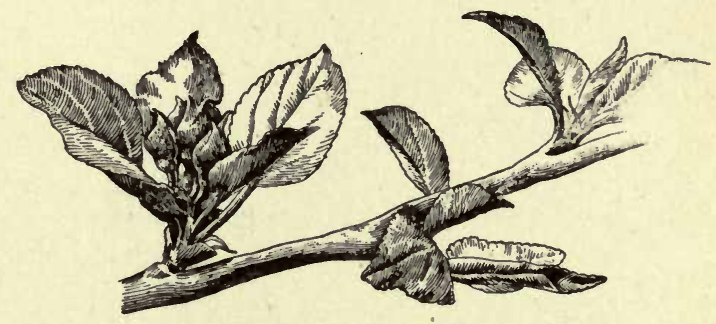

107. Ready for the first general spraying.

petals fall; for the scab as soon as the buds are well burst (Fig. 107). In badly infected regions and on very. susceptible varieties, it may be necessary to spray first for the scab before the buds swell. Since there are insects (as canker-worms, case-bearers, bud-moth) which appear 
before the flowers open, it is advisable to add Paris green or other arsenical poison to the Bordeaux mixture at the early spraying. The number of times to spray depends

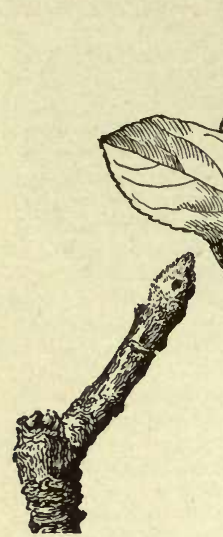

108. Spur and fruitbud of Apple.

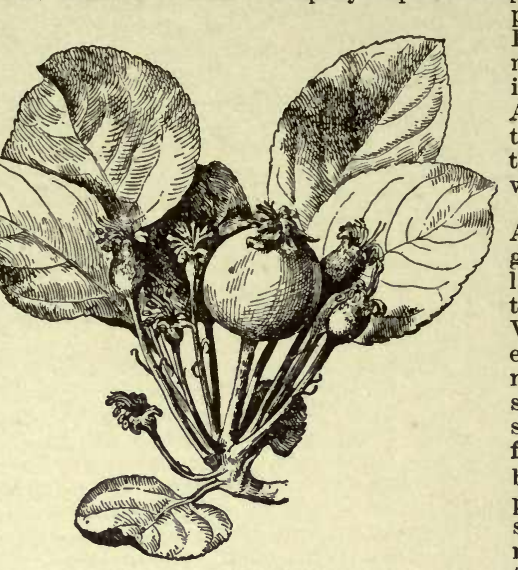

109. One Apple sets in a cluster. upon the thoroughness of the work, the pests to be combatted, and the season; but it is a good rule to expect to spray with the combined Bordeaux and Paris green mixture when the buds burst, and again when the petals have fallen. In the Plains country, less spraying may be necessary for the fungous diseases.

The A pple commonly bears on spurs. The fruit-bud is distinguished by its greater size (usually somewhat thicker than its branch), its greater width in proportion to its length, and more conspicuous pubescence. It is also distinguished by its position. A fruit-bud is shown in Fig. 108. A fruit-scar is shown near the base of the branch. If this fruit was borne in 1898 , the side branch grew in 1899, from a bud which came into existence in 1898. If we go back to the spring of 1898 , the matter can be made plain. A cluster of flowers appeared. One flower set a fruit (Fig. 109). 'This Apple is at the end of the branchlet or spur. The spur cannot increase in length in the same axis. Therefore, a bud appears on the side (Fig. 110). The fruit absorbs the energies of the spur. There is little nourishment left for the bud. The bud awaits its opportunity; the following year it grows into a branchlet and makes a fruit-bud at its end (Fig. 108); and thereby there arises an alternation in fruit-bearing.

The Apple is budded or root-grafted upon common Apple seedlings. These seedlings are usually grown from

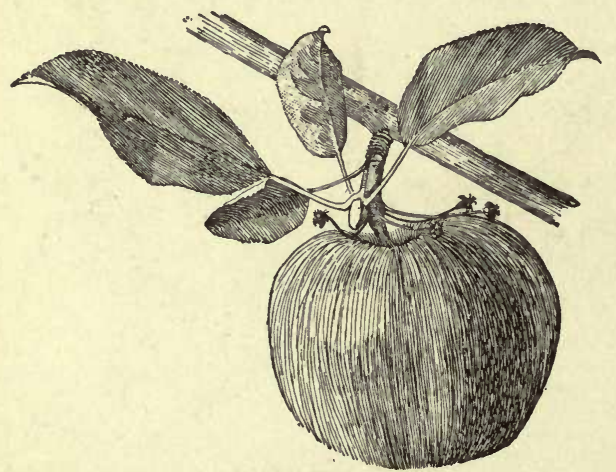

110. Showing the side bud which is to continue the spur the following year.

seeds obtained from cider mills. In the East, budded trees are preferred. In the West, root-grafted trees are preferred, largely because own-rooted trees of known hardiness can be secured. (See Graftage.) In Russia, seedlings of Pyrus baccata are used as stocks. They prevent root-killing, and give earlier fruit-bearing. Apples are dwarfed by working them on various kinds of Paradise and Doucin stocks. These stocks are merely naturally $d$ warf forms of the common apple, and which, in some remote time, have originated from seeds. Dwarf Apples are much grown in Europe, where small-areacultivation and wall-training are common, but they are little known in America. Apple trees are usually planted when two or three years old.

The varieties of Apple trees actually on sale in North America in any year are not far from 1,000 kinds. Each great geographical area has varieties which are particularly adapted to it. In the northern Mississippi valley, there are few of the eastern-states Apples which thrive. Varieties have been introrluced from Russia with the expectation that they will be adapted to the region; but more is to be expected of their progeny than of themselves. Varieties of local origin, coming from various stem types, are now providing that country with satisfactory Apples. In the selection of varieties, one should be guided by this adaptation to the region, and by the purpose for which the fruit is designed to be grown. Consult the recommended lists of the state horticultural societies; ask persons who have had experience in the given region; write to the experiment station; enquire at the markets. The leading commercial varieties in North America are Albemarle Pippin, American Golden Russet, As-

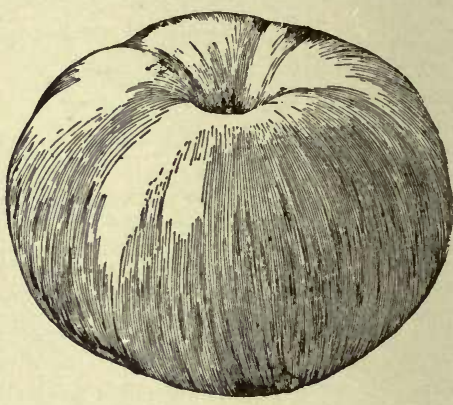

111. The flat or oblate American apple. trachan, Baldwin, Ben Davis, Blue Pearmain, Duchess of Oldenburg, Fameuse, Gilliflower, Gravenstein, Janet, King, Lawver, Maiden's Blush, Missouri Pippin, Newtown Pippin, Northern Spy, Peck's Pleasant, Pennock, Rhode Island Greening, Rome Beauty, Shockley, Twenty Ounce, Wealthy, Willow Twig, Wolf River, York Imperial. See Plate I. Baldwin and Ben Davis, the former of inferior quality and the latter of worse, hold the supremacy in American market Apples. The Apples of the eastern and central country tend toward flattened or oblate shape (Fig. 111). The typical form of the so-called long or conical American Apple may be seen in Fig. 110. The Apples of

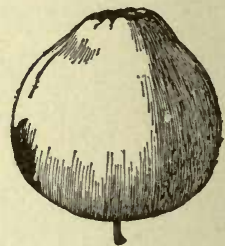

112, An Irish apple.
Europe are often distinctly attenuated and ribbed at the apex (Fig. 112); and this form is also accented in the regions beyond the Rockies.

Three books devoted wholly to the apple have appeared in North America: Warder, Apples, 1867 (the best); Todd, Apple Culturist, 1871; Bailey, Field Notes on Apple Culture, 1886. Consult, also, Vol. 25, Nebraska State Horticultural Society, 1894 ; The Apple, a report of the Kansas State Horticultural Society, 1898. Nearly all the fruit manuals devote space to the apple.

L. H. B.

APPLESEED, JOHNNY. An interesting and eccentric character, who sowed apple seeds in the wilds of Ohio and Indiana between 1801 and 1847. His real name was Jonathan Chapman. He was born in Boston in 1775 , and died in 1847. For 46 years he walked barefoot through the wilderness, and was nerer harmed by snakes, wild animals, or Indians. He was often clad in a coffee-sack, in which he made holes for the arms and legs. He would never kill any creature, and considered pruning and grafting wicked. Swedenborg and the 
New Testament he read aloud in many frontier log cabins. He had many peculiarities, but was always welcomed and respected everywhere. In the war of 1812 he saved many lives by warning the settlers of Hull's surrender and the approach of the Indians. He lived to see trees bearing fruit over a territory of 100,000 acres. The story of this self-sacrificing and useful man is told by W. D. Haley in Harper's, $43: 830-836$ (1871).

W. M.

APRICOT. Rosdcece. The Apricot is a fruit somewhat intermediate between the peach and the plum. The tree is a round-headed, spreading grower, with dark, somewhat peach-like bark, and very broad or almost circular leaves. The fruit, which generally ripens in advance of both the peach and plum, is peach-like in shape and color, with a smoother skin, rich, yellow flesh and large, flat, smooth stone. The flesh is commonly less juicy than that of the peach, and, as a rule, perhaps, of higher quality. The Apricots are of three species, all probably native of China or Japan. The common Apricot of Europe and America is Prunus Armeniaca: fr. variable, but smooth at maturity, red or yellow, the sweet and firm flesh free, or very nearly so, from the large, smooth, flat stone : tree with a round, spreading top, and a reddish, cherry-like or peach-like bark: lvs.(Fig. 113, right) ovate or round-ovate, with

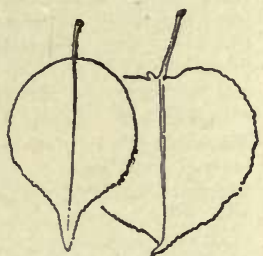

113. Apricot leaves.

P. Mume on left ,

P. Armeniaca on right. a short point and, sometimes a

heart-shaped base, thin and bright green, smooth, or very nearly so below, as are the gland-bearing stalks, the margins rather obtusely and mostly finely serrate : fls. pink-white and borne singly, sessile or very nearly so, preceding the leaves (Fig. 116). The Russian Apricot is a hardy but smaller-fruited race of this species. The Japanese Apricot, in Japan grown for flowers rather than for fruit, is Prunus Mume: fr. small, yellowish or greenish, the flesh rather hard and dry, and adhering tightly to the pitted stone : tree like the common Apricot, but with a grayer or greener bark and duller foliage: lvs. grayish green, generally narrower (Fig. 113, left) and long-pointed, more or less hairy along the veins below and on the shorter mostly glandless stalk, thick in texture and prominently netted beneath : fls. fragrant, borne singly or in 2's, and sessile (without stalks). Only recently introduced into this country, chiefly under the name of Bungoume plum. The third species is the purple or black Apricot, Prunus dasycarpa, which is little cultivated: fr. globular and somewhat plum-like, with a distinct stem, pubescent or fuzzy even at maturity, dull dark purple, the sourish, soft flesh clinging to the plum-like fuzzy stone: tree round-headed, with much the habit of the common Apricot, with lvs. ovate and more or less tapering at both ends, thin, dull green, on slender and pubescent mostly glandless stalks, finely appressed-serrate, and hairy on the veins below: fis. large and plum-like, blush, solitary or in 2's, on pubescent stalks a half-inch or more long, and appearing in advance of the leaves. See Prunus for related species. The Apricot-plum, Prunus Simonii, is discussed under Plum.

The Apricot is as hardy as the peach, and it thrives in the same localities and under the same general cultivation and treatment, but demands rather strong soil. It is grown commercially in New York and other eastern states. There are three chief reasons why the Apricot has remained in comparative obscurity in the East: Ignorance of the fruit; loss of crop by spring frosts, because of the very early season of blooming of the Apricot; the fondness of the curculio for the fruit. To these may be added the fact that we have not yet arrived at an understanding of the best stocks upon which to bud the Apricot; but this difficulty may be expected to disappear as soon as greater attention is giren to the truit and our nurserymen begin to propagate it extensively. Aside from the above difficulties, there are probably no reasons why Apricots should not be grown in the East as easily as plums or pcaches. The varieties of
Apricots which are chiefly prized in the eastern states are Harris, Eariy Moorpark, and St. Ambroise for early: Turkish or Foinan (Fig. 114), Montgamet, Royal and Moorpark for nild-season and late. Of the Russian race, the best known are Alexander, Gibb, Budd, Alexis, Nicholas, and Catherine.

The ideal soil for the Apricot seems to be one which is deep and dry, and of a loamy or gravelly character. The rolling loamy lands which are well adapted to apples seem to be well suited to the Apricot, if the exposure and location are right. The Apricot seems to be particularly impatient of wet feet, and many of the failures are due to retentive subsoils. Particular attention should be given to the location and exposure of the Apricot orchard. In the East, the best results are obtained if the plantation stands upon elevated land near a large body of water, for there the spring frosts are not so serious as elsewhere. Generally, a somewhat backward exposure, if it can be obtained, is desirable, in order to retard blooming. Apricots will be sure to fail in frosty localities. The Apricot should always be given clean culture. For the first two or three years some hoed crop may be grown between the trees, but after that the trees should be allowed the entire land, particularly if set less than 20 feet apart. Cultivation should be stopped late in summer or early in the fall, in order to allow the wood to mature thoroughly. The trees are pruned in essentially the same way as plums. The fruitbuds are borne both upon spurs (two are shown in Fig. 115), and also on the wood of the last season's growth, on either side of the leaf-bud, as shown in the twin and triplet buds above $a$ in Fig. 115. Each bud contains a single naked flower (Fig. 116). As the fruit begins to swell, the calyx-ring is forced off over the top (Fig. 117); and the injury from curculio may then be expected.

When grown under the best conditions, the Apricot may be considered to be nearly or quite as productive as the peach. Like other fruit trees, it bears in alternate years, unless the crops are very heavily thinned; but it can never be recommended for general or indis criminate planting. Only the best fruit-growers can succeed with it. Apricots are to be considered as a dessert or fancy fruit, and, therefore, should be neatly packed in small and tasty packages. The most serious enemy of the Apricot is the curculio, the same insect which attacks the plum and peach. It seems to have a particular fondness for the Apricot, and as the fruit sets very early the crop may be expected to be destroyed unless the most vigilant means are employed of fighting the insect. Spraying with arsenical poisons is uncertain. The insect must be caught by jarring the trees, in the

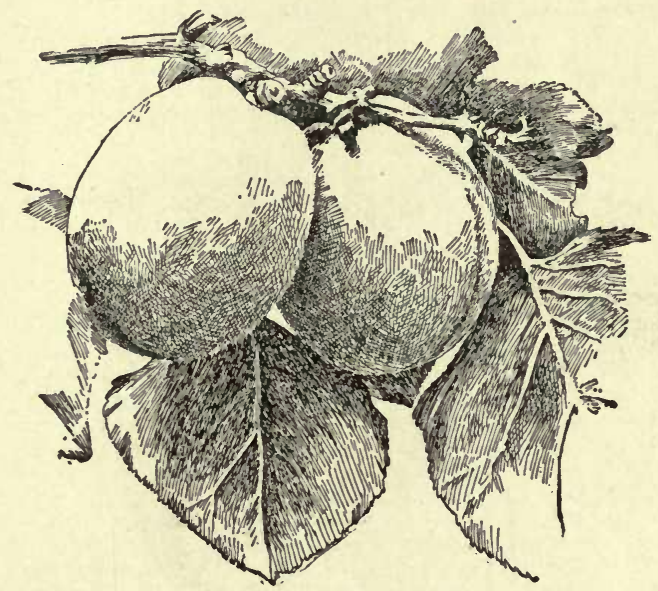

114. Apricot, the Roman $(X 1 / 2)$.

same manner as on plums and peaches, but the work must be even more thoroughly done than upon those fruits. The jarring should begin as soon as the blossoms fall, and continue as long as the insects are nu. merous enough to do serious damage. It will usually be 
necessary to catch the insects for three to six weeks, two or three times a week, or, perhaps, even every day. The work must be done early in the morning, while the curculio is indisposed to fly. The operation consists in knocking the insects from the tree by a quick jar or shake, eatching them upon a white sheet or in a canvas hopper. The catcher most commonly used in western New York is a strong cloth hopper mounted upon a wheelbarrow-like frame, and running upon two wheels. The hopper converges into a tin box, into which the curculios roll as they fall upon the sheet. One man wheels the device, by barrow-like handles, under the tree, then drops the handles and jars.the tree ; or sometimes two men go with a machine, one wheeling it and the other jarring the trees. This device is used extensively by practical fruitgrowers for catching the curculio on the various stone frults.

It is not yet certain what are the best stocks for Apricots in the East, in commercial orchards. It is probable that no one stock is best under all circumstances. The Apricot root itself seems to be impatient of our cold and wet soils, which are drenched by the drainage of winter. It needs a very deep and rich soil, but it is doubtful if it is safe for the East. The common plum (not myrobalan) is an excelient stock for plum soils, and the Apricot does well either nursery-budded or topworked upon it. Peach is probably the commonest stock, and, for peach soils, it is probably the best that can be used. If the Apricot thrives upon various stocks, it is thereby adapted to many soils.

The Apricot is often trained on walls, where the fruit reaches the hlghest perfection. Care should be taken that the wall does not face to the east or the south, or the early-forced flowers may be caught by frost. An overhanging cornice will aid greatly in protecting from frost.

L. H. B.

The Apricot in California. -The Apricot is one of the leading commercial fruits of California. It was introduced by the Mission Fathers, for Vancouver found it at the Santa Clara Mission in 1792. However, there is

15. Fruit-buds of the A pricot.

Borne beside the leaf bud, as on the peach. and also on spurs.

no relation between this early introduction and the expansion which quickly followed the American occupation, because the Mission Fathers had only seedling fruits, while the early American planters, shortly before the gold discovery, introduced the best French and English varieties, and were delighted to find that these sorts, usually given some protection in the Old World, grew with surprising thrift of tree and size of fruit in valley situations in California in the open air. Upon these facts the Apricot rose to wide popularity. The acreage has steadily increased during the last fifty 'years, and with particularly swift rate during the last twenty years, until the number of trees at the present date (1899) is about three millions, occupying upwards of forty thousand acres of land. This notable increase, and the present prospect of much greater extension, is based upon the demand which has arisen for the fruit in its fresh, canned, dried and crystallized forms, in all the regions of the United States, in England and on the Continent, where, by reason of its superior size and acceptable manner of curing, it has achieved notable popularity. The year 1897 was the greatest thus far in amount of dried product realized, viz.: $30,000,000$ pounds. The year 1895 was greatest in amount of canned product, which reached upwards of 360,000 cases, each containing two dozen $2 \frac{1}{2}$-pound cans. "The shipment of fresh Apricots out of California during the summer of 1897 was 177 carloads.

The chief part of the Apricot crop of California is grown in the interior valleys. In the low places in these valleys, however, the fruit is apt to be injurGd and sometimes almost wholly destroyed by spring frosts, a! though the trees make excellent growth. In foothill situations adjacent to these valleys, there is also serious danger of frost above an elevation of about fifteen hun dred feet above sea-level, and the tree is rarely planted for commercial purposes. In southern California the Apricot succeeds both in the coast and interior valleys. But along the coast northward, excepting the very important producing regions of the Alameda and Santa Clara valleys, eastward and southward from the Bay of San Francisco, the Apricot is but little grown owing to frost troubles. In respect to these, the Apricot is somewhat less subject to harm than the almond, but it is less hardy than the peach, and has, therefore, a much narrower range of adaptation. The average date of the blooming of Apricot varieties is about two weeks later than that of the almonds. The Apricot is adapted to a wide range of soils, because to the rather heavy, moist loams which its own root tolerates, it adds the lighter tastes of the peach root, upon which it is very largely propagated. However, attempts to carry the Apricot upon heavier, moister soils by working it upon the plum root have not been very successful, owing to the dwarfing of the tree; and the movement toward the light, dry loams, by working upon the almond root, has failed because the attachment is insecure, and the trees are very apt to be snapped off at the joining, even though they may attain bearlng age before the mishap occurs. The Apricot root itself is a favorite morsel with rodents, and is for that reason not largely used. Ourmainstay for the Apricot, then, is the peach root, and the soils which this root enjoys in localities sufficiently frost-free are, therefore, to a great extent the measure of our Apricot area.

Apricot trees are produced by budding on peuch or Apricot seedlings during their first summer's growth in the nursery row, from pits planted when the ground is moist and warm, at any time during the preceding winter. When there is a great demand for trees, planting in orchard is sometimes done with dormant buds, but ordinarily the trees are allowed to make one summer's growth in the nursery. The trees branch during the first year's growth from the bud, and usually come to the planter with a good choice of low-starting branches, from which to shape the low-headed tree which is universally preferred. The method of secul ing such a tree is identical with that already described for the almond, but the treatment of the tree after reaching bearing age, in its third vear, is very different from the after treatment of the almond. The Apricot is a rampant grower and most profuse bearer. Unless kept continually in check it will quickly rush out of reach, and will destroy its low shoots and spurs by the dense shade of its thick, beautiful foliage. There is continually necessary, then, a certain degree of thinning of the sur plus shoots and shortening of the new growth to continue the system of low branching, to relieve the tree from an excess of bearing wood, and to avoid small fruit and exhaustion of the tree, resulting in alternate years of bearing. In the coast regions, where the tree makes moderate wood growth, it can be kept in good form and bearing by regular winter pruning. In warmer regions. where the tendency is to exuberant wood growth, the main pruning is done in the summer, immediately after the fruit is gathered. This has a tendency to check wood growth and promote fruit bearing, and where the main cutting is done in the summer, winter pruning is reduced to thinning

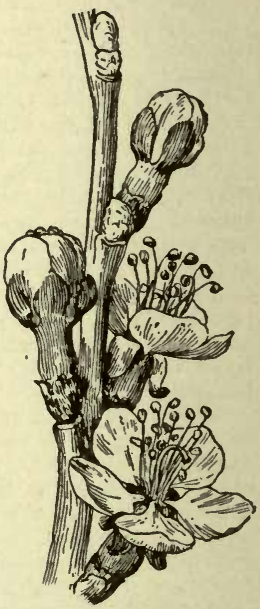

116. Flowers of the Apricot. out shoots, to prevent the tree from becoming too dense and to lessen the work of hand-thinning of the fruit later on. In addition, however, to the most intelligent pruning, much fruit must be removed by hand when there is a heavy set of it, in order to bring the fruit to a size 
satisfactory to shippers or canners, and to reach the highest grades, if drying is practiced. California Apricot orchards are all grown with clean tillage, for the main purpose of moisture conservation. In regions of

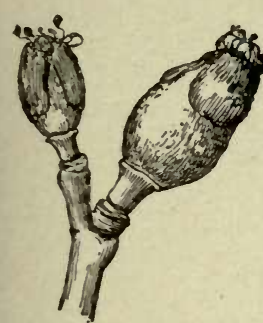

117. Young Apricots shedding the ring. good rainfall and sufficiently retentive loams no irrigation is required; good tillage will suffice for the production of large fruit and perfection of fruit-buds for the following year. As the trees are becoming older and bearing larger crops the demand for moisture increases. and the use of irrigation water is growing. In most places, however, one irrigation is sufficient, and that is given after fruit gathering, to carry the tree through the last half of its season's work. In the regularly irrigated regions of the state, water is periodically applied through the growing season, in such amount and at such intervals as the local climate and soils require.

Though probably all the good varieties of theApricot in the world have been introduced into California during the last half century, and scores of selected seedlings of local origin have been widely tested, the varieties which have survived the tests and are now widely grown are comparatively few in number. Most of the rejected varieties met this fate because of shy bearing, and those which now constitute the bulk of the crop are very regular and full bearers under rational treatment. A local seedling, the Pringle, was for many years chiefly grown for the earliest ripening, but this has recently been largely superseded by another local seedling, the Newcastle, which is of superior size and abont as early. The European varieties, Large Early and Early Golden, are fine in a few localities where they bear well, and do better in southern California than elsewhere. The universal favorite is the Royal ; probably three-fourths of all the trees in the state are of this variety, though recently the area of the Blenheim has been increasing largely. The Hemskirk stands next to the Blenheim in popularity. The Peach is largely grown in the Sacramento valley. The best Apricot grown in California is the Moorpark ; in size and lusciousness, when well ripened, it heads the list. It is, however, rather shy in bearing, and is forsaken for this fault in most regions. It shows the best behavior in the Santa Claravalley, and is there retained, in spite of frequent lapses, because of the high prices which it commands at the canneries. About a dozen other varieties are carried in small num. ner by the nurserymen to meet limited local demands.

Apricots for canning and drying are graded according to size: Extra, not less than 21/4 inches in diameter; No. 1, 2 inches; No. 2, 11/2 inches; No. 3, 1 inch. The first three grades must be sound, clean and free from blemish, and No. 3 must be of good merchantable quality. The shippers and canners require well-colored but only firm-ripe fruit, because both the long rail transportation and the canning process réquire it; soft-ripe fruit will neither can nor carry. For drying, riper fruit is used, and yet over-ripeness has to be guarded against to avoid too dark color. For canning, the fruit must be carefully hand-picked ; for drying, much is shaken from the trees. The drying process consists in cutting the fruit in halves longitudinally, dropping out the pits and placing the halves cavity uppermost upon light wooden trays. Breaking or tearing the fruit open will not do ; it must show clean-cut edges. When the trays are covered they are placed in a tight compartment, usually called a "sulfur box," though it may be of considerable size, and the fruit is exposed to the fumes of slowly burning sulfur, to ensure its drying to the light golden color which is most acceptable to the trade. The production of the right color is the end in view, and different dryers regulate the amoant of sulfur and the length of exposure according to the condition of their fruit and their judgment of what it needs. The exposure varies from half an hour to two or three hours, according to circumstances. After sulfuring, the trays are taken to open ground, and the fruit is cured in the sun. Only a very small fraction of the California product of evaporatedA pricots is cured in an evaporator. It requires about six pounds of fresh Apricots to make one pound of cured fruit.

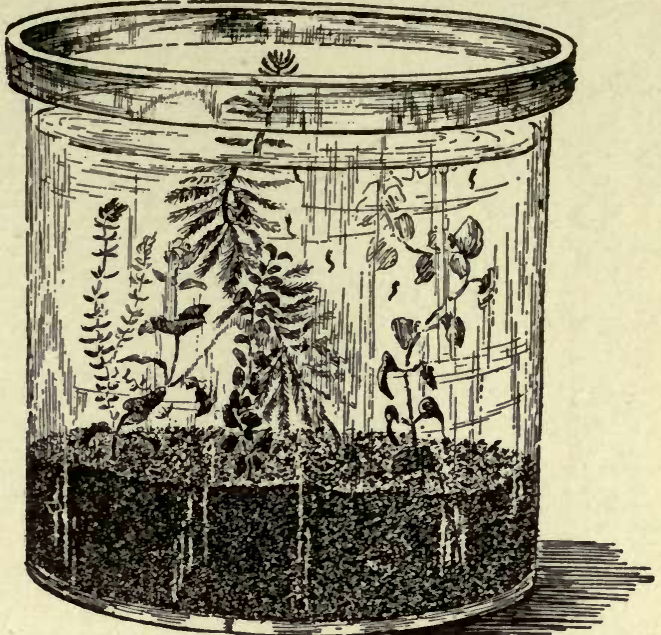

118. A museum-jar Aquarium.

More animal life would make a better equilibrium.

A moderate estimate of the yield of Apricots might be placed at seven and one-half tons to the acre : extreme yields are far away from this both ways.

TheApricot is, as a rule, a very healthy tree in California. It is, however, subject to injury by scale insects of the lecanium group in some parts of the state. During recent years there has been increasing injury by a shot-hole fungus, which perforates the leaves and makes ugly pustules upon the fruit. Such fruit is unfit for canning except the fruit be peeled, which is little done as yet. It also makes low-grade dried product. This fungus can be repressed by fungicides of the copper class.

EDWARD J. Wickson.

AQUARIUM. AnAquarium, to be in a healthy condi. tion, should contain living plants-oxygenators - which are as necessary as food, as fish cannot live on food only. The Aquarium must be kept clean. The sediment should be removed from the bottom with a dip tube trice a week, and the inner side of the glass cleaned with a wiper once a week. Encourage the growth of the plants at all seasons; admit plenty of light, but no direct sunshine. There should also be a few tadpoles and snails in the Aquarium. These are very essential, as they are scavengers, and devour the confervoid growth that frequently accumulates on the plants. In fall, give a thorough cleaning and rearrangement of the Aquarium, so that all are in the best condition possible before winter sets in. In March it should be carefully looked over, and undesirable plants removed or transplanted. Additions $\mathrm{may}$ be made, or any change if necessary. Fol lowing are some of the best plants to place in the Aquarium, all of which can be easily and cheaply procured from dealers who make a specialty of aquatics: Cabomba viridifolia ( $C$. Caroliniana), the Fanwort (sometimes called Washington Fish Grass, being found in quantities in D.C. and southward), is

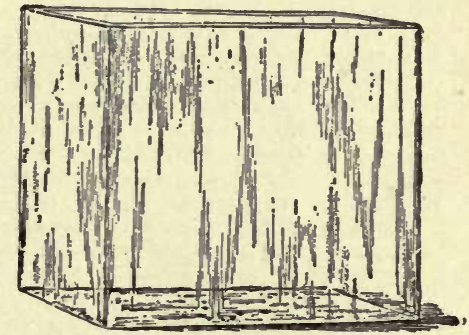

119. A rectangular glass Aquarium. 
most beautiful and interesting plant of a light green color. The leaf is fan-shaped, composed of filaments or ribs, much like a skeletonized leaf. Ludwigia $M u$ lerttii is also a beautiful plant, as well as a valuable oxygenator, having dark green, glossy foliage, the under side of the leaf bright red. Vallisneria spiralis is the well known eel grass: Lvs. strap-

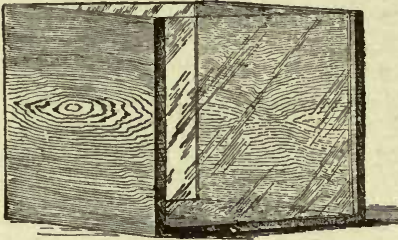

120. Permanent Aquarium made of wood and glass. like: root creeping and spreading: fls. strictly diocious: a very interesting plant in large Aquariums. Sagittaria nutans somewhat resembles Vallisneria, but the lvs. are wider and not so long, of a bright green color, and it makes better growth in winter,

which is very desirable. Myriophyllum verticillatum: lvs. pinnately parted into capillary divisions; foliage and stem of a bronzy green color. This, with $\boldsymbol{M}$. heterophyllum, as well as Cabomba, are sold by dealers in bunches, but established plants are preferablo for stocking the Aquarium. The above plants are wholly submerged, growing under the surface of the water, and are of the most importance in the Aquarium. Another submerged plant that does not require planting, and is sometimes used, is Stratiotes aloides, the water soldier or water aloe. The young plants are very pretty, but the large plants are stiff and the edges of the lvs, are dangerous, being armed with spines. Numerous floating plants are adapted to the Aquarium, but too many must not be in evidence, or the fish may become suffocated. The Azollas are very pretty, and the fish will occasionally eat the plants. The Salvinia is another small plant often seen in the aquarium, but under favorable conditions it grows very rapidly, and forms a complete mat, which must be avoided. The European and American frog's-bits (Limnobium Spongia, Hydrocharis Morsus-ranoe) are very attractive plants, their long, silky roots reaching down in the water. The water hyacinth, Eichhornia crassipes, var. major, in a small state is a curious and pretty plant, but does not continue long in a good condition, generally resulting from too much shade and unnatural conditions of atmosphere. This plant is of benefit to the Aquarium in the breeding season, as the roots are receptacles for fish spawn. The water lettuce (Pistia Stratiotes) is another very attractive plant, but it should be avoided except where the water is kept warm.

WiLliam Tricker.

Aquariums are rapidly increasing in popularity for home use, and are of great service in nature study. The following points, together with the illustrations, are taken from Life in an Aquarium, Teachers' Leaflet No. 11, published by the College of Agriculture, Cornell University, Ithaca, N. Y.: A permanent Aquarium need not be an expensive affair. The rectangular ones are best if large fishes are to be kept, but they are not essential. A simple home-made Aquarium of glass and wood is described in Jackman's Nature Study, as follows (the dimensions being slightly altered): "Use an inch board $11 \frac{1}{2}$ inches wide and 12 inches long for the bottom, and two boards of the same thickness and length, $103 / 4$ inches high,

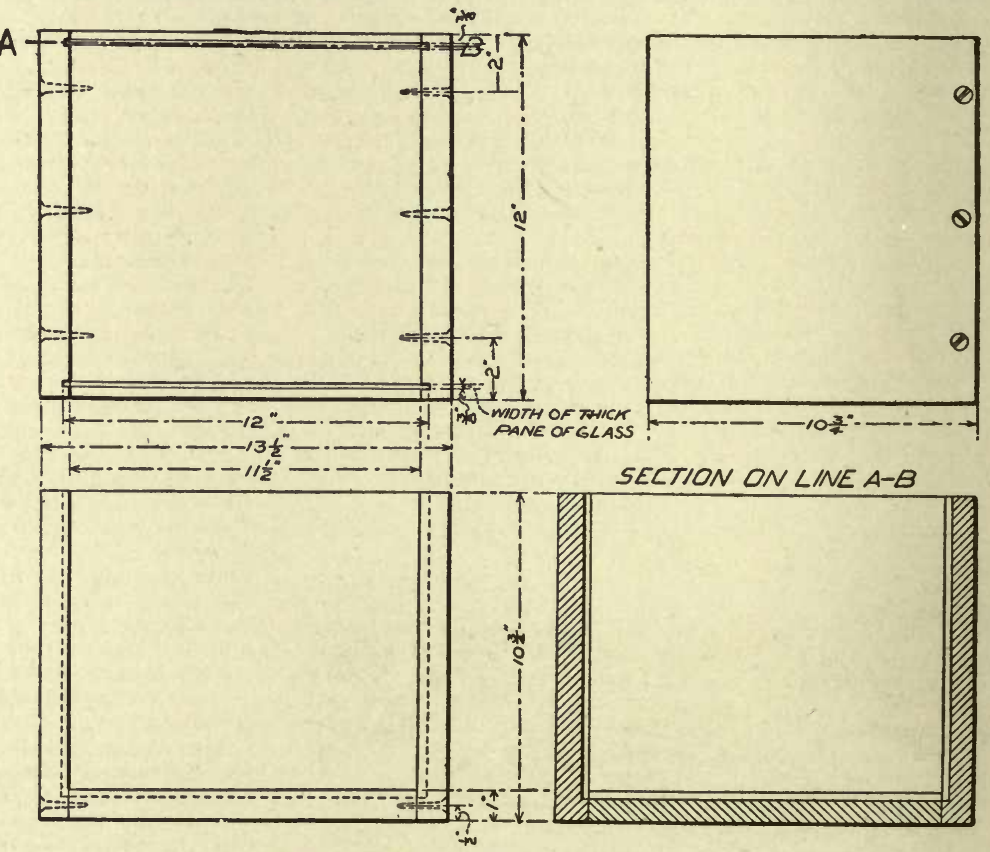

121. Working drawings for making box shown in Fig. 120.

for the ends. Three-eighths of an inch from the edge on either side, with a saw, make a groove $1 / 4$ inch deep and wide enough to receive loosely double-strength glass. Groove the end boards and fasten them to the bottom with screws, so that the grooves will exactly match. Partially fill the grooves with soft putty. or, better, Aquarium cement, and press into each side a pane of glass. By making the bottom board $11 \frac{1}{2}$ inches long, an ordinary $10 \times 12$ window pane will be the proper size. When the glass is pressed to the bottom of the groove, draw the two ends in at the top until the glass is held firmly and then fasten them in place by narrow strips of wood, one on each side of the tank, placed on top of the glass and screwed to the end pieces. These strips also protect the hands from injury while working with the specimens in theAquarium. Before filling with water, the inner surface of the bottom and ends should be well rubbed with oil or paraffine and the grooves inside the glass well packed with putty." After the box is made it would be well to let it stand in water for a day or two. The wooden sides will swell and tighten the joints, and leakage will be less probable.

AQUATICS. America is the most highly farored country in the world for the cultivation of Aquatic plants. Collections can easily be made to furnish a display of flowers from April to October in the open without artificial heat.

All Aquatics require a rich soil, and this without limit, a depth of water from 1 to 3 feet, and ample space to spread their succulent leaves. In a natural pond, where there is an accumulation of humus overlaying a clayey subsoil, nothing more is wanted, but on a sandy or gravelly bottom it is necessary to place a layer of rich soil 12 to 18 inches deep. In artificial ponds, built of masonry (Fig. 122), a layer of rich soil is necessary if the plants are to be planted out, as is best for Nelumbiums. The soil best suited for Aquatics is a turfy loam, inclining to heavy, and thoroughly rotted cow-manure, two parts of the former to one of the latter, and, where possible, it should be composted some time before using, and turned over two or three times to thoroughly incorporate the manure. When cow-manure can not be obtained, other thoroughly rotted manure may be used. The next best fertilizer is pulverized sheep manure, but, this being less bulky and stronger in proportion, should not be used as freely as other manures; one part sheep manure to 
nine of soil is sufficient. Chemical manures, ground bone, horn shavings, etc., should not be used unless in extreme cases, and then very cautiously.

IEPTH OF WATER. - In natural ponds, water-lilies are found growing in water from a few inches to 4 and 6 feet deep, but in artificial ponds a depth of 12 to 18 inches will be found sufficient for most Nymphæas, and 18 to 24 inches is a good depth for Victorias. In constructing an artificial pond, a depth of 2 to $2 \frac{1}{2}$ feet is ample. Water to the depth of 12 inches above the crowns of the plants is sufficient, and a box containing the soil may be 12 inches (leep. Thus a pond 2 feet in depth is deep enough, and will allow a man, with hip boots on, to walk between the plants with ease. For a small pond, less than 12 feet over, a plank laid across will suffice for all operations.

Protection. - Where severe frosts are prevalent in winter, and ice 12 to 18 inches in thickness is found, there will be danger of the roots freezing. In such cases, an additional depth of 6 inches will be a great advantage, and a protection of bracken, salt hay, green manure, leaves, or any other non-conducting materials should be used to protect the masonry, in severe weather, against expansion and breakage.

Planting. - All hardy Nymphras may be planted any time between the 1st of April and the 1st of September. Those planted early, other things being equal, will give good results the same season, while those planted late will get well established before winter, and will be in excellent condition to start at nature's summons early the following spring. The hardy Nymphæas differ considerably as to rootstocks. Those of the native varieties are long and of a spongy, soft texture, and rambling in growth, while the European species have a much larger and very firm rootstock, and grow more compact. In planting, all that is necessary is to press the rootstock firmly into the soil, and if there is any danger of the root rising to the surface, place a brick or any weight upon it, to keep it in position until anchored by its own roots. Tender Nymphras should not be planted until the latter end of May or beginning of June, according to location. They should not be planted out before Coleus, Alternanthera, and other tender bedding plants. They require to be started indoors, and will be grown in pots, which are much handier to plant than roots of the hardy varieties, and can be planted under the water with ease and facility. Nelumbiums should not be planted until about the ist of May. Southward the season is earlier. The existing conditions should be such that tubers shall start at once into active growth. They should be already "started" before setting out. The tubers should be laid horizontally in a slightly excavated trench and covered with 2 or 3 inches of soil, using a weight, if necessary, to keep the tubers in position. Plants, established in pots or pans, are very convenient for planting, and may be purchased when tubers can no longer be procured, and can be planted a month later in the season with good results.

The Victoria Regia has always been an aristocrat among water-lilies, and few cultivators could indulge in such a horticultural luxury. To grow it satisfactorily, a large surface space with a greater depth of water is necessary than for other aquatics, and a higher temperature is needed at the early stages. It can be cultivated in the open air, but artificial heat must usually be applied and protection afforded, so as to maintain a temperature of $85^{\circ} \mathrm{F}$. This applies more particularly to the varieties $V$. Regia and $V$. Randi. In 1898 the introducer of $V$.

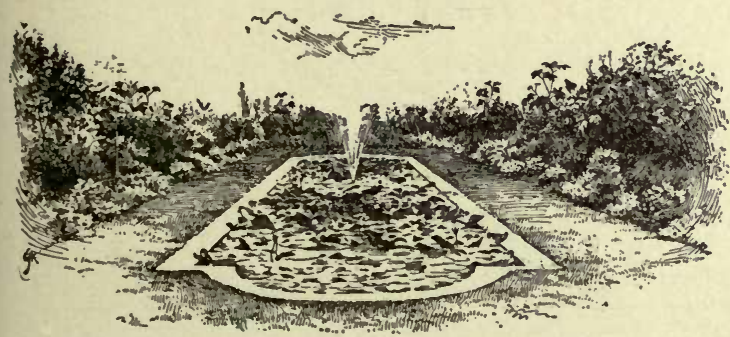

122. Lawn pond of aquatics, with mason-work margin.
Trickeri brought the Victoria within easy reach and cuiture of all lovers of aquatic plants. V. Trickeri is entirely distinct from other known varieties, and can be grown in the open alongside of Nymphoa Zanzibarensis and $N$. Devoniensis, and under precisely the same con-

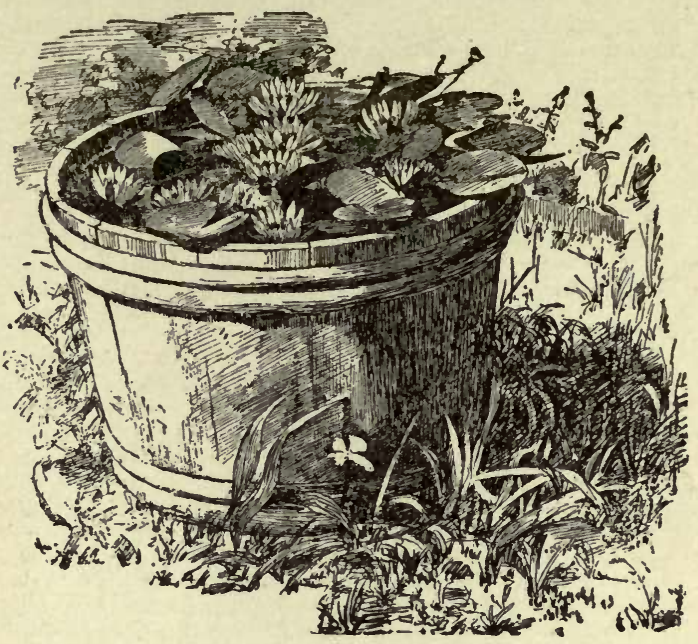

123. Tub of water-lilies.

ditions. When planted out about the middle of June, the plants grow rapidly, and will develop their gigantic leafage and magnificent flowers in August, and continne to do so until destroyed by frost.

EnEmies. - Aquaties, like other plants, have their enemies in the line of insect pests, though in a less degree than most plants. Aphides are sometimes troublusome, or at least very unsightly. These, however, have their enemies, especially the coccinella (lady-bird), insectivorous birds, etc. Where these do not keep them down, a weak application of kerosene emulsion will make a clearance. Another method of getting rid of these pests, especially in a small artificial pond, where an overfiow is (or should be) provided, is to take the hose with a spray, using a little force, and drive the insects off the plants, and, as they readily float on the water, the action with the hose will drive them out at the overflow pipe. Recently an insect pest that has its home in Florida has migrated north ward, causing some annoyance. The larva of the moth (Hydrocampa proprialis) eats the leaf, and also cuts out pieces of the same, which it uses for protection, thereby greatly disfiguring the plant, and at the same time making it difficult to get at the enemy. The best remedy for this and the Nelumbium moth, which is very much like it, is a lamp trap. Any ordinary lamp placed near the plants at night, and standing in a shallow vesessl containing kerosene, will attract the insects, which, on striking the lamp, fall into the kerosene and are no further trouble. Muskrats are more or less troublesome, especially where Nelumbiums are grown. They will eat the tubers in winter and early spring, and will make sad havoc with banks. They will also eat the roots of some Nymphæas. The best remedy for these is the steel trap. A sporadic disease has also made its appearance. The leaves are affected with spots, which, under a damp, warm atmosphere, spread rapidly. Sueh climatic conditions, followed by bright sunshine, cause the affected leaves to shrivel up. This greatly weakens and ehecks the plants. This disease yields readily to a weak solution of Bordeaux mixture. The same remedy is also very valuable in ridding the pond of all confervoid growth.

TuB Culture should be resorted to only from lack of space, or when no other method can be adopted (Fig. 123). For this system of culture, Nymphæas should be selected that are moderate growers, yet free-flowering, and other miscellaneous aquatic plants. The tubs should hold from 4 to 12 cubic feet of soil for Nymphæas, according 
to the variety, some being moderate growers, others vigorous and robust.

WILLIAM TRICKER.

[The best book on the American culture of Aquatics is The Water Garden, by Wm. Tricker, N. Y. 1897, pp. 120 , to which the reader is referred for extensive cultural directions and for lists of Aquatic plants. For botanical descriptions of the various kinds of Aquatics, with brief, special cultural directions, the reader may consult the Cyclopedia of American Horticulture, under the various genera, as $N y m p h c e a$, Nelumbium, and Victoria. -L. H. B.]

AQUILEGIA (from aquilegus, water-drawer, not from aquila, eagle). Ranunculdceo. Columbine. Hardy perennial herbs of the northern hemisphere; mostly with paniculate branches, terminated by showy flowers, and 1-3 ternately-compound leaves, commonly glaucous; the

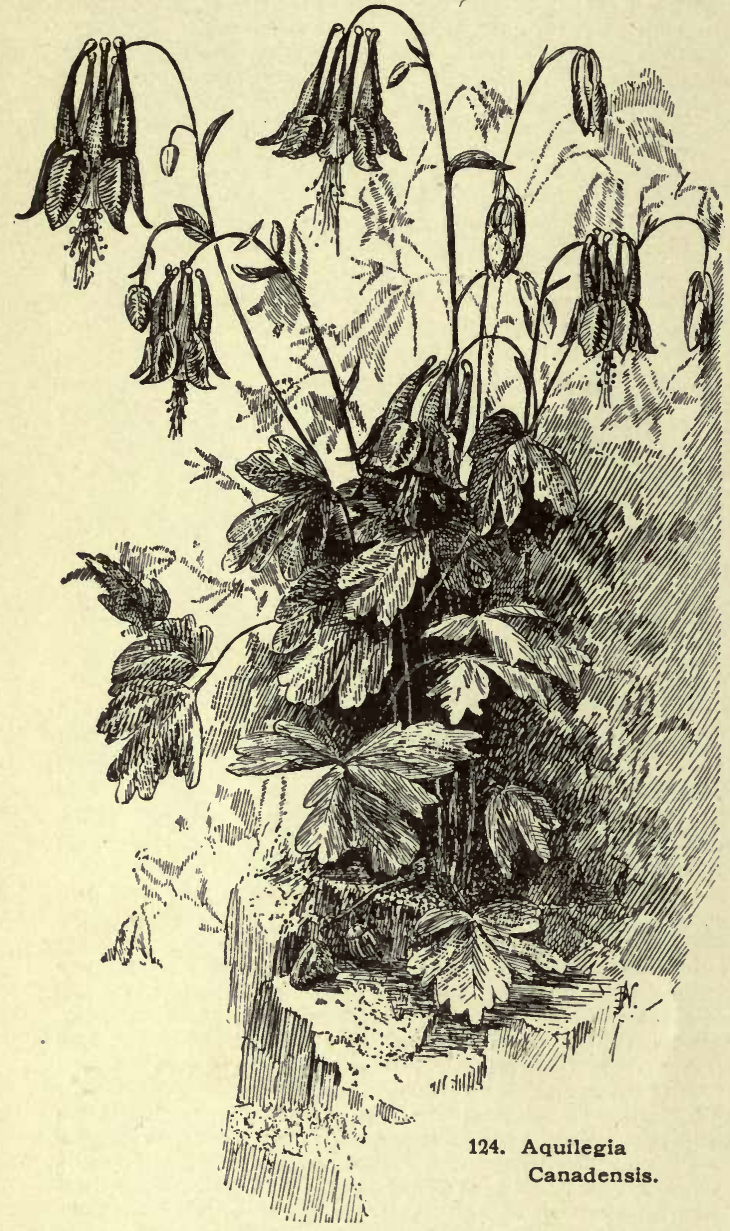

leaflets roundish and obtusely lobed : fis. large, showy, usually in spring or early summer; sepals 5, regular, petaloid ; petals concave, produced backward between the sepals, forming a hollow spur; stamens numerous: fr. of about 5 many-seeded follicles. About 30 distinct species. The Columbines are among the most beautiful and popular of all hardy plants. Seeds sown in pans, in coldframes in March, or open air in April, occasionally bloom the first season, but generally the second. The different species should be some distance apart, if possible, if pure seed is desired, as the most diverse species hybridize directly. They may be propagated by division, but better by seeds. Absolutely pure seed is hard to ob- tain, except from the plants in the wild state; and some of the mixed forms are quite inferior to the true species from which they have come. A. carrlea, glandulosa. and vulgaris are likely to flower only two or three years. and should be treated as biennials; but $A$. vulgaris may be kept active for a longer period by transplanting. $A$. Gray, Syn. Flora of N. A., Vol. 1, Part 1, Fasc.1, pp.42-45. J. G. Baker, A Synopsis of the Aquilegia, in Gard. Chron. II. $10: 19,76,111,203$ (1878). K. C. Davis

A light, sandy soil, moist, with good drainage, sheltered, but exposed to sun, is what they prefer. Some of the stronger species, when of nearly full-flowering size, may be transplanted into heavier garden soil, even heavy clay, and made to succeed; but for the rearing of young seedlings, a light, sandy loam is essential. The seed of most Columbines is rather slow in germinating, and it is necessary to keep the soil moist on top of the ground until the young plants are up. A coldframe, with medium heavy cotton covering, is a good place to grow the plants. The cotton retains sufficient moisture to keep the soil moist on top, and still admits sufficient circulation of air to prevent damping-off of the young seedlings. When large enough, the seedlings may be pricked out into another frame for a time, or, by shading for a few days until they get a start, they may be set into the permanent border, or wherever they are to be placed.

F. H. HORSFORD.

The following is an alphabetical list of the species described below : A. alpina, 16 ; atrata, 9 ; atropurpurea, Miq., 6; atropururea, Willd., 4 ; bicolor, 10 ; blanda, 9; Buergeriana, 6 ; cærulea, 15 ; ecerulea, var. flavescens, 5 ; Californica, 11; Canadensis, 5 ; Canadensis, var. aurea, 13 ; Canadensis, var. formosa, 11 ; caryophylloides, 19 ; chrysantha, 13 ; flabellata, 7 ; flavescens, 5 ; flaviflora, 5 ; formosa, 11; Garneriana, 10; glandulosa, 17; Jonesii, 1; lactiflora, 3 ; leptoceras, Fisch. \& Mey., 8; leptoceras, Nutt., 15 ; leptoceras, var. chrysantha, 13 ; longissima, 14 ; macrantha, 15 ; Olympica, 9 ; oxysepala, 2 ; Sibirica, 10 ; Skinneri, 12 ; Skinneri, var. hybrida, 13 ; speciosa,10 ; stellata, 9 ; Stuarti, 18; truncata, 11; viridiflora; 4 ; vulgaris, 9 ; Wittmanniana, 9.

A. Sepals not more than $1 / 2$ or $3 / 4$ in. long: expanded fls. 1 or $1 \frac{1}{2} \mathrm{in}$. in diam.

B. Limb of petal shorter than the sepal.

1. Jonesii, Perry. True st. very short or almost wanting, soft pubescent : tufted root-lvs. 1-2 in. high from the stout, ascending branches of the rootstock, biternately divided; partial-petioles very short or none; leaflets very crowded: fls. blue; sepals oblong-obtuse, equaling the spurs and twice the length of the petal-limbs and head of stamens : follicles glabrous, large, nearly $1 \mathrm{in.long;} \mathrm{styles} \mathrm{half} \mathrm{as} \mathrm{long;} \mathrm{peduncles} \mathrm{lengthening} \mathrm{to}$ about 3 in. in fr. July. Wyom. and Mont. G.F. 9: 365.

2. oxysépala, Traut. \& Mey. Plant $2 \frac{1}{2} \mathrm{ft}$., slightly pubescent above : radical lvs. long-petioled, secondary divisions sessile: sepals blue, ovate-lanceolate, much exceeding in length the petal limbs, which are 6 lines long, white, rounded-truncate; stamens not protruding beyond the petal limb: spur knobbed, bent inward, shorter than petal-limb : follicles pubescent, with styles their own length. June. Siberia. - In 1898 F. H. Horsford said : "The first to bloom with me, and one of the most attractive in the list. It is one of the most dwarfed; fls. large, blue, yellow and white : it comes so much before the others that its capsules, as a rule, all fertilize before any of the other species come into flower." Only recently introduced.

3. lactiflora, Kar. \& Kir. St. 11/2ft. high, glabrous in the lower part: partial-petioles of root-lvs. $1 \frac{1}{2}-2$ in. long; lfts. sessile or short-stalked, 1 in. long, many lobes reaching half way down; st.-lvs. petioled and compound: fls. about 3 to a st.: sepals nearly white or tinged with blue, over $1 / 2$ in. long, narrow; petal-limb half as long as sepal; spur $1 / 3$ in., slender, nearly straight, not knobbed at tip; stamens equal in length to the limb. June. Altai Mts., Siberia.-A desirable species, but not much used.

BB. Limb of petal about equal to sepal.

4. viridiflora, Pallas. St. 1-11/2 ft. high, finely pubescent throughout, several-fld.: the partial-petioles of rootlvs.1-2 in.long; lfts. sessile or the end one shortly stalked, 
lobes rather narrow and deep; lower st.-lvs. petioled, biternate : sepals oblong, obtuse, ascending, greenish, equaling the broad, greenish petal-limb, but not reaching the head of stamens ; spur straight, slender, $1 / 2 \mathrm{in}$. long, not knobbed: pubescent follicles as short as their styles. Summer. E. Siberia. - Not so much used as the following variety :

Var. atropurpùrea, Vilm. (A. atropurpùrea, Willd.). Limbs of the petals deep blue or lilac-purple, and the sepals and spur somewhat tinged with the same hue. B.R. 922

5. Canadénsis, Linn. Common Columbine of America. Fig. 124. Height 1-2 ft.: primary divisions of petioles of root-lvs. 1-2 in., having 3 divisions ; 2 or 3 of the st. lvs. petioled, biternate : fls. several to a st.; sepals yellowish or tinted on the back with red, about $1 / 2$ in. long, not reflexing ; limb of petals a little shorter, yellowish, truncate; spur $3 / 4$ in. long, nearly straight, knobbed at the end, bright red throughout; stamens much protruding : follicles $3 / 4$ in. long, with styles half as long. MayJuly. Stony banks, etc., east of Rocky Mts. Int. 1890. B.M. 246. L.B.C. 9: 888. Mn. 5:21 R.H. 1896, p. 109 G W.F.1. There are some beautiful hybrids of this and the blue species. Var. nana, Hort. Plant $1 \mathrm{ft}$. high or less: fls. like the type.

Var. flavéscens, Hook. A pale-lvd. yellow-fld. variety. Very pretty. Int. 1889. This has often been called $\boldsymbol{A}$. flavescens, Wats.; A. carulea, var. flavescens, Lawson; and $A$. flaviflora, Tenney; A. Canadensis, var. flaviflora, Brit. B.M. 6552 B.

6. Buergeriàna, Sieb. \& Zucc. (A. atropurpùrea, Miq.). More slender than A. vulgaris; $1 \mathrm{ft}$. high, finely pubescent toward the top; branched to form several heads, bearing 2-3-petioled, biternate lvs.; partialpetioles of basal lvs. $1 / 2-1$ in. long, with 3 sessile divisions : fls. yellow, tinted with purple, $1-1 \frac{1}{2}$ in. in diam.; sepals $3 / 4$ in. long, acute, spreading; spurs erect, nearly straight, as long as the limb of petals, and about equalling the sepal; head of stamens equal to limb in length: follicles pubescent, $3 / 4 \mathrm{in}$. long, style half as long. Early. Japan. - Brought from St. Petersburg, 1892.

AA. Sepals about $1 \mathrm{in}$. long: expanded fl. aboul $2 \mathrm{in}$. in diameter.

B. Spurs shorter than the petal-limb, and incurved.

7. flabellàta, Sieb. \& Zuce. Stem 1-11/2 ft., few-fld.: partial-petioles of root-lvs. 1 in. or more, lfts. nearly sessile ; st.-lvs. large and petioled : fls. bright lilac, or pale purple or white ; sepals 1 in. long, obtuse ; limb of petal half as long, often white in the lilac-fld. form; spur shorter than the limb, slender toward the end, much incurved; stamens not protruding beyond the petallimbs : follicles glabrous. Summer. Japan. R.H. 1896, p. 109. Var. nàna-álba, Hort. (var. flore-alba, Hort.). Fls. pure white : plant dwarfish. R.B. 15: 157.

\section{BB. Spur at least as long as petal-limb. \\ C. Stamens short, not much protruding.}

8. leptocèras, Fisch. \& Mey. Stem several-fld., about $1 \mathrm{ft}$. high : partial-petioles of root-lvs. over 1 in., lfts. sessile ; st.-lvs. petioled, biternate : fls. violet, with the tips of the sepals greenish, and tips of the short petallimb yellow; spur slender, slightly curved, 1/2in. long, not knobbed; stamens protruding a little beyond the limbs of petals : follicles slender, glabrous, nearly $1 \mathrm{in}$. long. Summer. E. Siberia. B.R.33:64. F.S. 3:296.Little used in America.

9. vulgàris, Linn. (A. stellàta, Hort. A. atràta, Koch). Common C. of Europe. Stems 11/2-2 ft. high, many-fld., finely pubescent throughout: root-lvs. with 3 partial-petioles $1 \frac{1}{2}-2$ in. long, secondary branches certain, ultimate leaf-lobes shallow and roundish, texture firm; lower st.-lrs. petioled and biternate: fls. violet, furnished with a claw, acute, 1 in. long, half as wide; petal-limb 3/4in. long, equaling the head of stamens ; spur about same length, stout, much incurved, knobbed : follicles densely pubescent, 1 in. long, style half as long. Summer. Eu., Sib., and naturalized in Am. Gn. 12, p. 288. Var. flòre-plèno, Hort. Fls. much doubled, ranging from pure white to deep blue. Here belong many horticultural varieties with personal names.
Var. Vervæneàna, Hort. (var. foliis-aúreis, Hort. Var. atrovioldcea. Hort.). Lvs. with yellow variegated lines.

Var. nívea, Baumg. (var. álba, Hort.). Munstead's White C. Often 2-3 ft. high : a great profusion of large, pure white fls. for several weeks in early spring.

Var. Olýmpica, Baker (A. Olýmpica, Boiss. A.Wittmanniana, Hort. A. blánda, Lem.). A fine variety, with several large flowers; sepals light lilac or bright purple, 1 in. or more in length ; petal-limb white. I.H. 4: 146. R.H. 1896, p. 108.

Var. hybrida, Sims. Much like the last variety, but with stout, lilac-purple spurs as long as the sepals, only slightly incurved. Probably a hybrid of $A$. vulgaris and A. Canadensis. B.M. 1221.

10. Sibírica, Lam. (A. bícolor, Ehrh. A. Garnieridna, Sweet. A. speciòsa, DC.). Stem $1 \frac{1}{2}-2 \mathrm{ft}$. high, manyfld.; often nearly glabrous throughout : partial-petioles of root-lvs. 1-2 in., sometimes showing 3 distinct branches; terminal lfts. 1 in. or more broad, lobes rather shallow and rounded; lower st.-lvs. petioled and biternate : fls. pale or bright lilac-blue ; oblong sepals fully $1 \mathrm{in}$. long, spreading or reflexed a little ; petal-limb half as long, equaling the head of stamens, and often white spur rather stout, $1 / 2$ in. or more, very much incurved, or even coiled : follicles ylabrous, 1 in. long, style 1/3in. Summer. E. Siberia. S.B.F.G. II. 1: 90. Var. flore-plèno, Hort. (A. bicolor, var. flore-pleno, Hort.). Fls. much doubled by the multiplication of both the limbs and the spurs.

Var. spectábilis, Baker (A. spectábilis, Lem.). A large, bright lilac-fld. var.; petal-limbs tipped yellow. Amurland. I.H. 11: 403.

cc. Stamens long, protruding far beyond the petal-limb.

11. formosa, Tesch. (A. Canadénsis, var. formosa, Wats.). Habit as in A. Canadensis ; root-lvs. and st. lvs. like that species, but fls. brick red and yellow, or wholly yellow, and sepals larger, quite twice as long as petal-limb ; spurs more spreading, somewhat more slender, and often shorter. May-Aug. Sitka to Calif. and E. to the Rockies. Int. 1881. B.M. 6552. F.S. 8: 795 Gt. 32: 372. R.H. 1896, p. 108. G.C. 1854: 836. Var. hyे brida, Hort. (A. Californica, var. hybrida, Hort.). Fls. large, with scarlet sepals and yellow petals; spurs spreading, long and slender. A supposed hybrid with A. chrysantha. F.M. 1877:278. Vick's 1:33 f.2. Var. rùbra plèno, Hort. (var. flore-pleno, Hort.). Fls. as in var. hybrida, but several whorls of petal-limbs. Var. nàna álba, Hort. Fls. pale, often nearly white; plant not exceeding $1 \mathrm{ft}$.

Var. truncàta, Baker (A. truncdta, Fisch. A. Californica, Lindl.). Fls. with short, thick spurs and very small sepals and a small petal-limb. Int. 1881. F. S. 12: 1188 (as A. eximia, Hort.).

12. Skínneri, Hook. Stem 1-2 ft. high, many-fld., glabrous : root-lvs. long-petioled, with both primary and secondary divisions long ; lfts. cordate, 3-parted; several st.-lvs. petioled and biternate : sepals green, keeled, lanceolate, acute, never much spreading, 3/4-1 in. long; petal-limb greenish orange, half as long as sepal; spur brigt red, tapering rapidly, over 1 in, long ; stamens protruding far beyond the limb ; styles 3 : fr., at least when young, bearing broad, membranous, curled wings. After flowering, the peduncles become erect. July-Sept. Mts. of Nor. Mex. B.M. 3919. P.M. 10: 199. B.H.4:1. F.S. 1: 17. Vick's $1: 33$ f. 5 (poor). $-A$ handsome plant, requiring a light soil in a sunny border. Var. florepleno, Hort. Fls. double. Gt. 34:57. Very fine.

BвB. Spurs very long, several times the length of petal-limb.

13. chrysántha, Gray (A. leptocèras, var. chrysántha, Hook.). Fig. 125. Height 3-4 ft.: root-lvs. with twice 3-branched petioles, lfts. biternate; st.-lvs. several, petioled : fls. many on the plant, $2-3$ in. across ; sepals pale yellow, tinted elaret, spreading horizontally ; petallimb deep yellow, shorter than the sepals, and nearly as long as the head of stamens ; spur rather straight, very slender, divergent, about 2 in. long, descending when fl. is mature : follicles glabrous, 1 in. long; style half as long. May-Aug. N. Mex. and Ariz. Gn. 16: 198. B.M. 
6073. Gn. 51, p. 385. R.H. 1896: 108. F.R. 2: 169 . Gt. 33: 84. G.C. 1873: 1501. F.M. 1873:88. Vick's 1: 33 f. 3 . F.S. 20:2108. Var. flavéscens, Hort. (A. aìrea, Junk. A. Canadénsis, var. aùrea, Roezl.). Fls. yellow, tinged with red; spurs incurved, and shorter than in the type. Gt. 21: 734. Var. álba-plèna, Hort. (var. grandiflòra álba, Hort.). Fls. very pale yellow or nearly white, with two or more whorls of petal-limbs. Int. 1889. Vick's 12:311. Var. nàna, Hort. (A. leptocèras, var. lùtea, Hort.). Like the type, but plant always small, not exceeding $1 \frac{1}{2} \mathrm{ft}$. Var. Jaéschkani, Hort. About the same height as last : fls. large, yellow, with red spurs. Thought to be a hybrid of $A$. chrysantha $\times S k i n n e r i$, hence sometimes called $A$. Skinneri, var. hybrida, Hort.

14. longissima, Gray. Tall, somewhat pubescent with silky hairs, or smoothish : root-lvs. biternate, even in the petioles; lfts. deeply lobed and cut, green above, glaucous beneath; st.-lvs. similar, petioled : fls. pale yellow, sepals lanceolate, broadly spreading, 1 in. or white or yellow. The true form of this is probably $A$. carulea $\times$ A. chrysantha. Gn. 51, p. 385. R.H. 1896:108. A.G. 15:315. Gn. 16:198. I.H. 43:61 (1896). Var. flòreplèno, Hort. Fls. longer and very showy, more or less doubled toward the center.

BB. Spurs incurved and hardly longer than petal-limbs.

16. alpina, Linn. (incl. var. supérba, Hort.). Fig. 126. Stem nearly $1 \mathrm{ft}$. high, finely pubescent upwards, 2-5fld., bearing petioled, biternate lvs.; partial-petioles of basal-lvs. 1-2 in. long, with 3 nearly sessile divisions, deeply lobed : expanded fl. 11/2-2 in. across, blue, rarely pale or white ; sepals $1 \frac{1}{4}$ in. long, half as broad, acute ; petal-limb half as long as sepals, often white; spur stout, incurved, same length as the limb; head of stamens not protruding : follicles pubescent, 1 in. long; style much shorter. May-June. Switzerland. L.B.C. 7:657. Gn. $9: 17$.

17. glandulosa, Fisch. Fig. 127. Stem $1-11 / 2 \mathrm{ft}$. high,

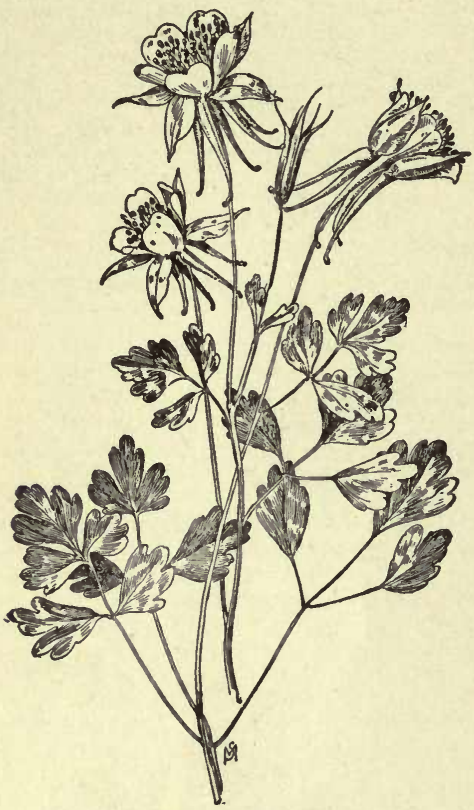

125. Aquilegia chrysantha $(\times 1 / 4)$.

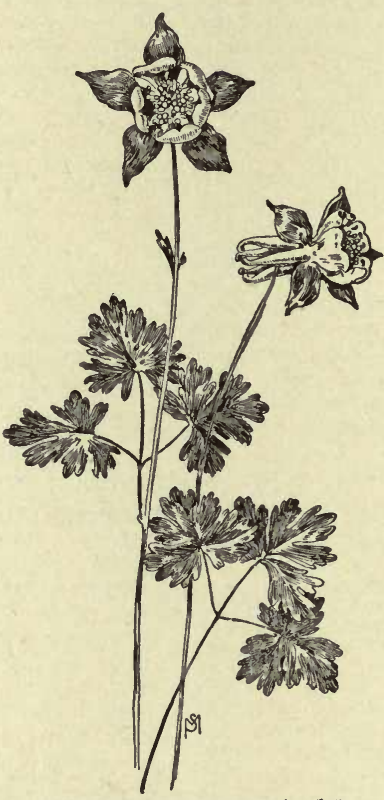

126. Aquilegia alpina $(\times 1 / 4)$.

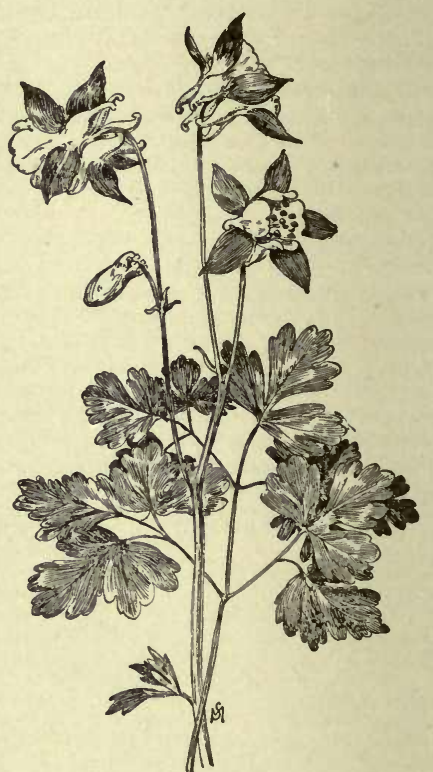

127. Aquilegia glandulosa $(\times 1 / 4)$. more, the spatulate petals a little shorter, about equaling the head of stamens; spur with a narrow orifice, 4 in. long or more, always hanging. Distinguished from A. chrysantha by its longer spur with contracted orifice, by the narrow petals, and by the late season of flowering. Late July to Oct. 1. Ravines S.W.Texas into Mex. G.F. 1:31. - The seed must be obtained from wild plants, as those cult. usually fail to produce seed; hence not much used.

AAA. Sepals 11/4-11/2 or even $2 \mathrm{in}$. long: expanded $\mathrm{fls}$.

21/2-3 in. in diam.; stamens not protruding.

B. Spurs long and not incurved.

15. cærùlea, James (A. leptocèras, Nutt. A. macrántha, Hook. \& Arn.). Stem 1-11/2 ft., finely pubescent above, bearing several fls.; lower st.-lvs. large and biternate ; basal-lvs. with long 3-branched petioles ; lfts. 3-lobed on secondary stalks : fls. 2 in. across, whitish, but variously tinted with light blue and yellow; sepals often blue, oblong, obtuse, twice as long as the petal-limb; spurs long, slender, knobbed at the end, rather straight, but curving outward; head of stamens equaling the petals : follicles pubescent, 1 in. long; style $1 / 3$ in. Apr. July. Lower mt. regions, Montana to N. Mex. B.M. 4407. Gn. 16: 198. Mn. 6:61. Vick's $1: 33$ f. 4. B.M. 5477. F.S. 5: 531. Var. álba, Hort. Fls. of same size but entirely white. Int. 1883. Var. hybrida, Hort. Sepals some shade of blue or pink, or mixed, and petals nearly glandular pubescent in the upper half, 1-3 fld.: partialpetioles of root-lvs. 1-2 in. long, each with 3 distinct divisions; lft.-segments narrow and deep; st.-lvs. few, bract-like : fls. large, nodding ; sepals bright lilac-blue, ovate, acute, about $1 \frac{1}{2}$ in. long and half as broad; petallimb same color, but tipped and bordered with creamy white, less than half the length of the sepals, very broad; spur very short, $1 / 4$ in., stout, much incurved; stamens not protruding: follicles 1 in. long, 6-10 in number, densely hairy, with short, falcate style. Allied to $A$. $a l$ pina, but a taller plant, with shorter spurs, larger fls., and a greater number of follicles. May-June. Altai Mts. of Siberia. B. 5:219. F.W. 1871:353. Gn. 15: 174 ; 45 , p. 193. Gt. 289 f. 1. - One of the handsomest.

Var. jucúnda, Fisch. \& Lall. Fls. rather smaller than in the type ; petal-limb white, more truncate at the tip ; stamens as long as limb. B.R. 33:19. F.S. 5: 535.-A fine variety, with some tendency to double.

18. Stùarti, Hort. A recorded hybrid of $A$. glandu$\operatorname{los} a \times A$. vulgaris, var. Olympica. Fls. very large and beautiful. It very much resembles the latter in form of sepals and petals, and the former in shape of spurs and coloration. May-June. Int. 1891. Gn. 34:670.

19. caryophylloides is a garden name given to some very mixed forms, with a great variety of colors. Special characters seem not to be well fixed.

K. C. Davis 
ÁRABIS (A rabia). Crucifera. Rock-cress. Smull perennial or annual herbs, with white or purple fls., grown mostly in rockwork. Fls. mostly in terminal spikes or racemes, small, but often many, or appearing for a considerable period of time : siliques long, linear, flat: stigma 2-lobed. In temperate regions, several native to this country. Usually prop. by division; also by seeds and cuttings. Hardy, requiring plenty of sun, and thriving even in poor soil. The following four species are perennials:

\section{A. F'ls. purple or rose.}

muràlis, Bertol. (A. ròsea, DC.). A foot high, with a rather dense raceme of pretty fls.: lvs. oblong, sessile (the radical ones with a long, narrow base), prominently and distantly blunt-toothed, sparsely pubescent. Spring and summer. Italy. B.M. 3246.

$$
\text { AA. Fls, white. }
$$

serpyllifolia, Vill. (A.nivalis, Guss.). Tufted, 2-6 in.: radical lvs. entire or few-toothed, the st. lvs. small and sessile, not clasping : fls. in a short cluster, the calyx as long as the peduncle, the limb of the petals linearoblong and erect. Eu.

álbida, Stev. (A. Caucásica, Willd.). A few inches high, pubescent : lower lvs. narrow at the base, the upper auriculate-clasping, all angle-toothed near the top : Hls. in a loose raceme, the calyx shorter than the pedicel, the petal-limb oval and obtuse. Eu. B.M. 2046. Also a variegated var. (Gt. 45: 108). - Blooms early, is fragrant, and is well adapted for rockwork and edgings, and for covering steep banks.

alpina, Linn. Fls. smaller than in the last, plant only slightly pubescent and hairy: Ivs. somewhat clasping but not auriculate, small-toothed nearly or quite the entire length, the cauline ones pointed. Eu. B.M. 226. - Blooms very early, and is one of the best rock plants. There is a dwarf form (nana compacta, Gt. $44: 203$ ); also a variegated variety.

A. arendsa, Scop. Fls. rose varying to white: 1vs. pinnatifid, those on the st. deep-toothed. Eu.-A. blepharóphylla, Hook. \& Arn. Fls. large, rose-purple: lvs. sharp-toothed, sessile or clasping, the margins hairy. Calif. B.M. 6087.-A. lucida, Linn, f. Fls. white: lvs. shining, obovate, clasping. There is a variegated form. Eu. $-A$. móllis, Stev. Fls. white: lvs. pubes cent, large-toothed, the lower ones rounded and long-stalked Eu. - A. petroea, Lam. Fls. white: lvs. toothed, the radical ones often parted, the st. Ivs. oblong-linear. Eu.-A. pricecox Wald. \& Kit $=A$ procurrens, $-A$, procurrens, Wald. \& Kit. Fls. white: lvs, ciliate, those on the st. entire and sessile, the others stalked: stoloniferous. A variegated var. Eu. -A. vérna, R. Br. Annual, hairy: fls. large, purple: lvs. oblong vérna, $\mathrm{R}$. Br. Annual, hairy : fls. large, purple: lvs. oblong
ovate to round-oblong, the upper ones clasping, rather coarsetoothed. Eu. B.M. 3331 .

L. H. B.

\section{ARACE正. See Aroidec.}

ARACHIS (Greek, without a rachis). Leguminòsa. Peanut. Goober. Sometimes grown in the economic house of botanical gardens. The genus has seven species, of which six are Brazilian. Fls. 5-7, yellow, in a dense, axillary, sessile spike. As a hothouse annual, the seeds of the Goober may be sown in heat, and the plants potted in sandy loam. For outdoor culture, see Peanut, by which name the plant is commonly known.

hypogæa, Linn. One ft. or less high : lvs. abruptly pinnate, with two pairs of leaflets and no tendril. Mn. 7:105. Procumbent.

ARALIA, including Dimorphánthus (derivation obscure). A ralidcece. Perennial herbs or shrubs : lvs. al ternate, deciduous, large, decompound: fls. small, whitish, in umbels, usually forming large panicles petals and stamens 5: berry, or rather drupe, 2-5-seeded, black or dark purple, globular, small. Some of the Aralias are hardy outcloor deciduous herbs and bushes; others are fine stove plants, botanically unlike the true Aralias as defined above.

ALFRED REHDER.

There are about 35 kinds of tender Aralias in cult. Some of them are of robust growth, and make hanùsome specimens for greenhouse and bothouse decoration when grown to a height of 10 or $12 \mathrm{ft}$.; others of more delisate and slender growth, such as $\boldsymbol{A}$. Chabrieri (really an Elæodendron), A. concinna (see Delarbrea), A. elegantissima and $A$. Veitchii, var. gracillima, are most beautiful as smaller plants, say from 1-3 ft. in height. These small plants are very beautiful as table pieces, and are not surpassed in delicate grace and symmetry by any plants; $\boldsymbol{A}$.Veitchii, var. gracillima, is one of the very finest of the dwarfer-growing kinds. The more robust sorts are usually prop. by cuttings, in the usual manner, or by root cuttings, as Bouvardias are. The more delicate varieties, as A. Chabrieri, elegantissima, etc., do best when grafted on stronger-growing varieties, like A. Guilfoylei, A. reticulata (which is an Oreopanax), etc. The slender-growing sorts require light, rich soil, made of equal parts of sandy loam and peat or leaf-mold. They require plenty of water and a moist atmosphere. They are much subject to attacks of scale, which may be removed or prevented by frequent careful sponging with a weak solution of seal-oil soap, firtree oil, or other like insecticide.

Cult. by Robert Craig.

The glasshouse species are much confused, largely because some kinds receive trade and provisional names before the fls. and frs. are known. See Acanthopanax for $A$. Maximowiczii, pentaphylla, and ricinifolia; Delarbrea for $A$. concinna and $A$. spectabilis; Eloeodendron for A. Chabrierii; Fatsia for A. Japonica, papyrifera, and Sieboldii; Oreopanax for $\boldsymbol{A}$. reticulata; Polyscias for A.latifolia; Sciadophyllum for $A$. Amboinense. Other related genera are Heptapleurum, Monopanax, Oreopanax, Panax, Pseudopanax.

A. Tender evergreen Aralias, grown only under glass. (By some regarded as belonging to other genera.)

B. Lvs. digitate.

Kerchoveana, Hort. Lvs. the shape of a Ricinus, the 7-11 leaflets elliptic-lanceolate or oblong-lanceolate, with undulate and serrate margins and a pale midrib. $\mathrm{S}$. Sea Islands. Certificated in Eng. in 1881 (Gn. 19, p. 457). R.H. 1891, p. 225. - Slender-stemmed, of beautiful habit.

Veitchii, Hort. Leaflets 9-11, very narrow or almost filiform, undulate, shining green above and red beneath. New Caledonia.-One of the best and handsomest species. Var. gracíllima, Hort. (A. gracilina, Linden, R.H. 1867, p. 38). Leaflets still narrower, with a white rib. R.H. 1891, p. 226. Gn. 39 , p. 565 . Very desirable. Originally described as $\boldsymbol{A}$. gracilina (thin-lined), which name has been mistaken for gracillima (very graceful).

elegantíssima, Veitch. Petioles mottled with white: leaflets 7-11, filiform and pendulous. New Hebrides. - Excellent.

leptophylla, Hort. Slender plant : leaflets filiform and drooping,

broadened at the extremities, deep green. Australasia.

Regina, Hort. Graceful : petioles olive, pink and brown : lfts. drooping, roundish. New Hebrides.

$$
\text { BB. Lvs. pinnate. }
$$

Guilfoylei, Cogn. \& March. Fig.128. Leaflets 3-7 (digitate-like), ovate or oblong, irregularly cut on the edges or obscurely lobed, white-margined and sometimes graysplashed : st. spotted, erect. New Hebrides.-Rapid grower, showy, and good for pots.

monstròsa, Hort. Leaflets 3-7, ovate-acute, deeply and often oddly cut, broadly white-margined, also grayspotted : lvs. drooping. S. Sea Isl. R.H. 1891, p. 225. Gn. 39 , p. 565.

filicifollia, Moore. Stem erect, purplish, white-spotted: lvs. fern-like (whence the name); leaflets 3-7 pairs, lance-oblong and acuminate, long, deeply notch-toothed, 
deep green and purple ribbed. Polynesia. 1.H. 23: 240 . R.H. 1891, p. 224. Gn. 39, p. 565. A.G. 19:374.-One of the best.

4. Ohabrièri, Hort.; see Elæodendron.-A crassifolia, Soland; see Pseudopanax. $-A$. lóngipes, Hort. Lvs. digitate, the lfts. oblong-lanceolate, acuminate, wavy. N. Austral. $-A$. nóbilis, Hort. "A theophrasta-like plant, with closely packed, bold foliage, the lvs. oblong obovate-acuminate, undulate at the margins." Once offered by Saul. $-A$. Osyàna, Hort. Like A. leptophylla, but leaflets deeply bifid, and nerves and veins brown. S. S. Isl. - A quercifòlia, Hort. Leaflets 3 , sinuate ; lvs. opposite. New Britain. $-A$, rotunda, Hort. Leaf of a single orbicular-cordate leaflet or sometimes 3-foliolate, white-toothed. Polynesia.-A. spectábilis, Hort.=A. filicifolia. $-A$. splendidissima, Hort. Livs. pinnate, the leaflets shiny green. New Caledonia.-A ternàta, Hort. Lvs. opposite, ternate or 3-lobed, the leaflets oblong-lanceolate and sinuate. $-A$. Victòriae, Hort. See Panax. Some of the above probably belong to Oreopanax and other genera.

$$
\text { AA. Hardy or true Aralias. }
$$

B. Prickly shrubs or rarely low trees : lvs. bipinnate, 2-3 ft. long: umbels numerous, in a large, broad, compound panicle: styles distinct.

spindsa, linn. Angelica Tree. Hercules' Club. Devil's Walking-stick. Stems very prickly, $40 \mathrm{ft}$. high : lvs. 11/2-21/2 ft. long, usually prickly above; lfts. ovate, serrate, $2-3 \frac{1}{2}$ in. long, glaucous and nearly glabrous beneath, mostly distinctly petioled; veins curving upward before the margin. Aug. S. states north to Tenn. S.S. 5:211. Gn. 50, p. 126.-The stout, armed stems, the large lvs., and the enormous clusters of fls. give this species a rery distinct subtropical appearance. Not quite hardy north.

Chinénsis, Linn. (A. Japónica, Hort. A. Mandshúrica, Hort.). Chinese Angelica Tree. Stems less prickly, $40 \mathrm{ft}$. : lvs.2-4 ft. long, usually without prickles; lfts. ovate or broad ovate, coarsely serrate or dentate, usually pubescent beneath, nearly sessile, $3 \frac{1}{2}-6$ in. long; veins dividing before the margin and ending in the points of the teeth. Aug., Sept. China, Japan.-In general appearance very much like the former species, but hardier. Nearly hardy north. Grows well also in somewhat dry, rocky or clayey soil. Var. elata, Dipp. (Dimorphánthus elatus, Miq.). St. with few prickles: lfts. pubescent beneath. The hardiest and most common form in cult. Var. canéscens, Dipp. (A.canéscens, Sieb. \& Zucc.). Lvs. often prickly above; lfts. glabrous beneath, except on the veins, dark green above. More tender. Var. Mandshúrica, Rehder (Dimorphán-

thus Mandshùricus, Maxim.). St. prickly: lfts. pubescent only on the veins beneath, more sharply and densely serrate than the foregoing var., and hardier. There is also a form with variegated lvs. (I.H. 33:609).

BB. Unarmed herbs: styles united at the base.

c. Umbels numerous, in elongated puberulous panicles : 3-10 ft. high.

racemdsa, Linn. SpIKenard. Height 3-6 ft. : glabrous, or slightly pubescent : lvs. quinately or ternately decompound; leaflets cordate, roundish ovate, doubly and sharply serrate, acuminate, usually glabrous beneath, 2-6 in. long : fls. greenish white. July, Aug. E. N. Amer. west to Minn. and Mo. B.B. 2:506.

Californica, Wats. Height 8-10 ft.: resembles the preceding: lfts. cordate, ovate or oblong-ovate, shortly acuminate, simply or doubly serrate : panicle loose ; umbels fewer, larger, and with more numerous rays. Calif.

cordàta, Thunb. (A.édulis, Sieb. \& Zucc.). Height 4-8 ft.: lvs. termately or quinately decompound, pinnæ sometimes with $7 \mathrm{lfts}$; lfts. cordate or rounded at the base, ovate or oblong-ovate, abruptly acuminate, un. equally serrate, pubescent on the veins beneath, 4-8 in. long. Japan. Gt. 13: 432 as $A$. racemosa, var. Sacha. linensis. R.H. 1896 , p. 55. A.G. 1892 , pp. $6,7$.

Cachemírica, Decne. (A. Cashmeriana, Hort. Saul 1891. A macrophýlla, Lindl.). Height 5-8 ft. : lvs. quinately compound, pinnæ often with 5-9 leaflets ; leaf. lets usually rounded at the base, oblong-ovate, doubly serrate, glabrous or bristly on the veins beneath, 4-8 in. long. Himalayas.

\section{cc. Umbels several or few on slender peduncles;} pedicels glabrous : 1-3 ft. high.

híspida, Vent. BRIstLY SARSAPARILLA. WILd ELDER, Height 1-3 ft., usually with short, woody stem, bristly: lvs. bipinnate; lfts. ovate or oval, rounded or nar. rowed at the base, acute, sharply and irregularly serrate, 1-3 in. long: umbels 3 or more in a loose corymb; fls. white. June, July. From Newfoundland to N. Carolina, west to Minn. and Ind. B.M. 1085. L.B.C. $14: 1306$.

nudicaùlis, Linn. Wild Sarsaparilla. Small SPIKENARD. Stemless or nearly so : usually 1 leaf, $1 \mathrm{ft}$. high, with 3 quinately pinnate divisions; lfts. oval or ovate, rounded or narrowed at the base, acuminate, finely serrate, $2-5$ in. long : umbels 2 or 3 ; fls. greenish.
May, June. Newfoundland to N. Carolina, west to Mo. B.B. 2: 506 .

A. quinquefolia, Decne. \& Planch.=Panax quinquefolium. $-A$. trifolia, Decne. \& Planch. $=$ Panax trifolium. (See also Ginseng.)

\section{AlFRED REHDER.}

ARAUCARIA (Chilian Araucariea. About 15 species of S. Amer. and the Australian region, grown for their striking symmetrical habit and interesting evergreen foliage. In the S. some species will thrive in the

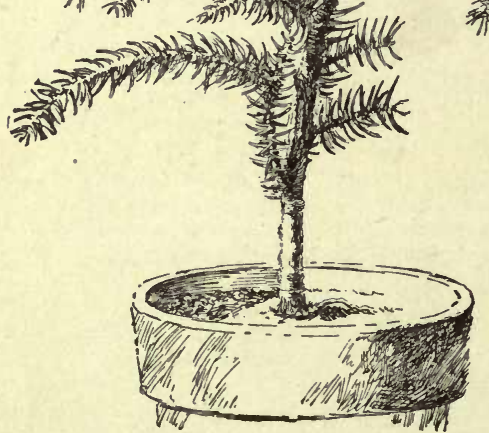

129. Unsymmetrical Araucaria grown from a side shoot. open, where the climate is not too dry, but in the N. all
are grown under glass only. Lvs. stiff, sharp-pointed, crowded: cones globular or oblong, terminal, hard and woody, of some species several inches in diameter. Most of the species become gigantic forest trees in their native haunts. As here treated, the genus includes $\mathrm{Co}$ lumbea and Eutacta.

L. H. B.

There are some 15 Araucarias in cultivation. Most of these, however, are grown in limited numbers in private and botanical collections. The kinds most popular in this country are $A$. excels $a$ and its varieties glauca and robusta compacta. Of $A$. excelsa, probably 250,000 plants in 5-inch and 6-inch pots are annually sold in the U.S. These are nearly all imported in a young state from Ghent, Belgium, where the propagation and growing of them is made the leading specialty at many nur- 
series, of which there are over 700 in that one city. The trade of the world has been supplied for many years from Ghent. Some of the large English growers have

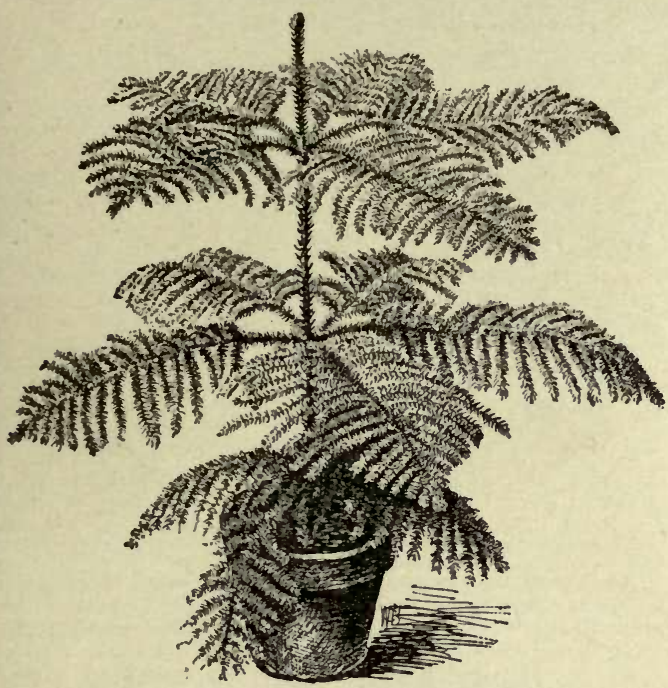

130. Good specimen of Araucaria excelsa.

begun to grow them in considerable quantities in the past five years, but it is likely that Ghent will be the main source of supply for many years to come. A few are now propagated in this country, and as they grow easily here, it is likely that the number will be largely increased in the near future, the high price of labor being the greatest drawback. The Araucaria is the most elegant and symmetrical evergreen in cultivation, and for this reason is very popular as an ornamental plant for home decoration. It is particularly popular at Christmas time, and is then sold in great quantities. Araucarias are propagated from seed and from cuttings; the latter make the most compact and handsome specimens. To make symmetrical specimens, take cuttings from the leading shoots (see Fig. 129). If used as house plants, they thrive best in a cool room, where the temperuture is not over $60^{\circ}$ at night, and they should be placed near the light. In summer they grow best if protected by a shading of light laths, placed about an inch apart, which will admit air and at the same time break the force of the sun's rays. They do well in any good potting compost, and should be shifted about once a year (in the spring) into larger pots. The cuttings should be planted in light compost or sand in the fall or during the winter in a cool greenhouse, with moderate bottom heat, and will root in about 8 or 10 weeks, after which they may be potted into small pots. In adclition to $A$. excels $\ell_{\text {and }}$ its variations, the following attractive species are grown in small quantities: A. Biduillii, which, being of a tough and hardy nature, does remarkably well as a room plant, and it is hardy in Florida and many of the most southern states; $A$. Goldieana, a very distinct and handsome form, and rather scarce at present; A. elegans (a form of $A$. Braziliana), an elegant form of dwarf and exceedingly graceful habit, and a most beautiful table plant.

Cult. by Robert Crajg.

A. Lvs. (or most of them) awl-like.

excélsa, R. Br. Norfolk Island Pine. Figs. 130 , 131, 132. Plant light green : branches frondose, the lvs. curved and sharp-pointed, rather soft. and densely placed on the horizontal or drocping branchlets. Norfolk Isl. F.R. 2:411. - The commonest species in this country, being much grown as small pot specimens. A blue-green form is cult as $A$. glanca. There is also a strong-growing, large variety, with very deep green fo- liage (A. robuista). In its native wilds the tree reaches a height of over $200 \mathrm{ft}$. and a diameter of even 9 or 10 ft. The solid, globular cones are 4 or 5 in. in diam. F.S. 22:2304-5. - An excellent house plant, and keeps well in a cool room near a window. In summer it may be used on the veranda, but must be shaded.

Cúnninghami, Sweet. Plants less formal and symmetrical than $A$.excelsa, the upper branches ascending and the lower horizontal: lvs. stiff and very sharppointed, straight or nearly so. There is also a glaucous form (A. glaùca); also a weeping form. Austral., where it reaches a height of $200 \mathrm{ft}$., yielding valuable timber and resin. Locally known as Hoop Pine, Moreton Bay Pine, Colonial Pine, Coorong, Cumburtu, Coonam.

Coòkii, R. Br. (A. columnaris, Hook.). Branches disposed as in $A$. excelsa, but tree tending to shed the lower ones: young lvs. alternate and rather distant, broad and slightly decurrent at base, slightly curved, mucronate; adult Ivs. densely imbricated, short and orate, obtuse ; cones 3-4 in. in diam. and somewhat longer. New Caledonia, where it reaches a height of 200 ft., making very straight and imposing shafts. B.M. 4635. A.F. 12: 559. - Named for Captain Cook.

\section{AA. Lvs. broader, usually plane and imbricated.}

Rùlei, Muell. Leafy branchlets very long : lvs. ovalelliptic, imbricated, plane or lightly concave, arched towards the branch, nearly or quite obtuse, with a prominent dorsal nerve. Variable at different ages. When young, the branches are often drooping and the lvs. compressed and obscurely 4-angled and nearly or quite subulate (var. polymórpha, R.H. 1866, p. 350. There is a var. compacta). New Caledonia. Reaching $50 \mathrm{ft}$. in height. R.H. 1866, p. 392, and plate. I.H. 22:204. The figure in G.C. 1861: 868, is A M Melleri, Brongn. \& Gris., a broader-leaved species.

Goldieàna, Hort. Like A. Rulei, and perhaps a form of it: Ivs. in whorls, dark green, variable : branches drooping.

Bídwillii, Hook. Fig. 133. Rather narrow in growth, especially with age, the branches simple: lvs. in two rows, lance-ovate and very sharp-pointed, thick, firm and shining. Austral., where it attains a height of

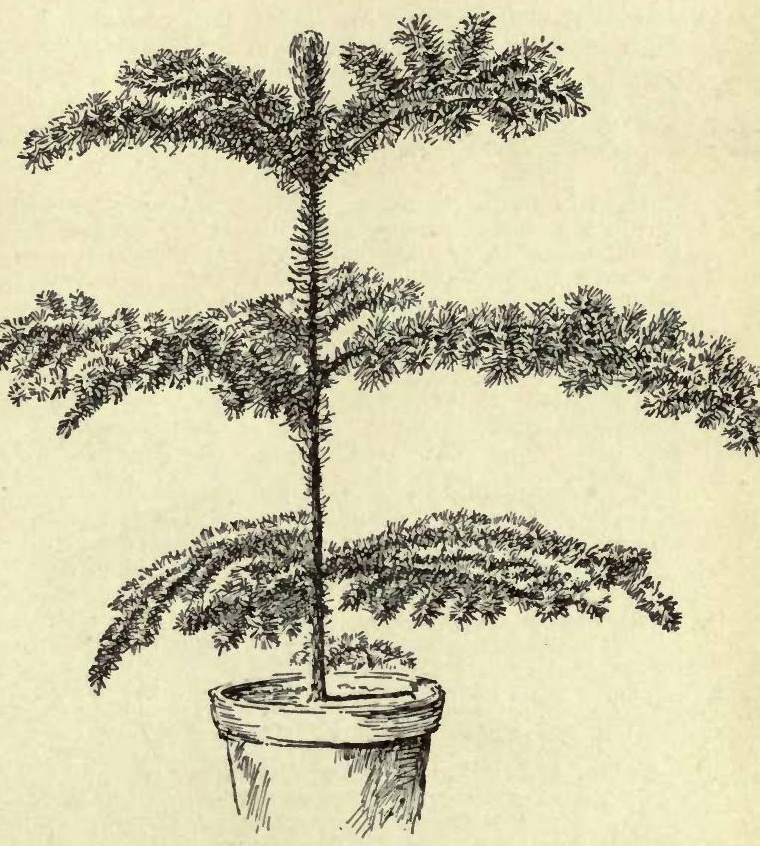

131. Araucaria excelsa.

A ragged plant, grown with insufficient room and attention. 
$150 \mathrm{ft}$., and is known as Bunga-bunga. R.H. 1897, p. 500. G.C. III. 15:465, showing the pineapple-like cone. - One of the best and handsomest species for pots.

Braziliàna, A. Rich. Branches verticillate, somewhat inclined, raised at the ends, tending to disappear below as the plant grows : lvs. alternate, oblonglanceolate, somewhat decurrent, much attenuated and very sharppointed, deep green, loosely imbricated: cone large and nearly globular. S. Braz., reaching a height of 100 ft. F.S. 21: 2202. A. Elegans, Hort., is a form with very numerous branches and more crowded and often glaucous lvs. Var. Ridolfidna, Gord., is a more robust form, with larger and longer lvs.

i m b ricà $t a$, Pav. Monkey P OzzLE. Branches generally in 5's, at first horizontal, with upward-curving (sometimes downwardcurving) tips, but finally becoming much deflexed, the If.-shin-

133. Araucaria Bidwillii $(\times 1 / 2)$.

gled branchlets in opposite pairs: lvs. imbricated and persisting, even on the trunk, ovate-lanceolate, very stiff and leathery and sharp-pointed, an inch long and half as wide, bright green on both sides : cone 6-8 in. in diam. Western slope of the Andes in Chile, reaching a height of $100 \mathrm{ft}$. F.S. 15: 1577-80. R. H. 1893 , p. 153 ; 1897 , pp. 271,319 . Gt. $44: 115$. G.C. III. $21: 288 ; 24: 154 .-$ Hardy in the $S$. This is the species which is grown in the open in England and Ireland.

ARAÙJIA is treated under Physianthus. L. H. B.

ARBORICULTURE. The culture of trees. It is a generic term, covering the whole subject of the planting and care of trees. More specific terms are sylviculture, the planting of woods ; orchard-culture, the planting of orchards or fruit trees.

ÁRBUTUS (ancient Latin name). Ericacece. Trees or shrubs : branches smooth and usually red : lvs, evergreen, alternate, petiolate : fls. monopetalous, ovate or globular, white to red, about $1 / 3 \mathrm{in}$. long, in terminal panicles : fr. a globose, many-seeded berry, granulose outside, mostly edible. About 10 species in W. N. Amer., Mediterranean reg., W. Eu., Canary Isl. Ornamental trees, with usually smooth red bark and lustrous evergreen foliage, of great decorative value for parks and gardens in warm-temperate regions; especially beautiful when adorned with the clusters of white fls. or bright red berries. They grow best in well-drained soil in somewhat sheltered positions not exposed to dry winds. Very handsome greenhouse shrubs, thriving well in a sandy compost of peat and leaf soil or light loam. Prop. by seeds sown in early spring or in fall, or by cuttings from mature wood in fall, placed in sandy peat soil under glass; they root but slowly. Increased also by budding or grafting, usually veneer-grafting, if seedlings of one of the species can be had for stock. Layers usually take two years to root.

\section{A. Panicles short, nodding: lvs. usually serrate.}

Unèdo, Linn. Strawberry Tree. From 8-15 ft.: lvs. cuneate, oblong or oblong-lanceolate, 2-3 in. long, glabrous, green beneath : fls. white or red, ovate : fr. scarlet, warty, 3/4in. broad. Sept.-Dec. S. Eu., Ireland. L.B.C. 2:123. Var. integérrima, Sims. Los. entire. B.M. 2319. Var. rubra, Ait., and var. Croomi, Hort.
(Gn. 33, p. 320), have red fls. - Very beautiful in autumn when the tree bears its large, scarlet fruits and at the same time its white or rosy fls.

$$
\text { AA. Panicles erect: lvs. usually entire. }
$$

Ménziesi, Pursh. Madrona. Ocèasionally $100 \mathrm{ft}$. high : trunk with dark reddish brown bark: lvs. rounded or slightly cordate at the base, oval or oblong, 3-4 in. long, glabrous, glaucous beneath : fls. white, in 5-6 in. long panicles : fr. bright orange-red, $1 / 2 \mathrm{in}$. Iong. Spring. W. N. Amer. B.R. 21:1753, as A. pròcera, Dougl. S.S. 5: 231 . P.M. $2: 147$. G.F. $3: 515 ; 5,151$. Mn. $3: 85$. -The hardiest and probably the handsomest species of the genus; it stands many degrees of frost.

Arizónica, Sarg. (A. Xalapénsis, var. Arizónica, Gray): Tree, 40-50 ft.: trunk with light gray or nearly white bark : lvs. usually cuneate at the base, oblonglanceolate, $11 / 3-3$ in. long, glabrous, pale beneath : fls. white, in loose, broad panicles 2-3 in. long : fr. globose or oblong, dark orange-red. Spring. Ariz. G.F. 4: 318 . S.S. 5:233. - The contrast between the white bark of the trunk, the red branches, and the pale green foliage makes a very pleasant effect : fr. and fls. are also very decorative.

A. Andráchne, Linn. From 10-30 ft.: lvs. oval-oblong, usually entire, yellowish green beneath : fls. yellowish white : fr. bright red. Greece, Orient. B.M. 2024. B.R. 2:113.-A. andrachnoides, Link (A. Andrachne $X$ Unedo. A. hybrida, Ker. A. serratifolia, Lodd.). Lvs. serrate: panicles drooping; fls. white, B R 8.619.) Lvs. serrate: panicles drooping; fis. wh-30 ft. : lvs. oblong-lanceolate, serrate, glaucous beneath : panicles erect; fls. greenish white. Canary Isl. B.M. 1577.$A$. densiflor $\alpha$, HBK. Height $20 \mathrm{ft}$.: lvs. oblong or ovate, serrate, downy beneath : fis. white. Mex. $-A$. hỳbrida, Ker. $=$ A. arachnoides. $-A$. laurifòlia, Hook $=\mathrm{A}$. Menziesi. $-A$. laurifòlia, Lindl.=A. Xalapensis. $-A$. móllis, HBK. Shrub or small tree: lvs, oblong, serrate, pubescent beneath : fls. white, often tinged greenish red. Mex. B.M. 4595.-A. pilosa, Grah.= Pernettya pilosa. $-A$, pròcera, Dougl. =A. Menziesi $-A$, serratifonettya pilosa. $-A$. pròcera, Dougl. $=$ A. Menziesi. $-A$. serratifò-
lia, Lodd., not Salisb. $=$ A. andrachnoides. $-A$. Texana, Buckl. =A. Xalapensis.-A. tomentòsa, Pursh.= Arctostaphylos tomentosa. - A. Uva-Ursi, Linn.= Arctostaphylos Uva-Ursi.-A. Xalapénsis, HBK. (A. laurifolia, Lindl.). Height 10-20 ft.: lvs. oval or ovate-lanceolate, entire or crenately serrate, glabrous or downy beneath: fls. reddish ; corolla abruptly contracted above the middle. Mex., Tex. S.S. 5:232. B.R. 25:67.

Alfred Rehder.

\section{ÁRbTUS, TrAILING. See Epigara.}

ARCHANGELICA (Greek, chief angel, from fancied medicinal virtues). Umbellíferce. A few strong-smelling coarse herbs closely allied to Angelica, but differing in technical characters associated with the oil-tubes in the fruit.

officinàlis, Hoffm. A European and Asian biennial or perennial, known also as Angelica Archangelica. Stout herb, with ternately decompound lvs. and large umbels of small fls. The stems and ribs of the lvs. were once blanched and eaten, after the manner of celery, and they are still used in the making of sweetmeats. Little known in this country, although it is offered by American dealers. Its chief value to us is its large foliage. Seeds may be sown in the full as soon as ripe, or the following spring.

ARCHONTOPHOENIX (Greek, majestic phonix). Pal. macece, tribe Arècen. Tall, spineless palms, with stout, solitary, ringed caudices : lvs. terminal, equally pinnatisect; segments linear-lanceolate, acuminate or bidentate at the apex, the margins recurved at the base, sparsely scaly beneath, the midnerves rather prominent, nerves slender; rachis convex on the back, the upper surface strongly keeled; petiole channelled above, sparsely tomentose ; sheath long, cylindrical, deeply fissured ; spadices short-peduncled, with slender, flexuose, glabrous, pendent branches and branchlets : spathes 2 , entire, long, compressed, deciduous : bracts crescent-shaped, ad nate to the spadix ; bractlets persistent ; fls. rather large : fr. small, globose-ellipsoidal. Species, 2. Austral. They are beautiful palms, requiring a temperate house. Prop. by seeds. The Seaforthin elegans of gardeners belongs here. For cult., see Palms. 
A. Leaf segments whitish underneath.

Alexándreæ, H. Wendl. \& Drude (Ptychospérma A lexdudrea, F. Muell.). Trunk 70-80 ft.: lvs. several ft. long; rachis very broad and thick, giabrous or slightly scurfy: segments numerous, the longer ones $1 \frac{1}{2} \mathrm{ft}$. long, $1 / 2-1$ in. broad, acuminate and entire or slightly notched, green above, ashy glaucous beneath. Queensland. F.S. 18:1916.

\section{AA. Leaf segments green on both sides.}

Cúnninghamii, H. Wendl. \& Drude (Ptychospérma Cunninghamii, H. Weudl.). Trunk and general habit like the preceding, but the segments acuminate and entire or scarcely notched. Queensland and N. S. W. B.M. 4961 as Seaforthia elegans.

JARFD G. SMITH.

ARCTIUM (from Greek word for bear, probably alluding to the shaggy bur). Compdsita. BuRdock. A few coarse perennials or biennials of temperate Eu. and Asia, some of them widely distributed as weeds. Involucre globular and large, with hooked scales, becoming a bur: receptacle densely setose : pappus deciduous, of bristles : lvs. large and soft, whitish beneath : plant not prickly: fls. pinkish, in summer.

Láppa, Linn. (Láppa major, Gærtn.). СоммоN Burpock. The Burdock is a common and despised weed in this country, although it is capable of making an excellent foliage mass and sereen. In Japan it is much cult. for its root, which has been greatly thickened and ameliorated, affording a popular vegetable. It is there known as Gobo (see Georgeson, A.G. 13, p. 210).

ARCTOSTAPHYLOS (Greek, bear and grape). Ericdcece. Manzanita. Shrubs or small trees: lvs. alternate, evergreen, usually entire, rarely deciduous : fls. small, urceolate, mostly white, tinged red, in terminal, often panicled racemes, in spring : fr. usually smooth, a red berry or rather drupe, with 1-10 1-seeded, separate or coherent cells. About 30 species in N. and Cent. Amer. 2 species also in N. Eu. and N. Asia. Handsome evergreen shrubs, though generally with less conspicuous fls. and frs. than those of the allied genus Arbutus. Some Cent. Amer. species, however, as A. arbutoides, arguta and polifolia are beautiful in flower, and well worth a place in the greenhouse or in the garden in temperate regions; of the American species, A. Pringlei, viscida and bicolor are some of the bandsomest. Only the trail ing species are hardy north. For culture, see Arbutus. Includes Comarostaphylis.

\section{A. Trailing or creeping: lvs. $1 / 2-1 \frac{1}{2}$ in. long: fls. in} short and rather few-fld.clusters.

Ũva-Ursi, Spreng. BEARBERRY. Lrs. obovate-oblong, tapering into the petiole, retuse or obtuse at the apex : fls. small, about $1 / 4 \mathrm{in}$. long, white tinged with red. Northern hemisphere, in N. Amer. south to Mex. Em. 2: 431. - Hardy trailing evergreen shrub, like the following valuable for covering rocky slopes and sandy banks. Cuttings from mature wood taken late in summer root readily under glass.

Nevadénsis, Gray. Lvs. obovate or obovate-lanceolate. abruptly petioled, acute or mucronate at the apex : fls. in short-stalked clusters, white or tinged with red. Calif., in the higher mountains.

$$
\begin{aligned}
& \text { AA. Erect shmibs: lvs. usually 1-2 in. long: fls. in } \\
& \text { mostly many-fld. panicled racemes. }
\end{aligned}
$$

B. Lvs. glabrous, rarely minutely pubescent.

\section{c. Pedicels glabrous.}

púngens, HBK. From 3-10 ft.; glabrous or minutely pubescent : lvs. slender-petioled, oblong-lanceolate or oblong-elliptic, acute, entire, green or glaucescent : fls. in short, umbel-like clusters : fr. glabrous, about $1 / 4 \mathrm{in}$. broad. Mex., Low. Calif. B.R. 30:17. B.M. 3927.

Manzanita, Parry (A. puingens, Authors). Fig. 134. Shrub or small tree, to $30 \mathrm{ft}$.: Ivs. ovate, usually obtuse and mucronulate at the apex, glabrous, dull green : fls. in prolonged panicled racemes : fr. glabrous, $1 / 4-1 / 2$ in. broad. W. N. Amer., from Ore. south. G.F. 4:571. cc. Pedicels glandular.

glaùca, Lindl. From 8-25 ft.: lvs. oblong or orbicular, obtuse and mucronulate at the apex, ylaucescent or pale green: fls. in prolonged panicled racemes; pedicels glandular: fr. minutely glandular. Calif. Int. 1891.

víscida, Parry. From 5-15 ft.: lvs. broad ovate or elliptic, abruptly mucronulate, acute or rounded at the base, glaucous: Hs. in slender and spreading, panicled racemes ; pedicels viscid ; corolla light pink : fr. depressed, about $1 / 4 \mathrm{in}$. broad, smooth. Ore. to Calif.

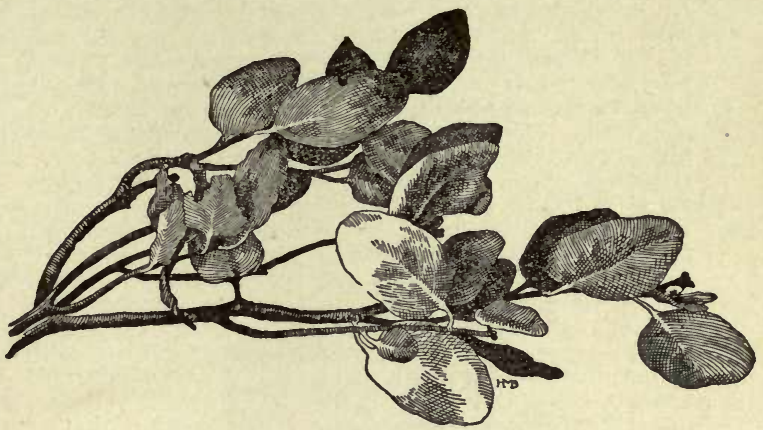

134. Manzanita.-Arctostaphylos Manzanita.

Вв. Lvs. more or less pubescent; branchlets mostly bristly-hairy.

tomentosa, Dougl. From 2-6 ft.: 1vs. oblong-lanceolate or ovate, acute, sometimes serrulate, pubescent beneath, pale green : fls. in rather dense and short, usually panicled racemes; pedicels short : fr. puberulous, glabrous at lengtb. W. N. Amer. B.R. 21:1791. B.M. 3320. - The hardiest of the erect species.

Prínglei, Parry. Shrub : lvs. broad-ovate or elliptic, usually abruptly mucronulate, pubescent, sometimes glabrous at length, glaucous : panicled racemes peduncled, usually leafy at the base, many-fld.; slender pedicels and calyx glandular-pubescent : fr. glandular hispid. Calif., Ariz.

bicolor, Gray. From 3-4 ft.: lvs, oblong-oval, acute at both ends, revolute at the margin, glabrous and bright green above, white-tomentose beneath : fls. in nodding, rather dense racemes; pedicels and calyx tomentose; corolla $1 / 3$ in. long, rose-colored : fr. smooth. Calif.

A. alpina, Spreng. Prostrate shrub : lvs. deciduous, obovate, serrate : racemes few-fld.: fr. black. Aretic regions and mountains of northern hemisphere.-A. arbutoddes, Hemsl. Five to $6 \mathrm{ft}$. lvs lanceolate-oblong, ferrugineously pubescent beneath: $6 \mathrm{ft}$.; lvs. lanceolate-oblong, lorres. B.R. 29:30.-A argùta, Zuce. panicles erect, loose. Guatem. B.R. $29: 30 .-A$ arguta, Zuce.
A nitida, Benth.). Five to $6 \mathrm{ft.:}$ ivs. oblong-lanceolate, ser(A. nitida, Benth.). Five to 6 ft.: lvs. oblong-lanceolate, ser rate, glaucous and glabrous : panicles loose, erect. S. Mex.
B.R. 31: 32. B.M. 3904 as A. nitida.-A. Califórnica, Hort.=A. Nevadensis. $-A$. diversifolia, Parry. Six to $15 \mathrm{ft}$.: lvs. ovate or narrow-oblong, acute, nsually serrate, tomentose beneath : racemes elongated Calif Mn 5:231-A nitida, Benth =A arcuta:glaucons and puberulous beneath: fls. red, in loose, erect raglaucons and puberulous beneath: fls. red, in loose, erect
cemes. Mex.
ALFRED REHDER.

ARCTOTIS (Greek for bear's ear, alluding to the akene). Compósitoe. Herbs with long-peduncled heads and more or less white-woolly herbage, of 30 or more African species: akenes grooved, with scale-like pappus: involucre with numerous imbricated scales : receptacle bristly. One species, treated as an annual, is sold in this country.

breviscàpa, Thunb. (A. leptorhiza, var. breviscapa, DC.). Stemless or nearly so ( 6 in. high), half-hardy, readily prop. from seeds, and to be grown in a warm, sunny place. Lrs. usually longer than the scape, incised-dentate : scape hirsute, bearing one large $\mathrm{fl}$. with dark center and orange rays.

ARDISIA (pointed, alluding to the stamens or corolla lobes). Myrsindceo. Large genus of tropical trees and shrubs, with 5-parted (sometimes 4 - or 6-parted) rotate corolla, 5 stamens attached to the throat of the corolla, with very large anthers and a 1-seeded drupe the size of 
a pea. Lvs, entire, dentate or crenate, thick and evergreen : fls. white or rose, usually in cymes. Ardisias are grown in hothouses or conservatories, and bloom most of the year.

There are about a dozen Ardisias in cultivation ; only two, however, are grown in quantity in America, $-A$. crenulata (red-berried) and $A$. Japonica (white-berried). The former is the more beautiful and valuable. It is one of the handsomest berry-bearing plants, and is very popular, particularly at Christmas time. The $A$. Japonica is not nearly so showy nor handsome as $A$. crenulata, and for this reason is not so generally grown. Ardisias are readily grown from seed, which should be sown in the spring; the seedlings will bloom the following spring, and the berries will be well colored by the next Christmas. They will thrive in almost any good potting compost and in a winter night temperature of about $50^{\circ}$. They are most beautiful when about 2 feet high, after which they generally lose their bottom fo. liage, and present a naked or "leggy" appearance. When they get in this state it is well to root the tops over again, which may best be done without removing them from the plant, by making an incision in the stem and covering the wounded part with moss, which should be tightly wrapped with string and kept damp; the moss will be filled with roots in about a month, when the tops may be cut off and potted, thus obtaining most beautiful young plants, covered with foliage to the bottom. This process will not interrupt the blooming at all; they frequently set an abundance of buds while undergoing this operation. The crop of berries on an Ardisia will remain on the plant for more than a year, if the plant be grown in a cool temperature, say not exceeding $50^{\circ}$ at night in winter. Two full crops of ripe berries at one time are not unusual. Ardisias may be propagated also from cuttings of half-ripened wood ; early spring is the best time to strike them. The greatest insect enemy of the Ardisia is the large brown scale ; frequent sponging of the stems and lvs. with strong tobacco water is the best preventive.

Cult. by Robert Craig.

\section{A. Fls, red or rose-colored.}

crenulàta, Lodd. (A crend̀ta, Sims, A crispa, Hort.). Fig. 135. As cult., a compact and neat shrub, with lanceoblong, wavy-margined, alternate lvs. and drooping clusters of small coral-redl frs. Sweet-scented. Prob-

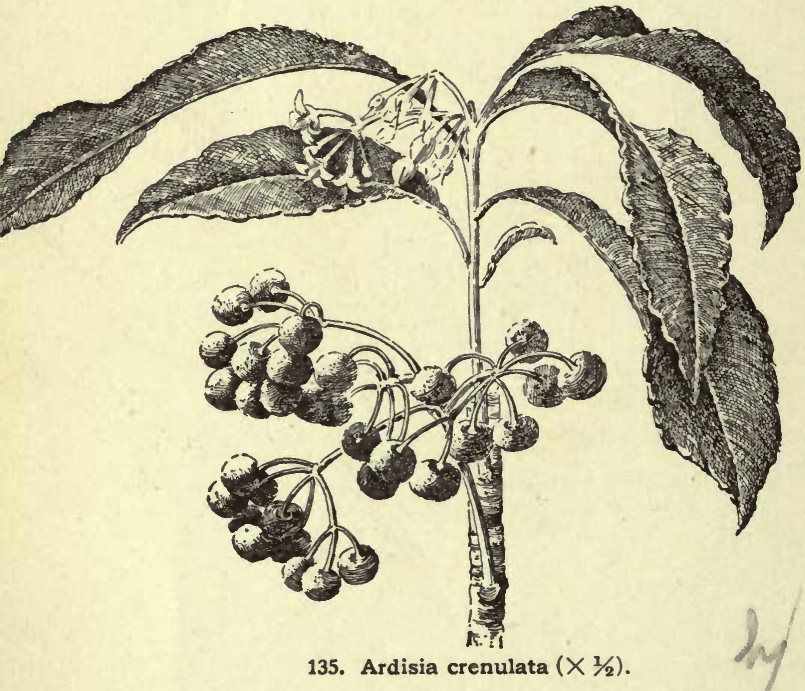

ably native to E. Ind. or China. B.M. 1950. L.B.C. 1: 2 . Mn. 1:58. A.F. 13:558. - The commonest species. It thrives in a conservatory temperature (not lower than $45^{\circ}$ ). Best plants are obtained from seeds. The young plants should be given bottom heat and kept growing rapidly. If they become stunted, it is very difficult to make them into satisfactory plants. Well-grown plants should bear fruit in a year from the seed. 'The seed may be sown whenever ripe. The fruits often hang on for a year and more. Hardy in the South.

hùmilis, Vahl. Lvs. lance-oblong, shining : frs. shining black. India.

Óliveri, Mast. Lvs. nearly sessile, recurved, oblanceolate and acuminate, 6-8 in. long, entire : fls. pink, in large, dense heads, like an Ixora, the limb rotate, 1/2in. across. Costa Rica. G.C. II. 8: 681.-Elegant stove plant.

\section{AA. Fls, white.}

Japónica, Blume. Lvs. short-oblong or somewhat cuneate, whorled, serrate : fls. on red pedicels in drooping racemes: berries white. Dwarf. Jap. Probably hardy in the North.

polycéphala, Wall. Lvs, bright green, red or winecolored when young, opposite : fr. black. E. Ind.

AAA. Fls. black-dotted.

Pickeríngia, Torr. \& Gray. Glabrous, 5-9 ft.: Ivs. ovate to lance-oblong, entire, narrowed to a petiole : panicle many-fld.; corolla lobes oval and becoming reflexed: fr. as large as peas. E. Fla. Int. 1891.

A. umbellàta is offered in this country as coming from India. The A. umbellata, Baker (of the botanists), is a Madagascar plant, and it is doubtful if it is in eult. in this country. Species with white fls. are A. acuminàta, Willd., B.M. 1678 ; capitàta. Gray ; mamillàta, 'Hance; punctàta, Roxbg.; villòsa. Wall. Species with red or reddish fls, are $A$. macrocarpa, Wall. B.M. 6357 ; paniculàta, Roxbg., B.M. 2364 ; serrulàta, Swartz ; Wállichii, DC.

$$
\text { L. H. B. }
$$

ARECA (from a native name in Malabar). Palmacece, tribe Arècea. Spineless palms, with trunks solitary or cespitose in a ring: lvs. terminal, equally pinnatisect, the segments lanceolate, acuminate, plicate, with the margins recurring at the base, the upper ones contluent and bifid or truncate and many-parted : rachis 3 . sided, convex on the back, the upper face acute, the base and petiole concave : sheath elongated; spadix broad or narrow, the spreading branches at length pendent : spathes 3 or many, papery, the lowest complete, the upper ones bract-like; fls. white : fr. nedium or large, red or orange. Species, 24. Trop. Asia, Malay Arch., Trop. Austral. and New Guinea. The name Areca is one of the most familiar of all palm genera, but most of the well-known species are now referred to other genera. A. lutescens, the most popular kind, is Chrysalidocarpus lutescens. A.Catechu and A.trian$d r a$ are both very quick in germinating. They form very ornamental plants for a moderate sized greenhouse. For A. aurea, see Dictyosperma. For A. Madagascur. énsis, see Dypsis.

Aliceæ, W. Hill. Sts. several from the same rhizome, $9 \mathrm{ft}$. or more high, slender: $1 \mathrm{vs}$. 3-6 ft. long ; segments acute, several confluent, especially at apex. Queensland.

Cátechu, Linn. Betel Nut. St. solitary, 40-100 ft.: lvs. 4-6 ft.; leaflets numerous, 1-2 ft., upper confluent, quite glabrous : fr. $1 \frac{1}{2}-2$ in., oroid, smooth, orange or scarlet. Asia and Malayan Islands.

Ilsemanni, Hort. Resembles a red-stemmed Chrysalidocarpus : young lvs, very dark red, becoming green ; fronds slender, arching, with curving pinnæ. Oceanica. A.G. 20:223 (1899).

triandra, Roxb. Trunk 40-50 ft. high, 1 ft. thick, cylindrical : fronds $8 \mathrm{ft}$. long; segments with 6 primary nerves about 1 line apart; petiole about $1 \mathrm{ft}$. long. India.

A. álba, Bory.=Dictyosperma alba. - A. Baúeri, Hook. f.= Rhopalostylis Baueri. - A. elegantissima, Hort. Trade name -A furfuracea, Hort = Dictyosperma furfuracea. - A. gigantè Hort.=Pinanga Cernatensis. $-A$. grácilis, Roxb.=Pinanga gracilis.-A. grácilis, Thou.=Dypsis pinnatifrons.-A. grácilis, Gis. - A. gracils, C rysalidocarpus lutescens. - A.monostàchy $a$, Mart.=Bacularia C rysalidocarpus lutescens. - A.monostàchya, Mart. = Bacularia monostachya.-A. montàna, Hort. Trade name?-A. Nibung, doxa oleracea. $-A$. pùmila, Blume.=Nenga Wendlandiana. $-A$. rùbra. Hort.=Dictyosperma rubra. $-A$. rùbra, Bory.=Acanthophoenix rubra $-A$. Sanderiàna, Hort. Trade name? - A. sápida, Soland = Rhopalostylis sapida - A specidsa. Hort. Trode name? - A tigillària, Jack= Oncosperma filamentosa. $-A$. Verschafféltii, Hort.=Hyophorbe Verschaffeltii.

JARED G. SMITH. 
ARENARIA (arena, sand, where many of the species grow). Caryophylldceae. Low herbs, mostly with white fls., usually forming inats, and suitable for rockwork or alpine gardens. Only the perennial species are commonly cult. Of easiest culture in almost any soil. Prop. by uivision; also by seeds, and rare species sometimes by cuttings. The species inhabit temperate and cold regions. The stamens are usually 10 ; styles 3 or 4 ; petals 5 as a rule, entire or emarginate. Nearly 200 recognized species. Monogr. by F. N. Williams, Journ. Linn. Soc. $33: 326$ (1897-8).

\section{A. Lis.ovate or lanceolate.}

Baleárica, Linn. Very low (3 in. high), with small ovate glossy lvs. Balearic Is., Corsica. - Not hardy in latitude of New York City.

macrophýlla, Hook. Sts. decumbent and angled, pubescent : Irs. lanceolate or elliptic, mostly acute : peduncles slender, 1-5-fld. Lake Superior to the Pacific. Int. 1881 .

$$
\text { AA. Lis. linear or aul-like. }
$$

$$
\text { B. Sepals obtuse. }
$$

Grœnlándica, Spreng. Annual : very low, forming mats, the decumbent or erectish sts. bearing $1-5$ fls.: lvs. linear and obtuse, 1/2in. or less long: sepals and petals blunt, the latter sometimes notehed. High altitudes and latitudes, but coming to the sea coast in parts of N. Eng., and ranging down the mountains to N. Car. Int. 1884. - A neat little alpine.

graminifolia, Schrad. A foot or less high : 1vs. long and filiform, rough-margined : fls, in 3-forked loose pubescent panicles. Eu.

\section{BB. Sepals pointed or even awned.}

grandiflora, Linn. Variable: 6 in. or less high : lvs. flat-awl-shaped, 3-nerved and ciliate: fls. solitary or in 2 's or 3's, long-stalked. Eu.

montàna, Linn. Smaller: lrs. linear or nearly so: fls. large, solitary, very long-stalked. S. W. Eu.

vérna, Linn. (Alsine vérna, Bartl.). Dwarf : 1-3 in. high: Ivs. linear-subulate, flat, strongly 3 -nerved, erect: fls. on filiform peduncles, with strongly 3 -nerved sepals. Eu. and Rocky Mts.-Excellent little rock plant. Var. cæspitosa, Hort. . is a compact, leafý form.

aculeata, Wats. Sts. 4-6 in. high : 1rs. stiff and sharp, glaucous, fascicled, white, but often purple. W. Amer. Int. 1889.

Fránklinii, Dougl. Sts. 3-5 in. high, nearly or quite glabrous : lvs. in 3-6 pairs, narrow-subulate, sharppointed : fls. in dense cymes at the top of the st. W. Amer. Int. 1881.

L. H. B.

ARÉNGA (derivation doubtful). Palmdece, tribe A rèceu. Spineless palms, with the thick caudex clothed above with dead, fibrous leaf-sheaths, at length bearing vigorous shoots. Lvs. terminal, elongated, unequally pinnatisect, the linear or cuneate somewhat petiolate segments præmorse or obliquely divided at the apex ; midveins prominent; nerves parallel; margins irregularly toothed above the middle, recurved at the base and one or the other of them auricled, pale below: petiole plano-convex, with the margin spiny : sheaths short, reticulatefibrous, the margin crenate: spadix large, with short reflexed peduncle and elongated. slender, pendulous branches; spathes numerous, attached to the peduncle, membranaceous, deciduous : bracts and bractlets broad: fls. brown or brownish green or purplish: fr. yellow, fleshy. Species 5. Trop. Asia, Malay Archipelago, New Guinea, and Trop. Austral.

JARED G. SMITH.

Arenga saccharifera, in a young state, is surpassed in beauty by most palms. Specimens eight to ten years old, however, show their characteristics well, and from that period till they begin to flower (which they do from the top of the stem downwards in the axils of the leaves) they are among the most striking subjects for high and roomy conservatories. The temperature should not be allowed to fall below $55^{\circ} \mathrm{F}$. during the coldest weather.

$$
\text { G. W. Oliver. }
$$

obtusifolia, Mart. Trunk 20-30 ft. high, 1-11/2ft. thick: fronds 9-13, 12-16 ft. long: petiole thickly spiny : segments 11/2in. apart, $2-3 \mathrm{ft}$. long, $1 \frac{1}{2}-2 \mathrm{in}$. wide, alternate, lanceolate-linear, unequally acutely dentate, attenuate, 2 -auricled at the base, the lower auricle the larger, glaucous beneath ; branches of the spadix short, lax, nodding. Java.

saccharifera, Lablll. Trunk $40 \mathrm{ft}$. high : petioles smooth : segments fasciculate, in 4's or 5's, linear-ensiform, 1-or 2-auricled at the base, the lower auricle the longer, 2-lobed or variously dentate at the apex, white or silvery beneath ; branches of the spadix long, fastigiate, pendulous. Malaya.

JARED G. SMith.

ARETHU்A (the nymph Arethusa). Orchiddcea. A few species of handsome terrestrial orchids. Fl. gaping, the sepals and petals lanceolate and nearly alike, arching over the column.

bulbossa, Linn. A very pretty hardy orchid, 8-10 in., with one linear, nerved lf. and a bright rose-pink $\mathrm{fl}$. on an erect scape, the lip recurved and bearded. Bogs, $N$. Car., N. and W.; not common. May, June. Mn. 5:141. G.IW.F. 17.-Requires a moist and shady, cool situation and open, porous soil. A shady nook on north slope of rockery, where it can be watered in dry weather, is an ideal place. Prop. by the solid bulbs.

\section{AREtIA. See Douglasia.}

\section{J. B. KELLER.}

ARGEMONE (fanciful name). Papaverdceo. ARGEMONY. A few American plants, mostly herbs, with prickly sepals and pods, 3-6-lobed stigma, coarse often whitespotted foliage, and yellow juice. Annuals, or eult. as annuals. Easy to manage from seeds sown where the plants are to stand, or transplanted from pots. They need a light soil and full sunny exposure. Monogr. by Prain, Journ. Bot. 33: 207 et seq.

\section{A. Fls. yellow or yellowish.}

Mexicàna, Linn. (A.specidsa, Hort.). PrickLY PoPPY. Fig. 136. A moderately prickly-stemmed herb, 1-2 ft. high, sprawling, glaucous : lvs. coarsely sinuate-pin-

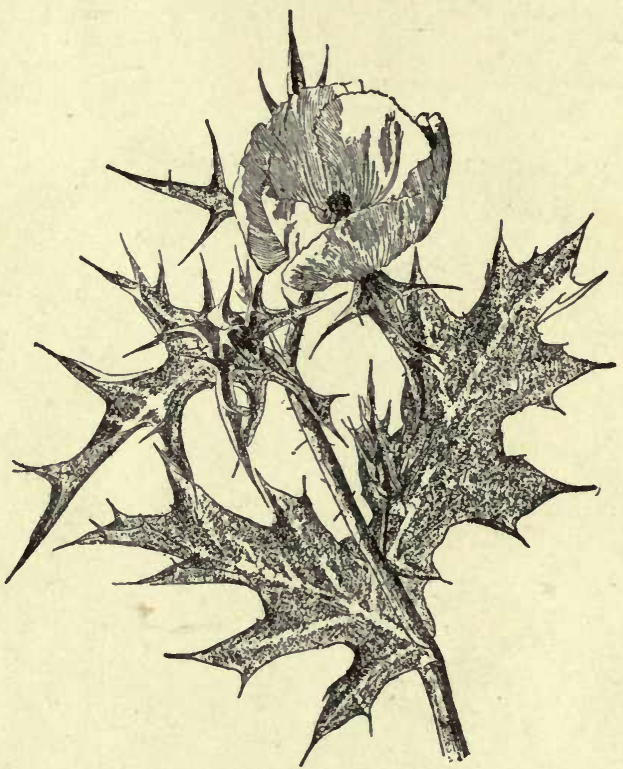

136. Argemone Mexicana $(\times 1 / 2)$.

natifid : fls. sessile or nearly so, the petals obovate and an inch or less long, orange or lemon-colored. Trop. Amer., but naturalized in E. and S. states and in the Old World. B.M.243.

Var. ochroleùca, Lindl. Petals yellowish white, and style longer. Tex. B.R. 1343. 
AA. Fls. white (rarely purple).

grandiflora, Sweet. Glabrous and glaucous, 1-3 ft. high, almost destitute of prickles : lvs. sinuate-pinnatifid, the lobes only weakly spinescent: bracts scattered along the fl. branches: capsule valves scarcely crested. S. W. Mex. B.R. 1264. L.B.C. 16:1546. B.M. 3073 .

platycèras, Link \& Otto. Robust, $1 \frac{1}{2}-4 \mathrm{ft}$., very spiny, the lvs. glaucous; lvs. sinuate-pinnatifid, spiny : fl.bracts aggregated below the fls.: petals large (rarely purple): capsule valves crested or spiny. Mex. to Colo.

Var. híspida, Prain. (A. hispida, Gray). Petals rounded; sepals and capsule densely prickly: plant hispid. Wyo. and Ark., W. and S.

L. H. B.

ARGYREIA (silvery, referring to the under side of the (vs.). Convolvuldcen. Tender climbers from the orient, allied to Ipomoea. Lvs. usually large, silvery, tomentose or villous beneath : cymes usually few-fld. They require too much room before flowering to be popular here. A. cuneata is one of the dwarfest and most floriferous kinds. Light, rich soil. Prop. by cuttings or seeds.

tiliæfolia. Wight. Lvs. heart-shaped : fls. white and violet. Prop. from seeds. E. Ind.-Int. 1890 by Peter Henderson \& Co.

\section{ARIA. See Sorbus.}

ARIS 底MA (Greek-made name, of no particular significance). A ròidece. A bout 60 widely distributed herbs, with tuberous roots, and a spathe rolled in or convolute about the spadix below, and often arched over it: fls. unisexual, the pistillate on the lower part of the spadix, and each consisting of a 1-loculed ovary, and generally ripening into a showy berry. Some species are native, and several of them are hardy in the open; others are cult. under cover, as recommended for Arum (which see). Monogr. by Engler in De Candolle's Monographiæ Phanerogamarum, Vol. 2

\section{A. Leaflets $7-11$.}

Dracontium, Schott. Dragon-root. Sending up a solitary leaf 1-2 ft. high, pedately divided into oblong-

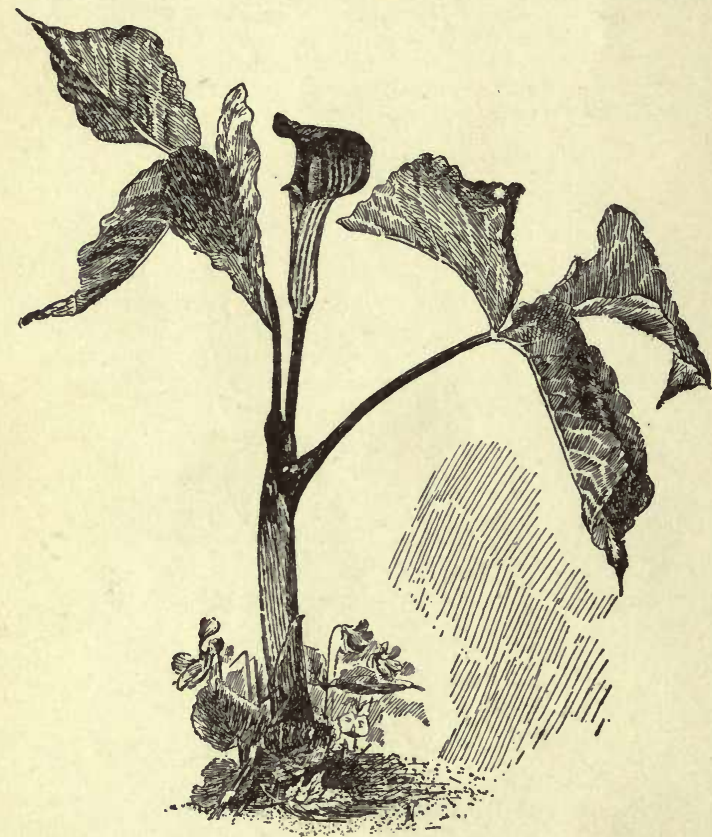

137. Jack-in-the-Pulpit, Arisaema triphyllum $\left(\times \frac{1}{3}\right)$.

lanceolate pointed lfts.: spadix long-pointed and projecting beyond the greenish spathe : scape much shorter than the leaf. Low grounds in E. Amer.-Occasionally grown in borders and rockwork.
AA. Leaflets 3.

triphýllum, Torr. JACK-IN-THE-PULPIT. INDIAN TURNIP. Fig. 137. Usually diøecious : lvs. usually 2, with ovate or elliptic-ovate lfts.: spadix club-shaped and

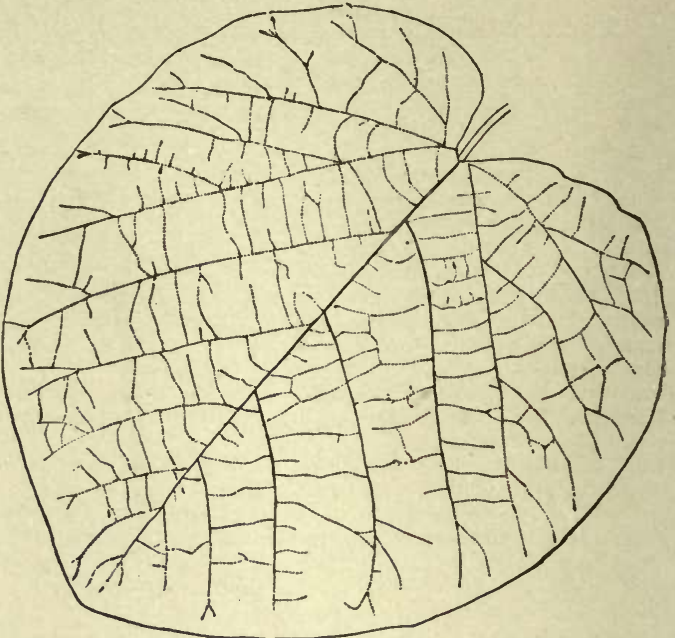

138. Aristolochia macrophylla.

covered by the arching purplish spathe, Common in woods. G.W.F. 28. D. 281. - Tuber or corm flattish and large; very acrid, often employed as a domestic remedy. Berries red and showy, ripening in early summer. Planted in a moist, shady place, the lvs. remain until fall; but in exposed places they die down early in summer. This and the last are very interesting native plants of easy culture, propagated by tubers and by seeds.

fimbriàtum, Masters. Fringed Calla. Leaf solitary, the petiole a ft. or less high, sheathed below ; lfts. broadovate and acuminate, short-stalked: scape as long as the petiole, bearing a large, purple-limbed, whitestreaked, long-pointed spathe : spadix ending in a long and gracefully drooping, feather-like appendage. E. Ind. G.C. II. 22: 689; III. 15: 763. B.M. 7150. Mn. 8: 59. -A handsome and striking pot-plant, blooming in summer. Grow in rich soil. Dry off the tuber when the lvs. turn yellow after flowering, and keep dry in sand or earth until spring.

Other species are: A. anómalum, Hemsl. Lfts. 3, broad-ovate, acuminate : spathe small, purplish and streaked, arching over the short spadix : suggests A. triphyllum. Malacea. B.M. 7211 . - A.concinnum, Schott. Leaf solitary, with 10 or more lfts.: spathe colored, tailed. India. B.M. 5914. - A curvàtum, Hook. $=$ A. tortuosum. - A.galeàtum, N. E. Br. Leaf solitary, with 3 Ifts.: spathe purple inside. India. B.M. 6457.-A. Griffithii, Schott. Lvs, 2, lfts. 3, nearly orbicular: spathe very large, with, a spreading and wrinkled limb several inches broad, and rich a spreading and wrinkled limb several inches broad, and rich
purple with green veins. India. B.M. 6491. One of the handsomest of all Arisæmas. $-A$. nepenthoides, Mort. Leaf pedate, of 5 narrow lfts.: spathe auricled. India. B.M. 6446.-A. ringens, Schott. Lfts. 3, ovate, acuminate : spathe purple, arched. Japan. Perhaps hardy in the open. Gn.37, p. 577.-A. Sieboldii, De Vriese $=$ A. ringens. $-A$. speciòsum, Mort. Lfts. 3 : spathe large and very dark purple; spadix with a very long, string-like tip. India. Gn 37.758, ; ally 2 , with several or many lfts.: spathe purple outside: spaally 2, with several or many lfts.: spathe purple outside : spa-
dix long-tailed but erectish, greenish. India. B.M. 5931 (as A. curvatum). $-A$. itile, Hook. Lvs. 2, with 3 crenate lfts.: spathe reddish, green-ribbed : spadix purple : tubers eaten by natives in India. B.M. 6474.-A. Wràyi, Hemsl. Leaf' solitary, pedate, the lfts. lanceolate: spathe green or whitish: spadix slender recurved. India. B.M. 7105-Except A. ringens, probably all the above species require pot eult. in the N. $\quad$ L. H. B.

ARISARUM (old Greek name). Aròidece. Three or four variable species of Arum-like plants of the Mediterranean region. Differs from Arisæma, its nearest ally, in having the margins of the spathe connate rather than convolute, and in other technical characters. For culture, see Ariscema and Arum. 
vulgàre, Targ. (Árum Arisarum, Linn.). A foot high : lvs. cordate or somewhat hastate, long-stalked : spathe purple, incurved at the top.-Has many forms and many names. Can be grown in the open with protection.

ARISTOLOCHIA (named for supposed medicinal vir tues). A ristolochidece. Birthwort. Many species of tropical and temperate regions, remarkable for the very oddshaped fls. The corolla is wanting, but the calyx is corolla-like, tubular, variously bent, and commonly tumid above the ovary : stamens commonly 6 , short and adnate to the style (Fig. 140). Mostly woody twiners, the greater part of them known to eult. only in warm glass-houses. Many species are evergreen. The tender species are cult. for the strikingly irregular and grotesque fls. Monogr. by Duchartre in $\mathrm{De}$ Candolle's Prodromus, Vol. 15, Part 1 (1864).

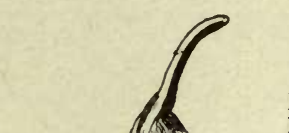
PiPe. Figs. 138, 139, 140. Very tall, twining, glabrous: lvs. very large, broadly reniform or rounded, becoming glabrous : fls. solitary or 2 or 3 together in the axils, U-shaped, enlarged above the ovary, with a 3-lobed, spreading limb, purplish. E. states. B.M. 534. G.W.F. 43. Gng. 1:53. G.F. 5:509 (habit). - An excellent vine for porches, the great lvs. affording a dense shade.

tomentòsa, Sims. Much like the last, but very tomentose : lvs. less rounded : fl. yellow, with reflexed lobes. N. Car. to Mo. and S. B.M. 1369.

Californica, Torr. Silky pubescent, 6-10 ft. : Jvs. ovatecordate, 2-4 in. long, obtuse or acutish, short-petioled: fls. U-shaped, little contracted at the throat, the limb 2-lobed, with the upper lip of 2 broad, obtuse lobes and a thickening on the inner side. Calif.

\section{BB. Greenhouse or warm house.}

\section{Flower-limb of 2 narrow lobes.}

ridícula, N. E. Br. Very slender, stiff-hairy throughout : lvs. round-reniform, cordate : fls, axillary and solitary, 2 in. long aside from the limb, with a long sac at the base of the tube, pale yellow with dull purple veining; limb of two spreading, deflexed, narrow lobes, glandular, reminding one of donkeys' ears. Brazil. B.M. 6934. G.C. II. $26: 361$.

cc. Flower-limb ample and flowing.

cymbifera, Mart. \& Zucc. (A. labiòsa, Sims). Glabrous : st. striate : Ivs. reniform, obtuse and deeply eut at the base, pedately 7-9-nerved, long stalked : fls. longstalked, 8-10 in. long, strongly 2-lipped ; the upper lip short and lanceolate, acute or acuminate; the lower lip (which, by position of fl. may seem to be the upper) very large, dilated at base, and produced into a long, boat-

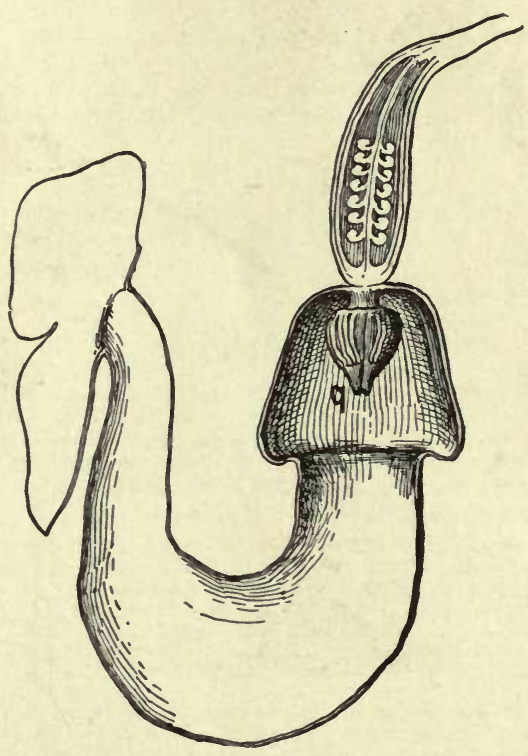

140. Longitudinal section of flower of Dutchman's Pipe.

Showing the ovary, and short column of stamens at $q$.

Cult. by E. O. OrPet.
Serpentària, Linn. Virginia SNAKeRoot. Height 3 ft. or less : pubescent, with short rootstocks and aromatic roots: lvs. ovate to lanceolate, cordate, acuminate

The best known representative of this genus is Aristolochia macrophylla (or A. Sipho), the "Dutchman's Pipe," than which there is no better hardy climbing vine for shade or screen purposes. No insects or other troubles seem to mar its deep green foliage, for which it is most valued, as the fis. are small, siphon-shaped, and inconspicuous, in early spring soon after the lvs. are formed. There are many tropical Aristolochias, the fls. and odor, but they are rarely seen on account of the last characteristic, the odor being so suggestive of putridity as to make its proximity apparent to all, and even to deceive the flies as to its origin. One of the most gigantic varieties is $\boldsymbol{A}$. grandiflora, var. Sturtevantii. Another fine species is $A$. Goldieana; but the best of the tropical kinds for general culture in glass structures grown seeds, flowers the first year, is very drom homeas a climber, and has no odor. We find it very easy of culture in rich soil, and it is evergreen, as, indeed, are most of the tropical kinds. The Aristolochias are of easy , requiring only good loam and carefnl attention trained on trellises, pillars, or rafters. Most of them require a rather warm temperature, but if in pots they may be flowered in the conservatory. The large-growing species require much room, and do not bloom, as a rule, until they are several feet high. Prop. readily by cuttings in a frame. Except as oddities, most of the Aristolochias are of hittle value.

\section{A. Herbs, not climbing.}


shaped (whence the name, from cymba, a boat) usually 2-lobed projection: 11. creamy white, marked and blotched with maroon. Brazil. B.M. 2545. P.M. 6:53 as $A$. hyperbòrea, Paxt.

Brasiliénsis, Mart. \& Zucc.(A. ornithocéphala, Hook.). Glabrous: Ivs. cordate-reniform, obtuse, with deep sinus at base : peduncle 8-10 in. long, 1-fd.: fl. very large, dingy yellow, with marks and reticulations of purple, the limb strongly 2-lipped; upper lip 5 in. long, lanceolate-acuminate, projecting from the inflated headlike tube like the long beak of a bird, hairy within ; lower lip on a stalk 2 in. long, then expanding into a flattened, wavy, beautifully marked limb 4-6 in. across. Brazil. B.M. 4120. Gn. 45, p. $289 .-$ A most odd and interesting species, not infrequent in fine establishments.

grandiflòra, $\mathrm{S}$ w a $\mathrm{r} \mathrm{tz}$ (A.gigas, Lindl.). PEJ.ICAN - FLOWER. GOOSEFLOWER. Fig.141. Downy climbing shrub: lvs. cordate-acuminate; peduncles opposite a leaf, striate, exceeding the petiole, 1 -fld. the fl. -bud is "bent like a siphon in the tube, so as to resemble the body and neck of a bird, while the limb, in that state, resembles the head and beak thrown back upon the body, as pelican when that bird is at rest, whence the name" (Hook. in B.M. vol. 74): the great expanded cordate-ovate limb several inches across, wavy-margined, purple-blotched and veined, terminating in a long and slender ciliated tail: strongscented. W. Ind., Cent. and S. Amer. B.M. 4368-9. B.R. 28:60 F. S. $4: 351-2$. G. F. $3: 597-9$ A.F. $10: 157$. G.C. III. 19: 73 . Gng. 3:23. Gn. 50:378. Var. Stúrtevantii, W. Watson, is the form chiefly known in cult., being very large-fld., and with a tail $3 \mathrm{ft}$. long. Var. Hodkeri, Duchartre $(A$. gigantèa, Hook.), is glabrous, inodorous, with a short-tailed fl. B.M. 4221.

Goldieana, Hook. Glabrous : Ivs, ovate-cordate or triangular-cordate, acuminate, the base deeply cut: fls. very large, greenish outside but brown-veined and biotched inside, the lower part of the tube straightish and 8 in. long, the upper part sharply bent over and a foot long, with a funnel-shaped, spreading limb a foot or more across, and indistinctly 3-lobed, each lobe terminated by a short tail: stamens 24. W. Afr. B.M. 5672. G.C. III. 7:521 ; $21: 337$. G.M. $1890: 286$.

6́legans, Masters. Slender, glabrous, the fls. borne on the pendulous young wood: ivs. long-stalked, reniformcordate, 2-3 in. across, with wide sinus and rounded basal lobes, the tip obtuse : fls. solitary, long-stalked, the tube yellow-green, $1 \frac{1}{2}$ in. long, the limb cordate-circular, 3 in. across, purple and white blotched, white on the exterior, the eye yellow : not strong-smelling. Braz. G.C. II. $24: 30$ i ; III. $22: 123$. B.M. $6909 .-\mathrm{A}$ small-fld. and graceful, free-blooming species.

A. altissima, Desf. Fls. 2 in. or less long, brownish. Sicily and Algeria. Would probably be hardy with protection in the Middle states. B.M. 6586-A anguícida, Jaca. Lvs, long-cordate: fls, smail, 1-2 in long, with s long-pointed limb. New Granada. B.M. 4361. F.S. 4: 344.-A. barbata, Jaca. Lvs. oblong and cordate. fs, $2 \frac{1}{2}$ in., purple. Venezuela. B.M. 5869. A. caudàta, Booth=A. macroura $-A$, ciliàta, Hook, and $A$. A. caudàta, Booth=A. macroura. $-A$. ciliàta, Hook., and $\boldsymbol{A}$.
cilidsa, Benth =A. fimbriata $-A$. clypeàta, Lindl. \& André. cilidsa, Benth. $=$ A. fimbriata.-A. clypeàta, Lindl. \& André.
Lvs. triangular-ovate, pointed : fls, with a large, oval, purpleLvs. triangular-ovate, pointed : fls. with a large, oval, purple-
spotted, tailless limb. S. A mer. I.H. 17: 40 . B.M. 7512.-A. Duchártrei, André=A. Ruiziana.-A.fimbriàta, Cham. Lvs. small, cordate-orbicular : fls, small, the little limb glandularciliate. Braz. B.M. 3756 (as A. ciliata) - A. hians, Willd. Lvs. round-cordate : fls. bronze-green, with lobed limb and a hairy beak. Venezuela. B.M. 7073. Allied to A. Brasiliensis.-A. Kámpferi, Willd. Tall-climbing : lvs, ovate-cordate or hastate, variable: fls. solitary, tomentose, with narrow rim, yellow outside, purple inside. Jap. Probably hardy in the N, $-\boldsymbol{A}$, longicaudàta, Masters Lvs, ovate and cordate : fls. cream-colored. with throat, with no expanded limb but a very long tail. S. Amer. G.C. III. 8: 493. $-A$. longifolia, Champ. Branches climbing, from a woody rootstock : lvs. thick, linear-lanceolate:- fls. U-shaped, with a 2-lobed purple limb $2 \frac{1}{2}$ in. across. Hong Kong. B.M. 6884-A. macroúra, Gomez. Lvs. reniform, lobed: f. dark, 6-spurred, the lip with a twisted cusp. Braz B.M. 3769 (as A. caudata). -A. odoratissima, Linn. Lvs. cordateovate: fl. solitary, purple, sweet. Jamaica.-A. ringens, Vahl. Lvs, round-reniform : fi. 7-10 in. long, green marked with dark purple, hairy inside, with 2 long lips, one of which has a much. expanded limb. Braz. B.M.5700.-A. Ruiziàna, Duchartre. Lvs. reniform - cordate: fls. with tube 1 in. or less long, the cordate. ovate limb 3 in. across, and brown. spotted. Braz. B.M. 5880 and G.C. 1868 : 516 (as A. Duchartrei) - $-A$. saccato Wall Avs longrove fls. small, U-shaped, with a small, U-shaped, with a very narrow rim (suggesting the Dutchman's Pipe), red. India. B.M. 3640. $-A$. Sálpinx, Misters. Lvs, ovate-lanceolate: fls. small, with a trumpetshaped, somewhat 2-lipped mouth, purplish. Paraguay. G.C. II. 26: 457. $-A$. tricaudàta, Lem. Lvs. oblong - acuminate, rugose ciliate fls purple, with 3 long talls $\mathrm{Mex}$ : fls. purple, with 3 long talls. Mex. -A. ungulifòlia, Masters. Lvs. 3-A. ungulifòlia, Masters. Lvs. reddish, with a ciliate, tongue-like lip. Borneo. G.C. II. 14: 117. B.M. 7424. - A. Wéstlandii, Hemsley. Lvs. oblong-lanceolate: fi. pendulous, with a spreading purple-marked limb 5 or 6 in. across. China. B.M. 7011. $\quad$ L. H. B.

ARISTOTELIA (after the Greek philosopher Aristotle). Tiliacece. Trees and shrubs from the southern hemisphere, allied to Elæocarpus. Lvs. nearly opposite, entire or toothed: fls. polygamous; sepals $4-5$, valvate; petals of the same number: berries snall, edible.

racemosa, Hook. f. Small tree, $20 \mathrm{ft}$. : Ivs. glossy : fls. white. New Zeai. Cultirated somewhat in southern California.

ARIZONA. In no part of Arizona, with the exception of occasional areas of a few ucres in extent on the high mountains, is there sufficient rainfall to grow horticultural plants without irrigation. The rivers of Arizona available for irrigation on an ex tended scale are confined to the southern half of the territory. All of northern Arizona is drained by the Colorado River and its tributaries, but here the river lies at the bottom of a deep cañon, and is practically valueless in its application to horticulture. All of this region has very limited possibilities from a horticultural standpoint, the flow of the few available streams being small and very uncertain. On the many mountain ranges of Arizona, at an elevation varying from five thousand to eight thousand feet, are isolated areas of limited extent where crops of great variety are grown without irrigation. Although these areas are utilized largely for growing hay, grain and hardy vegetables, some of the best flavored and choicest apples, peaches and small fruit grown in the territory are from these mountain "garden patches." The mountains at every side temper the climate, offer protection from winds, and make them almost ideal localities for the growing of a great variety of deciduous and small fruits, as well as many sorts of vegetables. Although these isolated, restricted areas are worthy of consideration, it is only in the valleys of southern Arizona having rivers of considerable size and regularity in their flow that large areas of land are arailable for cultivation. The shaded areas on the map (Fig. 142) show the leading horticultural areas thus far developed.

One cannot get an adequate conception of the problems confronting the horticulturist in this region without first carefully considering the meteorological conditions of this, the most arid, the most desert-like part of the United States. At Phœnix and Yuma, two repre- 
sentatire localities of southern Arizona, having the greatest horticultural possibilities, the average yearly rainfall is only 7 inches for the former and 3 for the latter. In general, the precipitation is during two distinct seasons. The heaviest, or summer rains, begin about the first of July and increase in frequency until August, the month of greatest precipitation during the year. The winter rains are at their maximum in Decem. ber. With the exception of infrequent intervals during the rainy season, dews are unknown and fogs are of rare occurrence. On the other hand, from experiments conducted at Tucson, the evaporation is about 78 inches per year, reaching the maximum of 11 to nearly 13 inches during the month of June.

At Phœnix the mean temperature may range from $32.2^{\circ}$ to $66^{\circ} \mathrm{F}$. in Jan. It steadily increases till July, when it may range from $72^{\circ}$ to $107^{\circ}$. It then steadily declines until the next Jan. The corresponding ranges at Yuma are $42^{\circ}-65^{\circ}$ for Jan., and $77^{\circ}$ to $106^{\circ}$ for July. The variation

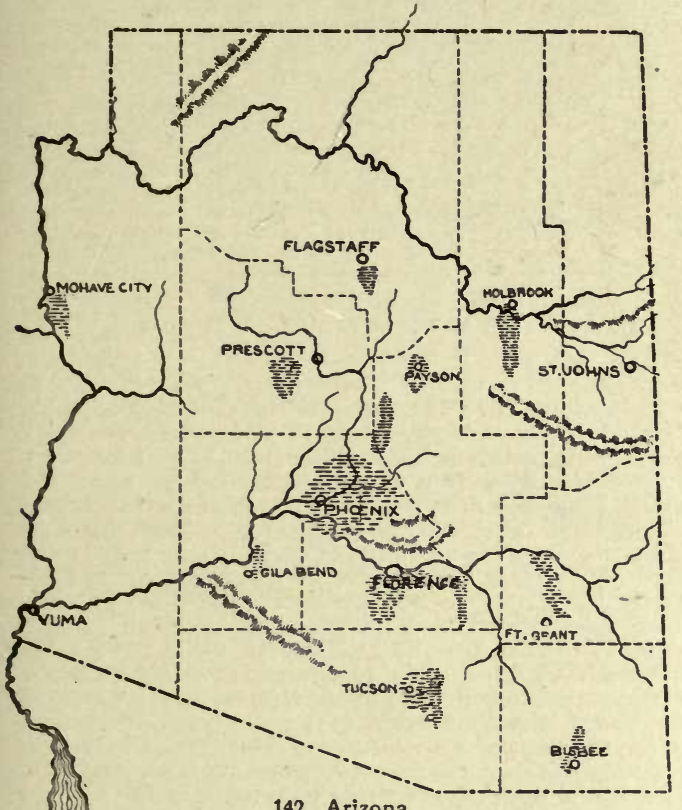

The shaded parts show horticultural sections.
The

There is also a horticultural section about Yunia.

in temperature from day to night is frequently, in sum: mer, from $25^{\circ}$ to $40^{\circ} \mathrm{F}$., while in winter it is even greater. The annual range, however, is not so great as it is in the northern states.

The intense heat and dryness of the atmosphere, with continuous sunshine and frequent scorching winds, not only draw the moisture in wonderful rapidity from irrigated fields, but the foliage of cultivated plants, save those with firm leaves, protected by thick epidermis, are overtaxed at times, and not infrequently the leaves wither and burn, even when the roots of the plants are well supplied with water. In some instances the difference of a few days in time of irrigating makes or loses the crop. At times. flooding at midday is disastrous, destroying the plants as effectually as if swept by fire. The temperature of water in irrigating ditches in mid: summer often ranges from $85^{\circ}$ to $92^{\circ} \mathrm{F}$.

The rivers of Arizona draw their moisture from the wooded mountains, but as these mountains are snowcovered only during winter and early spring, as the summer advances their supply gradually becomes less and less until the beginning of the rainy season. Consequently the cultivation of all crops must lead toward great economy in the use of water during the months of May and June. All crops sown broadeast or in narrow drills are irrigated by flooding, while orchards, vineyards and crops grown in rows are usually irrigated by running the water through furrows. In either system it is imperative that the land be graded and thoroughly worked, in order to attain the best results in the distribution of water. The desert lands of Arizona, in their virgin state, are seldom suited for orchards, vineyards, gardening, etc. It is expedient to grow alfalfa for a few years before attempting to produce horticultural crops. Usually the virgin soil is deficient in humus and nitrogen, constituents which are most economically supplied by growing alfalfa. Many orchards and vineyards bave failed in Arizona on account of being planted on virgin soil.

Market-gardening in Arizona is largely in the hands of the C'binese, who practice high culture, and keep their lands in a continual succession of crops. Cabbage and canliflower must be grown as winter crops. For years it was thought that corn could not be successfully grown in southern Arizona. When planted in the spring, the excessive heat and dryness of June renders the pollen impotent, and a well-developed cob bearing a few scattered kernels of corn is the result. Experience has re. cently taught that most excellent, well filled corn may be grown, if planted in July and pollenized at the end of the rainy season.

Artificial fertilizers are seldom used in Arizona. In preparing the soil for nearly all vegetables, both in amateur and commercial methods of culture, it is thrown into high ridges and the seed sown in hills or drills on either side of the ridge a few inches below the summit. In irrigating, the water is run between the ridges, so that it reaches the hills or drills without covering them, and is allowed to run for a greater or less length of time, depending upon the ability of the soil to take water. In many of the heavier adobe soils it is necessary, when planting melon and many other seeds, to cover them with sand. If the adobe soil of the field is used as a cover, it bakes so hard that the germinating seeds are unable to make their way to the surface. Beets, and occasionally other vegetables, when planted on an extended scale, are sown in drills without ridging the soil. After planting, furrows are made between the rows in which to run the water, it being imperative that the water be not allowed to break through the furrows and flood the crop.

In fruit-culture, the important principle is practically the same for all fruit, it being essential to fill the ground with water during the winter season, when the ditches are running full, and by thorough tillage during spring and early summer to retain the moisture, to fortify the plants against the lack of water in May and June. Orchards and vineyards may be flooded several times during the winter, or the same or better results may be obtained by making furrows at a distance of every 4 to 6 feet throughout the orchard, and running a subsoil plow in the furrows to loosen and break up the soil to considerable depth. When so prepared, the soil will take water with great avidity, and if the process be repeated two or three times during the winter, water required for subsequent culture will be much lessened.

In orchards and vineyards, frequent irrigation with little water is expensive and results are unsatisfactory. The ground should be thoroughly wet throughout, even between the rows, and as soon as practicable after irrigating, tilled and later leveled by using a fine-toothed harrow. This process will leave a mulch of loose earth a few inches in thickness over the moist soil, and assist greatly in retention of moisture. When necessary to improve the condition of the soil by adding plant food, it is most economically and satisfactorily accomplished by green-manuring, growing the crop during the fall and winter and turning it under in the spring.

Great variation in temperature during February and March is very disastrous to successful fruit and nut culture in southern. Arizona. Almonds begin to bloom in February, and are followed in succession by apricots and peaches, all of which are likely to be injured by spring frosts.

In humid regions, methods of pruning tend toward thinning out the center of the tree, so that the sun may reach the fruit spurs within. In Arizona fruit trees are usually headed low, in order that the trunk be shaded. Deciduous trees are usually cut back annually, throwing the fruit spurs toward the center of the tree, that as much as possible of the developing fruit be siaded by 
the foliage. Citrous, olive and fig trees are rarely if ever pruned, and grapes are usually eut back to two or three buds. Among small fruits, strawberries, although producing the larger part of their erop during April or May, ripen fruit every month of the year.

The following is a brief list of the best and most profitable commercial varieties of the more important fruits and nuts grown in the irrigated regions. The list is compiled from the answers to a circular letter sent to 60 of the largest fruit-growers in southern Arizona :

Almonds. - Ne Plus Ultra, IXL.

Apples, early.-Early Harvest, Early Strawberry, Red Astra-$$
\text { chan. }
$$

Apples, late-White Pearmain, Ben Davis.

Apricots, early - Bennet's Early, New Castle, Peach, Pringle.

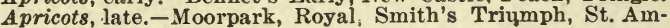
broise.

Blackberries.-Lawton's Early, Crandall's Early, Early Harvest.

Dewberries.-May's.

Grapes.-Thompson's Seedless, Sultana Seedless, Rose of Peru, Salem, Muscat, Rogers' No. 9.

Grape Fruit.-Triumph, Walter, Bowin.

Lemons.-Villa Franca, Sicily.

Mulberries,-Downing, Russian.

Olives.-Manzanillo, Nevadillo Blanco, Mission

Oranges.-Ruby Blood, Jaffa, Parson's Brown, Mediterranean Sweet, Bahia (Washington Navel).

Peaches, early.-Early Crawford, Parson's Early, Triumph, Sneed, Strawberry.

Peaches, late.-Globe, Salway, Oldmixon, Heath's Freestone, Muir, December Cling.

Pears, early - Wilder, Brandywine, Bartlett.

Pears, late-Winter Nelis, Pia Berry.

Plums. - Wickson, Kelsey, Botan White, Royale Hative.

Pomegranates.-Ruby, Sweet, Red Papershell (?), Golden.

Quinces.-Champion, Portugal, Orange.

Strawberries.-Arizona Everbearing.

\section{J. W. TOUMEY.}

ARKANSAS. The horticultural products of Arkansas are varied, owing to the great differences of climate, elevation and soil. The seasons in the southern part of the state ale about three weeks earlier than in the northern. There is much variation betweeu nearby points. In the western part of the state, owing to the difference in altitude, within a distance of 60 miles there is from a week to 10 days difference in the seasons. This admits of a great diversity of fruit and vegetable production within the limits of the state.

The northwestern section of the state is noted for its fine apples, and they are grown extensively for market. 'This section has also produced a number of seedling apples that are being largely planted there as well as elsewhere. There are several of these new apples, and others of value are constantly coming into notice. A few of those of special value are Arkansas, Oliver, Collins, and Givens. It is probable that some of these new apples will become standard varieties, for in addition to being productive they are good keepers. Winter apples are not grown so extensively in other sections of the state, but summer and fall varieties are grown to some extent in all sections.

Peaches are grown for market along the lines of railroad in the western section of the state, and the acreage is being largely increased each year. For marketable purposes the Elberta is grown almost exclusively, and is shipped in car lots to the northern markets. The earlier varieties have not proved profitable for ship. ping purposes. Peaches are grown for home market throughout the state. Strawberry-growing is an important industry in western Arkansas, and is carried on to some extent in many localities in the eastern and southern parts, where they are grown in small quantities for shipment. The acreage around some of the shipping points in the western part is large, reaching about three thousand acres at one point. The varieties grown most extensively are Michel and Crescent. Owing to the strict laws against the selling of wine in the state, grapegrowing is not carried on to any great extent. On the elevated sections the table and wine grapes succeed well, and in some localities table grapes are grown for shipment. The Scuppernong succeeds in south Arkansas. Pears are grown in some sections for market, but not to any great extent, owing to the prevalence of pear blight, while blackberries and raspberries are grown for the home market in most sections. Cherries are grown only for the home market, the Morello type alone being successful.

In order to describe more accurately the horticultural condition of the state, we have divided it into four sections, in the order of their present development and their natural adaptability to horticultural productions (Fig. 143). Section 1, located in the northwestern part of the

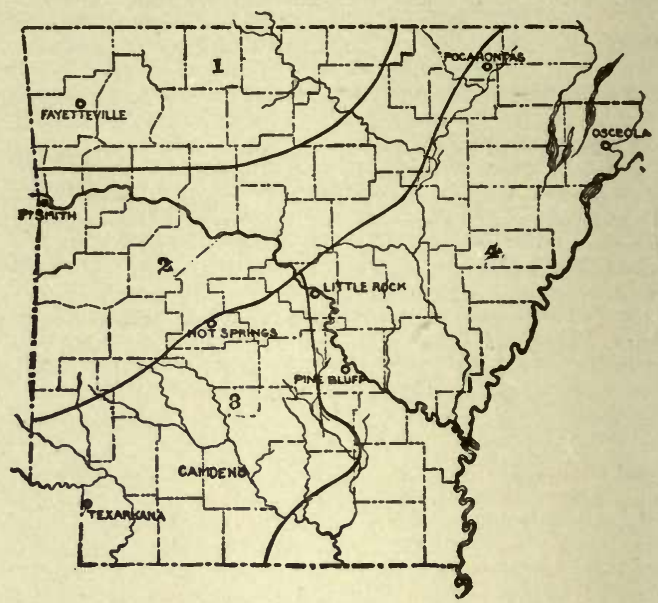

143. The horticultural zones of Arkansas.

state, is a mountainous country, fairly well developed, and is adapted to all classes of horticulture. Section 2, located south of section 1 , is partly mountainous and partly low land and, from a horticultural standpoint, is not so well developed as section 1 , while in sections 3 and 4 , located in the extreme southern and eastern parts of the state, horticulture has received little attention.

SECTION 1. - The elevation of this section ranges from 800 to 2,000 feet, the greater portion being about 1,200 feet. The country is mostly uneven, and parts of it are somewhat mountainous. The Ozark Mountain system enters the state from the northwest, while the Boston Mountains, a range of this system, extend across the section just north of and parallel with its southern boundary. Fruit and vegetables are grown for shipping along the lines of railroad in the western part. The remainder of this section, although remote from railroads, is well adapted to fruit-growing, and with transportation facilities it promises to be equally productive. The apple leads as a fruit product. In 1897, there were shipped from the western part, principally from two counties, over 2,000 cars of apples.

SECTION 2. - The elevation of this section ranges from 300 to 2,820 feet, the greater part of it, however, ranging from 300 to 800 feet. Most of this section consists of rough land. Strawberries are grown for shipment, principally in the western part. The berries ripen early in this locality, and the growers usually begin shipping the latter part of April. At a few points, peaches are extensively grown for shipment. Plums, blackberries, raspberries and summer apples are grown to some extent in all localities, while winter apples are successfully grown on the higher land. Here, vegetable-growing for the northern markets is receiving much attention. Such crops as beans, peas, tomatoes and cantaloupes are extensively grown in some localities along the railroads. The area in cantaloupes reaches nearly 1,000 acres at some of the shipping points. These crops can be grown early enough to bring good prices in the markets of the north, and are shipped in car lots.

SECTION 3.-This section is mostly low, but the land is uneven, and much of it is adapted to fruits and vegetables. It ranges in elevation from 140 to 360 feet. Peaches and summer apples succeed on the higher land, and are grown to some extent in all localitiés. Vegetables can also be successfully grown, but little attention has been given to these lines of farming here. Strawberries are grown only for home market. 
Section 4.-This section comprises the low lands of the eastern part of the state. It ranges in elevation from 130 to 350 feet, and the land is low and flat, with the exception of a ridge a few miles wide running through it north and south. But little fruit is grown in this section for commercial purposes; however, fruits could be grown successfully for market in some parts of it, and early vegetables are now grown for market at several points.

JонN T. Stinson.

ARmentaca. See under Prunus.

ARMiria (an old Latin name). Plumbagindece. Sea PINk. Thrift. Small perennial herbs, with rosettes of narrow evergreen lvs. on the ground, sending up a naked simple scape 2-12 in. high, on which is borne a compact head of pink, lilac or white fls., the head being subtended by small bracts, forming a kind of involucre. Species much confused. They are excellent for borders, especially where a low edging is wanted; also for rockwork. They are of easiest culture, being hardy and free growers. Prop. by division of the stools; also by seeds. See Boissier, in DeCandolle's Prodromus, vol. 12.

\section{A. Calyx-tube pilose all over.}

maritima, Willd. Lvs. linear, 1-nerved, somewhat obtuse, glabrous or slightly ciliate : scape low, somewhat villose ; calyx-tube about the length of the pedicel, the limb nearly equal to the tube, with very short ovate and aristate lobes. Eu. and Amer., along the sea coast.The A. vulgdris of horticulturists seems to belong here. A. Lauchedna, Hort., with very bright rose-colored fls., is a form of it. Var. álba, Hort., has white fls. Also a white-lvd. form. A. argéntea, Hort., is perhaps another form, with small white fls.

Sibirica, Turcz. Lvs. linear, I-nerved, obtuse, glabrous : scape rather taller, thicker; calyx-tube longer than pedicel, the limb about length of tube, with triangular, short-mucronate lobes : involucre brown : fls. white. Siberia.

júncea, Girard (A. setdcea, Delile). Outer lvs. of rosette narrow-linear and subdentate, the inner ones longer and filiform: head small, with pale involucre, the pedicel much shorter than the calyx-tube: calyx-limb short, the lobes ovate-obtuse and aristate: fls. pink. Eu.

\section{AA. Calyx-tube glabrous, or pilose only on the ridges.}

\section{B. Lvs. elliptic-lanceolate or broader.}

latifollia, Willd. (A. cephaldtes, Link \& Hoffm., not Hook.). Glabrous and glaucous : lvs. broad-oblong, 5-7nerved, the margin remotely denticulate: head large, the involucre dry : calyx-limb long, with very small or no lobes and long teeth: fls. bright pink. S. Eu. B.M. 7313. P.M.11:79 (as Statice Pseudo-Armeria).-A. formosa, Hort., probably belongs here.

Mauritánica, Wallr. (A. cephald̀tes, Hook., not Link \& Hoffm.). Lvs. broad-spatulate or elliptic-lancenlate, 3-5 nerved, glaucous-green, the margin scarious-white: heads large (2-3 in. across), the involucre brownish, the calyx short-toothed and aristate : fls. pink. Eu., Algeria. B.M. 4128 .

$$
\text { Bв. Lvs. linear-lanceolate or narrower. }
$$

alpina, Willd. Glabrous : lvs. linear-lanceolate, equaling the scape, 1-nerved or obscurely 3-nerved: head large, the involucre pale brown: pedicels shorter than calyx-tube, the tube equaling the oblong long-aristate lobes : fls. deep rose. Mts., Eu.

elongàta, Hoffm. Lvs. linear, long, I-nerved, acutish: involucre white: pedicels as long as calyx-tube, limb equaling the tube, and the lobes ovate-aristate : pink. Var. purpurea, Boiss. (A. purpùrea, Koch), has purple heads. Central Eu.

plantagínea, Willd. Glabrous : lvs. linear-lanceolate, 3-7-nerved, acute or acuminate : scape tall : head dense and globular, the involucre white: pedicels as long as calyx-tube, the lobes ovate and long-aristate and as long as tube ; pink. Central and S. Eu. Var. leucántha, Boiss. (A. dianthoides, Hornm. \& Spreng.), has white flowers. argyrocéphala, Wallr. (A. unduldata, Boiss.). Glabrous : outer lvs. in rosette, short and lanceolate or linear-lanceolate and 3-nerved and often sinuate, the inner ones linear or setaceous and 1-3-nerved : head large, the involucre white: pedicel nearly as long as calyxtube, the calyx-limb with long-triangular aristate lobes: fls. white, showy. Greece.

$$
\text { L. H. B. and J. B. KELr.ER. }
$$

ARMERIÁSTRUM. See Acantholimon.

\section{ARNATT0. See Bixa.}

ARNĖBIA (Arabic name). Boraginàcea. Annual or perennial hispid herbs, of nearly 20 species in Africa and Asia. Lvs. alternate : fls. yellow or violet, in racemes or cymes, the color changing with the age of the blossom; corolla slender-tubed, with 5 obtuse lobes.

echioldes, DC. (Macrotòmia echiòdes, Boiss.). PROPHET - Flower. Hardy perennial, 3-12 in. high, shorthairy, with spreading, obovate-oblong lvs.: fls. in a scorpioid raceme or spike, yellow, with purple spots, fading to pure yellow. Caucasus, Armenia, etc. B.M. 4409. G.C. II. 11: 689.- Blooms in spring. In full sun or in rather dry ground, it is difficult to keep this charming plant in a healthy condition ; partial shade is essential to its welfare. One can grow luxuriant specimens on the northern slope of a rockery or close to a building on the east or north side. Prop. by seeds, division, or by root-cuttings.

cornuta, Fisch. \& Meyer. Arabian Primrose. Annual, $2 \mathrm{ft}$., bushy : lvs. lanceolate or linear-oblong, pointed : fls. $3 / 4$ in. across, yellow and black-spotted, changing to maroon and then to yellow. Orient. G.C. III. 7: 52. J. H. III. $31: 29$. A. F. 5: 400 . A. G. $44: 181$ (1890).- An attractive and not very common annual, easily grown in the open.

A. Griffithii, Boiss. Annual : lvs. narrow-oblong, obtuse, ciliate: fls. long-tubed, with a black spot in each sinus : 9-12 in. India. B.M.5266.-Not known to be in the American trade.

$$
\text { L. H. B. and J. B. Keller. }
$$

ARNICA (ancient name). Compósitoe. Small genus of perennial herbs, with clustered root-ivs. and large, long-peduncled yellow heads. Native to Eu., Asia, and N. Amer. - Tincture of the European A. montana is used in medicine. Grown mostly as alpines or in rockwork ; some species also grow fairly well in the common border. Prop. by division, and rarely by seeds.

A. Radical lvs, cordate, with slender or winged petioles.

cordifolia, Hook. Two ft. or less high, hairy : heads few or even solitary, with inch-long rays ; involucre $2 / 3$ in. high, pubescent. Rocky Mts. and W.

latifolia, Bong. Glabrous or very nearly so, the stemlvs. not cordate or petioled : heads smaller than in preceding. Rocky Mts. and W.

\section{AA. Radical lvs, not cordate, but petioled.}

amplexicaulis, Nutt. Glabrous or nearly so : lvs. ovate to lance-oblong, acute, those on the stem clasping and dentate : stem leafy to the top. Oregon and N.

foliosa, Nutt. Pubescent : lvs. lanceolate, strongly nerved, small-toothed, the upper ones somewhat elasping : heads sometimes solitary, short-peduncled : stem leafy, strict. Rocky Mts. and W.

montàna, Linn. Mountain Tobacco. Mountain SNUFF. A foot high, the stem sparsely hairy : radical lvs. oblong-lanceolate, glabrous and entire : heads 3-4, large. Eu. B. M. 1749. J. H. III. 34:441. - The best known species in cult.; but none of the Arnicas are common in American gardens.

L. H. B.

AROIDEE, or ARACEE. AROIDS. A large order of spathe-bearing, tuberous herbaceous plants, containing many of the most highly prized greenhouse plants. The culture of Aroids is too diverse to be given in any one place. See the leading genera, as Aglaonema, Alocasia, Anthurium, Arisama, Arum, Caladium, Colocasia, Dieffenbachia, Dracunculus, Helicodiceros, Homalomena, Monstera, Philodendron, Richardia, Schizmatoglottis, Spathiphyllum, Xanthosoma, etc. 
ARÒNIA. See Sorbus. A. alnifolia, Nutt.=Ame. ianchier alnifolia.

ARPOPHYLLUM (Cimiter and leaf). Orchiddcea, tribe Epidéndrece. Epiphytes : racemes dense, cylindrical, erect: lvs. strap-shaped or linear. on jointed, terete stems : fls. small, inverted; segments concave. - Orchids of minor importance. Consult Epidendrum.

gigantèum, Lindl. Plants robust: sts. about 10 in. high : Ivs. coriaceous, strap-shaped; peduncle stout : raceme several in. long; fls. numerous, pink-purple. Mex.-Give plenty of light.

spicàtum, Llave et Lex. Smaller than the above : lvs. linear : fls. paler. B.M. 6022.

ARROW-ROOT. An edible starch, obtained from the rhizomes of vprious scitaminaceous plants, as Maranta, Cureuma, Tacca, Canna. The West Indian Arrow-root is mostly from Maranta arundinacea, Linn. The Brazilian is from Manihot utilissima, Pohl. The East Indian is chiefly from Curcuma angustifolia, Roxbg. Potato and maize starches are also a source of Arrow-root. Arrow-root is also obtained from Manihot.

ARTABOTRYS (suspend grapes, alluding to the hanging fruit). Anonacece. About 25 tropical climbing shrubs, with 3-sepaled and 6-petaled solitary or fasciculate fls., and shining, evergreen foliage.

odoratíssimus, R. Br. Lvs. oblong or lanceolate, pointed, thick, dark glossy green : fls. brownish, very fragrant: heoks on the peduncles. E. Ind. B.R. 423.Hardy in S. Fla. and S. Cal., and somewhat cult. The ylang-ylang perfume is made from the fls. The lvs. are used in native medicine.

ARTEMISIA (Artemisia, wife of Mausolus). Compósitce. A large genus of aromatic herbs and small shrubs, mostly in the northern hemisphere, and most abundant in arid regions. Lvs. alternate, often dis sected : heads small and mostly inconspicuous, numerous, and generally nodding, with yellow or whitish florets. In the West, many of the species, particularly $A$. tridentata, are known as Sage Brush. Grown for their medicinal properties or for foliage effects. The cult. kinds are perennials, and thrive in the most ordinary conditions, even in poor and dry soil. Prop. mostly by division. For an account of the species, see Besser, in DeCandolle's Prodromus, vol. 6, and Gray, in Synoptical Flora, vol. 1, part '2.

A. Heads with two kinds of florets (heterogamous).

B. Disk-fls. with both stamens and pistils, but the ovary abortive (not producing seed): style usually entive.

Dracúnculus, Linn. Tarragon. Estragon. Herb; green and glabrous. with erect, branched stems $2 \mathrm{ft}$. high : radical lvs. 3-parted at the top ; stem-lvs. linear or lanceolate, entire or small-toothed : panicle spreading. with whitish green, nearly globular fl.-heads. Eu. R.H. 1896, p. 285. - Tarragon lvs. are used for seasoning, but the plant is little grown in this country. The lvs. may be dried in the fall, or roots may be forced in a coolhouse in the winter. Prop. by division; rarely produces seed.

Canadénsis, Michx. Herb, $2 \mathrm{ft}$. or less high, glabrous or very nearly so : lvs. usually 2-pinnate, with filiform, plane lobes: fls. in a long, narrow panicle, with numerous small greenish heads. Wild on banks and plains in the northern part of the country. Int. 1891.

filifolia, Torr. Shrubby, canescent, $3 \mathrm{ft}$. or less high, very leafy, the branches rigid: Ivs, filiform, the lower usually 3-parted : panicle long and leafy. Plains, W.Plant has a purplish, mist-like aspect when in fruit.

\section{Bв. Disk-fls. perfect and fertile: style 2-cleft.}

$$
\text { c. Receptacle hairy. }
$$

frigida, Willd. Herb, 8-12 in., with a woody base, silvery canescent: lvs. much cut into linear lobes : heads small and globular, with pale involucre, in $\mathrm{nu}$ merous racemes. Plains and mountains W. Int. 1883. -
Good for borders. Known in Colo. as "Mountain Fringe," and used medicinally.

Absinthium, Linn. Wormwood. Almost shrubby, 2-4 ft. high, spreading and branchy, white-silky : lvs. 2-3parted into oblong, obtuse lobes: heads small and nuinerous, in leafy panicles. - Wormwood is native to Eu., but it occasionally escapes from gardens. It is a common garden herb, being used in domestic medicine, especially as a vermifuge. Wormwood tea is an odorous memory with every person who was reared in the country.

argéntea, L'Her. Shrubby, erect: Ivs. white-silky, 2-pinnate, the lobes linear or lanceolate: heads globular, tomentose, nodding, in racemose panicles; $1-2 \mathrm{ft}$. Madeira.-Useful for rockwork.

\section{cc. Receptacle not hairy.}

Abrotanum, Linn. Southernwood. OLd Man. Shrubby, 3-5 ft., green and glabrous, the st. rather strict: lvs. 1-3-pinnately divided, the divisions finefliform : panicle loose, with yellowish white heads. Eu. -Southernwood is grown for its pleasant-scented foliage ; and it sometimes escapes into waste places.

Pontica, Linn. Roman Wormwood. Shrubby, erect, 1-4 ft.: lvs. canescent below, pinnatisect, the lobes linear: panicle open and long, with small, globular, nodding, whitish yellow heads. Eu.-Roman wormwood is used for the same purposes as $A$. Absinthium, and is more agreeable. Chief source of absinthe.

vulgàris, Linn. MuGwORT. Herb, erect, paniculately branched: lvs. white-cottony beneath but soon green above, 2-pinnately cleft, with lanceolate lobes: upper lvs. sometimes linear. heads many, oblong, yellowish. Eu. and northern N. Amer., and naturalized in $\mathbf{E}$. states. - Mugwort is grown for the ornament of its foliage. There are variegated-leaved and golden-leaved varieties. It was once a domestic remedy. Variable.

Stelleriàna, Bess. Old Woman. Herb, $2 \mathrm{ft}$., from a woody creeping base, densely white tomentose: lvs. pinnatifid, with obtuse lobes ' heads large and manyfld., in a racemose-glomerate inflorescence. N. E. Asia and on the coast of Mass.-Attractive from its whiteness. Useful for borders.

Ludoviciàna, Nutt. Herb, 2-3 ft., white-tomentose or lvs. becoming greenish above : lvs. linear to oblong, the lower ones toothed or parted, the upper ones entire heads small, bell-shaped, paniculate. Plains and banks, W. Int. 1891.

\section{AA. Heads with perfect fls, throughout: receptacle} not hairy.

arbúscula, Nutt. SAgE BRUSH. Shrubby : a foot or less high : lvs. short, wedge-shaped, 3-lobed, the lobes obovate and often 2-lobed, canescent: panicle simple and strict, often spike-like, the 5-9-fld. heads erect. Plains, W.

tridentàta, Nutt. SAgE Brush. Shrubby ; reaching height of $12 \mathrm{ft}$., although often only a foot high, branchy, canescent: lvs, wedge-shaped, 3-7-toothed or lobed, truncate at the summit, the uppermost ones narrower : heads 5-8-fl. Plains, W. Int. 1881.

I. H. B.

ARTICHOKE (Cynàra Scólymus, Linn.). Compósitce. A coarse and robust perennial, cult. for the edible fl. heads and lvs. The fl.-heads are $3-5$ in. across just before they open, and at this stage they are cut for the table. The fleshy outer scales and the "bottom" of the head (this is, the receptacle, the florets being removed) are eaten raw or cooked. When the blue florets begin to show, the head is too old for eating. Fig. 144 shows edible heads. For pickling, the heads are often taken when only half grown. The young sts, and lvs. are sometimes blanched and eaten, after the manner of cardoons; and these parts comprise the "Artichoke salad "of the markets. There are a score or more varieties in European gardens, but the Globe is the one generally scld here.

Although the Artichoke is perennial, the plant declines in vigor after it has borne two or three crops. In the $\mathrm{N}$. the plants should be protected in winter with a liberal mulch. Artichokes are of easiest culture on rich soil. As they grow 3-5 ft. high and branch freely, and make ivs. $3 \mathrm{ft}$. long, they should not be set nearer than 2 or 3 
$\mathrm{ft}$. in the rows, and the rows should be 4 or $5 \mathrm{ft}$. apart. In this country, the plant is propagated mostly by seeds. These are sown early in the spring. Seedlings rarely

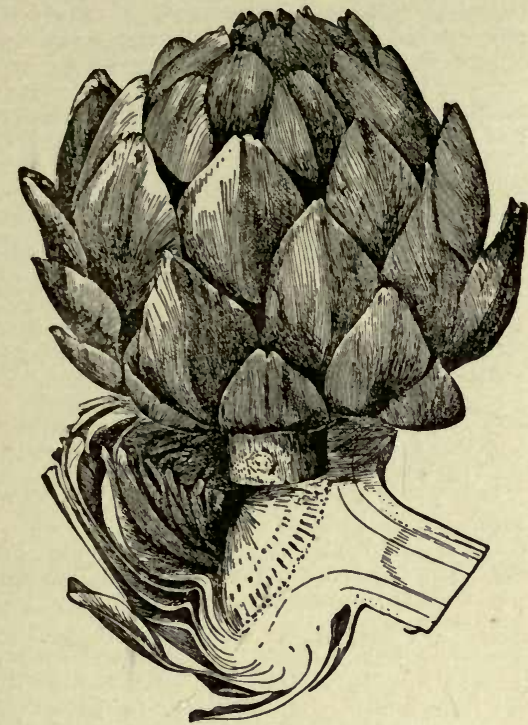

144. Edible heads of Artichoke $(\times 1 / 2)$.

give many heads before the second year. A quicker and better method of propagation is to use the suckers, which are freely produced about the crown. The suckers reproduce the variety. The Artichoke is little known in America, but is worthy greater attention. The habit of propagating by seed is, perhaps, one reason why the Artichoke has not obtained greater prominence in this country. The great woolly, pinnatifid lvs. and strong habit make the plant an attractive ornamental subject. See Cardoon. L. H. B.

ARTICHOKE, JERUSALEM (Helianthus tuberdsus, Linn.). Compósitoe. While the Globe Artichoke is seldom seen in American gardens or on American tables, and surely not appreciated by our people, the Jerusalem Artichoke is so common as to be despised as a weed. The Jerusalem Artichoke is the tuber of a perennial sunflower-like plant. (Fig. 145.) It thrives on almost any drained land, without much attention as to manuring, and without coddling. The tubers may be cut to single eyes and planted like common potatoes. The cultivation is about the same as that usually given to corn or potatoes. Any time in the fall after frost has killed the tops, or the latter have matured, the crop can be gathered. Pull up the whole plant by the roots, or dig the tubers with a potato hook or prong hoe. Or, swine may be turned into the field and allowed to root up and feed on the tubers. All kinds of farm animals seem to be fond of them. They may be ground and fed, mixed with ground

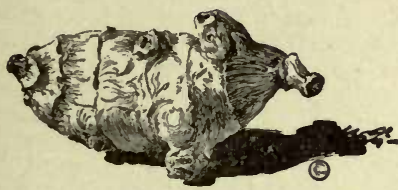
grains, to poultry with good results. As a succulent food for cattle, sheep, swine, and perhaps other farm stock, this tuber seems to deserve more general attention on the part

145. Tuber of Jerusalem Artichoke of the American $\left(X^{1 / 4}\right)$ farmer than it has usually received. It is far ahead of the potato in productiveness, and much more cheaply grown. Raw or boiled and served with vinegar, the tuber also makes a very good winter or spring salad, and for this purpose it may find a limited sale in our markets. The chief demand for it will be for seed purposes. The easiest way of keeping the crop over winter is by leaving the tubers in the ground where they. grew, as they are not hurt by frost when covered with soil. Tubers already gathered can be pitted like beets or turnips, but will need even less covering of soil. The Mammoth White French is said by some propagators to be an improved strain of the ordinary or Jerusalem Artichoke. The plant often becomes a weed; but hogs will root it out. The plant is native to upper Canada and middle parts of the U.S. It was cult. by the Indians. See Helianthus.

T. GREINER.

ARTOCÁRPS (artos, bread, and carpos, fruit). Urticacece. BREAD FruIT. Tropical fruit plants, originally from the East Indies, sometimes cult. with difficulty in northern botanic gardens for their great economic interest. They need a hot, moist atmosphere, much water, and perfect drainage. Prop. slowly by cuttings of young lateral growth. The fruits do not bear shipment to the N.

incisa, Linn. $f$. BREAD FruIT. Tree, 30-40 ft., with a viscid, milky juice: branches fragile : lvs. 1-3 ft. long, leathery, ovate, cuneate and entire at base, upper part 3-9-lobed: male fls. in a dense club-shaped yellow catkin 10-16 in. long; female fls. in a subglobular echinate head, having a spongy receptacle: fr. as large as a melon, typically muricated, but in the best cult. varieties reticulated only, and seedless. Gt. 39, p. 273. Gng. 5: 233, and B.M. 2869-71, where the romantic story of its transfer to the West Indies is told. Sparingly cult. in S. Fla.

integrifolia, Linn. f. JACK FrUIT. Tree, $30 \mathrm{ft}$., with milky juice: Ivs. 4-6 in. long, very various; those of fertile branches nearly obovate, entire; those of higher branches more obovate and oblong; those of young shoots from the root very narrow, or 2-3-lobed : fr. attaining a weight of $60-70 \mathrm{lbs}$. Less palatable than the bread fruit. The oily seeds when roasted are said to resemble chestnuts. G. C. III. 20:717. B. M. 2833-4. Gt. 39, p. 273. Gn. 35: 455 .

Cánnonii, Bull. Lvs. varying from cordate to deeply 3-lobed, $1 \mathrm{ft}$. long, red beneath, bronzy crimson and purple above, very showy. Society Is. F.S. 21:2231-2.

ARUM (ancient name). Aròidea. Tuber-bearing low herbs, of few species, in Eu. and W. Asia. Lvs. simple, the petiole sheathed at the base: spathe convolute, variously colored, mostly including the short spadix : pistillate fis. at the base. Grown usually as oddities, mostly under the general name of Callas. Some of the species are hardy ; others, as A. Paloestinum, are tender, and require glasshouse treatment. The tender kinds are managed in essentially the same way as the fancy-leaved Caladiums. Plant the tubers sufficiently deep that roots may form from near the top. Give rich soil, and water freely when growing or in bloom. The hardy species should be well mulched in late fall. They thrive best in partially shaded places and in rich soil. Prop. by natural offsets ; also by seeds or berries, which some species produce freely. Some of the species are acridpoisonous. Monogr. by Engler in DeCandolle's Monographiæ Phonerogamarum, vol. 2.

The following names are in the American trade: albispathum, Nos. 5, 7; alpinum, 6; Arisarum = Arisarum vulgare; Byzantinum, 7; Canariense, 7; concinnatum, 7 ; cornutum $=? ;$ Corsicum, 1 ; crinitum $=$ Helicodiceros crinitus ; cylindraceum, 7 ; Cyprium, 2; detruncatum, 3; Dioscoridis, 2; Dracunculus = Dracunculus vulgaris; elongatum, 5 ; gratum, 5 ; immaculatum, 6; intermedium, 6; Italicum, 7; maculatum, 6; Malyi, 6; marmoratum, 7; nigrum, 5; Nordmanni, 5; orientale, 5; Palcestinum, 4 ; pictum, 1 ; sanctum, 4 ; spectabile, 2; Syriacum, 2; ternatum = Pinellia tuberifera; variolatum, 5 ; vulgare, $6 ;$ Zelebori, 6 .

A. Mature lvs. cordate, oblong-ovate.

1. píctum, Linn. f. (A. Córsicum, Lois.). Lvs. appearing in spring, long-petioled, light green : spathe bright violet, swollen at the base : spadix purple-black, exceeding the spathe. Corsica, Balearica, etc.-Hardy.

AA. Mature lvs, hastate or sagittate.

B. Tuber round-flattened or oblate, the lvs. and peduncles urising from a depressed center: lvs. appearing before the spathe.

2. Dioscorldis, Sibth. \& Smith (A. spectábile, Regel. A. Syriacum, Blume. A. Cýprium, Schott.). Leaf- 
blade oblong-triangular or ovate-triangular: spathe tube pale within, the limb 6-8 in. long, lanceolate-oblong, and colored with large lenticular purple spots: spadix short, included. Asia Minor.-Runs into many forms, with variously marked spathes. Pots.

3. detruncatum, Meyer. Lvs. more or less truncate at the base, the blade shorter than in the last: yellowish green and purple-spotted, large (10-15 in. long) and short-stalked, the limb acuminate. Persia.-Hardy.

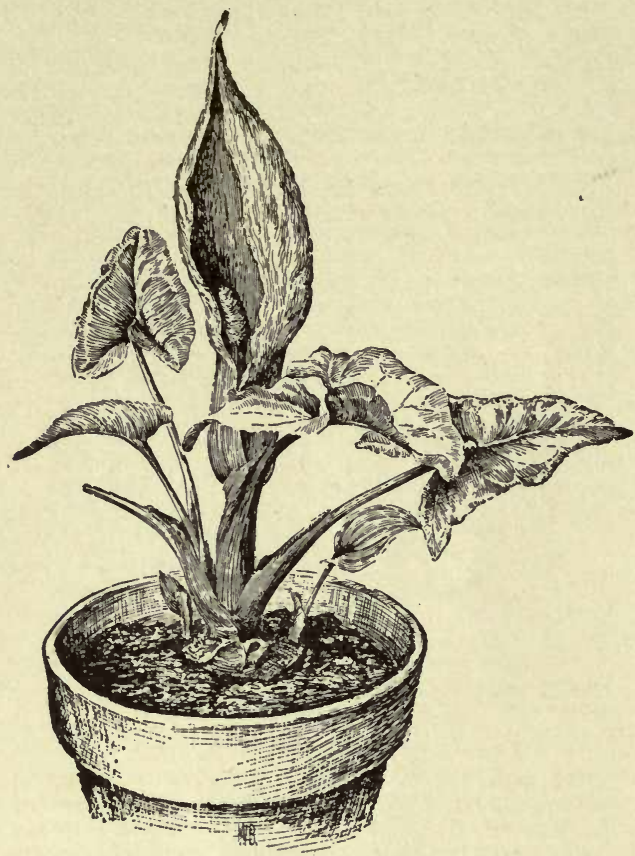

146. Arum Italicum $(\times 1 / 4)$.

4. Palæstinum, Boiss. (A. sánctum, Hort.). BLACK Calla. Solomon's Lily. Lvs, cordate-hastate, 6 in. broad across the base and about equal in length, the middle lobe broad-ovate and nearly blunt: spathe about the length of the leaf, with a short green tube, and an elongated lance-oblong-tapering limb. which is greenish on the outside and continuous black-purple within, the tip sometimes recurving: spadix shorter than the spathe, the upper part dark colored. Palestine. B.M. 5509. Gn. 45, p. 311. - Perhaps the most popular Arum at present, being grown in pots as an oddity.

5. orientàle, Bieb. A foot high : lvs. brownish, broadly hastate-sagitate, the front lobe oblong-acute : spathe tube oblong-ovoid and white within, the limb ovate to oblong and intense black-purple (rarely pale), resembling $A$. maculatum. $-\mathrm{A}$ hardy species from Asia Minor, running into many forms. Some of the plants referred here are $A$. nigrum, variolatum, Nordmanni, gratum, Schott.; $A$. elongatum and $A$. albispathum, Steven (not A. albispathum, Hort., which is A. Italicum).

BB. Tuber ovoid or oblong, propagating horizontally, the lvs. and peduncles arising from the apex: lvs. appearing before or with the spathe.

6. maculatum, Linn. (A. vulgdre, Lam.). LoRDS-ANDLadies. Cuckoo Pint. Wake Robin (in England). About a foot high : lvs. usually black-spotted, hastate or sagittate, the front lobe triangular ovate, about as high as the spathe : the spathe swollen at its base, the margins of the lance-ovate limb becoming inrolled, spotted with purple: spadix shorter than the spathe, purple. Eu.-A hardy species, of many forms. A form with spotless lvs. and a whitish tube with a medial purple zone, is A. immaculatum and Zelebdri, Schott.
Var. angustàtum, Engler, has a narrow light-purple spathe (A. intermèdium, Schur. A. Mályi, Schott.). Var. alplnum, Engler (A. alpinum, Schott. \& Kotschy) has peduncles longer, and an ovate-lanceolate spathe.

7. Itálicum, Miller (A. cylindrdceum, Gasp.). Fig. 146. Larger than the last: Ivs. hastate, nearly truncate below, light-veined : spathe scarcely swollen below, the limb erect and not expanding and including the short spadix (tip sometimes deflexed after flowering). Yellowish or white and faintly striate. Eu. B.M. 2432.-A hardy species; also grown in pots. In the open, the lvs. appear in the fall. A very variable species. Var. Canariénse, Engler (A. Canariénse, Webb. \& Berth.), has narrow leaf-lobes and spathe. Var. concinnatum, Engler (A. concinnatum and marmoratum, Schott.), has broad gray-spotted lvs. Var. Byzantinum, Engler, (A. Byzantinum, Schott.), has spathe tube oblong, white inside and purple at the mouth, and an acuminate purple or green limb. Var. albispathum, Hort., has a white spathe.

L. H. B.

ARÚNCUS (old name). Rosacex. Tall perennial herbs, often referred to the genus Spiræa, with numerous small diœcious white fls. in panicled spikes: stamens many; pistils commonly 3. Two species, American and Japanese.

sylvéster, Kost. (Spirì̃a Arúncus, Linn.). Tall (5-7 ft.), erect branchy herb : lvs. large, 1-2-pinnate, of 3-7 ovate lfts. : follicles deflexed in fr. Rich woods, N.Amer., N. Eu. and Asia.-A desirable hardy border plant of easy culture.

astilboldes, Maxim. (Spirò̀a A rúncus, var.astilboides, Maxim. S. astilboides, Hort. Astílbe astilboides, Lemoine, Gn. 48, p. 355-6). Dwarfer and more graceful than the above $(2 \mathrm{ft}$.): pedicels erect in $\mathrm{fr}$. Japan. - Neater than the American species. See Astilbe for illustration.

ARUNDINARIA. See Bamboo. L. H. B.

ARUNDO (Latin, reed). Graminea. Tall leafy perennial grasses resembling bamboos, 5-15 ft. high, or even $30 \mathrm{ft}$. in favorable locations. Lvs. broad and gracefully arching : sts. leafy to near the top, terminating in an immense plume 1-2 ft. long: spikelets long and pointed.

Donax, Linn. Giant Reed. Figs. 147, 148. Towering straight stems 8-30 ft. high, which grow very rapidly, clothed with broad, pointed leaves at regular intervals. Grown for lawn decoration and to conceal unsightly objects. In some countries used for laths, woven work and thatching, and the roots as a diuretic. The tall, showy plumes are reddish at first and last a long time. Mediterranean, Orient. Gn. 1, p. $391 ; 3$, p. $493 ; 8$, p. 199 ; 17, p. 407 . P.G. $3: 2$. Var. variegàta, Hort. (var. versícolor, Hort.). Much dwarfer and less hardy than the type, usually 4-7 or even $12 \mathrm{ft}$. high, with elegant longitudinal stripes of creamy white and green. Gt. 39, p. 209. F.S. 14:1425. Var. macrophýlla, Hort. has large, very glaucous Ivs.

conspícua, Forst. f. A rare and handsome form, bearing silky white fls., which are beautiful for months. Less hardy than $A$. Donax, and with narrower lvs. Lvs. 2-4 ft.

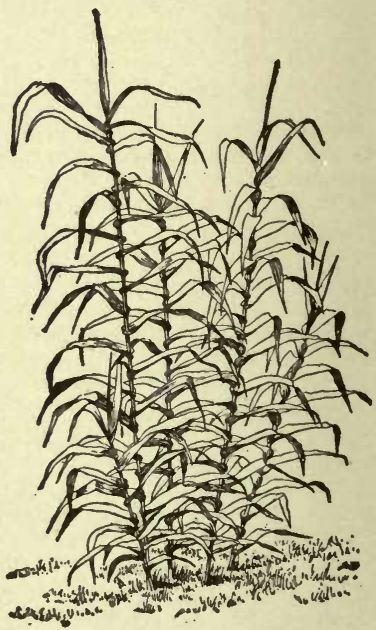

147. Arundo Donax. long, very slender, involute, coriaceous, deeply channeled ; upper surface, margins, and long, slender point roughish. N. Zeal. B.M. 6232 . Gn. 18, p. $479 ; 49$, p. 229.
P. B. KENNEDY 
A rundo Donax is one of the most popular of all grasses or hardy foliage plants, especially wherever the Pampas Grass is not hardy. Although it succeeds almost anywhere in borders, beds, and on lawns, it is really at home in moist soils and is, therefore, one of the standard plants for striking aquatic effects. Prop. chiefly by division, or as follows: The ripe canes may be laid on damp moss during winter, and in a few months nearly every joint will sprout and form a small rooted plant. The canes may then be cut up and the young plants potted off singly, to be planted out the following spring.

\section{J. B. KELLER}

ÁSARUM (obscure name). Aristolochidcece. Low, neurly stemless herbs of a few species, but widely disseminated in N. Temp. zone, with odd purplish or brown fls. on the surface of the ground (or nearly so), underneath the heart-like or kidney-like Ivs.: corolla wanting, but calyx corolla-like stamens 12: ovary inferior. The Asarums inhabit rich, shady woods, spreading on the ground, and the fis. are unseen except by the close observer. They are of easy culture if transplanted to rich, moist places. They make attractive car pets in borders and groves. The species described below are sold by dealers in native plants. Some of the species are reported to have medicinal properties.

\section{A. Plant markedly pubescent.}

Canadénse, Linn. Wild Ginger. Canada Snakeroot. Lvs. about 2 to a plant, thin, kidney-shaped, pointed, with a deep and open sinus, not mottled : fl. slender stalked, with lance-acuminate calyx-lobes an inch or more across at the expanded mouth, chocolate-brown : style 6-lobed. Frequent in woods E. B.M. 2769. A.G. 13: 517 . D. 279 .

Hártwegi, Watson. Tufted, loose-pubescent : lvs. large and thick, cordate, with rounded basal lobes, mostly acute at the apex, margin ciliate, glabrous and mottled above: fl. stout-stalked, the lobes often ovate and long-pointed, the ovary inferior: styles 6. Sierra Nevadas, 4,000-7,000 ft. alt.

Europæum, Linn. Lvs. kidney-shaped, evergreen, dark green, the petiole 3-5 in.: fls. greenish purple, $1 / 2$ in., with incurved lobes : styles 6 , and grooved or 2 parted, recurved. Eu.

\section{AA. Plant slightly or not at all pubescent.}

caudàtum, Lindl. Rather slender, with long rootstocks, sparingly pubescent: lvs. cordate-kidney-shaped, and more or less cupped or cucullate, acute : fis. slen- der-stalked, the calyx-lobes oblong and attenuate : styles united. Pacific coast.

Lémmoni, Watson. Like the last, but lvs. plane or flat, rounded at apex, less pubescent, calyx lobes short. Sierra Nevadas.

Virginicum, Linn. Lvs. broad-ovate or orbicular, rounded at the top, the sinus narrow : fl. short-stalked, purple, the calyx-lobes broad and rounded: styles 6 , 2-lobed; anthers not pointed. Va., S.

arifolium, Michx. Lvs. thickish and usually mottled, orbicular to hastate, obtuse : fl. stout-stalked, urn shaped and much contracted at the throat: styles 6,2 . lobed ; anthers pointed. Va., S.

L. H. B.

ASCLEPIAS (ancient Greek and Latinized name) Asclepiaddcece. MILKWEed. SilkweEd. Many herbs, mostly North American, generally with opposite or whorled lvs., milky juice, and umbels of odd fls. The fls. are gamopetalous, the corolla segments generally strongly reflexed; stamens 5 , attached to the corolla, the anthers more or less united about the stigma; between the corolla and the stamens is a erown of five cornucopia-like appendages ; pollen cohering into a waxy mass (pollinium), which is removed bodily by insects which visit the fl. The pollination of an Asclepias fl. is shown in Fig. 149. The pollen-masses are usually twin (as at $b$ ), and the handle or caudicle lies in a chink on the side of the stigma. The pollen-masses become at tached to the legs or mouth parts of the insect, and are thereby transferred to another $\mathrm{fl}$. The Milkweeds are common in waste places in $\mathrm{N}$. Amer, and are rarely cult. Several species (described below) have been int. by dealers in native plants. The Butterfly-weed and some others are very showy and worthy of more general attention. The large-lvd. kinds are desirable when heavy foliage effects are wanted. They are all perennials of the easiest culture. Prop. by division, rarely by seeds. See Gray, Syn. Fl. N. Amer. 2., pt. I (which is here followed).

\section{A. Fls. (corolla and crown) orange.}

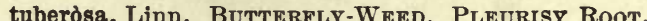
Hairy, 2-3 ft. high, from long, horizontal roots, with more or less alternate, lance-oblong or lance-linear lvs.: umbels several, short-peduncled : pods pnbescent, erect. Dry banks and flelds ; widespread, and not infrequent. B.R. 76. D. 223. - A handsome plant.

\section{AA. Fls. in shades of red or purple.}

Curassávica, Linn. Plant glabrous, $2 \mathrm{ft}$. or less : lvs. opposite and short-petioled, thin, oblong-lanceolate : corolla scarlet: pods glabrous, erect. Fla. and La. B.R. 81.

incarnata, Linn. Glabrous or nearly so, leafy and branching, $3 \mathrm{ft}$ : lvs. opposite, oblong-lanceolate : corolla rose-purple to flesh color, with oblong lobes : pods glabrous, erect. B.R. 250. Var. púlchra, Pers. Hirsute, and lvs. broader. Swamps.-Common.

AAA. Fls. greenish, yellowish or white (sometimes purple-tinged, especially in A. quadrifolia).

B. Pods tomentose and soft-spiny.

speciòsa, Torr. (A. Doùglasii, Hook.). Stem stout and simple, $3 \mathrm{ft}$. or less, fine-tomentose or becoming glabrous: lvs. large and broad, ovate, transversely veined, short-petioled : fls. purplish and large, the peduncle of the umbel shorter thun the lvs. Neb. W. and S. B.M. 4413 .

Cornuti, Decne. (A. Syriaca, Linn.). Differs from last in having obtuse and short hoods to the crown, taller, less pubescent : lvs. oblong or oval : fls. dull purple, in large, more or less nodding umbels. Mn. 7:221.The common milkweed of the E. states.

BB. Pods glabrous and unarmed.

c. Fruiting pedicels decurved or deflexed, the pods erect or ascending.

amplexicaùlis, Michx. Plant glabrous and glaucous : st. decumbent, 1-2 ft. long : Ivs. numerous, cordateovate and clasping, obtuse. succulent : corolla greenpurple. Barrens, N. Car. and S. 
phytolaccoldes, Pursh (A. nivea. Sims). Plant glabrous and green, 3-4 ft., erect: lvs. thin, oval to lanceoval, acuminate and short-petioled : fls. greenish, in large, loose umbels. Moist ground ; frequent. B.M.1181.

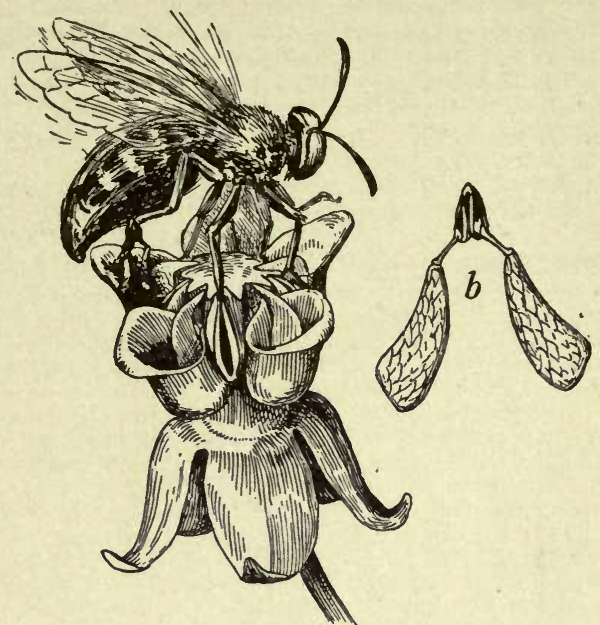

149. Milkweed flower, showing pollination.

variegàta, Linn. Two ft. or less high : lvs. 3-7 pairs, oval, ovate or oblong, thinnish, green and glabrous above and pale beneath: fls. white and pink, in 1-3 umbels. Dry, shady places, Cent. and S. states. B.M. 1182.

eriocárpa, Benth. Densely woolly all over : lvs. alternate or in 3's, long-oblong or lanceolate, short-petioled : fls. dull white, in few or several umbels. Calif.

cc. Fruiting pedicels erect, and the pods erect.

quadrifolia, Linn. About $2 \mathrm{ft}$., not branched, with lvs. towards the top of the st. in whorls of $4:$ lvs. ovate or lance-ovate, acuminate, thin, nearly or quite glabrous : fls. pink to white in 2-4 loose umbels. Dry soil ; frequent. L.B.C. 13:1258.

verticillata, Linn. About $2 \mathrm{ft}$, slender, very leafy : lvs. in whorls of 3-6, very narrow-linear and revolute : fls. greenish white, in many small umbels. Dry soil : frequent. L.B.C. 11: 1067.

Var. pùmila, Gray. A few in. high, from a fascicled root: lvs. flliform, crowded. Plains, W.

Mexicàna, Cav. Height, $5 \mathrm{ft}$. or less : 1vs. in whorls of 3-6, or sometimes opposite or fascicled, linear or narrow-lanceolate : fls. greenish white or purplish in dense, many-fld. umbels. Ore. W. and S. L. H. B.

ASCYRUM (Greek, not hard or rough). Hypericdcen. Low herbs or subshrubs, with bright yellow fls., 2 small sepals and 2 large ones, 4 petals, and many stamens. Dry, sandy soils in E. states (also one or two West Indian and one Himalayan species), sometimes grown in borders. Of easiest culture, but should be covered in winter in the N. Prop. by division; also, by seeds.

hypericoldes, Linn. (A. Crux-Ándrece, Linn.). ST. ANDREw's CRoss. A ft. or less high, branchy : lvs. oblong or obovate, narrowed to the base : styles 2. G.F. 5:257. Mn. 3:65.

stáns, Michx. St. Peter's-wort. Taller, scarcely branched: lvs. broad-oblong or oval and clasping: styles 3-4.

L. H. B.

\section{ASH. See Fraxinus.}

ASIMINA (from Assiminier, a French-and-Indian name). Anondceo. PAPAW (the papaw of literature is Carica, which see). Small trees or shrubs: lvs. alternate, entire, usually deciduous: fls. purple or whitish, campanulate, solitary or few, uxillary; sepals 3 ; petals 6 , the inner ones smaller; stamens numerous : fr. consisting of one or a few large berries. Eight species in E. N. Amer. Ornamental trees or shrubs, with large fls, in early spring, and handsome foliage. Only 2 species are cultivated, of which the arborescent one is the hardier and the handsomer in foliage, while the more tender $\boldsymbol{A}$. grandiflora has larger and showier fls. They grow best in rich and moist soil. They transplant with difficulty. Prop. by seeds sown in autumn, or stratified and sown in spring, or by layers in autumn; also, by root-cuttings. In the North, the seeds should be sown in pots or pans. Description of all species is given in Gray, Syn. Fl. N. Amer. 1, pt. 1, pp. 62 and 464.

tríloba, Dun. (Anòna tríloba, Linn.). Fig. 150. Small tree, $10-40 \mathrm{ft}$ : lvs, cuneate, obovate-oblong, acute, $1 / 2-1$ ft. long, glabrous: fls. with the lvs. from branches of the previous year, green when expanding, changing to purplish red, with yellow in the middle, 2 in. broad : fr. oblong, 2-6 in. long, dark brown. S. states, north to N. York, west to Mich. and Kansas. S.S. $1: 15,16$. Gn. 33 , p. 321. G.F. $8: 495$. A.G. $44: 713$. - This is the only arborescent species of the genus. It is well worth a place in the garden, for its large foliage is very handsome and the fls., appearing in the early spring, are attractive. The large fr. is edible, and may be still improved by cultivation and careful selection of the best varieties. Many people do not relish the highly aromatic flavor; and the large seeds are a disadvantage. The tree has proved hardy in Mass. and Ontario. One or two named forms have been offered.

grandifldra, Dun. Shrub, 2-6 ft.: Ivs. cuneate, obovate or oblong, obtuse, 2-4 in. long, rufous-pubescent when young, at length glabrous and chartaceous : fls. large, appearing with the lvs, outer petals cream-colored, over 2 in. long, much larger than the inner ones: the large fr. is said to be very delicious. S. Georgia, Fla.

\section{ALFRED ReHDER.}

ASPARAGUS, ESCULENT (Aspáragus officindlis, Linn.). Lilidcece. A perennial herb, cult. for the succulent young shoots which arise from the roots in spring. The plant is native to Eu. and Asia, and has been cult. for 2,000 years and more. It was known to the Greeks and Romans. The so-called lvs. of asparagus are really leaf-like branches. The lvs. are the scales, which are well shown on the shoot at the left in Fig. 151. From

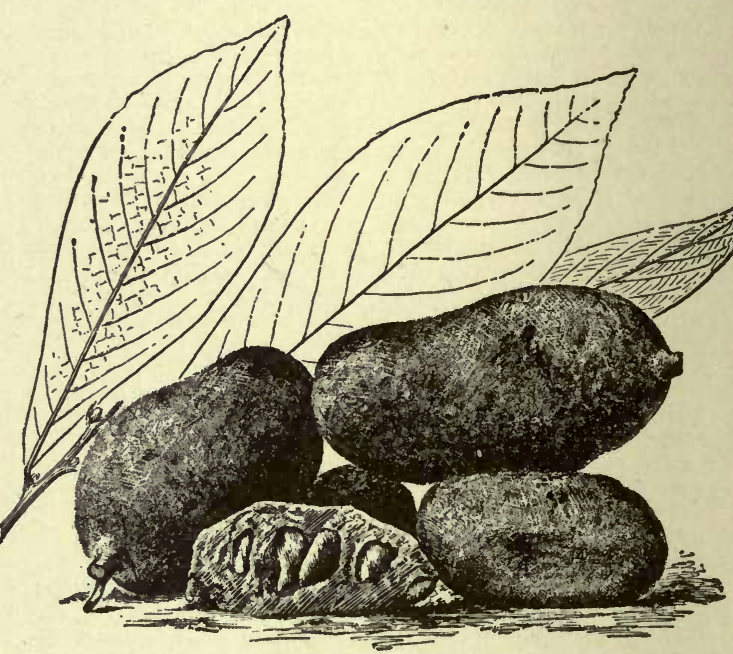

150. Asimina triloba $\left(X^{1 / 3}\right)$.

the axils of these scales branches may arise, $a a$. At $b b$ are shown clusters of branchlets, or "leaves," issuing from the axils of scales or Ivs.

Asparagus, being a rather rugged plant, will live, and in a measure thrive, on almost any kind of soil, even under neglect. One frequently finds apparently thrifty plants in neglected fence rows, or strong stalks pushing up through stone heaps or other rubbish piled several feet in thickness upon an abandoned asparagus bed. The stalks that are wanted for the table and for a dis- 
criminating market, however, are those an inch or more in diameter and deliciously succulent, which one can grow only on good plants set far enough apart on welldrained, well-manured and well-tilled soil. To secure earliness of crop, the land selected for an Asparagus patch should be a warm loam, preferably exposed to south or east. Manures of any kind may be used with greatest liberality, too much being almost out of the question. Unless the soil is already well supplied with vegetable matter, and for that reason rery loose and mellow, bulky manures, such as fairly-well rotted stable manure or rich compost, are almost indispensable at the start. A heavy dressing is to be plowed under. Afterwards concentrated manures, rich in nitrogen and potash, will do very well for locse soils, and may be used broadcast on top, as the crop seems to need them from year to year. Much depends on good plants. These are easily grown. To grow one's own supply for starting a plantation is ordinarily a safer plan than to depend on purchased plants. Use strong 1-year plants in preference to older ones. The male, or pollen-bearing plants, are more vigorous, therefore more productive of good stalks and more profitable than the female or seedbearing plants ; but it is not always an easy task to distinguish the one from the other at an early age unless they bloom. To raise the plants, sow seed in early spring thinly in drills, in a well-prepared seed-bed. Have the drills a foot apart; cover the seed half an inch to an inch deep, and thin the plants early to stand 3 inches apart. With the same attention as that demanded by other close-planted garden vegetables, strong plants will then be the sure outcome. Get the land ready for setting the plants by deep and careful plowing and thorough harrowing. Then plow out furrows 5 or even 6 feet apart. If the demand is for the green stalks (those grown above ground), popular in some markets, the furrows may be made 6 or 7 inches deep. If blanched shoots are wanted (and they are of superior flavor and tenderness, provided they are grown in mellow soil and under high and skillful culture), they have to be grown below ground; hence the furrows are to be made a few inches deeper than for plants set for green stalks. Set the plants in the furrows not less than 2 feet apart, each on a little mound of soil, spreading the roots in the same way as they grew in the seed bed. Cover with mellow soil to the depth of a few inches, and afterwards, in the course of some weeks and by means of suitable tools (smoothing harrow, cultivator, etc.) gradually fill the furrows even with the ground level. A still better plan where the material can be had, is to fill the furrows with fine old compost, as the covering above the crowns of the plants can not be made tco loose. It is advisable, and will insure closer attention in cultivation, to grow some hoed crop, like beets, turnips, cabbage, beans, peas, radishes, etc., between the rows of Asparagus the first year. In the fall, and every fall thereafter, cut the Asparagus stalks close to the ground and remove them from the patch, to avoid the scattering of the seed.

In early spring of the second year, the surface of the ground is to be loosened by shallow plowing or deep cultivating; and when the first sprouts appear, the rows may be hilled up to some extent, especially if blanched stalks are to be grown. The wisdom of cutting that season more than a very few, if any, of the shoots for the table or sale may well be doubted. Plants left intact until the third year will grow much stronger and be more productive afterward. In the absence of a specially devised Asparagus knife, any ordinary table or pocket knife may be used for cutting the shoots, or in mellow soil the shoots may be broken off at the base with the finger. In cutting, be very careful to avoid injury to later shoots or to the crown of the plant. The third season and every year thereafter loosen up the ground as directed for the second season. The shoots are now to be cut indiscriminately and clean, up to the beginning of the green-pea season. After that, allow them to grow undisturbed, but continue cultivation, to keep the ground surface mellow and free from weed growth. For market, wash the freshly-cut stalks and tie them in neat, compact bunches of the size demanded by the particular market, using some bright-colored ribbon, or perhaps rubber bands. If to be shipped, especially for a longer distance, pack the bunches in moist moss or other material that will prevent the stalks from wilting. Variations in the Asparagus plant are due more to differences in culture and environment than to those characteristic of the variety. Americun seedsmen offer the following as distinct varieties : Colossal (Conover's), Palmetto, Mammoth (Barr's), Columbian (Mammoth Columbian White). The last named is perhaps the only one having an undisputed

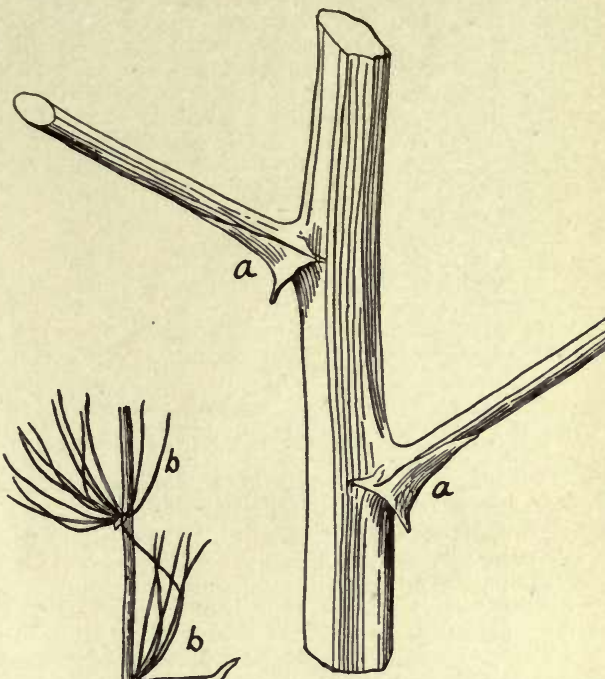

151. Leaves and branches of common Asparagus.

claim to varietal distinction, on account of the white color of its young shoots. To save the seed, strip the scarlet berries off the ripe stalks by hand, or thresh them off with a flail, put them in a sound barrel or tank, and mash them with a wooden pounder, to separate the hard, black seeds from the pulp. Clean them by washing in plenty of water, pouring off the pulp and skins ; dry and store.

In the Atlantic coast states, north of Virginia, the Asparagus rust ( Puccinia Asparagi) has often done considerable damage. Outside of that region this fungous disease is hardly known. Burning the infected stalks is recommended. According to the Massachusetts Experiment Station, "the best means of controlling the rust is by thorough cultivation in order to secure vigorous plants, and in seasons of extreme dryness plants growing on very dry soil with little water-retaining properties should, if possible, receive irrigation." Asparagus anthracnose has appeared in a few instances. Of insect enemies, only two have thus far attacked Asparagus plants in America, namely, the common Asparagus beetle (Crioceris Asparagi, Linn.), and the 12 spotted Asparagus beetle (C. 12-punctata, Linn.). The following remedies are recommended: Chickens and ducks ; close cutting of the young shoots in the early season, and the free use of fresh, air-slaked lime or of arsenites dusted on the dew-wet plants after the cutting period. Even with all kinds of vegetables in abundant supply and much cheaper than ever, there is hardly any danger that a superior article of Asparagus will go begging for customers in any of our markets, or that the grower of such product could not get several hundred dollars per acre for his crop.

There are no books of American origin devoted wholly or chiefly to Asparagus ; but all the vegetable-gardening manuals discuss it.

T. GREINER. 
ASPARAGUS, ORNAMENTAL. Lilideece. The genus Asparagus comprises about 150 species, which are widely dispersed in warm or tropical regions, being particularly abundant in S. Afr. The species are of very various habit. Some are climbers, some drooping or trailing, and some erect-bushy. Many of them are highly prized for their very graceful and fine foliage. Some species even surpass the most delicate ferns in elegance of habit and delicacy of spray. The foliage is really composed of leaflike branches (cladophylla) rather than of true lvs. (see Fig. 151, and the discussion of it). Although all are perennial, the sts. of some kinds annually die down or cast their lvs. With the exception of $A$. verticillatus, the following species must be grown under glass, except in S. Fla. and S. Calif. They are of easy culture. Best when propagated by seeds (which are usually freely produced), but are also multiplied by division and cuttings. Roots generally tuberous. Mongr. by Baker, Journ. Linn. Soc. 14 (1875); account of cult. species by Watson, G.C. III. 23:122, 147, 178.

\section{A. Foliage ovate.}

medeololdes, Thunb. (Myrsiphýllum asparagoides, Willd.). Smllax of florists. Fig. 152. Tall, slender, glabrous twiner : cladophylla 1 in. or more long, thick, glossy green on both sides, strong-nerved, standing edgewise to the branch : fls. single, fragrant : berries dark green. S. Afr. B.M. 5584. - Much grown by florists for use in decorations (see cultural notes below).

AA. Foliage narrow, but distinctly flat and plain.

Spréngeri, Regel. Figs. 153, 154. Tubers fleshy, white: branches long and slender, branched, drooping: lvs. 1 in. long, glossy green: fls. small and whitish, in short racemes, fragrant: berry small, coral-red. Natal. Gn. 54, p.88. A.G. 18:86, 883; 19:101. Gng. $4: 167$. F.E. 9: sup Mn. 8:151.-One of the most popular basket and decorative plants, of easy cult. Prop. by division, but most efficiently by seeds, which can be purchased. At a night temp. of $65^{\circ}$ they germinate in 4-5 weeks. Int. to horticulture by Dammann \& Co., Italy, in 1890 , and named for their collector, Herr Sprenger. There is a white-lvd. variety.

lùcidus, Lindl. Climber : tubers 11/2in. long : sts. 4-6 ft., spiny, branching : lvs. narrow and curved, 2 in. or less long, $2-6$ in a cluster, more or less deciduous : $\mathrm{fls}$. small, white, axillary : berries pink or white. $1 / 4 \mathrm{in}$. in diam. China and Japan, where the tubers are eaten (A.G. 13:78).-Needs warm treatment.

\section{AAA. Foliage filiform or thread-like.}

plumosus, Baker. Fig. 155. Tall-climbing, with spiny terete sts. (10-15 ft.): branches flattish and spreading horizontally in elegant sprays : lvs. short, bright green, in clusters : fls. white, commonly solitary : berry black. nearly globular, 1-seeded. S. Afr. G.C. III. 23:146.One of the most popular of decorative plants, the cut strands holding their shape and color for weeks ( see note on culture below). It is propagated by seeds, division, and cuttings. Several garden forms. Var. nànus, Hort., Fig.

\section{h}
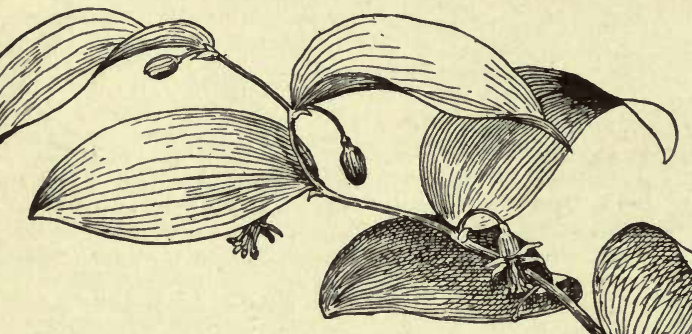

152. Asparagus medeoloides, or Smilax. Natural size.

155 (but not dwarf, as its name implies), is commoner than the type, from which it is distinguished, according to Watson, "by the fulness and flatness of its fronds, and by its refusal to multiply by means of cuttings, division of the plant or seeds being the only methods that answer for it." A.F. 11:1178. Var. tenuíssimus, Hort. (A. tenuissimus, Hort.). Fig. 156. Only partially climbing, very light

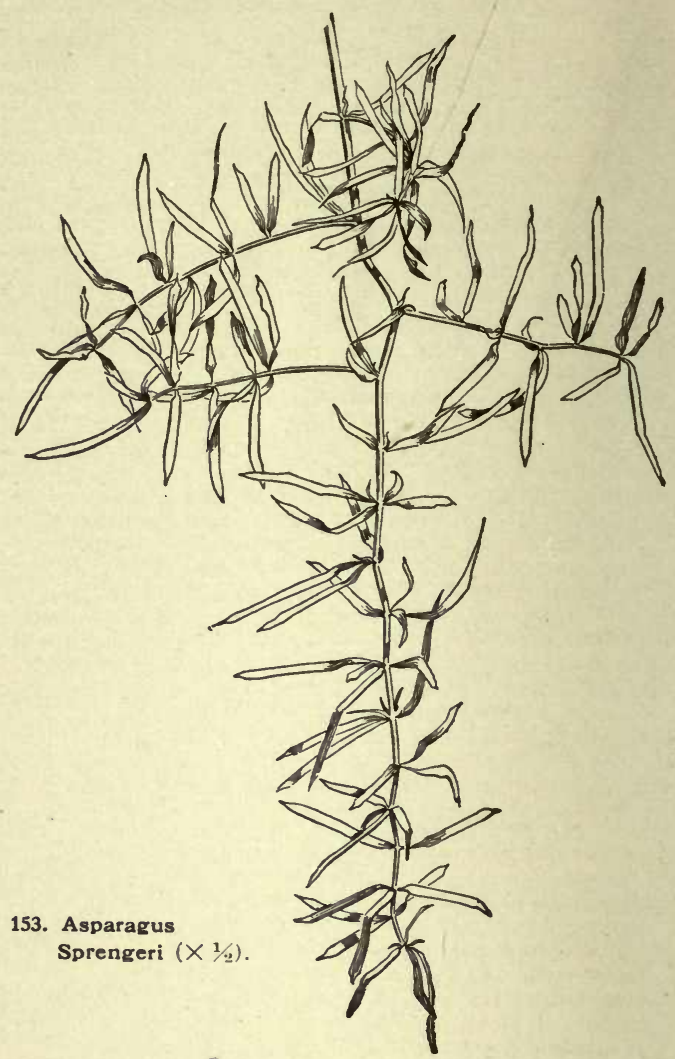

green: sprays more open and delicate than those of the type, because of the fewer and longer lvs. Var. declinatus, Hort., has drooping sprays. Var. cristàtus. Hort., has forking-tasseled sprays.

Comorénsis, Hort. Similar to A.plumosus : more robust, darker green, softer foliage: berries globular. G.C. III. 23:181. I.H. 42, p. 61 .

críspus, Lam. (A. decúmbens, Jacq., and Hort.). Tubers many, oblong: climbing ( $2-4$ ft.), the sts. fine or almost hair-like and annual, the branches zigzag: lvs. numerous, usually in close pairs, very short (1/4in.) glaucous-green : fls. white, with orange anthers : berry large (1/2in. long), oval, soft, brown, about 6-seeded. S. Afr. A. deflexus. Hort., is probably a form of this species.

verticillatus, Linn. Tall-climbing (10-15 ft.) hardy plant : rootstock woody: sts. stout (1/2in. in diam.), said to be edible when young, but becoming woody, spiny: lvs. in tufts, hair-like, 2 in. or less long: fls. small : berries red. Persia, Siberia

retrofráctus, Linn. ( $A$. retrofráctus arbdreus Hort.). Sts. slender (4-8 ft.), becoming woody and gray, scarcely climbing, zigzag, spiny, the branches wiry: lvs. in close clusters, green, hair-like, 1-2 in. long: fls. white, small, umbellate : berry small, nearly globular, 1-seeded. S. Afr.

virgatus, Baker. A bushy, branchy plant 3-6 ft. the branches arching: lvs. in 3's, dark green, 1 in. or less long : fls. small, white: berries red, 1-seeded. S. Afr.

A acutifòlius, Linn. Hardy, rigid, 5 ft.: lvs. tufted, hair-like: fls. yellow : berry red. Eu. - A. AEthiòpicus, Linn. Suggests A. 
sending up new shoots. If the bed is well made in the beginning, the Asparagus need not be disturbed for eight or ten years. However, at the end of that time it is well to take the plants up and fill the beds with fresh soil and manure.

In the spring, when the sun gets high, the Asparagus houses are shaded with a light coating of white lead, whiting and kerosene oil. This is absolutely necessary, as the summer sun would in a very short time burn the tops of the vine. The vine flowers in the fall, and only on strings that have been matured six months or more.

The vine alone is not the only source of profit. When the plant is a year old, a few of the most nearly perfect sprays may be taken without injuring its growth. These are very desirable in the market. There is, of course some waste in working up the Asparagus to be shifted, but, on the whole, it is very slight. The different forms in which it is sold utilize by far the greater part of it.

Insects destroy the shoots and sprays. This is prevented to a great extent by insect powder. The cutworms do the most damage. About the only way to get rid of them is to pick them off the strings during the night, as they generally seek shelter under the thick clusters of the plant at daylight. There are many drawbacks in growing Asparagus, among which are expensive houses, the slow growth of the plants (which makes it necessary to wait at least two years before receiving any return from the expenditure), injury from insects, and the great amount of labor involved in looking after the houses.

William H. ELLIOTt.

ASPASIA (Greek personal name, of little significance here). Orchiddcea, tribe Vándece. Pseudobulbous: Ivs. sub-coriaceous : racemes radical: perianth spreading : lateral sepals free, the upper one connate at the base of the petals : labellum concave: column semi-terete : pollinia 2. Eight or 10 Trop. Amer. species. The genus is closely allied to Odontoglossum.

epidendroides, Lindl. Lvs. linear-lanceolate : racemes, with about $4 \mathrm{fls}$; erect : sepals and petals streaked with brown ; labellum white, dotted with violet-purple. Panama and Colombia.

OAKES AMES.

\section{ASPEN. See Populus.}

ASPER ELLA (diminutive of asper, rough). Syn., As prella. Graminea. Perennial grasses, with looser and more slender terminal spikes than Elymus. Spikelets usually in pairs, on short pedicels, empty glumes wanting or appearing as simple rudiments in the lowest spikelets of each spike. Species 4. N.Amer., Siberia, New Zeal.

Hystrix, Humb. Bottle-BrUsh Grass. Spikelets stand out at right angles, suggesting brushes used for cleaning bottles. A native grass, growing in woodlands and on the borders of thickets; sometimes used for lawn decoration.

P. B. KeNNEDY.

ASPERULA (roughish; referring to lvs.). Rubidcece. Mostly dwarf, hardy herbs, for borders, rockeries and shady places, with square stems, whorled lvs, (some of the Ivs. are really stipules), and many small, 4-parted fis., produced freely from May to July. The commonest species is A. odorata, the Waldmeister of the Germans, which is used in their Maitrank, or May wine, and in summer drinks. The dried lvs. have a hay-like fragrance, lasting for years, and are often kept with clothes. The plant occasionally escapes from gardens. $A$. hexaphylla, with its delicate, misty spray, is used with sweet peas and other cut-flowers that are inclined to look lumpy. Other plants for this purpose are Gypsophila paniculata, Statice latifolia, and several Galiums, all of which have small, abundant fls. in very loose panicles on long, slender stems. In half-shaded and moist soil, Asperulas grow very luxuriantly until late fall. In dry and sunny places they soon become stunted, and die down before the season is over. Prop. by division and by seeds.

$$
\text { A. Plants perennial: fls. white. }
$$

B. Corollas 4-lobed.

odoràta, Linn. SweET WoopruFr. Fig. 157. Habit erect or ascending : height 6-8 in. : lvs. usually in whorls of 8 , lanceolate, finely toothed or roughish at the margin : corollas campanulate : seeds rough. Eu, and Orient.-Increases rapidly, and is used for carpeting shady places, and for edgings.

hexaphylla, All. Plant-stem glabrous : habit ascending, slender : height 1-2 ft.: lvs. in whorls of 6 , linear, acute, rough : corollas tubular-funnel shaped : panicles

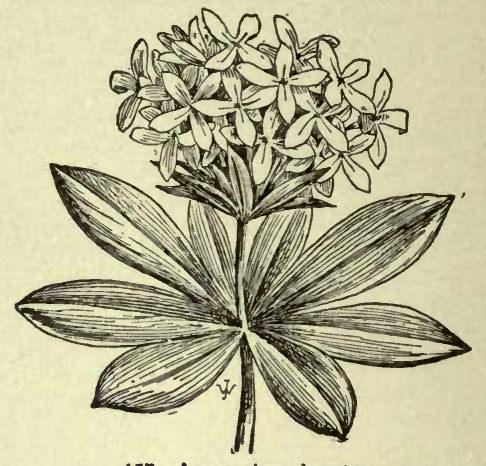

157. Asperula odorata.

very loose : fls. larger than the bracts : seeds smooth. Italy, Hungary, Pyrenees on high passes and dry $\mathrm{mt}$. sides. - Well grown specimens may be $3 \mathrm{ft}$. in diam. and nearly as high.

BB. Corollas often 3 -lobed.

tinctoria, Linn. DYER's WoODRUFF. Habit procumbent unless supported : height 1-2 ft.: lvs. linear lower ones in 6's, middle ones in 4's, uppermost ones in 2's : bracts ovate : fls. reddish on outside : roots large, creeping widely, reddish. Dry hills and rocks of Eu.

AA. Plants annual: fls.blue.

orientàliss, Boiss. \& Hohen. (A. azùrea and A. seṫ̀sa, Jaub. \& Spach. A. azurea-setosa and A. setosa-azurea, Hort.). Height $1 \mathrm{ft}$ : lvs. in whorls of 8 , lanceolate, bristly: fls. longer than the bracts. Eu. and Orient. N. $1: 124$.

J. B. KeLLer and W. M.

ASPHODEL. See Asphodeline and Asphodelus.

ASPHODELINE (name modified from Asphodelus). Liliacece. Hardy herbaceous plants, distinguished from Asphodelus by their erect and leafy sts. They have long racemes of yellow or white fls. in June and July. All the older species were described under Asphodelus. In 1830, Reichenbach made the new genus Asphodeline for $A$. lutea and others. The only species advertised in America is $A$. luteus, but all those described below are likely to be in cult. Monog. by J. G. Baker in Journ. Linn. Soc. 15: 273-278 (1877). W. M.

The culture of Asphodeline lutea is simple. Any soil will suit. Partial shade is allowable, but fls, are often better in the sun. Prop. readily by division.

$$
\text { A. Stems leafy up to the raceme. }
$$

$$
\text { B. F'ls. yellow. }
$$

lùtea, Reichb. (Asphódelus lùteus, Linn.). TROK AsPHODEL of the ancients, or KING'S SPEAR. Height 2-4 ft.: roots thick, fleshy, stoloniferous: lvs. 3-12 in. long: margins rough: racemes 6-18 in. long, 3 in. wide: bracts large, membraneous, persistent. Italy, Mauritania and Algeria to Tauria and Arabia. B.M. 773. L.B.C. 12:1102 as $A$. Tauricus. - The best species.

$$
\text { BB. Fls, white. }
$$

Taùrica, Kunth. Height 1-2 ft.: roots slender : lvs. 3-9 in. long; margins membranaceous: raceme 6-12 in. long, 11/2-2 in. wide: bracts $9-12$ lines long. Caucasus, Tauria, Syria, Asia Minor, Greece. G.C. III. 21: 175.

AA. Stems leafy only a third or half the way to the raceme.

B. Fls. white: raceme dense.

globifera, J. Gay. Height 2-3 ft.: capsule globose Cappadocia. 
BB. Fls, yellow : raceme lax.

C. Bracts large, 6-12 lines long, long-cuspidate.

tenùior, Ledeb. Height $1 \mathrm{ft}$. Caucasus, Armen., $\mathbf{N}$. Persia. B.M. 2626. - Smaller than A. luteus, with finer lvs, and smaller, fewer and paler fls. Especially distinguished by the stalk being naked at the upper part, below the raceme of fls., and the bracts as short as or shorter than the peduncle.

cc. Bracts small, $1 \frac{1}{2}-3$ lines long, short-cuspidate.

Libúrnica, Reichb. (A. Crética, Vis., not Boiss.) Height 1-2 ft. Greece, Crete, Dalmatia, Austria, Italy, not Asia Minor. L.B.C. 10:915 as A. Cretica.

brevicaùlis, J. Gay (A. Crética, Boiss., not Vis.). St. often flexuose, that of all the others here described being erect and strict. Asia Minor, Syria, Palestine, Egypt.

AAA. Stems leafy only at the base: fls. white: rucemes dense.

B. Racemes usually simple.

C. Stems having leaf-scales : height $8 \mathrm{ft}$.

imperialis, Siehe. Tallest species of the genus : fls. large, reddish white. Cappadocia. G.C. III. 22: 397.

cC. Stems not having leaf-scales: height 11/2-2 ft.

Damascèna, Baker. Height $1 \frac{1}{2}-2 \mathrm{ft}$ : : bracts membranaceous, lanceolate, the lowest 9-12 lines long. Mt. Lebanou.

Balánsæ, J. Gay. Height 2 ft.: bracts scarious, 6-9 lines long. Cilicia. Gt. 46, p. 521. G.C. III. 23: 111 .

BB. Racemes much panicled.

isthmocárpa, Gay. Height $2 \mathrm{ft}$. Cilicia. G.C. III. $23: 117$.

ASPH0́DELUS (Greek name of unknown origin). Liliacece. Hardy herbaceous stemless plants, with white, lily-like flowers in long racemes, fleshy, fascicled roots, and firm, linear, radical,tufted leaves. Perianth funnel-shaped; segments 6 , oblong-ligulate, obtuse, equal, with a distinct nerve on the back, and always ascending. The Asphodel of the ancients, or King's Spear, is Asphodeline luteus, which see. Homer mentions the Asphodel meadows of the dead, where the shades of heroes congregated in Hades. The Asphodel in Greek mythology was the peculiar flower of the dead. It has always been a common weed in Greece, and its pallid yellow flowers are associated with desert places and tombs. The word daffodil is a corruption of Asphodel. The Asphodel of the early English and French poets is Narcissus Pseudo-narcissus. J. G. Baker, in his re. vision of the genus in Jour. Linn. Soc. 15: 268-272 (1877), refers 40 species of other botanists to $A$. ramosus, the dominant type, of which he makes three subspecies. These subspecies are here kept distinct, for horticultural purposes, as good species. They are the ones first described below. A.ramosus and $A$. albus are the only current trade names in America. Culture simple; see Asphodeline.

$$
\begin{gathered}
\text { A. Plant perennial: lvs.3-angled. } \\
\text { B. Scape long. }
\end{gathered}
$$

C. Racemes simple or sparingly branched.

álbus, Miller, not Willd. Branching AsphodeL. Bracts buff colored when young : flaments deltoid at the base : capsules medium-sized, 5-6 lines long, subglobular or ellipsoid. Southern Eu.

cerasiferus, J. Gay. Bracts pale yellow : tilaments wedge-shaped at the base, but rapidly becoming awlshaped : capsule large, 8-10 lines thick, flattish globular, umbilicate. Western Mediterranean region.

cc. Racemes much branched or panicled.

microcárpus, Vis. (A . astivus, Brot.). Bracts pale yellow at first: filaments 4-angled at the base : capsule small, 3-4 lines long, obovoid-globose. Mediterranean, Canaries.
BB. Scape short, almost wanting.

acaulis, Desf. Lvs. 6-20, in a dense rosette, $3-4$ in. long, minutely pubescent: fls. 6-20, in a crowded corymb: segments of perianth 2-3 lines wide. Algiers. B.M. 7004.

AA. Plant annual: leaves cylindrical, hollow.

fistuldosus, Linn. Height 16-20 in. : Ivs. 12-30, in a dense rosette, 6-12 in. long, striate, awl-like, glabrous : segments of perianth 1-2 lines wide, lined with pink: buds pink; fls. pinkish. France and Portugal to Syria, Arabia and Afghanistan. B.M. 984. L.B.C. 12:1124. - Needs protection under glass in winter. If removed early in autum to a greenhouse, it may be induced to seed freely.

A. Créticus =Asphodeline Liburnica. $-A$. lùteus $=$ Asphodel ine luteus. $-A \cdot{ }^{\prime}$ Villársii, Verl., is a form of A. ramosus, from E. France, with long, dense racemes and dark brown bracts. E. France, with long, dense racemes and dark brown bract.
N. $1: 125$.

ASPIDISTRA (Greek, a small, round shield; referring, probably, to the shape of the stigma). Lilideec. A popular florists' plant, grown for its stiff, shining, beautiful foliage, and still more interesting for its remarkable fis., which are inconspicuous because borne close to the ground. The casual observer never suspects that Aspidistra is a liliaceous plant. The parts of the fl. in monocotyledons are typically in 3's. The genus Aspidistra is considered abnormal, as usually having its parts in 4's. This tetramerous state (which is here considered the normal one, and described below) is pic. tured in B.M. 2499, but the species was first described upon a trimerous state, and pictured in B.R. 628. In $A$. lurida the trimerous state must be regarded as an exceptional reversion: in $A$. typica, B.M. 7484, the trimerous state is thought to be constant. Of all plants that

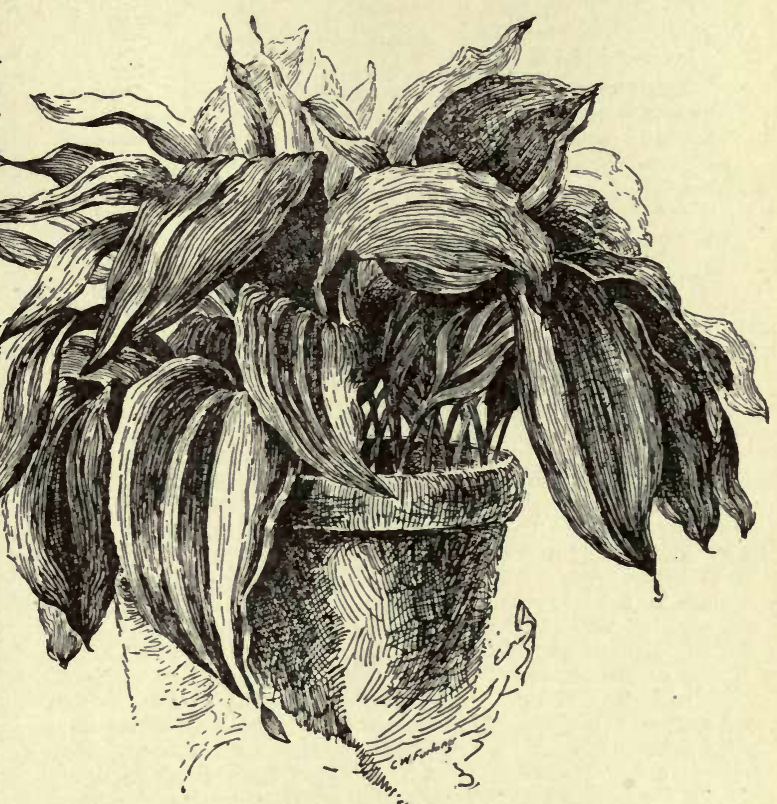

158. Aspidistra lurida

are rented for the temporary decoration of public halls, Aspidistra lurida is one of the greatest favorites, as it stands much abuse, such as dust, dry air, and lack of water and light. It is, however, naturally fond of water, and grows freely on the margins of ponds or streams, especially south. In rich soil the variegation often disappears altogether until the plants begin to starve, hence a compost of nearly half sand is desirable. The best method of propagation is by means of division in spring. before active growth begins, as the young leaves are not then disfigured.

lùrida, Ker-Gawl. Fig. 158. Lvs. 15-20 in. long, stiff, evergreen, oblong-lanceolate, sharp-pointed, radical; 
blade narrowed into a channeled petiole a third of its length: fls. lurid purple, on short 1-fld. scapes; perianth segments 8 ; stamens 8 ; stigma broadly shield-shaped, like a small mushroom. China.-The variegated form is more commonly grown, the alternation of the green and white stripes being singularly beautiful. No two Ivs. are exactly alike.

E. O. ORPET and W. M.

\section{ASPIDIUM. See Dryopteris and Polystichum.}

\section{ASPLENENDRIUM. See Thamnopteris.}

ASPLENIUM (Greek, not the spleen; referring to supposed medicinal properties). Polypodidcece. A large, widely distributed genus of ferns, containing some 200 species. Easily distinguished by the free veins, and by the elongated sori covered by an indusium, which normally is attached to one side of a vein.

Aspleniums enjoy an abundance of moisture at the roots, but they will turn brown in the winter months in an excessively moist atmosphere. They should be kept in a very lightly shaded position. A good potting material consists of equal parts of rich soil and leaf-mold or peat. The following are some of the most useful commercial kinds : $A$. Belangeri, height $2 \frac{1}{2} \mathrm{ft}$.; $A$. bulbif erum, $2 \mathrm{ft}$; $A$. laxum, which grows quickly into a handsome specimen about $20 \mathrm{in}$. high, and seems to stand the hot, dry American summers better than other species ; $\boldsymbol{A}$. salicifolium; and $A$. viviparum, which is dwarf, compact, with lace-like fronds, and easily propagated. For hanging baskets, $A$. flaccidum is best. The foregoing species and others of like habit develop smal plantlets on the surface and edge of pinnæ. As soon as these are sufficiently strong, they may be detached, with a small piece of old pinnæ, and pricked into shallow pans, the older part being placed below ground to hold the young plant firmly in position until roots have formed. The best soil for this purpose is composed of equal parts of fresh garden soil,leaf-mold or fine peat, and sand. Plant very firmly, and place in a shady, moderately moist and close position, where in 10 to 15 days they will make roots. The foregoing ones do best in a temperature of $50^{\circ} \mathrm{F}$. A. cicutarium is easily grown from spores, and is very useful for fern dishes.

NICHOL N. BRUCKNER.

Alphabetical list of species described below : A. Adiantum-nigrum, 14 ; affine, 13 ; angustifolium, 10 ; Bap tistii, 12 ; Belangeri, 23 ; bulbiferum, 18 ; cicutarium, 20 ; cuneatum, 15 ; ebeneum, 8 ; ebenoides, 4 ; Filix-fœmina, 25 ; foniculaceum, 16 ; fontanum, 17 ; formosum, 9 ; fragrans, 16; Hemionitis, 2; laxum, 18; myriophyllum, 19; nobilis, 24; obtusilobum, 21; palmatum, 2 ; parvulum, 7 ; pinnatifidum, 3 ; platyneuron, 8 ; rhizophyllum, 19 ; rutæfolium, 22; salicifolium, 11; serratum, 1; spinulosum, 27; thelypteroides, 26 ; Trichomanes, 6 ; viride, 5 ; vivip arum, 24. The following are native and hardy: Nos. $3,5,6,7,10,25,26$.

\section{A. Sori linear or oblong, straight, borne on the back of the $l f$.}

B. Lf. simple, with a serrate margin.

1. serràtum, Linn. Lf. 1-3 ft. long, on a very short stipe, 2-4 in. wide, gradually narrowed below: sori 1 in. or more long. Fla. to Brazil.

\section{Bв. Lf. lobed or pinnatifid.}

2. Hemionitis, Linn. (A. palmatum, Lam.). Lf. 4-6 in. each way, hastate, with a triangular terminal lobe and two lateral ones, and a large, rounded sinus at the base: sori often over 1 in. in length. Spain, Canary Islands. S. $1: 586$.

3. pinnatifidum, Nutt. Lvs. clustered, from a short rootstock, 3-9 in. long, with mostly rounded lobes at the base and terminating in a slender point ; texture thick, herbaceous; occasionally rooting at the tip. Pa. to Ala. S. $1: 628$.

4. ebenoldes, R. R. Scott. Texture thin : lvs. 5-10 in. long, with a few irregular divisions near the base, and a long, slender, much-incised apical portion, occasionally rooting at the apex. A very rare native species.
BBB. Lvs, once pinnate.

C. Pinna less than $3 / 4$ in. long, blunt.

D. Rachises greenish.

5. víride, Huds. Lvs. 3-8 in. long, scarcely more than $1 / 2$ in. wide, with numerous rather distant lfts., which are ovate and deeply crenate : sori abundant, oblique. A subalpine species of N. Eu. and N. Amer. S. 1:661.

\section{DD. Rachises purplish or blackish.}

6. Trichomanes, Linn. Lvs. densely clustered, 3-8 in. long, $1 / 2$ in. wide, with densely crowded oval leaflets, which are slightly crenate on the upper side and suddenly narrowed at the base. Northern hemisphere generally. A.G. 1892: 653 . S. $1: 653$.

7. párvulum, Mart. \& Galeotti. Leaf 5-9 in. long, with 20-30 pairs of mostly opposite lfts., which are $1 / 4-3 / 8$ in. long, rounded at the outer margin and squarely truncate at the base. Southern states and Mex.

cc. Pinnoe $8 / 4-1$ inch long, with a strong auricle at the upper side of the base or deeply incised on the upper margin.

8. platyneùron, Oakes (A. ebenèum, Ait.). Lvs. 6-15 in. long, with 30-35 pairs of lfts. which have an enlarged auricle at the upper side at the base, the lower lfts. reduced to mere triangular auricles : sori, when mature, covering the entire surface. Canada to S.Amer. A.G.1892:654. S. $1: 535$.

9. formòsum, Willd. Lvs. $12-16$ in. long, with numerous alter-

nate pinnæ which are mostly deflexed, with the upper margin deeply incised and the lower margin toothed : sori 3-5 to each lft. Trop. Amer. S. 1:576.

\section{ccc. Pinnoe 2-6 in. long, linear or lanceolate.}

10. angustifdlium, Michx. Lvs. 18-24 in. long on stout stalks, 4-6 in. wide, with $20-30$ pairs of nearly sessile pinnæ, which are truncate at the base and extend to a tapering point ; fertile pinnæ narrower and more distant. Moist woods northward. S. 1:496.

11. salicifolium, Linn. Lvs. 12-18 in. long, with about 20 distinctly stalked horizontal pinnæ, which are wedgeshaped at the base, and curve upward to a long point : sori strongly oblique to the midrib, wide apart, not reaching either margin or midrib. W. Ind. to Braz.

\section{вввв. Lvs. 2-4 pinnate.}

c. Ultimate divisions linear or cuneate: venation somewhat fan-shaped: texture thick.

12. Báptistii, Moore. Leaf bipinnate, with broadly ovate pinnæ 5 in. or more long, each with about 4 stipitate linear toothed pinnules; sori nearly parallel with the midvein and close to it; rachises scaly, with purplish lined scales. South Sea Islands.

13. affine, Swz. Leaf 9-18 in. long, with numerous pinnæ on either side, the lower ovate deltoid, the upper lanceolate; pinnules incised: sori linear. Mauritius and Ceylon to E. Ind.

14. Adiántum-nigrum, Linn. Stalks brownish, lvs. 3pinnatifid from winged rachises, triangular, 5-9 in. long; ultimate divisions ovate, sharply incised and serrate on both sides. Old World generally. S. 1: 486. 
15. cuneatum, Lam. Lvs. 12-16 in. long, 4-6 in. wide, tripinnate below, the ultimate divisions broadly obtuse above and strongly cuneate below ; sori linear, usually long for the size of the segments. Trop. regions generally.

16. fràgrans, Swartz (A. faniculdaceum, Kunth.). Lvs. 2-3-pinnate; ultimate segments lanceolate, sharpserrate above; veins simple or the lowest forked : sori oblong, extending from midrib to near base of the lobes: petiole brownish, rachis flattened. W. Ind. S. 1:577.

cc. Ultimate division rhombic, sharply spinulose: texture herbaceous.

17. fontànum, Bernh. Growing in dense clusters: 1vs. 3-6 in. long, 1 in. or more wide, 2-pinnate; segments with 2-5 spinulose teeth which are widely divergent: sori at maturity covering nearly the entire surface of the segments. Eng. and Spain to the Himalayas. S. $1: 574$.

ccc. Ultimate divisions longer, not spinulose: texture membranous or herbaceous.

18. bulbiferum, Forst. ( $A$. laxum, Hort.). Lvs. 1-11/2ft. long, 6-8 in. wide, 3-pinnatifid; pinnæ tapering to a slender toothed point : often bearing bulbs from which new plants originate while still attached to the leaf. Afr. and Australasia. S. 1:508.

19. rhizophýllum, Kunze (A.myriophýllum, Presl.). Fig. 159. Growing in extensive tufts, with grayish brown stalks and rachises : lvs, 6-15 in. long, 3-pinnate or 4-pinnatifid, the ultimate segments frequently deeply 2-lobed with a single sorus to each division. Fla. to S. Amer.

20. cicutàrium, Swz. Lvs. 3-pinnatifid with a winged rachis, 8-18 in. long: pinnules ovate, with 5-7 narrow divisions, each bearing a single sorus; texture thin, membranous. Trop. Amer., rare in Fla.

AA. Sori linear, marginal or submarginal, on narrow, linear, ultimate divisions of the leaf. (Darea.)

\section{B. Lvs. bipinnatifid, less than a foot long.}

21. obtusílobum, Hook. Lvs. 4-7 in. long, 2 in. wide or less, with about 10 pinnæ, which are made up of 5-7 narrow segments bearing occasional sori on the outer margin of the segments. New Hebrides and Fiji Isls. S. $1: 624$

BB. Lvs. 2-pinnate or 3-pinnatifid, over a foot long.

c. Pinna short, with close segments.

22. rutæfolium, Kunze. Lvs. 13-15 in. long, with 12-20 pinnæ on each side, eich with 7-11 narrow segments, 2 or 3 of the lower ones 2 -fld. or rarely 3 -fld. S. Afr., Ind. and Jap.

23. Belángeri, Kunze. Fig. 160. Lvs, 15-18 in. long, 3 in. wide, with numerous horizontal pinnæ on each side, eut into about 12 segments on either side, which are set nearly at right angles to the rachis; the lower basal segment often forkerl. E. Ind.

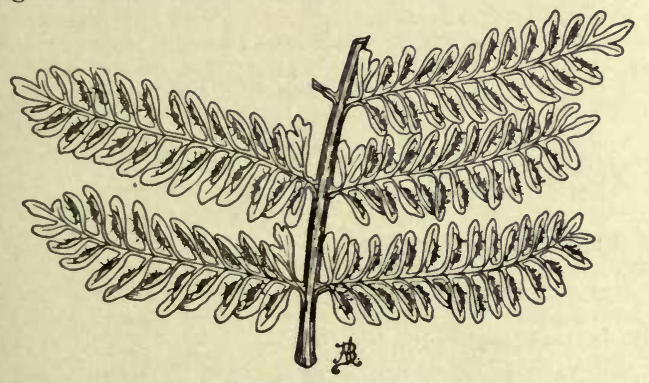

160. Asplenium Belangeri.

cc. Pinna longer, with scattered narrowly linear segments.

24. viviparum, Presl. Lrs. 15-24 in. long, 6-8 in. wide, on rather short stalks with pinnatifid pinnules and ulti mate segments, which are narrowly linear and often forked: plant often bulb-bearing, like $A$. bulbiferum Mauritius and Bourbon. Cult. under various names. S. 1:662. A. nóbilis, Hort., is a garden variety.

AAA. Sori more or less curved, sometimes horseshoeshaped: lvs. ample, 2-4 pinnatifid.

25. Filix-fómina, Bernh. Lvs. 18 in. to $3 \mathrm{ft}$., broadly ovate-oblong, bipinnate ; pinnæ 4-8 in. long, lanceolate, with numerous more or less pinnately incised or serrute segments. Eu. and N. Amer.-Very variable, especially in cult. Schneider describes 56 varieties.

26. thelypteroides, Michx. Lvs, 1-2 ft. long, on long, straw-colored stalks : 6-12 in. wide, 2-pinnatifid, with linear-lanceolate pinnæ; segments crowded, oblong, minutely toothed : sori 10-12 to each segment. Rich soil in the eastern U.S. S. $1: 651$.

27. spinulosum, Baker. Lvs, 9-12 in. each way, deltoid, 3-4-pinnatifid, with 9-12-pinnæ on either side, the lowest much the largest; segments short and sharply toothed. China and Jap.

Supplementary list of less common trade names : A. aculeàum, Hort. Hab. ?-A. arbòreum. See Diplazium. $-A$. biti$d u m=$ A. lineatum. $-A$. decussàtum. See Callipteris. $-A_{\text {. ell }} p$ ticum, Hort. a trade name.-A. fláccidum, Forst. Coolhouse basket fern from Australia, Tasmania and N. Z. Fronds $2-3 \mathrm{ft}$ long, 4-8 in broad; stipes stout, flexible, greenish, naked inno numerous, close or distant, lanceolate, leathery, 4-8 in pinns numerous, close or distant, lanceolate, leathery, 4-8 in. pictum, Mettenius. (Athyrium Goringianum, var. pictum, pictum, Mettenius. (Athyrium Goringianum, var. pictum,
Hort.). Distinguished from all other members of the genus by Hort.). Distinguished from all other members of the genus by 15 in. long, spear-shaped, and pendulous. Possibly the only hardy variegated fern. It, however, needs glass protection for best results. Stalks purple or claret-colored; lvs, green with a lfts divided into sharply toothed pinmul central band of gay: lfts: divided in arranged in two rows parallel to the midvein. Jap-A lánceum. See Dipla zium.-A. lineàtum, Swz. Warmhouse species from Mauritius and Bourbon, is very variable, running into forms with lfts. again pinnate, which have either small, linear pinnules or these again twice cut: lvs. 1-2 ft. long, 4-6 in. wide : stalks erect, 6-9 in. long, more or less scaly. -A longissimum, Blume. The best of all the renus for large baskets. Lvs $2-3 \mathrm{ft}$ long, 4-6 in. broad; stalks blackis E. Ind. S, 1.602, from Polynesia, Malaya China, and Himalayas. Lvs. 6-18 in long, 6-12 in. wide; stalks brownish ; lfts. 6-12 pairs, stalked, $3-6$ in. long, 1-3 in. wide, sharp-pointed, serrate $-A$. Nidus, or A. Nìdus-Avis. See Thamnopteris.-A. Shépherdi, Spreng. See Diplazium.

L. M. UNDERWOOD.

\section{ASPRELLA. See Asperella.}

ASTER (a star). Compósitoc. Aster. Starwort. Michallmas DaISY. A large temperate-zone genus of attractive but botanically-confused herbs, particularly abundant in $\mathrm{N}$. Amer. The genus is characterized by numerous flattish rays (white, blue, red, or purple), slender style appendages, compressed severalnerved akenes, and an involucre with unequal bracts in few or several rows, the pappus simple, soft, and abundant (Fig. 161). Leafystemmed, mostly blooming in the autumn. Some of the species are annual, but those in cult. are perennial (or rarely biennial). All are easy of cultivation in ordinary soil and exposures, and are among the best plants for the hardy border or for naturalizing in the freer parts of the grounds. They grow readily from seeds, but are generally prop. by division of the clumps. Calimeris and Linosyris $a$, pappus; $b$, corolla; clumps. Calimeris and Linosyris $c$, stamens; $d$, styles.
are kept distinct in this book.

A. Old World Asters, some of them old garden plants, and somewhat modified by cult.

B. Stems simple and scape-like, bearing a single $f l$.

alpinus, Linn. Lvs. entire and spatulate, forming a cluster on the ground, those on the stem small and linear : st. 3-10 in., bearing a large violet-rayed, handsome head. B.M. 199. - In its wild state, the plant also 
occurs in the Rocky Mts. Valuable alpine or rockwork plant, with fls. varying to pink and white. Var. specidsus, Hort., is taller and stronger, with heads 3-4 in. across. Var. supérbus, Hort. (Gn. $54: 1193$ ), is a large and showy form.

Himalàicus, C. B. Clarke (A. Himalayénsis, Hort.). Similar to $A$. alpinus, but dwarfer: rays lilac-blue, slightly recurved at the tip : sts. 4-12 in., slightly villous : Irs. oblong or elliptic, nearly entire. Himalayas, 13,000-15,000 ft. - Little known in America.

diplostephioldes, Benth.

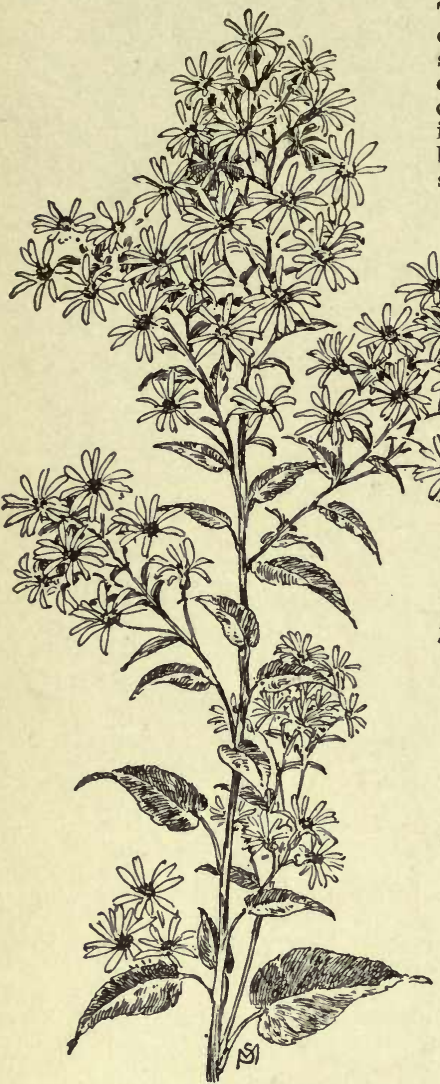
wo to $3 \mathrm{ft}$, soft-pubescent or hairy, the st. simple and solitary : lvs. obovate or oblanceolate, entire but ciliate : solitary head large, inclined, 2-3 in. across, blue or pale purple, very showy. Himalayas. B.M. oblong-spatulate to broad-lanceolate, serrate : heads violet or lilac. Arctic Eu. and Amer., and Rocky Mts.Excellent rockwork plant.

àcris, Linn. About 2-3 ft., slender-branched: 1vs. linear, or lance-linear : heads large and blue, with long, distinct, handsome rays. S. Eu. Gn. 37: 744 .

trinérvius, Roxbg. About $3 \mathrm{ft}$., stout, corvmbose at summit: lvs. lance-ovate and strongly toothed: heads large, blue or purple (a pale var.), wi.h narrow, spreading rays. Himalayas. R.H. 1892: 396. - Hardy, handsome, variable.

Tatáricus, Linn. f. St. erect and striate, hispid, corymbose at the summit, often $7 \mathrm{ft}$. high : lvs. large (the radical $2 \mathrm{ft}$. long), lanceolate or oval lanceolate, attenuate at base, entire : involucre scales purplish at tip ; heads blue or purple, late. Siberia. G.F. 4:197.Excellent for the hardy border, particularly for its very late blooming.

Aa. Native Asters. These plants are one of the charms of the Amer. autumn, and are amongst the best of all hardy border plants. They generally inuprove greatly in habit when transferred to cultivated grounds. Any of these wild Asters are likely to come into cultivation at any time. The number of kinds is large. The student will find them all described in Grar's Synoptical Flora of North Amerisa, 1, pt. 2. Those of the northeastern states and adjacent Canada will be found in Britton and Brown's Illustr. Flnra of the U. S., and Gray's Manuil. Those of the S. are described in Chapman's Flora of the $\mathrm{S}$. states. The following list comprises those known to be in cult. Of these, only A. Nova-Anglice is well known in domestication. The species are much confused :

A. acumindtus, Michx, amethýstinus, Nutt. (G.F. 5:378); Andersoni, Gray ; Bígelovii, Gray(B.M. 6430); canéscens, Pursh; Caroli. niànus, Walt.; Chamissònis, Gray ; Chápmani, Torr. \& Gray ; commutàtus, Gray; cóncolor,Linn.; conspícuous, Lindl.; cordifòlius, Linn. (Fig. 162); corymbdsus, Ait.; Cùsickii, Gray; diffùsus, Ait., and var.horizontalis ; Doúglasii,Lindl. ; Drúmmondii, Lindl.; dumòsus, Linn.; ericotdes, Linn.; falcdtus, Lindl.; F'éndleri, Gray; folidceus, Lindl.; F'vèmonti, Gray ; grandiflòrus, Linn.; Hállii, Gray ; Hérveyi, Gray (G.F. 2:473); integrifòlius, Nutt.; làvis, Linn.; linariifòlius, Linn.; Lindleydnus, Torr. $\begin{aligned} & \text { One of the best and most showy of native Asters. } \text { \& Gray (G.F. 2:449); longifòlius, } \\ & \text { Lam. (G.F. 9:507, G.W.F. 10); } \\ & \text { macrophýllus, Linn. (G.F. 4:89); }\end{aligned}$

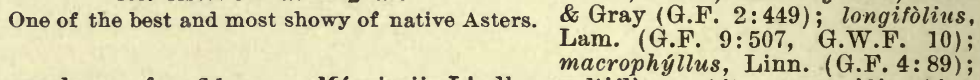

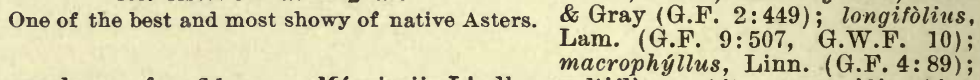
Ménaiesii, Lindl.; multifldrus, Ait. ; nemordlis, Ait.; Nòvo-Angliae, Linn. (Fig. 163. A.F. 9:283), and var. ròseus ; Nòvi-Bélgii, Linn.; oblongifòlius, Nutt.; paniculatus, Lam.; patens, Ait., and var. Meèhanii; polyphýllus, Willd.: Porteri, Gray ; prenanthoides, Muhl.; ptarmicoides, Torr. \& Gray (G.F. 3: 153); pulchellus, Eaton ; puniceus, Linn. (Fig. 164), and var. laevicaùlis and var. lucidulus; radulinus, Gray ; sagitifòlius, Willd.; salicifòlius, Ait.; sericeus, Vent. (G.F.5: 473); Shórtii, Hook.(G.F. 4:473); spectábilis, Ait.(Mn. 5:41); surculdsus, Michx. (G.F. 5:521); tanacetifollius, HBK. Tradescánti, Linn.; turbinéllus, Lindl. (G.F. 6:17); unduldtus, Linn. (G.W.F. 4); versícolor, Willd.

In the following list, those marked* are offered by Amer. dealers : ${ }^{*}$. coccíneus Nevadénsis $=?-*_{A}$. Dátschi $i=?-*_{A}$. hy bridus nanus = ? "Rosy color, only 6 in high "-*A, lancifo. lius Oalifornicus $=?-*_{A}$. lilacinus Nevadénsis $=?-*_{A}$. flexed, the disk bright golden and broad.

Sibiricus, Linn. A foot or less high, somewhat pubescent, each branch terminating in a single head : lvs. 
Meèhani, Hort., is a well marked form of A. patens, found by Joseph Meehan at Antietam- - *A. Nòvoe-coerùleus $=?-{ }^{*} A$. pyr. amidàlis = ? - A Reevesii, Hort is A ericoides, var. Reevesii, Gray, a "rigid form, comparatively stout, glabrous, except that the Ivs. are often hispidulous - ciliate toward the base, the heads and rays as large and the latter about as numerous as in $\mathrm{A}$. polyphyllus." N. Amer. -*A. rotundifòlius, Thunb.=Felicia.A. Sikkiménsis, Hook. Three to $4 \mathrm{ft}$., stout and erect: Ivs. lanceolate-acuminate, spinulose-serrate : heads purple, in large corymbs. Himalayss. B.M. 4557.-A. Stràcheyi, Hook. Stemless and sarmentose, with 1-tld bracted scapes: radical lvs. loss and saren. spatulate, hairy: heads inlac-blue, 1 in. across. Pretty: Hima. $\begin{array}{ll}\text { layas. B.M. 6912. }{ }^{*} \text { A. terminalis }=--A . \text { Townshendii, Hoo } & \text { L. B. B. B. }\end{array}$

- The native Asters are amongst the very best plants for borders and roadsides. They should be better known. A. acuminatus grows well in shade in ordinary soil, not necessarily moist; increases in vigor under cultivation. $A$. cordifolius prefers open or partial shade; improves much under eultivation with good soil. A. corymbosus prefers at least partial shade, and will grow even in very deep shade; seeds very freely; does well on dry ledges and in small erevices in rock; very tenacious of life. $A$. dumosus prefers full sunlight and dry situation. A.ericoides wants full sunlight and dry situation; will grow in very poor or shallow soil, but does best where roots can penetrate deep. A. lovis grows in either full sunlight or partial shade and good soil. A. Novo-Anglice will not endure much shade; prefers moist soil, but grows well in ordinary garden situations. Fall-sown seedlings of $A$. Nove-Anglice, var. roseus, come practically true to varietal name, though varying in shade of color, and these seerllings bloom later than clder plants and at height of 18 inches, making the plant of value as a late bedding plant treated as an annual. $A$. Novi-Belgii prefers moist soil ; will not endure heavy shade. A. paniculatus prefers moist soil, but will do well in rather dry situations; will endure more shaile than either of the two above species. A patens wants open or half-shaded places, and good soil ; one of the w:aker species, often proving short-lived. A.puniceus will not endure shade; prefers moist places, but will grow in good soil not over moist; in dry situations it loses its vigor; spreads rapidly in favored locations. $A$. spectabilis prefers open or partly shaded places; one of the weaker species in wild state ; rather short-lived. A. undulatus wants open or half shade; late-flowering, hand some plant, forming large bushes where allowed to develop. A. vimineus, although not in the trade, is a fine plant in cultivation.

ASTER, CHINA. Callistephus horténsis, Cass. (Callístephus Chinénsis, Nees. Callístemma horténsis, Cass. Aster Sinénsis, Hort.). Compósitce. The genus Callistemma is older than Callistephus, but it is too like Callistemon to stand. B.M. 7616. Gn. 53: 1163.-One of the most popular of all garden annuals, being particularly valuable for its fall blooming. The evolution of the China Aster suggests that of the chrysanthemum at almost every point, and it is, therefore, a history of remarkable variations. The plant is native to China. It was introduced into Europe about 1731 by R. P. d'Incarville, a Jesuit missionary in China, for whom the genus Incarvillea of the Bignonia family was named. At that time it was a single flower; that is, the rays or ligulate florets were of only 2-4 rows. These rays were blue, violet or white. The center of the flower (or head) was comprised of very numerous tubular, yellowish florets. Philip Miller, the famous gardener-botanist of Chelsea, Eng., received seeds of the single white and red Asters in 1731, evidently from France; and he received the single blue in 1736. In 1752 he obtained seeds of the double red and blue, and in 1753 of the double white. At that time there appears to have been no dwarf forms, for Miller says that the plants grew 18 in. or $2 \mathrm{ft}$. high. Martyn, in 1807, says that in addition to these varieties mentioned by Miller, there had then appeared a "variegated blue and white" variety. The species was well known to American gardeners at the opening of this century. In 1806 M'Mahon, of Philadelphia, mentioned the "China Aster (in sorts)" as one of the desirable garden annuals. Bridgeman, a New York seedsman, offered the China and German Asters in 1837 "in numerous and splendid varieties," specifying varieties "alba, rubra, cerulea, striata purpurea, etc." In 1845, Eley said that "China and German Asters" "are very numerous" in New England. This name German Aster records the fact that the first great advances in the evolution of the plant were made in Germany, and the seed which we now use comes largely from that country. The first marked departure from the type appears to have been the prolongation or great development of the central florets of the head, and the production of the "quilled" flower. This type of Aster was very popular 40 and 50 years ago. Breck, in the first edition of his Flower Garden, in 1851, speaks of the great improvement of the Aster "within a

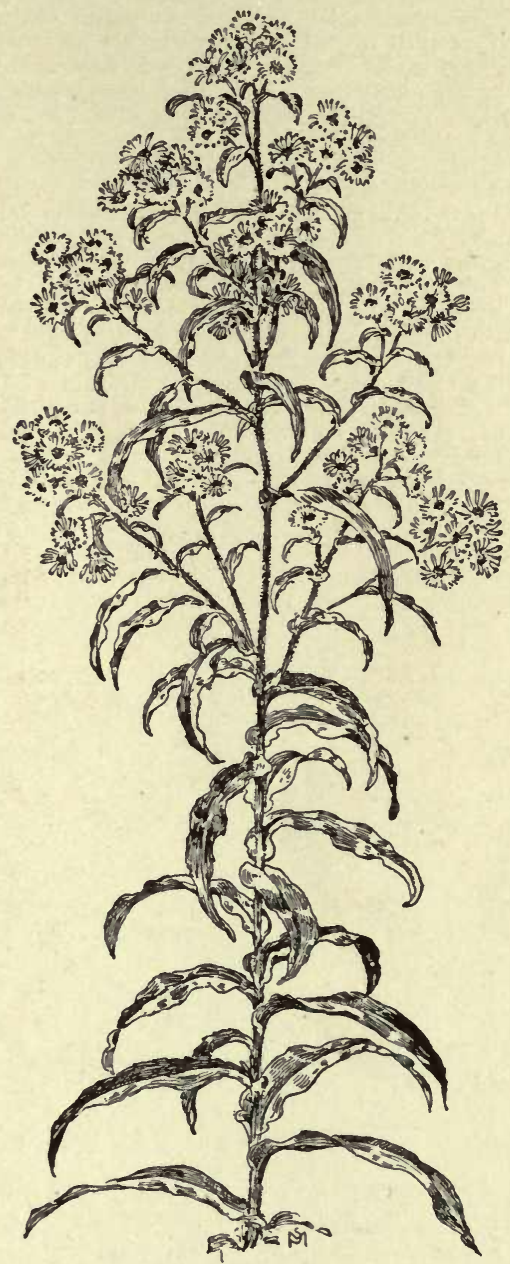

164. Aster puniceus.

few years" "by the German florists, and others" and adds that "the full-quilled varieties are the most highly esteemed, having a hemispherical shape, either a pure white, clear blue, purple, rose, or deep red; or beautifully mottled, striped, or edged with those colors, or having a red or blue center." About 50 years ago the habit of the plant had begun to vary considerably, and the progenitors of our modern dwarf races began to attract attention. The quilled, high-centered flower of a generation or more ago is too stiff to satisfy the tastes of these later days, and the many flat-rayed, loose and fluffy races are now most in demand, and their popularity is usually greater the nearer they approach the form of the uncombed chrysanthemums. The China Aster had long since varied into a wide range of colors 
of the cyanic series-shades of blue, red, pink and purple. The modern evolution of the plant is in the direction of habit, and form of flower. Some type variesgenerally rather suddenly and without apparent causeinto some novel form, still retaining its accustomed color. The florist fixes the variation by breeding from the best and most stable plants, and soon other colors appear, until he finally obtains the entire range of color in the species. So it happens that there ure various well marked races or types, each of which has its full and independent range of colors. The Comet type (with very flat rays), now one of the most deserving of the China Asters, illustrates these statements admirably. The Comet form - the loose, open flower with long, straplike rays-appeared upon the market about 1886 or 1887 , with a flower of a dull white overlaid with pink. The pink tended to fade out after the flower opened, leaving the color an unwashed white. The rose-colored Comet next appeared, and the blue was introduced in 1890 . The first clear white was introduced in America in 1892, coming from Vilmorin, of Paris, and the China Aster had reached its greatest artistic perfection.

It is impossible to construct a satisfactory classification of the China Asters. It is no longer practicable to classify the varieties by color. Neither is it feasible to classify them upon habit or stature of plant, for several of the best marked types run into both tall and dwarf forms. Vilmorin, however, still divides the varieties into two groups, the pyramidal growers, and the nonpyramidal growers. The most elaborate classification is that proposed by Barron, from a study of extensive tests made at Chiswick, Eng. Barron has $17 \mathrm{sec}-$ tions, but they are not coördinate, and they are really little more than an enumeration of the various types

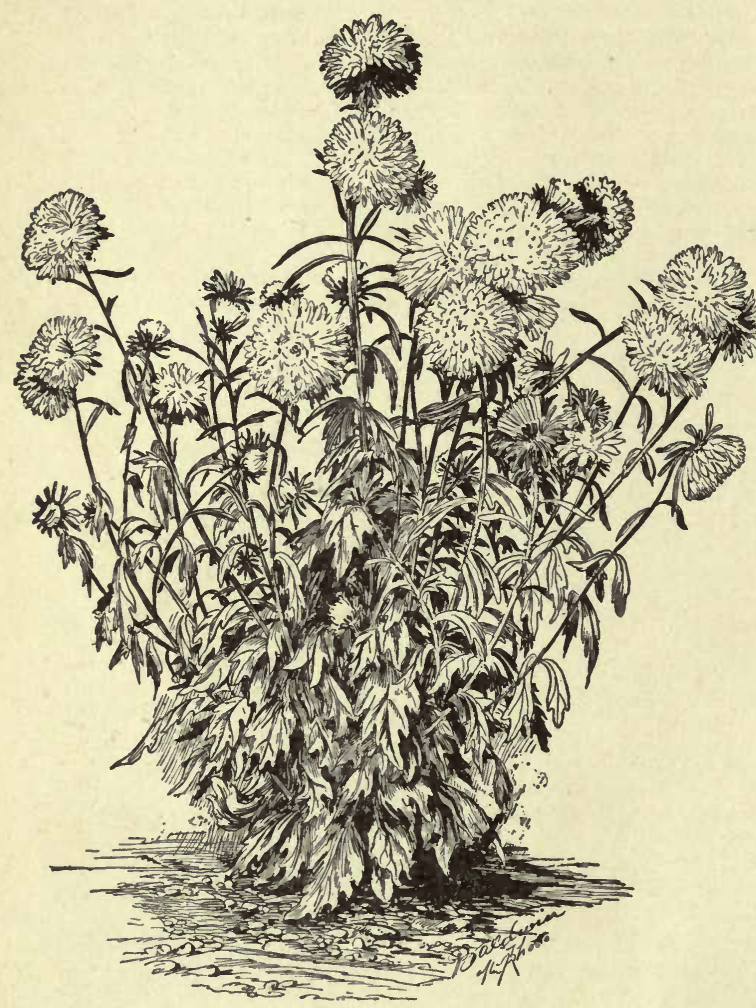

165. China Aster-The branching type.

or classes. After considerable study of the varieties in the field and herbarium, the following scheme seems to be serviceable:
A. Flat-rayed Asters, in which all, or at least more than 5 or 6 rows of rays, are more or less prominently flat and the florets open.

B. Ineurved or ball-shaped.

BB. Spreading or reflexed.

AA. Tubular or quilled Asters, in which all, or all but the 2 or 3

outer rows of florets, have prominently tubular corollas.

B. Inner florets short, outer ones longer and flat. Represented by the German Quilled.

BB: All the florets elongated and quilled.

In 1895, 250 varieties of Asters were offered by Amer. seedsmen. For growing in borders, perhaps the best type is the Comet, in various colors. Other excellent races are the Branching (Vick'sBranching is shown in Fig. 165), Truffaut (Fig. 166), known also as Perfection and Peony-flowered; Chrysanthemum-flowered; Washington; Vic toria, Mignon; and Queen of the Market. The last is commended for earliness and graceful, open habit, and it is one of the best for cut-flowers. Many other types are valuable for special purposes. The Crown or Cocardeau is odd and attractive. Amongst the quilled Asters, the various strains of German Quilled (Fig. 167), Victoria Needle (Fig. 168), and Lilliput are excellent. The very dwarf tufted Asters are well represented in Dwarf Bouquet or Dwarf German, and Shakespeare. All these are easily grown in any good garden soil. For early bloom, seeds may be started under glass ; but good fall bloom may be had, even in the North, by sowing seeds in the open as late as the 1st of June.

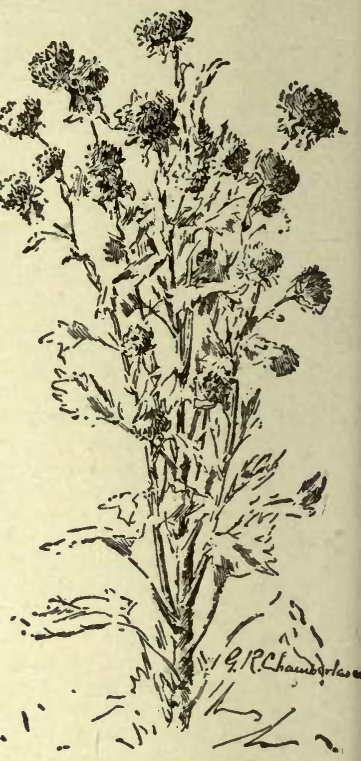

166. China Aster-

Truffaut's Peony-flowered. Asters make very showy plants when grown in large masses, and are aiso valuable for filling up vacancies in the mixed herbaceous border, where they ought to be planted in clumps, the dwarfer kinds put in front and the taller behind.

There are two or three insects which prey upon the China Aster, but they do not appear to be widespread. The most serious difficulty with them is the rust, a fungus (Coleosporium Sonchi-arvensis) which attacks the under side of the leaf and raises an orange-colored pustule. Timely sprays with the copper fungicides will keep this disorder in check. The Bordeaux mixture discolors the plants, and it is, therefore, better to use the ammoniacal carbonate of copper. Spray it upon the plants before the fungus appears, and repeat every week or ten days. Use a cyclone nozzle and spray upwards, so as to strike the under sides of the leaves.

L. H. B.

In recent years, the Branching Asters have come to be prominent, and they are bound to increase in popularity as their merits become known. The long stem, large size, and soft shades of pink and lavender have made this the most useful to the florist of all the Asters. The Comet has been rather short-stemmed for a commercial cut-flower. As to culture, it does not seem to be generally understood, even by florists, that the young Aster plants will stand more frost than cabbage. If started under glass about the middle of February, in New York state, they will be ready to plant out the latter part of April or first of May. They will then come in at about the same time they would if grown entirely under glass, although not so long-stemmed. For fall flowers, we sow out-of-rloors with seed drill. vate with wheel hoe. Plants have been ruined by being planted near squashes. The late brood of striped beetles fed on the Aster flowers.

GEORGE ARNOLD, JR. 
The first requisite to the growing of China Asters is to have good, plump seed. As soon as the ground is in good or fair condition in spring, spade up a seed-bed

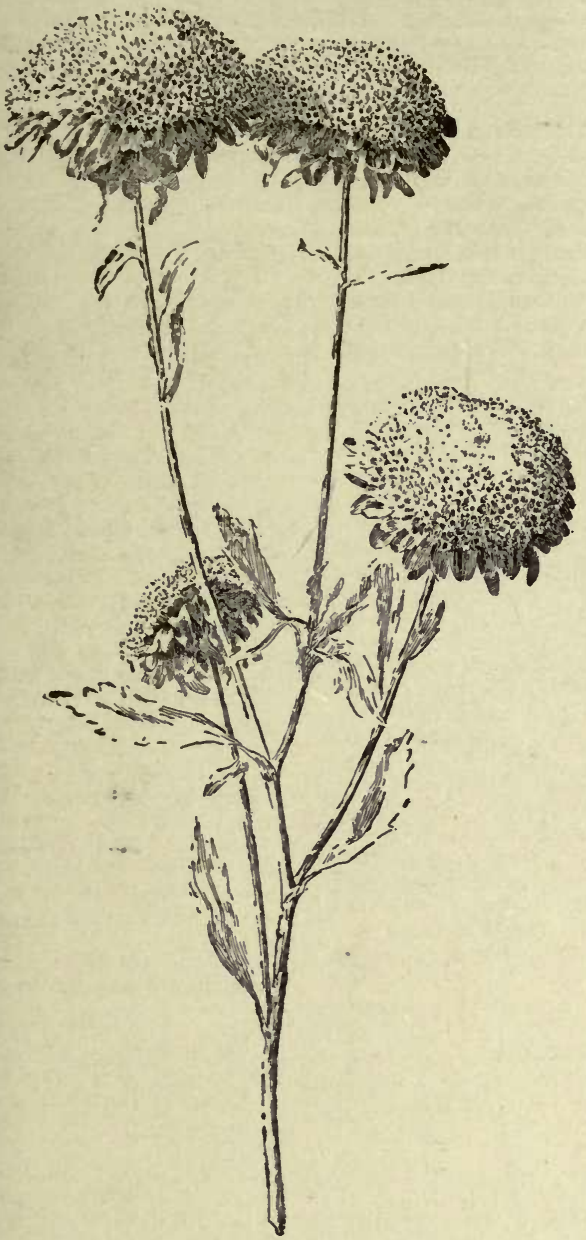

167. China Aster-German Quilled.

where the ground is rich, and rake it fine. Then make shallow drills about an inch deep; whiten the drills with air-slaked lime, to keep worms and insects from eating the young roots. Sow the seed in the drills, covering about $1 / 4 \mathrm{in}$. deep with fine dirt run through a sieve of $3 / 8$ in. mesh. When plants are about an inch high, draw good, fine dirt to the roots, so that the seed-bed is nearly level and all the weeds are covered. The plants are hardier and better when grown in the open ground than when started under glass. For the permanent quarters, plow ground that has been well and heavily manured with cow-manure the previous season; then harrow thoroughly. Seatter 20 to 30 bushels of common lime to the acre, if thought necessary, then plow again and harrow well. With a one-horse plow make furrows the length of the field about 3 or 4 inches deep and $21 / 2$ feet apart. In these furrows one man drops the plants in two rows about 12 or 16 in. apart, for two men to plant. Do not furrow much ahead of the planters, so that they have fresh dirt to put to the roots of the plants. By this method the plants seldom wilt. If a dry spell follows in three or four days, level the furrow with a hoe ; if wet, let stand for about two weeks, then scatter 100 pounds of guano or other fertilizer to the acre, and work the land with a spike-tooth eultivator, with no shovels, so that no dirt is thrown on the small plants. Hand-hoe between the plants, running horse and cultivator twice in each row. The cultivator loosens the ground as deep as it was plowed. Cultivate and hoe every two weeks, especially after it has rained, until buds appear; then keep clean by hand. When blooms begin to appear, mulch liberally with tobacco stems, to keep down weeds and to kill aphis at the roots. When the fls. begin to open, keep a strict watch for the black beetle. When it makes its appearance, put about a pint of water and a gill of benzine in an old can and hold it under the bugs; they drop into it. These pests last from six to nine days. Have them looked after three times a day.

JAMES SEMPLE.

ASTLLBE (Greek name, of no particular significance) Saxifragdcece. Includes Hotèia. Tall perennial herbs, of 7 or 8 species in eastern N. Amer. and Asia. They look much like Aruncus (which see), and are often called Spiræa. Aruncus and Spiræa are rosaceous genera, and are characterized by many stamens and usually by several to many separate pistils, whereas Astilbe has 8 or 10 stamens (twice the number, or of the same number, as the petals), and a 2-3-lobed pistil (which finally separates into more or less distinct follicles). Astilbe and Aruncus are so much alike that they are constantly confounded by horticulturists and even by botanists. They probably inter-cross. It is probable that they should be placed in the same family, despite the technical botanical differences. The Astilbes are hardy plants of great merit. They are easily grown in any well-made border. They give conspicuous masses of bloom in summer. Prop. mostly by division.

L. H. B.

Forcing of Astilbe. - Few herbaceous plants force with greater ease than Astilbe Japonica and its var. compacta; but three weeks longer time should be given the latter to fully develop its feathery spikes. Astilbes are so easily and cheaply imported that for the commercial florist it is cheaper to buy than to divide and grow his own plants. When first received, the clumps of roots should be stored, with a little earth or moss between the roots and a little soil over the crown, until the florist is ready to pot them. No amount of freezing does them the slightest harm; but the boxes or flats in which they are stored are best covered with a little straw or litter, and should have the full benefit of rain or snow to keep the roots from drying. From potting or burying into the greenhouse, it requires from ten to fourteen weeks to bring them into flower, according to the earliness of the season at which they are wanted in flower. The quality of soil is of no consequence, provided it is light and easily handled. They need water in great abundance. Temperature is also of little consequence. Anything above $50^{\circ}$ at night will do ; but it is best not to flow. er them in higher temperature than $60^{\circ}$, or they will quickly wilt when cut or used for decorations. F'rom the time the sprays begin to show white color until they are fully developed, every Astilbe should stand in a sancer in which there should be constantly an inch of liquid manure. When 168, China Aster-Victoria Needle. sold for window plants or for decoration, Astilbes are often disappointing. It is merely want of water. Before the full development of the shoots and lvs. they are easily hurt by tobacco smoke, and should be covered with paper or well wetted 
when fumigation is necessary. Aphis, spider or thrips never trouble Astilbe. As a border plant, Astilbe is one of the hardiest of our hardy herbaceous plants ; but the feathery plume obtained in the greenhouse is much shorter, more compact, and lacks the pure whiteness of the outdoor-grown specimens.

WILLIAM SCOTT.

\section{A. Fls, opening white or yellowish.}

decándra, Don(A.biternata, Britt.). Somewhat pubes cent, 3-6 ft.: Ivs. 2-ternate, the lfts. ovate and cordate or abrupt at base, sharp-serrate : fls. yellowish white, in a large (10-12 in. long) racemose panicle; stamens 10. Woods, Va. and S.-Often confounded with Aruncus sylvester.

Japonica, Gray (Hotèia Japónica, Morr. \& Decne. H.barbata, Morr. \& Decne. Spiràa Japónica, Hort.).

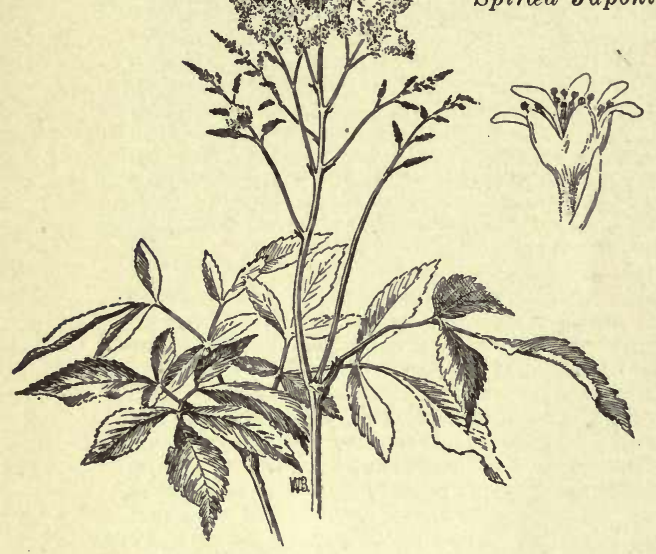

169. Astilbe Japonica.

Fig. 169. Erect, 1-3 ft., hairy on the petioles and nodes: Ivs. 3-2-ternate, petiole reddish; lfts. ovate-acute, tapering to the base, serrate : fls. white, in a pubescent racemose panicle; stamens 10. Japan. B.M. 3821. Gn. 48, p. 366. Mn. 5:174.- Commonly known as a spring glasshouse plant in this country, but hardy in the open. There are various cult. forms, as var. grandifldra, Hort., with larger and denser panicle; var. compácta, Hort., the panicle more compact; var. multifldra, Hort. ; var. variegàta, Hort., with variegeted lvs.; var. purpurea, Hort., with purple-shaded foliage. Astilbe Japonica is often confused with Aruncus astilboides; Figs. 169 and 170 will aid in distinguishing them.

Lemoinei, Hort. Foliage graceful, standing $1 \frac{1}{2} \mathrm{ft}$. high, with lfts. broad-oval, dentate and crimped, satiny green, hairy : fls. with white petals and 10 pink stamens, very numerous, in plume-like clusters disposed in panicles 11/2ft. long. Gn.48, p.355. R.H.1895, p.567. A.F. 11: 459 . - Garden plant, supposed to be a hybrid of $A$.Japonica and Aruncus astilboides. Hardy, and forces well.

rivulàris, Hamilt. Rhizome creeping: st. 3-5 ft.: lvs. 2-ternate, the lfts. ovate, dentate, the petioles tawnyhairy: fls, yellowish white, changing to reddish, in large spikes, which are disposed in panicles; stamens 8 or 10 pure white. Nepal. Gn. 48, p. 355.-Attractive border species, blooming late. Probably needs protection.

Thúnbergii, Miq. Silky-hairy, 1-2 ft.: lvs. pinnate, the lfts. oval, serrate, yellowish green: fls. white, on reddish stalks, ehanging to pink, in clusters on the fl.-branches. Japan. R.H. 1895, p.565. - A graceful plant. Forces well.

$$
\text { AA. Fls. opening pink or red. }
$$

Chinénsis, Franch. \& Sav. Plant 11/2-2 ft., graceful : lvs. 3-ternate, the lfts. serrate : fls. in a branchy, rather compact panicle, with purplish or pink reflection, but the petals whitish. China.-Possibly a form of the preceding. Yet rare in Amer.

rùbra, Hook. \& Thom. St. simple, 4-6 ft., long-hairy : Ivs. 2-ternate; lfts. oblique-ovate, more or less cordate, sharp-serrate : fls. numerous, rose-red, in compact, robust panicles; stamens 10, shorter than petals. India. B.M. 4959. - Needs protection. Little known in Amer.

L. H. B.

ASTRAGALUS (ancient Greek name of some shrub). Leguminòsce. MiLk VeTCH. A genus of over 1,000 species of hardy herbs or subshrubs. Lvs. mostly odd-pinnate: fls. in spikes or racemes, yellow, purple or white. They prefer a light, porous soil and no shade. The dwarfer kinds may be placed in the front of the border or in the rockery. Prop. chiefly by seeds, which germinate slowly, or slowly by careful division in early spring. Many kinds are likely to die if divided or transplanted. Many kinds are cultivated in the Old World, but the four described below are the only kinds commonly sold in America. Of the many native kinds, mostly known as rattle-weeds, the following are advertised at present : A. Canadensis = A. Carolinianus, A. caryocarpus, $A$. Drummondii, A. flexuosus, A. Laxmanni, A. Parryi, A. racemosus, A. Robbinsii, A. Shortianus. The Locoweed of the prairies, which is said to poison cattle, is $A$. mollissimus. For these and many others the student is referred to Britton and Brown's Illus trated Flora, and Coulter's Manual of Rocky Mountain Botany.

A. Fls. yellow.

alopecuroides, Linn. St erect, strict height 2-5 ft.: lfts. ovate-lanceolate, $\mathrm{pu}$ bescent. Siberia. B.M. 3193.

\section{AA. F'ls, not yellou.}

Monspessulànus, Linn. St. trailing : height 9 in.: fls. purple, purplish or white, in smaller and looser heads than the above. Eu. B.M. 375

hypogl6ttis, Linn. Height 3-24 in.: lfts. 17-25 : fls. violet-purple, 6-10 lines long, in dense heads : pods 4-5 lines long, 2-celled, densely villous, with white hairs. Eu., Asia, and from Kansas W. to Nev. and N. to Alaska. -Also a white var., excellent for pots.

alpinus, Linn. Height 6-15 in. : lfts. 13-25: fls. violet, keel darker : pods 1-celled, black-pubescent. Northern and Arctic regions round the world.

\section{J. B. KELLER and W. M.}

ASTROCARYUM (Greek, astron, star, and karyon, nut ; referring to star-like arrangement of the fruits). Palmacea, tribe Cocoinea. Spiny palms, stemless or with a short caudex, or with a tall, ringed, spiny cau. 
dex : lvs. terminal, pinnately parted; segments ap proximate, equi-distant or fasciculate, lanceolate-acuminate or attenuate to the obliquely truncate apex, plicate, whitish beneath, the terminal ones free or confluent, the spiny margins recurved at the base; petiole very short sheath short, open: spadices short or long, the finely divided branches pendulous, thickener at the base, thence very slender, long, naked, the fioriferous naked basal portion, as it were, pedunculate ; spathes 2, the lower one membranous, deciduous, the upper fusiform, coriaceous or woody, open on the ventral side, persistent; bracts of the female fls. bread, imbricated, like the bractlets; pistillate fls. with a stipitate male one on either side: fr. rather large, ovoid or subglobose, beaked, smooth or spiny, red or orange. Species 30 . Tropical America.

Astrocaryums are elegant palms of medium height, very suitable for moderate sized conservatories. $A$ Murumuru, A. Mexicanum and A.argenteum are the kinds most commonly met with in collections. The lvs. are pinnate, and in small plants, at least in some of the species, the segments are narrow, four or five pairs of these alternating with two very broad ones. A. argenteum has the under surfaces of the lvs. of a much lighter color than the others. In a young state, the plants require the temperature of the stove, and after attaining the height of a few feet they may be removed to a house where the temperature frequently falls as low as $45^{\circ} \mathrm{F}$. Specimens 8-10 ft. high fruit freely. Prop. by seeds, which are slow in germinating. The soil in which they are sown should be changed occasionally, to prevent it from becoming sour. Be careful not to overpot, or the fleshy roots will decay. See Palms.

A. Lvs. scurfy, at least beneath or on the petioles.

Murumuru, Mart. Lrs. 9-12 ft. long; segments lanceolate, somewhat falcate, rich green above, silvery beneath : sts. 12-15 ft. high, densely covered with stout, black spines 6 in. long. Brazil. I.H. 22: 213.

argenteum, Hort. Petioles and under surface of the lvs. covered with silvery white scurf; lvs. arching, wedge-shaped, 2 -lobed, distinctly plicate, bright green above; petioles with numerous dark, spreading spines 1 in. long. Colombia. F.R. 3:569.

filiàre, Hort. Small, slender : lvs. erect, narrowly cuneate, with 2 divergent lobes, inversely sagittate; petioles densely scurfy; rachis scurfy on both sides spines numerous on the petioles and rachis, and on the principal nerves above; brown. Colombia.

$$
\text { AA. Lvs. not scurfy. }
$$

Ayri, Mart. Trunks 18-30 ft. high, 8-12 in. in diam., usually cæspitose : lvs. $15 \mathrm{ft}$. long, equally pinnatisect to the apex ; petiole plano-compressed, membranaceous on the margins, densely scaly and with scattered spines; lower segments over $3 \mathrm{ft}$. long. $13 / 4-2$ in. wide, 2 in apart, the upper ones $2-21 / 3 \mathrm{ft}$. long, $1 \mathrm{in}$. wide, $11 / 4 \mathrm{in}$. apart, conduplicate at the base, linear, long attenuate, pointed, minutely and remotely spiny along the margins, white-tomentose below. Braz.

Mexicànum, Liebm. St. 4-6 ft. high, cylindrical, thickly covered with rings of black, straight, ancipital spines : petiole $2 \mathrm{ft}$. long, 4 -sided, the 2 upper sides concave, clothed (as is the rachis) with straight black spines ; blade $6 \mathrm{ft}$.; segments 15-18 in. long, 1 in. wide, alternate, broadly linear, acute, straight, white beneath, with deciduous black spines along the margins. Mex.

A. Granaténse, Hort., is an unidentified trade name.

JARED G. SMith and.G. W. Oliver.

\section{ASTROPHYेTUM. See Echinocactus.}

ASYSTASIA (obscure name). Including Henfreya and Mackaya. Acanthacea. Twenty to 30 herbs or shrubs of the Old World tropies. Corolla tube straight or curved, the spreading limb 5-lobed and nearly or quite regular: stamens 4 , unequal : stigma blunt or minutely 2-lobed : lvs. thin, entire : fls. white, blue or purple, in axillary or terminal clusters, often very showy. General treatment of Justicia, in intermediate or warmhouses. bélla, Benth. \& Hook. (Mackdya bélla, Harvey), Glabrous, upright subshrub : lvs. ovate-oblong, acuminate, spreading, short-stalked, sinuate-toothed: fls. li lac, 2 in. long, with a long tube below the flaring throat, the spreading segments ovate-obtuse, disposed on one side of a raceme 5-8 in. long. S. Afr. B.M. 5797.-A beautiful plant, rarely seen, and thought to be difficult. to manage ; but it seems to flower readily in fall in our climate, if rested during the previous winter and brought on in the summer. Prop. by cuttings of firm wood in spring or summer. Young plants in small pots. often bloom well.

A. Coromandeliàna, Nees (A. Comorensis, Bojer. Justicia. Gangetica, Linn.). Zigzag subshrub: Ivs. ovate-cordate, wavy: fls. purple, nearly sessile, in 6-10-fld. raceme. Ind. B.M. 4248. P.M. 14:125. F.S. 2:179-A. scándens, Lindl. (Henfreya scandens, Lindl) Climbing: lvs, obovate to ovate, thick, entire: fls. large, yellow, white and blush, in a thyrse. Afr. B.M. 4449. B.R. 33: 31. F.S. 3: 231 .

L. H. B.

ATAMÁSCO LILY. See Zephyranthes.

\section{ATHANASIA. Consult Lonas.}

ATHYेRIUM. See Asplenium.

ATRÁGENE. See Clematis.

ATRAPHAXIS (ancient Greek name). Polygonàcece. Low shrubs: Ivs. alternate or fasciculate, deciduous fls. small, apetalous, in few-fld. axillary clusters, forming terminal racemes; sepals 4-5; stamens $6-8$ : fr. a small akene, enclosed by the enlarged inner sepals. Summer. About 18 species in central and western Asia, Greece, and N. Afr. Low shrubs of spreading habit, with usually small ivs., attractive with their numerous racemes of white or rose-colored fls., which remain unchanged for a long time, owing to the persistent calys. They grow best in well-drained soil and sunny situations, but do not stand transplanting well when older. Prop. by seeds sown in spring; the seedlings are liable to rot if kept too moist, or in damp air. Increased, also, by greenwood cuttings under glass in early summer, and by layers.

A. buxifòlia, Jaub. \& Spach. (Polygonum crispulum, Sims). Height 1-2 ft., spineless: 1vs. obovate, erenate, dark green, 1/2-1 in. long : racemes short. Transcaucasia, Turkestan. B.M. 1065.-A. frutéscens, Koch (A. lanceolata, Meissn.). Height 1-2 ft., spineless : lvs. ovate-lanceolate, glaucescent, $1 / 8-1$ in. long: racemes loose. Caucasus, Turkest., Siberia. L.B.C.5:489. long: racemes loose Caucasus, Turkest., Siberia. L.B.C.5:489. Erect, 2-3 $\mathrm{ft}$., spineless : lvs. lanceolate, crenate, $3 / 4^{-2}$ in. long: fls. white, in compact racemes. Turkest. B.M. 7435. Gt. 40:1344. $-A$. spinòsa, Linn. Height 1-2 ft., spiny : lvs. elliptic, entire, glancescent, $1 / 4-1 / 2$ in. long : racemes short. S. Russia, Orient, Siberia.

ALFRED REHDER.

ATRIPLEX (derivation disputed). Chenopodiacea. A large genus containing many succulent weeds of desert regions. $A$.hortensis is a garden vegetable used like spinach ; for culture, see Orach. A. leptocarpa and $A$. semibaccata are two plants lately introduced as supplementary forage plants for arid regions. See Circular No. 3, Div. of Agrost., U. S. Dept. Agric.

\section{A. Garden vegetable (with ornamental-lvd. variety).}

horténsis, Linn. Orach. Sea Purslane. Annual : stem herbaceous, erect : Ivs. hastate, cordate, or triangular-oblong, acute, 4-5 in. long, $2 \frac{1}{2}-3$ in. wide; petioles 12-18 lines long : fruiting bracts 4-8 lines long, shortpediceled. Var. atro-sanguínea, Hort., is a crimsonleaved ornamental about $4 \mathrm{ft}$. high, sometimes grown with amarantus-like plants.

\section{AA. Ornamental shrubs.}

canéscens, James. A pale, densely scurfy shrub, 1-3 ft high : lvs. oblanceolate, entire : fruiting bractlets with 4 vertical, reticulated wings. July-Sept. N. Mex. to S. Dak. and W. to Calif.

Hálimus, Linn. Low-spreading shrub with grey foliage, cult. in Calif. for hedges and for seaside planting:

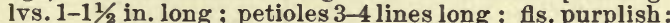
fruiting bracts $1 \frac{1}{2}$ lines long, 2 lines wide, sessile, reniform, obtuse, entire: seed compressed, yellowish. Mediterranean region and S. Afr.

W. M. 
ATROPA (after Atropos, that one of the three Fates who cut the thread of life). Solandece. BeLladonna. 'Calyx with 5 ovate leafy divisions, enlarging in fruit; corolla bell-shaped or funnel form. The purple bercies are poisonous. The plant is used in medicine.

Belladónna, Linn. Plant low, spreading: lvs. ovate, entire, pointed: fls. single or in pairs, nodding on lateral peduncles; corolla dull purple. Eu. to India.

ATTALEA (attalus, magnificent). Palmacea, tribe Cocoinece. Spineless palms, with a single, thickish ringed or scarred caudex: lvs. arising almost perpendicular and the upper part arched, pinnately cut, linear-lanceolate, acuminate, with the margins recurved at the base; petiole concave above: fls. yellow: fr. rather large. Species 20. Trop. Amer. The leaflets on the lower side of the rachis hang straight down, and those on the upper side point straight up. The Attaleas are unprofitable to grow as commercial decorative plants, because they take too long to make good sized plants from the seedling state. Perfect drainage, and a soil having a mixture of leaf-mold or peat, with a temperature ranging from $60^{\circ}$ to $80^{\circ} \mathrm{F}$., will be found to suit them. Put the seeds about 2 in. deep in a box and sink the box in a warm border out of doors in summer, cover with a mulch of moss, and water frequently.

\section{A. Trunks becoming tall.}

excélsa, Mart. St. 90-100 ft. high in the wild, 16-20 in. in diam.: lvs, erect-spreading: pistillate fls. solitary on the branches of the spadix: drupe obovate. Braz.

funifera, Mart. St. 18-30 ft., 8-13 in. diam., smooth: lvs. as long as the caudex; petioles with very long hang. ing fibers; segments broadly linear-acuminate, in clusters of 3-5, divaricate: drupe 4 in. long. Braz.

Cohùne, Mart. St. 40-50 ft.: lvs. erect, pinnate, the dark green pinnæ $30-50$ and 18 in. or less long; petiole flat above and rounded below: drupe broadly ovate, nearly 3 in. long, with a very short beak. Honduras.Fruit used for soap-making, and exported from Cent. Amer. for that purpose. Used for thatching.

\section{AA. Without trunks.}

spectábilis, Mart. Stemless, or with a very short caudex: lvs. 18-21 ft. long, the lower segments $3-4 \mathrm{ft}$., the upper 12-16 in., $1 / 2$ in. wide, linear-acuminate. Braz.

amygdalina, HBK. (A. nucifera, Karst.). Stemless : 1vs., 5-6 ft. loug, crowded, pinnatisect; segments 90-100 on each side, ensiform, glabrous above, with hairs along the outer margins beneath, $2-1 / 3-2 \frac{2}{3} \mathrm{ft}$. long, about $1 \frac{1}{4} \mathrm{in}$. wide; petiole with rusty scales beneath. Braz.

A. Guichire is a trade name: "extremely long-leaved." $-\boldsymbol{A}$. Máripa, Mart. (A. Mariposa, Hort.) See Maximiliana.

JARED G. SMIth and G. W. Oliver.

A UBRIEेTIA (Claude Aubriet, French natural history painter of last century). Cruciferce. Perennial, more or less evergreen trailers, excellent for rockwork or edgings. Prop. by seeds, or by layers or cuttings. The genus is distinguished chiefly by the outer sepals being saccate at base, the shorter filaments toothed, and the valves of the silique convex and not ribbed. Italy to Persia.

deltoidea, DC. Lvs. oblong-spatulate, deltoid or rhomboid, with 1 or 2 teeth on either side, grayish, narrowed into a very short petiole : fls. in few-fld., lax clusters, the violet or purple petals twice the length of the calyx. - Grows 2-12 in. high. Pretty spring bloomer. Hardy in the north. Var. Bougainvillei, Hort. Fls. light violet: dwarf and compact. Var. Cámpbelli, Hort. Fls. large, purple : plant large. Var. Eỳrei, Hort. Fls. large and long, deep violet. Var. Græca, Hort. Dwarf and compact, large-fld. One of the best. Var. Hendersoni, Hort., probably the same as Campbelli. Var. Leichtlini, Hort. Profuse bloomer, pink fls. Var. Olympica, Hort. Fls. large, violet, like var. Eyyrei. Var. violacea, Hort. One of the largest forms.

L. H. B.

AUCUัBA (its Japanese name). Corndcece. One erergreen shrub, with glossy, often variegated lvs., enduring smoke and dust: fls. small, diœcious, 4-merous, in panicles: fr. a 1-seeded drupe. Hardy S. In the N. states, Au- cubas are grown in coolhouses - those adapted to azaleas are excellent-and they are kept evergreen by keeping them in a pit during winter, or by holding them cool and partially dry in the house. They will stand 5 or 6 degrees of frost in a pit. From euttings of half-ripened wood, good specimen plants may be had in 2 or 3 years. Fruiting plants, with their numerous bright scarlet berries, are exceedingly attractive, but as the plant is diocious, there must be male plants with the female ones. If grown in pots and under glass, the plant must be fertilized by shaking the flowering male plant over the female, or by applying the pollen with a camel's hair pencil. If the male plant flowers earlier, the pollen may be collected and kept dry until the female plant is in flower; it remains effective for some weeks. In the open, Aucuba grows well in any good, somewhat moist though well-drained soil, in a half-shaded position. In pots, it will thrive in a sandy loam with sufficient drainage, and requires plenty of water during its growing period. Fruiting plants should not have too large pots. Prop. very easily by half-ripened greenwood cuttings at nearly any time of the year, under glass, and by seeds sown soon after maturity; the varieties are sometimes grafted on the common form in early spring, under glass.

Japónica, Thunb. Shrub, 4-15 ft.: fls. usually ovate, 3-8 in. long, remotely and coarsely dentate, acuminate, shining : berries scarlet, rarely white or yellow, usually oblong. From Himal. to Jap. B.M. 5512. I.H. 11:399. Var. Himalàica, Dipp. (A. Himalàica, Hook. \& Thom.). Lvs. ovate-lanceolate, more dentate: panicles more pilose: fr. orange to scarlet. Himal. F.S. 12:1271. I.H. 6:197. - There are many garden forms, mostly with variegated lvs. which are more cultivated than the green forms. Handsome variegated varieties are: albovariegàta, aùrea, aùreo-maculàta (Flor. Mag. 10:527. Flor. World 1876:353), bícolor, latimaculàta, limbàta, mèdio-variegàta, picturàta, punctàta, variegàta (B.M. 1197. F.M. 5:277). The following forms have green lvs.: angustifolia, dentàta, macrophýlla, ovàta, salicifòlia, pýgmæa. A. cranifòlia, once offered in Amer. trade, is probably a form of A.Japonica.

ALFRED REHDER.

AUDIBÉRTIA (M. A udibert, of Tarascon, Provence). Labiatre. Perennial, hoary, aromatic herbs from Calif., with rugose, sage-like lvs.

grandiflora, Benth. St. villous, glandular, 1-3 ft. high : lvs. woolly beneath ; lower lvs. hastate, obtuse, 3-8 in. long, coarse ; bracts crowded, conspicuous : fls. $1-11 / 2$ in. long, red or crimson-purple, in dense, showy glomes or clusters. - Prized for bees.

AURICULA (Primula Aurícula, Linn.). Fig. 171. A European perennial, sending up short scapes, bearing fls. of many colors. It is one of the most famous of florists' flowers, but it has never received the attention in this country that it has in Europe. Our summers are generally too hot for it. In this country generally treated as a greenhouse plant; but it is hardy, and in the Old World is grown largely in frames. See Primula.

Auriculas may be propagated by seed for general purposes and for the production of new varieties, but to perpetuate very choice varieties, it is necessary to propagate either by offsets or division of the plants. Seed should be sown in shallow pans or 4-inch pots early in March, so that the seedlings will be well developed before very warm weather sets in. The soil used in the seed pans should be very light and sandy, the surface should be made smooth, and the seeds then pressed lightly into the soil, after which a light covering of sand should be given, and the pans placed in a temp. of $60^{\circ}$ until they have germinated, which usually takes from three to four weeks ; they should then be removed to a light position, shaded from direct sunlight, in a rather lower temperature, to induce a stocky growth. As soon as the seedlings are large enough to handle conveniently, they should be pricked off into other pans or shallow boxes containing a mixture of three parts leaf-mold and one part sifted loam and clean silver sand. Watering should be carefully attended to, and everything done to promote active growth, so that, if possible, the plants may be large enough to require a second shift into other boxes, similarly prepared, by the end of June. Auricula seedlings 
go through the hottest months much better in boxes than in pots, as they can be kept more evenly moist. For their summer quarters, a wooden frame placed on sifted coal ashes on the north side of a building or wall, or almost any position where they will be sheltered from the sun and still receive plenty of light, should be given them. The frame should be provided with sash, which should be kept over the plants most of the time, giving air in abundance in favorable weather, and during the warmest weather the whole frame should be raised by placing a brick under each corner, so as to allow a good circulation of air among the plants. About the second week in September the young plants should be potted, using a compost of two parts good, fibrous loam, one part leaf-mold, and one part well decayed cow or sheep manure, with a little sand added. The frame should be kept a little close for a few days after potting, and from this time care must be taken not to wet the foli-

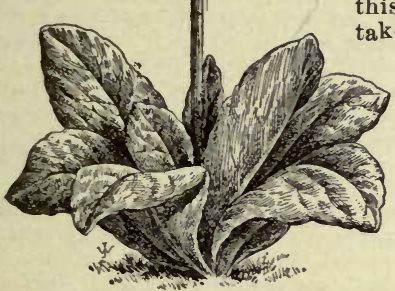

171. Auricula $(\times 1 / 2)$. age in watering. The plants may remain in the frame until danger of freezing, when they should be transferred to a cool greenhouse for the winter. All decaying leaves should be carefully removed, and but little water will be required during the dull winter months.

Towards the end of February the plants will show signs of flowering, when they should be given a top-dressing of pulverized sheep manure and placed in a light, airy position, in a temp. of $55^{\circ}$. The flowering season lasts about two months, after which the plants should receive their annual potting. All diseased or decayed roots should be cut away, and most of the old soil carefully removed. The propagation of very choice varieties by offsets or division is best done at this time. The pots used in potting should be well drained, and no larger than will just accommodate the plants. The soil best suited is the same as before recommended. After potting they may be placed in their summer quarters. Offsets should be inserted round the edge of 4-inch pots, using very sandy soil, and kept in a moist, shaded position until rooted. By annually repotting and giving a little extra care during the summer months, a batch of Auriculas will return very satisfactory results, and may be kept in a good, healthy condition for several years.

Edward J. Canning.

AVÈNA (classical name). Graminece. OAts. A genus of annuals or perennials well known from the cultivated oat. Panicles wide open, and loosely flowered, bearing large 2-6-flowered spikelets. A long, twisted, geniculate awn present, except in the cultivated oat. Species, about 50. Widely spread in the temperate regions of the Old and New World.

fátua, Linn. Wind-oats. Sand-oats. Resembles the eultivated oat; can be distinguished by the larger spikelets and long, brown hairs on the flowering glume. Awn an inch in length. Eu.-A very troublesome weed in some parts. Not cult.

stérilis, Linn. ANTMATEd OATs. Much larger than the cultivated oat: spikelets large, in a drooping panicle; awn very long and geniculate. Mediterranean region and E. - Occasionally cult. for the odd behavior of the "seeds." It is the twisting and untwisting of this awn, when exposed to moisture and dryness, that has given to the grass the name Animated Oats. The untwisting of the awn causes the spikelet to tumble about in various directions, suggestive of independent motion.
The common oat is Avena sativa, Linn., native of the Old World. Pasture grasses sold as Avenas are A. elatior, which is an Arrhenantherum; and $A$.flavescens, which is a Trisetum.

P. B. KENNEDY.

AVERRHOA (after Averrhoes, the Arabian physician). Geranidcea. Tropical fruit trees, cult. in India and China, and sometimes grown under glass for ornament. Lvs. alternate, odd-pinnate; lfts. alternate, ovateacuminate, entire, stalked, sensitive : fls, borne on the naked stems and branches, minute, fragrant, rose-colored to reddish purple, racemose; calyx red; corolla campanulate; petals 5.

Carambòla, Linn. Carambola. Height 15-20 ft.: lfts. 4-5 pairs : fls. rosy purple : fr. varying in size from a hen's egg to a large orange, ovate, acutely 5-angled, yellow, fragrant, the pulp acid. The half-grown fr. used as pickles ; the ripe fr. for preserves. Said to produce 3 crops a year. P. M. 15:231. Cult. sparingly in S. Calif.

A. Bilimbi, Linn. Cucumber Tree. Bilimbi. Height 8-15 ft.: lfts. 5-10 pairs: fls. red, in longer racemes than the above: fr. smaller than the Carambola, cucumber-shaped, smooth, green rind, and acid pulp. Extensively cult. in S. Amer. P.M. green 231 .

\section{Avocád, alligator PEAR. See Persea.}

AZALEA (from Greek azaleos, dry: Linnæus believed, them to grow in dry locations). E'ricdcece. Shrubs : ivs, deciduous or persistent, alternate, more or less nairy and ciliate, rarely glabrous and never lepidote or scurfy: fls. in terminal umbellate racemes, rarely lateral; corolla 5-lobed, funnel-form, campanulate or rotate; stamens 5-10; ovary 5-celled, hairy or setose, with or without glands : fr. a loculicidal capsule (Fig. 172), with numerous minute seeds. This genus is often united with Rhododendron, which is easier to distinguish by its lvs. and general habit than by its fls. In Rhododendron, the lvs. are coriaceous, generally persistent, usually revolute at the margin, glabrous or tomentose beneath, often lepidote, not ciliate, or ciliate and lepidote: stamens usually 10 : ovary glabrous, glandular, lepidote or tomentose, never setose, sometimes more than 5-celled. The glabrous species of Azalea have 5 stamens and deciduous lvs. There are 35 species in Asia (especially E. Asia) and N. Amer. Consult Maximowicz, Rhododendrem Asim Orientalis, St. Petersburg, 1870. The Azaleas belong to our most ornamental and beautiful flowering shrubs, and are often completely covered with large showy fls. of brilliant and various colors. They grow best in peaty or sandy soil containing no limestone, and prefer somewhat moist and half-shaded situations. In regard to the culture, they may be divided into two groups: Hardy deciduous Azaleas, and Indian Azaleas.

HARDY Deciduous Azaleas. - These include the species of the sections Euazalea and Rhodora, and the hybrids known as Ghent Azaleas. They are hardy, but in the N. and in exposed situations a protection with brush, hay or mats should be given during the winter, to prevent the flower-buds from sudden changes of temperature. They are usually increased by seeds sown in early spring in frames or pans, in sandy peat, without covering, and kept moist and shady. When the seedlings appear they should have air and a daily syringing. In autumn they are transplanted into boxes or frames, in sandy, peaty soil. The seeds germinate very readily sown in cut sphagnum, but ought to be pricked into boxes as soon as they can be handled. The second year the seedlings should be planted out in beds, sufficiently wide apart to allow a growth of two years. Long upright branches should be shortened, to secure well-branched plants. The named varieties are grafted on any of the common species, usually by veneer-grafting in autumn in the greenhouse, on potted stock. They may also be increased by cuttings of mature wood 2-3 in. long, taken with a heel late in summer, and placed in sand under glass. Layers usually require 2 years to root sufficiently; they are made in spring, and the buried part enclosed in moss. Azaleas are easy to transplant, either in early spring or in early autumn, when the year's growth has ripened. If desired, they may be planted for decorative purposes in early spring, in beds, without injuring the abundance or brilliancy of the flower, and after- 
wards removed to give space for other decorative plants, and planted carefully in nursery beds, where they remain till next spring; and so on every year. Especially the hybrids and varieties of $A$. mollis are often and easily forced for winter-flowering. If intended for early forcing, they should be grown in pots, and care taken to allow them to finish their growth as early as possible; for later forcing, after Christmas, they may be potted in fall, or even just before bringing them into the forcing. house. With a temperature of $50-55^{\circ}$ at night, they will bloom in about 6 weeks. The Ghent Azaleas are grown in great quantities in the Low Countries and in Germany tor export to America; it is usually more profitable to buy this stock each fall than to attempt to raise it here, where labor is high-priced and the climate dry and hot.

In the open, the flowering period of hardy Azaleas extends from A pril to July. First comes A.Canadensis, $A$. rhombica and $A$. Vaseyi; then $A$.nudiflora and $A$. mollis, followed by $A$. Pontica and $A$. calendulacea, and nearly at the same time $A$. Schlippenbachi and $A$. Albrechti; somewhat later, $A$. occidentalis, and last, $A$. arborescens and $A$. viscosa. One of the most beautiful is the American A. calendulacea, which is hardly surpassed in the brilliancy and abundance of its flowers by any of the Ghent hybrids. Some good hybrids, or Ghent Azaleas, are the following:

Single-fld. varieties : Albicans, white with yellow blotch, fragrant ; Admiral de Ruyter, deep red scarlet; Altaclarensis, white, bordered pink, spotted yellow, fragrant, B.R. 28:27; Anthony Foster, orange-yellow ; Comte de Gomer, bright rose, spotted orange, R.B. $1: 97$; Daviesi, nearly pure white, fragrant, Gt. 42:1307; Directeur Charles Baumann, cherry red, spotted yellow; Géant des Batailles, deep crimson ; Hilda, red-orange ; Louis Hellebuyck, carmine, blotched orange, F.S. 19: 2019; MarieVerschaffelt, pink, blotched yellow; Morteri, rosy pink with yellow blotch, S.B.F.G. II. 1: 10 ; Princesse d'Orange, salmon-pink; Sanguinea, deep crimson; Tsarine, bright pink, R.B. 20:277; Van Dyck, blood-red; Viscosa floribunda, pure white, fragrant.

Double-fld.varieties : Arethusa, creamy white, tingel yellow; Bijou de Gandbrugge, white, bordered rose, F.S. 19: 2024; Louis Aimé Van Houtte, carmine, tinged orange, F.S. 19:2022 ; Madame Mina Van Houtte, pink, tinged salmon and white, F.S. 19:2021; Murillo, pink, tinged purple, R.B. 19:232; Phebe, yellow, tinged orange, R.B. 19:232; Raphael de Smet, pink; Virgile, pale rose, striped yellow in the center, R.B. 19:232.

INDIAN AzALEAS. - This group contains $\boldsymbol{A}$. Indica and other species of the section Tsusia and the hybrids of them. They are well known evergreen shrubs, in the N. requiring cultivation in the greenhouse during the winter, but some varieties, as $A$. Indica, var. Kompferi and var. amœena, are hardy even near New York. A. rosmarinifolia and $A$. linearifolia will stand many degrees of frost in somewhat sheltered positions. They are rarely increased by seeds, which may be sown in the greenhouse in the same way as with the former group. Usually they are propagated by cuttings or grafting. The cuttings root best when made in August from halfripened wood, and placed in sand under a frame, with gentle bottom heat. Choicer varieties are usually increased by veneer-or tongue-grafting, either in winter or in July and Aug. on vigorous-growing varieties raised mostly from cuttings. Grafting on Rhododendron is now used in some German nurseries with very good results. The best soil for Azaleas, if grown in pots, is a sandy compost of half peat and half leaf-soil, with an addition of good fibrous loam. It is essential to plant them firmly, and to give very good drainage. The base of the stem should be just above the surface. The best time for repotting is after flowering, when the new growth commences. During the summer, they should be kept in a coldframe or in the open in a sheltered spot, with the pots plunged in the soil, or planted out in prepured beds, where they make a very vigorous and healthy growth. In Sept. they should be repotted and transferred to the greenhouse. They must have plenty of water and free syringing during the hot months. The natural flowering time is from April to June, but in the greenhouse, Azaleas may be had in flower from Nov. till June. Against the red spider and thrips, from which the Azaleas are liable to suffer if the air is too clry, free syringing with water is the best remedy. Most of the plants used for forcing in this country are imported from Holland and Belgium ; and it is cheaper to buy them than to attempt to raise them. Formerly Azaleas were kept in summer in shade or partial shade, but now it is the custom of the best growers to give them full exposure to the sun, either planted out or in the pots plunged to the rim in ashes or other good drainage material ; in the latter case a top-dressing of 2 or 3 inches of old cow manure is very beneficial. The only American treatise is Halliday's Treatise on the Propagation and Cultivation of Azalea Indica, Baltimore, 1880 .

Some of the best varieties of Indian Azaleas are the following (for a completer account, see August Van Geert, Iconographie des Azalées, abbreviated here as Ic. Az.):

Single-fl.: Antigone, white, striped and spotted violet, R.B. 7:241; Ic. Az. 3; Apollo, vermilion, Ic Az. 20; Charmer, rich amaranth, very large, F.M. 5: 303-4, 1; Comtesse de Beaufort, rich rose, blotched deep crimson: Criterion, rich salmon-pink, bordered white tnıl blotched crimson, F.S. 8: 796 ; Dianıond, white, blotched dark crimson, F.S. 21:2233-34; Duc de Nassau, rich rosy purple, very free and large; Eclatante, deep crimson, shaded rose ; Fanny Ivery, deep salmon-scarlet, blotched magenta, F.M. 10: 242 ; Fielder's White, pure white, early, A.F. 13:1169; Flambeau, rich, glowing crimson, Gn. 16:242,4 ; Fuerstin Bariatinsky, white, striped red, Gn.16, 242, Ic.Az. 13 ; Jean Vervæne, salmon, striped, bordered white, R. B. 2: 145, Ic. Az. 11; lohn Gould Veitch, lilac rose, bordered and netted white, striped crimson, F.S. 20:2071-72; La Victoire, redish, white towards the edges, spotted maroon crimson; Louise von Baden, pure white, sometimes speckled pink ; F.S. 17:1796, F.M. 3: 158; Madame Charles Van Eeckhaute, pure white, with crisped edges ; Madame Van Houtte, scarlet rose, bordered white, F.S. 23: 2383, Ic. Az. 5; Marquis of Lorne, brilliant scarlet, very fine; Miss E. Jarret, pure white, with crisped edges, R.B. 14:213; Mrs. Turner, bright pink, bordered white, spotted crimson, F.S. 8: 451; Mons. Thibaut, orange-red; President Victor Van den Hecke, white striped and speckled crimson, with yellow center, F.S. 15: 1567-68; Princess Alice, pure white, one of the best; Princesse Clementine, white, spotted greenish yellow; Reine des Pays-Bas, rich violet-pink, bordered white, I.H. 13: 479 ; Roi de Hollande, dark blood-red, spotted black ; Sigismund Rucker, rich rose, bordered white, blotched crimson, very showy, F.S. 19:2010-11, Ic.Az. 31 ; Stella, orange-scarlet, tinged violet; Wilson Saunders, pure white, striped and blotched vivid red.

Double-fld.: Borsig, pure white ; Alice, deep rose, blotched vermilion, I.H. 23:244 ; Baron M. de Rothschill, rich purple-violet, large, F.S. 23:2477-78; Bernard An-

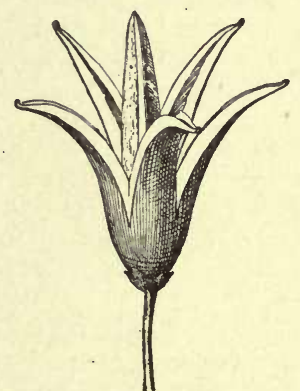

172. Capsule of

Azalea nudiflora.

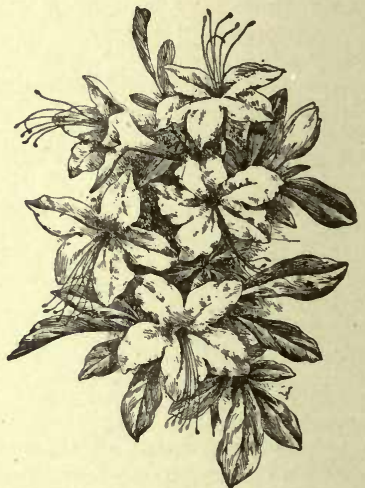

173. Azalea nudiflora $\left(X_{1 / 3}\right)$. dré, dark violet-purple, large; Bernard Anđró alba, white, I.H. 17:15, Ic. Az. 19; Charles Leirens, dark salmon, blotched dark purple, good form and substance, F.S. 19: 1971-72 ; Charles Pynaert, salmon, bordered white, R.B. 10:25; Chicago, deep carmine, bordered white, large; Comtesse Eugenie de Kerchove, white, flaked redcarmine; Deutsche Perle, pure white, early, R.H. 1886: 
516, Gn. 33:619, Ic. Az. 2j ; Dominique Vervæne, bright orange; Dr. Moore, dee $\mu$ rose, stuaded white and violet, very fine, R. Br. 11:61; Empereur du Brésil, rich rose, banded white, upper petals marked red, Ic. Az. 15; François de Vos, deep crimson, I.H. 14:512, Ic. Az. 14, F.M. 8:443 ; Imbricata, white, sometimes flaked rose, I. H. $24: 281$, F.S. $22: 2284-85$; Imperatrice des Indes, salmon-rose, festooned white and dark carmine, F.M. 18: 357 , Ic. Az. 21 ; Johanna Gottschalk, white ; Louise Pynaert, white, R. B. 4: 209 ; Mme. Iris Lefebvre, durk orange-carmine, shaded bright violet and blotched brownisll red, F.S. 18: 1862-63 ; Madame Van der Cruyssen, piuk, fine form, A.F. 12:1003; Madeleine, white, large, semi-clouble; Niobe, white, fine form; Pharailde Mathilde, white, spotted cherry-red, R.B. 13:145; President Ghellinck de Walle, bright rose, upper petals spotted yellow and striped crimson; President Oswald de Kerchore, pink, bordered white, blotched carmine; Raphael, white; Sakuntala, white, very free-flowering; Souv. du Prince Albert, rich rose-peach, broadly margined white, very free-flowering, F.M. 4:201, Ic. Az. 24; Theodore Reimers, lilac, large; Vervæneana, rose, bordered white, sometinies striped salmon.

The following Azaleas are described below : A. alba, No. 15 ; albiflora, 16 ; Albrechti, 12 ; amœna, 14: arborescens, 2 ; balsaminceflora, 14 ; calendulacea, 5 ; Californica, 1 ; calyciflora, 14 ; Canadeusis, 9 ; canescens, 4 ; crispiflora, 14 ; crocea, 5 ; Danielsiana, 14 ; flammea, 5 Gandavensis, 7 ; glauca, 3 ; hispida, 3 ; Indica, 14 ; Kæmpferi, 14 ; lateritia, 14 ; ledifolia, 15 ; liliiflora, 15 macrantha, 14; mollis, 8 ; nareissiflora, 15 ; nitida, 3 ; nudiflora, 4 ; obtusa, 14 ; occidentalis, 1 ; Pontica, 6 . punicea, 15 ; purpurea, 15 ; rhombica, 10 ; Rollissoni, 14 rosiflora, 14 ; rosmarinifolia, 15 ; Schlippenbachi, 13 ; Simsi, 14 ; Sinensis, 8 ; speciosa, 5 ; Vaseyi, 11 ; riscosa, 3 .

A. Fls. in terminal 1-many-fld. clusters.

B. Lv's. and fls. from different buds: winter-buds with many scales: lv's. deciduous.

c. Corolla with rather long tube and usually acute segments, pubescent or hairy outside: stamens 5 : lis. ciliate. (Euazalea.)

D. Stamens as long as or longer than the limb: tube long and narrow, outside glandular.

E. Color white, pink or rose.

1. occidentàlis, Torr. \& Gray (Rhodociendron occidentale, Gray. A. Califórnica, Hort.). Height 2-6 ft.: branchlets glabrous or pubescent : lvs. oborate-oblong, finely ciliate, slightly pubescent beneath when young: corolla $2-2 \frac{1}{2}$ in. long, white or slightly tinged rose, with vellow on the upper lobe, fragrant. May, June. Calif. B.M. 5005. F.S. $14: 1432$. Gn. $34: 673$.

2. arboréscens, Pursh (Rhododéndron arboréscens, Torr.). From 8-20 ft.: branchlets nearly glabrous : lvs. obovate or obovate-oblong, acute, ciliate, glabrous, green or glaucescent beneath : fls. white or tinged rose, 2 in. long, fragrant: style and stamens red. June, July. Allegh. Mts. G.F. 1:401. L.B.C. 17:1632, as A.verticillata.

3. viscòsa, Linn. (Rhododéndron viscòsum, Torr.). From 4-8 ft.: winter-buds glabrous: branchlets with stiff hairs : lvs. obovate-oblong, obtuse or mucronulate, ciliate, bristly hairy on the veins beneath : fls. white or

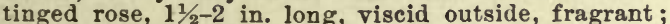
style red. June, July. E. N. Amer. Em. 2:438. Var. nitida, Nichols. From 1-3 ft.: lvs, oblanceolate, bright green on both sides: corolla tinged red. B.R. 5:414. Var. glaùca, Ait. Lvs. whitish-glaucous beneath, dull and glaucous above. L.B.C. 16:1518. Var. híspida, Britt. (A. hispida, Pursh). Pedicels bristly hispid : fls. usually pink : lvs. glaucescent beneath. L.B.C. 5: 441 .

4. nudiflora, Linn. (A. lùtea, Linn. R. nudiflorum, Torr.). Figs. 172, 173. Height 2-6 ft.: winter-buds more or less pubescent : branchlets pubescent and often with stiff hairs: Irs. oblong or obovate, hairy on the midrib or pubescent beneuth : fls. pink to nearly white, before or with the lvs., about $1 \frac{1}{2}$ in. broad, pubescent outside. Apr., May. E. N. Amer. B.R. 120. L.B.C. 1:51. G.W.F. 36. Mn. 2:17. Var. canéscens, Rehder (A. canéscens, Michx.). Lvs. tomentose or pubescent beneath, usually elliptic: fls. glandular outside.
EE. Color yellow to flume-red.

5. calendulàcea, Michx. ( $R$. calenduldceum, Torr.). From 4-10 ft.: branchlets glabrous or with stiff hairs : Ivs. obovate or ovate, usually pubescent beneath, serrulate-ciliate : fis. orange-yellow or flame-red, often 2 in. broad, with the lvs., nearly scentless; tube usually shorter than the limb; stamens thickened at the middle. May, June. E. N. Amer. Var. flámmea, Michx. ( $A$. speciosa, Willd.). Fls, flame- or orange-red. B.R. 145 L.B.C. 7: 624. B.M. 180. Var. cròcea, Michx. Fls. yellow or orange-yellow. B.M. 1721. L.B.C. 14:1324.-One of the niost showy species.

6. Pontica, Linn. (R. flàvum, Don). Plant 2-6 ft.: branchlets hairy: pedicels and petioles glandular: lvs. cuneate, oblong, usually hairy on both sides when young, $2-4$ in. long: fls. yellow, $2-2 \frac{1}{2}$ in. broad, very fragrant ; stamens as long as the limb. May. Orient, Caucasus. B.M. $433 ; 2383$ (var. albiflora). - A very fragrant and free-flowering specios, not common in eult. Nearly all varieties referred to this species in nursery catalogues are hybrids, for which the collective name $A$. Gandavensis may be used.

7. Gandavénsis, Hort. Ghent Azaleas. Fig. 174. These are hybrids between $A$. Pontica, and the American

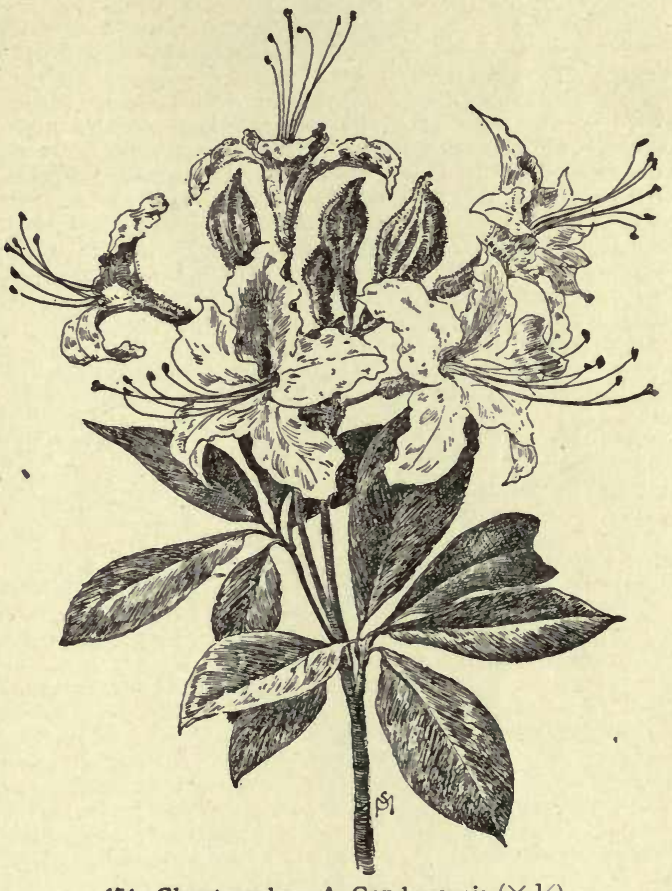

174. Ghent azalea-A. Gandavensis $(\times 1 / 2)$.

species, and $A$. Sinensis, now more in cult. than the typical species. Of a number of them the parents are easily recognized, but many are hybrids of the second degree or more, and it is impossible to be sure about their parentage. They vary in all shades of white, yellow, orange, pink, carmine, lilac, and red, with single and double fls., and also in the time of flowering, from May to July. A short selection of some good varieties has already been given.

DD. Stamens shorter than the limb: corolla funnelform-campanulate, outside pubescent, not glandular.

8. Sinénsis, Lodd. (A. móllis, Blume. R. Sinénse, Sweet). From 3-8 ft: branches hairy : lvs, oblong or obovate-oblong, 2-4 in. long, appressed-setose above, glaucescent beneath and nearly glabrous except on the midrib, rarely pubescent : fls. $2-2 \frac{1}{2}$ in. broad, yellow, orange or pink. April, May. China, Japan. F.S. 19: 2032-36. Gn. 46, p. 265, 546. B.R. 15:1253. L.B.C. 9: 885. 
Gt. 16:556. Gng. 4:279. - A valuable species, with large but scentless fls. A large number of varieties and hy. brids has been raised, which are well adapted for forcing purposes and also for groups in the open, being as hardy as the American species. See Rhododendron for picture.

cc. Corolla with very short tube, rotate-campanulate or two-lipped, glabrous outside: segments obtuse: stamens 7-10. (Rhodora.)

D. Limb of corolla 2-lipped, not spotted, the two lower segments divided nearly to the base: fls. before the lvs.

9. Canadénsis, O. Ktze. (Rhodòra Canadénsis, Linn. Rhododéndron Rhoddra, Don). From 1-3 ft.: lvs. oval, obtuse and mucronulate, glaucous and slightly pubescent beneath : fis. $5-7$, on very short pedicels $1-1 \frac{1}{2}$ in. broad, rose-purple; segments narrow, the lower ones revolute; stamens 10. Apr., May. E. N. Amer.: Newfoundland to Pa. Em. 2: 441. B.M. 474.

10. rhómbica, O. Ktze. (Rhododéndron rhómbicum, Miq.). Shrib, 3-8 ft.: lvs. rhombic-elliptic, acute at both ends and sparsely hairy above, yellowish pubescent at the nerves beneath : fls. $2-3$; corolla $1 \frac{1}{2}-2$ in. broad, somewhat campanulate, bright rose-colored, segments oblong; stamens 10. Apr., May. Japan. B.M.6972. Gt. $17: 586$; G.C. III. $20: 38$.

DD. Limb of corolla rotate-campanulate, or slightly z-lipped, divided usually till below the middle: upper lobes spotted.

11. Vàseyi, Rehder (Rhododéndron Vàseyi, Gray). From 5-15 ft. high; branchlets without bristles : Ivs. oblong or oblong-lanceolate, acute, sparsely hirsute: fls. before or with the lvs.; corolla slightly 2-lipped, lower lobes widely spreading; stamens 7, rarely 5. Apr., May. N. Car. G.F. 1:377. G.C. III. 20:71.-Excellent.

12. Albrechti, O. Ktze. (Rhododéndron Albrechti, Maxim.). From 2-5 ft.: branchlets glandular-pilose : lvs. obovate or elliptic, acute, 3-5 in. long, appressed. pilose above, pubescent along the veins beneath : fls. purple, with the lvs. 2 in. broad; stamens 10. Japan.

13. Schlíppenbachi, O. Ktze. (Rhododéndron Schlip. penbachi, Maxim.). Three to $5 \mathrm{ft} .:$ branchlets glandular-pilose : lvs. cuneate, broadly obovate, 2-5 in. long, rounded and mucronate at the apex, hirsute on both sides or glabrous at length : fls. with the lvs., 2-3 in. broad, pale rose-colored, upper lobes spotted reddish brown: stamens 10. May. Japan. B.M. 7373. Gn. 46: 972 . G.C. III. $19: 561$

Bв. Lvs. and fls. from the same terminal bud: winter buds with 2-4 scales of nearly equal length: corolla glabrous outside: lvs. usually persistent. ('Tsusia.)

14. Indica, Linn. (Rhododéndron Indicum, Sweet).

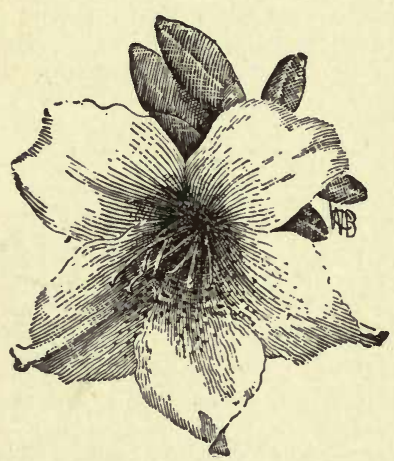
Figs. 175, 176. From 1-8 ft.: branchlets, lvs.and pedicels more or less rufously appressed-strigose :Ivs. lanceolate or obovate: fls. $1-3$; calyx densely setose, not glandular, with usually small lobes ; corolla pink or purple. upper segments spotted; stamens 5-10. China, Jap. Gn. 50, p. 192 ; 54, p. 487 . R.B. 20:121: 21:85; $23: 37$. A.G. $14: 473$. Gng. 4: 359. F. E. 9:431. F.R. 2:579. This is a very variable and much-cultivated species, and

the following varieties are often described as species.

(1) Lvs. lanceolate or elliptic, acute, 2-3 in, long, dull above and rufously strigose: shrubs. 2-8 ft. high, somewhat loosely branched.

Var. K'æmpferi, Rehder. Lvs. deciduous, only a few small ones below the fi.-buds persisting till spring, elliptic, bright green: fls. $2-3$, with or before the Ivs.; calyx-lobes oval, rounded ; corolla 1-2 in. broad, pink or orange-red; stamens 5, with yellow anthers. Apr., May. Jap.-This is the hardiest variety ; hardy even in New Eng.

Var. Simsi, Rehder (A. Indica, Sims, not Linn.). Lvs. persistent, dark green. lanceolate : fls. 1-3, rose-

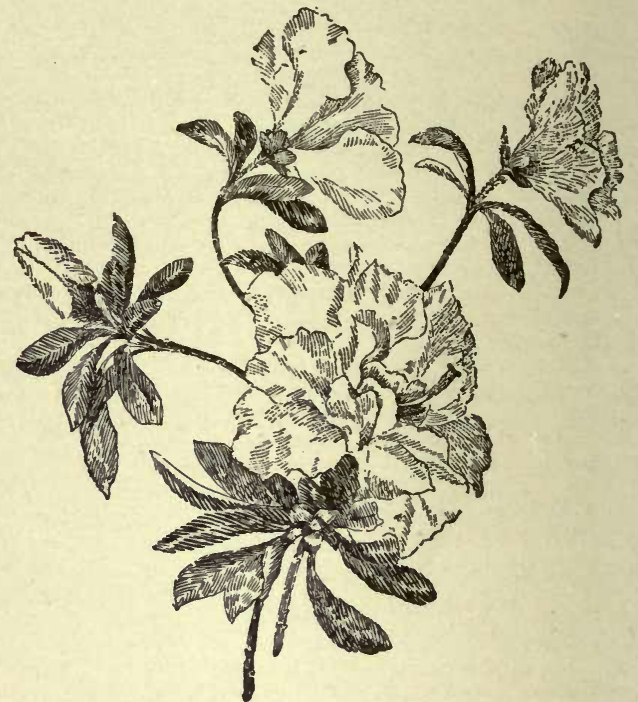

176. Double-flowered Azalea Indica $(\times 1 / 2)$.

colored or carmine ; calyx-lobes lanceolate ; stamens 10, with purple anthers. May, June. China. B.M. 1480. L.B.C. $3: 275$.

(2) Lvs. obovate or obovate-lanceolate, obtuse, rarely acute; $1 / 2-2$ in. long, less strigose, and usually shining above: low, much-branched shrubs.

Var. macrántha, Reichb. (A. mucrántha, Bunge. A. Danielsidna, Paxt.). Lvs. coriaceous, dark green, shining, obovate or oval : fls, usually single, 2-3 in. broad, pink or purplish pink; stamens 5-10, usually enclosed. May, June. China. P.M.1:129. S.B.F.G. II. $3: 261$. - From this variety nearly all of the beautiful garden forms of the Indian Azaleas have originated by cross-breeding with other varieties and forms of $A$. Indica introduced from Japanese and Chinese gardens, and by hybridizing, especially with $A$. rosmarinifolia. To this variety may be referred the following remarkable forms : Var. crispiflora, Van Houtte. Fls. large, rose-colored, with distinctly crisped segments. F.S. 9: 887. B.M. 4726. Var, lateritia, Lindl Lvs. oblong-lanceolate: fls. salmon or brick-red. B.R. 1700.

Var. rosifldra, Rehder (A. rosiflora, Flor. Mag. A. balsamincefldra, Carr. A. Róllissoni, Hort.). Lvs. oblong-lanceolate: fls. salmon-red, very double, with imbricated, oblong segments, resembling the blooms of a camellia-tld. balsam. F.M. 19:418. Gn. 18:249. R.H. $1882: 432$.

Var. obtùsa, Rehder (A. obtìsa, Lindl.). Lvs. obovate or ovate, obtuse : fls. $1-3$, pink or orange-red ; corolla $1-1 \frac{1}{2}$ in. broad, lobes oval-oblong ; stamens 5 , exserted, anthers yellow. May. China, Jap. B.R. 32:37. G.C. II. 25:585. R.H. 1876: 370. Var. obtùsa álba, Hort. Fls. white. G.F. 9: 395. Var. calyciflora, Rehder (A. calycifldra, Hort.). Fls. brick-red, corolla double (bose-in-hose).

Var. amòna, Rehder ( $A$, amōena, Lindl.). Lvs, obovate or elliptic, obtuse or acute, $1 / 2-1$ in. long, dark green : corolla usually double (hose-in-hose), purple, 1/2-1 in. broad ; stamens 5. Apr., May. China, Jap. B.M. 4728. F.S. 9: 885 . G.C. III. 23: fig. 125. A.G. $15: 373 ; 18: 568$. Gng. $2: 385$. A.F. $12: 33$. F.E. $9: 573$. -Flowering early and very abundantly ; hardy north 
to New York. There are some forms and crosses of this variety, of which the following may be recom. mended: Caldwelli, with larger purple fls., Geert,

Ic. Az 18 : Marvel, lilac-earmine, double, Flor. Mag. 11; 14; Princess Maud, rosy magenta, R.H. 1886: 516; Mrs. Carmichael, crimson-magenta ; Princess Beatrice, bright mauve ; Prime Minister, soft pink ; Miss Buist, pure white.

15. rosmarinifollia, Burm. (A. álba, Sweet. A. ledi. folia, Hook. A liliiflora, Poit.). Much branched, low shrub, 1-3 ft.: branches, lrs. and pedicels densely ru. fously appressed-strigose : ivs. elliptic or elliptic-lanceolate, persistent, 1-3 in. long: fls. 1-3; calyx with lanceolate serrate-glandular lobes; corolla pure white or rosy purple, $2-3$ in. broad, fragrant ; stamens usually 10. May. China. B.R. 10:811. B.M. 2901. L.B.C. 13: 1253. - Some remarkable varieties of this species are the following: Var. álba, Rehder (A.Indica, var. álba, Lindl. $R$. levcanthum, Bunge). Fls. white, sometimes striped pink. Var. purpùrea, Rehder $(R$. ledifolium, var. purpùreum, Max.). Fls. rosy purple. Var. narcissiflors, Rehder (A. narcissifldra, Fort.). Fls. double, white ; rarely purple. Var. punícea, Rehd. (A. punícea, Sweet. A. ledifolia, var. phrenicea, Hook. A. Indica, var. calycina, Paxt.). Fls. single, purple; calyx with linear, not serrate and less glandular lobes. B.M. 3239. L.B.C. 18:1735. A. rosmarinifolia has produced, with $A$. Indica, a large number of beautiful hybrids, of which one of the first was figured in 1833 as Rhododendron pulchrum.

AA. Fls. from lateral 1-fld. buds toward the end of the branches : corolla rotate campanulate, glabrous. (Azaleastrum.)

16. albiflòra, O. Ktze. (Rhododéndron albiflòrum, Hook.). About 2-3 ft.: branches strigose and glandular when young: lvs. oblong, pale green, appressed-strigose above and at the midrib beneath, slightly ciliate : fls. nodding, on short pedicels ; corolla white, 5-cleft, about 1 in. broad; calyx glandular; stamens 10 . Rocky Mts. B.M. 3670 .

A. Dahùrica, Koch $=$ Rhododendron Dahuricum. $-A$. di anthiflora, Carr $=\mathrm{A}$, rosmarinifolia, var. dianthiflora. $-\mathrm{A}$. dila tatta, O. Ktze. (R, dilatatum, Miq.). Allied to A. rhombica. Lvs. glabrous: stamens 5. Japan.-A. Fárrerce, Koch (A. squaglabrous : stamens 5. Japan.-A. Farrerce, Koch (A. squamata, Lindl.). Allied to A. Schlippenbachi. Lvs. rhomboidovate, somewhat coriaceous: fls. whitish pink, spotted. China. B.R. 33: 3.-A. Japónica, Gray=A. Sinensis.-A. Kamschática, trate shrub to 10 in. high : lvs, obovate, setose : fls. 1-5, longpednncled, 11/2-2 in broad, campanulate, purple. N. E. Asia N. W. Amer Gt 36:1260, A Lappónica Linn = R. Lapponi(R. eum. - A. linearifolia, Hook. (R. linearifolium, Sieb. \& Zuce.) Allied to A. rosmarinifolia. Lvs, linear-lanceolate : corolla pink, deeply divided into 5 linear-lanceolate segments. April, May. Japan. B.M. 5769. - A. macrosèpala, O. Kuntze (R. macrosepalum, Maxim.). Height 1-2 ft.; branchlets densely villose lvs. deciduous or semi-persistent, elliptic : fls. umbellate, roselilac, spotted, about 2 in. broad; calyx pubescent-glandular. Japan. Gt.19:662. $-A$, mucronàta, Blume=A, rosmarinifolia.-
A. obtùsa, Lindl. =A. Indica, var. obtusa. $-A$. ovàta, Lindl. ( $\mathrm{R}$. ovatum Planch.) Allied to A. albiflora, Height 2-12 ft. lys. ovatum, planch.) A Alied or nearly white, spotted, rotate, $1 \frac{1}{4}-1^{3} / 4$ ovate, glabrous: fis. pink or nearly white, spotted, rotate, $1 / 4-1 \% / 4$
in broad: stamens 5 . China. in. broad; stamens 5. Chibarbàta, $\mathrm{O}$. Kuntze (R. semibarbatum, A. rhombica.- A. semibarbàta, O. Kuntze (R. semibarbatum, setose beneath : fls. greenish yellow, spotted purple, $1 / 2-3 / 4 \mathrm{in}$. broad. Japan. Gt. 19:666.-A. serpyllifólia, Gray (R. serpyllifolium, Miq.). Allied to A. Indica. Low, rigid shrub : lvs deeiduous, obovate $1 / 1 / 1 /$ in long: fls, single rosy red, $1 / 2-3 / 4$ in broad, obove, broad. Japan. B.M. Torers - $-A$. Tschonoskii, 0 . Kuntze (R. Squamata, Lindl. $=$ A. Farreri. $-A$. Tschonoski, O. Kuntze (R. Tschonoskii, Maxim.). Allied to A. Indica. Low shru
elliptic, $1 / 4-3 / 4$ in. long: fls. 2-4, white, $1 / 4$ in. brosd. Japan.

ALFRED REHDER.

AZARA (I. N. Azara, a Spanish promoter of science, especially of botany). Bixdcece. Shrubs or small trees : Ivs. evergreen, alternate, with usually enlarged and leaflike stipules : fis. small, in axillary peduncled racemes or clusters, apetalous ; sepals 4-5; stamens numerous, rarely 5: fr. a many-seeded berry. About 20 species in S. America, especially Chile. Handsome evergreen shrubs, with small but fragrant fls., for warm temperate regions; probably only $A$. microphylla will thrive farther north in a sheltered position and protected during the winter. Grow best in a sandy compost of loam and leaf soil. Prop. by seeds or cuttings of mature wood in autumn, placed in slight bottom heat under glass.

microphylla, Hook. f. From 3-12 ft.: lvs. obovate, serrate, or nearly entire, $1 / 2-3 / 4$ in. long, shining, glabrous, the stipules similar, but half the size: fls. greenish, in few-fld. clusters; stamens 5: berries orange. Feb., Mar. Chile. G.C. II. 1: 81. - Graceful evergreen shrub, regularly pinnately branched, excellent for covering walls; the hardiest of all the cultivated species.

Gilliesi, Hook. \& Arn. Height 10-15 ft.: Ivs. 21/2-3 in. long, broad-ovate, with coarse, spiny teeth, glabrous; stipules orbicular, much smaller : fls. in dense, elliptic, nodding heads, yellow. Feb., Mar. Chile. B.M. 5178. F.S. 23:2445. - The handsomest of all Azaras.

A. crassifolia, Hort. = A. Gilliesi. - A. dentàta, R. \& Pav. Height $12 \mathrm{ft}$.: lvs. obovate or elliptic, crenate-serrate: fls. yellow in small corymbs. Chile. B.R. 21:1788.-A. integrifolia. R. \& Pav. Height 10-20 ft. Ivs, entire: tls, yellow, in oblong heads. Chile. Has a variegated form.

ALFRED REHDER.

AZÓLLA (Greek, to destroy by drying). Salvinidcece. A small genus of floating aquatics with small, pinnate stems and minute tleshy 2-lobed lvs., producing two sorts of spores in globular sporocarps. The species multiply rapidly by self-division, but will grow readily in water containing a little nutriment. The species are distinguishable only by microscropic examination.

Caroliniàna, Willd. Plant $3 / 4-1$ in. long : anchor-like processes of spores with septa. N. Y. to the Gulf of Mex.

filiculoldes, Lam. Plants 1-2 in, long: anchor-like processes without septa. Calif. to Chile.

L. M. UNDERWOOD. 
BABIANA (said to come from Dutch for baboon, because those animals eat the bulbs). Iridacece. About 50 cormous plants of S. Afr. Fls. showy, red or purplish, in a short spike-like cluster or raceme, tubular at the base, the segments with claws or narrow bases, and the limb erect-spreading: ovary 3-loculed: lvs. narrow, hairy, plaited, standing edgewise to the stem. Low plants, of easy culture if treated like freesias or hyacinths. Three or 4 corms in a 4-in. pot give attractive bloom in March or later. Grown only indoors or under frames in the N. They are showy and useful plants. Monogr. by Baker in Handbook of the Irideæ, 1892.

\section{A. Perianth limb regular or nearly so, and wide-} spreading.

strícta, Ker. (B. villòsa, and B. purpùrea, Ker.). Fig. 177. A foot or less high: lvs. broad, oblong-lanceolate or sword-shaped, barely reaching the spikes : fls. scattered, showy, usually red or purple, with a prominent tube, the segments oblong-lanceolate. B.M. 583, 621. - Babianas are not sold under species-names in this

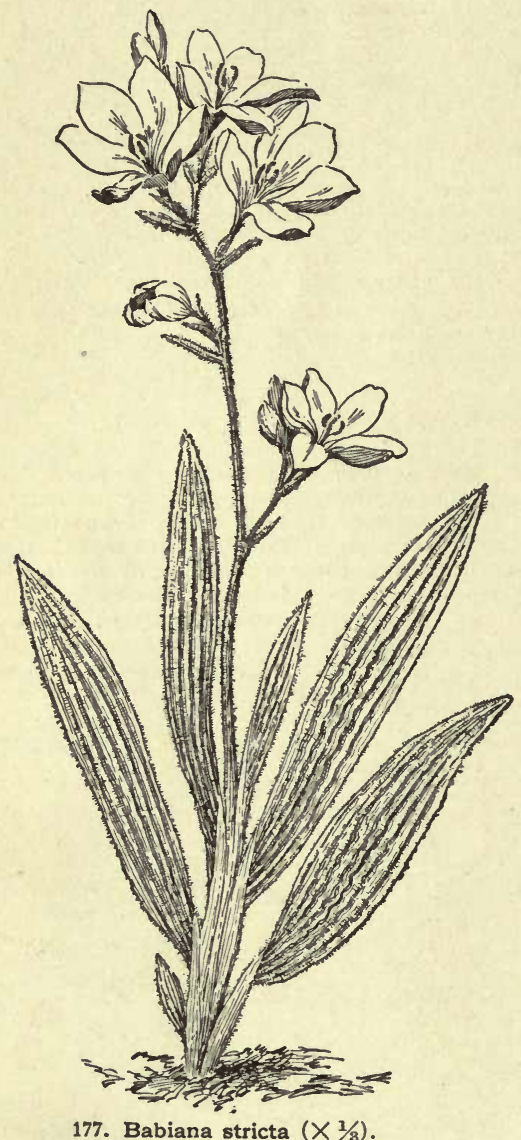

country, but as mixed varieties. These varieties are chiefly, if not wholly, of this species. Many forms and colors. Var. angustifolia, Sweet. Lvs, linear. B.N. 637. Var. rubro-cyànea, Ker. Limb lilac, throat red. B.M. 410. Var. sulphurea, Ker. Yellow or whitish. B.M. 1053. Two other long-cultivated types are described below.
AA. Perianth limb distinctly ringent or gaping.

plicàta, Ker. Low: lvs. lanceolate, hairy, usually overtopping the spikes : fls. lilac or red, long-tubed, the segments oblong and unequal. B.M. 576.

disticha, Ker. Differs from the last in having the perianth-tube distinctly exserted from the spathe.

\section{BABY'S BREATH. See Gypsophila.}

BÁCCHARIS (bakkaris, an ancient Greek name). Compósitoe. Groundsel Tree. Shrubs or herbs: lvs. alternate, usually serrate, deciduous or persistent: heads of fls. small, white or yellowish, diøcious; involucre with many imbricate scales: akenes with pappus. About 250 species in America, mostly in tropical regions. A few species are cultivated particularly for the snow-white pappus, which gives the fruiting plant a very showy appearance. They grow in almost any well drained soil in a sunny position, and are well adapted for dry and rocky slopes, and valuable for seashore planting. Prop. by seeds or by cuttings under glass.

halimifollia, Linn. Shrub, 3-12 ft.; branches angular: lvs. cuneate, oblong or obovate, coarsely toothed, the uppermost entire, glabrous, 1-2 in. long: fls. in large panicles : pappus white, about $1 / 3$ in. long. Sept. Seacoast, from N. Eng. southward. Gng. 7:113.-The hardiest species; in fruit resembling a shrub with abundant snow-white fls.

B. Patagònica, Hook. \& Arn. Low evergreen shrub: lvs. 1/8-1/2in. long: heads mostly axillary. Patag.-B. pilulàris, DC. Height $6 \mathrm{ft}$.; evergreen: lvs. 1 in. long: heads in racemose panicles. Pacific coast. - B. salicifolia, Torr. \& Gray, Allied to B. halimifolia. Lvs, narrow-oblong or linear-lanceolate. Colo. to W. Texas.
Wrs. narrow-oblong or linear-lanceolate. Colo.

BACHELOR'S BUTTONS. See Centaurea Cyanus, Gomphrena globosa and Ranunculus acris.

BÁCTRIS (Greek, baltron, cane; the young stems used for walking-sticks). Palmàceo, tribe Cocoineoe. Usually low palms, very rarely entirely spineless, with solitary or fasciculate ringed, spiny or smooth caudices, sprouting from the roots : lvs. terminal or scattering, equally or unequally pinnatisect, glabrous or pubescent; segments sparse or aggregated, or more or less imperfectly connate, forming a bifid blade, acute or rarely obtuse at the apex, the ciliate margins recurved at the base; petiole short or long; sheath long, spiny; spadices sessile or pedunculate, perforating the leaf-sheaths; spathes 2 , the lower short, open at the apex, the upper coriaceous or woody, exceeding the spadix, or fusiform, ventrally dehiscent, smooth, bristly or spiny ; bracts persistent: fls. small or medium, pale yellow or greenish: fr. small, green, ovoid or globose. Species, about 100. Tropical America. Ornamental, but little grown on account of the spines. See Palms.

\section{A. Spines yellow, tipped black.}

pallidispina, Mart. (B. flavispina, Hort.). St. 10-18 ft. high, 1-2 in. in diam., the internodes spiny: lvs. showy, 5-9 ft. long, equally interruptedly pinnatisect; petiole 4-6 ft., brown-scaly, thickly covered with very long $\left(3 / 4-2 \frac{1}{4}\right.$ in. $)$, black-tipped yellow spines, either solitary or in groups of $2-4$; segments linear-lanceolate, caudateacuminate, prickly on the margins, the basal ones 2-8 in. long, $1 \frac{1}{2}$ in. wide, the upper, 12 in. by $1 \frac{1}{4}$ in. Brazil.

$$
\text { AA. Spines black. }
$$

B. Lf.-segments acute at both ends.

màjor, Jacq. St. 9-15 ft. high, 1-11/2in. in diam., armed with rows of black spines, 2 in. long: petiole armed with very long black, terete spines; lvs. 4-6 ft.long, equally pinnatisect nearly to the rachis; sheath and rachis spiny and white or brown tomentose ; segments linear, acute at both ends, 25-35 on each side, 1-nerved, 8-12 in. long, $1 / 3-1 / 2$ in. wide, glabrous on both sides, densely setose, with black hairs along the margin. Brazil. 
BB. Lf.-segments acute at tip.

Gasipäës, НВК. (Guiliélma speciòsa, Mart.). St. about $60 \mathrm{ft}$. high, single or crspitose, with rings of subu-

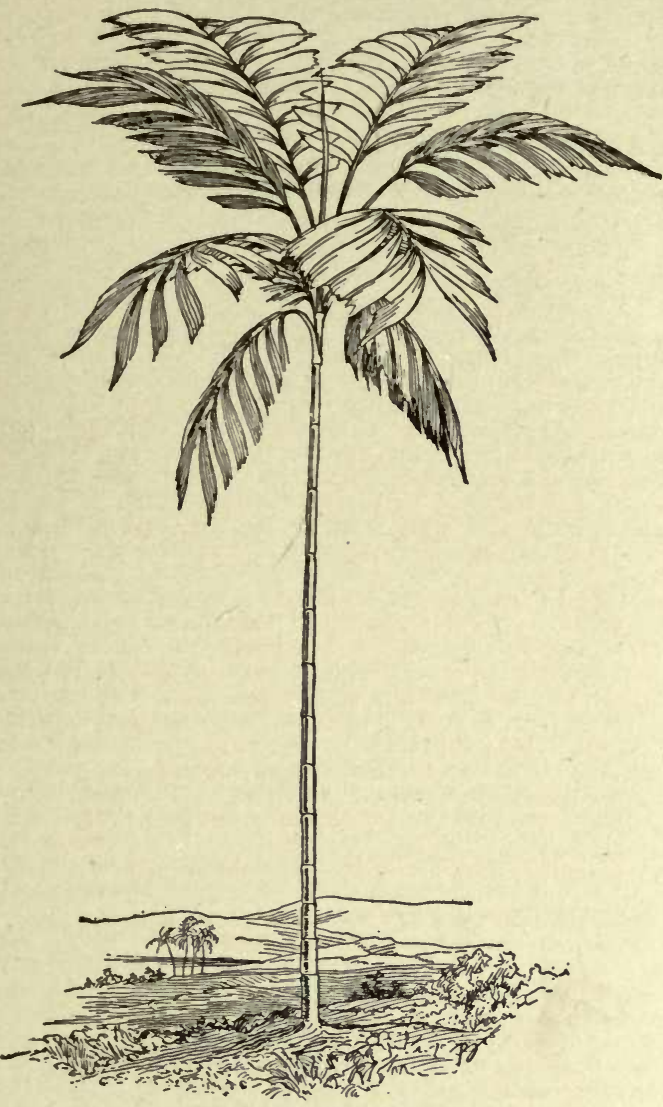

178. Balaka Seemanni.

late-compressed black spines, 1 in. long, the rings about as far apart as the diam. of the st.: lvs. $6 \mathrm{ft}$. long, curv. ing; segments dark green above, pale green below, very numerous, approximate, $1 \frac{1}{2} \mathrm{ft}$. long, $11 / 4 \mathrm{in}$. wide, linearlanceolate, long-acuminate, bristly or minutely prickly along the margins. Lower Amazon.

horrida, Oerst. Cæspitose stems 6-8 ft. high, 8-9 in. diam., very spiny, sheathed for most of its length with bases of dead lvs.; spines 3-4 in. long, 4-sided, whitish tomentose, at length glabrous: lvs. $2 \frac{1}{3}-3 \mathrm{ft}$. long; sheath 8 in., brown-tomentose; petiole $11 / 2 \mathrm{ft}$., densely spiny, subtetragonal, densely brown-tomentose beneath: segments 7 in. long, $1 / 2 \mathrm{in}$. wide, lanceolate, rigid, glaucous. Nicaragua.

JARED G. SMITH.

BACULARIA (Latin, baculum, a small walking-stick). Palmacece, tribe Arècea. Low spineless palms, with annular reed-like single or fasciculate sts: lvs, terminal, unequally pinnatisect; segments membranous, broad or narrow, split or toothed at the apex, the broader ones many-nerved, the narrow ones 1-nerved, the terminal confluent; midrib and nerves without scales below: margins not thickened, recurved at the base; petiole and rachis sparsely scurfy, convex on the back, flat above or concave toward the base : sheath short, open : spadices numerous, longer than the lvs., spreading, recurved: peduncle very slender, scurfy, compressed at the base : spathes 2 , remote, the lower one at the base of the peduncle tubular, the upper membranaceous, linear, ensiform : fls. green : fr. small, elongate-ovoid, subacute, green, $1 / 4-1 / 2$ in. long. Species 2 . Temperate and tropical Australia. See Paims. monostàchya, F. Muell. (Arèca monostachya, Mart. Kéntia monostachya, F. Muell.). Trunk 6-12 ft. high: Ivs. $1 \frac{1}{2}-4 \mathrm{ft}$. long; the sheath broad, coriaceous, about 6 in. long, produced into 2 stipular lobes; segments very irregular, acuminate, very variable in breadth and distance, adnate to the rachis, or tapering at the base, the longest about $1 \mathrm{ft}$. long. Queensland, N.S.W. B.M. 6644. JARED G. SMITH.

BAERIA (after the Russian zoölogist, Karl Ernst ron Baer). Compósita. Californian annuals (or one perennial species), with numerous showy, inch-wide yellow fls, in early summer.

grácilis, Gray (Burrièlia grácilis, DC.). Easily distinguished from Actinolepsis coronaria by its hairy sts. and follage and undivided lis.: plant much branched: height 4-12 in.: lvs. opposite, connate, linear-lanceolate: fls. solitary, on slender terminal peduncles : involucre leafler than in Actinolepsis coronaria, the scales longer, downy, in 2 series: rays 8-12. B.M. 3758.-This is likely to be cult. as Lasthenia Californica, which, however, is not hairy and has much longer lvs.

B. chrysóstoma, Fisch. \& May. Lvs. narrowly linear, 1 line or less wide : fls. larger than in B. gracilis : habit more erect. $-B$. coronaria $=$ Actinolepsis coronaria.

BALAKA (the Fijian vernacular name). Palmdcece, tribe A rècece. Differs from Ptychosperma in having the seed not sulcate, and in the half-rhomboid segments of the Ivs.; and from Drymophlous in the form of the leaf and the caducous spathes. Species 2. Fiji Islands.

Seł̀manni, Becc. (Ptychospérma Seèmanni, H. Wendl.). Fig. 178. Caudex slender, 8-12 ft. high, straight, ringed, about 1 in. in diam.: Ivs. pinnatisect, $4 \mathrm{ft}$.long; segments erose-dentate at the apex, alternate, 9 on each side, semi-rhomboid, obliquely truncate, the upper margin longer, cuspidate at the apex, the terminal one deeply bifid. Growing as underwood in dense forests. Fiji. - Stems used for spears by natives, because of their strength and straightness. Fig. 178 is adapted from Seeman's Flora Vitiensis.

JARED G. SMith.

BALLOON VINE. See Cardiospermum.

BALM (Melíssa officindlis, Linn.). Labiata. Sweet herb, the lvs. being used for seasoning, particularly in liquors. It has a lemon-like flavor. It is a hardy perennial from southern Eu. The plant grows 1-2 ft. high, somewhat hairy, loosely branched, with ovate-crenate

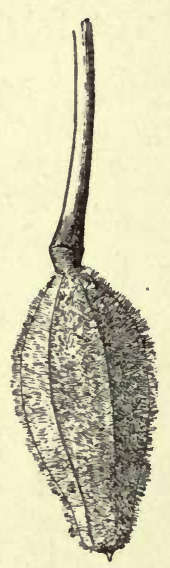

179. Pod of

garden Balsam. lvs. and yellowish or whitish fls. in loose axillary clusters. Thrives in any warm position, and is easy to grisw. Prop. by seeds; also by dirision.

BALSAM, Impatiens Balsámina, Linn. (Balsámina horténsis, DC. Balsámina Impdtiens, Hort. Impatiens coccínea, Sims, B.M. 1256). Geranidcece. An erect, much-branched, half succulent annual, long ago introduced from India, and now widely cult. for its showy 
fls. It has varied immensely in the doubling, size aud color of its fls. and in the stature of the plant. It was known to Gerarde in 1596. The plant has lanceolate, toothed lvs., the lower ones being mostly in pairs. The fls. are clustered in the axils of the lvs., on very short

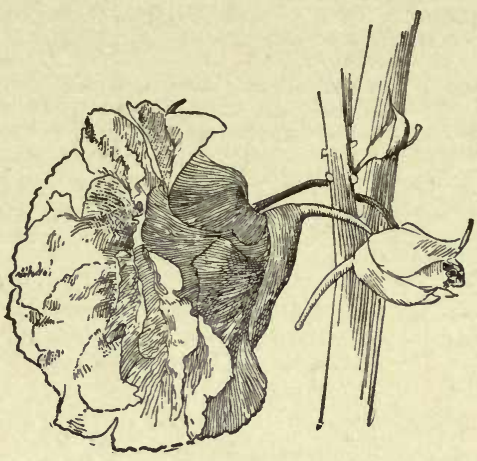

181. Camellia-flowered Balsam.

stalks; sepals and petals similarly colored and not easily distinguished, one of the sepals (of which there seem to be 3) long-spurred; petals apparently 3, but two of them probably represent two united petals, thus making 5 ; stamens 5 . The pod, shown in Figs. 179 and 180 , is explosive. It has 5 carpels and very thin partitions, and seeds borne on axile placentæ. When the capsules are ripe, a pinch or concussion will cause the valves to separate and contract, the seeds being thrown with considerable force.

The full-double Balsams are known as the Camelliaflowered varieties (Fig. 181). In well selected stock, the greater part of the flowers from any batch of seedlings should come very double. The colors range from white to dark blood-red, yellowish and spotted. Balsams are of very easy culture. They are tender, and should be started in thumb-pots or boxes indoors, or in the open when danger of frost is past. The seeds are large, and germinate quickly. The plants prefer a rich, sandy loam, and must not suffer for moisture. Transplanting, and pinching-in the strong shoots, tend to make the plants dwarf and compact. It is well to remove the first flower-buds, especially if the plants are not thoroughly established. Better results are obtained when only a few main branches are allowed to grow, all the secondary and weak ones being pinched out. The lower lvs. may

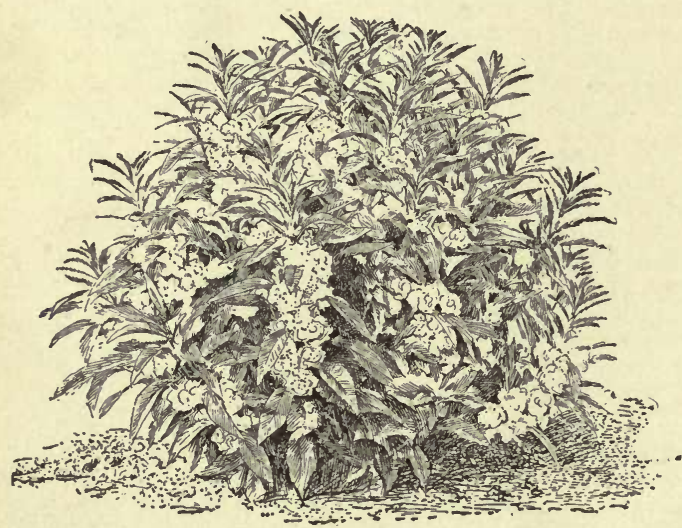

182. The garden Balsam.

be removed if they obscure the fls. Well grown plants should stand $2 \mathrm{ft}$. apart each way, and the tall kinds will reach a height of $2-21 / 2 \mathrm{ft}$. Seed of the finest double strains is expensive, but inferior or common seed gives little satisfaction. Plants started early in May should give fls. in July, and should bloom until frost. A full grown plant is shown in Fig. 182. At the present time, Balsams are grown chiefly for their value as flower-garden plants; but some years ago the fls. were largely used as "groundwork" in florists' designs, particularly the double white varieties. The flowers were wired to toothpicks, and were then thrust into the moss which formed the body of the design.

L. H. B.

BALSAMORRHİZA (Greek, balsam root). Compósitce. Low perennials with thick, deep, resinous roots, tufts of radical lvs., and large, yellow fls. Cent. and W. N. Amer

Hodkeri, Nutt. Height 4-12 in.: lvs. lanceolate, 1-2 pinnately parted : fls. solitary, on naked scapes. Int. 1881 by E. Gillett, but scarcely known to horticulturists.

BAMB00. Various giant perennial grasses consisting of the genera and species of the tribe Bambùsece, order Graminea. Usually large and often tree-like, woody, rarely berbaceous or climbing, of wide geographical range. The species are irregularly distributed throughout the tropical zone, a few occurring in subtropical and temperate zones, and reaching their maximum development in the monsoon regions of Asia. About 23 gevera, only 2 being common to both hemispheres. Something more than 200 species are recognized, of which ipwards of 160 occur in Asia, about 70 in America, and 5 in Africa. They extend from sea-level to altitudes of more than $10,000 \mathrm{ft}$. in the Himalayas and $15,000 \mathrm{ft}$. in the Andes, and under the most favorable conditions some species may attain a height of 100-120 ft., with a diam. of culm of 8-12 inches.

An attempt to portray the many economic uses of the giant-grasses would greatly overreach the field of this article; but as objects of grace and keauty in the garden, conservatory, and special conditions of landscape, the Bamboos are invaluable. Not only are they available to planters where the climatic conditions are very favorable, but it is possible to grow certain species where the cold of winter may reach zero Fahrenheit, or even occasional depressions of greater severity.

Bamboos delight in a deep, rich loam, and generously respond to good treatment. A warm, slightly skady nook, protected from the prevailing winds of winter, and where moist but well-drained soil is plentifui, is an ideal location for these beautiful grasses. A top-dressing of manure and leaves is not only beneficial in winter, by preventing the frost from penetrating the ground too deeply, but it also preserves the moisture that is so essential to the welfare of the plants during the growing season. Some species produce rampant subterranean stems, and spread rapidly when once established. It is best to plant each group of but one species, and to restrict the rapidly-spreading sorts to isolated positions. The most effective results to be obtained by planting Bamboos are secured on gentle banks above clear water and against a strong background of the deepest green. In such situations the gracefully arched stems, the dainty branches, bending with their wealth of soft green lvs., and the careless lines of symmetry of each individual, lend a bold contrast of the richest beauty. It will require a few years to thoroughly establish a clump of Bamboos in the open air, and until this is effected the vigor, hardiness and beauty that characterize some noble sorts are lacking. During the early life of the groups, some protection should be given where the winters are trying, and even with this precaution it is likely the plants will suffer to some extent at first during cold weather. Planted out in conservatories or confined in tubs or large pots, the Bamboos present many admirable qualities. As decorative plants in tubs or pots, either alone or associated with palms and other stock, several species offer many inducements to their cultivation, especially as they may be grown in summer and wintered in a coolhouse. Propagation is best effected by careful division of the clumps before the annual growth has started. The difficulty of procuring seeds in some instances is very great ; indeed, the fruiting of a number of species has never been observed. Some species flower annually, but the majority reach this stage only at intervals of indefinite and frequently widely separated periods. In some species the fls. appear on leafy branches ; 
in others the 1vs. fall from the culms before the fls. appear, or the inflorescence is produced on leafless, radical stems. Fructification does not exhaust the vitality of some species; but others, on the other haud, perish even to the portions underground, leaving their places to be filled by their seedling offspring. Owing largely to the difficulty in obtaining flowering specimens, the systematic arrangement or nomenclature of the Bamboo is in a sad plight. As it is sometimes even impossible to accurately determine the genus without $\mathrm{fls}$., the correct positions of some forms are not known.

Four subtribes of Bambusem are regarded by Hackel, namely: Arundinariece. - Stamens 3; palea 2-keeled: fr. with the seed grown fast to the seed-wall. To this belongs Arundinaria. Eubambusece.-Stamens 6: fr. with the seed fused to a delicate seed-wall. Bambusa is the only garden genus. Dendrocalamea. - Stamens 6 (rarely more): palea 2-keeled : fr. a nut or berry. Here belongs Dendrocalamus. Melocannea.-Characters of last, but palea not keeled. Melocanna is an example.

The genera Arundinaria, Bambusa and Phyllostachys contain the most important species in cultivation, some of which are briefly described below. Roughly, the species of Arundinaria may be separated from Pbyllostachys by the persistent sheaths and cylindrical stems. In Phyllostachys the sheaths are early deciduous, and the internodes, at least those above the base, are flattened on one side. Arundinaria and Bambusa cannot be separated by horticultural characters. It is probable that many of the forms now classed as species of Bam. busa will eventually be found to belong to Arundinaria. Extended information regarding the Bambusem may be found in the following publications : Munro's Monograph, in Transactions of the Linnæan Soc.ety, vol. 26 (1868); Hackel, in Die Natürlichen Pflanzenfamilien, vol. 2, part 2, p. 89 (1887), English Translation by Lamson-Scribner \& Southworth, as The True Grasses, N. Y., 1890 ; papers by Bean in Gardeners' Chronicle III., 15: 167, et seq. (1894); FreemanMitford, The Bamboo Garden, 1896, N. Y. Macmillan, p. 224 ; A. and C. Rivière, Les Bambous, Paris, 1879. The first two are systematic; the others contain popular and cultural notes. The following species are commended as being among the hardiest: Phyllostachys Henonis, $P$. nigra, P.viridi-glaucescens, Arundinaria Japonica, A. nitida, A. macrosperma, Bambusa palmata, B. tessellate and $B$. pygmoea.

C. D. BEADle.

The illustrations in the present article are adapted from Mitford's Bamboo Garden. Mitford's work cannot be praised too highly. It has done much to create a popular appreciation of Bamboos, and also to clear up the complete confusion into which the trade names have fallen. Mitford's book has a literary quality that is very rare in horticultural writing, and represents a type that deserves the warmest appreciation in America; viz., the discriminating enthusiasm of the expert amateur.

Arundinaria is derived from Latin arundo, a reed; Bambusa from a Malay name; Phyllostachys from Greek phyllon, leaf, and stachys, spike. W. M.

The following alphabetical list contains all the kinds of Bamboos known to be cult. in Amer. A = Arundinaria ; $\mathbf{B}=$ Bambusa ; $\mathrm{D}=$ Dendrocalamus ; $\mathbf{P}=\mathbf{P h y l l o}$ stachys; $\mathrm{T}=$ Thamnocalamus, which is here considered a subgenus of Arundinaria. No Japanese native names are given below, although many Bamboos are still advertised under such names. The prevailing tendency is to discard Japanese native names in every branch of horticulture, as they breed hopeless confusion.

B. angustifolia, $15 ;$ B. arundinacea, $11 ; B$. aurea, 28 ; P. aurea, 28 ; A. auricoma, 16 ; P. bambusoides, 32 ; P. Castillonis, 26 ; A. chrysantha, $17 ; B$. chrysantha, 17; B. disticha, 18 ; B. erecta, $10 ; \mathrm{A}$ falcata, $9 ; B$. fal-

cata, 9 ; A. Falconeri, 8 ; T. Falconeri, 8 ; A. Fortunei, 14 ; A. Fortunei, var. aurea, $16 ; A$. Fortunei, var. viridis, 22 ; B. Fortunei, 14 ; B. Fortunei, var. aurea, 16 ; B. gracilis, 8 ; B. Henonis, 30 ; P. Henonis, 30 ; A. Hindsii, 10 ; A. humilis, 22 ; A. Japonica, 6 ; P. $K u$ masaca, 33 ; P. Kumasasa, 33 ; A. macrosperma, 4 ; $A$. macrosperma, var. suffruticosa, $5 ; B$. Maximowiczii, 7 B. Mazeli, $29 ; B$. Metake, 6 ; B.mitis, 25 ; P. mitis, 25 ; B. nana, 18 ; A. Narihira, 7 ; B. Narihira, 7 ; B. nigra, 24 ; P. nigra, 23; A. nitida, 3 ; B. palmata, 19; B. plicata, 7 ; A. pumila, 2 ; B. pumila, 2; B. pygmæa, 21 ; B. quadrangularis, 12 ;B. Quilioi, 29 ; P. Quilioi, 29 ; B. Kagamowskii, 20 ; B. miscifolia, 33 ; P. ruscifolia, 33 ; A. Simoni, 7; B. Simoni, 7 ; A. tecta, 5 ; B. tessellata, 20 ; A. Veitchii, 1;B. Veitchii, 1;B. Vilmorini, 15;B. viminalis, $33 ; B$. violascens, $24 ; P$. violascens, $24 ; B$. viridi-striata, $7 ; B$. viridi-glaucescens, 31 ; P. viridiglaucescens, 31 ; B. vulgaris, 13.

SECTION I.-Intemodes not flattened: sheaths persistent. (The genera Arundindria and Bambùsa.)

A. Color of stems purple, or purplish. B. Height 1-2 ft.

1. A.Vèitchii, N. E. Brown (Bambùsa Vèitchii, Carr.). Fig. 183. Height about 2 ft.: stems purple, white-waxy below the nodes: lvs. 5-7 in. long, about 2 in. wide, bright green above, below pale and minutely pubescent, serrate. Jap. M. 77, but not G.C. III. 15: 169, or R.B. 23, p. 270,

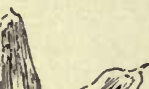

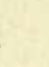

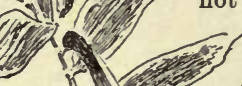


long, 3/4-2 in. broad, smoothish or pubescent: sheaths very persistent: stems arborescent, rigid, simple the first year, branching the second, afterwards fruiting at indefinite periods, and soon after decaying. Banks of the

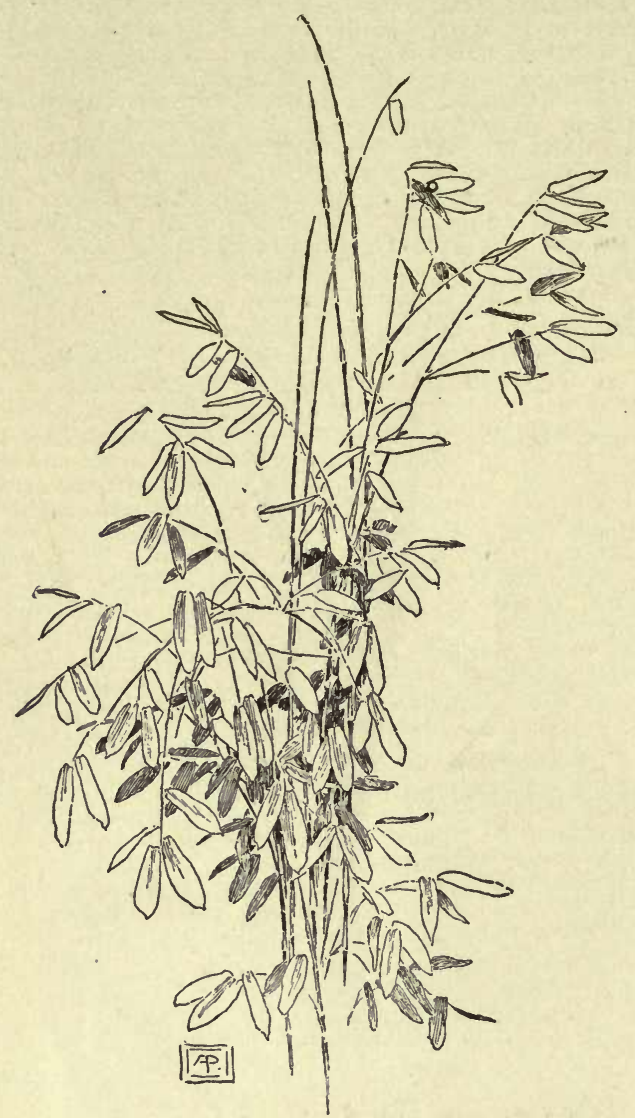

184. Arundinaria nitida.

larger rivers N. C. to Fla., forming cane-brakes.-This and the next are the only two species of Bamboos native to the U. S. They are rarely cult. in Calif. and Eu. as ornamentals.

5. A. técta, Muhl. (A. macrospérma, var. suffrutic̀sa, Munro). SMall Cane. Switch Cane. Scutch Cane. Height 2-15 ft.: stems slender: $1 \nabla \mathrm{s} .31 / 2-8$ in. long, 4-12 lines wide, roughish: sheath bearded at the throat. Swamps and moist soil, Md. and $\mathrm{S}$. Ind. southward. B.B. 1:233. - Sometimes fruiting several years in succession.

cc. Species not native to the $U$. S.

D. Plants relatively hardy.

E. Branches borne singly in the axils.

6. A. Japónica, Sieb.\& Zucc.(B.Metáke,Sieb.). Height 6-10 ft.: lvs, 6-12 in. long, 1-2 in. wide, above smooth and shining, below whitened and finely pubescent: sheaths conspicuous. Jap. M. 1. G.C. III. 15:239; 18: 185. - The commonest of all hardy Bamboos, and readily distinguished from all other tall kinds by the broader and larger lvs. and by the broad, persistent sheaths which almost cover the sts. It is especially distinguished from $A$. Simoni by the bud being a simple flattish scale instead of a complex scaly one, and also by the less amount of waxy bloom on the st. Particularly recommentlid for cities.
EE. Branches borne in dense, semi-verticillate clusters (which easily distinguishes the Himalayan species from Phyllostachys).

\section{F. Plants sometimes variegated.}

7. A. Simòni, A. and C. Rivière (B. Simoni, Carr. B. viridi-striata, Hort. $A$. and $B$. Narihira, Hort.). Height 10-20 ft.: lvs. 8-12 in. long, about 1 in. wide, pale beneath, very minutely pubescent,tapering to a long, fine point: mid-vein glaucous on one side toward the apex, green on the other. Himal. and China. G.C.III. $15: 301 ; 18: 181 .-A$ silver variegated form is sometimes known as B. Maximowiczii, Hort., and B. plicata, Hort. B.M. 7146. This is the tallest of the genus, and, next to $P$. mitis, the tallest of all hardy Bamboos. The plant is very late in beginning growth, and many of the culms should be removed in order to let the strong ones ripen, as weak shoots are untidy. It flowers occasionally, but dies not die thereafter. It has a shabby appearance until midsummer, and may take several years to become established, meanwhile sending up dwarf, slender shoots and narrow foliage, but Mitford urges patience, as the plant is hardy, and ultimately very vigorous and handsome.

$$
\text { FF. Plants never variegated. }
$$

8. A. Fálconeri, Mitford ('T'. Fálconeri, Hook. f. $B$. grácilis, Hort., not Wall.). Height 10-15 ft.: stems slender, bright green, the internodes white-waxy : lvs. thin, $3-4$ in. long, about $1 / 2$ in. wide. Himal. - Not very hardy. The leaf-sheaths are smooth, cut short at the top, without a fringe, and with an elongated ligula; while $\boldsymbol{A}$. falcata, No.9, has very downy leaf-sheaths, fringed with long hairs at the intersection with the leaf. The serrations of the leaf-edges are more pronounced in $A$. Falconeri, especially on one side. Venation of lvs. on upper surface is striate, not tesselated.

9. A. falcàta, Nees (B. falcata, Hort.). Height 6-10 ft.: lvs. $3-5$ in. long, about $1 / 3$ in. wide, light green : stems annual (perennial under glass), slender, tufted. Himal. - The great majority of the plants cult. under this name are really $A$. Falconeri, which has larger lvs. In a small state, $A$, falcata can be distinguished from No. 8 only by the glabrous leaf-sheaths of the latter. The flower-bearing and leaf-bearing sts. of $A$. falcata are distinct, the former flowering and seed. ing each year.

10. A. Hindsii, Munro (B. erécta, Hort.). Height sometimes $7 \mathrm{ft}$., branches quasi-verticillate : lvs. upright at first, of various lengths up to 9 in., and about $5 / 8$ in. wide ; veins conspicuously tesselated; internodes 3-7 in. long, waxy-white; leaf-sheaths with a few hairs. Jap. - The erect habit of growth is very marked. A recent species of doubtful hardiness. Adv. by Dr. Franceschi, who considers it one of the hardiest.

\section{DD. Plants relatively tender (Nos. 11, 12, 13).}

$$
\text { E. Branches spiny. }
$$

11. B. arundinàcea, Retz. A majestic species, often attaining a height of more than 40-60 ft. The stems, which are produced in dense clumps, are green and shining, with more or less spiny branches: lvs. $4-8$ in. long, $1 / 2 \mathrm{in}$. or a little more wide, nearly glabrous; sheaths persistent: fls. are produced at long intervals, and after perfecting seeds, the plants die. India. - Nos. 11 and 12 are greenhouse plants, not recommended by Mitford for outdoors.

$$
\text { EE. Branches not spiny. }
$$

12. B. quadrangulàris, Fenzi. Stems square,especially in older plants, $20 \mathrm{ft}$. or more high : lvs. deep green, serrate, 6-7 in. long, about 1 in. wide. Jap. - Franceschi says it is as hardy as any Phyllostachys. See No. 11.

13. B.vulgàris, Schrad. Height 20-80 ft. : stems hollow, 4 in. in diam. or more; branches numerous, striate; internodes $1-1 \frac{1}{2} \mathrm{ft}$. long : lvs. usually $6-10 \mathrm{in}$. long, $8-15$ lines wide, sometimes $1 \mathrm{ft}$. long, 2 in. wide, rough on and near the margins and beneath. India. G.C. III. 25:390. - Sold south, but not recommended by Mitford. This and $D$. giganteus are the only two Bamboos extensively cult. in the Orient, though others are more useful. It is also naturalized and cult. in the W. Ind., Mex. and Braz., but there is no evidence of an Amer. origin. 
Bв. Height less than $6 \mathrm{ft}$.

c. Variegation white.

14. A. Fórtunei, A. and C. Rivière (B. Fórtunei, Van Houtte, and var. variegata, Hort.). Height 3-4 ft.: lvs. 4-5 in. long, half as wide or a little more, striped with white. Jap. F.S. 15: 1535. - Loses its lvs. in winter, but quickly recovers in spring. More popular than the nex two species. The internodes are rarely more than 1 in. apart, while in $\boldsymbol{A}$. auricoma they are 3-5 in. apart. Var. aurea, Hort., with yellow variegation, is $A$. auricoma. Var. viridis, Hort. $=A$. humilis. This is an old favorite, and far more common than the next 4 species. Rhizomes are more active than the next, and demand more rooln.

15. B. angustifolia, Mitford (B. Vilmorini, Hort.). Height about $1 \mathrm{ft}$.: sts. slender, purplish or light green: lvs. 2-4 in. long, about $1 / 4 \mathrm{in}$. wide, serrute, frequently variegated with white. Jap.

\section{cc. Variegation yellou.}

16. A. auricoma, Mitford (A. and B. Fortunei, var. a ùrea, Hort.). Height 2-3 ft.: ivs. 5-6 in. long, about 1 in. wide, brilliantly variegated with yellow, softly pu. bescent beneath, serrate. Jap.

17. A. chrysántha, Mitford (B. chrysántha, Hort.). Height 3-5 ft.: lvs. 5-7 in. long, 1 in. or less wide, nearly smooth, sometimes variegated with yellow, but not so brightly as in A. auricoma. Jap. Also distinguished from $A$. auricoma by the lower surface of the leaf being markedly ribbed, and lacking the soft, velvety down. "Being neither frankly green nor frankly variegated, it is rather a disappointing plant."-Mitford.

\section{ccc. Variegation absent.}

D. Arrangement of $l v s$. distichous.

18. B. disticha, Mitford (B. nana, Hort., not Roxb.). Height 2-3 ft.: branches numerous : lvs. 2-2 $\frac{1}{2}$ in. long, $1 / 2$ in. wide or less, serrate, green, produced in two vertical ranks. Origin uncertain. A recent and rare species of great interest, the distichous arrangement of lvs. being quite unique among Bamboos, and giving a very distinct habit.

\section{DD. Arrangement of lvs. not distichous.}

$$
\text { E. Lvs. long, 10-18 in. }
$$

19. B. palmata, Burbidge. Fig. 185. Height 2-5 ft.: Ivs. $10-15$ in. long, 2-3 $\frac{1}{2}$ in. wide, bright green, sharply serrate, smooth and shining above, below pale and $\mathrm{mi}$ nutely pubescent : longitudinal veins very prominent. Jap. M. 79 . Gn. 49, p. 59, shows a clump 36 $\mathrm{ft}$. in circumference.

20. B. tessellàta, Munro (B. Ragambuskii, Hort.). Height 2-3 ft.: lvs. 12-18 in. long, 3-4 in. wide, smooth and shining above, whitened beneath, sharply serrate ; midrib prominent, and bearing a tomentose line on one side. China and Jap. G.C. III. $15: 167 ; 18: 189$. R.B. 23 , p. 269. - Produces the largest lvs. of any hardy Bambusa in cult., which is especially remark able on account of its dwarf habit. Much confused in gardens, but unnecessarily, with $\boldsymbol{A}$. Veitchii, as the tomentose line on one side of the midrib is unique in $B$. tessellata. The lvs. are used by the Chinese for wrapping tea.

\section{EE. Lis, shorter, 3-6 in. (Here might be sought}

$$
\text { A. pumila, No. 2.) }
$$

21. B. pygmæ̀a, Miq. Height $1 / 2-1 \mathrm{ft}$.: stems very slender, much branched : ivs. $3-4$ in. long, about $1 / 2$ in, wide, serrate, pubescent, bright green above, glaucous and pubescent beneath. Jap. - The smallest of Bamboos, and remarkably hardy. It is especially valuable for making a thick carpet in wild places, but its rampant growth makes it a nuisance in a border. The sts. are purple : the nodes prominent, and furnished with a waxy, glaucous band round the base.

22. A. hùmilis, Mitford (A. Fórtunei, var. viridis,
Hort.). Height 2-3 ft.: branches in 2's and 3's, long in proportion to sts.: lvs. 4-6 in. long, the largest about $7 / 8$ in. wide : internodes $2-5$ in. apart. Dies down in a hardy winter. A rare species, liable to confusion with A. pumila, No. 3.

Section II.-Internodes flattened, at least on one side: sheaths early deciduous. (The genus Phyllostachys.)

\section{A. Color of stems black.}

23. P. nigra, Munro (B. nigra, Lodd.). BLACK BAMBoo. Fig. 186. Height 10-20 ft.: stems green at first, but changing to black the second year: Ivs. very thin, 2-6 in. long, 6-10 lines broad. China and Japan. M. 142, and frontis. G.C. III. $15: 369 ; 18: 185$. R.B. 23 , p. 268 . - One of the most popular of all Bamboos, and very distinct by reason of its black stems. Var. punctàta, Hort. Franceschi, has yellowish stems spotted with black.

24. P. violáscens, A. and C. Rivière (B. violáscens, Carr.). Height sometimes $13 \mathrm{ft}$ : stems violet, almost black the first months, changing the second year to a dingy yellow or brown: lvs. very variable in size, 2-7 in. long, $1 / 2-2$ in. wide, the larger lvs. borne on young shoots or on the ends of the lower branches near the ground. The lvs. are sharply serrated and have a well-defined purplish petiole. Franceschi says it is hardy, and that $\boldsymbol{P}$. bambusioides is often sold under this name.

AA. Color of stems yellowish, or striped yellou.

25. P. mitis, A. and C. Rivière (B. mitis, Hort., not Poir.). Height 15-20 or more ft.: stems arched, yellowish ; internodes at the base not short: leaf characters identical with $P$. aurea, with which it is closely allied. Japan. Gn. 17, p. 44. - The tallest of all Bamboos, but, unfortunately, not one of the hardiest.

26. P. Castillonis, Hort. (B. Castillonis, Hort.). Unique in the genus for having both sts. and lvs, variegated. Height 6-20 ft.: sts. 1 in. or more thick, much zigzagged, bright yellow, with a double groove of green : lvs. sparingly striped yellowish white, 7 in. long, $11 / 2$ in. wide, serrated on both margins : leaf-sheath topped by a whorl of dark brown or purple hairs. Jap.-Cult. by Dr. Franceschi, Santa Barbara, Calif.

27. B. striàta, Lodd. Height 4-5 ft.: stems striped yellow and green, as thick as the thumb ; internodes 4-6 in. long: lvs. 6-8 in. long, $8 / 4-1$ in. broad. China.

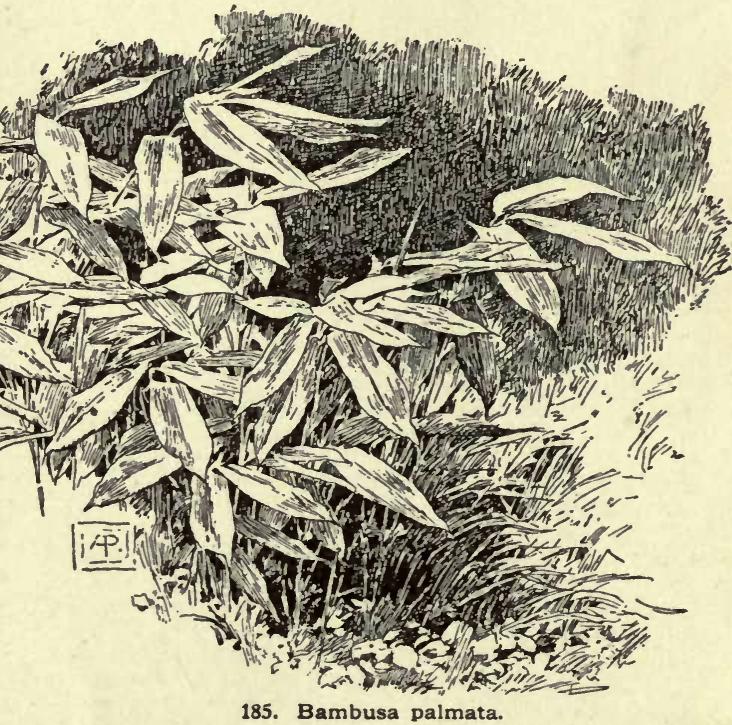

185. Bambusa palmata.

B.M. 6079 , which shows a flowering specimen with conspicuous anthers, red-purple at first and fading to lilac. Not ilescribed by Mitford. Sold S. and by Yokohama Nursery Co. 
28. P. aùrea, A. and C. Rivière ( $B$. aùrea, Hort.). Height 10-15 ft.: stems straight, yellowish ; internodes at the base remarkably short: IVs. narrowed from near the base to the apex, minutely and regularly serrate on only one border, usually $2-4 \mathrm{in}$. long and $3 / 4 \mathrm{in}$. wide, but variable, light green, glabrous; sheaths deciduous, marked with purple. Japan. Gn. 8, p. 206. A.F. 5:41. -The name is not distinctive, as others of the Phyllostachys group have yellowish stems. Hardier and easier of cult. than $P$. mitis.

AAA. Color of stems green, often yellowish when ripe. B. Height 6-18 $\mathrm{ft}$.

c. Lv's. spotted with brou'n.

29. P. Quílioi, A. and C. Rivière (B. Quilioi, Hort. B. Mazéli, Hort.). Height sometimes $18 \mathrm{ft}$ : : habit looser than in P. mitis or aurea: stems arched: Ivs. much larger and especially broader than in any other Phyllostachys, the largest 8 in. long, $13 / 4$ in. wide, the serration of one edge conspicuous; lvs. dark green, often spotted brown, very

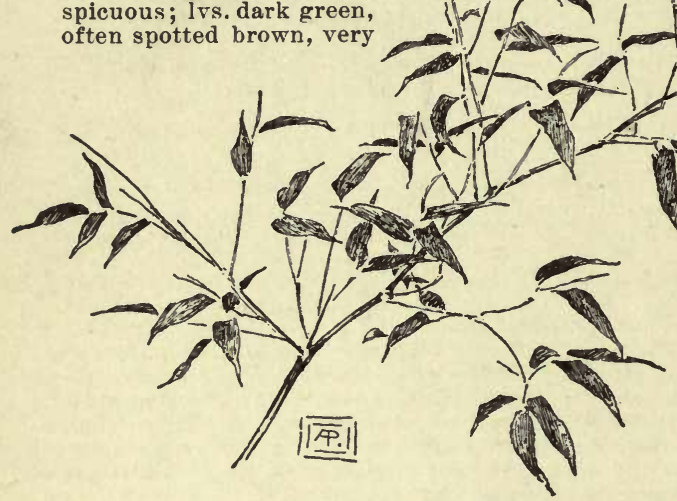

186. Phyllostachys nigra.

glaucous beneath; leaf-sheaths a peculiar feature, being pinkish brown, deeply mottled with purple spots. Cult. S. and in Calif. - Rare.

\section{cc. Lvs. not spotted with brown.}

\section{Habit sliqhtly zigzag.}

30. P. Henònis, Mitford (B. Henònis, Hort.). Height 6-15 ft.: stems arched : lvs. 2-3 in. long, a little under $1 / 2$ in broad, narrowed below the middle to the base and long attenuate at the apex, bright green; sheaths deciduous, yellowish, inclined to purplish: internodes 5-6 in. long near the base and middle of the stem, distinctly grooved with a double furrow. Japan.-This is Mitford's favorite Bamboo.

\section{DD. Habit strongly zigzag.}

31. P. viridi-glaucéscens, A. and C. Rivière ( $B$. viridiglaucéscens, Carr.). Height 10-18 ft.: stems slender, zigzag, arched, bright green at first, fading as they ripen to a dingy yellow : lvs. $3-4$ in. long, about $1 / 2$ in. wide or little more, bright green above, whitened below. China. Gn. 7, p. 279. G.C. III. $15: 433: 18: 183$. The name is unfortunate because not distinctive, as all Bamboos have green lvs. with more or less whitened lower surfaces. Very hardy and common.

32. P. bambusoides, Sieb. \& Zucc. Height about $5 \mathrm{ft}$. in the second year : stems zigzag, green at first, ripening to yellow, the branch-bearing side flattened rather than grooved, as in other species of Phyllostachys : internodes long in proportion to length of stem, sometimes 8 in.: branches in 3's, the longest at the middle of the st., and only about 9 in.: lvs. of various sizes, the largest $8 \mathrm{in}$. long, 11/4 in. wide, edges serrate, sharply on one side. Jap. - Cult. by Dr. Franceschi, Santa Barbara, Calif.
BB. Height $2 \mathrm{ft}$. or less: habit zigzag.

33. P. ruscifòlia, Hort. Kew. (P. Kumasáca, Munro P. Kumasása, Mitford. B. ruscifòlia, Sieb. B. vimind̆lis, Hort.). Height 11/2-2 ft.: stems zigzag, dark green; sheaths purple: lvs. $2-3$ in. long, about 1 in. wide, ovate in outline. Jap. G.C. III. 15: 369. G.C. III. 18: 189. The stem is channeled on the branching side, almost solid : nodes 1-2 in. apart: branches in 3's and 4's, not more than 1-11/2 in. long. - Dwarfest species of Phyllostachys.

C. D. BEADLE.

The following are trade names in America of rare kinds: B. agréstis, Poir. India, Cochin China. Adv. by Yokohama Nurs. Co. $-B$. argéntea, Hort. $=$ B. argentea-striata, Regel $?-B$. aureo-striàta, Regel. Jap.-A. foliis-variegátis, Hort., is presumably A. Fortunei, the commonest low-growing, variegated Arundinaria.-B. Marliàcea, Hort. Adv. by Yokohama Nurs. Co. as a "wrinkled Bamboo." Doubtless named after M. Latour Marliac, the celebrated French hybridizer of water-lilies, and dealer in Bamboos and aquaties.D. membranàceus. Munro. Height attaining 60-70 ft. lvs $4-5$ in. long, $4-6$ lines wide, roundish or narrowed at the base, mucronate, rough above and on the margin, hairy below, petiolate. Burma. Rare. Adv. by Dr. Franceschi, Santa Barbara, Calif. $-P$. heterocycla, Carr., the "Tortoise Shell Bamboo," is really an abnormal or malformed condition of several species, especially P. mitis, aurea and nigra, as explained in G.C. III. 24:92. For the first foot or two above ground each internode is long on one side and very short on the other. $-A$. Metáke, Sieb.=A. Japonica. $-A$. Narihira, Hort., Yokohama Nurs. Co., is presumably A. Simoni.-B. orientàtis, Nees. E. Ind. Adv. by Dr. Franceschi, Santa Barbara, Calif., who regards it as a form of B. arundinacea, with lvs. larger and velvety to the touch. It forms elumps quickly. $-P$. quadrangulàris Hort Yokohama Nurs Co $=\mathrm{B}$ quadrangularis ?rangularis, Hort., Yokohash Rheedei Kunth)=Nelocanna B. scriptoria, Dennst. (Beesha Rheedei, Kunth)= Melocanna bambusoides, Trin. This was John Saul's favorite hardy Bamboo at Washington in 1890, but is no longer advertised. doned trade name never recognized by botanists. $-B$. stricta, Hort., Saul, 1890, an old trade name, probably not B. stricta, Roxb.-D. stríctus, Nees. Int. 1889 by Reasoner Bros., Onéco, Fla. and now adv, by Dr. Franceschi, Santa Barbara, Calif. Height 50-60 ft.: sts. 3 in in diam. The true species flowers every Height $50-60 \mathrm{ft}$. : sts. 3 in. in diam. The true species flowers every year. Ind. $-B$. variegáta, Sieb. $=$ A. Fortunei.-B. verticillàta,
Hort. Franceschi. Height $15-20 \mathrm{ft}$.: stems orange-yellow : lvs. in whorls, striped white.

W. M.

BANÁNA (Mùsa sapiéntum, Linn., chiefly). Scitamindceo. This very valuable tropical plant is prized for its fruit, textile fiber, and decorative effect in landscape gardening. Most species are cultivated for their fruit, and one or two species for fiber-although all sorts have a fiber of considerable value. Every species is worthy a place in decorative planting. For an account of the species and their ornamental values, see Musa.

The species mostly in demand for fruiting seldom or never produce seeds, and naturally increase by suckers around the base of each plant. These form a large clump, if allowed to grow without care. They are most readily separated from the parent root-stalk by a spade, and are then fit for further planting. This is a slow process of increase, but it is sure, and the suckers so produced make large and vigorous plants. A quicker method of propagation is to cut the ertire root-stalk into small, wedge-shaped pieces, leaving the outer surface of the root about 1 by 2 inches in size, planting in light, moist soil, with the point of the wedge down and the outer surface but slightly covered. The best material for covering these small pieces is fine peat, old leaf-mold, mixed moss and sand, or other light material which is easily kept moist. The beds so planted should be in full open sunshine if in a tropical climate, or given bottom heat and plenty of light in the plant-house. The small plants from root-cuttings should not be allowed to remain in the original bed longer than is necessary to mature one or two leaves, as that treatment would stunt them. The textile and ornamental species, also, may be 
increased by the above process, but as these species usualiy produce seeds freely, seedlings can be more quickly grown, and with less trouble. The seeds of Bananas should be sown as fresh as possible, treating them the same as recommended for root-cuttings. As soon as the seedlings show their first leaves, they should be transplanted into well-prepared beds of rich, moist soil, or potted off and plunged into slight bottom heat, as the needs of the grower or his location may demand. Both seedlings and root-cuttings should have proper transplanting, sufficient room and rich soil, as a rapid, unchecked growth gives the best and quickest results.

The cultivation of Bananas for fruit is carried on very extensively in all tropical countries. In the $W$ est Indies, Central America and Mexico, they are raised for export to the United States and Canada. The site selected is usually a level plain in the lowlands, near the coast, or in valleys among the hills, where the rainfall or artificial moisture is sufficient. The variety most commonly grown at present is the Martinique, having large bunches, with long, yellow fruit. The Baraçoa (or Red Jamaica) is more sparingly grown now than formerly, and its dark red fruits, of largest size, are not commonly exported. For distant shipping, bunches of fruit are cut with "machetes" or knives, after they reach their full size and are almost mature, but quite green in color. Ripening is effected during shipment in warm weather, and by storing in dark, artificially-heated rooms during cold weather. Banana flour is a valuable product of ripe Bananas prepared among the plantations in the tropics. It is nutritious, and has an increasing demand and use as human food. A recently invented process of drying ripe Bananas has been found very successful, and the industry promises to be of vast importance as the marketable article finds ready sale. In the United States there is little commercial cultivation of Bananas, since the frostless zone is narrow and the fruit can be grown

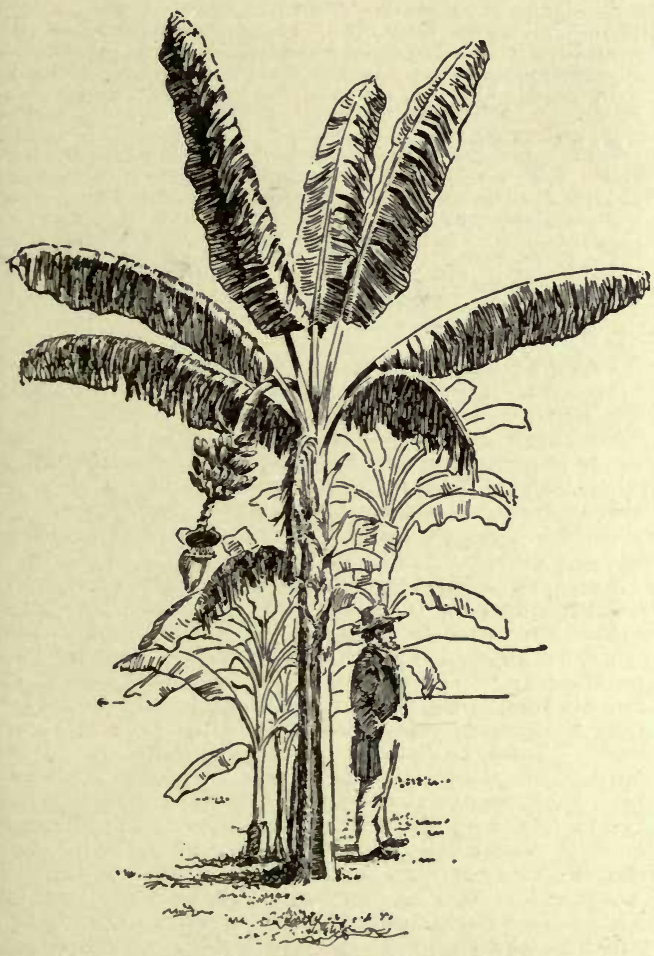

187. A bearing Banana plant.

of much more cheaply in Central America and the West Indies. Small Banana plantations are common in southern Florida, however, and eveu as far north as Jacksonville. They are also grown in extreme southern Louis- iana, and southwestwarl to the Pacific coast. The plants will endure a slight frost without injury. A frost of 5 or 6 degrees will kill the leaves, but if the plants are nearly full grown at the time, new foliage may appear and fruit may form. If the entire top is killed, new suckers will spring up and bear fruit the following year. A stalk, or trunk, bears but once; but the new sprouts which arise from the roots of the same plant continue

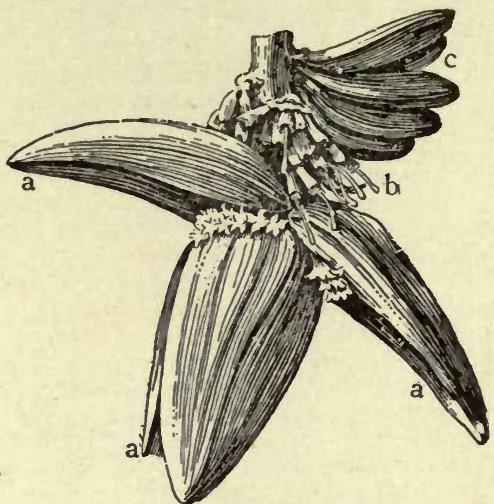

188. Tip of flower-cluster of Banana.

the fruit-bearing. A strong sprout should bear when 12-18 months old (from 2-3 years in hothouses). The plantation will, therefore, continue to bear for many years. A bearing stalk, as grown in southern California, is shown in Fig. 187.

The peculiar flower-bearing of the Banana is shown in Fig. 188, which illustrates the tip of a flower-cluster. This cluster may be likened to a giant elongating bud, with large, tightly overlapping scales or bracts. Three of these bracts are shown at $a a a$, in different stages of the flowering. As they rise or open, the flowers below them expand. The bracts soon fall. The flowers soon shed their envelopes, but the styles, $b$, persist for a time. The ovaries soon swell into Bananas, $c$. The bracts are royal purple and showy.

E. N. REASONER.

BANCROFT, GEORGE. The famous American historian (1800-1891) deserves remembrance among horticulturists for his splendid collection of roses at his summer home in Newport, R. I., an account of which may be found in the American Garden, 1891. For a portrait and sketch, see Appleton's Annual Cyclopedia for 1890. In Mr. Bancroft's garden, George Field found a rose without a name, which is now known to be the French variety Mme. Ferdinand Jamin. It was introduced by Field \& Bro. as the American Beauty. Though little known abroad, it is, probably, the most famous of all roses cult. in America.

\section{BANEBERRY. See Actoa .}

BANKSIA (Sir Joseph Banks, 1743-1820, famous English scientist). Protedcece. Many species of Australian evergreen shrubs, with handsome foliage, but scarcely known in cult. here. Prop. by nearly mature cuttings, in frames.

BANYAN TREE. See Ficus Indica.

\section{BAOBAB. See Adansonia.}

BAPTISIA (Greek, to dye, alluding to the coloring matter in some species). Syn., Podalýria. Legumindsa. Small genus of perennial herbs of eastern N. Amer. Corolla papilionaceous, the standard not larger than the wings : calyx campanulate, the 5 teeth separate and equal or the 2 upper ones united: stamens 10, distinct : pod stalked in the calyx. - Plants usually turn black in drying. Baptisias are suitable for borders. They thrive in any ordinary soil and under common treatment, preferring free exposure to sun. Prop. by division or seeds. 
A. Lvs. simple: fls.yellow.

simplicifolia, Croom. Branchy, 2-3 ft.: lvs. 2-4 in. long, sessile, broadly ovate and obtuse : fls. in numerous terminal racemes. Fla. - Int. 1891.

perfoliata, R. Br., of S. Car. and Ga., with small axillary fls. and broad perfoliate lvs., is occasionally planted, and is hardy as far $N$. as Washington, but is evidently not in the trade. B.M. 3121 .

\section{AA. Lvis:compound, 3-foliolate.}

$$
\text { B. Fls. yellow. }
$$

tinctòria, R. Br. WiLD INDigo. Bushy-branched, 2-4 ft., glabrous : lvs. stalked, the ifts. small, obovate or oblanceolate, and nearly or quite sessile and entire : fls. $1 / 2$ in. long, bright yellow, in numerous few-fld. racemes. Common in E. States. B. M. 1099. Mn. 5: 81 .

lanceolàta, Ell. About $2 \mathrm{ft}$., pubescent when young, but becoming nearly glabrous: lvs. short-stalked, the lfts. thick, lanceolate to obovate and obtuse : fls. large, axillary and solitary. Pine barrens, N. Car. S.

$$
\text { BB. Fls. blue. }
$$

austràlis, R. Br. (B. caerìlea, Eat. \& Wr. B. exaltàta, Sweet). Stout, 4-6 ft., glabrous : lvs. short-stalked; lfts. oblanceolate to oval, entire, obtuse : fls. lupine-like, nearly or quite an in. long, in loose-fld., long terminal racemes. Penn. W. and S. J.H. III. 29: 64; 34:511.Handsome. Probably the best species for cultivation.

$$
\text { ВвВ. Fls. white or whitish. }
$$

álba, R. Br. Wide-branching, 1-3 ft., glabrous : 1vs. stalked ; lfts. oblong or lanceolate, obtuse, thin, drying green : fls. white, 1/2in. long, in long-peduncled, elongated lateral racemes. N. Car.W. and S. B.M. 1177.

leucántha,Torr. \& Gray. Branching, more or less succulent, 2-4 ft., glabrous: lvs. stalked; lfts. obovate to oblanceolate to cuneate, very obtuse, drying black : fls. white, nearly an in. long, in loose-fld., lateral racemes. E. states.

leucophæa, Nutt. Stem stout and angled, but low and wide-branched, $1-2 \frac{1}{2} \mathrm{ft}$., hairy or nearly glabrous : lvs. short petioled; lfts. oblanceolate to obovate, stiff, drying black : fls. large and cream-colored, on slender erect pedicels, borne in 1-sided declined racemes. Ga. W. B.M. 5900. Mn. 3: 177. F.S. 23: 2449 .

L. H. B.

BARBACENIA (Barbacena, a Brazilian governor) A maryllidàcece. About 20 Brazilian plants, with scape bearing a single large purple flower. Grown mostly in baskets, after the inanner of many orchids. B. purpurea, Hook., is occasionally seen in fine collections, but does not appear to be in the Amer. trade. Grown in a warm, moist house. It has many scapes and long, grass-like, toothed lvs. B.M. 2777.

\section{BARBADOES CHERRY is Malpighia ; B. Lily, Hip.} peastrum.

BARBAREA (from the old name, Herb of Saint Barbara). Crucifera. Hardy biennials, with yellow fls.; allied to water cress and horseradish.

vulgàris, R. Br. Common Winter Cress. Upland Cress. Yellow Rocket. Height 10-18 in.: lower lvs. lyrate, the terminal lobe round, the lateral usually 1-4 pairs : upper lvs. obovate, cut-toothed at the base. Eu. Asia. - Cult. for salad. Var. variegata, Hort., lvs. splashed and mottled with yellow, is cult. as a border plant, and grows freely in rich soil. If the fls, are picked off, stem and all, before they open, the plant will be practically perennial. A common native.

præcox, R. Br. EARLY Winter, or Bell Isle Cress. Distinguished by the more numerous divisions of the lvs. (4-8 pairs). Slightly cult. as a salad, and known S. as Scurvy Grass. Naturalized from Eu. J. B. KeLLer.

BARBE DE CAPUCIN. See Chicory.

\section{BARBERRY. See Berberis.}

BARBIERIA (after J. B. G. Barbier, French physician). Leguminosce. A genus of only two species, one from Porto Rico and one from Peru. Its nearest allies familiar to the horticulturist are Indigophera and $\mathrm{Te}$ - phrosia. It is distinguished from allied genera by the long fls. Tender evergreen shrubs, with odd-pinnate lvs., numerous entire lfts., and awl-shaped stipules : fls. large, racemose red. Prop. by seed.

polyphýlla, DC. (Clitòria polyphýlla, Poir.). Lfts. 9-11 pairs, elliutlc-oblong, mucronate, pubescent with age : racemes few fld.. shorter than the lvs.: fls. 2 in. long. Porto Rico. $-B$. glabélla, Hort., Peter Henderson \& Co., 1899 , is probably a variety.

BARK. Is often used in a general way to designate the softer outer envelope of a stem or root. In this sense, it includes all that peels readily, as the bark of the hemlock and oak, used for tanning leather. In a stricter sense, it is applied to the corky layers formed on the outer surface of woody plants. It is formed from an active layer of tissue, - the phellogen. The bark is de veloped in different ways upon different trees. So distinct are the resulting tissues that species of trees may be readily recognized by their bark alone. Cork of commerce is the bark of the cork oak, a native of southwestern Europe.

W. W. ROWLEE.

\section{BARKERIA. See Epidendmum.}

PARLĖRIA (J. Barrelier, 1606-1673, French botanist). Acanthacece. Many species of tropical shrubs, mostly African, sometimes seen in fine collections of stove plancs, but not offered in the Amer. trade. They have large fls. (yellow, purple or white), often in clusters. Prop. oy softwood cuttings. B. cristàta, Linn., E. Ind., is a good blue-fld. bedder.

BARLEY. Various kinds of Hordeum of the Gramineae. Common Barley is $H$. sativum, Jess. According to Hackel, it " undoubtedly originated from $H$. spontaneum, C. Koch, which grows wild from Asia Minor and Caucasian countries to Persia and Beloochistan, as well as in Syria, Palestine, and Arabia Petræa." The common Barley has a 4-rowed ear or head. There are also 2-rowed and 6-rowed races, and other well marked forms. They are probably all domestic forms of one parent stock.

BARÓSMA (heavy scent). Rutdcece. Some 25 to 30 South African heath-like shrubs. They are evergreens, and in the N. must be grown under glass. Prop. by mature-wood cuttings. B. pulchélla, Bart. \& Wendl., is now handled by florists from imported stock. It grows $3 \mathrm{ft}$. or less high, and has axillary purplish fls., with 5 sepals, 5 petals and 10 stamens.

BARRY, PATRICK. Plate II. Nurseryman, editor and author; was born near Belfast, Ireland, in May, 1816, and died in Rochester, N. Y., June 23, 1890. He came to America at the age of twenty, and after four years of service with the Princes, at Flushing, on Long Island, he founded, in 1840, with George Ellwanger, at Rochester, N. Y., the Mount Hope Nurseries. Ellwanger and Barry introduced fruit-growing into western New York at a time when there were no collections of fruits, no railroad or telegraphic facilities, nor any fast ocean steamers to bring over their importations from Europe. From 1844 to 1852, Barry edited "The Genesee Farnner," an excellent and influential paper-afterwards merged in "The Cultivator and Country Gentleman." After the death of A. J. Downing he succeeded to the editorship of "The Horticulturist," which he removed to Rochester, until June, 1855, after which this famous magazine had many vicissitudes until 1887 , when it went to swell the number of periodicals now represented commercially by "American Gardening." In 1851 appeared his "Treatise on the Fruit-Garden," a new and thoroughly revised edition of which was issued in 1872, under the title of "Barry's Fruit-Garden." It is still one of our most popular books on pomology, and deservedly so. The catalogue of fruits which he compiled for the American Pomological Society is a monumental work. Mr. Barry did much to make Rochester a city of nurseries and western New York a famous fruit-growing region. The Western New York Horticultural Society, of which he was president for more than thirty years, and until his death, has long exercised a more than sectional influence. The work of Barry was truly national, and essentially 

that of a pioneer. He must be considered in the front rank of pomological authors, with the Downings, Warder, and Thomas, whose combined weight gave a great impulse towards establishing orcharding on a large scale in America. For a fuller account, with portrait, see "Annals of Horticulture," 1890, 287-290.

W. M.

BARTONIA. See Mentzelia.

BARTRAM, JOHN. Called by Linnæus the greatest natural botanist in the world. Was born at Marple, near Darby, Pennsylvanir, Mar. 23, 1699, and died Sept. 22, 1777. He was a Quaker farmer, who became interested in botany after the age of twenty-four. In 1728, at Kingsessing, on the Schuylkill River, he established the first botanic garden in America, which, together with his house, built in 1731, of stone hewn by his own hands, is happily preserved to-day as part of the park system of Philadelphia. He traveled much in America, and was for many years the chief medium of exchange between Europe and Ameriea of plants of all kinds, especially new and important species, as Rhododendron maximum and Cypripedium acaule. His correspondence with Peter Collinson lasted nearly half a century. The letters, preserved to us in Darlington's "Memorials of John Bartram and Humphrey Marshall," are rich in botanical, historical and general interest. "Observations on the Inhabitants * * * made by John Bartram in his Travels from Pensilvania to Onondago, Oswego, and the Lake Ontario * * * London, 1751," is similarly reatable, and a rocument of great value in the study of aboriginal races.

At the age of seventy he undertook, with his son William, an expedition to Florida, which is recorded in the "Journal Kept upon a Journey from St. Augustine up the River St. Johns." Bartram was probably the first American to perform successful experiments in hybridization. His sons, John and William, continued his garden. For many years it was the largest and best collection of trees and shrubs in America, and the services of the garden to early American horticulture were very great. $\mathrm{He}$ is commemorated in Bartramia, a genus of mosses, and in "Bartram's Oak," for the literature of which, see I. C. Martinale's "Notes on the Bartram Oak, Quercus heterophylla, Michx.," published at Camden, N. J., 1880. Bartram's garden is a unique spot in America. Many of the trees have attained great age, size and beauty. The garden also contains many quaint and picturesque relics which have associations of great interest. On the whole, John Bartram is one of the most illustrious, and by far the most picturesque, of the early botanists and horticulturists of America, and his simple, wholesome, powerful personality presents a picture that is altogether amiable. New editions of the works of Bartram and Darlington are much to be desired, and offer a promising field to critical labors. John Bartram's son William is well known to students of American history for his" Observations on the Creek and Cherokee Indians, 1789." It is very much to be regretted that no authentic portrait of John Bartram is known. For an excellent illustrated account of Bartram and his garden see the article by Miss M. L. Dock in Garden and Forest, 9: 121-124 (1895). See also Harper's Mag. 60:321-330 (1880).

W. M.

BASELLA (native Malabar name). Chenopodidcece. Malabar Nightshade. A genus containing only one species, which is, however, remarkably variable. Annual or biennial herbs, cult. in the tropics as a pot-herb. like spinach. Rarely cult. N. as an ornamental warm house climber. It may also be started indoors, and set out in May for use as a garden vegetable, to follow spinach. Prop. by seeds.

rùbra, Linn. Lvs. succulent, alternate, rarely opposite, almost entire, of various forms: fls. not pedicelled, in simple spikes or racemes; spikes short or long, lax few-fld. The following species are now considered only forms of the above : álba, a white-fld. form rarely cult. as a trailer from roofs of warm-houses, or as a basket plant; caninifolia ; cordifolia, with heart-shaped lvs. 4-5 in. long and 2-21/2 in. wide; crassifolia ; Japónica; lùcida, from India ; nigra, a Chinese form ; ramosa and volùbilis. Under the name of Sweet Malabar Vine, A.
Blane advertises a form with tiny yellow and red fls., and 1v8. variegated with white, pink, and green. He says, "with age it assumes a drooping habit. When cut keeps fresh for weeks."

BÁsIL. Species of Ocimum, of the Labiatce. They are Indian annuals, and are cult. as pot-herbs, the cloveflavored foliage being used as seasoning in soups, meats and salads. They are of easiest culture, the seed being sown in the open as soon as the weather is settled. Common Basil is $O$. Basilicum, Linn., a ft. high, branching, with ovate toothed lvs., and white or bluish white fls. in leafy terminal racemes or spikes. O. minimum, Linn., the Dwarf Basil, is lower, and smaller in all its parts ; rarely seen. When Basil is in bloom, it can be cut and dried for winter use.

BASKET PLANTS. Fig. 189. Under this term are included all those plants which, from their habit of growth and blooming, have been found especially suitable for use in hanging baskets. Most of these are dwarfish plants of indeterminate growth, of gracefully drooping or vine-like habit, and are valued either for their grace, or for freedom and daintiness of bloom. Some of the plants used in baskets are of upright habit. These are either plants of naturally small stature, or are practically such for a season from a slow habit of growth. The suitability of these erectgrowing plants for the purpose is determined, aside from their stature, by their freedom of bloom, beauty of foliage, striking form, or grace of habit. Such plants are used prin. cipally for filling the central part of the basket; whereas, plants of trailing habit are inserted near the sides-some to droop, others to twine upwards on the cords or handle by which the basket is suspended. In addition to the ong drooping or climbing plants, there are a number of half-erect habit, like the lobelia, sweet alyssum and russelia. These may droop somewhat, but are not of a truly vine-like habit. Some plants are more suitable than others for shady places: the selaginellas, for instance. Others thrive only with several hours of direct sunshine each day.

The following list of common trade names embraces a number of the most important basket plants, arranged according to their habit of growth and blooming. The list is not given as a complete one. Any list would need amending from year to year to suit individual taste and experience. Plants whlch will bear considerable shade are marked with au asterisk $\left(^{*}\right)$; those which will bear more are marked with two asterisks $\left({ }^{* *}\right)$ :

\section{PLANTS OF VINE-LIKE HABIT.}

\section{a. LONG-DROOPING.}

**English Ivy, *Kenilworth Ivy,*Vinea major, *V. Harrisonii, Saxifraga sarmentosa, *Cissus discolor,* Moneywort Ivy, Tropæolums (Nasturtiums), Lonicera Halliana, L. aurea, var. reticulata, Nepeta Glechoma, Ampolopsis quinquefolia, A. Veitchii.

Note.-The Ampelopsis is deciduous, and not snitable for winter baskets. 


\section{b. Climbing,}

Maurandia, **Lygodium scandens, *Senecio scandens, Thunbergia, Cobøa scandens, Japanese Variegated Hop, Manettia bicolor, Lonicera Halliana, L. aurea, vur. reticulata, Clematis coccinea, Tropæolum peregrinum.

c. SHORT-DROOPING, OR HALF-ERECT.

*Lobelia Erinus, *Othonna crassifolia, *Sweet Alyssum, *Tradescantia, Petunias, Oxalis floribunda, *Russelia juncea (also bears sun well), *Fittonia, *Fuchsia procum bens, Ice Plant, Verbena, *Ivy Geranium, **Selaginellas, *Begonia glaucophylla, var. scandens, *Sedum Sieboldi, *S. carneum, var variegatum, *Asparagus Sprengerii, *Passifleras, *Panicum variegatum Gazania splendens, A putilon m , vantan delicatissima, Solanum jasminoides, S. Seaforthianum, Convolvulus Mauritanicus.

2. PLANTS OF UPRIGHT HABIT.

a. LOW-GROWING.

1. Flowering Plants.

*Torenia, *Pansy, Cuphea platycentra, C. hyssopifolia *Primula obconica, Dwarf Alyssum, Bellis perennis, Linum or Reinwardtia trigynum, Phlox Drummondii, Dutch bulbs.

\section{Foliage Plants.}

*Peperomia, *Begonia Rex, *Farfugium grande, Alter nanthera, **Maidenhair Fern, Geraniums (especiall Mme. Salleroi), *Isolepis gracilis (droops with age).

\section{b. TALLER Growing.}

\section{Flowering.}

Geraniums-Pelargonium *Fuchsias, Petunias, *Begonias, Browallia, *Stevia serrata, var. nana, Madagascar Periwinkle, *Nierembergia, Lantana, ${ }^{*}$ Impatiens Sultana, Cuphea Llavea, Swainsona, Chrysanthemum frutescens, Salvias.

2. Foliage.

*Dusty Miller, *Crotons, *Palms, **Ferns, *Fancy Caladiums, Coleus, Achyranthes, **Aspidistra, *Cyperus alternifolius, *Dracæna indivisa, *D. terminalis, Coccoloba platyclada.

Some of the above plants make large subjects when growing in the open ground. Of such, only young or smaller plants are available for use in hanging baskets. Ordinarily, several different sorts of plants are used for filling a basket. In some cases, however, a pretty basket is made by using but one kind of plant. A hang ing basket filled with sword fern, for instance, makes a handsome object.

Baskets of a variety of patterns are obtainable from florists and other dealers. The baskets most extensively used, perhaps, are made of strong wire, woven into hemispherical or other forms. These are sometimes plain, and again of ornamental character. The better form has a flat bottom, or a stand, formed of wire, to support the basket in an upright position when it is not pendent. Another style is $f$. rmed of rustic work. Here the vesse or plant basin is covered about the sides with rough bark or knotted roots. For this purpose the roots of the laurel are much used. Above the basket there is an arch or handle by which it is suspended. Again, earthenware vessels, to be suspended by wires, are offered for sale in a variety of shapes. Some of these are moulded ancl painted in imitation of logs, and are known as "stick" and "log baskets." Such baskets are often without pro vision for drainage. When this is the case, boles should be drilled at the lowest point in the bottom. A special form of basket is nuch used for orchids. It is made of square cedar slats in raft- or log-fashion. Fern-fiber and broken bits of brick, flower-pots or charcoal, are used for filling them.

The soil used in hanging baskets is simply good, common florists' potting soil. This usually contains about 25 per cent of humus, and a small amount of sharp sand to make it porous. Prior to filling, wire baskets must be lined with moss. This is merely common woodland moss from rotting logs, or rich, damp soil. In filling baskets, a few drooping or climbing plants are disposed around the sides; then one or more uprightgrowing or half-erect plants, according to the size of the plants and basket, are planted in the center. Immediate effects require plants which have already made consideruble growth. Florists usually carry a stock of suitable plants. In case seedlings or cuttings are grown for the purpose, it is usually best to start them in seed-pans or cutting-boxes, and transfer them later to the basket.
Seeds may be sown, or the cuttings started in the basket, but it is so long before they fill the basket that there is no advantage in it.

A common mistake in arranging baskets is crowding, or filling them too full. Fewer plants will appear more graceful, growth will be more vigorous, and the basket will retain its grace and beauty for a longer time. Exercise vigilance and care in watering. After the roots have well filled the basket, watering is best done by dipping the basket in a tub or barrel of water, and allowing it to remain until it is well saturated. Dipping the basket in weak liquid manure once or twice a month will greatly promote vigor when the plants have been long in the basket. These remarks also apply in a general way to vases and rustic stands.

\section{BASSW00D. See Tilia.}

ERNest WaLKer.

BAST. The soft part of the fibro-vascular bundles in plants, abundant in the inner bark. It increases in thickness simultaneously with the wood, but much less rapidly. The fibrous elements in the bast of Basswood have been used in making cordage; also in making strong paper.

W. W. ROWLEE.

BATATAS. See Ipomøa.

BATEMANNIA (in honor of James Bateman, the distinguished collector and cultivator, and author of important works on Orchids). Orchiddcea, tribe Vándea. Pseudobulbs short: leaf-blades-coriaceous : fls. large, $2 \frac{1}{2}-3$ in. in diam., single or in pairs. Cult. like Cattleya. During the growing period they should be well supplied with water and kept from strong sunlight.

Colleyi, Lindl. Petals and sepals purplish or umberbrown, shading to yellowish green at the base. Demerara. B.R. 1714. B.M. 3818 .

Meleagris, Reichb.f. Petals and sepals pale yellow, brown toward the summits, broad at the base : labellum white at the base. Brazil.

B. Búrtii, Endr. \& Reichb. f., with 1-fld. peduncles, =Zygopetalum. OAKES Ames.

BAUHINIA (after John and Caspar Bauhin, sixteenth century herbalists; the twin leaflets suggesting two brothers). Leguminosa, but there is nothing to sug. gest the legume family to the northern horticulturist except the pod. Mountain EBony. A genus of over 200 species, allied to Cercis. Tropical trees, shrubs, or vines, with showy fls. ranging from white to purple, and Ivs. which may be entire or 2-lobed, in some cases the lfts. being entirely free; the petiole is prolonged into a short but characteristic awn between the Ifts.: petals 5 . The number and fertility of the stamens are important characters in determining the subgenera. They are much cult. in S. Fla. and S. Calif. in sandy soils. Prop. by seeds ; rarely by cuttings of half-ripened wood.

$B$. variegata and $B$. purpurea are two of the commonest and showiest small trees of India, and, although frequently introduced into northern greenhouses, have rarely succeeded permanently. $B$. variegata is much cult. in India, and, when covered with blossoms, resembles a gigantic Pelargonium. The astringent bark is used in tanning and dyeing, and the lvs. and fl.-buds as a vegetable, the latter being pickled. "The reason for these plants being so little grown in our hothouses," says J. D. Hooker, "is, no doubt, that they must attain some size before they flower, and that they require a dry season to ripen their wood, the giving of which, without killing the plant by drought, is the standing crux of all establishments." Great numbers of species of Bauhinia are likely to be introduced from time to time because of their gorgeous appearance in the tropics. In the experience of Old World gardeners, the most reliable species under glass are $B$, variegata, $B$. corymbosa, and $B$. Natalensis. These can be planted outside here in summer, and kept over winter as oleanders are.

\section{A. Lvs. divided not to the middle.}

B. Fls. usually colored.

variegàta, Linn. Tree, 6-20 ft.: lvs. 3-4 in. across, orbicular, 9-11 nerved, lobes rounded; petiole 1-2 in. long : fls. about 7 , in a short raceme, 4 in. across ; calyx 
spathe-like ; petals 5, clawed, obovate-oblong, veined, rose-colored, the lowest one larger, broader above the midlle, strongly marked with crimson : pod 1-2 ft. long. India. B.M. 6818. - The coloring of the fls. varies.

Var. cándida, Roxb. (A. álba, Buck-Ham.). Height $12 \mathrm{ft}$.: fls. white, beautifully veined with green; fls. Feb. to May. B.M. 7312. "A taller grower than $\boldsymbol{A}$. acuminata, blooming in late winter and early spring. Very quick-growing, and ornamental even when not in bloom."-Reasoner Bros.

purpùrea, Linn. Height $6 \mathrm{ft}$ : : 1vs. coriaceous, rufoustomentose beneath when young; ifts. broadly ovate, 4-nerved : petals red, one streaked with white on the claw, lanceolate, acute; fertile stamens 3 , very long, the rest sterile or abortive : pod $1 \mathrm{ft}$. long. India, Burma, China. - Without doubt one of the finest flowering small trees in S. Fla. Flowers are borne in the greatest profusion, 3 to 5 inches across, varying in color from almost white to a shade of rich purple, and marked and shaded with many tones. The plant is very robust and hardy here, growing to a height of 15 feet in less than 2 years, and blooms all winter and spring.

Gálpini, N. E. Brown. Half-climbing shrub, 5-10 ft. : lvs. 1-3 in. long, 2-lobed from one-fifth to one-half their length, 7-nerved; petiole about $1 / 4 \mathrm{in}$. long: racemes 6-10-fld.: petals 5, all alike, $1-1 \frac{1}{2}$ in. long; claw as long as the limb; limb orbicular, cuspidate, brick-red ; fertile stamens 3: pod 3-5 in. long; seeds dark brown. S. and Trop. Afr. B.M. 7494.-Discovered 1801. Fls borne continuously from spring to late autumn.

\section{BB. Fls. pure white.}

acuminàta, Linn. Height 5-6 ft.: lfts. ovate, acuminate, parallel, 4-nerved, closing at night : fls. $2-3$ in. across ; fertile stamen long and nearly free, the other 9 short, connected, and sterile. India, Malaya, China. -One of the most satisfactory of all, either for open ground or greenhouse culture, as it will bloom the first summer, when but a few months old and but a foot or two high, and in succeeding summers blooms continuously from May to September.

AA. Lvs. divided beyond the middle.

B. Leaflets not entirely free: fls. colored.

corymbòsa, Roxb. Woody elimber, branching from the ground.: branches grooved: tendrils opposite, revolute: Ivs. $1 \frac{1}{2}-2$ in. long, outer edges slightly rounded, inner edges straight and parallel; nerves $2-4$ : fls. numerous, corymbose, $1 \mathrm{in}$. across, rosy, ithw fluted petals, and characteristic venation; stamens 3 , bright red, 3 very long, the rest abortive. China. B.M. 6621.

\section{Bг. Leaflets entirely free fls. white.}

Natalénsis, Oliver. Sinall shrub: lvs. numerous; leaflets each 1 in. long, with a midrib and a few nerves, dark green; petioles $1 / 4-1 / 2$ in. long: fls. single or in 2 's, $1 \frac{1}{2}$ in. across, white, the midvein of the 3 upper petals reddish; petals erect or spreading, the 2 lower ones larger ; stamens 10,5 long and 5 short: pod 3 in. long. S. Afr. B.M. 6086. - Not advertised at present.

B. Hoòkeri, F. Muell., from Austral., and B. Richardsoni, Hort., Franceschi, are also advertised at present.

\section{E. N. REASONER and W. M.}

\section{BAY TREE. See Laurus.}

BEAN. A name applied to various plants of the Legumindsce. The Beans chiefly known to a griculture are of five types: (1) The Broad Bean (Vicia Faba), or the Bean of history, an erect-growing plant, producing very large and usually flat, orbicular or angular seeds. Probably native to S. W. Asia (Figs. 190, 191, a). See Vicia. These types of Beans are extensively grown in Europe, mostly for feeding animals. They are either grown to full maturity and a meal made from the Bean, or the plant is cut when nearly full grown and used as forage or made into ensilage. The Broad Bean needs a cool climate and long season. In the U.S. the summers are too hot and dry for its successful cultivation on a large scale, and the plant is practically unknown there. In Canada, the plant s used in connection with corn to make ensilage; and this combination is known as the "Robertson mixture."
(2) Kidney Bean (Phaseolus vulgaris, which see ; Figs. $191, b, 192)$. This is the plant which is everywhere known as Bezin in North America, comprising all the common tield, garden, snap and string Beans, both bush and climbing. By the French it is known as Haricot, and this

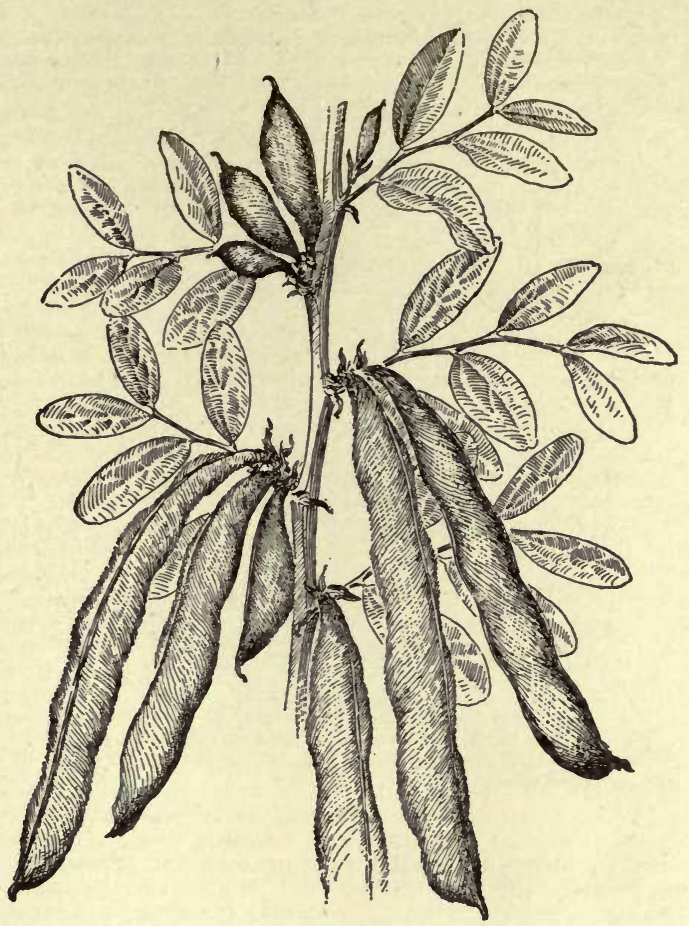

190. Broad Bean-Vicia Faba ( $\times 1-5)$.

word is often found in our literature. Its nativity is unknown, but it is probably of tropical American origin. For inquiries into the nativity of the Bean, see DeCandolle, Origin of Cultivated Plants; Gray \& Trumbull, Amer. Jour. Sci. 26:130 ; Sturtevant, Amer. Nat. 1887: 332 ; Wittmack, Ber. der Deutschen Bot. Gesellschaft, 6:374 (1888). (3) Lima or Sugar Beans (Phaseolus lunatus, which see). Long-season, normally tall-climbing plants, producing large, flat seeds (Figs. 191, c, 193). Native to S. Amer. See Bailey, Bull. 87, Cornell Exp. Sta. (4) Various species of Dolichos (as D. sesquipedalis). Vines which produce very long, slender pods and small, narrow Beans (Figs. 191, $d, 194$ ). Native to trop. Amer. See Dolichos. (5) Soy, or Soja, Bean (Glycine hispida, which see). A bushy, erect, hairy plant, producing small pods in clusters, and pea-like seeds (Figs. $191, e, 195)$. In this country comparatively little known, and used mostly for forage. Native to China and Japan, where it is much grown. Aside from these types, there are others of less economic importance. The Scarlet Runner type is a perennial Phaseolus ( $P$. multiflorus), grown in this country mostly for ornament (Fig. 196). Various other species of Phaseolus are also cult. ni various parts of the world under the name of Beans. $P$. radiatus is prized in Japan, and has been int into the U. S. as Adzuki Bean (see Georgeson, Bull. 32, Kans. Exp. Sta.). Vigna Sinensis, known in N. Amer. as Cowpea (which see), is sometimes called a Bean. The Velvet Bean of the South is a Mucuna (which see). The Jack Bean is a Canavalia (Fig. 197). The Sea Beans of the Florida cosst are seeds of various tropical leguminous plants, and are transported by ocean currents (see Coe, in G.F. 7:503).

L. H. B.

Culture of the BeAN. - The practical grower usually divides the many varieties of Beans into two groupsthe bush and the pole Beans. The one includes all those 
grown as "field Beans" for the dry-shelled seeds, as also both the green-podded and the yellow-podded garden, string, or snap Beans. The pole or running sorts are usually grown for garden purposes, and rarely for the dry-shelled Bean. The ordinary bush Beans make no great demands for soil fertility. They do well on ordinarily good, warm farm loam. If the soil contains a fair proportion of humus, the plants will secure much of their nitrogen from the air ; and if additional fertilizers are needed, they may be given in potash and phosphoric acid alone. Plant only after danger from

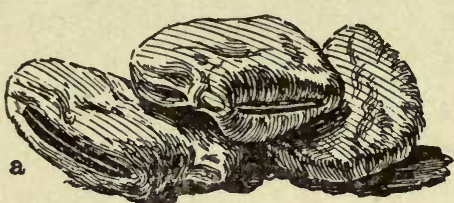
late frosts is past. The work may be done by hand, or with any of the various tools devised for the purpose. The rows are to be from $2-3$ feet apart, with plants standing

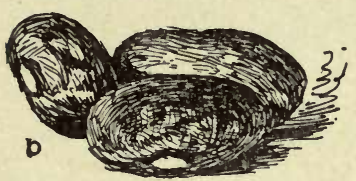
singly every 3-6 in., or in bunches of 3 or 4 erery 12-18 in. A quart of seed will plant about $150 \mathrm{ft}$. of row. Keep the soil between the rows well stirred with a fine-toothed, nar-

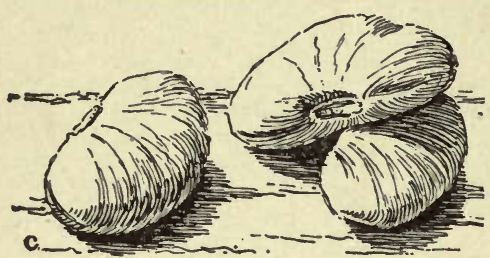
row cultivator. Hand - ho when needed. The pods of the garden Beans are picked and used as snap or string Beans as soon as well formed, and must be picked

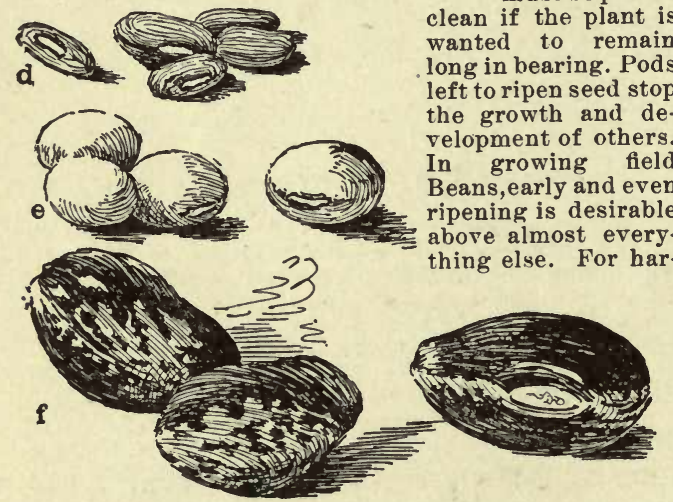

191. Types of Beans. Natural size.

a Vicia Faba. b, Phaseolus vulgaris. c, Phaseolus lunatus. d, Dolichos sesquipedalis. e, Glycine hispida. f, Phaseolus multiflorus.

vesting the crop, special tools have been devised and are in use by those who make a business of Bean-grow ing ; but when a regular Bean-puller is not available or when hand labor is cheap, the plants may be pulled by hand and placed in rows on the ground, bottomside $u p$, and when sufficiently cured put in stooks or taken to the barn, and, in due time, threshed with the flail or with a regular Bean-thresher. After being cleaned by running through a fanning mill, picking over by hand will also be required in most cases.

Among the leading sorts of field Beans are White Marrowfat, Navy or Pea Bean, Medium, and the Kidneys. For string Beans, Early Valentine, which has various strains, probably stands first in popular favor as a green-podded variety for the market-garden at the present time. Other good current sorts are Stringless Green Pod, Early Mohawk, Refugee, etc. The best among yellow-podded sorts are Black Wax or German Wax, Golden Wax, Kidney Wax and White Wax. The Wax or Yellow-podded sorts need a richer soil than the other kinds. A good string Bean has a thick, meaty

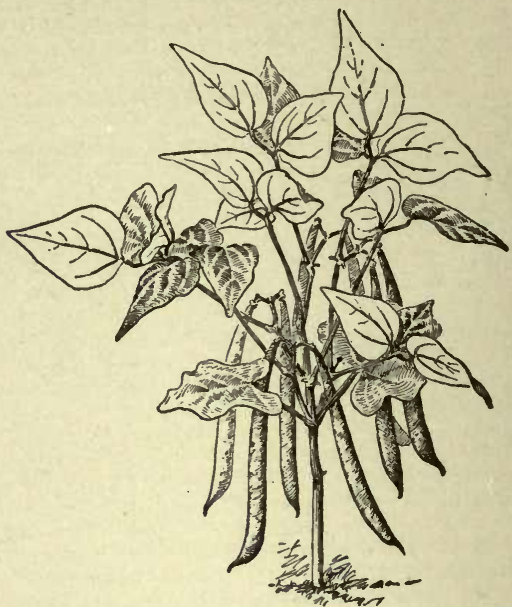

192. Common or Kidney Bean - Phaseolus vulgaris.

pod, which snaps off completely when broken, leaving no string along the back. Fig. 198 shows ideal pods.

Pole or running varieties of Beans require fertile soil; and for that king of table Beans, the Lima of all forms, too much can hardly be done in the way of enriching the ground. Warm soil is one of the first essentials of success in growing pole Beans. When poles are to be used for support, they should be set not less than $4 \mathrm{ft}$. apart each way, before the Beans are planted. Four or five Beans are to be placed around each pole, 1 to $1 \frac{1}{2}$ in. deep. While it is a safe rule to put the seed eye downward, it is not a necessary condition of prompt and uniform germination. In case of absence or scarcity of poles, a serviceable, cheap and ornamental trellis may be constructed by setting posts firmly at proper distances along the row, connecting them with two wires, one a few inches and the other 5 or $6 \mathrm{ft}$. from the ground, and finally winding cheap twine zigzag fashion around the two wires. Cultivate and hoe frequently. A topdressing of good fertilizer, or of old poultry or sheep manure, hoed in around the plants, may be of great help in keep.ng up the productiveness of the plants to the end of the season. To have a continuous supply during the entire season, the pods, when large enough must be gathered fre quently and clean. Among the varieties used both for string and shell Beans, we have the Green-podded Crease back, several wax varie ties, Golden Cluster, and the popular Horticultural or Speckled Cranberry Bean, besides any number of others. A very fine Bean is the Dutch Runner (Fig. 196), which approaches the Lima in quality and resembles it

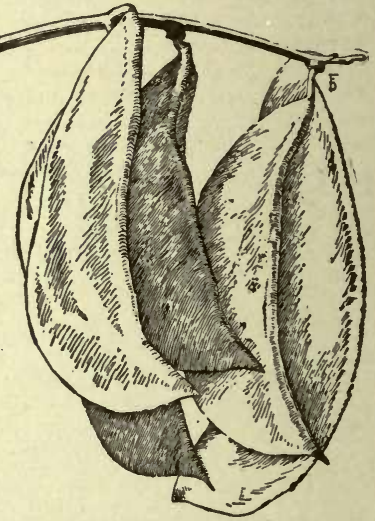

193. Large White Lima Bean (X1/3). in habit of growth. The seed is of largest size and clear white in color. Highly ornamental is the closely related Scarlet Runner, with its abundance of showy scarlet blossoms. This Bean is grown in Europe for eating, but is rarely used for that purpose here. 
Of all pole Beans, the Limas hare undoubtedly the greatest economic value. They enjoy a deserved popularity, and are usually grown with profit by the marketgardener. The tarieties might be classed in three types, -that of the Large Lima, the Dreer Lima, and the Small Lima or Sieva. Each of them has a number of sub-varieties or strains, and appears in both pole and bush form. The old Large Lima (Fig. 193) is a very large, flat Bean, and yet largely grown for main crop. To the same type belong Extra-early Jersey, King of the Garden, and others. The pods of these are very large, and the Beans ir. them somewhat flattened. The dwarf form of this type is known as Burpee's Bush Lima. The Dreer Lima of both forms is appreciated especially for its high quality. The seeds are more roundish and crowded close together in the pods, the latter being much smaller than those of the Large Lima. The seeds of these two types are light colored, with a greenish tinge, but the Large Lima is also represented by red and speckled (red-and-white) sports. The Small Lima, or Sieva, with its dwarf form, Henderson's Bush Lima, seems to be hardier and earlier than the two largar types, but pod and Bean are quite small. The color of this Bean is nearly clear white, but there is also a speckled sub-variety of it. Wherever there is a place for the Sieva, its bush form will be appreciated. The bush forms of the two larger types, however, are not uniformly productive enough to take the place of the pole forms entirely. The latter will often be found preferable where a long season of continuous bearing is desired. For further notes on Lima Beans, dwarf and pole, see Bailey, Bulls. 87 and 115, Cornell Exp. Sta.

Beans are easily forced under glass, in a temperature suitable for tomatoes. They may be grown either in pots or beds. The bush varieties, as Sion House, are preferred. Keep them growing, and look out for red spider. See Bailey, Forcing-Book; and for the forcing of pole Beans, see Rane, Bull. 62, N. H. Exp. Sta. See Forcing.

Three other members of the Bean tribe might be mentioned in this connection; namely, the Black Bean or Cow-pea of the South, the Japanese Soy Bean, and the English or Broad Bean. The Cow-pea takes in some measure the same place in the southern states that red clover takes at the North, being used both as stock food and as a green-manure crop. There are many varieties of it, early and late, some of strictly bush habit and some producing long runners. (See Cow-pea.) Of greater value for the same purposes, north of New Jersey, seems to be the Japanese Soy Bean, which is early enough to come to maturity almost anywhere in the United States. Its foliage is rather thin or open, however, which impairs its value for green-manuring. The dry Bean constitutes one of the richest vegetable foods known, and its flavor seems unobjectionable to all kinds of stock. Sow 1 bus. to the acre. Similar to this in value is the English Broad Bean, several varieties of which, as the Broad Windsor, the Horse Bean, etc., are grown

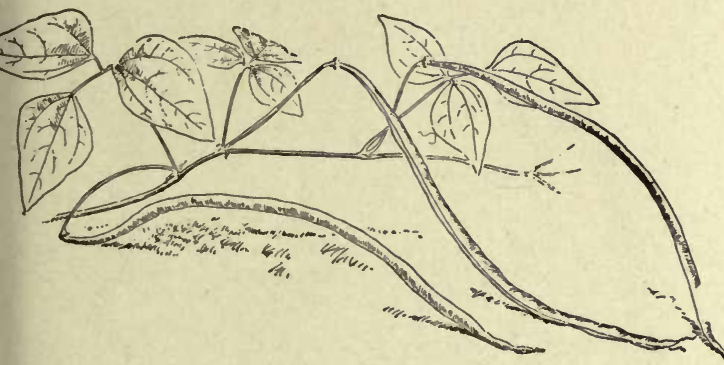

194. Dolichos sesquipedalis, or Yard-long Bean.

and are popular in England and in some parts of the European continent. In most parts of the United States they are scarcely known, and in none generally cultivated. Only a few of our seedsmen list them in their otherwise complete catalogues. Yet they are a decidedly interesting group of plants, and worthy of greater at- tention in the cooler parts of the country. Being about as hardy as peas, they may be planted much earlier than would be safe for ordinary Beans. The Windsor is used

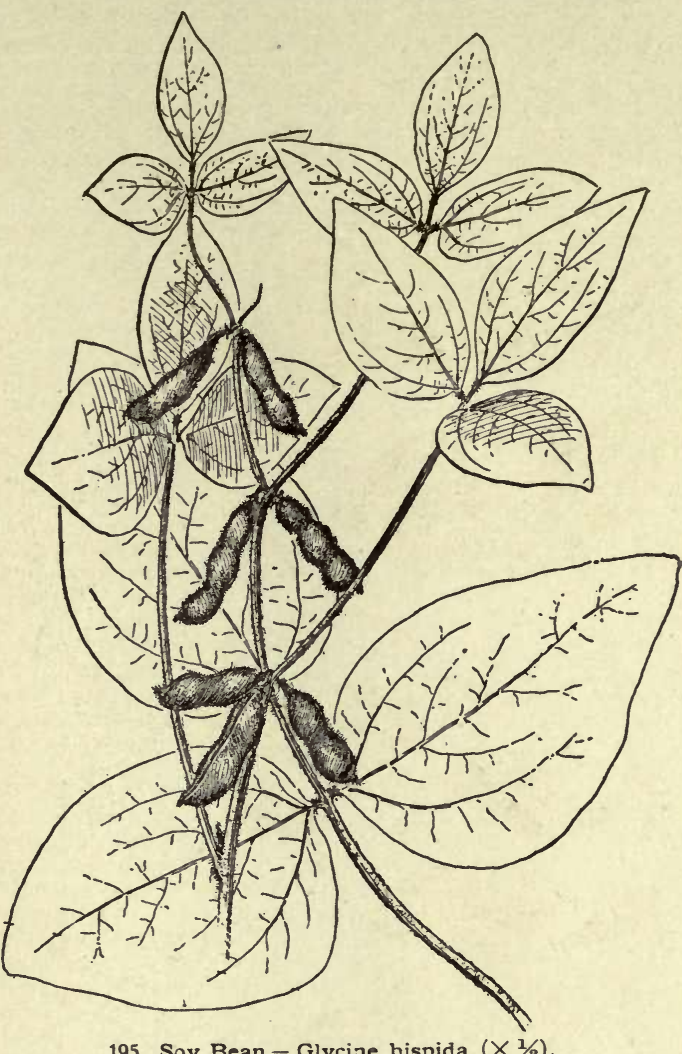

by people in England much in the same way that we use Lima Beans; but the latter are so much better that in the United States we have no need of planting the former as a table vegetable.

BEARBERRY. See Arctostaphylos.

T. Greiner.

BEAR'S BREECH. See Acanthus.

\section{BEAUCARNEA. See Nolina.}

BEAUMONTIA (after Mrs. Beaumont, of Bretton Hall, Yorkshire, Eng.). A pocyndcece. A genus of three East Indian trees or tall climbers, with very large, white, fragrant, bell-shaped fls. in terminal cymes. The genus is more nearly allied to the familiar greenhouse shrub Trachelospermum jasminoides than to the splendid tropical climbers in Allamanda and Dipladenia. B. grandiflora has been neglected of late, presumably be cause it needs so much room. It should be planted out in the strong, fibrous, loamy soil of a warm house, as it rarely succeeds in pots. It is best trained to the roof, as full light is necessary for flowering, if not for growt's. The shoots may be thinned if the large lvs. cast too much shade on the plants beneath. The wood should be well ripened to produce an abundance of winter bloom. The fls, are produced on the growth of the previous season. After flowering, the plant should be severely pruned to produce lateral shoots for the next season's bloom. In its native country, this vine climbs over very tall trees.

grandiflora, Wall. Lvs, obovate, cuspidate, wavy margined : sepals 5, large, ovate, wavy, pink-tipped; corolla tube veined with green, the limb 5-cleft. B.M. 3213. Gn. 45, p. $138 ; 49$, p. 314. J.H. III. 28: 243 . 
BEDDING, or BEDDING-OUT. The temporary use out-of-doors of plants that are massed for showy and striking effects. There are four main types: spring, summer, subtropical, and carpet bedding.

SPRING BEDDING is the most temporary of all, and is usually followed by summer bedding in the same area.

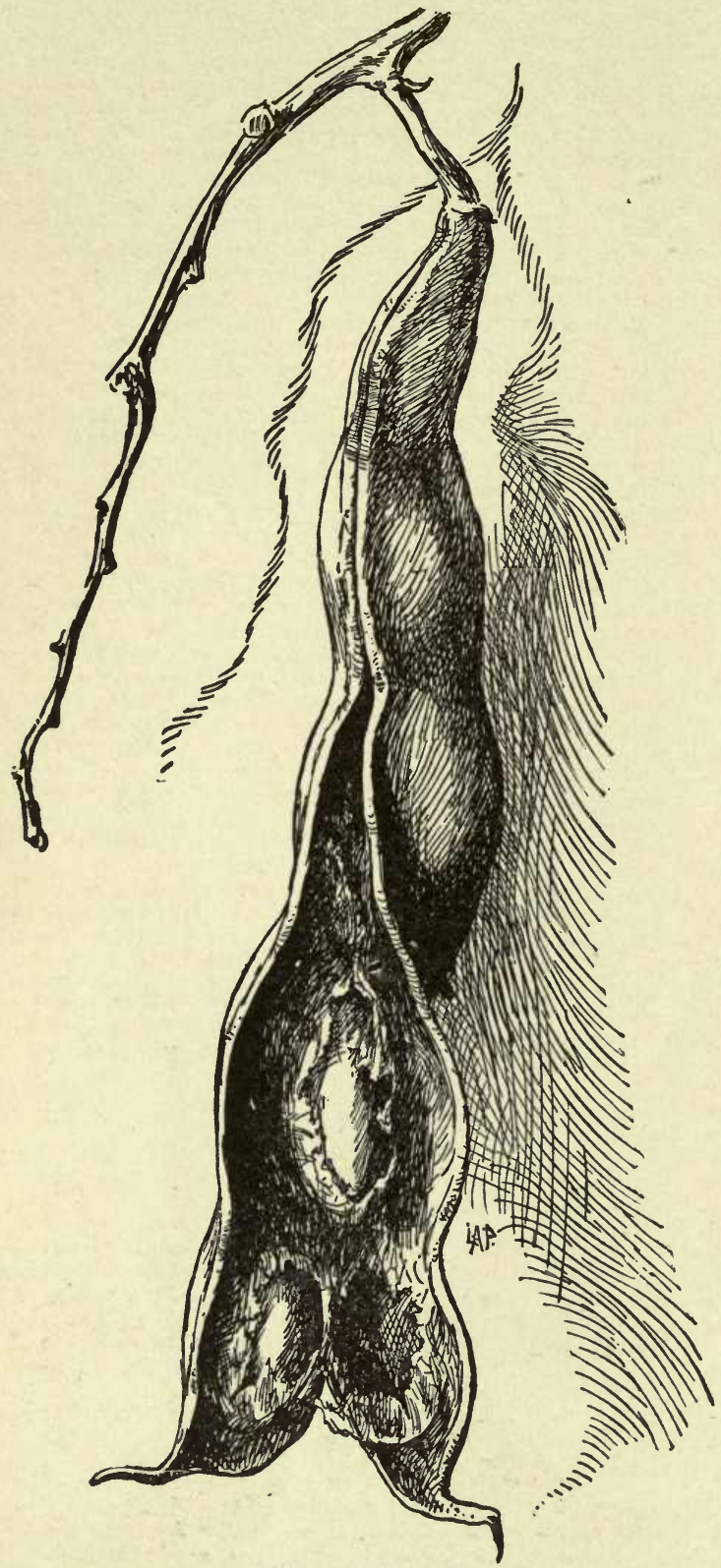

196. Phaseolus multiflorus. Natural size. (See Bean, p. 135.)

It is the only kind that largely employs hardy plants, as crocuses, narcissi, daffodils, tulips, hyacinths, and other Dutch bulbs. All four types of bedding are commonly seen in public parks, but spring bedding is the most appropriate for amateur and home use, as the bulbs fiower at a dreary time of the year, when their brave colors are most cheering, and also because they are much more familiar than the subtropical and foliage plants of summer. Then, too, hardy bulbs are more easily cultivated than any other class of plants, and they are cheap. The main principle is to plant them early enough to secure a strong root development. Hence they should be ordered early, and planted in the latter part of October or firsi of November. The colors may be massed or mixed according to taste, the terms massed and mixed bedding referring to unity or variety of effect, and being applicable in each of the four main types mentioned above. Opposed to this style of bedding is the naturalizing of bulbs in the lawn. Crocuses and squills are particularly charming when they appear singly, or in twos or threes, at unexpected places in the lawn. Daffodils are usually naturalized in large masses in spots where the grass is not mowed. Pansies are the only other plants that are used extensively for spring bedding. English double daisies and catchflies are largely used for edgings. Pansies are set out between April 1 and 15. In large operations, pansy seed is sown in August of the preceding year, and the young plants are transplanted once and wintered in a coldframe. After flowering, the plants are thrown away. The other method is to sow the seed in a greenhouse in January. The Augustsown pansies give larger and earlier blooms, but the January-sown pansies will last longer, and in partially shaded places will give scattering bloom all summer, especially if protected from drought.

SUMMER BEDDING often follows spring bedding in the same space of ground, and employs chiefly geraniums, coleus, begonias, ageratum, salvia, vinca, alyssum, petunia, verbena, heliotrope, grasses, cacti, and aquatic plants, the culture and varieties of which may be sought elsewhere in this work. As to tenderness, these fall into two groups, the first of which may be set out about May 15 in New York, and the second about June 1. Geraniums are the most important of the first group, and coleus is an example of the tenderest material, which is set out simultaneously with subtropical plants when all danger of frost is past. As to fondness for sunlight, there are again two groups, but the only bedding plants of importance that prefer shade are tuberous begonias and fuchsias. The wonderful popularity lately achieved by the former in Europe will probably never be duplicated in America. The secret of their culture is shade, shelter, and moisture at the roots. Hence a clay bottom is desirable for a bed of tuberous begonias, as being more retentive of moisture than a sandy or porous soil. They enjoy cool air and as much indirect light as possible, but not the direct rays of the sun. Hence the north side of a building is better for them than a station under trees, as the trees usually give too dense a shade, and their roots interfere. On the other hand, coleus is more highly colored in full sunlight than in shade. The only fibrous-rooted begonias largely used for bedding are varieties of the semperflorens type, of which Vernon and Erfordii are extremely popular at present. In the manipulation of tender perennials, there are often two methods of propagation, either of which may be better, according to the ideal in view. As a matter of general tendency, propagation by cuttings gives bloom that is earlier but not as continuous or profuse as by seeds. Salvias and verbenas are pronounced examples. On the contrary, cuttings must be depended on, as a rule, to keep the choicest varieties true to type, as the mission of seeds in nature seems to be to produce more variation than can be attained by non-sexual methods of propagation, as by bulbs or cuttings. Salvias are also an example of plants that are particularly effective when seen at a great distance, and also of plants that are generally massed for unity of effect, and not mixed with others. Verbenas are commonly grown by themselves, but this is because they demand much room by reason of their trailing habit.

SubTropical BedDING is a department of summer bedding which employs chiefly cannas, musas, castor-oil plants, crotons, palms, ferns of coarser habit, screwpines, dracænas, araucarias, elephant-ear caladiums, and to a lesser extent, abutilon, acalyphas, achyranthes, anthericum, Carica Papaya, sanchezia, and others. Cannas are by far the most popular at the present time. especially for mass-work. Sometimes the tall, purpleleaved, old-fashioned, small-flowered types are used in the center or at the back of the bed, and the dwarf, 
modern, large-flowered types around the edges or in front. Frequently, massing with a single variety of canna is practiced. Next to cannas in popularity probably come the crotons or codiæums, - the broad-leared types, as Queen Victoria, being better for this purpose

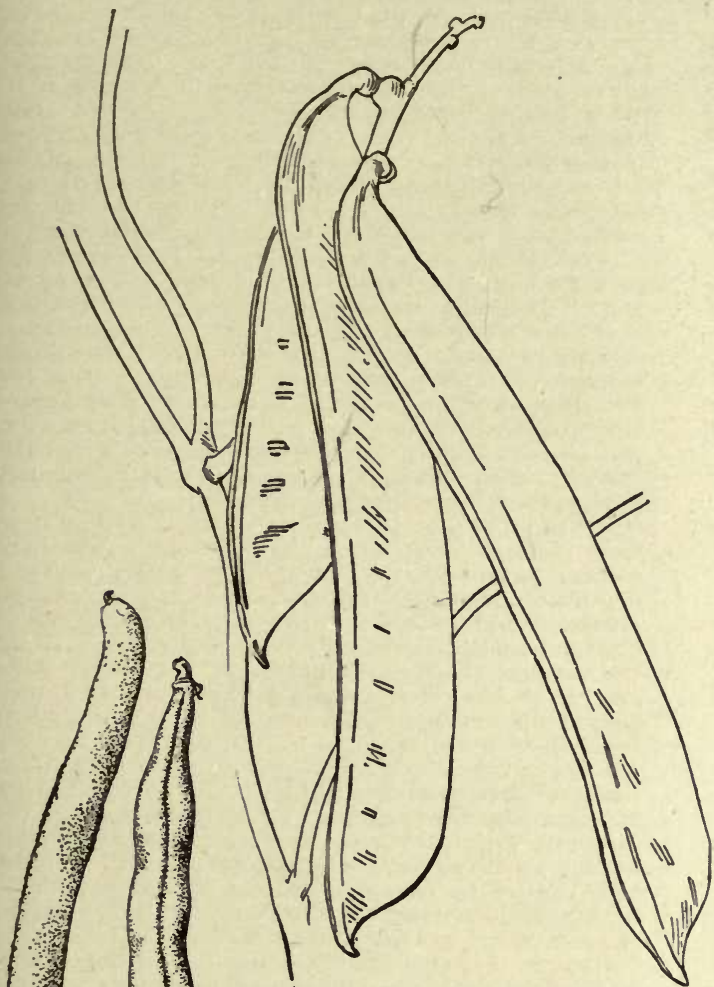

197. The Chickasaw Lima, or Jack Bean Canavalia ensiformis $(X 1 / 3)$. (See Bean, p. 135.)

than the narrower - leaved or simply curious kinds, as Codiceum interruptum and $C$. volutum, which belong to fanciers' collections. For carpeting the ground in a croton bed, two variegated trailers can be used with good effect, the wandering jew or tradescantia and $O p$. lismenus Burmanni, which is familiar to gardeners as Panicum variegatum. The large leaves of bananas give a very rich tropical effect, especially if they can be so sheltered that the wind will not split them. One of the very

198. west plants for encircling a public Typical Snap, or best plants for encircling a public
String Beans fountain is the huge-leared elephant$(\times 1 / 2)$. (See p.136.) ear caladium. For interesting points concerning its culture, see Colocasia. Among the first half-dozen favorites for subtropical bedding is the castor-oil plant, or ricinus. Its marvellous growth from seed in a single season makes it one of the very best of all plants for rapidly filling up large areas temporarily. Grasses furnish an exception to the general rule that bedding plants are tender. There are many kinds of bamboos that are perfectly hardy in the northern states, and these are bound to increase in popularity. A favorite combination of grasses for bedding is A rundo Donax, the giant reed, surrounded by eulalias. Grasses and their kind are particularly effective in aquatic groups. No well kept establishment is complete without a pond or body of water in which aquatic plants are naturalized. For a more extended account of this attractive subject, see the article Aquatics. There is a large class of tender material-as palms, screw-pines, the coarser ferns, dracænas, araucarias -2 class of foliage plants which really does better outdoors during summer in a shady and sheltered position than indoors all the year round. In the more formal styles of ornamental gardening, such planis often form the nucleus of a subtropical bed, the large tubs of the paims being hidden by lower-growing plants, as begonias, or whatever may be left over from the spring operations. In less formal gardening, the tubs may be hidden by plunging them half-way into the ground and grading the sod, which has been previously broken, in such a manner as to conceal the tubs entirely. The plants are arranged in a freer and more natural manner, and the outer fringe of begonias and the like may be dispensed with. The chief dangers to such plants are from the sun and wind. Palms once scorched or wind-whipped are ruined. Hence, a sheltered position on the north side of a building, or under the shade of trees, is usually the best spot for their summer vacation.

CARPET BedDing is the most formal and most expensive of all kinds of bedding, and employs plants that stand pinching and shearing, as coleus, achyranthes, alternanthera, lobelia, one of the dusty millers (Centaurea gymnocarpa, $-C$. candidissima will not bear the shears), certain succulents of the hen-and-chickens type (as echeverias), and many others, which list may be found in a classified and convenient form at $p .245$ of Bailey's Garden-Making. The terms "geometrical bedding " and "fancy bedding" are somewhat synonymous. Here belong the imitations of buildings and animals, the portraits of men, the lettered greetings to conventions, the calendars, floral slocks, and similar ingenuities. A single example is pictured in Fig. 199. A ground plan for a fancy carpet bed is shown in Fig. 200. For designs and for extended cultural information, the reader is referred to the numerous German books on the subject, to Mottet's La Mosaïculture, and to a book published by Geo. A. Solly \& Son, Springfield, Mass. This style of bedding requires the highest degree of technical skill, and is especially enjoyed by the Germans, whose gardeners excel in it.

The position of a bed is far more important than the style of bedding or the kinds of plants that are used. The natural school of landscape gardening, as opposed to the various schools of ornamental gardening, makes no objection to beds in themselves, but dislikes their usual position. They are commonly given the most conspicuous places, where they must be seen, whether people like them or not. They should be in a place by themselves where they do not interfere with the quieter and larger pictures of the whole place. Sunken areas,
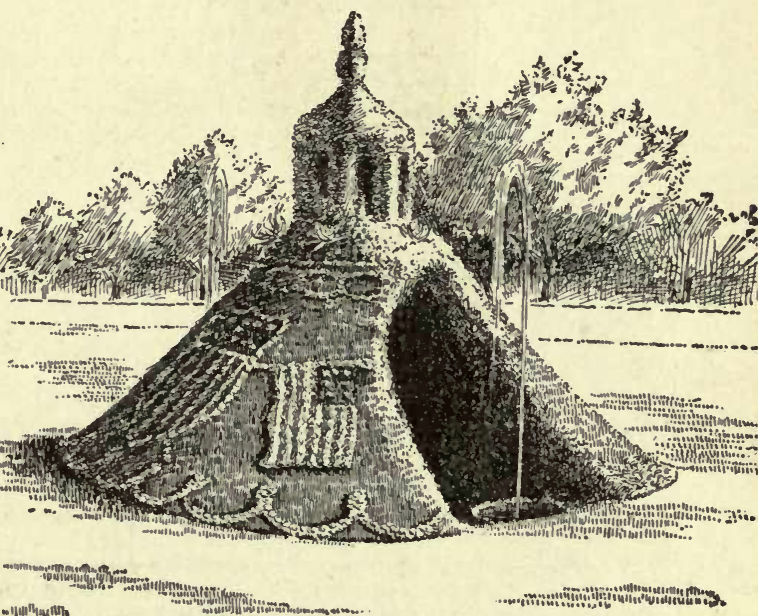

199. Example of fancy bedding.

as in Fairmount Park, Philadelphia, are particularly commendable. A flower-bed should not be in the middle of a large lawn, because it distracts the attention 
from the larger picture, and because the lawn is the canvas upon which the landscape gardener makes his picture. The chief merit of beds is their attractiveness and brightness, which accounts for their presence in parks and public places. On the other hand, they are expensive, and they are at their best only two or three months in the year, while a mud-hole in a lawn for nine months of the year is an unsightly object. Formal beds, especially of foliage plants, with their gaudy colors and unchanging monotony, are considered by some the most unnatural and the least artistic style of gardening. Nevertheless, they require a high degree of technical skill, which deserves appreciation.

A few practical suggestions may be given for making a bed. The soil should be rich and full of vegetable matter. If a foot or $18 \mathrm{in.} \mathrm{of} \mathrm{the} \mathrm{surface} \mathrm{soil} \mathrm{is} \mathrm{so} \mathrm{poor}$ that it must be removed, it may be replaced by two parts of fibrous loam and one of well-rotted manure, with some upturned broken sods in the bottom for drainage. The fall is the proper time to apply manure, and if the bed be thoroughly spaded over and left rough during the winter, the alternate freezing and thawing will fine both the soil and the fiber of the manure. Beginners nearly always fail to supply perfect conditions for wa-

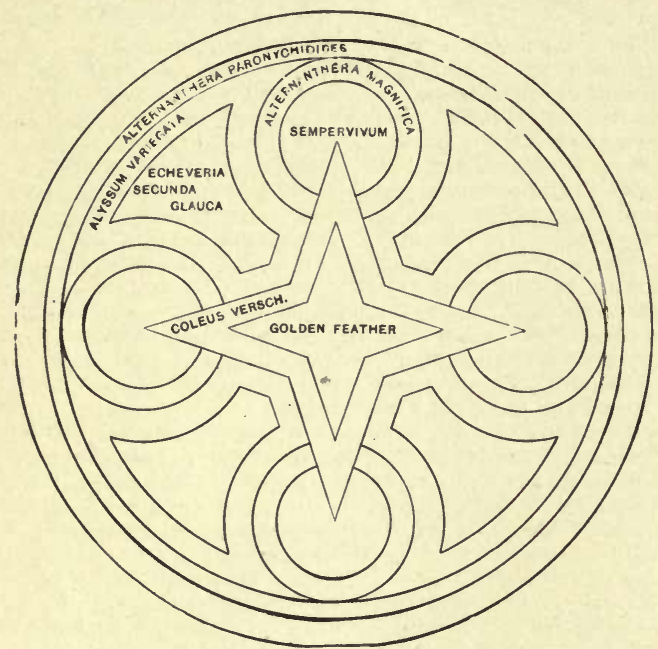

200. Plan of a complex carpet bed.

tering. A midsummer mulch of half-rotted manure en. ables the plants to take all the moisture they need during the drought and to keep it. The soil should be in ideal condition before the plants are set into it,-mellow, rich, full of fiber, and of firm and uniform texture. Begin in the middle and work toward the edges. When the bed is finished, give it one thorough soaking, to settle the soil at the roots.

\section{BEECH. See Fagus.}

ROBERT SHORE.

BEECHER, HENRY WARD (1813-1887). The celebrated American clerygyman and orator deserves especial remembrance for his work as editor of the Western Farmer and Gardener in pioneer days of western horticulture. A selection of his contributions was printed in 1859 as a book of $420 \mathrm{pp}$., entitled "Plain and Pleasant Talk About Fruits, Flowers and Farming." A second edition was published in 1874 as "Pleasant Talk, etc.," a book of 498 pp., containing also articles written for the New York Ledger. These papers have a higher literary quality than is usual in horticultural writings, and are still entertaining and suggestive. They did much to spread the taste for country life and gardening.

BEET. There are 4 or 5 species of the genus Beta, which are sometimes cultivated under the name of Beet, but Beta vulgaris, Linn., is the only one of practical importance. From it all our common garden varieties are derived. According to DeCandolle, the aborigi- nal slender-rooted species is found in sandy soil, and especially near the sea, throughout southern Europe, and on nearly all the coasts of the Mediterranean. It also occurs as far eastward as the Caspian Sea and Persia. "Everything shows that its cultivation does not date from more than two or three centuries before the Christian era." It is now highly improved, principally in the one direction of large and succulent roots, and is much esteemed in all civilized countries. See Beta.

Young Beets constitute one of the most important early crops in truckgardening. Many acres of them are grown near all the eity markets, and as they bear transportation well, they are often grown at comparatively remote places. Large quantities are shipped early from Norfolk, Va., and from other southern points to northern markets. Like all root crops, the Beet needs a loose, light, fresh,

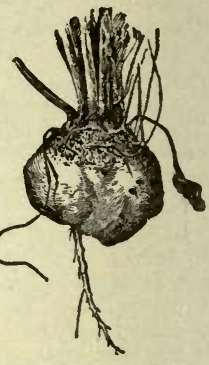

201. Bassano Beet. clean, rich soil, which must be in the best condition of tillage. No fermenting manure should be used, but instead fully rotted barn manure, with some good potash fertilizer. The seed for the first crop is sown early in spring, as soon as the soil can be well worked. Where intensive gardening is practiced, the drills may be as elose as $1 \mathrm{ft}$. apurt, in which case the young Beets are thinned to 6 in. apart in the row. But in ordinary gardening, it will be found most convenient to run the rows 2-3 ft. apart, allowing cultivation with the horse. The plants in such rows can be left 4 in. apart at thinning time. The thinning is done when the young plants are large enough to be pulled for "greens," for which purpose they find a ready market. Beets are also grown in quantities as a fall crop, and are stored for winter use. When this is to be done, the seed is sown in June, and the plantation is managed in all respects like the spring sowing. Beets are sometimes forced in greenhouses, but as they are hardly profitable, they are grown only in vacant spaces or after other crops are out. When the young roots are ready for the early market, they are pulled and tied in bunches of five or six. The fall erop is pulled soon after the first frost, the tops are removed, and the roots stored in pits or root cellars.

The most popular varietal types of the garden Beet are the following: Bassano(Fig. 201).-Flesh white and light red mixed; an old-time early variety, now less grown than formerly. Early Blood Turnip.-Rich, deep bloodred, flattened turnip-shape ; an old and well-known sort. Edmand.-Moderate size; handsome, rounded, smooth, deep red; good grain and flavor; not quite first early. Eclipse. - Uniformly globular, bright red; fine-grained and sweet; one of the best quick-growing early Beets. Egyptian Turnip.-Tops quite small; roots fair size, rich, deep red; a standard early variety.

For field culture of culinary Beets, the long-rooted varieties are chiefly used. These are sown in the field as soon as the weather is settled, in rows far enough apart to allow of tillage by horse. Most of them require the entire season in which to mature. They are grown mostly for storing for winter use. They were once grown for stock, but the Mangel-wurzels give much greater yields. The various types of Long Blood Beet (Fig. 202) are chiefly used for field culture.

Favorite varieties of Mangel-wurzels are Golden Tankard, Golden Yellow Mammoth, Mammoth Long Red. Several sorts of Sugar Beets, mostly imported from Germany, are being grown in divers places in America. Of Chard, there are no selected varieties offered in America.

The varieties of Beta vulqaris may be conveniently divided into five sections, though the distinctions are somewhat arbitrary and of no fundamental importance. These sections are as follows :

1. Garden Beets. Varieties with comparatively small tops : roots of medium size, smooth, regular and finegrained: mostly red, but sometimes whitish or yellowish.

2. Mangel-wurzels, or Mangels. Large, coarsegrowing varieties, with large tops and often very large 
roots, the latter frequently rising some distance out of the ground: rather coarse-grained. Extensively grown for stock-feeding.

3. Sugar Beets. Sometimes said to belong to another species, but doubtless to be classified here. Rather small-growing varieties, with medium tops: roots small to medium, usually fusiform, smonth, nearly always yellowish or whitish.

4. Chard, or Swiss Chard. Varieties with comparatively large tops, broad leaf-blades and very large, succulent leaf-stems, which are cooked and eaten somewhat like asparagus. The thrifty, tender young lvs. make a very excellent pot-herb. Chard has sometimes been referred to a separate species, Beta Cicla, but should be included with $B$. vulgaris. See Chard.

5. Foltage Beets. A race which has been developed to produce luxuriant foliage of many colors and varied markings. Of such varieties are the Brazilian, Chilian, Victoria, and Dracæna-leaved. The ribs of the lvs. are usually beautifully colored. Where the leaf-blight fungus is not serious, these foliage Beets make excellent borders where strong and heavy effects are desired, and they are excellent for bedding. Raised from seeds, as other Beets are ; roots may be kept over winter.

The Beet is not often damaged by insects. It is sometimes attacked by rust, rot, spot-diseases, and

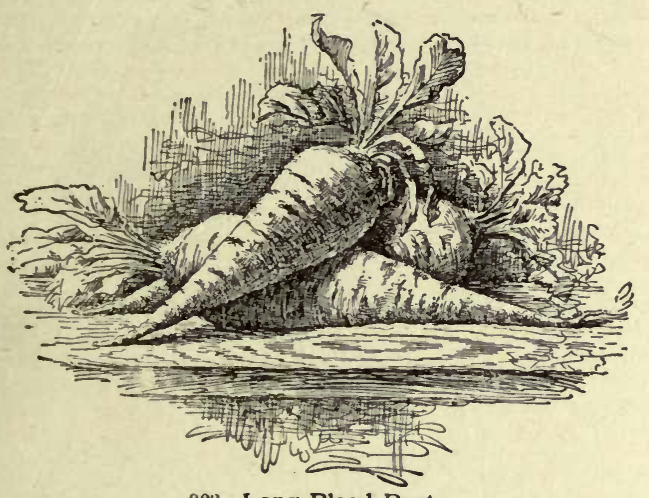

20'2. Long Blood Beet.

scab, of which the last is the worst. The scab is the same disease which attacks the potato, and one of the chief precautions is, therefore, to avoid following potatoes with Beets. For the most part, clean culture and proper rotations will forestall serious injury from plant diseases. Spraying with Bordeaux mixture may be expected to prevent the leaf diseases.

\section{F. A. WAOGH.}

BEGONIA (named after M. Begon). Begonideece. Elephant's Ear. Beefsteak GrraniUm. A large genus of very popular and useful plants for the house, conservatory and garden. Succulent herbs or undershrubs, having the stem in some cases reduced to a thick rhizome, in others to a distinct small tuber, while a few others possess a semi-tuber, in which there are a number of closely set scales or suppressed lvs., resembling bulbs : lvs. variable, alternate, more or less unequalsided, entire, or lobed, or toothed, ovate-acuminate, orbicular or peltate : fls. usually in axillary cymes, monoclous, large ; males usually with 4 petals, females with 5 (rarely 2 ), pink, white, rose, scarlet, yellow, and all shades of these, being represented; stamens numerous filaments free or united at the base; styles 2 or 4 , free, sometimes connate; stigmas branched or twisted like a corkscrew : fr. usually a 3-winged capsule, which is often colored ; ovary inferior; seeds numerous, very minute. 'The first Begonia was introduced into England in 1777 . Since then, out of the 350 species known, about 150 have proved of value to the horticulturist. Few other plants have been improved so rapidly, there being thousands of varieties now in cult., displaying the most gorgeous colors in their fls. and beauty and coloring in their Ivs. Their geographical distributiou is very disjunctive and localized. They are indigenous to Mex, Cent. and S. Amer., Asia, and S. Afr. They seem to have no genetic relationship with other plants now living. For literature, see Dryander, The Genus Begonia, Trans. of the Linn. Soc., Vol. 1, 1789; Klutzsch, Begoniaceen-Gattungen und Arten, 12 plates, 1855 ; DeCandolle's Prodromus, 15, 1864; Ravenscroft, B.C., Begonia Culture for Amateurs, 1894 ; Wynne, Tuberous Begonias.

The Begonias now in cult. may be roughly divided into four sections or groups :

I. FIBRous-RUOTED, OR WINTER-FLOWERING. Nos. 1-71.

II. Semi-tuberous, or Socotrana. Nos. $72-76$

III. TUberous, or SUMmer-Flowering. Nos. 77-99.

IV. REX, OR ORNAMENTAL-LEAVED Nos. 100-103.

In the following account, the dates refer to introduction into cultivation, not into American trade. They are European dates.

P. B. KeNNEDY.

There are four sections of the Begonia family, and as each requires somewhat different directions for their cultivation, it is desirable to treat them separately. The first section, the Fibrous-rooted, comprises such varieties as B. nitida, semperflorens, var. gigantea rosea, albo-picta, Haageana, and Duchartrei. Cuttings taken from clean, healthy stems will strike readily in an ordinary propagating box or bench, and if potted-on, as they require root-room, will make fine plants for late winter-and spring-flowering. As soon as one neglects good treatment, especially in regard to light, fresh air and fresh soil, the red spider, a physiological disease appearing like rust, and the dreaded nematodes, will soon attack them and give them a sickly and stunted appearance. They require a temperature of from $55-60^{\circ}$ at night and $65-70^{\circ}$ in the day time. The plants should be kept close to the glass during the early stages of their growth, on account of the tendency of many of the varieties to send out rather long shoots. A compost of 3 parts good loam, 1 part well-rotted manure, and 1 part sand, will be found very suitable for their growth. While Begonias in general are injured by too strong sunshine during summer, they are benefited by all the sunshine they can get during the winter and early spring months. Strong sunshine, however, pouring through imperfect glass upon wet foliage, is apt to blister the leaves of any Begonia. Such varieties as $B$. Drege $i$ and Weltoniensis, which produce at their base a thickened, fleshy stem like a potato, may be propagated either by division or by cuttings. Nearly all the varieties belonging to this section can be grown by amateurs, and make excellent house plants, especially $B$. manicata, rubra, speculata, argyrostigma, var. picta, ricinifolia, heracleifolia.

The second section, the Semi-tuberous, comprises such Begonias as $B$. Socotrana and Gloire de Sceaux. They require greater care, and should be grown in a soil with considerably more leaf-mold and a temperature of $65-70^{\circ}$ in the daytime and $60^{\circ}$ at night. Of Gloire de Sceaux and other hybrids, plants 2 years old will be found best for decorative purposes.

The third section, the Tuberous Begonias, are grown in pots, boxes or baskets, under glass, or as bedding plants in a shaded border. If the plants are intended for pot culture in the greenhouse, it is best to use the tubers. For early flowering, start the tubers in February or March, either in small pots or shallow boxes. 'The soil may be composed of loam, sharn sand and leaf-mold, and the temperature about $60^{\circ}-65^{\circ}$. When the plants are ready for repotting, well-rotted manure may be added, and when the roots have taken a fresh hold a cooler temperature may be maintained. For bedding purposes, seedling plants, as well as tubers, may be used, providing they are of a first-class strain. Tubers are preferred if earlyflowering plants are desired. They bloom more abundantly in the early part of the season, as they have the strength of the already formed tubers. Plant in the mid- 
dle of May or beginning of June, according to locality, from $3 \frac{1}{2}$ - or 4 -inch pots. Although they grow fairly well under trees, the north side of a building is to be preferred; but they must not be crowded. Plenty of light, with moisture at the roots, and a mulching with half-rotted leaves

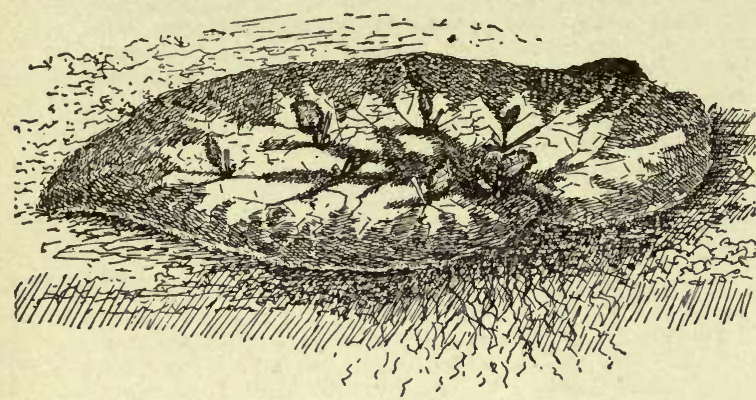

203. Young plants starting from the incisions on a Begonia leaf.

in hot weather, will greatly benefit the plants. Water, when necessary, under the leaves. See Bedding.

The tubers should be lifted after the first light frost, and stored. Seeds sown in March will produce flowering plants by July or August, but 2-year-old tubers are more satisfactory for continual blooming. The seed may be sown in any shallow box or seed-pan, which should first be filled with material which will give plenty of drainage, over which place some finely sifted soil to receive the seed. Scatter the seed thinly. Sufficient covering will be given by simply pressing the soil down level. Keep in darkness by covering with glass or 1 aper for a few days, in a temp. of not less than $70^{\circ}$. As soon as the seedlings appear the covering must be removed, and when the little plants attain roots about $1 / 4 \mathrm{in}$. long they may be pricked into nicely prepared soil. In most places in this country, Tuberous Begonias do not thrive out-of-doors, but in some places and with careful treatment they do well. They are very satisfactory for blooming in a well-shaded greenhouse in the summer.

The fourth section, the Rex Begonias, are grown entirely for the beauty of their foliage. They may be prop. by means of either shoot- or leaf-cuttings, the latter being the better when plants have to be raised in
204. Plant arising from the base (or tip) of a triangular leafcutting.

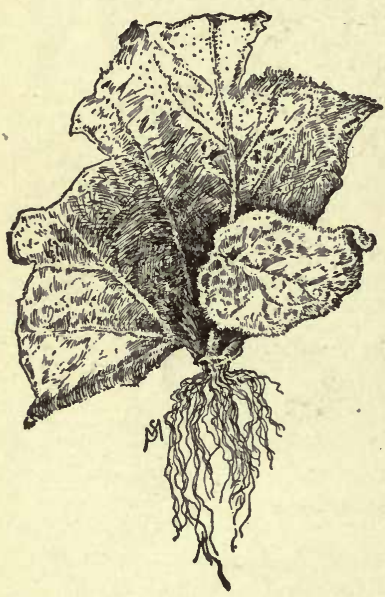
quantity. Large and well-matured, but still healthy and vigorous, leaves may have the principal nerves cut on the under side. The leaf is then pegged or weighted down on the surface of a welldrained propagating bed. If carefully shaded, roots will be formed at every cut, a tiny leaf will follow (Fig. 203), and the little plants may be inserted singly in small pots. Another method is to cut the large leaves into triangular parts, with a bit of the main petiole at the tip of each, and insert the pieces about 1 in., with the lower or thickest end of the rib downward (Fig. 204). Still another method is to cut the leaf in two, across the veins (Fig.

205), and stand it edgewise in the propagating bed. The young plants may be potted-up into small pots, using a light, porous, sifted soil. Keep shaded in a low house with a moist atmosphere. The soil may be gradually made coarser with each potting until, in the final shift, an unsifted compost of 2 parts loam, 1 part leaf-mold, 1 part well-rotted manure, and 1 part sand, is used, adding a sprinkling of lime. While watering, avoid wetting the leaves as much as possible, and keep large, well developed plants in a shaded house, with plenty of ventilation day and night during the summer.

\section{ROBERT SHORE.}

The Begonia is exacting in its requirements ; yet these requirements are simple. It responds readily to intelligent culture ; most of the varieties are extremely rapid in growth, and a year's time will produce an excellent specimen from a rooted cutting. For horticultural purposes, Begonias are usually divided into three general classes: the Tuberous-rooted, Rex, and Shrubby or Flowering sections. Tuberous-rooted Begonias attained a short-lived popularity in this country some 12 or 15 years ago, when they were imported in large quantities from France and England and used as bedding plants. It was hoped that they might share patronage with the Geranium, but our burning summers and long-continued droughts wrought such havoc with them that they speedily fell into disfavor, and very few growers now handle them. This is much to be regretted, for they are. gorgeous flowers, and careful selection has produced blooms of enormous size and wonderful form, in the most vivid shades of red, white, yellow and pink.

The Rex division has been a great favorite for many years. In no other class of plants are the rich metallic shades of various colors found so satisfactorily blended

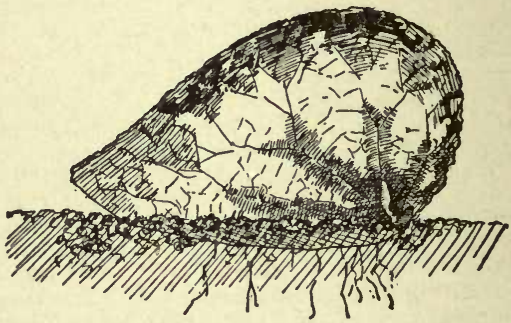

205. Upright leaf-cutting of Begonia.

as here, while the form and size of the lvs. are of the greatest variety ; those of the old Rex and of Mrs. Bonner are frequently a foot and more in length, while little Marquis Peralta makes a compact mass of tiny zoned foliage averaging only 2 or 3 in. long. To the Rex varieties showing bright green, pure silver, bronze, and velvety green, have been added Lucy Closson and Louise Closson, both showing bands of bright, rosy plum color, and Mme. Gache, with its zone of light, dull red. A class of Hybrid Rex contains some of the most useful and beautiful of ornamental plants. They are nearly all crosses between Lesoudii and Diadema. These all show the Rex texture and general habit, while the lvs. are deeply notched and zoned; they are more substantial than the average Rex, and they make symmetrical specimens with less trouble. Some of the principal American varieties of this section are Anna Dorner, Elsie Coles, Bertha McGregor, Flora Hill, Mrs. Shepherd, and Richmond Beauty. Rex Begonia culture is simple. Soil should be a mixture of loam, woods earth, sharp sand, and well-rotted cow-manure. It must be light and porous. Temperature required is a warm greenhouse for growing; but grown specimens can be hardened to a much lower temperature. They enjoy a moist atmosphere, and must be shaded from hot sunshine. They have few insect enemies. Of later years they have been subject to the attack of a very destructive fungous-like disease, but careful attention to handling and propagation will keep it in check. The propagation of Rex Begonias is very simple, a leaf, or portion of leaf with a strong midrib, rooting very readily in the propagating bench with bottom heat.

The Shrubby or Flowering Begonias comprise a number of ornamental sorts with inconspicuous flowers, and also varieties that are huge bouquets of bloom. Among the former are Albo-picta, Diadema, Nigricans, Mme. 
Lionnet and Metallica, all forming beautiful specimens of foliage. Of the flowering sorts, two of the most widely cultivated are the old favorites, Rubra and Weltoniensis. Vernon and Erfordii are veritable weeds for growth, and are covered with bloom. Paul Bruant is one of the freest bloomers of the group, the plant being covered with tls., while the Ivs. are large, dark, pointed and shining. Gloire de Lorraine is the most wonderful of recent Begonias, a well grown plant being a sight never to be forgotten. 'The fls. are large, bright pink, and borne in wonderful profusion. It is semi-tuberous in character, and requires a season of rest each year. The Semperflorens gigantea class is a very useful one, and many improved varieties now add value to it. Among them are La France, Elegantissima alba, Goliath, Mastodonte and Obelisque. The Shrubby section thrives in much the same soil as Rex, or a trifle heavier, requiring less heat and moisture. Cuttings can be struck as easily as those of the geranium.

E. G. HiLl.

Index to the Begonias here described : Abel Carrière, No. 104 ; Abundance, 39 ; A. Dallière, 105; Admiration, 99AA; Adonis, 74; Adrienne Schmidt, 105; alba fimbriata, 99AA; Albatross, 20 ; albo-coccinea, 19 ; albo-picta, 15 ; Alice Manning, 99AA ; athæiflora, 99AA ; Ameliæ, 40 ; angularis, 41 ; argenteo-guttata, 38 ; argyrostigma, 28 ; Ascotiensis, 42 ; atropurpurea compacta, 20 ; Autumn Rose, 76 ; aucubafolia, 12 ; Buron A. Vriere, 104 ; Baumannii, 86 ; Bertha de Chateaurôcher, 43 ; Bertha MacGregor, 108 ; Bexley White, 99AA ; bicolor, 87 ; Bijou, 76; Bijou deGand, 44; Bismarcki, 45; Boliviensis, 81; Bruanti, 47, sub 3 ; Caffra, 24 ; Cannell's Gem, 99AA; caroliniæfolia, 46 ; Carrière, 47; Charles Baltet, 99AA ; Chelsoni, 83 ; cinuabarina, 89 ; Clarkei, 84 ; Clementinæ, 105 ; coccinea, 29; Comte de Limminghe, 18; corallina, 29 ; Corbeille de Feı, 48 ; coronata, 26 ; Count Erdody, 108; Countess Louise Erdody, 107; Countess of Craven, 93aA ; Credneri, sub 3 ; Crimson Gem, 20 ; crinita, 90 ; cvelophylla, 91 ; dædalea, 32 ; Dandy, 99AA; Davisii, 77 ; Dewdrop, 47; Diadem, 20 ; diadema, 49 ; digitata, 50 ; Digwelliana, 66 ; discolor, 85 ; diversifolia, 87; Domini, 107 ; Dr. Masters, 99AA ; Dr. Nachtigal, 23 ; Dregei, 24; Duchartrei, 2; Duchesse de Brabant, 108 ; Duchess of Edinburgh, 20; Duchess of York,20; Duchess of Leinster, 99AA; Duke of York, 99AA; Duke Zeppelin, 99AA ; D. Wettstein, 105 ; echinosepala, 51 ; Edward B. Kennedy, 104 ; Ed. Pynäert, 104 ; elegantissima, 20 ; elliptica, 16 ; Erdody, 107, 108 ; Erfordii, 52 ; Evansiana, 85 ; Fairy Queen, 20; Feastii, 53; Flaningo, 99AA F. E. Laing, $99 \mathrm{~A}$; foliosa, 14 ; Froebeli, 78 ; Froebeli vernalis, 78 ; fuchsioites, 13 ; geranifolia, 92 ; geranioides, 80 ; Gilsoni, 54 ; glaucophylla, 18; Gloire de Lorraine, 75; (Hloire de Sceaux, $76 ;$ Glory of Stanstead, $99 \mathrm{AA}$; Goegoensis, 30 ; Goliath, 20 ; gracilis, 87 ; gracilis, var. Martiana, 87 ; Grahamiana, 19 ; grandiflora, 94; grandis, 8.5, 107 ; Griffithi, 100 ; gunneræfolia, 9; Haageana, 3 ; Hasskarli, 5 ; Hecla, 99AA ; Henri Dorneck, 105; Henri Vilmerin, 104; Hensliaw Russell, 99AA; heracleifolia, 33 ; hernandicefolia, 63 ; hybrida multiflora, 55 ; hydrocotylifolia, 8 ; Illustration, 20 ; imperialis, 4 ; imperialis, var. smaragdina, 4 ; incarnata, 12 ; Ingrami, 56 ; insignis, 12 ; John Heal, 74; Julia, 74 ; Knowlsleyana, 57 ; Kunthiana, 58 ; laciniata. 101 ; Lady Balfour of Burleigh, 99AA; Lady Grinthorpe, 99AA ; La France, 20 ; leopardinus, 107; Leopoldi, 107; Lesoudii. 105 ; Linée, 105 ; Lothair, 99AA; Louise Closson, 108 ; Louise Chretien, 108 ; Lubbersi, 59; Lucaniæ, 60 ; Lucy Closson, 108 ; lucida, 16 ; Lyncheana, 61 ; maculata, 28; maculata, var. corallina, 29; Mad. d'Lamagny, 105; Madame de Lesseps, 62 ; Mad. Treyve, 104; Mad. Funck, 10ł; Mad. F. Alégatière, 104; Mad. Georges Bruant, 105 ; Mad. Chas. Weber, 104 ; Mad. G. Van Meerbeeke, 104 ; Mad. Jos. Moens, 104 ; Mad. Luizet, 104; Mad. Isabella Bellon, 105; Mad. D. Wettstein, 105; Mad. Wagnet, 107 ; manicata, 17 ; manicata. var. aureo-maculata, 17 ; Margaritæ, 6; Marquis de Peralta, 108; Martiuna, 12; Mastodun, 20; Margarita, 99AA; Matilda, 108; M. Crousse, 105 ; metallica, 10 ; minor, 23; Miranda, 107 ; Miss Edith Wynne, 99AA; Miss Falconer, 99AA; Miss A. de Rothrehild, 99AA ; Moonlight, 99AA ; Mrs. Brassey, 99AA ; Mrs. J. Thorpe, 99AA ; Mrs. Regnart, $99 \mathrm{AA}$; Natalensis, 93 ; nelumbiifolia, 63 ; nigricans, 68 ; nitida, 23 ; nitida, var. odorata alba, 23 ; Obelisque, 20; obliqua, 23 ; Octavie, 99AA ; octopetala, 94 ; Olbia, 36 ; Otto For3ter, 107; Packe, 99AA ; palmata, 50 ; Papillon, 105 ; parvifolia, 24 ; Paul Bruant, 64 ; Pearcei, 88 ; pèltata, 5 ; phyllomaniaca, 22 ; Picotee, $99 \mathrm{AA}$; picta, 100 ; Pictavensis, sub 3; platanifolia, 9; polypetala, 95; Pres. Belle, 104; Pres. Carnot, 65 ; Pres. de Boureuilles, 68 ; Pres. de la Devansaye, 104 ; Prince Troubetzkoi, 107 ; Princess May, 99AA ; Queen of Whites, 99AA ; Reading Snowtlake, 20 ; Rex, 103 ; Rex $\times$ diadema hybrids, 103 ; Rex $\times$ discolor hybrids, 103 ; ricinifolia, 11 ; Roezlii, 61 ; rosæflora, 79; Rosy Morn, 99AA ; rubella, 34; rubra, 29; rubricaulis, 96 ; Sandersoni, 66 ; sanguinea, 31 ; Sauli, 53A ; scandens, 16 ; Scarlet Gem, 99AA ; sceptra, 49; Scharfi, 3; Scharffiana, 1; Schmidti, 7 ; Schmidtiana, 7 ; Sedeni, 97 ; Sellowii, 20 ; semperflarens, 20 ; semperflorens gigantea rosea, 21; Sieheriana, 21; Sir Joseph Hooker, 104; Socotrana, 72 ; Souv. de Mad. la Baronne de Bleichröder, 104 ; Sovereign, 99AA ; speciosa, 23 ; speculata, 35 ; Stanstead Surprise, 99AA ; stigmosa, 67 ; strigillosa, 32 ; subpeltata nigricans, 68 ; Sunderbruchi, 69; Sutherlandi, 98; tenera,99; Teuscheri, 37; Theodore Schmidt, 105; Thurstoni, 70; Thwaitesii, 99 ; Torrey Laing, 99AA ; Triomphe, 99AA; Triomphe de Lemoine, 73 ; Triomphe de Nancy, 73 ; Veitchi, 82 ; Vernon, 20; Verschaffelti, 27; Verschaffeltiana, 27; Vesuvius, 99AA ; Washingtoniana, 9; Weltoniensis, 25 ; Wettsteinii, 71 ; Wilhelm Pfitzer, 105 ; Winter Gem, 74 ; xanthina, 102 ; zebrina, 41.

I. Fibrous-rooted or Winter-flowering.

A. Lvs. hairy, velvety, or downy on the upper surfacc. B. Shape of lvs. obliquely ovate-acuminate, orbicularacuminate, or peltate.

c. Size of lvs. large, more than 2 in. wide.

D. Fls. with red hairs on under surface of petals, large.

1. Scharffiàna, Regel. Fig. 206. A robust herbaceous perennial, $1 \frac{1}{2} \mathrm{ft}$. high : lvs. large, thick, fleshy, hairy, olive-green above, crimson below : stipules very large and prominent: fls. waxy white. Braz.-This Begonis requires warmth and care to succeed well. When wellgrown, it is an excellent bracket plant.

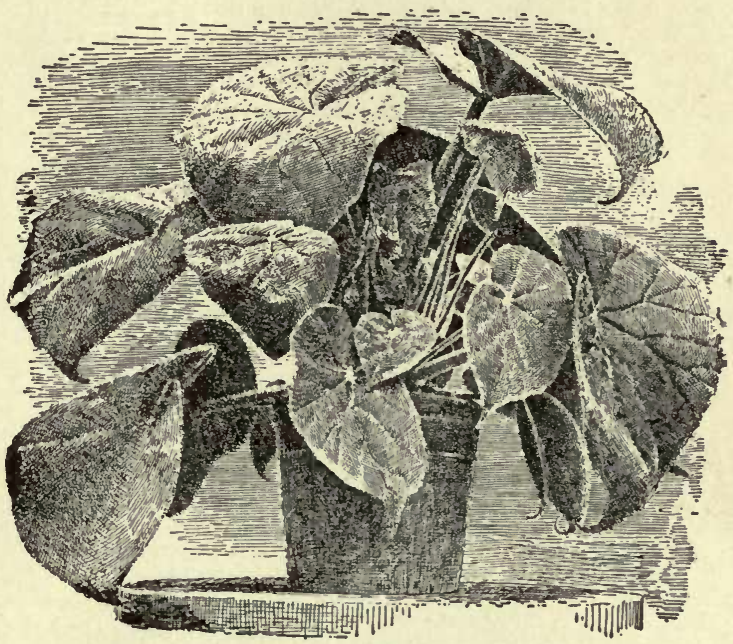

206. Begonsa Scharffiana. No. 1.

2. Duchártrei, Hort., hybrid (B.echinosépala $\times$ Scharffidna): st. 2-3 ft. high, branched profusely, hairy, purple: Ivs. ovate-lanceolate acuminate, green above, hairy, red below: fls. large, waxy white, a few red hairs on the under surface of petals. - Int. by Bruant in 1892.

3. Haageàna, Watson (B. Schárffi, Hook.). Fig. 207. Tall-shrubby, whole plant hairy: lvs. ovate-cordate, acuminate, wavy, red-nerved abovi: fls. rose-pink, with a cyme $8-12$ in. in diam., males with 2 round and 2 narrow petals, females with 5 equal petals. Brazil. G.C. 
III. $16: 633$ (1894). B.M. 7028 , as B. Scharfii.-One of the most beautiful plants of the genus. Has been distributed as $B$. Scharffiana by mistake.

$B$. Crédneri, Hort. (B. Scharffiàna $\times$ metállica). Int. by Haage \& Schmidt, 1890 . There is another plant named $B$. Credneri, whicb was raised by Lemoine in 1891 from the same parents. Bruant also used these two parents in 1891 , and ealled his plant $B$. Pictaviensis. All three plants are identical, and can only be distinguished from B. Haageana by their smaller flowers and the peduncles standing erect and not gracefully bending over, as in Haageana. There is another plant spelled B. Pictavensis, raised by Bruant in 1881, a cross of $B$. Schmidtii $\times s \mathrm{em}$. perflorens. It has also been called $B$. Bruanti. (See R.H. 1882 , p. $377 ; 1883$, pp. 8,52 .)

Dn. Fls. white or greenish white, small.

4. imperiàlis, Lem. St. short, herbaceous, green: Ivs. 4-6 in. wide, very hairy, brownish green, with irregular bands of bright green along the nerves : fls. insignificant, white. I.H. 8:274. Var. maculàta, Hort., has brown lvs. with green blotches. Var. smaragdina, Hort., has wholly bright green lvs. I.H. 7: 262 .

5. peltata, Hassk. (B. Hasskarli, Zoll.). St. perennial : lvs. peltate, ovate-acuminate, thick and succulent, covered with a whitish tomentum, 6-9 in. long: fls. small, white, on long peduncles. Braz. - It is the only Begonia in cult. with thick, felted, peltate, silvery lvs.

cc. Size of lvs. small, less than 2 in. wide.

6. Margaritæ, Hort. (B. metállica $\times$ echinosépala). Plant 1-2 ft. high : sts. purple, hairy : lvs. ovate-acuminate, sinuously dentate, green above, red beneath : fls. in cymes, large, rose colored; sepals with long hairs at the base. - Int. by Bruant in 1884 .

7. Schmidtiàna, Regel (B. Schmídti, Hort.). Dwarf, herbaceous, $1 \mathrm{ft}$. or less in height: lvs. lobed, toothed, hairy, about 2 in. long, reddish beneath : fls. white, tinted with rose. Braz. R.H. 1883 , pp. 56,57. Gn. 17, pp. 268,269. - A very use ful plant for summer bedding.

8. hydr oc ot ylifòlia. Otto. St. succulent, creeping: lvs. rotundatecordate : petiole short whole plant hairy: peduncles $1 \mathrm{ft}$. high, pilose; fls. dipetalous, rose-col ored. Mex. B.M. 3968.

207.

Begonia Haageana $\left(\times \frac{1}{2}\right)$. No. 3 .

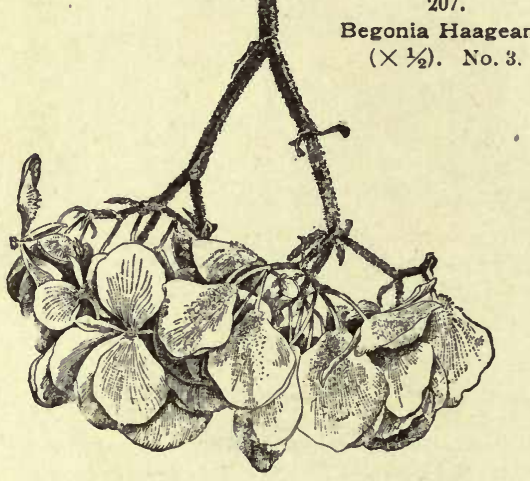

BB. Shape of leaves incised, or parted.

c. F'ls, white or whitish.

9. platanifolia, Graham. St. 5-6 ft. high, erect, robust, smooth. green, joints annulated : lvs. 8-10 in. in diam., reniform, lobed, hispid on both sides, dark green, lobes acute, toothed, ciliated: fls. in axillary dichotomous cymes, large, white, tinted rose. Braz. B.M. 3591.-B.

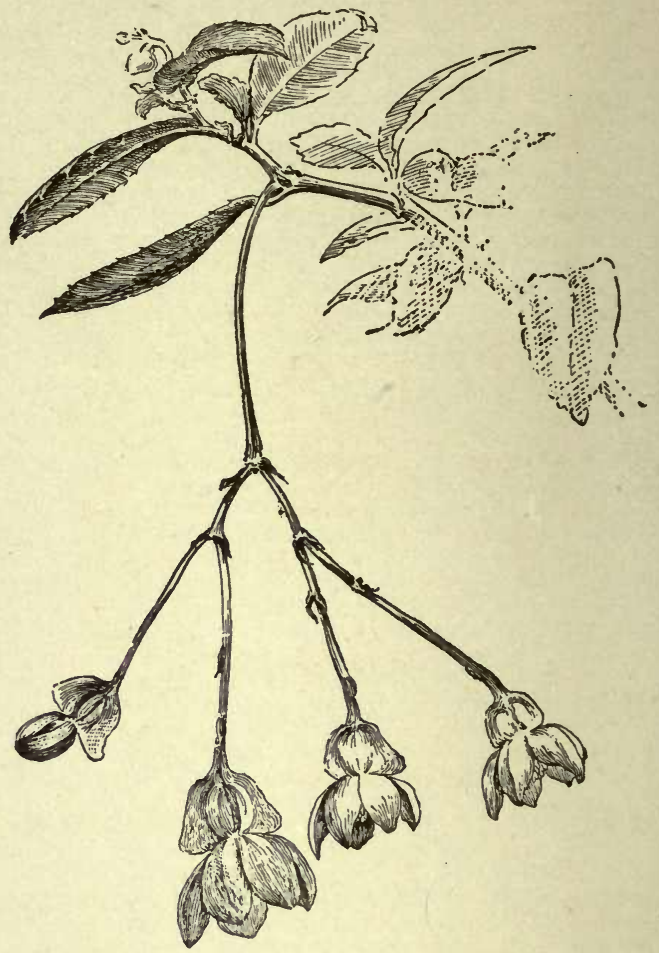

208. Begonia fuchsioides $(\times 1 / 2)$. No. 13.

gunnerofolia, Lind. (B. Washingtoniana, Hort.), once (fffered by Saul, is very similar to this, but its lvs. are not so deeply lobed and the fls. are very insignificant. 1.H. $22: 212$

\section{cc. Fls.pink.}

10. metállica, G. Smith. Sts. perennial, succulent, hairy, $4 \mathrm{ft}$. high, branched : Ivs. obliquely cordate, lobed and serrated, 3-6 in. long, upper surface green, shaded with a dark metallic color : fls. blush-white, under side of petals clothed with red bristly hairs. There are a number of varieties; e. g., var. variegàta, var. velùtina, var. cyprea, but they do not differ much from the original. Bahia. R.H. $1844: 218$. G.C. 11.5:397.-A very attractive plant, both in foliage and flower.

11. ricinifollia, Hort. ( $B$, heracleifòlia $\times$ peponifòlia). St. a short, thick rootstock : lvs. large, bronzy green, lobed, resembling castor-oil plant: fls. numerous, on long, erect peduncles, rose pink.

AA. Lvs.glabrous, or only a feu scattered hairs on the upper surface or on the margins.

B. Under surface of lvs.green.

C. Margins entire or toothed.

D. Width of lvs. less than $1 \mathrm{in}$.

E. Fls. pink, scarlet, or carmine.

12. incarnàta, Link \& Otto (B. aucubefolia, Hort. B. Martiana, Schlecht. B.insíynis, Grah.). St. erect, herbaceous, 2-3 ft. high : Ivs. unequally cordate, lanceolate, toothed : fls. rose-colored, abundant, males $1 \frac{1}{2}$ in. across, with 2 ovate and 2 narrow petals; females smaller, with 5 equal petals. B.M. 2900, as B. insignis. A.G. 16:97. A.F. $12: 724-5 ; 13: 588$. R.H.1870, p. 266; 1875:151. Var. grandiflòra, Hort., is a new and much improved variety, which is very useful for cut-flowers or decoration in winter. 


\section{BEGONIA}

13. fuchsioides, Hook. Fig. 208. Rootstock woody : sts. tall and succulent: lvs. orate, $1 \frac{1}{2} \mathrm{in}$. long, tinged with red when young : fls. drooping like a fuchsia, rich

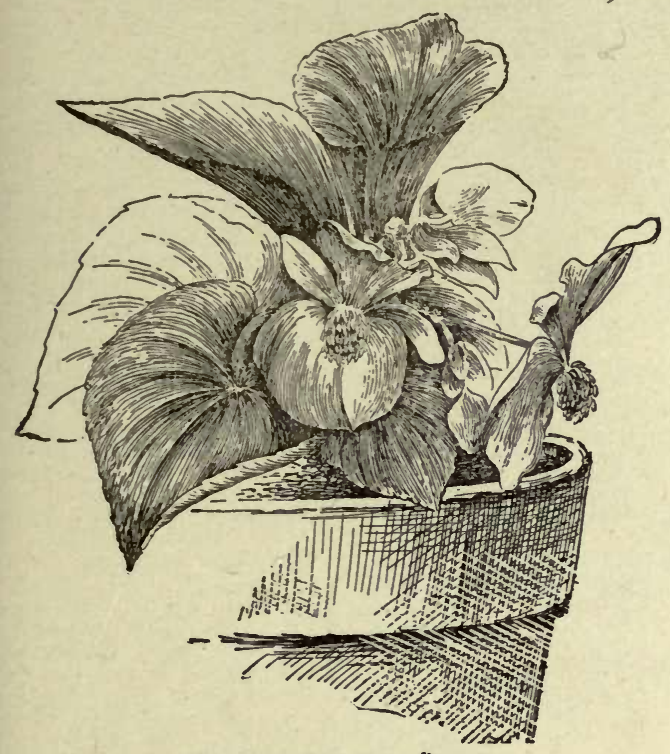

209. Begonia semperflorens.

A recently struck cutting. To show the precocity of bloom. No. 20.

scarlet, males with 4 petals, females with 5 petals. New Granada. B.M. 4281. Var. miniàta, Linden (B. cinnabarina, Hort.), differs ouly in having Hesh-colored fls. R.H. 1855:221. F.S. 8: 787 .

EE. Fls.white or whitish, small.

14. foliosa, HBK. Shrubby, sts. herbaceous, slender, branching: lvs. frond-like, very small, 3-lobed, glossy green: fls. white, tinged with rose. Blooms early summer. New Granada. - An elegant basket and ornamental plant.

15. álbo-picta, Hort. Shrubby, compact growth freely branched: Ivs. elliptical, lanceolate, covered with numerous small silvery white spots: fls. green ish white, males with 2 broad and 2 narrow petals, females of 5 subequal petals. Braz.-An elegant foliage plant. Int. by Bull in 1885 .

\section{DD. Width of lvs, more than $1 \mathrm{in}$.}

E. Stem rhizomatous, creeping, or climbing.

16. scándens, Swartz (B. lùcida, Otto \& Dietr. $B$. elliptica, Kunth). Sts. climbing or trailing, clinging by means of short aërial roots: Ivs, ovate, acuminate, lobed, glossy green, 4 in. long: fls. sniall, white, hang ing in ball-like clusters. W. Ind. R. H. 1879, p. 300 . - An excellent basket or climbing plant.

17. manicata, Brongn. A short-stemmed, succulent plant: Irs. ovate, obliquely cordate, thick, fleshy, smooth, shiny green, $6-8$ in. long: petioles covered with tleshy, scale-like hairs: peduncles a foot or more long, bearing loose panicles of pink dipetalous fls. Mex. Var. aurreomaculatta, Hort., has large blotches of yellowish white on the Ivs. F.E. 8:1159. F.R. 2: 435 .

18. glaucophylla, Hook. (B. glaucophýlla spléndens, Hort. B. glaucophýllie scándens, Hort. B. Comle de Limminghe, Hort.). Probably a hybrid, but parents not known. Sts. long. drooping or creeping: lvs. ovate, wary, 3 in. long, glaucous-green, reddish and variegated in bud: Hs. rose-red, males 1 in. across, with 2 ovate and 2 narrow petals, females of 4 equal petals. Braz.? B. M. 7219. - A good basket plant, flowering freely all winter.
19. álbo-coccinea, Hook. (B. Grahamiàna, Wight). Rootstock creeping: lvs. peltate, ovate, leathery, 6 in. long: peduncles $1 \mathrm{ft}$. long, coral red; male fls. 1 in. across, with 4 petals ; female $\mathrm{Hls}$. also of 4 petals, white above, coral-red beneath. Flowers in winter. Braz. B.R. 32 : 39. B.M. 4172.

\section{EE. Stem erect}

20. semperflorens, Link \& Otto (B. Séllowii, K1.). Fig. 209. St. herbaceous, smooth, green or reddish, 6-18 in high: lvs, ovate, rotundate, obtuse at the base, toothed and ciliate along the margin, pale glossy green, tinged with red on the midrib and petiole : peduncles axillary, few-flowered : fls. white or rose-colored ; males with 4 petals, females with 5 petals : capsule green, wings tinged with red. Braz. L.B.C. 15:1439. R.H. 1897, p.46. B.M. 2920. - This is an exceedingly variable species. An endless number of garden forms has been produced from it. Some of the mcst important are as follows: Var. atropurpùrea compácta, Gt. 44, p. 570 (Vernon), an excellent bedder, deep red; Fairy Queen, bright rosy carmine, bedding; Duchess of York, crimson, bedding ; Crimson Gem, foliage crimson-bronze, fls. elegant carmine; Duchess of k'dinburgh, fls. large, white, easily grown from seed; Reading Snowflake, white; Diadem, dark rose; Illustration, carmine ; Albatross, elegantissima, Mastodonte, Goliath, La France, Obelisque, etc.

21. Var. gigantèa ròsea (B. semperflorens $\times$ Lyncheana). Very distinct : rootstock woody ; sts. succulent, about $3 \mathrm{ft}$. high: lvs. on short petioles, ovate or reniform, toothed at the margins, about 7 in. across, bright green, with a red spot at base of sinus : peduncles axillary, stout, 4-8 in. long, bearing large panicles of large rosy red fls. of which the males have 2 ovate petals, the females 2-4 smaller petals. A.F. 13:586. A.G. 16:41.-One

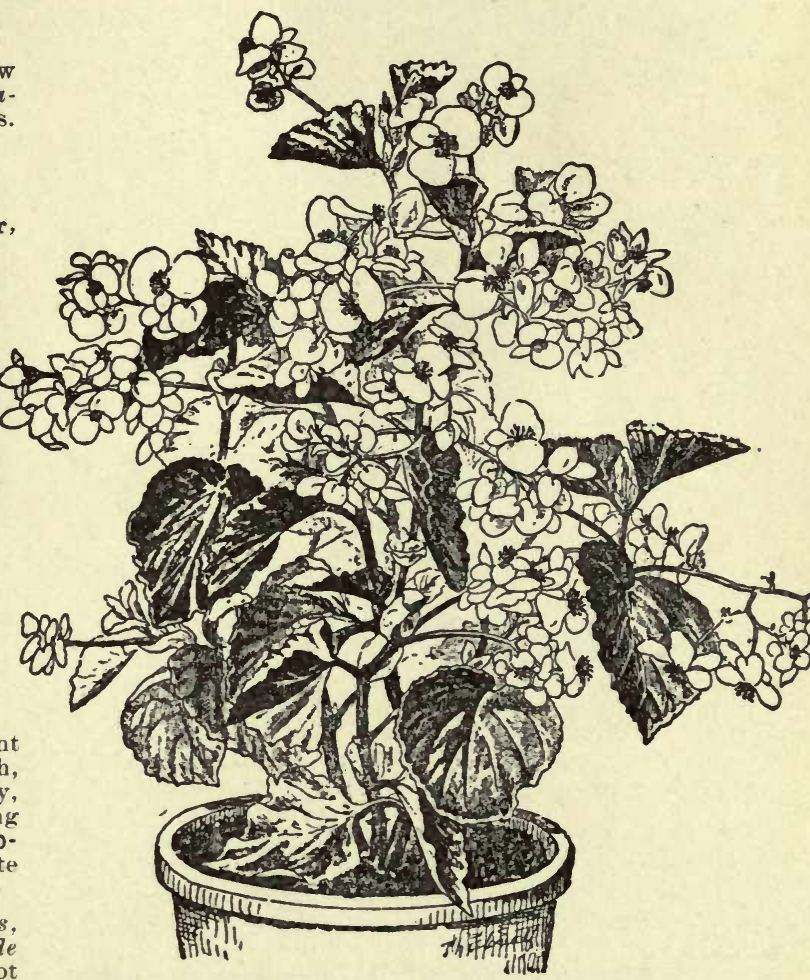

210. Begonia semperflorens, var. Sieberiana. No. 21.

of the best Begonias for winter decoration in the greenhouse. Int. by Lemoine in 1888. Var. Sieberiana, int. by Lemoine, is shown in Fig. 210 (from the French). 
22. phyllomaniaca, Mart. Fig. 211. St. perennial : Ivs. obliquely cordate, attenuate, 4-6 in. long, slightly laciniated and fringed : fls. pale pink. B.M. 5254. Brazil.This species is peculiar in that it produces from the stem, petioles and lvs. innumerable lfts. or small growths. It is one of the most interesting of plants, though not of much decorative value.

23. nítida, Dryander (B. minor, Jacq. B. speciòsa, Hort. B. obliqua, L'Her). St. 3-4 ft. high, perennial, fleshy, woody at the base when old : lvs. obliquely ovate, wavy, 4-6 in. across, glossy dark green : fls. on long, axillary peduncles, pale pink, with a silvery blush; males $1 \frac{1}{2}$ in. across, with 2 broad and 2 narrow petals; females smaller, with 5 equal petals. Jamaica. B.M. 4046 . -A very useful plant in the greenhouse, flowering all winter. Also interesting on account of being the first Begonia introduced into Europe (1777). Var. odoràta alba is a very handsome variety of this species, which
В В. Lvs, red, reddish or red-veined on the under surface. c. Margins entive or servate.

28. maculàta, Raddi (B. argyrostígma, Fisch.). St. erect, branching, woody when old : Ivs. cordate, lanceolate, wavy, 4-6 in. long, upper surface sometimes with large white, roundish spots: fls. pale rose or white, males with 2 ovate and 2 narrow petals, females with 5 equal petals. It includes several forms. Braz. B.R. 666. Var. argyrostígma pícta, Hort., is a common form, with very large white spots on the lvs.

29. coccinea, Hook. (B. rùbra, Hort. B. maculata, var. corallina, Hort.). Tall, succulent sts.: lvs. on short petioles, obliquely oblong, angular, with wavy red margins, 4-6 in. long: fls. deep coral-red; males $1 / 2$ in. across, with 4 unequal petals; females more attractive, owing to the length and rich color of the ovary, which has 3 small subequal wings. Braz. B.M. 3990. - The fls, are very

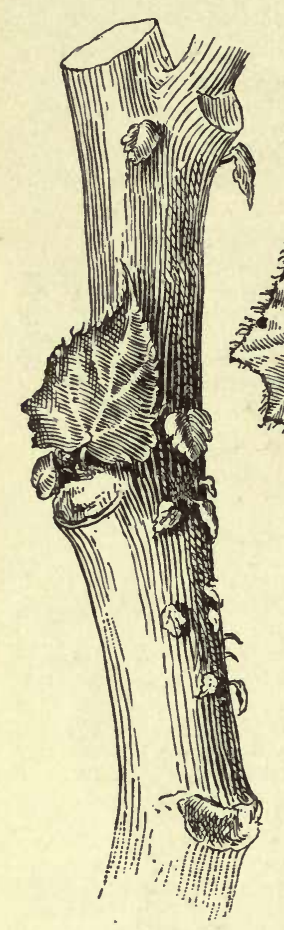
Rootstock a fleshy, globular tuber; sts. succulent, annual, 1-2 ft. high : Ivs. thin, small, green, deeply serrated, reddish on the under side: fls. white, small, profuse. Cape of Good Hope. B.M. 3720.

25. Weltoniénsis, hybrid (parents not known). St. reddish, 11/2-2 ft. high : lvs. light green, smooth, ovateacuminate, lobed, dentate, $11 / 2-2$ in. across : petiole red, $1-1 \frac{1}{2}$ in. long : fls. pink, profuse, on short peduncles.Int. by Major Clark, of Welton Park. Var. álba, Hort., has white fls.

\section{DD. Width of lvs. more than $2 \mathrm{in}$.}

26. coronàta, Hort., hybrid (B. carolinicefòlia $\times$ polyantha). St. shrubby, coarse, $2-3 \mathrm{ft}$. high, covered with numerous withered stipules: lvs. large, lobed, on long petioles: fls. pale pink, with large, somewhat drooping cymes.

27. Verschaffeltiàna, Regel. (B. Verschaffélti, Hort. B. manicata $\times$ carolinicefòlia). St. a thick rhizome: lvs. large, ovate, acuminate, lobed : fls. rose-colored, pendent on long peduncles. I.H. 2: 68. - Tall, coarse and unsightly as an old specimen, but when well grown from year to year from cuttings makes a splendid plant.
211.

11.

(1)

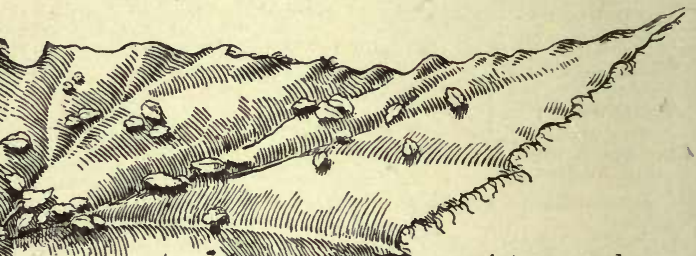

persistent and exceedingly ornamental, especially when planted out. Choice. a short, thick rootstock: lvs. peltate, ovateorbicular, 6-9 in. long, surface blistered or puckered, green, with dark, bronzy blotches, red on the under side: fis. small, rose-pink. Sumatra.-A distinct and ornamental-leaved plant.

31. sanguínea, Raddi. Sts. perennial, woody at the base, red: lvs. subpeltate, obliquely cordate, thick, fleshy, smooth, shining, bright green above, blood-crimson below: fls. small, white. Rio de Janeiro. B.M. 3520.-A handsome evergreen foliaged Begonia.

32. dædàlea, Lem. (B. strigillos $a$, Dietr.). St. a short, thick rootstock: lvs. large, green, ovate-acuminate, cordate, margins slightly serrate and beset with long reddish hairs, surface covered with a peculiar network of russet-brown: peduncles spotted and slightly hairy: fls. white, tinged with pink. Mex. I.H. 8:269.-A handsome foliage plant, not very widely known.

\section{Cc. Margins incised, lobed or parted.}

D. St. creeping; a short, thick rhizome.

33. heracleifolia, Cham. \& Schlecht. (B. jatrophofòlia, Hort. ). St. a short, thick rhizome : Ivs. 6-12 in. across, palmate, lobes toothed, rich green : peduncles 3-4 ft. long: fls. white or rose-tinted. Mex. B.M. 3444. B.R.1668. Var. nigricans, Hort., has the margins of the lvs. bordered with dark green. B.M. 4983 . Var. longipila, Hort., has long, fleshy hairs on the leafstalks and peduncles. Var. punctàta, Hort., has green lvs̀., reddish near the margin : fls. rose-colored, with deep red spots on the outside.

34. rubella, Hamilt. St. a short, thick rhizome : lvs. large, cordate, acuminate, deeply lobed, smooth, spotted with irregularly shaped dark brown marks : fls. pale pink, on long peduncles. Nepal.

35. speculàta, Hort., hybrid? St. a short, thick rhizome: lvs. broadly ovate, acuminate, cordate, on long, hairy petioles, dull green, rough, speckled with grey, hairy, reddish on the under side, veins very prominent, light green, profusely branched : fls. on long, hairy peduncles, pink-white, males and females both with 2 petals : capsule green, with small red spots. - Origin not known, though quite common in cultivation. A hardy and useful Begonia. 
DD. Stem erect.

36. Olbia, Kerchove. St. leathery, 2-3 ft. high : Ivs. lobed, hairy and olive-green above, smooth and red be neath, margins reddish, petioles grooved, smooth, veins prominent as dark lines: fls. concealed by lvs., in small clusters directly on the st. without peduncles, large, white, male and female in same cluster. Braz.

37. Teùscheri, Lind. St. 2-3 ft. nigh, erect, strong grower: Ivs. large, acutely lobed, ovate-lanceolate, margins serrate, bright green above, with greyish blotches, red-veined below! fls. in axillary clusters, bright red, large. Malaya. I.H. $26: 358$.

38. argénteo-guttàta, Hort. (B. álbo-pícta $\times$ Ólbia). Profusely branching: lvs. shining green, ovate-acuminate, slightly lobed, sinooth, $2 \frac{1}{2}$ in. wide, $3-5$ in. long, thickly dotted with white spots: fls. in clusters, variable: petals white, tinged with pink: capsule rose-pink.-Int. by Lemoine, 1889.

SUPPLEMENTARY LIST-FIBROUS-ROOTED.

39. Abundance (B. fuchsioides $\times$ semperflorens). Plant, 2 ft. high : st. reddish : lvs. glossy green, ovate, 2 in. long, dentate: fls, rose-pink.-Int. by Lemoine in 1891 .

40. A mèlice (B. BruantiXRoezlii). Plant, $2 \mathrm{ft}$ high Ivs, green, broadly ovate, smooth: tis, rose-colored.

-Int. by Bruant in 1886.

41. angularis, Raddi (B. zebrina, Hort.). St. smooth, st. culent, 2-3 ft. high: lvs, elongate, ovate-acuminate, margins undulate, shing green, veins white: fls, insignificant, light pink. Braz.

42. Ascotiénsis, Webb. Lvs. ovate, 2 in. long, smooth, brown, margin green, dentate: fls. on peduncles 4 in. long, bright red.

43. Bertha de Chateaurôcher, Hort. Var. of B. Ascotiensis : fls. bright currant-red.- Useful for cut-flower's.

44. Bijou de Gand, Hort Caulescent : fls, rose, in clnsters. Very similar to Teuscheri (which see).

45. Bismarcki, Hort. Caulescent: fls. in clusters, rose, males insignificant, females a gorgeous display. Very similar to Teuscheri.

Cáffra, Meissn. See B. Dregei.

46. carolinicefolia, Regel. St.erect, thick, fleshy: lvs.palmate, lobes deeply divided into 6 or 8 : fls. pink, on long peduncles. Mexico.

47. Carriérei, Hort.(B. semperflorens $X$ Schmidtii). DEwDroP. BRUANTI. Plant, about $1 \mathrm{ft}$. high : lvs. like semperflorens : fls white.-Excellent bedding Begonia. Int. by Bruant in 1883.

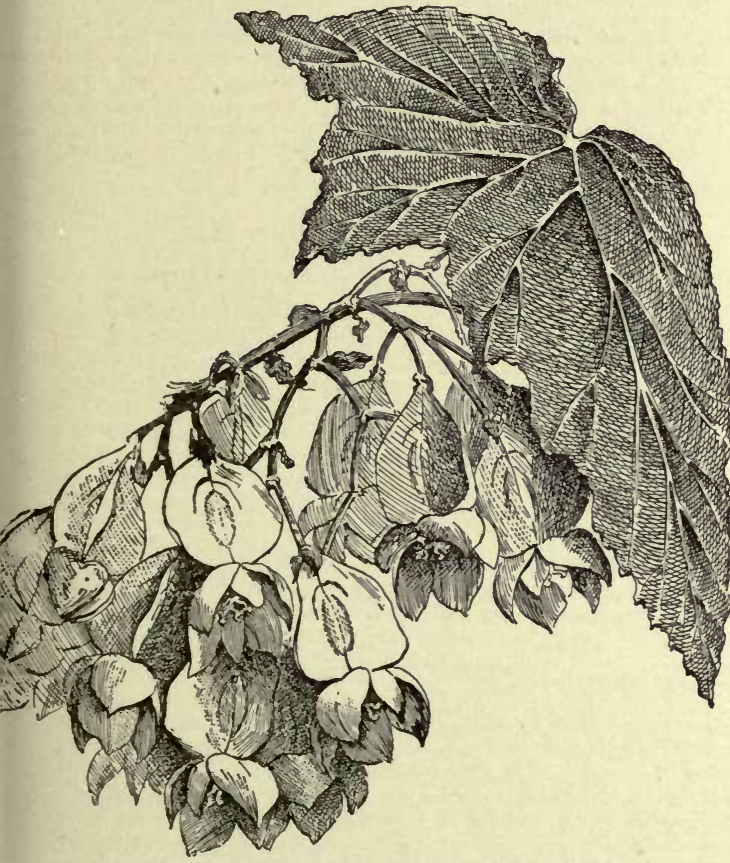

212. Begonia Madame de Lesseps $\left(\times \frac{1}{2}\right)$. No. 62 .
48. Corbeille de Feu (B. semperflorens $\times$ fuchsioides). Fls. bright coral-red. - Int. by Lemoine in 1891.

49. diadéma, Linden (B. sceptra, Hort.). Plant, $2 \mathrm{ft}$. high: lvs. green, deeply parted, blotched with white, dentate: fls. insignifcant. Borneo. I.H. 29: 446 .

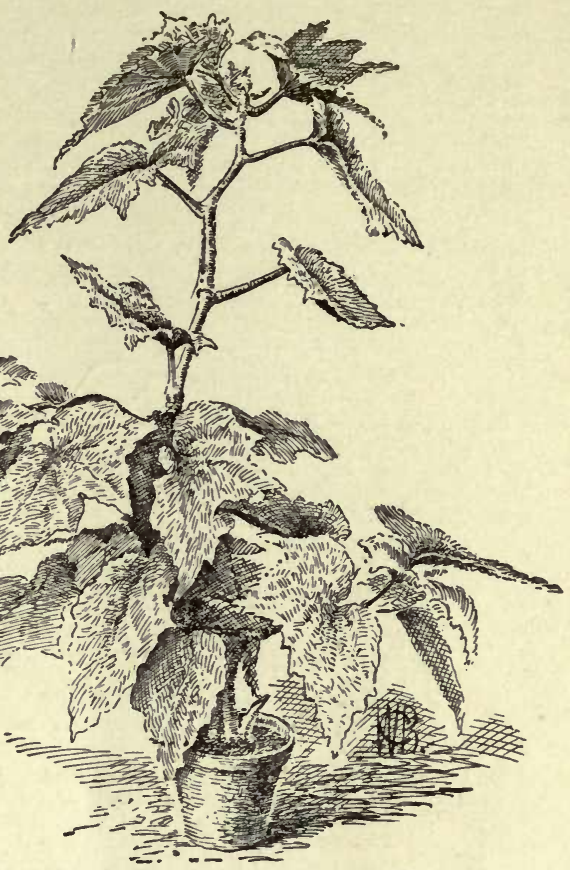

213. Begonia President Carnot. No. 65

50. digitàta, Raddi (B. palmata, Hort.). Lvs. palmate, 10-12parted, somewhat pubescent, green above, brownish beneath Brazil.

51. echinosépala, Hort. St. green, succulent: Ivs. obliquely oblong: fls. on axillary peduncles, white, with curiously papillose sepals.

52. Erfordii, Hort. (B. Schmidtii $\times$ semperflorens Vernon) Very dwarf and bushy, $1 \frac{1}{2} \mathrm{ft}$. high: fls. abundant, rose-carmine -Excellent for bedding. Int. by Haage \& Schmidt in 1894.

53. Feastii, Hort. (B. manicata $\times$ hydrocotylifolia). St. a short, thick rootstock: lvs, suborbicular, thick, red beneath, entire petioles irregularly marked : fls. light pink, on long peduncles. -Int. by John Feast, of Baltimore, before 1880 .

Saùli, Hort., is a newly introdnced species from Guatemala, resembling Feastii in the shape and color of its lvs., but with a distinct red sinus at junction of petiole with leaf.

54. Gilsoni, Hort. (origin American). Plant, $2 \mathrm{ft}$. high : st shrubby, coarse: lvs. large, lobed: fls. on long, erect peduncles, pale pink. - Interesting as being the only double-fld. fibrous rooted Begonia. Named for Gilson, colored gardener to Mrs. Livingston, N. Y.

55. hyेbrida multiflora, Hort. (B. hybrida floribunda, Hort.). Plant 2-4 ft. high : lvs. small, 1 in. long, $1 / 2$ in. across, dentate, green below : fls. rose-pink, hanging in clusters like a fuchsia.

56. Ingrami, Hort. (B. nitida $\times$ fuchsioides). Combines the characters of the two species : fls. light pink.-Int. by Ingram in 1849.

insignis. See B. incarnata, No. 12.

57. Knowlsleyd̀na, Hort. (origin not known). Very similar to B. incarnata.

58. Kunthiàna, Walp. Stem erect: lvs. lanceolate, acuminate, serrate, smooth, green above, red below : fls. white, large. B.M. 5284. Brazil.

59. Lúbbersi, E. Morr. Stem a short rhizome: lvs. large, palmate, green : fls. pink, on long peduncles. Brazil. G.C.III. 3:301. R.H. 1888, p. 225 .

60. Luciàna, Hort., hybrid (B. Lyncheana $\times$ Bruanti). Fls. large, in the axils of the lvs., rose.-Int. by Bruant in 1889.

61. Lyncheàna, Hook. (B. Rœzlii, Regel.). St. erect, talı, succulent, smooth : lvs, green, smooth, ovate-cordate ; sinus red : fls, in axillary, drooping cymes, deep, reddish crimson. New Granada. B.M. 6758.-Almost identical with B. semper florens gigantea rosea, but not so strong a grower. 
microphýlla, Willd. Is B. foliosa, No. 14 miniàta, Planch. \& Linden. Is B. fuchsioides, No. 13.

62. Madam de Lesseps. Fig. 212. Strong, erect grower: lvs. acutely lobed large, margins serrate, green above, red and strongly veined below: fls. large, white, in axillary clusters, males insignificant.

63. nelumbiifolia, Cham. \& Schl. (B. hernandiæfolia, Hort.). St. a short. thick rhizome: lvs. large, 12-18 in. long, 8-12 in. wide, peltate, hairy on the under side: fls. small, white or rose-colored. Mex.

Roezlii, Regel. See B. Lyncheana, No. 61.

64. B. Paul Bruant (B. manicata X(?)) . St. short, thick : lvs large, olive-green tinged with red, deeply lobed: petioles large long, striped with red; ring of fine hairs at the junction of petiole and leaf: fls. abundant, pale pink, large, on long' pe petiole and leaf : fls. abundant, pale pink, large,
duncles. R.H. 1888. p. 514. - Int. by Bruant in 1892 .

65. President Carnot. Fig. 213. Plant, 2-6 ft. high, leggy: lvs. ovate-lanceolate, acute-lobed, ribs on the under side red: fls. in a large cluster; males small, insignificant; females large, bright red-carmine, 2 in. long, including capsule.-Striking.

66. Sándersoni, hybrid (origin not known. B. Digwelliana, Hort.). Fls. scarlet. 1882

Saùli. See below B. Feastii, No. 53.

67. stigm $\partial a$, Lindl. St. a short, creeping rhizome: lvs, large, cordate-acute, irregularly toothed, smooth above, hairy beneath, green, with purple-brown blotches : fls. insigniflcant, white, in eymose panicles. Mex.

68. subpeltàta nigricans, Hort. (B. nigricans, Hort.). Plant 2-3 ft. high : lvs. ovate, acuminate, blood-red below, silvery and slightly hairy above, 4-8 in. long, 2-4 in. across : fls. rose-pink profuse: capsule wings equal, pink.- Very useful for decoration. Var. Pres, de Boureuilles, Hort., has lvs. of a much richer color and more profusely studded with red hairs: fls. of a deeper pink.

69. Súnderbruchi, Hort. An American form of B. heracleifolia, var. longipila : lvs. bronze-green, silver bands along the nerves, purple underneath.

70. Thúrstoni, Hort. (B. metallica $X$ sanguinea). St. 2 ft. high : lvs. orbicular-acuminate, shiny, smooth, rich purple, red on the under side, veins prominent: fls. insignificant, small, rosy white, on slender peduncles, A.F. 7: 728,-Excellent.

velutina, Hort. See B. metallica, No. 1 .

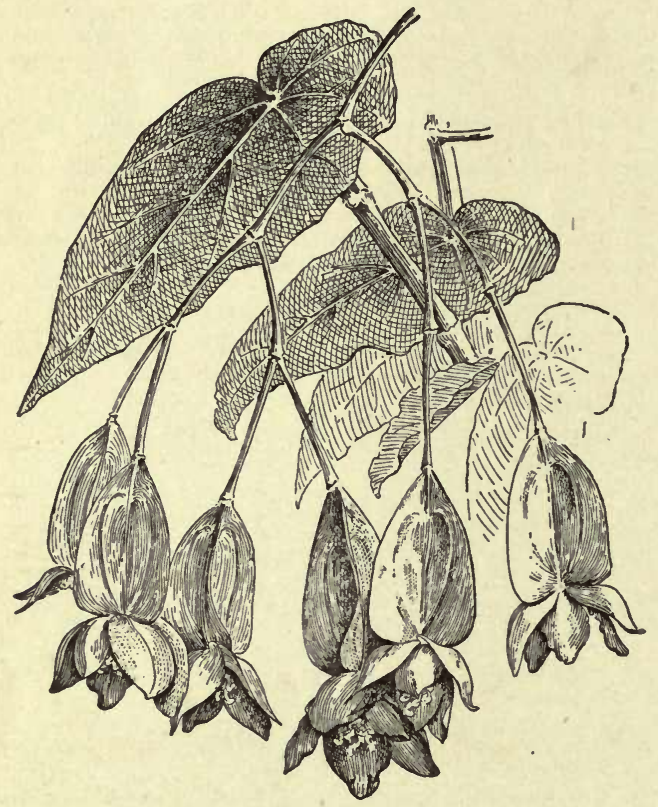

214. Begonia Wettsteinii $\left(\times \frac{1}{2}\right)$. No. 71 .

71. Wéttsteinii, Hort. Fig. 214. St. a foot high, branching from the base: lvs. slightly lobed, elongated, ovate-acuminate fls. on long, slender, graceful peduncles, large, in clusters, bright red : capsule large, red and showy, very profuse.

zebrina, Hort. See B. angularis, No. 41.

\section{Semi-tuberous or Socotran Section.}

72. Socotràna, Hook. Fig. 215. St. annual, stout and succulent, forming at the base a number of closely set scales or suppressed lvs. resembling bulbs: lvs. dark green, orbicular, peltate, 4-7 in. across, center depressed, margin recurved, crenate: fls. in terminal few-fld. cymes, bright rose. B.M. 6555. Gn. 21:327. Gn. 49:1069. G.C. II. 15:8. A.F. $13: 587,588$.-Semi-tubers were brought from the burning hot, sandy island of Socotra by Dr. I. B. Balfour, and given to Kew in 1880 . The plant was discovered by Alexander Scott, the gardener accompanying the expedition to Socotra sent out by the Geogr. Soc. of London. Semi-tubers should rest during summer and be planted in heat in winter.

The following are Socotrana derivatives:

73. Triomphe de Lemoine (B. Socotrana $\times$ Roezlii). Stem herbaceous, spreading, then erect and branching into numerous flowering branches : lvs. large, eoriaceous, orbicular, somewhat oblique, margins slightly cenerous, 6 in. diam.: fls. in dichotomous cymes from axils of lvs., rose-carmine, female fls. exceedingly rare, males very profuse, plant resembling a large bouquet when in full bloom. G.F.2:557. - Int. by Lemoine in bouquet when in full bloom. G.F. 2:557.-Int. by Lemoine in in Begonias. Another hybrid from the same parent is Triomphe in Bancy, with fls. rich yellow in the center, double, and the de $\mathrm{Nancy}$, with fls. rich yellow in the center, double,
outer petals of a paler hue.-Int. by Lemoine in 1888 .

74. John Heal (B. Socotrana XViscountess Doneraile). A tuberous variety. Plant intermediate between parents, 9 in. high, branching naturally and freely: lvs. obliquely heart shaped, not peltate, as in B. Socotrana; light green: fls. borne loosely on graceful peduncles, standing well above the foliage every stem developing male flowers, $1 \frac{1}{2}$ in. diam., bright, rosy carmine. Blooms from Sept. to Jan. Gn. 35:691. - No female fls. have been produced from this hybrid, so that seedlings have been impossible. Prop. by euttings and semi-tubers. Int. by John Heal in 1885. Adonis (John Heal Xtuberous variety). Plant more robust: fls. twice as large as John Heal, 3 in. diam. all male, soft rose color, on graceful, arching peduncles-Int. by John Heal. Winter Gem (B. Socotrana Xerimson tuberous variety). Habit like B. Socotrana, but more compact: fls large, deep carmine. - It combines the characters of the tuberous and semi-tuberous sections. Int. by John Heal. Julia (Socotrana $\times$ tuberous variety). The plant is very similar to a double summer-flowering tuberous Begonia. It has fls. of a salmon-pink shade.

75. Gloire de Lorraine (B. Socotrana $\times$ Dregei). Lvs. small, nearly regular, pure green: fls, almost exclusively male, 4 petaled, large, borne in broad panicles, covering the whole superior part of the plant, rose-colored, not deciduous. Gt. 42, p. 111. A.F. 12:842. G.F. 5:247.-Although B. Socotrana is semi-tuberous and B. Dregel has a thickened rhizome the hy brid forms show neither, but the base of the stem throws out many shoots, which can be separated and insure the multiplimany shoots, which can be separated and insure the mu
cation of the plant. Int. by Lemoine in 1892. - Exceilent.

76. Gloire de Sceaux (B. SocotranaXsubpeltata). Fig. 216. Plant stout, half shrubby, erect, vigorous, compact, $2 \mathrm{ft}$, high, 1-11/2ft. across : lvs. dark metallic green, thick, large, red beneath, veins red above, sub-orbicular, slightly obligne, fls profuse, beautiful rose-pink, shiny, females none. Fls. from Dec. fuse, beantiful rose-pink, shiny, females none. Fls. from Dec. till May. R.H. 1884:516. G.F. 7:185.-Interesting as connecting the fibrous-rooted and semi-tuberous sections. Int. by Thibaut and Keteleer in 18s. Autum oblique; fls. intermediate, clear, deep rose. Fls. all winter.-I1teresting as connecting the fibrous-rooted and semi-tuberous sections. Int by John Heal, of Veitch \& and semi-tuberous another hybrid from the same parents, with large green lvs. and red-carmine fls.; males and females present.

III. Tuberous or SuMmer-Flowering SECtion (Figs. 217, 218, 219).

A. Stemless, lvs, springing directly from tuber.

B. Color of fls. bright red or brilliant scarlet.

77. Dàvisi, Veitch. Stemless : lvs. springing directly from a rootstock, ovate-cordate, shining green, slightly hairy, underside red, petiole short, fleshy : peduncles, pedicels, and fis. bright red. Peru. B.M. 6252, F.M. 1876:231. G.C.II. 15:669. - A favorite with hybridists. Has given rise to numerous dwarf, erect-habited garden forms, with small but brightly colored fls.

78. Fròbeli, A. DC. Stemless: lvs. numerous, cordate, acuminate, green, covered with fleshy, purplish hairs: fls. in tall, lax, drooping, branching cymes, brilliant scarlet, large. Winter. Ecuador. Gn. 12, p. 376. - A beauti ful flowering plant, useful for conservatory work in winter. B. Frobeli vernalis, Hort., hybrid (Frobeli $\times$ Dregei), similar to type. Int. by Deleuil in 1880 . 


\section{BEGONIA}

BB. Color of fls. rose-red or white.

79. rosæflòra, Hook. Stemless : petioles, scapes, bracts, and stipules bright red: lvs. green, $2-4$ in. wide,

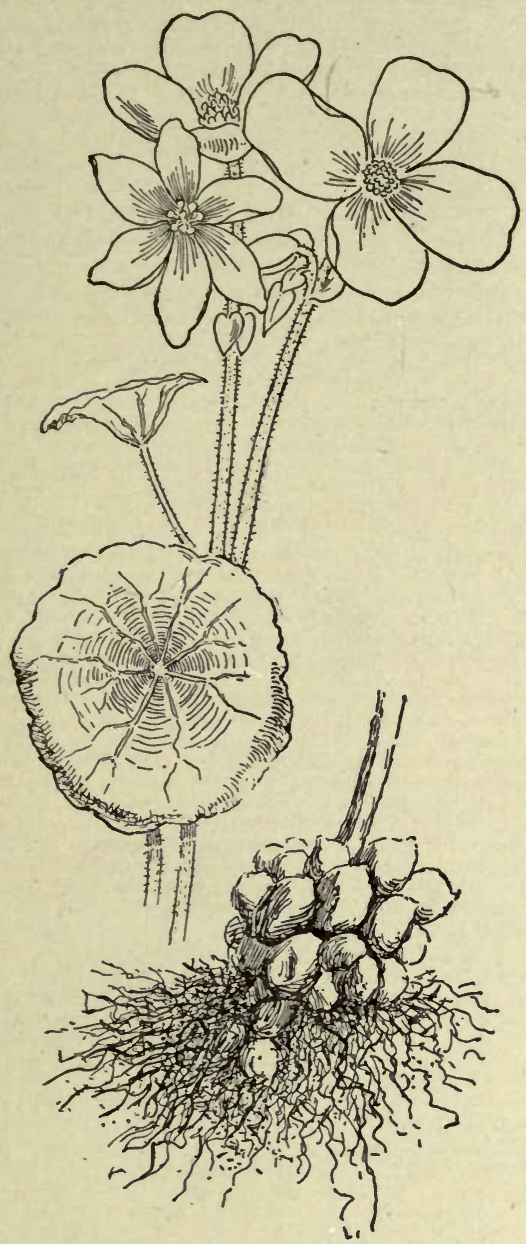

215. Begonia Socotrana $(\times 1 / 2)$. No. 72 .

on stout, hairy petioles, 2-6 in. long, orbicular, reniform, concave, margins lobed, red, toothed : fls. 2 in. across, rose-red. Peru. B.M. 5680.-Light colored seedlings of this species gave rise to Queen of Whites, put into commerce in 1878, and destined to be a most important factor in subsequent garden forms of the same color. Int. in 1867.

80. geranioldes, Hook. Stemless, rootstock fleshy : lvs. radical, reniform, 6 in. across, lobed and toothed, green, hairy, petioles 8 in. long: peduncles erect, 6-12 in. long, reddish, hairy, bearing a lax panicle of fis.. each $11 / 4$ in. across, pure white, with a button-like cluster of yellow anthers. Natal. B.M. 5583. - Planted in a border in a sunny greenhouse, this is a fine Begonia, flowering profusely during Oct. and Nov. Int. to Kew in 1866.

$$
\text { AA. St. present. }
$$

B. Color of fls. cinnabar-red, orange-red, bright red or scarlet.

81. Boliviénsis, A. DC. St. herbaceous, succulent, $2 \mathrm{ft}$. high, branching : ivs. lanceolate, acuminate, serrate, $3-5$ in. long: fls. in drooping panicles, cinnabarscarlet, fuchsia-like; males twice as large as females. Bolivia. B.M. 5657.- The first Tuberous Begonia introduced into England, 1864
82. Veitchii, Hook. St.very short, thick, fleshy, green: Irs. orbiculate, cordate, lobed and incised, margins ciliated, green, principal veins radiating from a bright carmine spot near the center. under side pale green; petiole thick, terete pilose: fls. $2 \frac{1}{4} \mathrm{in}$. in diam., cinnabar-red: capsule smooth, unequal wings. Peru. B.M. 5663. F.S. 22: 2326. - One of the progenitors of the Tuberous race Int. 1867.

83. Chélsoni, Hort. (B. SèdenixBoliviénsis). St. fleshy, 2 ft. high : Ivs. oblique, lanceolate, irregularly lobed : fls. large, orange-red, drooping. Gn. 4: 109.Int. by Veitch in 1870.

84. Clárkei, Hook. St. purplish, fleshy, stout: lvs. obliquely-cordate, serrate : fls. in pendulous racemes, abundant, large, bright red. Bolivia. B.M. 5675.Resembles B. Veitchii. It was the seed parent of Vesuvius and Emperor, two important and useful varieties for bedding out.

$$
\text { BB. Color of } \mathrm{fls} \text {, rose-red or pini. }
$$

85. Evansiàna, Andr. (B. discolor, R. Br. B graindis, Dry.). St. herbaceous, branching, smooth, $2 \mathrm{ft}$. high : lvs. ovate-acute, sub-cordate, lobed, margins denticulate, green above, under side and petioles red, peduncles branching, axillary: fls. numerous, flesh-colored, large. Java, China, Jap. B.M. 1473. - A handsome and almost hardy species. Int. in 1804 to Kew. Little cult. now.

86. Baùmannii, Lemoine. Tubers as large as ostrich eggs : lvs. large, orbicular, with short, thick petioles: peduncles 18 in. high, bearing panicles of 4-6 fls., which are rose-red, 4-petalled, from 3-4 in. across, and fragrant as roses. Bolivia. Gt. $40: 1348$ : 42, p. 25. A.F. 7:561. G.F. 5: 77. - It is described as plentiful in the moist valleys of the Cordilleras, where it is eaten by cattle. Sweet-scented. Distributed by Lemoine in 1890 .

87. grácilis, H.B.K. (B. bicolor, Watson. B. diversifòlia, R. Grah.). St. erect, not branched, succulent: lvs. thinly scattered along sts., almost heart-shaped, slightly hairy, lobed, denticulate, ciliate : fls. on short, axillary peduncles, pink. Mex. B.M. 2966. - In axils of lvs, between stipules a cluster of bulbils is borne. These may be gathered and sown as seeds. Along with its varieties, annulàta, diversifỏlia, Martiàna, etc., it makes a very beautiful summer-flowering greenhouse Begonia. Int. by P. Neil, of Cannon Mills, Edinburgh, in 1829 .

88. Pèarcei, Hook. St. $1 \mathrm{ft}$. high, succulent, branching : lvs. lanceolate, cordate, acuminate, toothed, glabrous above, tomentose beneath, pale red on under surface : fls. in loose, axillary panicles, large, bright yellow. Bolivia. B.M. 5545. - It has been the chief factor in the production of the hundreds of yellow, buff and orange-colored garden forms. Int. in 1865.

\section{SUPPLEMENTARY LIST-TUBEROUS-ROOTED.}

(A) The following tuberous-rooted species are not known to be in the Amer. trade, but they are in cultivation in greater or less purity :

89. cinnabarina, Hook. Sts, annual, short, green, zigzag. slightly downy: lvs. on short petioles, obliquely ovate, lobed

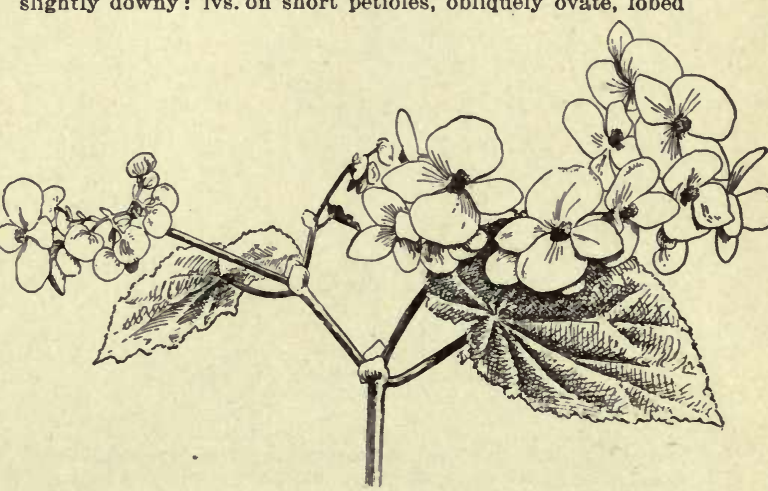

216. Begonia Gloire de Sceaux $(X 1 / 2)$. No. 76. 
and serrated: peduncles 9-12 in. long, red; fls. cinnabar-red, 2 in. across. Bolivia. B.M. 4483. P.M. 16: 225. - Int. by Henderson in 1849 .

90. crinita, Oliver. Sts. red, hairy, $1 \mathrm{ft}$. high : lvs. ovate-cordate, irregularly toothed, tinged with red on the under side: peduncles erect, red, producing 3 pale rose-colored fls. Bolivia. B.M. 5897, - Int, by Veitch in 1866.

91. cyclophýlla, Hook. Stemless : lvs. orbicular, 6 in. across, green; with fimbriated margin : peduncles erect, 6 in. long fls. rose-colored, with the fragrance of roses. China. B.M. 6926. - Int. to Kew in 1885.

92. geranifòlia, Hook. St. $1 \mathrm{ft}$. high, erect, greenish : Ivs. cordate, lobed, serrated, green, margins red, whole plant smooth : fls. 2 or 3 on terminal peduncles, outer petals orbicular, red the two inner obovate, white. Lima. B.M. 3387.-Int. 1833.

93. Natalénsis, Hook. Sts. fleshy, annual, 1-2 ft. high : lvs. obliquely cordate, lobed, sinuate, $2-3 \mathrm{in}$. long, green, sometimes mottled with grey, veins reddish: fls. bluish white, 1 in. across. Natal. B.M. 4841. - Int. to Kew in 1854.

94. octopétala, L'Her. (B. grandiflora, Knowl. \& West). Stemless, lvs. long, succulent, downy, petioles $1 \frac{1}{2} \mathrm{ft}$. long, cordate, deeply lobed and serrated, bright green : fls. greenish white, males with 8 petals, females generally fewer. Peru. white, males with 8 petals, females generally fewer.
B.M. 3559. F.S. 20: 2056-7. A.F. 4: 225 (var. Lemoinei).

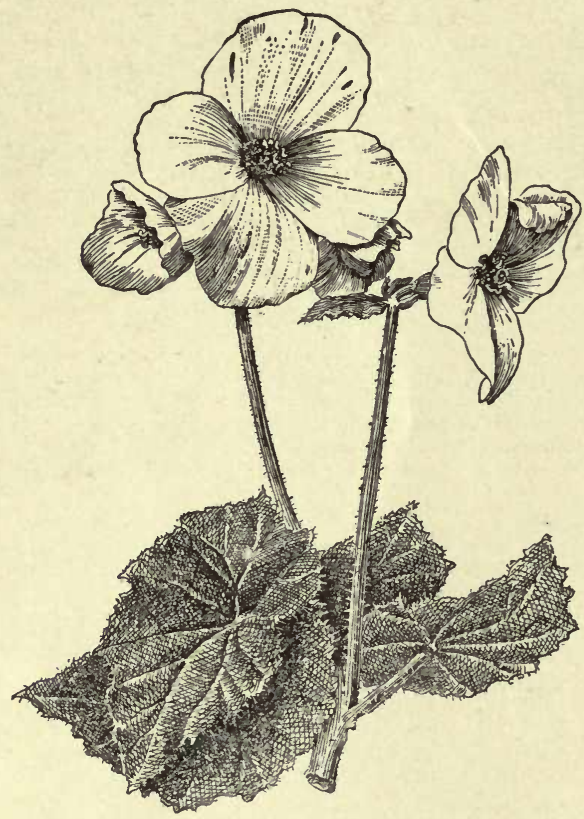

217. Single Tuberous Begonia $(\times 1 / 3)$.

95. polypétala, A. DC, St, short, fleshy, annual: Ivs, ovatecordate, tothed, with 9 or 10 ovate-oblong petals an inch long, red: ovary hairy. with 9 or 10 ovate-oblong petals an inch long, red : ovary hairy,
with one long wing. Peru. Gn. 14,p. 531.- Int. by Frobel in with 1878 .

96. rubricaùlis, Hook. Lvs. 4-6 in. long, ovate, wavy, ciliate along the margins, deep green. fls, large, males $1 \frac{1}{2}$ in. across, 5-petaled; females smaller, 6-petaled, reddish Country un known. B.M. 4131. - Int. to Birmingham Bot. Gar. in 1844.

97. Sedeni, Hort., hybrid (B. Boliviensis X Veitchii ?). Lvs. long, pale green : fls. solitary, brilliant red; females of 4 petals ; males of 5 petals. R.H.1872: 90.-Int. by Thibaut and Keteleer in 1872 .

98. Sútherlandii, Hook. St. annual, herbaceous, 1-2 ft. high, bright red: lvs. 4-6 in. long, lanceolate, lobed and serrated, green, with red veins and margin ; petioles slender, red: fls. numerous, coppery or salmon-red. Natal. B.M. 5689.-Int. by Backhouse in 1867 .

99. ténera, Dry. (B. Thwaitesii, Hook.). Lvs. radical, cordate, 5 in. long, coppery green, mixed with purple and blotched with grey, under surface crimson: fls. white, tinged pink. Ceylon. B.M. 4692.-Chiefly interesting as a variegated plant. Int. to Kew in 1852

(AA) The following list comprises some of the best and most distinct of the innumerable garden forms and hybrids now existing, which have almost all been pro- duced from six species ; viz., B. Boliviensis, B. Pearcei, B. Veitchii, B. rosaflora, B. Davisii, and B. Clarkei, by crossing and recrossing :

\section{(1) SINGLE-FLOWERED VARIETIES.}

a. CRIMSONS AND SCARLETS. - Admiration, fls, vivid orangescarlet, of dwarf. compact habit, free flowering: Charles Baltet, rich, velvety vermilion; Dr. Masters, fls. large, with immense spikes, deep red-crimson; $\boldsymbol{F}$. $\boldsymbol{E}$. Laing, deep, velvety crimson, full and free; Mrs. Brassey, deep, glowing crimson ; Lothair, dark scarlet-carmine ; Scarlet Gem, very dark scarlet, dwarf, and very floriferous ; Vesuvius, bright orange-scarlet, compact and free; one of the finest bedders.

b. ROSE-COLORED.-Lady Guinthorpe, rose color, extra large and fine; Marginata, large, round fls., white, with a margin of bright pink; Packe, soft, rosy red, shaded light rose; Stanstead Surprise, deep rose, very large.

c. Whites, - A lba fimbriata, a fine, large, pure white flower, with fringed petals ; Bexley White, an immense flower of the purest white; Mrs. J. Thorpe, white, the petals edged with reddish lake; Queen of Whites, large, erect, pure white fls. of great substance; Moonlight, pure white, very free.

d. ORANGE AND YELLOWS.-Duchess of Leinster, orange. buff, large, erect fls.; Miss A. de Rothschild, pure yellow; Sover-

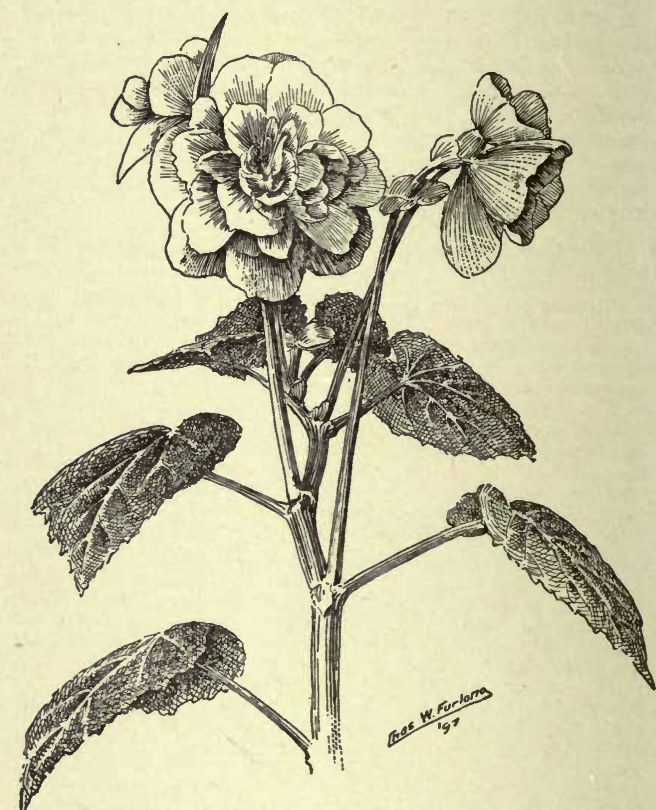

218. Form of double Tuberous Begonia $\left(\times^{1 / 3}\right)$.

eign, rich golden yellow, very free, and excellent in every way; Torrey Laing, reddish orange-yellow, an unusual color.

\section{(2) DOUBLE-FLOWERED VARIETIES.}

a. Crimsons and Scarlets, - Cannell's Gem, bright scarlet; Dandy, intensely bright scarlet, extremely free-flowering; Flamingo, brilliant scarlet; Henshaw Russell, scarlet, one of the best; Triomphe, rich, bright crimson; Duke Zeppelin, dazzling scarlet fls., new.

b. ROSE-COLORED. -Althoefflora, bright rosy cerise, distinct; Duke of York, deup rose. Glory of Stanstead soft rose, light center; Hecla, bright, glistening pink, free bloomer; Rosy Morn, rose-pink, large, broad, wavy petals.

c. Whites.-Countess of Craven, pure white fls., dwarf ; Miss Edith Wynne, pure creamy white ; Octavie, pure white blossoms, very floriferous ; Picotee, delicate white, pink margin, dwarf; Princess May, pure white, undulated or crimpled at the edges.

d. Yellows.-Lady Balfour of Burleigh, large yellow fls., erect: Miss Falconer, clear yellow; Mrs. Regnart, chromeyellow, petals prettily undulated; Alice Manning, primrose. yellow blossoms.

IV. Rex, or Ornamental-leaved Section.

100. Griffithii, Hook. (B. picta, Hort.). St.-lvs, and habit as in $B$. Rex: lvs. olive-green, with a broad zone 
of grey, tinged with red on the under side : fls. large, fleshy, pink : ovary curiously crinkled along the angles. Assam. B.M. 4984.-Int. by Henderson, England, in 1856.

101. laciniàta, Roxb. St. perennial : Ivs. roundly orate, lobed, pubescent, black-purple, with a broad zone of green, reddish on the under side : fls. as in $13 . R e x$. India, S. China. B.M. 5021.-Int. to Kew in 1857. Var. Bowringiàna, Hort., has green ivs. and rosy fls. B.M. 5182.

102. xanthina, Hook. Similar to $B$. Rex, and probably only a form of that species : lvs. large, Heshy, cordateovate, acuminate, sinuate-ciliated, dark green above, purplish beneath: fls. yellow : capsule with one large wing. B.M. 4683.-Var. pictifolia, Hort., B.M. 5102. Var. Lázuli, B.M. 5107.

103. Réx, Putz. Fig. 220. St. a short, fleshy rhizome, from which spring the long-stalked, large, ovate, wary lvs., which are hairy and colored a rich metallic green, with a zone of silvery grey: peduncles erect : fls. large, rose-tinted, males 2 in. across, with 4 unequal petals : females smaller, with 5 nearly equal petals : ovary 3 angled, with 2 short and 1 long wing. Assam. F.S. $12: 125 \overline{5}-1258$. B.M. 5101. - This magnificent species is the principal parent in the production of the numerous ornamental-foliaged Begonias. It has been crossed with a few species in the first place, and then hybrid seedlings have been raised again and again from the progeny. Fig. 220 is a copy of a part of the original figure in Flore des Serres (1857), and is given here for the purpose of showing what this species was like when first known to horticulturists.

Following are some of the derivative types of Rex Begonias :

104. Rex $\times$ discolor hybrids. I.H.28: 434. Mad. Jos. Moens, silvery white, with green articulations towards the margins, and a green disc. Mad. Chas. Weber, green, spotted with white. Mad.G.Van Meerbeeke, silvery, with a narrow green edge, and a central green disc running out along the veins. Souv. de Mad. la Barone de Bleichröder, dise and broad margin downy green, central portion silvery. Mad. Funck, disc and broad margin light apple-green, intermediate portion silvery. Baron $A$.V rière, light apple-green, intermediateportion silvery. Bar green, silverdisc dark green, center silvery, margin broad, dark green, silverspotted. Others are Mad. Treyve, Mad. Luizet, Edw. B. Ken nedy, Henri Vilmorin, Pres. Belle, Sir Joseph Hooker, Ed.Py-
näert, Pres, de la Devansaye, Mad. F. Alégatiere, Abel Carrière.

105. Rex Xdiadema hybrids. R. H. 1888, p. 20. R. B.15, p. 91 Lesoudii, very similar to B. Rex, but larger leaved. Adrien Schmidt, green on the margins, marked and spotted silver in the center. Clementina, lobes very acute, white blotches in center. Mad. Alamagny, lvs. very large, deeply lobed, pure metallie-white, with a green center. Mad. Isabelle Bellon, finely dentate, lobed and undulated, center olive-green, surrounded by a zone of white, becoming rose on the inner margin. $M$. Crousse, very long, dentate, green center, band of gin. M. Crousse, very long. dentate, green center, band of Domeck, Linée, Papillon, Mad. D. Wettstein, D. Wettstein, A Dalliere, Mad. Georges Bruant, Wilhelm Pfitzer.

106. Rex $\times$ Socotrana. A plant has been produced which com bines the characters of the two parents in a pleasing manner lvs. like B. Rex, but with shorter petioles, and crowded on the stem : prettily colored : ffs, in erect, sturdy racemes, which stand well above the plant; like B. Socotrana in color, but paler. Plant said to be evergreen.-Interesting as a connecting link between the Rex and semi-tuberous sections. Int. by Sander \& Co. in 1897.

107. Miscellaneous Rex hybrids of known origin : Rex leopardinus (Rex $X x a n t h i n a$, var, Reichenheimei) Very similar to B. Rex, but much larger. F.S. 13: 1317.-Int. by Van Houtte in 1859. Grandis (RexXsplendida). Very similar to B. Rex. F.S. 13:1330. - Int. by Rollison. Otto Forster (RexXimperialis) Dwf. habit : lvs, obliquely cordate, dark green, marbled with silvery greyish green : fls. greenish white, inconspicuous. Mranda (RexXimperialis, var, smaragdina). Very similar to above, but marbled with silver. Domini (Rex $X$ argentea). Leo. poldi (GriffithiXsplendida). I.H. 6:205. Prince Troubetzkoi,
double hybrid (GriffithiXXanthina, var. marmorata and rubrodouble hybrid (Griffithi XXanthina, var. marmorata and rubro-
venia). I.H. 5:158; also, from the same cross, Madame Wagvenia), I.H. 5:158; also, from the same eross, Madame Wag-
ner, I.H. 5:161, and Miranda. Countess Louise Erdody (Alexander, var. Humboldt $X$ argentea-cupreata). Fig. 221. Lvs. obliquely cordate, ovate-acute, the smaller of the two lobes twisted in a spiral manner, with as many as 4 coils; urper surface silvery, with veins deep green : under surface reddish, pilose. 1.H.31:516 G.C. II. 22:205-Int. by F. Nemeczik, gardener to Count Erdody, a Hungarian nobleman, in 1884.

108. Other Rex varieties of unknown or uncertain origin Louise Closson. Lvs, ovate-acuminate, lobed, veins deep purple, surface blotched with deep purple bronze, metallic luster very bright. Lucy Closson is very similar, but more vigorous, with the blotches more numerous and better distributed. Marquis de Peralta. Lvs. small, margins hairy numerous silvery spots on surface. Compact, dense

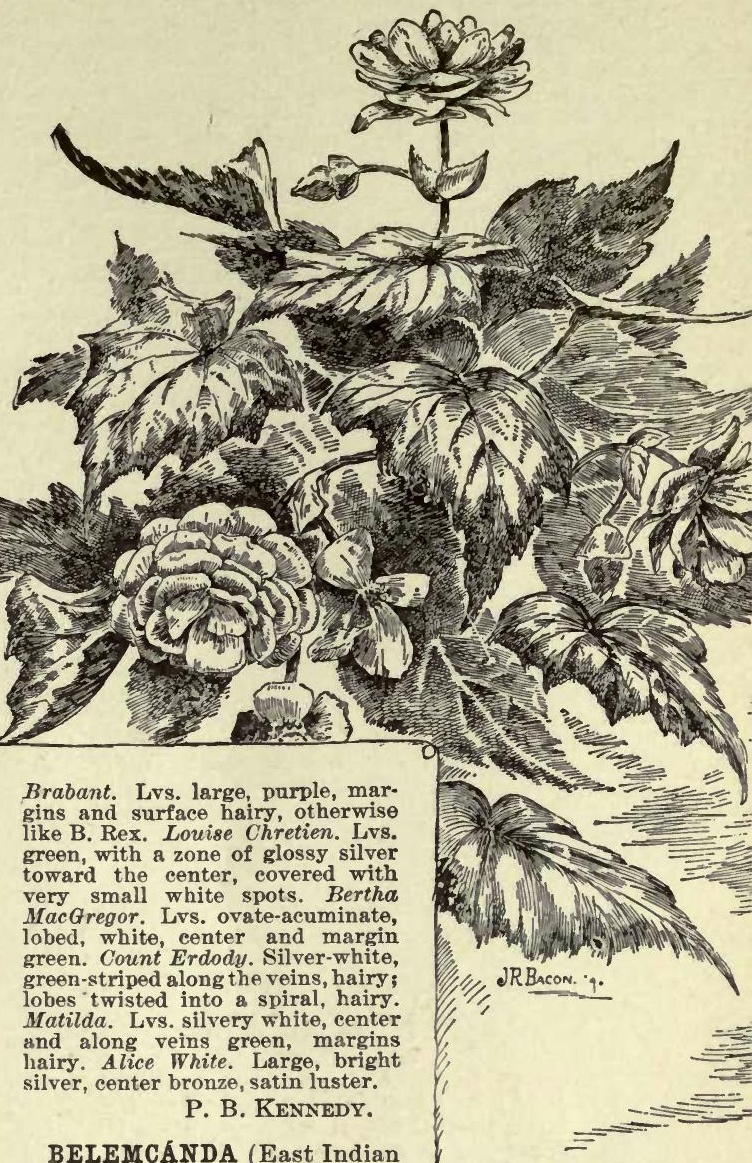

Dast Indian name). Iriddcece. BLACKBERRY Lily. LeOPard Flower. A monotypic genus, containing an

219. A type of Tuberous Begonia. double-flowered. mord perennial plant, which is an old garden favorite. The first of the popular names comes from the clusters of shining, black, roundish seeds, and the second from the flower, which is orange, spotted red. It is more commonly sold as a Pardanthus, which also means Leopard Flower. Perianth segments oblong, the 3 inner slightly shorter and spirally twisting as they fade. Prop. by seeds or by division. Of easy culture in rich, sandy loam and in a sunny place. Commonly spelled Belameanda.

Chinénsis, Leman. (Belameánda punctata, Moench. Ixia Chinénsis, Linn. Pardánthus Chinénsis, KerGawl. P. Sinénsis, Van Houtte). Fig. 222. Height 2-3 ft. ; rootstock a short, stoloniferous rhizome : lvs. about 6 , in a lax tuft, equitant, striate, $1-1 \frac{1}{2} \mathrm{ft}$. long, 1 in. broad : outer spathe valves $1 / 2-1$ in. long; pedicels 1-2 in. long: capsule 1-11/2 in. long; valves reflexing, persistent. China and Jap. B.M.171. F.S. 16:1632. L.B.C. 19:18/4 -The seed-stalks are sometimes used with dried grasses for decoration. It is said that the birds sometimes mistake the seeds for blackberries.

BELLFLOWER. See Campanula.

BELLADONNA. See Atropa.

BELLADONNA LILY. See Amaryllis. 
BELLIS (Latin, bellus, pretty). Compósitce. EngLISH DAISY. The Daisy, as it grows wild in England, has a yellow center. surrounded $b v$ numerous rays in a

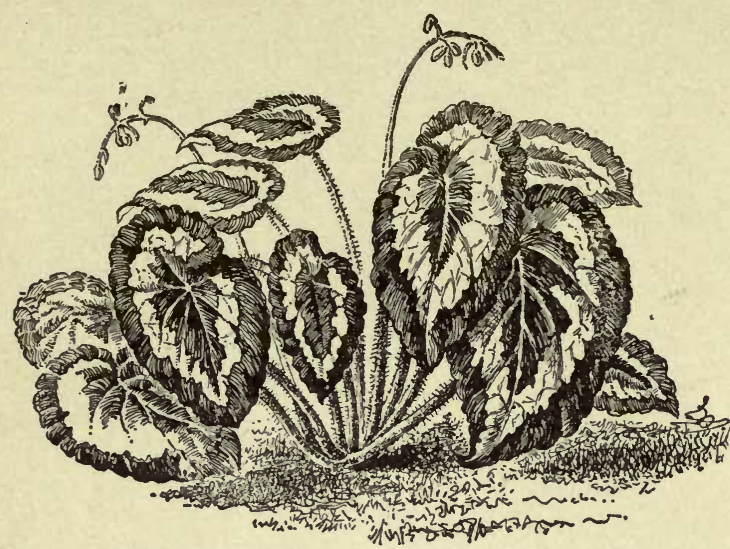

220. Begonia Rex, in its original form. No. 103. (See Begonia, p. 151.)

single row, but the favorite cultivated forms are double, the rays rising in tier upon tier, and frequently crowding out every trace of a yellow center. The English Daisy is essentially a pink or pinkish fl. in its general effect, the tips of the rays sometimes and the under surfaces usually being pink or red. There are 27 species in the genus, only one of which is American. B. integrifolia is found in moist soil from $\mathrm{Ky}$. and Tenn. to Ark. and Tex., but is too rare and sectional to become a general favorite. The plant that is most commonly called Daisy in America is Chrysanthemum Leucanthemum. For an illustrated account of the various plants known as Daisies in America, see Daisy.

Daisies are favorite border plants, and are much used in spring bedding, especially for edging. They thrive in a cool soil and moist atmosphere, and are, therefore, much better adapted to English than American gardens. A light mulch is desirable for winter protection. In home gardening, the plants, after flowering, are divided into single crowns. These are planted about 6 in. apart in good, rich garden soil. Each crown soon sends out side growths, which, in time, form new crowns. Before winter sets in the young clumps can be moved readily to any place in the garden where they are wanted to bloom. Daisies are also forced by florists for winter bloom. When Daisies are desired for edging

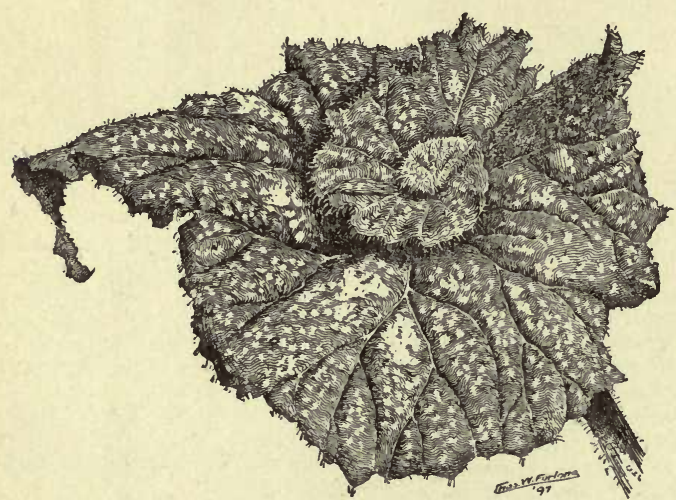

221. Erdody Begonia $(\times 1 / 3)$. No. 10 \% (See Begonia, p. 151.)

spring flower beds, the clumps are divided into siugle plants during the previous September, or early enough to allow the new plants to get a firm hold before winter, and are placed 3 in. apart in a narrow trench. These edgings must be renewed each year, as the plants, if they grow well, spread too wide, or irregularly. In dry summers many roots fail, and if they remain in the same spot year after year, the fls. will degenerate to the single condition.

The simplest way of propagating and growing English Daisies for spring bedding in this country is to sow the seed in shallow boxes about August 10. As soon as large enough to handle, transplant 5 inches apart into coldframes, and when the winter sets in put on the sash, giving air whenever the weather may be mild. Transplant to the flower beds as early as pos. sible in the spring, where in a very short time they will be a mass of bloom, and will continue to bloom till the beginning of June, when they should be thrown out, and the summer bedding plants planted. Longfellow and Snowball are the two best varieties for this purpose. Myosotis alpestris and Silene pendula may be grown the same way, using the Daisies as edging when in the beds, and the others as center pieces.

The Daisy is propagated by seed (which are sown early), and by divisions, the choicest varieties being maintained by the latter method. The main types growd from seed are the white, rose, quilled, and white with red center, all of which are double. A dark red is less common. Of kinds prop. by seed, Longfellow is now the best rosecolored, and Snowball the best white variety, the latter being especially prized by florists for cut-flowers, as it has long, stiff stems. Other varieties are Maxima, Snowflake, and Rob Roy, which is perhaps the best red.

perénnis, Linn. True or English DAISY. Hardy herbaceous perennial, 3-6 in. high : lvs. clustered at the root, spatulate or obovate: fls. 1-2 in. across, solitary, on hairy scapes. Apr.-June. W. Eu.; naturalized in Calif.: rarely runs wild in the eastern states. B.M. 228. F. S. 6:584, which shows

11 well marked types.-An interesting but not permanent form, which is a result of overfeeding, is the "Henand-Chickens Daisy," in which a number of small fl.heads are borne on short stalks springing out of the main th.-head. Cockscomb forms, in which several scapes unite to produce a monstrous flower, are sometimes seen, but cannot be perpetuated. The rays are sometimes wholly incurved, or reflexed, or quilled. Other English names of the Daisy are Herb Margaret, Ewe- or May-gowan, Childing Daisy, Bone- or Bruisewort, Bone Flower, March Daisy, Bairn-wort.

\section{J. B. Keller, E. J. Canning, and W. M.}

BELLW0RT. In England, any member of the Campanuldcece. In America, Uvuldria.

BELVIDERE, or SUMmer CyPRESS. See Kochia.

BENE, See Sesamum. 
BENI, JAPANESE. See Caryopteris Mastacanthus.

BENINCÁSA (name of an Italian nobleman). Cucurbitdceo. One species from E. Ind. Annual, running, squash-like herbs, with solitary yellow monøecious fls., the staminate long-peduncled, the pistillate nearly sessile ; corolla deeply lobed; tendrils 2-3-branched.

cerffera, Savi. Fig. 223. WAX Gourd. ZIT-Kwa. Chinese Preserving Melon. Chinese Watermelon. Vine long, like a muskmelon, hairy, with cordate lobed Ivs.: fr. mostly oblong, 10-16 in. long, hairy, white-

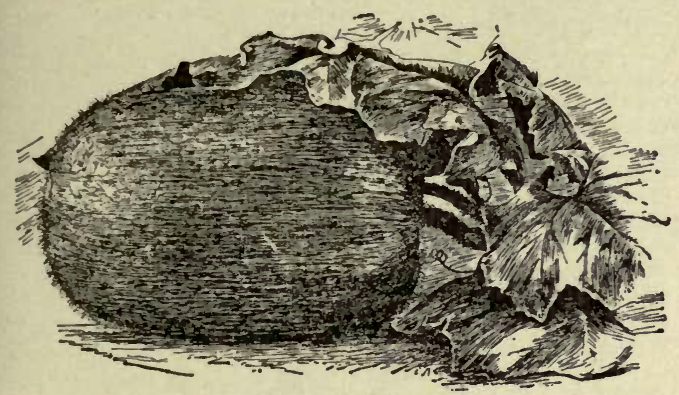

223. Benincasa cerifera.

waxy, with solid white flesh and small, cucumber-like seeds. Cult. the same as muskmelon or cucumber R.H. 1887:540. - Recently int. into the U. S. (Bull. 67, Cornell Exp. Sta.), and used for making preserves and sweet pickles ; said to be eaten raw in warm countries.

BENJAMIN BUSH. Benzoin odoriferum.

L. H. B.

BENT GRASS. See Agrostis.

BENTHÁMIA. Referred to Cornus.

BENZOIN (of Arabic or Semitic origin, meaning a gum or perfume). Syn., Lindèra. Laurdcece. Trees or shrubs, aromatic : lvs. alternate, usually deciduous, entire or sometimes 3-lobed: fls. polygamous-diœcious, apetalous, small, in axillary, umbel-like clusters ; calyx 6-parted; staminate fls. with 9 stamens : fr. a berry. About 60 species in trop. and E. Asia and N. Amer. Some E. Asiatic species yield an odorous oil, used in perfumery. Only a few deciduous species are cult. They are attractive on account of their handsome foliage, which turns bright yellow in fall, and their black or scarlet fr. The hardiest species is $B$. odoriferum, though $B$. obtusilobum and $B$. hypoglaucum may also be grown north in sheltered positions. They thrive best in peaty and sandy soil. Prop. usually by seeds sown after maturity; also by layers, which root best in peaty soil ; of greenwood cuttings under glass, one-half may be expected to root. The Benzoin of the druggists is a balsamic resin obtained from Styrax Benzoin.

odoriferum, Nees (Lindèra Bénzoin, Blume). Spice Bush. Benjasin Bush. Wild Allspice. Fever Bush. Fig. 224. Shrub, 6-15 ft., nearly glabrous : lvs. oblong. obovate, finely ciliate, bright green, pale beneath, $3-5$ in. long: fls. yellow, before the lvs.: berry red, oblong, spicy. N. Eng. southward and west to Kans. Em. 365. -The bark is aromatic, stimulant, tonic, astringent.

$B$. aestivàle, Nees = B. odoriferum. $-B$. grácile, 0 . Kuntze (Daphnidium gracile, Nees). Lvs, ovate, 3-nerved, chartaceous. Habitat unknown. Stove plant, $-B$, hypoglaùcum Rehd. (Lindera hypoglauea, Max.) Lvs. penninerved glancous beneath : elnsters few-fld., with or before the lvs.: berries cous beneath : clusters few-tld., with or before the lvs.: berries hlack. Japan. - B. melissifollium, Nees. Allied to B. odoriferum. Branches pubescent : lvs. oblong, downy beneath. S. states. B.M. 1470. - B. obtusilobum, O. Kuntze. Lvs. 3-nerved, ovate or 3-lobed : clusters many-fld.: berries black. Japan. G.F. 6:295. $-B$. präecox, S. \& Z. Lvs. penninerved, elliptic-oblong: clusters few-fld., before the lvs.: berries brownish, $1 / 2$ in. diam. Japan.-B. sericeum, S. \& Z. Lvs. penninerved, pubescent beneath : clusters many-fid., with the lvs. Jupan.

\section{ALFRED REHDER.}

BERBERIDÓPSIS (from Berberis and Greek opsis, likeness). Berberidadcea. Climbing evergreen shrub: lvs. alternate, petioled, dentate : fls. on long pedicels in terminal racemes; bracts, sepals and petals gradually passing into one another, 9-15, the inner ones concave ; stamens 8-9: fr. a berry. One species in Chile. Ornamental low-climbing shrub, with deep green foliage and crimson $\mathrm{fls}$. in drooping racemes, for temperate regions or the cool greenhouse, growing in almost any soil. Propag. by seeds sown in spring, by greenwood cuttings in spring, or by layers in autumn.

corallina, Hook. Lvs, cordate, oblong-ovate, coarsely spinulose-dentate, 2-3 in. long: fls. globose, over $1 / 3$ in. long, crimson, in many-fld. leafy racemes. B.M. 5343. F.S. $20: 2137$.

AlFRED ReHDER.

BERBERIS (Arabic name). Berberiddcec. BARBERRY. Shrubs, with yellow inner bark and wood, often spiny: lvs. alternate, often fasciculate, usually glabrous, simple or pinnate, deciduous or persistent, mostly spinulose-dentate : fls. in racemes, rarely umbellate or solltary ; sepals, petals and stamens $6: \mathrm{fr}$. a 1-celled berry with one or several oblong seeds. Nearly 100 species in America from Brit. Col. to Patagonia, Asia, Eu., and N. Afr. Low ornamental shrubs, of which a large number is eultivated. Most of the deciduous species are quite hardy, while the evergreen ones are to be recommended for more temperate regions, except $B$. Aquifolium and $B$. repens, which may be cultivated even north in somewhat sheltered positions. Both evergreen and deciduous kinds are very attractive in spring, with their bright or orange-yellow fls., and in fall with their red, dark blue or nearly black fruits. Some, as $B$. Amurensis and $B$. Thunbergii, while amongst the handsomest in fr. assume a splendid fall coloring. They grow in almost any soil, but prefer drier situations; the evergreen species thrive best in a sandy compost of peat and loam. Prop. by seeds sown soon after maturity, or stratified and sown in spring; even $B$. vulgaris, var. atropurpurea, may be increased in this way, as a large percentage' $\mathrm{comes}$ true. The evergreen species grow from cuttings in September, placed in sand under glass. Most of the deciduous species can be grown from greenwood cuttings, taken from forced plants in spring and put under glass with slight bottom heat. Layers put down in autumn usually remain 2 years before they can be separated. Some species may be propagated by suckers. Rarer kinds and varieties are sometimes grafted on B. vulgaris or Thunbergii, in August or September under glass, or in early spring in the greenhouse. The root and the inner bark are sometimes used for dyeing yellow. Some species have medicinal properties. In wheat-growing districts, planting of Berberis should be avoided, as it is the

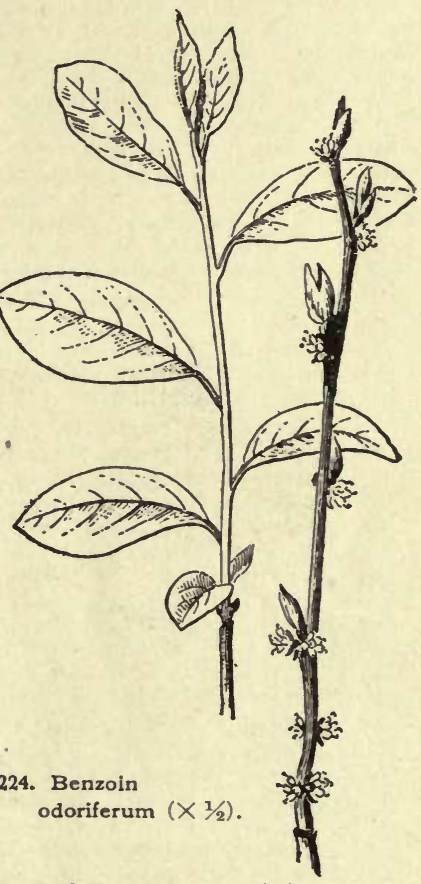
host of the Acidium-stage of Puccinia graminis, a fun. gus which causes the wheat-rust. Destroying the Berberis, however, will not check the propagation of the fungus, as it is able to grow and to spread for years without forming the Ecidium-stage. Monogr. of spe- 
cies cult. in England in Flore des Serres, 6: 66 and 73 (1850-1).

Index : Amurensis, No. 2; Aquifolium, 21 ; aristata, 15 ; asperma, 1 ; atropurpurea, 1 ; Bealii, 19 ; buxifolia, 9; Canadensis, 4; Caroliniana, 4; Darwini, 12; dulcis, 1, 9 ; emarginata, 3; Fortunei, 24; Fremonti, 17; Hakodate, 2 ; heteropoda, 6 ; ilicifolia, 11,14 ; integrifolia 7 ; Jamesoni, 13, 16 ; Japonica, 2, 19 ; Maximowiczi, 8 ;

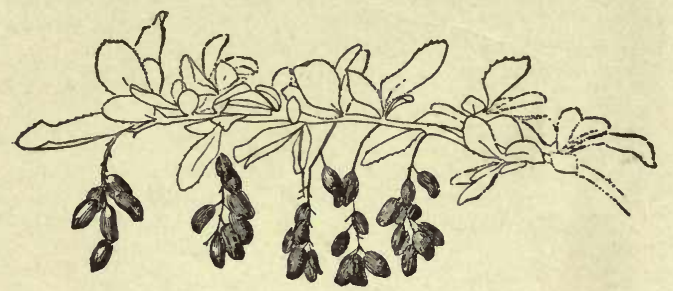

225. Berberis vulgaris, in fruit.

Nepalensis, 20: nervosa, 22 ; Neuberti, 14 ; pinnata, 18 ; pluriflora, 8 ; repens, 23 ; Sieboldi, 2, and suppl. list ; Sinensis, 5 ; stenophylla, 10 ; Thunbergi, 8 ; vulgaris, 1; Wallichiana, 13.

A. Lvs. simple, usually fasciculate in the axils of spines, deciduous or persistent.

B. Foliage deciduous : lvs. membranaceous or chartaceous.

c. F's. in racemes.

D. Branches gray, except those of the purple-leaved form.

1. vulgàris, Linn. CoMmon Barberry. Fig. 225, 226. From 4-8 ft., rarely 15: branches grooved, upright or arching: lvs. oblong-spathulate or obovate, setulosedentate, membranaceous, 1-2 in. long: racemes pendulous, many-fld.; fls. bright yellow: fr. oblong, usually purple. May, June. Eu. to E. Asia ; escaped from culture and naturalized in E. N. Amer. Gn. 35: 693.-Handsome in spring, with its golden yellow fls. and light green foliage; and in fall, with its bright scarlet fruits, remaining through the whole winter. A very variable species; also the six following species are included by some botanists as varieties. Of the many garden forms, the most effective is var. atropurpurea, Rgl., with purple colored lvs. Gt.9:278, 1. There are also varieties with variegated lvs. and purplish black, whitish or yellow berries, as var. álba, white-fruited; var. aspérma, seedless ; var. dúlcis, less acid ; var. lùtea, yellow-fruited ; var. mitis, less thorny ; var. nigra, black-fruited ; var. violàcea or frúctu-violàceo, violet-fruited. The spines of the Barberry are, morphologically, lvs., and the lvs. are borne on short branches in their axils (Fig. 226). The stamens are sensitive. Touch the flaments with a pin when the fls. first open, and the stamens fly forward upon the pistil.

2. Amurénsis, Rupr. (B. vulgàris, var. Amurénsis, Rgl.). Three to $8 \mathrm{ft}$. : branches straight, upright, grooved: lvs. cuneate, oblong or elliptic, densely ciliate-dentate, distinctly veined beneath, 1-3 in. long: racemes upright or nodding, 6-12-fld., about as long as lvs.: fr. oblong, searlet. Manchuria, N. China. Gng. 5:119. Var. Japònica, Rehd. (B. vulgdris, var. Japónica, Rgl. B.Sièboldi, Hort., not Miq. B. Hakodate, Hort.). Lvs. firmer and more chartaceous, prominently veined beneath, shorter petioled, dark green above. Jap. G.F. 3: 249 as B. Sieboldi. A.G. 18:454. - Vigorous-growing shrubs, standing drought well, with brilliant orange and scarlet fall-coloring, especially the variety.

3. emarginàta, Willd. One to $3 \mathrm{ft}$., in culture usually higher: spines simple to 5-parted, sometimes longer than the lvs.: lvs. cuneate, obovate or obovate-oblong, setulose-dentate, $1 / 2-1 \% / 4$ in. long: racemes short, upright ; petals usually emarginate. S. Eu. to Himal. Low spiny shrub with handsome fall-coloring.

DD. Branches reddish brown or brown: lvs. usually sparsely dentate, sometimes entire.

4. Canadénsis, Mill. (B. Caroliniàna, Loud.). One to $3 \mathrm{ft}$.: spines small, 3-parted; lvs. cuneate-oblong, re- motely spinulose-dentate, rarely entire, 1-2 in. long: racemes few-fld., nodding, about as long as the lvs.; petals retuse or emarginate : fr. short-oval or nearly globular, coral-red. Alleghanies. - The plant sold under this name is usually $B$. vulgaris.

5. Sinénsis, Desf. From 4-6 ft., with slender, often arching branches and small, 3-5-parted spines : lvs. cuneate, oblong or obovate-lanceolate, coarsely setulosedentate, sometimes entire, green or glaucescent beneath, 1-2 in. long: racemes pendulous, slender-peduncled, bright or pale yellow : berries oval or oblong, blood-red. From Caucasus to Himal, and China. B.M. 6573.-A hardy, graceful species, very handsome in fruit.

6. heterópoda, Schrenk. Three to $6 \mathrm{ft}$.: branches stout, spreading, with few short spines: lvs. broadly obovate, entire or remotely serrate. pale bluish green, $1 \frac{1}{2}-2$ in. long, some short and some slender-petioled: fls. in long-stalked, few-fld. racemes, orange-yellow, fragrant: fr. oblong, dark blue with glaucous bloom. May. Turkestan, Songaria. G.F. 8: 455.-Handsome and very distinct species.

7. integerrima, Bunge. In habit and appearance very like No. 6, and difficult to distinguish without fl.-clusters : stems terete and brown: lvs. broad-obovate, remotely dentate or entire, dark bluish green above : racemes dense and upright. Persia, Turkestan, Songoria.

cC. Fls. usually solitary, rarely in few-fld. umbels : lvs, entire.

8. Thùnbergii, DC. Figs. 227, 228. Dense, low shrub, 2-4 ft.: branches spreading, deeply grooved, brown, with simple spines: lvs. obovate or spathulate, quite entire, glaucescent beneath, $1 / 2-11 / 2$ in. long: fls. $1-3$, pale yellow : fr. elliptic or nearly globose, bright red. Apr., May. G.F. 2:53. B.M. 6646. R.H. 1894:173. A.G. 18:357. Gng. $4: 241 ; 5: 119,353,355$. Mn. 2:118. A.F. 8: 526. One of the most valuable species, especially remarkable for its low, dense, horizontal growth, its large, brilliant red frs., remaining fresh till the following spring, and for its bright scarlet fall-coloring; hardy. Very valuable for borders of walks and drives. Endures partial shade. Cattle and sheep do not browse it much. Var. Maximowiczi, Franch. \& Sav., has the lvs. green beneath. Var. plurifiora, Koehne, with 3-10 fls. in short, umbel-like raceme, is perhaps a hybrid with $B$. vulgaris; it has almost gray branches. China, Japan.

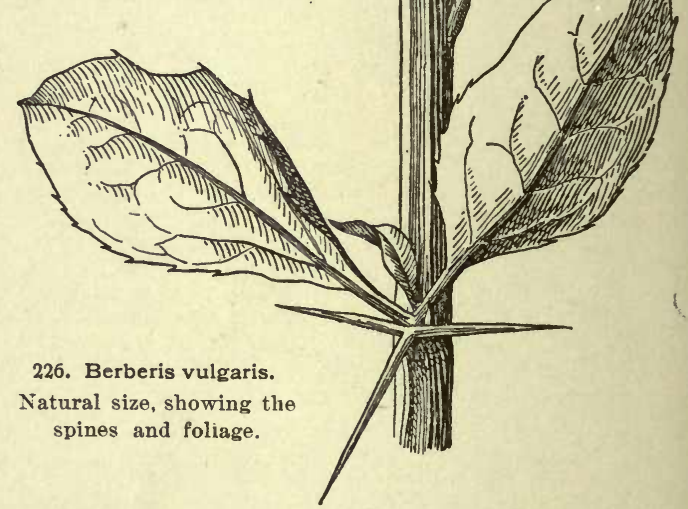

BB. Foliage evergreen or half-evergreen.

c. Lvs, entire, or rarely with few spiny teeth.

9. buxifolia, Poir. (B. duileis. Sweet). One to $3 \mathrm{ft}$.: branches brown, grooved ; spines usually 3-parted, short : lvs. cuneate, obovate or elliptic, $1 / 3-1$ in. long : fls. solitary, on long pedicels, orange yellow : fr. nearly 
globese, blackish purple. May. Chile to Strait of Magellan. B.M. 6505. S.B.F.G. II. 1: 100. P.M. 10: 171. -A very graceful, free-flowering shrub; one of the hardiest of the evergreen species ; will stand the winter even north if somewhat protected.

10. stenophýlla, Mast. (B. Dáruini $\times$ empetrifòtia). Height 1-3 ft., with slender, arching branches : lvs. narrow-oblong, revolute at the margins, spiny pointed, $1 / 2-11 / 4$ in. long, dark green above : Hs. $2-6$, in peduncled, pendulous umbels. Of garden origin. May. G.C. III. $7: 619$. A.F. $6: 325 .-$ Handsome. shrub, nearly as hardy as the former.

$$
\text { cc. Lvs. coarsely spiny dentate. }
$$

D. Fls. in simple racemes or clusters.

11. ilicifolia, Forst. Holly-leaved. Lvs. partially evergreen, persisting till late in winter, shining dark green, ovate, tapering at base, coarsely spiny-toothed: pedicels short, 4-fld., somewhat corymbose ; fls. orange-yellow. Terra del Fuego. B.M. 4308. F.S. 3: 291.

12. Dárwini, Hook. Height 1-3 ft.: branches brown, pubescent when young : lvs. sessile, cuneate, oborate, usually 3 -fld at the apex, glossy dark green above, $1 / 2-1$ in. long: racemes short, many-fld., pendulous ; fls. orange-yellow, often reddish outside : style longer than the ovary: fr. dark purple. Chile to Patagonia. B.M. 4590. F.S. 7:663. P.F.G. 2:46.

13. Wallichiàna, DC.(B.Jamesoni, Hort., not Lindl.). Shrub, to $10 \mathrm{ft}$., with grayish brown branches : spines 3-parted, nearly an inch long: Ivs. sessile, oblong-elliptic or lanceolate, remotely spiny serrate, shining on both sides, 1-2 in. long: fls. long-pedicelled, nodding, 3-6 in a cluster. Himalayas. B.M. 4656. P.F.G. 1:79.

14. Neùberti, Lem. (B. ilicifolia, Hort., not Forst. B. Aquifolium $\times$ vulgàis). Branches grayish brown, without spines, upright : lvs. simple, oval or ovate, sometimes with 1 or 2 smaller lateral lfts., spiny or setulose-dentate, dark grayish green above, 11/2-3 in. long: fls. in racemes. Of garden origin. I.H. $1: 111$. G.C. III. $9: 73,75 .-$ Hardy north, but lvs. not persistent.
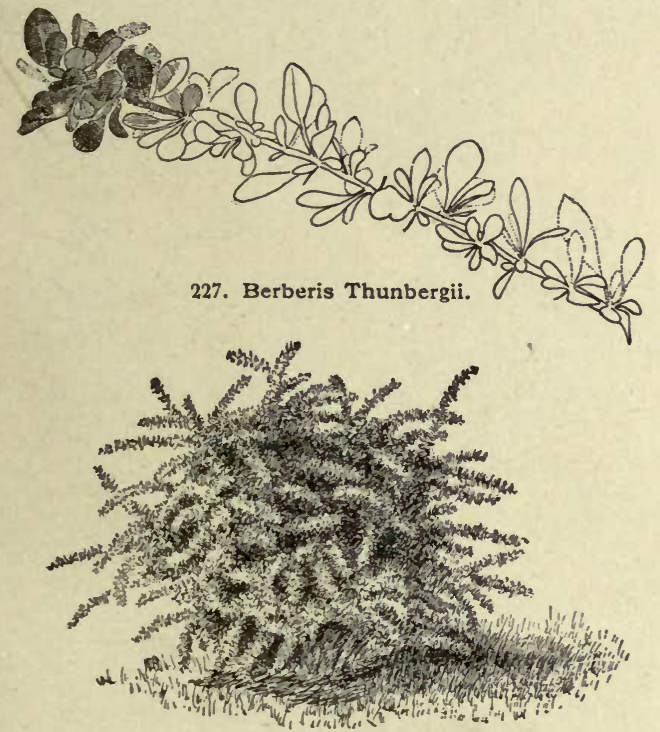

228. Berberis Thunbergii.

DD. F'ls. in compound, pendulous racemes.

15. aristàta, DC. Bush, 2-6 ft.: lvs. oblong, semi-persistent, usually spinose-dentate, 1-3 in. long: fls. in long-peduncled, compound racemes. Himalayas. B.R. 9:729.

16. Jàmesoni, Lindl. Shrub, much branched : Ivs. oblong, 2-3 in. long, with few large and strong spines: fls. orange, in drooping panicles or compound racemes. Ecuador. I.H. 6:201.
AA. Lvs. pinnate, persistent: branches spineless. (Mahonia.)

B. Petioles short or almost none.

c. Racemes few-fld., slender, mostly lateral.

17. Frèmonti, Torr. From 5-12 ft.: lfts. 3-7, rigidly coriaceous, ovate or oblong, with few strong, spiny teeth, glaucous, dull, 1/2-1 in. long: racemes loose, 3-7-fld.;

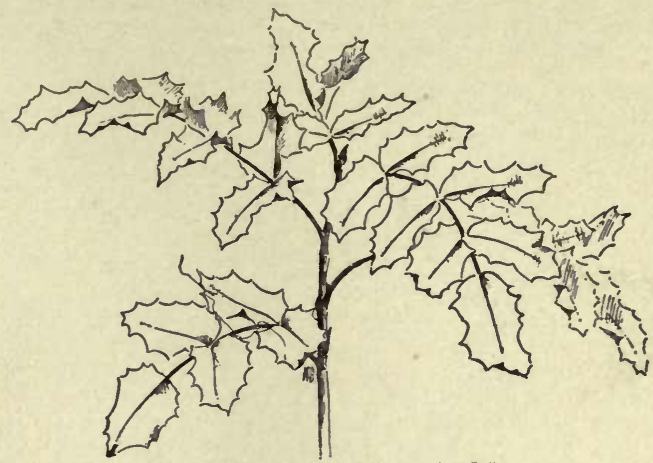

229. Berberis Aquifolium $(X 1 / 3)$.

pedicels slender : fr. at least 1/2in. in diam., red, in flated, and rather dry. W. Texas to Utah and Mex. G.F. 1:497.-Remarkable for its pale, glaucous foliage and large berries. Not hardy north.

cc. Racemes many-fld., dense.

18. pinnàta, Lag. (Mahònia fasciculdris, DC.). Two to $3 \mathrm{ft}$.: lfts. 5-17, ovate or ovate-lanceolate, coriaceous, undulate at the margin and with few spiny teeth, dark green, somewhat shining: fls. in short, fascicled racemes: fr. blue. Calif., N. Mex. B.M. 2396. B.R. 9:702. -Not hardy north.

19. Japònica, Spreng. (M. Japónica, DC. B. Bèalii, Fort.). Height 5-10 ft.: lfts. 9-13, roundish or ovate, coriaceous, usually truncate at the base, with large, remote, spiny teeth, $2-5$ in. long : racemes $3-4$ in. long, fascicled : fr. bluish black. China, Japan. B.M. 4846, 4852. P.F.G. $1: 11$. F.S. $6: 79$. - Very effective by its large foliage, thriving best, like the other Mahonias, in a partly shaded position. Hardy north to New York in sheltered positions.

20. Nepalénsis, Spreng. (B. Japónica, Hort.). Tall, 4-6 fí.: lfts. 5-25, rigid, obovate-oblong, repand-toothed, with few spiny teeth on each edge. India to Japan. N. $1: 182$. A.G. 18:355.

BB. Petioles prominent or elongated.

c. Lfts. truncate or rounded at the base.

21. Aquifolium, Pursh (Mahònia Aquifolium, Nutt.). Fig. 229. From 3-6 ft.: lfts. 5-9, oblong or oblong-ovate, shiny dark green above, spinulose-dentate: racemes erect, fascicled: berries blue, small. May. British Columbia to Ore. B.R. $17: 1425$. L.B.C. 18:1718. P.M.B. $9: 5$. - Handsome evergreen shrub, hardy north in sheltered positions.

22. nervòsa, Pursh. Dwarf evergreen shrub : sts. but a few inches high, tipped with long, husk-like, pointed bud-scales : lfts. 11-21, lance-orate, 3-5-ribbed, remotely spiny-toothed, borne on a strongly jointed stalk: racemes elongated, erect: fr.oblong, blue. Ore. B.M. 3949 . L.B.C. 18:1701. F.S. 2:127. P.M. 7:55, as Mahonia glumacea.

23. rèpens, Lindl. (Mahònia rèpens, Don). Rarely over $1 \mathrm{ft}$. high, stoloniferous : lfts. $3-7$, roundish ovate or ovate, pale or glaucous and dull above, spinulosedentate : fls. and fr. like the former. Brit. Columbia to Calif. and N. Mex. B.R. 14:1176. L.B.C. 19:1847.

cc. Lfts, cuneate at base, narrow-lanceolate.

24. Fortunei, Lindl. Dwarf : lfts. 5-9, distant, narrowly lanceolate; spiny teeth numerous, small : racemes erect, fascicled. China. F.S. 3:287 bis.

B. actinacántha, Mart. One to $3 \mathrm{ft}$., evergreen: spines 5parted : lvs. small, spiny : fls. in sessile clusters. Chile. B.R. 
31:55.-B. AEthnénsis, Prsl. Allied to B. emarginata. Low, dense shrub, with small lvs, and long spines. Sicily, Sardinia, Corsica. $-B$. angulòsa. Wall. Height $4 \mathrm{ft}$.: lvs. deciduous, small, entire or sparsely spinulose: fls, solitary or few. Himsmall, entire or sparsely spinulose : fls. Solitary or few. Him-
alayas. B.M. $7071 .-B$. A siática, Roxb. Three to $10 \mathrm{ft}$ : lvs. alayas. B.M. 7071.-B. Asiática, Roxb. Three to $10 \mathrm{ft.:}$ lvs. persistent, oblong, entire or with few teeth, whitish beneath, 1-3 in. long: fls. in short, sessile racemes. Himal. $-B$. Belstaniàna. Hort. $=\mathrm{B}$. virescens. $-B$. brachybòtrys, Edgew. $=\mathrm{B}$. emarginata, var. $-B$. Chítria, Hamilton = B. aristata. - B. concinna, Hook. Low: lvs. small, semi-persistent, glamcous beneath, spinulose: fis. solitary, pendulous. Himal. B.M. 4744. - B. congestiflòra, Gay. Five to $7 \mathrm{ft}$.: lvs. persistent, orbicular, or broad-oblong, spinose, glaucous beneath : fls. in dense, gloor broad-oblong, spinose, glaucous beneath : fls, in dense, globunda $-B$. cratoegina, DC. Low : Ivs. small, semi-persistent, bunda. $-B$. cratagina, DC. Low : lvs. small, semi-persistent,
entire or spinulose : fls. in short, erect racemes : fr. blue. Orientire or spinulose: fls, in short, erect racemes : fr. blue. Orient to Himal. - B. Crética, Linn. Spines 3-parted : lvs. decidu ous, small, usually entire: fls. $2-5$, in short, sessile umbels. orbicular, with few spiny teeth. racemes short dense, nodding. Mex. B.R. 21:1750,-B. diáphana, Max. Lvs. deciduous, sparsely spinulose : fls long-pedicelled, fascicled : fr translucid. China. spinulose : fls.long-pedicelled, fascicled : fr. translucid. China. ent, linear, revolute at the margin : fis. 1-2, slender-peduncled.
('lile to Patagonia. B. R. 26:27. - B. fasciculàris, Sims = B. pinnata.-B. Féndleri, Gray. Allied to B. Canadensis. Spines 3-5-tld : lvs. obovate-lanceolate, entire or spinulose : racemes dense, pendulous. Colo. to N. Mex. G.F. 1:462.-B. floribúnda, Wall. Lvs, deciduous, entire or sparsely spinulose-ciliate : ra cemes long-peduncled. Himal. B.R. 27:46 (as B. coriaria) and 36: 44 (as B. umbellata). - B. Guimpeli, Koch = B. Sinensis. B. heterophýlla, Juss. Lvs. persistent, ovate-lanceolate, entire or with $2-4$ spiny teeth: fls, solitary, Straits of Magellanor with $2-4$ spiny toeth : fls. solitary. Straits of Magellan.$B$. Iberica, Stev. \& Fisch. = B. cratægina.-B. Iberica, Hort.
B. vulgaris, var. -B. Loxénsis, Benth. Lvs. persistent, shining, with few spiny teeth : fls. small, on peduncled, loose racemes. Peru. F.S. 6, p. 69.-B. Lýcium, Royle. Lvs. semi-parsistent, obovate-lanceolate, entire or spinulose: racemes sessile, much longer than the lvs., drooping: fr. violet. Himal. B.M. 7075 . -B. pállida, Benth. Lvs. pinnate, persistent; lfts. 9-13, ovate or ovate-lanceolate, spinose raemes B.R. 30:16, - B, ruscifólia, Lam. Lvs, persistent, oblong, entire or with few coarse teeth at the apex : fls. 4-5 on a short pedun. cle. Argentina. $-B$. serótina, Lange. Allied to B. Sinensis. Lvs. usually entire, bright green : racemes short, dense, peduncled. Origin unknown.-B. serràta, Koehne (B. microphylla, var. serrata, Hort.). Lvs. small, spinulose, deciduous : racemes dense, much shorter than the lvs. Origin unknown B. Sibirica, Pall. Lvs, deciduous, obovate, remotely dentateciliate: fls. short-pedicelled, solitary or $2-3$. Siberia. B.R. 6:487. cilia: Sieboldi, Mia. Low: branches brown, 2-edged towa is the end : lvs, oblong, densely ciliate-dentate: raceme few-fld. nodding. Japan.-B. Sieboldi, Hort., not Miq. = B. Amurensis, var.-B. tenuifòlia, Lindl. Lvs. pinnate, persistent ; lfts. 3-7, lanceolate, entire: racemes nodding, very long and loose. Mex. B.R. 30:26. - B. trifoliolata, Moric. (B. trifoliata, Hartw.). Lvs. 3-foliolate, persistent ; lfts. sessile, pale, coarsely spinosetoothed: racemes short, few-fld. Tex. to Mex. B.R. 31:10. F.S. 1:56. P.F.G. 2:68.-B. trifúrca, Fort. Allied to B. Nepalensis, and probably a var. Leaflets oblong-ovate, 3-pointed at the umbellata, Wall. Lvs. deciduous, sparsely serrulate: racemes long-peduncled, umbel-like. Himal. B.M. 2549.-B. viréscens, Hook. Lvs, deciduous, small, entire or remotely spinulose, pale green : fls. greenish yellow, fascicled, or in very short racemes. B.M. 7116 .

\section{Alfred Rehder and Fred W. Card.}

BERCHEMIA (derivation uncertain). Rhamndcece. Shrubs, mostly climbing, rarely trees: lvs. deciduous, alternate, slender, petioled, entire or nearly so, with ninute stipules: fls. inconspicuous, 5-merous, in terminal, usually leafy panicles : fr. a small berry-like drupe with 2-celled stone. Twelve species in E. Asia, N. Amer., E. Afr.-Ornamental climbing shrubs, not quite hardy north, with small, bright green graceful foliage, usefu for covering trellis work in sunny positions. They grow in almost any soil. Prop. by seeds and by root. cuttings in spring under glass ; also by layering the young shoots and by cuttings of mature wood in fall under glass.

scándens, Koch (B. volùbilis, DC.). SupPLE JACK. Ten to $15 \mathrm{ft} .:$ lvs. ovate or oblong-ovate, acuminate, often undulate, 1-2 in. long, with 9-12 pairs of latera voins: As. greenish white: fr. bluish black. June. S. states.

racemòsa, Sieb. \& Zucc. Closely allied to the former. Lvs. cordate, ovate, with 6-8 pairs of veins : fls. greenish : fr. first red, becoming black at length. July. Jap., China.-Hardier than the former, not high-climbing ; attractive in late summer, with its red fruits.
BERGAMOT. Name applied to various aromatic plants, particularly to members of the Labidtre, as Menthas and Monardas. The Bergamot essence of commerce is made from a citrous fruit. See Citrus.

BÉRRIA (after Dr. Andrew Berry, a Madras botanist). Syn., Berrya, DC., not Klein. Tilideece. A genus of one or two species, with no familiar allies.

Ammonílla, Roxb. High tree : lvs. entire, heart-shaped, long-petioled, smooth, 5-7-nerved, alternate : fls. in racemes, small, white, very numerous: fr. a 3-celled capsule with 6 wings, the $3-12$ seeds with stiff hairs, which readily penetrate the skin and produce a painful itching. Growing abundantly in the Philippines and Ceylon, where it is one of the largest and most valuable timber trees. The wood, being light and strong, is used for building, for oil casks, and for boats. It is exported as "Trincomalee wood." Cult. by Dr. Franceschi, Santa Barbara, Calif.

G. T. Hastings.

BERTHOLLETIA (after Louis Claude Berthollet, French chemist). Myrtacece. Brazil Nut. PARA Nut. Cream Nut. Nigger Tok. Large trees: lvs. alternate, bright green, leathery, about ' $2 \mathrm{ft}$. long, 6 in. broad : fls. cream colored; calyx parts united and tear ing into 2 parts when the flower opens; petals 6 , stamens many, united into a hood-shaped mass, the upper ones sterile : fr. round, about 6 in. in diam., with a hard shell containing 18-24 3-sided nuts. Fig. 230. Spe-

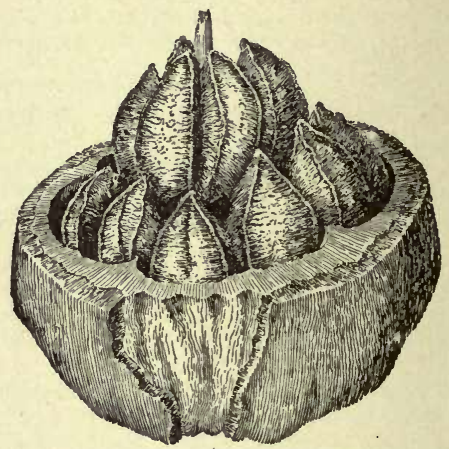

230. Bertholletia excelsa.

Cross-section of husk, showing Brazil nuts (X $1 / 3)$.

cies 2, both of which furnish Brazil nuts. Curiously enough, the common trade name of the Brazil nut is Castanea, which is properly the name of the genus that includes the chestnuts.

excélsa, Humb. \& Bonpl. Fig. 230. A tree, 100-150 ft.; with a smooth trunk $3-4 \mathrm{ft}$. in diam.: branches near the top. It forms large forests on the banks of the Amazon and Rio Negro. The natives gather the nuts in large quantities, chopping the fruit open. They are exported in large quantities, chietly from Para. An oil is expressed from the kernels, and the bark is used at Para for caulking ships. The tree is of little value for decorative purposes, and, according to the Bulletin on Nut Culture of the Division of Pomology, U.S. Dept. of Agr., is too tender for growth anywhere in the United States. - Cult. at Santa Barbara, Calif.

G. T. Hastings.

BERTOLONIA (after A. Bertolini, Italian botanist). Melastomaceœ. Splendid warmhouse foliage plants from Brazil, always dwarf, and sometimes creeping; the garden forms with membranaceous, 5-7-nerved leaves 5-S in. long, and purple beneath: fls, rose-colored, 5 petaled, in scorpioid racemes or spikes. Within the restricted definition of the latest monographer of the Melastomaceæ (A. Coigneaux, in DC. Mon. Pban. vol. 7), there are only five good species, but some earlier botanists do not separate certain aliied genera which usually cannot be distinguished by habit alone. The surest character is the inflated and 3-angled or 3-winged calyx of Bertolonia. In Bertolonia, flower-parts are in 5's, but 
the ovary is 3-celled. Gravesia has a 5-celled ovary, and Sonerila is trimerous. In Bertolonia the connective of the anthers has no appendage ; in Salpinga there is a spur below and behind the connective; in Monolena there is a spur in front, and the calyx is not hairy.

Bertolonias are essentially fanciers' plants. It is somewhat difficult to bring out their true characteristics under ordinary stove treatment, as they require a more humid atmosphere than can usually be maintained, even in a small house. The additional shelter of a small frame should be provided, where the atmospheric conditions will be much more easily regulated. A plentiful supply of water at the roots is necessary ; syringing or sprinkling overhead is not advisable. The most con venient method of propagation is by cuttings, which strike readily, in a moderately close propagating case filled with sharp, clean sand. The pots should be thoroughly clean and drained, and the compost open and porous. Thrire in dense shade. Old plants are not so brilliant as young ones.

Bertolonias and their allies furnish an excellent ex ample of Van Houtte's triumphs in hybridization. The two species described below have probably been important factors in the plant-breeding, and Gravesia gut tata even more so. Gravesia is a Madagascar plant, and has, perhaps, been crossed with the Brazilian Bertolonias. Unfortunately, the pictures in Flore des Serres show no flowers, and the pedigree is not given. The Bertonerilas figured and described in I.H. 43, pp. 188 and 189 , with colored plates 64 and 68 , are presumably hybrids between Bertolonia and Sonerila. Excepting $C$. maculata and $C$. marmorata; the following are hybrids.

\section{A. Veins not lined on both sides with a colored band.}

marmoràta, Naudin. Stem less densely hairy than the above: lis. more narrowly ovate, or ovate-oblong, acute, sparsely hairy, streaked with white along the veins: calyx sparsely hairy, not glandular: petals somewhat blunter, dilute purple. R.H. 1848: 381 , as Eriocnema marmorata, Naudin. F.S.7: 750, as B. maculata, var. marmorata, Planchon. Coigneaux recognizes two varieties, var. genuina, with lvs. green above, and banded with white along the veins; var. ænèa (Eriocnèma cenè and $B$. ànèa, Naudin), with lvs. dark green with a coppery cast, but not spotted or only slightly so.

Mirándæi, Van Houtte. Spots red on the lower lvs. and white on the upper or younger ones : lvs. purple beneath. F.S. 21: 2235 (1875)

\section{AA. Veins lined on both sides with a white or colored band.}

B. Bands and spots magenta or purple.

maculàta, DC. Stem short, decumbent, rooting at the base, densely clothed with rusty hairs: lvs. longpetioled, cordate, broadly ovate, obtuse, hispid above and at margins, dark velvety green above, often spotted: calyx densely clothed with glandular hairs: petals oborate, somewhat acute, rose-colored. B.M. 4551 .

Houtteàna, Van Houtte (B. Van Hoùttei, Hort.). Lvs. purple beneath. This was the sensational plant of 1874 , and Van Houtte refused $\$ 2,000$ for his stock of it. It was originated by his propagator, Marchand. F.S. $20: 2120$.

\section{BB. Bands and spots silvery white.}

$$
\text { c. Spots very distinct. }
$$

Hrubyàna, Van Houtte. This has bars of white connecting the veins. The under side of the lvs. seems to be green instead of purple, at least toward the tip. F.S. 23: 2381 .

Rodeckiàna, Van Houtte. Distinguished from the above and all others of this group by the abundance of dark red color in the upper surface of the lvs. Veins of the under side prominent and green. F.S.23:2382.

$$
\text { cc. Spots very faint. }
$$

Legrelleàna, Van Houtte ( $B$. Legrélle, Hort.). There are a few longitudinal bars, but they do not connect the veins. Reterred to Gravesia guttata by Coigneaux. F.S. 23: 2407 .

Other trade names are $B$. guttata, Hook, f.= Gravesia guttata. - B. margaritàcea, Hort. Bull. =Salpinga margaritacea.B. primulaflora, Hort.= Monolema primulæflora. -B. pubés cens, Hort., with long white hairs and a chocolate band down the center. Equador. $-B$. punctatissima, Hort. $-B$. superbis sima, Hort. (B. superba? Hort.), with rose colored spots, which are larger and brighter near the margin. F.M.151 (1875). Probahly a var. of Gravesia guttata.

Wм. Scotr', Tarrytown, N. Y., and W. M.

BERTONERILA. A class of handsome foliage plants, presumably hybrids between Bertolonia and Sonerila. I.H. vol. 43 (1896). For culture, see Bertolonia.

BESCHORNERIA (after H. Beschorner, German botanist). A maryllidacece. Succulent desert plants, al lied to Bravoa and Doryanthes. Lvs. in a rosette, glaucous, roughish at the margins, not so thick, firm or fleshy as in Agave (which has a strong end-spine and horny marginal prickles): rootstock short, tuberous. In Beschorneria, the perianth is usually reddish green, with scarcely any tube and with long, oblanceolate seg. ments; in Doryanthes the perianth is bright red, the segments long, narrowly falcate ; in Bravoa the perianth is red or white, the tube curved, subcylindral, and the segments short. J. G. Baker, Amaryllideæ, 161. Culture similar to Agave. The species are very closely allied, and difficult to distinguish. The following are the only kinds well known, and they are all from Mex. They flower at long, irregular periods, as do century plants.

The species succeed best when treated similarly to Agaves, with the exception of the soil, which may be made richer by the addition of crushed bone and a little vegetable mold. All of the species need greenhouse protection in the northern states. Useful for bedding.

\section{A. Roughish on both surfaces of lvs.}

tubiflora, Kunth. Lrs. 12 or more, $11 / 2-2 \mathrm{ft}$. long, 1 in. broad, linear, long-acuminate, narrowest of the genus. B.M. 4642. - The oldest and best known species.

AA. Roughish beneath and on the margins of lvs. B. Lis. very glaucous.

Tonélii, Jacobi (B. T'oneliana, Jacobi): Allied to $B$ tubiflora, but with looser habit and much broader lvs. Lvs. 15-20, 1-11/2 ft. long, 2-21/2 in. broad, short-acuminate, and more boldly contracted below the middle. B.M. 6091 .

Bв. Lvs. less glaucous.

C. Base of les. thick, about $1 / 2$ inch.

Dekosteriàna, C. Koch. Lvs. 15-20, 2-41/2 ft. long 2-21/2 in. broad, oblanceolate, long-acuminate, very gradually tapering both ways from the middle, $1-1 \frac{1}{4}$ in. broad above the base; the bases thickest in the genus. B.M. 6768 .

$$
\text { cc. Base of lvs. thinner. }
$$

D. Narrowed to less than 1 inch above the base.

bracteàta, Jacobi. Lvs. 20-30, 11/2-2 ft. long, 2 in. broad, short-acuminate ; texture thin but firm. B.M. 6641.- In the picture the margins are rougher than in any other species, and they are also wavy or revolute at intervals.

DD. Narrowed to $1 / 2$ inch above the base.

yuccoldes, Hook. f. Lvs. about 20, 1-11/2 ft. long, 2 in broad, lanceolate, short-acuminate. B.M. 5203.-The Ivs. are broader than in A.tubiflora, shorter acuminate, and more boldly narrowed below the middle. In the picture eited, the lvs. seem more spreading and less revolute than in the rest of the genus.

B. Californica is offered by Dr. Franceschi, Santa Barbara, Calif., without description.

As Beschornerias can be certainly identified only when in flower, the following key is added :

A. Inflorescence racemose.

B. Fls. highly colored, purple and red-Tonelii.

BB. Fls. dull-colored, reddish green-tubiflora.

AA. Inflorescence panicled.

B. Fls. 2 or 3 in a cluster-Dekosteriana.

BB. Fls. more numerous in the cluster, $3-7$. c. Peduncles bright red-yuccoides. cc. Peduncle dull reddish brown-bracteata. G. W. Oliver and W. M. 
BESLERIA (after Basil Besler, Nuremberg apothecary, and reputed author of the superb Hortus Eystettensis, 1613). Gesnerdcece. Tropical plants, mostly subshrubs, with somewhat 4-angled stems, large, nembranaceous, opposite, petiolate lvs. prominently veined beneath, and yellow, white or purple fls. $B$. Imray is herbaceous, with serrate lvs. and yellow axillary fls. B.M. 6341. Prop. by cuttings. None are known to be offered in America.

BESSERA (after Dr. Besser, professor of botany at Brody). Mexican Coral Drops. An exceedingly pretty summer-flowering bulbous plant, with umbels of pendulous fls., which are vermilion outside, have a white corona or cup within, and long, purple stamens. It is a monotypic genus allied to Androstephium. Perianth cup-shaped, the tube shorter than the oblong-lanceolate segments; stamens 6 . Culture simple. Bulbs planted out, and lifted when ripe. Belongs to lily family.

élegans, Schult. f. Bulb globular, 1 in. thick, tunicated : lvs. $2-3$, about $10-12$ in., or even $2 \mathrm{ft}$., long: scape 1-2 ft. long, hollow, fragile; umbels 4-10-fld.; pedicels 1-11/2 in. long; perianth 9-10 lines long, keeled on the back, variously marked with white within, but usually with vermilion margins and center-band: fls. borne through two months of late summer and early autumn. G.F. 4:125. Gn. 25:423. B.R. 25:34. B.R. 1546, as Pharium fistulosum. F.S. 4:424, as B. miniatum. - Strong bulbs sometimes throw up 6-10 scapes, with 12-20-fld. umbels.

W. M.

BÈTA (Latin name). Chenopodidcece. Perhaps a dozen or 15 species of herbs, ranging from the Canary Islands to eastern India. One polymorphous species yields the cultivated Beets. This is B. vulgaris, Moq., the original form of which is perennial, and grows on the coasts of southern Europe, reaching as far N. as the Straits of Dover. Moquin (DC. Prodr. 13, pt.2:56) divides the derivatives of this species into three groups: (1) The slender-and hard-rooted, essentially wild forms, including $B$. maritima of Linnæus ; (2) Leaf Beet (B. Cicla), comprising the various kinds of Chard or Spinach Beet (see Chard); (3) the common garden Beets, or Beetroot. The ornamental Beets, grown for their handsome colored lvs., are akin to the Chards. All these races have been developed in comparatively modern times, probably from one original form. Cf. Sturtevant, Amer. Nat. 1887:433. See Beet.

L. H. B.

BETEL, or BETLE. The leaf of Piper Betle, a kind of pepper used in wrapping the pellets of betel-nut and lime which are commonly chewed in the Orient. The pellets are hot, acrid, aromatic, astringent. They redden the saliva and blacken the teeth, and eventually corrode them. The betel-nut is the fruit of Areca Catechu, a palm.

\section{BETÓNICA and BETONY. See Stachys.}

BETULA (ancient Latin name). Betuldcece, a tribe of Cupulfferce. BIRch. Trees or shrubs, with the bark usually separating into thin, papery plates : lvs, alternate, deciduous, petioled, serrate : fis. monœcious, apetalous, in catkins, opening in spring with the lvs.: staminate catkins usually long and pendulous, formed in the autumn and remaining naked during the winter, every scale bearing $3 \mathrm{fls}$., each with 2 stamens divided at the apex ; pistillate catkins oblong or cylindrical, bearing in the axil of every scale 3 naked ovaries: fr. a minute nut, often erroneously called seed, with membranaceous wings, dropping at maturity with the bracts from the slender rachis. About 35 species in N. America, Europe, $\mathrm{N}$. and Oent. Asia, especially in the northern regions. No tree goes farther north than the Birch ; in N. America $B$. papyrifera reaches $66^{\circ} \mathrm{N}$. lat., and in Europe B. alba goes to the North Cape, and is still a forest tree at $70^{\circ}$. The hard and tough wood is often used in the manufacture of furniture and of many small articles, in making charcoal, and for fuel; from the bark, boxes, baskets, and many small articles are made; also canoes from that of the B. papyrifera; in Russia and Siberia it is ased in tanning leather. The sap of some species is used ss a beverage. The Birches are very ornamental park trees, hardy, except 2 or 3 Himalayan species, and especially valuable for colder climates. Their foliage is rarely attacked by insects, and turns to a bright or orange-yellow in fall. Their graceful habit, the slender, often pendulous branches, and the picturesque trunks make them conspicuous features of the landscape. Especially remark. able are those with white-colored bark, as $B$. papyrifera, populifolia, alba, Ermani, and also B. Maximowiczii with yellow bark. Most Birches prefer moist, sandy and loamy soil ; but some, as $B$. alba and populifoliā, grow as satisfactorily in dry localities and poor soil as in swamps and bogs, and they are especially valuable in replanting deserted grounds as nurses for other trees ; both are comparatively short-lived trees. Prop. readily by seeds, gathered at maturity and sown in fall, or usually kept dry during the winter, or stratified; but $B$. nigra, which ripens its fruits in June, must be sown at once, and by fall the seedlings will be several inches high. The seeds should be sown in sandy soil, slightly or not at all covered, but pressed firmly into the ground and shaded. The seedlings must be transplanted when one year old. Rarer species and varieties are grafted, usually on B. lenta, papyrifera, nigra or alba. Cleft or tongue-grafting in early spring, on potted stock in the greenhouse, is the best method. Budding in summer is also sometimes practiced. Shrubby forms may also be increased by layers, and $B$. nana by greenwood cuttings under glass. Monographs by Regel: Monographische Bearbeitung der Betulaceæ (1861); and in De Candolle, Prodromus, 16, 2, p. 162 (1869).

Index : alba, 10 ; atropurpurea, 10 ; Bhojpattra, 2 ; Carpatica, 10 ; cordifolia, 8 ; costata, 6 ; Dalecarlica, 10 ; Ermani, 5 ; excelsa, 4, 10 ; fastigiata, 10, 13 ; glandulosa, 12 ; Japonica, 10 ; laciniata, 10, 9 ; lenta, 3 ; lutea, 4 ; Maximowiczii, 1 ; minor, 8 ; nana, 14 ; nigra, 7 ; occidentalis, 11 ; odorata, 10 ; papyracea, 8 ; papyrifera, 8 ; pendula, 10, 9 ; persicifolia, 14 ; platyphylla, 8 ; Pontica, 10 ; populifolia, 9 ; pubescens, 10 ; pumila, 13 ; pyrifolia, 8 ; rubra, 7 : tortuosa, 10 ; urticifolia, 10 ; utilis, 2 ; verrucosa, 10.

\section{A. Veins of lvs. more than 7 pairs, usually impressed above. Trees.}

B. Lvs. large, 4-6 in, long, deeply cordate: cones cylindrical, racemose, $2-4$.

1. Maximowiczii, Regel. Tree, 80-90 ft., with smooth, orange-colored trunk and dark reddish brown branchlets: lvs. long-petioled, broadly ovate, coarsely and doubly serrate, membranaceous, pubescent on younger trees, nearly glabrous on older ones: cones $1 / 2-3$ in. long, slender, nodding; fr. with very broad wings. Jap.-This is probably the most beautiful of all Birches, perfectly hardy north and of rapid growth; its large foliage and the yellow color of the trunk render it a highly ornamental and conspicuous park tree.

BB. Lvs.2-5 in. long: cones solitary, erect: wings narrower than the fruit.

c. Shape of lvs, ovate or oblong-ovate, rounded and often cordate at the base, broadest about the middle: veins distinctly impressed above, comparatively short-petioled.

2. ùtilis, Don (B. Bhojpáttra, Wall.). Tree, 40-60 ft. : trunk with reddish brown bark: lvs. ovate, rounded at the base, acuminate, densely irregularly serrate, pubes cent when young, $2-3$ in. long, with 8-12 pairs of veins: cones peduncled, cylindrical, 1-2 in. long; bracts with erect oblong lobes, the middle one much longer. Himal. Jap. - Not quite hardy N.

3. lénta, Linn. Cherry, Sweet, or Black Birch. Tree, 60-70 ft.; trunk dark reddish brown, young bark aromatic, of agreeable flavor: lvs. oblong-ovate, usually cordate at the base, sharply and doubly serrate, hairy beneath when young, nearly glabrous at length, $2-5$ in. long : cones ovoid-oblong, $1-1 \frac{1}{2}$ in. long; bracts with broad lobes, the middle one slightly longer. From Newfoundland to Florida, west to Illinois and Missouri. S.S. 9:448. Em. 232.-Very handsome tree, roundheaded, and with pendulous branches when older; attractive in spring, with its long staminate catkins.

4. lùtea, Michx. (B. excélsa, Pursh, not Ait.). YeLLow Birch. Fig. 231. Tree, sometimes $100 \mathrm{ft}$.: bark 
silvery gray or light orange, on old trunks reddish brown; young bark aromatic, but somewhat bitter: branchlets usually pilose: lvs. orate or oblong-ovate, usually rounded at the base, acuminate, sharply and

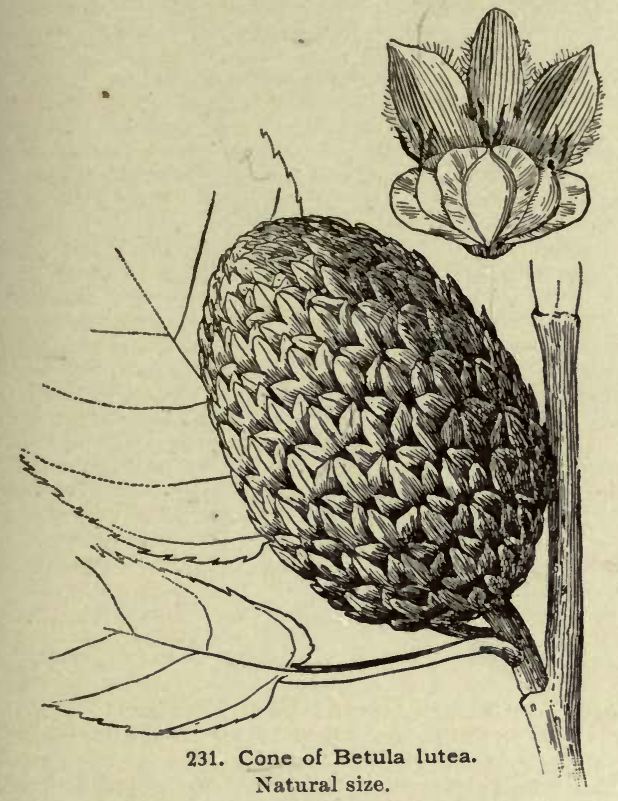

doubly serrate, usually hairy along the veins beneath: cones like the last, but thicker, and bracts larger, pubescent outside. From Newfoundland south to N. Carolina and Tenn., west to Minn. S.S. 9:449. Em. 235.One of the most valuable forest trees in the northern states, much resembling the former in habit. Var. persicifolia, Dipp., has larger and longer lvs., often ovatelanceolate.

cc. Shape of lis. ovate, broad and usually truncate, sometimes cordate at the base: veins not impressed above: long-petioled.

5. Ermani, Cham. Tree, $60 \mathrm{ft}$.: trunk white; branches orange-colored; branchlets usually glandular and pubescent when young: lvs. broadly triangular-ovate, acuminate, irregularly coarsely serrate, 2-4 in. long, hairy when unfolding, with 7-10 pairs of veins : cones oblong; bracts pubescent, with linear-oblong lobes, middle one somewhat longer. N. E. Asia, Japan.Handsome round-headed tree, with slender branches.

6. costàta, Trautv. Tree, $50 \mathrm{ft}$.: bark yellowish brown : branches not or slightly glandular: lvs. ovate, rarely oblorg-ovate, irregularly doubly serrate, with 9-12 pairs of veins, long acuminate, $2-31 / 2$ in. long, glabrous : cones elliptic ; bracts glabrous, with short, rhombic or obovate lateral lobes. Japan. Manchuria.

ccc. Shape of lvs. rhombic-ovate, cuneate at the base; veins slightly impressed above: petioles rather short: cones erect, peduncled, cylindrical.

7. nigra, Linn. (B. rùbra, Michx.). REd or River Birch. Tree, 50-90 ft.: bark reddish brown, or silvery gray on younger branches, separating into numerous thin, papery flakes: branchlets pubescent : lvs. rhombic-ovate, acute, doubly serrate, pubescent when young, at length only on the veins beneath, pale or glaucescent beneath, $2-3 \frac{1}{2}$ in. long: cones $1-12 \frac{1}{8}$ in. long, eylindrical, ripening in May or June; bracts pubescent, with erect, linear-oblong, nearly equal lobes. From Mass. south to Fla, and west to Kans, and Minn. S.S. 9:452. -A moisture-loving, graceful tree, with slender, very numerous branches, and remarkable for its torn and ragged bark.
AA. Veins of lvs. 7 or less, not impressed pairs.

B. Wings usually broader than the nut.

c. Trunk with white bark. Trees; rarely shrubs.

8. papyrifera, Marsh.(B. papyrdcea, Ait.). PAPER or CANOE BIRCh. Fig. 232. Tree, 60-80, exceptionally 120 , ft. : branchlets glandular, hairy when young : lvs. ovate, narrowed to cordate at the base, acuminate, coarsely and usually doubly serrate, pubescent on the veins beneath or nearly glabrous, $1 \frac{1}{2}-4 \frac{1}{2}$ in. long : cones peduncled, 1-2 in. long; bracts with short and broad divergent lateral lobes. N. states from the Atlantic to Pacific coast. S.S. 9:451. Em. 238. G.F. 8:223. - Ornamental tree, with very white trunk and a loose, graceful head when older. Var. cordifolia, Regel. ( $B$. pyrifòlia and platyphýlla, Hort.). Lvs. broadly orate, usually cordate, large. Var. minor, Tuckerm. Low, bushy tree with smaller lvs. and frs. Mts. of N. Eng. and N. York.

9. populifolia, Ait. (B. álba, var. populifolia, Spach.). White Birch. Small tree, exceptionally $40 \mathrm{ft}$., with smooth white bark; branchlets with numerous resinous glands : lvs. slender, petioled, triangular or deltoid, long acuminate, coarsely doubly serrate, glutinous when young, glabrous at length and shining: cones slender, stalked, cylindrical, about 1 in. long ; bracts pubescent, the lateral lobes divergent, about as long as the middle one. From N. Brunswick to Delaware, west to Ontario. S.S. $9: 450$. Em. 1:242. - A small, graceful, but shortlived tree, yet thriving in dry and poor soil. Var. laciniàta, Hort. Lvs. incised-laciniate. Var. péndula, Hort. Branches distinctly pendulous. Var. purpùrea, Hort. Lvs. purple when young, groen at length. $B$. populifolia $\times$ papyrifera is shown in G.F. $8: 356$.

10. álba, Linn. European White Birch. Fig. 233. Tree, sometimes $80 \mathrm{ft}$., with white bark: lvs, slenderpetioled, ovate or rhombic-ovate, acute or acuminate, doubly serrate : cones erect or pendulous, cylindrical; bracts with horizontally spreading lateral lobes about as long as the middle one. From Eu. to Jap.-This very variable species may be divided into 2 subspecies:

(1) péndula, Roth (B. verrucdsa, Ehrh.). Branches. more pendulous, glabrous, usually glandular: lvs. rhombic-ovate, glutinous when young: cones all pendulous. The following varieties belong here: Var.

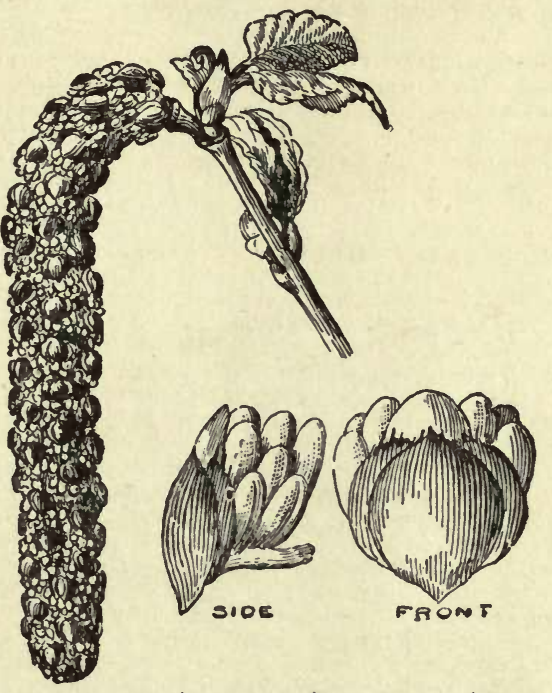

232. Staminate catkin (natural size) and flowers (enlarged) of Betula papyrifera.

atropurpùrea, Hort. Lvs. dark purple. Var. Dalecárlica, Linn. (B.lacinidta, Hort.). Fig. 234. Lvs. more or less deeply lobed with incised-serrate lobes. Var. fastigiàta, Hort. Of straight, upright, columnar growth. Var. Japónica, Miq. (B. álba, var. Taùschi, 
Regel.). Lrs. broad-ovate, usually truncate at the base. Var. péndula, Hort. Branches slender, distinctly pendulous ; cult. in several different forms, as var. pendula laciniàta, Hort., with laciniate lvs.; a very graceful form (Fig. 234); var. péndula élegans ; var. péndula Yoùngi, and otbers.

(2) pubéscens, Ehrh. (B. odoràta, Bechst.). Less pendulous or upright, sometimes shrubby ; branchlets usually pubescent, not glandular: lvs. ovate, pubescent beneath, at least when young : cones pendulous or erect. The first grows more in dry situations, while the latter is found growing in moist places, often in swamps. To this subspecies belong the following varieties: Var, excélsa, Regel, (B. excélsa, Ait.). Tree: lvs. ovate, short petioled, pubescent beneath. Var. pubéscens, Regel. Branches and lvs. pubescent, at least when young; lvs. ovate, acute. Var. urticifòlia, Spach. Lvs. small, deep green, irregularly incised-serrate, unequal at the base. Var. Carpática, Regel, Pontica, Dipp., and tortudsa, Regel, are small trees, without any horticultural value.

\section{cc. Trunk with dark bronze-colored bark.}

11. occidentalis, Hook. Small tree, occasionally $40 \mathrm{ft}$; branchlets slender, glandular: lvs. broadly ovate or nearly orbicular, acute or obtuse, sharply serrate, shortpetioled, glabrous or sparsely pubescent at the veins beneath, 1-2 in. long: cones $1-1 \frac{1}{4}$ in. long ; bracts with erect, oval lobes, the middle one usually longer. Northwest Amer., east to Dakota and Nebraska. S.S. 9: 453.

BB. Wings smaller than the nut: shrubs 1-15 ft.: lvs. small, short-petioled: cones erect.

c. Branchlets glandular, not pubescent.

12. glandulòsa, Michx. Only 1-4 ft.: Ivs. short-petioled, rounded or cuneate at the base, orbicular or broadly obovate, obtuse, dentate, glabrous, $1 / 4-11 / 2$ in. long: cones peduncled, $1 / 2-3 / 4 \mathrm{in}$. long: lobes of bracts nearly equal, slightly spreading. Newfoundland to Alaska, south to Michigan, and in the Rocky Mountains to Colorado. B.B. 1:510.

\section{cc. Branchlets pubescent or nearly glabrous, not} glandular.

13. pùmila, Linn. Usually $2-8 \mathrm{ft}$., rarely 15 : branchlets tomentose or pubescent, at least when young: lvs. orbicular or oval, acute or obtuse, coarsely dentate, pale and glabrous or pubescent beneath, $1 / 2-2$ in. long: cones peduncled, $1 / 2-1$ in. long ; lateral lobes of the pubescent bracts spreadirg, shorter than the middle one. Newfoundland to Minn., south to Ohio. B.B. 1:511. Var.
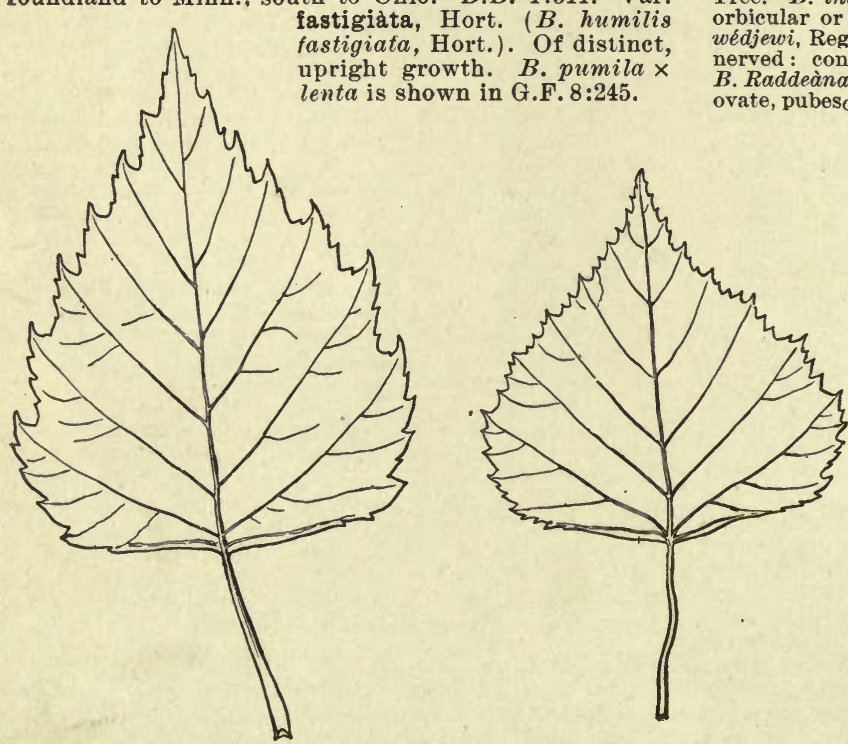

233. Leaves of Betula alba. Natural size.
14. nàna, Linn. Low, spreading, rarely $4 \mathrm{ft}$.: Ivs. - bicular or cuneate-obovate, crenate, rounded at apex, glabrous, $1 / 4-3 / 4$ in. long : cones nearly sessile, $1 / 4-1 / 2$ in. long; the upper bracts usually entire, the lower ones

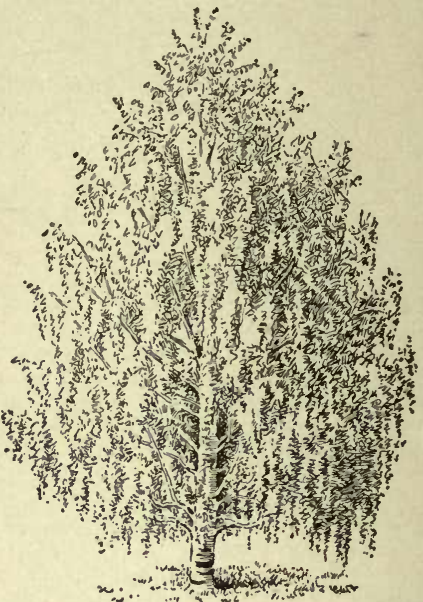

234. Cut-leaved Weeping Birch-Betula alba.

3-lobed. Aretic N. E. Amer., N. Eu., Siberia. B.B. 1:511. -A low, graceful shrub for rockeries and rocky slopes.

B. alnoides, Hamilt. (B. cylindrostachya, Wall.). Tree, 50-60 ft.: bark brown : lvs. ovate-oblong, doubly cuspidately serrate: cones racemose. Himal. Tender. $-B$. alpéstris, Fries $=B$. intermedia.-B. carpinifolia. Ehrh.=-B. lenta.-B. corylifòlia, Regel. Allied to $\mathrm{B}$. nigra. Lvs. broad elliptic or obovate, coarsely dentate: cones cylindrical. Japan. B. cylindrostàchya. Wall.= $B$ alnoides $-B$. Dahurica, Pall. Tree, to $60 \mathrm{ft}$ : bark brown. lvs, ovate, pubescent on the veins beneath, 1-2 in. long: cones oblong. Dahur., Manchuria.-B. fruticòsa, Pall. Shrub, to 15 ft.: lvs. ovate, glabrous at length and usually glandular beneath, 1-2 in. long. Siber., Manchuria.-B. Gmélini, Bunge= B. fruticosa.-B. grándis. Ṡchrad.=B. papyrifera. $-B$. gròssa, Sieb. \& Zuec. Allied to B. lenta. Lvs, ovate, unequally serrate, $1 / 2-2$ in. long: lobes of bracts rounded. Jap. $-B$. hùmilis, Schrank. Two to $6 \mathrm{ft}$.: branchlets glandular: lvs. $1 / 2-11 / 4$ in. long, crenately serrate, glabrous, M, and N. Eu., N. Asia - $B$. hybrida, Bechst. Natural hybrid of $B$. pendula X pubescens. Tree. $-B$. intermedia, Thomas (B. alba $\times$ nana). Shrub : lvs. orbicular or ovate, 1\%-1 in. long, glabrous. N. Eu.-B. Med wédjewi, Regel. Tree, allied to B. Ermani : lvs. elliptic, 8-11nerved: cones cylindrical. Trans-Caucasia. Gt. 36, p. 384.B. Raddeàna, Trautv. Allied to B. fruticosa. Treo: Ivs. small, ovate, pubescent on the veins beneath : cones oblong. Cauce sus. Gt. 36, p. 384.-B. ulmifòlia, Sieb. \& Zuce. Tree: lvs ovate, doubly serrate, with $10-14$ pairs of veins : bracts of cone with linear oblong lobes. Jap. - B.Yoùngi péndula, Hort. $=$ B. alba, var. pendula Youngi. A LFRED REHDER.

BIARUM (old and obscure name). Aroidece. Dwarf, tuberous perennials of the same tribe with our native jack-inthe-pulpit. They are hardy in England, but probably are suitable only for pot-culture in the northern U.S. They have a spathe which is tubular at the base, mostly with a long limb, and usually a long taillike spadix. They grow a few inches high. Odd. Little known in America.

tenuifollium, Schott (Àrum tenuifolium, Linn.). Lvs, linear-lanceolate or spatulate, appearing after the fls. decay: spathe long-acuminate, at length recurved and twisted spirally, about 10 in. long, ontside green, streaked purple ; inside dull purple, spotted ; margins wavy : spadix 15 in. long. Spain. B.M. 2282.

Pyrámi,Eng. (Íscharum Pyrámi, Sehntt). Lvs. oblong above the middle, narrowing abruptly to a very long petiole, resembling 
Calla palustris : spathe green outside, shining, velvety purple within, shorter and broader than in B.tubiflorum, at length revolute; tube swelling, connate only at the very base: spadix thicker and shorter. Syria. B.M. 5324

Bdvei, Blume. Lrs. similar to B. Pyrami: spathetube connate a fourth of its length; blade of spathe longer and more narrowly lanceolate, green outside, dark purple within. Syria, Asia Minor.

BIDENS (Latin, twice-toothed, referring to the seed). Compósita. BUR MARIgold. Mostly American hardy annual and perennial herbs, allied to Dahlia and Coreopsis, and distinguished by the barbed awns of the seed, which, in $B$. frondosa, our commor Stick-Tight, or Devil's Bootjack, are very troublesome by clinging to the clothing. B. grandiflora, Balb., from S. Amer., is a yellow-fld. hardy annual, growing $2 \mathrm{ft}$. high, bearing glabrous pinnatisect lvs.; occasionally cult. For $B$. atrosanguinea, Hort., see Cosmos diversifolius.

BIENNIAL. A plant living two years; particularly one which does not bear flowers and fruit until the second year from the seed. Plants vary greatly in their duration, depending upon the climate in which they grow and the treatment which they receire. Comparatively few plants are true biennials. The common mullein and bull thistle (Cnicus lanceolatus) are examples. Most cultivated biennials become annuals if grown in a warm or long-season climate, as turnips, celery, cabbage, onion. If the plants are crowded, or not allowed to attain their full development, they tend to run to seed and complete their growth the first year. Gardeners are familiar with this fact in celery, carrots and beets. Plants which are practically annuals under such conditions, but which have the power of carrying themselves over winter by means of bulbs, corms, tubers, and other food-storage parts, have been called pseud-annuals. DeCandolle estimates that true or natural biennials comprise 1 or 2 per cent of the total number of species of seed-bearing plants.

BIFRENARIA (Latin for twice and strap, referring to the connective of the pollinia). Orchidacea, tribe Vándece. Very like Maxillaria, and distinguished by technical characters of the pollinia. About 25 trop. Amer. species, of which the two following are best known to the horticulturist. These species do well at the cool end of the Cattleya house, and, in general, should be treated like Maxillaria and Lycaste.

aurantiaca, Lindl. Pseudobulbs ovate or ovoid, monophyllous; leaf-blades about 6 in. long, oval or nearly so: fis. about 1 in. across, yellow, dotted with deeper yellow. British Guiana. B.M. 3597 .

vitellina, Lindl. Fls. deeper yellow than in the above, with a brown spot on the labelium. Brazil.

OAKes Ames.

BIGELOVIA (after Dr. Jacob Bigelow, author of Florula Bostoniensis, Medical Botany of U. S., etc.) Composita. The only species in cult. is the original one, which resembles a goldenrod. Prop. by cuttings and by seed. Culture simple.

gravèolens, Gray (Bigeldwia dracunculoides, DC.). Low shrub, 1-6 ft. high, densely white-tomentose, much branched, very leafy, malodorous only in drying: lvs. linear, 1-2 in. long: fl.-heads, yellow, 5-8 lines high, very numerous, crowded, in terminal corymbose cymes, rayless. Alkaline soils Dak. to B.C. and S. to S. Calif. and Ariz. Var. albicaulis is more permanently and densely woolly, dwarfer, and recommended by D. M. Andrews, Boulder, Colo., for low hedges and edgings.

BIGELOW, JACOB. Botanist, physician, educator, and founder of Mt. Auburn Cemetery, the prototype of all garden and landscape cemeteries, was born at Sudbury, Mass., February 27, 1787, and died at Boston, January 10,1879 . He was graduated from Harvard in 1806 , and began the practice of medicine in 1810. His Florula Bostoniensis, 1814 (2d ed. 1824), was the first American local flora of importance, and served for many years as the only popular manual of New England botany. He was Professor of Materia Medica in Harvard from 1815 to 1855. and for twenty years Physician to the Massachusetts General Hospital. His American Medical Botany, 1817-20, was the flrst work of its kind. Each of the three volumes contained descriptions of 20 species, with a colored plate of each produced by the aqua-tinting process, a method invented by Dr. Bigelow just before lithography. His essay on "Self-limited Diseases," an attack on heroic remedies and a plea for the recuperative processes of nature, marked an epoch in medical reform. Dr. O. W. Holmes said that it probably had more influence on medical practice in America than any work ever published in this country. He also did much to introduce science into colleges that were too exclusively classical. The genus Bigelovia, named after him by DeCandolle, was founded on a western plant resembling goldenrod. He was the one man without whoin Mit. Auburn Cemetery would never have existed. This cemetery has been one of the most important factors in the development of landscape gardening in America, and without the revenues derived from it the Massachusetts Horticultural Society could never have played so important a part in American horticulture. Dr. Bigelow was one of the most versatile, useful and interesting men of his day. The popular use of the word "technology" dates from his "Elements of Technology," 1827. For a fuller account, see the sketch by L. H. Bailey, in Botanical Gazette, 8: 217 (1883), and Scientific Papers of A. Gray, 2: 413. See, also, Dr. Bigelow's book on the history of Mt. Auburn.

W. M.

BIGNONIA (The Abbe Bignon, librarian to Louis XIV.).Bignonideca. Climbing American shrubs, mostly tropical, of more than 100 species. Fls. mostly large and showy, long-tubular, with a contracted base, 5-lobed or -toothed, 2-lipped limb; perfect stamens 4 : seeds winged, in a linear, compressed capsule.

Bignonias are strong and rapid-growing evergreen greenhouse climbers, requiring considerable space for their best development, such as the roof of a large conservatory, or the back wall of a lean to greenhouse. If convenient, they should be planted out under the plant stage of the greenhouse, or otherwise in boxes placed on the stage. A box $5 \mathrm{ft} . \times 11 / 2 \mathrm{ft}$. and $1 \mathrm{ft}$. deep will be found a conrenient size for them. As with most greenhouse climbing plants, the roots like considerable freedom; but with Bignonias the roots must be somewhat restricted (though not to the limitations of a flower-pot) otherwise an immense growth and few flowers will be the result. They are not very fastidious as to soil. A good, fibrous loam, to which one-third well decomposed cow or sheep manure bas been adiled, suits them admirably. A winter temperature of $45^{\circ}$ to $50^{\circ}$, with a gradual rise as the days lengthen, should be given them, admitting air freely whenever the weather is favorable. They like plenty of moisture at the roots-especially during the spring and summer (the growing season)-but perfect drainage should be ensured, as the soil at no time must become saturated or sour. Except when in flower, a good syringing on all fine days will be very beneflcial. They should also be sprayed once or twice a week with a moderately strong solution of kerosene emulsion, or kerosene and water, to keep them free from mealy bug, as they are very subject to this pest. The vines should be trained so as to allow a free circulation of air among the branches for the purpose of ripening the wood, as upon this depends the assurance of flowers. All superfluous branches and weak shoots should be removed, and before the growing season begins all the branches should be shortened from 1 to 3 feet, according to their strength; this will throw the energy of the plant into the lateral buds, which will produce the flowering branches, providing the wood has been properly ripened the previous season.

Propagation is effected by cuttings taken in late spring and inserted in sand under a bell glass, or in a propagating box, in a warm temperature. Choose, if possible, stout, short-jointed lateral growths for the purpose. They must be carefully watered until rooted, which usually takes from 6 to 10 weeks.

\section{Cult. by Edward J. Canning.}

$$
\text { A. Lvs, simple, opposite. }
$$

magnffica, Bull. Free-growing and floriferous, needing warm treatment: lvs, ovate-elliptic, stalked, entire: 
fis. panicled, large ( $3 \frac{1}{2}$ in. across), ranging from mauve to purple-red, the throat primrose, limb wide-spreading. Colombia. G.C. II. $12: 73$.

regàlis, Hort. Lvs. elliptic-lanceolate : fls. large, yellow and red. Guiana. - Of recent introduction. Requires warm treatment.

argỳreo-violáscens, Hort. Lvs. ovate, cordate at base, short-stalked, purple when young, but becoming beautifully veined and blotched with white: fls. purple. S. Amer.? I.H. 13: 469 .

AA. Lvs. pinnately compound, the a lower lfts. usually foliaceous and the others represented by tendrils.

B. Fls. normally from the axils of the lvs.

\section{c. Pedicels 1-fld.}

capreolàta, Linn. TruMPET-FLOWER. Cross-vine. QUARTER-vine. Climbing to great heights (often $50 \mathrm{ft}$. or more), glabrous, evergreen : lfts. stalked, oblongacuminate, cordate, entire : fls. in many 2-5-fld. shortpeduncled cymes, yellow-red and lighter within, tubu$\operatorname{lar}$ ( 2 in. long), with a stout limb Native from Md. S. and $W$., and often a pest in orchards, climbing on the trees. B.M. 864. Gng. 1:370, 371.-Handsome vine for outdoor use. Good for covering walls. Sometimes grown in conservatories. A cross-section of the stem presents a cross-form appearance, whence one of the common names.

Var. atrosanguínea, Hook. f. (B. atrosanguínea, Hort.). Lvs. longer and narrower: fls. dark purple, the lobes short and triangular-ovate. B.M. 6501. F.R. $2: 27 .-$ Handsome.

Tweediàna, Lindl. Leaflets lanceolate and pointed, cordate, 3 in. or less long : fls. trumpet-shaped, 2 in. long, orange-yellow, the limb of rounded, spreading lobes and from 2-4 in. across. Argentina. B.R. 26:45. Gn. $40: 812$. Will stand a little frost if grown in the open in the South.

CC. Pedicels 2-fld.

Líndleyi, DC. Glabrous : lfts. oblong or ovate-oblong, cordate, acute, somewhat wavy-margined : fls. pale purple, with spots and stripes, the tube oblong-cylindrical ( 2 in. long), the limb short and the lobes obovate-rounded and undulate. Argentina.-Blooms when young.

specidsa, R. Grah. Glabrous: leaflets 3 in. long, elliptical and more or less acuminate, shining, the midrib

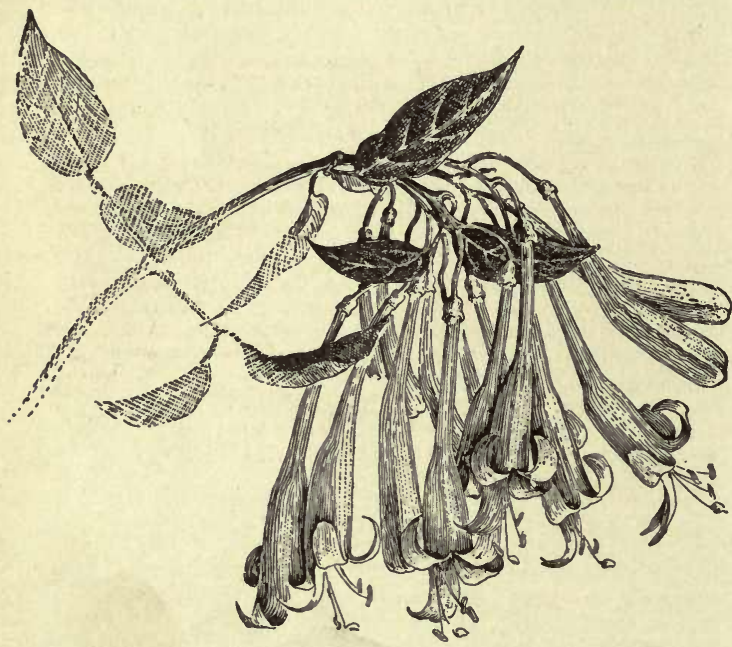

235. Bignonia venusta $(\times 1 / 2)$.

prominent : fls. 3 in. long, with compressed tube, which is furrowed or plaited below and yellowish with lilac streaks, the limb2-3 in. across, purple and streaked, the lobes spreading-reflexed, obtuse and wavy. Argentina. B.M. 3888. - Needs warm or intermediate temp.; blooms in spring and early summer. When grown in the open in the S., will stand a little frost.

BB. Fls. in clusters terminating the branchlets.

c. Branches prominently 4-angled.

buccinatòria, Mairet. ( $B$. Cherère, Lindl. B. Kerère, Hort.). Tall: leaflets 2-3 in. long, elliptic or ovate-oblong, obtuse or only cuspidate, pellucid-dotted, the petioles (as the racemes) tomentose: fl. long-tubular (4 in. long), blood-red, but yellow at base, the limb rather narrow, with retuse lobes. Mex. Gn. 26:471. B.M. 7516. R.H. 1898: 580. - Needs coolhouse treatment. Strong grower. One of the finest species.

\section{c. Branches terete or very nearly so.}

æquinoctialis, Linn. Glabrous: Leaflets ovate to oval-lanceolate, obtuse or acuminate, shining above: fls. in both terminal and axillary panicles ; corolla glabrous, trumpet-shaped, $2 \frac{1}{2}$ in. long, purple, with dark rose stripes (but said in garden books to be yellow); fls. sometimes only in 2's. W. Ind. and S. Amer.-Perhaps not the plant known under this name in the trade.

Chàmberlaynii, Sims. Glabrous : leaflets ovate-acuminate, glabrous, shining above, paler beneath, nore or less tapering at base : fls. tubular, contracted below, 3-4 in. long, the limb comparatively short and spreading, bright yellow; cluster many-fld. Braz. B.M.2148. - Perhaps a form of the last. This species and $B$. aquioctialis are referred to the genus Anemopagma by some.

venùsta, Ker-Gawl. Fig. 235. Sts. striate or somewhat angular, the young ones pubescent: leaflets usually 3 , glabrous, ovate-acuminate, more or less tapering at base : fls. in corymbose, mostly drooping racemes ; corolla slender and long-tubular, contracted in the lower half (2-3 in. long), with 2-lipped limb and oblong, obtuse, reflexing lobes, crimson-orange. Braz. B.M. 2050. A.F. 11:1023.-Requires a rather warm house. Profuse bloomer; early winter. One of the best rafter plants.

purpurea, Lodd. Glabrous, tall-climbing : leatlets often 3 , usually 2, lance-obovate, abruptly acuminate, short-stalked, toothed or entire : fls. mauve or rose-purple, with a white eye, the flaring tube $1 \mathrm{in.long}$, the wide-spreading lobes rounded. S. Amer. B.M. 5800 . G.C. III. 24: 399. - Requires warm treatment.

B. adenophýlla, Wall.=Heterophragma. $-B$. álba, Hort. $=$ Pithecoctenium.-B. grandiflòra, Thunb.=Tecoma. -B. radi. cans, Linn. =Tecoma.-B. suavèolens, Roxbg.=Stereospermum. $\begin{array}{ll}-B \text {. Thúnbergii, Hort:= Tecoma. } & \text { L. H. B. }\end{array}$

BILIMBI. See Averrhou.

BILLARDIERA (after J. J. Labillardière, French botanist and traveler.) Pittosporàcea. Tender Austra. lian climbers, with terminal, solitary, pendulous, tubular, stalked fls., generally yellow, and edible fr. B. longiflor $a$ and $B$. scandens are cult. abroad as greenhouse climbers. $B$. cymosa, cult. outdoors at Santa Barbara, Calif., is Sollya heterophylla.

BILLBERGIA (for the Swedish botanist, J. G. Billberg). Bromeliacea. About 40 tropical American evergreen epiphytal herbs, now much cult. by amateurs and in fancy collections. A few kinds are well known to florists. A closely allied genus is Achmea, which see for botanical differences. The fls. are in a spike or spicate panicle, which rises from the center of the rosette of long, spiny edged, and usually stiff, pineapple-like lvs.: fls. showy, with 3-parted calyx and 3 long petals, 6 exserted stamens, thread-like style, and berry-like fr. The colored bracts of the fl.-clusters are usually very showy. Cf. Charles Mez, the latest monographer, in DC. Phaner. Monogr. 9. Species confused; but the artificial arrangement given below may aid the gardener.

Billbergias can be cultivated best in greenhouses, planted in pans, pots, wooden cribs, or wire baskets, with loose, light material about their roots, such as pieces of charcoal, roots of very fibrous plants, or fern roots and sphagnum moss, and such material. They require little water at the roots in winter, and nothing but light sprinkling over the foliage is required to keep them alive during that time. But in summer, when the heat is great and they are making their growth, they 
can withstand an abundance of moisture, at the roots as well as at the top, most of the time holding water in the funnel-like center or body of the plant. They generally bring their conspicuous, showy flowers in the spring, when moisture overhead or sprinkling should be withheld in order to prolong the beauty of the flowers. They require at night a temperature of from $50^{\circ}-75^{\circ}$, but, of course, can stand auy amount of heat in summer. Billbergias, like all other Bromeliads, make very good house plants, and they will thrive exceedingly well in a livingroom temperature. They love plenty of light and sun. All first-class private garden establishments should have at least a few of this class of plants. They are propagated best from suckers or sprouts, which arise from the base of the old plant, generally after it has bloomed and performed its functions. - The old plant then gradually deteriorates, sending out from two to flve young plants from its base. These can be taken off as soon as they are hardy and substantial enough, and can be mounted or potted into the same kind of material. Then, suspended in the greenhouse, conservatory, or window for an exhibition, they thrive best. Besides their beautiful and attractive flowers, they have very handsome foliage, which is of a tough and leathery texture. Billbergias, Echmeas, and the like, are natives of the tropics, and, therefore, require a warm temperature. Æchmeas are usually larger than Billbergias and Tillandsias.

Cult. by H. A. Siebrecht.

A. Fls. greenish or yellowish, often tipped with blue. B. Petals curling spirally after fl. expands.

$$
\text { (Helicddea.) }
$$

zebrina, Lindl. (Bromèlia zebrìna, Herb. Échmèa zebrina, Hort.). St. very short, or none : lvs. sheathing, deep green, with blotches and zones of gray-white, strongly spine-margined: fl.-cluster loose, long and drooping : fls. green or vellow-green, the stamens becoming long-exserted : bracts salmon or rose, long-lanceolate. S. Amer. L.B.C. $20: 1912$. B.M. 2686.

decòra, Poepp. \& Endl. (Helicddea Baraquinidna, Lem.). Differs from the last in having longer petals, denser spike and longer bracts : lvs. 8-10, from 1-2 ft. long, mealy, white-blotehed and banded. Brazil. I.H. $11: 421$. B.M. 6937.

\section{BB. Petals not spirally twisting.}

speciosa, Thunb. (B. amčna, Lindl. B. pállida, KerGawl). Lvs. strap-shaped, connivent, and forming a tube at the base, 1-2 ft. long, somewhat spine-margined, green above and lepidote and somewhat striped on the back : fl.-cluster large and loose, erect or drooping; bracts rose : fls. pale green or whitish, tipped with blue. Brazil. B.R. 1068.-An old and well known species.

nùtans, Wendl. Stemless, stoloniferous : lvs. linear and long-pointed, 1-2 ft., distantly small toothed, finely striate on the back : fls. 4-8, in a loose, drooping spike ; petals green, blue-edged; bracts lanceolate, red. Brazil. B.M. 6423. Gn. 32, p. 107 .

\section{AA. F'ls. markedly red or purple.}

\section{B. Essentially red.}

thyrsoidea, Mart. Lvs. 1-2 ft., broad-ligulate, spinemargined, concave on upper surface, green above and paler beneath, abruptly acuminate : fl.-cluster shorter than lvs., farinaceous, densely red-bracted : fls. numerous, bright red, petals reflexing. Brazil. B.M. 4756.Showy. Runs into several varieties, some of them with purple-tipped fls. (as vars. spléndida and fastuosa, André, R. H. 1883: 300). B. spléndens, Hort., is evidently one of the forms. Species too near the next.

pyramidalis, Lindl. (Bromèlia pyramidalis, Sims. $B$. Croyidna, De Jonghe). A foot high : differs from the last in having more gradually acuminate lvs., which are more strongly and distantly toothed and whitish, or even banded on the back : fl.-cluster less farinaceous, broader and looser, the fls. less numerous. Peru. B.M. 1732.

\section{BB. Essentially purple.}

Morélii, Brongn. (B. Moreliana, Hort. B. Wétherellii, Hook.). Lvs. short (1-1 $1 / 2 \mathrm{ft}$.), with few weak spines, wide, glabrous and green: fl.-cluster exserted and drooping, with showy, pointed red bracts, the rachis woolly : fls. with red sepals and purple-limbed petals. Brazil. B.M. 4835. - Very showy.

vexillària, André. Fig. 236. Hybrid of B. thyrsoidea and $B$. Morelii. Fls. purple : lower bracts longpointed and red; spike-erect, exceeding the lvs. R.H. 1889: 468 .

vittàta, Brongn. (B. Lèopoldi, Hort., not Morr.). Vigorous, 2-3 ft.: lvs. long and large, concave above, recurved at the summit, obtuse or abruptly pointed, red - spined, crossbanded on the back: fl.- cluster loose and nodding, shorter than the lvs., red-bracted: fls. deep blue, with recurving limbs. Brazil. Gn. 32 : 608 . R.H. 1869 , p. 87.

Liboniàna, De Jonghe. Small, 1-11/2 ft., producing runners: lvs. long-linear or strap - shaped, spiny, very sharppointed, concave and green above and whitish-mealy below: fl.- cluster erect or nearly so, rather slender, the bracts not prominent : fls. with red sepals and erect blue petals. Brazil. B.M. 5090. F.S. 10: 1048.

Quesneliàna, Brongn. (Quesnélia Cayennénsis, Baker). Lvs. numerous, arising from a trunk or stem, rigid and

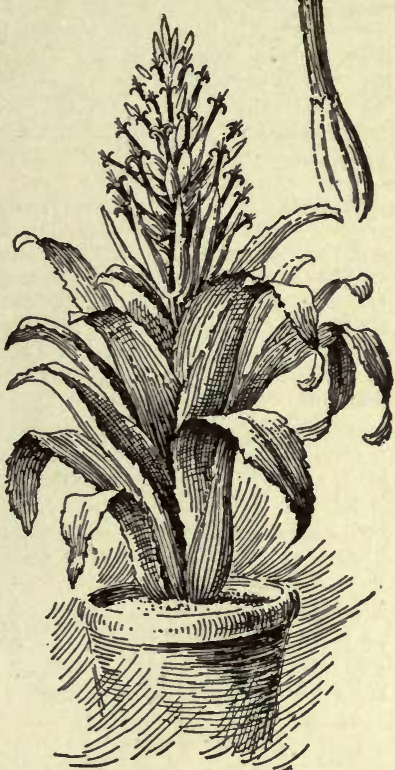

236. Billbergia vexillaria. spreading or recurved, concave above, very sharpspined, more or less white-marked on the back, longacuminate : fl.-cluster a dense, erect spike, with red and white-blotched obtuse bracts : fls. deep purple. Guiana. F.S. 10: 1028.

In the American trade the following names have been used: $B$. clavàta longifolia, once offered by Pitcher \& Manda, is probably AEchmea bromeliæfolia. $-B$. fasciàta $=$ Aehmea fasciata.$B$. máxim $a=q-B$. ornàt $a=q-B$. rhodocyànea $=\$$ Achmea fasciata. - B. stricta $=$ ?

Any of the following may be expected to appear in the Amer. trade at any time: $B$. Andegavénsis, Hort., is $\mathrm{B}$. thyrsoidea $X$ Morelii ; fls. red and blue,-B, Bàkeri, Morr. (B, pallescens, Baker). Fls. greenish, tipped purple. B.M. $6342-B$. Breaute àna, André. B palleseens $\times$ vittata bas reddish Breautelima, André. B. palleseens $\times$ vittata, has reddish, purpledecora; fls. greenish, bracts red.-B. Enderi, Regel. Small : fls. very deep blue; bracts coral-red. Brazil. $-B$, iridifotia, Lindl. Fls. red and yellow, blue-tiped. Brazil. B. R. 1068, - B Lietzei, Morr. Fls and bracts rose, Brazil - $B$. Portedng, Brongm, Fls, green, the petals rolling spirally. Brazil. B.M. 6670-B. Sanderiàna, Morr. Fls green, tipped blue Brazil - $B$. Saìn. dersi, Bull. Fls. greenish, tipped blue: ivs. striking, green
above, reddish beneath, white-blotehed and red-spined. Brazil. Gt. 39:1316.

L. H. B.

BILSTED. See Liquidambar.

BINDWEED. Name applied to various twining, weedy plants, particularly to various kinds of Convolvulus.

BIOTA. See Thuya.

BIRCH. See Betula.

BIRD-OF-PARADISE FLOWER. See Strelitzia.

BIRD'S-NEST FERN. See Thamnopteris.

BIRD'S-TONGUE FLOWER. See Strelitzia.

BIRTHWORT. See Aristolochia ; also Trillium. 
BISMÁRCKIA (in honor of Prince Bismarck). Palmàcea, tribe Borássece. A genus nearly related to Latania and Borassus, distinguished by fruit characters. Forms a tree $200 \mathrm{ft}$. high, with a gigantic crown of palmate lvs. with white streaked petioles and blades 10 ft. in diam.: fr. borne in large, drooping clusters, dark brown, plum-like, $1 \frac{1}{2}$ in. in diam., with a thin outer shell and a fibrous inner one enclosing a rounded, wrinkled seed 1 in. in diam., reticulated like a walnut and ruminated, as in the nutmeg. Cult. as for Latania. nóbilis, Hildeb. \& Wendl. Young plants : petiole convex on the back, channelled above, finely serrate on the ridges above, thinly clothed with tufts of fibrous scales, half as long as the blade ; blade blue-green, rigid, $3 \mathrm{ft}$. in diam.; segments 20,2 in. wide, $1 \mathrm{ft}$. long, apex blunt, obtuse, with a long curved filament from the base of each sinus. Madagascar. G.F. 6:246. F.R. 2:257. Gt. 1221.

JARED G. SMITH.

\section{BITTER-SWEET. See Celastrus and Solanum.}

BIXA (South American name). Bixdcex. A genus of two species of tropical trees with large, entire lvs. and showy fls. in terminal panicles. B. Orellana is cult. in the $\mathrm{E}$. and $\mathrm{W}$. Indies for the Annatto dye which is prepared from the orange-red pulp that covers the seeds. It is the coloring matter chiefly used in butter and cheese. It is also used in dyeing silks, and preparing chocolate.

Orellàna, Linn. Height $30 \mathrm{ft}$ : lvs, cordate : fls. pinkish. B.M. 1456. - It is rarely grown in northern greenhouses as an ornamental. Cuttings taken from a flowering plant will produce flowering plants of a convenient size. Plants from seed usually flower less freely, and must attain a greater size before flowering.

BLACKBERRY. A name applied to various species of Rubus, of which the receptacle remains with the drupelets when fruit is picked. As a commercial fruit, it is known only in America. Although a well-known

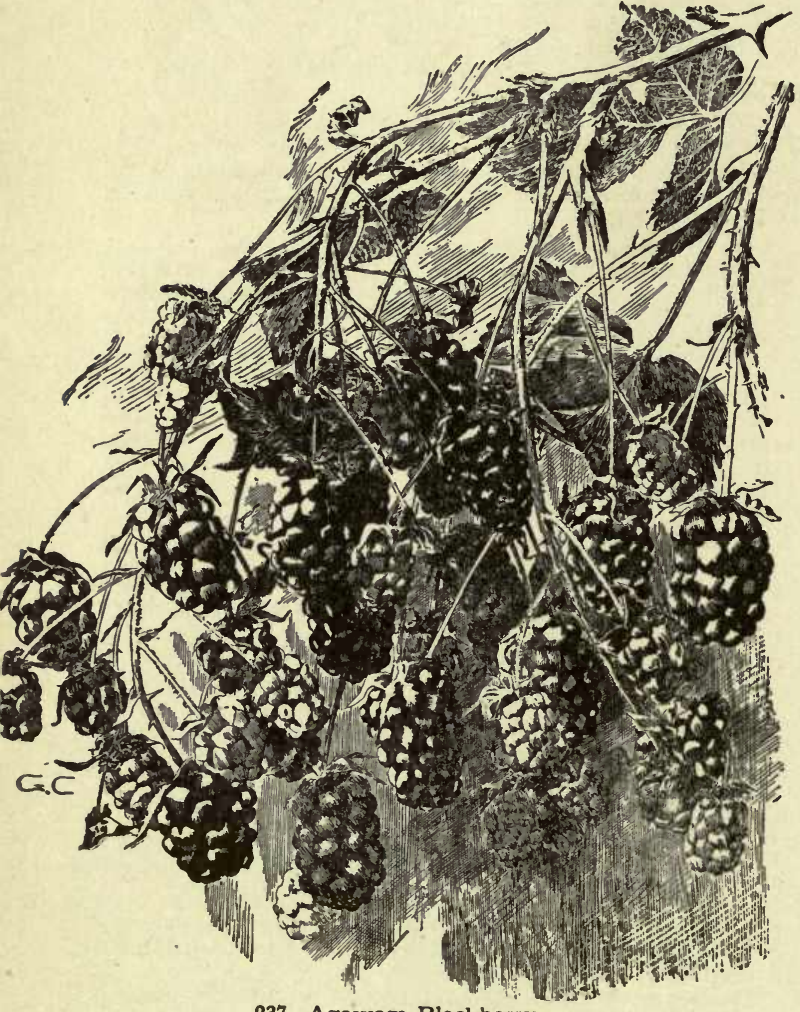

237. Agawam Blackberry wild fruit from the earliest times, the Blackberry has only recently made its appearance among the more orderly and promising garden fruits. The type species is $R$ ubus nigrobaccus, although it has long been known under the name Rubus villosus (see Rubus). It is a most variable species, and the number of forms which may be recognized depends only upon the judgment of the botanist who is reviewing them. There are several distinct types or groups in cultivation. (1) The LongCluster Blackberries, Rubus nigrobaccus. The plants grow tall and upright, the leaflets are long-stalked, rather finely serrate and taper pointed. The flower cluster is long, leafless and open, with the individual flowers standing almost at right angles to the central stem. The fruit is normally oblong or thimble-shaped, sweet, rather dull in color, with drupelets small and closely packed. The Taylor is one of the best representatives of this class. (2) The White Blackberry, R. nigrobaccus, var. albinus. Similar to the above, but with nearly round, yellowish green canes and pinkish cream- or amber-colored fruit. Many varieties of this type have been introduced, but none have attained prominence. (3) The Short-Cluster Blackberries, $R$. nigrobaccus, var. sativus. This is the commonest form of cultivated Blackberry, and includes such varieties as the Snyder, Lawton and Agawam (Fig. 237). In this type the clusters are shorter, but leafless, the pedicels more oblique, the fruits shorter and rounder, glossy black, the drupelets large and irregularly set. The leaflets are broader, coarsely and unevenly serrate, or jagged and less tapering at the point. (4) The LeafyCluster Blackberries, $R$. argutus. This is a lower and more bushy form, with narrow, coarsely toothed, lightcolored leaflets and short cluster, having simple leaves intermingled with the flowers. Its best common representative is the Early Harvest. (5) The Loose-Cluster Blackberries, $R$. nigrobaccus $\times$ villosus. This is a group of hybrid origin, being intermediate between the Blackberry and dewberry (see Dewberry). The plants have a low, spreading habit of growth, broad jagged and notched leaves, short dewberry-like clusters, with large, roundish fruits, made up of very large, loosely set drupelets. The Early Wilson and Wilson Junior are its best known representatives (Fig. 238). (6) The Sand Blackberry, $\boldsymbol{R}$. cuneifolius (Fig. 239). A sturdy little shrub, armed with vicious recurved thorns, with thickish, wedge-shaped leaflets, whitened woolly beneath. The clusters are few-flowered, opening from the center outward, the fruit roundish, loose-grained, very black and good. Known in cultivation only as the Topsy, or Tree Blackberry. (7) There is still another type of Blackberry, known as the Thornless or Mountain Blackberry ( $R$. Canadensis), but it is not in cultivation. This is characterized by smooth, unarmed canes, narrow, sharppointed leaflets, the upper ones borne on long, slender leaf-stalks, an open flower-cluster, a short, roundish, glossy black fruit, with large drupelets. It ripens later than the common Blackberry, and is not so good in quality. For further account of the Blackberry tribes, see Bailey, Evolution of Our Native Fruits.

The first Blackberry introduced into cultivation was the Dorchester, which was exhibited before the Massachusetts Horticultural Society in 1841. This was followed by the Lawton a few years later, which became much more prominent. The Kittatinny soon divided honors with this, and both now largely have given place to the Snyder, which is undoubtedly the most widely grown variety of the present day. This, like many commercial fruits, is a variety of poor quality, but extremely hardy and productive. The rapid strides made by the Blackberry in cultivation prove that a place was ready and waiting for it in the pomological world, a place which it has proved itself eminently fitted to fill, owing both to its desirable qualities in general and to its ability to rapidly vary and develop new types. At the present time it is one of the most important, most generally liked and most profitable bush-fruits grown.

The Blackberry thrives on almost all soils, but to reach perfection demands a strong loam, retentive of moisture and tending toward clay rather than sand. Soil must be well drained at all times. If too rich in humus and nitrogen, a tendency toward a rank growth of plant, with diminished fruitfulness, appears, while a light, sandy soil will fail to carry the fruit through periods of 
drought, which is usually the greatest obstacle to success with this fruit. For this reason a cool northern exposure is always desirable, and in the region of the Plains, a good windbreak on the south and west is very beneficial. Fertilizers containing a liberal proportion of potash are most suitable. Too much stable manure, or nitrogen in other forms, will induce a rank growth of eanes at the expense of fruit.

Plants are propagated either by root-cuttings, or by means of the suckers which naturally spring up about the parent plants. The latter are most commonly used in commercial work. Root-cuttings may be made in the fall and carried over winter in sand, or started under glass toward spring, or the cuttings can be made in spring and sowed in furrows, like peas. Planting is best done in spring, as a rule. If set in the fall, each plant should be covered with a mulch of earth or strawy manure, which should be removed in spring. The rows pruning is the method of thinning the Blackberry, and judgment must always enter into the question of thinning fruit. In the region of the Plains, where moisture is likely to be deficient, both in soil and atmosphere, it is frequently found better not to cut back the growing shoots in summer, but to let them develop one straight cane, which is cut back to $2 \frac{1}{2}$ or 3 feet in spring. This will generally develop all the fruit which the plant can carry to maturity under such conditions. A few growers in other parts of the country train to wires, and in that case the shoots are also allowed to grow at will, but are left much longer in spring and tied to the wires for support. Close-pruned, stocky bushes may be covered with straw as a protection against late spring frosts.

The best of cultivation is always demanded. In a crop in which so much depends upon an abundant supply of moisture in the soil, none should be allowed to go to waste. Hence, the cultivation should be frequent and

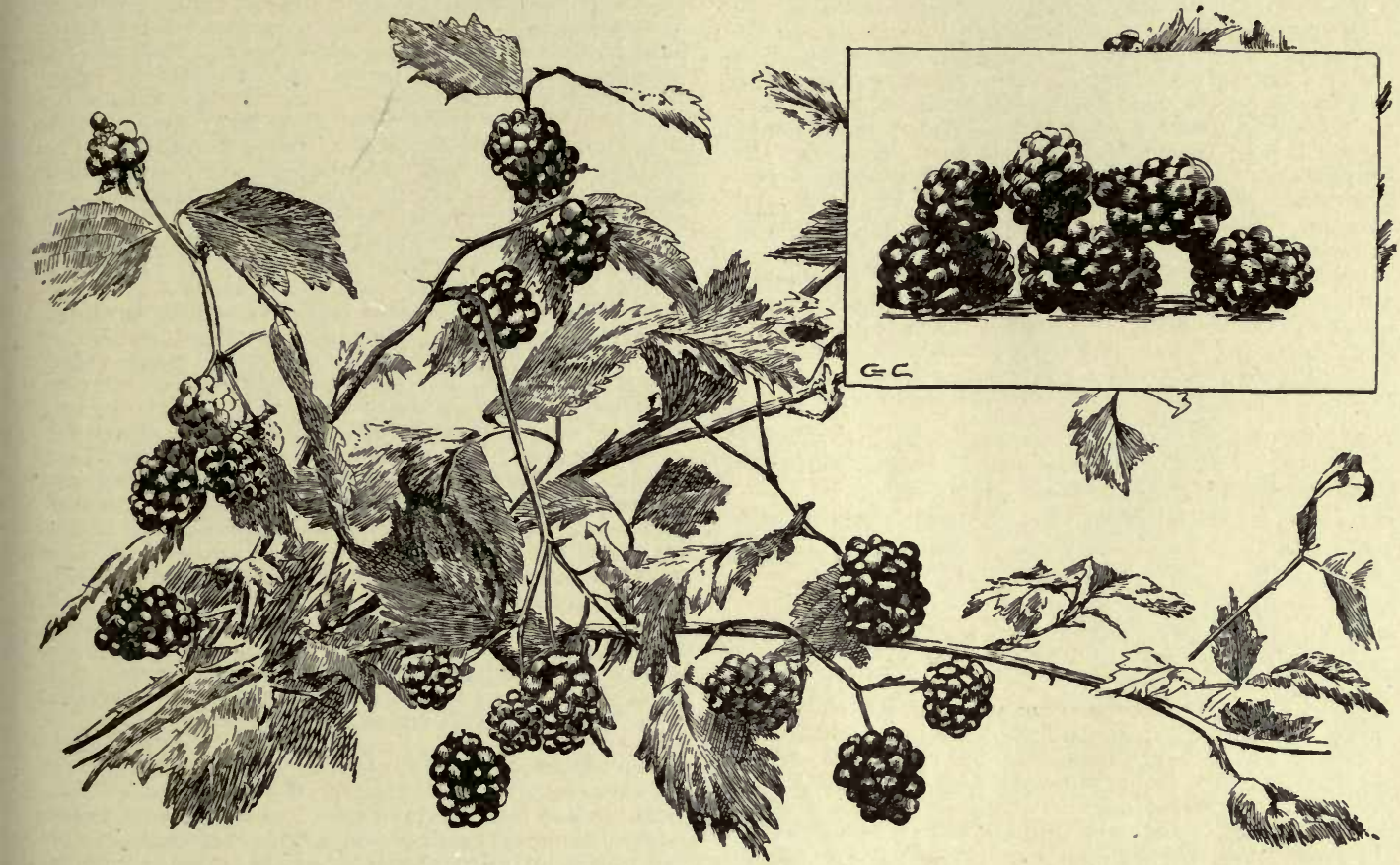

238. Wild hybrid of Blackberry and Dewberry.

should be about 8 feet apart, and the plants may be set from 2 to 4 feet apart in the row. At the latter distance, cultivation may be given in both directions for the first year or two. With high culture, good results may be obtained by planting in hills, 7 or 8 feet apart each way.

Pruning the Blackberry is not difficult, yet upon its proper performance depends much of the success of the erop. The old canes should be removed yearly, preferably in summer, as soon as they have borne their crop of fruit. They then no longer interfere with the symmetrical development of the young canes, and if gathered and burned at once, much is gained in keeping the field clear of certain fungi and insects. The young eanes should be clipped off when they reach a height of 18 nches or 2 feet, in order to induce early branching and a stocky bush with well developed laterals, capable of producing and holding up a heavy crop of fruit. It is very important that the shoots be not allowed to get higher than 2 feet before this clipping is done. They will then elongate and make the bush high enough. If neglected, and later cut back to 2 feet, the buds will be weak, the growth poor, the bush low, and the crop small. The laterals are usually eut back to about 18 inches in length the following spring, but varieties differ in their habit of bearing fruit-buds, and it is not safe to cut by measure. It should be remembered that this spring constant, but always shallow, for deep cultivation disturbs the roots and induces increased suckering. In small garden patches mulching may be substituted. Growers in the middle West have found mulching with green clover in the row, and cultivating between, very beneficial.

In many parts of the country winter protection is absolutely essential to success, and often adds greatly to the yield in other regions, where not considered a necessity. This protection is by no means always called for by reason of extreme cold. The winters of Nebrask and Kansas are nearly always milder than those of central New York; yet during one of the mildest of these, when the mercury reached zero but once, and was then only five degrees below, Taylor Blackberries were killed to the ground, while the succeeding winter, which was decidedly colder, they came through unharmed. It may be as much a matter of moisture as of temperature. The needed protection is best given by loosening the earth on both sides of the plant, carefully turning it down and covering the tips with soil, laying the next plant upon the roots of this, and so on. In mild climates, covering the tips is sufficient; in especially unfavorable ones the whole plant must be covered. The cost of this need not exceed $\$ 5$ to $\$ 8$ an acre.

The fruit of the Blackberry should be left upon the 
plants as long as possible before picking, for it is not ripe when it first turns black. It should never be exposed to the sun after it is removed from the bushes. The Blackberry generally outyields all the other members of this family, and is usually one of the most profit-

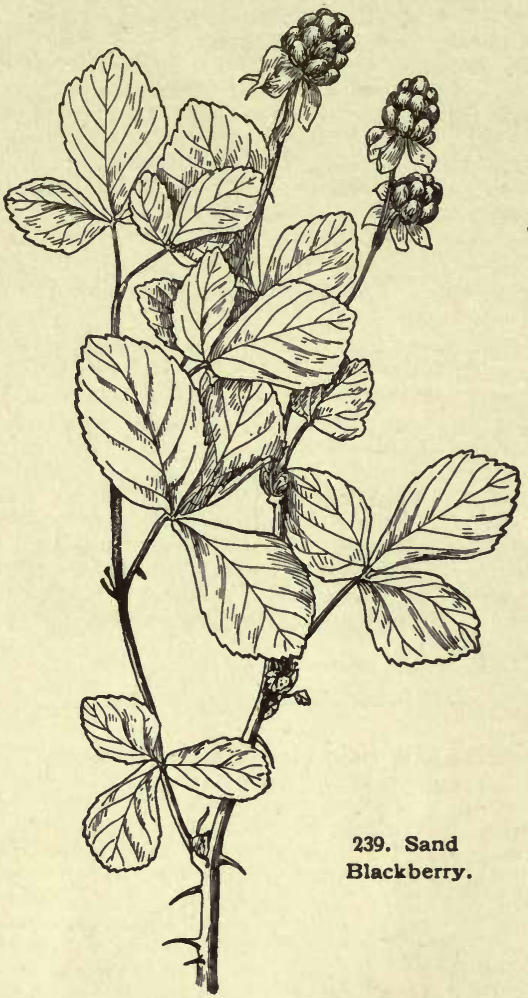

able to grow when properly managed, provided the climate and other general conditions are favorable.

There are several formidable enemies of the Blackberry, but they are generally easily mastered by the alert and energetic grower. Cutting out the bearing canes as soon as they are through fruiting will circumvent the borer which sometimes works in the canes, and will aid in preventing the spread of anthracnose and leaf rusts. The orange rust must be fought by digging up and burning infected bushes as soon as detected, for there is no cure. But this trouble is seldom serious.

Fred W. Card.

\section{BLACKBERRY LILY. See Belemcanda.}

\section{BLACKW00D. See Acacia.}

\section{BLADDER NUT. See Staphylea.}

\section{BLADDERW0RT. See Utricularia.}

BLANDFORDIA (after George, Marquis of Blandford). Lilidcece. Tender bulbous plants from Australia and Tasmania, placed by J. G. Baker (Jour. Linn. Soc. 11: 364 ) between Kniphofia and Funkia, but very different in general appearance from Funkia. Roots tuberous fibers: lvs. in two vertical ranks, narrowly linear, hard, persistent : fls. large, 11/2-3 in. long, showy, nodding, in short racemes, usually orange-red to crimson, with yellow tips.

Being tenderer than the poker plant, and of more difficult culture, Blandfordias are rarely grown in America. B. flammula, var. princeps, is the best kind. In New South Wales they grow in peat bogs and on shady mountain sides. During the growing season they must be shaded from bright sunshine, and during the resting season they may be placed in a light pit, where they are not crowded or shaded by taller plants. They like a moist atmosphere and plenty of air, but not draughts. The chief element of the potting soil should be peat ; if the peat is heavy, use sand freely ; if light, use some loam, and pack firmly ; if spongy, add some chareoal. Pot after flowering, in early spring, being careful not to overpot, and plan to leave roots undisturbed for two years at least. A top-dressing each year and liquid manure during growing season, is necessary to produce a good flowering. Prop. by seeds sown in sandy peat with mild bottom heat, or usually by eareful and not too frequent divisions of the root, made in early spring, after flowering, at the time of repotting, and preferably when strong offsets are formed.

$$
\text { A. Margin of lvs. not roughish. }
$$

Cúnninghami, Lindl. Lvs. 18-24 in. long, 3-4 lines wide, broader than in $B$. flammea : fls. $10-15$, or even 20. Blue Mts. of Australia. B.M. 5734. Gn. $24: 411$. This has lately been held to be synonymous with $B$. grandiflora, but it is horticulturally distinct, and the pedicels are shorter.

$$
\text { AA. Margin of lvs, roughish. }
$$

B. Fls. golden yellow, without any red.

aùrea, Hook. f. Lvs. 8-12 in. long, 11/2-2 lines wide: fls. $3-6$, the only ones in the genus not touched with red ; perianth wide-swelling, sometimes nearly as wide as long, more bell-shaped than any other species. N.S. Wales. B.M. 5809 .

\section{BB. Fls. red-tubed and yellou'-tipped.}

c. Perianth long, 3-4 times as long as wide.

nóbilis, Smith. Lvs. 12-18 in. long, 1/2-3/4 lines wide, dark green, sharply 3 -angled : fls. $4-9$, smallest of the genus, and narrowest. Neur Port Jackson. B.M. 2003. B.R. 286 .

flámmea, Lindl. Lrs. 12-18 in. long, 2-21/2 lines wide: fls. 4-12, typically constricted near the base of the tube and much lower down than in B. C'unninghami. E. Australia. B.M. 4819. P.M. 16: 354. F.S. 6:585. F.S. 18: 1829 , as $B$. Cunninghami.

Var. prínceps, Baker (B. princeps, W. G. Smith), has larger and brighter colored fls, and is the best of the genus. The perianth is longer and less spreading than in the type, and swells very gradually from the base, instead of being constricted near the base. B.M. 6209 . F.M. 1875:170. F.S. 22:2314. Gn. 47:1013.

cc. Tube short, scarcely twice as long as wide.

grandiflora, R. Br. Lvs. $12-18$ in. long, 3-41/2 lines wide: fls. 10-30. Distinguished from all others by having the filaments inserted above instead of at the middle, but in var. intermedia, Baker, which connects $B$. grand $i$. flora and nobilis, the filaments are inserted at the middle of the tube, the lvs. are narrower, and the fls. smaller. Tasmania. B.R. 924. - The name grandiflora is now a misnomer, as the fls. are smaller than in any other species except $B$. nobilis. The rarest species. W. M.

\section{BLANKET FLOWER. See Gaillardia.}

\section{BLAZING STAR. See Liatris.}

BLECHNUM(Greek name for some fern). Polypodidcece. Rather coarse greenhouse Ferns, with pinnatifid or pinnate lvs., and rows of almost continuous sori parallel to the midvein and close to it, covered with a membranous indusium. Blechnums will thrive in al most any compost, but their lvs. quickly turn brown and then black if watered overhead. Prop. by spores. In Blechnum we have a singular knot in nomenclature. Linnæus described two species in 1753 , and to the West Indian one he gave the name $B$. orientale, citing figures, etc., to show that it is the plant that recent writers call $B$. occidentale. His East Indian plant he similarly called $B$. occidentale. The normal or ordinary usage has been followed below, the name $B$. orientale being given to the eastern plant.

Blechnums are very useful to florists for jardinières, and for specimen Ferns. To attain best results, it is necessary to maintain an abundance of moisture at the 
roots, with a drier atmosphere than most other Ferns require, to prevent fronds from turning brown during winter months. Average temp. $60-65^{\circ} \mathrm{F}$. Soil, equal parts of rich loam and leaf-mold or peat. The spores of most Blechnums germinate very freely if sown on a compost of loam and leaf-mold or peat in equal parts, and placed in a moderately moist and shady position in a temp. of $60-$ $65^{\circ} \mathrm{F}$. Some of the species send out creeping rhizomes, which develop young plants at the ends. When of sufficient size these may be detached and potted, and in a short time they will develop into good specimens.

\section{cies are found among th
hardy British Blechnums. \\ Cult. by N. N. BruckNer.}

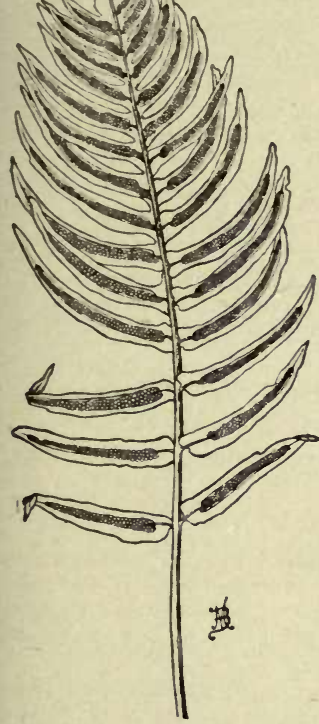

A. Pinnce strongly decurrent
at the base, joining with the one next below.

Brasiliénse, Desv. Growing from a stout, slightly arborescent trunk $1 \mathrm{ft}$. or more long : lvs. 2-3 ft. long, $1 \mathrm{ft}$. or more wide, with the pinnæ set at an acute angle with the rachis, the lower much shorter and more distant. Braz. S. 2: 4 .

nitidum, Presl. Habit of B. Brasiliense, but much smaller: lvs. pinnate; pinnæ oblong-falcate, thickish, 2-4 in. long, serrate. Braz.Plant 1-2 ft. high.

Corcovadénse, Raddi. Pinnæ not cut to the rachis, much crowded and shorter than the last; longest pinnæ less than 6 in. long, attenuate at the tips; lvs. crimson when young, and gradually turning to a metallic hue before becoming permanently green. By some con240. Blechnum occidentale. nently green. By some consiliense. Braz. Var. crispum, Hort., with wavy edges, may be commoner in cult. than the type.

AA. Pinnce contracted at the base to the midrib, forming a very short stalk.

occidentàle, Linn. Lvs. from an erect caudex, which is covered with brownish scales: lvs. 9-18 in. long, 4-6 in. wide, with the pinnæ truncate or even cordate at the base and slightly falcate. Mex. and W. Ind. to Braz. See Fig. 240.

serrulàtum, Rich. Growing from an ascending nearly naked rootstock : Ivs. 1-2 ft. long, 6-15 in. wide, with numerous narrow pinnæ, which are contracted at the base and of nearly uniform width throughout; margins finely serrulate; texture coriaceous. Fla. to Braz.

$B$. orientale, Linn., is a large East Indian and Polynesian Fern, with lvs. often $3 \mathrm{ft}$. long; well worthy of eultivation.

L. M. UNDERWOOD.

\section{BLEEDING HEART. See Dicentra.}

BLEPHARIS (Greek, eyelash; referring to fringed bracts). Acanthdcece. An unimportant genus of dwarf, often spiny shrubs and herbs, allied to Acanthus, and of similar culture.

carduifolia, T. Anders. (Acánthus carduifolius, Linn. Acanthddium carduifolius, Nees). Plant villous : lvs. lanceolate, sinuate-dentate, spiny: spike terminal, cylindrical : bracts roundish, palmately 5-spined at the apex.

BLÈTIA (Louis Blet, Spanish botanist). Orchiddacee, tribe Épidéndrece. Terrestrial or epiphytal herbs, widely distributed : lvs. plicate, membranaceous, sheathing the st., erect. This genus lends itself readily to cultivation, but is not showy enough to be popular. They need a long season of rest. The commonly cult. kinds are terrestrial, and thrive in ordinary orchid loam.

hyacinthina, R. Br. Lvs. about $1 \mathrm{ft}$. long: fls. looking down, in various shades of purple, on a scape about $1 \mathrm{ft}$. high. China. B.M. 1492, as Cymbidium hyacinthinum. - Stands some frost.

verecúnda, $\mathrm{R} . \mathrm{Br}$. The first exotic Orchid introduced (1731). Racemes showy and branching, 2-3 ft.: fls. purplish. W. Ind.; also in Middle and E. Fla.

Shépherdii, Hook. Very like the last, and perhaps a form of it: fls. deep purple; center of labellum yellow. B.M. 3319 .

Sherratiàna, Bateman. Lf.-blades pointed at both ends: fls. large, more showy than in the above, brilliant lilac or rose color; labellum purple, with 3 golden yellow lines. New Grenada. B.M.5646.

pátula, Hook. Fls. deep pink-lilac, numerous and large ( 2 in. across). B. M. 3518. - Requires culture given Cattleyas.

campanulàta, La Llave \& Lex. Fls. bell-like, purple, with white center. Mex. - Not common in cult.

B. aphýlla, Nutt., is a native species growing as far N. as N. Carolina.-B. Tánkervillea, R. Br., is a Phaius.

OAKES AMES.

BLIGHT. An indefinite term, popularly used to desig. nate any sudden and inexplicable death of plants. The term is now restricted by botanists to parasitic diseases. These diseases are of two classes, - those due to bacteria or microbes, and those due to parasitic fungi. For an account of these troubles, see Diseases.

\section{BLITE. See Chenopodium.}

\section{BLOODR00T. See Sanguinaria.}

BLO0MERIA (named for Dr. H. G. Bloomer). Lilidece. A genus of two species, natives of southern California. In every way they are closely allied to Brodiæa, but differ in having the perianth parted nearly to the base. Bloomerias have a flattish corm, much like Crocus, covered with fiber, and not often producing offsets. The lvs. are Nadical, slender, and grass-

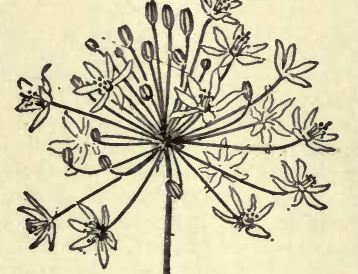
like; scape slender but stiff, 6 to 18 in. high, naked, ex. cept for short bracts beneath the many-rayed umbel ; pedicels slender, jointed; fls. nearly rotate, less than an inch across, orange. Bloomerias prefer a sandy, warm and welldrained soil. In northern California, with a minimum temperature of $15^{\circ}$ above zero, they are perfectly hardy. In a colder climate, a covering of straw or leaves or a position in the coldframe would be a judicious precaution. Plant early, and see that the soil is light and sweet. They like the sun, and are good for forcing. The light soil and warmth of a pot more nearly approximates natural conditions than the open ground does in cool. er climates. After ripening, it is best to dig and replant in fall. The seeds grow readily, and the plants flower in 3 to 4 years.

241. Bloomeria aurea $\left(X^{1 / 4}\right)$. aùrea, Kellogg. Fig. 241. Scape roughish, $6-18$ in.:
f $1 / 4-1 / 2$ in. broad: fls. numerous, bright orange, in a 
dense umbel: stamens nearly as long as the perianth, the filaments dilated at the base. B.M. 5896 (as Nothoscordum aureum). G.C. III. $20: 687$.

Clèvelandi, Wats. Mare slender: lvs. 3-7: fls. smaller, keeled with brown, the stamens shorter. G.C. III. 20:687. -Less valuable than the other.

\section{BLUEBELL. See Campanula.}

BLUEBERRY. Species of Vaccinium.

BLUE FLAG. See Iris.

\section{BLUETS. See Houstonia.}

BLOMENBÁCHIA (after Dr. J. F. Blumenbach, professor at Göttingen). Loasdcece. A genus of S. American plants allied to Loasa and Mentzelia (Mexican prickly poppy), not cult. in Amer. because of their covering of stinging hairs. The fls, are odd and pretty. The garden forms are mostly treated as tender annuals.

B. Chiquiténsis, Hook, f. Lvs. 8-10 in. long: fls, $1 \frac{1 / 2^{-2}}{\text { in }}$ long, brick red, tipped yellow without, and yellow within; petals 5-10, boat-shaped. Peru, Equador. B.M. 6143. - B. grandiflora, G. Don (B. contorta, Hook. f. B.M. 6134). Lvs. 4-6 in. long: fls. $1 \frac{1}{2}-2$ in. long, wholly red; scales $1 / 4$ in. long, cupshaped, $112-2$ in. long, wholly red ; scales 4 in. long, cupPeru.-B. insignis, Schrad. Stem elimbing, 4-sided : petals Peru.-B. insignis, Schrad.
white, unguieulate. B.M. 2865.

BOCCONIA (after Dr. Paslo Bocconi, Sicilian botanist and author). Papaverdcere. Plume PopPY. A genus of 5 species, of which $B$. cordata is the only one worthy of cultivation. The large, handsome, glaucous lvs. remind one, by their texture and lobing, of bloodroot and Stylophorum, which belong to allied genera. The fls. are very unlike our common poppies, being small and without petals, but they are borne in great feathery or plumy masses. in terminal panicles raised high above the heavy foliage, making the plant unique in its picturesque general appearance. Hence, it is much used for isolated lawn specimens, or for very bold and striking effects, being especially adapted to be viewed at long distances. It is also placed in shrubberies, wild gardens, and at the back of wide borders, as it spreads

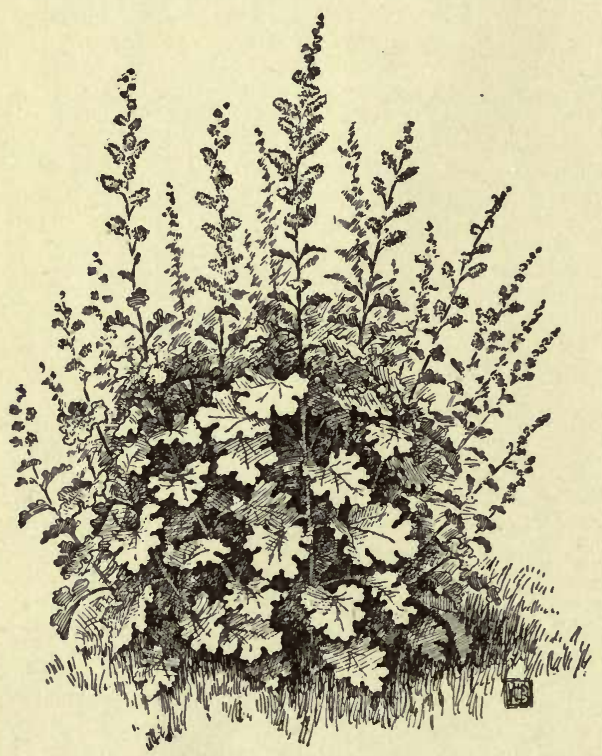

242. Bocconia cordata.

rapidly by suckers, any one of which, if detached, will make a strong plant in a single season. The Plume Poppy seems to be much hardier in America than in the Old World. It was popular early in the century, but was neglected, probably because it spread so rapidly.
Lately it has become popular again. It deserves to be permanently naturalized in the American landscape. To produce the largest specimens, it is well to plant in very rich soil, give the old clumps liquid manure in spring, and cut off the suckers. Prop. chiefly by suckers.

cordàta,Willd. (B. Japónica, Hort.). Fig. 242. Hardy herbaceous perennial : height 5-8 ft.: lvs. large, glaucous, heart-shaped, much-lobed, deeply veined : fls. pinkish ; stamens about 30. China, Japan. B.M. 1905. Gn. 54, p. 279 . Gng. 5: 342.

\section{J. B. Keller and W. M.}

BCEHMERIA (G. R. Bøehmer, a German botanist). Urticdeece. Many widely distributed species. B. nívea, Gaud., of trop. Asia, is cult. in some countries as a fiber plant, and has been introduced into this country for that purpose. It is a strong-growing, large-lvd. perennial, well suited to the border as an ornamental subject. B.argéntea, Lind., a stove plant, is useful for subtropical bedding; but it is not in the Amer. trade.

BOLANDRA (H. N. Bolander, Californian botanist). Saxifragdcea. Two species of small west American herbs, with purplish fls, in lax corymbs; petals 5 , inserted on the throat of the 5-lobed calyx; stamens 5 , alternate with petals. Delicate herbs, suitable for rockwork.

Oregàna, Wats. A foot or two high, pubescent and glandular : lvs. laciniately toothed and lobed : fls. deep purple ; tube of the calyx equaling the teeth and a little shorter than the petals: pedicels reflexed in front. Oregon.-Int. by Gillett in 1881.

The first-described species, B. Califórnica, Gray, seems not to have been offered in the trade. It is a smaller species, less pubescent, with smaller fls., the lower lvs, round-reniform and 5-lobed: plant 3-12 in. high, the stems weak and slender.

BOLDOA FRAGRANS, cult. in S. Calif. See Peumus.

BOLETUS. Consult Mrushrooms.

BOLLEA. See Zygopetalum.

BOLTONIA (James Bolton, English botanist). Compósitoe. FALSE CHAMOMILE. Four or 5 species of asterlike glabrous, often glaucous herbs of the United States and eastern Asia. They are tall and leafy plants, blooming profusely in late summer and autumn, and excellent for the hardy border. Differs from aster in having a convex receptacle, short pappus bristles and awns, and other technical characters. Boltonias are of easiest culture. They take care of themselves when once established. Prop. by division. Should be better known to gardeners. They stand without staking.

asteroides, L'Her. (B. glastifòlia, L'Her.). Sts. 2-8 ft., simple below and branching at the top: Ivs. broadly lanceolate or the upper narrower: heads short-peduncled, numerous, the rays varying from white to violet and purple; involucre bracts lanceolate and acute, greenish; scales of the pappus numerous and conspicuous, the two awns sometimes missing. Pa. to Ill. and S. B.M. 2381, 2554. Mn. 1:33. - Perennial.

latisquàma, Gray. A handsomer plant, with larger and more showy heads with blue-velvet rays : involuere bracts oblong or obovate and obtuse (often bearing a minute point); pappus scales small, the awns present and conspicuous. Kans. and Mo. G.F. 5: 271. Perennial.

B. Cantoniensis, Franch.\& Sav., is native to Japan, where the young plants are used for greens. See Georgeson, A.G. 13, p. 8, fig. 4. It is annual. Has not yet appeared in the Amer. trade. Gray restricts Boltonia to the U.S., and regards this species as of another genus.

L. H. B.

BOMAREA (derivation doubtful). Amaryllidicece. Tender South American plants allied to Alstromeria, and with similar fls. but a twining habit. Lvs. parallelveined, usually borne on short, twisted petioles: fls. in pendulous umbels, variously colored and spotted, borne in early spring and summer: perianth funnel-shaped tube none. See Baker, Amaryllideæ.

Bomareas delight in a rich, fibrous soil, and require plenty of water during the growing season, which com- 


$$
\begin{aligned}
& \text { S I BRAR } \\
& \text { OF THE }
\end{aligned}
$$

UNIVERSITY

CALIFORNIA 


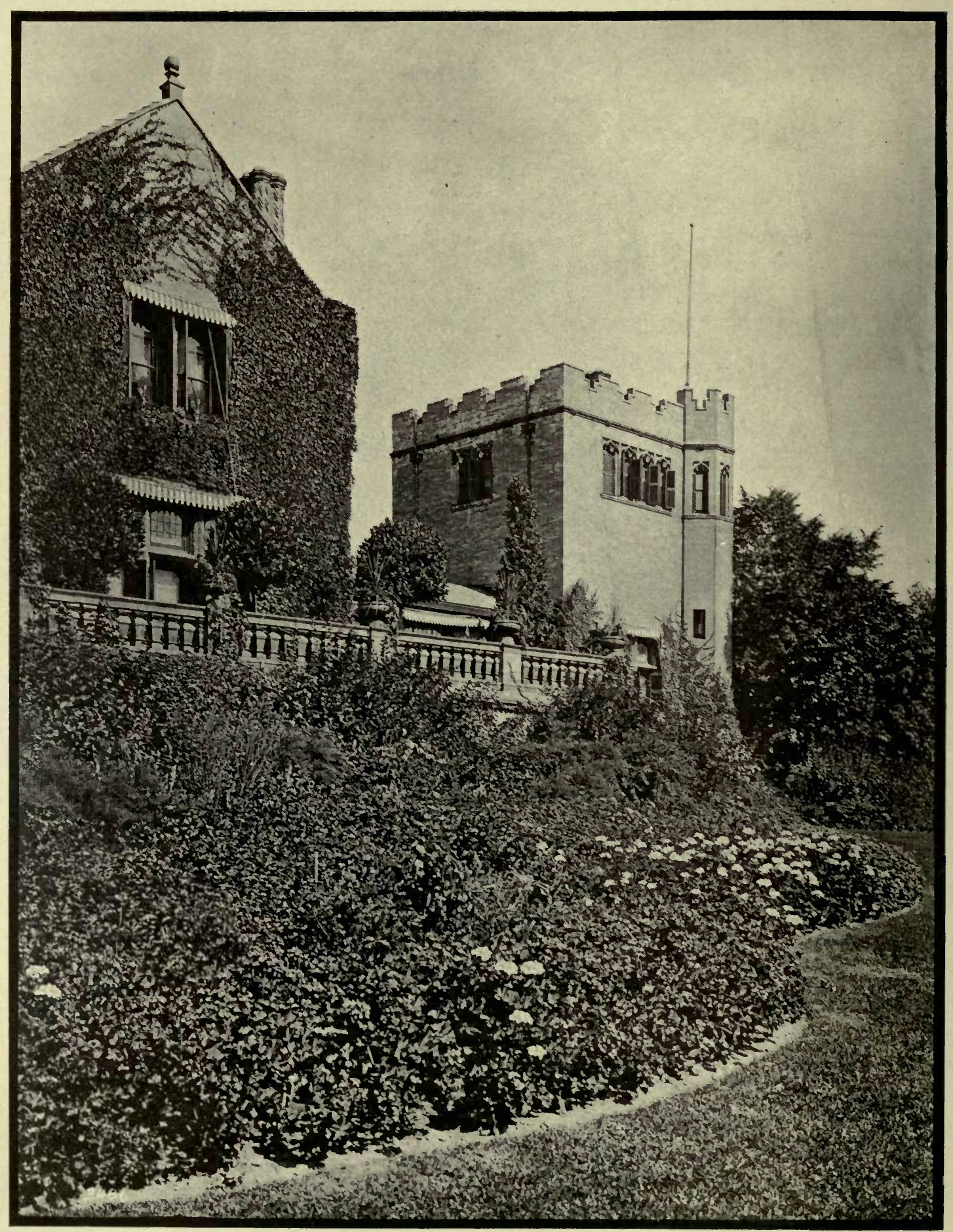

Plate III. A hardy border

A permanent plantation of woody and herbaceous plants, well grown and well placed. John Sloane estate, Lenox, Mass. 
the greater possibilities we have are due largely to our greater wealth in plants.

To have a good flower border is by no means an expensive undertaking if a few essentials are regarded.

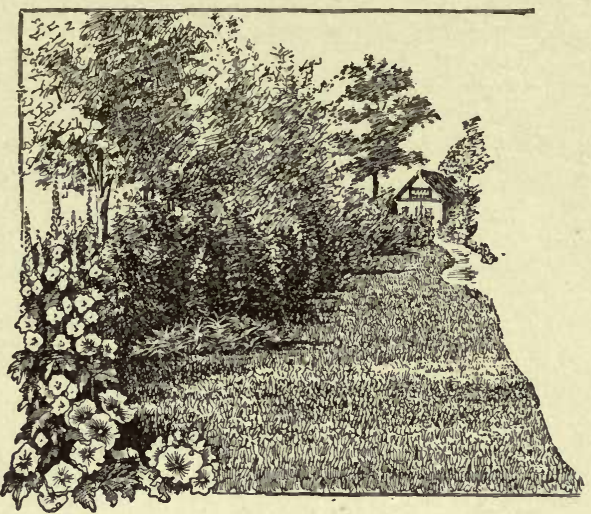

245. Border on the side of a lawn, the body of the plantation being made of shrubbery.

The first and most important requisite is a good depth of soil ; it matters little what the kind of soil, if good, but it is better, if possible, to vary the texture and be able to control the quantity of moisture. Lilies are among the most beautiful of border flowers, but they like a soil that is light, cool and moist; hence decayed humus, as leaf-mold, is valuable. Many other subjects, as annuals from warmer climates, like a soil that absorbs heat rapidly and retains it, such as a soil of a sandy texture. In this will thrive all bulbs that die down early in summer, such as tulips and narcissuses. It enables the bulbs to mature well and remain dry in winter, and to make an early start in spring. The great majority of plants, however, require a retentive compost, that will not dry out readily in hot weather, and it must be made rich enough to grow vegetable crops. One cannot starve the plant and expect a good harvest of bloom. If the natural soil be not really good or suitable, make it so. If it is not possible to do it all at once, begin well, and add to it as time goes on and the plants need the space, for it will be found that in a mixed border of plants which practically take care of themselves, there will always be plenty for one's own use, and a quantity of roots to spare.

The location of such a border is an important consideration so far as general effect and efficiency are concerned. Along the line of a fence or boundary, near the margin of a walk, drive, or avenue, or next the house, are good locations. The front line may be straight, curved or irregular in outline, according to the situation or fancy of the owner. The plants will lend themselves kindly to one or all forms, oftentimes forming a line of their own by outgrowing their al lotted space. The number of subjects suitable for this kind of work are many. Begin with the old-fashioned flowers, such as peonies, dicentras, larkspurs, perennial poppies, pyrethrums, iris, hemerocallis, and a host of others. Hollyhocks are most excellent, but in the East the disease or rust must be kept off by thorough spraying. The perennial garden phlox must be added, but see to it that it does not seed the bed and produce a tiresome crop of poor, weedy sorts. The same may be said of the larkspur. In fact, unless some specially marked flowers are wanted for seeds, it is best not to allow border plants to seed in the soil, for they speedily make trouble. Sweet-smelling plants are very desirable, such as bergamot, monarda, the perennial fennel, with its graceful foliage for blend. ing with cut-flowers, a little bush of rue, one of marjoram, a plant of the lemon-scented verbena or aloysia (which may be wintered over indoors), the scented geraniums, southernwood, and many others that have old associations, and help to take the memory back of self and friends. Spring flowers must not be neglected, as they "come before the swallow dares." Nareissuses in many kinds are hardy and permanent; so, also, are the Darwin tulips, even though unlike the florists' ideal. This recent race of tulips and those of the Gesneriana type live year after year and grow better, besides giving fine blooms for cutting. Crocuses may be placed near the margins in warm corners, planting over them or sowing a few seeds of annuals to cover the soil that hides them in summer. Stocks, zinnias, asters and mignonette are all admissible and most suitable, with a clump or row of sweet peas near the back at intervals. Gladioluses are excellent. The lilies ought to be planted in a group, to do them justice, and the bulbs can then be covered in fall with a coat of dry leaves or pine needles to protect them. The regal Japan iris needs much water, and may be given a special bed, where it can be supplied freely, other semi-aquatic plants being placed with them, provided the one border does not give the desired variety of soils; but the whole of the above-named plants may be made to grow in a mixed border if it be properly prepared.

One of the best uses of a border is to make it a re. pository or catch-all for hardy plants. Here plant wild asters and goldenrods, wild lilies and buttercups, and anything and everything which interests you in the woods or flelds. These plants may be dug even in summer. Cut off the tops, leaving a few leaves just above the ground, plant them firmly, and most of them will live. The border reflects the personality of its maker.

One caution must be given,-never spade up or fork over such a border. Let all enrichment be given as a top-dressing in fall, allowing the plants to come up through it as they will. The best time to plant is early in fall, before the soil loses its stored-up warmth, as the plants then get well established before spring; but if division and replanting are necessary, wait until things have made a visible start in spring, so that nearby plants are not injured by the

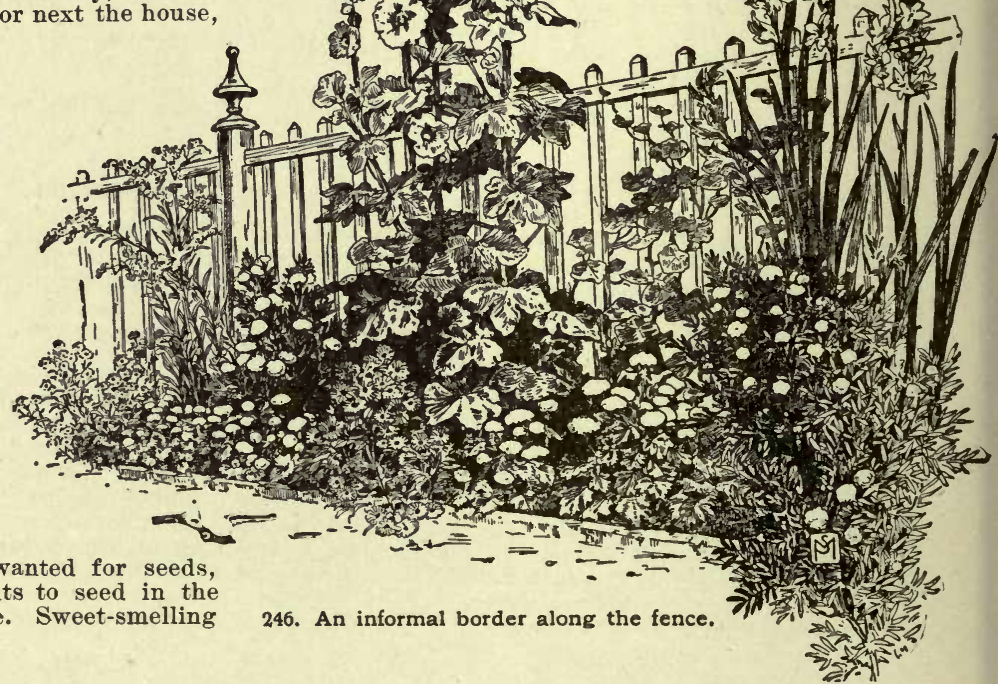


spade or fork. The border is an important conception in landscape gardening (see Landscape Gardening).

E. O. ORPET.

THE HARDY BORDER may be made a most attractive feature of any planting. A good model to follow may often be found along a country road which has not been "cleaned up" into formality and monotony. The charm of the hardy border lies as much in its happy faculty of change as in its beauty; every day of the growing season, and every week of the year, there appear new points of interest. It is apparently nature's workshop, and the changing habits of plants are of vital interest. It is always crowded, never full; the shy beauty found on a ramble takes its place promptly among the older friends. With a little care and previous observation, and reasonable preparation of the soil, the hardy border can be made to reflect the preferences and personality of the planter. The available material is so rich and plentiful that there need nerer be duplication. Nor is the best hardy border an expensive luxury; it requires no rare exotics, and its chief members may well be the common plants of the neighborhood, brought together under conditions which give each a chance for development. A border is recalled which shows as its chief glory in September an enormous boneset; visitors who exclaim at its beauty do not recognize the roadside weed. This particular border is most catholic in its hospitality to all American plants - no foreigners are allowed admission. In early spring the great fiddle-heads of the uncurling cinnamon ferns mate with the trilliums, and the moss-pink carpets the edge, alternating with the spring beauty and bluet. The columbines hang their bells against a rocky point, which later is a glory of wild roses. Shady corners have the laurels and the rhododendrons, and the warmth of early summer brings out the yarrow and the rudbeckia, just before the happy succession of asters and goldenrods start on their procession toward winter. No two days show the same blooms; often a visit in the afternoon gives a totally different impression from the morning view.

Artistically treated, and with care to keep out any of the formal and comparatively artificial plants (geraniums, coleus, verbenas, and the like), the hardy border may be a source of much enjoyment and edification, whether it be in a city back yard or a great park. Often an existing cluster of shrubs or bed of lilies in the home grounds may serve as a starting for the border; and some fine examples are remembered as incidental adjuncts to the farm vegetable patch, while one which has a most distinct individuality of beauty unobtrusively flanks a unique Connecticut grass garden.

To create an individual hardy border, the planter must direst himself of prejudice, and cheerfully start a burdock where its richness of foliage is needed, backed up with a skunk cabbage for greater breadth of green, if need be. He should estimate plants for their beauty, their individuality and their season of bloom, as mem bers of his general plan. He should be prepared to consider any plant a prize in the border if it fits, and any plant a weed if it is inharmonious.

\section{BORECOLE. See Kale.}

\section{J. Horace McFarlaxd.}

BORONIA (after Francis Borone, an Italian who lost his life at Athens in the service of Dr. Sibthorp). Rutacece. A genus of Australian shrubs with numerous fls. having a rue-like fragrance : lvs. opposite, odd-pinnate, or simple. $B$. megastigma and its allies, B. elatior and $B$. heterophylla, are remarkable for their very large stigma (which is 4-lobed at the base), and their curious stamens, 4 of which are small, yellow, pollen-bearing, and hidden under the stigma, while the 4 large, conspicuous ones are dark purple or black, and bear no pollen.

The chief value of Boronias is their delicious fragrance. A small specimen will perfume a whole house for two or three weeks. Boronias are cultivated like Cape heaths in a cool greenhouse. After flowering they should be cut back, in order to make compact, bushy specimens. The leading shonts may be frequently pinched, to prevent a straggling growth. As most of them are natives of barren, sandy places, not bogs, good drainage is necessary. Sour soil is very disastrous to them. The English florists set their young plants in the open ground during summer, being careful to shade them with lath frames. Plants that hare flowered two seasons are thrown away and replaced by younger specimens. Robert Cameron propagates them by cuttings from half-ripened wood inserted in 4 -inch pots, which are filled to within an inch of the top with a compost of finely sifted loam, peat and sand, over which is spread a layer of sharp sand. After a thorough watering, they may be placed under a bell-glass in a greenhouse where the temperature ranges from $45-50^{\circ} \mathrm{F}$; and shaded from bright sunshine. Seeds germinate readily in the same temperature, and make good flowering

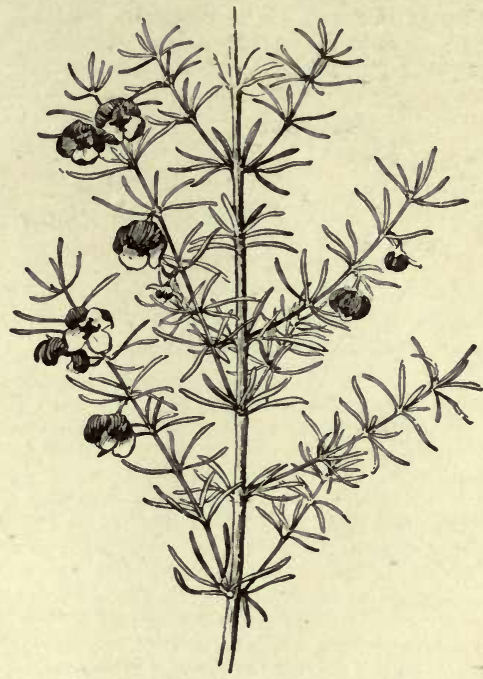

247. Boronia megastigma $(X 1 / 2)$

plants in one season. Seeds can be obtained from German or Australian dealers, large quantities being collected in the wild. Boronias belong to a large class of hard-wooded Australian plants that were popular along with the Cape heaths in the early part of the 19th century. These were largely replaced by quicker-growing, soft-wooded plants. The renewed interest in Boronias is largely due to the more recently introduced species, of which the first three described below are the best. American florists have lately grown them somewhat for Easter, especially $B$. heterophylla. Many species are likely to be introduced, as these shrubs are very brilliant in Australia, blooming when very young, and remaining attractive for two or three months. A. Stigmas large.
B. Lis. less than $1 \mathrm{in.}$ long: leaflets in 1 or 2 pairs, plus an odd one.
c. Fls, borne singly

megastígma, Nees. Fig. 247. Height about $2 \mathrm{ft.:}$ lvs. very sparse, $1 / 3-2 / 3$ in. long, sessile, the upper with one pair, the lower with two pairs of lfts. beside the end one ; lfts. narrowly linear : fls. maroon-purple outside, yellow within, borne less densely than in $B$. elatior. At times some fls. are chiefly brown, others chiefly purple. B.M. 6046. - The best species.

cc. Fls, borne in whorls of 4 or 6 .

heterophylla, F. Muell. Height 5-6 ft. in Australia : Ivs. $1-1 \frac{1}{2}$ in. long, sometimes simple, usually with 1 pair, rarely 2 pairs of lfts.: fls. bright scarlet, but usually pictured as purplish crimson. Differs from $B$. elatior and $B$. megastigma in its larger leaves, fewer lfts., more brilliant fls. and longer filaments. Cult. only in its var. brévipes, Hook, f., which differs merely in the shorter peduncles. B.M. 6845. Gn. 32:622.-Of late years it has been grown for Easter by florists to a considerable extent. 
B. Lvs. more than 1 in. long: leaflets in 2-6 pairs, plus an odd one.

elàtior, Bartl. Height about $4 \mathrm{ft}$.: pubescence variable : lvs. close-set, $1-2$ in. long, $1 / 2-3 / 4$ in. broad, petioled, with lfts. in 2-6 pairs : lfts. broader and shorter-acuminate than in B. megastigma : fis. dark red-brown, or rosy red, or purple, sometimes showing groups of widely different colors on the same branch, and borne so densely as to hide one side of the branch. B.M. 6285 . Gn. $10: 39$. F.E. 9: 491 .

\section{AA. Stigmas small.}

pinnàta, Smith. Lfts. in 2-4 pairs, very smooth, acute: peduncles dichotomous, 5-7-fld.: stamens 8 . B.M. 1763. L.B.C. 5: 473 .

tetrándra, Labill. Lfts. in 4-5 pairs, obtuse, glabrous: branches pilose : pedicels short, 1-fld.: stamens 4.

W. M.

BOSTON FERN. See Nephrolepis.

BOTANY. The science which treats of plants ; plantknowledge. In its widest sense, and properly, it in cludes much that, by common consent, is usually included in horticulture, - as amelioration of plants by domestication, hybridizing, and the like.

BOTRYCHIUM (Greek, in allusion to the grape-like sporangia). Ophioglossdcex. Native Ferns of woods and pastures, with fleshy roots, broad ternate lvs., and sporangia borne in a panicle, which branches from the common st. Grown in the hardy border, or against a building on the shady side. They require no special treatment, and are little cultivated.

A. Lf. ample, sessile near the middle of the stem.

Virginiànum, Swz. MooNwORT. Six in. to $2 \mathrm{ft}$. high, with a broad, triangular leaf, with 3 main tri-quadri-pin natifid divisions: sporophyl long-stalked. Eastern U. S. - The only species which is

large enough to make a display.

$(\times 1 / 2$.

\section{AA. Lf. stalked from near the base of the com-}

mon stem.

obliquum, Muhl. Fig. 248. Plant, 6-15 in. high, with a ternate If. 2-6 in. wide: segments obliquely ovate or oblong, $1 / 2-3 / 4$ in. long : sporophyll long-stalked. (B. ternatum, Authors, not Swz., which is a very different Japanese species.) Eastern U.S.

dissectum, Spreng. Plant, 6-18 in. high, with a ternate, finely dissected lf., $3-8$ in. wide, the ultimate divisions $\frac{1}{10}$ in. or less wide. Eastern U. S. - Evergreen; delicate and graceful. Grows in woods.

L. M. UNDERWOOD.

\section{BOTTLE-BRUSH. See Metrosideros.}

BOTTOM HEAT. Said of soil temperature which is higher than that of the superincumbent air. Most tender plants require to have the roots warmer than the tops, particularly when grown under glass.
B0UGAINVILL开A (De Bougainville, 1729-1811, a French navigator). Nyctagindcea. A half dozen or more species of S. American shrubs, with alternate petiolate entire lvs. The fls. are small and inconspicuous, tubular, the margin 5-6-lobed; stamens 7-8, on unequal capillary filaments ; ovary stipitate. Fls. in 3's, each one subtended by a very large colored bract. These bracts are very gaudy, and constitute the decorative value of the plants. Two more or less scandent species are chiefly known in cultivation. Bougainvilleas are just now receiving much attention in this country.

glàbra, Choisy. Fig. 249. Growing 10-16 ft. high and wide, when planted in the ground and allowed to have its way; glabrous : lvs. ovate and acuminate, glabrous and bright green : bracts cordate-ovate, bright rosy red, distinctly veined. Brazil. G.C. III. 23: 168. Gn.54, p. 257. R. H. 1889:276. A. G. 16:15. A.F. 11:137. F.E. 10: 106. - Free-flowering and handsome; often grown in pots and kept dwarf. Var. Sanderiàna, Hort. Very floriferous, blooming even in very small pots : bracts deeper colored. Gn. 45:962. A.F. $10: 307 ; 11: 977 ; 12: 1185$. Gng. $4: 281 ; 5: 345$. - A very worthy plant.

spectábilis, Willd. (B. specidsa, Lindl. B. spléndens, Hort.). Taller and stricter, with larger and thicker lvs., hairy : fls. in large panicles ; bracts larger, deep rose color, but varying to purple and greenish. Brazil. B.M. 4810, 4811. P.M. 12:51. I.H. 42:30. - Variable; known also as B. Brasiliensis, B. bracteata and B. Peruviana. Var, lateritia, Lem. (B. lateritia, Hort.), has brick-red bracts. I.H. 14:466. More showy than the last when in full bloom, but more difficult to grow, and, therefore, not so desirable. Int. to cult. earlier than B. glabra.

refúlgens, Bull. Lvs. pubescent : racemes long and drooping, and bracts purple. Brazil.-Perhaps a form of $B$. spectabilis.

L. H. B.

There is much confusion in species and varieties of Bougainvilleas in the trade. They seen to vary considerably. B. spectabilis and its varieties seem to be unpromising. Our experience with thousands of plants of B. glabra and var. Sanderiana leads us to say that we cannot think of any class of plants so readily handled.

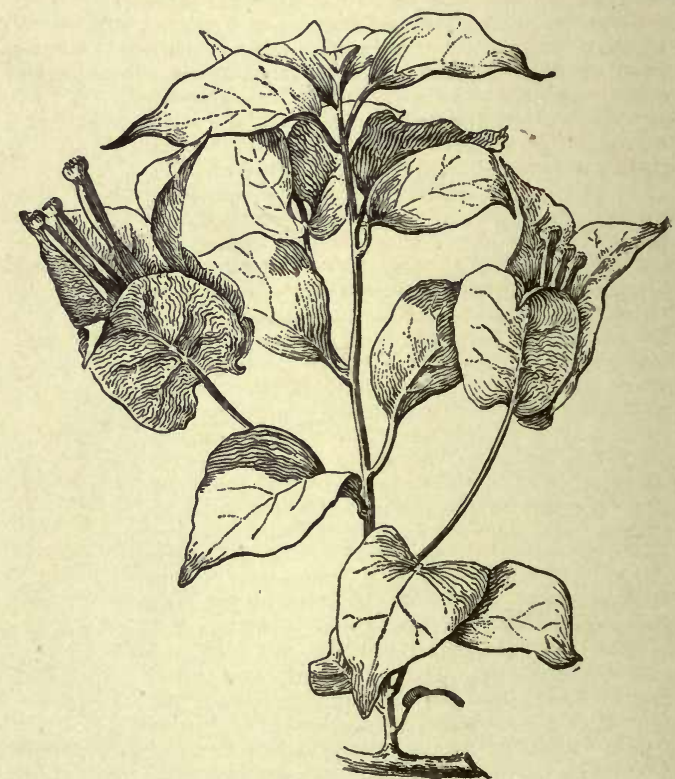

249. - Bougainvillaea glabra $(\times 1 / 2)$.

They are easily propagated, are not particular as to soil or treatment, their growth is strong and rapid, they can be flowered with ease and certainty, and they are but little subject to insect attacks. Their flowering character is so persistent that a small stock of plants will afford 
cutting material for almost six months. The bloombracts are extremely durable. They harmonize well with some of the popular orchids, and also go well with American Beauty roses. Entire heads of plants produce very decorative results, and are very satisfactory on account of their durability.

Bougainvilleas are propagated easily in April, May and June. Secure half-ripened or old-wood euttings - no wood is too old or too heavy and cut into $6-12$-in. lengths, or shorter if more attention is given to them. Place the lower part 2-4 in. deep in sand in an airy situation, fully exposed to the sun during April, with some bottom heat for this month. In May and June give no bottom heat, but slight shade should be given during the brighter hours of the day. The sand should be kept moist, not wet, and cuttings be syringed several times every day in bright weather. The foliage will drop mainly at the end of the first week; after the second week, roots may be seen. The time of rooting varies from 12 to 30 days, according to conditions. In propagating in quantity, it is advisable to grade the wood according to ripeness, enabling the removal of the same from sand with less trouble and loss of time. For first potting, use a light, sandy loam, with pots to suit the roots ; place in a sunny situation, keep them on the dry side for a week or so, giving light syringing daily, and shade during midday hours. In four or five weeks they can be shifted to larger pots, and water may be given more freely; after this they can be shifted almost monthly. From the time they are in 5 in. pots they should have careful drainage, as they will want daily syringing and a free supply of water. They should be grown with full sun exposure under glass, and plenty of air, and in July and August may receive almost daily drenchings of water. All growths should be exposed to the sun by occasional turning of plants; this secures a ripened condition of wood, which is essential to best results. So grown, every shoot will flower freely. If crowded or shaded, satisfactory results are risked. The aim should be to secure strong, well-ripened growths by the last of October. For earliest bloom, plants may be held drier from this time on, but in the case of B. glabra not enough to yellow the foliage, unless in very strong plants. With a little experience, the earliest rested plants can be flowered for Christmas, and others can be brought in successively. The new growths will afford cut-flower material until midsummer. In June, the flowering plants should be held as cool and airy as possible, but not shaded or only slightly so. If held too warm or dry, the bracts drop in a short time. After the flowering season is all completed, the plants may be held dry for a week or ten days; then all old soil should be removed, the roots and tops pruned to suit, and the plants repotted to smallest suitable pots, with perfect drainage. Then treat exactly as for a rooted cutting. As an excess of water is injurious at this stage, shade for a few days and syringe frequently. Keep on the dry side-until the foliage indicates that water may be given more freely. Hundreds of eyes will push from strong plants; and the plants will soon make rapid growth, when they may be syringed and watered daily. A yellowish foliage is evidence of too much water, but this will hardly occur with plants thoroughly drained and exposed to the full sun. Growths may be pinched according to the end in view.

Strong, well-ripened shoots of B. glabra, tied horizontally, produce numerous laterals, whose inflorescence is very distinct in character from the earlier bloom, clusters of intense mauve bracts crowding the shoots, offset by the dark green, glossy foliage. The arrangement or disposition of the bracts on such shoots is a revelation of beauty compared with the more familiar form. B. glabra is generally spoken of as a climbing plant, which may apply in a large state or when the plant is unrestricted as to root room. In pots up to 12-15 in. we have frequently seen shoots $20-25$ ft. long, but these always prove mainly selfsupporting. Both $B$. glabra and its variety make distinct and extremely showy subjects for the lawn. In a partially sheltered situation they could be held in fair condition for at least a month.

B. glabra, var. Sanderiana, has proved valuable as a decorative plant, particularly for Easter, as it can be flowered unerringly, and possesses the merit of being durable for weeks, $-a$ decided advantage over most subjects grown for that season. B. glabra also may be grown into showy specimens, but, being less compact than Sanderiana, requires more attention to secure shapely plants. It should be noted that $B$. glabra, - on account of the larger size of the bracts (fully three times as large as those of Sanderiana) and their arrangement on the branches, offset by luxuriant glossy foliage,-appears to be the most desirable variety for cutflower material: while Sanderiana. from its elegant, compact habit, affords a splendid subject for pots.

Theo. F. Beckert.

BOUSSINGAÙLTIA (J. B. Boussingault, born in 1802, a famous agricultural chemist). Chenopodidcea. A few tropical American climbing herbs. Fls. small, perfect, with a 5-parted, shorttubed perianth, 5 stamens, and 3 divided style, in long racemes. Lvs. alternate, thick, entire.

baselloides, HBK. MADEIRA VINE. Mignonette Vine. Fig. 250. Perennial, root tuberous: stems smooth and twining, reaching 10-20 ft. in a season, and in late summer or fall bearing profusely of the fragrant white fis. (which become nearly black with age), and producing little tubercles, by means of which the plant is propagated. Equador. B.M. 3620.-A common vine, prized for porches and arbors. The roots are stored in the winter, and planted out after danger of frost is past. The plant will not endure frost. Sometimes grown in the conservatory and window garden.

L. H. B.

BOUVÁRDIA (Dr.Charles Bouvard, physician to Louis XIII. and superintendent of the Royal Gardens in Paris). Rubidcece. Between 20 and 30 American 250. Madeira Vine, or Boussingaultia. (chiefly Mexican) shrubs or per$\left(X^{1} / 3.\right)$ ennial herbs. Mostly tropical, but some of them range as far N, as Texas. They have entire and mostly sessile, opposite or verticillate lvs. with small stipules interposed, and terminal cymes of long-tubular fls, with 4-parted limb (lobes becoming more numerous in cult.), 4 stamens, and 1 style with a slightly 2-lobed stigma.

Bouvardias are verv useful late fall or early winter- 
flowering greenhouse plants. Though they may be propagated by cuttings inserted in sand in a propagating frame with bottom heat, yet a better and more expeditious way is to cut up the largest roots of a healthy plant into pieces about 1 inch in length, placing them thickly in pans of light, peaty soil and covering them to the depth of 1 inch with the same misture. If the pans are then placed in a warm temperature with bottom heat, every piece will quickly develop one or more buds and grow into a young plant. March is perhaps the best time for propagating. As soon as the young plants are well rooted they should be potted singly into small pots and grown along in a temperature of about $60^{\circ}$. By the end of May the plants may be planted out, either in spent hotbeds or frames prepared with a goodly proportion of leaf-mold mixed with the soil, if fine pot plants is the ultimate aim ; or if grown for cut-flowers only, they may be planted out in the greenhouse benches about 15 inches apart, giving al the air possible and a plentiful supply of moisture. In both cases, the plants must be kept well pinched back to induce a bushy habit, and also to insure a greater profusion of flowers. Towards the end of September those intended for pot plants should be lifted and potted and placed in a close frame for a week or ten days, keeping them moist and well shaded until they have recovered from lifting. Before the approach of frost they should be removed to the greenhouse and given a temperature of $50^{\circ}$. They are very subject to the attacks of mealy bug and green fly. They therefore should be sprayed once a week with an insecticide, with a vaporizer sprayer, choosing fine mornings for the operation. After flowering, the plants should be rested by keeping them almost dry. 'Towards the end of April they should be well pruned back, and in May again planted out for the summer. The same plants may be grown in this way for several years, when in 4 or 5 years' time they will make very fine specimens.

\section{Cult. by Edward J. Canning.}

The Bouvardias of florists do not represent any of the type species. They are sports, hybrids, and other types of variations. The Latin-form names in American trade catalogues nearly all belong to these garden forms. The species which are of most import to the horticulturist are mentioned below:

$$
\text { A. Fls. in shades of red. }
$$

B. Lvs. normally in s's (except, perhaps, on the branchlets).

triphylla, Salisb. (B. Jácquini, HBK.). Small pubescent shrub, 2-6 ft. high : lvs. in 3's or 4's (or oppo-

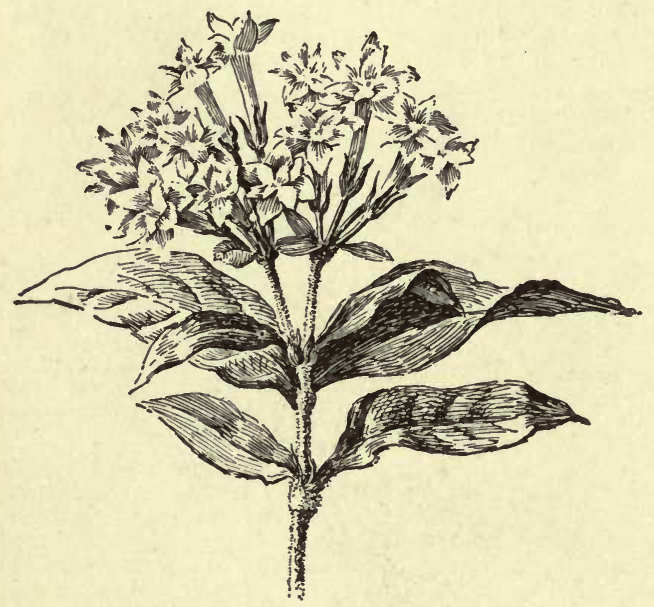

251. Common garden form of Bouvardia. Terminal truss.

site on the branchlets), lanceolate to lance-ovate,glabrous above: fls. an inch long, pubescent, red. Mex., and reaching N. to Ariz. B.M. 1854 ; 3781 as B. splendens, Grah.
- The genus Bouvardia was founded upon this species, which was introduced into England about 100 years ago. It is evidently the most important parent strain, although it is probably not in cult. in its original form. Figs. 251 and 252 partake very strongly of this species. In fact, Fig. 251 compares well in botanical characters

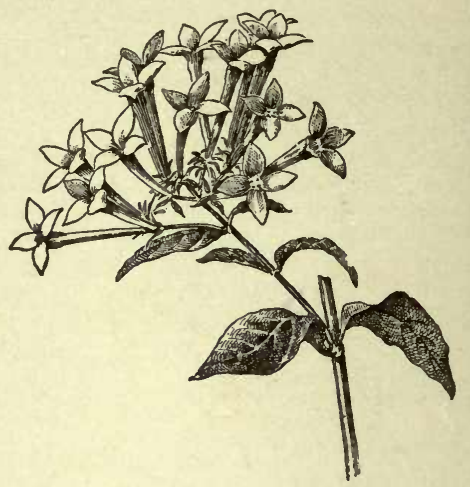

252. Bouvardia

Cluster from a side growth.

(except less long-pointed lvs.) with the early pictures of B. triphylla.

leiántha, Benth. Much like B. triphylla ; more bushy and better grower : stems hairy : lvs. hairy above : fls. glabrous. Mex. R.H. 1851: 81. - Perhaps only a form of the preceding.

Other red-fld. 3-lvd. species are: B. angustifolia, HBK. Lvs. lanceolate, revolute, glabrous above and fine-pubescent below : branches nearly glabrous. Mex. B. hir télla, HBK. Very similar : lvs. pubescent on both surfaces. Mex. B. scabra, Hook. \& Arn. Lvs. ovate, short-stalked: fls. large, in dense clusters, pink : stem hairy. Mex.

$$
\text { B. Lvs. opposite. }
$$

Cavaníllesii, DC. (B. multiflòra, Schult.). Hairy: Ivs. ovate-acuminate, broad at base, short-stalked, edges hairy: fls. $1 \frac{1}{2}$ in. long, very slender, glabrous. Mex.

$$
\text { AA. Fls. yellow. }
$$

flàva, Decne. Lvs. opposite, ovate-lanceolate or lanceelliptic, very short-stalked, ciliate : fls. very long, drooping, in 3-5-fld. racemes, bright yellow. Mexico. F.S. $1: 43$.

$$
\text { AAA. Fls, white. }
$$

longiflora, HBK. Glabrous, branching shrub : Ivs. opposite, ovate-acuminate, stalked : fls. 11/2-2 in. long, with a very slender tube and a wide-spreading, large limb, 2 or 3 together and aggregated into a terminal cyme. Mex. B.M. 4223. F.S. 2:123.-Gray supposes (Proc. Amer. Acad. Arts and Sci. iv., p. 314) that this species belongs to the genus Houstonia. Not known to be in the American trade.

Húmboldtii, Hort. Lvs. opposite, ovate-acuminate : fls. very large, fragrant, in a large, terminal cluster. G.C. 1873:717. - This is a choice conserratory plant, and is in the Amer. trade. It is usually catalogued as $B$. Humboldtii corymbiflora. Blooms from summer to winter. Probably a derivative of $B$. longiflora. B. candidissima, Hort., white-fld., is said to be a hybrid, with $B$. Humboldtii as one of its parents.

jasminiflora, Hort. Compact and dwarf, very floriferous, the fls. in close, terminal clusters. G.C. 1872:215. - Probably a derivative of $B$. longiflora.

L. H. B.

BÖWIEA (after J. Bowie, collector for Kew). Liliàcea. A monotypic genus containing one of the most curious plants in the vegetable kingdom. A round, green bulb 4-5 in. thick throws up yearly a very slender, twining flower-stem 6-8 ft. high, with many compound, forked, curving branches below, and numerous small green fls. above. The st. is somewhat asparagus-like. There are: 
no lrs. except two small, linear, erect scales at the apex of the bulb, which quickly vanish. The Irs, show its relation to Drimia and Scilla.

volùbilis, Harv. Fig. 253. Perianth 6 -cleft to the base: segments incurved at the tips. S. Afr. B.M. 5619.Sold by Reasoner Bros., Oneco, Fla., and cult. in botanic gardens with cactus-like Euphorbias and other curiosities.

W. M.

Boviea rolubilis is a useful plant for twining on the supports of a moderately warm greenhouse, and is of the easiest possible culture. Propagation is effected by

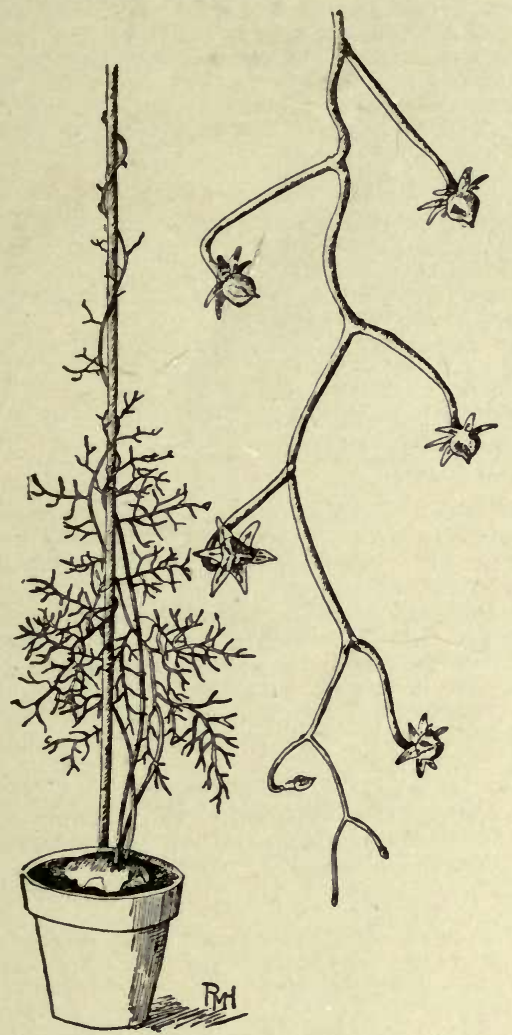

253. Bowiea volubilis.

seeds, or occasionally by the natural division of the bulbs. The season of growth nsually begins about the first of October, when the bulbs should be repotted in any light, rich soil, and kept well watered until the stems begin to mature, which usually occurs in May, when water should be gradually withbeld, and the plants stored away in some shaded part of the greenhouse and kept quite dry until the season of growth begins again.

Edward J. Canning.

\section{B0X. See Buxus.}

BOX ELDER (Acer Negundo, which see). Fig. 2 5̈4. A very popular small native tree for planting on the prairies and in trying climates. It propagates most readily from seeds. It is an excellent nurse tree for other species. The wood is of inferior quality. It grows with great rapidity for a few years.

BRACHYCH \&̀TA (Greek, short bristle). Compósitoe. One species, growing in open woods from $\mathrm{Ky}$. to N. C. and Ga. Closely allied to Solidago, from which it differs in the very short pappus (the bristles shorter than the akene), and the lower lvs, cordate. B, cordàta, Torr. \&
Gray, which has been int. by dealers in native plants, is 2-3 ft. high, soft-pubescent, with thin, serrate lvs. fls. golden yellow, in small heads, which are borne on raceme-like secund branchlets. Recommended for the native border.

\section{BRACHYCOME (short} hair, from the Greek, alluding to the pappus). Compositce. Australian herbs, with membranaceous involueral bracts, naked receptacle, very short pappus bristles, and diffuse leafy growth. One species in cult.:

iberidifolia,Benth. SwAN RIver DaISY. Figs. 255, 256. A very graceful little annual ( $6-12$ in. high) from Austral., suited to borders, and also attractive in pots; seeds may be sown in the open or under glass. Fls. blue or white, an inch across: lvs. small, pinnate, with very narrow divisions ; glabrous.

L. H. B.

BRAHEA (Tycho Brahe, the astronomer). Palmacea, tribe Coryphea. Spineless palms, with medium caudices, ringed below, and clothed above with the bases of the fibrous sheaths. Leaves terminal, orbicular, somewhat peltate, flabellate - plicate, split down the middle, the lobes bifid, infolded, filamentous on the margins; rachis short, narrow; ligule subtriangular; petioles flattened, dentate along the margins ; sheaths fibrous: spadices long, pendulous, paniculately much branched, the ultimate long vermiform obtuse branches rigid, spreading, very densely velvety tomentose : spathes many, long linear, firm, coriaceous, split, glabrous; bracts and bractlets minute: fls. smaller than the diameter of the branches, hidden in the tomentum: frs. $1 / 2$ in. long, obliquely ellipsoidal, minutely pubescent, laterally keeled, pale when dry. Species 4 , Mex. to the Andes. Of simple culture in a fibrous compost, with an admixture of sand. Prop. by seeds.

dúlcis, Mart. Palma Dulce. Stem 10-20 ft., 6-8 in. thick, cylindrical: lvs. 4-5 ft. long; petiole plano-convex, green, with pale margins; ligule short, subtriangu-

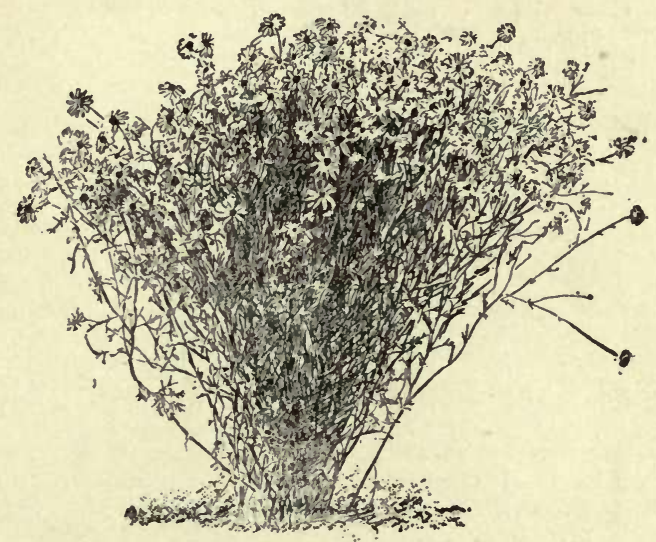

255. Brachycome iberidifolia. 
lar, green, the scarious villous margin at length deciduous: fr. edible. Mex.

B. filamentòsa, Hort. $=$ Washingtonia filifera. $-B$. filifera Hort. $=\mathrm{W}$. filifera. $-\boldsymbol{B}$. glauca, Hort $=$ Washingtonia filifera.B. robuista, Hort, = Washingtonia. - B. Roezlii, Lindl.(B. glauca, Hort.) $=$ Washingtonia filifera. JARED G. SMITH.

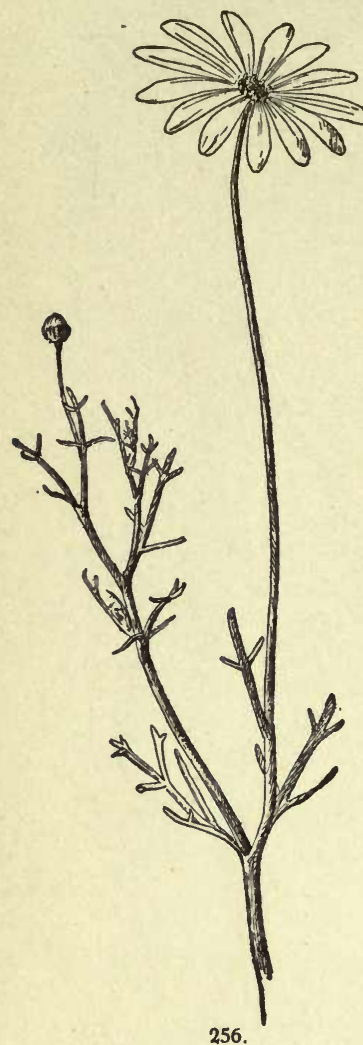

Brachycome iberidifolia.

Natural size.
BRAKE. A name applied to various coarse ferns, particularly to Pteris aquïlina.

BRAMBLE. Thorny plants of the genus Rubus,-raspberries, blackberries, dewberries.

BRASENIA (meaning unexplained). Nymphodcec. WATER SHIwLd. One species of aquatic plant widely distributed (in $\mathrm{N}$. Amer., Asia, Afr., Austral.). Lvs. oval and entire, floating, centrally peltate : fls. axillary near the summit of the stem, small, purple; sepals 3 or 4 ; petals 3 or 4 , linear ; stamens 12-18, on filiform filaments ; pistils 4-18, forming indehiscent follicles. B. peltàta, Pursh, is not a showy plant, but is interesting for ponds. It is catalogued by dealers in native plants. Grows in 1-6 ft. of water.

L. H. B.

BRASSÁVOLA (A, M. Brassavola, Venetian botanist). Or chidacea, tribe Epidéndrea. About 20 Trop. Amer. epiphytes, closely allied to Lælia, and demanding similar treatment. Suspend on blocks. The fls, are large, solitary or racemose, the sepals and petals narrow and greenish, the lip white: lvs. thick, solitary. For the cultivator, the treatment of Brassavola is identical with that of the Mexican Lælias. Plenty of sun to mature the young growths, and water when growing, with a somewhat drier atmosphere when resting, will

be found to suit them. B. Digbyana, Lindl., is Lalia Digbyana; B.glauca, Lipndl., is Loelia glauca.

\section{A. Flower solitary.}

cucullata, R. Br. (B. cuspidata, Hook.). Leaf terete and subulate, grooved above: scape very short but bearing a very long-tubed fl., so that the blossom seems to be elevated on a stem: sepals cream-colored, tinged red; petals white; lip 3 -lobed, fimbriate, the middle lobe beak-like. S. Amer. B.M. 543, 3722.

\section{AA. Fls, in racemes on corymbs.}

acaùlis, Lindl. \& Paxt. Low: lvs. very narrow: fls. large, greenish white; lip cordate; tube red-spotted at base. Cent. Amer.

cordàta, Lindl. Lvs. linear, rigid, recurved: fls. corymbose; sepals and petals lance-linear, acuminate, pale green; lip roundish-cordate, cuspidate, entire, scarcely as long as the claw. Jamaica, Braz. B.M. 3782.

nodosa, Lindl. (B. grandifldra, Lindl.): Lvs. lanceolate, acuminate, channeled above : fls. few and large, corymbose; sepals and petals linear-acuminate; lip round-ovate, long-cuspidate, entire, longer than the claw. Jamaica, Mex., S. B.M. 3229, of this name, is $B$. subulifolia.

L. H. B.

BRÁSSIA (William Brass, botanical collector of last century). Orchiddcece, tribe Vandeo. About 30 'Trop. Amer. plants, closely allied to Oncidium. Distinguished from that genus by the very long and pointed sepals and the wingless column. The fls, are odd and spiderlike in form, and are cultivated chiefly for that reason. They can be grown with Cattleyas. They bloom in summer, and during that time should have liberal supplies of water. Keep them quiet in winter, but do not dry them off completely. Grow in pots with thorough drainage, in a soil of fibrous peat and sand. Prop. by division.

The Brassias succeed well in the Orchid house devoted to Cattleyas, one that is not too warm in winter and furnishes plenty of air during the warm months. They have not been popular in gardens, as their flowers lack brilliant coloring, but their shape is weird, and to the collector they have charms that are almost as alluring as the Odontoglossums. Pot culture is best, as the plants make fine specimens, and are vigorous root-producers. B. Lawrenceana and its variety longissima, with $B$. verrucosa, are the best known in gardens, and are most desirable from a cultivator's standpoint.

Cult. by E. O. ORPET.

A. Sepals and petals whitish or greenish.

verrucòsa, Batem. Fig. 257. Strong : foliage deep green: fls. many and large, the greenish white petals and sepals blotched with dark purple, the lip white and warty. Guatemala. Var. grandiflora, Hort., has fls. twice larger than in the type.

AA. Sepals and petals greenish yellow.

maculàta, R. Br. Sepals and petals pale or greenish yellow, short for the genus, marked with large, irregu-

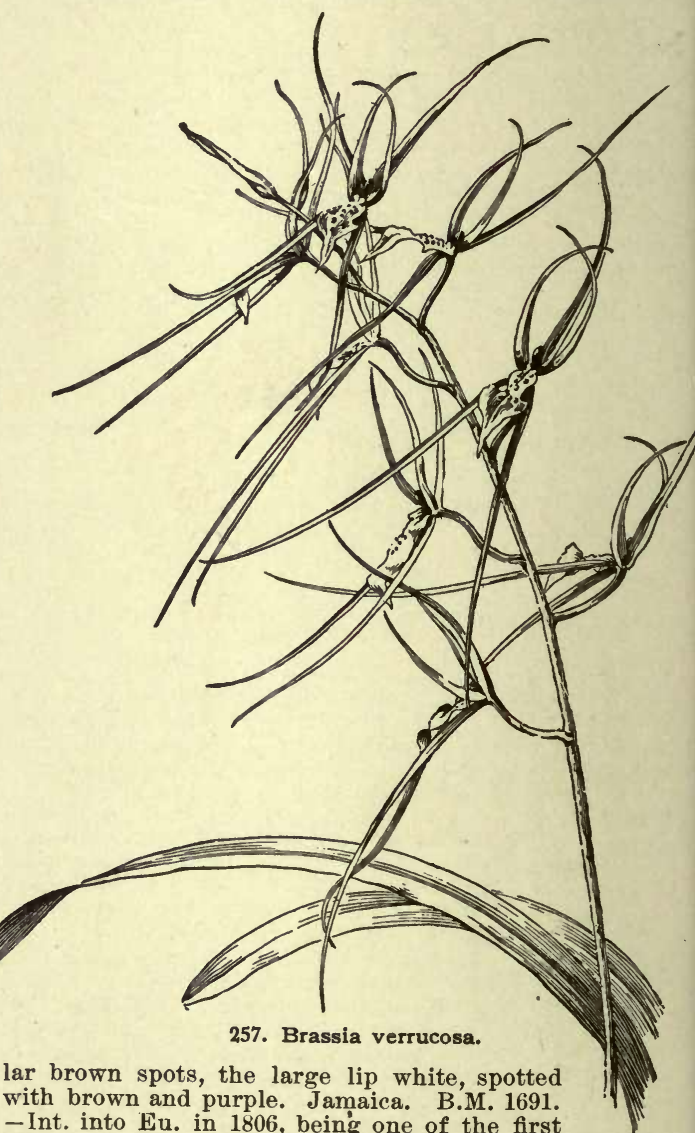
-Int. into $\mathrm{Eu}$, in 1806 , being one of the first known of exotic Orchids. Flowers large, but not very showy.

Var, guttàta, Lindl. (B. Wràyø, Skinner). Fls. greener, much spotted, lip yellowish : spikes $2-3 \mathrm{ft}$. high. Guatemala. B.M. 4003. 
AAA. Sepals and petals clearer yellow.

caudàta, Lindl. Spikes drooping, 12-18 in.: sepals and petals very long ( $4-6$ in.), barred with brown; lip yellow and broad spotted. W. Ind. A.F. 6: 609.

Lanceàna, Lindl. Robust, with 2 dark green leaves from each pseudobulb: fls. large and numerous, very fragrant, lasting 2 or 3 weeks; sepals and petals bright yellow, long and tapering, blotched with brown or red, the lip yellow and wavy, spotted at the base. S. Amer. B.M. 3577.-A handsome species. There are two or three varieties.

Lawrenceàna, Lindl. Sepals and petals bright yellow, spotted with brown and green; lip yellow tinged with green : otherwise much like the last. Braz. J.H. III. $30: 275$.

Var. longíssima, Reichb. f., has a spike 18-20 in. long, and very slender sepals, which are 6 or 7 in. long, the lip purple-spotted near the base. Costa Rica. B.M. 5748. - A remarkable plant.

Gireoudiàna, Reichb. f. \& Warse. Large, with manyfld. scapes: fls. larger than in $B$. Lanceana, the sepals and petals very long, they and the lip bright yellow, blotched with deep red. Costa Rica.

L. H. B.

BRÁSSICA (old elassical name). Cruciferce. Probably 100 species of annual, biennial and perennial herbs, natives of temperate regions of Europe, Africa, and Asia. Petals and stamens 4: pod long, beaked : seeds not winged (Figs. 258, 259). Includes all the mustards, cabbages, turnips, and the like ; and to these plants the reader should refer for other information.

In common with nearly all cultivated plants, especially those which are perplexing, the Brassicas have received too little attention from botanists. The inevitable outcome of such neglect or of any superficial study is a reduction of species, and in this direction Brassica has suffered greatly. It is usually confusing to reduce types. The most perplexing species in our manuals are those which contain the greatest number of old types or synonymous names. It is true that this is supposed to
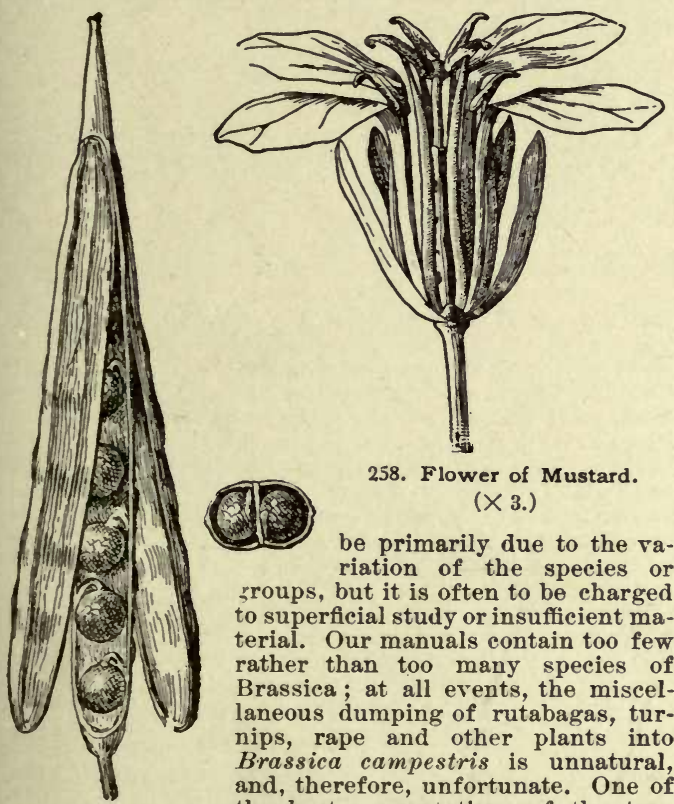

258. Flower of Mustard.

(X 3.)

be primarily due to the variation of the species or yroups, but it is often to be eharged to superficial study or insufficient material. Our manuals contain too few rather than too many species of Brassica ; at all events, the miscellaneous dumping of rutabagas, turnips, rape and other plants into Brassica campestris is unnatural, and, therefore, unfortunate. One of the best presentations of the true 259. Pod or silique Brassicas is that of De Candolle's of Mustard-Brassica Prodromus, as long ago as 1824 (also

juncea $(\times 2)$. in Trans. Lond. Hort. Soc. vol. 5 , following scheme and in Systema, 2:582-607), and the of the forms which are here kept separate as speeies may be derived from their fellows, but the evidence of such origin is lost, and perspicuity demands that they be kept distinct in a horticultural treatise.

The confusion into which our Brassicas have fallen is

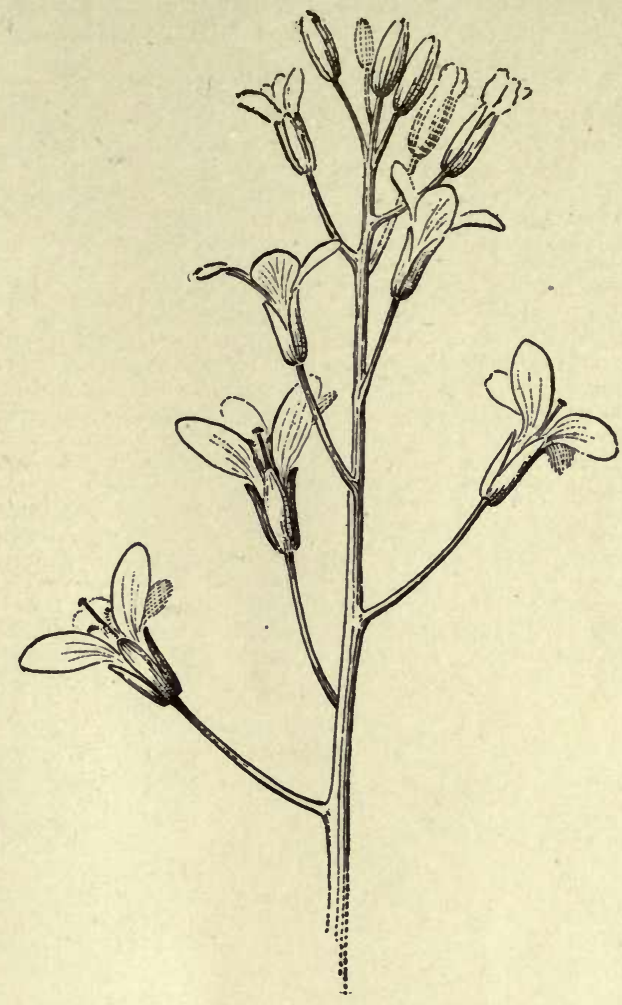

260. Flowers of Cabbage - Brassica oleracea $(X 1 / 2)$.

in some measure due to the different vernacular names which they bear in different countries. The French use the word chou generically to include all forms of $B$. oleracea and the rutabaga-that is, all the blue, thickleaved Brassicas-while in England the rutabaga is ealled the Swedish Turnip. A tabular view of the different vernaculars may be useful:

French. English. American.

Chou Cabas, Cabbage,

Chou de Milan

Savoy, Savoy Cabbage.

Brussels Sprouts, Brussels Sprouts.

Choux-verts, Borecole or Kale,

Chou-rave,

Borecole or Kale, Borecole or Kale.

Chou-navet,

Chou-flear. Turnip Cabbage

or Kohlrabi, Kohlrabi. Turnip-rooted $\left.\begin{array}{l}\text { Cabbage or } \\ \text { Swedish Turnip }\end{array}\right\}$ Rutabaga. Cauliflower, Cauliflower. Navet(or Chou-navet), Turnip, Turnip.

A. Whole plant glaucous-blue when in flower: lvs. of the flower-stems clasping: fls.various. (Brassica proper.)

B. Lis. from the first more or less fleshy throughout, and glaucous-blue even when young: fls. large and creamy yellow, the petals conspicuously longclawed, and the sepals usually erect.

oleràcea, Linn. CABBage, Cauliflower, Brussels Sprouts, Kale. Fig. 260. Lvs. smooth from the first, and the root never tuberous. Sea shores of the Old World, and naturally perennial. See Cabbage.

Napus, Linn. RAPE. Lvs. smooth from the first; differing from $B$. oleracea chiefly in habit and more deeply scalloped lvs. The botanical position of the Rapes is open to doubt.

campéstris, Linn. Rutabaga. Fig. 261. First lvs. hairy, the root usually tuberous. 
BB, Lvs. (except upon the flower-stem) thin and green: fls. smaller and bright yellow, less prominently clawed.

c. Plant potentially biennial (that is, the root hard and thickened, often distinctly tuberous): foliage firm in texture.

\section{Foliage distinctly hairy.}

Ràpa, Linn. Common TuRNIP. Lvs, prominently Iyrate or interrupted below, the root tuberous. - Whatever the origin of the Rutabaga and Turnip may be, the two plants show good botanical characters. The tubers of the two are different in season, texture and flavor. In the Rutabaga, the small leaves immediately following the seed-leaves are sparsely hairy, but all subsequent leaves are entirely smooth, densely glaucous-blue, thick and cabbage-like, with a fleshy petiole and midrib. In the Turnip, the radical leaves are always more or less hairy, and they are green and radish-like, thin, with slender petiole, and the leaves are much more lyrate, with interrupted leaflets on the petiole; the small leaves following the seed-leaves are also thinner and narrower and more deeply scalloped. In the Rutabaga, the flowers are large and more cabbage-like, whereas in the Turnip they are small, yellow and mustard-like, with shorter claws and more spreading calyx. The Turnips vary in hairiness, but the cone of expanding leaves, or the "heart-leaves," always shows the hairs distinctly, while the heart-leaves of the Rutabagas are entirely gla-

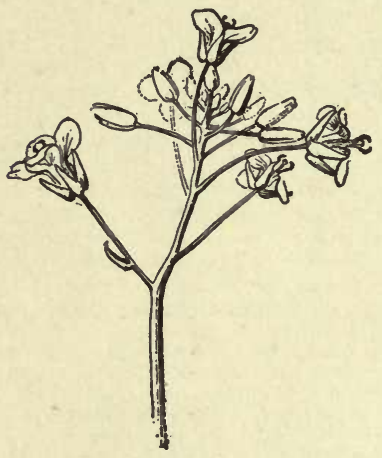

261. Flowers of Rutabaga -

Brassica campestris $(\times 1 / 2)$. feathered petioles, sharply and irregularly toothed, with a thin bloom: beak of the pod more abrupt : root distinctly hard and tuberous. - This vegetable appeared in France in 1882 from seeds sent by Dr. Bretschneider, of the Russian legation, Pekin. It was offered by Amer. seedsmen as early as 1889. The plant is a biennial, with thin, bluish foliage, and a small tuberous root like a conical turnip. These roots reach a diameter of 3 or 4 inches, and are scarcely distinguishable from white turnips in appearance, texture and flavor. In China the tubers are used as a winter vegetable, the seeds being sown in summer. The plant is native to China. It does not appear to have been brought to the attention of botanists until Bretschneider published an account of it in a French journal in 1881. Paillieux and Bois (Le Potager d'un Curieux) regard it as a variety of Brassica juncea, to which the Chinese mustard belongs, but it is very different from that plant. It is nearly related to Pak-Choi, and it may have sprung from the same species; but it is clearly distingulshed by its sharply toothed Ivs., one of which is shown in Fig. 264.

cC. Plant truly annual: foliage profuse, loose and soft.

Pe-tsài, Bailey. Pe-tsai CabBage. Fig. 265. Numerous radical lvs., large and light green, oblong or ovate-oblong, crinkled and very veiny, and the mar. gins wavy, contracted into a flat and ribbed petiole $1-3$

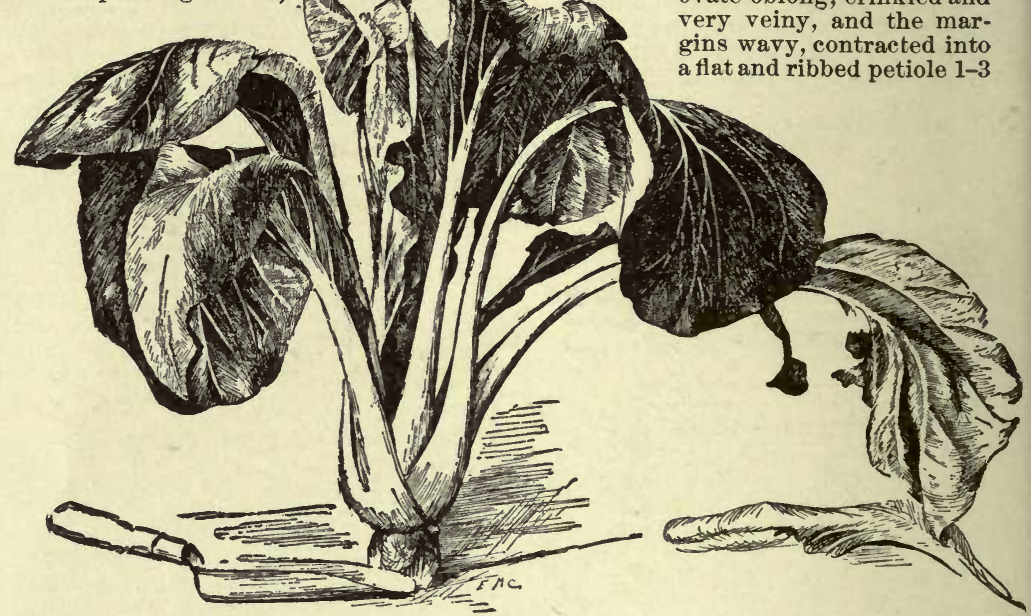

262. Pak-Choi-Brassica Chinensis. brous, fleshy, and remind one of the young shoots of sea-kale. The Turnip usually produces seed freely if the bottoms are left in the ground over winter: and thereby the plant spreads, becoming a true annual and a bad weed, with a slender, hard root.

\section{DD. Foliage not hairy.}

Chinénsis, Linn. Pak-Chor CABbage. Figs. 262, 263. Radical lvs, wavy and ample, glossy green, obovate or round-obovate in general outline, either entire or obscurely wavy or even crenate, tapering to a distinct and thick, strong petiole, which is generally not prominently margined; pod large and tapering into a beak half an inch long; root sometimes tuberous. - This plant is grown by the American Chinese, and is occasionally seen in other gardens (see Bailey, Bull. 67, Cornell Exp. Sta.). It is impossible to determine if this particular plant is the one which Linnæus meant to distinguish by his Brassica Chinensis, but it best answers the description in his Amœnitates (vol. 4). In Linnæus' herbarium is a Brassica marked "Chinensis" in his own handwriting, but it is purple-fld. and has lyrate-lobed lvs., whereas Linnæus described his plant as having yellow fls. and Cynoglossum-like lvs.

napifórmis, Bailey (Sindpis jüncea, var. napiformis, Paill. \& Bois). Tuberous-rooted Chinese Mustard. Fig. 264. Radical lvs. comparatively few, the blade thin and oval in outline, and on long and slender, slightly in. wide, which is provided with a wide, thin, notched or wavy wing; stem lvs. sessile and clasping; pod of medium size, with a short cone-like beak. - The Pe-tsai, or Chinese Cabbage, is no longer a novelty in Amer. gardens, although it does not appear to be well known, and its merits are not understood. Its cultivation and peculiarities were described in France as long ago as 1840, by Pépin, who says that, while the plant had been known in botanic gardens for 20 years, it was brought to notice as a culinary vegetable only three years before he wrote. It appears to have attracted little attention in Europe until very recent years, however, and it is still included in the seconu edition of Paillieux \& Bois' Le Potager d'un Curieux, 1892. It began to attract attention in the United States probably about 15 years ago. The leaves tend to form an oblong, loose head, like Cos lettuce. See Cabbage.

Japónica, Sieb. California Pepper-grass. PotHERB MUSTARD. Fig. 266. Rather numerous radical lvs., oblong or oblong-obovate, the margins either crisped or cut into many very fine divisions, the petiole distinct at its lower end; stem lvs. all petioled; pod very small, with a slender beak. - The soft, thin lvs. make excellent "greens." Long known, but with no designative name, in old gardens in this country, and occasionally runs wild. Int. in 1890 by John Lewis Childs as California Pepper-grass, A very worthy plant (see Bull. 67, Cornell Exp. Sta.). 
AA. Whole plant green or but slightly glaucous when in flower: li's. on the fl.stems not prominently clasping: fls. small and yellow. Annuals. (Sinapis or Mustard.)

B. Pod terete or nearly so.

júncea, Coss. (Sinàpis juincea, Linn.). Chinese MusTARD. Figs. 259, 267. Rank and coarse grower, in the common forms making great tufts of root-lvs. if sown early: radical lvs. generally abundant and often very large, oval or oboval in outline, the blade angled or toothed, tapering into a narrow petiole, which generally bears leafy uppendages; lower stem-lvs. more or less toothed and petiolate, the upper ones oblong or oblonglanceolate, entire and usually sessile or clasping : flowering stems and lvs. more or less lightly glaucous : fls. bright yellow : pod slender, of medium size, tapering into a short beak. Asia. - This much abused species is held by Hooker and Thomson (Journ. Linn. Soc. v. 170) to include a great variety of forms, as Sinapis lovigata, Linn.; S. integrifolia, Willd.; S. ramosa, rigosa, patens. cuneifolia, Roxbg.; S. lanceolata, DC., and others. There are two types of it in cultivation in our gardens, one with the radical lvs. somewhat sharply toothed and nearly smooth below (sometimes grown as Brassica [or Sinapis] rugosa), the other with root-lvs. obtusely toothed and spinescent on the veins below (comprising Chinese Mustard, Chinese Broad-leaved Mustard, and Brown Mustard). Linnæus founded his Sinapis juncea upon a figure in Hermann's Paradisus (Hermann, Paradisus Batavus, t. 230, 1705), which represents a plant anth-tube : fr. 3-celled, many-seeded. Native of the mountain and table land region of Mex. - Five species have been described, but recent explorations have brought to light some 5 or 6 additional species. While

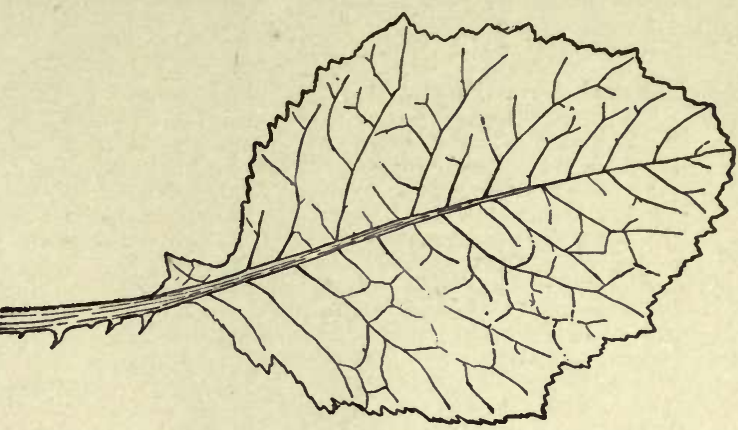

264. Lower stem-leaf of Tuberous-rooted Mustard Brassica napiformis.

the flowers are not as showy as the common tuberose, yet the genus should be found in every choice bulb collection. Only one species has been cultivated to any extent, and even this species is not well known. As the species often grow in the high mountains of Mexico, they ought to be hardy in the southern stretches of the temperate zone.

geminiflòra, Llav. \& Lex. Mexican Twiv Flower. Stems 1-2 ft. high: bulbs small, 1-11/2 in. long, the outer scales cut into fine fibers at the top: basal lvs. linear, erect, 6 lines or less broad, smooth: fls. in a slender raceme, reddish or orange-colored; lobes minute, rounded. B. M. 4741. - Handsome, and worthy of more attention.

B. Bulliàna, Baker. Basal lvs. described as lanceolate, $1-1 \frac{1}{2}$ in broad: fls. in 5 or 6 pairs, white. Seemingly too near the little known Polianthes Mexicana. Not in cult.$B$. sessiliflòra, $B$. densiflòra, and $\boldsymbol{B}$. singuliflòra are rare species, only known from herbarium specimens. The latter two, however, should probably be excluded from this group. $\quad$ J. N. Rose.

263. Tuberous Root of Pak-Choi.

very like the former type mentioned above, and which Hermann described as "lettuce-leaved."

álba, Boiss. WiLd Mustard. Tall : lvs, pinnatifid and rough-hairy: pods spreading, hairy, the lower part thick and few-seeded : seeds pale brown, large. Weed, from Europe.

Sinapístrum, Boiss. CHARLock. Tall : lvs. strongtoothed, or sometimes nearly lyrate: pods knotty, glabrous or hairy, the upper third indehiscent and 2-edged, usually 1-seeded. Weed, from Europe.

\section{BB. Pod distinctly 4-angled.}

nigra, Koch. Black Mustard. Fig. 268. Widespreading and loose grower : lvs. pinnatifid, somewhat hairy: pods short and erect, glabrous ; seeds small and dark brown, pungent, supplying the mustard of commerce. Cult. in Eu., but a weed in this country. $\rightarrow$ Commercial mustard is the flour of the seeds of this species chiefly, but the seeds of $B$. alba and probably of $B$. juncea are sometimes used.

L. H. B.

BRAVOA (Bravo, Mexican botanist). Amuryllidacea. A small genus, much resembling in some of its species the tuberose (Polianthes), and considered by the writer as hardly distinct from it. Stems slender, from small thickened rootstocks: lvs. mostly basal: inflorescence a lax spike or raceme; fls. always in pairs more or less bent or curved; stamens 6 , included within the peri-
BRAZIL NUT. See Bertholletia.

BREAD FRUIT. See Artocarpus.

\section{BREAD NUT is Brosimum Alicastrum.}

BRECK, JOSEPH (1794-1873). Plate II. Boston seedsman, and author of "The Flower Garden, or Breck's Book of Flowers," first published in 1851, and reissued in 1866

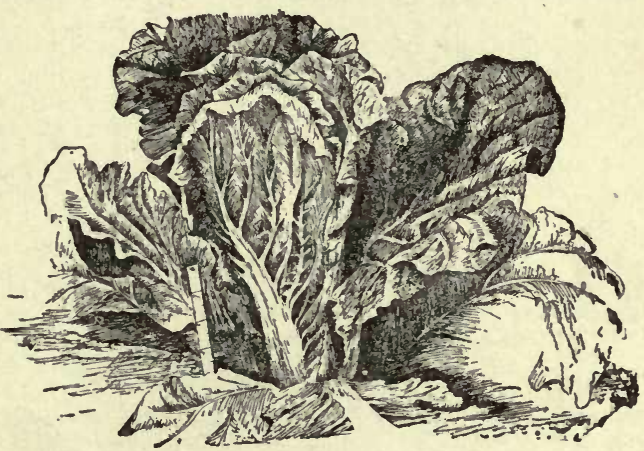

265. Pe-Tsai Cabbage - Brassica Pe-Tsai. 
as the "New Book of Flowers." This was preceded, in 1833 , by "The Young Florist." In 1822, he founded the seed business now conducted at 51 North Market St., under the name of Joseph Breck \& Sons. He was one of the original members of the Massachusetts Horticul-

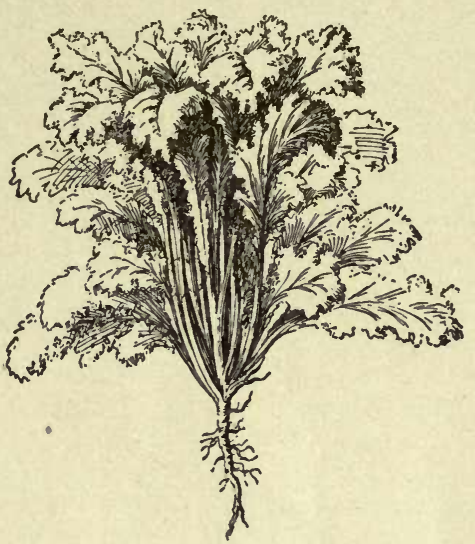

256. Brassica Japonica.

tural Society, and its president from 1859-1862. He edited the old New England Farmer for many years, but discontinued it in 1846, when he turned over his list of subseribers to Luther Tucker, of Albany, N. Y., at the time of the founding of The Horticulturist, which was edited by the illustrious A. J. Downing. He also edited The Horticultural Register from 1836-1838, in company with Thomas Fessenden. The revision of his book in 1866 was undertaken when the author was 70 years old. It was a popular book in its day. A portrait of Joseph Breck is seen in the catalogues of the present firm.

W. M.

BREV0ORTIA (J. Carson Brevoort, Regent N. Y. State University). Lilidcece. Differs from Brodiæa in the long-tubular and 6-saccate corolla. One species.

Ida-Màia, Wood. (B. coccinea, Wats. Brodicea coccínea, Gray). Floral Fire-Cracker. Lvs. slender, grassy: scapes slender, 1-2 ft. high, with 3-60 pendulous tubular-saccate fls. 1-2 in. long, which are brilliant crimson-red, tipped with pea-green. N. Calif. to Ore. B.M. 5857. G.C. III. $20: 687$. Gn. 46, p. 503.The flowers are very lasting and beautiful. Half-hardy. Needs partial shade and a deep, loose soil, thoroughly

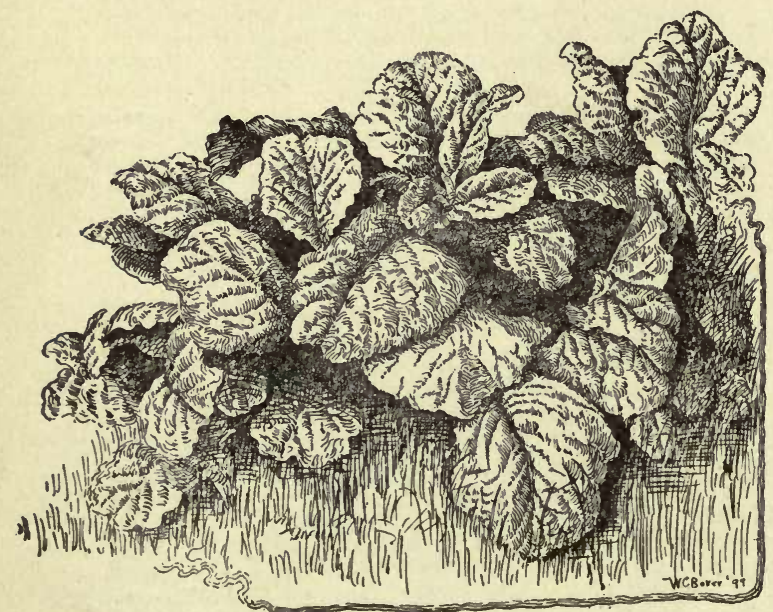

267. Broad-leaved Chinese Mustard - Brassica juncea. drained, and with some leaf mold. Bulb the size of a nutmeg. Grows $2-3 \mathrm{ft}$. high.

Carl Purdy.

BREWERIA (Samuel Brewer was an English botanist of last century). Convolvulacea. Herbs, rarely somewhat woody: fls. much like those of Convolvulus, but style 2-cleft, the divisions simple, with capitate stigma, the corolla pubescent outside in the bud: lvs. simple. Trailing plants of 30 or more species in warm climates.

grandiflora, Gray. Root tuberous: stem pubescent: lvs. broad-ovate and very short-stalked : peduncles 1-fld.: fl. very large ( 3 in. long), bright blue and showy, funnel-shaped; stigmas large and globose. S. Fla. - Int. by Reasoner Bros.

BRIAR. In America, commonly applied to brambles or thorny plants of the genus Rubus, especially blackberries. In the Old World, it is applied to large, wildgrowing roses.

BRICKELLIA (Dr, John Brickell, an early American naturalist). Compósitoe. About 40 species of herbs or small shrubs in the warmer parts of the U. S, and Mex. only one of which seems to be in the trade. Somewhat allied to Eupatorium. Lrs. veiny, either opposite or alternate: fls. white, eream-colored or flesh-colored, small, with pappus either scale-like or somewhat plumose : akenes striate.

grandiflora, Nutt. TAssel Flower. Nearly glabrous, 2-3 ft., branchy above: lvs triangular-cordate or triangular-lanceolate above, coarsely toothed: heads about 40 -fld., drooping, in large panicles, tasselshaped and yellowish white. Rocky Mts. - Recommended for moist, shady borders.

BRIDAL WREATH. See Spiroea pmenifolia.

BRIDGEMAN, THOMAS. Plate II. Gardener, florist, seedsman and author; was born in Berkshire, Eng., came to Ameriea in 1824, and established the business which is now conducted under the name of his son, Alfred Bridgeman, at 37 E. 19th St., New York. An historical account of this business may be found in the catalogue of the present firm. In 1829, Thomas Bridgeman published "The Young Gardener's Assistant," which was many times reprinted and eventually enlarged to five times its original bulk. It was copyrighted in 1847, when it appeared as a large-sized work in three parts, covering fruit, vegetable, and ornamental gardening. Two of these parts were published separately in the same year as "The Kitchen Gardener's Instructor," and "The Florist's Guide." The flrst-named work was revised by

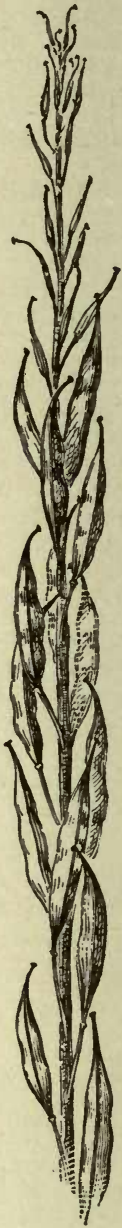

268. Brassica nigra.

Natural size. Sereno Edwards Todd, and republished in 1866 by Alfred Bridgeman. Thomas Bridgeman died in 1850 . W. M.

BRINCKLE, WILLIAM DRAPER. Plate II. Physician and amateur pomologist, was born in Delaware, began the practice of medicine at Wilmington in 1820 , moved to Philadelphia in 1825, where he passed most of his life as a busy physician, and died at Groveville, N. J., in 1863, at the age of sixty-four. In a room of his Philadelphia home he hybridized strawberries, and had fruit at every season of the year. He also had a little garden about the size of a parlor. He produced the Cushing strawberry, the Wilder, President Cope, Cushing, and Orange raspberries, and the Wilmington and Catherine Gardette pears. Unfortunately, most of his work with raspberries was done with Rubus Idcus, the Old World species, which is not hardy in America, but his yellowfruited variety of raspberry is still regarded by many as 
the acme of quality. He was for many years vice-president of the Pennsylvania Horticultural Society, and was regarded as a leader of American pomology. In raising pear seedlings, he was wont to graft and regraft annually, after the second or third year from seed. He thus produced new fruits in half the time required by Van Mons, many of whose novelties did not fruit within twenty years from seed. Dr. Brinckle gave away thousands of grafts to amateurs and tradesmen everywhere, and always prepaid the carriage. In 1860 he edited "Hoffy's North American Pomologist," a high-class periodical with colored plates, which, unfortunately, did not survive. Some sprightly anecdotes of Dr. Brincklé are reprinted from the Gardener's Monthly for 1863, in Bailey's "Evolution of Our Native Fruits." W. M.

\section{BRITISH COLUMBIA. See Canada.}

BRIZA (Greek name of a grain). Graminece. QUAKING GRAss. A genus of grasses cultivated for the graceful panicles, which tremble in the slightest breeze. Lvs. flat or convolute; panicles loosely flowered and open ; spikelets many-flowered, triangular or heartshaped, nodding ; glumes membranaceous and rounded on the back; awnless. Species, 12 in Eu., N. Afr., S. Amer. About 5 are considered to be ornamental and useful for dry bouquets.

geniculàta, Thunb. Fig. 269. Plant 12-18 in. high: culms geniculate at the base: lvs. 3-5 in. long, smooth above, slightly rough below: spikelets showy, nodding, oblong-cordate, $\frac{1}{8}$ in. long, 9-12-fld., with a striking ribbed appearance.

máxima, Linn. (B. màjor, Presl.). Annual, 14-18 in. high: lvs. long and linear-acuminate : panicles nodding: spikelets oblong-cordate, 13-17-fld. Eu.-A handsome ornamental grass.

media, Linn. Common Quaking Grass. Plant 6 in. to $2 \mathrm{ft}$. high: lvs. short, linear-acuminate : spikelets triangular, $\frac{1}{12}$ in. long, 5-12-fld. Eu.

minor, Linn. (B. grácilis, Hort. B. minima, Hort.).

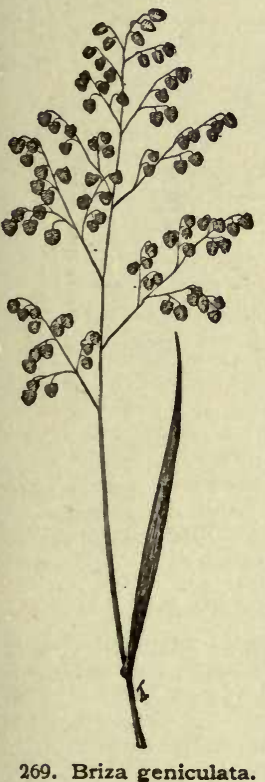
Plant 4-15 in. high: lvs. 1-5 in. long: panicle with hairlike branches ; spikelets triangular, 3-6-fld.; empty glumes longer than the flowering glumes. Eu.,

N. Afr.-An exceedingly pretty little ornamental grass.

\section{P. B. KeNNEDY.}

\section{BRIZOPỲRUM. See Desma-} zeria.

\section{BROCCOLI. See Cauliflower.}

BRODI㐫A (J. J. Brodie, a Scotch botanist). lilidcece. West American cormous plants of low growth, some of which are now becoming popular in cult. The fls. are several on a scape, the perianth mostly funnel-form, and either saccate or non-saccate, ranging from purple to red, white and yellow; stamens 6,3 of them sometimes reduced to staminodia. In Bot. of Calif., Watson includes under Brodiæa a number of genera erected by previous authors. Baker, in his latest revision of Brodiæa, still further enlarges the genus by including $\left(X^{1 / 4 .)}\right.$ some species of South American bulbs heretofore separated under Milla and Triteleia. Brodima, as thus outlined, includes Hookera, Triteleia, Milla, Calliprora and Hesperoscordum. For horticultural purposes, it is better and more convenient to merge all into Brodiæa. In this broad sense Brodiæa includes about 30 species, which must be divided into several groups. The species differ so widely in every way that cultural directions must follow the group. For $B$. volubilis, see Stropholirion; for $B$. coccinea, see Brevoortia. Monogr. by Baker, in G.C. III. 20, pp. 213, 238, 459, 687: also Watson, Proc. Amer. Acad. Arts and Sc1. 14: 236.

Index to the species: Bridgesii, 4; Californica, 11; candida,2 ; congesta, 19; Douglasii, 22; erecta, 6 ; filifolia, 16; gracilis, 9; grandiflora, 10 ; Hendersoni, 5 ; Howellii, 23 ; hyacinthina, 7 ; ixioides, 6 ; lactea, 8 ; laxa, 1 ; lilacina,

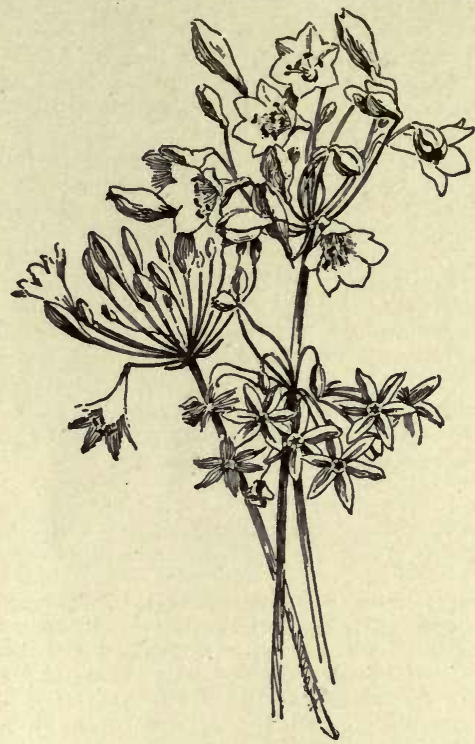

270. Brodiaeas.

At top, B. candida ; at bottom, B. ixioides, var. splendens : at left. $B$. Bridgesii.

8,23 , and supplementary list; major, 8 ; minor, 6, 12; multiflora, 20; Orcuttii, 15; parviflora, 20; peduncularis, 3 ; Purdyi, 18 ; rosea, 17 ; splendens, 6 ; stellaris, 14 ; terrestris, 13.

Group 1.

In this group, which contains some of the best speeies in cultivation, the plants have a fibrous-coated flattened corm, resembling that of the crocus; not usually bulbiferous. The lvs. are few, all radical and grass-like; the scapes are slender but stiffly erect, naked except for bracts below the many-fld. umbel; the fis. are oftener broadly tubular, borne on slender pedicels, and are in purples, white and yellow. All are hardy, but a protection of straw or leaves is advisable in the colder regions. A light, loose, well-drained. sandy or loamy soil best meets their needs, and an excess of moisture and very rich soils are to be avoided.

1. laxa, Wats. Strong, with many broadly tubular purple fls.: tube very narrow, and equaling or exceeding the segments; filaments very slender; stamens in 2 rows. N. Cal. G.C. III. $20: 241$. - Showy, and one of the best. There are many variations.

2. cóndida, Baker. Fig. 270. Much like $B$. laxa in characters of bloom, but segments white or bluish with a green vein, and the fls. set at an angle on the pedicel, so that they all face one way : further distinguished by early flowering and the very broad and glossy, scarcely carinate lvs. Calif.

3. pedunculàris, Wats. Still stouter (1-2 ft.), with smaller and fewer white fls. on pedicels a few inches to a foot long; flaments short or none. N. Calif. G.C. III. $20: 243$. - This species grows in wet, heavy ground close to water, and is very bulbiferous.

4. Brídgesii, Wats. Fig. 270. Similar to $B$. laxa, but stamens in one row, corolla with a spreading limb, and color reddish purple ; filaments deltoid. Cent. Calif. G.F. 1: 126. - Grows a foot or more high.

5. Héndersonii, Wats. Resembles B. Bridgesii: yellow, banded purple: filaments somewhat winged, but not deltoid: small-fld. Central and N. Calif. to Ore. 
6. ixioldes, Wats. Allied to B. laxa, but dwarfer (3 in. to $2 \mathrm{ft}$.). Fls. few to many, on pedicels 1-4 in. long, in shades of yellow and often purple-tinged; filaments winged, 2-toothed above. S. Calif. to Ore. B.R. 1590. B.M. 3588(as Calliprora lutea). G.C. III. 20: 459.-Many handsome varieties. The best is var. splendens, Hort. (Fig. 270), with large, bright yellow fis., the limb wheelshaped. Var. minor, Hort. Dwarf : fls. yellow, with dark band and blue anthers. Var. erécta, Hort. Dwarf.

7. hyacinthina, Bailey, Ann. Hort. 1891, 267 (Triteleia hyacinthina, Greene). From 1-2 ft.: lvs. linear: fls. 10-30,1 in. or less long, milky white or purplish. Calif. - Probably a form of the next.

8. lactea, Wats. In the type, has the habit of B. laxa, but the fls. have a short tube with a rotate corolla; and are white, with green midvein; filaments deltoid. Calif. to Brit. Columbia, in many forms. B.R. 1639 (as Hes peroscordum lacteum and H. hyacinthinum). G.C. III. 20: 459.-Var. lilacina, Wats., is much stronger, very bulbiferous, grows in wet, heavy soils, and has a larger H., which is usually lilac-colored. Var. màjor, Purdy. Like var. lilacina, but fls. white.

9. grácilis, Wats. A tiny species, with small yellow fls. Scape 2-4 in. and purplish: lf. 1: fls. $1 / 2$ in. long, on pedicels of equal or greater length; filaments elongated and very slender. N. Calif., in Sierras.

\section{Group \&.}

In this group the corm is not flattened, and bears many strong offsets; the coating is hairy and reddish. The lvs, are linear and grassy; the scapes stiff, few-fld.; the fls. of a thick, waxy texture, funnel-form (except $B$. Purdy $i$ ), very lasting, usually purple. These Brodiæas are native to a heavy soil, in rather moist situations, and are hardy. They will thrive under conditions recommended for Group 1. (Hookera.)

10. grandiflora, Smith (Hookèra corondria, Salisb.). Scape 4-10 in. high: lvs. nearly terete, dying before the fl.-st. appears: fls. $3-10$, blue, of good size (1 in. long), very lasting; staminodia obtuse; anthers linear. Calif. to Brit. Col., Ore., and Wash. B.R. 1183. B.M. 2877. G.C. III. $20: 213$.

11. Califórnica, Lindl. (Hookèra Califórnica, Greene). Very like B. grandiflora: scape longer (12-30 in.): fls. $10-20,1 \frac{1}{2}-2$ in. long, rose to deep purple : staminodia linear and cuspidate. N. Calif. G.C. III. 20:215. - "The finest species for garden purposes," acc. to Baker.

12. minor, Wats. Very slender, $3-6$ in.: fls. $1 / 2-1$ in. long: staminodia broad and usually emarginate; anthers oblong. Calif. to Ore.

13. terréstris, Kellogg. Scape short or practically none, the umbel sitting on the earth: lvs. nearly terete: fls. 3/4-1 in. long; staminodia emarginate, yellowish: anthers sagittate-oblong. Central Calif., along the coast.

14. stellàris, Wats. Low: scape with long pedicels and 3-6 bright purple fls., with white centers : lvs. nearly terete: anthers winged behind: staminodia white, longer than the stamens, emarginate. N. Calif. G.C. III. $20: 213$. - Very pretty.

15. Orcuttii, Bailey, Ann. Hort. 1891, 267 (Hookèra Orcuttii, Greene). Plant rather stout, a foot or more high: lvs. linear, flat or nearly so: fls. 5-15, less than an inch long, short-tubed, lilac; staminodia a small, triangular scale or none. S. Calif. G.C. III. $20: 215$.

16. filifollia, Wats. (Hookèra filifòlia, Greene). From 6-12 in.: lvs. slightly flattened: fls. $3-6,3 / 4$ in. or less long, dark colored; staminodia triangular, twice shorter than the anthers. S. Calif.

17. ròsea, Baker (Hookèra ròsea, Greene). About 3-6 in.: lvs. nearly terete: fls. 5-8, under 1 in. long, rose-red ; filaments dilated; staminodia white, obtuse and entire, longer than the anthers. N. Calif. G.C.III. $20: 213$. A pretty species.

18. Púrdyi, Eastw. Different from others in having a short-tubed fl. with broadly spreading, declinate segments, the throat constricted. Cent. Calif., in Sierras.

\section{Group 3 .}

In these pretty Brodiæas the corm is long and bulbif erous. Lvs. grassy; the scape tall, slender and flexuous; the fls, in a close, head-like umbel, the separate fls. waxy and narrowly tubular. They like a loose, perfectly drained, loamy soil, with some humus. Hardy. 'The species are not readily distinguished. All are from Cent. Calif. to Wash. Known as "California Hyacinths."

19. congésta, Smith. Tall (2-3 ft.), with a globular head of purple fls. lvs, somewhat terete : fls. 6-12, sessile or nearly so, $3 / 4 \mathrm{in}$. long; flaments 0 ; staminodia purple, 2-toothed. N. Cal. G.C. III.20:213.-Blooms late.

20. multiflòra, Benth. Sinilar to $B$. congesta: fls. 6-20, sessile or short-stalked, umbellate, $3 / 4$ in. long, blue; staminodia lanceolate, entire. Calif., Ore., Utah.

21. capitata, Benth. Lower (1-2 ft.): lvs. narrowlinear: fis. many, in a capitate umbel, $3 / 4$ in. or less long, lilac (a var. alba); three inner anthers winged. Calif., Utah, N. Mex. B.M. 5912. G.C. III. 20:238.-Early blooming.

Var. parviflora, Torr. Dwarf (3-6 in.), very early.

\section{Group 4.}

Bulb as in Group 1: fls. many, in a dense umbel, the tube about as long as the segments.

22. Doùglasii, Wats. Lvs. linear: scape $1 \frac{1}{2}-2 \mathrm{ft}$. : $\mathrm{fls}$. few, in a close umbel, saccate as in Brevoortia coccinea, blue : segments as long as the tube, the inner ones wavy: filaments winged. Ore. and Wash. B.M. 6907.

23. Howellii, Wats. (Tritelèa Hóvellii, Greene). Fls. bell-shaped, white: differs from $B$. Douglasii in smaller fls., and segments not more than half as long as tube. Wash. B.M. 6989 .

Var. lilacina, Hort. One of the handsomest of all Brodiæas, and a good grower. Fls. porcelain-blue, suggestive of Brevoortia coccinea. Wash. G.C. III.19:767; 20:239. Gn. 46:992. - Large and strong.

$B$. crocea, Wats. $1 \mathrm{ft}$. or more: fls. 6-15, yellow. N. Calif. $-B$. insularis, Greene. Like B. capitata, but more robust and larger fld. Islands off Calif.-B. Lémmonoe, Wats. $1 \mathrm{ft}$.: $\mathrm{fls}$. small, deep orange. N. Ariz. $-B$. leptándra, Baker. $1 \mathrm{ft}$. or less : fls. 2, purple. Calif.-B. lilacina, Baker. $1 \mathrm{ft}$. or less : fls. 10-15, lilac-purple. Calif.-B. lùgens, Baker. Like B. ixioides, but fls. saffron color within and brown-black.on tube and ribs Calif.-B. Pálmeri, Wats. Lvs. linear: fls. many, lilac. S. Calif. G.F. 2: 245.-B. pulchélla, Greene. Probably the same as B. congesta. - B. scabra, Baker. Like B. ixioides, but scabrous: B. congesta. - B. scábra, Baker. Like B. ixioides, but scabrous:
fis. bright yellow. Calif. CARL PURDY and L. H. B.

BROMELIA (Bromel, a Swedish botanist). Brome7idcece. About two dozen species of tropical Amer. herbs, with stiff, pineapple-like lvs., and fls. in panicles; corolla 3-parted; calyx of 3 ovate-oblong sepals. Differs from-Billbergia and Ananas in technical characters, particularly in the deeper-cut calyx. Less popular as stove plants than Achmea and Billbergia. B. bracteata and $B$. macrodontes of trade lists belong to Ananas. Culture as for Billbergia, which see. Monogr. by Mez, in De Candolle's Monogr. Phaner. 9.

Pínguin, Linn. Pinguin of Jamaica. Wild Pine. Three or $4 \mathrm{ft}$. high: lvs. broad-toothed and spiny, bright green, but becoming pink and red with age : fis. reddish, pubescent, in a dense panicle, with a mealy rachis, the sepals acute : fr. as large as plums, acid. W. Ind.-Makes a good hedge in tropical countries, and the fr. yields a cooling juice.

Binoti, Morr. Panicle lax: sepals rounded at the top: habit open and spreading. Braz. L. H. B.

\section{BROMPTON STOCK. See Matthiola.}

BROMUS (Greek, food). Graminece. Brome Grass. Annual or perennial grasses, with large spikelets, usually over $1 \mathrm{in}$. long. Lvs. flat, the sheaths often closed: panicle branched, somewhat spreading; spikelets several-fld., erect or drooping, awned, rarely awnless; empty glumes 2, unequal, acute; flowering glumes usually rounded on the back (except $B$. unioloides). Species about 40 , most abundant in the North Temperate zone, some also in temperate S. Amer.; a few on the mountains of the tropies. A number of kinds used as forage grasses. The common Chess is B. secalinus.

\section{A. Spikelets 10-flowered or more.}

brizæfórmis, Fisch. \& Mey. (B. squarròsus, var.mùticus, C. A. Mey.). An elegant biennial grass with droop- 
ing panicles of spikelets about as large as those of $\mathrm{Briza}$ maxima: lvs. 5-7, soft-pubescent, blades $2-3$ in. long : spikelets 10-15-fld., nodding, awn short. Int. from $\mathbf{E u}$. -Very useful in the mixed border, and for drying for winter decoration.

macróstachys, Desf. (B. lanceoldtus, Roth. B. divaricatus, Rohde). An erect, smooth annual: lvs. soft, covered with hairs; sheaths slit : panicles erect, narrow, the branches very short or the lower ones somewhat long; spikelets large, lanceolate, 10-16-fld. Mediterranean, Siberia.

\section{AA. Spikelets from 1-10-flowered.}

Madriténsis, Linn. (B. polystàchyus, DC.). LoxGAWNED BROME Grass. Fig. 271. A soft, erect, slender annual, geniculate at the base: sheaths longer than the internodes; blades $21 / 2-3$ in.long; spikelets dull green, 7-10-fld.: flowering glume linear-lanceolate, about $3 / 4$ in. long, including the two slender points: awn about 1 in. long. - Pretty ornamental grass. Int. from $\mathrm{Eu}$.

uniololdes, H B K. ( $D$. Schrdderi, Kunth). ResceE Grass. A stout, erect annual, 2-3 ft. high : sheaths shorter than the internodes; blades flat, smooth on the lower side, scabrous on the upper; panicle variable, about 8 in. long; rays stout, bearing 1 to few spikelets along the upper part. $\mathrm{N}$. Amer.

$B$. inérmis, Leys. (B. giganteus, Hort.). An erect perennial 2-5 ft. high. In Europe classed among the best forage plants. Int from $\mathrm{Eu},-B$, móllis, Linn fis, Linn. An eroct amual 1-3 ft. high. Resembles (B. secalinus), from which it differs by its more erect panicle and hairiness.- B. secálinus, Linn. Chess. Cheat. A well-known weedy annual grass, with spreading and more or less drooping panicles. As it very often occurs in wheat fields, it is erroneously regarded as degenerated wheat. Int. from $\mathrm{Eu}$.

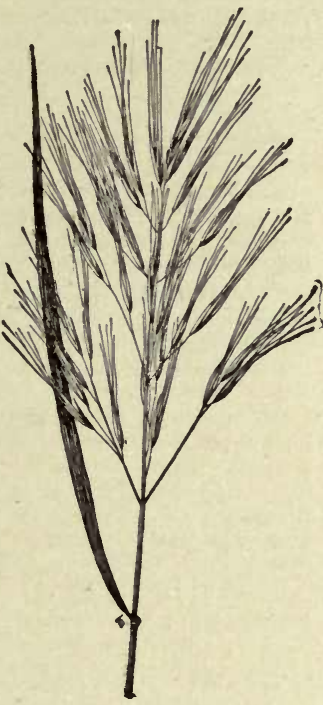

271. Bromus Madritensis. $\left(X^{1 / 4 .}\right)$

\section{BR00M. See Cytisus and Genista.}

BROOM CORN. Brooms are made of the rays or peduncles of the flower-cluster of Andropogon Sorghum (Sorghum vulgare), the species which in other forms is known as Sorghum, Kaffir Corn, and Guinea Corn. Broom Corn is grown in various parts of the U.S.

BROSIMUM (Greek, edible). Urticacece. A few large trees of Trop. Amer, yielding edible fr. $B$, Alicástrum, Swz., is the Bread-nut of Jamaica, but it is not grown within the U.S. It bears round yellow fr., about an inch in diameter, containing a single large, edible seed. The tree has shining lance-elliptic lvs.

BROUGHTONIA (Arthur Broughton, English botanist). Orchidacea, tribe Épidendrea. Two or three W. Indian Orchids much like Lælia and Cattleya. Several species which have been referred to this genus are now distributed in Epidendrum, Maxillaria, Phajus, etc. Plant producing pseudo-bulbs, and sending up a bracted seape bearing several or many showy fls.: calyx of equal lanceolate sepals; two lateral petals broad-orate and somewhat crisped, the labellum round-cordate and somewhat 2-lobed, crenate, with a spur at the base adnate to the ovary. Require warmhouse treatment. Culture like that for Lrelia. Do not dry off enough to shrink the bulbs. Prop. by division.

sanguínea, R. Br. (B. coccinea, Hook.). Pseudobulbs clustered, roundish-ovate and somewhat flattened, often brown-marked : scape $1 \mathrm{ft}$. high: fls. stalked, in a loose, erect raceme, bright crimson, lasting a long time in perfection. Jamaica. B.M. 3076,3536 . L. H. B.

BROUSSONĖTIA (after T. N. V. Broussonet, a French naturalist). Urticdcece. Trees or shrubs : lvs, deciduous, alternate, petioled, large : fls. diœcious, inconspicuous, apetalous, the staminate in cylindrical, nod ding catkins, with 4-parted calyx and 4 stamens, the pistillate in globular heads : collective fr. globular, consisting of small fleshy nutlets. Three species in E. Asia, and there often cultivated, the bark being used for paper-making. Ornamental trees with broad, round heads, but under culture often shrubby, of vigorous growth when young, and effective by its large, often deeply lobed foliage, not hardy north or only in very sheltered positions. They thrive best in rich, somewhat moist soil and sheltered positions. Prop. by seeds, sown after maturity or in spring, by greenwood cuttings under glass, or by cuttings of ripened wood, kept in colder climates during the winter in the greenhouse ; also by root-cuttings and layers. Budding in summer or grafting in early spring in the greenhouse is sometimes practised. Known as Paper Mulberries.

papyrifera, Vent. Tree, 30-50 ft., with thick, pubes cent branches: lvs. long-petioled, usually cordate-ovate, acuminate, coarsely dentate, often deeply lobed, especially on younger plants, rough above, pubescent beneath, 3-8 in. long: fr.-heads $8 / 4$ in. across, red. May. China, Jap. B.M. 2358.-Many varieties. Var. cucullàta, Ser. (B. naviculdris, Lodd.). Lvs. small, curled upward. Var. laciniàta, Ser. Lvs. deeply lobed and in cised. Decorative form, but more tender than the type. Var. macrophýlla, Ser. Lvs. large, usually undivided.

Kazindki, Sieb. (B.Kámpferi, Hort.). Branches slender, glabrous at length : lvs. short-petioled, ovate or ovate-oblong, nearly glabrous, only somewhat rough above, entire or 2-3-lobed, 2-8 in. long: fr.-head less than $1 / 2$ in. in diam. China, Jap. - This species is more tender than the former, which is also cultivated sometimes as $B$. Kompferi, while the true $B$. Koempferi, Sieb., with the Irs. resembling in shape those of $B$. Kazinoki, but much smaller and pubescent, and with very small fr.-heads, seems nut to be cultivated.

AlFRED REHDER.

BROWÁLLIA (after John Browall, Bishop of Abo Sweden). Solandcece. A genus of about 10 South American annuals, with abundant blue, violet or white flowers. The seeds can be sown in the open border, but for the sake of the earlier bloom it is better to start them indoors in early spring and transplant into the open about May 15, where they will bloom profusely all through our hot, dry summers, and until frost. They can be grown in poorer soil than most half-hardy an. nuals, and make excellent bedding plants. They are also used for winter decoration, the seeds being sown in midsummer, earlier or later according to the size of the specimens desired. They should be placed near the glass and frequently stopped, in order to produce compact plants. Large specimens are excellent for cutting, and small potted plants should be grown more com monly by florists for home decoration at Christmas. It is even possible to lift flowering plants from the open before the first frost of autumn and pot them for conservatory decoration, though the flowers are likely to become successirely smaller. Blue flowers are rare in winter, and Browallias are especially desirable for their profuse bloom all through winter and early spring. The flowers are, however, likely to fade, especially the purple ones. In the names of the early species, Linnæus commemorated the course of his acquaintaneship with Browall : elata, reflecting the exalted character of their early intimacy ; demissa, its rupture; and alienata, the permanent estrangement of the two men.

A. Corolla segments long, acuminate: fls. large.

speciosa, Hook. Lvs. sometimes opposite, sometimes alternate: fls. thrice as large as in $B$. grandiflora, all solitary, axillary : peduncle shorter than the lvs.: corolla-tube thrice as long as the calyx, and abruptly swelled at the top into a globular form: limb of 5 ovate, 
striated, dark purple segments, pale lilac beneath. Colombia. B.M. 4339. P.M. 16:290.-There are blue, violet and white-fld. varieties. Var. màjor, Hort., has violet fls. 2 in. across. R.B. $20: 240$. B. gigantè, Hort., is a florist's variety, with very deep blue fls. and longblooming habit. Int. into Amer. trade in 1899.

AA. Corolla-segments short, 2-lobed or notched: fls. smaller.

B. Upper lvs, not stalked: fls. all in loose racemes: calyx not hairy.

grandiflora, Graham (B. Róalii, Hort.). Stem and lvs. glabrous, or in the upper part of the plant minutely clammy-puberulent: lvs. ovate, the lower petioled: calyx-teeth oblong, somewhat obtuse, equal, scarcely shorter than the tube, spreading: corolla white or pale blue, the limb wider than in B.demissa. Peru. B.M. 3069. In B. Roalii, from Rocky Mts., some fls, are white, some pale blue. No dark blue or violet colored forms are known.

вв. Upper lvs. stalked: fls. solitary and axillary below, racemose above.

c. Calyx hairy.

demíssa, Linn. (B. elata, Linn.). Fig. 272. Stem and lvs. pubescent or glabrous : lvs. ovate, with longer stalks than in $B$. grandiflora: calyx-teeth acute, unequal, much shorter than the corolla-tube. The lvs. are variable, cuneate, rotund, or rarely cordate. S. Amer. B.M. 34 and 1136. The following are now referred to the above: B. Americana, elata, elongata, nervòsa. This species is the commonest, and is usually known as B. elata. Blue, violet, white and dwarf forms are cult.

$$
\text { cc. Calyx sticky or clammy. }
$$

viscòsa, HBK. (B. pulchélla and B. Czerniakowskiana, Hort.). Plant viscous-pubescent : lvs. short-peti-

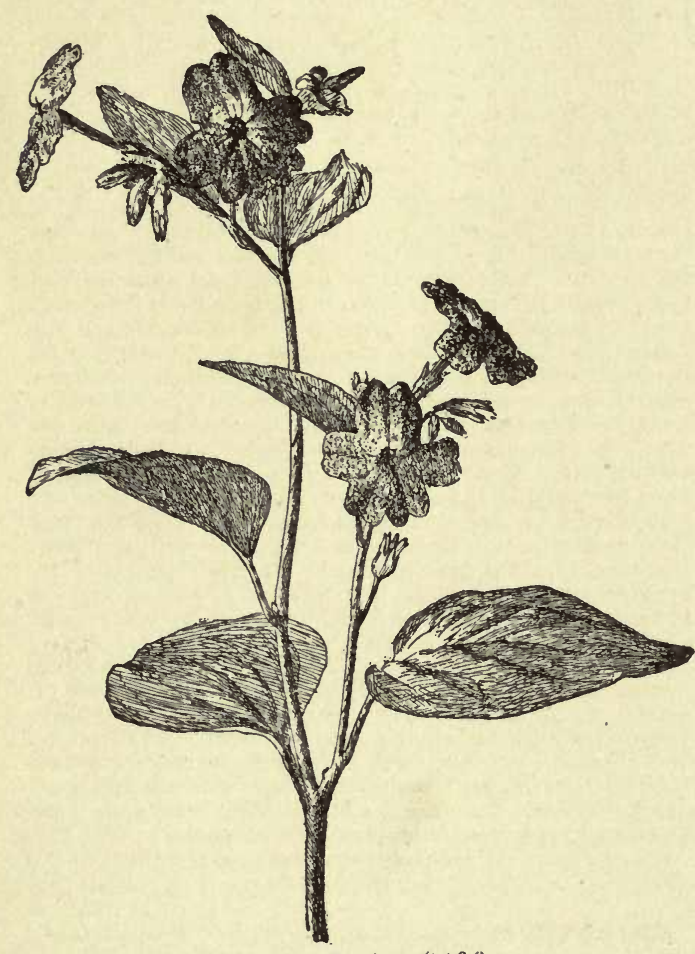

272. Browallia demissa $\left(\times \frac{2}{3}\right)$.

oled, ovate, rough-hairy on both sides : pedicels a little shorter than the calyx : calyx teeth very clammy, oblong, shorter than the corolla tube. The lvs. are similar to
B. demissa, but the habit is stiffer and the fls. more numerous. The calyx teeth spread less than in $B$. grandiflora. So. Amer.

B. Americàna, Linn., is considered by some a separate species from the above, but in Germany, where most seeds of annual flowers are grown, it is used by Siebert and Voss (in Vilmorin's Blumengärtnerei) to include B. demissa, B. elata, and orin's Blumengartàresonii, Benth = Streptosolen Jameand other forms. $-B$. Jamesonii, Benth. $=$. Sulchella, Hort., is likely to be either B. grandiflora or B. viscosa.

W. M.

BROẀNEA (Patrick Brown wrote a history of Jamaica). Leguminosce. Several small evergreen trees of trop. Amer., allied to Amherstia, but little known in the Amer. trade. Lvs. alternate and pinnate : fls. showy, red, in dense terminal or-axillary clusters. Cult. in hothouses. B. Ariza, Benth. (B. Princeps, Lind.) has drooping heads of scarlet fls. B. grándiceps, Jacq., fls. red, in capitate spikes : lfts. about 12 pairs, lance-oblong. B. Ròsa-de-Monte, Berg., fls. scarlet, in dense heads: lfts. 2-3 pairs, oval, acuminate.

BRUCKENTHALIA (after S. von Bruckenthal, an Austrian nobleman). Ericacece. Low, heath-like, evergreen shrub, 5-8 in. high, with small, linear, whorled Ivs.: fls. rosy pink, nodding, in short, terminal racemes. Only one species-B. spiculiflora, Reichb., in the mountains of S. E. Europe. A pretty little plant for rockeries, quite hardy, and requiring the same treatment as hardy Ericas.

ALFRED REHDER.

\section{BRUGMÁNSIA. Consult Datura.}

BRUNELLA (probably from old German breune or braune, quinsy, which it was thought to cure). Often written Prunella. Labiatoe. Low-growing, hardy, herbaceous perennials, with fls. usually violet or purple, produced all summer on heads an inch or more high. They are best suited for the rockery and slightly shaded parts of the border, succeeding in almost any soil that is not excessively dry.

vulgàris, Linn. Self-Heal. Heal-All. Lvs. ovateoblong, entire or toothed, usually pubescent : corolla violet or purple, rarely white, $1 / 2-3 / 4 \mathrm{in}$. long, not twice as long as the purplish calyx. Amer., Eu., Asia. D. 255. - One of the most cosmpolitan of all plants, being too common in the wild to be cult. A form with variegated lvs. is rarely found wild.

grandifldra, Jacq.( B. Pyrendica, Phillipe). Lvs. often toothed, especially at the base : corolla over 1 in. long, more than twice as long as the calyx. Eu. B.M. 337.The best of the garden kinds.

Webbiàna, Hort. Los. shorter than in B. grandiflora, and not so pointed: fls. very freely produced, more than twice as long as the calyx, bright purple. JuneSeptember.

J. B. Keller and W. M.

BRUNFELSIA (Otto Brunfels, physician and botanist of the 16th century). Syn., Franciscea. Solandcea. More than 20 trees and shrubs of tropical America, a few of which are grown in warm glasshouses. Lvs. entire, oblong, often shining : fls. in terminal cymes or clusters, or solitary, large and showy, fragrant; corolla with 5 rounded and nearly equal spreading lobes (or two of them a little more united); stamens 4 , in the throat of the corolla, the anthers all alike : fr. berry-like. Brunfelsias are usually winter-flowering plants. The wood must be well ripened before flowering begins. Grow in a rather sandy compost. Of easy culture. Require a night temperature of $50^{\circ}$. They bloom best when pot-bound. Prop. by cuttings from the new growth in spring.

Hopeàna, Benth. (Franciscea Hopedna, Hook. F. uniflora, Pohl.). Compact and dwarf : lvs. lance-oblong, alternate, paler beneath : fls. solitary or in 2's, with a whitish tube and a bluish violet or purple limb. Brazil. B.M. 2829.-Grows 12-18 in. high. One of the least worthy species.

pauciflora, Benth. ( $F$. calycina, Hook.). Branches terete and glabrous, with abundant evergreen foliage : fls. in large trusses, purple, with a lighter ring about 
the mouth of the tube; calyx large, as long as the curved tube of the corolla. Brazil. B.M. 4583. Gn. 40:815. -A handsome plant, flowering in succession most of the year. The commoner species in cult.

B. confertifldra, Benth, =B. ramosissima. - B. eximia, Bosse -B. macrophylla. $-B$. grandiflora, Don. Fls. large (2 in. across) greenish, in terminal corymbs. - B. Lindeniàna, Nicholson. Fls. 3 in. across, violet-mauve.-B. macrophýlla, Nicholson. Fls. il in. across, violet-mauver Benth. Fls. $2-2 / 2$ in. across, deep purple: 1vs. longer and duller than those of F. calycina.- $B$, ramosissima, Benth. Fls. large, One of the best; may be grown cooler in winter than the other species.

L. H. B.

BRUNSVIGIA (after the Duke of Brunswick). Amarylliddcece. Tender flowering bulbs from S. Afr., with umbels of large, numerous, brick-red fls. The bulbs must be thoroughly rested from the time the lvs. fade until the scape appears, or from May to Aug. Brunsvigias are hard to flower. They require rich, sandy soil, plenty of heat and sunlight. When growing, give water and liquid manure freely. They propagate by offsets. J. G. Baker, Handbook of the Amaryllideæ, p. 96 .

\section{A. Lvs. sstrap-shaped.}

Josephinæ, Ker-Gawl. Bulb 5-6 in. thick : lvs. 8-10, strap-shaped, glaucous or greenish, thick, closely ribbed, 2-3 ft. long, $1 \frac{1}{2}-2 \mathrm{in}$. broad : scape $1 \mathrm{in}$. thick, $1 \frac{1}{2} \mathrm{ft}$. long: fis. $20-30$, rarely $50-60$, in an umbel: pedicels $1 / 2-1$ ft. long: capsules smaller than in $B$. gigantea, less conical and less strongly angled. B.M. 2578. F.S. 4:322. - Named after the Empress Josephine, who purchased the original bulb after it flowered at Malmaison.

\section{AA. Lvs. tongue-shaped.}

gigantèa, Heist. (Amarýllis gigantèa, Van Marum. A.orientalis, Ecklon). Bulb very large: lvs. about 4 , tongue-shaped, closely ribbed, 3-5 in. broad, usually under $1 \mathrm{ft}$. long: scape red or green, a finger's thickness: fls. 20-30 in an umbel, paler than in B. gigantea, and less numerous ; pedicels stout, strongly ribbed, 4-6 in. long. B.M. 1619 as B. multifora.

B. falcàta, Ker-Gawl=Ammocharis falcata.

\section{H. A. Siebrecht and W. M.}

BRUSSELS SPROUTS. Fig. 273. Although this vegetable is popular in England and on the Continent, and is extensively grown there, it is infrequent in American home gardens; it is also but little grown as a market-garden crop. The edible part of the plant consists of the little "sprouts" or diminutive heads which form along the stalk in the axils of the lvs. These small heads may be boiled like cabbage or cooked in cream the same as cauliflower. This is considered by many to be one of the most delicately flavored vegetables of the whole cabbage family. The requirements of the crop and its general treatment differ but little from those of cabbages and cauliflowers. Any soil which will produce good crops of these vegetables is well adapted to the growing of Brussels Sprouts-a good, rich, well-drained soil being the best.

For early fall use, the seeds should be sown in April (in the North), in a mild hotbed, or if the weather is sufficiently warm the open ground will suffice. As soon as the first true leaves have developed, the seedlings should be transplanted to a coldframe or some protected place, being set 2-3 in. apart each way. These plants will be ready to transfer to the field or garden in June. June-set plants should be ready for use in September.

For field-culture, the plants should be set in rows about $3 \mathrm{ft}$. apart and $18 \mathrm{in}$. to $2 \mathrm{ft}$. asunder in the rows. Ordinarily good cultivation should be given during the growing season. As soon as the sprouts become large enough, so that they crowd at all, the leaves should be cut or broken off as close to the stalk as possible, in order to give the sprouts more room to develop. A tuft or rosette of leaves only should be left at the top of the stalk. These early-set plants will continue to develop sprouts for some weeks.

The crop for late fall and winter use requires the same general treatment, up to the time of severe freezing, as the earlier crop does, except that the seeds should be sown in June. The plants will be ready for setting out in August. These plants will make much of their growth in the cool fall days, and by the time of freezing weather they will be in condition for storing.

The late crop is usually less troubled by aphis, and more profitable. Where the climate is not too severe the

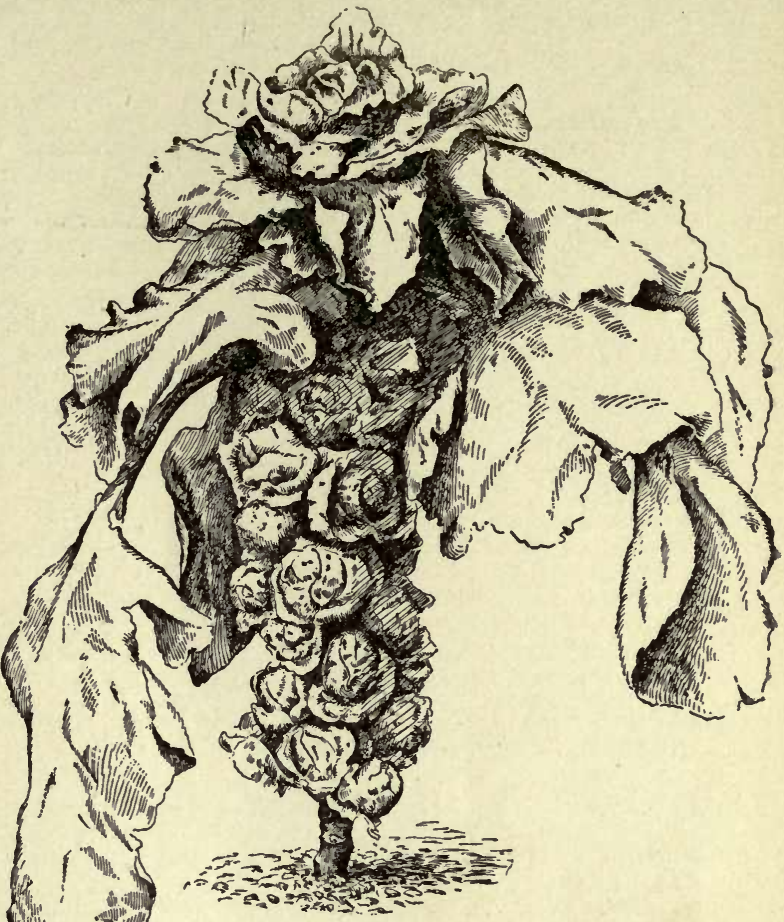

273. Brussels Sprouts.

plants may be left in the field undisturbed, and the sprouts gathered from them during the winter as they are desired. This method is followed by some of the Long Island growers. But where the climate is too rigorous, the plants may be dug, with considerable soil remaining on the roots, and packed as closely together as they will stand in some sheltered place, as in a vacant coldframe or some similar place where they can be sufficiently well protected, to prevent repeated freezing and thawing. The essentials for good storage are the same as for cabbages. Frosts improve the quality of the sprouts. They are hardier than cabbages.

In marketing, the sprouts are cut from the stalk and shipped in crates. They are usually sold by the quart. To bring the best prices, much care must be taken in preparing the sprouts. All discolored leaves should be removed, and it is also well to have them as uniform in size as possible.

Although a dozen or more sorts are catalogued by the seedsmen, there is but little difference between those of the same type or form, they being little more than different strains of the same thing. There are two forms, the tall and the dwarf. The former grows to a height of $21 / 2 \mathrm{ft}$. or more, and the sprouts are smaller and less closely packed along the stalk than the dwarf ones are. The latter seldom exceed 18 or $20 \mathrm{in}$. in height.

For the botany of Brussels Sprouts, see Cabbage.

\section{H. P. GOULD.}

BRYANTHUS (Greek, bryon, moss, and anthos, flower: growing among mosses). Syn. Phyllódoce. Ericdcece. Low evergreen shrubs : lvs. small, linear, alternate, crowded : fls. in terminal umbels or short racemes, nodding, on slender pedicels ; corolla urceolate or rotate-campanulate, 5-lobed; stamens 8 or $10:$ fr. a many-seeded capsule. Eight species in arctic regions 
of N. Eu. and N. Asia, in N. Amer. in the Rocky Mts. southward to California. Heath-like prostrate shrubs, quite hardy, with handsome, delicate fls., but rarely cultivated. They thrive best in peaty and sandy soil, and can only be grown successfully in localities where the air is moist and cool, but $\boldsymbol{B}$. erectus is less particular. Prop. by seeds, sown in spring in peaty soil or cut monœcious, fascicled: fr. about the size of a cherry, spherical, green, with pretty white $\cdot$ markings. Asia, Afr., Austral. F.S.12: 1202.

Var. erythrocárpa, Naud. (B. erythrocárpa, Naud.). Has red fr. with white marks. I.H. 12: 431. F.S. 21:2237. Gn. 6, p. 193. - A warmhouse plant, rarely grown in pots and trained to rafters. Prop. by seeds.

W. M.
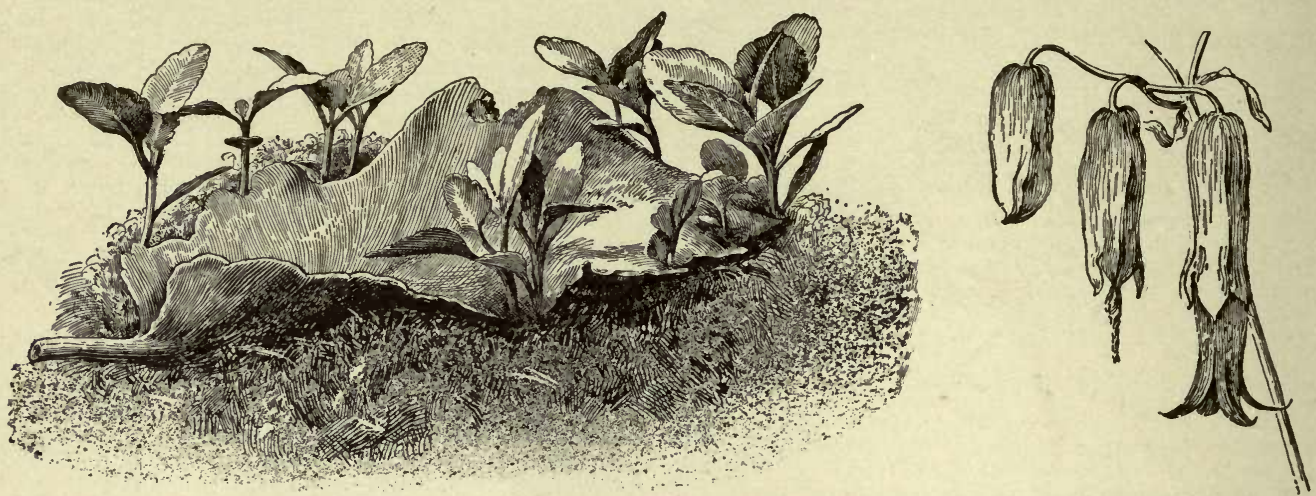

274. Sprouting leaf of Bryophyllum.

275. Flowers of Bryophyllum $(X 1 / 2)$.

sphagnum and kept moist and shady, by cuttings in August under glass, and by layers.

empetriformis, Gray. Five to 8 in.: Ivs. $1 / 4-1 / 2$ in. long, finely serrate: fls. campanulate, 6 or more on slender, glandular pedicels, in short racemes: corolla rosy purple, about $1 / 2$ in. broad. Brit. Columbia to Calif. B.M. 3176 (as Menziesia empetriformis).

eréctus, Lindl. (B. empetrifórmis $\times$ Rodothámnus Chamcecistus). Six to 10 in. high: lvs. slightly serrate: fls. $2-10$, rosy pink, rotate-campanulate, about $1 / 2$ in. broad. F.S. 7:659. P.F.G. 1: 19. - Of garden origin.

B. Breweri, Gray. Allied to B. empetriformis. Fls. larger; stamens exserted. Sierra Nevada.-B. glanduliflòrus, Gray. Fls. urceolate-ovate, sulphur-yellow. Sitka to Brit. Columb. B. Gmélini, Don. Fls. small, rosy, $3-10$ in slender peduncled racemes. Kamschatka, Behring's Isl.-B. taxifòlia, Gray. Fls. oblong-urceolate, purple. High Mts. of N. E. A mer., Greenland, N. Eu., N. Asia, N. Jap.

ALFRED REHDER.

BRYONIA (Greek, to sprout, referring to the annual growth from the tuber). Cucurbitaceac. A genus of 7 species of perennial cucurbits, natives of Europe and W. Asia. They are herbacecus perennial climbers, with the staminate fls. in racemes, while Bryonopsis is an annual plant, with the staminate fls. in fascicles. All species of Bryonia are diøecious except B. alba. Bryonopsis is monœcious. See Cogniaux, in DC. Mon. Phan. 2:469.

A. F's. dicecious: stigmas rough: fruits red.

didica, Jaeq. Bryony. Height 6-12 ft.: root long, fleshy, branching, white, a finger's thickness: lvs. ovate or roundish in outline, 5-lobed, margin wavy-toothed, rough with callous points, paler beneath : pistillate fls. greenish white, corymbose, short-peduncled. Common in Eng, and in central and S. Eu. Rarer in W. A sia and N. Afr. Not sold in Amer., but a common sight along English highways. It grows rapidly over hedges and fences.

AA. Fls. monocious : stigmas smooth: fruits black.

álba, Linn. Height 6-12 ft.: roots thick, tuberculate, yellowish outside, white within: lvs. long-petioled: pistillate fls. in long-peduncled racemose corymbs. Eu., Caucasus, Persia.

B. laciniòsa, Linn. $=$ Bryonopsis laciniosa.

W. M.

BRYONOPSIS (Greek, Bryony-like). Cucurbitdcece. A genus of two species of annual climbers. Consult Bryonia for generic differences.

laciniossa, Naud. (Bryònia laciniosa, Linn.). Lvs. deeply 5-lobed, rough, light green above, paler beneath; segments oblong-lanceolate, acuminate, serrate: fls.
BRYOPHYLLOM (Greek, sprouting leaf). Crassulaceo. A small genus of succulent plants in the same order with stonecrops, houseleeks and Cotyledon. The only species in cult. is a rapid-growing window-plant, and, like the Begonias, a familiar example of plants that are propagated by leaf-euttings. It is hardly a decorative plant, but is very odd and interesting. It is only necessary to lay the leaves on moist sand or moss, and at the indentations new plants will appear after a time (see Fig. 274). It is even possible to pin leaves on the wall, and without water new plants will come. Useful in botanical demonstrations.

calycinum, Salisb. Fig. 275 . Height 2-4 ft.: stem reddish, with raised, oblong, whitish spots : lvs, oppo-

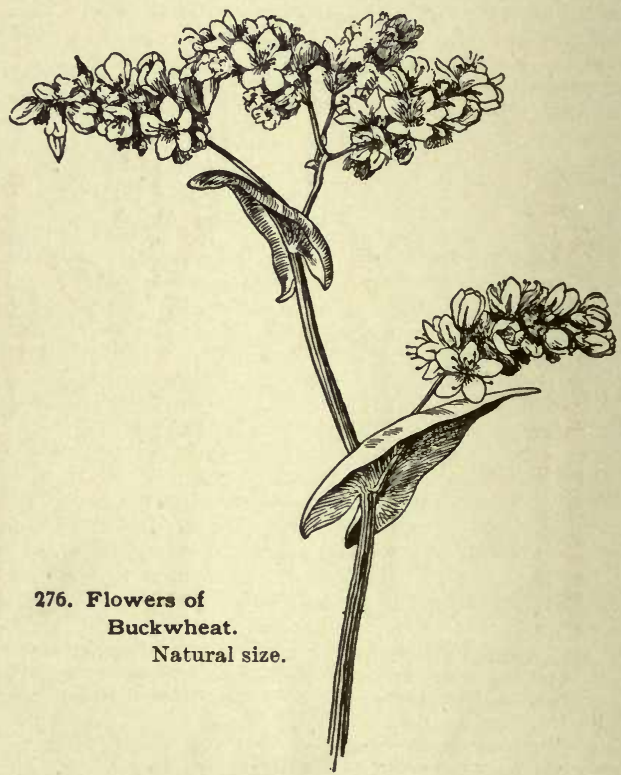

site, fleshy, simple or ternate, ovate, crenate, obscurely veined abore: fls. pendulous, in terminal-compound panicles: calvx and corolla cylindrical, reddish green, spotted white; calyx $1 \frac{1}{2}$ in. long ; corolla $2 \frac{1}{2}$ in. long, 
with 4 slightly curving tips (Fig. 275). Mex. B.M. 1409. LBC. 877 . - It is said that the Irs. are sour in the morning, tasteless at noon, and somewhat bitter towards evening. This change has been attributed to the absorption of oxygen at night and its disengagement in daylight.

W. M.

BUCKEYE. Consult Esculus.

BUCKTHORN. Rhamnus, particularly $R$. catharticus

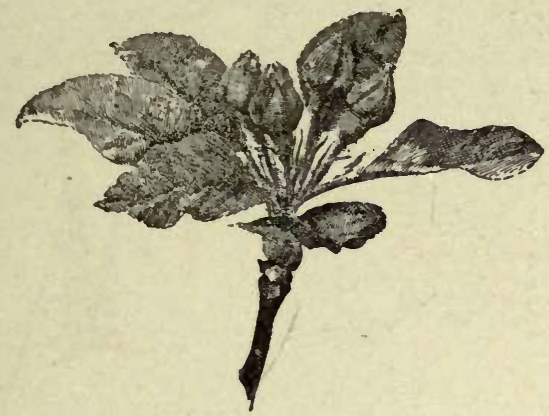

281. Apple twig, showing an expanding flower-bud.

BUCKWHEAT (Fagopỳmum esculéntum, Moench). Polygondcea. A tender annual grain plant, flour being made of the large 3-cornered fruit. It is much grown in the northern U.S., usually being sown about the first of July. It is also a favorite for bee forage. Buckwheat is native to central Siberia and Manchuria, and is now widely cult., although it is a grain of secondary importance. The flower-cluster is shown in Fig. 276. The Tartarian Buckwheat ( $F$. Tatáricum, Gærtn.) is occasionally seen. It has smaller and yellowish fls., and a smaller, roughish, wavy-angled fruit.

BUD. The undeveloped or embryo state of a branch. As commonly known to the horticulturist, the bud is a more or less dormant organ ; that is, the horticulturist does not recognize the bud until it has attained sufficient size to be obvious or to suggest some practice in the treatment of the plant. In this state the bud usually represents a resting stage of the plant. The bud-covering protects the growing point in the cold or dry season. The bud is a shortened axis or very condensed branch.

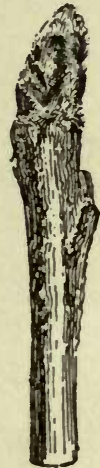

277. Apple buds-fruitbud on the left, leafbud on the right.

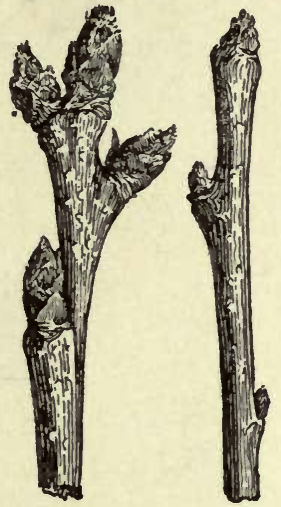

278. Pear twigs-fruitbuds on the left, leaf buds on the right.
The dormant or resting bud (as the winter bud of all trees) is covered with protective scales which are modified leaves : and the core of it is the nascent or embryo branch or flower-cluster, with rudimentary leaves. Since the bud is an embryo branch, it follows that disbudding is a most efficient means of pruning. A bulb is a form of bud; and a dense rosette of leaves (as in the common house-leek) is intermediate in structure between a bulb and a normal branch. A cabbage head is essentially a gigantic bud.

Horticulturists speak of buds as leaf-buds and flowerbuds, according as they give rise to barren, leafy branches or to flower branches (for flower-clusters are modified branches). True flower-buds or fruit-buds are those which produce only flowers, as those of the apricot (Fig. 116) and the peach. Mixed flower-buds or fruitbuds are those which contain both flowers and leaves, as those of the apple (Fig. 281) and pear. On dormant plants, leaf-buds and flower-buds are distinguished by position, size and shape. The position of the flower-bud varies with the kind of plant, but is commonly terminal, either on a branch of common length or on a very abbreviated branch or spur. The flower-bud is commonly larger and thicker than the leaf-bud, because it contains the embryo flower. Illustrations of flowerbuds and leaf-buds are shown in Figs. 277-280. With Fig. 279 compare Fig. 298, showing a section of cabbage head. The reader is referred to The Pruning-Book for detailed discussion of the subject.

Of all the buds which form, very many do not grow, being crowded out in the struggle for existence. These buds often remain alive and dormant for several years, each succeeding year decreasing their chances of growing even if favorable conditions occur. It is a common opinion that these dormant buds become covered by the thickening bark, and grow when large limbs are removed; but this is an error. The shoots which arise from a wound on an old limb are from true adventitious buds, or those which are newly formed for the occasion in the cambium. Buds are normally formed in close proximity to leaves, usually in their axils; but adventitious buds form under stress of circumstances, without reference to leaves.

L. H. B.

\section{BUDDING. See Graftage.}

BUDDLEIA (after Adam Buddle, an English botanist). Syn., Buddlea. Loganidcea. Shrubs or trees, with usually quadrangular branches: 1 rs. opposite, shortpetioled, deciduous or semi-persistent, usually tomentose when unfolding, entire or serrate: fls. in racemes, panicles or clusters ; corolla tubular or campanulate, 4-lobed; stamens included, 4: fr. a 2-celled capsule, with numerous minute seeds. About 70 species in tropical and temperate regions of America, Asia and S. Africa, of which only a small number of hardier species is cultivated. Ornamental shrubs, flowering freely in summer; not quite hardy north; the hardiest seems to be B. Japonica, which may be grown in sheltered positions north, but also many of the others, as $B$. globosa, variabilis, Lindleyana, Colvillei, will stand many degrees of frost, and, when killed to the ground, they freely push forth
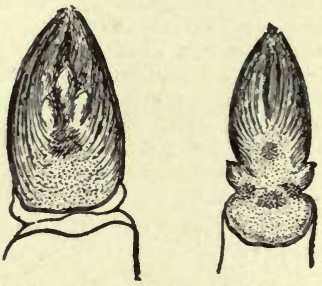

279. Sections of pear buds fruit-bud on the left, leafbud on the right.

young shoots, which will flower mostly the same season, especially $\boldsymbol{B}$. Japonica, Lindleyana and intermedia. The handsomest in flower are $\boldsymbol{B}$. Colvillei, variabilis, globosa and Lindleyana. They grow best in a light, well-drained soil, in a sunny position. Prop. readily by seeds sown in spring in gentle bottom heat, 
by greenwood-cuttings under glass, or by hardwood cuttings taken off in fall and kept during the winter in a frost-proof room

$$
\text { A. Fls. in panicles. }
$$

B. Corolla small, with long, narrow tube, 1/2-3/4 in. long.

$$
\text { o. Color violet or lilac. }
$$

Japónica, Hemsl. (B. curviflòra, Hort., not Hook. \& Arn.). Three to $6 \mathrm{ft}$., with quadrangular, winged branches : lvs. ovate-lanceolate, acuminate, remotely denticulate, slightly tomentose or nearly glabrous beneath, 3-6 in. long: fls. in dense, terminal, pendulous racemes, 4-8 in. long; corolla slightly curved, lilac outside, with grayish tomentum. Japan. I. H. 17:25. R. H. 1870, p. 337 , and 1878, p. 330 .

Lindleyana, Fort. Three to $6 \mathrm{ft}$.: lvs. ovate or oblonglanceolate, acuminate, remotely denticulate, pale green beneath, and slightly pubescent or glabrous, $2-4$ in. long: racemes dense, erect, $3-5$ in. long; corolla purplish violet, slightly curved, pubescent outside. China. B.R. $32: 4$. F.S. $2: 112$. P.M. $14: 5$.

intermedia, Carr. (B. Japónica $\times$ Lindleyàna). Hybrid of garden origin, similar in habit to $B$. Japonica. Lvs. ovate-oblong, dark green above, 4-5 in. long : fls. violet, in slender, arching or pendulous racemes, 10-20 in. long. R. H. 1873: 151. Var. insignis, Hort. (B. insignis, Carr.), has the upright habit of $B$. Lindleyana. Branches distinctly winged : 1vs. oblong-lanceolate, of ten in 3's : racemes erect, rather dense, 4-6 in. long, usually panicled at the end of the branches, with rosy violet fls. B.H. 1878: 330 .

variábilis, Hemsl. Three to $8 \mathrm{ft}$ : Ivs. nearly sessile, ovate-lanceolate or lanceolate, acuminate, coarsely serrate, whitish-tomentose beneath, 4-10 in. long : fls. in dense, terminal, erect panicles, 4-6 in. long ; corolla lilac, with orange-yellow mouth, glabrous outside. China. B.M. 7609. R.H. 1898: 132. G.C. III, 24: 139.A newly introduced, very handsome species, with showy and fragrant fls.

\section{cC. Color yellow.}

Madagascariénsis, Lam. Shrub, 6-12 ft., with densely tomentose branchlets: lvs. ovate-oblong, rounded or slightly cordate at the base, acuminate, entire, dark green and lustrous above, whitish or yellowish tomentose beneath : fls. tomentose outside, in large terminal panicles, appearing during the winter. Madagascar. B. R. 15: 1259. B. M.2824.-Hardy only in subtropical regions.

B B. Corolla with broad cylindrical tube, limb over 1 in. broad.

Colvillei, Hook. \& Thoms. Shrub, occasionally tree, to $30 \mathrm{ft}$ : : lvs. elliptic-lanceolate or lanceolate, serrate, pubescent, and pale or grayish green beneath, 5-7 in. long : panicles broad, pendulous, 12-18 in. long; corolla purple or crimson, with white mouth. B. M. 7449. R.H. 1893: 520. I. H. 41: 10. F. S. 14: 1487. J. H. III, 31: 85.The most beautiful of all Buddleias, and a very desirable shrub for warmer temperate regions ; only older plants flower freely.

AA. Fls. in globular heads.

globosa, Lam. Three to $10 \mathrm{ft}$., with the branches and lvs. beneath yellowish-tomentose : lvs. ovate or ovatelanceolate, acuminate, crenate, rugose above, 3-7 in. long: fls. orange-yellow, in dense, long-peduncled, axillary heads at the ends of the branches ; fragrant. Chile. B. M. 174.-A graceful and very distinct shrub, standing some degrees of frost.

$B$. A mericàna, Linn. Eight to $12 \mathrm{ft}$.: fls. in globular clusters, forming terminal panicles. Peru. Tender $-\boldsymbol{B}$ A siática, Lour. Three to $15 \mathrm{ft}$.: fls. white, in long, usually panicled spikes, fra

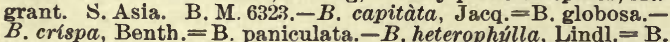
Madagascariensis. $-B$. Neemda, Roxb.=B. Asiatica $-B$. panic ulata, Wall. (B. crispa, Benth.), 6-15 ft.: Hs. lilac, in rather ulata, Wall. (B. crispa Benth.), 6-15 ft.: Hs. lilac, in rather
dense panicles: branches and lvs. tomentose. B. M. 4793. F.S. 9: 958. - B. salicifolia, Jacq. = Chilianthus arboreus. $-B$. salici fòlia, Hort. = B. Lindleyana.-B. saligna, Willd.=Chilianthus arboreus.

ALFRED REHDER.
BUEL, JESSE. American agriculturist and editor, was born at Coventry, Conn., Jan. 4, 1778, and died at Danbury, Conn., Oct. 6, 1839. He lived at Albany from 1813 until 1821, when he retired to his farm near by. He was one of the founders, in 1834, of The Cultivator, a monthly, "to improve the soil and the mind," the subscription price of which was fifty cents a year. In 1866, The Cultivator was merged with The Country Gentleman, a weekly founded in 1853, and The Cultivator and Country Gentleman is, therefore, the oldest surviving American agricultural paper.

BUFFALO BERRY. Fig. 282. Shephérdia argéntea, Nutt. (Lepargỳrcea argéntea, Greene). Elceagnàcea. The

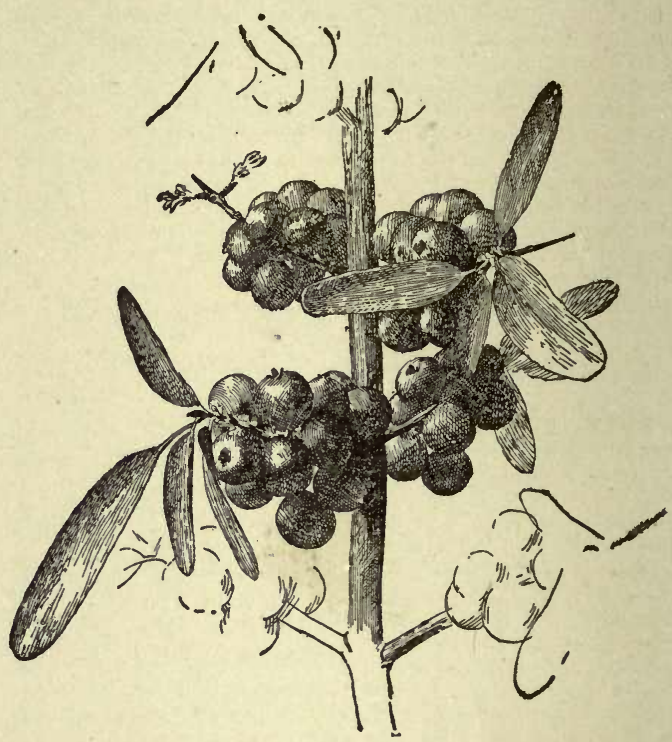

282. Buffalo berry $\left(X^{2} / 8\right)$.

Buffalo Berry has been long before the public, but it is only within the last few years that it has attained any prominence as a fruit plant. In Hovey's Magazine of Horticulture for 1841, page 251, it is mentioned as frequently cultivated, indicating that it found its way into our gardens earlier than the blackberry. Its position today bears evidence that no such place was awaiting it as stood ready for the blackberry, or that if there were, it has lamentably failed in attempting to fill it. The plant did not find its place as a cultivated shrub until the settlement of the West created a demand for hardy and drought-resisting fruits. The plant belongs to the Oleaster family, and now bears the name of Lepargyroea argentea (Nutt.), though more commonly known as Shepherdia argentea. It occurs commonly throughout the Rocky Mountain region and the dry plains to the eastward, from Saskatchewan to Colorado, and even New Mexico. Its fruit is frequently used for jelly, and is sprightly and agreeable, but small, with a single large seed, and borne among numerous thorns, so that it is far less promising than most of our other garden fruits. Apparently its chief value lies in its adaptability to regions where more desirable bush-fruits can not be grown. Where the currant thrives, there is little need for the Buffalo Berry, except as a novelty or for ornament. It possesses ornamental qualities of value, and may well be planted for that purpose. It is often recommended as a hedge plant for the Northwest. There are two forms, one bearing bright red and the other yellow fruit. The plant propagates readily, either by seeds or cuttings, and also by the suckers which sometimes spring up about the base of the plants. It is dioecious, and both staminate and pistillate plants must be grown together, or no fruit will result. These may be distinguished by the buds in winter, those of the pistillate 
plant being more slender, less numerous, and arranged in less compact clusters, those of the staminate plants being rounded, and borne in dense clusters.

BUGBANE is Cimicifuga.

Fred W. CARD.

BUIST, ROBERT. Florist, seedsman, and author, was born at Cupar Fyfe, near Edinburgh, Scotland, Nov. 14, 1805 , and died in Philadelphia, July 13, 1880. He was trained at the Edinburgh Botanic Gardens, came to America in August, 1828, and was employed for a time by Henry Pratt. In 1830 he became the partner of Hibbert, who had established the first notable florist's business in Philadelphia. He became noted for his successes with roses, which were at that time second in popular favor to the camellia with the Philadelphians. The great improvement of the verbena was largely due to him, and was immediately followed by the introduction into America of a distinct class of bedding plants. He introduced Poinsettia pulcherrima to the trade, and his sale of the double form is said to have been the first transaction of the kind accomplished by ocean telegraph. $\mathrm{He}$ was the author of The American Flower-Garden Directory, in 1832, The Rose Manual, 1844, and The Family Kitchen-Gardener (copyrighted, 1847), all of which were frequently reissued, and enjoyed a considerable sale for many years. An excellent account of his life may be found in The Gardener's Monthly 22:372 (1888). The frontispiece of the bound volume for the year is his portrait.

W. M.

BULB, BULBS. A bulb is a thickened, fleshy, and usually subterranean bud, generally emitting roots from its under side. The function of the bulb is to carry the plant over an unpropitious season, as over winter or a dry period. True Bulbs are either tunicated, formed in rings or layers, like those of hyecinths and onions (Fig. 283), or scaly, like those of liliums (Fig. 284); but as popularly understood and in commercial parlance, the term Bulbs applies to a large class of flowering and ornamental bulbous-like plants in their

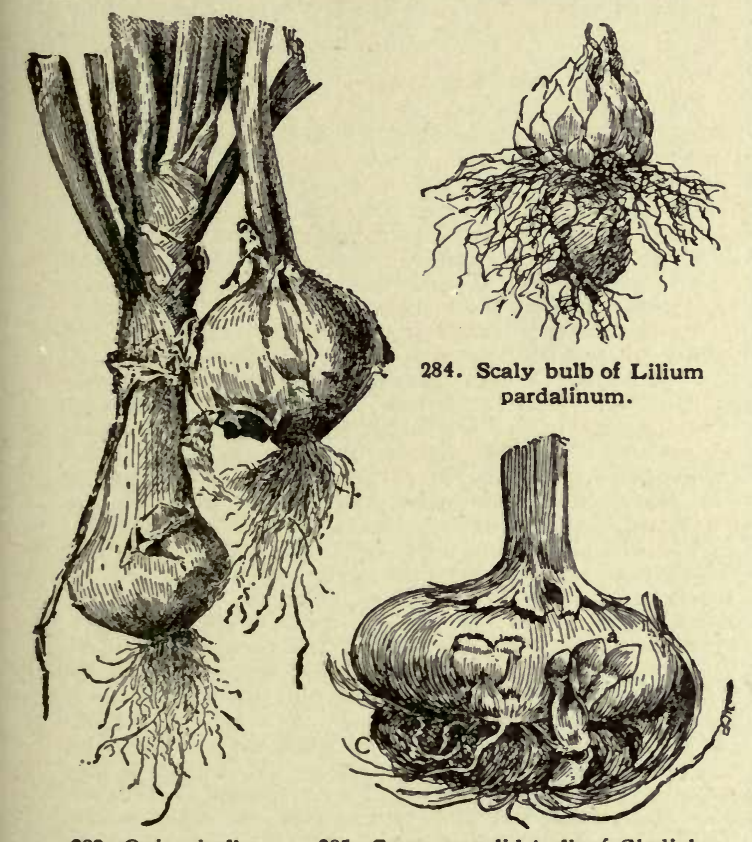

283. Onion bulbs.

285. Corm or solid bulb of Gladiolus.

dormant condition, during which period they are collected, dug, stored, shipped, sold and planted, like so many potatoes. This class includes, in addition to the true bulbs, many that are botanically known as corms, which are solid, as crocus and gladiolus (Fig. 285); tubers which are succulent and have the buds or eyes near the surface, as the dahlia and potato (Fig. 286); rhizomes, fleshy, creeping underground stems like cer-

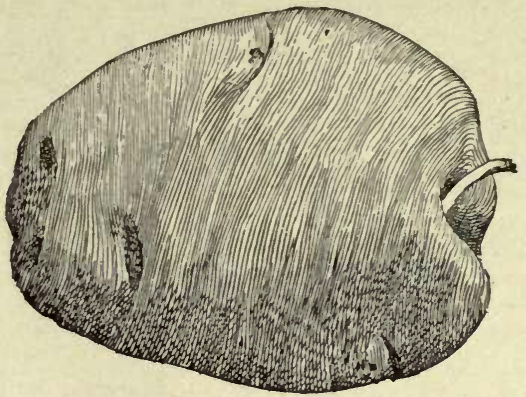

286. Potato-Example of a tuber.

tain iris, ginger, and many wild plants (Fig. 287 ; also, Fig. 53, p. 37); pips, the flowering crowns of lily-of-thevalley ; and certain other dormant fasciculated fleshy roots like those of peonies, ranunculus, etc. A variety of bulbs is shown in Fig. 288. The true or feeding roots grow generally from the base of the bulb, the stems, flowers and foliage from the crown of the bulb, or the eyes. There is an exception to this in certain lilies, which throw out roots above the bulb also (Fig. 289). The bulb is a storehouse for the plant, wherein is formed, after flowering, new stems, leaves and flowers. In fact, the bulb contains a new plant, which is protected and sustained within the bulb by the reserve food and energy collected therein during one season for the plant's successor. After the flowering period, the plant above the bulb and the roots beneath it ripen off and die away. The bulb is then in a dormant condition. It is during this state of rest, lasting approximately from three to six months, that bulbs are taken out of the ground and transported easily and safely from continent to continent, if required; after which the incipient roots, stems, foliage and flowers develop with as much luxuriance and perfection-conditions being congenial-as if the bulb had remained in its original environment.

Bulbous flowering plants (bulbs) are very popular with flower-loving people. There is a particular charm and interest in growing them. As a rule, they produce flowers of remarkable beauty, unsurpassed by any other class of plants, and many of them are deliciously fragrant. They comprise an endless variety in habit, form, size and color, are adaptable for many purposes, and many of them flower equally well under either garden or house culture. Soon after their beauty fades they hide away, or may be removed; and in the interval, their places may be occupied by other seasonable flowering plants. Not the least among the merits of bulbs is their ease of culture, and the great certainty and perfection with which their flowers are produced, under suitable conditions.

Among bulbous plants are many that are sufficiently hardy to withstand the severity of our northern winters. The kinds that are suitable are nearly all dormant in the fall, which is the proper time for planting them, and they will flower the coming season. In March or earlier, spring is ushered in with the blooming of snowdrops, chionodoxas, anemones, scillas, crocus, winter aconites, bulbocodiums, ete., followed in April with brilliant hyacinths, tulips, narcissus and hosts of others. In April appear the unapproachable late tulips, poet's daffodils, dicentras, etc., followed in succession until frost, notably with peonies, irises, hemerocallis, lilies, montbretias, tritomas, etc. All these are useful for gardens, lawns, and parks.

Gardeners usually think of bulbs as divided into two classes, - hardy and tender, or those which stand freezing and those which do not. There is a class from South Africa known as Cape bulbs, which usually bloom in the fall. There are now so many improved hybrids and breeds that are crowding out the types, that the term 
"Cape bulb" has lost its significance in this country. In the present article, bulbs are treated under the following general heads : hardy spring bulbs for design bedding; hardy bulbs in the herbaceous garden, mixed tlower border or lawn ; summer-and autumn-flowering tender bulbs for spring planting; bulbs for flowering

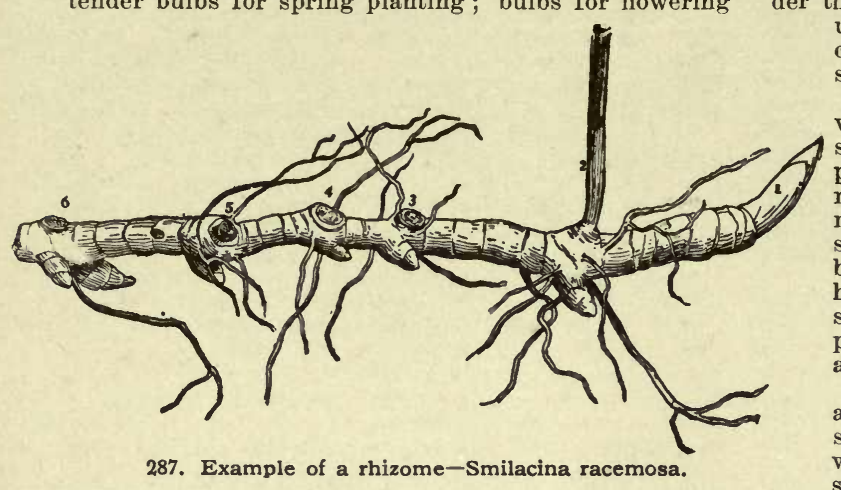

in the house and greenhouse ; keeping dormant bulbs, tubers, etc.; hints on buying and selecting bulbs; catalogue of bulbs.

Hardy Spring-flowering Bulbs for Design BedDING. - The only bulbs adapted for geometrical beds are Dutch hyacinths and tulips. It is not best to use both in the same bed for really fine effects. While there are hundreds of varieties in both hyacinths and tulips with colors, gradations and variegations innumerable, yet for this style of bedding only solid, bright, contrasting colors should be used. This limits the selection in hyacinths to dark crimson, rose-red, pink, purple, blue, lavender, white and yellow (the latter is seldom satisfactory), and in tulips to dark blood-red, scarlet, rose, blush-pink, yellow, white, and a bluish claret, which last is seldom used. In ordering the bulbs for this style of bedding, it is important to select kinds that bloom at the same time and are of uniform height. The bulb catalogues give this information; or, deal with a reliable firm and leave the selection to them. In planting bulbs in "design beds," it pays for the extra trouble to first remove the soil to a depth of 6 inches, spade up the lower soil, using well-rotted manure and plenty of bone dust worked in. Then level off, smooth, and cover with an inch of sand. This prevents the manure from touching the bulbs, allows the water to drain away from immediate contact with them, thus removing causes which may lead to their decay. Bulbs set in this manner on the sand may be placed in their exact position, after which the top soil is carefully replaced. It is a difficult matter to set bulbs just 4 inches deep and 4 to 6 inches apart with an ordinary trowel. The planter is almost sure occasionally to chop off a piece of a neighboring bulb or displace it. Bulbs planted in the manner advised, being all of an even depth, will flower uniformly; often, when planted with a trowel, some bulbs will be an inch too high and some an inch too low, which in early spring makes considerable difference in the time of blooming. Besides, when bulbs are planted with a trowel or dibble, there is danger of "hanging" a bulb occasionally, where it may perish on account of not touching bottom.

Hardy Bulbs in the Herbaceous Garden, Mixed Flower BORDER, OR LAwN.-The mixed border is a favorite place for most hardy bulbs. They should be planted in little colonies here and there among the hardy plants and shrubs; and it is here that bulbs seem to thrive and give the most pleasure. As spring approaches, the sombre winter browns and dull greens of the deciduous and evergreen plants are suddenly transformed into an unrivaled setting, studded with brilliantly colored and fragrant flowers, the contrasts being exceedingly effective and cheery; and besides, from the border one does not hesitate to eut a few flowers for the bouse for fear of spoiling the effect, as would be the case in formal bedding. Furthermore, bulbs seem to do better and last longer in a border because the flowers are cut freely in bud or when just approaching their prime, which is the best possible time for the benefit of the bulb, for the efforts of any bulb to form seeds weakens the bulb. A hyacinth bulb that matures seed is virtually destroyed. Then, again, in an herbaceous border the bulbs are not disturbed. The foliage remains uninjured until ripe, thus fulfilling its duty of recharging the bulb with new energy for the next. season's display.

Bold clumps of the taller bulbous plants are very effective on the lawn, where beds of one kind should be isolated, and be given a position not too prominent nor too near. The object desired is a mass of one color, which at a little distance is more striking on account of the contrast with the surrounding green grass and trees. Among the best hardy bulbous plants for this purpose are : hemerocallis, such lilies as candidum, tigrinum, speciosum and auratum; also dicentra, crown imperials, montbretias, tritomas, peonies, Kæmpferi and Germanica irises, etc.

Bulbs planted right in the sod on the lawn make a very pleasing picture when in bloom in the early spring. Make patches here and there of golden, white and purple crocus, the little chionodoxas, snowdrops, Scilla amona, winter aconite, snowflakes, bulbocodium and triteleia. These grow, increase, bloom and ripen the foliage before it is necessary to use the lawn mower, so that the surface of the lawn in summer is not marred. The bulbs may be dibblerl in when the ground is moist and soft during the fall rains, but it is better to cut and turn back the sod here and there, plant the bulbs under it, then press the sod back again.

For parks, groves and wild outlying grounds beyond the closely clipped lawn, a very happy style of "naturalizing" bulbous and other plants is coming much into vogue. Such bulbs should be used as can be planted in quantity, twenty-flve to a hundred or more of a kind in a patch, and only those should be used which are hardy, and will flower and thrive and increase under neglect. Fortunately, there are many bulbous plants that succeed even better in such rough places than in the prim garden. Among them are hardy anemones, camassia, convallaria, dicentras, erythroniums, funkias, certain iris, liliums, poet's narcissus, Von Sion narcissus, trilliums, and numerous others.

In regard to the preparation of beds for hardy bulbs, planting and treatment, we can only generalize. Detailed directions suited to the different species, and also varieties where treatment varies, will be found under their respective headings in this Cyclopedia. As a rule, well-rotted manure (mind that it is well rotted, not fresh

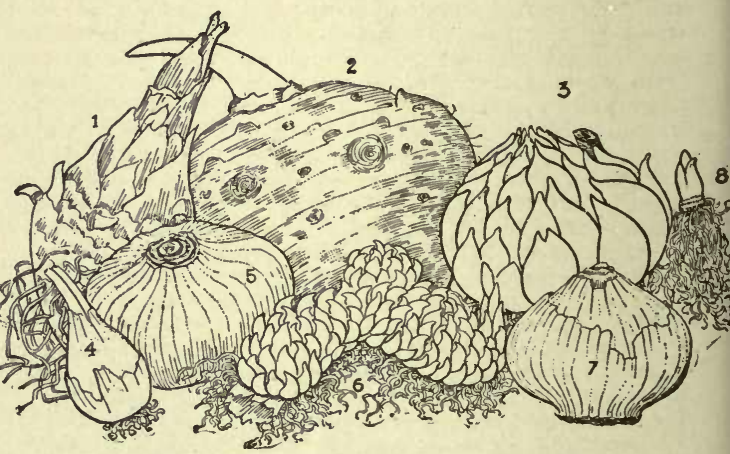

288. Various types of bulbs and tubers.

1. Tuberose. 2. Colocasia Antiquorum (Caladium esculentum). 3. Easter Lily. 4, Jonquil. 5. Gladiolus. 6. Lilium pardalinum. 7. Hyacinth. 8. Lily-of-the-Valley.

and heating) should be liberally applied and dug into the ground deeply. It must be where the long, feeding roots can get at it, and yet not touch the bulbs, nor be too near their base. This is easily accomplished by removing a few inches of the top soil first, as described under "Design Bedding," above. If it is impracticable to 
do this, then it is not advisable to use manure at all, for the bulbs are liable to come in contact with it and become diseased. Bone meal alone is then the safest fertilizer to use, and it should be applied lavishly. Most bulbs like rich food if properly applied. Although the embryo flowers were formed within the bulb the season

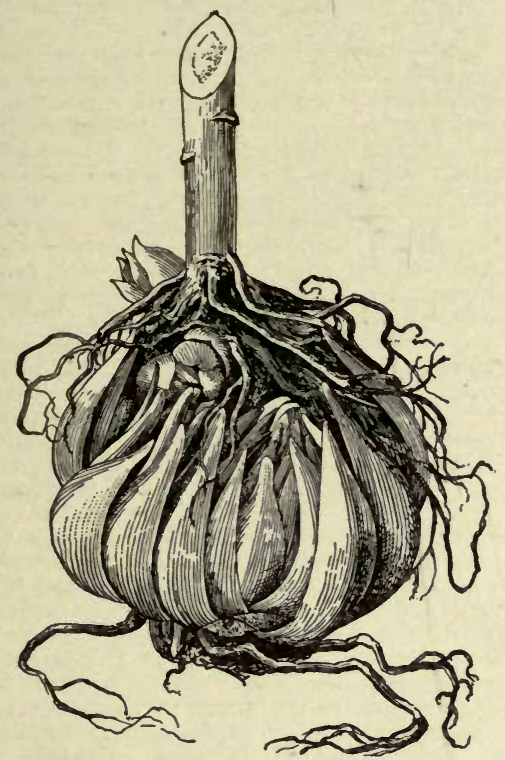

289. The Easter lily throws out feeding roots both below and above the bulb.

before, yet their size, luxuriance and brilliancy this season depend largely upon the nutrition the roots receive. Liberal applications of manure water, when the bulbs are in bud, often produce excellent results.

The proper depth to plant bulbs varies according to the kinds. It is a common fault to plant them too near the surface. Some kinds, notably the Californian Humboldtii and Washingtonianum lilies, do best when 10 to 12 inches deep ; hyacinths, tulips, narcissus, and similar large bulbs from 4 to 6 inches deep; smaller bulbs somewhat shallower. Hardy bulbs root during the fall and early winter, and if planted too near the surface the freezing, thawing and heaving of the upper crust of soil in mild winters often causes the bulbs to break from their roots, and, in consequence, only inferior flowers are produced. When good, cold weather has set in and a light crust has been frozen on the soil, then cover the bed with leaves, straw, marsh hay or reeds to a depth of from 4 to 6 inches. This protects not only from severe freezing, but from equally injurious unseasonable thaws. Do not put the covering on too early, for it might warm the soil so that the bulbs would commence to grow and afterward be injured from freezing. Gradually remove the covering in the spring.

The general run of bulbous plants thrive in a loamy soil, inclining to sand. This soil attracts moisture, allows free drainage, and admits air. If the soil is cold and stiff, a liberal admixture of leaf-mold and sand, with the addition of manure applied as above described, will be beneficial. The texture of the soil should be such that stagnant water will not remain around the bulbs, as it tends to rot them, particularly when dormant. An excess of humus is, therefore, to be guarded against for most bulbs. While the majority of bulbous plants thrive under the soil conditions advised above, yet there are many notable exceptions. Happy should be the man on whose grounds can be found a variety of soils and exposures, shade and sun. A small wooded valley or ravine, with a brook flowing through it into an open, moist meadow, affords conditions suitable for growing to perfection the greatest variety of bulbous and other plants, many of which cannot be enjoyed in the average monotonous garden.

The sooner bulbs can be put in the ground after they are ripe the better for the bulbs; for, no matter how long they will keep, they do not improve when out of the ground, but tend to dry out and lose vitality. There are, however, many reasons why bulbs cannot be planted as soon as ripe; and when they are to be kept for certain purposes, they should be stored as advised below. Hardy spring-flowering bulbs should be planted in the open ground in the fall, not earlier than six weeks before regular frosty and freezing nights are expected. Plant as much later as necessary, providing the bulbs are keeping sound, but it is not advisable to plant them earlier. Cool weather is necessary to deter top growth, which is very liablo to start after four to six weeks of root development; and young, succulent top growth is apt to be injured by the succeeding freezing. In Maine, Ontario, Wisconsin, and other northern parts (about 45 degrees north latitude), such hardy bulbs as hyacinths, tulips, narcissus, etc., may be planted in September. In New Jersey, Pennsylvania, Ohio, etc. (about 40 degrees), plant about the middle of October. In the latitude of Richmond, Louisville, St. Louis, etc., the middle of November is early enough. In the latitude of Raleigh, Nashville, and south, do not plant until middle of December; and for the latter section let the selection of bulbs run to late-flowering varieties, such as Bizarre, Darwin and late double tulips, late hyacinths, late narcissus, etc., for they are not so likely to be caught by the occasional freezing weather in January and February. In this southern latitude, however, very early-flowering bulbs, such as Roman hyacinths, Due van Thol tulips, Paper White narcissus, etc., if planted in September, are usually through blooming before freezing weather begins. South of the freezing belt, hardy spring-flowering bulbs are not very successful, as a rule, there being no sufficiently cool weather to deter top growth and force root action first, without which the flowers and foliage will not develop beyond such sustenance as the bulb can supply; and this sustenance is usually exhausted by the time the flower-spikes are half grown. But there are many half-hardy and tender bulbs that are more easily grown and flowered in the South than in the North.

The treatment of bulbs after flowering is important when the bulbs are to be used again, for it must never be forgotten that the flowers and resources for the next season are garnered within the bulb after blooming, through the agency of the roots and foliage. Imperfectly developed and matured foliage this year means poor flowers or none at all next year; so it is best to leave the bulbs alone until the leaves have died down. When summer bedding plants are to be substituted, it is sometimes necessary to remove bulbs before ripe. In such cases, the bulbs should be carefully taken up with a spade. Disturb the roots as little as possible, and do not cut or crush the leaves. Heel-in the plants in a shallow trench in some half-shady out-of-the-way place until ripe.

Summer- AND AUtumn-Flowering Garden Bulbs for SPRING Planting. - This class (Tender) includes some of our showiest garden flowers, which are almost indispensable. They are of the easiest possible culture. Planted in the spring, after danger from frost is over, in a sunny position in good, rich, loamy soil, they will flower with great certainty the same season. After flowering and ripening of the foliage, they should be taken up and stored for the winter as advised below, under "Keeping Dormant Bulbs," until wanted the next spring. Among the more important species of this class of bulbs are the undermentioned (those marked $F$ must be kept in a semi-dormant condition in a coldframe or greenhouse): Agapanthus (F), alstromeria (F), amorphophallus, anomatheca $(\mathrm{F})$, antholyza $(\mathrm{F})$, tuberous begonia, bessera, colocasia (caladium), cooperia, crinum, cypella, gladiolus, galtonia' Hyacinthus candicans), boussingaultia (madeira vine), montbretia, nemastylis, border oxalis, ornithogalum (F), pancratium, richardia (calla), schizostylis (F), sprekelia, tigridia, tuberose, watsonia, zephyranthes.

Bulbs for Flowering in the House and GreenHOUSE. - There is no class of plants that gives more satisfaction for this purpose, with so little skill, than 
the various bulbs. Perhaps the most important class of all bulbs for winter-flowering and forcing are certain hardy and half-hardy kinds. They are the most easily managed of all, and need occupy no space in the window or greenhouse, excepting when in bud and bloom. Under suitable treatment, they flower with great certainty, and their flowering period may be hastened (forced) or retarded at pleasure, so as to "bring them in "for certain occasions, or to give a continuous succession of bloom. There is a great variety of kinds of bulbs to select from for this purpose (see list of species at end of this article), yet the great demand, at this writing, has centered on the following leaders, especially for forcing purposes: Allium Neapolitanum, A.Hermettigrandiflorum, Anemone fulgens, convallaria (Lily-of-the-Valley), Freesia refracta alba, gladiolus "The Bride," early singleflowering Dutch Hyacinths and "Romans," Campernelle Jonquil, Lilium candidum, L. Harrisii and $L$. longiflorum. Several narcissuses are in demand, notably among the large trumpet varieties: Emperor, Empress, Golden Spur, Horsfieldi, Maximus and Trumpet major; among the medium and small trumpets: Sir Watkins, Barrii conspicuus and Poeticus ornatus; of the doubles are Von Sion and Orange Phœnix ; of the Polyanthus narcissus: Paper White grandifiora (Totus albus), and Double Roman (Constantinople). Of other species of bulbs, Ornithogalum Arabicum, Spircea astilboides floribunda (Aruncus), and single and double tulips of the early varieties are in demand. The principles of culture for hardy bulbs for winter flowering are the same, whether only a few are grown in pots for the window garden, or whether they are to be forced by the thousand by the florist. The first essential is to secure the strongest bulbs. Remember that the flowers were formed within the bulbs the previous season. If you buy bulbs of narcissus containing only one flower, or hyacinths with only ten bells on a spike, the best culture possible cannot make them produce more ; but good culture will develop such flowers larger and better. The next most important essential-we might say the secret of success in flowering bulbs in the house or greenhouse-is perfect root development before the tops begin to grow. To aid the uninitiated in this important matter, we will illustrate: When hardy bulbs are planted in the open ground in the northern states in the fall, the weather above them is cool or cold, the ground beneath them is warmer, and the conditions are congenial for root action but deterrent to top growth. This results in the perfect development of such flowers as the bulbs contain. On the other hand, when hyacinths, tulips, narcissus, and most other hardy spring-flowering bulbs are planted in fall in our extreme southern states, they usually prove disappointing, because the weather is warm, causing the flowers and foliage to begin to grow before the roots; and as soon as such sustenance as the bulb could supply has been exhausted, the plant stops growing and dwindles. When we grow bulbs under artificial conditions, we must make them produce roots first. Failure to do this is responsible for nine-tenths of the disappointments.

When hardy bulbs are to be grown in pots for winter blooming in the house or conservatory, the bulbs should be potted as soon as they are procurable, between $\mathrm{Au}$ gust and November. Some writers recommend that bulbs be planted in successional lots to give later and continuous flowers, but we think such advice is at fault, as the bulbs tend to dry out and lose vitality when kept dry too long. It is no trouble to retard the flowering of hardy bulbs in winter, as hereafter described, without keeping them out of the ground.

The soil should be rich loam. Fresh manure cannot be used. Of thoroughly rotted manure, some may be pulverized and worked into the soil, but it is safer to use pure bone meal, one part to fifty of soil. If the soil is stiff and heavy, mix it with sand and leaf-mold or peat. The size of pots depends upon the kinds of bulbs. A 5-inch pot is best for a first-sized hyacinth, or largebulbing narcissus, particularly the Polyanthus type. Tulips, small narcissus, and bulbs of a similar size, while they can go individually into a 4-inch pot, are better when put three or more of one variety together in a larger pot, as the soil retains a more even temperature and moisture; and for this reason some prefer earthen bulb-pans, which come in various sizes, from 8 to 18 inches in diameter. In potting, place a little broken pottery or lumps of charcoal in the bottom for drainage, then fill the pot with soil and shake it down, but do not pack it. Neither must the bulb be pressed or screwed into the soil, else the soil will be packed under it so that when the roots start they often raise the bulb out of the pot. Plant the bulb just deep enough that its top will not show. Large and soft bulbs, which are lia-

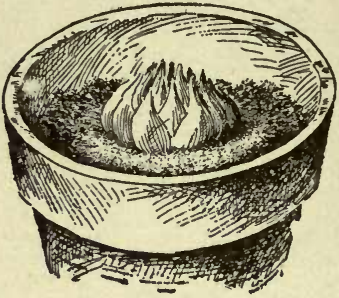

290. Bulb with a cushion of sand beneath it to prevent decay. ble to rot, may be set in a cushion of sand, and the bulb not covered with soil until it has taken root and become established (Fig. 290).

When planting mixed bulbs in the same pot, pan or box, care should be used in selecting different varieties that will flower at the same time. An early-flowering Duc van Thol and a double Tournesol tulip would flower a month apart under the same treatment. Some varieties of hyacinths, of narcissus, and of most species of bulbs vary greatly in time of blooming, which, of course, would spoil the effect.

When florists force bulbs in quantity for cut-flowers, they seldom use pots, but shallow boxes, or flats, of a size to economize bench room. Usually these boxes are cut down from soap boxes to a depth of 3 or 4 inches. The bulbs are planted closely in these, from an inch to 2 inches apart, according to the kind. The tops of the bulbs (excepting lilies) are kept about even with the top of the soil. Do not water them unless the soil is very dry, for bulbs in a dormant condition resent an excess of moisture. After the bulbs are potted, or boxed, as described, they should be placed in a coldframe or cold-pit to root. This is the most important detail in flowering bulbs under artificial conditions. Cover the pots, boxes or pans with 4 inches of sand, ashes, rotted leaves, tanbark or similar substance, and do not put the sashes on until freezing weather, and even then remove the sash on pleasant days. When no coldframes or pits are available, the pots may be covered as advised in a cool cellar. It is preferable, however, to sink them in the open ground. The writer never had finer flowers on hardy bulbs than when treated as follows: A trench a foot deep is dug in the garden where water will not settle on it, and it is protected from the north and west cold. Three inches of coal ashes is first placed in the trench, to allow drainage and keep the worms out. The pots are then placed on the ashes, the earth is filled in about the pots, fllling the trench rounding over. No further attention is required, as everything is congenial to perfect root development, while the weather is cool enough to check top growth. When the weather gets cold enough to freeze a crust on the soil, an additional covering of about 4 inches of rough stable manure, leaves or straw, is put over. Some early bulbs, such as Roman hyacinths, Paper White narcissus, Duc van Thol tulips, etc., will root sufficiently in five or six weeks to be taken up for first flowers, which should be out by Christmas or earlier, but it is safer to allow all bulbs not less than eight weeks for rooting. Every two weeks after the first removal of pots, or as needed, further relays of rooted bulbs may be taken out for a continuous display of bloom. When the pots of hardy bulbs have been taken up, place them in a cool greenhouse or cool, light store room, with temperature not over $50^{\circ}$. This temperature will allow the flower stems and foliage to grow, and at the same time prevent the opening of the flowers until the stems have attained their proper height, after which the pots may be taken to a sunny, warm window, or wherever they are wanted to flower. Bulbs treated in this manner will produce perfect spikes of flowers. A good rule to keep in mind in flowering hardy bulbs is: Temperature, $40^{\circ}$ for roots, $50^{\circ}$ for foliage and stems, $60^{\circ}$ for best flowers, $70^{\circ}$ for quick development, $80^{\circ}$ to rush bloom with loss of substance and risk of "going blind" (producing no flowers). 
The exceptions to the above adrice are liliums and lily-of-the-valley. Lilium Harrisii and Lilium longiflorum bulbs particularly, in addition to throwing out roots from the base of the bulbs, usually form roots from the new stem just above the buln, and the plants and flowers derive much strength from these top roots. So in potting lily bulbs, it is best to put them down so deep that there will be sufficient soil above the bulbs to entice and sustain the stem roots. In other respects treat the bulbs after potting as just advised. Winter flowering lily-of-the-valley forms no new roots. The thick, fleshy, fibrous old roots should be trimmed at the bottom, leaving them from 2 to 3 inches long. This al lows them to absorb the abundant moisture with which they should be supplied while the flowers and foliage are developing. They flower just as well in sand or moss, or anything that retains an even moisture and temperature, as they do in soil, but lily-of-the-valley for flowering in the house or greenhouse requires freezing before it can be successfully brought into flower. Without freezing, many pips will "come blind," or produce malformed spikes. So it is just as well for amateurs to plant their pips an inch or two apart in pots or bulb-pans, and plunge them in the garden, as recommended for other hardy bulbs. Florists generally freeze their pips in refrigerators, or have them placed, just as they arrive from Germany, 2,500 pips in a case, in cold storage, in a temperature of from 28 to $30^{\circ}$.

After being forced or flowered in the greenhouse or window, hardy bulbs are of little value, for most bulbs suitable for the purpose have attained their maximum size, and, in consequence, are ready to break up. Florists usually throw these bulbs away. Still, if space can be spared for the bulbs to complete their growth after flowering and ripening, many of them can be utilized for planting in the mixed border or garden, there to remain, where some of them will eventually recuperate and flower.

Half-hardy bulbs for winter-flowering and forcing should be treated the same as hardy bulbs, excepting that after potting they should be placed for rooting where they will not freeze. Yet they can go pretty close to it and be all the better for it. In northern states, a coldframe or pit or cold greenhouse to root them in is therefore, almost indispensable. For tender winter- and summer-flowering greenhouse bulbs, the culture varies with almost every species, and as no general instructions would suit all kinds, the reader may refer to their individual cultures given under their respective headings in this Cyclopedia. (See list of species at the end of this article.)

The flowering of bulbs in glasses, bowls, unique pots, etc., is always interesting. Among the most successful and interesting are hyacinth bulbs in glasses of water. Use early-flowering single varieties only. The seedsmen and dealers in bulbs supply special hyacinth glasses for the purpose. They come in various shapes, colors and decorations, and vary in price from 20 cts. to $\$ 1.50$ each. These are simply filled with fresh, pure water. A lump of charcoal thrown in absorbs impurities, but it is not absolutely necessary. The bulb rests in a cupshaped receptacle on top of the glass. In filling, the water should not quite touch the bottom of the bulb. Put in a cool, dark, airy place until the roots have reached the bottom of the glass, which should be in about six weeks. Do not place them in a close, warm closet. They must have fresh air. As the water evaporates, fill the glasses, and change the water entirely when needed to keep it sweet and clear. After rooting, place the glasses in a light storeroom where the temperature averages about $50^{\circ}$, until the stems and foliage have developed ; then remove to a warm, sunny window for flowers to open. There are other kinds that do equally well when rooted in water, providing the largest healthy bulbs are chosen. Among them are sprekelia (Jacobæan lily), Trumpet narcissus Horsfieldi and Golden Spur, polyanthus narcissus Grand Monarque and Gloriosa, large bulbs of Roman hyacinths, early single tulips, and Mammoth Yellow crocus, etc. We have flowered hyacinths on a piece of virgin cork floating in an aquarium, a hole being cut through the cork for the roots to reach the water. The so-called "Chinese Sacred Lily," a variety of Polyanthus narcissus, grows and flowers luxuriantly in bowls of water, provided they are not placed in a dry, furnace-heated room, which will cause the buds to blast before opening. Sufficient pebbles or shells should surround the bulbs to prevent them from toppling over.

Crocus, Roman hyacinths and lily-of-the-valley pips are very pretty when nicely flowered in columnar, hedge hog-or beehive-shaped hollow pots with holes for the reception of the bulbs. A bulb is placed in front of each hole from the inside, with the crown of the bulb looking outward. The pot is then filled with soil through the large opening in the bottom, moss being pressed in last to hold the contents in place, after which the pots are put outside for the bulbs to root, as explained for other hardy bulbs for the house.

Keeping Dormant Bulbs, Tubers, Etc. - Bulbs and tubers of the various species, as well as their varieties, vary greatly in size. Some, like oxalis, snowdrops, chionodoxas, etc., often do not exceed half an inch in diameter, while other bulbs, such as those of Caladium esculentum, certain arums, crinums, etc., attain great size, frequently weighing several pounds each. Such solid bulbs as those of tulips, hyacinths, narcissus, etc., will remain out of the ground solid and plump, in a suitable place, for three or four months. The larger the bulb the longer it will keep, as a rule. Large crinum bulbs have been kept for fifteen months. Still, it is always better to plant the bulbs as soon as possible, for, although they keep, they do not improve, and their tendency is always towards drying out and loss of vitality.

Never keep bulbs packed up air-tight. They are apt to generate heat or sweat, mold or rot, or to start. When solid bulbs are to be kept dormant for any length of time, they should be stored away from bright light in baskets, shallow boxes or slatted trays, in a room or cellar where there is a circulation of fresh air and the temperature is as cool as possible. Forty degrees is the desideratum for all excepting tender bulbs. Scale-like bulbs, as liliums, soon dry out and shrivel if exposed to the air for any length of time; therefore, they are best kept in open boxes packed with some substance that will retain a slight and even moisture, such as sphagnum moss, rotted leaf-mold, cocoanut fiber refuse, or moist sand, but they must be kept cold to check any efforts to start. Fleshy roots, like those of peonies, certain irises, astilbes, etc., should be treated like the lily bulbs. When a cold-storage room, with an average temperature of $36^{\circ}$ to $40^{\circ}$, is available, it is the safest place to carry over hardy bulbs and roots for spring planting.

Lily-of-the-valley pips are carried in rooms of about $28^{\circ}$ to $30^{\circ}$. The pips and packing freeze solid; and here they are kept for months until wanted for forcing. When they are removed from this aretic chamber, they must be thawed out gradually and as soon as possible, by plunging in cold water, before they are subjected to any heat; otherwise, they are likely to rot. For this reason, "cold-storage pips" cannot be safely shipped any distance in warm weather, this often being the cause of the country florists' disappointment in results.

Tender dormant bulbs, as begonias, gloxinias, amaryllis, pancratiums, tigridias, tuberoses, etc., must be kept in a warm, dry atmosphere, not below $50^{\circ}$. The cause of tuberoses not fiowering is often that the bulbs have been kept below $40^{\circ}$, which destroys the flower germ, although the foliage grows just as vigorously. Tender tubers, such as dahlias, cannas, etc., should be stored in dry sand in a warm, dry cellar or under the greenhouse bench.

Hints on Buying and Selecting Bulbs. - As already said, bulbs can develop only the flowers which were formed within them before they were ripened. A bulb may be poor because not full grown or too young, or because grown in impoverished soil or under uncongenial conditions, or because it may not have been matured when dug ; or it may be injured from heating, sweating, rotting or moldiness in storage or transit, caused by improper curing or packing, or it may be dried out from having been out of the ground too long. In the majority of cases in which poor bulbs are planted, however, it is the buyer's fault in procuring eheap bulbs, which in many cases are second grades, lacking age and 
proper size. The commoner varieties of a species usually propagate the fastest, and it is generally these less salable varieties and inferior seedlings and cullings from the named bulbs that go to make up most "mixed colors" and "mixed varieties." Therefore, for best results, it is advisable to expend a given amount of money for the first size named varieties, rather than for a larger quantity of cheaper seconds and mixtures, unless, of course, the bulbs are wanted for large permanent plantings, as in promiscuous borders for naturalizing, etc., where best flowers the first season are of secondary consideration.

The best named hyacinths - "top roots," as they are called in Holland-require from four to six years to attain full size and give best flowers. Such bulbs, according to the variety, should measure from 20 'to 24 centimeters ( 8 to 10 in.) in circumference. These naturally cost more to grow than the younger second or "bedding " grade of bulbs, measuring from 18 to 20 centimeters ( 6 to 8 in.). There is a third size, ranging from 16 to 18 centimeters ( 4 to 6 in.), that goes in mixtures, and a fourth size (12 to 14 centimeters) that goes out as "Dutch Romans," "Pan Hyacinths," "Miniatures," etc. Some growers even scale their sizes a centimeter or two less than mentioned, to enable them to quote lower prices. Crocus, narcissus, tulips and many other bulbs are also sorted into sizes, enabling the grower to catch all classes of buyers.

A first-size crocus bulb should measure 10 centimeters (4 in.) in circumference, and such bulbs produce from 6 to 12 flowers each. A small, cheap bulb produces only two or three flowers. A narcissus bulb of maximum size will produce from 3 to 5 flowers (sometimes more), and an inferior size usually but a single flower. A White Roman hyacinth bulb 14- to 16-centimeter size (5-6 in. circumference) will produce 3 and often 4 spikes of firsts and several seconds, while an 11- to 12-centimeter size will average only one first grade spike and a couple of seconds, or perhaps nothing but seconds. The best lily-of-the-valley pips bear from 12 to 16 bells on a spike, usually all firsts. Cheaper inferior grades of pips have seldom more than 7 to 10 bells. If the florist or planter wants the best bulbs, he must pay more money for them, but they are cheapest in the end, for secondgrade stock takes up just as much room and requires as much care, fire, and other expenses. It is the grade of flowers called firsts that sell and pay a profit. The supply of seconds is often so abundant that the market price for them does not pay the cost of the bulbs.

Catalogue of BulBs, - To aid in the selection of bulbs for particular purposes, we append a list of the leading species that are procurable while dormant (between the months specified) from seedsmen and bulb dealers, and we affix a sign to each to indicate the purpose for which the species - or certain varieties in it-are adapted. Some kinds are useful for more than one purpose, and such have a corresponding number of signs. For example: if a selection of bulbs is to be made for winter-flowering in the house, make a note of those to which an asterisk (*) is affixed, then turn to their respective headings in this Cyclopedia, where will be found full descriptions of the varieties as well as species - and cultural instructions - which will enable any one to make an intelligent selection.

For winter-flowering bulbs for greenhouse or window, select from species marked *

For summer-and fall-flowering bulbs for pots for greenhouse and other decoration, select from species marked + .

For spring-flowering hardy bulbs for gardens, lawns, etc., select from species marked $\ddagger$.

For summer-and fall-flowering hardy bulbs for gardens, lawns, etc., select from species marked $\|$

For summer-and fall-flowering (not hardy) bulbs for spring planting in garden, etc., select from species marked ?

For climbing bulbous plants, select from species marked $\uparrow$

Those marked $\mathrm{H}$ are hardy; Н.н, half-hardy; T, tender.

$$
\text { GENERA, ETC. HARDINESS. }
$$

DORMANT.

Abobra १ \&.

Achimenes $\dagger$

Agapanthus $\uparrow \ddot{z}$

Albuca $t$

Allium * $\ddagger$

Alstromeria

Amorphophallus 3

\section{H.H...}

T ............. Oct. to April

H. \& H.H.........Aug. to Dec.

H.H............. Sept. to Nov.

T............... Oet. to April
............... to April
GENERA, ETC.

HARDINESS DORMANT.

Anemone $* \ddagger \ldots \ldots \ldots \ldots \ldots \ldots \ldots \ldots$.. \& H.H......... Aug. to Nov.

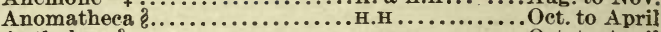

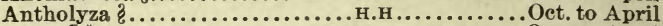

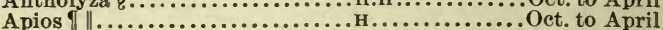

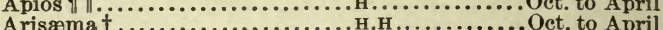

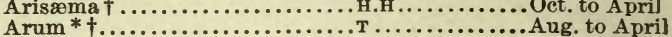

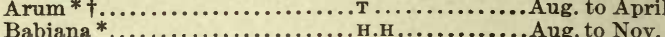

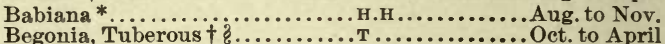
Bessera

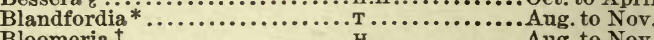
Bloomeria

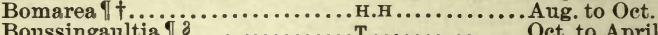

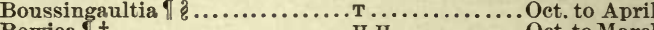
Bowiea f $t \ldots \ldots \ldots \ldots \ldots \ldots \ldots \ldots$. H............ Oet. to Mare Bravoa $f_{\ldots} \ldots \ldots \ldots \ldots \ldots \ldots \ldots \ldots \ldots$. $\ldots$.нt. to April

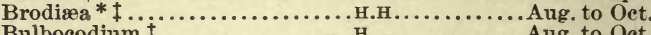

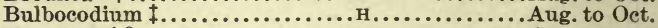

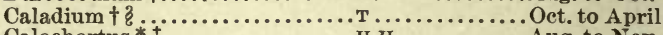

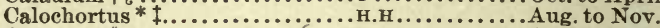

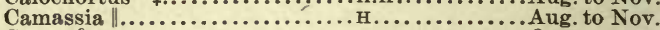

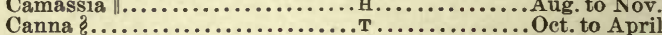

Chionodoxa**

Chlidanthus \&

Colchicum $\mid$

Commelina \&.

Cooperia \&

Corydalis $\|$

Crinum +8

Crocus * f..

Crown Imperials $f$

Cummingia $\dagger$.

Cyanella t

Cyclamen Persicum*

Cyclobothra \&

Cypella \&.

Cyrtanthus $\dagger$.

Dahlias ?

Dicentra $f$

Dioscorea

Eranthis $\ddagger$

Eremurus \|..

Eucharis $\dagger$

Eurycles $t$

Freesia*.

Fritillaria*

Galanthus*

Galtonia \&..

Geissorhiza $\uparrow$

Gesnera * +

Gloriosa of

Gloxinia

Griffinia $t$....

Hremanthus

Helleborus $\ddagger$.

Homeria ?

Hyacinth * 1

Hymenocallis \& $†$

Imantophyllum

Iris, Bulbous* *

* $t$.....................

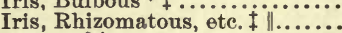
Ismene \& $\dagger$

Ixia *

Ixiolirion $\ddagger$

Jonquils * $\ddagger$

Lachenalia *

Leucojum $\ddagger$

Lilium *

Lycoris \&

Milla 8

Montbretia ||

Muscaria $\rfloor$

Nrogelia $* \dagger$.

Narcissus * $f$

Nerine $f$

Nerine $7 . . . . . . . \%$

Ornithogalum *

Oxalis, Winter-flowering * $¥$.

Oxalis, for

Pancratium $\dagger$

Phædranassa*

Polygonatum

Puschkinia $\ddagger$

Ranunculus *

Richardia $*+3$

Rigidella \&

Sanguinaria

Schizostylis *

Scilla $f *$

Sparaxis *
Aug. to Oct.

H.H.......... Oct. to April
H.H............

H.H............ Oct. to Apri

H.H.................... to April

H.................... to April

................. Nov. to April

H....................

H................

H................... to Oet.

................ Aug. to Oet.

............. Aug. to Oet.

....................... to Nov.

.................... Oet to A pri Oct. to April Oct. to March

Oct. to April

............Aug. to Oet.

................ tug. to Nov.

............. Sept. to Dec.

... Oct to Mareh

H............... tug. to Nov.

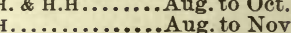

H.H.............. to April

H................ Aug. to Nov.

H.............

........................ to April .................... to April Oct. to April Aug. to Nov. Oet. to April

Oct. to Apri

Aug. to Nov

$\mathrm{H} . \ldots \ldots \ldots \ldots \ldots$ Aug. to Nov.
$\ldots \ldots \ldots \ldots \ldots$.

$\mathrm{H} . \ldots \ldots \ldots \ldots \ldots$ Aug. to Nov.
$\ldots \ldots \ldots \ldots \ldots$.

.................... Oct. to A April

\& H.H................ to Nov. to

H................ Oct. to April T............... Oct. to A pri

H................

................. H........... Ang to Oet. H.H................ to Oct.

H................ H................ Sept. to A pril H..................... to April H.H.................. Oct. to Apri H.H............... Oct. to Apri H.............. to Nov. ......................... to Aug to Opt. T................ to A pri T...................... to Nov. H. H.......... Aung to Nov. H.H................ Aug. to Nov H.................. to April ............... Oct. to Apri] .............. Oct. to April Hot. H................... T. T ............. Sept. to Dec H................... to April H.H.............. Oct. to A pri H. \& H.H .........Aug. to Nov. .H.H................ to Nov.
Act. to April H.H................. Sept. to April 


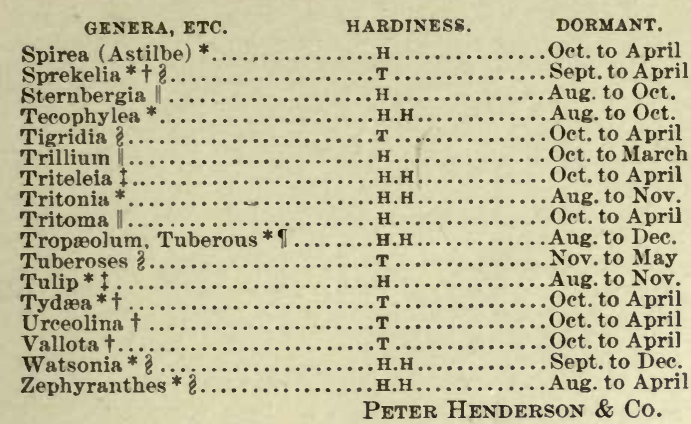

BULBINE (Greek, bolbos, a bulb). Lilidcece. Halfhardy African plants, of several species, allied to Anthericum, but practically unknown in this country. Some of the species are bulbous, and require the general treatment given Cape bulbs (see Bulbs).

\section{BULBINELLA. See Chrysobactron.}

BULBOCODIOM (Greek, woolly bulb). Lilidcea. A half dozen low, crocus-like bulbous plants of the Mediterranean region and eastward, some spring-flowering and others autumn-flowering. The spring-flowering species, $B$. vernum, is the only one in our gardens. It is hardy, and demands the same soil and location as crocuses.

vérnum, Linn. Fig. 291. Blooms in earliest spring, before the lvs, appear, the fls. resting nearly on the ground: fls. rosy purple, white-spotted on the interior, 1-3 from each bulb: lvs. broad and channelled. B.M. 153 (ef. Fig. 291). F.S. 11 : 1149. - Bulbs should be taken up and divided every 2 or 3 years. Plant in the fall. Usually blooms in advance of the crocus.

\section{H. B.}

BULBOPHYLUM (Greek, bulb-leaf). Orchidacea, tribe Epidéndrea. Many species of trop. orchids, mostly of the Old World, more odd than ornamental. Very few are known to cultivators. They are plants with a stout, creeping rhizome, small pseudobulbs bearing one or two stiff lvs.: lip jointed, moving when to u ched, sometimes hairy: fls. in racemes or spikes, or solitary. Require warm temperature and much water. Do not dry them off. 291. Bulbocodium vernum.

They thrive on blocks or trunks of ferns. B. Beccari, Reichb. f., is one of the largest of orchids, its rhizomes twining about trees, and its fls. emitting the vilest conceivable odor; see G.C. II. 11: 41, and 14: 326, 525; B.M. 6567 .

Lobbii, Lindl. Leaf solitary, broadly lance-elliptic : scape 1-fld., arising from the side of the pseudobulb, shorter than the lf.: fls. large and spreading (2 in. across); sepals lanceolate and acuminate, yellow, more or less marked with purple; petals smaller,streaked purple; lip cordate-ovate, yellow and orange-dotted, not bearded. Java. B.M. 4532.- Flowers in early summer. Once catalogued by Pitcher \& Manda.

BULL, EPHRAIM W. The introducer of the Concord grape lived a long, quiet, and useful life in Concord,
Mass., where he died Sept. 27,1895 , in his ninetieth year. In commercial importance, the greatest event in the early history of American grapes was the introduction, early in the fifties, of this variety of the northern fox-grape. The first fruit of this grape was obtained in 1849. Its exact origin is obscure. In 1840, Mr. Bull bought the house in which he lived until his death. That year some boys brought from the river some wild grapes, and scattered them about the place. A seedling appeared from which Mr. Bull obtained a bunch of fruits in 1843. He planted seeds of this bunch, and a resulting plant fruited in 1849. This variety was named the Concord. It soon became the dominant grape in all eastern America, as it was the first variety of sufficient hardiness to carry the culture of the vine into every garden in the land. It is a pregnant type, and has given rise to no less than fifty honorable seedlings, which range in color from greenish white to purple-black. The quality of the fruit is excelled by many varieties, but the latter usually demand more careful cultivation. The Concord is the one most important type of American grape, and the really successful commercial viticulture of the country dates from its dissemination; and yet this grape is a pure native fox-grape, and evidently only twice removed from the wild vine.

Ephraim W. Bull was loved of his neighbors and honored by every countryman who grows or eats a grape. He made very little money from his variety, and died in extreme poverty. The original vine is still preserved. It is a sprout from the old root.

L. H. B.

BULLACE. A small wild or half-domesticated plum, standing midway between the cultivated European sorts (Prunus domestica) and the wild sloe (P.spinosa). This plum is usually referred to $P$. insititia, but it is so elosely related to the Damsons as to be best classified with them. The Bullace would then take the botanical name of the Damsons, P. domestíca, var. Damascena (see Bot. Gaz. $27: 481)$. This plum is rather common in parts of $\mathrm{Eu}$ rope, but is very seldom seen in America.

F. A. WAUGH.

BUMELIA (ancient Greek name for an ash-tree). Sapotdcea. Small trees or shrubs, usually spiny, with rather small, entire, deciduous or persistent lvs. and small white fls. in axillary clusters: fr. an oblong black drupe. About 20 species from S. N. America to Brazil. None of them is of much horticultural value, but as they grow naturally, mostly on dry, rocky or sandy soil, they may be used sometimes with advantage for planting in similar situations. Prop. by seeds.

lanuginòsa, Pers. Tree, sometimes $50 \mathrm{ft}$.: lvs. oblongobovate or cuneate-obovate, rounded and often apiculate at the apex, dark green and lustrous above, tomentose beneath, sometimes nearly glabrous at length, 1-21/2 in. long: clusters many-fld.; pedicels slender hairy : fr. oblong or obovate, $1 / 2$ in. long. S. S. 5: 247 . S. states north to $\mathrm{S}$. Illinois, west to Texas. - This species and $B$. lyciotdes, Pers., are the hardiest. They have proved hardy in very sheltered positions even in Massachusetts ; besides these, $B$. angustifòlia, Nutt., and $B$. tenax, Willd., are the most common species in the $S$. states. B. Pálmeri, Rose, from Mex., is illustrated in G.F. $7: 196$.

ALFRED REHDER.

BUPHANE (Greek, cattle-destroyer, alluding to poisonous properties). A maryllidacea. Two or three South African bulbs, practically unknown in this country. They are large plants, with many red fis. in an umbel. Perianth tubular, segments equal and narrow, spreading: stamens 6, exserted : lrs. long and sword-like, thick. See Baker, Amaryllideæ.

dísticha, Herb. (B. toxicaria, Herb., Hoemainthus toxicárius, Thunb.). Bulb, 6-9 in. in diam.: lvs. several, distichous, 1-2 ft. long: peduncle or scape stout (6-12 in. high) and solid, compressed, glaucous, bearing a dense umbel. B. M. 1217.-Sparingly offered in this country. Lvs. said to be very poisonous to eattle in S. Afr.; bulb furnishes arrow poison for the natives.

Another species is $B$. cilidris, Herb., with fewer, shorter lvs., and shorter peduncle, bearing 50-100 fls. Not known to be in the Amer. trade. L. H. B. 
BUPHTHÁLMUM (Greek for ox-eye). Compósitoe. A few European and W. Asian perennial herbs, sometimes grown in the hardy border. Heads large, with long yellow rays: lvs. alternate, entire or dentate : pappus short, often connate into a corona: akenes g'abrous. Showy plants of easy culture.

speciosíssimum, Ard. Lvs. cordate and clasping, the upper ones oval and acuminate : heads solitary on the ends of the stems : 2-5 ft., flowering in July and later.

salicifolium, Linn. (B. grandiflorum, Linn.). Lvs. oblong-lanceolate, 3-nerved, somewhat pubescent and slightly serrate : fls. solitary and terminal, large : lower than the last.

specidsum, Schreb. (B. cordifolium, Waldst. \& Kit.). Lvs. very large, cordate, coarse-serrate : fls. very large and showy, on an upward-thickened peduncle : 3-4 $\mathrm{ft}$., blooming in June and later. B. M.3466, as Telèkia specidsa.

L. H. B.

BUPLEUेROM (Greek, $o x$ and rib : of no obvious application). Umbelliferce. Weedy plants of the Old World, of which one ( $B$, rotundifolium, Linn.), is naturalized in the Eastern states, and another (B. falcatum, Linn.), is eult. in Japan for greens (A.G. 13:9).

BURBIDGEA (after F. W. Burbidge, who discovered it in Borneo). Scitaminàcece. A monotypic genus allied to Hedychium, but with no lateral perianth segments and the lip reduced to a small blade. The showy orangescarlet fls. rival cannas in brilliancy. For culture, see Alpinia and Hedychium.

nitida, Hook. f. Tender herbaceous perennial : height 2-3 ft.: rootstock creeping, matted : stems tufted, slender : leaf-blades glossy, 4-6 in. long, eared at junction with the sheath : panicle terminal, 4-6 in. long, manyfd.; inner perianth tube 1-1 $1 / 2$ in. long; outer segments $11 / 2-2$ in. long, orange-scarlet, the dorsal one shorter and more roundish than the 2 lateral ones. B. M. 6403. Sold by Siebrecht \& Son.

BURCHELLIA (W. Burchell, botanical traveler). Rubidcece. One species from S. Afr., an evergreen shrub, with opposite short-petioled lvs. and dense terminal clusters of sessile scarlet fls.: corolla tubular, bell shaped; stamens 5 , inserted in the tube : fr. a 2celled, many seeded berry. B. Capénsis, R. Br., is in the Amer. trade, being cult. for its rich, dark foliage and brilliant fis. It is very variable, and has received several names, 3-10 ft. Prop. by cuttings. Grown under glass. B.M. 2339. R.H. 1886:420. J.H. III. 34: 81 .

BURDOCK. See Arctium.

\section{BURLINGTONIA. See Roariguezia.}

BURNET (Potèrium Sanguisòba, Linn.). A hardy cosaceous perennial, the piquant lvs. of which are sometimes used in flavoring soups and salads. The dried roots are occasionally used as a family remedy. Burnet is little known in this country as a condimental herb. It is worthy a place in the hardy border for the ornamental character of its odd-pinnate lvs. and its little heads of fls. with drooping stamens. The leaflets are very dark green, ovate and notched. Stems 1-2 ft. high, bearing oblong or globular monœcious heads. Of easiest culture, either from seeds or by division of the clumps. Native of Europe.

L. H. B.

\section{BURNING-BUSH. See Euonymus.}

\section{BURRIELIA. See Baeria.}

BURSARIA (Bursa, a pouch, alluding to the shape of the pods). Pittospordcea. Two species of shrubs with white fls. in clusters; sepals, petals and stamens each 5 : fr. a 2-loculed capsule, in shape like that of the Shepherd's Purse.

spinòsa, Cav. An elegant spiny shrub or small tree, with drooping branches and pretty white fls., produced in summer: lvs. small, oblong-cuneate, alternate and nearly sessile: fls. small, lateral or terminal, mostly terminal. Australia, Tasmania. B. M. 1767.-Cult. in S. California.
BURSEेRA (Joachim Burser, a disciple of Caspar Bauhin). Burserdceo. Generally tall trees, with sim. ple or pinnately compound lvs.: fls. small, in clusters, 4-5 parted, with twice as many stamens as petals or sepals, and a 3-parted ovary containing 6 ovules : fr. a 3 -parted drupe with usually only 1 seed. About 40 species of trees in tropical America. For B. serviàta, see Protium.

Simarùbra, Sarg. (B. gummífera, Jacq.). Lvs. oddpinnate, with 3-5 pairs of lfts.; lfts. ovate, acute, membranous, smooth on both sides, entire, the netted veins prominent on the under side : fls. in a very knotty raceme, 4-6 parted : fr. a drupe, with a 3-valved succulent rind and 3-5 nuts. A tall tree with a straight trunk and spreading head, found in Florida, Mexico, and Central America and the West Indies. - It yields a sweet, aromatic balsam, which is used in tropical America as a medicine for internal and external application; dried, it is known in the trade as Chibou, or Cachibou resin, or Gomart resin. It is a hardy greenhouse plant, and thrives in a compost of loam and peat. Prop. by cuttings under glass, with bottom heat.

\section{G. T. Hastings}

BUSH-FRUITS. A term used to designate those small fruits which grow on woody bushes. It includes all small-fruits - as that term is used in America-except strawberries and cranberries. Bush-fruits is an English term, but it has been adopted lately in this country, notably in Card's book on "Bush-Fruits." The common bush-fruits are currants, gooseberries, raspberries, blackberries, and dewberries.

BÙTEA (Earl of Bute). Legumindsce. Three or four species of trees or woody vines of India and China, with deep scarlet papilionaceous fls. in racemes and pinnate lvs. In the Old World rarely grown in stoves. In this country, one is cult. in $\mathrm{S}$. Calif.

frondosa, Roxbg. A leafy tree, yielding gum or lac : lfts. 3 , roundish, pubescent beneath, the lateral ones unsymmetrical : fls. 2 in. long, orange-crimson, very showy ; stamens 9 together and 1 free. India. - Reaches a height of $50 \mathrm{ft}$.

BUTOMUS (Greek, bous, ox, and temno, to cut; the leaves too sharp for the mouths of eattle). Alismacea. Hardy perennial aquatic of easy culture on margins of ponds. Prop. by division. All the species are referred by DC., in Mon. Phan., vol. 3, to B. umbellatus, or to the Australian Butomopsis, which is also a monotypic genus.

umbellàtus, Linn. Flowering Rush. Rhizome thick: lvs. 2-3 ft. long, iris-like, sheathing at the base, 3-cornered : fls. rose-colored, 25-30 in an umbel, on a long scape ; sepals 3 ; petals 3 . Summer. Eu., Asia.

BUTTERCUP. Species of Ranunculus.

BUTTERFLY WEED. Asclepias tuberosa.

BUTTERNOT. See Juglans.

BUTTON-BUSH is Cephalanthus.

BUTTONW00D. Consult Platanus.

BUTTERWORT. See Pinguicula.

BUXणS (ancient Latin name). Euphorbidcece. Box TREE. Evergreen shrubs or small trees : lvs. opposite, short-petioled, entire, almost glabrous, coriaceous and rather small: fls. nonœcious, in axillary or terminal clusters, consisting usually of one terminal pistillate flower, with 6 sepals, and several lateral staminate fls. with 4 sepals and 4 stamens : fr. an obovate or nearly globular 3-pointed capsule, separating into 3 valves, each containing 2 shining black seeds. About 20 species in the mountains of Cent. and E. Asia, N. Afr., and S. Eur., also in W. India and C. Amer. Ornamental evergreen shrubs of dense but rather slow growth, with shining, small foliage and inconspicuous fls. and fr. The common Box Tree and $B$. microphylla may be grown in sheltered positions even north, while $B . W a 7$ lichiana and $B$. Balearica, two very distinct and hand- 
some species, grow in the warmer temperate regions only. $B$. sempervirens stands pruning very well, and in the old formal gardens of Europe was formerly much used for hedges, and sometimes trimmed into the most fantastical shapes; the dwarf variety is still often planted for bordering flower beds. The very hard and close-grained wood is in great demand for engraving and finer turnery work. The Box Tree thrives in almost any well-drained soil, and best in a partially shaded position. Prop. by cuttings from mature wood early in

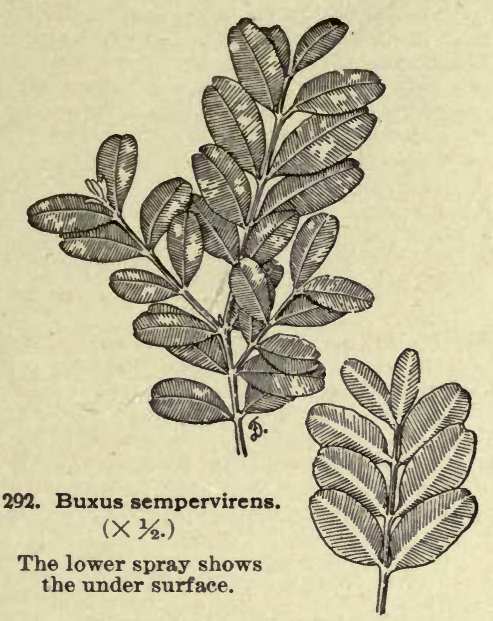

fall, kept during the winter in the cool greenhouse or under handlights in the open; in more temperate regions they may be inserted in a shady place in the open air ; 4-6 in. is the best size for outdoor cuttings. Layers will also make good plants. The dwarf variety is usually propagated by division. In planting borders, it is essential to insert the divided plants deeply and as firmly as possible, and to give plenty of water the first time.
Seeds are sown soon after maturity, but it takes a long time to raise plants of good size from them.

sempérvirens, Linn. Common Box Tree. Fig. 292. Shrub or small tree, to $25 \mathrm{ft}$.: branches quadrangular, sparingly pubescent: Ivs. oval-oblong or oval, rarely roundish oval or lanceolate, usually obtuse, $1 / 2-1 \frac{1}{2}$ in. long : fls. in axillary clusters; staminate fls. sessile, with a gland half as long as the calyx in the center. S. Eur., N. Afr., Orient, China. Very variable in size, color and shape of the lvs.; some of the most cultivated forms are the following: Var. angustifolia, Loud. (var. longifolia, Hort.; var. salicifolia, Hort.). Lvs. narrow, oblong-lanceolate, usually shrubby. Var. arboréscens, Linn. Tall shrub or small tree : lvs, usually oval. Var. argénteo-marginàta, Hort. Lvs. edged white. Var. aurea, Hort. Lvs. yellow. Var. aùreo-marginata, Hort, Lvs, edged yellow. Var. suffruticosa, Linn. (var. nàna, Hort.). Dwarf : lvs. small, oval or obovate : flowering clusters usually only terminal.

Japonica, Muell. Arg. (B. obcordàta, Hort. B. Fórtunei, Hort.). Shrub, $6 \mathrm{ft}$.: lvs, euneate, obovate or roundish obovate, obtuse or emarginate at the apex, $1 / 2-1 \frac{1}{4}$ in. long, with usually pubescent petioles; clusters axillary; staminate fls. sessile, with a central gland as long as the calyx. China, Japan.-Nearly as hardy as the former. There are also some variegated forms.

microphłlla, Sieb. \& Zucc. (B. Japónica, var. microphýlla, Muell. Arg.). Dwarf, often prostrate shrub, quite glabrous : lvs. obovate or obovate-lanceolate, $1 / 3-1$ in. long: clusters mostly terminal ; staminate fls. sessile, with a central gland, like the former. Japan.

Baleárica, Willd. Shrub, 6-15 ft.: lvs. elliptic or oblong, acute or obtuse at the apex, 1-2 in. long, light green: clusters axillary; staminate fls. pedicelled. S. Spain, Balear.-Handsome shrub, but less hardy than the former.

B. Califórnica, $\mathrm{Lk}=$ Simmondsia Californica. - B. Fórtunei, Hort = B. Japonica, - B. Hárlandi, Hance. Branches pubesHort. = B. Japonica. - B. Harlandi, Hance. Branches pubescent : lvs. narrow obovate, emarginate, $3 / 4-11 / 4$ in. long. China. in. long. Orient, China. $-B$. longifollia, Hort. = B. sempervirens, var. angustifolia. $-B$. Wallichiàna, Baili. Branches pubescent : lvs. linear-elliptic, $1-2 \frac{1}{2}$ in. long. Himalayas.

ALFRED REHDER. 
CABBAGE, Brássica olerdcea, Linn., is a cruciferous plant which grows wild on the sea-cliffs of western and southern Europe. Figs. 293 and 294, from nature,

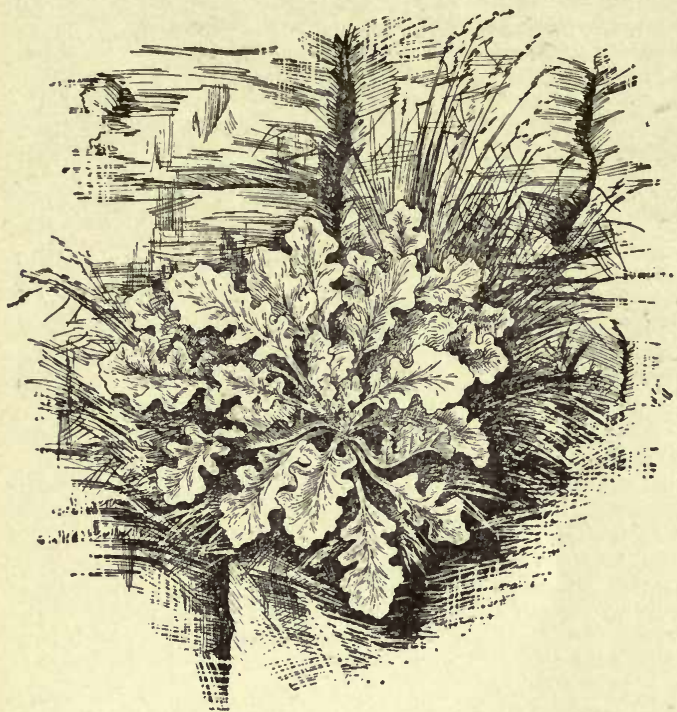

293. Wild Cabbage on the cliffs of the English Channel.

show the common form as it grows on the chalk cliffs of the English Channel. It is a perennial plant, or perhaps sometimes a biennial, with a very tough and woody root, a diffuse habit, and large, thick, deep-lobed leaves in various shades of green and reddish, and more or less glaucous. The leaves of this plant were probably eaten by the barbarous or half-civilized tribes; and when history begins, the plant had been transferred to cultivated grounds and had begun to produce dense rosettes or heads of leaves. It appears to have been in general use before the Aryan migrations to the westward. There were several distinct types or races of the Cabbage in cultivation in Pliny's time.

From the one original stock have sprung all the forms of Cabbages, Cauliflowers, Brussels Sprouts and Kales. For this family or group of plants the English language has no generic name. The French include them all under the term Chou, and the Germans treat them under Kohl. These various tribes may be classified as follows (cf. De Candolle, Trans. Hort. Soc. London, 5, 1-43 ; Prodr. 1. 213):

Var. acéphala, DC. The various headless Cabbages. It comprises the Kales, in many types and varieties, as the tall or tree Kales, Curled or Scotch Kales, and Collards. The Georgia Collards, grown in the south and shipped to northern markets, is shown in Fig. 295. Its likeness may be found wild on the cliffs of the southeastern coast of England to-day. A Curled Kale is shown in Fig. 296. The thick, tender leaves of the Kales are used as "greens." See Collards and Kale.

Var. gemmifera, Hort. The bud-bearing Cabbage, or Brussels Sprouts (see Fig. 273). In this group, the main stem or axis is tall and erect, and the axillary buds are developed into little heads.

Var. capitata, DC. The head-bearing, or true Cabbages. In this tribe, the main axis is short and thick, and the leaves are densely packed into a gigantic bud or head (Figs. 297, 298). The varieties of Cabbage are very numerous and various. A serviceable classification of them might follow this order:
A. Lrs. plain (not blistered).

B. Head oblong or conical (Fig. 299). c. Green.

cc. Red.

BB. Head oblate or flattened (Fig. 299), including $\mathrm{c}$ and CC, as above.

AA. Lvs. blistered or puckered. The Savoy Cabbages, Fig. 300 , $B$. oleracea, var. bullata, DC.), to be further divided, as in $\mathrm{A}$.

Var. botrytis, DC. Cauliflower and Broccoli, in which the head is formed of the condensed and thickened flower-cluster. See Cauliflower.

The Chinese Cabbage is a wholly different species from the common Cabbages (see Brassica). It does not form a compact and rounded head, but a more or less open and soft mass of leaves, after the manner of Cos Lettuce. It is of easy culture, but must be grown in the cool season, for it runs quickly to seed in hot and dry weather.

L. H. B.

Culture of CABBAGE. - The Cabbage is a gross feeder. It endures much abuse. We may cover its leaves with dust, dose it with all sorts of substances, mutilate its leaves or roots as we choose, plant it in heavy clay, black muck or pure sand, and it will do fairly well in spite of all conditions if we but supply an abundance of easily secured food and the right quantity of water to enable the plant to take it in and make it available. Next to plenty of food, its great requisite is a proper supply of water, and, though its native home seems to be near the ocean, it is by no means an aquatic, and suffers as much from an over-supply of water as from any untoward condition. Cabbages cannot endure hot sunshine and dry air, and do best at all stages of growth in a cool, moist atmosphere, and while young plants do fairly well in a higher one, provided there is plenty of light and air, the older ones cannot be made to form perfect heads in such weather as prevails in most parts of the United States during the summer months. They are quite hardy, and will endure a too low temperature better than one which is too high, their hardiness in this respect depending largely upon the condition of the plant. The leaves of one rapidly grown in a greenhouse will be killed by $2^{\circ}$ or $3^{\circ}$ of frost, while it will take $20^{\circ}$ to $25^{\circ}$, continued for some time, to kill one grown slowly outof-doors. It is clear that if the plant is to be grown successfully in our southern states, it must be during the cooler winter and spring months; and at the north seed-sowing must be so timed as to avoid bringing the plants to a heading condition during hot weather. Cabbages can be grown without protection at the south

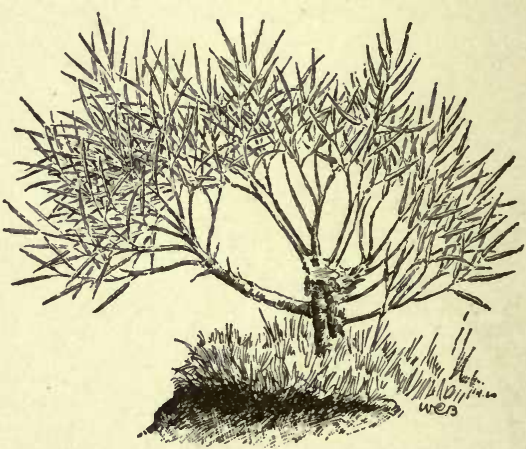

294. Wild Cabbage plant in seed.

wherever a minimum temperature of about $15^{\circ}$ above zero is the coldest that may be expected, and at the north well-grown and hardened plants for early crop may be set out as soon as danger of a temperature below about $20^{\circ}$ above zero is passed. The earliest maturing 
varieties, when grown without check, will come into heading condition in about ninety days from the seed, and the time necessary for the different sorts to perfect heads varies from that to some 200 days for the latest. In about sixty days from the seed the plant will be as large as can be profitably transplanted, so that when plants can be safely set out-of-doors early in March the seed should be sown early in February, the date of sowing to be determined by the local climatic conditions. We think the best plan is to sow the seed in boxes, about 3 inches deep, and of convenient size to handle, filled with rather heavy but very friable soil. We plant the seed in drills, about 2 inches apart, dropping about ten seeds to the inch. The seedlings need abundant light and air, and the great danger to be guarded against is their becoming soft and spindling through too high temperature and the want of light. They should be fully exposed whenever the weather will permit. In from fifteen to twenty days after sowing the seed the plants should be "pricked out," setting them about 2 inches apart, in a rich and somewhat heavier soil than was used in the seed boxes, and as soon as well established they should be given all the light and air possible. A few degrees of frost for a night will be an advantage rather than an injury. It was formerly the eustom, and one still followed by some successful growers, to sow the seed in the open ground in September, transplanting into coldframes in late October or November. and carry the plants through the winter in a dormant or slowly growing condition. Such plants, being very hardy, can be set out early, and, if all goes well, will mature somewhat earlier than spring-grown plants, but this method is now generally thought to be more expensive, less profitable and certain than spring planting. For the later or general crop at the north, and for those parts of the south where no protection is necessary, seed is sown in beds out-of-doors. For this purpose, select a well-drained, lovel spot, of rich, friable soil, as near the field where the crop is to be grown as practicable, and get it into the best possible condition as to tilth and moisture by repeated cultivation. In the latitude of New York, the latter part of May or the first of June is considered the best time for sowing seed for the general crop, but fine yields are often obtained there from seed sown as late as the middle of July, and many of the most successful growers wisely make several sowings, one as early as May 10 , and one or two later, so as to be sure to have plants in the best condition for transplanting at the time when the condition of the field and weather is favorable. The seed should be sown in drills, about a foot apart, at the rate of about fifty to the foot, or, if thicker, the plants should be thinned to about one-fourth inch apart, as

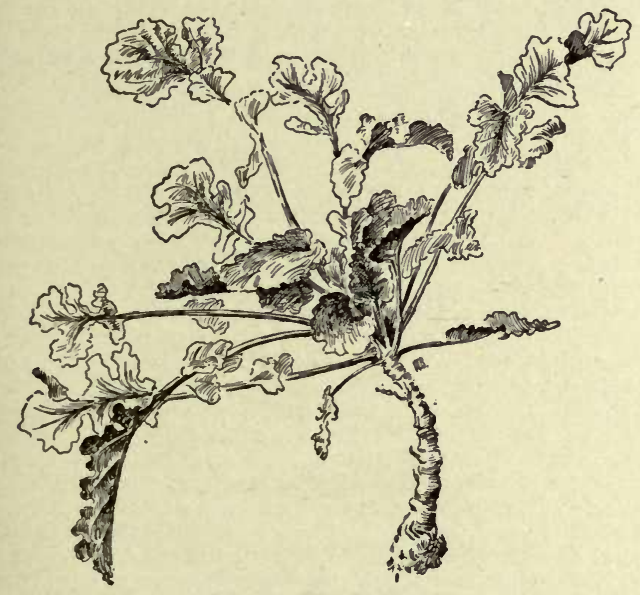

295. Georgia Collards.

soon as fairly up. Some growers sow the seed and leave the plants much thicker, but we think it pays to give them plenty of room. The seed should be lightly covered, and the soil pressed firmly over it with the hoe, a small roller, or, best of all, the foot ; this firming of the soil is often quite essential to success. It is sometimes the case that, in spite of all our efforts, the seed-bed becomes so dry that seed will not germinate. In such cases one can often get a good stand by watering the ground before planting, filling the drills two or three times with

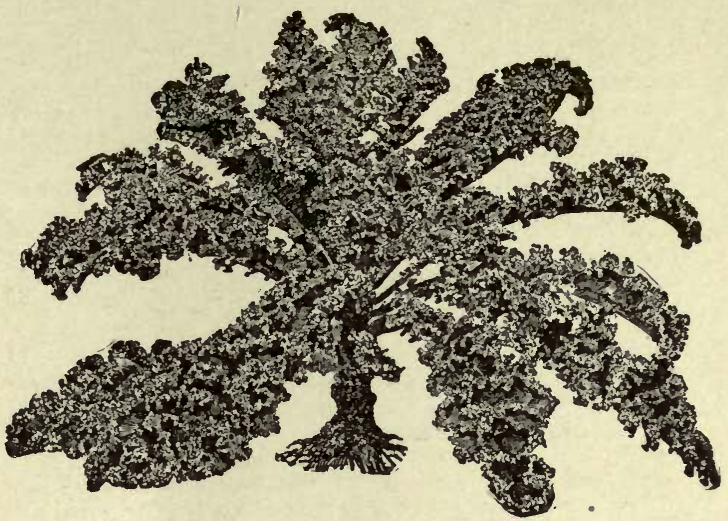

296. Curled Kale. Brassica oleracea, var. acephala.

water, and when it has settled away sow the seed and cover with dry earth, well pressed down. In most cases an attempt to wet the bed by sprinkling, either before or after the seed is planted, will do more harm than good. As soon as the starting seed breaks ground the surface should be carefully stirred with a rake, and this should be repeated at least as often as four times a week until the plants are taken to the field.

A full stand of healthy, well-established plants is of great importance, and does much towards assuring a profitable crop. So important is it, that many growers wait for damp weather before setting, regardless of the season. We think they often make a mistake in doing so, and, while a cloudy or damp day is desirable, it is of far greater importance that our plants are set at the proper time, and the moisture of the soil conserved by cultivation before and stirring of the surface immediately after setting. Careful attention should be given to so arrange the work that the young plants should be taken up so as to save all the root possible, protected from the sun, and set as soon as practicable. Just how this can be best done will depend upon each planter's circumstances and the help he has at his command. There is one point in transplanting which is of especial importance with Cabbage plants, that is that the roots are not doubled back upon themselves. This is often done by careless men, and some of the transplanting machines are worthless because of this fault. A Cabbage plant so set never does well, and seems to suffer much more than if the root had been cut off instead of folded back.

The Cabbage is very dependent upon a proper supply of water, and suffers more from the want of it than most of our garden vegetables. Its roots, though abundant and of quick growth, are comparatively short, and less capable of gathering moisture from a dry soil than those of such plants as the bean. On the other hand, it is quickly and seriously injured by an over-supply of water at the root. Want of consideration of these characteristics is a frequent cause of failure. Men seem to think that, because the plant is a rank feeder, all that is necessary is an abundant supply of food, and set them on rich, black soils, made up chiefly of vegetable matter, but so open that they quickly dry out during summer droughts and the plants die or fail to do well, or on lands so poorly drained that in a wet time the ground is flooded and the plants drowned out. Not only should we select ground where the natural water supply is good, but one where the physical conditions are such that we can conserve the soil moisture by frequent and thorougl. cultivation, both before and after setting the plants.

For the highest possible development, the evenness of 
distribution and the degree to which the plant-food has become immediately available is of equal or greater importance than the quantity. Land can be put into the best condition for raising a maximun crop by a heavy dressing of stable manure, thoroughly worked into a well-drained, loamy soil, and repeating the process yearly for several seasons. A much heavier dressing of manure can be profitably applied to a soil which has been well fertilized in previous years than to one which has received little or none. The most successful growers use large quantities of manure, often as high as one hundred tons to the acre. When stable manure cannot be readily obtained, it may be supplemented by commercial fertilizers, so made up as to contain about seven parts of nitrogen to eight of available phosphoric acid and about six of potash. If we depend entirely upon fertilizers, we should use from 2,000 to 3,000 pounds to the acre, and we should not forget that upon all ordinary soils the yield and profitableness of a crop of Cabbage is largely dependent upon the amount of available and evenly distributed plant-food and the degree to which the soil is kept always moist, and more with conditions which can only be secured by frequent and thorough cultivation,

Diseases and Some of the Most Common Insect PEsTs. - Club-root. - This is the effect of a fungus (Plas midiophora Brassica), which develops within the cells of the root, causing them to become distorted and the plant to develop imperfectly or die. On the death of the plant, the spores of the fungus become mixed with the soil, where they lie dormant until roots of some other host-plant come in contact with them, and the conditions are favorable for their development. They develop within several of our common weeds, and we believe that the spores are to be found in most of our cultivated fields, and need only favorable conditions to develop. We have found that the disease is seldom troublesome except where the cultural conditions, particularly as to moisture, are unfavorable to the Cabbage, and that the best preventive is careful attention to the health and vigor of the plant. We know of no practical remedy where a plant or field is badly affected.

Flea Beetle.-A small, quick-moving black insect (Phyllotreta vittata), which sometimes destroys the seedlings before they have formed true leaves. By attending to them promptly, we have always succeeded in protecting our plants by dusting them with tobacco dust, used liberally and as often as necessary, which may be twice a day. A great deal depends upon using the tobacco as soon as the first beetles appear. It is a great deal easier to keep them off than to dislodge them after they are once there.

Cabbage Root Maggot (Phorbia Brassica).-This is the larva of a fly very much like the common house fly, though a little smaller. They appear in the latitude

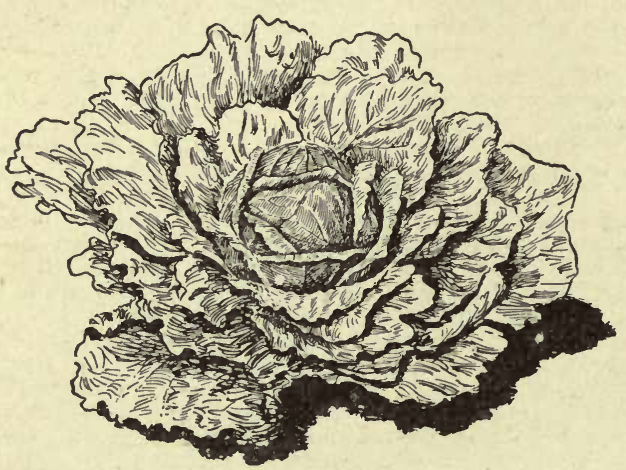

297. A modern Cabbage head-Early Flat Dutch.

of Detroit early in May, and the female deposits her eggs in the ground at or close to the plant, usually putting her abdomen into the opening in the soil formed by the movement of the plant by the wind. The eggs hatch in a few days, and the maggots feed upon the roots and soon destroy them. An effective but costly preventive, only practicable for use on early plants of high prospective value, is to surround the plants with shields formed of octagon pieces of tarred paper about three inches across, and having a small hole in the center, from which there is a slit to one edge, by means of

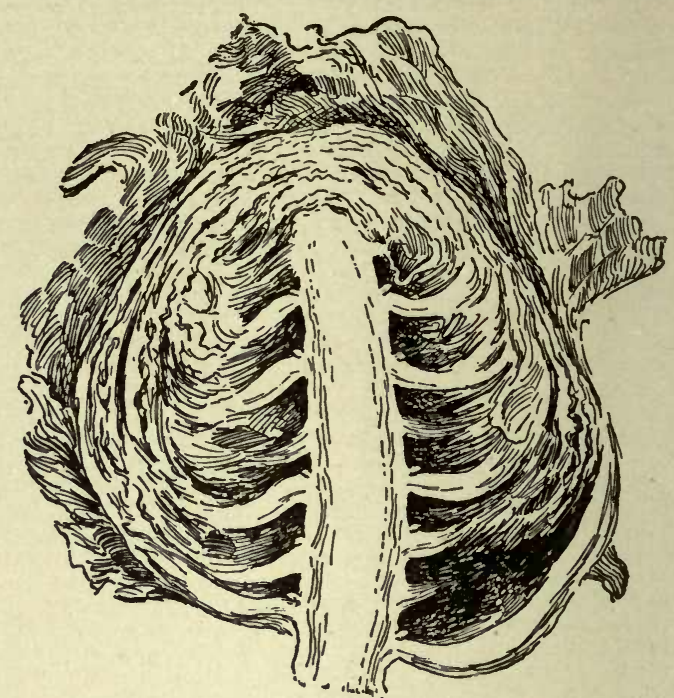

298. Section of Cabbage head.

Showing the thickened rachis and leaf-stalks, and the buds in the axils.

which the guard can be slipped around the plant and pressed down on the ground, so that the fly is prevented from laying her eggs in the earth, and, laid on the surface, they will perish for want of moisture. We have also done much to prevent injury by scattering among the plants bits of sticky fly-paper, by means of which a great many of the flies are caught and killed. It is important that the paper should be put out early, so as to catch as many as possible before they have laid their eggs. In the seed-bed, the maggot can be destroyed by injecting bisulfide of carbon about the roots from a syringe, or pouring it into a hole and quickly closing the hole (cf. Slingerland, Bull. 78, Cornell Exp. Sta.).

The Green Cabbage Worm (Pieris Rapa).-We have succeeded best in protecting our young plants from worms by spraying with Paris green and water in about the proportions used for potato bugs. As the plants become larger, and the use of the poison objectionable, we dust the plants with pyrethrum powder, which, if pure, will be very effective.

Harvesting, Storing and Marketing.-Nearly all of a well-grown crop of Cabbage of a good stock will mature at about the same time, and, while the earlier sorts remain in prime condition but a few days, the later ones remain so for two or three weeks, and can be stored so as to be salable for several months. Often the maturing of the crop can be delayed to advantage by partially pulling the plants and pressing them over to the north. The southern crop is usually marketed from the field as soon as it is fit, being sent forward in open crates containing from two to ten dozen heads. The early fall market is usually supplied by local growers, who deliver direct to retailers. The late fall crop is often shipped long distances in open or well ventilated cars. At the north they may be stored till spring. We have tried more than a score of highly praised methods of storing, and found that each, under certain conditions, had advantages, but we have found that generally the best and most certainly successful plan, at least for the latitude of Detroit, is to store in trenches, as follows: Plow and replow several times a strip of welldrained sandy land, where there is no danger from surface water, and open a trench some 10 inches deep and about 20 inches wide. Then pull the Cabbages, remove a few of the outer leaves, stand them on their heads for 
a fex hours, that any water at the base of the leaves may escape, and set them in the trench, heads up and as compactly as possible, throwing a little earth over the roots as we do so. We have found it profitable to build a roof of four rough boards over them, but this is not essential, and they may be slightly covered with corn-stalks or other coarse litter, or even the refuse leaves of the

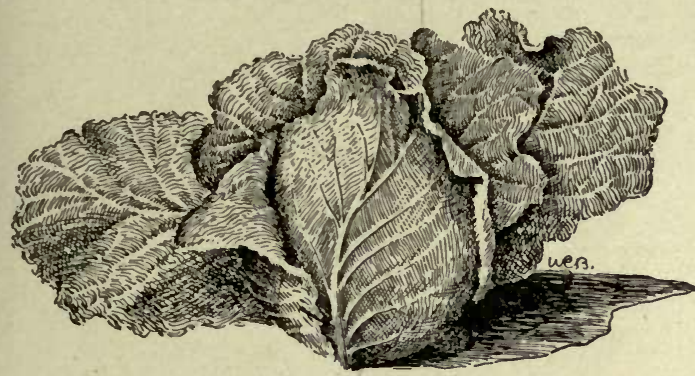

299. Jersey Wakefield Cabbage.

Cabbage may be used. As soon as there is danger of frost, cover with earth, to protect them from it and the rain. If the boards are used, they should be covered with earth in the same way, and in both cases the covering should be increased as the weather grows colder, and if it should be very cold, a covering of straw or coarse manure is desirable. The aim is to protect the heads from rain, but to keep them moist and at an even temperature-one of about $32^{\circ}$ is best, and one somewhat lower is less objectionable than one much higher. The cost of growing an acre of general crop or late Cabbage on good ground, not including ground rent, is about as follows : Fertilizer, $\$ 20$ to $\$ 40$; preparation of the ground, $\$ 10$; growing and setting about 8,000 plants, $\$ 13$; cultivating and boeing, $\$ 10$; harvesting and marketing, $\$ 10$. The yield should be about 7,500 heads, making the cost of growing about one cent a head.

VARIETIEs. - The Cabbage has been made more valuable to man by the development of a tendency to form more and larger leaves, and thickening them with thickwalled cells deposited both in the blade and the ribs. There has also been a shortening of the stem, particularly at the top, until the upper leaves are crowded and folded over each other and form a bud or head, the inner portion of which becomes blanched, tender and sweet, and, through the loss of much of the naturally strong taste, well-flavored. The thicker the leaves and the more solid the head, the sweeter, more tender and better flavored the Cabbage. If the leaves are long and narrow, with large midrib and little blade at the base, the upper part of the head may be solid; but the lower part, being made up chiefly of the thickened midribs, will be open and coarse. If the leaves are broad and proportionately too short, they will not lap well over each other, and the head will be soft and even open at the center. Many varieties have been developed, differing in season of maturity, shape of head, etc., and adapted to different cultural or market conditions. Many of them, though differing in some point, are essentially identical, and, as the list is an ever-increasing and constantly changing one, we would refer our readers to the various seedsmen's catalogues for descriptions, only speaking of a few representative sorts of the different types, between which there are many interniediate forms.

Jersey Wakefield (Fig. 299), Express, New York.-These are small-growing, early-maturing and small-headed sorts. Under favorable conditions they become fit for use in from 90 to 110 days from seed, and continue in edible condition but a comparatively short time. The plants are compact and erect-growing, with very thick, smooth and smooth-edged leaves, and are very hardy. The hearts are small, as compared with the later sorts, more or less conical in shape, quite solid, and of good quality. Owing to the hardiness and compact habit of the plants, they are the best sorts for forcing under glass and early spring planting at the north, and for winter culture at the south.

Winnigstadt is in some respects much like the above, but is larger in plant and head, somewhat later, and a much better keeper. The heads are sharply conical, with the leaves convolute rather than overlapping at the top, and very hard ; of good quality, and remain a long time in condition for use. The type is very sure heading and hardy, and will form good heads under circumstances where most others would fail.

Henderson's Early Summer, Early Flat Dutch (Fig. 297), All-Head, are strong-growing, vigorous sorts, becoming fit for use in from 100 to 140 days, and continuing in condition much longer than the Wakefield type. The plants are large, spreading, with large, broad, smooth thick leaves, and form a more or less flattened, oval head of good size ; solid, and of good quality. They are best adapted to early fall use.

Late Flat Dutch, Stone Mason, Late Drumhead.Strong-growing, spreading plants, forming very large, solid heads in from 120 to 180 days, and remaining a long time in usable condition. They are the best type for general crop, will give the largest yield, and keep well through the winter.

Hollander, Luxemburg.-A type of Danish origin, which has become quite popular of late years, particularly for shipping long distances. The plants are stronggrowing and the hardiest of all, enduring with but little injury frost or drought which would ruin other sorts. They come to maturity slowly, and form a comparatively small but very hard round head of good quality, which keeps well and which, because of its shape and solidity, can be handled in shipping better than most sorts.

Savoy (Fig. 300).-A class of Cabbage in which the leaves of both the plant and head are crumpled or savoyed instead of smooth, as in the preceding. There are varieties of all the types found in smooth-leaved sorts, though generally they are less certain to form good heads, and the heads are smaller. As a class they are very hardy, particularly as to cold. They are extensively grown in Europe, where they are esteemed to be much more tender and delicate in flavor than the smoothleaved sorts.

Red Cabbage. $-\mathrm{A}$ class of which there are many varieties, and in which the leaves of the plant are dark purple and those of the head bright red. The heads are

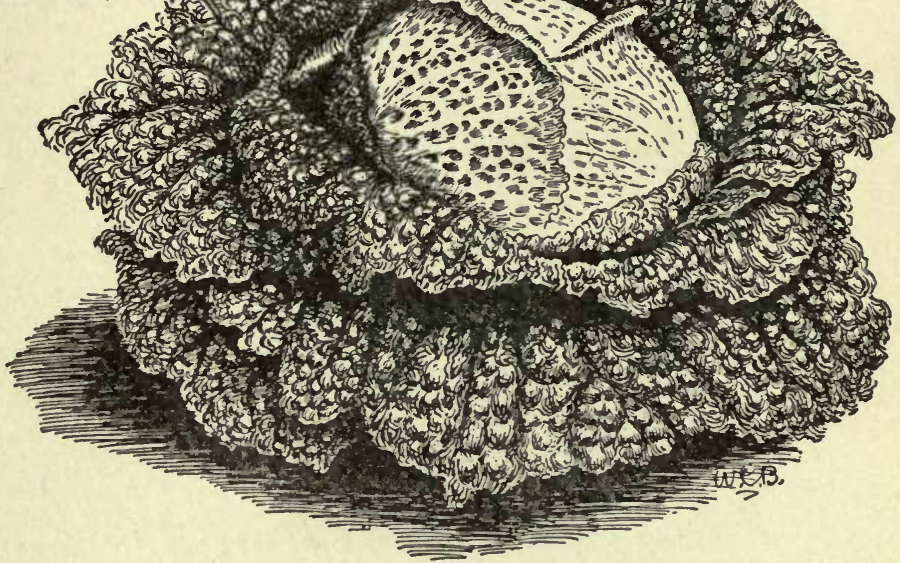

300. Savoy Cabbage.

small, but usually very solid, and are especially esteemed for use as "cold slaw."

SEED-GRowing. - It is only through the constant exercise of the utmost care and skill in the growing of the 
seed that this or any other vegetable can be improved, or even its present good qualities maintained. It would seem to be an easy matter to save and use only the seed of a few of the most perfect Cabbages, for the plant is capable of enormous seed production. We have known a single plant to yield 35 ounces of seed, enough, if every seed grew, to furnish the plants for 50 acres; but it is not quite so easy as this showing would make it-first, because the yield mentioned is an exceptional one, and, secondly, because it is very seldom that an isolated plant yields a crop of seed. The flower of the Cabbage is sexually perfect, and I think there is no discovered reason why individual plants are self-impotent, but we have never succeeded in getting more than a very few seeds from an isolated plant, either in the open air or when enclosed in an insect-tight structure of glass and cloth, in which a number of bees were confined. Again, we have repeatedly isolated the best plant of an hundred, setting the rest in a block, and the few seeds obtained from the isolated one produced plants showing more variation, and quite inferior in evenness and type, than those from the block. At least one of our popular varieties is made up of the descendants of a single isolated plant, but it is a curious fact that in the second and subsequent generations the stock was very different in type from that of the selected plant from which it was descended. The originator of one of our best varieties maintains that it is essential to the production of the best seed of that sort that seed-plants of very different types should be set together, and by crossing they will produce and give plants of the desired type. In spite of those facts, we believe that the general rule and practice which give the best results with other plants are equally desirable for the Cabbage, and that in this, as with other plants, we should first form a distinct and exact conception of the plant we wish to produce, and then raise seed from the one which comes nearest to that ideal. It would seem that the necessity of a distinct and well defined ideal of exactly what we want to produce would be self-evident, but some seed-growers have a very vague idea of the exact type wanted. Some years ago we visited the originator of one of our best varieties, for the purpose of learning what he considered the type or the variety. He was an intelligent man, a good cultivator, and had been growing this strain for over twenty years. He took us into a field of as handsome Cabbages as we ever saw, but which were far from uniform. We asked him to select an ideal plant of his strain, and carefully noted its every characteristic. Going to another part of the field, we asked him to select another, and he picked out one which in color, shape, and general character of the crop, was very different from the first. Both were fine market Cabbages, but so different that if either were taken as the true type of the variety, the other should be thrown out of a seed crop as being a different sort. Third and fourth selections were intermediate between the first two, and the fifth very nearly like the first. This man had been growing this strain for twenty years, and was intent upon developing a strain of superior quality for marketing, and in his selection and breeding had looked solely to the selling quality of the heads. His course was as unwise as it would be for a breeder of Jersey cattle to breed from black, red, white, big or little cows, regardless of anything but the quality of their milk. Having formed a carefully considered ideal, we should select from 10 to 100 of the plants which come nearest to it, and from these make an extra selection of about one-tenth of the best. We would set the whole lot in a nearly square block, with the extra selections in the center. We would save and plant seed from each extra select plant by itself, and having, by very careful examination, ascertained which lot adhered most closely and evenly to our ideal type, would select our plants for next year's seeding from it, rather than use the best individual plants found in all the lots. Experience has satisfied us that by this method we can gradually fix and improve our stocks, and grow seed much better than that usually produced.

In commercial seed-growing, they aim to so time the planting that the crop will be just coming to maturity at the time of storing for winter. Mixtures and inferior plants can be detected and thrown out then as well as when the plants are fully matured, and the younger plants will go through the winter and seed better than those which are fully ripe when put away for the winter. The plants are usually wintered in the manner described for storing for market use, except that the trench is usually narrower. The plants are set out for seed-bearing as early as possible in the spring. It is usually necessary to carefully open the head by two cross-cuts with a knife in order to let the tender seedstalk break through. The plants are given double or treble the space which they required the first year. It is generally true that the more developed and better the stock, the smaller the yield of seed. W. W. Tracr.

CABÓMBA (aboriginal name). Nymphredcece. Half a dozen aquatics of the western hemisphere, with small flowers having persistent sepals and petals, each 3 or 4 , and stamens few ; carpels 2-3, free and distinct, and submerged lvs. finely dissected and mostly opposite.

Caroliniàna, Gray ( $C$. aquática, DC., not Aubl. $C$. viridifòlia, Hort.). Floating lvs, green, oblong-linear : fls. white, with 2 yellow spots at base of each petal ; stamens 6. N. Car., S. and W. A.G. 15:157.-C. rosafòlia, Hort., is a form with reddish lvs. A.G. 15:157.

The true $C$. aquática, Aubl,, of trop. Amer., with yellow fls. and nearly orbicular floating lvs., is shown in B.M. 7090 .

Cabomba Caroliniana is very largely used by growers of aquatics. It is one of the indispensable plants for the aquariım. It is grown largely in North Carolina, District of Columbia and Maryland, where it can be obtained in quantities during the year for persons in the large eastern cities, where it is commonly called Fish Grass, Washington Grass, etc. It is tied in bunches with a metallic fastening, $\cdot$ which acts as a weight, thus retaining the same in a natural position in water. In a moderate temperature it soon emits roots and grows freely. It is a submerged plant, except in midsummer, when the flowers are borne above the water, accompanied by a few floating leaves. It is one of the best plants for domestic fish. It also grows in New Jersey, where it is quite hardy, C. roscefolia is tender, does not retain its delightful carmine coloring under confinement, and is not so often met, except in Florida.

WILLIAM TRICKER.

CACALIA (ancient Greek name). Compósitce. Perennial herbs, of which 9 or 10 are native to the U.S. Florets all hermaphrodite, with white or flesh-colored corollas, each of the 5 lobes with a midnerve : akenes

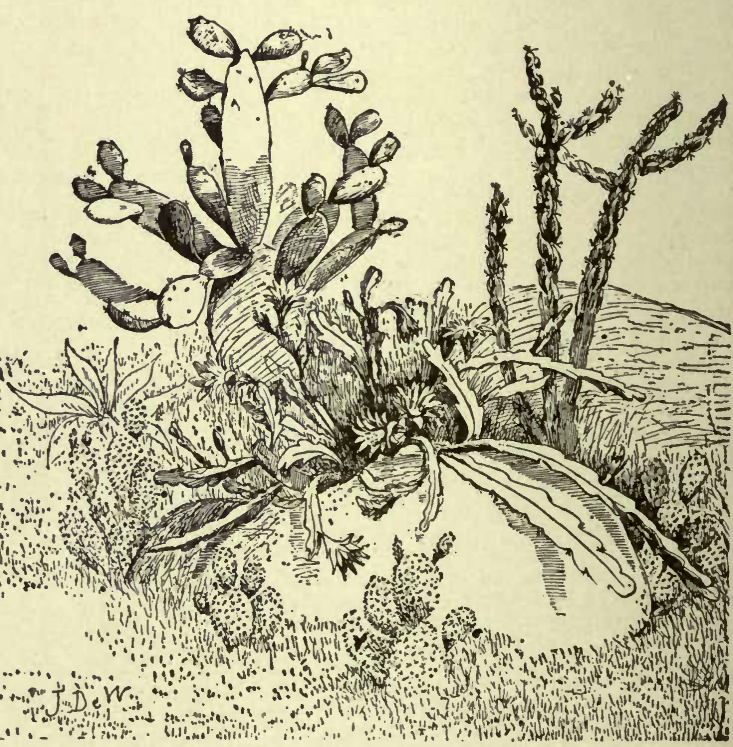

301. Cactus forms 
glabrous : 1rs. petioled. None of the species are known to be in the Amer. trade, but some of the native kinds may be expected to appear in commerce. For an account of the N. Amer. species, see Gray, Syn. Fl., vol. 1, p. 2, pp. 394-6.

\section{CACALIA of the florists. See Emilia.}

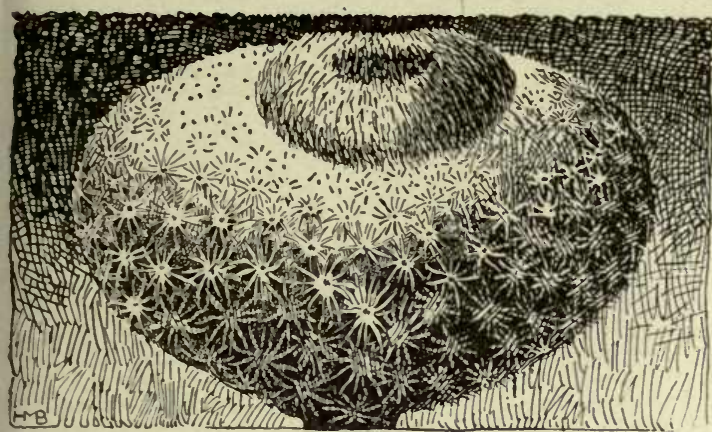

302. Showing the remarkable condensation of the plant body in a cactus-Mamillaria micromeris.

CACALIÓPSIS (Cacalia-like). Compósitoe. One species, with discoid, very many-fld. heads of perfect yellow florets, and palmate liss.

Nardosmia, Gray. Strong perennial, 1-2 ft. high, loose, woolly, but becoming nearly glabrous: lvs. nearly all radical, long-stalked, 5-9-cleft or parted, the lobes dentate or cut: heads an inch high, in a loose cluster at the summit of the nearly naked stem, fragrant. Pine woods, Calif. to Wash.-Int. by Gillett in 1881 as a border plant.

\section{CACA0, COCOA. See Theobroma.}

CACTUS, CACTI. The peculiar forms included under this name constitute the family Cactaceo. They are especially characteristic of the warm and dry regions of America, their display being greatest in Mexico, although extending from the plains of North America and east ward southward through the West Indies and Mexico to southern South America. Aside from certain African species of Rhipsalis, this great family, containing about 1,000 known species, is absolutely restricted to America. The common prickly pear (Opuntia F'ìcus-Indìca) has long been naturalized throughout the Mediterranean region, and its pulpy fruit is eaten under the name of "Indian fig." The chief display of Cacti in the United States is in the Mexican border states, representing the northern edge of the still more extensive Mexican display.

The peculiar habit of the family seems to be the result of perennial drought conditions, to which they have become remarkably adapted. The two-fold problem presented by such conditions is the storage of water and the regulation of its loss. As a result of water storage, the plant bodies are characteristically succulent. Los of water by transpiration is reduced to a minimum by heavy epidermal walls and cuticle, and other anatomical devices, but perhaps still more by reducing the surface exposure of the body in comparison with its mass (Figs. 301, 302, 303). For the most part, foliage leaves have been abandoned entirely, and their peculiar work has been assumed by the superficial tissues of the stem. The stem itself is flat or columnar or globular, the last form representing the least exposure of surface in proportion to the mass. The laterally developed leaves and branches common to ordinary stems are generally replaced by various ephemeral or abortive structures, the most notable of which are the bristles and remarkably varied spines. The real nature of Cactus spines is a disputed question, and not a very important one. When rudimentary leaves appear, as in Opuntia, they are found subtending the cushion or area in connection with which the spines are developed. This area is clearly an aborted branch. and the spines represent lateral members upon it; and most probably these lateral members represent leaves. The Cactus forms are not always leafless or compact, for the species of Pereskia are climbing, woody forms, with well-developed petiolate leaves (Fig. 309); and even the well-known prickly pears (Opuntia) are more or less expanded, and have very evident ephemeral leaves.

The flowers are usually conspicuous, in many cases remarkably large and brilliantly colored. The sepals and petals are numerous, arranged in several imbricating series; the stamens are indefinite in number and inserted at the base of the corolla: the style is prominent, with spreading, stigmatic lobes (Fig. 305). The inferior ovary contains numerous seeds, ripening into a smooth or bristly or spiny fleshy fruit, often edible (Figs. 304, 306).

The largest forms are species of Cereus, with huge, columnar and fluted, spiny bodies, bearing a few clumsy ascending branches, said to sometimes attain a height of 50 or 60 feet. These arborescent forms are especially developed in the drainage basin of the Gulf of California. On the western slopes of Mexico proper, and on the eastern slopes of Lower California, these Cactus trees occur in extensive forests, forming the so-called "cardon forests."

In Bentham and Hooker's Genera Plantarum, 13 genera of Cactacece are recognized, while in Engler and Prantl's Pflanzenfamilien, recently published, Schumann recognizes 20 genera. Of these 20 genera, 15 are included in trade catalogues, and five of them are represented in the United States. Generic and specific lines among the Cactacece are very indistinct, and the greatest diversity of opinion in reference to them exists. The group seems to be a very modern one geologically, and unusually plastic, responding readily to varying conditions, so that forms that have been described as distinct species will undoubtedly prove to be but different phases of a single species. The confusion has been further intensified by the description of numerous garden forms. As a result, many catalogue names are very uncertain, being applied differently in

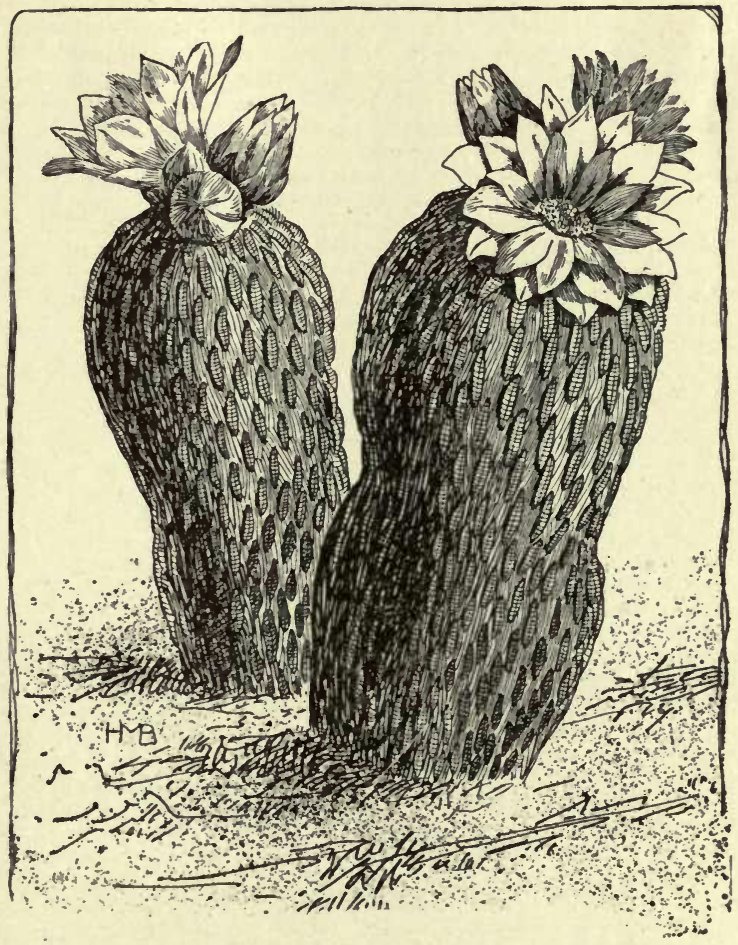

303. Extreme condensation of the plant bodyPelecyphora aseliformis. 
different garden collections. In addition to forms which appear normal, various so-called "monstrosities" are apt to arise, both in nature and in cultivation. These

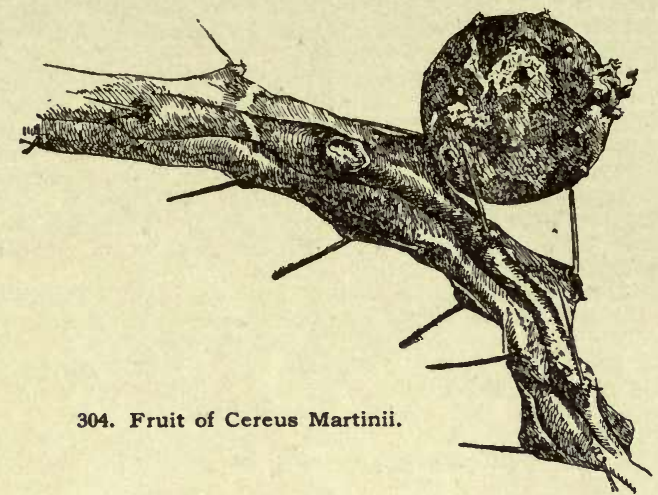

abnormal forms are of two general types: one, in which the body takes the form of a fan or contorted ridge, is designated by the varietal name cristatus and its gender equivalents; the other, in which there is an irregular bunching of branches, is designated in the same way as var. monstrosus.

A brief synopsis of the 15 genera announced in trade catalogues is as follows:

A. Calyx tube produced beyond the ovary: stems with tubercles or tuberculate ribs.

B. Stems short: fls. in axils of tubercles or ribs.

1. Melocactus. Nearly globular, strongly ribbed and spiny, easily recognized by the distinct flower-bearing crown. About 30 species, found chiefly in W. India and Brazil.

2. Mamillaria. Fig. 302. Globular to short cylindrical, not ribbed, but with prominent tubercles bearing terminal clusters of spines, and fls. usually in zones. The largest genus, nearly 300 species being recognized, ranging from northern U. S. into S. Amer.

3. Pelecyphora. Fig. 303. Like the last, but the spirally arranged tubercles are flattened, and bear two rows of flat, overlapping, horny scales instead of spines. A single Mexican species.

4. Anhalonium. Low, flat-topped forms, the tubercles spineless and resembling thick, imbricate scales. About

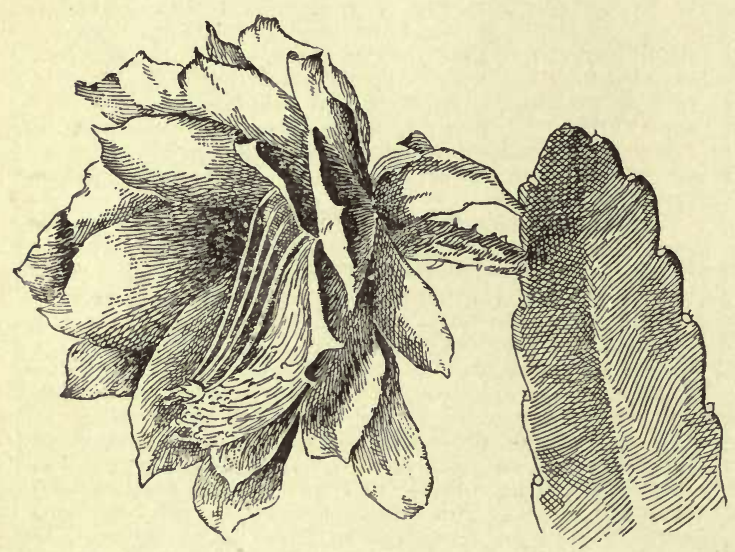

305. Flower of Phyllocactus.

5 species, all Mexican, one of which is found in the $U$. S. The proper name of this genus is Ariocarpus. By many it is considered as belonging to Echinocactus.
BB. Stems short: fls. terminal, on tubercles which are often confluent into ribs.

5. Echinocactus. Globular to short cylindrical, strongly ribbed forms. The second genus in the number of its species, 200 being recognized, ranging from the U. S. to Chile and Brazil.

6. Malacocarpus. Closely resembling the last, and often included under it. Distinguished by the woolly tuft at the very apex of the stem. About 8 species are recognized, restricted to Brazil and Uraguay.

BBB. Stems mostly elongated, erect or climbing, branching, ribbed or angled.

7. Cereus. Fig. 304. From almost globular to stout columnar, or slender, climbing, creeping or deflexed. A genus of about 100 species, extending from the U.S. into South America.

8. Pilocereus. Distinguished from the large, columnar forms of Cereus by the development of abundant white hairs instead of rigid spines. About 45 species are recognized, ranging from Mexico to Brazil.

9. Echinopsis. Like columnar species of Cereus, but very short (sometimes globose) and many-ribbed, with remarkably elongated calyx tubes. About 10 species, restricted to southern $\mathrm{S}$. Amer.

10. Echinocereus. Like cylindrical species of Cereus, but small, and with weak spines and short calyx tubes. About 30 species, found in both N. and S. Amer.

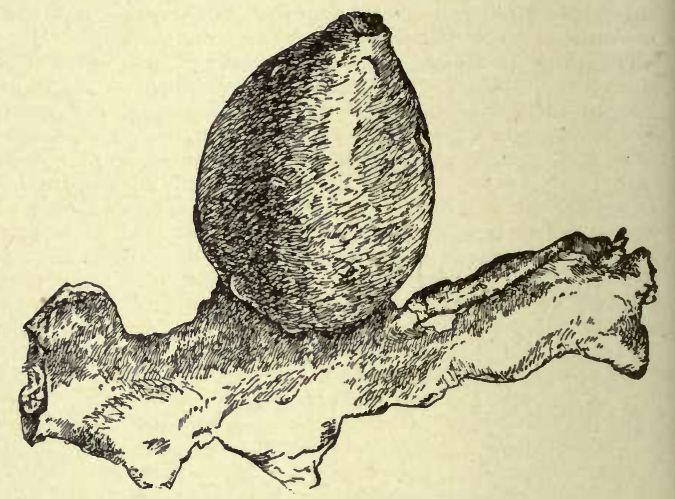

306. Fruit of Phyllocactus anguliger.

вввв. Stems flattened or winged, jointed.

11. Phyllocactus. Figs. 305, 306. Mostly epiphytic, the joints flat, becoming thin and leaf-like upon cylindrical stems. About 12 species are recognized in Cent. and S. Amer.

12. Epiphyllum. An epiphyte, with numerous hang ing, many-jointed stems. A single S. American species, the other species usually referred to this genus belong ing to Phyllocactus.

AA. Calyx tube not produced beyond the ovary: stems branching and jointed.

13. Rhipsalis. Small, epiphytic forms, with joints ribbed, eylindrical or flat, with or without bristles. A genus of 50 species, chiefly developed in Cent. and S. America.

14. Opuntia. Figs. 307,308. Branching, jointed forms, the joints flat or cylindrical, usually bristly und spiny. A large genus of 150 species, ranging from central N. Amer. to Chile. The cylindrical forms belong to the more desert regions, while the flat-jointed forms, or "prickly pears," as a rule occupy conditions not so extremely dry.

15. Pereskia. Fig. 309. Climbing, woody forms, with perfectly developed lvs. About 15 species are known, ranging from Mexico to Argentine. The name is ordinarily written Pereskia.

The completest monograph of Cacti, with descriptions of species, is Schumannn's Gesammtbeschreibung der Kakteen, Berlin, 1899.
JoHN M. CouLter. 
Culture of Cacti. - To enable one to hope to be fairly successful in the cultivation of a collection of Cacti, it may be well to observe the following suggestions : Always endearor to secure plants in Nay or early June, as at that time any wounds caused by packing or in transportation become quickly healed, and a perfect callus is formed, which generally prevents further decay. Again, always be sure that the plant is in perfect condition before it is potted. Plants collected from their native habitats are usually received without roots ; or, if they have roots, they will be found, in most cases, to be so injured that, for the safety of the plant, they would better be taken off close to the plant with a sharp knife. This done, proceed to closely examine the plant, and be sure that every part of it is perfectly free from all signs of sickness or rot. Plants which have been on the road only a few days may arrive with a certain percentage dead. Such plants undoubtedly looked good while being packed, but a careful examination would have shown them to be unfit for sale. If, on examination, any sign of sickness or decay should be found, let the bad parts be at once taken out until healthy tissue is resched, after which place the plants in full exposure to sun and wind, allowing them to so remain until every atom of the treated part has become covered with a dry and perfect callus. It may sometimes be found necessary to use a hot iron where decay is doing very rapid work. When the plant received is very large and old, or the bottom has become hard, dry and woody, or the roots injured, then at once cut off the woody bottom up to living tissue ; and plant only after the wound has been dried thoroughly. Treated thus, the plant will produce, in most cases, an abundant supply of new roots in a very short time, and thus give a virtually young plant; but if any old, woody part is left on, the chances will be against the forming of new roots. Never take the hard trunk of a plant for propagating purposes, but choose the active, growing part, in which the cells are full of life.

In preparing soil for Cacti, it will be found advisable to use one-half good, fibrous loam and one-half very old lime rubbish, secured from some old, torn down brick building, taking care to sift from it the fine, dusty particles to ensure material of perfect drainage. To this may be added good, clean sand. In potting Cacti, it is generally supposed that a pot as large as the body of the plant is sufficient; but it is better to select pots of a rather larger size, for during the season of growth the plant must be supplied with water, and when pots are too small this cannot be done. In such case the

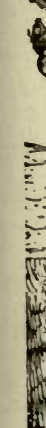

1
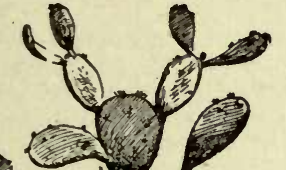
plant has to depend upon its own resources. In the process of potting, fill the pot one-third with rough lumps of coke or other such material, on the top of which place a liberal supply of finely broken crockery. Now add the soil, taking care to put the coarsest soil directly on top of the crocks, and then the finer, on whicl to place the cuttings or plants. Take care to plant very little below the surface. Be sure that the soil is fairly dry, and earefully abstain from watering for some time; but if the weather is very warm and bright, a very light syringing may be given once each day. If pots are plunged in open ground, this light daily syringing will be sufficient until the plant 307. Opuntia. shows signs of growth.

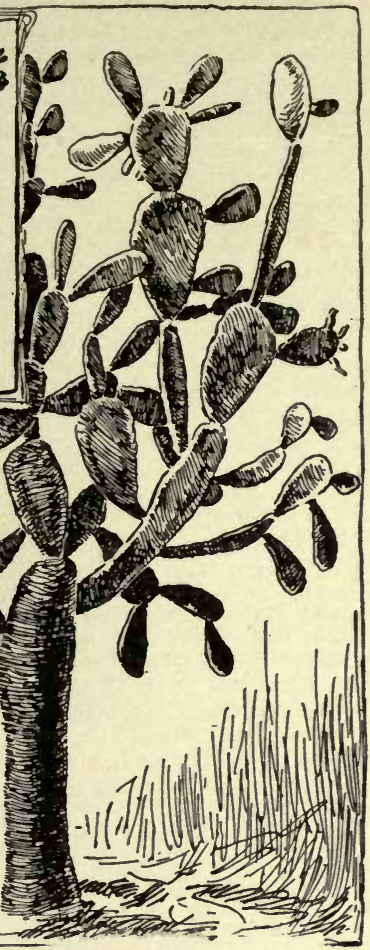

308. Leaf-like branches of Opuntia-Opuntia, or Nopalea, coccinellifera, the cochineal plant.

It is a mistake to repot Cacti very often, unless the roots have become infested with mealy bug or other pest. Should this occur, the plant must be turned out of the pot, roots thoroughly washed, and planted in a new pot and in new soil. The condition of the soil in each pot should be constantly and carefully examined, and if the slightest sign of imperfect drainage is manifest, the case should receive prompt attention.

In the summer season, some persons turn their plants out of pots into the open borders. They may do well during the season, but, as there is more or less danger of bruising or injuring them in taking them up from open ground and repotting, the practice is unwise. Avoid inflicting any injury on the plants in the late fall or winter. It will be found a much safer practice to plunge the plants, in their pots, in late spring or as soon as the cold spring rains are over. Any warm, welldrained bed or border may be selected for this purpose, where they may receive sunlight and perfect ventilation.

For winter protection, select a naturally damp house, - one with floor sunken two feet or more. It should not be made wet by constant syringing or by a leaky roof, but by keeping the floor of the house damp, thus rendering it unnecessary to be constantly watering the plants. Let the temperature of the house be kept as close as possible to $50^{\circ}$, promptly ventilating when the heat begins to increase. Avoid all severe changes. Use as mild a fire heat as possible to be safe from cold.

Cacti may be propagated from seed, by division of large clumps, and by cuttings or offsets. The most interesting, instructive and permanently successful method is from seed. Plants grown in this way will furnish the grower, in two or three years, with a fine stock of thrifty plants which will be a permanent source of satisfaction. Raising seedlings is better than importing the plants from their native habitats if one desires to secure a fine collection of Cacti. There would be many more amateur collections of Cacti if persons would start by raising plants from seed. The most 
desirable Cacti to be raised from seed are Pelecyphora, Mamillaria, Cereus, Echinopsis and Echinocactus. When raised from seed, any of these may be successfully grown as window plants, with little danger of loss.

Perhaps the most easily grown of the Cactus family are Opuntias, but these are not to be recommended for

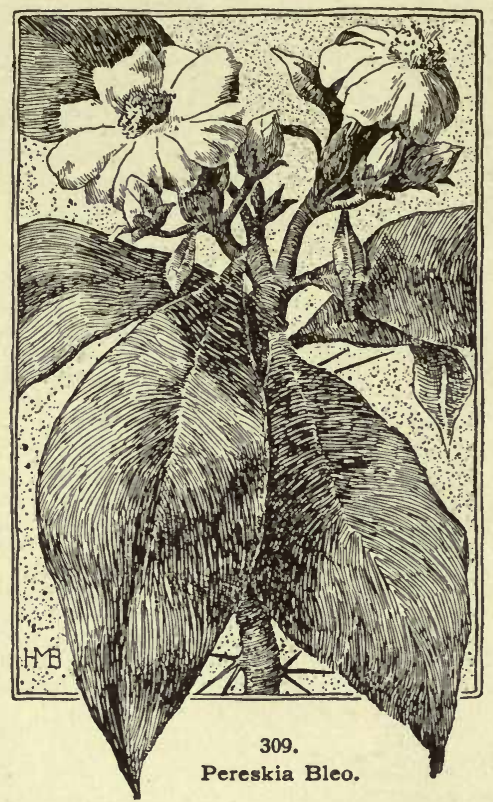

window culture, on account of their full equipment of barbed spines. Cereus flagelliformis, Rhipsalis, and Epiphyllums on their own roots, flourish well and are exceedingly attractive. But the best of all are the Phyllocacti ; these are without spines, grow vigorously, and produce an abundance of blooms if they are given a sunny window and the necessary amount of water. Cactuses generally are subject to insects and fungous troubles. One of the most common pests is a scale insect. The safest way to rid the plants of these is to clean them off with a small brush which has bristles of only moderate stiffness. The mealy bug may be easily disposed of by dissolving 5 grams castile soap in hot water, and adding $1 \frac{1}{2}$ quarts of alcohol ; then add 100 grams of fusel oil ; apply with a very fine spray.

\section{JAMES GURNEY.}

CADIA (Arabic name, Kadi). Legumindsa, tribe Sophòrea. About 3 species of small evergreen trees of Arabia and Africa, remarkable for their regular mallowlike fls.: lvs. pinnate : fls. axillary, mostly solitary, drooping ; stamens 10 , free.

purpùrea, Forsk. (C. vària, L'Her.). Lfts. $20-40$ pairs, very narrow : fls. bell-shaped, pedunculate, rose-red, pretty ; not spiny. Arabia.-Cult. in S. Calif.

C. Ellisiàna, Baker, has few large lfts. and rose-colored fls. Madag. B.M. 6685.-C. pubéscens, Bojer. Lfts. $8-10$ pairs, broad-oblong. Madag.

CESALPINIA (Andreas Cæsalpinus, 1519-1603, Italian botanist). Legumindsa. BRAsILETTO. Shrubs or trees, with bipinnate lvs. and racemes or panicles of red or yellow fls., with obovate more or less clawed petals, 10 stamens, and a very long style. The fls. are not papilionaceous. The species, all tropical, are nearly 50. The genus yields tanning materials and dye stuffs; and most of the species are very showy in flower and are favorites in tropical and semi-tropical countries. They are grown rarely in warm glass houses. The botanical status is confused.

L. H. B.

In Cæsalpinia, propagation is readily effected by seeds, which should be well soaked in warm water for some hours before sowing. A sandy soil should be chosen for the seed-bed, and lightly shaded. After the plants show the first true leaf, they should be potted off into small pots of ordinary garden soil, not too rich, made light by the addition of sand if of a clayey nature. The plants grow very rapidly, and must be shifted into larger pots as their size requires for greenhouse culture, but in tropical climates may be transplanted into permanent positions outdoors after they reach a fair size in pots. The dwarf species are elegant subjects for subtropical gardening during the summer months in temperate climates, provided a sunny location is given them, as they revel in rather dry, very warm soil, and do not require artificial watering after being established. A rocky, sunny situation may be given $C$. pulcherrima and its variety flava, where they will bloom during many weeks of summer, until frost checks them, if strong plants about a foot high are selected in early summer. Care should be taken to gradually harden off plants in the house, so that they may not be chilled when transplanted outdoors. While they will do well in a poor soil, an application of manure or chemical fertilizer may be given them to advantage, causing them to make a more vigorous growth and give better and larger heads of flowers. In the tropics, and also in subtropical climates, these shrubs and trees are always admired and are commonly planted for ornament. The Royal Poinciana ( $C$. Regia, but properly Poinciana Regia, which see), and also the Dwarf Poinciana, or Flower-fence $(C$. pulcherrima), will thrive in close proximity to the sea, and are valuable for planting in exposed coast situations.

E. N. REASONER.

A. Stamens long-exserted: fls. very showy: trees, unarmed or nearly so.

Gilliesii, Wall. Shrub or small tree, with very many small, elliptic pinnules : fls. light yellow, with brilliant red stamens protruding $3-5$ in., in terminal racemes ; sepals hairy-fringed. S. Amer. B.M. 4006, as Poinciana Gilliesii, Hook. F.S. 1:61. R.H. 1893, 400. G.C. III. 15:73.-Endures mild winters. A very showy and worthy plant.

pulchérrima, Swtz. Barbadoes Pride. Barbadoes Flower-Fence. Dwarf Poinclana. Shrub, with delicate, evergreen, mimosa-like lvs., few scattered prickles, and very gaudy red and yellow crisped fls. on the ends of the new growth : stamens and style red, and longexserted. Generally distributed in the tropics. B. M. 995. - One of the most popular shrubs in warm climates, as S. Fla. and S. Calif. There is a var. flàva, with yellow fis.

AA. Stamens not much exceeding the petals, or shorter.

B. Lfts. small, $1 / 3-1$ in. long, very obtuse.

$$
\text { c. Shrub, unarmed. }
$$

pannòsa, Brandegee. Shrub, 2-4 ft., with slender branches clothed with white, deciduous bark : lvs. decompound ; pinnæ 2-4, each with 4-6 oblong and retuse lfts. : fls. yellow, showy; pod glandular, 1-2-seeded. Lower Calif.-A rapid-growing species, recently discovered and introduced to the trade.

\section{cc. Shrubs or trees, prickly.}

$$
\text { D. Pod smooth : shrubs. }
$$

sepiària, Roxbg. Pinnules about 10 pairs, oblong, rounded on both ends : fls. yellow. India.-Furnishes dye wood; also used as a hedge plant.

Japónica, Sieb. \& Zucc. Loose, spreading shrub, armed with stout, recurved prickles : pinnules 7-9 pairs, oblong, very obtuse : fls. in large, panicle-like clusters, canary-yellow, the stamens bright red. Japan. Gn. 40:837. J.H. III, 34:531. - Endures the winters in some parts of England. The hardiest species of the genus, probably hardy as far north as Washington, D.C.

$$
\text { DD. Pod prickly: tree. }
$$

echinàta, Lam. Tree, with prickly branches, blunt, elliptic, shining, alternate lfts., yellow fis., and spiny pods ; stamens shorter than the petals. Brazil. - Yields dye wood. 
BB. Lfts 1-s in. long, acute or mucronulate: pod prickly.

Minax, Hance. Diffuse shrub, thorny: pinnæ 10, with $12-20$ ovate-lanceolate glabrous lfts., $1-1 \frac{1}{2}$ in. long : racemes panicled, many-fld., with very large bracts : fls. white and purple: pods 7-seeded (seeds large and black), spiny. China.

Bonduc, Roxbg. Climbing shrub, with prickly, pubescent lvs., oblong-ovate mucronate lfts., $1 \frac{1}{2}-3 \mathrm{in}$. long, yellow fls., and a few large yellow seeds in a short, prickly pod. Tropies; S. Fla.

C. bijitga, Swtz. (Acacia Bancroftiana, Bert.). Spiny shrub, with ultimate lfts. in 2 pairs : fls. paniculate. Jamaica. $-C$ Règia, Dietr.=Poinciana Regia.

\section{H. B. and AlFred ReHder.}

CAHOUN. Consult Attalea Cohune.

CAJANUS (aboriginal name). Leguminòsa. Tropical shrub with pinnate, 3 -foliolate lvs., yellow papilionaceous fls., and a small, hairy pod bearing edible seeds. Several species described, probably all derivatives of the following:

Indicus, Spreng. A shrub with yellow and maroon fls., blooming all through the year, and bearing a continuous crop of highly nutritious peas. Lfts. ellipticoblong. Plant more or less hairy. Grows from 4-10 ft. high, very diffuse and spreading. Much cult. in the tropics for the seeds or pulse. It varies greatly in stature and in character of seeds : C. flavers, DC., has yellow fls. and 2-3-seeded pods which are not spotted C. bicolor, DC., has red-striped fls., and 4-5-seeded pods which are spotted: see B.M. 6440 and R.H. 1874:190. Usually treated as an annual. Probably native to Chinese territory. Known under many local names, as Pigeon Pea, Congo Pea, Dhal, Toor, and others.

CALABASH GOURD. See Lagenaria.

L. H. B.

CALADIUM (origin of name obscure). Aròidea. Herbaceous perennials, arising from large rhizomes or tubers, acaulescent, with beautifully marked, longpetioled lvs. with a deep basal lobe. Differs from Colocasia in floral characters. A dozen or less species in Trop. Amer. Two of the species are immensely variable, and many named horticultural varieties are in the trade. Engler in DC. Monog. Phan. 2: 452 (1879); also F.S. 13.

In Caladium, propagation is effected by division of the tubers at the beginning of the growing season, which is about the first of March. The soil best suited to them is a mixture of fibrous loam, leaf mold, peat, and well-rotted cow or sheep manure in equal parts, with a sprinkling of sand added. The tubers should be potted at first in as small pots as will conveniently accommodate them, and shifted on into larger pots as they require it. But little water must be given at the roots till active growth commences, when, as the plants develop, they require an abundance. A warm, humid atmosphere, such as is recommended for Alocasias, is necessary for their best development. They must also be shaded from bright sunlight. As the leaves mature in the fall, water should be gradually withheld, though at no time must the tubers be allowed to become quite dry. Caladiums should be kept for the winter in the pots in which they have been grown, and stored away in some convenient place in a temperature not less than $50^{\circ}$ or more than $60^{\circ}$.

Fancy-leaved Caladiums. - As soon as the plants begin to lose their leares in the fall, water should gradually be withheld until the leaves are all gone. The pots should then be removed to a position under bench, and laid on their sides, or taken from the soil and placed in sand. During the resting period they should not be subjected to a lower temperature than $60^{\circ}$ F., and kept neither too wet nor too dry. About the beginning of March the tubers should be started for the earliest batch to be grown in pots. Arrange the tubers in their sizes, and keep each size by itself. The largest sized tubers will start quickest, and it is desirable to begin with these for pot plants. Start them in chopped moss in boxes. The tubers may be arranged pretty close together in the box, and merely covered over with the moss to the depth of about an inch. The new roots are made from the top part of the tuber, so it is important that this part should be covered to encourage the roots. For starting, a heat varying between $70^{\circ}$ and $85^{\circ}$ will suffice. As soon as a healthy lot of roots make their appearance, the plants should be potted, using as small sized pots as possible. The soil for this potting should be principally leaf-mold, with a little sand. In a short time they will need another shift; the soil should on this occasion be a little stronger; give a position near the glass, and shade from strong sunshine. New forms are raised from seed, this operation being an exceedingly easy one with the Caladium, as they cross-fertilize very readily. The flowers, unlike those of the Anthurium, are monoecious, the females ripening first. To pollinate them, part of the spathe must be cut away. Seedlings at first have the foliage green, and it is not until the fifth or sixth leaf has been developed that they show their gaudy colorings. Propagation of the kinds is effected by dividing the old tubers, the cut surfaces of which should be well dusted with powdered charcoal to prevent decay. As bedding plants, the fancyleaved Caladiums are gradually getting more popular. To have them at their best for this purpose, the ground should be worked for some time previous to planting out, with a goodly quantity of bone meal incorporated with the soil. The tubers are best put out in a dormant state, as then they make very rapid progress, and eventually make finer plants than when they are first started in the greenhouse, as by this system they are too apt to sustain a check in the hardening-off process, and lose their leaves. The fine, highly colored kinds are not so well suited for outdoor work as those having green predominating in the foliage, but some of the kinds, such as Dr. Lindley and Rosini, do remarkably well. Frequent watering with manure water is absolutely necessary to the development of the foliage, both outdoors and in.

G. W. OLIver.

The following species and varieties, most of which are in the American trade, are here described, the synonyms being in italic : albinervium, 55; albomaculatum, 16; albostriatulum, 51 ; Alfred Bleu, 16; amœnum, 17; A ppunianum, 56; argyrites, 57; argyroneuron, 5; argyrospilum, 36; Baraquinii, 12; Belleymei, 49; bicolor, 8 , 11; Brongniartii, 32; Chantini, 17; Conncertii, 17; cor datum, 3; cupreum, 53; Curwadlii, 37; Devosianum, 28. Devosianum, 28; discolor, 29; Duchartrei, 35; Eckhartii, 23; elegans, 54; Enkeanum, 45; erythræum, 3; esculentum $=$ Colocasia Antiquorum esculenta; firmulum, 9; Gardtii, 15; griseo-argenteum, 39 ; Haageanum, 17 ; hæmatostigmatum, 29; hoemostigmatum, 29; hastatum, 50; Hendersoni, 24; Houbyanum, 26; Houlletii, 18; Humboldtii, 57; Ketteleri, 13; Kochii, 38; Kramerianum, 20; Laucheanum, 43; Lemaireanum, 55; Leopoldii, 15; Lindeni, 46; macrophyllum, 39; marginatum, 19; marmoratum, 7; marmoreum, 2; Martersteigianum, 17; mirabile, 33 ; Mooreanum, 18; myriostigma, 58; Neumanii, 40 ; Ottonis, 28 ; Osyanum, 52 ; pallidinervium, 30 ; pellucidum, 27, 29; Perrierii, 22; pictum, 4, 34; picturatum, 48; poecile, 30 ; porphyroneuron, 53 ; punctatissimum, 17 ; Purdieanum, 9; pusillum, 9; regale, 31; Reichenbachianum, 41; Rogierii, 15; roseum, 14; rubellum, 41; rubicundum, 11 ; rubronervium, 42 ; rubrovenium, 42 ; sagit tofolium, 31; Schmitzii, 3; Scholleri, 5; Schomburgkii, 1; Sieboldii, 25; splendens, 14; Spruceanum, 9; Stangeanum, 21; subrotundum, 6; Surinamense, 31; thripedestum, 7; .transparens, 10; Troubetskoyi, 56 ; Vellozianum, 9; Verschaffeltii, 47; viridissimum, 55; Wagneri, 31; Wallisi, 28; Wightii, 44.

It will be seen that most of the cultivated Caladiums are considered to be forms of $C$. bicolor and $C$. picturatum. Only 5 species are concerned in the following list: Schomburgkii, 1 ; marmoratum, 7; bicolor, 8; picturatum, 48 ; Humboldti, 57 . C. odoratum, Lodd.= Alocasia macrorrhiza.

\section{A. Blade not at all peltate, obliquely elliptical-ovate.}

1. Schomburgkii, Schott. Petiole slender, 4 times longer than the blade, sheathed $1 / 3$ its length; blade obliquely elliptical-ovate; midrib and 4-5 acutely ascending primary nerves silvery, pale, or red; sparsely spotted above, paler beneath. French Guiana to Para.-Runs into the following forms: 
(1) Veins red.

2. Var. marmòreum, Engl. Blade dull green, with brownish red nerves, bordered with yellow.

3. Var. erythræ̀um, Engl. (C. Schmitzii, Lem. C.cordatum, Hort.). Midribs and nerves red. I.H. 8:297.

4. Var. píctum, Engl. With white or red spots between the red veins. S Amer.

\section{(2) Veins silvery or green.}

5. Var. argyroneùrum, Engl. (C. argyroneìron, C. Koch. C. Schálleri, Lem.). Midrib and veins silvery. I.H. $8: 297$.

6. Var, subrotúndum, Engl. (C'.subrotúndum, Lem.). Leaf-blade rounded at the base, or shortly cordate, with white or red spots. Brazil.

\section{AA. Blade distinctly peltate. \\ B. Leaf sagittate-oblong-ovite.}

7. marmoràtum, Mathieu (Alocàsia Rázlii, Bull. C . thripedéstum, Lem.). Petiole cylindrical, 12-16 in. long, twice as long as the blade, variegated; blade dark green, with irregular gray, yellowish green and snow-white spots, glaucous-green beneath, sagittate-oblong-ovate, the upper lobe semi-ovate, slightly cuspidate, the basal ones unequal, $1 / 3$ or $1 / 2$ as long as the upper, connate $2 / 3-3 / 4$ their length. Equador. I.H. 5, p. 59 .

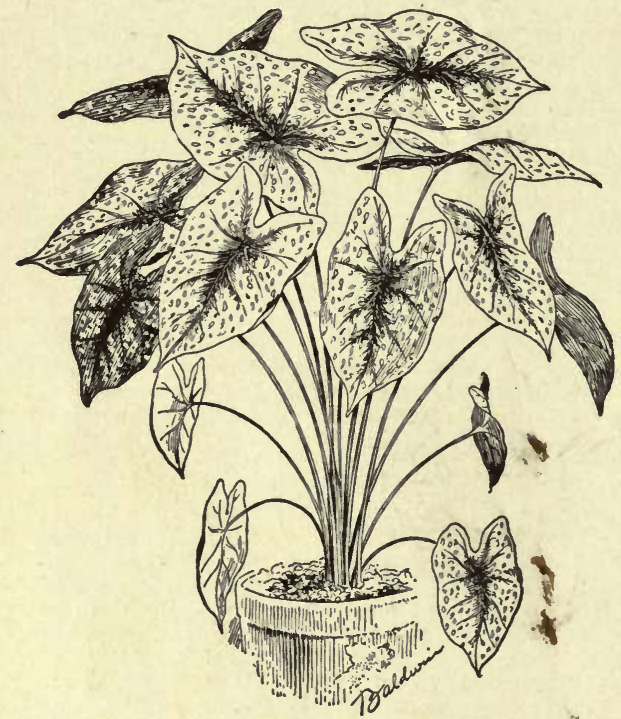

310. Caladium bicolor, var. Chantini. (No. 17.)

BB. Leaf ovate-triangular, or ovate-sagittate.

8. bícolor, Vent. (Á rum bicolor, Ait.). Fig. 310. Petiole smooth, 3-7 times as long as the blade, pruinose toward the apex ; blade ovate-sagittate, or ovate-triangular,variegated above, glaucous beneath; upper lobe semiovate, narrowing gradually to a cuspidate point, the basal ones $1 / 2$ to but little shorter than the upper, oblong-ovate, obtuse, connate $1-5-1 / 8$ their length. $S$. Amer. Introduced into cult. in 1773. B. M. 820.-Very common in cult., furnishing many of the fancy-leaved Caladiums. The marked varieties are as follows:

(1) Leaf-blade and veins of one color.

9. Var. Velloziànum, Engl. (C. Vellozidnum, Schott. C. Purdiednum, Schott. C. pusíllum, C. Koch. C. Sprucednum, Schott. C. firmulum, Schott). Leafblade dark green above; basal lobes connate past the middle. Brazil, Peru. R.B. 10: 169.

(2) Leaf-blade more or less variegated.

(a) With a colored disc.

(b) Disc transparent.

10. Var. transpárens, Engl. (C. transpárens, Hort.). Blade with a pale green, nearly transparent disc ; midrib and primary veins red-purple.
11. Var, rubicúndum, Engl. (C. bicolor, Kunth). Petiole green, or variegated green and violet; blade green, with a red, transparent, central dise, and a very narrow red line between the dise and the margin.

(bb) Disc opaque.

(c) Purple disc.

12. Var. Baraquínii, Engl. (C. Baraquinii, Hort.). Petiole violet; blade with a purple-red disc; beautiful green between the dise and margin; nerves and midrib red-violet. Para. I.H. 7:257. F.S. 13:1378.

13. Var. Kétteleri, Engl. (C'. Kétteleri, Hort.). Petiole crimson, variegated toward the base; blade with purple dise, midrib and primary veins, sparsely marked between the veins with many small, rosy spots.

(ce) Red disc.

14. Var. spléndens, Engl. (C.ròseum, Hort. C.spléndens, Hort.). Petiole green below, red above; blade with a red dise at the middle; midvein and primary veins red-purple; green between the nerves and along the margin. L. 4.

15. Var. Lèopoldi, Engl. (C. Lèopoldi, Hort. $C$. Gerdtii, C. Koch. C. Rogièri, Ch. \& Lem.). Petiole violet beneath, red-purple above; blade with a broad, reddish dise ; margin green, red spotted; midrib and primary veins dark red-purple. Para, 1864.

16. Var. albomaculàtum, Engl. (C. Alfred Bleu). Petiole green ; blade green, with red disc, midrib and primary veins, and marked clear to the margin with many large, white spots between the nerves.

(ecc) Rose disc.

17. Var. Chántini, Engl. (C'. Chántini, Lem. C. Conncertii, Hort. C. amònum, Hort. C. Martersteigiànum, Hort. C. punctatíssimum, Hort. C. Haagednum, Hort.). Fig. 310. Petiole more or less violet; blade broadly red-purple along the midrib and primary nerves, rosy at the center, and with very numerous, unequal spots between the nerves clear to the marginal vein. I. $H$. $5: 185$. F. S. $13: 1350,1351$. B. M. 5255. B. L. P1. 19 (1891). Para, 1858. A.F. 8: 129 .

(ccec) light green disc.

18. Var. Houllétii, Engl. (C. Houllétii, Lem. C. Mooreanum, Hort.). Petiole green, the sheath and a little of the base violet-variegated; basal lobes of the blade somewhat introrse, rounded, connate $1 / 3$; blade obscurely green toward the margin, the midrib and primary veins slightly reddish, and with a pale dise marked with many irregular white spots.

(a) Without a colored disc.

(b) Margins colored throughout.

(c) Red margin.

19. Var. marginàtum, Engl. (C. marginatum, C. Koch). Blade dark green, with a red line on the outer margin.

(ce) Yellow margin.

20. Var. Krameriànum, Engl. (C. Kramerianum, Hort.). Veins purple ; yellow margin.

21. Var. Stangeanum, Engl. (C. Stangeanum, C. Koch). Blade reddish; green along the narrow margin, yellowish toward the margin.

(cce) Solid white margin.

22. Var. Perriérii, Engl. (C. Perriéri, Lem.). Petiole violet-black; blade dull green, with many red-purple spots, and white along the margin. Brazil, 1861.

(cece) spotted margin.

23. Var. Eckhartii, Engl, (C. Éckhartii, Hort.). Petiole violet-blotched at the base, green above the middle blade green, with few rosy spots along the margin, and small white ones in the middle.

24. Var. Héndersoni, Engl. (C. Héndersoni, Hort.). Petiole variegated violet and green, reddish toward the apex; blade mostly green, reddish next the lower parts of the nerves; midrib and primary veins red-purple spotted; small red spots along the margin.

25. Var. Sieboldii, Engl. (C'. Sièboldii, Hort.). Petiole violet and green, reddish toward the apex; basal lobes of the leaf somewhat introrse, connate $1 / 3$ their 
length, dark green; midrib and primary reins beautifully red-purple spotted, and a very narrow white border, marked with small, purple-red spots. A.F. 8: 127.

(cecc) Purple margin.

26. Var. Eoubyànum, Engl. (C. Houbydnum, Hort.). Petiole dirty green on the lower surface, bright red above; blade bright green, with large pale spots, and small red-purple ones between the midrib and primary veins ; a red-purple spot above the insertion of the petiole, and a pale purple line around the margin.

27. Var. pellùcidum, Engl. ( $C$. pellùcidum, DC.). Petiole reddish, variegated with violet; blade broadly reddish purple spotted along the midrib and primary veins, and more or less marked with transparent, reddish purple spots between the primary veins ; a continuous purple line along the outer margin.

(bb) Unly the margin of the basal sinus colored.

28. Var. Devosianum, Engl. (C. Devosianum, Lem. C. Wallisi, Hort. C. Ottonis, Hort.). Petiole green; blade bright green, with small, irregular white spots between the midrib and primary veins, and a narrow crimson border at the sinus. Para. I.H. 9:322.

2y. Var. hæmatostígmatum, Engl. (C. hamatostígmatum, Kth. C. pellucidum, DC.). C. díscolor, Hort.). Petiole violet; blade dark green, with a purple line on the basal sinus, and sparsely marked with blood-red spots. Para.

30. Var. pøcile, Engl. (C. pœcille, Schott. C. pallidinérvium, Hort.). Petiole reddish brown, or closely streaked-variegated; blade dark green; midrib and primary veins paler, often whitish; a red-purple spot where the petiole joins the blade, narrowly purple-margined in the sinus. Brazil.

31. Var. regàle, Engl. (C. regàle, Lem. C. Wágneri, Hort. C. Surinaménse, Miq. C. sagittcefolium, Sieb.). Blade bright green, purple-margined at the sinus, everywhere marked with small, confluent white spots. West Indies, 1710. I.H. 9:316.

\section{(bbb) No colored disc or colored margin.}

\section{(c) Variegated green blade.}

32. Var. Brongniártii, Engl. (C'. Brongniártii, Lem.). Very large; petiole variegated violet and green, reddish toward the apex; blade green, excent along the nerves below, where it is colored reddish, paler green between the primary nerves, deep green toward the margin; veins and nerves red-purple. Brazil-Para, 1858. F.S. 13: 1348, 1349. I.H. 5, p. 58.

33. Var. mirábile, Engl. (C. mirábile, Lem.). Petiole green; blade bright green, densely covered with large and small irregular pale green spots between the primary nerves and midvein. Para. I.H. 10:354.

\section{(cc) Blue-green blade.}

34. Var. pictum, Kunth (C. pictum, DC.). Petiole greenish, variegated beneath; basal lobes connate 1-5 their length; blade thin, blue-green, marked with large, irregular, usually confluent, pale yellowish semitransparent spots. L. 43.

\section{(cec) C'olorless blade.}

35. Var. Duchártrei, Engl.(C. Duchártvei, Hort.). The long petiole green above, variegated below the middle with violet-black; blade colorless, except the midrib and all the veins, or here and there pale rosy or red spotted, or even more or less dirty green. A.F. 8: 129.

\section{(cece) Solid green blade.}

\section{(d) Dark green.}

36. Var. argyróspilum, Engl. (C. argyróspilum, Lem.). Petiole grayish red, sparsely and finely streaked; blade a most beautiful green, with a crimson spot at the middle, and with many small white spots between the primary veins. Para. F.S. 13: 1346,1347.

37. Var. Curwádlii, Engl. (C. Curwádlii, Hort.). Petiole greenish, slightly violet-blotched toward the base; blade reddish purple along the midrib and primary veins, marked between the veins with large white spots, otherwise dark green.
38. Var. Kochii, Engl. (C. Kochii, Hort.). Leafblade more rounded, dark green, with small white spots midway between the midrib and margin. Para, 1862 .

39. Var. macrophýllum, Engl. ( $C$. macrophýllum, Lem. $C$. griseo-argénteum, Hort.). Petiole green ; blade dark green, marked everywhere with many small, scarcely confluent white or slightly rosy spots. Para, 1862. I.H. $9: 316$.

40. Var. Neùmannii, Engl. (C. Neùmannii, Lem.). Petiole green; blade very beautiful dark green, with scarcely paler veins, marked between the primary veins with large and small white-margined, reddish purple spots. F.S. 13: 1352, 1353. B.M. 5199.

\section{(dd) Light green.}

(e) Not spotted.

41. Var. rubéllum, Engl. (C. mıbéllum, Hort. C. Reich. enbachidnum, Stangl.). Blade green, with reddish purple midrib and primary reins.

42. Var. rubrovènium, Engl. (C. Mubrovènium, Hort. C. rubronérvium, Hort.). Petiole variegated green and violet; blade small, oblong-ovoid, the basal lobes somewhat introrse, obtuse, connate almost to the middle, pale caulescent or red-green along the midrib and primary veins; veins pale red or scarlet. Para, 1862.

$$
\text { (ee) Spotted. }
$$

(f) With white spots.

43. Var. Laucheanum, Engl. (C. Lauchednum, C. Koch). Blade bright green, with white spots at the middle.

$$
\text { (fi) With purple and white spots. }
$$

44. Var. Wightii, Engl. (C. Wightii, Hort.). Petiole pale green; blade very beautiful green, marked between the primary veins with large, red-purple and small white spots. French Guiana.

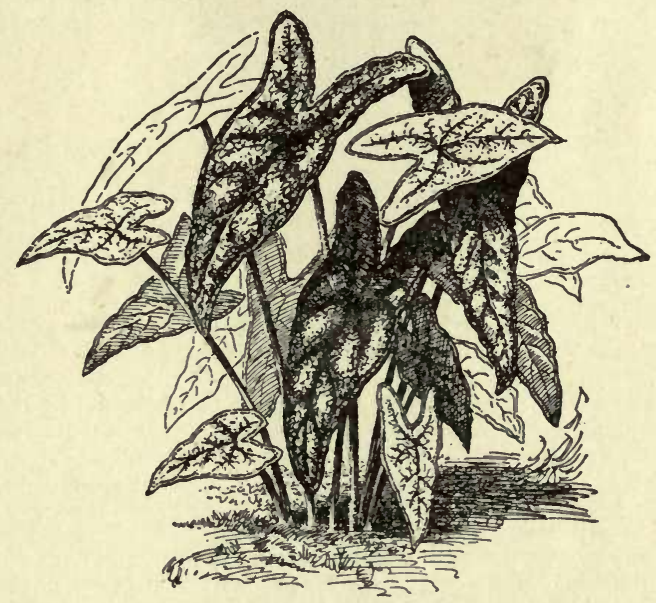

311. Caladium picturatum, var. Belleymei. (No. 49.)

(fff) With red or crimson spots.

45. Var. Enkeanum, Engl. (C. Enkednum, C. Koch). Blade bright green, marked with large and small red spots.

46. Var. Líndeni, Engl. ( $C$. Lindeni, Hort.). Blade bright green, with confluent small red spots.

47. Var. Verschafféltii, Engl. (C. Verschafféltii, Lem.). Petiole pale green; blade very beautiful green, with few irregular crimson spots. I.H.5:185. B.M. 5263 . L. 46 .

BвB. Blade lanceolate-sagittate.

48. picturatum, C. Koch. Petioles usually green, variegated below, elongated; blade lanceolate-sagittate, cuspidate and submucronate at the apex, the upper lobe nearly triangular, oblong or ovate-lanceolate, basal lobes over half as long, lanceolate subacute, connate 1-6-1/4 their length, separated by a triangular sinus ; primary 
lateral veins 4- 7 , erect-spreading or spreading. Brazil. Variable, furnishing many of the fancy-leaved Caladiums.

\section{(1) Transpxrent white blade.}

49. Var. Belleỳmei, Engl. (C. Belleỳmii, Hort.). Fig. 311. Petiole greenish above, variegated violet beneath; blade slenderly hastate-sagittate, white, translucent ex-

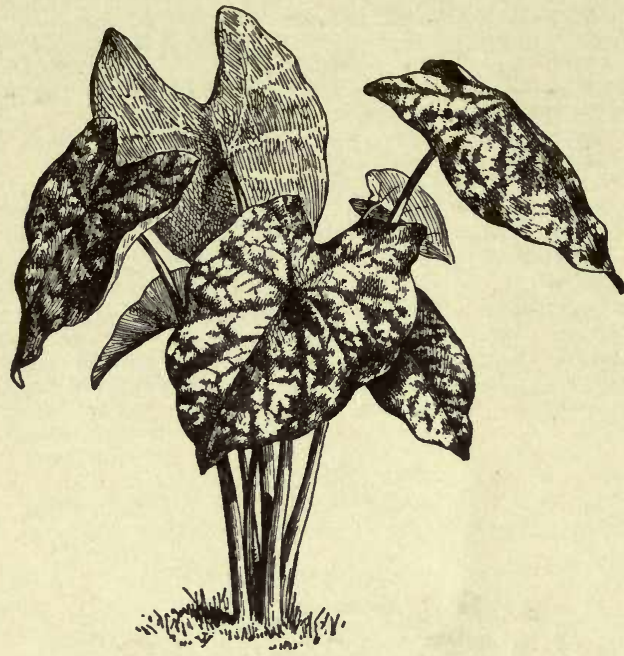

312. Caladium Humboldtii. (No, 57.)

cept the green veins and nerves, with small green spots along the margin; basal lobes $1-5$, or rarely $1 / 4$ or $1 / 3$ connate. Para. I.H. 7:252. A.F. 8: 127.

(2) Pale green blade.

(a) With transparent blotches.

50. Var. hastatum, Engl. (C'. hastatum, Lem.). Petiole long, stout, white, violet-spotted; blade hastatesagittate, slightly contracted above the lobes ; dull, pale green,very irregularly marked with transparent blotches ; basal lobe $1 / 4$ connate, crimson margined in the sinus. Para.

(aa) Opaque.

51. Var. albostriátulum, Engl. Blade greenish white along the midrib and veins, white-striped and dotted between the nerves.

52. Var. Osyanum, C. Koch. Blade white along the midrib and primary veins, with purple spots between the veins.

53. Var. porphyroneùron, Engl. ( $C$. porphyroneùron, C. Koch. C. cùpreum, Hort. Alocàsia porphyroneùra, Lem.). Petiole pale reddish, variegated with dull violet; blade broadly hastate-sagittate, dull, pale green, slightly reddish on the veins, opaque basal lobes $1-6-1 / 3$ connate. Peru and Brazil. I.H. 8:297.

\section{(3) Dark green blade.}

54. Var. élegans, Engl. Petiole rosy, greenish below, variegated; blade narrowly hastate-sagittate, slightly contracted above the lobes, dark green above, broadly red or purple next the midrib and primary lateral veins; basal lobes 1-5 connate.

55. Var. Lemaireànum, Engl. ( $C$. Lemairednum, Barr. C. picturatum albinérvium, C. Koch. C. picturatum viridissimum, C. Koch). Blade shaped like preceding, dark green; midrib and primary veins pale green or white. S. Amer., 1861. I.H. 9: 311.

56. Var. Troubétskoyi, Engl. (C. Troubétskoyi, Chantin. C. Appunianum, Hort.). Petiole red, variegated; blade very narrowly hastate-sagittate, slightly contracted above the lobes, dark green above, broadly marked with pale red along the midrib and primary veins, and with scattered, transparent, small white or rose spots. F.S. 13: 1379 . вввв. Blade oblong-ovate, or oblong: plant small.

57. Húmboldtii, Schott ( $C$. argyrites, Lem.). Fig. 312. Petiole slender, variegated, 2-3 times longer than the blade ; sheath slender, narrow; blade oblong-ovate, or oblong, green along the margin, midrib and primary veins, with many large and small transparent spots between; shortly and very acutely acuminate, the apical lobe oblong-ovate, twice as long as the oblong or ovatetriangular, obtuse basal ones; basal lobes $1 / 3$ connate, separated by an obtuse triangular sinus, the 3-4 primary veins of the apical lobe uniting in a collective nerve remote from the margin. Brazil. I.H.5:185. F.S.13:1345. Gng. 3:279. A.F. 10:197. L. 22 .

58. Var. myriostígma, Engl. (C. myriostigma, C. Koch). Blade marked everywhere with small white spots.

JARED G. SMITH.

CALAMAGRÓSTIS (Greek for reed grass). Graminece. REED BENT-GRASS. A genus of perennial grasses with running rootstocks. Very similar to $\mathrm{A}$ grostis, but spikelets usually larger. Can be distinguished from it by the tuft of long hairs at the base of the fl.-glume, and the flowering axis continued beyond the palet. Spikelets 1-flowered (rarely an aborted or second flower present). Glumes 3, the first two nearly equal and empty, the third, or fl.-glume, awned on the back, usually below the middle. Species about 120 , very widely distributed over the world in the temperate and arctic zones and on the high mountains of the tropies. For C. brevipilis, see Calamovilfa.

Canadénsis, Beauv. Bluk-Joint Grass. Very common in the northern and northwestern states, usually growing in moist meadows and swales. Under such conditions it yields a large amount of indifferent hay, which is used 'in some places. It is not used for horticultural purposes. This species grows 3-5 ft., and has flat, glaucous-blue Ivs.: panicle oblong, becoming open upper glume weak-awned near the middle.

strícta, Beauv. (C. neglécta, Gærtn.). Pony Grass. A rather slender, erect perennial, with narrow leaves and a contracted, densely-flowered panicle, 3-6 in. long: fl.-glume about $3 / 4$ as long as the second empty glume, and nearly twice the length of the basal hairs; awn bent, exceeding the glume. Northern U.S.-A variegated form has been brought into cultivation for ornamental purposes.

\section{P. B. KenNedy}

CALAMINTHA (Old Greek name, meaning beautiful mint). Labidtoe. Various species of herbs or very small shrubs, 2 or 3 of them occasionally grown in borders for their fls, and aromatic fragrance. Calyx 2-lipped, oblong or tubular; corolla with a straight tube, and generally exceeding the calyx, the throat commonly enlarged; stamens parallel under the upper lip: fls. in whorls, which are usually arranged in a long interrupted spike. Plants mostly of temperate regions, and of easy culture. The cult. kinds are perennial, more or less hairy, mint-like herbs, 1-3 ft. high.

grandiflora, Mœnch. Lvs. ovate, serrated : stems decumbent, branching from the base : fls. in axillary whorls, quite large, $1 \frac{1}{2}$ in. long, with a straight tube ; upper lip flattened, purple; June-July ; h. 9-12 in Europe ; this and $C$. alpina, Lam., which is smaller in all its parts, are the two best species for garden use. C. officinalis, Mœnch, the common Calamint of Eu., is sometimes seen in gardens, being an old domestic medicinal plant. It has long, ascending branches, ovate crenate-serrate lvs., and few-fld. cymes : 1-3 ft.

\section{J. B. KELLER.}

CALAMOVILFA (Calamos, reed, and Vilfa, a kind of grass). Graminece. A genus recently separated from Calamagrostis. Distinguished from it only in that the flowering axis is not produced beyond the flower. Tall grasses, with stout, horizontal lvs, and paniculate inflorescence. Spikelets 1 -flowered, with a ring of hairs at the base of fl.-glume. Three known species, natives of the temperate and subtropical regions of $\mathrm{N}$. America.

brevipilis, Hack. (Calamagróstis brevipìlis, Gray). PURPLE BENT-GRASs. Culms hard, wiry, 2-4 ft. high: lvs. flat, with an open, purplish panicle. - A rare grass, 
apparently limited to the sandy swamps and pine barrens of New Jersey. Now in cultivation as an ornamental grass.

P. B. KenNedy.

\section{CALAMPELIS is Eccremocarpus.}

CÁLAMUS (Greek for reed). Palmacea, tribe Lepidocárpoe. Slender, cespitose or climbing palnis, with pinnatisect lvs.; lfts. with reduplicate sides, acuminate, entire, with parallel nerves : fr. of many carpels, clothed with reflexed, shining, closely imbricated appressed scales : spathes tubular, persistent, flowering annually. Species about 150. Tropical Asia.

ciliàris, Blume. Stem slender, climbing by means of long, axillary, leafless branches, covered with hooked spines: lvs. 1 ft. long, 6 in. wide; lfts. numerous, hairy; petiole 2 in. long, with few hooked spines. Malaya. F. R. 1: 607. G. C.III. 21: 86. - Introduced into cultivation in 1869.

C. Andreànum, Hort., P. \& M. $=$ ? $-C$. calicárpus, Griff.= Dæmonorops calicarpus, Mart.-C. Lewisiànus, Griff.=Dæmonorops Lewisianus, Mart. JARED G. SMITH.

Calamus is an easily grown group of palms, very ornamental, even in a young state. Some of the species have stems several hundred feet long, which enable them to unfold their leaves at the tops of the tallest trees. The leaves are peculiarly well adapted to assist the plant in climbing, having numerous hook-like processes arranged on a long continuation of the midrib of the leaf. Where accommodations can be given these plants should be selected, as their growth is rapid, and they are capable of furnishing a large conservatory quickly. Numerous suckers are produced, so that when the main stem ascends the lower part is clothed in foliage. Calamus tenuis (or C. Royleanus) and C.Rotang furnish the rattan canes. Malacca canes are furnished by $C$. Scipionum. Young plants thrive best in a rooting medium containing a considerable quantity of leafmold. Older plants need soil of a more lasting nature; a quantity of ground bone and charcoal in the soil may be used to advantage. Old, well-furnished plants need enormous quantities of water. All of them require stove temperature.

G. W. Oliver.

CALAMUS or SWEET FLAG. See Acorus Calamus.

CALANCHÖ̈. See Kalxnchö̈.

CALANDRINIA (J. I Calandrini, Genevan botanist of last century). Por tulacacea. Fleshy, spreading, or nearly trailing plants, with mostly alternate lvs. and red fls. of short duration. Petals 3-7; stamens 3-5-12. A number of species in $\mathrm{N}$. and $\mathrm{S}$. America and Austral. Sometimes cult. in borders and rockeries, or used for edgings in sunny places. Prop. from seeds, and usually treated as annuals (which some of them are).

umbellata, DC. Four to 6 in.: lvs. linear and hairy: fls. in a corymb, or umbel-like terminal cluster, bright crimson. Peru. R.H. 1853:5. - This species is hardy in many parts of the U.S.; in our northern climate, it should be planted in a well-sheltered position, or provided with ample protection in winter; sometimes it acts like the biennials, but, as seeds are produced very freely, young seedlings spring up constantly between the old plants, and one does not miss the few which may decay during the second year; the plant forms a very neat, slightly spreading tuft; flowers are produced in manyflowered umbels, terminal, numerous, and large, glowing crimson-magenta, saucer-shaped, very showy. June to November. Full exposure to sun, and light sandy soil, are needed to bring out the rare beauty of these plants. The flowers close up when evening comes, like the annual portulacas, but they reopen on the following day. In the sunny, sloping part of a rockery, even when quite dry, or among other low plants in a bed or border, they are highly satisfactory. This is the only species which we have found to be tolerably hardy with us in the north as a perennial; it may also be treated like the annuals, as it flowers the first summer just as freely as afterwards. Can be prop. by cuttings. díscolor, Schrad. (C. élegans, Hort.). One to $2 \mathrm{ft}$. lvs. fleshy and obovate, purple beneath: fis. bright. rose, with yellow stamens. Chile. B.M. 3357.

cauléscens, HBK., var. Ménziesii, Gray (C. speciòsa, Lindl.). Three to 12 in. high, with green herbage, glabrous, or nearly so: lvs. linear, or spatulate-oblanceolate: fls. rose-red or purple, rather large and long-peduncled (petals $1 / 2$ in. long). Calif., N. B. R. 1598.-Variable. There is a white-fld. var. advertised.

\section{J. B. Keller and L. H. B.}

CALANTHE (Greek for beautiful flower). Orchiddcece, tribe Vándece. A genus of sub-epiphytal or terrestrial orchids found in the eastern hemisphere, and sparingly in the western hemisphere. Scapes erect, manyflowered : lvs. broad, plaited : fls. white or rose-colored, rarely yellow: pseudobulbs angulate, with greyish green sheaths in the Vestitæ section, but absent in the Veratrifoliæ section. Many species are known to orchid fanciers.

vestita, Lindl. (C. oculdta, Hort.). Lvs. broadly lanceolate, nearly $2 \mathrm{ft}$. long, from greyish green pseudobulbs : fls. nearly 3 in. across, numerous, in racemes; petals and sepals whitish, all more or less overlapping, the former oval-oblong, the latter obovate-oblong; labellum flat, large, three-lobed, the midlobe cleft; a yellow or crimson blotch in front of the short column; scapes from 2-3 ft. high, hairy. Blooms in winter. Malaya. B. M. 4671. F.E. 9: 325. A. F. 6:655. F. S.

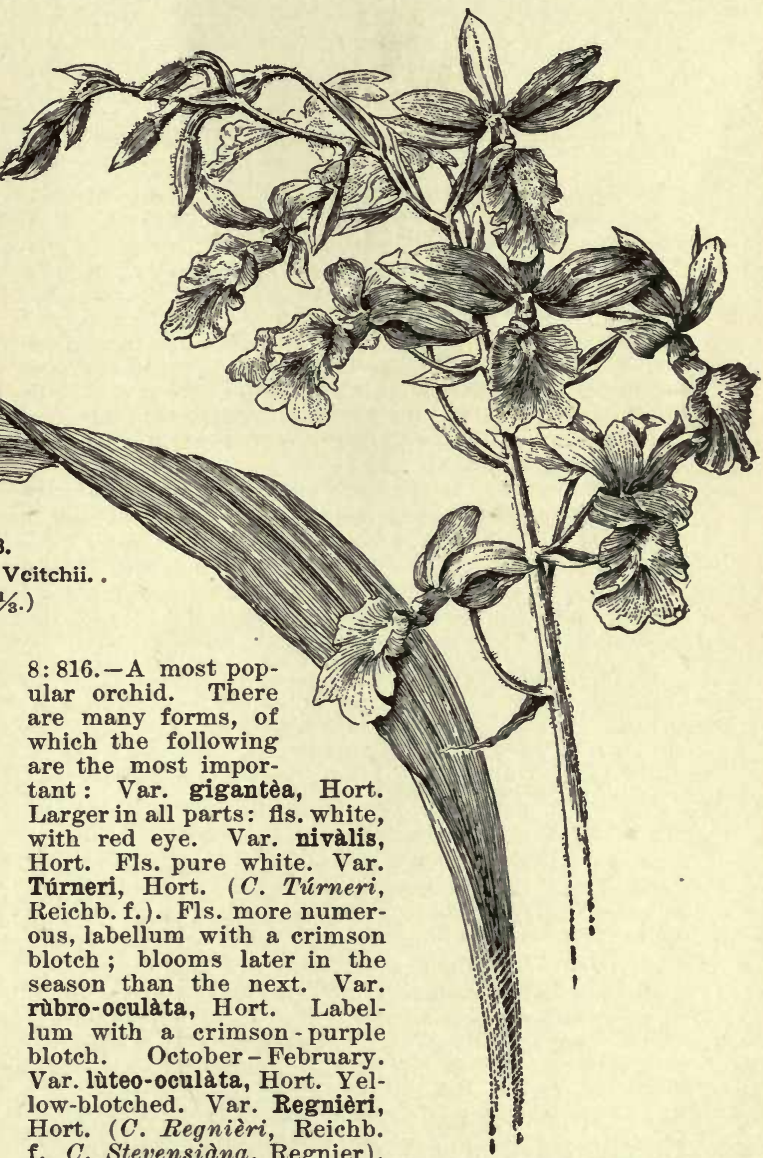

f. C. Stevensidna, Regnier).

Pseudobulbs more elongated, with a depression above the middle, labellum rose-colored, with a purple blotch in front of column, less deeply lobed than in the type. A.F. 6: 655 .

veratrifolia, R. Br. Lvs. oblong-lanceolate, about 2 ft. long, from a creeping rhizome : fls. white, in dense 
corymbose racemes; petals obovate-spatulate, sepals obovate-oblong; labellum 4-parted, the anterior lobes usually broader than the posterior or basal lobes. Blooms from May to July. Malaya. B.M. 2615.

Vèitchii, Lindl. Fig. 313. A hybrid between C'rosea and $C$. vestita: fls. rose-colored; labellum with white spot near the base. Winter-flowering. There is also a white variety. This hybrid was raised by Veitch, in 1856. B. M. 5375. Forms of this are var. bélla, Hort., with pink fls.; var. Sandhurstiana, Hort., with crimson fls.; var. Sédeni, Hort., with deep rose fls. C'. Eyer manii, Hort. (G.F. 4:17), is a hybrid of $C$. Veitchii and C. vestita. Var. supérba, Hort., has richer color.

Masùca, Lindl. Scape $2 \mathrm{ft}$. long, with large, manyribbed, dark Ivs.: fls. 1 in. across, the segments over lapping ; deep violet, fading to lilac, the lip deep violet purple. Summer and autumn. N. India. B. M. 4541. Var. grandiflora, Hort., is of greater size throughout.

C. discolor, Lindl., and C. Japónica, Blume, both of Japan, have been offered by dealers in Japanese plants; but they are unknown to general cultivation. OAKes Ames.

CALATHEA (Greek for basket, the application not agreed upon). Scitamindceo. Perennial foliage plants which are commonly cult. as Marantas. From Maranta the genus differs chiefly in technical characters. In Maranta the fruit is 1-seeded, in Calathea usually 3 seeded; in the former the fl.-clusters are branched and few-fld., in Calathea usually capitate or cone-like. Of Calatheas there are 70 or 80 species, mostly of trop Amer., but a few of trop. Afr. The lvs., for which the plant is grown, are variously marked with shades of green, red, brown, yellow, and white. The lvs. spring from the very base of the short stem, just above the rhizome. Sepals 3, free and equal : corolla tubular, with 3 spreading lobes : stamens 3 , petal-like, 2 sterile and 1 bearing an anther on its side (compare Canna). I H.

Calatheas are among the handsomest of ornamental leaved stove plants. They may be propagated by divi sion of the crowns, or in those species which make secondary growths, by cuttings taken just below the node and inserted in sharp silver sand in thumb-pots and plunged in a propagating box with bottom heat. About the beginuing of April, or just before active growth commences, is the best time for propagating and also for repotting. The soil best suited to them is one-third good, fibrous loam in small lumps, one-third fibrous peat or chopped fern-root, and one-third leaf-mold and clean silver sand, to which may be added a few nodules of charcoal to keep the mixture sweet. In repotting, the old soil should be shaken from the roots, and the plants potted loosely in the new mixture, using clean, welldrained pots, or for the creeping and shallow-rooting species, pans are preferable. All matured leaves should be removed at this time, and after repotting they should be placed in a close, warm, moist atmosphere and kept shaded, to induce active root growth. As the leaves develop they require an abundant supply of water at the roots, frequent spraying with a fine syringe, and to be well shaded from direct sunlight. These conditions should be reduced on the approach of winter, but at no season must the plants be allowed to become dry. The temperature during winter should not fall below $60^{\circ}$. Stronggrowing species, as $C$. zebrina, do best planted out in a palm house under the shade of palm trees, while the low-growing or creeping species are excellent subjects for inside rockeries, where a warm, humid atmosphere can be maintained.

Cult. by Edward J. Canning.

There are many species of Calathea in fancy collections, but the following list includes those which are known to be in the Amer. trade. Since the plants are often named and described before the flowers are known, it is not always possible to determine the proper genus. Consult Maranta, Phrynium, and Stromanthe. For horticultural purposes, botanical characters cannot be used in classification of the species; the following scheme, therefore, is based on evident leaf characters.

Index : C. albo-lineata, 3; Bachemiana, 9; Chimboracensis, 10 ; crotalifera, 20 ; eximia, 21 ; fasciata, 4 ; Lageriana, 7; Lagrelliana, 19; Lietzei, 11; Lindeniana, 12 ; majestica, 3; Makoyana, 13; Marcelli, 25; medio-picta 22 ; micans, 23 ; nitens, 14; olivaris, 13 ; ornata, 3 ; Prin- ceps, 15; pulchella, 2 ; regalis, 3 ; rosea-lineata, 6 ; rosea picta, 6; smaragdina, 5; tubispatha, 8; Vandenheckii, 24 ; Veitchiana, 16 ; virginalis, 25 ; Wagneri, 6 ; Warscewiczii, 17; Wiotiana, 18; zebrina, 1.

A. Lvs. marked only by transverse bars.

1. zebrina, Lindl. (Maránta zebrìna, Sims). Large, free-growing plant : lvs. 2-3 ft. long, purple beneath, satiny green above, with alternating bars of deep and pale green : fls. dull purple, on a very short scape. Braz. B.M. 1926. L.B.C. 5: 494. R.H. 1865:90. S.H 1:164. L. 1. - The commonest species, occurring in nearly all collections of warm greenhouse plants.

2. pulchélla, Kœern. Weaker grower than $C$. zebrina, the Irs. lighter colored, with two series (large and small) of broad green bars. Braz. - By some considered to be a form of $C$. zebrina.

3. ornàta, Kœrn. (Maránta regalis, Hort.). Dwarf: Ivs. oblong-acuminate, the stalks $1 \mathrm{ft}$. long and blades usually shorter, red beneath, green above and marked with two bars between each of the transverse veins. Colombia. - The transverse markings are usually bright red, and this form is taken as the type of the species (I.H. 2:74. L. 20). In var. álbo-lineàta, Hort. (Calathè and Maránta álbo-linedta, Hort.), the lines are white (F.S. 4:413. L. 55). Var. majéstica, Hort. (M. majestica, Lindl.), attains a height of 4-5 ft. It has redstriped lvs. I.H. $41: 1$.

4. fasciàta, Regel \& Kœrn. Dwarf: lvs. long-cordate the blade 10-12 in. long, pale green and purple-tinged below, green above, with white bands running off to the margin. Braz. Gn. 2, p. 3. L. 23.

5. smaragdina, Lind. \& André. Two ft.: lvs. widespreading, oblong-lanceolate and acuminate, silvery green below, dark green above, with prominent bands of different shades of green, the midrib prominent S. Amer. I.H. 17: 16 .

AA. Lis. variously marked and blotched, often margined, or only the midrib colored.

B. Markings red, parallel with the margin.

6. rosea-picta, Regel ( $C$. rosea-linedta, Hort.? $M$. Wágneri, Hort.). Dwarf : Ivs, nearly orbicular, purple beneath, the upper side dark green, the midrib red, and an irregular red zone (sometimes two zones) two-thirds of the distance from the midrib towards the margin. Amazon. F.S. 16:1675-6. Gn. 2, p. 3

BB. Markings in shades of brown or bronze.

7. Lageriàna, Hort. Lvs. large, dark red beneath, the prominent veins rich bronze.

8. tubispatha, Hook. f. Two feet or less high : lvs. obovate-elliptic, short-acuminate or cuspidate, thin, greenish beneath, lively green above, and marked midway between the rib and the margin with lighter green and squarish patches of brown. W. Afr. B.M. 5542.

Ввв. Markings in shades of yellow and green.

9. Bachemiana, Morr. Lvs. unequilateral, cordate at the base, long, smooth, finely striate, with parallel greenish or whitish markings along the primary nerves, purplish beneath. Brazil.

10. Chimboracénsis, Lind. Dwarf : lvs. oblong-ovate, 8-12 in. long, acuminate, green above and below, with 8 very dark green white-margined band running lengthwise the blade midway between the rib and each margin. Neighborhood of Mt. Chimborazo. I.H. 17:6.

11. Liètzei, Morr. Lvs. oval-lanceolate, truncate or shallow-cordate at base, undulate, purple beneath, deep green and shining above, with feather-like blotches of deeper green. Brazil.

12. Lindeniana, Wallis ( $C$. Lindeni, Wallis \& André) Lvs. elliptic-oblong, short-acuminate (12 in. or less long), deep green above with an olive-green zone either side of the midrib, and bey ond which is a darker zone of green, the under side counterfeiting the upper side, but with purplish zones. Peru. I.H. 18:32.-By some considered to be a form of $C$. rosea-picta.

13. Makoyàna, Morr. (Maránta olivaris, Hort.). One to $4 \mathrm{ft}$. : lvs. broad-oblong, obtuse or somewhat short-pointed, the stalks red, the leaf olive-green or cream-colored above but marked against the midrib 
with outspreading, dark green blotches of oblong, oval or pyriform shape, the under surface similarly marked, but in red. Brazil. F.S. $20: 2048-9$. G.C. 1872:1589. Gn. 4 , p. 87.

14. nitens, Hort. Dwart : Ivs. oblong, glossy green, on each side of the rib marked with oblong, pointed greenish bars, which alternate with dark green lines. Brazil.

15. prínceps, Regel. Leaf elongated or elliptical-lanceolate, $7-10$ in. long, 3-31/2 in. broad, light green above, with broad black-green, flaming, broken band along the middle nerve, violet-purple below. Amazon.

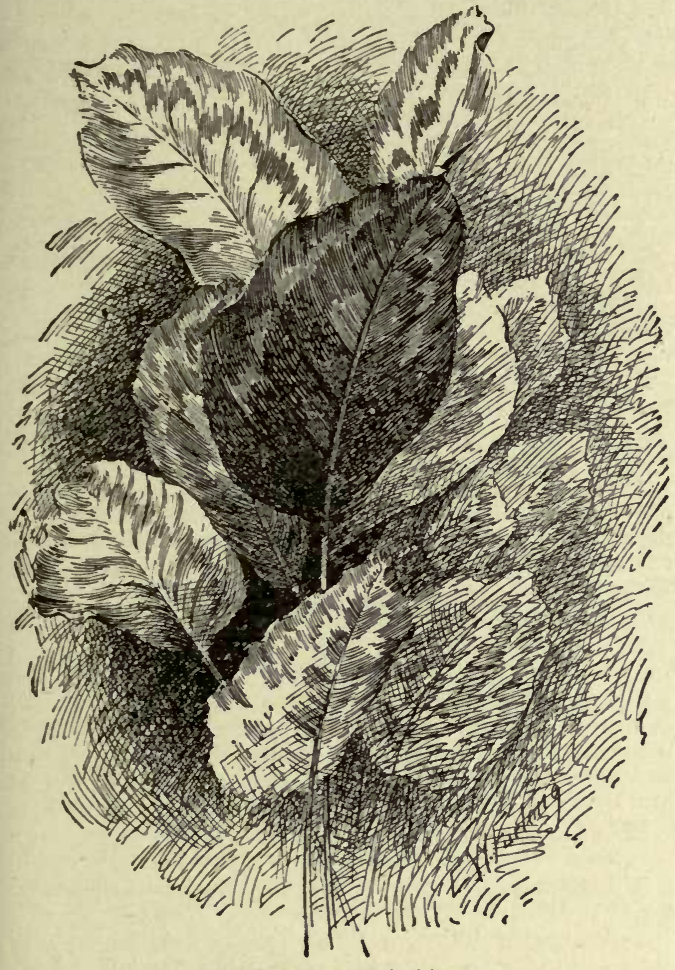

314. Calathea Veitchiana.

16. Veitchiàna, Veitch. Fig. 314. Very handsome, 3-4 ft.: Ivs. large, ovate-elliptic, obtuse or nearly so, rather thin, glossy, purplish below, dark, rich green above and marked with one or two rows of light yellow-green irregular blotches running the length of the blade (often shading into white). Tropical Africa. B.M. 5535. G.C. 1870:924. Gn. 2, p. 545. F. S. 16:1655-8. - Common ; one of the handsomest and most serviceable species. The darker parts of the blade are often bronze-brown.

17. Warscewiczii, Kœrn. Rather large : Ivs. $2 \mathrm{ft}$. long, oblong-lanceolate, acuminate, purple beneath, dark, velvety green above, but the midrib broadly feathered with yellow-green. Trop. Amer. F.S. 9:939-940. Gn. 17:238. L. 17.- One of the best.

18. Wiotiàna, Makoy (C.Widti, Hort.). Lvs. bright green, with two rows of olive-green blotches. Brazil.

ВвВв. Markings white or very nearly so.

19. Legrelliàna, Regel. Leaf elliptical, pointed, 5-6 in. long, $2-31 \frac{1}{2} \mathrm{in}$. broad, above shining green, with broad, white, flaming, broken middle band along the middle nerve and numerous broken white linear small bands between the side nerves; lower surface whitish green and marked with red and green. Equador. - Neat species.

20. crotalifera, Wats. Rattleesnake Plant. Lvs.oval, abruptly acute at each end, $2 \mathrm{ft}$. or less long and half as broad, yellowish green, with $a$ white-margined midrib; petiole 2-3 ft. long, curved, sheathing: peduncles 1 or 2 and 8-10 in. high, bearing distichous yellow-fld. spikes. Guatemala. - Offered in Fla.

21. eximia, Kœrn. (Phrỳnium exímium, Koch). Petiole grooved, greenish, closely covered with soft hair and naked only on the somewhat thickened end. Leaf surface somewhat long-elliptical, pointed, in full-grown lvs. 8-10 in. long and 4-5 in. broad, lightly shining blue-green, and marked with broad white cross bands; the under side of the lvs. covered with short, velvety hair, and of a brownish purple color. S. Amer. Gt. 686.

22. mèdio-pícta, Makoy. Lvs. oval-lanceolate and tapering to both ends, dark green, with the rib feathered with white from base to summit. Brazil.

23. micans, Kœrn. Very small : lvs. 2-3 in. long, oblong-lanceolate, somewhat acuminate, green and shining above, the rib in a feathered white stripe. Brazil. L. 49.

24. Vandenhéckei, Regel. Lvs. dark green, shining, red-purple beneath, the upper surface marked with two concentric zones of white, and the rib margined with white. Brazil ?

25. virginàlis, Lind. Lvs. soft-hairy below, broadoval, rather blunt, 7-9 in. long, 4-6 in. broad, upper surface light green, and below, in the common form, whitish green and lighter zones shown, as on the upper surface, - or in another form, which has been distributed in gardens as $C$. (Maranta) Marcelli, under side shaded a light violet and without zones. Brazil. A.F. 7:611.

C. argyraea, Kœrn. Has been offered in the American trade. - C.arrécta, Lind. and André. Tall : lvs. oblong, red beneath, green above, with the nerves all prominent. Equador. I.H.18:77 $-C$. Baraguini Regel. Lvs oval-lanceolate green, with bands of white. Brazil.-C. Fascinator, Hort. Dwarf: lvs. broad ovate-oblong, purplish beneath, green above and with blotehes of lighter color and transverse narrow bars of red. Brazil I.H. 41:104, as Maranta Faseinator.-C. hieroglýphica, Lind. and André. Dwarf: lvs. short-ovate, short-pointed, purplish beneath, green above and marked by many oblique bands or bars of silvery white. Colombia. I.H. 20:122-3.-C. illuistris, Hort. (Maranta illustris, Lind.). Dwarf: lvs, broad-ovate or somewhat obovate, purple beneath, green above, with oblique bars of what obovate, purple beneath, green above, with oblique bars of lighter green and an encircling zone of shaded white. Equador. long, olive-green, with blotehes of deep green. Brazil.- C. Massangeàna, Hort.= Maranta Massangeana.-C. pardina, Planch. \& Lind $=$ C. villosa. - C. rufibárba. Hook. f. Brown-hairy: lvs. long-oblong or linear-oblong, bright green above, and bluish green and violet-tinged beneath: fls. yellow. Brazil? B.M. 7560 . gres splénders and spléndida, Hort $=$ Maranta splendida, $-O$. villdsa, Lindl. Large: lvs. 10-20 in. long, oblong-ovate, pale villosa, Lindl. Large : ivs. 10-20 in. long, oblong-ovate, pale green, with dark brown angular blotehes: fls. yellow. S. Amer.
F.S. 11:1101-2, as C. pardina ; also, L. 32.- C. vittata, Koern. Lvs. ovate-acuminate, less than $1 \mathrm{ft}$. long, light green, with many transverse bars of yellow-white. Brazil. L. 38 .

L. H. B.

CALCEOLARIA (Latin calceolus, a slipper, alluding to the saccate fl.). Scrophularidcea. Many species of herbs and shrubs, chiefly natives of S. Amer., but some in Mexico and New Zealand. Corolla 2-parted nearly to the base, the lower part or lip deflexed and inflated-slipper-like, the upper lip smaller and ascending, but usually saccate; stamens 2 or rarely 3 , and no rudiments (A, Fig. 315) : fruit a many-seeded capsule: Ivs. usually hairy and rugose, mostly opposite. Calceolarias are grown for the variously colored and usually spotted lady's-slipper-like fls. The colors are often very rich and intense. The genus falls into two horticultural sections, the herbaceous kinds, and the shrubby kinds. The former are the only ones generally known in this country. They are grown from seeds. They are often known as the hybrid Calceolarias ( $C$. hybrida, Hort.), since the common varieties are evidently the products of inter-crossing and plant-breeding.

L. H. B.

Of the hybrid section, seeds are best sown at the end of June or beginning of July, in pans. Care should be taken to have the pans thoroughly clean. Good drainage is essential. A good soil is one composed of equal parts of sand, leaf-mold and sod soil. This should be finely sifted. After filling the pans, thoroughly dampen, and allow to drain before sowing. It is unnecessary to cover the seeds with soil, but a close-fitting pane of glass should be placed over the pan until the little plants are well started, when the glass should be gradually removed. In the early stages, watering is best done by immersion, but it is not advisable to keep the pans standing in water. 
Prick off, when large enough to handle, into pans or shallow flats one inch apart. Same compost as for seeds will suit. When plants begin to crowd, pot into thumbpots. This time the compost should have the addition of a sixth part of finely sifted dried cow-manure. Subsequent shifts should be given as required, the last being into 7 -inch pots. Shade is necessary all along, but should not be so heavy as to induce the plants to become drawn. A house or frame with a northern elevation is most suitable for their culture, keeping the temperature as low as possible during the warmer months. Later on, provide a night temperature of $40^{\circ}$ and a day temperature of $50^{\circ}$ to $55^{\circ}$. Water carefully, avoiding extremes, and when the flower spikes begin to show, weak liquid manure may be frequently used with advantage. Green-fly is the only really troublesome insect enemy. This can be kept in check by the free distribution of tobacco stems around the benches where the plants are set. If it gets thoroughly established, evaporate tobacco extract in the house.

The shrubby Calceolarias are grown extensively in Europe, especially Britain, as a bedding plant, but the heat of an American summer proves too much for them. Propagation is effected chiefly by cuttings, which are taken there the end of August, struck, and wintered over in cold frames protected from frost.

WM. Sсотт, of Tarrytown.

The herbaceous garden forms of Calceolarias cannot often be referred to botanical species. In the following account, the important stem species are described. Rodigas considers the garden hybrids to be off shoots chiefly of $C$, arachnoidea and crenatiflora, and he has called this race $C$. arachnoideo-crenatiflora (see I.H. 31:528, 536; 35:54). Fig. 315. C. crenatiflora seems to have left its impress most distinctly on the greenhouse forms.

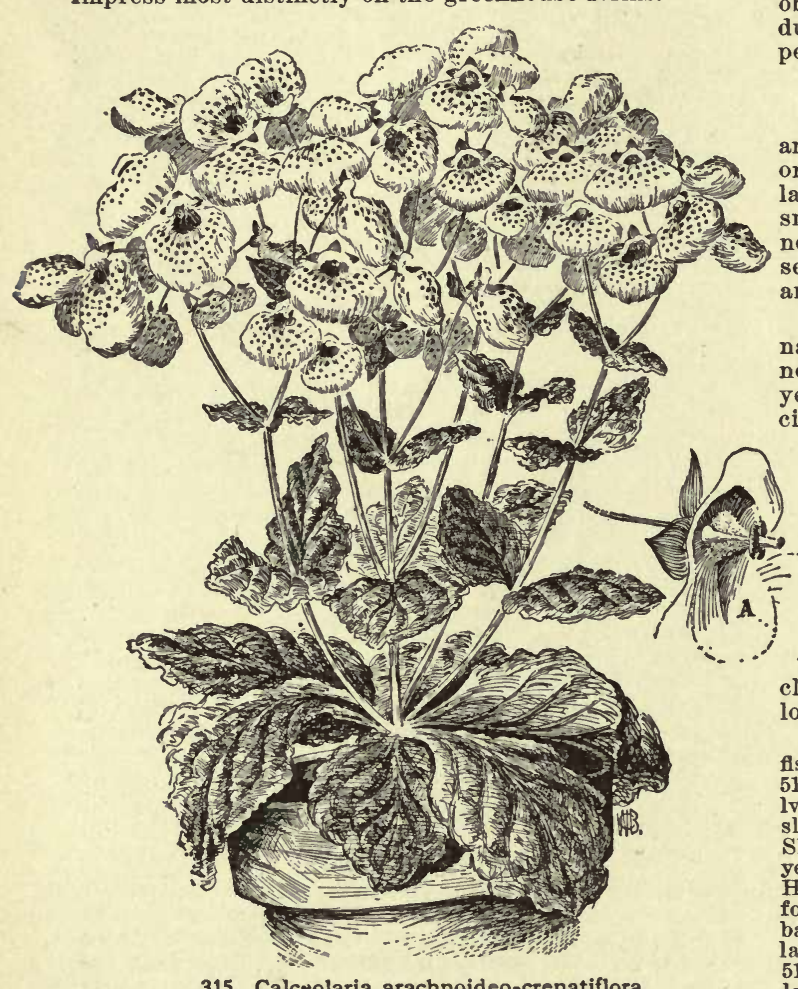

315. Calceolaria arachnoideo-crenatiflora.
A. Herbaceous Calceolarias, parents of the florists varieties of this country. B. Lvs. simple.
c. Fls. essentially yellow.

crenatiflora, Cav. ( $C$. pendula, Sweet). One-2 ft., the stem soft-hairy, terete: radical lvs. ovate and long peti- oled (the petioles winged at top), undulate and dentate, sometimes obscurely lobed, rugose and pubescent, paler beneath, often purplish towards the tip ; stem-lvs. shorterpetioled and becoming sessile above : fls. in a forking corymb, the slipper large, oblong or oblong-obovate, furrowed or crenate, hanging, yellow, with orange-brown dots. Chile. B.M. 3255. - From this species we seem to have derived the spots of Calceolaria fls.

corymbosa, Ruiz \& Pav. One-2 $\mathrm{ft}$., the stem 4-angled : radical lvs. ovate and sometimes cordate, obtuse or nearly so, doubly crenate, rugose and hairy, whitish beneath: stem-lvs. smaller and narrower, somewhat clasping, opposite : fls. small (about half as large as in $C$. crenatiflora), in a broad, somewhat loose corymb, the slipper somewhat short-oblong, clear yellow outside and marked with red lines inside. Chile. B.M.2418.

amplexicaulis, HBK. A ft. or two high: lvs, cordateovate to ovate-lanceolate, long-acuminate, pubescent, woolly beneath and deep-rugose above, clasping: fls. small in an upright corymb, pale yellow and spotless, the slipper hoof-shapec. Equador, ete. B.M. 4300.

\section{cc. Fls. purple.}

purpùrea, Grah. Stems erect, pubescent, 1-2 ft.: radical lvs. spatulate and acutish, with a strong midrib, sparsely hairy, rugose, dentate; stem-lvs. broad-cordate and clasping, less toothed: fls. in loose corymbs, small, purplish or reddish violet, the slipper somewhat furrowed. Peru. B.M. 2775. - Supposed to have entered largely into purple-fld. varieties.

arachnoldea, Grah. Stem a foot or two high, terete, branchy, woolly, with appressed hairs : lvs. oblong or lingulate, narrowing into long winged petioles, clasping, obscurely toothed, rugose, woolly on both sides : peduncles in pairs, forking: fls. small, dull purple, the slipper nearly globular and furrowed. Chile. B.M. 2874.

\section{B. Lvs. compound, or essentially so.}

scabiosæfolia, Sims. Often $2 \mathrm{ft}$., the stem terete, hairy and leafy: lvs. opposite, with clasping petioles, cut nearly or completely to the midrib : Ifts. varying from lanceolate to broad-oval, acuminate, ciliate, dentate : fls. very small, in small hairy corymbs, pale yellow, the slipper nearly orbicular in outline. Peru. B.M. 2405. - In essentially pure form, this is sold by seedsmen as an annual and bedding plant.

pinnàta, Linn. Often reaches $3 \mathrm{ft}$. or more : Ivs. pinnatifid or completely compound, the divisions short and nearly entire, obtuse or nearly so : fls. small, sulfuryellow. Peru. B.M. 41. - The first known garden species, still sold as an annual.

\section{AA. Shrubby Calceolarias.}

integrifolia, Murr. (C. rugàsa, Ruiz and Pav. C. salvioefòlia, Pers.). Two ft. or less high, branchy and bushy: lvs. glabrous, oval-lanceolate, crisped and dentate, the short petioles winged : fis. in terminal clusters, small, yellow. Chile. B.M. 2523.-

Variable. Probably the chief source of shrubby Calceolarias.

thyrsiflora, Grah. More shrubby: lvs. linear and clustered, toothed, sessile, not hairy : fls. small, yellow, in a close, terminal cluster. Chile. B.M. 2915.

O. álba, Ruiz \& Pav. Shrubby : lvs. linear, toothed above fis. small, white. Chile. B.M. 4157. G.C. III. $22: 141$. Gn 51:1102. - C. Andina, Benth. Shrubby, glandular-pubescent: lvs. orbicular-ovate, thick, rugose, hairy : fls. small, yellow, the slipper crenate. Chile. B.M. 7326.-C. bicolor, Ruiz \& Pav. Shrubby: lvs. ovate, dentate : fls. small, the slipper sulfur yellow above and white below. Peru. B.M. 3036.-C. Búrbidgei, Hort. Handsome yellow-fld.hybrid of C. Pavonii X C. fuchsigfolia. Gn. 47:1012,-C. flexuossa, Ruiz and Pav. Shrubby at base: lvs, large-ovate coarsely crenate-dentate: fls, rather large, clear yellow, with very large green calices. Peru. B.M. 5154. F.S. 22:2331. $-C$. fuchsioefolia, Hemsl. Shrubby : lvs. lanceolate: fls. yellow, panicled, upper lip very large. Peru Gn. 15:173. G.C. II. 15:269.-C. Hénrici, Hook. f. Shrubby, evergreen : lvs. willow-like, small-toothed : fls. panicled, clear yellow, the upper lip large. Equador. B.M. 5772,-C. hyssopifolia, HBK. Shrubby : lvs, erowded, small, lanceolate and toothed, or at top of stem linear and entire, margins revolute: fls, rather large, in many-fld. corymbs, pale sulfur-yellow, the slipper obovate-orbicular and corymbs, pale sulfur-yellow, the Slipper obovate-orbicular and crenate. Equador. B.M. 5548.5-7-lobed, dentate: fls, in terminal clusters, clear, pale yellow, 
and spotted on the up-curved slipper. Peru, Bolivia. B.M. 6330.-C. Pavdnii, Benth. Herbaceous : lvs. large and wrinkled, ovate, truncate or eordate at base, the radical ones winged, all jagged and toothed : fls. large, clear yellow, the lip up-curved. Peru. B.M. 4525.-C. Pisacoménsis, Meyer. Shrubby : lvs. ovate-cordate, nearly or quite obtuse, nearly sessile, irregularly crenate, margins reflexed: fls. large, orange varying to red, the slipper up-curved. Peru. B.M. 5677.-C. plantaginea, red, the slipper up-cursed. Sinith. Herbaceous, stemless : lvs. ovate-spatulate, toothed at top : scapes many, few-fld., the fls. large, yellow, the under
side of the slipper dotted with red. Chile. B.M. 2805.-C. Sinclairii, Hook. Herbaceous, half-hardy: lvs. oblong-ovate stalked, crenate-dentate, hairy : fls. small, lilac or flesh-colored, spotted within, the two lips nearly equal, not saceate. New Zeal. B.M. 6597.-C. tenélla, Poepp. \& Endl. Herbaceous, half-hardy, 6 in. high : lvs. ovate or orbicular, small (1/8in, long), nearly or quitesessile: fls. yellow, spotted within. Chile. B.M. 6231, - C violacea, Cav. Shrubby : lvs. small, Chile. B.M. 6231.- violacea, Cav, Shrubby : lvs. small, ovate-cordate, deep-toothed, stalked : fls. yellow-salmon,
spotted within and without, the two lips not saccate. Chile. B.M. 4929 .

L. H. B.

CALENDULA (Latin, calendoe or calends: flowering throughout the months). Compdsitce. Herbs of temperate regions, of 20 or more species. Annuals or perennials, with alternate simple lvs., mostly large heads with yellow or orange rays, glabrous incurved akenes, plane naked receptacle, pappus none, and involucre broad, with scales in one or two series.

officinalis, Linn. Pot Marigold. Fig. 316. Annual: 1-2 ft. high, more or less hairy : lvs. oblong and more or less clasping, entire, thickish : heads solitary, on stout stalks, large with flat, spreading rays, showy, closing at night. S. Eu. B.M. 3204,-One of the most universal garden fls., running into many vars., distinguished by size, color, and degree of doubling. The color varies from white-yellow to deep orange. This is the Marygold of Shakespeare's time. The fl.-heads are sometimes used in cookery, to flavor soups and stews. The Calendula is of the easiest culture in any warm, loose soil. The seeds are usually sown where the plants are to stand, but they may be sown indoors or in a frame and the plants transplanted. The akenes are large and germinate quickly. The plant blooms the whole season, particularly if the fls. are picked. It is a hardy annual, and in the southern states will bloom most of the year.

suffruticòsa, Vahl. More diffuse, annual : lvs. sessile, lanceolate. somewhat dentate : heads bright yellow, not doubled, very numerous, on long peduncles. W. Mediterranean region.-Seeds are sold by American dealers.

C. Póngei, Hort., and C. pluviàlis, Linn., will be found under Dimorphotheca.

L. H. B.

\section{CALICO BUSH is a Kalmia.}

CALIFORNIA, HORTICULTURE IN. California occupies the mountain slopes and plain-like valleys of a vast area, much of which is peculiarly well-fitted to horticultural uses. New York, Ohio, Maine, New Jersey, Vermont, Massachusetts, New Hampshire, Connecticut, Delaware, and Rhode Island, united, have a less area than California. The range of products grown successfully in California is nearly or quite as great as that of all the rest of the United States ; the humid sealevel islands of Florida are adapted to some plants, such as Cassava, which do but poorly in California, but on the sheltered uplands of California many species which entirely fail in Florida are perfectly at home. Here, as every tourist can see in a single summer, one finds, and often on an enormous scale, the vines, walnuts and prunes of France ; the olives, oranges, lemons, chestnuts, figs and pomegranates of Italy and Spain the Acacias, Eucalypts, Casuarinas, and salt-bushes of Australia; the melons of Turkestan; the cotton and tobacco of the south; the hemp, flax, rye, Russian mulberries, and other products of the more extreme north, the cereals of the great west, the bulbs of Holland, the costly seed-crops of European gardens, and, in brief, examples of the greater part of the useful horticultural productions of the temperate zones.

While the American pioneers of Kentucky were fighting Indians, and struggling to obtain the right to navigate the Mississippi, the Spanish pioneers of California were planting pear, orange and olive trees, date palms, and European grapes, about the early Missions. After the American conquest, and the gold discovery of 1848 , horticulture gained a foothold in the mountain lands below the Sierra peaks. Every village and town had its gardens and its beginnings of orchards. Soon the thoughts of men turned to the broad, fertile, untilled valleys, and in a few years the wheat farmer became the typical Californian. Lastly, the state entered upon a magnificent and still continuing period of horticultural development, which well deserves to be written down in history as one of the most important facts of modern material progress.

Not so long ago almost 160,000 square miles of California were considered "nearly all waste." Now,

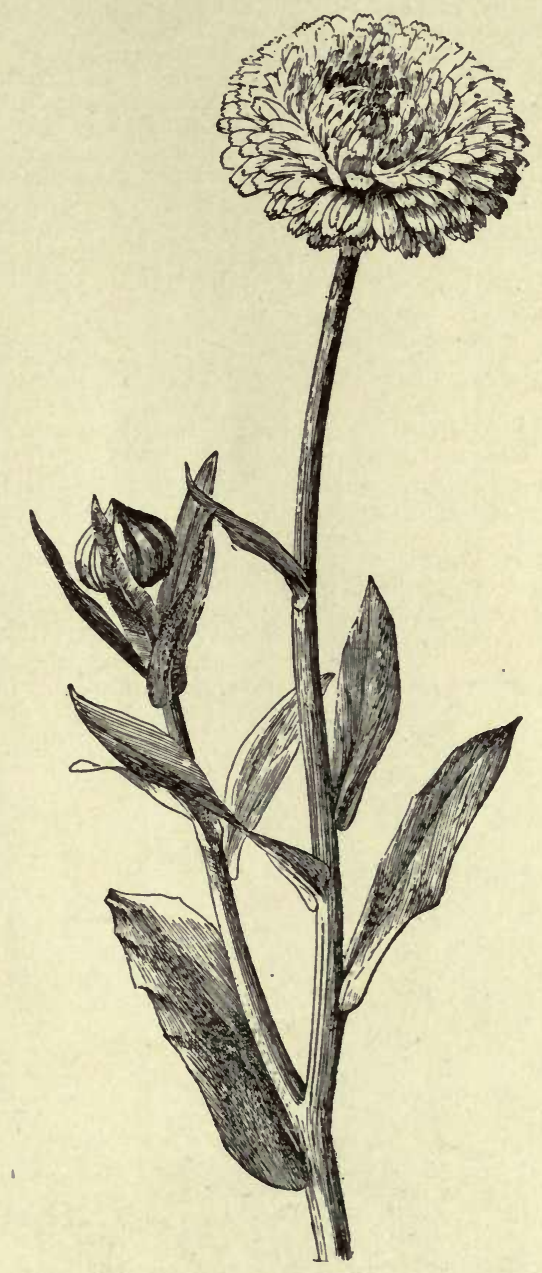

316. Calendula officinalis, double-flowered $(\times 2 / 3)$.

one finds that forests, pastures, farms, gardens, so sug gestively occupy the land that, although there is room for many more, it is difficult to call anything worthless except the great heights that shelter and water the valleys below. Even the deserts have underlying streams, and blossom with tree and vine as men sink artesian wells there. The miracles of Italy, ancient Palestine, modern India, are being repeated over large districts of California.

The great valleys and nearly level lands of California, the true cereal belts, subject to frosts, comprise about $40,000,000$ acres of land; the foothill fruit-belts, 
of Coast Range and Sierra, hardly as yet one-tenth occupied, comprise fully 25,000,000 acres; in timber and fine grazing lands, capable of perpetual renewals, are $12,000,000$ acres; high mountains cover some $13,000,000$ acres; arid lands, often yielding enormously under irrigation, or slowly conquered by neutralizing their superabundant alkali, occupy about 10,000,000 acres. Over these great areas every wind current, every mountain spur, every alteration in slope or altitude, helps to make a local climate. The complicated geological development of California has produced soils almost as varied as its local climates. Still, the state can be conveniently divided into five characteristic climate-zones: in the high Sierras the mean annual temperature is from $30^{\circ}$ to $44^{\circ}$; in the lower Sierras it is from $44^{\circ}$ to $52^{\circ}$; near the Pacific ocean it is from $52^{\circ}$ to $67^{\circ}$; in the central valleys of Sacramento and San Joaquin it is from $60^{\circ}$ to $68^{\circ}$, and in the southern counties from $68^{\circ}$ to $72^{\circ}$. But every part of California shows very sharp horticultural contrasts upon farms not a mile apart. Local climate is the key-note of California life. Placer county, for instance, extends from the center of the Sacramento valley east to the summit of the Sierras. It has upland Canadian valleys, pines and snow-blockades at one end; groves of oranges and lemons in the Sierra foothills, and rich alfalfa fields along the "bottoms" of the Sacramento valley rivers. See Fig. 317.

Statistics are apt to be dull reading, but the horticulture of California can be shown only by some of its results in recent years. Let us glance at a few of the records. Take the well-known industry of raisin-making. In 1873, 120,000 pounds were produced in California. By 1894 this crop had grown to $103,000,000$ pounds. The interstate shipments of fresh fruits, beginning late in the seventies, rose by 1894 to nearly $180,000,000$ pounds. The interstate shipments of dried fruits rose between 1884 and 1897 , from about $2,000,000$ pounds to $150,000,000$ pounds. During the same period of only 13 years, the product of beet-sugar increased from about $2,000,000$ to over $70,000,000$ pounds. Oranges, for many years a noted California product, rose between 1884 and 1898 , from 850,000 boxes to $4,640,000$ boxes. Turning to some other separate industries, in 1897 the dried apricot crop was over $30,000,000$ pounds, the prune crop was over $97,000,000$ pounds, the dried peach crop was over

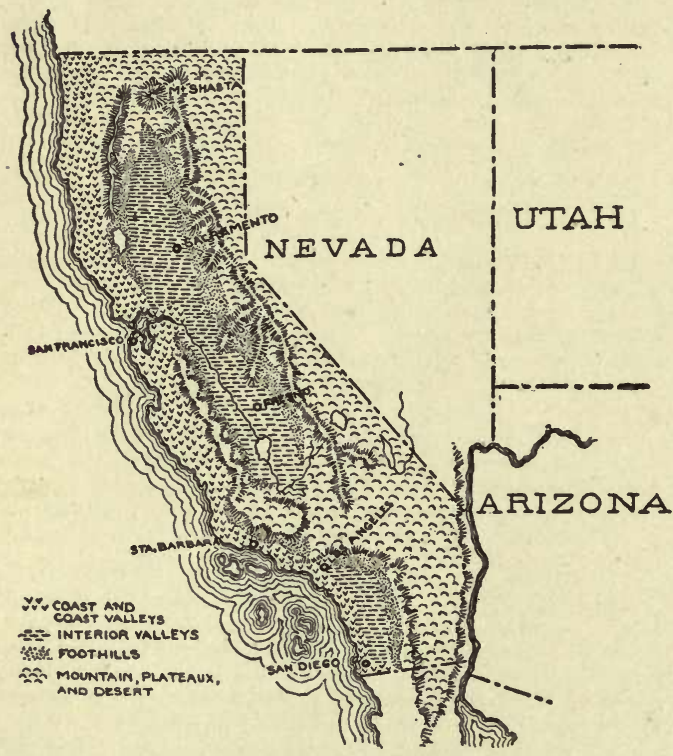

Fig. 317. Horticultural regions of California.

$27,000,000$ pounds. The wine-production of the state in 1897 was $34,500,000$ gallons. The pack of canned fruit in 1898 was $2,000,000$ cases. In 1893, in a very careful tabulation of the area planted to fruit-trees and vines, made by me for the Popular Science Monthly, I estimated as follows:

\section{Kind}

Acreage

Citrus and semi-tropic................. 95.000

Deciduous fruits......................200.000

Nut-bearing trees............................ 25,000

Grapes..........................191,933

Small fruits ......................... 5,081

Total..................... 517,014

At the usual distances of planting, this would give $48,000,000$ fruit trees and about $240,000,000$ grape-vines. Since 1893 nearly six years have passed, and yet the acreage has not greatly gained. Some vineyards and worn-out orchards have been destroyed. The area in small fruits has nearly doubled. The citrus and semitropic fruits have somewhat increased in area. There have been seasons of heavy frosts and of light rainfall. The industry has been less generally profitable during recent years. A multitude of lesser horticultural oceupations have attracted attention.

Among these new horticultural industries of the last decade or so are the extensive growth of tree, flower and vegetable seeds, of cut-flowers, of vegetables and of decorative plants. California has always had important nurseries and large market-gardens, but there is now a tendency to specialize more than ever before, and to supply, in many departments, the markets of America and Europe. Portugese, Italian, Chinese and Japanese peasants have settled in large numbers in the richer districts of California, introducing their special horticultural industries. Large farms and orchards are still profitable, but every year the small, well-tilled plots increase in number and relative importance.

Charles H. Shinn.

\section{CALIFORNIA POPPY is Eschscholtzia.}

CALIFORNIA YELLOW BELLS is Emmenanthe penduliflora.

CALIMERIS (Greek, beautiful arrangement). Compositce. A few Asian herbs, often united with Aster, but horticulturally distinct, and differing from that genus in the hemispherical involucre of few, nearly equal, scarious-margined bracts, and broad, convex receptacle. Akene flat and hairy. Hardy perennials of low growth, suited to the border in front of stronger plants. $\mathrm{C} . \mathrm{Ta}$ tarica is described in the genus Heteropappus.

incisa, DC. (Aster incisus, Fisch.). One to $2 \mathrm{ft}$., erect, corymbose at the summit: Ivs. lanceolate, remotely incise-dentate : scales of involucre red-margined : fls. large, purple-rayed or almost white, and yellow-centered. - Of easy culture in any good soil, making a display throughout July and Aug. The commonest species.

Altàica, Nees (Aster Altaicus, Willd.). Lower, pubescent or hispid: lvs. linear-lanceolate and entire : scales of involucre pubescent and white-margined : rays narrow, blue.

L. H. B.

CALIPHRURIA. See Calliphruria.

CÁLLA (ancient name, of obscure meaning). A ròidece. A monotypic genus, containing a native bog-plant with a white spathe. Herbs, with creeping rhizomes and 2 ranked lvs. Differs from Orontium in the parallel secondary and tertiary veins of the leaf-blade. See Richardia for C. Athiopica, albomaculata, Elliottiana, and nana. The Calla of florists, or Calla Lily, is Richardia.

palústris, Linn. Fig. 318. Rhizome bearing many distichous lvs, one year, the next only 2 lvs, and the peduncle : petioles. cylindrical, long-sheathed : blade cordate : spathe elliptical, or ovate-lanceolate, white. Eu., N. Asia, and E. N. Amer. B. M. 1831.-An interesting little perennial plant, useful for outdoor ponds.

JARED G. SMITH.

CALLIÁNDRA (Greek, beautiful stamens). Legumindsae. Tropical American shrubs, distinguished from Acacia by the presence of a thickened margin on the pod. Lvs. bipinnate; lfts. numerous: fls. usually borne in globose heads; corolla small, obscured by the numerous, long, silky, purple or white stamens. Cult. in s. Calif., and prop. by cuttings. 
Lambertiàna, Benth. (Acdeia Lambertidua, D. Don). Unarmed : branches terete : lvs. puberulous-villous : pinnæ 2-3-yoked : lfts. 9-12-yoked, oval-oblong, obtuse at both ends: petiole not glandular: peduncles $3-5$, racemose : heads roundish ; stamens $20-25$, exserted. Mexico. B.R.721

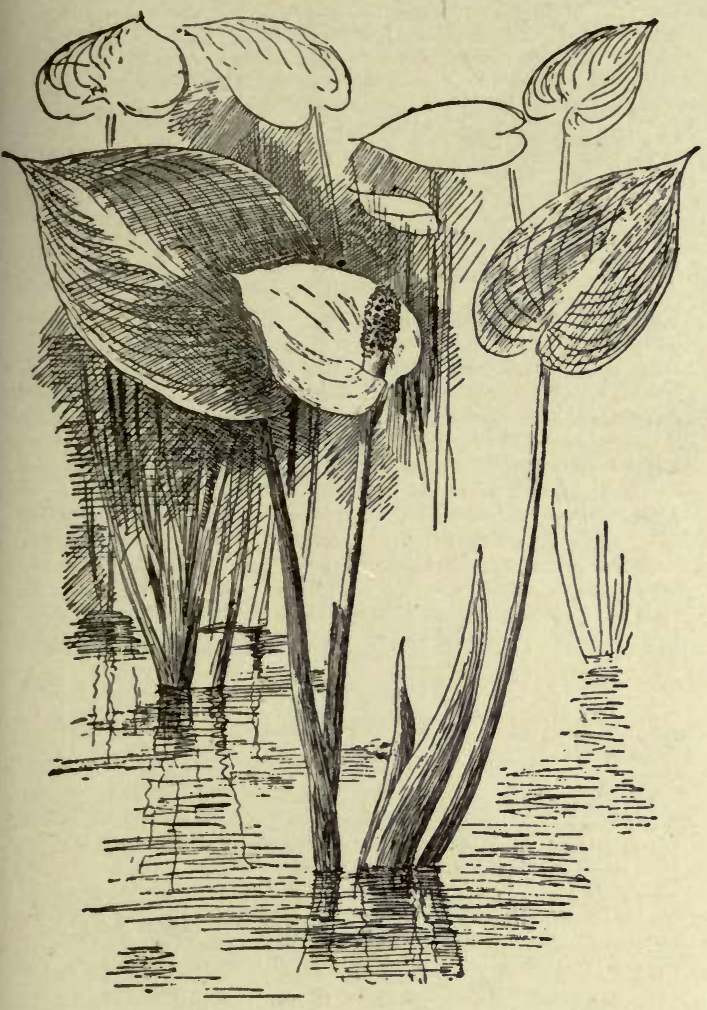

318. Calla palustris.

tetrágona, Benth. (Acdcia tetrágona, Willd.). Unarmed, glabrous: branches tetragonal: pinnæ 5-6-yoked : lfts. 16-29-yoked, linear, acute, the outer larger : heads pedunculate, axillary; fls. white : pod linear-obtuse, thickened at the margin.

Portoricénsis, Benth. (Acacia Portoricénsis, Willd.). Unarmed shrub, $10 \mathrm{ft}$. high: pinnæ 5-yoked : lfts. 15-25yoked, linear, obtuse ; petioles not glandular: branchlets pubescent: heads globose, pedunculate, axillary: calyx ciliate on the margin : filaments long, white : stamens 20-25: pod straight, linear, tapering at the base. West Indies.

CALLICARPA (Greek, beauty and fruit). Verbendcece. Shrubs or trees, mostly with rough, stellate hairs: lvs. opposite, usually dentate and deciduous : fls. small, perfect, in axillary cymes; corolla with short tube, 4lobed; stamens 4: fr. a small, berry-like drupe, red, lilac or violet, with 2-4 seeds. About 30 species in trop. and subtrop. regions of Asia, Australia, N. and C. Amer. Some species are cult. chiefly for their decorative fr., profusely produced in fall; the hardiest are $C$. pur purea and $C$. Japonica, and they may be grown even north in sheltered positions, if somewhat protected during the winter. If killed to the ground, young shoots spring up vigorously, and will produce fls. and fr. in the same season. If grown in the greenhouse, they require a sandy compost of loam and peat, and plenty of light and air. Prop. readily by greenwood cuttings in spring or summer under glass, also by hardwood cuttings, layers and seeds.

\section{A. Irs. tomentose beneath.}

Americàna, Linn. Shrub, 3-6 ft., with scurfy, downy tomentum : lvs. cuneate, elliptic-ovate, acuminate, obtusely serrate, 3-6 in. long: cymes short-stalked; corolla bluish, glabrous: fr. violet. July-Aug. Virg. to Texas and $W$. India. - One of the handsomest in fr., but more tender than the Japanese species. There is a var. with white fr.

AA. Lis. glabrous beneath, but glandular: corolla glandular outside.

Japónica, Thunb. Shrub, 2-5 ft.: lvs. cuneate, elliptic or ovate-lanceolate, acuminate, crenately serrate, $2 \frac{1}{2}-5$ in. long: cymes peduncled, many-fld.; fls. pink or whitish: fr. violet. August. Japan. P.F.G.2, p. 165.

purpùrea, Juss. (C. grácilis, Sieb. \& Zucc.). Shrub, 1-4 ft.: lvs. cuneate, elliptic or obovate, coarsely serrate above the middle, entire toward the base, $1 \frac{1}{2}-3$ in. long: cymes peduncled, few or many-fld.; fls. pink: fr. lilacviolet. August. Japan, China. Gn. 23: 392.-Closely allied to the former, but smaller in every part.

C. càna, Linn. Shrub : lvs. broadly elliptic, shining above and whitish-tomentose beneath : fr. deep purple. E. India, China, Philippine Isl. $-C$. dichótoma, $\mathrm{C}$. Koch $=\mathrm{C}$. purpurea.C. lanàta, Schau., not Linn.=C. pedunculata.-C. Mimurazàki, Sieb =C. Japonica - C móllis, Sieb. \& Zuce. Shrub, to $4 \mathrm{ft}$. lvs. oblong-lanceolate, rounded at the base, tomentose beneath: lvs. oblong-lanceolate, rounded at the base, tomentose beneath:
fls. and $\mathrm{fr}$. pink. Japan. - C. pedunculata, $\mathrm{R}$. Br. Shrub: lvs. oblong-ovate, nearly sessile, and rounded at the base, green and slightly tomentose beneath: cymes slender-peduncled. E. Ind. Austr. Sieb. Flor. d. Jard. 4: 97. - C. rubélla, Lindl. Shrub or small tree, to $20 \mathrm{ft}$.: lvs, cordate-oblong, tomentose benesth: fr. purple. Himal., Chins. B. R. 11: 883. F. S. 13: 1359 (as C. purpurea).

ALFRED REHDER.

\section{CALLIOPSIS. Consult Coreopsis.}

CALLIPHRÙRIA (Greek, beautiful prison; referring to the spathe inclosing the flowers). Written also Caliphuria. Amarylliddcea. Tender bulbs from New Granada, distinguished from Eucharis by the stamens, the filaments being petalid, with three large linear teeth on top, the middle one bearing the anther. The fls. appear with the lvs. Prop. by offisets. J. G. Baker. Amaryllideæ, p. 112.

Hartwegiàna, Herb. Bulb ovid, 1 in. thick, stoloniferous, with brown membranous tunies: lvs. bright green, firmer and more closely veined than in Eucharis, with an oblong-acute blade 4-5 in. long, 2 in. broad, narrowed into a petiole, which is flat above, and round beneath : scape slender, $1 \mathrm{ft}$. long: fls. 6-8, in an umbel, white perianth 1 in. long and wide. Andes of Bogota. B.M.6259. Int. in 1889 by Reasoner, who has never flowered it.

C. subedentàta. Baker $=$ Eucharis subedentata.

CALLIPRORA is included in Brodiaca.

CALLIPTERIS (Greek, beautiful fern). Polypodidcece. A genus of ferns allied to Asplenium, with elongate sori formed on both sides of the veins, and the veins uniting to form meshes or areolæ. Some fifteen species are known from the warmer parts of both hemispheres. The following is the only one in cultivation. Culture of tropical Aspleniums.

prolifera, Bory (Asplènium decussàtum, Swz.). Lvs. 2-4 $\mathrm{ft}$. long besides the stalks, which are 1-2 ft. long, with numerous pinnæ 6-12 in. long, 1-2 in. wide, with deeply crenate margins and frequently with bulblets in the axils; veins pinnate, with the branches of contiguous veins uniting. Polynesia and Malaya. L. M. UNDERWOOD.

CALLfRHÖ̈ (Greek mythological name). Malvdcece. POPPY-MALLOW. Seven native species of hardy, showy herbs of the easiest culture and deserving a much greater popularity. The two kinds mentioned are chiefly prop. by seeds, but the perennial species may also be prop. by cuttings. The name is also written Callirrhoë.

\section{A. Annual: involuore absent.}

pedàta, Gray. Fig. 319. Height 1-3 ft.: stem erect, leafy: radical, and lower lvs. round-cordate, palmately or pedately 5-7-lobed or -parted, the lobes coarsely toothed or incised, upper 3-5-cleft or -parted, usually into narrow divisions : fls. red-purple, cherry red, varying to lilac. Common in Texas. R.H. 1857, p. 430. 
AA. Perennial: involucre present.

involucràta, Gray. Height 9-12 in., plant hirsute or even hispid : root large, napiform : stems procumbent: lvs. of rounded outline, palmately or pedately 5-7-parted

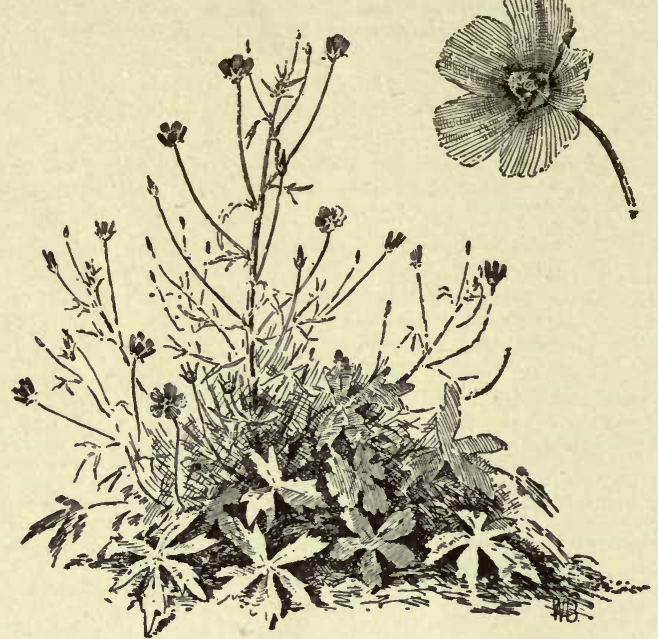

319. Callirhoë pedata.

or -cleft, the divisions mostly wedge-shaped, incised, the lobes oblong to lanceolate : fls. crimson-purple, cherry red or paler. All summer. Minn. to Tex. G.W.F. 26. R.H. 1862:171, as C. verticlllata.

Var. lineariloba, Gray. Less hirsute than the type : stems ascending: lvs. smaller, 1-2 in. across, the upper or all dissected into linear lobes. - An excellent trailer, especially for rockeries. Thrives even in very dry soils, the root penetrating to a great depth. A sunny position is preferable.

J. B. KELLER and W. M.

CALLISTÉmMa, CALLISTEPHUS. See Aster, China.

CALLISTEMON (Greek, kallos, beauty; stemon, a stamen; in most of the species the stamens are a beautiful scarlet color). Myrtacece. BotTle-Brush. Australian shrubs : lvs. evergreen, short: fls. in dense, cylindrical spikes, at first terminal, but the axis growing out into leafy shoots ; anthers versatile, with parallel cells opening longitudinally : fr. persisting several years. Prop. by ripened cuttings in sand under a handglass, which flower when small; or by seeds, but the seedlings are slow in reaching the flowering state. Rapid growers ; very ornamental ; greenhouse in the north; hardy in California, thriving in any soil and without irrigation.

$$
\text { A. Lvs. flat, penniveined. }
$$

speciosus, DC. Lvs. thick, narrow-lanceolate, pubescent when young: spikes dense, large : fls, scarlet, the calyx and corolla pubescent ; stamens obscurely or very shortly 5-adelphous. March-April. West Australia. B.M. 1761, as Metrosideros speciosa. Height $10 \mathrm{ft}$.

lanceolàtus, Sweet. Fig. 320 . Height 6-10 ft.: 1vs. crowded, thick, lanceolate, punctate, reddish when young: spike rather loose, of reddish fls. N.S.Wales. $6 \mathrm{ft}$.

rígidus, R. Br. Lvs. linear or narrowly linear-lanceolate, rigid, almost pungent-pointed : spikes dense : fls. red; anthers dark. New South Wales. $4 \mathrm{ft}$.

AA. Lvs. channeled above, linear, nerveless or 1-nerved.

lineàris, DC. Height 4 to $6 \mathrm{ft}$.: fis. dark or pale scarlet: fr. more globular and more contracted at the mouth than in $C$. rigidus. June. N. S. Wales.

$$
\text { J. Burtt Davy. }
$$

CALLITRIS (from the Greek for beautiful). Coniferae, tribe Cupressinea. About 15 trees or shrubs, growing in Africa and the Australian region, allied to
Thuja. The small cones have 4-6 separating woody scales : lvs. small and scale-like, persistent. Of very attractive habit. The only species in the Amer. trade is

robústa, R. Br. Cypress Pine. Somewhat resembles our native red cedar, but is conical in form and very dense. It is a fine tree for tall hedges and windbreaks. Young trees planted out in S. Fla. make fine specimens, branching from the ground. In five years the plants reach 10-12 ft. high. Little known in this country. Queensland.

L. H. B.

CALLƯNA (Greek, to sweep; the branches are sometimes used for making brooms). Ericacea. Heather. Low evergreen shrubs with imbricated, scale-like lvs. in four rows, the branchlets therefore quadrangular: fls. in terminal racemes ; corolla campanulate, 4-lobed, shorter than the 4-parted colored calyx; stamens 8: fr. capsular. One species in W. and N. Eu., also in Asia Minor ; in E. N. Amer. in some localities naturalized. For culture, see Erica.

vulgàris, Salisb. (Erica vulgaris, Linn.). From 1/2-3 ft.: lvs. oblong-linear, obtuse, sagittate at the base, glabrous or pubescent : fls. small, in long, erect, rather dense racemes, rosy pink, sometimes white. Aug.Sept.-Cultivated in many varieties: Var. alba (and var. alba Hammondi), with white fls.; var. Alporti, of more vigorous growth, with rosy carmine fls.; var. cárnea, with flesh-colored fls.; var. flore-plèno, with double

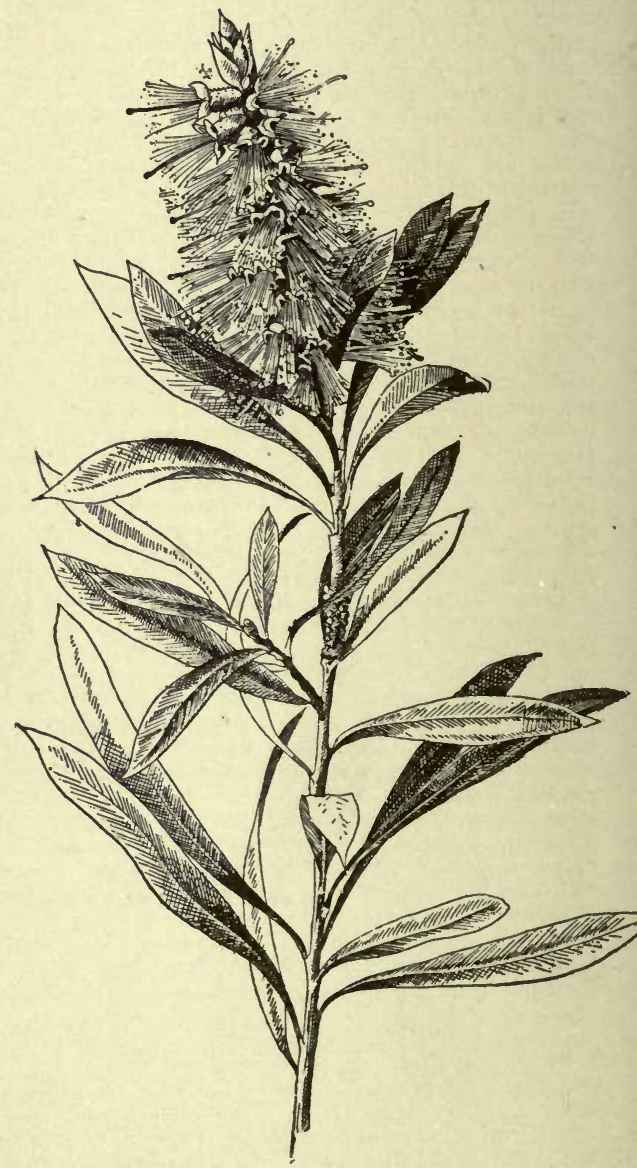

320. Callistemon lanceolatus.

rose-colored fls.; var. pygmæa, forming low, moss-like tufts; var. tomentosa, the branchlets and lvs. with grayish tomentum. The Heather is a very handsome 
small shrub, well adapted for borders of evergreen shrubberies, or for dry slopes and sandy banks and preferring sunny positions ; it is also found growing well in swamps and in partly shaded situations. Cut branches keep their life-like appearance for many months.

ALFRED REHDER.

CALOCHORTUS (Greek for beautiful and grass). Lilidcece, tribe Tulipece. West American cormous plants, the occidental representatives of Tulipa. St. usually branched, and from a coated corm, more or less leafy: perianth of unequal segments, the outer ones the smaller and more or less sepal-like, the 3 inner ones large and showy and bearing glands and hairs; stigmas 3 , sessile and recurved; stamens 6 ; fls. showy, shallow-cupped on the inner segments, arching. Nearly all the species are in cult. Monogr. by J. G. Baker, Journ. Linn. Soc. 14: 302-310 (1875); and by S. Watson, Proc. Amer. Acad. Arts and Sci. 14:262-268 (1879). See also Colochorti in the Sierra Nevada, by George Hansen, Erythea, 7: 13-15; A. Davidson, Erythea, 2: 1-2, 27-30. L. H. B.

Calochortuses are natives of western North America. One or two extend into British America, and a few, belonging to a peculiar group, are found in Mexico; the remainder are natives of the United States, from Nebraska to the Pacific ocean. While the generic characteristies are unmistakable, the species and even varieties have the most variable tastes as to soil, exposure and climate. The Colorado desert and the summits of the Sierra Nevada, the heavy clay lands of Californian valleys, the volcanic soils of the foothills and the meadows of the Northwest, each has its own representatives of this beautiful tribe. The character of the genus can be treated better under the various groups. Nearly every known species is in cultivation to some extent. Some are readily grown, others present considerable cultural difficulties; but while there are some which will probably always be difficult to cultivate, there are many species - and the number includes the very bestwhich can be successfully grown by any one who is willing to give a little special care to their culture; and there are a few which possess such vigor and hardiness as to be adapted to extensive cultivation. All Calochortuses ure hardy in the sense of withstanding extreme cold, but they will not withstand alternate thawing and freezing nearly so well; and thus we have the paradox of their going safely through severe eastern or European winters and suffering the loss of foliage in mild ones. They should be planted in the fall, and it is better to plant late, so that leaf growth is delayed until spring. Diverse as are their natural habitats, one soil will answer the needs of all. In my own experience, a light loam, made lighter with sand or sawdust, powdered charcoal, or spent tan-bark, is best. My very best results have been with a mixture of equal parts of a good light loam and spent tan-bark, with a little broken charcoal. Wallace, one of the most successful English growers, recommends making a bed sloping to the south, composed of leaf-mold and road grit in equal parts, with a smaller proportion of sharp sand. The idea is a light, porous, not too stimulating soil, with perfect drainage. Wallace recommends covering the beds with reeds to throw off the heavy rains. I accomplish the same end by such thorough drainage that the rains pass through quickly. It is better to lift the bulbs as soon as they ripen, and replant in the fall. Water sparingly at all times. They take well to pot culture with similar soils and treatment. While not to be forced rapidly, they considerably anticipate their out-ofdoor season. The same treatment can be used in coldframe culture, but do not coddle them too much. Under suitable conditions they are really very hardy and tenacious of life, but excessive moisture, either in air or ground, is not to their liking after the flowering season arrives. Theoretically, all Calochortuses of Section A (Star Tulips) should have shade, and all Mariposas (AA) sunshine; but I find that the light shade of the lath-house suits all alike, giving much finer bloom in the Mariposas. The flowering season extends over three months, according to species.

Carl Purdy.

Index: albus, No. 1 ; amœnus, 1,6 ; apiculatus, 8 ; atroviolaceus, 25 ; aureus, 22 ; Benthami, 4 ; cæruleus,
5; Catalinæ, 28; citrinus, 17, 21; clavatus, 23; concolor, 21 ; elegans, 6 ; flexuosus, 26 ; Greenei, 14 ; Gunnisoni, 31 ; Howellii, 16; Kennedyi, 20 ; Leichtlinii, 30 : lilacinus, 10 ; Lobbii, 6 ; longebarbatus, 15 ; luteus, 21 ; Lyallii, 6 ; macrocarpus, 32 ; Maweanus, 3 ; nanus, 6 ; nitidus, 13 ; nudus, 12 ; Nuttallii, 29 ; Obispoensis, 19 ; oculatus, 21 ; Palmeri, 27 ; paniculatus, 1 ; pictus, 24 ; Plummeræ, 18 ; pulchellus, 2; Purdyi, 9; purpurascens, 24 ; roseus, 3,24 ; ruber, 25 ; sanguineus, 24 ; splendens, 25 ; sulphureus, 24 ; Tolmiei, 7 ; uniflorus, 11 ; venustus, 24; Vesta, 24; Weedii, 17.

A. Star Tulips. - Blossoms or fruit more or less nodding : inner perianth segments strongly arched.

B. Fls. subglobose, nodding: st. usually tall and branching. GLOBE TULIPS. - These have a single long and narrow shining leaf from the base, and slender, flexuous, leafy stems, the perfection of grace in outline. The flowers are exquisite in delicacy of tints. Woodland plants.

1. álbus, Dougl. Fig. 321. Strong, $1 \mathrm{ft}$. high: fls. globular, pendent, 1 in. across, of a satiny texture, delicately fringed with hairs. Calif. B.R. 1661. F.S. 11: 1171.Chaste and delicate.

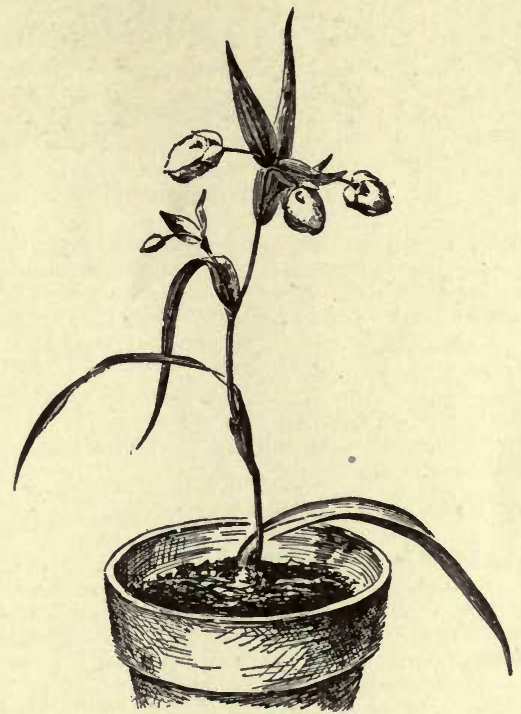

321. Calochortus albus $(\times 1 / 4)$.

Var. paniculàtus, Baker. Lower : Ivs, narrower, fls. smaller.

Var. amœenus, Hort. Like $C$. albus, but rosy colored. Cent. Calif.

2. pulchéllus, Dougl. Similar, but fls. flatter, of pure yellow, the edges of petals with a line of stiff hairs: very handsome. Northwest Calif. B.R. 1662.

BB. F'ls. bell-shaped, erect when open, mostly lined with hairs, the pedicels becoming recurved: stem mostly low, and fls. often more or less umbellate. Star Tulips Proper.- Like the Globe Tulip, but smaller as a rule, and the fls. dainty open cups. All of the species resemble each other, and were first included under $C$. elegans.

3. Maweànus, Leichtl. Plant low (4-10 in.), usually branched: fls. white, purplish at the base, filled with silky hairs, the gland covered by a broad semicircular scale : capsule long-elliptic. Calif. N. B.M. 5976 as $C$. elegans.-Variable. Var. màjor, Hort. Fig. 322. Twice as large in all its parts. Var. ròseus, Hort. Fls. tinged rose.

4. Bénthami, Baker. Resembles $C$. pulchellus : sts. low : lvs, narrow: fls. nearly erect, yellow, the segments $-1 / 2$ in. long and brown at the base. Sierra Nevadas, in Calif. J.H. III. $30: 549$. 
5. cærùleus, Wats. Similar to $C$. Maweanus, but lined and dotted with blue : low, 2-5-fld., the pedicels very slender : perianth ciliate inside: capsule nearly or quite orbicular. Calif., in the Sierras.

6. elegans, Pursh. Similar to the last: petals greenish white and purplish at base, bearded, little or not at all ciliate: gland covered by a deeply fringed scale. Oregon, Idaho.

Var. amœ̇nus, Hort. Fls. lilac, large and showy. G.C. III. $15: 808$.

Var. Lóbbii, Baker ( $C$. Lóbbii, Hort.). Dwarfer, alpine: fls. straw-colored, with dark eye; anthers less pointed. Ore.

Var. nànus, Wood (C. Lyallii, Baker). Subalpine, dwarf: petals narrow and usually more acute, more hairy and ciliate. Mts. Calif., N.

ввв. Fls. bell-shaped: like вв, but tall (1 ft. or more), and stoutly erect, with several fine, erect cups, similar to C.Maweanus. Giant Star Tulips.In this splendid group we have the very dainty, silky fls. and handsome, glossy lvs. of the Star Tulip, with a stout st. a foot or two high, and large fls. Unlike the others, they naturally grow in open places, and have a vigor and health which are a high recommendation.

7. Tolmiei, Hook. \& Arn. Stout, a ft. high, generally branched : petals often more than an inch long, tinged lilac, with purple and white hairs: gland without a scale : capsule broad-elliptic, acutish. Mt. Shasta, N.Remains a long time in bloom.

8. apiculatus, Baker. Taller and stouter, with umbellate straw-colored fis. N. Idaho.

9. Púrdyi, Eastw. Fls. silvery white, filled with blue hairs. S. Ore. G.C. III. 23: 395. - Very handsome.

вввв. H'ls. bell-shaped, the petals naked or hairy only at the base: low: leaf solitary. MEADOW Tuuips. - These Calochortuses are natives of wet meadows. $C$. lilacinus and $C$. Vesta grow well in all soils as long as well drained, and as garden plants thrive everywhere. In habit they are low, flexuous and leafy. The cups are open, erect and numerous, an inch or so in diameter.

10. lilacinus, Kellogg ( $C$. umbellatus, Wood). A handsome species, with large, clear lilac fls., hairy only at base : fls. 4-10, on long, slender scapes : capsule elliptic, obtuse. Grows naturally in wet meadows, and makes off'sets freely. N. Calif. and Ore. B.M. 5804 as $C$. uniflorus. Perhaps the same as the next.

11. uniflòrus, Hook. \& Arn. St. very short, bearing bulbs at base, 1-2-fld.: petals lilac, with purple claw and hairy on the lower half. Coast ranges, Calif.

12. nùdus, Wats. Low, delicate : leaf solitary : fls. 1-6, umbellate, small, white or pale lilac, not hairy, denticulate. Calif., in the Sierras.

aA. Mariposa Tulips. - Blossoms on stout, erect pedicels, the stems stout and strict: fls. open-bellshaped. Excepting in B, the Mariposa or Butterfly Tulips have slender, grassy, radical lvs. stiff, erect stems bearing cup-shaped fls., and sparingly leafy and with an erect capsule. Bulbs small.

B. Capsule acute-angled or winged: fls. lilac or white. These are hardy species, growing in the meadows from Oregon to Montana, where they endure much cold. They form a connecting link between the Giant Star Tulips and the true Mariposas. Their Ivs. are like those of the Star Tulips-long, broad and glossy. Like the Star Tulips, too, the seed-pod is handsome, 3-cornered and winged. The stems are stiffly erect: the fls. cup-shaped, not so brilliant as the true Mariposas, but very delicate: the plants are hardy, healthy and vig. orous, and are to be highly recommended for cold climates.

13. nítidus, Dougl. Scape erect, but not stiff : leaf solitary, glossy, narrow: fls. 1-3, large and showy, lilac, yellowish, or white, with a deep incligo blotch in the cen- ter, lined with yellow hairs. Meadows, E. Ore. to Mont. - Very beautiful and showy.

14. Greènei, Wats. St. stout and branching, $1 \mathrm{ft}, \mathrm{C}^{2}-5$ fld.: sepals with a yellowish hairy spot; petals lilac barred with yellow below, and somewhat purplish, loosehairy, not ciliate : capsule beaked. Calif. and Ore.

15. longebarbatus, Wats. Slender, about $1 \mathrm{ft}$. high, bulb-bearing near the base, with 1 or 2 narrow radical 1vs., 2-branched and usually 2-fld.: fls. erect or nearly so, lilac with yellow at base, scarcely hairy except the long-bearded gland. Washington.

16. Howellii, Wats. St. erect, $1 \mathrm{ft}$. or more, 1-2-fld. : lvs. very narrow: sepals ovate, short-acuminate; petals yellowish white, 1 in. long, denticulate, slightly ciliate near the base, brown-hairy inside, the gland yellowhairy. Ore.

\section{Bв. Capsule obtuse-angled.}

c. Color yellow or orange or orange-red, more or less marked with brown and purple (except in forms of $C$. luteus): in cult. forms running into other colors.

17. Weedii, Wood. Radical leaf single, glossy, broad: st. tall, leafy, bearing large orange-colored fis. dotted with purple: petals triangular, square-topped : gland small, hairy: bulb heavily coated with fiber. Calif. B.M. 6200 , as $C$. citrinus. G.C. III. 16: 183. - Varies to white.

18. Plúmmeræ, Greene. Similar', but purple and very showy. Calif. G.C. III. 16: 133. J.H. III. 29:289. Gn. 47:999.-A fine species, with $\mathrm{fl}$. of large size and full outline, lined with long, silky yellow hairs. It is the $C$. Weedii, var. purpurascens, of Watson.

19. Obispoénsis, Lemm. Tall and slender, branching, very floriferous : petals yellow, verging to red at the tip and less than half the length of the orange-brown sepals. Calif. G.F. 2: 161.-Odd and bizarre.

20. Kénnedyi, Porter. Bulb small and ovoid: st. slender, 18 in., sometimes branches: lvs. linear, tufted from the branching of the st.: fls. $2-5$; sepals broad with a purple spot; petals red-orange to vermilion, not

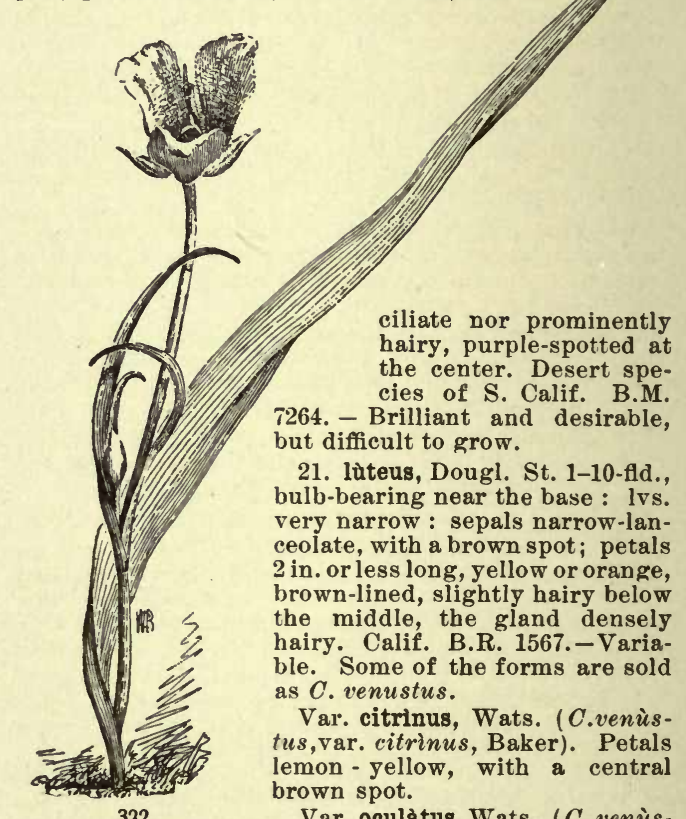

Calochortus Maweanus, tus, var. oculdtus, Hort.). Petals var. major $\left(X^{1 / 4}\right)$. pale or white, lilac or yellowish,

Var. cóncolor, Baker ( $C$. cóncolor, Hort.). Petals deep yellow, marked with red bands, hairy below. Gn. 48: 1043 . 
22. aureus, Wats. Very low: petals yellow, not huiry, the hairy gland purple-bordered. S. Utah.

23. clavatus, Wats. Petals yellow lined with brown, the lower part bearing club-shaped (or clavate) hairs, the gland deep and eircular ; anthers purple. Calif.In this excellent sort we have the largest-flowered and stoutest-stemmed of all Mariposas. The bulb is very large, the single bare leaf 1 or $2 \mathrm{ft}$. long: the st. is heavy, stout and zigzag. The fls. are shaped like a broad-based bowl, sometimes 5 or 6 in. across. The color is a deep, rich yellow, and the lower half is covered thickly with stiff yellow hairs, each tipped with a round translucent knob, and in the light like tiny icicles. There are varions strains : El Dorado, the largest, not so deep yellow; Ventura, very stout, deep yellow; Obispo, like the last, but the upper half of the back of each petal is ollve brown, which shows through the deep yellow of the inside, giving changeable shades.

\section{cc. Color white or lilac: sometimes running into} yellow's.

24. venùstus, Benth. Butterfly Tulip. Stout, 6-36 in.: petals white or pale lilac, with a reddish spot at top, a brown-yellow center, and brown base: gland large and oblong, usually densely hairy: capsule 1-21/2in. long. Calif. B.R. 1669. F.S. 2: 104. Gn. 46, p. 395.Very variable. The yellow forms (as var. sulphùreus, Hort.) are often treated as forms of $C$. luteus. To this group of Calochortuses is properly applied the Spanish name Mariposa (butterfly), for their brilliantly colored fls., with eye-like spots on each petal and sepal, and other delicate markings with dots, lines and hairs, which are strongly suggestive of the wings of a brilliantly colored butterfiy. Botanists have variously dirlded this great group of allied forms between $C$. luteus and $C$. venustus. Botanically all can be considered as either strains of one variable species or as a number of closely allied species.

Var. pictus, Wallace (G.C. III. 18, p. 14). Creamy white, brilliantly marked, often with a gold blotch. Gn. 48, p. 277.

Var. purpuràscens, Wats. Petals deep lilac or purplish, darker at center, the fi. fully 3 in. across. Strong grower. Gn. 46: 986.

Var. ròseus, Hort. (C. ròseus, Hort.). Creamy white or lilac, with un eye midway and a rose-colored blotch at apex. Gn. $46: 986$

Var. sanguíneus, Hort. Fls. deep red, with very dark eye, and without the rose blotch at the apex. Perhaps a form of $C$. luteus.

Var. Vésta, Hort. (C. Vésta, Wallace). Tall, longstemmed, vigorous, bearing large white fls. tinged with lilac and beautifully marked. Produces large offsets, which flower in 2 years. Gn. $46: 986$.

25. spléndens, Dougl. Strong and tall, 1-2 ft.: fls. 2-3 in. across ; petals large, pale, clear lilac, paler below, with a darker claw and scattered long, white hairs below the middle. S. Calif. B.R. 1676.

Var. atroviolàceus, Hort. Tall and slender: fls. 1-11/2in. across, of a deep purple color, with a dark spot on the claw, and short hairs on the lower third.

Var. ruber, Hort. As large as the type but deep, reddish purple, with a dark purple spot at base of claw.

26. flexuosus, Wats. Related to $C$. splendens, but with sts. so weak as to almost be said to creep. The fls. are large and very brilliant, a dazzling purple, with a darker purple eye, and yellow hairs below. S. Utah.Int. by Purdy in 1897.

27. Pálmeri, Wats. St. 1-2 ft., very slender and flexuous, 1-7-fld., bulb-bearing near the base: sepals with long, narrow, recurved tips, spotted; petals 1 in, or less long, white (or yellowish below), with a brownish claw and bearing scattered hairs about the gland : capsule very narrow. S. Calif. - The $C$. Palmeri of dealers is not always this species.

28. Catalinæ, Wats. Habit of $C$. venustus : st. $2 \mathrm{ft}$, branching : fls. white to lilac, or deep lilac, very large and handsome, a large round black spot at base of each petal. - A lovely species between $C$. splendens and $C$. venustus. Remarkable for blooming with the Star Tulip section, fully a month before other Mariposas. Native to Santa Catalina Isl., off S. Calif.; also to Calif. coast.

29. Núttallii, 'Torr. \& Gray. Sego Lily. St. slender, bulb-bearing at base, usually with only 1 cauline leaf, 1-5-fld.: sepals ovate-lanceolate, often dark-spotted; petals 1-2 in. long, white tinged with greenish yellow or lilac, with a purplish spot or band above the yellow base and hairy about the gland; anthers obtuse. Dak. to Calif. and N. Mex. - There are no more exquisitely beantiful fls. thrn these Sego Lilies (the Mormon name) of the Great Basin. Most of them are plants of the sagebrush deserts. The lvs. are an ashy green, the foliage scant, but the great fls. are wonderful in tintings. There are shades in blue, pink, lilac, and yellowish; also white.

30. Leichtlinii, Hook. f. Slenler alpine species (5-6 in. high) by some regarded as a form of C. Nuttallii: fls. smoky white banded with green and marked with dark brown. Sierra Nevadas. B.M. 5862. F.S. $20: 2116$.

31. Gúnnisoni, Wats. Fig. 323. Much like $C$. Nuttallii: anthers acuminate : fls. light blue or almost white, delicate yellowish green below the middle, purplebanded at the base, and bearing a band of green hairs across each petal. Rocky Mts., Wyo. to New Mexico.

32. macrocárpus, Dougl. St. stiff, the cauline lvs. 3-5: fls. 1 or 2 ; sepals acuminate, sometimes spotted; petals 2 in. or less, acute, lilac with a greenish midvein, somewhat hairy. B.R. 1152. N. Calif. to Wash. and Idaho.This fine species forms a group by itself. It has a very large bulb, a stout almost leafless stem, and a large flower of an exquisite pale lavencler, banded down the back with green. Petals long, narrow and pointed.

CARL PURDY and L. H. B.

CALODENDRUM (Greek, beautiful tree). Rutdcea. One of the handsomest deciduous trees at the Cape of Good Hope. Cult. in northern greenhouses, and outdoors in S. Calif. and S. Fla. Its great panicles of white or flesh-colored fls, are sometimes $7 \mathrm{in}$. across and 6 in. deep. A monotypic genus. It is a symmetrical tree, with attractive, evergreen foliage, and many interesting features. Called "Wild Chestnut" in Africa. Prop. by cuttings of half-ripened wood under glass in heat.

Capensis, Thunb. Cape Chestrut. Height in Africa, $70 \mathrm{ft}$.: branches opposite, or in 3's: lvs. simple, decussate, ovate, obtuse, retuse or acute, parallel-nerved, 4-5 in. long, studded with oil cysts, which look like translucent spots when held to the light : panicles terminal ; peduncles usually trichotomous : calyx deciduous : petals 5, linear-oblong, $1 \frac{1}{2}$ in. long, 2 lines wide, sprinkled with purple glands: stamens 10,5 alternate, sterile, and petaloid : seeds 2 in each cell, larger than a hazelnut, black and shining. G.C. II, 19:217.

CALOPHACA (Greek, kalos, beautiful, and phaka, lentil). Leguminòsc. Deciduous shrubs or herbs, with alternate, odd-pinnate, pubescent, and often glandular Ivs.: fls. papilionaceous, solitary or in racemes : pod pubescent and glandular, cylindrical. About 10 species from $\mathrm{S}$. Russia to $\mathrm{E}$. India. The two cultivated species are low, prostrate shrubs, with grayish green foilage, and rather large yellow fls. in erect racemes, followed by decorative, reddish pods. They prefer a well-drained soil and sunny position, and are well adapted for burders of shrubberies and sandy or rocky slopes. Prop. by seeds, sown in spring; the young seedlings should have plenty of light and air, as they are very liable to 
damp-off if kept too moist and shady. Sometimes grafted high on Caragana or Laburnum, forming a very attractive, small standard tree.

Wolgàrica, Fisch. Two-3 ft.: pubescent and glandular : lfts. 11-17, roundish.ovate or oval, $1 / 3-1 / 2$ in. long: racemes long-peduncled, with $4-7 \mathrm{fls}$.; corolla over $3 / 4$ in. long. June-July. S. Russia, Turkestan. -C. grandiflòra, Regel, is similar, but lfts. 17-25: racemes 10-16fld.; corolla 1 in. long. S. Russia. Gt. 35: 1231.

\section{ALFRed ReHDER.}

CALOPHYLLUM (Greek, beautiful-leaved). Guttiferdcece. Tropical trees, with shining, leathery, evergreen penninerved lvs. and panicled fls. The following is cult. outdoors in S. Fla. and S. Calif., and possibly in northern warmhouses. Prop. by cuttings.

Inophýllum, Linn. Branches terete : Ivs. obovate, usually marginate : fls. white, fragrant, in loose, axillary racemes; peduncles 1-fld., usually opposite; sepals 4: fr. reddish, as large as a walnut. E. Tropies. - Int. by Reasoner, 1893. Also in S. Calif. A tall tree, with beautiful glossy lvs. and white fls. Oil is extracted from the seeds. Has medicinal properties.

CALOPOGON (Greek, beautiful beard). Orchiddcea, One of our daintiest native orchids, with pink fls. an in. across, grass-like lvs., and a small bulb. The lip is on the upper side of the flower, spreading, distant from the column, with a narrowed base. One of the choicest hardy bog plants. A moist and shaded position and very porous soil are most suitable for this pretty plant, though I have seen it do admirably well on a rockery only slightly shaded at midday, but here the plants were watered very freely every day during hot or dry weather. Prop. by offsets, separated from the old tubers, but the old established plants should not be disturbed very often. Collected clumps of all our native orchids are offered at very reasonable figures, and these give immediate satisfactory results, while the small off sets would not be strong enough to flower for several years, and require much attention during the first year, or perhaps longer.

pulchellus, R. Br. Height $12-18$ in.: scape $2-6$-fld.: fls. pink, magenta, or purple : lip bearded with white, yellow, and purple club-shaped hairs. Bogs, Newf. to Fla., west to Minn. and Mo. G.W. F. 14. G. F. 10:505. J. H. III. 35: 45. B.M. 116, as Limodorum tuberosum.Eleven fls. on a scape is the average number in Pennsylvania bogs.

J. B. KELLER and W. M.

CALOTHAMNUS (Greek, beautiful bush). Myrtacece. Australian shrubs somewhat similar to Callistemon but more graceful in habit: lvs. long, alternate : fls. showy, usually red, in lateral clusters: stamens united in bundles opposite the petals ; anthers erect, attached by the base, oblong or linear; cells parallel, turned inwards, opening by longitudinal slits. Ornamental greenhouse shrubs. Hardy out of doors in California. For cult., see Callistemon.

quadrifidus, R.Br. Height $2-4 \mathrm{ft}$.: lvs. narrow, terete or slightly flattened, heath-like, glandular-dotted: fls. rich erimson, 4-merous ; calyx 2 -lobed in fruit ; staminal bundles nearly equal, of 15 to 20 or more flaments. W. Austral. B.M. 1506.

J. Burtt Davy.

CALPURNIA (after Calpurnius, an imitator of Virgil, because these plants are allied to Virgilia). Legumindsce. Trees and shrubs from tropical and southern Afr. cult. out of doors in S. Calif. Lvs. odd-pinnate ; racemes long, axillary and terminal : fls. yellow.

sylvática, E. Mey. Shrub, 6-10 ft. high : 1vs. 2-6 in. long: lfts. in 3-10 pairs, membranous, obovate-elliptical, retuse or obtuse: fls. 1/2 in. long: ovary glabrous. Caffraria.-Also rarely cult. north as a greenhouse shrub.

lasiogyne, E. Mey. (C. aùrea, Benth.). A taller shrub, with larger lvs. and fis., more coriaceous, more pubescent, and exactly elliptical or oblong leaflets. The silky ovary at once distinguishes it. Natal.
CÁLTHA (Latin name of the Marigold). Ranuncu. lacece. A genus of beautiful marsh plants, about 10 species, of temperate and frigid regions. Succulent, perennial herbs, glabrous, with a fascicle of strong, fibrous roots : lvs. simple, rather rounded-cordate at base : fls. yellow, white or pink ; sepals large, deciduous, petal-like ; petals none ; stamens numerous, carpels sessile, becoming follicles, with two rows of seeds. They flourish best in wet places near running water. Though naturally bog plants, they succeed admirably well in an ordinary border in rather rich soil. They should be introduced more liberally into the flower garden, where they flower very freely year after year, and generally mature a second quite abundant crop of bloom in the fall. The flowers last a long time in water, and sell readily in the cut-flower market. Monogr. by G. Beck, in Kaiserlich-Königliche Zoöl.-Bot. Gesellschaft (Vienna, 1886), 36:347-363 ; E. Huth, Monogr. in Helios 9: 69-74.

biflora, DC. No true stem; scape slender, usually 2-fld.: lvs. as in $C$. palustris : sepals 6-9, nearly white or sometimes bluish : follicles at maturity distinctly stalked. Spring. Calif: to Alaska. Int. 1881.

leptosépala, DC. Stout scape, 8-12 in.: lvs. all basal or barely one on stem ; nerves at base nearly parallel, otherwise like those of $C$. biflora: sepals $7-10$, oblong, becoming narrower, white; fls. solitary: follicles scarcely stalked. May-June. Alaska to Wash. and Colo. Gn. 30:565.

palústris, Linn. Marsh Marigold. Stem hollow, 1-2 ft., branching, several-fld.: lvs. cordate or reniform, den-

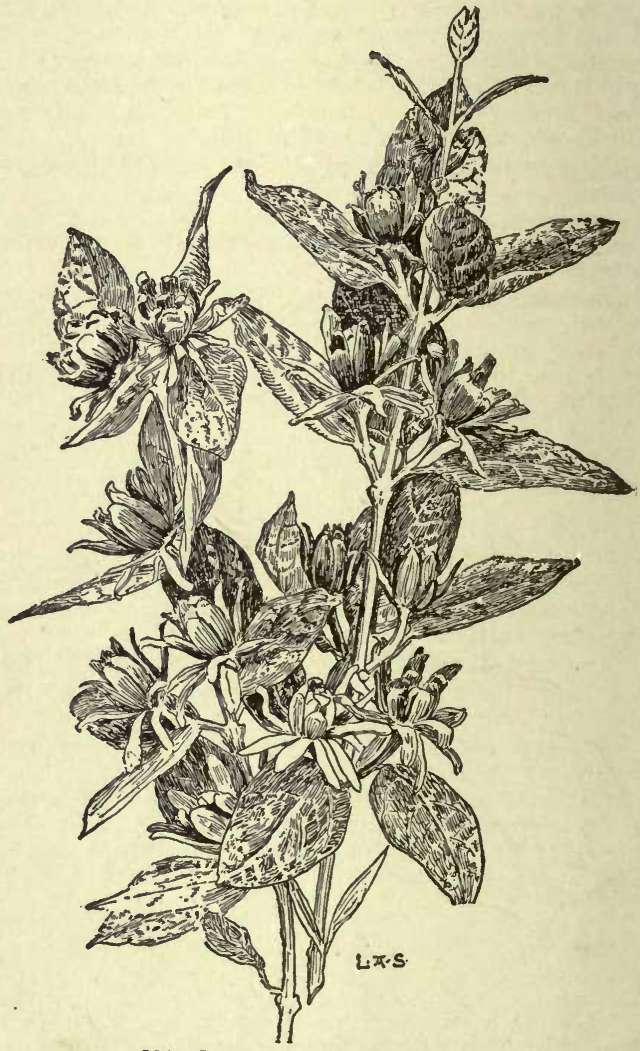

324. Calycanthus floridus.

tate, crenate or entire : fls. bright yellow, 1-2 in. broad; sepals 5 or 6 , rarely 7 : follicles compressed, $1 / 2$ in. long. Apr.-June. Wet ground. Carolina to Canada and westward. Gt. 47, p. 630. D. 115, pl. 35. - Used before flowering in the spring as "Cowslip greens." Var. mon- 
stròsa-plèno, Hort. (var. flore-pleno, Hort.). An improvement on the above : fls. larger, of greater substance, and often much doubled. Very beautiful.

K. C. Davis and J. B. Keller.

CALTROPS. Trapa.

CALYCANTHUS (Kaly $x$ and anthos, flower; the calyx is large and conspicuous). Calycanthdece. CAROLINA Allspice. Sweet-scented Shrub. Deciduous shrubs of aromatic fragrance: Ivs. opposite, petioled, entire, usually rough above : fls, terminal or axillary, solitary, rather large, with numerous sepals and no distinct petals; stamens 5-23: fr. capsule-like, but not dehiscent, like the rose-hip, formed by the calyx tube and containing numerous akenes. Six species in N. America and E. Asia. Ornamental shrubs, with rather large, handsome foliage and mostly sweet-scented fls.; they are almost hardy north, except $C$. occidentalis and $C$. proecox. They grow in almost any well drained and somewhat rich soil, and succeed as well in shady as in sunny positions. Prop. by seeds sown in spring; also, increased by layers put down in summer, and by suckers or division of older plants.

A. Winter-buds without scales, very small: fls.broun, in summer.

в. Lvs. densely pubescent beneath.

floridus, Linn. Fig. 324. Three-6 ft.: lvs. oval or broad-ovate, acuminate, dark green above, pale or grayish green beneath, 11/2-3 in. long: fls. dark reddish brown, fragrant, about 2 in. broad. Va. to Fla. B.M. 503. - This species is the most cultivated for its very fragrant fls.

\section{Вв. Lv's. glabrous beneath or nearly so: fls. slightly} or not fragrant.

fértilis, Walt. (C. fèrox, Michx. C. laevigdtus, Willd.). Three-6 ft. : lvs. usually elliptic or oblong, acute or acuminate, green beneath, $2-51 / 2 \mathrm{in}$. long: fls. reddish brown, $11 / 2$ in. broad. Alleghanies. B.R. $6: 481$.

glaùcus, Willd. Fig. 325 . Four-6 ft.: 1vs. usually ovate or oblong-ovate, acuminate, glaucous beneath, $2-4 \frac{1}{2}$ in. long: fls. reddish or yellowish brown, $1 \frac{1}{2} \mathrm{in}$. broad. Va. to Ga. B.R. 5: 404.-Var. oblongifolius, Nutt., with oblong-lanceolate lvs.

occidentàlis, Hook. \& Arn. (C. macrophýllus, Hort.). To $12 \mathrm{ft}$.: lvs. usually rounded at the base, ovate or oblong-ovate, green beneath and sometimes slightly pubescent, 4-6 in. long : fls. light brown, 3 in. broad. Calif. B.M. 4808. F.S. 11:1113. R.H. 1854: 341 .

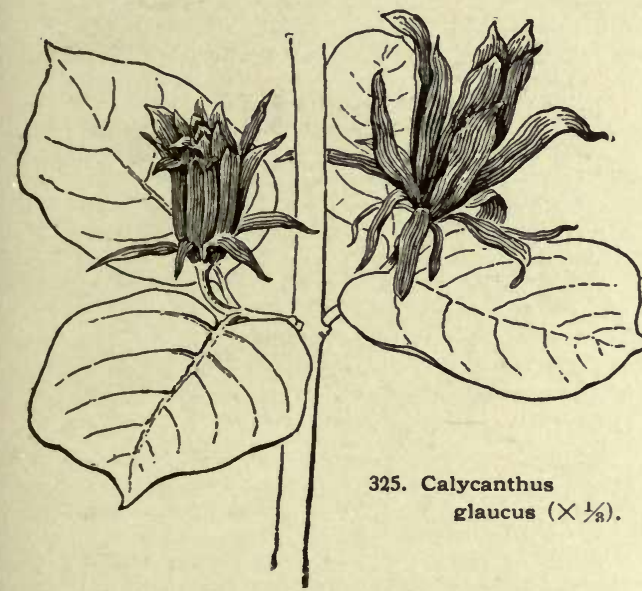

AA. Winter-buds with scales: fls. before the lvs., axillary, with 5 fertile stamens. (Chimonanthus.)

præ̀cox, Linn. (Chimonainthus fràgrans, Lindl.). Lvs. elliptic-ovate or oblong-lanceolate, acuminate, green and glabrous beneath, 3-5 in. long: fls. very fragrant, 1-11/2in. broad, outer sepals yellow, inner ones striped purplish brown. China, Japan. B.M. 466. B.R. 6:451. L.B.C.
7:617. G.C.III.11:213. - Desirable for temperate regions for its very early, sweet-scented fls.

The newly introduced $C$. nitens, Oliv., from China, allied to $C$. procex, has the ivs. coriaceous, long-acuminate, shining and smooth above. AlFreD REHDER.

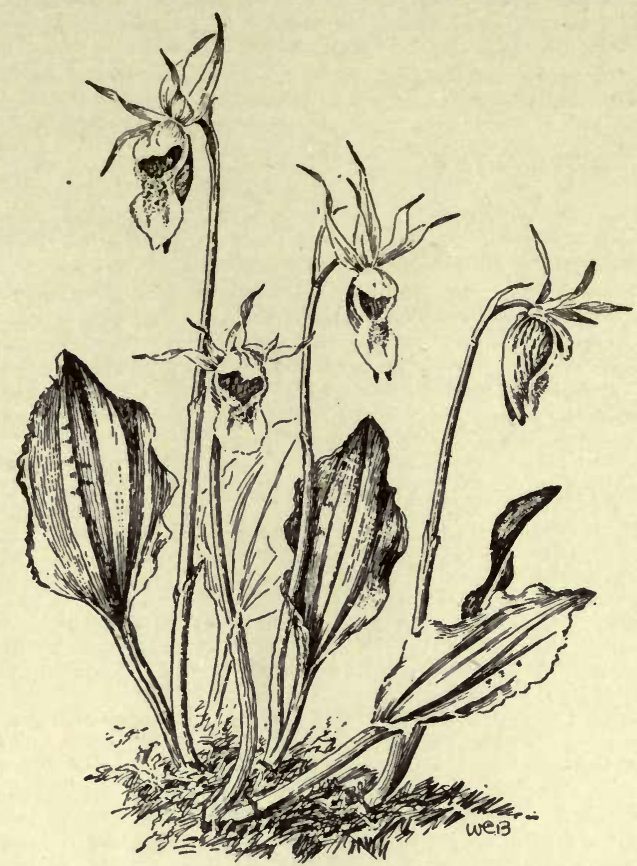

326. Calypso borealis.

CALYCOTOME (Kalyx, and tome, a section or cut; calyx looks as if cut off ). Leguminòsa. Low, spiny, divaricate shrubs: lvs.3-foliolate, deciduous: fls. papilionaceous, yellow, fascicled or in short racemes ; calyx truncate, obscurely denticulate. Four species in the Mediterranean region, of which two are sometimes cultivated; not hardy north. They prefer a sunny position and well drained soil. For prop., see Cytisus.

villòsa, Link. Two-4 ft.: branchlets grayish tomentose: leaflets obovate, densely silky beneath, under 1/2in. long: fls. $1 / 2$ in. long, 3 or more, fascicled : pod villous. May, June. - It is excellent for dense, low hedges.

spinòsa, Link. Closely allied, but somewhat larger in every part, and with glabrous branchlets and pods : fls. solitary or few. B.R.32:55. ALFRED REHDER.

CALYPSO (from the Greek goddess, whose name signifies concealment ; referring to its rarity and beauty). Orchiddceo. One of our rarest and most prized native orchids, a delicate bog-plant, 3-4 in. high, with a small bulb, one roundish or ovate, striated leaf, and one pink Hower with a spotted sac. A monotypic genus. For culture, see Calopogon; but more difficult to grow than that plant.

borealis, "Salisb. Fig.' 326 . Leaf an inch wide and long: scape $3-4$ in. high, with about 3 sheaths : sepals and petals similar, ascending, lanceolate, acuminate, pink: lip larger than the rest of the fl., with brown spots in lines and purple and yellow markings, woollyhairy within : column petal-like, ovate, bearing the lidlike anther just below the apex. Maine to Minn. and N.; also Eu. Abundant in parts of Oregon and Washington. B.M. 2763.

CALYPTROGYNE (Greek-made name). Palmacea, tribe Arècece. Spineless stoloniferous palms, with short or long caudices, ringed below: lvs. terminal, unequally pinnatisect : segments a few joined together, narrow or broad, falcate, very long-acuminate, plicate; margin 
recurved at the base ; nerves numerous : petiole very short : sheath short, open; spadices simple or branched at the base, long-pedunculate; spathes 2, narrow, the lower much shorter than the peduncle, split at the apex, the upper deciduous, elongated, split its entire length ; bracts connate, bordering the lower lip of the flowerbearing cavity; bractlets minute : fr. small, oblong or obovoid. Species 8. Trop. Amer.

Ghiesbrechtiàna, H. Wendl. (Geonòma Ghiesbreghtiana, Lindl. \& H. Wendl.). Stem short or almost none : petiole $5 \mathrm{ft}$. long: Ivs. elongate-oval ; segments in 6 pairs, unequal, almost opposite, rather remote, lanceolate, very long-acuminate, falcate, the two uppermost on each side very wide. Chiapas, Mex.

C. spicigera, 'H. Wendl. Stem evident : lvs. irregularly pinnate, $3 \mathrm{ft}$. or less long, the stalks flat on upper side. Guatemala.-C. Swártzii, Hort., is a Geonoma.

Calyptrogynes are handsome palms, seldom seen outside of large collections. Special care must be given to the soil so that it will be sweet and porous, especially after the plants leave the seed-pan. Well-drained pots and a little charcoal mixed with the soil, and the plants kept in a uniformly moist state, are conditions essential to the healthy growth of the plants.

In this genus, $C$. Ghiesbrechtiana is the most widely known species, another garden name for which is Geonoma Verschaffelti. These are shade-loving palms, having leaves of comparatively thin texture, and consequently are subject to attacks of red spider unless properly cared for in regard to moisture. Calyptrogynes are most useful in a small state, old plants in general being rather leggy and poorly furnished.

Jared G. Smith, G. W. Oliver and W. H. TAPLin.

CALYSTÉgIa. See Convolvulus.

CALYX. The outer floral envelope. See Flower.

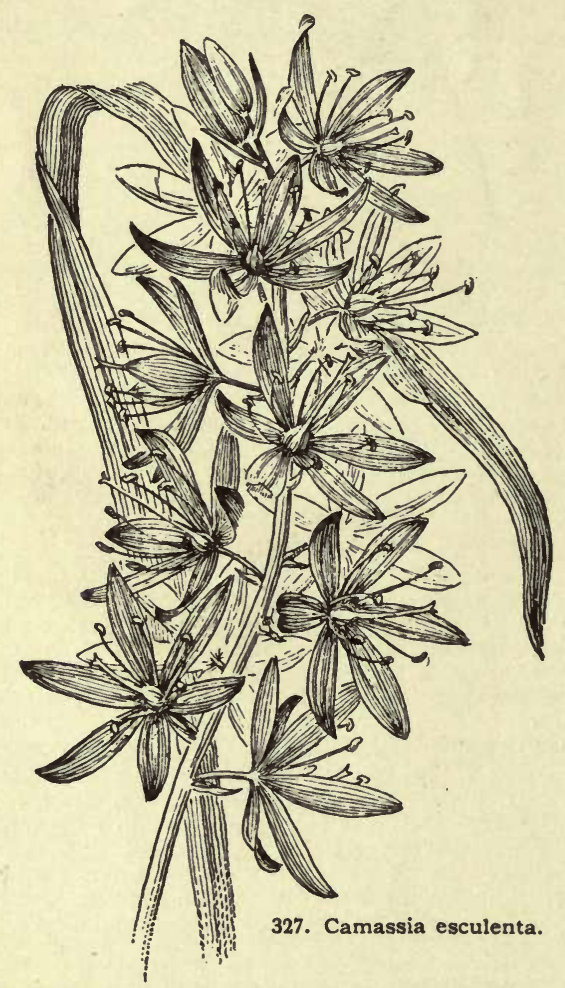

CAMÁSSIA (Quamash or Camass is the Indian name). Liliacere. Fls. blue, purple, or whitish, with 6 spreading, 3-7-nerved sepals, and 6 filiform stamens, filiform style, and 3-angled, 3-valved, several-seeded capsule.
The Camassias are bulbous plants, found only in the temperate regions of N. Amer., and closely allied to Scilla. Bulb, as in Scilla; the many lance-shaped Ivs. sheathing at base : st. erect, many-fld., bracted below each flower, and flowering in long succession from the bottom. The genus has not been carefully studied, and many forms are confused under the same names. Monogr. by J. G. Baker, Jour. Linn. Soc. 13:256 ; S. Watson, Proc. Amer. Acad. Arts and Sci. 14:240. On questions of nomenclature, consult Coville, Proc. Biol. Soc. Wash. 11: 61 .

Camassias are natives of rich meadows, very wet in winter and spring but dry in summer. They do well in any good loam, avoiding too rank nianures. They are perfectly hardy. Bulbs should be set in es,rly fall, at a depth of 4-6 inches, and left undisturbed. As cut-flowers, they open in long succession. The bulbs produce offsets very sparingly. Seeds grow readily, and seedlings bloom in three to four years.

\section{A. Plant $2 \mathrm{ft}$. or more high, robust: fls. very many}

(30 or more).

Cùsickii, Wats. Bulb very large (weighing 4-8 oz.): lvs. numerous, broad, glaucous, somewhat undulate (15 in. long, often $1 \frac{1}{2}$ in. wide): st. often $3 \mathrm{ft}$. high : fls. $30-100$, very pale, delicate blue; segments spreading, crinkled at the base, faintly 3-5-nerved. Ore. G.F. 1:174. - One of the best of the genus. Differs from $C$. esculenta in its larger bulb, more numerous lvs. and stouter and more clustered habit. Grows on drier land. Hardy in New Eng., and grows well in good garden soil.

\section{AA. Plant usually less than $2 \mathrm{ft}$. high, with shorter} spikes : fls. fewer.

esculénta, Lindl. Camass. Fig. 327. Not very stout, 1-2 ft.: Ivs. $2 / 3 \mathrm{in}$. or less broad : fls. $10-40$, dark blue or purple, the perianth irregular (5 segments on one side and 1 on the other, and deflexed); segments 3-5-nerved and a little longer than the stamens, narrow and channeled at the base : pedicel not exceeding the fls.: capsule ovate to oblong, obtuse, transversely veined. Calif. to Utah and N. B.R. $18: 1486$. F.S. $3: 275$. Gn. 46, p. 339 , 983. - Bulb cooked and eaten by the Indians. The fls. vary to white.

Leichtlinii, Wats. Stout, often $3 \mathrm{ft}$ high: fls. creamcolored, ranging to white, nearly regular, the stamens and style ascending; segments broad and flattened at the base, usually 5-7-nerved : capsule oblong-ovate, emarginate, obliquely veined. Mts., Calif., N. B.M. 6287 , as $C$. esculenta, var. Leichtlinii, Baker.-Purple-fld. Camassias are sometimes referred to this species, but it is doubtful if they belong with it.

H6wellii, Wats. Bulb rather small : lvs. few, $1 \mathrm{ft}$. long and less than $1 / 2$ in. wide : st. often $2 \mathrm{ft}$. high, manyfld., with spreading pedicels twice or more longer than the linear bracts : fls. pale purple, opening in the afternoon, the segments $1 / 2$ in. long, 3-5-nerved: capsule small, broadly triangular-ovate and very obtuse. Ore. -Int. 1892 by Pilkington \& Co.

Fràseri, Torr. Scape 12-18 in. high : lvs. keeled : fls. light blue, smaller than in $C$. esculenta; segments 3 nerved: pedicels mostly longer than the fls. Penn. W. and S. B.M. 1574, as Scilla esculenta.

Var. angústa, Torr. ( $C$. angústa, Hort.). Very slender, and lvs. narrower ( $1 / 4 \mathrm{in}$. wide): fls. smaller, $1 / 3$ or 1/4in. long. La. and Ark. to Tex.

L. H. B. and Carl Purdy.

CAMBIOM is a nascent layer of tissue between the wood and bark of trees and shrubs. From it is developed secondary wood and bast. The thickening of stems and roots is mainly due to activity of the cambium. It is most evident in June and July, when tissues are rapidly forming. Woodsmen take advantage of this to peel bark. Boys also take advantage of the readiness with which bark and wood separate at the cambium to make whistles of basswood or willow. Trees are more easily bruised at this time in the year than at any other. The cambium plays an important part in the healing of wounds upon stems. It is the union of the cambium layers of cion and stock that makes grafting possible. W. W. ROWLEE. 
CAMÉLIA (after George Joseph Kamel or Camellus, a Moravian Jesuit, who traveled in Asia in the seventeenth century). 'Ternstromidcea. Evergreen trees or slirubs: lvs. alternate, short-petioled, serrate: fls. large, axillary or terminal, usually solitary, white or red; sepals and petals 5 or more: stamens numerous, connate at the base:

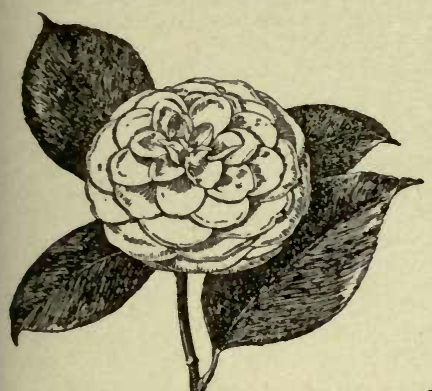
r. a 3-5-celled,dehis cent capsule, with large, globular or ovoid seeds. About 10 species in trop. and subtrop. Asia, divided into the subgenera Eucamellia and $T h e a$, considered by some to be distinct genera, by some all united under Thea. The species of Eu-

328. Camellia Japonica Abby Wilder.

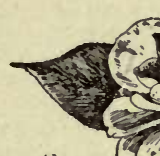

camellia, especially $C$. Japonica, are popular decorative shrubs, with very showy fls. About 50 years ago one of the most appreciated greenhouse shrubs, and several hundred varieties were cultirated. Of the second subgenus, $C$. Thea is cultivated in nearly all subtropical countries and in the mountainous regions of the tropics for its leaves, which yield the well-known tea, and are an article of great commercial importance. There is a monograph of this genus by Seemann in Trans. Linn. Soc. XXII. p. 337-352. Illustrated monographs of the horticultural varieties are: Curtis, Monogr. of the genus Camellia (1819); Baumann, Bollweiler Camelliensammlung (1828); Chandler, Camellieø (1831) ; Berlèse, Monogr.du genre Camellia a (1839); Verschaffelt, Nouvelle Monographie du Camellia (1848-60): the last with 576 and the foregoing with 300 colored plates.

A. Fls. sessile, erect, terminal and axillary; calyx-lobes deciduous. Camel-

lia proper.

Japónica, Linn. Figs. 328-331. Shrub or tree, sometimes to $40 \mathrm{ft}$., glabrous: 15s. very shining and dark green above, ovate or elliptic, acuminate, sharply serrate, 2-4 in. long: fls. red in the type, $3-5$ in. across ; petals 5-7, roundish. China, Japan. B.M. 42. S.Z. 82. F.S. 20:2121.Var. álba, Lodd. Fls. white. L.B.C. 7: 636. Gn. 54, p. 213. Var. álba plèna, Lodd. Fls. white, double. L.B.C. 3:269. Var. anemoniflora, Curtis. Fls, red, with 5 large petals, the stamens changed into numerous smaller and narrow petals; the whole fl. resembling that of a double Anemone. L.B.C. 537. B.M. 1654. For the numerous other garden forms, see the abore mentioned monographs ; also, Flore des Serres, L'Illustration Horticole, and other older horticultural publications contain a large number of varieties with illustrations.

reticulata, Lindl. Large shrub, glabrous : lvs. dull green, not shining above, reticulate, flat, elliptic-oblong, acuminate, serrate, $3-5$ in. long : fls. 5-7 in. across, pur plish rose; petals 15-20, obovate, loosely arranged. China. B.R. 13:1078. B.M. 2784. P.M. 3:101.-Var. plèna, Hort. Fls. with twice as many petals, and more regularly arranged. B.M. 4976. F.S. $12: 1279-80$.

Sasánqua, Thunb. Shrub of loose, straggling habit, with the branches pubescent when young : lvs. elliptic, bluntly pointed at the apex, crenate-serrate, shining, dark green and hairy on the midrib above, $13 / 4-3$ in. long: fls. $1 \frac{1}{2}-2$ in. across, white ; petals 5 or more, obovate or oblong. China, Japan. Gn. 54:1189. S.Z.83 (except the red vars.) - Var. seminlèna, Hort. Fls, semidouble, white. B.R. 1:12 and 13:1091. Var. anemoniflora, Seem. Fls. large, double, outer petals white, inner ones much smaller, yellow. B.M.5152. Var. oleifera, Rehd.(C.oleifera, Lindl.). Of more robust habit, with Irs. and the single white fls. larger than in the type. B.R. 11:942. L.B.C. 11:1065.

\section{AA. F'ls. pedicelled, nodding, mostly axillary: calyx-} teeth persistent. Thea.

Thèa, Link. (C. theífera, Griff. Thèa Sinénsis, Linn.). TEA. Shrub, sometimes tree, to $30 \mathrm{ft}$. : lvs. elliptic-lanceolate or obovate-lanceolate, acuminate, serrate, glabrous, sometimes pubescent beneath : fl. white, fragrant, 1$11 /$ in broad; petals 5 . China, India. - Usually two varieties are distinguished: Var. Bohèa (Thèa Bohèa, Linn.). Lvs. elliptic, dark green, to 3 in. long: branches erect. B.M. 998. L.B.C. 3: 226. Var. víridis (Thèa víridis, Linn.). Lvs. pale green, lanceolate, to 5 in. long: branches spreading. B.M. 3148. L.B.C. 3:227 and 19: 1828. The black tea, however, and green tea of commerce do not come from certain varieties, but are the result of different treatment of the leaves after gathering.

C. axillàris, Roxb $=$ Gordonia anomala. - C. drupifera, Lour. (C. Kissi, Wall.). Shrub to $8 \mathrm{ft}$ : lvs. elliptic, long acuminate: fls. 11/2in. wide, fragrant, white: petals obovate. Himal., India. L.B.C. 19:1815. - O. euryoides, Lindl. (Thea euryoides, Booth). Shrub to $4 \mathrm{ft}$ : lvs. ovate-lanceolate, silky beneath: fis. white, nodding, axillary, rather small. B.R.12:983. L.B.C. 15:1493.O. euryoides, Hort. = C. rosiflora, var. maliflora. $-C$. rosiflòra, Hook. (C. Sasanqua, fl. rubro, Sims). Shrub: lvs. ovate, acuminate : fls pink; petals 5 , obcordate: ovary glabrous. China. B.M. 5044 Var. maliftòna, Rehd. (C. malitlora Iindl). Fls. B.M. 5044 Var maliflora, Rehd. (C. malitiora, Lindi.). Fls. 7ouble, pink. B.R. 1134. B.M. 2080 . ALFRED REHDER.

Camellias are not hard to grow either the well. known $C$. Japonica or the less common $C$. $S a-$ sanqua, and $C$. Thea, the Tea Plant. They require a coolhouse, not too dry an atmosphere, and

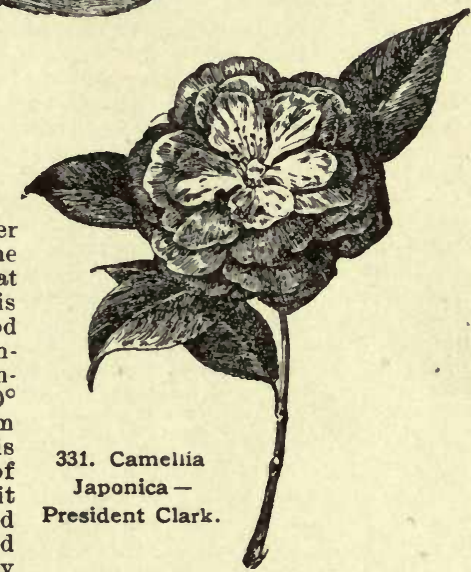

must never suffer from dryness at the roots ; a somewhat shady position is helpful, and good ventilation is essential. A night tem. perature of $45^{\circ}-50^{\circ}$ F. is best for them while at rest; this is also the time of blooming, but it may be increased during the period of growth; the day temperature should be from $60^{\circ}-70^{\circ} \mathrm{F}$. The soil for es tablished plants should be made mainly of well-rotted sods, to which should be added some leaf-mold, rotted cow-manure, and enough sand to insure good drainage; sod and leaf-mold should be unsifted. For young plants, the Dutch growers use a rather fine soil of peat, leaf-mold and sand ; the Japanese gardeners use 
a heavier soil, apparently containing some clay. The pots and tubs should be well drained with potsherds and charcoal, the drainage being protected by sphagnum to insure durability, the older plants not requiring frequent shifts. Potting should be done just before new growth starts, when the flowering is about over; the exact time can be determined by noting the beginning of the root growth, which generally precedes the expanding of the leaf-buds. The soil should be moist, not wet, and made firm. Large shifts should be avoided; in many cases, by renewing the drainage and removing the surface soil, a larger pot will be found unnecessary. After potting, the temperature may be increased, and the plants should be kept close until a new growth is established.

When the weather in May becomes settled, they should be placed in summer quarters. This may be a cool greenhouse, well shaded, or, preferably, a position in the open air, protected from sun and wind. Lath screens may be employed, or the shade of trees or fences. In any case there must be plenty of light and air. Great care must always be given to watering, but especially at this time, while they are making and ripening their growth; the dropping of flower buds in November is often the result of careless watering in summer. Plenty of water must be given to the roots, never in driblets, and the foliage should be syringed night and morning in dry weather. The forcible application of water in the form of spray not only keeps the plant in good condition, but checks mealybug and red-spider. In September they should be put in the cool end of the coolhouse, or they can be stored in a pit and brought in later. The Camellia is nearly hardy, but should not be exposed to actual frost. Large specimens can be planted out in a coolhouse or winter garden. They thrive wonderfully in the evenly moist soil of such a position, and give an abundant bloom at Christmas and New Year, when flowers are scarce; the foliage, too, can be freely cut, since growth under these conditions is so much improved.

Propagation is now effected by cuttings and grafts. Formerly inarching and even layering were employed. Cuttings should be made, November to January, from wood of the previous season's growth, from $1 \frac{1}{2}-2$ or $21 / 2$ inches long, each having from 1-3 eyes; in single-eye cuttings the leaf is left entire, in others 1 or 2 leaves are removed. Plant firmly in sharp sand, keeping them cool, well watered and carefully shaded for the first few weeks. Sometimes they will be sufficiently rooted in June for potting in thumbs, but at others they will not be ready until October. Shift on the young plants as their growth requires, never giving them too large pots; they make a surprisingly good growth when once established. Flower luds should be picked from young stock; sometimes there is trouble from blind eyes, but a new bud will eventually form. Grafting is done in November, December and January, using the improved veneer graft; a close frame is not necessary, but is often used, in which case great care must be given to watering and ventilation. If raffia is used for tying, it should be smeared with grafting wax to prevent decay; the process of uniting is lengthy. Stock can be obtained from seed or by cuttings of easily rooted varieties. Mealy-bug and redspider can be avoided by proper syringing ; thrips and aphis are kept down by tobacco fumigation; scale must be checked by washing and spraying; a troublesome leafeating insect is only removed by hand picking.

Consult Practical Camellia Culture, by Robert Halliday, Baltimore, 1880. Illus. The only other American book on Camellias is an American edition of The Abbe Berlese's Monography of the Genus Camellia, by Gen. Dearborn: Boston, 1838. For a list of varieties, see also Nouvelle Iconographie des Camellias, Amb. Verschaffelt Fils; Ghent, 1856-60. Illus. B. M. WATSON.

Camellias are general favorites with most people, and, when well-grown, have few equals among hardwooded, cool, greenhouse plants. They may be propagated by seeds, cuttings, layering, grafting or inarching ; the two latter methods are best for the double forms, as they succeed better when grafted or inarched on the single forms than on their own roots, the operation being performed immediately after the flowering season, or just as soon as new growth is about to commence, and the method known as "side-grafting" is best if this means of propagation is used. The single species are best propagated by seeds, if these can be obtained fresh. They should be sown in early spring, in 4-inch pots, containing a mixture of peat, leaf-nold and sand, in equal proportions. The pots should be placed in a warm temperature, where they will usually germinate in from 4 to 6 weeks. If propagated by cuttings, the half-ripened wood should be chosen, and the euttings inserted around the edge of 4 -inch pots containing a sandy, peaty mixture, pressed very firm. The pots should be placed in a shaded, close position, where an even temperature of about $60^{\circ}$ can be maintained. The pots plunged in a half-spent hotbed would be an ideal place. If carefully attended to, they should be rooted in about two months, after which they should be potted singly, in small pots, and grown on as rapidly as possible. When of suitable height, stopping should be attended to, to induce a bushy habit. As the plants increase in size, a slightly heavier soil should be used when potting, a mixture of equal parts loam, leaf-mold and fibrous peat being most suitable. Camellias require at all seasons a good supply of water at the roots, and during the flowering season they should have an abundance. If allowed to become dry, the flower buds will fall off. They also require to be shaded from direct sunlight during the spring and summer months. A lean-to greenhouse, with a north aspect, is an ideal one in which to grow Camellias. In such a house they might ce planted out, providing an abundance of air could be given during the summer; they make much larger plants and flower more freely when planted out than when grown in pots or tubs. The flowering season is usually from the beginning of February to the middle of April, if grown in ordinary cool greenhouse temperature, but they will stand gentle forcing if the flowers are wanted earlier. After flowering, they should be kept syringed to encourage the new growth, and also to keep them free from thrips. If grown in pots or tubs, they should be placed in a sheltered, shaded position outside for the summer.

Edward J. Canning.

\section{CAMEL'S THORN. See Alhagi.}

CAMPÁNULA (Latin, a little bell). Campanulacea. Bell Flower. A genus of about 300 species, confined to the northern hemisphere, and containing some of the most popular garden plants, especially of hardy herbaceous perennials. The root-lvs. are usually larger than the stem-lvs., and often of different shape, and more or less transitory. Fls. blue, violet or white; calyx 5 -fid ; corolla 5-lobed or 5-fid ; stamens 5, free ; filaments wide at the base, membranaceous ; stigmas 3 or 5, filiform : capsule 3-5-valved, dehiscing laterally by 3-5 valves : seeds ovate, complanate, or ovoid. Allied genera of garden value are Adenophora, Canarina, Jasione, Lightfootia, Phyteuma, Platycodon, Specularia, Symphyandra, Trachelium, and Wahlenbergia, in which genera many species originally described as Campanulas may be sought. Of these, perhaps the two best known cases are Platycodon grandiflorum, the "Balloon Flower," with its characteristic inflated buds, dark green, glossy leathery lvs., and Specularia Speculum (C. Speculum), "Venus' Looking-glass," a pretty annual, which grows in the grain fields of $\mathrm{S}$. Europe, and is cult. for its violet fls. with a white eye. The calyx-tube of Specularia is much longer, proportionately, than in any Campanula.

Botanically, Campanulas are divided into two important groups, based on the presence or absence of calyx appendages. The subgenus Medium has the appendages, and Eucodon lacks them. In straightening out one's garden labels, the calyx appenduges are one of the first things to be looked for, and they are often minute and disguised. In cultivation, Campanulas tend to become taller and more robust, less hairy, more branched, and more floriferous. A very few have white or yellowish fls., with no blue or violet forms. Any blue or violet-flowered form is likely to have white varieties, and double and semi-double forms are common in 3 or 4 of the most popular species. All flowers tend to become larger and more numerous on a stem. In cultivation, the 3-celled species are likely to have 5 stigmas instead of 3 , and 5-celled capsules, often along with normally constructed fls. on the same plant. The height 
is the most variable feature of all, and in the scheme below $C$. Carpatica and $C$. punctata especially will seem wrongly placed to many. But the characters used by De Candolle in vol. 7 , part 2 of the Prodromus are wellnigh useless to the gardener, and nothing else but a distinction of height can bring out the two important cultural groups of Campanulas, viz: Border or tall kinds, and rock-garden or dwarf kinds. The best garden monograph of Campanulas is by F. W. Meyer, in The Garden, 48: 294-299 (1895). See, also, The Garden for May 13, 1899, and 8:173-180 (1875).

The most popular of all Campanulas is the Canterbury Bell ( $C$. Medium and its var. calycanthema). Of all wild forms the best known is certainly $C$. rotundifolia, the true "Hairbell," or "Blue Bells of Scotland." Of the border kinds, the 6 most popular are probably C. $\mathrm{Me}$ dium, $C$. rotundifolia (in its many forms), $C$. pyramidalis, $C$. persicifolia, $C$. glomerata and $C$. Carpatica. Of the rock-garden kinds, the most popular in America are possibly $C$. Carpatica, $C$. caspitosa, and $C$. rotundifolia. The greatest curiosities are $C$. punctata, $C$. macrostyla, $C$. Zoysii and $C$ rotundifolia, var. soldanelloeflora. For exhibition and for pot-culture, C.pyramidalis is most used. For pendent effects in rockeries, baskets or window boxes, $C$. fragilis is best. For edgings, $C$. Carpatica is perhaps the favorite. For large, isolated specimens, $C$. pyramidalis, the tallest species, is best. F. W. Meyer's choice of varieties and classification should be consulted by all who intend to import Campanulas. England is probably the most favored spot in the world for the culture of Bell-flowers, and the Eng. lish dealers offer the greatest variety. Unfortunately, Campanula-culture is at a low ebb in America to-day, partly because the plants are less hardy here, and also because rock-gardens and amateurs' collections are less frequent than in England. Many failures with Campanulas, however, are directly traceable to ignorance of their natural term of life. Some species are perennial in the wild, but practically biennial in cultivation, and each kind must be studied by itself. Unless otherwise specified, they are presumed to be perennial. $C . M e-$ dium may be treated as a hardy annual or biennial, or as a tender annual or biennial. The general rule is that Campanulas give the most and best flowers in the second year, but $C$. Medium ean be sown indoors in early spring and set out later, with the expectation of getting the best bloom the same year. As a rule, all border Campanulas that are propagated by division should be divided every year, or every 2 years at most. Mr. Cameron recommends several species which are not described below, as they can be obtained only through botanic gardens.

W. M

The genus Campanula is a very important one, and contains many showy and useful plants. Their cultivation is very easy, and most of the strong-growing kinds can be grown in any rich, well-drained garden soil, while the dwarf kinds can be grown in the rockery, and many of them in the front row of the mixed border. Propagation is done either by division, cuttings or seeds. The genus can easily be divided into three groupsannuals, biennials, and perennials.

The annuals can be raised in the border by sowing the seeds late in April or May, or raised in the greenhouse and then transferred to the border. The best of the annuals are $C$. ramosissima and var. $a l b a, C$. $d \cdot r a$ bifolia, $C$. Erinus, $C$. macrostyla, and $C$. Americana.

Of the biennials, many will flower the first season if the seeds are sown early in spring in the greenhouse and the plants put out-of-doors when the weather is favorable. One of the most important is $C$. Medium (Canterbury Bells), and its numerous varieties. Its variety calycanthema is so named because the calyx has broadened out into a saucer-shaped secondary flower, which is very showy and interesting. Canterbury Bells are generally raised from seeds, which can be sown in April, May or later, in pots, boxes or beds, and can then be transferred into some sheltered place where they can be slightly protected during the winter, and then transplanted in spring to their permanent places into good, rich soil, where they will make a great show if they have obtained the right treatment. A few other good biennials are $C$. primulafolia, $C$. Sibirica, $C$. spicata, and $C$, thyrsoides.
Of the perennial species, the best border plants are the following: C. Carpatica and vars. alba and turbinata;C. glomerala, especially var. Dahurica; C.lac. tiflora; $C$. latifolia, especially its vars. eviocarpa and macrantha; $C$. nobilis (about $2 \mathrm{ft}$. in height); $C$. per sicifolia and its numerous vars., especially the white kinds ; $C$. punctata (about $1 \frac{1}{2} \mathrm{ft}$.); $C$. pyramidalis, a very showy plant when well grown, but not quite relia ble in the eastern states as to hardiness ; makes a good pot-plant for the cool greenhouse; $C$. rapunculoides, which spreads rapidly and must be so placed that it will not crowd out the other plants that are near it ; $C$. rotundifolia ; $C$. Trachelium; C. Van Houttei, a hybrid,

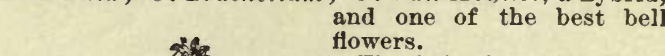

The following are the best low-growing kinds for the rockery: $C$. Carpatica and its varieties, $C$. Caucasica, C. fragilis (which needs protection, but makes a good pot-plant), $C$. pulla in sheltered position, $C$. Por tenschlagiana, $C$. rotundifolia, and $C$. pusilla. Many of the larger-growing kinds are also good for the rock garden. R. CAMERON.

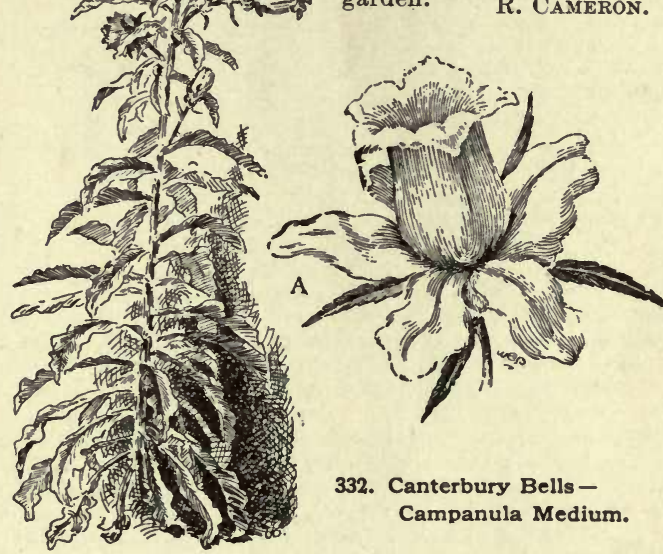

Alphabetical list of species described : C. alliariæfolia, 3; Allionii, 23; alpina, 26; Americana, 7 ; barbata, 24 ; Bononiensis, 16; cæspitosa, 41 ; Carpatica, 35; celtidifolia, 11 ; divaricata, 21 ; Elatines, 31 ; excisa, 42; floribunda, 36 ; fragilis, 29 ; Garganica, 30 ; glomerata, 10 ; grandis, 9; Grossekii, 5 ; Hohenackeri, 27 ; Hostii, 39 ; isophylla, 36 ; lactiflora, 11 ; lamiifolia, 3 ; Langsdorffiana, 40 ; latifolia, 15 ; latiloba, 9; linifolia, var. Scheuchzeri, 40 ; macrantha, 15 ; macrophylla, 3 ; macrostyla, 1; Medium, 2; mirabilis, 6 ; mollis, 25 ; muralis, 32 ; nobilis, 22 ; persicifolia, 8 ; Portenschlagiana, 32 ; pulla, 38 ; pumila, 41 ; punctata, 22 ; pusilla, 41; pyramidalis, 14 ; Rainerii, 33; rapunculoides, 19 ; Rapunculus, 44; rhomboidalis, 17; rotundifolia, 39; Kuthenica, 16 ; Sarmatica, 4 ; Scheuchzeri, 40 ; Scouleri, 37; Sibirica, 27; Soldanella, 39 ; Tenorii, 34; thyrsoides, 12 ; Trachelium, 18 ; turbinata, 35 ; urticifolia, 18; Valdensis, 40 ; versicolor, 20 ; Vidalli, 13 ; Waldsteiniana, 28 ; Zoysii, 43.

A. Tall or Border Campanulas, a foot or more high.

B. Calyx with an appendage at the base of each sinus.

$$
\text { c. Capsule 5-celled: stigmas } 5 \text {. }
$$

D. Style excessively long, the stigma an inch or more long.

1. macrostyla, Boiss. \& Heldr. Annual, 1-2 ft. high, branched from the base, hispid with rigid, spreading, scattered bristles: branches stout: lvs. scattered, small for the size of the plant, sessile, bristly on both surfaces; lower ones ovate-oblong, acute ; upper ovatelanceolate, recurved, cordate, eared at the base : calyx 
tube hidden by the bladdery appendages, small, broader than long: is. solitary, on stout peduncles, $2-21 / 2$ in. broad ; corolla very broad and open, pale purple without, dull purple within marked with violet and hairy toward the bottom : lobes very broad, short and acute. Mt. Taurus in Anatolia. Gn. 15: 178 and 12, p. 209. B.M. 6394. - Easily told from all other species by the very long exserted style, which is brown and spindleshaped before spreading open. Self-sown seeds sometimes wait a year before sprouting.

\section{DD. Style not excessively long.}

2. Medium, Linn. Canterbury Bells. Fig. 332 Biennial, 1-4 ft. high : plant pilose : st. erect ; lvs. sessile, ovate-lanceolate or lanceolate, crenate-dentate; petioles not marginal : raceme lax, many-fld.: calyx lobes ovate-acuminate, the appendages half as long as the ample, ovate, obtuse lobes : corolla very large, bellshaped, inflated. S. Eu. Much less cult. than var. calycánthema, Hort. CUP A IDD SAUCER. Hose iv Hose. Has the calyx colored like the corolla. A fair per cent come true from seed. G.C. III. $24: 65$. R.H. 1897, p. 238. R.H 1896:301. Gng. 5: 88. Gn. 48, p. 295. F.S. 19, p. 152. Canterbury Bells are probably the oldest and most popular of all Campanulas. They are most commonly treated as hardy biennials, the seed being sown in the open border, but they do not flower the first year. They can also be treated as tender annuals, the seed being sown indoors in early spring and the plants set out May 115. They will then flower well the first season, but always better the second year. Double forms are very popular and interesting, 1-4 perfect bells being formed one within another. The name Medium has no reference to size of plant or flower, but was the name of an old genus, now a subgenus of Campanula.

\section{cc. Capsule 3-celled: stigmas 3.}

\section{DD. Corolla with a curious projection at the base of} each sinus.

3. alliariæfòlia, Willd. (C. lamiifdtia, Bieb. C.mac rophýlla, Sims). Fig. 333. Height 11/2-2 ft.: stem erect, striate, woolly, branched only at the top: root-lvs. large, heart-shaped, crenate, tomentose : stem-lvs. on petioles which gradually shorten upwards, the highest

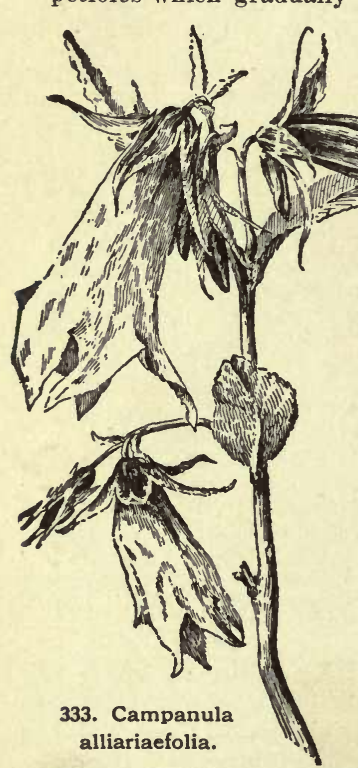
being sessile: fls. white, nodding, on short stalks, borne singly in the axils of the fioral lvs. as in $C$. Sar matica, but the floral- 1vs. larger and broader: calyx a third or a fourth shorter than the corolla, with margins rolled back, and appendages less minute than in $C$. Sarmatica: corolla always white, 2 in. long, ciliated at the margin, and with characteristic tooth-like processes at the base of each sinus, which are especially interesting in the bud. Caucasus, Asia Minor. B.M. 912.-Int. into England about 1805 by Loddiges. No blue-fld. form seems to be known. Prop. by seeds.

4. Sarmática, Ker-Gawl. Height 1-2 ft.: stem simple, striate, pubescent: lvs, remarkable for their gray color, harsh, leathery, wrinkled, tomentose, oblong-cordate, crenate, the lower long-petioled, the upper sessile : calyx with minute reflexed appendages, and a short, densely hairy tuft: fls. about 6 on a stem, nodding; corolla about 1 in. long, and $1 \frac{1}{2}$ in. across, marked with 5 hairy lines. Caucasus, subalpine portions. B.M. 2019. L.B.C. 6: 581 .

5. Gròssekii, Heuff. Has the habit and inflorescence of $C$. Trachelium, but the calyx is appendaged. Height
$21 / 2 \mathrm{ft}$., branching from the base, angled, pilose : lvs. hispid, the lower cordate unequally petioled, doubly crenate-serrate, the uppermost ovate-acute, narrowed into a petiole: calyx setose-ciliate, lobes lanceolate, spreading, reflexed at the apex, appendages lanceolate, a third shorter than the lobes ; corolla hispid, 2 or 3 times longer than the calyx lobes: fls. large, bellshaped, violet, in a long raceme. Hungary. Gt. 35, p. 477 , f. 55. - A rare plant.

6. mirábilis, Correvon. Height $1 \mathrm{ft}$. or more. "The leaves forming the rosette are somewhat thick and fleshy, the lower ones spreading out to a diameter of about 9 or 12 inches, the succeeding leaves smaller and arranged in an overlapping manner." Upper lvs. ovateserrate : fls. pale blue, hairy, 2 in. across, bell-shaped, sometimes strongly angled : raceme lax or dense. Caucasus. G.C. III. $24: 33$. Gt. $47: 192$. Gn. 54, p. 454.Int. in Europe in 1896 by Leicthlin. Very rare and in teresting. Probably a biennial rock plant. Slow from seed.

\section{Bв. Calyx without an appendage at the base of} each sinus.

c. F'ls, rotate or wheel shaped.

7. Americana, Linn. Annual and biennial : height 3-6 ft.: st, erect, simple: lvs, thin, serrate, somewhat pilose, root-lvs. ovate-acute, subcordate, petiolate ; stemIvs. ovate-lanceolate, acuminate at both ends : calyx tube long, obconical, the teeth linear-acuminate, almost entire, spreading shorter than the 5-fid, wheel-shaped corolla : fls. light blue, 1 in. broad, in long spikes, solitary or in 3 's; corolla shallow, lobes pilose outside and at the apex; style long, strongly declined and upwardly curved : capsule cylindrical, grooved. Shaded low ground western N. Y. to Iowa, south to Ga. and Ark. Rarely cult. It is possible that Phyteuma canescens is still cult. as $C$. Americana.

cc. Fls. saucer-shaped or broadly bell-shaped, i.e., the tube shallower and the limbs more widely spreading than the bell-shaped.

D. Stem-lvs. linear-lanceolate, crenulate.

8. persicifolia, Linn. Fig. 334. Height 2-3 ft.: stem erect: lvs. glabrous, rigid, crenulate; root-lvs. lanceolate-obovate; stem-lvs. linear-lanceolate or spatulate, often 3 in. long : calyx lobes acuminate, wide at the base, entire, half as long as the broadly bell-shaped corolla : fls. blue or white, pedicelled, solitary, terminal and axillary, often $11 / 2$ in. long, 2 in. broad : capsule ovoid, 3-grooved. Eu. B.M. 397. Var. macrántha is a large-fld. form with fls. all along the stem. Gt. 44, p. 148. Gn. 48, p. 306. A.F. 6:383. S.H. 1:131. Var álba grandiflòra and var. Báckhousei are among the p'spular whitefld. forms. There are double and semi-double forms in blue and white. The double white is useful for cutting. The var. alba grandiflora is F. W. Meyer's favorite of all Campanulas. This species occasionally runs wild, especially in England. The lvs. are very characteristic, and, once seen, are never forgotten. Var. coronàta, Hort., is a semi-double white form. F.S. 7:699. The pictures in B.M. and F.S. show distinctly saucer-shaped flowers.

DD. Stem-lvs, wider and coarsely toothed.

9. latíloba, DC. (C. grándis, Fisch. \& Mey. Height $1-1 \frac{1}{2} \mathrm{ft}$.: glabrous : stem erect, simple, terete : stemIvs. 3-5 in. long, 4-6 lines wide, lanceolate, narrowed at both ends, crenate-serrate : calyx lobes ovate-acute, broad, entire, erect, one-half shorter than the broadly bell-shaped corolla: fls. blue, with a white form, often 2 in. wide, sessile, solitary or somewhat clustered, sometimes equaling the ovate-acute, dentate bracts. Mt. Olympus. P.M. 10:31.-Fls. like $C$. persicifolia. Quickly forms a dense carpet. Int. into Eng. about 1842 from St. Petersburgh.

\section{ccc. Fls. bell-shaped or tubular, not saucer-shaped.}

D. Inflorescence a dense roundish head.

10. glomerata, Linn. One of the most variable: DeCandolle makes 8 botanical varieties. Height 1-2 ft. : typically pubescent : stem erect, simple, terete: lvs. serrulate, lower ones rough, with very short, stiff 
hairs, 11/2-3 in. long, 1-2 in. wide, with a cordate, ovateoblong blade shorter than the petiole ; upper ones sessile, ovate, acute : fls. in dense heads or glomes, 15-20 in the terminal heads, fewer in the axillary ones. Eu.

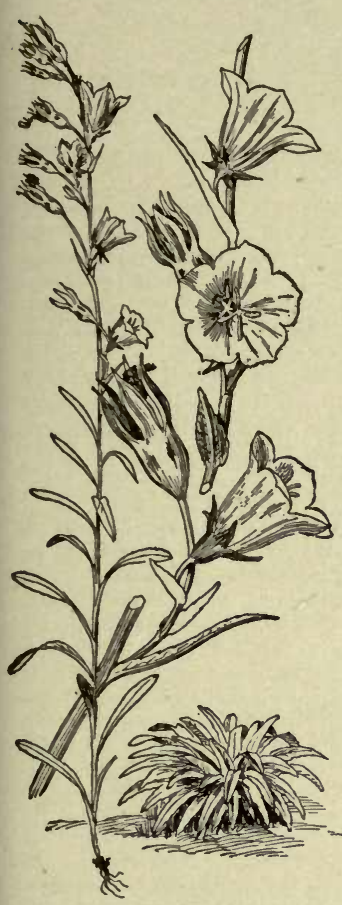

334. Campanula persicifolia.

(There are forms with more broadly bell-shaped flowers.)
Armenia, Persia, Siberia. B.M. 2649 is var. speciosa, which has the largest fls. L.B.C. $6: 505$ is var. sparsiflora, with much smaller clusters. - This is one of the earliest flowering and easiest of cultivation. Fls. typically dark purple, with no recorded white varieties. Var. Dahùrica, Hort., is probably the commonest form. Terminal clusters 3 in. or more thick; a very characteristic inflorescence. The fl. has a longer tube than $C$. lactiflora and thyr soides.

DD. Inflorescence a spike or raceme, dense or loose.

E. Color of fls. normally white or yellowish.

F. Corolla small, shorttubed.

11. lactiflora,Bieb. Height $21 / 2-5 \mathrm{ft}$ : stem crect, branching : Ivs. sessile, ovate-lanceolate, acutely serrate : calyx lobes very broad, acute, serrulate, one-half shorter than the broadly bell-shaped corolla: fls. in a loose or dense panicle, which may be $3 \frac{1}{2}$ in. long and thick ; corolla white or pale blue, 1 in. long, nearly $11 / 2$ in. broad: capsule oroid, erect. Caucasus, Siberia. B.M. 1973. - Not advertised in Amer. at present. $C$. celtidifolia, Boiss., referred to the above, may be a strongly marked variety. A plant once cult, at Harvard Botanic Gardens has very characteristic, perfectly elliptical lvs., blue fls., and more open inflorescence.

12. thyrsoldes, Linn. Biennial : height $1-1 \frac{1}{2} \mathrm{ft}$ : stem grooved: lvs, all covered with long hairs at the margin ; root-lvs. sessile, spatulate or obtusely lanceolate, $2 \frac{1}{2}$ in. long, $3 / 4$ in. wide, in a dense rosette, lying on the ground; upper lvs. more narrow and acute: fls. 40-50, sulfur or creamy yellow, in a dense thyrse-like spike, which may be 6 in. long and $21 / 2$ in. broad : style exserted. B.M. 1290. L.B.C. 17:1644.-Intermingled with the fls. in the spike are lvs. which are longer than the fls., which is not true of $C$. lactiflora. Should not be confounded with $C$. thyrsoidea, Lapeyr., which = C. speciosa. No blue or purple forms are known. The picture in B.M. shows a characteristic red-tipped calyx.

\section{FF. Corolla large, long-tubed.}

13. Vidálli, H. C. Wats. Perennial : height 1-2 ft. stem branching from the base : some branches short, sterile, others tall, floriferous, all grooved, clammy, glossy : Ivs. 3-4 in. long, oblong-spatulate, coarsely serrate, thick, fleshy, firm, viscid, the upper ones gradually becoming bracts : fls. 2 in. long, nodding, about 9 in a loose terminal raceme; calyx lobes triangular, thick, onefourth shorter than the corolla; corolla tubular, swelled below, constricted above, with a yellow base. Azores. B.M. 4748. F.S. $7: 729$. A.Fl. 3:116. Gn. 54, p. 299. G.C. III. 18:95. - Very distinct.

EE. Color of fls. normally blue or purple, with white varieties.

$$
\text { F. Size of fls. large. }
$$

G. Raceme pyramidal, usually dense.

14. pyramidàlis, Linn. Chimney Campanula. Figs. 335, 336. Glabrous : Ivs. glandular-dentate, lower petio- late, ovate-oblong, subcordate ; stem-Ivs. sessile, ovatelanceolate: calyx lobes acuminate, spreading, half as long as the broadly bell-shaped corolla : fls. numerous, in pyramidal racemes. Austria, near Adriatic. Gn. 45, p. $67 ; 48$, p. $306 ; 51$, p. 221 (a staked pot plant). R.H. 1897, p. 238 . Gn. 53, p. 535 (with extensive cultural notes).

Var. compácta, Hort. S.M. 2:97. Gn. 47, p. 86 (with very full cultural notes). The tallest of Campanulas and one of the oldest. Much grown in pots for exhibition. The compact variety is very floriferous and convenient for conservatory, but lacks the characteristic tall, pyramidal habit.

GG. Raceme not pyramidal, usually looser.

15. latifolia, Linn. Height 3-4 ft.: Ivs. large, doubly serrate; root-lvs. sometimes 6 in. long, petiolate, cor date, covered with soft hairs ; stem-lvs. sessile, more acuminate : peduncle 1-fld.: calyx lobes long-acuminate, one-third shorter than the corolla : fls. $6-15$ in a loose spike or raceme about 8 in. long, erect, very large, $21 / 2$ in. long, purple or dark blue, hairy. Eu., Persia. Var. macrántha, Sims (C.macrántha, Fischer), is commoner in cult. than the type, a little hairier, with a glabrous calyx and very large fls. B.M. 2553 and 3347. R.H. 1897, p. 239. Var, eriocárpa, DC., has the stem and lvs. pilose and more pallid, and a hispid calyx tube. There is a white-fld. form. It is native to England, and is easily naturalized in their wild gardens. The stem-lvs. are probably the largest of any of the garden kinds, often $3 \frac{1}{2}$ in. long and 2 in. wide.

FF. Size of fls. small; less than $1 \mathrm{in.}$ long.

16. Bononiénsis, Linn. Height $2-2 \frac{1}{2} \mathrm{ft}$ : : scabrous: stem simple : Ivs. serrulate, ovate-acuminate, pallid beneath ; root-Ivs. cordate-petiolate ; upper lvs. clasping: calyx lobes acuminate, one-fourth shorter than the funnel-shaped corolla: fis. normally purfis. normally pur
loose, pyramida loose, pyramida

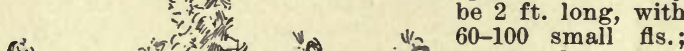
4 n 证 A m. mentose beneath.

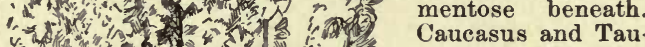
ria. B. M. 2653.
There is a whiteof are much smaller than in $C$. latifolia, and the raceme is much larger.

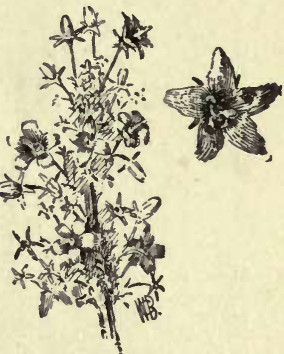

335. Pot plant of Campanula pyramidalis.

336. Nearer view of flowers-Campanula pyramidalis.

17. rhomboldalis, Linn. Height $1 \mathrm{ft}$, sometimes 2 : stem simple, erect: lvs. sessile, ovate-acute, serrate : calyx lobes awl-shaped, one-half shorter than the bellshaped corolla : fls. 8-10 in an almost corymbose raceme, the lower pedicels of which may be 3 in. long, the 
uppermost 1 in. or less : corolla purplish blue, with a white variety, 1 in. long and a little wider. Mts. of Eu. B.M. 551, as C. azùrea.-It flowers in July and August, after which the stems and lvs. die down quickly.

18. Trachèlium, Linn. Fig. 337. Height 2-3 ft.: stem angular, covered with dense, short hairs : lvs. rough,

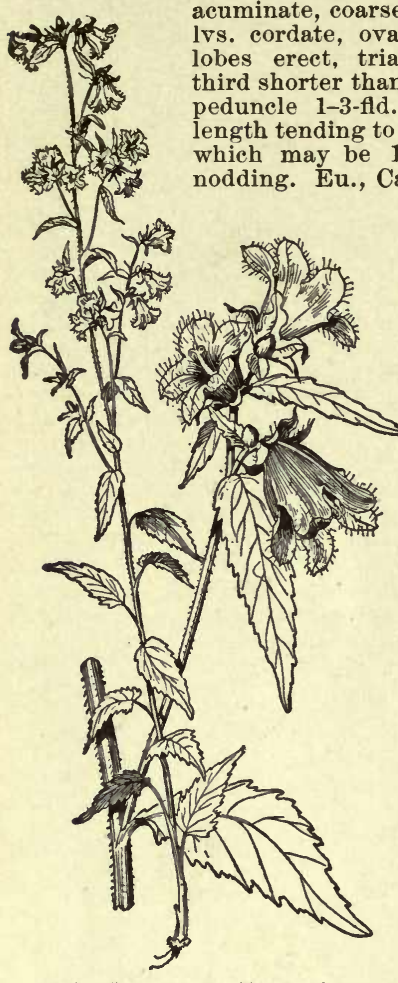

337. Campanula Trachelium ascending: lvs, serrate; root-lvs. long-petioled, ovate-acute, subcordate; stem-lvs. short-petioled, ovate-lanceolate, acuminate : ealyx-teeth acuminate, spreading, at length reflexed, onehalf as long as the corolla : fls. in long, spicate racemes; style exserted : capsule spheroid. Greece.-Rare.

DDD. Inflorescence an open, compound panicle.

21. divaricàta, Michx. Glabrous: height 1-3 ft.: stem erect, slender, paniculate above : branches slender, divergent : lvs. sparse, subsessile, ovate-lanceolate, acuminate at both ends, coarsely serrate : calyx-lobes awlshaped, one-half shorter than the tubular, bell-shaped corolla : fls, small, nodding, blue, in a very open and compound panicle; style straight exserted. Alleghanies, from Va. to Ga.-Rare in gardens.

A4. Low-growing or rock-garden Campanulas, mostly less than a foot high

B. Calyx with an appendage at the base of each sinus, often minute or disguised in form.

c. Throat of corolla spotted violet.

22. punctàta, Lam. (C.nóbilis, Lindl.). Named from the spotted corolla, the purplish spots being inside and showing through faintly in the fresh fl. but more plainly in the dried specimen. Height $1 \mathrm{ft}$.: stem with longer and looser hairs than in $C$. alliariafolia: upper lvs. nearly sessile, and more sharply toothed than the lower: calyx-lobes one-third as long as the corolla, longer, looser and hairier than in $C$. alliariofolia, and the margins much more recurved: peduncle 1-4-fld.: fls. nodding; corolla eylindrical, $2 \frac{1}{4}$ in. long, white, spotted within, strongly ribbed. Siberia, Japan. $C$. nobilis has been considered distinct. In F.S. 3: 247 the corolla is dark violet without, the limb hairy, while in B. M. 1723 (C.punctata) the corolla is white outside and not bearded. In F.S. $6: 563$ (C. nobilis, var. alba) the limb is not bearded and the stem is red, and not hairy. The three pictures show great differences in foliage, pubescence and appendages. This is one of the most interesting of all Campanulas, and is, unfortunately, usually considered more quaint than beautiful. Cannot be used for cutting. The spotted throat readily separates it from all Campanulas. See supplementary list for $C$. Van Houttei, a supposed hybrid.

\section{Cc. Throat of corolla not spotted.} D. Stems 1-flowered.

23. Allionii, Villars. Height 3-5 in.: rootstock slender, creeping underground, sending up stems at intervals of $1 / 2-1$ in.: lvs. few, about 7 on a stem, 1-2 in. long, linear-lanceolate, sessile, slightly hairy, entire, midrib distinct, lower ones in a whorl of about 5, upper ones similar but more erect : calyx-lobes lanceolate, half as long as the corolla, the appendages ovate, reflexed, onethird the length of the calyx-lobes: fls. purple, with a rare white variety, only one on a stem, inclined or nodding, $11 / 2$ in. long, and as broad across the mouth, the largest for the size of the plant of any Campanula. A very local species, found only in the Alps of Piedmont and Savoy. B. M. 6588. - No white-fld. form is known. Int. into Eng. about 1879 by G. Maw. "It is an excellent rock-plant, and, though requiring plenty of moisture, it should have a well-drained position, and is therefore best grown in a narrow crevice filled with sandy loam and an abundance of small stones and grit." $-\boldsymbol{F} . W$. Meyer.

\section{DD. Stems several-flowered.}

E. Margin of corolla bearded.

24. barbàta, Linn. Height 6-9 in.: stem pilose : lvs. villous, entire or nearly so; root-lvs. tufted, lanceolate; stem-lvs. few, ligulate?: raceme loose, $3-4$-fld.: fls. nodding, pale blue; calyx appendage ovate, obtuse, half as long as the lobes; corolla bell-shaped, shorter than in C. Allionii, and with a bearded mouth. Alps. L.B.C. $8: 788$. Gn. 48, p. 297. - There is a white-fld. form, but apparently no purple. Readily told from $C$. Allionii by the different colored, bearded and smaller fls., which are rarely borne singly, and by the dense, soft hairs of the stem. Commonest species in the Alps. "In the rock-garden it should be grown in poor, stony soil, as it is apt to become somewhat coarse when grown in rich soil." $-F$. W. Meyer.

EE. Margin of corolla not bearded.

\section{F. Fls. erect.}

25. mollis, Linn. Perennial : velvety gray : height 6-8 in.: stems procumbent, about 2 -fld.: root-lvs. tufted, obovate or spatulate; stem-lvs. ovate or rotund: fls. loosely panicled; calyx-lobes lanceolate, erect, half shorter than the glabrous, bell-shaped corolla ; appendages minute, shorter than the calyx tube; corolla erect, dark purplish blue or lavender, with a white throat, the tube long, segments short, broad, spreading, acute. Spain, Crete. B.M. 404. - Rock or border plant; not adv. in America.

$$
\text { FF. Fls, nodding. }
$$

26. alpina, Jacq. Height 3-8 in.: stem furrowed: lvs. smaller than in $C$. barbata, more narrowly lanceolate, entire, hairy : fls. typically deep blue, bell-shaped, with broader and shorter segments than in $C$. barbata: calyx-lobes proportionately very long, surpassing the fl.-bud, and nearly as long as the flower, but widely spreading. Swiss and Austrian Alps. B.M. 957. J.H. III. 29: 5. - There is a white-fld. var. Int. into England about 1805 by Loddiges. The plant has a characteristic shaggy appearance from the hairy lvs. Easy of eult.

27. Sibírica, Linn. ( $C$. Hòhenackeri, Fisch.). Setaceous-pilose : stem erect, simple, panicled above : Ivs. crenulate ; root-lvs. petioled, obovate, obtuse ; stemlvs. lanceolate-acuminate : calyx hairy, the lobes longacuminate, a third shorter than the corolla : calyx appendages like the lobes but half shorter and reflexed: fls. 25 or more, violet, with a longer and narrower tube than in C. alpina, and longer divisions of the limb. N. Asia, Caucasus, W. Eu. B.M. 659. R.H. 1861: 431.The type is rare, but var. exímia, Hort., is somewhat 
commoner. It is dwarfer, much branched, with long, scabrous lvs. and pale bluish to violet fls. See Mottet's translation of Nicholson, Dict. Gard. Var. divérgens, Willd., has larger fis. and broader lvs. than the type. G.C. III. 16:597. C. Sibirica usually does best when treated as a biennial.

BB. Calyx without appendages.

c. Fls. very wide-spreading, i.e., rotate, wheel-shaped, almost flat.

D. Blossoms all erect.

28. Waldsteiniàna, Roem. \& Schult. Perennial : height $4-6$ in.: stems rigid, glabrous : lvs, fleshy, sessile, gray-green, lanceolate, slightly serrate-dentate, the lower obtuse, the upper long-acuminate: calyx lobes awl-shaped, spreading or recurved, one-fourth shorter than the corolla : fls. 5-9 in a corymbose raceme $1 \frac{1}{4}$ in. long, $3 / 4$ in. wide, pale purplish blue; corolla rotate, almost starlike, with a dark spot in the throat: pistil large, white, twice the length of the corolla, with a yellow stigma. Hungary. Gn. 8, p. 173.-Not advertised in America at present.

$$
\text { DD. Blossoms not all erect. }
$$

E. Habit trailing or pendulous.

29. frágilis, Cyrill. Perennial : height 4-6 in.: stems diffuse, trailing : root-lvs. long-petioled, roundish-cordate, obtusely dentate, or crenately lobed; stem-lvs. smaller, scattered, the uppermost ovate-lanceolate : fis. pale purplish blue with a white center, $1 \frac{1}{2}$ in. wide, in loose corymbs ; calyx lobes linear-lanceolate, acuminate, erect, almost equaling the corolla; style exserted: capsule ovoid. Italy. B.M. 6504. P.M. 11:25. Gn. 8, p. 174 , and 47, p. 278 . Var. hirsuta, DC., is a hairier form. - This is the best species for hanging baskets, window and veranda boxes, and for covering large stones in the rockery. Prop. by cuttings in spring, the roots being too fragile to divide well. Not so hardy as C. Garganica.

30. Gargánica, Tenore. Height 3-6 in.: stem diffuse: lower lvs. reniform-cordate, crenate-dentate ; upper lvs. orate-acute, dentate : raceme lax : peduncles 1-2-fld.: calyx tube spheroid, the lobes spreading, a third or fourth shorter than the glabrous corolla. Mt. Gargano in Italy. B.R. 21:1768. Gn. 48, p. 295, and 43, p.25. Var. hirsuta, Hort., is a hairier form. Gn. 46, p. 253, and 48, p. 297. - "Owing to the pendent character of its flowering branches, its proper place is against a rocky ledge, over which its masses of flowers may hang." $-J$. $C$. Niven. Half-shaded position. Prop. by cuttings or by division.

\section{EE. Habit not trailing or pendulous.}

31. Elatines, Linn. Perennial, more or less pubescent: height 5-6 in.: lvs. cordate, coarsely and acutely dentate, lower rotund, others ovate-acute: raceme lax : calyx tube spherical, the lobes spreading, linear-lanceolate, somewhat unequal, a half shorter than the rotate corolla : style exserted. Piedmont. - Rare rock plant for light, stony soil.

32. Portenschlagiàna, Roem. \& Schult. (C. muràlis, Port.). Height 6-8 in.: stems somewhat erect : Ivs. all alike petiolate, cordate, roundish, acutely angular-dentate: calyx tube spheroid, lobes erect, acuminate, a third shorter than the infundibuliform corolla : fls. racemose. Dalmatia.-Allied to $C$. Garganica, but the corolla not so deeply 5-cut. Little known. For conflicting descriptions, see Gn. 8, p. 173, and 48, p. 297.

cc. Fls. broadly bell-shaped, less widely spreading than in $C$. , wider than in $C C C$.

\section{Height $2-3$ in.}

33. Ràinerii, Perpenti. Height 2-3 in.: stems suberect, branching; branches 1-3-fld.: lvs. subsessile, ovate, distantly serrate, the lower smaller and obovate: calyx tube obconical, the lobes long-acuminate, erect, half shorter than the broadly infundibuliform corolla: fls. large, solitary, erect, dark purplish blue; style short, not exserted: capsule obovate. Mts. near Lake Como. F.S. 18:1908.One of the choicest roc's plants, but somewhat rare. Several forms of the hybrid Campanula G. F. Wilson are often cult. under this name, but their lvs. are lighter green and less tomentose than $C$. Rainerii. Enjoys a well drained, sunny position.

$$
\text { DD. Height more than } 2-3 \text { in. }
$$

34. Tenòrii, Moretti. Height 8-12 in., glabrous : stem ascending or prostrate: Ivs. leathery; root-lvs. long-petioled, ovate, subcordate, irregularly serrate; stem-lvs. petiolate, ovate-acute, coarsely serrate : calyx lobes linear-lanceolate, spreading, half as long as the broadly bell-shaped corolla: fls, racemose : capsule spherical. Naples.-This is now referred to the Grecian species $C$. versicolor, which is typically taller. In the garden, $C$. Tenorii resembles $C$. pyramidalis in foliage and flower, but is shorter.

$$
\text { E. Style not exserted. }
$$

35. Carpática, Jacq. Fig. 338. Height 9-18 in., glabrous : stem branching : lower lvs. thin, long-petioled, ovate-rotund, cordate, coarsely dentate, undulate; upper ones shorter petioled, ovate-acuminate: peduncles long, terminal and axillary, 1-fld.: fls. large, often $1 \frac{1}{2}$ in. wide, deep blue or white: calyx tube obconical, the lobes acute, wide at the base, subdentate, erect, a third or half as long as the broadly bell-shaped corolla : style not exserted : capsule ovoid-cylindrical. Carpathian Mts. of Austria. B.M. 117. Gn. 48, p.297. Var. turbinàta, Hort. (C. turbinàta, Schott), is dwarfer, more compact, with fls. more bell-or top-shaped, and often 2 in. across, purplish blue. It also has larger Ivs. and more decumbent habit. Gn. 45, p. 171. A form with pallid fls. is rarer. Var. G. F. Wilson, Hort., is a hybrid of var. turbinata and $C$. pulla, with the large fls. of the former and the handsome dark foliage of the latter. It is compact, dwarf, and small, ovate, very hairy lvs., with crenate-serrate margin. $C$. Haylodgensis, Hort., is a garden hybrid, probably between C. Carpatica and C. caspitosa. Raised by Anderson Henry, Hay Lodge, Edinburgh. Height 6-9 in.: root-lvs.tufted, roundish cordate, slightly dentate : stemlvs. light green, ovate-cordate, conspicuously toothed : tis. light blue, bell-shaped, few, at the ends of stems. Var. pelviformis, Hort., from Crete, has very large, pale lilac, almost saucershaped fls. R.H. 1882, p. 509. Var. Héndersoni, Hort., is generally referred to var. turbinata, but is more robust. Lvs. ovate and ovate-cordate, $11 / 2$ in. long, $3 / 4$ in. broad, slightly hairy on both sides, folded upwards, serrate; petioles $1-1 \frac{1}{2}$ in. long: fls. dark blue, $11 / 2-2$ in. wide, in short, 6-9. fld. racemes. - This species is among the first dozen in popularity, and is very variable in height and in shape of flowers.

EE. Style exserted.

36. isophylla, Moretti (C. floribúnda, Viv.). Stem suberect : lvs. all alike, petiolate, roundish cordate, crenate-dentate: calyx lobes acuminate, half shorter than the broadly bell-shaped corolla: fls. pale blue, 1 in. or more wide, corymbose ; style exserted : capsule ovoid. Italy. B.M. 5745. Gn. 49, p. 483; 48, p. 297.-An excellent basket or rock plant in sun or half shade. The white variety seems to be more popular. Fis. may be saucer-shaped.

$$
\begin{gathered}
\text { ccc. Fls, bell-shaped. } \\
\text { D. Style exserted. }
\end{gathered}
$$

37. Scouleri, Hook. Height 8-12 in.: stem simple or branched : Ivs. acutely serrate, somewhat hirsute; lower ones ovate-acute, petioled; middle ones ovate-lancea 
late ; upper linear-lanceolate, sessile : calyx lobes awlshaped, erect, one-third shorter than the corolla: fls. racemose, or more or less panicled: style exserted : capsule ovoid. Columbia river. - The capsular valves are a little above the middle, while in $C$. Carpatica and $C$. persicifolia they are near the apex. A rare western American species.

\section{DD. Style not exserted.}

E. Color very dark purple.

38. púlla, Linn. Height 3-5 in.: stem normally 1-fld.: lvs. glabrous, crenulate-dentate; lower ones short-petioled, ovaterotund; upper sessile, ovateacute: calyx lobes long-acuminate,

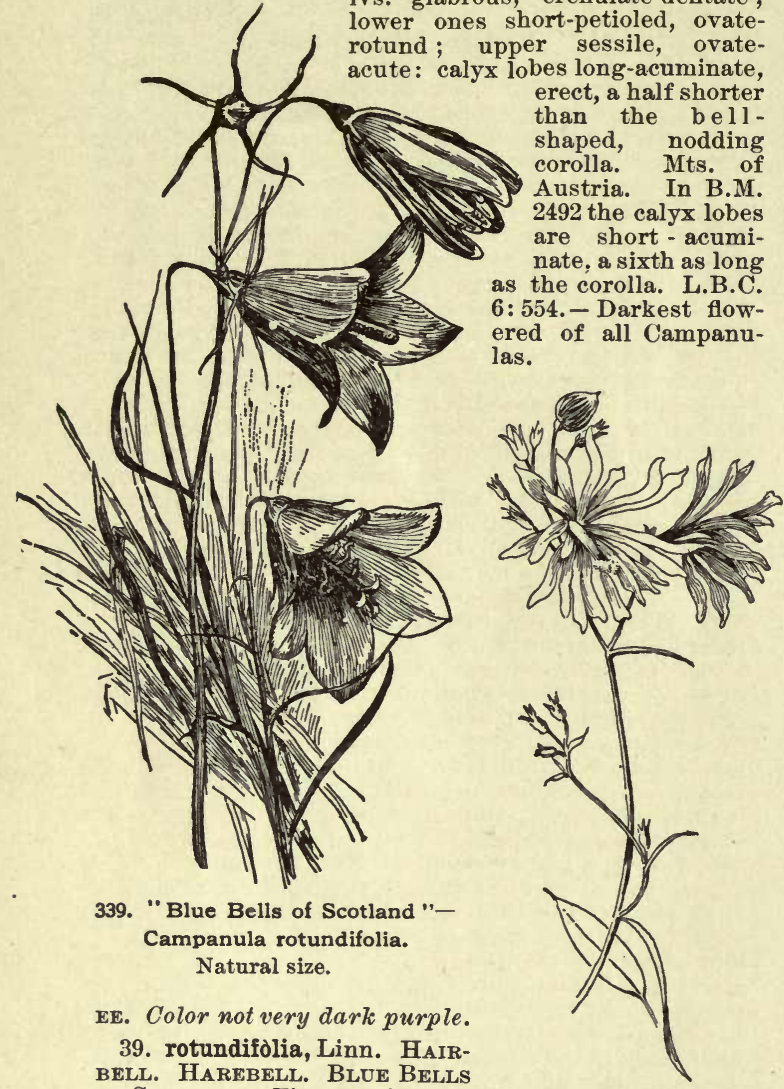

Betu. of Scothand. Fig. 339. Height 340. Campanula rotundifolia 6-12 in. Root-lvs. petiolate, cordate, crenate-dentate : stem-

var. soldanellaeflora.

lvs. linear or lanceolate, usually entire: calyx lobes awlshaped, erect, a third shorter than the bell-shaped corolla fl. buds erect. Eu., Siberia, W. N. Amer. Gn, 53:1153. -This is one of the most cosmopolitan of all Campanulas, and the true hairbell or bluebell of literature. In the wild it is slenderer and taller than in the garden. In shady woods it often grows $2 \mathrm{ft}$. high. The type has a white-fld. variety which is much less popular, but G.C. 1861: 698 shows an excellent pot-plant of it. Var. Hostii, Hort. ( $C$. Hostii, Baumg.), has larger fis. than the type and stouter stems. The lower stem-lvs. are lanceolate, remotely dentate, the upper linear entire : calyx lobes longer than in the type, a half shorter than the corolla. The white-fld. form is not as vigorous. The most pronounced form is var. soldanellæflora, Hort. ( $C$. soldanélla, Hort.). Fig. 340 . With semidouble blue fls. split to the base into about 25 divisions. F.S. 18: 1880. - This curious variation is unique in the genus. The alpine soldanellas are famous among travellers for melting their way through the ice. They have fringed blue fls. The name of this species seems singularly inappropriate until we have sought the root-lvs. in early spring.
40. Scheúchzeri, Vill. (C. linifolia, var. Scheúchzeri) Height 4-12 in.: stem 1-4-fld., usually 1-fld.: root-lvs roundish, ovate, or cordate : stem-lvs. linear or narrowly lanceolate, sessile, denticulate, the lowest stem lvs. spatulate : calyx lobes slender, linear-awl-shaped, nearly as long as the bell-shaped corolla. Alpine and subarctic regions of Newfoundland, Labrador, Alaska. F.S. 21: 2205 , not L.B.C. 5: 485 , which DeCandolle states most emphatically is $C$. rotundifolia and nothing else. The stem-lvs. of $C$. Scheuchzeri are distinctly serrate, while in $C$. rotundifolia they are entire; the flowerbuds nod in the former, but are erect in the latter. The calyx lobes are relatively longer in $C$. Scheuchzeri, and perhaps the bell is deeper.

41. cæspitòsa, Scop. (C. pùmila, Curt. C. pusílla, Hænk.). Height 4-6 in. : root-lvs. tufted, short-petioled, ovate, glandular-dentate, shining : calyx lobes linear, erect, a third shorter than the bell-shaped corolla : fls. nodding, pale blue or white; pollen violet-colored. B.M. 512. Gn. 43: 892. Gn. 48, p. 297. - Dwarfer than $C$. rotundifolia, with root-lvs. never reniform, shorter-petioled, and lasting until after fls. have gone. Perennial, quickly forms a dense mat. Border, edgings, or rockery. The European trade catalogues usually offer $C$. caspitosa and C. pusilla separately, and doubtless plants of distinct horticultural value are passing under these names, but there seem to be no botanical or horticultural dese riptions that will distinguish them.

42. excisa, Schleich. Perennial, glabrous : height 4-5 in.: stems slender, 1-fld.: roct-lvs, spatulate: upper lvs. linear: calyx lobes bristly, spreading, at length reflexed, a third shorter than the bell-shaped corolla : fls. pale blue, divided to about half their depth, with a round hole at the base of each sinus, which easily distinguishes it from $C$. pulla and all other Campanulas. Rare in Alps. B.M.7358. L.B.C. 6:561.-A rare rock plant. Likes cool, moist air, and not too full exposure to sun. Not advertised in America.

cCcc. Fls. long-tubular, abnormal.

43. Z6ysii, Wolf. Height 3-4 in.: plant tufted, glabrous : stems few-fld.: root-lvs, entire, crowded, petiolate, ovate-obovate, obtuse: stem-lvs, obovate-lanceolate and linear: peduncles 1-fld, terminal, rarely axillary : calyx lobes linear, awl-shaped, spreading, a fourth shorter than the corolla : corolla long-cylindrical, constricted at the apex, wider at the base, sharply angled. Austrian Alps. Gn. 8, p.173. G.C. III. 20:183. - A rare and abnormal species. "Fls, large in proportion to the size of the plant, azure blue, *** terminated before expansion by a pretty stellate process, arising from the infolding of the segments of the corolla after expansion. These are seen to be densely bearded, forming a mass of hairs surrounding the large capitate stigma."-J.C. Niven.

AAA. Kitchen garden vegetable: roots radish-like. A salad plant.

44. Rapúnculus, Linn. RAMPION. Biennial: height 2-3 ft.: root spindle- or long-radish-shaped, $1 / 2 \mathrm{in}$. thick, white : stem erect, sulcate : lower lvs. obovate, shortpetioled, somewhat crenate: stem-1vs. linear-lanceolate, entire: fls. lilac, in a spike or raceme: calyx tube obconical, lobes glabrous or bristly, erect, awl-shaped, a half shorter than or nearly equal to the funnel-shaped corolla. Eu., Orient, N. Asia, N. Afr. - The roots and lvs. are eaten as a salad. The seeds, which are the smallest of any kitchen garden vegetable, are sown in the open ground in early May either broadcast or in drills. A little sand mixed with the seed gives an evener sowing. Press firmly, and water carefully. Thin out the seedlings if necessary. Water freely in hot weather. A fresh sowing may be made in June, as early sown plants may run to seed. Roots are gathered in October, and may be stored in sand for winter use. Rapunculus means a little turnip. Vilmorin-Andrieux, The Vegetable Garden.

C. abietina, Griseb. Rare, tufted, rockery plant, with slender, wiry stems 9-15 in. high : fls. light blue in loose, branching spikes. July-Aug. E. Eu.-O. calycánthema, Hort.= C. Medium, var. calycanthema.-C. Cenisia, Linn. A rare rock plan from $\mathrm{Mt}$. Cenis and other mts. of the Alps, is a rare tufted rock plant with solitary deep blue fls. on stems 2 in. high. Root-lvs, obovate, obtuse ; stem-lvs. ovate-oblong ; all lvs. sessile-entire: shorter than the deeply 5-cut, spreading corolla.-C. Dahùrica. 
Hort, Plants sold under this name are likely to be C. glomHort. Plants sold under this name are likely : plant hispid : erata, var. speciosa. - C. Erinus, Linn. Annual : plant hispid: height 3-9 in.: lvs. small, glossy, $14-3 / 4$ in. broad, cordate, deeply cut, the pointed lobes conspicuous : fls. sessile, pale blue with a light center, tubular (or star-shaped ?), 1/2 in. broad, with acute narrow lobes; style long, conspicuous, colored like corolla : racemes long, semi-prostrate, 10-20-fld. Mediterranean. Rare short-lived rock plant. Also for edgings and pots. $-O$. grandifldra, Jacq. = Platyeodon grandiflorus. - C. Lamárckit, D. Dietr. = Adenophora Lamarekit. - . Ait.). Glabrons: height flora.-C. planifldra, Lam. (C. nitida, Ait.). Glabrons: height 3-9 in.: stem simple : lvs. sessile, leathery, shining : root-lvs. crowded in a dense rosette, ovate or obovate-obtuse, crenulate, fls. blue or white, with double varieties, in spicate racemes; calyx lobes ovate, acute, broad, erect, a third shorter than the broadly bell-shaped or saucer-shaped corolla. Not American, though commonly so stated. Habitat unknown. J.H. III. 33: 283 . Rock plant, for sunny position.-C.speciòs $a$, Pourr., is 33: 283. Rock plant, for sunny positionsing under this name are a rare species. Most of the plants passing under this name arelikely to be C. glomerata. B.M. 2649 is C. glomerata, var. speciosa. $-C$. Speculum, Linn. $=$ Specularia Speculum.-C. urticifolia. This name is now abandoned. Plants are likely to be $\mathrm{C}$. long-petioled, roundish cordate, more or less lobed; stem-lvs. sessile, oval-lanceolate, irregularly bi-dentate, $2 \frac{1}{2}-4$ in. long, more or lass villous, strongly nerved : fls, usually solitary, nodding at the end of a small branchlet, 2 in. long, half as noding at the or violet; calyx lobes linear, spreading, 1 broad, indigo blne, or violet; calyx lobes linear, spreading, in. long. A garden hybrid resembling C. punctata. Int. into Var. pallida has pale lavender fls.

W. M.

CAMPHORA (from camphor, made from its juice). Laurdcee. The Camphor Tree (Camphòra officindlis, Steud.) is native to China and Japan, but it is now introduced into S. Fla. Botanically, it is very closely allied to the cinnamons, and is often referred to that genus (as Cinnamomum Camphora), but it differs in its scaly buds, membranaceous calyx, and leaf characters. Camphora officinalis attains a height of $40 \mathrm{ft}$., and endures light frosts. It has alternate, ovate-elliptic, entire, thick lvs., and axillary panicles of small, yellow fls. The whole plant contains camphor. The gum is obtained from the extracted juice.

\section{CAMPION. See Silene.}

\section{CAMPSIDIUM. See Tecoma.}

CAMPTOSOROS (Greek, bent sori, alluding to the irregular arrangement). Polypodidcea. A small genus of hardy ferns, with simple, pointed lvs., which take root at the apex, and are hence known as "Walking-leaf Ferns." A single species is native mostly on lime-bearing rocks, and an allied species is known from Japan and N. Asia.

rhizophyllus, Link. Fig. 341. Lvs. simple, tapering from a heart-shaped base, 4-12 in. long; veins forming meshes near the midrib; sori irregularly scattered. Canada to Alabama. - Sometimes grown in rockeries and wild gardens.

L. M. UNDERWOOD.

CAM PYLOBOTRYS. See Hoffmannia.

CANADA. Figs. 342-4. The most important fruit regions of Canada are those surrounded wholly or in part by bodies of salt or fresh water. In the extreme east the Atlantic ocean with its indentations, is

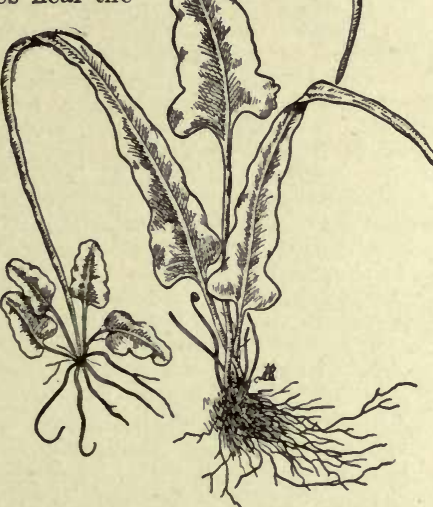

341. Camptosorus rhizophyllus. the influencing climatic factor. In central Canada the great lakes, Ontario and Erie, serve the same useful office, while in the extreme west the Pacific ocean, with its gulf stream, tempers the climate of British Columbia, and gives sufficient atmospheric moisture, so that all but tropical and citrus fruits may be grown in the most favored localities. It is interesting to note that while on the eastern Atlantic coast apples are successfully grown as far north as the 47th parallel north latitude, and in British Columbia as far north as the 52d degree north latitude, yet in the interior of Ontario and Quebec they have not succeeded north of the 46th parallel.

The fruits of Canada of to-day are attributable to 5 main sources: 1. Seeds, brought by the first French missionaries and English colonists. 2. Seeds and plants obtained from Virginia and New England. 3. Plants and seeds brought in by United Empire Royalists. 4. Chance seedling production. 5. Recent importation from Europe, and systematic plant-breeding.

In order to obtain an idea of the character of fruits cultivated in the Dominion, it will be necessary to consider the provinces separately :

Prince Edward Island. - Latitude, 46 degrees to 47 degrees north, area about one and a quarter million acres. The surface is undulating, the whole island eminently agricultural and pastoral. Soil, a reddish loam, sometimes sandy and occasionally clayish. The climate is sufficiently mild to admit of the cultivation of pears and of plums of the Prunus domestica type. The winters are long and tedious, with heavy snowfalls, and frequent fogs and sleety rains. The first fruits introduced were apples, by French colonists. Later, the English and Scotch settlers brought other apples and pears, in addition to Kentish cherries. It is probable, also, that some of these early fruits were introduced by the Acadian French. We still find on the island a few of the old French orchards of apples and cherries. Cherries have been cultivated-in fact, they have taken care of themselves - with success since the time of their first introduction. They belong to the Kentish type, and ripen in that locality a month later than do the same varieties grown in eastern Ontario. Black-knot has lately appeared, but is being attended to. Apple-growing is on the increase. The better practices in fruit-growing are being introduced; a few large orchards are already established and are bearing satisfactorily. The climate has an important effect upon the keeping properties of apples and pears. Such late-maturing varieties as Ben Davis, Stark, and Missouri Pippin do not, as a rule, attain full size and perfection. The autumn and early winter apples of the west are the most suitable varieties. Of these are Ribston, Blenheim Pippin, Hubbardston and Grimes Golden. The same is true of pears. The early and midseason varieties do best. Clapp, Bartlett, Howell, and Anjou are doing well. Among plums, Moore's Aretic, Early Damson and Lombard are favorites. Peaches cannot be grown successfully unless artificially protected during winter.

Small-fruits are grown successfully in all parts of the island. The most important of these is the cranberry. The area devoted to this fruit is extending rapidly. The product is shipped to England. There is undoubtedly a future for fruit-growing on this island, with its natura under-drainage in many parts, its equable climate, and its proximity to the European market.

Nova Scotia and Cape Breton. - The Dominion owes very much to this province for the good pioneer work done in advertising the fruit-growing capabilities of Canada in the European markets. The best advertisement that could be given by any country was afforded by the magnificent display of fruit made by the Province of Nova Scotia through its Fruit Growers' Association at the Indian and Intercolonial exhibition in London in 1886. As early as the middle of the last century, the Acadian French, who then peopled Kings and Annapolis counties, cultivated apples and pears with great success. When these lands fell into the hands of Connecticut and English immigrants in 1760 , old pear and apple trees were found in many places; some of the latter exist at the present day. It must not be supposed that the apple growing of Nova Scotia is restricted to the Annapolis valley. This valley is only one of several, and the contiguous fertile valleys of the Cornwallis and Gaspereaux rivers are equally well adapted and equally productive. The protection afforded in this, the best fruit section of 
the province, by the low parallel lines of hills, known as the north and south mountain ranges, is important and valuable as windbreaks. The numerous bays and inlets assist in equalizing temperatures, and exercise a marked influence upon the longevity of the apple tree in this region. The soil consists of sand, sandy loam and clay, overlaying sandstone formation. The enormous rise and fall of the tides have produced extensive deposits constituting the present marsh and dyked lands. These marsh lands serve the purpose of supplying an abundant annual supply of herbage, in addition to yielding an inexhaustible store of cheap, natural fertilizer, used by fruit-growers with great advantage upon the upland orchard areas. Figs. $342,343$.

Fruit Regions and F'ruits.-Kentville, Wolfville, and Berwick are important fruit producing centers. Here are found many of the old English types of apples, such as Golden Pippin and Devonshire Quarrenden. Good apples are grown in nearly all parts of the province, but the valleys already mentioned contain the major portion of the bearing orchards. The total orchard area is estimated at 80,000 acres, and is rapidly increasing. Pears have long been cultivated, but the industry has not grown like the apple. Plums are widely cultivated. Domesticas and Japans do well; Moore's Arctic is the favorite of the former class and Burbank of the latter.

The export of apples to Britain began in 1875, and has been steadily on the increase since that time. The mar ketable crop of apples in 1896 amounted to 500,000 barrels, nearly all exported to Britain. The characteris tic apple of the province is Gravenstein. This, with Ribston Pippin, was imported from England by Hon. Charles Ramage Prescott, between 1830 and 1835. Col. John Burbidge introduced the Nonpareil Russet. Doctor Inglis, the first bishop of Nova Scotia, introduced Yellow Bellefleur to the Annapolis valley, where it is now known by the name of Bishop's Pippin.

The cranberry industry is developing rapidly. In 1890 the output from the cultivated bogs amounted to 400 barrels; in 1898 it had nearly reached 4,000 barrels. The varieties cultivated are selected from the wild marshes.

The fruit-growers of the province are intelligent and energetic. The Provincial Fruit-growers' Association, the oldest in the Dominion, assists in maintaining a horticultural school, which was established at Wolfville and is affiliated with Acadia College.

The fruit-growing industry in Cape Breton is yet in its infancy. The climate and soil resemble that of Prince Edward Island, and practically the same class of fruits are being tested.

NEW BRUNSwICK. - The climate of this province favors a mixed husbandry. Wild raspberries, strawberries, blueberries and cranberries grow in wild profusion, and have to some extent hindered the growing of culti vated forms. Apples may be grown successfully for home use in nearly all parts. Commercial orchards are now

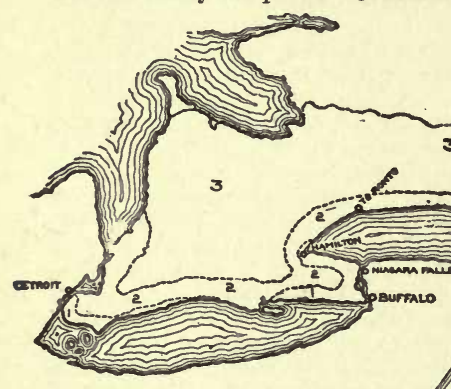

342. Ontario, Quebec and Nova Scotia.

1, 1, peach and grape regions; 2 , mixed fruit zone; 3 general a criculture, and apples. Nova Scotia: 1, plums, pears, apples; 2, apples.

being planted in the valley of the St. John river, at and about Woodstock. Damson and Moore's Arctic plums are grown to a considerable extent. A few growers have found it profitable to protect their plum trees in winter by planting them in such a manner as admits of the trees being reclined on the ground in the autumn.
The snowfall is heavy, and is a sufficient protection. Thomas A. Sharpe, of Woodstock, is a pioneer in this work. Of apples, the following varieties have been most successful in the St. John river valley: Duchess, Wealthy, Fameuse, Pewaukee, Longfield, and Scott's Winter. The small-fruit harvest is a week later than in Nova Scotia. New Brunswickers are therefore enabled to place their berries upon the Boston market at a time when competition from other quarters is light in these classes of fruits. Native raspberries and wild cranberries (Vaccinium Vitis-Idcea) are gathered and shipped in large quantities to Boston. V.Vitis-Idoea is commonly known in New Brunswick as Wolfberry or Lowbush Cranberry. In the past, lumbering, fishing and mining have absorbed much attention in New Brunswick, but fruit culture is constantly receiving increased attention. Bright minds are at work in the province. What to grow, and how to grow it, are questions receiving earnest attention.

QUEBEC.-The climatic conditions in eastern Quebec approach quite closely those obtaining in many parts of New Brunswick. We find the principal fruit areas lying south of that great artery of commerce, the St. Lawrence river. Here and there, not on the low clay flats, but on the higher middle elevations, with gravelly subsoil affording natural drainage, we find orchards made up of "La Belle Fameuse," Pomme Gris, and St. Laurent, truly Canadian and truly delicious apples. In the lower St. Lawrence region, especially on the north side, the keeping season of apples is very much extended-or rather, the ripening season is very much retarded. At Chicoutmi, on the Saguenay, Red Astrachan ripens about the end of September and Wealthy is late winter.

In L'Islet county, about 70 miles northeast of the city of Quebec, plum-growing has become a somewhat specialized industry during its evolution, which covers a period of a century and a quarter. Varieties of Reine Claude and of Orleans plums have originated, and are now peculiar to that district. Reine Claude de Montmorency is a fine flavored strain of the parent group. All plums grow in stocky form, with widely spreading branches, and are very productive. The trees are grown in sod, with little pruning and fertilizing. The marketing season extends from September 15 to October 15. Hardy forms of Kentish cherries have also been developed. The season is a month later than at Ottawa, Ont. Between Quebec and Montreal, along the St. Lawrence river, plums and apples are grown to a limited extent only. The heavy blue clay of the region between the Richelieu and St. Lawrence rivers is unsuited to the cultivation of fruits. A wild fruit which is being grown by the French habitant of the Richelieu and its tributaries is the choke cherry, Prunus Virginiana, Linn. The fruit is eaten raw, but is also made into jellies and conserves. A yellow variety is common to gardens in the vicinity of St. Hyacinth, Que. The Island of Montreal is undoubtedly the cradle of the fruit industry of the province. Here a truly intensive style of fruit-growing prevails. Apples,plums and pears are staples. Strawberries, gooseberries, and other small fruits are largely cultivated. Convenient market facilities, both at home and abroad, assist the fruit-grower. The hardier types of Prunus domestica, such as Damson and Orleans plums, succeed except in seasons of unusual severity, when their fruit buds fail. Japan plums have not yet been sufficiently tested on the island, with the exception of Burbank, which fruits uncertainly. So far as can be ascertained, the Island of Montreal is the home of the Fameuse and St. Lawrence, and possibly Pomme Gris. About the foothills of those curious outcroppings of the Vermont mountains that we find in the Richelieu valley and in the eastern townships-localities peopled by U. E. Loyalists - fruit-growing is a leading branch of rural labor. Beloeil, Rougemont and Abbotsford are well known to Quebec fruit-growers 
as leading fruit-growing centers of the province. The standard commercial apples of Ontario and New York, as Greening, Baldwin and Spy, do not succeed. Fameuse, Wealthy and Duchess, with Canada Baldwin and Winter St. Lawrence, do well, the latter two being natives of the Province, and much appreciated. The fruit area along the New York boundary line is rapidly extending. Apples and plums are staples, while pears and grapes are grown for home use. The earlier varieties of grapes only are grown. Concord does not ripen with certainty every year. Delaware, Lady and Moore's Early are generally reliable in this western region.

Gibbland Farm. once the home of Charles Gibb (deceased 1890 ), a prominent amateur fruit-grower and philanthropist, is located at Abbotsford, Que., and contains a large collection of Russian fruits. These fruits were widely distributed in Quebec through the efforts of Mr. Gibb. A few of the summer varieties have superseded older kinds. The only winter Russian apple which has become at all well known in Quebec is

Arabka of Ellwanger \& Barry. Longfield is also successful in eastern Quebec, where it keeps till midwinter. Unless carefully managed, this variety soon deteriorates by overbearing.

Montreal is the chief apple shipping port during September and October. Later in the year Ontario and Quebec apples go to Europe via Halifax, Portland or Boston. For a number of years past fruit-growers in the vicinity of Montreal have shipped Duchess and Alexander apples to Liverpool and Glasgow. The unsatisfactory feature about the commercial side of fruitgrowing in Quebec is the scarcity of good winter export apples. The old standards are not reliable and desirable substitutes have not been found. Canada Baldwin, Scott, Winter and Pewaukee are generally recommended.

ONTARIO. - From the standpoint of a fruit-grower, the province may be divided as follows :

1. An apple-growing region in the extreme east, on the north side of the St. Lawrence.

2. A pear, plum and apple-growing region between Toronto and Kingston, along the shore of Lake Ontario.

3. An extended and distinctively apple-growing area between Toronto on the south, Owen Sound on the north, Haliburton on the northeast, and Lake Huron on the west. [In the vicinity of Owen Sound, on the south shore of Georgian Bay, plums of $P$. domestica class are extensively cultivated. $]$

4. A peach, grape, pear, plum and small-fruit region in the Niagara peninsula, between the overlapping ends of Lakes Erie and Ontario. 1, Fig. 342.

5. A peninsula in the west, between Lakes St. Clair and Erie-an area where fruits similar to those noted in the last are cultivated. Pelee Island, in Lake Erie, might be included in this fruit zone. 1, Fig. 342.

Historical.-Along the banks of the Detroit river, in the extreme southwest, are gigantic pear trees. These are from seed planted probably by French missionaries. One of the oldest trees is said to date from 1705. These trees are productive, but the fruit is not valuable. The planting of apple orchards began in this region about the year 1784. 'The planting of vineyards, for which the region is noted, dates back about 40 years. The Niagara Peninsula was settled somewhat later than the Essex region. Here, between 1780-90, the United Empire Loyalists received grants of land from King George, and planted seeds of apples brought from their homes in the United States. Here we are told that John Smith, in the early part of this century, offered to sell his claim to 200 acres of land for a cow, but found no buyer. This land is now valued at from $\$ 300$ to $\$ 500$ per acre. The improvement of native fruits began in 1830 by the in. troduction of foreign varieties, and by the establishment of home nurseries.

Commercial and statistical. - The peach industry of 
MaNitoba aND THE Northwest TerRItories.-As far as the tree fruits are concerned, those which can be grown successfully in these regions without extraordinary care have yet to be produced. A few Russian apples and Siberian crabs have survived and have produced some fruit in southeastern Manitoba. Pyrus baccata (the berried crab of Europe) is hardy at the Dom. Experiment Stations at Brandon, Man., and Indian Head, N. W. Terr. This has been crossed with the hardiest Russian apples in the hope that the resultant seedlings, of which there are now many thousands, will prove hardy in tree, and produce fruit of edible size.

With the protection afforded by belts of timber, small fruits of nearly all kinds-grapes, however, being a nosuccess. The natural obstacles are appreciably less in Manitoba than in the Provinces of Assiniboia, Alberta and Saskatchewan, where late spring frosts, high winds and periods of summer drought and severe winter cold make the cultivation of the hardiest fruits, such as gooseberries and currants, difficult and precarious. Native types of these fruits are cultivated. Juneberries are much appreciated. Without doubt the rancher and wheat grower of these northwest provinces will be dependent for his fruit supply upon Ontario and British Columbia for many years to come. The chief sources of horticultural information in this region are the Dominion experiment stations already referred to. table exception - are grown with a moderate degree of

procured from California, and in most cases all were found to be successful. Up to this time (between 1855 and 1860 ), most of the fruit was the produce of seedlings, the offspring of seeds procured from other countries, which being acclimatized, with a good climate, freedom of insect pests and diseases, produced wonderful crops without the trouble of cultivating, pruning and spraying. Now, however, fruit trees of a superior quality began to be imported, and for some time throve equally well as those of humbler origin, but by and by, for some unaccountable reason, the trees did not bear as well as formerly, nor was the fruit as good or as large as it used to be, and old-timers wondered what was the matter, and so things went on from bad to worse, until people of a new generation began to settle in the province, who soon ascertained the cause of failure to be due to the importation with the trees, from the neighboring states and provinces, of pests and diseases hitherto unknown in the province. It was then that the legislature enacted the Horticultural Board Act, which provides for the appointment of a "Board," whose duties are, inter alia, to inspect all fruit and fruit trees entering the province, and orchards within the province, and to make such recommendations in the interest of fruit-growers as they may deem necessary. It has followed, as a matter of course, that in consequence of the stringent regulations, a better class of nursery stock is now imported into the province, and although it is quite impossible, even with the strictest inspection, to detect all infestations, and although people have been slow in adopting even those measures best calculated for their benefit which have been recommended by the Board of Horticulture, there is a marked improvement in the state of the orchards of the prov-

ince, and of the fruit produced.

The young orchards planted out since the inauguration of the newer and more intelligent methods, are likewise coming into bearing. The production of fruit is even now in many lines in excess of local demands, and hence, in view of the line of action pursued by the Board of Horticulture, which now prevents this province from being the dumping ground for the refuse fruit of the neighboring states,

344. British Columbia. The fruit regions are between the parallel series of dotted lines.
British Columbia.- Fig. 344. I am indebted to J. R. Anderson, Deputy Minister of Agriculture for the province, for much of the following data. British Columbia is wonderfully diversified, and has great fruitgrowing possibilities in its deltas, its coast line, its valleys, its benches, its irrigated lands. Great climatic variation means a corresponding widening of the possibilities of fruit-culture, and there is here undoubtedly a more extended range of thermometric variation and atmospheric moisture than is found in any other province of the Dominion.

Historical.-Regarding the early history of fruitgrowing, and some of its later developments, Mr. Anderson writes as follows :

"It was soon discovered by the early settlers in and about the old Hudson's Bay Company's forts of Victoria and Langley, that apple trees would mature and bear fruit. There was, however, a deep-rooted belief that the greater part of the country would not produce fruit, or, indeed, for that matter, crops of any kind. However, gradually trials were made by adventurous spirits, miners, packers, and others (probably never by practical farmers or fruit-growers), and it gradually dawned upon the sparse population that apples and field crops would grow in most parts of the coast line of the province, and of that part known as the dry belt lying between the Coast Range and the Rocky mountains. Then it appeared to occur to the residents that other fruits might do, and thereupon trees and plants were it may reasonably be concluded that the imports of fruits will be restricted in the future to those early fruits which mature in the south, or to the production of the antipodes at a time when those of this country are not in season.

Fruits. "The principal fruits produced in the province are apples, pears, cherries, plums, prunes, and all the small fruits. Other fruits, such as peaches and grapes, have not been produced in sufficient quantities to meet the demand, those like the first named having been at first considered unsuitable to the country, but are now found to do excellently in many parts."

Fruit Sections. - Some of the best fruit lands are to be found along the mountains and foothills on either side of the numerous valleys of the province. This is particularly true of the region along the Fraser river between Chilliwack and Hope. The region along the Fraser river from Agassiz to the coast is one abundantly supplied with water and now producing large quantities of plums, apples and berries. Some of the interior valleys are eminently adapted to the requirements of the tenderest tree fruits. Peaches are being successfully cultivated here and there on the lower bench lands. The accompanying map shows the principal fruit-producing areas of the province. At Vernon, in the Okanagan valley, the Earl of Aberdeen, a late governor-general of Canada, has an extensive orchard of 200 acres. Here an irrigation plant, while not deemed absolutely essential to fruit-growing, is thought to be a 
desirable adjunct. This valley is producing apples, pears and plums of good quality.

IIarkets. - "The exportation of fresh fruit to the Northwest Territory and Manitoba, which is the natural mar-

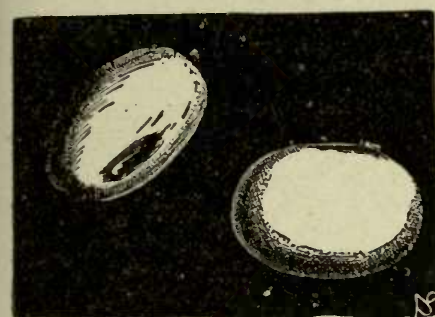

345. Seeds of Canavalia ensiformis. Full size. ket of the province, is assuming large proportions, more especially in plums, for which British Columbia is specially noted. The markets of the Orient and Australia will in the near future also be outlets for the surplus fruits of the country. Canneries and fruit - preserving establishments of various kinds also afford means of disposing of some of the surplus fruits which are not in a condition to be exported. The high price of labor, and the competition which has to be met, in the matter of the cheap jams and other products, adulterated with foreign substances and glucose, which come from the east and California, are, however, very serious factors which militate against the success of such establishments."

Pests.-Most of the pests which have caused such serious loss to the orchardists of other countries have made their appearance in the province, but, thanks to the efforts made for their suppression, the codlin moth and curculio are notable exceptions.

Climate.-The climate of the coast is most equable. The temperature seldom falls to zero nor rises above $75^{\circ}$ or $80^{5}$. In the interior the variations are naturally greater, but even there, in the coldest part of the winter, the temperature does not long remain at or below zero. On the coast, the precipitation is almost entirely in the form of rain, which is sufficient for the most

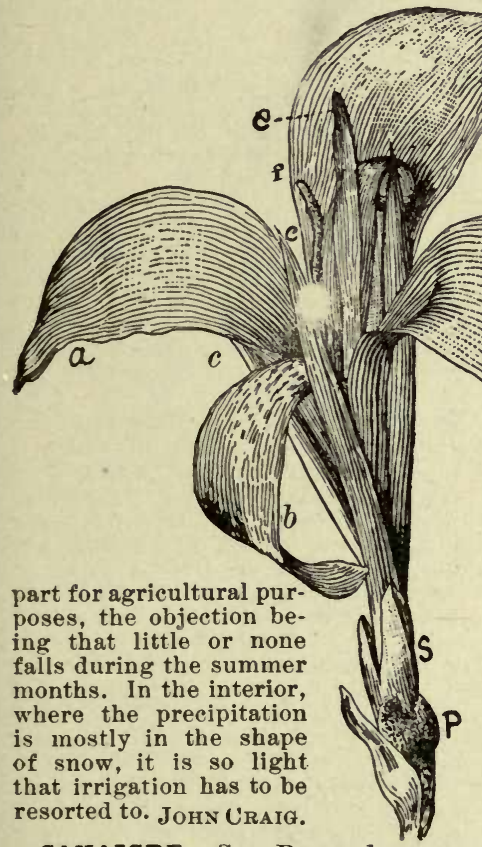

346. The parts of the Canna flower. (See Canna, p. 238.)
CANAIGRE. See Rumex hymenosepalus.

CANARINA (from the Canary Islands). Campanuldceo. Three species of tropical herbs closely allied to Campanula, but with the tubes of the calyx and corolla grown together, and the floral parts in 6's. C. campanulata, Linn., is a tender plant from the Canaries, with drooping, inflated buds and solitary, bell-shaped fls. more than $1 \mathrm{in}$. long and $1 \frac{1}{2} \mathrm{in}$. wide, dull yellow, flushed and reined with dull purplish brown. Lrs. hastate. B.M. 444. - Not in the Amer. trade.

\section{CANARY-BIRD FLOWER is a Tropoolum.}

\section{CANARY GRASS is a Phalaris.}

CANAVALIA (an aboriginal name). Leguminosa.. Trailing or twining herbs: fls. in axillary racemes, with bell-shaped, 2-lipped calyx, papilionaceous corolla, 9 stamens united and 1 free for most of its length : pods large and ribbed on edges. Several species, widely distributed in warm countries.

ensiformis, DC. (C. gladidta, DC.). JACK BEAN. Chickasaw Lima. Figs. 197, 345. Grown in the southern states for stock, but the pods make passable snap beans when not more than 4 or 6 in. long. In warm countries it is a bushy plant, with little tendency to climb. The pods reach a length of $10-14$ in., the walls being very hard and dense when ripe. The halves of the pod, when split apart, roll up spirally, often into an almost perfect cylinder. The large white,

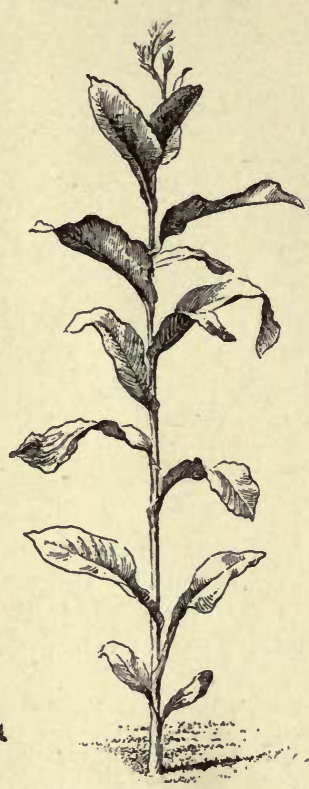

347. Old-time Canna.

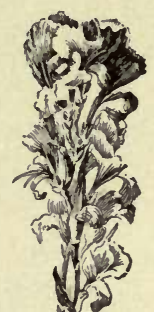

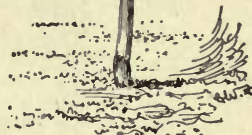

348. Modern flowering Canna.

turgid beans, bearing a very prominent brown seedscar, are packed crosswise the pod, imbedded in a very thin white, papery lining. The flowers are small and light purple, resembling those of the Cow-pea (though larger) and of various species of Dolichos. The leaflets are 3 , large and broad (5-8 in. long and half or three-fifths as broad), strongly veined and dull, dark green, abruptly pointed and smooth. Tropics. A.G. 14:84. B.M.4027.Beans said to be used as a coffee substitute. L. H. B.

CANDLEBERRY, CANDLENUT. See Aleurites.

CANDYTUFT. See Iberis.

CANE-BRAKE. Species of Arundinaria (treated under Bamboo).

\section{CANISTRUM. See Echmea.}

CÁNNA (name of oriental origin, of no application). Scitamindcece. Stout, unbranched, large-leaved tropical and warm-temperate herbs of both hemispheres, with large and ornamental foliage. Fls. mostly red or yellow, 
in a terminal raceme or panicle, very irregular : capsule 3-loculed and several-many-seeded (p, Fig. 346); sepals, $s, 3$ and small and usually green ; petals $3, c c c$, mostly narrow and pointed, green or colored; style single and long, $e$; the stamens are represented by petal-like, oblanceolate bodies or staminodia, $a a a b, 2$ or 3 of which are usually much produced and broadened, and one is deflexed and narrower and forms the lip of the flower, $b$; the pollen is borne in a single-loculed anther, $f$, borne on the side of a narrow and more or less coiled staminodium.

A generation ago, Cannas were grown for their foliage or mass-effect. They were tall and longjointed, with small and late flowers (Fig. 347). The parent of the old-time garden race of tal Cannas was $C$. Anncei, raised by M. Année, of France, from seeds of $\mathrm{C}$. $\mathrm{Ne}$ palensis, sown in 1848. The flowers from which the seeds were taken probably had been pollinated by some other species, most likely with $C$. glauca. In 1863 , a new race appeared, as the result of the union of $C$. iridiflora with $C$. Warscewicaii. This hybrid was known as $C$. Ehemanni (and $C$. iridiflora hybrida). This was of intermediate stature, with showy foliage and better drooping flow-

ers. Under this name plants are still sold, but the may not be identical with the original $C$. Ehe manni. This race has been variously crossed with other species and forms, and from innumerable seedlings there have been selected the dwarf and large-flowered Cannas (Figs. 348, 349), which have now practically driven out the old, tall, smallflowered forms. These dwarf Cannas are often known as French Cannas, from the country of their origin ; also, as Crozy Cannas, from the most renowned breeder of them. Within recent years, another race of Cannas has arisen from the amalgamation of our native Canna flaccida with the garden forms and with $C$. iridiflora. These have come mostly from Italy and are known as Italian Cannas; also, as orchid-flowered Cannas. The flowers are characterized by soft and flowing iris-like outlines, but they are short-lived. Of this class are the varieties Italia (Fig. 350), Austria, Bavaria, Burgundia, America, Pandora, Burbank and others. For a sketch of the evolution of the garden Cannas, see J. G. Baker, Journ. Roy. Hort. Soc., Jan., 1894; also, Bailey, Plant-Breeding, 140 ; also, particu larly for the history of the Italian race, Revue Horticole, 1895, 516, and Gardeners' Chronicle, Dec. 14, 1895 .

The culture of Cannas is simple and easy. They demand a warm, friable, rich and moist soil. They are injured by frost, and therefore should not be planted out until the weather is thoroughly settled. For mass effects, set the plants not more than 1 foot apart each way; but if it is desired to show individual plants and their flowers at the best, give three times that amount of room to a single plant. Pick the flowers as soon as they wilt, to prevent the formation of seeds (which causes the plant to lessen flowering), and keep the plants in fidy condition. If the best plants are desired, give the soil and treatment which produce the best results with Indian corn.

New varieties are raised from seeds. The seeds úsually germinate slowly, and sometimes not at all, unless the hard integument is cut or filed, or is softened by soaking in water; these precautions taken, they germinate quickly. Sow late in winter, in rather strong bottom heat, either in flats or pots. Prick out, and give plenty of room as they grow. Commonly, Cannas are propagated by dividing the rootstock. This rootstock is a branchy mass, with many large buds. If stock is not abundant, as many plants may be made from a rootstock as there are buds, although the weak buds produce weak plants. Leave as much tissue as possible with each bud. These 1-bud parts usually give best re- sults if started in pots, so that the plant is 6-12 in. high at planting time. The commercial Canna plants are grown mostly in pots. If one has sufficient roots, however, it is better not to cut so close, but to leave several strong buds on each piece (as shown in Fig. 351). These pieces may be planted directly in the ground, although more certain results are to be secured by starting them in the house in boxes or pots. If strong effects are desired, particularly in shrub borders, it is well to plant the entire stool. In the fall, when the plants are killed by frost and the tops have dried a few days, dig the roots, and let them dry as if they were potatoes. Then store them on shelves in a cellar which will keep Irish or round potatoes well. Take care that the roots do not become too warm, particularly before cold weather sets in; nor too moist. Well cured roots from well matured plants usually keep without difficulty.

Cannas are commonly used only in formal beds, but most excellent effects may be secured by scattering them singly or in very small clumps in the hardy border or amongst shrubbery. Against a heavy background of green, the gaudy flowers show to their best, and the ragged effect of the dying
flowers is not noticed. They also make excellent center-pieces for formal beds. The tall-growing Cannas, with small and late flowers, have given way almost wholly to the modern race of Crozy or French dwarf Cannas, which usually remain under $4 \mathrm{ft}$. high, and give an
bundance of large early flowers. The Canna alabundance of large early flowers. The Canna al-
ways must be used for bold planting effects, because the flowers have not sufficient durability to be useful as cut flowers. As individual blooms, the flowers are not usually attractive, but they are showy and interesting in the mass and at a distance. The new race of Italian or Flaccida Cannas has more attractive flowers, but even these are most useful when on the plant. Of varieties there are legion, and many new ones are imported each year, chiefly from France; and there are so many new aspirants each year that it is not worth while to enumerate varieties in a cyclopedia.

The garden Cannas are now so much varied and inter-bred that it is no longer possible to classify them by the characters of the species. One of the best classificatory schemes is the following (adapted from G. C. III. 14: 432) :

I. Tall varieties.

A. Foliage green

B. Self-colored varieties.

c. Minor flower-segments narrow.

cc. Minor flower-segments broad.

BB. Bicolor forms, in which the lip is of a different color from the other segments. Divided into $\mathrm{C}$ and $\mathrm{Cc}$, as above.

BвB. Spotted varieties. Including $\mathrm{C}$ and $\mathrm{CC}$, as above.

вввв. Blotehed varieties. Including $\mathrm{C}$ and $\mathrm{CC}$. ВвВвВ. Margined varieties. Including $\mathrm{C}$ and $\mathrm{Co}$. AA. Foliage purple. Divisions as under A.

349. II. Dwarf varieties. Divisions as under I.

Flowering or To many of the garden forms and hybrids specific Latin names have been given; but the follow-

- Prince Ing synopsis (adapted from Baker's "Synopsis of the Species of Cannas," in G.C. III. 13: 42, 70, 164, 196) gives a general view of the original species. The names here accounted for are : aurantiaca, 14; aureovittata, 4; carnea, 15 ; cinnabarina, 6 ; coccinea, 6 ; commutata, 14; compacta, 13 ; crocea, 14 ; densifolia, 5 ; denudata, 20; discolor, 19; divaricata, 20 ; edulis, $S$; Ehrenbergii, 5 ; esculenta, 9 ; excelsa, 20 ; exigna, 5 ; Fintelmanni, 3 ; flaccida, 21 ; flavescens, 5 ; floribunda, 4 ; formosa, 6 ; fulgida, 6 ; gigantea, 7 ; glauca, 10 ; heliconirefolia, 11; humilis, 5; Indica, 1; iridiflora, 22 , 
lotu, 4; Lagunensis, 14; Lamberti, 2 ; lanuginosa, 12 ; latifolia, 7 ; leptocheila, 16 ; leucocarpa, 14 ; liliitiora, 23 ; limbata, 4 ; longifolia, 10 ; lutea, 14 ; macrocarpa, 14; macrophylla. 7; maculata, 14; Mexicuna, 10; Moritziana, 14 ; Nepalensis, 16 ; occidentalis, 4 ; orientalis, 5 ; pallida, 14 ; paniculata, 20 ; patens, 4 ; pedunculata, 8 ; polyclada, 17 ; polymorpha, 16 ; Portoricensis, 6 ; pulchra, 5 ; recurvata, 4 ; Reevesii, 21 ; Roscoeana, 14; rubra, 6; saturate-rubra, 4 ; Schlechtenduhlianu, 3 ; Sellowii, 4; speciosa, 16 ; spectabilis, 4 ; stolonifera, 10 ; sulphurea, 14 ; Surinamensis, 6 ; sylvestris, 6 ; Texensis, 4 ; Tinei, 14 ; variabilis, 15 ; variegata, 4; ventricosa, 4 ; vitellina, 14 ; Warscewiczii, 18.

A. Eucanna. - Corolla lobes and staminodia united into a short tube: two or three of the upper staminodia petal-like.

B. Three upper staminodia petallike.

c. Lis. of ordinury consistency or thickness.

$$
\text { D. Lip entire. }
$$

1. Indica, Linn. INDIAN Sнот. Stem slender, glabrous, green, $3-5 \mathrm{ft}$.: Ivs. oblong and acute, green, half as broad as long (1 ft. long): racemes simple and lax, some of the fls. in pairs, the bracts green and nearly orbicular: fls. small ; sepals oblon: and green, $1 / 4$ in. long; petals lanceolate, pale green, about $11 / 2$ in. long; 3 upper staminodia bright red, entire, 2 in. long but narrow ; lip linear, red-yellow, spotted with red; capsule globose, 1 in. in diam. W. Indies and Guiana.

2. Lámberti, Lindl. Stem stout, green and glabrous, 12-14 ft.: lvs. oblong, green, acute: raceme simple or forked, lax and few-fld., the bracts large and oblong, green : sepals lanceolate, pale green, $1 / 2 \mathrm{in}$. long; petals lanceolate, 2 in. long, reddish; staminodia entire, scarcely longer than the petals, bright crimson; lip bright erimson: capsule oblong, large. W. Ind., S. Amer.

3. Fíntelmanni, Bouché. Stem green and glaucous, 4-5 ft.: lvs. oblong and acute, green and glaucous : raceme few-fld. and lax, the bracts green and oblong: sepals oblong, $1 / 3$ in., green; petals lanceolate, pale green, $1 \frac{1}{2}$ in.; staminodia obtuse and entire, 2-3 in., yellow; lip oblanceolate, yellow, mottled red : capsule large. Trop. Amer. sibly a hybrid of $C$. glauca and $C$. Indica. $C$. Schlechtendahlidna, Bouché, is similar, but has the staminodia spotted red.

\section{DD. Lip emarginate.}

4. pàtens, Roscoe. Stem slender, green and glabrous, 4-5 ft.: lvs. oblong and acute, green, the lower $1 \mathrm{ft}$. long: raceme few-fld., simple and lax, the bracts orbicular and green, the fls. single or in pairs : fls. small ; petals lanceolate, pale green, about $1 \frac{1}{2}$ in. long; upper staminodia bright red, entire, 2 in. long, and narrow; lip bright red-yellow, with minute red dots: capsule globose, 1 in. in diam. Trop. Amer. B.M. 454 as C. Indica.

Var. limbata, Baker (C. limbata, Roscoe, $C$. aureo-vittdta, Lodd.). Upper staminodia bright red, with a border of bright yellow.-To $C$. patens Baker would refer the following: $C$. floribunda, lata, recurvata, saturaterubra, Sellowii, spectabilis, Texensis, variegata and ventricosa of Bouché. C. occidentalis, Roscoe, has only 2 staminodia, petal-like.

5. orientàlis, Roscoe. Stem slender, glabrous, 3-4 ft.: lvs. oblong-lanceolate, a foot or more long : raceme lax, simple or forked, the bracts oblong: sepals oblonglanceolate, green, $1 / 2 \mathrm{in}$. or less long; petals lanceolate, greenish, 11/2in. long; upper staminodia $2 \frac{1}{2} \mathrm{in}$. or less long, bright red, often emarginate; lip red-yellow: capsule globose and very small. Old World tropies.
Var. flavéscens, Baker (C. flavéscens, Link). Upper staminodia and the lip entirely yellow. - With $C$. orientalis probably belong $C$. densifolia, Ehrenbergii, exigua, humilis and pulchru of Bouché.

6. coccínea, Miller (C. rìbra, Willd.). Stem slender, green, 4-6 ft.: lvs. longer than those of $C$. Indica, oblong and acute: raceme simple and lax, with small, green, orbicular bracts: sepals lanceolate, $1 / 2 \mathrm{in}$. or less long, tinged with red; petals lanceolate, $1 \frac{1}{2}$ in. long, tinged with red; staminodia 2 in. lon'g and narrow, often enarginate; lip. red-yellow: capsule globose and small. Trop. Amer.-To this species Baker would refer C. cinnabarina, formosa, fulgida, Portoricensis and Surinamensis of Bouché.

Var. sylvéstris, Baker (C'. sylvéstris, Roscoe). Staminodia longer, plain deep crimson, that and the lip with a long claw. Trop. Amer.

7. latifolia, Miller (C. $g i$ gantèa, DC. C. macrophýlla, Bouché). Stem stout and pubescent, 10-16 ft.: lvs. oblong. and acute, green, the lower ones often 3-4 ft. long: fls. in several racemes forming a. panicle, the bracts oblong or the lower ones becoming several inches long; sepals oblong and green, $1 / 2$ in. long; petals lanceolate, 2 in. long, tinged with red; staminodia 3 in. or less long, entire or emarginate, bright red ; lip bright. red: capsule large. S. Amer. B.M. 2316.

8. pedunculàta, Sims. Stem slender, green and glaucous,
glabrous, 5-6 ft.: Ivs. oblong-
lanceolate, green and glauslender, green and glaucous,
glabrous, 5-6 ft.: Ivs. oblong-
lanceolate, green and glauslender, green and glaucous,
glabrous, 5-6 ft.: Ivs. oblong-
lanceolate, green and glaumany-fld. lax raceme, with a hairy rachis and long-spreading pedicels, the bracts small, oblong and obtuse; sepals oblong, small and green; petals lanceolate, green, reflexed, 1 in. long; staminodia emarginate, about 1 in. long, pale. yellow; lip oblanceolate, plain yellow : capsule globose, small. S. Brazil. B.M. 2323.-Probably not in cult.

9. édulis, Ker. (C. esculénta, Lodd.). Rootstock thick and edible: stem stout, 8-12 ft., purple: lvs.. oblong, green or bronze, 1-2 ft. long : raceme lax, forked or simple: fls. usually in pairs; bracts or-. bicular or oblong; sepals oblong-lanceolate, $1 / 2 \mathrm{in}$. long, tinged with red; petals lanceolate, 11/2-2: in.; staminodia entire or emarginate, $2 \frac{1}{2} \mathrm{in}$. long, bright red or orange; lip bright red or yellow-red: capsule large. Trop. Amer. B.M. 2498. - Starch is procured from the roots, and for this purpose the plant is widely cult. in the tropics.

10. glaùca, Linn. Stem green and glaucous, 5-6 . ft.: lvs. green and glaucois, oblong-lanceolate and very acute, tapering both ways (the middle of the blade about 4 in. wide): raceme lax, simple or forked: sepals lanceolate, green, $1 / 2 \mathrm{in}$. long; petals lanceolate, yellow-green, $1 \frac{1}{2}-2$ in.; staminodia entire, $21 / 2-3$ in., yellow, not spotted; lip linear, emar350. ginate, pale yellow: capsule oblong, $1 \frac{1}{2}-2$ in. long. stolonifera of Bouché belong here.

$$
\text { cc. Ivs. thin and papery. }
$$

11. heliconiæfolia, Bouché. Stem 6-8 ft.: lvs. oblong, green, 2-3 ft. long (resembling those of Heliconia): fls. in a panicle formed of several lax racemes; sepals lanceolate, $1 / 2 \mathrm{in}$. long; petals lanceolate, $1 / 2 \mathrm{in}$. long, colored; staminodia not much longer than the petals, scarlet; lip scarlet: capsule ellipsoidal, large. Mex.

\section{BB. Two upper staminodia petal-like.}

$$
\text { c. Stem voolly-pubescent. }
$$

12. lanugindsa, Roscoe. Stem green, woolly, 4-6 ft.: lvs. oblong, acute, green : raceme lax, few-fld, simple. 
or forked, the bracts obtuse, small and green : sepals lanceolate, green, $1 / 2 \mathrm{in}$. or less long; petals lanceolate, $11 / 2$ in. long, tinged with red; staminodia entire, red or red-yellow; lip the same color, oblanceolate and emarginate. Brazil.

\section{Cc. Stem glabrous. \\ D. Leaves green.}

13. compácta, Roscoe. Stem stout and green : lvs. broad, oblong and acute : raceme simple and many-fld., dense: sepals lanceolate, 1/2in. long; petals unequal, lanceolate, $1 \frac{1}{2}$ in. long, red-yellow ; staminodia slightly emarginate, $1 \frac{1}{2}-2$ in. long, bright crimson ; lip emarginate, red-yellow. Trop. Amer.

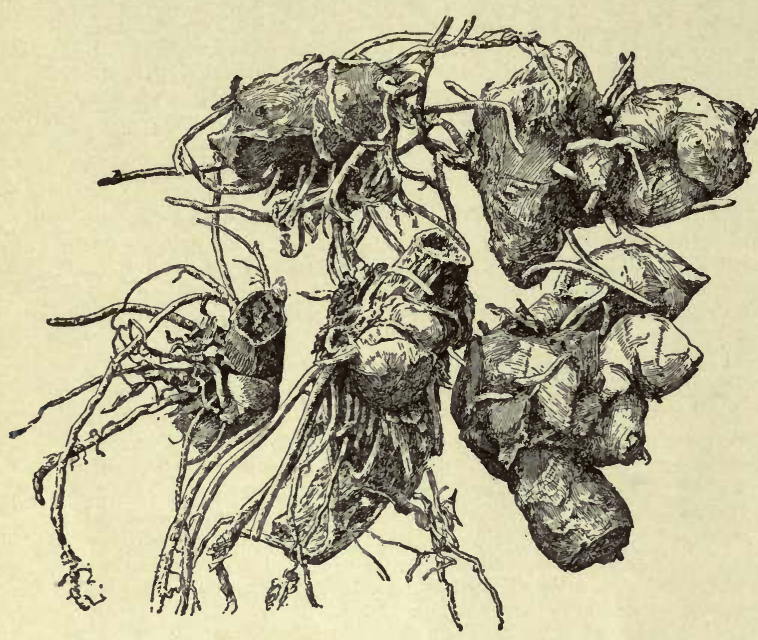

351. Stool of Canna, showing how it may be divided.

14. Iùtea, Miller. Stem slender and green, 3-4 ft.: lvs. oblong and acute : raceme lax, simple or forked, the small green bracts oblong and obtuse: sepals greenish, oblong, 1/3in.; petals lanceolate, pale green, 1-11/4 in. long; staminodia pale yellow, often emarginate, $1 \frac{1}{2-2}$ in. long; lip linear, pale yellow, emarginate. Trop. Amer.

Var. pállida, Roscoe. Staminodia and lip pale yellow, spotted red.

Var. aurantiaca, Roscoe (C. Tinei, Todaro). Petals tinged red; staminodia red-yellow; lip red-yellow and red-spotted. - To $C$. lutea are to be referred $C$. commutata, leucocarpa, Moritziana, and Roscoeana, of Bouché; $C$. crocea, Lag.; C. Lagunensis, Lindl.; C. maculata, Link ; C. macrocarpa, sulphurea and vitellina, of Horaninow.

15. variábilis, Willd.(C. cárnea, Roscoe). Stem green, 3-4 ft.: lvs. oblong and acute : raceme simple and lax, the small bracts oblong and obtuse : sepals lanceolate, green, 1/2in. long; petals lanceolate, 11/2 in. long, pale green; staminodia pale red, entire; lip linear and entire. Brazil.

16. speciosa, Roseoe (C. leptocheila and polymórpha, Bouché ). Stem green, 5-6 ft.: lvs. broad-oblong, acute: fls. in a deeply forked, long-branched panicle; sepals lanceolate, $3 / 4 \mathrm{in}$. long, pale red ; petals lanceolate, 2 in. long, pale red ; staminodia 3 in.long, emarginate, bright red; lip emarginate, bright red-yellow. Himalayas. B.M. 2317.-C.Nepalénsis, Wall., has 3 upper staminodia.

DD. Lvs. bronze or brown, at least on the margins.

17. polyclàda, Wawra. Stem tall and slender: lvs. oblong and acute, base rounded, brown-edged: fls. (often in pairs) in a long, much-branched panicle, the bracts nearly orbicular; sepals lanceolate, $1 / 2 \mathrm{in}$. long; petals lanceolate and unequal, the longest 2 in., tinged red; staminodia acute, not longer than the petals, bright crimson; lip oblanceolate, the claw yellow-spotted, the limb bright crimson. Brazil.
18. Warscewíczii, Dietr. Stem claret-purple and glaucous, 3-4 ft.: lrs. oblong and acute, more or less claret- or bronze-tinged: raceme simple and rather dense, with ovate, brown, glaucous bracts : sepals lanceoblong, $1 / 2$ in., glaucous ; petals lanceolate, 2 in. long, reddish and glaucous ; staminodia (sometimes 3 ) entire or nearly so, $2 \frac{1}{2}-3$ in. long. bright scarlet; lip oblanceolate, emarginate, bright scarlet. Costa Rica. B. M. 4854 .

19. díscolor, Lindl. Stem stout, 6-10 ft., purple and glaucous : lvs, broad-oblong, acute, brown-tinted, the lower ones sometimes $3 \mathrm{ft}$. long: $\mathrm{fls}$. in a deeply forked panicle of lax racemes, the bracts small and orbicular; sepals lanceolate, $1 / 2 \mathrm{in}$. long, green; petals lanceolate, $11 / 2$ in. long, pale green ; staminodia entire, $21 / 2$ in. long, bright red; lip lanceolate and emarginate, brick-red. Trop. Amer.

\section{AA. Distemon.-Corolla tube short: upper stami-} nodia suppressed.

20. paniculàta, Ruiz \& Pav. (C. denudàta, Roscoe $C$. excélsa, Lodd. $C$. divaricata, Klotsch). Stem tall and slender, glabrous : lvs. oblong and acute, green and glabrous: racemes lax, disposed in a large panicle; sepals lanceolate, $1 / 2 \mathrm{in}$. long ; petals lanceolate, yellowgreen, 2-3 in. long; lip rather longer than the petals, erimson. S. Brazil.

AAA. Eurystylus. - Corolla tube 2-21/2 in. long: 3 staminodia produced, clawed: lip orbicular.

21. fláccida, Salisb. ( $C$. Reèvesii, Lindl.). Stem green and glabrous, 4-5 ft., very leafy below : lvs. oblonglanceolate, green : raceme simple, lax and few-fld., the bracts very small : sepals lanceolate, 1 in. long, green ; corolla lobes lanceolate and reflexed, nearly as long as the tube ; 3 upper staminodia obovate, sulfur-yellow, $2-3$ in. long by 1 in. broad; lip large, yellow. Swamps, S. Car. to Fla., near the coast. L.B.C. $6: 562$. - Useful for its good habit and iris-like fls.

AAAA. ACHIRIDIA. - Tube of corolla and staminodia as long as the blade: fls. large and pendulous.

22. iridiflora, Ruiz \& Pav. Stem green, 6-10 ft.: Ivs. oblong, bright green, slightly pubescent beneath : racemes paniculate, drooping: sepals lanceolate, $i$ in. long, green : corolla lobes lanceolate, red-brown, 21/2in. long; 3 upper staminodia somewhat longer than the corolla lobes, obovate, nearly or quite 1 in. broad, rosecrimson ; lip narrow, deeply emarginate, rose-crimson. Andes of Peru. B.M. 1968. R.H. 1861: 110.

23. liliiflora, Warscew. Stem robust, green, 8-10 ft.: lvs. many, oblong, green, 3-4 ft. long, spreading from the stem at a right angle : fls. in a corymbose panicle ; sepals linear, as long as the tube of the corolla ; corolla lobes lanceolate, 2-3 in. long, pale green, the tube of equal length; 3 upper staminodia white, united into a tube for half their length, the blade obovate and spreading; lip oblanceolate, as long as the staminodia. Colombia. R. H. 1884: 132. F.S. 10: 1055-6. -A fine species. The white fls. finally become tinged with brown; lonicera-scented.

CANNABIS (the ancient Greek name). Urticacece. HEMP. A single species, probably native to central Asia, and now widely cult. as a fiber plant. Hemp is also grown oceasionally as an ornamental plant, being grown from seeds and treated as a half-hardy annual. It makes excellent screens in remote places. It thrives best in a rich, rather moist soil. C. sativa, Linn., is the only species, but various forms have received specific names. In gardens, the form known as $C$. gigantèa is commonest; this reaches a height of $10 \mathrm{ft}$. and more. The seeds are usually sown where the plants are to stand; but if quick effects are wanted, they may be started indoors in pots or boxes. Hemp is diøcious. The staminate fls. are in axillary panicles, and have 5 sepals and 5 drooping stamens. The pistillate fls. are in short spikes, with 1 sepal folding about the ovary. Lvs. digitate, with 5-7 nearly linear, coarse-toothed leaflets. The plant is annual, roughish and strong-smelling.

L. H. B. 
CÁNTUA (from Cantu, Peruvian name). Polemonidcea. Ten species of South American flowering shrubs with very variable foliage and showy, tubular fis. of var.ous colors. C. buxifolia is cult. out of doors in S. Calif., and is recommended in Europe as a coolhouse shrub. Probably no tenderer than Fuchsias. Prop. by cuttings.

buxifolia, Lam. (C. depéndens, Pers.). Much branched shrub, about $4 \mathrm{ft}$. high ; branches more or less downy: Ivs. very variable, generally oblong-obovate, acute, tapering at the base, entire or serrate, downy or glabrous : fis. $\bar{y}-8$, drooping vertically, in a kind of leafy, terminal corymb; calyx pale, membranous, green-streaked, 5-toothed, a fourth shorter than the corolla tube; corolla long-funnel-shaped, the tube $2 \frac{1}{2} \mathrm{in}$. long, red, usually streaked ; limb of fringed, obcordate, crimson lobes: stamens included. Peru. B.M. 4582. F.S. 7:650. R.H. 1858 , p. 294. - One of the choicest of European greenhouse plants. Very liable to red spider in our climate.

C. bicolor, Lem. Distinguished from the above by the entire Ivs., which are shorter, about 1 in. long, and the solitary fls., with 8 short, yellow tube, the limb not fringed. The fls. droop, but not vertically. Peru. B.M. 4729. F.S. 4:343. Probably less desirable than the above. $-C$. pyrifòlia, Pers. Lvs. generally broader and more toothed than in C. bicolor: fls as many as 17 , in an erect, terminal, compound corymb; calyx red-tipped, nearly half as long as the yellow corolla tube ; corolla about nearly half as long as the yellow corolla tube; corolla about
$11 / 4$ in. long, with a white limb : stamens long, exserted. Peru. R.A. 4386. F.S. 4:383.

W. M.

CAPE BULBS. Treated under Bulbs.

CA P E CHESTNUT is Caloden. drum Capensis.

CAPE GOOSEBERRY is a Physalis.

CAPE JESSAMINE. See Gardenia.

CAPE PONDWEED. See Aponogeton.

CAPER. See Capparis. For Caper-spurge, see Euphorbia Lathyrus.

CÁPPARIS (Greek, caper). Caper-bUSh, or Caper Tree. Cappariddcece. Capers are pickles made by preserving the flower buds of $C$. spinosa, a straggling shrub which grows out of old walls, rocks, and rubbish in Mediterranean regions and India. Also rarely cult. as a greenhouse flowering shrub. The genus is large and polymorphic, and none of its relatires are familiar north. Prop. by cuttings in greenhouses, and by seeds south.

spinòsa, Linn. Spiny shrub, $3 \mathrm{ft}$. high : lvs. roundish or orate, deciduous : fls. borne singly, alternately, and fading before noon; sepals 4 ; petals 4, oblong, clawed, wavy, white, 11/2in, long: stamens 40-50: filaments purple above, perhaps the chief beauty of the plant. B.M. 291. - What seems to be the long style with a short, unopened stigma, is really the elongated peduncle or torus topped by

352. Capriola Dactylon. Nat. size. W. M.
CAPRIOLA (the wild goat, which feeds upon this grass). Graminex. Low, ereeping perennials, with short, flat leaves and slender spikes, which spread out at the apex into finger-like branches. Spikelets 1-fld., awnless, sessile, in two rows along one side of a slender, continuous axis. Glumes 3, the first 2 narrow, keeled, usually acute, empty; the third or floral glume broader and usually a little longer than the empty ones. Species 4. One distributed throughout the tropical and warmer temperate regions of the world.

Dáctylon, Kuntze (Cýnodon Dáctylon, Pers.). BERMUDA Grass. Fig. 352. A widely dispersed grass, with a creeping habit of growth, extending rapidly over the surface of the ground and rooting at the joints. Used extensively in the south for lawn-making, where Kentucky blue grass and the bent grasses cannot be successfully grown. Except in the far south, however, it is not a desirable lawn grass, as it quickly turns brown upon the approach of cold weather, and is rather late in becoming green in the spring. A variety known as St. Lucie Grass is regarded as a more desirable form for lawns than the species. Experiments made in central Michigan by Beal seem to show that Bermuda Grass is valuable to mix with June grass for a lawn where the soil is rather thin, the June grass occupying the soil from early spring until hot, dry weather, when the Bermuda covers the ground. In the cool autumn, June grass appears again at the surface.

\section{P. B. KENNEDY}

CÁPSICUM (name of uncertain origin, perhaps from kapto, to bite, on account of the pungency of the seed or pericarp; or from capsa, a chest, having reference to the form of fruit). Solandcece. Red PEPPER. CAyenne Papper. Herbs or shrubs, originally from trop. Amer. but escaped from cultivation in Old World tropics, where it was once supposed to be indigenous. Stem branchy, 1-6 ft. high, glabrous or nearly so : Ivs. ovate or subelliptical, entire, aciminate: fls. white or greenish white, rarely violaceous, solitary or sometimes in 2's or 3's ; corolla rotate, usually 5 lobed; stamens 5 , rarely 6 or 7 , with bluish anthers dehiscinglongitudinally;ovary originally 2-3-loculed : fr. a juiceless berry or pod, extremely variable in form and size, many-seeded, and with more or less pungency about the seeds and pericarp. Fig. 35j3. The fruit be comes many-loculed and

monstrous in cultivation. 353. Normal 2-loculed fruit of About 90 species have been Capsicum, in cross section. named, most of which are now considered forms of one or two species. Monogr. by Irish, 9th Ann. Rept. Mo. Bot. Gard. For culture, see Pepper.

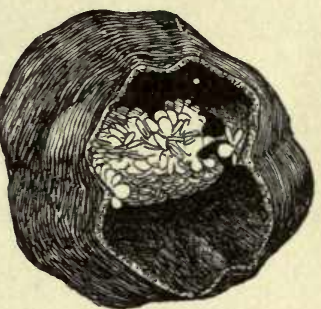
A. Annual or biennial.

ánnuum, Linn. Herbaceous or suffrutescent, grown as annuals in temperate climates, but in warmer latitudes often treated as biennials. All of the leading commercial varieties in the United States readily find classification within the types or botanical varieties. The species has never been found wild.

\section{B. Fruit oblong-linear.}

c. Calyx usually embracing base of fruit.

Var. conoldes, Irish (C. conoides, Miller). Suffrutescent: Ivs. numerous, rather small, $2-3$ in. long, $3 / 4-2$ in. wide: peduncles slender, straight, erect: fls. small; calyx obconical or cup-shaped, usually embracing base of fruit; corolla greenish white, spreading, $3 / 8-3 / 8$ in.: fr. erect, subconical or oblong cylindrical, about $1 \frac{1}{4} \mathrm{in}$. long or less, usually shorter than the peduncles and mostly borne above the lvs., very acrid. Coral Gem, Tabasco.

Var. fasciculàtum, Irish (C. fasciculatum, Sturt.). Stem herbaceous, round or nearly so: branches few: lvs. clustered or crowded in bunches about the summit, elliptical-lanceolate, pointed at both ends : fr. also clustered, erect, slender, about $3 \mathrm{in}$. long by $1 / 4 \mathrm{in}$. in diam., very acrid. This is the Red Cluster Pepper.

CAPRIFOLIUM. See Lonicera. 
Var. acuminàtum, Fingerh. (C.Chilénse, Hort.). Herbaceous, very branchy, about $2 \frac{1}{2} \mathrm{ft}$. high, bearing a dense mass of foliage : fl. medium size, spread $1 / 2-3 / 4$ in.: fr. larger than the preceding, either erect or pendent. Chile. Long Cayenne.

cC. Calyx not usually embracing base of fruit.

Var. lóngum, Sendt. (C. ánnuum, Linn. C. lóngum, DC.). Plants herbaceous, about $2 \frac{1}{2} \mathrm{ft}$. high, with comparatively few branches : lvs. large, often 4 in. long by 21/\%in. wide: fl. large; corolla spreading, 7/8-11/4in., dingy white ; calyx usually pateriform or funnel-form, rarely embracing base of fruit: fr. often a foot long by 2 in. in diam, at base; flesh thick and in some varieties very mild. Black Nubian, County Fair, Elephant's Trunk, Ivory Tusk.

BB. Fruit of various shapes, but not oblong-linear.

Var. gròssum, Sendt. (C. gròssum, Linn.). Fig. 354. Herbaceous, about $2 \mathrm{ft}$. high, with few branches : lvs. very large, often 3 by 5 in., sometimes coriaceous, lower ones usually pendent; petioles deeply channeled: peduncles stout, about 1 in. long; corolla large, spreading, $7 / 8-11 / 4$ in.: fr. large, oblate, oblong, or truncated, 3-4lobed, usually with basal depression, more or less sulcate and rugose; flesh thick, firm, and of a mild flavor. Emperor, Monstrous, Bell, Sweet Mountain, Golden Dawn,

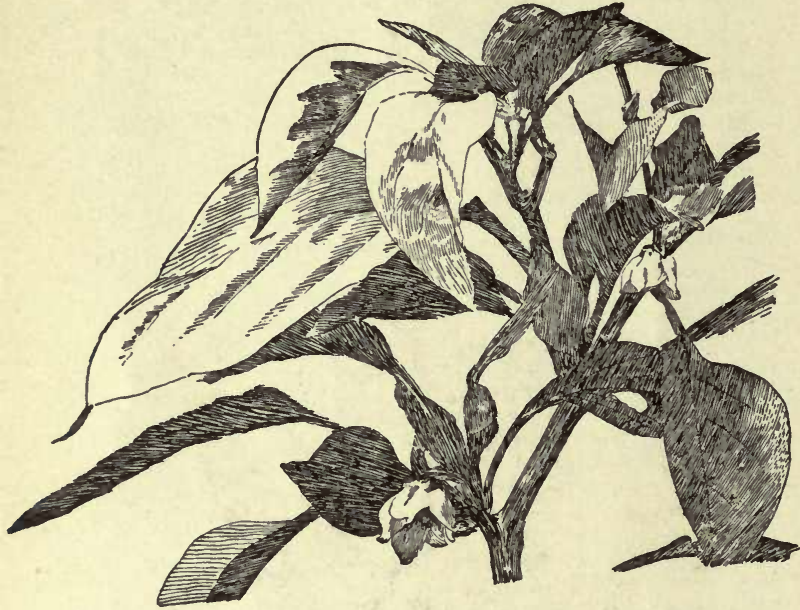

354. Foliage and flowers of Capsicum annuum, var. grossum.

Ruby King, Golden King, Brazilian Upright, Golden Upright, Squash.

Var. abbreviàtum, Fingerh. (C. umbilicatum, Vell. $C$. lùteum, Lam.). Suffrutescent: lvs. broadly ovate,2-4 in. long: peduncles slender, straight or curved, as long as or longer than the berry: fr. about 2 in. long or less, varying much in the different horticultural varieties, in general ovate, quite rugose, except in one variety, sometimes turbinate. While this variety is used to some extent for pickling, it is noted more as an ornamental plant. Celestial, Etna, Kaleidoscope, Red Wrinkled, Yellow Wrinkled.

Var. cerasiforme, Irish ( $C$. cerasifórme, Miller). Fig. 355. Suffrutescent : lvs. medium size, ovate or oblong acuminate, about $1 \frac{1}{4}-3 \frac{1}{2}$ in.: calyx seated on base of fruit ; corolla large, spreading, $7 / 8-1 \frac{1}{2}$ in. : fr. spherical, subcordate, oblate, or occasionally obscurely pointed or slightly elongated, smooth or rarely minutely rugose or sulcate; flesh firm, one-twelfth-1/8in. thick, extremely pungent. Cherry, Yellow Cherry, Oxheart.

\section{AA. Perennial.}

frutéscens, Linn. Fig. 356. Shrubby, perennial, 3-6 ft. high, with prominently angled or somewhat channeled stem and branches: branches loosely spreading or trailing: lvs. broadly ovate acuminate, $3-6$ in. long, $2-3 \frac{1}{2}$ in. wide: peduncles slender, 1-2 in. long, often in pairs, usually longer than the fruit: calyx cup-shaped, embracing base of fruit; corolla often with ocherous markings in the throat: fr. red, obtuse or oblong-acuminate, $3 / 4-11 / 4$ in. long, $1 / 4-3 / 4$ in. in diam., very acrid. - Cultivated only in the south, as the seasons in temperate latitudes are not long enough to mature the fruit.

Var. baccatum, Irish $(C$. baccatum, Linn.). Plants not as tall, but more erect than the species : branches slender, fastigiate, flexuose: corolla small, spreading, about $1 /$ in.: fr. ovate or subround, about $1 / 4 \mathrm{in}$. in diam.

H. C. IRISH.

CARAGANA ( $\mathrm{Car}$ agan, its Mongolian name). Leguminòsce. Pea Tree. Shrubs or small trees : lvs. deciduous, abruptly pinnate, often with spiny - pointed and persistent rachis ; lfts. small, entire, mucronulate ; stipules deciduous or spiny and persistent : fls. papilionaceous, axillary, solitary or fascicled, usually yellow : fr, a linear pod. About 20 species from S. Russia to China. Ornamental shrubs, with handsome yellow fls., appearing late in spring or early in summer; quite hardy, except a few Himalayan species. They grow in almost any soil, but best in a sandy soil and sunny position, and are well adapted for shrubberies. $C$. ar borescens is the only one which grows into a small tree, and is of upright habit, like $C$. frutescens, which is about half as high and more graceful; all the other species are low shrubs, of usually spreading habit. Prop. by seeds sown in fall or in spring ; if kept dry during the winter, soaking in tepid water for 2 or 3 days before sowing will be of advantage; also, increased by rootcuttings and layers, or by grafting on seedling stock of $C$. arborescens in spring.

\section{A. Lfts. 8-18: rachis of the lvs. deciduous.}

arboréscens, Lam. Shrub or small tree, to $20 \mathrm{ft}$.: lfts. $8-12$, obovate or oblong, sparsely pubescent beneath or glabrous at length, $1 / 2-1$ in. long: fls. $2-4$, pale or bright yellow, $3 / 4 \mathrm{in}$. long; pedicels usually longer than the fls. May, June. Siber., Manchuria.-There are some varieties, of which var. péndula, Hort., with pendulous branches, is the most remarkable ; it should be grafted high.

microphylla, Lam. (C. Altagana, Poir.). From 4-6 ft.: lfts. 12-18, obovate, pubescent when young, one-sixth $-1 / 8$ in. long: fls. 1 or 2 , yellow, $3 / 4$ in. long; pedicel about as long as the $\mathrm{fl}$. Siber., China. L. B. C. $11: 1064$. - Under this name a dwarf form of the former is often cultivated.

AA. Leaflets 2-4.

B. Rachis of the lvs. deciduous: pedicels as long as or longer than the fls.

\section{frutescens, DC.} frùtex, C. Koch). Fig. 357. From 6-10 ft.: lfts. 4, approximate, nearly digitate, cuneate, obovate or oblong, rounded or emarginate at the apex, glabrous, $1 / 3-1$ in. long : fls, solitary, $3 / 4-1$ in, long, yellow. May. S. Russia to China. Gt. 10:348. S.B.F.G. 3:227.-Var. grandiflòra, Hort. Fls. somewhat larger: lfts. usually large and broad. 
BB. Rachis persistent, spiny: pedicels shorter than the fls.

Chámlagu, Lam. Shrub, 2-4 ft.: spines long: lfts. 4, in 2 somewhat remote pairs, chartaceous, obovate, emarginate or rounded at the apex, glabrous, $1 / 4-3 / 4$ in. long: als. solitary, reddish yellow, $1 \frac{1}{4}$ in. long. May. N. China.

pýgmæa, DC. One to 3 ft.: spines short, $1 / 4$ in.: lvs. nearly sessile; lfts. 4, approximate and almost digitate, cuneate, linear-elliptic or linear-lanceolate, glabrous, $1 / 3-1 / 2$ in. long: fls. solitary, $3 / 4 \mathrm{in}$. long, golden yellow. Cauc. to Siber. and Thibet. B. R. 12: 1021 . - Grafted high on $C$. arborescens, it forms a graceful, standard tree, with pendulous branches.

grandiflòra, DC. Similar to the former. Lfts. cuneateoblong: fls. 11/4in. long; calyx gibbous at the base. Cauc. - Under this name mostly a variety of $C$. frutes cens is cultivated.

C. Altagàna, Poir $=$ C. microphylla.-C. arboréscens arenària, Hort. $=\mathrm{C}$. microphylla. $-O$. arenària, Dipp. $=\mathrm{C}$. aurantiaca arenaria, Dipp.= arenària, Loud. $\begin{array}{cl}\text { frutescens. } & \text { Koehne. C arenària, Loud.; } \\ (1 / 2 .) & \text { see C. cuneifolia. - C. auranti- } \\ & \text { aca, Koehne. Allied to C. pyg- } \\ & \text { mæa. Fls. orange-yellow; calyx }\end{array}$ $\begin{array}{cl}\text { frutescens. } & \text { Koehne.-C. arenària, Loud., } \\ \text { (1/2.) } & \text { see 0. cuneifolia. - C. auranti- } \\ & \text { àca, Koehne. Allied to C. pyg. } \\ & \text { mæa. Fls. orange-yellow; calyx }\end{array}$ $\begin{array}{cl}\text { frutescens. } & \text { Koehne. C. arenària, Loud., } \\ (1 / 2 .) & \text { see C. cuneifolia. C. auranti- } \\ & \text { aca, Koehne. Allied to C. pyg- } \\ & \text { maa. Fls. orange-yellow; calyx }\end{array}$ as long as broad: ovary glabrous. Siber.-O. brevispina, Royle. peduncle. Himal. P. F. G. 2: 184.-C. cuneifolia, Dipp. (C. Redowskii, Hort., not DC.). Probably var. of C. arborescens. Stipules spiny: lfts, small, Probably var. of arborescens. Stipseeds brown, spotted black. C. arenaria, Loud. (B. M. 1886), seeds brown, spotted black. C. arenaria, Loud. (B. M. 1886), seems to be the same. $-C$. frutex, $\mathrm{C}$. Koch $=\mathrm{C}$. frutesceins $-O$.
Gerardiana, Royle. Spines $1 \frac{1}{2}-2$ in. long: stipules large, scarious: lfts. 8-12, densely pubescent: fls. 1-2, short-pedicelled. Himal. $-C$. grácilis, Hort = C, pyomæa-C, jubàta, Pall. Branches spiny, villous, thick, with rounded lvs.: stipules large, scarious : lfts. $8-10$, villous beneath : fls. whitish, shortpedicelled. Siber. F. S. 19:2013 L B.C.6:522. Gt. 10:331. A very distinct and eurious looking species; hardy.-C. Kedò very distinct and eurious looking species; hardy.-C. Redòw-
skii, Hort., not DC. = cuneifolia, Dipp. $-C$. spindsa, DC. Spines 1 in. long: lfts. 4 , rarely more, approximate, cuneate-lanceolate, glabrous: fls. solitary, short-pedicelled. Siber. $-O$. spinosissima C. Koch = C. spinosa. - C. tragacanthoides, Poir. Spiny: lfts 4-8, euneate, oblong, pubescent : fls. solitary, short-pedicelled ealyx villous-pubescent. Himal. $-C$. triflòra, Lindl. $=\mathrm{C}$. brevispina. - C. vulgàris. Hort. $=\mathrm{C}$. arboreseens.

\section{ALFRED REHDER.}

CARAGUATA. By the latest monographer referred to Guzmania, which see.

\section{CARAMBOLA. See Averrhoa.}

CARAWAY (Carum Carui, Linn.). Umbellíferoe. A biennial or annual herb grown for its seeds, which are used in flavoring bread, cakes and cheese ; also occasionally for the young shoots and leaves, which are eaten. It grows a foot or two high, has finely-cut, pinnately compound foliage, and small white flowers in umbels. It is of the easiest culture. The seed is usuallv sown in spring and the crop of seed taken the following year. It thrives in any garden soil. The plant occasionally runs wild. See Carum.

CARBENIA (name of doubtful meaning). Compósitie. Blessed Thistle. A monotypic genus allied to Centaurea, and distinguished from it botanically by involucre, achenes, pappus and anthers. Its habit in the garden is very different from the Bachelor's Buttons, being thistle-like, and more interesting than ornamental. A hardy annual, low-growing herb, rough, branching and pilose. Once thought to counteract poison. Culture easy. Fit for wild gardens and rockeries. benedícta, Adans. (Cárduus benedíctus, Authors. Cnicus benedíctus, Linn. Centaurèa benedícta, Linn.) Fig. 358. Height 2 ft.: lvs. alternate, sinuate-pinnatifid, the lobes and teeth spiny: fls. terminal, yellow, 1 in. wide. Mediterranean regions and Caucasus. Sometimes eult.; also rarely seen in waste places of southern Atlantic states and Calif. as a weed adventive from $\mathrm{Eu}$.

CARDAMINE (Greek name of a cress). Crucíferce. Small perennials growing in low, rich land, blooming in spring or early summer. Petals obovate or spatulate; pods linear and straight, the wingless seeds in 1 row.

praténsis, Linn. Cuckoo Flower. Plant slender and usually glabrous, $12-20$ in., somewhat branched : lvs. pinnately divided; lfts. of root lvs. small and rounded ( $1 / 3$ in. or less across), those of the upper stem-lvs. oblong or even linear and entire or somewhat toothed: fls. $1 / 2$ in. long, in a corymb, white or rose-color, pretty. Eu. and Amer., in the northern parts. - In the gardens it is chiefly known in the double-fld. form, which probably has been obtained from European rather than American sources. There are other forms of it. It is an excellent little plant to grow in moist places, particularly along ereeks and about springs. It is also useful in drier places, as in rockeries.

angulàta, Hook. Erect, 1-2 ft. high: lvs. 3-5-foliolate, the lfts. ovate or oblong and the middle one usually coarsely toothed : fls. rather large, white, in short, few-fld. racemes. Mts. of Ore. and Wash.-Int. 1881 by Gillett.

C. gemmàta, int. by Pilkington, 1892, is evidently Dentaria macrocarpa.

L. H. B.

CARDAMON. See Amomum and Elettaria.

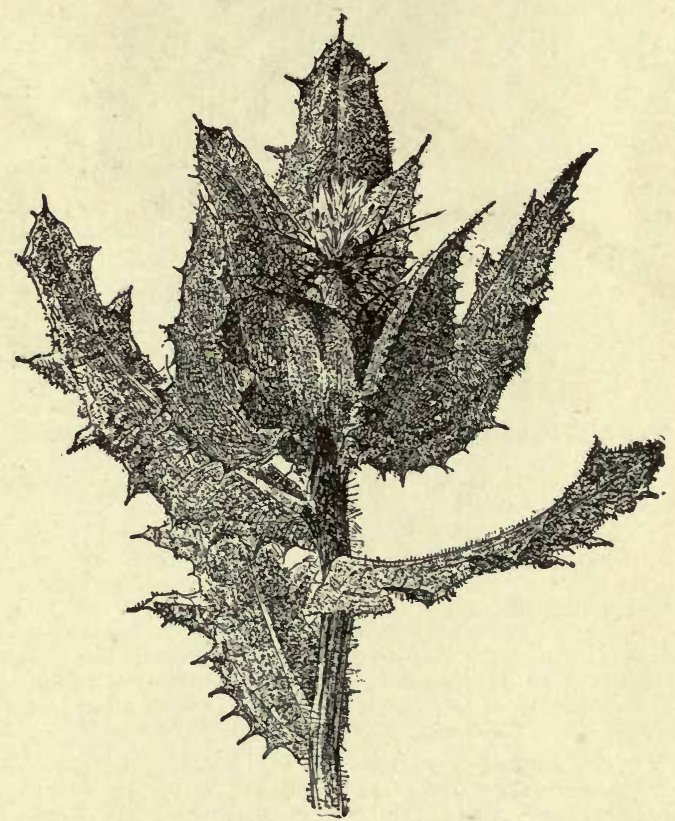

358. Carbenia benedicta.

CARDIÁNDRA (Greek, heart, and man or stamen: alluding to the shape of the anthers). Saxifragdceo. Low deciduous shrub, allied to Hydrangea, with alternate, rather large lvs.: fls. in terminal, loose corymbs, small, those of the margin large, radiant and sterile. One species in S. Japan and China. Tender and suffruticose, thriving in any good garden soil ; best in a partly shaded position. Prop. by greenwood cuttings under glass.

alternifolia, Sieb. \& Zucc. 1-3 ft.: Ivs. broadly elliptic to elliptic-lanceolate, tapering into a very short 
petiole, coarsely serrate, sparsely pilose, membranaceous, 3-7 in. long : fls. white, tinged red. Summer. S Z. $66,67$.

AlfRed ReHDER.

CARDINAL FLOWER. Lobelia cardinalis.
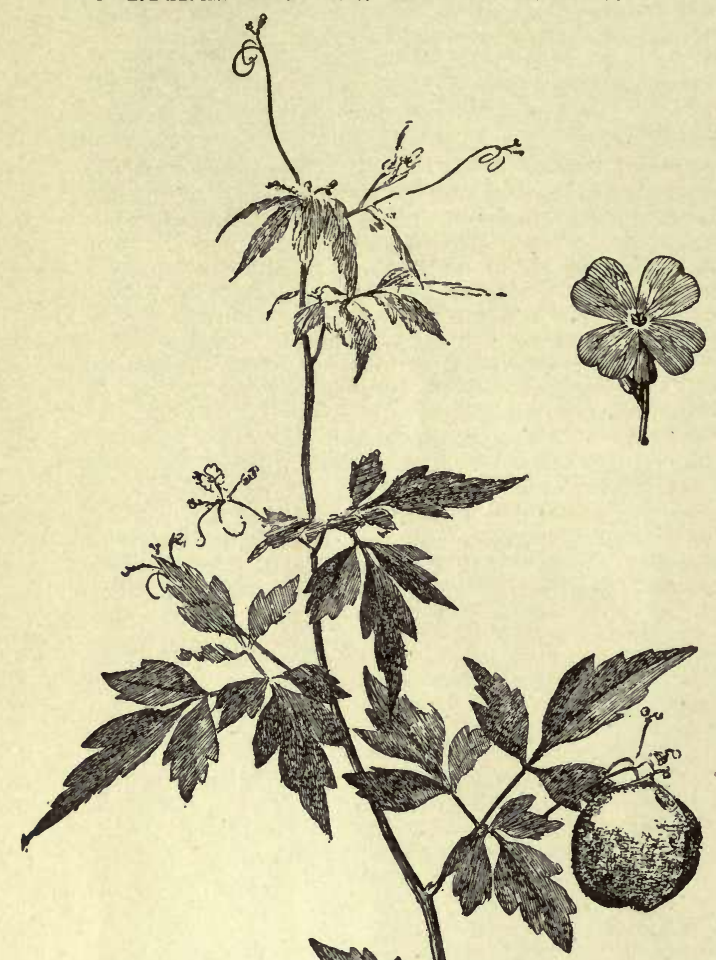

359. Balloon Vine-

Cardiospermum Halicacabum.

\section{m.}
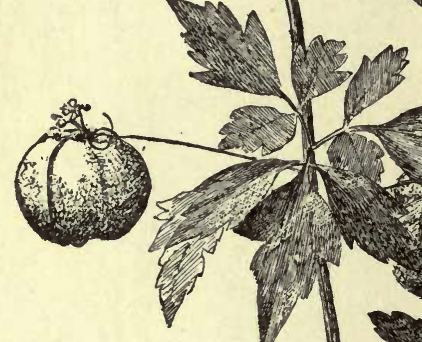

(n)

CARDO0N (Cynara Cardunculus, Linn.). A thistle-
like plant of southern Europe, cult. for the thick leafstalk and midrib. It is thought to be of the same species as the artichoke, and to have been developed from it by long cultivation and selection. The plant has been introduced into South America, and has run wild exten. sively on the pampas. Darwin writes that "no cultivated plant has run wild on so enormous a scale as the Cardoon." From the artichoke it differs in taller and more prickly growth and smaller heads. The Cardoon is perennial, but it is not hardy, and is treated as an annual. Seeds are sown in spring, either in pots under glass or in the open where the plants are to stand. The later sowing is usually preferred. The plants are given rich soil and should have abundant moisture supply, for they must make continuous and strong growth. When the leaves are nearly full grown, they are tied together near the top, straw is piled around the head, and earth is banked against it. This is to blanch the plant, for it is inedible unless so treated. From two to four weeks is required for the blanching. The procedure is not very unlike that adopted for the blanching of celery or endive. If the plants are late, they may be dug just before frost and blanched in a storage pit. The plants are usually grown from 2-3 ft. apart in rows which are $4 \mathrm{ft}$. apart. They are sometimes grown in trenches, after the old manner of growing celery. Cardoon is almost unknown in America, except amongst foreigners.

CARDUUS. For $C$. benedictus, see Carbenia.

CAREX (name of obscure origin). Cyperdcea. SEDGE. Hundreds of grass-like plants in temperate climates. Fls. unisexual, in spikes, the staminate naked and subtended by a bract or scale, the pistillate comprising a single pistil enclosed in a thin sac or perigynium. The two sexes may be in the same or separate spikes; and rarely they are on different plants (plant diøecious). Carices are very abundant in cool temperate regions, both in species and in individual plants. Many of them grow on dry land, but the largest species grow in low grounds and swales, and often form much of the bulk of bog hay (Fig. 360). The species are very difficult to distinguish because they are very similar, and the study of them is usually left to specialists. Some of our broad-leaved native species make excellent borders and interesting clumps in corners about buildings and along walls. Many of the lowland species are excellent adjuncts to the pond of hardy aquatics. Others have very graceful forms, with drooping spikes and slender culms (Fig. 361). The following native species have been offered by collectors : aurea, eburnea, flava, Grayi, hystricina, lupulina and its var. pedunculata, lurida, Magellanica, Pennsylvanica, plantaginea, Pseudo-Cyperus, retrorsa, Richardsoni, riparia, Tuckermani, utriculata, vulpinoidea. The following species are in the Amer, trade :

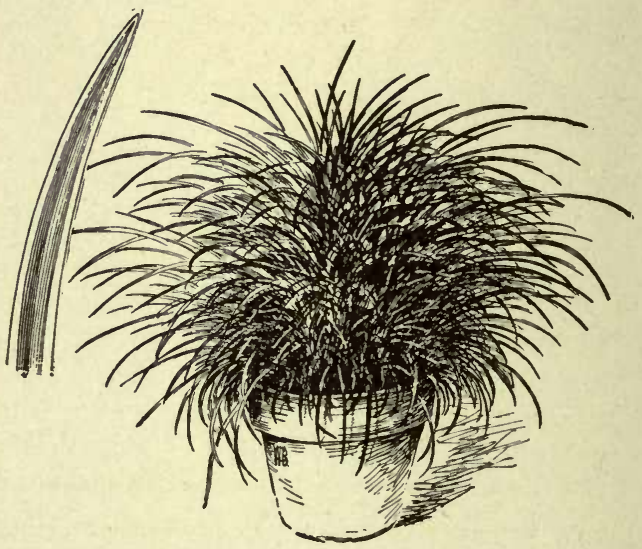

362. Carex Morrowi.

Morrowi, Boott. (C. Japónica, Hort., not T'hunb. C. tenuissima, Hort. C. acutifolia, Hort.). Fig. 362 .

CARDIOSPERMUM (Greek, heart-seed, from the white heart-shaped spot on the round black seed; bence the plant was thought a cure for heart diseases). $S a$ pinddcea. Thirty tropical American species of climbing herbs, with alternate, biternate lvs., coarsely serrate lfts., and small white fls. in axillary racemes or corymbs. The most popular is the interesting Balloon Vine, which is a rapid-growing, tender annual, curious for its inflated seed-vessels.

Halicácabum, Linn. Fig. 359. Height, $10 \mathrm{ft}$. : stem and branches grooved: balloons an inch or more thick. E. and W. Indies. B.M. 1049.-A general favorite, especially with children.

W. M. 
Lvs. stiff and evergreen, long-pointed, in the common garden form with a white band near either margin: culm $1 \mathrm{ft}$., with a terminal staminate spike and two or three slender pistillate spikes ( 1 in. long) from sheaths: perigynium small and firm, somewhat excurved, 2 toothed, glabrous. Jap. G.C. III. 13:173. R.B. 20, p. 9. -A very handsome plant, suited for pots or the border. The stiff, clean, white-edged foliage keeps in condition for months, making the plant useful for decorations in which pot-plants are used. It is perfectly hardy in central New York, holding its foliage all winter. A useful florists' plant.

tenària, Hort. (C. ténera, Hort.). Slender but stiff : lvs. narrow, rolling more or less when dry: staminate spikes long-stalked: pistillate spikes 1 or 2, shortstalked, short, with few large-turgid, tapering, shining

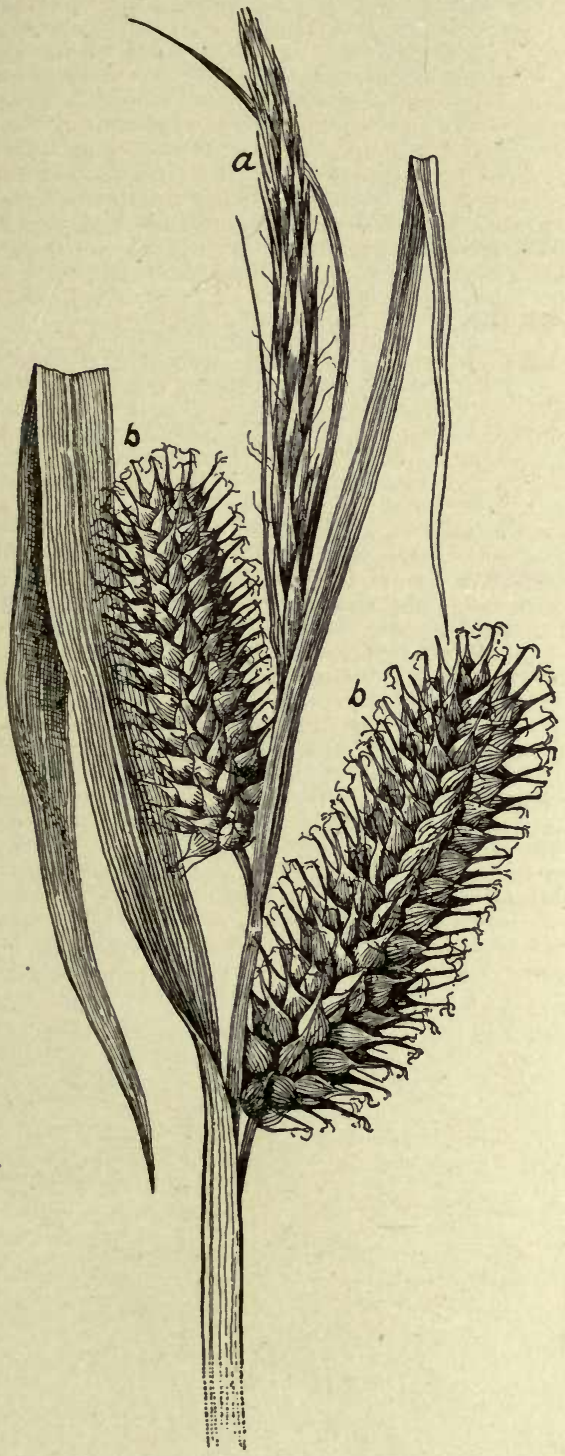

360. Carex lurida, one of the common bog species. (Natural size.)

$a$, staminate spike; $b, b$, pistillate spikes.

perigynia and awl-like, rough-pointed scales. Probably Japanese.-Cult. for its stiff foliage. Grows 18-30 in. high. Allied to the N. Amer. C. bullata, Schk.
Gaudichaudiana, Kunth (C. vulgdris, Fries, var. Gaudichaudiana, Boott). Culms erect, 1-2 ft.: lvs. long and grass-like: staminate fls. in terminal spikes: pistillate fls. in 2-3 cylindrical, sessile or subsessile spikes: perigynium lenticular, small, very short beaked, obscurely 2 toothed, finely nerved, longer than the narrow scale. Jap.. Austral., N. Zeal.-Useful for bog planting.

Fràseri, Andrews, Lvs, 1 in. or more broad, stiff, but with no midnerve, flat and thick, evergreen : culm 16 in, or less high, bearing at its summit a single whitish spike which is staminate at top : perigynium ovoid, thin and inflated. Rich mountain woods, Va. B.M. 1391 as C. Fraseriana.-Rare, and a very remarkable plant.

L. H. B.

CARİCA (a geographical name). Passiflordcece. PAPAw. Small trees, mostly with unbranched trunks, the juice milky. Lvs. near the top of the trunk, alternate, large and variously lobed, soft, long-stalked: plant usually diœeious: fls. in racemes from the leaf-axils, the staminate funnel-shaped and bearing 10 anthers on the throat, the pistillate larger and with 5 distinct petals and 1 pistil with 5-rayed stigma. There are about 20 species, in tropical Amer. They have somewhat the aspect of palms. Under glass in frosty countries, the common $C$. $P a$ paya is frequent, and is grown for its foliage and interesting habit (Fig. 363). In frostless countries, this species is grown for its fruit (Fig. 364), which is oblong or - egg. shaped, a foot or so long, orange - yellow when ripe, thick-skinned, with many small black seeds. The young fruit is cooked and eaten, and the ripe fruit is eaten by natives.

\section{H. B.}

The soil most suited

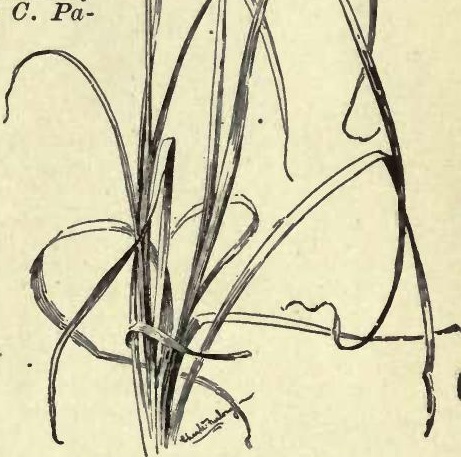

361. Carex longirostris $(\times 1 / 8)$.

for Caricas is a rich loam, having perfect drainage. As the stem is succulent and tender, great care is necessary to avoid bruising; hence pot-grown plants are much to be preferred to seedlings from the open ground. Seeds should be selected from the best and largest fruits and sown in a well-worked bed under a slight shade. If seeds are quite dry or old, they should be soaked in warm water before sowing. The seedling plants are delicate, and require close watching at first to avoid damping-off. Soon as plants are well up remove the shading, and after the third leaf appears they may be pricked out into a larger bed, or better, potted off in fairly rich soil. After plants are a few weeks old, and have been shifted once into larger pots, they may be set permanently outdoors in the tropics. Caricas seldom branch, but usually grow upright like a palm, hence cuttings are not often available. Sometimes small branches form, and these may be cut off and as readily rooted as most tropical decorative plants, provided the cutting is not too young and tender. In temperate climates, Caricas have been 
found to be good decorative plants for both conservatory and summer bedding, the deeply cut, palmate leaves forming a striking contrast to ordinary vegetation. In bedding out, select open, sunny exposure, with perfect drainage, and make the soil rich and friable. Constant cultivation with a light hoe will cause a luxuriant growth under these conditions, and the planter will be amply repaid for his trouble by beautiful, showy specimens as unique and tropical-appearing as palms.

Cult. by E. N. REAsoner.

Papàya, Linn. PAPAw. Melon Papaw. Melon Za POTE. Figs. 363, 364. Trunk reaching 20 ft.: lvs. often 2 ft. across, palmately 7-lobed: fr. 6-12 in. long and half as thick, hanging from the lower axils of the pistillate plant. Trop. Amer., but widely natu ralized. Grows spontaneously in the wild in S. Fla. B.M. 2898-9. A. G. 18: 137.- The

plant seems sometimes to be polygamous (to bear both kinds of flowers). The fruit is used as a vermifuge and a cosmetic. The juice of the fruit or the macerated leaves, if rubbed on animal flesh, make it very tender. It is best to roll the meat and leaves together for a few hours. The fruits are made into sauces or conserves, and are sometimes eaten raw. The Papaw is variable. C.pyriformis, Hort., has pear-shaped fr. $C$. atroviolacea, Hort., with purple fr., is evidently only a form of it.

grácilis, Hort. Larger than $C$. Papaya, with finely cut palmate lvs. with pink veins. A form of $C$. Papaya?

Candamarcénsis, Hook. f. (C. Cundinamarcénsis, Lindl.). Lvs. numerous, dark green above and pale beneath, pubescent below, circular-cordate in outline ( $1 \frac{1}{2} \mathrm{ft}$. across), 5 -lobed to the middle, the lobes more or less pinnatifid: fls. green and pubescent: fr. small, obovoid and pointed, contracted at the base, 5-angled, golden yellow, 5-loculed. Equador. B.M. 6198. - "Probably the most hardy of all Papaws makes rapidly a bold foliage plant, the sweet-scented yellowish flowers being produced here all the year." - Franceschi, S. Calif.

quercifolia, Benth. \& Hook. (Vasconcélla quercifolia, St. Hil.). Lvs. shaped like those of the English oak, palmately 3-nerved, ovate or ovate-lanceolate and sometimes obscurely cordate, the margin undulate or inequally few-lobed, the lobes obtuse or the lower ones acute. S. Braz. and S.-"A quick-growing, hardy kind, with small fruits, but its large halberd shaped leaves contain a higher percentage of papaine, now much used in medicine in preference to pepsin."-Franceschi.

L. H. B.

CARISSA (aboriginal name). A pocyndceae. About 20 very branchy spinose shrubs ornament or for the edible berry-like fr. Els. white, solitary or in cymes; lobes of calyx and corolla 5 , the 5 stamens free and included in the throat, the ovary 2 loculed: lvs. opposite and thick, simple. In the Old World sometimes cult, in warmhouses, but in this country known only in the extreme S. Prop. by seeds and cuttings of ripe wood.

Carándas, Linn. Caraunda. Christ's-Thorn. Evergreen shrub or small tree, with dark green ovate or elliptic mucronate entire lvs., strong axillary spines (which are often forked) and fragrant white fls. in clus ters of $2-3$, the corolla twisted to the left in the bud : fr. the size of a cherry ( 1 in. in diam.), reddish, pleas ant-tasted. India. L.B.C. 7:663.- Reaches $20 \mathrm{ft}$. Half hardy in central Fla. The fruits are eaten from the hand when ripe, and pickled when green. Might serve for hedges.
Arduina, Lam. Amatungula. Maritzgula. Spines strong, often 2 in. long: lvs. ovate and subcordate, mucronate, glabrous and entire : fls. white, the corolla twisted to the right in the bud. S. Afr. - A choice evergreen shrub, rather hardy, with thick camellia-like lvs., very glossy: fls. large, fragrant, white, and borne profusely: fr. dark red, 1-1 $1 / 2$ in. long, resembling in flavor red raspberries, and having a papery skin and few small seeds. A fine pot shrub. Well worth extensive planting in S. Fla. and Calif. The fruit is said to be unsurpassed for jan making.

acuminàta, DC. Spines weak: lvs. smaller, ovateacute, subcordate, mucronate: peduncles short, forked, axillary : fls. with lauce-acuminate caly lobes, the corolla twisted to the right in the bud. S. Africa.

grandiflora, DC. NATAL Plum. Spiny shrub lvs. ovate-acute, tapering to the base: fls. large, white, fragrant, solitary and terminal, twisted to the right: fr. red, size of a cherry, good. S. Afr. B.M. 6307. E. N. REASONER and L. H. B.

CARLINA (said to have cured the army of Charlemagne [Carolinus] of the plague). Compósitce. Sonie 15 or 20 species in the Mediterranean region. Low, rather coarse annuals, biennials or perennials, with thistle-like foliage, large white or purplish heads, a feathery pappus, and chaffy receptacle.

acaùlis, Linn. A small and very dwarf hardy plant: height 3-6 in.: lvs. glossy, pinnatifid, divided, with spiny ends : fl. arising barely above the foliage, solitary, very interesting, the scales surrounding the flower-heud being long and narrow and ray- or petallike, silky, shiny: head 6 in. across when expanded. June, July and late fall. G.C. II. 13:720, 721.-Cult.: an open, sunny place and ordinary garden soil are all they require. They are capital for the sunny part of a rockery. Prop. by cuttings or seeds.

\section{J. B. Keller.}

CARLUDÓVICA (Charles IV., and his Queen Louisa, of Spain). Cyclanthacece. Palm-like plants of Trop. Amer., allied on the one hand to screw pines and on the other to aroids. The plants are monœcious, the two sexes being on the same spadix, which is enclosed in a 4-leaved spathe. Staminate fls. with many stamens and manylobed calyx, 4 of them surrounding a pis- 
35-40 species and 4 genera (Stelestylis, Carludovica, Ludovia, Cyclanthus); it is often united with the Pandanaceæ or screw pine family.

L. H. B.

Carludovica palmata is the species most frequently met with under cultivation. Under favorable conditions it grows to a height of about 8 feet. All of the kinds need stove treatment during the winter months; in summer they may be used for subtropical bedding with good results. They have a certain palm-like appearance, but the leaves are of a softer texture than any of the palms. They mas be propagated by division, choosing the early spring for the operation. $C$. palmata seeds freely. The fruit, when ripe, has an ornamental appear ance for a short time after bursting open. The seeds are very small, and should becarefully washed free from

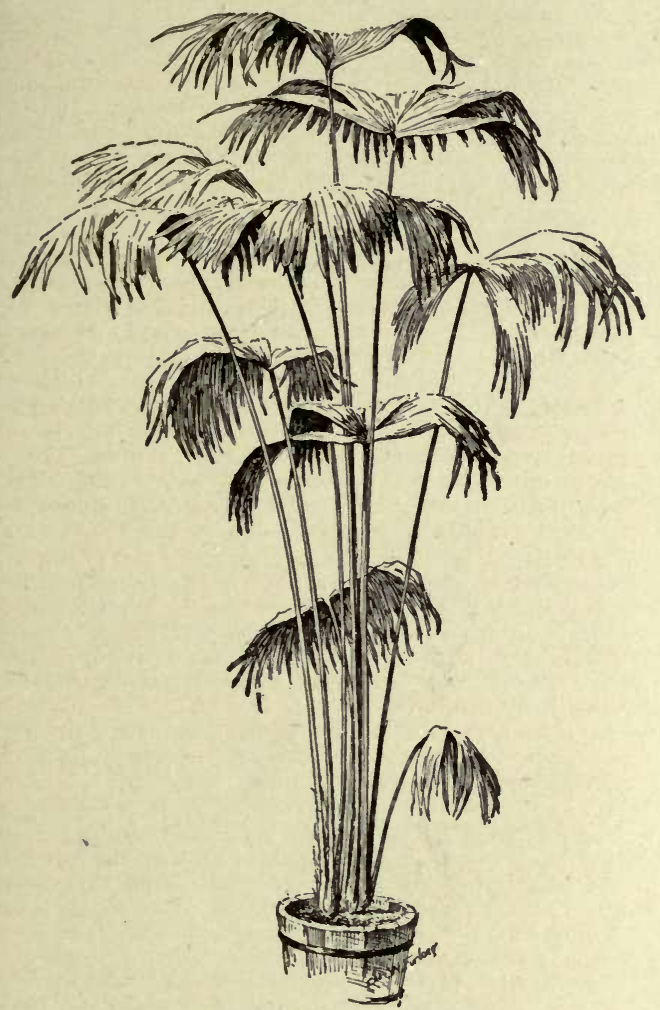

365. Carludovica palmata.

the pulp, and sown on the surface of a pan of finely chopped sphagnum moss. Germination takes place in two weeks from sowing if kept in a brisk, moist heat. The species are not particular as to soil, but the drainage must be perfect, as the plants require an abundance of water when growing.

G. W. OLIVER.

$$
\text { A. Lvs. 3-5-lobed. }
$$

palmàta, Ruiz \& Pav. Fig. 365. No trunk : petioles 3- 6 ft. long, glabrous, terete and unarmed; blades 4-lobed, the lobes again cut into narrow segments, dark green, gracefully spreading, and drooping at the mar gin. Peru. R.H. 1861, p. 10.-The common species, and a very useful plant. Panama hats are made from this plant.

rotundifolia, H. Wendl. Much like the last, but more compact under cult., owing to the shorter petioles, but growing much larger: petiole distinctly pubescent: leaf-blade large and orbicular, 3- or 4-lobed. Costa Rica. B. M. 7083 .

élegans, Williams. Blades with 4 or 5 lobes, which are very deeply cut into straight strap-like divisions. Probably of horticultural origin.
AA. Lis. 2-lobed.

atròvirens, H. Wendl. Blades very deeply 2-lobed and very deep, rich green (whence the name, dark green), glabrous. Colombia.

hùmilis, Poepp. \& Endl. Dwarf: blades angular, 2-lobed at the summit, the segments more or less jagged but not divided, a foot or less broad. Colombia. R.H. 1869, p. 327. - One of the best.

Plùmerii, Kunth ( $C$. palmofolia, Sweet). Caudex erect: blades with 2 lanceolate and plicate divisions, bright green above and pale beneath: spadices pendulous. Martinique.

imperialis, Lind. \& André. Caudex short and prostrate: blades with 2 ovate-lanceolate entire segments, with very prominent veins, the lobes about 5 in. wide and shining green; petiole purplish, canaliculate, tumid at the base. Equador. I.H. 21:166 (by error 165).

\section{H. B.}

CARNATION (Diánthus Caryophýllus, Linn.). Cary. ophyllaceo. Figs. 366,367 . Half-hardy perennial, herbaceous, suffrutescent at base : height $2 \mathrm{ft}$ : : stem branching, with tumid joints : Ivs. linear, glaucous, opposite: fls. terminal, solitary; petals 5, flesh-colored, very broad, beardless margins toothed; calyx cylindrical, with scaly bracts at base. June-August. Native of southern Eu.; occasionally met in the wild state in England, where it was introduced through cultivation.

Theophrastus, who lived about 300 years B.C., gave the name Diunthus (Greek Dios, divine; anthos, flower) to the genus, probably suggested by the delightful fragrance. The specific name Caryophyllus (Greek, Caryon, nut; and phyllon, leaf) has been applied to the clove tree (Caryophyllus aromaticus), and because of the clove-like fragrance of the Carnation, this name was applied to the species; otherwise it would have no significance. The name Carnation (Latin, carnatio, from caro, carnis, flesh) has reference to the flesh-color of the flowers of the original type. This plant has been in cultivation more than 2,000 rears, for Theophrastus (History of Plants, 300 B.C.) says : "The Greeks cultivate roses, gillyflowers, violets, narcissi, and iris," gillyflower being the old English name for the Carnation. It was not, however, until the beginning of the sixteenth century that the development of the Caruation into numerous varieties made an impression upon its history. The original flesh-color of its flowers was already broken up into its component colors, red and white. The gardeners of Ituly, France, Germany, Holland and England, with their respective ideals of beauty in this flower, contributed so many varieties that in 1597 Gerard wrote that "to describe each new variety of carnation were to roll Sisyphus' stone or number the sands."

There were many attempts at classification, but most of them, like the varieties they serve, have disappeared. Two of them are as follows: The French scheme arranged all varieties into three classes, thus :-Grenadins (Fig. 368), including those with strong perfumes, flowers of medium size, either single or double, petals fringed, and of but one color; Flamands, including those with large flowers, round and double, rising in the center to form a convex surface, petals entire, either unicolored or striped with two or more colors : F'ancies, including those with colors arranged in bands on light grounds, the petals toothed or not. The English classification of these varieties makes four categories : Selfs, or those possessing only one color in the petals ; F'lakes or those having a pure ground of white or yellow and flaked or striped with one color, as scarlet, purple or rose : Bizarres, or those having a pure ground marked as in the Flakes, but with two or three colors; and Picotees, or those having a pure ground of white or yellow, and each petal bordered with a band of color at the margin. This last class has been regarded with the distinction of a race.

In the early part of the nineteenth century English gardeners exercised very great care, in the growing of Carnations, to mature only perfect flowers. Imperfect and superfluous petals were extracted with forceps petals appearing out of place were arranged in a per- 
fect imbrication ; the calyx tube was cut partly down between the teeth, to prevent excessive splitting at one side and to give more freedom to the expansion of the

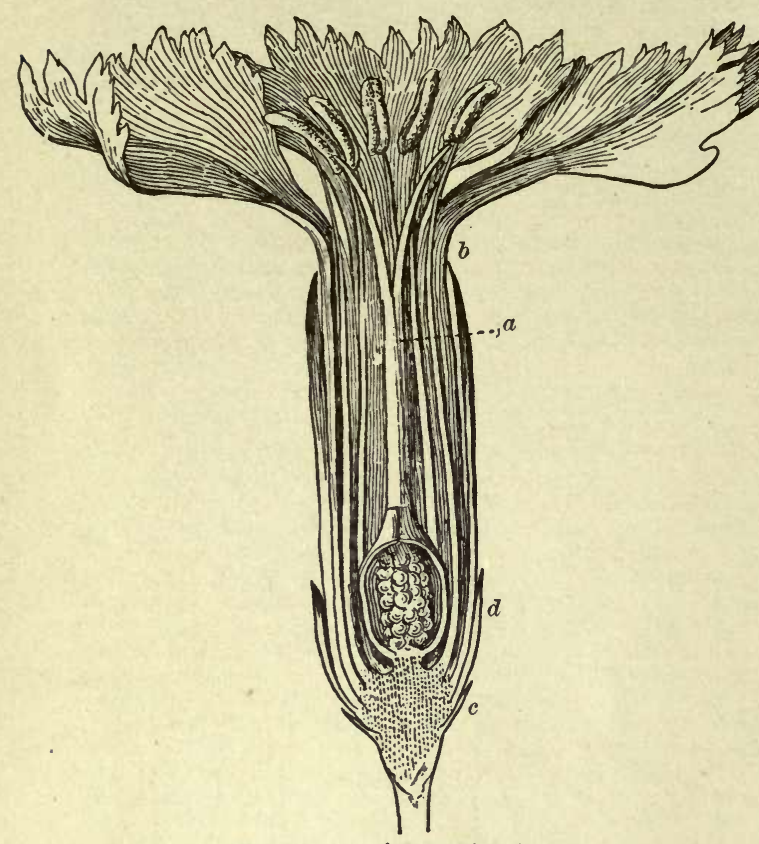

366. Section of Carnation flower.

$c, d$, bracts; $b$, calyx; $a$, style.

flower. These and many more tedious details seem to have wrought the downfall of this sweet flower about the middle of the nineteenth century.

All the foregoing has reference to those types of Carnations which are but little known or grown in America at the present day. The varieties so common in Europe are usually kept in coldframes or coolhouses during the winter, and as spring approaches the plants are brought into their blooming quarters, for no flower is expected to appear until the month of July, when there is a great profusion of blossoms, but for a short season. Therefore, they can all be classed as a summer race. They are also grown permanently in the open.

Perpetual-Flowering Carnation (Remontant, Monthly, or Tree).-The Carnations so common in America, and grown so extensively under glass for winter cut-flowers, originated about 1840 as a distinct race of Perpetual-fiowering Carnations. A French gardener, M. Dalmais, according to M. Jean Sisley, of Lyons, obtained the first real constant-blooming Carnation, which was called Atim, and sent out in 1844 . It was the result of artificially crossing Oeillet de Mahon, or St. Martin, because it was regularly bloomed in November, with pollen from Oeillet Biohon. The first gain was crossed with Flemish Carnation with repetition. In 1846 he obtained a great number of varieties of all colors. M. Schmitt, a distinguished horticulturist of Lyons, followed in the work, and obtained several fine varieties, like Arc-en-ciel and Etoile Polaire, which were cultivated for several years. The next enthusiast who aided materially in the development of this new race of Carnations was M. Alphonse Alegatiere, who, by careful crossing, obtained varieties with stiff stems. About 1866 the number of such varieties was increased, and as a class they received the name of Tree Carnations, but in America they were more generally termed the Monthly Carnations. The earliest importation of this race of varieties into America seems to have been made in 1868, and included such varieties as Edwardsii, President Degraw, La Purite and Variegated La Purite, and for a period of ten years were grown as pot plants for summer or winter blooming. About 1875 bench culture was introduced in coolhouses, and was attended with such marked success that soon entire greenhouses were devoted to the cultivation of the Carnation, and there arose the carnation specialist, or carnationist, the latter title being used first, in 1892, with such men as Starr, Swayne, Tailby and Dorner. There are now about 500 distinct varieties in this country, all of American origin. The winter forcing of Carnations is now more highly developed in America than anywhere else in the world. For sketches of the evolution of the Carnation, particularly of the American cut-flower race, see Bailey, "Survival of the Unlike."

Propagation. - The perpetual-flowering Carnations are propagated by cuttings (Fig. 369). The best "wood" for this purpose is found in the lateral shoots at the base of thrifty branches; shoots appearing high on the flowering stem are not desirable. No cuttings should be taken from stems bearing small, sickly, or poorly colored flowers. Diseased plants, and plants which have been greatly stimulated and forced in a high temperature, should also be avoided in propagation. The material for cuttings is pulled from the plants by a lateral movement, and in this condition, - that is, without further cutting or trimming, -is considered by many propagators as ready for the sand-bench ; others remove a portion of the leaves or the tips of the long ones. Cuttings are successfully made from December 1 to May 1 . Growers choose different portions of this period for the best results. February is, perhaps, most frequently chosen. The cuttings are usually planted in sandbenches to be rooted, either in a separate propagating house or upon a portion of bench prepared for the purpose in the regular Carnation house. For a limited number of cuttings, "flats" may be used and placed where they will receive proper treatment. The temperature in which cuttings are best rooted is $50^{\circ} \mathrm{F}$. for the first few dars, then increased to $55^{\circ}$ or $60^{\circ} \mathrm{F}$. During sunshine the young cuttings are shaded, and at all times moisture is carefully regulated, to avoid the "damping off" fungus and the flagging of the cuttings. In about four weeks a good bunch of roots will be formed, and the cuttings are transplanted into small pots or flats. They are then kept in coolhouses $\left(45\right.$ to $50^{\circ} \mathrm{F}$.) until it is possible to plant them in the field. Propagation by lay-

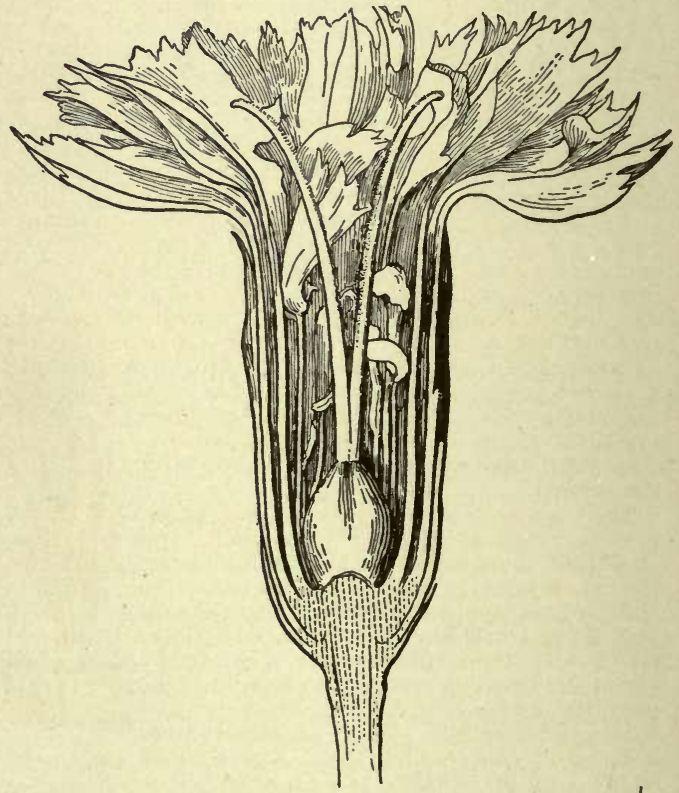

367. Showing the anthers becoming leaves, - a stage in the doubling of the Carnation.

ering is practiced abroad (Fig. 370), but is too slow for American conditions. Plants are grown from seed only when it is desired to obtain new varieties. 
Summer Treatment.-The young plants are carefully hardened in the spring, to enable them to be planted in the open fleld in May. Various soils have given good results. A sandy soil yields fine plants if a drought does not prevail; a clay soil will make short, stiff plants, which are slow to yield flowers in the fall; a sandy loam is the best soil.

The field soil is well pre. pared by applying a liberal quantity of well. rotted manure or an equivalent in commercial fertilizer, plowing deeply and harrowing thorough17. The plants are then set, as soon as danger from heavy frosts is past, putting them 10 inches apart, in rows 12 inches apart if to be worked entirely by hand, and 3 feet apart if to be worked with horse and cultivator. Throughout the summer the plants are kept free from weeds and frequently cultivated. No blossoming by plants intended for winter flowering is permitted. All rising shoots are cut back to 2-4 inches as fast as they appear. Such prun. ing ceases about August 1 to 10 . In the month of September the plants are lifted and planted upon the benches. Some growers transplant with "balls" of ground, others without any soil elinging to the roots.

Winter Treatment. - The Carnation house usually stands east and west, and is provided with both raised and solid benches. Much experience and a long controversy have resulted in the conclusion that some varieties of Carnations should be planted on raised benches and others on solid benches. The soil is prepared some time pre368. Grenadin Carnation, vious to its use, with three$\left(X^{2} / 3.\right)$

fourths loam and one-fourth well-rotted manure, turning several times to thoroughly mix the elements. A bout September 1 it is placed on the benches, enough to be 4 or 5 inches deep when settled. The plants are set 8 to 12 inches apart each way, watered thoroughly, and syringed frequently until established. Staking is necessary to keep the branches off the ground and the flowers above the foliage. Various arrangements of wires and strings are devised. The use of plant-stakes has been unirersally abandoned.

The temperature of the Carnation house is maintained at 50 to $55^{\circ} \mathrm{F}$. at night and about $10^{\circ}$ warmer in the daytime, during the whole winter. The proper use of water maintains a healthy growth, ensures substantial flowers, and prevents red spider. On bright days the houses are freely syringed. Fertilizers are used with great liberality on the plants in the benches, and with good results. Liquid manures from horse, cow, sheep or hen droppings, diluted 369. Carnato the color of weak tea, are applied about tion cutting. once a week, beginning about January 1, or a mulch of well-rotted cow manure is put over the ground after the plants become well set. Disbudding is practiced to produce large flowers on stiff stems.

Carnations are not very seriously annoyed by insects or fungous diseases. The red spider is usually kept under control by syringing judiciously with water, and the greently by fumigation with rose-leaf extract or the use of tobacco stems on the floor of the house. Three fungous diseases have recently become annoying ; viz., rust (Uromyces caryophyllinus, Schr.), anthracnose (Volutella sp.), and spot or blight (Septoria Dianthi, Desm). The best treatment is to destroy diseased plants and to spray the rest with Bordeaux mixture.

Varieties are constantly changing. The following represent the conmon range of variation:

White-Lizzie MeGowan (Fig. 372), Ivory, Alaska, Uncle John, Flora Hill, White Cloud.

Pink -Wm. Scott Daybreak (Fig. 374), Albertini, Bridesmaid, Della Fox, Triumph, Victor.

Scarlet-Hector, Portia, Dazzle, Jubilee (Fig. 373).

Variegated - Minnie Cook, Helen Keller, Mrs. Geo. M. Bradt, Armazindy.

Yellow-Eldorado, Buttercup, Mayor Pingree, Gold Nugget.

Crimson-Meteor, Tidal Wave, Cartledge.

Carnations in Pots.-For pot culture, the Carnation is propagated and treated as previously described in fleld culture up to the time of lifting the plants, when they are taken up and planted singly in pots, - 4-, 5-

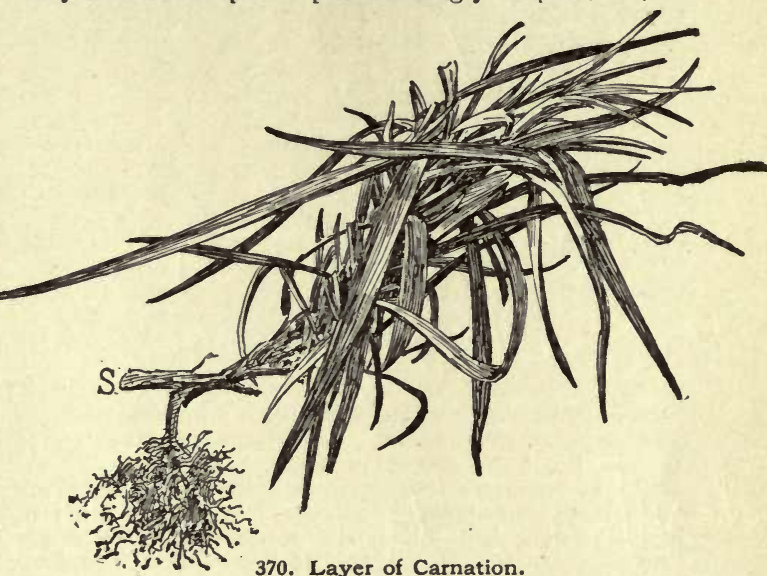

The parent stem was severed at $\mathrm{S}$.

6-, or 7-inch sizes, suiting them to the size of the plants. If the heading-back was not continued too late in the field, many plants may be in bud in October and be excellent specimens for fall sales. The bulk of the potted plants, however, are intended for spring sales, and are carried over the winter in well-built coldframes, left uncovered as long as fine weather will permit; frosts and even light freezes will not hurt the plants. At the approach of severe weather, sashes are covered over the plants, but on mild days liberal ventilation is given, and during extreme winter cold additional covering is placed over the frames. About the first of March these plants are brought into a coolhouse, and one mouth later they are graced with a profusion of buds and blossoms ; with proper care they will continue to flower throughout the summer. The varieties preferred for pots are those of dwarf habit, with stems stiff enough to hold up the flowers without staking. In color, the varieties known as "fancies" are usually more salable than those with single colors. Varieties recommended for pot culture are Portia, Mrs. Fisher, Grace Wilder, Buttercup, American Flag, Robert Craig, E. G. Hill.

Other Carnations. - Aside from the forcing Carnations, the following groups receive attention in this country:

Carnation, Malmaison. - This is a group of varieties grown in Europe. It is said (Revue Horticole, 1888) that the original variety of the group was taken from La Malmaison in the time of Napoleon I. It was pure white in color, but now all the shades of red are in the group. The flowers are very large, even 6 inches in diameter with good culture. The plants are dwarf, very florifer. 
ous, but not constant bloomers, never seeding. The stems are strong and straight. Usually propagated by cuttings or layers.

Carnation, Victoria. - A group of varieties under this name originated with M. Benary, Erfurt, Germany, in 1879 (Revue Horticole. 1890), probably descendants from Souvenir de la Malmaison, which it closely resembles, but of greater merit because of a firmer calyx. All the colors of Carnations are represented; petals are large, finely fringed. The plant is dwarf, not remontant. Propagated by layers or cuttings. The members of this group, as of the preceding, have not received much attention in this country.

Carnation, Marguerite (Fig. 371).-A comparatively new class of Carnations. Origin not definitely known; supposed to have been in somewhat obscure cultivation in Italy and Algeria a very long time. The plants are generally raised from seed, and blossom in about four months. A very large majority of flowers come double or semi-double, strongly clove-scented, deeply fringed; color red, pink or white. The plant is dwarf, 10-15 inches high, compact, erect, branching. It is a constant bloomer, but in quality the flowers are far inferior to the Perpetual-flowering Carnation. The Marguerite Carnations are highly prized for massing in summer beds, and are treated as annuals. GEORGE C. Butz.

Commercial Carnation Culture.-Carnation culture can be divided into three parts or periods-propagation of the young plants during the winter aud early spring months ; the summer culture, generally carried on in the field or garden, for the growing of the young plants to a stage of maturity suitable for the transfer to the houses in the fall; and the winter or house culture, which is often prolonged through spring and early summer, depending on the condition of plants and $\mathrm{va}$. riety. Of late, experiments have been made with summer culture under glass, a subject which is treated below.

To make the mode of cultivation more comprehensible, it will be well to speak first of the habit of the Carnation in general, for there is a great difference in growth and blooming of the different varieties, without making one variety or the other less profitable. Although the same treatment may be applied, a slight deviation from general rules may often be practical and more fitting to certain varieties. We find among our present varieties some with a more spreading, straggling growth, as Daybreak, while others grow more compact, as Jubilee. We find early and late bloomers; some that are continuous bloomers, as Mrs. Geo. M. Bradt, and others that show a tendency to "crop", while with some varieties the coming-off crop and the new comingin are so linked together that it will only be noticed by a less quantity and smaller flowers, as in White Cloud; with others it is so marked that often an interval of from four to six weeks, or an entire cessation of blooming, will take place, as in Bridesmaid. In the aggregate, the continuous bloomer and the cropper may furnish the same number of flowers through the season, and, under circumstances, one may be as profitable as the other.

Propagation can be carried on from January to May. Early propagation is preferable, as often in April warm weather will interfere with good results. When the plants are expected to commence to bloom early in fall

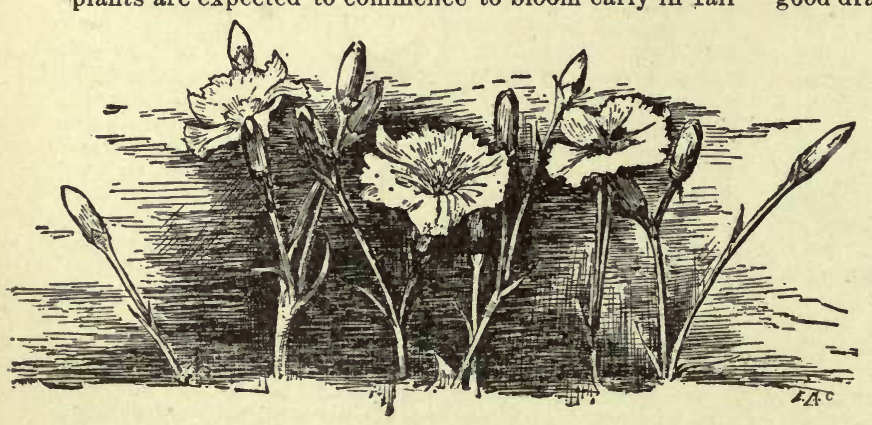

371. One form of the Marguerite Carnation (X1/3). and furnish a good quality of blooms, early propagation is a necessity. Late-blooming varieties, when propagated early, advance their time for blooming consider. ably. Late-propagated plants may have to be transferred from the propagating bed to the field at a time when the hot weather will prove very severe on the little plants ; they are deprived of the advancing spring growth, and consequently make little headway through the hot summer months, but will make good plants for late blooming, or, when not allowed to bloom, will furnish excellent cuttings for early propagation.

Any young shoots not advanced into bud formation, but seeming to be capable of producing a good flower in time, will, as a cutting, make a good plant. If the bud has commenced to form, even only to half the size of a pinhead, it is bound to develop; it retards root formation, and when eventually roots are formed, all the nourishment taken up is used to mature that bud. Such cuttings, doubtful at their taking, but which will in time develop a flower-bud, are not to be necessarily classed as bad cuttings if, at the first symptoms, the bud is removed; when left to develop it may still make a plant after a lapse of two or three months, but time is lost. In general, the strongest and best cuttings are found at the base of the flower-stem; those that appear upon the flower stem are of an inferior quality, and will in time show symptoms of degeneration; the same will be the case when taken from exhausted blooming plants. For this reason the late-propagated plants, whose growth has been made through the late fall months, and where the flower stems are removed as fast as they appear, and the whole strength thrown into the young shoots appearing below the break, will furnish the best cuttings. The plant is in quite a different stage of growth when producing new shoots, and when young shootscuttings - are produced only in connection with the maturing of flowers. This will lead to the conclusion that to produce the best cuttings, a separation of the culture for flowers and the culture for cuttings is the best solution.

A cutting should have an average length of 4 inches, with at least 1-inch clean stem. When taken off close from the branch or stem out of the axil of a leaf, no further trimming of the heel is necessary except an occasional removing of some wood fibers that may adhere from the break. When the shoot is too long and demands a cut with the knife, the cut should be made at or right above a joint, so that the two leaves can be peeled off and leave a clean heel. If cut too high above a joint, the stem gets too hard; if below, the bark will be peeled off with the leaves, and gives occasion to rot. Leaves should be removed as far as the cutting is inserted in the sand, and the top of the leaves shortened, so as not to give too much surface to evaporation.

The propagating bed should be filled with 3 inches of clean, sharp sand, not too coarse, and well packed. When the cuttings are to be inserted, a line should be drawn with a knife to the required depth of about 1 inch, the cutting inserted and the sand pressed on. A tile or brick bottom in the propagating bed is much superior to a common wooden bottom; it assures better drainage and less danger of fungus. The utmost cleanliness should be observed in a propagating house, and no decaying matter be allowed to lie around. Water is needed every two or three days when the bench has good drainage. The house should be shaded either from the outside with a whitewash of white lead and coal oil, or on the inside with a light white muslin. Ventilation is advisable whenever the temperature comes near to $60^{\circ}$; general temperature $55^{\circ}$, and all available means should be employed to keep it at that point. Day temperature may be two or three degrees abore, and night temperature as much below.

Average time to root Carnation cuttings is four weeks, and depends much on the variety. Mary Wood may root in two weeks, while it may take six weeks to root Mrs. Geo. M. Bradt. In a higher temperature, cuttings will root more quickly, but it is not advisable, as it increases the danger of cutting-bench fungus and softens the young plants.

As soon as rooted, transplant into a light soil enriched with well decomposed manure-none 
other should be used-in a light, well-rentilated house either on benches, in flats or small pots, the latter preferable, as early-rooted plants can be shifted into larger pots, and the later-rooted be just in good shape for the transfer to the field. Temperature the same as in the propagating house, but when the young plants become well established may be kept $5^{\circ}$ lower.

The ground for the field or summer culture should be well prepared, and any working in it be avoided when too wet: planting to be done as soon as the weather will permit. A good spring growth is of the greatest advantage, especially if good plants are wanted for early fall blooming. Late spring frosts will not injure the plants, and a cool atmosphere is more congenial to a good growth than the hot summer weather, when growth is comparatively slow; plants to stand at least 15-18 inches apart each way, or at any greater distance, as through a drought than when resort is had to watering. Watering, unless it can be done thoroughly and kept up, should not be resorted to, and only as a last measure in a severe drought.

When the plants attain the height of 5-6 inches, topping should be commenced and be kept up as long as the plants remain in the field. This operation is for the purpose of removing the top shoots where buds are forming, or
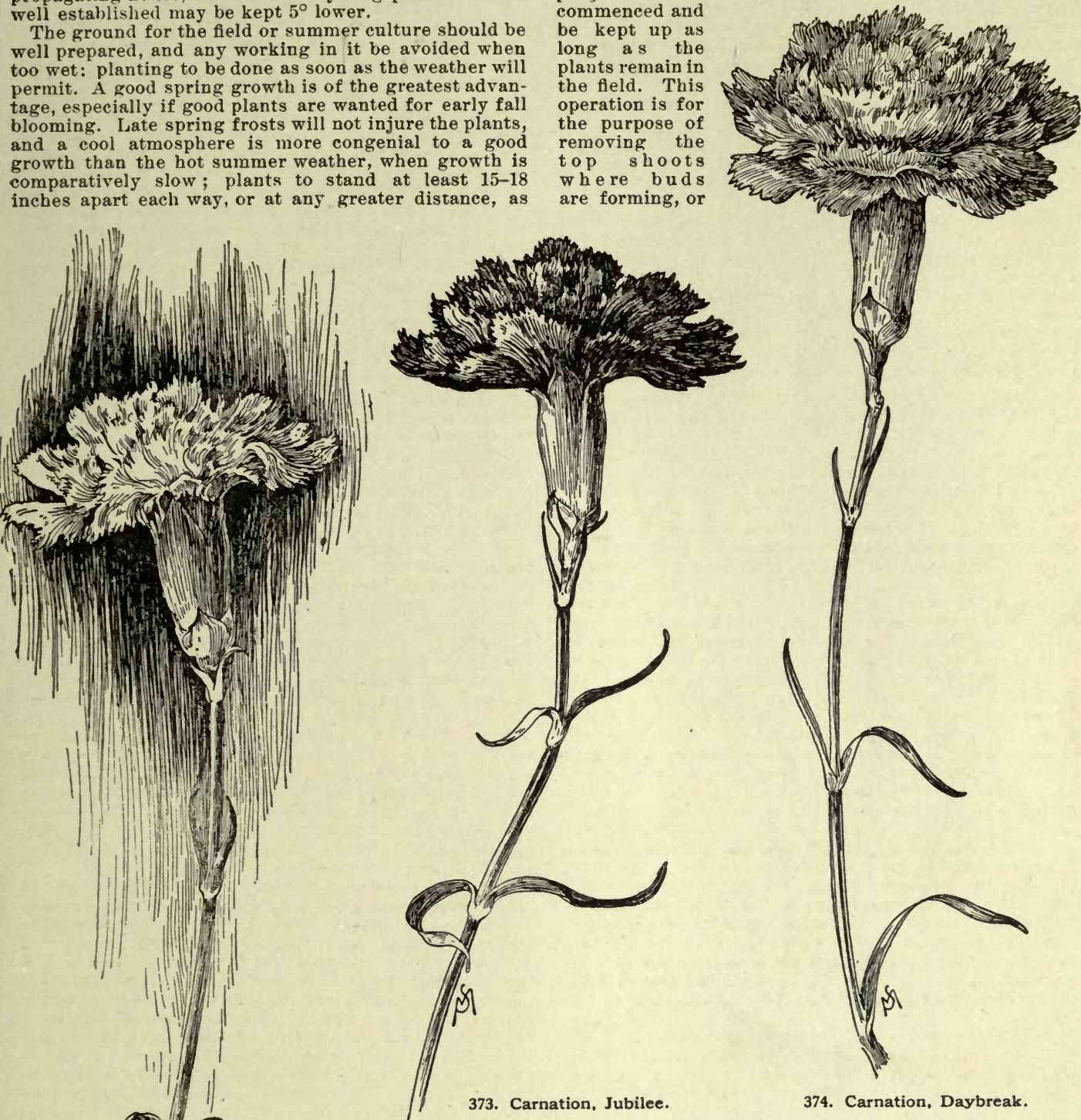

(4) it the mode of cultirating the soil to be adopted may require. From the time of planting, as soon as a crust forms after a rain it should be broken and the surface of the soil kept in a mellow condition to a depth of 2 inches throughout the summer; any deeper cultivating is injurious rather than beneficial to the plants. A

372. Carnation

Lizzie McGowan. ticial to the plants. A thorough cultivating will not only destroy weeds, but will keep the soil in condition in which it retains moisture the longest, and will carry the plants much better where a part of the plant grows out of proportion to the other, to force the plant to grow into a symmetrical, bushy form. At the same time, care must be taken not to cut any more than the purpose of topping calls for, for the plant is just as dependent on all its leaves as on its roots. Any bloom is at the expense of the fall and winter crop, for it retards the growth of the plant and uses up energy that is wanted at a more desired time.

The transfer from the field to the house for the following winter culture is an ordeal to the plants and much anxiety to the grower. If early flowers are wanted, an early transfer has to be made-as early as the latter part of August and beginning of September. Laterooted plants, that had not the chance of any spring growth, should be given the benefit of a fall growth and be transferred later. 
The preparation of the soil for the benches in the houses should be commenced the year before. If possible, select a piece of sod-but other ground will answer-give it a good coat of stable manure and plow under. In the spring, add nore manure or any fertilizer that the soil may mostly require, especially bone, woodashes and lime, if not already in the soil, plow again, and repeat the plowing two or three times during the summer. As to the texture of the soil, a loam that con-

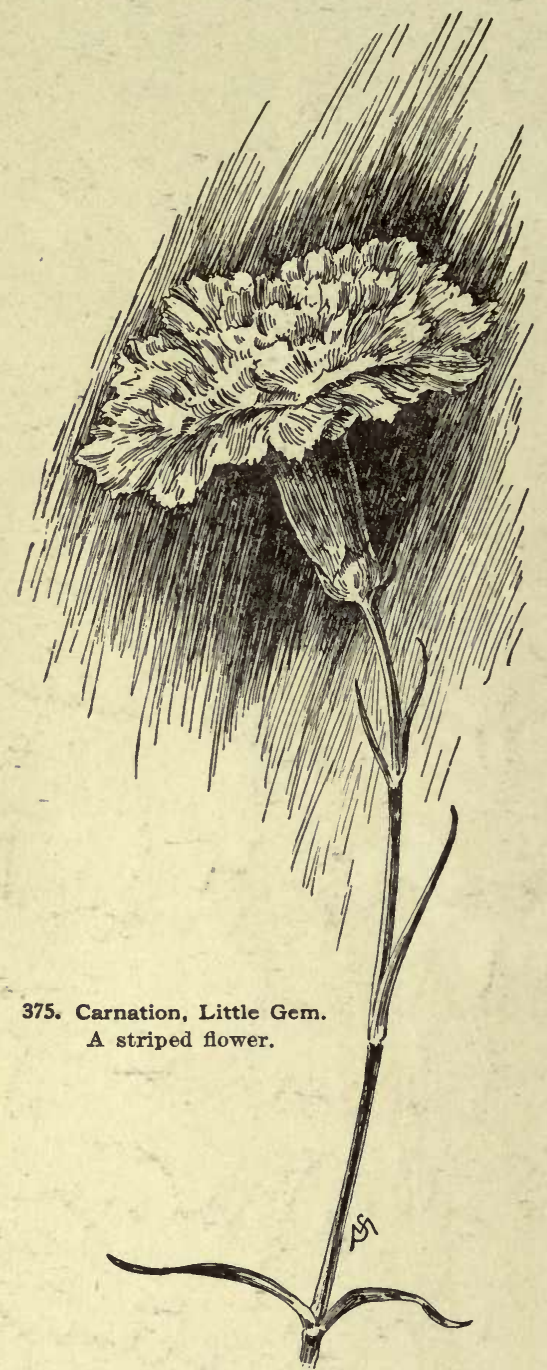

tains some clay without making it too heavy, is preferable. It requires a rich soil and, therefore, the preparation has to be commenced in time, so that the manures become decomposed and well incorporated, ready for assimilation.

Light, roomy houses, with good ventilation, are required to insure a bountiful crop. Whether solid or raised benches, especially for the latter, fresh soil is required every season. Good drainage and an even filling and packing of the soil insures an even, bealthy growth. Strong-growing varieties should be planted 12-15 inches each way, less strong ones closer; any crowding, when not diminishing the quantity of flowers to the square foot, will certainly degrade the quality of the same. Transplanting is an ordeal for the plants, and has to be done with the greatest care and dispatch, especially as the ordeal is often aggravated by hot weather during early transplanting. Points to be observed are, in the first place, a careful lifting. When the ground is sandy and loose, the ground may be shaken off, but when hard and baked, so there is danger of breaking the roots, it is better to leave a ball. In setting, plants should be cleaned of all decaying leaves, and buds removed. Place the plants in a natural position by spreading the roots out over a little mound formed in the excavation made for the plant, and press the ground on firmly. Any deeper planting than the plants have stood in the fields invites stem-rot. Water well after transplanting, after that more sparingly, as a too wet, cloggy soil will retard root-formation. Other precautions to facilitate the establishing of the plants are shading of the house, and reduction of ventilation to a minimum. A moist, cool air, even if close, that otherwise would be injurious, has to be employed to prevent. a too strong enervating evaporation from the leaves-in other words, to prevent wilting. An occasional syringing two or three times a day will give enough moisture to the soil after the first watering, and keeps a moist atmosphere. When plants showing signs of having formed new roots become established, any of the precautions employed to gain this end become injurious. Tho shading is to be gradually removed, ventilation increased, syringing reduced, and a normal treatment of growing plants assumed. House culture may be summed up as follows: Average night temperature $55^{\circ}$, day temperature on cloudy days $60^{\circ}$ to $65^{\circ}$. When over $60^{\circ}$, rentilation should be given, and increased when necessary to retain the desired point. Fresh air is a necessity, and ventilators should be opened whenever it is practicable to do so. All syringing is to be avoided and the water applied to the soil below the plants. Water should be given freely when needed, and care be taken to make the watering thorough, reaching the bottom of the bench. Glass roof should be kept clean, so the plants will derive the benefit of every moment's sunshine. Cultivating the soil, with the exception of a mere scratching, is of more injury than benefit, as it will destroy the white roots coming near the surface in quest of food.

The principles of support are to hold the body of the plant off from the soil for a free circulation of air underneath, and to support the flower stems in a way so as not to impair the plant in its freedom of growth, and leave free access to cut the blooms with any desired length of stem.

The Carnation is rather a heavy feeder, and quantity and quality of blooms depend largely on the nourishment supplied. The necessity for feeding depends on the richness of the soil, and to avoid a disastrous overfeeding, food has to be applied judiciously - rather weak and often than too strong at a time. Feeding can be done with a mulch of well decomposed manure, or best, with prepared liquid manure. If it can be arranged so a part of the liquid manure could be given with each or every other watering, best results will follow and clanger of overfeeding be avoided. In the preparation of liquid manure, it is best to take fresh cow-manure as a base and add any other ingredients desirable, as chicken manure, bone meal, sulfate of potash ; but avoid anything that contains lime, as lime will set free the valuable ammonia.

Summer culture under glass has been experimented with in late years, but with no generally satisfactory results. The bot, close, greenbouse air is against it ; the plants grow, as greenhouse plants do, soft and drawn, not to be compared with the sturdy, short-jointed, hardier outdoor growth, so productive of a good crop. Indoorgrown plants lack the foundation gained in the field. True, the plants will not have the set-back of a transplanting, but better results have to be shown befors this mode of summer culture will become general.

Every year new varieties are produced and introduced, superseding older ones. A list of the varieties grown at present may be useless in three or four years, so we mention only the best grown now. Among the whites, Lizzie McGowan (Fig. 372) has been a standby, but White Cloud now stands as the best. Maceo is the best deep red or maroon yet produced; a very free and continuous bloomer. In the scarlets, Jubilee (Fig. 373) wants first place, but indications are that it will be superseded 


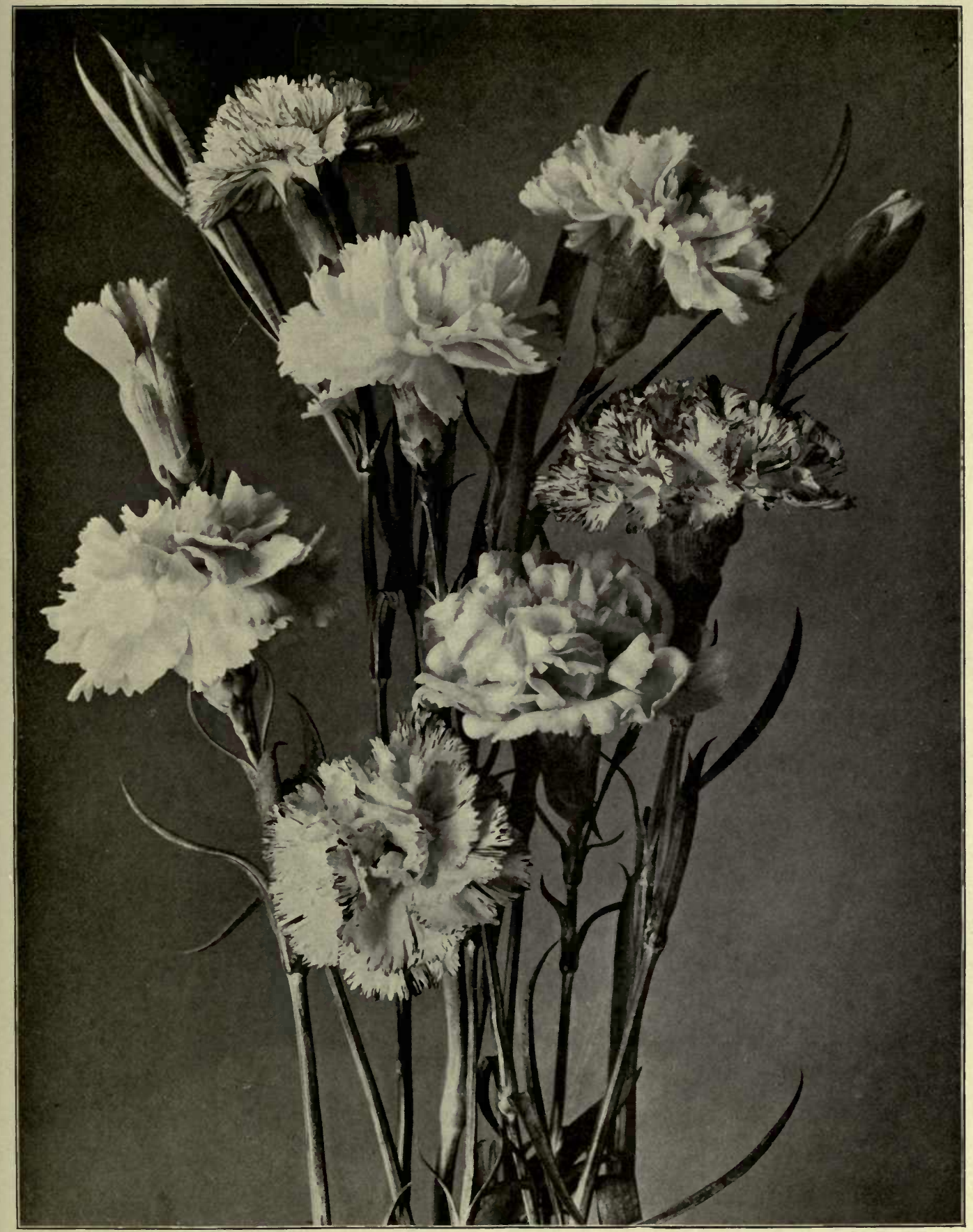

Plate IV. Carnations

Types of the American winter-flowering Carnation. Half size 


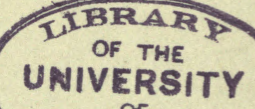

CALIFORNIA 
by G. H. Crane. Among the light pinks, Daybreak (Fig. 374) is still a standby, but there are some among the new ones that will, to all appearance, push it into the background. In the dark pinks, Scott yet claims the honors, but Mrs. Francis Joost, as the newer variety, may succeed to its place. In yellow, Gold Nugget is conceded the best. Mayor Pingree is a good large flower, but rather of a pale color, and a shy bloomer. The Carnation par excellence is Mrs. Geo. M. Bradt, white striped scarlet-an even, continuous bloomer throughout the whole season; a fine, large flower, admired wherever grown.

Fred Dorner.

\section{CAROB. See Ceratonia.}

\section{CAROLINA ALLSPICE. See Calycanthus.}

CARPEL. One of the separable or component parts of a compound pistil. See Flover.

CARPENTERIA (after Professor Carpenter, of Louisiana). Saxifragdcea. Evergreen shrub, with rather large opposite lvs.: fls. large, in terminal, loose corymbs; calyx 5 -parted; petals 5 ; stamens numerous; ovary almost superior, 5-6-celled: fr. a many-seeded dehiscent capsule. One species in Calif. A highly ornamental evergreen shrub, with very large, white and fragrant fls., but not hardy north. It requires a well-drained, light and sandy soil, and sunny, somewhat sheltered position; it especially dislikes moisture during the winter, and its perishing is often more due to an excess of moisture than to the cold. Prop. by greenwood cuttings under glass in summer, and by suckers, which it produces freely; also, by seeds, sown in spring.

Califórnica, Torr. Shrub, 6-10 ft.: Ivs. elliptic-lanceolate, entire or remotely denticulate. bright green above, whitish-tomentose beneath, 2-4 in. long: fls. pure white, $21 / 2-3$ in. in diam., fragrant; petals orbicular, concave. June, July. B.M. 6911. Gn. 31:581, and 54, p. 248. G.C. II, 26: 113. R.H. 1884, p. 365. J.H. III, 29: 251 .

\section{CARPET BEDDING. See Bedding.}

ALFRED REHDER.

CARPINUS (ancient Latin name). Cupuliferce (or Betuldcea). Hornbeam. Tree, of medium size, sometimes shrubby: lvs. deciduous, petioled, alternate, serrate: stipules deciduous: fls. in catkins, appearing with the Ivs.; staminate catkins pendulous, each scale bearing 3-13 stamens, 2-forked at the apex ; pistillate catkins terminal, slender, each scale bearing two ovaries, the bracts and bractlets of which develop into a large, leafy, more or less 3-lobed bract, embracing the small, nut-like fruit at the base. About 8 species in $\mathrm{C}$. and $\mathrm{E}$. Asia, 2 in Europe and W. Asia and 1 in N. and C. Amer. Hardy, ornamental tree, usually with dense, round head, and of somewhat slow growth. The wood is very hard and close-grained, and much used in making tools and other sma'l articles. The hand some foliage is rarely attacked by insects, and assumes a yellow or scarlet color in fall. The most beautiful are $C$. cordata, with large Ivs., and $C$. Japonica, of graceful habit and with elegant foliage. The Hornbeam bears severe pruving well, and is pery valuable for high hedges, and the European species was formerly much used in the old formal gardens for this purpose; the latter makes, also, an excellent game cover, as it retains its withered foliage almost roughout the whole winter. They grow in almost any soil, and even in dry, rocky situations. Prop. by seeds, sown usually in fall, germinating rery irregularly; if they do not spring up the first spring, the seed bed should be covered until the following spring with moss or leaf-mold, to keep the soil moist. If intended for hedges, the seedlings should be transplanted after the first year, and allowed sufficient space to prevent them from growing into slender, tall plants, unfit for hedges. The varieties of rarer species are grafted in spring under glass, or in the open air on seedlings of one of the common species.

Caroliniàna,Walt. (C.A mericdna, Michx.). A MERICAN Hornbeam. Blue Beech. Fig. 376. Bushy tree, rarely $40 \mathrm{ft}$.: Ivs. ovate-oblong, usually rounded at the base, acuminate, sharply and doubly serrate, glabrous at length, except in the axils of the veins beneath, 2-4 in. long: fruit-clusters peduncled, $2-4$ in. long: bracts orate or ovate-lanceolate, $3 / 4-1$ in. long, with 2 broad and short inequal lateral lobes, and a much longer middle lobe, usually serrate only on one margin. E.N. America, west to Minnesota and Texas; also, in Mexico and C. Amer. S. S. 9:447. Em. 1:199.-Bushy tree, with dense, but

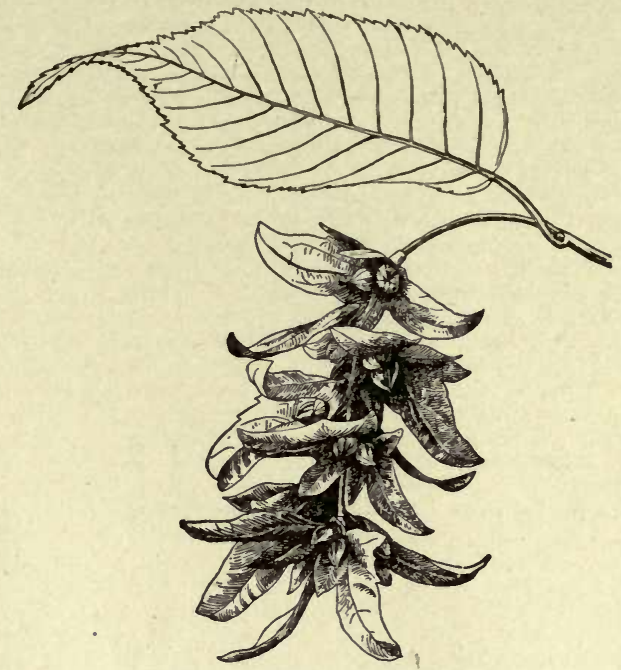

376. Carpinus Caroliniana $(\times 1 / 2)$.

slender and often somewhat pendulous branches, and dark bluish green foliage, changing to scarlet or orangeyellow in fall.

Bétulus, Linn. Europian Hornbeam. Tree, to 60 or $70 \mathrm{ft}$.: lvs. similar to those of the former, cordate or rounded at the base, ovate or oblong-ovate, of somewhat thicker texture, and the veins more impressed above: fruit-clusters $3-5$ in. long : bracts over $1 \frac{1}{2}$ in. long, with ovate, lateral lobes, and much longer oblong-lanceolate middle lobe, the margins almost entire or remotely denticulate. Europe to Persia.-The most remarkable of the garden forms are the following: Var. incisa, Ait. (var. quercifolia, Desf.). Lvs. incised or lobed, smaller. Var. fastigiata, Hort. Of upright growth. Var. purpùrea, Hort. Lvs. purplish when young, green at length. It grows into a taller tree than the American species, though the former is of more vigorous growth when young; the foliage turns yellow in fall, and remains on the tree throughout the winter.

C. Americàna, Michx $=$ C. Caroliniana. $-C$. cordàta, Blme. C. Americana, Michx. $=$ C. Caroliniana. $-C$. cordata, Blme. pairs of veins, 4-7 in. long. Japan, Manchuria. G. F. 8: 295. The most beautiful species, and quite hardy. $-C$ duinénsis, Scop.=C.orientalis. - C. Japónica, Blme. To $50 \mathrm{ft}$.: Ivs. slightly cordate or rounded, oblong-ovate, 3-4 in. long, with about 20 or more pairs of veins. Japan. G.F. 6: 365 (as Carpinus Carpinus). R.H.1895:427. A very graceful species,-C. laxiflora, Blme. To $50 \mathrm{ft}$.: lvs. ovate or elliptic-ovate, long acuminate, 2-3 in. long, $50 \mathrm{ft}$.: Ivs. ovate or elliptic-ovate, long acuminate, 2-3 in. long, with 10-14 pairs of veins. Japan. Very attractive in fall, with
its long and slender catkins.-C. orientalis, Mill. Bushy tree, to $15 \mathrm{ft}$. lvs. ovate or oblong-ovate, $1 \frac{1}{2-2}$ in. long, with about 10 pairs of veins. S. E. Europe to Persia. - C. Turczanindwi Hance. Shrubby tree: lvs. ovate, acnte, 1-2 in. long, with 10-12 pairs of veins. N. China.-C. Virginiàna, Michx. $f=C$. Caroliniana.-C. Yedoénsis, Maxim. Small tree: branchlets and lvs. beneath pubescent; lvs, ovate-elliptic or ovate-lanceolate, with about 12 pairs of veins, $2-3$ in. long. Japan.

Alfred ReHDer.

CARRIERIA (after E.A. Carrière, prominent French horticulturist and botanist, died 1896). Bixdcece. Deciduous trees, with alternate, long-petioled, glabrous lvs., resembling in appearance the genus Idesia. Two species, recently discovered in China, of which one, $\mathbf{C}$. calycina, Franch., has been introduced. It is a tree to $50 \mathrm{ft}$. high, with rather large, oval or obovate lvs. and apetalous fls. with 5 large sepals in few-fld. terminal racemes. It will be probably of the same hardiness and culture as Idesia. R. H. 1896, p. 498. 
CARROT (Daùcus Caròta, Linn.). Umbellífera. A native of the British Isles, and one of the bad introduced weeds of eastern North America (Fig. 377). The improved succulent-rooted garden varieties are believed to be descended from the same stock. though this has been denied. It seems probable that the horticultural improvement of the species was begun in Holland, and it is said that the cultivated forms were introduced thence into the gardens of England during the reign of Queen Elizabeth. The Carrot is now very generally, though not extensively, cultivated everywhere, both for culinary purposes and for stock-feeding. It is sometimes forced under glass, but to no great extent. Carrots are most useful in culinary practice for soups, stews, and salads, and as this class of cookery has never been reasonably popular in America, this vegetable has not received the attention it deserves.

The Carrot requires a loose, friable, warm soil, in the very best mechanical condition, and especially for the early crop of tender spring roots, this needs to be liberally fertilized with well-rotted stable manure and some rapidly available potash fertilizer. Seed for the first crop of Carrots should be sown as sonn as the ground is warm and dry enough, in rows 1-2 feet apart. As they germinate slowly, the land should be free of weeds. When they are large enough to be thinned, the plants are decimated to stand $2-3$ inches apart in the rows. Careful, clean cultivation is requisite, and drought is to be especially avoided, even at the cost of any practicable irrigation. Later crops, and Carrots grown for stock feed, may be sown in May or early June. and treated like the early sowing. When the young roots are ready for market they are pulled and tied in bunches of six or ten or a dozen (Fig. 378). In the early spring, when a considerable appetite for green stuff can be depended on, a great many young Carrots are shipped north from southern gardens. Well-ripened roots of the fall crop may be stored in pits or in the root-cellar. The Carrot has no enemies of importance.

The varieties of Carrots differ chiefly in respect to size and grain, with differences in earliness closely correlated. The following are favorite varieties:

French Forcing (Earliest Short Horn).--One of the smallest and earliest; root small, almost globular, orange-red.

Danvers.-Cylindrical stump-rooted, medium large, dark orange, fine-grained; the favorite all-purpose variety.

Oxheart.-Medium size, oval, rather light colored, fine grain and flavor; recently introduced from France, and quite surcessful.

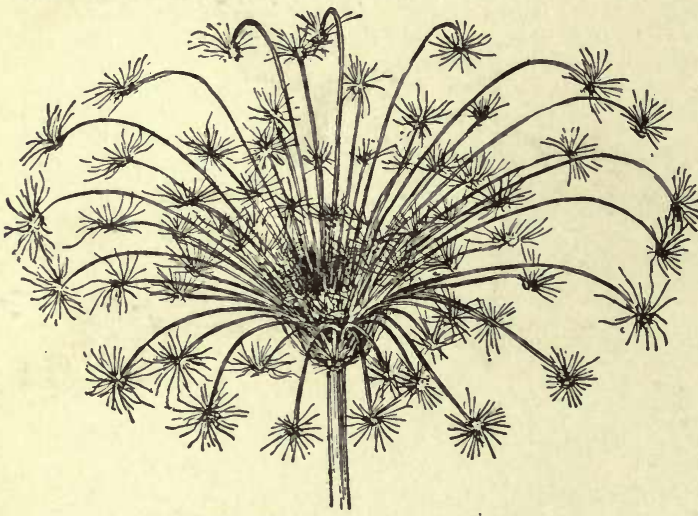

377. Last year's umoel of wild Carrot.

Half-long Scarlet.-Top small, roots medium size, cylindrical pointed : much used for bunching.

Early Scarlet Horn.-Top small, roots half-long, somewhat oval, smooth, fine grain and flavor; a favorite garden sort.

Large White Belgian.-Very large and rather coarse, whitish; principally grown for stock-feeding.

F. A. WAUGH.
CARTHAMUS (Arabic name, alluding to the coior). Compósitce. Hardy annuals $2-3 \mathrm{ft}$. high, with spiny lvs. Involucre with spreading and leafy outer scales and the inner ones more or less spiny: receptacle chaffy : akenes glabrous, mostly 4-ribbed, the pappus none or scale-like. Of easiest culture, from seed.

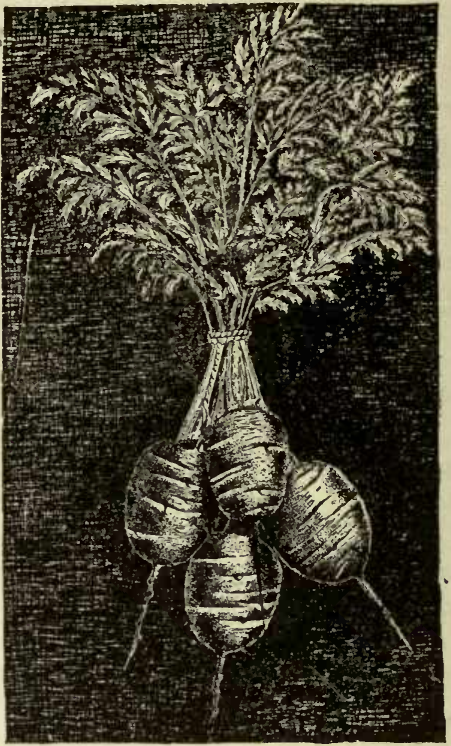

378. A bunch of Carrots.

tinctòrius, Linn. Safflower. False SAFFron. One to $3 \mathrm{ft}$. high, glabrous, branched: lvs. ovate, spinytoothed: fl.-heads with upward-tapering involucre, and a globular crown of orange florets. Asia. - The flowers furnish a dye material, which is used in place of the true Saffron (which is a Crocus).

L. H. B.

CARUM (Caria, in Asia Minor). Umbelliferce. Glabrous annual or perennial herbs, widely distributed in temperate and subtropical regions. Lvs. pinnate, or ternate and pinnately decompound : fls. white or yellowish, small, in compound umbels, the calyx-teeth small : fruit ovate or oblong, sometimes compressed, more or less ribbed, glabrous, or sometimes hispid. Roots often tuberous. Fifty or more species.

Cárui, Linn. Caraway (which see). Stem slender but erect, furrowed, 1-2 ft. : lvs. pinnately decompound, with thread-like divisions. Old World. - Sometimes runs wild.

Petroselinum, Benth. \& Hook. f. (Petroselinum sativum, Hoffm.). PARSLEY (which see). Erect, 1-3 ft.: lvs. ternate-pinnate, the lfts. ovate and 3-cleft (much cut in the "curled" garden vars.), the upper ones narrower and nearly entire : fls. yellowish. Old World. - Much cult., and occasionally runs wild.

Gàirdneri, Gray. Stem solitary, 1-4 ft.: lvs. mostly simply pinnate, with 3-7 linear or thread-like lfts., the upper lfts. usually entire, but the lower ones often divided: fr. with long style. Dry hills, in Calif. and Nev. -Int. 1881 by Gillett as an ornamental plant. Roots tuberous and fusiform.

L. H. B.

\section{CARUMBIUM. See Homalanthus.}

CARYA is treated under Hicoria.

CARYOPHYLLUS, the Clove Tree, is now referred to Eugenia.

CARYÓPTERIS (Greek for nut and wing). Verbendcece. Small shrubs with deciduous opposite lvs. and blue or violet fis. in axillary cymes: corolla 5-lobed, 
one segment larger and fringed; stamens 4, exserted; fr. separating into 4 somewhat winged nutlets. About 6 species in E. Asia. Free-flowering, small shrubs, very valuable for their late blooming season; not hardy north; even if well protected they will be killed almost to the ground, but the young shoots, springing up freely, will flower profusely the same season. They require well-drained and sandy soil and sunny position: if grown in pots, a sandy compost of peat and leaf soil or loam will suit them, and they will flower in the greenhouse until midwinter. Prop. readily by cuttings of half-ripened wood in summer or fall under glass, and by seeds sown in spring.

Mastacánthus, Schauer (C. incàna, Miq. C. Sinénsis, Dipp.). Fig. 379. Suffruticose, 1-5 ft.: lvs. petioled, ovate or oblong, coarsely serrate, pubescent above, grayish tomentose beneath, $2-3$ in. long: cymes peduncled, dense-fld.; fls. small, violet-blue or lavenderblue. Aug.-Nov. China, Jap. B.R. 32:2. B.M. 6799 . R.H. 1892:324. R.B. 19:273. G.C. II. 21:149. Mn. 5: 5 . S. H. 2, p. 89.- Known in the nursery trade as "Blue Spiræa." There is also a new variety with white fls.

C. Mongolica, Bunge. Lvs. lanceolate, almost entire : cymes with fewer but larger fls. R. H. 1872: 450 .

\section{ALFRED REHDER.}

CARYOTA (old Greek name). Palmacea, tribe $A$ rèceae. Fish-TaIl PaLM. Spineless, monocarpic palms, with tall, stout, ringed halms, at length bearing suckers. Lvs. disposed in an elongated terminal fringe, ample, twice pinnately divided; segments dimidiate-flabelliform, or cuneate, entire, or split, irregularly dentate, plicate, folded back in the bud : midnerves and primary nerves flabellate: petiole terete below: sheath keeled on the back, fibrous along the margins : ligule short ; spadices usually alternately male and female : peduncle short, thick : branches long, pendent : spathes 3-5, not entire, tubular; bractlets broad : fls. rather large, green or purple : fr. the size of a cherry, globular, purple. Species, 12. Malaya, New Guinea, Australia.

Remarkable for the delta-shaped or fish-tail-shaped leaflets, which make the graceful, spreading fronds very attractive. They are excellent warmhouse palms, very useful for decoration, particularly when young. They are frequently planted out in protected places for the summer. Prop. by seeds and suckers. For culture, see Palms.

There being so many different genera to choose from in selecting plants for moderate-sized conservatories, the members of this genus are not very popular for providing small specimens. In a high, roomy structure, howerer, they are among the most ornamental of the tribe. They are quick-growing, with large, broad leaves, finely cut up, the small divisions resembling the tail of a fish ; hence the name "Fish-tail Palm." After reaching maturity the plant begins flowering at the top, and continues downwards until the vitality of the stem is exhausted. Suckers are freely produced by some species, but these, as a rule, do not become so robust as the parent stem, owing probably to the soil becoming exhausted. Seeds are offered by most dealers. The young plants should be grown in a warm, moist atmosphere, the soil consisting of loam with about one-third of its bulk leafmold and sand in equal parts. They sometimes lose their roots if kept too cool and wet in winter.

mitis, Lour. (C. sobolifera, Wall.). Caudex 15-25 ft. high, 4-5 in. in diam., soboliferous: petioles, leafsheaths and spathes scurfy-villous ; lvs, 4-9 ft.; pinnz very obliquely cuneiform, irregularly dentate, upper margins acute ; pinnules 4-7 in. long. Burma to Malaya.

ùrens, Linn. Wine Palm. Toddy Paly. Caudex stout, $30-40 \mathrm{ft}$. high, $1 \mathrm{ft}$. thick, not soboliferous : lvs. 18-20 by 10-12 ft.; pinnæ 5-6 ft., curved and drooping, very obliquely truncate, acutely serrate, the upper margin producerl aud caudate ; pinnules 4-8 in.: petiole very stout. India, Malaya. A.F. 12:295. Gng. 5:131.

Rumphiàna, Mart. Lvs. 2-pinnate, several feet long, the pinnules thick, sessile, 6 in. long or nearly so, oblong. Malaya. - Var. Albertii, Hort. (C.A lbertii, Muell.), is in the trade. It is large and free-growing, the lvs. being 16-18 ft. long and two-thircls as broad; lf.-seg ments fan-shaped and oblique, toothed.

C. Blancòi, Hort., from the Philippines, is in the Amer. trade. It is probably a form of $\mathrm{C}$. urens.

JARED G. SMith and G. W. Oidver.

CASHEW is Anacardium occidentale.

CASIMIROA (named in honor of Cardinal Casimiro Gomez). Rutdcea. Evergreen trees: lvs. alternate, long-petioled, digitate, 3-7-foliolate; lfts. petiolulate, lanceolate, entire or slightly serrate, smooth or pubescent beneath : fls. regular, polygamo-diœcious ; calyx 5 -parted, small; petals 5, oblong, valvate, apex incurved; dise inconspicuous, circular ; stamens 5, free; filaments subulate; anthers cordate : ovary sessile, on disc, globose, 5- or occasionally 6-8-lobed, 5-celled : stigma sessile, 5-lobed : ovules solitary in the cells, axillary : fr. a drupe, large, depressed-globose; pulp agreeable to taste, edible: seeds oblong, compressed, exalbuminose. Mexico. Two species, of which the following only is in cultivation :

édulis, LaLlave. White Sapota. Cochil Sapota. I arge tree : trunk ashen gray, with warty exerescences: lvs. dark green, glossy: fls, greenish yellow, small: fr. greenish yellow when ripe, with strong, thick epicarp, $1 / 2$ in. thick, about the size of an orange : seeds nearly 1 in. long and half as wide. Mex. Cultivated to a limited extent in Calif. - The fruit of this species is said to have a delicious flavor, similar to that of a peach. They are used in Mexico as an aid in inducing sleep, and the leaves are used as a remedy for diarrhoea. Trees grown at Santa Barbara, Calif., are said to have reached an age of over 80 years and to have borne fruit regu-

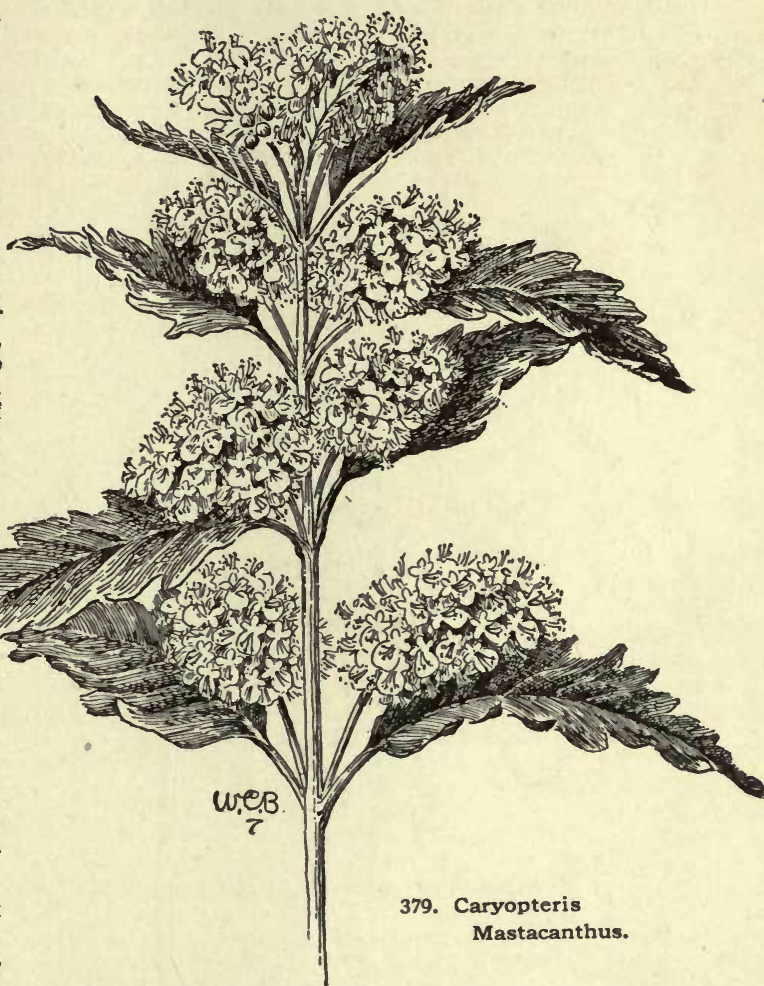

larly, though entirely neglected. The tree would probably succeed well in southern Texas, Louisiana and Florida. It grows on the coast of Mexico to an altitude of about 7,000 feet. It does not root well from cuttings, but may be raised from seeds.
H. J. WEBBER. 
Cassabanana. See Sicana.

\section{CASSÁNDRA. See Chamadaphne.}

CASSAVA. Consult Manihot utilissima.

CASSEBEERA (from a German botanist). Polypodidcece. A small genus of small Brazilian ferns allied to the maidenhair, but rarely seen in cultivation.

CÁSSIA (ancient Greek name). Leguminòsæe. Senna. Several hundred herbs, shrubs or trees in many parts of the world, of which a very few are in cult. in Amer., mostly as border plants. Lvs. even-pinnate: fis. nearly regular (not papilionaceous), with the nearly equal calyx-teeth mostly longer than the tube ; corolla of 5 spreading, nearly equal clawed petals; stamens 5 or 10 , frequently unequal, and some of the anthers abortive : fr. a stalked pod which is either flat or terete, containing numerous seeds. The Cassias delight in a sunny exposure. Most of those which are cultivated here are herbs or herb-like shrubs, attractive for the flnely cut foliage and the showy fls. Some of them are cultivated only in the extreme south. Prop. mostly by divisions and seeds, - the annual species always by seeds.

Senna leaves, used in medicine as a cathartic, are derived from various species, chiefly from $C$. acutifolia of Egypt, and $C$. angustifolia of India and other Old World tropics. The "Cassia lignea" of drug stores is made from a Cinnamomum.

A. Hardy border plants : leaflets 6 or more pairs.

Marylándica, Linn. Wild Senna. Perennial, glabrous or nearly so, stems nearly simple: lfts. 6-10 pairs, oblong or lance-oblong and entire, short-acuminate or nearly obtuse: fls. in axillary racemes near the tops of the stems and often appearing as if panicled, bright yellow, wide open. New Eng. to Mich. and south, mostly in wet soil. - Grows 3-4 ft. high, and has attractive light green foliage.

Chamæcrísta, Linn. Partridge Pea. Annual, erect or spreading, $2 \mathrm{ft}$, or less high: lfts, 10-15 pairs, small, narrow-oblong, mucronate, sensitive to the touch : fls. large, 2-5 together in the axils, canary-yellow and 2 of the petals purple-spotted.-Dry soil, Maine S. and W.

AA. Tender plants, grown far south, or under glass : lfts. mostly feuer.

B. Tree, with very long, woody, indehiscent pods.

Fistula, Linn. Pudding Pipe Tree. Lvs. large, the lfts. 4-6 pairs, and ovate-acuminate : fls. in long lax racemes, yellow : pods cylindrical, black, 3 -furrowed, 1-2 ft. long, containing 1-seeded compartments. India, but introduced in W. Ind. and other tropical countries. Sparingly cult. in S. Fla.-Furnishes the Cassia pods of commerce.

BB. Shrubs or herbs, with shorter and more or less dehiscent pods.

Sophèra, Linn. (C. schinifolia, DC.). Shrub, 6-10 ft.: lfts. 6-10 pairs, lanceolate-acute : fls, yellow on manyfld. axillary and terminal peduncles, which are shorter than the lvs.: pod thin, tardily dehiscent. Oriental tropics. Int. in S. Calif.

tomentosa, Linn. f. Shrub, 4-8 ft.: lfts. 6-8 pairs, oral-oblong and obtuse, white-tomentose beneath : fls. yellow. Mex. - Said to be a good winter bloomer in S. Calif.

corymbòsa, Lam. Shrub, half-hardy in middle states, 4-10 ft. : lfts, 3 pairs, oblong-lanceolate and somewhat falcate, obtuse or nearly so: fls. yellow, in long-stalked, small axillary and terminal corymbs. Argentina. B.M. 633. Gn. 50, p. 139. - The best known stove species.

artemesioldes, Gaud. Tree-like shrub, soft-canescent and gray all over : lfts. 3-4 pairs, very narrow-linear : racemes axillary, 5-8-fld., the fis, deep yellow. Austral. -Int. in S. Calif. Withstands drought.

biflora, Linn. Shrub, 4-8 ft.: lfts. 6-8 pairs, broadoblong, very obtuse: fls. large, yellow, on 2-4-fld. peduncles, which are shorter than the lvs. S. Amer. B.M. 810. - Sparingly cult. in greenhouses.

C. Schràderii, "yellow, dark spotted fls. in racemes, 2-3 ft.," is offered, but its systematic position is doubtful. L. H. B.

CASSIOPE (Greek mythological name). Ericacea. Low, procumbent, evergreen, heath-like shrubs: Ivs. small, usually imbricated and opposite : fls. solitary, nodding; corolla campanulate, 5-lobed; stamens 10 , included: fr. capsular. Ten species in aretic regions and high mountains of N. Amer., N. Eu., N. Asia and Himal. Graceful, delicate plants, adapted for rockeries, flowering in summer. They are of somewhat difficult culture, and require peaty and sandy, moist but welldrained soil and partly shaded situation, though $C$. hypnoides grows best in full sun, creeping amongst growing moss. Drought, as well as dry and hot air, is fata to them. Prop. readily by cuttings from mature wood in August under glass; also by layers, and by seeds treated like those of Erica. Formerly included under Andromeda.

O. fastigiata, Don. Ascending: lvs. imbricate, in 4 rows, with white fringed margin : fls. axillary, white. Himal. B.M. 4796 . -O. hypnoides, Don. Creeping : lvs. linear, loosely imbricate fis, terminal, deeply 5-cleft. Aretic regions. B.M. 2936. L.B.C. 20:1916.-U.Mertensiana, Don. Erect or ascending to $1 \mathrm{ft}$. high: lvs imbricate in 4 rows, carinate on the back : fls. axillary white or slightly tinged rosy Sitka to Calif-C. tetrágona, white or slightly the former, but lower, and the lvs. with deep furrow on the back. Aretic regions. B.M. 3181 . ALFRED REHDER.

CASTANEA (ancient Latin name). Cupullferce (or Fagdcea). Chestnut. Deciduous

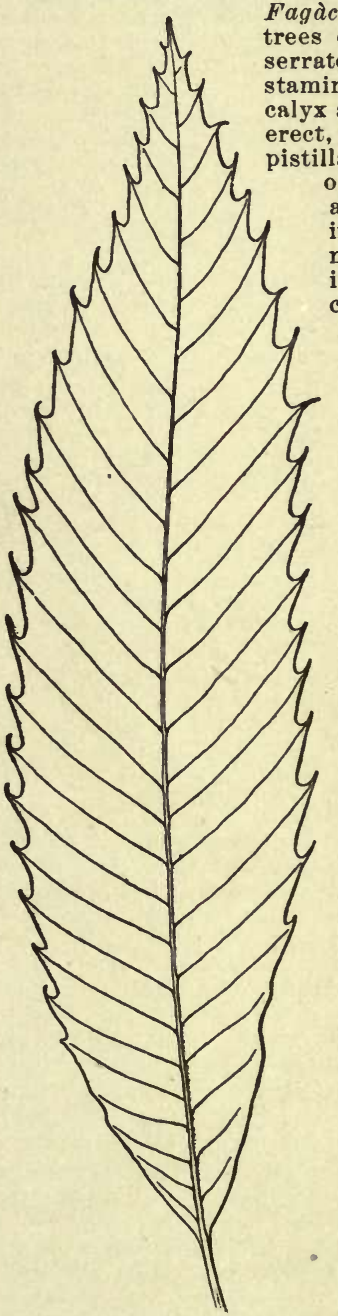

380. Castanea Americana. $(X 1 / 2$. or shrubs, with alternate Ivs, : fls, monœcious, the aminate ones with 6-parted y and 10-20 stamens, in long, cylindrical catkins; the ate ones on the lower part f the upper catkins, usually 3 together in a prickly involucre: fr. a large brown nut, 1-7 together in a prickly involucre or bur. Five species in the temperate re.

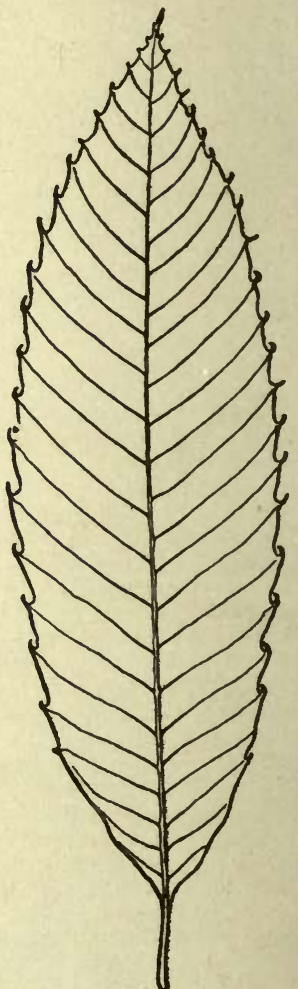

381. Castanea sativa. $(X 1 / 2$. 
gions of N. E. Amer., Eu., N. Afr. and Asia. Hardy ornamental trees or shrubs with handsome foliage, which generally is not injured by insects or fungi; very attractive when in bloom. $C$. Americana and $C$. sativa are large-sized trees, while $C$. pumila and $C$. crenata usually remain shrubby. The coarse-grained wood is much used for furniture, railway ties and fence-posts, as it is very durable in the soil. The Chestnut is extensively cultivated in Europe and E. Asia for its edible fruit. It grows best in well-drained soil on sunny slopes, and even in rather dry and rocky situations, but dislikes limestone soil. Prop. by seeds, sown in fall where there is no danger of them being eaten by mice or squirrels; otherwise they should be stratified in boxes and buried 1 or 2 feet deep in a warm soil until early spring, when they are sown in rows about 3 inches deep. If growing well they can be transplanted the following fall or spring 2 or 3 feet apart from each other, and planted where they are to stand after three or four years. They are also increased by layers in moist soil. Varieties are usually worked on seedling stock or on sprouts by whip-grafting above the ground when the stock is just beginning to push into leaf. Crown-grafting, root-grafting and budding are also sometimes practiced, but no method gives wholly satisfactory results, and usually only one-half take well. See Chestnut.

A. Lvs. glabrous or nearly so at maturity.

Americàna, Raf. (C. dentata, Borkh.). Fig. 380. Tree, occasionally $100 \mathrm{ft}$ : : lvs. cuneate, oblong-lanceolate, acuminate, coarsely serrate, nearly glabrous when young, 6-10 in. long and somewhat pendulous : fls. of heavy fragrance, in June or July : nuts $1 / 2-1$ in. wide. S. Maine to Mich., south to Ala. and Miss. S.S. 9:440-41. Em. 187. G.F. 10:373. - The tallest, most vigorous-growing and hardiest species. The nuts, though smaller, have a better flavor than the European varieties.

sativa, Mill. (C. vésca, Gärtn.). Fig. 381. Tree, 50-80 ft.: lvs. oblong-lanceolate, coarsely serrate, slightly pubescent or tomentose beneath when young, nearly glabrous at length, 5-9 in. long, erect : nut over 1 in. wide. June. From S. Eu. and N. Afr. to China. Gn. 50, p. 389. Gng. 3:209. - There are some garden forms with variegated lvs., and others, of which var. asplenifolia, Lodd., with laciniately cut and divided Ivs., is the most remarkable. Of several varieties cultivated for their fruit, Paragon, a precocious kind, and Numbo, a variety with very large fr., are the most extensively planted in this country. See Chestnut.

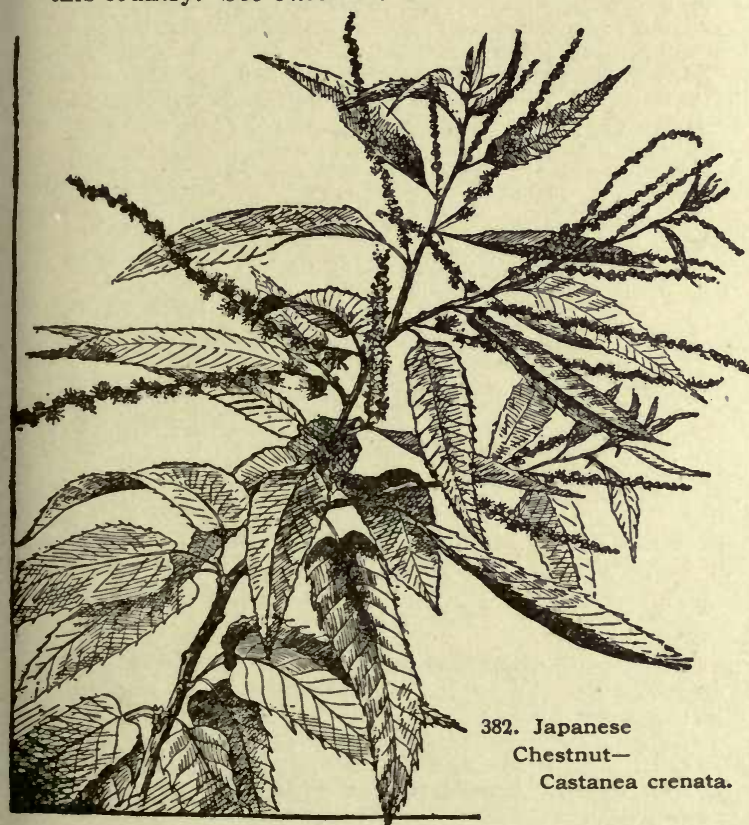

crenà ta, Sieb. \& Zucc. (C. Japónica, Blume). Fig. 382. Shrub or tree, to $30 \mathrm{ft}$.: Ivs. elliptic or oblong-lanceo late, usually rounded at the base, acuminate, crenately serrate, or the teeth reduced to a long, bristle-like point, slightly pubescent when young, glabrous at length or only pubescent on the veins beneath, 3-7 in. long, erect: nut over 1 in. wide. Japan, China. - Shrubby and very precocious; it usually begins to fruit when about six years old. Hardy as far N. as Mass.

\section{AA. Lvs. whitish tomentose beneath.}

pùmila, Mill. Chinquapin. Shrub or small tree, rarely $50 \mathrm{ft}$.: Ivs. cuneate, elliptic-oblong or oblongobovate, acute, serrate, teeth often reduced to bristlelike points, $3-5$ in. long: fr. usually solitary, ovate, small, about $1 / 3$ in. wide and $8 / 4-1$ in. long. May, June. From Pa, to N. Fla, and Texas. S.S. 9:442-43,-Useful for planting on dry and rocky slopes; attractive when in flower, and again in fall, with its abundant light green burs among the dark foliage. The closely allied $C$. alnifolia, Nutt., in the S. states, grows only a few feet high, and has larger lvs. and fr. ALFRED REHDER.

CASTANEA of commerce. The nuts of Bertholletia.

CASTANOPSIS (Castanea and opsis, chestnut-like). Cupulífera. (or Fagdcea). Evergreen trees or shrubs, closely allied to Castanea and in some degree also to Quercus, with sometimes entire lvs. and spiny or tuberculate involucre. About 25 species, chiefly in the trop. and subtrop. mountains of Asia, and 1 in W. N. Amer., which is the hardiest, and is sometimes cultivated. For propagation, see Castanea.

chrysophýlla, DC. (Castànea chrysophýlla, Hook.). Tree, to $150 \mathrm{ft}$., shrubby at high elevations : lvs. ovateoblong or oblong-lanceolate, narrowed at both ends, entire, dark green above, coated with minute golden yellow scales beneath, $2-6$ in. long: nut about $1 / 2$ in. wide, usually solitary in the spiny involucre. Summer. Ore to Calif. S.S. 9:439. B.M. 4953. G.C. III. 22:411. F.S. 12:1184. R.B. 7:240.-A highly ornamental tree with beautiful foliage, hardy only in the warmer temperate regions, but the shrubby form is much hardier.

ALFRED REHDER.

CASTANOSPERMUM (Chestnut seed, because of the taste of the seeds). Legumindsoe. One tall Australian tree, with odd-pinnate lvs., the lfts. broad, thick, entire; fls. large, orange-colored, in lateral racemes; petals 4 ; stamens free: ovary long-stipitate, many-ovuled: seeds larger than Italian chestnuts, globular. C. australe, Cunn. \& Fraser, is the species known locally as "Moreton Bay Chestuut." The seeds are roasted and eaten. Int. in S. Calif.

CASTILLEIA (a Spanish botanist, D. Castillejo). Scrophularidcea. PAINTED CuP. Herbs, with small, solitary fls. in terminal, gaudy-bracted spikes, mostly N. Amer.: corolla tubular, sometimes flattened laterally, 2-lipped; lower lip smaller, more or less 3-toothed : stamens 4: Ivs. alternate, entire or cut. C. coccinea, Spreng., the common Painted Cup of the E. states, has been offered by collectors. It has showy laciniate bracts. Castilleias are little known in gardens. They are of simple culture.

indivisa, Engelm. Annual, 1-2 ft.: lvs. lance-linear and entire (or sometimes 2-3-lobed): bracts not laciniate, bright red and showy. Texas.-Blooms early in spring.

affinis, Hook. \& Arn. Perennial, 1-2 ft.: Ivs. narrowlanceolate, entire or the upper ones toothed at apex : fl.-bracts becoming short and broad, red : spike lax below. Calif., in moist soils. - Int. 1891 by Orcutt.

folioldsa, Hook. \& Arn. Woolly perennial, 1-2 ft., the base woody : lvs. small ( 1 in. or less long), narrowlinear, crowded or fascicled : bracts 3-parted : spike dense. Calif., in dry soils. - Int. 1891 by Oreutt.

L. H. B.

CASTOR BEANS are discussed under Ricinus.

CASUARINA, (said to be derived from Casuarius, the Cassowary, from resemblance of the branches to the feathers). Casuarinacea. BeEFwood. She OAK. A 
score or more of trees and shrubs in the Australian region and the Indies, being the only plants of the family. They are usually classified near the walnut and hickory tribes, although very unlike them-or other known plants-in botanical characters. They are jointed and leafless plants, somewhat suggesting Equisetums in gross appearance of branches. The fls. are unisexual. The staminate are in cylindrical terminal spikes, each fl. consisting of a stamen inclosed in 4 scales, 2 of the scales being attached to the filament. The pistillate fls. are in dense heads borne in the axils, and this head ripens into a globular or oblong cone; they are composed of 1-ovuled ovaries subtended by bracts. The fruit is a winged nutlet. The branches are long and slender. Beefwood is planted in the extreme south for its very odd habit, and also to hold sands of the sea coast. The wood burns quickly, and is very hard and durable. The redness of the wood has given the popular name, Beefwood. Remarkable for rapid growth. They grow well in brackish and alkaline soils. Prop. by seeds and cuttings.

equisetifolia, Linn. Tree, becoming $150 \mathrm{ft}$. high in favorable climates, and a most rapid grower. Branches drooping, pale green, simple, 6-8-angled or terete, the internodes very short (less than 1/4in.): sheath-teeth 7 (6-8) lanceolate and appressed : staminate cone nearly terete: pistillate cone short-peduncled, ellipsoidal, about 12-sided. Widely distributed in old World tropics, and the best known species in this country (S. Fla. and Calif.).-The wood is valuable for many purposes.

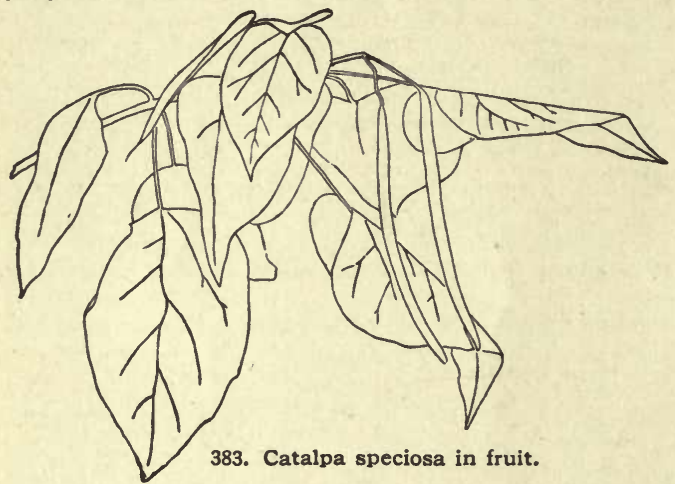

stricta, Dryand. Becoming 20-30 ft. high : branches erect, simple, 6-7-angled, scarcely green, internodes short, as in the latter : sheath-teeth usually 7 , ovatelanceolate and appressed: staminate cone slender; pistillate cone nearly sessile, oblong (sometimes staminate above), about 14-sided. Austral.

toruldsa, Dryand. (C. tenuissima, Sieber). Reaches 70 or $80 \mathrm{ft}$.: branches erect, capillary, mostly terete, internodes short: sheath-teeth 4, very short, triangular appressed: staminate cones filiform: pistillate cones ellipsoidal, 8-10-sided. Austral.

L. H. B.

CATALPA (the Indian name of $C$. bignonioides). Bignonidcece. Deciduous trees with opposite or whorled, long-petioled, large and simple lvs.: fls. in large, showy panicles; corolla tubular-campanulate, 2 -lipped, with 2 smaller upper and 3 larger lower lobes; calyx 2-lipped: fertile stamens 2: fr. a very long, cylindrical capsule, separating into 2 valves, with numerous small, oblong, compressed seeds bearing a tuft of white hairs on each end. Eight species in N. Amer., W. India and E. Asia, of which 4 are hardy in the colder temperate regions. Highly ornamental trees with large, bright green foliage and beautiful white or yellowish fls. in large, showy panicles. The coarse-grained and soft wood is very durable in the soil, and, therefore, much valued for fence-posts and railway ties. They grow in almost any somewhat moist soil, and are hardy as far north as New England. Prop. by seeds sown in spring, in the north, best with slight bottom heat, or by cuttings from ripe wood, the varieties often by softwood cuttings in early summer or by grafting on seedlings or on roots under glass in spring; also increased sometimes by layers and root cuttings.

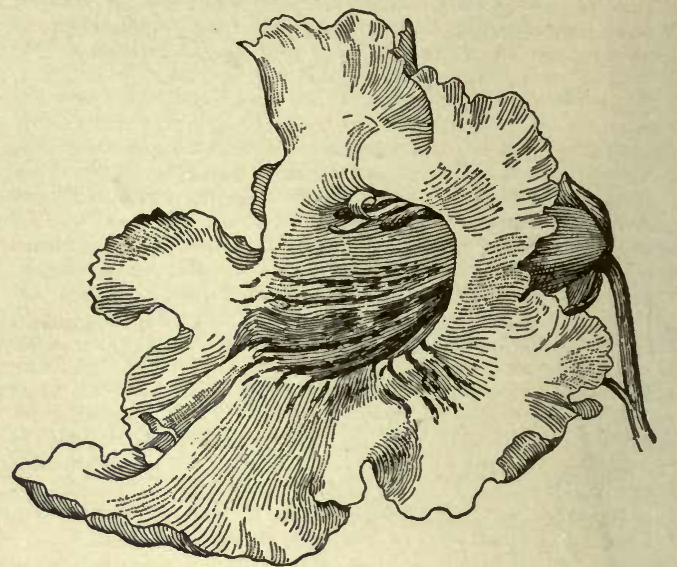

384. Catalpa speciosa. Natural size.,

A. Fls. white, with two yellow stripes inside, and spotted purplish brown.

bignonioides, Walt. (C. syringifollia, Sims). Tree, 20-50 ft.: lvs. often whorled, cordate-ovate, abruptly acuminate, sometimes with 2 lateral lobes, pubescent beneath, 5-8 in. long, of unpleasant odor: panicles many-fld.; fls. about 2 in. in diam., thickly spotted inside : pod $6-20$ in. long, $1 / 4-1 / 3$ in. thick. June, July. S. states, north to Tennessee, often naturalized elsewhere. B.M. 1094. L.B.C. 13:1285. S.S. 6: 288-89. Gng. $6: 118-119$. G. F. $3: 537,539$. J. H. IIl. $32: 121$. G.C.III. 21:298. - Usually low tree, with very widespreading branches. There are some garden forms. Var. aurea, Hort. Lvs. yellow. Var. nana, Hort. $(C$. Búngei, Hort., not C. A. Mey.). Forms a dense, round bush, often grafted high. Gng. 3:195. Var. purpùrea, Hort. Lvs. purple when young, green at length.

speciosa, Warder. Fig. 383, 384. Tree, to $100 \mathrm{ft}$. : lvs. cordate-ovate, long-acuminate, pubescent beneath, 8-12 in. long: panicles usually few-fld.: fls. about $2 \frac{1}{2}$ in. in diam., inconspicuously spotted inside: pod $1 / 2-3 / 4$ in. thick. June. From southern Illinois and Indiana to Louisiana and Mississippi. S.S. 6:290-91. R. H. 1895:136. A very desirable ornamental tree, closely allied to the former, but taller and hardier.

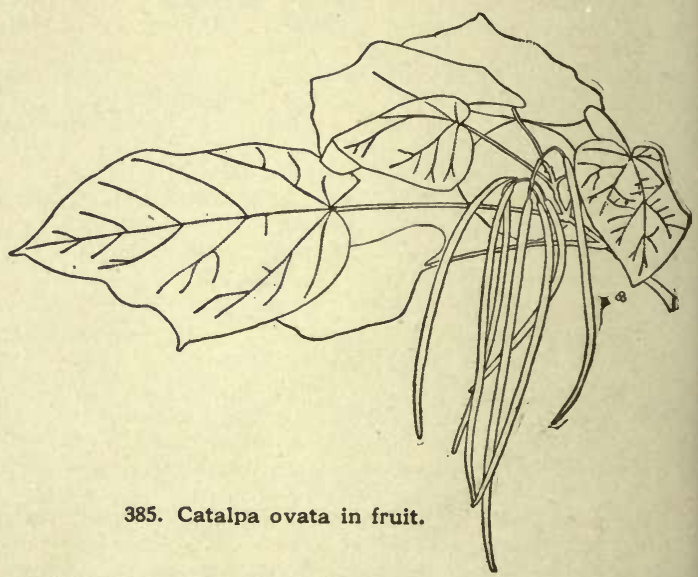

hỳbrida, Späth. (C. bignonioides $\times$ ovata). TEAs' JAPAN HYBRID. Large tree, intermediate between the parents: the lvs. resemble more those of $C$. ovata, and are purplish when unfolding, but much larger and 
slightly pubescent beneath, while the fls. are more like $B$ bignonioides, with the inflorescence often twice as long. Originated at J. C. Teas' nursery, at Baysville, Ind., about 20 years ago. G.F. 2:305. Gt. 47:1454.-A very valuable tree, flowering profusely; of rapid growth and hardy. Seedlings usually resemble C.ovata.

AA. Fls. yellow, striped inside orange and spotted dark violet, about 1 in. in diam.

ovàta, Don (C. Kiempferi, Sieb. \& Zucc.). Fig. 385. Tree, to $20 \mathrm{ft}$.: Ivs. broadly cordate-ovate, abruptly acuminate, often $3-5$-lobed, nearly glabrous at length, with reddish spots in the axils of the veins beneath, $5-8 \mathrm{in}$. long: panicles many-fld., 4-7 in. long, fragrant. June. China, much eult. in Japan. B.M. 6611. I.H. 9:319.Hardier than the American species.

C. Bungei, C. A. Mey. Allied to C. ovata. Lvs. truncate at the base, long acuminate. 3-5 in. long: fls. large, nearly white, in few-fld. panicles. China. - C. Buingei, Hort. $=$ C. bignonoides, var, nana $-C$. longissima, Sims. Tree, to $50 \mathrm{ft}$.: lvs. oblongovate, coriaceous: fls, small, white. W. Ind., often planted as shade tree in Cuba. ALFRED REHDER.

CATANANCHE (Greek name, referring to ancient custom of using the plant in love-making). Compósitoe. A half dozen annual or perennial herbs of the Mediterranean region,with the lvs. crowded at the base of the stem, and linear or lanceolate. Head long-peduncled, blue or yellow. Akene oblong, ribbed and generally villose or setose. Pappus of 5-7 scales. Of easiest culture in any garden soil, particularly if lights Useful for cutting.

cærulea, Linn. Perennial, 2 ft.: lvs. tomentose, lanceolate and few-toothed: fl.-heads 2 in. across, with wide, flat-toothed blue rays, on long, slender stems. Blooms in June, July and Aug. S. Eu. B.M.293. R.H. 1890, p. 523. Var. álba, Hort., has white fls. Var. bícolor, Hort., has white margin and blue center. Often used as Everlastings. Prop. by seeds and division. L. H. B.

CATASEेTUM (Greek for downward or backward, and bristle). Orchiddcea, tribe Vándene. Flowers globose or expanded; labellum fleshy; colunı erect; pollinia 2. Stems short fusiform; Ivs. plaited, membranaceous scapes basal, fls. in racemes; the column provided with sensitive appendages which, when touched, cause the pollen-masses to fly out. There are about 50 or 60 species in the Amer. tropies, either terrestrial or epiphytic. The fls, are in racemes or spikes, firm in texture, and white or in shades of green, yellow, brown or purple. Catasetums are not much cultivated, since most of the species are not showy, but they are interesting to the botanist and amateur because of the striking ejection of the pollen-masses. Gardeners often have trouble with Catasetums, but they are not difficult to grow if given good care. They need a high temperature, long period of rest, and free supply of water during the growing season. They are grown in both pots and baskets. Readily propagated by dividing the plants at the base; also from very ripe pseudobulbs eut in pieces and put in sand. The genus includes Monachanthus and Myanthus.

\section{A. Flowers white.}

Bungeròthii, N. E. Brown. Stems 8-9 in. tall; sepals larger than the petals, nearly 2 in. long; labellum tending toward concave, roundish ; appendages thickish. Equador. B.M. 6998. G.C. III. 1:142. I.H. 37:117; $34: 10$. Gn. 33:646. A.F. 6: 633. - A striking plant.

\section{AA. F'ls. yellowish, more or less marked with brown} or red.

macrocárpum, Rich. (C. Cláveringi, Lindl. C. tridentatum, Hook.). Fls. large, nearly $3 \frac{1}{2}$ in. across ; petals and sepals yellow, verging on green, spotted with reddish brown; labellum yellow. Guiana. B.M. 2559, 3329. I.H. $33: 619$.

fimbriàtum, Lindl. \& Paxt. Pseudobulbs, 2-3 in. long: raceme pendulous, 8 - or more-fld.: fls. $2 \frac{1}{2}$ in. across ; sepals whitish or pale yellow, closely barred with red. Braz. B.M. 7158. A.F. 6: 609 .

longifolium, Lindl. Pseudobulbs deflexed: lvs, narrow and glaucous, reaching $3 \mathrm{ft}$.: $\mathrm{fls}$. on drooping, compact spikes; sepals and petals greenish yellow tipped with dull red; lip belmet-like, orange-yellow. Guiana. Epiphyte.

AAA. Fls.essentially red or brownish.

decipiens, Reichb. f. Fls. 11/2 in. across ; sepals and petals lanceolate, red-brown and spotted; lip saceate, yellowish outside and red-brown inside. Venezuela. A.F. $6: 609$.

$$
\text { AAAA. F'ls. many-colored, grotesque. }
$$

Gnòmus, André. Pseudobulb, oblong-ovate and ulternate, articulated: fls. in a long loose raceme on slender pedicels; sepals greenish and purple-barred; 2 lateral petals spreading, concave, purple ; lip bluntly conical olive-green spotted outside, ivory white within, fringed above. S. Amer. I.H. 24:270. A.F. 12:293.

C. barbàtum, Lindl. Fls. green, blotched with purple. Guiana - . callòsum, Lindl. Odd: fls. with chocolate-brown, narrowlanceolate sepals and petals; lip greenish, speckled with red. Venezuela. B.M. 4219, 6648. - O. Christyànum, Reichb. f. Sepals and petals usually chocolate; lip greenish yellow, purple finged. S. A ur ? G.C. III 18:617. C díscolor Lindl. puld purple. An old sort, now rarely seen. Braz.- C. Garnettianum, Rolfe. Allied to C. barbatum : fls. small; sepals and petals
very narrow, green, with large bars of red-brown: lip white, fringed. Amazon. B.M. 7069.- C. imperiale, Lind. \& Cogn. Sepals and petals ovate-acute, white, purple spotted; lip orbic ular-cordate, purple in center and white margined. G.C. III. 17: 329. S.H. 1, p. 369. J.H. III. 30:25.-C. Lindeni, Cogn. Fls. large (as of $\mathbf{C}$. Bungerothii); sepals and petals yellow with 17:329. S.H. 1, p. 369-C mirábile, Cogn. Fls, very large, the sepals and petals oblong-lanceolate, and yellowish, with purple spots and bars; lip kidney-shaped, bright yellow with 2 purple spots, toothed. G.C. III. 17:329. S.H. 1, p. 369.- C. Scúrra Reichb. f. Compact: fls, fragrant, yellowish white, greenveined; lip 3-lobed. Guiana. G.C. II. 7:304, 305.-C. spléndens Cogn. Intermediate between C. Bungerothii and C. macrocarpum: sepals greenish white with purplish center; petals white with many purple spots: lip cream-color, purple-marked. with many purple spots: lip cream-color, purple-marked. nearly so. Var. Aliciæ, Lind. \& Cogn. Fls. large ; sepals and petals purplish; lip white, toothed. Var. aureo-maculatum. Bossch. Yellow. I.H. 43: 54. Var. atropurpureum, Hort. Blackish purple.- $C$. Warscewiczii, Lindl. \& Paxt. From Panama. Now rarely seen.

OAKES AMES.

\section{CATCHFLY. Consult Silene.}

\section{CATECHU. See Acacia Catechu.}

CATERPILLARS. The worm-like pods of Scorpiurus vermiculdta, Linn., S. subvillosa, Linn., and others (Legumindsa), are sometimes used as surprises in salads and soups; and for that purpose they are cult. in parts of Europe, and seeds are sold in this country. They are sometimes catalogued as Worms. They are annuals of the easiest culture. The pods of Medicdgo scutellata, Mill., and others are known as Snails. The pods are not edible. European plants. A.G. 13:681.

CATMHNT or CATNIP. See Nepeta.

L. H. B.

\section{CAT-TAIL, Typha.}

CÁTTLEYA (William Cattley, an early English naturalist). Orchiddcea, tribe Epidéndrece. Epiphytes of tropical America. Pseudobulbous : leaf-blades 1-3, coriaceous: fls. usually terminal, large, fleshy or membranaceous; petals and sepals nearly equal, or the former much broader: labellum cucullate, usually trilobed, proximal part inclosing the fleshy, clavate column, except in $C$. Aclandice and $C$. bicolor: pollen masses 4 (2 pairs), with short appendages. A genus generally cultivated for its large, showy flowers, which for intensity of color have few, if any, equals in the family of orchids. Most of the species do satisfactorily under artiflcial conditions, although there is an opinion prevalent that they degenerate or "run out." Naturally, some kinds are difficult to grow, since the horticulturist is not well enough informed concerning their requirements, but there is no reason why the majority of the species should degenerate if properly treated. The genus Cattleya was founded on $C$. labiata by John Lindley in 1824. As a genus, it is very closely allied to Lælia, being distinguished by having two pollinia (4 pollen masses), whereas that genus has four (or 8 pollen masses.)

OAKES AMES. 
The Cattleyas are indigenous to the western hemisphere only, Central and S. America being the regions where they abound, particularly in the latter, from the different countries of which large quantities are imported yearly. During the last few years the collecting and importing of Cattleyas into the U. S. has assumed large proportions, owing to a continually and steadily increased demand, not only by amateurs but also by the trade in general. There are two particular reasons for this increased demand : First, the exquisitely beantiful flowers, combined with size and marvelous colors, and adapted for decorations at all sorts of functions, they being never out of place; second, their easy culture. Florists and amateurs alike are beginning to realize that, after all, orchids are only plants, and if only treated in a cominon-sense way they are by far easier to grow than a good many plants, and especially so the Cattleyas, provided some attention is paid to their requirements.

Cattleyas in general delight in a genial, moist atmosphere and a temperature ranging all the way from $55^{\circ}$ to $70^{\circ}$. They all require an abundant supply of water, accompanied by a liberal supply of air and light, during their respective growing seasons. A Cattleya house should, if possible, have bottom and top ventilators, which when open produce a current of fresh air impossible to obtain or imitate in any other way, and in which these plants delight. The glass should be shaded with a thin coat of naphtha and white lead, enough to prevent the sun from burning the plants, for, while they enjoy all the light possible, the full sun in our climate is too strong for them, and they are liable to dry and shrivel, and thus lose their natural luxuriance. The shading, however, may be removed entirely during the dullest winter months. Cattleyas will grow equally well in baskets, pots, or on boards ; the former are preferable where limited quantities are grown, inasmuch as they are easily managed and may be hung up or taken down or moved from one place to another with the greatest ease. The large blocks or boards are to be rec ommended where large quantities of plants are grown for cut-flowers, being more economical in every sense of the word. When boards are used, the width ought not to be less than 10 inches, as the plants would very soon grow over the sides of the boards; the length may be adjusted to suit the house, but should not exceed 5 feet-anything larger is liable to be too clumsy to handle conveniently.

The best potting material is soft, fibrous peat, with a sprinkling of live sphagnum intermixed. Too much stress cannot be laid on soft peat, as frequently too coarse material is used, resembling a mass of wire, with the result that the water benefits the plants but very little, and root-action is slow, if taking place at all. One thing is imperative in the cultivation of Cattleyas, in whatever receptacles they are grown : they inust be firm, without going to the extreme of ramming in the stuff too hard. A plant lying loose in a basket or a pot will never grow well, but will gradually dwindle away to nothing. Where boards or large blocks are used, the plants are fastened on by means of galvanized staples, inserting a piece of peat between the staple and the rhizome, so as to keep the staple from burning while new. In this way freshly imported Cattleyas may be fastened on to clean boards or blocks, and by liberal overhead syringing the roots soon appear, when a mixture of chopped peat and sphagnum may be shaken in between the plants to cover the roots. In using baskets, it is advisable to use them shallow and less material, the compost thus keeping fresh and sweet for a considerable period of time. Cattleyas, as previously mentioned, enjoy a copious supply of water during their respective growing seasons. In our climate the best method is to use the hose, and water overhead, which, if adhered to, will cause the plants to soon assume a natural green color and luxuriance common to them in their native habitats. Besides, the overhead watering will keep down vermin, such as scales, etc. By the socalled resting season of Cattleyas is generally understood the time after the plants have finished the flow. ering bulb, and until they begin to send up the next growth. During this time, when they are, in a sense, dormant, the quantity of water should be diminished, which causes the new eyes to move slowly and break strong. As soon, however, as the new breaks are fairly under way they should be encouraged in the way of moisture, when the new roots will soon appear and the plants go ahead with renewed vigor. If the plants are in baskets, suspended under the roof, they should be taken down at intervals and dipped thoroughly. Handin-hand with a copious watering must go a liberal supply of light and air at all times. In order to obtain the best results, the plants should be placed as near to the light as possible-say, from 1-3 feet from the glass, according to kinds and to the space available in the house. Kinds such as $C$. Triancei, C.labiata, C. Mendelii, $C$. Mossice and $C$. Harrisoniana will grow and flower well in any part or position of the house, provided they have plenty of light and air, but 3 feet is the maximum distance from the glass at which any of the Cattleyas should be placed, to be successfully grown. A capital illustration of the above is, for instance, $C$. gigas, which does admirably suspended under the ridge of the house, where it receives the full benefit of air and light, in which position it flowers profusely, while if grown on a bench or stage it rarely flowers.

The best twelve varieties of Cattleyas for commercial purposes, and, indeed, for amateurs also, are the following: C. Trianæi, flowers Jan.-March; Schrœederiana, fls. March, April ; Mossiæ, fls. April, May; Mendelii, fls. April, May; Warneri, fls. May, June; gigas, fls. June, July ; chrysotoxa, tls. June, July ; Gaskelliana, fls. Aug., Sept.; Harrisoniana, fls. Sept., Oct.; labiata, fls. Oct., Nov.; Bowringeana, fls. Oct., Nov.; Percivaliana, fls. Dec.

With a number of plants of each of the above kinds, it will be seen that it is possible to have a succession of flowers from one end of the year to the other.

JOHN E. LAGER.

Index : Aclandiæ, 18 ; amethystina, 21 ; amethystoglossa, 25 ; aurea, 2 ; autumnalis, 16 ; bicolor, 19 ; Bluntei, 6 ; Bogotensis, 1 ; Bowringeana, 16 ; bulbosa, 30 ; candida, 23 ; Carrierei, 1 ; Chocoensis, 9; chrysotoxa, 2; citrina, 17 ; Dawsonii, 5 ; dolosa, 21 ; Dowiana, 2; Eldorado, 3 ; Ernesti, 1 ; Forbesii, 22 ; Gaskelliana, 4; gigas, 12 ; gloriosa, 1; granulosa, 26; guttata, 24; Harrisonia, 23 ; Harrisoniana, 23 ; Holfordi, 30 ; imperialis, 1; intermedia, 21 ; Keteleerii, 25; labiata, 1; Lawrenceana, 14; Leeana, 1; Lemoniana, 1 ; Leopoldii, 24; Loddigesii, 23; Luddemanniana, 5 ; luteola, 30 : Massangeana, 1 ; maxima, 13 ; Mendelli, 6 ; Morgana, 1; Mossiæ, 7 ; Nalderiana, 1 ; nobilior, 31; pallida, 1; Parthenia, 21 ; Peetersii, 1 ; Perci. valiana, 8 ; Perrinii, 1; Prinzii, 25; punctatissima, 21; quadricolor, 9 ; Reineckiana, 7; Rozlii, 1; Rollissoni, 1; Sanderiana, 12 ; Schilleriana, 29; Schofieldiana, 27; Schroederiana, 9; Skinneri, 15; speciosissima, 5; splendens, 28; superba, 28; Trianæi, 9; Victoria-Regina, 20; violacea, 28 ; virginalis, 1 ; Wagneri, 7 ; Walkeriana, 31; Wallisii, 3; Warneri, 10 ; Warocqueana, 1; Warscewiczii, 11.

The following Amer. trade names belong to Lælia : crispa, lobata, marginata, pumila. See, also, the list of hybrids at the close of Cattleya. For C.aurantiaca, see Epidendrum.

Of several of the following species, there are named vars. in the Amer. trade, varying in stature, habit, and particularly in the color of the flowers.

A. Blossoms from a leafy pseudobulb.

B. F'ls. membranaceous, not fleshy.

c. Number of fls. not more than 5, or rarely 6 : pseudobulb 1-leaved.

1. labiàta, Lind. Pseudobulbs 4-8 in. high, compressed, from stout creeping rhizomes: leaf-blades broadly ovate or oblong, about 6 in. in length: fls. 2-5, ranging in color from rosy mauve to white; petals $3 \frac{1}{2}$ in. long, $2 \frac{1}{2}$ in. wide, ovate-oblong, several times broader than the sepals ; labellum $2 \frac{1}{2}-3 \frac{1}{2}$ in. long, expanded portion 2 in. across, blotched or veined with crimson or magenta-purple, the margin crisped and paler; the posterior part stained with yellow and veined with erimson-purple. Blooms in autumn. B.M. 3998. P.M. 4:121. Gn. 51:1107. G.C. III. 19:13. R.B. 22: 25. A.G. 17:65; 19:811. F.R. 1:8; 2:531. Gng. 2:275. F.E. $9: 327$. A.F. $6: 607$. - Int. in 1818 from the Organ moun- 
tains of South America. It was lost for many years and became exceedingly rare, but recently its rediscovery his made it a common orchid, and many beautiful varieties are in cultivation. Some of the varieties have heretofore been regarded as species, but as the points of distinction are too slight to be specific, it has seemed best to put such forms as $C$. Warneri, $C$. Triancei and C. Mossice in their proper place under the original species. C. labiata is probably the most useful species of orchid. Immensely variable : some of the leading varieties are described below. These forms are regarded variously as species, varieties or sub-varieties, by different authors. Besides the names given below, the following are to be referred to C.labiata: $C$. Bogoten sis, Lind.; $C$. Carrièrei, Houll.; $C$. Ernesti, Hort.; C.gloridsa, Carr.; C. imperidlis, O'Brien; C.Leedna, Hort.; C. Lemonidna, Lindl.; C. Massangedna, Reichb. f.; C. Mórgance, Warner ; $C$. Nalderiana, Reichb. f.; $C$. pállida, Lindl. \& Paxt.; C. Peètersii, André; $C$. Pérrinii, Endl. (not Lindl.); $C$. Razlii, Reichb. f.; $C$. Róllissonii, Moore ; $C$. virginalis, Lindl. \& André ; $C$. Warocquedna. More than 100 other specifically made names are referred to this species. 'There are whitefld. forms of nearly all the vars.

2. Var. Dowiàna, Veitch (C. Dowiàna, Batem.). Fls. nankeen-yellow, except for the disproportionately large labellum; petals about twice as wide as the sepals, about the same length as the labellum, wavy margined, obtuse ; sepals lanceolate, acute; labellum amply expanded, margin crisped, surface velvety, dark purple, beautifully and finely veined with golden yellow lines, which radiate from the median line. Strong plants produce 3 or more fls, on each peduncle. B. M. 5618 . R.H. 1869:30. - Discovered in Costa Rica by Warscewicz. Little was known about it until 1864, when Mr. Arce found plants and sent them to England, where they flowered in the autumn of 1865 . There are now several geographical varieties of this orchid, the one called aurea or chrysotoxa (I.H. 30:493. J.H. III. 31:253. R.H. 1892: 492. A.F. $6: 563 ; 12: 10$. F.R. $1: 76)$, being more easy to grow. This variety is recognized by having deeper yellow petals and sepals, and more copious veining on the labellum. The fragrance of this orchid sug. gests vanilla, and renders it readily distinguishable from other varieties.

3. Var. Eldoràdo, Veitch (C. Eldorddo, Linden). Fls. pale rosy lilac, except for the more or less tubular labellum, which bears at its distal end a border of crimsonmagenta, which shades into an orange-yellow dise ; petals narrowly ovate ; sepals lanceolate. Int. in 1866 from Braz. F.S. 18:1826. - The fragrance of this orchid is very characteristic, while its fls., which are much smaller than in the type, are produced in July and Aug. There are several recognized forms. Sub-var. crocat is paler in the sepals and petals. Sub-var. Wállisii is a white form (A. Wállisii, Linden).

4. Var. Gaskelliàna, Hort. Petals and sepals usually narrower than in the type, perhaps paler. Blooms from June to Aug. The usual forms are not distinct enough to be varietal. Venezuela. I.H. 33:613. A.F. 6:185. Gng. 5:72.

5. Var. Luddemanniàna, Hort. (C. Luddemanniana, Reichb. f. C. Dáwsonii, Warner. C. speciosíssima, Hort.). Petals and sepals delicate rose color or pink-lilac, petals much broader than the sepals; labellum wavy or crisped at the margin, compressed dorsiventrally, apex deeply divided, front lobe deep crimson-purple, the color earried back into the throat in streaks, front part of the lateral lobes nearly white, margined with blush-rose ; throat yellowish. Venezuela.

6. Var. Méndellii, Backhouse ( $C$. Méndellii, Hort.). Fig. 386. Petals and sepals pale rosy mauve to white ; labellum blotched with crimson-purple, throat yellowish. Blooms in May and June or earlier. Of this variety there are many beautiful forms. Eastern Cordilleras, New Granada. S.H. 2:413. $-C$. Bluintei, Hort., is a pure white form with a beautifully fringed lip.

7. Var. Mossiæ, Hook. (C. Mbssia, Parker). Habit as in type, or very similar; petals broadly orate: labellum broad in expanded part, crisped at the usually whitish margin; throat yellow lined with purple, expanded portion mottled with crimson; frequently much intermingled with orange-yellow. La Guayra. B.M. 3669. R.H. 1857, p. 322. S.H. 1:149. A.G. 14:70. A.F. 6: 563 . -C. Wágneri, Hort., is a white form of this Cattleya. C. Reineckidna, Reichb. $\mathrm{f}$., is the most beautiful form. It has white sepals and petals and a richly colored labellum.

8. Var. Percivaliàna, Reichb. f. (C. Percivaliana, O'Brien). Fls. rather small; petals and sepals deeper colored than in the type species!; labellum relatively

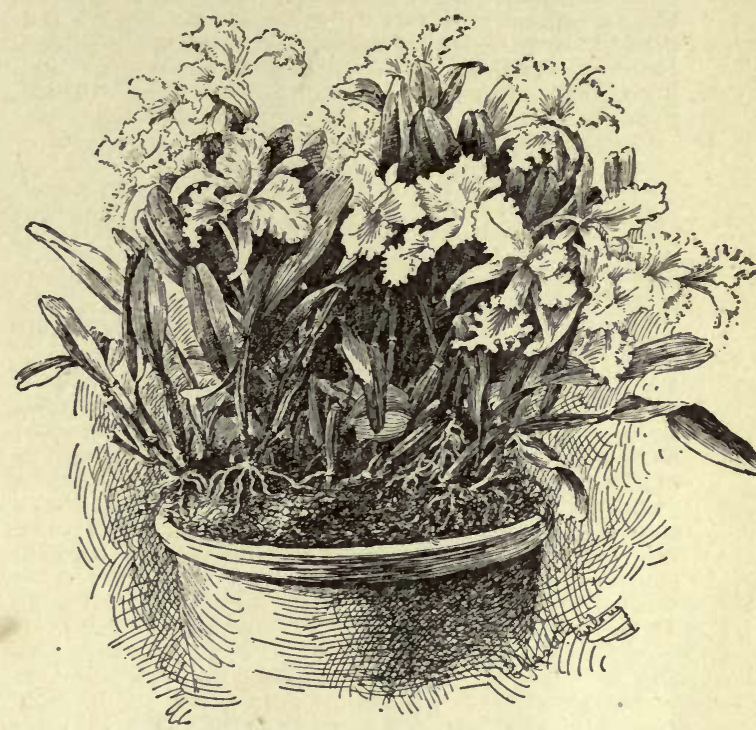

386. Cattleya labiata, var. Mendellii.

small, pale at margin; throat deep yellow streaked with crimson, expanded part crimson-purple. F.R. 1:298, J.H. III. $32: 179$.

9. Var.Triànæi, Veitch ( $C$. Trianøi, Lind. \& Reichb. f. C. quadrícolor, Lindl.). Fig. 388. Foliage more robust, perhaps, than in the type species, though, of conrse, cultivation has much to do with this; petals broader than in the type species, ovate-rhomboid; exceedingly variable in color; expanded portion (not usually so wide or spreading as in $C$. labiata) crimson-magenta, the margin less wavy than in the other varieties. New Grenada. B.M. 5504. R.H. 1860, p. 406-7. A.G. 17:177. Gng. 3:151. A.F. 6:607 ; 13:715. F.E. 9:325. F.R. $1: 672-3$. S.H. $1: 11,27 ; 2: 403,405$. - The fls. are produced 3-5 on the stout peduncles. Sub-var álba. White fls., yellow blotch in throat. Sub-var. Chocoénsis, Hort. Very similar to the above, but the fls. have the appearance of not wholly expanding. Colombia. I.H. 20:120. A.F. 6:563. Sub-var. Schrcederiàna, Hort. ( $C$. Schroderidna. Reichb. f.). Fragrant; petals and sepals vary from white to pale rosy mauve; labellum has more orange-yellow than usual. Blooms at about the same time with the above, and on account of its pale fls. is a valuable variety. G.C. III. 20:73. A.G. 15:211. F.E. 9:331.-C. Triance i is probably the most popular single garden orchid.

10. Var. Wárneri, O’Brien ( $C$. Wárneri, Moore). Very similar to $C$. labiata itself, differing from it, perhaps, only in its blooming season. May, June and July. S. Brazil. A.F. 6: 563 .

11. Var. Warscewiczii, Reichb. f. Fls. large; labellum yellow in the throat, streaked with magenta-red, the infolding portion similar in color to the expanded portion, which is uniformly crimson-purple. New Granada. G.C. III. $22: 163$. - At the entrance to the throat there are usually two yellow blotehes, or "eyes." 
12. Var. Sanderiàna, Hort. (C. gìgas, Lind. \& André). Fig. 387. A noble-fld. form, which, besides being rich in color, is larger than the usual varieties of $C$. labiata. New Grenada. I.H. $21: 178$. Gn. 45, p. 445. G.F. 1:437. A.G. July 23, 1898, Suppl. F.R. 1:77 and 674. F.E. 10: 892. - This is a form of var. Warscewiczii.

13. máxima, Lindl. Plants about $1 \mathrm{ft}$. high : sepals and petals pink-lilac; labellum oval-oblong, obscurely 3-lobed, richly veined with crimson, expanded part crisped at the margin, a yellow median band on the disk. Equador. B.M. 4902. F.S. $20: 2136$. F.R. 1:298.

14. Lawrenceàna, Reichb. f. Pseudobulbs 12-15 in. high, frequently brownish, rarely green: sheath reddish brown : fls. few, about 4 in. across ; petals oblong, blunt at the apices; sepals pale mauve, narrow; labellum purple shaded with maroon. March. British Guiana. B.M. 7133 .

cc. Number of fls. usually more than 6: pseudobulb 2-3-leaved.

15. Skinneri, Batem. Stems about $1 \mathrm{ft}$. high, attenuated at base, 2-lvd.: fls. $6-8$, sometimes more, about 4 in. across, rose-mauve ; disk of labellum whitish, bordered with deeper rose-mauve or deep purple. Guatemala. B.M. 4270. P.M. 11:193. R.B. 22:201. G.C. III. $20: 6$. G.F. $3: 201$ - Common, and a favorite. Runs into white-fld. forms.

16. Bowringeàna, Veitch (C. autumnalis, Hort.). Pseudobulbs about 18 in tall, 1/2in, in diam., subcylindrical, jointed, nodes about 6 , base swollen, 2-3-lvd.: fls. 5-30, on stout peduncles $1 \mathrm{ft}$. long, double-sheathed; petals $1 \frac{1}{2}$ in. long, deep rose-mauve; labellum magentapurple at distal end, deeper colored toward sulfurous yellow throat. Blooms in autumn. Honduras. R.B.21:37. R. H. 1890:300.-Undoubtedly a variety of the preceding.

the preceding.
BB. Fls. not membranaceous, fleshy,
thick: usually z-leaved.

c. Peduncles pendent.

17. citrina,Lindl. Pseudobulbs ovoid, not erect, with membranaceous whitish sheaths: lf.-blades glaucous, about 6 in. long: fls. cc. Peduncles erect.

D. Lateral lobes of labellum practically uanting.

18. Aclándiæ, Lindl. Dwarf : sts. slender, 4 in. tall : Ivs, elliptical: peduncle 1-2-fld.: fls. about 4 in. across ; sepals and petals nearly equal, oblong, yellowish verging on green, spotted and blotched with dark purple (much less distinct on dorsal surface); labellum with small lateral lobes that do not include the column, pale purple, with dark veins and a yellow line under the fleshy column. Brazil. B.M. 5039.

19. bícolor, Lindl. Sts. nearly $3 \mathrm{ft}$. high, 2-lvd.: lvs. oblong-lanceolate, about 6 in. long : peduncle 2-5-fld. sometimes more : fls. 4 in. across; petals and sepals greenish brown, sometimes spotted with brown; labellum tongue-shaped, crimson or deep rose-mauve, margins recurved; lateral lobes do not cover the column. Brazil. B.M. 4909.

DD. Lateral lobes of labellum inclosing column.

20. Victòria-Regina, O'Brien. Pseudobulbs slightly clavate : lvs. elliptical-oblong: peduncle short, 2-3- or more fld.: sepals oblong-lanceolate, obtuse, inferior ones tinged with yellow at the base, otherwise pinklilac; petals undulate, similar to the sepals in color; labellum 3-lobed, lateral lobes whitish, with purpleviolet blotch near summit, midlobe rounded on distal margin, crimson; disk yellow, striated with crimson. Pernambuco, 1891.-A hybrid between $C$. labiata and C. Leopoldi, var. Pernambucensis. One peculiarity that tends to show this origin is the variability in the number of leaves, sometimes 1 , sometimes 2 being borne on a stem.

21. intermedia, Graham ( $C$. amethýstina, Morr.). Pseudobulbs 18 in. high, jointed, rarely 3-lvd.: lvs. narrowly ovate, serrulate on basal margins : fls. white, suffinsed with pale rose-lilac: lubellum distinctly 3-lobed; throat whitish streaked with crimson-magenta, midlobe rather narrow, crimson-magenta. Rio de Janeiro. B.M. 2851. P.M. 1:151.-Var. punctatíssima, Sander, is similar to the type, but the petals and sepals are peppered unevenly with crimson spots of various sizes. Var. Parthènia, Reichb. $f$., is white throughout. Brazil, 1886.

22. Forbesii, Lindl. Fls. about 5 ; sepals oblong, obtuse, pale greenish yellow; petals oblong-lanceolate, undulate, same color: labellum trilobed, lateral lobes pale yellow without, brighter yellow within; the midlobe rather dentate, pale yellow; the disk brighter yellow, spotted with reddish purple toward the base. Braz. B.M. 3265.

23. Lóddigesii, Lindl. 'C. cándida, Williams). Pseudobulbs about $1 \mathrm{ft}$. high: If.-blades ovate, 5 in. long: fls. $2-4$, pale pink-lilac; sepals ellipticoblong; petals very similar; labellum 3-lobed, throat and inner surface of lateral lobes whitish, colored on the outside like the petals, the midlobe colored like the petals, spreading, base yellowish: column closely pressed to the labellum. Brazil.-This Cattleya was formerly called Epidendrum violaceum, and as an horticultural species is much older than $C$. labiata, which is often considered the oldest species in the group.

Var. Harrisoniàna, Hort. (C. Harrisoniana, Batem. C. Hárrisoniae, Paxt.). Surface of the labellum more corrugated. Really too like the preceding even to be a variety. P.M. 4:247. Gn. 48:1040.

24. guttàta, indl. Pseudobulbs fusiform, 2-3-lvd.; lf.-blades elliptic-oblong: peduncle stout, bearing several large fs.; sepals oblong-lanceolate; petals rather broader, all yellowish green (metallic), spotted with brown-purple ; labellum 3-lobed, lateral lobes pinklilac, midlobe large, cuneiform. deeper colored. Rio de Janeiro. Var. Lèopoldi, Hort. (C. Lèopoldii. Versch. \& Lem.), has smaller and more numerous fis. I.I. 2:69.

25. amethystoglossa, Linden \& Reichb. f. ( $C$.guttata, var. Prinzii, Reichb. f. C. Prinzii, Hort. C. outtdta, never-fully expandiug; sepals and petals very thick lemon-yellow; labellum yellow, anterior margin crisped and white. Mex., at high elevations. B.M. 3742. J.H. III. $30: 399 .-$ Not an especially easy orchid to grow. Fragrant. 
var. Keteleèrii, Houlbt.). Lvs. oblong-lanceolate: racemes many-fld.: petals and sepals about equal, the former obovate, the latter narrower, all suffused with rose and spotted with deep crimson; labellum 3-lobed, lateral lobes white outside, the reflexed apices crimson, midlobe broad, deep crimson, disk corrugated and pap illose. Bahia, Brazil. B.M. 5683. R.H. 1869:210.

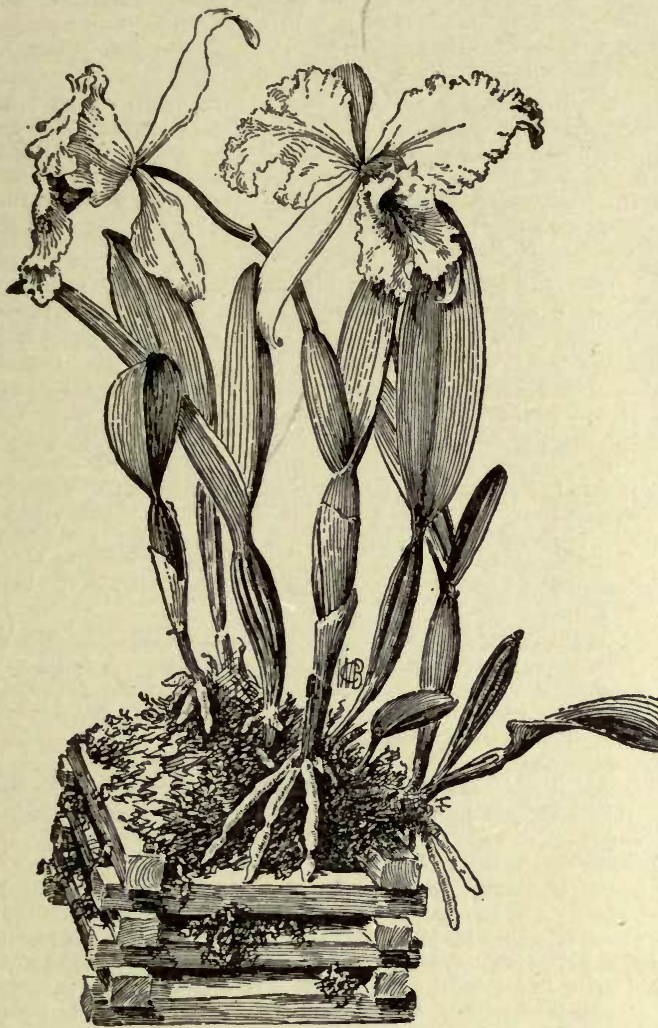

388. Cattleya labiata, var. Trianæi.

26. granuldsa, Lindl. Foliage very similar to that of the preceding species: peduncles stout, bearing several large fls.: sepals oblong, olive-green, spotted with red; petals obovate-oblong, undulate, margined, otherwise like sepals; labellum 3-lobed, lateral lobes yellow inside, whitish outside, midlobe attenuated toward the disk, expanded part subreniform, white, covered with numerous purple papillæ. Guatemala.

27. Schofieldiàna, Reichb. f. Lvs. 2, dark green, 6 in. long and 2 in. wide: sepals and petals light greenish yellow, the petals very narrow at the base and very broad and blunt at the top; lip much like that of $C$. granulosa, the side laciniæ whitish, the middle laciniæ purple-amethyst. Brazil. G.C. III. $22: 252$. - Fls. larger than in $C$. granulos $\alpha$, and the lip is granulated.

28. superba, Lindl. (C. violdcea, Hort.). Sts. clavate, about $1 \mathrm{ft}$, high: lvs, ovate-oblong, very thick : fls. about 6,5 in. across; sepals and petals oblong-lanceolate, about equal, deep rose color, pale at the base labellum 3-lobed, lateral lobes deep, rich crimson outside; midlobe broadly margined with same color, passing abruply into yellow, veined with crimson British Guiana. B.M. 4083. P.M. 9:265. J.H. III. 31:321. A.F. 11:1351. - This plant is reputed difficult to grow. There is a form called var. spléndens, Hort. It is paler in color than the type.

29. Schilleriàna, Reichb. f. Sts. 5 or 6 in. high, reddish brown, 2-lvd.: lvs. elliptical, dark above, brownish purple beneath : peduncles usually 2 -fld.: fls. several in. across; petals and sepals equal, oblong-lanceolate, purple-brown, spotted with deeper brown : labellum 3 -lobed, lateral lobes infolding the column, whitish without, yellow veined wilh purple within; midlobe reniform, deep rose-maure with whitish veins, throat yellow. Braz. B.M. 5150. F.S. 22:2286. A.F. 6:563.

30. lutèola, Lindl. (C. Holfordi, Hort.). Lf. 1, short and broad ( 3 in. long), the pseudobulb compressed : peduncle short, 5-6- or more-fld.: fis. very small, yellow, the sepals and petals uniform and 1-2-in. long and obtuse ; lip about as long as the petals, 3-lobed, velvety within. Brazil. B.M. 5032. F.S. 23:2479.

\section{AA. Blossoms from a leafless pseudobulb.}

31. Walkeriàna, Gardner (C. bulbdsa, Lindl.). Stems 2-5 in. tall, 1-2-lvd.: lvs. oblong, 3-5 in. long; peduncles come from the rhizome near the base of the folia-stems, and are leafless; fls. large, 1 or 2 ; petals and sepals rosy mauve or pink-lilac ; labellum 3-lobed, lateral lobes erect, partially infolding the column, midlobe spreading, anterior end deeper rose-mauve; posterior end yellowish, striated with rose-mauve. Braz. A.G.11:159.This Cattleya is distinct from all others in producing its fls. from a leafless shoot.

Var. doldsa, Veitch (C. doldsa, Reichb.f.). Peduncles produced from between two lvs. This variety, together with several others, must be regarded as perpetuated anomalies of $C$. Walkeriana.

Var. nobilior, Veitch ( $C$. nobilior, Reichb. f.): Large and handsome : front lobe of lip spotted with creamy white. I.H. $30: 485$.

Some of the hybrid Cattleyas are the following : C. Albertii -intermedia $X$ superba. $C$ Ballantidna $=$ Triangi $X$ Warsce. wiczii : C. Brabántioe =LoddigesiiX Aclandiæ; C. Brymeriàna,

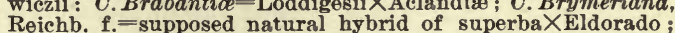
C. Cassándra=Loddigesii $\times$ Lølia elegans; C. Chamberlainiàna $=$ Leopoldii XDowiana ; $C$. Dormaniàna =Lælia pumilaX Cattleya bicolor?; $O$. Exoniénsis, Veitch (Lælia Exoniensis) supposed natural hybrid of C. Mossiæ XLælia purpurata; C. faùsta=Loddigesii X Exoniensis ; C. Hardyàna, doubtful parentage, probably=DowianaXgigas(F.R. 1:78); C.Hárrisii= LeopoldiiX Mendellii; $C$.hybrida picta = guttata Xintermedia; $C$. Krameriàna, Reichb. f., is a supposed natural hybrid of intermedia $\times$ Forbesii ; $O$. Lowrydna $=$ intermedia $\times$ Forbesii ?; $O$. Mánglesii=Luddemanniana $\times$ Loddigesii; $C$. Márdelli=Luddemanniana XLoelia elegans; $C$. Márstersonia $=$ Loddigesii Xlabiata : $C$. Meásuresii=Aclandiæ $\times$ Walkeriana ; $C$. velùtina, Reichb $f$ is probably a hybrid with bicolor and some other species (Gt $44: 140$. G.C. III 24.333) C. Whitei, Reichb $f$ supposed natural hybrid of labiataX Schilleriana? O. Zenobbia supposed natural hybrid of labiataX Schilloriana?
$=$ Loddigesii $\times$ Lælia elegans. OAKES AMES.

CAULIFLOWER (Brássica olerd̀cea, Linn., var. botrytis, DC.). One of the cabbage tribe, of which the head is composed of the metamorphosed flowers and flower-cluster (Fig. 389). (See Cabbage.) The Cauliflower is one of those crops in the culture of which the unskilled amateur is liable to stumble upon success, and the more experienced professional to meet with failure. One can undertake to grow this crop intelllgently and with some assurance of a favorable outcome only when he thoroughly understands the particular requirements of this fastidious vegetable. These requirements mean especially a high degree of soil fertility, perpetual moisture with proper drainage, and protection from an excess of direct sun heat. In the heat of mid-season, Cauliflowers seldom head well, ex cept in more than ordinarily favorable locations or seasons. For this reason, the early crop is usually expected to head before midsummer, while the late crop is planted with the expectation to have it come to a head after the hottest summer weather is over. In all cases, try to select the richest land for Cauliflower, giving a rich pasture or clover-field the preference. A strong loam, neither too clayey nor too sandy, is best. Plenty of good manure, horse manure being considered best, must be well incorporated with the soil, and the latter be brought into the highest state of tilth.

For the early crop, start the plants from best seed obtainable, under glass, as early as the early cabbage plants are started. This can be done in a greenhouse or a hotbed. The possessor of the greenhouse, of course, has the advantage that he is sure to be in position to plant, and that no postponement will be necessary on account of the weather. The aim is to have the seed- 
lings pricked out into a coldframe and grown to good transplanting size, and also well hardened off by exposure, by the time that the soil can be brought into good working order in early spring. With properly hardened plants, late spring frosts are not much to be feared. Liberal applications of good commercial fertilizers, say up to a ton per acre, and made either before or after the

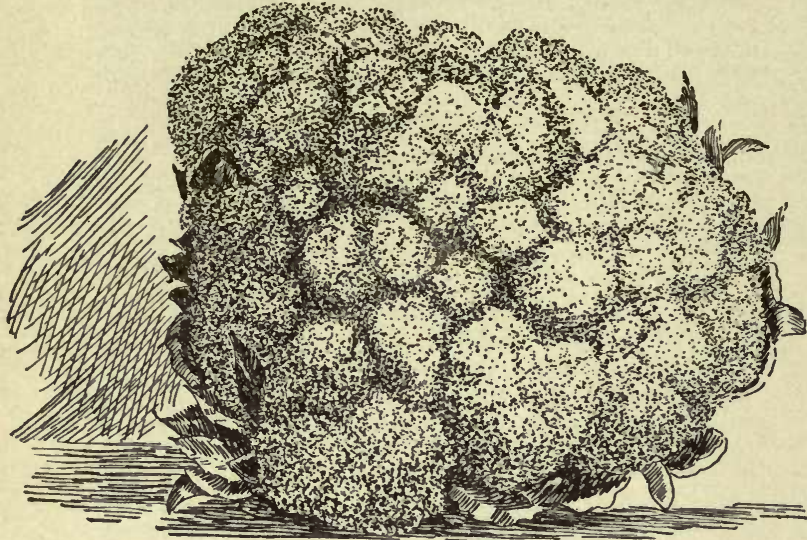

389. Cauliflower, trimmed for market.

plants are set, are often of material help; and an onnce or two of nitrate of soda scattered around each plant soon after setting seldom fails to show marked or even remarkable results. Salt, lime, kainit, or muriate of potash frequently tend to aid the plants in making increased growth. No application, however, can be more necessary or more useful than that of cultivator and hoe. The soil at all times should be kept loose and mellow.

The best demand for Cauliflower is usually during the pickling season, in September and October. Plants can be started from seed and transplanted to the field at the same time that we start and set late cabbage plants, or a little later. In a general way, the crop is handled similarly to the early crop. It is not always an easy task, however, to get the plantation started during the hot and dry weather of July. A favorite method of raising late Cauliflower is to sow a few seeds right in the hill where the plants are wanted to grow. Put the soil in perfect tilth previously, then mark out rows 3 feet apart, drop the little pinches of seed about 2 or $2 \frac{1}{2}$ feet apart in these shallow marks, and lightly cover with the foot, firming well by stepping on each hill. Later on the plants are thinned to one in the hill. The soil must be kept stirred frequently, unless - and this is a much better plan, and one which we always try to practice-the soil is kept well covered with a mulch of fresh manure, thick enough to keep down all weed growth. In dry weather, water may be poured upon this layer of manure, and will furnish both food and drink for the plants.

Of the enemies of the crop, none is more formidable than the cabbage root-maggot. This seems to have a special liking for the Cauliflower. The protective measures which are used for early cabbages are all the more necessary for early Cauliflower. Among such measures, that of enveloping each plant with a tight. fitting collar of tarred felt, and the other of injecting about a teaspoonful of bisulfide of carbon into the soil under the roots of each plant, are probably the best and most surely effective. Plant lice are another serious pest of this crop. Effective remedies are dusting with fine tobacco dust, or spraying with strong tobacco tea or kerosene emulsion. At times we have had fair success by dashing hot soap-suds upon the plants.

VARIETIES.-There are no typical or very marked differences between any of our most popular varieties. Most of them are selected strains of the Early or Earliest Dwarf Erfurt. Among these are Alabaster, Best Early, Gilt Edge, Ideal, Lackawanna, La Crosse Fa- vorite, Long Island Beauty, Sea Foam, Snowball, Snow. storm, and others. All these may be planted for early as well as the late crop. A large form of the Early Erfurt (and a little later) seems to be slightly better adapted to growing in warm weather. Early Paris and Half-early Paris are varieties well suited to summer conditions. Autumn Giant or Giant Naples is a rather late sort, which gives good satisfaction in some of our coast states.

The hot summers of the United States are not favorable for the production of Cauliflower seed, so that, until quite recently, almost every pound of seed used here was imported from Europe. Now, however, a considerable portion of it is being grown on the Pacific coast (Puget sound), and seems superior to the imported in plumpness and vitality. We have always secured especially strong plants from this Americangrown seed. For seed-growing purposes, sow seed during July, transplant, and winter the partially-developed heads over in coldframe or cellar, to be set in open ground again in early spring, and otherwise to be handled similarly to early cabbage when grown for seed.

CaVan is Acacia Cavenia.

T. GreINer.

CEANOTHUS (ancient Greek name). New Jersey TEA. Rhamnaceo. Shrubs or rarely small trees, sometimes spiny: lvs, alternate, sometimes opposite, serrate or entire, and usually 3-nerred at the base : fls. perfect, 5-merous, white, blue or purplish, small, but in showy, often panicled clusters: fr. a 3-celled drupe, dry at length and separating into 3 stones. Thirty-six species in $\mathrm{N}$. America, chiefly Pacific coast region. Ornamental, freeflowering shrubs, some especially valuable for their late flowering period. Many of them are only hardy in the warmer temperate regions, but $C$. A mericanus, $C$.ovatus, and $C$. Fendleri are hardy north, while the numerous hybrids of $C$. Americanus are only half hardy, and even if protected they are killed to the ground in the north, but the young shoots will usually flower the same season. The safest way, however, to have good, free-flowering plants of these beautiful hybrids will be, in the north, to dig them up in fall, store them away in a frost-proof pit or cellar, and to plant them out arain in spring. Pruning of the late flowering species will be of advantage; about one-half of last year's growth may be taken away. They grow in almost any soil, but best in a light and well drained one, and most of the Californian species prefer a sunny position. Prop. by seeds sown in spring and by cuttings of mature wood in autumn, inserted in a coldframe or greenhouse; softwood cuttings also grow readily if taken in early spring from forced plants. Sometimes increased by layers, and the varieties and hybrids by grafting on roots of $C$.A mericanus under glass in early spring; the cions must be fresh and with leaves, taken from plants kept in the greenhouse during the winter.

$$
\text { A. Lvs, alternate. }
$$

B. Margins of lvs. serrate or crenate.

$$
\text { c. Fls. white. }
$$

D. Foliage deciduous.

Americànus, Linn. Fig. 390. Low, erect shrub, to $3 \mathrm{ft}$. ; lvs. ovate, usually acute, finely and irregularly serrate, bright green and dull above, paler and pubescent or nearly glabrous beneath, $11 / 2-3$ in. long: fls. in terminal and axillary panicles on slender peduncles, forming large, corymbose panicles. July-Sept. From Canada to S. Carolina and Texas. B. M. 1479. - Common in dry woods and making a profusion of bloom, which, however, is short-lived. Many hybrids have been raised from this species in Eu. (see C. hybridus). Var. intermedius, Trel. ( $C$. intermèdius, Pursh), has smaller, ovate or ovate-lanceolate lvs. and the fls. in small, very slender, peduncled, short racemes or panicles. Tennessee to S. Carolina.

ovàtus, Desf. (C. ovalis, Bigel.). Low shrub: Ivs. elliptic to elliptic-lanceolate, obtuse or acute, crenulate-serrate, nearly glabrous, glossy above, 1-2 in. long: inflorescence like the former, but usually smaller. New England to Colorado and Alabama. 
sanguineus, Pursh (C. Oregànus, Nutt.). Tall shrub, with purple or reddish glabrous branches: lvs. orbicular to ovate or obovate, obtuse, serrate, nearly glabrous, 1-3 in. long: fls. in rather long, narrow panicles, on stout, leafless peduncles, axillary, from branches of the previous year. May, June. Brit. Columbia to Calif. B.M. 5177.

\section{DD. Foliage persistent, shining above, canescent} beneath.

velùtinus, Dougl. Tall shrub : lvs, broadly elliptic, mostly subcordate, obtuse, serrate, dark green and gla brous above, $2-3$ in. long: fls. in large, compound panieles at the ends of the branches. June, July. Brit. Columbia to Colo. and Calif. B.M. 5165 .

\section{cc. Fls. blue, purplish or pink: lvs. half evergreen.}

hirsùtus, Nutt. Shrub or small tree, with villous branches: lvs. broadly elliptic or ovate, rounded or cordate at the base, obtuse or acute, with glandular teeth, villous and usually green beneath, $1 / 2-2$ in. long: fls. deep blue to purplish, in narrow panicles, 1-2 in. long. April, May. Calif. - Var. Orcutti, Trel. (C. Orcutti, Torrey). Fls. blue, paler: fr. loosely villous.

thyrsiflorus, Eschsch. Shrub or small tree : lvs. oblong, obtuse, crenate-serrate, nearly glabrous, 1-1 1/2in. long: fls. blue, rarely white, in narrow panicles, about 3 in. long. May-July. Oregon to Calif. B.R. $30: 38$. S.S. $2: 64$. G.C. III, $20: 363$. -A very fine, free-flowering species of beautiful blue color. Probably natural hybrids of this species are: C. Veitchidnus, Hook. (C. thyrsiflorus $\times$ rigidus), with deep blue fls. in dense panicled clusters : B.M. 5127; F.S. 13:1383, and C. Lobbianus, Hook. (C. thyrsiflorus $\times$ dentatus), with deep blue fls., in oval, peduncled, solitary clusters. B.M. 4810 (4811 by error). F.S. 10:1016.

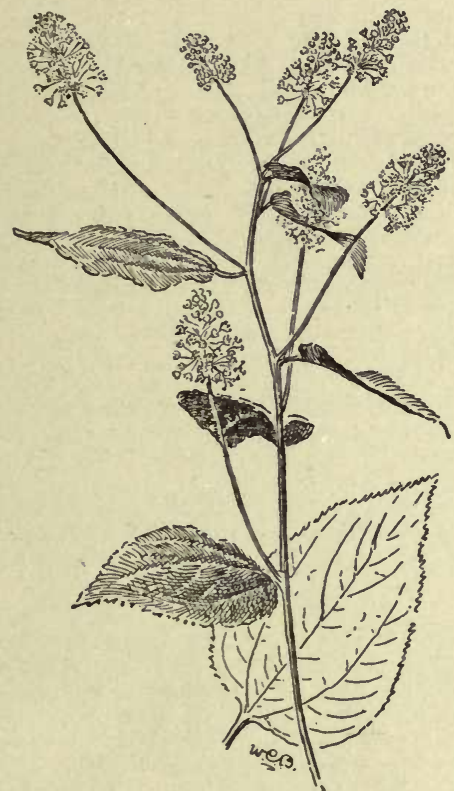

390. Ceanothus Americanus $(\times 1 / 8)$.

hybridus, Hort. Hybrids of garden origin, chiefly between $C$. Americanus or $C$. ovatus and $C$. thyrsiflorus or $C$.azureus, mostly raised in French nurseries. Some of the most distinct are: Álbus-plènus, with double white fls.; Atrocarùleus purpùreus, fls. blue, foliage purple when young; Arnoldi, fls. sky-blue, in large panicles; Gloire de Versailles, with bright blue, large panicles; Gloire de Plantières, fls. dark blue, in large panicles ; Marie Simon, fls. flesh-colored ; Roseus, fls. pink. R.H. 1875: 30 .
BB. Margins of lvs, entire or nearly so: half evergreen.

Féndleri, Gray. Low, prostrate and spiny shrub: lvs. oval, rounded or nearly acute at both ends, entire, rarely finely serrulate, grayish green, minutely tomentose beneath, $1 / 2-1$ in. long: fls. white, in short racemes, termlnal, on short, lateral branchlets. June, July. From S. Dakota to New Mexico and Arizona.-A very graceful and free-flowering shrub of almost creeping habit, well adapted for covering dry, sandy banks; half evergreen and hardy north.

integérrimus, Hook. \& Arn. Tall, erect shrub, with glabrescent branches : lvs, broadly elliptic or ovate, sparingly hairy or glabrous, bright green beneath, 1-3 in. long: fls. blue, sometimes white, fragrant, in 3-6-in. long, narrow panicles. April-June. Washington to Calif. and S. E. Arizona.

divaricatus, Nutt. Tall, erect shrub, with usually glaucous branches and often spiny : Ivs. ovate, obtuse or nearly acute, glaucous and glabrous or grayish tomentose, $1 / 8-1$ in. long: fls. pale blue, sometimes whitish, in 2-3.in. long, narrow panicles. April-June. Calif.

$$
\text { A A. Lvs. opposite, persistent. }
$$

cuneàtus, Nutt. Tall, much-branched shrub: lvs. spatulate or cuneate-obovate, mostly obtuse, entire, minutely tomentose beneath, $1 / 4-1$ in. long: fls. white, in small clusters along the branches. March-May. Oregon to Calif. B.H. $8: 170$.

prostràtus, Benth. Procumbent shrub : lvs. cuneate, obovate or spatulate, coarsely and pungently toothed, sometimes only 3 -pointerl at the apex, often minutely silky when young, $1 / 2-1$ in. long : fls. blue, in clusters, terminal on short branchlets. Spring. Washington to Calif.

C. Africànus, Linn $=$ Noltea Africana $-C$, atrocorùleus purpùreus, see C. hybridus.-C. azùreus, Desf. Low shrub : lvs. membranaceous, oblong, serrate, pubescent : fls. blue, in large panicles. Summer. Mexico. L.B.C.2:110. B.R.4:291. P.MI. $2: 74$. Under this name a hybrid of this species with C. Amerieanus is often cultivated. $-O$. bicolor, HBK. $=$ C. azureus. $-C$. carùleus, Lag. $=\mathrm{C}$. azureus.- $C$. dentàtus, Torr. \& Gray. Low shrub : lvs. oblong, penninerved, dentate, glandular-papillate shrub: lvs. oblong, penninerved, dentate, glandular-papillate F. S. 6:567, 2 B.H 3.101.C. dentàtus, var, floribuindus. Trel. (C. floribundus, Hook.). Fl.-clusters numerous, nearly sessile: lvs. smaller. B.M. 4806. F.S. 10:977. I.H. 7:238. B.H. 5:129 C. foliòsus, Parry. Low shrub: Ivs. small, broadly elliptic, glandular-toothed, slightly hairy, pale or glaucous beneath: fis. deep blue, in numerous small clusters. Calif.- $C$, intermèdius. Pursh =C. Americanus, var. intermedius. - C. laevigàtus, Dougl. Tall shrub: lvs. broadly elliptic, serrate, glabrous, glaucous beneath: fls. neath: fls. yellowish white, in large panieles. Calif.- C. Lobbiànus, Hook., see C. thyrsiflorus.-C. microphýllus, Michx. Low
shrub: lvs. very small, obovate or elliptic, nearly glabrous: fls. shrub: lvs. very small, obovate or elliptic, nearly glabrous: fls.
white, in small, short-peduncled clusters. Florida.-O. Orewhite, in small, short-peduncled clusters. Florida.- O. Orevar. Orcutti. - C. papillòsus, Torr. \& Gray. Low shrub: lvs. narrow-oblong, dentate, glandular-papillate above, villous beneath : fls deop blute in peduncled, axillary oblong clusters. neath C. Párryi, Trel. Large shrub: lvs elliptic or ovate, denticulate, cobárryi, Trel. Large shrub: lvs. elliptic or ovate, denticulate, Calif.- C. rigidus, Nutt. Rigid, much-branched shrub : lvs. opposite, cuneate-obovate, denticulate, usually glabrous, small: fls. blue, in small, nearly sessile, axillary clusters. Calif. B.M. 4660 (as C. verrucosus) and 4664. - C. Veitchiànus, Hook, see C. thyrsiflorus.- $C$. verrucòsus, Nutt. Low shrub: lvs. mostly alternate, roundish obovate, emarginate, denticulate, nearly glabrous, small: fls. white.in small, axillary clusters along the glabrous, small: fls. white. in small, axillary clusters

Alfred Rehder.

CEDRELA (from Cedrus, the wood resembling that of Cedrus). Mrelidcea. Tall trees, with alternate, usually abruptly pinnate lvs., without stipules; lfts. petioled, entire or slightly serrate : fls. inconspicuous, whitish, usually perfect, 5 -merous, in large, pendulous, terminal panicles; the 5 petals forming a tube with spreading limb : fr. a capsule, dehiscent, with 5 teeth, with many flat, winged seeds. Eigbt species in trop. Amer. and 8, forming the subgenus Toona, in E. India and Australia. Tall, ornamental trees, and well adapted for avenues; only hardy in S. Calif. and in the Gulf states, except $C$. Sinensis. The wood of some species is known as cedar wood, and much valued for making furniture and boxes. 'They thrive best in rich loam, and are prop. by seeds or by cuttings of mature wood, and, also; by rootcuttings, all with bottom heat. 
A. Lfts. 10-25, quite glabrous.

Sinénsis, Juss. Fig. 391. Tree, to $50 \mathrm{ft}$.: lvs. longpetioled, 10-20 in. long; lfts. 10-22, oblong or oblonglanceolate, acuminate, slightly and remotely serrate, 4-8 in. long: fls. white, in very long, pendulous ra-

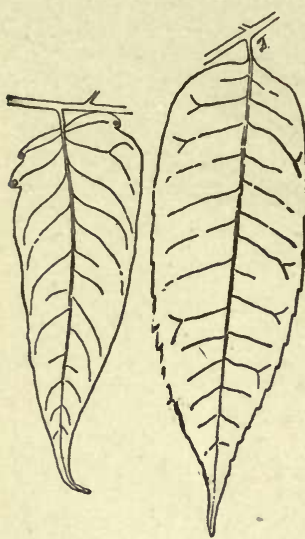

391. Leaflets of Cedrela and Ailanthus.

Cedrela on the right $(\times 1 / 3)$ cemes : fr. oblong or obovate, about 1 in. long. June. China. R.H. 1891, p. 574-75, and 1875, p. 87. Gng. 4:1.Ornamental tree, with large, feathery foliage; very valuable for avenues; similar to Ailanthus, and nearly of the same hardiness, but of more regular and dense growth, and without the disagreeable odor when flowering. Ailanthus can be easily distinguished by the few coarse teeth near the base of the lfts., each bearing a large gland beneath (Fig. 391).

serràta, Royle. Tree, to $70 \mathrm{ft}$. : lvs. usually odd-pinnate, 15-20 in. long; lfts. 15-25, ovate-lanceolate or ovate-acuminate,irregularly serrate, glaucous beneath: panicles long, pendulous : fls. fragrant. Himalayas. This is probably the hardiest of the tropical species.

Closely allied to this species is $C$. Toona, Roxb. from E. India, but lvs. abruptly pinnate, and lfts. usually entire.

odorata, Linn. Tree, to $80 \mathrm{ft}$ : : lvs. 10-20 in. long; lfts. $12-20$, ovate-lanceolate, acuminate, nearly entire, 4-6 in. long: panicles shorter than the lvs.: fr. obloug, almost $1 \frac{1}{2}$ in. long. W. India. - The cedar wood comes mostly from this species.

$$
\text { AA. Lfts. 6-10, finely ciliate. }
$$

Dugèsi, Wats. Tree: lvs. 10-15 in. long; lfts. cuneate, ovate-lanceolate, long and slender acuminate, nearly entire, shining above, 4-6 in. long: panicles rather compact, much shorter than the lvs. Mexico.

\section{ALFRED ReHDER.}

CEDRONELLA ( $a$ little Cedar, from the odor of $C$. triphylla, a species from the Canary Islands, sometimes called "Balm of Gilead"). Labiatoe. Eight species of herbs or shrubs, allied to Dracocephalum. The two native kinds described below are compact, free-flowering border perennials, with aromatic lvs, and numerous showy, purplish pink fls. with blue stamens, and borne in dense whorls on long racemes or spikes. They are not quite hardy north, and should have a sheltered, sunny position, or some winter protection.

càna, Hook. Height 21/2-3 ft.: stems hard, square, subshrubby: branches numerous, especially at the vase, opposite, hoary with a minute pubescence: upper lis. small, $1 / 2-1 \frac{1}{2}$ in. long, entire, hoary, numerous near the fls., ovate; lower lvs. larger, cordate-ovate, dentateserrate : spikes numerous: whorls dense, 15 or more fld.: corolla 1 in. long, limb 5 -cleft, the lowest lobe largest, crenate, revolute. June-Oct. Mex. and N. Mex.

Mexicàna, Benth. (Garddquia betonicoides, Lindl.). Height 1-3 ft.: root creeping: lvs. $1 \frac{1}{2}-2 \frac{1}{2}$ in. long, ovate-lanceolate (the lower ones cordate), crenate-dentate, becoming purplish below, petioled: fls. very like above, bright pink. Mex., Mts. S. A riz. B. M. 3860 Rarer in cult. than above. Lvs. larger, longer and fewer.

triphylla, Mœnch (Dracocéphalum Canariénse, Linn.). Balm of Gilead. Shrubby: leaflets 3, oblong or lanceolate: fls. purple or white, in loose spicate whorls. Aromatic plant from Canary Is. Three to $4 \mathrm{ft}$.

J. B. KeLler and W. M.

CÈDRUS (Kedros, ancient Greek name). Coníferce. CEDAR. Large evergreen trees, with quadrangular, stiff, fasciculate lvs.: fls. monœerious, forminu coliudrical catkins : cones ovate, $3-5$ in. long, with troad, closely imbri- cate bracts, attaining maturity in two or three years ; seeds winged. Three closely allied species in N. Africa, Asia Minor and Himalayas. Large ornamental Conifers, with wide-spreading branches, very distinct in habit from most other Conifers; not hardy north, but the hardiest, $C$. Atlantica, may be grown as far north as New York in sheltered positions, while $C$. Deodara can be only grown safely in Calif. and S. states. The very durable and fragrant wood of all species is highly valued. The Cedars prefer well-drained, loamy soil, and will also grow in sandy clay, if there is no stagnant moisture. Prop. by seeds, sown in spring; the varieties by veneer grafting, in late summer or in fall, on seedlings of $C$. Atlantica; or, in warmer regions, on $C$. Deodara; they grow also from cuttings, if the smali shoots are selected which spring occasionally from the old wood. Plants of this genus are the true Cedars; but trees of other genera are often called Cedar. See Chamceyparis, Juniperus, and 'Thuya; also Cedrela.

A. Branches stiff, not drooping: cones truncate, and often concave at the apex.

Atlántica, Manetti. Fig. 392. Large, pyramidal tree, to $120 \mathrm{ft}$., with upright leading shoots : lrs. mostly less than 1 in. long, usually thicker than broad, rigid, glaucous-green : cones $2-3$ in. long, light brown. N. A frica. Gng. 2: 163. G.F. 9:417. R.H.1890, p. 32. Var. glaùca, Hort. Foliage glaucous, with silvery hue; a very desirable and vigorous form. Var. fastigiàta, Carr. Of upright columnar habit. R.H. 1890, p. 32.

Libdni, Barr. Large tree, with wide spreading, horizontal branches, forming a broad head when older, leading shoot nodding: lvs. 1 in. or longer, broader than thick, dark or bright green, sometimes bluish or silvery: cones 3-4 in. long, brown. Lebanon, Taurus, S. Anatolia and N. Africa. Gng. 5: 65. Mn. 1:39. G.F. 8: 335. Gn. 48, p. 237. Var. argéntea, Loud. With blue or silvery hue. Var. nàna, Loud. Dwarf form.

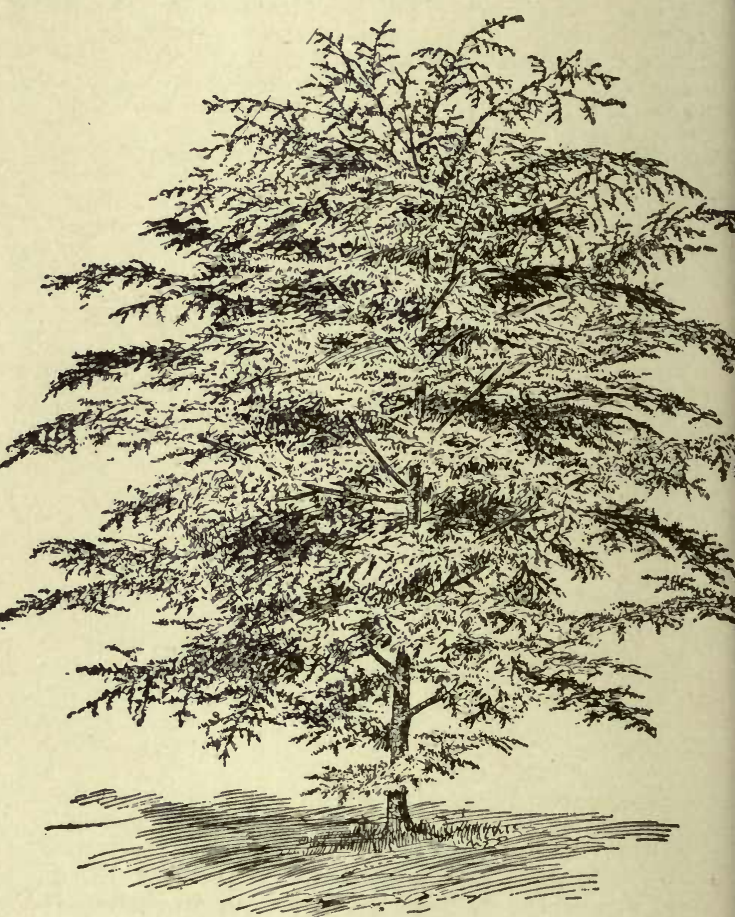

392. Cedrus Atlantica.

AA. Branches and leading shoot pendulous : cones obtuse.

Deodàra, Loud. Tall tree, of pyramidal habit, to 150 ft.: lvs. 1-2 in. long, dark bluish green, rigid, as thick as broad : cones $3 \frac{1}{2-5}$ in. long, reddish brown. Himal. 
Gng. 2: 8. Var. argéntea, Hort. Lvs. with silvery hue. Var. viridis, Hort. Lvs, bright green. Var. robústa, Hort. Lvs. about 2 in. long, very rigid.

AlfRed RehDer.

CEIBA. See Eriodendron.

\section{CELANDINE. See Chelidonium.}

CELÁSTRUS (Kelastros, ancient Greek name). Celas trdcea. Shrubs, usually climbing, with alternate, petioled, usually decidnous and serrate glabrous lvs.: fls. polygamous, 5-merous, inconspicuous, greenish white, in axillary or terminal panicles or racemes: fr. a capsule, dehiscent into 3 valves, each containing 1 or 2 seeds, enclosed in a fleshy crimson aril. About 26 species in S. and E. Asia, Australia and America. Hardy ornamental shrubs, very effective by their bright-colored fruit remaining usually throughout the winter; they are very valuable for covering trellis-work, trees or rocks and walls. They grow in almost any soil and situation, and as well in shaded as in sunny positions. Prop. by seeds, sown in fall or stratified, and by rootcuttings or layers; suckers are freely produced, and become sometimes a nuisance in nurseries ; they can be also increased by cuttings of mature and of soft wood. The species with perfect fls. in axillary cymes and with evergreen lvs., being rigid and often spiny shrubs, are now included under Gymnosporia, which see.

scéndens, Linn. False BitTer Sweet. Fig. 393. High, climbing to $20 \mathrm{ft} .:$ lvs. cuneate, ovate to ovatelanceolate, acuminate, crenate-serrate, glabrous, 2-4 in. long : fls, in terminal, many-fld. panicles or racemes : fr. about $1 / 2$ in. in diam., orange-yellow, with crimson seeds. Canada to S. Dakota and N. Mexico. Em. 545. A.G. 11:29,31. G.F. 5: 569. Gng. 5: 119.

orbiculàtus, Thunbg. (C. articuldtus, Thunbg.). High climbing shrub : lvs. cuneate, suborbicular to oblong or obovate, acute or acuminate, crenate-serrate, $2-3$ in. long: fr. globular, orange-yellow, with crimson seeds. Japan, China. B.M. 7599. G.F. 3:550. A.F. 9:534. G. C. III, 23:29. Gng. 5:119. Var. punctàtus, Rehder $(C$. punctatus, Thunb.). A less vigorous grower, with smaller, elliptic lrs. C. orbiculatus is of more vigorous growth than the former species, and fruits very profusely, but the fruits are hidden by the foliage, and are not very conspicuous until the lvs. have fallen, while $C$. scandens bears its fruits above the lvs.

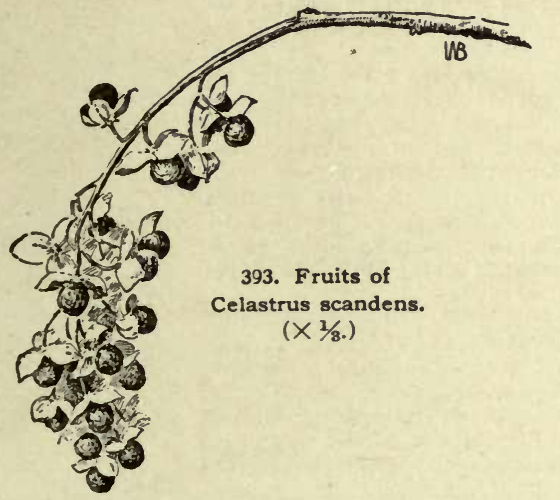

paniculàtus, Willd. (C.depéndens, Wall.). Branches with white lenticels, pendulous: lvs. ovate-oblong or obovate: fls. in terminal pendulous panicles. Himalayas. Not hardy $\mathrm{N}$.

C. nùtans, Hort. Reasoner, not Roxbg.=Quisqualis Indica.c. Orixa, Sieb.\& Zuec.=Orixa Japonica.

Alfred Rehder.

CELERIAC (Apium gravèolens, Linn., var. rapdceum, DC.). Umbelliferce. Fig. 394. An offshoot of the celery species, producing an edible root instead of edible leaves. Just how long Celeriac, or Turnip-rooted Celery, has been in cultivation is unknown. Its history as a garden vegetable can be traced definitely as far back as the middle of the seventeenth century, although writers for a century or more previous to this time made references which would seem to relate to this vegetable, but the identity is obscure. Its origin was probably the same as that of the common garden celery, of which it

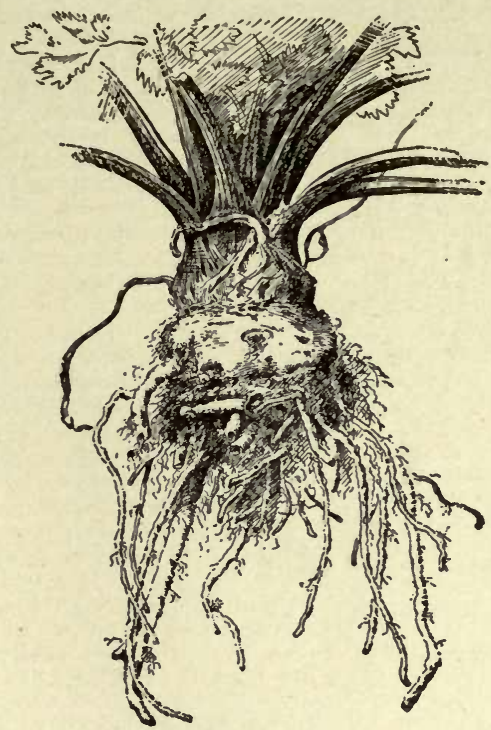

394. Celeriac $(\times 1 / 3)$.

is doubtless a state wherein the root has become en. larged and edible. This form is supposed to be the one most remotely removed from the wild state.

Celeriac is very little grown in this country, and to Americans is almost unknown, but it is much prized in Europe. It is cultivated chiefly where there is a German population. Fifteen or 20 varieties are mentioned in the seed catalogues, but there is very little difference in the various sorts, some seedsmen even making no distinction between varieties, but catalogue the plant simply as Celeriac.

In general, the culture is the same as for celery, except that no blanching is required, since it is the enlarged root which constitutes the edible portion. Sow the seed during the spring in a well-prepared seed-bed, preferably in a more or less shaded location. A coldframe or a spent hotbed is a good place. The seed is slow to germinate, and must be kept well watered. When the plants are 2 or 3 inches tall, they ought to be transplanted; about 3 inches apart each way is a good dis. tance to place them at this handling. Later, again transplant them to the open ground, in rows about 2 feet apart and 6 or 8 inches distant in the row. The soil should be a rich, light loam well supplied with moisture.

The seed may be sown where the plants are to remain, and thinned to the required distance, but stronger, more stocky plants are obtained by transplanting as more stocky plave directed.

Plants thus treated will be ready for fall and winter use. If they are desired for earlier use, the seeds may be sown in a mild hotbed and transplanted to the open as soon as the ground is in good condition in the spring. Aside from frequent tillage, Celeriac requires but little attention during growth. It is a frequent practice among growers to remove a little of the earth from about the plants after the root has become well enlarged, and to cut off the lateral roots. This tends to make the main root grow larger, smoother and more symmetrical in shape.

For winter use, the plants may be protected with earth and straw sufficient to keep out frost, or packed in moist sand and placed in a cool cellar.

The principal use of Celeriac is for the flavoring of soups and stews, but it is also served in sereral other 
ways. It may be boiled and eaten with a white sauce, like cauliflower ; as a salad, either first being cooked as beets or turnips, or else cut up into small pieces and used raw ; when boiled, sliced and served with oil and vinegar, it forms the dish known as "celery salad." An extract may be obtained from it which is said to have certain medicinal properties.

\section{H. P. GOULD.}

CELERY (Àpium gravèolens, Linn.). Umbellíferce. Annual or biennial plants: leaf-stalks 6-15 in. long, bearing 3 pairs and a terminal leaflet, all of which are coarsely serrate and more or less ternately lobed or divided: flower stalk 2-3 ft. high, branched and leafy, bearing numerous rather small compound umbels of inconspicuous white flowers: fruit small, flattened on the sides, broader than long. An ounce contains between 60,000 and 70,000 seeds.

Celery is known in America only as a garden vegetable, and is cultivated mainly for the leaf stalks, which are blanched and eaten raw with salt, made into salads, or boiled and served like asparagus. Celery roots, leaves and seeds are also used in flavoring soups, meats, etc. The garden form resembles wild celery, which grows over a wide range in Europe and Asia, but the plants are less acrid and pungent and the leaf-stalks are much larger and more meaty and solid. Ancient writers left little definite information about this plant, and it is doubtful if its cultivation as a staple garden vegetable really began until after the Middle Ages. Previous to that time it does not appear to have been clearly distinguished from parsley, which was mainly used at funeral ceremonies, and not at all as a salad plant. It is supposed that the Selinon mentioned by Homer in the Odyssey was wild celery, and it has also been stated that Dioscorides distinguished between the wild and the cultivated forms of this plant, but later writers were singularly silent about garden celery until the seventeenth century. In 1629 Parkinson wrote that "sellery" was a rarity in England. It seems to have been introduced there from Italy, where its cultiration as a garden vegetable probably began. In $1699 \mathrm{John}$ Evelyn wrote of "sellery" as A pium Italicum, and described it as a hot and more generous form of Macedonian parsley or smallage, which, he stated, for its high and grateful taste was ever placed in the middle of the Grand Sallet at the great men's tables and Prætors' Feasts as the grace of the whole board. During the seventeenth and eighteenth centuries celery was frequently called smallage in England and ache in France, but now these names have fallen into disuse. Until about 1850 celery was grown in trenches; later level culture was gradually adopted. For 20 or 25 years following 1850 celery was used almost entirely as a winter vegetable. The plants were only partially blanched

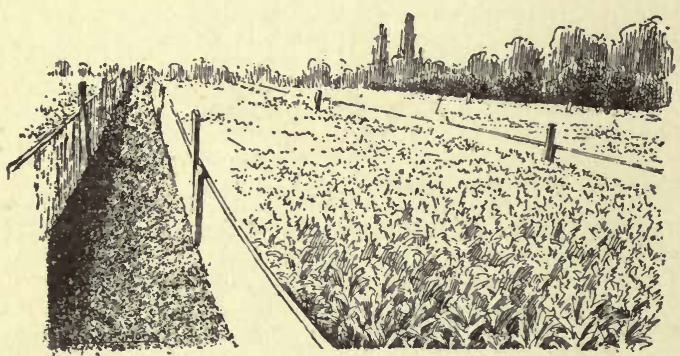

395. Celery planted thick, and the patch edged with boards.

in the field, then lifted aud placed in trenches or celery pits, where they remained until the blanching process was completed, being taken out from time to time during the winter. Celery is reported as naturalized on the coast of southern California, and as escaped from cultivation in southeastern Virginia.
The demand for earlier celery increased after 1875 or 1880. The introduction of two new kinds of celery a few years later, namely the White Plume and the Paris Golden, both with distinct self-blanching tendencies, gave a fresh impetus to the cultivation and the consumption of early celery. These new kinds were more attractive as table decorations, and they were also more easily grown and blanched than any varieties previously cultivated. Soon after their introduction boards began to be used in the place of earth in blanching early

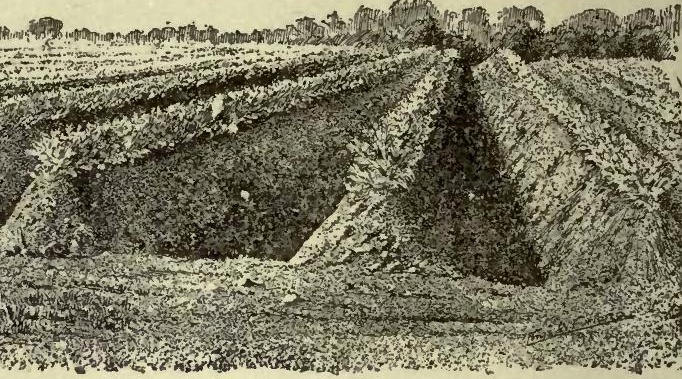

396. The last earthing-up of Celery.

celery. This proved a decided advantage to growers because the rows could be from $2 \frac{1}{2}$ to 3 feet apart instead of 4 or 5 feet, as was necessary before, and also less labor was required in caring for the crop and preparing it for market. With the new varieties and improved methods of blanching, early celery began to be grown on a large scale after 1885 , and now large markets are supplied with Celery throughout the entire year.

Starting the Plants. - Celery seed is usually sown in frames where there is but little artificial heat. The seeds germinate slowly, and the seedlings require about three months after the seed is planted to mature sufficiently to be set in the field. Sowings for the early crop begin in January, and those for the late crop about the middle of March in the northern states. The seed is sown broadcast, and when the plants are large enough to handle they are transplanted into other frames, being set 2 or 3 inches apart each way. The soil in these frames, and also where the seed is sown, is made very fertile, to insure a strong growth of both roots and foliage. After being transplanted the plants are allowed to remain in the frames only long enough to send out a new set of roots and leaves. If for any reason the plants remain in the frames too long, they often go to seed prematurely when set in the field. This is much more likely to occur with the early than with the late crops.

FIE L D COLTURB. - Moist, peaty soil is preferred, but celery is successfully grown on clayey and even sandy soils, when these are highly fertilized and irrigated. Level culture is now generally practiced, the old method, in which plants were set in single or double rows in trenches (Fig. 397) being nearly obsolete. The plants are set

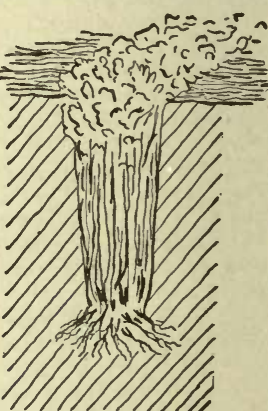

397. The old method of growing Celery in trenches. Plants are sometimes stored for winter in such trenches. from 6 inches to a foot apart in the rows, and the rows from $2 \frac{1}{2}$ to $3 \frac{1}{2}$ feet apart. Early and late varieties are often set in alternate rows. Boards are used to blanch the plants that mature first, and when these are out of the way there is room to bank the remaining rows with earth (Fig. 396).

Celery plants are also set 7 or 8 inches apart each way in beds. This method requires intensive culture. The plants must be frequently fertilized and copiously watered during their growth. In this case the crowding of the leaves is sufficient to blanch the stalks of the 
Paris Golden, which is the variety generally grown in this way, and boards are used only around the outside of the beds (Fig. 395). This method is known as the "New Celery Culture," or Niven's method.

BLANCHING. - When the weather is warm in summer celery often blanches in two weeks after boards are set up beside the rows, but later in the fall it takes three or four weeks, and the winter varieties are often banked with earth considerably longer than this and then placed in celery pits, where the blanching process continues. Hemlock boards an inch thick, a foot wide and 12 feet long, are largely used for blanching summer celery. These are placed on edge beside the rows and drawn nearly together at the top, where they are held by small wooden cleats. When thus placed the boards enclose the entire plants, with the exception of ends of scattering leaves, which project above them. In market gardens these boards are moved from one field to another after the crops mature, and kept in constant use from the middle of June until late in November. When freezing weather is expected, the remaining plants of the early varieties are lifted and set in beds in the field, where they are enclosed on the sides and covered as closely as circumstances may require with the boards.

Late celery is blanched mainly by banking with earth, the earth being thrown up against the plants at two or three different times; first, the base of the bank is thrown up about one foot high, the leaves being held together during the operation to prevent the soil from filling in between the stalks. The top of this bank is left broad and dishing so that the plants can be watered. Two or three weeks. later the bank is raised 8 inches or a foot higher, and often it is again raised, the top of the highest banks being about 3 feet above the ditches between the rows. The plow is used in loosening the soil, but the banking is mainly done by hand. The old method of growing celery in trenches (Fig. 397) in order to bleach it is now entirely obsolete in this country. A well-hilled field is shown in Fig. 396.

Celery is sometimes blanched by wrapping the plants in thick paper (Fig. 398), or by placing large pieces of drain tile over them.

Preparation For MARKET. - After pulling, the celery is trimmed, then taken to the packing room, where it is washed and tied in bunches, the bunches being from 3 to 4 inches in diameter and containing from 2 to 6 "heads" or plants. The root is cut to a point, as shown in Fig. 399. After bunching, it is packed in cases of various patterns which hold from 2 to 5 dozen bunches each. A common style of celery crate, for the marketing of trimmed plants, is shown in Fig. 400. Sometimes celery, especially the early crop and for nearby markets, is not trimmed at the roots; but the roots are left intact, the plant washed and stripped of its dead and broken leaves and then shippod in a tray which holds water. Fig. 401 shows Niven's tray, used for this purpose. This tray or crate will hold $24-30$ roots. The sides, A A, are $20 \times 40$ in.; B B, $14 \frac{1}{2} \times 40$ in.; top pieces, $C, 1 \frac{1}{2}$ in. wide by $5 / 8$ in. thick; posts, D, $1 \times 1 \times 12$ in. The joints are mitered and painted before nailing. The inside of the tray is painted white.

VARIETIES. - Not less than 50 kinds of celery, which are more or less distinct, are catalogued by American seedsmen. The plants vary in size from the Paris Red Ribbed, which is scarcely a foot high, to the Giant Pascal, which is fully three times as tall; and in color of the foliage from the deep green of the Boston Market to the golden yellow of the Paris Golden and the almost pure white of the White Plume. Some kinds are turniprooted (see Celeriac), others have red leafstalks, and still others are very bitter and pungent; yet all of these variations seem to have resulted from high cultivation and, possibly, in some cases, from crossings of the different kinds. A half dozen leading types may be described.

Paris Golden or Golden Self-blanching. - This rariety was raised by $M$. Chemin in his market-gardens near Paris. France, and it was introduced into the United States about 1885. It was entirely distinct from all other varieties, and it gained favor among growers rap. idly. Since 1892 or 1893 it has been the leading summer kind, and more generally planted in market-gardens than any other. The plants are stocky, they can be planted closely, conveniently blanched with boards, packed in small space when bunched, the bunches keep remarkably well, are exceptionally attractive when exposed for sale in the market, and the stalks are never disagreeably bitter. Leaf-stalks below the lower pair of leaflets 6 to 8 inches long and from $1 \frac{1 / 4}{4}$ to $13 / 4$ inches in circumference, generally with 9 distinct ridges and 13 rather small fibrovascular bundles, the latter not imbedded in green cells, the ridges flattened and the furrows between them shallow; leaf-bearing part of the stalk 12 to 14 inches long, with a decided constriction where the lower pair of leaflets unite with it; leaflets thick, shurply serrate, usually wedge shaped at the base and with characteristic yellow specks, which increase in

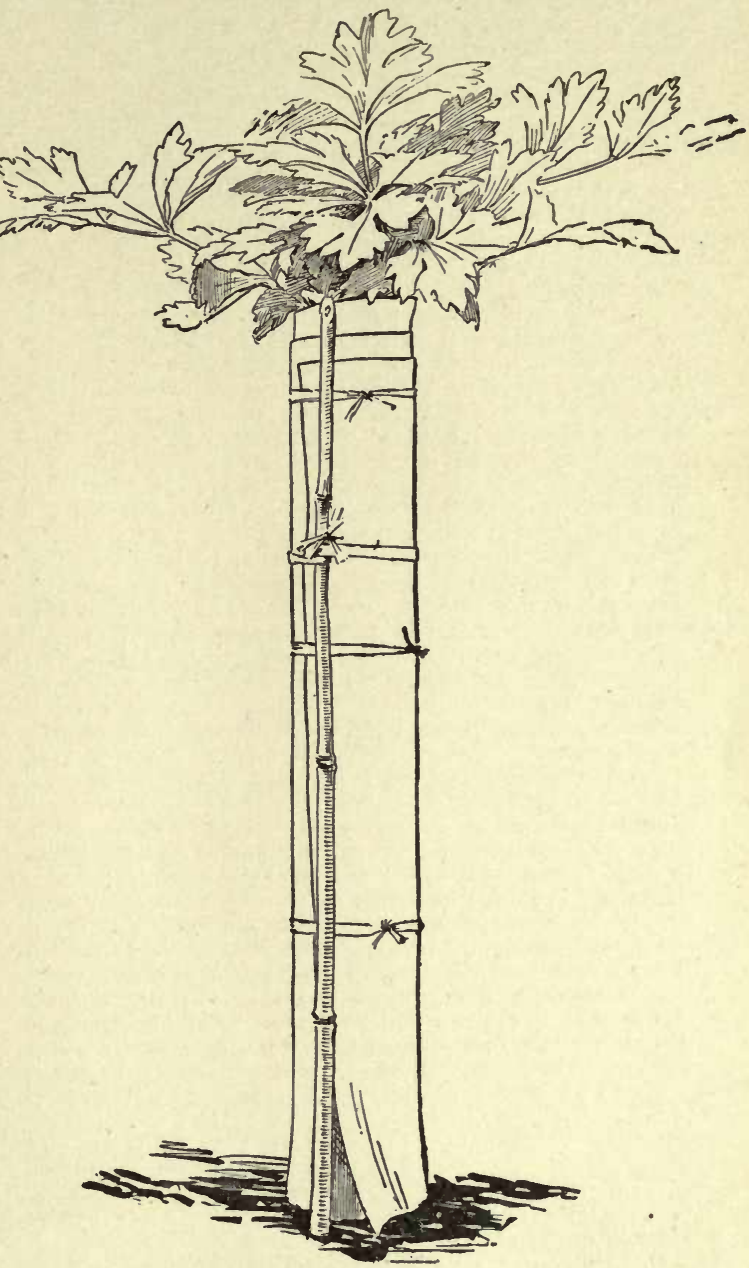

398. Blanching Celery by wrapping it with paper.

numbers as the plants mature until the entire foliage appears to be of a light golden hue.

The Paris Red Ribbed celery is a very dwarf variety, having thick leatlets with yellow specks in them like the Paris Golden, but the plants are smaller, not so full in the centers and the leaf stalks are shaded with red. Another variety of recent introduction, known as the Broad Ribbed celery, is evidently nearly related to the preceding kinds. The foliage shows the yellow specks, the leaf stalks are large and rounded on the edges, and the plants mature early, but they are open in the center. Some strains of this variety have reddish leaf stalks.

White Plume.-Introduced by Peter Henderson in 1884. For severul years this variety was more generally grown than any other kind. The plants are distinctively 
self-blanching ana beautiful, and it has been claimed that this variety surpasses all others as a table decoration. Leaf-stalk below the lower pair of leaflets 8 to 10 inches long, 1 to 2 inches in circumference, light green, becoming pure white when blanched, ridges 9 , fibrovascular bundles 13 imbedded in green cells; leaflets large, borne on slender divisions of the main stalk, turning light colored and sometimes nearly pure white when the

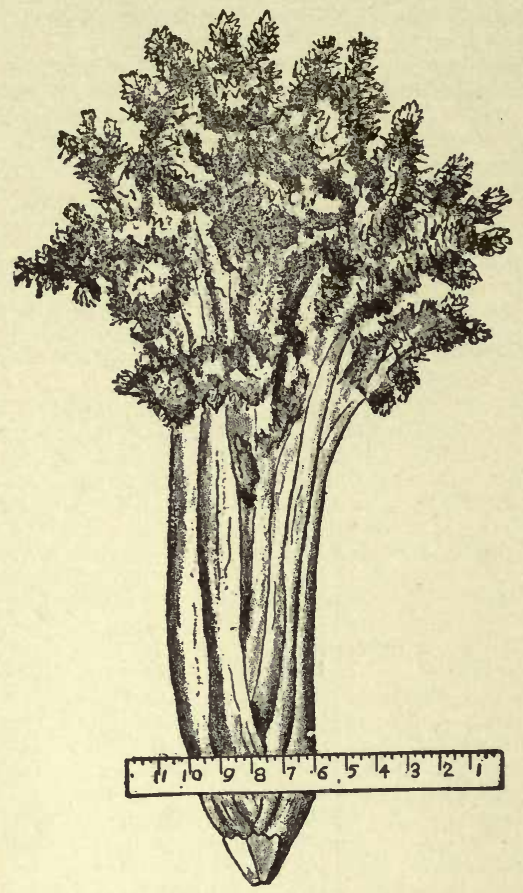

399. Celery plant trimmed for market.

plants approach maturity. This variety often requires artificial ripening to reduce the strong fiavor, in addition to what is necessary to whiten the stalks.

The Pink Plume is a nearly related variety, having reddish stalks but is hardly equal to the preceding kind.

Boston Market. - An old variety, that has been grown in the vicinity of Boston since about 1850. Plants low and spreading, very dark green and glossy, forming numerous secondary crowns, leaf-stalks short and stout, ridges 9 or 11, with shallow furrows between them, fibrovascular bundles 13 or 15 , imbedded in green cells; leaflets thick, rounded in outline, deeply cleft, serrations shallow, each terminating in a whitish point. There is a constriction where the lower pair of leaflets unite with the stalk, and the stalk is lighter colored here than elsewhere; above this point the central stalk tapers rapidly to the end.

The Early Arlington celery is a sub-variety of the Boston Market.

Golden Heart. - A popular kind before the introduction of the self-blanching varieties, but now placed in the background with the Golden Half Dwarf, White Solid, Schumacher, Perle le Grande, and Alpha.

Rose. - A tall, red variety, better known than any other kind of this class. It was introduced in 1886 by Peter Henderson, but it never has been extensively grown for market. Leaf-stalk red or purplish, 10 to 15 inches long, $1 \frac{1}{2}$ to 2 inches in circumference, ridges 9 , fibrovascular bundles 13; leaflets dull green, thin, and the edges inclined to turn upward; the whole plant tall, slender and rather hard to blanch. The young stalks retain the red color when blanched, and are exceptionally attractive in appearance, crisp, and have the nutty flavor that is so highly prized in choice celery. It was formerly supposed that the red varieties of celery kept better than the others, but the supposition does not seem to be well founded.
Other varieties of this class are the Crimson Bouquet, Pink Aromatic, and Convent Garden Rose.

Giant Pascal.-This variety is peculiarly adapted to the production of a large amount of edible matter. The stalks are of the largest size, tender, and never pungent, even before they are blanched; grown both in private gardens and for market. Leaf-stalks very large, long and thick, generally with 12 flattened ridges and 16 fibrovascular bundles; leaflets dark green, thick, deeply cleft and coarsely serrate. Plants with full centers and usually without secondary crowns.

Although the variety is much, the value and appearance of the plant depend much upon the growing. There are different ideals in different parts of the country. In the west, a plant of the type of Fig. 402 is wanted. About Boston, a broad-based and thick-set plant (obtained by much transplanting and less crowding) is demanded (Fig. 403).

Fertilizers.-Celery rarely makes satisfactory growth on land of ordinary fertility; it is a crop that must have liberal treatment to yield good returns. Organic fertilizers rich in nitrogen are mainly used, although generally in market-gardens these are supplemented with potash and other salts. It is customary to apply the or ganic fertilizers in a decomposed condition and plow them in before the plants are set. Later, when the plants are about half grown, some commercial fertilizer is scattered along the rows before each hoeing. It is important that the fertilizers used should not make the land too porous. They should increase its capacity for holding noisture, and not hasten evaporation. When coarse, light manures must be used for this crop, it is better to place them on the surface as a mulch than to plow them in.

Diseases. - Of diseases, there are two or three serious blights or rusts, but there are no widespread and serious insect depredators. (See Duggar, Bull. 132, Cornell Exp. Sta., and reports from stations in Conn., N. Y. (state), N. J., Dept. Agric., etc.) The best general treatment is to start with healthy seed on land which has not bred the disease, and then spray early and frequently with Bordeaux mixture, or other fungicide. The treatment should all be done early in the life of the crop.

Storing.-If celery is to be kept for winter use, it must be cool and moist. It is usually set out again, so that the roots take sufficient hold upon the earth to prevent the plant from wilting. For home use, the plants may be set in an old shoe case, in which there are a few inches of earth in the bottom, the top of the box being left uncovered. If the box is as deep as the height of the Celery, holes should be made in the side of the box to admit of ventilation. The box may now be kept in a cool cellar. Taking similar precautions, Celery may be stored in barrels in the cellar. For market, Celery may be set in trenches, as shown in Fig. 397. Two boards are then leaned over the plants, to form a ga ble roof; and as cold weather approaches, straw is thrown on top. In large celery areas, however, the crop is now stored in sheds or cellars made for the purpose. In these sheds, the celery is planted out, and the temperature is kept above hard

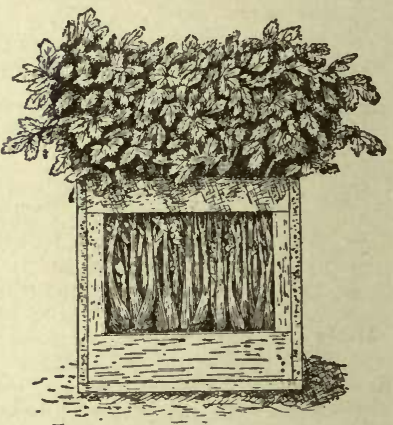

400. Celery crate. frost. Full discussion of this method will be found under Storing.

For further information, see Greiner's "Celery for Profit"; Vaughan's "Celery Manual"; Van Bochove's "Kalamazoo Celery"; Hollister's "Livingston's Celery Book." L. F. KINNEY.

Commercial Crlery Culture. - The increasing demand for this delicious vegetable has interested both the gardener and farmer in studying its needs. They have 
succeeded so well that the quality has been Improved and the length of the market season increased to such an extent that instead of finding it for sale only during the fall and winter months, we now have it the greater part of the year. The greater part of the crop is prepared for shipping by trimming off the outer stalks

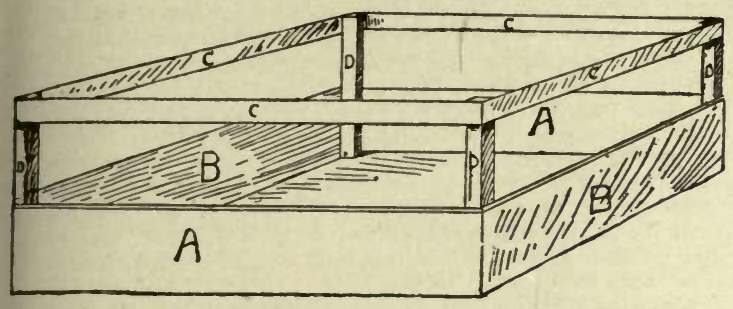

401. Water-holding Celery crate.

aud roots, washing and tying in bunches of one dozen roots, and packing in boxes containing from 4 to 8 dozen, uccording to the size of the roots. The California and some of the Michigan and New York growers ship with the roots on unwashed, and load in refrigerator cars, with two decks put in and the bunches placed on the decks. A car contains by this process from 1,200 to 1,500 dozens, while a car loaded with the boxed product contains from 1,500 to 2,000 dozens.

The seeds are very small and slow to germinate. The first leaves are small and digest food slowly, which makes it necessary to have plant-food available at all times during the growth of the plant, so that nature may be assisted in her work of building it up and giving to it a constitution strong enough to resist disease, which sometimes comes in the shape of a fungus which attacks the leaves, and, with the plant in its weak condition, absorbs the sap and destroys the digesting surface of the leaf to such an extent that the outer stalks, and sometimes the inner ones as well, dry up, and the crop is a total loss. Fortunately, the climatic conditions for the development of the fungi do not remain more than 3 or 4 days at a time, and, with means for irrigation and with food containing the different materials that the plant desires, this difficulty is successfully met. In Colorado and other parts of the west, they expect to demonstrate that the disease cannot exist, on account of irrigation keeping the plant well supplied with food, the large amount of lime the soil contains, the bright sunlight, and cool nights, as all these are to the advantage of the plant and against the development of fungi.

The soils best adapted to the plant are cranberry bogs and low marshes, filled with a deposit of decayed vegetable matter from 2 to 15 feet deep, which, when drained by open and tile druinage, cleared of trees and roots,

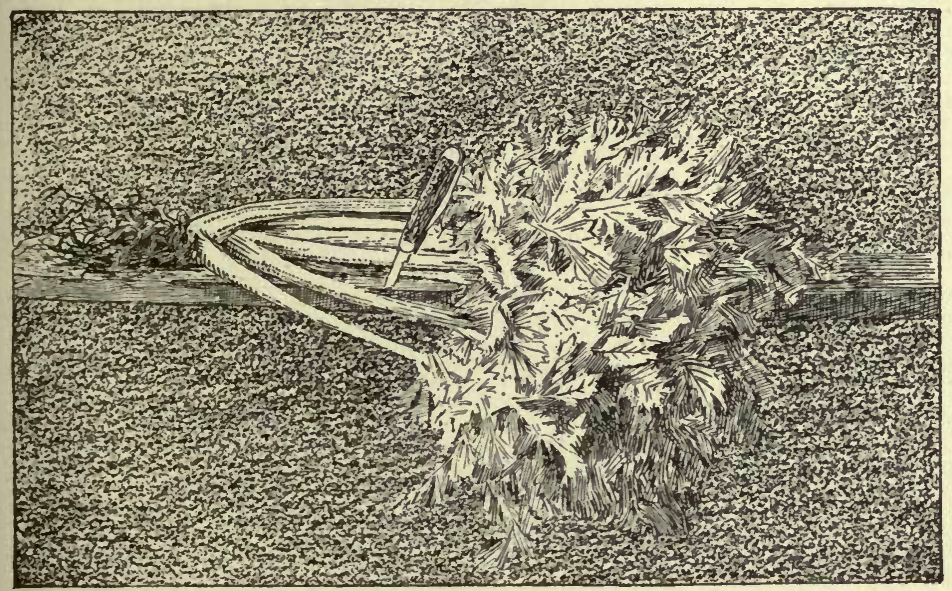

402. A good Celery plant of the middle and western states. the surface cut with disk-harrow, smoothed and pulverized with common harrow and roller, are then ready for a crop of corn or millet the first season. The following season the surface is treated with a ton of air-slaked lime to the acre, which is turned under to hasten the decay of the vegetable matter and correct the accumulated acidity which abounds from the decay of such large quantities of vegetables. The lime also destroys fungous growth and tends to strengthen the constitution of the plant. The surface is then dressed with a fertilizer composed of 1 ton of fine raw bone, 40 bushels of wood ashes, and 500 pounds of salt to the acre. Where barnyard manure can be had, the raw bone is reduced 1,000 pounds, and 20 loads of manure are applied. In Florida the amount of bone is increased to 3,000 pounds, and 200 pounds of high-grade potash added and the ashes omitted. In Colorado, where the soil contains 10 per cent of lime, it is not necessary to use lime. With fertilizers containing 10 per cent of potash, 4 per cent of nitrogen, and 10 per cent phosphoric acid, applied at the rate of 1 ton to the acre, and with the physical conditions of the land improved by turning under green crops, such as corn or alfalfa, success is anticipated. Celery is also raised on sandy loam, but unless 50 loads of coarse manure is plowed under, and water plentifully supplied during growth, either by rains or irrigation, the crop is poor in quality and light in quantity.

In the north and middle states, the early plants are started on hotbeds March 1, and transplanted in coldframes March 10-12, then into the open field after May 10. For the late or main crop, the seed is sown in the open ground April 1, and by June 1 the plants are large enough to cut back to the heart leaves. This makes them stocky and increases the root-growth, and by June 10 they are large enough to be removed to the field, where they are cultivated frequently by both horse and hand cultivators. In Florida, plants are all started under a half shade in August, and transplanted under another half shade made by setting posts in the ground, 5 feet high and 12 feet apart, on the tops of which a board is nailed, forming a rest or frame, and 3-inch slats nailed on 3 inches apart, thus protecting the beds from the bright sun in day time and cold at night. The plants are removed to the open field after September, and planting is continued until about February 1. In Colorado the early plants cannot be grown successfnlly with glass close to the plants. The bright sun penetrates the soil and takes up the moisture so fast that germination is retarded and takes place very unevenly. By covering the glass with plant-cloth, tacked on the inside, the light is subdued and success attained. For the month of April, beds covered with plant-cloth alone do very well. It is not practical to sow late plants in the open ground without the

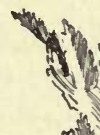

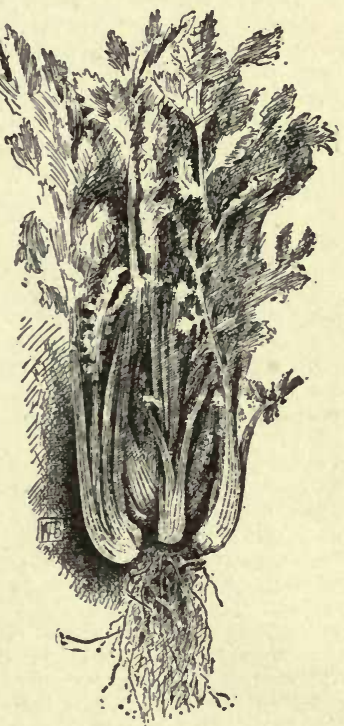

403. The Boston ideal. 
plant-cloth protection against the bright sunlight and frequent winds that prevail during April and May in this latitude. Close watching and spraying twice each day will bring the seed up, and, after the fourth leaf is well started, the cloth is removed for a few hours toward night each day until the plants are 2 inches high; then the cloth is removed during the night after May 10, and the plants are hardened.

From 20,000 to 30,000 plants are set on an acre. In sixty days plants are large enough to blanch for the early market. Pine boards 1 foot wide, 1 inch thick, 16 feet long, dressed on both sides, are placed against the celery on both sides of the plants, and are held in an upright position by a piece of wire bent at each end so as to form a double hook. The lumber excludes the light, inducing the heart of the plant to grow rapidly and blanch at the same time, and in 15 to 18 days after the lumber is put up, the celery is ready to market. Lumber induces a taller growth, but the flavor is not quite as tine as that blanched with earth. The lumber is safer for early blanching for the reason that the disease commonly called rust is liable to attack the stalks if earth is used before September 10. Earthing up becomes a necessity after September 20, as frost may appear any night after this date and damage the crop where the lumber is used, while that with the earth up to it is protected. The process of earthing up with a spade is seldom seen nowadays, as there are banking plows with attachments that push the leaves into an upright position and turn the earth up at the same time, one horse handling the plow very easily.

In harvesting the crop, leading growers have washing machinery to elean and cool the stalks, which adds to its keeping qualities during transit and delivery from market to the consumer. Great pains is taken to sort and grade the different sized roots, bind them into bunches, and pack them into neat new packages made for the purpose. Large quantities are marketed from September 20 to Octoher 20, to save the expense of storing in the winter houses, as the loss in those is liable to be great from evaporation, disease and consequent decay. California and Florida shipments come in Novem ber, and all through the winter months the leading markets are supplied with this appetizing vegetable.

The popular varieties are: First, the White Plume, which is early and makes a very fine appearance, quality medium; and next the Dwarf Golden Heart, which is a little later but much hardier than the former, also possessing much better flavor. The best for winter use are the old reliable Boston Market and its half brother, the Giant Pascal. These two, when grown to perfection, are good keepers and of excellent quality.

\section{E. J. Hollister.}

CELOSIA (Greek, kelos, burned; referring to the burned look of the fls. in some species). Amarantdcece. Cockscom в. The genus containing the common Cockscomb of old-fashioned gardens bas about 42 species, all tropical and mostly annual herbs, with alternate, entire lvs. narrowed into a petiole, various in form, and with fls. borne in dense spikes. There are two main types of Celosias, the crested form and the feathered or plumy ones. The crested Cockscomb is very stiff, formal and curious, while the feathered sorts are less so, and are used to some extent in dried bouquets. The plumy sorts are grown abroad for winter decoration, especially under the name of $C$. pyramidalis, but to a small extent in America. The crested Cockscomb is less used as a summer bedding plant than formerly, but it is still commonly exhibited in pots at small fairs, the object being to produce the largest possible crest on the smallest plant. For garden use, the seeds are sown indoors in early spring, and the plants set out May 1-15. If the roots dry out the lvs. are sure to drop off. The Cockscomb is a moisture-loving plant, and may be syringed often, especially for the red spider, which is its greatest enemy. A light, rich soil is needed.

\section{A. Spikes crested, monstrous.}

cristàta, Linn. Cоскsсомв. Height 9 in. or more ; stem very glabrous : lvs. petiolate, ovate or somewhat cordate-ovate, acute, glabrous, $2-3$ in. long, 1 in. wide: spikes crested, subsessile, often as wide as the plant is high: seeds small, black, shining, lens-shaped. Tropies.
Gn. 13, p. 231. R.H. 1894, p. 58. - There are 8 or 9 well marked colors in either tall or dwarf forms, the chief colors being red, purple, violet, crimson, amaranth and yellow. The forms with variegated lvs. often have less dense crests. A. Japonica, Mart., little known to botanists, is said to be a distinct garden plant with branching, pyramidal habit, each branch bearing a ruffled comb.

AA. Spikes plumy, feathery, or cylindrical.

argentea, Linn. Taller than the above: lvs. shorterstalked, varrower, 2-21/2 in. long, 4-6 lines wide, linearlanceolate, acute: spikes 1-4 in. long, erect or drooping, long-peduncled, pyramidal, or cylindrical. India.-This species is considered by Voss (in Vilmorin's Blumengartnerei), to be the original one from which the crested forms are derived. He makes 9 botanical forms, to one of which he refers $C$. cristata. The range of color is even greater in the feathered type than in the crested type, as one form has whitish fls. The spikes are very various in form and habit. Various forms are shown in Gn. 6, p. $513 ; 9$, p. $149 ; 17$, p. 33I. R.H. 1857, p. 78 and 1890 , p. 522 .

Húttoni, Mart. Height I-2 ft.: habit bushy, pyramidal : stem sulcate-striate : lvs. reddish or crimson, lower ones lanceolate, subsessile : spikes red, cylindrical, oblong, obtuse, $1 \frac{1}{2}$ in. long: perianth segments oblong (not lanceolate, as in $C$. argentea). Java. G.C. I.32:214. - A foliage plant, and less common than the two species above.

W. M.

CELSIA (Olaus Celsius, 1670-1756, a Swedish orientalist). Scrophularidcea. Herbs, with yellow fls. in terminal racemes or spikes, closely allied to Verbascum, but has only 4 stamens, and they are of two sorts. There are many species. Only C. Crética, Linn.f., is known in Amer., and that very sparingly. It is a hardy or halfhardy biennial, with alternate lvs., of which the lower are pinnate and the upper toothed and clasping: fls. large and rotate (nearly 2 in. across), yellowish, with dark markings in the center and conspicuous deflexed stamens. Stout, hairy plant, 3-6 ft. high, from Crete. B.M. 964 .

CELTIS (ancient Latin name). Urticdceo. NetTle TREE. Trees or shrubs : lvs. alternate, petiolate, stipulate, deciduous or persistent, usually oblique at the base and 3-nerved : tls. polygamous-monœcious, inconspicuous, apetalous, 4-5-merous, staminate in small clusters, pistillate axillary and solitary : fr. a 1-seeded, small drupe, edible in some species. Sixty species in the temperate and tropical regions of the northern hemisphere, of which few hardy ornamental species are cultivated; they are valuable as shade trees or as single specimens on the lawn, mostly with wide spreading head and light green foliage, which is rarely seriously injured by insects or fungi; they thrive in almost any soil and eren in dry situations, they are of vigorous growth when young, and are easily transplanted. The straight-grained wood is light and elastic, easily divided, and much used for the manufacture of small articles and for furniture; that of C. australis is valued for carving. Prop. by seeds, sown after maturity; also by layers and cuttings of mature wood in fall: rarer kinds are sometimes grafted on C. occidentalis.

\section{A. Lvs. entire, or rarely with few teeth, thin,} at length glabrous.

Mississippiénsis, Bose (C. loevigdta, Willd. C. integrifólia, Nutt.). Tree, 60-80 ft.: lvs. unequally rounded or cuneate at the base, oblong-lanceolate or ovate, acuminate, usually falcate, smooth above, $2-4$ in. long: fr. orange-red, nearly globular, $1 / 4 \mathrm{in}$. thick, on slender pedicel, longer than the petiole. From S. Illinois to Texas and Florida, west to Missouri. S.S. $7: 318$. G.F. 3:41, figs. 9-11. Mn. 7:225, 227. - Var. reticulata, Sarg. Lvs. smaller, ovate, usually cordate, rough above. S.S. $7: 319$.

$$
\text { AA. Lvs. serrate. }
$$

B. Foliage scabrous above, membranaceous, more or less pubescent.

occidentalis, Linn. Large tree, occasionally $120 \mathrm{ft}$ : ivs. oblique and rounded at the base, ovate, acuminate, pubescent when young, light green, $2-4$ in. long: fr. 
orange-red, 1/2in. long, on slender pedicel, longer than the petiole. S.S. 7: 317. G.F. 3: 40, 43. Em. 304. Mn. 7: 231, 233. - Very variable species. Var. crassifolia, C. Koch, has firm, very rough and large lvs., to 6 in. long, usually cordate at base. Michx. Hist. Arb. 3:228. Var. pùmila, Gray, is a dwarf form with smaller lvs.

australis, Linn. Tree, to $60 \mathrm{ft} .:$ Ivs. oblique, cordate or rounded at the base, orate oblong, acuminate, pubescent beneath, $2 \frac{1}{2}-5$ in. long : fr. over $1 / 2$ in. long, dark purple, sweet : pedicels 2-3 times longer than the petioles. Mediter. region to Persia. - Not hardy north.

BB. Foliage smooth and glossy above, glabrous or nearly so, leathery.

Sinénsis, Pers. (C. Japónica, Planch.). Tree, to $30 \mathrm{ft}$ : lvs. usually rounded or cordate at the base, broadly ovate to oblong ovate, acuminate, serrate-dentate, pubescent when young, pale or glaucescent and prominently reticulate beneath, $2-4$ in. long : fr. dull orange-red ; pedicels rather stout, not much longer than the petioles. China, Japan.-Not hardy north; often the following is cultivated under this name.

Bungeàna, Blume (C. Davidiana, Carr.). Tree: lvs. narrow or rounded at the base, ovate or narrow elliptic, acuminate, crenate-serrate, nearly glabrous when young, green and shining on both sides, $2-4$ in.: fr. purplish black, small: pedicels 2-3 times longer than the petioles. N. China.-Hardy, and a very distinct species, with dark green and glossy foliage.

Kraussiàna, Bernh. Tree : lvs. oblong ovate, usually rounded at the base, acuminate, crenate-serrate, pubescent on the veins beneath, semipersistent: ovary tomentose: fr. mostly pubescent, slender pedicelled. S. Africa to Abyssinia. - Hardy only south.

\section{ALFRED REHDER.}

\section{CEMETERY. See Landscape Gardening.}

CENCHRUS (ancient Greek name). Graminece. Annual or perennial grasses, with spreading or erect culms bearing an intlorescence of globular, spiny burs. Spiklets 1-fld., 1-4 together, with an ovoid or globular involucre of rigid, more or less connate bristles, forming spiny burs, which fall off at maturity. Glumes as in Panicum, awnless. Species about 12, in the tropical and warmer temperate regions of both hemispheres.

tribuloldes, Linn. SAND-BUR. BUR-Grass. Culms ascending, branching, 1-2 ft. long, with spikes composed of 10-15 coarse, spiny burs, which readily attach them. selves to passing objects. It is one of the worst of annual weeds wherever it becomes abundant. It is distributed more or less throughout the United States in sandy districts, and said to be perennial in the southern states.

P. B. KENNEDY.

CENIA (Greek for empty, in allusion to the hollow receptacle). Compósitce. Low herbs from South Africa, with the aspect of Mayweed. Head small and rayed, the ray fls. pistillate, the dise fls. compressed and 4-toothed, the receptacle gradually enlarged from the top of the peduncle, and hollow. C. turbinata, Pers., is a common weed in Cape Colony, and it is occasionally seen in Amer. gardens. It is annual, diffusely branched, and a foot or less high, with finely dissected, soft, almost moss-like foliage, and long-peduncled, small, yellow heads. Of easy culture.

L. H. B.

CENTAUREA (a Centaur, famous for healing). Composita. Cenraury. Dusty Miller. Bachelor's BUTTON. CORN FLOWER. KNAPWEED. Annuals or half-hardy perennials ; fine for bedding, vases, baskets and pots, and for borders and edgings. Differs from Cnicus in having the achenes obliquely attached by one side of the base or more laterally. Species about 400 , much confused, mostly in Eu., Asia and N. Afr., 1 in $\mathrm{N}$. Amer., 3 or 4 in Chile. The involucre is ovoid or globose, stiff and hard, sometimes prickly. Receptacle bristly. The marginal florets are usually sterile and elongated, making the head look as if rayed. Several Old World species have become weeds in this country.

The following species of Centaurea are here described, the synonyms being in italics: Americana, 7 ; argentea, 2 ; atropurpurea, 13 ; Babylonica, 14 ; Benedict $a=$
Carbenla benedicta; calocephala, 13 ; candidissima, 1; Cineraria, 1; Clementei, 3 ; Cyanus, 4 ; dealbata, 12 ; declinata, 10; flore-pleno, 4 ; gymnocarpa, 2 ; imperialis, 5 ; leucophylla, 10 ; macrocephala, 8 ; Margaritacea, 6 ; Margaritoe, 5 ; montana, 11 ; moschata, 5 ; nigra, 9 ; odor. ata, 5 ; plumos $a, 2$; splendens, 6 ; suaveolens, 5 ; variegata, 9 ; Victoria, 4.

A. Dusty Miluer.-White-tomentose low plants, used for bediing or for the saks of their foliage.

1. Cinerària, Linn. (C. candidissima, Lam.). Fig. 404. Perennial : sts. erect, $3 \mathrm{ft}$., brarched, the entire plant white-tomentose : lvs. almost all bipinnate (except the earliest), the lower petioled, all tie lobes linear-lanceolate, obtuse : scales of the ovate involucre appressed, with a membranous black margin, long-ciliate, the apical bristle thicker than the others: fls. purple. S. Italy, Sicily, etc. - Much used as a bedding plant, not being allowed to bloom. The first lvs. of seedlings are nearly entire (as shown in Fig. 404), but the subsequent ones become more and more cut. Grown both from seeds and cuttings. Seedlings are very apt to damp off unless care is taken in watering.

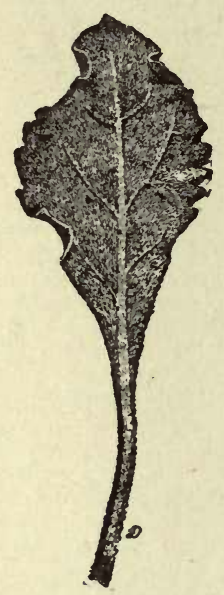

404. Lower leaf from a young plant of Centaurea Cinera. ria $\left(\times \frac{1}{2}\right)$.

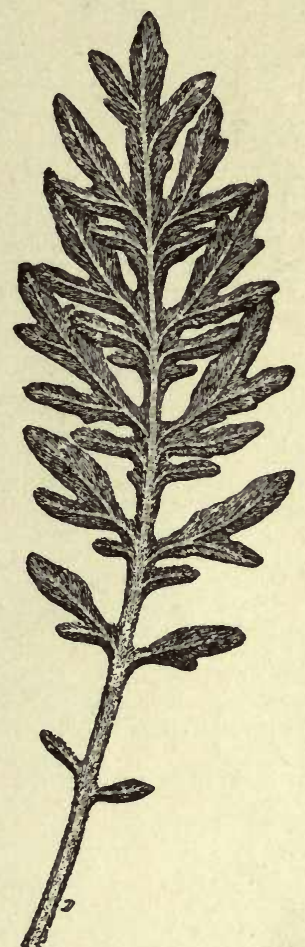

405. Radical leaf of Centaurea kymnocarpa. $(X 1 / 2$.
2. gymnocárpa, Moris \& DeNot (C. argéntea, Hort. $C$. plumdsa, Hort.). Fig. 405. Perennial: entire plant covered with velvety white pubescence: sts. 11/2-2 ft. high, erect: lvs. bipinnatisect; segments linear, entire, acute : f.-heads small, in a close panicle, mustly hidden by the lvs.: fls. rose-violet or purple. Caprea.-Very ornamental on account of its velvety finely cut lvs. Much used, like the last, for low foliage bedding; Ivs. more compound, and usually not so white.

3. Clementei, Boiss. Perennial, the entire plant densely white-woolly : sts. erect, branching, with few lvs.: root-lvs. petioled, pinnate, the lobes ovate-triangular, sharp-pointed: st.-lvs. sessile : fl.-heads termi$\mathrm{nal}$ on the branches, globose: involucre scales with scarious, ciliate margins, scarcely spiny: fls. yellow. Spain.

aA. Corn Flower, or Bachelor's Button. - Tallgrowing annual, with very narrow lvs., grown for the showy fls.

4. Cyanus, Linn. Bluebottle. Bluet. Bachelor's Button (see also Gomphrena). CoRn Flower. RagaEd SaILor. Fig. 406. Annual, slender, branching, 1-2 ft. 
high, woolly-white when young: lvs. linear, entire, or the lower toothed, sometimes pinnatifid : fls. blue, purple or white, the heads on long, naked stems : involucral bracts rather narrow, fringed with short, scarious teeth. S. E. Eu. Gt. 38, p.641; 39, p. 537.-One of the most popular of garden fls., running into many varieties. It is perfectly hardy, blooming until frost and coming up in the spring from self-sown seed. The following are

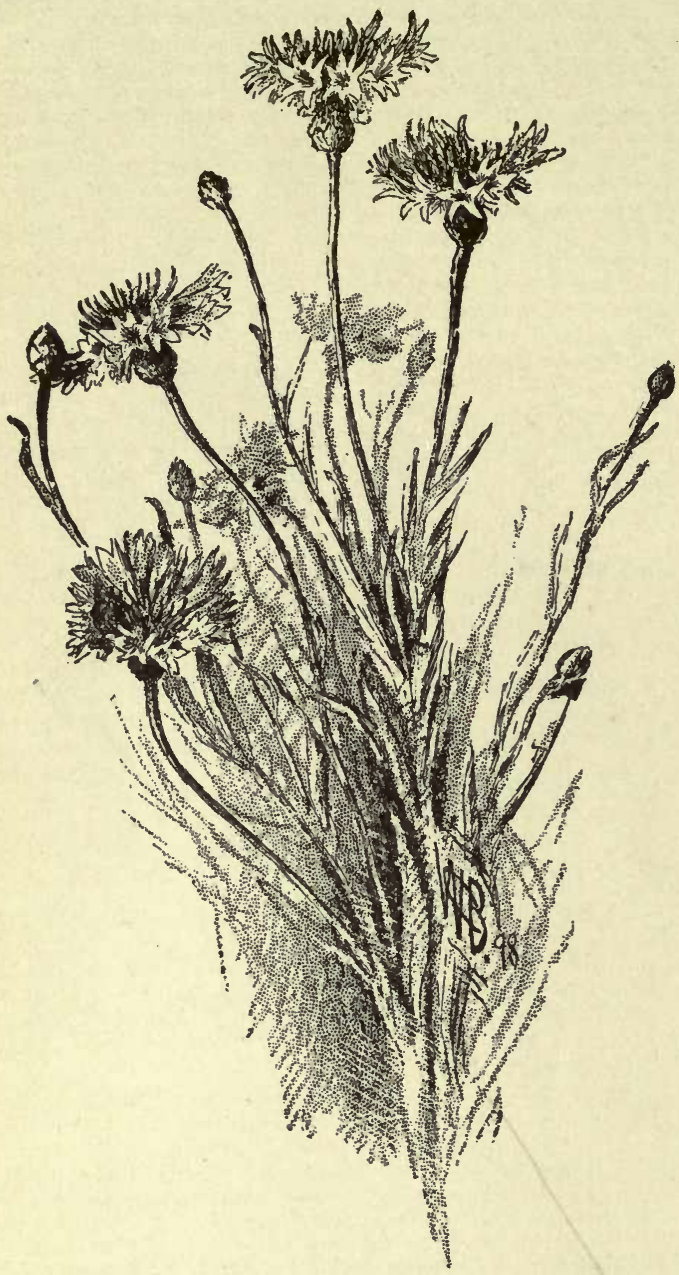

406. Centaurea Cyanus $(X 1 / 2)$.

varieties of this: Pure White; Victoria, a dwarf, for pots and edgings ; Emperor William, fine dark blue; flore pleno, with the outer disc fls. converted into ray fls.; nana compacta, dwarf.

AAA. SweET Sultans. - Straight-growing, smooth annuals or perennials, with dentate lvs., grown for the large fragrant heads.

5. moschàta. Linn. (C. suavèolens, Linn. C. odoràta, Hort. C. Amberbòi, Mill. Amberbòa moschàta, Less.). Sweet Sultan. Fig. 407. Annual : sts. 2 ft. high, branching below, erect: whole plant smooth, bright green : lvs. pinnatifid, the lobes dentate : fl.-heads longpeduncled; invol. round or ovate, smooth; only the in nermost of the invol. scales with scarious margins: fls. white, yellow or purple, fragrant. Orient. Mn. 4: 149. Gn. 54:1195. I.H. 42, p. 106. Gng. 4:147.

Var. álba, Hort. (C. Margarita, Hort.). Fls. white. Gn. 19, p. 337: 54:1195. A.G. 13:607. This form, known as $C$. Margaritce, is pure white and very fragrant. It was int. by an Italian firm in 1891.

Var. rùbra, Hort. Fls. red. Gn. 54: 1195.-A popular, old-time garden flower, with long-stalked heads; of easy culture. It does not bear transplanting well.

$C$. imperidlis, Hort., is the offspring of C. moschata and $C$. Margarite, int. into the American trade in 1899. Plants are said to inherit the vigorous, free growth of $C$. moschata, being of the same easy culture and forming clumps $3-4 \mathrm{ft}$. high. The fis. resemble $C$. Margarito, but are twice as large and abundantly borne on long stems from July until frost. They range through white, rose, lilac and purple, are fragrant, and if cut when first open will keep 10 days. C. Maria, Hort., int. 1899, resembles $C$. imperialis, but the fls. open sulfur-yellow, become lighter, and are tipped with rose.

AaAa. Other CentaUReas of various kinds, occasionally grown in hardy borders for their fls. or imposing stature.

B. Foliage green on both sides.

C. Lvs. pinnate or bipinnate.

6. spléndens, Linn. (C. margaritàcea, Ten.). Perennial : sts. erect, branched : lvs. smooth, the lowest bipinnate, the upper pinnate, all with very narrow, linear, entire, acute lobes : fl.-heads subglobose ; scales of the involucre with a rounded, almost entire, rather lax tip ; fls. purple. Spain, Italy.

cC. Lvs. entire or dentate, not pinnatisect.

7. Americàna, Nutt. (Plectocéphalus Americanus, Don). BASKET FLOWER. Fig. 408. Hardy annual, nearly smooth : sts. stout, simple, $2-5 \mathrm{ft}$., thickened under the naked head: lvs. mostly entire, oblong-lance-shaped : involucre $1 / 2-1 \frac{1}{2}$ in. in diam., its bracts all with fringed, scarious appendages ; fls. rose or flesh-colored; disc 1-3 in. diam.; narrow lobes of the ray flowers often 1 in. long. Ark. to Ariz. F. S. $4: 327$. S. H. $2: 223$. - Very attractive.

8. macrocéphala, Puschk. Perennial : stems simple, erect, swollen below the flower-head, leafy, $2 \frac{1}{2}-3 \mathrm{ft}$. high : lvs. ovate-lanceolate, slightly decurrent, scabrous, acute, somewhat serrate, gradually diminishing upwards to the base of the single terminal head: head subglobose, larger than a hen's egg, often 3-4 in. in diam.; involucre of 8-12 rows of appressed, scarious-margined, rusty, fringed scales : fis, yellow, the marginal and disc alike. Armenia. B. M. 1248. J. H. III, 33: 331.-Often grown from seeds.

9. nigra, Linn. KNAPWEED. HARD Heads. Perennial, 1-2 ft. high : sts. branching, rough pubescent: lvs. lanceshaped and entire or lower sparingly toothed : involucral bracts with pectinate-ciliate-fringed black appenrages: fls. all alike, the disc and marginal ones of the same size. Europe. - Var. variegata, Hort. Lvs. edged with creamy white, tufted. A very striking border plant.

Bв. Foliage white or tomentose, at least be mentose, at least beabove).

c. Stems low, weak, not strict.

10. leucophýlla,Bieb. $(C$. deolindta, Bieb.). Perennial : stems short, decum bent, with very few lvs.: root-lvs, petioled, tomen-

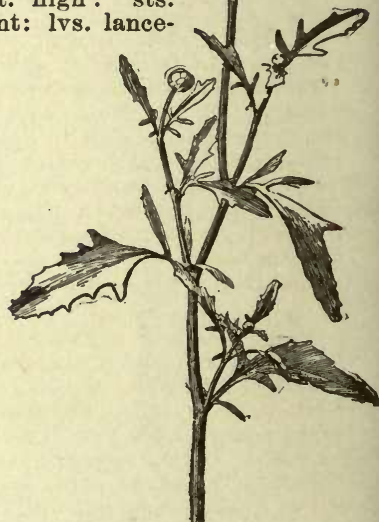

407. Centaurea moschata. $(\times 1 / 4$. tose-woolly on both sides, pinnate, the ovate lobes undulate, sparsely cut-lobed or sinuate-toothed : fl.-head with few bracts, solitary, terminal ; scales of the ovate involucre lanceolate, acuminate, brown, long-ciliate: fls. purple. Caucasus. 
11. montàna, Linn. Mountain Bluet. Perennial : sts. low, stoloniferous, unbranched, $12-16$ or rarely 20 in. high: lvs. decurrent, the young ones silvery white, oval-lance-shaped : involucre of 4 or 5 rows of scales, black-ciliate along the margins; fls. blue, the margina ones 1 in. long, dise-fls. very short, becoming purple. Europe. B. M. 77. Var. álba, Hort. Fls. white. Var. ròsea, Hort. Fls, rose-colored. Var. citrina, DC. (var. sulphùrea, Hort.). Disc-fls. brown, rays yellow. Armenia. B.M. 1175 .

\section{cc. Stems erect, simple or branched.}

12. dealbàta, Willd. Perennial : sts, sub-erect, 8-24 in. high : lvs. white-villous beneath, glabrous above, the lower ones $1-1 \frac{1}{2} \mathrm{ft}$. long, petioled, pinnate, the obovate lobes coarsely cui-toothed or auricled at the base; stem-lvs. sessile, pinnate, with oblong-lance lobes: fi.-head solitary, just above the uppermost leaf: fls. red, those of the dise rosy or white: outer scales of the involucre with lanceolate tips, the middle rounded, deeply fringed, ciliate. Asia Minor, Persia.

13. atropurpùrea, Waldst. \& Kit. (C. calocéphala, Willd.). Perennial : sts. erect, branched, about 2-3 ft. high, the branches whitewoolly at the summit: lvs. bipinnate, lobes linear-lanceolate, acumi408. Centaurea Ameri- nate ; lowest lvs. petioled, uppercana $(X 1 / 4)$ most pinnatifid: fl.-heads without bracts ; invol. scales with fringed iliate white lanceolate tips, the innermost ones rounded, scarious-margined : fis. black-purple. Hungary.

14. Babylonica, Linn. Silvery white perennial : sts. simple, stout, ereet, $6-10$ or $12 \mathrm{ft}$. high : lvs. long, coriaceous, strongly decurrent on the stem, the radical lyrate, the lower stem-lvs. oval or oblong-acute, entire or undulate, the upper lance-acute: fls. yellow, the globular heads almost sessile in the axils of narrow braet-like lvs.; $1 / 2-1 / 2$ of the stem flower-bearing: involucre-scales with a short, recurved tip. Asia Minor, Syria. Gn. 2,p.73; 8, p. 263 . R. H. 1859, pp. 540-1. - Tall, stout and striking plant.

JARED G. SMITH and L. H. B.

\section{CENTAURIDIUM. See Xanthisma.}

CENTRADENIA (Greek for toothed gland, alluding to the anther glands). Melastomdcece. Four species in Mexico and Central Amer., grown in warmhouses for their showy-colored lvs. and pretty fls. They are herbs or shrubs, with angled or winged branches, petiolate, opposite lanceolate or ovate-entire, ribbed lvs., and fls. with 4-lobed calyx, 4 petals, 8 stamens, and a 4 -loculed ovary. The blossoms are pink or white, in axillary or terminal clusters. Prop. by cuttings. Very showy and desirable plants. Stems often colored. Centradenias like rich leaf-mold with sharp sand, and brisk beat. Give a light but shady position. Strong plants are much benefited by liquid manure, and such applications give better colors in both flowers and fruit. Monogr. by Cogniaux, DC., Monographiæ Phanerogamarum, 7: 116.

grandifolia, Endl. Branches 4-winged : lvs. ovatelanceolate, strongly 3-nerved, brilliant red beneath, long-pointed and curving at the end: cymes many-fld., shorter than the lvs., the fls. light rose, rotate, the petals very obtuse, the stamens unequal. B.M. 5228. The plant grows $2 \mathrm{ft}$. high, and blooms in winter. Very showy. The cut branches hold their color a long time, making the plant useful for decorations.

floribúnda, Planch. Branches obscurely angled, pu bescent, red: Ivs. narrow-lanceolate, tapering below, 3 nerved, red-nerved below : fls. pink, in terminal pani cles. F.S. 5:453. - Smaller than $C$. grandifolia.

inæquilateràlis, G. Don ( $C$.ròsea, Lindl.). Lvs. ovatelanceolate, unequal-sided, entire, ciliate, reddish beneath: fls. pink, in terminal corymbose racemes: dwarf. Mex. B.R. 29:20.

L. H. B. and H. A. Siebrecht.
CENTRANTHUS (Greek, spurred flower). Valeriandcece. A few annual and perennial herbs of the Mediterranean region, with dense clusters of small red or white fls. terminating the branches, and opposite entire or cut lvs.: calyx cut into 5-15 narrow divisions, enlarging after flowering; corolla slender-tubed, 5-parted, spurred at the base; stamen 1: fls. with a pappus-like crest. Of easiest culture.

rùber, DC. Red Valerian. Jupiter's Beard. Perennial, 1-3 ft., smooth and glaucous, forming a compact. and floriferous, bushy plant: lvs. ovate to lanceolate. some of them toothed at base: fls. very numerous, deep crimson. - A very handsome old garden plant, too much neglected. It blooms all summer. Excellent for cutting. Increased by division; also by seeds. There is a white-fld. form (var. dlbus).

macrosiphon, Boiss. Annual, of easy culture in any good soil: 1-2 ft.: lvs, ovate, glaucous, toothed: fls. larger than in the last, red. Spain. - There are whitefld. (var. albus) and dwarf (var. ndnus) forms. Excellent for rockeries and borders; also good for lawn vases.

\section{H. B.}

CENTROPOGON (Greek kentron, spur, and pogon, beard, referring to the fringed stigma). Campanulacece. About 36 tropical Amer. sub-shrubs or shrubs, often scandent, with alternate, mostly dentate lvs., and long, tubular fls. which are violet, purple, red, or orange, and usually borne singly on long peduncles: bracteoles very small or wanting. Warmhouse perennial, prop. by euttings.

Lucyànus, Houllet. Height 1-2 ft.: stem somewhat woody: lvs, short-petioled, finely toothed: fls, rose, winter; hemispherical, with lanceolate segments recurved at the tips. R.H. 1868:290. - Said to be a hybrid of $C$. fastuosus and Siphocampylus betuloformis, but seems to show little influence of the latter, which has longer petioles and peduncles, more coarsely toothed IVs., longer calyx-segments, and a yellow-tipped corolla.

fastudsus, Scheidw. Lvs. peach-like, oblong, acute, bordered with glandular teeth, very glabrous, shortpetioled: fls. rose-colored, winter ; calyx hemispherical, with 5 lanceolate, denticulate segments. Mex. R.H. 1853:181.

W. M.

CENTROSÈMA (Greek, spurred-standard). Legumindsa. ButTerfly PEA. Twining herbs (at least those in cult.), with pinnate, 3-7-foliolate Ivs., and showy white or reddish fls, in the axils. Fl. papilionaceous, the standard spurred on the back, the keel broad, and the style bearded at the apex. Species nearly 40 in tropical Amer. and 2 in U.S.

Virginiànum, Benth. Roughish, climbing, 2-6 ft.: lfts. ovate to linear, shining, stipitate : fls. 1-4 in the axil, $1 \mathrm{in}$. long, violet and splashed, showy: pod straight and long-pointed, 4-5 in. long. Md. S., in sandy lands. A.G. 13:649. - Int. to cult. many years ago, but again introduced in 1892 (as $C$. grandiflorum), and much advertised. It is a hardy and desirable perennial vine, blooming the first season from seed. There is a white-fld. var.

L. H. B.

CENTURY PLANT. Consult Agave.

CEPHALANTHERA (Greek for head and anther). Orchiddcea, tribe Neottiea. About 10 species of small. temperate-region terrestrial orchids, allied to Epipactis, Pogonia, etc. Some of them are western N. American, and others are European. Sepals 3: petals small, ovate: lip saccate: Ivs. (sometimes wanting) lanceolate or oblong: fls. mostly small (sometimes showy), in an open spike. The species are searcely known in cult., but two Japanese species have been offered by importers. These are E. falcàta, Blume, yellow, and E. erécta, Blume, white.

CEPHALANTHUS (Greek, head and flower; fls. in heads). Rubidcea. Butron Bush. Shrubs with opposite or whorled, entire, stipulate lvs.: fis. small, tubular, white or yellowish, 4-merous, with included stamens and long, exserted style, in globular heads: fr. dry, separating into 2 nutlets. Six species in Amer., Africa and Asia, of which only the one North American specles is 
cult. Hardy ornamental shrub, with handsome glossy foliage and very attractive with its flower balls appearing late in summer. It thrives in any good garden soil, best in a sandy, somewhat moist one. Prop. by seeds or by cuttings of ripened wood in fall, and also by greenwood cuttings taken from forced plants early in spring.

occidentàlis, Linn. Shrub, 3-12 ft.: lvs. long-petioled, ovate or oval, acuminate, glossy above, glabrous or slightly pubescent below, 3-6 in. long: heads about 1 in. in diam., long-peduncled, 3 or more at the end of the branches. July-Sept. From New Brunswick south, west to Ontario and Calif. Em. 394. R.H. 1889, p. 280.Var. angustifólia, André. Lvs. oblong, lanceolate, usually in 3's. R.H. 1889, p. 281.

ALFRED REHDER.

CEPHALARIA (Greek for head, alluding to the capitate flower-clusters). Dipsacece. Coarse annual or perennial herbs of Europe, Africa and Asia, much like Dipsacus, but the heads less spiny. The heads are terminal and globular, bearing many 4-parted yellowish, whitish or bluish florets.

Tatárica, Schrad. Perennial, 6 ft., rank, with striate stems, suited to the rear border, where strong effects are desired, with showy cream-white flat heads in July and Aug.: lvs. pinnate, the lfts. broad-lanceolate and serrate. Grows readily, and is increased by seed or dividing the clumps.

I. H. B.

CEPHALOTÁXUS (Greek, head : Taxus-like plant, with fls. in heads or clusters). Coniferce, tribè 'Taxacece. Trees or shrubs, with evergreen, linear, pointed lvs. with 2 broad, glaucous lines beneath, arranged in 2 rows: fis, dioecious, staminate in 1-8-fld., short-stalked clusters, pistillate consisting of a small cone with several bracts, each bearing 2 naked ovules. Seed enclosed in a fleshy envelope, drupe-like, about 1 in. long, reddish or greenish brown. From allied genera it may be easily distinguished by the resin-canal in the center of the pith, and by the glaucous lines beneath from Taxus, which has the lis. yellowish green beneath, and from Torreya by the glaucous lines being broader than the 3 green lines, while in Torreya the glaucous lines are narrower than the green ones. Six closely allied species from Himal. to Jap. Ornamental evergreen shrubs, in appearance very like a yew, but of more graceful habit. Not hardy north, or only in very sheltered positions. They thrive best in a somewhat moist but welldrained, sandy loam, and in partly shaded situations. Prop. by seeds, stratified and sown in spring; imported seeds usually do not germinate until the second year; increased also by cuttings in August, under glass, and by veneer-grafting in summer, on one of the species or

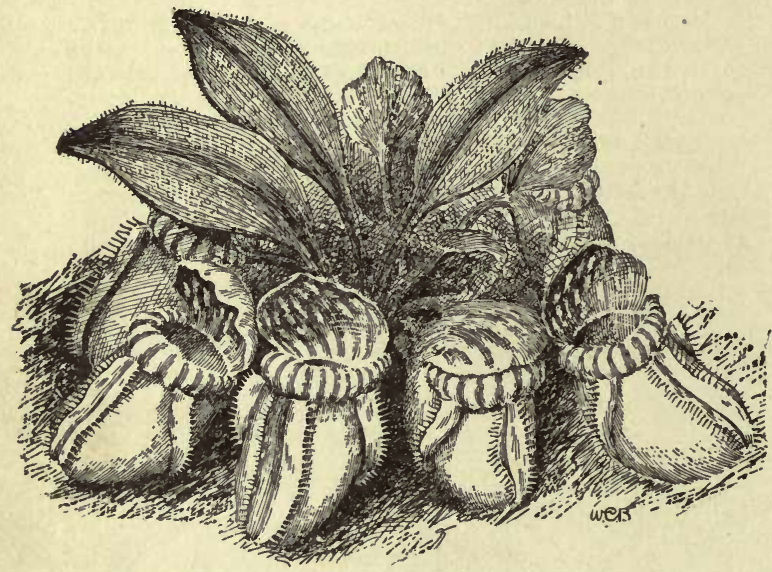

409. Cepnalotus tollicularis $(X 1 / 3)$.

on Taxus baccata. For cions and cuttings, terminal shoots should be selected, which form regular plants with whorled branches like seedlings, while cuttings from lateral branches grow into irregular, low, spreading shrubs.

\section{A. Lvs.2-3 in. long: branchlets yellowish green, pendulous.}

Fortunei, Hook. Lrs. tapering gradually into a sharp point, usually falcate, dark green and shining above fr. greenish brown, obovate. N. China, Jap. B.M. 4499. F.S. 6:555. R.H. 1878, p. 117. - This is the most graceful species, with long and slender branches, attaining in its native country $50 \mathrm{ft}$. in height, in culture usually remaining a shrub.

AA. Lvs. 1-2 in. long.

pedunculàta, Sieb. \& Zucc. With spreading, often somewhat pendulous branches, dark green when young: lvs. to 2 in. long, narrowed into a sharp point, shining and dark green above: fr. ovoid, rounded at both ends, rarely giobulär. Jap., China. G.C. III. 18: 716.-In fapan, tree to $25 \mathrm{ft}$. high, usually shrub in culture. A remarkable form is var. fastigiàta, Carr. (Podocárpus Koraidna, Sieb. \& Zuec.), of columnar habit, with upright branches and spirally arranged lis. G.C. II. 21:112. S.H. 2:450. Gng. 2:341.

drupàcea, Sieb. \& Zucc. Branches spreading, stiff, usually light green when young: lvs. about 1 in. long, abruptly pointed, narrow and straight, often upturned: fr. usually obovate, narrowed at the base. Jap. G.C. III. 18:717. - This is the dwarfest species, usually forming a low bush with stiff, spreading branches.

ALFRED ReHDER.

CEPHALOTUS (Greek, in a head, referring to the crowded stamens). Saxifragdcea. One species in Australia. Lvs. all radical, of two kinds, the ordinary foliage lvs. being spatulate or elliptic, hairy, and entire, the others being pitchers with purple tints and a netted and veined lid. The fls. are borne in an interrupted spike, on an erect scape; they are apetalous, and have a white, 6-parted calyx, 12 stamens in two sets, and 6 1 -seeded carpels. The species is C. folliculàris, Labill. (Fig. 409). It is cult. in coolhouses for its odd insectivorous pitchers, which are 1-3 in. long and beautifully lined and shaded with purple and green. The plant is grown in peat and moss, after the manner of Drosera and Dionæa. Delights in plenty of moisture, mounted on sphagnum moss. Give a cool and shady position. Prop. by seeds (allow only one seed vessel to mature) and also by division. A most interesting plant. R.B. $23: 233$. I.H. $27: 391$. J.H. III. $35: 260$.

\section{H. B. and H. A. Siebrecht.}

CERASTIUM (Greek for horn, alluding to the shape of the pod). Caryophyllacea. Decumbent annuals or perennials, with weak, slender stems, small, opposite Ivs. and small white fls.: differs from Arenaria in the shape and dehiscence of the capsule: sepals 5 or 4; petals as many, often 2 -cleft; stamens 10 or less. Valuable in rockeries or for bedding and borders. Species about 100 , of world-wide distribution.

$$
\text { A. Lvs.green, merely pubescent. }
$$

arvénse, Linn. (var. oblongifollium, Holl. \& Britt.). Starry Grasswort. Fig. 410. Perennial, low, much branched and matted; stems 8-12 in. long; lvs. oblong or lanceolate, pale green, pubescent, obtuse, $1 / 2-1 \frac{1}{2}$ in. long, $1 / 4$ in. wide: fls. very numerous, appearing in April and May; petals 5, deeply bifid; capsules twice as long as the calyx. On magnesian rocks, N. Y. to Va. and westward. Bul. 74, Ind. Agr. Exp. Sta., from which Fig. 410 is adapted.-Recommended as a bedding plant, for its mat-like habit, covered with white bloom.

\section{AA. Lvs. silvery or grayish.}

B. Capsule equaling the calyx.

grandiflorum, Waldst. \& Kit. Creeping perennial : lvs. linear, acute, the margins reflexed; inflorescence dichotomous : fl.-stems $6-8$ in. high : petals oval, 2parted, transparent white, twice as long as calyx. E. Europe.

BB. Capsule much longer than the calyx.

Biebersteinii, DC. Stems 6 in., creeping. diffuse, branched : lvs, ovate-lanceolate, tomentose-woolly ; peduncles erect, dichotomous ; capsule ovate-cylindrical. Tauria. B.M. 2782.-Like C. tomentosum, but with larger lvs. Fine for edgings. 
Boissièrii, Gren. Low: lvs. silvery, ovate-lanceolate, acute, entire, sessile; peduncles 4-12 in. high : inflorescence a dichotomous cyme: fls. large, white. Spain.

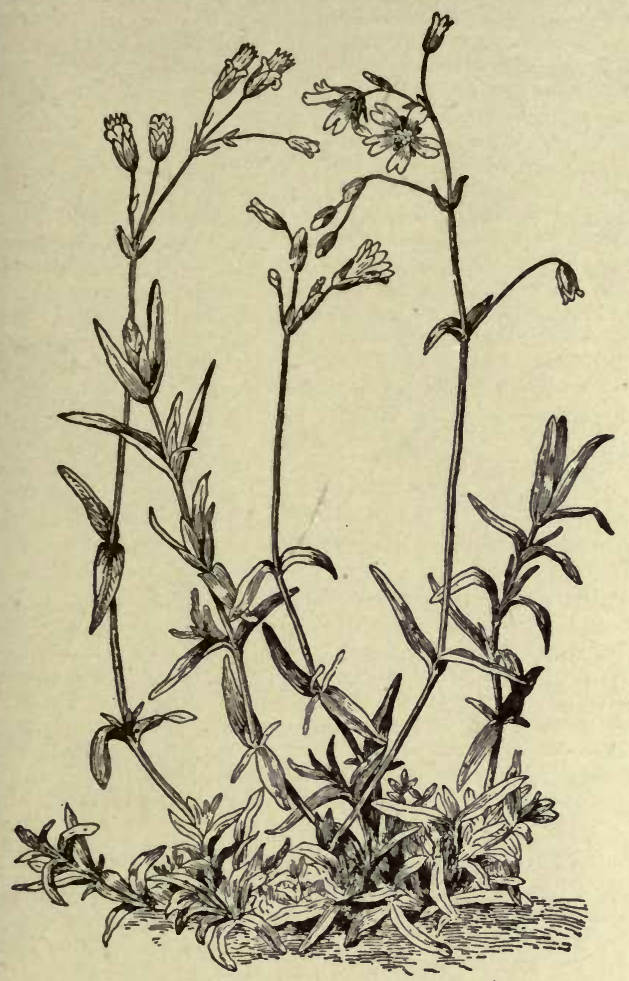

410. Cerastium arvense.

tomentòsum, Linn. Low, creeping, branched: lvs. oblong, spatulate, grayish woolly, upper lvs. lanceolate; peduncles 6 in. high, erect, dichotomous: capsule cylindrical. Eu. - Much used for edgings.

JARED G. SMITH.

Cérasus. Consult Prunus.

CERATIOLA (Greek, a little horn, referring to the 4-branched, serrate stigma). Empetrdcec. A heathlike evergreen, much-branched shrub from the sand barrens of Ga. and S. C.; rarely cult. N., but not hardy. Only 1 species.

ericoldes, Michx. Height 2-8 ft.: branches subverticillate, marked with scars of numerous fallen lvs., the younger and upper ones only retaining foliage: lvs. crowded, almost whorled, $1 / 2-3 / 4$ in. long, linear, rigid, shining, pale, rounded above, grooved beneath: fls. inconspicuous, diøcious, of peculiar structure : berries round, orange-yellow. B.M. 2758.

CERATÓLOBUS (Greek for horned pod). Palmacea. Spiny Javanese palms, with pinnate lvs., sometimes seen in fine collections, but not in the Amer. trade. The species are $C$. cóncolor, Blume; C. glaucéscens, Blume; C. Micholitzidna, Hort. G.C. III. $23: 251$; $C$. Findleydnus, Hort., A.G. 15:169. Treated the same as Calamus.

A small genus of warmhouse palms, natives of Java and Sumatra. The members of this genus are slendergrowing, spiny palms, with pinnate leaves, one of the best being $C$. Micholitziana, which has rather short pinnæ irregularly grouped along the rachis. A shaded house, with a night temperature of $65^{\circ}$ to $70^{\circ}$, a moist atmosphere, and plenty of water at the root, are the most essential points in their culture.

L. H. B. and W. H. TAPLN.
CERATONIA (Greek for horn, in reference to the large pod). Leguminose. A tree of the Mediterranean basin, belonging to the Cassia tribe. The petals are wanting; stamens 5 ; pod long, flled with a pulpy substance. C. Silíqua, Linn., the only species, is now widely distributed in warm countries, being grown both for shade and for the edible pods. It reaches a height of 40-50 ft. It is evergreen. Lvs. pinnate, shining, the lfts. oval and obtuse. It thrives well in S. Calif. and $S$. Fla. The pulp about the seeds is sweet and edible, but the fruit is used chiefly for feeding stock. In Europethese pods are much prized for the fattening of swine. The dry pods are occasionally seen in the fruit stands: in northern markets. Var. longissima differs only in having very long pods. The Ceratonia is known as Algaroba, Carob, Karoub, Caroubier, and St. John's Bread. The last name records the notion that the seeds and sweet pulp are respectively the locusts and wild honey which St. John found in the wilderness. The dry valves or pods have been supposed to be the husks which became the subsistence of the prodigal son. See G.F. 3:318, 323.

L. H. B.

CERATOPTERIS (Greel; horn fern). Ceratopteriddcece. A genus of aquatic tropical ferns, forming the type of a distinct family. The plants root in mud, and the sterile lvs. either floai 'n the surface or are carried above the surface of the water. The sporophylls are bitripinnate, with pod-like ultimate segments, entirely unlike the sterile lvs. Only a single species is known. C. thalictroldes, Brongn. Tropical waters of both hemtspheres, rare in Florida.-Useful in ponds and aquaria. Must be taken indoors on approach of cold weather. Best grown when planted in loam and leaf-mold topped with spagnum, and tied in a pan or crib and set into a tub in medium temperature, with the crown on top of the water. To propagate, pull out several of the center leaves, and new crowns will form; these can be divided.

L. M. Underwood and H. A. Siebrecht.

CERATOSTIGMA (Greek, horned stigma). Plumbagindcea. Different from Plumbago in having no glands on the calyx, stamens adnate to the corolla tube, fls. in dense clusters rather than spicate, and other technical characters. There are 3 or 4 species in warm regions of the Old World. Herbs or sub-shrubs, with alternate, obovate lvs. and blue or rose-red fls.

plumbaginoldes, Bunge (Plumbàgo Lárpenta, Lindl. Valorddia plumbaginoides. Boiss.). Perennial herb, 6-12 in., the stem red and branchy: lvs. entire, strongly ciliate on the edges : fls. slender-tubed, with a widespreading, deep blue limb, the 5-lobes minutely toothed, collected in dense heads or umbels. China. B.M. 4487. F.S. $4: 307$. - A hardy bedding plant, producing profusely of its deep blue fls. late in fall. Very valuable. Needs covering in winter in the $\mathrm{N}$.

L. H. B.

CERATOTHECA (Greek for horned capsule). Pedalidcece. Tropical African herbs of 3 or 4 kinds, with usually opposite lvs. which are ovate, 5-parted calyx, 2-lipped corolla, fis. solitary in the axils, and a 2-horned capsule. C. tríloba, Meyer, is occasionally grown in S. Fla., and it. may be adapted to glasshouses. It is a tall herb ( $5 \mathrm{ft}$.), with the habit of foxglove, probably biennial, hairy: lvs. stalked and crenate-dentate: fls. 3 in. long, blue, pubescent, deflexed, the lower lobe prolonged. Handsome. B.M. 6974 .

CERATOZAMIA (Greek, horned Zamia; referring tothe horned scales of the cones, which distingulsh this genus from Zamia). Cycaddcea. Hand some Mexican foliage plants, with Cycas-like lvs., but less commonly cultivated in American palm-houses than Cycas. Best. raised from young imported plants, but rarely prop. by seeds, or by offsets from the slow-growing trunk. Burn out the center of the plant with a hot iron, and a number of offsets will spring from the trunk and the crown; these may be used for propagation.

Mexicana, Brongn. Trunk thick, short, covered with the remains of fallen leaf-stalks : ivs. rich, dark green, pinnate, on prickly petioles 5-6 in. long, which are. shaggy when young; leaflets very numerous, 6-12 in. 
long or more, lanceolate : cones produced annually on separate plants ; female cones 9-12 in. long, 4-6 in. thick, the scales 2-horned; male cones narrower, longer, on a hairy stalk, the scales with two small teeth. Mex. Gn.9, pp. 308, 309.-An excellent decorative plant, best grown in sandy loam. Give freely of water and heat in spring and summer, but keep cooler and dryer in winter.

\section{H. A. Siebrecht and W. M.}

CERCIDIPHYLLOM (Cercis and phyllon, leaf; the Ivs. resemble those of Cercis). Trochodendracece. Tree, with deciduous, usually opposite, petioled and palmately nerved lvs.: fls. dioecious, inconspicuous, apetalous, solitary, staminate nearly sessile, bearing numerous stamens with slender fllaments, pistillate pedicelled, consisting of 3-5 carpels, ending in long, purplish styles and developing into about $3 / 4 \mathrm{in}$. long, dehiscent pods, with many seeds. One species in Japan. Hardy, ornamental, shrubby tree of pyramidal and, when young, almost fastigiate habit, with handsome, light green foliage, purplish when unfolding, turning bright yellow or partially scarlet in fall. It prefers rich and moist soil, and grows rapidly when young. Prop. by seeds, sown in spring, and by greenwood-cuttings, taken from forced plants in early spring, or by layers; cuttings from half-ripened wood in summer, under glass, grow also, but not very well.

Japónicum, Sieb. \& Zucc. Bushy tree, usually 20-30 ft., but sometimes rising to $100 \mathrm{ft}$., with slender, glabrous branches: lvs. opposite, occasionally alternate, slender petioled, cordate, orbicular or broadly ovate, obtuse, crenate-serrate, glabróus, glaucous beneath, 2-3 in. long. Japan. G.F. 7:106, 107, and 6:53. Mn. 3:74. Gng. 5:135. -A very desirable tree, one of the best of the newer introductions from Japan.

ALFRED REHDER.

CERCIS (Kerkis, ancient Greek name). Legumindsce. JuDAS TREe. RED BUD. Trees or shrubs : lvs. deciduous, alternate, petioled, palmately nerved, entire : fls. papilionaceous, pedicelled, pink or red, appearing before or with the lvs., in clusters or racemes from the old

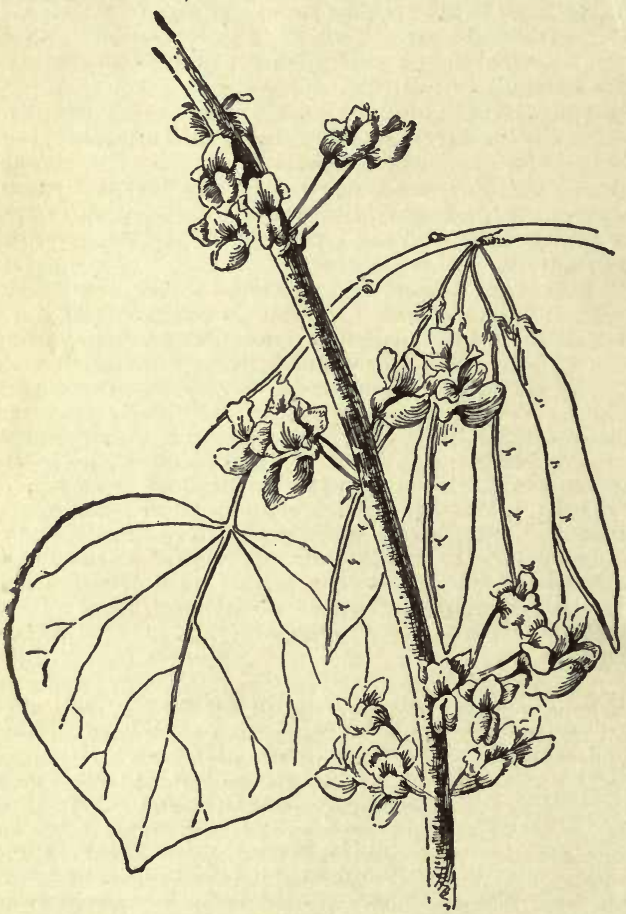

411. Cercis Canadensis $(\times 1 / 2)$.

wood: calyx 5-toothed, red: petals nearly equal, the uppermost somewhat smaller : pod compressed, narrowoblong, narrow-winged on the ventrical suture, many- seeded. Seven species in N. America, and from S. Europe to Japan. Very ornamental trees or shrubs, with handsome, distinct foliage and abundant showy fls. in spring, very effective by their deep pink color. They are well adaped for shrubberies or as single specimens on the lawn, and attain rarely more than 20 or $30 \mathrm{ft}$. in height, forming a broad, irregular head when older. Only $C$. Canadensis is hardy north, while none of the others can be grown successfully farther north than New York. They grow best in rich, sandy and somewhat moist loam, and should be transplanted when young, as older plants can be hardly moved with success. Young plants, 4 or 5 years old, produce fls. freely and may be recommended for forcing, especially $C$. Chinensis, which is the most beautiful of all. Prop. by seeds, sown in spring, best with gentle bottom heat; sometimes increased by layers, or by greenwood cuttings from forced plants in early spring; C.Chinensis grows also from greenwood euttings in summer under glass.

\section{A. Lvs, abruptly and short acuminate, usually slightly pubescent} near the base beneath.

Canadénsis, Linn. Fig. 411. Tree, to $40 \mathrm{ft}$.: lvs. roundish or broadly ovate, usually cordate, 3-5 in. long : fls, rosy pink, 1/2in. long, 4-8 in clusters: pod $21 / 2-31 / 2$ in. long. From New Jersey south, west to Missouri and Texas. S. S. 3: 133-34. A. F. 13: 1370 .

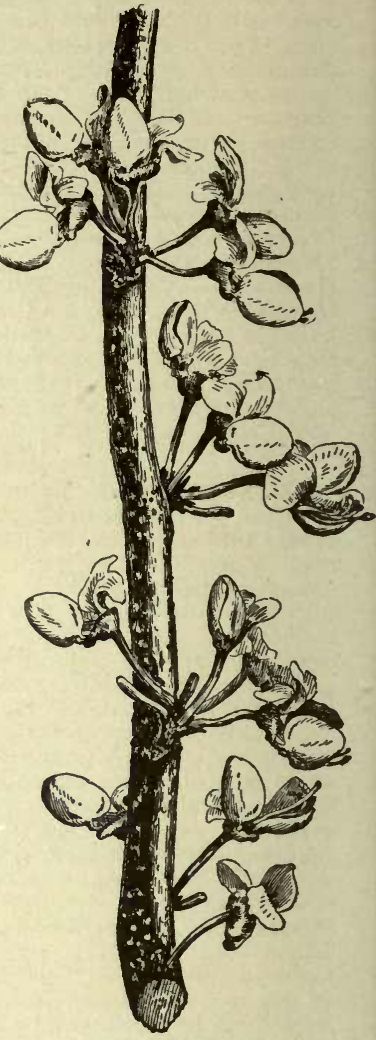

412. Cercis Chinensis Natural size. Gng. 6:290. F.E. 9:593. - A very desirable ornamental tree for the northern states. There is also a variety with double fls.

Chinénsis, Bunge (C. Japónica, Sieb.). Fig. 412. Tree, to $50 \mathrm{ft}$., shrub in culture: lvs. deeply cordate, roundish, with a white, transparent line at the margin, subcoriaceous, shining above, 3-5 in. long: fls. 5-8, purplish pink, 3/4in. long: pod 3-5 in. long, narrow. China, Japan. F.S. 8: 849. Mn. 2:139. G.F. 6: 476. - The most beautiful species, with the fls. nearly as large as those of $C$. Siliquastrum and more abundant.

\section{AA. Lvs, rounded or emarginate at the apex, usually} broader than long.

occidentalis, Torr. (C. Califórnica, Torr.). Shrub, to $15 \mathrm{ft}$.: Ivs. cordate, roundish, glabrous, about 2 in. wide: fls. rose-colored, $1 / 2$ in. long: pod $2-21 / 2 \mathrm{in}$. long. Calif: $-\mathbf{A}$ closely allied species is C.reniformis, Engelm. (C. Texénsis, Sarg.). Small tree : Ivs. subcoriaceous, 3-5 in. wide, sometimes pubescent beneath : pod 2-4 in. long. Texas, N. Mexico. S.S. 3:135.

Siliquástrum, Linn. Tree, to $40 \mathrm{ft}$ : $1 \nabla s$. roundish, deeply cordate, glabrous, $3-5$ in. wide : fls. 3-6, purplish rose, $3 / 4$ in. long : pod 3-4 in. long. S. Europe, W. Asia. B.M. 1138. Gn. $42: 879$, and 52 , p. 5. - There is a variety with white fls.

ALFRED REHDER.

CERCOCARPUS (Greek, tail and fruit; the fruit with a long, hairy tail). Rosdcea. Small trees or shrubs, with alternate, persistent, rather small lvs.: fls. inconspicuous, apetalous, whitish or reddish, in the axils of fascicled lvs.: fr. an akene, surmounted by the persistent, 
long and hairy style. Small genus of about 4 species, in the Rocky Mts. from Montana south to Mexico; without decorative value, but probably valuable for covering dry, rocky or gravelly slopes in arid temperate regions, as they thrive under very unfarorable conditions. The very heavy and close-grained wood is manufactured into small articles, and valued as fuel and for making charcoal. They may be cultivated in a peaty and sandy, well drained soil in sunny positions, and prop. by seeds or by cuttings of half-ripened wood under glass. C. ledifolius, Nutt., is the hardiest, and stands frost to zero. It has narrow, entire lvs., while the Mexican C. fothergilloides, HBK., has the lvs. somewhat larger, serrate and tomentose beneath, and clustered fls. C. parvifolius, Nutt., has cuneate-obovate, coarsely serrate lvs. D. M. Andrews, of Colorado, who handles this shrub, writes of it as follows: "Mountain Mahogany, 6 feet. A nearly evergreen rosaceous shrub of peculiar and attractive habit of growth. Flowers white, early, followed by the long, plumose akenes, which are 3-5 in. long, strangely curled and twisted, arranged above and on each side of the slender branches, so that at a little distance they have an appearance suggestive of ostrich plumes. Easily transplanted, and thrives anywhere."

ALFRED REHDER.

CEREUS (from the Latin; some think it comes from the word for candle, in allusion to the shape of the stem; others that it comes from the word for pliant). Cactdcea. A genus of varying habit, from stout-columnar to almost globular, deflexed or creeping or slender-climbing, generally ribbed. The fls. are borne singly on the side of the stem; they have a long tube which, with the ovary below it, is beset with seales or bracts; petals numerous and spreading. The sts. bear numerous tubercles or woolly tufts, which bear spines; these spines are usually of two kinds or groups, - the interior ones, or "centrals," which stand at nearly right angles to the stem, and the outer ones, or "radials," which are variously spreading. The largest Cacti are Cereuses. A genus of about 100 species, extending from the arid regions of southwestern U. S. southward through Mex. and Cent. Amer. into S. Amer. Formerly the genus was made to include the numerous species of Echinocereus, but these are now regarded as forming a distinct genus. Those who miss well known Cereus forms from the following list should look under Echinocereus. Not all of the specific names to be found in the trade catalogues can be accounted for at present, but the following synopsis contains the most important in the Amer. trade; and the unidentified names will be found in the supplementary list. See Cactus.

\section{JohN M. Coulter.}

The Night-blooming Cereuses are the only species (except $C$. flagelliformis) which are generally cultivated. The sts. of the Night-blooming Cereus are either cylindrical or angled, and are trailing or climbing in habit. Some species grow to a great height. They are excellent for growing against pillars or rafters in the greenhouse. They grow most luxuriantly where they receive abundant light and a good circulation of air. They are not particular about soil, but do well in any open, porous compost. Great care should be taken that the drainage is perfect, as stagnation at the roots of such fleshy succulent plants is sure to prove disastrous. During the summer months the stems should be syringed twice a day; but during the winter they require no syringing and very little water. Good plants can be grown in pots, using a compost of one-half good fibrous loam and the other half lime rubbish, broken brick and sand. The best species are $C$. grandiflorus, $C$. MacDonalda, $C$. nycticalus, and $C$. triangularis. At the Harvard Botanic Garden is a very large plant of $C$. triangularis, which has often had as many as 65 to 70 flowers open in one night. The flowers of all the species open but once. They collapse when the sun strikes them.

Robert Cameron.

The following Cereuses are here described: Alacriportanus, 22; Alamosensis, 8; atropurpureus, 45; azureus, 34 ; Baumanni. 27 ; Belieuli, 24 ; Bonplandii, 44 ; Baxaniensis, 43 ; Bridgesii, 33 ; cæsius, 35 ; candelabrum, 24; candicans, 4; Cavendishii, 29; chalybæus, 25; Chilensis, 7; Chiotilla, 10; coccineus, 37 ;
Cochal, 21; cærulescens, 32 ; colubrinus, 27; Donkelæri, 49 ; Dumortieri, 16 ; Dyckii, 11 ; eburneus, 19; edulis, 19 ; Emoryi, 39 ; eriophorus, 30 ; eruca, 41 ; euphorbioides, 12 ; extensus, 59 ; Fernambucensis, 42 ; flagelliformis, 47 ; formosus, 42 ; gemmatus, 15 ; geometrizans, 20 ; giganteus, 1 ; grandiflorus, 50 ; grandis, 42 ; Greggii, 36 ; gummosus, 40 ; hamatus, 56 ; Hankeanus, 17 ; inermis, 55 ; isogonus, 28 ; Jamacuru, 23 ; lageniformis, 33 ; lamprochlorus, 5 ; Landbecki, 32 ; leptophis, 47 ; MacDonaldiø, 61 ; macrogonus, 18 ; Mallisoni, 48 ; marginatus, 15 ; Martianus, 53 ; Mar tinii, 46; Maynardii, 51 ; Mexicanus, 38 ; monacanthus, 46 ; monoclonos, 22 ; Napoleonis, 58 ; nyeticalus, 54 ; Olfersii, 12 ; Pasacana, 3 ; Pecten-aboriginum, 18 ; Pernambucensis, 42; Peruvianus, 22; Pitajaya, 42; platygonus, 31,48 ; princeps, 43 ; Pringlei, 1 ; pruino sus, 19; pugioniferus, 20 ; Queretarensis, 9; Regelii, 57; repandus, 30 ; Rœzlii, 13; rostratus, 56 ; Schrankii, 37 ; Seidelii, 34 ; serpentinus, 26; Smithii, 48; Spachianus, 6 ; speciossisimus, 37 ; speciosus, 37 ; spinulosus, 52 ; splendens, 29 ; stellatus, 11 ; tephracanthus, 14 ; Thurberi, 2 ; Tonelianus, 11; tortuosus, 45; triangularis, 60 ; uranos, 50 ; validus, 23 ; variabilis, $42,43$.

A. Sts. erect, $2 \mathrm{in}$. or more in diameter.

B. New grouth green, not pruinose (i. e., not covered with a bloom or glaucum).

c. Ribs of stem 10 or more.

1. gigantèus, Engelm. Suwarro. Fig. 413. A stout form, 25-60 ft. high, simple or with a few erect branches shorter than the main st. : ribs 12-15 below, 18-21 above, often almost obliterated and spineless on older parts: spines straight, bulbous at base, white or straw-color, becoming ashy or dark, the 6 centrals stout, the 11-17 outer ones setaceous : fls. yellowish or whitish : fr. oval or pear-shaped, 2-3 in. long and 1-2 in. in diam. In rocky valleys and on mountain sides from Ariz. into Sonora and L. Calif. B.M. 7222. A.G. 11:451, 528. - The best known of the tree forms. The young plants are globular for several years. Forms the cordon forests of the Sonoran region. Runs into crested or cristate forms.

$C$. Pringlei, Wats., is one of the cordon Cereuses of N. Mex. Not so tall as $C$. giganteus, ribs fewer, and fls. scattered. Not in cult. G.F. 2:65.

2. Thúrberi, Engelm. Several stems arising from the same root, becoming 10-15 ft. high, fasciculate-jointed: ribs 13-16, very slightly prominent: spines 7-16, slender and rigid or almost setaceous, very unequal in length : fls. greenish-white : fr. globose, 1-3 in. in diam., olivecolor, with crimson pulp. Southwestern Ariz., through Sonora and L. Calif.

3. Pasacana, Weber. A gigantic species, reaching a height of 20-30 ft., and sometimes even $50 \mathrm{ft}$., and a diam. of 12-16 in.; sparingly branching above ; in new growth dark green, becoming gray or bluish: ribs 1520 , or in young plants only $9-10$ : areolæ $3 / 8-3 / 4$ in. apart, large, brown, becoming yellowish and finally gray: radial spines 10-13, about 1 in. long, the under one or lowest pair straight, subulate, the others curved; centrals mostly 4, the under and upper ones the longest, reaching 2 in. in length, straight or curved; the young spines are clear brown, often with alternating rings of light and dark tissue, later gray, bulbose at the base : fls, from the lateral areolæ, about 6 in. long, white. Argentine Republic. - This is the giant Cereus of the Argentine desert, as $C$. giganteus is of the Mojave desert.

4. cándicans, Gillies. Stems upright, low, cylindrieal, bright green, $2 \frac{1}{2}-3 \mathrm{ft}$. high by $6-8$ in. in diam.; freely branching from the base: ribs 10, obtuse angled: areolæ 5/8-3/4in. apart, large, depressed, white, becoming gray : radial spines $11-14$, spreading, at first thin, needle form, later stronger, stiff, straight, about $3 / 4$ in. long ; central solitary or later, $3-4$ additional ones appearing above, stronger, reaching a length of $11 / 4$ in. sometimes somewhat curved; all the spines horn-colored, with tips and bases brown, later becoming gray: fls. long, funnel form, resembling those of Echinopsis 10 in. long by 6 in. in diam.: fr. spherical to ellipsoidal, about 3 in. in diam., red, somewhat spiny, flesh white. Argentine Republic. 
5. lamprochlorus, Lem. Related to $C$. candicans . of a taller growth, cylindrical, 3-61/2 ft. high by about 3 in. in diam., at first simple, but later branching at the base; in new growth bright green, later dirty green : ribs 10-11 or occasionally 15 ; conspicuously crenate, later blunt and but little crenate: areolæ medium size, about $1 / 2$ in. apart, yellowish white, becoming gray; above each areola two radiating grooves form a letter $\mathrm{V}$ : radial spines 11-14, spreading, straight, sharp-pointed, about 3/8in. long, clear to dark amber color; some are strong and rigid, while others are bristle-form; centrals mostly 4 , somewhat longer, stronger and deeper colored, with brown bases, becoming dark gray, about $3 / 4$ in. long: fls. from the previous year's growth, about 8-10 in. long by 6 in. in diam., white. Argentine Republic.

6. Spachiànus, Lem. Stems upright, at first simple, later profusely branching at the base, branches ascending parallel with the main stem, $2-3 \mathrm{ft}$. high by $2-2 \frac{1}{2}$ in. in diam., columnar: ribs 10-15, obtuse, rounded : areolø about $1 / 2$ in. apart, large, covered with curly yellow wool, becoming white: radial spines $8-10,1 / 4-3 / 8$ in. long, spreading, stiff, sharp, amber-yellow to brown; central solitary, stronger and longer; all the spines later becoming gray: fls. about 8 in. long by about 6 in. in diam., white. Argentine Republic.

7. Chilénsis, Colla (C.Chiloénsis, DC.). Stems strong, upright, simple (so far as known.), about $21 / 2 \mathrm{ft}$. high by $3 \frac{1}{2}-5$ in. in diam., cylindrical to somewhat clavate, bright, clear green: ribs 10-12, obtuse : areolæ about an inch apart, large: radial spines straight, sharp, rigid, at first 9 , but later 4 others appear above these; centrals mostly 4, seldom but a single one, bulbose at the base; the young spines are brown honey-yellow, becoming white, with dark tips, and finally gray : fls. from the upper lateral areolø, about 6 in. long, white, resembling those of Echinopsis. Chile.

\section{co. Ribs of stem 7-9.}

8. Alamosénsis, Coult. Upright columnar, about $2 \mathrm{ft}$. high by about 2 in. in diam., several stems arising from a common root-crown: ribs $\mathbf{7}-\mathbf{9}$, compressed and slightly crenate: areolø prominent, about 1-11/2 in. apart, hemispherical, densely covered with short, reddish brown wool: radial spines 15-18, slender but rigid, rather unequal, spreading, straight or curved, $3 / 4-1$ in. long, ashy gray; centrals commonly 4 , much stouter and longer, the three upper ones erect or divergent, the lowest (usually the longest and somewhat flattened), porrect or deflexed, all more or less angular, sometimes teretish, 11/4-2 in. long, when young yellowish, with dark brown base, finally becoming gray: fls. from the upper lateral areolæ, funnel-form, about $1 \frac{1}{2} \mathrm{in}$. long, red. Northern Mexico.

9. Queretarénsis, Weber. Arborescent, with a trunk about $3 \mathrm{ft}$. high by about $14 \mathrm{in}$. in diam.; the muchbranched erown has a diameter of $12-16 \mathrm{ft}$., the total height of a plant being about $20 \mathrm{ft}$; branches dark green, in young growth frequently of a peculiar violetbrown: ribs 6-7, separated by sharp grooves, which later become much flattened, and the stem consequently more cylindrical : areolæ depressed, dark brown: radial spines 6-9, the lower ones the longest, about $1 \frac{1 / 4}{\text { in }}$. long; centrals 4 (often but 2 ), reaching $1 \frac{1}{2}$ in. : fls. numerous from the upper part of the branches, about 4-5 in. long: fr. yellow to red, about 2 in. long, covered with dark yellow to brown spines, about 1 in. long, and bulbose at the base. Mexico.

10. Chiotilla, Weber. Arborescent, stem reaching a diameter of 16 in., freely branching from the base upward, the whole plant reaching a height of $16 \mathrm{ft}$., with a crown 12-14 ft. in diam., branches 8 in. in diam., dark green : ribs mostly 7 (seldom 8): areolæ elliptical, pointed above and below, large, gray: radial spines $10-15$, straight, very stiff, radiate, $1 / 4-3 / 8$ in. long ; centrals $1-2$, rarely $3-4$, the under one long and very strong, about 2 in. long, curved downward, and either to the right or to the left, the others about half as long; all the spines are horn colored; the narrow groove connecting the areolm bears a few bristles: fls. from the lateral areolæ, near the end of the branches, $1 \frac{1}{4}-1 \frac{1}{2}$ in. long, sulphur-yellow: fr. spherical, little more than an inch in diameter, scaly, brown-red, with a violet flesh within. Mexico.
11. stellàtus, Pfeiff. (C. Dýckii, Mart. C.Tonelliànus, Lem.). Stems upright, columnar, 10-14 ft. high, light green ; branches upright, $2-3$ in. in diam.: ribs 7-10, rarely 15 : areolæ $1 / 2-1$ in. apart, sunken between adjacent swellings of the rib: radial spines $8-10$, about $3 / 8$ in. long; centrals 3-5, the upper ones upright or divergent, the under one porrect, about $1 / 2-3 / 4$ in. long; all the spines bulbose at the base, rigid, white, and sometimes with dark tips, turning gray with age : fls. forming a crown at the end of the stem, about 2 in. long, light pink : fr. spherical, $1 \frac{1}{2}$ in. in diam., red outside and carmine-red within. Central Mexico.-Fruit edible and common in the Mexican markets.

12. euphorbioldes, Haw.(U. Ólfersii, Otto). Columnar, simple, 10-16 ft. high by about $4 \frac{1}{2}$ in. in diam., in young growth pale green, changing with age to gray-green : ribs 8-10, separated by sharp grooves, sharp-angled, becoming flattened in older growth : areolæ about $3 / 8$ in. apart, small, white to gray: radial spines mostly 6 , the under one the longest, reaching a length of over an inch, strong, yellowish brown to black, the upper ones shorter and bristle form ; central solitary, in young plants twice as long as the radials; all the spines finally become gray: fls. from near the crown, $3 \frac{1}{2}-4$ in. long, beautiful flesh-red, remaining open for 24 hours. Brazil. R.H. 1885 , p. 279.

13. Rœzlii, Haage. Upright, columnar, about 3 in. in diam.: ribs 9, separated by sharp, somewhat serpentine grooves, obtuse; above the areolæ, two radiating, slightly curved grooves form a letter $V$ : areola $1 / 2-3 / 4$ in. apart, comparatively large, slightly sunken, yellowish, later gray: radial spines 9-12, radiate, nearly 1/2 in. long, straight, subulate, tolerably sharp, slightly thickened at the base, clear brown, with darker stripes; central solitary, reaching $1 \frac{1}{2}$ in. in length, straight, porrect, later somewhat deflexed, clear brown; later all the spines become gray. Andes of Peru or Equador.

14. tetracánthus, Lab. Upright, arborescent or bushy, freely branching, young branches leaf-green, later gray-green: ribs 8-9, low, arched : areolæ medium sized, slightly sunken, about $1 / 2 \mathrm{in}$. apart, white to gray: radials 5 , later 7 , radiate, about $3 / 8 \mathrm{in}$. long, straight, subulate, stout, white, with brown tips and bases, later ashy gray; centrals 1-3, under one largest and porrect, when young yellow and translucent, later gray: fls. resemble those of $C$. tortuosus. Bolivia.

$$
\text { ccc. Ribs of stem } 3-6 \text {. }
$$

15. marginàtus, DC. (C. gemmatus, Zucc.). Simple or branching at apex, 2-3 in. in diam., with 5-6 obtuse ribs, which are woolly their whole length: spines shortconical, rigid, $7-9$, all nearly alike: fls. brownish purple, about $1 \frac{1}{2}$ in. long : fr. globular and spiny. Mexico.Frequently used for hedges in S. Mexico. The stem is often covered with a woody crust.

16. Dumortièri, Salın-Dyck. Tall, strong, 6-angled, columnar stems, much resembling $C$. marginatus, but with the confluent areolæ armed with slender, needleform, yellow spines: radials about 9-15, radiating, about $3 / 8-3 / 4$ in. long; centrals $1-4$, the under one longest, reaching $1 \frac{1}{2}$ in. in length : fls. numerous, funnel-form, about 2 in. long, opening to about 1 in. in diam., white. Mexico.

17. Hankeànus, Weber. Upright, robust, not branching (so far as known), young growth bright green, later dark green, about 2 in. in diameter: ribs 4-5, compressed, about $1 \frac{1}{4} \mathrm{in}$. high, conspicuously erenate, with an S-form line passing from each areolø toward the center of the stem : areolæ $3 / 8-1$ in. apart, horizontally elliptical to heart-shaped, brown, becoming gray below and yellow above: radial spines 3 , needle-like, stout, sharp-pointed, about $3 / 8$ in. long, amber-colored when young, turning to brown; central solitary, straight, porrect, $5 / 8$ in. long, stronger than the radials, horn-colored; later all the spines become gray: fls. 4-5 in. long, white. S. Amer.

$$
\text { BB. New growth blue, white-or gray-pruinose }
$$

$$
\text { (i. e., covered with a bloom). }
$$

c. Ribs of stem comparatively broad and low; more or less triangular in transverse section.

18. macrógonus, Otto. Arborescent, sparsely branching, reaching a heigh of $20 \mathrm{ft}$. (in cultivation, $6 \mathrm{ft}$. high 
by $3-5$ in. in diam.), branches columnar : ribs mostly 7 , seldom 8-9, thick, slightly undulate, obtuse and with convex faces, about 1 in. high, bluish green, frequently having a depressed line near the areolø: areolæ about $1 / 2$ in. apart, large, gray: radial spines $6-9$, radiate or spreading, strong, subulate, $3 / 4$ in. long, horn color, later black; central spines $1-3$, somewhat stronger and longer than the radials, more or less conspicuously porrect fls, from the lateral areolo, near the end of the branches, $21 / 2-3$ in. long, tolerably fleshy, white : fr. depressed-globose, 2 in. in diam. by little more than 1 in. long. Brazil.

C. Pécten - aboriginum, Wats., is closely allied to the above. It is Sonoran, but not known to be in eult. G.F. $7: 335$.

19. ebúrneus, Salm-Dyck (C. pruinòsus, Otto, C. édulis, Hort.). Stem simple and glaucous, with $7-10$ ribs: spines subulate, rigid, ivory-

white, with black tip (purplish when young), radials $8-10$, central usually solitary (sometimes 3-4): fls. purplish. W. Ind., Mex.,

Cent Amer., S. Amer.

20. geométrizans, Mart. (C. pugioníferus, Lem.). Simple, 4 in. in diam, with 5-9 obtuse ribs with broad intervals : spines 3-6, unequal, stout and blackish, the solitary central one (sometimes wanting) very long and stout : fls. pinkish white, about 1 in. long and 2 in. broad. Mexico.

21. Còchal, Orcutt. Stout at base, and repeatedly forking above, becoming 4-10 ft. high: ribs 4-8, obtuse, with wide, shallow intervals : spines few and stout, the solitary central one stoutest : fis. purplish green, 1-11/2 in. long: fr. the size and shape of an olive, not spiny, red (frequently grayish or yellowish brown). L. Calif.The short and stout woody trunk is often $1 \mathrm{ft}$. in diam. the long branches $2-8$ in. in diam.

cc. Ribs of stem strongly compressed laterally.

22. Peruviànus, Haw. (C. monoclònos, DC.). Hedge CAcrus. Tall, 30-50 $\mathrm{ft}$., branching freely toward the base, columnar, 4-8 in. in diam., new growth dark green and glaucous, becoming a dull green with age, and, in old stems, becoming corky: ribs 5-8, compressed : areolæ $1 / 2-1$ in. apart, in new growth covered with conspicuous, curly brown wool, becoming gray: radial spines about $6-7$, about $8 / 8-1 / 2$ in. long ; central solitary, reaching a length of $2 \frac{1}{2}$ in.; the number of spines increases with age to as many as 20 , all are rigid, brown : fls. abundant, from the lower part of the stem, white, nocturnal, 6-7 in. long by 5 in. in diam. Fla., W. Ind., Mex. and S.Amer. G.C. III, 24: 175 (var. monstrosus).

Var. Alacriportànus, K. Sch. (C. Alacriportanus, Mart.). Of somewhat weaker growth, low, and less conspicuously pruinose in the new growth, which is consequently nearly clear green. S. Brazil.

23. Jamacàru, Salm-Dyck (C. válidus, Haw.). Stems upright, robust, rigid, 12-16 ft. high by as much as 6 in in diam.; young growth azure-blue, turning dark green with age, glaucous: ribs 4-6, thin, compressed, crenate radial spines $5-7$, stiff, needle-like, clear yellow with brown points, or brown and finally black, about $1 / 2-3 / 4$ in. long; centrals $2-4$, somewhat stronger, porrect, $3 / 4-3$ in. long: fls. large, $10 \mathrm{in}$. long by 8 in. in diam., white nocturnal. Braz., Venezuela.

24. candelàbrum, Weber ( $C$. Belieǹli, Hort.). Tall, columnar, simple or branching only at the base, dark green with a faint trace of blue, $30 \mathrm{ft}$. high by 4 in. in diam.: ribs 9 , blunt, strongly compressed, $3 / 4 \mathrm{in}$. high, slightly crenate: areolæ 1-2 in. apart, ovate, large,

white: radial spines mostly 9 , the under ones longest and about an inch long, laterally compressed, the upper ones shorter, round, all bulbose and black at the base, ivory-white above ; central solitary, very large, 3-4 in. long, dagger-like, laterally compressed and faintly angled, porrect, ivory-white to gray, base black and strongly bulbose : fis. from the lateral areolæ, $3-4$ in long, white: fr. the size of a small orange, covered with small scales, in the axils of which are wool and bristles Mexico.

25. chalybæus, Otto. Stems upright, branching above, arborescent, azure blue and pruinose, later dark green, $11 / 2-4$ in. in diam.: ribs 6 , in young growth very much compressed, later depressed till the stem is nearly cylindrical : areolø about $8 / 8$ in. apart, dark gray-brown; radial spines mostly 7 , about $1 / 2$ in. long; centrals $3-4$, similar but somewhat stronger and a little longer; all the spines are pointed, stiff, when young are black, later brown to gray with black tips, bulbose at the base: fls. very similar to those of $C$. carulescens. Argentine Republic.

\section{A4. Stems erect, less than 2 in. in diam.}

$$
\text { B. Ribs of stem } 10 \text { or more. }
$$

26. serpentinus, DC. Stems columnar, tall, slender flexuose, 5-8 ft. high by 1-11/2in. in diam., tapering at the point : ribs $10-13$, low, obtuse : areolæ about $8 / 8$ in. apart: radial spines $10-12$,'slender, needle form, stiff, $3 / 8$ in. long; centrals 1-4, pink and white when young, later gray; the number of spines increases by new ones appearing later : fls. from the upper lateral areolæ, slender, green, spiny tube with funnel-shaped corolla, about 6 in. long by 3 in. in diam., white, nocturnal: fr. ovoid, red, covered with deciduous spines. Cent. Mex. B.M. 3566 .

27. Baùmannii, Lem. (C. colubrinus, Otto). Stems dark green, slender, flexuose, columnar, reaching a height of $6 \mathrm{ft}$. and a diam. of $1-1 \frac{1}{2}$ in., the few branches ascend- 
ing slender, parallel with the main stem : ribs 12-16, rounded: areolæclose together, brown; spines fine, slender, very sharp, 15-20, fascicled, white to yellow or dark brown, about $1 / 4$ in. long; sometimes a single one from the center reaches a length of $3 / 4$ in.: fls. numerous, tubular, zygomorphous, $2 \frac{1}{2}-3$ in. long by about $1 / 2$ in. in diameter throughout, red or sometimes with orange-red petals and red tube. Uruguay, Paraguay and Argentine Republic.

28. isógonus, K.Sch. Stem upright, columnar, about $1-1 \frac{1}{4}$ in. in diam., in young growth light green to yellowgreen, later darker : ribs 15-16: areolæ approximate, white, turning gray: radial spines as many as 20, spreading, at first clear or dark yellow, becoming white, and finally gray, bristle form, flexible, about $3 / 8$ in. long: centrals $6-8$; two of these are somewhat stronger and stiffer, about $3 / 4 \mathrm{in}$. long, one directed upward and one downward, yellowish brown to dark honey-color; later gray, as in the radials. S. Amer.

29. spléndens, Salm-Dyck. Columnar, slender, short, rigid, more or less branching from the base, reaching a height of about $2 \mathrm{ft}$. and about $1-1 \frac{1}{2}$ in. in diam., light to yellowish green : ribs about 10-12, rounded : areolæ prominent, about $1 / 4$ in. apart, tawny, becoming white, tomentose: radial spines 8-12, radiating, yellow and light brown, becoming gray; centrals 1-3, scarcely larger than the radial, yellowish to white; all the spines slender, bristle form, about $1 / 4-3 / 4 \mathrm{in}$. long. - This may be but a lower, stouter form of $C$. repandus. C. Cavendishii has been referred to this species, but with some question.

$$
\text { BB. Ribs } 3-10 \text {. }
$$

30. repándus, Haw. ( $C$. erióphorus, Pfeiff.). Stem simple, $20 \mathrm{ft}$. high, tapering at summit and jointed, with 8-10 obtuse ribs: spines 9-12, needle-shaped, white with black tips: large white, funnel form flowers, the calyx-tube covered with long wool. W. Indies.

31. platýgonus, Otto. At first upright, later somewhat reclining, branching, at the base about 1 in. in diam., tapering in the new growth: ribs 8 , low, arched: areolø about $1 / 4 \mathrm{in}$. apart, very small, yellow, becoming gray, subtruded by a small 3-angled bract; radial spines $12-15$, spreading, bristle form, little more than $1 / 8$ in. long; central solitary, slightly longer and stronger; all the spines at first yellow-brown, changing to white or gray with age.

32. cæruléscens, Salm-Dyck ( $C$. Lándbeckí, Phil.). Arborescent or shrubby, 3-5 ft. high: stems 1-11/2 in. in diam.: ribs usually 8 , obtuse: areolø approximate, white bud soon becoming black : spines rigid ; radials 9-12, $1 / 4-1 / 2$ in. long, black ; centrals $4,3 / 4$ in. long, stronger, black or white : fls. from the side of the stem, slightly curved, 6-8 in. long by 6 in. in diam., tube bronze-green, corolla white or occasionally rose-pink: frs. ellipsoidal, pointed at both ends, about 3 in. long and half that in diam., bright red, with blue glaucous covering. Argentine Republic. B.M. 3922.

33. Brídgesii, Salm-Dyck. Upright, tall, columnar, simple or later branching at the base, bright green when young, becoming blue to gray-green, $1 \frac{1}{2}-2$ in. in diam.: ribs 5-7, very broad and low : areolø $1 / 2-3 / 4$ in. apart, yellowish to gray: spines $3-5$, radiating, the under one, or seldom the upper one, the longest, $1 \frac{1}{2}$ in. long, stiff, sharp, straight, dark honey-yellow, with brown tips, becoming gray with age. Bolivia.

Var. lagenifórmis, K. Sch. (C. lagenifórmis, Först.). Spines more numerous, somewhat longer.

34. azùreus, Parm.(C.Sèdelii, Lehm.). Stem upright, tall, slender, columnar, branching from the base, in the young, fresh bluish green, later dark green with gray, glaucous covering, about $3-4 \mathrm{ft}$. high and about 1 in. in diam.: ribs 5-7, rounded, enlarged at the areolæ: areolæ about $3 / 4-1 \mathrm{ft}$. apart, elevated, large, abundantly woolly when young: spines $8-18$, nearly alike, about $1 / 8-3 / 8$ in. long, stiff, slender, needle-form to bristle-like, black; the 2-4 central ones somewhat longer : fls. 8-12 in. long, obliquely attached to the stem, slightly curved, white. Braz.

35. cæsius, Otto. Upright, columnar, branching at the base, somewhat tapering above; in new growth, beauti- ful light blue, pruinose ; later, light green to slightly bluish, about $1 \frac{1}{2}$ in. in diam.: ribs $5-6$, separated by sharp grooves, about $1 / 2$ in. high, compressed, faintly crenate, becoming depressed in older growth : areolæ about $3 / 8$ in. apart, small, yellow at first, later becoming white and finally gray : radial spines 8-10, sometimes more appear later; radiate, light amber-color, brown at the base, the lower pair the longest, mostly about $1 / 2$ in. long ; centrals 4-7, like the radials but usually somewhat stronger, longer and darker; all the spines thin, needle-form, flexible, sharp ; later, light horn-color, finally gray. S. Amer. (?).

36. Gréggii, Engelm. Slender and branching, 2-3 ft. high and $3 / 4-1$ in. in diam., from an extraordinarily large, tuberous root (often 6-10 in. long and 4-6 in. in diam.): ribs 3-6, acute : spines subulate from bulbous base, very short and sharp, $7-11,1$ or 2 being central: fls. white or yellowish, 6-8 in. long; fr. ovate, alternate at base and apex, bright scarlet, fleshy and edible, 1-2 in. long. Southwestern Tex. to Ariz., and south into Chihuahua and Sonora. Generally in gravelly or hard, clayey soil.

37. speciosus, K. Sch. (C. coccineus, Salm-Dyck. $C$. Schránkii, Zucc. C. speciosissimus, DC.). Slender, much branched from toward the base; stems about $2 \mathrm{ft}$. in length by about 1 in. in diam., sometimes having aërial roots near the young growth: ribs 3-5, serrated: areolæ occupy the short upper side of the serrations, large, copiously white, woolly: spines fascicled, 5-8, more in age, spreading, slender, stiff, sharp-pointed, the under one bristle-form, about $1 / 2$ in. long, yellow : fls. appearing from the older growth of the stems ; large, 6 in. in diam., remaining open several days, purple-red, with irridescent, bluish center : fr. oroid, with a few scattering scales, $1 \frac{1}{2}-2$ in. long. Mex. and Cent. Amer. B.M. 3822. I.H. 32:548. Gn. 53, p. 153. -This species is commonly hybridized with other species of Cereus and of Phyllocactus, giving rise to numerous horticultural varieties.

38. Mexicànus, Lem. Said by Lemaire to be a garden hybrid between $C$. speciosus and some other species not mentioned.

AAA. Stems prostrate.

39. Emoryi, Engelm. Prostrate, cylindrical, 2-4 ft. long, with ascending or erect branches $6-10 \mathrm{in}$. high and 1-2 in. in diam.: ribs 15, tuberculate: spines slender and rigid, interlocked, yellow; radials $40-50$, very slender; central usually solitary, stouter and much larger : fls. greenish yellow, 1-2 in. broad : fr. globose, very spiny, $1-1 \frac{1}{2}$ in. in diam. Rocky hills, $S$. Calif. into $L$. Calif. and adjacent islands. - Grows in thick masses, covering patches 10-20 ft. square.

40. gummosus, Engelm. (C. gummindsus, Hort.). Prostrate and assurgent, 1-4 ft. long, 3-4 in. in diam. dull purplish green: ribs (on young branch) 7-9, tuberculate: spines stout and rigid, black, from a strong, bulbous base; radials about 12 ; centrals $3-6$, stout and angled: fls. purple, 4-5 in. long: fl. subglobose, about 3 in. in diam., spiny, bright scarlet with purple pulp ("color of ripe watermelon"), acid and pleasant. L. California.

41. erùca, Brandegee. Prostrate and stout, single or slightly branched, 2-4 $\mathrm{ft}$. long, 3-7 in, in diani. rooting from the under surface, generally in patches of $20-30$ : ribs 13-21: spines stout, ashy, interlocked; centrals 5-8, stouter, the lowest flattened and strongly deflexed : fls. 4-5 in. long, reported to be yellow: fr. globular, 2 in. in diam., somewhat spiny, dull red, with purple pulp. Sandy plains, coasts of L. Calif. and adjacent islands. - A plant of curious and uncouth habit, often in large masses, and from a distance" looking like a lot of firewood thrown at random on the ground."

AAAA. Stems weak, clambering over rocks or other plants for support; without aërial roots.

42. Pitajaya, DC. (C. Pernambucénsis [F'ernambucensis], Lem. C. formòsus, Salm-Dyck. C. variábilis, Pfeiff.). Stems at first simple, later branching, in young growth light green, turning grayish green with age, pointed, $3 / 4-11 / 4 \mathrm{in}$. in diam. : ribs $3-5$, commonly 4 : areolæ about 1 in. apart, large, bearing a conspicuous amount of 
curly hair, about $1 / 2$ in. long, in new growth: radial spines $5-7$ and a solitary central one, uniform, about $3 / 8-5 / 8$ in. long, amber color to brown and finally gray: Hs. from the older growth, large, about 8 in. long, slightly curved, white, nocturnal. Uruguay, Brazil, Columbia. B.M. 4084. $-C$. grandis, Haw., according to Dr. Weber, is but a larger form of this species.

43. princeps, Pfeiff. (C. Baxaniénsis, Karw. C.varia bilis, Engelm.). Erect, 3-10 ft. high, 2 in. in diam., and 3-or 4-ungled: spines 4-6, stout and radiant, unequal, the larger 1-11/2in. long: fls. white, long-tubular, 7-8 in. long: fr. oval, spiny, 2-3 in. long, searlet, and with luscious red pulp. Lower Rio Grande, on Mex. side.-The young shoots are said to have 8 ribs and more numerous slender spines, and in cultivated forms the spines are often much longer than given above.

44. Bonplandii, Parm. Stems at first upright, later clambering over rocks and bushes, about $1-1 \frac{1}{2}$ in. in diam., branching and spreading, in new growth commonly of a bluish or purplish green, later gray-green : ribs 4-6, sharp, compressed, crenate, separated by broad, concare faces; later the ribs become much depressed, so that the stem is sometimes nearly cylindrical; the ribs commonly run spirally around the axis of the stem: areolø 1/2-11/2in. apart, at first considerably depressed, later shallower, white, becoming gray: radial spines 4-6 (later 1-4 more appear), straight, spreading, the largest about $1 / 2-1$ in., stout, subulate, pointed, the under one needle form and shorter ; central solitary, straight, stronger, 1 in. long, deflexed or porrect ; the stronger spines are white, with tips and bases brown, when young beautiful ruby-red, later all are gray, with black tips and bulbous bases: fls. from the lateral areolæ, about 10 in. long, white, nocturnal : fr. nearly spherical, about 2 in. in diam., mammate, dark carmine-red. Paraguay, Brazil, and Argentine Republic.

45. tortuòsus, Forbes (C. atropurpùreus, Haage). Stems slender, weak, at first upright, but later reflexed, reaching a length of $3-4 \mathrm{ft}$, and 1-11/2in. in diam.: ribs commonly 7 , sometimes but 5 , rounded, low, separated by regular serpentine grooves: areolø about 1 in. apart, large: radial spines $5-8$, about $3 / 8-1$ in. long: centrals $1-4$, about $3 / 4-1 \frac{1}{2}$ in. long; all the spines slender, rigid, redbrown when young, becoming ashy with age : fls. from the previous year's growth, about 6 in. in length, trumpet-shaped, tube olive-green and spiny, in the axils of the reddish green scales; outer petals pale green, tinted with brown; inner petals clear white : fr. spherical, brilliant red without and white within, mammate, bearing a few spines on the summits of the lower mammas. Argentine Republic.

46. Mártinii, Lab. (C. monacánthus, Hort.). At first upright, later requiring a support; freely branching from the base, branches long, reaching nearly $5 \mathrm{ft}$., $3 / 4-1$ in. in diam., slightly tapering, dark green: ribs $5-6$, separated by serpentine grooves, contracted between the areolæ; sometimes the ribs are not evident, when the stem is cylindrical: areolø about $1-1 \frac{1}{2}$ in. apart, white: radial spines 5-7, reddish, short, bristle-form, with bulbous bases or short conical, usually about $1 / 8$ in. long; central solitary, mostly deflexed, $1 / 2-1$ in. long (in young growth, frequently not longer than the radial), subulate, robust, light brown or white, with bases and tips black : fls. from the older growth stems, 8-9 in. long, clear white, nocturnal : fr. spherical (very similar to C. tortuosus), pointed, dark earmine-red, about 2 in. in diam., mammate, a few spines on the mammas, toward the base of the fr. Argentine Republic. R.H. 1860, pp. 658-9. -This species is commonly sold under the name of C. platygonus
AAAAA. Stems more or less climbing, attaching them. selves to trees, walls, etc., by means of aërial roots.

B. Ribs of stem 5 or more.

47. flagellifórmis, Mill. Rat-tail Cactus. Creeping or pendent, slender and very branching, cylindrical, $1 / 2-1$ in. in diam., branches $1 \mathrm{ft}$. long or more: ribs 10-12, tuberculate: spines short, rather rigid; radials 8-12, reddish brown ; centrals 3 or 4 , brown, with golden tip: fls. funnel-form, crimson, 2-3 in. long: fr. globose, $1 / 2$ in. in diam., reddish and bristly, the pulp greenish yellow ("with the taste of a prune"). W. Ind., Mex., Cent. Amer., S. Amer. - This is commonly hybridized with other species. It is a very common window plant.

Var. léptophis, K. Sch. (C. léptophis, DC.). Of more handsome appearance : new spines on the growing point carmine-red : ribs at the most 8 : fls. somewhat smaller and lighter.

48. Mállisoni, Hort. (C. Smithii, Lindl.). This is a garden hybrid of $C$. flagelliformis on $C$. speciosus. Habit of $C$. flagelliformis, but stouter: fls. more like those of C. speciosus. B.M. 3822 .

49. Donkelàeri, Salm-Dyck. A bushy epiphyte, richly branching, clinging to the bark of trees by aërial roots, commonly in company with orchids; branches very long and thin, scarcely $3 / 8$ in. in diameter, cylindrical or inconspicuously 6-angled, or rarely 7-8-angled : areols very close together, small, white : spines $10-15$, very short, snow-white; sometimes 2-3 short, stronger spines appear in the center of each cluster : fls. resembling those of $C$.grandiflorus. Brazil.

50. grandiflorus, Mill. Fragrant Night-BLOOMING Cereus. Fig. 414. Diffusely ereeping, with very long and flexuous climbing 5-7-angled branches, 1/2-1 in. in diam. with bunches of white bristles associated with the 5-12 short spines: fls. white and fragrant, 6-8 in. broad. W. Ind., Mex. B.M. 3381. - Long cultivated in gardens as the "Night-blooming Cereus," and made to vary widely. C. Uranos, Hort., is but a form of this species.

51. Màynardii, Lem. (C.grandiflorus, var. Màynardii, Hort.). A garden hybrid of $C$.grandiflorus on $C$. speciosus. Habit of $C$.grandiflorus, but red colors of $C$. speciosus.

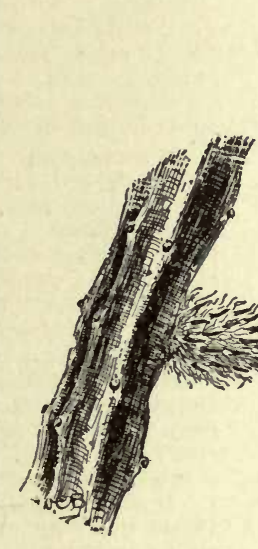

414. Cereus grandiflorus, one of the night-blooming Cereuses $(X 1 / 8)$. 52. spinulosus, DC. Stems slender, climbing, reach
ing a height of $8-10 \mathrm{ft} ., 3 / 4-1$ in. in diam., branches more slender : ribs commonly 5 , sometimes 6 , sharp, becom. ing obliterated with age: areolæ small, about 1/2in. apart : radial spines about 8 , very short, bristle-form, brown, becoming gray; central solitary, somewhat longer: fls, 5-6 in. long by 3-4 in. in diam., white, flushed 
with pink, nocturnal. W. Ind. and Mex. - The plant much resembles $C$. grandiflorus, but is easily distinguished by its smaller and different colored fls.

53. Martiànus, Zucc. Of bushy growth, branching, reaching a height of $3 \mathrm{ft}$. and more ; branches slender, provided here and there with aërial, roots, cylindrical, about $3 / 4$ in. in diam : ribs commonly 8 , straight, separated by sharp grooves, very low : areolæ $1 / 4-3 / 8$ in. apart, small, white: radial spines 6-10, bristle-form, spreading, clear honey-yellow, at base brownish, later whitish and becoming gray, about $1 / 4$ in. long ; centrals 3-4, similar, only somewhat stouter and darker : fls. usually abundant, straight or slightly S-shaped, 4-5 in. long, scarlet-red : fr. spherical, reddish green, covered with bristles. Southern Mex. B.M. 3768.

\section{BB. Ribs of stem $3-5$.}

54. nycticalus, Link. Night-Blooming Cereus. Suberect, very long-jointed, $1 / 2-1$ in. in diam.: joints variable, some cylindrical, others 4-6-angled : ribs acute at first, obtuse later: spines 1-4, and very small : fls. white and fragrant, about 7 in. long. Mex.-The commonest Night-blooming Cereus.

55. inérmis, Otto. Sts. branching, climbing, branches 4-5-angled, sharp-winged, yellowish green, later darker, slightly crenate: areolæ in the depressions, small, bearing a few bristles when young, but soon naked. Venezuela.

56. hamàtus, Scheidw. (C. rostràtus, Lem.). Stems slender, weak, climbing, bright green, less than 1 in. in diam., reaching a length of $10 \mathrm{ft}$.: ribs remotely serrate, the serrations repand, and bearing on their anterior edge the small areolæ: spines 5-6, bristle-form, whitish to brown, very short and partly deciduous: fls. large, 10-16 in. long and nearly the same in diameter, white, nocturnal. Central Mexico.
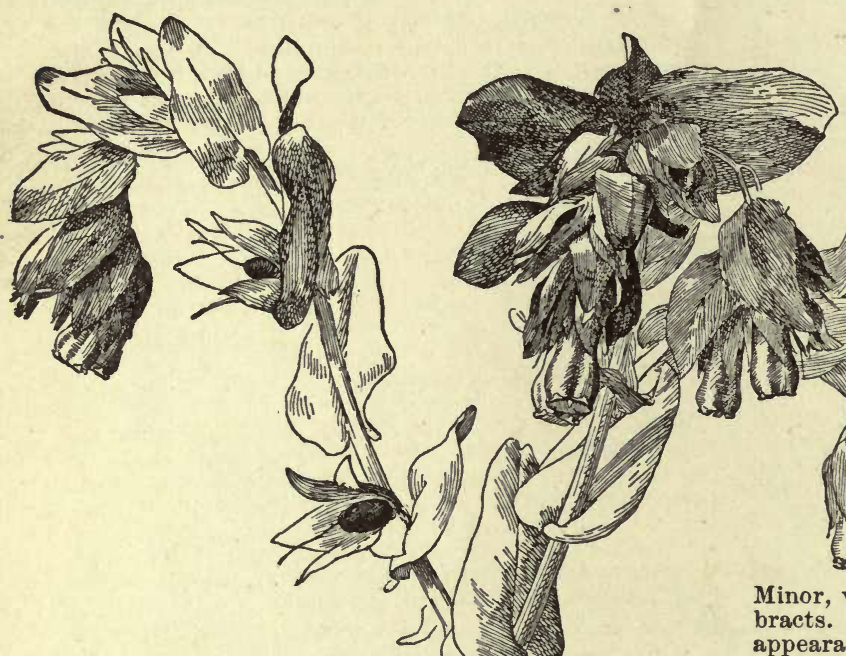

58. Napoleònis, Graham. Suberect and long-jointed, the joints 3 -angled and with flat sides, 12 in. or more long, $3 / 4-1$ in. in diam.: spines 3 or 4 , subulate, unequal, black; sometimes a few white bristles: fls. snowy white, 8 in. long and 6 in. broad: fr. bluish and spiny, 3 by 4 in. W. Ind., Mex. B.M. 3458.

59. exténsus, Salm-Dyck. Climbing: stems richly branching, about $3 \mathrm{ft}$. long by about $3 / 4 \mathrm{in}$. in diam., dark green, soon becoming covered with gray-yellow, corky flakes: 3-angled, angles blunt, later becoming depressed so that the older stems are cylindrical : areolæ $1 / 2-21 / 2$ in. apart, white, becoming gray: spines $2-4$, very short and strong, straight or very slightly curved, dark brown, becoming gray with age : fls. from the sides of the branches, 8-9 in. long, rose-red. Trinidad. B.M. 4066.

60. triangulàris, Haw. Stems jointed, long and slender, climbing : ribs 3, compressed, thin, and about 1 in. or more high, crenate, with a corneous margin connecting the areolæ: areolæ about $1-1 \frac{1}{2}$ in. apart: radial spines $2-4$, bristle-form, short, soon deciduous ; centrals 1-3, conical from a bulbous base, dark colored: fls. large, about $1 \mathrm{ft}$. long by about the same diameter when fully open, white, nocturnal, tube covered with large, leaf-like scales : fr. large, covered with the persistent large scales. Mexico and West Indies. B.M. $1884 \mathrm{Mn}$ $6: 5$. - The fruit is edible and very refreshing, and is common in the Mexican markets.

BвB. Ribs inconspicuous or wholly absent.

61. MacDónaldiæ, Hook. Climbing, and of rapid growth, richly branching, branches very long, cylindrical or with here and there very obtuse and not continuous angles, dark green : areolae elevated on tubercles which are arranged spirally on the branches, small : spine solitary (or rarely 2), short, porrect, brown or black, inconspicuous: fls. lateral, about 14 in. long, white, nocturnal. Honduras. B.M. 4707.

The following horticultural names, in the Amer. trade, are not accounted for in the foregoing synopsis: $O$. Ohildsii, $O$. diversispina, $O$. eréctus, $O$. farinòsus, O. frágilis, O. Gébseri, O. Guadalupanus, $O$. Zaucacdri.

The following names, in the Amer. trade, belong to Echinocereus: C. Berlandièri, C. caespitdsus, O. chloránthus, O. coccineus, C. conoideus, O. ctenoìdes, C. dasyacánthus, $C$, dùbius $O$. Engel. manni, $C$ enneacánthus, $O$. Féndleri, $C$. gonacánthus, O. longisètus. O. Mojavénsis, $O$, paucispinus, $O$. pectinàtus, vensis, O. paucispinus, O. pectinatus, C. phoeniceus, O. procúmbens, O. Roet-
teri, O. Scheèri (Schlini), O. stramineus, $O$. tuberòsus, $O$. viridiflòrus.

C.cylindricus is Opuntia. C. Nickelsii and $C$. senilis are Pilocereus.

JoHN M. Coulter and C. H. THOMPSON.

CERINTHE (Greek, keros, wax; anthos, flower: the ancients believed that the bees visited the flowers for wax). Boragindcece. About 6 species of annual or perennial herbs from Europe and Asia Minor, with alternate, glaucous Ivs. and showy purple bracts. The best species is $C$. retorta, which has a unique appearance in the garden, and is strongly recommended for more general cultivation. It is a hardy annual of easy culture. For a garden review of the other Honeyworts, see Gn. 41, p. 212.

retórta, Sibth. \& Sm. HoNerwort. Fig. 415. Height 11/2-2 ft. : lvs. glaucous, often spotted white or red lower lvs. obovate-spatulate; upper lvs. amplexicaul, with 2 round ears, on the flowering branches gradually becoming smaller and eloser together until they pass into purple bracts, which form the chief attractive feature of the plant: fls. when full-blown protruded beyond the bracts : corolla tubular-club-shaped, yellow, tipped purple, with 5 small, spreading teeth. Greece. B.M. 5264. Gn. 41: 847 .

W. M.

57. Régelii, Hort. This form is very common in the trade; is a very excellent plant, with good, fixed characters; is a slender climbing plant. Its origin is obscure, but, from its vegetative characters, as well as floral, it is apparently closely related to either $C$. hamatus or C. MacDonaldice, with one of which it may be a hybrid.
CEROPEGIA (Greek, wax and fountain, the Howers having a waxy look). A sclepiaddcece. Greenhouse vines of Africa and Asia, not in the Amer. trade. A dozen species are known in Old World collections. Many of them have tuberous roots, and need a season of rest and dry. ness. Prop. by cuttings. Odd and handsome. 


\section{CEROXYLON NIVEUM, Hort.= Diplothemium.}

CESTRUM (old Greek name). Syn., Habrothámnus. Solandcece. Greenhouse shrubs of many species, in tropical Amer. Some of them have a climbing habit. The tubular fls. are in axillary or terminal cymes, red, yellow, greenish or white, often very fragrant. Lvs. alternate and entire, usually rather narrow. Fruit a berry. Cestrums are among the most useful of bright-flowering, shrubby, greenhouse plants, and they may be grown either as pot plants, or planted out against the back wall or supports of a greenkouse, where, if given a light position, they will produce an abundance of flowers from January to April. The Mexican species will do well in a winter temperature of $45^{\circ}$ to $50^{\circ}$, but the species from Central America require stove temperature. They are propagated by cuttings taken in February or early in March, and inserted in sand in a warm temperature, keeping them somewhat close until rooted, when they should be potted in a light soil, after which they may be grown in pots, shifting on as often as required, or planted

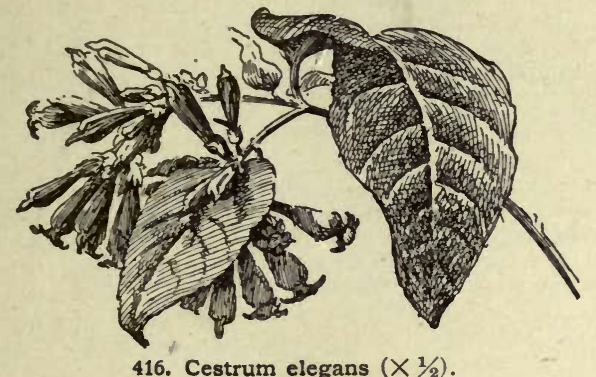

out in the open ground towards the end of May in a sunny position, where, if kept pinched back to induce a bushy growth and attention is paid to watering, they will make fine plants by the first of September. They should then be lifted and potted in a light, rich soil and kept close and shaded for a few days, and then transferred to their winter quarters. After flowering, the plants should be given a rest for a month or six weeks, gradually reducing the supply of water to induce the leaves and wood to ripen, after which they should be cut well back, the old soil shaken off, and the roots trimmed back, and then either potted again or planted out for the summer. While in the greenhouse, Cestrums are very subject to the attacks of insects, especially the mealy bug (Coccus adonidum). To keep these in check they should be given an occasional spraying of kerosene emulsion. The Cestrums are much grown in warm countries, and they bloom continuously. Following are the only species known to be in the Amer. trade

$$
\text { A. Fls. red. }
$$

élegans, Schlecht. (Habrothámnus élegans, Brongn.). Fig. 416. Tall and slender, half-climbing, the branches pubescent: lvs. ovate, lanceolate, long-acuminate, of medium size, pubescent beneath: fls. red-purple, swollen near the top of the tube, in loose clusters, which nod at the ends of the branches, the lobes ciliate. Mex. F.S. $2: 82$. - One of the commonest and best of greenbouse shrubs, blooming almost continuously. There is a form with variegated lvs.

fasciculatum, Miers. Spring bloomer, with larger fls. than those of $C$. elegans, and more compact, nearly globular fl.-clusters, the cluster subtended by small lvs. as if an involucre: lvs. ovate. Mex. B.M. 4183 (and probably the $C$. elegans, B.M. 5659.)

Nèwelli, Hort. (H. Nèwelli, Veitch). Fls, bright crimson, larger and more brilliant than those of $C$. ele gans and $C$. fasciculatum. Gn. 34:660.-A free-growing plant, originating from seed by Mr. Newell, Downham Market, Eng. Evidently an off shoot of one of the preceding species.
AA. Fls, Orange.

aurantiacum, Lindl. Of half-climbing habit: lvs. oral to orate, more or less undulate: fls. sessile, in a panicle, orange-yellow. Guatemala. R.H. 1858, p. 238.

AAA. F'ls. white, greenish, or cream-yellow.

Párqui, L'Her. Shrub, half-hardy : lvs. lanceolate, petioled, short, acuminate: fls. long, tubular, with a widespreading limb, in an open panicle, greenish yellow, very fragrant at night. Chile. B. M. 1770.

diúrnum, Linn. Quick-growing evergreen shrub: Ivs. oblong and short-acute, thickish and glabrous, shining above: fls. white, very sweet-scented by day, in axillary long peduncled spikes: fr. white. W. Ind.

noctúrnum, Linn, Shrub 6-9 ft.: branches brownish, very slender or flexuose, glabrous or nearly so: lvs. thinner, ovute or elliptic, prominently acuminate : fls. creamy yellow, very fragrant by night. Jamaica.

E. J. Canning and L. H. B.

CHENÁCTIS (Greek, gaping ray: the marginal corollas often ray-like). Compósitce. West American herbs or under-shrubs, with alternate and mostly dissected IVs., and yellow, white or flesh-colored fls. on solitary peduncles or in loose eymes. Florets of one kind, but the marginal ones with a more or less enlarged limb: involucre campanulate: receptacle flat and generally naked : pappus of scales (wanting in 1 species). Three species have been introduced as border plants, but they are little known to gardeners. Of easy culture. Prop. by seeds or division.

A. Pappus of entire or nearly entire persistent scales.

tenuifolia, Nutt. Small, tufted annual, white pubes. cent when young but becoming nearly or quite glabrous: $1 \mathrm{ft}$.: lvs. once or twice pinnately parted, the lobes linear or filiform: heads $1 / 3$ in. high, lemon-yellow. S. Calif.

Doùglasii, Hook. \& Arn. Biennial or perennial, 3-15 in. high, usually white-woolly when young: lvs. broad, pinnately parted into short and crowded, obtuse lobes: heads $1 / 2-3 / 4$ in. high, white or whitish. Mont. S. and W. -Variable.

AA. Pappus of fimbriate and deciduous scales, or even wanting.

artemisiæfolia, Gray. Tufted annual, 1-2 ft., rustypubescent and somewhat sticky : lvs. 2 or 3 , pinnately parted into short-linear or oblong lobes : heads $1 / 2$ in. high, the involucre viscid, the florets white or creamcolor. S. Calif.

L. H. B.

\section{CHENOMELES. Cydonia.}

CHENOSTOMA (gaping mouth, in allusion to the shape of the corolla). Scrophularidcece. About 30 African herbs or sub-shrubs, with simple lvs. mostly opposite, and axillary or terminal-racemose, showy fls.; stamens 4, in 2's, attached to the throat of the corolla, more or less exserted: style filiform and club-shaped, and obtuse at the apex : corolla tubular, swollen in the throat, with a 5-lobed spreading limb.

hispidum, Benth. Small perennial, with opposite, oval or oblong-toothed lvs., and blush-white, star-like fls. $1 / 4$ in. across, in dense clusters. S. Afr. J.H. III. 33:636. - An old and deserving greenhouse or pot plant, but rarely seen at present. It blooms almost continuously, the fls. sometimes hiding the foliage. Prop. by seeds or cuttings, either in fall or spring. Begins to bloom when 4-6 in. high. To be recommended for windows, and for summer vases.

CHAMEBATIA (Greek, dwarf, and bramble, alluding to its bramble-like fls.). Rosdceo. Low shrub, clothed with glandular pubescence: lvs. alternate, stipulate, tripinnatifid, persistent : fls. in terminal corymbs, white, with 5 petals and numerous stamens: fr. a small akene. One species in Calif. Ornamental shrub of agreeable aromatic odor, with graceful foliage and showy white fls. in June and July; hardy only in warmer temperate regions. . It thrives best in sandy, welldrained soil and sunny position. Prop. by seeds sown in spring and by greenwood cuttings under glass. 
foliolòsa, Benth. Two to $3 \mathrm{ft}$.: lvs. nearly sessile, oval or ovate-oblong, closely tripinnately dissected, $1 \frac{1}{2}-2 \frac{1}{2}$ in. long: fls. white, $3 / 4$ in. wide, in $4-8$-fld. corymbs. B.M. 5171 .

ALFRED REHDER.

CHAMEBATIARIA. See Sorbaria.

CHAMECERASUS. See Lonicera.

CHAMECYPARIS (chamai, dwarf, and kuparissos, Oypress; referring to its affinity). Coniferce. Evergreen trees, with opposite, scale-like lvs. in 4 rows, densely clothing the compressed branchlets: fls. monœecious, small ; pistillate inconspicuous, globose ; staminate yellow or red, oblong, often conspicuous by their abundance: cones small, globular, with $6-8$ bracts, each bearing 2 or rarely 5 , winged seeds, ripening the first season. Closely allied to Cupressus, which differs by its larger cones maturing the second year, the bracts containing 4 or more seeds, and by its quadrangular branches and minutely denticulate lvs. Five species in N. Amer. and Japan, all very valuable timber trees in their native countries. Highly ornamental evergreen trees of pyramidal habit, of which only C. spharoidea is fully hardy north, while the Japanese species are hardy in sheltered positions north to New England, and C. Lawsoniana only from New York south. They grow best in somewhat moist but well-drained, sandy loam and in a partly shaded position, sheltered against dry winds. $C$. Lawsoniana and $C$. obtusa like more dry, the others more moist situations, and $C$. sphceroidea grows well even in swamps. Prop. by seeds, sown in spring; increased also by cuttings from mature wood in fall, inserted in a sandy soil and kept in a coolframe or greenhouse during the winter; if in early spring gentle bottom

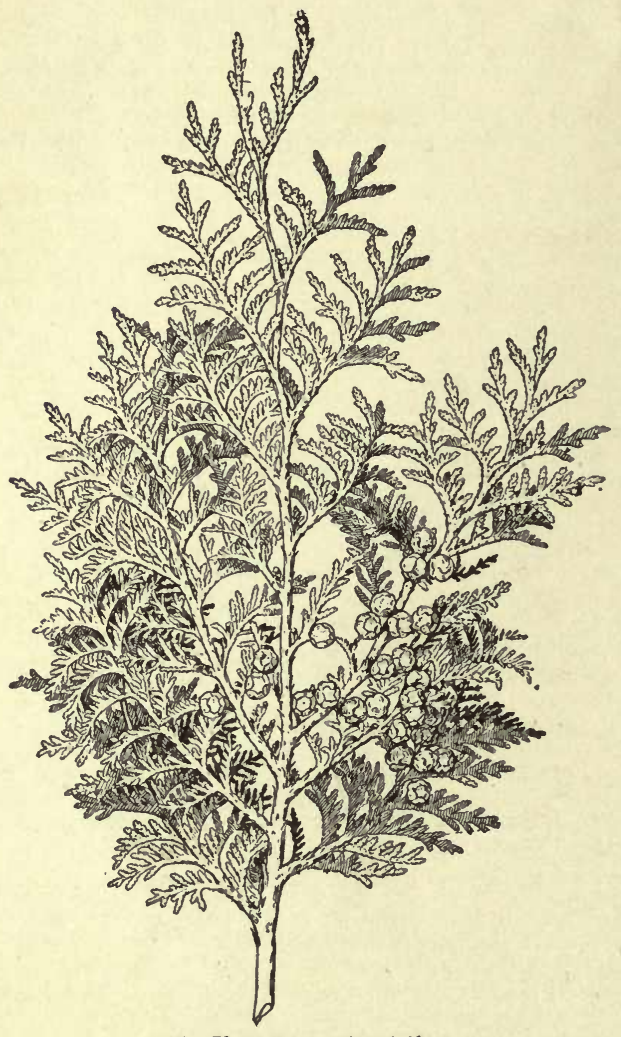

417. Chamæcyparis pisifera.

heat can be given, it will hasten the development of roots considerably. All the so-called Retinosporas and the dwarfer forms, and most of the varieties of C. Lawsoni- $a n a$, are readily increased in this way, while the typical forms of $C$. Nutkaensis, obtusa and sphoroidea do not grow well from cuttings; therefore for most varieties veneer grafting on seedling stock during the winter in

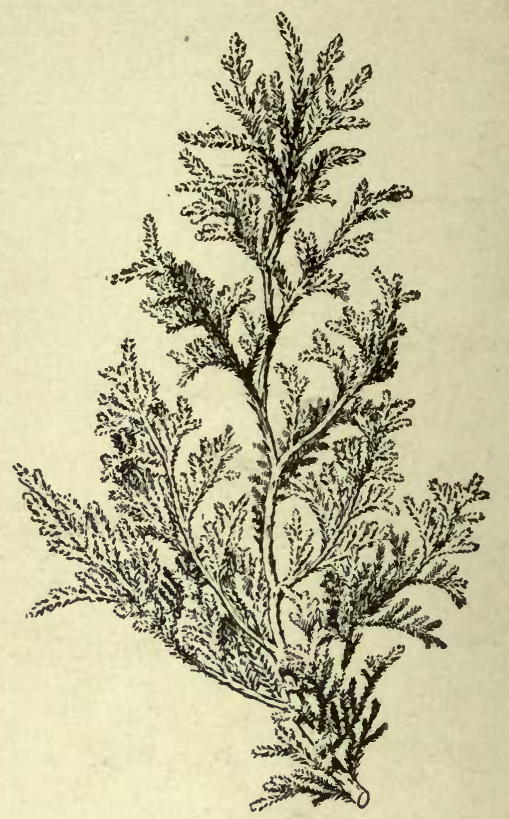

418. Chamæcyparis pisifera, var. plumosa.

greenhouse is preferred, but dwarf forms always should be grown from cuttings, as they often lose their dwarf habit if grafted. The so-called Retinosporas of the gardens, withlinear, spreading lvs., are juvenile forms, which have retained the foliage of the seedling state. There are similar forms in Thuya. For their distinguishing characters, see Retinospora. For the numerous garden forms, see Beissner, Handb. der Nadelholzk., pp. 64-99.

A. Lis.green on both sides or paler beneath.

sphæroídea, Spach (Cupréssus thuyoides, Linn.). White CEDar. Tree, to 70 or $80 \mathrm{ft}$., with erect, spreading branches : branchlets irregularly arranged, spreading, not pendulous, very thin and slender, flattened: Ivs. closely imbricate, glaucous or light green, with a conspicuous gland on the back, fragrant: cones small, 1/4in. in diam., bluish purple, with glaucous bloom. From Maine to Florida, west to Mississippi. S.S. 10:529. - Var. ericoldes, Beissn. \& Hochst. ( $C$. ericoides, Carr. Retinós pora ericoldes, Hort.). Compact shrub, of erect, dense habit : Ivs. linear-lanceolate, spreading, with two glaucous lines beneath, coloring in winter usually reddish brown. Var. Andelyénsis, Carr. (Retinóspora leptocldda, Hort.). Intermediate form between the former and the type; bluish green, and of erect growth, with loosely appressed, lanceolate lvs.; often some branchlets with lvs. of the type and some with lvs. of the var. ericoides. R.H. 1869, p. 32, and 1880, p. 36. Var. glaùca, Endl. (var. Kewéns is, Hort.). Of compact habit, very glaucous, with silvery hue. Var. variegàta, Hort. Branchlets partially colored golden yellow.

Nutkaénsis, Spach (Cupréssus Nootkaténsis, Lamb. Thuybpsis boredlis, Hort.). YeLLOW CEDAR. Tree, to $120 \mathrm{ft}$., with ascending branches, pendulous at the extremities : branchlets distichously arranged, slightly flattened or nearly quadrangular, pendulous: lvs.densely imbricate, usually dark green, acute, mostly without glands : cones subglobose, nearly $1 / 2 \mathrm{in}$. in diam., dark red-brown, with glaucous bloom. From Sitka to Oregon. S.S. 10:530. R.H. 1869, p. 48. - Var. glaùca, Hort. With very glaucous foliage. Var. péndula, Hort. Distinctly pendulous. There are some forms with variegated lvs. 
Gn.50, p.68. C. Nutkaensis is about as hardy as the Japanese species.

AA. Lvs. with glaucous or whitish marks beneath: branches with horizontally spreading ramifications.

Lawsoniàna, Parl. (Cupréssus Lawsoniana, Murr.). Tree, to $200 \mathrm{ft}$., with horizontally spreading and usually pendulous branches: branchlets frond-like arranged, fattened: lvs. closely appressed, obtuse or somewhat

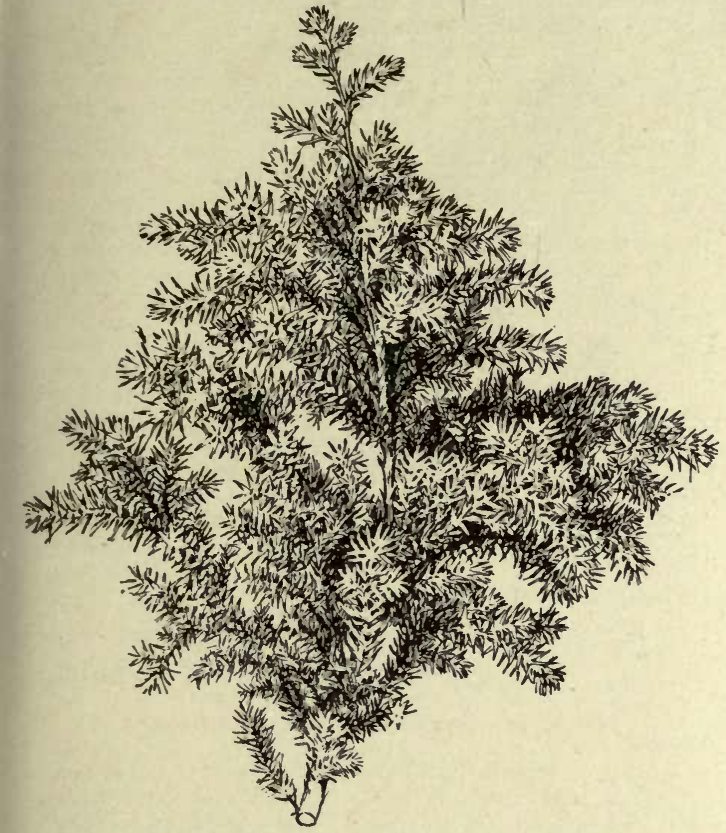

419. Chamæcyparis pisifera, var. squarrosa.

acute, usually bright green, with a gland on the back : staminate catkins brightred (yellow in all other species) : cone globose, about $1 / 3$ in. across, red-brown and often glaucous. From Oregon to Calif. S.S.10:531. Gng.2:327. - This is one of the most beautiful Conifers and very variable, about 60 garden forms being cultivated in European nurseries and collections. The following are some of the best : Var. álbo-splca, Hort. Tips of branchlets ereamy white, of slender habit. Var. Alumi, Hort. Of columnar habit, foliage very glaucous, with a bluish metallic hue. The best blue columnar form. Var. argéntea, Hort. Of slender habit, with very glaucous, almost silvery foliage. Var. erécta víridis, Hort. Dense, columnar habit and bright green foliage. One of the most beautiful varieties, but somewhat tender. Var. erécta glauca, Hort. Similar in habit, but with glaucous foliage. Var. filiformis, Hort. Branches elongated, somewhat pendulous, with few lateral branchlets, of low, globular habit. Var. glaùca, Hort. Foliage of metallic glaucous tint. One of the hardier forms. Var, grácilis, Hort. (var. gracilis pendula, Hort.). Elegant light green form, with graceful, pendulous branchlets. Var. intertéxta, Hort. Glaucous form, of vigorous growth, with remote, pendulous branches and distant, thickish branchlets. Var. lùtea, Hort. Of compact habit, young growth clear yellow. G.C. III. 20:721. Var, nàna, Hort. Dwarf, globose habit; with some variegated and glaucous forms. There are also different variegated forms with the habit of the type.

obtùsa, Sieb. \& Zucc. (Cupréssus obtìsa, Koch. Ret inóspora obtùsa, Sieb. \& Zucc.). HINoKI CYPRESS. Tree, to $120 \mathrm{ft}$, with horizontal branches : branchlets frond-like arranged, flattened, pendulous : lvs. bright green and shining above, with whitish lines beneath thickish, obtuse, and very closely appressed, with a gland on the back: cones globose, nearly $1 / 2$ in. in diam., brown. Japan. S. Z. 121. G.C. IL 5: 236 R. H. 1869, p. 97.-
Var. álbo-spica, Hort. Tips of branchlets whitish. Var. aùrea, Hort. Golden yellow. Var. breviràmea, Rehder (C. brevirdmea, Max. Var. filicoides, Hort.). Of slow growth, with short and densely frond-like arranged branchlets. G.C. II, 5:235. Var. grácilis aùrea, Hort. Graceful form, foliage bright golden yellow when young, changing later to greenish yellow. Var. lycopodioides, Carr. Low form, of somewhat irregular habit, with spreading, rigid branches and thick, nearly quadrangular, dark green branchlets. Var. nana, Carr. Low form, of slow growth, with short, deep green branchlets. Var. péndula, Beissn. (C. pendula, Maxim.). Branches elongated, thick and thread-like, pendulous, with few distant branchlets. Var. pygmæa, Carr. Very dwarf form, with horizontal, almost creeping branches, densely frond-like branched. Exceedingly interesting form for rockeries.

pisifera, Sieb. \& Zuce. (Cupréssus pisifera, Koch. Retinóspora pisifera, Sieb. \& Zucc.). Sawara CyPRESS. Fig. 417. Tree, to $100 \mathrm{ft}$., with horizontal branches: branchlets flattened, distichously arranged and somewhat pendulous: Ivs. ovate-lanceolate, pointed, shining above, with whitish lines beneath: cones globular, $1 / 4-1 / 3$ in. in diam., brown. S.Z. 122. G.C. II. 5:237. - This is, next to $C$. sphoroidea, the hardiest species, and some varieties are much cultivated, while the type is less planted. Var. aùrea, Hort. Yellow foliage. Var. filifera, Hort. (Retinospora filifera, Hort. C. obtusa filifera, Hort.). Branches elongated and slender, threadlike, gracefully pendulous, with distant branchlets and lvs. Very decorative forms. G.C. II. 5: 237. Var. plumosa, Hort. Fig. 418. Of dense, conical habit: branches almost erect, with slender branchlets of feathery appearance: lvs. subulate, pointed and slightly spreading, bright green. Intermediate between the type and var. squarrosa. G.C. II. 5:236. Var. plumosa argéntea, Hort. Tips of branchlets whitish. Var. plumosa aúrea, Hort. Young growth of golden yellow color. A very showy form. Var. squarrosa, Beissn. \& Hochst. (Retinospora squarrosa, Sieb. \& Zucc. R. leptoclada, Zucc.). Fig. 419. Densely branched, bushy tree or shrub, with spreading, feathery branchlets: Ivs. linear, spreading, glaucous above, silvery below. A very distinct and beautiful variety. S.Z. 123. R.H. 1869, p. 95, and 1880, p. 37.

ALFRED REHDER.

CHAM正DAPHNE (chamai, dwarf, and daphne, the laurel in ancient Latin, alluding to its dwarf habit and evergreen lvs.). Syn., Cassándra. Ericàcece. Leather LEAF. Low shrub with evergreen, alternate small lvs.: fls. nodding in terminal, leafy racemes: corolla urceolate-oblong, 5-lobed, with 5 included stamens: fr. a capsule. One species in the colder regions of the northern hemisphere. Low, hardy, ornamental shrub, valuable for the earliness of its pretty white fls. It thrives best in a peaty and sandy, moist soil. Prop. by seeds sown in sandy peat, only slightly or not covered, and kept moist and shady; also by layers and suckers and by cuttings from mature wood in late summer under glass.

calyculàta, Mœnch (Cas sándra calyculata, Don). Fig. 420. Shrub with spread. ing or horizontal branches, 1-3 ft.: lvs short-petioled, oblong, obtuse, slightly serrulate and revolute at the margins, dull green above and rusty-lepidote beneath: fls. short-peduncled, nodding; corolla white, oblong, about $1 / 4$ in. long. B.M. 1286 . L. B. C. $6: 530 ; 15: 1464$; 16:1582. Em. 423. - Var. angustifdlia, Gray. Lvs. linear-lanceolate, undulate and crisped at the margin. Var. nana, Lodd. One foot or less high, with horizontal branches. L.B.C. 9:862.

ALFRED REHDER. 
CHAM EDORÈA (Greek, dwarf and gift). Palmàcea, tribe Arècea. Spineless, erect, procumbent or rarely climbing palms, the trunks solitary or cespitose, slender or reed-like. Lvs. simple, bifid at the apex or variously equally-pinnatisect: lobes broad or narrow, straight or oblique, acuminate, plicate-nerved, usually callous at the base, the basal margins folded back or recurved: petiole usually cylindrical ; sheath tubular, oblique at the throat; spadices among or below the lvs., simple or paniculately branched; spathes 3 or many, alternate, sheathing, elongated, split at the apex, membranous or coriaceous, usually persistent : pistillate fls. very small : fr. small, of 1-3 globose or oblong-obtuse carpels, coriaceous or fleshy. Species about 60. Mex. to Panama.

Peat or leaf-mold, loam and sand in equal parts, with a little charcoal added, form the best soil. The species common in cultivation are quick-growing. They are well suited for planting out in greenhouse borders. The sexes are on different plants, therefore several should be planted in a group if the handsomely colored fruit is desired. All of the kinds require warm temperature in winter. Increased from seeds. Of the many species, only the following appear in the Amer. trade:

\section{A. Lvs. simple.}

ólegans, Mart. Stem strict, $6 \mathrm{ft}$., closely ringed: $1 \mathrm{vs}$. narrowly lanceolate, acuminate, straight : fr. globose. Mex. G.C. I. 33: 508 .

Ernesti-Augústi, Wendl. Stem 3-4 ft., reedy, erect, radicant at base; blade obovate, cuneate at the base, deeply bifid, coarsely serrate along the margins; petiole shorter than blade; sheath amplexicaul; sterile spadix 8-9 in., the simple branches 6-8 in., attenuate, slender : fertile spadix simple: fls. red. Venezuela. B.M. 4837. G.C. 1. 33:508.

\section{AA. Lvs. pinnate.}

B. Plant becoming of climbing habit.

desmoncoldes, H. Wendl. Lvs. 2-3 ft. long, with drooping, narrow Ifts. a foot long, and glaucous petiole : plant tending to climb after it becomes a few feet high. Mex.

\section{BB. Plant not climbing.}

C. Stem or trunk evident.

Sártorii, Liebm. Stem 8-14 ft., ringed, clothed above with leaf-sheaths: lvs. $3-3 \frac{1}{2} \mathrm{ft}$. long; petiole terete, sulcate, dilated at the base; sheath, petiole and rachis white on the back; lfts. 12 in. long, $11 / 2-2$ in. wide, alternate, falcate, acuminate, narrowed at the base. Mex.

Tepejildte, Liebm. Stem 4-6 ft. high, elosely ringed: lvs. $4 \mathrm{ft}$; lfts. 1-nerved, close, alternate, falcate, acute, narrowly lanceolate, $13-15 \mathrm{in}$. long, $1 \frac{1}{2} \mathrm{in}$. wide : rachis convex on the back, canaliculate above. Mex. B.M. 6030 .

glaucifolia, H. Wendl. Stem $20 \mathrm{ft}$ : lvs.long, plnnate; lfts. narrowed, long and slender, dark green, glaucous. Guatemala. G.F. 8:507.

Arenbergiàna, H. Wendl. (C. latifolia, Hort.). Stem slender, 5-6 ft., green : lvs. erect-spreading; lfts. 10-15 pairs, alternate and drooping, very long-pointed, plicate and many ribbed. Guatemala. B.M. 6838.

\section{cc. Stem or trunk none.}

Prínglei, Wats. Acaulescent or nearly so ; lvs. erect, pinnate, 3 ft.; lfts. $12-15$ on each side, linear-lanceolate, acuminate, $6-8$ in. long, $1 / 4-1 / 3$ in. wide ; rachis triangular; spadix simple, 8 in. long. San Louis Potosi, Mex

JAREd G. SMith and G. W. OLIVER.

CHAM五PEUัCE. Now referred to Cnicus.

CHAM ERANTHEMUM (dwarf and flower, from the Greek). Acanthdcea. Three or 4 Brazilian small herbs, allied to Eranthemum, but readily distinguished by the 4 (instead of 2 ) stamens. Lvs. large and membranaceous, entire, variously marked. Fls. showy, white or yellow, in bracteate clusters. Grown chiefly for the beautiful foliage. C. igneum, Regel (Evánthemum igneum, Lind.), is in the Amer trade. It is a low, spreading, warmhouse plant (culture of Eranthemum and Justicia), with dark green Ivs. and veins, richly banded with orange or yellow. Fls. small. F.S. 17:1722.

CHAM \& ROPS (Greek for dwarf bush). Palmàcece, tribe Corỳphea. Low, fan-leaved palms, with cespitose caudices branched from the base and clothed with the bases of the leaf-sheaths. Lvs, terminal, rigid, semi orbicular or cuneate-flabillate, deeply laciniate, the lobes narrow, bifid, plicate; no rachis ; ligule very short; petiole slender, bi-convex, the margins smooth or rough; sheath split, reticulate, fibrous; spadices short, erect compressed : branches short, densely flowered: spathes $2-4$, broad, thickly coriaceous, the lower ones split, the upper entire; bracts small, subulate; bractlets none : fls. small, yellow : fr. globose or ovoid, 3-sided toward the base, brown or yellow. Species 2. Mediterranean region. The common $C$. humilis is widely cult., and very variable. Many of the specific-made names of the genus are forms of this species. Of such cases are evidently the garden names $C$. arborescens, argentea, Canariensis, elata, elegans, farinosa, gracilis, littoralis, nivea.

Fibrous loam two parts, leaf-mold and sand one part, with good drainage. Prop. by suckers and by seeds. These are among the hardiest of all palms, and are well suited to greenhouses where a high temperature is not kept up.

hùmilis, Linn. (Phònix Hancedna, Hort.). Fig. 421. Stem 1-11/2 ft. high : lvs. ragged, fibrous ; margins of the petioles armed with stout, straight or hooked spines; blade suborbicular, truncate or cuneate at the base, rigid, palmately multifid ; segments acuminate, bifid. Mediterranean. B.M. 2152. R.H. 1892: 84 (showing habit and a colored plate of the fruit). Reaches $20 \mathrm{ft}$.

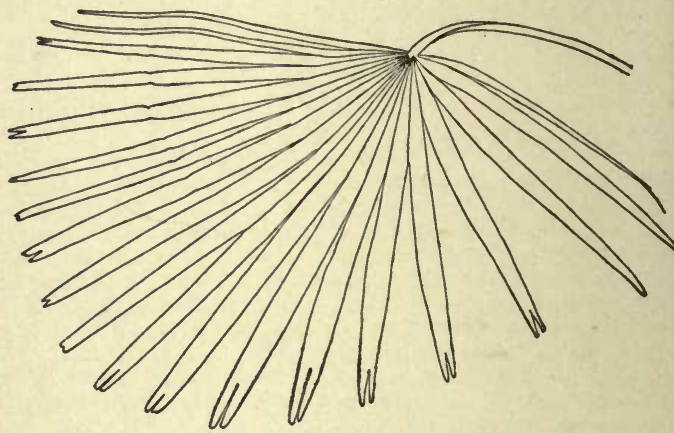

421. Chamærops humilis.

C. Bíroo, Sieb.=Livistona rotundifolia. $-C$. Býrrho, Hort. $=$ Livistona rotundifolia. $-O$. excélsa. Thunb. $=$ Trachycarpus excelsus.- O. Fórtunei, Hook. $=$ Trachycarpus. - O. hümilis $\times$ Hýstrix, Hort. Said to be a "choice garden hybrid of Florida origin."- . Hýstrix, Fras.=Rhapidophyllum Hystrix.-O. stauracantha, Hort. = Acanthorhiza aculeata.

$$
\text { Jared G. Smith and } G \text {. W. Oliver. }
$$

CHAMOMILE. Consult Anthemis

\section{CHAPMAN, JONATHAN. See Appleseed, Johnny.}

CHAPTALIA (J. A. C. Chaptal, agricultural chemist). Compósita. American low perennial herbs, with white or purplish fls. on naked scapes, blooming in spring and summer. Heads radiate, the ray-fls. pistillate, and the disk-fls, perfect, but some or all of them sterile: involucre campanulate or turbinate, of appressed and imbricated bracts: pappus of soft capillary bristles: akenes oblong or fusiform, narrowed above, 5-nerved. The only species in the Amer. trade is $\mathbf{C}$. tomentosa, Vent., of $\mathbf{N}$. Car. and S. Of this the scape is $1 \mathrm{ft}$. or less high, and the heads are purple-rayed: lvs. spatulate or lanceolate, entire or nearly so, rather thick, white tomentose beneath. Introduced as a border plant.

CHARD (ch pronounced as in charge). A form of the plant (Beta vulgaris) which has produced the common beet. Often known to horticulturists as Beta Cycla. 
See Beet and Beta. The beet plant has given rise to two geveral types of varieties: those varieties with thickened roots (the beet of America, the beet-root of European literature); and those with large and pulpy or thickened leaves (but whose roots are small and woody). The lat-

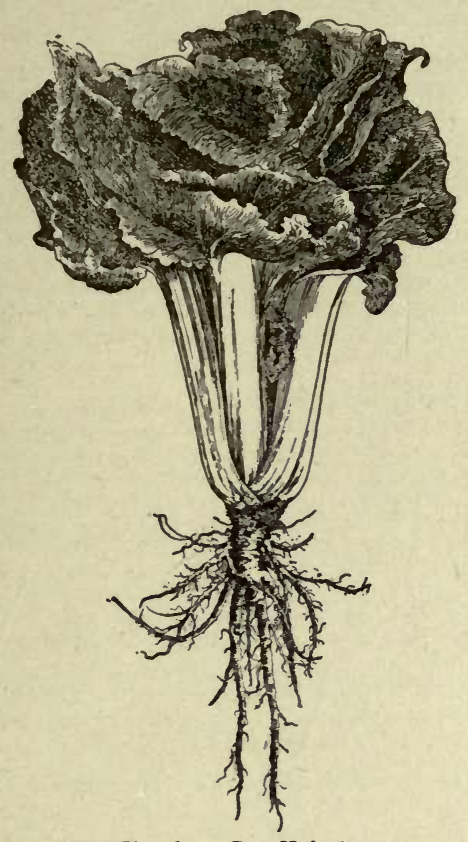

422. Chard, or Sea-Kale beet.

ter type is known under the general name of leaf-beets. These leaf-beets may be ranged into three sub-groups: (1) common or normal leaf-beets, or spinach beets, in which the leaf-blade is large and pulpy, and is used as spinach is; (2) Chard, in which the petiole and midrib are very broad and thick (Fig. 422); (3) ornamental beets, of which the foliage is variously colored.

Chard is of the easiest culture. Seed is sown in spring, as for common beets. The broad petioles, or Chards, may be gathered from midsummer until frost. These broad white stalks or ribs are used as a pot-herb; and, if desired, the leaf-blades may be cooked with them. The dish is usually more attractive, however, if only the Chards are cooked. This vegetable is also known as Sea-kale Beet and Swiss Chard.

L. H. B.

CHARLOCK. Consult Brassica ; also Raphanus.

CHASTE TREE. See Vitex.

CHEAT, or CHESS. Bromus.

\section{CHECKIRBERRY. Gaultheria.}

\section{CHEESES. Vernacular for Malva rotundifolia.}

CHEILANTHES (Greek, lip-flower, alluding to the indusium). Polypodidcea. Semi-hardy or hothouse ferns of small size, often hairy or woolly, with the sori terminal on the veins and covered with a roundish indusium. Some 60 or 70 species are known, nearly a third of which are natives of the west and southwest, one species as far east as Connecticut. They are of easy culture, enjoying a position near the glass, and disliking strong, close heat and syringing or watering overhead.
A. Lis. pentagonal-deltoid, the indusium confined to a single veinlet.

Califórnica. Mett. (Hypólepis Califórnica, Hook.). Lrs. densely cespitose from a short ereeping rootstock 2-4 in. each way, on stems 4-8 in. long, quadripinnatifid; ultimate segments lanceolate, incised or serrate. Calif. meifolia, D. C. Eaton. Lvs. cespitose, with slender brown stems 5-7 in. long, the lamina $2-3$ in. each way, 3-4-pinnatifid, with finely cut segments 1-10 of an in. wide. Mex.

AA. Lis. ternately divided, with dark polished stems.

pedàta, A. Br. Lvs. cespitose, on long (9-12 in.) stems, about 6 in. either way, the 3 divisions bipinnatifld; sori numerous, placed on both sides of the segments. Jamaica, Cuba.

AAA. Lvs. lanceolate or ovate-lanceolate.

B. Segments flat: indusia extending over the apices of several veinlets, but not continuous.

c. Surface of lvs. smooth.

microphylla, Swz. Lvs. 4-10 in. long, on stems nearly as long, from a short, creeping rootstock, bi-tripinnate: stems glossy, rusty-pubescent on the upper side. Fla. and New Mex. southward.

cc. Surface of lvs, viscid-glandular.

víscida, Davenp. Lvs. 3-5 in. long, on stems of the same length, tripinnatifid; segments toothed, everywhere glandular. Calif.

ccc. Surface of lvs. hairy, not woolly.

hírta, Swz. Lvs. densely cespitose, with short, scaly stems which are brownish, like the rachides: pinnæ numerous, rather distant bipinnatifid, the segments with much incurved margins. The lvs. are usually 6-15 in. long. Cape of Good Hope.-Var. Ellisiana is more commonly cult.

lanòsa, Wats. (C. vestita, Swz.). Fig. 423. Cespitose, with stems 2-4 in. long, slightly hairy, as are the segments : lvs, tripinnatifid, 4-10 in. long, $1-2 \frac{1}{2}$ in. wide, the pinnæ lanceolate-deltoid: indusia formed of the ends of roundish or oblong lobes. Conn, to Kan, and Ala.-Hardy.

Codperæ, D. C. Eaton. Lvs. 3-8 in. long, bipinnate, the stems covered with nearly white hairs, each tipped with a gland; pinnules roundish ovate, crenate and incised. Calif. to Mex.

BB. Segments bead-like, minute: indusium usually continuous.

D. Lvs. hairy or woolly

beneath, but not scaly.

E. Upper surface of segments smooth.

gracíllima, D. C. Eaton. LACE FERn. LVs. cespitose, 1-4 in. long, besides the nearly equal dark brown stems, bipinnate ; pinnæ with about nine pinnules, finally smooth above. Idaho to Calif.-Hardy.

Clèvelandii, D. C. Eaton. Lvs. 4-8 in. long, tripinnate, dark brown beneath, with closely imbricate, ciliate scales, which grow on both the segments and the rachides; segments nearly round, the terminal larger. Calif.

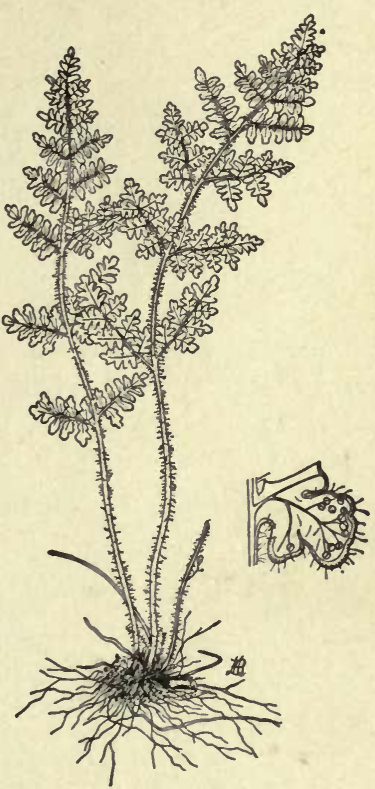
(X1/8.)
423. Cheilanthes lanosa.

EE. Upper surface of segments pubescent.

tomentosa, Link. Lvs, 8-15 in. long, on stems 4-6 in. long, everywhere covered with brownish white hairs, tripinnate; terminal segments twice as large as the lateral. Va. to Ariz.

DD. Lws. covered beneath with scales, but not woolly.

Féndleri, Hook. Lvs. 3-6 in. long besides the chaffy stems, rising from tangled, creeping rootstocks, tripinnate: rachides with broadly-ovate white-edged scales, which overlap the subglobose segments. Tex. and Colo. to Calif. 
DDD. Lis. covered beneath with both scales and wool.

myriophýlla, Desv. (C. élegans, Desv.). Lvs. densely cespitose from short, erect, scaly rootstocks, 3-9 in. long, beside the chestnut-colored scaly stems ; triquadripinnatifid : ultimate segments minute, innumerable. Tex., Ariz. and Trop. Amer.

Another native species worthy of cultivation is $C$. leucopdda, Link, from Tex., with broadly deltoid-ovate leaves.

L. M. UNDERWOOD.

CHEIRANTHUS (derivation in dispute, but probably from Greek for hand and flower). Cruciferce. A dozen or more Old World herbs, with large purple or yellow

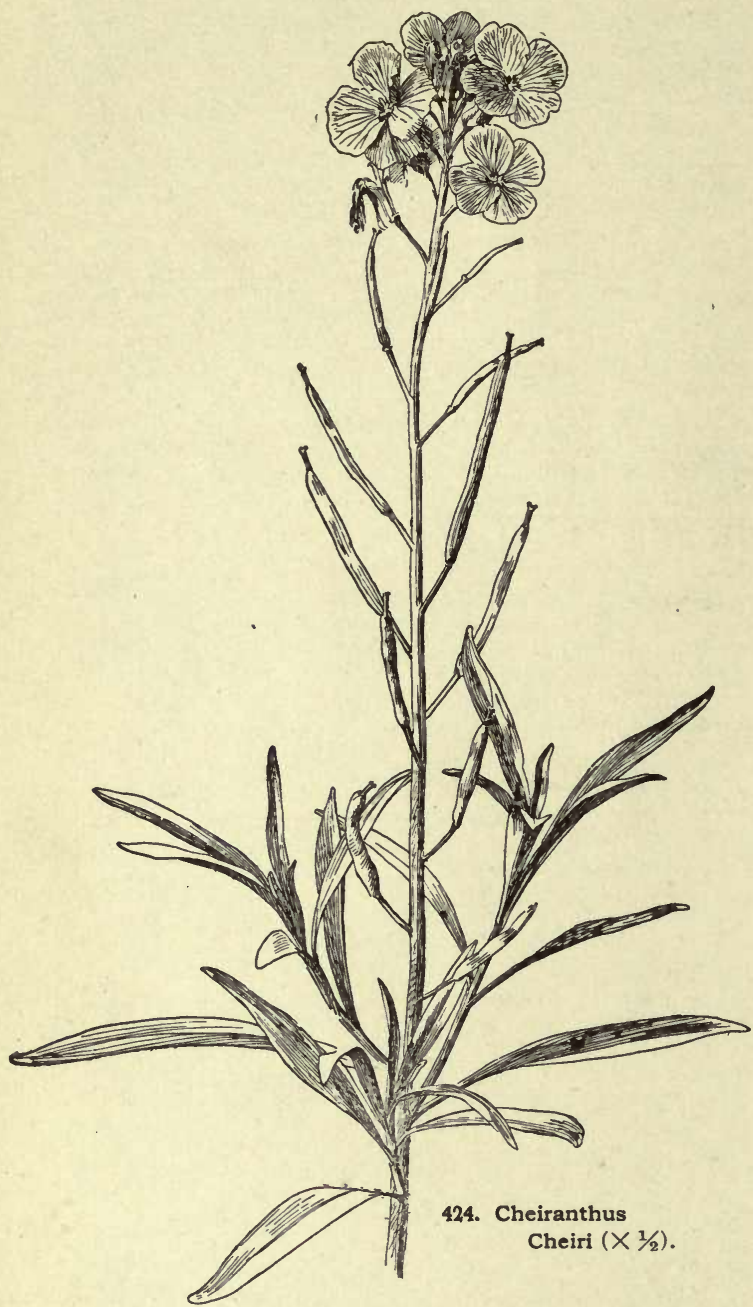

fls., entire 1vs., and a strict or upright habit. Lateral sepals sac-like at the base: valves of the pod with a strong midnerve. Much confounded with Matthiola, and the genera are not sufficiently distinct. In Cheiranthus, the lvs. are acute, stigma more spreading, pod more flattened and seeds not thin-edged.

Cheiri, Linn. Wallflower. Fig. 424. Perennial, slightly pubescent, 1-21/2 ft.: lvs. lanceolate and entire, acute : fls. large, mostly in shades of yellow, in long, terminal racemes. S. Eu. - An old garden favorite, blooming in spring. Although a woody perennial, it is best to renew the plants from seed, for they begin to fail after having bloomed one or two years. Seedlings should bloom the second vear. There are dwarf and double-fld. varieties, and innumeraioie forms in various shades of yellow, brownish, and even purple. Not prized so much in Amer. as in Eu. It thrives in any good garden soil.

C. ánnuus, Hort.= Matthiola, but early-blooming forms of C. Cheiri seem to pass under this name.-C. Ménziesii, Benth. \& Hook. = Parrya. L. H. B.

CHELIDONIUM (Greek for the swallow: the fls. appear when the swallow comes). Papaverdcece. CeLANDINE. One or two loose-growing herbs, with fl.-buds nodding, and small yellow fls. in small umbel-like clusters : sepals 2 ; petals 4 ; stamens $16-24$ : style very short, the stigma 2-lobed; pod slender, 2-valved, opening first at the bottom. C. majus, Linn., is a European plant, now run wild in waste places, and often seen in old gardens. It is biennial or perennial, with brittle, hairy stems and pinnately-parted lvs., the lobes rounded and toothed (or, in var. laciniatum again dissected). The plant has yellow juice. Lrs. light-glaucous underneath.

CHELONE (Greek for tortoise or turtle: the corolla fancied to resemble a reptile's head). Scrophulariacere. Turtle Head. Several North American perennial herbs, some of which are now sold by dealers in native plants. Allied to Pentstemon. Corolla more or less 2-lipped or gaping, white or red: anthers 4, woolly, and a rudiment of a fifth stamen : seeds winged: Ivs. opposite, serrate: fls. large and showy. Half-shaded places are preferable for these easily cultivated plants. Very dry ground should be avoided, from the fact that they are best in swampy places. In the ordinary border they should have a very liberal mulch of old manure in their growing season : 4 to 5 in. thick is none too much ; the surface roots will feed in this compost, and the plants are not so liable to suffer from drought when thus protected.

A. F'ls. in terminal and axillary close spikes.

B. Lvs. broad-ovate, long-petioled.

Iỳni, Pursh. Plant, about $2 \mathrm{ft}$. high: lvs. often cordate at base, thin, evenly serrate: fl.-bracts minutely ciliate; fls. rose-purple. Mts., N. Car. and S.

BB. Lvs. lanceolate or oblong, short-petioled.

obliqua, Linn. Two ft. or less: lvs. 2-5 in. long, broadlanceolate or oblong, very veiny, sharp- or deep-serrate: fl.-bracts ciliate: fls. deep rose. Damp grounds, Ill. and Va., $\mathrm{S}$.

glàbra, Linn. (C. obliqua, var. álba, Hort.). Une-2 or more ft. high : lvs. narrower, acuminate, appressedserrate, nearly sessile, not very veiny: fl.-bracts not ciliate : fls. white or rose-tinged. Wet grounds : common.

AA. Fls. in a loose thyrse or panicle.

nemorosa, Dough. Two ft. or less high, of unpleasant odor: lvs. ovate and acute, sharp-dentate, sessile or nearly so: fl.-bracts none; corolla 1 in. long, violet-purple. Calif. and N.

O. barbàta of gardens is Pentstenion barbatus.

J. B. KeLLeR and L. H. B.

CHENILLE PLANT. A proposed name for Acalypha hispida, better known as A. Sanderi.

CHENOPODIUM (goose-foot, alluding to the shape of the IVs.). Chenopodidcea. Widely dispersed weedy herbs, with very inconspicuous greenish fls. in glomerules $^{\wedge}$ or spikes. Spinach, beet, and orach are allied plants. Fls. perfect; calyx 4-5-parted; petals wanting; stamens usually 5 ; styles 2 or 3 . The calyx sometimes enlarges and becomes succulent and colored, enclosing the fr., and the glomerules may then look like berries, as in the common Strawberry Blite (C. capitatum, Wats., or Blitum capitatum, Linn.). This plant has been introduced to the trade as a pot-herb. It is an annual of easiest culture, with hastate-ovate toothed lvs. and fleshy red glomerules. The common pigweeds are Chenopodiums of several kinds, the commonest being C. album, Linn. This species and others are used as pot-herbs or greens in the country. The Good-KingHenry is $C$. Bonus-Henricus, Linn. It is a perennial, often cult. for its succuient spring shoots and lvs., which 
CALIFORMIL 


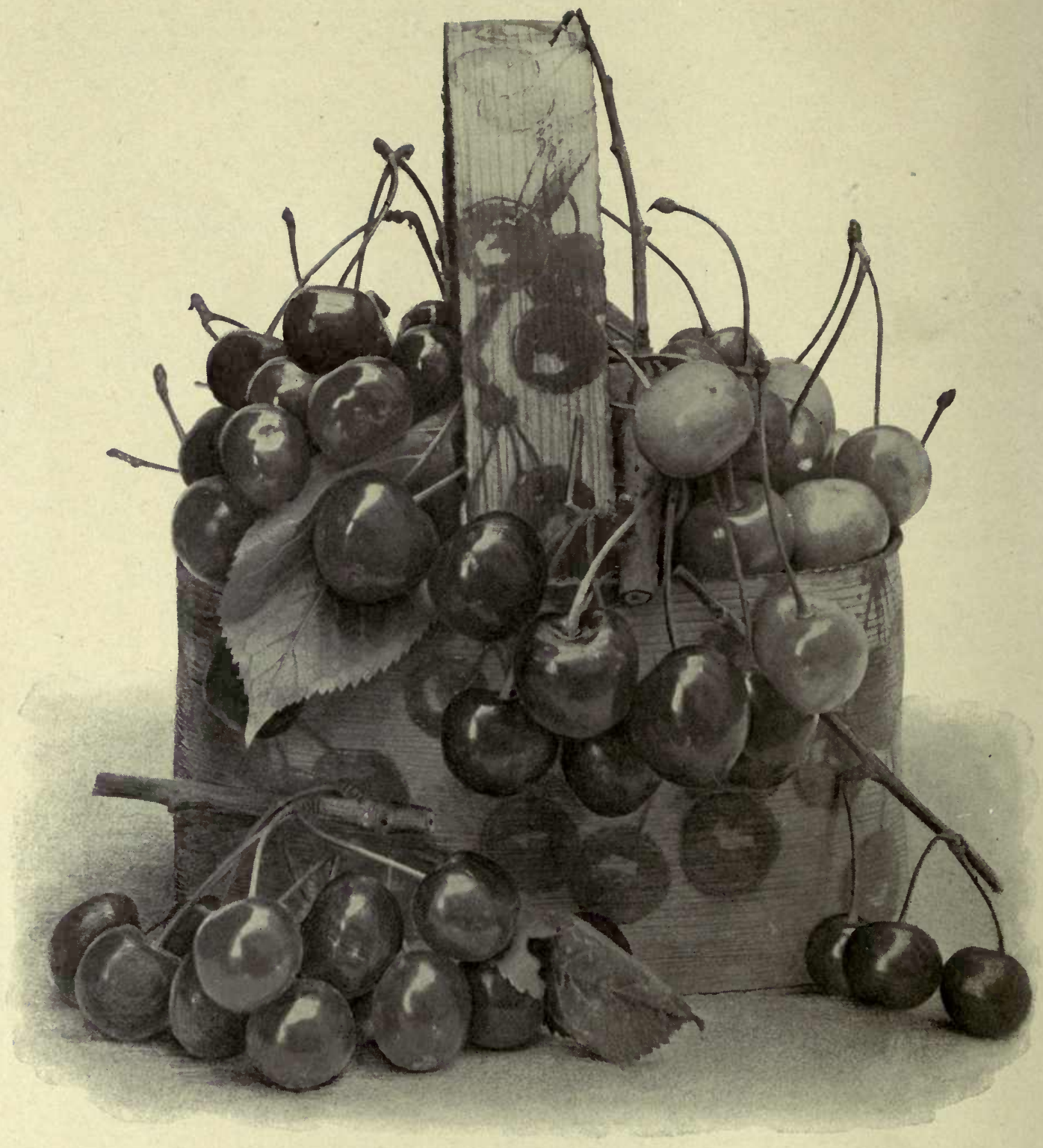

Plate V. Cherries

Showing several commercial varieties of sweet and sour kinds 
are used as greens. In American gardens it is usually known as Mercury (the name is sometimes corrupted to Markery). Lvs. triangular-orate, with very long, widespreading basal lobes; margins entire; plant mealy. The plant is of the easiest culture; $1-2 \mathrm{ft}$. high. Other Chenopodiums of economic interest are the Quinoa ( $C$. Quinoa, Willd.), of S. Amer., of which the large seeds are used as food (it is an annual, with aspect of the common pigweed, $C$, album; seeds sold by European dealers. B.M. 3641); $C$. ambrosioides, Linn., Mexican Tea, affords a medicinal extract ; $C$. anthelminticum, Linn., Wormseed, affords a vermifuge. The Feather Geranium or Jerusalem Oak of florists is C. Botrys, Linn. It is annual, glandular-pubescent and aromatic, 1-3 ft. high, with pinnatifid lvs. and long, feather-like, enduring spikes, for which it is used in vases and baskets. Pretty.

L. H. B.

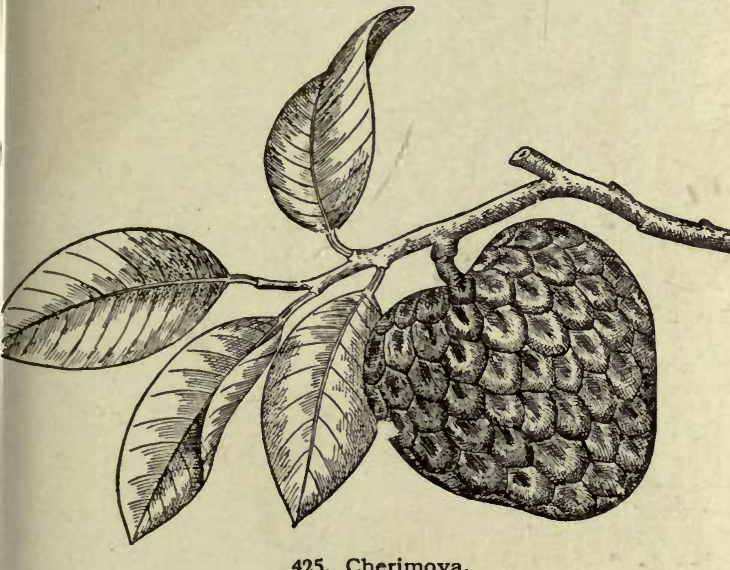

CHERIMOYA, CHERIMOYER (Anona Cherimolia, Mill.). Fig, 425. The Cherimoya is considered by many to be the finest of the subtropical fruits, and that not only by the natives of the countries where it grows, but also by Europeans. It is somewhat like the Sweet Sop (A. squamosa); both are excellent when grown in elimates that suit them; but the Cherimoya has a decided acidity, which is most agreeable and grateful to the taste. See Anona. The fruit is rounded, but irregular in shape, weighing from 3 to $5 \mathrm{lbs}$, and even double that under cultivation. There is a thin, greenish rind, marked off by somewhat raised lines into pentagonal or hexagonal spaces. Beneath is a white pulp, embedded in which are the black seeds, radiating from an internal central stalk. The white pulp is the edible portion; it is of the consistence of a corn-flour pudding. If picked when fullgrown, they will ripen gradually, and can be kept 7 or 8 days before eating.

The tree is from 15 to 30 feet in height, with a broad spreading head and pendent branches. The leaves are oblong, with velvety down on the under surface. The flowers have 3 outer petals, which are oblong-linear in shape, and keeled on the inner side; the 3 inner petals are minute, alternate with the outer. It is found growing spontaneously at certain elevations in Central America, and western South America, as far south as Chile, but it is quite uncertain where it is truly wild in all this region. De Candolle, in his "Origin of Cultivated Plants," considers it most probable that it is indigenous in Equador, and perhaps in the neighboring part of Peru. It was introduced into Jamaica in 1786 by $\mathrm{Mr}$. Hinton East, and is now of spontaneous growth in a limited area at a certain elevation on the southern slopes of the Blue mountains, corresponding fairly well with the district in which the far-famed Blue Mountain coffee is cultivated. The altitude at which it is found is between 2,500 and 5,000 feet. In Madeira, the Cherimoya has taken the place of the grape vine on many of the estates on the warm southern slopes of the island. The cultivation is systematic. The 2-year-old seedlings are grafted. The trees are pruned and trained, and manure is regularly supplied. The result of careful selection is that there are varieties with scarcely any seeds, and weighing 12 to $16 \mathrm{lbs}$. Ordinary fruits, weighing 3 to $8 \mathrm{lbs}$., are sold in the London market at $\$ 1.50$; large ones are sold at $\$ 2.50$, and even $\$ 3$.

\section{FAWCETT.}

CHERRY. Cultivated tree Cherries have probably sprung from two European species, Prunus Avium, Linn, and Prunus Cerasus, Linn. The domesticated forms of Prunus Avium are characterized by a tall, erect growth (Fig. 426); reddish brown, glossy bark, which separates in rings; flowers generally in clusters on lateral spurs, appearing with the limp, gradually taper-pointed leaves ; fruit red, yellow, or black, generally sweet, spherical, heart-shaped, or pointed ; flesh soft or firm. Sour Cherries are lowheaded and spreading (Fig. 427); flowers in elusters from lateral buds, appearing before the hard, stiff, rather abruptly pointed, light or grayish green leaves. The following is the latest classification (Bailey, Bull. 98, Cornell Exp. Sta.):

Prunus Avium has four representatives in the United States:

I. The Mazzards, or inferior seedlings; fruit of various shapes and colors; common along roadsides. In the middle Atlantic states, the wild Mazzard trees often attain great age and size, particularly in the Delaware-Chesapeake peninsula (Fig. 428).

II. The Hearts, or heart-shaped, soft, sweet Cherries, light or dark, represented by Black Tartarian and Governor Wood.

III. The Bigarreaus, or heart-shaped, firm-fleshed, sweet Cherries, like the Napoleon and Windsor.

IV. The Dukes ; light-colored, somewhat acid flesh, such as May Duke and Reine Hortense.

From Prunus Cerasus two classes have sprung:

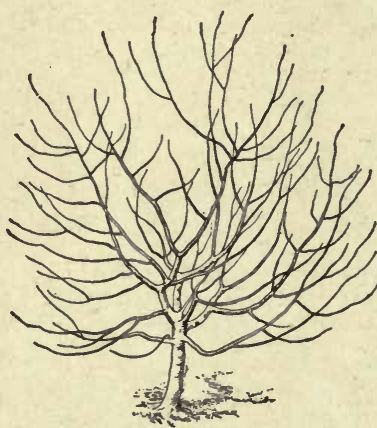

I. The Amarelles, or light - colored sour Cherries, with colorless juice, represented by Early Richmond and Montmorency.

II. The Morellos, or dark-colored sour Cherries, with dark-colored juice, like the English Morello and Louis Philippe.

The following species also have horticultural value: Prunus Mahaleb, an Old World type, hardier and smaller, on which other Cherries are largely worked; Prunus Pennsylvanica, the native
427. Low-headed and spreading growth of Sour Cherry. wild red, pin, or bird Cherry, whose hardiness may adapt it as a stock for the Plains states; Prunus Bessey $i$ and Prunus pumila, the native sand or dwarf Cherries, the former represented by the Improved Dwarf Rocky Mountain Cherry. See Prunus.

The Cherry is not cultivated as a leading industry east of the Rocky mountains, except in western New York, where the sour varieties are grown for canning. The sweet Cherry is confined mostly to door-yard and fencecorner plantings. Sour kinds are found in orchard blocks in New York, New .Jersey, Pennsylvania, Ohio, Michigan, Indiana, Illinois, Kansas and Nebraska. Sweet Cherry culture, however, is adapted to the states between the 
39 th and 44 th degrees of latitude and the 68 th and 86 th degrees of longitude, and to contiguous areas having similar climatic conditions. Spontaneous forms of it attain great size on the Chesapeake peninsula (Fig. 428). The sour Cherry may be grown with profit between the 35 th and 45th degrees of latitude and the 68th and 100th degrees of longitude.

The Mazzard is the best stock for both sweet and sour Cherries in the east. The Mahaleb is more widely used for the sour kinds, however, as it is easier to bud, and it is free from leaf blight in the nursery. The Mazzard forms a better root system, stronger union, a longer lived tree, and is sufficiently hardy. For the Plains states the hardier Mahaleb stocks should be used.

The Cherry likes an elevated, naturally light, dry, loamy, retentive soil. The sour kinds need more mois ture, and will thrive in heavier land. A soil not natur ally dry may be corrected by under-draining, and on light, dry knolls, the moisture capacity may be increased by green manures and surface tillage.

The sweet Cherries should be set 28 feet to 30 feet apart each way; the sour kinds, from 16 feet to 18 feet.

The trees are generally set at two years from the bud.

The sweet kinds are started with 3 to 5 main arms, with no central leader, about $3 \frac{1}{2}$ feet high, and the branches are pruned to side buds for a few years to induce a spreading, rather than a spire-like form. The top of a sour Cherry is made like that of a peach tree.

Plow the Cherry orchard lightly in the early spring, and cultivate it every ten days, or after every rain, till the middle of June or the first of July. Seed at the last cultivation with a winter cover-crop. Stimulate the trees with leguminous cover-crops when needed, but the sweet Cherry is a gross feeder and a rapid grower, and undue stimulation must be avoided. Keep the orchard in sod and pasture it with sheep, along the southern and western limits of profitable 'sweet Cherry culture, and withhold nitrogenous manures.

Nitrogen, potash, and phosphoric acid are the three essential fertilizers. Nitrogen may be supplied in legu minous crops; potash as muriate, at 150 lbs. to $300 \mathrm{lbs}$. and phosphoric acid in dissolved rock, at $300 \mathrm{lbs}$. to 500 lbs per acre.

Cherries should be picked by the stems into small baskets a few days before ripe. Sort out all stemless, small and imperfect fruits. Face the perfect Cherries in small, attractive boxes or baskets, and pack these in small cases or crates. The choicer the fruit, the more strikingly it should be displayed. Guard against breaking the fruit spurs in picking the sweet Cherries. Fruit for canning is less laboriously packed, but may be as carefully picked.

The profits depend on the varieties and markets, but

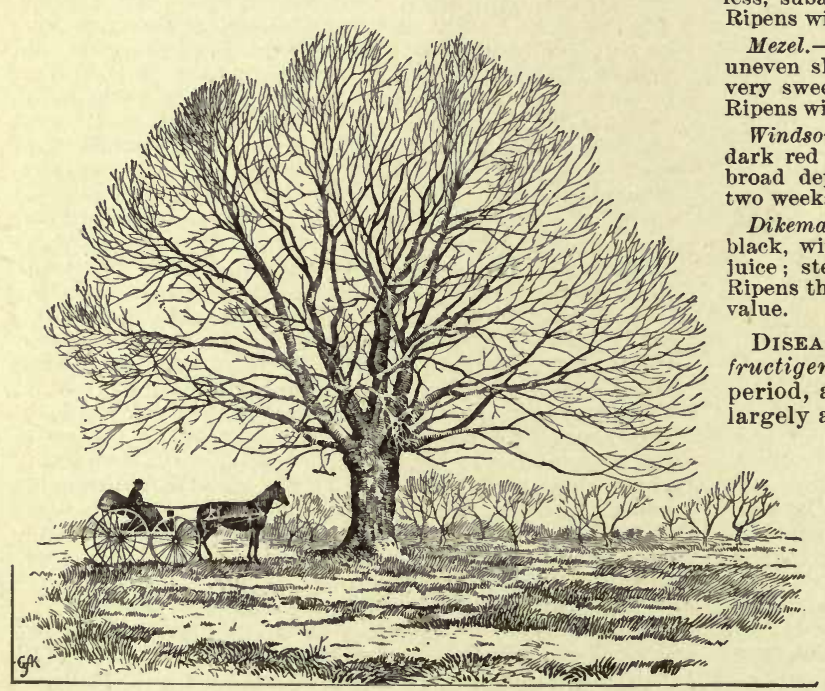

428. Old Sweet Cherry tree on the Chesapeake peninsula. largely on the personality of the grower, and on his skill as a salesman. The range of profit for the sour Cherry is from $\$ 30$ to $\$ 100$ per acre, and from $\$ 50$ to $\$ 300$ or more for the sweet.

The varieties adapt themselves to a wide range of territory. An imperative need, however, is the development of varieties with striking features for local adaptation. In the prairie states and the extreme north, the hardier Amarelles and Morellos comprise the profitable kinds. Formally the dark-colored, more acid Morellos were most sought after; now the milder Amarelles are demanded by both canners and consumers. In the following lists, the varieties are named more for the purpose of illustrating the different types than for recom. mending specific varieties.

Amongst Amarelles, the Early Richmond and Montmorency are the leading types.

Early Richmond (Fig. 429).-Size medium; pit large; light red; poor quality; vigorous growth. Ripens June 20 in New York.

Montmorency.-Large, broad, flattened ; pit medium; light red; flesh nearly colorless : juice moderately sour; vigorous growth ; generally productive. Two weeks after Early Rich mond. Most valuable Amarelle for the east.

Among the Morellos, Ostheim, Louis Philippe and English Morello are important types.

Ostheim (Fig. 430).-Dark red; roundish; flesh dark, tender; juice mild, dark; productive; hardy; growth slender. A week after Early Richmond, smaller. Too early for the east.

Louis. Philippe.-Size of Montmorency, and ripens with it; round; acid; skin and flesh dark. Rather shy bearer in the east, but valuable in the west.

English Morello.-Two weeks later than Montmorency; more open, drooping habit: fruit medium, roundish; red-black; very sour, slightly astringent; flesh and juice dark, purplish crimson.

Among the sweet Cherries, the firm-fleshed red or black Bigarreaus are the most profitable. The light Bigarreaus and Hearts are more susceptible to the fruitrot, and sell less readily. Representative types of Heart and light Bigarreau Cherries are the following:

Black Tartarian. - The most valuable Heart Cherry. Productive; vigorous, hardy, early ; large : dark red or black; flesh dark purplish; very juicy, sweet.

Napoleon (Fig. 431).-One of the best light Bigarreaus, Fruit large; flesh hard, brittle, colorless; light lemon yellow, with reddish cheek; heavy bearer; rots if not picked before ripe; splits in wet weather. A week before Black Tartarian.

From the dark Bigarreaus the following are among the best types:

Robert's Red Heart.-Bright, dark red, with an under motling; as large as Napoleon; tlesh pinkish; juice nearly coloress, subacid; heavy, regular bearer in Hudson river valley. th Napoleon.

ezel.-Large, heart-shaped obtuse, flattened at both sides neven skin, dark red to black ; firm, but heart-like; juicy Ripens with Napoleon.

Vindsor-Large ; roundish-oblong; firm ; juicy; mottled red; flesh pinkish white; stem medium, set in slight, broad depression; heavy bearer, vigorous, upright. Ripens weeks after Napoleon. Very profitable.

Dikeman. - Large, heart-shaped, obtuse, flattened on one side , with extremely firm, reddish flesh; subacid, reddish ce ; stem medium, in a slight, broad depression ; vigorous. pens three weeks or more after Windsor. A variety of great

Diseases AND 1NSECTS. - The brown rot (Monilia metigena), which attacks the fruit at the ripening period, and particularly during sultry weather, can be argely avoided by picking the fruit a few days before ripe. It may also fatally attack the flowers, leaves and twigs. In localities where the Cherry blooms, but does not fruit, the trees should be sprayed with Bordeaux mixture before the buds unfold, again when the fruit is set, and two or three times thereafter, with a colorless fungicide.

Black knot (Plowrightia morbosa, Sacc.). See under Plum.

Leaf blight (Cylindrosporium Padi, Kurst). See under Plum.

Powdery mildew (Podosphara oxycantha, 
De Bray) is often severe in the sour Cherry, but can be checked by thorough applications of a fungicide.

The aphis (Myzus cerasi, Linn.) appears in the early part of the season on the young shoots, the leaves, the stems, and less frequently on the body of the fruit of the sweet Cherries. It excretes honey-dew abundantly. The leaves curl upward and inward. Spray with kerosene emulsion, 1 part to 6 of water; or with fish-oil soap, 1 pound to 6 gallons of water, before the leaves curl.

The curculio (Conotrachelus nenuphar). See same on Plum.

Climatic injuries. - Sun scald and bursting of the bark. -The sweet Cherry is liable to a fatal injury from sun-scald in the south and prairie states. The trouble occurs in the spring, when the rays of the sun cause alternate freezing and thawing of the growing tissues on the
429. Early Richmond Cherry $(\times 1 / 2)$. south and west sides. In these localities, the bark of the tree frequently bursts open, and large quantities of gum exude. A rich garden loam, a summer drought followed by fall rain, excessive wood stimulation, violent changes of temperature in the winter, or other factors unfavorable to the maturing of the wood, aggravate the difficulty. The bursting of the bark is probably caused by the freezing and thawing of the tissues under these unfavorable conditions. Both troubles are more injurious to trees with exposed trunks. A low-headed and spreading top, soils not too rich, and cultural methods which favor the early maturity of the wood, lessen the danger. The trunks may also be protected by a board, matting, or screen of some kind on the sunny side during the spring months.

G. Harold Powell.

The Cherry in California. - In commercial importance, the Cherry is least of the fruits of the temperate zone grownin California on a commercial scale. This is not because the finest Cherries cannot be grown, but because the avenues for the disposition of the product are not as wide as for other leading fruits. Recently there are indications that these avenues will be widened, for last year (1898) about 300 car loads were profitably shipped in a fresh state to eastern markets, and a product of 150,000 cases of canned Cherries was disposed of to advantage; but until it is demonstrated that such distant demands will increase, present plantations will not be largely extended. Cherries are costly in picking and packing, and to incur the chances of a local market, over supplied when ever the trees do their full duty, the grower does not enjoy. Cherry drying has never seemed warranted on a large scale, because of the large amount of labor required to the pound of product; and the grower has had no recourse when the canner and local consumer would only pay the cost of picking and boxing. A good shipping demand seems, therefore, the measure of the extension of California's Cherry interest, and the early
ripening of the fruit, which permits its sale during the blooming season of eastern Cherry trees, is the leading surety of such demand. On several occasions early varieties have been shipped from the Vacaville district overland, on March 31, but the usual opening date is about two weeks later, and thence onward later varieties, and from later regions, may be shipped until July, if found profitable.
But, though there is plenty of good land upon which to multiply the present total of half a million trees, the Cherry regions of California are restricted. It is one of the most exacting of all trees, and is only profitable when its requirements are respected: About one-half of the present acreage lies in valleys opening upon the bay of San Francisco, where deep and moist, but well drained alluvial soil fosters strong and sound root-growth, and modified atmospheric aridity favors leaf and fruiting. On similar deep and moist soils, however, the tree enters the hot interior valleys to certain limits, chiefly along the river bottoms. It abhors dry plains. In dry air it usually refuses to fruit, although if the soil be moist, it may make stalwart tree growth. In foot-hill valleys it sometimes does admirably, both in growth and fruiting, and in mountain valleys, above an elevation of 2,000 feet, on good soil, and in the greater rainfall, and even with the snow flurries, which are experienced every year at proper elevations, the tree becomes very thrifty and profitable to the limits of local markets. The tree seems to have no geographical limitations in California; whereever suitable soil and weather conditions occur, it accepts the situation - the Dukes and Morellos succeeding under conditions too trying for the Hearts and Bigarreaus, but the latter comprise all the varieties that are of commercial account.

Cherry trees are grown by budding upon Mazzard and Mahaleb seedlings - the latter chiefly imported. It is cus-

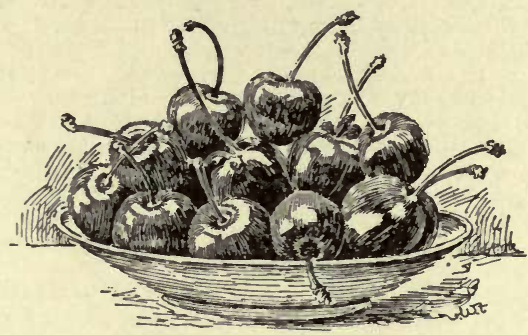

431. Napoleon Cherry $(\times 1 / 3)$.

tomary to plant out in orchards at the end of the first year's growth from the bud, though 2-year-old Cherry trees can be more successfully handled than other 2 year-olds. The trees are headed at 1 to 2 feet from the ground, eut back to promote low branching for two years, and then allowed to make long branches, and not usually shortened-in, so long as thrifty and healthy. The tree, in a good environment, is, however, a very hardy tree, and will endure pruning to almost any degree. We have many trees which have made a very broad but not usually high growth, bearing 1,000 lbs. of fruit to the tree, and a few others which have even doubled that figure, while others have been dwarfed and trained en espalier. The commercial orchards are, however, uniformly of low trees, approximately of vase form in exterior outline, and with branches curving outward without shortening.

The Cherry is very readily grafted over by the usual top-grafting methods, and large orchards have been thus transformed into varieties more acceptable for canning or shipping. Comparatively few varieties are grown. Early Purple Guigne, Guigne Marbre, and Knight's Early Black are grown in early ripenilg localities. Black Tartarian and Lewelling are the main stay for black Cherries. The Napoleon Bigarreau (locally known as Royal Ann) is the ideal for a white Cherry, and almost excludes all others, though the Rockport Bigarreau has some standing. Of all the varieties grown, the Black Tartarian and Napoleon Bigarreau, constitute 70 per cent of the crop, and probably 90 per cent of the amount marketed.

California-grown Cherries attain large size; the canner's requirement for fancy fruit is a diameter not less than $7 / 8$ of an inch, and for No. 1, not less than $3 / 4$ of an inch. Wholesale prices usually range from $\$ 40$ to $\$ 60$ per ton for black and $\$ 80$ to $\$ 120$ for white, but this 
year (1899) canners have paid as high as $\$ 160$ per ton for white Cherries. The higher rates can only be expected during years of short crops.

EDWARD J. WICKSON.

CHERVIL. A term applied to two umbelliferous plants which produce edible parts, neither of which is well known in America. The name is sometimes applied, also, to the sweet cicely.

Salad Chervil or Leaf Chervil is Scandix cerefolium, Linn., a native of S. Eu. It is annual. The neat and aromatic lvs. are used like parsley, which they much resemble. The lvs. are decompound, with oval cut leaflets; and there are varieties with much cut and curled foliage. The cultivation of Salad Chervil presents no difficulties. Leaves are ready to use in 6 to 10 weeks from seed sowing, and any good garden soil is congenial. It thrives best in the cooler and moister part of the year.

Tuberous or Turnip-rooted Chervil is Chorophyllum bulbosum, Linn., of S. Eu. It is biennial or plur-annual, like the radish and carrot. The roots are like small carrots in shape (4-5 in. long), but are gray or blackish, and the flesh is of different flavor. The roots are eaten as carrots are, either boiled or in stews. The one difficulty in the growing of Tuberous Chervil is the fact that the seeds germinate very tardily, or even not at all, if kept dry over winter. It is customary, therefore, to sow them in the fall, although they do not germinate unti spring. If they are to be reserved for spring growing, they should be stratified (see Seedage) or kept in sand. In four or five months after germination, the roots are fit to use, although they improve in quality by being left in the ground.

\section{CHESS, or CHEAT. Bromus.}

L. H. B.

CHESTNUT. Three species of tree or true Chestnuts are cultivated in this country for fruit,-the European Castanea sativa, the American Castanea Americana. the Japanese Castanea crenata. (See Castanea). The horticultural characters which distinguish these three types are as follows:

European Chestnuts. - Tree large, with a spreading but compact head, stocky, smooth-barked twigs and large glossy buds of a yellowish brown color; leaves oblong lanceolate, abrubtly pointed, with coarse sometimes in curved serrations, thick and leathery, generally pubescent beneath when young, but green on both sides when mature. Burs very large, with long, branching spines, and a thick, relvety lining. Nut larger than American Chestnut, sometimes very large, shell dark mahogany brown, pubescent at tip, thick, tough and leathery; ker nel enclosed in a thin, tough and astringent skin : quality variable from insipid, astringent to moderately

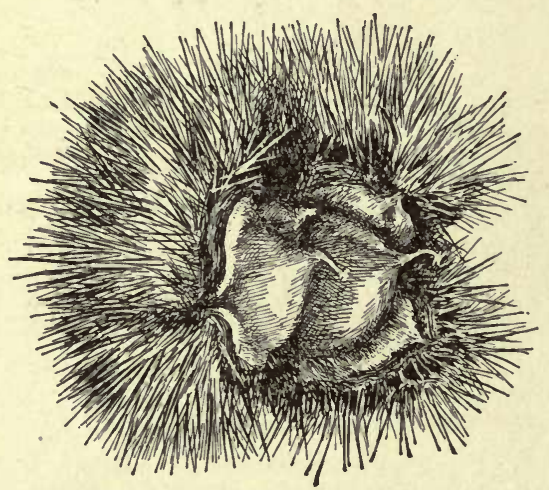

432. Native wild Chestnuts. Nearly natural size.

sweet. The leaves remain on the trees until late in autumn, but are more susceptible to the attacks of fungi than the American and Japanese species. At least one variegated and one cut-leaved variety are grown as ornamentals. This species is variously known as European, French, Spanish and Italian Chestnut (Castanea sativa), and Sweet Chestnut of English writers. It is an inhabitant of mountain forests in the temperate regions of western Asia, Europe and north Africa. Esteemed for its nuts in Spain, France and Italy, where they have constituted an important article of food since an early day. Introduced to the United States by Irénée Dupont, at Wilmington, Del., in 1803, though recorded by Jefferson, under the designation "French Chestnut," as grafted by him on native Chestnut near Charlottesville (Monticello), Va., in 1773.

American Chestnut (C. Americana).-Fig. 422. A tall straight, columnar tree, in forests reaching a height of $100 \mathrm{ft}$. and a diameter of 3 to $4 \mathrm{ft}$.; when grown in the

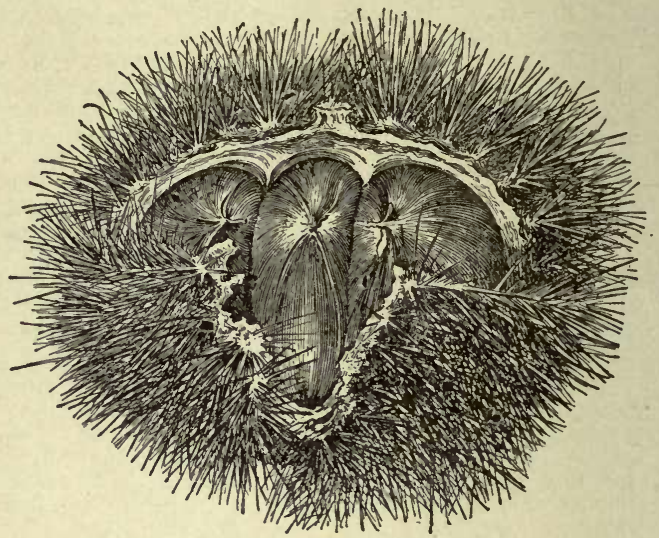

433. Japanese Chestnuts $\left(X \frac{1}{2}\right)$.

open, forming a low, round-topped head of slightly pendulous branches. Leaves thinner than in Castanea sat iva, oblong-lanceolate, acute, long pointed at the apex, coarsely serrate except toward the wedge-shaped base, green and glabrous on both surfaces, changing to bright, clear yellow late in autumn. The staminate flowers open in June or July, after leaves have attained full size, and exhale a sweet, heavy odor, disagreeable to many persons, and sometimes causing symptoms of hay fever. The 2- or 3-flowered involucres of pistillate flowers are on short, stout peduncles at the bases of androgynous aments which bear toward their tips scattered clusters of staminate flowers. Burs smaller and spines sharper than in C. sativa. The nuts, usually 2 or 3 , rarely 5 to 7 , are usually broader than long, and much compressed by crowding, though sometimes nearly oblong and approaching cylindrical. They are of a bright brown color, covered at the apex with thick, pale tomentum, which sometimes extends nearly to the base of the nut. The nuts are sweet and agreeable in flavor, the best among Chestnuts, and are marketed in large quantities from the forests of the Appalachian region, eastern North America, Me. to Ga., westward to Michigan, Mississippi and Louisiana. Gradually receding from its southern areas from causes not yet understood. A few selected forms have been propagated by grafting.

Japanese Chestnut ( $C$, crenata) - Fig. 433. A dwarfish, close-headed tree of slender growth, said to attain a height of $50 \mathrm{ft}$. in Japan, with small buds; leaves smaller than other Chestnuts, lanceolate-oblong, usually pointed, with a truncate or cordate base, finely serrated, with shallow, sharp-pointed indentations, whitish tomentose beneath, pale green abore, less subject to injury by fungi than other species. Burs small, with a thin, papery lining and short, widely branching spines. Nuts large to very large, glossy, usually 3 , sometimes 5 or 7 in a bur, usually inferior to the other Chestnut in quality, though good when cooked, and in a few varieties excellent in the fresh state. Many cultural varieties are recognized. Introduced to the United States in 1876 by S. B. Parsings, Flushing, N. Y.

Aside from these three types, there are certain dwarf and small-fruited Castaneas known as Chinquapins. The two native Chinquapins may be contrasted as follows: 
Common or Tree Chinquapin (Castanea pumila).Fig. 434. A shrub 4 or 5 feet tall, rarely a tree, attaining a height of 50 feet, with slender branchlets marked with numerous minute lenticels, and coated with a pale tomentum, which disappears during the first winter. Leaves oblong, acute and coarsely serrate at apex, bright yellowish green, changing to dull yellow before falling in autumn. Flowers strong-smelling, the catkins of staminate ones appearing with the unfolding leaves in May or June, the spicate, androgynous aments later, with pistillate flowers in spiny involucres, producing solitary, cylindrical nuts $3 / 4$ to 1 inch in length and $1 / 3$ inch in diameter, with sweet seeds. This species occurs in dry lands from southern Pennsylvania to Florida and Texas, and its nuts, which ripen earlier than the American Chestnut, are esteemed for food and marketed in considerable quantities. Apparent intermediates between this species and the American Chestnut, probably of hybrid origin, are reported from several localities in Virginia and Tennessee. This species attains truly arborescent proportions in southern Arkansas and eastern Texas. The shrub form is sparingly introduced to cultivation, and is being somewhat used in its native regions as a stock on which to graft improved Chestnuts. It promises to become useful for this purpose, but has the troublesome habit of throwing up numerous suckers or stolons. One named variety, the Fuller, has been published. Fig. 434 is adapted from the Nut Culture bulletin of the U. S. Dept. of Agric.

Bush Chinquapin (Castanea alnifolia).-A shrub, rarely more than $3 \mathrm{ft}$. in height, forming small thickets, by means of stolons, in sandy barrens, South Atlantic states, westward to Lousiana and Arkansas. Distinguished from $C$. pumila by larger, oval-lanceolate, mostly obtuse leaves, which are but slightly tomentose beneath, and by its larger nuts, which ripen earlier.

The cultural range of Castanea in America is not well defined, but extends from Florida and Texas to Massachusetts and Wisconsin, and on the Pacific slope. The 3 species cultivated in America thrive best on dry, rocky or gravelly ridges or silicious uplands, failing on heavy clays and on limestone soils unless deep, dry and rich.

Propagation of species is by seeds. Certain types reproduce their striking characteristies in their seedlings, but varieties are perpetuated by grafting; occasionally by budding. Seeds for planting should be free from insect larvæ, and should not be allowed to dry out before planting. They may be planted in drills in fall on deep and well-drained loam, or, to avoid damage by rodents, may be stratified in damp sand until spring. Nuts held in cold storage at $15^{\circ} \mathrm{F}$. from October to April have germinated well at Washington, D. C. Young trees destined for removal to orchard should be transplanted in nursery at one year old, to promote symmetrical development of root system. Grafting may be done on any of the species of Castanea, and on some of the oaks, notably the Chestnut Oak, Quercus Prinus, though the durablity of grafts on the oak is questionable. Where the Chestnut is indigenous, bearing orchards of improved varieties are quickly secured by cutting down and removing the timber and grafting the young sprouts which spring up in abundance about the Chestnut stumps (Fig. 435). Recently the Chinquapin has been similarly used with good success where Chestnut does not occur. Grafting may be by splice method on 1-year-old seedling roots ; by splice or cleft at crown on 2- or 3-year trees in place; or by veneer, splice or cleft methods on 1- to 3 -year-old sprouts or branches. Top-working of old trees is uncertain and only practiced in special cases. Cions should be dormant, and work may be done at any time after freezing ceases, but in trunk and branch grafting best results are obtained by most grafters if work is done alter leaves begin to unfold. Two- or 3 -bud cions are preferred. The fitting of cion to cleft or splice and the waxing should be carefully done. If strips of waxed muslin are wrapped about the stubs the danger of loss by summer cracking of wax is lessened. In cleft-grafting young sprouts or seedlings, the stub should be cut 2 or 3 inches above the departure of a branch, to prevent too deep splitting of cleft. Two or three weeks after growth begins the waxing should be inspected and repaired if cracked. If grafts make rank and brittle growth they should be checked by pinching, and if in exposed situations, tied to stakes to prevent breaking out of cions. Budding is sometimes practiced, usually by use of dormant buds inserted in shoots of previous year, when the bark "slips" after growth has begun in spring.

The Chestnut is admirably adapted to ornamental planting, either singly or in groups on suitable soils. The native species is successfully used as a roadside tree in many sections outside of its natural range. It requires a space of at least 40 feet for development when thus used; the European species 30 feet and the Japanese 20 feet. If in orchard, the last mentioned may be planted as close as 20 feet, and thinned when the trees begin to crowd, thus securing several crops of nuts from land otherwise unoccupied.

CARE OF ORCHARDS. - Planted orchards are yet few in America, most of the extensive commercial efforts having consisted in the grafting of sprouts on rough lands where the American Chestnut is indigenous. On such lands no cultivation is attempted, the brambles and undesired sprouts being held in check by occasional cutting in summer, or by pasturing with sheep. Much care is necessary to protect against damage of the sprouts by fire on such land. Clean cultivation, at least during the

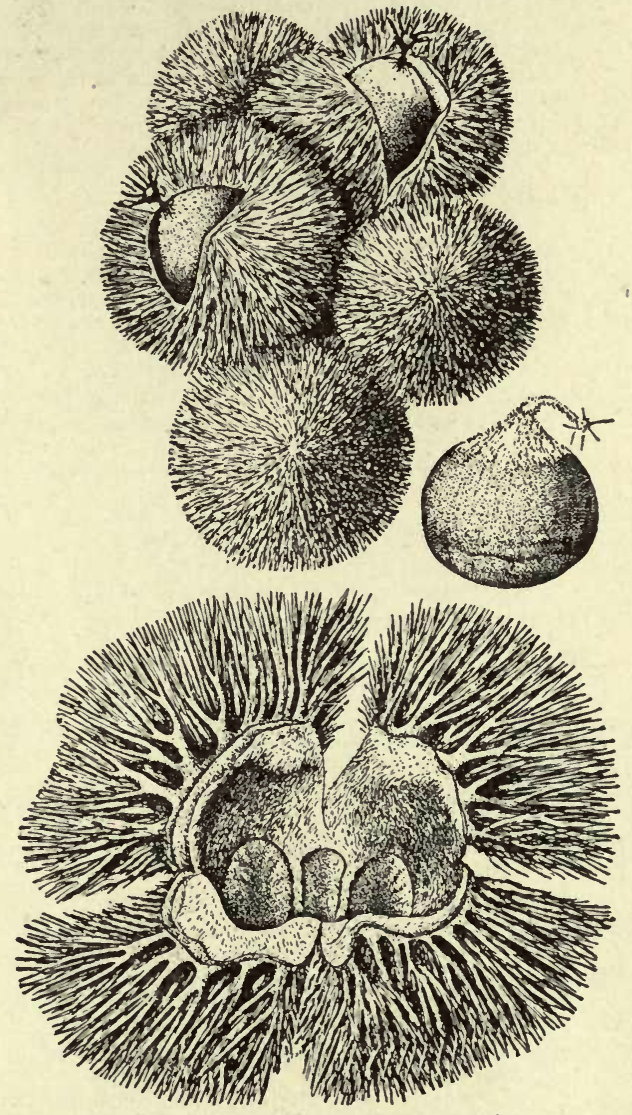

434. Chinquapin. Nut and bur natural size.

first few years, is probably best in planted orchards, though heavy mulching may be found a satisfactory substitute. The Japanese and some of the American varieties of the European species require thinning of the burs on young trees to avoid over-bearing, with its consequent injury to the vitality of the tree.

Leaf diseases are apparently subject to control by Bordeaux mixture, but for the weavils, which damage the nuts previous to maturity, no satisfactory remedy has yet been discovered. 
The varieties of the three species, though possessing many points in common, differ sufficiently in important characteristics to justify separate grouping for cultural discussion. As Chestnut culture is new in this country, it seems best to append descriptions of all the varieties

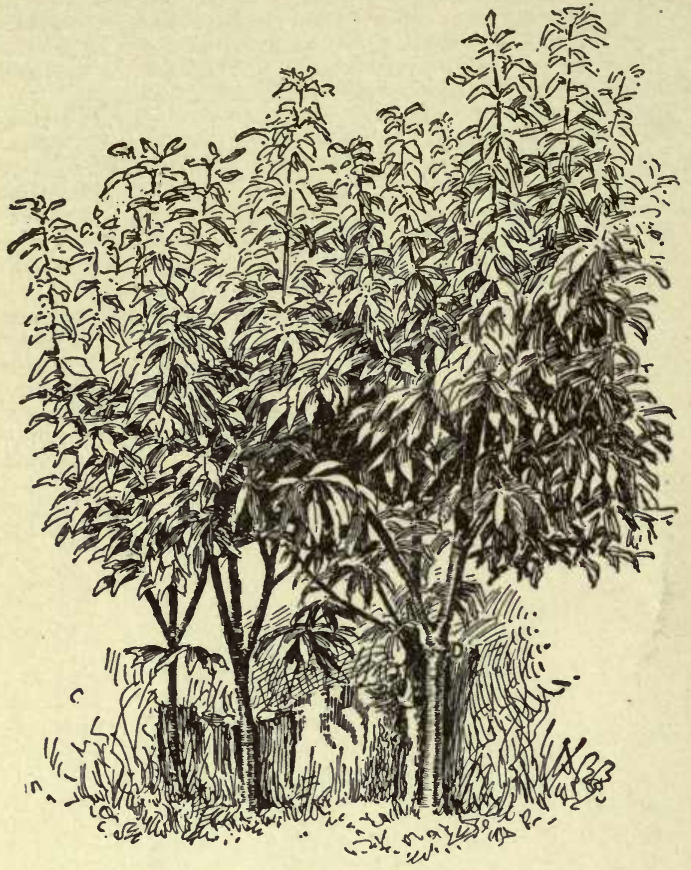

435. Chestnut sprouts two years grafted.

The cion was inserted where branching begins.

which are in the American trade. For fuller discussion of cultivated Chestnuts, see Nut Culture in the United States (Bull. Div. of Pomology, U. S. Dept. of Agric.), from which Fig. 434 is adapted; Nut Culturist, A. S. Fuller, 1896 ; European and Japanese Chestnuts in Eastern U. S., G. Harold Powell (Bull. Del. Exp. Station), 1898; Nut Culture for Profit, Jno. R. Parry, 1897.

AMERICAN GROUP. - Though the wild nuts exhibit wide variations in size, form, quality, productiveness, and season of ripening, but few varieties have been dignified by names and propagated. Solitary trees are frequently sterile, though producing both staminate and pistillate flowers, apparently requiring eross-fertilization to insure fruitfulness. This is especially true of planted trees of this species on the Pacific slope, where productive trees are reported to be rare. The susceptibility of the species to injury by leaf diseases, as pointed out by Powell, and the injury to nits by larva of weevils, are drawbacks to its extensive culture.

The following varieties are propagated to some extent:

Dulaney. - Bowling Green, Ky. Large, and of fine quality. Original tree productive, though isolated.

Griffin.-Griffin, Ga. A large, very downy nut, of good quality. Hathaway.-Little Prairie Ronde, Mich. A large, light colored, sweet nut, annually productive, frequently having 5 to 7 nuts to the bur.

Ketcham.-Mountainville, N. Y. Above medium in size, oblong, tomentose, sweet. Tree productive and vigorous in heavy sod at 50 years of age.

Murrell.-Coleman's Falls, Va. 'A large, high flavored nut, bearing 3 nuts to the bur.

Otto.-Otto, Teun. Large, oblong, very downy at tip, very sweet, and rich.

Watson.-Fay, Pa. Medium to large, slightly downy, compressed, very good.

EUROPEAN GROUP.- It is a significant fact that, during the century that has elapsed since the introduction of this species, the imported named varieties of Europe have not found favor in eastern America. Seedling trees have been found produetive and profitable at many points in New Jersey, Pennsylvania, Delaware, and Maryland, however, and these form the basis of the eulture of the species east of the continental divide. West the culture of the species east of the continental divide. West
of the Rocky mountains, several of the choice French "Mar- rons" are reported to succeed in California and Oregon. Among the more important varieties of the European group in America, are tne following

Anderson,-Flushing, N.J. Bur medium to small; nuts of medium size, bright reddish brown, pubescent at the tip and over half of the nut. Tree a strong grower, with medium to small leathery leaves. Very productive.

Bartram.- Milltown, Pa. Bur medium to small; nut medium, thickly pubescent at tip, dark, reddish mahogany color; 3 in a bur; unusually free from insect attack; quality good. Tree vigorous, spreading, with large leaves; productive.

Chalon (syn., Marron Chalon Early). - France. Sparingly grown in California. Nut of medium size, early, productive, precocious.

Combale (Marron Combale).-France. A large and handsome, bright brown striped nut, with but little tomentum at tip; usually 2 , sometimes but 1 , in a bur. Somewhat grown in California, where it was introduced from France about 1870.

Corson.-Plymouth Meeting, Pa. Bur large, with thin husk; nuts large, nsually 3 in a bur; dark brown, ridged, heavily pubescent at tip; quality very good. Tree vigorous, spreading, very productive.

Dager.-Camden, Delaware. Bur medium; nut medium to large, dark brown, thickly tomentose, usually 3 in a bur; quality good. Tree vigorous, spreading, productive; a seedling of Ridgely.

Darlington.-Wilmington, Del. Bur medium to small: nut medium to large, usually 3 in a bur; dark distinctly striped, thickly tomentose at tip; sweet, good. Tree vigorous. One of the earliest to ripen of this group.

Lyon (Marron de Lyon).- France. A large, round nut of fair quality, grown in a small way in California, but less productive than Combale, which it resembles.

Marron.-This term is used by the French to designate the larger eultivated Chestnuts, most of which have relatively few nuts, often only 1 in a bur.

Moncur-Dover, Del. A seedling of Ridgely. Bur medium; nuts medium, of light color, heavily tomentose; tree vigorous, spreading, very productive.

Nouzillard. France. A large, handsome variety from central France, and there consldered very productive and valuable. Has been tested in New Jersey, Pennsylvania and California, without marked success in any locality

Numbo.-Morrisville, Pa. (Fig. 11, Pl. 14.) Bur medium conical: nut large from 2 to 3 in a bur. bright brown striped, thinly tomentose of good quality. Tree compact and drooping; rather uncertain in bearing.

Paragon (syn uncertain in bearing. Germantown Philadelphia, Pa. Bur very large; uut large, usually 3 in a bur, broad, plump, thickly tomentose at the tip, and thinly over two-thirds of surface, color dull brown, quality very good. Tree hardy. spreading, vigorous, with narrow, coarsely serrate leaves hav ing a narrow base: subject to leaf blight, but very productive. The most widely planted and most puiformly sucessful variety of Chestnut yet cultivated in the nited States. Mybrich.

Quercy (syn., Marron Quercy).-France. A beautiful, medium sized nut, commended in portions of California for pre cocity, earliness, productiveness and quality.

Ridgely (syn., Du Pont).-Wilmington, Del. Bur medium; nut medium to large, moderately tomentose, dark, of very good quality; tree vigorous, with narrow leaves free from blight; spreading, very productive, hardy. (Fig.12, Pl. 14.)

Scott-Burlington, N. J. Bur medium, nut medium, slightly pointed, usually 3 in a bur; glossy, dark brown, slightly tomentose at the tip. Tree open, spreading, very productive said to be comparatively free from attacks of weevil.

Styer.-Concordville, Pa. Bur medium; nut medium pointed, dark brown, striped, tomentose at tip, 1 to 3 in a bur. Tree very vigorous, upright, with large, dark green leaves free from disease.

JAPANESE GROUP.-Though most of the imported Japanese Chestnuts have been found of poor quality for eating in the fresh state, the product of many imported seedling trees, and of a number of American-grown seedlings of this type, is equal to the Furopean nut in flavor. The Japanese varieties in genera have the advantage, also, of greater precocity and productiveness, larger size and earlier maturity of nut, greater freedom from injury by leaf diseases and nut-eating insect larvæ. As productiveness and earliness are the most important points in Chestnut culture at the present time, this type is the most important to commercial nut growers. The most important named varieties are as follows:

Alpha.-New Jersey. Bur medium; nuts medium to large, generally 3 in a bur, dark, of fair quality, ripening very early. Tree upright, very vigorous and productive.

Beta-New Jersey. Bur small; nut medium, light brown, smooth, slightly tomentose at tip: good; ripening just after Alpha.

Biddle.-New Jersey. First fruited in Maryland. Bur medium; nut large, bright brown, broad, rather thickly tomen tose, 2 to 5 in a bur; of medium season and fair quality. Tree regular, round-headed, vigorous.

Black (syn., Dr. Black).--New Jersey. First fruited in Maryland. Bur large; nut medium to large; 3 to 7 in 9 bur, consequently irregular in shape; dark brown, slightly 
tomentose, very early and of good quality. Tree round, close-headed, vigorous, productive.

Coe.-California. A large, very sweet variety, but recently disseminated. Tree upright, somewhat spreading.

Felton.-New Jersey. First fruited in Delaware. Bur small; nut medium, durk brown, slightly tomentose, rather early and of excellent quality. Tree roundheaded and fairly productive.

Giant.-Japan. A trade name, under which a number of varieties have been imported from Japan. See Parry.

Hale (syn.,Eighteen Months).-California. A newly introduced variety, having a large, dark brown nut of excellent quality. Very precocious.

Kent (syn., Extra Early).-New Jersey. First fruited in Delaware. Bur small; nut medium to large, dark, usually 3 in a bur; very early, of good quality. Tree round-headed, precocious, productive.

Kerr.-New Jersey. First fruited in Maryland. Bur small, nut medium to large, dark brown, broad, 3 in a bur, early, and of excellent quality. Tree vigorous, symmetrical, round-headed, very productive.

Killen-New Jersey. First fruited in Delaware. Bur very large; nut very large, broal, light brown, slightly ridged, of excellent quality, midseason. Tree upright, open, spreading, moderately vigorous, productive. The largest Chestnut yet brought to notice.

Mammoth.-A trade name for the imported Japanese il am and trees, not restricted to any particular variety. Jarsey. fruited in Maryland. Bur large; nut large to very large, broad, bright reddish brown, slightly tomentose, 3 to 5 nuts in a bur. Midseason; of good quality for cooking. Treo vigorous, open, spreading, productire $\theta$.

McFarland. - California. Bur very large: nut large, and of fine quality; early. Tree spreading, very productive. A newly disseminated ing, very productive. A

Parry.-Japan. Bur very large; nut very large, 1 to 3 in a bur, broad, with apex sometimes depressed; dark brown, ridged, of fair quality. Tree moderately vigorous, open, spreading, with large leaves. One of the largest and most beautiful of this group. Selected for propagation as the best of 1,000 imported gratted Japanese Chestnuts. (Fig. 13, Pl.14.)

apanese Chestnuts. (Fig. 13, P1. 14.) medium, rather long, striped, 3 in a bur; early. Tree vigorous, compact, with small narrow leaves. Reliance.-New Jersey. Bur medium; nut medium to large, rather long, light brown, ridged; midseason, and of fair quality. Tree dwarfish, spreading, drooping, very precocious and productive; inclined to overbear, and needs thinning. Seedling of Parry.

Success. - New Jersey. Bur very large; nut very large, usually 3 in a bur; midseason; of rather poor quality until cooked. Seedling of Parry. Tree upright, productive.

Superb (syn., Parry's Superb).-New Jersey. Bur large; nut large, broad, brown, usually 3 in a bur early, and of fair quality. Tre vigorous and very productive.

W. A. Taylor.

CHE VA L I E R A, CHEVALIERIA, CHEVALLIERA, CHEVALIIERIA. The species in the American trade are Echmeas.

CHICK-PEA. See Cicer.

CHICKWEED. See Cerastium and Stellaria.

CHICORY, or SUCCORY (Cichorium Intybus, Linn.). Compósitoe. Fig. 436. A native of Europe, naturalized in America and familiar to many as a weed, is a potherb, a salad, and the leading adulterant of coffee. It has come prominently before the public since 1897 as an American farm crop. Prior to that year, its cultivation as an adulterant and substitute for coffee was largely prevented by the prejudice of the principal consumers, our foreign-borm population, who insisted that American was inferior to European root, and also by the low tariff, which allowed the root to enter duty free, or with $\dot{a}$ very small impost. During 1898 and 1899 advantage has been taken of a protective duty, and sev- eral factories have been erected, for which farmers have shown a willingness to grow the roots. It is probable that within the next few years our home market will be fully supplied from Ameri can fields, in which development reliance is placed in the substitution of horse-power for manual labor, improved plows and cultivating implements for crude ones, machine-digging of the roots for hand-digging, efficient slicing machines, and improved eraporating kilns.

Chicory will probably succeed wherever the sugar beet is grown in this country, the climatic requirements being similar. In general, it may be said to thrive upon all stone-free soils that will produce paying staple crops, except clays, lightest sands and mucks. The first are too hard, the second too dry, the third too rich in nitrogen and too sour. The surface layer of soil should be deep, the subsoil open and well drained. If the water supply be sufficient, high land is as good as low land of the same texture, though if too dry for profitable grain growing, the former may yet be made to produce paying erops of Chicory; but if too wet for cereals, the latter will generally be found unsuitable for this root. The fertilizing of the land should be the same as for other root crops, nitrogen being used sparingly, potash and phosphoric acid rather freely $-11 / 4$ to $1 \frac{1}{2}$ times as much of the former and $21 / 2$ times the latter as has been removed by the preceding crop. It is best to apply these fertilizers to preceding crups that do not make heavy demands upon them. In rotation, Chicory is classed with root crops, and should be preceded by a small grain, since this is harvested in time for fall plowing. Clover should not immediately precede, since it leaves too much nitrogen in the soil. The ground being warm, fairly moist, thoroughly prepared by deep plowing, harrowing and scarifying with a weeder, the seed, which must be fresh and clean, is sown rather thickly but covered thinly, in drills 18 inches apart.

There are but few well-defined varieties of this plant used for field culture, and even the garden sorts are not as stable as could be desired. Of the former group, Magdeburs, Brunswick and Schlesische are the principal; of the latter, Witloof (so-called), Red Italian, Broad-leaved, Improved Variegated and Curled-leaved are best known. Witloof and Barbe de Capucin can be produced from any variety, the difference being brought about by the method of growing.

Chicory has no specific enemies in this country, and is troubled by only a few of the general-feeding insects, such as cutworms and wire-worms.

From 6 to 10 tons is the general crop per acre, though with good management, 15 tons $\mathrm{m}$ iy be produced. The cost of growing and the returns are about as follows: Rent, wear of tools, etc., $\$ 5$; preparation of land, $\$ 4.50$; seed, 75 cents; cultivating and teading, $\$ 15$; harvesting and delivering, $\$ 12$; total, $\$ 37.25$. Average price per ton, $\$ 7$.

F:om a purely horticultural standpoint, C licory is of interest as a root, a pot-herb, and a salad plant. The young, tender roots are occasionally boiled and served with butter, pepper and salt, like young carrots, but they have never become widely popular in this form. As a pot-herb, the young leaves are equal to those of dandelion. They are cut when 6 or 8 inches long, boiled in two waters to remove the bitter flavor, and served like spinach. As a salad, Chicory is famous in three forms: Common Blanched, Barbe de Capucin and Witloof. Barbe de Capucin is comprised 
of small, blanched leaves. Witloof is a more solid head. The pink, red and curled varieties make a very pretty appearance, and if well grown and served fresh are delicious, there being only a slightly bitter flavor. The method of growing is the same as for endive.

For Barbe and Witloof, well grown roots are dug in October, trimmed of unnecessary roots and of all but an inch of top. For Barbe, the roots are laid horizontally in tiers in moist earth, the whole forming a sloping heap, the crowns of the roots protruding an inch or so. Since darkness is essential, a warm vegetable cellar is the usual place selected to grow this vegetable, which requires 3 or 4 weeks to produce its fine white leaves. These are cut when about 6 inches long, eaten as a salad, boiled like kale or cut up like slaw. If undisturbed, the roots will continue to produce for some time. The most rapid way to produce Witloof is to plunge the roots (shortened to 5 inches) in spent tan bark, or such material, and cover with 2 feet or more of manure, the space under a greenhouse bench being used. In about 2 weeks, heads resembling cos lettuce may be dug up, boiled like Brussels sprouts, or served as salad. If the roots be left in place, protected from the light, but uncovered, a crop of leaves resembling Barbe may be gathered. Sowing and other cultural management is the same as for other garden roots, as beets and carrots. It is a pity that these vegetables are so little known in this country.

Chicory has run wild along roadsides and in dry fields in many parts of the country, and is considered to be a bad weed. However, the handsome sky-blue flowers (Fig. 436), which open only in sunshine, are very attractive.

M. G. KaINS

\section{CHILdSIA WERCKLEI. See Hidalgoa.}

CHILIANTHUS (a thousand flowers). Loganidcece. Four or 5 South African trees or shrubs, very closely allied to Buddleia, from which it differs in having stamens exserted from the short tube: lvs, opposite, entire or dentate: Hs.very numerous, in dense, terminal cymes or panicles. Unknown to the Amer. trade. The plants known as Buddleia salicifolia, Jacq., and B. saligna, Willd., are Chilianthus arboreus, Benth. (which is probably identical with $C$. oleaceus, Burch.).

CHILOPSIS (Greek, lip-like). Bignonidcece. One shrub or low tree, C. salígna, Don (known also as $C$. linearis, DC.), growing in dry districts from S. Texas to Calif., and in Mex. From its narrow-lanceolate or linear lvs., it is known as Desert Willow; also called Flowering Willow and Mimbres. It is a continuous-blooming plant, valuable for our extreme southern districts. It grows from 10 to $20 \mathrm{ft}$., bearing slender branches, opposite or verticillate lower lvs., and handsome, Bignonia-like fls. in a short, terminal raceme. The corolla is 1-2 in. long, 5 -lobed and crimped, the tube and throat lilac, and two yellow stripes inside. Anthers 4 ; rudiment of a fifth stamen.

L. H. B.

CHIMÁPHILA (Greek, winter and friend; green in winter). Ericacece. PIPSIssewa. Half shrubby or herbaceous, with creeping stem: lvs. evergreen, serrate, in irregular whorls: fls. nodding, forming a terminal, fewfld. umbel, on a long, naked peduncle; petals 5 , spreading; stamens 10: fr, a dehiscent, 5-celled capsule. Four species in N. America, Europe, and N. Asia to Japan; formerly united with Pyrola. Low, evergreen plants, with pretty white or reddish fls. in summer. They grow best in a light, sandy soil, mixed with peat or leaf-nold, and prefer a half-shady position. Prop. by division of the creeping rootstock. Useful in wild borders.

umbellàta, Nutt. (C. corymbdsa, Pursh). Five-8 in.: lvs. 3-6 in a whorl, short-petioled, cuneate-lanceolate, sharply serrate, dark green and shining above, 1-2 in. long: fls. 4-7, white or reddish, 1/2-3/4in. wide. N. Amer., from Canada to Mexico, Europe, Japan. B.M.778. L.B.C. 5: 463. Mn. 7:161.

maculàta, Pursh. Fig. 437. Lower and less branched than the foregoing: lvs. usually in 3 's, ovate or oblong lanceolate, sparsely and sharply serrate, variegated with white along the nerves, $1-2$ in. long: fls. $2-5$, white, $3 / 4 \mathrm{in}$. wide. From Canada to Georgia and Mississippi. B.M. 897. Mn. 9:1.

\section{ALFRED REHDER.}

\section{CHIMONANTHOS is Calycanthus.}

CHINESE LANTERN PLANT. See Physalis.

CHINESE SACRED LFLY. Consult Narcissus.

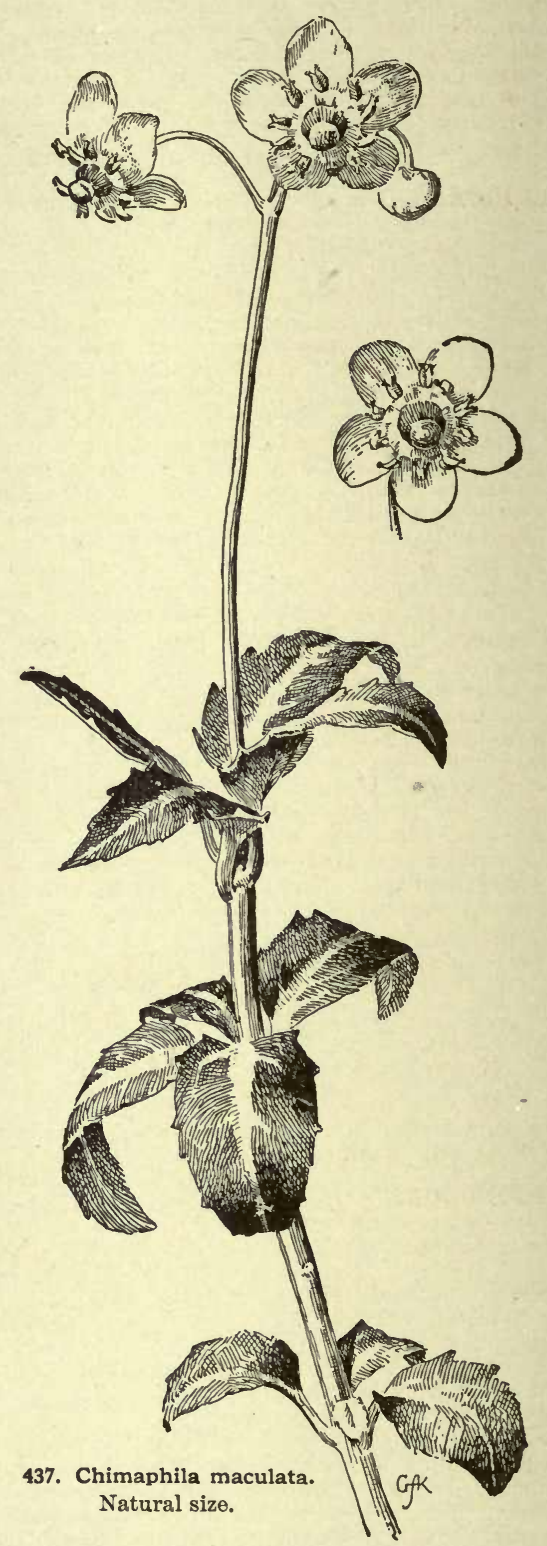

CHIOcócCA. Rubidcece. SNowberRY (which the name means in Greek). Shrubs, mostly climbing, of tropical Amer., and one in extreme S. Fla. Fls. in axillary panicles, the corolla funnel-form and 5-parted; stamens 5, inserted on the base of the corolla, the filaments cohering at base; style filiform, the stigma club-shaped: ovary 2-3-loculed, becoming a small, globular drupe. C. racemosa, Linn., of the Florida Keys and S., is sometimes cult. in hothouses for its panicles of yellowish 
white fls. and the white frs. Lvs. ovate to lanceolate, thick and shining, entire: drupes $1 / 4 \mathrm{in}$. in diam. Twining ; glatrous.

L. H. B.

CHIOGENES (Greek, snou, offspring ; referring to the snow-white berries). E'ricacea. Trailing evergreen, with small alternate lvs. and inconspicuous axillary tis.; corolla 4-cleft ; stamens 8 , included : berry white, hirsute. Two species in the colder regions of N. Amer. and Japan. Slender trailing evergreens, in appearance much like the cranberry, rarely cultivated. Thriving best in moist and peaty soil, in a shaded position, creeping amongst growing moss. Prop. by seeds, by division or by cuttings in August under glass. The American species, C. hispidula, Torr. \& Gray (C. serpyllifolia, Salisb.), has hirsute branches and ovate, $1 / 4-1 / 8$ in.-long ciliate lvs. and greenish white fls.

ALFRED REHDER.

CHIONÁNTHUS (Greek for snow and flower; alluding to the abundance of snow-white fls.). Oledcece. Fringe Tree. Shrubs or low trees, with deciduous, opposite and entire Ivs.: fls. in loose panicles from lateral buds at the end of last year's branches, white ; corolla divided nearly to the base in 4 narrow petals; stamens 2, short : fr. a 1-seeded oval drupe. Two species in E. N. Amer. and China. Ornamental shrubs, with large, dark green foliage, and very showy white fls. in early summer. The American species is almost hardy north, but requiring a somewhat sheltered position; the Chinese may be more tender, but it thrives in W. New York. They thrive best in a somewhat moist and sandy loam, and in a sunny position. Prop. by seeds sown in fall or stratified; increased also by layers and by grafting under glass or budding in the open air on ash seedlings (in Europe Fraxinus Ornus is preferred); sometimes by cuttings from forced plants in early spring.

Virgínica, Linn. Fig. 438. Large shrub or slender tree, to $30 \mathrm{ft}$ : Irs. oval or oblong, acuminate, pubescent beneath when young, mostly glabrous at length, 4-8 in. long : panicles 4-6 in, long, pendulous ; petals 1 in. long: fr. dark blue, oval, 1 in. long. May, June. From Penn. to Fla. and Tex. L.B.C. 13: 1264. Gt. 16:564. Mn. 2:154. G.F. 7:325. - Variable in shape and pubescence of the lvs., and several varieties have been distinguished, but none of them sufficiently distinct for horticultural uses. Handsome shrubs.

C. retùsa, Lindl. (C. Chinensis, Max.). Lvs, obovate, obtuse or acute, sometimes emarginate : petals shorter and broader, oblong; panicles more compact, shorter and erect. China. P.F.G. 3, p. 85 . G.C. II. $23: 821$. Gt. 35, p. 667 A.G. 13:374. Mn. 2:157, G.F. 7:327? A.G. $20: 107$.

ALFRED REHDER.

CHIONODÓXA (Greek, snow and glory). Lilideea. A small genus of hardy bulbous plants. Natives of Crete and Asia Minor (Mt. Taurus). Very closely allied to Scilla, but differs, among other churacters, in having a short tube to the corolla. Fls. small and

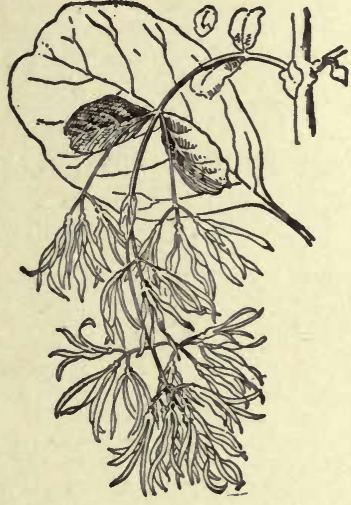

438. Chionanthus Virginica. $(\times 1 / 2$. blue (running into white and red forms), with recurvedspreading acute segments, dilated filaments, and small or capitate stigma. These are among the best of earlyflowering plants, blooming in February, March and A pril, according to the locality, with the early Snowdrops and Scillas. Since their introduction to cultivation by Mr.Maw in 1877, they have been widely cultivated under the popular name of "Glory of the Snow, "in allusion to their early blooming habit. $C$. Lncilioe is the most widely cultivated species. This varies much in color, the type having fls. whose petals are more or less deeply tipped with blue, shading to white at their bases. C. Lucilioe also occurs with pure white fls., and in reddish and pink forms. C. Sardensis has smaller fls. of a deeper tone of blue and without the white markings of the petals. There are two varieties of this, one with white and the other with black stamens. Chionodoxas hybridize

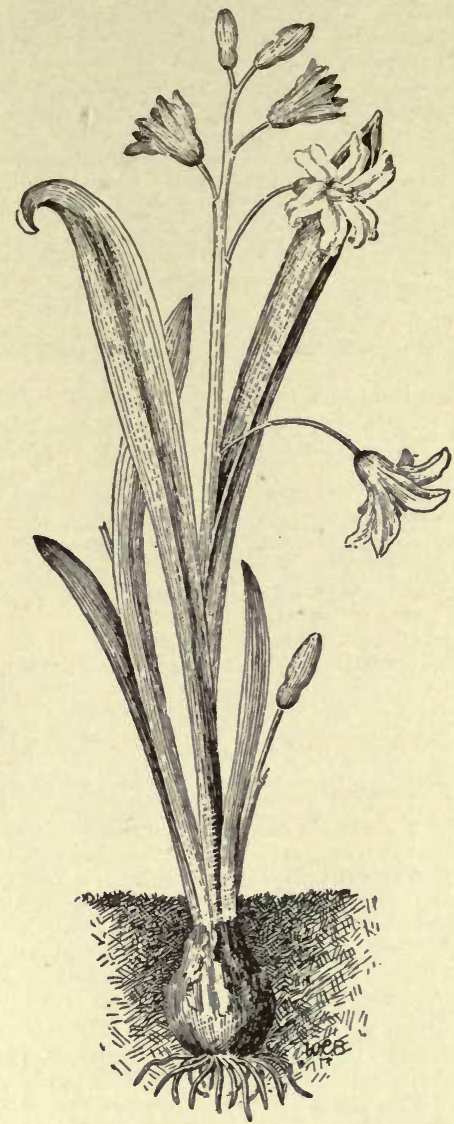

439. Chionodoxa Luciliz $(\times 1 / 2)$.

with Scilla, and the hybrids are sometimes known as Chionoscillas.

Chionodoxas thrive in any fertile soil, well drained and not too heavy, and in any exposure, the main requisite for growth being that they have light and an adequate supply of moisture while growing and till the foliage if ripened. The bulbs should be planted about 3 inches deep, and closely, say an inch or two apart. Lift and replant about third year. They need no winter covering. They flower well in pots in winter in a coolhouse temperature. Must be forced only gently, and given abundance of air, light and moisture. They are increased by offsets and seeds, which they produce freely. Under favorable conditions, they increase rapidly by self-sown seeds. Preferably, seeds should be sown in a frame, and may be expected to germinate the following winter.

Lucíliæ, Boiss. Glory of the SNow. Fig. 439. Bulb ovoid, brown-coated: lvs. long and narrow, two or three with each stem: scape 3-6 in. high, bearing a dozen or less bright blue, more or less hanging, white-centered fls. Asia Minor and Crete. B.M. 6433. Gn. 28, p. 179.Runs into several forms, one of which has white fls. $C$. gigantèa, Hort., is evidently a larger form of it, distinct in habit. C. grandiflora, Hort., is the same. C. Tmolusi, Hort., is a late-b'ooming form, bright blue and white.

Sardénsis, Hort. Fls. smaller, much darker blue, with no white in the eye. Sardis. Gn.28:505.-Probablv a form of the preceding. 
Crética, Boiss. \& Held. Slender: fls. smaller and fewer (1-2 on a scape) than $C$. Lucilia, white or very pale blue. Crete.-Of little horticultural value.

Álleni, Hort. (Chionoscílla Alleni, Hort.). Perianth segments cut to the base: habit of $C$. Lucilia, but the white eye is indistinct. Supposed natural hybrid of Scilla bifolia and Chionodoxa Lucilia. G.C. III. 21: 191.

J. N. Gerard and L. H. B.

CHIONOSCILLA. Consult Chionodoxa.

CHINA ASTER. See Aster.

CHINA TREE. Consult Melia.

CHINKAPIN, CHINQUAPIN, See Chestnut and Castanea.

CHIRITA (Hindostani name). Gesnerdece. Plants much like Gloxinias and Streptocarpuses; none of them in the Amer. trade. They are natives of eastern Asia. Fls. in shades of purple and blue, tubular, in clusters on the tops of short scapes.

CHIVES. See Cive.

CHLIDANTHUS (delicate flower, from the Greek). A maryllidacea. Two or three S. Amer. bulbs, flowering in advance of the lvs. Allied to Zephyranthes. Fls. yellow, in a small umbel, terminat-

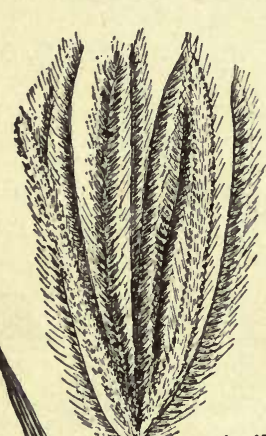
ing a solid scape, long-tubed, with wide-spreading segments: lvs. long and strap-shaped. C. fràgrans, Herb., is the species in cult. It bears fragrant fls. $3-4$ in. long, in summer, on scapes 15-18 in. high. It is increased by offsets or by seeds. The bulbs should be kept dry and cool during winter and in spring started in a moderately warm house. After flowering, care must be taken to have the bulbs make their annual growth. They may either be grown in pots plunged in ashes, or planted out where they can be watered occasionally during dry weather. Like other similar plants, they will benefit by a mulching of spent hops or rotted manure. G. W. OLIVER and L. H. B.

CHLORANTHUS (green flower). Chloranthdcea. The type genus of a small family ( 25 species) of tropical herbs, shrubs or trees. Chloranthus has about 8 species. They are perennial herbs or evergreen shrubs, with jointed stems, opposite, simple lvs., and small, inconspicuous fls., in slender, terminal spikes. Perianth represented by a single scale, in the axil of which is the 1-loculed ovary, and 3 united stamens (the side stamens sometimes obsolete). C. brachýstachys, Blume, from Ind. and China, is in the Amer. trade. It is a shrub used for pot-growing, reaching a height of 1-2 ft., bearing glossy foliage and small, yellow berries There is a variegatedleaved form.

L. H. B.

440. Chloris CHLORIS (Greek for green). Gra elegans. mineo. FINGER GRASs. Usually perennial grasses, with flat lvs. and attractive inflorescence: spikelets 1-fld., awned, sessile in two rows along one side of a continuous rachis, forming unilateral spikes, these usually several together, and digitate at the apex of the culm. Species about 40, widely distributed through the warmer countries of the world. Several are cultivated for ornament.

élegans, HBK. (C. álba, Presl). Fig. 440. An erect perennial 2-3 ft. high, with slightly inflated sheaths,

441.

Chloris truncata. Star Grass.

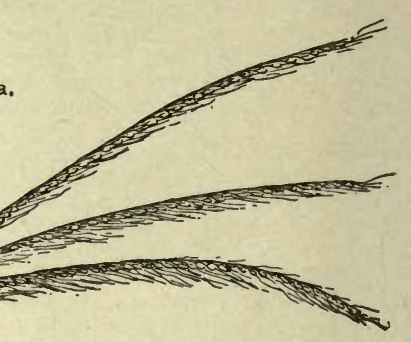

flat blades and 8-12 silky-bearded spikes, clustered or umbellate at the apex of the culms. - In cult. as an ornamental grass. Annual in the northern states.

truncàta, R. Br. (C. barbata vèra, Hort.). Fig. 441. A perennial with jointed, creeping culms : sheaths compressed and hairy at the apex : inflorescence consisting of digitate spikes, widely spreading; the spikelets 2 -flowered and long-awned. Austral. In cult. as an ornamental grass.

verticillata. Nutt. WiNDMILI Finger Grass. A low, spreading perennial with upright culms 6-20 in. high. The dark brown, awned spikelets are arranged on slender spikes, which are ir whorls near the summit of the culm. Both fl.-glumes and empty glumes awned.-It is a good turf-former, and is spoken of by some as a good grazing grass, and one not easily trampled out. The arrangement of the spikes gives it an odd and pleasing appearance making it useful as an ornamental species for gardens. The cult. form is an improvement on the type.

C. polydáctyla, Swartz. A W. Indian species which has been found in southern Fla., is attractive, and has long and graceful spikes.- O. grácilis, Dur., a native of Cent. Amer. and Mex., is another species occasionally eult. for ornament.-C. petroea, another species occasionally cult. For orna to N. Car, is as at. tractive as many of the grasses grown in gardens as ornamentractive as many of the grasses grown in gardens as ornamentals. - C. glaica, Vasey, is a handsome species, well deserving
the attention of the florist, and is found growing in brackish marshes and along the borders of eypress swamps.

$$
\text { P. B. KENNEDY. }
$$

CHLOROCODON (Greek for green and bell, alluding to the flowers). Asclepiaddcea. One species from S. Afr., C. Whiteii, Hook. f. B.M. 5898. G.C. III. 18:243. It is now cult. in S. Fla. and S. Calif. It is a strong, woody twiner, with large opposite, cordate-ovate, thick lvs. and axillary elusters of odd fls. $3 / 4-1$ in. in diam.; corolla rotate-bell-shaped, thick, green ; the segments ovate and acute, purple at the base inside, and bearing long-notched lobes; anthers connivent over the capitate stigma. The roots are used medicinally in Natal, under the name of Mundi. The plant is an interesting greenhouse climber, but not handsome.

L. H. B.

CHLOROGALUM (green and milk, from the Greek, referring to the juice of the plant). Lilidcea. Three species of California, allied to Camassia (C. Leichtlinii, Baker =Camassia Leichtlinii). Bulbous : fls. white or pink, in a pancle terminating a leafy stem; segments of perienth 3-nerved, at length twisting over the ovary; style long and deciduous: lvs. with wavy margins. Plants of easy culture, to be treated like Camassias or Ornithogalums. Monogr. by Baker, Journ. Linn. Soc. 13: 29] ; IVatson, Proc. Amer. Acad. 14: 242. 
A. Pedicels nearly as long as the fls.: segments spreading from near the base.

pomeridiànum, Kunth. SOAP-PLANT. AMOLE. Stem reaching $3 \mathrm{ft}$., many-branched, from a very large bulb:

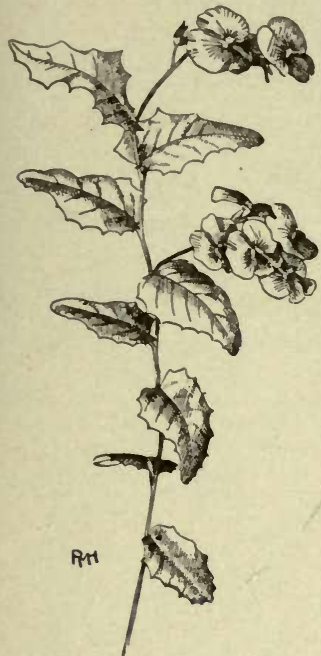

442. Chorizema ilicifolium. (X1/3.) fls. small ( 1 in. or less long) and star-like, numerous, white, with purple veins, on spreading pedicels, opening in the afternoon. - Bulb used by Indians and Mexicans for soap-making.

AA. Pedicels very short: segments spreading from above the base.

parviflorum, Wats. Bulb small ( 1 in. in diam.): stem 1-3 ft., slender-branched: lvs. narrow and grass-like: fls. pinkish, $1 / 4$ in. long: ovary broad and acute.

angustifolium, Kellogg. Low, about $1 \mathrm{ft}$. Resembles the last, but fls. white and green-lined and somewhat larger, the ovary acute above. $\quad$ L. H. B.

CHLOROPHYेTUM (name means, in Greek, green plant). Lilidceae. Very closely allied to Anthericum, but differing in the thickened filaments of the stamens and the 3 -angled or 3-winged capsule; inflorescence often denser; lvs. broader, often oblanceolate and petiolate: seed disk like. About 40 species, in Asia, Africa, and S. Amer. Consult Anthericum and Paradisea.

elatum, R. Br. (Anthericum variegatum, vittatum, picturatum, Williamsii, Hort.). Root fleshy and white: Ivs. freely produced from the crown, often 1 in. wide, flattish and bright green, or in the garden varieties with white lines along the margins, and often (var. picturatum) also with a yellow band down the center: scape terete and glabrous, 2-3 ft. high, branched : fls. white, 1/2in. long, with revolute, oblanceolate segments, which are obscurely 3-nerved on the back. S. Africa. F.S. 21: 2240-1. - A valuable and common plant for vases and pots, and sometimes used in summer borders. Anthericum Cali. fornicum, Hort., is perhaps a form of it.

L. H. B.

CHLORÓPSIS BLANCHARDIANA. See Trichloris.

\section{CHOCOLATE. See Theobroma.}

CHÓISYA (J. D. Choisy, Swiss botanist, 1799-1859). Rutdeea. One Mexican shrub, C. ternàta, HBK., grown in S. Calif. and S. Fla., and sometimes under glass. It grows 4-8 ft. high, making a compact, free-blooming bush, with opposite, ternate lvs., the lfts. lance-obovate or oblong, thick and entire, with pellucid dots: fls. in a terminal, forking cluster, white, fragrant, orange-like (whence the vernacular name Mexican Orange), 1 in. across. R.H. 1869: 330. Gn. 50, p. 203. J.H. III. 34: 253. -A handsome shrub, worthy of greater popularity. It will endure several degrees of frost, and should succeed in the open in many of the southern states. Blossoms in summer.

L. H. B.

CHOKE CHERRY is Prunus demissa and P. Virginiana.

CHONDRORYNCHA (cartilage and beak). Orchiddcea, tribe Vándec. Three species of S. Amer. epiphytal orchids. Cult. as for Odontoglossum crispum. They are practically unknown in the Amer. trade. They are shortstemmed herbs without pseudobulbs, and oblong, plicate, petioled lvs., the simple scape bearing a single large, odd, yellowish flower. $C$. Chéstertoni, Reichb f. $C$. fimbriata, Reichb.f., and $C$. rosea. Lindl., are the species. Keep cool and moist.
CHORISIA (Greek, separate or distinct). Malvdcea. A very few spiny trees, of tropical America. Lvs. alternate, digitate, of 5-7 leaflets : fls. large, with linear or oblong petals, the peduncles axillary or racemose: ovary 5-loculed and many-ovuled. C. speciosa, St. Hil., of Brazil, the "Floss Silk Tree," is cult. in S. Calif., and is adapted to warm glasshouses. It is a medium-sized tree, allied to Eriodendron and Bombax. Lfts. lanceolate, acuminate, dentate: ealyx irregular, shining outside, but silky inside: petals obtuse, yellowish and brown-striped at the base, pubescent on the back.

L. H. B.

CHORIZEMA (fanciful Greek name). Sometimes spelled Chorozema. Legumindsa. Fifteen to 20 Australian shrubs, of a diffuse or half-climbing habit, with thick and shining simple evergreen lvs. and pea-like red or yellow fls.: ovary villous. Handsome plants for the cool greenhouse, less popular in this country than abroad. When not grown too soft, they will stand slight frost at times. Grown in the open in S. Calif. and S. Fla. They are grown in a rather peaty soil, after the manner of Azaleas. Usually rested in the open in summer. They are excellent for training on pillars and rafters. Prop. easily by cuttings; also by seeds.

vàrium, Benth. Lvs. roundish or round-ovate, somewhat cordate, spiny-toothed : fls. orange and red, in erect racemes. -The commonest species. Runs into many forms, of which $C$. Chándleri and $C$. grandiflorum, Hort., are examples.

ilicifolium, Labill. Fig. 442. Lvs. orate or lance-ovate, deeply repand-spiny-toothed: fls. yellow and red.

macrophýllum, Hort. Dwarf : fls. red.

L. H. B.

CHOROGI. See Stachys.

CHRIST-AND-THE-APOSTLES. Fanciful name of Crinum scabrum, which sometimes has 13 flowers.

CHRYSALIDOCÁRPOS (Greek for golden fruit). Palmacece, tribe Arècece. Spineless, stoloniferous palms, with medium, fasciculate, ringed stems; lvs. pinnatisect; long-acuminate segments about 100 , bifid at the apex, the lateral nerves remote from the midrib. Species 2 , one of them being a popular thorist's plant. Madagascar.

lutéscens, H. Wendl. (Hyophorbe Indica, Gaertn. H. Commerson. idna, Mart. A rèca lutés cens, Bory). Figs. 443, 444. Stem 30 ft. high, 4-6 in. in diam., cylindrical, smooth, thickened at the base; lvs. very long; segments almost opposite, lanceolate, $2 \mathrm{ft}$. long, $2 \frac{1}{2}$ in. wide, acute, with 3 prominent primary nerves, which are convex below and acutely 2 -faced above. Bourbon. A.G. 13:141. A.F. 4:566. -Fig. 443 is from Martius' Natural History of Palms. Iu growing Chrysalidocarpus (or Areca) lutescens in quantity, it will be found a good plan to sow the seeds either on a bench, in boxes or seed-pans, so prepared that the seedlings will remain in the soil in which they germiuate until they have made two or inore leaves.

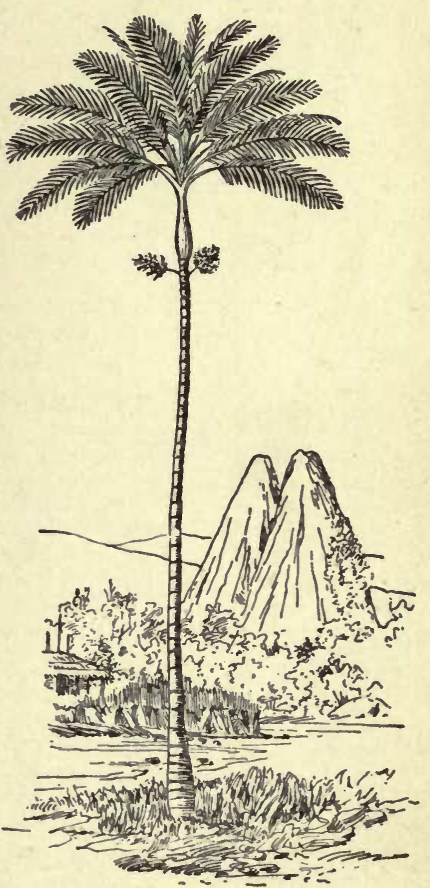

443. Chrysalidocarpus lutescens.
The first leaf made alinve the soil is small. and if plants are potted off at this stage they must be very 
carefully watered in order not to sour the soil. In the preparation of the receptacles for the seed, a little grarel in the bottom will be found good, as the roots work very freely through it, and when the time comes to separate the plants previous to potting, it is an easy matter to

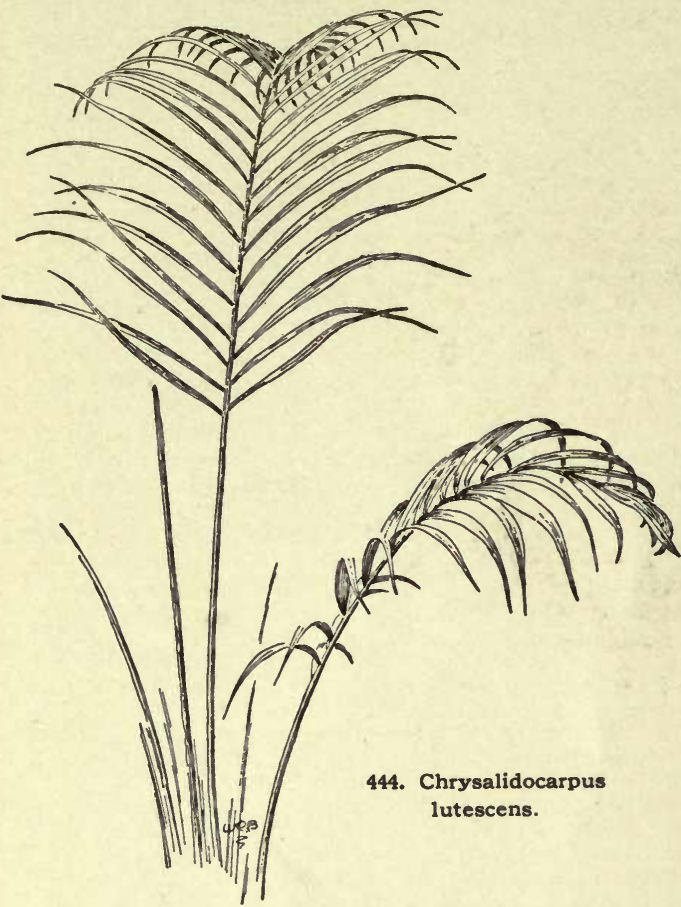

disentangle the roots without bruising them. Probably the plan which works best is to wash the soil and gravel entirely from among the roots. Pot in soil not too dry, and for the next few days keep the house extra warm and humid, and the plants shaded from the sun without, any moisture applied to the soil for the first few days. Jared G. SMith and G. W. Oliver.

CHRYSANTHEMUM (Greek, golden flower). Including Pyrèthrum. Compósitce. A large genus of herbaceous and sub-shrubby plants, mostly hardy, and typically with white or yellow single fls., but the more important kinds greatly modified in form and color. Bentham and Hooker make 22 subgenera (of which about 6 include the garden forms), based chiefly on the manner in which the seeds are ribbed, cornered, or winged, and the form of the pappus. The garden Pyrethrums cannot be kept distinct from Chrysanthemums by garden characters. The garden conception of Pyrethrum is a group of hardy herbaceous plants, with mostly single flowers, as opposed to the florists' or autumn Chrysanthemums, which reach perfection only under glass, and the familiar annual kinds, which are commonly called Summer Chrysanthemums. When the gardener speaks of "Pyrethrums," he usually means P.roseum. Many of the species described below have been called Pyrethrums at va rious times, but they all have the same specific name under the genus Chrysanthemum, except the most important of all garden Pyrethrums. viz., $P$. roseum, which is $C$. coccin eum. The Feverfew and Golden Feather are still sold as Pyrethrums, and the only other species of importance is $P$. uliginosum.
The insect powder known as "Pyrethrum," is produced from the dried flowers of $C$. cineraricefolium and $C$. coccineum. The former species grows wild in Dalmatia a long, narrow, mountainous tract of the Austrian empire. "Dalmatian Insect Powder" is one of the commonest insecticides, especially for household pests. $C$. cineraricefolium is largely cultivated in France. C.coccineum is cult. in Calif., and the product is known as Buhach. See Lodeman, The Spraying of Plants, and Rep. U. S. Com. Agr. 1881-2, p. 76.

There are over one hundred books about the Chrysanthemum, and its magazine literature is probably exceeded in bulk only by that of the rose. It is the flower of the east, as the rose is the flower of the west. Aside from oriental literature, there were 83 books mentioned by C. Harman Payne, in the Catalogue of the National Chrysanthemum Society for 1896. Most of these are cheap cultural guides, circulated by the dealers. The botany of the two common species has been monographed by W. B. Hemsley in the Gardeners' Chronicle, series III., vol. 6 , pp. $521,555,585,652$, and in the Journal of the Royal Horticultural Society, vol. 12, part I. The great repositories of information regarding the history of the Chrysanthemum, from the garden point of view, are the scattered writings of C. Harman Payne, his Short History of the Chrysanthemum, London, 1885, and the older books of F. W. Burbidge and John Salter. For information about varieties, see the Catalogues of the National Chrysanthemum Society (England) and the Liste Descriptive, and supplements thereto, by $O$. Meulenaere, Ghent, Belgium. The best book written by an American is Chrysanthemum Culture for America, by James Morton, N. Y., 1891. There are a number of rather expensive art works, among which one of the most delightful is the Golden Flower : Chrysanthemum, edited by F. Schuyler Mathews, pub. by Prang, Boston, 1890.

Types of the Common Chrysanthemum. - The common Chrysanthemums of the florists are also called "large-flowering," and "autumn Chrysanthemums," though neither of these popular names is entirely accurate or distinctive. They are the blended product of $C$. Indicum and $C$. morifolium (or $C$. Sinense), two species of plants that grow wild in China and Japan. From 10 to 15 dominant types are recognized by the National Chrysanthemum Society of England.

The words "types," "races," and "sections," have always been used by horticulturists to express much the same thing, but types can always be clearly defined, while sections cannot, and the word race should be restricted to cultivated varieties that reproduce their character by seed, which is not the case with the largeflowering Chrysanthemums. The following explanation and scheme, it is hoped, will clearly set forth the main types, and explain some of the many terms that confuse the beginner. The horticultural sections are wholly arbitrary, being chiefly for the convenience of competitors at exhibitions, and therefore changing with the fashions. The present classification is based wholly on $\begin{array}{ll}\text { the form of the flower, as each type } & \text { the } \\ \text { can be had in any color found in }\end{array}$

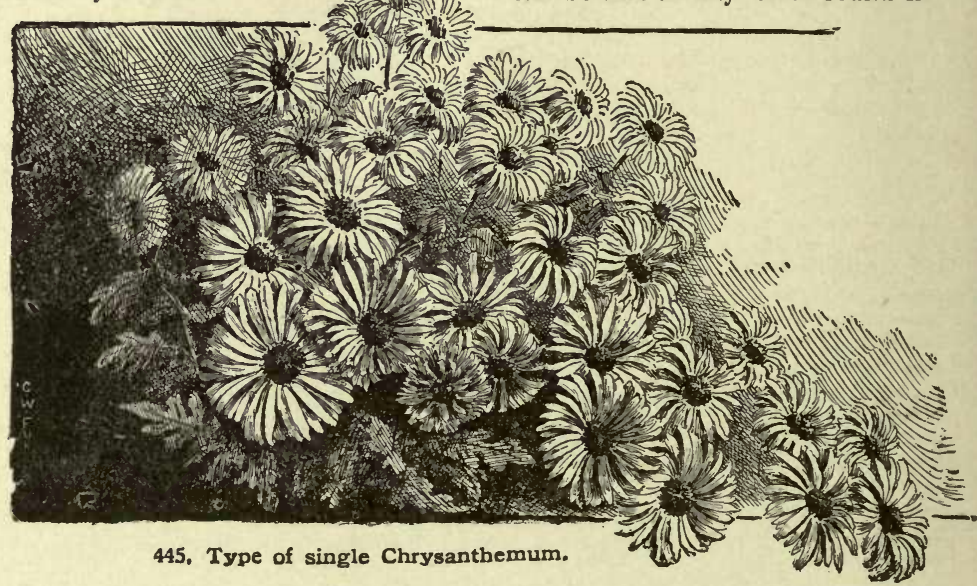




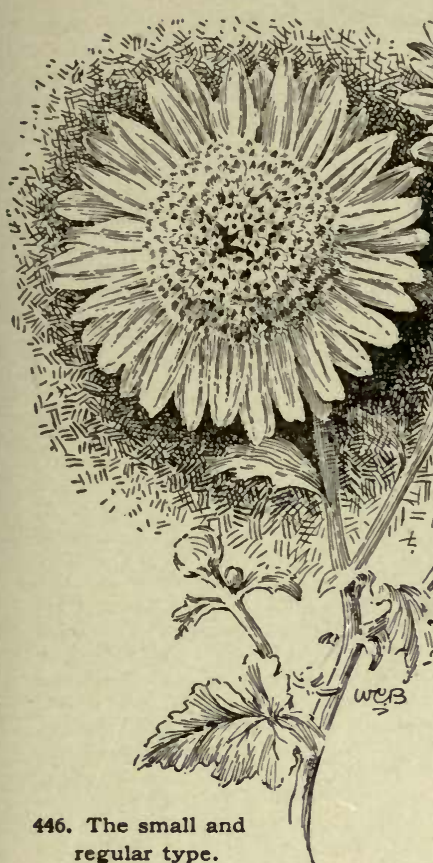

regular type. single forms, they are less popular than the double kinds, and the varieties are, therefore, less numerous and more subject to the caprices of fashion.

Bв. Fls. large, fewer, regular.

4. The Large Anemone Type.-Fig. 447. Fls. 4 in. or more across and fewer. Gn. 9, p. 33.
446-449. The anemone-flowered types of Chrysanthemums.

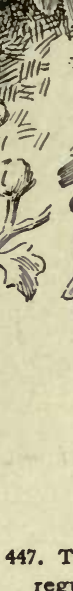
The large and

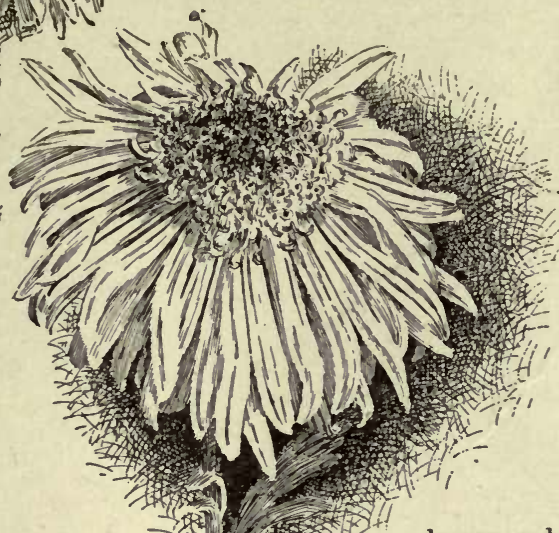

ввв. F'ls. large, few, irregular.

5. The Japanese Anemone Type.-Figs. 448,449 . Fls. 4 in. or more across, and irregular in outline. $\mathbf{H}$. Rider Haggard is an excellent example. Gn. $47, p .161 ; 31: 601$.

AAA. Double-fld.forms: rays in many series: disk absent or nearly so.

B. Fls. small : rays short.

6. The Pompon Type. -Fig. 450. Fls. 1-2 in. across. The outdoor kinds are likely to be small, flat and buttonlike, while those cult. indoors are usually larger and nearly globular. Fig. regular type.

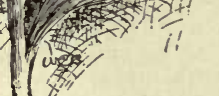

450 shows the former condition. It is from one of the old hardy kinds long cultivated in the gar-

the whole genus. For examples of each type, see N. C. S. catalogues.

A. Single forms : rays in 1 series, or few series : disk low and flat.

1. The Small Single Type.-Fig. 445. Fls. about 2 in. across, star-like, i.e., with the rays arranged in one series around the yellow disk. "Single," however, is a relative term, and in Fig. 445 there are really several series of rays, but they do not destroy the "singleness" of effect. All fls. are either single, semi-double, or double, but all the intermediate forms between the two extremes of singleness and doubleness tend to disappear, as people usually do not like them.

2. The Large Single Type.-

Like Fig. 445 , but the fls. 4 in. or more across, and fewer. The difference between the large and small single types is admirably shown in Gn. 37:756. These types are practically never grown outdoors and are best suited for pot culture, each specimen bearing $20-80 \mathrm{fls}$.

AA. Anemone-fld. forms: rays as above: disk high and rounded.

B. Fls. small, numerous, regular.

3. The Small Anemone Type.- Commonly called "Pompon Anemone." Fig. 446. Fls. 2 or 3 inches across, and usually more numerous than in the large anemone type. All the anemone forms are essentially single, but the raised disk, with its elongated, tubular fls., usually yellow but often of other colors, gives them a distinct artistic effect, and they are, therefore, treated as intermediates in character between the single and double forms. Like the

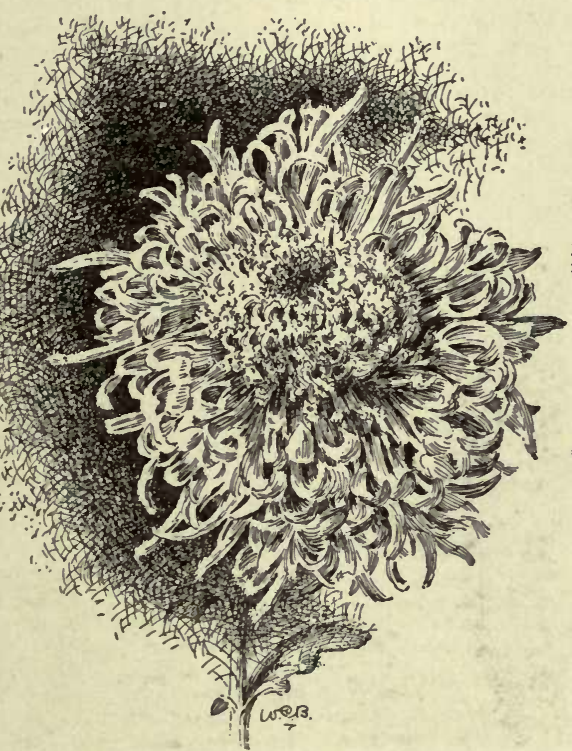

448. The large and irregular type. An early stage. dens as "Chinese" or "small-flowered" Chrysanthemums, and generally supposed to be the product of $C$. Indicum, as opposed to the "Japanese" or "large-flowered" kinds introduced in 1862, which marked a new era by being less formal and more fanciful than any of the preceding kinds. Pompons are little cult. under glass in Amer. The Pompon section of the N.C. S. Cat. 1896 refers to indoor types, and a separate section was made for the outdoor types under the name of "Earlies," with two subgroups, "Pompons" and "Japanese," referring to the old small-flowered, hardy race, and the new large-flowered Japanese kinds, which are grown to perfection only under glass, but are sometimes grown outdoors, though they are usually less hardy. 
BB. Fls. large.

c. Blossoms hairy.

7. The Hairy Type.-Also called "Ostrich Plume" and "Japanese Hairy." The famous prototype is the variety Mrs. Alpheus Hardy, pictured in Gn. 35, p. 307. which was sold for $\$ 1,500$ in 1888 , and started the American craze. White fis. with long hairs are very delicate and pretty, but the hairs are often minute, and on many of the colored fls. they are considered more curious and interesting than beautiful. So far, nearly all hairy Chrysanthemums are of the Japanese Incurved type.

$$
\text { CC. Blossoms not hairy. }
$$

$$
\text { D. Rays reflexed. }
$$

8. The Reflexed Type.-Also called "Recurved." Fig. 451. The reflexed forms can be easily broken up into three types, $(a)$ the small and regular, $(b)$ the large and regular, and $(c)$ the large and irregular types. Lately the irregular kinds have been removed by the N.C.S. from a section called "Japanese Reflexed" into the "Japanese" section, which section, as explained under No. 11, means little more than "miscellaneous."

\section{DD. Rays incurved.}

E. Form absolutely regular.

9. The Incurved Type.-Fig.452 shows the general idea, but such a flower would hardly win a prize at an English show, where anything short of absolute regularity is relegated to the "Japanese Incurved" section (No. 10). This type is by far the most clear-cut ideal of any of these types, and for many years this ideal of the florists has so completely dominated the English Chrysanthemum shows that the incurved section has come to be known there as the "exhibition" or "show type." In Amer. the Japanese types, which are less formal and fanciful, prevail, but in England this is the most important section of all. The N.C.S. Cat. for 1896 says: "The distinguishing characteristics of the incurved varieties are the globular form and regular outline of the

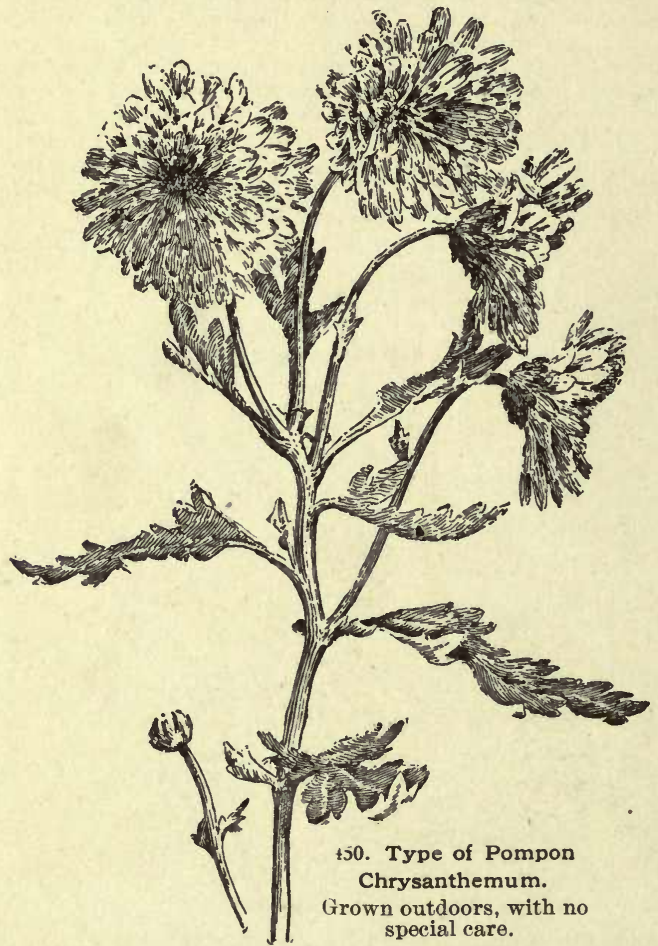

blooms. The incurved bloom should be as nearly a globe as possible, as 'depth' is an important point in estimating its value; the florets should be broad, smooth, round at the tip, and of sufficient length to form a graceful curre. They ought to be regularly arranged, and the color clear and decisive. A hollow center or a

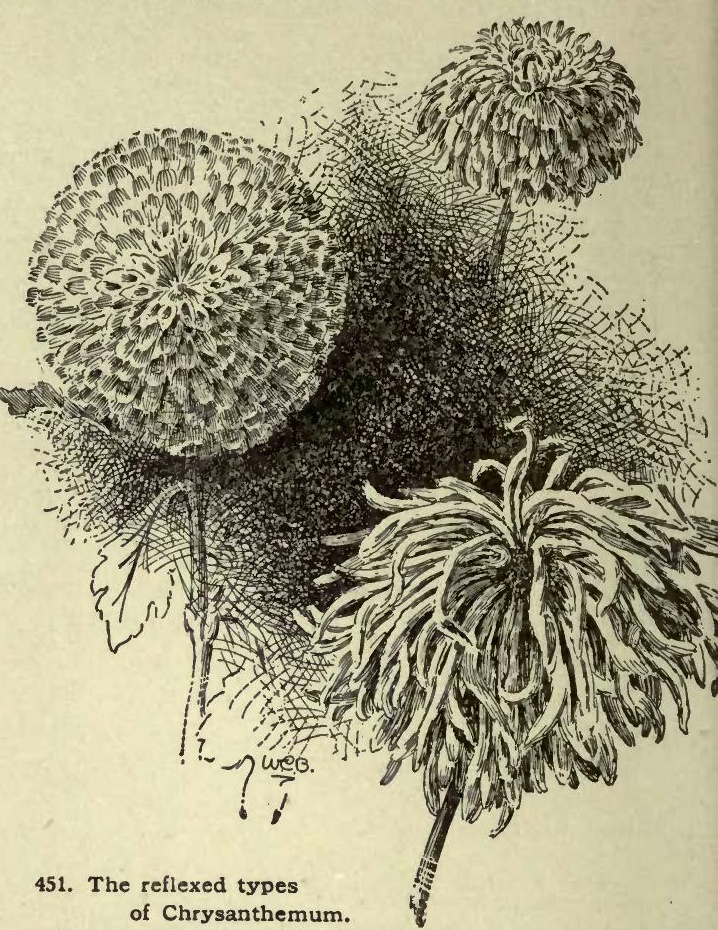

Small and regular; large and regular; large irregular.

prominent eye is a serious defect, as also are a roughness in the blooms or unevenness in outline, and a want of freshness in the outer florets." A perfect picture of this ideal of the florists may be seen in Gn. 9, p. 269 , or A.F. 5:5. Such blooms are "dressed" with tweezers so that the rays all overlap one another in perfect order. Each flower is shown separately without foliage, while the prevailing American idea in exhibition is a mass effect, with a vase of 12 or more long-stemmed fis., usually of the same variety.

$$
\text { EE. H'orm more or less irregular. }
$$

10. The Japanese Incurved Type.-Fig. $45 \%$ would be referred to this type by the English florists, together with all of the many other forms that are not globular and entirely regular. This section and the next are the most important in America. There are many variations of this type. It often happens that the outer 4 or 5 series of rays gradually become reflexed, but if most of the rays are incurved, the variety may be exhibited in this section.

DDD. Rays of various shapes: forms various.

11. The Japanese Types.-Plate VI. The word "Japanese" was originally used to designate the large-fld. fantastic kinds, introduced by Robert Fortune from Japan in 1862. It has never been restricted to varieties imported directly from Japan, but has always included seedlings raised in the western world. Before 1862, all florists' fls. in England were relatively formal and small. The informal, loose, fantastic, Japanese Chrysanthemums, introduced by Fortune in 1862, broke up the formal era, and the craze for large specimen blooms which resulted in flower-shows all over the world reached America in 1889. The "Japanese section" of the National Chrysanthemum Society now means little more than miscellaneous. The 10 types previously mentioned can be rather accurately defined, but the Japanese section is purposely left undefined to include everything else. All the tubular and quilled sorts are now included in it, though formerly kept distinct. 
Marked forms are Laciniatum, Lillian B. Bird, Millbrook, Mrs. W. H. Rand, A. H. Wood, Shavings, Northern Lights.

Relative Importance and Uses of the Types. - In general, the large-fld. forms are more popular than the small-fld. forms, especially at exhibitions, where great size is often the greatest factor in prize-winning. Types 9, 10 and 11 are the most important in America, especially the Japanese section. The fls. of types 9 and 10 are likely to be more compact and globular, and hence better for long shipments than the looser and more fanciful types. Types 9, 10 and 11 are the ones to which most eare is given, especially in disbudding and training. They are the ones most commonly grown by the Horists for cut-fls. and whenever one large fl. on a long stem is desired. The anemone-flowered forms are all usually considered as curiosities, especially the Japanese Anemones, which are often exhibited as freaks and oddities. The single and anemone-flowered forms are used chiefly for specimens in pots with many small fls., but all the other types are used for the same purpose. For outdoor culture, the hardy Pompons, with their numerous small fls., are usually better than the large-flowering or Japanese kinds. In America, the Chrysanthemum ranks fourth in economic importance, although its season is practically only six weeks, while the season of the florists' roses, carnations and violets is from six to nine months. If one were to put a guess in the form of figures, it might be said that possibly 60 per cent of all American Chrysanthemums are raised for eut-fls., 30 per cent for potted plants, while 10 per cent are hardy old-fashioned Pompons cultivated outdoors.

W. M.

SECTION I.-CULTURE OF THE LARGE-FLOWERED CHRYSANTHEMUMS GROWN UNDER GLASS ( $C$.

Indicum $\times$ morifolium).

Introduction and General Principles.-The first step towards success is good, healthy cuttings, and as they become established plants they should receive generous cul ture throughout their entire growing season. This requires close attention to watering, airing, repotting, and a liberal supply of nutriment.

Chrysanthemums are propagated in four ways, - by cuttings, division, seeds, and grafting. By far the most important is the first, because it is the most rapid. It is the method of the florists. In localities where the plants can remain out doors over winter without injury, they may be increased by division. This system is practiced more by amateurs than florists, being the easiest method for the home garden but not rapid enough for the florist. Propagation by seeds is resorted to only to produce new varieties, and is discussed at length under subsection IV. Grafting is very rare. Skilful gardeners sometimes graft a dozen or more varieties on a large plant, and the sight of many different colored $\mathrm{ts}$. on the same plant is always interestins at exhibitions.

\section{Subsection I.-Culture of Chrysan-} themums for cut-flowers.

This is the method chiefly employed by florists, the plants being grown in benches.

1. Propagation by Cuttings.-Plants of the preceding year afford stock from which to propagate the following season. They produce quantities of stools or suckers, which form excellent material for the cuttings. These are generally taken from $1-2 \frac{1}{2}$ in. in length, the lower lvs. removed, also the tips of the broad lvs., then placed in propagating beds close together, where they are kept continually wet until rooted. To insure a large percentage, the condition of the cuttings should be moderately soft. If the stock plants are al. lowed to become excessively dry, the cuttings are likely to barden, and thus be very slow in producing roots. Single-eye cuttings may be used of new and scarce varieties when necessary. These are fastened to a tooth. pick with fine stemming-wire, allowing half of the toothpick to extend below the end of the cutting, and when inserted in the cutting-bed the end of the cutting should rest upon the sand. It requires more time to produce good plants by this system than where fair-sized cuttings can be taken, but it is often of service where stock is limited. The propagating house should be well aired, and it is advisable to change the sand after the second or third batch of cuttings has been removed, to avoid what is termed cutting-bench fungus. The cuttings should never be allowed to wilt, and this is avoided by giving abundance of air, and when the temperature reaches over $70^{\circ}$ from sun heat, by shading with some material, either cloth or paper.

2. Planting.-Cuttings should not be allowed to remain in the cutting-bench after the roots are 1/2 in in length, or they will become hardened, which will check the growth. As soon as rooted, they should be potted into 2 -in. or $2 \frac{1}{2}$-in. pots, using good, mellow soil with a slight admixture of decomposed manure. Most of the large fls. are produced under glass, and the bench system is generally employed, which consists of 4 or 5 in. of soil placed upon benches. In these benches the small plants are planted 8-12 in. apart each way, from the latter part of May to the middle of July. Those planted at the first date generally give the best results. The soil should be pounded rather firm either before planting or after the plants have become established.

3. Soil. - There are many ideas as to what soil is best suited for the Chrysanthemum, but good blooms may be grown on clay or light, sandy loam, provided the cultivator is a close observer and considers the condition of the soil in which they are growing. Clay soil, being more retentive of moisture, will require less water and

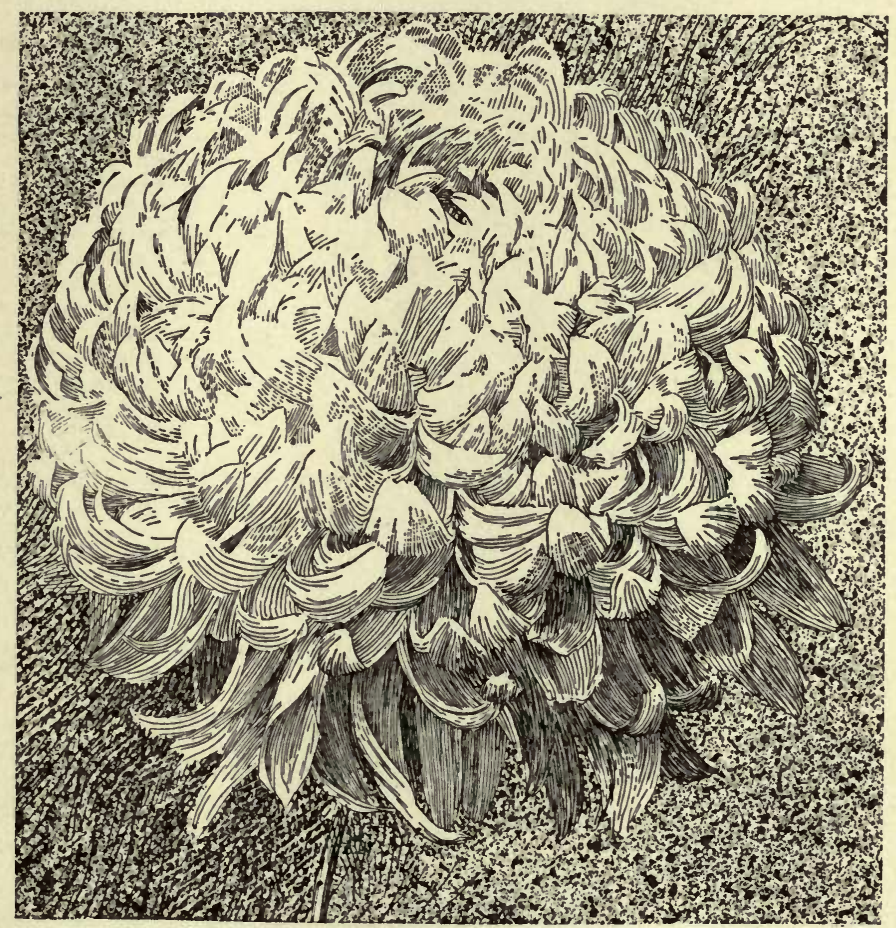

452. Type ot Japanese (ncurved Chrysanthemum.

feeding than soil of a more porous nature. The Chrysanthemum is a gross feeder, and, therefore, the fertility of the soil is very important in the production of fine 
blooms. Each expert has a way of his own in preparing the soil, but as equally good results have been obtained under varied conditions, it is safe to conclude that the method of preparing the soil has little to do with the results, provided there is sufficient food within their

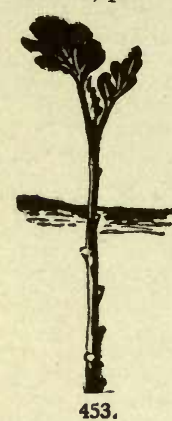

One kind of

\section{Chronthemum}

cutting. reach. All concede that fresh cut sod, piled late the preceding fall or in early spring, with $1 / 2$ to $1 / 3$ its bulk of halfdecomposed manure, forms an excellent compost. Many use 1 or 2 in. of manure as a mulch after the plants have become established. Others place an inch of half-decomposed manure in the bottom of the bench. This the roots find as soon as they require it. Good blooms have been grown by planting on decomposed sod and relying on liquid applications of chemicals.

4. Feeding. - No definite rule can be given for this work, as so much depends on the amount of food incorporated in the soil. If the soil be very rich, the liquid applications should be only occasional and very dilute. There is more danger of overfeeding by the use of liquids than by using excessively rich soil. Each grower must depend on his own judgment as to the requirements, being guided by the appearance of the plants. When the lvs. become dark colored and very brittle, it is safe to consider that the limit in feeding has been reached. Some varieties refuse to bud when overfed, making a mass of lvs. instead. Others show very contorted petals, giving a rough, unfinished bloom. Still others, particularly the red varieties, are likely to be ruined by decomposition of the petals, called burning, especially if the atmosphere is allowed to become hot and stuffy. The same result will follow in dark weather, or when the nights become cool, if the moisture of the house is allowed to fall upon the blooms. Under such conditions, the ventilation should remain on every night, or heat be turned in according to the outside temperature.

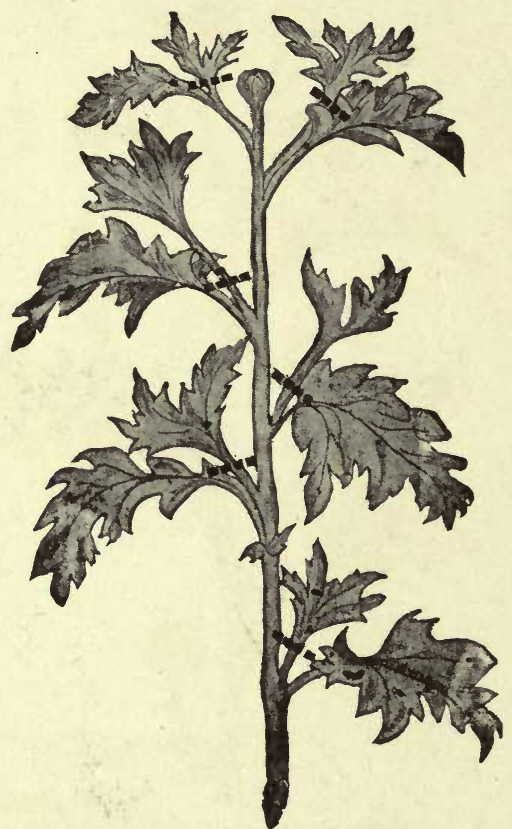

454. Crown bud of Chrysanthemum at an early stage. Showing the shoots to be removed if the crown bud is to be saved.

5. Watering.-Let the foliage be the index to watering. If it appears yellow and sickly, use less water, and see that the drainage is perfect. There is but little dan ger of overwatering as long as the foliage is bright green. A little shading at planting time is not objectionable, but it should be removed as soon as the plants are established. It is often necessary to shade the pink

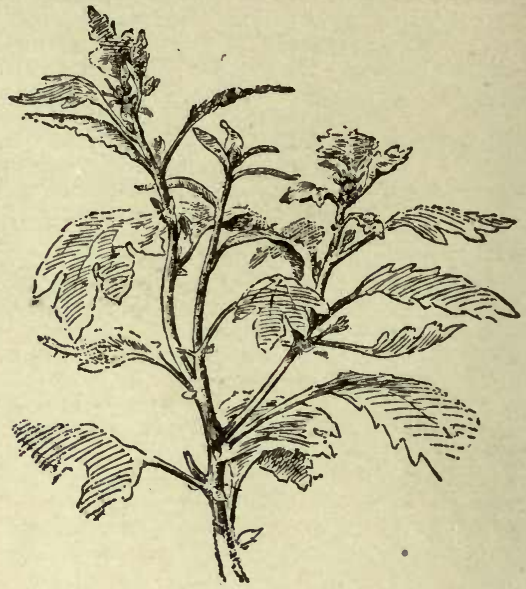

455. Crown bud of Chrysanthemum at a later stage.

Showing how its strength is sapped by the shoots beneath, which are just showing clusters of terminal buds.

and red flowers if the weather continues bright for some time, to prevent their fading.

6. Training. - When the plants are $8 \mathrm{in}$. high, they should be tied either to stakes or to jute twine. In the former system, use one horizontal wire over each row, tying the stake to this after the bottom has been inserted into the ground. Two wires will be necessary where twine is used, one above the plants and the other a few inches above the soil. From the first of August until the flowers are in color all lateral growths should be removed as soon as they appear, allowing only the shoots intended for flowers to remain. The above remarks refer to the training of benched Chrysanthemums as grown by florists for cut-flowers. Other kinds of training are described under Subsection $I I$.

7. Disbudding. - No special date can be given for this work, as much depends on the season and the earliness or lateness of the variety to be treated. Buds usually begin to form on the early sorts about Aug. 15, or soon after, and some of the late varieties are not in condition before Oct. 10. The object of removing the weak and small buds and retaining the best is to concentrate the whole energy of the plant and thereby increase the size of the flower. There are two forms of buds, crowns and terminals. A crown bud is formed first, never comes with other flower-buds, and is provided with lateral growths which, if allowed to remain, will continue their growth and produce terminal buds later. Terminal buds come later, always in elusters, are never associated with lateral growths, and terminate the plant's growth for that season. If the crown bud is to be saved, remove the lateral growths as shown by the dotted lines in Fig. 454 , and the operation is complete. If the terminal bud is desired, remove the crown and allow 1, 2 or 3 (according to the vigor of the plant) of the growths to remain. In a few weeks these will show a cluster of buds, and, when well advanced, it will be noticed that the largest is at the apex of the growth (the one saved, if perfect, as it usually is), and one at each of the leaf axils (see Fig. 456). The rejected buds are easiest and safest removed with the thumb and forefinger. Should the bud appear to be one-sided or otherwise imperfect, remove it and retain the next best. In removing the buds, begin at the top and work down. By so doing there are buds in reserve, in case the best one should accidentally be broken, while if the reverse course were taken, and the best bud broken ai the completion of the work, all the labor would be lost. A few hours' disbudding will teach the operator how far the buds should be advanced to disbud easily. Early and late in the day, when the 
growths are brittle, are the best times for the work. Some growers speak of first, second and third buds. The first is a crown, and generally appears on early propagated plants from July 15 to August 15 . If re-

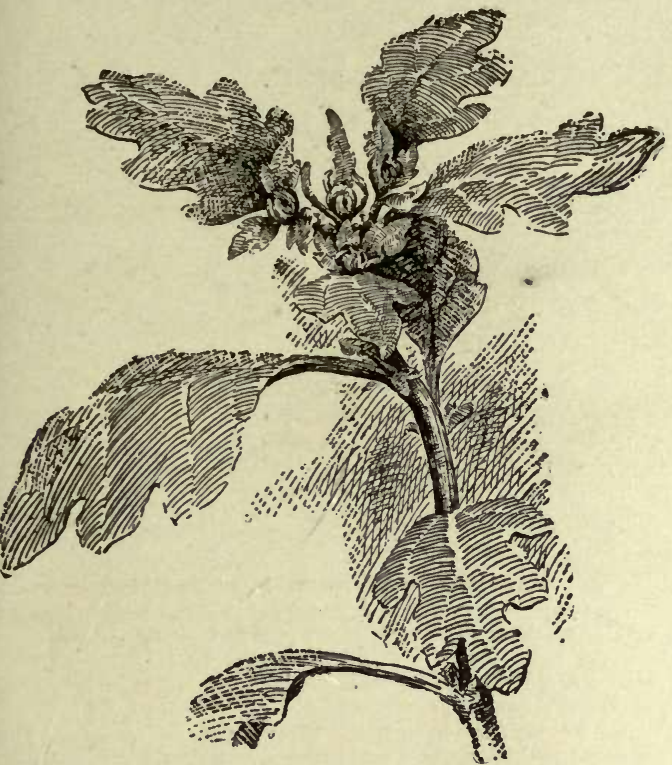

456. Terminal budz of Chrysanthemum at an early stage. None too early for disbudding.

moved, the lateral growths push forward, forming another bud. In many cases where the crowns are removed early, the next bud is not a terminal, but a second crown, which is termed the second bud. Remove this, and the third bud will be the terminal. Plants propagated in May and June generally give the second and third bud, not forming the typical crown. Those struck in July and planted late give the terminal only. Most of the best blooms are from second crown and terminal. Pink, bronze and red flowers from first crowns are much lighter in color than those from later buds. They are large, but very often abnormal to such an extent as to be decidedly inferior. This is doubtless due to the large amount of food utilized in their construction, owing to the long time consumed in development. The hot weather of September and October must have a detrimental effect upon the color. Consult Figs. 454-457.

8. Enemies.-Green and black aphis are the most destructive insects. Through the summer months tobacco dust broadcasted over the plants is an effective remedy. At the approach of cool weather it is best to resort to light fumigations of tobacco. Grasshoppers are sometines very destructive. Handpicking is conceded to be the best method, although if there are quantities of small ones a weak solution of Paris green may be resorted to.

Subsection II.-Culture of Chrysanthemums in pots.

The same principles are eniployed in pot culture as when planted upon the bench, with the exception that the plants are generally allowed to produce more blooms. The most popular type of pot plant for home growing, or for sale by florists and intended for home use, is a compact, bushy plant, $1 \frac{1}{2}-2 \mathrm{ft}$. high, branched at the base, and bearing from 4-20 fis. averaging 3-4 in. across. They are here called "market plants." "Single-stem plants" are also popular. Great quantities of large fls. (say 20-100) are rarely grown on a potted plant, except for exhibitions. Such plants are commonly called "specimens," and the three leading forms are the bush, the standard and the pyramid.

1. Market Plants.-Dwarf plants of symmetrical form, with foliage down to the pots, are the most salable, and, when thus grown, require constant attention as to watering and stopping, allowing each plant plenty of room to keep the lower leaves in a healthy condition. Cuttings taken June 1 and grown in pots, planted on old carnation benches or in spent hotbeds (light soil preferable), and lifted by August 15, will make very nice plants $1-1 \frac{1}{2} \mathrm{ft}$. high. The reason for lifting early is to have them well established in their flowering pots before the buds are formed.

2. Single-stem Plants. - Same culture as market plants, except that they are restricted to one stem and flower. Those from 1-2 ft. in heigut are more effective and useful than tall ones. For this reason many prefer plunging the pots out of doors where they have the full benefit of the sun and air, making them more dwarf than when grown under glass.

3. Pot Plants for Cut-flowers.-Culture same as for specimen plants, except that the nipping should be discontinued July 1 to give sufficient length to the stems. If large flowers are desired, restrict the plants to 8 or 10 growths. Such plants can be accommodated in less space than specimens, where the chief object is symmetry.

4. Bush Plants. - For large bush plants, the cuttings should be struck early in February, and grown along in a cool, airy house, giving attention to repotting as often as necessary. The final potting into 10 - or 12 -inch pots generally takes place in June. They are potted moderately firm, and watered sparingly until well rooted. As soon as the plants are 5 or $\mathbf{6}$ in. high the tips should be pinched out, to induce several growths to start. As the season advances and the plants make rapid growth, pinching must be attended to every day up to the latter part of July, to give as many breaks as possible and keep them in symmetrical form. By the middle of $\mathrm{Au}$ gust (if not previously attended to), staking and getting the plants in shape will be a very important detail. If stakes are used, they must be continually tied-out, as the stems soon begin to harden, and this work can be best accomplished by looking them over daily. Light

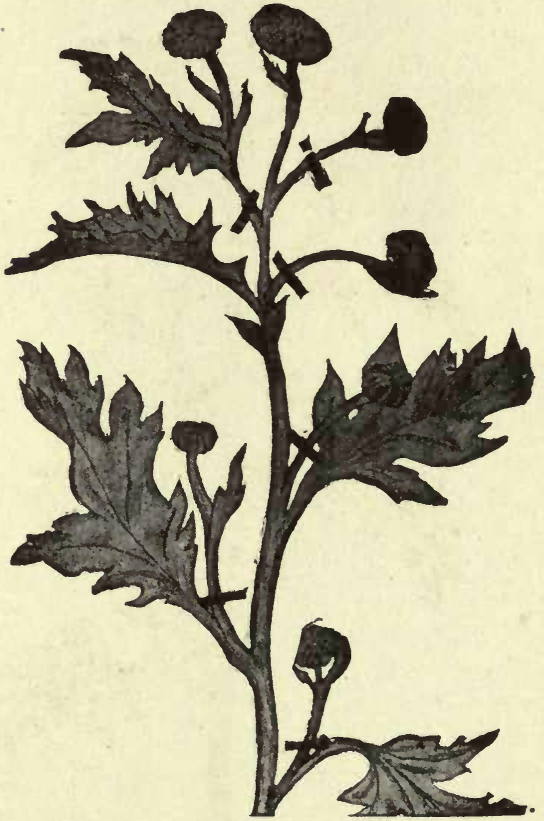

457. Terminal buds at a later stage.

The top one is usually the strongest, and being retained, is called "the terminal bud." The others should have been removed long before they were as large as here shown.

stakes of any material may be used. Many other methods are in use, such as wire hoops and wire frame-work. to which the growths are securely tied. 
5. Standards differ from bush plants in having one stout, self-supporting stem, instead of many stems. They require the same culture as bush plants, with the exception that they are not stopped, but allowed to make one continuous growth until 3,4 or $5 \mathrm{ft}$. high, and are then treated the same as bush plants. They will require the same attention as to stopping and tying to secure symmetrical heads.

6. Pyramids are only another form of bush plants, and it is optional with the grower which form he prefers.

Subsection III.-Culture of Chrysanthemums for the production of new varieties.

The objeet of seed-saving is the improvement of existing varieties. It is not conclusive, however, that all seedlings will be improvements ; in fact, it is far from this, as the greater portion are inferior to their antecedents. Only those who give the most careful consideration to cross-fertilization are certain of marked success. Handhybridized seeds possess value over those haphazardly fertilized by wind and insects only according to the degree of intelligence employed in the selection of parents. What the result will be when a white flower is fertilized with a yellow one, the operator cannot determine at the outset. It may be either white, yellow, intermediate, or partake of some antecedent, and thus be distinct from either. Improvements in color can be obtained only by the union of colors, bearing in mind the laws of nature in uniting two to make the third. Red upon yellow, or vice-versa, may intensify the red or yellow-give orange or bronze, as nature may see fit: The operator is more certain of improving along other lines, such as sturdiness or dwarfness of growth, earliness or lateness of bloom, or doubleness of flowers. The selection of those most perfect in these particulars is very sure to give similar or improved results. Always keep a record of thin work showing the parents of a seedling. The satisfaetion of knowing how a meritorious variety was produced more than pays for the trouble, and may lead to further improvements in certain lines. The operation begins when the flower is half open, eutting the petals off close to their base with a pair of scissors, until the style is expord. Should the flower show signs of having disk or staminate florets, remove these with the points of the scissors and thes avoid self-fertilization. When the styles are fully grown and developed, the upper surface or stigma is in condition to receive the pollen. By pushing aside (with the thumb) the ray florets of the flower desired for pollen, the disk florets which produce the pollen will become visible. The pollen may be collected on a camel's-hair pencil or toothpick and applied to the stigma of the flower previously prepared. If a toothpick be used, never use it for more than one kind of pollen. By alkowing the camel's-hair pencil to stand in an open-monthed vial of alcohol a few moments after using, it may be again used, when dry, upon another variety without fear of the pollen of the former operation affecting the present. Cuttings struck in June and July and grown to single bloom in 4 -inch pots are the most convenient for seeding. Such flowers, if not given too mueh feed, are more natural and furnish abundance of pollen, as well as being easier to trim than the massive blooms produced for the exhibition table. The pollenizing should be done on bright, sunny days, and as early in the day as possible. As soon as the seed plants are trimmed, they should be placed by themselves to avoid fertilization by insects, and should there remain until the seeds are ripe. Keep the plants rather on the dry side, and give abundance of air. Seeds, which ripen in 5 to 6 weeks, should be saved without delay, and carefully labelled. In sowing seeds, they should be covered very lightly and kept in a temperature of $60^{\circ}$. When the seedlings are large enough to handle easily, remove to small pots, or transplant further apart in shallow boxes. Chrysanthemums flower the first season from seed.

\section{Subsection IV.-Varieties.}

Of the long list of new varieties sent out each year, but few are retained after the second year's trial. This is probably due to the fact that most American growers are more interested in the commercial value of the flower than the curious forms or striking colors they present. Exhibitions have not reached the hearts of the people here as in Fngland and France. There are a few varie- ties that hare stood the test for several years; such as Ivory, 1889 ; W. H. Lincoln and Minnie Wanamaker, '90 ; Mrs. J. G. Whilldin, '91; Mrs. Jerome Jones, Col. W. B. Smith, Mrs. A. J. Drexel, Margaret Jeffords, Jos. H. White, Geo. W. Childs, Merry Monarch, '92 ; Niveus, Maud Dean, The Queen, Golden Wedding, H. L. Sunderbruch, Good Gracious, Pres. W. R. Smith, '93. There are many other varieties that have stood the test for 4 or 5 years.

It is not the purpose of this article to recommend varieties of Chrysanthemums, but the following list includes the best varieties now known. The list will be valuable as showing a serviceable classification:

Selection of varieties based upon the main types.(1) Incurved: Belle Poitevine, Congo, Irma, Lorelei, Mrs. T. D. Hatfield, Mongolian Prince, Mrs. Robt. Craig, Mrs. L.C. Madeira, Major Bonnaffon, Mrs. R.C. Kingston. (2) Japanese: Chito, Geo. W. Childs, Golden Gate, Golden Wedding, Mayflower, Modesto, Thornden, Mutual Friend, Black Hawk, Niveus, Viviand Morel, Yanoma. (3) Japanese Incurved: Nyanza, Mrs. W. C. Egan, Eugene Dailledouze, Georgiana Pitcher, Good Gracious, Jennie Falconer, Mrs. Geo. West, Philadelphia, The Queen, Mrs. Jerome Jones, Western King. (4) Hairy: Golden Hair, Louis Boehmer, Mrs. A. Hardy, R. M. Grey, White Swan, Queen of Plumes. (5) Reflexed: Cullingfordii, Dorothy. Toler, Gold Standard, Miss Elma O'Farrell, Tuxedo, Parthenia. (6) Large Anemone: Ada Strickland, Descartes, Falcon, Junon, Marcia Jones, Thorpe, Jr. (7) Japanese Anemone: Condor, Enterprise, Mrs. F. Gordon Dexter, San Joaquin, Surprise, Satisfaction. (8) Pompon: Black Douglass, Golden Mlle. Marthe, Mile. Marthe, Mrs. Bateman, Snowdrop, Wm. Kennedy. (9) Pompon Anemone: Antonius, Emily Rowbottom, Marie Stuart, Mme. Chalonge, Mme. Sentir, Queen of Anemones. (10) Early Hardy Pompons: Bronze Bride, Flora, Frederick Marronet, Mme. Jolivart, Mr. Selley, Miss Davis, Mrs. Cullingford, Mlle. Elise Dordan, Illustration, St. Mary. (11) Single: Mizpah, Framfield Beauty.

Selection of varieties based upon color.-White Ivory, Mrs. M. A. Ryerson, Mrs. H. Weeks, Mrs. Henry Robinson, Mutual Friend, Niveus. Pink-Merula, Mme. F. Perrin, Helen Bloodgood, Harry Balsley, Iora, Autumn Glory. Amaranth, Purplish Crimson, Magenta, and the like - Casco, Mrs. A. J. Drexel, Mrs. Geo. West, Elma O'Farrell. Crimson - Shilowa, Black Hawk, Geo. W. Childs, John Shrimpton, Fisher's Torch, Defender. Red and Yellow, Bronze, Buff-Chito, Nyanza, Chas. Davis, Edwin A. Kimball, Buff Globe, Rustique, Hicks Arnold. Yellow - Modesto, Eugene Dailledouze, Golden Wedding, Thornden, Major Bonnaffon, Liberty.

Selection of varieties based upon special uses. -Bush Plants: White - Mutual Friend, Jos. H. White; Yellow -W. H. Lincoln, C. Chalfant; Pink - Viviand Morel, Iora; Bronze-Col. W. B. Smith, Hicks Arnold; Crimson-Geo. W. Childs, J. Shrimnton. Single Stem Pot Plants: White - Mrs. H. Robinson, Merza ; YellowMajor Bonnaffon, H. L. Sunderbruch; Pink-Mme. F. Perrin, Merula ; Bronze - Boule d'Or, Rinaldo : Crimson - Geo. W. Childs, John Shrimpton. Exhibition Blooms: White-Frank Hardy, Fee du Champsaur, Mme. Carnot, Western King; Pink - Viviand Morel, Iora, Good Gracious ; Yellow-Modesto, Golden Wedding, Eugene Dailledouze, G. J. Warren; Bronze-Chas. Davis, Rustique, Nyanza; Crimson-Geo.W. Childs, Shilowa, Black Hawk; Miscellaneous - Chito, yellowish bronze; Lady Hanham, golden cerise; Mrs. Geo. West, rosy purple. Commercial Blooms (based upon quality, and ease of culture : White-Ivory, Mrs. Henry Robinson, Mrs. Jerome Jones; Pink-Mrs. S. T. Murdock, Mme. F. Perrin, Glory of Pacific; Yellow-Marion Henderson, Major Bonnaffon, Yellow Mrs. Jerome Jones : Crimson - Geo. W. Childs, Shilowa, Black Hawk. Odd Varieties : Lillian B. Bird, Mrs.W. H. Rand, Heron's Plume, Pitcher \& Manda. Best Early: White-Mme. F. Bergmann, Ivory, Midge, Geo.S. Kalb; Pink-Glory of Pacific, Pink Ivory, Merula, Lady Playfair : Yellow-Harry Hurrell, H. L. Sunderbruch, Marion Henderson, Golden Trophy. Best Late : WhiteMrs. Jerome Jones, Yanoma, Wm. H. Chadwick, Merry Christmas; Pink - Francis B. Hayes, Harry Balsley, Mrs. S. T. Murdock, Maud Dean. Yellow-W. H. Lincoln, H. W. Rieman, Liberty, Yellow Mrs. Jerome Jones. 


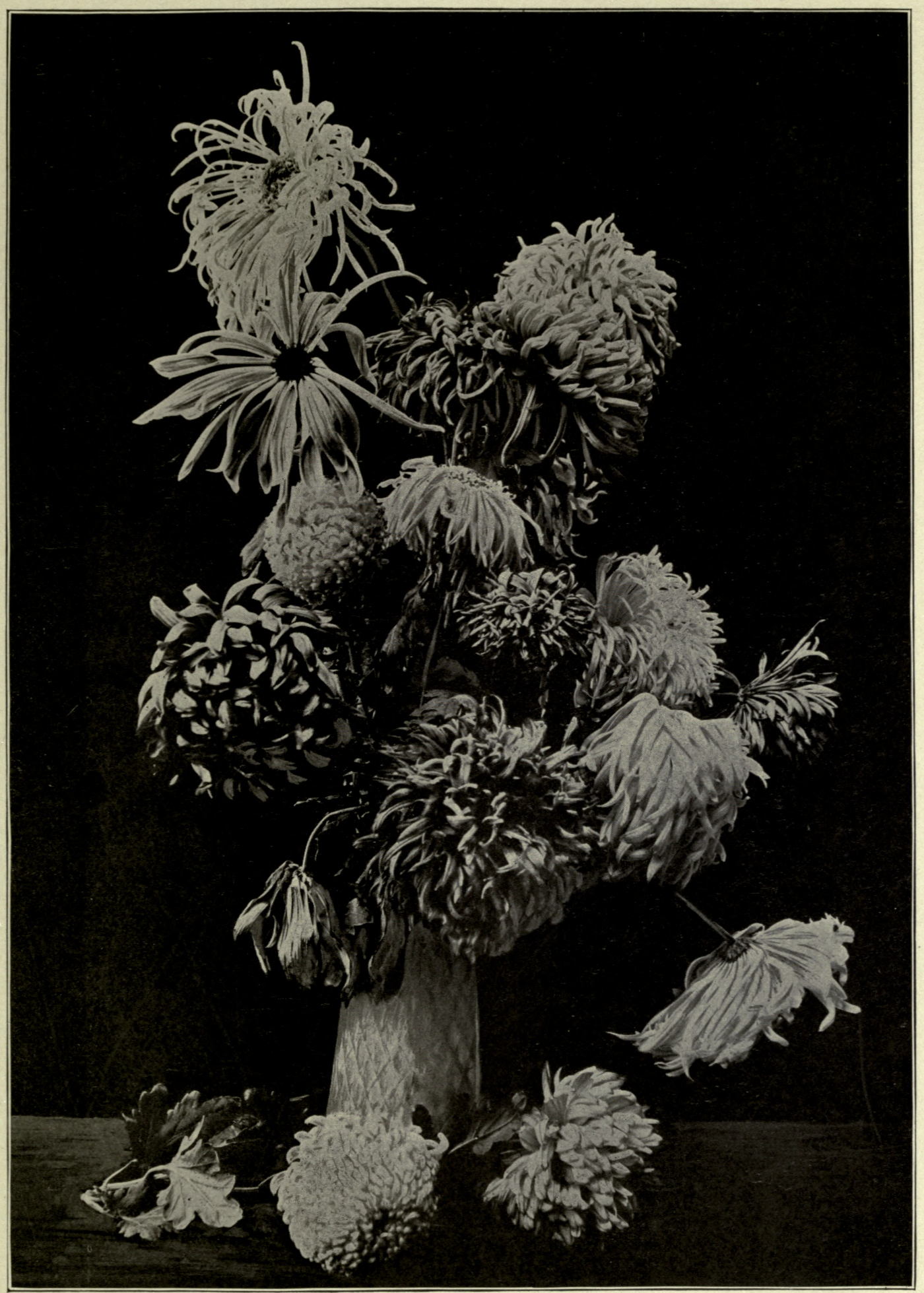

Plate VI. Chrysanthemums, mainly Japanese types

The two ball-shaped flowers belong to the Chinese or Incurved type. Specimens of the Single and Anemone types are also seen 

Many of the midseason varieties are good for Thanksgiving and after if planted late. ELMER D. SMith.

Subsection V.-Culture of Chrysanthemums for Exhibition.

This branch of cultivation naturally requires more care than any other, and the cultural side counts for very little compared with the personal qualities of the exhibitor after the fls. are delivered at the exhibition hall. Prize-winning is more like business than floriculture, and is, therefore, largely a matter of experience. It is hard to extricate any fundamental principles, but some suggestions are made under Exhibitions. Many towns have never seen any kind of a flower show but a Chrysanthemum show. The prizes are often larger and more specialized than with any other flower. As soon as the schedule of prizes is published the competitor should pick out the classes he intends to try for. The importance of strong stock can hardly be overstated. Novelties or highly forced plants are more likely to give poor results than selected stock carefully grown by the competitor himsclf. Next to a general comprehension of Chrysanthemum culture, perhaps the two most important factors in success are the quality of stock and the choice of variety. In the biggest exhibitions, novelties are classed by themselves. One of the commonest mistakes that beginners make is to depend too much upon novelties for general prizes. It is desirable to exchange visits with other growers, to take the horticultural periodicals, to master the art of shipping, and to study the analysis of successful varieties. To meet a desired date, crown buds can be used to hasten late varieties.

As the century eloses the varieties that win the most prizes are: White-Mrs. Henry Robinson, Mayflower, Nivens, The Queen, Mrs. Jerome Jones, Our Mutual Friend; Yellow-Major Bonnaffon, Modesto. W. H. Lineoln, Golden Wedding, Miss Georgiana Pitcher: Pink-Viviand-Morel, Mrs. Perrin, Maud Dean; Red-Geo. W. Childs.

W. M.

SECTION II.-CULTURE OF MARGUERITES INDOORS.

There are two types of Marguerites, the common one, or Paris Daisy, with coarser green foliage, and the glaucous Marguerites, with finer cut, glaucous foliage. The former, $\boldsymbol{C}$. frutescens, is better for cut-flowers. The latter, $C$. anethifolium, is probably better for large specimens. Marguerites are standard plants with florists and in the conservatories of amateurs, being of easy culture and remarkably free from enemies. They are cultivated for two distinct purposes, - for eut-flowers and for specimen plants, young plants being used for the former purpose, and older ones for the latter. For cut-flowers, the cuttings are rooted in spring, and the florists usually keep the plants in pots all summer outdoors, though this is not necessary for amateurs, and $\mathrm{Hs}$. are produced during the following winter. It is sometimes said that Marguerites do not lift well in the fall after being planted out all summer in the garden, and that unrestricted root-room makes the plants too large for the best production of cut-flowers. The principles underlying the matter are as follows : in turning plants out of pots into the open ground in spring, a plant that has filled its pot well with roots tends to make a much more compact root-system in the garden than the plant that had but a few roots in its pot, and the former plant is easily lifted in the fall and with less damage to the roots. As a matter of fact, Marguerites do not belong to the class of plants that are difficult to lift in the fall, and it is only a matter of starting the cuttings early enough in spring to get the plant moderately pot-bound before it is planted out into the open ground: Specimen plants are most attractive in the second winter following the spring in which cuttings were struck. After that they are likely to become too large and straggling. While in the garden the fls. should not be allowed to form, if the main object is highgrade cut-flowers in quantity for the winter. Old plants that are unfit for further use in the conservatory may be turned out in summer and will furnish scattering bloom all summer, though the fls. are likely to be

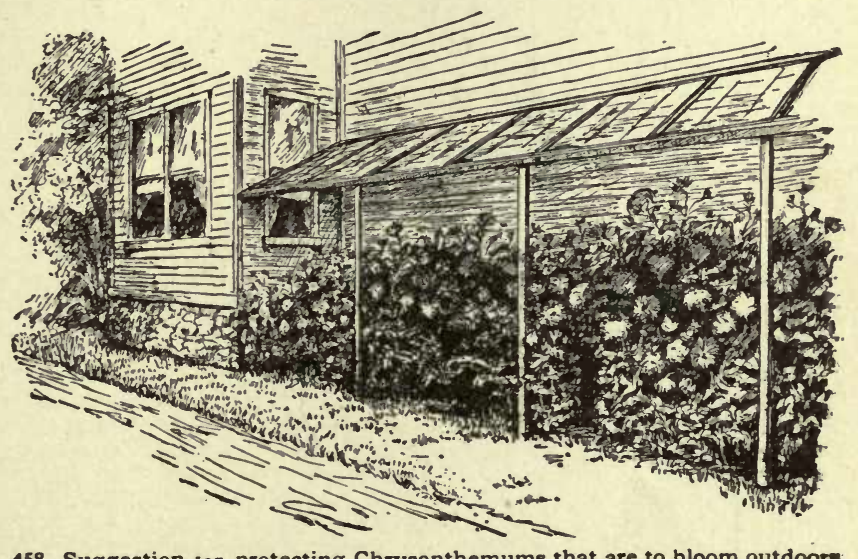

rather small. If there were sufficient demand it coulā be easily managed to ha:e fls. in every month of the year. It is a great pity to cut Marguerites without any foliage. The rule is that all fls. look best with some foliage, especially their own. With a little forethought, just as many fls. can be secured, and they will look much prettier and last longer. There are very few conservatories without some Marguerites. An excellent plan is to have a number of plants in 6-inch pots from cuttings struck the previous spring. A plant looks bad at first when the fls. have been removed on sprays a foot long, but in a short time they are ready for cutting again. With a little management a succession of fls. can be maintained without making all the plants thin or unsightly. Such sprays will last a week or two in water, and the opening of the larger buds is an additional feature of beauty which is lost if $\mathrm{fls}$. are cut with

\section{SECTION III.-CULTURE OF CHRYSANTHEMUMS OUT OF DOORS.}

The oldest of the outdoor types are the Pompons (Fig. 450), which produce from 40-100 buttons an inch or two across, with short and regular rays. Such plants can be left outdoors all winter. A selection of these oldfashioned kinds is given on page 307 , under head of " (8) Pompon." Since the large-flowering or Japanese types have come in, numberless attempts have been made to grow them outdoors, but with poor results. The greenhouse varieties are not so hardy. In the north they are likely to be killed by the winter. Their fls. usually lack in size, depth and symmetry, largely because there are more of them on a plant than a florist allows for his best blooms, but chiefly because they do not get as much care in general as is given to plants under glass, where space is precious. For the very best results, Chrysanthemums must be flowered under glass, and they need the greatest care and forethought practically all the year round. Half-way measures are unsatisfactory. Thus it happens that the Japanese varieties are usually unsatisfactory out of doors, and the Pompons are ehosen by those who can give very little care to plants and would rather have many small fls. than a few large ones. This also partly explains why no two dealers recommend anything like the same list of Japanese varieties for outdoor culture. Nevertheless, it is possible to grow excellent fls. 4 and 5 or even 6 in. across outdoors, but it requires staking, disbudding, and some kind of temporary protection, as of a tent or glass, during frosty weather. Fig. 458 shows a cheap and simple structure of coldframe sashes resting on a temporary framework. In severe weather a canvas curtain can be dropped in front, and the window of a warm cellar in the rear den and Forest 1:523, where J. N. Gerard has left a detailed and delightful account of his success, which is sure to rouse the enthusiasm of expert amateurs. For general outdoor culture, however, where no special care short stems and without foliage. ROBERT SHORE. opened to temper the air. Fig. 458 is taken from Gar- 
is given to the plants, the Japanese kinds are usually less satisfactory than the Pompons. These Pompons are a much neglected class since the rise of the large-flowered Japanese kinds, but they are unlike anything else in our garden flora. Their vivid and sometimes too artificial colors harmonize with nothing else at Thanksgiving time, and they are so strong and commanding that they should have a place by themselves. It is not uncommon for the fls. to be in good condition even after several light falls of snow, and they may be considered the most resistant to frost of any garden herbs. In fact, their peculiar merit is blooming after the landscape is completely desolated by successive frosts. The fis. are not ruined until their petals are wet and then frozen stiff. They are essentially for mass effects of color, and great size is not to be expected. Masses of lorown and masses of yellow, side by side, make rich combinations. The whole tribe of crimsons, amaranths, pinks, and the like, should be kept by themselves, because their colors are variable and because they make a violent contrast with yellow, which few persons can render agreeable.

The preceding remarks have applied wholly to varieties of $C$. Indicum and $C$. morifolium. The culture of all the other outdoor species is too easy to need any further remarks, except in the case of $C$. coccineum, better known as Pyrethrum roseum. In the cultivation of ornamental plants in general, and of hardy, herbaceous plants in particular, few cases are so striking as the great popularity of Pyrethrum roseum in the Old World, and the feeble and uncertain hold that it has in America.

W. M.

\section{SECTION IV.-CULTURE OF PYRETHRUM ROSEUM.}

This beautiful late spring and early summer flower, so popular and extensively cultivated in gardens abroad, has not yet found much favor here. This fact must be attributed to the general neglect of hardy flowers that prevails in most gardens, as it is an easily grown flower, hardy enough to withstand our winters. As represented to-day in the hundreds of varieties extant, it should command attention. These varieties have everything to recommend them. First and foremost, they are easy to grow. Any good garden soil will suffice for them, but they are rich feeders, and therefore the ground should be deeply dug and liberally enriched with manure. A cool, moist root-run is most conducive to their flowering, and as they are surface-rooting plants (and by consequence liable to suffer soon from hot sun), they are materially assisted by a mulch of manure, or anything that tends to conserve moisture. Propagation is best performed by division in spring. The plants may be lifted, divided into small pieces and potted up separately or planted in a bed of prepared soil in a coldframe, and in a few weeks they will make nice pieces. They can also be rapidly raised in quantity from seed, which, sown in spring, will give plants that will flower the following year. Unless the seed, however, is from very fine varieties, seedlings may result in disappointment; and, in any case, they will not give that richness and variety of form and color as represented in the best named varieties of to-day, which are the result of many years of patient labor and painstaking selection on the part of those who have made Pyrethrums a specialty. Pyrethrums are now obtainable with either single or double flowers, embracing most varied shades of color, from purest white to the richest of crimsons, and even yellow, though for a long time non-existent in Pyrethrums, seems to be an assured possibility. This hue is now possessed by several of the newer acquisitions. To select the best varieties and recommend them is not easy, when the list of one specialist alone contains 400 named varieties, about equally divided between singleand double-flowered kinds, and the best selection of today is - ertain to be superseded less than a decade hence. A few, however, of the very best are: Lord Roseberry, carmine-red; Primrose, pale yellow : Aphrodite, pure white; Alfred Henderson, deep purple ; Leonard Kelway, clear rose; Pericles, bright yellow, with guard petals of pale pink; $\mathrm{Ne}$ Plus Ultra, white, and very large; Melton, deep crimson ; Solfaterre, cream; Princess Beatrice, bright pink ; King Oscar, crimson, and Captain Nares, red. These are all double. In singles, a dozen of the best would be : Ascot, peach-pink ; Apollyon, bright pink; James Kelway, brilliant red; Oliver Twist, cream; Mary Anderson, flesh-pink; Princess Marie, pure white; Ruth, rose, tipped with white; Stanley, deep carmine-rose; Merry Hampton, dazzling crimson; Ianthe, rose ; Ochroleuca, sulphur, and Devonshire Cream, cream color.

A. Herrington.

Pyrethrum roseum in its numerous varieties possibly may never become as popular in America as in England, owing to the fact that it is not hardy under all soil and exposure conditions in the climate of northern United States. With the proper soil conditions and such attention as may be necessary, it is possible to raise Pyrethrums to the best advantage and with splendid flowering results. The ideal soil for Pyrethrums is a rich, sandy loam that is sufficiently porous to prevent stagnant moisture accumulating about the crowns of the plants. This is the first and principal essential in the culture of Pyrethrums. While they have been grown to comparatively good advantage in soils of a clayey nature, yet unless extreme care is taken to prevent this accumulation of moisture about the crowns, sad havoc is frequently made during severe winters, and especially during unusually abundant rains in the fall. While it is possible to grow Pyrethrums even under the adverse

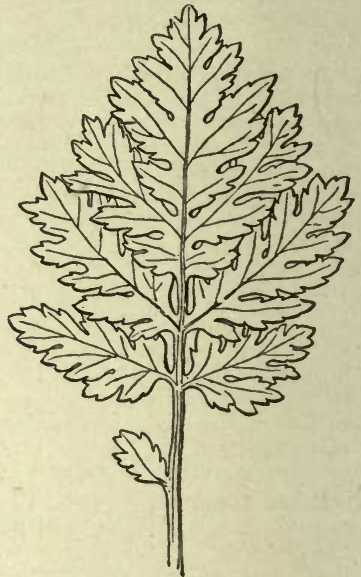

459. Leaf of Feverfew

(C. Parthenium.) conditions of a retentive clayey soil, yet in such instances, coldframe culture is preferable to depending upon the plant to take care of itself under ordinary conditions. Aside from the danger of winter-killing, there is the danger of crown rot during extremely wet periods in hot weather. In many instances, valuable collections have been quite lost owing to this trouble and the lack of appreciation of the fact that this trouble could be easily remedied by cutting away the rotting foliage nearly to the ground, so as to admit light and air to the center of the crowns to induce fresh and healthy growth. In late autumn, however, this would not be a successful treatment, except in a modified degree. From a commercial point of view, Pyrethrums are among the most difficult of plants to handle through the danger of crown rot, which is the most frequent cause of loss in shipping plants. They are among the most difficult plants to import, and can only successfully stand importation by the utmost care in packing and by shipment of the plants in late fall or very early spring; it is also essential that they should be strong, well-developed clumps in order to withstand the dangers of transportation. A stock of Pyrethrums once established in this country is easily shipped by means of our quick express transportation, if a little care is given to ventilation as well as to packing the plants as dry as possible. The confusion in the names of the varieties offered by American nurserymen is due to the inordinate desire on the part of the European dealers to produce a long list of varieties, many of which are very similar in all outward characteristics. Some of the leading dealers publish a list of from 50 to 100 varieties, and others in still greater number. At the present time, over 400 varieties of Pyrethrums are catalogued, which, while it illustrates the great interest taken in this particular plant in Europe, is evidence that many varieties must be very similar where the range of color extends only from pure white through shades of scarlet to purple, and with only a few varieties that are in any way a satisfactory yellow shade. The yellowflowered forms at best are hardly deeper than a rich buff or light lemon, and while these shades are distinctly yellow in their effect, still there is no clear golden yellow yet offered in the trade. 
Alphabetical list of species of Chrysanthemums described below (many of these names are more familiar as Pyrethrums): C. achilleæfolium, 1; anethifolium, 9 ; atrosanguineum, 10 ; aureum, 4; Balsamita, 12 ; Bur ridgeanum, 5 ; carinatum, 5 ; cinerariæfolium, 11 ; coccineum, 10 ; coronarium, 7 ; corymbosum, 2 ; Dunnetti, 5 ; feniculaceum, 9; frutescens, 8 ; hybridum, 10; Indicum, 19 ; Japonicum, 19 ; lacustre, 15 ; latifolium, 15 ; Leucanthemum, 18; maximum, 16 ; morifolium, 20 ; multicaule, 14; parthenifolium, 4 ; Parthenium, 3 ; præaltum, $4 ; P$. roseum, 10 ; C. segetum, 13 ; Sinense, 20 ; tricolor, 5 ; Tehihatchewii, 6 ; uliginosum, 17; venustum, 5 .

\section{A. Lis. cut to the midrib or nearly so.}

B. F'ls.borne in corymbs, i.e., flat-topped, dense clusters. c. Rays yellow.

1. achillexfolium, DC. (Achillèa aùrea, Lam.). Perennial, $2 \mathrm{ft}$. high: stem usually unbranched, except along the creeping and rooting base : stems and lvs. covered with fine, soft, grayish white hairs, oblong in outline, about 1 in. long, $1 / 4$ in. wide, finely cut: rays $7-8$, short, a little longer than the involucre. Siberia, Caucusus.Rare in cult. Less popular than the Achilleas with larger flower clusters.

\section{cc. Rays white.}

D. Stems grooved, striate, or angled.

2. corymbosum, Linn. Robust perennial, 1-4 ft. high: stem branched at the apex : lvs. sometimes 6 in. long, 3 in. wide, widest at middle and tapering both ways, cut to the very midrib, the segments alternating along the midrib. Eu., N. Africa, Caucasus. G. C. II. 20:201.Rare in cult. Segments may be coarsely or finely cut, and lvs. glabrous or villous beneath.

3. Parthènium, Bernh. Feverfew. Glabrous perennial, 1-3 ft. high : stem usually branched, especially toward the top: flower cluster sometimes very open and loose, especially in cultivation: fls. $3 / 4$ in. across, whitish : rays twice as long as the involucre : pappus a minute crown. Naturalized from Eu. and escaped from old gardens in Atlantic states. - The single form cult. in old physic gardens, and the full double white form commonly cult. for ornament. Foliage has a strong, bitter odor. The foliage plants commonly advertised under this specific name belong to No. 4 .

DD. Stems not grooved or striated.

4. præáltum, Vent. (P. parthenifolium, Willd.). Perennial, 6 in. high or more : pubescent, or becoming

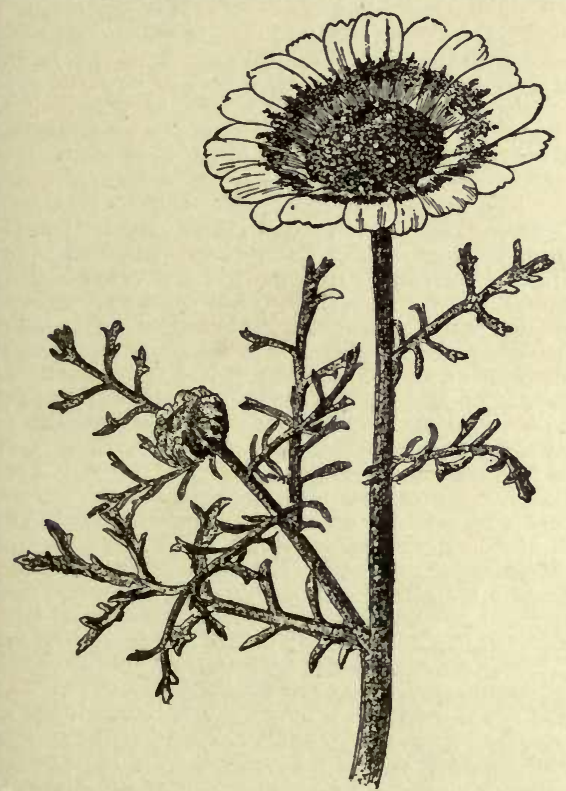

460. Chrysanthemum Burridgeanum $\left(X^{1 / 3}\right)$.

A popular strain of the summer-flowering annual, O. carinatum. nearly smooth: rays thrice as long as the involucre. Asia Minor, Persia. Var. aureum, Hort. ( $P$. aùreum, Hort.), is the Golden Feather commonly used for carpet bedding. It has yellow foliage, which becomes green later in the season, especially if flowers are allowed to form.

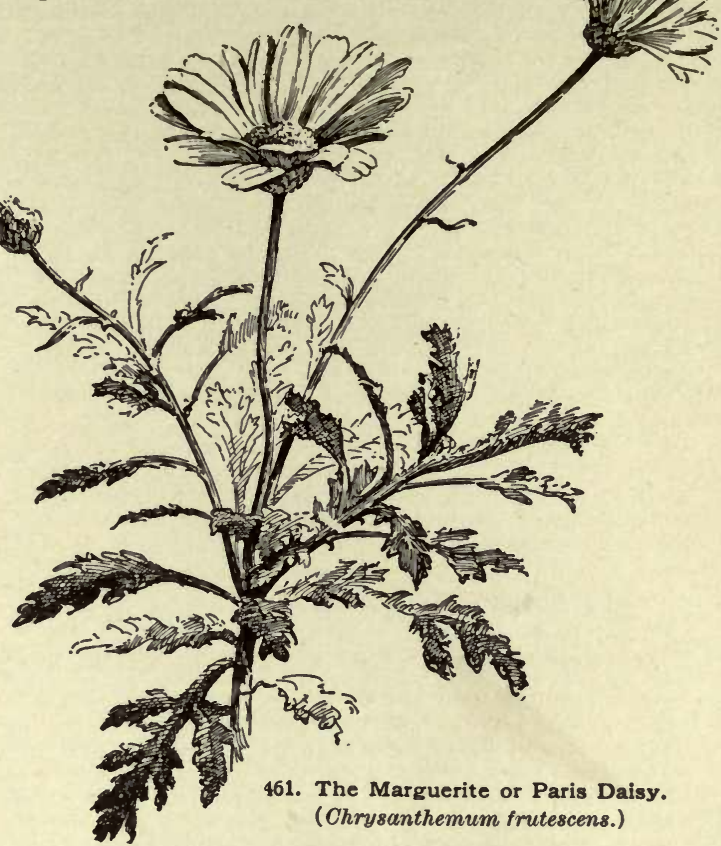

It is used for edgings. Fig. 459. Var. aureum crispum, Hort., is dwarf, compact, with foliage curled like parsley. Var. selaginoldes and var. laciniatum, Hort, are distinct horticultural forms. Var. glaucum, Hort., has dusty white foliage, and does not flower until the second year. Int. by Damman \& Co., 1895. All these varieties are prop. by seeds. - This species is considered not distinct from No. 3 by Voss in Vilmorin's Blumengärtnerei.

BB. Fls. borne singly, on the branches or stems. c. Disk dark purple.

5. carinàtum, Schousb. (C. trícolor, And.). Fig. 460 . Glabrous annual, $2 \mathrm{ft}$. high : stem much branched: Ivs. rather fleshy: fls. about 2 in. across, with typically white rays and a yellow ring at the base. Summer. These two colors together with the dark purple disk gave rise to the name "tricolor." The typical form introduced into England from Moroceo in 1798 was pictured in B.M. 508 (1799). By 1856 signs of doubling appeared (F.S. $11: 1099$ ). In 1858 shades of red in the rays appeared in a strain introduced by F. K. Burridge, of Colchester, Eng., and known as C. Burridgednum, Hort. (see B.M. 5095 , which shows the ring of red on the rays, adding a fourth color to this remarkably brilliant and varied flower, and F.S. $13: 1313$, which also shows $C$. venùstum, Hort., in which the rays are entirely red, except the original yellow circle at the base). C. annulatum, Hort. is another name for the kinds with circular bands of red, maroon, or purple (R.H. 1869:450). C. Dinnetti,'Hort., is the name of another seed-grower's strain. There are full double forms in yellow, margined red, and white, margined red, the fls. 3 in. across (see R.H. 1874:410). See, also, Gn. 26 , p. $440 ; 10$, p. 213 , and $21: 319$. R.H. 1874 , p. 412. S.H. 2: 477. - The commonest and gaudiest of annual Chrysanthemums, easily distinguished by the keeled or ridged scales of involucre and the dark purple disk. "Carinatum" means "keeled."

\section{cc. Disk yellow.}

D. Height less than $1 \mathrm{ft}$.

6. Tchihátchewii, Hort. Turfing Daisy. Densely tufted plant for carpeting dry, waste places. Height 2-9 
in.: stems numerous, rooting at the base: foliage dark green, finely cut: fls. borne profusely for several weeks in midsummer : rays white. Siberia or Asia Minor? R.H. 1869 , p. 380 and 1897, p. 470 . Gn. 26, p. 443. - Prop. by division of roots or simply by cutting the rooted stems, but chiefly by seeds. This has never been fully deseribed, and it is possible that the lvs. may not be cut to the midrib or near it.

\section{DD. Height more than $1 \mathrm{ft}$.}

\section{E. Plants annual.}

7. coronàrium, Linn. (Ánthemis coronària, Hort.). Height 3-4 ft.: lvs. bipinnately parted, somewhat clasping or eared at the base, glabrous, the segments closer together than in C. carinatum: involucral scales broad, scarious : rays lemon colored or nearly white. JulySept. Mediterranean. Gn. 26:467. G.C. II. 19:541.The full double forms, with rays reflexed and imbricated, are more popular than the single forms. This and $C$. carinatum are the common "summer Chrysanthemums." This is common in old gardens, and is also slightly used for bedding and for pot culture.

\section{EE. Plants perennial.}

F. Greenhouse plants, shrubby at the base: stems branched at the top: rays white or lemon.

\section{G. Foliage not glaucous.}

8. frutéscens, Linn. Marguerite. Paris Daisy. Fig. 461. Usually glabrous, 3 ft. high : lvs. fleshy, green : fls. numerous, always single : rays typically white, with a lemon-colored (never pure yellow or golden) form. Canaries. G.C. II. 13:561. Gn. 12, p. $255 ; 17$, p. 5, and 26, p. 445. - Int. into Eng. 1699. This is the popular florists' Marguerite, which ean be had in flower the year round, but is especially grown for winter bloom. Var. grandiflorum, Hort., is the large-fld. prevailing form. The lemon-colored form seems to have originated about 1880 . Under this name an entirely distinct species has also been passing for about a century, yet it has never been advertised separately in the Amer. trade. See No. 9.

\section{GG. Foliage glaucous.}

9. anethifölium, Brouss. (C. fæniculàceum, Steud. $P$. fouiculdeeum, var. bipinnatifidum, DC.). GLAucous MaRguerite. Fig. 462. Rarer in cult. than No. 8 (which see), but distinguished by its glaucous hue and by the way in which the lvs. are cut. The segments of No. 9 are narrower, more deeply cut, and more distant. The Ivs. are shorter petioled. Canaries. - The dried specimen in the Garden Herbarium of Cornell University
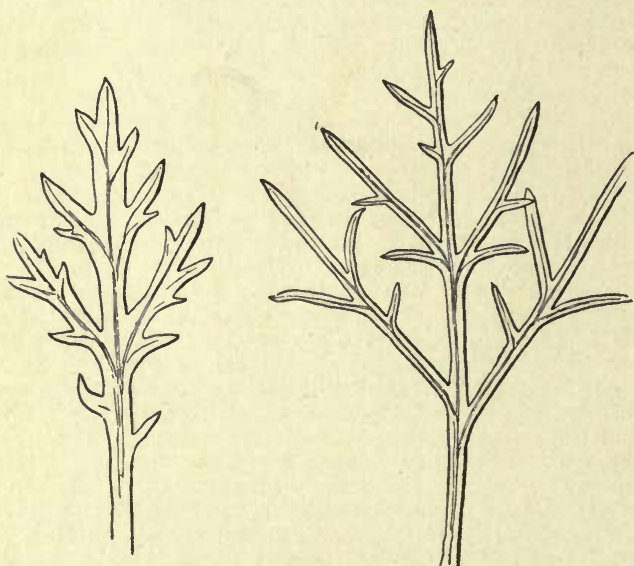

462. Leaves of common and glaucous Marguerites (Chry. santhemum frutescens and anethifolium).

Showing the difference. Glaucous kind on the right.

Experiment Station from a plant long cultivated in Sage conservatories was identified by L. H. B. with the picture in Andrews' Botanical Register 272, published early in the century, since when the plant has almost never been mentioned in garden literature. This species is doubtless cult. in Amer. greenhouses as $C$. frutescens. A lemon-fld. form

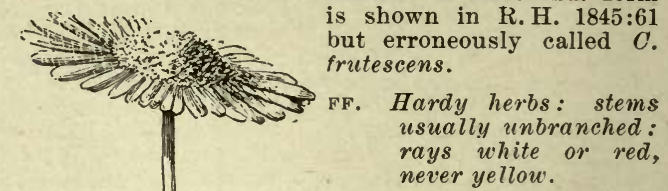
G. Foliage not glaucous: fls. sometimes double.

10. c occíneum, Willd. Pyrèthrum ròseum, Bieb.
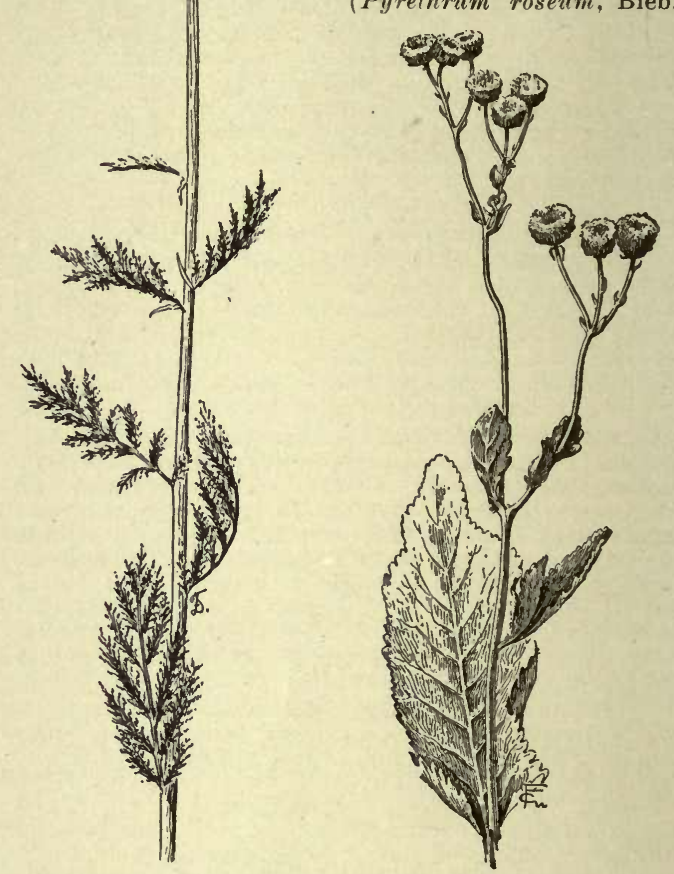

463. Chrysanthemum coccineum.

The familiar Pyrethrum roseum of the gardens.
464. Costmary or Mint Geranium - Chrysanthemum Balsamita, var. tanacetoides.
P. hỳbridum, Hort.). Fig. 463. Glabrous, 1-2 ft. high: stem usually unbranched, rarely branched at the top: lvs. thin, dark green, or in dried specimens dark brown: involucral scales with a brown margin : rays white or red in such shades as pink, carmine, rose, lilac, and crimson, and sometimes tipped yellow, but never wholly yellow. Caucasus, Persia. F.S. 9:917. Gn. 26, pp. 440, 443. Gng. 2:7 and 5:309. K.H. 1897, p. 521. Not B.M. 1080 , which is $C$. coronopifolium. The first picture of a full double form is R.H. 1864:71. - This species is the most important and variable of all the hardy herbaceous kinds. There have been perhaps 600 named horticultural varieties. There is an anemone-fld. form with a high disk. The species is also eult. in Calif. and France for insect powder. C. atrosanguineum, Hort., is said to be a good horticultural variety with dark crimson fls.

GG. Foliage glaucous: fls. never double.

11. cinerariæfollium, Vis. Glaucous, slender, 12-15 in. high : stems unbranched, with a few short, scattered hairs below the fl.: lvs. long-petioled, silky beneath, with distant segments : involucral scales scarious and whitish at the apex. Dalmatia. B.M. 6781. - The chief source of Dalmatian insect powder. Rarely cult. \&s a border plant. Ccmmon in botanic gardens. 
AA. Lvs. not cut to the midrib: the primary incisions shallow.

B. Fls. borne in flat-topped clusters.

12. Balsámita, Willd. (Tanacètum Balsámita, Linn.). Tall and stout : lvs. sweet-scented, oval or oblong, ob-

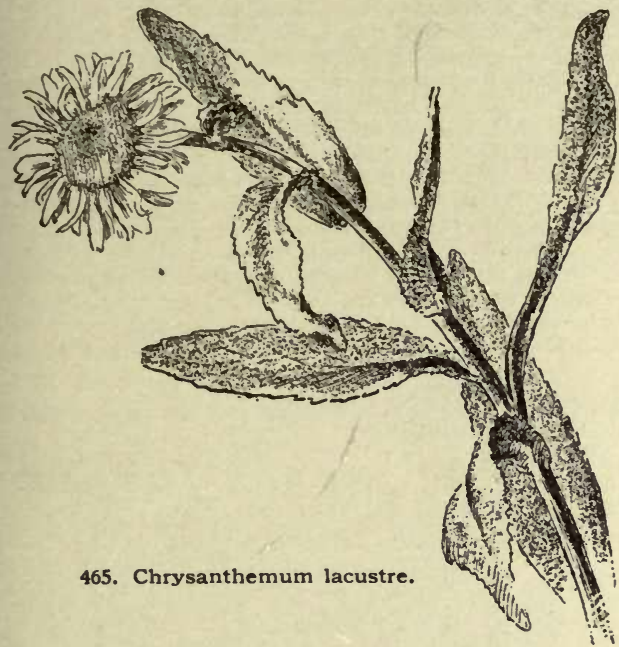

tuse, margined with blunt or sharp teeth, lower ones petioled, upper ones almost sessile, the largest lvs. 5-11 in. long, $1 \frac{1}{2}-2$ in. wide. W. Asia. - Typically with short white rays, but when they are absent the plant is var. tanacetoides, Boiss. Costmary. Mint Geranium. Fig. 464. Also erroneously known as lavender. This has escaped in a few places from old gardens.

BB. Fls. borne singly on the branches or stems.

C. Plants annual : foliage glaucous : rays golden yellow.

13. segètum, Linn. Corn Marigold. Annual, 1-11/2ft. high: lvs. sparse, clasping, very variable, incisions coarse or fine, deep or shallow, but usually only coarsely serrate, with few and distant teeth. June-Aug. Eu., N. Afr., W. Asia. Gn. 18, p. 195 . R.H. 1895, pp. 448, 449. - Var. grandiflorum, Hort., is a larger-fld. form of this weed, which is common in the English grain fields. The var. Cloth of Gold, J.H. III. 12:445, is probably the oest. This species is much less popular than $P$ carina tum and coronarium. It is also forced to a slight extent for winter bloom. "Segetum" means " of the corn fields."

14. multicaùle, Desf. Glabrous and glaucous annual, 6-12 in. high : stems numerous, simplé or branched, stout, terete: lvs. fleshy, variable, usually linearspatulate, $1-3$ in. long and $1 / 2-3 / 4$ in. broad, very coarsely toothed or lobed, sometimes shorter, with few narrowlinear, acute, entire segments about 1 line broad : rays much shorter and rounder than in No, 13 . Algeria. B.M. 6930.-Rarer in cult. than No. 13. Said to be useless as a cut-flower.

cc. Plants perennial : foliage not glaucous (except in wild forms of No. 20).

D. Rays always white: fls. never double: practically never cult. under glass.

15. lacústre, Brot. (C. latifòtium, DC.). Fig. 465 . This is endlessly confused with $C$. maximum in gardens, and the two species are very variable and difficult to distinguish. The fls. cannot be told apart. C. lacustre is a taller and much more vigorous plant, and sometimes it is branched at the top, bearing $3 \mathrm{fls}$., while $C$. maximum is always 1 -fld. Height 3-6 ft.: stem sparsely branched: lvs, partly clasping, ovate-lanceolate, with coarse, hard teeth: fls. not distinguishable from No.16: raya about 1 in. long; pappus of the ray 2-3-eared. Portugal, along rivers, swamps and lakes. R.H. 1857, p. 456.-According to R. Irwin Lynch, in Gn. 26, p. 441, C. lacustre has coriaceous; oval lvs, about 3 times as long as broad, while in $C$. maximum the lvs. are 5 times as long as broad. H. Cannell, Swanley, Eng., says that C. lacustre is $2 \mathrm{ft}$. high and blooms 3 weeks before $C$. maximum. With Woolson, Passaic, N. J., it grows 4-5 ft. high. The rays in Fig. 465 are rather shorter than usual.

16. máximum, Ramond. Fig. 466. This species has narrower lvs. than No. 15, and they are narrowed at the base. Height $1 \mathrm{ft}$.: stem more angled than the above. simple or branched at the very base, always 1-fld. und leafless for 3-4 in. below the fl.: lower lrs. petioled, wedge-shaped at the base, lanceolate, dentate from the middle to the apex; stem-lvs. sessile, wide- or narrowfanceolate, typically serrate throughout their whole length, but variable, as in Fig. 466 : pappus none: involucral scales narrower and longer, whitish-transparent at the margin, while those of $C$. lacustre are broader, more rounded at the apex, and with a light brown, scarious margin. Pyrenees. - For other pictures of these two species, see J.H. III. 5:25, and Gn. 26, p. 437. Var. filiformis,"Hort., "with long, narrow, thread-like petals." Int. 1899. Var. Triumph has "fls. 4 in. across, with broad, overlapping petals."

17. uliginòsum, Pers.(P. uligindsum, Waldst.). GIANT DAIsy. Stout, erect bush, 4-5 ft. high, with light green foliage: stem nearly glabrous, striate, branching above, rather deeply serrate, roughish : fls. $2-3$ in. across. Hungary. B.M. 2706. A.F. 4: 523 and 8: 813. Gng. 2: 375 and 5:183. A.G. 19: 403. R.H. 1894, p. 82. Gt. 46, p. 103 G. C. II. 10: 493. Gn. 26, p. 442 and 38, p. 523. - Next to $C$ coccineum, this is the most popular of the hardy herbaceous kinds. In A.F. 4:465 Wm. Falconer shows a 2 year-old plant $6 \mathrm{ft}$. high, $17 \mathrm{ft}$. in circumference at a point $4 \mathrm{ft}$. from the ground, and carrying thousands of flowers. It blooms the first year from seed or division, and has been forced for Easter somewhat as $\mathrm{Hydrangea}$ paniculata can be treated. Excellent for cut-fls. The

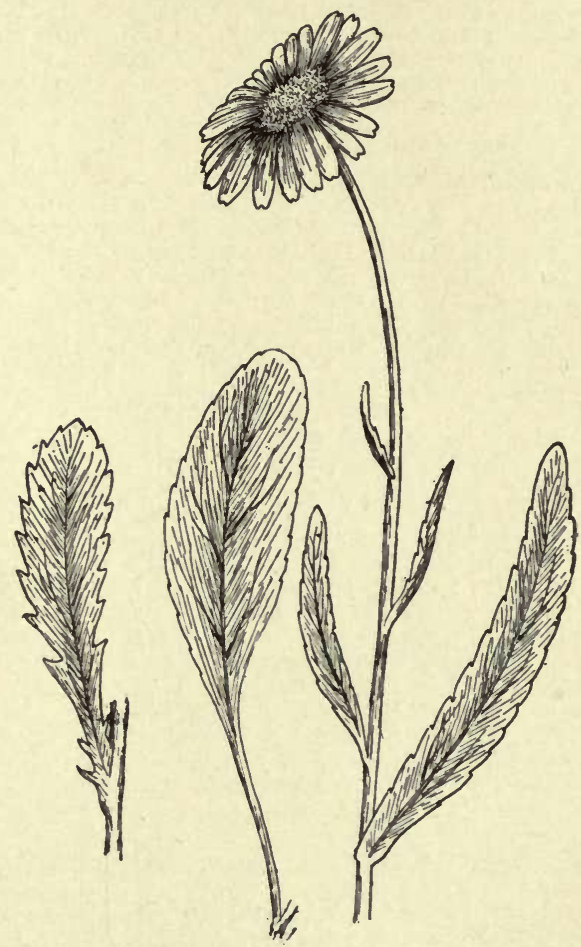

466. Chrysanthemum maximum.

blossoms should be cut soon after opening, as the disks: darken with age. The plant needs a rich, moist soil, and deserves a greater popularity. "Uliginosum " means. "inhabiting swampy places." 
18. Leucánthemum, Linn. OX-EYe DaISY. WhITEWEED. Fig. 467 . Glabrous weed, $1-2 \mathrm{ft}$. high : root-lvs. long-petioled, with a large, oval blade and coarse,

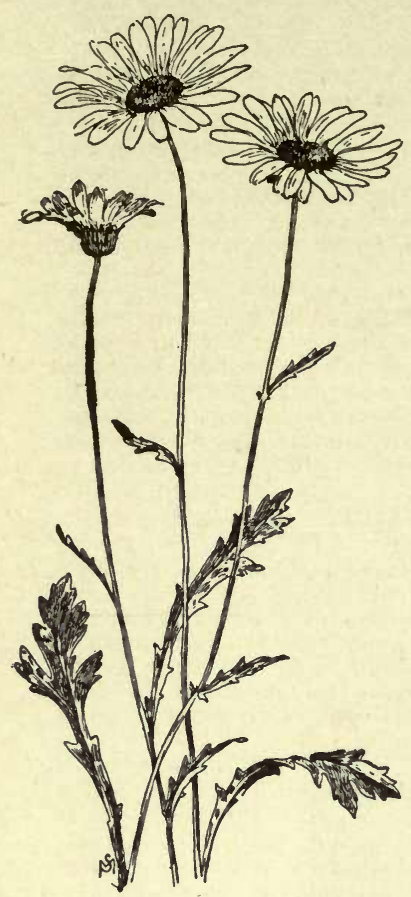

rounded notches; stemlvs. lanceolate, becoming narrower toward the top, serrate, with few distant and sharper teeth. June, July. Eu., N. Asia.-One of the commonest weeds in the eastern states, being the characteristic plant of New England's wornout meadows. The daisies are never cultivated, but they are often gathered for decoration, and make excellent cut-flowers. See, also, Daisy.

DD. Rays many-colored: fls. often double: the common "Chrysanthemums" of the florists.

19. Indicum, Linn. (C. Japbricum, Thunb.). The wild plants native to China and Japan are dwarfer than $C$. morifolium, with Ivs. thinner, more sharply cut, and green on both sides, not glaucous: involucral scales with wider and more scarious margins: no 467. Ox-eye Daisy, or Whiteweed. chaff' fls. smaller, nu(Chrysanthemum Leucanthemum.) merous, and with rays short, not much longer than the involucre. For pictures of wild plants, see G. C. III. 8:565 and G. M. 33:729.Neither this species nor the next grows wild in India, and the name given by Linnæus was inappropriate. This species has varied greatly in cultivation, and its progeny has been hybridized with that of $C$. morifolium. Neither species in its pure form is in cultivation. Unfortunately, it is not possible to definitely trace the origin of any of the main horticultural types, races or sections. See historical sketch above. $C$. Indicum is often used in Germany in a wide sense, including $C$. Sinense.

20. morifolium, Ramatuelle ( $C$. Sinénse, Sabine). The wild plants in Japan and China are more robust than $C$. Indicum, 2-4 ft. high, more or less tomentose, with very variable lvs., which are usually ovate in outline, sinuately cut and lobed, thick, firm, leathery, long-petioled, and glaucous beneath: fls. larger and fewer, with rays never (?) yellow; involucral scales with narrower scarious margins: chaff present on the disk. - This species was founded upon a cultivated and double form, and there have been different opinions as to the original wild progenitor. The above definition is an enlargement of Hemsley's, in G.C. III. 6: 522. B.M.327 (erroneously named $C$. Indicum). Fig. 468 is the original double purple-flowered, partly quilled variety, on which Ramatuelle, in 1792, founded the species $C$. morifolium.

C. inodòmum, Linn. $=$ Matricaria inodora.

W. M.

CHRYSOBACTRON (golden wand, from the Greek). Lilidece. Two New Zealand bulbs, bearing many small yellow fls. in a long raceme on the top of an elongated seape. Plant often diocious. Very closely allied to Anthericum, with which Baker unites it, whereas Bentham \& Hooker refer it to Bulbinella. C. Hodkeri, Colenso, is in cult. in this country. It is a hardy plant 2-3 ft. high, with sword-like foliage. B.M. 4602. - Cult. in the ordinary border, and treated like the Asphodel, they do well, but are vastly improved in rich, deep and rather moist soil. Strong clumps, 4-6 years old, are then at their best and are very excellent plants. After that they should be divided. Prop. by division or seed. Blooms in June and July. J. B. KelLer and L. H. B.

CHRYSOBALANUS (golden acorn, from the Greek, referring to the fruit). Rosaceo. Two species in the warm parts of Amer. and Afr. The CocoA PLUM, C. Icàco, Linn., grows on coasts and along streams in $\mathrm{S}$. Fla., in south to S. Amer., and also in Afr. It is sometimes planted in the extreme south (and in the tropics) as an ornamental shrub and for its sweetish but insipid and dry plum-shaped fruits. The Cocoa Plum is a mere bush on the northern limits of its distribution, but in extreme S. Fla. it reaches a height of $25-30 \mathrm{ft}$. It has glossy, thick obovate (sometimes obcordate) lvs.: fls. small and white, in axillary, erect racemes or cymes ; calyx 5-cleft, pubescent ; petals 5 ; stamens about 20 : fr. 1-seeded, often 1 in. in diam., varying from nearly white to almost black. It is best propagated by seeds, but may also be had from cuttings of half-ripened wood. L. H. B.

CHRYsocoma. See Linosyris, for the only species in the American trade.

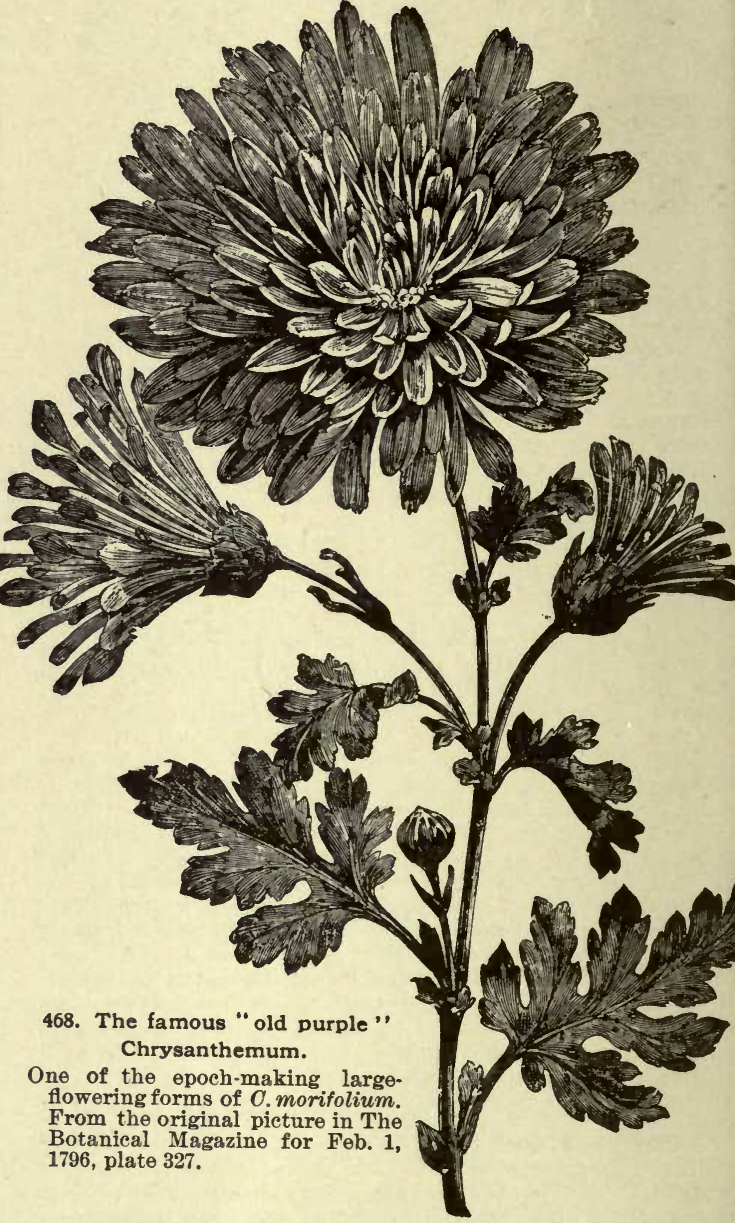

CHRYSODIUM. See Acrostichum.

CHRYSOGONUM (Greek-made name, golden knee or joint). Compositoe. C. Virginiànum, Linn., is a perennial yellow-fld. plant of S. Penn. and south, which is sometimes cult. as a border plant. It blooms in spring or early summer on stems which become $1 \mathrm{ft}$. high, the 
heads being solitary and peduncled in the axils. Lvs. ovate and mostly obtuse, crenate. Prop. by creeping rootstocks and runners. Of little merit horticulturally.

CHRYSOPHYLLUM (Greek, golden leaf, in reference to the color of the under surface of the handsome leaves). Sapotdcea. Many species of trees, with milky juice, widely distributed in the tropies. Fls. small, solitary at the nodes or in fascicles; calyx mostly 5-parted; corolla tubular-campanulate, usually 5-lobed or -parted; stamens 5, standing on the corolla tube: fr. usually tleshy, sometimes edible. C. Cainito, Linn., is the STAR APPLE, Fig. 469. The fruit is the size of an apple, symmetrically

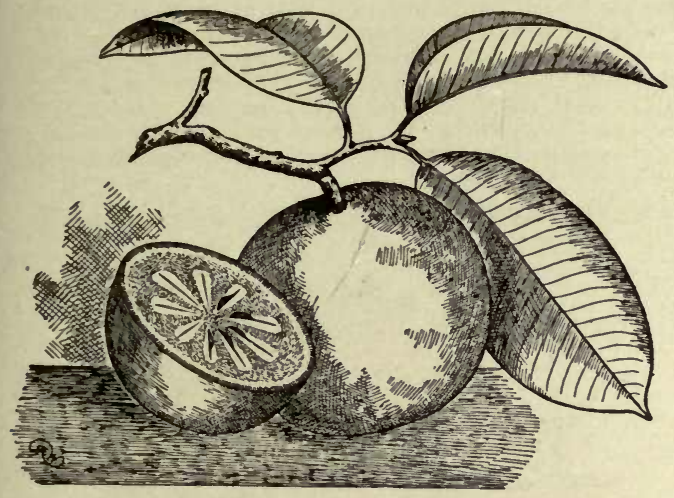

469. Chrysophyllum Cainito $(X 1 / 8)$.

globular and smooth. A cross-section shows the starshaped core, whence the common name. It varies from white to purple in color of skin and also of flesh. The pulp is delicious (used uncooked) if the fruit is allowed to remain on the tree until ripe. It has large, pumpkinlike seeds. The tree reaches a height of 25 to $30 \mathrm{ft}$. It is very impatient of frost. It is native to the $W$. Indies. I.H. $32: 567$. A.G. 11:405. C. oliviforme, Lam., is also in the Amer. trade, but as an ornamental plant. It is a smaller West Indian tree, native also in extreme S. Fla. Lvs. like those of the last: stigma 5-crenate (in $C$. Cainito 8-10-crenate): fr. ovoid-oblong and small, 1-seeded, blackish, insipid. These plants are allied to the Sapodillo.

The various species of Chrysophyllum have beautiful broad green leaves, with under surfaces of a silky texture, varying in color from a silvery white, through golden, to a russet brown, and are well worth a place in the conservatory as ornamental trees. By giving them sufficient room, they will bear fruit in the course of a few years, under glass, which in the case of $C$. Cainito, the Star Apple of the West Indies, is edible, and well liked even by people of a temperate clime. All species are strictly tropical, and cannot be grown where frosts occur unless properly protected. Propagation is ordinarily effected by seeds, which readily germinate if planted when fresh, and it is stated that all species may be grown from euttings of well-ripened shoots placed in strong, moist heat. The soil most suited for their growth is of a sandy character, and if not of a good quality should be well manured, using a considerable proportion of potash in the fertilizer for fruiting specimens. They seem to do well on a great variety of soils, however, that are sufficiently well drained, wet land not agreeing with them.

\section{E. N. REASONER and L. H. B.}

CHRYSOPOGON (golden beard). Graminea. Very like Andropogon, with which some authors unite it: differs in having spikelets in pairs (or sometimes in 3 's), the lateral ones stalked and sterile or often reduced to mere pedicels, only the middle or terminal one fertile. C. nùtans, Benth. (Andropògon avendceus, Michx.), is in the trade. It is native on dry soils in the eastern U.S. growing $2-5 \mathrm{ft}$. high : perennial : culm unbranched, terete: lvs. glaucous and narrow, short: panicle narrow, with nodding, shining yellowish spikelets. Useful for the wild border.
CHRYSOPSIS (golden appearance,"from the heads). Compositoe. Allied to Solidago and Erigeron; N. American. Heads of medium size and many-fld., usually with numerous yellow rays ; involucre bell-shaped or hemispherical, of imbricated bracts : akenes compressed, bearing a pappus of numerous hair-like bristles. C. villosa, Nutt., is the only species in the trade. It is widely distributed from 11l. W., N. and S.: 1-2 ft., grayish pubescent: lvs. oblong to lanceolate, entire or fewtoothed : heads usually at the ends of leafy branches, aster-like in shape. Extremely variable, and has several named forms. Mn. 7:101. Var. Rútteri, Rothr., is larger and later. Of value as a border plant. Cult. the same as Aster. Perennials, but bloom the first year from seed, if sown early.

L. H. B.

CHRYSOSPLENIUM AMERICANOM, Schw. (name from golden and spleen, referring to some old medicinal tradition). Saxifragdcece. A native plant creeping in mud, which is sold for bog-planting. Stems forking, bearing roundish or cordate small mostly opposite lvs., with very small, nearly sessile, greenish, inconspicuous fis. Searcely known in cult.

\section{CHRYSƯ RUS CYNOSUROtDES. See Lamarckia.}

CHUFA. The edible subterranean tubers of Cyperus esculentus, Linn., much prized in the S. They are eaten raw or baked, or used for the making of coffee. The plant is sometimes cult. in the N., but it will not withstand the winter. The tubers are oblong, $1 / 2-3 / 4$ in. long, cylindrical, hard. The plant is grass-like, and in the N. does not flower. Nuts are planted in the spring, and the new crop is ready for digging in the fall.

CHỲSIS (Greek for melting, alluding to the pollen masses). Orchidacea, tribe Vándece. A genus of orchids found in Trop. Amer., pendulous from trees. Pseudobulbs usually spindle-shaped, attenuate toward the base, leafy upwards: lvs. broadly-lanceolate, plicate, conspicuously nerved, bases sheathing: fls. fleshy, few to many, in lateral racemes from the young growths; lateral sepals adnate to base of column; labellum 3 lobed, with 5 whitish callosities near the base. The species bloom in spring and early summer. Handsome orchids, requiring tropical treatment; not largely grown in American collections. Remove to a lower or intermediate temperature when resting. Grown in pots or baskets, in peat and moss.

aùrea, Lindl. About $1 \mathrm{ft}$. high: lvs. about 5, 10-15 in. long: fls. 2 in. in diam.; petals and sepals oval-oblong reddish yellow, pale yellow at the base: lateral lobes of labellum incurved, midlobe roundish, spotted with red and yellow. S. Amer. B.M. 3617.-There is a var. maculàta.

bractéscens, Lindl. Sepals und petals cuneate-oblong, concave; labellum white outside, yellow, streaked and stained with red inside: fls. 3 in. in diam. From Mex., found at an altitude of $1,500 \mathrm{ft}$. B.M. 5186. R.H. 1859, pp. 294,295 . I.H. $27: 398$. J.H. III. $28: 263$. - One of the most showy orchids.

lævis, Lindl. More robust than the preceding: lvs. shorter than the pseudobulbs : racemes 9-10-fld., from among sheathing scales of new growth ; fls. $2 \frac{1}{2}$ in. in diam.; sepals bright yellow, upper one linear-oblong, lateral ones acuminate, about 1 in. long; petals yellow, falcate; labellum yellow with streaks and dots of orange. Mex., 1840.

Límminghei, Lind. \& Reichb. f. Stems short : racemes about 5-fld.; sepals and petals oblong-lanceolate, blush-white tipped with rosy mauve; lateral lobes of labellum obtuse, yellow streaked with crimson, midlobe large, pink-lilac striped with rose-mauve. From Mex., near the sea-coast. B.M. 5265.

Chélsoni, Hort. (C. bractescens $\times$ C. lavis). Pseudobulbs narrow : raceme 6 in. long and curved, with 5-6 yellow and purple-blotched fls.

Sedeni, Hort. (C. Limminghei $\times C$. bractescens). Fls. much like those of $C$. bractescens but smaller, white, petals with mauve streaks; lip more like that of $\checkmark$, Limminghei, yellow or whitish.

OAKES AMES. 
CIBŌTIUM (Greek, a little seed-vessel). Cyatheacen. A small genus of tree-ferns from Mexico and Polynesia, with copious, bivalved, coriaceous indusia, differing from Dicksonia in having the outer valve entirely distinct from the leaf. For eulture, see Dicksonia.

$C$. Barometz is the plant that gave rise to the wonderful stories of the Barometz or Seythian Lamb (Fig. 470), which, according to Bauhin, 1650, had wool, flesh and

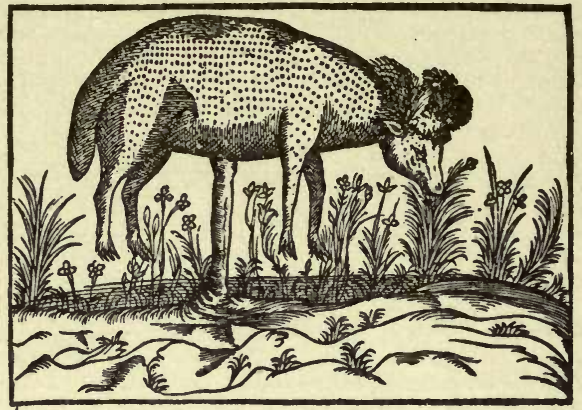

470. The Scythian Lamb. See Cibotium Barometz.

blood, and a root attached to the navel. The plant was said to resemble a lamb in every respect, but grew on a stalk about a yard high, and turning about and bending to the herbage, consumed the foliage within reach, and then pined away with the failure of the food until it died. Wolves sought it and ate it as if it were a true lamb. In 1725 Breyne, of Dantzig, declared that the Barometz was only the root of a large fern, covered with its natural yellow down and accompanied by stems, which had been placed in museums in an inverted position, the better to represent the appearance of the leg; and horns of a quadruped. A.G. 12:258.

A. Outer valve of the indusium larger, or the valves subequal.

glaùcum, Hook. \& Arn. Lvs. ovate-lanceolate, tripinnate; pinnules about 6 in. long, taper-pointed; segments close: outer valve of indusium larger, broader than the inner: veins once- or twice-forked. Hawaiian Islands.

Bárometz, J. Sm. Scrthian Lamb. Trunkless: lvs. scented, tripinnate, the lower pinnæ ovate-lanceolate pinnules short-stalked, 4-6 in. long, with falcate seg ments : valves of the indusium nearly equal: veins prominent, rarely forked. China.

\section{AA. Outer valve of the indusium smaller than} the inner.

Schièdei, Hook. Caudex 10-15 ft. high : lvs. oblongdeltoid, triplnnate, with pinnæ 1-2 ft. long; segments falcate, sharp-pointed: sori sparse: veins forked, on the lowest pinnate. Mexico.

regàle, Linden. Caudex 10-12 ft. high : lvs. oblong deltoid, tripinnate, with pinnæ 18-24 in. long; pinnules sessile, with close, falcate, deeply incised segments : veins pinnate in the lobes. Mex. L. M. UNDERWood.

\section{CIBOULE. Consult Onion.}

\section{cicca. Now combined with Phyllanthus.}

CICER (old Latin name for the Vetch). Leguminosa. Pea-like plants, with 5-parted calyx, oblong turgid 2-seeded pod, mostly 1-fid. peduncles, odd-pinnate lvs. and toothed leaflets. Small genus, with a MediterraneanAsian range. C. arietinum, Linn., the CHICK-PEA, is sometimes cult. in vegetable gardens for the edible ripe seeds. It is an annual and is cult. the same as bush beans. Withstands dry weather well. It grows $2 \mathrm{ft}$. high, making a bushy, hairy plant. Lvs. with small, roundish leaflets fls. white or reddish, small, axillary. Seed roundish, but flattened on the sides, with a projection on one side. Little known in Amer., but much cult. in S. Eu. and A sia.

$$
\text { L. H. B. }
$$

CICHÒRIUM (Arabic name). Compósitce. A very few Old World herbs, with ligulate corollas, double-rowed scales to the involucre, angled akenes, bristly or chaffy pappus, and blue fls. Two species are of interest to the horticulturist, $C$. Intybus, Linn. (Fig. 436), the Chicory, and $C$. Endivia, Linn., the Endive. See those entries for fuller information.

\section{CIENKÒWSKIA. See Kampferia.}

CIMICfFUGA, Linn. (cimex, a bug; fugere, to drive away). Ranunculdcece. BugBane. Allied to Actoea. Tall, hardy, herbaceous perennials, ornamental, but badsmelling, suited for the back of borders or for partially shaded places in the wild garden. About 10 species, natives of the north temperate zone. Lvs. large, decompound: fls. white, in racemes ; sepals $2-5$, petaloid, deciduous; petals 1-8, small, clawed, 2 -lobed or none: follicles 1-8, many-seeded, sessile or stalked; stigma broad or minute. Half shady or open places ; any good garden soil. Prop. by seeds and division of roots in fall or early spring.

Americàna, Michx.(A ctìea prodocárpa, DC.). Slender, 2-4 ft. high: Ivs. pale beneath: fls. in elongated raceme; petals 2-horned; pedicels nearly as long as the fl.: follicles 3 or 5, stalked: seeds in 1 row, chaffy : stamens and pistils usually in same fl. Aug.-Sept. Moist woods of Alleghanies.

fótida, Linn. Lvs. bipinnate, terminal lft. 3-lobed : petals of the white fls. often tipped with anthers; no staminodia: follicles $3-5$; seeds very chaffy. Summer. Siberia. - Following var. only is cult.

Var. simplex, Reg. (C. simplex, Wormsk.). Tall and handsome : fls. short-pedicelled, forming a fine, dense raceme, and at first pubescent : follicles short-stalked. Kamtschatka.

racemdsa, Nutt. (C. serpentàia, Pursh). Fig. 471 Stem 3-8 ft. high : Ivs. 2-3 times 3-4-parted; lfts. mostly ovate, firm texture: racemes few, rigidly erect, often becoming $2 \mathrm{ft}$. long - follicles rather shorter than the pedicel, nearly $1 / 4$ in. long, short style abruptly recurved. Very pretty in fr., with its two rows of oval follicles always extending upward from the lateral branches. July-Aug. Georgia to Canada and westward. Int. 1891. Gt. 13: 443. Gn. 46, p. 269. G.C. II. 10:557. D. 79. - The commonest in gardens.

Var. dissécta, Gray (C. spicata, Hort.). Lrs. more compound than the type: small white fls. closely packed on lateral and terminal branches. Lasting until Sept. Del. and S. Penn. J.H. III. 33:381.

C. cordifòlia, Pursh. Lvs. very broadly ovate or orbicular. B. M. 2069-O elàta, Nutt. (C. foetida Pursh Actæa Cimicifnga. Linn.). Üsed in medicine. Reg. Veg. Med. 1:37. $-C$. Japónica, Spreng. Three ft. high: lvs, very large. F.S. 22: 2363 (as Pithyrosperma acerinum).-O. palmàta, Michx. = Trautvetteria Carolinensis, Vail.

K. C. Davis.

CINCHÒNA (from Countess Chinchon). Rubidcece. This genus of plants contains, according to Index Kewensis, 67 species, some of which yield bark containing quinine. The species grow isolated in various districts of the Andes, at elevations ranging from 2,300 to $9,000 \mathrm{ft}$., and between $22^{\circ} \mathrm{S}$. and $10^{\circ} \mathrm{N}$. latitude. Some of the species are lofty trees, others are mere shrubs. The lvs, are opposite, with deciduous stipnles. The fls, are fragrant, much frequented by humming birds, white and pink in color, growing in terminal panicles. The calyx is small, 5-toothed, and persistent. The corolla has a long tube with 5 short, spreading, valvate lobes, hairy at the margins. The stamens are 5 , included in the corolla. The ovary is 2celled, with very numerous ovules inserted on linear axile placentr. The capsule opens septicidally from the base upwards. The seeds are small, numerous, flat and surrounded with a wing.

Commercial Cinchona bark is known under the following names: "Crown" "Loxa" or "Pale bark, yielded by Cinchona officinalis and its varieties Condaminea. Uritusinga, crispa; "Red bark," from C. succirubra; "Hybrid bark," from hybrids of $C$. officinalis and $C$. succirubra; "Royal," or "Yellow bark," from C. Calisaya 
richer in alkaloids than the original. In this way, by taking successive strips of bark in different years, the tree yields a continuous supply of bark.

WM. FAWCETT.

Cinchonas are sometimes seen in collections of economic plants, but only one of them seems to be regularly in the trade at this time. This is $C$. officinalis, var. Condaminea, which Franceschi says is "probably the least delicate and most easily grown of all Cinchonas."

L. H. B.

CINERARIA (ash-colored, from the Latin, referring to the gray foliage). Compósita. Herbs or under-shrubs, closely allied to Senecio, from which they are separated chiefly by technical characters of the akene. The genus is variously understood by different authors. As limited by Bentham \& Hooker, it comprises about 25 South African species, and the common garden Cineraria becomes a Senecio. The Cineraria of the florists (Fig. 472 ) is now much modified by cultivation. There are two views of its origin, one holding that it is a direct development of $C$. cruenta, Mass., the other that it is a hybrid, into which $C$. cruenta, $C$. Heritieri, $C$. populifolia, and perhaps others, have probably blended. These are all natives of the Canary Islands. The writer is inclined to believe that it is a direct evolution from $C$. cruenta. This species is figured in B. M. 406. For the more important literature of the recent discussion respecting the origin of the garden Cineraria, see Nature, $51: 461,605 ; 52: 3,29,54,78,103,128 ; 55: 341$. G.C. III. $3: 654$ and $657 ; 17: 588,655,742 ; 18: 89,186$.

See Senecio for Cineraria acanthifolia, $C$. candidissima, and $C$. maritima. To the garden or florist's Cineraria ( $C$. cruenta) belong the horticultural names $C$. hybrida, C.grandiflora, C. Keuensis, C. nana, and the like. There are full-double forms (see R. H. 1874, p. 47; 1886, p. 41. F.S. $22: 2347-8$. I.H. $32: 556)$. L. H. B

The single hybrid Cinerarias are among the most useful and beautiful of all greenhouse flowering plants. The ease with which they can be raised, the little heat required, together with their free-blooming qualities, brilliant and various-colored flowers, which last for a considerable time in blosson, make them popular with most people possessing even only a small greenhouse. Though they are herbaceous in character and may be propagated by cuttings or division of the roots, the single varieties are best treated as annuals, raising them from seed each vear and throwing away the plants after flowering. Though anyone may save one's own seed, the Cineraria, like most hybrids, will deteriorate both in size and quality of the flower after one or two generations un lass they are hybridized; therefore, unless one cares to hybridize his own plants, it is best to purchase fresh seed from some reliable firm who obtain their stock from hybridists. For florists' use, or where a succession of these flowers is required, two sowings of seed should be made; the first about the middle of August, and the second a month later. The seed should be sown in pans or shallow boxes one foot square; these should be well drained, and the soil should consist of one part fine loam, one part leafmold, and one part clean, sharp silver sand. The surface should be made very fine and pressed down evenly. The seed should then be sown evenly and rather thinly, and covered with sand about the eighth part of an inch. This will in a great measure prevent the seedlings from what gardeners term "damping-off," which they are very apt to do if the atmospheric conditions become a all stagnant. The seed-pans or boxes should be earefully watered with a fine rose and then placed in some cool, shaded place, such as a frame placed on sifted coal ashes on the north side of a wall or building, where they will germinate in about a week or ten days. As soon as large enough to conveniently handle, the seedlings should be potted into thumb-pots and grown on as rapidly as possible, shifting on into larger size pots as otten as required, never allowing them to become the least pot-bound, or suffer in any way during the season of growth. The soil should consist of half leaf-mold and half fine fibrous loam, with a good sprinkling of silver sand, until the final shift into their flowering pots, when the soil should be three parts fibrous loam and one part well-decayed cow-manure or pulverized sheepmanure. About the first of October the plants should all be removed to the greenhouse, where the atmosphere should be kept cool and moist, but not stagnant. If a rainy spell should set in, a little artificial heat should be given to cause a circulation of the atmosphere, and as the fall advances the temperature should be kept about $45^{\circ}$ at night, with a rise of ten degrees by day. Liquid stimulants should not be given until the flower buds begin to appear, when they are greatly benefited by an occasional watering of clear, liquid cow- or sheepmanure water. Cinerarias are very subject to the attacks of green-fly. To keep these in check, the house in which they are grown should be fumigated with tobacco about once in ten days, or tobacco stems placed among the plants if fumigating is objectionable.

Double-flowered varieties of Cineraria are not commonly grown, neither are they as beautiful as the single varieties. They may be propagated by seed or by cuttings, the latter being the best method, as a large percentage of seedlings are sure to turn out single, which will be inferior in size of flower as compared with the best single varieties. Double-flowering varieties must be propagated each year to obtain the best results. As soon as the plants have finished blossoming, the flower stalks should be cut away to induce the plants to make

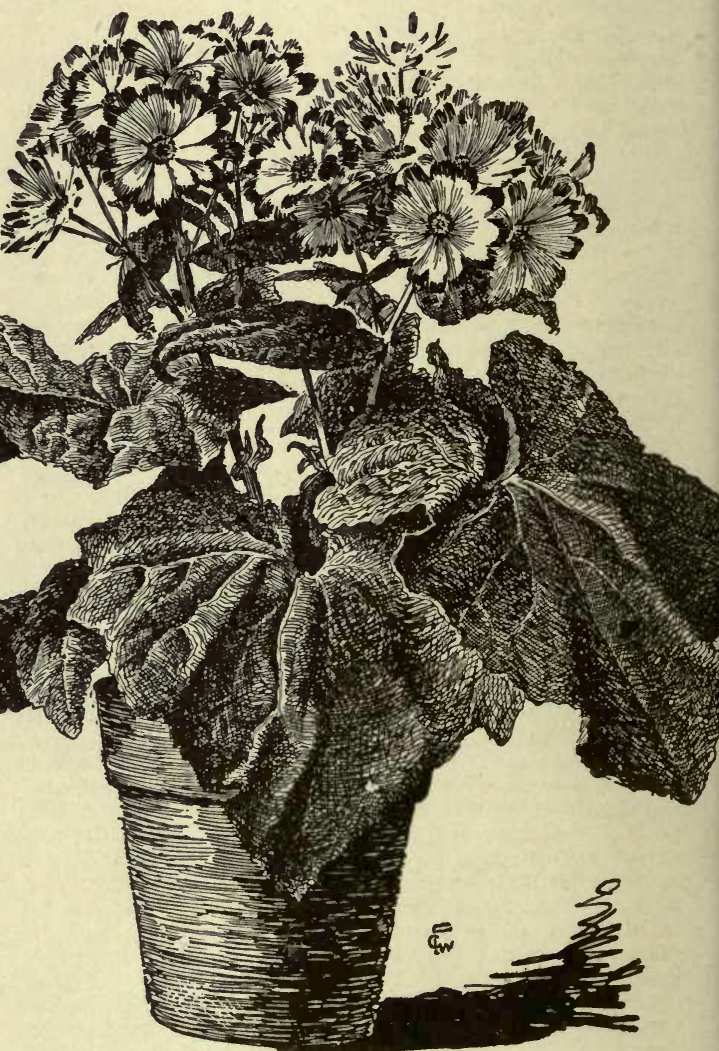

472. The florists' Cineraria-C. cruenta.

fresh growth, which, as soon as large enough for cuttings, should be taken off and inserted in an ordinary propagating bed, where they will soon root, after which they should be potted and shifted on as often as required, growing them during the hottest months in as 
cool and shaded a position as can be provided. Of the different species of Cineraria from S. Europe, $C$. maritima is perhaps the best. It is of dwarf habit, with tomentose, silvery, pinnatifid leaves, and is a most useful subject for edging flower beds. It is not hardy in this climate, consequently must be treated as an annual, sowing the seeds early in March in the greenhouse, afterwards treating them as ordinary summer bedding plants. The other species from south and eastern Europe do not prove hardy here, and if grown should be treated as tender annuals, planting them in the herbaceous borders for the summer. The species from the Cape of Good Hope require greenhouse treatment, the culture being the same as for the common Cineraria, though, from an ornamental point of view, they would hardly pay for the room they would occupy.

EDWARD J. Canning.

CINNA (old Greek substantive). Graminece. Perennial woods grasses allied to Agrostis and Calamagrostis, with 1-fld., much-flattened spikelets, 1-nerved palet, 1 stamen, and a loose open panicle. The two northern species are offered by collectors: C. arundinàcea, Linn., with the branches of the panicle ascending or erect c. pendula, Trin., with the branches very slender and drooping. These grasses (growing 3-7 ft.) are useful in wild borders.

CINNAMOMUM (the ancient Greek name). Laurdceac. Fifty or more trees and shrubs of Asia, mostly tropical, of which 2 or 3 are cult. in the extreme southern U.S. The lvs. are thick and ribbed, mostly opposite: fls. usually perfect, with 9 perfect stamens in 3 rows and a row of imperfect ones : fr. a small, 1-seeded berry, in a cup-like calyx : buds not scaly. The Cinnamon of commerce is mostly the bark of C. Zeylánicum, Nees ; and this is sparingly cult. in S. Fla. and S. Calif. It is cult. in Ceylon and other oriental countries. It is a small tree, with ovate-oblong, shining, 3-5-nerved lvs., and small, yellow-white fls., in terminal, loose clusters. It is native to E. Ind. and Malaya. C. Camphora, T. Nees and Eberm., is the Camphor tree. By some it is retained in the genus Camphora, and it will be found there in this book. C. Cássia, Blume, of Burma and China, furnishes Cassia bark or "Cassia lignea" of commerce. It is hardier than the $C$. Zeylanicum. It is a handsome tree, with stiff, long-oblong, acutish, 3-ribbed shining lvs., and small :fls. in tomentose terminal or axillary panicles. The bark is thicker and coarser than that of $C$. Zeylanicum, and is used to adulterate Cinnamon. The unexpanded, clove-like flower-buds are often sold as Cassia buds. C. Lourèirii, Nees. A middle-sized tree of Cochin China, is rarely sold as a glasshouse plant. It has an aromatic odor. Lrs. opposite or alternate, rigid, elliptic or oblong. Petiole $1 / 3-1 / 2$ in. long. There is a form with variegated lvs. C. pedunculàtum, Presl, from Japan, is also sold as a glasshouse subject. It is a glabrous tree, with thick, petioled, oblong-lanceolate, 3-nerved lvs., which are shining above. Petiole $1 / 2-3 / 4$ in. long.

The genus embraces tropical and semi-tropical shrubs and trees, which are mostly of economic value, and in one or more cases are valuable shade trees for lawn and street planting. The lvs, are evergreen, usually of a rich, shining green, and in C. Camphora have a silvery blue color on the under surfaces. C. Camphora, the Camphor tree, is hardy in the lower Gulf states, and is now being extensively planted, both for shade and extraction of gum (see Camphora). C Cassia is not quite so hardy, but withstands a temperature of $20^{\circ} \mathrm{Fahr}$. without injury, and has been planted in Florida for manufacture of its various products, - oil, gum, buds and cinnamon bark. The true Cinnamon of commerce is prepared from the bark of $C$. Zeylanicum, a tropical species, likely to be extensively grown in Mexico and the West Indies. The various species are usually propagated by seeds, which are sown as soon as ripe in a shaded bed, the seedlings being transplanted when very small into pots and kept thus growing until permanent planting out. The species, without exception, are very difficult to transplant from the open ground, and hence potgrown plants are almost a necessity. Cuttings of halfripened wood of some species may be rooted in the spring in moderate heat, following the usual method of preparation, and planting in coarse sand. The soil best suited to Cinnamomums in general, and $C$. C'amphora in particular, is sandy loam, although a heavy loam, where well prepared, answers fairly well. The sandy soil of Florida, when moderately manured, suits all species so far tried admirably.

$$
\text { E. N. REASONER and L. H. B. }
$$

CINNAMON VINE. A name for species of Dioscorea.

\section{ciNQUEFOIL. A species of Potentilla.}

CIRCÀA (Circe, the enchantress). Onagràcea. A few species of low woods herbs in N. Amer. and Eu., two of which are in the trade for growing in shady places and about garden bogs. They are interesting little plants, but not showy. Of easy culture in shady, damp spots. Lvs. opposite and stalked: fis. perfect, small, and white, in terminal and lateral racemes; calyx tube hairy: fr. a small, bristly bur.

Lutetiàna, Linn. Erect and branching, 1-2 ft., the stem swollen at the nodes: lvs. ovate-acuminate, more or less rounded at the base: pedicels slender, reflexed in fruit: fr. 2-celled. Woods, E.

Pacifica, Asch. \& Mag. From 6-12 in.; smaller than the above, lvs. less acuminate, fls. smaller, fr. 1-celled and less bristly. Col., N. and W.

L. H. B.

CIRRHOPETALUM (tendril petal, alluding to the narrow lateral sepals). Orchidacece, tribe Epidéndrea. Nearly 50 Old World tropical orchids, none of which are in the American trade. The tail-like lateral sepals give the fls. an odd appearance. Allied to Bulbophyllum They are epiphytes, and are grown in baskets or on blocks in a warmhouse. Leading species are : C. Cumingii, Lindl. (B.M. 4996) ; C. Medusae, Lindl. (B.M. 4977. I.H. 39:154. G.C. III, 21:25) ; C. picturatum, Lodd. (B. M. 6802); C. pulchrum, N. E. Brown (I. H. 33:608. A. F. 6:609); $C$. Thouarsii, Lindl. (B.M. 4237). C. Sinense is evidently a trade name.

Being of rambling habit, with creeping rhizomes, Cirrhopetalums should be grown in baskets, sufficiently large to afford plenty of growing surface, and suspended from the roof, where they will get plenty of light and free access of air to the roots, which is equally essential. Liberal allowance must be made for drainage, which should consist of either broken potsherds or charcoal, the latter being preferable, as it is light, durable and con tains nothing detrimental. Two-thirds osmunda, or other clean fiber, and one-third chopped live sphagnum moss, well mixed together, afford a good compost ; and after this has been carefully tucked in about the roots and interstices, the plant should be held firm with brass or copper wire until reëstablished. The compost should be used rather sparingly to prevent over-watering. Many of the smaller-growing species do very well on orehid blocks, firmly attached, with a small quantity of compost beneath them. During the winter months, little or no shade is required. The temperature may range from $58^{\circ}$ to $65^{\circ} \mathrm{F}$. by night, with about $10^{\circ}$ rise through the day, or even a little more, with sun-heat, will do no injury. No artificial heat is necessary in summer, except in extreme cold or wet weather, but a shaded, moist location should be selected, such as is afforded in the cattleya or palm department. When the plants are dormant, light syringing overhead will keep the compost moist and the plants in healthy condition, but as the growing season advances, a liberal quantity of water and copious syringing in bright weather will be necessary. The stock is increased by division, the most judicious method being to cut nearly through the rhizome with a sharp knife, about three pseudobulbs behind the lead, just before growth action, allowing the part to remain until the dormant eyes start to grow, when it may be removed and treated as an established plant. A little extra heat and moisture at this period will prove beneficial with the weak plants. All are of moderately easy culture.

CIRSIUM. Refer to Cnicus.

RobT. M. GRey.

CISSÁMPELOS (Greek for ivy and vine). Menispermacece. Vines : fls. in axillary racemes or clusters, the plant diœeious; sterile fls. with 4 or 2 sepals and as many 
petals united, the anthers $2-4$, on a staminal column; fertile fls. with 2 united fleshy sepals, subtended by a sepal-like bract, and solitary ovary, with 3 styles: fr. a subglobose drupe, with a flattened and tuberculate stone. Many species or distinct forms in tropical regions, but many of them are evidently forms of the widely distributed C. Pareira, Linn. This plant, as $C$. heterophylla, DC., and under other names is cult. in S. Fla. and the tropies. It is known as Velvet-Leaf and Pareira BrAva. It is an exceedingly variable vine, with downy, round-cordate or peltate Ivs., the sterils fls. in stalked corymbs and the fertile in large-bracted racemes, and a hairy, nearly globular, red fruit. It occurs in all tropical countries.

L. H. B.

cfssus (Greek name of ivy). Vitacece. Very like Vitis, but differing in having the parts of the flower in 4's, the corolla not falling off as a cap, and the disk about the ovary ring-like or cup-like. Ampelopsis is distinguished by 5-merous fls. and the absence of a disk.

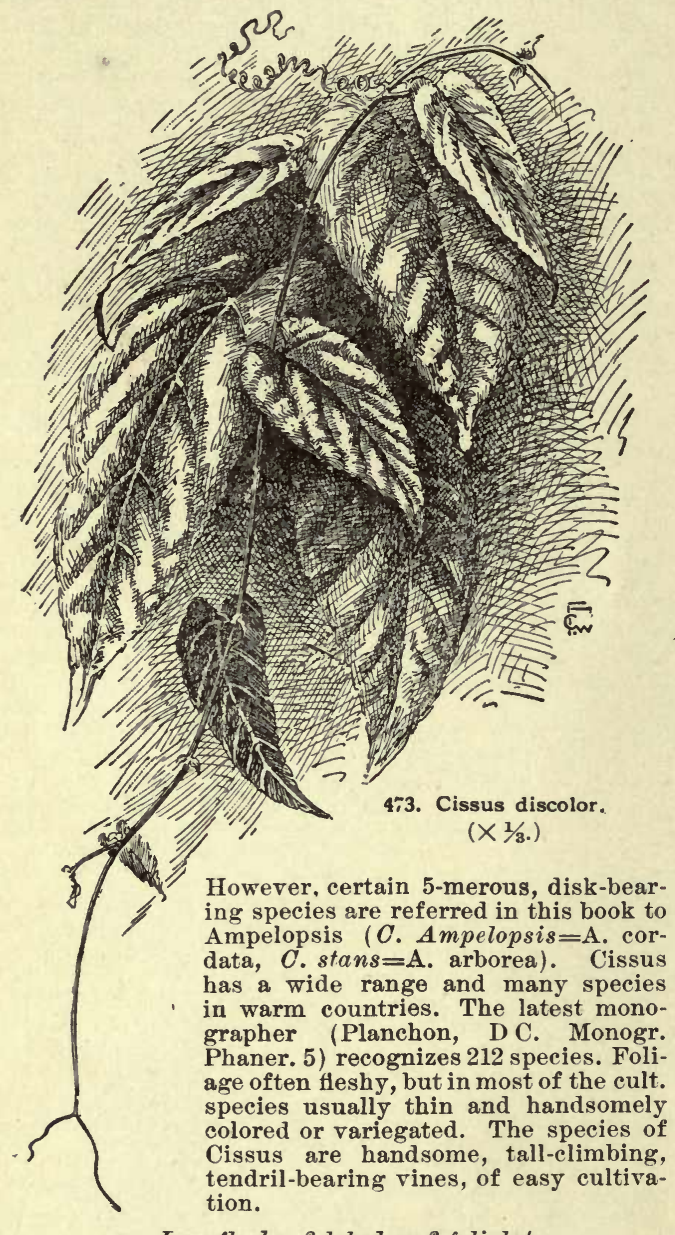

A. Lis. fleshy, 3-lobed or 3-foliolate.

ácida, Linn. Low elimber, with slender and striate somewhat tleshy glabrous branches: lfts. or leaf-divisions rather small, broad-cuneate and sharply toothed near the apex : fls. small, in corymb-like or umbel-like clusters: fr. an ovoid and mucronate dark purple berry, with 1 or 2 large seeds, the pedicel being recurved at maturity. Key West and S.; also, in Ariz. and S.Sometimes planted.

incisa, Desm. ( $C$. Rochedna, Planchon). Climbing 20-30 ft., the stems very fleshy and the tendrils root- like: lvs. pale green, very fleshy; lfts. or divisions wedge-ovate, notched on both sides and top, the middle one sometimes again lobed: inflorescence umbel-like: fr. an obovoid blackish berry, with 1 or 2 seeds, the pedicel being strongly recurved. Fla., to Ark. and Tex. R.H. 1884, pp. 272-3.-Often planted in the extreme S. Sometimes called "Marine Ivy."

\section{AA. Les. not fleshy, not lobed.}

díscolor, Blume. Fig. 473. Lvs. oblong-ovate, acuminate, cordate at base, bristly serrate, reddish beneath, relvety green and mottled with silvery white above: both lvs. and stems glabrous, the latter red and more or less angled: fls. small and yellowish, in dense and very short, axillary clusters. Java. B. M. 4763. L. 13 . F. S. 8:804-5.-One of the best of all warmhouse foliage plants. Easily grown. Prop. by cuttings. Must have a season of rest, usually in spring or early summer. If wanted for winter growth, temperature must be about $75^{\circ}$. Known to some as "Trailing Begonia."

Antárctica, Vent. (C. Baudiniàna, Brouss.). KaNGARoO ViNe. Lvs, rather thick, glossy, ovate to oblong, very short-acuminate, rounded at base, mostly strongly toothed or notched, green: fls. green, in few-fld., axillary clusters : fr. a globular berry. Austral. B. M. 2488.Valuable for cool greenhouses, but does not withstand frost. Grows well on walls in darkish and neglected places.

Amazónica, Linden. Lvs. glabrous and glaucous, ovalacuminate and narrower, reddish beneath and silvery veined above. Brazil. - Warmhouse climber.

álbo-nitens, Hort. Lvs. oblong-acuminate, more or less cordate at base, silvery white and shining over the upper surface. Brazil. - Warmhouse climber.

sicyoides, Linn. Branches terete or compressed, tuberculate or smooth, striate: lvs. ovate or oblong, often cordate at base, margin more or less serrate or even cut, thickish, green: inflorescence corymb-like, opposite the lvs., the fls. small, and varying from greenish to white and purplish : fr. an obovoid, 1-seeded berry. Very widely distributed in trop. Amer., and exceedingly variable. One form (var. Floridana, Planch.), occurs in $\mathrm{S}$. Fla., but is not in the trade. The $C$. argéntea of horticulturists is var. ovata, Planch., which has glabrous ovate or ovate-oblong remotely serrate and somewhat glaucous lvs. Called "Season Vine" in tropics.

C. Davidiàna,Carr., is a Vitis (which see).-O. Lindeni, André (I.H. 17:2), is perhaps an offshoot of C. sicyoides. It has large ovate-cordate silver-blotched lvs.-C. Japónica, Willd. Her baceous, glabrous: lvs. 5-foliolate, with serrate-oblong lfts.: fls. greenish ; eymes many-fld. Jap., Java, Austr. The only species hardy north. $-C$. porphyrophýlla, Lindl., is a Piper. (which see) - C striàta Ruiz \& Pav. (Ampelopsis sempervi(which see).- C. striata, Ruiz. \& Pav. (Ampelopsis sempervirens, Hort.). Low, shrubby evergreen vine: lvs. small, 5 -yellowish, in many-fld. eymes. Chile, S. Braz. Graceful small climber for the cool greenhouse. $-C$. Veitchii, Hort.=Ampelopsis tricuspidata.

L. H. B.

cISTUS (ancient Greek name). Oistacece. Rock Rose. Shrubs, usually with villous and glandular tomentum, aromatic : lvs. opposite, mostly persistent, entire, the opposite petioles connate at the base: fls. large, in terminal and axillary cymes at the end of the branches, rarely solitary, white to purple; petals 5 ; stamens numerous; capsule many-seeded, splitting into 5 valves. About 30 species in the Mediterranean region. Ornamental, freeflowering shrubs, usually only a few feet high, with very showy purple or white fls., similar to a small single rose, appearing in early summer. They are only hardy in warmer temperate regions, but many of them will stand $10^{\circ}$ of frost without injury, and C. laurifolius even more. They thrive best in a well drained, light soil, mostly preferring limestone soil, and in a sunny position; the dwarfer species are well adapted for rockeries with southern aspect. The Cistuses do not bear transplanting well, and should be grown in pots until planted out. Some species yield ladanum, a resin, used in perfumery. .Prop. by seeds sown in spring in pans or boxes and the young seedlings shaded; increased also by layers and cuttings in spring or late summer, inserted in sandy peat under glass. Illustrated monograph: R. Sweet, Cistineæ (S.C. of the following pages). In the Old World, the Cistuses 
are important garden plants, but they are little known in America.

$$
\text { A. Fls. purple or red. }
$$

B. F's. $1 \frac{1}{2}-2$ in. wide; petals imbricate.

villòsus, Linn. (C. incànus, Linn.). Erect shrub, 3-4 ft, villous or tomentose : lvs. penninerved, roundishovate or oblong, narrowed into a very short petiole, rugose above and grayish green, tomentose or villous reneath, 1-2 in. long: fis. 1-3, long-peduncled, reddish purple, 2 in. wide; petals light pink or yellowish at the base. May, June. Mediterr. region. B.M.43. S.C. 35. -A very variable species. Var. Créticus, Boiss. Lvs. smaller, more spatulate at the base : fls. purple. Fl. Græca 5: 495. S.C. 112. Var. canéscens, Nichols. Lrs. elliptic-oblong or narrow-oblong, obtuse: fls. dark purple. S.C. 45. Var. rotundifolius, Loud. Dwarfer, with more roundish lvs. S.C.75. Var. undulàtus, Willk. Lvs. linearoblong, acute, undulate: tls. solitary. S.C. 63.

crispus, Linn. Compact shrub, to $2 \mathrm{ft}$, villous : lvs. sessile, 3-nerved, linear-lanceolate or oblong-elliptic, undulate, rugose above, villous beneath : fls. $3-4$, nearly sessile, $1 \frac{1}{2-2}$ in. wide, deep rose-colored. June-August. S. W. Europe. S.C. 22.

heterophylllus, Desf. Erect, to $2 \mathrm{ft}$ : lvs. short-petioled, elliptic- or oval-lanceolate, green on both sides and slightly hairy, $1 / 2-1$ in. long : fls. $1-3,2$ in. wide ; petals red, yellow at the base. N. Africa. S.C.6.-More tender.

BB. Fls. 1 in. wide, petals not imbricate.

parviflorus, Lam. Much branched shrub, 1-2 ft.; tomentose: lvs, 3-nerved, elliptic-ovate, undulate rugose above, reticulate beneath, twisted, 1 in. long : fls. $3-5$; petals pale rose, yellow at the base. June. Greece, Crete. S.C. 14.

$$
\text { AA. Fls. white: lvs. 3-nerved. }
$$

Cýprius, Lam. Erect shrub, to $6 \mathrm{ft}$, glutinous: lvs. Cblong-lanceolate, glabrous above, villous-tomentose beneath: fls. $5-7$, nearly 3 in. wide; petals blotched purple at the base. June. Cyprus. S.C. 39.

ladaniferis, Linn. Shrub, to $4 \mathrm{ft}$., glutinous: lvs. shortpetioled, lanceolate, glabrous and viscid above, whitish tomentose beneath, $1 \frac{1}{2}-4$ in. long : fls. usually solitary, long-peduncled, $3-3 \frac{1}{2}$ in. wide; petals yellow at the base. June. S. W. Europe. S. C. 84. - Var. maculatus, Sweet. Petals with a dark brownish crimison spot above the base. B.M. 112. Gn. 30:552. S.C. 1. Probably the most beautiful of all Cistus.

laurifdlius, Linn. Shrub, to $6 \mathrm{ft}$.: lvs. petioled, ovate or ovate-lanceolate, glabrous above, whitish or brownish tomentose beneath, 1-21/2in. long : fls. $3-8,2-3$ in. wide; petals with yellow blotch. June-August. S. W. Europe. Gn. 53, p. 131. S.C. 52.-The hardiest species.

C. álbidus, Linn. To $4 \mathrm{ft}$.: lvs. sessile, whitish tomentose: fls. $3-8$, lilac or rosy, $2 \frac{1}{2}$ in. S.W. Europe. S.C. 31 - C. Algarvénsis, Sims $=$ Helianthemum ocyimoides. - O.candidissimus, Dun.; S.C. 3 = C.vaginatus, var. - C.Corbariénsis, Pourr. (C. populifoliasXsalvifolius). To $5 \mathrm{ft}$.: lvs. slightly cordate, glutinous: fls. $1-5$, white, $1 \frac{1}{2}$ in. S.C. 8 -C. Cupanianus, Presl. To $3 \mathrm{ft}$. lvs. cordate-ovate: fis 2-3, white Sicily S.C. 70-C. Florentinus, Lam. (C. Monspeliensis Xsalvifolius). Dwarf: lvs. lanceolate: fls. white, 2 in. Gn, 27:497, and 53, 134. S.C. 59-C. formòsus, fls. white, 2 in. Gn. 27:497, and 53, p. 134. S.C. 59. - C. formosus, Curt. $=$ Helianthemum formosum.-C. glaùcus, Pourr. $=$ C. Le-
don. - C. hirsùtus, Lam. One to $3 \mathrm{ft}$. , clothed with spreading and don. - C. hirsiutus, Lam. One to $3 \mathrm{ft}$., clothed with spreading and rope. S.C.19.-C.latifollius, Sweet; S.C.15=C.populifolius, var. - C. láxus, Ait. = C. longifolius. - C. Lèdon, Lam. One to $2 \mathrm{ft}$ : lvs. lanceolate, glossy above: fls. $5-10$, white, $1 \frac{1}{2}$ in. S. France.C. longifòlius, Lam. Two to $4 \mathrm{ft}$. glandulur: lvs. oblong-lanceolate, glossy above: fls. white, $11 \%$ in. S. W. Europe.- S. C. 12 Variable - C.Monspeliénsis. Linn To 5 ft. Lurope. S.C. 12. late: fls. white, cymose, 1 in. S. Europe. S.C. 27 . - . oblongilate: fls. white, cymose, 1 in. S. Europe. S.C. 27.-C. oblongi-
folius, Sweet; S.C. $67=\mathrm{C}$. longifolius,var-C.obtusifolius, Sweet; S.C. $42=$ C. longifolius, var.-C. populifòlius, Linn. To $6 \mathrm{ft}$., glntinous : lvs. petioled, cordate, acuminate, rugose above : fls. white, cymose, 2 in. S.W. Europe. S.C.23.-C.purpùreus, Lam. Three to $4 \mathrm{ft}$ : lvs, oblong-lanceolate; rugose above: tls. 1-6 reddish purple : petals yellow at the base and with maroon bloteh above Orient Gn $31 \cdot 591 ; 45,33$ B R. 5:408, S.C. 17 - C salvifólius . Linn To 2 ft. lvs, p. 33 . B R. 5:408, S.C.17.salvifolius, Linn, To 2 ft.: lvs. oval, obtuse. tomentose, small :
fls. 1-2, white, $1 \frac{1}{2}$ in. S. En., Orient. S.C. 54.-C. vaginatus, tls. 1-2, white, $11 / 2$ in. S. En., Orient. S.C. 54.- C. vaginatus,
Linn. (Rhodocistus Berthelotianus, Spach). To 2 ft.: lvs. petioled, ovate, acuminate: fls. cymose, deep rose-colored, yelow in center. Canary Islands. S.C. 9. B.R. 3:225. F.S. 15:1501.

CITRON. A form of Watermelon.
CITRON (Cítrus Mèdica, var. genuina). See Citrus. Fig, 474, - A large, thick-rinded, lemon-like fr, somewhat cult. in Flor. and Calif. The rind is used in the making of preserves and confections.

The Citron is propagated by cuttings, layers, budding, and grafting. The usual method of propagating is by budding on a vigorous stock, in Florida preferably the

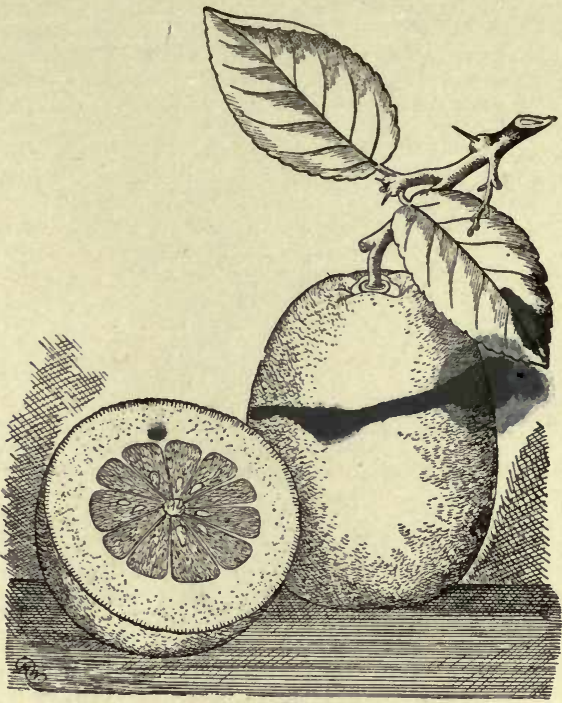

474. Citrus Medica, the Citron $\left(X^{1 / 4}\right)$.

rough lemon ("French lemon" or "oranged loomie"), but also on the sour orange. Grafting is so uncertain, owing to the prevailing high temperature, that it is seldom attempted. Cuttings of ripe wood root readily, both in the open ground and the propagating house. For open ground, select wood thoroughly ripe in December, and cut in lengths about 6 to 10 inches; clip off all but the top leaf, and insert in rows in well-drained soil, leaving the top bud exposed to the air. Watering must be thoroughly kept up until the succeeding rainy season. A shade of lath or brush should be provided the rows of cuttings. By November of the following year, the young plants will be sufficiently well rooted to transplant. By making short euttings, 2 or 3 inches long, of ripe wood, and inserting in the moist sand of the propagating house, less wood is necessary and a higher percentage of rooted plants will result in a shorter period. These cuttings may be inserted at any time of year, but winter and early spring are preferable. The young rooted plants may be grown into large size in the nursery, until wanted for orchard setting. Layers are easily rooted by pegging down low branches of the Citron during the rainy season. They do not make such symmetrical trees as those grown from cuttings, or by budding.

The site for the Citron orchard should be on welldrained land, either naturally, or otherwise, of the best quality, similar to that selected for the lemon In orchard planting, the trees should be set about $15 \times 24$ feet apart (although this is not arbitrary), as sufficient room should be allowed for cultivation, hauling fertilizer and fruit, and plenty of sunlight and air. An abundance of sunshine and breezes are the greatest aids in keeping down insect pests and fungous troubles. The Citron is rather low-growing and inclined to make long lateral branches, which, if not cut back occasionally, touch the ground and form roots, rendering cultivation and fruit-gathering difficult. Cultivation is essentially the same as for the orange and lemon: shallow plowing in December at the time of applying fertilizer, followed by thorough harrowing every two or three weeks until the latter part of June. This keeps the top soil loose, conserving the moisture, and keeping down weeds and grass during the dry season. After the rains set in 
during the summer all cultivation is stopped, and grass, beggar-weed, or field-peas allowed to cover the ground, preventing sunburning and providing a source of humus so necessary in keeping up proper fertility and texture of the sandy soil of Florida.

\section{E. N. REASONER.}

CITRULLUS (from Citrus). Cucurbitdcex. The genus which includes the Watermelon. Cogniaux, the latest monographer (DC. Monogr. Phaner. 3), recognizes three species, all of the Old World, with the largest dispersion in Africa. Plant monœeious, the two kinds of fls. solitary in the axils of the lvs.: fls. with a short, bell-like calyx tube and a deeply 5-cleft, yelJow corolla. c. vulgàris, Schrad., is the Watermelon (which see), native to tropical and south Africa. C. Colocýnthis, Schrad., is the Colocynth, extract from the fruit of which furnishes a well-known purgative drug. It is native to the Mediterranean region and tropical Africa. The fruit is small and globular, gourd-like, smooth and partly colored, the flesh very bitter: lvs. deeply divided.

L. H. B.

CITRes (ancient name for Citron). Rutacece. ORANGE, LEMON, CITRON, ete. Aromatic, glandular shrubs or small trees, mostly thorny: lvs, alternate, with more or less winged petioles, compound, mainly unifoliolate (appearing as a simple leaf but really compound, as shown by the joint between the petiole and lamina, Fig. 475), in one species trifoliolate: fis. hermaphrodite; calyx cupulate, 3-5-toothed; petals 4-8, linear-oblong, thick, glandular, imbricated in the bud; stamens numerous, $20-60$, occasionally only 5 ; filaments more or less united; disk eushion-shaped; ovary compound, composed of 5 to many united carpels, with a single style and stigma, and central axial placenta; ovules 4-8 in each carpel, arranged in two rows : fr. a round, oblong or pear-shaped berry with leathery rind, containing numerous oil glands and juicy, aromatic pulp : seeds white, exalbuminous, with leathery coats, frequently containing 2 or more embryos. Native of tropical and subtropical Asia. Several species are extensively cultivated and have given rise to numerous cultivated forms. The so-called navel oranges have a second series of cells developing in the center of the fr., this being an incidental variation (Cf. Fig. 476). See Citron, Lemon, Lime, Orange, Pomelo.

A. PseUdo-aegLe.-Lvs. trifoliolate, deciduous, with elliptical, dentate or crenate lfts.: fls. white, 1-2 in the axil of each leaf, opening before the lvs. appear in spring; petals spatulate: ovary and disk hairy.

trifoliàta, Linn. (C. triptera, Desf. Algle sepidria, DC.). Trifoliate Orange. Figs. 477, 478, 479. A small tree armed with very strong, stiff thorns, $1-1 \frac{1}{2}$ in. long: fr. golden yellow, about the size of a walnut, covered with short hairs; pulp rather dry, sour and bitter. Jap., and cult. widely in the United States. R.H. 1869 , p. $15 ; 1877$, p. $73 ; 1885: 516 ; 1886$, p. 533. Gn. $46: 980$ and p. 273. Mn. 3:101. - The fr. of the Trifoliate Orange

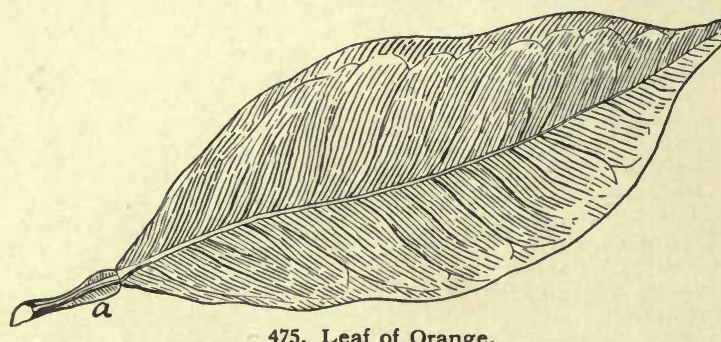

475. Leaf of Orange.

is worthless as a whole, but is sometimes used for preserves. The plant is largely used for hedges, for which it is well adapted, forming a close, compact growth that nothing can penetrate. It is also used as a hardy stock on which to bud certain oranges and lemons, particularly the Satsuma and Kumquat. It is said to have the effect of somewhat dwarfing the more robust orange va- rieties budded on it, and of making them more hardy by rendering them dormant earlier in the fall, and retarding them from starting early in the spring. The Trifoliate Orange is hardy as far north as Philadelphia and New York. It is propagated by seeds, which are very numerous. Hybrids have been made between this and the common orange. The Trifoliate Orange is frequently listed in trade catalogues under the names Limonia trifoliata and Triphasia aurantiola. These are tender,
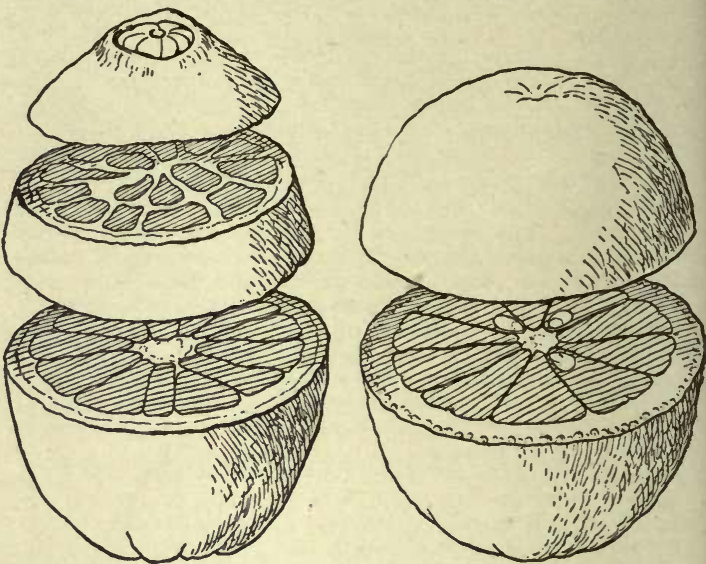

476. Normal orange on the right; abnormal or navel orange on the left, showing the adventitious cells in the center.

tropical shrubs, and should not be confused with the hardy $C$. trifoliata.

\section{AA. Eucitrus. - Lvs, unifoliolate, evergreen : petals} oblong: ovary and disk glabrous.

Aurántium, Linn. (C. vulgàris, Risso). ORANGE. Figs. 476,480. A small tree or shrub: young shoots light green, glabrous : lvs. elliptical or ovate, acute, obtuse, or acuminate; petiole narrowly or broadly winged : fls. hermaphrodite, pure white: fr. oblate-spherical or elliptical, not mamillate.

Var. amàra, Linn. (C. Bigard̀dia, Duham.). Sour, BitTer, or Seville Orange. Lvs. deep green, ovate, pointed, very aromatic; petiole broadly wing-margined: fls. white, sweet-scented: fr. round, dark orange, frequently with tinge of red, very aromatic; rind somewhat rough; pulp sour and bitter. Southeastern Asia, and cult. in tropical and subtropical regions throughout the world. - There are very few cultivated sorts oî this variety or subspecies grown in the United States, and of these only the two following are well krown : Sour ("sour orange"): Fr. deep orange or orange-red ; pulp very sour. This is grown very extensively as a stock on which to bud varieties of the sweet orange, lemon, pomelo, etc. Very valuable as a stock because resistant to the serious disease mal-di-gomma or foot-rot.-Bitter Sweet: Fr. of same external appearance as the Sour Orange but mildly acid and pleasant to the taste. Cultivated mainly for home use. The Sour Orange was evidently introduced into Florida very early by the Spaniards, and escaped from cultivation, becoming esiablished as a wild species here and there throughout the peninsular portion of the state. In this wild state it was limited to moist lands near streams and lakes, in the socalled hammocks; and in some instances grew abundantly among the larger forest trees, over areas of 100 acres or more. The fls. of this var. A mara are slightly bitter, and are the officinal Folia aurantii or Folia citri vulgaris. An ethereal oil is manufactured from the fls., young sprouts and unripe fr. The pleasant-smelling, bitter Bigaradia oil is taken from the rind of the ripe fr. Large quantities of oil for perfume are manufactured from the fls. in southern France. The fr. is used for marmalade, and makes a very refreshing drink known in Florida as "orangeade."

Var. Bergàmia, Wight. \& Arn. Bergamot OrangE. A bush or small tree : lvs. oblong; petiole wing-mar- 
gined, of medium width : fls. small, white, sweet-smelling: fr. medium size, pear-shaped, smooth, light yellow, pulp subacid, greenish yellow. Cult. in Eu. since the seventeenth century. Only rarely cult. in the United States. B.M. 7194.-Bergamot oil is manufactured from the rind of this subspecies.

Var. Sinénsis, Engler. (C. Aurántium, var, dúlcis, Linn. C. Tahiténsis, Hort.). Common Sweet Orange, including the Malta or Portugal Orange. Tree, 20-35 ft. : young branches pale green, angular, glabrous: lvs. oblong-ovate, pointed; petiole narrowly winged : fls. large, white: fr. mainly round, occasionally elliptical or ovate, orange or yellowish ; pulp when ripe sweet or slightly acid. India. Cultivated extensively in all tropical and subtropical regions of the world.-The Sweet Orange is valued mainly for its sweet, delicious fruit, which is eaten raw or made into marmalades, wine, etc. The rind is sweet and aromatic, and is used for culinary purposes. The extensive cultivation of the orange has led to the development of numerous variations, some 70 varieties being cultivated in the United States. Some of these forms are propagated fairly true to seed, but the majority are not, and must be propagated by budding or grafting. The following is a list of some of the most highly prized of the cultural forms: Bahia (also known as Washington Navel and Riverside Navel): Fig. 476. Fr. large, solid and heavy, seedless, with prominent navel mark at apex; pulp juicy and of fine texture. Introduced from Brazil. The most popular variety cultivated in California, where it bears heavily. In Florida it is a shy bearer.-Boone (Boone Early): Fr. round, medium size, fair quality; very early. Florida. - Centennial : Fr. round, medium size, early medium, quality excellent. Florida.-Du Roi : Fr. round, small or medium size, late medium; seeds ribbed: thorns few. An excellent fruit in Florida, but has not given satisfaction in Cal. Foreign.- Hart Late (Tardive, Excel-

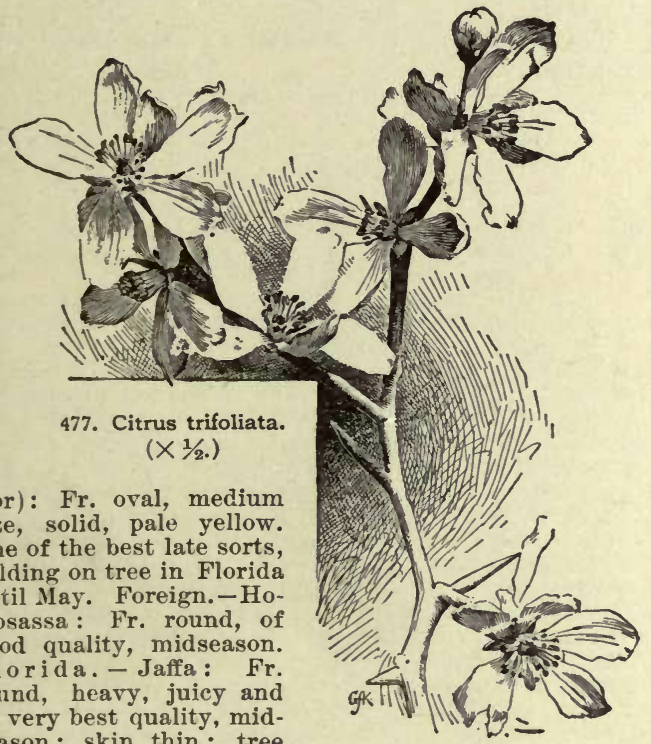

of very best quality, midseason; skin thin: tree nearly thornless. Foreign. - Jaffa Blood: Fr. oval, small, of excellent quality. Florida.-Lamb Summer : Fr. oval, medium size, of good quality, very late; one of the best late sorts, ranking with the Hart Late. Florida.Majorca: Fr. round, medium size, heavy and very juicy skin smooth and thin; quality excellent. Foreign. One of the very best late midseason sorts. - Maltese Blood : Fr. oval, small, orange red, juicy and sweet, of very best quality; pulp reddish or streaked with red; midseason. Foreign. Mediterranean Sweet: Fr. large, oval, of good quality, late. Foreign.-Parson (Parson Brown): Fr. round, medium size, of fair quality; very early. Florida. Very extensively planted as an early variety in Florida. -Ruby: Fr. medium size, round, of excellent quality; pulp reddish or streaked with red. Foreign. - St. Vichael : Fr, round, medium size, quality fair, midseason. Foreign. -St. Michael Blood: Fr. round, medium

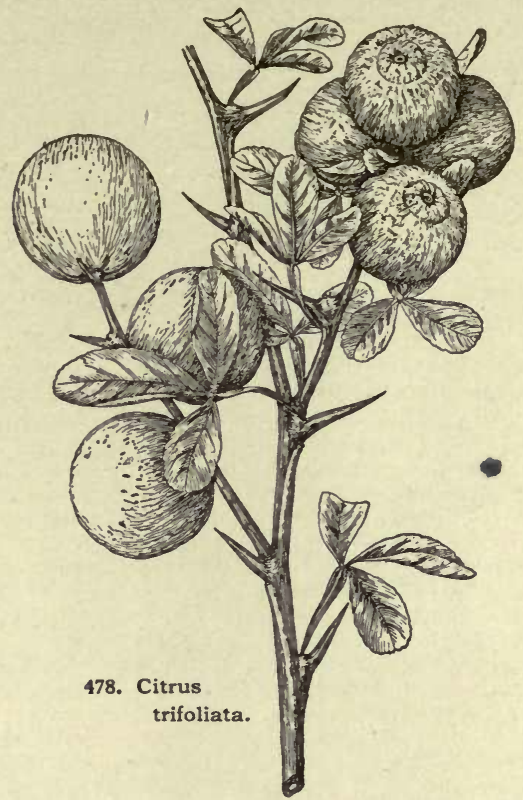

size, quality the very best; pulp reddish or streaked with red. Foreign. This Orange seems to the writer superior in flavor to any he has ever tested, though there is but little noticeable difference between any of the best sorts, much, doubtless, depending on the conditions under which the fruit is grown.-Valencia (Valencia Late): Fr. large, oval, light orange, of good quality, very late. Foreign. One of the most highly prized varieties in California.

The so-called Otaheite Orange (C. Aurantium, var. Otaitense, Risso \& Poit.) is probably to be considered a variety of $C$. Aurantium, var. Sinensis. Reasoner thinks it is Gallesio's " $C$. Aurantium Sinense pumilum fructu dulci." The foliage resembles that of a lemon, and the flowers are pinkish. The fruit is small, slightly flattened, rough, and reddish orange in color ; pulp mainly sweetish, sometimes sour. It may be a hybrid of orange and lemon. It is used extensively as a dwarf pot plant, for which it is well suited.

nobilis, Lour. Mandarin, or Kid-glove Orange. Shrubs or very small trees, with dense foliage: lvs. small, lanceolate, weakly crenate; petioles short, scarcely winged : fls. small, white, fascicled; filaments only slightly united: fr. compressed, spherical, or somewhat pyriform, 5-6 $\mathrm{cm}$. in diameter ; rind orange-yellow or reddish, loose, baggy, and easily removed; segments 9-10, loosely adherent; pulp sweet; seeds ovate or oblong, green when cut: odor of leaves, twigs, fruit, etc., very characteristic in all varieties and easily recognizable. Cochin China or China. Cultivated extensively in tropical and subtropical regions free from hot winds, to which it is said to be very sensitive. - The principal horticultural varieties grown in the United States are the following: China "Mandarin," "Willow-leaved Mandarin," etc.): Fr. small, light orange, early medium, excellent quality : lvs. small, myrtle-like. Foreign.Dancy Tangerine : Lvs. larger, nearly the size of those of the common orange: fr. dark orange or reddish, early medium, quality excellent. Florida. The most prized of any of the Mandarin Oranges cultivated in the United States. - King : Fr. large and rough, dark orange, late: young twigs blackish. A good late sort. Foreign.Satsuma (Oonshiu): Fr. medium size, flattened at the ends, orange, early, quality fair. Foreign. A much valued early ripening sort, which is somewhat more hardy than the common sweet orange, particularly when 
budded on the hardy trifoliata orange stock. - Tangerine: Fr. very early, light orange, medium size. Foreign.

Decumàna, Linn. (C. Pomelànus, Hort.). Pomelo, Pumelo, Shaddock, Grape-Fruit, Pompelmos, ete. Tree

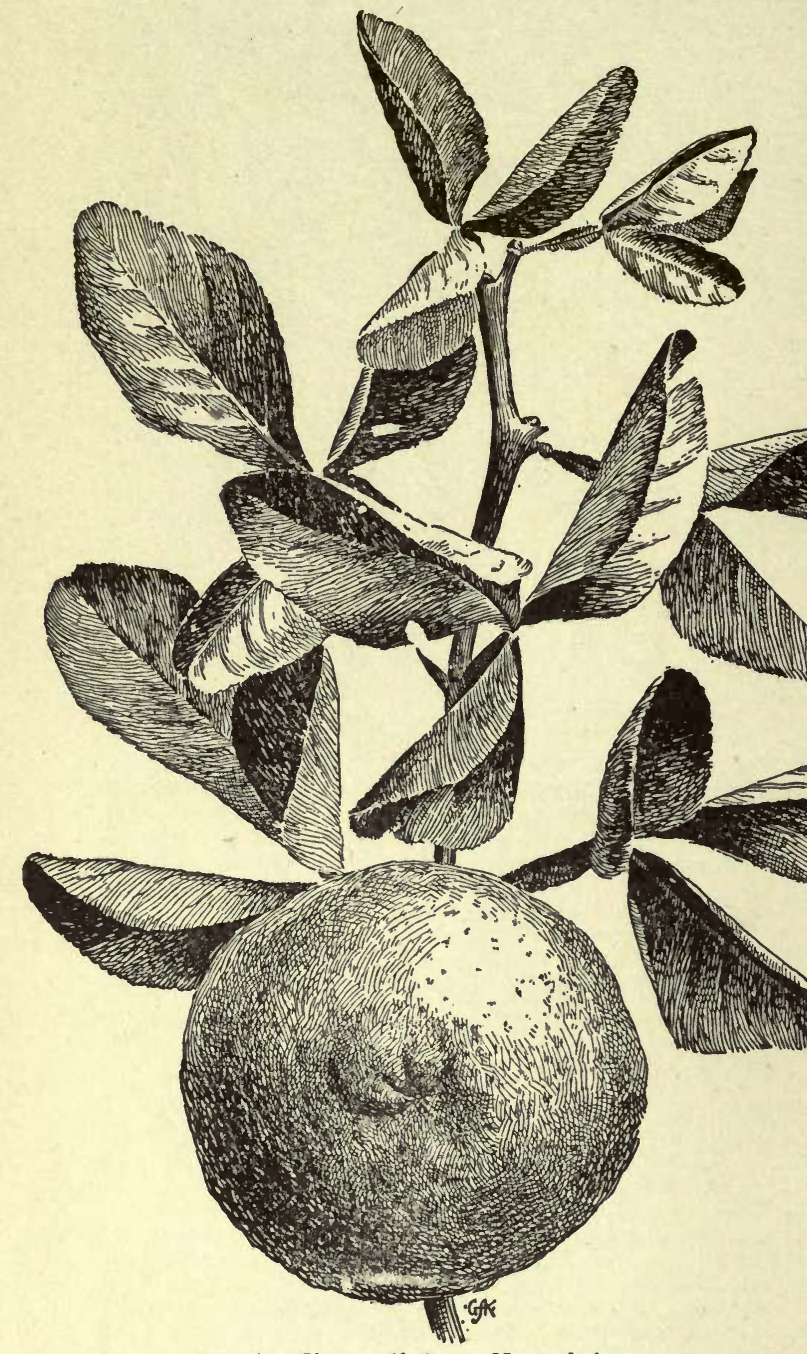

479. Citrus trifoliata. Natural size.

small, 25-30 feet high : young shoots slightly pubescent, finally becoming smooth: Ivs. large, ovate or ovateoblong, obtuse, frequently emarginate; petiole broadly winged: fls. large, white; stamens 16-24: fr. pale lemonyellow, or in some cases reddish or flesh colored, globose or pyriform, very large, in hort. vars, reaching 6-7 in. in diameter and weighing 8-12 lbs.; rind smooth, thick, very bitter; pulp pale yellow, in some reddish, sweet or acid. Malayan and Polynesian Islands. Extensively cultivated in India, Florida and California, and in most tropical and subtropical countries. A.G.11:717. Mn.9:47. -The l'omelo is an excellent dessert fruit, and is being very extensively planted, particularly in Florida. The majority of the horticultural varieties cultivated in America have originated in Florida, though some valuable sorts have been introduced. The round-fruited sorts, commonly called Pomelos or Grape-fruits, are the most valuable commercially. The pear-shaped sorts, or Shaddocks, are cultivated more as curiosities, and are seldom found in the markets. Round varieties-Pomelos:
Aurautium : Fr. late medium, size medium. Florida.Josselyn: Fr. large, late medium, quality good; prolific. Florida.-Hart : Fr. late medium, large, of very good quality. Florida.-Marsh (Marsh's Seedless): Fr. with very few seeds, said to be of good quality and prolific, of recent origin. Florida. - Pernambuco : Prolific : fr. late, large: thorns short. South America.-Royal: Fr. small, early medium, only slightly bitter; prolific. Florida.-Tresca : Pulp rose-colored, said to be of excellent quality. Bahama Islands. - Triumph: Fr. small, late medium, quality very good. Florida. - Walter: Fr. late medium, large, of recent origin. Florida. Pearshaped varieties-Shaddocks : Blood : Fr. large : pulp reddish or flesh-colored, of fair quality.-Mammoth: Fr. very large, but practically worthless. - "Forbidden Fruit": Fr. small, orange-colored, of fair quality. The so-called "Bell Grape-fruit" is probably identical with this.

Japónica, Thunb. KUmquat, KIN-Kan, KIN-Kits, etc. Fig. 481. A low bush, with smooth, angular branches: lvs. small, linear-lanceolate, slightly serrate, pointed or blunt, wedge-shaped at the base ; petioles narrowly wing-margined: fls. small, solitary or in clusters, in the axils of the lvs.; petals 5; stamens about 20 , filaments united: $\mathrm{fr}$. small, often only $3 / 4$ of an in. in diam., ovate, oblong or spherical, orangecolored, 5-6-celled; pulp sour; rind sweet. Cochin China or China. Cultivated extensively in Japan, Florida and California. R. H. 1875, p. 209. The following are the two cultivated varieties commonly grown in the United States: Marumi (Round Kumquat): Fr. round, small, $3 / 4-1 \frac{1}{4}$ in. in diam.: tree slightly thorny. $-\mathrm{Na}$ gami (oval or oblong Kumquat): Fr. ovate or oblong, $3 / 4-1$ in. in diam. and 11/4-2 in. long : tree thornless. - The fruit of the Kumquat, as it is most commonly called in America, is coming to be much prized for preserving, and is also used fresh to considerable extent, the sweet rind, as well as the pulp, being eaten. Both the round and the oval sorts have beautiful dense, dark green foliage, and form excellent orange trees of dwarf habit for pot culture. They are commonly budded or grafted on trifoliata or sweet orange stocks.

Medica, Linn. (named for the country Media). Fig. 474. Citron, in the broadest sense, including citron, lemon and lime. Bush or small tree: young shoots glabrous, mostly reddish or purplish, in some yellowish green : lvs. smooth, oblong, acute : fls. hermaphrodite or frequently unisexual, mostly reddish or tinged with red without: fr. spherical, ovate or oblong. often mamillate at apex. India. - A very variable species, much modified by cultivation and apparently mixed by hybridization, so that it is almost impossible to determine the relationship of the different forms.

Var. genuina, Engler. Citron proper. Lvs. oblong, serrate or crenate; petiole short, wingless fr. large, frequently $3-4$ in. in diam. and 6-7 in. long, mostly ovate-oblong, mam illate; rind very thick, tender, aromatic, more or

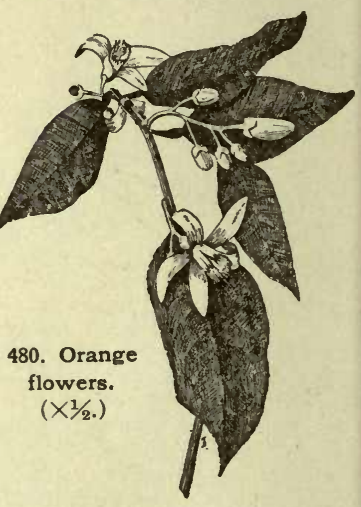
less rough and warted (rugose); pulp but slightly developed, dry (lacking in juice), acid or sub-acid. The Citron is cultivated to some extent in Florida and California, but not so extensively as in Italy and the Mediterranean region. All varieties are very tender, 
probably being the most easily injured by cold of any of the citrous fruits. It is prop. by seeds, cuttings, layering, etc. The cultivated varieties do not propagate true to seed, and must be budded or grafted. 'The fr. is prized for the thick, tender, aromatic rind, which is preserved or candied, and used extensively for culinary and confectionary purposes. Many forms and horticultural varieties are grown in Florida and California, but none have thus far proved of noteworthy commercial value. The Corsican, a variety recently introduced by the U.S. Department of Agriculture from Corsica, has given evidence of being a desirable commercial sort for cultivation in this country.

Var. Limon, Linn. LEMos. Small, spreading trees or shrubs: young branches smooth, yellowish green: Irs. ovate-oblong, crenate or serrate; petiole short, marginless or slightly winged : fr. medium sized, yellow, round, ovate or elliptical, mostly mamillate ; rind thin, aromatic ; pulp abundant, very juicy and acid. India. Cultivated extensively in all tropical and subtropical regions of the world.-The Lemon is one of our most important commercial fruits, and is grown extensively in California and Florida. Large quantities of the fruit are also imported, mainly from Italy. The Lemon is not so easily injured by cold as the citron, but is more tender than the orange or pomelo. The entire fruit, rind and pulp, is used extensively for culinary and confectionary purposes, for the manufacture of citric acid and for lemonade, etc. It is commonly prop. by seeds, but may also be readily grown from cuttings. The cultivated varieties must be prop. by budding or grafting, or by cuttings, as they do not come true to seed. The following are the most important horticultural varieties : Belair : Fr. lemon-shaped, blunt. Foreign.-Eureka: Fr. early, few-seeded: tree thornless. Foreign.Genoa: Fr. medium size, early, oval, nearly seedless: tree everbearing, thornless. Foreign.-Lisbon ; Fr. medium size, fine grained, strongly acid; few seeds: tree thorny. Foreign. - Villa Franca: Fr. medium size, qual-

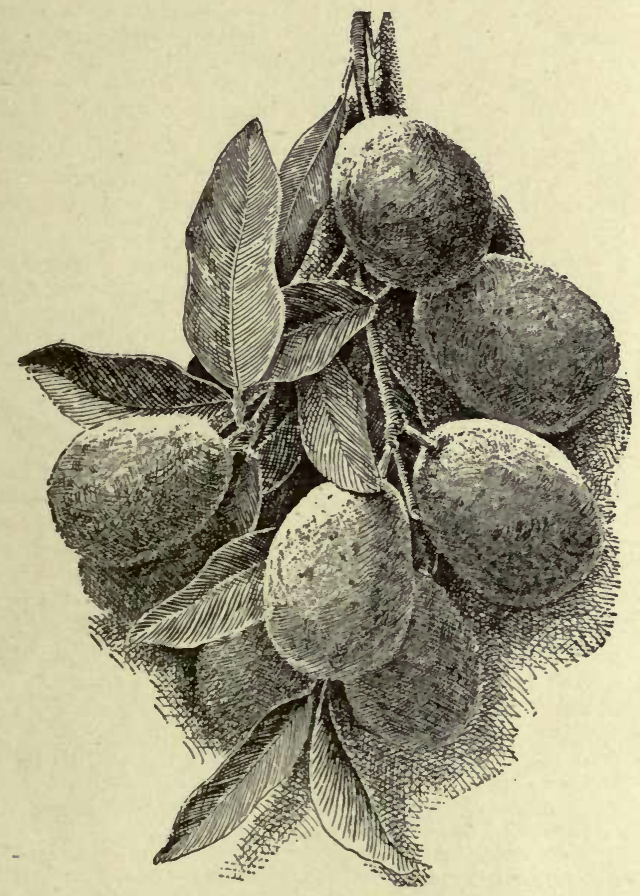

481. Kumquat - Citrus Japonica $(\times 1 / 2)$.

ity excellent; rind smooth, thin; seeds few or none. One of the finest Lemons grown. - The so-called Fingered Citron or Lemon, var. digitata, Risso (or var. chirocarpa), in which the individual carpels of the fruit are separated above, is an interesting and striking monstrosity. (See Fig. 482, which is taken from a Japanese fruit known locally as the Bushiukan.) The Florida Rough Lemon, or simply " Rough Lemon," as it is called,

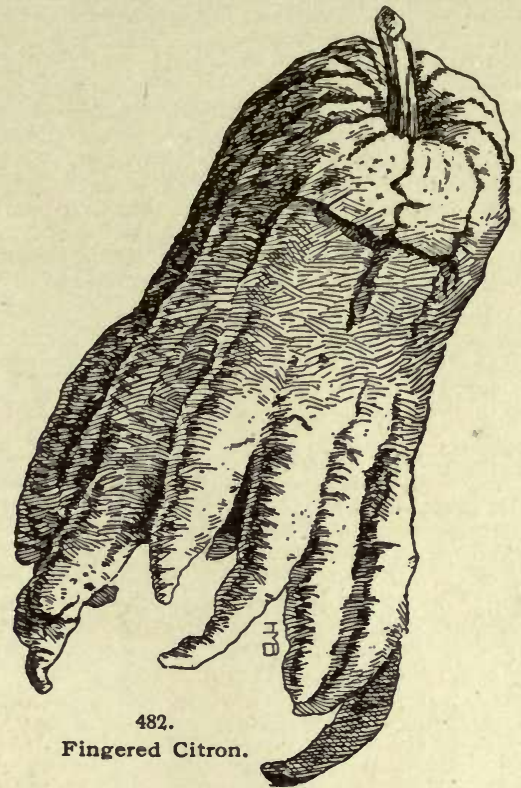

is a fruit of doubtful relationship. Its appearance sug. gests that it may be a hybrid between the Citron and Lemon. It is a strong, vigorous grower, and forms an excellent stock, in warm localities, for the various orange varieties. It is the best stock for the Bahia navel orange, usually increasing its fruitfulness.

Var. ácida, Hook. (C. Mèdica, var. Limétta of trade catalogues, etc.). Lime. A bush or small tree, 10-20 ft. high : lvs, oval or elliptical, small, crenate or serrate; petiole wing-margined, but not as broadly so as in the sour orange and pomelo: fls. small, white or with a slight pinkish tinge without; petals normally 5 , but often 4: fr. small, spherical, ovato or elliptical ; rind thin, light lemon-yellow, bitter; pulp very sour and somewhat bitter, juicy. India. Extensively cultivated in the West Indies and Florida, where it has escaped from cultivation and grows abundantly wild, frequently forming dense thickets. B. M. 6745. The horticultural varieties commonly cultivated in the United States are: Mexican (West Indian): Fr. small, oblong. Escaped from cultivation in South Florida and the West Indies. Supposed to have been introduced from Mex.Persian: Fr. larger than in the preceding; said to be of excellent quality. Introduced from Persia.-Rangpur (Mandarin Lime): Fr. resembling a mandarin orange in having easily removable rind and separable segments or carpels; said to be of excellent quality. Introduced from India.-Tahiti: Fr. large, early, nearly seedless, of fine quality: tree nearly thornless; prolific. Introduced from Tahiti. This is probably the most highly prized variety of Lime grown. Until recently, the Lime had been used mainly for the manufacture of lime juice, which had become a standard article of commerce, and citric acid. Recently, limeade has became very popular at the soda fountains throughout the country, and this use is so rapidly extending that in a few years it will doubtless make Lime-growing an important industry.

H. J. WEBBER.

CIVE (written also Chive). Allium Schoenoprasum, Linn., a perennial plant native to Europe and the northern borders of the U.S. and northward. See Allium. The leaves of Cive are used green as seasoning in soups, salads and stews; but, like other vegetables of this class, it is little known in America. Cive grows 6 to 8 inches high, making dense mats of narrow, hollow leaves, and 
blooming freely in violet-colored heads, which scarcely overtop the foliage. The plant makes an excellent permanent edging, and is worth growing for this purpose alone. It is easily propagated by dividing the clumps; but, like other tufted plants, it profits by having the stools broken up and replanted every few years. It rarely seeds. It thrives in any garden soil. The leaves may be cut freely, for they quickly grow again.

L. H. B.

CLADANTHUS (Greek, klados, branch, and anthos, flower ; alluding to the branching, which distinguishes this monotypic genus from Anthemis). Composita. An annual, yellow-rayed herb, branched from the base in a forking manner. A flower terminates each branch, whereupon two new branches start from directly beneath the flower. Each of these is temporarily stopped by a flower, and so on. A free-flowering, hardy annual, requiring no special care.

prolíferus, DC. (Ánthemis Arábica, Linn.). Annual: glabrous, $2-3 \frac{1}{2} \mathrm{ft}$. high: lvs. alternate, pinnately parted; lobes linear, trifid: fls. solitary, bracted. N. Africa, not Arabia.

W. M.

CLADOTHAMNUS (klados, branch, and thamnos, bush, from the Greek). Hricacea. Erect shrubs, with many virgate branches: lvs. deciduous, alternate, entire: fls. pink, terminal, 1-3, nodding ; corolla divided to the base or nearly so into 5 oblong petals; stamens 10 ; capsule 5-6-celled. Two species in Pacific N. America, from Alaska to Washington. Hardy deciduous shrubs, with handsome, rather large, pink fls. in summer; rarely cultivated. They will probably grow best in peaty and sandy soil, in a half-shady position; prop. by seeds or by cuttings of soft wood under glass, and by layers.

C.pyrolaeflòrus, Bong. Shrub, 4-10 ft.: lvs. nearly sessile, obovate-lanceolate, mucronulate, glabrous, pale green, $1 \frac{1}{2}-2 \frac{1}{2}$ in vate-lanceolate, mucronulate, glabrous, pale green, $11 / 2-21 / 2$ in. G.F. 10: 215. - C. campanulàtus, Greene. Lvs. smaller: fls. 1-3, with the petals united into a short tube. Washington.

\section{ALFRED REHDER.}

CLADRÁSTIS (Greek, brittle branch). Virgilia of gardens. Legumindsa. Deciduous trees: lvs. alternate, odd-pinnate, with few, rather large, entire, short-stalked leaflets: fls. in long, often panicled racemes, white, papilionaceous; calyx campanulate, 5-toothed; stamens 10 , free or connate only at the base: pod linear, compressed, with 3-6 seeds. Two species in N. Amer. and E. Asia. Hardy ornamental trees of medium size, with showy fls. and hand some foliage, turning bright yellow in fall. They thrive in almost any soil. Prop. by seeds, sown in spring, or by root cuttings, dug up in fall and kept in sand or moss, moderately moist and cool, until spring.

tinctòria, Raf. (C. lùtea, Koch. Virgília lùtea, Michx.). Tree, with yellow wood and smooth bark, sometimes $50 \mathrm{ft}$. leafiets 7-9, oval or ovate, glabrous, bright green, 3-4 in. long: panicles loose, drooping, 10-20 in. long: fls. white, fragrant, over 1 in. long. June. Kentucky, Tennessee and N. Carolina. S.S. 3:119-20. Mich. Hist. Arb. III. 266. Gng. 2:401; 5:98. F.E. 8:427. G.F. 1:92.-One of the most beautiful flowering native trees, with wide, graceful head and a short trunk, well adapted as single tree on the lawn. Hardy north to New Eng. and Ont. The wood yields a clear yellow dye. Known as Yellow-wood.

Amurénsis, Koch (Maáckia A murénsis, Rupr.). Tree, to $40 \mathrm{ft}$.: leaflets 7-11, elliptic-or oblong-ovate, rounded at the base, glabrous, 2-3 in. long: racemes erect, dense fld, often panicled at the base, 4-8 in. long: fls. whitish, about 1/3in. long. July, Aug. Manchuria. B.M. 6551.Var. Buérgeri, Maxim., from Japan, has the lvs. pubescent beneath.

\section{ALFRED REHDER.}

CLARKIA (Captain Wm. Clark, companion of Lewis, explorer of the Rocky Mt. region). Onagracea. Herbs of western N. Amer., with alternate, mostly entire lvs. and showy fis. in the upper axils or in terminal racemes. Fls. regular, the calyx tubular, the petals 4 , narrow at the base and entire or lobed, wide-spreading ; stamens 8 , the alternate ones shorter; stigmas 4, large : pod oblong or linear, 4-sided. Clarkias are hardy annuals of easy cult. They thrive in a warm, light soil, either fully exposed to the sun or in partial shade. Useful for low masses or for edgings; also for vases and baskets. They have been much improved by domestication.

\section{A. Petals entire, or at least not lobed.}

elegans, Dougl. (C. neriifòlia, Hort.). Fig. 483 . From 1-3 ft. high in cult., glabrous or nearly so, the stems reddish and glaucous, simple or sparingly branched: lvs. broad-ovate to linear, remote-dentate: fls. purple or rose-colored, running into white vars.; double forms in cult.: claw of the petal about as long as its rhomboidal limb: capsule sessile. B.M. 3592. R.H. 1845:385. Mn. 1:22.-One of the commonest annual fls.

rhomboídea, Dougl. Not so tall and more slender : lvs. thin, lance-oblong or ovate-oblong, entire : claw often toothed, shorter than the rhomboidal limb: capsule stalked. R.H. 1864:151? - Perhaps not in cult.

$$
\text { AA. Petals deeply 3-lobed. }
$$

pulchella, Pursh. Fig. 484. One ft. to $18 \mathrm{in.} \mathrm{high,}$ branchy, often tufted and dwarf, the stems mostly puberulent: lvs. narrowly lance-oblong to linear, narrowed

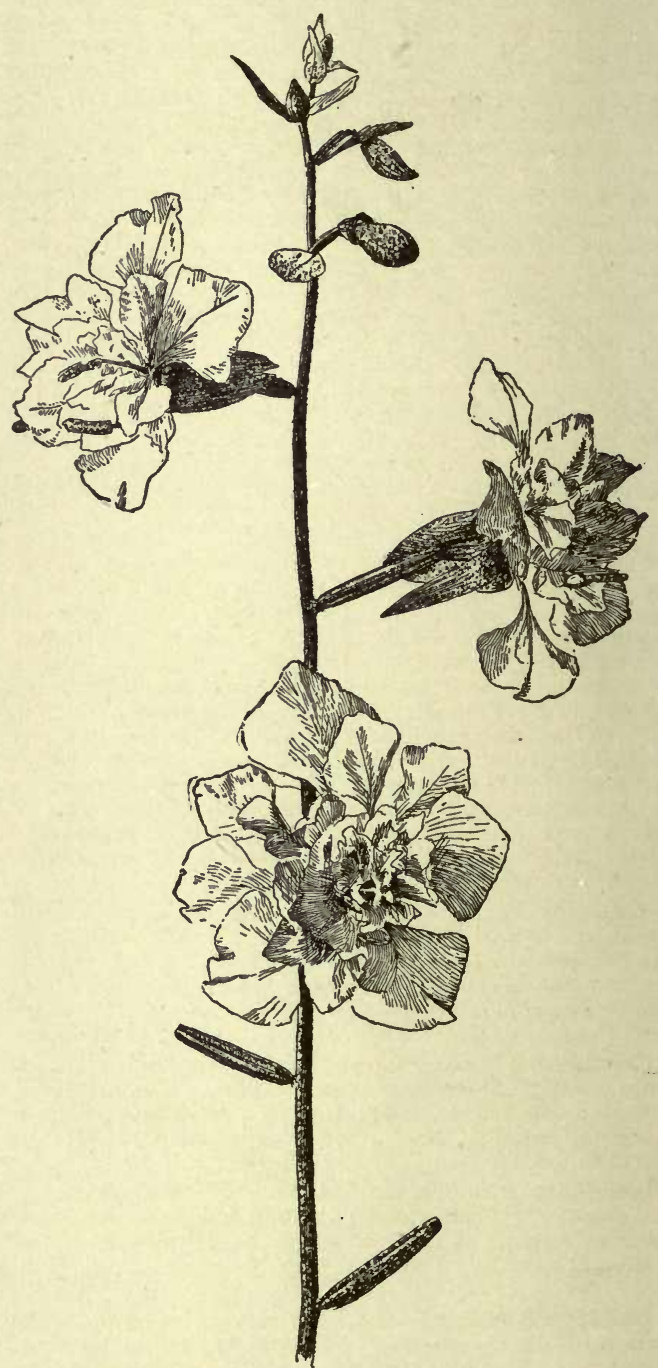

483. Clarkia elegans.

Showing double flowers and the capsules $(\times 2 / 3)$.

into a petiole, entire: fls. lilac, running into white vars. : capsule stalked. B. M. 2918 . R. H. 1845:385; 1886, p. 557. - Common in cult. There are semi-double forms.

L. H. B 
CLARY. The dried lvs. of Salvia Sclarea, which are used for seasoning. Other species of Salvia have been used fo" the same purpose. See Salvia.

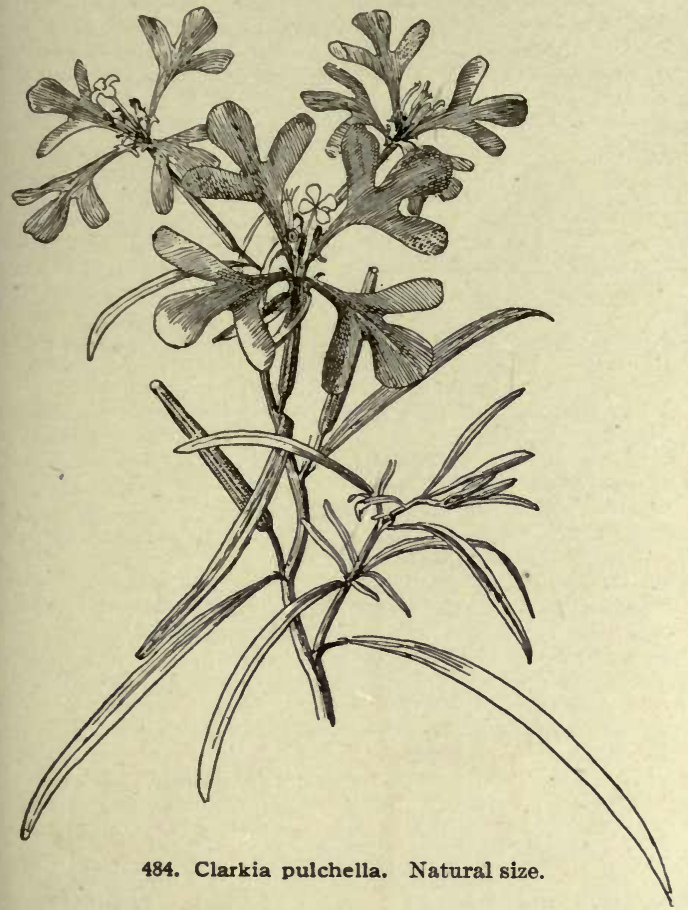

CLAYTONIA (after John Clayton, of Virginia, one of the earliest American botanists. From his collections Gronovius edited the Flora Virginica). Portulacdcece. SPRING BEAUTY. Small, hardy, glabrous, succulent, perennial herbs, with slender, 2-leaved stems from a deep, globular corm, and loose racemes of white or rosecolored fls. with deeper veins, appearing among the first wild fls. and lasting only a few days. The genus has about 25 species, mostly N. Amer., and is characterized by its oval, persistent sepals and 5 stamens. Plants can be obtained from dealers in native plants. They can be naturalized in moist places, and do well in half-shady spots at the bottom of a rockery. For C.parvifolia, parviflora and perfoliata, see Montia.

Virgínica, Linn. Plant 4-8 in. long, often forcing an irregular way through the leaf-mold of damp, rich woods: lvs. linear-lanceolate or linear, 2-6 in. long, in cluding the gradually tapering base : fls. larger and more numerous than in C. Caroliniana. Colo, to Atlantic and S. to Gulf. B.M. 941. L.B.C. 7:643. D. 33.

Caroliniàna, Michx. Lower and fewer-fld.: Irs. 1-2 in. long, oblong, oblong-lanceolate, or somewhat spatulate, with a blade 1-2 in. long, abruptly contracted into a marginal petiole. Minn. to Atlantic and S. to Mts. of North Carolina.

lanceolata, Pursh. About 4 in. high : lvs. oblong or lanceolate, $1 / 2-1 \frac{1}{2}$ in. long, sessile, the base broad or narrow: raceme short-peduncled : petals emarginate or almost obcordate. Utah and Calif.

W. M.

CLEISOSTOMA (Greek, closed mouth, referring to the structure of the spur). Orchiddcece, tribe Vándece. Epiphytes : stems leafy : lvs. coriaceous, flat or nearly terete: sepals and petals adnate to the column, spreading; labellum with a large saccate spur; column short, thick ; pollinia 2. From eastern Asia and Austral. A genus comprising in this neighborhood 40 species, which suggest Saccolabium. The plants are little known in Amer. The leading species are $C$. crassifolium, Lindl., and C. ringens, Reichib. f. C. Dawsonia- num, Reichb. f., is a Trichoglottis ; C.multiflorum, Hort., is probably Érides multiflorum.

OAKES AMES.

CLEMATIS (Greek name of a climbing plant). Ra. nunculdeec. Climbing vines, or erect or ascending perennial herbs, more or less woody : lvs. opposite, slender petioled, pinnately compound, lobed, or in some species entire: sepals usually 4 or 5 , sometimes more, valvate in the bud, petaloid; petals none (or small in Atragene section); stamens many; pistils many; akenes in a head, 1-seeded; style persistent, long, plumose, silky or naked. Fig. 492. About 150 species of very wide geographical distribution, most abundant in temperate regions. About 20 species found native in North America.-Les Clematites, Alphonse Lavallée, Paris, 1884 ; referred to below by "Lav."-The Clema. tis as a Garden Flower, Thomas Moore and George Jackman, London, 1872 ; referred to below by "M. \& J." - Clematises, DH. Jules le Bele, in Bull. de la Societe d'Hort. de la Sarthe; republished in The Garden (vol. 53), June-Oct. 1898.-O. Kuntze, Monogr. der Gattung Clematis in Verh. Bot. Ver. Brandenb. 26 (1885).-A. Gray, Fl.N. Am. 1: 4-9, 1895.

A rich soil of a light, loamy character is the best for Clematises, and a little mixture of lime will make it better. The soil must be well drained, and must be kept rich by at least annual applications of horse- or cow-manure. On dry, hot soils cow-manure is best, while on heavy soils a thorough dressing of rich leaf-mold would best serve the purpose. Mulching with half-rotted manure on the approach of winter tends to increase the strength of the plants and the size of the flowers. In dry seasons, spraying is always helpful during the growing season.

Clematises belonging to the Montana, Cærulea, Florida, and Lanuginosa types should be pruned in February or March, by cutting away all weak, straggling and overcrowded branches. The flrst three mentioned flower from the ripened wood; it is essential, therefore, that in orderto secure blossoms, enough of the strong oneyear-old wood should be retained. Viticella, Jackmani and Lanuginosa should be vigorously cut back, say in November; they blossom from the new shoots. Those of the Cærulea type should be pruned very little, soon after the flowers have disappeared, by simply trimming off useless branches and seed-bearing peduncles.

Clematises of the vigorous climbing varieties are used in many places to cover walls, root fences, mounds, arbors, balconies, trellises, small buildings, and, in fact, many other places the ingenious gardener will think of. For pot culture in the greenhouse, and for conservatory walls, the less vigorous species are best suited. All the many varieties and hybrids of the Cærulea and Lanuginosa types, including Henryi and the forms of Jackmani, are well adapted to this use, as well as for outdoor purposes. The dwarfer and more bushy species are used in greenhouses to some extent, but are found principally in borders or on large rockeries. Of the latter J. B. Keller says : "Their flowers are not so large as we see them in most of the climbers, yet they are indispensable in the flower garden, being prolific bloomers and free growers in ordinarily rich, deep garden soil. There is room for improvement in this class, however, and specialists who hitherto have done so much for the climbers, ought to direct their efforts now to the long-neglected bush Clematises. A noble beginning has been made, resulting in the large-flowering C. integrifolia, var. Durandi, but we expect more of them in the future." See special notes on culture and hybrid-forming qualities after the descriptions of some of the species and varieties.

The most common method of propagation is by grafting. Roots of $C$. Flammula or $C$. Viticella are used ; the cions are taken from plants that have been grown under glass, and are used before the wood is entirely ripe. Cions taken from plants grown in the garden in summer are rarely successful. The grafts, in pots or trays, are grown in a moist coolhouse, over gentle bottom heat. Another method of propagation, involving less labor but usually successful, is to take cuttings of nearly ripe wood, grown under glass, and treat them as the cions first above mentioned, without the roots. The latter method is practiced preferably in summer in 
gentle hotbeds; shading, spraying, and later on airing, must be strictly attended to. Layering is practiced where large old stools are at hand. The knife is not used in the operation, but a twist of the stem will split the inner bark lengthwise. Every other joint is thus treated, pegged down, and covered with soil. It is best to leave the layers undisturbed until the following spring. Many of the species are often propagated by seed, and many new varieties have thus been formed. The number of hybrids is almost countless ; in this account are carefully recorded all those in the American trade which are traceable to their origin.

The Clematis is subject to a very serious disease, due to the depredations of a nematode worm in the roots. This trouble is most serious under glass and alongside buildings where the ground does not freeze deep. The parasite is probably distributed in the soil adhering to pot-grown plants. It is probable that hard freezing kills the parasite. There is no remedy, so far as kncwn, for affected plants. Using only soil which has been frozen is to be recommended to the propagator. K. C. DAvis.

The hybrid varieties of Clematis, commonly known as the large-flowering sorts, are, when successfully grown, among the most beautiful of hardy climbing plants. The commercial propagation and growing of most of the large-flowering varieties, however, is attended with so many difficulties and disappointments that it has never been very generally attempted by nurserymen or florists in this country. At the present time there are scarcely half a dozen houses on this continent who attempt the propagation of Clematis to any considerable extent, and it is only within the past fifteen years that Clematises have been commercially grown even by this limited number. Prior to that, practically all of the large-flowering Clematis planted in this country were imported from Europe, the major part being supplied by Holland, whose moist atmosphere and black soil produces large, vigorous plants, but whose climatic conditions are so entirely different from those usually found in this country that the plants often failed to adapt themselves to their new surroundings, and did not thrive to the extent that their good size and vigorous condition seemed to give promise.

The propagation of Clematis throughout Europe is usually effected by grafting pieces of well-ripened, yearold wood upon roots of almost any of the more vigorous growing species, Clematis Flammula being most commonly used. In this country, on the contrary, the method commonly pursued is by means of cuttings from young wood, struck in sand, with gentle bottom heat, usually during May or June. So far as concerns the comparative vigor and desirability of plants produced by these two methods, there is small choice between them. It has been our experience that propagation by cuttings is, in this country, the more rapid and economical way, and, further, it removes the possibility, sometimes realized in grafted plants, of sprouts being thrown up from the roots, and, if in the hands of an uninformed amateur, entirely "running out" the variety grafted in.

Clematises hybridize so readily that the number of varieties resultant from various crosses forms a long list. But while so many have been dignified with names and places in the catalogues of nurserymen, yet the varieties of large-flowering Clematis that have proved so valuable as to secure permanent places for themselves in popular demand can almost be counted upon one's fingers. There are many varieties possessing most beautifu shades and variations of coloring that fail to attain popularity, chiefly on account of deficiency in two es- sential characteristics, - vigorous habit of growth and abundance of bloom. Clematis Jackmani, purple, originated in 1862 , by Mr. George Jackman, was one of the first hybrid Clematises introduced, and still stands as the most popular, and, of its color, the most valuable variety yet known. The new variety, Madame Edouard André, a deep, rich crimson, is distinct and novel, being at this time the only large-flowering sort of a truly crimson shade. It is of fully as vigorous habit as the Jackmani, and its flowers are similarly massed, though not produced in quite such profusion. Clematis Madame Baron Veillard is another new and distinct variety that promises to prove a valuable acquisition. It is of exceedingly vigorous habit, and the flowers are quite freely produced, though, being more dispersed over the plant, they do not make so much of a show as do varieties whose flowers are closely massed. The flowers are of very large size and of a light rose color, shaded with lilac. Of white varieties, Henryi, Mrs. George Jackman and Lanuginosa Candida, all of them introduced long ago, still remain about the most desirable ones known. Ramona, deep sky-blue, is a variety which originated on our grounds some ten years ago. It is of extra large size, often 9 to 10 inches across, of very vigorous habit and free-flowering.

Of double-flowered varieties, Duchess of Edinburgh, white, is the best known in this country, and about the most desirable, though a new double white variety, called "Snowdrift," originated by the famous Luther Burbank, and now being propagated by us, promises to excel it in both floriferousness and vigor of growth. John Gould Veitch is a double sort with flowers of lavender-blue, but, with us at least, has seemed a shy bloomer and of weak habit. Mme. Grange (purplish violet), Star of India (purple), Velutine Purpurea (purple), and Viticella Venosa (reddish purple), are all desirable varieties.

Although they are in reality slightly less hardy than the Florida and Patens types, we would recommend for northern localities varieties of the Lanuginosa, Viticella and Jackmani types, which produce their flowers from young growing wood. Plants of these types, even if frozen back to the ground, will still produce a good show of flowers, since, as stated, they bloom from the young growing wood. Indeed, they need to be pruned back considerably anyway to induce a free growth of young wood. With plants of the Patens and Florida types, which blossom from year-old wood, a severe freezing back of the plants would destroy the crop of flowers for the year.

Of the small-flowering varieties, Clematis paniculata (white), introduced from Japan, has proved a wonderfully

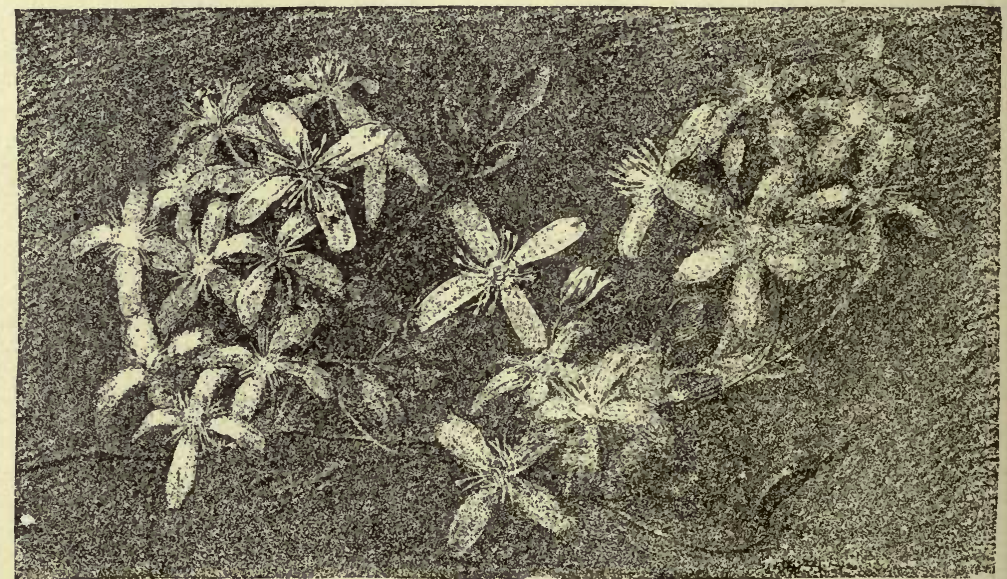

485. Spray of Clematis paniculata.

valuable acquisition in this country, and has already become exceedingly popular. It is of remarkably vigorous habit, often making a growth of 20 to 25 feet in a season. It seems thus far to be entirely free from 
disease, is delightfully fragrant, and so floriferous that the blossoms form a dense sheet of bloom, remaining in full beauty for several weeks. The foliage is very thick and heavy, thus making it very desirable for covering porches and arbors.

Crispa (blue) and Coccinea (red) are varieties with very pretty, bell-shaped flowers. They are easily grown and do well in almost all situations.

The perennial, non-climbing varieties of Clematis are most pleasing border plants, succeeding well in all ordinary soils and making a rich show of bloom at their Howering season. Davicliana (blue) and Recta (white) are about the best known and most desirable varieties of this class.

To grow Clematis most successfully, they should be given a good depth of loamy soil, with a fair supply of well rotted manure spaded in and thoroughly distributed through the soil. In hot, dry weather, the plants should be regularly watered in order to obtain the greatest number of fls. possible, for the plants are very susceptible to injury by drought. A point of great importance, especially in caring for newly set plants, is to provide a firm support for them to climb upon. A solid wooden or metal trellis is preferable, for the reason that it prevents the plants from being whipped about by the winds, which often results either in breaking the stalks just above the ground or else in cracking the outer bark of the stalks and rendering them more liable to the attacks of insects and fungous diseases. Training the vines upon strings, or a pliable support of any kind, is not to be advised for this reason. Propagation of the hybrid varieties is effected both by euttings and by grafts. All of the type varieties grow readily from seed.

\section{JACKSON \& PERKnNs Co.}

Index: alpina, 32 ; aristata, 9 ; aromatica, 29 ; azurea, 14. bicolor, 20 ; brevicaudata, 6 ; cærulea, 14 ; Californica, 8 ; campaniflora, 19 ; candida, 12 ; Catesbyana, 7 ; cirrhosa, 15; coccinea, 21; Columbiana, 31 ; crassifolia, 9: crispa, 22; Davidiana, 25; Douglasi, 26; Drummondi, 3 ; erecta, 1 ; eriostemon, 18 ; excelsior, 12 ; Flammula, 2 ; floribunda, 19 ; florida, 20 ; Fortunei, 20 ; Fremonti, 27 ; fulgens, 18 ; grandiflora, 14. 15 ; graveolens, 11; Hendersoni, 18; Henryi, 12; heracleæfolia, 25; Hookeri, 25 ; indivisa, 17 ; integrifolia, 28 : Jackmani, 12 ; Kermesinus, 18 ; lanuginosa, 12 ; ligusticifolia, 8 ; lilicinafloribunda, 18; marmorata, 18; Meyeriana, 10; modesta, 18; montana, 15; nivea, 12 ; occidentalis, 32 ; ochroleuca, 30 ; odorata, 15 ; orientalis, 11 ; paniculata, 5 ; potens, 14 ; Pieroti, 16; Pitcheri, 24: purpurea-hybrida, 18; rect 3,1 ; reticulata 23 ; rubella, 2 : Sargenti, $24 ; \mathrm{Si}$ birica, 32 ; Sieboldi, 20 ; Standishii, 14; Stanleyi, 13 ; stans, 25; tubulosa, 25; Tunbridgensis, 12; verticillaris, 31; Viorna, 21; Virginiana, 7; Vitalba, 4; Viticella, 18.

A. True petals none; sepals petaloid. Clematis proper.

B. Styles of fruit very long and plumose (Fig. 492).

C. Fls. on the new growth, numerous, small, appearing in the last half' of the season, often in panicles. Flammula section.

D. Herbaceous, nearly erect.

1. récta, Linn. (C. erécta, Linn.). Herbaceous, some-

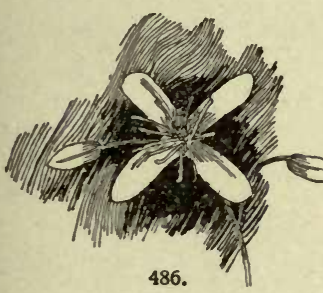

Flower of

Clematis paniculata.

Natural size. what tufted, 2-3 ft. long: lvs. pinnate; lfts. stalked, ovate, acuminate, entire: fls. numerous, on a large, branching,terminal corymb; white, sweet-scented, 1 in. across. June-Aug. S. Eu. Gn. 52, p. $510 ; 53$, p. 547. - Var. plèna, Lemoine. Fully doubled, button-like blossoms.

DD. Woody or half-uoody, climbing.

E. Fls. usually perfect, nearly white.

2. Flámmula, Linn. ( $C$. Pállasi, J. F. Gmel.). A slender but vigorous elimber, reaching 10-15 ft.: dark green lvs., remaining fresh till midwinter; lfts. variable but usually bipinnate, small, ovate, oblong or linear : fls, small, numerous in axillary and terminal panicles; sepals 4, linear-oblong white; stamens white; fr. bearing white plumes. Aug.-Oct. Mediterranean region. Gn. 52, p. 499.- Must have a sunny expesure ; very beautiful.

Var. rubélla. Bele ( $C$. mubélla, Pers., not Hort.). Differs from the 487.
Leaf of Clematis 487.
Leaf of Clematis

Virginiana.

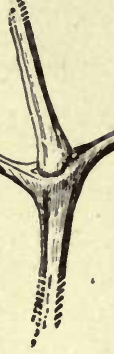

3. Drúmmondi, Torr. \& Gray. Allied to $C$. Flammula: stem and lvs. ashy pubescent ; lvs. finely pinnate : fls. white, much less abundant; styles becoming 2-3 in. Iong. Sept. Dry ground, Tex. to Ariz.

4. Vitálba, Linn. In Europe called Traveller's Joy. The most vigorous ciimber of the genus, ascending 20$30 \mathrm{ft}$.: lvs. pinnate; lfts. ovate-lanceolate, acuminate, cordate at the base, partly cut: fls. numerous, in axillary panicles, dull white, $3 / 4$ in. across, with a faint odor of almonds: styles of fr. long and feathery, from which it is given the name Old Man's Beard. July-Sept. Eu., N. Afr., Caucasus region. Gn. 53, p. 546. S.H. 2:540.

5. paniculata, Thunb. Figs. 485,486 . A vigorous climber: lfts. 3-5, often lobed, acuminate, $1-4$ in. long, g.abrous : fls. fragrant, $1-1 \frac{1}{2}$ in. across, in axillary and terminal panicles ; sepals 4, dull white. Sept. Japan. G.F. 3: 621; 5:91; 9:75 and 185. F.R. 2: 581. Mn.7:113; Gng. 1: 101 and $165 ; 6: 291 ; 4: 229$. A.F. 13:1314.Prop. by seed. By far the most common of the fallblooming species in American gardens. Thrives best in sunny situations. - Will stand severe pruning in winter.

6. brevicaudàta, DC. (C. brevicordata, Hort.). Climbing vigorously: lvs. pinnate to bipinnate; segments ovate-lanceolate, acuminate, coarsely toothed, nearly glabrous: fls. in axillary panicles, white. Aug.-Oct. China. G. F. 5:139. - Very little used.

\section{EE. Fls. monæcious or diøcious, white or whitish.}

7. Virginiàna, Linn. Fig. 487. Climbing 12 to $15 \mathrm{ft}$ : lvs. ternate; lfts. glabrous, cut-toothed, bases often cordate : fl, white, in leafy panicles, often monœcious or diœcious, about 1 in. across when expanded : plumose styles 1 in. or more in length. July-Sept. Nova Scotia to Ga., westward to Kans. G.W.F.A. 12. D. 103.

Var. Catesbyàna, Britton (C. Catesbyàna, Pursh). Lvs. somewhat pubescent, often biternate. S. E. states. Fl. 736 (1814). Int. 1883.

8. ligusticifolia, Nutt. Allied to C. Virginiana, but having 5-7 lfts., of firmer texture, rather more pubescent, variable in form and margin, but usually 3 -lobed or coarsely toothed: fls. white, $3 / 4 \mathrm{in}$. across, in terminal and axillary panicles; styles densely silky-pubescent, with long, straight hairs. Aug. Missouri to N. Mexico and Brit. Columbia. Int. 1881. Var. Califórnica, Wats.. has no marked difference : lvs. usually smaller and perhaps more tomentose. 
9. crassifolia, Benth. Climbing : Ivs, coriaceous, 3-parted; segments nearly entire, ovate-acuminate, with bases cuneate: fls. in small, axillary panicles; sepals 4 , spreading, dull or white; anthers shorter than the filaments. Late summer. China.-Suitable for greenhouse use, but not yet well introduced. C. aristata, of B. R. $3: 238$, is a fair representation of this plant.

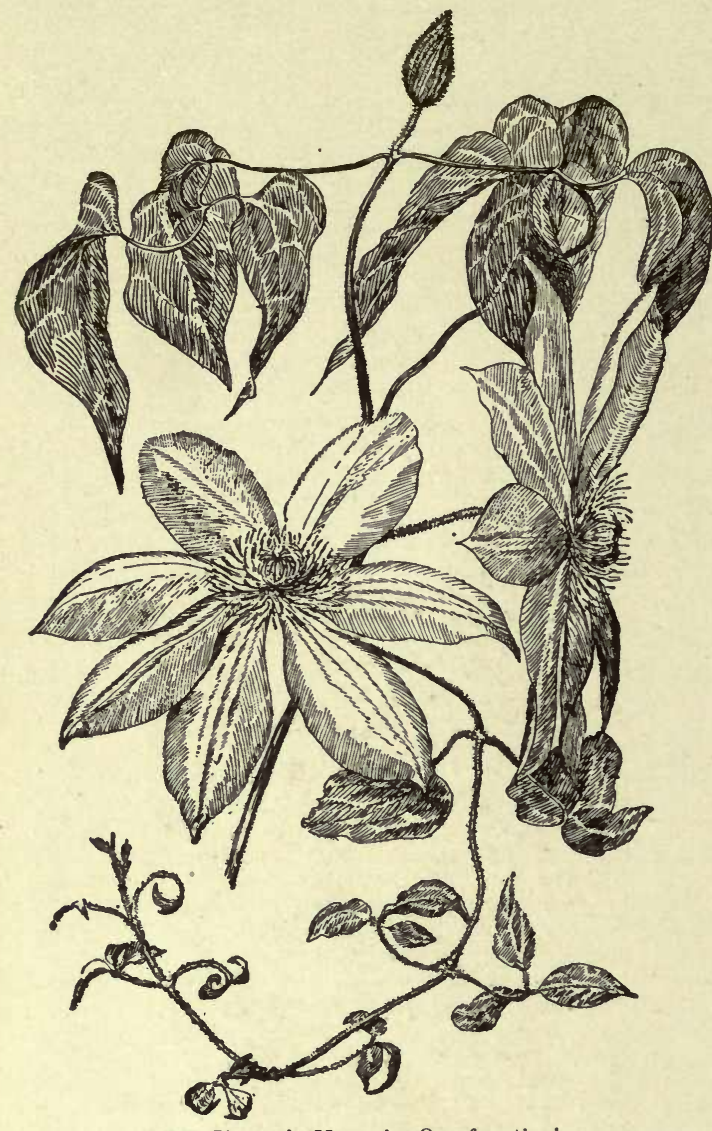

488. Clematis Henryi. One-fourth size.

10. Meyeniàna, Walp. Climbing rapidly, more hardy than $C$. crassifolia: lvs. much the same, but with the segments obtuse or cordate at the base : fls. much as in that species, but with the anthers longer than the filaments. Late summer. China.

EEE. F'ls. perfect, yellow, and more spreading than the preceding.

11. orientàlis, Linn. (C. gravèolens, Lindl.). A rapid climber, reaching 12-15 ft.: lvs. thin, glaucous and shiny, twice or thrice ternate; lfts. 3-parted or -lobed, with small, ovate, entire or cut-toothed divisions: fls. solitary, becoming erect or nearly so, $1 \frac{1}{2}$ in. across; sepals 4 , yellow, tinted with green, somewhat reflexed; styles plumose. Aug.-Sept. Himalaya region. Lav. 21. Figured as $C$.graveolens in the following : B.M.4495. Gn. 45:954, p. 240 . F.S. $4: 374$ b; $6: 548$.

cc. Fls. on the new grouth, appearing successively throughout the summer.

D. Climbing plants.

12. lanuginòsa, Lindl. (including var. pállida, Hort.). Climbing only 5 or $6 \mathrm{ft}$.: lvs. simple or of 3 lfts., cordateacuminate, woolly beneath: fls. erect, woolly in the bud, the largest of the wild species, being 6 in. across; sepals 5 or 6 , broadly ovate, leathery, rather flat, overlapping, lavender or bluish gray; center of stamens pale reddish brown; styles plumose. Summer. Native near Ningpo,
China. F.S. 8:811. I.H. 1:14. Lav. 1. M. \& J.4.-It is to this species, more than to any other, that the beauty and popularity of the garden varieties and hybrids are due. The finest hybrids, including C.Jackmani and its section, and $C$. Henryi, contain more or less of the blood of $C$. lanuginosa.

Var. cándida, Lemoine ( $C$. cándida, Hort.). Like the type, except that the simple lvs. and lfts. of the compound lvs. are much larger, and the fls. are larger, being 7-8 in. across. - Perhaps a hybrid of $C$. carulea.

Var. nívea, Lemoine (C. nívea, Hort.). Sepals 6-8, narrowish, pure white: anthers pale brown. - Thought to be of the same origin as the above var.

Other forms of $O$. lanuginosa are :

Lady Caroline Nevill (C. Lady Caroline Nevill, Hort.). Fls. often 7 in. across ; sepals 6 , nearly white, with mauve-colored stripe down center of each. Gn. 46 p. 33.-One of the finest light-colored varieties.

Marie Lefebvre (C. Marie Lefebvre, Hort.). Resembles the last, but has 8 sepals, more pointed, and darker in shade.

Sensation (C. Sensation, Hort.). Fls. like the type, but with 6-7 grayish blue sepals; tls. 6 in. across.

Madame】Van Houtte (C. Madame Van Houtte, Hort.). Lateblooming ; sepals pale,blue, beeoming white.

Madame Thibaut (C. Madame Thibaut, Hort.). Fls. very abundant.-Thought to be a hybrid with $\mathrm{C}$. Viticella.

The President (C. The President, Hort.). A rich violet-blue flower.

Excelsior (C. Exeelsior, Hort.). Fls. double; sepals grayish purple, with a reddish bar down the center of each. F.S. 20:1995.

Of the more certain hybrids of this group, some of which are so closely allied to $C$. lanuginos $\alpha$ as to be considered varieties of it, the following are the best in the American trade:

$$
\text { E. F's. white or whitish. }
$$

Gloire de St. Julien, Carre. ( $\times$ C. eærulea, var. plena). Plant, much like C. lanuginosa, but with larger fls.; sepals $6-8$, white or pale gray at first; stamens yellow.

Hénryi, Anderson-Henry (XC.florida,var. Fortunei). Fig. 488. Robust plant: free bloomer; fls. creamy white, becoming fully expanded when grown in the open sun or under glass. Aug.-Nov. -It resembles more the lanuginosa parent.

Otto Froebel, Lemoine (X C. cærulea). Livs. leathery, simple or 3-parted: fls. of fleshy texture, grayish white, sometimes becoming bluish; sepals 8, blunt, broad; anthers brownish.

Imperatrice Eugenie, Carre. (C. 1. var. pallida $\times$ C. cærulea). Lvs. simple or 3-parted; lfts. broad and woolly : fls. 8-9 in. across, with 8 broad, white sepals.

Jeanné d'A rc, Dauvesse. Same cross as last and much like it, but the sepals are grayish white, with 3 bluo bars down the center of each.

EE. F'ls. some shade of blue, lavender, purple, etc., except in some vars. of C. Jackmani.

Lawsoniàna, Anderson-Henry ( $\times$ C. florida, var. Fortunei). Fls. very' large; sepals 6-8, broad, rose-purple, marked with darker veins. Aug.-Nov.

rubro-violàcea, Jackman ( $\times$ C. Viticella, var. atrorubens). Lvs pinnate, with ovate-acuminate or sometimes ovate-lanceolate lfts.: sepals $4-6$, maroon-purple; stamens greenish. F.S. 16:1630. F.M. 1876:217. Var. Prince of Wales, Hort., has fls. of lighter tint.

La France, Hort. (X C. Jackmani). Lvs. smooth ; buds woolly: sepals deep eobalt-blue, pointed, with wavy edges.

Reine des Bleues, Boisselot (same cross as the last). Fls. large, blue, with broad, recurved sepals.

Devoniénsis, Hort. (same cross). Fls. 8-9 in. across ; sepals' 8 , delicate lavender-blue. Gn. 9, p.563 (note).

Symesiána, Anderson-Henry ( $\times$ C. florida, var. Fortunei). Fls. 7 in. across; sepals 6-8, pale mauve; a profuse bloomer.

Gem, Baker ( $\times$ C.: Standishi). Lvs. 3-parted or simple: fis. like C. lanuginosa in form; grayish blue.

Jáckmani, Jackman ( $\times$ C. Hendersoni, 1858-60). Habit and lvs of C. lanuginosa : fls flat, $5-6$ in broad : sepals $4-6$, very broad, velvety purple, with a ribbed bar down the center; broad, central tuft of pale green stamens. M. \& J. 5, 6, 9, 10, 11, 12, 14 . I.H.11:414. F.S. 16:1629. Gn. 22:349; 53, p.262. A.G. 19:269. A.F. 10:1329. R.H. 1868: 390. Var. alba, Hort. Fls. nearly pure white. Gn. 25: 427. Var. supérba, Hort. Fls. violet-purple, resembling C. Madame Grangé. See Fig. 489.

Other hybrids or varieties of C. Jackmani are: Var. Gipsy Queen, Cripps (C. Gipsy Queen, Hort.), deep violet. Var. Alex. andra.Jackman (C. Alexandra, Hort.), reddish violet. Var. Star of India, Cripps (C. Star of India, Hort.), 5 in. meross, purple, barred with red. Var. Tunbridgénsis, Cripps (C. Tunbridgensis, Hort.), reddish purple, barred with light blue. Var. magnifica. 
Jackman (C. magnifica, Hort.), rich purple, shaded with erim. Jack 3 bars of red in each sepal. Var. Madame Grangé, Hort. (C. Jarse Grangé, Hort.), sepals very concave, purole crimson. Var. Mrs.James Bateman. Noble (C. Mrs. James Bateman, Hort.), pale lavender ; a probable cross of C. J. with C. lanuginosa : N. \& J. 2, f. 1; F.S. 20:1779. Var. MIrs. Moore, Jackman (C. Mrs. Mloore, Hort.), 8-9 in. across, sepals rather narrow, white. Var Thomas Moore, Jackman (C. Thomas Moore, Hort.), Wh largens the last rich violet with white stamens. Vur Madame Baron Veillard, Baron Veil. (C. Madame Baron Veillard, Hort.), Baron Villar, Barome André, Baron Veil. (C. Madame André, rose-lilac. Var. earmin -violet. R.H. 1893:180. Var. velutina-purpurea, Hort.), earmin 9 -violet. R.H. 1893:180. Var. velutina-purpurea, ally 4 , sometimes 5 or 6 sepals, blackish purple.

\section{DD. Herbaceous, erect.}

13. Stánleyi, Hook. (C. Stanleydana, Hort.). Erect, robust herbs, $3 \mathrm{ft}$. high : lvs. biternate; lfts. sessile or petioled, variable in size, cuneate, silky: fls. 1-3 in. across, white to pink-purple; sepals becoming widely expanded; stamens yellow; styles becoming very plumose, white. July-Oct. Transvaal. Int. 1893. B.M.7166. Gn. 39:789. G. F, 3:513. G.C. III. 8:327. - Suitable for greenhouse culture; in the northern states it is apt to winter-kill if left unprotected.

ccc. Fls. on the year-old ripened wood, appearing in late winter, spring, or early summer.

D. Sepals more than 4, usually 6-9.

14. cærùlea, Lindl. (C. pàtens, Morr. \& Decne. C. azù rea, Hort., ex. Turcz.). Taller and more slender, and lfts. smaller and narrower than $C$. lanuginosa: fls. spreading; sepals about 8 , rather narrow, delicate lilac: stamens purple. Spring. Isle of Nippon, Japan. M.\& J. 3. Lav. 2 and 3. B.R. 23:1955. P.M. 4:193. B. 3:126. Should be grown on a northern exposure to preserve the color of the flowers. It is almost as prolific as $C$. lanugi$n \circ s a$ in producing garden varieties and hybrids, and it is the most likely of all to produce double-flowered forms.

Var. grandiflora, Hook. (C. azùrea, var. grandiflòra, Hort.). Fls. larger than the type. B.M. 3983.

Var. Stándishi, Moore (C. Stándishi, Hort.). Fls. about 5 in, across ; sepals light purple, of metallic luster. - A fine variety from Japanese gardens.

The following other garden varieties:

Mrs. James Baker (C. Mrs. James Baker, Hort.). Sepals nearly white, ribbed with dark earmine,

Miss Bateman, Noble (C. Miss Bateman, Hort). Fls, more compact than the type, 6 in. across: sepals ovate, shortly acumicompact than the type, 6 in. across: sepals ovate, shortly acuminate, pure white, with cream-colored bars; anth
Probably of hybrid origin; allied to var. Standishi.

Stella, Jackman (C. Stella, Hort.). Fls. not so large as the ast: sepals deen mauve, with a red bar down the center of each. F.S. $22: 2341$.

Amalia, Siebold (C. Amalia, Hort.). Sepals 6 or more, oblong lanceolate, light lilac. From Japanese gardens. F. S. 10:1051.

Lord Lanesborough, Noble (C. Lord Lanesborough, Hort.). Sepals bluish lilac, each with a metallic purple bar.-A good variety to gradually foree to blossom in the greenhouse by March.

Lady Lanesborough. Noble (C. Lady Lanesborough, Hort.). Sepals silver-gray, the bar being lighter colored-It will blossom in March in the greenhouse.

Marie, Simon-Louis (C. Marie, Hort.). Fls. darker than the type.

The Queen, Jackman (C. The Queen, Hort.). Fls. rather compact, the sepals being broader than the type.

John Murray, Jackman (C. John Murray, Hort.). Habit and foliage bolder than the type: fls. somewhat later. Gn. 46:970.

Fair Rosamond, Jackman (C. Fair Rosamond, Hort.). Sepals apieulate, broader than the type, and of the same color. F.S. $22: 2342$.

Countess of Lovelace, Jackman (C. Countess of Lovelace, Hort.). Fls. double, blue-violet; sepals much imbricated. In the second erop of blooms the fls. are single, as is often the case in other double varieties.

Albert Victor, Noble (C. Albert Victor, Hort.). Fls. much like the type, but large and more compact. - Suitable for forcing under glass.

Duchess of Edinburgh, Jackman (C. Duchess of Edinburgh, Hort.). Fls. double, white, strongly imbricated.

Louis van Houtte, Hort. (C. Lonis van Houtte, Hort.). Semidouble, rosy white.

Vesta, Endlicher (C. Vesta, Hort.). Sepals gray; anthers red. Gt. 39:1333. Gn. 9:18.

Helena, Siebold (C. Helena, Hort.). Fls. pure white, with yellow stamens. F.S.11:1117. I.H. 1:21 monstrosa, Van Houtte (C. monstrosa, Hort.). Fls. seml. double, pure white. F.S. 9: 960 .

Sophia, Siebold (C. Sophia, Hort.). Sepals deep lilac-purple on the edges, with light green bars. F.S. 8: 852. 1. H. 1:21. B.H. $\therefore 97$.

\section{DD. Sepals 4.}

15. montàna, Buch.-Ham. ( $C$. odord̀ta, Hort., not Wall.). A vigorous climber, often reaching a height of 15-20 ft. : lvs, ternate, with oblong-acuminate cut-toothed lfts.: fls. several in each axil, following each other in succession of time, resembling white anemone blossoms, sweet-scented; sepals 4, elliptic-oblong, 1 in. long, spreading, becoming pink ; stamens conspicuous, yellow. May. Himalaya region. B. R. 26:53. M.\& J. 8. Gn. 49, p. 39; 51, p. 349. A. G. 19:391. R. H. 1856:161.The species prefers a mild elimate. The section of Clematises to which it belongs includes the evergreen forms, such as $C$. cirrhosa, Linn., of the Mediterranean region.

Var. grandifldra, Hort. Fls. 3-4 in. across. B.M. 4061.

16. Pieroti, Miq. Closely allied to the last: lvs. and Ifts. shaggy-hairy, much toothed, veins prominent : fls. small. Early summer. Japan.

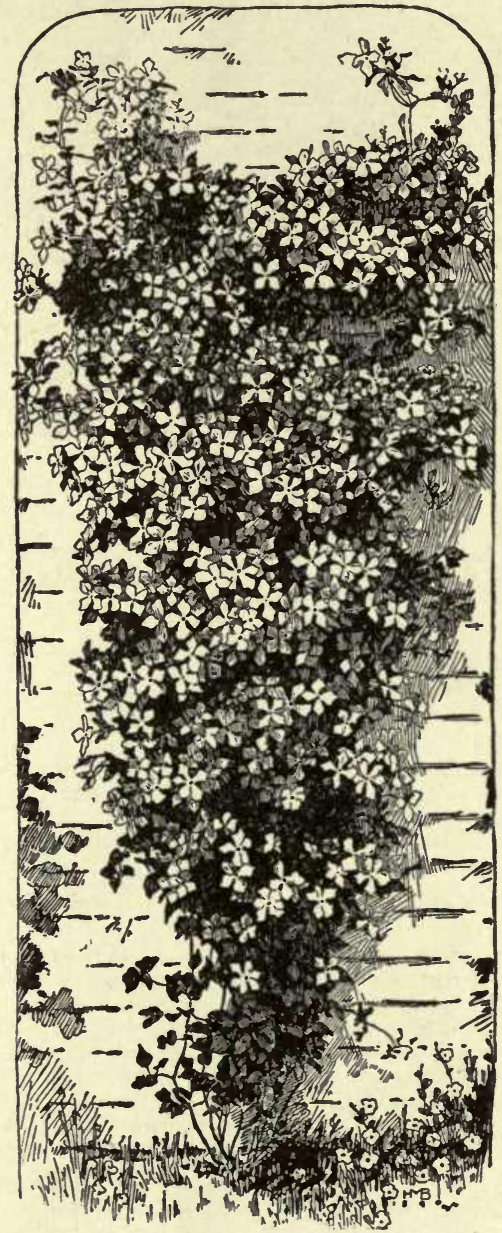

489. Clematis Jackmani, var. alba.

17. indivisa, Willd. Much like $C$.montana : fls.white; requires cool greenhouse culture, and is then very beautiful : lvs, evergreen. G. F.6:167. A. F. 13:879. Gn. 53, p. 546. - Indivisa, var. lobàta, Hook., differs very little from the type. B.M. 4398. R.H. 1853:241. Gn.53 p. 547. F.S. 4:402. 
BB. Styles of fr. usually rather short, often becoming plumose, but not so much as in B.-Viticella section.

\section{Climbing plants.}

D. Fls, large, expanded when mature.

18. Viticélla, Linn. Climbing 8-12 ft.: lvs. sometimes entire, but usually divided into 3 nearly entire lfts.: fls. $1 \frac{1}{2}-2$ in. in diam., growing singly on peduncles; sepals 4, blue, purple or rosy purple, obovate, pointed, reflexed; stamens yellow: fr. with rather short tails, devoid of plumes. June-Aug. S. Eu. to Persia. R.H. 1860 , p. $183 ; 1876: 110 ; 1879: 350$ (vars.). B.M. 565 . Lav. 7. - This is the type of one of the leading groups of garden Clematises, and is one of the parents of the Jackmani type of hybrids.

The four following are garden varieties :

Kermesinus, Hort. (C. Kermesinus, Hort.). Fls. of bright wine-red color, purple being absent. Gn. 39:787.

Lilicina-floribúnda, Hort. (C. lilicina-floribunda, Hort. C. floribunda, Hort.). Fls. pale gray-lilac, conspicuously veined. Gn. 18, p. 389 (note).-An abundant bloomer. Produced in an English garden in 1880 .

Lady Bovill, Jackman (C. Lady Bovill, Hort.). Fls. cupformed, sepals being concave and little or not at all recurved at the ends, fls. 4 in. across; sepals $4-6$, grayish blue; stamens light brown. M. \& J. 15 .

Marmoràta, Jackman (C. marmorata, Hort.). Fls. rather small, with 4 broad sepals, grayish blue, 3 longitudinal bars. M.\&J.1, f. 2; same plate in F.S. 20:2008 (opp. p. 17.)

Hybrids of $C$. Viticella which are closely allied to that type:

Héndersoni, Henderson (C. erióstemon, Dene. = C.V. $\times$ C. integrifolia).' Stem and habit of C.Viticella: lfts. and fls. much like C. integrifolia: climbing 8-10 ft.: 4 blue sepals, spreading, reflexed at the tips. R.H. 1852:341. F.S.13:1364 (as var.venosa).

Othéllo, Cripps. (= C. V., var. rubra $X$ C. Flammula). Fils. of medium size, of a deep velvety purple; continues blooming until October.

Purpúrea-hybrida, ModesteGuérin (= C.V.X C. Jackmani) Fls. $4-6$ in. across, deep purple violet, with red veins, but not barred.

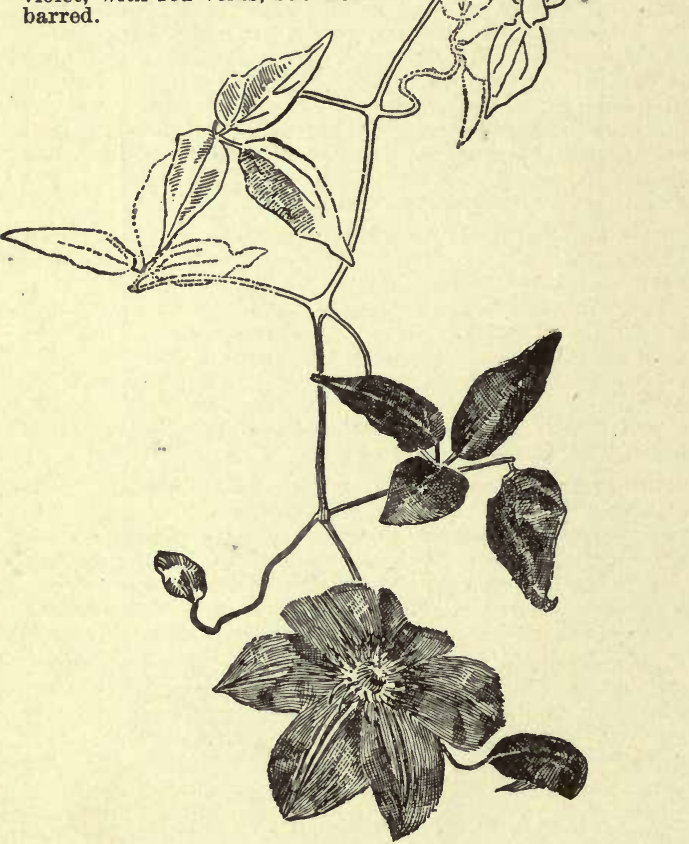

490. Clematis florida, var. bicolor.

Modesta, Modeste-Guérin (=C. V.X C.lanuginosa). Fls. well expanded, large, bright blue, bars deeper colored.

Fulgens, Simon-Louis $(=$ C. V., var grandiflora $\times$ C. lanuginosa). Sepals 5-6, rather narrow, dark purple to blackish crimson, velvety, edges somewhat serrate.
Boskoop, Hort. (C. Boskoop Seedling, Hort. = C. V. $\times$ C. integrifolia). A new race in 1892: growing 3-5 ft.: fls. blue, lavender, rose or reddish rose.

19. campaniflòra, Brot. Climbing 10-15 ft.: fls. re flexed and bell-shaped as in the above type or more so; purple or whitish. June, July. Native of Portugal. L.B.C. 10:987. Lav. 8. - This has been called $C$. Viticella because of its close resemblance in flower, fruit and leaf; but the lvs. are often twice ternate, and the plant is much more slender in habit.

20. flórida, Thunb. A slender plant, climbing 9-12 ft.: Ivs. variable, more or less ternate or biternate; lfts. small, ovate-lanceolate: fls. 2-4 in. across, flat when ex panded ; the 5-6 broad, ovate sepals creamy white, barred with purple beneath: stamens purplish. May, June. Japan. B. M. 834 . R.H. 1856:41.

Var. bícolor, Steud. ( $C$. Sièboldi, D. Don). Fig. 490. Like the type, but with the purple stamens somewhat petal-like, and forming a dense, purple head in the center. F. S. 5:487. Lav. 5. M.\& J. 16. B. R. $24: 25$. P.M. 4:147. Gn. $22: 349$. R. H. $1856: 401$.

Var. Fortunei, Moore ( $C$.

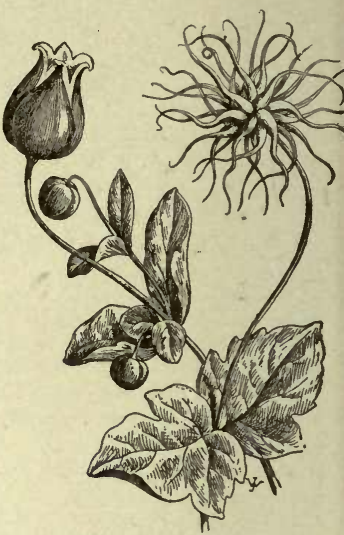

491. Clematis Viorna.
F'ortunei, Hort.). Fls. large, very much doubled; sepals creamy white, becoming pink. F. S. 15: 1553 . G. C. $1863: 676$. I. H. 10, p. 86. M. \& J. 13.

Belle of Woking (C. Belle of Woking, Hort.), A hybrid form: fls. very full and double; sepals purple.

John Gould Veitch (C. John Gould Veitch, Hort. C. Veitchii, Hort.). Fls velvet, double, resembling var. Fortunei, except in the color of the sepals. From Japanese gardens. F.S.18:1875-6.

DD. F'ls. smaller, pitcher-shaped or tubular.

21. Viorna, Linn. Fig. 491. Climbing 8-10 ft.: lvs. not glaucous nor coriaceous ; lfts. subcordate-ovate to ovate-lanceolate, slightly reticulated : fls. solitary, on long peduncles, pitcher-shaped ; sepals 4, 1 in. long, variable in color, often dull purple, thick and leathery, tips often recurved; styles plumose when mature. June-Aug. Penn. to Alabama and westward. Lav. 17.

Var. coccínea, A. Gray ( $C$. coccínea, Engelm.). Lvs. glaucous, subcoriaceous; lfts. broader than the type, often obtuse or retuse : sepals carmine or scarlet. Texas. Lav. 19 (as C.Texensis). B.M. 6594. Gn. 19:275. Gt. 32: 86, R. H. 1878:10; 1888:348.-Much superior to the type, because of its beautiful flowers. Some of the garden forms of this variety, which have probably been produced by crossing it with hardier Clematises, are found under the names: Countess of Onslow, deep scarlet, G.C. IIl. 16:9; Countess of York, white, tinted with pink ; Duchess of Albanny, clear pink, Gn. 52:1140.

22. críspa, Linn. A slender climber, reaching 3-4 ft.: lvs, very thin; lfts. 3-5 or more, variable in outline and sometimes undivided, often 3-5-lobed: fls. purple, varying to whitish, cylindrical or bell-shaped, 1-2 in. long; points of sepals recurved: styles of fr. hairy but not plumose. June-Sept. Virginia to Texas. B. R. 32:60. Lav. 14. - This and the allied species are fragrant.

23. reticulàta, Walt. A slender climber, allied to the last: Ivs. much reticulated and very coriaceous : fls. solitary in the axils of the lvs., nodding, bell-shaped; sepals recurved, crispy at the margin: mature fr. with plumose tails. June, July. S. Car. to Ala. and Fla. B. M. $6574 ; 1892$ (as C. crispa); 1816 (as C. cordata). Lav. 16.

24. Pitcheri, Torr. \& Gray. Lvs. of 3-4 pairs of Ifts. and a terminal lft: reduced almost to a midrib; lfts. coarsely reticulated : fls. 1 in. long and $3 / 4 \mathrm{in}$. in diam., with swollen base; sepals dull purple, recurved at the tips: akenes pubescent, styles not plumose. June-Aug. S. Ind, to Mo., southward to Mex. Lav. 15. 
Var. Sárgenti, Lavallée (C. Sárgenti, Hort.). Fls. smaller. Lav. 18.

cc. Herbaceous, erect, or somewhat climbing in case of C. aromatica.

D. Sepals some shade of blue.

25. heracleæfolia, DC. (C. tubuldsa, Hook.). Stout, erect, woody only at the base: Irs. ternate, large, bright green; Ifts. mucronately toothed: fls. numerous in corymbs, either axillary or terminal, tubular in form, with 4 light blue sepals, becoming reflexed; peduncles and pedicels downy; recurved stigmas club-shaped. Aug.-Sept. China. M. \& J. 17. B. M. 4269; 6801 (as var. Hoólieri). P.M. 14:31. F.S. 3:195.-Prop. by root division.

Var. Davidiana, Bean (C. Davidiana, Deene.). About $4 \mathrm{ft}$. high, hardly strong enough to stand without support: lvs. larger than any other cultivated Clematis : fls. in clustered heads, 6-15 together, and also singly or clustered in the leaf axils. R.H. 1867, p. 90. Gn. 49, p. 99.

Var. stáns, Hook. (C. stáns, Sieb. \& Zucc.). Herbaceous, non-climbing, 4-5 ft. long: Ivs, pubescent : fls. less dense than the above variety, in terminal panicles and in close clusters in the leaf-axils, tubular in form; the blue sepals revolute from near the middle. Sept.Oct. Jap. B.M. 6810.-Used chiefly because of the striking foliage and its late-blooming qualities.

26. Doùglasi, Hook. Has habit of $C$. integrifolia, about $2 \mathrm{ft}$. high: stem and petioles angled and ribbed: Ivs. twice pinnately or ternately compound; lfts. narrowlinear or lanceolate: fls. tubular or bell-shaped, 1 in. long; sepals recurved, deep purple within, paler without. June. In Mts., Montana to N. Mex.-Int. 1881.

27. Frèmonti, Watson. Closely allied to $C$. ochroleuca, but with lvs. 3-4 in. long, nearly sessile, either entire or with a few coarse teeth : fls. often drooping; sepals thick, purple, nearly glabrous, except the tomentose edges; styles when young downy rather than feathery. July-Aug. Mo. to Colo. G. F. 3:381.

28. integrifolia, Linn. Herbaceous, erect, becoming $2 \mathrm{ft}$. high: Irs. rather broad, entire, ovate-lanceolate: fls, solitary, nodding; sepals 4, rather narrow, blue, coriaceous, 1-2 in. long. June-Aug. Eu. and Asia. B.M. 65. Var. diversifòlia, Hort. Lvs. sometimes divided. Var. Durándi, Hort. (C. integrifolia $\times$ lanuginosa). Taller and fls. larger than in the type; sepals recurved. Gn.49:1052. Gng. 5:276. - Very beautiful.

29. aromática, Lenné \& C. Koch $(C$. ccerùlea, var. odorata, Hort.). Slender, herbaceous or somewhat elimbing, reaching $6 \mathrm{ft}$. high if supported : lvs. of 3-7 ovate, nearly entire lfts.: fls. solitary, terminal, very fragrant, $1 \frac{1}{2}-2$ in. across; se pals 4 , spreading, reflexed,

492. Akene of Clematis verticillaris.

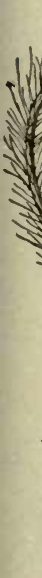
reddish violet; stamens white. July-Sept. Nativity, perhaps, S. France. It is thought by some to be an old garden hybrid of the Viticella type, or $C$. integrifolia $\times C$. recta, or $C$. Filammula $\times$ integrifolia. R. H. 1877, p. 15 .

\section{DD. Sepals yellow.}

30. ochroleùca, Ait. Herbaceous, 1-2 ft. high, silky-pubescent, becoming glabrate : lis. ovate, entire : fls. erect, solitary, terminal; sepals yellow outside, cream-colored within: styles becoming somewhat plumose. July-Aug. Dry grounds, N. Y. to Ga. L.B.C. 7:661. - Int. 1883.

AA. True petals small, spatulate; sepals petaloid; involucre none. Atragene section.

31. verticillàris, DC. Fig. 492. Trailing or sometimes climbing, 8-10 ft.: usually 4 trifoliate Ivs. from each norle ; lfts. thin, ovate, asute, toothed or entire, somewhat cordate: fls. solitary, blue or purple, nodding at flrst, 2-4 in. broad when expanded ; 4 thin sepals, silky along the margins and veins; petals $1 / 2-3 / 4$ in. long. May-June. Woodlands, Va. to Hudson Bay, west to Minn. B.M. 887 (as Atragene Americana).-Int. 1881.

Var. Columbiàna, Gray. Sepals narrower and more pointed than in the type. Rocky Mts.

32. alpina, Mill. (Atragene alpina, Linn.). Stems 3-5 ft., slender, with prominent joints becoming swollen with age: lvs. once or twice ternate, with ovate or ovatelanceolate lfts., serrate or incised : many petal-like stamens, which are devoid of anthers: sepals 4, bright blue. Spring. Northwestern N. Amer., Siberia to south and central Eu. B.M. 530 (as var. A ustriaca). Gn. 46:982.A very hardy climber, preferring a northern exposure.

Var. álba, Hort. (Atragene Sibírica, Linn.). Fls. white or nearly so. B.M. 1951.

Var. occidentàlis, Gray. Petal-like stamens very few, and often bearing rudimentary anthers. Rocky Mits.

The following are well worthy of cultivation, but are not at present found in the American trade: $O$. Addisoni, Britton. More bushy and less spreading than C. Viorna. G. F. 9:325.$O$ oethuscefolia, Turez. Bushy; fls. tubular, white. Gn. 45:241. R.H.1869, p. 10. B.M. 6542 (var. latisécta, Hook.).-O. apiźfolia, DC. Allied to C.Virginiana: lfts. smaller and narrower, coarsely incisely-serrate, often 3-lobed or serrate, pubescent beneath. Japan. Graceful species, hardy.-O.barbellata, Edgew. Differs from C. montana mainly in wanting the involucre. Himalaya region. R.H. 1858, p. 407. B.M. 4794. F.S. 9:956-- O. cirrhdsa, Linn. Allied to C. montana. Fls. greenish white, yellow, or red, bell-shaped. Gn. 45, p. 240. L. B. C. 19:1806; 8:720 (as C. ealycina). B.M. 1070:959 (as C. calycina). K. C. DAvis.

CLEMATIS, MOCK. Agdestis clematidea, which is cult. in S. Calif. and S. Fla.

CLEOME (meaning unknown). Cappariddcea. A large and mostly tropical genus of sub-shrubs or annual herbs, simple or branched, glabrous or glandular, with simple lvs. or 3-7 lfts., and white, yellow or purplish fls. borne singly or in racemes. The genus is distinguished from Gynandropsis by its short torus, which often bears an appendage, and by the 4-6, rarely 10 , stamens." The garden Cleomes are chiefly interesting for their long, purple, spidery stamens and showy rosecolored petals. They succeed in sandy soils and sunny situations, and can be used like castor-oil plants to fill up large gaps in a border. C. spinosa is the best, and has lately been planted considerably in public parks amongst shrubbery. Prop. by seeds, which are produced freely in long, slender pods borne on long stalks. For C. speciosa, see Gynandropsis.

spindsa, Jacq. ( $C$. púngens, Willd.). Giant SPIDER Plant. Clammy, strong-scented, 3-4 ft. high : lfts. usually 5 , sometimes 7 , oblong-lanceolate, with a pair of short, stipular spines under the petioles of most of the lvs., and in the tropies some little prickles on the petioles also: fls. rose-purple, varying to white; petals 4 , obovate, clawed, $1 / 2$ in. long; stamens $2-3$ in. long, blue or purple. N. C. to La. (nat. from Trop. Amer.) and escaped from gardens. B.M. 1640.-A tender biennial north, but annual in the tropies.

integrifolia, Torr. \& Gray. Rocky Mountain BeEPLANT. Glabrous, 2-3 or even 6-ft. high: lfts. 3, lanceolate to obovate-oblong, entire, or rarely with a few minute teeth: bracts much narrower than in $C^{\prime}$. spinosa; petals rose, rarely white, 3 -toothed: receptacle with a flat, conspicuous appendage. Along streams in saline soils of prairies. - In cult. about 20 years as a bee plant.

speciosissima, Deppe. Annual or half-shrubby, sometimes $5 \mathrm{ft}$. high: stems strongly hairy: lfts. 5-7, lanceolate, dentate, narrowed at the base, conspicuously hairy on both sides: fls. light purple or purplish rose. July to fall. - Said to be the showiest of Cleomes. Under this name a very different plant is passing, the lfts. of which have only minute hairs but rather numerous spines.

W. M.

CLERODENDRON (Greek, chance and tree: of no significance). Includes Siphonantha and Volkameria. Verbendcea. Many species in the tropies, and also in China and Jap. Some of them are greenhouse climbers; others are hardy shrubs; others are almost herbaceous. 
Calyx campanulate or rarely tubular, 5-toothed or 5lobed: corolla tube usually slender and cylindrical, the limb 5-parted and spreading: stamens 4, affixed on the corolla-tube, long-exserted and curved : style exserted, 2-cleft at the end: ovary 4-loculed: fr. a drupe enclosed in the calyx. Lvs. opposite or in 3 's, usually entire, never compound.

\section{A. Climbing shrubs.}

Thómpsonæ, Balfour (C. Bálfouri, Hort.). Fig. 493. Tall, twining, glabrous evergreen: lvs. opposite, oblongovate and acuminate, strongly severalnerved: fls. in axillary and terminal forking panicles; calyx strongly angled, narrowed at the apex, white; corolla-limb red and spreading. W. Afr. B.M. 5313. R. H. $1867: 310$. - A warmhouse plant of great merit, and the most popular of the tender species. Blooms profusely on the young wood. Var. deléctum, Hort. ( $C$. deléctum and $C$. delicatum, Hort.). Panicles very large: calyx pure white or greentinged: corolla large, rose magenta.

AA. Erect shrubs or sub-shrubs.

B. Corolla-tube little if any longer than the large calyx: fls. white or light blush.

fràgrans, Vent. (C. coronaria, Hort. ?). Pubescent, half shrubby, with angled branches, $3-5 \mathrm{ft}$.: lvs. broadly ovate, with truncate or cordate base, acuminate, coarsely toothed: fls. white or blush, in terminal, compact, hydrangea-like corymbs, usually double. China, Japan. B. M. 1834. - Very desirable and fragrant plant for the coolhouse. Hardy in Fla. Lvs. ill-scented.

viscòsum, Vent. Height 5-7 ft., pubescent, with square branches: lvs. opposite and stalked, cordate-ovate, toothed: fls. in a loose terminal panicle, white, with a flesh-colored center, flaring, the tube projecting beyond the loose, hairy, large, 5-angled calyx. E. Ind. B. M. 1805. - Fls. sweet-scented. Greenhouse. C. infortunàtum, Grrtn., is said to be the same species (and the name is older), but it has scarlet fls. - perhaps a result of domestication. Even if the same species, it is better to keep the forms separate for horticultural purposes.

trichótomum, Thunb. (C. serótinum, Carr. Volkamèria Japónica, Hort., not Thunb. ). Fig. 494. Slender but erect, graceful, pubescent sub-shrub, 4-10 ft. high or even higher: lvs. mostly opposite, soft and fiaccid, ovate-acuminate, narrowed at the base, very closely serrate or entire, hairy: fis. white, with a reddish brown calyx, on forking, slender, reddish peduncles, the corollatube sometimes twice as long as the calyx. Japan. B.M. 6561. Gn. 43: 914; 51, p. 320. R. H. 1867, p. 351.-A very handsome, hardy shrub. In the N. it kills to the ground, but sprouts up if the crown is protected.

\section{BB. Corolla-tube thrice or more longer than the small calyx. \\ c. F'ls. white.}

tomentòsum, R. Br. Shrubby and erect, pubescent, 3-5 ft. and more, often purplish: lvs. opposite and petioled, ovate-oblong, entire or sparingly toothed, pubescent on both sides, but thickly so on the under side:

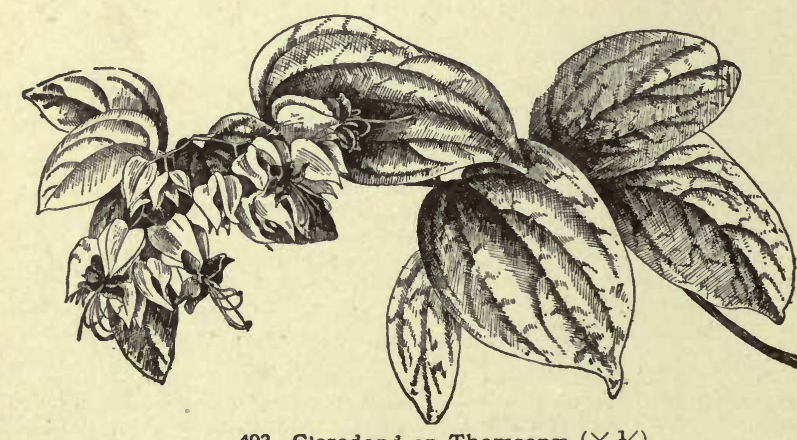

493. Clerodendron Thomsonæ $\left(\times \frac{1}{2}\right)$. fls. in few-fld. opposite, forking cymes, the calyx not enlarged, the slim corolla-tube long-exserted (3-4 times

.

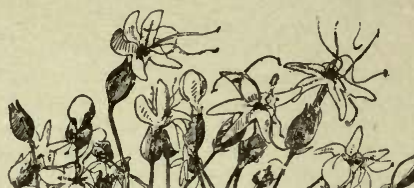


China. R.B. 22:253. Gn. 42: 889. - Very showy. Cult. in warm greenhouses or in the open in S. Calif. and S. Fla.

fótidum, Bunge ( $C$. Búngei, Steud.). Grows 3-6 ft., making a bush; pubescent, spiny: lvs. opposite, broadovate and acuminate. stalked, coarsely toothed : fls. lilac-purple, tube 3-4 times as long as calyx, in a dense eapitate corymb 4-8 in. across. China. B.M. 4880. Gn. 5:25. - Cool greenhouse. Hardy in middle and southern states. Killed to the ground in the latitude of Philadelphia, but sprouts up and blooms. Blooms in August. Fls. not foetid, but name given because of the odor of the bruised lvs. Spreads by the root.

Volkameria odorata, offered in the Amer. trade, is a climbClerodendron $V$, odorata of the botanists is a bushy Carying Clerodendron. is not a vine, as described, but "a shrub, which grows from $2-4$ is not a vine, as described, but "a shrub, which grows from 2-acute point and glaucous-hairy or almost woolly, compact clusters of white fls., shading to pink on the outside of the petals. the clusters $11 / 2-3$ in. across. Indigenous to several of the West Indian islands particularly to Dominica Yartinique and Guadaloupe." It is not now in the American trade.

L. H. B.

CLETHRA (ancient Greek name of the Alder, transferred to this genus on account of the resemblance of the lvs.). E'ricaceae. White Alder. Shrub or small trees: lvs. alternate, usually serrate, deciduous or persistent: fls. white, in terminal, often panicled racemes; petals 5 , erect; stamens 10 ; capsule splitting into 3 valves, many-seeded. About 25 species in America, E. Asia, Madeira. Only a few hardy, deciduous species are generally cultivated; valuable for their showy spikes of white, fragrant fls., appearing late in summer. They grow best in a moist, peaty or sandy soil. Prop. by seeds, sown in spring in pans in sandy and peaty soil, and by greenwood cuttings under glass, growing best if taken from forced plants in early spring and placed in slight bottom heat; also, increased by layers and by division of large plants. Handsome when forced under glass.

\section{A. Lvs. deciduous : stamens exserted.}

alnifolia, Linn. Sweet Pepperbush. Shrub, 3-10 ft. lvs. short-petioled, cuneate, obovate or oblong, sharply serrate, mostly glabrous or nearly so, $2-4$ in. long: fls. fragrant, in erect, usually panicled racemes. July-Sept. Maine-Florida. M.D.G. 1895: 65. J.H. III. 31: 375. G.W.F.A.22. Em.426. - Very variable. The following forms are often described as species : Var. paniculata, Arb. Kew.(C. paniculdta, Ait.). Lvs. cuneate-lanceolate, less toothed, green and glabrous on both sides: racemes panicled. Var. scàbra, Arb. Kew. (C. scabra, Ait.). Lvs. scabrous above, pubescent beneath: panicles with fewer racemes. Var. tomentoss, Michx. (C. tomentdsa, Lam.). Lvs. canescent beneath: racemes solitary or few, larger, and appearing later than the foregoing. B.M. 3743 . G.F. $4: 65$.

acuminàta, Michx. Tall shrub or small tree, to $15 \mathrm{ft}$. lvs. petioled, oval or oblong, acuminate, sharply serrate, almost glabrous, 3-7 in. long: racemes usually solitary, nodding. July-Sept. Alleghany Mts. Virginia to Georgia. L.B.C. $15: 1427$

canéscens, Reinw. (C. barbinérvis, Sieb. \& Zuce.). Shrub or tree, to $30 \mathrm{ft}$.: lvs. petioled, cuneate, obovate or elliptic, acuminate, sharply dentate-serrate, pubescent beneath, 3-6 in. long : racemes panicled ; fls. fragrant; pedicels about as long as the fls. July-Sept. E. Asia, Philippine Isl., Java. Gt. 19: 654.

\section{AA. Lvs.evergreen: stamens included.}

arbòrea, Ait. Shrub or small tree, to $20 \mathrm{ft}$ : lvs. cuneate, narrow-elliptic, acuminate, serrate, almost glabrous, shining above, $3-4$ in. long: racemes panicled; fls. fragrant. Aug.-Oct. Madeira. B.M. 1057.-It stands only a few degrees of frost.

C. quercifolia, Schlecht. Shrub: lvs. obovate-oblong, tomentose beneath: racemes panicled. Mexico. B.R. 28:23. - C. tinifolia, Swartz. Shrub: lvs, oblong, entire, tomentose beneath racemes panicled. Jamaica. These two only hardy in subtropical regions.

ALFRED REHDER.

CLEYERA (after Andrew Cleyer, Dutch physician of the seventeenth century). Ternströmidcece. C.ochnacea is a tender shrub rarely cult. in northern greenhouses.
In the south it is cult. outdoors. It has glossy foliage, numerous creamy white, fragrant fls., borne in June, and red berries, which last all winter. The genus has about nine species, and is distinguished by its petals free or scarcely coalesced, its pilose anthers, numerous ovules, and scarcely bracted flowers. Sepals 5, with 2 bractlets: petals 5 : stigmas 2-3: berries 2-3-celled.

ochnàcea, DC. (C. Japónica, Sieb. \& Zucc.). Height about $6 \mathrm{ft}$. : lvs. oval-oblong, acute at both ends, veined above, entire. Himalayas.-C. Japónica was distinguished by DeCandolle by its oblong-lanceolate lvs., which are veinless, and minutely serrate at the apex. Var. tricolor, Hort., has dark green lvs., with greyish markings, and a margin of white and rose, the variegation being more brilliant in younger lvs.

W. M.

CLIANTHUS (Greek, glory-flower). GLORY PEA. Glory Vine. Parrot's Bill. Legumindsa. About five species of tender, half-trailing shrubs, with large, showy flowers of unique appearance. See Fig. 495. Swainsona is an allied genus, but its general appearance is very different. Interesting plants, with pinnate lvs. of many lfts., and fls. in racemes. Fls. scarcely papilionaceous. Pod stalked, many-seeded. Prop. by seeds and cuttings.

Clianthus Dampieri is anything but easy to grow in the latitude of Washington. Red spider is its greatest enemy, but too much moisture in the soil, followed by hot sun, proves equally fatal to it. In a sandy soil, when the seeds are sown early in spring, the plants, during ordinary summers, make a very fine display. The plants will not bear transplanting. Even when they are grown in pots, it is a risky piece of work to shift from small pots into larger ones. C.puniceus is an oldfashioned greenhouse plant, grown sometimes to cover rafters or trellis work, but more frequently trained around sticks placed around the edge of the pot. The flowers, not very unlike those of the common Erythrina, are freely produced in hanging clusters. Cuttings rooted in early spring may be grown into good-sized plants during the summer. Water should be given sparingly during the dull months. Pruning, repotting and tying the shoots should be done just before the growth begins. A sharp lookout should be kept for the red spider, frequent syringings being the only remedy for this pest.

Dampièri, A. Cunn. Glory Pea. Fig. 495. Height 2-4 ft.: plant glaucous and hoary, with long, whitish, silky hairs : stems slightly tinged with red: petioles longer than in $C$. puniceus : lfts. about 15, nearly opposite, sessile, usually acute: stipules larger than in $C$. puniceus fls. 4-6 in a raceme, large, drooping, about 3 in. long, rich erimson or searlet, with a handsome velvety, purple-black area on the raised center. Austral. B.M. 5051. R.H. 1868:230. Gt. 48, p. 272. Gn. 20:294. - Var. Germánicus, Hort. is also sold, and is proba bly var. marginatus, Hort., which has one petal white, margined scarlet. See Gn. $37: 746$ and p. 299 for an ac. count of grafting this species on stocks of $C . p u$ niceus.

puníceus, Banks \& Soland. Parrot's Bill. Height about $3 \mathrm{ft}$ : plant glabrous: lfts. 19-21, each with a very short petiole, alternate (at least towards the end of the leaf), blunt or slightly notched: fls. 8 or more in a raceme, crimson, fading with age. New Zealand. B.M. 3584. - Cult. in eastern greenhouses, and a favorite Californian outdoor shrub. Blooms all winter in Golden Gate Park, San Francisco. G. W. Ouiver and W. M.

CLIDEMIA (old Greek name). Melastomacece. An unimportant group in a family famous for its foliage plants. C. vittàta, Linden and André, once offered by 
John Saul, has large, oval, pointed lvs, with 5 strong nerves, and a narrow band of white down each side of the midrib. I.H. $22: 219$. R.H. 1876, p. 233.

\section{CLIFF BRAKE. See Pelloea.}

CLIMBERS are distinguished from twiners by having some means of attachment, as tendrils or other special devices, while twiners rise by twisting their stems round their support. In a wider sense the word is often used synonymously with "vines." By "trailers," nurserymen commonly mean low-growing vines, and by "climbers," taller-growing vines. See Vines.

CLIMBING FERN. See Lygodium. Climbing Fumitory is Adlumia cirrhosa. Climbing Hempweed, Mikania scandens. Climbing Lily, Gloriosa superba.

CLINOSTfGMa (Greek, inclined stigma). Palmacere, tribe A rèceoe. Spineless, with low or tall, prominently or obscurely ringed trunks: lvs. terminal, equally pinnatisect; segments somewhat falcate-lanceolate, broad at the base, plicate, acuminate, the apex bifid or obliquely truncate and dentate, the thick margins scarcely recurved at the base ; rachis scaly, convex on the back, obtusely keeled above : spadix long : fertile branches long, thick, the floral areas distant: spathes 2-3: fr. globose or subglobose, small, red at maturity. Species 3. Australasia and Samoa.

This graceful and recent palm resembles Howea For steriana somewhat in habit of growth, but its arching lvs. spread wider, and its stems are dark purplish, and its pinnæ tough and leathery. The palm is free and clean in growth.

Mooreanum, F. Muell. (Kéntia Mooredna, F. Muell.). Dwarf palm, 3-4 ft. high : lvs. 3-4 ft. long : segments about $1 \mathrm{ft}$. long, longitudinally plicate when young. New South Wales.

JARed G. SMith and H. A. Siebrecht.

CLINTONIA (after DeWitt Clinton, the famous Governor of New York and promoter of the Erie canal) Lilidcea. A small genus of low-growing, hardy, herbaceous plants with a few, tufted, dark green, broad, shin ing Ivs., and usually umbels of fls. They grow in cool, moist woods, and fanciers can obtain them from some dealers in native plants. It is difficult to tell the species apart by the lvs. S. Watson, in Proc. Am. Acad. 14:271 (1879). For $C$. pulchella and other species of the aban doned genus Clintonia of Douglass, see Douningia

\section{A. Scape bearing an umbel of fls.}

B. Fls. greenish yellow.

boreàlis, Raf. Height 1-2 ft.: fls. 3-6, nodding, green, margined yellow. Labrador to Winnipeg and south to N. C. D. 123. B.M. 1403 as Smilacina borealis.-This is one of the choicer plants of cool, moist woods, known to plant lovers chiefly by its handsome umbels of blue berries found in autumn, which are borne above the large, dark green, shining lvs. The commonest species.

$$
\text { Вв. Fls. white, with green spots. }
$$

umbellata, Torr. Fls. 10-20 or more, smaller than in $C$. borealis, erect or nearly so, white with a green or purplish spot at the tip of each segment. Allegheny Mts, from N. Y, to Ga B.M. 1155.-This species has the smallest fls. of the group, and is the only one that has but a single pair of ovules in each cell of the ovary.

ввв. F'ls. deep rose.

Andrewsiàna, Torr. Fls. 20 or more, nearly erect. California, in deep, cool woods, in clayey soil rich in moid. B.M. 7092. - The showiest of the group. Cult. by C. Purdy, Ukiah, Calif.

AA. Scape bearing 1 white flower.

uniflora, Kunth. The only species in which the scape is shorter than the lvs.: fi. nearly erect. Rarely there are $2 \mathrm{fls}$. Calif. to Brit. Columb.

W. M.

ULITORIA (derivation recondite). Legumindsa. Butterfly Pea. A wide-spread and variable genus allied to Centrosema, and characterized by the calyx tube being cylindrical and longer than the lobes : standard narrowed at the base, not appendaged on the back: style often bearded. The most important garden plant is $C$. Ternatea, a warmhouse annual twiner, reaching $15 \mathrm{ft}$. and requiring no special culture. It has very showy blue fls., and lately interest in it has revived.

\section{A. Leaflets 5 .}

Ternatèa, Linn. (C. carùlea, Hort.). Annual warmhouse climber : lfts. 5, oblong, obtuse, short-petioled: fls. 1 in. or more long, rich blue, with beautiful and variable markings, especially on the standard. B.M. 1542 Gn. 38:765. P.M. 7:147 and 13:79. - Name from Ternate, one of the Molucca Islands, and not from ternate, meaning 3-leafleted. Prop. by seeds. C. alba, Hort., is a white form. More or less double forms have been known for over a century.

\section{AA. Leaflets 3 .}

Mariàna, Linn. Hardy, perennial, smooth, erect, or slightly twining, 1-3 ft. high: lfts. 3 , obovate or ovatelanceolate: fls. light blue, 2 in. long, on short peduncles: pod straight, few-seeded. Summer. Dry banks, N. Y. to Fla. and west to Mo. Also India and Burma.-Rarely sold by dealers in native plants.

W. M.

CLIVIA (after a Duchess of Northumberland and member of the Clive family). Syn., Imantophyllum. Amarylliddcece. A genus of 3 species of tender bulbous plants from South Africa, with handsome evergreen foliage and showy, bright red fls. in large umbels. $C$. miniata is the best species, and perhaps a dozen varieties and hybrids of it have been offered at various times. The genus is distinguished by its fruit being a berry, its several ovules, and imperfect bulb. J. G. Baker, Amaryllideæ, p. 61. Clivias make excellent house plants, but, like Amaryllis, they are too costly to be very popular. They have the advantage over Amaryllis of having attractive foliage all the year round, and are more certain to bloom well. They have thick, fleshy roots, like an Agapanthus.

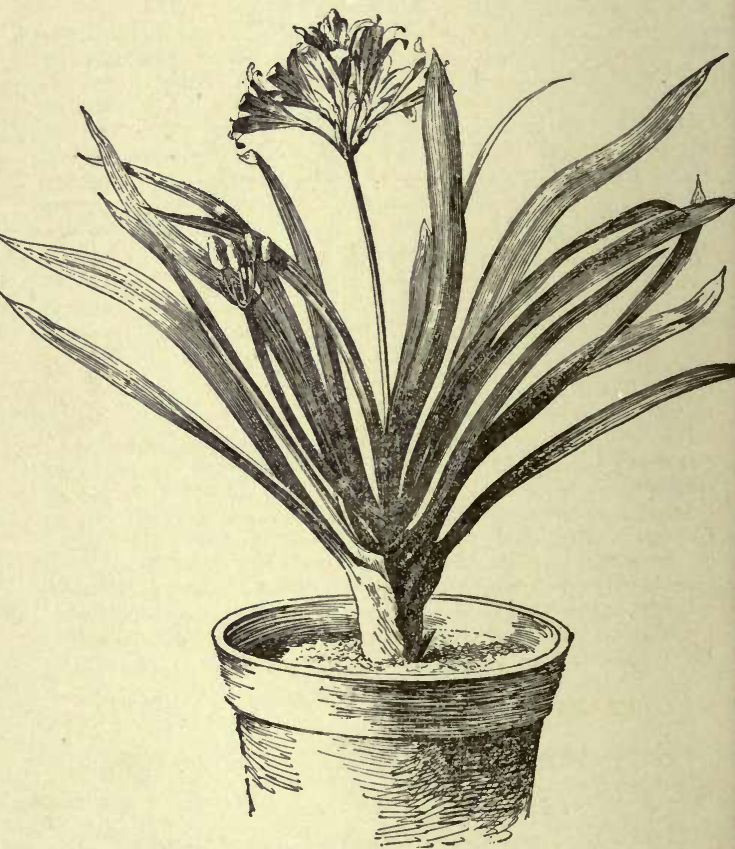

496. Clivia miniata.

All of the species are well worth growing, because of their handsome umbels of flowers, produced during the spring and early summer months. They are evergreen plants of the Amaryllis family, with thick, leathery, strap-shaped leaves. Clivia miniata is the species most commonly grown. There are several distinct forms of 
this, with larger and deeper colored flowers. Established plants may be grown in the same pots for several years. if the plants are fed during the growing period with weak liquid manure. In potting, the soil given should be of a lasting nature, not easily soured, nor apt to become sodden. In arranging the drainage, place one large piece, concave side down, over the hole, and around this arrange several smaller pieces. Over these place one or two handfuls of pieces small enough to go through a No. 2 sieve. The best time to pot is after the flowers have been produced. The plants should then be kept for some time in a humid atmosphere to encourage growth, receiving an abundance of water after they are well started. After growth has been completed, they will winter safely in an ordinary greenhouse temperature (not under $40^{\circ}$ ), if kept rather dry at the root. For propagation, select old plants which have become erowded in their pots, so that the entire plant can be pulled to pieces. After trimming the roots, put the growths in small pots and keep in heat, to encourage root action. Clivias are well suited for planting permanently in the front part of greenhouse borders. The soil for this purpose should be rich and well firmed about the roots. Withhold water as much as possible during the resting period, or the plants will produce leaves at the expense of the flowers.

497.

Trifolium pratense. A. Fls.erect; perianth broadly

Root-system. funnel-shaped.

miniàta, Regel (Imantophýllum miniatum, Hook.). Fig. 496. Lvs. 16-20, in a tuft, sword-shaped, tapering to a point, $1 \frac{1}{2} \mathrm{ft}$. long, 11/2-2 in. broad : fls. 12-20, in an umbel ; perianth erect, bright scarlet, with a yellow throat; tube broadly funnelshaped, longer than $C$. nobilis; segments about 2 in. long, the inner ones broader than the outer; stamens shorter than the segments; style not exserted: berries ovoid, bright red, 1 in. long. Natal. B.M. 4783 . R.H. 1859 , pp. 126,127 . F.S. $9: 949 ; 23: 2373$. I. H. $26: 343$ $36: 80 ; 37: 102 ; 40: 177$. R.H. 1869: 250 , and 1894 , p. 572. I. cyrtanthiflorum, Van Houtte (F.S. 18:1877), is a hybrid between this species and the next.

Ad. Fls. pendulous; perianth narrowly funnel-shaped.

nóbilis, Lindl. (Imantophýllum Àitoni, Hook.). Lvs. about 12 , strap-shaped, very obtuse, with a roughish edge: fls. 40-60, in an umbel; perianth curved and drooping; tube narrowly funnel-shaped, shorter than in $C$. miniata; segments tipped with green, about 1 in. long; stamens as long as the segments; style exserted. Cape Colony. B.M. 2856. L.B.C. $20: 1906$. Int. to cult. 1828. I. cyrtanthiflorum, Van Houtte (F.S. 18:1877), said to be a hybrid between this and the above, shows little if any influence of $C$. miniata. It has the narrow-tubed, pendulous fls. and the greenish tinge of $C$. nobilis. R.H. 1894, p. 573 .

G. W. OLIVER and W. M.

\section{CLOUDBERRY，See Rubus.}

CLOVE PINK. The Carnation, Dianthus Caryophyllus.

CLOVER, Species of Trifolium (Leguminosæ), particularly those which are useful in agriculture. The word is also applied to species of related genera, as Medicago. The Sweet Clover is Melilotus. Bush and Japan Clover are Lespedezas. Prairie Clover is a Petalostemon.

Of Trifolium there have been described about 300 species. These are widely dispersed in temperate climates. The fls. are papilionaceous but small, and are disposed in dense heads or spikes. Lrs. are digitately or palmately 3 -foliolate. The common Red Clnver is $T$. pratense, Linn., now thoroughly naturalized in $\mathrm{N}$. America, but supposed not to be native here. It is $\mathrm{Eu}$ ropean. It is valuable both for stock feed (as pasturage and hay), and also as a green manure. As a manure crop, it is particularly valuable because of its deep rootsystem and its power (in common with other leguminous plants) of fixing the nitrogen of the air by means of its subterranean parts. Fig. 497 illustrates the rootsystem. Fig. 498 shows the root of a 15-months' old plant which grew in hard clay soil. It is 22 inches long, and some of the root was left in the ground. The Mammoth Red Clover ( $T$. mèdium, Linn.), is probably an offshoot of $T$. pratense. It is usually a larger plant, with zigzag stem, entire and spotted lfts. and longer-stalked head. White Clover, or Shamrock, is T. rèpens, Linn. intr. from Europe, and supposed to be native to $\mathrm{N}$. America as well. Alsike Clover, 'T. hybridum, Linn., is of European nativity. The Crimson or Scarlet Clover (Fig. 499), an annual from S. Eu., is now much grown

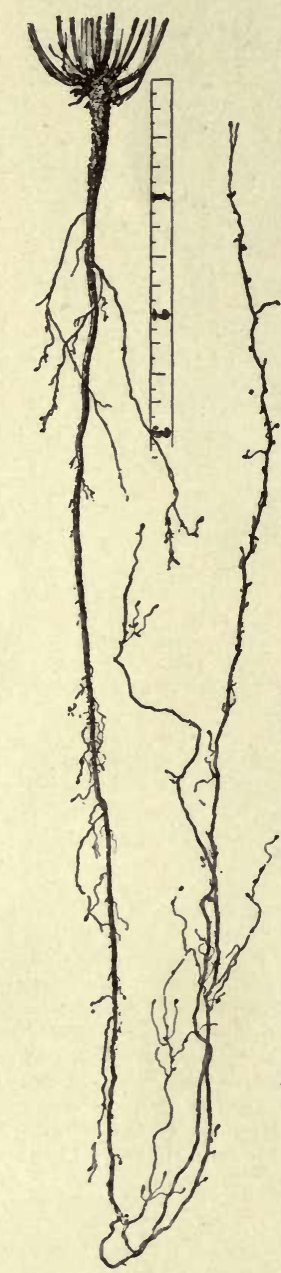

498. The penetrating root of the Red Clover. as a catch- or cover-crop in orchards. See Cover-crops. It is also highly ornamental, and is worthy the attention of the florist

L. H. B.

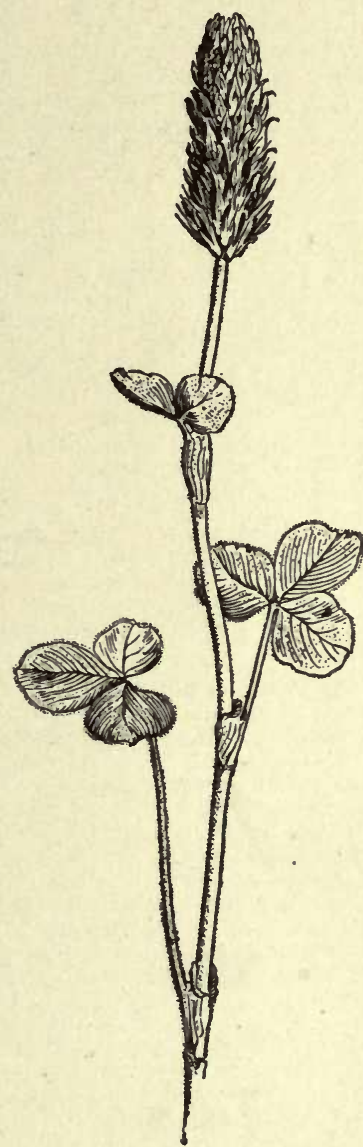

499. Crimson Clover -

Trifolium incarnatum $(\times 1 / 3)$.

CLOVES are the dried flower-buds (Fig. 500) of a handsome tree of the myrtle family, Engenia caryophyllata, better known as Caryophyllus aromaticus, a native of the Spice Islands, but now cultivated in the West Indies and elsewhere. Caryophyllus, the ancient name of the Clove, means nut-leaf. The carnation, or "clove pink," was named Dianthus Caryophyllus because of its clove 
like odor, and it has become the type of the great order Caryophyllaceæ, which, however, is far removed botanically from the Myrtaceæ. The word "gilliflower" is a corruption of caryophyllus, and, until Shakespeare's time

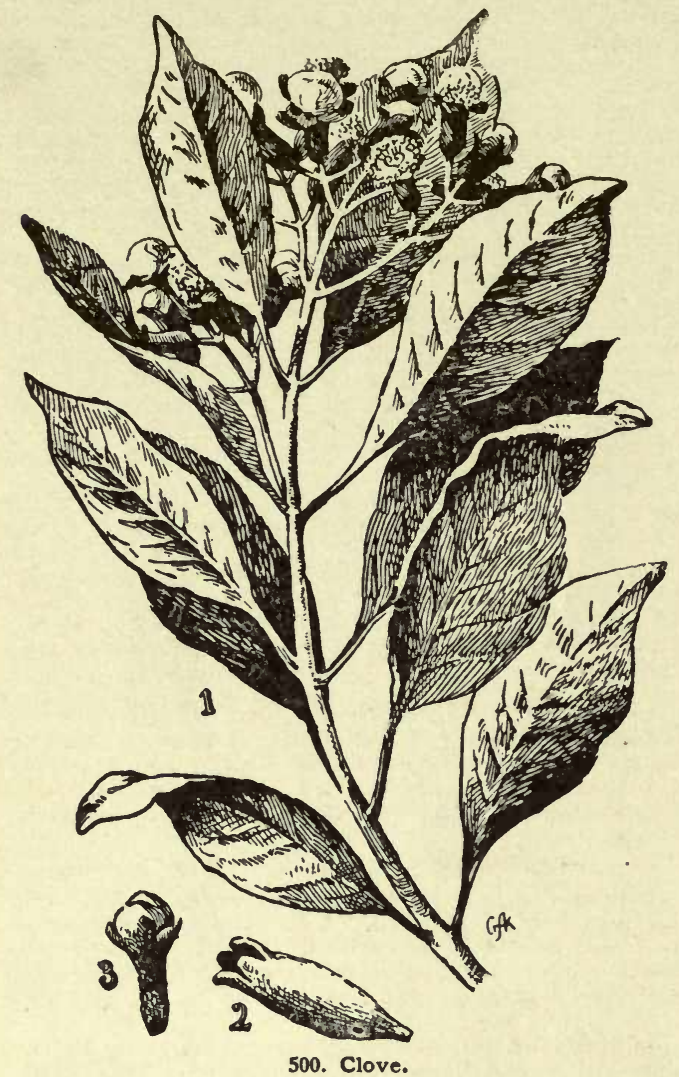

Spray of leaves and flowers (1); an unopened bud or clove (3); the expanded flower (2).

and after, was applied to the carnation, but now-a-days it usually refers to several cruciferous plants of the genus Cheiranthus and Matthiola.

\section{CLUB MOSS. See Lycopodium.}

CNICUS (Greek, knizein, to injure). Compósita. THISTle. A genus of perhaps 200 species, containing many much-hated weeds, especially the common Thistle, $C$. lanceolatus, and the Canada Thistle, $C$. arvensis, Fig. 501. About a dozen species have been slightly cultivated in rockeries and wild gardens. The genus Chamæpeuce, now referred to Cnicus, contains 3 plants slightly used abroad in subtropical and carpet bedding: $C$. A fer, C. Casabonce, and C. Diacantha, which are cult. for their rosettes of prickly lvs. The fls. appear the second year. C. benedictus is an old name of the Blessed Thistle, for which see Carbenia.

COBBETT, WILLIAM (1762-1835). The once famous English author had two periods of enforced residence in America, and wrote "The American Gardener," which is one of the spiciest books in the whole history of American horticulture. Plate II. He was of thorough Saxon ancestry, and while a gardener's lad and during eight years of military service, made strenuous efforts at self-education. In 1792 his personal liberty was endangered by the publication of "The Soldier's Friend" (an appeal for an increase of pay), and he came to Philadelpilia in the autumn of that year. His first success was a pamphlet entited,"Observations on Dr. Priestly:s Emigration," a bitter attack on the French Rerolution. He took the loyalist side in American polities, and is regarded as the founder of the American party press. His attack on Benjamin Rush, the leading physician of Philadelphia, for his advocacy of unlimited bleeding for yellow-fever, resulted in a libel suit, and damages of $\$ 5,000$, which nearly ruined Cobbett, and sent him to England in June, 1800. In 1802 he began "Cobbett's Weekly Political Register," which he edited for 33 years, and until his death, except during an interval of imprisonment and a second withdrawal to America. His real work was domestic reform, and the circulation and influence of his journal were immense. In 1801-2 he reprinted his American writings in 12 volumes, entitled, "Porcupine's Works." After 1804 he usually lived on his farm at Botley, in Hampshire, where he conducted many experiments. In 1817 he was again compelled to leave England, and for the next two years he lived in America. His life was one incessant conflict. He lived to see the reform of 1832 , and his work was fittingly rewarded by a place in Parliament, but he was then too old to do much damage, and he died within three years thereafter. Cobbett's faults are all obvious, his egotism towering above the rest, and barely falling short of sublimity. He was not a genius, but his talents were extraordinary, and his versatility amazing. His "English Grammar" (London, 1818), written from Long Island in the form of letters to his 15-year-old son, was said by Bulwer Lytton to be the only amusing grammar in the world. Hazlitt declared that it is as interesting as a story-book, and Alfred Ayers, in his admirable edition (New York, 1883), declares that it is probably the most readable grammar ever written, and that for purposes of self-education it is unrivalled. (For a list of Cobbett's writings, see Edward Smith's excellent sketch in the Dictionary of National Biography.) After Cobbett's death, his sons published in 6 volumes (beginning 1857) "Selections from Cobbett's Political Works; being a complete abridgment of the 100 volumes which comprise the writings of 'Porcupine,'and 'The Weekly Political Register.'" These 100 volumes, of course, do not take into account his non-political writings, nor his editorial work in the 36 volumes of "Cobbett's Parliamentary History of England from the Norman Conquest, in 1066, to the year 1803" (continued as Hansard's Parliamentary Debates), nor Cobbett's Complete Collection of State Trials (afterwards known as Howell's), nor many other works which he either edited, translated, or published. The anti-Cobbett literature is exceedingly voluminous, and almost every charge has been made against the man, except that of being uninteresting. According to Henry Cabot Lodge (whose masterly appreciation in "Studies in History" [Boston, 1885], should be consulted by the student immediately after direct contact with Cobbett's writings), Cobbett's true value is understood by his thoroughly representative character as a type of his time and people. As historical documents, his works are indispensable.

Cobbett's horticultural writings of chief interest to us are "Cottage Economy," "A Year's Residence in the United States of America, and, most of all "The American Gardener" (1821), which was reproduced with considerable modifications as "The English Gardener," in

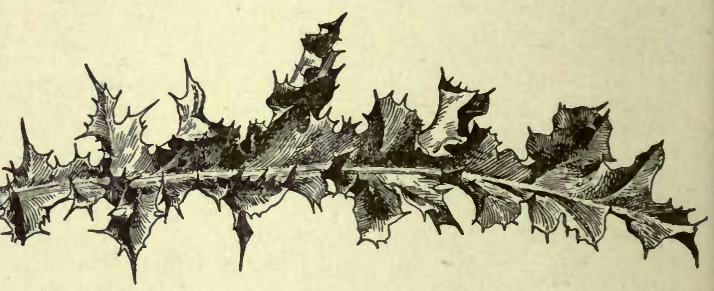

501. Leaf of Canada Thistle $(\times 1 / 3)$.

London, 1827. The imerican edition of Wm. Forsyth's excellent "Treatise on the Culture and Management of Fruit Trees," was published at New York and Philadelphia in 1802, and in Albany in 1803, and was one of the most influential books on fruit growing in the 
period before orcharding over large areas gave rise to essentially American horticultural writings. Unfortutunately for horticulturists of the present day, Cobbett's thunder seems forever silenced. He has the fatal faults of being old and amusing. Yet, to the discriminating mind, Cobbett's horticultural writings, especially "The American Gardener" ( which is still not uncommon in second-hand book stores), are full of suggestiveness and refreshment.

W. M.

COBஷ̇EA (after Father Cobo, Spanish Jesuit of the seventeenth century, naturalist, and resident of America for many years). Polemonideece. A genus of 6 tropical American climbers, of which $C$.scaindens, a tender pereunial plant, is amongst the dozen most popular vines commonly treated as annuals. This is the only genus of climbers in the order. Prop. by seeds, which should be placed in moist earth, edge down. It is a rapid grower.

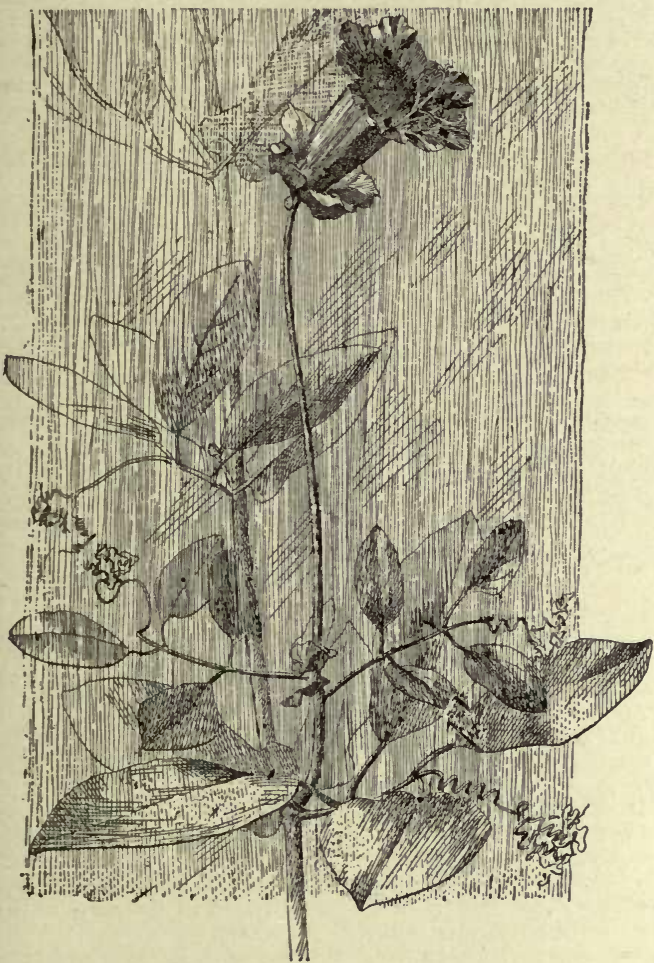

502. Cobcea scandens $(\times 1 / 3)$.

scándens, Cav. Figs. 502, 503, 504. Height 10-20 ft. : Ifts. in 2 or 3 pairs, the lowest close to the stem, and more or less eared : fls. bell-shaped, 1-11/2 in. across, light violet or greenish purple, with protruding style and stamens: tendrils branched. Mex. B.M. 851. There is a white-fld. form (C. albba, Hort.), and one with variegated lvs., var. variegàta, Hort. - The terminal lft. is represented by a tendril (Fig. 502). Sometimes there ure indications of tendrils on other lfts. (Fig. 504), making the plant an interesting one for students of morphology.

macrostémma, Pav. Taller, later-flowering, the stems and foliage not purple-tinged : fls. yellow-green, with exserted stamens. Guatemala.

W. M.

COBNUT. Consult Corylus.

\section{COBÚRGIA. See Stenomesson.}

COCA. The lvs. of Erythroxylon Coca, used in medicine. Sold chiefly as a fluid extract. Cocaine is the famous local anæsthetic.
COCCINEA (Latin, scarlet; referring to the ornamental gourds). Cucurbitacere. Thirteen species of tender perennial vines, from the tropies of Asia and Africa, usually with tuberous roots. Lrs. angled or

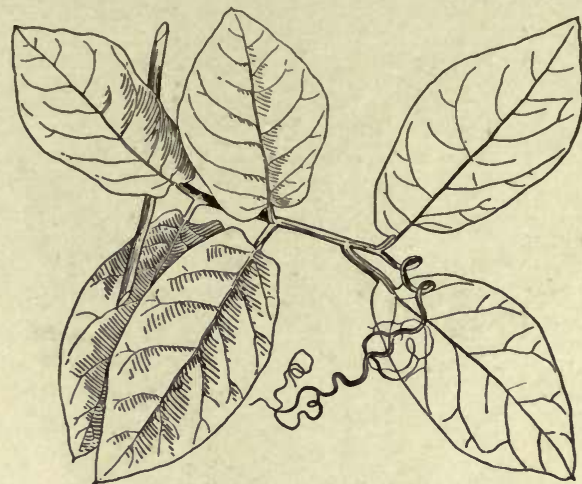

503. Normal leaf of Cobcea scandens.

lobed, sometimes glandular: fls. white or yellowish, large : fr. a small, scarlet gourd, sometimes marbled, with an insipid pulp. A. Coigneaux in DC., Mon. Phan. 3:528. C. cordifolia is treated as a tender annual, requiring an early start and no special culture.

A. Tendrils simple: male fls. solitary: lvs. small.

cordifòlia, Cogn. (C. Indica, Wight \& Arn.). Height about $10 \mathrm{ft}$.: lvs. small, 1-2 in. long, glossy, ivy-like, short-petioled, obtusely 5-angled: fis.white, bell-shaped: fr. roundish at both ends, about 2 in. long, 1 in. thick. India.

AA. Tendrils bifid: male fls. in racemes: lvs. large.

palmàta, Cogn. (Cephalándra palmata, Lond.). Attaining $30 \mathrm{ft}$.: lvs. large, 3-4 in. long and wide, longpetioled, palmately 5-lobed: fls. yellowish : fr. ovate, acute. Natal. Int. by P. Henderson \& Co.. 1890. - A rare greenhouse plant.

W. M.

COCCOLOBA (Greek, lobed berry; referring to the ends of the pear-shaped fr.). Polygondcece. This genus, which contains the 2 interesting fruits described below, consists of about 80 tropical trees and shrubs, sometimes tall climbers, with alternate, usually leathery, entire lvs., which are sometimes very large, sometimes very small: sheath or ocrea various: fls. in racemes, on short pedicels between small, ocrea-like bracts. For $C$. platyclada, see Muehlenbeckia.

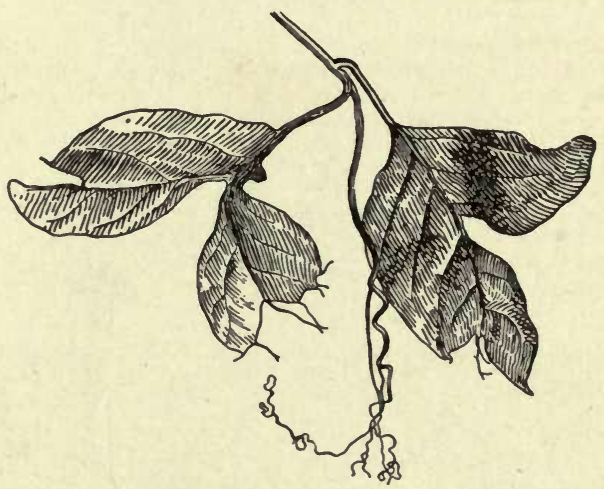

504. Monstrous or abnormal leaf of Cobcea.

Coccoloba is a genus of tropical evergreen shrubs and trees, mostly of an ornamental character. C. uvifera, the Sea-grape or Shore-grape of the West Indies, bears an edible fruit, and has particulary beantiful foliage. This species is the most important of the genus, and is 
worthy of a place among ornamental plants under glass. As it will withstand but slight frost, its cultivation outdoors in the United States is limited to warmer parts of Florida and California, but it may be bedded outdoors during the summer, in temperate latitudes forming a stipules at the base : racemes 6 in. long, erect, in $\mathrm{fl}$. nodding in fr.: fls. $1 \frac{1}{2}$ in, across, white, fragrant ; petals 5 ; stamens 8 ; styles 3 : berries 9 or more in a raceme, small, about $1 / 2 \mathrm{in}$. long, pear-shaped, reddish purple, dotted green, sweetish acid: nut roundish, with a short, sharp point on top, and vertical wrinkles. Sandy seashores of Trop. Amer., especially S. Fla. and West Indies. B.M. 3130.-The wood is used in cabinet work, and, when boiled, gives a red color.

Floridàna, Meissn. Pigeon Plum. Tree, 25-30 ft.: lvs. $1 \frac{1}{2}-3$ in. long, 1-2 in. wide, ovate or elliptical, narrowed at both ends, obtuse, margin slightly recurved: berries small, 1/3in. long, pear-shaped, edible, but not marketable. S. Fla. - This has lately been considered a synonym of $C$. laurifolia, but the two species are well distinguished in DC. Prod. $14: 165$.

W. M.

CóccuLUS (diminutive of kokkos, berry ; the fr. being berry-like). (Cebatha.) Menispermàcen. Twining or erect shrubs: lvs. alternate, petioled, entire or lobed, with entire margin, deciduous or persistent, palminerved: fls. inconspicuous, diœcious, in axillary panicles or racemes, sometimes terminal ; sepals, petals and stamens 6 : carpels $3-6$, distinct, developing into berry-like, 1-seeded drupes; seed reniform. About 25 species in America, Asia, Africa and Australia, chiefly in trop. and subtrop. regions. Only a few species are cultivated, thriving in almost any somewhat moist soil ; the evergreen kinds are sometimes grown in pots, in a sandy compost of peat and loam. Prop. by seeds or by cuttings of half-ripened wood in summer, under glass, with bottom heat.

"Cocculus Indicus" is the trade name of the berries used by the Chinese in eatehing fish. The berries contain an acrid poison, which intoxicates or stuns the fish until they can be caught. The berries are imported from the East Indies to adulterate porter, and "Cocculus Indicus" is a trade name with druggists, not a botanical one, just as "Cassia lignea" is a trade name of a kind of Cinnamon bark, derived, not from a Cassia, but from a species of Cinnamomum. The name "Cocculus Indicus" was given by Bauhin, but binomial nomenclature began later, with Linnæus, in $\mathbf{1 7 5 3}$. The plant which produces the berries is Anamirta Cocculus.

Carolinus, DC. A rapid-growing, twining shrub, attaining $12 \mathrm{ft}$., with pubescent branches: lvs. long-petioled, usually ovate, sometimes cordate, obtuse, entire or 3-, rarely 5-lobed, pubescent, glabrous above at length, $11 / 2-3$ in. long: fr. red, $1 / 4$ in. in diam. Along streams, froin Va. and Ill. to Fla. and Tex.-Decorative in fall, with its bright red fr. Not hardy N. of New York.

C. Japónicus, DC.=Stephania hernandifolia.-C. laurifòlius, DC. Erect shrub, to $15 \mathrm{ft}$, glabrous: lvs, evergreen oblong, acute at both ends. Himal. Decorative, with its bright Decor bergi, DC. Similar to C. Carolinus, but fr. bluish black. Hardier. Japan. ALFRED REHDER.

COCHLEARIA (Latin, cochlear, a spoon; referring to the lvs.). Cruciferce. This genus, which includes the Horse Radish and Scurvy Grass, is composed of glabrous herbs, mostly perennial, of various habit, with lvs. alternate or in rosettes: fls. mostly white, racemose, bractless : pods various, but never winged. The word cochlear is a technical term used in describing alstivation, and refers to one piece which is larger than the others, hollow like a bowl or helmet, and including the rest, as in Aconitum.

Armoràcia, Linn. (Nastírtium Armord̀cia, Fries). HORSE RADish. Hardy perennial, $2 \mathrm{fi}$. high : roots large and fleshy, furnishing the familiar condiment: root-lvs. very large, more or less cordate or oblong; stem-lvs. lanceolate, uppermost linear, entire : fls. white. May. Naturalized from $\mathrm{Eu}$. and escaped.-It flowers frequently, and very rarely perfects any seeds. For culture, see Horse Radish. 
officinàlis, Linn. Scurvr Grass. Hardy biennial, 2-12 in. high, but cult. as an annual : root-lvs. petioled, cordate; stem-lvs. sessile, oblong, more or less toothed: fls, early spring; calyx lobes erect. Aretic regions. Vilmorin, Veg. Gard. 515. - Prop. by seerl, which is small, oval, slightly angular, rough-skinned, reddish brown. The germinating power lasts 4 years. The green parts of the plant are strongly acrid, and have a tarry flavor. The seed is sown in a cool, shady position, where the plants are to stand. The lvs. are rarely eaten as salad, but the plant is mostly grown for its anti-scorbutic properties.

W. M.

COCHLIODA (Greek for spiral, in reference to the structure of the lip). Orchiddcea, tribe Vándece. A small genus of orchids found at high elevations in South America. Pseudobulbous. Flowers bright rose-color or scarlet. Some of the species are retained by various authors in Odontoglossum and Mesopinidium. Culture of Odontoglossums.

Noetzliàna, Rolfe. Pseudobulbs ovate-oblong, compressed, about 2 in. long, monodiphyllous : lvs. linear, peduncles arcuate : fls. numerous, in graceful racemes, orange-scarlet, about 1 in. across; sepals oblong; petals rather ovate ; labellum 3 -lobed, disk yellow, otherwise similar in color to the petals. Andes. B.M. 7474. Gt. 43:1403. G.C. III. 16:71.

ròsea, Hort. Plants similar to $C$. Noetzliana : fls. rose color. Peru. B.M. 6084. I.H. 18:66.

vulcánica, Benth. \& Hook. Peduncles more or less erect: Hs. larger than in the preceding, bright rose-color; labellum 3-lobed, provided with 4 ridges. Peru. B.M.6001.

OAKES AMES.

COCHLIOSTEMA (Greek, spiral stamens). Commelinacece. A genus of 2 species, which are among the most curious and gorgeous plants cultivated under glass. They are epiphytes, with the habit of Billbergia and great axillary panicles of large flowers of peculiar structure and beauty. They are stemless herbs from Equador, with large, oblong-lanceolate lvs., sheathing at the base, and fls. which individually last only a short time, although a succession is kept up for several weeks; sepals 3, oblong, obtuse, concave; petals 3 , nearly equal, wider than the sepals, margined with long hairs; staminodes 3 , villous, 2 erect, linear, the third short, plumose; staminal column hooded, with incurved margins, enclosing 3 spirally twisted anthers; style slender, curved. For an interesting theory of the peculiar staminodes, see G.C, $1868: 323,264$.

Cochliostemas are handsome stove-flowering perennial plants, closely related to the Commelinas, and are of comparatively easy culture, thriving well in ordinary stove temperature in a mixture of 2 parts loam and 1 part fibrous peat, with a little well-decayed cow-or sheepmanure added when potting mature plants. They like a copious supply of water at the roots during the summer months, and at no season must they be allowed to become dry. Propagation is effected by division of the plants in early spring, or by seeds, to obtain which the flowers must be artificially fertilized. The seeds should be sown as soon as ripe in shallow pans of light, peaty soil, and placed in a warm, close atmosphere until germinated. As soon as the seedlings are large enough, they should be potted singly into thumb-pots, and shifted on as often as they require it, when they will flower in about 12 months. The chief reason why Cochliostemas are grown in America so little is, probably, that we have to keep a much more humid atmosphere in stove-houses here than in England, and that is very much against all stoveflowering plants, causing the season of blossoming to be very short.

A. Lvs. red beneath: panicle hairy: fls. very fragrant.

odoratíssimum, Lemaire. Lvs. lighter green above than in C. Jacobianum, and deep purplish red beneath, narrower, and with a similar margin : fls. very numerous; sepals more leaf-like, hairy, green, with a reddish tip. I.H. $6: 217$. R.H. 1869, p. 170. - Not advertised at present, but fully as interesting as the next.

$$
\text { AA. Lvs. green beneath: panicle not hairy: fls. less }
$$
fragrant.

Jacobiànum, C. Koch and Linden. Height 1-3 ft.: lvs. in a rosette, spreading or recurved, dilated and sheatb- ing at the base, margined brown or purplish, $3-4 \mathrm{ft}$. long, 6 in. broad at the base, 4 in. broad at the middle: peduncles stout, white, tinged purple, $1 \mathrm{ft}$. long: bracts large, opposite and whorled, 3-4 in. long, acuminate, concave: panicle branches $4-6$ in. long: fls. $2-2 \frac{1}{2}$ in. across; sepals purplish; petals violet-blue. Autumn. B. M. 5705. R. H. 1868:71.

\section{EDWard J. Canning and W. M.}

Cochliostema odoratissimum is much like C. Jacobianum. Is a very interesting plant of rapid growth and easy culture. It is raised from seed. It seeds freely when fertilized at the proper time. Only a few of the stronger or larger flowers should be allowed to bear seed. Sometimes a simple shaking of the flower stalk will accomplish the necessary work of fertilizing, but it is safer to employ the regular method to insure thorough impregnation. The seeds ripen within 6 weeks' time, and they can be sown soon thereafter. In 5 or 6 months from seed the plants will bloom. The flowers, while not very showy, are fragrant and interesting. The plant itself is ornamental by reason of its curiously marked, striped and veined leaves. The plant thrives best in rich, light, loamy soil. First sow in boxes or seed pans in light, sandy soil; then transplant into small pots; keep the young plants in a warm, moist place and repot before the pot is filled with roots, never allowing the plant to get "hard," as it is called, but keep it growing continuously, and when in 6- or 7-inch pots, allow the plant to get somewhat pot-bound and give more air, and it will soon set flower buds. Then place a mulch of old cow- or sheep-manure on the top of the pot, or use liquid manure once or twice a week, keeping the plant in a cool position. The above treatment will secure numerous flowers over a long period. Fall and winter. H. A. Siebrecht.

Cockscomв. See Celosia.

COCKSFOOT GRASS. Same as Barnyard Grass, Panicum Crus-Galli.

COCOA. Seeds of Theobroma Cacao.

\section{COCOA PLUM. Chrysobalanus Icaco.}

cocos (Portuguese, monkey, from the nut, which suggests a monkev's face). Palmaceo, tribe Cocoinea. This genus includes the Cocoanut tree, $C$. nucifera, and a few palms that are cultivated for ornament in the north under glass, and in S. Fla. and S. Calif. as avenue and ornamental trees. Of the species cult. for ornament, $C$. Weddelliana is by far the most important. It is sold in great quantities from 3-and 4-inch pots when the plants are 12-15 in. high. They are favorite house-plants, as their culture is easy, and they grow slowly and retain their beauty a long while. They are much used in fern dishes. As a house-plant, $C$. Weddelliana is probably the most popular species of all the smaller palms. It is especially suitable for table decoration. The genus is allied to Maximiliana and Attalea, and distinguished by its male fls. having lanceolate petals, 6 included stamens, and a 1 -seeded fruit.

Low or tall spineless palms, with slender or robust ringed trunks, often elothed with the bases of the lvs. Lvs. terminal, pinnatisect; segments ensiform or lanceolate, equidistant or in groups, 1- to many-nerved, entire at the apex, or with 1 lateral tooth, or more or less deeply lobed,-the margins smooth, recurved at the base: rachis 3-sided, acute above, convex on the back: petiole concave above, smooth or spiny on the margins: sheath short, open, fibrous ; spadices erect, at length drooping, the branches erect or drooping; spathes 2, the lower one the shorter, split at the apex, the upper one fusiform or clavate, woody, furrowed on the back; bracts variable; fls. white or yellow : fr. large or medium, ovoid or ellipsoidal, terete or obtusely 3-angled. Species about 30. Tropical and sub-tropical S. Amer., 1 in the tropies around the world.

\section{J. G. SMITH and W. M.}

The Cocoanut Palm naturally grows on the seashore, or in its immediate vicinity, and does not bear well when at a great distance from salt water, although its growth may be strong. In cultivation, this fact is kept 
in mind and plantations are laid out on sandy or shelly tracts of land bordering the sea, where it is almost impossible to raise anything else of value. This soil consists of coarse sand, broken shells and litter of the sea, and is apparently very poor in quality, yet the Cocoanut thrives on it and bears abundantly. Propagation is by seeds only. These are selected from the most desired strains, as the nuts vary greatly in size, shape, and quantity and quality of the meat. They must be perfectly ripe before planting, which is usually done without removing the outer husk. A shallow trench is scooped out of the sand, the nuts are laid in thickly on their sides and then the sand is thrown back over them to a depth of from 4-10 in., according to the moisture of the soil. After some months, when they have germinated and the seed leaf is well developed, they are usually dug and planted out permanently about $20 \mathrm{ft}$. apart. The young palms are kept free from weeds and eneroaching beach creepers for 3 or 4 years, until they reach a considerable size, after which they seldom get any cultivation. A mulching of seaweed and other vegetable matter proves of much benefit, but as the profit is so small in Cocoanut culture, thorough manuring is not attempted. Cocoanut Palms are of tropical growth. yet may be grown outside the tropics to a slight extent, as in southern Florida, where occasional light frosts occur.

\section{E. N. REASONER.}

As a decorative subject under glass, Cocos nucifera is but little grown, owing to its large size, but when given an abundance of water, a rich, loamy soil, and a night temperature of $70^{\circ}$, it is not especially difficult to manage, and while the young plants do not give a proper idea of the mature Cocoanut Palm, their development is interesting to watch.

The most valuable Cocos to the florist is the Dwarf Cocoanut, $C$. Weddelliana, the seeds of which are sent from Brazil to the large American and European palm growers by the million each season. These seeds are about half an inch thick. They usually arrive in the spring, and should be sown at once in a warm greenhouse and kept continually moist, and if they are in good condition and kept at a temperature of about $75^{\circ}$, they frequently begin to germinate in 6 to 8 weeks.

A light and rather open soil is preferable for Cocos seeds, some growers using pure peat for this purpose with good results. When the seedlings are making their second leaf they may be potted off, and this is one of the eritical periods in the culture of $C$. Weddelliana, the young roots being so stiff and brittle that much care is needed to get them into a 2 - or $2 \frac{1}{2}-$-inch pot, and if the main root is broken the seedling seldom recovers.

Deep pots are, therefore, best for this purpose. The seedlings should be kept rather close during the day for the first few weeks after potting, and then may be aired quite liberally, and also syringed freely. A night temperature of $65-70^{\circ}$ will answer very well for the young plants, and they should never be allowed to become very dry, or a yellow and unhealthy condition is liable to follow. Through the summer the plants may be repotted as they may need it, but it is not wise to disturb the roots after the middle of October, the root action of these plants being rather sluggish during the winter months.

Soil should be well-drained, rather sandy in texture, and may be enriched with some dry cow-dung, or a moderate quantity of bone dust.

\section{Cult. by W. H. 'TAPLIN.}

The Cocoanut is the example most commonly cited of dispersal of seeds by water. Its buoyant, impervious husk is said to enable it to cross an ocean without losing its germinating power. Its structure is interesting and at first puzzling. Although it is a dry, indehiscent, 1-seeded fruit, it seems very unlike an akene, as for instance, in the Compositæ. Structurally, it is more like a drupe, for the fibrous husk is formed from the outer part of the pericarp, and the hard shell enclosing the meat from the inner. In other words the husk is exocarp and the shell endocarp. The milk of the Cocoanut is unsolidified endosperm. In the cereal grains it is the endosperm which affords most of the material used for human food. Only a part of the liquid matter of the Cocoanut solidifies, and the milk is left in the center.
The eyes of the Cocoanut (Fig. 506) mark the positions of the micropyles, and germination takes place only through the larger one. Palm pistils are 3-carpelled and each carpel in Cocos has 1 ovule. The marks of the 3 carpels are seen in Fig. 506, but only 1 ovule develops

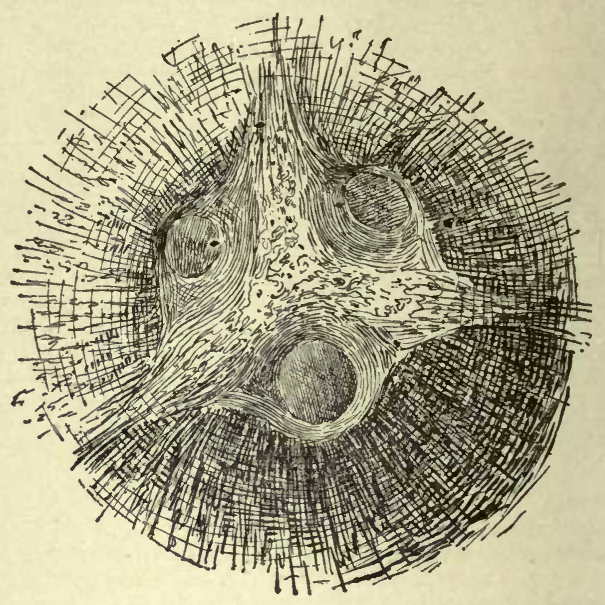

506. End of a mature cocoanut.

The nut sprouts usually from the largest eye.

into a seed. Fig. 507 tells the story of the growth of a Cocoanut. In $a$, the young nut is enveloped by 3 petals and 3 sepals. At $b$, the pericarp has far outgrown the sepals and petals. The floral envelopes remain upon the tree when the nut is picked. Cocoanuts, like many other fruits, often grow to a considerable size without pollination, and then perish.

In distinguishing tropical from subtropical regions, the Cocoanut is an excellent guide. It flourishes best where frost is never known. The oil extracted from the nuts is an important article of commerce. The fiber refuse is much used by florists and gardeners. Being open, spongy, very retentive of moisture, clean and easily handled, it is a favorite material in which to root bedding plants and to start very small seeds; but it is not used for permanent potting.

L. H. B.

\section{A. Filaments present on the rachis.}

eriospàtha, Mart. Stem 9-15 ft. high, 10-14 in. thick, capitately thickened with the persistent bases of the petioles; lvs. ample, glaucous, finely pectinate: margins of the rachis with excurrent filaments; segments about 1 in. apart, the lower elongated, linear, 20-24 in. long, very long-acuminate, the upper narrowly linear, short, attenuate, $1 \mathrm{ft}$. long, 2 lines wide, all rigid, faintly nervose-striate S. Braz. - "The hardiest of the genus and one of the hardiest palms in southern Calif. Fronds bluish: fr. pulp tastes like apricots." $-\boldsymbol{F}$. Franceschi, Santa Barbara. Rather coarse for cultivation under glass.

\section{AA. Flaments absent.}

\section{B. Rachis abruptly contracted above the insertion of} the lowest lfts.

flexuòsa, Mart. Stem 9-12 ft. high, 2-31/ in. in diam., arcuate-ascending, naked just above the base, thence densely clothed with dead petiole bases; lvs. lax, 3-6 ft. long: petiole flat above, arcuate, at first tomentose, later smooth : rachis abruptly narrowed above the insertion of the lowest leaf-segment, thence linear-filiform at the apex, excurrent ; segments $70-90$ on each side, rigid in opposite groups, the middle 10-14 in. long, $1 / 3 \mathrm{in}$. wide, the upper 4 in. long, 1-12in wide. Braz, - Cult. in northern greenhouses. An avenue tree in S. Fla. and S. Calif. "Similar in habit to S. plumosa, but with more finely cut Ivs., and in S. Eu. considered to stand more frost."-Franceschi. 
BB. Rachis not abruptly contracted. c. Leaflets flaccid.

D. Form of lfts. linear.

E. Arrangement of lfts. equidistant.

Weddelliàna, H. Wendl. Fig. 508. Stem 4-7 ft. high, $11 / 4$ in. in diam., densely covered with persistent sheaths: Ivs. equally pectinate-pinnatisect, $3-31 / 4 \mathrm{ft}$. long: petiole 8-20 in.: sheath coriaceous-fibrous, glabrous or tomentose, with slender brown hairs, at length evanescent: blade 2-3 ft.: segments about 50 on each side, widely spreading, the middle 5 in. long, 2 lines wide, subequidistant, glaucous beneath: rachis filiform at the apex, brown-scaly. Trop. Braz. R.H. 1879, p. 434 . I.H. $22: 220$. A.G. 16:345. - The most important of small ornamental palms for the north.

EE. A rrangement of lfts. in groups of $2-4$.

plumossa, Hook. Stem 30-36 ft. high, 10-12 in. thick, ringed at intervals of a foot, clothed near the apex with remnants of the dead petioles; lvs. erect-spreading, 12$15 \mathrm{ft}$. long, recurving: petiole $1 / 8-1 / 2$ as long as the blade: segments linear acuminate, sparse, solitary or mostly in groups of $2-4,1 \frac{1}{2} \mathrm{ft}$. long, deflexed near the apex. Cent. Braz. B.M.5180. - The chief avenue palm of the genus. A quick-grower, ultimately $50 \mathrm{ft}$. high in S. Fla. and Calif.

\section{cc. Leaflets rigid.}

butyràcea, Linn. Stems very tall, naked : 1vs. pinnate; lfts. simple ; spathe cylindrical-oblong, 4-6 ft. Venezuela.-Rare and perhaps confused with Scheelea butyracea. Little known.

D. Form of lfts. sword-shaped.

Romanzoffiàna, Cham. Stems $30-40 \mathrm{ft}$. high, somewhat fusiform above: lvs. about half as long as the cau dex, the withered ones deflexed, pendent, the upper spreading, incurved, segments conduplicate at the base, ensiform. S. Braz., near the sea.

DD. Form of lfts. linear: apex obtuse: petiole glaucous.

austràlis, Mart. Pindo Paly. Height $8 \mathrm{ft} .:$ stem erect, columnar, equal, strongly annular above ; petiole naked ; segments linear, glaucous, rather rigid : fr. as large as a pigeon's egg, outer pulp sweet, edible, seed oily. Paraguay. G.C. III. 18:739. A.F. 5, 515, and 7:805. R.H. 1876, p. 155. - A slow grower. Cult. under glass and outdoors in Fla. and Calif.

nucifera, Linn. Coco Palm. Coconnut Tree. Figs. 507, 508. Caudex 40-100 ft. high, flexuous, thickened at the base: lvs. 12-18 ft. long; lfts. linear-lanceolate, 2-3 ft., coriaceous, flaccid: petiole $3-5 \mathrm{ft}$., stout. Seashores within the tropics. Indigenous to Cocos or Keeling Islands of the Indian ocean. R. H. 1895 , p. 457. Mn. 2: 171 . G.F. 7:15. - Produces the cocoanuts of commerce. Rarely cult. in northern greenhouses.

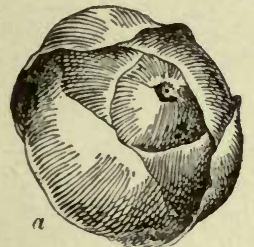

(Nat. size at this stage.)

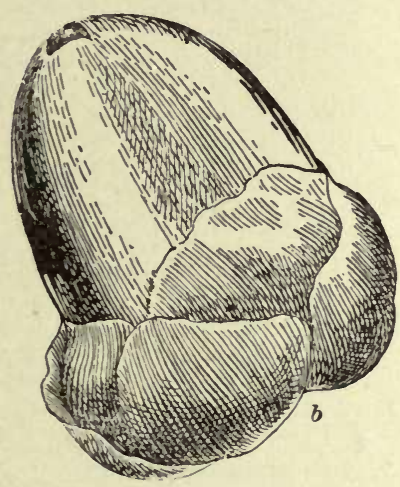

(Nat. size.)
507. Stages in the growth of a cocoanut.

DDD. Form of lfts. narrowly lanceolate.

E. Lvs.long, 6-15 ft. in mature specimens.

F. Petiole spinose-serrate: segments of leaf less numerous.

Yatày, Mart. Stem 12-15 ft. high, over $1 \mathrm{ft}$. in diam., naked below, covered with dead sheaths above: lvs. recurved, spreading 6-9 ft.: sheath $1 \mathrm{ft}$. long, fibrous at the mouth; petiole $1 \frac{1}{2} \mathrm{ft}$. long, spinose-serrate ; segments $50-60$ on a side, crowded below, then equidistant, linear-lanceolate, the uppermost long-setaceous filiform,

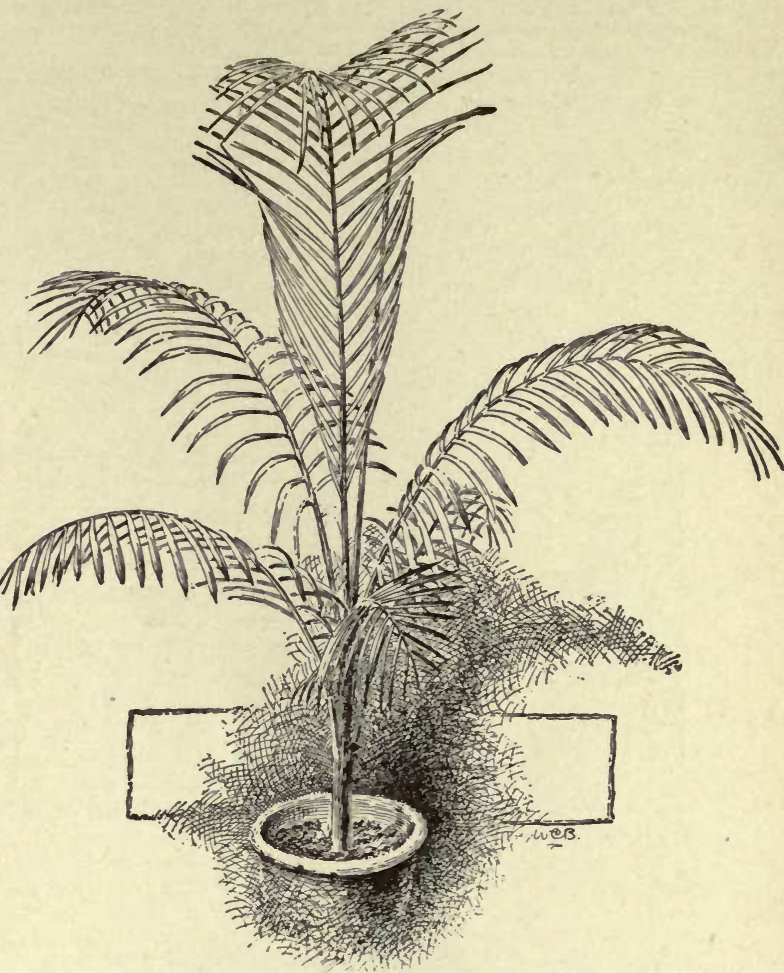

508. Cocos Weddelliana.

the middle ones $2 \frac{1}{2} \mathrm{ft}$. long, 2-5 in. wide, the upper 20 in. long, $1 / 4 \mathrm{in}$. wide, all rigid, glaucous beneath. Brazil, Argentina.

FF. Petiole not spinose-serrate: segments of leaf very numerous.

Dàtil, Drude \& Griseb. Stem $30 \mathrm{ft}$. high, 8-12 in. diam. : lvs. 12-15 ft. long: sheath about 16 in. long; petiole 11/ ft. long, $1 \frac{2}{3}$ in. wide, $2 / 3$ in. thick; segments linear-acuminate, glaucous, densely crowded in groups of 3 or 4 150-160 on each side, the lowest $2 \mathrm{ft}$., middle $21 / 3 \mathrm{ft}$. and apical $1 \mathrm{ft}$., the uppermost filiform, all narrow, stiff and rigid, the dried lys. glaucous green or whitish. Argentina; islands and river banks. The fruits are edible, resembling those of the date palm. Hardier in S. Calif. than C.plumosa, flexuosa, and Romanzoffiana.

coronàta, Mart. Trunk at length $18-30 \mathrm{ft}$. high, 8 in. in diam., erect, deeply ringed: lvs. erect-spreading, 6-9 $\mathrm{ft}$. long, short-petioled, arranged in a close, 5-ranked spiral, the long-persistent bases of the petioles forming a spiral-twisted column below the crown; leaf-segments in groups of 2 or 3, folded together from the base (conduplicate), linear lanceolate, acute, coriaceous, densely crowded, about 100 on each side; midrib 4 -sided below, 3 -sided above. Brazil.

EE. Li's, shorter, 3-41/2 ft. in mature specimens. F. Apex of lfts. obtuse.

campéstris, Mart. Stem 8-10 ft. high, thickened, scaly: lvs. spreading-recurved, rigid, $3-4 \frac{1}{2} \mathrm{ft}$. long: rachis elevated, triangular above, convex below: segments narrowly lanceolate, $30-40$ on each side, obtuse at the apex and shortly cordate-acuminate. Brazi1.-Hardier than C. nucifera.

$$
\text { FF. Apex of lfts, acuminate. }
$$

insígnis, Mart. (Glaziòva insignis, Hort.). Stem 3-6 ft. high, $1 \frac{1}{2}$ in. in diam.: $1 \nabla s .4 \frac{1}{2}-6 \mathrm{ft}$. long; sheath densely 
brown-lanate; petiole shorter than or equaling the sheath, a fourth or fifth as long as the rachis; segments equidistant, 50 on each side, narrowly lanceolate, obliquely acuminate and caudate, silvery glaucous beneath. Braz.

The following are obscure trade names of rare plants not sufficiently described : C. Alphónsei, O. Bónneti, O. Gaértneri, C. Maximiliàna and $\dot{C}$. Ýurumàgnas.

\section{JARED G. SMith and W. M.}

CODI Æ̀ेM (Malayan name). Euphorbiàcece. CRoton of florists. Four or 5 Malayan species of shrubs or trees. Plants monocious : racemes axillary, long and slender: pistillate fls, with small 5-lobed ealyx and no petals, the ovary 3-loculed : stamens 15-30, surrounded by calyx and 5-6 small petals: lvs. alternate and petiolate, normally entire, thick, more or less Aucuba-like. Differs from Croton in the absence of petals from the pistillate fls., and in technical characters of stamens.

The Codiæums of gardens are of many widely different kinds, and many of these forms have Latin-made names. They are all derived, however, from one polymorphous natural group, which J. Müller, the latest monographer (DC. Prodr. 15: pt. 2, 1119), considers to be one species (C.variegatum). This plant is widely distributed in the Malayan region, and is commonly planted in the Moluceas and other parts. The Crotons or Codiæums of horticulturists fall into three groups, those with ovate, short-stalked lvs., those with narrower and spatulate lvs., and those with very narrow and often twisted lvs. These correspond with Müller's three natural divisions :

variegatum, Linn., var. píctum, Müller ( $C$. pictum, Hook.). Fig. 509. Lvs. short-petioled, ovate or oratelanceolate, more or less cordate at the base, $1 \frac{1}{2} \div 3$ times longer than wide, beautifully and variously marked with red, yellow and green. L.B.C. 9:870. B.M. 3051 .

Var. Moluccànum, Müller. Fig. 510. Lvs. long- or short-petioled, widely or narrowly spatulate, acute at base, and short-acuminate.

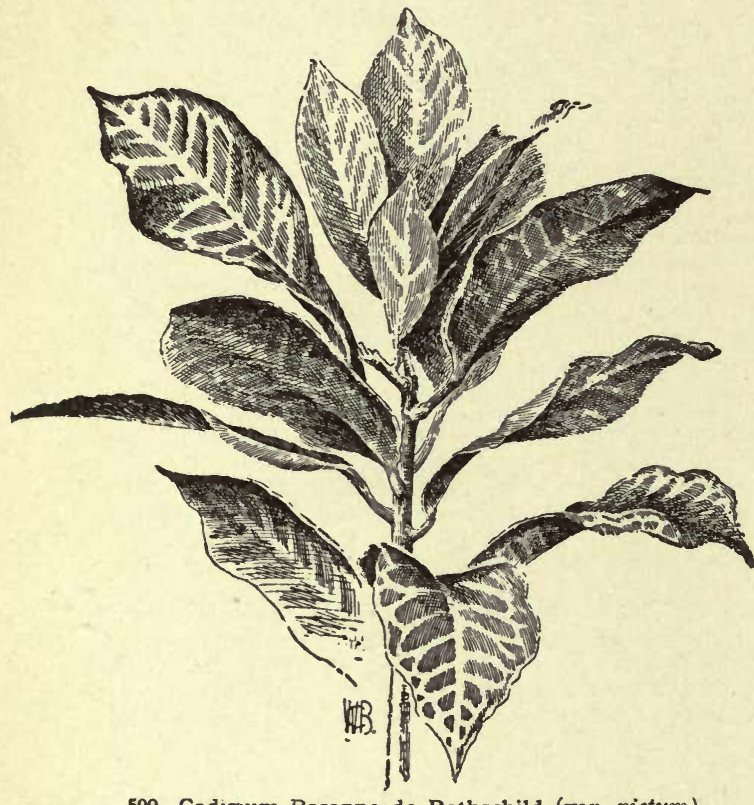

509. Codiæum Baronne de Rothschild (var. pictum).

Var. genuinum, Müller (Cròton variegàtus, Linn.). Figs. 511, 512. Lvs. broad- or narrow-lanceolate, equally narrowed at both ends, acutish or obtuse, never cordate at base.

The Codiæums of gardens are prized chiefly for the varied and brilliant markings of the lvs. The colors are in shades of red, yellow, orange and purple, and the markings often run into white. The plants have been modified almost endlessly by domestication. Some of the modification is the result of crossing. The Codiæums are prized both as indoor foliage plants and as subjects for massing in the open. In the open air they develop most brilliant colors in our bright, hot summers. The plants will not stand frost. Specimens which are becoming too large for the greenhouse may be placed in the center of the bed for summer and thrown away after frost. With Crotons it is especially desirable to have the ball of roots well developed. The smallest sized plants, which naturally form the outer ring in the summer bed, may be plunged in their pots into the soil, and are easily removed in the fall to the greenhouse. Such plants, when taken up in the fall and brought indoors, should be cut back at the time of potting. They do not make the best subjects for winter decoration, although good results may be got from them by the exercise of care.

L. H. B.

Codiæums (or Crotons, as they are popularly known in America) are beautiful plants, with many forms of handsome and odd foliage of the most brilliant coloring. The colors range from almost pure white to light and deep yellow, orange, pink, red and crimson, in the most charming combinations. In some cases one color predominates, as in Carrierei (yellow), Czar Alexander III. (crimson), Hawkerii (light yellow). These varieties of distinct coloring make beautiful specimen plants for jardinieres; and their beauty is enhanced when used in jardinieres of appropriate color. As exhibition plants they are very effective, and may be grown to specimens 5 or 6 feet high, or even larger. In smaller sizes, Codiæums are much used as table plants, for which purpose well colored tops are rooted and grown on until they are from 12 to 15 inches high. The narrow-leaved varieties are most used for this purpose. Codiæums are also very attractive in vases and window boxes and for mantel and table decorations. They are also very valuable as bedding plants. Planted in clumps or masses, the effect of the combination of rich colors is charming. They should be planted in only good, rich, not too heavy soil, and regularly syringed to keep down red spider. They color best when fully exposed to the sun, and should not be planted out until about the 10th of June in the neighborhood of New York and Philadelphia. If something is needed to make the beds look attractive early in the season, it is a good plan to plant pansies in April, to remain until it is time to plant the Codiæums. Some of the tender varieties, such as Reedii, Albicans, and a few others, are inclined to burn in the extremely hot weather, but nearly all the sorts do well bedded out. Among the very best for this purpose are Queen Victoria, Dayspring, Baron Rothschild, Andreanum, Lady Zetland, Carrièrei, Barryi, Hawkerii, Fasciatum, Anietumense.

The house culture of Codiæums is very simple. It is necessary that a night temperature be maintained of $70^{\circ}$ to $75^{\circ}$, and that the air be kept moist by frequent syringings. Cuttings of half-xipened wood may be easily rooted at any time from October until June, a bottom heat of $80^{\circ}$ being just what they need. When very fine specimens are desired, root strong and shapely tops by making an incision in the stem and tying moss around the wounded part; it will be rooted ready to pot in about three weeks. By this method all the foliage may be retained, and a perfect plant be the result. The more light the plant gets, the better will be the color; but with some kinds of glass it is necessary to shade lightly to prevent burning of the leaves. They may be grown finely in a house glazed with ground glass, which admits the light and does not require shading. It is well to syringe two or three times a week with tobacco water, to kill mealy bug and red spider. Little's Antipest, or any emulsion of coal-oil, is a good insecticide for Codiæums. New varieties from seed (the result of crossing existing sorts) are continually being raised. Seed ripens freely under glass in North America, and there is no doubt that the list of about eighty choice varieties now in cultivation will be largely extended in the near future.

The following horticultural varieties are in the American trade :

Aigberth Gem.

Albo-lineatum. 
Albicans. Lvs. broad-lanceolate, 18 in. or less long, shining green, variegated ivory-white, tinted crimson beneath: dense grower.

Andreanum. Lvs, broad-oblong, deep green, with yellow and crimson vein-markings. R.H. 1876, p. 234. I.H.22.201.

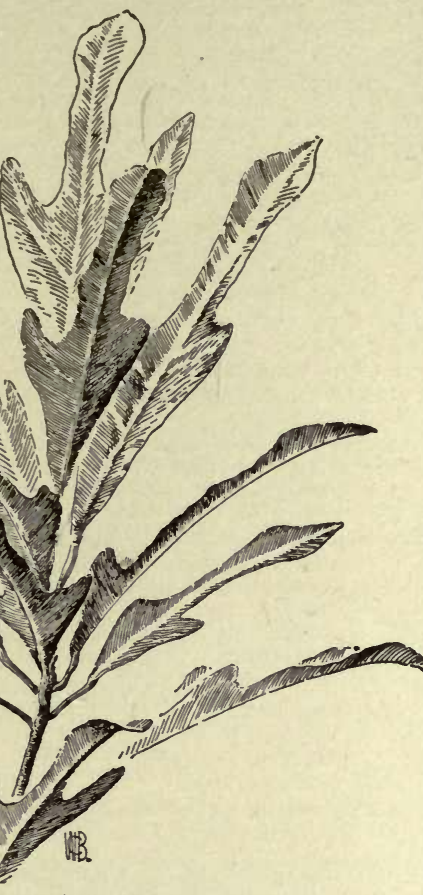

510. Codiæum Disraeli (var. Moluccanum).

Angustissimum (angustifolium). Lvs. 1-11/2 ft. long, linear, drooping, yellow-margined and-ribbed.

Anietumense.

Aucubofolium. Lvs. short and broad, green, blotehed with yellow and crimson.

A ureo-maculatum. Lvs. long and narrow, yellow-spotted.

A ureum. Lvs. beautifully and symmetrically marked with rich yellow.

Baron Adolph Seillière. Strong and robust growth. Large, brilliant green lvs., with pale yellow nerves, which soon become ivory-white, the contrast of color producing a striking effect.

Baronne de Rothschild (Fig. 509). Lvs. broad, olive-green and yellow, changing to crimson.

Barryi.

Beauty. Lvs. lanceolate, profusely and strikingly variegated with golden yellow on a rich green ground; as they attain age the green ground color gradually becomes a deep bronze, while the yellow variegation develops into a rich, rosy crimson.

Bergmani. Lvs. short, broad-oblong, cream-yellow, with green blotches. I.H. 27: 389 .

Brilliantissimum.

Burtonii. Lvs. lanceolate, 16 in. or less, shining green, marbled with golden yellow.

Carrièrei.

Challenger (Imperator). Long lvs.; midribs at first ereamy white, suffused with red, deepening to bright carmine. One of the best.

Chelsonii. Lvs, narrow and drooping, more or less twisted, salmon-tinted and blotched.

Chrysophyllum. Lvs. small, yellow-tinted.

Compte de Germiny.

Cooperii. Lvs. yellow-veined and-blotehed, changing to red.

Cornutum. Lvs. oblong and obtuse, lobed, rounded at the base, wavy-margined, dark, shining green and mottled with yellow, the midrib projecting at the tip.

Cronstadtii. Lvs. lanceolate, twisted and crisped, tapering to a sharp point, glossy green, variegated with light golden yellow.

Crown Prince. Lvs, lanceolate and acuminate, 18 in. or less

long, shining green, with golden veins.

Czar Alexander $I I I$.
Dayspring. Orange-yellow, edged green and tinged red.

Delight. Lvs, oblong acute, bright yellow, margined with green, the veins cream-color, the bright central variegation changing to clear ivory-white, with here and there a few dots of the same color scattered through the margin of the leaf.

Disraeli (Fig. 510). Lvs, rather narrow, variously lobed, dark green, with yellow veins, changing to crimson.

Dodgsonce. Lvs. lance-linear, $1 \mathrm{ft}$. or less long, sometimes twisted, green, with golden rib and margins.

Earlscourt.

Elegans. Lvs. linear-lanceolate, but short (about 6 in.), green above, with yellow or crimson rib and margins, dull green and nottled purple beneath.

Elegantissimum. Lvs.narrow, of considerable length; variegaion of a rich, bright golden color, which contrasts strongly with the bright red tint of the petioles, producing a very pretty effect.

Evansianum. Lvs. 3-lobed, veined with yellow and mottled with yellow, bronze and orange.

Excelsior.

Fasciatum. Deep green, with yellow veins.

Flambeau.

Flamingo.

Gloriosum (Prince of Wales). Lvs. long, narrow and drooping, variously spotted with creamy yellow.

Golden Ring.

Goldiei. Lvs. spatulate, 3-lobed, 12 in. or less long, olive-green, with golden veins.

Grande. Dark green, with yellow spots.

Hanburyanum. Lvs. oblong, 18 in. or less, olive-green, with golden and rose markings.

Harwoodianum (Triumphans Harwoodianum). Lvs. oblong, ribbed with gold and crimson.

Hawkerii. Lvs. broad-lanceolate, $1 / 2 \mathrm{ft}$. long, light yellow, with reen margins.

Henryanum. Lvs. ovate-oblong and pointed, 10 in., mottled or overspread with golden yellow.

Hilleanum. Lrs. broad-oblong or spatulate, 9 in. or less, wavymargined, purplish green, marked with crimson.

Hookerianum. Lvs. lance-ovate, dark, shining green, with . golden blotches.

Ilustris. Lvs. with 3 narrow-oblong lobes, golden barred and variegated.

Imperator. See Challenger.

Interruptum (Fig. 511). Lvs, very narrow, with notched places, twisted, with crimson rib.

Irregulare. Lvs. oblong and tapering at base, contracted below the middle, acute at apex, shining green, with yellow spots and ribs.

Jamesii. Lvs. ovate, 10 in, or less, dark green, irregularly blotched with whitish and yellow.

Johannis. Lvs. linear-lanceolate, tapering at each end, channelled above, ribbed and margined yellow. A.F. 13:1070.

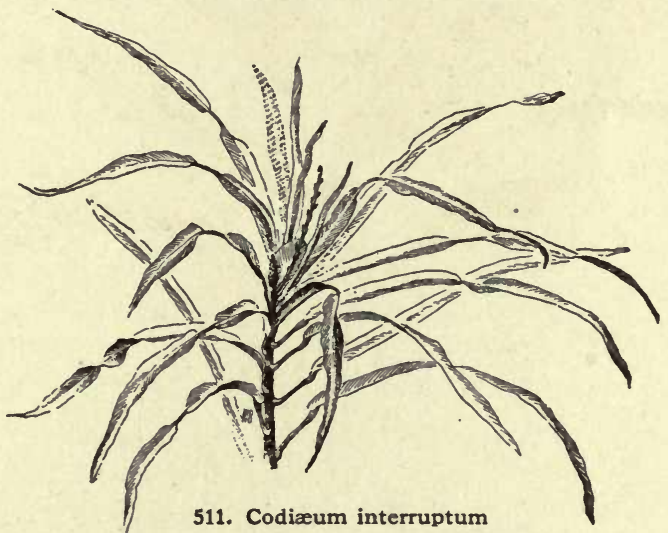

(var. genuinum).

Katoni. Lvs. lanceolate, bright green, with circular yellow spots.

Lady Zetland. Graceful habit.

Lord Derby.

Macfarlanei. Lvs. linear-lanceolate, drooping, $1 \mathrm{ft}$. long, green and yellow blotehed, but becoming bright erimson.

Magnolifolium. 
Majesticum. Lvs. narrow and long, mottled green and yellow, and shaded with crimson.

Marquis de Castellane.

Mortfortiense.

Mortii.

Mrs. Chas. Heine.

Mrs. Dorman. Lvs. linear-lanceolate, $1 \mathrm{ft}$, with scarlet rib and green margins.

Mrs. H. F. Watson. Large-lvd.: green, but as they mature the green deepens and changes to a bright, bronzy crimson, striped, spotted and blotehed with rich golden yellow and edged with salmon, the midribs and veins bright red.

Mrs. Swan. Lvs. broad-lanceolate and acuminate, golden yellow in the center and on the margins and petiole.

Multicolor. Lvs. like Irregulare, but blotched and veined with yellow, changing to orange and erimson.

Musaicum. Lvs. oblong-lanceolate, wavy, acuminate, green, crimson and cream-color. R.H. 1882: 240 .

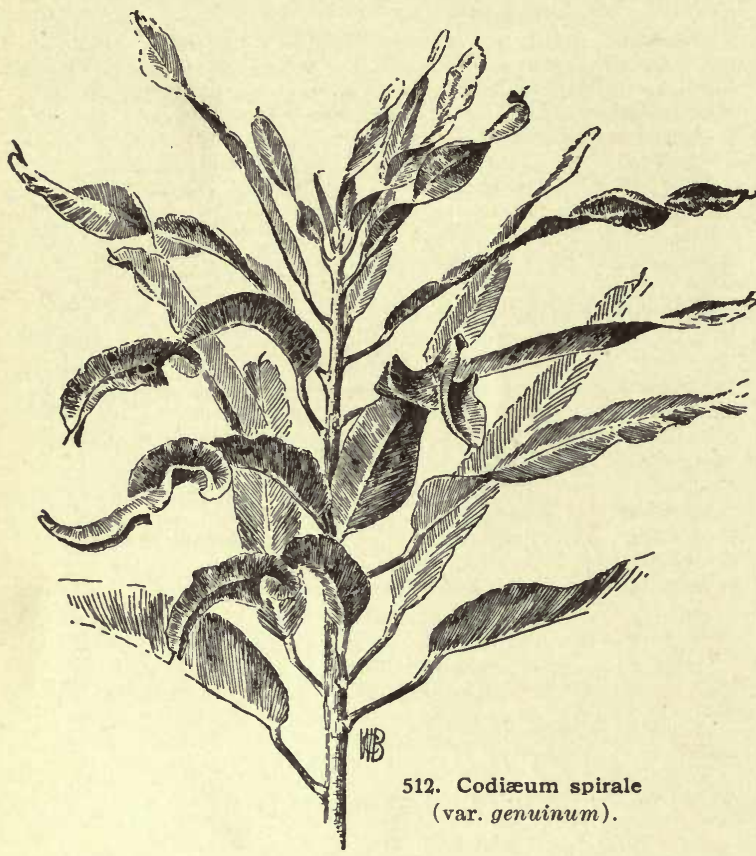

Nestor. Lvs. large, lanceolate, with a broad crimson midrib, spotted margin, and bright yellow central variegation.

Nevillioe. Lvs. oblong-lanceolate, barred and marked yellow, changing to orange and metallic erimson.

Nobile.

Orvilla.

Ovalifolium.

Pictum. Lvs. broad-oblong and acuminate, less than 10 in. long, crimson, with irregular blotches of green and blackish. old but good. B.M. 3051 .

Picturatum. Lvs. similar to Interruptum, highly colored.

Pilgrimii. Lvs. ovate and pointed, 10 in., green, overspread with pink, golden-blotched.

Prince of Wales. See Gloriosum.

Princeps. Lvs. broad-linear, with yellow rib and margins, the green becoming bronze and the yellow becoming crimson.

Princess Matilda.

Punctatum.

Queen Victoria. Lvs. oblong-lanceolate, 12 in. or less, golden yellow blotched and magenta ribs.

Recurvifolium. Lvs. broad and heavy, recurved, veined with crimson and yellow, and handsomely blotched.

Reedii.

Roseo-pictum.

Ruberrimum. Lvs, crimson, narrow, drooping, marked' with creamy white.

Rubro-lineatum

Rubro-striatum.
Senitzianum.

\section{Sollerii.}

Spirale (Fig. 512). Lvs. long, narrow-oblong, twisted, striped and marked with yellow, changing to crimson.

Stewartii. Lvs. obovate, blunt at base, olive green, with reddish rib and petiole and orange bands and margin.

Sunbeam. Dark, bronzy lvs., from 9 to $10 \mathrm{in}$. long and about $2 \mathrm{in}$. wide, in the young state freely blotched with yellow, gradually changing into rosy crimson, which in turn, as the leaf arrives at maturity, becomes of a rich blood-red.

\section{Sunshine.}

Superbissimum.

Thompsonii.

Tricolor. Lvs. oblong-spatulate, very acute, gradually tapering from the upper third to the base ; margin sinuous; upper surface dark, shining green, central part and midrib golden yellow, lower surface dull, reddish green.

Triumphans. Lvs. oblong, deep green and crimson, changing to greenish bronze and rosy crimson.

Undulatum. Lvs. broad and long, undulated or crimped, with laret, erimson and purplish veins.

Victory. Lvs, of deep orange-yellow, blotched with crimson, changing with age to deep olive-green, with crimson veins and costa, and a blotehing of red.

Veitchii. Lvs. lance-oblong, rounded at base, bright green, mottled yellow and crimson. R.H. 1867, p. 190

Volutum. Lvs. broad, rolled at tip, golden veined.

Warrenii. Lvs, linear-lanceolate, 2-3 ft. long, twisted, drooping, overspread and mottled with orange and erimson, changing to crimson.

Weismanii. Lvs. lance-linear, 12 in. or less long, very acute at ip, more or less undulate-margined, shining green and goldenblotched.

Williamsii. Lrs. ovate-oblong, $1 \frac{1}{2} \mathrm{ft}$. or less long and $4 \mathrm{in}$. or less broad, undulated, magenta, crimson and yellow.

Wilsonii. Lvs. linear-lanceolate, 1-2 ft., drooping, bright green, overspread with yellow.

Youngii. Lvs, long, nearly 1 in. wide, dark green, irregularly blotched with yellow and rose-red. RoBERT CRAIG.

CODLIN, or CODLING. Used in England to mean a mall, green, half-wild, inferior apple. It is used in distinction from grafted or dessert fr. It is about equivalent to our use of the word "crab."

COELIA (Greek, koilos, hollow : referring to the polen masses). Orchidacece, tribe Vándea. Six species of central and South American epiphytic orchids, divided into 2 strongly marked groups with widely different kinds of inflorescence. $\quad$ '. macrostachya is a type of the first section, with long racemes of numerous small, horizontal fls., which are much exceeded by the long spreading bracts, and the base of the column short. $C$. bella is typical of the second section, with the fls. few, larger, erect, in groups of about 3 , longer than their bracts, and the base of the column produced to twice its own length, which gives the fls. a tubular appearance. Cœlias are of minor importance. They grow best in pots of peat and sphagnum, with a little charcoal.

A. Fls. rosy red, numerous, small, in a long raceme.

macrostàchya, Lindl. Pseudobulbs $2 \frac{1}{2}$ in. long, almost round, with brown scales at the base: lvs. about 3 , from the top of the pseudobulb, $1 \mathrm{ft}$. or more long, lanceolate, arching, broader than in $C$. bell $a$, and not channeled: sepals red; petals white. Mexico. R.H. 1878:210. B.M. 4712 shows a dense raceme 8 in. long, with more than $75 \mathrm{fls}$.

AA. Fls. white, tipped purple, few, large.

bélla, Keichb. f. Pseudohulbs smaller and more constricted at the top : lvs. 6-10 in. long, narrower, channeled above, arching: fls. 2 in. long, erect, 3 or 4 in number, with the midlobe of the lip orange-colored. Guatemala. B.M. 6628.

CELOGGNE (hollow pistil). Orchiddcea, tribe Epidéndrea. A genus of useful plants, all pseudobulbous, found in tropical Asia growing on trees and on rocks. Sepals and petals membranaceous, labellum large, cucullate with 2, 3 or more longitudinal ridges; column erect, winged, membranaceously margined at and toward the apex; pollinia 4. The botanical details of Coelogyne speciosa are shown in Fig. 513. At the top is a general 
view of the flower. Below, on the left, is the column, frout and side view. In the center is the lip, with the column lying along its top. Below the lip, on the left, is the stigma. To the right, on the bottom row, are the pollinia, front and back view; and at the right center are separate pollen masses.

Coelogynes may be grown in pots, pans or baskets, but it is hardly advisable to undertake growing them on

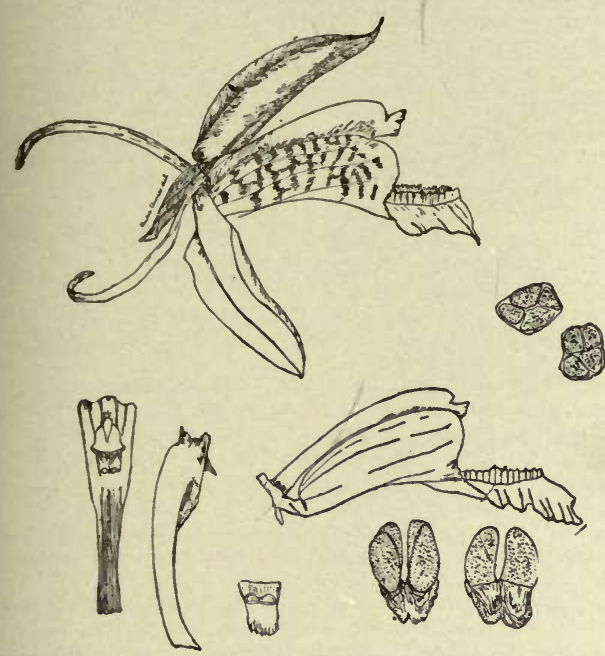

513. Details of Cclogyne speciosa.

blocks, as they are a thirsty class of plants when growing, and, in fact, when at rest should not be allowed to become very dry. Cœlogynes, as a rule, do not care to be disturbed; therefore, it is a good plan not to repot until the plants have outgrown the pots or baskets, or the old compost has become exhausted. They should be potted then in a compost consisting of equal parts.fresh sphagnum moss and fibrous peat, to which may be added a little broken charcoal. The pots or baskets to be used should have a good supply of crocks, so that the water may pass away freely, otherwise the compost would soon become sour. A good time to repot or top-dress is just after the flowering season. When repotted, the plants should be kept in a rather moist, shady place until the new roots commence to take hold of the fresh compost. They may then be put in their growing quarters and given a good supply of water all through the growing season; but after the growth is completed they will require only enough water to keep the bulbs in a plump condition. Manure water applied once a week when growing will be found beneficial, but should be given in a weak form to begin with.

There are about 50 kinds of Cologynes, a number of which are well worth a place in the most select colleccions. One of the most beautiful species is $C$. cristata, with its varieties hololeuca, Chatsworthii, Lemoniana and maxima. To insure a good crop of fls., the above should all have a good supply of light and air when crowing, only a very light shading being necessary. They also may be syringed overhead once or twice a day in bright weather to keep down red spider and other insect pests. In the winter they may be rested in any cool greenhouse in which the temperature does not fall below $40^{\circ} C$. corrugata, $C$. flaccida, $C$. ocellata and $C$. Massangeana will all do nicely in an intermediate house, while $C$. Dayana and C. Sanderiana should be grown in a warmhouse where the night temperature in winter is not below $60^{\circ}$. Coelogynes may be propagated by dividing the plants, always being careful to get one or more leading growths with each piece.

Cult. by Albert J. Newell.

\section{A. Racemes pendulous or drooping.}

B. Fls, green or yellow.

panduràta, Lindl. Fls. large: sepals and petals green. labellum flddle-shaped, with black veins and stains on a yellowish green ground; central disk 3-ribbed; pseudobulbs oval oblong, 4 in. long; lvs. rather oblong, 15 or more in. in length: racemes many-fld. Borneo. B.M. 5084. F.S. $20: 2139$. J.H. III. $30: 377$. A.F. $6: 633$.

Dayàna, Reichb. f. Pseudobulbs pyriform, cylindric, about 6 in. long: lvs, oblong-lanceolate: fls. numerous; sepals and petals pale yellow, margins reflexed; petals much narrower than sepals; labellum with 6 erect ridges fringed with brown: racemes $2 \mathrm{ft}$. or more long. Borneo. G.C. III. 15:695.

Massangeàna, Reichb. f. Pseudobulbs pyriform, about $3 \frac{1}{2}-4$ in. long, lvs. elliptical, large, tapering toward the base; the long racemes many-fld.; sepals and petals equal, pale yellow, lateral lobes of labellum brownish within, lined or streaked with yellow; mid-lobe with a verrucose brown and yellow disk : raceme sometimes 2 ft. long. Assam. B.M. 6979.

\section{BB, Fls. white or cream-colored.}

cristata, Lindl. A free-flowering species, with large white flowers: sepals and petals lanceolate-ob. long, undulate; lateral lobes of labellum slightly incurved; mid-lobe provided at the center with 5 bright yellow fringes and 3 ridges. Nepal. J.H. III. $31: 349$. P. G. $1: 55$. A. G. $14: 331 ; 15: 513$. A.F. $4: 497 ; 6: 87$; 9:1111; 13:1133. F.E.9:331. Gng. 2:393 ; 4:225. - Var. hololeuca, Hort. (var. alba), has white fls., labellum without yellow. Var. Lemoniana, Hort., has citron-yellow fringes. Var. Chátsworthi, Hort., has large pseudobulbs and large fls. of good substance. Var. máxima, Hort., has very large fls. Cologyne cristata is one of the best and most popular of orchids. It is one of the easiest to grow. Can be grown with Cattleyas.

fláccida, Lindl. Pseudobulbs ovate, anguiate, 2-3 in. long lvs. lanceolate, about 8 in. long: raceme $7-10$ fld., often more: fls. $1 \frac{1}{2}$ in. across: sepals and petals whitish: labellum with 3 ridges, bright yellow blotch on the disk. Nepal. B.M. 3318.

Gardneriàna, Lindl. Pseudobulbs long and tapering, flask-shaped : lvs. 2, thin, 18 in. or less long : raceme many-fld.: fls. large, long-petaled, pure white except the lemon-yellow lip, not opening wide. Ind. P.M. 6:73.

asperàta, Lindl. (C. Lówii, Paxt.). Large species (18-24 in. high): pseudobulbs large and oblong, each bearing a pair of broad, dull green lvs.: raceme $1 \mathrm{ft}$. long, many-fld.: fls. 3 in. across, cream-colored, but the lip with an orange crest and radiating brown and yellow streaks. Borneo. P.M. 16:227.

Sanderiàna, Reichb. f. Pseudobulbs ovate and wrinkled or costate, 2 in. long, each bearing a pair of lvs, a foot long: fls. about 6 in a raceme, 3 in. across, snow-white; sepals narrow and pointed, keeled; petals broader; lip 3-lobed, the side lobes striped with brown and the middle lobe blotched with yellow. E. Ind.Distinct and handsome. C. Sánderæ, Kränzlin (G.C. III. $13: 361$. J.H. III. $35: 451$ ) is probably the same. It is described as having the "disk of the lip deep orange in front, much paler behind, and with three parallel keels, covered with long dark hairs" (G.C. III. 13, p. 392).

\section{AA. Racemes erect.}

barbatta, Griffith. Pseudobulbs about 2 in. long, ovate: lvs. broadly lanceolate, about $1 \mathrm{ft}$. long: fls. large, petals linear, whitish; sepals ovate-oblong, white; mid-lobe of labellum brownish inside, curiously fringed with brown; crests 3. Khasia hills.

ocellata, Lindl. Pseudobulbs pyriform or nearly so: lvs. about $1 \mathrm{ft}$. long, narrowly lanceolate; racemes 6 in. long: fls. large, white, with two bright orange-yellow spots on each of the lateral lobes of the labellum, and two smaller spots at the base of the midlobe; also brown lateral streaks; column bordered with yellow. E. Ind. Found at an elevation of 7,000 feet. B.M. 3767 .

speciosa, Lindl. Pseudobulbs ovoid, distinctly angled, 2 or 3 in. long, monophyllous ; racemes short: fls. 1, 2 or 3 , on short peduncles, which emerge from imbricated scales directly below the fls.; sepals oblong-ovate, translucent, dull salmon-pink; petals linear reflexed; lateral lobes of labellum erect, slightly incurved, reticulated, with dull copper-brown on a blush-salmon ground, midlobe roundish, partly broad-margined with white; 
disk with two fringed ridges and umber-brown markings. Inner surface of column brownish. Java. B.M. 4889. Gn. 49, p. 62.

corrugàta, Wight. Pseudobulbs ovate-pointed, in tufts, with lvs. 3 in. long: racemes 3-6-fld.: fls. white ; sepals and petals nearly equal, oblong and acute; lip 3lobed, the lateral lobes smaller and blunter than the central one. E. Ind. B.M. 5601.

Páríshii, Hook. f. Like $C$. pandurata, but racemes not drooping, the pseudobulb 4-angled and narrow, bearing a pair of stout broad lvs., the fls. about 6 , and smaller. A small species. Burma. B.M. 5323.

Fórstermanni, Reichb. f. Pseudobulbs cylindrical or fusiform, producing 1- or 2-sheathed peduncles from the side: fls. large, snow-white; sepals and petals lanceolate, the former keeled outside; lip 3-lobed, the middle lobe rounded and minute-pointed, the side lobes rounded, the disk marked with yellowish brown : lvs 3-4 in. wide and 18 in. long, very short-stalked. E. Ind.

\section{OAKES AMES.}

COFFEA (from the Arabian name for the drink, itself conjecturally derived from Caffa, a district in southern Abyssinia). Rubidcea. A genus of about 20 Old World species, mostly natives of tropical Africa. Shrubs or small trees, usually glabrous, with slender branches : lvs. elliptical, pointed, glossy, coriaceous, mostly opposite, rarely in whorls of 3 : fls. creamy white, tuberoselike, delicately fragrant, subsessile, clustered in the axils of the lvs. The genus is technically distinguished by the short calyx limb : corolla throat villous or glabrous: style branches 2 , linear. The fr. is a berry containing 2 horny seeds, which afford the Coffee of com. merce. For Coffee production, two species, $C$. Arabica and $C$. Liberica, are now extensively cultivated throughout the tropies, and are occasionally to be found in con. serratories; also in gardens in Florida and California.

The Coffee of commerce consists of the seeds of these two species of Coffea, $C$. Arabica and $C$. Liberica, the cultivation of which is one of the most important agricultural industries of the tropics, the annual production reaching $1,500,000,000$ pounds, valued at $\$ 150,000,000$. Of this amount, Brazil turnishes over 70 per cent. A new Coffee from the Congo is receiving much attention in Europe, $-C$. Maragogipe. It is very vigorous growing.

W. M.

Climate and soil.-Although $C$. Arabica will endure a low temperature, and has, with slight protection, survived the winter in Germany, successful commercial culture requires a rainfall of from $100-150$ in. and an equable temperature, having an average minimum of not less than $60^{\circ}$. The Liberian species is at home under thoroughly tropical conditions, and endures exposure to the sun at low elevations, where for $C$. A rabica shade trees are commonly supplied. Coffee thrives in a great variety of soils, but those containing a large amount of humus are preferable and volcanic deposits are also excellent. The use of fertilizers is increasing, but the requirements of particular localities must be carefully considered.

Cultivation.-The seed germinates in from 4 to 6 weeks after ripening, and will endure only partial drying. Seedlings are raised in shaded seed-beds or flowerpots, whence they are transplanted at the beginning of the rainy season, preferably when 2 years old, to their permanent places. The distance between trees is determined by the soil and climatic conditions, varying from $6 \mathrm{ft}$. for $C$. A rabica, under circumstances unfavorable to the growth of wood, to $15 \mathrm{ft}$. or more for $C$. Liberica in fertile ground. For the reception of the seedlings, large holes are dug in order to insure loose soil and avoid injuring or bending the long tap-root. Subsequent culture consists largely in the frequent removal of all weeds, by means of hoes or other implements. which also stir the surface soil. Trees are headed or pruned to a height of from 3-6 ft. in order to keep the berries within easy reach, and after each harvest the old twigs are removed, also the epiphytes and parasites. Spraying with fungicides and insecticides is also practiced when necessary.

Harvest. - Production begins, under favorable circum. stances, the second or third year from transplanting, but a paying crop can scarcely be expected before the fifth or sixth year. The berries ripen unevenly, requiring two or more visits to each tree. The yield is estimated in general at 1 pound of dry Coffee per tree, but careful methods increase this to 3 or 4 pounds, while in exceptional cases from 6 to 12 and even 25 pounds have been reported. The life of the Coffee tree has been stated at 20 or 30 years, but with good care production may be maintained for 50 years or more. The berries may be dried as picked and the seeds afterward extracted by machines called "hullers;" or, by means of a "pulper," the outer fleshy material is removed before drying. For the latter process, running water, eisterns, buildings and machinery are necessary. After being "pulped," the Coffee is fermented in order to further disintegrate the saccharine matter of the external coat; it is then dried in the sun or by artificial heat, after which the tough inner integument, the so-called "parchment," is removed by other machines and the "beans" are polished, graded and sent to the market.

In all of the recently acquired tropical territories of the United States, Coffee culture may become an important industry, the excellence of the Porto Rican product being already well known. From the agricultural standpoint, little has been attempted in the selection of superior seed or the application of scientific methods of propagation. Grafting has recently been accomplished in Java.

Books.-Coffee, Its Culture and Commerce, edited by C. G. Warnford Loch, 264 pages, 1888, contains a compilation of nearly all the literature then existing, but the article in German in Semler's Tropische Agrikultur contains more recent and original matter. A French work, Culture du Caféier, by C. Raoul, Paris, 1897 , is the latest important contribution to the subject.

O. F. Соок.

A. Corolla 5-parted, sometimes 4-parted.

B. Segments of corolla narrow: lvs. oblong, 4-5 in.long, $1 \frac{1}{2}$ in. wide.

Arábica, linn. Common or Arabian Coffee. Fig. 514. Lvs. 3-6 in. long, rather thin, oblong, nearly three times as long as broad, more or less abruptly contracted near the apex to a point about $1 / 2$ in. long: fls. in axillary clusters of 3-5; segments of corolla four times as long as wide: fr. a 2-seeded, deep crimson berry, but the "berries" or beans of commerce are the seeds. The commercial varieties of Coffee are based largely on the size, shape, color and flavor of the seeds, and hence the fr. is very variable, but the typical fr. may be considered to be oval and half an inch long. Indigenous in Abyssinia, Mozambique and Angola; supposed to have been introduced in early Mohammedan times from Abyssinia to Arabia, whence it became

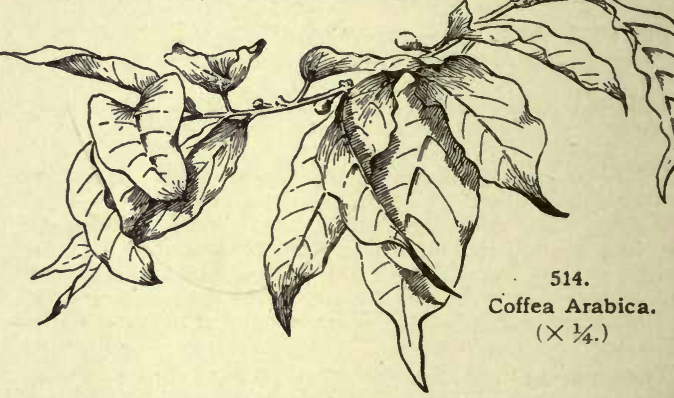

known to Europeans in the sixteenth century. This species furnished until recently the entire commercial product. B.M. 1303. Gng. 6:55. - As it grows wild in Afr. it is a sinall tree 10-15 ft. high, with the trunk 9-12 in. thick at the base, and with horizontal or even nodding branches, which in old age become one-sided. Often cult. under glass in the north for its economic interest, and in S. Calif. it is a good outdoor ornamental shrub, esteemed for its shining lvs., fragrant white fls., and red berries. 
BB. Segments of corvlla wide: lvs.ovate.

Beugalénsis, Roxb. Bengal Coffee. Lvs. ovate, barely twice as long as broad, acute, but not having a lons. abrupt point: fls. in 2's or 3's ; segments of corolla barely twice as long as wide. E. Ind., Malaya. B.M. 4917. - This has much showier fls, than $C$. A rabica. A small shrub with glabrous, dichotomuus branches. A native of the mountains of northeastern India, whence it was brought to Calcutta and much cult. there for a time. It is now neglected, the berries being of inferior quality and the plants not productive enough.

$$
\text { AA. Corolla 6-, 7-, or 8-parted. }
$$

B. Fls. in dense clusters or glomes: lvs. short-pointed, 6-12 in. long.

Libèrica, Hiern. Liberian Coffee. Lvs. longer than in $C$. Arabica, and wider above the middle, with a proportionately shorter and less abruptly contracted point: fls. 15 or more in a dense cluster; corolla segments usually 7. Trop. Afr. Trans. Linn. Soc. II. 1:171 (1876) G.C. II. $6: 105$. R.H. 1890 , pp. 104,105 . - Said to be more robust and productive than $C$. A rabica, with berries larger and of finer flavor. It is a more tropical plant than the common Coffee, and can be grown at much lower lerels. "It is a small tree, similar in general to $C$. A rabica, but of more vigorous and upright habit, and larger in all its parts. Lvs. 6-12 in. long: corolla 6-8 parted: berries dull erimson, larger, more numerous, and more nearly spherical than those of most forms of C. A rabica. In its native forests in W. Afr. it attains a height of $30 \mathrm{ft}$. or more, and flourishes near sea level. Owing to its greater size, rigor and productiveness, it is now being extensively planted in coffee-growing regions, particularly in the E. Ind., where it has been found resistant to a rust fungus, Hemileia vastatrix, which had destroyed the plantations of $C$. A rabica. In cultivation, both species are pruned low to facilitate the picking of the berries." $-O . F^{\prime}$. Cook.

BB. Fls. solitary or in 3's : lvs. long-pointed, $21 / 2-5$ in. long.

stenophýlla, G. Don. Lvs. 4-6 in. long, 1-11/2 in. broad, narrower than in C.Arabica, with a relatively longer and more tapering point : corolla segments usually 9. W. Afr. B.M. 7475 . - This is said to yield berries of even finer flavor than the Liberian Coffee, and quite as freely, but the bush is longer in coming into bearing. This is a promising rival to the $C$. Arabica of com merce. Seeds have been distributed by British botanical gardens, but are not known to be for sale at present in America.

W. M.

\section{COFFEE. See Coffea.}

COFFEE BERRY. A name of Glycine hispida, which should be abandoned in favor of Soy Bean.

COFFEE PEA. A western name for the Chick Pea, Cicer arietinum, which is used as a substitute for coffee.

CoHosh. See Actora. The Blue Cohosh is a Caulophyllum.

COIX (old Greek name). Gramínea. A genus somewhat closely related to Indian Corn, and similar to it in leaf structure. A hardy annual, $2-3 \mathrm{ft}$. high, with broad lvs, and a curious nodding inflorescence. The female fls. are inclosed in a nearly globular, capsule-like covering, which is very hard. This capsule (or involucre) is at first green, then a jet black, becoming nearly white with age. Southern Asia.

Lácryma-Jobi, Linn. Job's Tears. Tear-grass. CORN-BEadS. Fig. 515. So called from the resemblauce of the inflorescence to a tear-drop. In cult. as an ornament or as a curiosity. In India it is cultivated for food by some of the hill tribes of that country. Var. aurea zebrina, Hort., has yellow-striped lvs.

P. B. KenNedY.

COLA (native name). Sterculidcece. Cola. Also called Kola, Korra, Gorra. This genus of perhaps 14 species of tropical African trees is chiefiy interesting for the Cola nuts, which are said to sustain the natives in great feats of endurance. The tree grows on the east coast of Africa, but is very abundant on the west coast, and is now cultivated in the West Indies. Within the tropies the trade in this nut is said to be immense. It has lately become famous in the U. S. through many preparations for nedicinal purposes and summer drinks. The seeds are about the size and appearance of a horse chestnut, and have a bitter taste. Although repeatedly introduced to Kew, England, the plant never flowered there until 1868. Consult Stewart's Monograph on Kola.

Colas are tropical African trees, requiring a rich, welldrained soil. Those introduced into West Indies and other parts of America, especially $C$. acuminata, thrive best on a sandy loam. The trees are grown from seeds, which are large and fleshy, keeping well for some weeks after ripening. As the tree is difficult to transplant, the seeds may be planted singly in small pots, and the young

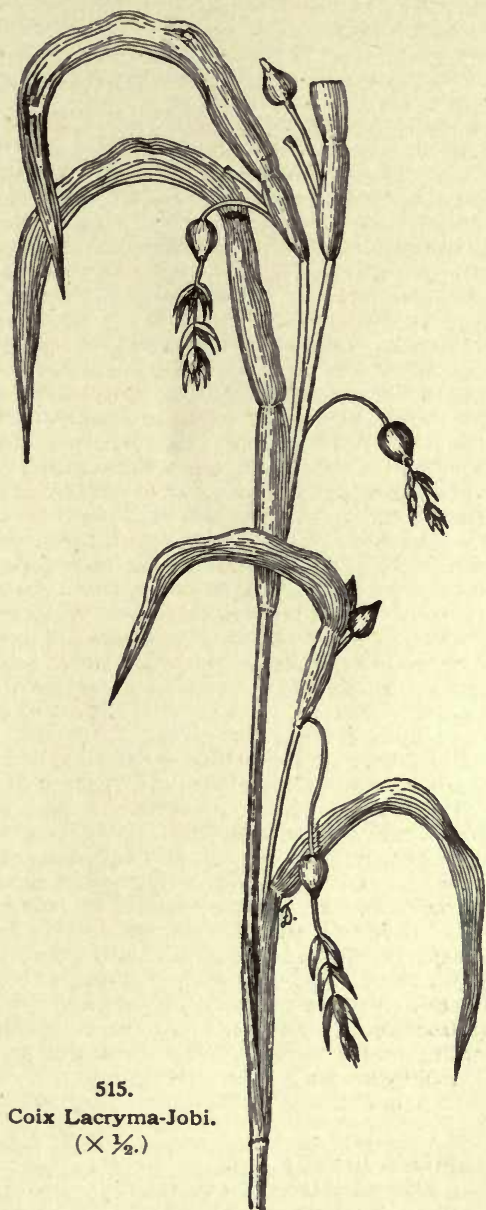

trees kept growing thus until wanted for permanent planting. Propagation may also be effected by cuttings of ripe wood, which should be placed in bottom heat, and treated in the usual way.

acuminata, Schott and Endl. About $40 \mathrm{ft}$. high in Africa, resembling an apple tree: Ivs. alternate; petiole $1 / 2-6$ in. long; blade 4-6 in. long, leathery, with prominent ribs below; older lvs. entire, obovate, acute; younger lvs. often once or twice cut near the base about half way to the midrib: fls. yellow, 15 or more in a cluster, about 1 in. across, with a slender green tube and a showy yellow, 6- or 5-cut limb, which is a part of the calyx, as the petals are absent in the tribe Sterculiæ. B.M. 5699 .

E. N. REASONER and W. M.

COLAX. Now referred to Lycaste. 
CÓLCHICUM (from Colchis, a country in Asia Minor). Liliacea. Meadow Saffron. Autumn Crocus. A tribe of fall-(rarely spring-) blooming bulbous plants. Perianth crocus-like but much larger, long and tubular, varying from rosy purple to white, with one yell.wflowered species: lvs. long and broad, appearing in early spring and dying down in June: stamens six styles three and very long; ovary a round, 3-celled pod : corm long, solid, with a brittle skin. "Colchicum root" and seed are employed in gout and rheumatism. They are narcotic poisons. Colchicums are natives of Europe and the Mediterranean region. They are most charming and interesting plants of easy culture. The bloom comes in August and September, at a season when the herbaceous beds begin to lose their freshness, and, although individual flowers are fugacious, others follow in quick succession, thus prolonging the time of flowering. Opening, as they do, without foliage, some help is required from the greenery of other plants; for this purpose any low-growing, not too dense kind, can be used, such as the dwarf Artemesias, Sedums, Phlox subulata, etc. Colchicums are most effective in masses, which can be established by thick planting, or as the result of many years' growth. They can be grown in rockwork, in beds, or in grass which is not too thick nor too often mown; they will thrive in partial shade, but succeed best in an open, sunny border. They should be planted in August or early September, in deep, well-enriched soil, a light, sandy loam, with the tip of the long bulbs 2 to 3 inches below the surface; some protection should be given in winter. They remain in good condition for many years, and should not be disturbed unless they show signs of deterioration, fewer flowers and poor foliage. Then they should be lifted and separated, just after the leaves die, end of June or early July. This is the usual method of propagation, but they can also be increased from seeds, sown just after ripening, June-July; the seedlings may not appear until the following spring. Seedlings bloom when 3 to 5 years old. The bulbs are obtainable from the Dutch growers at moderate prices, and they must be imported early; otherwise they are apt to bloom in the cases. C. autum nale, with rosy purple flowers, is a well-known and the most commonly cultivated species. There are numerous varieties, of which the best are the white, the double white and the double purple. Belonging to this same group and not differing much except in size and shading of the flower, are $C$. Byzantinum, $C$. montanum, and $C$. umbrosum. C. speciosum, a native of the Caucasus, is the finest in every way of the genus. The flowers are much larger and of better shape, and the color, a rosy pink, is much more delicate; the habit of growth is robust, and the plant is most easily handled.

$C$. Parkinsoni (a form of $C$. variegatum) is distinct from the above varieties inasmuch as the flowers are tessellated, purple and wbite, giving a curious checkerboard appearance which is unique; the leaves are much smaller and are wavy. C. Aggripinum, $C$. Bivonce, $C$. Cilicicum and $C$. Sibthorpi, are other species having checkered flowers more or less similar to Parkinsoni. C. Bulbocodium = Bulbocodium vernum. Monograph by J. G. Baker in Jour. Linn. Soc., vol. 17 (1880).

B. M. WATSON.

Alphabetical list of species described below: Aggripinum, 5 ; alpinum, 13 ; antumnale, 10 ; Bertolonii, 1 ; Bivonæ, 6; Byzantinum, 9; Cilicicum, 9; luteum, 3 ; montanum, 1; Parkinsoni, 4; Sibthorpi, 7; speciosum, 8 Stereni, 2; Troodi, 11; umbrosum, 12; variegatum, 4.

A. Blooming in spring: lvs, appearing with the fls.

B. Color rosy lilac: size of anthers small.

c. Anthers oblong, purple.

1. montànum, Linn. (C. Bertolònii, Stev.). An important and variable species, with many synonyms and variations. Baker makes 7 forms. Corm ovoid, $1-1 / 2$ in. thick, the tunics brown, membranaceous, the inner ones produced to a point $2-4$ in. above the neck: 1vs. $2-3$, rarely 4-6, linear or lanceolate, about $2-3$ in. long at the time of flowering, finally 6-9 in. long: fls. 1-4, in spring and autumn. Oct.-June. Mediterranean region, from Spain to Persia. B.M. 6443. - It appears in early spring with the snowdrops and crocuses.

\section{cc. Anthers linear, yellow.}

2. Stèveni, Kunth. Corm narrower than in No. 1 , about $1 / 2-3 / 4$ in. thick: lvs. at length $4-5$ in. long: fis. Oct.-Jan. Syria, Arabia, Persia.-Less popular than No. 1.

$$
\text { Bв. Color yellow: size of anthers large. }
$$

3. lùteum, Baker. 'This is the only yellow-flowerer' form in the genus, all the others ranging from purple to white. Although it belongs to the Mediterranean group, with lvs. and fls. produced at the same time and in spring, it is a native of western India at an elevation of 7,000-8,000 ft. Corm tunies dark brown, sometimes almost black: lvs. 3 or 4 , wider and less tapering than in No. 1, at the time of flowering $3-4$ in. long, finally $6-7$ in. long. B. M. 6153. - Not advertised in American trade, but very desirable.

AA. Blooming in autumn: lvs. appearing after the fls. B. Perianth tessellated or checkered

\section{c. Tessellation distinct.}

D. Lvs. spreading or prostrate.

4. variegatum, Linn. Lvs. 2-3, lanceolate, about 6 in. long, 12-15 lines wide, lying flat on the ground; margins wavy : fis. 2-3 from each spathe, 4 in. across, with a white tube. Islands of the Levant and Asia Minor. B. M. 1028.

C. Párkinsoni, Hook. f. (B. M. 6090), is the best of all the tessellated forms, the tessellation being more sharply defined and more delicate than the type. It is a smaller plant, and has shorter and more strongly undulated lvs., which lie closer to the ground. Of this plant Parkinson said in his Paradisus Terrestris, 1629: "This most beautiful saffron flower riseth up with his flowers in the Autumn, as the others before specified do, although not of so large a size, yet far more pleasant and delightful in the thick, deep blew or purple-colored beautiful spots therein, which make it excel all others whatsoever. The leaves rise up in the Spring, being smaller than the former, for the most part 3 in number, and of a paler or fresher green colour, lying close upon the ground, broad at the bottom, a little pointed at the end, and twining and folding themselves in and out at the edges as if they were indented. I have not seen any seel it hath borne. The root is like unto the others of this kinde, but small and long, and not so great; it flowreth later for the most part than any of the other, even not until November, and is very hard to be preserved with us, in that for the most part the root waxeth lesse and lesse every year, our cold country being so contrary unto his natural that it will scarce shew his flower; yet when it flowereth anything earlie, that it may have any comfort of a warm Sun, it is the glory of all these kindes."

\section{DD. Lvs, ascending.}

\section{E. Margin of lvs, wavy.}

5. Aggripinum, Baker (C.tessellatum, Hort.). Corms a trifle thicker than in No. 4: lvs. 3-4, 6-9 in. long, 12-15 lines wide, margin wavy: fls. 2-4 from each spathe. F.S. 11:1153. - This is a marked form of $C$. variegatum, of garden origin, which has similar fls., but a more robust habit and more nearly erect lvs.

\section{EE. Margin of lvs. flat, not wavy.}

6. Bivònæ, Guss. Lvs. 6-9, nearly 1 ft. long, 9-15 lines wide, rather hooded at the apex, margin flat, not wavy: fls. 1-6 from each spathe. Sicily.

\section{cc. Tessellation less distinct.}

7. Síbthorpi, Baker. Easily distinguished from Nos. 4,5 , and 6 by the much broader segments of the perianth, and by the lvs., which are nearly erect, obtuse, and not at all wavy: lvs. 5-6, dull green finally $1 \mathrm{ft}$. or more long, $1 \frac{1}{2}-2 \frac{1}{2}$ wide, narrowed gradually to the base: spathe striped with green, and tinged with lilac at the tip : fls. 1-5 from each spathe; perianth tube often 6 in. long. Mts. of Greece. B. M. 7181.-A large, cupshaped flower, showing no open spaces between the broad, overlapping segments. Very handsome. 
BB. Perianth not tessellated.

C. Size of fls. large, $s \mathrm{in}$. or more across.

D. Lvs, broad, s-4 in. wide.

E. No. of fls. 1-4.

8. speciosum, Steren. Corm 2 in. thick, the largest of the genus: stem $1 \mathrm{ft}$. high: 1vs. 4-5, 12-15 in. long, 3-4 in. wide, narrowed from the middle to the base, shining green: fls. 1-4 from each spathe, violet, with a white cye, but varying almost to pure pink, often 6 in. across. Caucasus. B. M. 6078. F.S. 23:2385. F. M. 1876:235. Gn. 11:80.-Generally considered the finest species of the genus.

$$
\text { EE. No. of } \mathrm{fls} \text {. 12-20. }
$$

9. Byzantinum, Ker-Gawl. Closely allied to the above, but with wider lvs., smaller and paler fls., and broad, short anthers : stem 6 in. high : lvs. 5-6, oblong, dark green, striate, 9-12 in. long, 3-4 in. wide: fls. smaller than in No. 8, usually 3-4 in. across, lilac-purple, and often 12-20 from each spathe. Transylrania and Constantinople. B. M. 1122. C. Cilícicum, Hort., has rosy fls., somewhat tessellated. G.C.III. 23:35.

DD. Lvs. narrow, 1-2 in. wide.

10. autumnàle, Linn. Fig. 516. Stem 3-4 in. high: Ivs. $3-4$, rarely $5-6,9-12$ in. long, $1 \frac{1}{2}-2$ in. wide: fls. $1-4$, rarely 5-6, from each spathe, purple, with a white va-

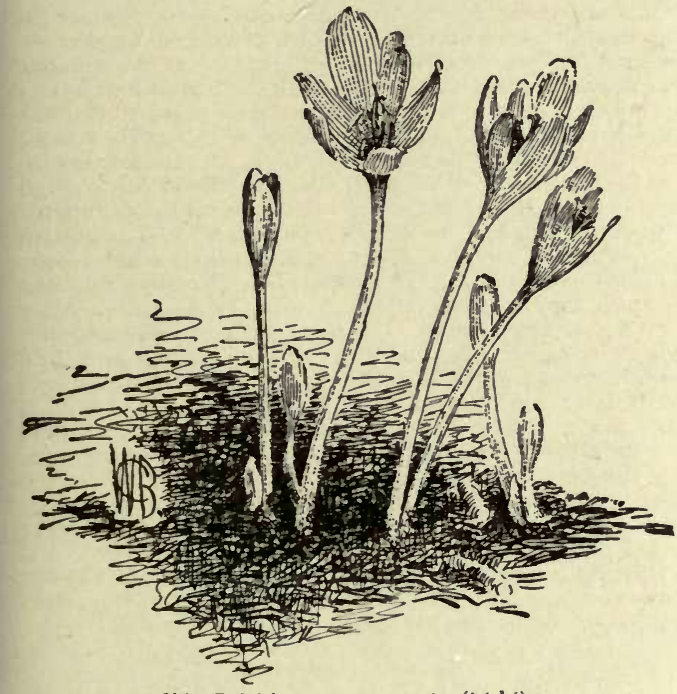

516. Colchicum autumnale $(\times 1 / 8)$.

riety, about $4 \mathrm{in}$. across: perianth veined. Europe and N. Africa. B.M. 2673, as C. crociflorum.-Possibly the commonest in the American trade. It has beautiful double forms in purple and pure white. F.S. 19: 1936.

cc. Size of fls. small, about 2 in. across.

D. No. of fls. from each spathe more than 1 or 2.

E. Perianth segments acute.

11. Troddi, Kotschy. Corm medium-sized: Ivs. 3-4, 6-12 in. long, 9-12 lines wide, dark green above: fls. 4-5 or even 12 , lilac-purple, about 2 in. across; perianth segments lanceolate-acute. Cyprus. B.M. 6901 shows a pure white variety.

\section{EE. Perianth segments obtuse.}

12. umbròsum, Steven. Corm small : lvs, 4-5, 6-9 in. long, 9-12 lines wide: fls. 1-5 from each spathe, lilac, about 2 in. across; perianth segments oblanceolate, obtuse, with 8-12 veins. Caucasus.

DD. No. of fls. from each spathe 1 or 2.

13. aipinum, DC. Lvs, rarely 3 , nearly erect or preading, 4-8 in. long, 3-6 lines wide, obtuse, chan- neled, shining green, narrowed from the middle to the base: fls. 1 or 2 from erch spathe, about 2 in. across, lilac; segments oblanceolate, obtuse, $3-4$ lines wide, with 10-15 veins. Mts. of France and Switzerland. W. M.

COLEUS (Greek for sheuth, referring to the monadelphous stamens). Labiatce. Nearly 50 species in Trop. Afr. and Asia, some of whlch are cult. for the very showy colored foliage. The cultivated kinds are herbs, but some of the wild species are shrubs. Lvs, opvosite, dentate or serrate: stem 4-angled : fls. in a terminal spike-like raceme, small and usually bluish, the 5 -toothed calyx deflexed in fr.; corolla bilabiate, the lower lobes longer and concave, and inclosing the essential organs.

Coleuses are of most easy culture. They root readily from short cuttings, cut either to a joint or in the middle of an internode (Fig. 517). No plant is more easy to root than this. They may be rooted at any time of the year when new wood is to be obtained. Formerly Coleuses were much used for bedding, but the introduction of better plants for this purpose has lessened their popularity. They require a long season; they are apt to burn in the hot summers of the interior country; they have a weedy habit. However, they withstand shearing and are, therefore, useful for carpet-bedding. The leading variety for this purpose is still the old Golden Bedder, whose golden yellow foliage is used as filling for fancy designs. Coleus plants make excellent specimens for the window-garden and conservatory. Best results are obtained when new plants are started from cuttings each spring. The old plants become leggy, lose their lvs., and lack brightness of color. They are very subject to mealy-bug. They are also liable to root gall (the work of a nematode worm), as shown in Fig. 518. When plants are thus affected, take cuttings and burn the old plants, and either bake or freeze the soil in which they grew.

The garden varieties of $\mathrm{Co}-$ leus are legion. These are the issue of C. Blùmei, Benth., of Java (B.M. 4754. 1.H. $27: 377$; $35: 46 ; 39: 164$. F. S. $22: 2287-8$ ). This is a soft perennial herb growing 2-3 ft. high, little branched: lvs. ovate, narrowed or broad at base and long acuminate, sharply and nearly regularly toothed, variously colored with yellow, dull red and purplish. An extreme form of this is var. Verschafféltii. Lem. ( $C$. Verschaffeltii, Lem.), Fig. 519, which is more robust and branchy, the lvs. more brilliantly colored, acute but not acuminate, truncate or even cordate at base, and irregularly cut-dentate, with rounded teeth, giving the margin a crispy effect (I. H. 8: 293). In some forms, the ivs. are laciniate.

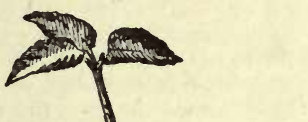
C. thyrsoideus, Hook., is a recent novelty, but is not yet in the
Amer. trade. Unlike the other well known species, its foliage is not brilliantly colored and its flowers are conspicuous. Tender 
shrub, 2-3 ft. high: stems pubescent: lvs. cordate, coarsely crenate, lower ones 7 in long. fls blue, in racemes which contain as many as 18 forking cymes with about $10 \mathrm{fls}$. in each. B.M.7672. L. H. B.

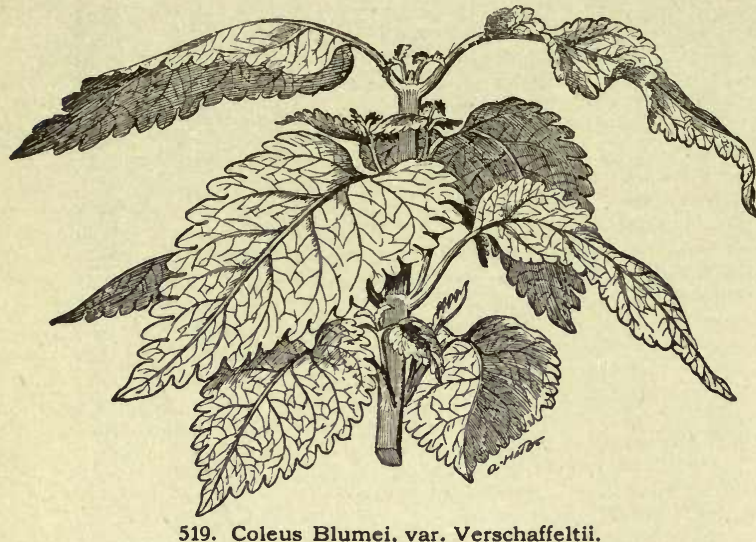

COLIC-ROOT. Aletris farinosa.

COLLARDS. A kind of kale. In the south, a form of the plant known as Georgia Collards is much grown for domestic use and the southern market. The plant grows to $2-3 \mathrm{ft}$. high and forms no head, but the central lvs. often form a kind of loose rosette. These tender lvs. are eaten as a pot-herb, as all other kales are. Fig. 295, page 199, shows a Georgia Collard, although the rosette is not well marked. The seeds may be started in a frame under glass, or in a seed-bed in the open. As far south as the orange-belt, they are usually started in February and March, in order that the plants may mature before the dry, hot weather. Farther north they are started in July or August, and the plants are ready for use before cold weather. Transplant to rows $31 / 2-4 \mathrm{ft}$. apart, and $3 \mathrm{ft}$. apart in the row. Till as for cabbage.

Young cabbage plants are sometimes eaten as "greens" under the name of Collards; and cabbage seeds are sown for this specific purpose. In the north, where heading cabbages can be raised, Collards of whatever kind are not greatly prized.

L. H. B.

COLLINSIA (after Zaccheus Collins, American philanthropist and promoter of science, Philadelphia, 17641831). Scrophularidcece. About 18 species of hardy annuals from California and western North America, not far removed botanically from Pentstemon and Chelone. They are free-flowering and of the easiest culture. They may be sown outdoors in the fall in well-drained soil, and will bloom earlier than if sown in spring. Their fls., borne in midsummer, range in color from white through lilac and rose to violet, with clear, bright blue also, at least on one lip of the $\mathrm{f}$. There is no yellow. All those described below have fls. in whorls. Lvs. opposite, rarely in whorls of 3, entire, or toothed, the lower lvs. rarely 3-cut.

A. Fl.-stalks very short, giving the clusters a dense appearance.

B. Corolla strongly declined: throat as wide as long.

bícolor, Benth. Fig. 520. Height $1 \mathrm{ft}$., hairy, glabrous, or sticky : stems weak and bending: lvs. more or less toothed, and oblong or lanceolate, sessile, opposite or in 3 's: fls. typically purple and white, with 5 or 6 well marked color varieties. Var. álba, Hort. (Fig. 521), has pure white fls., or the lower lip greenish or yellowish. Var. multícolor, Voss. (C.multícolor, Lindl. \& Paxt.), has variegated fls., the same fl. being white, lilac, rose or violet on either lip or both. Var. multícolor marmoràta, Hort., has the lower lip white, suffused lilac, and upper lip light lilac, spotted and striped carmine. Calif. B.M. 3488, P.M. $3: 195$ - This is the most widely distributed and variable species, and the one on which the genus was founded. California, mostly in moist ground.
BB. Corolla less strongly declined; throat much longer than broad.

bartsiæfolia, Benth. Height $1 \frac{1}{2} \mathrm{ft}$.: sticky and somewhat glandular, rarely hairy: lvs. from ovate-oblong to linear: fls. purplish or whitish : seeds not wrinkled. Calif.

AA. Fl.-stalks $1 / 2$ in. long or more, giving the clusters a looser look.

vérna, Nutt. Height about 6 in.: lvs. ovate or oblong, or the lowest rounded and slender-stalked, and the upper ovate-lanceolate and partly clasping: whorls about 6-fld.: fl.-stalks longer than the fis.: throat of the corolla as long as the calyx lobes; lower lip bright blue; upper lip white or purplish: seeds thick, not flattened, oblong, arched. Moist woods, western New York and Penna. to Wis. and Ky. B.M. 4927.

grandiflora, Dougl. Height 4-12 in.: lvs. thickish, the lowest roundish and stalked; whorls 3-9-fld.: fl.-stalks about as long as the fls.: lower lip deep blue or violet; upper lip white or purple: throat of the corolla sac-like, as broad as long, or as long as the upper lip : seeds roundish, smooth. Shady hills of Calif.

W. M.

COLLINSONIA (after Peter Collinson, the friend of Linnæus and John Bartram, a most interesting man). Labiata. Horse-BALM. Horse-WeEd. STONE-ROOT. A genus of 4 species confined to Atlantic N. Amer. Hardy perennial herbs with large, odorous, ovate, serrate, mostly long-stalked lvs., thick roots, and simple or panicled, naked, terminal racemes of vellow or whitish fls. The following is of the easiest culture and may be

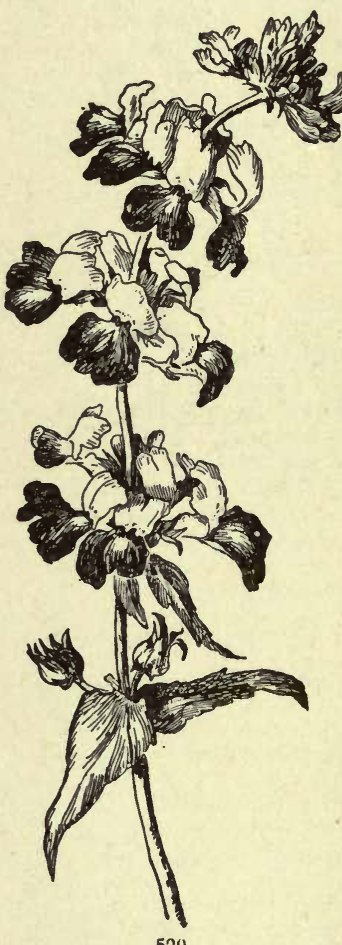

520.

Collinsia bicolor. obtained from dealers in native plants:

Canadénsis, Linn. Height 2-4 ft. lvs, 4-9 in. long, broadly ovate to oblong: racemes panicled : calyx in fl. 1 line, in fr. 4 or 5 lines long: corolla lemon - yellow, lemon - scented, $1 / 2$ in. long. Rich woods, Canuda to Wis., and south to Florida.

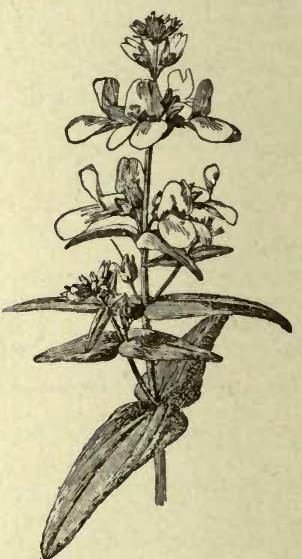

521. Collinsia bicolor,

var. alba $(\times 1 / 2)$

COLLOMIA. This genus is included by Gray in Gilia, which see. Collomia is derived from kolla, glue, from the large quantity of mucus in the outer covering of the seed. When these seeds are placed in water, the mucous matter dissolves and forms a cloud about them. This cloud, according to Lindley, "depends upon the presence of an infinite multitude of exceedingly delicate and minute spiral vessels lying coiled up, spire within spire, on the outside of the testa, and the instant water 
Is applied they dart forward at right angles with the testa, each carrying with it a sheath of mucus, in which it for a long time remains enveloped in a membranous case."

COLOCASIA (old Greek substantive name). A ròidece. Perennial herbs with cordate-peltate lvs., which are often handsomely colored in cultivation. Differs from Alocasia and Caladium in floral characters: spadix terminating in a club-shaped or subulate appendage destitute of stamens. Species 5. Tropics. Monogr. by Engler, DC. Phaner. Monogr. 2: 490.

Colocasia includes the plants known as Caladium esculentum, which are much grown for subtropical bedding. $C$. odorata (which is an Alocasia) has very large, thick stems, which may be wintered over safely without lvs., or at most with 1 or 2 , the stems, to save space, being placed close together in boxes. C. esculenta rests during the winter and is kept under a greenhouse bench or anywhere out of the reach of frost or damp. Rich, damp ground suits both kinds. Of easy culture. Consult Caladium for treatment.

Colocasias furnish the much-cultivated Taro of the Pacific tropics, this edible product being the large, starchy roots. From it is made the Poi of Hawaii. In Japan and other countries the tubers of Colocasias are much cultivated, and are handled and eaten much as we use potatoes (see Georgeson, A.G. 1892:81). The young lvs. of some kinds are boiled and eaten.

antiquorum, Schott. Lvs. peltate-ovate : basal lobes half as long as the apical one, connate $2 / 3-3 / 4$ their length, separated by a broad, triangular, obtusish sinus. India. B.M. 7364 .

Var, euchlora, Schott (C. euchldra, C. Koch). Petioles violet; blade black-green, with violet margins.

Var. Fóntanesii, Schott (Alocasia violdcea, Hort. Calddium violdceum, Hort. C, albo-violdceum, Hort.?). Petioles violet; blade dull green, with violet margins.

Var. illústris, Engl. (C.illustris, Hort.). Petioles violet; blade more oblong-ovate, with black-green spots between the primary veins.

Var. esculénta, Schott (Calddium esculéntum, Vent. Colocdsia esculénta, Schott). Elephant's Ear. Fig. 522. Spadix with an appendage half as long as the staminate inflorescence; lvs. bright green, often $3 \mathrm{ft}$. or more long, nearly as wide. Hawaii and Fiji.

affinis, Schott. Blade thin, membranaceous, roundedovate or ovate, the apical lobe scarcely $1 / 4$ or $1 / 3$ longer than wide; basal lobes connate nearly their entire length, bright green above, glaucous beneath; blade only 4-6 in. long. Himalaya.

Var. Jénningsii, Engl. (Alocdsia Jénningsii, Veitch). Petiole purplish, with transverse purple lines; blade cordate, emarginate, with large, oblong or triangular black-green or black-violet spots between the primary lateral veins. I.H. $16: 585$. F.S. $17: 1818-19$.

Nèo-Guinénsis, Lind. Remarkable for its tufted habit, the shortness of the leaf-stalks, its short-stalked inflorescence, and the beautiful green tone of its smooth and shiny lvs., spotted with creamy white. New Guinea. I.H. 27:380.

Márchalli, Engler (Alocdsia Márchalli, Hort. A. hyेbrida, Bull). Hybrid, probably of $C$. affinis and $C$. antiquorum. Larger in all parts than $C$. affinis, the petioles pale green, very slightly emarginate, with large, confluent spots.

C. Bataviénsis = Alocasia Bataviensis ? - C. Cara casàna, Engler = Xanthosoma, - C. Javánica, Hort. $=$ ? $-\dot{O}$. Mafaffa, Hort.=Xanthosoma.-C. marginàta Hort. = Caladium bicolor. - C. odòra. Brongn.=Alocasia odora, Koch. Tree-like, the stem or caudex $3-6 \mathrm{ft}$. and 6 in. in diam.; lvs. green, cordate, stalked, bearing peduncles in pairs in their axils. E. Asia B.M. 3935. $-C$. odoràta, Hort, = Alocasia macrorrhiza.

Jared G. SMith and G. W. Oliver.

COLOCYNTH. See Citrullus.

COLOR. The range of simple colors common among flowers is not a very extensive one. It comprises yellow, gold-yellow, orange, scarlet, red, crimson, magenta, purple, violet, and ultramarine blue. 'The variation of these hues is, however, manifold. Diluted with white, or mixed with one another, colors assume an infiuite number of phases not easily described (Fig. 523). But the generic character of flower colors is certainly comprehended in the few names given above. Color-names are of little consequence so long as the color is identified. Unfortunately, scientists and artists have not yet established a standard no. menclature of color, so that the name of a particular hue is largely determined by popular opinion, and that, of course, is not always unanimous.

It is, therefore, necessary to accept both popular and scientific estimates of color if colors are to be considered in relation to flowers. The scientific definition of a color like scarlet, magenta, or violet amounts to its identification with certain lines in the spectrum. Such definitions are properly given in the Century Dictionary. They are satisfactory so far as they go, but the relation of colors in the spectrum to flower petals or artists' pigments is not so satisfactorily determined. Apparently the stan. dard of the spectrum must be supplemented by another of a more tangible nature - that is, a standard of pigment color. But it is just as well to substitute a flower petal for a pigment, and if this is done, the result would be about this :

Yellow.-Evening primrose.

Gold-yellow. - Pure gold calendula or deep yellow calendula.

Orange.-Deep-hued eschscholtzia and orange nasturtium.

Scarlet.-Mme. Crozy canna.

Red.-Portia carnation.

Crimson. - Deep-hued sweet-william and pæony.

Magenta. - Deep purplish red cineraria.

Purple.-Deep-toned larkspur, aster, and cineraria.

Violet.-Deep-toned English violets.

Ultramarine blue. - New compact blue delphinium.

Pure green is best represented by the artists' pigment called emerald-green; it is rarely present in foliage, except perhaps in spring.

If the simple colors, yellow, orange, red, purple, blue, and green, are arranged in a circle (Fig. 524), the colors opposite each other harmonize by reason of absolute contrast.

If these simple colors are subdivided into intermediate hues (Fig. 525), so that about
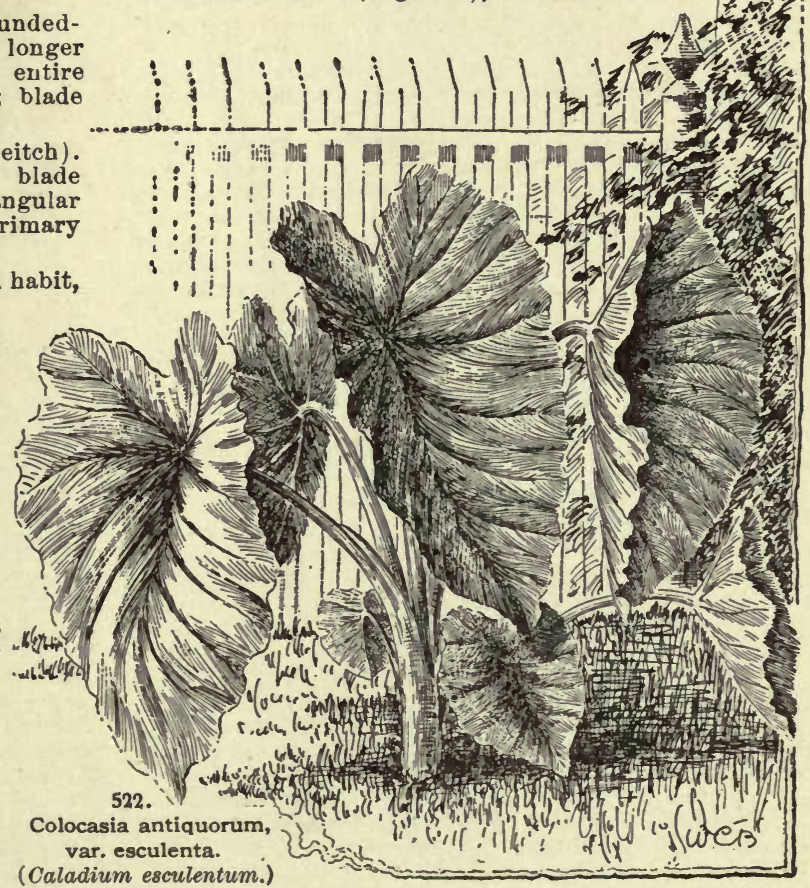

28 
three of the latter lie between the six original colors, the result will be a circle of twenty-four divisions, having the effect of a rainbow. This will perfectly illustrate the principle of color harmony and color discord. Besides

\begin{tabular}{|c|c|c|}
\hline OLD GOLD & SULPHUR & YELLOW \\
\hline OCHRE & STRAW Y. & COLD Y. \\
\hline $\begin{array}{l}\text { BURNT } \\
\text { ORANGE }\end{array}$ & SALMON & ORANCE \\
\hline $\begin{array}{l}\text { TERRA } \\
\text { COTTA }\end{array}$ & SHRIMP P. & SCARLET \\
\hline CARDINAL & PINK & RED \\
\hline MAROON & C.PINK & CRIMSON \\
\hline PLUM & P.LILAC & MACENTA \\
\hline $\begin{array}{l}\text { DARK } \\
\text { B. PLUM }\end{array}$ & LILAC & PURPLE \\
\hline $\begin{array}{l}\text { LOGWOOD } \\
\text { VIOLET }\end{array}$ & B. LILAC & VIOLET \\
\hline INDIGO & V. BLUE & ULTRAM'E \\
\hline
\end{tabular}

523. Color phases in flowers.

the opposing colors which harmonize by contrast, there are neighboring colors which harmonize by analogy or harmony. For instance, any four or five colors lying side by side in the circle are bound together harmoniously by reason of their near relationship. Therefore, all these four or five colors may be combined-and nature does combine them-with rsthetic results. But skip over four of the colors and attempt a combination of the first and sixth, and the result will prove a discord, the bond of relationship is broken, and the eye is disturbed by the aggressiveness of two colors between which there is evidently no bond of sympathy. It would be safe to say, therefore, that the circle demonstrates the fact that its colors situated at right angles with $\epsilon$ ach other are discordant, and those lying nearly parallel with each other are harmonious.

This is the theoretical side of color harmony. The practical side is scarcely different; it simply modifies the theory. Brilliant blue and orange, which are theoretically harmonious, are scarcely as agreeable in each other's company as the rule would imply. The trouble, however, lies with the brilliancy. The golden calendula and the deep blue-purple aster in association are rather violent

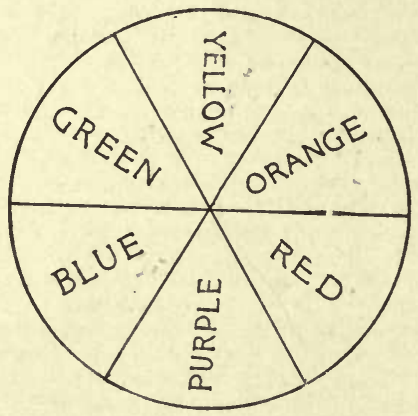

524. Harmony by contrast.

and aggressive. Remove the one or the other and substitute a pale-tinted flower of either hue, and the result will be a harmonious one.

Flower families are very apt to sustain harmonies of analogy; hyacinths, sweet peas, and nasturtiums represent families with most extraordinarily near-related colors. There is a predominating force of crimson in the sweet pea, and a predominating force of orange in the nasturtium. It is rather a nice bit of color adjustment in either family to choose flowers which excel in harmony of color the careless grouping together of flowers picked at random.

But the theory that analogous colors harmonize is correct only if it is not carried to excess. Attempts to force deep-hued flowers into harmony often lead to contrary results. A range of color from crimson to ultramarine depends for its harmony npon the simplicity or the delicacy of the hues. Such colors, in full force, would do violence to each other. It is tempting the hardness of a diamond to pound it with a sledge hammer. It is taxing crimson too heavily to expect it to show its strength in the presence of strong violet! If the effort is to merge the personality of the crimson flower into the purple one, and effect a play of color between the two, the combination of strong hues thus is justifiable.

The theory that coiors at right angles on the wheel are discordaut is also subject to some modification. Rela tively the right-angled colors must be crude and strong to objectionably affect the eye. Yellow and red in the rose is an agreeable color combination. Yellow and red dahlias crowded together are abominably harsh under a sensitive eye.

A country bouquet of asters, marigolds, fuchsias and dahlias is bad, because the country garden is not a part of it. A few feet of air and space and a stretch of green foliage nuke a world of difference.

It is wisest to try the effect of one color upon another before allowing two or three strong bues to wage war

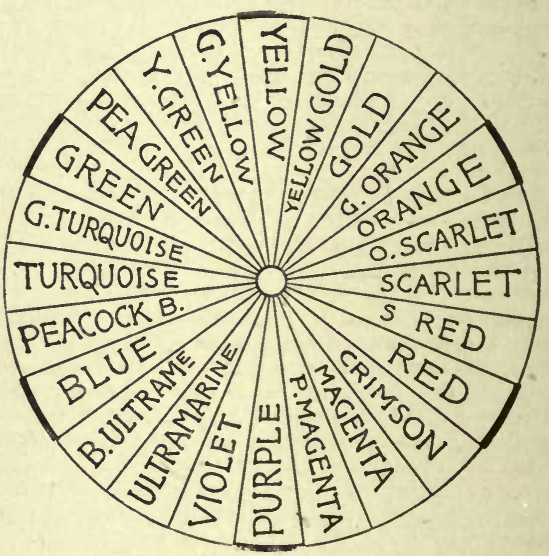

525. The intermediate hues.

with each other. It will be quickly found that white is a peacemaker, and green is an invaluable mediator. With these colors at command, the chances of color discord are reduced to a minimum. Everything also depends upon simplicity in color combinations. It is questionable whether a combination of more than two colors can ever ve æs thetically a success. The adjustment of many colors needs the hand of an expert. F. SchuYLER Mathews.

COLORADO, HORTICULTURE IN. The state of Colorado includes the territory lying between the parallels $37^{\circ}$ and $41^{\circ}$ north latitude, and between the meridians $102^{\circ}$ and $109^{\circ}$ west longitude. Its surface is diversified by mountains, bigh table lands, plains and valleys, with a range above tide-water of from 3,400 feet on the eastern border to over 14,000 feet in many snow-clad peaks. It is traversed from north to south by the great Rocky mountain range, and thus divided into two well marked though unequal divisions: The main "continental divide" is supplemented by several well-defined ranges, and by numerous mountain spurs, between which, and at altitudes ranging from 7,000 to 10,000 feet, lie the four large and several smaller parks or valleys, 
which are in great part utilized as hay runches and for stock ranges. The following figures regarding acreage are from the report of the state engineer for the year 1890. The total is given as approximately $66,560,000$ acres. East of the continental divide lie $40,800.000$ acres, and on the west $25,760,000$ acres. Of the area east of the divide, one-third, or $10.200,000$ acres, lies within tne mountains and the remainder, $30,600,000$ acres, consists of plain and valley lands. On the western slope the proportion of mountain and plain is reversed, there being $16,360,000$ acres within the mountains and about $9,400,000$ acres of plain and valley lands.

For the western slope the rainfall is given as 33 inches for the mountains and $\mathbf{1 0 . 7}$ for the plains and valleys, and for the eastern slope as 30 inches for the mountains and 15 inches for the plains. The tillable lands of the state are in the main outside the mountains, and the average annual rainfall on these lands is near 13 inches for the whole state. This rainfall comes mainly in the months of April, May and June, the precipitation for the other months being usually very small. It follows, from the small rainfall, that crops can only be suc. cessfully grown by irrigation, and it is this idea that has dominated the agriculture and horticulture of the state ever since the begin-

ning, nearly forty years ago

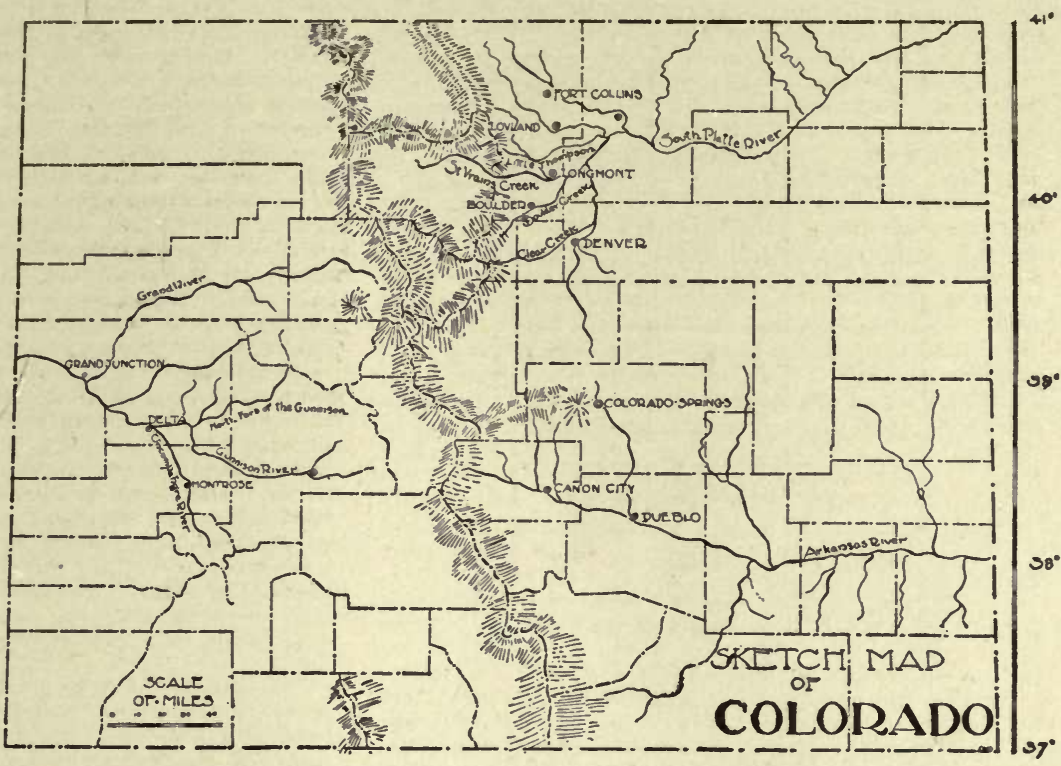

526. To show horticultural regions of Colorado. tom lands along Clear creek, between Denver and Golden, planted a number of apple trees which he hauled in a wagon from Iowa City, Ia. In the fall of the same year, Messrs. Perrin and Wolff, of Denver, hauled a load of trees from Des Moines, Ia., and such as survived the journey were planted on ranches about Denver. In 1866, u representative of a Kansas nursery sold trees and plants to many of the farmers along the St.
Irrigation being a necessity, the lands useful for agricultural purposes would be those reasonably level tracts bordering the streams, and extending back only as far as the water can be carried. The first ditches were constructed cheaply, and for the irrigation of first bottom lands only. A little later the idea of utilizing the higher mesas gave rise to canal systems of great magnitude, that have made productive vast tracts of fertile soil. The period of canal construction east of the continental divide has about ended, there being now as many ditches as the streams can supply, or possibly more. On the western slope, where the water supply is greater, additional systems may yet be constructed. The present most pressing problem on the eastern slope is the conservation of the available water. Attention is being given to the construction of reservoirs, and this, coupled with that economy in the use of water which experience is gradually teaching, will go far toward solving the problem, and it may yet be possible to considerably extend the area now irrigated. Owing to differences in latitude, altitude, and climatic conditions, the irrigable regions of the state are naturally separable Into three divisions, and in considering the horticultural features, it is best to recognize these divisions because they differ in the range of horticultural productions. The divisions are:

1. The Northern, which embraces the drainage basin of the South Platte and its tributaries, Clear creek, Boulder creek, St. Vrain, Little Thompson, and Cache la Poudre.

2. The Southern, embracing the valley of the Arkanas and its tributaries.

3. The Western, embracing all the cultivated valleys of the western s.ope lying along the Uncompahgre, Funnison, and Grand rivers and their branches, and being mainly in the counties of Montrose, Delta and Mesa

The Northern District.-From such statistical information as is at hand, it appears that the commencement of fruit planting in Colorado dates from 1863 . In that year William Lee, who owned a ranch on the bot-
Vrain, and about the same time a few trees were planted on the ranches along the Thompson. These early attempts to start fruit culture in the northern district were practically failures, for very few of the trees lived. The long journey from the nursery to the farm, improper preparation of the ground, lack of care in the application of water, and in protecting from stock, and the sentiment commonly expressed by the majority of the inhabitants, that fruit could not be grown in Colorado, were obstacles hard to overcome. A few of the early settlers, however, having hope of ultiinate success, made a second attempt in 1870 , and from the plantings of that year have grown the many fine orchards that dot the northern valleys. In the most northern valley, that of the Cache la Poudre, planting did not commence until about 1873, and except with small fruits, very little was done in the 10 or 12 years following, or until the success of the pioneers in planting demonstrated that the hardier fruits could be growu. During the past 5 years the area in fruit has increased rapidlv, until now the farm without its orchard is the exception. The apple is here, as in the other fruit districts, the principal fruit, corering the greatest number of acres and receiving more attention than all other fruits. All standard varieties are grown, and the product meets a ready sale. Plums are successfully grown, and prove profitable, but the range of varieties is restricted to those derived from Prunus Americana and a few of the hardier varieties of Prunus domestica. Cherries of the Morello class are very productive, and the demand for the fruit is encouraging growers to plant freely. Throughout the district much attention is given to the growing of small fruits and vegetables. All kinds of berries find a ready market in the cities and mountain towns, and the staple vegetables, such as onions, cabbages and celery, are shipped in large quin. tities to southern points.

The Southern District. - Here the counties most prominent in fruit culture are Fremont, Pueblo and Otero. The first planting was done in Fremont county, and the following concerning the circumstances I quote 
from an address by Judge W. B. Felton before the State Horticultural Society, as published in the report for 1887-8: "The first fruit trees were set out in Fremont county in 1867. W. C. Catlin went to Pueblo for an invoice of trees which had been ordered by himself and by Governor Anson Rudd, W. A. Helm and Jesse Frazier. They had been brought across the plains in a wagon to Pueblo, and Mr. Catlin brought them tu Canon, something over $\$ 500$ worth of trees occupying a small space in his wagon. A few of these trees, and only a few, are still living. After his first attempt, which was almost a total failure, Jesse Frazier procured several thousand root grafts and set them out in nursery rows. When they became large enough he transplanted them into his orchard." By the year 1879, Mr. Frazier had an orchard of 15 acres, the older portion of which produced 3,000 bushels of apples. Since 1880 , the yearly additions to the orchard area of this county have steadily increased, and fruit-growing is now recognized as one of the leading industries of the county. As in the other districts, the apple receives the most attention, but pears, plums, and the small fruits are grown in quantity. Peaches have been raised, but are not a sure crop, owing to the liability to late spring frosts.

Farther down the Arkansas valley, in Otero county,

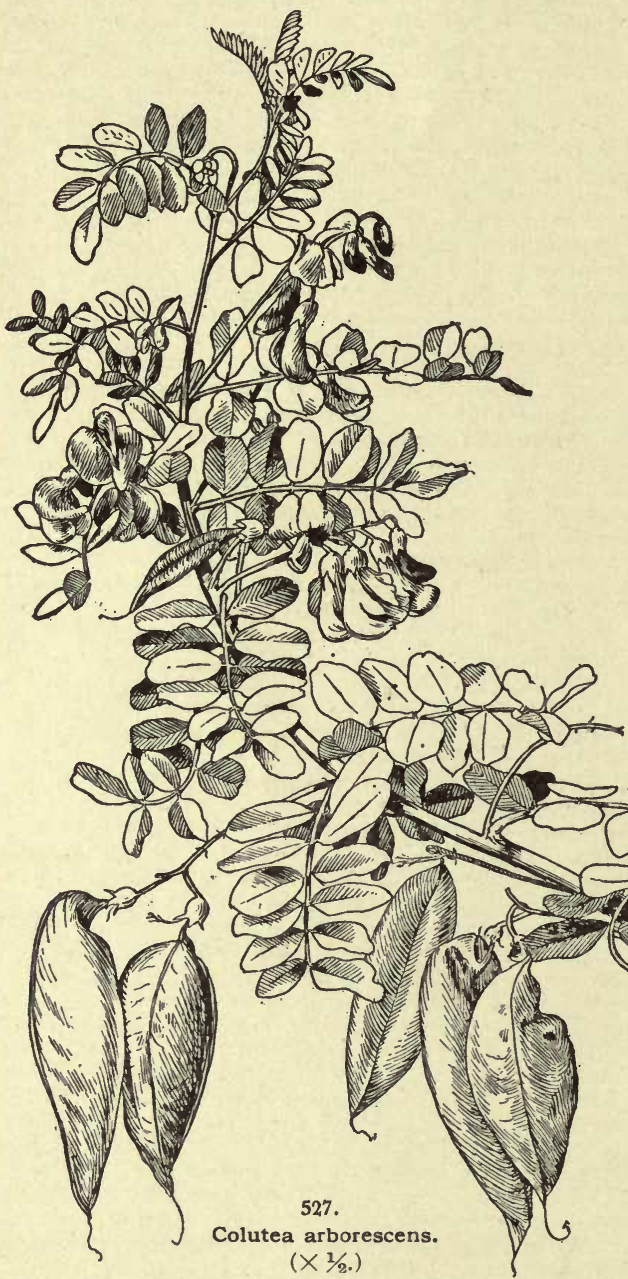

the tirst fruit trees were planted about 1882 , but general interest in orchard planting did not develop until some years later. During the past 5 years the area planted has rapidly increased, and the county now stands about fourth in orchard acreage. The growing of melons has within a few years brought this county into prominence. Started in a small way by farmers near the town of Rocky Ford, the business has spread into a great industry, and Rocky Ford melons and cantaloupes have found their way into all the large markets of the country.

The Western District. - The valleys constituting this were included in the Ute Reservation, which was first opened for white settlement in the fall of 1881. The first fruit trees were planted the next spring by Messrs. Hotchkiss and Wade, on their ranches lying along the North Fork of the Gunnison in Delta county. In the spring of $1883 \mathrm{~W}$. S. Coburn began planting what is now one of the finest orchards in the state; others followed, and soon the fame of the "North Fork" as a fruit region went abroad and served as a stimulus to planting in other sections. It was not, however, until 1886 that planting became general. In that year orchard planting about Grand Junction, in Mesa county, began in earnest, and at the same time the farmers of Montrose turned their attention in the same direction. The development of the industry from 1886 down to the present time has been phenomenal. There appears to be no limit to the successful culture of all temperate region fruits. On the low bottom lands along the streams, the earlier blooming varieties have occasionally been subjected to injury from late frosts, but on the mesas this trouble is never experienced, and here the tender varieties of European grapes are successfully grown without winter protection. The "peach belt" of the state lies within this western district in the three counties-Montrose, Delta and Mesa. The experimental stages of culture have been passed, success is assured, and the business of growing this fruit is in a fair way to become a large one.

The number of acres planted with orchard and small fruits that received water from the ditches during the year 1896 is given in the report of the state engineer as follows : Northern district, 15,025 acres; Southern district, 8,456 acres ; Western district, 22,162 acres. The State Horticultural Society, which was organized in September, 1880, has done much by its meetings and exhibits to advance the horticultural interests of the state, and its work has been supplemented by several active county societies.

From the present state of advancement, which has been reached within a comparatively short time, it seems certain that the fruit industry of the state has before it a promising future.

C. S. Crandall.

COLTSF00T. See Tussilago Farfara. Sweet Coltsfoot is Petasites, formerly called Nardosma.

COLUMBINE. See Aquilegia.

COLQUHOUัNIA (after Sir Robert Colquhoun). Labiatoe. Tender plants with dense whorls of gaping fis. an inch long or more, colored scarlet and yellow. The genus has 5 species, all from the Himalayas and Burma. Erect or twining shrubs, woolly in all parts when young: lvs. large, crenate : whorls few-fld., axillary or crowded into a terminal spike.

coccínea, Wall. Tall climber, with very long branches: lvs. stalked, ovate, acuminate, $3-5$ in. long, crenate, dark green above, roughish, typically with scarcely any toolliness except when young: corolla twice as long as the calyx. B. M. 4514. C. tomentosa, Houll., is probably identical. The dense woolliness is probably temporary. R.H. 1873:130 shows a bandsome terminal spike in addition to axillary clusters, containing about $20 \mathrm{fls}$. - Not advertised, but probably as worthy as the next.

vestita, Wall. Very similar to $C$, coccinea, except that it is a low-growing, erect plant, and more densely and permanently woolly on the stem, calyx and under side of Ivs. Cult. outdoors at Santa Barbara, Calif., but not promising.
W. $M$. 
COLOMN. A solid central body formed of stamens and styles grown together, us in orchids.

COLUMNEA (after Columna or Colonna, Italian writer on plants, sixteenth century). Gesnerdcece. Tropical American shrubs and climbers, with widely gaping, showy tls. of ten 2 in. long: lvs. opposite, nearly equal or widely unlike: fls. solitary or numerous, axillary, stalked or not, without bracts or with bracts in an involucre; corollas scarlet, carmine or yellowish. Half a dozen species, mostly red or orange-fld., are cult. abroad and may be known to a few fanciers at home, but none are advertised by the dealers.

COLÙTEA (Koloutea, ancient Greek name). Leguminosi. BLADDER SENNA. Deciduous shrubs, with alteruate, odd-pinnate Ivs.; Ifts. many, rather small: fls. papilionaceous, in axillary, few-fld., long-peduncled racemes, yellow to brownish red : pod inflated, bladderlike, many-seeded. About 8 species in the Mediterranean region to Himal. Ornamental free-flowering shrubs of rapid growth, with pale green or glaucous foliage and yellow or brownish red fls. during summer, followed by large, usually reddish-coloring and decorative pods. They grow in almost any soil, but prefer a tolerably dry and sunny position; not quite hardy north. Prop. by seeds sown in spring or by cuttings of mature wood inserted in fall in sandy soil; rarer species and varieties are sometimes grafted on $C$. arborescens in spring under glass.

A. Fls. yellow: pod closed at the apex.

arboréscens, Linn. Fig. 527 . Shrub, to $15 \mathrm{ft}$. : lfts. 913, elliptic, dull green, mucronulate, usually slightly pubescent beneath, $1 / 2-1$ in. long: fls. $3-8$, about $3 / 4$ in. long; wings nearly as long as the keel, flat. June-Sept. S. Eu., N. Afr., N. B.M. 81. - Var. crispa, Hort. Dwarf, with crisped lvs.

AA. F'ls, orange-yellow or brownish red; wings shorter than the keel.

mèdia, Willd. Shrub, to $10 \mathrm{ft}$.: Ifts. 7-13, obovate, grayish green or glaucous, $1 / 3-2 / 3$ in. long, nearly glabrous: His. 3-6, orange or reddish yellow: pod closed at the apex. June-Sept. Probably hybrid of garden origin between the former and the following, often cult. under the names of the following species:

orientalis, Mill. (C. cruenta, Ait.). Shrub, to $6 \mathrm{ft}$.: Ifts. 7-11, obovate, glaucous, thickish, $1 / 3-1 / 2$ in. long, nearly glabrous : fls. $3-5$, reddish yellow or brownish red: pod open at the apex. June-Sept. S. E. Eu., Orient.-Often cult. under the name of $C$. Halepica or C. Istria.

C. Halépica, Lam. (C. Istria, Mill.). To $4 \mathrm{ft.:}$ lfts. glaucons, small and numerous: fls. yellow, nearly 1 in. long; wing longer than the keel.-C. longialàta, Koehne (C. melanocalyx, Hort., not Boiss.). Similar to C. arborescens: wings longer than the keel. G.C. III. 16:155 as C melanocalyx, - C. Nepalénsis, Hook. Similar to C. arborescens: racemes drooping. B.M. 2622. B.R. 20:1727. Tender.

COLVILLEA (after Sir Charles Colville, governor of Mauritius). Leguminosce. The gorgeous fls. of this tropical tree are a worthy rival of the Royal Poinciana, which is closely allied, but easily distinguished. It has drooping racemes $1 \frac{1}{2} \mathrm{ft}$. long, densely crowded with perhaps $200 \mathrm{fls}$. of curious shape and of a splendid scarlet. The fls. open at the stem-end of the pendent dense raceme, and display masses of long, showy, yellow stamens. The unopened fls, are about the size and shape of a filbert, and these are gradually smaller towards the end of the raceme. The genus has only this one species, and is characterized by its large, oblique, colored calyx, having 4 segments, the standard being the smallest instead of the largest part; the wings very long, narrow, erect, obovate, the pod 2-valved. Supposed to be a native of E. Afr., but discorered in 1824 by Bojer on the west coast of Madagascar, where a single tree was cult. by the natives. It flowered there in April or May. Its culture is similar to that of Cæsalpinia. Prop. in the south only by seeds.

racemosa, Boj. Tree, 40-50 ft. high, with the general aspect of Poinciana regia but with a thicker trunk and ampler foliage: branches very long and spreading: lvs. about $3 \mathrm{ft}$. long, alternate, remote, twice pinnate, with
20-30 pairs of pinnæ which are opposite, 4 in. long, and have 20-28 pairs of lfts., each $1 / 2$ in. long : keel very small, almost covered by the wings: free stamtns 10,3 inserted below the standard, 2 under the wings, 1 under the keel, and 4 under the ovary. B.M. 3325-6.

COMAROSTAPHYLIS is included with Areto staphylos.

COMARUM (an old Greek name). Rosdcece. One species allied to Potantilla, and often referred to that genus C. palústre, Linn., the Marsh Cinquefoil, is a decumbent herb growing in swales in the N. states (also in the Old World), with pinnate, 3-7-foliolate lvs. (lfts. dentate), and solitary or cymose purple fls. 1 in. across: petals shorter than the calyx lobes, acute; stamens numerous. An odd and interesting but not showy plant, sometimes planted in bogs. Mn. 3:97. - The fr. somewhat resembles a strawberry, but is spongy instead of juicy. In some parts of Scotland, it is said, they are called Cowberries, and are rubbed on the inside of milk pails to thicken the milk.

COMBRETUM (old Latin name): Combretacece. Many tropical surubs and trees in Asia, Africa and America, particularly in S. Africa. Many of them are climbers, by means of the persistent leaf-stalks. Lvs. mostly opposite, entire : fls. in spikes, polygamous; calyx bell-shaped; petals usually 4 ; stamens usually 8 : fr. winged and indehiscent, 1-seeded. The Combretums are warmhouse plants, little known in this country. Prop. by cuttings of firm wood. One climbing species is in the Amer, trade: C. coccíneum, Lam. (C. purpùrent, Vahl. Poivrea coccinea, DC.), from Madagascar. Lvs. oblong-lanceolate, acuminate, evergreen: fls.small, brilliant red, with long-exserted stamens, the handsome loose spikes often in panicles : parts of the $f$. in 5's. B.M. 2102. L.B.C. 6: $563 .-$ Hand some.

COMFREY. See Symphytum.
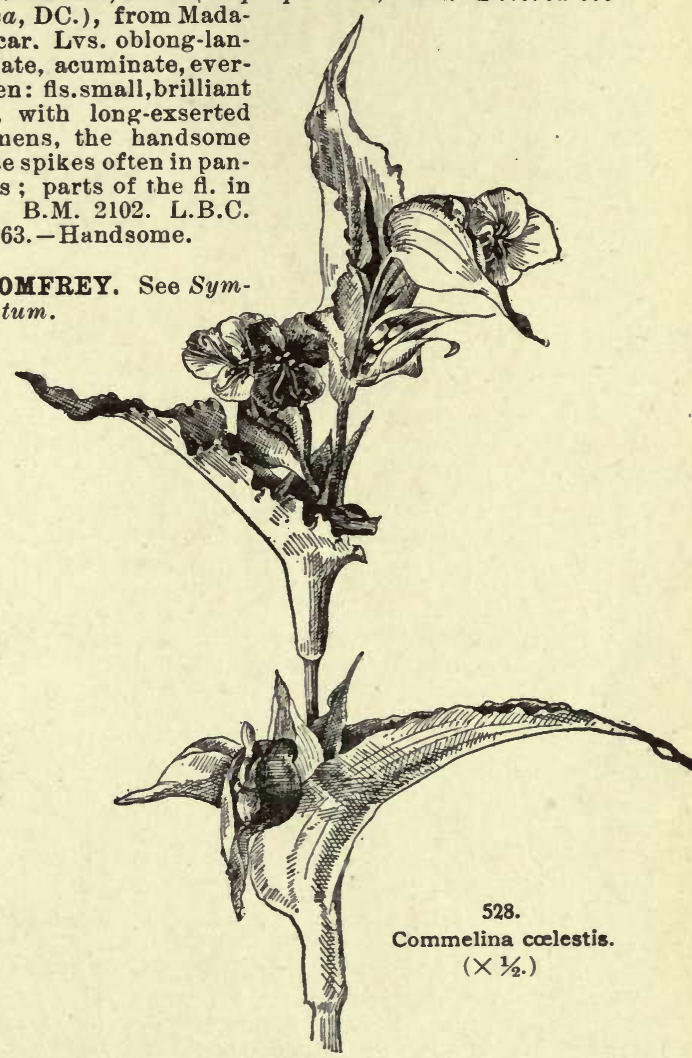

COMMELINA (to the early Dutch botanists, J. and K. Commelin. A third brother published nothing. Linnæus is said to have meant to designate the two authors by the fully developed petals, and the third by the small petal). Also written Commelyna. Commelinacea. About 100 widely dispersed perennial herbs, of which a very 
few are cult. for their interesting flowers. Fls. irregular, the calyx often colored, with unequal sepals; petals $\ddot{3}$, the 2 lateral ones rounded or reniform and long-clawed; stamens 6, 3 shorter; capsule 3 -loculed. There are sereral native tradescantia-like species, some erect and others creeping. These are not in the trade. The cult. species are erect warmhouse plants. Some are tuberousrooted. In the Amer. trade, only C. cœléstis, Willd., is offered. Fig. 528. It grows 10-18 in. high, branching, with clasping, long, broad-lanceolate pointed lvs. and blue fls. (2-10 together) on elongating axillary peduncles. Var. álba, Hort., has white fls. Var. variegàta, Hort., has fls. blue and white. Mex. Prop. by seed, cuttings and tubers. The native C. nudiflora, Linn. (as $C$. Sellowidna, Schlecht.), is in cult. It ranges all around the world. It is a creeping plant, rooting at the joints, with lanceolate lvs., and small irregular blue fls. in the axils. Commelina is monographed by C. B. Clarke in DC. Monogr. Phaner. 3.

Conmelinas are mostly of easy culture, thriving well in any light, rich soil. The evergreen stove und greenhouse species are readily propagated in March or April by cuttings inserted in an ordinary propagating

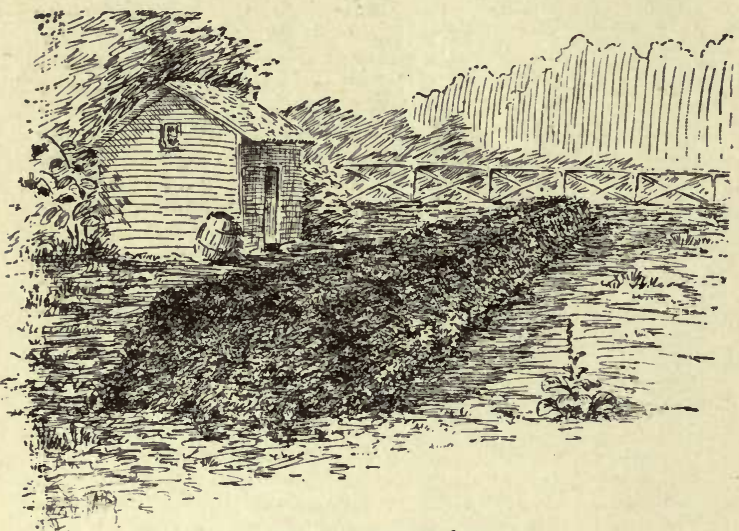

529. A Compost heap.

bed and kept close for a few days ; while the tuberousrooted half-hardy herbaceous species may be propagated either by division of the tubers or by seeds sown in a frame early in April and afterwards transplanting the seedlings in the herbaceous border. In the fall, they should be lifted and the tubers stored away in the same manner as Dahlias. Of the tuberous-rooted species, $C$. colestis is perhaps the best, its bright blue flowers being very effective, especially when planted in masses.

EDwARD J. CANNING and L. H. B.

COMPARETTA (Andreas Comparetti, 1746-1811, Italian botanist). Orchidacere, tribe Vándece. A small genus of graceful epiphytes, found in equatorial $\Lambda \mathrm{mer}$ ica. Pseudobulbs monophyllous, racemes simple or branched: fls. small, lateral sepals united in a single piece, lengthened at the base into a conspicuous horn; lateral petals converging; labellum large, produced into a double spur, which is hidden in the horn made by the sepals; column free, semi-terete, erect; pollinia 2. Grown on blocks or in baskets in a light intermediate or warmhouse.

coccínea, Lindl. Pseudobulbs small, bearing lanceolate, coriaceous lvs., purple beneath : racemes severalfld., fls. 2 in. across; petals and sepals yellowish, labellum large, broader than long, crimson. Braz.

falcàta, Poep. et Endl. ( $C$. ròsea, Lindl.). Similar in habit to $C$. coccinea: fls. deep crimson; labellum broad racem's pendent. Peru. B.M. 4980. A.F.6:609.

macroplèctron, Reichb. f. Fls. 10 or more, dorsal sepal whitish, often spotted with purple; midlobe of la bellum cleft, suborbicular, magenta-rose, dotted at the angled base; spurs conspicuous. New Grenada. B.M 6679 .

L. H. B.
COMPASS PLANT. Celebrated by Longfellow. It tends to turn the edges of its root-lvs.north and south Rosin Weed is the prairie name for it. See Silphium.

CoMPOST. Mixed and rotted vegetable matter, particularly manure and litter. The mixture of bulky fertilizing materials, known as Compost, while of little importance to the general farmer, plays an important part in garden practices. Many of the garden crops must be made in a very short time, or are of delicate feeding habits. Their food, therefore, must be easily assimilable. It is good practice to pile all coarse manures, sods, weeds, or any rubbish available for the purpose, in big flat heaps (Fig. 529), to ferment and rot before being applied to the garden soil. If desired, chemical manures, especially superphosphate (dissolved bone or South Carolina rock) and potash (muriate or kainit), may be added to make the Compost the richer. By spading or forking the heaps over a few times at reasonable intervals, a homogeneous mass is easily obtained, which can be applied in greatest liberality without fear, or more sparingly, in accordanco with the needs of the particular crop. Of equal, if not still greater importance, is the Compost heap which gives soil for greenhouse benches, flats, hotbeds and coldframes. This Compost is principally made of sods shaved off a rich pasture or meadow and piled in alternate layers with stable manure, more of the latter being used for forcing succulent crops, and less in growing plants which should be short and stocky, like cabbage or tomato plants. Garden litter may be added to the pile, as leaves and trimmings. All Compost heaps, during dry weather, need frequent and thorough moistening with water, or, better, with liquid manure. Turn several times during the year, to ensure thorough rotting of the materials.

T. GREINER.

COMPTONIA (after Henry Compton, Bishop of London, patron of horticulture, d. 1713). Myricácece. One species, by some authors united with Myrica, from which it differs in the pinnatifid, stipulate lvs. and 8 linear, persistent bractlets subtending the ovary. C. asplenifollia, Gærtn. ( $C$. peregrina, Coulter. Myrica asplenifòlia, Linn.), the Sweet Fern, grows in dry, sterile soil in the eastern U.S., and is also in the trade. It is an attractive undershrub (1-3 ft.) with fern-like, scented foliage and brownish, axillary heads of imperfect fls. Lrs. linear, pinnatifid: roots long and cord-like. Useful for foliage masses on rocky or barren places.

L. H. B.

CONE-FLOWER. The genus Rudbeckia. The Purple Cone-flower, however, belongs to the allied genus Echinacea.

CONANDRON (cone-shaped anther). Gesnerdcea. C. ramondioides, Sieb. \& Zucc., of Japanese mountains, is the only species. It is an interesting little tuberousrooted herb, with oblong, rugose, serrate root-lvs. and scapes bearing 6-12 white or purple, nodding Dodocatheon-like fls. It is one of several groups of rare and widely scattered herbs, of which Ramondia, Haberlea, Wulfenia, Didymocarpus, Shortia and Schizocodon are examples. Conandron is adapted to growing in shady rockeries. Scapes less than $1 \mathrm{ft}$. high. Little known in cult., but is in the trade. B.M. 6484 .

CONIFERS. The cone-bearing trees (Coniferce) are decidedly the most important order of forest trees in the economy of civilized man. They have furnished the bulk of the material of which our civilization is built. The remarkable combination of strength and stiffness with the smallest weight compatible, and the abundance and gregariousness of their occurrence, gives them this important position. From the standpoint of the horticulturist, they also take a prominent place among the materials for landscape gardening effects, and, in the more practical use, as windbreaks. Their evergreen habit-for all except the larch and ginkgo tribes are evergreen-and their conical form, especially in earlier periods of life, with a branch system persisting to the base for a long time, are the elements which make them desirable. To these graces may be added the peculiar form and striking coloring of their foliage, which, in 
combination with deciduous trees or in elumps, by themselves or in single specimens, offer striking effects.

There are two types of natural or native beauty in the Conifers - the symmetrical and verdurous beauty of the young specimen (Figs. 530, 531 ; Fig. 1, p. 1), and the picturesque and rugged beauty of the old and timeworn tree (Figs. 532. 533). Aside from these, there are also odd, grotesque and formal cultivated varieties, as typified in the weeping spruce (Fig. 534), the columnar junipers (Fig. 535), and the various dwarf pines and spruces (Fig. 536).

The majority of the species belonging to this group, as well as their greatest numerical development, is found in the temperate zones, only a few belonging to subtropical or tropical countries, among which are the Araucarias, from South America; the Dammara, Dacrydium, and Phyllocladus, from Australia, etc.

The order Coniferæ comprises nearly 40 genera, and about 300 species. Our own native flora, with 15 genera and not less than 100 species and subspecies, is among the richest, the bulk of these being found on the Pacific coast. The Atlantic side offers 28 species, representing the genus Pinus with 12 species out of $39 ; 1$ Larix out of $3 ; 3$ Piceas out of $7 ; 2$ Tsugas out of $5 ; 2$ Abies out of $12 ; 1$ Taxodium; 1 Thuja out of $2 ; 1$ Chamæeyparis out of 3 ; 3 Juniperus out of $11 ; 1$ Tumion (Torreya) out of $2 ; 1$ arborescent Taxus out of 2 : being without representatives of the genus Pseudotsuga, Sequoia, Libocedrus, and Cupressus. There are to be added a large number (not less than 400 ) of nurserymen's varieties, which have been enumerated in Bull. 17 of the Division of Forestry, U. S. Dept. of Agriculture.

There are also a number of exotic Conifers which promise satisfactory results if used in suitable localities, climate and soil. The Norway Spruce (Picea ex. celsa) recommends itself by its elegant gothic form, often with pendulous branchlets, its very rapid growth, and its wide adaptation to soils and climates, together with its ease of propagation and cheapness. It excels in form and rapidity of growth most of the American spruces. Like all Conifers, after the 25 th to 40 th year it must pass through a period of change in form, during which it loses, for a time, its shapeliness. The Scotch Pine (Pinus sylvestris) has nothing to recommend it which may not be found in native species, except, perhaps, adaptation to the dry climate of the west, and cheapness. The Austrian Pine, on the other hand, is an

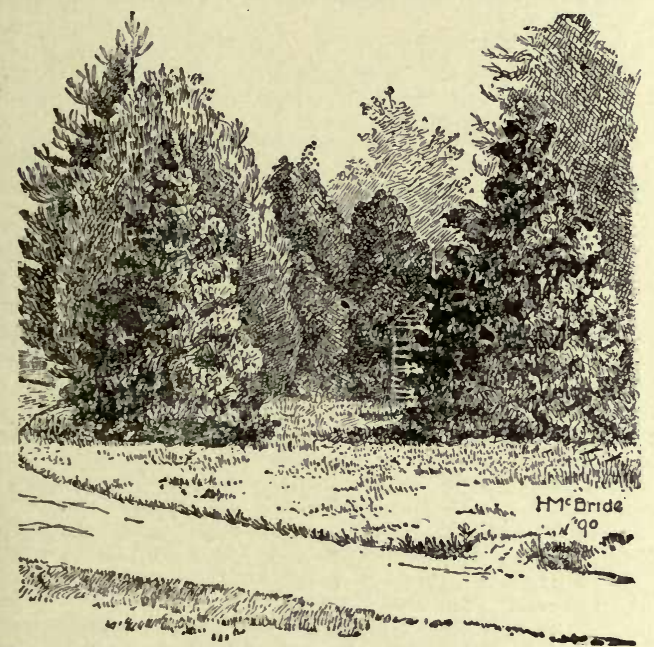

530. The beauty of young evergreens lies in their symmetry and the preservation of the lower limbs.

acquisition by its stout growth in its youth, although the Red Pine (Pinus resinosa) would probably do as well; so far, its small cones and seed have made the latter expensive. The European Larch outgrows the native northern one easily, but Larix occidentalis, from the interior basin, will probably do as well or better. There is no particular commendation for the Europe Fir, but the Nordmann Fir, from the Caucasus, is a most decided aquisition, by its beauty and adaptation; so is the most graceful of all spruces, Picea orien talis, while the Span ish Abies Pinsupo will always attract at tention by its peculiar shape and foliage.

Of other ornamental forms which are without representatives in the U. S., and hence fill vacancies, may be mentioned, as capable of adaptation, and, more or less in use, from South America, the Araucarias ; from Africa and Eastern Asia, Cedrus Deodara, Libani, Atlan tica, Abies Appolinis and Cilicica; from Korea, the promis ing, more densely foliaged White Pine, $P$ Koraiensis; from China, Cunning . hamia, Biota, Glyptostrobus, Cephalotaxus, Podocarpus, Pseudolarix, and above all, that interesting remnant of former ages, the Ma id enhair-tree,

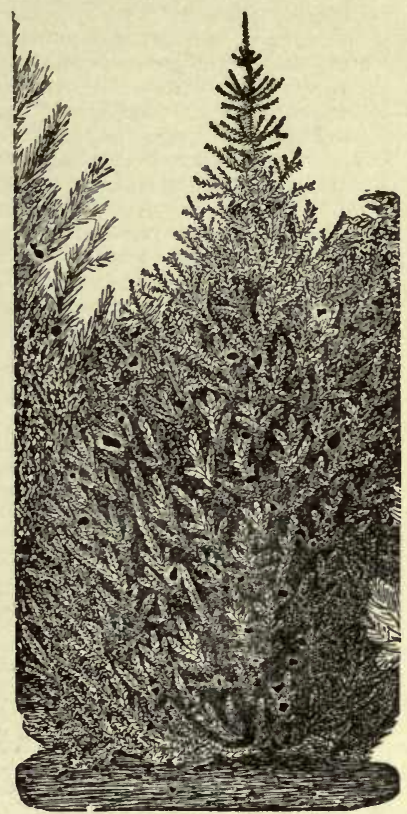

531. A good spruce tree. Gingko biloba, which

will maintain itself anywhere along the Atlantic coast if propagated from seed of the proper localities. Japan has furnished a number of additions, especially Retinosporas, Torreyas, Taxus, various Pinus, Piceas and Tsugas, with the peculiar Sciadopitys verticillata, the Umbrella Pine, and, the most acceptable of all, the graceful Cryptomeria Japonica.

As with all introductions from one country to another, nay, from one climatic region to another, caution is advised, so it may be laid down as a rule, that exoties should be used with great discretion, and, until their adaptation is amply demonstrated, only in a subordinate manner. If it is in general true that perennial plants can only be transplanted with permanent success into similar climatic conditions, it must be especially true with the conifers, which do not lose their foliage, and hence must be able to bear summer as well as winter conditions. The Long-leaf Pine of the south, most striking of our pines, may, therefore, not be transplanted far beyond its northern limit, and, if we desire to utilize any of the Pacific coast species in the east, we will have to secure them at least from the highest and driest altitudes and exposures or, if, as in the case of some species, like the Douglas Fir and Engelmann Spruce, their field of distribution covers the dry slopes of the Rocky mountains as well as the moist slopes of the coast ranges, we may be successful if we choose our plant material from these drier slopes.

Of the many native species, we may discard a num. ber that are not of any particular value, although the distinction could be more readily accomplished from the economic point of view than from the standpoint of the horticulturist and landscape gardener, for almost every one has a distinctive feature of either form or adaptation to soil or other interest. For each climatic region the choice must be different; hence it would be impossible to give, in the brief space of an article, intelligent advice as to best selections. In general, besides climatic limitations, the following considerations may serve in the choice of native species. The pines, as a rule, are not to be placed on compact, clay soil, and, on account of their taproot, not on shallow soils, on 
which they soon become spindly; they thrive best on loose, sandy soils, and can endure dry soils, the White Pine adapting itself perhaps best to the clay soils without detriment to its development. On wet soils pines are, as a rule, decidedly out of place, although the Red Pine ( $P$. resinosa), of the north, and the Loblolly ( $P$. Toda), and some other southern species are capable of supporting such conditions. For such situations here, however, the cedar tribe furnishes better material, - the Chamæcyparis, Thuyas and Taxodium. These trees of the bog and swamp are, however-it should not be overlooked-capable of thriving even better on drier soils. They are merely indifferent to moisture conditions at the foot.

The shallow-rooted spruces are trees of the higher mountain ranges, and are, therefore, more adapted to

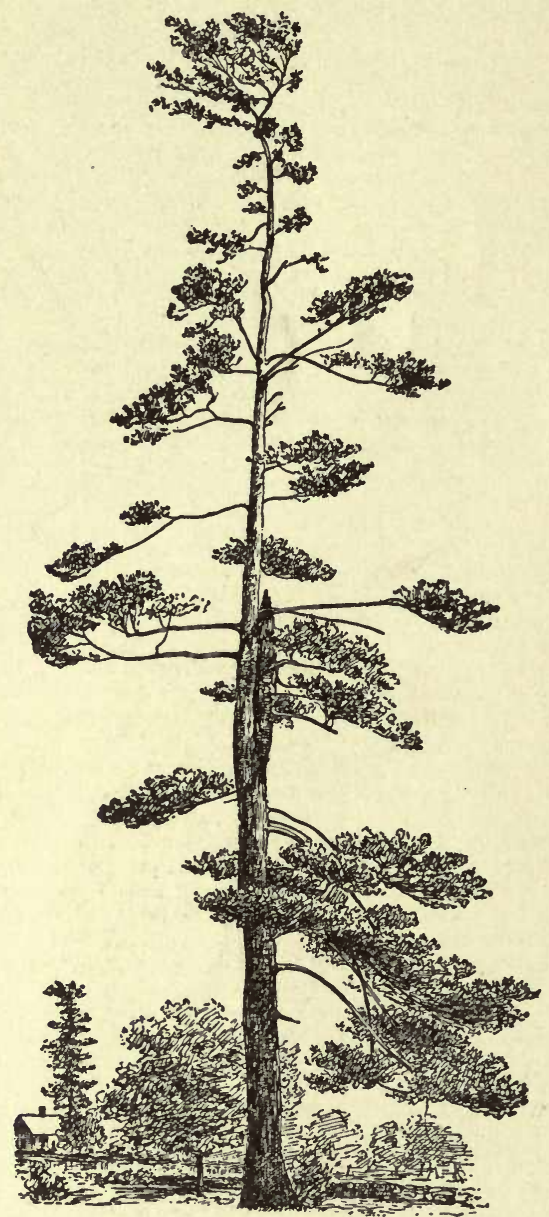

532. A lone field pine, remnant of a forest.

moist and cool situations, although some of them, the Norway Spruce, the Blue Spruce of Colorado and the northern White Spruce will-the former, at least, during its juvenile period-endure more droughty situations. The firs, too, are rather more species of northern climates and high altitudes, the Red Fir, so-called (Pseudotsuga taxifolia), which is not a fir proper, being, perhaps, best capable of supporting drier and hotter situations. The most ornamental, and, in many respects, most serviceable of the firs, Abies Nordmanniana, from the Caucasus, develops its magnificent dense and dark green foliage in the warm but moist climate of Washington, while our most ornamental Abies concolor from Colorado will thrive even in our drier atmospheres of the Middle states. The fine firs of the Pacific coast will probably not thrive anywhere in our drier and hotter eastern climates for any length of time, unless placed in cool and shady situations.

The Douglas Fir (Pseudotsuga taxifolia) is, perhaps, most readily acclimated if seed is secured from the dry slopes of Colorado. The Lawson Cypress (Chamacyparis Lawsoniana), with its graceful pendulous branches and foliage, and the pyramidal Libocedrus decurrens are unquestionably desirable additions to our ornamental stock, while the Sequoias, especially Washingtoniana, the Big Tree, has shown itself capable of thriving in the latitude of Rochester.

One important feature which enters into consideration when grouping Conifers, is the relative endurance of shade or tolerance which the species exhibit, thereby indicating their use in various positions. The yews and firs are the most tolerant of shade, together with the hemlocks; next may be placed the spruces,Arborvitæ(Thuya), and Juniperus, while the pines are mostly intolerant of shade, excepting the White Pine, which is the most shadeenduring of the pines; the larch and the bald cypress are the most light-needing of all, and will perish soon if placed under the shade of any other trees. All species, to be sure, are capable of more shade-endurance when young and on deep, moist soil. Their relative shade-endurance under the same conditions remains, however, the same, and may be studied in the forest by observing the density of the individual crowns, the capacity of maintaining a thrifty foliage under the shade of different species, and especially of young plants to persist in such shade.

Propagation.-Most Conifers ripen their fruit in the fall, September to November, and are best gathered soon after or before ripening. The pines take two years to mature their cones. White Pines ripen fruit in the first two weeks of September, and the cones opening, shed the seeds at once, the empty cones remaining on the branches. The cones of the firs fall apart upon ripening, hence must be gathered before being quite ripe. Spruces and hemlocks shed seeds from time to time, opening and closing into next spring. Some pines, like Pinus pungens and serotina, keep their cones closed for years, and artificial heat must be employed to make them open and give up their seed. In gathering seeds for the trade, such artificial heat is frequently applied with pines in specially constructed seed roasters; such seed should be carefully inspected, as it sometimes suffers from improper use of the heat.

The proportion of germinating seeds, and the vitality, i. e., the ability of retaining germinative power, varies greatly not only with the seasons in the same species, but from species to species.

The lowest germination percentage and vitality is found in firs and larch, which show rarely more than 50 per cent of good seed, and soon lose their vitality, while spruce and pine, when entirely fresh, may show as much as 95 to 100 per cent germination, an 1 retain vitality for 2 to 5 years, losing each year a proportion, Norway Spruce 5 years old still having 10 per cent germination.

In trade, a germination percentage for spruce of 75 to 80 ; pine, 70 to 75 ; fir, 30 to 50 ; larch, 20 to 40 , should be acceptable.

Seeds are best kept in a dry, cool garret in tight bags or boxes, excluding the air as much as possible.

All seeds require a short rest or after-ripening of two to four weeks before they are ready to germinate, and some, like the Taxus and Juniper, lie over, even in nature, for a year or more before they germinate. The latter should be prepared for sowing by macerating them, and removing the pulp in hot water, then mixing with sharp sand in bags, and by friction freeing the seed from the pulp.

In the seed-bed somewhat more care is required than with most other species of trees. A thoroughly mellow, well pulverized seed-bed of light, loamy sand, possibly enriched with well decomposed manure (cow-dung better than horse-dung), is required, the covering of the seed varying, according to size, from a mere sprinkling for larch to one-quarter inch for the heavy-seeded pines. They may be sown as soon as the weather is settled, in northern latitudes the second or third week in May, best 
in rows not more than 6 inches apart, and preferably in dry weather, when the soil does not clog, which sometimes prevent seeds from germinating, and can be rolled over them. Mulch between the rows with pine needles or sphagnum moss, or other fine mulch, to reduce necessity of watering and weeding. Conifer seeds need very little water for germination. The seeedlings, on

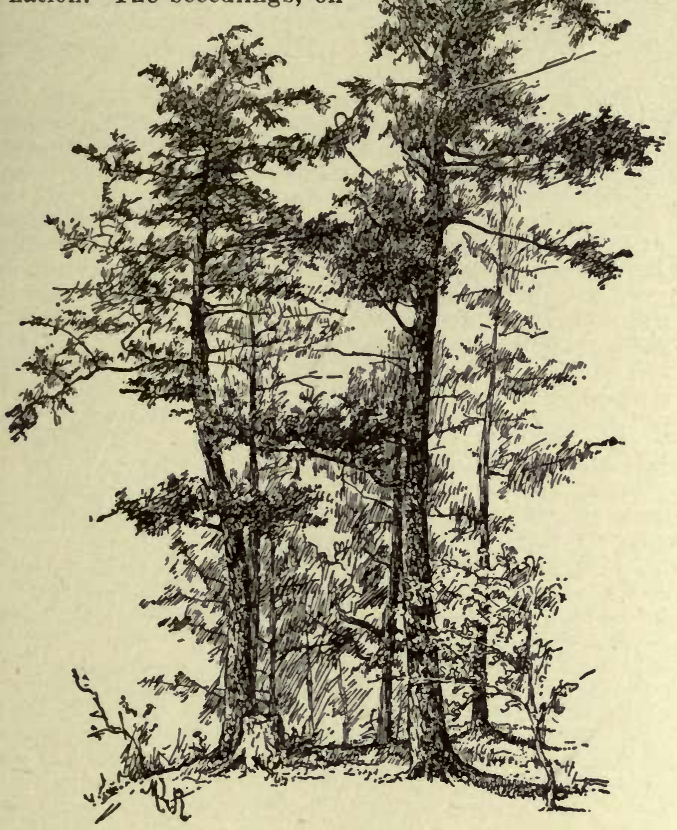

533. Picturesque old hemlock spruces.

the other hand, for the first three months, until they have made their crown bud, need to be either kept well watered or else protected against the drying effects of sun and wind by shading, for which purpose lath screens are best. These latter must be lifted for airing after the sun is gone, especially in muggy weather, to avoid "damping-off." For wintering, a covering with conifer branches or very clean meadow hay is advisable (the latter is apt to bring in weeds).

For growing small quantities, the use of boxes, as described by Jackson Dawson, of the Arnold Arboretum, in Proceedings of the Massachusetts Horticultural Society, is highly commendable. In well drained boxes, sow the seed soon after gathering, pile four or five deep in a pit or sheltered place, cover with boards, and when cold weather comes, cover up with leaves or hay. About the middle of April, move them into a place where they get the early morning sun. Keep the seedlings well watered and free from weeds, and shaded as described. Winter the seedlings in same manner as the seed-boxes, well covered up. They are ready for transplanting next spring, when they are making their first or second set of rough leaves.

Since pine and spruce seedlings take about 7 to 10 pounds of phosphoric acid, 10 to 20 pounds of potash and 15 to 30 pounds of lime, besides 20 pounds of $\mathrm{ni}$ trogen, per acre from the soil, for continuously used nurseries the addition of mineral materials in the shape of bone-meal and wood-ashes may become desirable.

A large number of seedlings may be grown in a small space; thus 30,000 Norway spruce may be grown on a square rod, requiring about 2 pounds of seed. The quantity of seed sown depends, in part, upon the length of time it is expected to leave seedlings in the seed-bed, besides size and quality of seed; the quantities vary from $1 / 4$ to $1 / 2$ pound per 100 square feet if sown in drills, and the yield of seedlings will vary from 200 to 15,000 seedlings, according to species and seasons.

Conifers, like any other trees, may be transplanted at any time of the year, provided the necessary care is taken in moving the plant. This care is least required, as with other trees, in the fall and early spring, when activities of root and foliage are, if not at rest, at least reduced. Which of these seasons is preferable depends on the locality, and the dependent character of the season. On the whole, spring planting will probably be preferable in most parts of the United States which do not suffer from dry spring winds. In localities of the southwest, which have commonly a dry spring followed by a rainy season in July, this latter time should be chosen. There is a belief that planting in August is specially farorable. We see no reason for this belief, unless favorable weather (a rainy season) follows.

Conifers may be transplanted later than deciduous trees, even after the buds have started, excepting the larch, which buds out very early; with this species, fall planting may be recommended. Cloudy weather, rather than rainy or very dry, should be chosen, especially when transplanting into nursery rows.

Young trees are naturally more readily and successfully transplanted than older ones, with which there is more difficulty in securing the whole root-system when taking them up. Since, however, the seedlings develop slowly for the first one or two to three years, they should be left in the seed-bed for that length of time, root-pruned, and then transplanted into nursery rows. Although those with a shallow root-system, like spruces and firs, may be moved even when $30-40$ feet in height, it is best, even for ornamental purposes, not to take them more than 3-4 feet in height. In forestry, 1- to 4-year-old plants, according to species, from 2-12 or 15 inches in height, are preferred for reasons of economy.

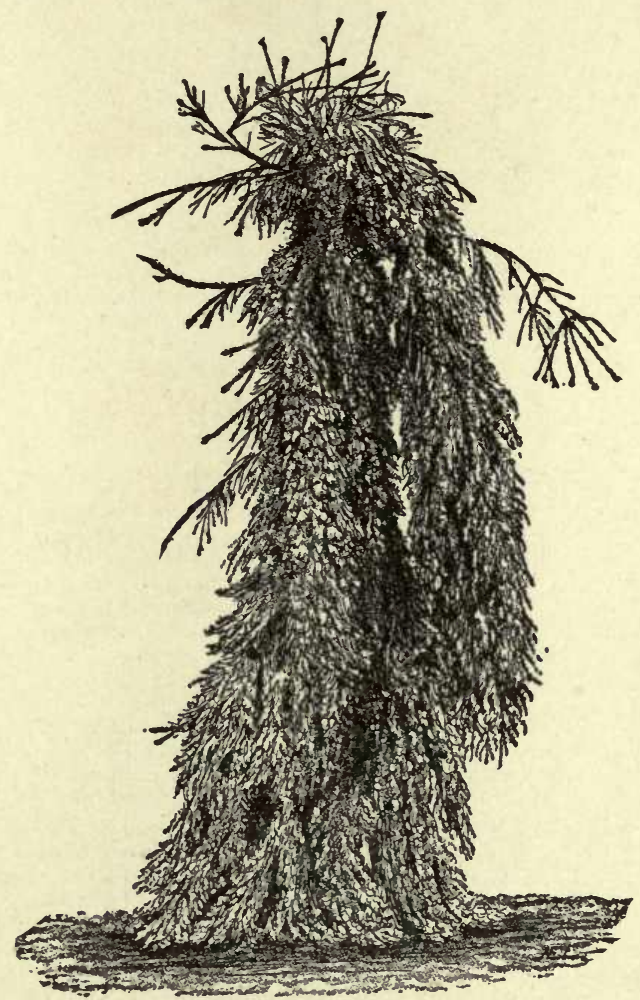

534. A weeping Norway spruce.

Much greater care than with deciduous trees is necessary, when transplanting without an earth-ball, in keeping the root fibers from drying out; a large amount 
of loss in transplanting is explained from neglect in this respect. As soon as taken up, the roots should be immersed into a loam-puddle and kept protected by wet sphagnum moss or canvas until set into their new place.

The question of trimming when transplanting must be consiclered with more care than is necessary with broadleaved trees, which possess much greater recuperative power. It should be confined to the smallest amount, smoothing bruised roots, and if for proper proportioning pruning at the top becomes absolutely necessary, shortening the leader rather than branches. Larch will stand more severe pruning than most other Conifers. From the artistic as well as physiological point of view, it is barbarism to remove the lower branches, which the tree needs to shade its trunk and standing room, and often, when deprived of the same, will replace first before starting again in its height growth. Attention should, however, be especially paid to preventing double leaders, which are detrimental to future form-development; cut them out as early as possible, preferably in the bud. Laterals may be somewhat shortened-in while standing in the nursery, to lengthen the time during which the lower branches are to persist. Breaking out buds is, as with all trees, the best method, provided the pruner has an eye for his business. Even in after-life, when pruning is done to keep the tree shapely, the minimum use of the pruning-knife should be the rule.

There are three marked periods in the development of Conifers - the jurenile period, when the entire tree is a erown, branched symmetrically to the base, the perfectinn of symmetry; then follows the adolescent stage, when the lower hranches die out, a period of unshape-

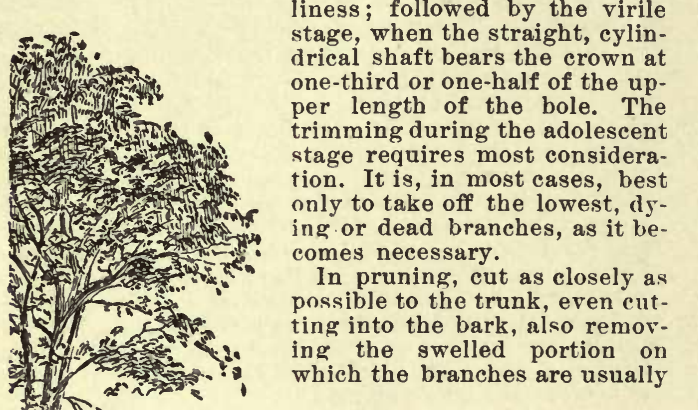
liness; followed by the virile drical shaft bears the crown at one-third or one-half of the upper length of the In pruning, cut as closely as In pruning, cut as closely as ing the swelled portion on which the branches are usually inserted, when the callusing will be more rapid and satisfactory in shape.

If at this stage or at any time the trees show trouble at the top by drying (becoming "stag-headed"), it is a sign that they suffer at the root from lack of moisture.

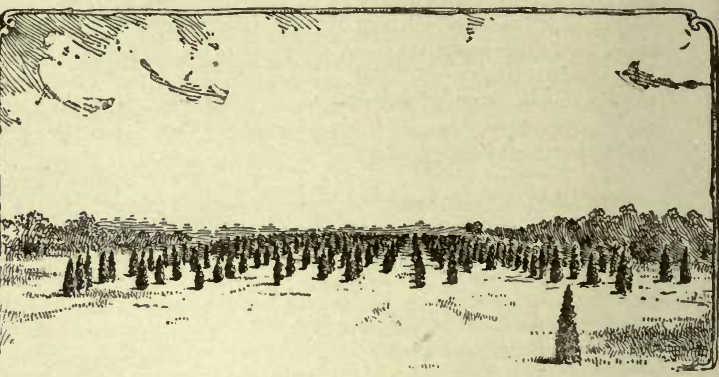

535. Pyramidal evergreens. Junipers.

Trimming off a few tiers of lower branches, loosening the soil as far as the ambitus of the crown, and mulching will largely correct this. When used for hedges, the treatment is, of course, different. For such a purpose the shade-enduring species, spruces and hemlocks, are best, since they are capable of preserving a dense interior foliage, while the pines are bound to thin out.

There are a number of dangers and damage from insects to which Conifers are exposed. Drought and frost are most dangerous to seedlings in the seed-bed. These are obviated by proper location of the seed-bed (protection against sun and wind), by covering with a mulch of moss, straw, pine-straw or the like (which also prevents the heaving out by frost and the washing out by rain, to which the young seeds are liable). By shading and watering the danger of drought is overcome, although at the same time that of "damping-off" is invited. The cause of this disease, consisting in the reddening of the needles and their falling off, is as yet undiscovered, a fungus being held responsible by some. Birds may be kept away from the seeds by mixing them with red oxide of lead, by lath screens, and the usual methods.

Various fungi and insects, too many to mention, some polyphagous, more or less specific, are at work during the various stages of development. A host of leafuniners, saw-flies and caterpillars destroy the foliage,
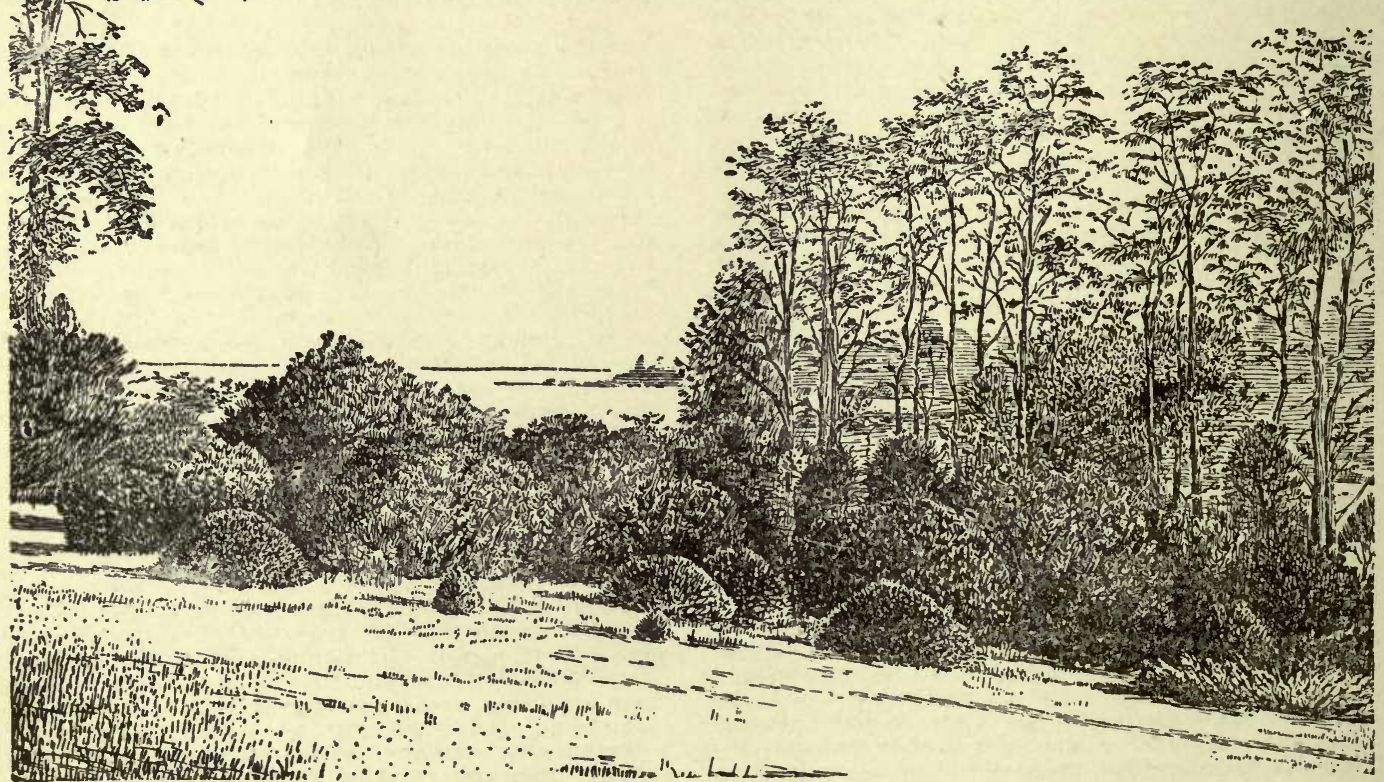

536. Dwarf conifers, of horticultural origin. Pines and spruces. 
and weevils sap the young shoots. Bostrichi, or barkbeetles, mine under the baik, mostly of trees which are sickly from otber causes; borers enter the wood of the boles. Tortrices bore into the base of leaders and cause them to break off. The best remedies against most of these are preventives, namely: providing the trees with such chances of vigorous growth, or satisfactory soil conditions, that they are able to ward off or overcome the enemies. Otherwise, watching and destroying the enemies in time, and the usual remedies to kill them, may be employed. Literature: Veitch, Manual of Conifers ; Carrière, Traité des Conifères; Beissner, Handbuch der Nadelholzkunde.

B. E. Fernow.

CONIUM maculatum, Linn. Umbelliferce. The Poison HeMLOck, "by which," as Gray writes, "criminals and philosophers were put to death at Athens." It is a rank, much-branched European herb which has run wild in eastern $\mathrm{N}$. America, and which is offered in the trade as a border plant. It is biennial, rank-smelling, and poisonous, and is scarcely worth cultivating, although the finely cut dark foliage is highly ornamental. It grows from $2-4 \mathrm{ft}$. high, and has large umbels of small white fls. An extract is sold in drug stores for a sedative. For this purpose the fruit is gathered while green.

CONNECTICUT, HORTICULTURE IN. Fig. 537. While one of the smallest states and covering but one degree of latitude (41 to 42 ), owing to the great diversity of soil and varying elevations from the sea lerel, along the whole southern border, to 900 and 1,200 feet in sections of Tolland county, and 1,200 and 1,500 in portions of Litchfield, Connecticut is adapted to as wide

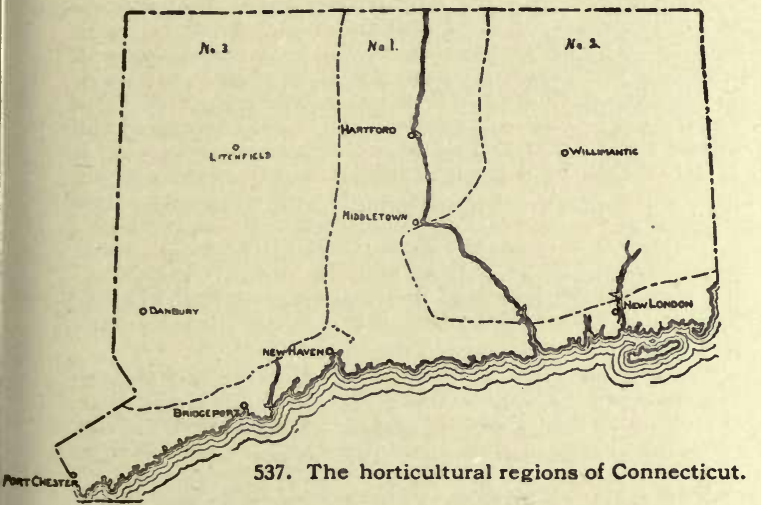

a range of horticultural productions as any state outside of the semi-tropic fruit belt. The "season" of many of the quick-maturing species and varieties of fruits, flowers and vegetables is often entirely over on the ligbt soil in the Connecticut valley and along the Sound shore when like species and varieties are but just beginuing to ripen on the cooler, moist soils of the hills of Tolland and Litchfield counties. Strawberries and green peas from East Hartford and Glastonbury supply the Hartford niarket, while on the Bolton hills, only 12 miles away, the blooming vines give promise of the crop that is to come after the valley season is entirely over so that "home-grown" strawberries are usually to be had in the Hurtforl market for a period of six or seven weeks. The Sound shore, Housatonic valley and Litchfield hills supply New Haven, Bridgeport and other cities of the state through equally long seasons.

From the earliest settlement of the state, fruit-growing for the family home-supply has been a prominent feature of Connecticut agriculture, the apple being a main reliance. The old seedling trees scattered over all our farms to-day are plain evidence that our ancestors took their apple juice through the spigot of the cider barrel rather than fresh from the pulp of the ripe fruit of some finer variety. A hundred years ago every farm-house cellar wintered from 30 to 50 barrels of cider, while to-day it is hardly respectable to have any, and probably not one family in ten now has even one single barrel on tap as a beverage. Yet in quantity und variety the family fruit supply has wonderfully increased and a daily supply of fresh home-grown fruit is the rule ruther than the exception in most farm homes, - small fruits in variety, apples, pears, peaches, plums (both European and Japan), cherries and quinces, in all the best standard varieties, coming to their highest perfection in every section of the state where rational methods of culture are followed. The topography of the state is such, and soils are so varied within short distances, that it is difficult to district the state, except in the most general way. Aside from the alluvial, most of the light sandy and sandy loam lands are along the river valleys and the Sound shore; while in "the hill towns" and along the ridges the soils are heavier, with more or less mixtures of clay, and many of the hilltops are moist und springy. Rocks are very abundant nearly all over the state except in the valleys, while the natural timber and semi-abandoned farm and pasture lands, growing up to brush and timber, cover fully one-half the acreage of the state. Acting at present as wind-breaks and climatic equalizers, thay will in the future furnish the "new lands" for extensive horticultural enterprises. Lying midway between New York and Boston,-the greatest horticultural markets of America-Connecticut is better situated than any other state in the Union to realize quick cash returns from her horticulture. Every farm is within driving distance of some one or more of her own busy manufacturing towns and villages, whose people are appreciative of choice fruits and are able to pay for them.

District No. 1. - This comprises the Connecticut river valley and adjacent hills, along the Northampton branch and the main line of railroad from Hartford to New Haven, and all of the shore towns. This district contains most of the sandy plain lands of the state, and the loams and clay most free from rocks and stones. On the hills back from the river, on the ridges either side of the railroads, and a few miles back from the Sound shore, there are many places where soil and topographical conditions are much the same as in districts Nos. 2 and 3 ; but, having much larger tracts of easily cultirated lands and being better located as to market conditions, this district is more highly developed horticulturally than either of the others. Here are the great market-gardens and small-fruit farms, peach orchards, vineyards and melon fields.

District No. 2. - This district comprises Tolland and Windham counties and all of Middlesex and New London counties except Cromwell and the shore towns, and is particularly well suited to apple and peach culture, ow ins to the rolling condition of the country and natural fertility of many of the hills. Erery few miles are lit tle valleys and pockets suited to the production of small fruits aud vegetables in variety. A few townships in the northeast grow apples quite extensively, while in the west and southwest comniercial pear.h orchards are found to considerable extent.

District $N$ o. 3. - This district comprises western Hartforl, northwestern New Haven, northern Fairfield, and all of Litchfield counties, and is somewhat similar to district No. 2, except that the soil is generally heavier, with rather more mixture of clay and the hills are more abrupt and rocky. Some sections of Litchfield county are too cold and bleak for any but the most hardy fruits.

Apples grow freely everywhere, and, while always of good quality, the brightest colors, firmest texture and highest quality of fruit is produced on the rocky hills, at an elevation of from 400 to 1,000 feet. Baldwin, Rhode Island Greening, Roxbury Russet and Spy are the leading varieties, al hough all the varieties that thrive well in the northeastern U. S. grow to perfection here when properly cared for. Old commercial orchards have always been profitable, and just at this time large plantings are being made. the largest orchard in the state containing about 4.000 trees.

Peach culture on an extended scale is a recent devel. opment. Eighteen years ago the only commercial orchard in the state contained about 2,000 trees, and probabiy 
5,000 trees would be a liberal estimate for the state; now upwards of $2,000,000$ peach trees are in the statemany orchards of 5,000 and 6,000 trees, quite a number with 10,000 to 15,000 trees, and at least one with nearly 50,000 . While many varieties are grown to some extent, the main plantiugs are of Mountain Rose, Oldmixon, Crawford Early, Crawford Late and Stump. More recently, however, Waddell, Carman, Champion and Elberta have been heavily planted. High culture, close pruning and a thinning of the fruit are generally practiced, and fruit of brightest color, largest size and high quality is thus secured. In the markets of this and neighboring states, "Connecticut peaches" usually sell at a much higher price thau those from ans other section. The only serious drawback is the winter-killing of the fruit-buds in the valleys, this happening probably three years out of five, while on many hillsides and hilltops at least two crops out of three are assured; but there are many favorable localities where annual crops are almost a certainty.

Japanese plums were early planted in this state, and so quickly proved their adaptability to soil and climate that they are now planted in a small way in every section of the state, fruiting almost as freely as the apple for family supply, while in a commercial way they are being quite largely planted in district No. 1. Several orchards have from 2,000 to 4,000 trees each. Of varieties longest tested, Burbank, Abundance and Chabot are most satisfactory and profitable. Red June and Satsuma are rapidly growing in favor, the latter com manding extremely fancy prices for canning purposes.

Raspberries, blackberries, currants and gooseberries grow and produce freely all over the state, and all local markets are abundantly supplied in season.

Grapes can be grown successfully all over the state, except on the highest and coldest hills; and on the sandy plains and warm, rocky hillsides all the best standard varieties can be produced in perfection. There are a number of small vineyards in district No. 1, and home-grown grapes sell for double the price of those coming from the outside; yet, on the whole, the grape industry is but lightly thought of.

Pears thrive and fruit well except on the lighter lands, and nearly every home garden has from one to half a dozen trees. There are a few small commercia orchards in district No. 1, Bartlett and Clapp being most largely grown at Hartford and the adjoining towns. On the west side of the river the Bose is pro duced in its highest perfection.

Cherries have been steadily failing in the state for twenty-five years past. Not enough for home supply are grown. Newly planted trees soon die out, and there is a general discouragement. They seem to do best in the vicinity of Middletown and Meriden, and the few commercial orchards there are quite profitable.

Quinces are grown all over the state for home supply, but thrive best along the Sound shore, where there are a lar $x \theta$ number of small commercial orchards.

Strawberries are very largely grown, both for home and outside markets, mostly in medium matted rows, with an average yield of 80 to 90 bushels per acre. Some cultivators, who follow the hill system or grow in narrow, thinly matted rows, secure 150 or more bushels per acre. A number of the berry farmers have systems of irrigation which add greatly to the surety of the crop, besides increasing the size and appearance of the fruit. The rolling character of the country and vast number of small streams abundantly supplied with water make it possible, at moderate expense, to irrigate many thousands of acres in this state, and the time is not far distant when the streams of Connecticut wil be more valuable to her horticulturists than they ever were to her manufacturers in the old days of many small factories and water-wheels.

Almost from the earliest settlement, small local nurseries have abounded in the state, and are here to-day to the number of 53. An extensive general nursery at New Canaan, in Fairfield county, is much the largest of any in New England, while the small fruit and specialty nursery at South Glastonbury, Hartford county, distributes plants by the million all over the world. At Cromwell, Middlesex county, is a floricultural establishment which. with one exception, has the largest area under glass of any such establishment in America, and surpasses all others in the annual production of superb roses.

The late Judge A. J. Coe, of Meriden, was one of the first men in America to take up the new chestnut culture by the importation of the best foreign varieties and the selection of the best natives and their crosses. He commenced the grafting on native sprouts and seedlings, and stimulated quite a general chestnut grafting, so that a goodly number of chestnut orchards are being established on land too rongh for cultivation, yet strong in its ability to grow the chestnut tree and nut to perfection.

At Wethersfield, in Hartford county, Orange and Milford, in New Haven county, and Southport, in Fairfi. Id county, are many farms devoted to seed-growing. Ouion seed and sweet corn are the great specialties, but a great variety of other seeds are also grown, especially at Wethersfield and Orange.

Market-gardening is carried on quite extensively by specialists near all large towns and cities, while, with so many good markets always close at hand, vegetables and fruits are sold in moderate quantities from nearly every farm. The largest general market-garden farm is at New Haven, wliere over 400 acres are under annual cultivation with vegetables and small fruits. At Southport, Fairfield and Westport there are many farms, both large and small, devoted entirely to the production of onions. "Southport onions" are famous for fine appearance and quality, and nowhere in America is the annual yield so great or price received so high as in this district. Marketing is done in sailing vessels direct from the farms to the dock markets in New York, where the onions are sold direct to retail dealers, boat captains acting as salesmen without commission for the sake of carrying the freight.

Trolley car lines are widely extended through many farming sections of the state, and, running express cars at certain hours of the day with freight movements at. night, they are proving quite a factor in the distribution of horticultural products. The Hale peach farms, at South Glastonbury, were the first in America to use this new electric power in the marketing of their products. Fruit is loaded at the farm side-track as gathered during the day, and transported to market at night, after passenger service has closed for the day. It is unloaded in the city from the main-line tracks directly in front of the stores in the early morning hours before the tracks are ugain required for passenger service, and the empty cars are returned to the farm side-track before a new day's work in the orchard has begun.

The Connecticut Pomological Society, organized some ten years ago, is a prominent feature in the lively fruit interests of the state. It has a large, active membership, and, aside from its annual winter meeting it holds each summer three or more "field meetings," on fruit farms in different sections of the state, and there, around tree, plant and vine, the members meet and discuss the live topics of the hour, gathering inspirution which, carried to their homes, is pushing Connecticut into the very front rank of horticultural states.

\section{J. H. HALE}

CONOCEPHALUS (Greek, cone head). One of the liverworts (Marchantiaceæ), with broad, flat, forking evergreen thullus, growing on moist banks, like a moss, C. cónicus, Dumort., is offered by collectors as a plant for rockeries.

CONOCLINIUM (Greek, cone and bed). Composita. Differs from Eupatorium in having a conical receptacle and the somewhat imbricated involucral scales nearly equal. Most authors now unite the species with Eupatorium (which see)

cœlestinum, DC. (Eupatzrium calestinum, Linn.). Mist Flower. Perennial, 1-2 ft. high, somewhat pubes cent : Ivs. opposite, stalked, triangular-ovate and somewhat cordute, coarse-toothed : heads in compact cymes, many-fld., blue or violet. Mich. and Ill., to N. J. and S. Late-blooming heliotrope-fld. plant, very useful for low borders.

Lasseàuxii, Dur. (Ageràtum Lasseduxii. Carr.). Spreading pubescent perennial, with habit of Agera- 
tum conyzoides: lvs. lance-elliptic, obtuse-toothed, long-attenuate, short-stalked or somewhat decurrent heads numerous, handsome rose-color Uruguay. R.H. 1870:90. - Handsome plant for bedding. Grows 1-2 ft. high. Not hardy.

L. H. B.

CONOPHÁLLUS Konjak, Schott, is Amorphophallus Rivieri, var Konjac, Engler. The great tuber is much grown in Japan for the making of flour (see Georgeson, A.G. 13:79). A morphophallus Revieri is figured ou p. 59 ; also in R.H. 1871 , p. 573 ; and in B.M. 6195 (as Proteinophallus Revieri). Konjak is offered by importers of Japanese plants.

CONSERVATORY. Literally, a place in which things are kept or preserved. Used to designate a glass house in which plants are kept for display, rather than for propagating or growing.

Every well-ordered private establishment should have a Conservatory wherein to display to the best advantage the plants which bave been brought to their attractive state in the greenhouses and hothouses thereon, and the nearer it is located to the residence, all other things being equal, the better. It would be best if it were a part of it. Many architects, in preparing plans and arranging for the erection of Conservatories, look more to the architectural beauty of the structure rather than to the well-being of the plants to be grown therein. One of the worst faults hitherto has been inadequate ventilation. A practical grower of plants should always be consulted upon this essential point before definite arrangements for building are made. In addition to a generous opening in the roof, which should, in all cases, be operated by one of the most approved lifters to be had, the silles also should have door openings that may be easily manipulated. The foundations may be made of any substantial material, either of stone, brick or concrete, and the wall should extend $2 \mathrm{ft} .6$ in. or $3 \mathrm{ft}$. high above the ground-line and up to where the glass begins. Hollow brick walls are considered the most satisfactory, if the house to which the Conservatory is to be attached be built of stone or brick, being less amenable to the winter extremes in temperature, when outside the thermometer may register zero, and inside $55^{\circ}$ or $60^{\circ}$. The glass from the wall to the eaves should be of good quality; and as transparent as possible, but that on the roof should be the translucent, "frosted" or ground glass. Contrary to the general belief, rose blooms of as fine quality have been produced under ground glass in the climate of the United States as have been grown under glass of the clearest transparency, and that fact is here stated so that the glass recommended may, without hesitation, be used; besides, it is better for nearly all plants grown for their foliage; survatory, should behigh enough to give a pleasing general effect and yet such that each individual plant inay be examined at pleasure; and at the same time the table should be low enough that the pots in which the plants are growing may not be seen through the glass from the outside.

some large plants may find a permanent home in the Conservatory, such as vines, to be trained on the rafters and girders, if the size and style of the building will allow of their training and proper care. Other large plants, as palms of the various species and varieties, can aiso be used to advantuge. The great trouble with many ot the vines and other plants growing permanently herein, is their proneness to insects in such structures, and the methods genera'ly in use for their exterminatiun, put into operation in aConservatory attached to a resideuce, are out of the question in most cases. We refer principally to the old style method of fumigation by burning tobacco for the destruction of aphis. Experiments are being made in the uses of different gases, and by vaporizing insecticides, which may allow of this part of the cultivation of flowers and plants under glass to be made less disagreeable for the operators and for the owners of Conservatories in the future than it has been in the past. For the destruction of the various scale insects and mealy bug, sponging by hand is generally resorted to, but it is a slow and tedious process. Syringing with a weak solution of tobacco water once or twice a week will kill the scale, and aid in keeping down mealy bug, especially if a strong pressure of water, when syringing, ean be brought into requisition. The aphis, before referred to, or what is generally called "green-fly," affects only what are termed soft-wooded plants, and as they are only brought in when at their best, should be entirely free from that pest before they leave the greenhouse, in which they have been brought to their most interesting and showy stage. Sometimes, however, no matter how much care has been exercised, some of these pests will be found on the plants, and as they increase very rapidly, some means will have to be resorted to for their extermination. Fumigation, by burning tobacco stems, is out of the question, but tobacco dust, - the sweepings of a cigar factory, - when burning is not at all disagreeable, learing little more smell than the burning of a good cigar. Liquid tobacco extract is often used with good effect by evaporation, using hot irons in the liquid. This has its objections, being somewhat clumsy to operate. Evaporating pans attached to the heating pipes, in which the liquid, somewhat diluted, is placed, are effective, and are not at all disagreeable. Cleanliness and neatness are the great essentials in a Conservatory with interesting plants well grown, to make it a source of pleasure to the owners, and must at all times be kept in view. For further information, see Glasshouses.

Edwin Lonsdale.

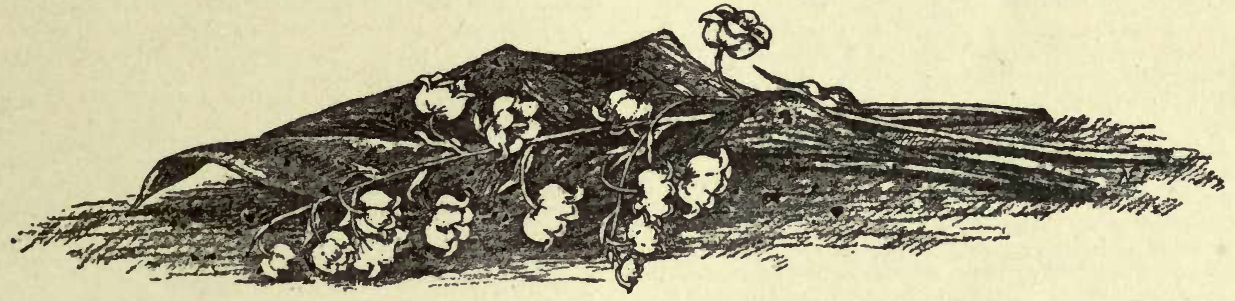

538. Spray of Lily-of-the-valley $(\times 1 / 2)$.

and the beauty of flowering plants in bloom may be conserved much longer than it is reasonable to expect they would be under the more or less glaring unobstructed snnlight.

The interior arrangement of a Conservatory is a question to be decided largely by the owner and gardener in charge, and is largely a matter of taste, although convenience in operating must never be lost sight of. The former depends upon the individuality of those most interested, and the latter must, in all cases, be provided for, if the best success in plant-growing is to be achieved. The table or stage along what might be termed the front, or nearest to the outside of the Con.
CONVALLARIA (old Latin name, derived ultimately from convallis, a valley). Lilidceoe. LILT-OF-THE-VALLEY. Fig. 538 One dainty herb in temperate Europe and Asia, and native also in the high mountains from Va. to S. Car. LFs, radical, from an upright rootstock or pip (Fig. 539): fls. white (sumetimes pink-tinged), small and tubular, nodding, in a short, radical raceme (Fig. 540), the stamens 6 and style 1 (Fig. 541). Much prized for its delicate, sweet-scented fls. The rhizome and roots are sold in drug stores. They are poisonous in large doses; in small doses used as a heart tonic. The plant is popularly supposed to be the one referred to in the Sermon on the Mount, but this is not to be 
determined. It is essentially a shade-loving plant. The species is C. majalis, Linn. R.H. 1886:84. Gn. 47, p. $179 ; 52: 1134$ and p. 319 (the latter in fruit). A.F. 13:402. Gng 5:56-7. F.R. 2:4. G.C. III. 23:149 (var. grandiflora). Lowe, 42 (var. variegata).

Lily-of-the-Valley is hardy, and is easily grown in partially shaded places and moderately rich ground. Old beds are liable to run out. The roots and runners become crowded, and few good flower-stems are produced. It is best to replant the beds every few years with vigorous, fresh clumps,

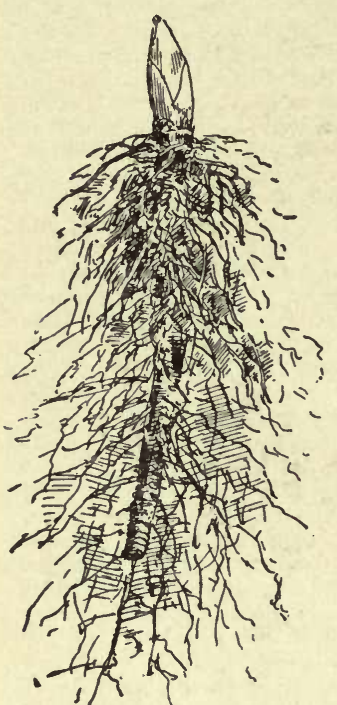

539. Lily-of-the-valley pip.

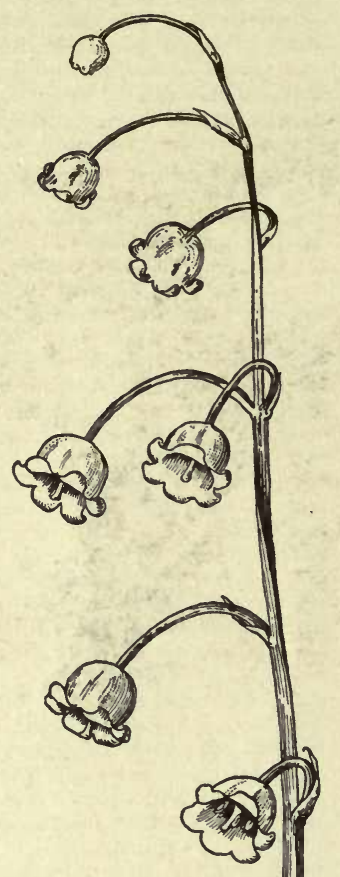

540. Raceme of Lily-of-the-valley. Natural size. whith have been grown for the purpose in some out-of-the-way place. Five or 6 strong pips, with their side growths, planted close together, will form a good clump in two years if not allowed to spread too much. The mats of clean foliage make attractive carpets under trees and in other shady places. If the bed is made rich and top-dressed every fall, it may give good results for 4 or 5 years; and plants in such beds thrive in full sunshine. One form has prettily striped foliage, very ornamental in the early part of the season. Liliesof-the-valley bloom early in spring. They run wild in many old yards, in cemeteries, and along shady roadsides. There are double-fld. forms; also one (var. prolificans) with racemes $2 \mathrm{ft}$. long.

J. B. KeLLER and L. H. B.

Few cultivated plants give so much satisfaction at so little cost as the Lily-of-the-Valley. It is one of our earliest spring flowers. Its time of blooming is always a subject of note to the household. It succeeds best in partial shade, and may be planted in the wild garden with good effect. It is especially appropriate for planting in irregular patches along the borders of wooded drives. The Lily of-the-Valley is one of the few flowers we seldom tire of. In and out of season, there is always a demand for its flowers. Hundreds of thousand:a of crowns are specially grown and matured in France, Germany and Holland for early forcing. They are detached from the clumps, grown separately for two years, sorted before shipment, and known as "pips." Berlin pips are considered best for early forcing. They usually come in bundles of 25 , and to have them force evenly it is considered essential to freeze them for a week or two. This may be effected by leaving th $3 m$ in the packing case, moss and all, in some open shed, taking them out as required. They are often placed in ice-houses, and frequently kept in cold storage for summer use. In forcing, no new roots are made. In ordinary propagating bed, with bottom beat, answers the purpose, and sand or sphagnum moss is the plunging medium in most general use. The bundles of crowns are given time to thaw out, the pips separated, and the crowns set in as thickly as possible. The frame is covered to exclude light until growth commences. The crowns are often put at once into a strong bottom heat of $85^{\circ} \mathrm{F}$. or thereabouts, but a better way is to start with $50^{\circ}$ and gradually increase the temperature. Batches intended for Christmas and New Year's Day often fail because there has not been sufficient preparation for the final high temperature. It is seldom that any leaves appear, even if the flowers come. In such cases, it is customary to put in a few leaf-eyes from the clumps. Later and more carefully prepared batches usually come well and with abundance of leaves, without which the flowers lose half their eharm. Bundles of 25 pips are often potted in 6 - or 7 -inch pots, for Easter sales. As the natural season approaches, less preparation is required. The pots are usually set under greenhouse benches, with a sprinkling of moss over them, away from heating pipes, until some growth is made, and afterwards finished in better light, but not bright sunlight. Clumps are potted and treated in the same way. As there is a large percentage of nonblooming buds in the clumps, they lose in effectiveness. There are rose-colored varieties, double varieties, and varieties with foliage striped with white.

T. D. Hatfield.

Millions of the single crowns, commercially called "pips," are grown on the European continent and exported for forcing. One English firm alone forces during the year upwards of seven millions. We usually receive the pips during the early part of November. They should be unpacked at once, the best pips selected for the earliest forcing, and the smallest kept for the latest forcing. The pips are tied in bundles of 25 . If one forces a limited number, say 500 to 1,000 per week, then put the bundles in 8- or 10-inch deep boxes, in any quantity he may choose, place a little soil between the bundles, and give them a good sosking. Then place the boxes in a cold frame or some place where the rains can be kept off-this is important-cover the tops of pips with a few inches of hay or straw. Frost does not hurt the pips in the least, but it is not essential. Never try to force the newly imported pips before New Year's. The cold storage pips are much best for the December crop. In keeping them in cold storage they should be removed from the frames and put into cold storage before there is the slightest movement of growth in the spring. The boxes should be covered with slats, so that one box can be put on another. or charge for storage will be exces sive. The tem perature should be from $28^{\circ}$ to $30^{\circ}$ Fahr.

The principal thing in forcing Lily-of-the-Valley is to obtain a strong bottom heat with a cool atmosphere. So, to obtain this, the bed for forcing should have a slate bottom with 6 inches of sand on it and be over some hot water or steam pipes. The temperature of the sand should be $80^{\circ}$ to $90^{\circ}$ and the atmosphere $50^{\circ}$. As spring approaches less bottom heat will be needed. A copious watering shonld be given the sand daily, but when the bells are showing color they should not be wet. Keep a covering of boards or cloth orer the pips for the first 10 
days : after that admit the light gradually, and when in full flower give them the full light, but never much sunlight, and avoid dranghts. A dozen or 20 pips can be forced the same way in a 5 - or 6 -inch pot. The flowers should be cut about 24 hours before using, and placed in jars of cold water. This prevents wilting when used.

William Scott.

CONVÓLVULUS (Latin, convolvo, to entwine). Convolvulacece. Includes Calystegia. BindweEd. A genus of about 175 species, widely distributed in temperate and tropical regions. Annual or perennial herbs, sometimes suffrutescent, twining, trailing, erect or ascendIng, with filiform, ereeping rootstocks lvs. petiolate, entire, toothed or lobed, generally cordate or sagittate : fls. axillary, solitary or loosely cymose, mostly opening only in early morning ; corolla campanulate or funnel-form. the limb plaited, 5-angled, 5-lobed or entire. The botanical distinction between Convolvulus and Calystegia is not sufficiently well marked to warrant retaining the latter as a separate genus. When the $\mathrm{fls}$. of $C$. oc cidentalis are borne singly, the calyx bracts are broad aud Calystegia-like: when borne in elusters the bracts ar greatly reduced.

S. W. Fletcher.

The species thrive in a rariety of soil. without especial care. The greenhoust species do best in a soil with considerable fiber. The hardy perennials are usually prop. by dividing the roots, otherwise by cuttings or seeds, the tender species preferably by cuttings. C.tricolor is the most important of the hardy annuals. It may also be started in the greenhouse, and makes an excellent plant for the hanging basket. All are vigorous growers, and may become troublesome weeds in some places if not kept within bounds. $C$. Japonicus and $C$. Sepium should be used with caution. This is the chief reason why the hardy perennials are not often found in wellkept gardens, except along wire fences or lattice screens, where the turf is laicl up close so as to allow only a narrow border for the roots. The double-flowered form of $C$. Japonicus is seen to best advantage in halfwild places, or on rocky banks, where shrubs make but a stunted growth. Here it will grow luxuriantly, forming graceful festoons from branch to branch, and covering the ground with a pretty mantle of green.

Cult. by J. B. KeLLER.

A. Calyx with 2 membranaceous bracts at the base: peduncles usually 1-fld. (Calystegia.)

B. Stem prostrate, $8 \mathrm{in}$. to $2 \mathrm{ft}$. high: peduncle usually shorter than the lvs.

villosus, Gray (Calystègia villòsa, Kellogg). Plant densely white-villose throughout: stem prostrate, scarcely twining: lvs. slender-petioled, reniform-hastate to sagittate, the upper acuminate, 1 in. or less long, the basal lobes often coarsely toothed: bracts oval or ovate, completely enclosing the calyx: fls. cream-yellow, 1 in. long. Calif. Perennial.

BB. Stem twining or trailing, 3-10 ft. high: peduncle exceeding the lvs.

Japónicus, Thuab. (Calystègia pubéscens, Lindl.). California Rose. Fig. 542. Hardy perennial, herbaceous twiner: growth very vigorous, often $20 \mathrm{ft}$.: whole plant more or l(:ss densely and minutely pubescent: Ivs. hastate, lanceolate, obtuse or broadly acute, with angular or rounded lobes at the base; variable, occasionally without lobes, rarely sharp lanceolate : fls. brigut pink, 1-2 in. liroad, produced freely during the summer months aud remaining expanded for several days. Japan and E. Asia. The double form is now naturalized from southeastern $\mathrm{N}$. Y. to D. C. and Mo. P. M. $13: 243$. F. S. $2: 172$. B. R. $32: 42 .-$ The double form is completely sterile, with narrow, wavy petals, irregularly arranged, the outer somewhat lacerate. A valuable decorative plant for covering stumps and walls. In rich soil the roots spread rapidly, and will smother out all other plants unless confined in tubs. The Calystegia pubescens of Lindley has been wrongly referred to I pomoel hederacea, but the two plants are very different, the former being perennial and the latter annual. See Journ. Hort. Soc. 1:70 (1846). The plant is commonly confounded witb $C$. Sepium.

occidentalis, liray. Hardy perenuial, nerbaceous or with suff rutescent base: stem twining, several ft. high, glahrous or minutelv pubescent: lvs. from angulate- 
Scammònia, Linn. Hurdy perennial trailer, deciduous : stem angular, glabrous : Ivs. cordate-sagittate, grey-green, the lobes entire or dentate: sepals glabrous, ovate, obtuse; corolla white, creamy or light pink. Asia Miuor. - The large tap-roots supply the resinous cathartic drug scammony. Bв. Stem erect or ascending, silky.

Cneòrum, Linn. Stem shrubby, half-hardy, 1-4 ft. high: Ivs. persistent, lanceolate or spatulate, silky grey: inflorescence a loose panicle, 1-6-fld.: fls. white or tinged with pink, borne freely during the summer. $\mathrm{S}$. Eu. - Valuable as a pot-plant for greenhouse or window decoration, or trained to a warm wall. Confused with C. olecefolius.

oleæfollius, Desr. Tender perennial: Ivs. linear-lanceolate, acute, slightly villose: fls. bright pink, borne freely in loose, umbellate panicles in the summer. Greece. B.M. 289 (as $C$. linearis). - Many plants now passing as $C$. olecefolius are $C$. Cneorum. The latter may be distinguished by its broader, blunter, silvery-rillose lvs. and lighter colored blossoms.

trícolor, Linn. (C. minor, Hort.). Fig. 544. Hardy annual : stem trailing, ascending 6-12 in., angulate, densely covered with long brownish hairs: lvs. linearoblong or subspatulate, obtuse or rounded at the apex, usually pubescent but sometimes glabrous, the margin ciliate towards the base: peduncle 3 -fld., exceeding the lvs.: sepals ovate, lanceolate, villose, acute: limb of the corolla azure-blue, throat yellow, margined with white. S. Eu. B.M. 27. - One of the best annuals for the home border. Each plant covers a ground space of $2 \mathrm{ft}$., and blooms continuously throughout the summer. Flowers remain open all day during pleasant weather. There are many variously striped and spotted forms of this popular annual, none of which surpasses the type in beauty. A variety with pure white fls. is attractive. Other well marked horticultural forms are : Var. vittata, prettily striped with blue and white. F.S. 3:298.

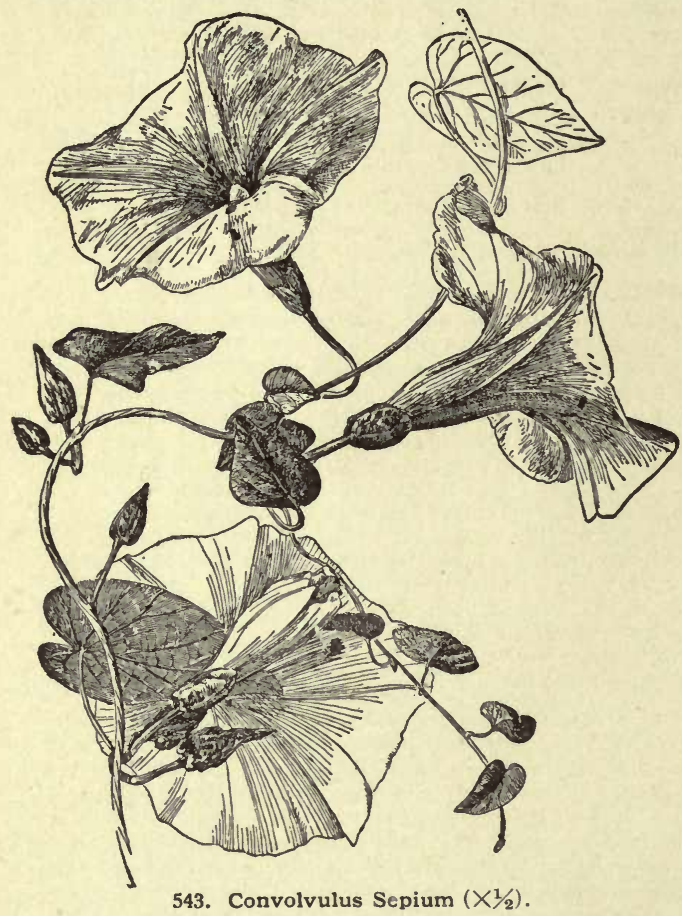

R.H. 1848:121. Var. compáctus. Dwarf, and valuable for pot culture. Gt. 47, p. 635. A 5-petaled form is also recorded. F.S. $8: 116$.

aùreus supérbus, Hort. A tender perennial, but may be treated as an annual, since it flowers the first season from seed : stem trailing or twining, 4-5 ft. long: fls. golden. Valuable as a greenhouse climber and for hanging baskets. - Not sufficiently described for identification.

O. althceoides, Linn. (C. Italicus, Roem. \& Schult.). Stem prostrate, scarcely twining : upper lvs. pedatifid; lower ovate.

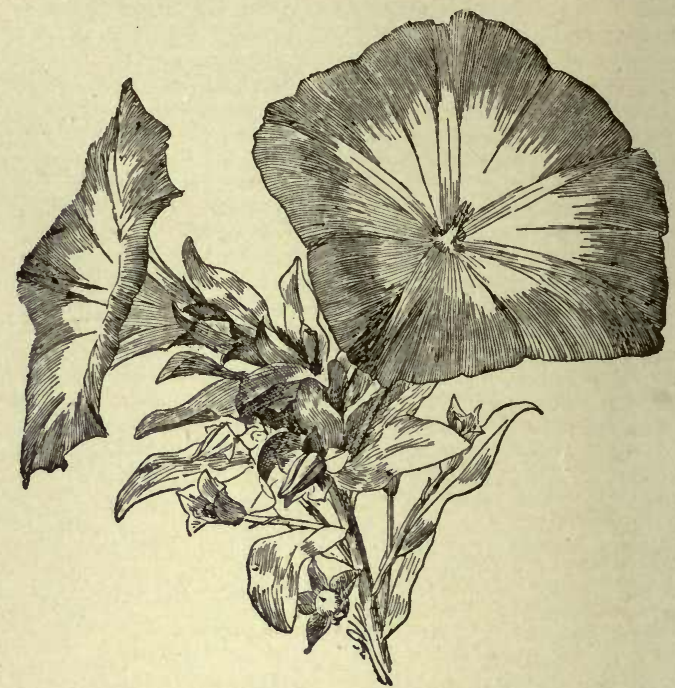

544. Convolvulus tricolor. Natural size.

cordate, crenate, silvery: fls. pink. May-Aug. Mediterranean region. B. M 359, F S 10:1021 ( as var. May-Aug. Mediterranean O. arvénsis, Linn. Slender perennial trailer, $1-3 \mathrm{ft}$. long, glabrous or nearly so: lvs. ovate-sagittate or hastate, variable: fls. white or pink. Eu. and E. Asia. Naturalized in old fields through the Atlantic states and Calif. A troublesome weed.C. Dahùricus, Herb. (Calystegia Dahuricus, Fisch.). Hardy deciduous twiner, $3-6 \mathrm{ft}$.: lvs. oblong-cordate, shortly acute: fls. pink or rose-violet. June, July. N. Eu, B. M. 2609. F. S. 10:1075. - C. Canariénsis, Linn. Greenhouse evergreen : lvs. oblong-cordate, acute, villose : fils, violet-purple : peduncle 1-6-

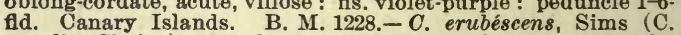
acaulis, Choisy). Tender biennial : lvs. oblong, hastate, the basal lobes toothed: fls. small, 5-lobed, rose-pink. A ustralia, B.M.1067.-C. macrostegius, Greene. The plants in the trade under this name may be referred to $C$. oceidentalis.-C. major. Hort., not Gilib. $=$ Ipomøea purpurea.- $C$. ocellàtus, Hook. Stove evergreen: limb of the corolla white, 5-angled: throat reddish purple : ivs. sessile, linear, acute, 1-veined, villose. S. reddish purple: lvs. sessile, linear, acute, 1-veined, villose.
Afr. B.M. 4065 .

\section{COONTIE of S. Fla. is Zamia integrifolia.}

COOPÈRIA (after Joseph Cooper, English gardener). Amaryllidacece. A genus of only two or three species of tenfer, bulbous plants from Texas, with the habit of Zephyrunthes but night-blooming (which is anomalous in the order), and with erect anthers, while those of the latter are versatile. The fls. are fragrant, solitary, 2 in. or more across, waxy-white, tinged red outside, and more or less green within. The lvs, appear with the fls. in summer. They are long, narrow, flat and twisted. The bulbs should be taken up in autumn and stored during the winter in dry soil. Culture easy and like Zephyranthes. Lately a new and little-known plant has been offered by the trade, $C$. Oberwetteri, with "bright green" fis.

\section{A. Neck of bulb short: perianth tube long.}

Drúmmondii, Herb. Evening Star. Bulb roundish, 1 in. thick, with a short neck : lvs. narrowly linear, erect, $1 \mathrm{ft}$. long : peduncle slender, fragile, hollow $1 / 2-1$ ft. long: spathe $11 / 2-2$ in. long, 2-valved at the tip : perianth tube $3-5$ in. long; limb $3 / 4-1$ in. long. white, tinged with red outside: segments oblong, cuspidate. Var. chlorosolen, Baker, has a perianth tube stouter and tinged with green: limb longer and less wheel-shaped : lvs. a little broader. B.M. 3482 . 
AA. Neck of bulb long: perianth tube short.

pedunculàta, Herb. Giant Fairy Lily. More robust than C. Drummondii: bulb with a longer neck, 2-3 in. long: lvs. about $6,1 \mathrm{ft}$. long, $1 / 4 \mathrm{in}$. broad : peduncle about $1 \mathrm{ft}$.long: spathe 1-2-valved at the tip: perianth tube shorter, $1 \frac{1}{2}$ in. long: limb nearlv as long as the tube, tinged red outside. B.M. 3727. R.H. 1853: 401.The best species. Fls. larger, of purer color, and remaining open a day or two longer.

W. M.

COPROSMA (Greek name referring to the fetid odor of the plants). Rubidcece. Shrubs or small trees, often trailing, of New Zealand, Australia and Hawaii. Cult. for their pretty fr. or variegated lvs. Lvs. opposite, mostly small. Fls. small, solitary or fascicled, white or greenish, polygamous diøcious; corolla-linb 4-6-lobed, the lobes revolute; stamens 4-6: fr. an ovoid or globose drupe. Coprosmas are greenhouse plants in the north, but they are rarely cult. In $\mathrm{S}$. Calif. 2 species are cult. in the open. Prop. by hardened cuttings. The soil which is found among Kalmia roots, mixed with good loam and sand, if necessary, will suit these plants. Cuttings should be rooted in moderate heat in spring, before growth commences. If placed under a handlight or propayating frame, care must be taken to prevent damping, to which the cuttings are liable.

Baùeri, Endl. (C. Baueriana, Hook. f. C. Stockii, Hort.). Trailing plant, with oval-obtuse or rounded entire lvs., which are oddly blotched with yellow and whitish or even almost wholly yellow. New Zealand. - With age it forms a compact shrub. Vars. picturata, Hort., and variegata, Hort., are the common forms.

aceross, A. Cunn. Low and spreading, with minute lvs., small white fls., and pretty sky-b!ue drupes or berries. New Zealand. G. W. OLIver and L. H. B.

COPTIS (Greek, to cut, from the cut eaves). Ranunculdcea. Eight species of hardy perennial herbs of the cooler parts of the northern hemisphere. Low, stemless plants, with slender rootstocks : lvs. radical, compound or divided, lasting over winter: fls. white or yellow, scapose ; sepals 5-7, petal-like ; petals 5-6, small, linear, hood-like; stamens numerous: carpels stalked, few, becoming an umbel of follicles. The bitter roots yield the tonic medicine known as "gold thread;" also a yellow dye. The plants should have peaty soil, with a little sand, and prefer shade in damp situations. They require some protection in winter, as in a cold pit. Prop. by root division and seed.

trifolia, Salisb. No stem : rootstock yellow : lvs. compound, long-petioled; ifts. broadly obovate, cuneate, obtuse, the teeth mucronate: fl.-stem slender; sepals white, with yellow base; petals small, club-shaped : follicles 3-7, spreading, equaled by their stalk; seeds black. MayJuly. Adirondacks and westward. L.B.C. $2: 173$. - Neat and pretty with shining lvs.

\section{K. C. Davis.}

CORAL BERRY. Symphoricarpus vulgaris.

CORAL DROPS. Bessera elegans.

CORALLORHIZA(Greek

545. Corallorhiza multiflora. $(\times 1 / 3$. for coral-root). Orchiddceae, tribe Epidéndrea. CoRal RoOT. Low native orchids, growing in woods and parasitic on roots, destitute of green foliage, the plant usually brownish or yellowish and inconspicuous. Fl. small, somewhat 2- lipped, usually obscurely spurred at the base; sepals and petals nearly alike; lip small, slightly adherent to the base of the column ; pollinia 4. Species few, in $N$. Amer., Eu. and Asia. The Coral-roots have little merit as garden plants, although very interesting to the student. They may be grown in rich, shady borders. Two species have been offered by dealers in native plants: C. multiflora, Nutt. (Fig. 545), is purplish, 11/2ft. or less high, 10-30-tld., lip deeply 3-lobed: grows in dry woods in northern states; C. Mertensiàna, Bong., scape many fld., 8-15 in. high, the lip entire and broadly oblong: occurs in Brit. Col. and N. to Alaska.

L. H. B.

CORAL-ROOT. Corallorhiza.

\section{CORAL-TREE. Erythrina.}

CORCHORUS Japónicus. See Kerria. The genus contains the two plants that furnish Jute, $C$. capsularis (which yields most) and $C$. olitorius. They are annual plants, natives of Asia but cultivated throughout the tropics, growing 10 or $12 \mathrm{ft}$. high, with a straight stem as thick as the little finger and branched only at the top. The young shoots of both are used as pot herbs. C.olitorius is much grown for this purpose in Egypt, and is known as Jews' Mallow. They belong to the Tilideece.

CORDIA (an early German botanist, Valerius Cordus). Borragindcea. Warm-climate trees or shrubs, mostly American. Calyx tubular or campanulate, toothed or lobed : corolla tubular, lobed, the parts and the stamens 4 or more: style 2-lobed: fr. a drupe which is 4-loculed and usually 4-seeded: lvs. entire or toothed. The Cordias are greenhouse plants with showy fls., of easy cult. Grown in the open in the extreme S. Prop. by cuttings of firm wood and by seeds.

Sebestèna, Linn. (C. specidsa, Willd.). Geiger Tree. Tall shrub or small tree, hairy, with rough, broad-ovate, large-stalked lvs.: fls. 1-2 in. long, scarlet, stalked, in large, open, terminal clusters, the crumpled corollalobes and stamens 5-12: drupe enclosed in the hazellike husk formed by the persistent calyx. Keys of Fla. and S. B.M. 794 .

Fráncisi, Tenore. Tall: lvs. dark green : fls. white. S. Amer.

Other Cordias, of which there are many, are likely to come into cult. in the southern country. C. Gréggii, Torr. var. Pál. meri, Wats. (G.F.2:233), of Mexico, "in the size and beauty of its fls. equals the C. Sebestena."-C. Myxa, Linn, from trop. Asia and Austral., is one of the best woods for kindling fire by friction, and is useful in many other ways. $\quad$ L. H. B.

CORDYLINE (club-like: referring to the fleshy roots). cilideece. Dracana. A genus of greenhouse plants closely related to Dracæna, but the ovary contains sev. eral ovules in each cell, and the solitary pedicels are provided with a 3-bracted involucre : stem tall, often woody, bearing large, crowded lvs., to the striking variegation of which the group owes its value: fls. panicled; stamens 6: pedicels articulated: perianth 6-parted : ovary 3-celled : fr. a berry. Cultivated for the ornamental foliage. The horticultural forms and names have become very numerous. The various species are in the trade under Dracæna, which see for a key to the species of both genera combined. In the following paragraphs, the initial $D$ indicates that the plant in question is known in the trade as a Dracæna, and $C$ that it is known as a Cordyline (see Dracana). For a monograph, see Baker, Journ. Linn. Soc. 14:538 (1875). K. M. WIEGAND.

Of Cordylines or Dracæna, propagation is generally effected by cutting the ripened stems or trunks, from which all lvs. have been removed, into pieces from $2-4$ in. long. These are laid either in very light soil or in sand in the propagating bed, where they receive a bottom heat of about $80^{\circ}$, being barely covered with sand or moss (Fig. 546). The eyes soon start into growth, and, as soon as they have attained a height of 3-4 in., are eut off with a small heel and again placed in the propagating bed until rooted, after which they are potted off into small pots in light soil, kept elose until they become established. They are then shifted on into larger pots as soon as well rooted. They delight in a mixture of 3 parts good, turfy loam and 1 part well. 
decayed cow-manure, with a liberal sprinkling of sharp sand. A warm, moist atmosphere suits them best while growing, but towards fall the finished plants must be gradually exposed to full sunshine and a dry atmosphere, which develops their high colors.

The kinds enumerated below are such as are mainly grown in large quantities for decorative purposes, and

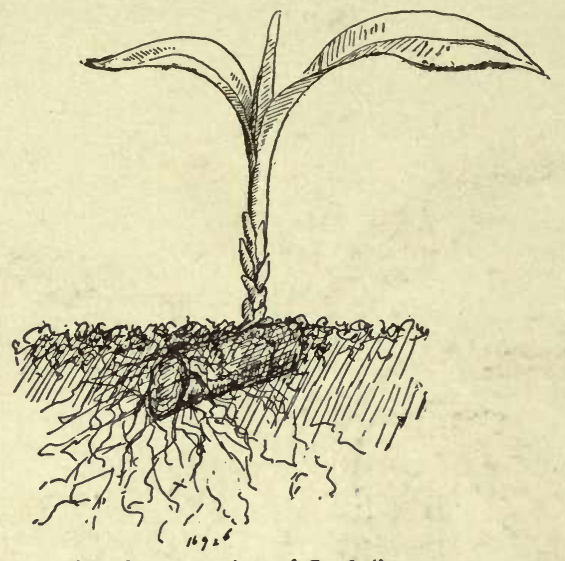

546. Stem-cutting of Cordyline.

are sold principally during the winter months, especially during the holiday season, when plants with bright colored foliage are always in strong demand: Cordyline amabilis.-A strong-growing species with broad green foliage, which is prettily variegated with white and deep rose. One of the hardiest varieties, either for decorations in winter or for outdoor work, vases, etc., in summer. C. imperialis. - Another strong-growing species, with deep olive-green foliage, which changes to deep rose with white edge. $D$. fragrans. - An African species with broad, massive, deep green foliage which makes noble decorative plants, being frequently grown into specimens from 6-8 ft. high. Its foliage is of heavy texture, making it a useful plant for the dry atmosphere of a living-room. Two handsomely variegated forms of the above are $D$. Lindeni and $D$. Massangeana, both very desirable varieties. C. terminalis. - This is the most popular variety, and is grown in immense quantities. The foliage on well-matured plants is of an intense rich crimson marked with lighter shadings. C.australis (commonly called $C$. indivisa).- Used principally as an outdoor decorative plant in summer, but extensively used for furnishing vases, window-boxes, etc. It succeeds best when planted out in the open border during summer, potted in the fall and stored during winter in a cool greenhouse. It is propagated almost exclusively from seed, which germinates freely if sown during the early spring months in sandy soil, in a temperature of 60 to $65^{\circ}$, growing them on during the first season in small pots. These, if planted in the open border the second season, make fine plants for 6 - or 7 -inch pots. There are a number of varieties of Indivisa, among them several handsomely variegated forms, which, however, are but little distributed yet.

Among the principal varieties and species besides the above which are grown to some extent in a commercial way are : Baptistii, Cooperi, Porphyrophylla, Shepherdi, Stricta grandis, Youngi, Goldieana, Congesta, Bruanti, Marginata and Lord Wolseley, the latter a most beautiful, graceful, high-colored variety, undoubtedly the most distinct and useful commercial sort yet introduced and which, as soon as it becomes more plentiful, is certain to be very popular.

J. D. Eisele.

Cordyline australis and its allied forms are easily raised from seed, which is readily obtainable in a fresh state. The seed should be sown rather thinly in a light, sandy soil, and, as there is little danger of the seedlings damping off, they may be allowed to grow in the receptacles in which they are sown until large enough to go into 3-in. pots. If sown early in spring, the plants will be large enough for 6 -in. pots by the end of the following September.

Dracana Knerckii, C. canncefolia, D. Lindenii and D. Massangeana are among the best decorative plants for the dwelling house. D. Knerckii and the two variegated forms of $D$. fragrans are rooted from cuttings taken from headed-back plants. In propagating $C$.cannoefolia, when seed cannot be obtained, old plants should be mossed so as to produce roots before the top is taken off, as it is a shy-rooting species from cuttings. $D$. Goldieana should be topped and rooted in a good bottom heat, and the stems cut into pieces small enough to be put in pots when the shoot is of sufficient length, instead of cutting off the shoots and rooting afresh. $D$. Godseffiana and D. maculata evidently belong to the same section; every little branch of these will root in sharp sand. Long stems of $D$. ensifolia and $D$. Borhavii, when cut in sections of from 4 to 6 in., with the leaves kept on, will root quickly and may be used as stock plants. C. Brasiliensis, an elegant species with broad green lvs., is best propagated by adopting the method practiced on the colored-lvd. kinds, of which $C$. terminalis is perhaps the best known. This method consists of cutting up the stems into small pieces and placing them in sand, with a brisk bottom heat. Small shoots are developed in a short time, which will frequently be found to have small roots at their bases, but they are of little use for the subsequent nutriment of the plantlet. The shoot, when large enough, should be separated from the piece of stem and inserted in the sand-bed, where it will develop thick feeding roots. Afterwards they are potted and kept in a warm, moist atmosphere. Cuttings may be put in at any time when bottom heat is at command. The soil used should be light and enriched with rotted cow-manure.

G. W. Oliver.

A. Foliage of sessile, thick, sword-shaped lvs. B. Lvs. glaucous beneath, broad.

indivisa, Kunth. Arborescent, 10-20 ft. high : lvs. dark green, densely crowded, 2-4 ft. long, 4-5 in. broad at the middle, $1 \frac{1}{2-2} \mathrm{in}$. at the base, rigid, coriaceous ; midrib stout, colored red and white, veins on each side of it 40-50: panicle nodding: pedicels .5-1 line long; bracteoles lanceolate, 3-4 lines long, membranous; perianth 3-4 lines long, white; tube very short, campanu-

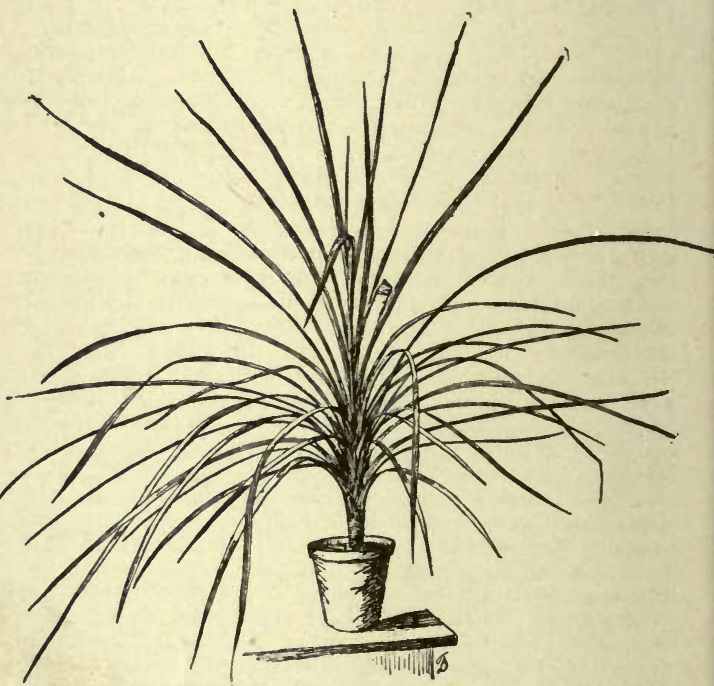

547. Cordyline australis $-C$. indivisa of the trade.

late ; segments equal, spreading : ovules $5-6$ in each cell. New Zealand. Gn. 49,p.86. Lowe, 52.-Coolhouse ; valuable for vases. Rare in cult.

Bв. Lvs. green on both sides, narrower.

strícta, Endl. (D. congésta, Hort.). Slender, 6-12 ft. high: lvs. less crowded than in the next, acuminate, 1-2 ft. 
long, 9-15 lines wide, base 3-6 lines wide, scarcely costate; veins scarcely oblique, margins obscurely dentate: panicle terminal and lateral, erect or cernuous : pedicels $.5^{-1}$ line long; lower bracteoles lanceolate; periunth lilac, 3-4 lines long, campanulate, interior segments longer than the outer: ovules 6-10 in each cell. Australia. B.M. 2575. G.C. III. 17:207 (D. congesta).-Coolhouse ; vases, etc. Var. grándis, Hort. Large, highly colored. Var. díscolor, Hort. Like var. grandis, but with foliage dark bronzy purple.

austràlis, Hook. (D. indivisa, Hort. D. calocòma, Wend.). Fig. 547. Arborescent, 20-30 ft. high : lvs. densely rosulate, $3-4 \mathrm{ft}$. long, 12-18 lines wide; base 6-9 lines wide, acuminate, green ; midrib firm, prominent, nerves on each side of it 12-20, scarcely oblique: panicle erect, terminal, ample: pedicels very short ; bracteoles deltoid, .5 line long; perianth white, 3-4 lines long; tube short, campanulate, segments nearly equal, spreading: mature seeds often solitary. New Zealand. B.M.5636. G.C. III. $23: 153$. Gn. 47, p. 312; 48, p. 197. I.H. 35:40 (var. Doucetidna); 37:114 (var. Dalleridna) ; 40:190 (linedta, var. purpuráscens). S.M, 1, p. 487, f. 189.-Coolhouse; vases, etc. Var. aùreastriàta, Hort. Variegated with a number of longitudinal yellow stripes. Var. atropurpùrea, Hort. Base of leaf and under side of midrib purple. Var. lineata, Hort. Lvs. broader, the sheathing base stained with purple. Var. Vèitchii, Hort. (D. Vèitchii, Hort.). Base of leaf and under side of midrib bright crimson. C. Hookeri, Hort., is a garden form.

\section{AA. Foliage of petioled lvs.}

B. Lvs. oblanceolate; petioles broad.

rùbra, Hugel. Slender, 10-15 ft. high : lvs. contiguous, ascending, 12-15 in. long, 18-21 lines wide above the middle, thick, dull green both sides, distinctly costate ; veins oblique ; petiole broad, deeply grooved, 4-6 in. long: panicle lateral, nodding: pedicels very short; bracteoles small, deltoid; perianth lilac, 4.5-5 lines long, inner segments longer than the outer: ovules 6-8. Country unknown. G.C. III. 22:285. - Coolhouse; vases, ete. D. Bruánti, Hort., is a garden form. R.H. 1897, pp. 514,515 . G.C. III. $22: 285$.

BB. Lvs. lanceolate; petioles narrow, nearly terete.

Haageàna, Koch (C. Múrchisonice, F. Muell.). Slender and small : lvs. contiguous, ascending, oblong-falcate, 4-8 in. long, 2-2 $\frac{1}{2}$ in. wide at the middle, acute, base rounded or deltoid, thick, dull green throughout, distinctly costate; veins slender, oblique ; petiole $3-4$ in. long, deeply channelled : panicle lateral : pedicels 1.5-2 lines long; perianth 4-4.5 lines long, tinged with lilac; segments spreading: ovules $6-8$ in each cell : berry with a dry pericarp. Australia.

terminàlis, Kunth (C. canncefòlia, F. Muell.). Low and slender, stem 3-6 lines thick : Ivs.contiguous, ascending, green or rarely colored, $12-18 \mathrm{in}$. long, $2-3 \frac{1}{2} \mathrm{in}$. wide, acute, thickish, distinctly costate; veins frequently unequal, strongly oblique ; petiole 4-6 in. long, deeply channelled : pedicels very short or none; bracteoles deltoid, membranous ; perianth 5-6 lines long, white, lilac or reddish, segments short: ovules $6-10$ : berry large, red. East Indies. A.G. 16:361. B.R. 21:1749, - The varieties in cultivation are almost innumerable. Those in the American trade are the following (all stove plants), usually considered as horticultural species : amábilis. Lvs. broad, shining deep green, in age becoming spotted and suffused with rose and white. Amboyénsis. Lvs, oblong-lanceolate, recurved, deep bronzegreen edged with rose-carmine below; petioles tinged with purple. Anerliènsis. Lvs. very broad, deep bronzered, with some white. Báptistii. Fig. 548. Lvs. broad, recurved, deep green, with some pink and yellow stripes ; stem also variegated. I.H. 26:334. Baùsei. Lvs. broad, dark green, with some white. bella. Lvs. small, purplish marked with red. Brasiliénsis, Schult. Lvs. broad. Cántrelli. Lvs. dark metallic crimson, young ones bright carmine. Coòperi. Lvs. deep wine-red, gracefully recurved : common in cult. férrea, Baker. Lvs. narrow and somewhat oblanceolate, 5-7, bright or dark crimson ; petiole short. Lowe 3 (var. versicolor); 29. B.M. 2053. L.B.C. 13:1224. Fràseri. Lvs. somewhat erect, broad, oblong, abruptly acute, blackish purple with bloom, margin below with a deep rosy lake stripe extending down the petiole. Gládstonei. Lvs. broad, brilliant crimson. Guilfoylei. Lvs. long and narrow, tapering both ways, recurved, striped with red, pink or white, white on lower part of leaf and margin of peti-

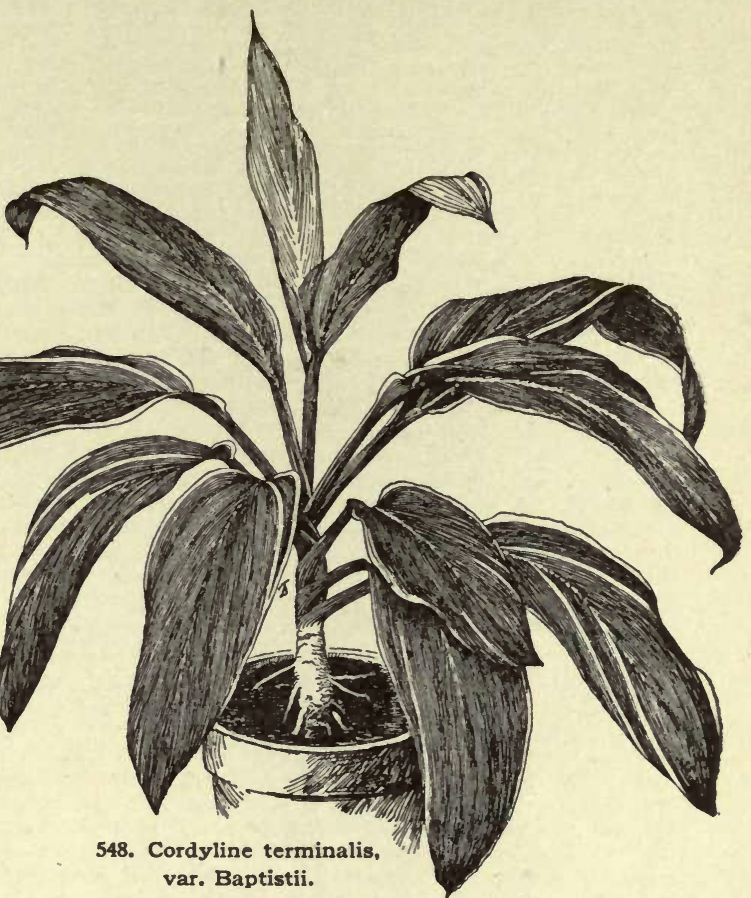

ole. I.H. 19, p. 249. hyेbrida, Lvs. broad, variegated, deep green margined with rose, in age deep rose, creamy white in young lvs. imperialis. Lvs. arching or erect, oblong, thick, deep metallic green, rayed all over with bright crimson or pink, handsome. Jardiniere (terminalis alba $\times$ Guilfoylei). Lvs. very small and compact, narrow, green broadly margined with white. metallica. Lvs. erect-arching, oblong, when young uniform rich coppery purple, in age dark purple-bronze ; petioles same. F.M. 1872:24. nigro-rùbra. Lvs. narrow, linear-lanceolate, dark brown with rosy crimson centers, young often entirely rose. Norwoodiénsis. Lvs. striped with yellow, green and crimson, last color principally confined to the margin; petioles brilliant. $\mathbf{R e}$ gina. A broad-lvd. form. Robinsoniàna. Lvs. long, lanceolate-acuminate, arched, light green, striped with bronze-green and brownish crimson.-- I.H. 26:342. Schúldii. Lvs. broad, variegated. F.E. 7:961. Sc6́ttii. Lvs. broad, arching, deep green, crimson edged; said to be a hybrid. Yoùngii. Lvs. broad, spreading, when young bright green streaked with deep red and tinged with rose, in age bright bronze. Yoùngii, var. rosea, Hort. Green, tinged with pink, white or carmine. Youngii, var. alba, Hort. Variegated with white instead of red. Crosses with Scottii are known as Stricta, Albo-lineata, Mrs. George Pullman, Mrs. Terry; with Norwoodiensis, as Little Gem.

List of synonyms, unidentified trade names and others: o. angústa, Hort. (C. terminalis var.). Lvs. narrow, arching, dull dark green above, purplish beneath. A slender form. - C. angustifolia, Kunth= C. stricta.-O. aurantiaca, Hort. $=$ ?- C. Balmoreana, Hort. Lvs. bronzy, with white and pinkish stripes.-C. Bánksii, Hook. Lvs. very long, linearpanceolate, 3-5 ft, long $2-3$ in, wide, petioled, green, glancous , Hort $=?-O$. Cassandva , Hort = $-C$ Chélsomi, Hort (form Hort. $=9-O$. Cassanovae, Hort. $=-C$. Chelsomi, Hort. (form of C. terminalis). Lvs. large, glossy dark green, almost black,
becoming suffused and edged with crimson. I.H. 19, p. 90, $O$. becoming suffused and edged with crimson. I.H. 19, p. 90.- $O$.
compácta, Hort. (C. terminalis form). Lvs. recurved, broad, dull green, with bronze and rose stripes in age.-O. Dénnisoni. Hort. (C. terminalis form). Dwarf: Ivs, broad, bronzy purpla 
-C. Elizabethioe, Hort.=? $-C$. Eschscholtziàna, Mart. $=$ C. terminalis $-C$ excélsa, $=$ Hort. (C) terminalis for Mart. $=\mathrm{C}$. terminalis.- $C$. excélsa, Hort. (C. terminalis form). Lvs. $=$ ?-C.frutéscens =? - C. gloridsa, Hort. (C. terminalis form). Lvs. very large and broad green, with a peculiar bronze-orange hue.-C. helychioides, F. Muell. $=\mathrm{C}$. terminalis. $-O$. heliconicefòlia, Ott. et Diet.=C. terminalis. $-O$. Héndersoni, Hort.=?O. magnifica, Hort. (C. terminalis form). Lvs. large and broad, bronzy pink, becoming darker.- $C$. Manners-Suttonice, $\mathrm{F}$. Muell.= C. terminalis. - O. porphyrophylla, Hort. (C. terminalis form). Lvs. deep bronzy purple, glaucous beneath. $=C$.

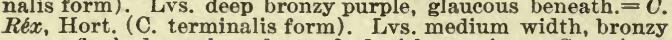
green, flushed purple and streaked with carmine.-C. rosàcea, Hort. (C. terminalis form). Lvs. recurved, broad, dark bronzy green margined with pink.- $C$. Salmonea $=?-C$. sepiària, Seem $=$ C. terminalis. $-C$. Sieberi, Kunth $=$ C. terminalis. $-C$. spléndens, Hort. (C. terminalis form). Lvs, dense, short, ovateacute, bronzy green, shaded with rose-carmine.-C. Zeelándica, Hort.= C. rubra.

K. M. WIEGAND.

COREOPSIS (Greek, signifying bug-like, from the fruit). Compósitoe. Tickseed. Annual or perennial herbs, flowering in summer and autumn. Nearly all natives of eastern N. Amer. Lvs, either opposite or alternate: heads pedunculate and radiate; the broad involucre with bracts of two kinds, the outer narrower and greener, receptacle chaffy; rays very showy, yellow particolored or rarely rose, neutral : disk fls. yellow, brown or dark. The genus differs from Bidens only in the broad, flat and winged akenes, with short or obsolete pappus. Many of the species are in the trade under the name Calliopsis. All the kinds are of easiest culture. The perennials are hardy border plants. The annuals are raised in any garden soil, and bloom freely with little care. They are all showy plants.

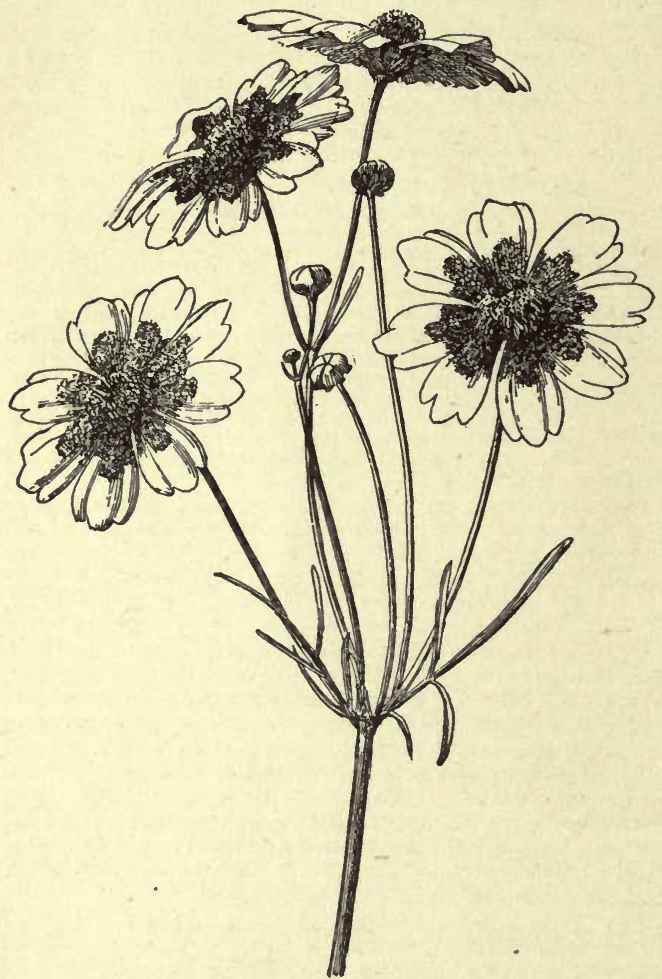

549. Coreopsis tinctoria-Calliopsis elegans of gardens $(\times 1 / 2)$.

Index : angustifolia, 2 ; aristosa, 16 ; aurea, 17 ; auriculata, 6 ; bicolor, 4 ; cardamiuefolia, 3 ; coronata, 8 ; delphinifolia, 13; Drummondii, 5; elegans, 4; grandiflora, 9; lanceolata, 7 ; major, 10; marmorata, 4 ; palmata, 12; pubescens, 6 ; rosea, 1 ; tinctoria, 4 ; trichosperma, 15; tripteris, 11; verticillata, 14.
A. Disk yellow: rays rose-purple.

1. ròsea, Nutt. Perennial : diffusely branched from slender, creeping rootstocks 1-2 ft. high, smooth: lvs. opposite and small (1-1.5 in. long), all narrowly linear-entire or rarely toothed or lobed: heads small, $2 / 3$ in. broad or less, short-peduncled ; rays wedge-shaped, lobed at the apex : akene oblong, wingless; pappus an obscure border. Southeastern U.'S.

AA. Disk and involucre dark purple: rays yellow or parti-colored, wedge-shaped and lobed.

B. Outer involucral bracts very short, triangular.

2. angustifolia, Ait. Perennial : strict and tall, $1-3$ ft. high, glabrous, sparsely branched at the summit: lvs. alternate, entire, thickish, basal few or wanting, lower cauline elliptical on long petioles, upper narrowly spatulate, sesslle or reduced to bracts : heads 1-1.5 in. broad; rays entirely yellow: akene with lacerate wings and setiform awns. Southern U. S.

3. cardaminefollia, Torr. \& Gray. Annual : low and diffusely much branched from the base, 6-18 in. high, glabrous : basal lvs, numerous-petioled, pinnatifid, divisions narrowly elliptical, becoming linear in the upper lvs.: heads as in the next, but smaller, and often entirely dark : akenes winged, smooth; pappus none. Southern U. S.

4. tinctoria, Nutt. (C. bícolor, Reich. C. Élegans, Hort. Calliópsis marmorata, Hort.). Fig. 549. Annual: stem strict, 1-3 ft. high, branched only at the summit, glabrous: basal lvs. wanting, cauline opposite, sessile, pinnatifid, divisions all long and narrowly linear: heads $3 / 4-11 / 4$ in. broad, small; rays with dark purple base : akenes oblong, wingless, smooth. Cent. U. S. B.M. 2512. B.R.10:846. Mn.1:85. - A common garden annual; showy and good. Var. nàna, Hort. Dwarf, low and compact. Tom Thumb varieties.

Var. atropurpùrea, Hook. (C. nìgra, Hort.). Rays almost entirely dark. B.M. 3511.

вв. Outer involucral bracts narrouly linear, equalling the inner.

5. Drúmmondii, Torr. \& Gray ( $C$. diversifòlia, Hook. C. picta, Hort.). Golden Wave. Annual: stem strict, branched above, 10-18 in. high, sparsely hirsute below: basal lvs. wanting, cauline petioled, pinnatifid, divisions short, broadly elliptical, those of the upper lvs. linear: heads 1-2 in. broad, large; rays usually dark at the base: akene oval, thick, wingless, smooth; pappus none. Tex. B.M. 3474. S.B.F.G. II. 4 : 315.

AAA. Disk yellow or brown: rays entirely yellow (except rarely $\mathrm{No}, 8$ ).

B. Rays uedge-shaped, lobed at the apex: peduncles 6-16 in. long, naked.

c. Lvs. all entire or with a few basal lobes : large.

6. pubéscens, Ell. (C. auriculàta, Schk. and Hort.). Perennial: tall, 1-4 ft. high, branched above, pubescent or nearly glabrous, more leafy than the following species: lvs. thickish, basal wanting, obovate-oval to oblonglanceolate, very acute, petioled or nearly sessile, entire or with small, acute, lateral lobes; outer involucral bracts lanceolate, nearly as long as the inner : akenes similar to those of the next species. Southern U. S.

7. lanceolàta, Linn. Fig. 550. Perennial : low, 1-2 ft. high, sparingly branched, glabrous or nearly so: lvs. few, opposite, mostly near the base, oblong-spatulate to linear, petioled, mostly obtuse, entire (rarely with a few lateral lobes ): heads i.5-2.5 in. broad; peduncles very long, outer involucre equaling the inner: akenes orbicular, papillose, broadly winged; pappus minute or obsolete. Eastern U. S. - Used extensively for cut fls.

Var. angustifolia, Torr. \& Gray. Low : stems scapiform: lvs. narrow and crowded, 2-4 lines wide.

Var. villòsa, Michx. Lvs. spatulate-obovate to oblong, villous, as is also the stem, with jointed hairs.

$$
\text { cc. Lvs. mostly pinnatifid, small. }
$$

8. coronat to, Hook. Annual: low and often weak, 1218 in. high, much branched from the base, sparsely hirsute: lvs. opposite, basal numerous petioled, pinnatifid, divisions ovate, lateral much smaller; cauline few, re- 
duced, spatulate, often entire : heads $1.5-2$ in. broad; rays often with a few dark spots above the orange base; outer involucre $1 / 2$ shorter than the inner : akene orbicular, broadly winged; pappus very minute. Tex. B.M. 3460. S.H. 1:270.

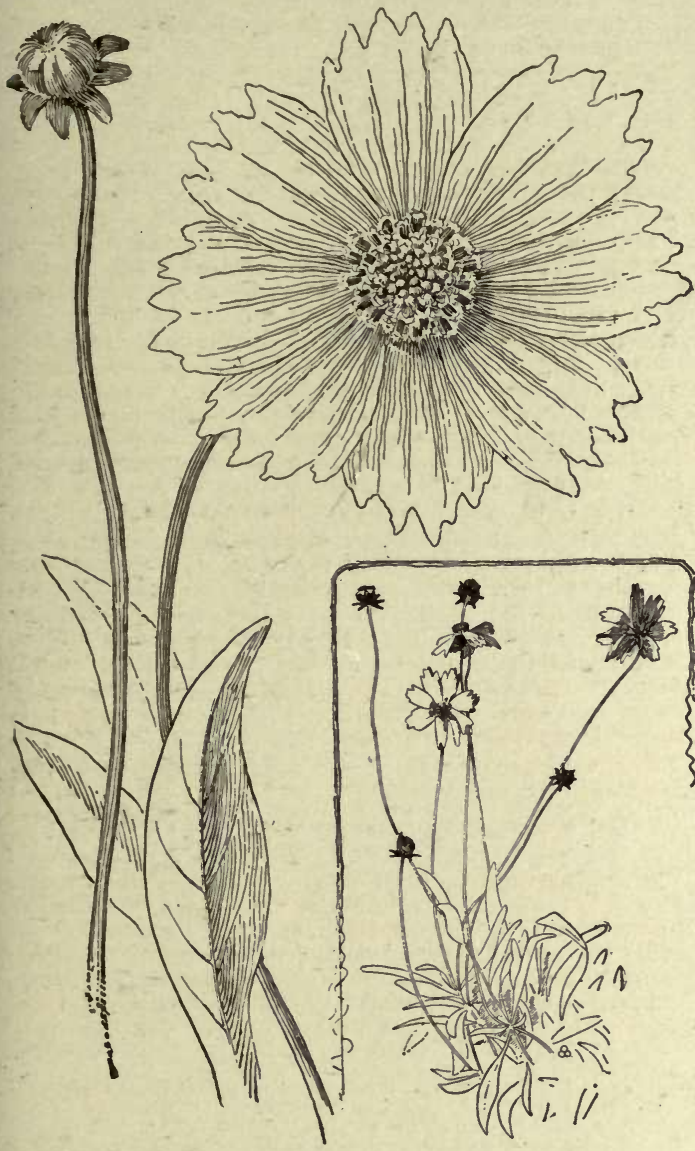

550. Coreopsis lanceolata. Single flower natural size.

9. grandiflòra, Nutt. (C. lóngipes, Hook.). Perennial : simple or few-fld., glabrous, 1-2 ft. high: lvs. opposite, basal wanting, lower cauline spatulate or lanceolate, entire, upper divided into several linear entire divisions: heads 1-2.5 in. broad: akene orbicular, papillose, broadly winged ; pappus paleaceous. Southern U. S. Sweet, B.F.G. 175. B.M. 3586. Gn. 47:995. Mn. 5:201.

\section{Bв. Rays elliptical, entire or nearly so.}

\section{c. Leaf divisions entire.}

D. Divisions lanceolate, large.

10. màjor, Walt. (C. senifòlia, Michx.). Perennial tall and stout, 2-3 ft. high, pubescent, much branched above : lvs, opposite, basal wanting, lower cauline small, upper sessile, 2-3 in. long, palmately 3-divided, divisions equal, broadly lanceolate, acute: heads 11/4-2 in. broad: akenes obovate-elliptical, winged, summit 2 toothed. Southeastern U.S.

Var. Emleri, Britton. Smooth, leaf-divisions more attenuate at the base. B.M. 3484 as $C$. senifolia.

Var. lineàris. Small. Smooth : leaf-divisions narrow, 2-4 lines wide.

11. tripteris, Linn. Perennial : very large and stout, 4-8 ft. high, branched above, glabrous : Ivs. opposite, petioled, 4-6 in. long, pinnatifid, divisions broadly or narrowly lanceolate: heads medium, pale : akene oblong, narrowly winged; pappus wanting. Cent. U. S.
DD. Divisions broally lineur to filiform.

12. palmàta, Nutt. (C. pripcox, Fres.). Perennial : tall and stout, $1 \frac{1}{2}-3 \mathrm{ft}$. high, sparingly branched at the summit: lvs. opposite, thick, cuneate, 2.5 in. long, 3 cleft to the middle, divisions broadly linear, midrib 3 nerved below: heads $1 \frac{1}{2}-2 \frac{1}{2}$ in. broad : akenes oblong, narrowly winged; pappus minute or obsolete. Cent. U. S. R.H. $1845: 265$.

13. delphinifdlia, Lam. Perennial: glabrous, branched above, 1-3 ft. high : lvs. opposite, sessile, $2-3$ in. long, the basal wanting, pinnatifid, divisions $3-7$, broadly linear; disk dark brown: akene obovate, narrowly winged; pappus teeth short. Southeastern U.S.

14. verticillàta, Linn. (C. tenuifolia, Ehrh.). Perennial: sparingly branched, $1-3 \mathrm{ft}$. high: basal lvs. wanting, cauline opposite, sessile, 1-2-ternately divided, divisions linear-filiform: heads $1-1 \frac{1}{2}$ in. broad : akenes obovate-wedge-shaped, narrowly winged; pappus nearly obsolete. Eastern U.S.

\section{cc. Leaf-divisions coarsely serrate or incised.}

15. trichosperma, Michx. Annual : tall, 2-5 ft. high, branched near the summit, glabrous: lvs. 2-4 in. long, the lower wanting, pinnatifid, on very short petioles, divisions narrowly lanceolate, acute, serrate or incised; rays pale: akene 4 lines long, cuneate, flat, wingless, ciliate and hairy; awns 2, very short. Eastern U.S.

Var. tenúlloba, Gray. Leaf-segments linear.

16. aristdsa, Michx. Ancual : like the last, but lvs. slightly pubescent beneath : akenes broader, with slender awns as long as the body. Cent. U. S. B.M. 6462. R.H. 1869:72.

17. aùrea, Ait. Annual : glabrous, 1-3 ft. high: 1vs. pinnatifid, the upper sometimes simple; divisions from lanceolate to linear, sparingly incised; outer involueral bracts narrowly linear, inner black-punctate : akenes broadly cuneate, very small (1-2 lines long), nearly glabrous; pappus of two blunt, chaffy, very short teeth. Southeastern U. S. - Very variable.

C. aristòsa, Michx., C. involucràta, Nutt., and C. trichospérma Michx are now nsually placed under Bidens. - $C$. At kinsoniana Dougl, differs from C. tinctoria in its lurger size and winged akenes. Annual. Western U. S.- C. auriculàta Linn. Perennial: low, stoloniferous, hirsute: livs, petioled, short, oval, mostly entire: heads large, very long, peduncled: probably not in the trade. Southern U. S. - $C$. involucràta Nutt. Annual: like C. aristosa, but heads larger, involnera bracts more numerous, awns shorter. Cent. U. S. - C. Léavenworthii, Torr. \& Gray. Annual: leaf-divisions linear-spatulate: rays cuneate, lobed, yellow; awns 2 slender: akene winged. Southern U.S.-C. nudàta, Nutt. Perennial: rush-like, lvs. mostly basal, long, filiform; rays rose-colored: wing of akene. pectinate. Southern U.S.

C. argùta, Pursh $=$ C. aurea, Ait. $-C$. atropurpùrea, Hort. $=$ Thelesperma, sp. - C. Boykiniàna, Nutt=C. grandiflora - $C^{\prime}$ dichótoma, Michx $=\mathrm{C}$. angustifolia. $-C$. diversifólia, $\mathrm{DC}=\mathrm{C}$.

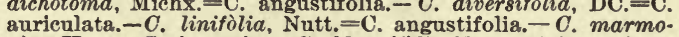
ràta, Hort $_{.}=\mathrm{C}$. tinctoria. $-C$. oblongifolia, Nutt. $=\mathrm{C}$. lanceolata.

K. M. WIEGAND.

CORIANDER is the seed-like fruit of Coriandrum sativum, Linn., an umbelliferous annual of S. Europe. The plant grows 2-3 ft. high, glabrous, strong-smelling, with lvs. divided into almost thread-like divisions, and small-white fls. The plant is easily grown in garden soil. It oceasionally becomes spontaneous about old yards. The seeds (or fruits) are used as seasoning and flavoring in pastries, confections and liquors, although they are less known in this country than caraway. The plant is occasionally cultivated in Amer. gardens along with sweet herbs.

\section{CORIANDRUM. See Coriander.}

CORIARIA (corium, skin, leather ; as fmetex coriarius, a shrub used for tanning leather, was described by Pliny). Coriaridcece. Shrubs or perennial herbs: Ivs. deciduous, entire, 3-9-nerved, opposite and distichous : fls. polygamous-monœcious in slender racemes, small; petals and sepals 5; stamens 10: fr. berry-like, consisting of 51 -seeded nutlets enclosed by the enlarged and colored petals. About 8 species in Himal. and E. Asia, Mediterranean region, N. Zealand and S. Amer. Ornamental shrubs or herbs, with slender, arch 
ing branches imitating pinnate lvs., and with very showy yellow, red or black fr. The lvs. of some species are used for tanning leather; the frs. are poisonous. C. Japonica has proved hardy with slight protection in Massachusetts, and $C$. terminalis seems to be of the same hardiness; the other species are more tender. They grow in almost any good garden soil, and prefer sunny position. Prop. readily by seeds and greenwood cuttings in summer under glass; also by suckers and layers.

Japónica, Gray. Shrub, 2-3, sometimes to $10 \mathrm{ft}$.: branches quadrangular: Ivs. nearly sessile, ovate or ovate-lanceolate, 3 nerved, smooth, 2-4 in. long : fls. in axillary racemes from the branches of last year: $\mathrm{fr}$. becoming bright red in summer, changing to violet-black when ripe. Jap. B.M. 7509. G.F. 10:343.

terminàlis, Hemsl. Herbaceous or suffruticose, 2-3 ft. branches quadrangular : lvs. nearly sessile, broadovate to ovate-lanceolate, 5-9-nerved, scabrous on the veins beneath, 1-3 in.: fls. in terminal racemes on shoots of the current year: fr. bright yellow. Sikkim, China.-A very ornamental plant, keeping its yellow fr. from July until late in fall ; being herbaceous, it is easier to protect from frost than the former. Recently introduced into cult. as $C$. Nepalensis.

C. myrtifòlia, Linn. Shrub, 4-10 ft.: lvs. 3-nerved, glabrous: fls. greenish, from the old wood: fr. black, poisonous. Mediterranean region. Yields a black dye.-C.Nepalénsis, Wall. Shrub, 8-10 ft.: lvs. 3-5-nerved, glabrous : fls. brownish : fr. black. Himal. - C sarmentòsa, Forst. Suffruticose, procumbent: racemes axilary on soung branches. $\mathrm{B}$ M 2470 . The Wineberry shrub of the natives. The berries yield a pleasant .drink, but the seeds are poisonous. ALFRED REHDER.

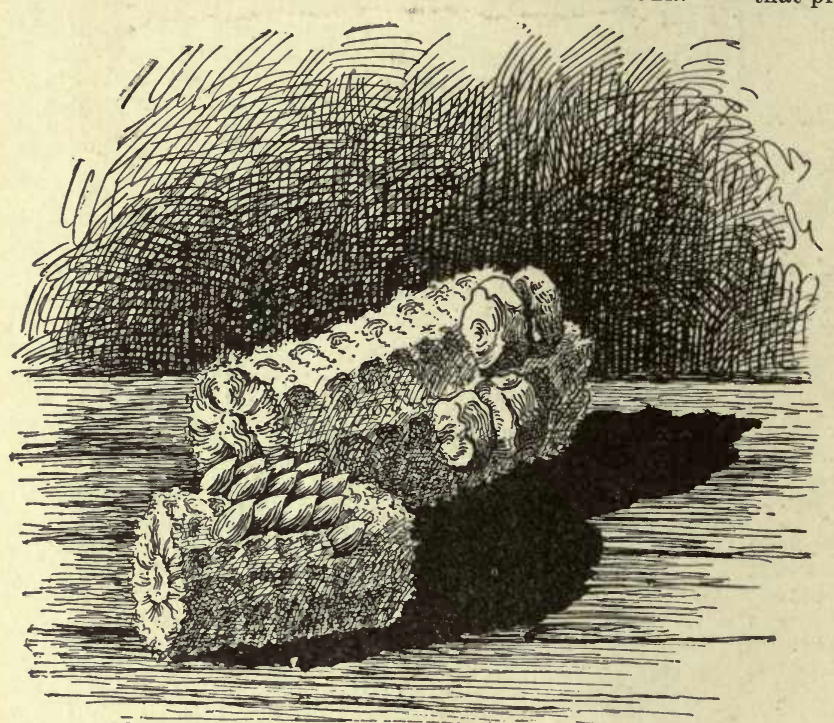

551. Kernels of Corn on the cob-Sweet Corn behind. Pop Corn in front $(\times 1 / 2)$.

CORK is the name applied to the outer impervious part of the bark in plants. In Euonymus Thunbergianus, the English maple, the corky barked elm, and other trees and shrubs, it forms wings on the branches. The cork of commerce comes from the bark of Quercus Ilex (better known as $Q$. Suber), plantations of which grow in southwestern Eu. The cork tree of the catalogues, Phellodendron Amurense, is a curious tree, cult. solely for ornament.

W. W. ROWLEE.

CORN, MAIZE (SWEET and POP). A tender annual, cultivated in America from prehistoric times. The word Maize, Spanish Maiz, is derived from the name Mahiz, which Columbus adopted for this cereal from the Haytians. Maize has not yet been found truly wild. Its close relation to Teosinthe, Euchloena Mexicana, Schrad., is indicated by the known fertile hybrids, or cross-breeds between Teosinthe and Maize. Teosinthe and the only other species which show close botanical relationship to Maize are indigenous to Mexico. Botanists now almost unanimously concede that Maize originated in America, and it is probable that it is indigenous to Mexico. See $Z e a$.

The white settlers early learned from the American Indians the use of Maize as an article of food. Several Indian names for certain preparations which they adopted or adapted, have passed into the language of the American people, as, for example, samp, horniny, succotash. They cultivated Maize both as a staple field crop and in the garden under the name of Indian Corn, which name, or the simple name of Corn, remains to the present time its almost exclusive designation throughout the English-speaking portions of the continent. It now holds first rank among the agricultural products of the United States in the area devoted to its cultivation, and in the value of the annual crop. The kinds now commonly found in garden culture are sweet Corns and pop Corns. The other kinds, which are more strictly agricultural, are called field Corns, but in some localities sweet Corn and pop Corn are also found under field culture, the former either as a truck crop or for canneries, the latter to supply the comparatively limited demand in domestic markets. Sweet Corn and Pop Corn only will receive special attention in this article.

Botanical Classification.-Zea almost uniformly has been called by botanists a monotypic genus, its one species being Maize. But Maize is an extremely variable species, including groups which are separated by definite characteristics. As a working classification, that proposed by Sturtevant is the best which has yet appeared. He describes 7 "agricultural species." These are Zea tunicata, the pod Corns; $\dot{Z}$. everta, the Pop Corns (Fig. 551); Z. indurata, the Flint Corns; $Z$. indentata, the Dent Corns; $Z$. amylacea, the soft Corns; $Z$. saccharata, the sweet or sugar Corns (Figs. 551, 552); Z. amyleasaccharata, the starehy Sweet Corns. Zea MIays, Linn., belongs to the natural order of grasses or Gramineæ. Culms 1 or more, solid, erect, $1 \frac{1}{2}-15 \mathrm{ft}$. tall, or more, terminated by a panicle of staminate fls. (the tassel); internodes grooved on one side: branches ear-bearing or obsolete: lvs. long, broad, channeled, tapering to the pendulous tips, with short, hyaline ligules and open, embracing sheaths: fls. monocious, awnless, usually proterandrous; staminate fls, in clusters of 2 to 4 , often overlapping; one fl. usually pediceled, the other sessile or all sessile: glumes herbaceous; palea membranaceous ; anthers 3 , linear. The ear contains the pistillate fls. on a hard, thickened, cylindrical spike ol spadix (cob), which is enclosed in many spatha. ceous bracts (husks); spikelets closely sessile. in longitudinal rows, paired in alveoli with hard, corneous margin; 2 fls. on a spikelet, the lower abortive ; glumes membranaceous; style single, filiform, very long (silk); ovary usually sessile. Ear variable in length and size, often distichous; grain variable in shape, size and color. See Plate VII.

SweEt CoRN (Zea saccharata, Sturt. Figs. 551,552.). - A well-defined species-group, characterized by horny, more or less crinkled, wrinkled or shriveled kernel, having a semi-transparent or translucent appearance. Sturtevant in 1899 lists 61 distinct varieties. He gives the first variety of Sweet Corn recorded in American cultivation as being introduced into the region about Plymouth, Mass., from the Indians of the Susquehanna in 1779. Schenck, in 1854 , knew two varieties. It appears, therefore, that the distribution of Sweet Corn into cultivation made little progress prior to the last half of the nineteenth century, green field Corn having largely occupied its place prior to that period.

Sweet Corn is preëminently a garden vegetable, al. though the large kinds are sometimes grown for silage or stover. As a garden vegetable, it is used when it has reached the "roasting ear" stage, the kernel then being well filled and plump but soft, and "in the milk." The kernel is the only part used for human food. When 


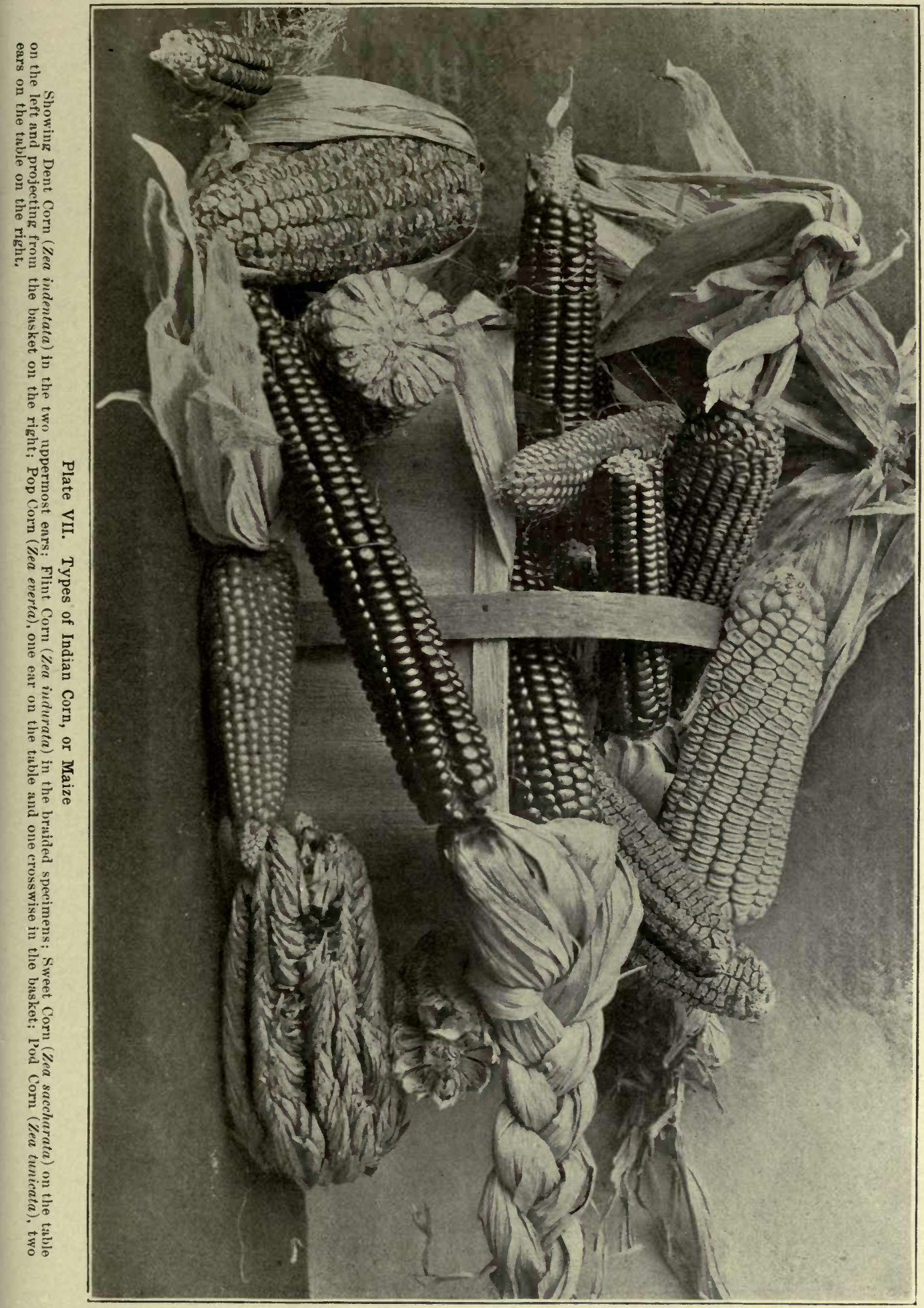



Sweet Corn is used as a fresh vegetable it is often cooked and served on the cob. In preparing it for canning or drying, it is always cut from the cob. Dried Sweet Corn, though never an article of commerce, was formerly much used, especially by the rural population. It is gradually being abandoned for canned Corn, for other cereal preparations, or for other vegetables. It is practically unknown as human food outside North America.

Canned Sweet Corn has come to be an important article of domestic commerce in the United States and Canada. A considerable amount goes to Alaska, but at the present time very little is exported. The American Grocer states that the annual Corn pack for the United States and Canada for the year 1898 was $4,398,563$ cases, each containing 2 dozen 2 -pound tins. New York leads with the production of $1,410,569$ cases. Maine, Illinois and Iowa follow in rank in the order named. These four states now pack 80 per cent of the Corn which is canned in the United States and Canada. While these figures are not strictly accurate, they are the best obtainable, and give a general idea of the extent and distribution of this industry. No better canned Corn is put on the market than that produced in Maine, where it is largely grown in localities having a season too short to mature the seed.

As a rule, Sweet Corn is grown for the canneries under contract. The canning company supplies the seed, guaranteeing it to be good and true to name. The farmer agrees to grow a certain number of acres and deliver the whole crop to the cannery at a stipulated price. The price now paid in western New York is about $\$ 10$ per ton of good ears, after deducting the ascertained average percentage of husks and rejected ears. Three tons per acre of good ears is considered a good yield. The ears are snapped from the stalks with the husks on and hauled in deep wagon boxes to the canneries. The stalks, when preserved either as ensilage or as stover, make excellent fodder. The overripe and inferior ears, being unmarketable, are left on the stalks and materially increase their value as a food for stock. The stover keeps best in loose shocks. It is liable to heat or mold when closely packed in large stacks or bays.

As a field crop, Corn is grown most extensively on medium heavy loams. It luxuriates in rich, warm soils. The crop rotation should be planned so as to use the coarse manures with the Corn, which is a gross feeder. On the more fertile lands of the central plain, nitrogenous manures may not always be used to advantage with Corn, but in the eastern and southern states, where the soil has lost more of its original fertility, stable manure may often be used profitably with this crop at the rate of from 8 to 10 cords per acre, or possibly more.

Plowing. - In the northern part of the Corn belt in the central and western states, that is to say north of the Ohio and Missouri rivers, deep fall plowing of Corn land is generally favored, but in experiments at the Illinois and Indiana experiment stations, the depth of plowing has had little influence on the crop. In sections of the eastern states, shallow plowing late in spring is favored, especially if the land be in sod. In warmer, drier regions, as in parts of Nebraska and Kansas, list ing has been much practiced on stubble ground. The listing plow, having a double mold-board, throws the soil into alternate furrows and ridges, the furrows being 8 or 9 inches deeper than the tops of the ridges. The Corn is planted in the bottom of the furrow, either by means of a 1-horse Corn-drill or by a Corn-drill attachment to the lister plow, consisting of a subsoil plow, through the hollow leg of which the Corn is dropped.

Great care should be used to secure seed-corn having high vitality as a precaution engainst the rotting of the seed in the soil should the season be cold and wet after planting. Select ears for seed as soon as the Corn is well ripened. Dry them at once by artificial heat so that the seed may better withstand unfavorable cendition of temperature or moisture. In many localities so-called kiln-dried seed is much in favor. In selecting seed for a field crop, seek systematically for stalks having little or no growth of stools and bearing single large ears. For garden use, seed from more productive stalks is desirable, even though the ears be smaller.

In the north, Sweet Corn should be planted as early as can be done without involving great risk of loss from frosts or from rotting of seed in the soil. In New York, field-planting is generally done from May 10 to May 20. in central Minnesota from May 10 to May 30 . The ground having been plowed and prepared so as to make a seed-bed of fine, loose soil 3 inches deep, the seed should be planted to a depth of from 1 to 3 inches. The drier and looser the soil the greater should be the depth of planting. In planting small fields, the ground may be marked in check rows so that the hills planted at the intersection of the rows will stand about $3 \frac{1}{2}$ feet apart each way, and the Corn planted by a hand-planter,

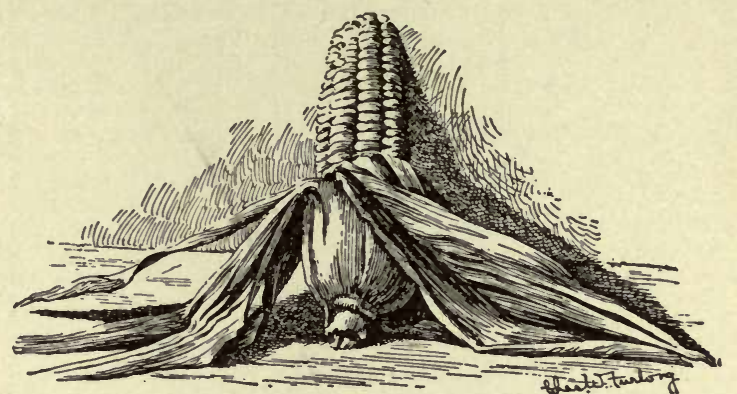

552. Early Marblehead Sweet Corn, eteitutuatoing

which drops the desired number of kernels each time it is thrust into the ground. For large fields, the checkrow type of planter may be used. These planters drop and cover the seed in hills at uniform distances apart, planting two rows at one trip across the field. Field Corn is often planted in drills by machines adapted to this purpose, but Sweet Corn should be grown under intensive culture, and should be in hills, so that the surface of the ground may be kept loose and entirely free from weeds.

Till for the purpose of retaining soil moisture as well as to kill weeds. This requires frequent shallow tillage, pulverizing the surface of the soil so that it will act as a mulch and retard the evaporation of soil moisture. Begin tillage as soon as the planting is done, using the slanting-tooth harrow and Breed's weeder types of implements till the Corn is 6 inches high, after which use spring-tooth cultivators or 2-horse cultivators of the type having several shovels on each side. These are preferable to the double-shovel type, formerly much used. The type having revolving disks, which throw the earth towards the Corn, is objectionable because the center of the furrow is left bare of loose soil, which should cover all the ground as a mulch.

Till at intervals of from 7 to 10 days. At first the cultivator may run from 2 inches deep near the plant to 4 inches deep midway between the rows. Each successive cultivation should gradually increase in depth between the rows; throw a half inch or more of earth towards the Corn and cover the weeds. At the last cultivation the cultivator may be kept a little farther from the Corn. It should leave the soil pulverized to a depth of from 2 to 3 inches over the entire field. The earlier cultivation may be deepened, if necessary, to kill weeds, even though some Corn roots are severed, but cutting the roots by deep cultivation late in the season is to be es pecially avoided. Till the soil until the Corn gets so large as to prevent the use of a 2-horse cultivator. Occasionally a later cultivation, with a 1-horse cultivator may be necessary if heavy rains leave the surface soil hard and start the weeds. Often catch crops for late pasturage, cover-crops or crops of winter wheat or rye are sown in the cornfield and cultivated in with the last cultivation. The seed is covered deeply by cultivating it in because the weather is apt to be dry at this period. The lower part of the furrow-slice is thus left compact, furnishing a compact seed-bed, in which small grains delight.

The cultivation of Sweet Corn in the garden should follow the general lines advocated for fleld culture, but stable manure and commercial fertilizers may be used more liberally. It is well to put a small amount of a com- 
plete commercial fertilizer in each hill, and mix it well with the soil before planting the Corn. A fertilizer which has a large amount of nitrogen in quickly available form should be chosen for this purpose. Dwarf early maturing varieties may be planted, for early use, as soon as the ground is sufficiently dry and warm. A little later, when the ground is warmer, the second early main crop and late varieties may be planted. Later successional plantings insure a supply of green Corn till frost kills the plants.

Corn is not grown commercially as a forcing crop. Attempts to force it in winter have not given encouraging results, but it may be successfully forced in spring, following any of the crops of vegetables which are grown under glass, providing the houses are piped so as to maintain the night temperature at $65^{\circ} \mathrm{F}$. Provide good drainage. Give a liberal application of stable manure, and thoroughly mix it with the soil. In the latitude of New York the planting may be made as early as the 1st of March. As soon as the first leaf has unfolded the temperature may be allowed to run high in the sun, if the air is kept moist by wetting the floors and walls. The glass need not be shaded. Keep night temperature close to $65^{\circ} \mathrm{F}$, not lower and not much higher. After the silk appears, jar the stalks every two or three days, when the atmosphere is dry, and thus insure abundant pollination. Early maturing varieties, like Cory, give edible Corn in about 60 days when thus treated. Corn may be forced in the same huuse with tomatoes, egg-plant, and other vegetables which require similar range of temperature.

VARIETIES. - Some of the desirable varieties for the garden, the market and for canning are listed below. These varieties are named for the purpose of showing the range of variation and of indicating the leading groups or types, not to recommend these particular kinds. New varieties are continually supplanting the old.

For the home garden.-Extra-early: Early Marblehead (Fig. 552), Burbank Early. Second Early : Crosby Early. Main Crop : Large Eight-Rowed, Hickox Improved, Stowell Evergreen. Late : Black Mexican, Country Gentleman.

For market.-Extra-early: Early Cory, Perry Hybrid; Extra-early Adams, though not a sweet Corn, is largely grown for early use. Second Early: Shaker Early, Crosby Early; Early Adams is grown extensively for market, though not a sweet Corn. Main Crop and Late: Mammoth, Stowell Evergreen, Egyptian, Country Gentleman.

For canning. - Hickox Improved, Crosby Early, Potter Excelsior, Country Gentleman, Egyptian, Old Colony, Stowell Evergreen.

Diseases AND Pests. - The most widespread and destructive disease of Corn in the United States is the smut produced by the parasitic smut-fungus, Ustilago Zea. The sorghum-head smut, Ustilago Reiliana, also attacks Maize. Smut causes most injury when it attacks the ears. The grains are transformed into a mass of dark-colored smut spores, and become exceedingly swollen and distorted out of all semblance to their normal outlines. Infection may take place at any growing point of the plant from early till late in the season, hence treatment of seed Corn by fungicides is of no value as a remedy for Corn smut. The destruction of smutted parts of the plants, and taking especial care that the smut does not become mixed with manure which is used for the Corn crop, are measures which may be expected to lessen the prevalence of the disease. No remedy is known.

The only other disease of Sweet Corn which is known to be of economic importance in the United States is the bacterial blight caused by Pseudomonas Stewarti. It has been found in New York, New Jersey and Michigan, but thus far has been seriously destructive only on Long Island on early dwarf varieties of Sweet Corn. It is characterized by wilting and complete drying of the whole plant, as if affected by drought, except that the leaves do not roll up. The fibro-vascular bundles become distinctly yellow, and are very noticeable when the stalk is cut open. The disease attacks the plant at any period of growth, but is most destructive about the time the silk appears. No remedy is known.

Over 200 species of insects are known to be injurious to Corn, either to some part of the growing plant or to the stored product. The Corn worm is also known south as the cotton-boll worm. It is destructive to Sweet Corn especially, for it burrows into the ear and feeds on the tender green Corn, rendering the ear unacceptable either at canneries or in market. It is known to do serious damage as far north as western New York. The best known method of fighting this insect is the breaking of the pupæ cells in the earth by shallow fall plowing, which, at best, is but a partial remedy. Wire-worms, northern corn-root worms, white grubs, and certain other grass insects attack Corn plants. One of the best preventive measures is to plan the rotation so that Corn does not immediately follow any cereal or grass crop.

POP CORN (Zea everta, Sturt.).-Characterized by the excessive proportion of the corneous endosperm, and the small size of the kernels and ear. The kernel split laterally shows the chit and corneous matter enveloping, and in some cases a fine, starchy line. The small size of the kernel and the property of popping makes identification certain. This species-group extends throughout North and South America, and has claims for prehistoric culture.

The preparation of soil, planting, and tillage recommended for Sweet Corn apply equally well to Pop Corn.

Varieties. - Sturtevant, in 1899, describes 25 varieties.

The following kinds are popular:

Dwarf Golden. - Ear 1 to 3 inches long. An early-maturing sort, with broad, golden yellow kerncis.

Rice, White Rice. - Ear 4 to 8 inches long. This vigorous late variety is widely cultivated. This and other Rice Corns are characterized by deep, tapering, beaked kernels.

Pearl.-Ear 4 to 8 inches long. Matures somewhat earlier than Rice and later than Dwarf Golden. Kernels rounded and silvery white.

S. A. BEACH.

CORN, BRO0M. See Sorghum.

CORN COCKLE. Lyehnis Githago.

CORNEL, CORNELIAN CHERRY. See Cornus. Mas.

CORN FLAG. Gladiolus.

CORNFLOWER. Centaurea Cyanus.

CORN, INDIAN. The common name for Zea Mays.

CORN, KAFFIR. See Sorghum vulgare, var. Durra.

CORN POPPY of Europe is the weed of the grain fields from which some of the garden poppies have been raised, Papaver Rhoas.

CORN SALAD (Valerianella olitoria, Pall.). Valeriandcece. Known also as Lamb's Lettuce, Fetticus, and Vetticost. It is a native of Europe. Sow the seed in early spring, at the time of the first sowing of lettuce, and make successional plantings as often as desired. For very early salads the seeds are planted in September, and the young plants are covered with a light mulch and wintered exactly as spinach is often managed. Sow in drills a foot or 18 inches apart and cover lightly. Work the ground thoroughly, and give an abundance of water. The leaves may be blanched, but are usually eaten green. It matures in 60-65 days during good spring weather. Only one variety is offered by most American seedsmen, but several sorts are known to European gardeners. It is sometimes used for a pot-herb, being served like spinach, but is chiefly valuable for salads. It is rather tasteless, and is not so popular as cress or lettuce on that account, but persons who prefer a very mild salad, or who would rather taste the salad dressing, will doubtless fancy Corn Salad. It is best served in mixture with other herbs, as lettuce, water cress or white mustard. It is easy to grow. There are no special enemies.

\section{F. A. WAUGH.}

CORNUS (ancient Latin name of Cornus Mas). Corndcece. Dogwoon. Shrubs or trees, rarely herbs: Ivs. opposite, rarely alternate or whorled, deciduous, entire : fls. small, 4-merous, usually white, in terminal cymes (Fig. 553) or heads: fr. a drupe, with 2-celled stone. Over 30 species in the temperate regions of the northern hemisphere and one in Peru. Hardy ornamental shrubs 
with handsome foliage, often assuming a brilliant fall coloring, and with attractive fls. and frs. Nearly all are rery desiruble for plancing in shrubberies. They grow

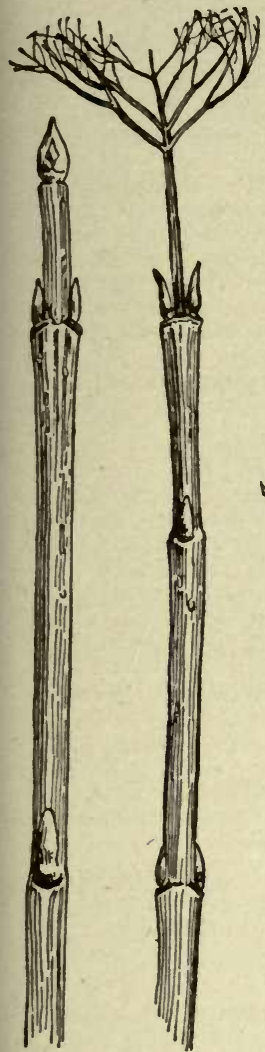

553.

Cornus winter shoots.

Showing the opposite bud and termina flower-clusters. Cor nus Baileyi. nearly as well in shady places under large trees as in sunny exposed situations, and thrive in almost any soil. One of the most beautiful in bloom is $C$. florida,

with extremely showy fls. in spring. C. candidissima is one of the best for shrubberies, blooming profusely in June. The red-branched species, as $C$. alba, $C$. A momum, $C$. Baileyi, $C$. sanguinea, are very attractive in winter. Prop. by seeds, which usually do not germinate untiI the second year. The species with willow-like soft wood, as $C$. $a l b a$ and its allies, grow readily from cuttings of mature wood, while the others are sometimes increased by layers. Horticultural varieties are mostly budded in summer on seedlings of the type, or grafted in early spring in the propagating house. They are often grown in this country from nearly ripened cuttings (Fig. 554), handled in frames in summer.

Various species of Cornus have many interesting uses. Our native $C$. florida, which in flower is the showiest member of the genus, furnishes a useful substitute for quinine. The bark of all parts contains the same substances found in Cinchona, but in different proportions. It is inferior in effectiveness and more difficult to obtain in large quantities. It is sometimes possible to ward off fevers by merely chewing the twigs. The powdered bark makes a good tooth-powder, and the fresh twigs can be used for the same purpose. The bark mixed with sulfate of iron makes a good black ink. The bark of the roots yields a scarlet dye. The wood, being hard, heavyं, and close grained, is good for tool handles. The Cornelian Cherry has pulpy fruits resembling cornelian in color and about the size and shape of olives, for which they can be substituted. The ripe fruits are soft and rather sweet. The name Dogwood comes from the fact that a decoction of the bark of $C$. sanguinea was used in Eng. land to wash mangy dogs. The small red berries of $C$. Suecica (not in the trade) are eaten by the Esquimaux.

Index : alba, 3 and 4 ; alternifolia, 1; Amomum, 7 . Baileyi, 5 ; brachypoda, 2 and suppl.; Canadensis, 17; candidissima, 9 ; capitata, 16 ; circinata, 6 ; corulea, 7 ; fastigiata, 10 ; femina, 10 ; florida, 13 ; Japonica, 15 ; Kousa, 15 ; macrophylla, 2 ; Mas, 11; mascula, 11; Nuttalli, 14; oblongata, 9; officinalis, 12 ; paniculata, 9 ; sanguinea, 8 ; sericea, 7 ; Sibirica, 4 ; stolonifera, 3 . stricta, 10; Tatarica, 4.

\section{A. Shrubs or trees.}

B. Fls. in cymes or panicles without involucre.

C. Foliage alternate: fls. in umbel-like cymes, cream-colored.

1. alternifolia, Linn. Fig. 555. Shrub or small tree, to $25 \mathrm{ft}$.: IVs. slender-petioled, elliptic or ovate, usually cuneate, acuminate, nearly glabrous above, pale or whitish beneath and appressed pubescent, 3-5 in. long: cymes $1 \frac{1}{2}-2 \frac{1}{2}$ in. wide: fr. dark blue, globular, $1 / 3$ in. across, on red peduncles. May, June. N. Brunswick to Georgia and Alabama, west to Minnesota. S.S. 5:216. Em.463.-Of very distinct habit, the branches being arranged in irregular whorls, forming flat, horizontally spreading tiers, as in the picture. A variety which shows this habit more distinctly than the common form is var. umbraculífera, Dieck. Var. argéntea, Hort., is a form with white-marked foliage.

2. macrophýlla, Wall. (C. brachýpoda, Auth., not C. A. Mey.). Tree, to $60 \mathrm{ft}$.: lvs. slender-petioled, broadly ovate or elliptic ovate, usually rounded at the base, abruptly acuminate, whitish and slightly hairy beneath, 3-5 in. long: eymes 3-4 in. wide: fr. bluish black. June. Himalayas to Japan. - With the habit of the former, but of more vigorous growth; not hardy north. Var. variegàta, Hort. Lvs. edged white. Gng. 3: 67 .

\section{cc. Foliage opposite.}

D. Fls. in umbel-like, flat cymes.

E. Lvs,whitish and with straight appressed hairs beneath: fr. white or light bluish.

3. stolonifera, Michx. ( $C$. allba, Wangh). RED-OsIER. DoGwood. Fig. 556. Shrub, to $8 \mathrm{ft}$., usually with dark blood-red branches and prostrate stem, stoloniferous : lvs. obtuse at the base, ovate or oblong-lanceolate, acuminate, 2-5 in. long: cymes dense, 1-2 in. wide; disk usually red : fr. white, with the stone broader than high. May, June. From Brit. N. Amer. to Illinois and California. B.B. 2:545. G.C. II. 8:679.-Var. flaviramea, Späth. Branches yellow. There are also varieties with variegated lvs. Habit bush-like, as in the picture.

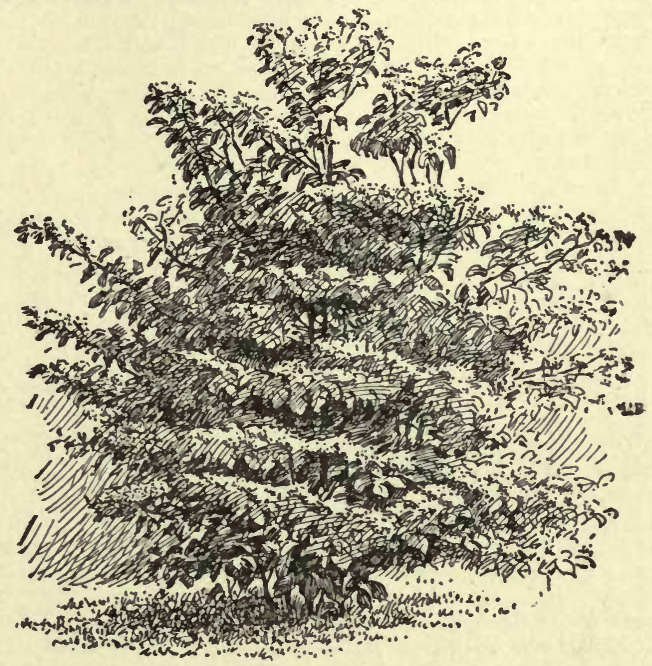

555. Cornus alternifolia. 
4. álba, Linn. (C. Tatárica, Mill.). Shrub, to $10 \mathrm{ft}$., with usualiy erect stem and bright blood-red branches, mostly with glaucous bloom when young: lrs. obtuse at the base, ovate or elliptic, somewhat bullate or rugose above, acute, $1 \frac{1}{2}-3 \frac{1}{2}$ in. long: cymes dense, small; disk

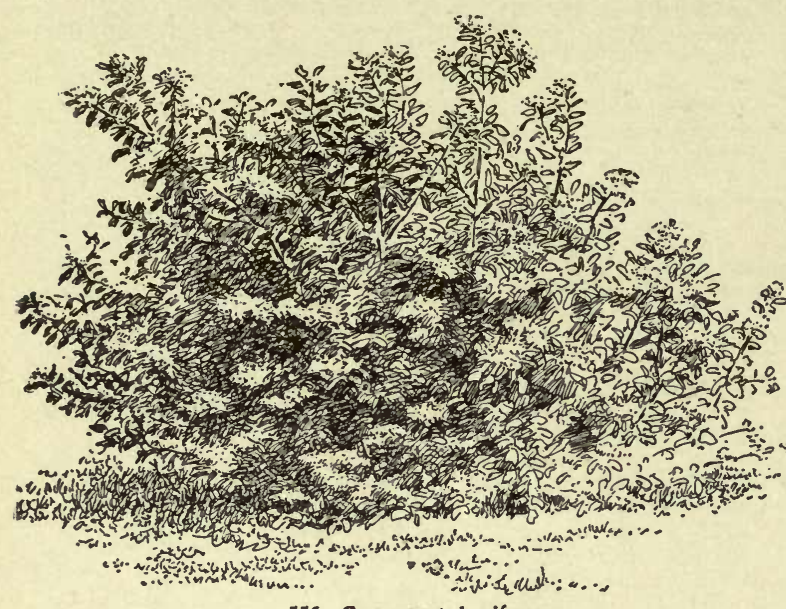

556. Cornus stolonifera.

yellow: fr. light bluish, sometimes whitish; stone usually higher than broad, flat. Siberia, N. China.-Var. argénteo-marginàta, Hort. Lvs. edged white. Var. Spæthi, Hort. Lvs. broadly edged yellow. Var. Sibírica, Lodd. Branches bright coral-red. There are also some other varieties with variegated lvs. EE. Lvs. with woolly pubescence beneath,
rarely nearly glabrous.

\section{F. Fruit white.}

5. Bàileyi, Coult. \& Evans. Fig. 553. Erect shrub, with reddish branches: Ivs. ovate to lanceolate, acute or acuminate, white beneath, with woolly and with appressed hairs, 2-5 in. long: fls. in small rather compact woolly cymes: stone of the fruit much broader than high, compressed and flat-topped. Pa. to Minn. and Wyoming. G.F. 3:465. - A very hand some species of upright growth, with dark red branches, blooming nearly all summer, and of a distinct grayish hue, due to the slightly upward curled lvs. The fall color of foliage and winter color of twigs are unequaled. Not as yet in the trade. Well adapted for sandy soil.

FF. Fr. black, blue or bluish or greenish white.

6. circinàta,L'Hérit. Shrub,3-10 ft. ; the young branches green, blotched purple, older ones purplish : lvs. orbicular or broadly ovate, acute or short acuminate, slightly pubescent above, pale and densely pubescent beneath, 2-6 in. long: cymes rather dense: $\mathrm{fr}$. light blue or greenish white. May, June. Em. 464.

7. Amòmum, Mill. (C. serícea, Linn. C. çrùlea, Lam.). Shrub, 3-10 ft., with purple branches: Ivs, rounded or narrowed at the base, elliptic-ovate or ovate-lanceolate, dark green and nearly glabrous above, pale or whitish beneath, usually with brownish hairs on the veins, 2-4 in. long : cyme compact : fr. blue or bluish white. June, July. N. Brunswick to Florida, west to Texas and Da kota. Em.466. R.H. 1888: 444 (as C. stolonifera).-Var variegàta, Hort. Lvs. variegated with yellowish white.

8. sanguínea, Linn. Shrub, to $12 \mathrm{ft}$.. with purple or dark blood-red branches : lvs. broad-elliptic or ovate, rounded or narrowed at the base, usually pubescent on both sides, pale green beneath, 11/2-31/2in. long: fls. green ish white, in dense cymes: fr. black. May, June. Eu., Orient. - Var. variegàta, Hort. Lvs. variegated with yellowish white. Var. viridissima, Dieck. With green mehes and green fruit.
DD. F's. in short panicles: fr. white or pale blue.

9. candidíssima, Marsh. ( $C$. paniculdta, L'Hérit. $C$. oblongdta, Hort.). Shrub, 6-15 ft., with gray branches: lvs. cuneate, ovate-lanceolate or lanceolate, acuminate, appressed-pubescent or nearly smooth, whitish beneath, $1 \frac{1}{2}-4$ in. long: petals white, lanceolate: fr. white. May, June. Maine to N. Carolina, west to Minnesota and Nebraska. B.B. 2: 545. - Free-flowering; very handsome when in bloom, and with its white fruits on red peduncles in fall.

10. strícta, L'Hérit. (C. fastigiata, Michx. C. foemina, Mill.). Shrub, to $15 \mathrm{ft}$, with purplish branches : lvs. ovate or ovate-lanceolate, sparingly and minutely appressed-pubescent, green on both sides, $1 \frac{1}{2}-3$ in. long: petals white, ovate-lanceolate: fr. pale blue. April, May. Virginia to Georgia and Florida. B.B.2: 546.-Tender north. Closely allied to the former, and perhaps only variety.

BB. Fls. in dense heads or umbels, with an involucre. c. Fls. yellow; involucre yellowish, not exceeding the fls.

11. Más, Linn. (C. máscula, Hort.). CoRnelian Cherry. Fig. 557. Shrub or small tree, to $20 \mathrm{ft}$. : lvs. ovate or elliptic, acute, appressed-pubescent, and green on both sides, $1 \frac{1}{2}-3 \frac{1}{2}$ in. long: tis. in sessile opposite umbels, before the lvs.; pedicels not exceeding the involucre: fr. oblong, scarlet, $3 / 4$ in. long, edible. March, April. S. Eu., Orient. Mn.5:192. - Handsome shrub of dense growth with glossy foliage, very attractive in early spring with its yellow fls., and again in fall with its shining scarlet frs. There are varieties with variegated lvs. and with yellow fr.

12. officinalis, Sieb. \& Zucc. Shrub or small tree, to $15 \mathrm{ft}$.: lvs. elliptic, acuminate, pale green beneath and with large tufts of dark brown hairs in the axils of the veins: fls. like those of the former; pedicels longer than the involucre: fr. scarlet, oblong. Japan, China. S.Z. 50. - Very similar to the last.

cc. Fls. greenish yellow, sessile, with a showy white involucre, much exceeding the fls.

D. Frs. in dense clusters, but individually distinct. (Benthamidia.)

13. flórida, Linn. Flowering Dogwood. Fig. 558. Shrub or small tree with spreading branches, $10-15 \mathrm{ft}$.,

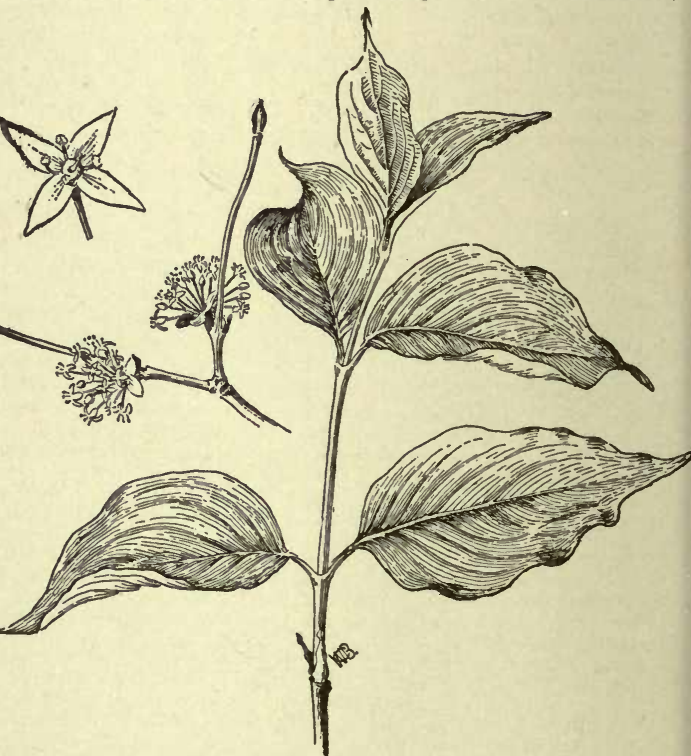

557. Cornus Mas (sprays $\times 1 / 2$ ).

rarely to $40 \mathrm{ft}$. : lvs. oval or ovate, acute, dark green and glabrous above, glaucous or whitish beneath, usually only pubescent on the veins, 3-6 in. long: involucre white 
or pinkish, 3-4 in. wide; bracts 4 , obovate, emarginate: fr. $1 / 2$ in. long, scarlet. May. Massachusetts to Florida, west to Ontario and Texas, also E. and S. Mexico. S.S. 5:112-13. Em. 468. G.F. 3: 431.' B.M.526. Gn. 52, p. 177; 53, p. 22: . J.H. III. 28: 453.-One of the most beautiful American flowering trees; hardy north. Var. péndula, Hort. With pendulous branches. Var. rubra, Hort. With pink involucre, but less free-flowering than the type. R. H. 1894:500. A.G. 18:441. F. E. 9:572. Neither variety as hardy as the type.

14. Núttalli, Aud. Tree, to 80 ft.: lvs, ovate or obovate, usually pubescent beneath, 4-5 in. long: involuere white or tinged with pink, 4-6 in. across; bracts $4-6$, oblong or obovate, sometimes roundish, mostly acute : fr. bright red ororange, erowned with the broad, persistent calyx. Brit. Columbia to S. Calif. S.S. 5: 214-15. Gng. 6:274. - This species surpasses the former in beauty, but is more tender and has not yet bee successfully cultirated outside of its native country, though introduced at several times into different American and European gardens.

DD. Frs. connate into a globular fleshy head. (Benthamia.)

15. Koùsa, Buerg. (Benthdmia Japónica, Sieb.\& Zucc. C. Japónica, Koehne, not Thunbg.). Shrub or small tree, to $20 \mathrm{ft}$ : Ivs. cuneate, elliptic-ovate, acuminate, dark green above, glaucous and appressed-pubescent beneath, $2-4$ in. long: involucre creamy white, $2 \frac{1}{2}-3$ in. wide ; bracts ovate, acute: frs. forming a globular head. June. Japan, China. S.Z. 16. Gn. 43: 898 G.C. III. 19:783. A. G. 13:6 64. Gng. 3:149. J.H. III. 35:9. M.D.G. 1899:328-9. - Fls. very showy, appearing after the lvs. in June and contrasting well with the bright green foliage; hardy as far north as Mass. Sometimes variegated.

16. capitàta, Wall. (Benthamia fragifera, Lindl.). Tree : lvs. coriaceous, elliptic-oblong, narrowed at both ends, appressed-pubescent above and more densely and whitish beneath, $2-4$ in.: involucre about $2 \frac{1}{2}-3$ in. wide, creamy white; bracts ovate, acute: fruit-head over 1 in. across, scarlet. June. Himalayas. B.R. 19:1579. Gn. 54, p. 310. G.C. III. 16:501. J.H. III. 30:213. - Evergreen tree, with showy fls. and frs.; hardy only south.

AA. Low herbs: fls. in dense heads, with a white (or pinkish) involucre.

17. Canadénsis, Linn. Herb, $1 / 3-2 / 3 \mathrm{ft}$. high, with creeping rootstock : lvs. whorled, sessile, elliptic or obovate, glabrous or nearly so, 1-3 in. long: head greenish, longpeduncled; involucre white, $1-1 \frac{1}{2}$ in. wide : fr. bright red, globose. May-July. N. Amer., south to Indiana, Colorado and Calif. B. M. 880.- Handsome plant for half-shady places.

C. asperifolia, Michx. Shrub, 8-15 ft.; branches reddish brown: lvs. rough above, woolly-pubescent beneath: fr. white. Ontario to Florida, west to Texas. G.F. 10:105.-C.brachýpoda C. A. Ney. Shrub: Ivs. opposite, glaucous and appressed-pubescent beneath: panicles large, loose. See C. macrophylla in the main list. Japan, China.-C.glabràta, Benth. Shrub, to $10 \mathrm{ft}$. branches gray: lvs. small, nearly glabrous, green and shining on branches gray: Ivs. small, nearly glabrous, green and shining on both sides: fr. white. Oregon to Calif.-C. Hessei, Koehne. Allied to C. alba. Dwarf, dense shrub: lvs. crowded, small: fr.
bluish white. Probably from E. Asia. $-C$. oblonga, Wall. Shrub or tree, to $30 \mathrm{ft}$.: ]vs. narrow-oblong, nearly glabrous, glaucous beneath, coriaceous : fls. white, fragrant, in eymose panicles. Himalayas. - C. pubéscens, Nutt. Shrub, to $15 \mathrm{ft}$., with purple branches : lvs. nearly glabrous above, glancous and woolly-pubescent beneath: fr.white. Brit. Columbia to Calif.- $C$. Suecica Linn. Allied to C. Canadensis: ivs. all opposite: fl.-head purple, the white involucre $1 \mathrm{in}$. or less wide. Aretic Amer., N. Eu. N. Asia. B.B. 2: 543 . ALFREd REHDER.

CORONA. Same as crown.

CORONILLA (Latin, a little crown: from the ar rangement of the fls.). Leguminose, tribe Hedysarea. Crown Vetch. Perennial shrubs or herbs, with odd- pinnate 17s., and purple or yellow fls. in peduncled heads or umbels ; pod jointed. Separated from Ornithopus by floral and fruit characters. Species 25-30, Mediterranean region. The shrubby $C$. Emerus and $C$. glauca are useful in southern California and the southern states. The species are occasionally grown in borders. C. glauca is sometimes grown under glass for spring bloom, after the manner of Cytisus.

All are of easy culture.

Cornus florida.

$(X 2 / 3$.

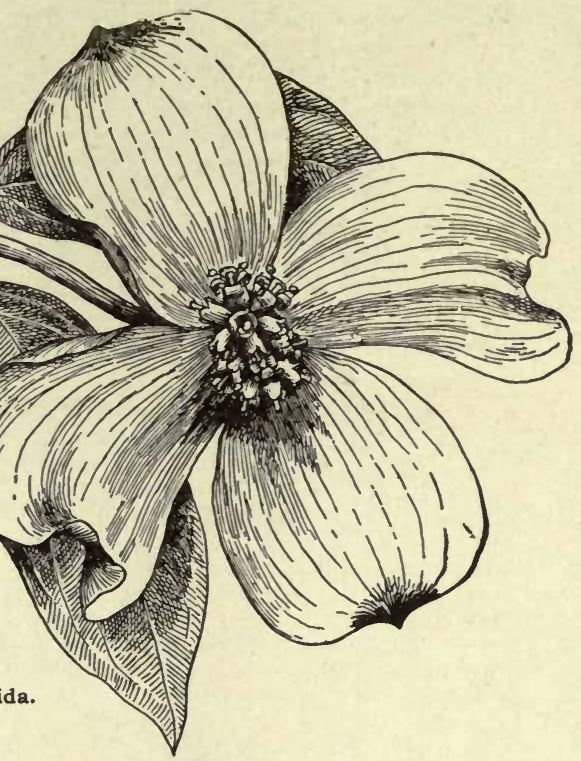

A. Flowers yellow.

B. Herbs.

Cappaddcica, Willd. ( $C$. Ibèrica, Bieb.). Low perennial herb, about $1 \mathrm{ft}$. high: lfts. 9-11, obcordate, ciliate: umbels 7-8-fld.: fls, yellow, large, July-Aug.: stipules membranaceous, rounded, ciliate-toothed. Asia Minor. L.B.C. 8:789. B.M. 2646.-A good trailer for rockeries and the margins of borders.

\section{BB. Shrubs.}

Emèrus, Linn. Scorpion Senna. Dense, symmetrical shrub, 4-6 ft. high: lvs. deep, glossy green ; lfts. 5-7, obovate; stipules small : peduncles 3 -fld.: fls. large, yellow, tipped with red. Blooms freely, May and June. Showy, half-hardy. S. Eu. B.M. 445. Gng. 5:36. Evergreen in S. states.

glaùca, Linn. Glabrous shrub 2-4 ft. high : stipules small, lanceolate: lfts. 5-7, obovate, very blunt, glaucous: fls. 7-8 in each umbel, yellow, fragrant by day but not at night. S. Eu. B.M. 13.-One of the common garden shrubs of S. Calif., flowering all the year.

\section{AA. Flowers white and pink.}

viminàlis, Salisb. Trailing shrub : stipules soon deciduous, ovate, membranaceous : lfts. 13-21, obovate, notched, glaucous: umbels 6-10-fld.: fls. pale red or white with a red stripe on the banner. Algeria. - Promising as a florists' plant for cut fls. Fls. all the year in S. Calif.

vària, Linn. Crown-Vetch. Fig. 559. Straggling or ascending, smooth herb, 1-2 ft. high: lvs. sessile ; lfts. $11-25$, oblong or obovate, blunt and mucronate, $1 / 2-3 / 4$ in. long: peduncles longer than lvs.: fls. in dense umbels, $1 / 2$ in. long, pinkish white. June to Oct. Eu. B.M. 258. Gng. 5:337. - Trailing plant for hardy, herbaceous border.

JARED G. SMITH.

CORREA (after Jose Francesco Correa de Serra, Portuguese author, 1750-1823). Rutdcea. Seven species of tender Australian shrubs, rarely cultivated under glass for their pendulous, tubular fls. an inch or two 
long, usually bright scarlet, but also white or yellow. Shrubs, usually with dense, minute, stellate hairs: lvs. opposite, stalked, entire, and with transparent dots. $C$. speciosa is probably the best and most variable species. It is a native of barren, sandy plains, and belongs to the large and much-neglected class of Australian shrubs.

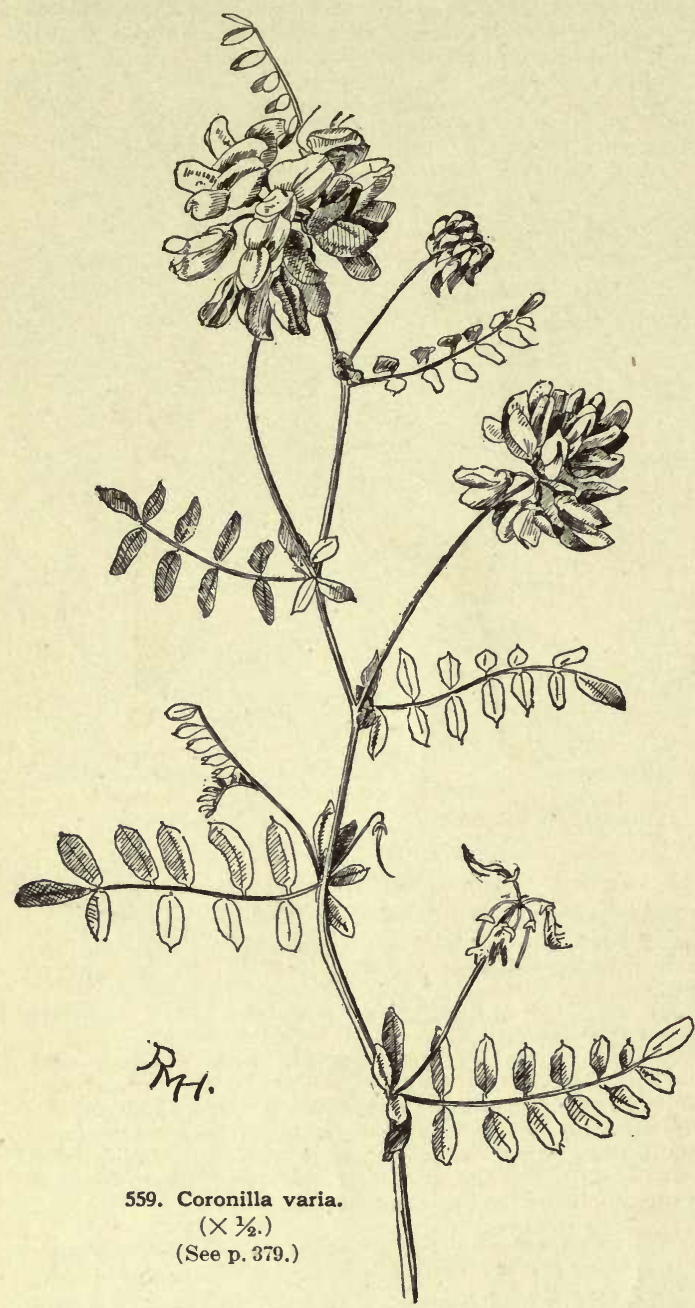

specidsa, Ait. ( $C$. cardindlis, F. Muell.). Tender shrub, 2-3 ft. high: branches slender, brown, opposite, covered with minute rusty hairs: lvs. opposite, about in. long, elliptic, about'a fourth as wide as long, wrinkled, dark green above, whitish below, margin entire, recurved : peduncles opposite, axillary, longer than the lvs., 1-fld., with a pair of leafy bracts: fls. $1 \frac{1}{2}$ in. long, pendent, tubular, bright scarlet, with a very short limb of 4 spreading, greenish yellow segments; calyx small, cup-shaped, with 4 almost obsolete teeth; stamens 8 , exserted, about $1 / 4$ in. B.M. 4912.-There are several varieties.

W. M.

\section{CORTADERIA. See Gynerium.}

CORTUัSA (named by the herbalist Matthiolus after his friend Cortusus, professor of botany at Padua). Primuldcea. A genus of possibly 4 species of which C. Matthioli, Linn., from the Swiss Alps, has long been a choice and delicate but not very popular plant, suited for shady parts of the rockery. It was long considered the only species of the genus. It is an herbaceous perennial, about 6 in. high, pubescent, rhizomatous, with a few long-stalked, cordate, 7-9-lobed, dentate Ivs., and a slender scape bearing an umbel of about 7 small, rosy purple, drooping fls., which appear in summer. It has some resemblance to Primula cortusioides. The genus has possibly 4 species, and is distinguished from Primula and Androsace by its stamens attached to the base of the corolla, and its long-acuminate anthers. According to J. B. Keller, its culture is similar to that of the hardy Primulas, but it needs winter protection in the northern states.

CORYÁNTHES (Greek, korys, helmet, and anthos, flower, referring to the shape of the lip). Orchiddcece, tribe Vándea. This complex genus, which is closely related to Stanhopea, is represented by several interesting species inhabiting tropical America. Sepals spreading, dilated, flexuose, conduplicate, lateral ones largest, distinct at the base: petals small, erect: labellum large, tridentate, basal portion forming a hood, continued into the column; distal portion bucket or pouch-like: column pointing downwards, elongated, terete, bicornute at the base, apex recurved : pollinia 2 , compressed, caudicle linear, arcuate. Pseudobulbous : Ivs, plicate, lanceolate, about $1 \mathrm{ft}$. long. The bucket part of the labellum is provided with a spout-like structure, by means of which the bucket overflows when about half full of a secretion which drops from a pair of glands near the base of the column. The fls. of the species known are not lasting, the sepals-being of such delicate texture that, though at first they fully expand, they soon collapse and become unsightly. Although much interest attaches to the species of Coryanthes, the genus is not generally cultivated, since the fls. last too short a time and are not particularly brilliant. For culture, see Stanhopea.

macrántha, Hook. Ground color rich yellow dotted with red. Hood and part of bucket brownish red: fls. few, in drooping racemes. Caracas. P.M. 5:31.

maculàta, Hook. Sepals and petals dull, pale yellow, bucket blotehed on the inside with dull red. B.M. 3102. - Var. punctàta has the petals and sepals bright yellow, speckled with red, the hood yellow, blotched with reddish orange, the pouch pale, speckled and spotted with red. Demerara.

OAKes Ames.

CORYALIS (Greek, lark, the spur of the flower resembling a lark's spur). F'umaridcece. A large genus of hardy plants allied to the Dutchman's Breeches, and with finely cut foliage of a similar character, but weedier and less delicate than the Dicentras. They are all of easy culture. They prefer full sunlight but will grow in half-shade. Prop. by division or seed.

A. Fls. chiefly purple or rose, sometimes tipped yellow.

B. Plant perennial: root tuberous: stem-lvs. few.

bulbòsa, DC. (C. sólida, Sw.). Erect, 6 in. high : lvs. 3-4, stalked, biternately cut, segments wedge-shaped or oblong: root solid: fls. large, purplish. Spring.

Bв. Plant annual: root fibrous: stem-lvs. many.

glaùca, Pursh. Annual, 1-2 ft. high, very glaucous : lobes of the lvs. mostly spatulate : racemes short, panicled at the naked summit of the branches: fls. barely $1 / 2$ in. long, rose or purple with yellow tips; spur short and round : capsule slender, linear; seeds with minute, transverse wrinkles. Summer. Rocky or sterile ground, Nova Scotia to Rocky Mts., and even Arctic coast, south to Texas. B.M. 179.- Not advertised for sale, but probably worth cult.

$$
\text { AA. Fls, chiefly yellow. }
$$

B. Plant perennial: root tuberous : stem-lvs. few. nóbilis, Pers. Perennial, erect: Irs. bipinnately cut ; segments wedge-shaped and lobed at the apex: fls. white, tipped with yellow, and a dark purple spot; spur 1 in. long. Spring. Siberia. B.M. 1953, as Fumaria nobilis. G.C. II. 19:725.

BB. Plant annual or biennicl: root fibrous: stemlvs. numerons.

aùrea, Willd. Annual, 6 in. high, commonly low and spreading : fls. golden yellow, about $1 / 2 \mathrm{in:}$ long, on rather slender pedicels in a short raceme; spur barely 
half the length of the body, somewhat decurved : capsules spreading or pendulous, about 1 in.long; seeds $10-12$, turgid, obtuse at margin, the shining surface obscurely netted. Rocky banks of Lower Canada and N. New England, northwest to latitude $64^{\circ}$, west to Brit. Col. and Ore., south to Tex., Ariz. and Mex.; not Jap.The western forms have the spur almost as long as the body of the corolla and pass into

Var. occidentalis, Engelm. More erect and tufted, from a stouter and sometimes more enduring root: fls. larger; spur commonly ascending: capsules thicker; seeds less turgid, acutish at margins. Colo., New Mex., W. Tex., Ariz. Cult. by D.M. Andrews, Boulder, Colo., who considers it biennial.

curvisíliqua, Engelm. Probably a biennial. Commonly more robust than $C$. ayrea, ascending or erect, $1 \mathrm{ft}$. high or less: fls. golden yellow, over $1 / 2$ in. long, in a spike-like raceme; spur as long as the body, commonly ascending : capsules quadrangular, $1 \frac{1}{2} \mathrm{in}$. long ; seeds turgid to lens-shaped, with acute margins densely and minutely netted. Woods in Tex. Cult. by D. M. Andrews, Boulder, Colo.

lùtea, DC. Erect or spreading, 6-8 in. high, annual, or forming a tufted stock of several years' duration : lvs. delicate, pale green, much divided; segments ovate or wedge-shaped, and 2-3-lobed: fls. pale yellow, about $1 / 2$ in long, in short racemes; spur short: pod a fourth or third of an inch long. Stony places of S. Eu., and runs wild in $\mathrm{Eu}$.

C. càva, Schweigg. \& Kort. (probaoly a form of C. tuberosa, DC.) is somewhat larger than C. bulbosa, with pretty fls. varying into purplish and white. Eu.-C.Scoùleri. Hook., grows 3 ft., and is cult. in some European gardens. W. Amer.

W. M.

CORYLOPSIS (Corylus and opsis, likeness; in foliage resembling the Hazel). Hamameliddcea. Deciduous shrubs, rarely trees : Ivs, alternate, deciduous, dentate : fls. in nodding racemes, appearing before the Ivs., yellow ; petals and stamens 5 : fr. a 2-celled, dehiscent capsule, with 2 shining black seeds. Six species in E. Asia and Himal. Low ornamental shrubs, with slender branches and pale bluish green, distinct foliage; very attractive in early spring, when covered with yellow, fragrant fis. Not hardy north of New York. They grow best in peaty and sandy soil. Prop. by seeds sown in spring, best with slight bottom heat, and by cuttings of half-ripened wood in summer under glass; also by layers, rooting readily in moderately moist, peaty soil.

pauciflora, Sieb. \& Zucc. Low, much-branched shrub, 2-3 ft.: 1vs. obliquely cordate, ovate, sinuate-dentate, ciliate, pubescent and glaucous beneath, 1-2 in. long: racemes $2-3$-fld., $1 / 2-3 / 4$ in. long : fls. light yellow. Jap. S.Z. 20. G.F. 5:342. Gt. 48:1467.

spicata, Sieb. \& Zucc. Shrub, to $4 \mathrm{ft}$.: lvs. oblique and rounded or cordate at the base, roundish ovate or obovate, sinuate-dentate, glaucous beneath and pubescent, 2-31/2 in. long: racemes 7-10-fld., 1-2 in. long: fls. bright yellow. Jap. S.Z. 19. B.M. 5458. F.S. $20: 2135$. R.H. 1869 , p. $230 ; 1878$, p. 198. - This species has larger and handsomer foliage and fls. of a deeper yellow, in longer racemes, but $C$. pauciflora flowers more profusely and is somewhat hardier.

C. Himalayàna, Griff. Shrub or small tree, to $20 \mathrm{ft}$.: Ivs. cordate-ovate, $4-7$ in.: racemes $1-2 \frac{1}{2}$ in. long. Himal. B.M. 6779. Tender.

CORYLUS (ancient Greek name). Cupulíferce, tribe Betuldcece. Hazel. Filbert. CoBNut. Shrubs, rarely trees : lvs. alternate, deciduous, stipulate, petioled, serrate and more or less pubescent: fis. monœcious, appearing before the lvs., staminate, in long, pendulous catkins, formed the previous year, and remaining naked during the winter (Fig. 560), each bract bearing $4 \mathrm{di}$ vided stamens; pistillate included in a small, scaly bud with only the red styles protruding (Fig. 561): fr. a nut, included or surrounded by a leafy involucre, usually in clusters at the end of short branches. Eleven species in N. Amer., Eu, and Asia are described. Numerous varieties are cult. in Eu. for their edible nuts. They are also valuable for planting shrubberies, and thrive in al most any soil. Prop. by seeds sown in fall, or stratified and sown in spring; the varieties usually by suckers, or by layers, put down in fall or spring ; they will be rooted the following fall. Budding in summer is some. times practiced for growing standard trees, ana grafting in spring in the greenhouse for scarce varieties. They may also be increased by cuttings of mature wood taken off in fall, kept during the winter in sand or moss in a cellar and planted in spring in a warm and sandy soil. Illustrated monograph of the cultivated rarieties by Franz Goeschke, Die Haselnuss

(1887). See, also, bulletin on Nutculture by the U. S. Dept. of Agr.

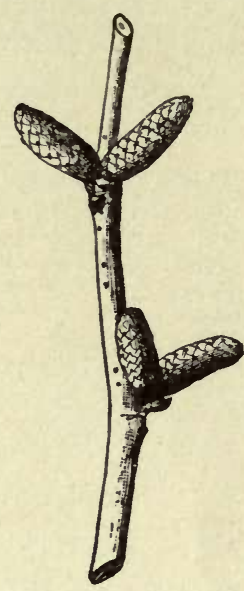

560. Winter catkins of Filbert.

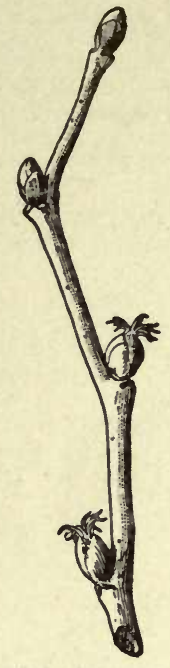

561. Pistillate flowers of Corylus rostrata.

Natural size.
A. Husk or involucre consisting of two distinct bracts (sometimes partly connate).

B. Involucre deeply divided into many linear, nearly entire segments, densely beset with glandular hairs. Tree.

Colúrna, Linn. Tree, to $70 \mathrm{ft}$ : Ivs. deeply cordate, roundish ovate to ovate-oblong, slightly lobed and doubly crenate-serrate, at length nearly glabrous above, pubescent beneath, 3-7 in. long: nut roundish ovate, 4-5 in. long. From S. Eu. to Himal.-Ornamental tree, with regular pyramidal. head, not quite hardy north. Rarely cult. for the fr. under the name of Filbert of Constantinople or Constantinople nut.

\section{B. Involucre sparingly glandular, with lanceolate or} triangular-dentate lobes : nut slightly compressed. Shrubs.

Americàna, Walt. Fig. 562. Shrub, 3-8 ft.: Ivs. slightly cordate or rounded at the base, broadly ovate or oval, irregularly serrate, sparingly pubescent above, finely tomentose beneath, 3-6 in. long: involucre compressed, exceeding the nut, the 2 bracts sometimes more or less connate, with rather short, irregular, toothed lobes : nut roundish ovate, about $1 / 2$ in. high. From Canada to Fla. west to Ontario and Dak. B.B. 1:507.Two forms of involuere are shown in Fig. 562. This figure is adapted from the bulletin of the Dept. of Agr. on Nut-culture.

Avellàna, Linn. Figs. 560, 562. Shrub, to $15 \mathrm{ft}$.: lvs. slightly cordate, roundish oval or broadly obovate, doubly serrate and often slightly lobed, at length nearly glabrous above, pubescent on the veins beneath : involucre shorter than the nut, deeply and irregularly incised: nut roundish ovate, $1 / 2-3 / 4$ in. high. Eu., N. Afr., W. Asia. - Var. aùrea, Hort. Lvs. yellow. Var, laciniàta, Hort. (var. heterophylla, Loud.). Lvs. laciniately incised or lobed. Var. péndula, Hort. With pendulous branches. There are also many varieties cultivated for their fruit. 
AA. Husk tubular, of connate bracts.

B. Involucre campanulate, with large, dentate, spreading lobes.

Póntica, Koch. Shrub: lvs. cordate, roundish ovate or broad-oval, doubly serrate : involucre finely pubescent, with few glandular hairs at the base: nut large, broad-ovate. W. Asia. F.S. 21: 2223-4 as $C$. Colurna.-From this species the Cob Nuts seem to have originated; also the Spanish Nuts are probably mostly cross-breeds between this species and $C$. Avellana or $C$. maxima, or between the two latter species.

BB. Involucre narrowed above the nut into a beak.

máxima, Mill. (C. tubuldsa, Willd.). Shrub, sometimes smal tree, to $30 \mathrm{ft}$.: Ivs. cordate, roundish-ovate, slightly lobed and doubly serrate, 3-6 in long : involucre finely pubescent outside: nut oblong, large; kernel with thin red or white skin. S. Eu. - Var. purpùrea, Hort. (C. Avellana pur purea, Hort.). L vs. deep purplish red. Many varieties, with large nuts, known as Filberts or Lambert's Filberts.

rostràta, Ait. Figs. 561, 562. Shrub, 2-6 ft.: lvs. rounded or slightly cordate at the base, oval or obovate, densely serrate and sometimes slightly lobed, nearly glabrous at length, except sparingly pubescent on the veins beneath, $2 \frac{1}{2}-4$ in. long : involucre densely beset with bristly hairs, beak long and narrow: nut ovoid, 1/2 in. long. Eastern N. Amer., west to Minn. and Colo. G.F. 8:345. B.B. 1: 508 .

Californica, Rose. Fig. 562. Allied to $C$. rostrata. Shrub, to $20 \mathrm{ft}$ : : lvs. more villous beneath: involucre with a short beak, which is often flaring and sometimes torn.

C. heterophýlla, Fisch. Allied to. heterophylla, Fisch. Allied involucre large, spreading, longer than th fr., with large, triangular, nearly entire teeth. N. China, Jap. (Offered by importers.)-C.Mandshuirica, Maxim Allied to C. rostrata. Lvs. large and broad: involucre thickly beset with strong brown bristles: tube slightly enlarged at the apex, and laciniately divided into enlarged at the apex, and laciniately divided into narrow, entire segments. Amurland, Jap.- $O$. Sièboldi, Blume. Allied to C. rostrata. Lvs. nar-
rower: involucre densely coated with loosely appressed, less bristly hairs; beak long and narrowed toward the end. A.G. 12:267.

ALFRED REHDER.

Culture for the Nuts. - Hazel, Filbert, Cobnut. The three native Hazels, $C$. Americana, C. Californica and $C$. rostrata, have been sparingly introduced to cultivation, but have not developed varieties worthy of naming or propagating. The foreign species, $C$. Avellana, $C$. Pontica and C. maxima, were introduced along the Atlantic seaboard at an early day, and are maintained in gardens throughout the New England and Middle Atlantic states. Efforts to make extensive culture profitable in the eastern United States have hitherto failed, probably from attacks of a fungous disease, Cryptospora anomala, common on $C$. Americana, but not specially injurious to that species. It attacks and destroys the young branches, and later the older branches and trunk, without killing the root. Bol deaux mixture has been suggested as a preventive, but recorded successful experiments are lacking. Experimental plantings on the Pacific slope indicate greater success with imported Hazels there than in the east, but they have not developed commercial importance.

The requirements of the Hazel in America, so far as known, are: moderately rich, well-drained soil; absence of $C$. Americana from vicinity ; freedom from mild periods in winter and late frosts in spring. It is specially subject to frost injury, as both staminate and pistillate catkins develop in fall and quickly swell and open under the influence of mild weather in winter. The staminate catkins commonly bloom first. If they are destroyed by frost, fertilization can be accomplished by suspending branches from trees from other localities, even of other species of Corylus.

Propagation by seeds is easily done by stratifying in fall and planting in nursery rows in early spring. Seedlings vary exceedingly, and varieties are perpetuated by budding, grafting, suckers or layers ; commonly by the last two methods. A considerable supply of well rooted suckers can be obtained from fruiting trees by banking in summer with rich soil or stable manure to promote root formation. Stools for layering should be heavily manured to force long and slender shoots suitable for bending. These should be staked down in winter or spring and covered with earth. They may be removed to nursery rows or orchard at end of first season.

Planting should be at a distance of 10 to 20 feet in well prepared soil, in fall or spring. Ground may be cropped with low growing, cultivated plants while trees are young, but should be maintained in good tilth and fertility.

Pruning is of special importance with this nut. Trees are usually headed at height of 1 or 2 feet, though often permitted to take natural form, which is that of a manystemmed bush,designated a "stool." Trees are classified according to height of clear trunk into "standard," "half standard," and "dwarf standard." A short trunk, with vase-form head of six or more branches, is preferred. Suckers should be kept down, unless desired for propagation. Both sexes of blossoms are borne on 1-year-old lateral twigs or spurs. March or April, after flowers of both sexes have bloomed, is considered best time for pruning, as unnecessary sacrifice of pollen can thus be avoided. Strong shoots should be headed back to promote spur formation, and old wood that has borne fruit should be removed annually. 
The nuts should not be gathered until ripe, a condition indicated by the browning of the edges of the husk. If left until fully ripe, many of the nuts will rattle out and be lost. The highest prices are obtained for freshly gathered nuts in the husks. To prevent husks from molding, they should be well dried or slightly sulphured. Hazelnuts may he held for considerable periods in tight receptacles, as casks or jars, by sprinkling salt over them and storing them in a cool, dry place, or in a refrigerated compartment.

Few insects trouble the European Hazelnuts in America, the nut weevil of Europe, Balaninus nucum, not having yet been naturalized. $B$. nasicus sometimes does considerable injury to the native species.

Nuts and Filberts are terms loosely used abroad, especially in England, to designate certain rather indefinite forms of $C$. Avellana and C. maxima. In general, such varieties as have husks shorter than their fruits are termed Nuts, while such as have husks as long as or longer than their fruits are designated Filberts.

But few varieties are known in America, most of the Hazels grown being seedlings from imported nuts. Varieties of $C$. Avellana and $C$. maxima are noto clearly distinguishable, but in general those with husks longer than the nuts are assigned to $C$. maxima, and those with short husks to $C$. Avellana.

A lba (White Filbert). Regarded in England as one of the best varieties. Can be kept in husk longer than most others because of constricted form of husk. Kernel covered with a white skin. Known as Avelinier Blanche, Wrotham Park, etc. Succeeds in California.

Cosford (Miss Young's, Thin-shelled). Nut oblong, thinshelled, of excellent quality; in a hirsute, laciniated husk, about the same length as nut.

Crispa (Cape Nut, Frizzled Filbert). Nut thin-shelled, somewhat flattened, late; in husks curiously frizzled throughout and wide open at the mouth. Very productive.

Downton Large Square. Nut very large, semi-square, thickshelled and well filled, of the highest quality; husk smooth, shorter than nut.

Dhe Chilly. A fine, large, compressed-cylindrical variety, with moderately thick shell, and of fine quality. Introduced from Fra nce by Felix Gillet, of California. The largest Filbert grown in America so far as known.

Grandis (Round Cobnut). Nut large, short, slightly com pressed, of good quality when fresh, with a thick and hard shell; in a short husk, much frizzled and hairy. One of the best varieties; considered the true Barcelona nut of commerce. Also known as Downton, Dwarf Prolific, Great Cob, Pearson's Prolific and Round Cob.

Jones. A short, roundish nut, of medium size. and good quality, somewhat grown for several years in central Delaware. Bush hardy and vigorous, producing suckers freely, and thus far free from disease.

Lambert (Lambert's Filbert, Lambert's Nut, Filbert Cob; Kentish Cob, erroneously). Nut large, oblong, somewhat compressed; shell rather thick; kernel plump and of rich flavor; an excellent keeper. Husk quite smooth, longer than nut and but excellent keeper. Husk quite smooth, longer than nut and but slightly cut in margin. Tree productive. Considered the best
variety grown in England, where it has been known since 1812 .

Purple-leaved. Nut large and of excellent quality; in a husk longer than the fruit. Planted for ornament, and productive of good nuts under proper treatment. The leaves and husks are of a deep purple color, which is retained until frost. The stami nate catkins are tender and often injured by frosts in winter. but when supplied with pollen from some more hardy variety it yields large crops.

Red Aveline (Avelineer Rouge, Red Hazel). Nut large, ovate, thin-shelled, with a smooth, red-skinned kernel, and of sweet nntty flavor. This variety is prized in eastern California as a productive sort of good quality.

Spanish. Nut very large, oblong, thick-shelled, with a smooth husk longer than the fruit. Sometimes confounded with Gran dis.

\section{W. A. TAYLOR.}

CORYNOSTYLIS (Greek, describing the club-shaped style). Violdcea. Woody climbers, with alternate Ivs. and racemes of long-stalked violet-like fls. C. Hybánthus, Mart. \& Zuce. (Calýptrion A ublètii, Ging. Corynóstylis A ublètii, Hort.), is native of trop. America. The Ivs. are large, ovate, serrate : fls. white, in short axillary fascicles, which are contiguous along the stem, longspurred, 2 or 3 times as large as a violet. F.S. $21: 2213$. -A hand some, vigorous warmhouse climber, and cult. in the open in S. California. Prop. by cuttings and seeds.
COR\PFA (Greek for summit or top, - where the lvs. grow). Palmacece, tribe Corỳphece. Tall, spineless, monocarpic palms : trunk stout, ringed : lvs. terminal, large, orbicular, flabellately divided to the middle into numerous linear-lanceolate segments; segments indupli. cate in the bud; rachis none; ligule small: petiole long, stout, concave above, spiny on the margins : sheaths split; spadix solitary,erect, paniculately much branched; spathes many, tubular, sheathing the peduncle and branches: fls. green: frs. as large as a cherry, with a fleshy pericarp. Species 6; tropical Asia and Malay Archipelago. These fan-palms are cultivated the same as Chammops and Livistona. They are warmhouse plants, prop. by seeds. Large fans, umbrellas and tents are made of the Talipot palm by the natives of Ceylon.

Coryphas are but little grown commercially, the growth of young plants being slow. Good loam well enriched with stable manure, a night temperature of $65^{\circ}$ and abundant moisture, are the chief requisites in their culture, with a moderately shaded house during the summer.

elàta, Roxb. (C. Gebánga, Blume). Trunk straight, $60-70 \mathrm{ft}$. high, $2 \mathrm{ft}$. in diam, spirally ridged: lvs. Junate, 8-10 ft. in diam.: segments $80-100$, separated nearly to the middle, ensiform, obtuse or bifid: petioles 6-12 ft., with black margins and curved spines. Bengal and Burma.

umbraculífera, Linn. Talipot Palm. Fig. 563. Trunk annulate, $60-80 \mathrm{ft}$.: lvs. sub-lunate, $6 \mathrm{ft}$. long by $13 \mathrm{ft}$. wide, palmately pinnatifid, conduplicate above the middle : segments obtusely bifid : petiole $7 \mathrm{ft}$., the spines

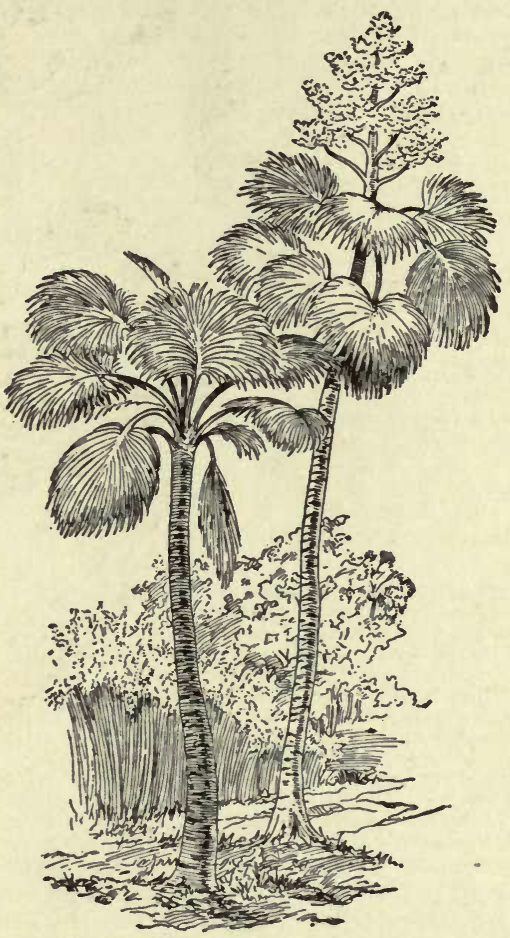

563. Corypha umbraculifera.

along its margins often in pairs. Malabar coast and Ceylon. A.F. 12: 313. Gng. 5:213. The picture (Fig. 563) is adapted from Martius' Natural History of Palms.

C. austràlis, R. Br. See Livistona.-C. macrophýlla,Hort.=?C. minor, Jacq. See Sabal.-C. Wogani, Hort., is a dwarf roundlvd. plant. A.G. 15: 307

JARED G. SMith. and W. H. TAPLIN.

COSMÁNTHUS. All included in Phacelia.

CosMfDIUM is Thelesperma. 
cósmos (from the Greek word with a root idea of orderliness; hence an ornament or beautiful thing, which fits the present case; finally and usually the universe, because of its orderliness). Compósita. A genus of at most 20 species of annual or perennial herbs, all tropical American, mostly Mexican, often tall, usually glabrous: lvs. opposite, pinnately cut in the garden kinds, in some others entire or lobed: fls. typically shades of rose, crimson and purple, with one yellow species, and white horticultural varieties, long peduncled, solitary or in a loose, corymbose panicle: akenes glabrous: chaff of the receptacle in $C$.bipinnatus with a long and slender apex, in other species with a blunt and short apex. The genus is distinguished from Bidens chiefly by the seeds, which are beaked in Cosmos but not distinctly so in Bidens, and by the color of the rays, which in Cosmos is typically some form of crimson, while in Bidens the rays are yellow or white.

The "Black Cosmos" ( $C$. diversifolius $)$ is, perhaps, better known to the trade as a Bidens or Dahlia. It has the dwarf habit and dark red early fls. of some Dahlias, but the akenes are very puzzling. They resemble those of Bidens in being 4-angled, and not distinctly beaked. They are unlike Bidens, and like Cosmos, in being not distinctly compressed on the back. They resemble both genera in having 2 rigid persistent awns, but, unlike these genera, the awns have no retrorse barbs or prickles. The akenes are linear, as in Cosmos and all our native tropical species of Bidens; but, although narrowed at the apex, they are not distinctly beaked, as in most species of the genus Cosmos. The plant is, perhaps, nearest to Bidens.

Among the garden annuals that have come into prominence in recent years, the Cosmos has a most brilliant future. Until 1895 there were in the two leading species only three strongly marked colors: white, pink and crimson. These and the less clearly defined intermediate shades have all come from $C$. bipinnatus; the yellow forms have come from $C$. sulphureus, which was introduced in 1896. Although Cosmos has been vastly im. proved within the last five years, it still leaves much to be desired and offers a most promising field to the plantbreeder. The two species are still too late in coming into bloom and too.tall and weedy looking in their habit of growth, but the season is being gradually shortened, with dwarfer forms continually coming on, and it is necessary to be patient while this interesting evolution is taking place. The chief improvement so far has been made in California and in Georgia. In the east, for best results it is still necessary to sow seed indoors in April and transplant outdoors as soon as danger of frost is past. Seed sown in the open ground often fails to produce flowers in some northern localities before frost. The slightest frost kills the typical species, but some of the new strains are said to resist a degree or two of frost. At first Cosmos flowers were only an inch or two across. The best varieties now average 3 inches, and sometimes reach 4 and 5 without thinning or disbudding. Pure white flowers of Cosmos are rarely if ever found wild, but some of the cultivated varieties are nearly pure. The group is totally lacking in bright reds. It would be interesting to try for shades of red by crossing with the dark blood-red $C$. diversifolius (known as the Black Cosmos, Dahlia Zimapani and Bidens atrosan. guinea), which, however, would be a somewhat violent cross, as that is a low-growing, early-flowering, tuberousrooted perennial. However, Cosmos is closely related to Dahlia, Coreopsis, and Bidens, the first two being of great garden importance and the latter, though weedy, having possibilities. The rays of Cosmos bipinnatus are typically obcordate in outline, narrow at the base, broad at the apex and with three strongly marked teeth, which, as in Coreopsis, are a great part of the characteristic beauty of the flower. In the wild single Dahlia these teeth are so short that they serve only to mar the symmetry of outline, and in the high-bred, cultivated varie. ties of single Dahlias these teeth are practically if not wholly obliterated. This will perhaps never happen to the Cosmos, at least in America. On the contrary; the rays of the Cosmos sometimes have an extra number of teeth, often 6 or 7 altogether, and the effect is very attractive and individual. Moreover, these teeth are often somewhat wavy, giving the whole flower a frilled appear. ance. The wild Cosmos is a stellate flower; that is, it has open spaces between its rays. These rays in cultivation have broadened and rounded in outline and have overlapped, so that the new forms do not show any vacant spaces between the rays but present a solid unbroken face. This same tendency has prevailed in the garden evolution of many other favorites, notably the "shouldered" Tulips, "rose-petaled Geraniums," and single Dahlias. The named varieties of Cosmos may always

(1)
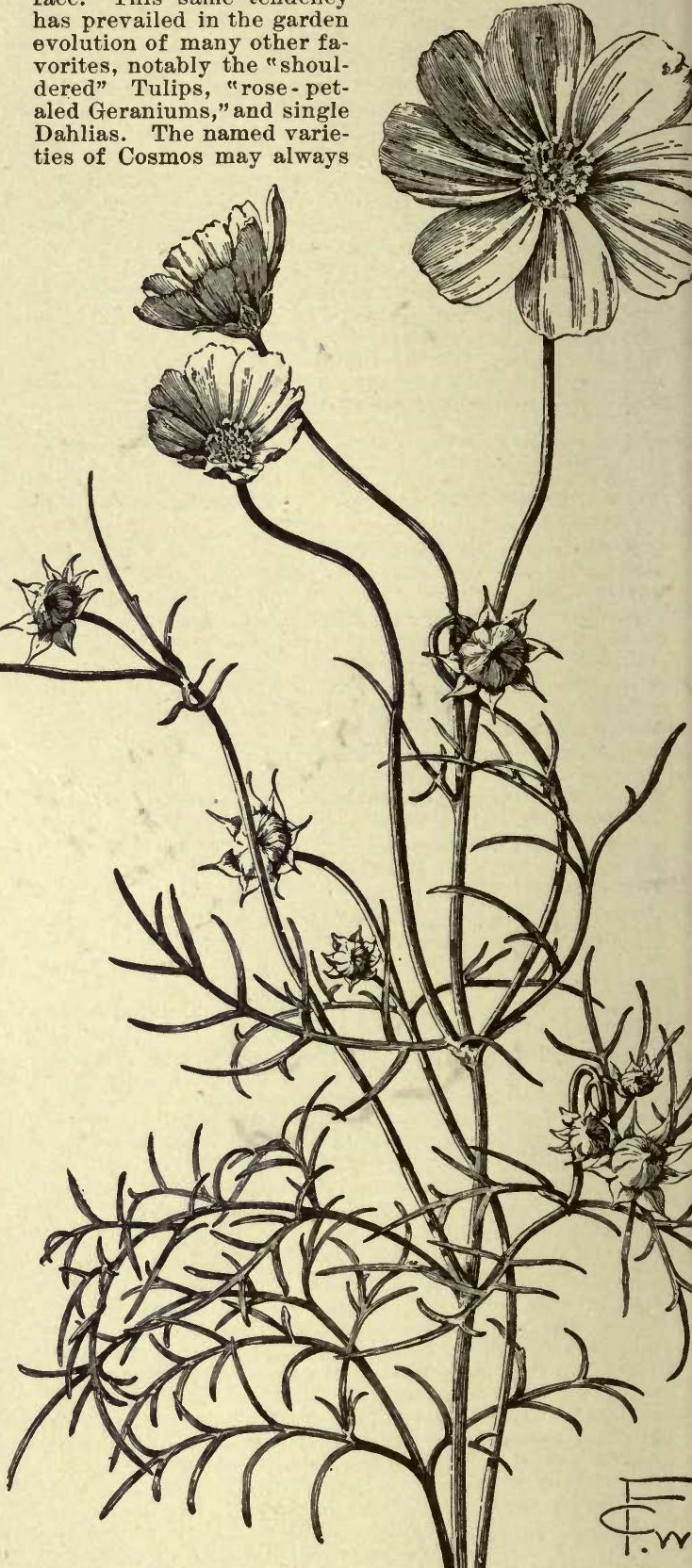

564. Cosmos bipinnatus. (X1/3.)

A cultivated form. The rays of wild flowers have only three teeth and flowers have only three teeth and
they are much more pronounced. 
be expected to have more symmetrical and perfectly formed flowers than the mixed and nameless varieties, much as the highest bred single Dahlias always have 8 rays all exactly alike, while it is a mark of Dahlias of low degree to have more than 8 rays or an unsymmetrical arrangement of them. A new feature, too, is the advent of a distinct ring of color formed by a dash of crimson at the base of each rar. The wild Cosmos is not troubled by a spot of yellow at the base of each ray, as is the wild Dahlia. In the case of the single Dahlia, the yellow color at the base of the ray never becomes definite and conspicuous enough to form an additional attractive feature, as it does in Chrysanthemum carinatum, but it often spoils the unity of effect and fails to harmonize with the ehief color of the flower, especially when the latter is magenta, crimson, rose, or any allied shade. There are no full double forms of Cosmos as yet, and, as regards strongly marked types of doubling, the Cosmos may be decades behind the China Asters. In the single forms, flat, incurved or cupping, and reflexed flowers are to be looked for, and can be fixed if there is sufficient demand for maintenance of the three types.

It is a mistake to grow Cosmos in too rich soil, as one gets too vigorous growth and too few flowers, which are also late. A sandy soil is to be preferred as being earlier, and not too rich. It is well to pinch out the leading shoots of young plants in order to make them bushy and symmetrical, instead of tall and straggling. W. M.

Cosmos bipinnatus has many varieties as to shapes, and its colors run through white, "washed " or faded pinks, and reds. The plants grow 7-10 ft., and bloom in fall only. A dwarf variety of this species, and starting out with Dawn (white shaded to pink at center) has developed colors until it now includes white, pink and crimson. The plants are some $4 \frac{1}{2} \mathrm{ft}$. high, and bloom in July. The seed is only one-half the length of the typical C. bipinnatus. This selection was continued until double blooms were secured, but double blooms perfected no seed.

C. sulphureus is entirely distinct from the above, the foliage being broad and handsomely cut, whilst the flowers vary from sulfur-yellow of the typical species, to the rich orange-yellow of Klondyke, and a tall, late variety. Cosmos sulphureus shows an inferior bloom $1 \frac{1}{2} \mathrm{in}$. in diameter, rather meager foliage, and grows about $3 \mathrm{ft}$. high. The tall, late variety has fine, rich orange fls. $2 \frac{1}{2}-3 \frac{1}{4} \mathrm{in}$. in diameter, with very heavy, coarse and dense foliage, grows $7-12 \mathrm{ft}$. high, and blooms in Georgia after October 15. The Klondyke, a hybrid of my own from Cosmos sulphureus, and the tall, late-blooming variety, has rich orange-yellow blooms, $2 \frac{1}{2}-3 \frac{1}{4}$ in. in diameter, with foliage a happy medium between its two parents, grows $31 / 2-4 \mathrm{ft}$. high, begins to bloom in Georgia from field-grown seed April 15, and by May 15 is a plant $2 \frac{1}{2} \mathrm{ft}$. tall, covered with blooms from base to top, which continue without cessation until killed by frost, when plant is $3 \frac{1}{2} \mathrm{ft}$. high and of the same spread. The culture of all varieties is simple, and only requires well-prepared soil, not too rich, early planting of seed, and the keeping of young plants free of weeds until they shade the ground. $C$. bipinnatus and the tall late variety should be planted in rows $6 \mathrm{ft}$. apart and 4 ft. in a row.

The variety Dawn and its companions in white, pink and crimson, and Klondyke should be planted in 3-foot rows, $3 \mathrm{ft}$. apart. Neither of the above yellow varieties should be confounded with the worthless Bidens offered as Cosmos sulphureus. The earlier Cosmos seed is planted after danger of frost the better, as it germinates unsatisfactorily when the weather is warm. When cabbage seed can be sown in the field with safety, Cosmos can also be sown. Cult. by A. W. Sмrith.

A. Rays white, pink or crimson: disk yellow.

bipinnàtus, Cav. Fig. 564. Glabrous annual '/-10 ft. high: lvs. bipinnately cut, lobes linear, remote, entire: involucral scales ovate-lanceolate, acuminate: fls. white, pink or crimson: seeds smooth, with an abrupt beak much sk.orter than the body. Mex. B.M.1535. Gn. 41:838. R.H. 1892:372. - The older and commoner species. C. hy bridus, Hort. is presumably a trade name for mixed varleties of $C$. bipinnatus, but see G.F. 1:475.

\section{LA. Rays yellow: disk yellow.}

sulphùreus, Cav. Pubescent, 4-7 ft. high, much branched: Ivs. often $1 \mathrm{ft}$. or more long, 2-or 3-pinnately cut, lobes lanceolate, mucronate, with rachis and midrib ciliate or hispid; pinnæ alternate, entire or 2-3-toothed: peduncles 7-10 in. long, naked: outer involucral bracts 8, linear, acuminate, green, 2 lines long; inner ones 8, oblong, obtuse, scarious, 5 lines long: fls. 2-3 in. across, pale, pure or golden yellow: rays 8 , broadly obovate, strongly 3 -toothed at the apex, ribbed beneath: anthers of the disk exserted, black, with orange tips: seeds linear, 1 in. long, including the slender beak. Mex. G.F. 8: 485.-Int. 1896; parent of all yellow forms.

$$
\text { AAA. Rays dark red: disk red. }
$$

diversifolius, Otto (Bidens atrosanguinea, Ortg. $B$. dahlioides, S. Wats. Dáhlia Zimapdni, Roezl). BLACK Cosmos. Tender annual, 12-16 in. high, with tubers more slender, and requiring more eare in winter, than those of common Dahlias: Ivs. pinnateiy parted; lfts. 5-7, entire or slightly serrate, the terminal lfts. largest: peduncles each bearing 1 head 6 in. or more above foliage: rays dark velvety red, sometimes tinged dark purple. Mex. B.M. 5227. Gt. 1861:347. F.C. 2: 47. J.H. III. $33: 403$. Var. supérba, Hort., is sold.-Prop. almost exclusively by seeds.

W. M.

COSTMARY. The rayless form of Chrysanthemum Balsamita, known as var. tanacetoides.

cóstus (old classical name). Scitaminàcea. SPIRAL FuaG. About 30 perennial thick-rooted herbs, in the tropics of America, Africa, Asia and Australia, cult. for their flowing-limbed showy fls., which are in terminal, bracteate spikes. Corolla tubular, equally eleft, not showy: one staminodium, enlarged and bell-shaped, usually with a crispy limb, and forming the showy part of the flower (called the lip), cleft down the back: ovary 3-loculed: fllaments petaloid. More or less fleshy plants, prized in warmhouses, and grown in the open in S. Fla.

This interesting genus of tropical herbs thrives in any rich, moist soil, but luxuriates in that of a gravelly or sandy character, when under partial shade. The plants are readily propagated by cutting the canes, or stalks, into short pieces of an inch or two in length, and planting in sifted peat, or fine moss and sand, covering but lightly. The roots may also be divided, but this is a slow means of propagation. Specimen plants require rather high tamperature to bring out the rich colors of the leaves, which in some species are prettily marked with a purplish tint, and are usually arranged spirally on the ascending stem. This gives rise to the name, "Spiral Flag."

$$
\text { A. Leaves green and plain. }
$$

B. Flower white.

specidsus, Smith. Four-5 ft., stout, erect: lvs. ovate or lance-ovate, nearly $1 \mathrm{ft}$. long, silky beneath: bracts red: fl. large, with a flowing white limb and pink center, 3-4 in. across, not lasting. E. Ind. I.H.43:56. Gn. $47: 1004$.

BB. Flower red.

igneus, N. E. Brown. One-3 ft.: lvs. elliptic-lanceolate, 4-6 in. long: bracts not colored nor conspicuous: fls. clustered, orange-red. Brazil. I.H.31:511. B.M.6821. J.H. III. 28:11.

AA. Leaves party-colored.

musàicus, Hort. Lvs. obliquely lanceolate, 4-5 in. long, dark green, marked and tessellated with silvery gray. W. Africa. $-C$. zebrina is very likely the same.

E. N. REASONER and L. H. B.

CótINUS. A section of Rhus.

COTONEÁSTER (cotoneum, quince, and aster, simllar; the lvs. of some species resemble those of the Quince). Rosdcea, subfamily Pomea. Shrubs, rarely small trees: lvs. alternate, deciduous or persistent, shortpetioled, entire, stipulate: fls. solitary or in cymes, terminal, on short lateral branchlets, white or pinkish; petals 5; stamens about 20 : fr. a black or red pomaceous drupe, with 2-5 stones. About 25 species; in the temperate regions of Europe and Asia, also in N. Afríca, but none in Japan. Ornamental shrubs, many of them with decorative frs., remaining usually through the whole 
winter, while only a few, like the hardy $C$. multiflora and the tender $C$. frigida, are conspicuous with abundant white fls. Of the species with decorative red frs., $C$. tomentosa, C. nummularia and $C$. vulgaris are quite hardy, and $C$. Simonsi. $C$. acuminata, $C$. rotundifolia, C. microphylla and others are hardy at least as far north as New York, while $C$. frigida and its allies are the most tender. The half-evergreen or evergreen $C$. horizontalis and $C$. microphylla, with its allied species, are well adapted for rockeries on account of their low almost horizontal growth. Cotoneasters thrive in any good, welldrained garden soil, but dislike very moist and shady positions. Prop. by seeds, sown in fall or stratified; the evergreen species grow readily from cuttings of halfripened wood in August under glass; increased also by layers, put down in fall, or by grafting on $C$. vulgaris, hawthorn, mountain ash or quince. Monogr. by $\mathrm{H}$. Zabel, Mitteil. Deutsch. Dendrol. Gesellsch., 1897:14-32; 1898:37-38.

\section{A. Foliage deciduous or semi-persistent: fls. usually} in cymes.

B. Fls. with erect petals, usually in few-fld. cymes.

c. Lvs. whitish tomentose beneath, deciduous.

vulgàris, Lindl. (C. integérrima, Med.). Shrub, to $4 \mathrm{ft}$. : lvs. ovate or oval, acute or obtuse and mucronulate, glabrous and dark green above, whitish and at length greenish tomentose beneath, $3 / 4-2$ in. long: cymes nodding, 2-4-fld.: fls. pale pinkish; calyx glabrous outside: fr. globular, bright red. May, June. Europe, W. Asia, Siberia.

tomentòsa, Lindl. Shrub, to $6 \mathrm{ft} .:$ lvs. broadly oval, obtuse, dull green above and pubescent when young, whitish tomentose beneath, $1-2 \frac{1}{2}$ in. long: fls. 3-12, white; calyx tomentose outside : fr. bright brick-red. June. Eu., W. Asia. - Sometimes cult. as C. speciosa, Hort.

cc. Lvs. green beneath, with appressed hairs, semipersistent or nearly so: calyx appressed-hairy outside.

acuminata, Lindl. Erect shrub, to $6 \mathrm{ft}$. : lvs. oblong to ovate-oblong, acute, appressed-hairy on both sides, dull above, $1 \frac{1}{2}-3$ in. long: cymes $2-5$-fld., nodding: fls. white or slightly pinkish: fr. deep red, oblong. June. Himalayas. L.B.C. 10: 919 (as Mespilus). R.H. 1889:348, Fig. 5 (as $C$. Nepalensis).

Simonsi, Bak. Shrub, with spreading branches, to $4 \mathrm{ft}$. lvs. roundish oval, acute, glabrous above, $1 / 2-1$ in. long, semipersistent: cymes $2-5$-fld.: fls. white, slightly pinkish: fr. bright red. June, July. Himalayas.-One of the best red-fruiting species, often under the name $C$. Simondsii or Symonsi.

horizontalis, Dene. Low shrub; branches almost horizontal and densely distichously branched: lvs. roundoval, acute at both ends, glabrous above, sparingly setosely hairy beneath, $1 / 8-2 / 3$ in. long : fls. erect, $1-2$, pink : fr. oblong, bright red. June. China. R. H. 1889: 348, Fig. 1. - One of the most effective fruiting shrubs for rockeries.

BB. Fls. with spreading petals, in erect, usually many-fld. cymes, white.

c. Lvs. obtuse or acute, $1 / 2-1 \frac{1}{2}$ in. long, deciduous.

nummularia, Fisch. \& Mey. Shrub, to $4 \mathrm{ft}$., with erect or spreading branches, rarely prostrate: lvs. roundish or broad ovate, whitish or grayish tomentose beneath, glabrous above: cymes very short-peduncled, 3-12-fld.: peduncle and calyx tomentose: fr. red. May, June. From N. Africa and W. Asia to Himalayas and Turkestan.Var. racemiflòra, Wenz. (C. F'ontanèsi, Spach). Lvs. acute at both ends: cymes 5-12-fld. R.H. 1867:31. Very decorative and hardy. Var. orbicularis, Wenz. Low and divaricate: lvs. roundish or obovate, $1 / 2-3 / 4$ in. long: cymes 3-6-fld.

multiflòra, Bunge ( $C$. refléxa, Carr.). Shrub, to $6 \mathrm{ft}$., with usually slender, arching branches: lvs. broad ovate, usually acute, slightly tomentose beneath, soon becoming glabrous: cymes very numerous, 6-20-fld.: calyx and peduncles glabrous: fr. red. May. Spain, W. Asia to Himalayas and China. R.H. 1892, p. 327. - Very decorative in bloom, and hardy, but less free fruiting. cc. Lvs. acute, 2-5 in. long, semipersistent.

frigida, Wall. Large shrub, to $20 \mathrm{ft}$.: Ivs. oblong, acute at both ends, glabrous above, tomentose beneath when young: cymes long-peduncled, very many-fld., pubes cent: fr, scarlet. A pril, May. Himalayas. B, R, 15:1229. L.B.C. 16:1512.- One of the most beautiful in $\mathrm{fl}$. and $\mathrm{fr}$. but not hardy north.

AA. Foliage persistent, small, 1/4-3/4 in., revolute at the margin: fls. 1-3, with spreading petals, white.

microphýlla, Wall. Low, prostrate shrub, densely branched: lvs. cuneate oblong or obovate, acute, shining above, densely pubescent beneath: fls. usually solitary; calyx pubescent: fr. bright red. May, June. Himalayas. B.R. 13:1114. L.B.C. 14:1374. R.H. 1889: 348, Fig. 3

buxifolia, Wall. Low shrub, similar to the former: lvs. eliiptic-ovate or broad oval, acute, dull and sometimes pubescent above, tomentose beneath, $1 / 3-1 / 2$ in. long: cymes 1-3-fld.: calyx pubescent: fr. bright red. Himalayas. R.H. 1889:348, Fig. 4.

C. acutifdlia, Lindl. Allied to C. acuminata. Lvs. oval, acute, glabrous and somewhat shining above: fr. black. Dahuria to N. China. Hardy.-C.affinis, Lindl. Allied to C. frigida. Lvs. broad-elliptic: fr. dark brown, globose. L.B.C. 16:1522. - C. angustifolia, Franch. Low, often spiny: lvs. linear-lanceolate, tomentose beneath, persistent. Yunnan. - C. arboréscens, Zab. not Wenz. Allied to C. nummularia. Fr. black. Himalayas.C. bacillàris, Wall. Allied to C. frigida. Lvs. smaller, usually glabrous beneath at length: fr, dark brown. Himalayas $-O$ laxiflora. Jaca = C. nigra, var. laxiflora. - C. melanocárpa. Lodd $=\mathrm{C}$. nigra - C. nigra. Wahlenb. Allied to C. vulgaris. Cymes erect, 2-10-fld.: fr. black. Europe, Siberia. L.B.C. 16:1531.-Var. laxiflora, Koehne. Cymes many-fld., nodding. B.MI. 3519. B.R. 14:1305. Hardy.-O. panndsa, Franch. Three ft.: lvs. ovallanceolate or elliptic, whitish beneath, persistent: fr. red. Yunnan.-O. Pekinénsis, Zab. Allied to C. acuminata. Lvs. dull and sparingly hairy above: calyx densely pubescent: fr. black. $\mathrm{N}$. China - O. Pyracántha, Spach=Pyracantha coceinea-C. ro. tundifolia, Wall. (C. microphylla, var. Uva-ursi, Lindl.). Allied to C. buxifolia, but of more upright growth. Lvs. nearly orbieuto $\mathrm{C}$. buxifolia, but of more upright growth. Lvs. nearly orbicu-
lar, appressed-hairy beneath: fls. 1-3; calyx glabrous: fr. red. Himalayas. B.R. 14:1187. $-C$. Sinénsis, Hort $=$ C. acutifolia. $-C$. thymifotia, Bak. Allied to C. microphylla. Lvs, cuneate, linearoblong, obtuse. R.H. 1889:348, Fig.2.C. uniflòra, Bunge. Allied to C. vulgaris. Lvs. glabrous: fls. solitory: fr. red. Songaria.$C$. Wheeleri, Hort. $=\mathrm{C}$. buxifolia, or C. nummularia, var. orbicularis.

ALFRED REHDER.

COTTON belongs to the genus Gossypium (name used by Pliny), of the Malvdcea. The species are now much confused, but it is generaly agreed that the Sea Island Cotton is of the species $G$. Barbadense, Linn. The up-

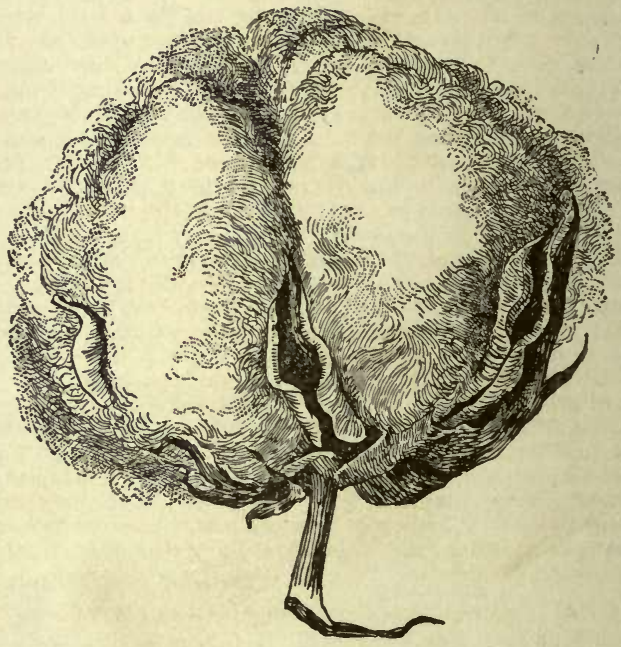

565. A Cotton boll.

land Cotton is probably derived chiefly or wholly from G. herbaceum, Linn. The former is native in the West Indies. The nativity of the latter is in dispute, but it is probably Asian. The Cotton flower is mallow-like, with a subtending involucre of 3 large heart-shaped bracts. 
The carpels or cells of the pod are 3-5. These carpels break open, and the cotton covering of the seeds makes a globular mass, - the Cotton boll (Fig. 565). Cotton is not a horticultural erop, and is therefore not considered in this work. The reader will find "The Cotton Plant" (published by the Dept. of Agr., Bull. 33), a useful monograph.

\section{COTTONWOOD. Species of Populus.}

COTYLEDON (a name used by Pliny). Crassuldcea. Includes Echevèria. Sicculent herbs or shrubs, rarely annual: branches and leaves thick and fleshy: lvs. opposite or alternate, petiolate or sessile: calyx 5-parted, as long as or shorter than the corolla tube; petals 5 , erect or spreading, connate to the middle, longer than the 10 stamens. Differs from Sedum in the connate petals. Species 60 or more. Calif. and Mex., Afr., As. and Eu. See I.H. 10:76 for an account of many of the species.

Large-growing Cotyledons, such as $C$. gibbiflora, var. metallica, should be increased by cuttings taken after the bedding season is over. The best method is to cut off the top of the plant, dress the bottom part, and place the cuttings in empty 4-inch pots, the bottom leaves resting on the rim of the pot until the cut heals over and a few small roots are formed. They may then be potted off into suitably sized pots, using sandy loam. No water will be needed for several days, and when given it must be only sparingly. The old stems should be placed rather close together in shallow boxes and kept in a warm, dry place, where they will form small growths along the stems; these, when large enough, may be put into boxes of dry sand, and potted in thumb- or 3-inch pots when they have made a sufficient quantity of roots. When it is desired to increase the low-growing bedding kinds on a larger scale, the plants should be lifted before the ground gets too wet and cold. They may either be boxed in dry soil and kept in a cool, dry house, or placed thickly together in a frame, taking care that no drip is allowed on the plants, and giving no water. The most convenient time for propagation by leaves is during the months of November and December, when the fall work of rooting soft-wooded plants is over. Leaves rooted at this time will make plants large enough for planting out the following season. They will take from three to four weeks to root, according to the kind. The leaves must be taken from the plant as follows: Grasp each leaf between the thumb and forefinger, give a gentle twist first to one side then to the other until the leaf comes off, taking eare that the dormant bud in the axil of the leaf accompanies it, otherwise the leaf will root but a plant will not form from it. Make a depression about two inches deep in the center and four inches wide across the sand bed, in this lay two rows of leaves with their bases touching each at the bottom of the depression. give no water until the small roots make their appearance, and only slightly afterwards. When the little plants are large enough they should be boxed, using sandy loam, and kept in a temperature of not less than $60^{\circ} \mathrm{F}$ at night.

For bedding purposes the following have been employed very successfully: C. atropurpurea, Californica clavifolia, coccinea, fascicularis, gibbiflora var. metallica, Pachyphytum, Peacockii, rosea, jecunda, secunda var. glauca, imbricata, Mexicana, eximia, globosa, globosa var. extensa, Scheideckerii, mucronata, mirabilis, parvifolia. Some of these are not offered in the American trade. Several of the kinds make ver ornamental winter flowering plants; among them are $C$. gibbiflore and its forms, $C$. fulgeus and $C$. coccinea. For this purpose the large plants should be lifted from the beds and carefully potted, as they make a much finer growth in the open ground than when grown in pots.

Cult. by G. W. Oliver.

A. Lvs. crowded in a rosette at the base of the stem.

$$
\text { B. Fls. white, tinged with green. }
$$

édulis, Brewer (Sèdum édule, Nutt.). Stems cespipitose, very short and thick: lvs. cylindrical or obtusely 3-sided, 3-4 in. long, erect, whitish or glaucous-green not mealy: fls. white, resembling those of Sedum, $1 / 2$ in in diam., short-pedicelled, along the upper sides of the flexuous branches of the cymose panicle; scape $1 \mathrm{ft}$. high. San Diego, Calif.-Int. 1883.

вв. F'ls. pale yellow.

Califórnica, Baker ( $C$. láxa, B. \& H.). Lvs. in a ro sette, concave, ligulate, lanceolate, acute, glaucous, mealy, slightly yellowish, 8 in. long: fls. pale yellow, on weak lateral Hlowering stems 1-2 ft. long, with short, ovate, clasping lvs. or bracts and bi- or trifid racemes. Calif.

ВвВ. Fls, pale flesh color.

pulverulénta, Baker (Echevèria pulverulénta, Nutt.). Lvs. in a rosette, silvery green, very mealy, spatulate, acute, the tips reflexed, the cauline lvs. gradually diminishing into broadly cordate, clasping bracts: pani-

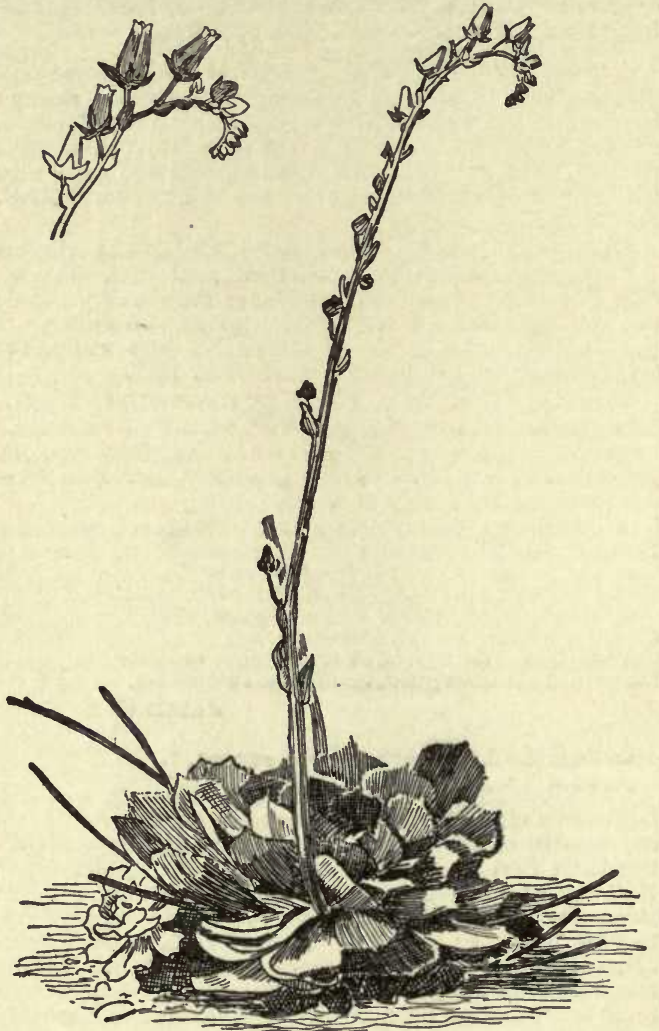

566. A species of Cotyledon.

cles dichotomously branched; pedicels slightly longer than the pale flesh-colored fls. Plants $1 \mathrm{ft}$. in diam. S. Calif. F.S. 19:1927, 1928.-A fine plant for carpet bedding.

ВвBв. Fls, red and green or red and yellow.

secúnda, Baker (Echevèria secúnda, Booth). Stemless: lvs. in a rosette, crowded, cuneiform, mucronate, glaucous, curving upward : fls. in a 1-sided, fecurved spike, reddish yellow: peduncle long, 6-12 in. high. June-Aug. Mex. - Fine for borders or carpet-bedding. There is a var. gla ùca, Hort.

lanceolàta, B. \& H. (Echevèria lanceoldta, Nutt.). Lvs. in a rosette, lanceolate, acuminate, slightly mealy; stem-lvs, or bracts small, cordate, clasping, distant : panicle narrow, dichotomous: fls. red and yellow. Calif.

Bárbeyi, Schw. Whole plant hoary-white: lvs thick, fleshy, shovel-shaped: fls, olive-green and red. Flowers freely in spring and summer. Abyssinia. Gt. 45, p. 465. - An exquisite plant for carpet-bedding.

AA. Lvs. scattered along the erect or branching stems.

fasciculàris, Soland. Smooth, 1-2 ft. high : lvs. pale greenish white with a yellowish margin, glaucous, few, 
sessile, cuneate-obovate, thick, flattened, slightly concave, cuspidate; panicle branches long, scorpioid: fls. large, 1 in. long, pendent ; calyx lobes short, broadly ovate-acute; corolla tube much longer than the calyx, yellow-green and dull red; corolla-lobes reflexed. S. Afr. B.M. 5602. J.H. III. 29:443.

orbiculàta, Linn. Plant erect, 2-4 ft. high: lvs. opposite, flat, obovate-spatulate, obtuse, mucronate, glaucous and mealy, with red margins: fls. large, reddish, panicled. Fls. June-Sept. S. Afr. B.M. 321. R.H. 1857, p. 347.-Grows well from cuttings.

Hispánica, Linn. (Pistorínia Hispánica, DC.). Annual or biennial, branched, 6 in. high, erect: lvs. small, nearly eylindrical, oblong, few, sessile : fls. erect, in eymes, reddish; corolla trumpet-shaped, lobes spreading. Spain, Morocco. R.H. 1895, p. 472.

AAA. Lvs. crowded at the ends of the branches.

reticulata, Thunb. Stems much-branched, fleshy : Iws. few at the ends of the branches, cylindrical, acute, ereet, fleshy, soft, smooth: fls. in an erect, dichotomous paniele. The wiry fl.-stalks remain on the plant and give it the appearance of being enclosed in a network. G.C. III. $21: 282$.

gibbiflora, Moc. (Echevèria gibbiflòra, DC.). Stems 1-2 ft. high: lvs. flat, wedge-shaped, acutely mucronate, crowded at the ends of the branches: fls. short-petioled: panicle branches 1-sided, spreading; corolla gibbous at the base between the calyx lobes, the tube white, the tips touched with crimson. Mex. B.R. 1247.

Var. metállica, Hort. (Echevèria metallica, Hort.). Lvs. large, obovate-spatulate, 6 in. wide by $7 \mathrm{in.} \mathrm{long,} \mathrm{a}$ beautiful glaucous purple with metallic reflections: fls. yellowish with red tips. Mex. Saunders' Ref. Bot. 65. An excellent bedding plant.

The following are doubtful species : Echeveria Mexicàna, Hort. Stems 8-12 in. high : fls. pink and yellow. Blooms in Tex all winter. Beantiful for borders.-Echeveria supérba, Hort. Annual, with yellow fls., used for carpet-bedding.

C. atropurpùrea, Baker (E. sanguinea, Hort.), and C. recisa, Baker, have been catalogued in this country. The former has red fls. and dark purple spotted lvs.; the latter has yellowish fls. and glaucous green more or less retuse lvs.

JARED G. SMITH.

COUCH GRASS. Agropyrum repens.

COVER-CROPS. The use of Cover-crops in orcharding marks a specific advance brought about by changed soil conditions. The term is less than 10 years old, having been first applied in this connection by Bailey, in Bulletin 61, Cornell (N. Y.) Experiment Station, p. 333, December, 1893, though Cover-crops were used previous to that date. In the early days of orcharding in this country, the soil, rich in humus and undepleted of its natural resources, gave satisfactory crops of fruit with trees growing in sod. As time went on, the waning vigor of the trees was stimulated by breaking up the sod, adding barnyard manure to the soil and giving thorough cultivation throughout the season. This system gave unsatisfactory results in many instances, particularly in the north, as it appeared to prevent the trees from ripening their wood sufficiently to enable them to endure the winters without frost-injury to the tips; root-killing was also noted as being occasionally severe on soils uncovered with vegetation during the winter. About this time the value of the members of the pea and bean tribe, as enrichers of the soil, became recognized more fully than formerly through the discovery of the nitrogen-collecting agents housed in the nodules borne by the' roots of legumes. The best orchard practice of the present day, whether in the peachgrowing areas of the south or the apple districts of the north, consists in giving the most thorough cultivation possible during the wood-producing period of the year, - that is, till about the time the fruit trees' terminal buds are formed, - then seeding this thoroughly pulverized surface with a suitable Cover-crop, which is plowed under early the following spring.

Cover-cropping is the raising of a crop in the orchard after cultivation should cease (about midsummer), that will protect the roots of the trees by preventing alternate freezing and thawing and deep freezing of the ground; that will add something to the fertility of the soil when turned under in spring; that will improve the physical condition of the soil; that will occupy the ground to the exclusion of weeds. In the south the considerations are practically identical, except that the contingency of root injury from frost is not weighed.

There are two classes of Cover-crops : the nitrogenous and the non-nitrogenous. Of the latter, rye, buckwheat, oats, millet, corn (maize), rape and turnips are principally used. These plants should be sown much later in the season than the clovers, cowpeas or most nitrogenous covers. They are valuable where the soil is hard and tough in texture, as advance agents of the legumes which may be used when an improved physical condition is secured. Buckwheat is particularly useful in ameliorating hard soils. It should not be sown early enough to allow seed to form before frost. These add comparatively little nitrogen to the soil. Among nitrogenous Cover-crops, crimson clover, red clover, cowpeas, soy beans, field pea, and vetch are the most prominent. In the south, crimson clover and cowpea (of which there are many varieties) are much in vogue. Cowpeas are unsatisfactory, however, north of the peach belt, owing to their sensitiveness to light autumn frosts. In applegrowing sections where the soil is mellow, red clover does well. A mixture of crimson clover and oats is used in peach sections in Michigan with suceess ; 12 quarts of the former to 3 pecks of the latter per acre are sown about the middle of August. The Geneva Experiment Station recommends a mixture of $1 / 2$ bushel of buckwheat to 1 bushel of field peas per acre for clay soils.

The question of what Cover-crops to use is best determined by an examination of the character of the soil, and the condition of the orchard trees. If the trees are growing slowly on mellow and friable soil, it will probably be advisable to use a nitrogenous Cover-crop. If, on the other hand, the trees are making a luxuriant growth, and the soil is of the heavy order, a member of the non-nitrogenous group should be tried.

$$
\text { Kinds of Cover-crops. }
$$

1. Non-nitrogenous-

a. Rye, two bushels per acre.

b. Buckwheat, $1 / 2$ bushel per acre.

c. Oats, $2 \frac{1}{2}$ bushels per acre.

$d$. Corn, broadcast 1 bushel per acre.

$e$. Rape or turnips, 3 pounds per acre.

2. Nitrogenous-

a. Crimson clover, 16 pounds per acre.

b. Red clover, 14 pounds per acre.

c. Sand vetch, 11/2 bushels per acre.

$d$. Soy beans, 2 bushels per acre.

. Cowpeas, 2 bushels per acre.

3. Mixtures of Nos. 1 and $2-$

a. Buckwheat, $1 \frac{1}{2}$ bushels per acre. Field peas, 1 bushel per acre.

b. Crimson clover, 12 pounds per acre. Oats, three pecks per acre.

c. Oats, 1 bushel per acre. Vetch, 1 bushel per acre.

John Cratg.

COWBERRY. Usually means Vaccinium Vitıs-Idcea. In parts of Scotland, Comarum palustre.

\section{COW-HERB. Saponaria Vaccaria; not cult.}

COWPEA. Fig. 567. The American name for Vigna Cátjang, Walp. ( $V$. Sinénsis Endl.), one of the Leguminosæ allied to Dolichos and Phaseolus. From Phaseolus (the common bean), Vigna differs in not having a spiral keel, style hairy above, stigma oblique or introrse, and other minor technical characters. In other than American literature, the Cowpea is known as China Bean and Black-Eyed bean. In the $\mathrm{S}$. it is commonly known as Black Pea. Botanically it is a bean rather than a pea. The Cowpea is a rambling, tender annual, native to China and Japan. In this country it is extensively grown in the southern states, as a hay crop. It is also invaluable as a green-manure crop (see Covercrop). It is to the south what clover is to the north and Alfalfa is to the west. It is sown broadcast after the manner of field peas. From 3 to 5 pecks of seed are used per acre. See Cowpeas, Farmers' Bull. 89, Dept. of Agric., by Jared G. Smith. 


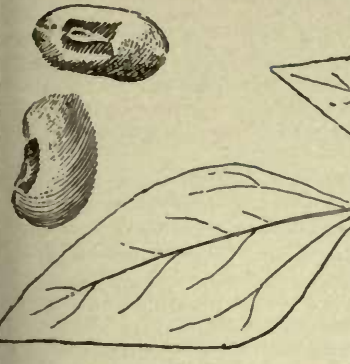

567. Cowpea $\left(X^{1 / 4}\right)$ Peas natural size.

COWSIIP. The true English Cowslip is Primula officinalis. The plant wrongly ealled Cowslip in America is the Marsh Marigold, Caltha palustris. The "American Cowslip" is a popular name for Dodecatheon Meadia. The Virginian Cowslip is sometimes used for Mertensia Virginica.

COXE, WILLIAM, of Burlington, N. J., was a pioneer pomologist. He was born in Philadelphia, May 3,1762 , and died on his farm on the Delaware river near Burlington, Feb. 25, 1831 . He deserves special remembrance for his excellent and now scarce book, "A View of the Cultivation of Fruit Trees, and the Management of Orchards and Cider, with accurate descriptions of the most estimable varieties of native and foreign apples, pears, peaches, plums and cherries cultivated in the Middle States of America-illustrated by cuts of two hundred kinds of fruits of the natural size." This was printed at Burlington, and published at Philadelphia in 1817. Grapes and small fruits were not included in the scope of his book, but an article of his in the American Farmer for July, 1828, shows that he was acquainted with many varieties of grapes, and had done much grafting. His book was a standard until the time of the Downings, and was freely used by other authors. The illustrations were excellent for their time, but show only the size and outline of a fruit, and whether it was dotted, splashed or streaked.

Coxe said, 1817, that he had been "for many years actively engaged in the rearing, planting and cultivating of fruit trees on a scale more extensive than has been attempted by any other individual of this county." He also had a national repntation for his cider at an age when it was the most famous and characteristic beverage of the people, and when apple trees were cultivated more for cider than for a table fruit.

William Coxe belonged to one of the most refined fam. ilies of Philadelphia. His early education was somewhat meager by reason of the Revolutionary war, but he became a cultured gentleman. John Jay Smith gives this pleasant picture of him: "Well do we remember his extensive library in his fine mansion on the 'Bank' at Burlington, when as a little boy we were assigned the duty of bringing away, or taking home, some book or pamphlet from his ever open stores of information. * * * His person was handsome, and his bearing that of the 'old-fashioned' gentleman, improved by mixing in the best society, but retaining the forms of the greatest politeness and suavity, that modern usages are too rapidly easting off. An errand to Mr. Coxe's was a cherished privilege; never was the opportunity neglected by him to place in the hand of his visitor some fruit that he so well knew would be appreciated by a youthful appetite. The finest Seckel pears we have ever seen were not unfrequent deposits. He had an especial fondness for the
Seckel pear, which is certainly among the half dozen most famous pears of American origin, and which was pronounced by Downing to be the finest flavored of all pears." Coxewas made an honorary member of the Horticultural Society of London for making known the merits of this pear through Dr. Hosack. The city of Burlington has exceptional interest, both natural and historical, and has a beauty of its own. Either the first willow or the first poplar planted there is said to have been brought from Halifax in the hand of William Coxe. He planted many trees to beautify the town and, in particular, extended the front of the "Green Bank." It is pleasant to think of William Coxe in connection with the willow-fringed bank of the Delaware. Biographical details are unfortunately only too meager. A few other details may be gleaned from the Horticulturist, 11: 304-307 (1856).

W. M.

CRAB'S-EYE VINE. See Abrus.

CRAB-APPLE in its widest sense means a small apple. The Crab-apples of history are fruits of Pyrus baccata. For more restricted uses of the word crab, see Pyrus.

CRAB-GRASS. One of several names for Eleusine Indica; also for certain Panicums, as P. sanguinale.

CRÁMBE (old Greek substantive). Crucíferce. Perennial hardy herbs, with small white, fragrant fls. in panicled racemes: lvs. mostly thick and large, more or less cut or lyrate. Of easy culture. Little known in this country. C. maritima, Linn., is the Sea Kale (which see). C. cordifolia, Stev., of the Caucasian region, is cult. as a border plant. It is an excellent foliage plant, withstanding the winters in the northern states. Lvs very large and heavy, cordate and ovate, toothed, glabrous or nearly so: fls. small but very numerous, in great branchy panicles 5-7 ft. high and nearly as broad. Gn. 50, p. 349. Gng. 4:291. - For the first two years from seed the plant makes only lvs.; but the third year it may be expected to bloom, after which the plant usually becomes weak and dies.

L. H. B.

CRANBERRY. A name applied to trailing species of the genus Vaccinium (Ericacea). Of the true Cranberries there are two species in North America, - the small (Vaccinium Oxycoccus), and the large (V. macrocarpon). These are native to swamps, where they trail their slender stems and little oval evergreen leaves over the sphagnum and boggy turf. The red, firm berries ripen late. in fall, and often persist on the vines until spring, when well protected with snow. Each berry is borne on a slender pedicel; and the curve of this pedicel in the European species is said to have suggested. the name Craneberry, which is now shortened to Cranberry. See Vaccinium.

The large Cranberry, Vaccinium macrocarpon, is now cultivated on hundreds of acres in the United States: and this Cranberry culture is one of the most special and interesting of all pomological pursuits. This Cranberry grows only in North America; and North America is the only country which has a domestic or cultivated Cranberry. Because Cranberry-growing is such an unusual type of horticulture, it is thought advisable to devote considerable space to it in this Cyclopedia.

Cranberries may be grown on land both low and high; but it is the general experience that low, boggy lands are the only ones which give permanently good results. In the winter, the natural Cranberry bogs are usually flooded, and in summer they are free of standing water. The flowers are often caught by the late frosts of spring. and the fruit may be injured by the early frosts of fall. Bogs are often ruined by fire in times of drought. Insects and fungi often play havoc with the crop.

The ideal bog for Cranberry culture is the one in which the natural environments of the plant are most nearly imitated, and in which the grower can have the greatest control over the difficulties mentioned above. It should have the following qualifications: (1) Capability of being drained of all surface water, so that frea water does not stand higher than one foot below the 
surface in the growing season. (2) Soil which retains moisture through the summer, for Cranberries suffer greatly in drought. (3) Sufficient water supply to enable it to be flooded. (4) A fairly level or even surface, so that the flooding will be of approximately uniform depth over the entire area. (5) Not over-liable to frosts. Bogs which contain moss or sphagnum and which have a peaty or mucky soil are usually chosen. If heath-like shrubs grow naturally in the bog, the indications are all the better. The presence of the Cassandra or Leatherleaf is regarded as a good augury. Black ash, red maple, swamp huckleberry, and white cedar swamps are often very satisfactory. Old mill-ponds often give good results.

Before the Cranberries are planted, the bog must be cleaned of trees, bushes, moss and roots. This may be done by "turfing," which is the digging out of the

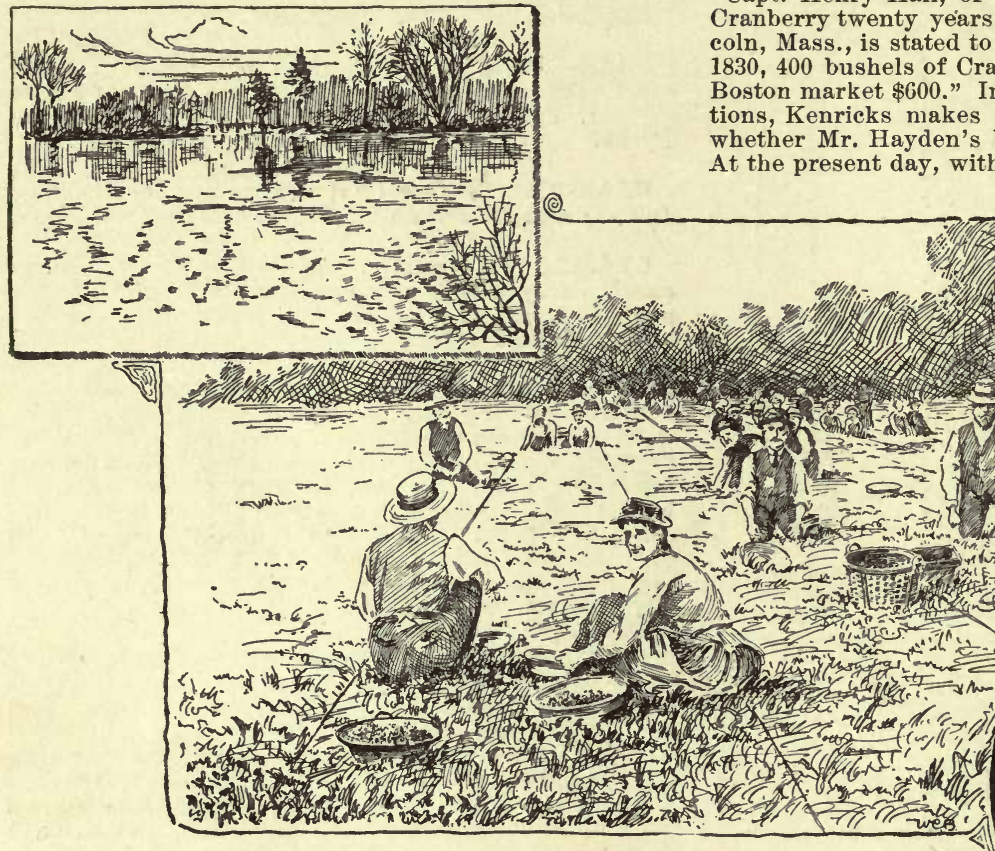

568. Cranberry-picking scene on a Cape Cod bog.

In the upper corner is a bog in full flood (in winter). In the lower is the flume or outlet dam.

swamp growth, or by "drowning," which is deeply flooding the place for a year. The method of preparing the surface for receiving the plants varies in different regions. Open ditches are run through the place in sufficient number to carry off the surface water. They are usually made 2 to 4 feet deep. If some water stands In them during the summer, better results are expected. These ditches usually feed into one main or central ditch; and this main ditch is preferably the one which, when dammed at its lower end, floods the bog by backing up the water. Growers prefer, if possible, to divert a living brook through the bog, or to straighten and deepen one which may exist there; but in the absence

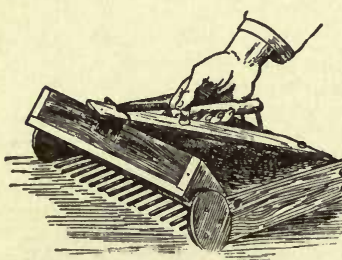
of a brook, a reservoir may be constructed above the bog. Sufficient water supply should be had to cover the entire area from December until A pril or early May, to a depth of at least one foot. The lower places will have a deeper covering, but 4 or 5 feet in places usually does no harm in the winter. It

569. Cranberry hand-picker. also may be necessary to flood in spring or fall, to kill insects or to protect from frosts. The objects of flooding are as follows: (1) to protect the plants from heaving in winter; $(2)$ to avoid late spring and early fall frosts ; $(3)$ to drown insects; (4) to protect from drought; (5) to guard against fire. Unless serious contingencies arise, the bog is flooded only in winter. A flooded bog looks like a lake (Fig. 568). Good results are obtained now and then in "dry" or upland bogs, which cannot be flooded; but such bogs or meadows rarely give uniform results, and they re less advised than formerly.

There are three centers of Cranberry growing in North America,-Cape Cod peninsula, New Jersey, Wisconsin. Each has methods peculiar to itself. It was in the Cape Cod region that Cranberry culture began. The first attempts were made early in this century. William Kenrick, writing in 1832 in this "Orchardist," says that "Capt. Henry Hall, of Barnstable, has cultivated the Cranberry twenty years;" "Mr. F. A. Hayden, of LinMass, is stated to have gathered from his farm in (anberries, which brought him in

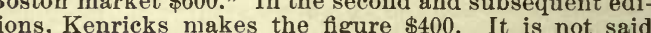
whether Mr. Hayden's berries were wild or cultivated. At the present day, with all the increase in production, received by Mr. Hayden.

In the third (1841) and subsequent editions, it is said that "an acre of Cranberries in full bearing will produce over 200 bushels; and the fruit generally sells, in the markets of Boston, for $\$ 1.50$ per bushel, and much higher than in former years." It was as late as 1850 , however, that Cranberry culture gained much prominence. It was in 1856 that the first treatise appeared : B. Eastwood's "Complete Manual for the Cultivation of the Cranberry." About 1845, Cranberry culture began to establish itself in New Jersey.

In the Cape Cod region, the bogs are "turfed." The surface covering is cut into small squares and hauled off. The object is to obtain a uniform surface in order that all plants may have equal opportunity. The bog is then "sanded." Rather coarse, clean sand is spread over the entire area to the depth of about 4 inches. In this covering, the vines are planted. The sand keeps down weeds and thereby lessens subsequent labor; it affords a moisture-holding mulch for the muck; it renders the plantation easier to be worked in wet weather, and it prevents the too vigorous growth of the vine. Every four of five years a fresh sanding, to the depth of an inch or less, is given. This keeps the vines short and close. Formerly, whole roots or "sods" of Cranberry were used 
for planting, but now cuttings are employed. These cuttings are 6 - or 8 -inch pieces of vigorous runners, with the leaves on. They are thrust obliquely through the sand, only an inch or two of the top remaining uncovered. They are set about 14 inches apart each way. In three or four years a full crop is obtained. The bogs are kept clean by means of hand weeding. At Cape Cod, it is estimated that the sum of $\$ 300$ to $\$ 500$ per acre is required to fit and plant a bog. A good yield from a bog in full bearing is 50 barrels to the acre; but 200 barrels have been grown.

In New Jersey, the general tendency is to omit the sanding. The bogs are not cleared so carefully. The plants are often set directly in the earth bottom, after the heavy turf is removed. The bogs - or meadows, as they are usually called-are not kept so scrupulously clean. It is thought that a reasonable quantity of grass prevents sealding of the berries. If the vines become too
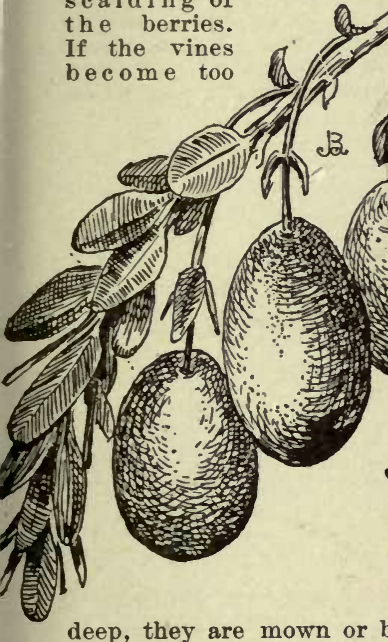

deep, they are mown or burned in order to secure a fresh growth from the roots.

The gathering of the erop is done preferably by hand-picking, particularly in plantations which are well cared for. In some cases the berries are raked off with a steel garden rake, but many of them are lost and bruised, and the vines may be injured. It is said by some that the tearing out of the old and large vines in the raking tends to renew the plants, and this is undoubtedly true; but there are better ways of keeping the rines young and short, as by sanding or mowing. In the East, raking is now rarely employed, unless the crop is very poor or prices very low; or unless hard frost is expected, in which case the berries may be raked, the bog flooded, and the berries eaught at the flume. Sometimes the bog is flooded when hard frost is threatened and the water is allowed to remain all winter, and the berries are harvested in the spring; but such early flooding may injure the vines. The price paid for the picking of Cranberries is usually about 40 to 50 cts. a bushel. Three to four bushels is considered to be an average day's picking. There are various devices to facilitate the picking. On Cape Cod a popular implement is the Lumbert picker (Fig. 569). The machine is thrust into the vines, and the operater closes the lid by bearing down with his thumb; drawing it backward pulls off the berries. Usually the pickers are "lined-off" (Fig. 568) by cords stretched across the bog, thus limiting each one to a particular area, which he is required to pick clean. The berries are cleaned by running them through a separator, by passing them over a sereen, by floating off the litter by dowsing them in water, and by other means. Dowsing usually reduces the market value. They are then marketed in barrels or crates.

Of varieties there are three general types, determined by the form of the berry, - the bell-shaped (Fig. 570), the bugle-shaped (Fig. 571), and the cherry-shaped (Fig. 572). There are many named varieties in each of these classes, differing in size, color, firmness, keeping qualities, productiveness. These varieties have been selected from plants which have appeared naturally in the bogs. Some of them have been discovered in wild bogs. The demands of the market, as respects varieties, are constantly changing. In Massachusetts, the following varieties are now popular: Early Black, Howe, Matthews, McFarlin.

The Cranberry is now a staple article of food in North America. "Turkey and Cranberry sauce" may be said to be the national dish. The berries are used in great variety of dishes. An effort has been made to open an European market, and an agent was sent abroad in 1893 for that purpose by the American Cranberry Trade Company. The export trade has now assumed some importance, and is growing. The approximate Cranberry crops for a series of years are shown below, in bushels:

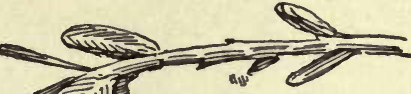

571. Dennis Cranberry.

Natural size.

Type of the Bugle Cranberries
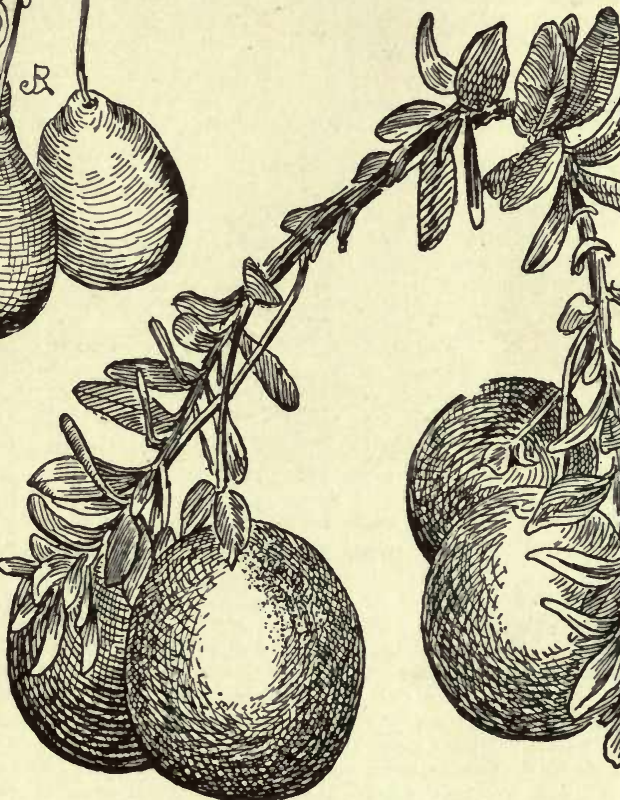

572. Makepeace Cranberry.

Natural size. Type of the Cherry Cranberries.

CRANBERRY CROPS, IN BUSHELS

\begin{tabular}{|c|c|c|c|c|c|}
\hline & & & & & \\
\hline & 1877 & 1878 & 1879 & 1880 & 1881 \\
\hline $\ln$ & & $\cdots$ & ...... & 250,500 & 160,825 \\
\hline • & & ... & ...... & 12 & 15 \\
\hline .. & ....... & . & . $\ldots \ldots$ & 113,430 & 143 \\
\hline & 400,828 & 295,760 & 233,000 & 492,630 & 461,025 \\
\hline & 18 & 1883 & 1884 & 1 & 1886 \\
\hline n & 193 & 14 & 13 & 28 & 27 \\
\hline & & & & & 23 \\
\hline & & 13 & 24,783 & 26 & 31,396 \\
\hline & & &, 014 & 743,436 & 540. \\
\hline
\end{tabular}




\begin{tabular}{|c|c|c|c|c|c|}
\hline & 1887 & 1888 & 1889 & 1890 & 1891 \\
\hline New England.... & 307,563 & 260,000 & 350,000 & 375,000 & 480,000 \\
\hline New Jersey....... & 163,788 & 225,000 & 200,000 & 200,000 & 250,000 \\
\hline West......... & 140,672 & 100,000 & 70,000 & 225,000 & 30,000 \\
\hline \multirow[t]{2}{*}{ Totals......... } & 612,023 & 585,000 & 620,000 & 800,000 & 760,000 \\
\hline & 1892 & 1893 & 1894 & 1895 & 1896 \\
\hline New England.... & 375,000 & 575.000 & 185,000 & 420,000 & 600,000 \\
\hline New Jersey.. & 160,000 & 325,000 & 200,000 & 200,000 & 200,000 \\
\hline The West.... & 65,000 & 100,000 & 25,000 & 10,000 & 30,000 \\
\hline \multirow[t]{2}{*}{ Totals......... } & 600,000 & $1,000,000$ & 410,000 & 650,000 & 830,000 \\
\hline & & 1897 & 1898 & 1899 & \\
\hline \multirow{3}{*}{\multicolumn{2}{|c|}{$\begin{array}{l}\text { New England.... } \\
\text { New Jersey...... }\end{array}$}} & 400,000 & 425,000 & 425,000 & \\
\hline & & 250,000 & 300,000 & 175,000 & \\
\hline & & & & & \\
\hline \multicolumn{2}{|c|}{ Totals..., $\ldots .}$. & 700,000 & 800,000 & 685,000 & \\
\hline
\end{tabular}

Average prices for Cranberries of good quality now range from $\$ 4.50$ to $\$ 6$ per barrel. The following table (by Rider) gives a summary of "opening" and "closing" prices per bushel for 18 Cranberry seasons:

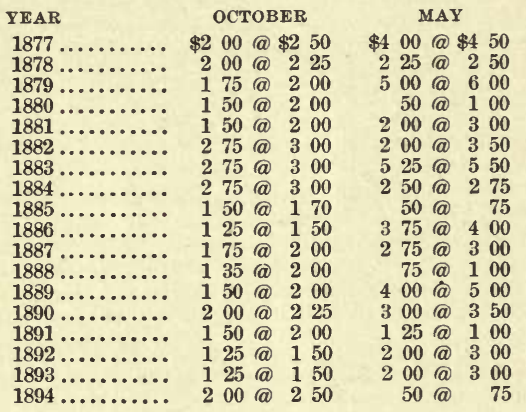

The Low-bush Cranberry, or Wolfberry ( $V$. Vitis$I d a c a$ ), is much used in Nova Scotia and other parts, and is gathered and shipped in large quantities to Boston; but it is not cultivated. This berry is also common in Europe, where it is much prized. The quantities of this fruit imported into the U. S. from various sources is considerable. For example, between July 24 and Dec. 31, 1897, the following imports were received (as compiled by Rider):

$$
\begin{aligned}
& \text { From Nova Scotia........... 31,748 qts. @ } \$ 1,284 \\
& \text { Sweden and Norway..... } 19,905 \text { qts. @ } 1,014 \\
& \text { Newfoundland ........... 7,256 qts. @ } 279 \\
& \text { Germany.............. 1,500 qts. @ } 180 \\
& 864 \text { qts. } \frac{27}{\$ 2,784} \\
& \text { or } 1,915 \mathrm{bu} \text {. }
\end{aligned}
$$

The Cranberry is subject to the attacks of various insects, for most of which the best remedy is flooding, although the fruit-worm is probably best destroyed by spraying with arsenites. There are also fungous troubles. For information on all these difficulties, the bulletins of the New Jersey Experiment Station are the best literature.

The best literature on the Cranberry is comprised in the Proceedings of the American Cranberry Growers' Association, with headquarters at Trenton, N. J. This society holds an "annual meeting" in January, and an "annual convention" in August. Beginning with 1880 , it has published regular reports of each of these gatherings. The standard books are White's "Cranberry Culture," largely from the New Jersey standpoint, and Webb's "Cape Cod Cranberries."

Notes BY A Wisconsin Grower.-Cranberries are raised mainly in the states of Massachusetts, New Jersey, Wisconsin, Michigan and Minnesota. The eastern marshes are mostly "made," while in Wisconsin there are thousands of acres of natural marsh as yet entirely uncultivated, as well as much that is cultivated.

The natural soil for the Cranberry is peat. Sand is also good, but, when used alone, must have a new coat of it spread over the ground every few years, as it becomes exhausted and the vines bccome woody and cease to bear. The ideal soil seems to be a foundation of peat, with from 2 to 4 inches of sand spread over it. It is very desirable that the surface should be level, so that it can all be kept equally moist. The leveling is usually done by "scalping," i. e., taking off the sod and carrying it away. This also removes the moss and other foul vegetation, and gives the vines a chance to take full possession of the ground. If scalping is considered too expensive, the moss may be killed by flooding in winter and drawing the water off in spring; but it takes two or three years for it to rot sufficiently to allow vines to do well. Plowing is sometimes resorted to where it can be done, or the sods turned upside down by some other means.

The best sites for Cranberry raising are those which afford a perfect water supply. There should be a reservoir of water on the upper side of the marsh (and if it is on the north or northwest so much the better, as it will then be more sure protection from frost), which can be emptied on to the marsh at short notice; and there must also be good drainage, to carry it away from the marsh quickly when desired. A level piece of marsh which has vines already growing on it looks very tempting to the uninitiated, but, if it has not a good water supply, it is better to leave it in the natural state and take the crops which grow in favorable seasons, than to spend money improving it.

A good sand marsh may be made near any stream in a sandy region by selecting a spot where water can be drawn from the stream, but there should also be a reservoir to hold water in, as that which comes directly from a running stream is sometimes too cold for Cranberries.

If dams are built from the sods thrown from the ditches, it is desirable, at least for the reservoir dams, to cover them with sand. This should be put mostly on the top and upper side, and should slope from the top of the dam to the center of the ditch. This prevents muskrats from doing very much damage, and the dam is not so apt to be washed out by high water as when built in a perpendicular wall. The cheapest way to move sand to build dams or for spreading on the marsh is to haul it on sleighs in the winter. A platform is built on rockers, so that the load may be dumped at one side of the sleigh ; and two loads in a place on a good peat dam will make a heavy reservoir dam. The pit from which sand is taken should be well protected with snow or sawdust to prevent its freezing badly. One of the best ways of making waste-gates is to place three joists lengthwise of the dam a little below the bottom of the ditch, and a platform built upon them, and the whole settled down as firmly as possible; then the dam is built right onto the platform for 3 or 4 feet on each side, and then the sideboards put in place, and cleats nailed up and down into which to slip the sluice boards. It is a good plan to have an outside ditch, which will carry surplus water around the marsh instead of across it, in wet seasons.

Planting.-There are several methods of planting vines. One way is to sort the vines and then cut them up, roots and all, in pieces about eight inches in length, laying them down three or four in a place, pushing the lower end into the ground by means of a stick shaped like a paddle; or it is sometimes done by a piece of iron fastenened to the bottom of a shoe. This method leaves the plants in an upright position, and they do not grow so rapidly as when pushed into the ground obliquely or laid on top of the ground, as their first growth is to make runners. Sometimes the vines are cut in a hay cutter. sown by hand like wheat, and then rolled. A good method of planting in the west is to take vines without cutting and drop two or three in a place and step on them; if put a foot apart, they will soon cover the ground, and will bear a good crop in three years. The greatest care must be taken, while sorting vines, that they do not dry out, for if they do they are worthless.

In subsequent culture is when water comes into use. The ditches should be about ten rods apart, each ditch having a dam built below it of the material thrown from the ditch; the drain ditches running down through the marsh need not be quite so close together. To promote the growth of vines, it is only desired to hold the ditches about half full, so that the ground may be moist, but if water is kept up onto vines at this time ther will be 
drowned and do nothing. When frosty nights come, after vines have begun to grow, water should be drawn from the reservoir to cover them, and let off the next morning. If the ends of the new shoots get frozen, it is a decided set-back, and especially so when the vines have reached the bearing age, as then it cuts off the crop and hurts the prospect for the coming year by taking the terminal bud. The vines do throw out side shoots, however, and sometimes the second season's crop does not seem to be much affected by it. When the plants are in blossom (which is all through July) the ground must not get too dry, or the blossoms will blast. This trouble was experienced in many places during the summers of ' 86 and ' 87 , when it was so dry that nothing but a stream fed by springs could begin to furnish a supply of water. Through the most of the summer, it is best to keep the water from 4 to 8 inches below the surface, but before the spring frosts are over it is better to keep it nearly to the surface, and if it is a season of drought, draw water down over the marsh about once a week. After the fruit has set, if obliged to flood as a protection against frost, be sure to draw the water off quickly the next morning, or the berries will be scalded.

The marsh should not be flooded for winter till quite late, some time in November, generally, as the fall frosts do not injure the vines, but help them harden, so that they will endure the winter's snow and ice without injury. Sometimes during the late winter, a rain or thaw will let surplus water on the marsh and this may lift the ice, and that will take the vines with it, right out of the ground. This should be guarded against by opening waste-gates and drawing off the extra water. The flood should be left on the marsh in the spring until the spring frosts are over ; in Wisconsin the time for drawing off the water is generally about the 20th of May, and it must be closely watched afterwards, as the vines are then very tender and will not bear as hard a frost as they will after they have been uncovered a few weeks.

Berries are gathered in two different ways : one is to pick them by hand, the other to rake them. The handpicking is mostly done by women and children or Indians. Every thirty pickers should have an overseer, whose duty it is to see that the vines are picked clean and that no refuse is allowed to go into the box; also to gire a check for every bushel box filled, and to carry the full boxes to the wagon, car or boat. The pickers in the west use shallow peck boxes to pick in, and when these are filled they empty them into the bushel box. The pickers are placed in a row, thirty of them occupying from 80 to 90 feet, and a rope should be stretched each side of them to keep them going straight ahead, or else they are very apt to turn to the right or left for better picking.

The cheapest way of gathering berries is to rake them with what is called a "scoop rake" (Fig. 573). It needs stout men to use these to advantage, at least those who are not troubled with backache, as they must keep a stooping position almost constantly. Rakes should not be used in young vines where there are a great many runners, as they would pull them up by the roots too much, but as the vines get older and the fruit shoots stand up out of the way of the runners, raking does not seem to injure them. The rakers should have ropes stretched between them, each man being given a space from one to three rods wide, end every ten should have an overseer, who

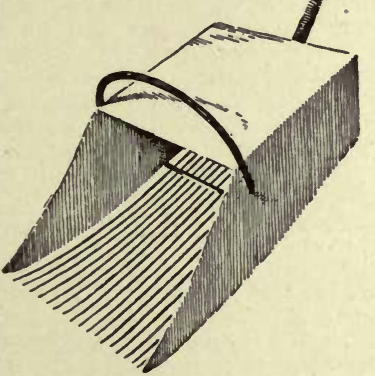

573. The hand scoop rake. will also rake most of the time. Rakers are hired by the day, but hand pickers pick by the box. The rake is much used in the west.

If the berries can be taken to the warehouse in a boat along the ditches, it is the best way, as they bruise easily and should be carefully handled: but if that is not practicable, then they must be taken in wagons which are driven as clese to the picking ground as pos, sible ; or a portable track may be laid onto the marsh. and a car used. The bushel boxes which are used have the sides and bottom made of lath, with small spaces between; and these boxes are used to cure the berries in, being piled up in tiers, so that the air can circulate between them. The berry-house should be built with dead air spaces in the walls, and windows should be darkened. and building kept closed during the day. See Storage.

Cranberries are generally shipped in barrels, but some use bushel crates, though in whatever they are packed, the greatest care should be taken to put them up in good shape. If picked before they begin to ripen, and then packed so that when they reach their destination they are settled from one to three inches in the barrel, dealers will not want them, and this kind of management has much to do with low prices. Before putting. into barrels, the berries are put through a Cranberry mill, and then, if there are still a few bad berries, they are put on tables made for the purpose, and the rest of the bad ones picked out by hand.

The profits of the business depend so much upon the amount of expense which has been necessary to improve the marsh that it is impossible to give any exact figures. The smaller the marsh, the quicker it can be improved and made to begin to pay a profit. Anyone who undertakes to improve a large marsh ought not to expect. much from it short of ten or fifteen years, though, if carefully managed, it may be made to pay cost of improving after three or four years.

There is a small sand marsh in Wisconsin, made after an attempt to farm the land had utterly failed because the soil was so poor, which has yielded a better income for several years than the best farm in the county. It is a profitable business when honest work and careful management are united in it, but not otherwise.

\section{H. B. TUTtLe.}

CRANBERRY TREE. Same as High-bush Cran. berry, Viburnum Opulus.

CRANESBILL. Loosely applied to the whole genus Geranium. In America it usually means $G$. maculatum.

CRASSULA (Latin, thickish; referring to the thick leaves and stems). Crassuldaceo. This genus gives the name to the order Crassulacem, which contains many cultivated succulent plants, and also others of widely different habit, - about 400 species altogether. The order is closely related to the Saxifragaceæ, and differs in having the carpels of the ovary entirely free and equal in number to the petals, but the forms pass easily into the Saxifragacer through Francoa and Tetilla, and back again through Triactina. The genera are ill defined, and certain species of Sedum cross over the lines of Crassula, Cotyledon aud Sempervivum, while between Crassula and Tilløa no good distinction can be made. For these reasons it seems best to give a key to the genera of garden importance.

A. Stamens as many as the petals.

B. Petals free, or connate only at the base.

1. Crassula. Floral parts in 5's: calyx shorter than the corolla.

Bв. Petals often connate to the middle or beyond.

2. Rochea. Calyx many times shorter than the tube of the corolla.

AA. Stamens normally tuice as many as the petals (sometimes equal in number, especiallg in Nos. $3,6,8)$.

B. Petals free, or connate only at the very base.

3. SEDUM. Floral parts usually 4-5: scales small.

4. Sempervivum. Floral parts 6 to many (rarely 5): scales small.

5. Monanthes. Floral parts 6-12: scales petal-like.

BB. Petals often connate to the middle or beyond.

6. Kalanchoz. Calyx 4-parted.

7. BRYOPHYLLUM. Calyx large, inflated, shortly 4-cut.

8. Cotyledon. Calyx 5-parted.

The floral parts of Crassula are normally 5, rarely 6-9, 
but cultivation probably changes the number of parts not infrequently. Crassulas are herbs or shrubs, rarely annuals, usually thick and fleshy: lvs. opposite, rarely stalked, often grown together at the base, entire or with a cartilaginous margin: fls. small, white, rose, or rarely yellow, usually in cymes, rarely in heads. For $C$. coccinea and jasminea, see Rochea. W. M.

Crassulas are greenhouse plants requiring a dry atmosphere during the resting period. While making growth, they may be treated like other greenhouse plants in the way of watering, placing them in the lightest and airiest part of the house. The pots must be drained so that any surplus moisture will easily pass through. The soil should consist of sand, loam, broken brick, and a very small quantity of leaf-soil or thoroughly rotted cowmanure. Propagation is usually from cuttings. Some of the species, such as. $C$. falcata, do not give much material for this purpose, and they should, therefore, be beaded over and the tops put in dry sand in the spring, allowing water only when they show signs of shrivelling. The cut-over plants should be encouraged to make side shoots, which may be rooted after they are large enough.

Cult. by G. W. Oliver.

A. Floral parts normally in 5's. B. Lvs. petioled.

cordàta, Soland. Height 1-3 ft.: stem shrubby: lvs. flat, wide, stalked, cordate, obtuse, entire, glabrous, spotted above : cymes panicle-like : fls. reddish, sometimes pure white. Winter.-Closely allied to $C$. spathulata.

spathulàta, Thunb. Glabrous herb: stem somewhat shrubby, decumbent, branching: lvs. stalked, roundish, crenate, glabrous, shining above: corymbs panicle-like:

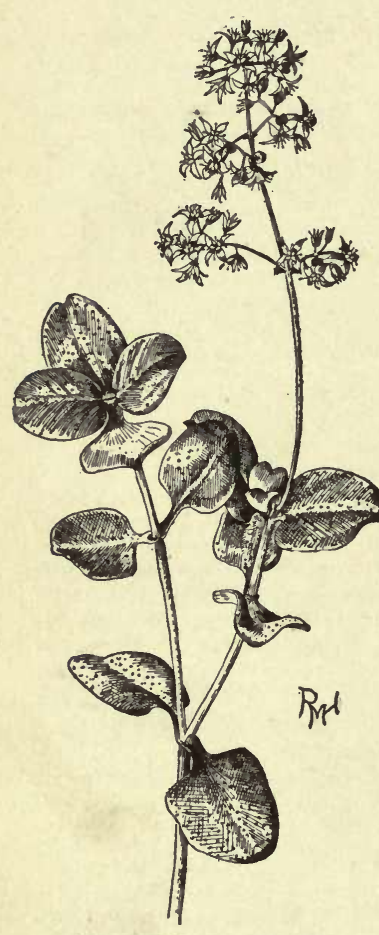

fls. rosy; petals acute. L. B. C. $4: 359$ as $C$. cordata. Not advertised for sale, but likely to be cultivated as $C$. cordata.

\section{BB. Lvs. not petioled.}

c. Foliage glaucous.

falcàta, Wendl. Height 3-8 ft.: lvs. grown together at the base, thick, glaucous, oblong, falcate: fls. small, numerous ( 50 or more), in a crimson, rarely white, dense, terminal corymb: corolla tube $1 / 3$ of an in. long, as long as the limb or shorter. B.M. 2035.

\section{cc. Foliage not glaucous.}

láctea, Soland. Height 1-2 ft.: stem shrubby, branching, tortuous below: lvs. ovate, narrowed and grown together at the base, glabrous, spotted along the margin: cymes panicle-like, many-fld.: fls. white, small. Winter. B.M. 1771. L.B.C. 8: 735.- A free-flowering window plant of easy culture. There is a form with variegated leaves.

AA. Floral parts in 4's. quadrifida, Baker. Fig. 574. Perennial: lvs. oblongspatulate, the upper ones rounder, decussate: fls. with their parts in 4's, panicled, white, tinged red. W. M.

CRAT 庆GUS (ancient Greek name, derived from kratos, strength, on account of the hardiness of the wood). Rosdcece, suborder Pómeo. Haw. HawthoRn. Shrubs or small trees, usually spiny: lvs. alternate, deciduous, stipulate, serrate, often lobed or pinnatifid: fls. white, in some varieties red, in corymbs, rarely solitary; petaland calyx-lobes 5 ; stamens many, rarely less than 10 ; styles 1-5: fr. a drupe-like pome, with 1-5 1-seeded bony stones. About 70 species, in the temperate regions of the northern hemisphere, most abundant in N. America. Hardy ornamental shrubs and trees, mostly of dense and low growth, with handsome foliage, turning, in most species, to a brilliant coloring in the fall; many have very decorative frs., and also handsome fls. Some of the best, with showy frs., are $C$. Crus-galli, $C$. Lavallei, $C$. cordata, $C$. pinnatifida major, $C$. mollis, but the frs. of the last drop very early, while in most of the others the frs. remain a long time on the branches. Some varieties of $C$. monogyna have very decorative fls.; also $C$. mollis, C. Crus-galli and others are handsome in bloom. For the $\mathrm{S}$. states, $C$. astivalis and the blue-fruited $C$. brachyacantha are among the most decorative. Well adapted for hedges are $C$. monogyna, $C$. Oxyacantha, C. Crus-galli, C. cordata and many others. The Hawthorns grow in almost any soil and position; best in a rich, loamy, somewhat moist one, and also in strong clay. Prop. by seeds, sown in fall or stratified; before stratifying, most of the pulp may be removed by laying the frs. in shallow piles and allowing them to decay. Then they are mixed with sand or sifted soil and buried in the ground or kept in boxes in a cool cellar. Some species, as $C$. cordata, $C$. coccinea, $C$. Crus-galli, germinate the first year and are sown in spring, while others, especially $C$. Oxyacantha and its allies, do usually not germinate until the second year, and may be kept stratified until the following fall or the second spring. If sown at once, the seed-beds must be heavily mulched during the first summer to prevent drying. The young plants should not be allowed to remain over one year in the seed-beds, as they form long tap-roots and are then difficult to transplant. Varieties and rarer kinds are easily budded or grafted on seedling stock of $C$. Oxyacantha, or other common strong-growing species.

Index : acerifolia, 13 and suppl.; apiifolia, 14 and suppl.; Aronia, 18; Azarolus, 18; Carrieri, 7; coccinea, 3; cordata, 13; Crus-galli, 5; Douglasi, 12, 10; flava, 2; Lavallei, 7; leucophloeos, 9; lucida, 5 ; macracantha, 10 ; mollis, 4; monogyna, 16; nigra, 21; odoratissima, 19; orientalis, 19: Oxyacantha, 15,16 ; parvifolia, 1 ; pinnatifida, 17: populifolia, 13 and suppl.: prunifolia, 6 ; punctata, 8 ; pyrifolia, 9 ; sanguinea, 11 ; subvillosa, 4 ; tanacetifolia, 20 ; tomentosa, 9 ; uniflora, 1.

\section{A. Foliage of the flowering branches not at all or very slightly lobed; no veins going to the sinuses.}

\section{B. F'ls. 1-3, rarely more.}

1. uniflora, Mœnch (C. parvifolia, Ait.). Dense, low shrub, with numerous slender spines, rarely spineless, 3-8 ft.: Ivs. on short not glandular petioles, cuneate, obovate or oblong-obovate, irregularly or doubly crenateserrate, pubescent on both sides, at length glabrous above, $1 / 2-1 \frac{1}{2}$ in. long: calyx pubescent, with large serrate lobes : fr. pyriform or globose, yellow, $1 / 3$ in. across, with 2-5 stones. May, June. N. Jersey to Arkansas and Florida. S.S. 4:191.

2. flàva, Ait. Shrub or small tree, to $25 \mathrm{ft}$., usually very spiny: lvs. on short glandular petioles, cuneate, obovate, glandular-dentate, pubescent, at length glabrous and shining above: fr. globular or pyriform, greenish, yellow or red, $1 / 3$ in. across. Va. to Florida. S.S. 4:189. B.R. 23:1932, 1939.

$$
\text { BB. F'ls. in 6-many-fld. corymbs. }
$$

c. Lvs. on slender, often glandular petioles, usually broadly ovate and truncate at the base, slightly lobed: calyx lobes dentate.

3. coccínea, Linn. Scarlet Thorn. Shrub or tree, rarely to $25 \mathrm{ft}$., with short spines: lvs. broadly ovate, sharply doubly serrate, nearly glabrous beneath, sparingly appressed-pubescent above, $2-3 \mathrm{in}$. long: corymbs usually slightly villous: fr. red, globose or oval, $1 / 3-1 / 2$ in. across. April, May. Newfoundland to Florida and Texas, west to Manitoba. S.S. 4:180. Em. 493. B.M. 3432. - There are a number of allied forms which have been considered usually as mere varieties, but may be perhaps distinct species. None of them, however, surpasses the true $C$. coccinea in decorative value, and they are only of botanical interest. 
4. mollis, Scheele (C. subvilldsa, Schrad. C.coccinea, var. móllis, Torr. \& Gr.). Fig. 575. Tree, to $30 \mathrm{ft}$., with short, stout thorns: Irs. broadly orate, sharply and doubly serrate, densely pubescent beneath, $3-4$ in. long: corymbs densely villous-pubescent: fls. with red disk : fr. about $1 / 2$ in. across, usually pear-shaped. April, May. Quebec to Pa., west to Nebraska. S.S. 4:182. Em. 494 (as C.tomentosa) G.F. 5:221, - One of the most decorative species, with large, bright green foliage and showy fls. and frs., ripening in September, but dropping soon after maturity.

Var. tiliifòlia, Koehne. Lrs. more pubescent, petioles not glandular: stamens 20 . veins beneath when young, $2-3$ in. long: corymbs pubes. cent: fr. red; stones with two furrows on the inner side. May-June.-Probably hybrid between C. Crus-galli and C. macracantha. B.R. 22:1868.

7. Lavállei, Herincq. (C. Carriéri, Vauv.). Small tree to $20 \mathrm{ft}$., with spreading branches, nearly unarmed, when older: lvs. elliptic or oblong-obovate, acute, pubescent, glabrous above at length, irregularly serrate, 3-4 in. long: corymbs rather few-fld., pubescent ; fls. large, with red disk : fr. bright orange or brick-red, ovoid or globular, $2 / 3$ in. across. May. R.H. 1883: 108. G.C. III. 21: 118, 119. - Probably hybrid between $C$. Crus-galli and $C$. Mexicana; originated in France.

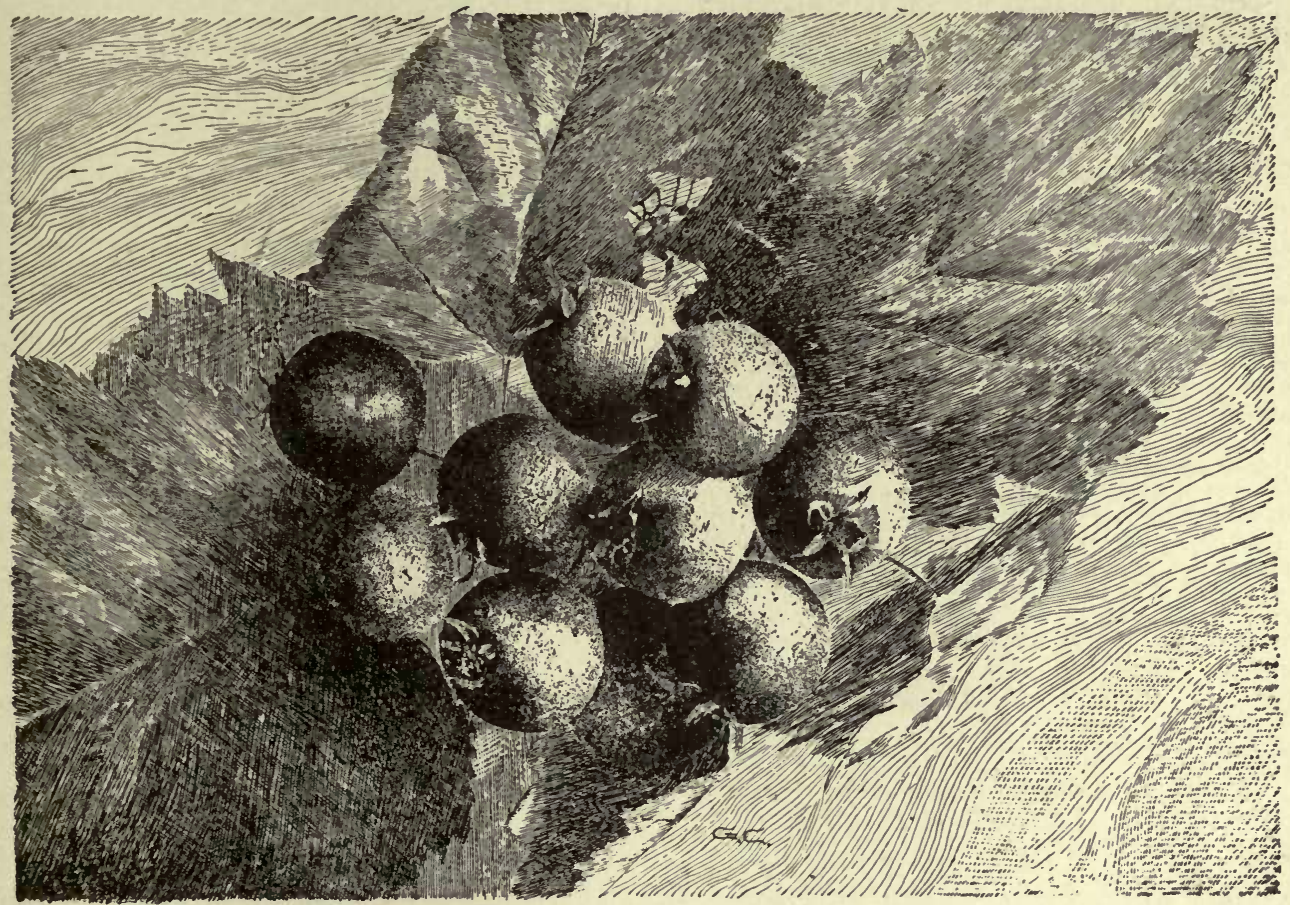

575. Cratægus mollis $\left(\times \frac{1}{2}\right)$. One of the best native thorns.

oc. Lis. on rather short and stout, not glandular, petioles, cuneate and usually entire at the base, and mostly broadest above the middle.

D. F'r. red or yellou, not shining.

E. Habit of fr. nodding or pendulous: rather hard.

F. Color of lvs. dark green and shining above, chartaceous: calyx lobes erect on the fr.

5. Crus-gálli, Linn. Shrub or tree, to $40 \mathrm{ft}$.; branches wide-spreading, rigid, often pendulous, with numerous slender spines: lvs. obovate or oblanceolate, irregularly and sharply serrate, quite glabrous, $1-2 \frac{1}{2}$ in. long, often semi-persistent: corymbs glabrous: fr. usually globose, red. May-June. Quebec, south to Fla. and Tex. S.S. 4:178. Em. 492. R.B. 1:116. G.F. 7:295. - A very decorative species of distinct habit, handsome in bloom and with showy, bright red fr., remaining on the branches often until spring; the lvs. assume a brilliant orange and scarlet color in fall. Var. inérmis, Lge. Spineless form. Var. lineàris, Ser. Lvs. linear-lanceolate. Var. nana, Nichols. Dwarf form. Var. ovalifollia, Lindl. Lvs. elliptic. B.R. 22:1860. Var. pyracanthifdlia, Ait. (var, salicifolia, Ait.). Lvs, oblanceolate. Var. spléndens, Ait. (var. lùcida, Hort.). Lrs. elliptic-oblanceolate, very shining.

6. prunifolia, Pers. Shrub or tree, to $30 \mathrm{ft}$.: branches spreading or somewhat ascending, spiny: lvs. obovate, or roundish obovate, doubly serrate, pubescent on the
FF. Color of lvs. dull above, with impressed veins, pubescent.

8. punctàta, Jacq. Fig. כ76. Tree, to $25 \mathrm{ft}$.: branches horizontally spreading, with short, stout spines or unarmed: Ivs. broadly obovate, obtuse or acute, narrowed at the base into a rather long-margined petiole, irregularly serrate : corymbs pubescent: fls. large; calyx lobes entire : fr. pyriform or subglobose, red, dotted, about 1/2 in. across. May. From Quebec to Ont. and Ga. S.S. 4:184. Var, aùrea, Ait. (var. xanthocárpa, Roem.). Fr. yellow: lvs. sometimes slightly lobed.

EE. Habit of fr. erect, becoming soft : corymbs many-fld., large.

9. tomentòsa, Linn. (C. pyritdlia, Ait. C. leucophlocos, Mœnch). Shrub or small tree, to $20 \mathrm{ft}$., with spreading branches unarmed or with short spines: lvs. cuneate, obovate-oblong or elliptic, acute, serrate and often slightly lobed, pubescent, 2-5 in. long: corymbs pubescent; fls. rather small; calyx lobes serrate: fr. usually oval, dull or yellowish red, $1 / 4-1 / 8$ in. across; stones with 2 furrows on the inner side. June. From Hudson Bay to Ga., west to Mich. and Mo. S.S. 4:183. G.F.2:425. B.R. 22:1877. - Var. aurantiaca, Lge. Fr. yellow.

DD. Fr. shining, blood-red or scarlet, rarely yellow, globose, with soft and juicy flesh; stones with 2 furrows on the inner side (plain in all the fore. going except Nos. 6 and 9).

10. macracántha, Ludd. (C. coccínea, var, macracán 
tha, Dudl.). Fig. 577. Shrub or small tree, to $20 \mathrm{ft}$., of dense growth, with numerous long and slender spines: lvs. rather slender-petioled, broadly elliptic or ovate, doubly serrate. glabrous, shining and dark green above, almost glabrous beneath : corymbs more or less vil-

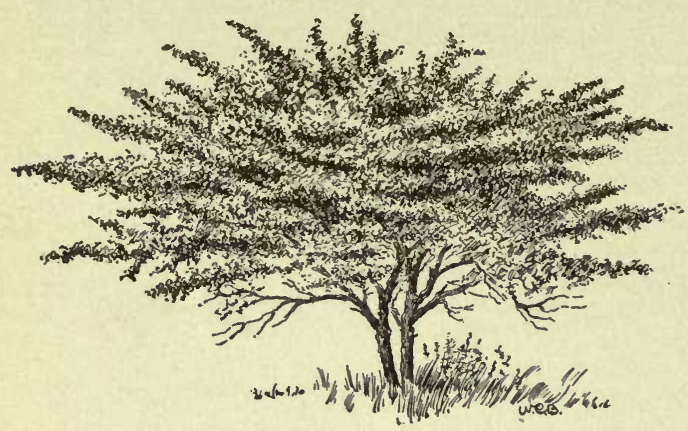

576. Cratægus punctata.

lous; fls. fragrant ; calyx-teeth glandular-serrate : fr. $1 / 8$ in. in diam. May, June. Quebec to Va., west to Mo. and Dak. S.S. 4:181. B.R. 22:1912. L.B.C. 11:1012 (as C. glandulosa). A.G. 11:509.-Sometimes cultivated under the name of $C$. Douglasi. Var. succulenta, Rehd. (C. succulénta, Schrad.). Lvs. pubescent beneath : pedicels and calyx densely villous.

11. sanguinea, Pall. Shrub or small tree, with upright, spreading branches and short spines: lvs. ovate or broadly ovate, narrowed into the petiole, irregularly serrate and slightly lobed, more deeply lobed on vigorous shoots, nearly glabrous, $11 / 2-3$ in. long: corymbs pubescent or glabrous; fls. large; stamens 20, with purple anthers : fr. $1 / 2$ in. in diam. Siber., Dahur., Amurland. Var. Altàica, Loud. (var. xanthocárpa, Regel). Fr. yellow, smaller : anthers whitish: Ivs. more deeply lobed.

DDD. Fr. black, shining; stones with 2 furrows.

12. Doùglasi, Lindl. (O. sanguinea, var. Doùglasi, Torr. \& Gr.). Tree, to $40 \mathrm{ft}$., with slender, often pendulous branches, unarmed or with short spines: lvs. shortpetioled, broadly ovate or oblong-ovate, serrate and slightly lobed, nearly glabrous, pubescent on the midrib above, chartaceous, 1-4 in. long: corymbs glabrous: calyx lobes triangular-ovate : fr. ripening in Aug. or Sept. May. Brit. Columb. to Calif. S.S. 4:175. B.R. 21:1810.

AA. Foliage distinctly lobed, with veins going from the midrib to the sinuses (see also No.1); stones plain on the inner side except No.15.

B. Fr. very small, about 1/6in. across : calyx lobes separated by a distinct line from the fr. and falling off at length.

13. cordàta, Ait. (C. acerifòlia, Mnch. C. populifolia, Walt.). Washington Thorn. Tree, to $30 \mathrm{ft}$., with slender spines: lvs. slender, petioled, triangular or broadly ovate, usually truncate at the base, 3-5-lobed, sharply serrate, $1 \frac{1}{2}-2 \frac{1}{2}$ in. long : corymbs many-fld., glabrous : styles 5: fr. depressed-globose, shining, bright coral-red. June. Ill. to Ala. and Va. S.S. 4:186. B.R. 14:1151.-A very desirable species, with beautiful fall-coloring and large clusters of bright red fr. remaining a long time on the branches.

14. apiifdlia, Michx. Shrub or small tree, rarely $20 \mathrm{ft}$., with stout spines and the branchlets pubescent when young: lvs. slender, petioled, broadly ovate, pinnately 5-7-cleft, serrate, glabrous or pubescent, $3 / 4-1 \frac{1}{2}$ in. long: corymbs few-fld., villous, pubescent; styles $1-3:$ fr, oval, 1-4-1-5 in. high. May. Va. and Fla. to Tex. S.S. 4:188. -A handsome species with graceful foliage and an abundance of white fls. in spring and small but brightcolored frs. in fall.

BB. Fr. $1 / 4$ in. or more across : calyx not separated.

$$
\text { c. Fr. red or yellow. }
$$

D. Branches and lvs. glabrous.

15. Oxyacántha, Linn. Hawthorn or MAY of English literature. Shrub or small tree, to $15 \mathrm{ft}$., with spreading branches and stout spines: lvs. short-petioled, cuneate or truncate at the base, roundish or broadly ovate, 3-5lobed, with incisely serrate lobes, 1-2 in. long: corymbs 5-10-fld., glabrous: fr. globular or roundish oval, $1 / 3-1 / 2$ in high, scarlet; stones 2 , with 2 furrows on the inner side. May. Eu., N.Afr. B.R. 13:1128 (as C. oxyacanthoides). Var. xanthocárpa, Roem. Has yellow fr., very distinct and showy.-Often confounded with the following, and less commonly cultivated.

16. monógyna, Jacq. (C. Oxyácantha, Hort.). Shrub or tree, to $20 \mathrm{ft}$., with stout spines: lvs. on rather slender petioles, ovate, 3-7-lobed, lobes with few teeth at the apex, 1-2 in. long: corymbs many-fld., with usually hairy pedicels: fr. oval, with usually 1 stone, $1 / 3-1 / 2$ in. high. May, June. Eu. and N. Africa to Himalayas.-Many garden forms are cultivated; some of the most distinct are the following. With single fls.: Var. bícolor, Hort. (var. Gumpperi bícolor). Fls. white, edged pink. F.S.16:1651. Var. punicea, Hort. Fls. deep red. F.S. 15:1509, Fig. 1. L.B.C. $14: 1363$. Var. ròsea, Hort. Fls, pink, petals with white claw. With double fls.: Var. álba plèna, Hort. With white double fis. F.S. 15:1509, Fig. 2. Var. Pauli, Hort. (var. coccínea, Hort. Var. Paul's New Double Scarlet). Fig. 578. Bright scarlet, one of the most showy. I.H. 14: 536. Var. punícea plèna, Hort. Scarletred. R.B. 24:161. Var. rùbra plèna, Hort. Red. F.S. 15:1509, Fig. 3. Varieties differing in lvs. and habit: Var. laciniata, Loud. Lvs. deeply pinnatifid with incised serrate lobes. Var. pteridifolia, Loud. (var. fiticifolia, Hort.). Similar, but lvs. longer, with narrower and more incised lobes. F. S. 20:2076. Var. quercifolia, Loud. Lvs. with broad, rounded and crenate lobes. Var. horrida, Carr. Branches with fascicles of numerous stout spines. F.S. 14:1468. G.C. III. 24:13. Var. péndula, Hort. With pendulous branches. Var. péndula ròsea, Hort. A pendulous form, with pink fls. Var. stricta, Loud. (var. pyramiddlis, Hort.). Of fastigiate, upright habit. Var. semperflorens, André (var. Brùanti, Carr.). Low, graceful shrub, flowering until fall. R.H. 1883, p. 140. There are also some vars. with variegated lrs.

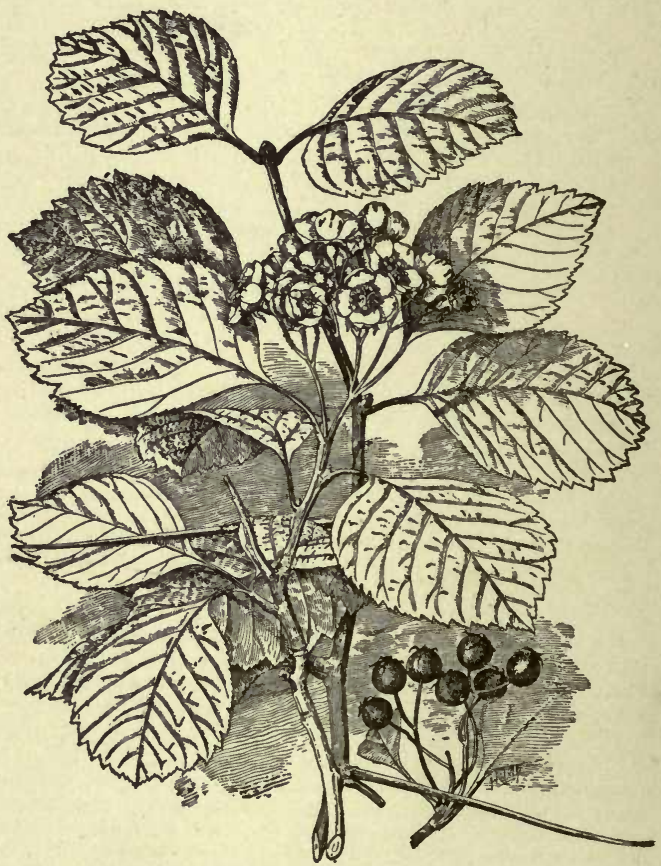

577. Cratægus macracantha $(\times 1 / 3)$.

17. pinnatifida, Bunge. Shrub or small tree, to $20 \mathrm{ft}$.: lvs. slender-petioled, cuneate, elliptic-ovate, pinnately 5-9-cleft, incisely serrate: corymbs many-fld., usually pubescent: fr. globular or pyriform, dark red, punctate, 
$1 / 2-3 / 4$ in. high; stones 3-5. June. Amurland, N. China, Japan. Gt. 1862: 366. - Var. májor, N. E. Brown. Lvs. larger, less deeply lobed : fr. oval, 1 in. long. G.C. II. $26: 620$.

DD. Branchlets and le's. pubescent, rarely lvs.glabrous: fr. large, often pubescent.

18. Azárolus, Linn. (C.A rònia, Sér.). Shrub or tree, to $25 \mathrm{ft}$ : : lvs. short-petioled, cuneate-obovate, deeply $3-5$-lobed, with the lobes nearly entire or incised at the

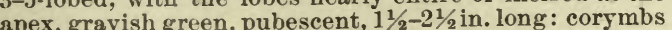
few-fld., densely tomentose: fr. orange-red or yellow, globular or .ovoid, $3 / 4-1$ in. across. May. N. Africa, W. Asia. B.R. 22:1897 (as $C$. Aronia). R.H. 1856: 441 . - Var. Sindica, Boiss. Lvs. glabrous: fr. smaller, reddish yellow. B.R. 22:1855 (as $C$. Maroccana).

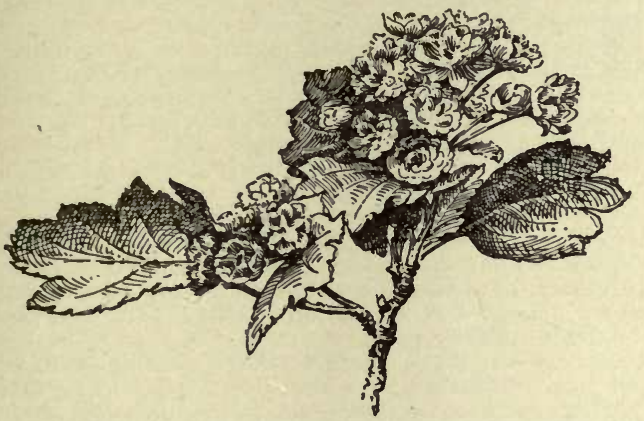

578. Paul's Thorn - Cratzgus monogyna, var. Pauli.

19. orientàlis, Pall. (C. odoratíssima, Lindl.). Shrub or small tree, with spreading, almost unarmed branches: lvs. short-petioled, cuneate, obovate or oblong, pinnately 3-5-cleft, with the lobes incisely serrate at the apex, tomentose pubescent, 1-2 in. long: corymb dense, tomentose: calyx lobes entire: fr. devressed globose, brick- or orange-red, $3 / 4-1$ in. across. June. S. E. Eu., W. Asia. B. M. 2314. B. R. $22: 1885$ (as $C$. odoratissima).-Var. sanguínea, Schrad. Fr. dark red. B.R. 22:1852.

20. tanacetifòlia, Pers. Shrub or small tree: lvs. cuneate, obovate, pinnately 5-7-cleft, with'the lobes glandularserrate, villous-pubescent, 1-2 in. long: corymb dense, 5-7-fld.: calyx lobes large, deeply glandular serrate: fls large fr. pubescent, yellow, 1 in. or more across, with laciniate bracts at the base. May, June. W. Asia. B.R. $22: 1884$. Gt. 43, p. 215.

\section{Fr. black, shining, globular.}

21. nigra, Kit. Shrub or small tree; branches pubescent, with short spines: lvs. short-petioled, ovate or ovate-elliptic, deeply pinnately 5-9-lobed with serrate lobes, slightly pubescent above, densely pubescent beneath: corymbs dense, 10-15-fld., tomentose; pedicels short: fls, white, becoming slightly red: fr. $1 / 2 \mathrm{in}$. across. S. E. Eu. L.B.C. 11:1021.

C. acerifòlia, Mnch. $=\mathrm{C}$. cordata. $-C$. acerifòlia, Hort. $=\mathrm{C}$. mollis -C. oestivòlis, Torr. \& Gray. Tree, to $30 \mathrm{ft}$.: lvs. cuneateoblong, crenate-serrate, pubescent below: corymbs few-fld., glabrous: fr. large, red. S. states. S.S. 4:192.-C. apiifolia, Hort. brous: $\mathrm{C}$. lientalis $-C$ arboréscens, Eill $=\mathrm{C}$, viridis $-C$. berber $\Rightarrow$ C. orientalis. - . arborescens, Ell. $=$ C viridis.-C. berberifolia, Torr.\& Gray. Allied to C.Crus-galli. Lvs. obovate, rounded -C.brachyacántha, Sarg. \& Engelm. Tree, to $50 \mathrm{ft}$.: lvs. elliptic or oblong-lanceolate, rarely 3-lobed, glabrous at length: corymbs many-fld : fr. large, bright blue, Louisiana, Texas. S.S. 4:177. many-liánica, Hort.= C. pinnatifida major - C. Carpáthica, Lodd = C. nigra. - C. Celsiàna, Bose. Shrub : lvs. pinnately lobed, slightly pubescent beneath: corymbs many-fld.: fr. ovoid, lobed, slightly pubescent beneath: corymbs many-fld.: fr.ovoid, red. Origin unknown.- O. chlorosarca, Maxim. Alled to C. sanguinea. Lvs. pinnately lobed, glabrous at length: corymbs many-fld.: fr. black, with green flesh. Manchuria.- C. coccinea, var. viridis, Torr. \& Gray.=C. pruinosa.- C. crenulàta, Roxb. = Pyracantha crenulata - $O$. cuneàta, Miq. Low shrub: lvs. cuneate, obovate-oblong, serrate or slightly lobed: corymbs fewfld.: fr. large, red. Japan. - C. Dahùrica, Hort. $\Rightarrow$ C. pinnatifida. - C. Douglasi, Hort., not Lindl.= C. macracantha.-C. Florentina, Zuec. = Pyrus (Malus) cratægifolia.- C. fldrida, Loud.= C. unifiora-C. Fontanesiana, Spach. Allied to C. Crus-galli. Lvs, elliptic or elliptic-lanceolate, almost glabrous, shining above: corymbs many-fld., pubescent: fr. red. Probably hybrid and belonging to C. prunifolia. - O. glábra, Hort., not Thbg.=
C. cordata.- C. glandulosa, Mnch. (C. flava, var. pubescens, Gray). Allied to C. flava. Lis. broader, of firmer texture, mor pubescent and glandular: fr.subglobose, red or yellow. S. states. S.S. 4:190 (as C. flava elliptica). B.R. 22:1890 (as C. spathulata) - C. grandiflòra, Koch. Small trees: lvs. elliptic, serrate, often slightly lobed toward the apex, pubescent: fls. 1-3, large: fr. brown, glokose, large. Supposed to be a hybrid between Mespilus Germanies and a Cratgegus G.F. 10:35, R.H. 1869, p. 80 pil C C as . lobata). - Clily trifid: fr. larger, bright red: corymbs manyLvs. larger, usually trifid: fr. larger, bright red: corymbs many-
fld. B.R. 14;1161 and $22: 1847$. - . Korolkowi, Hort.= C. pinnatifida, var. major; also $\mathrm{C}$. chlorosarea and $\mathrm{C}$. sanguinea, var Altaica are cultivated sometimes under this name.- $C$. lobàta Bose $=0$. grandiflora - O. lùcida, Mill $=\mathbf{C}$. Crus-galli, var. splendens. - C. Maùra, Linn. f.=C.Azarolus.- C. melanocárpa, Bieb $=\mathrm{C}$ pentagyna - C. Mexicàna, Sess. \& Moc. Small tree, to $20 \mathrm{ft}$. lvs, cuneate-oblong coarsely serrate or slightly lobed, pubescent: corymbs 3-10-fld., tomentose: fr. large, red or yellow. Iexico. B. R. 22:1010. S.B.F.G. II, 3:300.-O. microcárpa, Lindl. $=$ C. spathulata. $-C$. odoratissima, Lindl.=C . orientalis. $-O$.

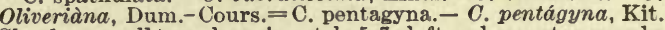
Shrub or small tree: lvs. pinnately 5-7-cleft, pubescent: corymbs many-fld.: fr. pyriform, black, dull, small. B. R. 22:1874; 23:1933. - C. populifòlia, Ell. Allied to C. coceinea. Lvs. smaller, glabrous: fr green-purple or dull purple, glancous. N. Eng, to Fla - O. pruindsa, Wendl. $=$ C. populifolia. $-C$. purpirea, Bose $=$ Fla.-O. pruinosa, Wendi $=$ C. populifolia.-C.purpurea,Bosc. $=$ pyrifolia, Ait. = C. tomentosa. - C. rivularis, Nutt. Allied to C. pyrifolia, Ait.=C. tomentosa.- C. rivularis, Nutt. Allied to C. length. Oregon to N. Mexico and Calif. S.S.4:176.-O.spathulàta. Mchx. Shrub or tree, to $20 \mathrm{ft}$.: lvs. cuneate, oblanceolate, erenately serrate or 3-lobed at the apex: corymbs many-fld: fr, scarlet, globular, $1 / 4$ in. across. S. states. S.S. 4:185. B.R. 22: 1846 (as C. mierocarpa) - - C. succulénta, Schrad = C. macra22:1846 (as C. mierocarpa).- - succulenta, schrad. cantha. - C. Tatárica, Hort. $=$ C. pllis. $-C$. Tourneforti, Griseb. tomentosa, var. móllis, Hort.=C. mollis. - C. Tourneforti, Griseb. losa. - O. viridis, Linn. Tres, to $35 \mathrm{ft}$.: lvs. cuneste, oblong-obo vate, irregularly serrate, often slightly lobed, glabrous: corymbs many-fld., glabrous or sparingly villous: fr. searlet or orange. S. Caro. and Fla. to Texas. S.S.4:187. ALFred REHDER.

CRAT isva (after Cratevas, an obscure writer on medical plants, not, as sometimes stated, at the time of Hippocrates, but at the beginning of the first century B.C., since he named a plant after Mithridates). Cappariddcece. A genus of 14 species of tropical trees and shrubs: leaflets 3 : fls. in corymbs, usually polygamous, with the odor of garlic: sepals and petals $4:$ stamens 8-23: torus elongated: berries ovate-globose, with a slender stripe. The bark of the Garlic Pear, C. gynandra, blisters like Cantharides. $C$. religiosa, from Malabar and the Society Islands, is a sacred tree, and is planted in native graveyards. The bitter, aromatic leaves and bark are used by them in stomach troubles. The above and some other species are cultivated in Europe as ornamental greenhouse shrubs.

religidsa, Forst.f.'(C.Nurvála , Buch.-Ham.). Leaflets $21 / 2$ to 3 times as long as broad: stamens $20-28$. - Cult. by Franceschi, Santa Barbara, Calif.

\section{CREAM NUT. See Bertholletia.}

CREEPING CHARLIE. A children's name for the fragrant little blue-fiowered weed, Malva rotundifolia, which bears the "cheeses" dear to boyhood's memory. The name is hardly dignified enough for most botanies. This name is sometimes applied to Lysimachia nummularia.

CREेPIS (the application of this name is obscure). Compositoe. This variable genus contains a few hardy annual and perennial herbs, especially $C$. Sibirica, which resembles a sow-thistle in habit, and has corymbs of reddish blue flowers, about the size of a hawkweed, or a small dandelion. It is one of the coarser border plants, and rare. Rather light, sandy soil, and full exposure to the sun are essentials to the welfare of this plant. It is contented in a rather dry position, either in the rockery, or in the border. It is prop. by division. A common plant on the moss of English thatched cottages is $C$. vivens, a yellow-fld. plant, resembling a dandelion.

Sibírica, Linn. Perennial, $2-3 \mathrm{ft}$. high, and at least as wide when in bloom: plant covered with short rough hairs: root, large, fleshy: lvs. rough, wrinkled, coarsely dentate, somewhat cordate, 12 in. long, including a petiole half as long: fls. bright yellow: involucre loose, 
hairy. July, Eu., Asia, Minor, Himalayas. Gn. 53, p. 493. - The tallest and largest-fld. of the genus. Its white, plumy masses of seeds are also attractive.

O. aùrea, Reichb. Height $1 \mathrm{ft}$., fls. orange. June. Eu. The commonest perennial species of the genus abroad. Repays rich soil.-C. rùbra, Linn. Annual height 6-32 in.: fls. red, usually solitary. Italy. Greece. The commonest of the annual species abroad.

CRESCENTIA (after Crescenzi, thirteenth century Italian agricultural writer). Bignonidcec. This genus is chiefly interesting for the Calabash tree, and has no near allies of horticultural importance. It consists of tropical trees, glabrous: lvs. alternate, solitary or clustered in nodes : fls. large, tubular, with a fluted 5-cut limb, yellowish, with red or purple veins: calyx 2-parted or deeply 5-cut. The Calabash tree is a native of tropicai America, is especially familiar in the West Indies, and can be grown outdoors in extreme S. Fla., S. Calif. The outer skin of the fruit is removed, and the seeds and pulp from within, and the hard, woody shell is used for water-gourds and for all sorts of domestic vessels, according to size and shape. The growing fruit can be made to assume various forms by skillful tying. It is a tree, $20 \mathrm{ft}$. high, and readily distinguished from all others by its peculiar habit of growth, as it bears large, horizontal, scarcely divided branches, which bear clusters of leaves at intervals.

Cujete, Linn. Lvs.4-6 in.long, broadly lanceolate,tapering at the base: fls. solitary, pendulous; calyx 2-parted corolla constricted below the middle, and then swelled above, malodorous when decaying; stamens 4, sometimes 5. B.M. 3430 .

CRESS. The ordinary garden Cress (Lepidium sativum), sometimes called peppergrass, is still absent in the majority of American gardens, although its leaves have the pleasant pungency of the Water Cress, and might be used more freely as a condiment, to be served with salads, or for garnishing. The quick sprouting habit of the seed is proverbial. If Cress is wanted in its prime continuously, seed must be sown every few days. The young plants, which may be left thickly in drills, need protection from the flea beetle, as this is as fond of Cress pungency as any gourmand. For winter use, garden Cress may be grown in large flower pots, boxes, or on a bench, in any light and reasonably warm place. There are curled and broad-leaved types. Australian or Golden Cress is a broad, yellowish-leaved variety. Water Cress (Nasturtium officinale), a hardy perennial and important market crop, can be grown in moist soil in the greenhouse, or in almost any ditch, pool, or shallow water course. Covered with water, it winters well. To introduce it in any suitable place, all that is necessary is to scatter seed or a few freshly-cut branches, and it will soon spread and flourish. "Erfurt Sweet" is a superior strain. Similar to Water Cress in form of leaf and in taste is the Upland Cress (Barbarea vulgaris), a hardy biennial which can easily be grown from seed.

T. GREINER.

CRIMSON FLAG. Schizostylis coccinea.

CRINRLE ROOT. One of the names of Dentaria diphylla.

CRINUM (Greek name for a lily). Amaryllidacece. A rather large and cosmopolitan genus of splendid flowering bulbs, mostly tender, closely allied to Amaryllis, and distinguished by the longer perianth tube. Lvs. mostly persistent, usually broad; fls. few or many in an umbel, often very fragrant and with three types of coloring, pure white, banded red or purplish down the center, or flushed with the same colors; perianth spreading or funnel shaped; tube straight or curved; segments linear, lanceolate or oblong.

The species of Crinum require widely different culture, and their geographical distribution furnishes an important clue as to their rarity and the degree of warmth required. There are only two hardy species, $C$. longifolium and $C$. Moorei, the latter being iess hardy than the former, but with finer flowers. These two species differ from all others in blooming all summer instead of during a short period, and in the greater lasting qualities of their flowers. An interesting hybrid between the two, C. Powellii, is hardier than C.Moorei, and the flower, though better than $C$. longifolium, is not quite as showy as that of $C$. Moorei. The hybrid has three well marked colors, white, rose and purplish. A single bulb of the white variety has given fifty flowering bulbs in four years. W. Watson says that this cross can easily be repeated by amateurs. The outdoor kinds require a deep, well drained soil and plenty of moisture during the growing season. Speaking of C. Moorei, W. Watson, London, says: "For placing in conspicous positions on terraces or lawns, or in corners where flowers are wanted to combine with architecture or statuary for summer effect, they are of the greatest value. The Agapanthus is frequently grown for such purposes, but the Crinum is scarcely known in this character. Of course large specimens are needed, but once obtained they are not easily lost." The bulbs of Crinums are mostly grown in Holland and in Florida. The only native species, $C$. A mericanum, the "Swamp Lily of Florida," makes a brilliant and striking spectacle when seen in dismal places far from civilization. It is no wonder that it is cherished in Florida gardens.

Of the greenhouse Crinums some are evergreen, others decidous; some warmhouse, others coolhouse species. Like Pancratiums, they require too much space to be as popular here as in the Old.World. Speaking especially of $C$. amabile and $C$. Asiaticum, Robert Cameron says (G. F. 10: 217): "Crinums thrive in a compost of turfy loam, dry cow-manure and a little charcoal. When they are grown in large pots they do not require annual repotting: in fact, our large plants have not been shifted for the past five years. A top-dressing of good, rich soil is all that is necessary, and when they are well established liquid manure is very beneficial." $C$. amabile may be taken as a type of the coolhouse and $C$. giganteum of the warmhouse kind. Of the latter species, W. Watson says (G. F. 4:221): "It is gigantic only in the size of its flowers. The erect scapes are produced several times a year at varying seasons. The flowers are powerfully and deliciously fragrant, and last about a week. This species requires plenty of moisture all the year round, and it is happiest when planted in a large pot of rich soil, or better still, in a bed under the shade of palms."

W. M.

Among the great family of large-flowering Amaryllids I do not recall any more beautiful in bloom than $C$ rinum Moorei and its hybrid $C$. Powellii. The culture of the former is of the simplest. It requires potting, and is not fastidious as to soil. It is well to grow it along into a fair-sized tub with its offsets, of which it is prolific, until it makes a good specimen, as it will then be more effective in the garden when in flower. In late fall it should be removed to a coolhouse and kept fairly dry till new leaves appear in midwinter, when it may have more moisture, the supply being increased on removal outdoors in spring. $C$. Powellii has a shorter necked bulb and drooping channelled leaves sometimes 4 feet long, while $C$. Moorei has spreading leaves 2 feet or more long. $\dot{C}$. Powellii is especially valuable for its hardiness. In a sheltered place at Elizabeth, N. J., it is cut to the ground, but reappears in the spring, being protected only by a small mound of ashes or earth, which serves to throw off moisture.

\section{J. N. GERARD.}

Alphabetical list of species described below: C. Abyssinicum, 16; amabile, 3 ; Americanum, 4 ; aquaticum, 15; Asiaticum, 1 ; augustum, 6 ; australe, 2 ; campanulatum, 15; Capense, 9; cappedum, 1; Colensoi, 10; cras sifolium, 13: Eboraci, 1; erubescens, Ait., 7 ; erubes cens, HBK., 8; fimbriatulum, 20; giganteum, 21; grandiflorum, 9; Herberti, 19; Herbertianum, 19; hybridum, 1; Kirkii, 11; Kunthianum, Hort., 19 ; Kunth i num, Roem., 8; lineare, 17 ; longifolium, 9; Mackenii, 10 ; Makoyanum, 10; Moorei, 10 ; Natalense, 10 ; ornatum, 14 ; pedunculatum, R.Br., 2 ; pedunculatum, Hort., 1 ; Powellii, 18; pratense, 5; riparium, 9; scabro-Capense, 19; scabrum, 19; Schmidtii, 10; Sinico-scabrum, 1; variabile, 13 ; Sanderianum, 14; virgineum, 22 ; Virginicum, 19 ; Zeylanicum, 12. 
A. Perianth erect, with spreading, linear segments : stamens spreading. Stenaster.

B. Color white: tube greenish.

1. Asis visum, Linn. Bulb 4-5 in. thick; neck 6-9 in. long: lvs. $20-30$ to a bulb, 3-4 ft. long, 3-4 in. broad : pedun sle $11 / 2-2 \mathrm{ft}$. long, 1 in. thick: fls. $20-50$ in an $\mathrm{um}$ pel; spathe valves $2-4$ in. long ; pedicels $1 / 2-1 \mathrm{in}$. long: perianth white; tube erect, tinged with green, 3-4 in. long; segments $21 / 2-3$ in. long; filaments tinged red, 2 in long: ovule 1 in a cell. Trop. Asia. B.M. 1073.Baker gives 5 botanical varieties, of which the most important in the American trade is probably var. Sinicum, Baker (C. pedunculatum, Hort., not R.Br.). ST. JoHN's LiLy. Bulb 6 in. thick, 18 in. long: lvs. 5 in. broad, with undulated edges, forming a massive crown 4-5 ft. high : peduncle $2-3 \mathrm{ft}$. long: fls. 20 or more : perianth white. China. The bulb usually divides into two of equal size, small offsets are rarely produced. Seedlings flower in 5 years. Var. declinàtum, Baker, has a sloping instead of erect $\mathrm{fl}$.; perianth segments tinged red at tip. Sillet. B.M. 2231. Var. pròcerum, Baker, is larger than the type, with lvs. $5 \mathrm{ft}$. long, 6 in. wide: perianth tube and limb 5 in. long, the latter tinged red outside. Rangoon. B.M. 2684. Var. anomalum, Baker, is freakish looking, its lvs. being expanded into a broad, membranous, striated and plaited wing. There is nothing like it in the genus. Var, angustifolium, Hort., is dwarf, $2 \mathrm{ft}$. high. China. B.il. 2908. C. Ebòraci, Herbert ( $C$. hỳ bridum Todorre, Hort.). Similar to the variety next mentioned, but half the size. Garden hybrid between a small form of $C$. A siaticum and $C$. longifolium. C. Eboraci, var. cappèdum, Reasoner $(C$. cappedum, Reasoner). Habit much like $C$. Asiaticum, but lvs. tapering to a slender point, semi-erect, $4 \mathrm{ft}$. high: fls. about 20 , segments 4 in. long, $1 / 2$ in. broad, spreading, white, sometimes changing to pink. Garden hybrid between C. Asiaticum, var. Sinicum and C. longifolium. Increases both by offsets and splitting of the bulb into two. C. Sinico-scábrum, Hort., hybrid of $C$. A siaticum var. crossed with $C$. scabrum, and intermediate in aspect and $\mathrm{H}$.

2. pedunculàtum, R. Brown (C. australe, Herb.). Bulb 4 in. thick; neck 6 in. long: lvs. $25-30$ to a bulb: fls. $20-30$ in an umbel; spathe valves $3-4$ in. long; pedicels 1-11/2 in.: perianth greenish white, not tinged with red outside : filaments short, bright red : style shorter than the flaments: ovules 3 in a cell. Austral. B.R. 52. - The bulb grows above ground on a large rootstock.

BB. Color purplish red outside: tube purplish red.

3. amábile, Don. Bulb large; neck $1 \mathrm{ft}$. or more long: lvs. 25-30 to a bulb : peduncle 2-3 ft. long : $\mathrm{fls}$. 20-30 in an umbel, very fragrant; spathe valves 4-5 in. long: pedicels $1 / 2-1$ in. long: perianth with a crimson center band, tinged outside bright purplish red; tube bright red; segments 4-5 in. long: stamens an inch shorter than the segments. Sumatra. B.M. 1605. R.H. 1856:241. - Supposed by Herbert to be a spontaneous hybrid betweon $C$. Asiaticum, var, procerum and $C$. Zeylanicum: fls. sterile, bulb increases by small offsets. A stately ornament of most Florida gardens; often sold under the name of $C$, augustum, which is a similar but smaller natural hybrid presumably between $\mathrm{C}$. bracteatum and $C$. Zeylanicum, and has more obtuse lvs. than $C$. amabile

AA. Perianth erect, with spreading. lanceolate segments : stamens spreading. Platyaster.

\section{B. Lvs. few, 6-10 to a bulb.}

4. Americànum, Linn. Fig. 579. Florida Swamp Lily. Bulb stoloniferous, ovoid, $3-4$ in. thick; neck short: lvs. $1 \frac{1}{2}-2$ in. broad: fls. $3-6$, usually 4 ; pedicels none or very short: perianth creamy white; tube greenish. Native in river swamps, Fla. and westward. B.M. 1034.

5. praténse, Herb. Bulb oroid, 4-5 in. thick; neck short: lvs. 6-8, 11/2-2 ft. long, 11/2-2 in. wide, channeled, margin entire: fls. 6-12; perianth white. Var. elegans, Carey, has a longer necked bulb, decumbent peduncle, and tube an inch shorter than the segments. B.M. 2592 var. veriustum, Carey, has about $30 \mathrm{fls}$. in an umbel. Ind.
BB. Lis. numerous, 20 or more to a bulb.

c. Bulb conical, large, with a long neck.

6. augústum, Roxb. (C. amábile, var. augústum, Gawl). Bulb conical, 6 in. thick; neck long: Ivs. 20-30, 3-4 in. broad: peduncle much compressed : fls. 12-20; pedicels sometimes an inch long; color strong purplish red outside, banded within : tube purplish. Mauritius. Seychelles. B. M. 2397. B. R. 8:679.

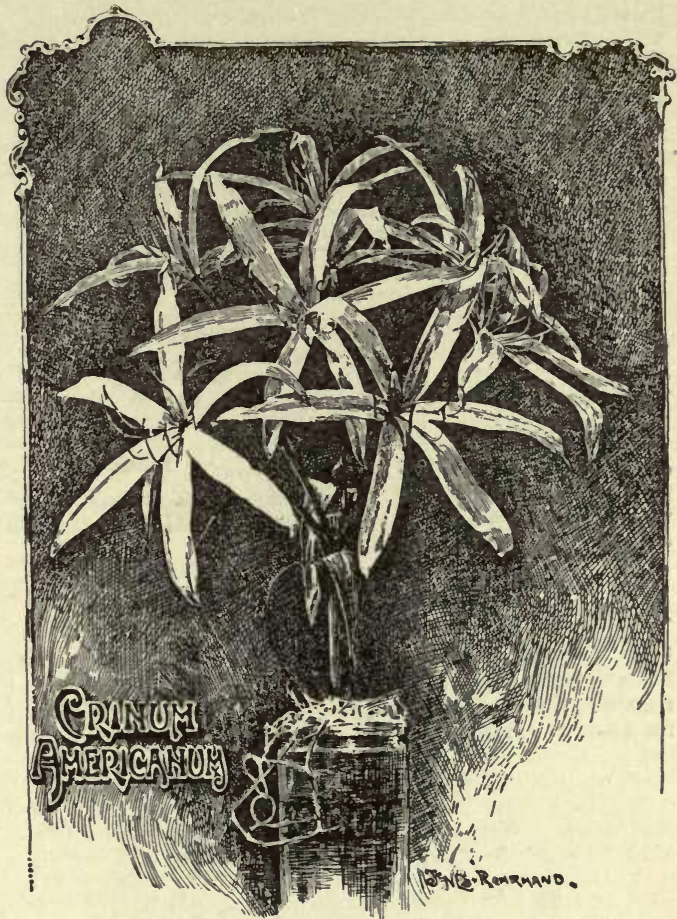

579. The Swamp Lily of Florida-Crinum Americanum. A type of the subgenus with wide-spreading perianth and lanceolate segments.

cC. Bulb ovoid, 3-4 in. thick; with a short neck.

7. erubéscens, Ait. Bulb ovoid, 3-4 in. thick; neck short: lvs, 2-3 in. broad, slightly rough : fls. 4-12; pedicels none or very short; color reddish outside, white within: tube bright red. Trop. Amer. B. M. 1232. L. B. C. $1: 31$.

8. Kunthiànum, Roem. ( $C$. erubéscens, HBK., not Aiton). Lvs. wavy: fls. 4-5 in an umbel ; tube longer than in No. 6, 7-8 in. long; color pure white. New Granada. Var. Nicaraguense, Baker, is purple outside, the segments longer and lvs. longer and narrower.

AAA. Perianth funnel-shaped; tube permanently curved; segments oblong ascending: stamens and style contiguous and declined. (Codonocrinum.)

\section{B. Bulbs long-necked.}

\section{c. Filaments red.}

9. longifolium, Thunb. ( $C$. Capense, Herb. Amarýllis longifolia, Linn. $C$. riparium, Herb.). Lvs. 2-3 ft. long, 2-3 in. wide; margins rough: fls. 6-12, pedicels 1-2 in. long; perianth tinged red on the back, and sometimes on the face, with a white variety. Cape Colony. Natal. B.M. 661. Var. álbum, Hort. Gn. 52, p. 123.-The hardiest Crinum, enduring the winter of the middle states, if protected with litter during cold weather. Propagation by offsets or seed, which is produced abundantly. C. grandiflorum, Hort., is a new hybrid with $C$. Careydnum, said to partake of the hardiness of C. longifolium. 
cc. Filaments white or pinkish.

D. Margin of lvs, entive: peduncle $2-3 \mathrm{ft}$. lonq.

10. Modrei, Hook. f. (C. Makoydnum, Carr. C. Colénsoi, O. Mackènii, and $C$. Natalénse, Hort. $C$. Schmídtii, Regel). Fig. 580. Bulb ovoid, neck 12-18 in. long: Ivs. $2-3 \mathrm{ft}$. long, 3-4 in. wide, margin entire, veins rather distant, distinct: fls. 6-12; pedicels $1 \frac{1}{2}$ to 3 in. long; perianth flushed with rose on both sides, with a white variety; segments wide. Natal and Kaffraria. B.M. 6113 . G.C. III. $2: 499$. R.H. 1877, p. 417. R.H.1887:300. R.B. 22: 196; 23: 61. Var. álbum, Hort. Gt. 1072. Gn. 52, p. 122, and var. platypétalum, Hort., are cultivated. $C$. Colensoi has a longer tube, smaller flower, with a paler and narrower limb. DD. Margin of lvs. ciliated: peduncle 12-18 in. long.

11. Kírkii, Baker. Bulb globose, 6-8 in. thick, sometimes 6 in. long: lvs. $3 \frac{1}{2}-4 \mathrm{ft}$. long, $4-41 / 2$ in. wide, margin rough, veins close: fls. $12-15$; pedicels none or very short; color white, with a very distinct crimson band down the center. Zanzibar. B.M. 6512.-Recog-

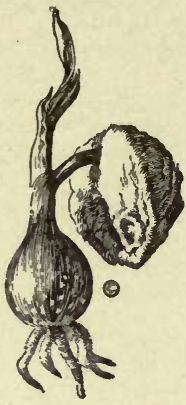

580.

young plant Crinum Moorei.

Quite weaned from its seed and beginning its own life nized at a glance by its short, very stout peduncle and very large acuminate lvs., with a distinctly ciliated edge. $-\mathrm{A}$ warmhouse species.

\section{BB, Bulbs short-necked.}

c. Fls, numerous, usually more than 8 in an umbel.

12. Zeylánicum, Linn. (A marýllis ornàta, B. M. 1171). Bulb globose, 5-6 in. thick : lvs. 10-12, 2-3 ft. long, 3-4 in. wide, wavy, margin roughish; peduncle stout, purple: fls. 10-20; perianth bright red outside in the middle
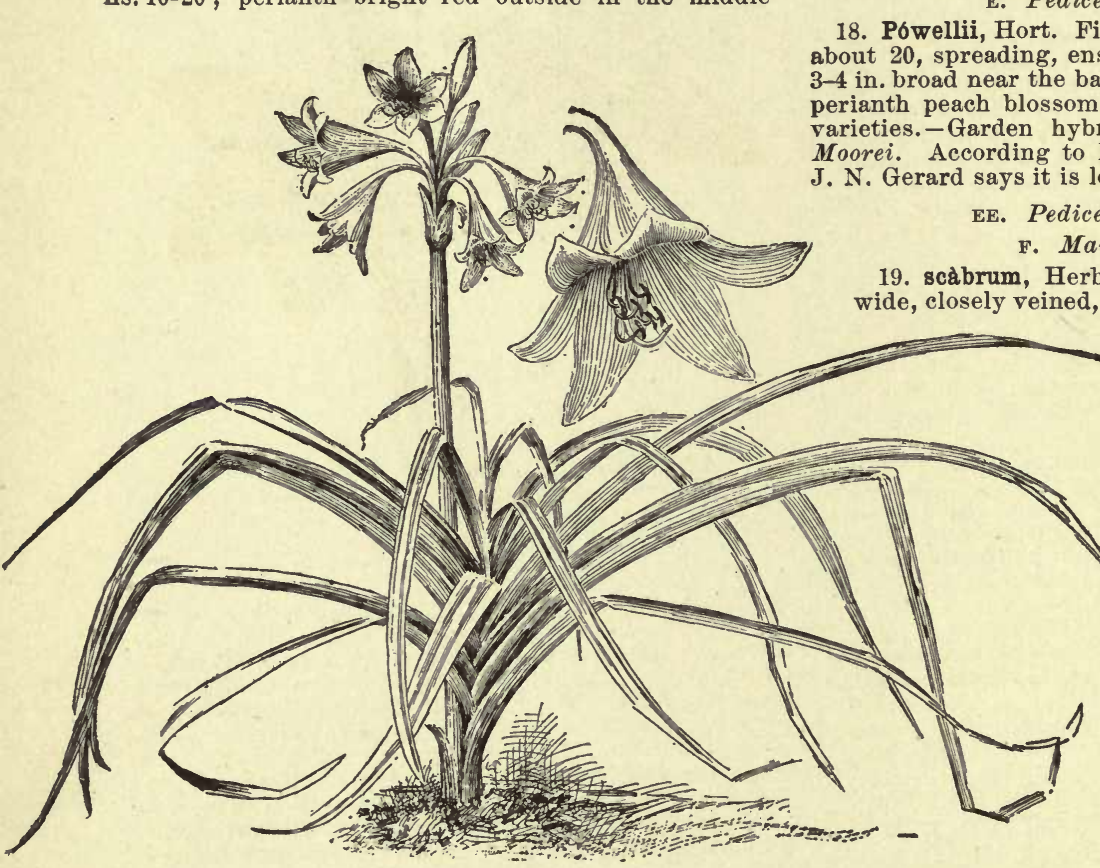

581. Crinum Powellii.

third; segments oblong lanceolate, 3-4 in. long, 1 in. broad. Midsummer. Tropical Asia and Africa. -A warmhouse species. The most commonly cultivated species of the genus. Native throughout tropical Asia and Africa. Usually sold as $C$. Kirkii, which is an allied species from Zanzibar, probably not known outside of one or two botanical gardens.

13. variábile, Herb. (C. crassifolium, Herb.). Bulb ovoid, $3-4$ in. thick : lvs. $1 \frac{1}{2}-2$ ft. long, 2 in. wide, weak: fis. 10-12; perianth flushed red outside : filaments red. Cape Colony. - A rare species.

.cc. Fls. fewer, usually less than 8 in an umbel. D. Bulbs small.

E. Tube long,5-6 in.: stamens nearly as long as the perianth segments.

14. Sanderiànum, Baker ( $C$. ornatum, Bury). Bulb globose, 2 in. thick; neck 2-3 in. long : lvs. 10-12, thin, $11 / 2-2 \mathrm{ft}$. long, $1 \frac{1}{2}$ in. broad, margin much erisped: fls. 3-6 ; perianth with a distinct band of bright red. Corisco island. Sierra Leone. Gn. 52: 1131.-Closely allied to $C$. scabrum.

EE. Tube short: stamens much shorter than the segments.

F. Lvs. 3-4 ft. long.

15. campanulàtum, Herb. (C. aquáticum, Burchell). Lvs. linear, deeply channelled, 3-4 ft.: fls. 6-8: perianth rosy red. Cape colony. Kaffraria. B.M. 2352.-A very distinct species.

$$
\text { FF. Lvs. 1-2 ft. long. }
$$

G. Pedicels very short or none.

16. Abyssínicum, Hochst. Bulb ovoid, 3 in. thick: Ivs. about $6,1 \mathrm{ft}$. long, $1 / 2-1$ in. wide, veins close, margin rough : fis. 4-6, pedicels very short or none. Mts. of Abyssinia.

\section{GG. Pedicels $1 / 2$ in. long.}

17. lineàre, Linn. f. Lvs. linear, $1 \frac{1}{2}-2 \mathrm{ft}$. long, $1 / 2 \mathrm{in}$. broad, glaucous, channelled : fls. $5-6$; pedicels $1 / 2$ in. long; perianth tinged red outside; filaments red. Cape colony. - Rare.

\section{DD. Bulbs large.}

E. Pedicels 1-11/2 in. long.

18. Powellii, Hort. Fig. 581. Bulb short-necked: 1vs: 20, spreading, ensiform, acuminate, $3-4 \mathrm{ft}$. long, -4 in. broad near the base, margin smooth: fls. about 8: peach blossom color, with white and purplish Moorei. According to Baker, the bulb is globose, but N. Gerard says it is long, like a leek.

E. Pedicels very short or none.

. Margin of lvs, rough.

19. argin scabrous: fls. 4-8: pedicels none or very short: perianth banded bright red. Apr., May. Tropical Africa from Guinea to Abyssinia. B. M. 2180 . F.S. $21: 2216 .-$ Common in Florida gardens, a very showy and easily cultivated species. C. Hérberti, Sweet (C. scabro-Capénse, Hort. C. Kunthidnum, Hort., not Roem.). Fls. similar to C.scabrum, but color lighter, the plant taller and larger. Garden hybrid between $C$. scabrum and $C$. longifolium. This is a doubtful name. $C$. Herbertianum, Wall. $=C$. Zeylanicum. $C$. Herbertianum, Hort. Roem. \& Schultes $=C$. strictum C. Virgínicum, Garden hybrid, resembles $C$. Herberti, but the plant is smaller and the flowers larger and brighter in color. See also No. 22.

20. fimbriátulum, Baker. Lvs, as in $C$. sccibrum, but margins eiliated with small membranous scales : perianth banded red. Angola. Gn. 55, Feb. 11. Allied to C. scabrum.-A wholly different plant is passing in the trade under this name. 
FF. Margin of lvs. smooth.

21. gigantèm, And. Bulb 5-6 in. thick : lvs. 12 or more, $2-3$ ft. long, $3-4$ in. broad, narrowed toward the base ; veins distant, with distinct cross veinlets : fls, 4-6, rarely 8-12 : tube 4-7 in. long; perianth pure white; segments much imbricated. So. Afr. B.M. 923. F.S. 23:2443. G. F. $4: 223$. I. H. 33: 617 . - A very fragrant species.

22. virgineum, Mart. Foliage as in $C$. giganteum : fls. about 6 ; tube $3-4$ in. long; perianth pure white. South Brazil. See also $C$. Virginicum, under No. 19.

In addition to the above species the following are advertised, but not sufficiently deseribed: $C$. nóbile, C. Yeménse, and $C$. Zanzibarénse.

T. L. MEAD and W. M.

CROCOSMIA (Greek, odor of saffron, which is perceivable when the dried fls. are placed in warm water). Ir $i$ dacere. This genus has only one species, and is not clearly distinguished by Baker from the closely allied Tritonia, but according to the author of the genus, it differs in the stamens being separated at equal distances instead of grouped at one side, the form of the limb, the tube not swelled at the top, and the fruit 3 -seeded instead of many-seeded. The name of this genus is spelled Crocosma by Baker, but it was first spelled Crocosmia.

Crocosmia aurea is a showy bulbous autumn blooming plant, which is hardy south of Washington, D. C., with slight protection, and in the north is treated like Gladiolus, the bulbs being set out in the spring, after danger of frost, and lifted in the fall for winter storage. It is of easy culture, and is propagated by offsets or by seeds. Bulbs should be stored in peat or sphagnum to prevent them from becoming too dry.

aùrea, Planch. (Tritònia aùrea, Pappe.). Height.2 ft. : bulb globose, emitting offsets from clefts in the side: scape $1 \frac{1}{2}-2 \mathrm{ft}$. high, leafy below, naked or only bracted above, compressed, 2-winged : lvs, distichous, shorter than the scape, linear, ensiform, striated, but with a distinct midrib : fls. sessile in the panicle, perhaps 25 scattered over a long season, with buds, flowers and seeds at the same time; perianth bright orange-yellow toward center; tube slender, curved, 1 in. long; segments longer than the tube, capsule 3-celled. Trop. and S. Afr. July-Oct. F. S. 7: 702. B. M. 4335. Also interesting as one parent of a bigeneric cross resulting in Tritonia crocosmiflora. Var. imperialis, Hort. (Fig. 582), grows about $4 \mathrm{ft}$. high. Var. maculàta, Baker, has dark blotches above the base of the 3 inner segments. J.H. III. $33: 567$.

J. N. GERARD and W. M.

CROCUS (Greek name of Saffron). Iridacece. Stemless plants (the grass-like lvs. rising from the ground or corm), with solid bulbs or corms. Fls. showy, in many colors, funnel-shaped and erect, with a very long tube and 6 nearly or quite equal segrnents. Stamens 3. Ovary 3-loculed: seeds many, nearly globular. The flowers open in sunshine. They come in fall or spring, but the best known species are spring-flowering, which are amongst the earliest of spring bloom. The new corm usually grows on top of the old one each year, so that the plants tend to rise out of the ground. The corms, therefore, should be lifted and replanted every three or four years. Crocuses force easily (see Bulb). A half dozen corms may be planted in a 4-inch pot for this purpose. The genus Crocus is S. European and Southwestern Asian. It has about 70 recognized species. The best account of the Crocuses is G. Maw's superb Monograph of the Genus Crocus, 1886. A popular account of the history and species, by Baker, will be found in Gardeners' Chronicle for 1873, pp. 107, 179, 291, 434, $542,609,680,1402,1431,1466,1533,1633$. A condensed account is contained in Baker's Handbook of the Irideæ, 1892.

L. H. B.

Many forms of Crocus are well known in gardens, where they are justly ralued as among the showiest and brightest of winter and spring flowers. About twothirds of the species are classed as vernal and the balance as autumnal flowering; but the various members of the tribe would furnish nearly continuous bloom from August to May were the season open. While there are numerous species interesting to a botanist or a collector, practically the best for general cultivation are $C$. Imperati, $C$. Susicinus (Cloth of Gold Crocus) and the Dutch hybrids, mostly of C. Mosiacus. These flower in about the order named. The rosy flowers of $C$. Imperati may be expected with the earliest snowdrops. The named species, having shorter flower tubes than the Dutch hybrids, are not as liable to injury by the severe weather of the early year. The autumnal species are not satisfactory garden plants, the flowers mostly appearing before the leaves, and being easily injured. C.speciosus and $C$. sativus are probably the most satisfactory. The latter species has been cultivated from time immemorial, the stamens having a medicinal reputation, and being a source of color (saffron). The cultivation of this species is a small industry in France, Spain and Italy.

The corms should be planted about 3 inches deep, in a well-worked and perfectly drained soil which is free from clay or the decaying humus of manure, etc. They should be carefully examined and all bruised and imper-

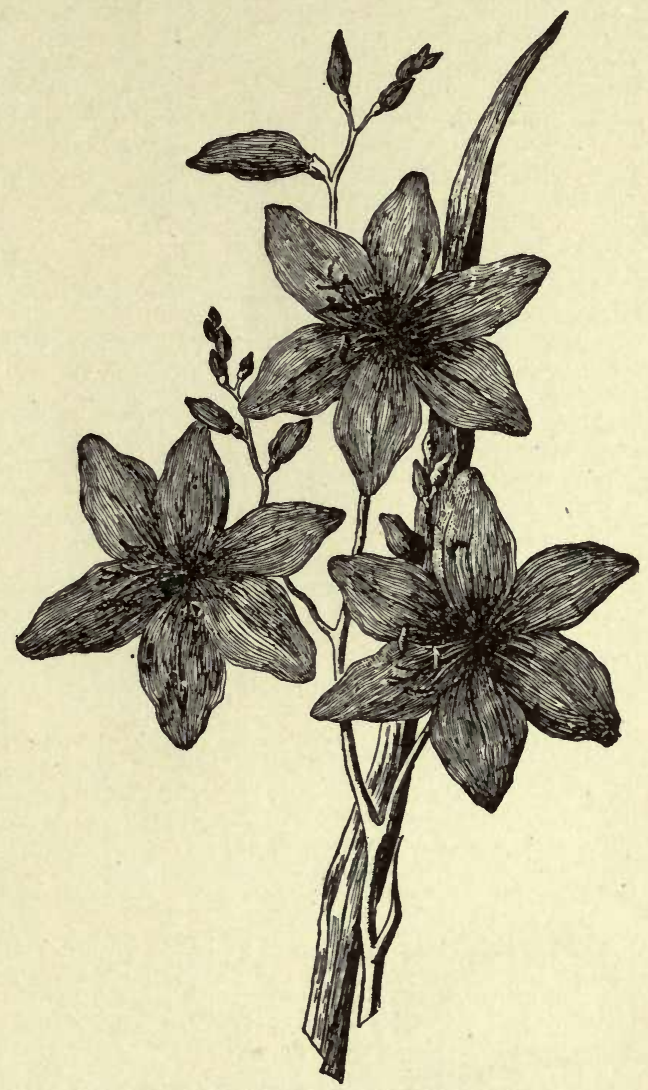

582. Crocosmia aurea, var. imperalis $\left(\times \frac{1}{2}\right)$.

fect ones rejected, as they are very susceptible to attacks of fungi, which, gaining a footing on decrepit corms, will spread to others. The careful gardener will exam ine all exotic small bulbs annually, or at least biennally, until they show by the perfection of their new bulbs that they have become naturalized, or are suited to their new environment. In this case they may be allowed to remain until crowding requires their division. This examination should take place after the leaves are matured and dried up. Increase may be had from new corms which are produced more or less freely in different species over or on the sides of old corms. Seeds are often produced freely, but are apt to be overlooked, as they are formed at the surface of the soil. These germinate readily and most freely at the growing time of the plant. They should preferably be germinated in seed pans, wrich should be exposed to freezing before the natural germi- 
nating time. They usually form flowers the third season. The Crocus, as is well known, is amenable to modern, forcing. It is also useful for naturalizing in the lawn, although the grass will run out the plants in a few years, if the bulbs are not replaced by strong ones.

\section{J. N. Gerard.}

Crocuses are scarcely known in the Amer. trade under their species names. They have been much hybridized and varied. The common Crocuses of the trade have descended from $C$. vernus chiefly, but $C$. Susianus, $C$. Mosiacus, $C$. stellaris, $C$. biflorus and $C$. sativus are frequent. The Dutch bulb-growers cultivate many species, and these are offered for sale in their American lists; the species are therefore included in the following synopsis.

Index: Ancyrensis, 4; asturicus, 26 ; aureus, 2; Banaticus, 8 ; biflorus, 6 ; Boryi, 24 ; Byzantinus, 29 ; chrysanthus, 5,15 ; etruscus, 13; Hadriaticus, 18; Imperati, 14 ; iridiflous, 29; lacteus, 2; longiflorus, 20; medius, 25; Mœsiacus, 2; nudiflorus, 23; Olivieri, 15; Orphanidis, 24: pulchellus, 28; reticulatus, 12; Salzmanni, 22; sativus, 17; serotinus, 21; Sieberi, 11; speciosus, 27; stellaris, 3; Susianus, 1; Suterianus, 15; Syriacus, 9; Tommasinianus, 10 ; Tourneforti, 24 ; vernus, 9 ; versicolor, 7 ; vitellinus, 16 ; zonatus, 19.

\section{A. Blooming in spring.}

B. Style-branches entire or merely toothed.

c. Fls. yellow, at least inside.

1 Susiànus, Ker. Cloth of Gold Crocus. Corm $3 / 4$ in. in diam.: lvs. 6-8 in a tuft, reaching to the fl., narrowlinear, with revolute edges and a central band of white: perianth segments $1 \frac{1}{2}$ in. or less long, orange-yellow, becoming reflexed, the outer ones brownish or striped on the outside; anthers orange, longer than the filaments; style-branches long and spreading. Crimea. B.M. 652.-Blooms very early.

2. Mœsiacus, Ker (C. aùreus, Sibth. \& Sm.). DuTcr Ckocus. Later, corm larger: lvs. 6-8 in a tuft, overtopping the fl., narrow-linear, with reflexed edges and white central band: segments very obtuse, bright yellow, $1 \frac{1}{2}$ in. long, $1 / 2$ to $1 / 3$ the length of the tube: anthers pale yellow, hastate at the base; somewhat longer than the filaments; style-branches overtopped by the anthers. Transylvania to Asia Minor. B.M. 2986 - Variable. A sulfur-yellow form is C. sulphùreus, Ker, B.M. 1384. There is a striped form. B M. 938. A creamwhite form is $C$. lácteus, Smith.

3. stellàris, 'Haw. Supposed to be a hybrid of the above, and known only in cult. Blooms with No. 2 Lvs. only 4-6, narrow-linear, reflexed edges, whitebanded : perianth-tube short, the segments $1-11 / 2$ in. long, bright orange, the outer ones striped and feathered with brown on the back; anthers pale orange, a little longer than the filaments; style-branches somewhat overtopping the anthers.

4. Ancyrénsis, Maw. Corm $3 / 4$ in. in diam.: lvs. $3-4$, as tall as the fl., very narrow : perianth-tube exserted segments bright orange-yellow, 1 in. or less long, not striped, nor colored outside ; anthers orange-yellow, much longer than the filaments; style-branches redorange. Asia Minor.-Blooms early.

5. chrysánthus, Herb. (not B.R. 33:4. Fig. 1, which= C. Olivieri, var. Suterianus). Corm small: Ivs, as high as the fl., very narrow: perianth-tube $2-3$ times as long as the segments, the latter $1 \frac{1}{4}$ in. or less long, and plain orange-yellow (varying tinted or striped on the outside, or even nearly white); throat glabrous ; anthers orange, twice as long as the roughened filaments ; style-branches red-orange. Macedonia and Asia Minor.

co. Fls. lilac or white.

6. biflòrus, Mill. Scotch Crocus. Corm $3 / 4$ in. or less in diam.: lvs. 4-6, overtopping the fls., very narrow, with deflexed edges and a white central band: perianthtube exserted, the segmen $7 \mathrm{~s} 1 \frac{1}{2}$ in. long, purple tinged, the outer ones 3-striped down the back, the throat bearded and yellowish ; anthers orange, exceeding the fllaments; style-branches orange-red. S. and southwestern Eu. B.M. 845.-Runs into many forms, some of them almost white
7. versícolor, Ker. Corm $3 / 4$ in. or less in diam.; Ivs. 4-5, as high as the fls., otherwise like the last; perianthtube exserted: segments $1 \frac{1}{2}$ in. long, pale or dark purple, often striped and feathered with dark purple; throats glabrous, whitish or yellowish; anthers yellow, twice as long as the filament; style-branches, orangeyellow, equalling or overtopping the anthers. S. France. B.M. 1110.

8. Banáticus, Heuff. Corm globular, $1 / 2$ in. in diam. Ivs. usually 2, thin and flattish, and becoming $1 / 4$ in. broad, glaucous beneath: perianth-tube scarcely exserted; segments $1 \frac{1}{2}$ in. or less long, bright purple, and never striped, but often dark-blotehed towards the tip; throat glabrous; anthers orange, a little longer than the white filaments; style-branches short, orange-yellow, somewhat fringed at the tip. Hungary.

9. vérnus, All. Fig. 583. Corm 1 in. or less in diam.: Ivs. $2-4$, as high as the fl., often $1 / 4$ in. broad, glaucous beneath, but green above, with reflexed edges, and a central white band; perianth segments $1-1 \frac{1}{2}$ in.

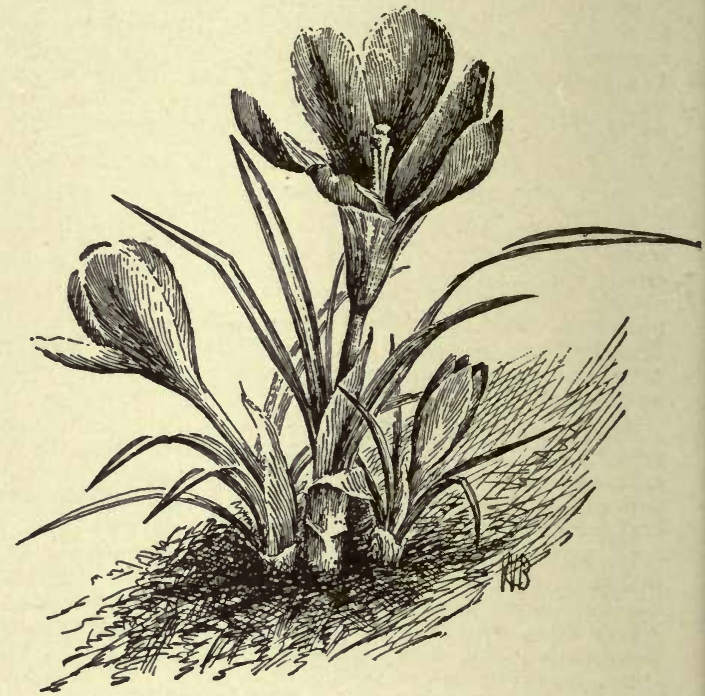

583. Crocus vernus $(X 1 / 2)$.

long, lilac, white or purple-striped; throat pubescent, never yellow; anthers lemon-yellow, exceeding the filaments; style-branches orange-yellow. S. Eu. B.M. 860,2240 . R.H. 1869 , p. 331. Gn. 54, p. 79. The commonest garden Crocus.

10. Tommasiniànus, Herb. Corm globular, $1 / 2$ in. in diam.: lvs. appearing with the fls., narrow (1/8 in. broad): perianth-tube little exserted; segments $11 / 2 \mathrm{in}$. or less long, pale red-bluish, sometimes dark blotched at the tip ; throat glabrous; anthers pale orange, a little longer than the white glandular filaments; stylebranches short, orange-yellow. Dalmatia and Servia. Distinguished from $C$. vernus by its glabrous throat.

11. Sièberi, Gay. Corm globular, $3 / 4$ in. diam.; lvs. 46 , as high as the fl., glaucous beneath, $1 / 6$ in. broad: perianth-tube short-exserted; segments 1-11/2 in. long, color of $C$. vernus; throat yellow and glabrous; anthers orange, twice as long as filaments; style-branches nearly entire, orange-red. Greece, Crete.

12. reticulàtus, Bieb. Corm $3 / 4$ in.in diam., covered with honey-combed fibers: lvs, 3-5, as high as the fl., very narrow, with reflexed edge and a white band: perianthtube much exserted; segments $1-11 / 2$ in. long, white to purple, the three outer ones striped; throat glabrous; anthers orange, twice the length of the orange filaments: style-branches scarlet, overtopping the anthers. S. E. Eu. - Varies to white.

13. Etrúscus, Parl. Corm 1 in. or less in diam.: lvs. about 3 , very narrow, as tall as the fl.: perianth-tube short exserted; segments $1-1 / 2$ in. long, lilac, or the outer 
ones cream colored and sometimes purple-feathered outside; throat yellow, slightly pubescent; anthers orange, twice as long as the glabrous filaments; stylebranches nearly entire, orange. Italy.

Bв. Style-branches fimbriate, branched, or cut into very narrow divisions.

14. Imperàti, Ten. Corm nearly or quite 1 in. in diam.: lvs. 4-6, exceeding the fls., very narrow; perianth-tube little exserted; segments $1-1 \frac{1}{2}$ in. long, lilac or even white, the outer ones buff and 3-striped on the outside; anthers yellow, exceeding the filaments; stylebranches fimbriate. Italy. B.R. 23:1993. Gn. 54, p. 79.

15. Olivieri, Gay. Corm nearly globose, $1 / 2-8 / 4$ in. in diam.: Ivs. 4-5, as tall as the fl., becoming $1 / 4$ in. broad: perianth tube little exserted; segments bright orange yel. low and never striped, $1 \frac{1}{2}$ in. or less long; throat glabrous; anthers orange, twice the length of the roughish filaments; style-branches orange, slender-forked. Var. Suterianus, Baker ( $C$. chrysánthus, Bot. Reg.) has narrower and more rolled lvs. Greece to Asia Minor.

16. vitellinus, Wahl. (C. Syriacus, Boiss \& Gaill.). Corm $3 / 4$ in. or less in diam.: lvs. 4-6, as high as the fls., narrow-linear; perianth tube short, exserted; segments 1 in. or less long, orange-yellow, the outer brown-tinged outside; style-branches divided into many capillary parts. Asia Minor. B.M. 6416.-Rare in culture.

\section{AA. Blooming in fall.}

\section{B. Style-branches entire.}

17. sativus, Linn. Safrron Crocus. Corm 1 in. or more in diam.: lvs. 6-10, as tall as the fl., very narrow, ciliate-edged; perianth-tube little exserted; segments oblong and obtuse, bright lilac or even white; throat pubescent; anthers yellow, longer than filaments; stylebranches 1 in. or more long, bright red (the source of saffron). Asia Minor. R. H. 1895, p. 573.-The commonest fall-blooming species.

18. Hadriáticus, Herb. Much like C. sativ'us: usually smaller-fld.. pure white, the segments pubescent at base anthers bright orange, more than twice longer than the white or purple filaments. Greece, ete.-Runs into several forms,

19. zonàtus, Gay. Corm somewhat flattened or deflexed, $1 / 2-3 / 4$ in. in diam.: lvs. appearing after the fls. narrow-linear: perianth-tube exserted, $2-3$ in.; segments 1-2 in. long, rose-lilac, purple-veined and orange-spotted within ; throat yellow, pubescent; anthers white, 2-3 times longer than the yellow filaments: style-branches short and yellow. Cilicia. G.C. III. 23:85.

BB. Style-branches fimbriated or forked at the top.

20. longiflorus, Rafin. Corm $1 / 2$ in. diam.: lvs. 3-4, very short at flowering time, very narrow: perianth-tube much exserted; segments oblong and bright lilac, $1 \frac{1}{2}$ in., never striped; throat slightly pubescent, yellow; anthers orange, more than twice as long as the filaments: stylebranches scarlet, slightly compound. S. Eu. - Not frequent.

21. serbtinus, Salisb. Corm 1 in. or less: Ivs. 4-6, as high as the fl., very narrow: perianth-tube little exserted; segments oblong, $1 \frac{1}{2}$ in., lilac or purple, indistinctly or not at all striped; throat glabrous; anthers yellow, much exceeding the filaments: style-branches orange-yellow, fimbriated. Spain. - Not frequent.

22. Sálzmanni, Gay (C. tingitànus, Herb.). Corm somewhat depressed, 1 in. in diam.: lvs. about 6 , not prominent at flowering time, very narrow: perianth-tube much exserted; segments $1 \frac{1}{2}$ in. long, plain lilac; throat pubescent, yellowish; anthers orange, longer than the fllaments: style-branches slender, orange. Morocco.

ввв. Style-branches capillary-divided.

23. nudiflorus, Smith. Corm very small, stoloniferous: lvs. 3-4, appearing after the fls., very narrow: perianth tube much exserted; segments $1 \frac{1}{2}-2$ in., lilac : throat glabrous; anthers large and yellow, twice as long as the flaments. Mts. S. France and Spain.-Long known in cult., but not common.

24. Boryi, Gay. Corm globular, $3 / 4$ in. or less in diam.: lvs. 3-6, narrow-linear, as high as the fls.: perianth-tube short-exserted; segments 1-11/2in. long, white, sometimes lilac-lined at the base outside; throat yellow, glabrous; anthers white, somewhat longer than the orange filaments: style-branches scarlet, divided into many capillary segments. Var. Tournefortii, Baker $(C$. Orphanidis, Hook. f. B.M. 5776) has lilac fls. Greece.

25. mèdius, Balbis. Corm globular,lin.or less in diam. : lvs. 2-3, appearing in spring, narrow, becoming a ft. or more high: perianth-tube much exserted; segments $11 / 2$ 2 in. long, bright lilac; throat glabrous, whitish; anthers pale orange, twice the length of the yellow filaments: style-branches scarlet, with many capillary divisions.

S. France, Italy.

26. Astùricus, Herb. Corm globular, $9 / 4$ in. or less in diam.: lvs. about 3 , appearing in fall but not maturing till spring: perianth-tube short-protruded; segments $1 \frac{1}{2}$ in. long, lilac; throat pubescent; anthers bright yellow, longer than the white filaments: style-branches orange, with many capillary divisions. Spain.

27. speciosus, Bieb. Corm not stoloniferous, 1 in. or less: Ivs. usually 3 , developing after the fls., thin, very narrow, becoming $1 \mathrm{ft}$. long : perianth-tube much exserted; segments 11/2-2 in., lilac and feathered with darker color; anthers very large, bright orange, much exceeding the filaments. S. E. Eu. and Asia. B.M. 3861. B.R. 25:40.- Handscici.

28. pulchéllus, Herb. Corm small, somewhat depressed : IVs. produced after flowering, maturing in spring: perianth-tube much exserted ; segments 1-11/2 in. long, bright lilac, more or less indistinctly striped; throat glabrous, bright yellow; anthers white, longer than the pubescent yellow filaments : style-branches orange, with many capillary branches. Greece to Asia Minor. B.R. $30: 3$.

29. Byzantinus, $\operatorname{Ker}(C$. iridiflòrus, Heuff.). Corm $1 / 2$ in. in diam.: lvs. $2-4$, developing after the fls.: perianth-tube much exserted; segments 2 in., or less long, the outer ones dark lilac and acute, the inner ones shorter and pale lilac or white; anthers orange, longer than the filaments. S. E. Eu. B.M. 6141. B.R. 33:4. An old garden plant, but rarely seen in this country.

CROSNES. See Stachys Sieboldi.

L. H. B.

CROSS. The offspring of any two flowers that have been cross-fertilized. A cross-breed is a cross between varieties of the sume species. Synonyms are halfbreed, mongrel, variety-hybrid. Crossing is the operation of cross-pollinating. Cross-pollination is the trans. fer of the pollen of one flower to the pistil of another.

CROSSANDRA (Greek, fringed anthers). Acanthdcece. Greenhouse evergreen shrubs of minor importance, comprising 9 species from India, tropical Africa. and Madagascar. The one in the trade has handsome 4 sided spikes or scarlet-orange fls. The perianth has 5 segments, the 2 upper ones being smaller. It is cultivated south outdoors to a slight extent, and also rarely in nor thern greenhouses.

undulæfolia, Salisb. (C. infundibuliformis, Nees). Height $1 \mathrm{ft}$., rarely $3 \mathrm{ft}$.: Ivs. often in 4's, especially below, but also opposite, ovate acuminate, stalked: fls. scarlet-orange, overlapping one another in dense spikes, 2-3 in. long. Ind. B.M. 2186. R.H. 1891:156.

C. flava, Hook. Unbranched shrub, 6-8 in. high: stem green, glabrous: lvs. opposite, close together, large for the size of the plant, 6 in. long, obovate lanceolate, dark ereen above, paler beneath, wavy, more obtuse than in the above; lower lvs. stalked, neath, wavy, more obtuse than in the above; lower lvs. stalked,
upper ones sessile: spike 4-sided, spiny: fls. yellow; tube
much exserted, jointed. Trop. W. Afr. B.M. 4710.-C. Guimuch exserted, jointed. Trop. W. Afr. B.M. 4710.-C. Guilvs. 2-4 pairs, 3-5 in. long, elliptic, green above, with golden netted nerves, reddish beneath: spike solitary, terminal, slender, 3-5 in. high: fls. numerous, small, pale lilac, with 2-darker spots on the 2 smallest segments, and a white eye. Guinea. B.M. 6346. - A handsome foliage plant.

CROssw0RT. Properly Crucianella. Loosely, the erucifers.

CROTALARIA (Greek, rattle, castanet; from the rattling of the seeds in the pod). RATTLE-BOX. A very large, tropical genus, of which the most interesting 
species is $C$. retusa, a hardy, yellow-fld. cnnual, which has been compared to a dwarf sweet pea. For best results, the seed should be started early indoors, after being soaked in warm water. The name is commonly mis spelled Crotolaria. Greenhouse kinds are subject to red spider. $C$.juncea, yields the Sunn hemp of India.

$$
\text { A. Lvs. simple. }
$$

retùsa, Linn. Annual, 11/2 ft. high: branches few, short: lvs. entire, very various in shape, but typically obovate with a short mucro, clothed beneath with short appressed hairs : -fls. about 12 in a raceme, yellow, streaked or blotched with purple; standard roundish, notched. Cosmop. June-Aug. - Introduced 1896, as a novelty and called "dwarf golden yellow-flowering pea," "golden yellow sweet pea," etc. The flowers are mu'h less fragrant than the true sweet pea.

\section{AA. Lvs. foliolate.}

longirostràta, Hook. \& Arn. Greenhouse plant, herbaceous or somewhat shrubby, much branched, $3 \mathrm{ft}$. high: branches long, slender, glabrous; petioles $1 \frac{1}{2} \mathrm{in}$. long; leaflets 3 , oblong, with a minute mucro, glabrous above, hoary beneath, with rery short, appressed, silky hairs: racemes erect: calyx with 2 upper lobes ovate, the 3 lower ones lanceolate: $\mathrm{Hs}$. as many as 25 in a raceme, yellow with reddish stripe along the back of the unopened flower; standard wider than long, reflexed, notched. W. Mex., Guat. B.M. 7306. F.R. 1:809.

Capénsis, Jacq. Stout, much branched shrub, 4-5 ft. high: branches terete, appressedly silky; stipules when present petiolulate, obovate and leaf-like, obsolete or wanting on many petioles; leaflets broadly obovate, obtuse or mucronulate, glabrous or minutely pubescent on one or both sides: racemes terminal or opposite the lvs., loose, many-fld.: calyx and pod pubescent; wings transversely wrinkled and pitted. S. Afr.-Cult. in Fla. by Reasoner Bros.

W. M.

CROTON (Greek name of another plant). Euphorbidcea. Some 500 species of trees, shrubs, or herbs, widely distributed. They are sometimes diøecious, but commonly the fls. are monœeious and mostly in termina spikes or racemes. Calyx of sterile fls. 4-6 (usually 5) parted, the stamens 5 or more; petals usually present, but small. Calyx of fertile fls. 5-10 parted, petals none or mere rudiments, the ovary 3-loculed. Lvs. usually alternate. A few species are native to the U. S.: they are mostly annual herbs of no horticultural value. The Crotons of florists are Codicums, which see.

C. Tíglium, Linn., is the only species known to be in the Amer. trade. The seeds yield the Croton oil of commerce, one of the most powerful of purgatives. It is a small tree of Southeastern Asia. Lvs, ovate-acuminate, serrate, stalked, varying in hue from metallic green to bronze and orange. Offered in South Cal. as an ornamental and curious plant.

L. H. B.

\section{CROWFOOT. See Ranunculus.}

CROWN, or CORONA. Any outgrowth from the throat of the perianth, as the trumpet of a Narcissus, or the fringe of a Passion Flower. Crown is also applied to the top of a bulb, corm, or upright rootstock: also that part of a plant at the surface of the ground.

\section{CROWN BEARD. Verbesina.}

\section{CROWN IMPERIAL. Fritillaria Imperialis.}

\section{CROWN OF THORNS. Euphorbia splendens.}

CROWN-TUBER. A tuber of which the top is stem and the lower part root, as the radish.

CRUCIANELLA (Latin, a little cross ; from the arrangement of the lvs.). Rubidcece. Cross-wort. This genus contains a hardy rock plant of minor importance. Not more than 21 species, of herbs often woody at the base; branches usually long, slender, 4-cornered: upper lvs. opposite, without stipules: lower lvs. or all in whorls of 3 or more, linear or lanceolate, rarely ovate or obovate: fls. small; white, rosy or blue. Natives of the
Mediterranean region and western Asia. The genus is लlosely related to Asperula, and is distinguished by $\operatorname{tn} \theta$ flowers having bracts, not an involucre, and the style branches distinctly unequal instead of nearly equal. The species below has lately been referred to Asperula. It is of easy culture, preferring light, moderate loam and partial shade. A delicate plant for the front of borders, and capital for the rockery. Prop. chietly by division. and also by seeds.

stylosa, Trin. (Aspèrula ciliàta, Rochel). Prostrate, 6-9 in. high: lvs. in whorls of 8 or 9, lanceolate. hispid: fls. small, crimson-pink, in round terminal heads half an inch in diam.; floral parts in 5's; style clubshaped, long exserted, very shortly twice cut at the top. June-Aug. Persia.

\section{J. B. KeLLER and W. M.}

CRUEL PLANT. Same as Mosquito Plant, Cynanchum acuminatifolium.

CRYPTÁNTHUS (Greek, for hidden flower: the Howers concealed beneath the bracts). Bromeliàcea. Brazilian epiphytal Bromeliads, differing from Achmea and Billbergia (which see for culture) in the tubular caly $x$ and the dense heads of fls. nearly sessile amongst the lvs. Mongr. by Mez (who recognizes 8 species) in DC. Monogr. Phaner. 9 (1896).

A. Lvs. not narrowed or petiolate above the sheath.

acaùlis, Beer (Tillándsia acaùlis, Lindl. C. unduld̀tus, Otto \& Dietr.). A few inches high, suckering freely: lvs. sea-green, long-pointed and spreading, weakspiny: fls. white, nestling deep in the foliage. B.R. 14:1157. - A very variable plant, of which Mez recog. nixes the following leading types:

Var. genuina, Mez. Stemless or very nearly so : lvs. sub-elliptic-lanceolate, strongly undulate, gray-scurfy beneath, scurfy above.

Var. díscolor, Mez (C.discolor, Otto \& Dietr.). Stemless or nearly so: lvs. elongated, scarcely undulate, silvery-scurfy below, glabrous or nearly so above.

Var. rubber, $\mathrm{Mez}$ ( $C$. ruber, Beer). Produces a branching stem or trunk: lvs. short, strongly undulate, reddish.

Var. bromelioldes, $\mathrm{Mez}$ ( $\boldsymbol{C}$. bromelioides, Otto \& Dietr.). Stem tall: lvs. much elongated, scarcely undulate, remotely spinulose.

Var. diversifolius, $\mathrm{Mez}$ ( $C$. diversifolius, Beer). Stembearing: lvs. elongate-lingulate, deep green above, silvery-scurfy beneath.

zonatus, Beer. Lvs, oblong-lanceolate, the margin undulate and densely serrate-spinulose, marked with transverse bands of white: fls. white.

bivittàtus, Regel (Billbérgia bivittàta, Hook. $\boldsymbol{B}$. vittata, Hort.). Nearly or quite stemless: lvs. long-oblong, curving, long-pointed, somewhat undulate, spiny, dull brown beneath, green above and with two narrow buff or reddish bars extending the length of the leaf: fls. white. B.M. 5270 .

AA. Lvs. narrowed or petiolate above the sheath.

Beùckeri, Morr. Lvs. 10-20, oblong, pointed, canaliculate at base, very finely spiny, brownish green or rosy and spotted or striped with light green: fls. white.

L. H. B.

CRYPTOGAMS are flowerless plants, and they produce not seeds but spores. The whole vegetable kingdom has been split into two vast classes, the flowering plants or phanerogams and the flowerless ones or cryptogams. Cryptogam means "concealed nuptials," and phanerogam means "visible nuptials." These names were given when it was thought that the sexual parts of the flowerless plants were very minute or even wanting. The word is now falling into disfavor with botanists. Cryptogams are of less horticultural interest than the flowering plants, although they include the Ferns, and some inter esting smaller groups, as Selaginellas, Lycopods or Club Mosses. Two other vast groups are the Seaweeds or Algæ, and the Fungi. For the edible Fungi, see Mushrooms. For parasitic Fungi, see Diseases and Fungus. For a general sketch of the Ferns ard their allies, see Ferns. 


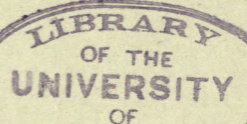

GALIFORNIE 


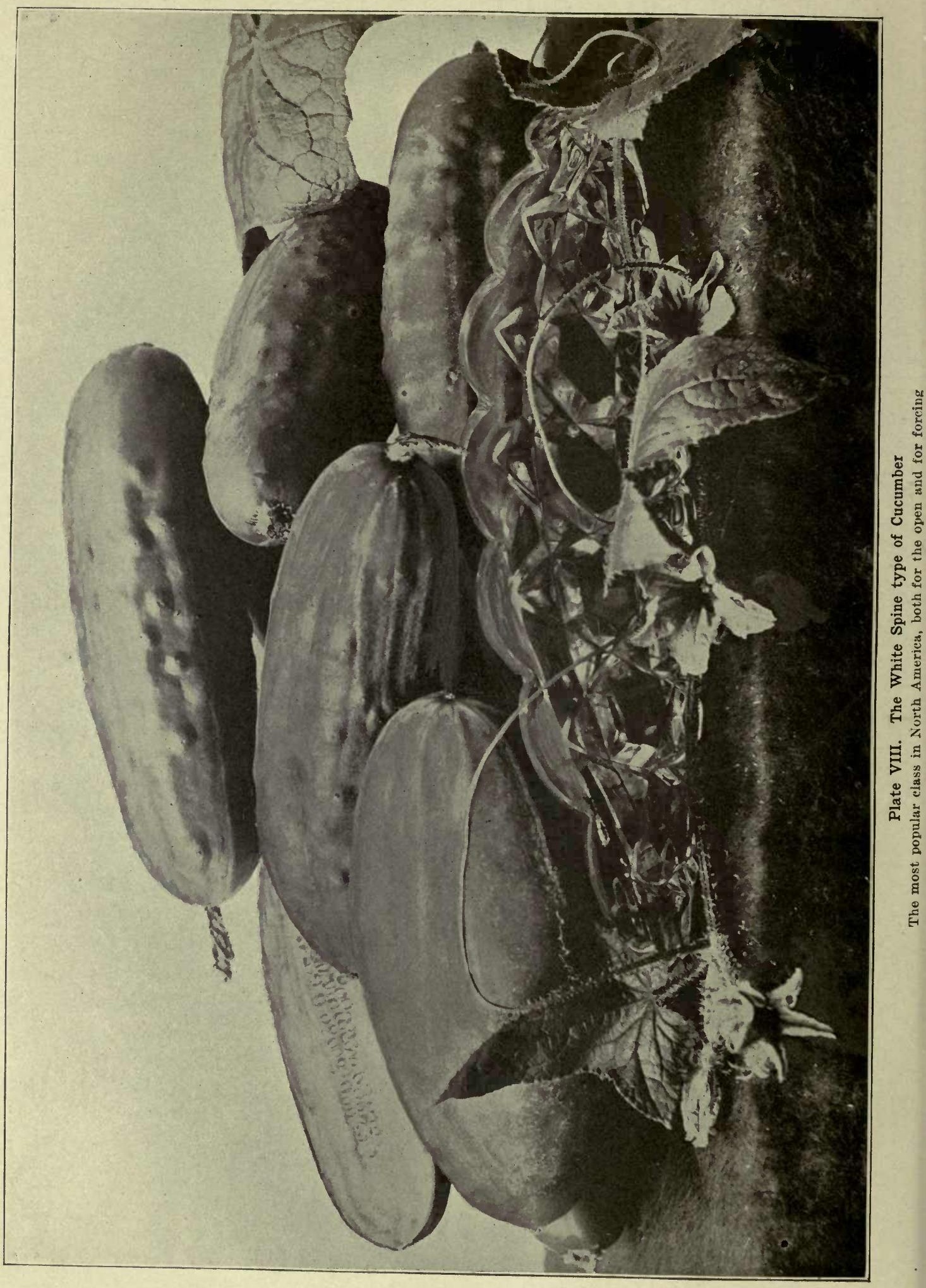


CRYPTOGRA MMA (Greek, c concealed line, alluding to the sub-marginal sori). Polypodidcea. A small genus of subalpine Ferns of both hemispheres. Lvs. of two sorts, the sporophylls contracted and the sori covered by the infolded margin of the segments, forming podlike bodies. Besides our native species, a second one, C. crispa, is found in Europe, and a third in the Himalayas. Name often incorreetly written Cryptogrammo. Culture easy.

acrostichoides, R. Br. Rock-Brake. Height about 8 in.: lvs. 4-6 in. long, on tufted straw-colored stalks, tri-quadripinnatifid, with toothed or incised segments, the sporophylls with longer stalks, less divided and with pod-like segments. Canada to Colorado, California and northward.

L. M. UNDERWOOD.

CRYPTÓLEPIS (Greek, hidden scale). Asclepiaddcere. Glabrous shrubs, erect or twining, of tropical A sia and Africa. Lvs. opposite. Fls. in a loosely forking, few-fll. cyme. Calyx deeply 5 -parted, with 5 scales at base. Corolla with spreading limb, the tube shortcylindrical or campanulate, the lobes 5 and linear, spreading or deflexed and twisted; corona of 5 scales attached at or near the middle of the tube. Follicles terete and smooth, spreading. Only cult. in S. Calif. and S. Fla. C. Buchánani, Roem. \& Schult. A twining shrub with yellow fls., resembling those of an Echites. C. longiflora, Regel. Dwarf and compact, growing with long lvs. tinted with red; tubular white fls., as in Bouvardia jasminiflora. Both species are from India.

CRYPTOMEेRIA (Greek, kryptos, hidden, meros, part; meaning doubtful). Coniferce. Large pyramidal tree, with a straight slender trunk, covered with reddish brown bark and with verticillate spreading branches, ascending at the extremities: lvs. spirally arranged, linear-subulate, acute, slightly eurved, decurrent at the base: fls.monocious; staminate oblong, yellow, forming short racemes at the end of the branches, pistillate globular, solitary, at the end of short branchlets: cone globular, with thick, wedge-shaped scales, furnished with a recurved point on the back and with pointed lobes at the apex, each scale with 3-5 narrow-winged, erect seeds. One species in China and Japan, extensively planted for avenues, and as timber trees in the latter country, where the light and easily worked but durable wood is much used. It is hardy as far north as New York, and thrives in sheltered positions even in New England. It seems, however, in cultivation, not to assume the beauty it possesses in its native country. With us, it looks best as a young plant, when it much resembles the Araucaria excelsa. It is therefore sometimes grown in pots. It thrives best in a rich, loaniy and moist soil and sheltered position. Prop. by seeds or by euttings of growing wood, especially var. elegans, which grows very readily. The horticultural varieties are also sometimes increased by grafting.

Japonica, Don. Tree, attaining $125 \mathrm{ft}$ : Ivs. linear-subulate, compressed and slightly 4 - or 3 angled, bluish green, $1 / 2-1$ in. long: cone brownish red, $3 / 4-1$ in. across. S.Z. 124 . R. H. 1887 , p. 392 . Gng. 4:197. F.E. 10:510. G.F. 6:446.Of the garden forms, the most desirable is var. élegans, Beissn. (C.élegans, Veitch). Low,dense tree, with horizontal branches and pendulous branchlets : lvs. linear, flattened, soft, spreading, longer than in the type, bright green, changing to bronzy red in fall and winter. Very handsome when young, but short-living. Var. araucaroides, Carr. Of regular pyramidal habit, with short, thick falcate lvs., resembling Araucaria excelsa. Var. compácta, Hort. Of very compact habit, with bluish green foliage. Var. Lobbi, Carr. Of compact habit, with shorter and more appressed bright and deep green lis. Var. nàna, Knight. Dwarf and procumbent, densely branched form; adapted for rockeries. Var. spiràlis, Veitch. Slender shrub, with strongly falcate lvs., twisted spirally around the branchlets. S.Z. 124, Fig. 4. ALFRED REHDER.
CRYPTOPYROM (Greek, hidden wheat). Gramineœ. This genus includes a plant sometimes catalogued with ornamental grasses, but it is no more ornamental than a long-awned form of quack-grass would be. C. Richardsoni, Schrad. (Agropỳrum Ríchardsoni, Schrad.), is similar to Agropyron caninum, but has longer awns. It is leafy, and grows 1-1 1 $\frac{1}{2} \mathrm{ft}$. high. $\quad$ P. B. KenNedy.

CRYPTOSTEGIA (Greek, krupto, conceal, and stego, cover; referring to the 5-scaled crown in the corolla tube, which is not exposed to view). A sclepiaddcec. A genus of only two species of tropical climbers, one from tropical Africa and one from Madagascar. The juice of $C$. grandiflora, when exposed to the sunshine, produces caoutchouc. The plant is cultivated in India for this purpose. It is rarely cultivated in Old World greenhouse. for ornament. It is said to be of easy culture in a warm house and propagated by cuttings.

grandifldra, R. Br. Stem erect, woody, branches twining : lvs. opposite, short-stalked, oblong, entire, 3 in. long, $1 \frac{1}{2}$ in. wide : fls. in a forked raceme, reddish purple, becoming lilac or pale pink, about 2 in. across, twisted in the bud. Trop. Afr. B. R. 5: 435.-Once cultivated at Oneco, Fla., by Reasoner.

\section{CUCKOO FLOWER. Cardamine pratensis.}

\section{CUCKO0 PINT. See Arum.}

CUCUMBER. Plate VIII. The common Cucumbers are derived from a South A sian species, Cucum is sativus (see Cucumis), which has long been known in cultivation. The so-called West India Gherkin, which is commonly classed with the Cucumbers, is Cucumis Anguria. The Snake, or Serpent Cucumber is more properly a musk melon, and should be designated botanically as Cucumis Melo, var. flexuosus (ef. Am. Gar. xiv. 206). The "Musk Cucumber" is Cucumis moschata, Hort. Probably this is identical with Concombre musqué, referred to Sicana odorifera by Le Potager d'un Curieux, known in this country as Cassabanana. The Mandéra Cucumber is

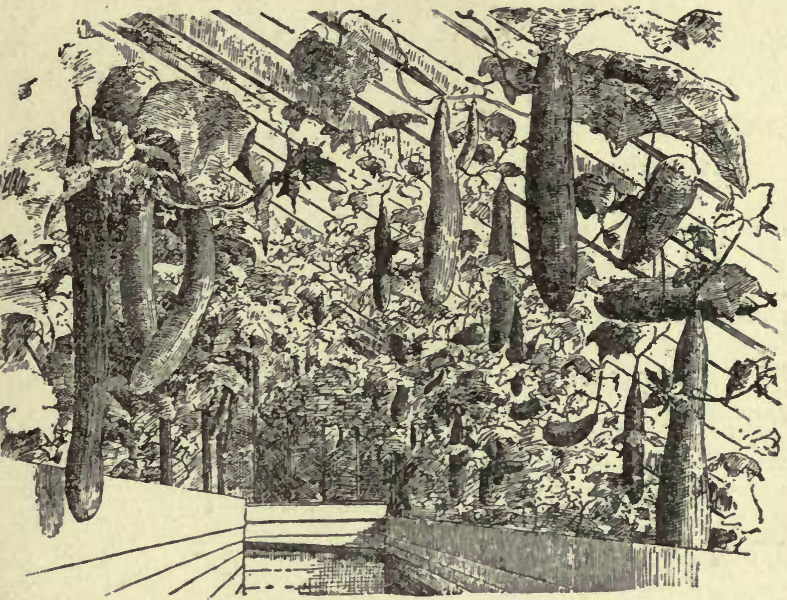

584. House of English Cucumbers.

Cucumis Sacleuxii, Paill. et Bois. (Pot. d'un Curieux), but it is not in cultivation in this country. None of these is of any particular importance except the common types of Cucumis sativus. These are extensively cultivated in all civilized countries as field and as garden crops. They come into commerce as pickles packed in bottles and barrels, and are very extensively used in this form. Of late, the forcing of Cucumbers under glass has come to be an important industry in the eastern states; and this industry seems to be rapidly increasing.

Cucumbers will thrive in any good soil not extremely heavy nor sandy. Good corn or wheat land, if in gardening condition with respect to tilth and drainage, will 
answer. Or for the earliest crop, a situation with a more pronouncedly sandy soil may serve best. In most parts of America the field crop of Cucumbers may be grown from seed planted in the open ground after danger of frost is past. Put 6 to 12 seeds in the hill (having enough to provide against the ravages of insects), the hills being 4 by 6 feet apart. The early crop may often be planted

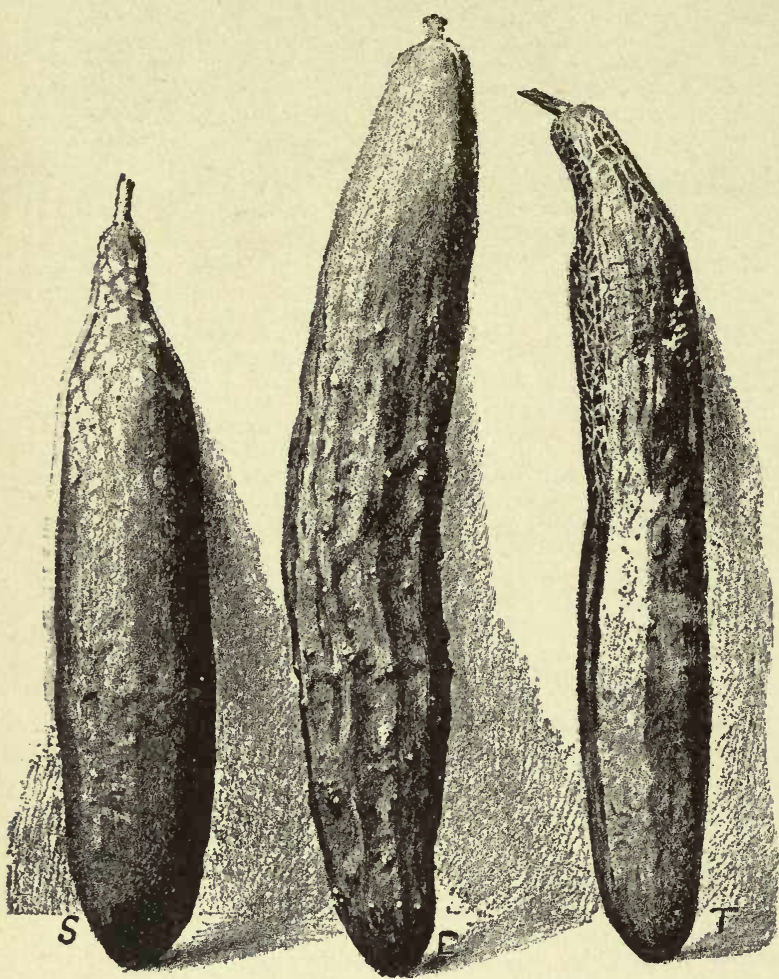

585. Three prominent varieties of English or Forcing Cucumber.

$S$, Sion House; $E$, Duke of Edinburgh; $T$, Telegraph.

in the same way, and protected for a time by a sashcovered frame placed over each hill. Plants are sometimes started in greenhouses or hotbeds, to be set later in the open ground; but this method is unsatisfactory unless great pains be taken. The method outlined by Henderson (Gardening for Profit), of starting plants on inverted sods in hotbeds and greenhouses, has proved successful with some gardeners, but is not capable of wide use. Early cultivation should be sufficient and timely, and accompanied by very careful combative operations against insects, for the first month is the most critical in the life of the Cucumber plant. When the vines begin to cover the ground, cultivation may be discontinued.

Cucumbers are often forced in warmhouses (Fig. 584) in winter and spring. The large English forcing varieties, as Telegraph and Sion House (Fig. 585), are preferred by some growers, but the White Spine varieties are more popular in America, especially for spring forcing after lettuce or flowering plants. The plants are started in 3-inch pots, and transferred directly to the benches at intervals of $2 \frac{1}{2}$ to 3 feet. They are then trained on wire trellises near the roof. The English Cucumbers like a night temperature of $60^{\circ}$ to $65^{\circ}$, and a day temperature of $70^{\circ}$ to $75^{\circ}$. The White Spine varieties are less fastid ious, and will take a somewhat lower temperature. In forcing Cucumbers, it is very important that the young plants should suffer no check from germination to fruitage. (Consult Bailey, Forcing-Book, and Cornell Bull. 31, and Munson, Me. Exp. Sta. Rept. 1896.)

Cucumbers for pickling should be gathered when quite small. In fact, their value as pickles seem to stand pretty much in inverse ratio to their size. Vines on which fruits are allowed to ripen cease bearing almost immediately. The young fruits may be successfully preserved in brine, from which they are soaked out with fresh water as wanted, and put into vinegar, which they readily absorb.

There are a great many varieties of Cucumbers in cultivation. This means that the group is variable, the varieties comparatively unstable, and varietal distinctions somewhat uncertain. Nevertheless, there are certain dominant types which may be separated, and around which most of the varieties may be conveniently classified. The principal types are the following:

Common Cucumber, Cucumis sativus.

I. English forcing ty ${ }^{-}$(var. Anglica): Fig. 585. Largeleaved, strong-growing, slow-maturing plants, not suited to outdoor culture; fr. large, long, smooth, usually green, with few or early-deciduous black spines. Telegraph, Sion House, Noa's Forcing, Tailby's Hybrid, Kenyon, Lorne, Edinburgh, Blue Gown, ete.

II. Field varieties (Hill or Ridge Cucumbers).

$a$. Black Spine varieties.

1. Netted Russian type: Small, short-jointed vines, bearing more or less in elusters, small, ellipsoidal fr. covered with many small, black, deciduous spines; fr. green, ripening to dark reddish yellow, on a cracking, chartaceous skin. Earlymaturing and prolific. Netted Russian, Everbearing, New Siberian, Parisian Prolific Pickle.

2. Early Cluster type: Small or medium vines: fr. small, usually less than twice as lon as thick, indistinctly ribbed, green, ripening yel, $w$, with scattered, large, black spines. Eariy Cluster, Early Frame, Green Prolific.

3. Medium Green type: Intermediate in size of vine and fr. between the last and next: fr. about twice as long as thick, green, ripening yellow, with scattering, large black spines. Nichol's Medium Green, Chicago Pickle.

4. Long Green type: One of the best fixed types, representing, perhaps, one of the more primitive stages in the evolution of the group. Vines large, long and free-growing: fr. large and long, green, ripening yellow, with scattered, large, black spines. Long Green, Japanese Climbing.

b. White Spine varieties.

5. White Spine type: A strong and important type: plants medium large, vigorous: fr. medium large, plants medium large, vigorous: fr. medium large, white, with scattering, large, white spines. white, with scattering, large, white spines. There are many selected strains of $W$
Cool and Crisp seems to belong here.

6. Giant Pera type: Mostly poorly fixed varieties, having large, rather unthrifty vines, bearing having large, rather unthrifty vines, bearing large frs. tardily and sparsely, which are white or
whitish, smooth or with seattering, deciduous, usually white spines. Chicago Giant, Goliath, Giant Pera, White Wonder, Long Green China.

Sikkim Cucumber, Cucumis sativus, var. Sikkimensis. Plant small and stocky, much like the common Cucumber: fr. large, reddish brown marked with yellow. (The Egyptian Hair Cucumber, of Haage \& Sehmidt, as we have grown it, is apparently an odd form of Cucumis sativus, and may belong here. It has a medium-sized white fr. densely covered with soft, white hair. The plant resembles the Sikkim Cucumber.) Not in general eult.

Snake or Serpent Cucumber, Cucumis Melo, var. flexuosus. Vines resembling those of muskmelon: fr. very long. twisted, ribbed-cylindrical, green, tardily yellowing, eovered with dense, woolly hairs.

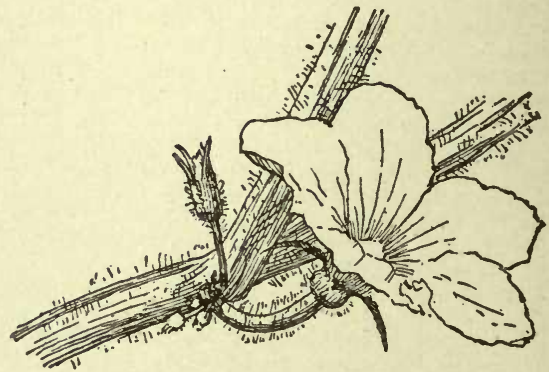

586. Staminate flower of Cucumis Melo. 


\section{CUCUMIS}

cal species, mostly African and East Indian. The cult. species are annual. Monogr. by Cogniaux, DC. Monogr. Phaner. 3. See, also, Naudin, Ann. Sci. Nat. (Bot.) IV. $11: 9 ; 12: 108$.

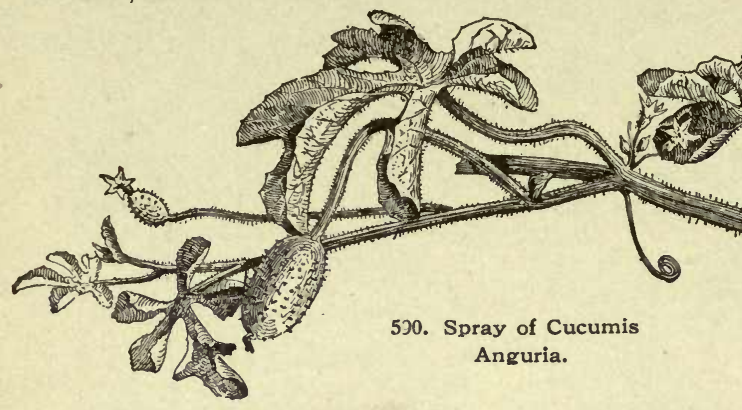

A. Fr. smooth (not spiny nor tuberculate) at maturity.

Mèlo, Linn. (C. Momórdica, Roxb. C. utilíssimus, Roxb.). Melon. Muskmelon. Figs. 586, 587. Long-running, hairy, prickly : lvs. round-heart-shaped or reniform, sometimes rounded-lobed : fr. in many sizes and shapes, the inner part being edible. S. Asia.-When forced under glass, the IVs. are usually more lobed. See Melon.

Var.Cantalupénsis, Naud. Cantaloupe. Rock Melons. Fruits mostly hard-rinded, more or less warty, scaly or rough, often deeply furrowed or grooved.-Name derived from Cantaluppi, near Rome, a former country seat of the Pope, whither this type of melons was brought from Armenia. In the U. S. the word Cantaloupe is often used as a generic name for Muskmelon, but it is properly a name of only one group of muskmelons - the hard and scaly-rinded (see Waugh, G. F. 8:183).

Var. reticulàtus, Naud. Nutmeg or Netted Melons. Fruits softer rinded, more or less netted, or sometimes almost plain or smooth. - Comprises the common muskmelons, aside from Cantaloupes.

Var. saccharinus, Naud. Pineapple Melons. Comprising varieties of oblong shape and very sweet flesh. Not sufficiently distinct from the last.

Var. inodorus, Naud. WINTER Melons. Lrs. lighter colored, less hairy, narrower : frs. possessing little or none of the common muskmelon odor, and keeping long. The winter muskmelons are little known in this country, although they are worthy of popularity. Much cult. in parts of the Mediterranean region. See Bull.96, Cornell Exp. Sta.

Var. flexudsus, Naud. (C. flexudsus, Linn.). SNake MELON. SNAKE CuCuMBer. Fr. many times longer than broad, greenish at maturity, variously curved and furrowed. A. G. 14: 203. - Fr. often 2-3 ft. long, and 1-3

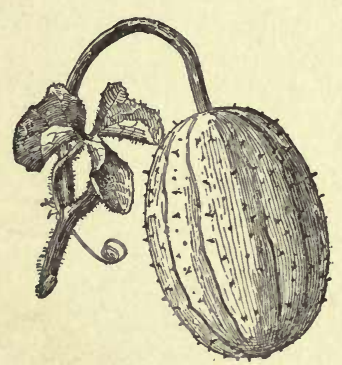
in. in diameter. Grown mostly as an oddity, but it is useful for the making of conserves. The hardshelled Snake Gourd is a Lagenaria (which see).

591. Fruit of Cucumis Anguria.

Var. acídulus, Naud. Cucumber Melon. Frs. oblong or cylindrical, mottled or unicolored, the flesh white and cucumber-flavored. No varieties in the Amer. trade are of this group, but they are occasionally seen in botanical gardens and experimental grounds, which import seeds of oriental plants.

Var. Chito, Naud. (C. Chito, Morr.). Orange Melon. Mango Melon. Melon Apple. Vine Peach. Garden
Lemon. Vegetable Orange. Vine less robust than that of the Muskmelon, and lvs. smaller : fr. size, shape and color of an orange or lemon, without markings, with a white or pale yellow cueumber-like flesh, with no muskmelon odor. - Not edible in its natural state, but useful for the making of preserves (or "mangoes") and pickles. Name pronounced keeto. Cf. Bull. 15, Cornell Exp. Sta.; A. G. 14: 206. Var. Dùdaim, Naud. (C. Dùdaim, Linn. $C$. odoratíssimus, Monch). Dudaim Melon. POMEgranate MeLON. QUEEN ANNE's POCKET MeLoN. Vine small, as in the last: fr. size and shape of an orange, somewhat flattened at the ends, verv regular and smooth, marbled with longitudinal markings of cinnamon-brown overlying yellow, exceedingly fragrant. - A most handsome gourd-like fruit, and highly and deliciously perfumed. Not eaten. A nearly odorless and scarlet-rinded form is separated by Naudin as var. erythrous.

\section{AA. Fruit spiny or tuberculate.}

sativus, Linn. CuCuMBer. Figs. 588, 589. Longrunning, prickly : lvs. usually 3-lobed ( or strongly angled), the middle lobe most prominent and often pointed: fr. prickly or muricate, at least when young, but in some varieties becoming smooth, mostly oblong, the flesh white. S. Asia. See Cucumber.

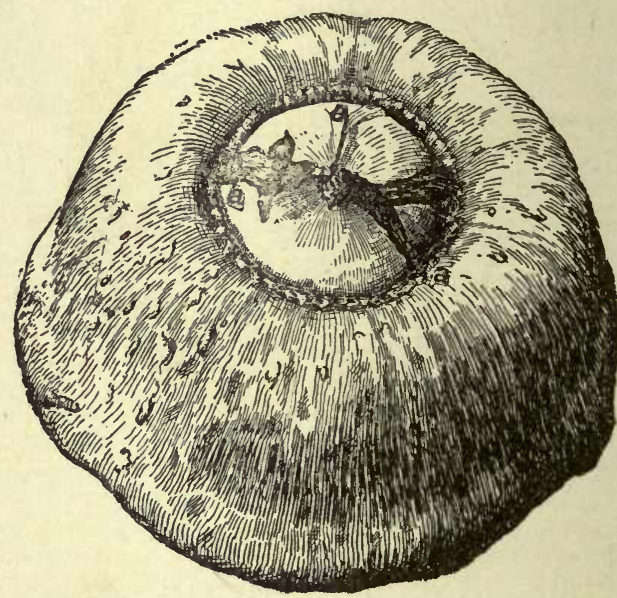

592. Young turban Squash, on which the remains of the corolla still persist.

The central part of the fruit is the ovary.

Var. Anglicus. Figs. 584, 585. English or Forcing CUCUMBER. A product of cultivation and selection, within the last century (see Forcing-Book, pp. 192-4), distinguished from the common or field Cucumbers as follows: fruits (and ovaries) very long and slender, little if any furrowed, spineless or nearly so at maturity, nearly or quite green at maturity, comparatively fewseeded: fls. very large: lvs. very broad in proportion to their length, with shallower sinuses: vines very vigorous, with long and thick tendrils.

Var. Sikkimensis, Hook.f., cult. in the Himalayan Mts., but not known to be in this country; has large 7-9. lobed lvs. and cylindrical-club-shaped fr. B.M. 6206.

dipsàceus, Ehr. (C. erinàceus, Hort.), Dipsaceous Gourd. Ostrich-EgG GoURD. HEDGEHOG GOURD. Plant and foliage like that of $C$. Melo: fls. longstalked: fr. 1-2 in. long, oblong or nearly spherical, becoming hard and dry, densely beset with long scales or hairs, and looking like a bur. Arabia, Afr. R.H. 1860, p. 210. Cult. as an ornamental Gourd.

Angùria, Linn. (C. grossulariafórmis, Hort.). BuR CUCUMBer.. West Indian GHerkin. GooseberRy Gound. Figs. 590, 591. Stems slender, hispid: 1vs. deeply cut into 3-5 narrow obovate or spatulate divisions, 
water-melon like: fls. small, the pistillate long-stalked: fr. 1-3 in. long, cucumber-like but more spiny. Supposed to be native to the Amer. tropies. B.M.5817.-Cult. both for the oddity of its frts. and for the making of pickles. The Gherkins of mixed pickles, howerer, are young Cucumbers.

C. acutángulus, Hort. $=$ Luffa. $-C$. perénnis, James $=\mathrm{Cu}$. curbita.

CUCURBIT. A plant of the genus Curcurbita. Sometimes shortened to Cucurb.

CUCÚRBITA (classical name). Cucurbitaceo. Gourd. Pumprin. Squash. Vinelike herbs, tendril-bearing, inhabitants of warm countries. Fls. monceious, large, yellow, solitary in the axils, the staminate long stalked, the pistillate shortstalked : corolla 5-lobed : stamens 3, arising from the bottom of the fl., and united in a column : stigmas 3 , but 2-lobed : orary inferior, enclosing a hollow receptacle: tendrils $2-3$ forked. About 10 species. The morphology of the Pepo or Gourd-fruit may be illustrated by the Turban Squash. (Figs. 592, 593, 594.) In this fruit, there is a "squash inside a squash." The inner part bears the corolla and the styles. It is the ovary. The corolla is attached about the edge of the

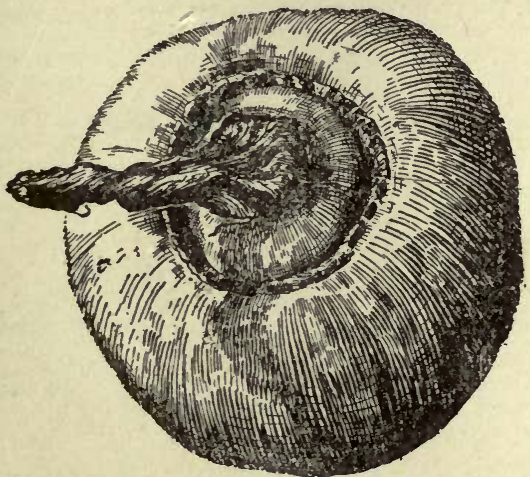

593. Young Turban Squash, in which the withered corolla has become detached, but hangs on the remains of the styles and stigmas.

inner Squash, as the withered remains in Fig. 592 show. Sometimes the withered corolla becomes detached, but hangs onto the withered remains of the stigmas, as in Fig. 593. The longitudinal section of the flower (Fig. 594) explains the structure. The corolla is shown at cd. The top of the ovary is at $O$. The stigmas are on the ovary. The part encircling the ovary (outside of $\mathrm{O}$ ) is the hollowed receptacle. Ordinarily the receptacle is closed at the top, completely confining the ovary; but in the Turban Squashes the receptacle does not extend over the top of the ovary, and

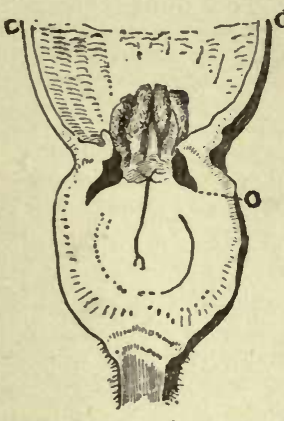

594. Section of Flower o Turban Squash.

Showing the ovary inside the hollowed receptacle. d the ovary therefore protrudes. The older morphologists held this outer part of the Squash to be adnate calyx, rather than receptacle. The Cucurbits are monographed by Cogniaux, DC. Monogr. Phaner. 3. Also by Naudin, Ann. Sci. Nat. (Bot.) 1V. vol. 6. See Pumpkin and Squash.

A. Li's. lobed: stalks of fruits strongly ridged.

Pèpo, Linn. (C. Melopèpo, Linn.). PUMPKiN. Figs. 595, 596. An-ual: long - running, prickly on stems and petioles: lvs. 3-5-lobed, dark dull green: corolla-tube widening upwards, the pointed lobes erect : calyxlobes narrow, not leaf-like : peduncle very hard and deeply furrowed when mature, not enlarging next the fr.: the fr. very various in form, color, season, size. - Probably native to trop. Amer., but unknown wild. Cult. by the Indians when Amer. was
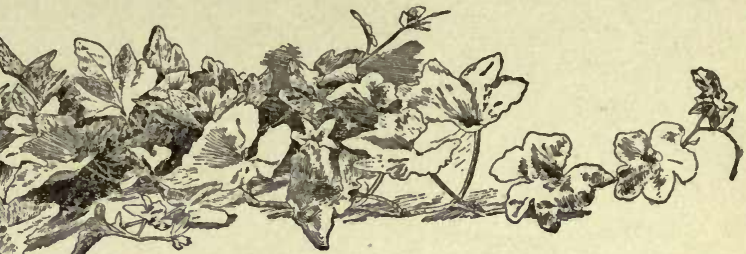

595. Plant of Cucurbita Pepo.

discovered, in fields of maize. For studies in the nativity of the Pumpkins and Squashes, see De Candolle, Origin of Cultivated Plants; Gray and Trumbull, Amer. Journ. Sci. 25: 372 ; Sturtevant, Amer. Nat. 1890: 727 ; Wittmack, Ber. der Deutschen Bot. Gesell. 6: 378 (1888).

Var. condénsa. Bush Pumpkins. Scallop and SumMer Crookneck Squashes. Plant compact, little or not at all running. Of horticultural origin.

Var. ovifera. (C. ovifera, Linn.). GouRd. Fig. 597. Plant slender, running: lvs. smaller than in $C$. Pepo, usually very prominently lobed: fr. small, hard and inedible, egg-shaped, globular, pear-shaped, oblate, often striped. R.H. 1894, p. 429. - Sold in many vars. by seedsmen, under the names of $C$. Pepo vars. pyriformis, depressa, annulata, etc. See Gourd.

moschàta, Duchesne (C. melonofórmis, Carr.). Cushaw. China, Canada Crookneck and Winter Crookneck Squashes. Figs. 598, 599, 600. Annual : iong-running, less prickly and sometimes soft-hairy: lvs. more rounded than those of $C$.Pepo, but lobed, often grayish : fl. with a widening tube, and large, erect lobes : calyx-lobes large, often leaf-like: peduncle becoming deeply ridged and much enlarged next the fr. Possibly of East Asian origin.

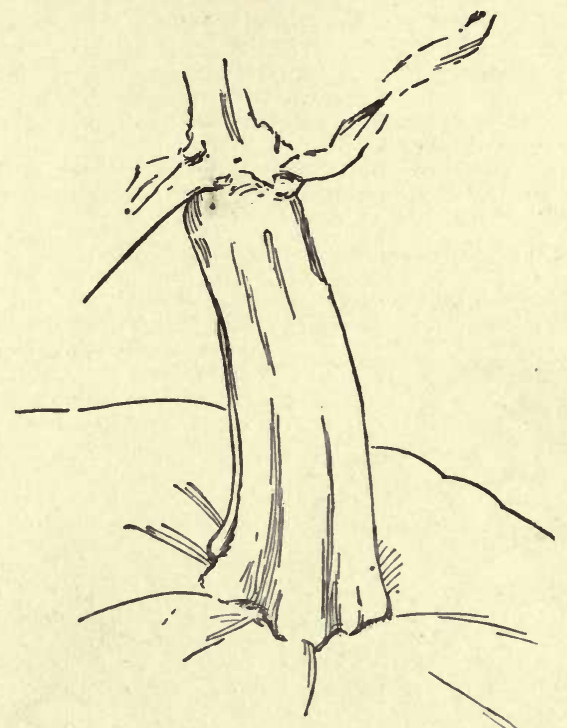

596. Stem of Cucurbita Pepo-Early Sugar Pumpkin.

AA. Lv's. not lobed (except sometimes on young shoots): stalks of fruits not prominently ridged.

máxima, Duchesne. SQuAsh. Figs. 601-604. Annual: long-running, the stems nearly cylindrical, little prickly and often hairy: lvs. orbicular or kidney-shaped, commonly not lobed, the basal sinus wide or narrow, the margin shallowly apiculate-sinuate: corolla-tube nearly 
the same diam. at top and bottom (Figs. 602, 603), the corolla-lobes large and soft, and wide-spreading or drooping: peduncle at maturity soft and spongy, not ridged

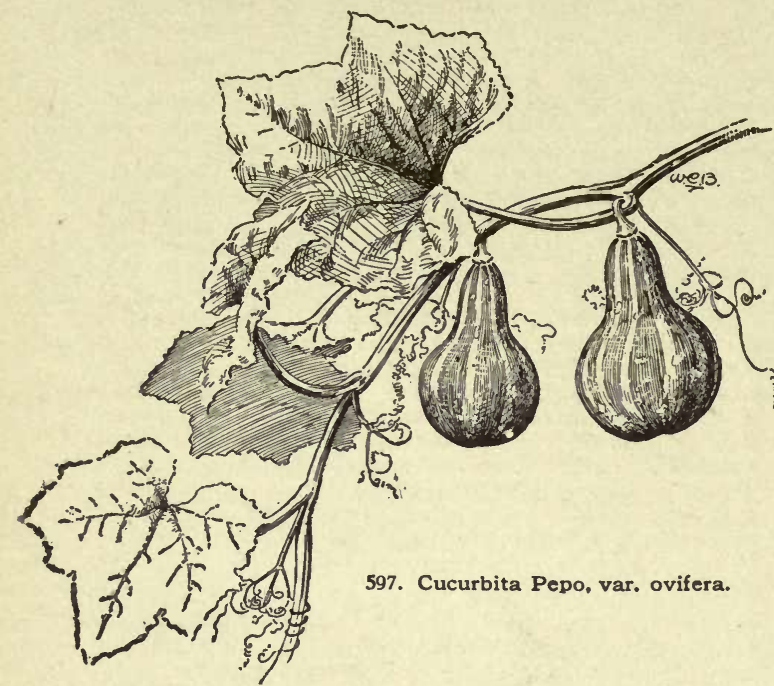

nor prominently enlarged next the fr.: fr. very various, but not light yellow nor warty nor crookneck-shaped, usually late-ripening, the flesh orange and not stringy. Probably American.

fœtidissima, Kunth ( $C$. perénnis, Gray. Cùcumis perénnis, James). Fig. 605. Perennial: long-running, scarcely prickly: lvs. large,cordatetriangular, grayish pubescent, the margin shallowly apiculate-crenate : fl. nearly as large as in $C$ $P e p o$ and similar in shape, the pistillate on a peduncle $2-3$ in. long: fr. size and shape of an orange, smooth, green and yellow splashed, not edible. Sandy, arid wastes, Neb. and Colo. to Tex. and Mex. and westward to Calif. R. H. 1855 : $61 ; 1857$, p.54. - In its native haunts, the root is tuberous, 4-7 in. in diam. and penetrating the earth 4-6 ft. Roots at the joints. The plant has a fetid odor. Sold by seedsmen as a gourd, but the fruit does not often ripen in the northern states. Use-

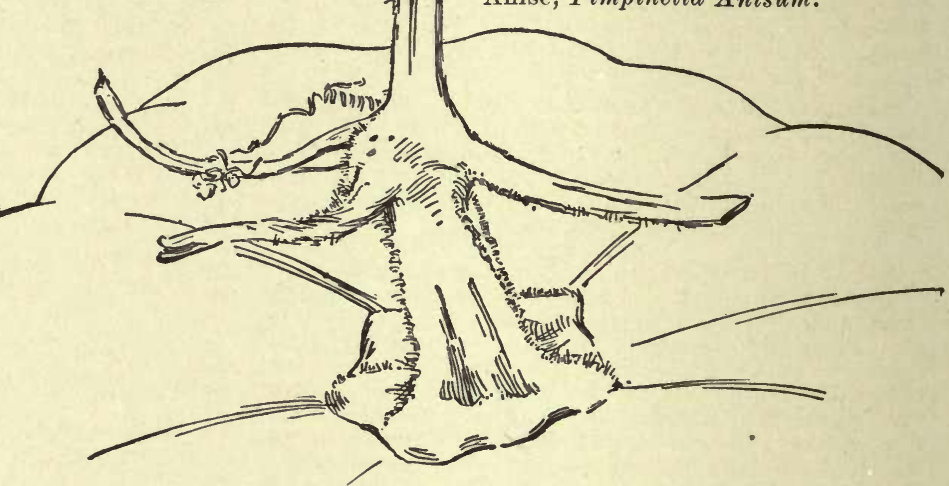

599. Stem of Cucurbita moschata-Large Cheese Pumpkin.

ful on arbors and small trees, when coarse vines are wanted

The terms Squash and Pumpkin are much confused. In Europe, the large varieties of Curcubita maxima are known as Pumpkins, but in this country the fruits of this species are known usually as Squashes. In America, the words Pumpkin and Squash are used almost indiscriminately, some varieties in all species being known
Japanese Crookneck, Dunkard, and Sweet Potato Pump. kins (or Squashes) are C. moschata. The fruit stem (as shown in Figs. 596, 599, 604) is a distinguishing characteristic of the ripe fruits. C. Pepo and C. maxima, and C. maxima and C. moschata do not intercross. C. Pepo and $C$ moschata have been crossed, but it is doubtful if they intermix when left to themselves. In Europe, the word Gourd (or its equivalent in various languages) is used generically for Cucurbitas; but in this country it is restricted mostly to the small, hard-shelled forms of $C$. Pepo (var. ovifera) and to Lagenaria vulgaris.

L. H. B.

CUDRANIA (derivation unknown). Urticdcece. Trees or shrubs, with deciduous, alternate, stipulate petioled lvs.: fls. diøecious, in globular heads: collective fr. globular. About 3 species, in S. and E. Asia and trop. Austr., of which only one is sometimes cultivated. It requires protection in the north, and is usually prop. by greenwood cuttings in summer under glass.

tricuspidàta, Bureau (Maclùra tricuspiddata, Carr.). Shrub, with slender, spiny branches: Ivs. elliptic-ovate, acuminate, entire, sometimes 3 -lobed at the apex, nearly glabrous, 11/2-3 in. long: fl.- heads axillary, on short peduncles: fr. globose, about 1 in. across. China. R. H. 1864 , p. 390. - Much resembling Maclura, and of no special decorative value. AlFred ReHDER.

CULM. The stem of a grass.

CULVER'S ROOT. Veronica Virginica.

CUMIN, or CUMMIN, the seeds of Cuminum Cyminum; Black Cumin, Nigella sativa; Sweet Cumin, or Anise, Pimpinella Anisum. borne in corymbed cymes or clusters. The genus con-

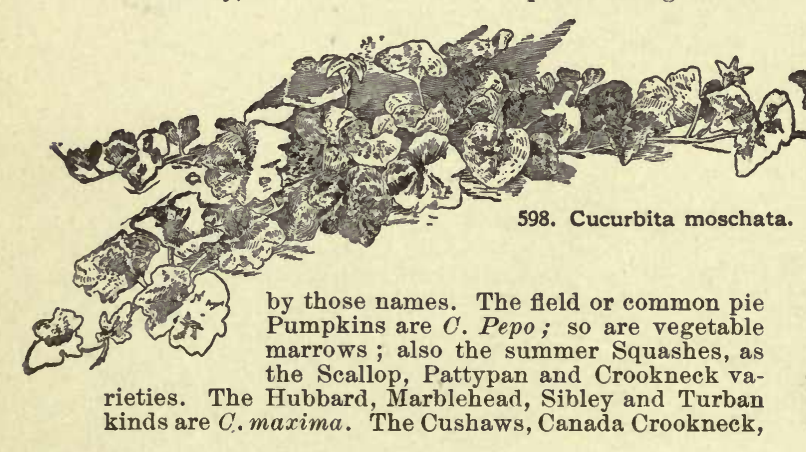

CUNILA (origin unknown). Labidta. This genus contains a low-growing, tufted, hardy, native perennial plant, rarely cultivated in borders for its profusion of small, white or purplish, 2-lipped flowers, which are tains not more than 16 species, 2 North American, 2 Mexican, and the rest Brazilian. They are somewhat woody, and usually have small lvs.: the whorls of flowers are sometimes loosely corymbose, sometimes axillary, few-fld., much shorter than the lvs., sometimes manyfld., in dense spikes or terminal heads ; calyx 10-13-nerved, 5-toothed: perfect stamens 2.

Mariàna, Linn. MARYLAND DitTANY. Height 1 ft.: lvs. smooth, ovate, serrate, rounded or heart-shaped at the base, nearly sessile, dotted, $1 \mathrm{in.} \mathrm{long.}$ Dry hills, southern N. Y. to S. Ind., south to Ga. and Ark. J.H. III. 35: 321.

Mn. 7:201. See also Dittany.

CUNNINGHAMIA (after J. Cunningham, botanical collector, who discovered this Conifer 1702 in China). Coniferce. Tree, with stout trunk and verticillate, spreading branches, pendulous at the extremities: lvs. 
linear-lanceolate, rigid, densely spirally arranged and 2-rowed in direction: fls. monocious; staminate oblong, pistillate globose, in small clusters at the end of the branches: cones roundish-ovate, 1-2 in. long, with round-

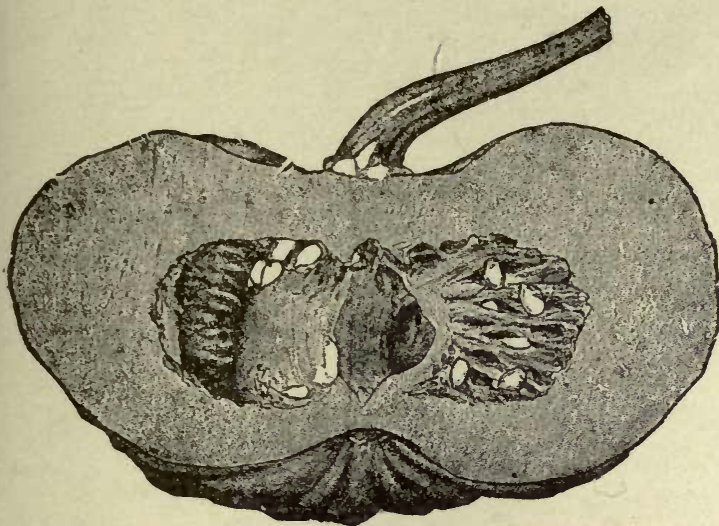

600. Fruit of Cucurbita moschata-Tonasu, a Japanese variety.

ish-ovate, serrate and pointed, coriaceous scales, each with 3 narrow-winged seeds at the base. One species, in China. A very decorative Conifer for warmer temperate regions, much resembling the Araucaria Brasiliensis. It prefers a half-shaded position and sandy and loamy, humid soil. Prop. by seeds or cutting of half-hardy wood in late summer under glass; short sprouts from the old wood of the trunk or larger branches are the best; cuttings from lateral branches grow into weak and one-sided plants.

Sinénsis, R. Br. ( $C$. lanceoldta, Lamb.). Tree, attaining $80 \mathrm{ft}$ : : lvs. linear-lanceolate, with broad, decurrent base, sharply pointed, finely serrulate, light green and shining above and with two broad, whitish bands beneath, $1 \frac{1}{2}-21 / 2$ in. long: cones $1-2$ in. high. China, cult. in Japan. B.M. 2743. S.Z. 104, 105. AlFred REHDER.

CUPANIA (after Francis Cupani, Italian monk, author of Hortus Catholicus, died 1710). Sapinddcece. A rather large and ill-defined genus of trees and shrubs, the most important of which is the Akee tree, naturalized in the West Indies from western Africa, which has rich, red edible fruits that are much improved by cooking. The flowers are so fragrant as to deserve distilling. The tree reaches a height of $30 \mathrm{ft}$., and is cultivated in Jamaica to a height of only $3,000 \mathrm{ft}$., but can endure a slight frost. It is also cult. in So. Fla. C. sapida is now referred to Blighia by reason of its long-exserted stamens and scale longer than the petals. C. anacardioldes, a rapid-growing tree with edible fruit, has been introduced into S. Calif. by Franceschi.

sápida, Voigt (Blighia sápida,Kon.). A KEe Tree. Leaflets 3 or 4 pairs, ovate-lanceolate, veined: fls. whitish. C. elegantíssima, Hort., was once advertised by Pitcher \& Manda as an ornamental warmhouse plant "with handsome leaves and racemes of white flowers."

CUPHEA (Greek, curved; referring to the prominent protuberance at the base of the calyx tube). lythrdcea.

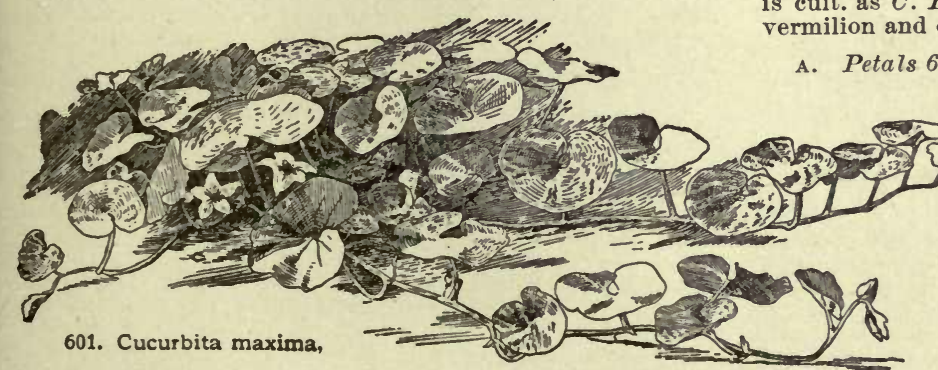

An exceedingly interesting genus of tropical and subtropical American herbs and shrubby plants, with remarkable variations in the petals. In $C$. ignea, perhaps the most attractive of the group, the petals are entirely absent, and the showy part is the brilliantly colored calyx tube. At the other extreme is C. hyssopi. folia with 6 petals (the normal number in the genus) and all of equal size. Between these two extremes (shown in Figs. 606 and 608) are at least two well marked intermediate types. One of these (exemplified in $C$. procumbens) has 2 large and 4 small petals: the other, ( $C$. Llavea), has 2 conspicuous petals, and the other 4 are completely abortive. These two types are unique among garden plants. The series of intergradient forms is completed by $C$. cyanea, in which there are only 2 petals, and these minute, and $C$. micropetala, in which there are 12 barely visible petals, alternating with and shorter than the calyx teeth. The genus is badly in need of thorough botanical revision. The plants are often clammy: lvs. opposite, rarely whorled or alter nate, ovate, lanceolate, or linear, entire. The flowers are often borne in one-sided racemes, and some of the species have a very odd look from the bold angle made by the slender ascending pedicel and the descending calyx tube, with its queer projection at the base. The purple stamens add to the interest. Nearly all Cupheas are

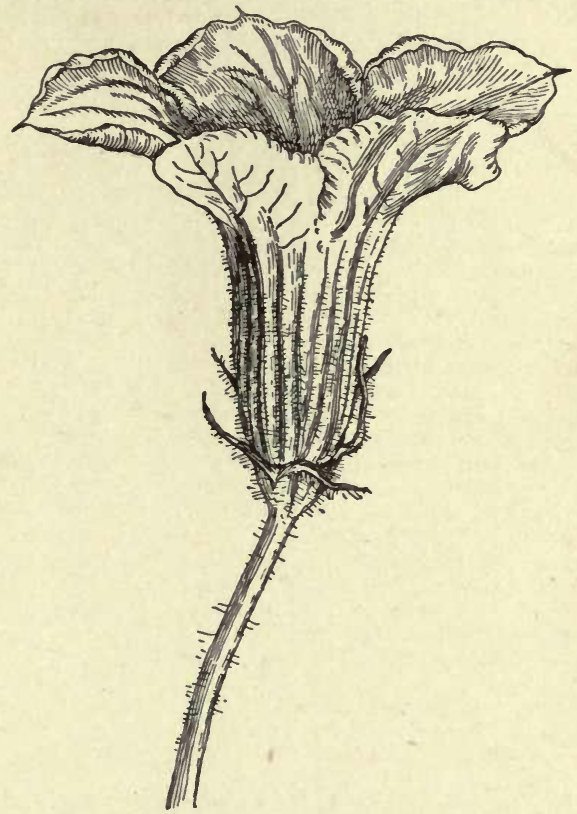

602. Staminate flower of Cucurbita maximaHubbard Squash $(X 2 / 3)$.

grown from seed and treated as tender annuals, but $C$. ignea is chiefly prop. by cuttings. They are of easy culture, and the whole series is worth growing. In addition to the species described below, $C$. Hookeriana, Walp. is cult. as $C$. Roezlii, Carr. It has lanceolate lvs., with vermilion and orange calyx. R.H. 1877:470.

A. Petals 6, but very minute and inconspicuous.

micropétala, HBK. (C.éminens, Planch, \& Linden). Stem shrubby, more or less branched : 1-2 $\mathrm{ft}$. high: branches and calyx scabrous : lvs. oblong - lanceolate, acute at both ends, but without a distinct petiole, rigid, scabrous: fls. borne singly in succession at a point above the axils, which distinguishes this species from all others here described; petals 6 , minute, borne between the calyx teeth, and shorter than them ; calyx 12 - 
toothed, scarlet at the base, yellow towards the top, greenish at the mouth; stamens and filaments red: ovary 2-celled, many-seeded. Mex. HBK. Nov. Gen.

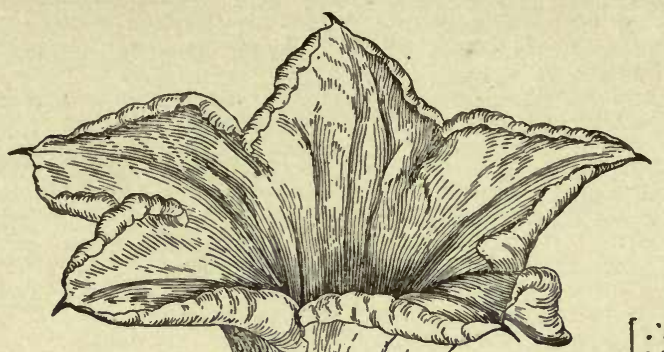

3 in. long, gradually decreasing in size until they become bract-like, petiole short: fls. numerous, peduncles longer than the petioles, 2 or 3 times shorter than the calyx; calyx 6 -toothed, purplish at the base, green at the tip, with 12 raised streaks, and a pubescence like that of the stem; petals 6 , the 2 larger ones on the upper lip of the calyx purple; filaments included. Mex. B.R. 3:182. C. purpùrea, Hort. F. S. 4:412. R. B. 22:85; said to be a hybrid between $C$. miniata and $C$. viscos$\operatorname{sima}$, is probably not distinct.

AAA. Petals 6, all of the same size.

hyssopifòlia, HBK. Fig. 606 . Stem shrubby; branches numerous, strigose: lvs. lanceolate, rather acute, obtuse at the base, glabrous above, strigose-pilose along the midrib and veins, as may be seen with a hand lens: fls. with their slender pedicels scarcely longer than the lvs. calyx glabrous: petals 6, somewhat unequal, dilute vio-
let; stamens 11 included; filaments villous : ovary 5-6shylla, Hex. - C. hyssopi- Manda, is presumably a typographical error. This is the i list least attractive of the species. longer advertised, but it still lingers in a few conservatories. It is easily told from its. showier relatives by its much smaller lvs. (less than $1 / 2$ in. long) and much branched and very woody appearance.

AAAA. Petals normally 2 , the other 4 abortive.

B. Size of petals very small.

cyànea, Moc. \& Sesse. (C. strigulòsa, Hort., not HBK.). Stem herbaceous, erect : branchlets hispid: lrs. oppo604. Stem of Cucurbita maxima-Hubbard Squash. site, stalked, ovate, cordate,
acuminate, villous on both 604. Stem of Cucurbita maxima-Hubbard Squash. site, stalked, ovate, cordate,
acuminate, villous on both sides: peduncles alternate, racemose : calyx slightly hispid, scarlet at the base, yellow at the top: petals 2 , clawed, spatulate; anthers and petals violet-blue. Mex. B.R. 32:14 (1846) as C. strigillòsa, Lindl. F.S. 1:15 \& P.M. 11:241 as B. strigulòs, , but neither of these plates is the $C$. strigulosa, HBK., which is a different species, with a shrubby stem: branches and calyx clammy-hispid: lvs. ovate-oblong, acute at both ends, clammy, glabrous above, strigose-scabrous below : petals nearly equal: ovary about 8-ovuled.

procúmbens, Cav. Annual, herbaceous, 1 in. high, procumbent, sticky-pubescent, with characteristic pur plish hairs: Ivs. ovate-lanceolate. with white hairs, $11 / 2-$

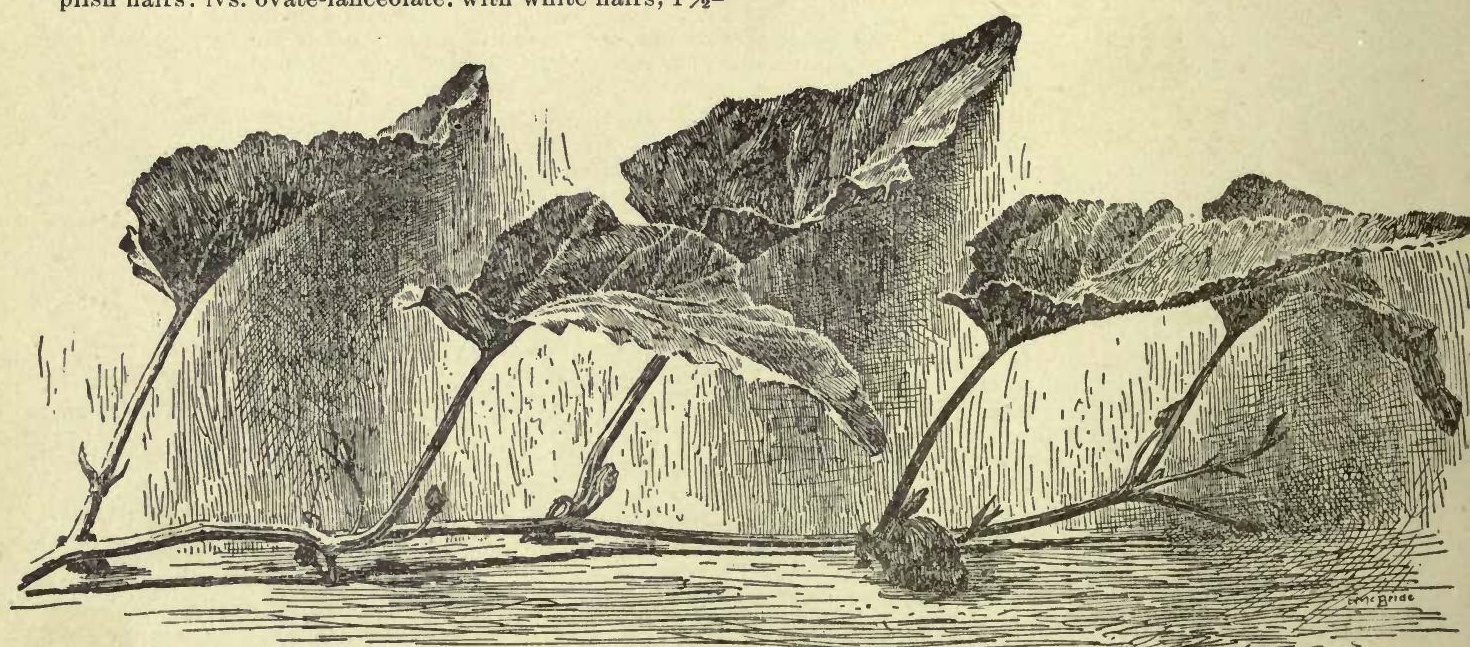

605. Cucurbita fotidissima. 
Bв. Size of petals larger.

$$
\text { C. Calyx 6-toothed. }
$$

Llàvea, Lindl. Red, White-And-Blue Flower. Fig. 607. Stems numerous, herbaceous, hispid: branches ascencling: lvs. almost sessile, especially near the top, ovate-lanceolate, strigose: racemes short, few-fld.: calyx green on the ventral side, purple on the back and at the oblique-6-toothed mouth; petals 2 large, scarlet, obovate, the other 4 abortive; stamens 11 . Guatemala. B.R. 16:1386. J.H. III. $31: 305$. - It is doubtful whether the plant described by Lindley is the same as the Mexican plant originally described by Lexarsa, which was said to have petals of "dilute scarlet." Lindley's plant had a green calyx, but the plant in the trade is colored. Used for baskets and bedding. Often misspelled Llave.

\section{cC. Calyx 12-toothed.}

miniàta, Brongn. Stem shrubby, erect: branches few, hispid: lvs. opposite, the upper ones not quite opposite, with a very short petiole, ovate, acute, entire, with white, silky hairs which are denser beneath: Hs. solitary, subsessile, axillary, the peduncle adnate to the branch in such a way as to appear between and below the petioles: raceme few-fld., one sided. F.S. 2:73. P.M. 14:101. R. H. 1845:225. R. B. 22:85.-Var. compácta, Hort. S.H.2:43. Gt. 46, p. 637 . This is referred to $C$. Llavea, Lex., by Index Kewensis. The above description is from the original one in F.S. 2:73. Van Houtte describes several hybrid varieties in F.S. 5 , p. 487, which differ chiefly in size, color, and marking of petals. Calyx 1 in. long, hispid, green at the base, purple above, 12-toothed at the tip: petals 2, scarlet, wavy. The specific name miniata means cinnabar-red, and refers to the petals.

\section{aAaAa. Petals none.}

1gnea, DC. (C. platycéntra, Hort., not Benth.). Fig. 608. Branches somewhat angled: lvs. petioled, ovatelanceolate, acuminate, narrowed at the base, lightly scabrous: flower stalks 2-4 times longer than the leaf stalks: calyx glabrous, shortly 6-toothed, bright red except at the tip, which has a dark ring and a white mouth:

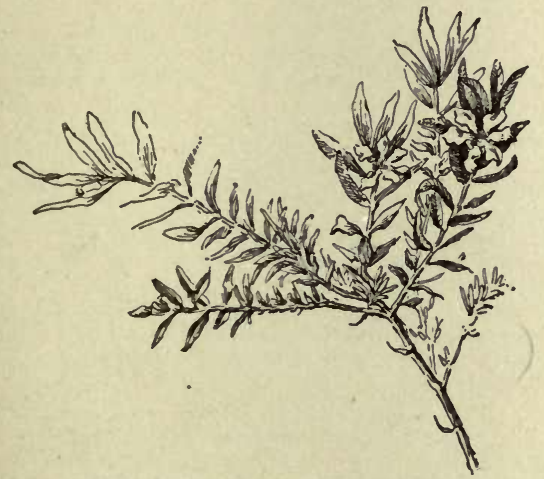

606. Cuphea hyssopifolia $(\times 1 / 2)$.

petals none: stamens 11 or 12 , glabrous. Mex. F.S. 2:180 (1846). P.M. $13: 267(1846)$. - This is sold only as $C$. platycentra, although De Candolle corrected the error in 1849 (F.S. 5:500 C.). This is a remarkable instance of the persistence of erroneous trade names.

W. M.

CUPULE. The husk or cup of an acorn. The oak belongs to the Cupuliferæ.

CUPRESSUS (ancient Latin name from Greek, $K u$ parissos). Cypress. Trees, rarely shrubs, with aro matic evergreen foliage: branchlets quadrangular or nearly so: lvs. opposite, small, scale-like, appressed, mi nutely denticulate-ciliate, on young seedling plants linear-subulate and spreading: fls. monœcious, minute, solitary on short branchlets; staminate ovate or oblong, yellow; pistiuate subglobose: cones globular or nearly so, consisting of 3-7 pairs of ligneous, peltate scales, with a mucro or boss on the flattened apex, each bearing

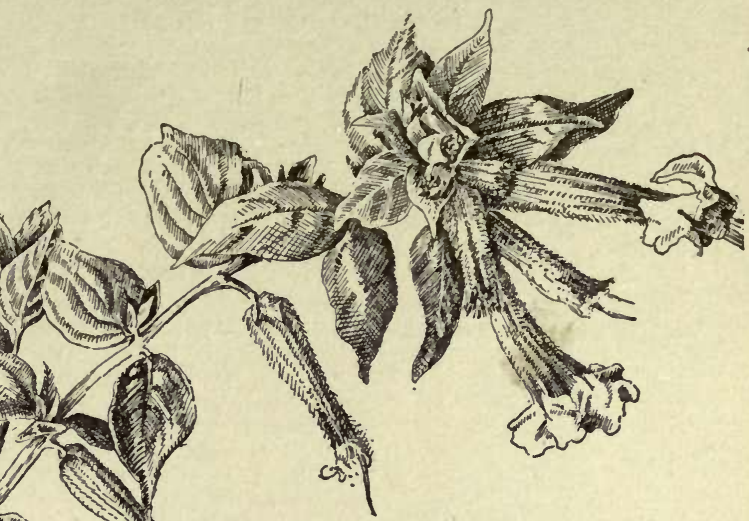

607. Cuphea Llavea.

Natural size.

many or numerous seeds, but che lower scales usually sterile and smaller; they ripen the second year. About 10 species in C. Amer., north to Calif. and Ariz., and from S. Eu. to S. E. Asia. By some botanists, the allied genus Chamæcyparis is included. Higbly ornamental evergreen trees, greatly varying in habit, only hardy in Calif. and the Gulf states. The hardiest seems to be C. Macnabiana, which will stand many degrees of frost in a sheltered position; also $C$. macrocarpa, $C$. Avizonica, $C$. sempervirens, funebris and torulosa are of greater hardiness than the others. They stand pruning well, and some species are valuable for hedges, $C$, mac. rocarpa being especially extensively planted for this purpose in Calif. The Cupressus seems to be less particular in regard to soil and situation, but prefers a deep, sandy-loamy soil. For prop., see Chamacyparis. The young plants should be removed several times in the nursery to secure a firm root-ball, otherwise they will not bear transplanting well. Monogr. by M. T. Masters in Journ. of Linn. Soc. 31:312-351 (1895).

Index: Arizonica, 5; Benthami, 6; Corneyana, 7; fastigiata, 1; funebris, 9 ; Goveniana, 4 ; Guadalupensis, 2; horizontalis, 1; Knightiana, 6; Lambertiana, 2; Lausoniana, see Chamæcyparis ; Lindleyi, 6 ; Lusitanica, 8 ; Macnabiana, 3 ; macrocarpa, 2 ; majestica, 7 ; sempervirens, 1 ; torulosa, 7 .

A. Branches and branchlets erect or spreading; branchlets short and usually rather stout.

B. Cones 1-11/2 in. across, with 8-14 scales.

1. sempérvirens, Linn. Tree, to $80 \mathrm{ft}$., with erect or horizontal branches and dark green foliage: lvs. closely appressed, ovate, obtuse, glandular: cones oblong or nearly globose; scales 8-14, with a short boss on the back. S. Eu., W. Asia. Var. fastigiata, Beissn. ( $C$. fas tigiata, DC.). With erect branches, forming a narrow, columnar head. The classical Cypress of the Greek and Roman writers, much planted in S. Eu. Var. horizontalis, Gord. (C. horizontalis, Mill.). Branches horizontally spreading, forming a broad, pyramidal head.

2. macrocárpa, Hartw Monterey Cypress. Tree,

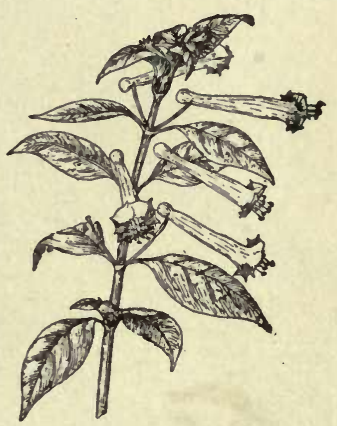

608. Cuphea ignea $(\times 1 / 8)$. 
to $40 \mathrm{ft}$., occasionally to $70 \mathrm{ft}$., with horizontal branches, forming a broad, spreading head: branchlets stout: lvs. rhombic ovate, obtuse, closely appressed, not or obscurely glandular, dark or bright green: cones globular or oblong; scales 8-12, with a short, obtuse boss on the back. Calif., south of Bay of Monterey. S.S. 10:525. P.F.G I., p. 167. F.S. 7, p. 192 (as C. torilosa). G.C. III. 22:53. Gn. 53, p. 219. G.F. 7:245. Var. Crippsi, Mast. Lvs. spreading, light glaucous. A juvenile form. Var. fastigiata, Knight. Of narrow, pyramidal, fastigiate habit. Var. Guadalupénsis, Mast. (C. Guadalupénsis, Wats.). Branches spreading: lvs. very glaucous: cones subglobose. Guadalupe Isl. G.C. III. 18:62. Var. Lambertiana, Mast. (C. Lambertiàna, Carr.). Dark green form with spreading branches. Var. lutea, Hort., has yellow foliage.

BB. Cones 1/2-1 in. across, with 6-8 scales.

3. Macnabiàna, Murray. Fig. 609. Shrub with several stems, or small tree, to $20 \mathrm{ft}$., forming a dense,

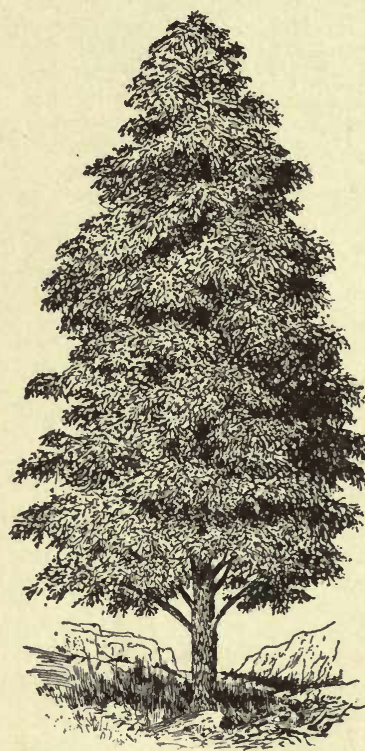

609. Cupressus Macnabiana.

From a cultivated tree. pyramidal head: Ivs. ovate, obtuse, thickened at the apex, glandular, dark green or glaucous: cones oblong, $3 / 4-1$ in. high ; scales usually 6 , with prominent conical and curved bosses on the back. Calif. S. S. 10:528. R.H. 1870, p. 155 . G.C. III. 9:403.

4. Goveniàna, Gord. Tree, to $50 \mathrm{ft}$, with slender, erect or spreading branches, forming a broad, open or pyramidal head: branchlets slender : lvs. ovate, acute, closely appressed, inconspicuously glandular: abundant staminate fls. in spring : cones subglobose or oblong; seales 6-8, with short, blunt bosses. Calif. S. S. 10:527. Var. compácta, André. Of compact, pyramidal habit. K.H. 1896 , p. 9. Var. glaùca, Carr., with glaucous, and var. viridis, Carr., with bright green foliage.

5. Arizónica, Greene. Tree, to 40, rarely to $70 \mathrm{ft}$., with horizontal branches, forming a narrow, pyramidal or broad, open head: branchlets stout: Ivs. ovate, obtuse, thickened at the apex, inconspicuously glandular, very glaucous: cones subglobose, $3 / 4-1$ in. across; scales 6-8, with stout, pointed, often curved bosses. Ariz., Calif. S.S. $10: 526$. G.C. III. 18:63.

6. Benthami, Endl. Tree, to $70 \mathrm{ft}$, with horizontal branches, forming a pyramidal head: branchlets slender: lvs. ovate-obtuse or acute, keeled and somewhat thickened at the apex, inconspicuously glandular, bright green: cones globular, $1 / 2-3 / 4$ in. across; scales $6-8$, with short-pointed bosses. Mex. Var. Líndleyi, Mast. ( $C$. Lindleyi, Klotzsch). Branchlets regularly arranged, of nearly equal length : cones small, with small-pointed bosses. Var. Knightiàna, Mast. Branchlets very regularly arranged, fernlike, drooping, glaucous: cones with stout, conical-pointed bosses. G.C. III. 16:669.

AA. Branchlets slender, more or less pendulous : lvs. usually acute and keeled, not thickened at the apex: cones about $1 / 2$ in. or less across (see also $C$. Benthami).

7. toruldsa, Don. Tall, pyramidal tree, to $150 \mathrm{ft}$., with short, horizontal branches, ascending at the extremities: branchlets slender, drooping: lvs. rhombic-ovate, acute, appressed or slightly spreading at the apex, bright or bluish green: cones globular, nearly sessile, about $1 / 2$ in. across; scales 8-10, mucronate. Himal. Var. Corneyàna, Mast. (C. Corneydna, Knight). With distinctly pendu- lous branches: cones oblong, larger. Var. majéstica. Gord. (C. majéstica, Knight). Of more vigorous growth, with drooping branchlets, greyish green.

8. Lusitánica, Mill. Tree, to $50 \mathrm{ft}$., with spreading branches and more or less pendulous branchlets: lvs. ovate, acute, glaucous : cones pedicelled, about $1 / 2$ in. across, covered with glaucous bloom; scales $6-8$, with conical pointed bosses. Habitat unknown; much eult. in southwestern Eu. G.C. III. 10:761.-With several varieties.

9. funèbris, Endl. Tree, to $60 \mathrm{ft}$., with wide-spreading, pendulous branches and branchlets, branchlets slightly flattened: lvs. deltoid-ovate, acute, light green, often slightly spreading at the apex: cones short, peduncled, globose, about $1 / 3$ in. across ; scales 8 , with a short mucro. China. P.F.G. I. p. 47, fig. 31. G.C. 1850:439. F.S. 6, p. 91 .

C. Oalifornica, Carr.=C. Goveniana.-C. Cashmeriàna, Hort. $=\mathrm{C}$. torulosa $-O$. élegans, Hort. $=\mathrm{C}$. Benthami, var. Knightjana.-C. ericoides, Hort. $=$ Thuya orientalis, var. ericoides. $-O$. glandulòsa, Hook. = C. Macnabiana.-O. glaùca, Lam.=C Lusitanica. -O. Hártwegi, Carr. = C. macrocarpa. - C. Kar winskydna, Regel=C. Benthami.-C. Nepalénsis, Loud. $=\mathrm{C}$. torulosa.- $O$, péndula, L'Her. $=\mathrm{C}$. Lusitanica. - O. péndula, Staunt. $=$ C. funebris. $-C$. Sinénsis, Hort. $=$ C. Lusitanica. $-O$. thurifera, HBK. Tree with spreading branches: lvs. oblonglanceolate, upright-spreading, not closely appressed : cones globose, about 1 in. across, with slightly mucronate scales.O. thurifera, Auth. $=$ C. Benthami.

CURCULIGO (Latin, curcu?io, weevil ; referring to the beak of the ovary). A marylliddcece. This genus contains an uncommon foliage plant with the habit of a young palm and a curious floral structure. The genus is closely related to Hypoxis, but differs in its succulent indehiscent fruit, and because in many species the ovary has a long beak which looks like a perianth tube, but this beak is always solid, and bears upon its summit the style, which is in the center of the perianth. The following species is grown south and north, being used by florists for vases, jardinieres, and general decorative work, and also used outdoors in summer. It is of easy culture, but requires perfect drainage, and is prop. by suckers or division.

The Curculigos are exceedingly ornamental plants for large greenhouses, where a high temperature is maintained. To have them looking their best they should, if possible, be planted out in a bed, where they will attain a height of 5 feet. Their gracefully arching leaves are so constructed that they move continually from side to side with the slightest movement of the air. The variety variegata is one of the best variegated-leaved plants. While not so robust as the green form, it is more adapted to pot-culture. The soil should be two parts loam and another of rotted cow-manure and sand. Drainage must be carefully arranged, as the plants need an abundance of water. The green-leaved kind stands the summers well in the neighborhood of Washington, if protected from the sun and afforded an abundant supply of water.

Propagation is by division. The pieces, before potting, will make new roots rapidly if placed in the sand bed of a warm propagating house for a few days.

recurvata, Dryand. Height $2 \frac{1}{2} \mathrm{ft}$. or more: root tuberous: lvs. from the root, 1-3 ft. long, 2-6 in. wide, with a channelled stalk one-third or one-fourth the length, the blade lanceolate, recurved, plated: scapes about as long as the leaf-stalks, covered with long, soft brown hairs, recurved at the end, bearing a head of drooping yellow fls., each $3 / 4$ in. across : bracts one to each fl., and about as long. Trop. Asia, Australia. B.R. 9:770. Var. striata, Hort., has a central band of white. Var. variegatta, Hort., has longitudinal bars of white.

$$
\text { G. W. Oliver and W. M. }
$$

CóRCUMA (Arabic name). Scitaminacea. A much neglected group of curious and showy warmhouse herbaceous plants with great spikes composed of large concave or hooded bracts, from which the flowers scarcely protrude their gaping mouths. These fleshy bracts are perhaps the showiest feature of the plant, the topmost ones being colored with gorgeous tropical hues. One species was once advertised by John Saul, but all the others mentioned below are equally interesting. These 
curious subjects are almost unknown in American conservatories, but with the spread of private greenhouses in America they will surely be grown, at least in some of the finer fanciers' collections. The following cultural

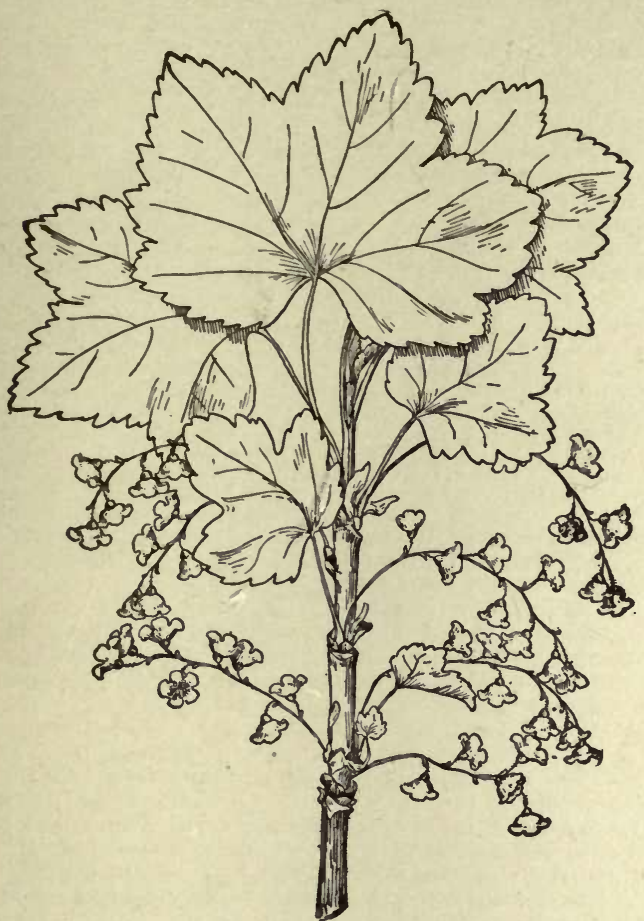

610. Common Currant-Ribes rubrum, in bloom $\left(X_{1}^{1 / 2}\right)$.

points are taken from B. M. 4435 , where it is said that these plants are of ornamental appearance, even when not in flower. In spring the tubers should be deprived of last year's mold and repotted in a fresh mixture of light loam, leaf-mold and turfy peat, the pots being well drained, and placed in a warm pit or frame in bottom heat. Water should be given sparingly until after the plant has made some growth. The young roots are soft and succulent, and are likely to rot if the soil remains wet for a long time. After flowering, the leaves soon show signs of decay, and water should be gradually withdrawn. During the resting period the soil should not be allowed to get dust-dry, or the tubers are likely to shrivel. The plants are propagated by dividing the tubers in spring. The flowers of Curcuma are large and gaping, hooded above, and with a 3 -toothed lower lip. In the throat are seen 2 teeth, which are the tips of the anthers. Curcumas are essen. tially tropical plants, and the great difficulty is said to be to maintain sufficient heat while allowing them enough air.

cordàta, Wall. Lrs. $1 \mathrm{ft}$. long, sheathing, ovate-cordate, acuminate, the same color on both sides, obliquely penninerved : bracts in a cylindical spike, the upper part forming a sterile portion called a coma, which is a rich violet, with a large blood-colored spot: fls. yellow, with a pink hood. Burma. B. M. 4435. - This is now referred to $C$. petiolata, Roxb., but B. M. 5821 seems at least horticulturally distinct, with its rose-pink bracts.

C. albiflora. Thwaites, differs from the others here described in having its spikes sunk below the lvs., instead of standing high above the lvs., and all the bracts have fls., while the others have a sterile portion of the spike which is brightly colored. In this species the spike is short and green and the fs. are prominent and white, Ceylon B.M. and green and làsica, Hook, f, has itsupper bracts soft, rosy pink and the fls làsica,Hook. f., has its upper bracts soft, rosy pink and the fls.
pale yellow. Australia. B. M. 5620.-C. Roscoeana, Wall., has. a long and splendid spike, with bracts gradually changing from green to the vividest searlet-orange: fls. pale yellow. Burma. B. M. 4667.-C. Zedoària, Roxb., has the upper bracts white, tinged with carmine, and handsomely-variegated lys. which, with the green of the lower bracts and the yellow of the flowers, makes a striking picture of exotic splendor. Himalayas. B.M. 1546 .

W. M.

CURLED LEAVES are often caused by aphids or plant lice. For remedies, see Spraying. The leaf-curl of the peach is a fungous disease. See Diseases.

\section{CURMERIA. All referred to Homalomena.}

CURRANT. Four species of Currant are known to American gardeners as fruit-bearing plants. Ribes rubrum (Fig. 610) includes all the red and white varieties. This species is found wild both in Europe and North America. Ribes nigrum (Fig. 611), the European black Currant, although well known in America, has never become generally popular, although it is much prized by the foreign population. Ribes Americanum (Fig. 612), more commonly known as Ribes floridum, is the wild black Currant of America. It is very similar in character to the European black Currant, and is now and then transferred to gardens. Ribes aureum (Fig. 613 ), oftener grown for ornament, has also been planted for fruit, having been sold from time to time under various varietal names, the most recent being the Crandall. See Ribes. To the commercial fruit-grower only the first of these species is of great importance. It is a native of cool climates, and its profitable culture is confined to northern latitudes. It does not thrive in the Gulf states and, except under irrigation or in specially favorable locations, makes but a partial success in the drier region of the Plains.

Both experience and the natural habitat of the plant indicate that a cool, moist soil is best adapted to its growth. Strong, moist loams, with a considerable admixture of clay, are preferable. Even a stiff clay, well drained and in good tilth, will give good results. In small supply for the home garden, it may be grown in almost any soil. A cool northern exposure or partial shade is always desirable, and the more unfavorable the soil, or the more nearly does the location approach the southern range of adaptation, the more important does this become. For this reason western growers often find the best results to come from planting in orchards, and

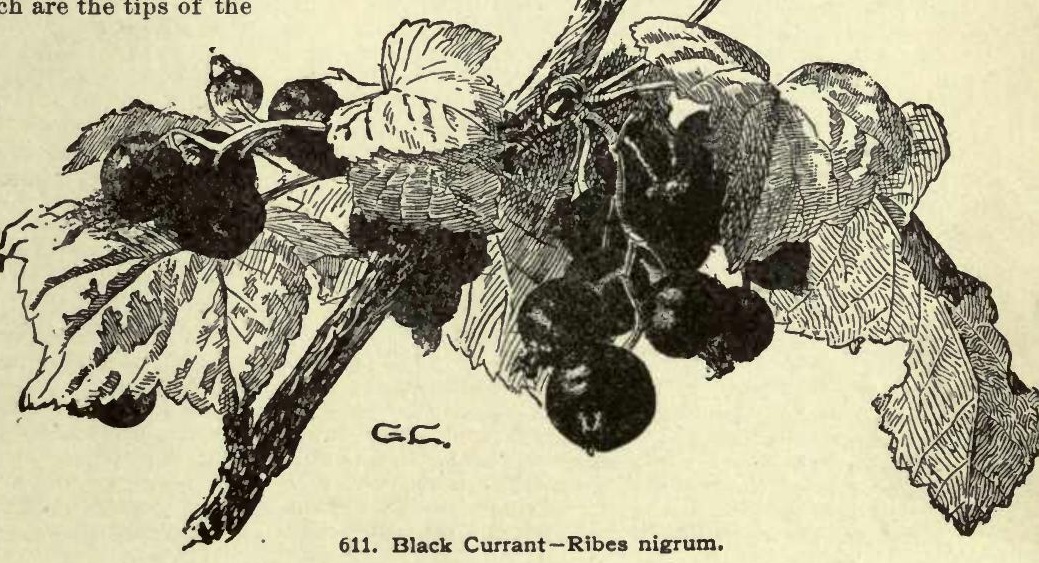

611. Black Currant-Ribes nigrum. 
the home grower may attain the same end by utilizing the north side of buildings or fences. Elevation may aid in offsetting the unfavorable influence of lower latitude. It is an extremely hardy fruit so far as cold is concerned, but cannot endure continuous high temperature.

The Currant needs a rich soil and an abundance of plant-food. It will endure much neglect, but responds quickly to liberal treatment. Stable manure, applied in the fall, is excellent, and this may be supplemented with applications of potash, which will improve the quality of the fruit.

Propagation is best effected by means of long hardwood cuttings (Fig. 614), taken either in fall or spring. In nursery practice they are commonly taken about September 1 , as soon as the leaves fall. The leaves are sometimes stripped from the plants a week or so before taking the cuttings, if they have not already fallen. The cuttings may be planted at once, or tied in bundles and buried upside down, with 2 or 3 inches of soil over the butts. This is thought to favor the production of the callus and to aid the formation of roots. At the approach of cold weather, they may be taken up and planted in nursery rows and covered with a mulch of soil or other material during the winter, this mulch being raked away to expose the tips early in spring. Planting may be delayed until spring, the bundles being taken up and stored in sand or moss in the cellar, or being more deeply covered and allowed to remain where they are. The commoner practice is to plant the cuttings in nur sery rows soon after they are taken. They are said to root more quickly if packed in damp moss a week or two before planting. Mulching of some sort is essential during the winter. Probably nothing surpasses the soil itself for this purpose, certainly not in the drier climate of the Plains. If the cuttings are kept until spring,

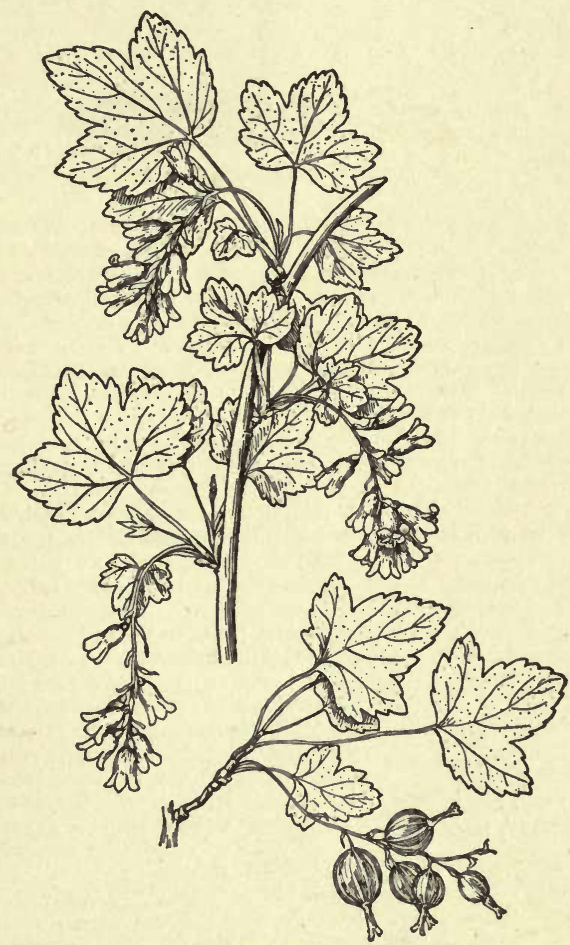

612. Native Black Currant-Ribes Americanum ( $X 1 / 3)$. The fruit is immature.

planting must be done very early, as growth begins at a low temperature. This makes spring planting undesirable in nursery practice. Cuttings vary in length from 6 to 10 inches, according to soil and climate; the drier the climate and the lighter the soil the longer should the cutting be. In planting, only 1 or 2 buds are left above the surface, and the soil should be pressed

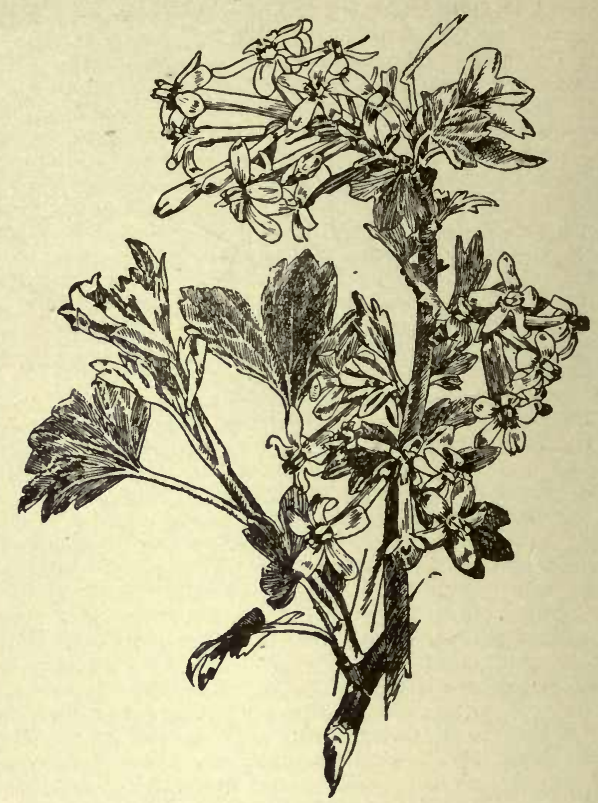

613. Buffalo Currant $(\times 1 / 2)$.

firmly about the base. Rich, moist soil should be selected. A former practice was to cut out all lower buds in order to insure a tree form of growth. This is seldom practiced now, and never for commercial planting. Single-eye cuttings under glass, greenwood cuttings and layers may be employed, but have little to recommend them. Seeds may be used as a source of new varieties, and are best sown or stratified as soon as taken from the pulp.

For the final planting either 1- or 2-year-old plants may be used, set at distances varying to suit the convenience of the cultivator. Four by 6 feet is a convenient combination, allowing cross cultivation at intervals. The land should be in fine, mellow tilth as deep as plowed, and if the underlying layers are hard and impervious, it should be subsoiled. Setting is most conveniently done by marking the land in each direction, plowing furrows one way and planting at intersections. The soil should be closely firmed about the roots, with a loose layer left at the surface to act as a mulch. Where fall planting succeeds it is desirable, since the Currant starts so early into growth in the spring. In many parts of the country fall planting is too uncertain, while spring planting, if done early enough, is always safe.

Subsequent tillage should be frequent but shallow, as the roots run near the surface and are easily injured by deep cultivation. Good results are obtained by mulching, which is sometimes more convenient in garden culture. Refuse material of any sort may be used; even coal ashes, especially on heavy soil, give good results. Mulching is seldom, if ever, desirable in commercial work.

Pruning is simple, but important. Fruit is borne on both old and young wood, but the best of it is near the base of 1-year-old shoots and on short 1-year-old spurs. The younger the wood the finer the fruit, but a fair supply of old wood must be left to insure productiveness. From 4 to 8 main stems are desirable, and these should be frequently renewed. No wood over three years old should be allowed to remain. Superfluous young shoots should be cut away, though the buds at their base may be left to develop fruit-bearing spurs. Shortening-in vigorous, straggling shoots may be called for, especially with young plants, but the most important thing is a judicious thinning out of the old wood, and 
replacing it with young (Fig. 615). The older plan of training to a tree form (Fig. 616) gave less productive plants, more subject to damage from the Currant borer, with no opportunity for renewal. Experiments in thinning the fruit by clipping off the outer end of the clusters have shown an increase in size and in yield.

The fruit should be picked when dry, taking especial care to prevent crushing the berries or tearing them from the stems. If properly picked it stands shipment well, but if carelessly picked it will quickly spoil. For shipping purposes it must be picked while still hard and firm, though for home use or near market it will be better if allowed to remain longer, especially for dessert use. If protected with netting, it will remain on the bushes until autumn. The fruit is commonly marketed in quart baskets, shipped in crates, like any other berries, though the 9-pound grape basket is now largely used. This is a convenient package, both for the shipper and the consumer.

Plantations may be kept in bearing for many jears with good care, liberal feeding and continuous renewing of the woud, but practical growers generally find it advisable to replant after eight or ten years of fruiting. The cost of replanting is light, and is more than repaid by the advantage of young, vigorous plants in fresh soil. Yields vary greatly. Many growers doubtless do not average 50 bushels per acre, while others may secure as high as 250 bushels. With good care Currants should yield from 100 to 150 bushels per acre, though even this amount will be obtained only by good culture and careful attention to details. In garden culture 2 to 4 pounds per bush may be expected, though many neglected plant. scarcely yield as many ounces. Under favorable conditions they are usually a profitable crop, though, like all other fruits. they are subject to fluctuations in price and market demands.

Red varieties are most profitable. Some of the white sorts are sweeter, but find little demand in market. Victoria is one of the most popular all-round varieties. Cherry and Versailles are probably more largely grown than any others. Fay is capricious, succeeding remarkably well in some locations, but proving unsatisfactory in others; its habit of growth is straggling and undesirable. Red Dutch, though small, is still highly prized on the Plains; Prince Albert, a very productive late variety, is popular with canners and for jelly. Among newer varieties the Wilder is promising. White Grape and the newer White Imperial are popular white varieties. Black Currants are little grown in the United States but are popular in Canada. Black Naples (Fig. 611) is the most popular kind.

The best-known insect enemy is the imported Currant worm (Pteronus Ribesii), which never fails to strip the leaves from neglected bushes throughout the eastern United States, though as yet unknown on the Plains. It begins feeding on the clusters of leaves close to the ground,

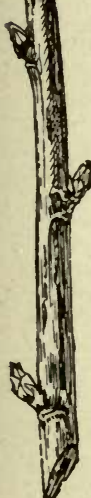

614.

Currant cutting. and if taken in time may be poisoned with arsenites, though powdered hellebore, at the rate of a teaspoonful to a gallon of water, is the common remedy, and the one which should be used after the fruit sets and

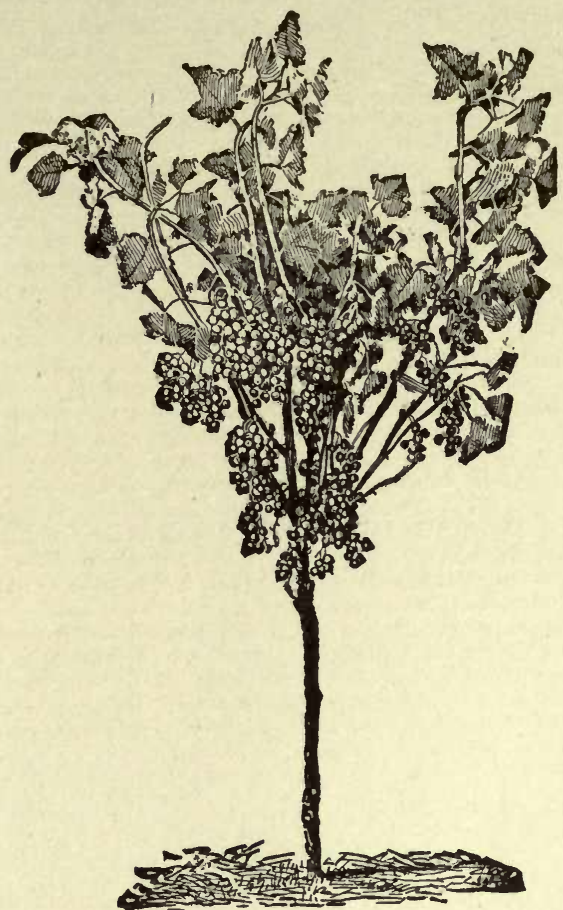

616. Tree-form training of Currant.

the insects have scattered over the bushes. The imported and native Currant borers also cause damage. They can only be controlled by cutting out and destroying infested canes early in spring, before the perfect insects emerge. The Currant fly (Epochra Canadensis) sometimes causes serious injury to the fruit, depositing its egg just beneath the skin, where the presence of the larva causes the fruit to turn red and fall prematurely. No practicable remedy has yet been suggested. Among fungous diseases, there are several which prey upon the leaves, causing them to fall prematurely, but they all yield to thorough treatment with fungicides. The Currant tubercle, a disease which has recently proved injurious in New York and New Jersey, threatens to be a serious enemy and a difficult one to fight. It is first shown by wilting of the leaves and premature coloring of the fruit. The clusters are small and straggling, and, together with the leaves, soon shrivel and fall, which is followed by the death of the canes. Digging and burning affected plants is the only remedy thus far suggested. The disease may be transmitted in apparently healthy cuttings, so that fields known to be affected should not be used as a source from which to propagate.

The treatment of black Currants does not differ materially from that of reds, except that the plants, being larger, require somewhat more room. The fruit, though possessing a most unpleasant odor and flavor, becomes agreo.
615. To illustrate the pruning of a Currant bush.

The old cane, $a$, is to be cut away. The straight new canes at left are to remain. 
able if scalded for a few minutes in boiling water, and then transferred to fresh water for cooking. It is much esteemed by those who have learned to use it, and is credited with medicinal qualities of value in bowel and throat affections. The plants are exempt from attacks of the Currant worm.

Fred W. Card.

Cđ́đCUTA (origin of name obscure). Convolvuldcex. DODDER. A genus of degenerate parasitic twiners, bearing clusters of small fls. They are leafless annuals, with very slender yellow or red stems, which become attached to the host-plant by means of root-like suckers. The seeds fall to the ground and germinate in the spring. As soon as the young shoot finds an acceptable host, the root dies and the plant becomes parasitic. Failing to find a host, the plant dies. Dodders are common in low, weedy places. Some species are also serious pests, as the Clover Dodder and Flax Dodder. One of the common species ( $C$. Gronovii, Willd.), of low grounds, is shown in Fig. 617.

CUSHAW. One of the many names of Cucurbita moschata.

\section{CUSTARD APPLE. Species of Anona.}

CUT-FLOWER INDUSTRY IN THE UNITED STATES. Fifty years ago it would not have been possible to purchase Cut-flowers during the winter season in any of the large cities of this country. Today there is scarcely a village of 2,000 to 3,000 population that does not boast of its florist, whose revenues are largely augmented by the sale of Cut-flowers. Millions of dollars are invested in the cultivation and sale of Cut-flowers in the neighborhood of the large cities of the United States. The growth and evolution of the business has been very rapid in the past 25 years. From 1860 to 1875 the camellia was the most valued of all Cut-flowers, either for personal adornment or bouquets, as much as $\$ 1, \$ 2$ and even $\$ 3$ having been obtained for a single flower at the holiday season. At the present time they are almost forgotten, and are only to be found in private collections and in the south, where the plants will live out during the winter season. The principal flowers forced at that time, in addition to the camellia, were daphne, bouvardia, abutilon, nasturtium, callas, sweet alyssum, poinsettia, carnations and a fow LaMarque, Bon Silene and Safrano roses. The taste was for set designs. All flowers were picked with short stems, or none at all, only the open portions of cluster flowers being taken, and the buds left to open. These small pieces were bound with wire to wooden sticks for basket work or to broom corn straws for making into bouquets. The popular table design was called a pyramid. It consisted of a number of bouquets each with one camellia in the center and a single row of smaller flowers around, backed up with lycopodium green. The smaller bouquets were then arranged in a wire frame, the sticks on which they were made serving to hold them in the desired position. The top of the pyramid was a bouquet with a calla lily in the center. These table pieces frequently cost from $\$ 35$ to $\$ 75$, and sometimes $\$ 100$ was asked for a particularly fine design. The small bouquets were distributed to the guests at the close of the entertainment.

Only small quantities of roses were forced for winter cutting at this time, a few florists in Boston and New York being engaged in their cultivation in the same houses with other flowers. Competition and a demand for better buds, together with the good prices obtained for the best, caused growers to give the "queen of flowers" more attention, and the result was that the rose steadily grew in favor and people began to wonder what they saw in the camellia to admire. A demand for larger roses than the small Teas resulted in a trial of some of the Hybrid Remontants. General Jacqueminot was found to force well and soon became a great favorite, bringing from $\$ 1$ to $\$ 2$ a bud for the first cutting. The beautiful yellow Marechal Niel was also forced. The flowers sold well, but it was scarcely prolific enough to be profitable, and the advent of the yellow Tea Perle des Jardins, an Everbloomer, very prolific and of easy cultivation, soon drove it from the market. The next rose sensation, and the most important addition that has been made to American forcing roses even to the present day, was the introduction of the Catherine Mermet. This beautiful variety, which sprang into great popularity at once with the flower-buying public, was found very profitable by the growers, who, by careful cultivation and the incentive of the high prices realized for choice flowers,

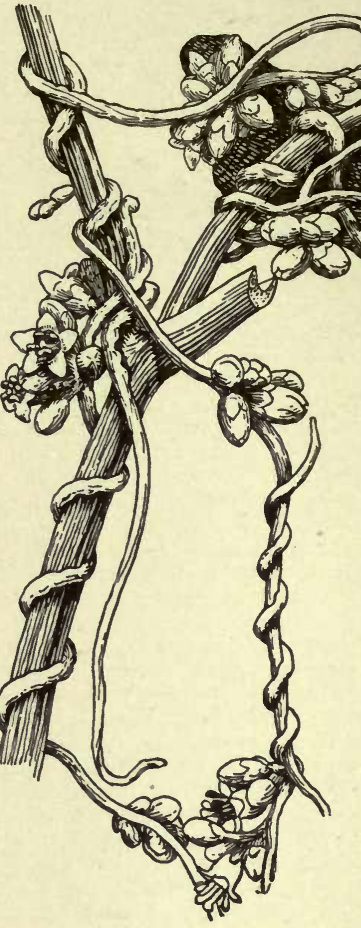

617. Dodder,

twining on its hostCuscuta Gronovii

soon elevated the standard of cut roses to a higher level, and attracted new capital to what had now become a thriving and lucrative business. While so famous in itself, Catherine Mermet will, however, probably be longer remembered as the parent of those truly grand Teas now so universally grown, the Bride and Bridesmaid, the standard pink and white roses of to-day. Many varieties for which special claims were made have been introduced from time to time, but, for the most part, they have proved vexatious and expensive experiments. Next to the Catherine Mermet in importance is the American Beauty (Mme. Ferdinand Jamin), the finest of all the forcing roses. The introduction of this variety by the Fields Brothers, of Washington, produced a great stir in rose circles. Fine as it appeared at first, however, its after development surprised even the most sanguine, and to-day it stands unrivaled as the most profitable and at the same time the most popular with the wealthy classes of flower-buyers.

While the development of the rose was taking place, the carnation, ever popular, was receiving the attention of the breeder, and new varieties showing great improvement in form, color and productiveness were introduced annually. It was soon found that roses and carnations did not give best results when grown together in the same house. They required different treatment. Roses thrive better in a warmer atmosphere than carnations. Different forms of greenhouse structures were also found necessary. The original means of heating was by brick furnaces and flues. Hot water and steam generated in iron boilers and distributed through pipes, although more expensive to install, were found much more efficient, and withal the most economical plan.

In the early growth of the business the grower was also the retailer. The rapidly increasing demand, however, ushered in the middle man or retail florist, who relieved the grower of his stock as soon as it was ready 
for the market, and enabled him to devote his entire at. tention to cultivation. From this period, the business began its most rapid development, as the more convenient location of the flower stores in the populous centers induced a better patronage and consequent love for flowers, and enabled the grower, by reason of his undivided attention, to produce more perfect stock and increase the productiveness of his plant.

It was soon found that by giving attention to but one kind of flower, better results were obtained, and many rose, violet, and carnation specialists were developed. The success of one grower often induced his neighbors to follow his example. Two or three successful men in a locality gave rumor to the place being, by reason of its soil, climate, etc., particularly adapted for the production of a certain flower, and a colony of such grow ers would soon spring up. Note the violet growers of the Hudson, in New York ; the rosarians of Madison, N. J., and the carnation belt of Chester county, Pa. As the business has developed and grown all over the United States, it has been found that it is not so much in the locality as in the methods of culture that success is attained. With the great expansion of the industry, the handling of the large quantities of flowers thrown on the market became a difficult problem. The Thirtyfourth St. cut-flower market, in New York, originated from the retail dealers meeting the Long Island growers every morning at the ferry. A convenient restaurant opened its doors during inclement weather, where for years a large business was carried on. An association of growers was finally formed, which established, in an adjoining commodious building, a market, which has since been very successful and a great convenience to both branches of the trade.

The wholesale handling of flowers on commission was commenced in New York eity in 1878 , by J. K. Allen. This plan soon became popular, numerous houses were established, and the stock coming to the New York market, particularly that of the large growers, is mainly disposed of through these channels. The excellence of the flowers supplied and the better market of the large cities caused a considerable shipping demand, which provided a much-needed outlet for the immense quantities of stock that at times were greatly in excess of the local needs. With the present complete shipping facilities, together with the improved methods of packing, Cut-flowers are now shipped long distances, arriving at their destination in a satisfactory condition after journeys of from 36 to 48 hours' duration.

The final distribution of the flowers through the avenues of the retail florist engages a considerable number of men in all the large cities of the country. Many of the establishments compare favorably with the finest stores of other lines, while the delivery service, with its fancy wagons and liveried attendants, is especially notable. Great attention is paid to the decorative features of these high-class establishments. Their show windows contain at all times samples of the finest plants or flowers in season, or examples of their artistic arrangement. The evolution of the business during the past twenty years has been gradual, but has moved steadily onward. Wire and sticks have almost entirely, or as much as possible, been displaced by the improved and natural stems of the flowers themselves. The arranged basket of flowers, once so popular as a gift, has now given way to the box of long-stemmed roses or cluster arrangement of the same, to which are added orchids, violets, or other choice flowers, as preferred. The custom of sending flowers to young lady debutantes, which has become fashionable the past few years, has become an important feature of the trade, and atones in a measure for the discontinuance of the ball bouquet, once so popular but now almost obsolete.

Christmas and New Year holidays were at one time equal factors in taxing the florists to the utmost to supply the demand for their goods, but of late years the lst day of January has lost this floral feature, and is no longer considered of importance. The Easter holiday trade has grown, however, from scarcely any business in the early days, to be the most important event of the year ; in fact, with many growers it is the greatest harvest, as almost all their winter season is given to preparing plants and flowers for the Easter demand.
Since the introduction of the Lilium Harrisii, or Bermuda-grown Lilium longiflorum, hundreds of thou sands of these bulbs are forced for this festival. Azaleas are probably next in demand, large quantities being annually imported for forcing. It would be diffi cult to estimate with any accuracy the amount of business transacted by the florists of this country for the Easter festival, but the sum total must be enormous.

The old-time florist was satisfied with one crop from his greenhouses - that of bedding plants for spring planting. During the summer the houses stood empty, and for a large part of the winter contained dormant or semi-dormant stock. The wide-awake grower of to-day never allows any portion of his plant to remain idle even for a week. one crop being arranged to follow another in close rotation.

As flowers are very perishable articles, and depend for their existence on certain conditions of light and heat, there are times when the supply is not sufficient for the demand; and again when the quantity coming into the market is more than can be disposed of at the current rates. Of late years over-production has been the bugbear of the business. Half of the season the market has been over-stocked. Consiznment follows consignment, until the commission houses are at their wits' ends to dispose of them. Here an important factor was introduced. The fakir, or street man, became a customer for job lots at low prices. Through him immense quantities of flowers, for which no other avenue was open, have been sold daily in all the large cities. Their plate glass cases in doorways or by blank walls are to be seen throughout the shopping districts filled, as a rule, with good flowers, with few exceptions.

The principal and most popular Cut-flowers grown in this country are distinctively American. The Bride and Bridesmaid roses are American sports of the Catherine Mermet. The American Beauty, as it is grown here, is vastly different from Mme. Ferdinand Jamin of Europe. The Kaiserin Augusta Victoria and Meteor are European sorts. The carnations grown are of an entirely different type from the European varieties, and are all American seedlings. The evolution that is taking place in this flower is wonderful, as the standard is being so constantly raised that varieties that were considered superior ten years ago are now scarcely known. The American Carnation Society, composed largely of commercial carnation specialists, has done much to advance the quality and general excellence of this superb flower. Chrysanthemums that produce best results here are nearly all of American origin, from plants imported from Japan. New varieties are introduced each year, some of which show improvement and spur hybridizers on to renewed efforts.

The demand for palms and decorative foliage plants has kept pace with that of flowers, if, indeed, it has not taken the lead. The increase in the greenhouse space given up to the growth of palms is at least threefold within the past ten years, and it may be said that the demand exceeds the supply, although the stock is augmented largely each year by importations from Europe. Whole houses are given up to the production of Ficus elastica, which plant is a great favorite with the masses. Great quantities of ferns for table decorations are now used, the little fernery being considered as indispensable as the china to the setting.

The public taste at the present day is mostly for loose arrangements of long-stemmed flowers. Stiff, formal designs are tabooed. The popular funeral emblem is forms of the wreath, which is made with a great variety of flowers, often all of one kind. Loose clusters tied with ribbons, and palm leaves (sago palms) crossed and tied with ribbons and flowers, are also favorites. House decorations are largely composed of long-stemmed roses carnations, etc., placed in vases, but few, if any, set pieces being allowed. Table decorations for dinners are also confined to the use of long-sterumed flowers in vases, and others arranged on the cloth with ferns. Churches are trimmed with palms, plants in flower and long-stemmed flowers in tall vases, all being done, as in other instances, to show, as far as possible, the natural grace of the flower. Bridal bouquets are also arranged loosely, some with shower effect, by means of Howers tied to narrow ribbons; others tied with 


\section{CUTTAGE}

broad ribbons, to be carried in the hand or over the arm. The flowers mostly used are roses and lilies-ofthe-valley. Tastes differ but little in the various cities, there being a similarity in all the first-class work. There is no essentially eastern or western flower. With the possible exception of some varieties of carnations, the assortment of flowers will be found the same the country over. In the census of 1890 Cut-flowers were estimated to make more than one-half of the florist's business. One good book especially devoted to the business has been produced,-the late M. A. Hunt's "How to Grow Cut-flowers."

ROBERT KIFT.

CUTICLE. The outer surface of herbaceous parts of plants. It consists of the outer walls of the epidermal cells. These walls are much thickened and cutinized. Minute waxy rods upon the cuticularized surface of many fruits, such as the grape and plum, give to them their peculiar bloom. The Cuticle is nearly impervious to water. The preservation of fruits depends in large measure upon the retention of moisture by the Cuticle. Cacti and other desert plants have their epidermis remarkably cuticularized.

W. W. ROWLEE.

CUTTAGE. The operation and practice of growing plants from severed parts. A cutting is the gardener's name for a piece of the stem, root, rootstock or leaf, which, if cut off and planted under suitable conditions, will form new roots and buds, reproducing the parent plant. This term is usually given to parts of the stem; a part or the whole of the leaf, when so used, is called a leaf-cutting; a piece of root or rootstock is called a root-cutting. The scales of some bulbous plants, e. g., the lily, can also be used as cuttings. A cion used in grafting might be called a cutting which unites and grows on the roots of another plant. See Graftage. Plants obtained by division or layering are provided with roots before they are detached from the parent plants, and, therefore, are not properly cuttings.

Multiplication by cuttings is a form of bud-propagation in contradistinction to sexual reproduction, i. e., propagation by seeds. It is a cheap and convenient way to obtain plants. All plants cannot be profitably increased by these means. Why they differ we do not know; the gardener learns by experience what species yield a good percentage of healthy plants, and acts accordingly.

The following table will show the different ways in which cuttings are made:

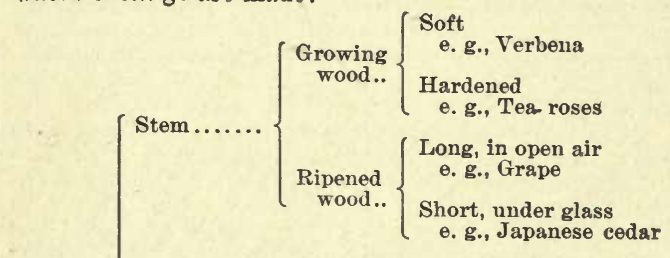

$$
\text { Cuttings }\left\{\begin{aligned}
\begin{array}{l}
\text { Roots or } \\
\text { rootstocks }
\end{array} & \left\{\begin{array}{c}
\text { Short, under glass } \\
\text { e.g., Anemone Japonica } \\
\text { Long, in open air } \\
\text { e. g., Blackberry }
\end{array}\right. \\
\text { Leaf........ } & \left\{\begin{array}{c}
\text { Entire } \\
\text { e.g., Echeveria } \\
\text { Divided } \\
\text { e.g., Begonia Rex } \\
\text { Bulb-scales } \\
\text { e.g., Lilies }
\end{array}\right.
\end{aligned}\right.
$$

(1) Cuttings of Growing Wood.-Fig. 618. These are made either of the soft growing tips, as in coleus, salvia, verbena, etc., or, of the same wood in more mature dition, but by no means ripe, as in tender roses, Azalea Indica, etc. The cuttings of plants like E'uphorbia pulcherrima, erica, epacris, etc., are used in the soft growing state, if a well built propagating house is obtainable; but in an ordinary house, a part of which is used for other purposes, the older and better ripened wood will be more successful. It is generally true that cut. tings of hardened wood will always root, although they require more time and may not make the best plants, but it is not true that cuttings of the soft wood will always root. In many cases, as in the rose, they succumb before they callus, much less produce roots. In plants of rapid growth and good vitality, the proper condition of the soft growing wood for cuttings can be determined

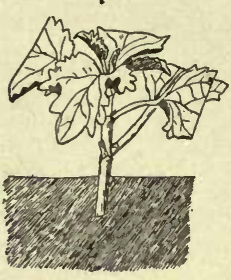

618. Cutting of soft (Coleus.) growing wood. by its readiness to snap, not bend, when bent back: the hardened wood is in the right state as long as it continues to grow.

The treatment of cuttings in both classes is practically the same. They should be planted in sand under glass. Large establishments have one or more houses set apari for this and similar purposes. In smaller places a propagating bed or bench can be made at the warmest end of the warmest house. It should be placed over the pipes where they leave the boiler, and, in order to secure bottom heat when needed, the space between the bench and the floor should be boarded up, having a trap door to open on cold nights (Fig. 619). Cutting-frames inside a greenhouse are also shown in Fig. 620 . Side partitions should also be provided to box in all the heat from the pipes under that part of the bench. Good dimensions for such a bed are, width 3 feet, length 6 feet or any multiple of 6 , thus making it simple to use a hotbed sash when confined air is wanted. The depth of the frame should be from 6 to 10 inches in front and from 12 to 15 inches behind. The bottom of the bed may be either wood, slate or metal and should be well drained: place a layer of potsherds first, then moss, and from 2 to 3 inches of sand on top. The sand should be clean, sharp and well compacted: before planting it should be watered if at all dry. It is sometimes advisable to bave the bed filled with moss (sphagnum), into which pots or boxes containing cuttings are plunged: the moss should be moist, neither too wet nor dry, and well packed.

In many cases, when large quantities of one sort of cuttings are to be planted, the ordinary greenhouse

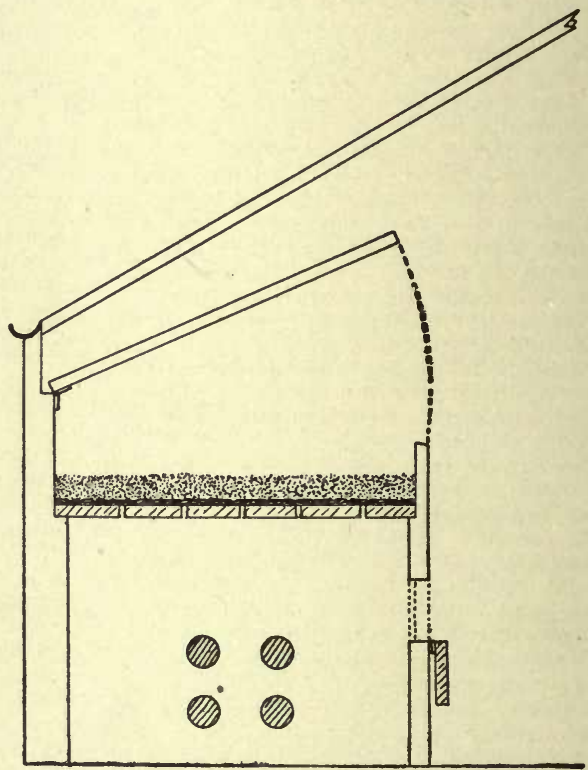

619. Section of propagating bed.

Shows four pipes beneath, the door on the side, and the frame eover.

bench covered with sand is sufficient (Fig. 621). Other forms of propagating beds are shown in Figs. 622, 623, 624. See, also, Bailey's Nursery Book, 3d ed., pp. 44-53. The wood for cuttings should be fresh, and precau. 
tions should be taken to prevent wilting during making and planting: if the weather is hot, sprinkle the floor and bench of the work room: if they are delicate, and exposed for an hour or more, lay them between folds

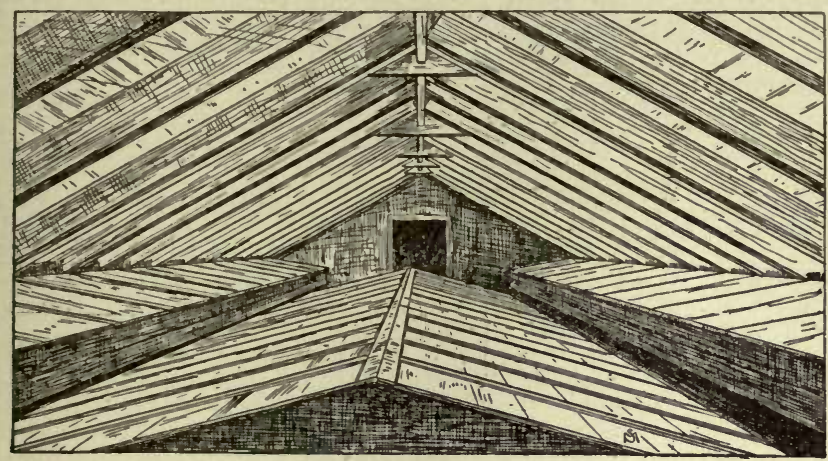

620. Permanent propagating frames in a greenhouse. or with a fine rose; the forcible application of water compacts the sand, thus excluding air, and prevents unlue wilting.

Give shade immediately, using lath shutters outside, or paper or cloth screens within, and attend to this very carefully for the first few days. Lift the shades early in the afternoon, and put them on late in the morning, but keep them on during the middle of the day, thus gradually accustoming them to full light.

Cuttings should never suffer from dryness. The sand should always be kept moist to the verge of wetness. Ventilation should be given on bright days, but all exposure to draft aroided. A good temperature for propagating is from $60^{\circ}$ to $65^{\circ} \mathrm{F}$, increasing these figures for tropical plants and reducing them for more hardy kinds. It is debatable whether bottom heat and confined air are advisable for cuttings of growing wood. The older gardeners employed both, but now neither is commonly used, except for tropical plants, like croton, or when a constant succession of erops of cuttings is required. There is no doubt that with this aid cuttings will root more quickly, but more skill and care are required, neglect bringing on fungous disease, which results in unhealthy plants or total loss. If bottom heat is used, the average temperature of the bed should be $10^{\circ}$ or so above that of the air, but less will suffice. Indeed, in beds made as described above, in good weather the sand is enough warmer than the greenhouse atmosphere to answer every purpose. If a confined air is used, ventilation and shading must be carefully looked after, and precautions taken against the accumulation of condensed moisture within the bell-glass or frame.

Sand is the medium eommonly employed for the rooting of cuttings, selecting the coarser kinds for plants like geraniums and finer for heaths. Brick dust and powdered charcoal are sometimes recommended, and "Jadoo fiber" is now on trial. Sphagnum is useful in rooting Ficus elastica, the base of the cutting being wrapped in a ball of moss and plunged in a bed of moss. English ivy, oleander and other plants can be struck in water, but this method is cumbersome. Peter Henderson's saucer method is valuable in hot weather : the cuttings are planted in sand, kept saturated and in Olea fragrans, Daphne odora, heath, etc., only enough for planting. Use a sharp knife; but scissors are handy for trimming and sometimes for making cuttings of those small wooded plants which root easily.

The cuttings of plants with milky juice should be washed before planting. Sometimes the lower ends are allowed to dry for several hours, the tops being protected against wilting. Large and succulent cuttings, e. g., of pineapple, cotyledon, cactus, etc., should be dried before planting by letting them lie on the surface of the propagating bed for several days, or they may be planted in dry sand at first. Under these conditions a callus forms which tends to prerent decay; but the wood must not shrivel.

Peter Henderson has introduced a method which is likely to increase the percentage of rooted plants, and which is desirable in slow-growing varieties, like the tricolor geraniums. He adrises that the cutting should be partly severed and allowed to hang to the parent plant for a few days; this results in a partial callus, or even roots, before the cutting is entirely removed.

In planting cuttings, use a dibble or open a V-shaped trench. Never thrust the cutting directly into the soil. Plant deep enough to hold the cutting upright and no deeper, making due allowance for the sand settling; the distance apart should be just enough to prevent them from pressing against each other. It must be remem-

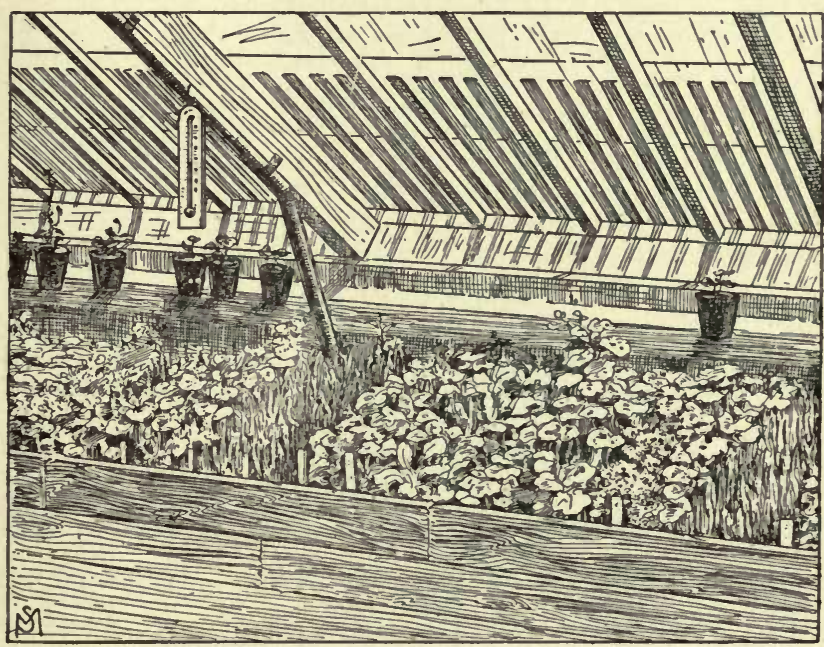
bered that they stay in the bed only until rooted. As soon as growth begins, they are potted off. When the cuttings are inserted, the sand should be firmly pressed about them, and they should be watered with a syringe

621. Cutting bench shaded with lath.

fully exposed to the sun. Large cuttings can be planted singly in 2- or 3 -inch pots, the pots then being plunged in the cutting bed. In such cases some well rotted leafmold, less than one-half, can be added to the sand. 
Although it is tender plants, in the main, which are propagated by cuttings of growing wood, the above methods can be practiced advantageously with some

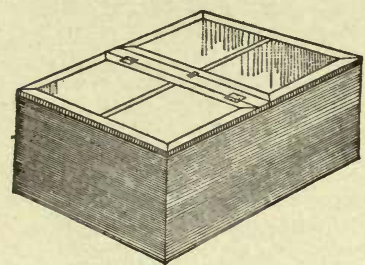

622. Propagating-box. hardy plants. The wood. which is invariably more successful if hardened, is obtained either from plants forced for this purpose, e. g., spirea, Deutzia gracilis, etc., or it is gathered in June and July out of doors, e. g., lilac, hydrangea, etc. Cuttings of growing wood should be potted in 2- or 3-inch pots, in a rather sandy soil, when the roots are from $1 / 4-1 / 2$ inches long. It is sometimes good economy to box them, i. e., plant them a few inches apart in flats, when not immediately required.

(2) Long Cuttings of Ripened Wood in Open Air.This method is used to propagate many hardy trees and shrubs, e. g., willows, currants, grapes, forsythia, etc. Wood of the current year's growth is gathered in autumn or early winter, before severe frost, and either stored in a cool cellar, covering with moss or fresh earth to prevent drying, or immediately made into cuttings. These (see Fig. 626) should be made 6 inches or more long and should contain at least 2 buds. It is not neces

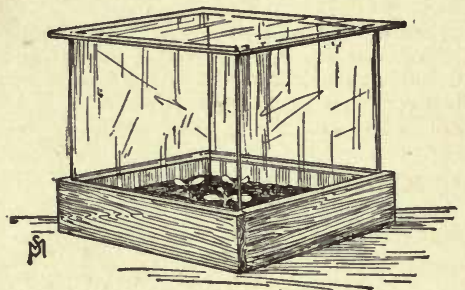

623. Small propagating-box, adapted to a window.

sary to cut to a bud at the base, but the upper eut should be just above one. They should be tied in bundles with tarred rope, taking care to have them lie "heads and tails" to facilitate planting, and with the butts on the same level, to promote callusing. They should then be buried in sandy soil, with the butts down and protected against frost. In early spring they should be firmly planted in $\mathrm{V}$-shaped trenches in well prepared soil : set an inch or so apart, with the rows 1 or $1 \frac{1}{2}$ feet apart. The upper bud should be just at the surface ; to prevent suckers the lower buds may be removed. In autumn they should be dug, graded and heeled-in for winter. Some varieties will

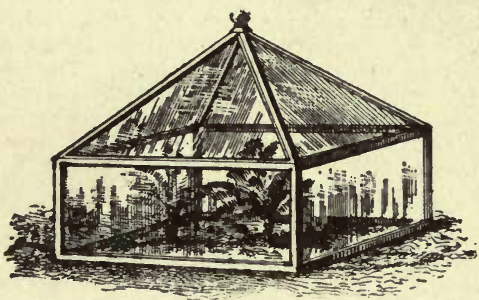

624. Propagating-box or hood.

require a second or third year's growth in the nursery; others are ready for permanent planting, as willows and poplars, which often srow 6 feet the first year This is one of the very cheapest ways of propagating, and will pay where only 25 per cent root. This method is generally used with deciduous-leaved plants, but some conifers, e. g., Siberian arborvitæ, will strike. Remove enough twigs to get a clean stem for planting, and allow 2 or 3 inches of top above ground.

The excrescences, knots or knaurs, which are found on the trunks and the main limbs of olive trees, are sometimes used as cuttings for propagation.

(3) Short cuttings of ripened wood (Fig. 627 ) are used under glass with tender or half-hardy species, with new introductions, in cases where the grower is short of stock, and when the plant is delicate and small. The wood should be gathered before severe frost and the euttings made and planted directly in October and November. Make them from 2-4 inches long (sometimes a single eye only is used), and plant with a dibble, in pure sand in pots, pans or flats (boxes about 16 inches square and 3 inches deep). If a layer of potting soil is placed under the sand, the young plants have something to feed upon and do not need to be potted so soon after rooting; if this is done, drainage should be given.

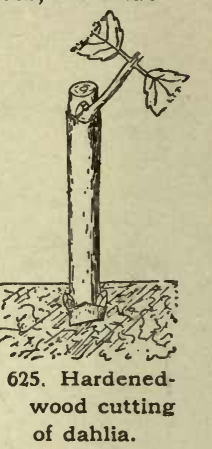

It is important to keep them cool until a callus is formed or roots produced. If the buds start into growth before this, the cuttings become exhausted and are likely to die. After rooting, - the time required varies from one to six months-they can either be potted or the

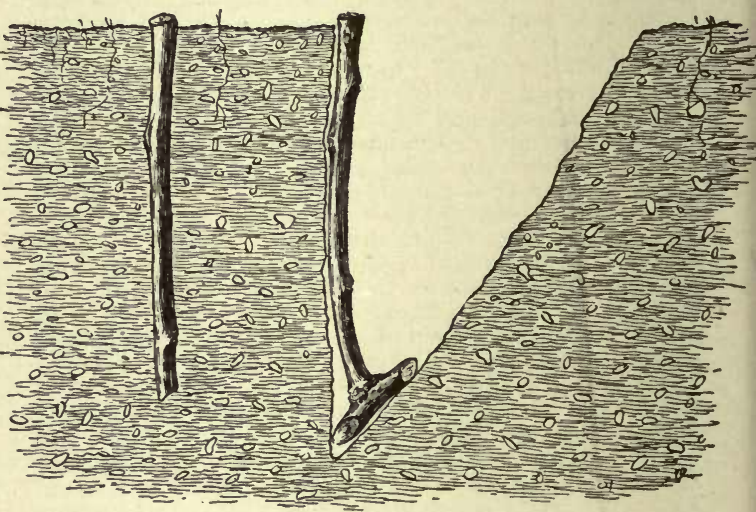

626. Long cuttings of ripened wood.

strong-growing sorts be planted out in well prepared beds in May or June, where they are likely to make a satisfactory growth. The weaker kinds can remain a year in pots or flats, be wintered in a pit, and planted out the next spring. Some greenhouse plants, e. g., Camellia Laurestinus, tender grapes, etc., are propagated in this way with cuttings of fully ripened wood, and others, as cactus, dracæna, etc., with wood which is much older. They should be given the care described under the head of (1) Cuttings of Growing Wood, but they must not be foreed too hard at first. The temperature should be regulated by the nature of the plant. The safest rule to follow is to give a few degrees more heat for propagating than the plant received when the cutting was removed.

(4) Root-cuttings (Fig. 628) are made of either root or rootstock and are useful in propagating some plants, either in the greenhouse or in the open air. Tender plants, like bouvardia, and those which are hardy but of delicate growth, e. g., Anemone Japonica, are handled under glass; blackberries, horseradish, etc.. out of doors. The cuttings are made in autumn or winter, the roots of hardy plants being gathered before severe frost and either planted directly or kept in moss until spring. This process of storing develops a callus and has a tendency to produce buds. For greenhouse work, the cuttings are made

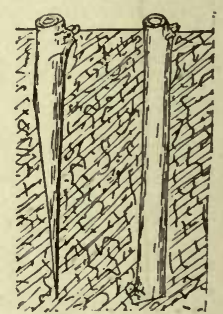

627. Short cuttings of ripened wood. 
from 1-2 inches long, the larger roots being selected, although the small ones will grow. They are planted in pans or flats, in soil composed of equal parts sand and well rotted leaf-mold. Ordinarily they are set horizontally. If planted vertically, in cuttings from the true root the end which was nearest the crown should be uppermost; but if made from the rootstock, that end should be uppermost which grew farthest from the crown. In either case they should be covered, as

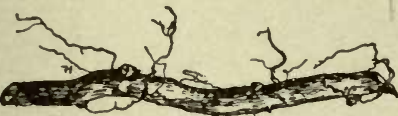
seeds are covered, and the whole made flrm. Rootcuttings of hardy plants should be kept cool at first and brought into

628. Root-cutting of blackberry $(\times 1 / 3)$, he at only when ready to grow. They may be kept in a pit or cool cellar. Tender plants require the same or a little higher temperature than that in which they thrive.

In sweet potato, the tuber is cut lengthwise and laid, with the cut side down, on moist sand or moss, the edges being slightly covered. Buds develop on these edges and are removed when of proper size and treated as euttings of growing wood, or allowed to remain until rooted. In dracena (see Fig. 546, page 370)-and this applies to stem-as well as root-cuttings - the buds are not taken off until rooted; the original cutting remains in the sand and sometimes produces a second or even a third erop. The tuberous rootstock of A rum maculatum, and plants of like nature, can be cut into pieces, remembering that the bud-producing portion of arum is the top, and each part will grow successfully. Exercise care in watering and maintain a good temperature.

Root-cuttings for planting in the open ground are made from 4 to 6 inches long, and are planted firmly in $\mathrm{V}$-shaped trenches or furrows in spring, being covered 2 inches or more deep. Roots as large as one's little finger are chosen, and good results are obtained with plants of vigorous growth. In plants like lily-of-thevalley, common lilac, calycanthus, Scotch and moss roses, etc., unless short of stock, it is better to encourage the natural growth of the suckers and propagate by division, but these can be multiplied as above described.

Variegation, curiously enough, is not always reproduced by means of root-cuttings.

(5) Leaf-cuttings. - Many leaves are capable of producing roots. Some have the further power of developing buds after rooting, and of these last a few furnish an economical means of bud-propagation, particularly where the stem growth is insufficient. In cotyledon (echeveria) the whole leaf is used, the smaller ones from the flower-stalk being often the best. Choose those which are fully matured, and, if large and succulent, expose them for a few days on the surface of dry sand, but do not let them shrivel. The treatment, othewise, is as given above for cuttings of growing wood. In gloxinia and other Gesneraceæ, the whole leaf (Fig. 629), half a leaf, or even a lesser portion, is used. When enough clear petiole is obtainable, no further preparation is needed. When a part only of the leaf is planted, some of the blade must be cut away. As a rule, no bud is developed the first season: a tuber is formed, which will grow in due time.

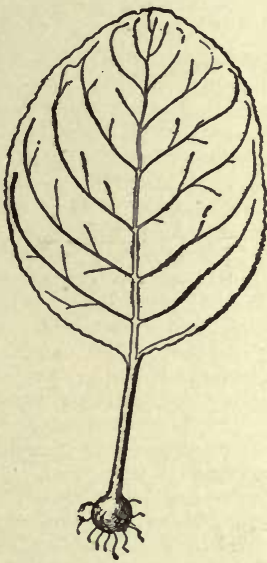

629. Leaf-cutting of gloxinia.
Begonia Rex is increased by leaves in various ways. The whole leaf may be planted as a cutting, keeping the petiole entire or cutting it off where it unites with the blade; or the whole leaf can be pinned or weighted to the surface of moist sand (Fig. 203, page 142), and, if the principal veins are severed at intervals of an inch, a plantlet will appear at every cut. The best way is to divide the leaf into somewhat triangular pieces ( see Fig. 204, page 142), each part having a strong vein near the center. Plant in sand, in good temperature, and treat precisely as if they were cuttings of growing wood. Roots and buds will soon grow, and a good plant will result within a reasonable time. Pot off when roots are $1 / 4$ in. long.

The thickened scales of bulbs, like lilies, can be used for propagation. Remove the scales intact and plant upright, like seeds, in soil made of equal parts of sand and rotted leaf-mold (Fig. 630): September and October are the usual months for this work. If they are kept in a cool greenhouse, the young bulblets will appear in the course of the winter, but top growth will come later, in summer. This is a slow, laborious process, and is seldom practiced except in propagating new varieties. The granular scales of achimenes and plants of like nature can be used for propagating, sowing them in a sandy soil as seeds are sown; but this method is not a good one in ordinary cases. The scales of Zamia horrida have been made to produce new plants, and also the tunicated scales of an amaryllis. See Transactions of Horticultural Society [London], 6, p. 501.

True variegation, that which comes from

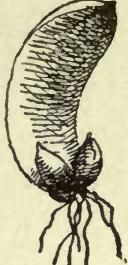

630.
Lily scale bulblets.

lack of chlorophyll matter, is not always reproduced by leaf-cuitings. The characteristic coloring in the foliage of Begonia Rex is never lacking in plants obtained by these means.

For further details of Cuttage, consult Lindley's Theory and Practice of Horticulture, 2d ed.; Burbidge, The Propagation and Improvement of Cultivated Plants; Peter Henderson's Practical Floriculture; Bailey's Nursery Book, $3 d$ ed.

B. M. Watson.

\section{CYANOPHÝLLM. Consult Miconia.}

CYATHEA (Greek, a cup, alluding to the indusia). Cyathedcece. A large genus of tree ferns found in both hemispheres, with a globose indusium which ultimately ruptures at the apex and becomes cup-shaped. All the species in cultivation have decompound lvs. Many other species from Columbia and the West Indies besides those described below are well worthy of cultivation.

L. M. UNDERWOOD.

This genus includes some of the most beautiful of all tree ferns. The species offer a great variety in size of trunks. Those of temperate regions are mostly stout and not spiny; the tropical species are more slender and in many cases densely armed with stout spines. All species are evergreen. Their culture is simple but exacting. They require an abundance of water at the roots and the trunks should be kept constantly moist. By these means only can a vigorous growth and fine heads of fronds be secured. The foliage lasts longer if it has been inured to the sun during summer. Like all other tree ferns, Cyatheas need little pot-room. None of the species produces adventitious growths along the trunk or at the base and none is proliferous. The plants are, therefore, usually prop. by spores, which are produced abundantly and germinate freely, making attractive young plants in two seasons.-Abridged from Schneider's Book of Choice F'erns.

A. Rachides unarmed; lvs. white beneath.

dealbata, Swz. Rachides with pale rusty wool when young; lvs.firm, bi-tripinnate, almost pure white beneath. N. Zealand. $C$. Smithii, Hort., is regarded by some as a horticultural variety.

AA. Rachides unarmed; lv's. green beneath.

Búrkei, Hook. Stalks with tubercles near the base bearing large, glossy rusty scales: lvs. bipinnate, with broad pinnules. S. Africa.

meridénsis, Karst. Figs. 631, 632. Lvs. tripinnatifid, with oblong-lanceolate pinnm and rather narrow lanceolete pinnules; segments scaly on the ribs beneath. U. S. Columbia. 
AAA. Rachides spiny;

lvs. green beneath.

medullàris, Swz. Lvs. bi-tripinnate, densely scaly when young, with soft, deciduous hair-like scales; segments coarsely serrate or pinnatifid, on sporebearing lvs. N. Zealand.

L. M. UNDERWOOD.

CỲCAS (classical Greek name). Cycaddcea.

Twenty or fewer species of widely distributed tropical or warm-temperate palm-like plants. Plants diøceous. The fls, appear in a mass in the busom of the great crown of lvs. Staminate His. are anthers borne beneath a scale; the pistillate fls. are naked ovules borne in the angles of rusty-fuzzy, pinnatifid lvs. They have striking analogies with the gymnosperms and ferns. Cycads are popular conservatory plants, for they are of easy culture, and the crowns of lvs. withstand much neglect, or even abuse. Cycas stems and leaves are imported in vast quantities directly from Japan. Staminate plants are rare in cultivation. For a horticultural synopsis of the genus, see I. H. 11, under tab. 405. A running sketch, by W. Watson, is in G.F. 4: 113 .

Cycads in the various species are among the most popular decorative plants for both house and garden. Their culture is comparatively simple, as they succeed in varying temperature and any well drained soil. $C$. revoluta is probably the most hardy species, withstanding the trying climate of the upper coast of the Gulf of Mexico, where it occasionally loses its entire crown of leaves during severe freezes, but is seldom killed outright. It usually stands well at Savannah. Plants are propagated by seeds, which keep well for a month or more after ripening. They should be sown in shallow boxes or the greenhouse bench, lightly covered with sand, and, after germination, potted off in small pots of moderately rich, light soil. The growing plants do their best in partial shade, where they should have proper attention in watering and weeding. The old plants frequently send up suckers around the base of the trunk, which may be cut off and rooted, if taken in a dormant state. The leaves, if any have formed, should be cut off at the time of its removal, as otherwise they would dry up the sucker before it was established. The large stems, or trunks, are safely shipped from their native home to most distant countries, after cutting off leaves and roots and packing in cases in a dry condition. Upon arrival at their destination, the stems are planted in as small pots as possible and kept close and moist until new leaves form, when a cooler and drier air will answer for them. Their use as decorative specimens for the home is increasing, although many failures result from lack of moisture and sunshine. The soil which suits them best is a sandy or gravelly loam, and should never be allowed to get quite dry, but be kept in a moderately moist condition at all seasons. When dormant, they may be placed in the most shaded positions occasionally, but ought to have sunshine daily, when possible, for at least an hour. During their periodical growth, they should have a great deal of sunshine to insure a stocky and vigorous growth otherwise the leaves will be drawn to an unnatural length, with few pinnæ, ruining their symmetrical form.

Cult. by E. N. REASONER. revolùta, Thunb. SAGO PalM. Figs. 633, 634. Becoming 6-10 ft. high, and then branching: lvs. long and recurved at the end $(2-7 \mathrm{ft}$.$) , the many pinnæ$ curved downward, narrow,

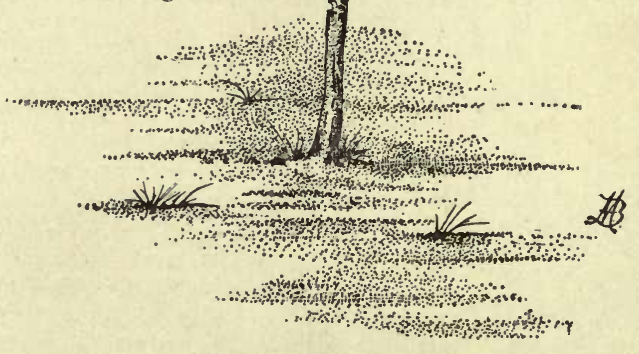

631. Cyathea meridensis. sharp-pointed and stiff, dark, shining green. Japan. B. M. 2963-4. J.H. III. $29: 379$. R.B. 21:163. R. H. 1896, p. 369. A. G. $13: 141 ; 18: 1$; 19:436. Mn. 2: 88 ; $6: 134$. - The commonest species in cult. Produces a handsome crest or crown of outward-flowing lvs., which remains in perfection for months and years. The fruit is densely tomentose, but is not often seen in cultivated plants. Much usec at funerals.

circinalis, Linn.(C'Thouársii, R. Br.).

Taller, rarely branching: Ivs, twice longer than those of $C$. revoluta, gracefully arching, the pinnæ a foot or less long, falcate, dark green above and pale beneath. Moluccas. B. M. 2826-7. F. S. 20: 2118-19. - Fruit glabrous at maturity. Not uncommon in good collections. Rapid grower as compared with some other species.

Rúmphii, Miq. Usually low, but said to be tall in the wild : crown large and full : the lvs. 3-6 ft. long and 12-18 in. wide ; pinnæ pale, thin, lanceolate, $12-14$ in. long and $1 / 2$ in. wide ; petiole spiny. E. Ind.

Bellefonti, Lind. \& Rod. Stem short, cylindrical and erect: lvs. long and graceful, recurved, the linear-lanceolate slightly falcate, sessile pinnæ entire and plane on the border, somewhat glaucous; petioles spinulose at the base. China. I.H. 33: 586 .

media, R. Br. Tall (10-15 ft.), the trunk cylindrical, bearing a large erown: lvs. curved downwards, $4 \mathrm{ft}$. or more long, elliptic or lanceolate; pinnæ numerous, linear and pointed ; petiole convex below, flat or nearly so on top. Australia. I.H. 26:368.

Names which have appeared in the Amer. trade are: C. Comoriénsis $=$ ? $-C$. Léhmanni = Encephalartos Lehmanni.-O. Neo-Caledónica, Lind. Much like C. circinalis, but the fronds narrower and the pinnæe eloser, C.Sanderiàn $a=$ ?

Other cultivated Cyeads are: $C$. Béddomei, Dyer. Perhaps a small form of C. eireinalis. E. Ind.- C. Normanbyàna, Muell. Lvs. oblong-ovate, with numerous linear pinnæ 6 in. long. Australia.-C. pectinàta, Griff. Stem short, sending up very long, rich green, plume-like, semierect lvs with long, thin, blunt-tipped pinnm. Ind G.F. $4: 114$. Said to be the finest species.-O. Riuminiana. Regel. Stem rather stout : lvs. bright green, erect, spreading in a vase-form crown, the pinnæ fine-pointed. Philippines. I. H. 11: 405.-C. Siaménsis, Miq. Much like C. circinalis: lvs. 2-4 ft. long, bright green, graceful : trunk much swollen at the base. Siam and Cochin China. I.H. 28: 433. R. H. 1881, p. $397 . \quad$ L. H. B.

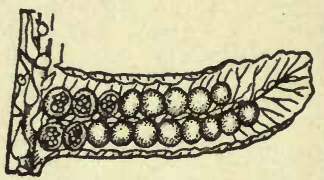

CYCLAMEN (classical name, probably from the Greek word for circle, in allusion to the spirally twisted peduncles). Primulacea. A dozen or more species, mostly of the Mediterranean region and the Caucasus. Herbaceous and low, from a flattish tuber or corm : fl. single, on a scape, with usually 5-parted calyx and corolla (the parts strongly reflexed), 5 connivent stamens, with pointed, sessile anthers, 1 style and stigma, and a 5 -splitting capsule. $C$. latifolium is the source of the standard florists' Cyclamens. Most of the other species are grown only as curiosities in this country; and they are essentially outdoor plants. Old English name Sowbread, from the tubers being sought by swine. Con- 
sult Fr. Hildebrand, Die Gattung Cyclamen, Jena, 1898. L. H. B.

All Cyclamens are very beautiful, and would be much more popular were they hardy in our eastern climate. On the Pacific slope many of them probably would be perfectly at home as outdoor plants, producing a great number of flowers above the bare soil in the depth of winter before the leaves are developed. It is, however, with the Persian Cyclamen, which is tender, that florists have had the greatest success. There is no common winter-flowering subject of as much value for duration in bloom, variety of coloring, or wealth of color.

It is preferable at all times to begin the culture of Persian Cyclamen with seeds, sown in the early winter months. Grow on without any check for the following year. They should bloom freely about fifteen months from planting. Old tubers, such as are offered in fall with other florists' bulbs, rarely give any satisfaction as compared with a packet of seeds. It is not the nature of the plant to have all its roots dried off, as if it were a Hyacinth or Tulip. Our summers are rather too warm to suit Cyclamen perfectly, and it will be found that the most growth is made in the early autumn. It is best to give them a little shade in the hot months, such as a frame outdoors near the shade of overhanging trees at midday. This is better than growing them under painted glass, as more light is available, together with plenty of fresh air on hot days. It will be found that Cyclamen seeds require a long time in which to germinate, - often two months. This is due to the fact that the seed produces a bulb or corm before leaf growth is visible. As soon as two leaves are well developed, place the plants around the edge of 4- or 5-inch pots until every one is large enough for a 3 -inch pot. The roots are produced sparingly in the initial stages, and too much pot room would be fatal at the start. By the middle of summer another shift may be given, and in September all will be ready for the pots in which they are to flower, -5 - or 6 -inch pots, according to the vigor of the plants. It will always be found, however, that there will be a certain percentage that will not grow, no matter how much persuasion is used. These may be thrown away to save time and labor early in the season. The Giganteum

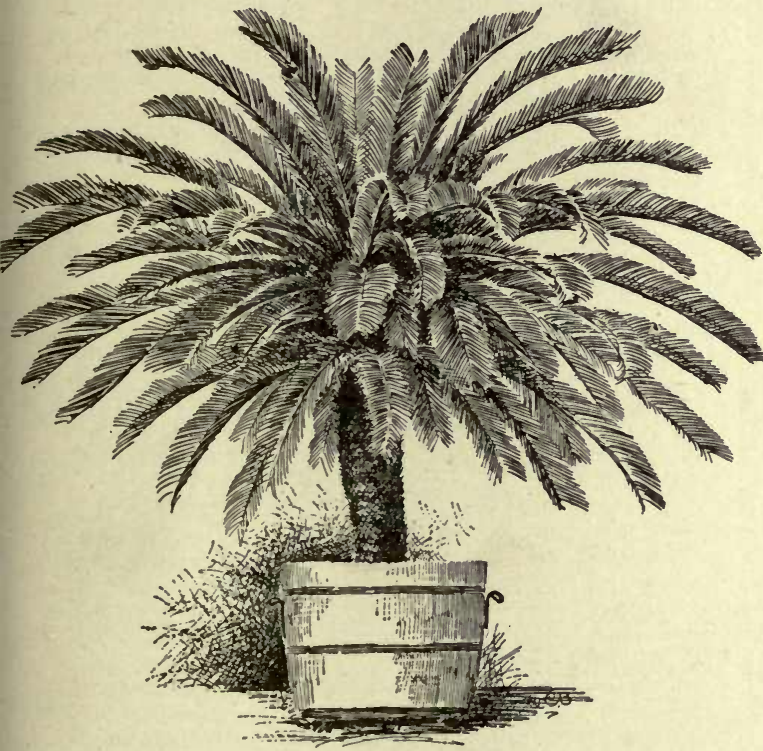

633. Cycas revoluta.

Specimen grown in partial shade.

strains produce the largest blooms, but at the expense of quantity. For the average cultivator it is better to try a good strain that is not gigantic. There is a recent departure in the form of crested flowers. Cyclamens come true to color from seeds, and one can now buy named varieties that will reproduce themselves almost to a certainty.

Of recent years cultivators have had much trouble with a tiny insect or mite that attacks the plants and renders them useless for bloom. Its work is done mostly

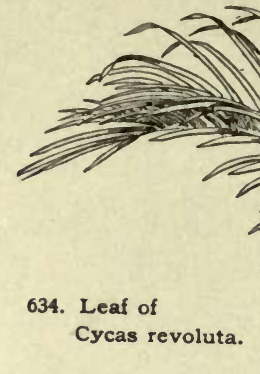

after the plants are taken into the greenhouse and when about to mature into blooming specimens. If the first flowers come deformed, or abnormally streaked with colors that are darker in shade, it is a sure indication that the pest is present. No other treatment can be recommended but to destroy the infected plants and keep the stock clean, for the pest has not yet been studied carefully.

Cult. by E. O. ORPet.

Cyclamens should be removed to the greenhouse about the end of September, or before any danger of frost. In the house they should always have the lightest bench. It is impossible to grow them in a warm, shady house. About $50^{\circ}$ at night is the ideal temperature when in flower. The soil best suited to them is a fresh, tufty loam, with a fourth or fifth of well rotted horsemanure, to which add some clean sand if the soil is heavy. At all times, the pots should be well drained. Greenfly is sure to attack the plants at all stages of their growth. In the frames the plants can be plunged in tobacco stems, and in the greenhouse they must be fumigated or, what is better still, vaporized with some of the nicotine extracts.

A. Fall-blooming species.

WILLIAM ScotT.

Africanum, Boiss. \& Reut. The largest of Cyclamens: tubers often as large as a turnip (4-10 in. across): Ivs. ovate-cordate, coarsely toothed, pale beneath, dull and pale green marbled above: calyx pubescent, the lobes broadly ovate-acuminate: corolla nearly white, faintly. rose- or purple-tinged, the segments 1 in. long and deep purple at the base. Algeria. B.M. 5758. F.S. 8:841.Little known in this country, but sold by the American agencies of the Dutch bulb houses. The same remark will apply to most other species, except $C$. latifolium. Perhaps a form of the next.

Neapolitànum, Ten. Tuber very large, black, thickrinded: lvs. variable, from hastate to round-reniform, more or less wavy-plaited on the edges, green or somewhat parti-colored: calyx small: corolla pink or rarely white, the segments short and twisted and the edges raised and white-edged at the base. S. Eu. B.R. 24:49. Gn. 51, p. 37. R.H. 1855: 21. as C.hederafolium.

Europæum, Linn. (C. Clùsii, Lindl.). Lvs. ovate-orbicular, entire or nearly so, with a deep and narrow basal sinus, more or less white-marbled above, purpletinted beneath: fls. on scapes $4-5$ in. high, bright red and very fragrant, the corolla-segments oblong-spatulate ( $3 / 4$ in. or less long); calyx glabrous. Central and S. Eu. B.R. 12:1013.-Lvs. appearing with the fls. Variable.

Cilícicum, Roiss. \& Heldr. Much like C. Europaum: fls. white, with purple at the mouth, about twice larger; calyx puberulent. Sicily G.C. III. 23: 81 . 
AA. Spring-blooming species.

latifolium, Sibth. \& Sm. (C. Pérsicum, Mill.). Fig. 635. The common greenhouse or Persian Cyclamen, in many forms: Ivs. appearing with the fls., ovate, crenatedentate, usually marbled or variegated with white: fls. on scapes 6-7 in. high, large, scentless, white, purpleblotched at the mouth, but varying into rose-colored, purple and spotted forms, oblong-spatulate in shape, not eared or lobed at the base.

Greece to Syria.-C. gigantèm, Hort., is the common large-fld., improved form of this species. There are also double-fld. forms (R. H. 1886 , p. 250); also fimbriate or

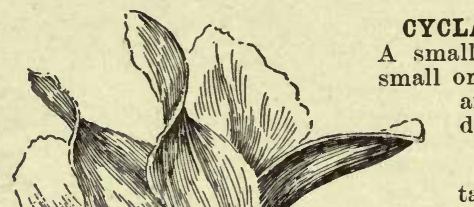

YYLANTHUS (flowers in a circle). Cyclanthacev. small tropical American genus, giving name to a all order which is allied to the palms. The species are not in the Amer. trade. Culture of Carludovica (which see).

CYCLOBOTHRA (name referring to the nectaries). Lilidcea. A small group of west American plants, now referred to Calochortus (which see). The fls, are open-campanulate, with naked or only sparsely hairy nectar glands, the sepals more or less pitted. $C$. flàva, Lindl. (now known as Calochortus flavus, Schult.), is in the trade as Yellow SHell-Flower. Stem rather tall, branching, with small, yellow black-dotted fls.: lvs, narrow-linear. Mex.

CYCLOLOMA (Greek for circle and border, from the encircling wing of the calyx). Chenopodidcea. One weedy herb ( $C . p l a$ typhýllum, Moq.) of sandy soils from Minn., west and south, which was once introduced as the Cyclone Plant, since the plant is a tumble-weed or rolls before the wind when it is matured and becomes detached from the soil. The plant is annual, 1-2 ft. high, pubescent or nearly glabrous, with narrow, but flat and sinuate lvs., and bractless fls. in an open panicle. The fls. are very small, perfect or sometimes lacking the stamens; calyx 5 cleft, the lobes strongly keeled and becoming winged and inclosing the seed. Plant not fleshy nor jointed.

howing a flower of perfect form, and the crested variety $\left(X^{1 / 2}\right)$.

crested forms, C. Papílio (I.H. 43:63. G.F. 5:235. G.C. III. $21: 71 ; 23: 173)$. C. Aléppicum, Fisch., is a form of it. F.S. $22: 2345$. Other portraits of $C$. latifolium are : I.H. $35: 43$. Gn. $47: 1016 ; 48: 1030$. J.H. III. $34: 578$. Gt. 1895 , p. 203 ; 1896, p. 164 . F.S. $22: 2345$. A.G. 14:390$392 ; 17: 261$. A.F. $7: 521-525 ; 11: 1176-9 ; 12: 499$.

Coum, Mill. Tuber smaller than in the last: lvs. with the fls., nearly orbicular, entire, firm, not marbled nor variegated : fls, small, deep red, scentless, half or less as large as those of the last. S. Eu. B.M. 4. F.S. 22: 2345. - There is a white-fld. form (C. album, Hort.).

Ibèricum, Goldie. Dwarf: 1vs, appearing with the fls., ovate-orbicular and rounded at the apex, entire or obscurely undulate, more or less zoned with white above: fls. red, with a purple mouth. Caucasus.-Perhaps a geographical form of C. Coum. C. Atkinsii, Hort., is a form (perhaps a hybrid) with larger white fls. F.S. 23:2425.

C. hedercefòlium, Hort. (and Ait,?). is C. Neapolitanum.-O. Libanoticum, Hild., is a new hardy species from Lebanon, with "large, rosy fls., with T-form deep carmine markings at the base of the petals" (see Bot. Jahrb 25:477) - C repándum, Hort. (not Sibth. \& Sm.) =C. Coum? - O. vérnum, Sweet=C. Hort. (not Sibth. \& Sm.)=C. Coum?-O. vérnum, Sweet=C.
Coum.
L. H. B.

CYCLANTHERA (Greek, anthers in a circle). Cucurbitacece. This genus is interesting as a plant with a fruit that explodes with a considerable noise when ripe. The plant is a climbing half-hardy annual of easy culture. The seed should be started indoors early. The genus is near Echinocystis and Elaterium, and has 30 or more species, all from tropical America. They are annual, climbing herbs, glabrous or pubescent, with a perennial root: lvs. entire, lobed or 5-7 foliolate : fls. minute, yellow, greenish or white, with their parts in 6's. Monograph by Coigneaux in DC. Mon. Phan. 3:822 (1881).

explddens, Naud. Stem slender, branched, angled or furrowed, slightly villous, especially at the joints, 6-8 ft. long: lvs. $2 \frac{1}{2}-3$ in. long, and about as wide, ovate-
CYCNOCHES (swan's neck, from the Greek, referring to the curved column). Orchidacece, tribe Vándece. SWAN ORCHID. An interesting genus of deciduous orchids found in tropical America. Pseudobulbs long, fusiform: lvs. lanceolate, plicate, labellum continuous with column; column arcuate, terete, flattening out and becoming clavate at the apex; pollinia 2 . The flowers are of different sexes. The same plant may produce male and female flowers. One kind of flower may be fragrant, the other kind scentless. Staminate flowers usually smaller than pistillate flowers; ovary of pistillate flowers thickish. Staminate flowers more numerous than pistillate flowers. About a dozen species. Cult. like Cat asetum, either in pots or baskets. Prop. by dividing the pseudo-bulbs just as growth begins. Very few forms are in cultivation in America, due to the want of brilliancy in the flowers. Some of the species produce varying flowers on different racemes on the same plant.

aùreum, Lindl. \& Paxt. Fls. numerous, large and yellow, drooping; sepals and petals lanceolate, purpledotted, the petals curved; lip small and much divided, the column purple-dotted. Cent. Amer.

chlorochilon, Lindl. Racemes about 3-flowered: fls. large, nodding, 5-8 in, across, green; sepals oval-oblong: petals falcate, slightly larger, labellum subsessile rather obovate and concave at base, yellowish green except at the base; column slender, with a wide base, greenish. Venezuela. I.H. 35: 65. J.H.III. 35: 285. Gn. 49, p.403; 51: 1108 and p. 173 .

pentadáctylon, Iindl. Fls. greenish or white, barred or blotched with brown; labellum partly white, spotted with crimson; column purple below the anther. Rio de Janeiro. B.R. 29: 22

ventricòsum, Batem. Raceme (often 2) about 5-fld.: fis. greenish yellow, fragrant; lip white, with a black callous spot on the claw. Gurtemala.

OAKES AMES.

CYDONIA (the fruits known to the Romans as mala Cydonia, apples from Cydon, now Canea, in Crete). Rosacex, sub-family Pomàcea. Quince. Shrubs or small 
trees, sometimes spiny : lrs. petioled, deciduous or semi-persistent, alternate, stipulate, serrate or entire : fls, white or red, rather large, solitary or in few-fld. clusters; petals 5; stamens numerous : fr. aromatic, a large 5-celled pome, each cell containing many seeds. Four species in Asia from Turkestan to Jap. Ornamental shrubs, nearly hardy north except $C$. Sinensis, which can only be grown south. C. Japonica and Maulei, with handsome glossy foliage and abundant fls. in early spring, varying in all shades from pure white to deep scarlet, are highly decorative, and especially adapted for borders of shrubberies and for low ornamental hedges. The fr. of all species can be made into conserves, but usually only $C$. vulgaris, a species of less decorative value, is grown for this purpose. The Quinces thrive in almost any soil, but require sunny position to bloom abundantly. Prop. by seeds usually stratified and sown in spring; C. Juponica and $C$. Maulei are readily increased by root-cuttings made in foll or early spriug, and rarer kinds or less vigorous. growing varieties are grafted in the greenhouse in early spring, on stock of the Japanese or common Quince; they grow also from cuttings of half-ripened or nearly mature wood, under glass and from layers. C. vulgaris (the Quince) is mostly increased by cuttings of 1-4year-old wood, taken in fall and stored until spring in sand or moss in a cellar or frame; also by layers and budding, or by grafting on vigorous growing varieties. See Quince.

A. Fls. solitary, on short leafy branchlets, with reflexed serrate calyx lobes: stipules small. (Cydonia proper.)

vulgàris, Pers. (Pỳrus Cydònia, Linn.). Quince. Fig. 636. Shrub or small tree, with slender, spineless branches: lvs. oval or oblong, rounded or slightly cordate at the base, acute, entire, villous-pubescent beneath, 2-4 in. long: fls. white or light pink, 2 in. across : fr. large, yellow, villous, pyriform or globular. May. Cent. and E. Asia. - Var. Lusitánica, Mill., is of more vigorous growth, with larger lvs. and fr. pear-shaped and ribbed. Var. maliformis has apple-shaped, and var. pyrifórmis pear-shaped fr. Var. marmorata, Hort., has whitish and yellow variegated lvs. See also Quince.

Sinénsis, Thouin (Pỳrus Cathayénsis, Hemsl.). Shrub or small tree: lvs. elliptic-ovate or elliptic-oblong, acute at both ends, sharply and finely serrate, villous beneath when young, $2-3$ in. long : fls. light pink, about $1 \frac{1}{3}$ in. when : fr, dark yellow, oblong, 4-6 in. long. May. China. B.R. 11:905. R.H. 1889:228. A.G. 12:16. -The lvs. assume a scarlet fall coloring. Not hardy north of Philadelphia, except in farored localities. See Quince.

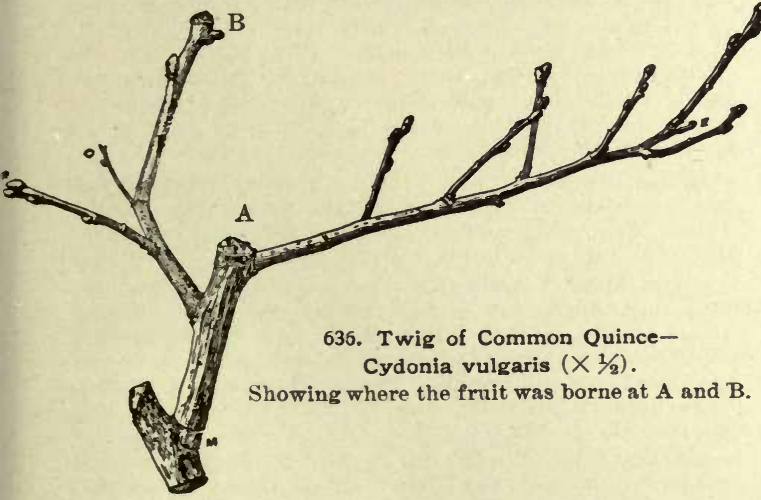

AA. Fls. in leafless clusters, nearly sessile, before or with the lvs.: calyx lobes erect, entire: stipules large. (Chonomeles.)

Japónica, Pers. (Pỳrus Japónica, Thunbg. Chonomèles Japónica, Lindl.). JAPAN QUINCE. JAPONICA. Fig. 637. Shrub, 3-6 ft., with spreading, spiny branches: lvs. ovate or oblong, acute, sharply serrate, glabrous, glossy above, $11 / 2-3$ in. long: fls. in $2-6$-fld. clusters, scarlet-red in the type, $1 \frac{1}{2-2}$ in. across: fr. globular or ovoid, 11/2-2 in high, yellowish green. March, April. China, Jap. R.B. 1:260. L.B.C. 16:1594. Gn. $50: 106$. Many garden forms in all shades from white to deep scarlet, and also with double fls. Some of the best are the following. Var. álba, Lodd., fls, white, blushed. L.B.C. $6: 541$. Var. atrosanguínea plèna, deep scarlet,

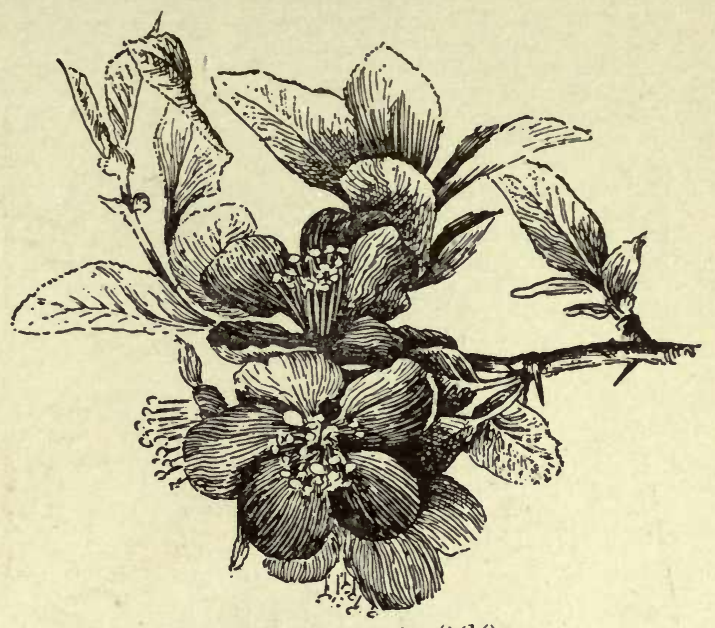

637. Cydonia Japonica $\left(X^{1 / 2}\right)$.

double. Var. cándida, pure white. Var. cardinàlis, deep scarlet. R.H. 1872:330 f. 1. Var. Gaujárdi, salmonorange. Var. grandiflora, nearly white, large fls. R.H. 1876:410. Var. Mállardi, fls, rose, bordered white. Var. péndula, Hort., with slender, pendulous branches. Var. ròsea plèna, rose, semi-double. Var. rùbra grandiflòra, fls. large, deep crimson. Var. sanguínea plèna, scarlet, double. Var. umbilicata, with rose-red fis., and large frs. umbilicate at the apex.

Maùlei, Nichols. (Pỳrus Maùlei, Mast. Chœnomèles alpina, Koehne). Low shrub, 1-3 ft.: branches spiny, with short, rough tomentum when young: lvs. roundish oval to obovate, obtuse or acute, coarsely crenateserrate, glabrous, 1-2 in. long: fls. bright orange-scarlet, $1-11 / 2$ in. across: fr. yellow, nearly globular, about $11 / 2$ in. across. March, April. Jap. B.M. 6780. G.C. II. 1:757 and $2: 741 .-A$ very desirable hardy shrub, with abundant fis of a peculiar shade of red. Var. alpina, Rehder (Chanomèles Japónica, var. alpina, Maxim. Cydonia Sárgenti, Lem.). Dwarf spiny shrub, with procumbent stems and ascending branches: lvs. roundish oval, 1/2-1 in. long: flowering and fruiting profusely. Var. supérba, Hort. Fls. deeper red. Var. trícolor, dwarf shrub, with pink and white variegated lvs. ALFRED REHDER.

CYMBIDIUM (boat, from the Greek, referring to the shape of the lip). Orchidacere, tribe Vándea. Plants epiphytal, rarely terrestrial, stems pseudobulbous or not so: leaves coriaceous, long, rarely short, persistent: sepals and petals sub-equal, labellum usually tri-lobed, adnate to the base of the column; column erect; pollinia 2. Species, tropical, sub-tropical, found on mountains at high elevations in Asia. A few species are found in Africa and Australia. For horticultural purposes this genus is of comparatively little value. OAKes AMes.

No difficulty will be experienced in growing the several species of Cymbidium under one method of treatment. A shaded position in the Mexican house or cool end of the Cattleya department, where the temperature ranges between $50^{\circ}$ and $55^{\circ} \mathrm{Fahr}$, at night and about $65^{\circ}$ or with sun heat $70^{\circ}$ through the day will be found suitable. During the warm summer months they must be kept shaded in a cool, moist atmosphere with a free circulation of air. As they are robust growing plants, pot culture will suit thein best, but those with pendulous inflorescence, such as $C$. Findlaysonianum, $C$. pendulum, etc., may be grown in baskets if desired. Repotting and top-dressing should be attended to in spring at the commence- 
ment of the growing season, and should be executed with judgment, so that it will last three or four years, as the roots dislike being disturbed. The potting soil should consist of one-half chopped sod, the balance of equal parts leaf-mold, peat and live chopped sphagnum moss, well mixed together; about one-third of the pot room should be devoted to drainage-potsherds or charcoal, covering the same with a little rough material to keep it open. When the large, fleshy roots are carefully distributed the material should be worked in firmly about them, leaving the base of the plant on a level with the rim of the pot when finished. Water sparingly until the new growths appear, when a more liberal supply will be necessary, but never enough to keep the soil constantly wet, or the new roots are liable to decay and the foliage to become spotted. Stock is increased by removing the old pseudobulbs, potting them up in small pots and giving them a little more heat and moisture until they start new growth action, when they may be removed to their proper department.

Robert M. Grey.

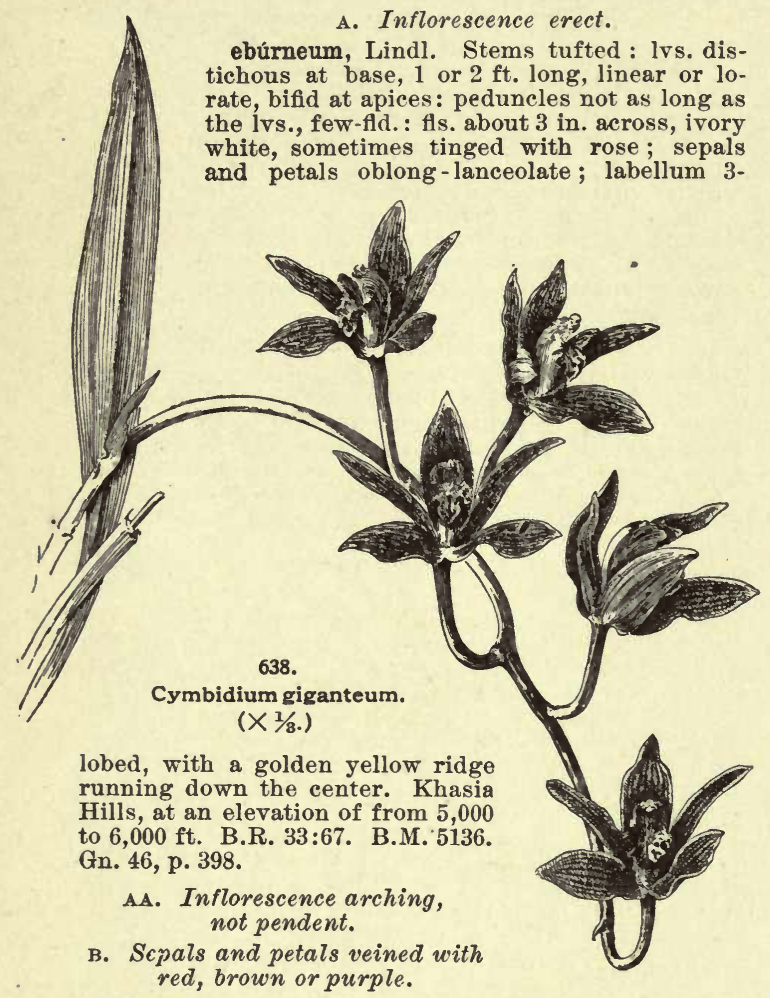

Lowiànum, Reichb. f. Pseudobulbs oblong : lvs. 2-3 ft. long, linear-acute, recurved: racemes many-fld.: secals and petals oblong-lanceolate (lateral ones sub-falcate), greenish yellow marked with brown; lateral lobes of labellum yellowish; midlobe reflexed, margined with yellow, the front blotehed with brown-crimson; fis. about 20 in number, several inches across. Burma. Gn. 48, p. 263. Gng. 5:73. - Var. Mandaiànum, Hort. (C. Mandaidnum, Hort.), has yellow fls. A beautiful hybrid of $C$. eburneum and $C$. Lowianum is shown in Gn. 48:1034.

gigantèum, Wall. Fig. 638. Fls. dull purple (brownish, or yellowish green striped with purple); sepals and petals oblong, the petals narrow and shorter; midlobe of labellum reflexed, yellow, spotted with red; lateral lobes yellowish green. Nepal. B.M. 4844. P.M. 12:241.

longifolium, Don. Lvs. linear-acuminate : peduncle stout, sub-erect, then drooping: fls. about 12 ; sepals sub-equal, oblong, the upper one broadest and incurved; both sepals and petals green striped with brownish pur- ple; disk and midlobe of labellum white, spotted with purple; lateral lobes with purple lines. Ind.

ensifòlium, Swartz. Lvs. ensiform, acute : peduncle many-fld.: fls. greenish yellow, veined with purple; sepals and petals linear-oblong, acute; labellum spotted. Ind., Jap. B.M. 1751.

Húttonii, Hook. f. Plant about $2 \mathrm{ft}$. high: fls. 10, in drooping racemes; sepals yellow, striated with brown; petals brown; labellum greenish, dotted with brown. Java. B.M. 5676 .

BB. Sepals and petals not veined with purple or broun.

tigrinum, Parish. Lvs. oblong-lanceolate: peduncles slender, 3-6-fld.: sepals and petals linear-oblong, acute, green spotted at base; petals often paler and with more spots than the sepals; labellum with yellow, red-brown striped lateral lobes; midlobe white, transversely streaked with purple. Burma. B.M. 5457.

Hookeriànum, Reichb. f. Lvs. about $2 \mathrm{ft}$. long, acute: peduncle arching above, erect at base : fls. from 6-12, large; sepals and petals oblong, greenish; labellum yellow, spotted with purple. Sikkim. B.M. 5574.

ввв. Sepals and petals whitish.

Mástersii, Griff. (Cyperórchis Mástersii, Benth.). Lvs. linear, acuminate: peduncle stout, longer than the raceme: sepals and petals sub-equal, oblong-lanceolate, white, flushed with rose at the apices; labellum minutely pubescent; laniellæ orange-yellow. Sikkim. B.R. 31:50. Var. álbum, Hort., has white fls. C. álbaflora, of Amer. trade, is equivalent to C. Mastersii, var. album.

\section{AAA. Inflorescence pendent.}

péndulum, Swartz. The leathery lvs. distichous, 2-3 ft: long, broadly linear: fls. yellowish; side lobes and midlobe of labellum rose-color; the disk more or less white with yellow crests; sepals and petals narrowly oblong, with a purple median line. E. Ind.

Finlaysoniànum, Lindl. ( $C$, péndulum, Lindl.). Lvs. ensiform: raceme many-fld: sepals and petals linearoblong, obtuse, dull yellow sometimes, with a reddish median line ; lateral lobes of labellum crimson ; midlobe white, tipped with erimson. Malaysia. - Var. atropurpùreum, Hort. Lvs. narrower, racemes longer, with larger fls.: sepals and petals purplish, front lobe of labellum white, spotted with purple. Borneo.

C. aloifotium, Swz., with pale purple fls., and C.viréscens, Lindl. (C. virens, Reichb. f.), with greenish sepals and petals and yellow, red-blotehed lip, are offered by importers of Japanese plants. $-C$. Lindleyi is a name which has appeared in the Amer, trade, but which is not identified.-For C. Sandersoni see Ansellia.

OAKes AMes.

CYNANCHUM (Greek, dog poison). Asclepiaddceo. About 20 species in S. Eu., Africa, Asia and Australia, herbaceous or sometimes half woody at the base, twining. Lrs. opposite, entire. Plant very like Vincetoxicum, but the fls. differ in having a scale or ligule on the inside of each of the 5 parts of the crown.

acuminatifòlium, Hemsl. (Vincetóxicum acuminàtum, Decne. V.Japónicum, Hort.). Mosquito Plant. Cruel Plant. Perennial: erect or nearly so, or the tips showing a somewhat twining habit: the stems grayish and more or less angular: lvs. opposite, broadly ovate and acuminate, short-petioled, strongly pinnate-veined, entire, usually conspicuously gray-pubescent beneath : fl.-clusters lateral (1-2 between the Jvs.), shorter than the lvs.: fls. white, small, in umbel-like cymes: fr. a milkweed-like follicle. Japan. - In the flowers, mosquitoes and other insects are caught, much as they are in other asclepiadaceous plants. The native Amsonia Tabernomontana is sometimes sold as this plant, and it has been figured as such.

L. H. B.

CYNARA (involucre spines likened to a dog's tooth). Compósitce. A half-dozen S. European species, of which the Artichoke and Cardoon (which see) are cultivated.

CYNODON. See Capriola. 
CYNOGLOSSUM (Greek, hound's tongue, from the shape and soft surface of the lrs. of the commonest species). Borragindcea. A large and widely dispersed group of little horticultural interest, being mostly tall,

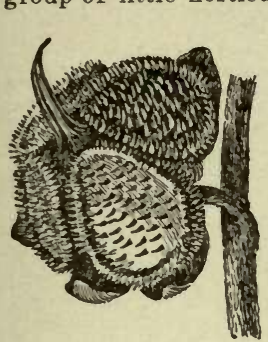

639. coarse, weedy herbs. C. officinale, Linn., Fig. 639, has a bur that becomes attached to clothing and to the fleece of sheep. It is a biennial weed, naturalized from the Old World, grows about $2 \mathrm{ft}$. high in pastures and waste places of the Atlantic states, and has softpubescent, lanceolate lvs., and dull red-purple (sometimes white) fls. in panicled racemes. $C$. gránde, Dougl. Once cult. from California as a hardy border perennial; grows about

Bur of Hound's-tongue $2 \mathrm{ft}$. high, with lower lvs. ovateoblong, or somewhat heart(X3.) shaped at the base, acute or acuminate, 4-8 in. long, on margined petioles of about the same length: upper Ivs. smaller, ovate to lanceolate, abruptly contracted into shorter winged petioles: fls. violet or blue. For $\boldsymbol{C}$. $\boldsymbol{A} \boldsymbol{p}$ penninum, Linn., see Solenanthus.

CYNÓRCHIS (Greek for dog orchid). Orchidacea, tribe Ophrýdece. A dozen Habenaria-like African orchids, not in the Am. trade. Culture of Bletia. Not to be confused with Cycnoches.

CYNOSÜRUS (Greek, dog's tail). Graminece. Annual or perennial, cespitose grasses, with flat leaves. Spikelets of two forms in small fascicles, these forming a dense somewhat unilateral, spike-like panicle; terminal spikelets of the fascicles 2-4 fld., hermaphrodite; lower spikelets sterile, consisting of many empty glumes: flowering-glumes mucronate or awn-pointed: stamens 3 . Specles 4 or 5 , in the north temperate regions of the Old World.

cristatus, Linn. CRESTED DoG's-TAlL. A slightly tufted perennial grass, 1-2 ft. high, with narrow lvs. and a rather slender, erect, spike-like panicle. Int. from Europe. - Well adapted for shaded lawns and woodlands. Also recommended for mixed pastures, especially in hilly regions. The mature stems are used in the manufacture of Leghorn hats.

élegans, Desf. Silky-AWned Dog's-tall. A pretty perennial grass varying in height from 6 in. $-11 / 2 \mathrm{ft}$. : lvs. small and scarce: panicle one-sided and spike-like: spikelets with long white silky awns $1 / 2-1$ in. long. Int. from Europe.-Handsome for dry bouquets.

\section{CÝNTHIA. All referred to Krigia.}

\section{P. B. KeNNEDY.}

CYPELLA (application obscure). Iriddceo. Eight species of South American bulbs, inferior to Iris for general culture because not hardy, and also less showy. The genus differs from Iris and Moræa in its stigmas, which are neither petal-like nor filiform, but erect, and in the anthers, which are broad, erect, not sloped, bearing the pollen on their edges, also in the plaited leaves. $C$. Herberti is the only species offered by the American trade, and the catalogues say it comes from Peru, but, traker (Irider, p.62), the only species from the western coast of South America is C. Peruviana. The bulbs should be set out in spring, lifted in fall and stored over winter. Prop. by offsets or by seed, which should be sown as soon as ripe. The blue-flowered speshould be sown as soon as ripe. The blue-flowered speC. plumbea, Lindl., from S. Brazil and Argentine, is shown in B.M.3710, with dull, lead-colored fis. In F.S. $4: 395$ and $14: 1466$ the colors are showier, the latter being a variety with handsome purple istreaks. For the still showier $C$. ccerulea, Seub., see Marica.

\section{A. Style appendages spur-like.}

Hérberti, Herb. Lvs, about $1 \mathrm{ft}$. long, linear, acuminate, twice plaiter, the angles of the plaits winged: scape 2-3 ft. high, erect, flexuose, glaucous, branched, many-fld.: fis, 3 in. across, chiefly yellow, odorless, soon withering; outer segments bearing a rather long cusp or tail. South Brazll. Uruguay. Argentine. B. R. 11: 949 and B. M. 2599 show utterly distinct colors, but Baker says there is a lilac variety.

\section{AA. Style appendages petal-like, flat.}

Peruviàna, Baker. Lvs, 6-9 in. long, linear, narrowed gradually from the middle both ways, glabrous, plaited : fls. $2-3$ in a solitary stalked cluster, soon withering, chiefly yellow; segments with a distinct long claw and a proportionately shorter and broader blade and a shorter cusp, at the base spotted brown. Peru. B.M. 6213.

W. M.

CYPERORCHIS (Cyperus and Orchis, from the sedgelike appearance). Orchiddcece, tribe Vándece. Very closely allied to Cymbidium, which see. There are only three species, of which $C$. Mástersii, Benth. (Cymbidium Mastersii, Griff., of this work, and $C$. elegans, Blume (Cymbidium elegans, Lindl., B.M. 7007) are cult. The latter does not appear in the Amer. trade.

CYPEेRUS (ancient Greek name). Cyperd̀cece. A large genus of the Sedge family, inhabiting both tropical and temperate regions. The species in cultivation are all perennials from rootstocks or tubers: leaves grass-like; stem simple and mostly naked above: flowers perfect, without perianth, borne in small, compressed spikes, which are variously aggregated in compound umbels, the latter surrounded by foliaceous bracts; styles and stamens 3. A few are cultivated in jardinieres, aquatic gardens and aquaria. Several others are pests in cultivated fields.

\section{A. Basal leaf-sheaths without blades.}

alternifolius, Linn. Umbrella Plant. Umbrella PaLM. Fig. 640. Strict, $1 \frac{1}{2}-3 \frac{1}{2} \mathrm{ft}$. high: stem nearly terete, ribbed, smooth and slender: involucral Ivs. very numerous, spreading or slightly drooping, linear, $8 \mathrm{in}$. long, $1 / 4-1 / 2$ in. broad. dark green, acute, rough-margined: umbel rays only 1-2 in. long, nearly simple: spikes few, in a cluster, ovate, very flat, 2 lines long, pale brown:

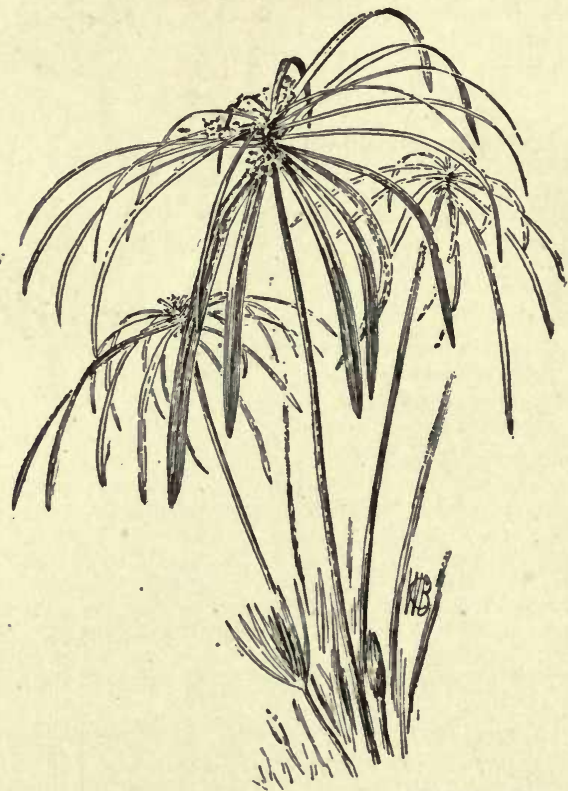

640. Cyperus alternifolius, or Umbrella Plant.

scale acute: rachis winged and pitted. Madagascar.Much used for aquaria and jardinieres. Var. variegatus, Hort. Stem and lvs. striate, sometimes entirely white. Var. grácilis, Hort. Involucral lvs. much narrower and not so spreading. 
Papỳrus, Linn. (Papỳrus Antiquòrum, Willd.). EGYPTIAN PAPET-Plant. Strict, tall and stout, 4-8 ft. high, dark-green: stem obtusely 3 -angled, smooth: involucral lvs. only 3-10, small, $3-6$ in. long, $1 / 4-1 / 2$ in. wide, linear, acute: primary rays of the umbel very numerous, terete, slender, equal and drooping, 10-16 in. long: secondary bracts prominent, filiform, 2-6 in. long: spikes clustered and sessile, pale chestnut: rachis wingless. Egypt, Palestine.-For aquaria and damp soil. Not hardy.

AA. Basal sheaths blade-bearing.

B. Lower lvs. few, very broad and conduplicate.

Natalénsis, Hochst. Stem $2 \frac{1}{2} \mathrm{ft}$. high, smooth, with 1-3 leaf-bearing sheaths and several leafless ones at the base: involucre 2-3-1vd., short: rays of the umbel short, unequal: spikes much congested, numerous, linearlanceolate, acuminate, pale brown, 10-12-fld.: rachis winged: scales oblong-ovate, obtuse. South Africa.Decorative. Not hardy.

fértilis, Borck. Stem short, slender, 4-5 in. high, 3-angled: Ivs. numerous, thin and broad, 4-9 lines wide, 6 in. long, equaling the stem, linear-lanceolate, folded below, dotted, margin denticulate: umbel simple, 5-7rayed: rays elongated, pendulous, often rooting at the apex, 1-2 ft. long: involucral bracts short: spikelets erowded, oblong-lanceolate, obtuse, slightly compressed, white. Central Atrica. - Recently introduced, and fine for hanging baskets; the umbel-rays often bear plantlets instead of flowers.

lùcidus, R. Br. Rather stout: stem 1-2 ft. high, terete above: lvs.numerous, large and broad, spongy-thickened at the base, spinulose-margined: umbel spherical, 6-8 in. in diam.: spikelets dense, digitate, long and linear: scales persistent: axis continuous. Australia.

BB. Lower lvs. numerous, narrow and grass-like, flat or nearly so.

élegans, Linn. (C. láxus, Lam. and Hort.). Stem 3-angled, 2-3 ft. high: Ivs. large, broadly linear, numerous, spreading, half as long as the culm: involucre short, spreading, few-lvd.: rays long and slender, unequal, compound: spikes small, distant, oblong, greenish brown, blunt, 6-11-fld.: scales round-elliptic, mucronate. West Indies, Brazil. G. C. II. $2: 99$; III. 13:41. - For table decoration.

strigòsus, Linn. Stout, 1-3 ft. high, sharply 3-angled, base bulbous: lvs. numerous, long and grass-like, smooth, 2-4 lines wide; involucral similar, 6-12 in. long: rays very unequal, 6 in. or less long: spikes 4-10-fld., awl-shaped, chestnut-brown, densely clustered, at the spike-like (1-1/2/2 in. long) tips of the rays. N. Amer.Hardy perennial, used for the borders of aquatic gardens.

esculéntus, Linn. Chura. Much like the last: rootstock slender and bearing little tubers: spikes pale: akene obovoid. Tropics. - Sometimes a weed in sandy fields; also cult. south for the edible tubers. Not hardy.

púngens, Borck. Stem very short and thick, 1-2 in. long, angled below: lvs. equaling the stem, rigid: umbel simple, contracted or capitate: spikelets linear-lanceolate, compressed, shining, straw-colored, 10-18-fld.: involueral bracts 2-4, scarcely 1 in. long. North Africa. Recently introduced. May be used for hanging baskets.

O. compréssus, Linn. Umbel lax: spikes linear-oblong: scales acuminate. Trop. - O. flabellifórmis, Rottb. Rare in Amer. trade. Central Africa. - Tall and palm-like, used by natives for wickerwork; very ornamental in water gardens - $C$.rotúndus, Linn darker and akene linear. Weed in cult. fields. - C. stríctus, darker and akene linear. Weed in cult. fields. - C. strictus,
Kor. M. WIEGAND.

CYPHOMANDRA (from the Greek, referring to the hump-shaped anthers). Solandcece. Two dozen S. American spineless shrubs or small trees (essentially herbs in culture in the north), distinguished from Solanum chiefly by the thickened anthers. The large lvs. are entire, 3-lobed, or pinnatisect.

betàcea, Sendt. (Solanum fragrans, Hook.). Tree Tомато. Fig. 641. Cult. occasionally for the eggshaped, reddish brown, faintly striped fruits, and under such conditions it becomes a tree-shaped, halfwoody plant 6-10 ft. high: lvs. large, soft-pubescent, cordate-ovate; more or less acuminate, entire; fls. small, pinkish, fragrant, in small axillary or super-axillary clusters: fr. about 2 in. long, on slender stalks, 2-loculed and seedy, musky-acid and tomato-like in flavor, agreeable to those who like tomatoes. Brazil. B.M. 3684. J. H. III. 31:470. G.C. III. 25:105. A.G. 11:409.-Bears

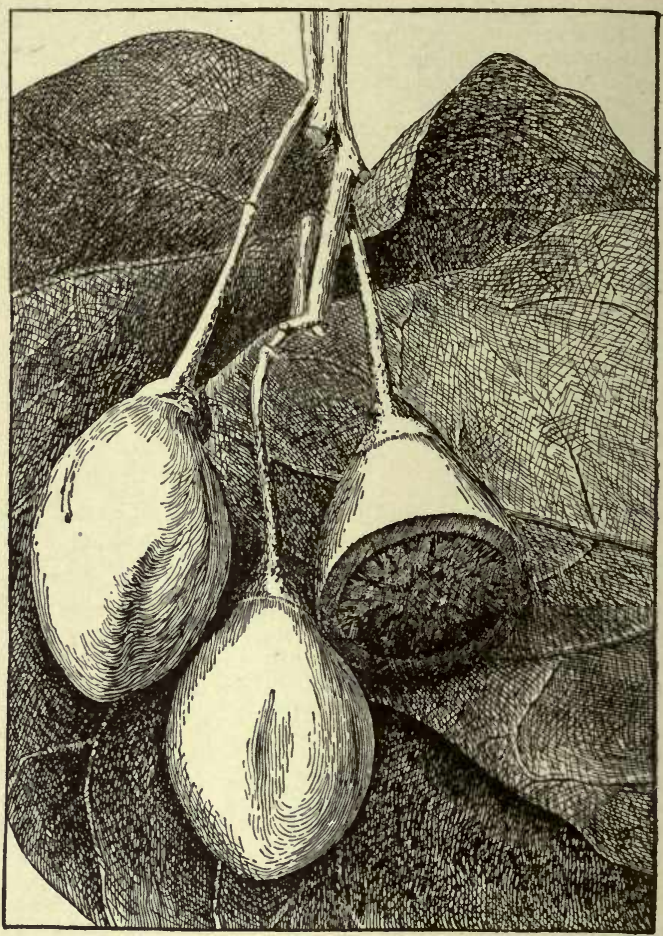

641. Cyphomandra betacea $(\times 1 / 2)$.

the second and third year from seed, under glass (where it must be grown in the northern states). For further notes, see Bailey, Forcing-Book.

L. H. B.

CYPHOPHCेNIX, (hump and Phonix, a palm). Palmacce, tribe Arècece. A genus of only 2 species of palms of minor importance. Spineless palms with a stout, ringed caudex. Leaves terminal, pinnatisect, the segments coriaceous, elongated, sword-shaped, narrowed toward the apex, the margins thickened, plicate, recurved at the base; the prominent nerves and midrib sparsely scaly beneath; rachis stout, rather broad, slightly convex on the back, acute above: spadices glabrous, the branches long, stout : bracts short; bractlets scaly ; fr. dark brown, medium, long-ovoid or ellipsoid, lentiform. Species 2. New Caledonia.

élegans, Benth. \& |Hook. (Kéntia élegans, Brongn. \& Gris.). Rachis convex below, flat above; leaflets alternate, approximate, scaly along the mid-nerve below: fr. oblong-elliptical, acute.

fulcita, Benth. \& Hook. (Kéntia fulcita, Brongn.). Stem clothed at the base with smooth aërial roots: fr. ovoid, attenuate above.

CYPHOSPERMA (Greek, hump and seed). Palmacece, tribe Arècece. Two Australian warmhouse palms, scarcely known in this country. C. Viellárdii, Benth. \& Hook., with pinnatisect lvs., and long-ensiform coriaceous segments, is sometimes known as Kentia robusta and $K$. Viellardii. Culture of Areca and Ptychosperma.

CYPRESS. See Chamocyparis, Cupressus and Taxodium.

CYPRESS VINE. See Ipomøa. 
CYPRIPEDIUM (Venus' slipper). LADY'S SLIPPER. Moccasin Flower. Orchidacea, tribe Cypripèdiea. The genus Cypripedium is widelydistributed, being found in both South and North America, Asia, Europe, Japan, and the Malay Archipelago. At present no species are reported from Australia or Africa. Scapes usually 1-fld.: floral segments fleshy: upper sepal usually larger than the petals: ovary 1-celled: fertile stamens 2; intermediate stamen sterile and petaloideous: column short, cernuate: apex trifid: lateral lobes anther-bearing: pollen viscid or mealy, not compound: stigma deltoid, on front of column beneath the stamens: capsule slender, pubescent: placentation parietal: the lower sepals commonly coalescent: labellum cup-form, inflated: lvs. usually ligulate, either tessellated or uniform green. The structure of the column (or essential organs) of a Cypripedium is shown in Fig. 642. The two anthers are at $a a$. The third stamen is represented by the body, $b$. The stigma is at $c$. The floral envelopes are torn away beneath. The majority of Cypripediums grow well, and increase in value from year to year. They do not require a period of rest like species of Cattleya. The hardy species, such as $C$. acaule and $C$. pubescens, are well worthy of a place in gardens. C. spectabile, for color and form, ranks among the finest species. It is a valuable orchid for forcing in the greenhouse. As yet, no bybrids have resulted from the intercrossing of our native Cypripediums. Intercrossing of tropical with hardy species has proved fruitless. There is a tendency to resolve Cypripedium into several genera. For the purposes of this work the old classification will be observed.

The genus is closely akin to Selenipedium, which see for C. caudatum, C. palmifolium, C. Rœzlii, C. Lindleyanum, C. Sargentianum, C. Schlimii, C. Schomburgkianum, C. vittatum, and the like. See, also, Houlletia. Selenipedium differs from Cypripedium in having a 3 -loculed and 3-ribbed ovary. Figs. 643 and 644 contrast some of the structural points in the two genera. The genus Cypripedium is naturally not a large one. Bentham and Hooker think that the species are less than 40 . The species have been much hybridized and modified by cultivation, however, so that the garden forms are legion. Most of the names represent horticultural varieties; and these uames may be expected to increase. One section of the genus has been separated recently as a genus, Paphiopedilum. Monogr. of Cypripedium and related genera by F. Desbols, Ghent, 1898.

OAKES AMES.

Nearly all Cypripediums are of easy culture and may be readily grown in one department, by devoting the cooler portion to $C$. barbatum, $C$. insigne, C. Javanicum, $C$. venustum and the Selenipedium group. The coriaceous-leaved evergreen species are all in more or less

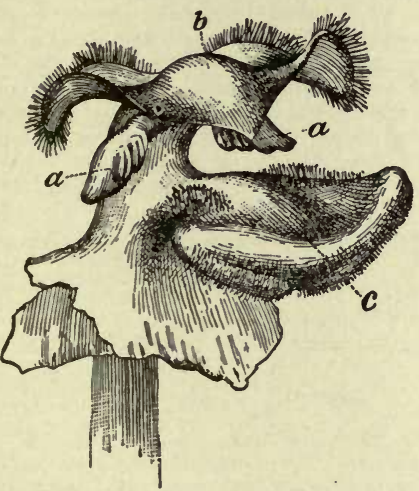

642. Structure of column of Cypripedium $(\times 1 / 4)$, c. Dormanianum.

active growth the year round; therefore a liberal supply of water must be given at all seasons, only allowing the compost to become dry occasionally to prevent stagnation.

Light syringing should be frequent in bright weather, and an application of weak liquid manure once or twice a week will be found of great assistance to keep the plants in health. The hygrometer should never register below 60, nor often above 80 , as moisture in excess of 80 is liable to damp-off the young growths. Ventilation reg.

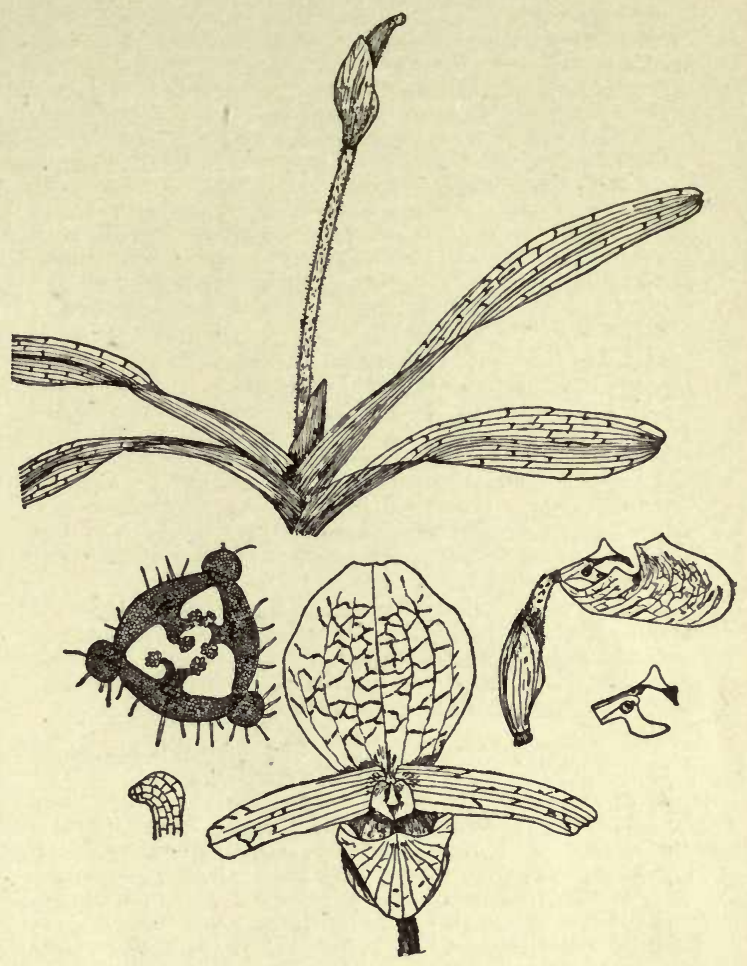

643. Cypripedium Charlesworthii.

Shows section of ovary; of labellum or lip on the right; stigms on the left ; column on the right below.

ulated according to external conditions is essential at all times to maintain atmospheric action.

During the winter months the thermometer should register from $60^{\circ} \mathrm{F}$. to $65^{\circ} \mathrm{F}$. by night and about $70^{\circ} \mathrm{F}$. by day. With sun heat a few degrees more will do no harm. On the approach of spring the temperature should be advanced to prepare the plants for summer heat, and accordingly decreased on the approach of fall. About the middle of February a light shading will be necessary to prevent excessive heat and sunburn, with heavier shading toward midsummer, this to be gradually removed in the fall and entirely dispensed with during the winter.

The greater part of the species grow best in pots in a compost of two parts peat-fiber to one part chopped living sphagnum moss, one-half of the pot room being devoted to clean drainage. The compost should be pressed in rather flrmly about the roots, and the surface left convex to discard surplus water and to insure the base of the plant against decay during dull weather. A few heads of living moss pricked in over the surface will give a neat appearance.

Cypripedium insigne and kindred species should have one-third chopped sod added to the above mixture (see note on culture in Veitch's Orchid Manual 2: 34). $C$. villosum and $C$. Exul sometimes suffer under pot culture from fungi, which attack the base of the plant during sultry summer weather. Basket culture will obviate this, as it allows a better circulation of air through the compost. C. Lowei, C. Parishii, C. Philippinense and allied species, together with Selenipedium cau. datum, are truly epiphytic and preferably should be grown in baskets. By this method the roots are better preserved and less liable to decay during the winter season. 
The Concolor section requires a warm, moist location with free access to the air. The species should be grown in rather small pots, with at least half the space devoted to drainage of broken charcoal or other free muterial. The potting compost should consist of equal parts chopped sod, peat-fiber and living sphagnum. Limestone is often recommended as essential in the culture of this section, but, the conditions being equal, I have never noticed any beneficial results from it (Orchid Review 4: 45̃; Veitch's Manual 2: 19-20).

The deciduous tropical species, of which $C$.Irapeanum, C.Thibeticum and Selenipedium palmifolium afford good

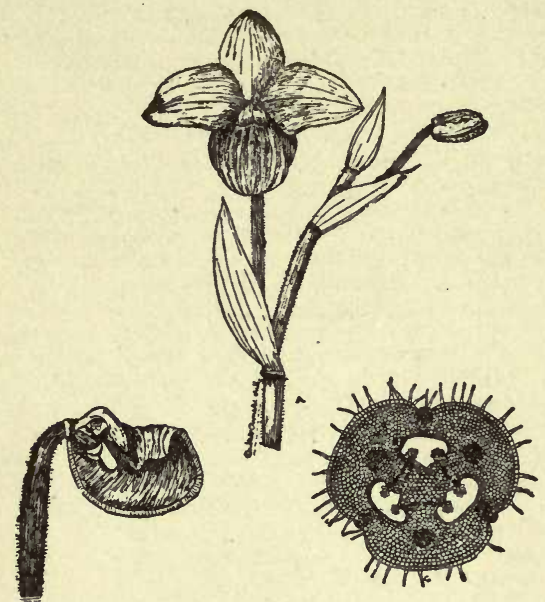

644. Selenipedium Schlimii.

The picture shows on the left a section of the labellum; on the right, a section of the ovary.

examples, require similar treatment to the evergreen kinds. They have a long dormant period during which they should be rested in a temperature of $50^{\circ} \mathrm{F}$., with sufficient water to keep the compost moist until growth starts, when they must be returned to their proper department and enjoy a liberal supply of water until after the flowering season, when they must be ripened off and the water supply gradually withheld.

The hardy species do better planted out in the open ground or in rockeries, where they should be so situated as to obtain good drainage and shade. The soil must be free and porous and consist of three parts chopped turf and equal parts of peat and sphagnum. They require a liberal amount of water and frequent syringing over the foliage while growing, but the supply should be gradually reduced after the flowering period until only enough water is given to keep the soil moist. During the winter the plants should be protected with leaves or pine boughs. $C$. spectabile and $C$. pubescens grow well under pot culture. A 7-10-inch pot will hold eight or a dozen crowns, which should be planted 2 inches below the surface. Two inches of drainage are sufficient. The pots should be fllled with soil (firmly pressed in) to $1 / 2$ inch below the rim. After a thorough watering they should be stored in a coldirame and protected with leaves and boughs. About the middle of February they may be removed to a coolhouse, where they should remain for a week, and then be placed in the cool end of the Cypripedium house, where they should be watered sparingly until growth action starts. These plants make strong growths under this treatment, and the flowers are a decided improvement over those produced normally outside.

All Cypripediums are propagated by division.

Robert M. Grey.

Index to species described in the main list: Abbotianum, 5 ; acaule, 40 ; albens, 25; Amesianum, 25; Appletonianum, 16; Argus, 6; arietinum, 43; Arnoldianum, 25; atropurpureum, 5; aureum, 25; auriculum, 5; barbatum, 1; bellatulum, 20; biflorum, 1; Boxalli, 28;
Breevisianum, 25; Brownii, 25 ; Bullenianum, 15 ; Calceolus, 48; candidum, 46; Californicum, 52; callosum, 4; caudatum is a Selenipedium; Chamberlainianum, 38 ; Chantinii, 25; Charlesworthii, 24; ciliolare, 7 ; cærulescens, 1 ; coloratum, 5 ; concolor, 17 ; corrugatum, 25 ; Coulsonianum, 25 ; Cowperianum, 25 ; Crossianum, 1; Curtisii, 9; Cuttingranum, 25; Dayanum, 12; Dominianum, 25 ; Dormanianum, 25 ; Druryi, 27 ; elegans, 41 ; Elliottianum, 37; Ernestii, 25; Exul, 26 ; Eyermanianum, 25; Fairieanum, 21; Fœrstermanni, 25; fuscatum, 25 ; giganteum, 1, 5; Gilmoreianum, 25; glanduliferum, 35; Godefroyæ, 19; gracile, 1, 25; grandiflorum, 1; grande, 5; guttatum, 25; Haynaldianum, 31; Hendersonianum, 1; Himalaicum, 44 ; hirsutissimum, 22 ; Hookeræ, 15 ; Horsmanianum, 25; Hyeanum, 5; illustre, 25; insigne, 25; Irapeanum, 54; Javanicum, 13; Japonicum, 42; Kimballianum, 25 , 35, 37; løvigatum, 34; Lawrenceanuin, 5 ; leucochilum, 19; Lindeni, 5 ; longisepalum, 25; Lowei, 30; Lutwycheanum, 25 ; Macfarlanei, 25 ; macranthum, 51 ; maculatum, 25; magnificum, 5; majus, 1; Mandevilleanum, 25; marmoratum, 5 ; Mastersianum, 14 ; Maulei, 25; maximum, 25; montanum, 53; Mooreanum, 25; mosaicum, 1; Moulmeinense, 25; nanum, 1; Neo-Guineense, 35; nigritum, 2; nigrum, 1, 5; Nilssonii, 25; nitens, 25; niveum, 18 ; nobile, 1 ; O'Brienianum, 1; Parishii, 32 ; parviflorum, 49 ; Petri, 12 ; Philippense, 34 ; pictum, 1, 5; Pitcherianum, 5, 6; pleioleucum, 5; plumosum, 1 ; præstans, 35 ; pubescens, 47 ; pulcherrimum, 1; purpurascens, 5; purpuratum, 3; purpureum, 1; Pynaerti, 25; roseum, 5; Rothschildianum, 37; Sallieri, 29; Sanderæ, 4, 25 ; Sanderianum, 36 ; spectabile, 50 ; Spicerianum, 23 ; Stonei, 33; Studleyanum, 25; superbiens, 8,25 ; superbum, 1, 5; Sylhetense, 25; Thibeticum, 45; tonsum, 10; Veitchianum, 8; venustum, 11; Victoria-Marie, 39; villosum, 28; virens, 13; virescens, 5; volonteanum, 15 ; Warnerianum, 1. Many other names are accounted for in the supplementary lists.

A. Leaves tesselated (or checkered in squares).

B. Petals more or less ligulate, smaller than the upper sep $x$ l.

C. Upper sepal veined with green and purple: spots on the petals marginal.

1. barbàtum, Lindl. Lvs. oblong, about 6 in. long, pale beneath, upper surface dull green with darker green markings: scape long, reddish brown: ovary slender, subtended by a small bract; upper sepal orbicular, evenly reflexed, white, with a green translucent base; veins green part way, becoming deep purple: petals green at the base, finely dotted, gradually passing into brown-pink at the apices, upper margin provided with several blackish warts; labellum brown-purple, infolded portion yellowish or purplish with raised dots; lower sepal narrow, greenish, veined with green: staminode pubescent, broadly crescent-shaped. June and July. Malay Peninsula. B.M. 4234.-Of this useful species there are many excellent varieties in which the flowers are larger or more richly colored. The variation in foliage is very remarkable. In general appearance this species resembles $C$. Lawrenceanum. Many vars. in cult.

The following are varieties of $\boldsymbol{O}$. barbatum: Biflorum. A chance variation, due undoubtedly in most cases to vigor. See Crossianum below. - Caruléscens. - Crossiànum. Same as Crossii. - Cróssii. Upper sepal very large, round-orbicular, white, veined with green and apparently transversed by a band of crimson: petals much deflexed. I. H. 35:72; $36: 81$. A F $6: 555$ - Gigantè ; petals much deflexed. I.H. 35:72; 36: 81. A.F. 6:555. unusually large.-Hendersonianum.-Május. A richly colored and vigorous form.-Mosaicum. - Nànum. - Nigrum. A dark flower, the labellum of a very deep brown-purple. - Nóbile.$O$ 'Brieniànum, or $O$ 'Brieni.-Pictum.-Plumòsum. This is not permanent variety. It does not maintain the characters to which it owes its name.-Pulchérrimum.-Purpùreum. $-\mathrm{Su}$ pérbum. Almost any good form of the type is called by this name.-Warnerianum, or Wárnerii. See Crossii.

2. nigritum, Reichb. f. Probably identical with $C$. purpuratum, var. obscurum. Dorsal sepal resembles that of $C$. purpuratum, in other respects very similar to $C$. barbatum.

3. purpuràtum, Lindl. Lvs, elliptic-oblong to narrowly ovate, 4-5 inches long, glaucous, pale green tesselated with darker dull green, pale beneath: scapes short (about 5 in. long), purplish : ovary subtended bP a 
small bract ; upper sepal white, 4-angled, appearing as if inserted at one of its angles, about 15-nerved, outer nerves carmine-purple, others metallic green; margins strongly reflexed; lower sepal greenish with white mar gins, veined with green; petals subspatulate, greenish at base, dotted, becoming purplish toward the apices, veined with deep inetallic green; labellum brown-purple, infolked portion with raised dots ; staminode crescent shape. Autumn. China. B. M. 4901. R. H. 1858, p, 182 1883, p. 353.

4. callosum, Reichb.f. Lvs. ovate-oblong, obscurely tesselated, pale beneath: scapes reddish brown; upper sepal about 3 in. across, unevenly reflexed, slightly concave at base, and translucent; blush ground color veined with green, upper part white-margined, suffused with rose mauve ; veins carmine-purple toward the apex petals oblique, recurving, pale green at base, pale rose mauve at and toward the extremities, upper margin with several blackish warts, ciliate; labellum dull reddish brown; infolded lobes greenish, with red-brown, shiny warts; staminodium crescent-shaped. February and March; also at other seasons. Siam. R. H. 1888: 252.

Var. Sánderæ, Hort. An albino form of the species, with no trace of rose-mauve or purple. The fls. are white and delicate green. 'J. H. III. 28: 423.

5. Lawrenceanum, Reichb. f. Lvs. oval-oblong, nearly $1 \mathrm{ft}$. long, tessellated with yellowish and dark green scapes tall, reddish brown, sometimes 2-fld.: fls. large; upper sepal orbicular, white, with broad carmine-purple veins, which are greenish at the base; lower sepal small; ovary long, subtended by a small bract; petals purplish at and toward the apices, otherwise greenish, provided with black warts along the margins; labellum dull brown-purple; staminode broadly crescent-shape. A pril-July. Borneo. B. M. 6432. I. H. 30:478. F.S. 23: 2372 . G.C. III. $21: 291$.

The following are forms of $C$. Lawrenceanum: Abbotiànum. Fls. large, with deep erimson veins on the upper sepal.-Atro purpureum. A dark form, upper sepal with deeply colored veins.-A uriculum.- Coloràtum. Veins deep colored, the interspaces suffused.- Giganteum. A variation from the type in the large size of the fls.-Gránde.-Hyednum. Upper sepal veined with green; petals green; labellum green. G.C. III 21.37 Lindeni. - Magníficum.-Marmoràtum.-Nìrum.-Pictum. Pitcheriànum - Pleiolècum Upper sepal white, with only a fow colored veins. - Purpuráscens. - Ròseum. - Supérbum. few color
Viréscens.

cc. Upper sepal veined with green, but slightly if at all veined with crimson; petals more or less spotted or dotted.

6. Argus, Reichb. f. (C. barbatum, var. Argus, Hort. C. Pitcherianum, Hort.). Lvs, oblong-lanceolate, about 6 in. long, pale green mottled with deeper green: scape long, reddish brown: ovary subtended by a small bract; upper sepal broadly ovate, acuminate, dotted at base, veined with green, the longer veins sometimes purplish: petals oblong, undulate, deflexed, pale green tinged with purple at the apices, irregularly spotted with blackish warts; labellum dull brown-purple, greenish beneath; infolded lobes purplish, spotted with deeper purple; staminode crescent-shaped. March, April. Luzon, Philippines. B.M. 6175. A.F. 3:179.

7. ciliolàre, Reichb. f. Lvs. oblong, pale green, tessellated with dark green: scapes tall, reddish brown: ovary subtended by a small bract; upper sepal broadly ovate, acuminate, ciliate on the margins, blush white at base, otherwise white, veined with green; petals ligulate, deflexed, recurved, with long murginal hairs, greenish at base, becoming pale mauve at and toward the extremities, thickly dotted with blackish warts; labellum dull brown-purple; infolded lobes yellowish, with reddish brown warts; staminode reniform. April-July and even later. Philippine Islands. I.H. 31:530. G.C. III. $21: 348$.

8. supérbiens, Reichb.f. (C.Veitchianum, Lem.). Lvs. oval-oblong, about 6 in. in length, yellowish green, mottled with deeper green, pale beneath: scapes tall, greenish: orary subtended by a small bract; upper sepal broadly ovate, whitish, evenly veined with green; petals deflexed, almost drooping, ligulate, hairy-margined, white, suffused with pale rose, tinged with reddish brown at base, veined with green and copiously dotted with reddish brown; labellum dull brown-purple; infolded lobes brighter, with raised dots; staminode reniform-subrotund, horns straight. June, July. Malay Peninsula. I.H. 12:429. F.S. 19:1996. A.F. 7:707. R H. 1871 , p. 596.

9. Cúrtisii, Reichb.f. Lvs. broadly oval oblong or narrowly oblong, pale green tessellated with darker green, pale beneath: scapes about $1 \mathrm{ft}$. high, reddish brown: ovary subtended by a small bract; upper sepal disproportionately large, broadly ovate, greenish with a white margin, tinged with brown-purple at the base, green veined with brown and green: petals ligulate, deflexed dull brown-purple or brownish green at the base, veined with green, pale along the median vein, and thickly dotted with red-brown; margins ciliate; labellum large, dull reddish brown, infolded lobes paler, dotted; stami node reniform. May-July. Sumatra. A.F. 6: 557. Gng. 1: $41 .-C$. ciliolare and $C$. superbiens are very closely related.

10. tónsum, Reichb. f. Lvs. ovate-oblong, pale green conspicuously maculate with dark green, pale beneath or spotted toward the base: scapes 12 in. or more long, brownish green: ovary pale green, subtended by a small bract; upper sepal broadly obovate, with wide base, abruptly acuminate, whitish, often with blush rose suffusion; veins green; petals broad, devoid of marginal hairs, oblong ovate or subspatulate, green, median nerve paler green, with a row of large reddish brown spots, other veins brownish, giving a tinge of brown to adjacent tissue; labellum large, compressed dorsiventrally, brownish; infolded lobes pale yellowish green, with raised pale dots; staminode crescent-shaped, the horns strongly oblique. Autumn. Mountains of Sumatra.

11. venùstum, Wall. Lvs. oblong, dull purple beneath, upper surface pale green, marbled with dark green: scapes about 8 in. tall: ovary subtended by a bract which sheaths it for half its length; dorsal sepal ovate, white veined with green; petals green at base, dull purple toward the extremities, provided with several blackish warts; labellum pale green, conspicuously veined with emerald-green, infolded lobes paler; staminode crescent-shaped. January-March. India. B.M. 2129.

ccc. Upper sepal distinctly veined with green: spots on the petals, if any, few.

12. Dayànum, Reichb. f. (C. Pètri, Reichb. f.). Lvs. oblong, pale green, remotely cross-veined with dark green, pale beneath: scapes reddish brown; upper sepal ovate, acuminate, whitish, veined with green, upper margin recurved; petals brownish green at base, salmonpink toward the apices, upper margins obscurely spotted, ciliate with dull crimson hairs ; labellum roughish, dustylooking, infolding portion greenish, with dull crimsonbrown warts ; staminode oblong. Borneo. May, June. F.S. $15: 1527$.

13. Javánicum, Reinw. Lvs. oblong, pale, maculate with dark green: scape greenish, 1-or 2-flowered: ovary subtended by a small bract; upper sepal ovate acuminate, greenish white veined with green, lower margin reflexed; petals oblong, greenish, with fine blackish dots, becoming purplish or pale rose color at the apices, ciliate on the margins; labellum darker green than the petals, infolded lobes pale green, but variously dotted; staminode reniform-subrotund. Java.-Var. virens, Hort., is smaller, the green color more pronounced.

cccc. Upper sepal not distinctly veined with green, but more or less with purple.

14. Mastersiànum, Reichb. f. Lvs. oblong, remotely tessellated: scape tall, brown-purple. ovary subtended by a short bract; upper sepal orbicular, acute, bright green with a greenish white or yellowish border, veined with greenish brown; petals spreading, brownish, paler at and toward the base, and provided with blackish warts on the upper margin and median vein; labellum large, brownish, infolded lobes paler, with dull purple spots; staminode crescent-shaped, horns converging. Java. G.C. III. 15: 593; 25: 274. B.M. 7629, as a Paphiopedilum.

15. Hookeræ, Reichb. f. Lvs. variegated dull green and greenish white, pale beneath, ovate oblong: scapes tall, slender: upper sepal rotund, acuminate, green, with 
a cream-colored margin; petals subspatulate, purplish at the apices, with a green stripe toward the base; labellum greenish brown, infolded portion greenish, with a few raised warts; staminode oval. Borneo. B.M. 5362 .

Var. Bulleniànum, Hort. (C. Bullenianum, Reichb.f.). Lvs. not so strikingly mottled: fls. smaller, upper sepal

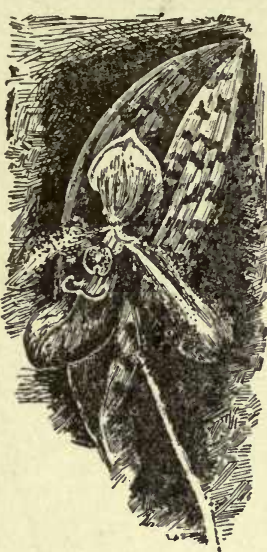

645. Cypripedium

Hookeræ, var. volonteanum $\left(X_{1 / 8}\right)$. streaked at the base. Borneo.

Var. volonteànum, Hort. Fig. 615. Fls. larger than in the type; petals oblong spatulate, green, except at extremities, where they are pale mauve, median portion richly dotted with crimson-brown; labellum greenish brown. June and July, and earlier. Borneo.

16. Appletoniànum, Rolfe (C. Bullenianum, var. Apple. tonianum, Hort.). Lvs. less tessellated than in the preced ing; staminodium very small, greenish. This form is some times considered as a sub-variety of $C$. Bullenidnum. Borneo.

\section{Bв. Petals and sepals nearly} equal: fls. fleshy.

17. cóncolor, Batem. Lvs. oval-oblong, mottled, dull purple beneath: scape short: up per sepal yellow, dotted with purple, similar to the petals labellum yellow, compressed.

\section{Autumn. Burma. B.M. 5513.}

18. niveum, Reichb. f. Lvs, oval-oblong to oblong short, mottled: fls. white; petals and upper sepal nearly equal, finely dotted at base with purple, dots variable in number and distribution. Burma. B.M. 5922.

19. Godefroyæ, Leb. Lvs. narrower than in the preceding: scape short: fis. whitish to pale yellow, spotted with purple-magenta; petals deflexed. Early, and as late as July. Cochin China. B.M. 6876. Gn. 25, p. 396.

Var. leucochilum, Hort. Upper sepal white, blotched with deep purple; labellum white; petals like the upper sepal, spots smaller. G.C. III. 15:815. J.H. III. 30:423. F.R. 1: 371 .

20. bellátulum, Reichb. f. Lvs. broad, rounded at apices, slate-green, mottled with darker green, thickly dotted beneath with brownish purple, except in var. album, when the lvs.are pale beneath: scapes very short: upper sepal concave, roundish, white, spotted with brown-purple; lower sepal also spotted; petals orbicu lar, tending to be concave, spotted with large, irregular, brown-purple spots; labellum ovate, finely dotted with brown-purple. Fls. in summer; also at other seasons. Shan States. G.C. III. 21:320. J.H. III. 30:513. A.F. 6:557; 13:77,622; 14:675. Gng. 7:129.-Var. álbum, Hort. Has white fls. devoid of spots: 1vs. not brownpurple beneath.

\section{AA. Lvs. coriaceous, ligulate, not tessellated or only obscurely so. \\ B. Fls, not more than 2, except in vigorous plants. \\ c. Staminodium without a protuberance or horn from its center.}

21. Fairieànum, Lindl. Upper sepal sub-rotund, whitish, veined with dark carmine-purple; petals oblong deflexed, recurved at the apices, whitish, veined with green and purple; labellum brownish green, reticulated; staminodium orbicular, with a pronounced beak or tooth from the lower margin, white, with green veins. Habitat unknown, 1857. - The only living records of this species in America are found in several splendid hybrids, such as $C . \times$ Niobe, $C . \times$ vexillarium, $C \times$ Arthurianum, $C$ $\times A$ mesie and $C . \times H$. Ballantine. There are several plants in English collections. There are no living plants in America. The species is not vigorous enough to be worth the growing.
22. hirsutíssimum, Lindl. Lvs. ligulate, uniform green: scape greenish: ovary and bracts clothed with shaggy hairs; upper sepal narrow at base, broader toward the summit, nearly ovate, brownish, with a green margin, finely dotted at base; petals green at base, finely dotted, becoming purplish; margin sinuate, undulate; labellum green, finely dotted, downy and ciliate; staminode bluntly quadrate or spade-shaped, with 2 white eyes. March, April and May. Java. B.M. 4990. R.H. 1859, pp. 182-3. - Int. at same time as C. Fairieanum (1857).

23. Spiceriànum, Reichb. f. Lvs. linear-oblong, dark green: scape about 8 in. long: ovary subtended by a spotted bract; upper sepal white, strongly reflexed so as to have a narrow base and broad, incurved summit, median line carmine-purple; petals short, wavy margined, yellowish green, with conspicuous mid-veins of reddish brown; labellum green or brownish; staminodium white-margined, otherwise pale mauve. Oct.-Dec. Assam. B.M. 6490. I.H. 30:473. Gn. 48, p. 304. A.G. 11:159. A.F. 3: 226. Gng. 1:242. F. E. 9:329. - Habitat unknown when first plants were introduced. Many varieties.

cC. Staminodium provided with a protuberance or horn.

24. Chárlesworthii, Rolfe. Lvs. ligulate, obscurely tessellated, heavily spotted beneath throughout or only at the base: scapes short, spotted like the lvs.: ovary spotted, subtended by a small, spotted bract; upper sepal orbicular, white, mottled and suffused with pale carmine, purple rose, brownish at base or clear petals short, rarely wavy margined, yellowish or brownish, veined with brown; labellum similar in color to the petals (variable), spreading at the aperture small in comparison with the upper sepal ; staminode shiny, pure white, with an orangeyellow tipped process. Autumn. E. Indies. B.M. 7416. R. B. $20: 241$. Gn. 47:1009 and p. 425. A.F. 13:430. - A very variable and beautiful species, which should give rise to interesting $\mathrm{hy}$ brids.

25. insigne, Wall. $\mathrm{L} \nabla \mathrm{s}$. linear-ligulate, uniform green, usually finely

spotted at the base: scape reddish brown, about $1 \mathrm{ft}$. high : upper sepal oval, arching at the summit, mainly green, upper margin white, surface covered with brownish spots; petals pale greenish brown, veined with deeper brown; labellum also brown ish; staminodium longer than broad. rough and pubescent, with a yellow projection. Autumn. India. B. M. 3412. G. C. III. 18: 763. A. F. $7: 633$. F. E. 9:327. Gng. 1:243. A. G. 16:73 19: 825 .

Var. Chántinii, Hort. Habit as in type : dorsal sepal larger with larger spots, broad toward the summit, mainly green, heavily spotted with brown, except on the upper portion, where it is white, with several pale mauve spots; labellum colored like the spots, deep polished brown. R. H. $1878: 130$.

Var. Ernestii, Hort., is a yellow form with faint spots on the upper sepal, which lack the characteristic brown and are called "false spots."

Var. Sánderæ, Hort. Fig. 646. Foliage pale to the base: scape very pale green: upper sepal white above, otherwise primrose-yellow, with minute reddish brown dots, which vary in number from season to season, and 
in different fls. on the same plant; petals colored like upper sepal; labellum waxy yellow, spreading at aperture; staminode yellow, with an orange-yellow projection. Gng. 7:196. - The most beautiful Cypripedium.

C. insigne runs into many forms. Following are some of them: Albo-marginatum. Fls. yellowish; upper sepal bordered all round with white; spots light colored, found only on the greenish yellow disk.-Albens. Color of fls. soft greenish yellow; upper sepal half white. - A mesiànum. Fls. rather large; upper sepal brownish, with a white margin, not spotted, suffused with rich brown.-A rnoldiànum. Fls. larger than in var. Maulei; upper sepal with a broad, white margin, spots confined to the greenish yellow disk. G.F.7: 425. A. F. 6:115,-Aùreum. Upper sepal pale yellow; petals and labellum brownish.-Breevesiànum. Upper sepal oblong, upper third white, otherwise yellowish green, with regular lines of brown dots; petals reddish brown. - Bròwnii. Fls. green; upper sepal heavily blotched or spotted. petals spotted. A.F. 7: 65. - Corrugàtum. Labellum corrugated, otherwise typical.-Coulsoniànum. A very large flower, with a broad upper sepai. Closely allied to var. Schroederianum (?) - Cowperiànum. Upper sepal spotted at base, similar to that of var. albo-marginatum; petals rather longer than usual; labellum large.-Cuttingiánum. Fls. large, greenish; upper sepal broad, with violet-purple spots on the white.-Dominianum.-Dormaniànum.-Eyermaniànum. Fls. light yellow, with several light brown spots at base of upper sepal.-Foer stermanni. Upper sepal with a broad white border; petals distinctly veined with brown.-Fuscàtum. R.B.20:25.-Grácile. Upper sepal narrow.-Gilmoreànum. Fls. rather large; upper sepal spotted with brown-Guttàtum. R. H 1851:201.-Horssepal spotted with brown.- Guttatum. R.H.1851:201.-Horsmanianum. Sepals long and narrow.- Illústre. Yellowish variety; sepals and petals spotted.- Kimballianum. Upper sepal lines into the white border; petals strongly veined. - Longisepalum. Long, narrow sepals; upper sepal brownish below, greenish above, not spotted. - Lutwycheànum. Upper sepal somewhat narrower than usual, basal margins wavy; upper margin white, passing to pale yellow; spots hardly visible, same color as the sepal. Belongs to the Ernesti group of varieties. Maculàtum. An obscure variety -Mandevilliànum. Form same as Albo-marginatum. Petals thickly covered with spots in regular lines.-Maùlei. White portion of the upper sepal predominating, extending to the base on either side of the green disk; uppermost spots violet-purple, otherwise the spots are larger brownish and few - Máximum. Upper sepal large deep als narrower, deeper yellow.-Mooreànum. Fls. pale yellow;

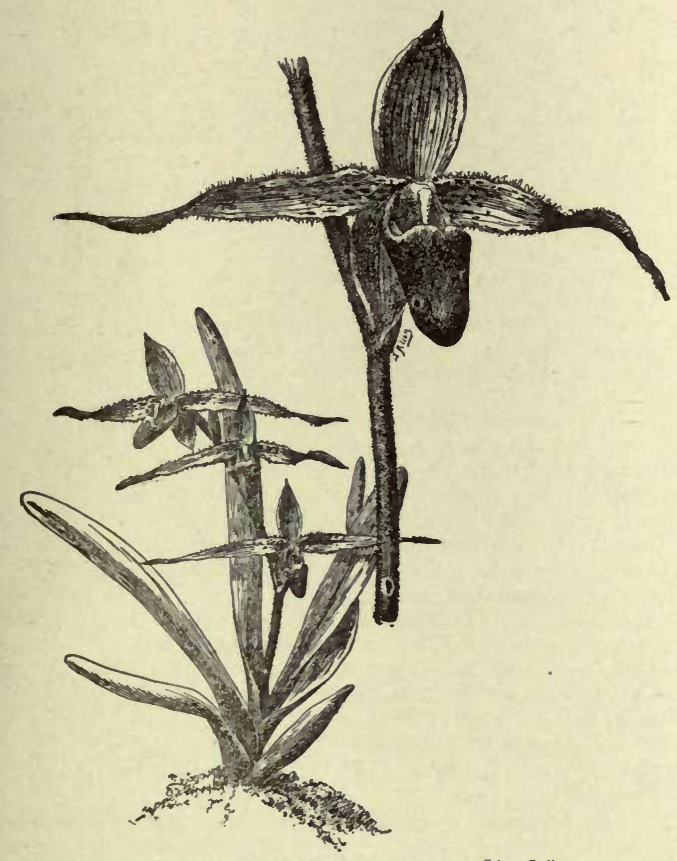

647. Cypripedium Rothschildianum ${ }^{-}\left(X^{1 / 4}\right)$.

spots large_-Moulmeinénse.-Nílssoni.-Nitens.-Larger than the type,stronger in growth: fls. very large; upper sepal whitemargined; spots in irregular rows. - Pynaérti. - Schroderianum. Fls. extremely large; upper sepal nearly orbicular, or petals pale greenish yellow; upper sepal margined with white; broadly ovate; basal margins finely dotted; spots largest at the center; petals brown-veined; staminode with a mucro - Studbyànum - Superliens. - Sylheténge. Largedark spot, somewhat confluent, in lines along the middle of the upper sepal.

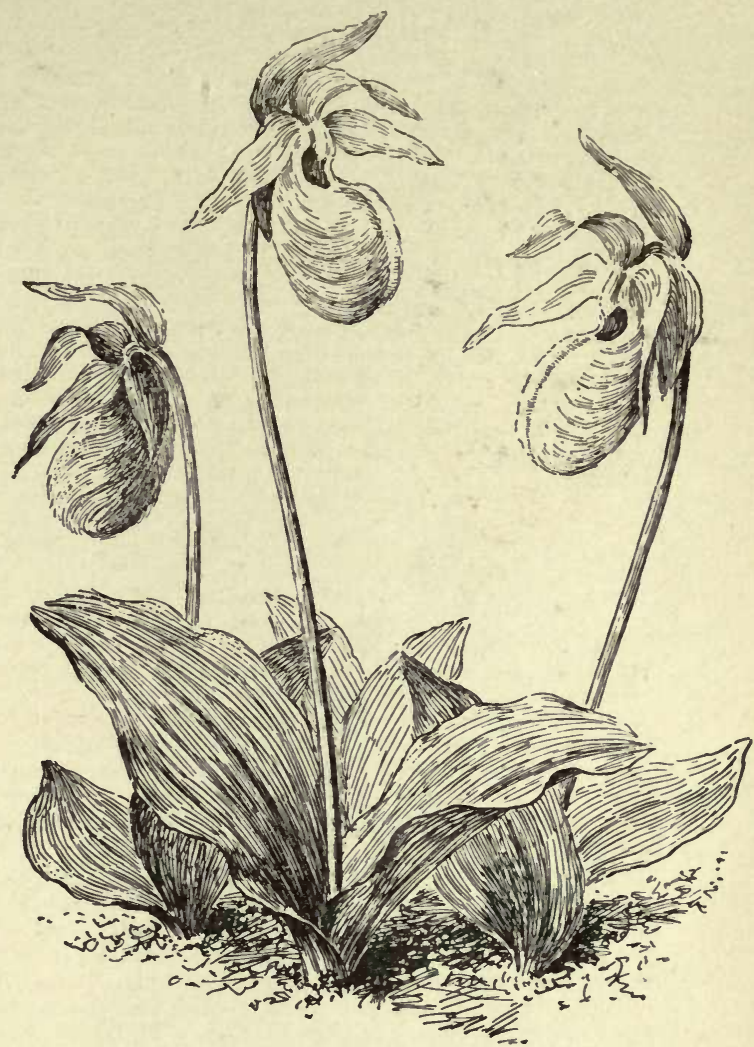

648. Cypripedium acaule $(\times 1 / 3)$.

26. Exúl, Rolfe. Lvs. narrower and more rigid than in the preceding species: upper sepal greenish yellow at the base, spotted with brown, upper part white ; petals and labellum similar to those of $C$. Druryi. Siam. B.M. 7510.-Considered by some to be a form of $C$. insigne.

27. Drùryi, Beddome. Lvs. ligulate, uniform green: scape about $1 \mathrm{ft}$. high : ovary subtended by a small bract; upper sepal arehing at the summit, yellowish with a dark median band; petals ligulate, yellow, with a dark median band; labellum yellowish. May, June. India I.H. $24: 265$. A.F. 6:555.

28. villòsum, Lindl. Lvs. linear-ligulate, uniform green spotted with brown-purple at the base: scapes copiously long-hairy : ovary subtended by a bract nearly as long as itself: upper sepal narrow at the base, broader above, brownish at the base, otherwise greenish yellow, finely margined with white; petals spatulate, broad at apices, wavy-margined, oblique, with a conspicuous brown midvein, otherwise brownish yellow; labellum brownish yellow; staminode large, oblong, yellowish. Jan., Feb. India. I.H. 4:126. A.F. 6:555.

Var. Bózalli. Hort. (C. Bbxalli, Reichb. f.). Upper sepal spotted with blackish spots, which are more or less confluent along the median line. Burma. I.H. $26: 345$.

29. Sállieri, Godef. Petals somewhat resembling those of the above; upper sepal large, broad at and toward the summit, yellowish green, spotted with brown, and provided with a broad white border round the upper half. Supposed natural hybrid between $C$. villosum and $C$. insigne. 


\section{Bв. Fls. more than 2. \\ C. Petals spatulate.}

30. Lòwei, Lindl. Lvs. ligulate, uniform green: scapes often more than $3 \mathrm{ft}$. long, arching, bearing several fis.: upper sepal yellowish veined with brownish purple at the base, broadly oval, basal margins revolute; petals fully 3 in. long, deflexed, twisted, spatulate, yellowish, with numerous brown-purple spots at and toward the base, the spoon-shaped extremities dull crimson-purple; labellum brown, infolded lobes paler; staminodium obcordate, with a horn-like projection at base. April, May. Borneo. F.S. $4: 375$. A.F. $11: 1349$. R.H. 1857, p. 402; 1883, p. $352 ; 1885$, p. 473.

31. Haynaldiànum, Reichb. f. Lvs. ligulate, leathery, uniform green: scapes about 20 in. long, villose, greenish brown, 1-5-fld.: upper sepal oval, lower margins revolute, cream-white above, purplish at the margins, the base yellowish, spotted with reddish brown; petals linear, broad at the extremities, and of a dull purple color, yellowish from the base about half way, with several large, reddish brown spots; labellum green tinged with dull purple; staminodium similar to that of preceding, but narrower. Jan.-May. Philippine Isls. B.M. 6296 .

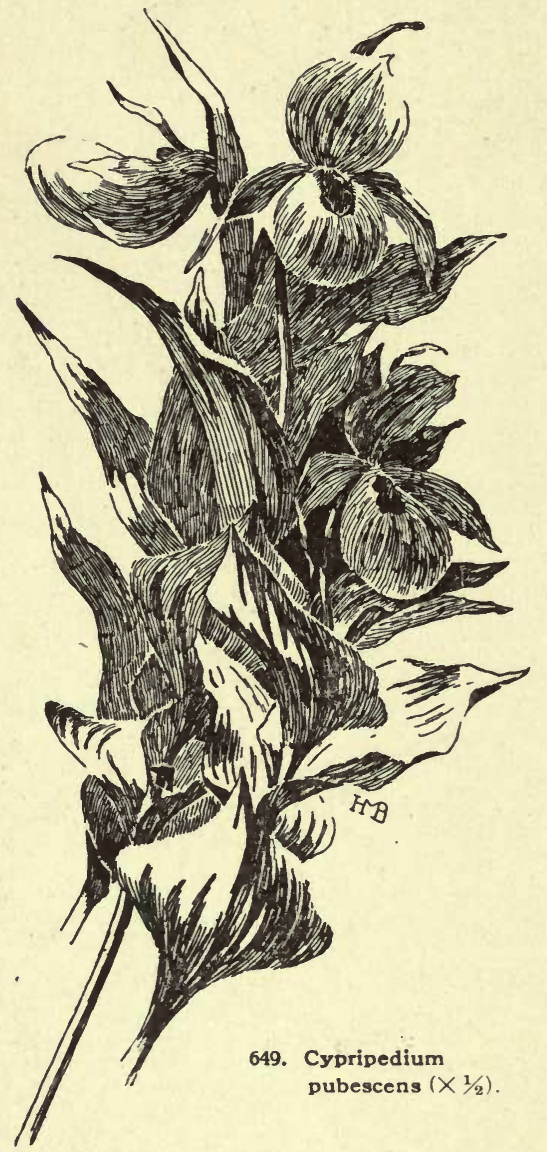

cc. Petals linear, usually drooping and twisted.

32. Párishii, Reichb. f. Lrs.coriaceous, thick, ligulate: scapes arching, pale green, bearing several fls.: upper sepal yellowish, with green veins, narrowly oval, basal margins reflexed; petals linear, twisted, obliquely pendent, greenish yellow at and toward the base, with several blackish spots and a row of marginal dots ; distal ends dull, glossy, brownish purple; labellum dark green, usually tinged with brown-purple; staminodium obcordate, with a tooth at base. Autumn. India. B.M. 5791. Gt. 47:25. I.H. 22:214. - Not a free-blooming species.

33. Stònei, Hooker. Lvs. ligulate, uniform green, decidedly coriaceous: scapes long, greenish brown, 3-5fld.: upper sepal nearly orbicular, white, with 4 crimsonmagenta veins or streaks, 2 on each side near the upper margin, suffused behind with crimson; lower sepal narrower, with several streaks, similar in color to those on the upper sepal; petals linear, at first spreading, then drooping, twisted at the extremities, pale yellow at the base, becoming deeper and finally reddish brown at and near the apices, spotted with crimson-brown; labellum calceiform, dull rose on the front, paler beneath, finely veined with deeper rose. Autumn. Borneo. B.M. 5349. -One of the finest in the genus.

34. Philippinénse, Reichb. f. (C. lovigatum, Batem). Lvs. thick, ligulate-oblong, uniform green: scape brownish, bearing from 2-5 fls.: upper sepals whitish, broadly ovate, striped with crimson-magenta; lower sepal striped with green; petals linear, twisted, drooping obliquely, greenish at base, becoming pale brown-purple toward the extremities; labellum small, yellowish; staminodium sub-cordiform. April, May. Philippine Isls., 1864. B.M. 5508. G.F. 3:309.

35. prǽstans, Reichb. f. (C. glandulíferum, Blume. C. Neo-Guineénse, Hort.). Lrs. coriaceous, deep green: peduncle longer than the lvs.: sepals about equal, broadly ovate, yellowish white, veined with reddish brown; petals with marginal warts, twisted, yellowish green; labellum calceiform, yellowish ; staminodium nearly quadrangular, lateral margins inflexed. Aug. New Guinea. I.H. $34: 26$. R.H. 1896, p. 421. - C. prostans, var. Kimballianum, Hort., is another form. This is not to be confounded with C. Kimballianum (see No. 37).

36. Sanderianum, Reichb. f. Lvs. ligulate, thick, uniform green: scape long, reddish brown, bearing several fis.: upper sepal narrowly ovate, yellowish, striped with brown; petals linear, about 18 in. long, yellowish at the base, marked with reddish brown, the middle part barred with reddish brown and yellow, purplish brown at and toward the blunt apices; labellum brownish. Feb.-May. Habitat known but not revealed: perhaps north Borneo. G.C. III. 19:329. Gt. 43:520.

37. Rothschildiànum, Reichb. f. Fig. 647. Lvs, thick: scape reddish brown, bearing several fls.: upper sepal ovate, acute, striped with brownish (almost black) veins, ground color yellowish; petals linear, spreading, oblique, yellowish, striped and spotted with dark brownpurple; labellum slipper-form, brownish, margin pale yellow, whitish beneath; staminode with a projecting beak. Winter months. Borneo. B.M. 7102. G.F. 6:145. -C. Elliottianum, O'Brien, is a variety of the above, or at least very closely allied to it. J.H. III. 32:55. A.F. $6: 557 ; 7: 855 .-C$. Kimballidnum, from Borneo, is a natural hybrid of $C$. Rothschildianum $\times C$. Dayanum: see A.G. $20: 719$, Fig. 186.

ccc. Petals much twisted, not drooping.

38. Chamberlainianum, O'Brien. Lrs. dark green, ligulate: scape arching, bearing several fls. that open in succession: ovary not conspicuously ribbed; upper sepal pale green, brownish at base, with about 12 veins which, brown at first, terminate green; margin whitish, ciliate, dorsal surface hairy; petals narrow, spreading, reflexed, twisted, green, with lines of numerous redbrown spots, tinged rose-pink near the column; labellum pale rosy mauve, copiously dotted with deeper mauve ; infolded lobes pale green : staminodium oval. Sumatra. B.M. 7578, as a Paphiopedilum. R.H. 1892, pp. 104-5. G.F. 5:413.

39. Victoria-Mariæ, Rolfe. Similar to the above: labellum dull purple; petals and upper sepal not lined with brown spots. Perhaps only a variety of $C$. Chamberlainianum. Sumatra. B.M. 7573, as a Paphiopedilum.

\section{AAA. Lvs. membranaceous, plicate.}

B. Foliage of two lvs. upon the ground, or nearly so.

40. acaule, Ait. Fig. 648. Lvs. ovate, oblong oval: scape naked, tall : upper sepal and petals brownish, lanceolate; labellum pink-purple to white (variable), 
with a fiss'ure in front; staminodium spatuliform. May and June. Newfoundland to N. C., west to Ind., Mich. and Minn. G.W.F. 11. A.G. 13:514; 14:405. Gng. 4:263. A.F. 11:1049.

BB. Foliage of two lvs, above the ground.

41. Slegans, Reichb. f. Plant about 4 in. high:-lvs. opposite, born $\Theta$ on an elongated aunual stem: upper sepal narrowly ovate, veined with reddish brown; petals lanceolate, similar in color to the sepals; labellum brownish, corrugated; staminode elliptic. July. Sikkim.Probably not in cultivation in this country.

42. Japonicum, Thunb. Lvs. nearly opposite, roundish, undulately plicate: bract longer than the ovary, fl. ter minating the scape: sepals and petals lanceolate, acuminate, greenish, dotted with red; labellum white-pink; staminodium cordate, channeled. April, May. Japan.

BBB. Foliage of several or many lvs. on the stem.

\section{c. Lower sepal divided.}

43. arietinum, R. Brown. Plant about 6 in. high, slender: lvs. lanceolate: fls. small, terminal, solitary; upper sepal ovate-lanceolate, brownish green; petals linear; labellum tapering at the apex, white veined with reddish purple, clothed with white, woolly hairs near the aperture ; staminodium nearly round. May. Maine to N. Y., Mich. and Minn., and northward. B.M. 1569. L.B.C. $13: 1240$. F.S. $20: 2095$, - Fls. curiously irregular in shape, resembling a ram's bead.

44. Himalàicum, Rolfe. Plant 8-12 in. high: lvs. 3, elliptic-oblong: upper sepal ovate, brownish, with deeper colored veins; petals narrow, oblong, paler than the upper sepal; labellum purple-brown, many-nerved; staminode heart-shape. July. Bhotan.-Probably not eultivated in this country.

45. Thibeticum, King. Lvs. 3, close together on the stem: labellum larger than in the preceding, and not depressed, brown-purple; petals pale brown; staminode oval-cordate, angled at the base. July. Sikkim. - Probably not in cultivation.

\section{cc. Lower sepal little or not at all divided.}

46. cándidum, Muhl, Lvs, oblong-lanceolate: fls, terminal, solitary; sepals broader than the petals, ovatelanceolate; petals spreading like the sepals, greenish; labellum white, striped inside with purple; staminodium lanceolate. May and June. N. Y., Penn., Minn., Mo. and $\mathrm{Ky}$.

47. pubéscens, Willd. Fig. 649. Lrs. oval, acute petals usually twisted, much narrower than the ovatelanceolate sepals; labellum pale yellow; staminodium triangular. Same range as No. 49. May and June. B.M. 911, as C. parviflorum. A.G. 13:513. Mn. 7:5.

48. Calcedlus, Linn. Fls. usually solitary; labellum yellow, slightly compressed, shorter than the lower sepal; sepals and petals deep, rich brown; staminodium triangular. Yorkshire and other northern counties of Eng., Eu. R.H. 1892, p. 392. R.B. 21:210.

49. parviflorum, Salisb. Lvs. ovate, acute: fls. smaller than in $C$. pubescens; labellum flattened from above and below, not laterally, bright yellow; staminodium triangular. May and June. Newfoundland to Ga., west to Minn. and E. Kans. A.G. 13:515.

50. spectábile, Swartz. Fig. 650. Plants stout: lvs. oval, acute: sepals ovate, rather roundish, white; petals oblong, white; labellum white or pale pink-purple ; staminodium oval-cordate. June. Maine, western New Eng. to Minn, and Mo., mountains of N. Car. R.H. 1868:410. Gn. 53, p. 77. R.B. 20, p. 198. A.F. 11:1048. Gng. $4: 262,327$.

51. macránthon, Swartz. Lvs. oblong, acute : fis. purple, not spotted ; upper sepal oblong, acute ; lower sepal smaller; petals ovate-lanceolate; labellum contracted at the aperture. Moist, shady places, northern Asia, Siberia. R.H. 1877:310.

52. Californicum, Gray. Plants either slender or stout, varying in height, sometimes exceeding $2 \mathrm{ft}$. : lvs, ovatealternate : floral bracts very large, becoming narrowly ovate: fls. small, from 6-12 open at the same time, an inch or more apart on the stem; labellum whitish; se- pals oval, yellowish green; petals narrowly oblong, colored like the sepals. Canf. B.M. 7188. G.F. 1:281.

53. montànum, Dougl. One to $2 \mathrm{ft}$., leafy, pubescent: lvs. ovate to broad-lanceolate, 4-6 in. long: fls. 1-3, short-pedicelled, the wavy-twisted petals brownish, the

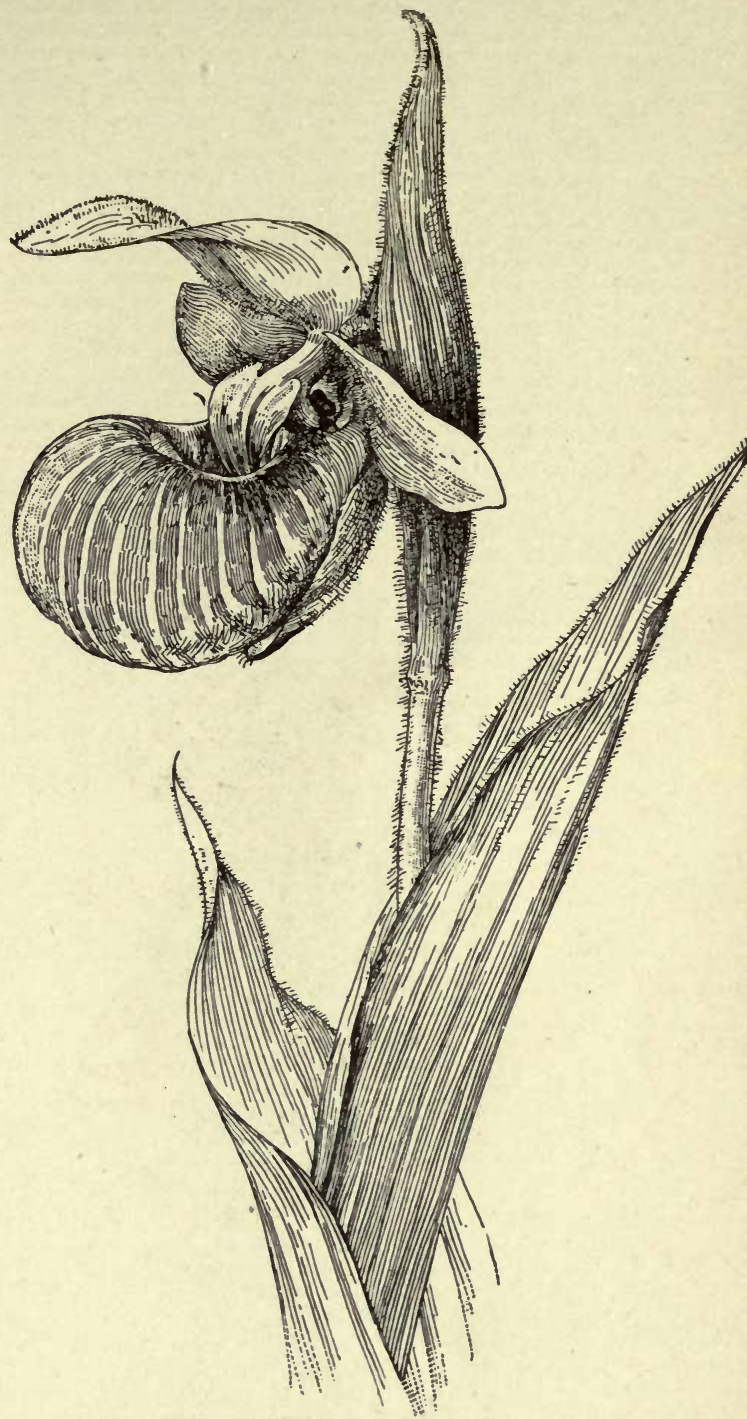

650. Cypripedium spectabile. Natural size.

inch-long lip dull white veined with purple; capsule erect or nearly so. Calif. to Wash. B.M. 7319.-Fragrant. Grows in clumps. Handsome.

54. Irapeànum, Llave et Lex. Lvs. ovate-lanceolate: fls. large, several, sepals and petals about equal ; labellum very large, much inflated, suggesting the inflated petal of a Calceolaria. Mex.-This species has not as yet been successfully cultivated.

Supplementary list, comprising hybrid Cypripediums (for catalogues of hybrids, see G.C. III. 17: 199 and A.G. 16: 118): Acis = Lawrenceanum $X$ insigne, var, Maulei - Adrastus = Leenum $X$ villosum $\times$ ar. Boralli - Alcides=insigne $\times$ hir Letissimum - Affed Hollington $=$ ciliolate $\times$ Philippinense Allanianum $=$ Spiceriannm $\times$ Curtisii - - Almum $=$ barbatum $\bar{X}$ Lawrenceanum. - A mandum $=$ insigne $X$ venustum. - A mesi-
anum $=$ villosum $X$ venustum (see Measuresiannm). - Apiculatum $=$ barbatum $\times$ villosum, var. Boxallii. - Artemis = Day. annm $\times$ Swanianum. - Arthurianum $=$ insigne $\times$ Fairieanum. 
A. F. 6:557- Arthurianum, var. pulchellum =insigne Chantini $\times$ Fairieanum. - Ashburtonioe (C. obscurum) $=$ barba-
tum $\times$ insigne. I.H. 35: 61. - Ashburtonioe, var. expansum $=$ same. - Aspasia $=$ selligerum majus $X$ tonsum. - Aureum $=$ nitens, var. Sallierii $\times$ Spicerianum. Dist. Icon. des O. A uroreum $=$ Lawrenceanum $\times$ venustum. - Beatrice $=$ Boxallii $\times$ Lowii. - Berggrenianum = Dauthierii Xinsigne. - Bryanii (Burfordense $)=$ Philippinense $\times$ Argus. - Buchanianum $=$ Druryi $X$ Spicerianum.-Calanthum = barbatum Crossii $\times$ Lowii. - Cali gare = venustum $\times$ Dayanum - Callo - Rothschildianum $=$ callogare $=$ venustum $\times$ Dayanum.- Callo-Rothschildianum $=$ callosum $\times$ Rothschildianum. - Calypso. See Lathamianum.-Cau-
hamii (Chas. Cauham) $=$ villosum $\times$ superbiens.-Carnusianum hamii $($ Chas. Cauham $)=$ villosum $\times$ superbiens. - Carnusianum tissimum. - Chelsiense $=$ Lowii $\times$ barbatum, var. Warnerii. Chloroneurum $=$ barbatum $\times$ venustum. - Cleopatra $=$ =nanthum $\times$ Hookeræ. -Clinkaberryanum $=$ Philippinense $\times$ Curtisii. $-C l o-$ tilde Moens=Leeanum, var. superbum $\times$ Haynaldianum. - Con cinnum $=$ villosum $\times$ purpuratum. - Conspicuum $=$ Harrisianum $\times$ villosum - - Constance $=$ Curtisii $\times$ Stonei. - Cooksonianum $=$ almum. - Oreon $=$ Harrisianum, var. superbum $X$ cenanthum, var. superbum. $=$ Crethus $=$ Spicerianum $\times$ Argus. - Crossianum = insigne $X$ venustum. - Oybele $=$ Lawrenceanum $\times$ Druryi.Dauthierii. See Harrisianum. - Dibdin, var. Davisianum = villosum, var. Boxallii $\times$ Argus, var. Moensii.- Dilectum $=$ vil. losum, var. Boxallii $\times$ hirsutissimum. - Discolor=venustum $\times$ ? - Donatianum =insigne, var. Wioti $\times$ Harrisianum. - Doncasteri . anum $=$ hirsutissimum $\times$ callosum. - Doris $=$ venustum $\times$ Stonei. - Drurio-Hookero $=$ Druryi $\times$ Hookeræ,- Electra $a=$ onanthum, - Drurio-Hookere = Druryi var. electra. - Enfieldense $=$ insigne, var. Chantini $\times$ auroreum. - Euryale $=$ Law . altes $=$ insigne,
renceanum $\times$ superbiens. - Euryandrum $=$ barbatum $\times$ Stonei. Eurylochus $=$ ciliolare $\times$ hirsutissimum. - Excelsior $=$ Roth schildianum $\times$ Harrisianum. - Fairy Queen $=$ Curtisii $\times$ Druryi.Finetianum $=$ Philippinense, var. Rœbbelenii $\times$ barbatum. Fitchianum $=$ Hookeræ $\times$ barbatum. - Frau Ida Brandt $=$ Io, var grande $X$ Youngianum - Galate $a=$ Harrisianum $X$ insigne Maulei - Gemmiferum = Hookeræ X purpuratum - Germiny Maulei. - Gemmiferum $=$ Hookeræ $X$ purpuratum. - Germinyanum, var. Godseffianum $=$ villosum, var. Boxallii $\times$ hirsutissiHarrisianum, var. superbum $\times$ Lawrenceanum. - Gowerianum - Lawrenceanum $\times$ Curtisii. - Greyanum $=$ Druryi $\times$ ciliolare. - Harrisianum $=$ barbatum $\times$ villosum. F. S. 22:2289-90. R. B. 22:148. A.F. 6: 557. - Harrisianum, var. superbum = barbatum $X$ villosum. - Harrisianum, var. Dauthierii $=$ bar.

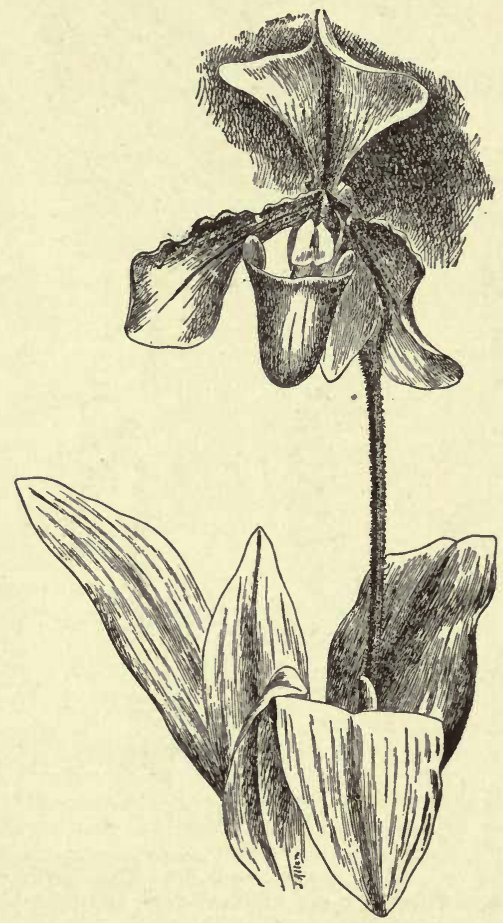

651. Cypripedium Lathamianum $\left(X^{1 / 3}\right)$.

Hybrid. (See supplementary list.)

batum $\times$ villosum. - H. Ballantine $=$ purpuratum $\times$ Fairieanum. - Hephoestus = callosum $X ?-$ Hobsonii $=$ Lawrenceanum (pistillate) $\times$ Philippense. A. F 14:1094 Gn 7.242 Hornianum $=$ Spicerianum $X$ superbiens. - Hurrellianum
$=$ Argus $\times$ Curtisii. - Hybridum $=$ villosum $\times$ barbatum Ino=Haynaldianum $\times$ Mrs. Cauham. - Intermedium. See Hy. bridum. - Io $=$ Lawrenceanum $\times$ Argus. - Javanico-Spicerianum. See Lutescens. - Javanico-superbiens. -Joseph Donat=

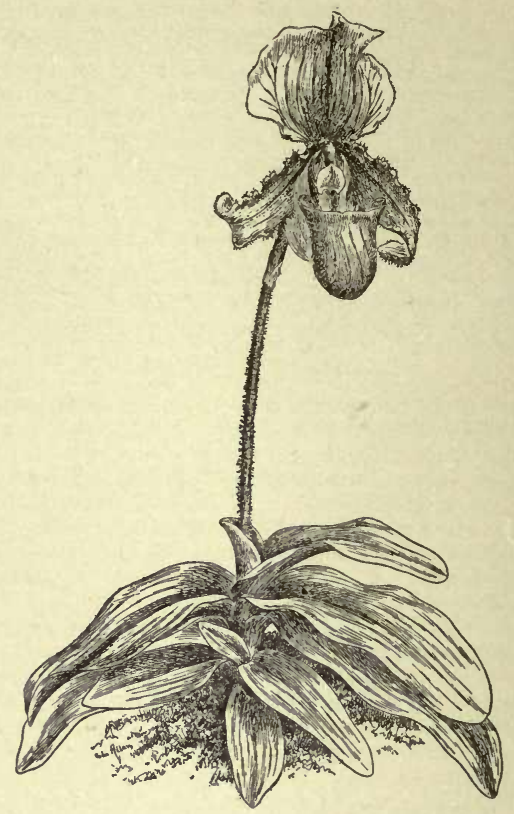

652. Cypripedium Niobe $\left(X^{1 / 3}\right)$. Hybrid.

(See supplementary list.)

Ashburtonæ $\times$ Spicerianum. - Josephianum $=$ Druryi $\times$ Javanico-superbiens. A.F. 7:707. - Juno $=$ callosum $\times$ Fairieanum. - Kimballianum $=$ Rothschildianum $\times$ Dayanum - Krameri . anum $=$ cenanthum $\times$ villosum $-K$ rishna =insigne $\times$ tonsum Laforcade $=$ barbatum $X$ insigne, var. Chantini. - Lathami. anum (Fig. 651) = Spicerianum $\times$ villosum. - Lathamianum, var. Calypso $=$ Spicerianum $\times$ villosum, var. Boxallii.-Leeanum $=$ insigne $\times$ Spicerianum. - Leeanum, var. giganteum $=$ insigne $\times$ Spicerianum. A.F.9:765. - Leeanum, var Masareelianum= insigne, var. Chantini X Spicerianum. I. H. 36:77. A. F. 6: 555. A.G. 12: 65. - Leeanum, var. superbum is a good form raised by Veitch - Loewegrenianum = Spicerianum $X$ Io grandis Lucidum $=$ Lowii $\times$ villosum - Luridum $=$ Lawrenceanum $\times$ villosum, var. superbum.-Lutescen $8=$ Spicerianum $X J a v a n i c u m$. - Lynchianum $=$ Spicerianum $\times$ sellegerum. - Macropterum $=$ Lowii X superbiens. - Marmorophyllum=Hookeræ $\times$ barbatum. - Marshallianum = venustum, var. pardinum $\times$ concolor. Masereelianum. See Leeanum. - Massaianum $=$ superciliare $\times$ Rothschildianum. - Maynardi $=$ purpuratum $\times$ Spicerianum. - Measuresianum $=$ villosum $X$ venustum. - Measuresianum, var paroninum =villosum,var. Boxallii X venustum - Morganae = superbiens X Stonei. I.H. 34:5.-Mrs. Cauham=superbiens $X$ villosum.-Mrs. G. D. Ower = superciliare Xvillosum.-Mulus villosum.-Mrs. G. D. Ower = superciliare $\times$ villosum. - Mulus
$=$ hirsutissimum $\times$ Lawrenceanum. - Niobe (Fig. 652) = Spicerianum $\times$ Fairieanum. - Nitens $=$ villosum $X$ insigne, var. Maulei Nitens, var. Sallieri $=i n s i g n e X$ villosum. - Nitens, var. Sallierii, sub-var. Hyeanum = insigne Xvillosum.-Nitens, var. Schlesingerianum=villosum, var. Boxallii Xinsigue-Nitens, var. Mons de Curte $=$ Boxallii $X$ insigne Chantini. - Numa $=$ Lawrenceanum $X$ Stonei.-Oakes Ames=ciliolare $\times$ Rothschildianum.-Obscurum =ønanthum. - Enanthum =Harrisianum $\times$ insigne. - Olivia $=$ tonsum $\times$ niveum. - Orestes $=$ - onanthum, var. Orestes. - . Or. phanum = barbatum $\times$ Druryi.-Osbornei = Harrisianum, var. superbum $\times$ Spicerianum. - Pageanum $=$ superbiens $\times$ Hookeræ. - Pallens $=$ Spicerianum $\times$ Dayanum. - Patersonii $=$ Lowii $\times$ Lawrenceanum.-Pavoninum. See Measureianum. A.F. 7:707. - Pelias $=$ Haynaldianum $\times$ insigne. - Pelop $s=$ Niobe $\times$ javanico. superbiens. - Pellucidum = insigne, var. Maulei X Dayanum Picturatum = Spicerianum $\times$ superbiens. - Pitcherianum =Har. risianum, var. superbum $\times$ Spicerianum - Pleistochlorum $=$ bar. risianum, var. superbum $X$ Spicerianum. - Pleistochlorum $=$ bar.
batum $X$ javanicum, var. virens. - Pleuroneuron $=$ venustum $X$ batum $X$ javanicum, var. virens. - Pleuroneuron $=$ venustum $X$
villosum. - Plunerum $=$ villosum $X$ venustum $(8)-$ Politum $=$ barbatum $X$ venustum. - Pollettianum $=$ calophyllum $X$ cenan. thum, var. superbum. - Prevettii $=$ Harrisianum $\times$ villosum Radiosum $=$ Lawrenceanum $\times$ Spicerianum. - Regale $=$ insigne var. Maulei X purpuratum. - Rowallianum $=$ villosum $\times$ venus: tum (see Measureianum) - Rubescens = vanthum, var. superbum $\times$ villosum, var. Boxallii.-Savageanum=Harrisianum $\times$ Spicerianum. - Selligerum $=$ barbatum $\times$ Philippense. - Sel. 
liaerum, var. majus = barbatum $\times$ Philippinense. A.F.11:1349. - Seegerianum $=$ Harrisianum $\times$ Spicerianum. - Superciliare = barbatum $X$ superbiens. - Susan $\Delta$ mes $=$ Leeanum $X$ nitens. -Svend-Brunn $=$ Lowei $\times$ Curtisii. - Swanianum $=$ Dayanum Xbarbatum. - Swinburnei $=$ insigne, var. Maulei $\times$ Argus.T. B. Haywood $=$ Drury $X$ superbiens. - Tesselatum $=$ concolor $\times$ barbatum. A.F . 7:707. - Thayerianum =Lawrencesnum $X$ villosum, var. Boxallii. - Thibautianum $=$ Harrisianum $X$ insigne, var. Maulei - Thorntonii=superbiens Xinsigne. - Thorn-

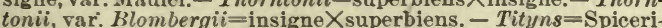
tonil, var. Blombergi $=$ insigne $X$ superbiens. - Tityns $=$ Spiceri anum $\times$ oenanthum, var. superbum. - Tonso-villosum $=$ tonsum $X$
villosum. - Turpe $=$ barbatum $\times$ Argus. $-T$. W. Bond $=$ hirsutissimum $\times$ Swanianum. - Umlauftianum $=$ insigne, var. Chantin $\times$ Lawrenceanum. - Van Houteanum $=$ niveum $\times$ Dauthieri. A.F. 6: 557. - Vernixum $=$ Argus $X$ villosum. - Vexillarium $=$ barbatum $\times$ Fairieanum. - Walloertianum $=$ Harrisianum $X$ villosum. - Wiganianum $=$ Harrisianum or Hookeræ X Ashburtonm - Williamsianum $=$ Harrisianum $X$ venustum or villosum. C. débile, Reichb. f., a small Japanese species, is offered by importers of Japanese plants. It is the $O$. cardiophyllum, Franch. \& Sav. Fls. very small, not much larger than those o Calypso borealis. - C. fasciculatum is offered by importers of Dutch bulbs. The $\mathrm{C}$. fasciculatum, Kellogg, is Californian 2-6 in., bearing a pair of nearly opposite, ovate, somewhat acute lvs.: fls. solitary or several, greenish, the depressed lip greenish yellow with a purplish margin.

OAKES AMES.

CYRILLA (after Dominico Cyrillo, professor of medicine at Naples, 1734-1799). Cyrillacea. Shrub, rarely tree: lvs. short-petioled, entire, glabrous, deciduous or nearly persistent: fls. small, white, in narrow slender racemes, 5-merous : fr. a small indehiscent 2-celled capsule with 2 seeds. Probably one variable species from N. Carolina to Florida, west to Texas, and in W. India and S. America. Ornamental shrub, rarely cultivated, with handsome bright green foliage, and graceful racemes of white fls., hardy north to New York. Thrives best in humid sandy soil and shady position. Prop. by seeds and cuttings under glass, with slight bottom heat.

racemiflora, Linn. Leatherwood. Shrub, occasionally tree to $30 \mathrm{ft}$.: lvs. cuneate, oblong or oblanceolate, usually obtuse, reticulate-veined, 2-3 in. long, bright green, turning orange and scarlet in fall, but in tropical climates evergreen: racemes 4-6 in. long, erect, at length nodding. B.M. 2456. S.S. 2:51. -The variety from W. India has been described as C. Antillana, Michx., and that of Brazil as C.racemifera, Vandelli. ALFRED REHDER.

CYRTANTHUS (Greek, curved flowers; from their pendulous habit). Amarylliddeece. Twenty species of tender bulbs from South Africa, known only in a few American greenhouses. Their culture is presumably like that of many other bulbs from the same region. They are suitable for pot culture, or for planting out in summer. The following analytical key gives an idea of the group, and its three subgenera.

$$
\text { A. Fls. many in an umbel, pendulous. }
$$

B. Lis. strap-shaped. (Cyrtanthus proper.)

obliquus, Ait. Bulb ovoid, 3-4 in. thick: lvs, 10-12, strap-shaped, distichous, produced after the fls., 11/2-2 ft. long: scape 1-2 ft. long, stout, mottled: fls. 10-12 in an umbel, entirely drooping, odorless, bright red, with more or less yellow, and greenish tips 2-3 in. long; pedicels $1 / 2-1$ in. long; style not exserted. Cape Colony. B. M. 1133 .

BB. Lvs. linear. (Monella.)

Míckenii, Hook. f. Bulb $1 \frac{1 / 2}{2}$ in. thick: lvs. 2-6, appearing with the fls., linear, $1 \mathrm{ft}$. long: scape slender, slightly glaucous: fls. 4-10 in an umbel, pure white, 2 in. long; style exserted. Natal. G.C. I. 29:641. Gn. 50, p. 63 .

AA. Fls. single, or few in an umbel, erect or slightly curved downward. (Gastronema.)

sanguineus, Hook. Bulb 2 in. thick: lvs. 3-4, appearing with the fls., lanceolate, petioled, $1 \mathrm{ft}$. long: scape slender, 6-9 in. long: fls. 1-3, bright red, 3-4 $1 / 2$ in. long, wider funnel-shaped than in the two preceding species, with a throat $I$ in. across. Caffraria, Natal. B.M. 5218.

O. Huttoni, Baker, belongs to Cyrtanthus proper, but its los. appear with the fis., and it has 6-8 or even 12 pale red fls. about $1 \mathrm{in}$. long, and a much shorter style than in O. obliquus. Cape Colony. B.M. 7488. Gn. 50:1076.
CYRTOCÁRPA (Greek, curved fruit). Anacardidcece. Two Mexican trees, of which one bears a small fruit, likened to a cherry by the natives of Lower Calif. Introduced into S. Calif. by F. Franceschi. Santa Barbara.

procera, HBK. Very tall tree, with slender, terete, dark purplish, resinous branches: lvs. alternate, oddpinnate: leaflets 5-7 or 9, oblong, entire, with a very slight silkiness, especially below, very shortly stalked, $1 \mathrm{in.}$ or more long, half as wide: fls. white, inconspicuous, in panicles 1-2 in. long; calyx 5-parted, villous, persistent ; segments roundish ; petals 5, elliptic ; stamens 10; style 1: fr. the size of an olive, edible. Mex. HBK. 6, t. 609 .

\section{CYRTOCHILUM. Referred to Oncidium.}

CYRTODEेIRA. See Episcia.

CYRTOMIUM (Greek, $a$ bow). Polypodidcec. A genus of Asiatic half-hardy or greenhouse ferns of rigid habit, with simply pinnate lvs., anastomosing veins and firm indusia fixed by the depressed center. Culture as for Polystichum, to which it is closely allied.

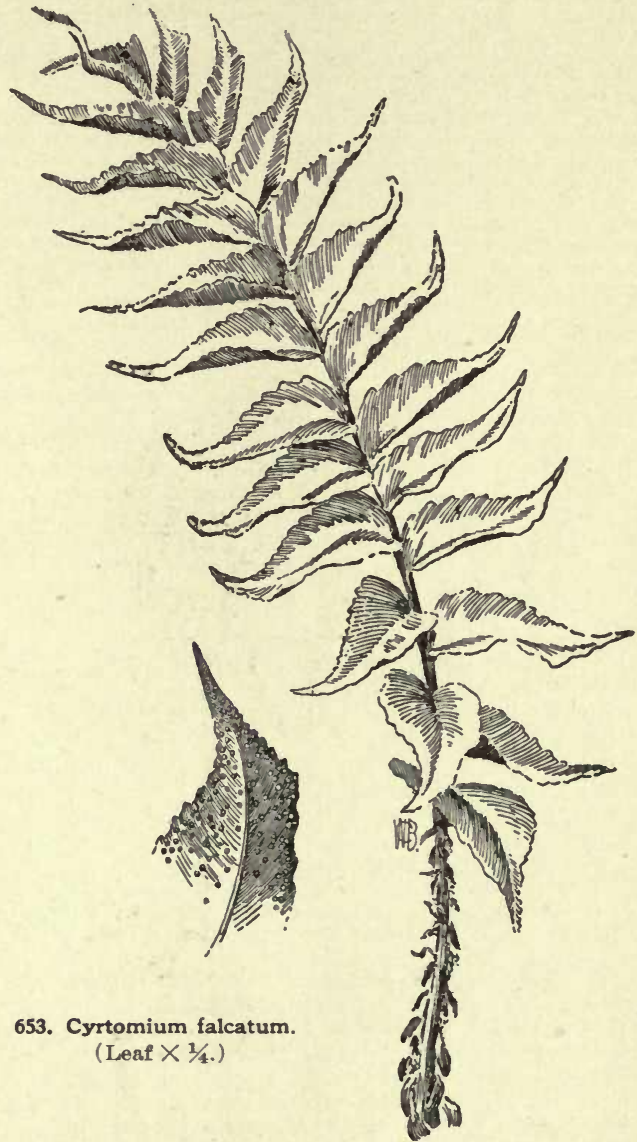

A. Margins of pinnce entire or slightly undulate.

falcatum, J. Sm. Fig. 653. Pinnæ ovate, falcate ; the lower rounded or obliquely truncate at the base, 4-6 in. long, 1-2 in. wide. Japan and India. - The large thick, glossy foliage makes it an excellent fern for decorations.

Fórtunei, J. Sm. Pinnæ lanceolate, opaque, 2-4 in long, $1 / 2-1$ in. wide. Japan.

B. Margins of pinnce toothed or sometimes lobed.

caryotídeum, J. Sm. Pinnæ larger, 5-7 in. long, 11/2$21 / 2$ wide, often auricled on both sides at the base, sharply toothed. India.
L. M. UNDERWOOD. 
CYRTOPERA. Consult Cyrtopodium Woodfordii.

CYRTOPODIOM (Greek for curved foot, from the shape of the lip). Orchidacece, tribe Vándece. Epiphytes: stems fusiform, bearing plicate leaves: sepals and petals equal, free ; column semiterete: pollinia 2, caudicle short, gland ovate: scapes radical, bearing numerous flowers, pure yellow or spotted with crimson. Probably two dozen species, widely distributed in the tropies. They are large-growing plants, with large and showy flowers. They need a rich, fibrous soil with manure. Grow in a warm or tropical house.

Ándersonii, R. Br. Stems $5 \mathrm{ft}$. high": lvs. long, lanceolate, sheathing at the base: scape often $3 \mathrm{ft}$. high, branching, bearing many yellow flowers: sepals and petals broad, bright yellow, the labellum brighter, front lobe slightly concave. Specimens with over $100 \mathrm{fls}$. have been recorded. Tropical Amer. B.M. 1800.

punctatum, Lindl. Habit as above: scape from 2-3 ft. high, branching about midway, dotted with dull purple, the branches subtended by membranaceous sheathing bracts, which are lanceolate, undulating, and dotted with crimson: sepals oblong-lanceolate, undulate, greenish yellow blotched with crimson; petals similar, spotted at the base; labellum $1 / 2$ in. long, fleshy, bright yellow, lateral lobes crimson, midlobe spotted and margined with crimson; column green. Extensively dis tributed through S. Amer. B.M. 3507. F.S. 22: 2352.Var. Saintlegerianum, Hort. (C. Saintlegerianum, Reich, f.). Has brighter markings on the bracts and flowers.

Woddfordii, Sims (Cyrtopèra Woddfordii, Lindl.). Stems fusiform: Ivs. lanceolate: scape radical, bearing a many-flowered raceme: fls. greenish, with a purple labellum; sepals linear lanceolate; petals oblong. Trinidad, Martinique. B.M. 1814.

OAKES AMES.

CYRTOSPÉRMA (Greek, curved seed). Aroideœ. This genus includes a handsome warmbouse tuberous foliage plant, with large, hastate red-veined leaves, resembling an Alocasia, but easily distinguished by its spiny stems. It was introduced into cult. in 1880 from the Solomon Islands as Alucasia Johnstoni, but two years later it flowered, and it became evident that the plant was a Cyrtosperma. This plant was once advertised by Pitcher \& Manda as Cyrtemeria, apparently a typographical error, as there is no such genus. Cyrtosperma has 9 species, remarkably scattered in the tropics. They are herbs with tubers or long rhizomes: leaf and flower-stalks often spiny or warty: Ivs. hastate or sagittate; petioles long, sheathing at the base. Culture presumably same as Alocasia.

Johnstoni, N. E. Br. (Alocàsia Jóhnstoni, Hort.). Tuberous: petiole 2-23/4 ft. long, olive green, spotted rose, covered with fleshy, spine-like warts: lvs. sagittate, depressed in the middle, $11 / 2-2 \mathrm{ft}$. long, olive-green, with prominent and beautiful red veins above. I.H. $27: 395$.

C. ferox, Lind. \& N. E. Br., is a second species of this genus, figured in I.H. 39:153, but not known to be in the Amer. trade. It has narrow-sagittate lvs. on slender, very prickly petioles: spathe rather large, reflexed, greenish white. Borneo.

CYRTÓSTACHYS (Greek for arched spike). Palmàcea, tribe Arècece. Three Malayan, spineless, pinnate-leaved palms, sometimes seen in choice collections. They thrive on the treatment given to Areca and Chrysalidocarpus. Spadix large, branching and pendent: fls. monocious, the two kinds in one spadix-each pistillate accompanied by two staminates with 6 stamens. Two species are offered in this country:

Rénda, Blume. Height 25-30 ft. : leaflets linear or ensiform, obtuse, unequally 2-toothed, delicate gray beneath, the petioles dark, brownish red.

Lákka, Becc. Petioles green : lvs. broad, boldly arched, the leaflets unequally 2-toothed.

CYSTACANTHUS (Greek for bladder Acanthus, because the flowers are inflated). A canthdcece. Five erect, evergreen herbs of Burma and Cochin China, with showy, sessile fls. in the axils of bracts, the entire in- florescence more or less crowded into a terminal panicle or thyrse. Corolla-limb spreading, unequally 5-lobed, the lobes short-rotund: stamens 2: style filiform, the stigma 2 -toothed : lvs. entire. One species is cult. in the. Old World, but is not known to be in the Amer. trade. This is C.túrgida, Nicholson, B.M. 6043 as Meninia túrgida, Fua. It comes from Cochin China; 2 ft. or less high, with prominently jointed stems and opposite, ellipticlanceolate lvs.: fls. white, yellow in the throat and pinkreticulated on the lobes. Cult. as other warmhouse Acanthads. (See A phelandra for example.) Prop. by cuttings of young wood.

CYSTÓPTERIS (Greek, bladder-fern). Polypodidcece. A small genus of hardy native ferns, with delicate foliage, and round sori, covered by a delicate indusium which is attached under one side and opens at the other, becoming hood-like in appearance and finally disappearing. The 5 species all grow in the north temperate zone. Of easy culture in shady, rich borders.

C. bulbifera, Bernh. Lvs. 8-24 in. long, widest at the base, tripinnatifid, bearing on the under surface of the rachis a series of bulb-like bodies, which germinate and propagate new plants. Thrives best on lime-bearing rocks. Canada to North Carolina.

C. frágilis, Bernh. Fig. 654. Lvs. clusi tered, 4-8 in. long besides the slender stalks,
tripinnatifid, widest above the base. Widely L. M. UNDERWOOD.

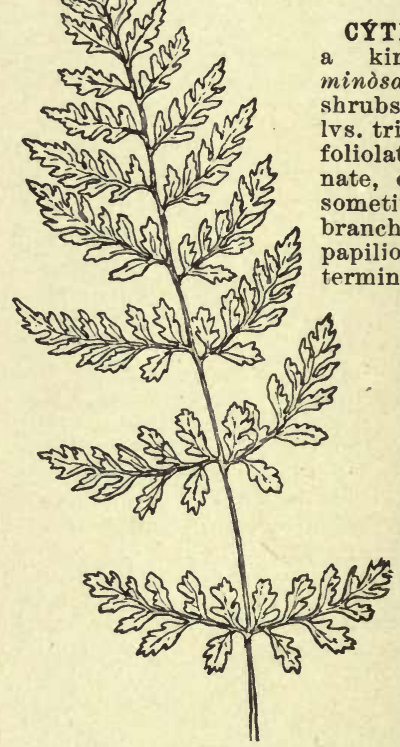

654. Cystopteris fragilis. $(X 1 / 3$.
CYTISUS (Greek name for a kind of clover). Legumindse. BROOM. Mostly low hrubs, rarely small trees: vs. trifoliolate, sometimes unimate, deciduous or persistent sometimes few and minute and branches almost leafless: fls. pilionaceous, axillary or in al heads or racemes, yellow, white or purple; stamens 10, connate; style curved : pod flat, dehiscent, with few or many seeds ; seeds with a callose appendage at the base. About 45 species in S. and M. Europe, Canary Isl., N. Africa and W. Asia. Ornamental free-flowering shrubs, blooming most in early spring and sumer. Nearly hardy north are C.hirsutus, C.capitatus, C. scoparius, C. nigricans, O.leucanthus, while the evergreen species $C$. Canariensis, $C$. candicans, $C$. filipes are hardy only south. Most of the species are well adapted for borders of shrubberies, and thrive in almost any well drained soil and in sunny position; they naturalize themselves often very quickly in dry, gravelly soil, where few other plants will grow; $C$. scoparius especially does so. The Cytisus ought to be transplanted carefully and when young, as they do not bear transplanting well as older plants. Some dwarf species like C. Ardoini, Kewensis, glabrescens, purpureus and leucanthus are very handsome for rockeries. The evergreen $C$. Canariensis and racemosus are much grown in the north as greenhouse shrubs, blooming profusely in early spring; also the white-flowering $C$. albus and filipes make handsome pot-plants, and may be had in bloom in February with gentle forcing. For potplants, a light sandy loam with peat added forms a suitable compost. After flowering the plants should be cut back and repotted as soon as they start into new growth. 


\section{CYTISUS}

After repotting ther are kept close and often syringed until they are established; then they ought to have plenty of air and only slight shade. When the new growth has been finished they may be put in the open air until frost is threatening. During the winter they should be kept in a cool greenhouse with plenty of light and carefully and moderately watered. From January they may be transferred gradually in a warmer house for forcing.

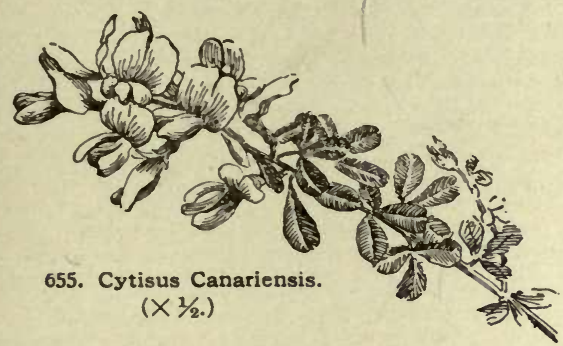

Cuttings started in early spring, transplanted several times and then gradually hardened off, can be grown into flowering specimens for the following spring. Prop. by seeds sown in spring and by greenwood cuttings under glass; they are also sometimes increased by layers or by grafting. As stock C. nigricans is much used, or Laburnum vulgare for small standard trees; for plants grown in the greenhouse or south, $C$. Canariensis is a good stock.

ALFRED REHDER.

Of Cytisus, the young growths root readily in December and January in the ordinary way. They should be shifted on as they grow. Good sized plants can be produced if shifting and pinching is not neglected. By the following winter, the winter-propagated plants should be in 5 -in. pots, in which size they are most useful. Keep very cool during winter and withbold any forcing. They flower in March, or, if kept at a night temperature of $45^{\circ}$, as late as April. Syringe at all times to prevent red spider. To produce good sized plants in one year, it is best to keep them plunged on a bench under the glass the entire summer, with little shade. Older plants can be plunged out of doors during July, August and September.

William Scott.

Index : albus, 2 ; Andreanus, 1; atropurpureus, 5 ; Canariensis, 10 ; candicans, 8 ; capitatus, 7 ; carneus, 5 ; elongatus, 14, and suppl. list ; Everestianus, 11 ; falcatus, 6 ; filipes, 3 ; hirsutus, 6 ; incarnatus, 2 ; Linkii, 2 ; linifolius, 13; Maderensis, 9; nigricans, 14; Palmensis, 3 ; pendulus, 5 ; proliferus, 4 ; purpureus, 5 ; racemosus, 11, 12; ramosissimus, 10 ; Schipkænsis (which is offered in the trade as this page goes to press) will be found in the supplementary list under $C$. leucanthus; scoparius, 1; stenopetalus, 12. See Laburmum and Adenocarpus.

$$
\text { A. Fls. lateral along the branches. }
$$

B. Style very long, spirally incurved at the apex: fls. large, yellow or partly crimson.

1. scopàrius, Link. (Sarothámnus scopdrius, Wimm. Spártium scopdrium, Linn.). Sсотсн BrooM. Shrub, to $10 \mathrm{ft}$, with erect, slender branches: $18 \mathrm{~s}$. short-petioled, 1-3-foliolate ; lfts. obovate or oblanceolate, sparingly appressed-pubescent, $1 / 4-1 / 2$ in. long: fls. usually solitary $3 / 4$ in. long ; calyx and pedicels nearly glabrous: pod brownish black, glabrous, villous only at the margin. May, June. M. and S. Europe.-Var. Andreànus, Dipp. (Genista Andredna. Puissant). Fls. yellow with dark crimson wings. R.H. 1886:373. Gt. 40:1342. R.B. 19: 129. J.H. III. $32: 462$. There are also varieties with double and with yellowish white fls. and a form with pendulous branches. All the vars. are more tender than the type.-The Scotch Broom, C. scoparius, has become established in this country, as a naturalized plant, in waste places from Nova Seotia to Virginia; and it is also reported from Vancouver Island. It is also recommended by landscape gardeners for covering raw and broken places. Its yellow fls. and nearly bare stems make a unique combination in the American landscape.
Even when it kills to the ground in winter, it throws up its stems again in the spring.

\section{BB. Style not or not much longer than the keel, slightly curved.}

c. Color of fls, white or purple.

D. Calyx short campanulate, not longer than wide: foliage scarce.

2. álbus, Link.(C. Linkii, Janka. Genista álba, Lam.). Shrub, to $3 \mathrm{ft}$, with slender, erect, grooved branches : lvs. short-petioled, 1- to 3-foliolate; lfts. obovate-oblong to linear-oblong, $1 / 4-1 / 2$ in. long, sparingly appressedpubescent: fls. axillary, 1-3, white, $1 / 8-1 / 2$ in. long: pod appressed-pubescent, usually 2-seeded. May, June. Spain, N. Africa. - Var. incarnatus, Dipp. Fls. white, slightly blushed. L.B.C. 11:1052 as a Spartina.

3. thlipes, Webb (Spartocýtisus fílipes, Webb). Shrub, with slender, angulate, thread-like branches : ivs. slender-petioled, 3-foliolate, nearly glabrous ; lfts. linearlanceolate: fls. axillary, 1-2, fragrant, pure white; wings much longer than the keel. Feb.-May. Teneriffa.-As C. Palmensis, Hort., in the Amer. trade.

DD. Caylx tubular, longer than wide: lvs. always 3-foliolate: branches terete.

4. proliferus, Linn. Shrub, to $12 \mathrm{ft}$., with long and slender pubescent branches: lfts. oblanceolate, silky pubescent beneath, green and sparsely pubescent above, $1-13 / 4$ in. long : fls. white, $3-8$ on rather long tomentose pedicels ; calyx tomentose ; standard pubescent outside; pod densely tomentose-villous, 11/2-2 in. long. May,June. Canary Isl. B.R. 2:121. L.B.C. 8:761.-Recommended as a fodder plant for California.

5. purpureus, Scop. Procumbent or erect shrub, to $2 \mathrm{ft}$., quite glabrous : lvs. rather long petioled; lft3. oval or obovate, dark green above, $1 / 2-1$ in. long : fls. 1-3, purple; calyx reddish : pod black, 1-11/2 in. long. May, June. S. Austria, N. Italy. B.M. 1176. L.B.C. 9: 892.-Var. álbus, Hort. Fls. white. Var. cárneus, Hort. Fls. light pink. Var. atropurpùreus, Hort. Fls. dark purple. Var. péndulus, with slender, pendulous branches, is sometimes grafted high on Laburnum.

cc. Color of fls. yellow.

6. hirsùtus, Linn. Shrub, to $3 \mathrm{ft}$., with erect or procumbent, villous, terete branches: lfts, obovate or obovate-oblong, villous pubescent beneath, $1 / 2-3 / 4$ in. long: fls. 2-3, short-petioled; calyx villous pubescent: pod 1 in. long, villous. May, June. M. and S. Europe, Orient. B. M. 6819 (leaflets erroneously shown as serrate). L. B. C. 6:520 (as C. falcatus) B. R. 14: 1191 (as $C$. multiflorus).

AA. Fls. in terminal heads, with bracts at the base.

7. capitàtus, Scop. Shrub, to $3 \mathrm{ft}$., with erect, terete, villous branches: Ifts. ob ovate or oblong - obovate, sparingly appressed pubescent above,villous pubescent beneath, $3 / 4-1$ in. long: fls. yellow, brownish when fading, nearly 1 in. long: pod villous, 1-1 1/2 in. long. July, Aug. M. and S. Europe. L. B.C. 5: 497. I.H. III. 31:161 (as Genista).

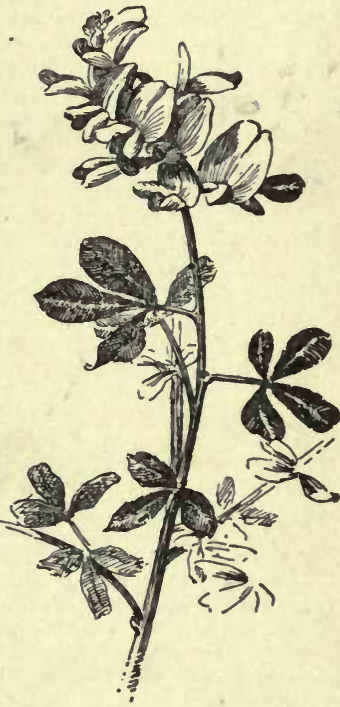

656. Cytisus racemosus. $(\times 1 / 2$.
AAA. F'ls, in terminal racemes.

B. Foliage persistent: branches grooved or striped. c. Lvs. distinctly petioled.

D. Racemes rather short and dense.

8. cándicans, Linn. Shrub, to $10 \mathrm{ft}$.: branches villouspubescent when young: Irs. short-petioled, usually gla- 
brous above, pubescent beneath; lfts. obovate or obovate-oblong, nucronulate, $1 / 3-3 / 4$ in. long: racemes $3-9$ fld., short, leafy at the base: fls. fragrant, bright yellow: pod rufous-villous, slightly torulose. May, June. Mediterranean region, Canary Isl.

9. Maderénsis, Voss (Genista Maderénsis, Webb). Large shrub or small tree, to $20 \mathrm{ft}$., closely allied to $C$. candicans and chiefly distinguished by the rufous woolly tomentum covering the young branches, petioles and pedicels, and by the longer petioles. Lvs. crowded; lfts. obovate, acute or mucronulate, often almost glabrous above, scabby beneath, $1 / 4-1 / 2$ in. long, about as long as petioles: racemes 6-12-fld., short: fls. bright yellow, slightly fragrant: pod 5-7-seeded. May, Jume. Madeira.

10. Canarínsisis, Linn. Genista of florists. Fig. 655. Much-branched shrub, to $6 \mathrm{ft}$., with villous-pubescent branches: petioles at least half as long as the lfts.; lfts. cuneate, obovate or oblong-obovate, pubescent on both sides, $1 / 4-1 / 2$ in. long: racemes usually many-fld., secund fls. fragrant, bright yellow. May-July. Canary Isl. A. F. 6:802.-Var. ramosíssimus, Rehder ( $C$. ramosissimus, Poir. C. Attleyanus, Hort.). Lfts. very small: racemes short, but numerous. L.B.C. 13:1201. B.R. $3: 217$.

\section{DD. Racemes elongated.}

11. racemòsus, Nichols., not Marn. Fig. 656. Shrub, to $6 \mathrm{ft}$. : branches pubescent: lvs. rather long petioled; lfts. oblong-obovate, mueronulate, $1 / 3-3 / 4$ in. long, silky $p u-$ bescent on both sides: racemes elongated, many-fld. secund and rather loose, 3-5 in. long. Probably of gar den origin and hybrid between $C$. Canariensis and $C$. stenopetalus. A.F. $6: 802 ; 13: 1136$. - Better florists' plant than the last. Var. Everestianus, Hort. Fls. of a deeper shade of yellow, very free-flowering. R.H. $1873: 390$.

12. stenopétalus, Voss (C.racemòsus, Marn.). Shrub, to $6 \mathrm{ft}$., with silky pubescent branches: lvs, slender petioled; Ifts. cuneate, oblong or narrow-oblong, obtuse, silky pubescent on both sides, $1 / 2-1 \frac{1}{2}$ in. long: racemes many-fld., loose: fls. large, bright yellow. May, June. Canary Isl. B.R. 26:23 (as Genista bracteoldta). - Sometimes cultivated as $C$. splendens, but less desirable as a greenhouse plant than the two former.

$$
\text { cc. Lis. nearly sessile. }
$$

13. linifolius, Lam. Shrub, to $3 \mathrm{ft}$., with erect, anpressed-silky tomentose branches: lfts. linear or lineailanceolate, acute, revolute at the margin, nearly glabrous and shining above, silvery pubescent beneath, $1 / 2$ 1 in. long: racemes short and compact: fls. bright yellow: pod torulose. April-June. Spain, N. Afr., Canary Isl. B.M. 442.
Bв. Foliage deciduous: branches quite terete.

14. nigricans, Linn. Shrub, $2-4 \mathrm{ft}$, with erect, ap. pressed-pubescent branches : lvs. long petioled; lfts. obovate or oblong-obovate, glabrous above, appressedpubescent beneath, $1 / 3-1$ in. long: racemes very long and slender, 3-8 in. long. June, July. Germany, N. Italy, Hungary. L.B.C. 6:570. B.R. 10:802. Var. elongàtus, Borkh. Blooming again in fall at the top of the elongated fruiting racemes. R.H. 1891, p. 149 (as var. Carlieri).

O. Adami, Poir.=Laburnum Adami.-C. álbus, Hacqu.=C. leucanthus - $O$ alpinus, Mill = Laburnum alpinum - $C$. Ar doini, Fourn. Prostrate shrub, to $1 \mathrm{ft}$. high : lvs. trifoliate, silky: fls. 1-6, axillary, yellow; calyx campanulate. Apr., May. Southeastern France.-O.Austriacus, Linn. Allied to C. capitatus. Lfts. narrow, oblanceolate, silky pubescent on both sides: fls. yellow; calyx densely villous. Southeastern Eu., Caucasus. $-O$ biflòrus, L'Herit = C. Ratisbonensis - $C$. Cantóbricus Willd Allied to $\mathrm{C}$ scoparius, but prostrate, with silky lvs. and large bright yellow fls.: pod villous. May. Spain.-C. Cantó bricus, Hort. =C. scoparius, var. pendulus. - C. congéstus, Voss (Teline congesta, Webb). Allied to C. Canariensis. Densely villous-tomentose, small-leaved: racemes short. Teneriffa.- $C$. decúmbens, Walp. Prostrate: lvs. simple, oblanceolate, loosely villous: fls. yellow, axillary, 1-2. S. Eu. L.B.C. 8:718, - C. elon gàto-purpùreus, Hort. $=\mathrm{C}$. versicolor. $-C$. elongàtus, Waldst. \& Kit. $=$ C. Ratisbonensis, var. elongatus.-C. elongàtus, Hort. = C. hirsutus - C fràgrans, Lam. Allied to C. filipes. Petioles short: lfts, densely pubescent: fls. fragrant, white. Spring. Teneriffa.-O. glabréscens, Sartor. Procumbent, sparingly appressed-pubescent : lvs. 3 -foliolate: fls. lateral, yellow : pod glabrous. iN. Italy.-C. Kewénsis, Bean (C. albus $\times$ Ardoini) Prostrate: lvs. 3-foliolate, pubescent: fls. creamy white. Originated at Kew.-O. Labúrnum, Linn. =Laburnum vulgare.-O leucánthus, Waldst. \& Kit. Allied to C. capitatus. Lfts. nearly glabrous above, acute: fls. white or yellowish white. June, July. Southeastern Eu. Var. Schipkænsis, Dipp. Dwarf: fls. pure white. Balkan.-C. nubigenus, Link=C. fragrans.- $C$. proco $x$, Hort. (C. albus $\times$ purgans). Shrub, to $3 \mathrm{ft}$., with ereet proecox, Hort. (C. albus $\times$ purgans). Shrub, to $3 \mathrm{ft}$., with ereet branches : lvs. 1-3-foliolate : fls. yellowish white. Of garden
origin.-C. polýtrichus, Bieb. $=\mathrm{C}$. hirsutus.-C.purgans, Willd Shrub, to $3 \mathrm{ft}$., appressed-pubescent: branches striped : lvs. 1-3-foliolate, oblong or linear-lanceolate: fls, axillary, yellow, fragrant: pod glabrous. May-July. Spain, S. France.- $O$. ramentàceus, $\mathrm{Sieb}=$ Petteria ramentacea.-C. Ratisbonénsis, Schaeff. Allied to C. hirsutus. To $3 \mathrm{ft}$ : branches slender, ap pressed-pubescent: lfts, glabrous above, silky beneath: fls, 1-2, yellow; calyx with appressed, yellowish, silky hairs. AprilJune. M. Eu., W. Asia. Var. elongatus, Koch. More erect: fls. larger, 3-5; calyx with somewhat spreading hairs. B.R. 4:308 (as C. bifiorus).-C. Ruthénicus, Hort., not Fisch. = C. hirsutus.-O. sessilifòtius, Linn. Allied to C. nigrieans. Quite glabrous: lvs. nearly sessile, with roundish-obovate lfts.: racemes short, 4-11-fld May, June. S. Eu. B.M. 255-O. triflòrus, L'Herit Similar to C hirsutus. Fls long-pedicelled yellow: calyx tube short, not tubular. April, May. S. Eu., N. Afr. Tender.- $O$. versicolor, Dipp. (C. hirsutus $X$ purpureus). Low shrub, with sparingly villous lvs.: fls. yellowish white and pale purple. Sometimes cult. as C. incarnatus. $-C$. Wélden $i$, Vis. $=$ Petteria ramentacea. 
DABĊCIA (after its Irish name St. Dabeoc's Heath). More commonly spelled Daboëcia. Syn., Boretta. Ericdcea. Low evergreen shrub with alternate entire lvs. and drooping pedicelled fls. in long terminal racemes: corolla ovoid, contracted at the mouth and shortly 4-lobed, with recurved lobes; stamens 8 , included : capsule 4-celled, dehiscent. One species in western Europe. Very pretty heath-like shrub, with purple or white fls. in elegant loose racemes, well adapted for rockeries or borders of evergreen shrubberies. Requires protection north during the winter, and thrives best in a peaty, sandy soil. Prop. by seeds treated like those of Erica, and by cuttings of half-ripened wood under glass.

polifolia, Don (D. Cantábrica, Koch. Menzièsia polifolia, Juss.). Irish Heath. To $2 \mathrm{ft}$.: branchlets glandular pubescent: IVs. elliptic, the uppermost narrower, revolute at the margin, whitish tomentose beneath, shining and dark green above, $1 / 4-1 / 2$ in. long: racemes many-fld.: corolla $1 / 3-1 / 2$ in. long, purple in the type. June-Oct. Ireland, W. France, N. Spain. Gn. 52:1142. Gt. $47: 1450$. L. B. C. $20: 1907$. S. B. F. G. $2: 276$. There are many varieties, as álba, with white fls.; bicolor, with white and purple striped fls.; rosea, with pink fls.; grandiflora, with larger purple fls.

AlFred REHDER.

DÁCTYLIS (Greek, finger, from the size of the spikes). Graminev. Cock's-FooT. A perennial tufted grass with flat-keeled or folded leaf-blades, and narrow panicles which expand when in flower: spikelets several-flowered, much flattened, sessile, and densely crowded in thick one-sided clusters. A single species in Eu., A sia and N. Africa, also naturalized in Australia and N. America.

glomeràta, Linn. Orchard Grass. Fig. 657. A somewhat coarse grass forming dense tufts. Culms $2-3 \mathrm{ft}$. high, very leafy: lvs, flat, spreading: spikelets compressed, 3-5 fid.: fl.-glumes lanceolate, very acute or short awn-pointed, eiliate on the keel above.-One of the best known and most useful pasture grasses, and useful for lawns under trees.

Var. variegàta, Hort., is a dwarf form of neat, compact habit, with beautifully variegated silver and green foliage. - Well adapted for forming edgings. It grows $11 / 2-2 \mathrm{ft}$. high, and is prop. by divisions.

\section{P. B. KENNEDY.}

DACTYLOCTENIUM (Greek, daktylos, finger, and ktenion. comb). Finger-COMB Grass. This genus closely resembles Eleusine, from which it differs chiefly in having the terminal spikes shorter and each tipped with a sharp prolongation of the axis. Annual, with culms tufted or creeping, and rooting at the joints, 11/2$2 \mathrm{ft}$. high. Spikes usually $3-5$ in number, digitate, about 2 in. long; spikelets several-fld., crowded in two rows along one side of a continuous axis. Species 2 , one in Australia, and the other appearing as a weed in all the warmer countries of the world.

Egyptiacum, Willd. (Eleusine Agýptica. Cynosìrus Egýptius, Linn.). CRow-Foot. Spikelets very closely packed, spreading at right angles to the rachis, 2 fld., with rudiments of two other fls. - An ornamental grass introduced into N. Amer. from Asia or Africa. Mojave Indians of S. California use the grain for food. In Africa a decoction is prepared from the seeds for inflammation of the kidneys.

P. B. KeNNEdY.

DEDALACÁNTHUS (Greek words, meaning an A canthad of curious structure). A canthdcea. This genus contains some tender shrubs of difficult culture under glass, but great favorites in the tropies, particularly in India. D. nervosus is a popular winter and springblooming shrub in S. Fla. It has blue flowers, an inch across, 5-lobed, and shaded purple at the mouth of the tube. The names are much confused with those of Eranthemum. The kinds mentioned below are, however, very distinct, from the garden standpoint, from any given in this work under Eranthemum by the color of their fls. and the great size and relative showiness of their bracts. For culture, see Justicia.

\section{A. Fls. dark blue.}

nervosus, 'T. Anders. (Eránthemum pulchéllum, Andrews and some dealers, while that of others is $E$. bicolor, and of Roxburgh is D. purpurascens. $E$. ner vosum, R. Br.). Fig. 658. Lvs. ovate or elliptical, acuminate at both ends, somewhat crenate or entire: spikes axillary, opposite, overlapping: bracts elliptical, acute: limb of the corolla as wide as the tube is long. India. B.M. 1358 as Justicia nervosa. Gn. 51:1118. G.C.II.

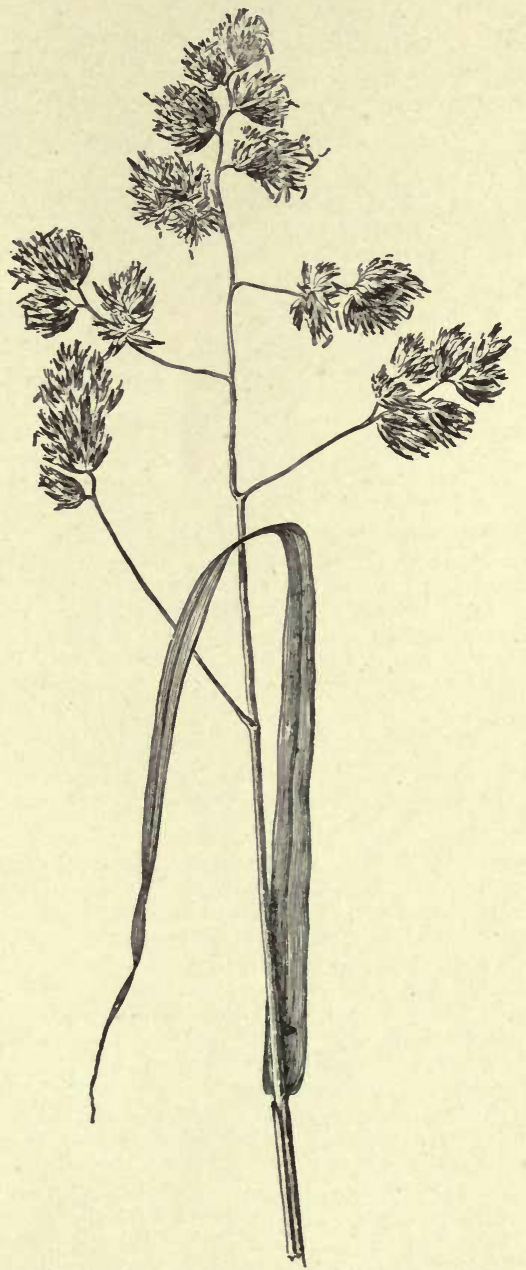

657. Dactylis glomerata- Orchard Grass (X1/4).

$21: 415$. - A very pretty shrub for the warmhouse, its fls. being of a color that is not very common in winterblooming plants. It is an easy subject to manage, requiring a light, rich soil, full sunlight and plenty of water. Cuttings of young growth root readily in a warmhouse.

$$
\text { AA. Fls, purple. }
$$

purpuráscens, T. Anders. (E. purpuráscens, Wight. E. pulchéllum, Roxb., not Hort.). Lis. broadly ovate, 
cuspidate-acuminate, repand-crenate: spikes as above bracts ovate-rhombic, with a slender beak, ciliate. Inserted for contrast. Probably not cult. India.

W. H. TAPLIN and W. M.

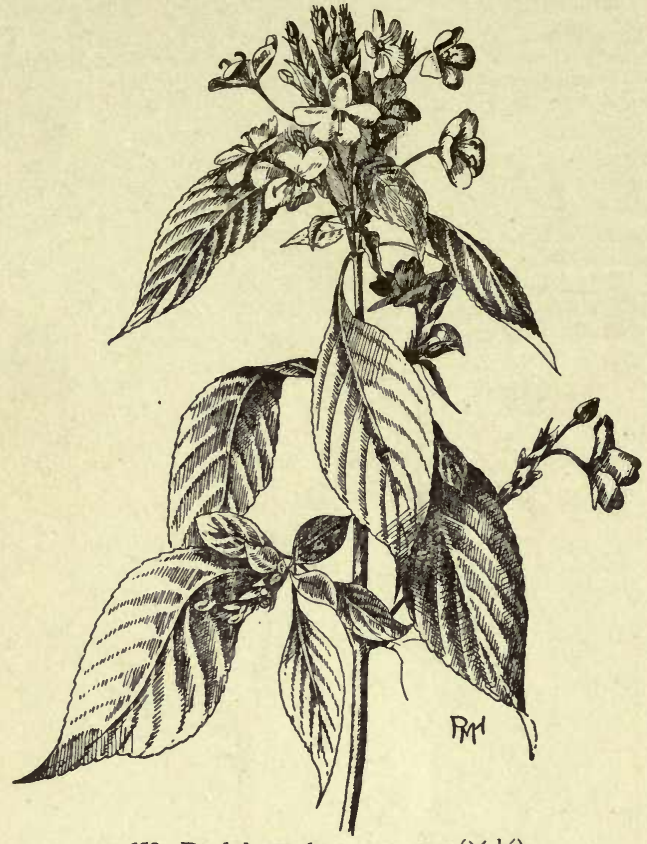

658. Dadalacanthus nervosus $(\times 1 / 3)$.

DEEMONOROPS (probably means God-like, of divine appearance). Palmacece, tribe Lepidocárpece. Slender palms, differing from Calamus in the deciduous, cymbiform or open spathes. Species about 40 . Tropical Asia. Same culture as Calamus. D. Draco produces some of the "Dragon's Blood" of commerce.

calicárpus, Mart. (Calamus calicárpus, Griff.). Stem erect or climbing, 1 in. diam.: lvs. 6-8 ft. long, upper small with long flagella; lfts. very many, 12-13 in. long, $1 / 3-1 / 2$ in. wide; petiole $1 \mathrm{ft}$., base not gibbous or puckered. Malacca.

Lewisiànus, Mart. (Cálamus Lewisidnus, Griff.) Stem climbing, 1 in. diam.: petiole $1 \mathrm{ft}$., base much swollen, armed below with scattered, short, deflexed spines, and above with straight and hooked spines 11/4 in. long ; lfts. 13-15 in. long, $3 / 4-1$ in. wide; sheath armed with solitary or seriate flat back spines. Penang.

Palembánicus, Blume. Stem erect: lvs, pinnate, broadly ovate, bright cinnamon-brown when young, and lfts. many, long, narrow ; petioles erect, with stout spines on the back, which are deflexed and not thickened at the base. Sumatra.

periacánthus, Miq. Height $15 \mathrm{ft}$. Resembles $D . P a$ lembanicus, but the young lvs, are nearly straw-colored, and the spines are placed in irregular rings. Sumatra. -A most graceful species.

melanochæ̇tes, Blume. Stem erect: lvs. pinnate, the pinnæ long and narrow, dark green and drooping, the petioles sharp-spined at the sheathing base. Malaya. - Very decorative. A small form is Var. microcárpus.

intermèdius, Mart. Lvs. long-petioled, 4-6 ft. long : lfts. opposite or scattered, 18-20 in. long, 1-11/2 in. wide, linear-lanceolate, acuminate, margins and 3-5 costr bristly above and below; rachis semi-cylindrical, sparingly armed; petiole $1 \mathrm{ft}$. long, with flattened spines; stems at length $15-20 \mathrm{ft}$. long, $3 / 4 \mathrm{in}$. in diam. Malaya.

plumòsus, Hort. Graceful plume-like lvs, with pinnm $4 \mathrm{ft}$. or less long, petioles with rigid black spines with white bases. India.

JARED G. SMITH.

DAFFODIL. See Narcissus.
DAHLIA (named after Professor Andreas Dahl, a Swedish pupil of Linnæus, and author of Observationes Botanicæ, a work of minor importance). Compósitoe. Dahlias are amongst the commonest and most important garden plants. The spelling of the word Dahlia shows that the $a$ should be given the broad sound, but in England it is everywhere given the long sound, and in America it is often given the short sound. The long sound of $a$ make he word indistinguishable from the leguminous gen alea, named after Dale. In Germany Dahlias are still commonly called Georginen, because in 1803 Willdenew ayn he name Georgina to these plants under the mistaken is ssion that some very different plants had been previously described as Dahlia. Practically all of the named warieties of Dahlias have come from one immensely variable species, usually known as $D$. variabilis. For garden purposes, however, a second form of grent importance, $D$. Juarezii, the parent of the cactus forms, must be kept distinct, as will be explained later. There are 5 other species cultivated to a slight extent. The genus has many names of species, but most of them are synonymous and ill-understood names. There are perhaps 8 or 9 fairly distinct species altogether, Mexican almost exclusively, with a very few in Central and. South America. It is curious that these showy plants should be closely related to a common weed, the beggar's tick, of the genus Bidens; but other species of Dahlia have leaves whose forms pass gradually into those of Bidens. Other close allies are Cosmos and Coreopsis. Cosmos flowers are some shade of purple, rarely white in wild nature, and only one species has yellow fls.; Coreopsis has yellow fls. only; Bidens yellow or white; and none of these genera have produced double-flowered forms of the first importance. Dahlia has all these colors and more, being far richer in bright reds, and lacking only sky blue and its closely related hues, which are seen to perfection in the China Asters. Few cultivated plants have such a wide range of colors as the Dahlia; even the Chrysanthemum is distinctly inferior in range, as it lacks the brilliant and vivid scarlet, vermilion, and other shades of red.

Although Dahlias are popular plants, especially in old gardens, they are destined to still greater popularity from the new "Cactus" and "Decorative" types. There exists a prejudice against Dahlias in many localities where these new types have never been seen. This prejudice is part of a reaction against formal and artificial flowers in general. The old-time Dahlias were as round and hard and stiff as a ball. The new-time Dahlias are flatter, and tend towards loose, free, fluffy chrysanthemum-like forms. The possibilities of the old form have been practically exhausted; those of the new form seem to be almost as boundless as those of the Chrysanthemum - which is the most fertile in new forms of all the garden composites.

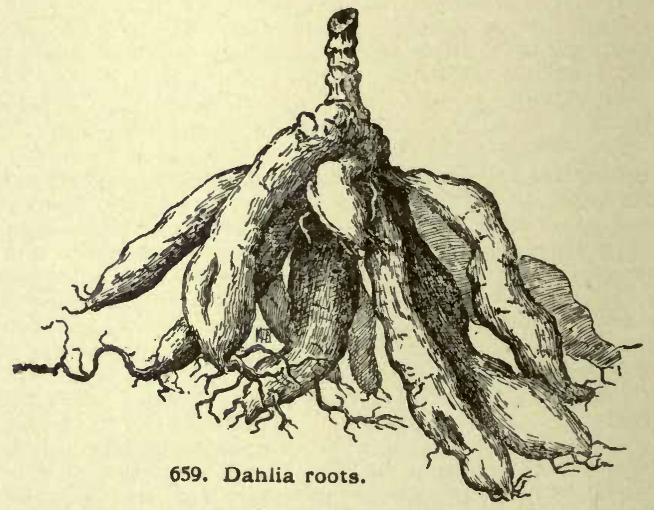

History of the DaHLIA. - Of the important and very variable florists' flowers the Dahlia was one of the latest to come into cultivation. The first break of considerable importance in the wild type occurred about 1814. Up to that time there were perhaps a dozen well-marked colors in good single-flowered varieties, Dahlias had been cul- 
tivated in Europe since 1789, and it is a curious fact that they showed signs of doubling the very first year of their European residence; but it was not until 25 years later that a marked gain in doubling was made. The Dahlia seemed to be undeveloped until 1814, when the era of doubling began. Before another 25 years had passed the Dahlia had sprung into the front lals: if garden plants. In 1826 there were already 60 varietie.s cultivated by the Royal Horticultural Society. 1841 one English dealer had over 1,200 varieties. Tr is not uncommon for the leading tradesmen to ieer, $5 v$ ' $-1,000$ distinct varieties. In the absence of $\mathrm{mm} \perp \mathrm{Ac}, \mathrm{ras}$ it is conjectured that over 3,000 differen es rf varieties have been published in the catalogies. Most of the varieties are the Show and Fancy types, "hic" are as spherical and regular as possible, and differ only in color. At first the distinction between the two types seems to have been the same as that between "stlf colored" and "variegated" flowers in general, the former presenting to the view ouly one color, while the latter presents two or more colors. Lately, for purposes of exhibition in prize competitions, the following arbitrary distinction has been adopted: A Show Dahlia is often of one color; but if the edges of the rays are darker than the ground color the variety can be exhibited in the Show section. A Fancy Dahlia always has two or more colors, and if the rays are striped or if the edges are lighter than the ground color the variety must be exhibited in the Fancy section. The two types reached full perfection certainly by 1840 , and after that date the improvements made were mostly in matters of secondary importance. The immense distance the Dahlia had travelled can be seen in Fig. 663. These types held full sway until about 1879 , when the first Cactus Dahlia appeared in England with a promise of new and freer forms. Most of the longestlived varieties belong to the Show and Fancy type. This form is the one which is perhaps farthest removed from nature, and it is probably so highly esteemed largely because the most work has been spent on it.

A reaction against formalism in all departments of life and thought set in about the time of our own Civil War. It was in the sixties that the Japanese Chrysanthemums did much to emancipate the floral world. With Dahlias the reaction eame much later and has proceeded more slowly, because the new forms did not come to us ready made, but had to be slowly evolved against long-standing prejudice. The first Cactus Dahlia was so called because of its resemblance in form, but chiefly in color, to the brilliant crimson-flowered Cereus spe ciosissimus, a well-known garden plant. The name is now highly inappropriate because the color range of the pure Cactus type has been extended to include all of the important well-defined colors of which the Dahlia seems capable. The original Cactus Dahlia was named Dahlia Juarezii, after President Juarez, the "Washington of Mexico." It was pictured for the first time in the Gardeners' Chronicle for 1879, and this interesting picture is here reproduced in a reduced size in Fig. 665 . The type is still cultivated under the same name, and in all essentials seems to be unchanged.

The origin of the Cactus type, as of all the other types of Dahlias, is wrapped in uncertainty, and our efforts to get full and definite information upon some of the most interesting points may perhaps always be baffled. A Dutch dealer got a root from Miexico that produced one plant, which is the parent of all the Cactus forms. It is not known whether the seed which may have produced the original root came from a wild or a cultivated flower. Neither is it known whether any wild single-flowered Dahlia of the Juarezii type has been found. To prove that $D$. Juarezii is at best only a variety of $D$. variabilis, it has been said that seedlings of the former have produced in cultivation forms approximating the Show type of $D$. variabilis. The reverse process is also said to have taken place, but full, authoritative and convincing statements are lamentably wanting. In the garden D. Jurrezii is exceedingly distinct from the florists' forms of $D$. variabilis. It is usually a slenderer, taller and longer jointed plant, with much handsomer and nore delicate foliage, the leaves being narrower than in the coarse and almost ugly foliage of the old forms. It has another peculiarity of growth, which is still one of the most serious defects in the pure Cactus type. The plants tend to hide some of their flowers beneath their foliage. This comes about in a curious way. At a node between 2 young leaves there commonly appear, at about the same time, 3 new growths. The middle one develops into a flower with a naked stalk only 2 or 3 inches long, while the side shoots quickly overtop it and repeat the same 3 -fold story indefinitely. The other most serious objection to the pure Cactus type is that it

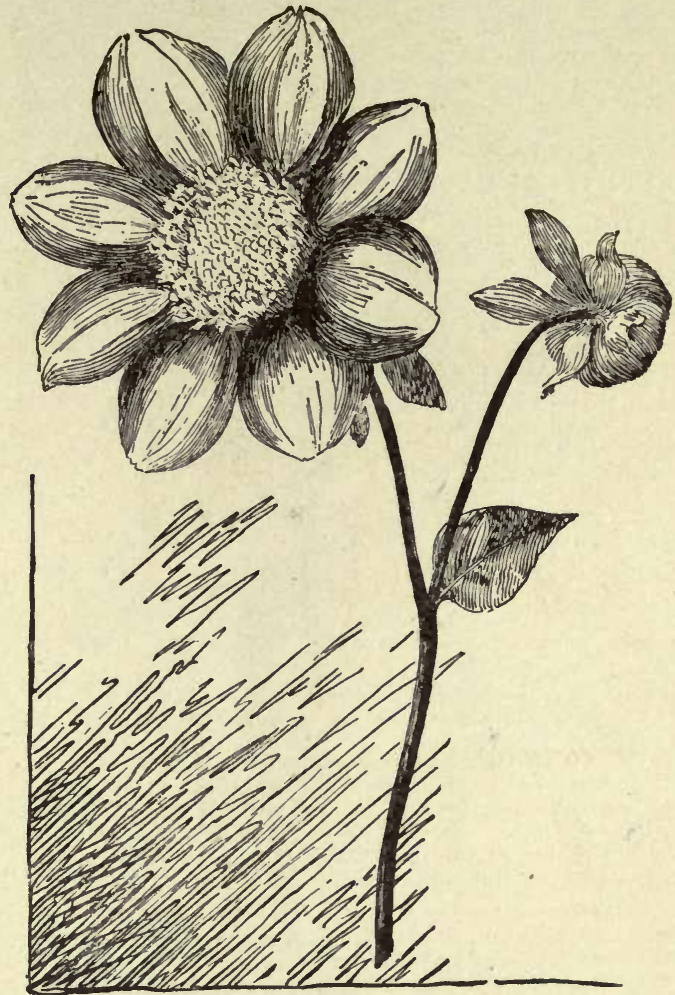

660. A single Dahlia with rounder rays than the wild prototype.

does not stand shipment well, and does not last as long as a cut-flower as the Show Dahlias.

The Decorative or Cactus Hybrid types are numerous, and their popularity comparatively recent. They have been largely seedlings from Show fls. Their rays are rarely, if ever, recurved at the margins. All the other types of Dahlias are well defined, and a single picture of each one will represent its type with sufficient exactness. No one picture, however, can give any conception of the great variety of forms included in this horticultural sec tion. The name Cactus Hybrids means practically "mis cellaneous," and is analogous to the "Japanese" section of Chrysanthemums, which is purposely left by the National Chrysanthemum Society as vague and undefined as pos sible. It is on this section and the pure Cactus type that the greatest hopes for the future of the Dahlia are based.

The Pompon type is a small brother of the Show and Fancy types. It has the same colors and the same form, but the flowers are smaller and more abundant. As a rule the smaller the flowers the prettier and more individual they are. The larger they are, the more they suffer by comparison with the Show type. Perhaps their greatest point is their productiveness. When profusion is the main idea, not great size and quality, the Pompons are the favorite type of Dahlia for cut-flowers. The single flowers may be just as freely produced, but they are not so lasting as cut-flowers.

The Single type has had many ups and downs. In the reaction against formalism it came to the front 
about 1881, and for several years thereafter several hundred forms were kept distinct, and they were made the chief feature of the European shows. It is exceedingly interesting to get seeds of wild Dahlias from Mexico. They give flowers like the star-shaped one in Fig. 663. When the Dahlia first came into cultivation its rays were relatively long, slender, acuminate, notched at the end, and with such wide spaces between the tips of the rays as to give the flower the stellate appearance seen in Fig. 663. In the course of the evolution of the single type, the gardeners retained the most regular and symmetrical forms. Single Dahlias with always and only 8 rays were preserved. The rays of Dahlias became broader and rounder, as in Fig. 660 , until finally in pedigree varieties they closed up the racant spaces, and the flower presents to the eye one unbroken picture-one concentrated impression of a single color. The same mental ideals have produced the

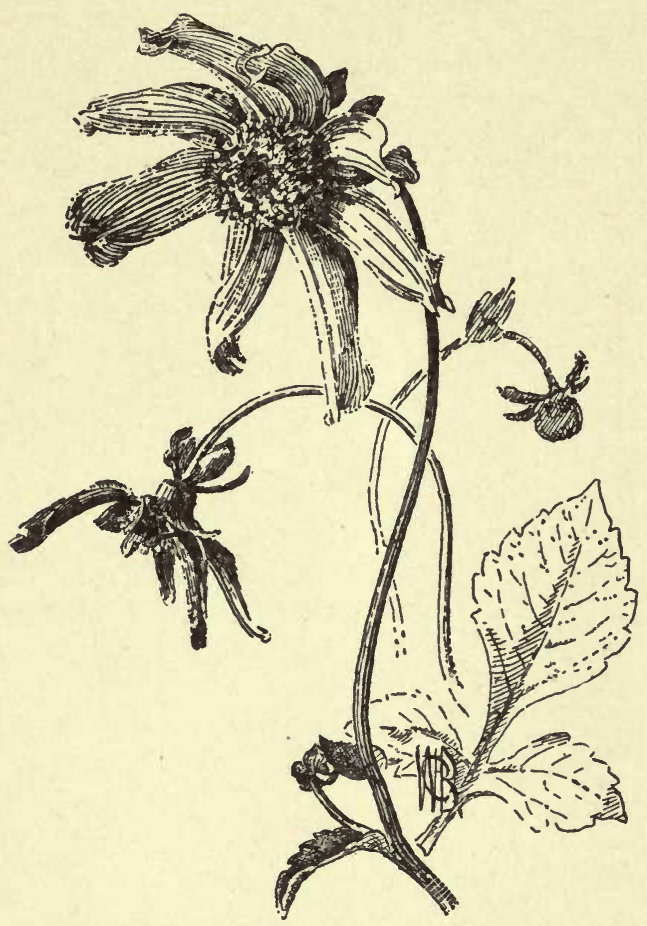

661. A Dahlia of the Single Cactus type $\left(X_{1 / 2}\right)$.

rose-petaled Geraniums and the shouldered Tulips. In a high bred single Dahlia there are no minute teeth or notches at the tips of the rays.

In the wild Dahlia, no matter what the color of the ray may be, the base of the ray is usually yellow; sometimes this yellow is very objectionable. Two different policies have been pursued in the matter-suppression and encouragement. Most of the single Dahlias of high pedigree have rays of uniform coloration with no secondary color at the base, but a few have a distinct ring of color at the base, often called an "eye or crown," which is sometimes yellow and rarely red or some other color. Usually the rays of a single Dahlia are spread out horizontally, sometimes they bend back, and rarely they bend inwards and form a cup-shaped flower. These three forms can doubtless be separated and fixed during those periods when the interest in the Single type warrants it.

Single Dahlias are likely to lose some of their rays after a day or two in a vase. In cutting them it is well to select the younger flowers. A vigorous shake often makes the older ones drop their rays. It is an easy matter to keep the seeds from forming and save the strength of the plant for the production of flowers.
There are three modern types of minor importance,the Single Cactus, Pompon Cactus and Tom Thumb. The Single Cactus type differs from the common single type, in having rays with recurved margins, which give a free and spirited appearance to the Hs. Instead of spreading out horizontally, the rays often curve inward, forming a cup-shaped flower. This type originated with E. J. Lowe, Chepstow. Eng., was developed by Dobbie \& Co. about 1891, and was first disseminated in 1894 . The Single Cactus Dahlias are very novel, interesting and pretty. There should be a Pompon Cactus form to connect the Single Cactus and Cactus types, just as the Pompon is intermediate between the Single and Show types. The writer has seen only two varieties of this type, "Pompon Cactus" and "Little Cactus." They have small fls., with flat, reflexed rays. The Tom Thumb type is a miniature race of round-rayed single Dahlias, which grow from 12-18 inches high, and are used for bedding. The type originated in England with T. W. Girdlestone, and was developed and introduced by Cheal \& Sons. The "green" Dahlia can hardly be called an important type, but it is an interesting abnormal form, in which the rays are partially or wholly suppressed, and the chief feature of interest is a confused mass of green stuff, not resembling petals at all, but evidently a multiplication of the outer involucral scales, which, in the Dahlia, are green, leafy bracts. This form is essentially unstable and unhealthy. It can never be propagated extensively. This freak was pictured as long ago as 1845 in G.C., p. 626. Several different varieties have probably degenerated into this condition. See F.S. 19:1994. Another inuresting variation, which hardly ranks in present importance with the 9 types contrasted below, is the laciniated form, which makes a very pretty and novel though rather formal effect. Examples are Germania Nova, Mrs. A. W. Tait and its yellow variety among large double forms, and White Aster among the Pompons. In these cases, the notches at the tips of the rays, instead of being minute and inconspicuous, are deepener so much that they give the laciniated effect. At present this form is available in a very narrow range of colors. It is not probable that it will be an important factor in producing chrysanthemum-like forms. Another form which baffles description, but is nevertheless very distinct, is that of Grand Duke Alexis. It is nearer the Show type than any other, but is perhaps best classed with the Cactus Hybrid section, simply because it seems advisable to keep the Show type the most sharply defined of all. It is to be hoped that the form of Grand Duke Alexis can be repeated in all the leading colors. Grand Duke Alexis is a very flat flower, and the rays are remarkably folded, leaving a round hole at the top of each. About midway between Grand Duke Alexis and the show or cupped type is an interesting form, the "quilled" Dahlia, a name which is necessary, perhaps, though unfortunate. In A. D. Livoni (which is one of the most popular of all Dahlias, and the nearest approach to a pure pink untainted by any suggestion of purple derivation) the rays are rather tightly folded for about two-thirds of their length, leaving a round hole at the tip as in Grand Duke Alexis, but giving a peculiar whorled effect, which plainly shows the spiral arrangement of the successive tiers of rays. Among Pompons, Blumenfalter is an example of this rosette-like or quilled form, and many colors are procurable. However, the word "quilled" usually suggests a long tube with a flared opening, whereas in the form described above the margins of the ray are merely rolled tightly together, but not grown together into a thin, seamless tube. Perhaps the most important variation that has not yet appeared in the Dahlia, is the wonderful elongation of the disk florets into long, thin, variously colored tubes which have produced such charming effects in the China Aster and have culminated in the marvelous grace of such Chrysanthemums as Iora, Northern Lights and Lillian B. Bird. The Dahlia may not be denied such possibilities, for in G.C. III. $20: 339$ (1896) a new Dahlia was described in which the quills are really tubes for two-thirds of their length. May we hope for some striking development of this form within our generation?

The main types of Dahlias may perhaps be distinguished more clearly by the following scheme : 
JBRARP

OF THE
UNIVERSITY
OF

CALIFORNIA 


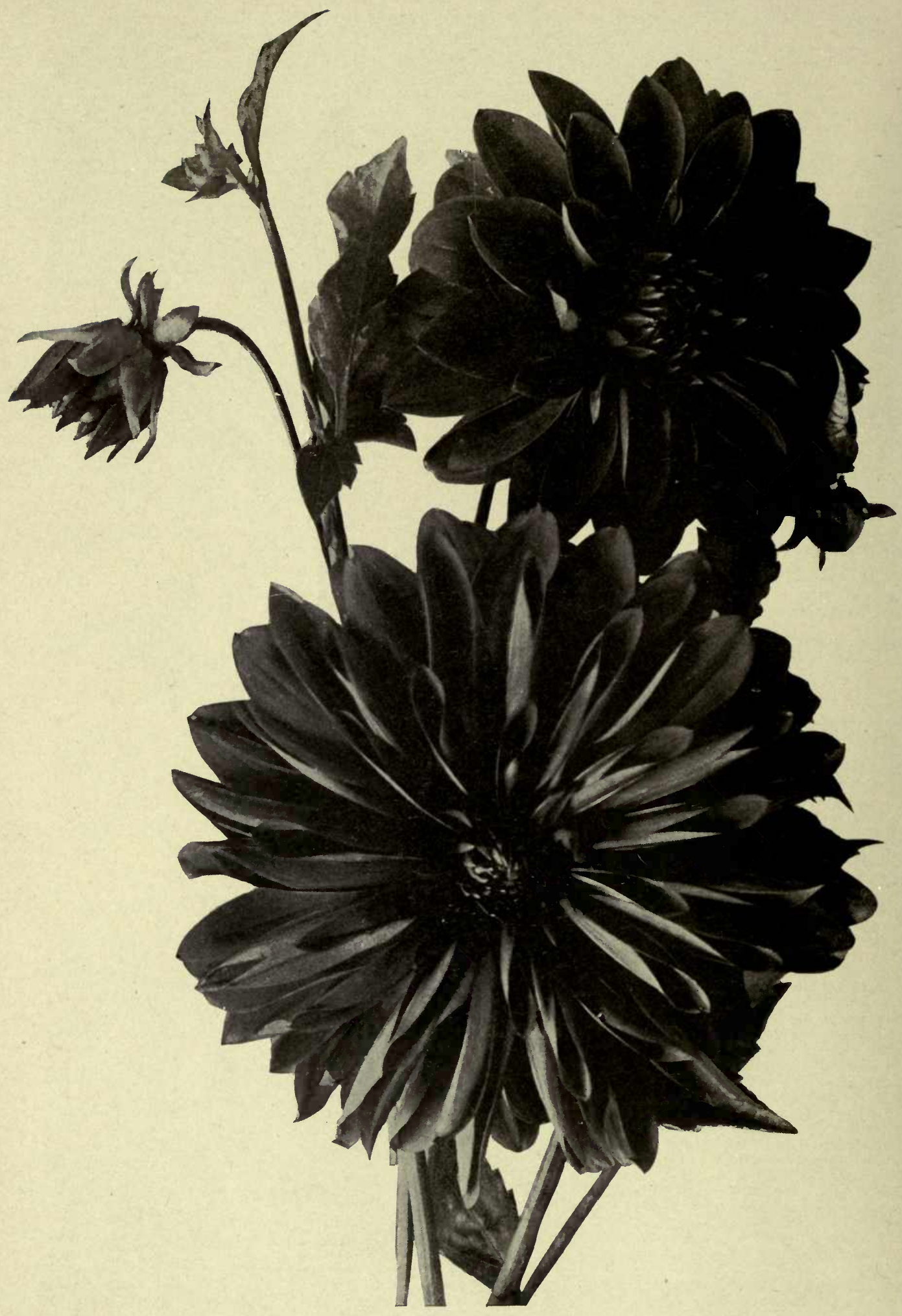

Plate IX. A modern Dahlia

One of the decorative or Cactus Hybrid section 


\section{A. Plants not very dwarf.}

B. Fls. single.

c. Rays flat, not recurved at the margins.

1. The Single Trpe. Fig. 660.

cc. Rays with recurved margins.

2. The Snngle Cactus Trpe. Fig. 661.

BB. Fls. double.

C. Size of fls. small, 1-2 in. across.

D. Rays cupped.

3. The Pompon Trpe. Fig. 662. Also called "Bouquet" and "Lilliputian."

\section{DD. Rays flat.}

4. The Pompon Cactus Type.

cc. Size of fls. large, $3-5 \mathrm{in}$. across, averaging $4 \mathrm{in}$.

$$
\text { D. Rays cupped. }
$$

E. Colors single, or the edges darker than the ground color.

5. The Show Trpe. Fig. 663.

EE. Colors 2 or more, striped, or with edges lighter than the ground color.

\section{THE FANCY TYPE.}

DD. Rays not cuppea, but long and flat, or with recurved margins.

7. The Cactus Trpe. Figs. 665, 666.

\section{DDD. Rays various in form.}

8. The Cactus Hybrid Types. Also called "Decorative" Dahlias.

\section{AA. Plants very dwarf.}

\section{The Toм Thumb Trpes.}

Societies AND Shows. - The Dahlia is one of about a dozen genera of plants whose horticultural value has been attested by permanently successful special societies. There are national Dahlia societies in England and America. Dahlia shows are usually held the second or third week of September. With the growing interest in nature-study, attempts are being made to make a permanent institution of local fall flower shows, which shall come at a sufficient interval before the Chrysanthemum shows, and in which the children may exhibit their own products. The Dahlia and China Aster are especially suited for such shows.

GARDEN Evolution OF DAHLIAS. - In the evolution of Dahlias in general, some of the great changes are as follows: (1) The growing season has been greatly shortened and the flowering season lengthened. In these and in all other particulars Dahlias were wonderfully variable even in the first decade of their European culture, but in general they bloomed for only a few days before frost. Nowadays, the Dahlia season is in full force a month and a half or two months before frost with a good show of blooms in favored localities for Independence Day; and June 15th is a record of extreme earliness for Wm. Agnew, after six weeks' growth from tubers planted out of doors. (2) The colors of the flowers have been greatly improved, as even the most sentimental objector to the idea of "improvement" in flowers would have to acknowledge if confronted with wild and cultivated plants. The number of colors has been greatly increased and the vividness of the colors intensified. Most people can distinguish and enjoy from 12 to 30 colors, and these colors have occurred in each type and been carefully saved, purified and strengthened. Dull and intermediate shades tend to drop out. (3) Immense numbers of variegated forms are produced. Broadly speaking, variegation is perhaps later to appear than pure colors, and is conserved by a formality-loving class. It is said that the Fancy Dahlia originated later than the Show Dahlia, and was for many years inferior in size and outline. It is also said by botanical collectors in Mexico that wild Dahlias are mostly self-colored, rarely variegated. Among the bewildering variety of variegated Dablias the leading types of variegation are perhaps only 5: (a) the "tipped" or "shaded" Dahlias, a very common form, in which the upper part of the ray is evenly painted with another color, the former term being used for the smaller, and the latter for the greater amount of secondary color; $(b)$ the "edged" Dahlias, in which the secondary color is confined to the sides of the rays, does not affect the tip, and is usually a broad strip; (c) the "margined "Dahlias, with a very narrow strip of color which outlines the whole margin of the rays, and often gives a very delicate and dainty effect; (d) the "striped and banded" Dahlias, with broad bands down the middle, and often merging into the "edged" forms; $(e)$ the "mottled" Dahlias, which are variously dotted and splashed. (4) Returning now to the broad features in the evolution of the Dahlia, a fourth is the production of varieties with long flowering stems suitable for cut-flowers. Many of the old sorts have thick, short stems with superabundant foliage, which requires thinning. (5) The process of doubling has been carried to an extraordinary degree. The "yellow center" has been the one thing about a forming variety that the florist has hated most and has most relentlessly suppressed. It is often a sign of poor stock. The temptation to over-propagate novelties is almost irresistible, and the appearance of a disk is usually taken as a symptom of over-propagation or deficient culture. A yellow center is considered objectionable by most people when it occurs with rays of magenta or allied shades, as the colors conflict. There is no question that it breaks the absolute regularity and unity of a perfect show flower, but it is a question, especially with white and yellowrayed forms, if the yellow disk does not often add a pleasant variation. Aside from matters of taste, it is probable that no other florists' flower has had more full, precise and minute rules laid down for its perfect form than the Show Dahlia. The process of doubling seems to be associated with a cool climate. Dahlias soon degenerate to a relatively single condition in our southern states, and new stock of desired varieties has to be secured from the north. (6) The habit has been vastly im-

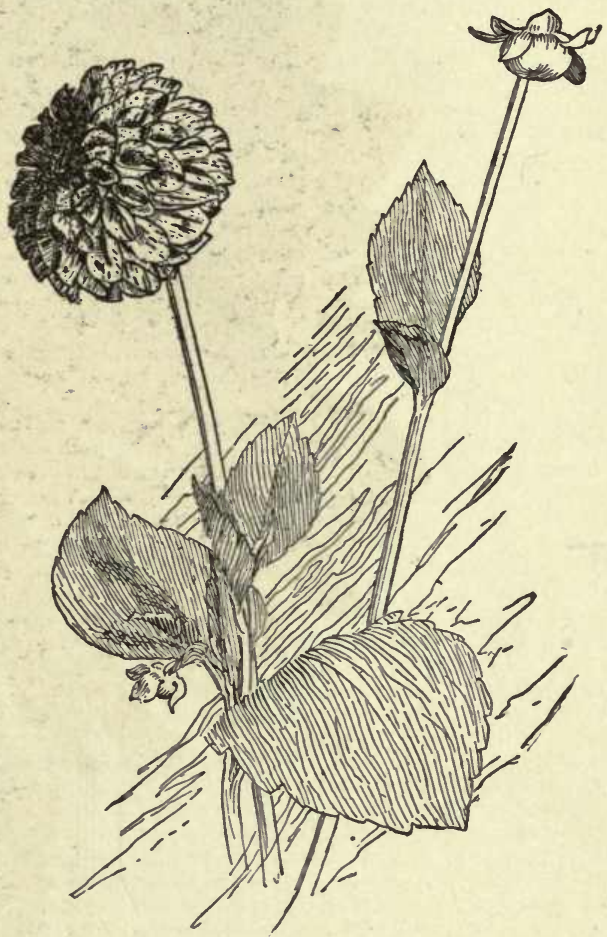

662. The Pompon type $(X 1 / 2)$.

This is really a Fancy variety, but the only distinction is one of size, and compared with Fig. 663 this is a Pompon. 
proved. Wild Dahlias, when brought into cultivation, soon grew too tall to be self-supporting. An old-fashioned unbranched Dahlia tied to a large and ugly stake was often a hopeless and helpless object. Many varieties of Dahlias can be made to branch at the ground and become self-supporting by successive early pinchings of

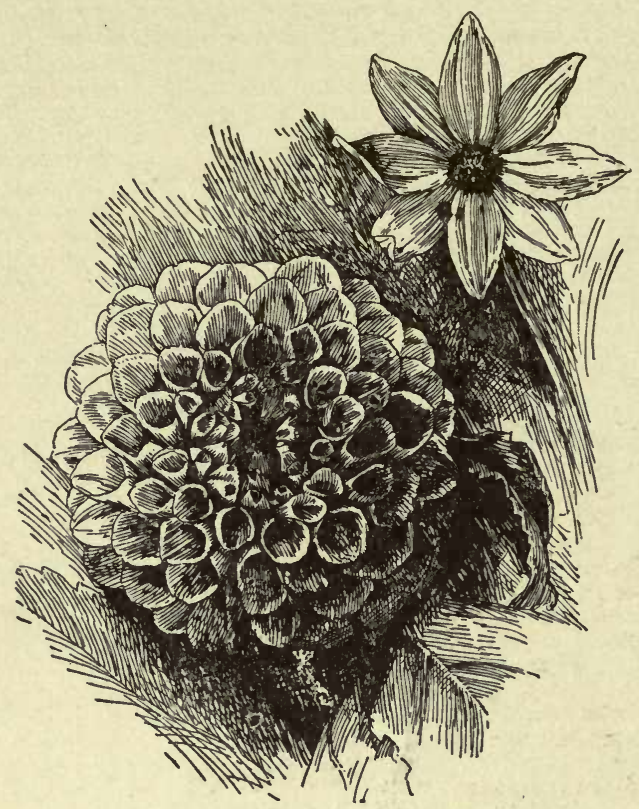

663. A Show Dahlia and its wild progenitor $(X 1 / 2)$.

the leading shoots, but some varieties seem to be too firmly set in the old tree-like habit to submit to pinching. In the early days the average height of plants may have been $5 \mathrm{ft}$. Nowadays $3 \mathrm{ft}$. is perhaps the average, but the tendency to retain only dwarf forms still continues, and the Dahlia must ultimately be freed from stakes. The main thing is to secure the good flower flrst and improve the habit $l a^{+} e r$, if possible. It is to be hoped that the coarser kinds of foliage will give way to more graceful and attractive forms. The "fernleaved" type is a much cut and delicate kind. Ami Barillet has handsome dark purple, finely cut foliage. All the above features represent general tendencies which, however, work out very differently in each important case.

The Dahlia has had one difficulty as peculiar to itself as the calyx bursting of the Carnation, or the different values of crown and terminal buds of Chrysanthemums. They are often troubled with a "green eye." This is a hard round button in the center of a blossom formed by the inner involucral bracts, which, at that stage, are longer than the unopened rays which they protect. Oftener still, this " green eye " is followed by a yellow center. This "green eye" is still considered to destroy the unity of a flower, and in exhibitions is often surreptitiously removed. The yellow disk can be cut out with a knife and the innermost rays carefully replaced. A fundamental difficulty associated with this matter is the slowness with which some Dahlias open. The outer rays open' first, and in Fig. 663 , where the successive stages are shown: the outer ones are the most expanded; then comes a series of cupped rays; then some that are tightly folded with two creases, and finally the hard green eye. A poor Show Dahlia opens slowly, and shows an eye while the outer rays are tumbling out, withering, or being burned by the sun. A good Show Dahlia opens its tiers in rapid succession, and shows no green eye.

Literature.-As in many other cases, the magazine literature of the Dahlia is the most bulky, and, in some respects, more important than the books on the subject.
The latest bibliography is that by C. Harman Payne in G.C.III. 21:329 (1897). There have been about 25 books devoted to the Dahlia, many of them pamphlets and cheap cultural manuals. These books were mostly published from 1828 to 1857 , with none at all for nearly 40 years after that date until 1896, when Lawrence K. Peacock's book, The Dahlia, which is the best American book, made its appearance. The first American treatise was by E. Sayers, published at Boston, 1839, and now forgotten. Many interesting facts came out in 1889, the centennial year of the Dahlia. A report of the National Dahlia Conference is reprinted from the Journal of the Royal Horticultural Society for 1890 , but Shirley Hibberd's statements therein regarding the botany of the Dahlia agree very poorly with Hemsley's revision of the genus in G. C. II. $12: 437,524,557(1879)$, which is the latest botanical monograph.

\section{A. Height tall, tree-like.}

\section{B. Fls. nodding, 'bell-shaped.}

imperiàlis, Roezl. Height 6-18 ft.: stem usually unbranched, knotty, 4-6-angled: lvs. 2-3-pinnately parted; leaflets ovate, narrowed at the base, acuminate, toothed, with a few short scattered soft hairs: fls. nodding, 4-7 in. across, white, more or less tinged with blood red, especially at the base: rays sterile or pistillate, lanceolate, sharp-pointed, not 3-toothed at the apex. Gt. 1863: 407 . G.C. $1870: 459$; Il. $12: 437$. B. M. 5813. Gn. 12:95; 33, p. 527. R.H. 1872:170. A.G. 15:313. Mn. 8:61.-As few conservatories can make room for so large a plant, it is common to graft this species on dwarf varieties of $D$. rosea. The inflated and pointed fl.-buds (3-4 in. long) are very characteristic. It is not known whether the original plant collected by Roezl was found in wild or cultivated surroundings. This species and the next are mostly cultivated under glass; the others are grown outdoors in summer, and the roots stored in winter.

вв. Fls. erect, not bell-shaped, but opening out flat.

excélsa, Benth. (D. arbòrea, Regel). Height $20 \mathrm{ft}$. or more: stem usually unbranched, glaucous, marked with horizontal rings made by the stem-clasping base of the petioles as the lower lvs. fall away: lvs. bipinnate, as much as $2 \frac{1}{2} \mathrm{ft}$. long, $2 \mathrm{ft}$. wide; leaflets as many as 25 , ovate, those of the upper lvs. often contracted at the base, acuminate, toothed, pale green beneath, with a few short scattered hairs or none: fls. $4 \frac{1}{2}$ in. across, dilute purple,

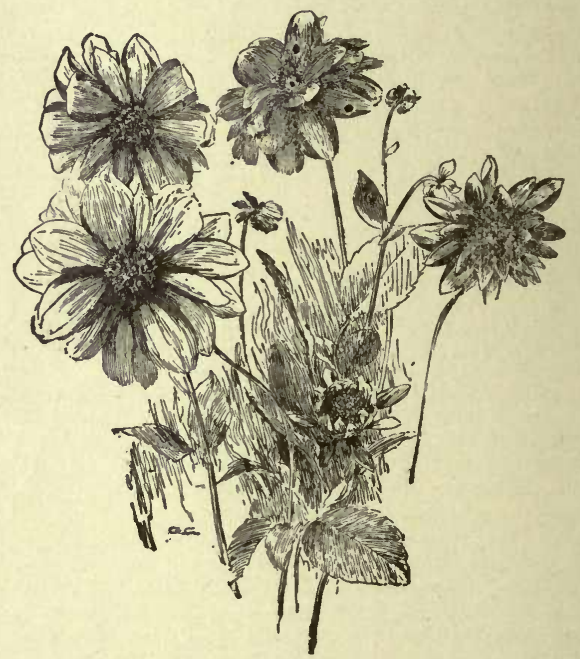

664. A semi-double form of Dahlia $\left(X^{1 / 3}\right)$.

This is one of many that have been crowded out in the struggle to perfect the Show and Fancy types.

crimson-pink. Maund, Botanist 2: 88 (1838?). G.C. II. 19: 80 . - This was described from a cultivated plant with 8 rays in a single row, but with considerably elongated disk fls. It was almost an anemone-flowered type, and 
all the florets were sterile. D. arborea has never been sufficiently described, but plants have been cultivated for many years under this name. The tree forms of Dahlias are not sufficiently known.

AA. Height medium, averaging $3 \mathrm{ft}$., commonly from 2-5 $\mathrm{ft}$., rarely exceeding these extremes.

B. Lvs.once pinnate: stem not branching from the ba $\because$ habit erect.

c. Stems not glaucous: rays fertile.

D. Rays of the single fls. not recurved at the margins; of the double fls. never flat, but cupped.

ròsea, Cav. (D. variábilis, Desf. ). Fig. 663. The original of practically all the old-fashioned Dahlias, particularly the Single, Pompon, Show and Fancy types. It is therefore the parent of the vast majority of the horticultural varieties. Lvs. typically once pinnate, sometimes bipinnate; leaflets ovate, toothed, broader and coarser than in the other species. B.R. 1:55. B. M. 1885. - This is a wonderfully variable species. Some plants are densely hairy, others scarcely at all. The lvs, are sometimes bipinnate in parts of plants or throughout an entire plant. In double forms the rays usually have abortive pistils. Many garden forms have glaucous stems. Some authors have doubted whether this species is distinct from $D$. coccinea, but the two types are very distinct, particularly in the garden, although there are intermediate forms in nature.

DD. Rays of the single fls. with recurved margins; of the double fls. not cupped, but long, flat and pointed, and some at least with recurved margins.

Juarézii, Hort. (D. Yuarézii, Hort.). Figs. 665,666 . The parent of the pure Cactus Dahlias. These all originated from one plant, which was flowered in Europe for the first time in 1864, and first pictured in G. C. II. 12:433 (1879). F.M. 1879: 383. Gn. 18, p. 589; $19: 283 ; 50$, p. 236.

cc. Stems glaucous: rays not fertile.

coccínea, Cav. Fig. 667 ; see B. M. 762 (1804). Always more slender than $D$. rosea, with narrower leaflets, and in the wild, at least, dwarfer than the $D$. rosea. The color range is much smaller, and does not include white or any shade of purple or crim. son. The colors vary from scarlet, through orange to yellow. There are no double forms, and it has been frequently said that this species will not hybridize with $D$. rosea. The named varieties pictured in I.H. 31:515 and 533 (1881), which are emphatically declared to be varieties of $D$. coccinea, are probably garden forms of $D$. rosea. The only characters that certainly distinguish $D$. coccinea from $D$. rosea are the glaucous stems and infertile ravs of the former, but these characters break down in garden forms. B. M. 762. Gn. 19:270. G.C. II. 12:525.

BB. Lvs.twice pinnate: stems branched from the base: habit spreading.

Mérckii, Lehm. (D. glabràta, Lindl.). Fig. 668 . confer B.M. 3878 (1841). Height 2-3 ft.: roots much more slender than those of $D$. rosea: stem and lvs. wholly devoid of hairs : lvs. bipinnate: floral bracts linear: fls. typically lilac; rays pistillate: outer involucral bracts linear. B.R. 26:29(1840). Gn. 19:270 (1881). -This is a very distinct garden plant, and is worth growing merely as a foliage plant. Seeds of species gathered from wild plants in Mexico by Pringle have been grown at the Cornell Experiment Station lately. The fine-cut character of the foliage makes it vastly more attractive than the coarse foliage of most of the varieties of $D$. rosea. Several of these seedlings had beautiful dark red or purple foliage. The plants are much dwarfer and wider spreading than most florists' Dahlias, and show no stem while growing. The branched flowering stems are remarkably long, slender and wiry, often rising 2-3 $\mathrm{ft}$. above the foliage. The rays are very short and often roundish, with a short sharp point instead of 3 minute teeth. There are no red, yellow or white forms in nature. The roots of this and $D$. coccinea, being slenderer than those of $D$. rosea, must be preserved with greater care during winter.

D. Zimapani. See Cosmos diversifolius.

W.M.

Propagation.-There are four methods by which Dahlias are propagated: by cuttings (an important commercial method); by division of roots (the amateur's

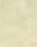


young shoots as fast as they form the third or fourth set of leaves. These cuttings are carefully trimmed and placed in pure sand in the propagating bench, using a dibble, and putting the cuttings in rows about 3 in. apart and $1 / 2-1$ in. between the cuttings.

The propagating bench is made by running a flue, hot water or steam pipes beneath an ordinary bench, and boarding up the side to confine the heat. Although there may be a difference of opinion among propagators, yet a bottom of sand heat of $65^{\circ}$, with the temperature of the iouse from $5-10^{\circ}$ less, will give the best practical results. With this temperature, the cuttings will root in about two weeks, and will be far stronger than if rooted in less time with greater heat. As soon as cuttings are rooted, they are potted off into small pots and grown in a cool greenhouse until danger of frost is over, when they are planted out in the open ground. Cuttings made too far below a joint, or too late in summer, will produce flowering plants but no tubers.

Grafting.-This is a very interesting, though not profitable, mode of propagation. The top of the tuber is cut slantingly upward, and the cutting slantingly downward, placed together and tied with raffia or any soft, handy material. They are then planted in a pot deep enough to cover the lower part of the graft with earth, and they will soon adhere if placed under a hand glass or in a frame. Grafting is practiced only for the preservation of rare and weak-growing sorts.

Seeds. - The chief use of seeds is the production of new varieties. Seeds are also used by those who chiefly desire a mass of color, and are not particularly desirous of finely formed blooms. If planted early enough indoors and transplanted to the open as soon as safe, fine masses of color can be secured before frost, and the roots of the more desirable kinds can be saved, and will give even better results the next season.

Positron.-Dahlias are easily destroyed by high winds unless they are given a protected position, and they need plenty of air and sunlight fur best results. In shaded, close, airless quarters the growth is sappy and the flowers are poorly colored.

SoIL-The soil is not so important, except in its ability to hold moisture during severe droughts. Any rich soil that will grow corn will also grow Dahlias to perfection, if all other conditions are favorable. They will grow equally well in clear sand, clay or gravel, if the proper kinds and quantities of plant-food are added and well and thoroughly worked in. It is, however, unreasonable to expect Dahlias or any garden plants to succeed in a hard clay, devoid of humus, easily baked and never tilled.

Feeding. - It is always best to broadcast the manure and plow or spade it into the soil; thorough spading is absolutely necessary if the manure is not well decom posed. On heavy clay or gravelly soils, loose, coarse manure may be used, but on light or sandy soils, manure should always be fine and well-rotted. Commercial fertilizers are also largely used, and are most valuable when used in connec tion with manure. Any good fertilizer, rich in ammonia and phosphoric acid, with liberal amount of potash, will answer at the time of planting, out as a top-dressing later, nothing equals pure bone meal and nitrate of soda, 4 parts bone to 1 part soda.

KINDS of STOcK. - Dahlias are offered in five forms: large clumps, ordinary field roots. pot roots, green plants and seeds. The clumps' give the best satisfaction the first year, but are entirely too large and unwieldy for anything but a local trade and exchange among amateurs. The ordinary field roots are the most valuable, as they can be easily and safely handled, and always give satisfactory results. Pot roots are largely used in the mailing trade, and, while they will not always give as good results the first year, are valuable for shipping long distances, where larer rot could not be profitably used owing to heavy transportation charges. Green plants are mainly used to make up any deficiency in the field erops, owing to unfavorable seasons, or an unusual demand for certain varieties.
Planting. - There is a diversity of opinion as to trie proper time to plant Dahlias, but the writer has always found it best to plant early, and would advise planting large, strong roots about two weeks before danger of frost is over. This would be, in the vicinity of Philadelphia, about April 15; and as it takes from two to three weeks for the plants to get up through the ground, there will be no danger, while the plants will bloom that much earlier. It is best, however, not to plant small roots or green plants until danger of frost is over-in the vicinity of Philadelphia, about May 1 to 10 , according to the season. A good rule to follow everywhere would be to plant small roots and green plants as soon as danger of frost is over, and large roots about three weeks earlier.

Tiluage. - The first requisite of successful garden cul+ivation is to thoroughly stir the soil to considerable depth and enrich it, if it is not already rich, by broadcasting and plowing or spading in a good coat of well rotted manure. Too much stress cannot be placed upon the thorough preparation of the soil, as it not only allows

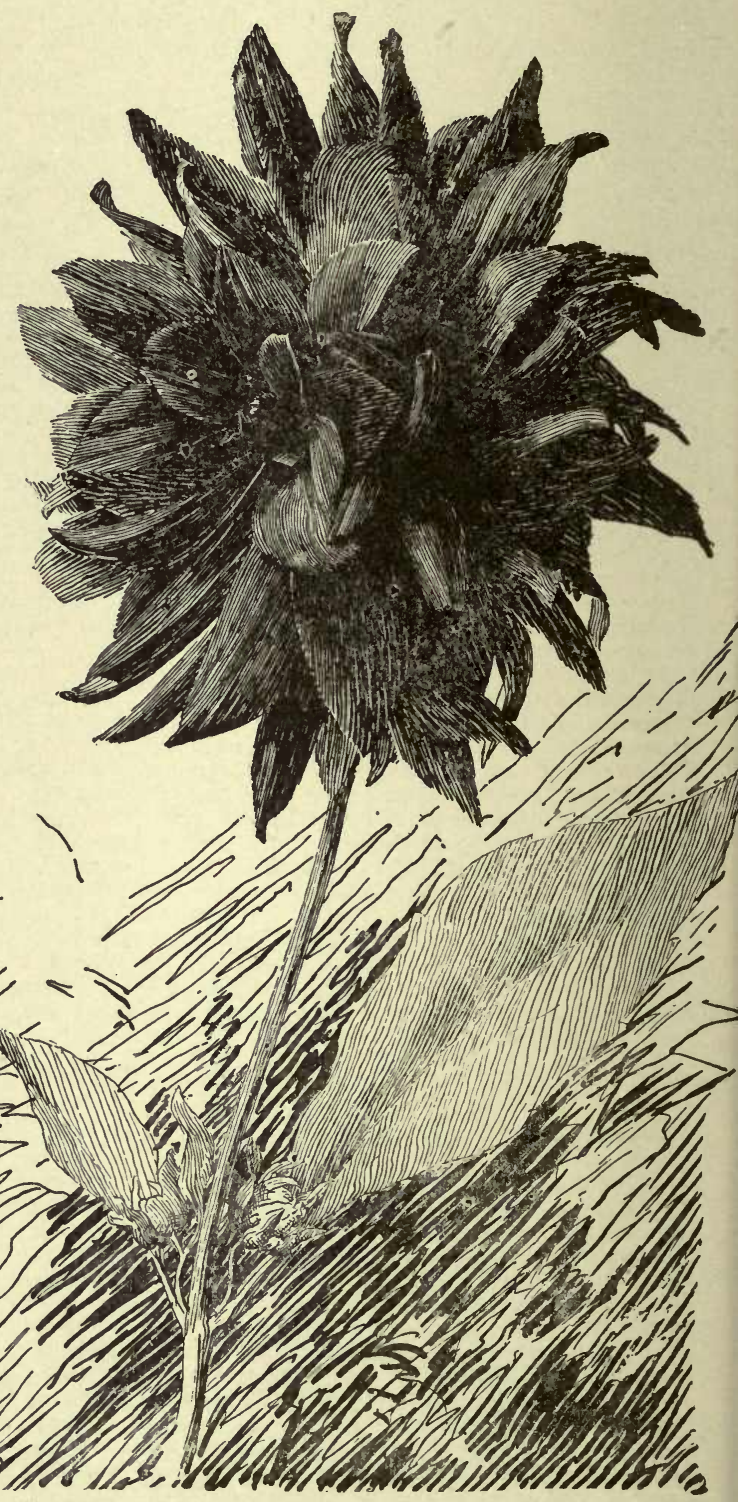

666. Matchless. Half size. A velvety maroon Cactus Dahlia. 
the roots to go down deep after the moisture more readily during ury weather, but affords good drainage during excessive rains. Having prepared the soil as above, mark out rows $4 \mathrm{ft}$. apart and 6 to $8 \mathrm{in}$. deep, and plant the roots from $18 \mathrm{in}$. to $3 \mathrm{ft}$. apart in the row, according as solid rows or specimen plants are desired.

During its early stage of development, the Dahlia grows very rapidly, and should be kept thoroughly tilled. But while deep tillage is beneficial during its early stages of development, it is almost fatal to the production of flowers if practiced after the plants come into bloom. Therefore, when the plants conimence to bloom, cease deep tillage and stir the soil to the denth of 1 to $3 \mathrm{in}$. only, but stir it often, and never allow the surface to become hard and baked. This will not only prevent excessive evaporation of moisture and keep the under soil cool and moist, but will also prevent the destruction of immense quantities of feeding roots.

As long as the roots supply more nourishment than is needed to support the plant, both the plant and the flowers increase in size and beauty; but as the supply gradually becomes exhausted, the plants cease growing and the flowers become much smaller. This condition is what is generally called "bloomed out," but what is really "starved out," and can easily be prevented if the proper attention is given to the plants. As soon as the flowers commence to grow smaller, broadcast around each plant a small handful of pure bone meal and nitrate of soda, in proportion four parts bone to one part soda, and carefully work it into the soil.

WATERING. - This is a debatable subject, and, although a judicious application of water during a severe dry spell is very beneficial, yet in nine cases out of every ten where water is applied a thorough stirring of the surface soil would give better results.

Many people believe Dahlias should be watered every evening, and as soon as they are up commence watering them daily unless it rains. This practice is very injurious, as it causes a rapid but soft growth, and as the soil is seldom stirred, the roots become so enfeebled for want of air that they are unable to supply the needs of the plant; as a consequence, but few buds are formed, and they generally blast before developing into flowers. In other cases, as the enthusiasm wears off, watering is stopped, probably right at the beginning of a severe drought, and the weak, pampered plants are fortunate to survive, much less to bloom.

If large, strong roots are planted and the soil is kept thoroughly stirred, there will be little need of artificial watering until after the plants come out in full bloom. However, if it should become hot and dry after the Dahlias come into bloom, it would be very beneficial to give them a thorough watering once each week or ten days during the continuance of the drought. But care should be taken to stir the soil to the depth of 1-2 in. the next day, carefully pulverizing it later, in order to seal the natural capillary tubes by which the moisture is evaporated.

The best rule to follow is not to allow the plants to suffer for want of moisture, nor to water them except where they need it, but to water them thoroughly when necessary, and not to allow excessive evaporation for want of frequent stirring of the soil.

Training. - In planting the roots or tubers, place them on their sides with the eye as near the bottom as possible, and cover only $2-3$ in. deep. As soon as the shoots appear, remove all but the strongest one, and pinch out the center of that one as soon as two or three pairs of leaves have formed, thus forcing it to branch below the level of the ground. As the plants develop, the soil is filled in gradually by subsequent hoeings. By this method the entire strength of the root and the soil is concentrated on the one shoot, causing it to grow vigorously; while the pinching back not only causes it to branch below the surface of the soil, and thus brace it against all storms, but also removes all of those imperfect, short-stemmed flowers that appear on some varieties. If the plants are pinched back low, as described, there is no danger of the branches splitting down, as the soil around themwill hold them securely in place. How ever, where they branch above ground and are inclined to split down, drive a short, stout stake near the stem and tie the branches to it. These short stakes are not to hold the plants up, but to prevent the branches splitting down where the above directions have not been followed closely.

The writer was the first to use and advocate this method of training, and by its practice has grown many thousands of Dahlia blooms on stems from $18 \mathrm{in}$. to $2 \mathrm{ft}$. long, selling them to florists by the thousands for four times the ruling price of carnations, and higher than that asked for roses.

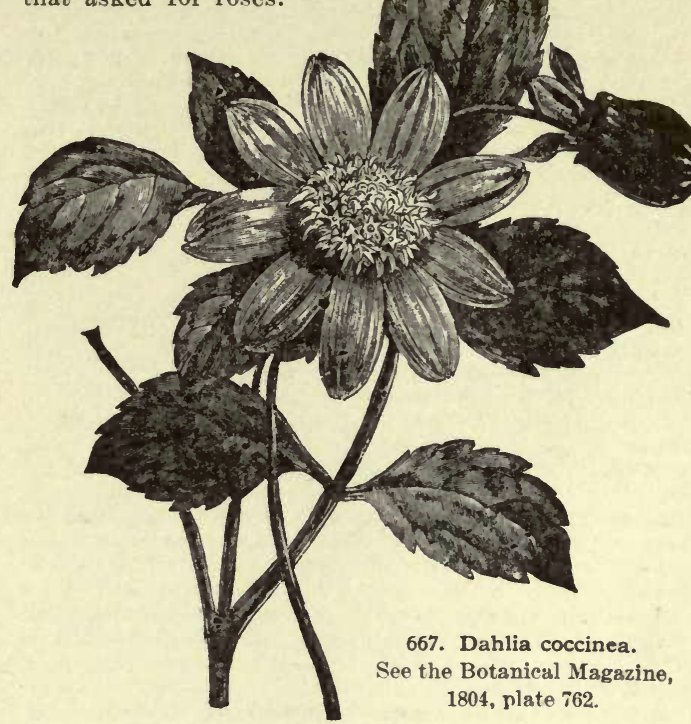

STORING THE ROOTs. - As soon as the plants are killed by frost, lift the roots, and, after removing all the soil from them possible, allow them to dry in the air for a few hours, when they should be stored in the cellar or some other cool place secure from frost. If the cellar is very dry or is not frost proof, put the roots in a barrel or box and cover completely with dry sand or some other suitable and convenient material, such as sawdust or tanbark, to prevent freezing or loss of vitality by drying or shrireling.

VARIETIES. - For cut-flowers, the Decorative or Cactus hybrid kinds are the most valuable, and the following are among the very best: Nymphæa, Clifford W. Bruton, Henry Patrick, Grand Duke Alexis, Wm. Agnew, Perle de la Tete d'Or, Evadne, Orange King, Sundew, Mrs. E. C. Monroe. The Cactus Dahlias are beautiful and artistic, but will not last long after being eut. The best are: Aiger, Austin Cannell, Strohlein Kronne, Henry F. Michell, Mrs. Bennett, John W. Roach, Geo. Marlow, Loreley, Beatrice and Mrs. Peart.

Of the Show Dahlias, among the best are : Miss May Lomas, A. D. Livoni, Storm King, Emily, Ruby Queen, Arabella, Constancy, Queen of Yellows, Willie Garrett, Lady Maud Herbert.

Fancy: Frank Smith, Miss Browning, Penelope, American Flag, Lottie Eckford, Uncertainty. Of the Pompon or Bouquet Dahlias, the best are Snowclad, Fairy Queen, Daybreak, Eleganta, Little Prince, Le Petit Jean, Carol, Little Beauty, Yellow Bird and Red Piper. The Single varieties are especially adapted for cutting, but should be cut as soon as opened, otherwise the petals will fall.

F'or bedding, the plants must be dwarf, of branching habit, and profuse bloomers. A few desirable kinds are: Marg. Bruant, Magnificent, Triomphe de Solferino, Colibre, Snowclad, Sunbeams, Mrs. Dodd and Bloomenfalter.

For Massing and Banking.-Cactus : Aegir, Strohlein Kronne, Mrs. A. Beck, Cyclops, Baron Sehroeder. Decorative: Wm. Agnew, C. W. Bruton, Perle de 
la Tete d'Or, Evadne, Mrs. E. C. Monroe, Indescent, Wilhelm Miller, Black Beauty, Grand Duke Alexis, Nymphæa, Oriental, Orange Scarlet.

Show: Storm King, A. D. Livoni, Model of Perfection, Willie Garrett, Honest John, Ernest Krebig, Psyche, Bird of Passage, Oakfield, Arabella, La France,

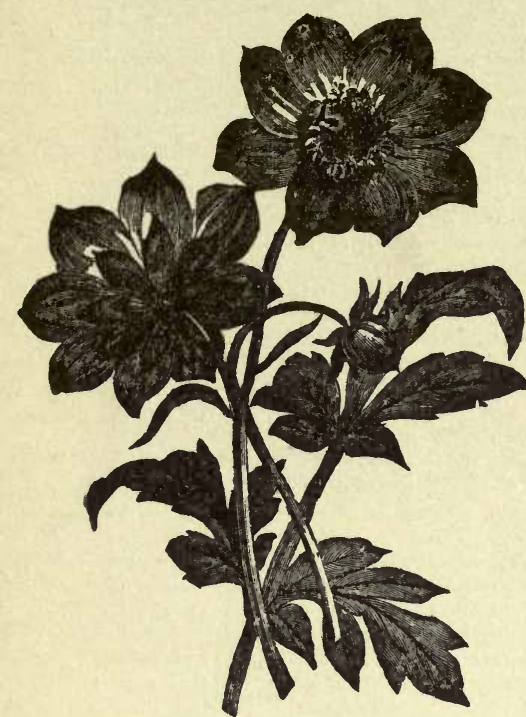

668. Dahlia Merckii.

See the Botanical Magazine, 1841, plate 3878. Princess Bonnie, Queen of Yellows.

Pompon: Klein Domitea, Snowclad, Carol, Fairy Queen,Catherine, Sunshine, Little Beatrice, Eleganta, Elfin, Miss Lou Kramer, Le Petit Jean, Bessie, Tom and Teddy.

Singles are valuable for this purpose, especially St. George, Ami Barrillet, A da, John Downie, Evelyn, Isaac Pitman, Painted Lady, Corinne, Brilliant and Nance.

For Borders and Hedges.-No special list of varieties can be recommended for this purpose, as it is largely a matter or taste.

OTher Purposes. - Dahlias are used for many other purposes, and are grown in many other forms with pleasing effect. Some train the tall varieties on trellises in espalier form; many train them to tall supports, while others spread them out on the ground and peg them fast, to give the appearance of a bed of largeflowering pigmies. The latter form is quite unique and satisfactory, as plants of some of the varieties grow unusually well and bloom profusely. The Fancy Dahlia Uncertainty and Cactus Dahlia Delicata are typical varieties that seem to do better in this form than any other.

Enemies. - Dahlias are generally remarkably free from enemies, but in some localities the tarnished plant bug (Lygus pratensis) makes success impossible, as there is no practical remedy. This bug is chiefly responsible for the blasted buds and one-sided flowers. It pierces

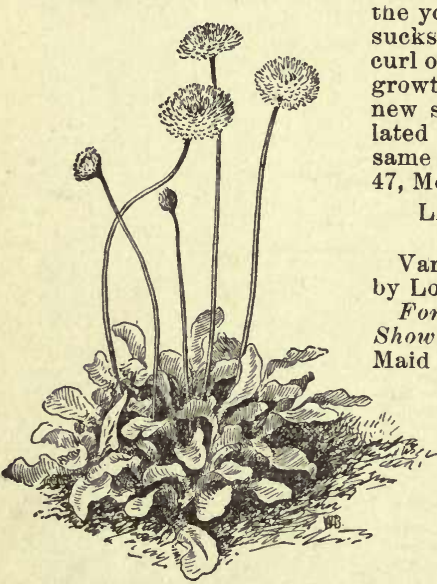

669. Bellis perennis. he young buds, shoots, and sucks the sap. The shoots over, blacken, check the wide shoots are stimuwhich often meet the fate. Consult Bulletin , Mo. Exp. Sta.

Lawrence K. Peacock.

Varieties recommended y Lothrop and Higgins: For General Purposes.Show : Dawn, Robin Adair Maid of Athens, Madam Zules, Madge Wildfire, Miss Miller, A. D. Livoni, Mary D. Halleck, Snow, Bird of Passage, Cham. pion Rollo, Dr. J. P. Kirtland.

Fancy: Rev C. W. Bolton, Young America, Mrs. J.
Downie, Rev. J. B. McCamm, John Forbes, Mrs. Browning, Keystone, Frank Smith.

Pompon: Burning Coal, Eurydice, Daybreak, Phœbe, Lillian, Purity, Sunbeam, Little Bessie, Brunette, Fashion, Snowclad, Virginale, Rosalie, Hedwig Polwig, Catherine, Guiding Star, Aillet's Imperial, Alewine, Vivid.

Decorative: Grand Duke Alexis, Wm. Agnew, Juno, Bowery Girl, Josephine, Lyndhurst, Perle de la Tete d'Or.

Cactus: Matchless, Bertha Mawley, Mrs. Bennett, Harmony, Edelcactus.

For Exhibition. - Show: Miss Cannell, Wm. Powell, Duchess of York, Harrison Weir, John Walker, R. T. Rawlings, Kaiser Wilhelm, Muriel, Pearl, Alice Emily, James Vick, Emily Edwards, A.D. Livoni, Wm. Fawcett, James Service, Madge Wildfire, Mrs. Langtry, Hector, John Lamont, J. T. Saltmarsh.

Fancy:' S. Mortimer, Dorothy, Sunset, Young America, Champion Rollo, General Grant, Mrs. J. Downie, Lottie Eckford, Salamander, Prince Henry, Matthew Campbell, Duchess of Albany,

Rev. J. B. McCamm, John

Forbes, Frank Smith, Keystone.

Cactus : Matchless, Ernest Glasse, Mrs. Bennett, John Welch, Harmony, Gloriosa, Mary Hillier, Beatrice, Prince of Orange, Mrs. A. Peart, Starfish, Green's Gem, John Roach.

Decorative: May Pictor, Wm. Agnew, Oban, Juno, Lancelot, Amphion, Bowery Girl, White Swan, Marchioness of Bute, Perle de la Tete d'Or, Rayon d'Or, Wilhelm Miller.

Pompon: Burning Coal,Eurydice, Phœbe, Eleganta, Minnie, Lillian, Hilda Searl, Henrietta, Mars, Purity, Ernest, Sunbeam, Mattie Mourey, Snowclad, Virginale, Rosalie, Iolanthe, Hedwig Polwig, Little Hermon, Golden Gem, Raphael, Alewine, Aillet's Imperial.

For Cut-flowers.-Cactus : Beatrice, Ernest Glasse, John Roach, Harmony, Matchless, Edelcactus, Starfish, Green's Gem.

Decoratıve: Grand Duke Alexis, C. W. Bruton, Alpha, Wm. Agnew, Nymphæa, Josephine, White Swan, Lyndhurst, Bowery Girl, Oban, Perle de la Tete d'Or, Rayon d'Or, Bennett Goldney.

Pompon: Alewine, Purity, Eurydice, Sunbeam, Rosalie, Guiding Star, Phœbe, Iolanthe, Minnie, Lillian, Golden Gem.

\section{DAHOON HOLLY. Ilex} Dahoon

DAIS (Greek, pine torch; application not obvious). Thymeloedceo. This genus contains a tree that yields a strong fiber, and is also rarely cult. for ornament, especially in Fla. and S. Calif., and possibly in one or two northern conservatories. It has lvs. resembling the Smoke Tree, Rhus Cotinus, and bears long stalked umbel-like heads of starry pink fls., with floral 670. Ox-Eye Daisy or White parts in 5's. The genus has Weed-Chrysanthemum

half a dozen species, all from Leucanthemum $(\times 1 / 2)$.

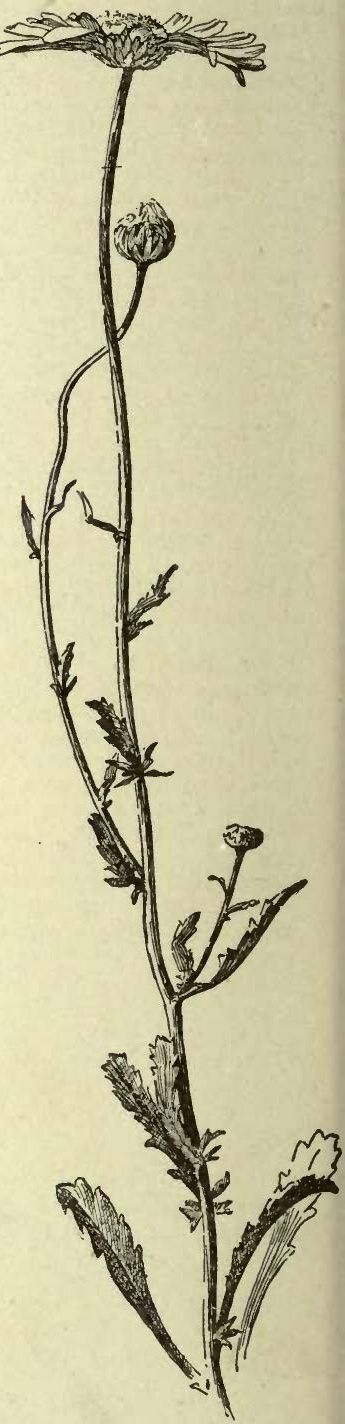


DAME'S ROCKET and DAME'S VIOLET. Hesperis matronalis.

\section{DÁmMarA. See Agathis.}

DAMNACANTHUS (Greek, powerful spines). Rubiacece. This monotypic genus contains a tender, evergreen, Japanese shrub, chiefly valued for its coral-red berries, which remain on the bush until the fls. of the next season are produced. Branches numerous, spiny: lvs. small, opposite, leathery, nearly sessile, broadly ovate, acuminate : fls. small, axillary, in 1's or 2's, white, fragrant; calyx tube obovoid, limb 4-5-cut; corolla funnel-shaped. Prop. by cuttings. This plant may be obtained from dealers in Japanese plants.

Indicus, Gærtn. (D. major, Sieb.\& Zucc.). Described above. Himalayas and Jap. - Var. submitis is not so spiny.

DAMPING-0FF. A gardeners' phrase for a disastrous rotting of plants, especially of seedlings and cuttings, and generally at the surface of the ground. It is usually associated with excessive moisture in the soil and air, with high and close temperatures, and sometimes poor light. Such conditions weaken the plants and allow them to fall a prey to the minute parasitic fungi which live upon the decaying vegetable matter in the soil, and can remain alive for months, even if the soil is thoroughly dry or frozen. As soon as the disease is noticed, the healthy plants should be removed to fresh soil, as the disease spreads rapidly. A whole bench of cuttings may be ruined in a night. 'The skillful propagator takes every possible precaution. His benches have perfect drainage, he uses fresh sharp sand, and sometimes sterilizes it with steam heat for several hours. Damping-off is one of the most trying experiences of the beginner, and nothing ean prevent it

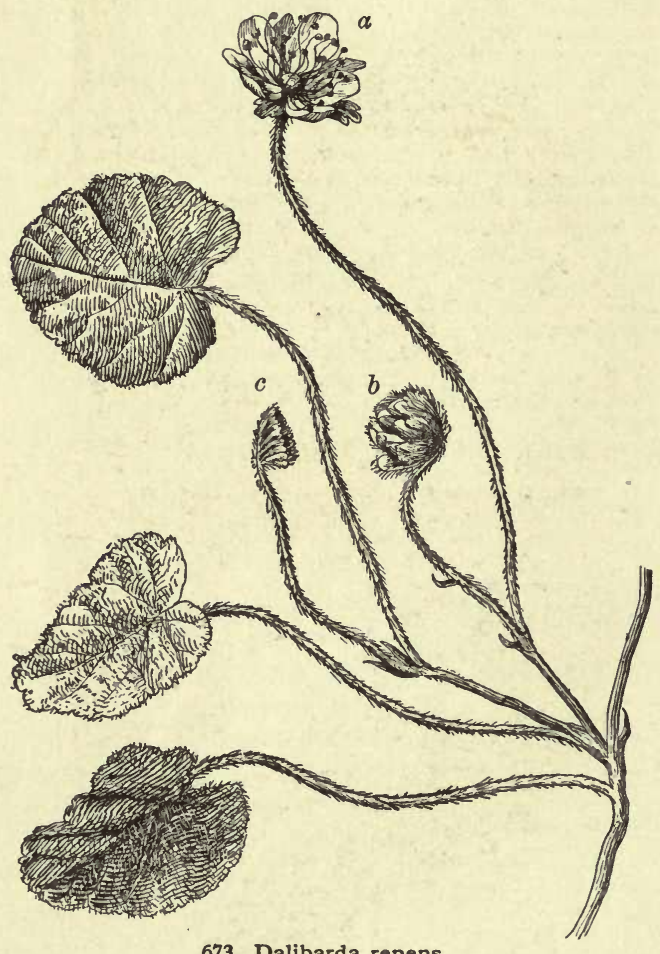

673. Dalibarda repens.

With perfect and cleistogamous flowers.

but a thorough grasp of the principles of Greenhouse Management in general, and Watering in particular. (Consult articles on these subjects.) The terms Damp- ing-off and Burning are also used for ruined flowers. Burning is often caused by sunlight or by imperfections in glass, but a flower spoiled by dripping cold water, or by some unknown cause, is said to have a burned look.

One of the commonest occasions of Damping-off is the sudden flooding of a bed or bench after leaving it too dry for a long time.

(5)

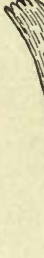

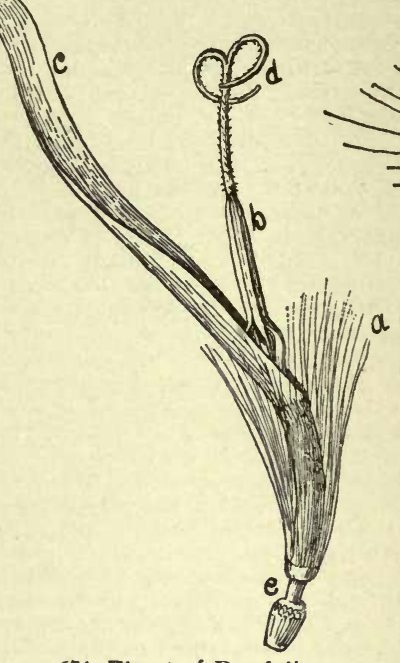

674. Floret of Dandelion: enlarged.

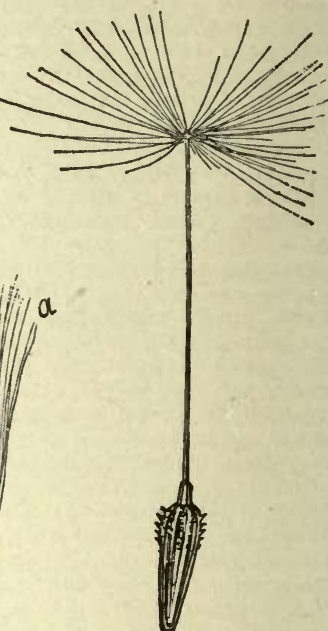

675. Mature fruit of Dandelion.
DAMSON. See Plum.

DAN ìA (a personal name). Marattiacece. A small genus of fern-like plants, with synangia sessile, arranged in rows, and covering the entire under surface of the leaf. They are rarely seen in cultivation in Amer.

DANDELION (i. e., dent de lion, French for lion's tooth; referring to the teeth on the lvs.). The vernacular of Taráxacum officinale, Weber, a stemless perennial or biennial plant of the Compositoe. It is native to Europe and Asia, but is naturalized in all temperate countries. On the Rocky Mts. and in the high north are forms which are apparently indigenous. A floret from the head of a Dandelion is shown in Fig. 674. The ovary is at $e$; pappus (answering to calyx) at $\alpha$; ray of corolla at $c$; ring of anthers at $b ;$ styles at $d$. The constricted part at $e$ elongates in fruit, raising the pappus on a long stalk, as shown in Fig. 675; and thus is the balloon of the Dandelion formed. A Dandelion plant, with its scattering fruits, is shown in Fig. 676. There is another species of Dandelion in this country, but evidently not common. It is the Red-seeded Dandelion (T. erythrospermum, Andrz.), with red seeds, not reflexed involucral scales, and shorter beak.

The Dandelion is much prized for "greens." For this purpose it is cultivated in parts of Europe; also about Boston and in a few other localities in this country. There are several improved large-leaved varieties, mostly of French origin. Some of these named forms have beautiful curled lvs. Seeds are sown in the spring, and the crop is gathered the same fall or the following spring,-usually in the spring in this country. Commonly the seeds are sown where the plants are to stand, although the plantlets may be transplanted. The plants should stand about 1 foot apart each way, and a good crop will cover the land completely when a year old. Sandy or light loamy soil is preferred. The erop is harvested and marketed like spinach. The lvs. or heads are often blanched by tying them up, covering with sand or a flower-pot. The plants are sometimes grown more closely in beds, and frames are put over them to force them. Roots are sometimes removed from the field to the hotbed or house for forcing. When treated like chicory (which see), the roots will produce a win. 
ter salad very like barbe de capucin. Roots dug in fall and dried are sold for medicinal purposes in drug stores under the name of Taraxacum.

L. H. B.

DANGLEBERRY Or BLUE TANGLEBERRY. Gaylussacia frondosa.

DAPHNE (Greek name of Laurus nobilis). Thy. meladcede. Ornamental evergreen or deciduous shrubs, with handsome foliage and sweet-scented; white, purple, lilac or rarely greenish fls., which, in warmer climates, often appear during the winter. Lvs. alternate, rarely opposite, entire, short-petioled : fls. in clusters, short racemes or umbels, apetalous, mostly fragrant; perianth tubular cr campanulate, 4-lobed, corolla-like, usually clothed with silky hairs outside; stamens 8 , included; stignia capitate, sessile or nearly so: fr. a fleshy or leathery 1-seeded drupe. About 40 species in Eu. and Asia. Only $D$. Mezereum, with very early lilac, fragrant fls. and decorative scarlet fr., and some low evergreen species, like $D$. Cneorum and $D$. Blagayana, are hardy north, while most of the evergreen species can be recommended only for warmer climates. D. Pontica and D. Laureola, with large evergreen lvs., are hardy as far north as New York. Daphnes thrive best in a well drained, light soil and in a partly shacied position, but some, as $D$. Cneorum and D. Blagayana, which are exceedingly pretty plants for rockeries, do better in sunny situations. In the north, $D$. odora and its varieties are often grown in pots for their sweet-scented and handsome fls. appearing during the winter. A sandy com. post of peat and loam in equal proportions will suit them; they require a good drainage and careful watering during the winter, and pots not larger than just necessary should be given; they may also be planted out in a cool greenhouse and trained as a wall plant. D. Genkwa, with abundant lilac fls, before the lvs., is sometimes forced. Prop. by seeds, sown after maturity or stratified, but germinating very slowly; also by layers put down in spring and taken off the following year. The evergreen species may be increased by cuttings of mature wood in fall under glass, and kept in a cool greenhouse during the winter. If gentle bottom heat can be given in early spring, it will be of advantage to the development of the roots; softwood cuttings taken from forced plants may also be used. D. odora is often veneer-grafted on seedling stock of $D$. Laureola in winter, or on roots of $D$. Mezereum. D. Cneorum and probably its allies are readily increased in spring by removing the earth around the plant, pegging down the branches and filling with fine compost almost to the tops of the branches. Next spring, if the compost is carefully removed, a large number of little buds, each supplied with a white root, are found along the branches; they are easily detached and planted in pans or boxes.

In California, according to Franceschi, the species most commonly grown is $D$. odora, the plants being mostly imported from Japan. Many plants are also sent from Japan for eastern greenhouse culture. A decoction of the bark of $D$. Mezereum is sold in drug stores under the name of Mezereum. It is stimulant and diuretic. It is also known as Olive Spurge.

Alfred ReHDER.

Although hardy Daphnes are generally recommended to be planted in partial shade, they invariably succeed in open, sunny places, and even in dry spots when the start is made with strong, well-rooted plants. They grow very freely in a light, open, well drained soil, enriched with thoroughly decayed manure. An annual topdressing of the same material is of great benefit to the plants, young or old.

For propagation by cuttings, half-ripened wood is best. Layers should not be separated until early in the following spring, and it is advisable to shade the young plants in their new quarters for a few weeks until the roots have taken hold in the ground and growth has started. Cuttings should not be subjected to a very strong bottom heat before a good callus has formed, as they are slow to emit roots, and free growth can not be expected until the young plants attain the age of 2 years. The commonest of the hardy kinds is $D$. Cneonum; but $D$. Blagayana, which is still very rare in Anerica, is a charming species, worthy of greater popularity. Grafts of this species are likely to die without apparent cause. D. Neapolitana needs a sheltered position.

J. B. Keller.

Alphabetical list of species described below : D. au tumnalis, 1; Blagayana, 5; buxifolia, 7 ; Cneorum, 4 ; collina, 6; Dauphini, 8; Delphini, 8; Fioniana, 7; for tunei, 3; Genkwa, 3; Houtteana. 3; hybrida, 8; Indica, 9; Japonica, 9; Jenkwa, 3; Laureola, 10; Mazeli, 9; Mezereum, 1, 2; odora, 9; odorata, 9; oleoides, 7; Pontica, 10; sericea, 6; Van Houttei, 2.

A. Lvs. deciduous : fls, axillary along the branches of the provious year, uppeuring before the lvs.

1. Mezèreum, Linn. Erect shrub, with stout branches, to $4 \mathrm{ft}$.: lvs. alternate, cuneate, oblong or oblanceolate, glabrous, grayish beneath, 1-3 in. long: fls. usually 3 , sessile, silky outside, fragrant, lilac-purple, appearing much before the lvs.: fr. roundish ovoid, scarlet. Feb. Apr. Eu. to Altai and Caucasus. Gn. 29:550.-Var.

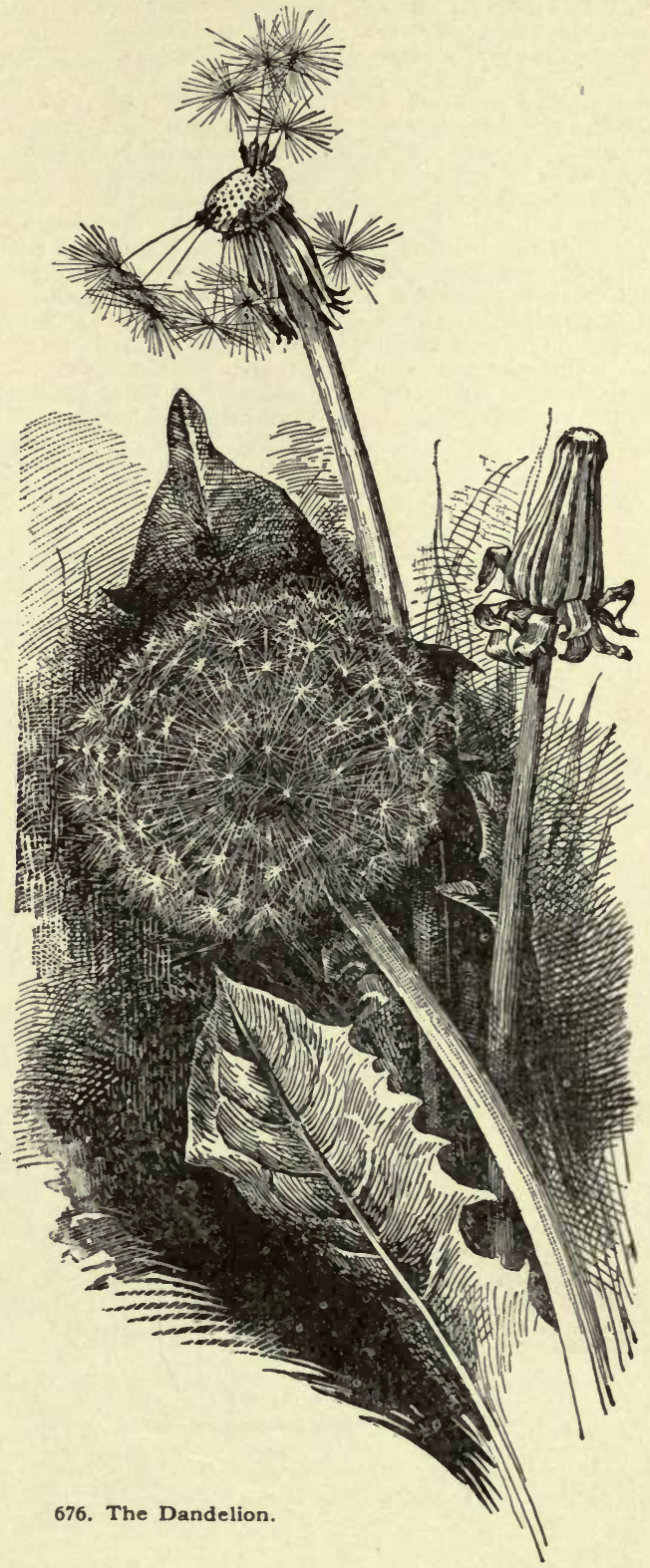


álba, Ait., has white fls. and yellow fr. Gn. 29:550. G.C. III. 21:183, 185. Var. álba plèna, Hort., has double white fls. Gn. 29:550. Var. grandiflora, Hort. (var. autumnalis, Hort.). With larger, very early fls., sometimes blooming in fall.

2. Houtteàna, Planch. (D. Mezerèum, var. atropurpùrea, Dipp.). Shrub, to $4 \mathrm{ft}$., with erect, stout branches: lvs. alternate, cuneate, oblong-lanceolate, glabrous, coriaceous and often persistent, purple : fls. appearing before the lvs., lilac-violet, $2-4$, in short-peduncled clusters. Apr. F.S. 6:592. - Of garden origin, and probably hybrid between $D$. Laureola and Mezereum.

3. Génkwa, Sieb. \& Zuce. (D. F́rtunei, Lindl. D. Jénkwa, Hort.). Shrub, to $3 \mathrm{ft}$., with slender branches: lvs. opposite, oblong-elliptic, appressed-pubescent on the veins beneath, $1 \frac{1}{4-2}$ in. long: fls. lilac, $3-7$, in shortstalked clusters, scentless, densely silky, villous outside. Mar., Apr. Jap. S.Z. 75. Gt. 15:499. F.S. 3:208. Gn. $42: 868$. R.B. $10: 73$.

\section{AA. Lvs, evergreen, alternate (see No.2).}

B Fls. in terminal heads, rarely axillary and pinkish. c. Habit low, procumbent or trailing.

4. Cneòrum, Linn. Fig. 677. With long, trailing, pubescent branches : lvs. crowded, cuneate, oblanceolate,

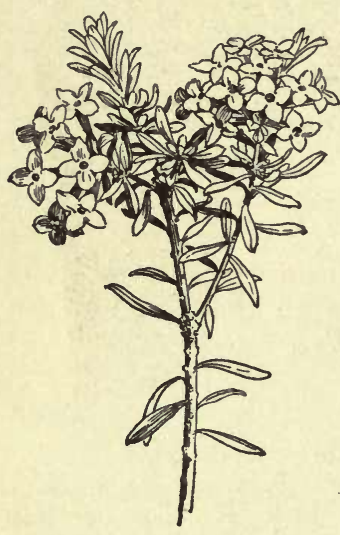

677. Daphne Cneorum. mucronulate, finally glabrous, dark green and glossy above, glaucescent beneath, $1 / 2-1$ in. long: fls. in sessile, many-fld. heads, pink, fragrant. Apr., May, and often again in summer. Mts. of M. Eu. B. M. 313. L. B. C. 18: 1800 . Gn. 45, p.237. - Var. màjus, Hort. Of more vigorous growth. Gn. 51, p. 358. Var. maximum of European nurseries $=D$. Neapolitana.

5. Blagayàna, Freyer. Branches often ascending, glabrous: lvs. cuneate, obovate or oblong, glabrous, 1-11/2in. long: heads many-fld.: fls. white or yellowish white, fragrant, nearly glabrous outside, almost 1 in. long. Apr., May. Mts. of southeastern Eu. B.M. 7579. F.S. 22:2313. Gt. $29: 1020$. Gn. 14:143. G.C. II. $13: 245 ; 17: 505$; III. $11: 491$.

\section{cc. Habit erect, 1-4 ft. high.}

D. Perianth densely pubescent outside.

6. sericea, Vahl (D. collina, Sm.). Height 1-3 ft.: branches pubescent: lvs. cuneate, oblong or oblanceolate, obtuse, slightly revolute at the margin, glabrous and shining above, appressed-pubescent beneath, 1-13/4 in. long: fls. fragrant, in few-fld. heads, with bracts, purple, densely pubescent outside, with ovate-obtuse lobes, $3 / 4$ in. long. Spring. Italy to W. Asia. B.M. 428. B.R. 24:56. L.B.C. $14: 1348$.

7. oleoides, Schreb. (D. buxifolia, Vahl). Shrub, to $3 \mathrm{ft}$.: branches pubescent: Ivs. obovate-elliptic to obovate-lanceolate, usually mucronulate or acute, villouspubescent beneath, sometimes glabrous at length, $1-1 \frac{1}{2}$ in. long: fls. in few-fld. heads without bracts, white or pale lilac, with ovate-lanceolate, pointed lobes, $1 / 2$ in. long. Southeastern Eu. L.B.C. 3:299. B.M. 1917. - Very variable in shape and pubescence of lvs. Var. Fioniana, Hort., with obovate-lanceolate, obtuse lvs. and lilac fls., is said to be a hybrid between this species and the former.

8. hỳbrida, Lindl. (D. Dariphini, Hort. D. Délphini, Lodd.). Garden hybrid of D. collina $\times$ odora. Similar to $D$. odora, but hardier. Erect shrub, to $4 \mathrm{ft}$.: lvs. cuneate, oblong-elliptic, dark green and shining above, glabrous or slightly hairy along the veins beneath when young, 2-3 in. long : fls. reddish purple, very fragrant, rather large, in few-fld. heads. B.R. 14:1177.
DD. Perianth glabrous outside, or nearly so.

9. odora, Thunbg. (D. Japónica, Thunbg. D. Índica, Loisel., not Linn.). Shrub, to $4 \mathrm{ft}$., with glabrous branches : lvs. oblong-elliptic, acute at both ends, bluntly pointed, glabrous, 2-3 in. long: fls. in dense, terminal heads, very fragrant, white to purple: ovary glabrous. Winter and spring. China, Jap. Gn. 28:499. Gng. 2:211. - Var. álba, Hort. Fls. white. Gn. 28:499. Var. Mazéli, Hemsl. Fls. in peduncled, axillary clusters along the branches, pink outside, white within. Gn. $14: 154$. R.H. 1872:392. Hardier than the type. Var. punctàta, Hemsl. Fls. in dense heads, white, spotted outside with red. B.M. 1587. Var. marginàta, Hort. Lvs. bordered yellow: fls. red. P.M. 8:175. R.H. 1866:251. Var. rùbra, Don. Fls. purple. S.B.F.G. II. 4:320. G.C. III. 21:173. D. odoràta, Hort., is a common misprint in eatalogues for $D$. odora. D. odorata, Lam.= D. Cneorum.

Bв. F'ls.axillary, yellowish or greenish white, glabrous outside.

10. Laurèola, Linn. Shrub, to $4 \mathrm{ft}$.: 1vs. cuneate, obovate-lanceolate, acute, shining and dark green above, glabrous, $2-3 \frac{1}{2}$ in. long: fls. in 5-10-fld., nearly sessile racemes, yellowish green, scentless : fr. black. Mar.May. S. Eu., W. Asia.-Var. purpùrea of the Kew Arboretum $=D$. Houtteana.

11. Pontica, Linn. Shrub, to $5 \mathrm{ft}$.: Irs. cuneate, obovate or obovate-lanceolate, acute, shining, glabrous, 2-3 in. long: fls. in long-peduncled, 1-3-fld. clusters, greenish yellow, fragrant, with linear-lanceolate lobes. Apr., May. Southeastern Eu., W. Asia. B.M. 1282. G.C. II. $14: 209$.

D. alpìna, Linn. Ereet shrub, to $2 \mathrm{ft}$.: lvs. deciduous, cuneate-lanceolate, sparingly silky: fls. white or blushed, terminal, fragrant. May, June. S. Eu. L.B.C.1:66. - D. Altàica, Pall. Shrub, to $4 \mathrm{ft}$.: lvs. deciduous, cuneate, oblong-lanceolate, glabrous: fls. white, in terminal, 1-5-fld. heads, fragrant. May, June. Altai, Songaria, Mongolia. B.M. 1875. L.B.C. 4:399.- D. austràlis, Cyrill. $=$ C. sericea. $-D$. Caucásica, Pall. Allied to D. Altaica. Lvs. narrower: fls. in 3-20-fld. heads. Caucasus. B.M. 7388. -D. Delahayàna, Hort.=D. Neapolitana. $-D$. glomeràta Lam. Allied to D. Pontica. Low: fls. light pink, fragrant, the
clusters crowded at the end of the branches. May. W. Asia.D. Gnidium, Linn. Evergreen shrub, to $2 \mathrm{ft}$.: lvs. linear-lanceolate, acute, glabrous: fls. yellowish white, fragrant, in terminal racemes or panicles. S. Eu. L.B.C. 2:150-D. Neapolitàna, Lodd. (D. Cneorum $\times$ sericea). Evergreen shrub, to $2 \mathrm{ft}$.: lvs. cuneate-oblong, obtuse, nearly glabrous: fls. in terminal heads, rosy purple, fragrant. May, sometimes again in fall. L.B.O 8:719, $-D$. papyrfera, Sieb=Edgeworthia Gardneri- $D$, petroea, Leyb. Dwarf evergreen shrub: lvs. linear-lanceolate troea, Leyb. Dwarf evergreen shrub : lvs. linear-lanceolate,
small, obtuse: fls. light pink, in terminal, $3-6$-fld. heads, frasmall, obtuse: fls. light pink, in terminal, 3-6-fld. heads, fra-
grant. June, July. S. Tyrol.-D. rupéstris, Facch.=petroea.grant. June, July. S. Tyrol. - D. rupéstris, Facch.=petroea.evergreen shrub : lvs. small, cuneate, linear-lanceolate, glabrous: fls. in terminal, many-fld. heads, pink. June, July. Switzerland and Carpath. Mts. ALFRED REHDER.

\section{DAPHNIDIUM. See Benzoin.}

DAPHNIPHYLLUM (Greek, literally a laurel-leaf). Euphorbiacea. A genus of oriental trees, perhaps 15 species. The following species are very rare in cultivation, and are obtained through dealers in Japanese plants. The genus has no near allies of horticultural value. Tropical glabrous trees: lvs. alternate, entire, stalked, leathery, usually narrow, feather-veined : racemes axillary, short: bracts minute or none: fls. stalked, diøecious, without petals : fr. an olive-shaped drupe.

macropodum, Miq. Lvs. leathery; petiole 2 in. long; blade about 8 in. long, $2 \frac{1}{2}$ in. wide, elliptic-oblong, with a very short, hard, abrupt point: racemes of female fls. 3 in. long, slender; pedicels distant. Japan.

glaucéscens, Blume. Tree, often $20-30 \mathrm{ft}$. high, in India, Java and Corea: petiole three to four-fifths in. long in the pistillate plant; in the staminate 8-13.tenths of an inch long; lvs. obovate-lanceolate, rounded at the tip; blade 3-4 in. long, 12-16-tenths of an inch wide. -There is a variegated form.

W. M.

DARLINGTONIA (after William Darlington, the American botanist, to whom we are indebted for the delightful Memorials of Bartram and Marshall). Sarracenidcece. One of the most interesting and distinct of all 
pitcher plants. There is only one species in this genus. The plant was first collected near Mt. Shasta by the Wilkes Exploring Expedition. Indians attacked the party, and as the explorers retreated to their camp W. D. Brackenridge grabbed something, which turned out to be fragments of this exciting plant. The Darlingtonia grows at an altitude of 5,000 feet on the Sierra Nevadas of California, in sphagnum bogs along with sundews and rushes. The pitchers grow in clusters, and are a foot or two high. The pitcher is slender, erect, spirally twisted and rounded at the top, something like a fiddle head. From this hangs a curious reddish structure with two long flaps. Underneath the rounded top is seen the entrance to the trap, which means death to all sorts of insects, big and little. How the plant attracts them is not obvious, but the fate of the insects is clear. They climb down a long, narrow funnel, guided by needle-jike downward-pointing hairs. Arrived at the bottom, the insects find these needles numerous and converging. As they attempt to escape they are confronted by an impassable array of lances. The manner of their death can be easily imagined. They sink into the bottom in a putrid, sticky mass, and the products of decomposition are presumably absorbed by the plant.

Darlingtonias have been geown outdoors in the east the year round in a few special localities. Edward Gil lett, at Southwick, Mass., grows them in a favored spot without artificial protection. F. H. Horsford can preserve them at Charlotte, Vt., with the aid of a winter mulch.

Califónnica, Torr. Fig. 678. Rootstock horizontal : lvs. forming pitchers as described above, which are curiously veined, and have a wing on the ventral surface and a crest on top, green, finally becoming a pear yellow: scape erect, $1 / 2-11 / 2 \mathrm{ft}$. high, clothed with obtuse, erect, concave, half-clasping bracts: fls. solitary, nodding, 3 in. across; sepals 5 , pale green; petals shorter than the sepals, about 1 in. long, converging, greenish yellow, with broad reddish brown veins, contracted above the middle; stigmas 5; ovary cylindrical below, dilated into a broad 5-lobed top with a deep depression in the center, 5 -celled: seeds obovate-club-shaped. B.M. 5920. I.H. 18:75. F.S. $14: 1440$. G.C. III. $7: 84,85$; $17: 304 ; 24: 339$. - Int. to cult. about 1861 . W. M.

As greenhouse plants, Darlingtonias require the same treatment as their allies, Sarracenias, Dioneas and Droseras. A well grown collection of these plants is not only very interesting and curious, but also very beautiful. To succeed, they must occupy a shaled position, and never be allowed to become dry. Give a cool, moist, even temperature. If possible a glass case should be provided for them, with provision made for ventilation; a constant moist atmosphere can be more easily maintained, and at the same time the greenhouse in which they are grown may be freely ventilated without injury to these plants. The material in which they grow best is two-thirds fern root fiber with the dust shaken out, and one-third chopped sphagnum moss and silver sand, with a few nodules of charcoal added. About the first week in July is perhaps the best time for potting, though one must be guided by the condition of the plants, choosing a time when they are the least active. When well established they wil only require potting once in two years. The pots should be placed in pot saucers as a safeguard against their ever becoming dry, and all the space between the pots should be filled with sphagnum moss up to the rims of the pots. A temperature of $40^{\circ}$ to $45^{\circ}$ during winter, with a gradual rise as the days lengthen in spring, will suit them admirably. During the summer they should be kept well shaded, or they may be removed to a well shaded frame outside, in some secluded position free from hot, drying winds. Propagation of these plants is effected by division of the ruots, or by seeds sown on live sphagnum moss in pans, the moss being made very even and the pans placed either under a bell jar or glass case in a cool, moist atmosphere. [For detailed English experience, see G.C. III. $24: 338$.

Edward J. Canning.

Darlingtonia Courtii was named after William Court, for many years hybridizer and traveler for James Veitch \& Son. Some say it is a hybrid between a
Nepenthes and Durlingtonia Californica. Its lvs. or pitchers are shorter and stouter than those of $D$. Californica, and more rounded at the mouth. The stalks of the pitchers bend out almost horizontally from the base or crown of the plant and then become erect. The treatment is much the same as for D. Californica, except that it must be kept indoors in winter. It thrives well in a house with Odontoglossum crispum and Masdevallia. It is generally sus. pended like Nepenthes. The writer has successfully grown it when it was potted in peat or sphagnum, in a

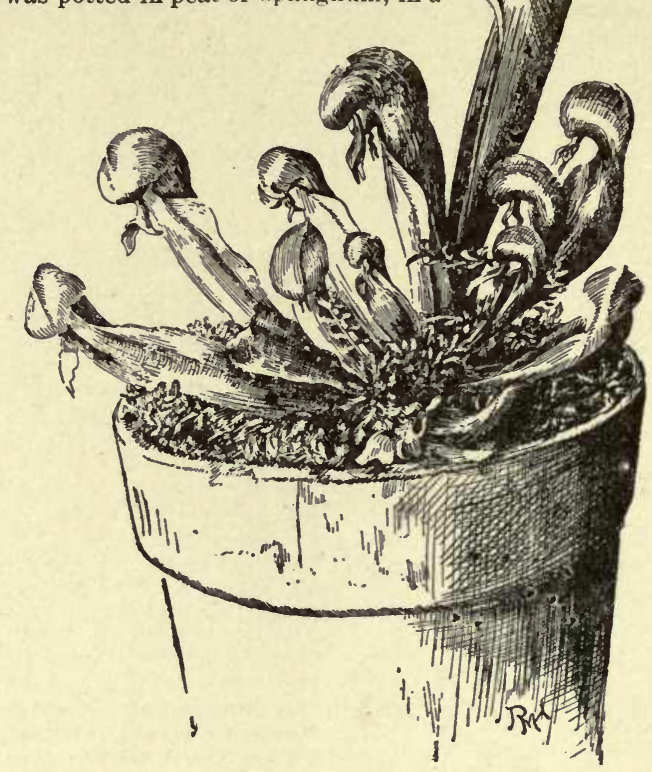

678. Young leaves of Darlingtonia.

small pot which was inverted into a larger pot, with a layer of sphagnum packed in between, and the whole kept constantly moist. It is an interesting and attractive plant, and enjoys considerable popularity in England.

Henry A. Siebrecht.

\section{DARNEL. Lolium perenne.}

DASYLIRION (Greek, tufted lily). Lilidece. Highly ornamental plants, well adapted for rockeries, for isolated specimens on lawns, decoration of conservatories, staircases, etc and eminently suitable for terraces and vases, in the formal style of gardening. Trunk short or missing altogether : lvs. in large number, inserted in a symmetrical way, so as to form a dome or globe-shaped, regular head, more or less serrulated, and in some species ending in a brush-like tuft of dried fibers. The tall panicles of numberless whitish green, minute flowers are also a striking feature. Dasylirions generally branch after blooming. They are of the easiest possible culture, and will stand some degrees of frost, particularly if kept dry. Easily propagated from seeds and from cuttings of the branches when produced, as they do not sucker as a rule. Six or perbaps more species altogether. Natives of the arid region com. prising southwestern Texas, New Mexico, Arizona and northern Mexico. The following are grown in southern gardens and in conservatories up north, but not as much as they deserve.

F. Franceschi.

These plants are inferior to Yucca filamentosa in hardiness and in showiness and regularity of flowering, but they have an individuality of their own which should commend them to amateurs who like things that everybody doesn't have. They are especially esteemed in Califoruia, where the great flower-stalks, 8 or $10 \mathrm{ft}$. high, 
give a strong impression of the desert, which contrasts forcibly with civilized surroundings. The individual flowers are not highly colored, but the spikes are several feet long. Three plants sold as Dasylirions belong to Nolina, a closely related genus, which is chiefly distinguished by fruit characters. In Dasylirion the ovary has 3 ovules, and the fruit is dry and indehiscent, or splits through the partitions and between the cells. In Nolina the ovary has 2 ovules, and the fruit is dry, often 3-winged, and bursts in an irregular fashion. The latest monograph is in Latin by J. G. Baker in Journ. Linn. Soc. Vol. 18 (1881).

$$
\text { A. Stems 4-angled, square in section. }
$$

quadrangulàtum, S. Watson. Trunk $3 \mathrm{ft}$. high : lvs. drooping, dark green, $2 \mathrm{ft}$. or more long, 2-3 lines broad at the base, soon narrower and quadrangular, the margin rough but not toothed. Mex. Discovered in 1878. This is the only species with entire, not toothed, leafmargins. With Franceschi the trunk is so short as to be almost globular; the Ivs. are 4-6 ft. long, slightly arching, and not splitting into fibers.

\section{AA Stems not 4-angled.}

B. Tips of lvs. not splitting into fibers.

glaucophýllum, Hook. (D. glaùcum, Carr.). Recognized by the above character and by the very glaucous, bluish green lvs., of which the inner ones are strict and rigid, not gracefully drooping, the outer ones recurved, 2-3 ft. long, 8-9 lines wide above the base. Mex. B.M. 5041. R. H. 1872, p. 435. G.C. II. 13: 205.

$$
\begin{gathered}
\text { BB. Tips of lvs. splitting into fibers. } \\
\text { c. Trunk long, } 2-5 \mathrm{ft} \text {. }
\end{gathered}
$$

D. Teeth on the leaf-margins yellowish.

Texànum, Scheele. Lvs. light green, 3-4 ft. long, 5-6 lines wide above the base; margin serrulate, armed with hooked teeth 1 line long and 3-6 lines apart; flower-stalk 8-10 ft. high. Tex. and New Mex.

\section{DD. Teeth on the leaf-margins brown.}

Wheeleri, S. Wats. Lvs, very similar to those of $D$. Texanum, 7-9 lines wide. The lvs. are shorter than in D. glaucophyllum, and they usually have a spiral twist, which gives the plant a remarkable appearance. Ariz and N. Mex.

$$
\text { cc. Trunk short. }
$$

D. Racemes short, densely fld.

$$
\text { E. Length of lvs. 3-4 ft. }
$$

graminifolium, Zucc. Trunk very short: rosette of lvs. 4-5 ft. across : 1vs. 3-7 lines wide above the base, tipped with 6-8 spreading fibers. Mex. Int. into cult. about 1835 . - This name and $D$. serratifolium were given by Zuccarini without description, and are greatly confused in botanical literature and perhaps also in gardens.

$$
\text { EE. Length of } l v s .2-3 \mathrm{ft} \text {. }
$$

acrótrichum, Zuce. (D. grácile, Zuce.). Trunk in gardens unbranched, finally 4-5 ft. high: lvs. 6-8 lines wide, pale green, hardly glaucous, splitting at the tip into 20-30 fibers, the outer lvs. recurved. Mex. B.M.5030. F.S. $14: 1448$. G.C. III. 19: 204.

\section{DD. Racemes long, loosely fld.}

serratifolium, Zuce. Lvs. exactly as in D. acrotrichum, 7-8 lines wide above the base. Mex. - Can be distinguished only in flower.

W. M.

DATE. A palm, Phonix dactylifera, Linn., native to N. Africa and Arabia, and extensively planted in countries under Arabic control. It is also grown to some extent in southern Asia and southern Europe and in other tropical and subtropical countries. The pulpy fruits constitute one of the most important articles of food of the Arabs; and the leaves and other parts of the plant afford materials for dwellings and many domestic uses. Nearly all parts of the plant are utilized in some way. The Date palm reaches a height of $100 \mathrm{ft}$., making a straight, shaggy trunk, and it continues to bear for one or two centuries. It is diøecious. See Phonix.

The Date palm has been grown in parts of the United States and adjacent Mexico for many years. In Florida, California, and restricted areas of a few other states, it has been grown for decorative purposes for more than a century. At the missions founded by the Spaniards at St. Augustine, and other places in Florida, and that long line of missions extending from far iato Mexico, northward and westward through southern New Mexico, Arizona and California, it is probable that the Date was planted wherever the climatic conditions were favorable. Within the borders of the United States the greater number of these early plantings were in Florida or along the coast of southern California, regions where the sum total of summer heat is not sufficient to perfectly develop the Date fruit. The Date, as a fruit producer, being indigenous to a desert en vironment, does not take kindly to humid regions, even where it is not sufficiently cold to prohibit the growth of the tree. For this reason the greater number of the early plantings in this country matured little fruit, while that produced was of poor quality, although in many instances the trees grew luxuriantly and to large size. In the more arid portions of Lower California and Sonora, where there is sufficient water for irrigation, the early plantings have been continued down to the present time, and Dates of fair quality have been grown for many years. Moreover, each year the area devoted to Dates is increasing. Not only have sufficient Dates been grown in Sonora to supply the local markets and the markets of the larger cities, Hermosillo, Guaymas and Altar, but during the past year a surplus has been shipped from the state.

The part of the United States suitable for growing the Date tree, for the profitable production of fruit, is confined to rather narrow limits; viz., the irrigable portion of southern Arizona below an altitude of 2,500 feet and the somewhat similar area of southern California east of the coast ranges of mountains, where the summer temperature is not lowered by proximity to the sea. As a tree, however, it will make excellent growth over a much larger area, including the semi-arid regions of central and southern California. Over the larger area it will oceasionally bloom and the earlier varieties mature fruit, but the summer heat will rarely be sufficient to bring it to a high degree of perfection. In recent years Dates have matured in favorable localities in California, in both the San Joaquin and Sacramento valleys, but it is only east of the mountains in the irrigable regions of the Mojave desert that there is sufficient summer heat to mature an annual crop. In the strictly desert regions of southern Arizona and southeastern California the planting of seedling Dates is rapidly increasing, and the time is not far distant when in this region not a little attention will be given to the production of this fruit. Among the older trees may be mentioned those on a ranch owned by Hall Hanlon, situated on the California side of the Colorado river it few miles below Yuma. In $1875 \mathrm{Mr}$. Hanlon received a box of Dates from La Paz, Lower California, which were grown at that place, and planted the seed the same year. From these seeds 12 pistillate and several staminate trees were raised, the trees beginning to bloom at the age of 5 years. All the pistillate trees have fruited abundantly each year since 7 years of age, and now vary in height from 20 to 50 feet, each tree producing yearly from 6 to 17 bunches of fruit, the bunches varying in weight from 20 to 38 pounds.

In recent years many seedling palms have come into bearing in southern Arizona, particularly in Salt river valley. On the Bartlett, Adams \& Co's, ranch at Glendale, several seedling Dates were in bearing in the fall of 1898, at which time one tree, 8 years from seed, bore an estimated crop of more than 400 pounds. On a ranch owned by E. L. Arthur, in the vicinity of Tempe, a dozen or more palms were in bearing the same year, several of which bore one or more bunches of fruit the fourth year after planting. In addition to those cited above, many seedling palms bore during the fall of 1898 at Phœnix, Tempe, Glendale, Mesa, Arizola, Florence, Yuma, Tucson, and other points in southern Arizona, and a number of localities in California.

An impetus was given to Date culture in this country by the importation by the U. S. Department of Agriculture, in the spring of 1891 and 1892, of 74 rooted suckers, 68 of which were supposed to have been taken from female trees of approved varieties, while the remaining six were labeled male. These tress were distributed to various 
points in New Mexico, Arizona and California. Those planted on the Experiment Station farm at Phoenix have made a much better growth and bloomed more freely than tile plants sent elsewhere, some of the specimens at this Station, in the fall of 1898 , measuring more

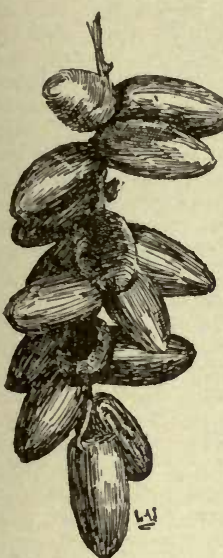

679. An American seedling Date. than 20 feet to the topmost leaf and producing 100 to 200 pounds of fruit to the tree. A sufficient number of the imported palms have blossomed to indicate that they are not true to name, more than one-half of those blossoming to date being staminate, while those that have fruited are inferior to a number of the choicer seedlings grown in Arizona. It yet remains for another importation to be made, when greater care may be taken that the imported plants are suckers from trees of recognized merit and approved rarieties.

An examination of specimens of fruit from many of the seedling Dates grown in the United States, as well as in the state of Sonora, Mexico, during the season- of 1898 , and also an examination of the fruit of the imported Dates at the Experiment Station farm at Phœnix, showed considerable variation in the size, flavor, shape, color, and generul desirability of the different specimens. Only about 50 per cent of the trees examined bore edible Dates, the remainder being astringent even when fully ripe, and little more than a skin over a pit. Of the remaining 50 per cent only about one-fifth were especially desirable and worthy of perpetuating by growing suckers. It must be remembered in this connection that Dates, like most other fruits, do not come true to seed; hence, it is not reasonable to expect a very large percentage of desirable Dates as a result of growing seedlings. Some of the best seedling Dates grown in Arizona in 1898 were light in color and varied in weight from two-sevenths to one-fourth ounce to the specimen, with from 10 to 11 parts in weight of flesh (mesocarp) to one part of pit. The largest of the imported Dates; viz., the variety labelled "Seewah," produced Dates averaging nearly one-third ounce to the specimen. Although this is the largest Date yet produced in Arizona, and probably in the United States, the pit is extremely large, there being but 8 parts of flesh to one of pit. Furthermore, the flesh is covered with a thick skin (epicarp), and there is a firm papery covering (endocarp) over the pit. An excessive development of either epicarp or endocarp is undesirable. Choice varieties of Dates should have thin skins and small seeds surrounded by a thin, papery covering. The flesh should be thick, of medium firmness, sweet, and of agreeable flavor. The Date industry in the United States is in its infancy. Approved varieties have not as yet been introduced and the quantity of fruit produced has not reached sufficient magnitude to give it a com mercial rating.

The Date palm grows upon nearly all kinds of soil. If it be sufficiently irrigated and has the requisite amount of heat, the soil seems to be a secondary consideration. In general it may be said, however, that lean, sandy soils of the desert, with a small percentage of clay and charged with alkaline salts, are preferable to rich and heavy soils, suitable for growing ordinary crops. The question of water is of great importance in the culture of Dates, as it is necessary that the roots of the Date palm be in moist earth throughout the year. In general, the amount of water required for successful culture is considerable. If sufficient water cannot be supplied by natural methods, we must resort to irrigation. Water should be supplied at frequent intervals throughout the year. However, the most should be supplied in the spring before blooming, and in the fall prior to the ripening of the fruit. The amount of water for each palm depends so much upon soil and local conditions that an estimate would be worthless. Care should be taken not to irrigate to excess at the time of blooming and immediately after, as it will militate against the successful setting of the fruit. The Date seems not only to enjoy a high atmospheric temperature, but a high temperature of the water supplied in irrigation as well. In irrigating small crops by flooding, it is necessary in midsummer to irrigate late in the afternoon or at night in order to prevent sealding. Care should be taken, during the warmer portion of the year, that the Date palm is not subjected to hot water about the roots, rising above the soil for a considerable length of time, and later left until the soil becomes exceedingly dry and baked by the sun. Such extremes may sometimes seriously injure or destroy the tree.

Dates are propagated either by seeds or suckers. As with the apple and most other fruits, Dates do not come true to seed, hence the only sure way to obtain good Dates is to secure a sucker from a tree of established excellence. Propagation from seed is of little value when we desire to obtain Dates of the same quality as those from which the seeds were obtained, or when we wish a correct proportion of male to female trees. Again, seedling palms are usually very much later in maturing their fruit, and generally the fruit from such trees have large seeds and little flesh. It is always preferable to propagate Dates from suckers unless one desires to originate new varieties, not only on account of the knowledge of the sex (it being hardly necessary to state that the sex of a sucker is the same as that of the plant from which it is taken), but on account of the ability to make a selection in the variety and quality of the fruit.

All species belonging to the genus Phœnix are diffcult to transplant with uniform success. Frequently as high as 50 per cent of transplanted Dates die even when watered daily and given the best of care. In planting suckers, with the best of attention, a large percentage die; while without care not one in a hundred will grow. It is due not so much to the lack of experience in removing the suckers as to lack of proper care after removal, that so large a percentage fail to grow. Suckers may be removed at any time during the spring or early summer, or even in the winter, if proper care be given them after removal. If they are to be planted in the open ground it is adrisable to remove them during the spring or early summer, April probably being the best month. In winter, when the plants are at a standstill, the suckers may be removed with comparatively small loss, if the bulbs be not less than 4 inches in diameter and have a few roots. It is necessary, when suckers are removed at this season, to set them in rather small pots, so that the earth, which should be given a daily soaking, may have a chance to get warm quickly. The pots

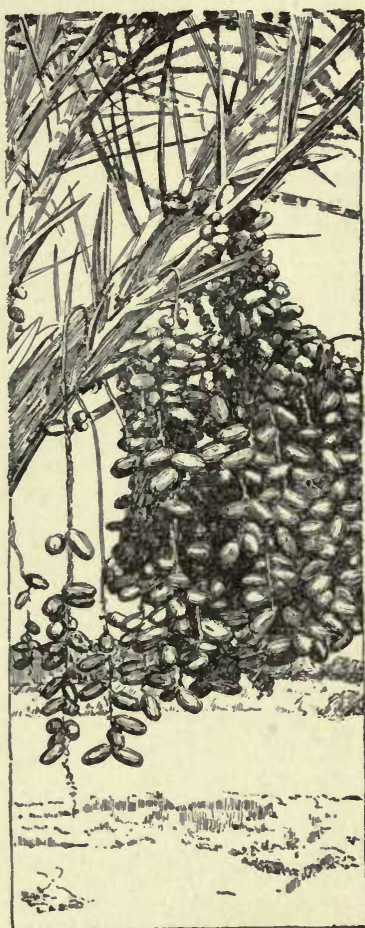

680. Fruit clusters of Date, as grown in Arizona, should be kept in a greenhouse, or, better yet, imbedded in a hotbed of manure, covered with the customary frame and glass. In all cases the leaves should be cut back to 6 to 12 inches in length. If proper attention can be given it is best to plant the suckers where 
they are to remain, as a second chance for loss occurs when they are planted in a nursery and later moved to the position that they are finally to occupy. A 2-inch chisel, well sharpened, and an appropriate mallet are the important tools to use in removing suckers. The leafstalks should be cut away, exposing the bulb of the sucker, care being taken not to injure the bulb in removing. One should cut in rather deeply at either side, not being afraid of injuring the old plant, cutting out a $V$-shaped portion extending from the base of the bulb downward for a foot or more, and being careful to secure in uninjured condition all the attached roots. If the position of the sucker be not too high above the ground the V-shaped portion should be continued downward into the soil, that all established roots be obtained.

Under proper cultivation the Date palm should produce from 10 to 14 leaves each year. A well developed tree will have at one time from 30 to 60 leaves, the old ones dying away below while new ones are forming at the top. The different varieties show great variation in rapidity of growth, form and length of leaves, size of stem, and general aspect of plant. The stem of the Date palm is very elastic, and when it reaches a height of 10 or more feet it is frequently necessary to tie the growing bunches of Dates securely to the lower leafstalks, that they be not broken and injured by the wind before maturity.

For further information, consult Bull. 29, Arizona Exp. Sta. J. W. Toumer.

A successful method of propagation of Date trees is to bank up earth about the base of the parent tree and above the base of the suckers, and keep moist by watering daily to induce formation of roots. Suckers may be partially severed from the old stock before the banking is done, or after the roots have started. When the roots are well grown, the suckers may be transplanted with little loss.

For purposes of pollination the Arabs usually plant about one male tree to 25 female or fruit-bearing trees. In order to secure perfect pollination, they cut sprays of male blossoms, when the pollen is in the best condition, and tie them to the leaf-stems above the pistillate flowers at the time they are opening. If this were done in cases where isolated female Date trees are growing in America, there would be much perfect and delicious fruit where now there is that which is worthless, because of the lack of pollination.

In the earlier importations the agents were imposed upon by either ignorant or designing natives of Egypt, by sending seedlings instead of rooted suckers, which were specifically ordered. The varieties from Algeria and Arabia were suckers from the best varieties, but unfortunately, most of them have died. At least two are yet living at the California Experiment Station at Tulare. This year, 1899, the Department of Agriculture at Washington has succeeded in importing, through a special agent sent to Algeria, a number of suckers from the best bearing trees in that country, and further efforts are being made to secure more plants from there, and from other famous Date-growing countries.

\section{H. E. VAN DEMAN.}

\section{DATE PLUM. Another name of Persimmon.}

DATÙRA (Arabic name). Includes Brugmansia. Solandcece. This genus contains the widespread James town Weed and several plants cultivated for their huge trumpet-like flowers, which have an odor that is very pleasant to some. The genus has perhaps 25 species, widely dispersed in warm and temperate regions. Herbs, shrubs and trees: Ivs. large, entire or wavy-toothed: fis. large, solitary, erect or pendulous, mostly white, with more or less violet, rarely red or yellow: fr. spiny. The most popular kind in northern gardens is commonly called D. cornucopia (Fig. 681), which is especially interesting when its flowers develop 2 or 3 well-defined trumpets, one within another. Sometimes, however, these double flowers are a confused mass of petalage. Double and triple forms are likely to occur in any of the species described below. The Horn of Plenty, $D$. cornucopia, has been especially popular in America since about 1895, when it was found in South America by an orchid collector of the United States
Nursery Company, and soon became widely distributed in "yellow, white, blue and deep carmine", all double forms. The "yellow" was probably a dull, creamy shade, and the "blue," a violet. The disseminators assert that seeds started in January, February or March will produce 200-300 fragrant flowers in a season.

Daturas contain strong narcotics. Large doses are po1sonous, small doses medicinal. Separate preparations of Stramonium seed and leaves are commonly sold in the drug stores. D. Stramonium (Fig. 682) is the Thorn Apple or Jamestown Weed, the latter name being corrupted into Jimpson Weed. Its foul, rank herbage and large spiny fruits are often seen in rubbish heaps. At the first successful settlement in America-Jamestown, Va., 1607-it is said that the men ate these thorn apples with curious results. Capt. John Smith's account of their mad antics is very entertaining. It has been conjectured that this same plant was used by the priests at Delphi to produce oracular ravings. The seeds of $D$. sanguinea are said to have been used by Peruvian priests that were believed to have prophetic power. The Arabs of central Africa are said to smoke parts of the dried plant for asthma and influenza.

Daturas are of easy culture. Some are treated as tender annuals. In the north the woody species can be grown outdoors in summer, and stored in cellars during the winter; in the south and in S. California they are almost everblooming. Daturas are sometimes kept in cool conservatories the year round, in which case they should be planted in the border, as Daturas rarely flower well in pots, their roots being large and spreading and requiring a constant supply of moisture. This method produces great quantities of bloom in spring. After flowering, the plants should be cut in to the main limbs, or a very straggling and unsightly growth will result.

\section{A. Hlowers red.}

sanguínea, Ruiz. \& Pav. Tree-like shrub, 4-12 ft. high : branches fragile, leafy at the apex: 1vs. clustered, 5-7 from the same point, ovate-lanceolate, acuminate, almost 7 in. long, $2 \frac{1}{2}-23 / 4$ in. wide, pubescent on both sides, shining green above, paler beneath, the lower lvs. wavy or angled, upper one entire; petioles $2 \frac{1}{2}$ in. long, channeled, pubescent : peduncles terminal : fls. pendulous, brilliant orange red, about 8 in. long; calyx ovate, 5angled, variegated, inflated. Peru. B.R. 20:1739. F.S. 18: 1883.-Franceschi says 1 is more erect-growing than $D$. cornigera and $D$. suaveolens, with smaller, less open and not fragrant fls. All the other species are said to be easily raised from cuttings, but this is very slow to take root.

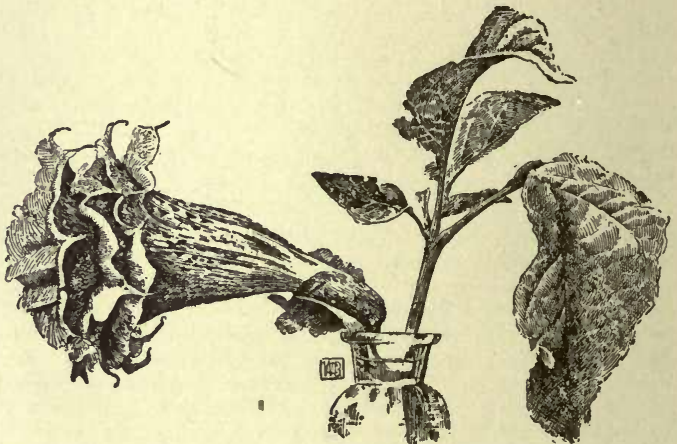

681. A triple form of Datura fastuosa, commonly known as D. cornucopia.

\section{AA. Flowers yellow.}

chlorántha, Hook. Shrub, glabrous throughout: lvs. broadly ovate, almost triangular; margin wavy, with short, rather sharp, very distinct teeth: peduncles axillary, very short: fls. pendulous, yellow; calyx tubular, with 5 nearly uniform, short, triangular teeth. Habitat unknown. B.M.5128. Gn. 46:988 and 49, p. 379,-Datura "Golden Queen" is presumably a horticultural variety of this species. While this species is horticurally distinct by reason of its yellow fls., it is a very doubtful 
species botanically, being founded on a very double garden form of unknown origin. In Vilmorin's Blumengärtnerei it is referred to $D$. humilis, Desf., but $D$. humilis, according to Index Kewensis, is to be referred to D. fastuosa.

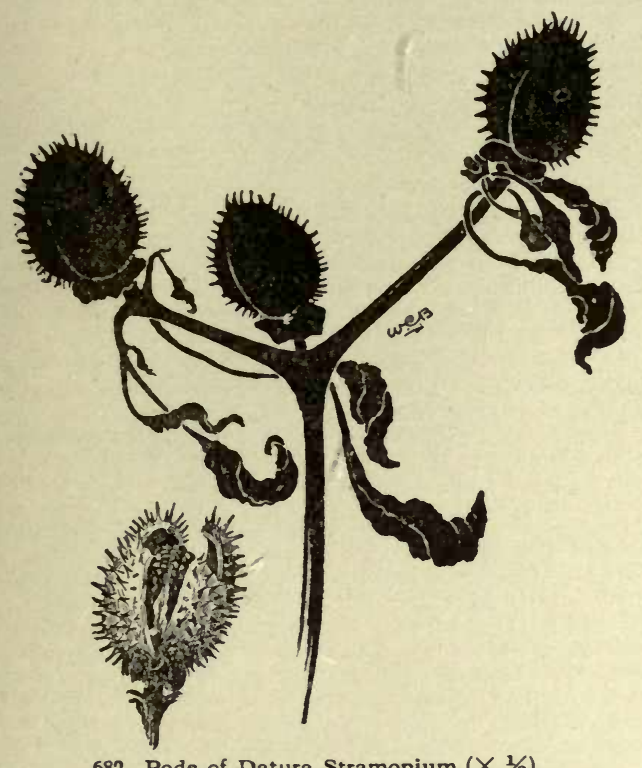

682. Pods of Datura Stramonium $(\times 1 / 3)$.

AA. Fls. white, sometimes touched with violet.

B. Plants tall, 7-15 ft. high: blossoms pendulous. c. Calyx tubular, with 5 obscure teeth.

suavèolens, Humb. \& Bonpl. (D. Gárdneri, Hook.). ANGEL's TRUMPET. This is the plant which is usually cultivated as $D$. arborea. It is said to be very distinct from the true $D$. arborea of Linn., but it can be separated with certainty only by the calyx. Tree-like shrub, 10-15 ft. high: lvs. ovate oblong, 6-12 in. long, 21/4-4 in. wide, entire, glabrous, petioled, often unequal at the base: fis. 9-12 in. long; calyx inflated, angled, glabrous, with 5 obscure teeth; corolla tube plaited, the limb with 5 short lobes; anthers erowded together. Mex. G.C. III. $11: 593 ; 23: 71$. S.H. $2: 433$. - Franceschi says it resembles $D$. cornigera in habit and fls., but the lvs. and stems are almost glabrous, and the calyx lacks the characteristic spur-like appendage of $D$. cornigera. The double form is much commoner in the gardens than the single.

\section{cc. Calyx spathe-like, not toothed.}

arborea, Linn. (Brugmánsia arbdrea, Steud.). ANGEL'S TRUMPET. Small tree: IvS. ovate-lanceolate, margin entire, never wavy or angled, pubescent, in pairs, one a third shorter than the other; petioles 1 in. or more long: fls. with a musk-ltke odor; calyx tubular, entire, spathe-like, acuminate; corolla tube terete, the lobes of the limb very long; anthers distinct, not conglomerate. Peru and Chile. G.C. II. 11: 141.-Most of the plants cult. under this name are presumably $D . s u a$ veolens. The extent to which the true $D$. arborea is cultivated is undetermined.

\section{BB. Plants less tall, only \&-5 ft high.}

C. Blossoms erect: calyx not spurred.

$$
\text { D. Corolla 5-toothed. }
$$

fastudsa, Linn. (D. and B. cornucopia, Hort.). Fig. 681. Annual, 4-5 ft. high, herbaceous: lvs. ovate-lanceolate, acuminate, acute and unequal at the base, toothed or wavy, glabrous on both sides, solitary, upper ones in pairs, one of which is larger, $7-8 \mathrm{in}$. long, $2 \frac{1}{2}-3 \frac{1}{2} \mathrm{in}$. wide; petioles $1 \frac{1}{2}-21 / 2$ in. long: fls. $6 \frac{1}{2}-7$ in. long, violet outside, whitish within; calyx purple, angled, 2 in. long, 5-toothed, the teeth triangular lanceolate, acuminate, 5 lines long, 2-3 lines wide. Native of India. Naturallzed in the tropies of both worlds. F.S. 14:1457. Gn. 46:978 and 1.H. 42:25. - There is a variety Huberiana. This is the commonest of all Daturas in eastern gardens.

\section{DD. Corolla 10-toothed.}

meteloldes, DC. (D. Wrightii, Hort.). Perennial (cult. as an aunual north): branches slender, forked : lvs. ovate oblong, almost entire, acuminate, acute at both ends, not cordate or angled, upper leaves often in pairs, the larger 2-21/4 in. long, 8-9 lines wide; petioles thickened at the base, 4-5 lines wide: calyx tubular, the teeth large, 5-10 in. long, very acute, unequal; corolla about 4-8 in. long, or twice as long as the calyx, 10-toothed, the teeth short. California. Gt. 1859:260. R.H. 1857, p. 571.-Misspelled metalioides, ete. The name means "like D. Metel" which is a common plant in S. Europe. " $D$. meteloides is a perennial, spreading over the ground in large clumps: lvs. greyish dull green color: fls. standing erect, white, delicately tinged with light violetpurple, not quite as fragrant as $D$. suaveolens. This can be grown also as an annual, easily blooming the first year from seed. The common statements that this plant is an annual are incorrect."-F'ranceschi.

cC. Blossoms pendulous : calyx with a long spur.

cornígera, Hook. (D. and B. Knightii, Hort.). Height 3-4 ft., branches downy: lvs. chiefly at the ends of branches, ovate, petioled, acuminate, margin entire, wavy or angled: fls. pendulous, white or creamy white, very fragrant at night, striated, 5-lobed, the lobes terminated by a long awl-shaped spreading or recurved point; stamens included. Mex. B.M. 4252. B. Knightii seems to be only a trade name for the double form. Gn. 45: p. 549.-Cornigera means horned or spurred, referring to the character of the calyx, which easily separates this species. "This and $D$. suaveolens are known as 'Floripondio' to the Spanish-Americans, perhaps no other plant being more popular with them."-F. Franceschi.

W. M.

DADCUS (ancient Greek name). Umbellifera. Perhaps 25 annual and biennial herbs of very wide distribu tion. One or 2 species are native to $\mathrm{N}$. Amer., and the wild Carrot is an abundant old-field weed in the northeastern states. See Carrot.

DAVÁLIA (a personal name). Polypodideece. A large genus of mostly tropical ferns, usually with firm, somewhat finely divided foliage and coriaceous semicylindric indusia, which are attached at both the base and sides. Some of the smaller species are largely used for hanging baskets. For $D$. concinna and $D$. fœniculacea, see Loxoscaphe; D. parvula, see Lencostegia : D. platyphylla, see Microlepia; D. stricta, see Stenoloma; D. tenuifolia, see Stenoloma; D. Tyermanni, see Humata.

L. M. UNDERWOOD.

The diverse habits of growth of the many different species of Davallias, and their good lasting qualities, peculiarly fit them under ordinary care for decorative purposes, where delicate and graceful plants are desired. Among the many species, the following are most often seen and best adapted for commercial purposes: $D . b u l$ lata, $D$. parvula, very dwarf; $D$. pentaphylla, young fronds of a dark bronzy green, and $D$. Tyermanni, are well adapted for hanging baskets. D. dissecta and var. elegans, D. concinna,D. Fijiensis and vars. plumosa and majus, D. faniculacea, D. solida, D. pallida (syn., Mooreana) and $D$. pyxidata are adapted for large specimen plants. D. tenuifolia and vars. stricta and Veitchi ana are desirable for fern dishes, because of their dwarfish habit of growth and the ease with which they may be raised from spores.

Old plants of Davallia may be cut into a number of smaller ones with a sharp knife. Planted firmly into shallow pans and placed in a temperature of $60-65^{\circ} \mathrm{F}$., they soon develop into symmetrical plants. The rhizomes should be firmly fastened to soil by strong copper-wire staples, where they will root in a short time. To gain a large number of small plants, the rhizomes should be detached, cleaned from all soil and roots, laid on sand and thinly covered with moss. Placed in a shaded posi- 
tion in a temperature of $65-70^{\circ}$ and kept moderately moist, a number of small plants will develop from the dormant eyes, which may be separately potted as soon as of sufficient size. Spores of Davallia should be sown on a fine compost of soil, leaf-mold or peat and sand in equal parts, and placed in a shaded position in a temperature of $60-65^{\circ} \mathrm{F}$. All the operations of propagation of Davallias will be most successful if carried on during the spring months. All Davallias delight in a rich and open compost, an abundance of light and air, and moisture at their roots, a temperature of $60-65^{\circ} \mathrm{F}$. and a thorough syringing every bright day.

N. N. BRUCKNER.

A. Lvs. once pinnate, with few linear segments.

pentaphylla, Blume. Lrs. scattered from a stout fibrillose rootstock, with 1 terminal and 4-6 lateral pinnæ, 4-6 in. long, $1 / 2 \mathrm{in}$. broad; sori in marginal rows. Java and Polynesia.

\section{AA. Lvs. tri-quadri-pinnatifid, deltoid.}

B. Length of lvs. usually less than $1 \mathrm{ft}$.

bullàta, Wall. Fig. 683. Lvs. scattered from a creepIng rootstock, which is clothed with light brown fibrillose scales, often whitish when young; 8-10 in. long, 4-6 in. wide, quadri-pinnatifid, with deeply incised segments; texture firm. India to Java and Japan. F.E. $11: 543$.

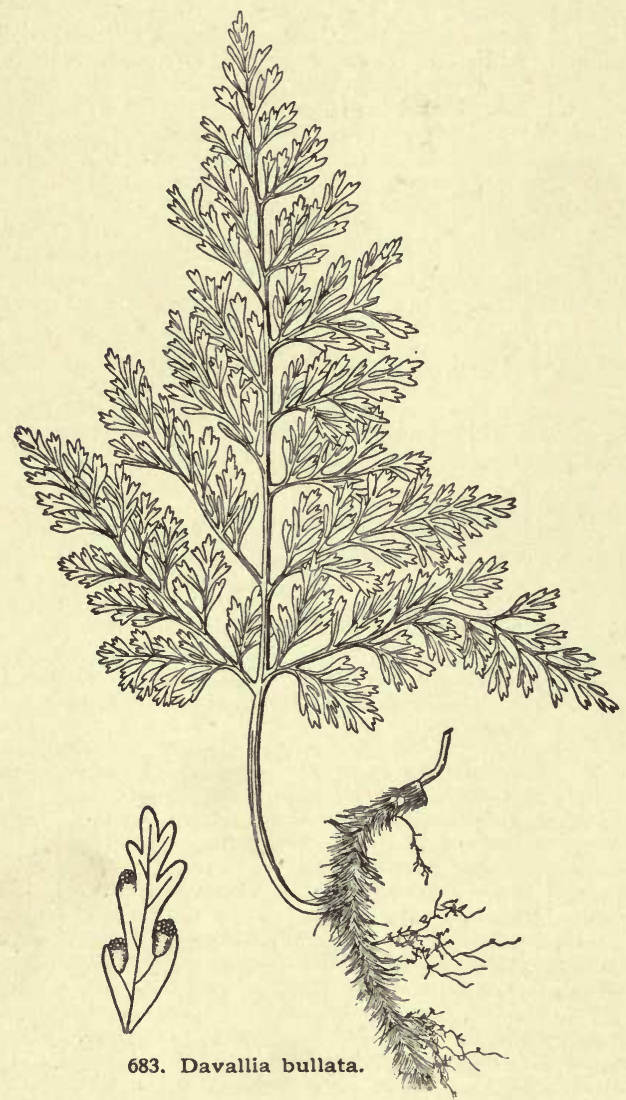

Màriesii, Moore. Rootstock stout, with brownish scales, which are lanceolate from a broad dilated base: lvs, deltoid, 4-6 in. each way, with the pinnæo cut away at the lower side at base; segments short-linear, 1-nerved; sori intramarginal. Japan. G.C. III. 13: 571.

BB. Length of lvs. 1-2 $\mathrm{ft}$.

C. Foliage commonly tri-pinnatifid.

Glegans, Swz. Rootstock clothed with woolly fibers: Ivs. 9-15 in. wide. with the main rachis slightly winged toward the apex ; indusia several to a segment, with the sharp teeth projecting beyond the cups. Ceylon to Aus tralia and Polynesia.

sólida, Swz. (D. ornata, Wall.). Rootstock clothed with appressed scales or fibers : lvs. 1-2 ft. long, 12-15 in. wide, the center of the apex broad and undivided; segments broad and slightly cut; indusia marginal. Malaya.

cC. Foliage commonly quadri-pinnatifid.

pyxidàta, Cav. Rootstock clothed with pale brown linear scales : Ivs, tri-quadri-pinnatifid, 6-9 in. broad, with oblong segments ; sori with a broad space outside, which is extended into a horn-like projection. Australia.

Fijiénsis, Hook. Lvs. 6-12 in. broad, with the lower pinnæ deltoid and the segments cut into narrow, linear divisions 1/8-1/4in. long; sori on the dilated apices of the segments, with no horn. Fiji Islands. A.F. 6:900; $9: 233$. G.C. III. 23: 323. - One of the finest species, with numerous varieties.

dissécta, J. Sm. Rootstock stout, with dense, rusty scales : lvs. 10-12 in. broad, on straw-colored stalks ; segments oblong, cuneate at base, with simple or bitid lobes; sori minute, often with two projecting horns. Java.

BвB. Length of lvs. 2-3 ft.

divaricàta, Blume (D. polyántha, Hook.). Rootstock with linear rusty scales : lvs. tri-pinnatifid, sometimes $2 \mathrm{ft}$. broad, with deltoid segments cut into linear oblong lobes; sori at some distance from the edge. India to Java and Hong Kong.

pállida, Mett. (D. Mooredna, Masters). Rootstock stout, with lanceolate dark brown scales : lvs. with strawcolored stalks 12-18 in. long, quadri-pinnatifid, with deltoid, stalked segments, the ultimate obovate-cuneate, bearing the sorus on the upper side at the base. Aneiteum and Borneo. A.F. $6: 901 ; 9: 231$. A.G. 13: 143.

L. M. UNDERWOOD.

DAY FLOWER. See Commelina.

\section{DAY LILY. Funkia and Hemerocallis.}

\section{DEAD NETTLE, Lamium.}

DEANE, REV. SAMUEL, poet and agricultural writer, was born at Dedham, Mass., July 30,1733 , and died at Falmouth (now Portland), Maine, Nov. 12, 1814, where be had been pastor since Oct. 17, 1764. While vice-president of Bowdoin College, he published, in 1790, his "New England Farmer, or Georgical Dictionary, "the first American encyclopedic work on agriculture. This had a much wider circulation, probably, than Jared Eliot's "Essays upon Field-Husbandry," 1747. Its influence may be traced to the middle of the present century. Deane's work was freely quoted by F. G. Fessenden until his death, in 1837. The second edition, 1797, was entitled The Georgical Dictionary. A third edition was published in 1822 .

Deme and Eliot were the chief writers in that early stage of American horticulture when it was hardly important enough to be considered distinct from general agriculture. For biographical details, see Drake's Dictionary of American Biography.

DEARBORN, HENRY ALEXANDER SCAMMELL, soldier, statesman and author (1783-1851), was also an ardent horticulturist. He was a moving spirit in the organization of the Massachusetts Horticultural Society, and was elected its first president on the 17th of March, 1829. He was partly instrumental in the establishment of an "experimental garden and cemetery at Mount Auburn," the parent of rural cemeteries. The plan of the cemetery was largely his (cf. Bigelow). He" devoted himself to this work most assiduously," writes the chronicler of the society, "spending the greater part of the autumn [1831] at Mount Auburn, in laboring with hands as well as mind, without money and without price." The Abbe Berlese's Monography of the Camellia was translated by him, and published in Boston in 1838. $\mathrm{He}$ also translated from the French, in 1830 , an account of the since famous Morus multicaulis. He left MS. writings on horticulture. For notes on his horticultural 
labors, see "History of the Mass. Horticultural Society," 1880, which contains a portrait; also John B. Russel in Tilton's Journ. Hort. $7: 88,157,276$. Gen. H. A. S. Dearborn was son of Gen. Henry Dearborn, of Revolu: tion and later fame.

L. H. B.

DECODON (Greek, ten-toothed). Lythricere. A hardy perennial herb rarely cultivated by dealers in native plants. It has opposite or whorled Ivs., the upper with axillary, short-stalked clusters of fls. Abroad Decodon is usually considered a subgenus of Nesæa. It is distinguished from Lythrum by having 5 (rarely 4 ) petals instead of 6, and 8-10 stamens, while Lythrum has mostly 6 or 12 .

verticillàtus, Ell. (Nesìea verticillata, HBK.). SwaMP Loose-STR1FE. Smooth or downy: stems recurved, 2-8 ft. long, 4-6-sided: lvs. lanceolate, nearly sessile: petals 5 , cuneate-lanceolate, rose-purple, $1 / 2$ in. long; stamens 10, half of them shorter. Swampy grounds, N. E. to Fla., west to Minn. and La.-Int. by H. P. Kelsey.

DECUMARIA (Latin, decumus, tenth, referring to the number of the parts of the fl.). Saxifragdcea. Shrubs climbing by aërial rootlets : lvs. deciduous, opposite, petioled : fls. in terminal peduncled corymbs, small, white, perfect; sepals and petals $7-10$; stamens 20-30: fr. a 5-10-celled ribbed capsule opening between the ribs, with numerous minute seeds. Two species in $\mathrm{E}$. N. Amer. and China, of which only the American species is in cultivation. Ornamental climbing shrub, with handsome glossy foliage and fragrant white fls., forming a corymb of feathery appearance, well adapted for covering walls, rocks, trellis work and trunks of trees, but not hardy north. Thrives in almost any humid soil. Prop. by greenwood cuttings in summer under glass, rarely by seeds.

bárbara, Linn. (D. sarmentòsa, Bose). Climbing to $30 \mathrm{ft}$., but usually less high : lvs. ovate, obtuse or acute, remotely denticulate or entire, glabrous and shining above, 2-4 in, long : corymbs $2-3$ in. broad, semiglobose. May, June. Va. to Fla., west to La. B.B. 2: 185. Mn. 1: 41.

DEERBERRY. Vaccinium stamineum. ALFRED REHDER.

\section{DEERGRASS. Rhexia.}

DELARBREA (after a French naturalist). A ralidecece. A genus of two species of tall, tender shrubs from New Caledonia, distinguished from Aralia by the fruits. Culture same as Aralia.

spectábilis, Linden \& And. (Aràlia concínna, Nicholson). Stem ashy grey, with brown, warty spots: lvs. odd-pinnate, lfts. in 8-10 pairs, each lft. 3-toothed or twice cut, sometimes so deeply cut as to make 3 entirely free segments. New Caledonia. I.H.25:314.-Under the name of Aralia spectabilis, two different plants have been sold. The English dealer Bull's plant was A ralia filicifolia. The Belgian dealer Linden's plant was Delarbrea'spectabilis. (See I.H. 23, p. 72. G.C.II. $5: 603$.) The two plants can be distinguished at a glance. The primary division of the leaf in A. filicifolia is long and narrow, thrice as long as in D. spectabilis, and tapering to a long point, while in D. spectabilis the primary division of the leaf is short and has 3 well-marked segments. In $A$. filicifolia the secondary divisions are deeply and irregularly cut; in D. spectabilis they are merely serrate. The two plants are also immediately distinguished by the spots on the stem.

DELAWARE, HORTICULTURE IN, The state of Delaware (Fig. 684) is situated close to the largest fruitconsuming cities of the New World. An emphatic commercial advantage in the development of a diversified horticulture arises from the modifying climatic influence of the Delaware and Chesapeake bays; from a variety of fertile soils; and from the ripening of its fruits and vegetables between the products of the North and South. There is probably no area in the United States which, in its natural commercial adrantages, in its climatic environment, and in the diversity of its soils, is so preëminently ftted for the development of an extensive and diversified horticulture as the peninsula to which Delaware belongs.
New Castle, the northern county, is hilly and rolling, and varies from a dense clay to a clay loam. Horticulturally, it is well adapted to plum, pear, apple and bushfruit culture, and, in restricted areas, to the cherry, peach and trucking industries. But the production of

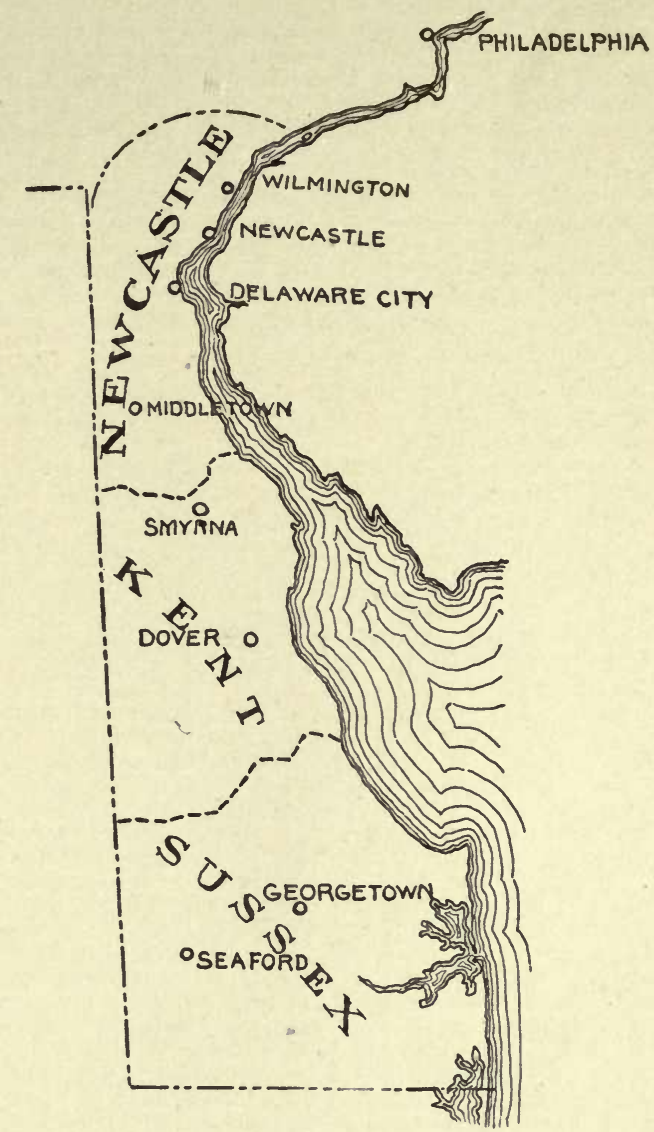

684. Delaware, to illustrate the horticulture.

hay, grain, and dairy products is the leading feature in New Castle's rural activities. Kent, the central county, is gently undulating. The soil varies from a clay loam in the northern part to a sandy loam along the southern border. The most diversified horticulture of the state, including tree fruits, bush fruits, strawberries, grapes, and vegetable products, has been developed here. In Sussex, the southern county, which is mostly level, a sandy soil predominates, although the underlying clay frequently approaches the surface and forms local areas of clay loam. The peach, strawberry, and bush fruits are most prominently developed in Sussex, the horticultural areas lying in the western half of the county.

Delaware horticulture was born in 1832 , with the peach industry, when the first extensive orchard was set near Delaware City. In a single year the value of its peach crop was $\$ 16,000$. Then an era of the most rapid horticultural extension was inaugurated. By 1840, half a million baskets of peaches were shipped from the county. But in 1842 the peach-yellows broke out near Delaware City, and by 1867 more than one-half of the crop of three million baskets was grown in southern New Castle county. The orchards of New Castle had largely disappeared in 1870, and in 1890 it contained less than 5,000 acres. Kent county, however, in 1890 had 23,000 acres, and Sussex county 20,000 acres. In 1899 , extensive orchards were being planted again in Neweastle county and northern Kent county. 
The center of the peach belt in 1890 was along the southern border of Kent county, where the trees were comparatively healthy, but in 1890 the yellows had extended into northern Sussex, where it has remained stationary for several years. In 1896 the Delaware division of the Philadelphia, Wilmington \& Baltimore railroad carried over two million baskets of Delaware peaches, which was over 90 per cent of the total crop, and estimated that there were between four and five million bearing trees in the state.

'The peach-yellows has been responsible, primarily, for the shifting of the peach-growing centers. No systematic, coöperative effort has been made to suppress the disease. Yellows legislation is inoperative from a lack of public and political support. Intelligent growers remove trees at the first indication of infection, but the efforts of a few individuals have not been effective in checking the progress of the disease. The ultimate remedy for the yellows in Delaware lies in a more diversified horticulture.

The principal varieties of peaches are: Hale Early, Foster, Crawford Early, Oldmixon, Moore Favorite, Mountain Rose, Reeves Favorite, Elberta, Brandywine, Crawford Late, Stump, and Smock.

Next to the peach in commercial importance are the small fruit interests, which are most extensively developed in the southern half of Kent and the western half of Sussex. There are between 7,000 and 8,000 acres of strawberries, raspberries, and blackberries in these counties, and in 1896 the Delaware Division of the P.W. \& B. R. R. carried 9,500,000 quarts, or over 90 per cent of the total product of the state. In 1898, this road carried over 24,000,000 quarts of berries, and a still larger quantity in 1899 .

Since 1896, the Lucretia dewberry has been set out in large quantities in both Kent and Sussex counties, while the blackberry acreage has fallen off in consequence.

Among the principal varieties of strawberries are $\mathrm{Bu}$ bach, Tennessee Prolific, Gandy, Greenville, Michel and Haverland. The Souhegan, Palmer and Mills comprise the prominent black raspberries; the Miller, Cuthbert, Loudon and Brandywine the red varieties; and Early Harvest and Wilson the blackberries.

In Kent county the pear industry is a prominent horticultural feature. The Kieffer is the leading variety. Its adaptability to various soils, its early and precocious bearing tendencies, and the cheapness of its production give it unusual commercial value throughout the state. In the fall of 1897 more than 40,000 Kieffer trees were sold in central and southern Kent county, and young orchards are not infrequently seen in Sussex and New Castle counties. Sussex county will develop the Kieffer to a large extent in the near future. In 1899, there were about 100,000 Kieffer trees under 3 years old and 60,000 trees over 3 years old in the state.

Previous to the advent of the Kieffer, the Bartlett, Duchess, Lawrence and Anjou were the leading kinds, the orchards existing in the two upper counties.

The introduction of the Japanese plum has opened the way to plum culture. Scattering orchards of Burbank and Abundance have been set in Sussex and New Castle counties, but an extensive development is under way in Kent. In the vicinity of Clayton and Smyrna there were 6,000 trees in bearing in 1897, since when 10,000 trees have been set. There were 32,000 trees in the state in 1899. The Japanese plums, as a class, are well adapted to the state. They are destined to prove an increasingly important factor in the horticulture in the future, but with their concentration in neighborhoods, their weak points may be expected to show more prominently. Burbank, Abundance and Ogon have been the leading varieties, and Red June, Chabot and Hale are growing in popularity.

The native plums of the Hortulana and Chickasaw groups, which ripen before the northern Domestica varieties, are rapidly attaining deserved prominence. They are hardy, easily grown, and generally command remunerative prices. Milton, Whitaker, Newman, Smiley and Wild Goose comprise the bearing orchards, but other,varieties are growing in favor. The later ripening natives are worthless for Delaware, as the markets are then supplied with Domestica plums.

In the vicinity of Smyrna and Clayton there are from
150 to 200 acres of grapes, where the history of viticulture began about 1855. Grape culture has been profitable industry in this neighborhood, the net income frequently exceeding $\$ 100$ per acre. Recently, however, the profits have been somewhat less on account of the lower prices and the grape diseases. Many of the vineyards are models of intelligent tilling, pruning, spraying and training. The principal varieties are Niagara, Moore's Early, Concord, Brighton, Agawam and Wyoming Red.

Delaware is widely known, not only through her extensive orchards and small fruit plantations, but also through the products of her canning factories. In 1895 the tomato output amounted to 280,000 cases; peaches to 50,000 cases ; peas to nearly a like quantity; corn to over 50,000 cases; and a large amount of berries, pears and other fruits, not separately classified. Since 1895, the amount of the various canned goods has not fluctuated widely, except with canned peas, which in $1898 \mathrm{had}$ reached 144,000 cases; and with tomatoes, which have steadily increased.

Although Delaware is preëminently a horticultural state, its capabilities in horticulture are largely undeveloped. Its physical environment makes it a natural fruit garden. There are several industries that could be profitably introduced or extended to larger acreages. Apple culture ; plum culture, of the Japanese and early native types; sour cherry culture, especially for canning; nut culture, on cheap land; vegetable growing, and glass-house gardening - all offer opportunities for a greater horticultural diversity. The various fruit interests are gradually extending over wider areas, and it may be expected that Delaware will not only maintain its present horticultural prestige, but will be an increasingly potent factor in American horticulture in the future.

G. Harold Powell.

DELPHINIUM (Greek, $a$ dolphin, from the resemblance of the flower). Ranunculdceo. LARKSPUR. A genus of beautiful hardy plants, with large, irregular flowers. About 60 species, native of the north temperate

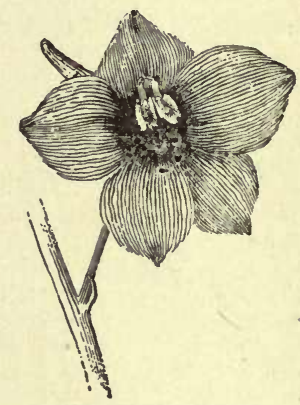

685. Single Larkspur.-
D. grandiflorum.

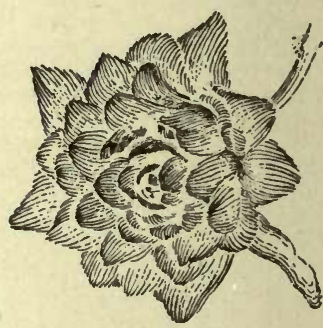

686. Double Larkspur.D. grandiflorum. zone. Annual or perennial, erect, branching herbs: lvs. palmately lobed or divided: fls. in a showy raceme or panicle; sepals 5, petal-like, the posterior one prolonged into a spur; petals 2 or 4 , small, the two posterior ones spurred, the lateral ones small, if present; the few carpels always sessile, forming many-seeded follicles. Full double forms are very common in a number of the species (compare Figs. 685, 686).

Delphiniums thrive in any good garden soil, but are improved by a deep, rich, sandy loam, exposed to the sun. Deep preparation of the soil is very important. The annuals are propagated from seed, which are very slow in'germinating, and often should be sown in the fall to produce flowers early the next season. The perennials may be prop.: (1) By root division in the fall or spring. (2) By cuttings, about which J. B. Keller says: "Take a few cut tings from each plant in early spring, when growth is about 3 or 4 inches long, or else use the second growth, which has come after the flower-stems have been removed. Cuttings root readily in a shaded frame, no bottom heat being required, but an occasional sprinkling during dry and hot weather is necessary. When rooted 
ther are treated like seedlings." (3) By seeds, started in the greenhouse or hotbed in March or even earlier. The young seedlings should be given plenty of room by transplanting as they grow, and may be set in the open garden by June. If started thus early they flower the first autumn, but the seed may be planted in late spring or summer, care being taken to water well during dry weather, and flowers will come the next summer. To get the best results, the perennials should be transplanted every 2 or 3 years. Two good crops of blossons may be secured in one season by cutting away the flowerstems of the first crop as soon as the flowers have faded; of course no seeds will be produced in this way. The Delphiniums are much grown in the open garden and border, and are of great value for cut-flower purposes. Four species are of much greater popularity than the others: the anmual, D.Ajacis, and the perennials, $D$. grandiflorum, $D$. hybridum and $D$. formosum. The last three have been especially prolific in named varieties.

Rocket and Candelabrum are names used to designate the forms of inflorescence in the two annual species. The "Rocket" or spike-like form is more commonly found in the Ajacis type, and the "Candelabrum," with a number of short spike-like heads of different heights, is found more often in Consolida. - A. Gray, An attempt to distinguish between the Amer. Delphiniums, Bot. Gaz. 12:49-54, 1887. E. Huth, Monographie der Gattung Delphinium, in Eng. Bot. Jahrb. 20:322-499, 1895.

Alphabetical list of species described below: Ajacis, 1 ; alpinum, 16 ; altissimum, 14; azureum, 18; bicolor, 7; Breckii, 17 ; Brunonianum, 8 ; cardinale, 4 ; Carolinianum, 18; Cashmerianum, 10; cheilanthum, 24; Chinense, 17; Columbianum, 22; Consolida, 2; decorum, 9; elatum, 16; exaltatum, 15; formosum, 25 ; grandillorum, 17; hybridum,27; Maackianum,26; Menziesii, 12; mesoleucum,19; nudicaule, 3 ; Nuttallii, 22; occidentale, 23; pauciflorum, 13 ; Prsewalskianum, 5 ; Przewalskii, 5; pyramidale, 16 ; scopulorum, 23; simplex, 21 ; Sinense, 17; sulphureum, 6 ; tricorne, 11 ; trolliffolium, 20 ; virescens, 18 ; Zalil, 6.

A. Annuals: petals only 2, united : follicle 1.

1. Ajàcis, Linn. Fig. 687. An erect annual, about 18 in. high, with a few spreading branches: lvs. of stem sessile, deeply cut into fine, linear segments; root-lvs. similar, but short-petioled: fls, showy, blue or violet, varying to white, more numerous than in $D$. Consolida, in a spicate raceme; petals 2, united; calyx-spur about equaling the rest of the flower: follicle only 1, pubescent; seeds with wrinkled, broken ridges. May-Aug. Eu. R.H. 1893, p. 228. Same figure in S.H. 2: 282.

2. Consólida, Linn. An erect, hairy annual, $1-11 / 2 \mathrm{ft}$. high : lvs. similar to $D$. Ajacis: fls. few, loosely panicled, pedicels shorter than the bracts, blue or violet or white; petals 2, united: follicle 1, glabrous; seeds with broken, transverse ridges. June-Aug. Eu. Baxter Brit. Bot. 4, t. 297. R.H. 1893, p. 228 (var. ornatum Candelabrum). Var. imperialis, Hort. (D. imperialis fl. pl., Hort.). Fls. double. From the English gardens.

\section{AA. Perennials: petals 4 : follicles $3-5$.}

$$
\text { B. Sepals red. }
$$

3. nudicaùle, Torr. \& Gray. Stem 1-1/2 ft. high, glabrous, branched, few-lvd.: Ivs. rather succulent, 1-3 in. across, lobed to the middle or farther 3-7 times, the secondary lobes rounded and often mucronate; petioles 3-5 in. long, dilated at the base: fls. panicled; sepals bright orange-red, obtuse, scarcely spreading, shorter than the stout spur; petals yellow, nearly as long as sepals: follicles 3 , spreading and recurved, soon becoming glabrous; seeds thin-winged. April-July. Along mountain streams, northern Calif. B.M. 5819. F.S. 19:1949. R.H. 1893, p. 259. A good perennial in the E.

4. cardinale, Hook. Stem erect, $2-31 / 2 \mathrm{ft}$. high, partly pubescent: lvs. smooth, fleshy, deeply 5-parted, the parts eut into long, linear lobes: raceme elongated, many-fld.: fls. bright red, with petal limbs yellow: follicles glabrous, usually 3 ; seeds smooth. July, Aug. Calif. B.M. 4887. Gt. 208. F.S. 11:1105. R.B. 6:101. Gn. 19:273.

BB. Sepals clear yellow or tipped with blue.

5. Przewálskii, Huth. (D. Prseualskianum, Hort.). Nearly glabrous, often branched at base, erect, varying much in height: lvs. 3-5 times deeply parted, parts divided into narrow, obtuse lobes: Hs, clear yellow, or sometimes tipped with blue; spur equaling the sepals: follicles 3, densely hairy. July, Aug. Asia. Int. 1892.

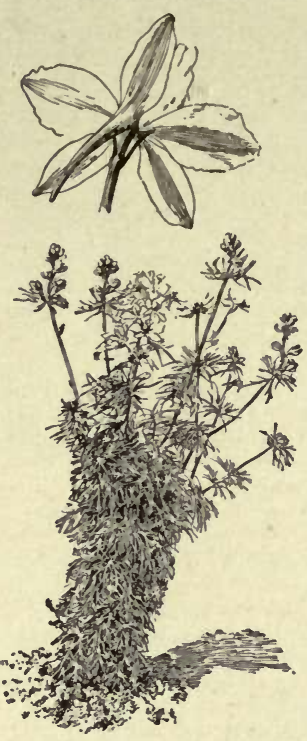

6. Zàlil, Aitch. \& Hems. (D. sulphùreum, Hort. $D$. hyेbridum, var. sulphùreum, Hort.). Stem nearly simple, erect, 1-2 ft. high, rather glabrous, or becoming so: Ivs. of several narrow, linear lobes, dark green, petioles not dilating at the base: fls. large light yellow, in long racemes: follicles 3 , longitudinally furrowed and ribbed; seeds with transverse, fibrous plates. June, July. Persia. Int. 1892. B. M. 7049. Gn. 50: 1094; 54 p. 347. G.C. III. $20: 247$. Seedlings from tubers and plants die down as if dead; but they make a second growth after a short period of rest.

ввв. Sepals blue or varying to white.

c. Height $1 \frac{1}{2} \mathrm{ft}$. or less.

\section{Petioles dilating at the} base.

7. bícolor, Nutt. Erect, rather stout, $1 / 2-1 \mathrm{ft}$. high, from fascicled roots : lvs. small, thick, deeply parted common annual Larkspur. and divisions cleft, except
perhaps in the upper lvs.; common annual Larkspur. and divisions cleft, except
perhaps in the upper lvs.; segments linear and obtuse: raceme rather few fld., the equal, $1 / 2$ in. long or more, blue; upper petals pale yellow or white, blue-veined; lower petals blue: follicles glabrous or becoming so. May-Aug. Dry woods, Colo., west and north to Alaska.

8. Brunoniànum, Royle. Musk Larkspur. Stems erect, 1/2-11/2ft. high: plant somewhat pubescent: upper lvs. 3-parted, lower ones reniform, 5-parted; segments deeply eut, musk-scented : fls. large, light blue with purple margins, center black ; spur very short; sepals 1 in. long, membranous and often clinging until the fr. is mature: follicles 3 or 4 , villose. June, July. China. B.M. 5461. R.B. $1863: 34$.

9. décorum, Fischer \& Meyer. Stem slender and weak, $1 / 2-11 / 2 \mathrm{ft}$. high, smooth or nearly so: Ivs. few, bright green; upper ones small, 3-5-parted into narrow lobes; lower and radical ones somewhat reniform in outline and deeply 3-5-parted, lobes often differing widely: fls. in a loose raceme, or somewhat panicled; sepals blue, $1 / 2$ in. long, equaling the spurs; upper petals at least tinged with yellow: follicles 3 , thickish, glabrous. Spring. Calif. Int. 1881. B.R. 26:64.

\section{DD. Petioles hardly dilating at the base.}

E. Upper petals never yellow.

10. Cashmerianum, Royle. Plant pubescent, not very leafy: stem, simple,erect, slender.10-18 in. high: root-lvs. orbicular, 2-3 in. in diameter, 5-7-lobed, coarsely, acutely toothed and cut; petiole 5-8 in. long; stem-lvs. shortpetioled, 3-5-lobed, cut like the radical ones, all rather thick and bright green : inflorescence corymbose, the branches rather spreading: fls. 2 in. long, deep azure blue; spur broad, obtuse, inflated, decurved, little over half as long as sepals; upper petals almost black, 2-lobed, lateral ones greenish: follicles 3-5, hairy. July-Sept. Himalayas. B.M. 6189. Gt. 1105. Gn. 18:261. R.H. 1893, p. 259. Hardy in Mass., and choice.

Var. Walkeri, Hook. Stem very short, leafy, manyfld.: upper lvs. less lobed or almost entire, small, long petioled: fls. very large, light blue with yellow petals. Suited to rockwork. B.M. 6830 .

EE. Upper petals yellow or striped with yellow.

11. tricórne, Michx. Stem succulent, about $1 \mathrm{ft}$. high: 1vs. 3-5-parted, with 3-5-cleft linear lobes; petioles 
smooth, hardly dilating at the base: fls. large, blue, rarely whitish; upper petals sometimes yellow, with blue veins, lower ones white-bearded; sepals nearly equaling the spur: follicles 3-4, very long, becoming glabrous, strongly diverging; seeds smooth. May. Northern states. L.B.C. 4:306. - Very beautiful and much used. Best for rockwork. The foliage dies down in midsummer and the plant appears as if dead.

12. Ménziesii, DC. Plant sparingly pubescent : stem simple, slender, $1 / 2-1 \frac{1}{2} \mathrm{ft}$. high, few-lvd.: lvs. small, 3-5-parted, the divisions mainly eleft into linear or lanceolate lobes; petioles hardly dilating at the base: fls. in simple, conical racemes; sepals blue, somewhat pubescent outside, nearly equaling the spurs in length; upper petals yellowish: follicles 3 , pubescent, or sometimes glabrous; seeds black, winged on the outer angles. April-June. On hills, Calif. and northward to Alaska. B.R. 14 : 1192.

13. pauciflorum, Nutt. Roots oblong or fusiform, fasciculate-tuberous : stems slender, nearly glabrous, $1 / 2-1$ ft. high : lvs. small, parted into narrow, linear lobes; petioles not dilating at base: fls. and fr. similar to those of D. Menziesii, but on shorter pedicels. May, June. Colo. to Wash. and Calif. Int. 1892.

CC. Height usually more than $1 \frac{1}{2} \mathrm{ft}$.

D. Seeds wrinkled or smooth, not winged nor scaly. E. Follicles always 3 .

14. altíssimum, Wallich. Plant shaggy-hairy above: stem tall and slender, branched: lvs. palmately 5-parted, the divisions 3-lobed and toothed: bracts long-lanceolate: fls. blue or purple, in long, branching racemes; spur straight or slightly incurved, equaling the sepals; petals 2-lobed : follicles 3, erect; seeds not winged or scaly. Aug., Sept. Himalayas.

15. exaltatum, Aiton. Stem stout, $2-4 \mathrm{ft}$. high, smoothish: lvs. flat, nearly glabrous, deeply cleft into 3-7 wedge-shaped lobes, which are often trifid; petioles usually not dilated at the base: fls. blue, with yellow on the upper petals, medium in size, on long, crowded, erect, pyramidal racemes ; sepals nearly equaling the spur in length : follicles 3 , pubescent or smooth ; seed coats irregularly wrinkled. Juno-Aug. Borders of woods, Ala. to Minn.

16. elàtum, Linn. (D. alpinum, Waldst. \& Kit. D. pyramídale, Royle). BEE LARKsPur. Glabrous, 2-6 ft. high : lvs. somewhat pubescent, 5-7-parted, parts rather narrow, eut-lobed ; upper lvs. 3-5-parted; petioles not dilated at the base: raceme much like $D$. exaltatum or more spike-like: fls. blue, with dark violet petals ; sepals ovate, glabrous, nearly equaling the spurs : follicles 3 ; seeds transversely wrinkled, not scaly, June-Aug. B.R. 23:1963. Gt. 736 b. \&c. (vars.) F.S. 12: 1287. (var. fl.pl.). R.H. 1859, p. 529; 1893, p. 258 -A polymorphous and complex species of Europe. It is probable that all or nearly all the plants sold here under this name should be called $D$. exaltatum, which is a closely allied species.

17. grandiflòrum, Linn. (D. Sinénse, Fischer). Figs. 685-6. Stem rather slender, $2-3 \mathrm{ft}$. high: lvs. rather small, many times parted into nearly distinct, narrow, linear lobes: fls. large, blue, varying to white, the spur and lower petals of ten violet, upper petals often yellow; spurs long and taper pointed: follicles 3, pubescent; seeds triangular, coats wrinkled, not scaly. July, Aug. Siberia. Int. 1880. B.M. 1686. Gn. 46:991 and p. 484 . Var. álbum, Hort. Fls. pure white. Var. albo-plèno, Hort. Fls. double and pure white. Var. flore-pleno, Hort. (var. hỳbridum fl.-pl., Hort.). Fls. double, blue, very pretty. R.H. 1893 , p. $259 ; 1895$, p. 379 (same).

Var. Chinénse, Fischer. Stem very slender, not much branched: lvs. and fls. like the type, but fls. more numerous. China. L.B.C. 1:71. - A favorite garden form. The double blue form has been known as $D$. Bréckii, Hort.

EE. Follicles varying from 3 to 5 .

18. Caroliniànum, Walt. (D. azùreum, Michx. $D$. viréscens, Nutt.). Plant somewhat pubescent: stem 11/2$21 / 2 \mathrm{ft}$. high, not much branched: lvs. 3-5-parted, the divisions 3-5-cleft into usually linear lobes: racemes spicate, usually many-fld.: fls, azure blue, but varying to whitish or white ; sepals often with a brownish spot: follicles 3-5, oblong, erect; seeds transversely wrinkled. July. N. C. to Ill., west and south. P.M. 16:258. Var. álbum, Hort. (var. álbidum, Hort.). Stems 2-3 ft. high: lvs. larger than the type and with broader divisions: fls. creamy white. - The double form of this is not much used.

Var. vimineum, Gray. Stem 2-4 ft. high, sometimes branched, broader-lvd., looser-fld.: fls. violet or white. Tex. B.M. 3593. B.R. 23:1999 (as D. azureum).

19. mesoleùcum, Link. Stem $3 \mathrm{ft}$. high, pubescent above: lvs. 3-5-parted, the segments wedge-shaped and deeply serrated; petioles somewhat dilated at the base: fls. blue, with pale yellow or whitish petals : seeds not seen. June. Nativity not known.

$$
\text { DD. Seed uinged. }
$$

E. Upper petals never yellow.

20. trolliifdlium, Gray. Stem 2-5 ft., leafy, often reclining : lvs. thinnish, large, often reniform at base, 3-7-parted; lobes wedge-shaped, incised: racemes in larger plants 1-2 ft. long and very loose: fls. blue, with upper petals white; spur and sepals each $3 / 4$ in. long: follicles glabrous; seeds with thin wing or crown at the end. Apr. Moist grounds, Columbia river. Int. 1881. EE. Upper petals often yellow.

21. símplex, Dougl. Stem nearly simple, $2-3 \mathrm{ft}$. high, soft-pubescent throughout : lvs. many-parted, into linear divisions and lobes: racemes dense, little branched: fls.pale blue, with upper petals yellow, lower petals white-bearded; sepals equaling the spur: follicles 3, pubescent; seeds dark, with margins whitewinged. June. Mountains of Idaho and Oregon. Int. 1881.

22. Núttallii, Gray (D. Columbianum, Greene). Stem erect, simple, nearly glabrous, leafy, $1 \frac{1}{2}-2 \frac{1}{2} \mathrm{ft}$. : lvs. thinnish, 3-5-parted, parts divided into many linear-oblong lobes : racemes long, many-fld.: sepals deep blue, ovate, sparingly pubescent, shorter than the spur; petals blue or upper ones yellow, lower ones white-bearded : follicles 3 , pubescent, rather erect; seeds thin, dark, with yellow wings. Summer. Low, open woods, Columbia river. Int. 1892.

23. scopuldrum, Gray. Stem 2-5 ft., glabrous, at least below : lvs. 57-parted, the upper ones the more nar. rowly cleft; petioles dilating at the base : racemes simple, densely many-fld.: fls. blue or purple, rarely white, upper petals often yellow ; spur $1 / 2$ in. long, equaling the sepals: follicles 3 , pubescent; seeds large - winged. Aug., Sept. Moist ground, west of Rockies.-A polymorphous species.

Var. subalpinum, Gray (D. occidentale, Wats.). A smaller

plant, pubescent above: broader divisions of lvs., shorter racemes, larger and deeper-colored fls.: follicles glabrous. Wasatch mountains. 
24. cheilánthum, Fischer. Stem erect, simple or branched, 2-3 ft.: lvs. glabrous or slightly pubescent, 5-parted, the lobes pointed, sub-trifid, and somewhat toothed: fls. dark blue, the upper petals sometimes pale yellow, the lower ones inflexed, ovate, entire; spur rather long, straight or somewhat curved : follicles 3 , either glabrous or pubescent; seeds 3-cornered, 3winged, not sealy. June, July. Siberia. B.R. 6:473. Gt. 13:253. P.M.16:258 (as D. magnificum) .

\section{DDD. Seeds scaly.}

25. formòsum, Boiss. \& Hult. Fig. 688. Stem strong, 2-3 ft., hairy below, rather glabrous above: lower lvs. 5-7-parted, long-petioled; upper ones 3-5-parted, shortpeticled or sessile, all alternate: racemes many-fld.: fls. blue, with indigo margins; spur long, violet, bifid at the tip: follicles 3, pubescent ; seeds scaly. June, July. Asia Minor perhaps, but its origin is disputed. F.S. 12:1185. Vick's Mag. 2305. R.H. 1859, p. 528. - The most permanent form for naturalizing.

26. Maackiànum, Regel. Erect, $3 \mathrm{ft}$. high, pubescent or glabrous, branched above: Ivs, pubescent on both sides, base often truncate or reniform, 3-5-parted, the parts serrate; petioles dilated at the base : peduncles yellow-hairy, with the bracts often inserted above the base: fls. in loose panicles, sepals blue, $1 / 2$ as long as the spurs; petals dark violet: follicles of ten glabrous, $3 / 4$ in. long; seeds small, distinctly scaly.

July. Siberia. Gt. 344 .

27. hybridum, Steph. Stem 3-4 ft., pubescent above: root somewhat bulbous: 1vs. 5-manyparted ; lobes linear; petioles dilated and sheathing at the base: racemes dense: fls.blue, lower limbs white-bearded; spur straight, longer than the sepals: follicles 3 , hairy; seeds ovate, with transverse scales. June-Aug. Mountains of Asia. R.H. 1893, p. 258 ; same cut in S. H. 2:282.-There are many double and semi-double vars. of this type.

Var. Bárlowi, Paxt. Very large, semi-double fls., deep blue, with brownish center. A supposed hybrid with $D$. grandiflorum. B. R. 23:1944. Int. 1892.

D. caeruléscens, Freyn. A fine Asiatic species, with single and double forms. s.M. $16: 258 .-D$. Whellerii is listed in the trade, but is of unknown origin.

$$
\text { K. C. Davis. }
$$

DEMAZE R I A (Desmazeria). Graminea. Annuals or perennials, with narrow, involute leafblades: spikelets peculiarly distichous on two sides of a 3-sided rachis, many-fld., sessile, or some of the lower spikelets pedicellate. Four species known. Mediterranean and $S$. African.

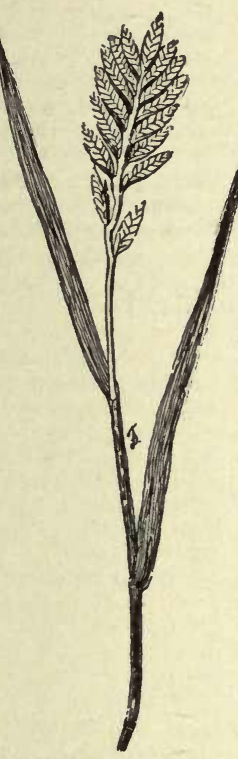

sícula, Dum. (Brizopỳrum Sículum, Link.). Spike Grass. Fig. 689. A smooth, erect annual, 8 in. to $1 \mathrm{ft}$. high: lvs. few: panicle spike-like, 2-3 in.long; spikelets ovate to linear, 8-20-fld. Mediterranean.-Frequently used for edging.

P. B. KENNEDY.

\section{DEMERARA ALMOND. Consult Terminalia.}

DENDROBIUM (tree and life: they are epiphytes). Orchiddcece, tribe Epidéndreo. A genus containing many species of great horticultural merit. Flowers racemose, fasciculate or solitary ; perianth usually spreading; labellum articulate or connate with the base of the column; column short, semiterete; base produced conspicuously; pollinia 4: stems cane-like, in some species deciduous, so that during the resting season the plants appear like a group of dried sticks. The species (more than 300) are distributed through the tropical countries of the eastern hemisphere, Australia, Japan, China, India and the Philippine Islands furnishing a large number. They are particularly abundant in parts of India. No species are known in Africa. The term pseudobulbs has been used throughout this article for the sake of uniformity, but these members are very variable in the genus, ranging from very large (several feet long) to very small and thin. The flowers are of many sizes, forms and colors. Some of the species resemble Epidendrums, Cattleyas, and other genera.

\section{OAKES AMES.}

The growing of most of the commercial Dendrobiums can generally be understood and accomplished in observing three steps: (1) The season of rain, that produces the abundance of growth. (2) The season of colder temperature, to ripen the wood. (3) The dry season, producing the flowers.

In the selection of varieties, there are very few that will not respond to the treatment suggested by this scheme. D. thrysiflorum, fimbriatum, chrysotoxum, Farmerii, and all varieties of this group, respond most generously to this treatment in the warm glasshouse. There are no plants more beautiful in the orchid family.

The soil required is equal parts of clean peat and moss. Fix the plants very firmly in pots or baskets. While growing, an abundance of water must be given, with syringing on all flne days. When the growth is well made and developed, then comes the season of rest, and water can be withheld gradually, until finally none is given. Commercially speaking, Dendrobiums can be flowered in any ordinary glasshouse, and with only partial shade. Another method is to give more shade at the growing season, and more air at the resting period.

The propagation of these species is by division of the growths, either in the resting season or the starting of the growing season. Pruning is not to be practiced, as, being of slow growth, they require the leaves for the furnishing of the plant. Shading should be adopted. With all Dendrobiums, care should be taken not to overpot. Grow in small pots or baskets, so as to confine the roots. D. Dearei may be grown continuously, without rest.

The commoner conservatory Dendrobiums, as $D$. Phalcenopsis, D. Ainsworthii, etc., are propagated by laying the stems flat on baskets, attaching them firmly by means of wire. Pruning of these varieties was once practiced extensively, but when there is plenty of growth the stem and flowers can be cut at the same time; this adds more beauty to the flower. $D$. nobile and $D$. Wardianum are easy to grow, only care should be taken not to be too severe on all classes of this section, after the growth is made, until midwinter. They bloom best when the late autumn sun partially ripens the stems. See Orchids.

Colin OGston.

Index : aggregatum, 14; Ainsworthii, 43; albiflorum, 10; albo-sanguineum, 48; amœenum, 58; anosmum, 68; Aphrodite, 63; aqueum, 53; aureo-flavum, 10; aureum, 50; Balleanum, 43; Barberianum, 60; barbatulum, 19. Bensoniæ, 67; bicameratum, 12; bigibbum, 22; Boxallii, 61; Brymerianum, 16; Calceolaria, 30; Calceolus, 30; capillipes, 41 ; cariniferum, 32 ; chrysanthum, 54 ; Chrysotis, 27; chrysotoxum, 17; clavatum, 24; Cooksonianum, 43; crassinode, 60; crepidatum, 66 ; cretaceum, 74 ; $\mathrm{cru}$. entum, 33; crumenatum, 6 ; cumulatum, 2 ; crystallinum, 65; Dalhousianum, 31; Dayanum, 18; Dearei, 3; densiflorum, 8; Devonianum, 57; dixanthum, 29; Draconis, 37; erythroxanthum, 13; Falconeri, 62; Farmerii, 10; Findleyanum, 46; fimbriatum, 25; formosum, 35; Freemanii, 69; fuscatum, 26; Fytchianum, 19; Gibsonii, 28; giganteum, 62, 68, 71; gratiosissimum, 64; Griffithianum, 9; heterocarpum, 49; hololeuca, 23; Hookerianum, 27; infundibulum, 36; Jamesianum, 36; Japonicum, 40; Jenkinsii, 15; lasioglossum, 52; leucolophotum, 4; Linawianum, 44; lituiflorum, 69 ; Loddigesii, 56 ; longicornu, 34 ; Lowii, 39; luteolum, 50; Macfarlanei, 20; macrophyllum, 18, 68; McCarthiæ, 70 ; moniliforme, 40; moschatum, 30; nobile, 43; nobilius, 43; ochreatum, 55 ; oculatum, 25 ; Palpebræ, 5; Parishii, 45; Paxtoni, 25, 54; Phalænopsis, 23; Pierardi, 73; primulinum, 72; pulchellum, 56; rhodopterygium, 49 ; Ruckeri, 51 ; scabrilingue, 38 ; Schroderianum, 23; Schroederi, 8; secundum, 1; suavissimum, 17; sulcatum, 11; superbiens, 21 ; superbum, 68 ; thyrsiflorum, 7; tortile, 47; transparens, 71; Veitchianum, 18; Wardianum, 59. 
A. Inflorescence racemose (fl. usually solitary in Jenkinsii).

B. Racemes densely flowered.

c. Petals pinkish or purplish.

i. secúndum, Wall. Pseudobulbs terete, nearly $2 \mathrm{ft}$. iong: lvs, ovate-oblong: fls. all on one side of peduncle, crowded; petals smaller than sepals, rose-mauve, la bellum paler, with an apical blotch of orange. Sumatra.

2. cumulatum, Lindl. Pseudobulbs tufted, slender, erect, about 18 in. long: lvs. oblong: fls. 1 in. across, purplish, suffused with white; inflorescence globose Burma.

\section{cc. Petals white.}

3. Dèarei, Reichb. f. Fig. 690. Pseudobulbs tall: lvs. about 2 in. long, oval-oblong: fls. about 2 in. across, white; sepals lanceolate; petals nearly orbicular; labellum oblong, with a pale, yellowish green bloteh in the throat. Philippine Isls. Gn. 54, p. 237. G.C. III. 24:193.

4. leucolophotum, Reichb.f. Psendobulbs stout, erect: racemes many-fld.: fls. white, lateral lobes of labellum greenish; midlobe narrowly oblong. Malay archipelago.

5. Pálpebræ, Lindl. Pseudobulbs clavate, 4-angled: ivs. oblong-lanceolate : raceme loosely tld.: fls. white, with a yellowish disk near the base of the labellum. Burma.

6. crumenàtum, Swartz. Pseudobulbs erect: Ivs. ovateoblong: raceme terminal, many-fld.: sepals and petals ovate; labellum white. Malay archipelago.

7. thyrsiflorum, Reichb. f. Pseudobulbs terete, jointed : lvs. oblong: racemes pendulous, ample: sepals and petals white; labellum yellow, downy-pubescent. Burma. B.M. 5780. I. H. $22: 207$. Gn. 50, p. 28. A.F. $3: 155$. F.E. $9: 329$. J.H. III. 31:229. G.C. II 15:463.Much like the next, and by some united with it.

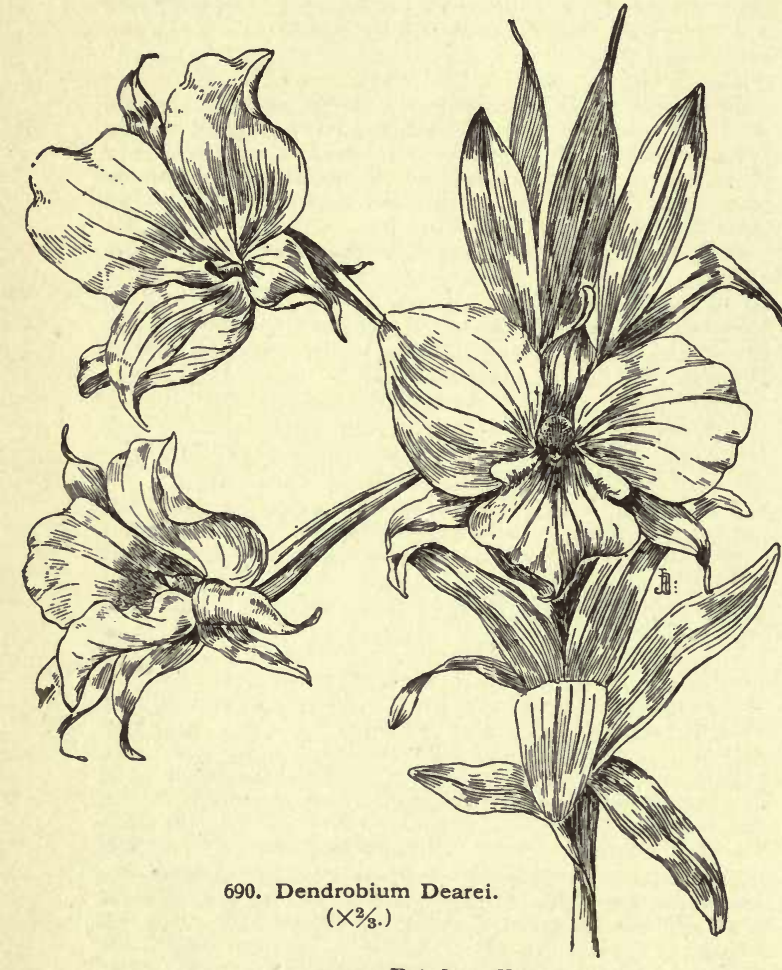

ccc. Petals yellow.

8. densiflòrum, Wall. Pseudobulbs jointed, about 15 in. high: lvs.oblong: racemes pendulous, ample: fls. $11 / 2-2$ in. across; sepals and petals yellow; labellum orange-yellow, downy-pubescent. Nepal. B.M. 3418. G.C. 11. 17:737; III. 14:123 and 24:185.
Var. Schrúederi, Hort. (var. álbum, Hort.), has whitish sepals and petals. A.G. $20: 5$.

9. Griffithiànum, Lindl. Pseudobulbs clavate: lvs. lanceolate-oblong: fls. in drooping, flexuose racemes; petals ciliate, yellow. Burma.

10. Fármerii, Paxt. Pseudobulbs round, attenuate at base, thickening above : lvs. oblong: racemes ample, pendulous: fls. 2 in. across, tinged with pink; throat of labellum orange-yellow; sepals oblong; petals oval. Khasia Hills. B.M. 4659. - Var. albiflorum, Hort. (var. álbum of catalogues), has white fls., the labellum marked with yellow. F.S. $23: 2461$. Var. aùreo-flàvum, Hort. (aùrea of catalogues?). Fls. golden yellow; disk of labellum deeper yellow.

11. sulcàtum, Lindl. Pseudobulbs clavate, compressed: lvs. ovate-oblong: racemes 10 or more fld.: fls. yellow, crowded. Khasia Hills. B.M. 6962.

12. bicameratum, Lindl. (D. breviflorum of catalogues). Pseudobulbs fusiform or clavate, about 18 in long: lrs. elliptic, oblong: fls. yellow, marked with red, clustered on a short rachis, forming a capitate raceme. Sikkim.

13. erythroxánthum, Reichb. f. Fls. in dense racemes, yellowisb striped with crimson-purple. Philippine Isls.

\section{BB. Racemes loosely flowered.}

c. Pseudobulbs one-leaved.

14. aggregatum, Roxb. Lrs. oblong, coriaceous, at the summits of ovate pseudobulbs: fls. yellow, numerous, in lateral drooping racemes; sepals ovate; petals broadly ovate; labellum broader than long, with orange throat; disk pubescent. Burma. B.M. 3643.-Var. màjus, Hort., is a larger-fld. form.

15. Jénkinsii, Wall. Pseudobulbs short, compressed: lvs. oblong, coriaceous: fls. orange-yellow, solitary; sepals oval; petals broadly ovate. Assam. B.R. 25:37.Very like $D$. aggregatum.

\section{cc. Pseudobulbs leafy at summit. D. Flowers yellow.}

E. Labellum pectinately fringed.

16. Brymerianum, Reichb. f. Pseudobulbs jointed, slender, about $2 \frac{1}{2} \mathrm{ft}$. high, sometimes much shorter: lvs. several, lanceolate: fls. fleshy, golden yellow; upper sepal oblong; petals and lateral sepals very similar; labellum reflexed at apex, disk downy; margin provided with a conspicuously long and pectinate fringe. Burma. B.M. 6383. A.F. $6: 609$. G.C.II. $11: 475 ; 16: 689$.

\section{EE. Labellum not pectinately fringed.}

17. chrysotóxum, Lindl. Pseudobulbs clavate : lvs. several, 4 in. long, coriaceous : racemes arching, manyfld.: petals and sepals about equal, golden yellow; labellum of similar color, deeper in the throat. Burma. B.M. 5053. G.F. 5:533, Gn. 48, p. 239.-Var. suavissimum, Hort. Pseudobulbs stout: fls. delightfully fragrant; labellum with blotch deeper-colored than in the type. Burma, 1847.

\section{DD. Flowers greenish.}

18. macrophyllum, Rich. (D. Veitchianum, Lindl.). Pseudobulbs clavate, compressed: lvs.oblong: racemes many-fld.: fls. large ; sepals greenish, hairy behind; petals whitish; lateral lobes of labellum greenish, shaded with purple; midlobe greenish, with purpledotted lines. I.H. 35:57.-Sold as D. Veitchianum, not D. macrophyllum of gardens (see $D$. superbum). Java. Dayanum, Hort., is said to be a better form than the type.

\section{cCc. Pseudobulbs more or less leafy to base.}

$$
\text { D. Flowers white. }
$$

19. Fytchiànum, Batem. (D. barbátulum, Hort.). Pseudobulbs slender: lvs. oblong-lanceolate, acute: racemes 10-15-fld.: fls. white; lateral lobes of the labellum tinted with purple. Burma. B.M. 5444.

20. Macfárlanei, Reichb.f. Fls. several inches across, white; labellum marked with purple, 3-lobed; sepals lanceolate; petals narrowly ovate-lanceolate, acuminate. New Guinea. 
DD. Flowers purple.

21. supérbiens, Reichb.f. Pseudobulbs cylindric: lvs. linear-oblong: racemes remotely fld.: fls, rich mageutapurple; sepals and petals undulate-margined; labellum similar in color, 3-lobed, lateral lobes incurved; disk with raised white lamellre. North Queensland.

22. bigibbum, Lindl. Pseudobulbs elongated, erect, $1 \mathrm{ft}$. or more high: lvs. oblong-lanceolate: racemes sub. erect: fls. magenta-purple; sepals oblong-lanceolate; petals spreading, reflexed ; labellum 3-lobed, lateral lobes incurved, deeper colored than the petals, with a white erest. Torres Straits. B.M. 4898. I.H. 30: 476 .

23. Phalænópsis, Fitzg. Pseudobulbs tall, terete: lvs. lanceolate: fls. on slender pedicels, pale mauve; sepals lanceolate, spreading, paler than the petals; petals orbicular, spreading; labellum 3-lobed, lateral lobes incurved. Australia. B.M. 6817. A.G. 20:5. G.F. 5: 440. A.F. 13:1224. For var. Schrœderianum, see G.C. III. $10: 642-3 ; 15: 339$. R.B. 23:85. A.F. 10:401. For var hololeùca, see G.C. III. 18: 397. J.H.III. 31: 149.-One of the most useful Dendrobiums for cut-flower purposes. There are many fine varieties, pale in color or even white.

DDD. Flowers yellow.

E. Labellum not slipper-like.

24. clavatum, Lindl. Pseudobulbs cylindric, 20 or more in. long: lvs. ovate-lanceolate: racemes few-fid.: fls. orange-yellow; labellum brighter yellow, with a maroon blotch, denticulate on the margin. Nepal. B.M. 6993 .

25. fimbriàtum, Hook. Pseudobulbs 2 or more ft. high, slender: Ivs. lanceolate, dark green: racemes lax, pendulous: sepals and petals orange-vellow, ciliate; labellum yellow, with an orange-yellow throat, margin irregularly fringed. Nepal. G.C. III. 25: 305. Var. oculàtum, Hort. (D. Páxtoni, Paxt.), has smaller fls., with a deeper colored blotch on the labellum. B.M.4160. G.C.III.14:97.

26. fuscatum, Lindl. Pseudobulbs eylindric or nearly so: lvs.ovate-lanceolate: racemes with a zigzag rachis, drooping: fls. yellow, with 2 maroon spots on the labellum. Sikkim, Himalayas.

27. Hookeriànum, Lindl. (D. Chrysotis, Reichb. f.). Pseudobulbs slender, swollen at the base: lvs. lanceolate to oblong: fis. large, in pendulous racemes, golden yellow ; labellum with 2 deep maroon blotches, margin fringed. Sikkin. B.M. 6013. J.H. III. 33: 221.

28. Gibsonii, Paxt. Lvs. lanceolate: racemes from the upper nodes of the stems: fls. 5 or more, yellow, with maroon spots on the labellum. Khasia Hills.

29. dixánthnm, Reichb.f. Pseudobulbs clavate, about $2 \mathrm{ft}$. long: lvs. linear-lanceolate: fls. yellow, in racemes from the upper part of the stems. Burma.

\section{EE. Labellum slipper-like.}

30. moschatum, Wall. Pseudobulbs sereral ft. high, leafy from the base: Ivs. oblong-linear, striate: fl.-stem radical, longer than the pseudobulbs: racemes pendulous: fls. $2-4$ in. across; sepals and petals about equal, oblong, orange-yellow; labellum inflated, colored like the petals, with crimson markings at the base. Burma. B.M. 3837. Var. Calceolària, Hort. (D. Calcèolus, Hort.). Fls. smaller, orange-yellow.

31. Dalhousiànum, Wall. Pseudobulbs elongated, rodiike, spotted with purple when young: lvs. clasping, narrowly ovate: racemes pendulous, lax: fls, large ; sepals spreading. yellow, tinted with rose; labellum concave, orbicular, blotched at base with maroon-purple. Burma. B.R. 32:10. I.H. 28: 423. Gn. 48:1032, p. 223. G.C. III. $21: 157$

\section{A A. Inflorescence not racemose. \\ B. Pseudobulbs black-hairy. \\ c. Leaves deciduous.}

32. cariniferum, Reichb. f. Pseudobulbs subcylindric, 6-9 in. Jong: Ivs. narrowly oblong: fls. 11/2in. across, solitary or in '2's or 3's, near apex of stem; sepals lanceolate, acute, strongly keeled at back, pale fawn-yellow, fading to ivory white; petals ovate, white; labellum 3 -lobec, spurted at base, side lobes triangular, reddish orange, midlote spreadiug, undulate, tufted, with long woolly hairs along the veins on the upper surface, redlish orange at base, usually white at apex. Burma. B.M. 6715 (var. Wattii).

33. cruéntum, Reichb. f. Pseudobulbs erect, terete, $1 \mathrm{ft}$. long, swollen at buse: Ivs. elliptic-oblong, deciduous: fls, solitary or in pairs, $11 / 2-2$ in. across; sepals triangular-ovate, keeled at back, pale green, longitudinally veined with darker green; petals linear-acute, colored like the sepals; labellum 3-lobed, lateral lobes oblong, erect, crimson-scarlet, midlobe ovate, apiculate, pale green, with red border, and a large warty crest, below which are 5 raised red lines, the 2 outermost being most developed. Malay Isl. G.C. III. 18:91.

34. longicórnu, Lindl. Pseudobulbs slender, 8-12 in. high: lvs. linear-lanceolate, 2-21/2 in. long: tis. solitary or in 2's or 3's, not fully expanding; sepals and petals sub-equal, elliptic-oblong, transparent white; labellum funnel-shaped, anterior portion fimbriate, white, with a broad raised orange-red central band, with divergent lateral streaks of same color; spur sleniler. Burma.

\section{cc. Lis. not deciduous.}

35. formosum, Roxb. Pseudobulbs stout, erect: Ivs. ovate-oblong: peduncle from the summit of the stem, 3-5-fld.: fis. 3-4 in. across, white; sepals oblong-lanceolate, apiculate; petals nearly orbicular; labellum large, the small basal lobes clasping the column, throat with a yellow band, which expands in a large yellow blotch near the distal end. Khasia Hills. B.R.25:64. Var. gigantèm, Hort. Fls. measure 4-5 in. across. G.C.III. 24:471. Gng. 1:118-9. F.E. 10:1240.

36. infundibulum, Lindl. Fls. white; sepals spreading, elliptic-oblong; petals broad; labellum large, with an orange-yellow blotch in the throat; basal lobes infolding the column. Burma. B.M. 5446. I.H. 21:172. Var. Jamesianum, Hort. Pseudobulbs stouter and more rigid: labellum of flower differently formed, especially the side lobes, which are roughened on their inner surface; disk cinnamon red.

37. Dracdnis, Reichb. f. Pseudobulbs stout, erect, 12-18 in. long: lvs. lanceolate, 3-4 in. long: fls. in fascicles from the uppermost joints of the stem, $11 / 2$ in. In diam., ivory white, striped with orange-red at base of labellum; sepals lanceolate, acute; petals oblong-lanceolate, reflexed at tips; labellum 3-lobed, lateral lobes small, rotund; midlobe oral, oblong, crisped and minutely toothed on the margin, with 3 longitudinal raised lines. India. B.M. 5159 .

38. scabrilíngue, Lindl. Pseudobulbs stout, erect, slightly attenuated below, 9-12 in. high : Ivs. oblong: fls. $1 \frac{1}{2}$ in. in diam., in fascicles from the uppermost joints of the stems; sepals anà petals similar, sub-equal, ovate-lanceolate, ivory white; labellum 3-lobed; lateral lobes oblong, erect, yellow-green; midlobe oval-oblong, reflexed, yellow, with 5-7 orange-yellow sunken lines on disk; spur small, conical. Burma.

39. L6wii, Lindl. Pseudobulbs slender: sepals and petals pale yellow; labellum marked on the side lobes and midlobe with crimson. Borneo. B.M. 5303. F.S. $23: 2395$.

BB. Pseudobulbs not black-hairy, upright.

\section{c. Leaves persistent.}

D. Petals and sepals white.

40. Japónicum, Lindl. (D. monilifórme, Swartz). Pseudobulbs tufted, 6-12 in. long, attenuated below : Ivs. linear-lanceolate, acute: fls. fragrant, $1 \frac{1}{2}$ in. across, solitary or in pairs, white, lotted or speckled with mauve at the base of the labellum. S. Jap.

DD. Petals and sepals yellow.

41. capillipes, Reichb. f. Dwarf, tufted plants, with fusiform pseudobulbs: lvs. lanceolate: fls. in pairs or solitary, golden yellow, with a deeper blotch on the labellum. India.

42. Iutèolum, Batem. Pseudobulbs erect, about $1 \frac{1}{2} \mathrm{ft}$. long: lvs. linear-lanceolate, acute: fls. about 2 in. across, yellowish or cream-white; labellum with a few reddish lines. Burma. J.H. III. 32:143. G.C. II. 19:340 (var. chlorocentrum). 
DDD. Petals and sepals rose-color.

43. nóbile, Lindl. Fig. 691. Stems stout: lvs. oblong: sepals and petals white, suffused with rose at the apices: labellum white, with a blotch of amethyst-purple at distal end, throat dark crimson. Himal., China. G.C. II 11:565; III. $23: 341$. J.H. III. $34: 295$. R.B. $23: 25$. A.F $4: 415 ; 13: 620$.

Var. nobilius, Hort., has larger fls., which are more intense in color, the sepals and petals pale only at the base. I.H. $42: 36$.

Var. Cooksonianum, Hort., is a pelorian form, the petals having acquired at the base the rich coloring so characteristic of the labellum. Gn. 55, p. 445.

Var. Balleànum, Hort. Sepals and petals white; labellum yellowi:sh, with pale crimson blotches on either side of the throat. Sikkim.

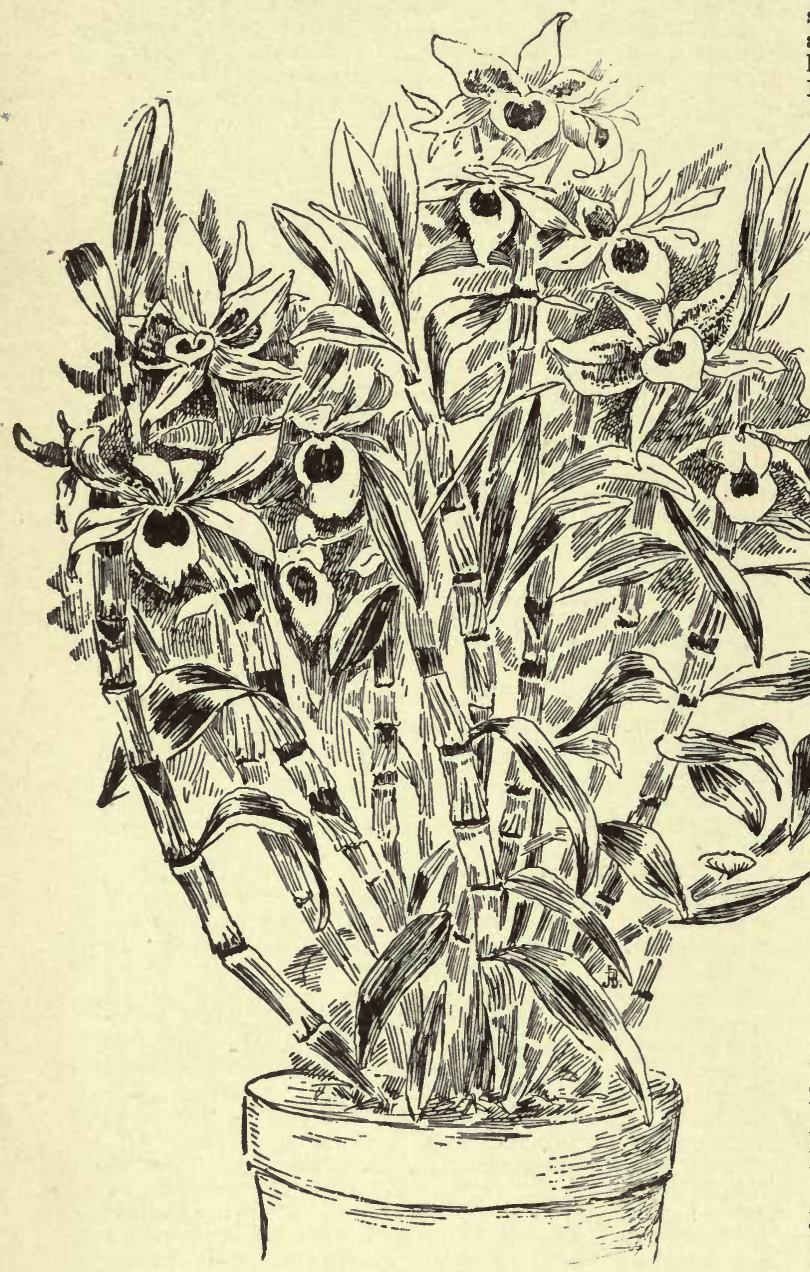

691. Dendrobium nobile.

D. Ainsworthii, Moore, is a beautiful and popular hybrid of $D$. heterocarpum and $D$. nobile. Blossoms in small. lateral racemes; sepuls and petals white; lip with a feathered, purple blotch, white. Gn. 51, p. 338 . G.C. II. 16:624

44. Linæwiànum, Reichb. f. Stems long, clavate: lvs. narrow, several inches long: sepals oblong; petals ovate, white at base, otherwise rosy mauve; distal end of la bellum pale mauve, anterior portion white, with 2 mauve spots. China, Jap. B.M. 4153.
45. Párishii, Reichb. f. Stems thick : Ivs. oblong. lanceolate: sepals and petals rose-mauve; labellum or bicular, amethyst-purple, blotched on each side with maroon. Burma. B.M. 5488.

46. Findleyànum, Parish $\&$ Reichb. f. Stems shining. yellowish, internodes slender : lvs, oblong-lanceolate fis. large, in pairs; lateral sepals and petals ovorlapping. pale pink-lilac; labellum yellow margined with white Burma. B.M. 6438. Gn. 49:1070.

47. tórtile, Lindl. Stems clavate, irregular when old: lvs. oblong-lanceolate, about 3 in. long: fls. 3 in. across ; sepals and petals pink-lilac; labellum pale yellow, witb a deep crimson blotch in the throat. Burma. B.M. 4477. - Var. ròseum, Hort. Fls. delicate rose color. The next is very similar.

cc. Lvs. deciduous.

48. álbo-sanguíneum, Lindl. Stems about $1 \mathrm{ft}$. high, stout: lvs. linear-lanceolate: fls. 2 or 3 together, 2-3 in. across, whitish; petals streaked with red at the base; labellum with 2 blotches in the middle. Burma. A.F. 11:1350. B.M. 5130 .

49. rhodopterygium, Reichb. f. Pseudobulbs cylindric, erect, about $1 \mathrm{ft}$. long : lvs, linear-lanceolate : fls. about 2 in. across; sepals oblong-lanceolate ; petals ovate, both pale purple mottled with white; labellum crimson-purple, striated, bordered with white. Burma.-Supposed natural hybrid between D. Parishii and D. Pierardi.

\section{ввB. Pseudobulbs drooping.}

C. Lvs. persistent: fls. yellow.

50. heterocárpum, Wall. (D. aùreum, Lindl.). Stems erect, attenuated at base, or nearly so: lvs. oblong-lanceolate: sepals and petals pale yellow; labellum orangeyellow, blotched and streaked with crimson. Assam, Khasia Hills, Nepal, Philippine Isls. B.M. 4708 .

51. Rúckeri, Lindl. Pseudobulbs slender, about $1 \frac{1}{2} \mathrm{ft}$. long, attenuated below: lvs. linear-lanceolate : fls, either solitary or in pairs; lateral sepals triangular; sepals and petals yellowish; labellum with white lateral lobes streaked with rose, yellow. Philippine Isls.

52. lasioglossum, Reichb. f. Pseudobulbs about $1 \frac{1}{2} \mathrm{ft}$. long, attenuate above and below: lvs. lanceolate : fls. $1 \frac{1}{2}$ in. across, in 2 's or 3's, white : lateral lobes of labellum lined with red. Burma.

53. áqueum, Lindl. Pseudobulbs decumbent: lvs. ovate-oblong: fls. solitary or in pairs, yellowish white, with a yellow disk on the labellum; upper sepal elliptic-oblong, acute; lateral sepals falcate; petals ovate. Nilghri Hills, India.

\section{cc. Leaves deciduous. \\ D. Flowers yellow.}

54. chrysánthum, Lindl. (D. Páxtonii, Lindl.). Pseudobulbs slender, tall, flexuose, leafy to the base: lvs. ovate-lanceolate : fls, yellow; sepals oblong: petals broader, oval, denticulate; labellum orbicular, fringed, throat maroon-purple, base infolding the column. Burma. B.R. 15:1299. G.C. III. 15:565.

55. ochreàtum, Lindl. Pseudobulbs with swollen joints : lvs. narrowly-ovate : fls. in pairs; sepals and petals about equal, golden yellow; labellum orbicularconcave, yellow, with maroon-purple blotch. India. B.M. 4450

DD. Fls. white or pinkish.

E. Labellum glandular, ciliate.

56. Lóddigesii, Rolfe (D. pulchéllum, Lodd.). Habit dense, dwarf: stems very slender, $3-4$ in. long: lvs. oblong-lanceolate: fls. on slender pedicels, solitary; sepals and petals pale pink or rose-lilac; labellum with an orange-yellow disk bordered with rose-lilac. India. Not $D$. pulchellum, Roxburgh, for which species it often passes in gardens. B.M. 5037.

57. Devoniànum, Paxt. Stems pendulous, about $3 \mathrm{ft}$. long: lvs. linear-lanceolate: sepals and petals white, 
tipped with amethyst-purple; labellum cordate, with an amethyst-purple blotch in front, otherwise white, with 2 orange-yellow blotehes in the throat, the margin delicately fringed. Khasia Hills. B.M. 4429. J.H. III. 34: 197. G.C. III. 7:680.

\section{Ex. Labellum not glandular, ciliate.}

F. Pseudobulbs conspicuously nodose.

58. amœ̀num, Lindl. Pseudobulbs slender: lvs. linearlanceolate: fls, usually solitary, otherwise in 2's or 3's; sepals and petals white, tipped with violet-purple; labellum violet-purple bordered with white and blotched with yellow. Nepal. B.M. 6199. G.C. II. 16:625.

59. Wardianum, Warner. Stems 2,3 or more ft. high, pendent: Ivs. oblong-lanceolate : fls. usually 2 or 3 together, 3-4 in. across; sepals and petals tipped with rose-mauve (amethyst-purple); labellum with an apical blotch of same color, otherwise yellow shading into white at the margin, and blotched with maroon in the throat. There is a variety in which the apical blotehes are wanting. Burma. B.M. 5U58. I.H. $24: 277$. F.R. $1: 231$. Gn. 47 , p. 84 . R.B. $23: 25$. J.H. III. $30: 454$ : $32: 237$.

60. crassinode, Reichb. f. Stems pendulous or nearly so, 1-2 ft. long, swollen conspicuously at the contiguous internodes: lvs. linear-lanceolate: fls. 2 or 3 together, about 2 in. across; sepals and petals white, tipped with rose-naure; labellum similarly tipped with rose-maure, atherwise yellow with a white border. Burma. B.M. 5766. - Var. Barberianum, Hort., is a stronger-growing form of the species, with brighter colored fls., the col oring at the tips of the petals covering more surface.

61. Bóxallii, Reichb. f. Pseudobulbs pendulous, about 30 in, long: lvs, linear-lanceolate, acute: fls, $2 \frac{1}{2}$ in. across, usually in pairs; sepals and petals white, tipped with pale mauve; labellum yellowish, bordered with white, tipped with pale mauve. Burma.

62. Fálconeri, Hook. Stems slender, knotted, branch ing above : lvs. linear: fls. solitary, about 3 in. across ; sepals and petals white, tinged with rose and tipped with amethyst-purple; labellum spreading in front, maroon-purple, with 2 deep orange blotches, tipped with amethyst-purple,bordered with white. India. B.M. 4944 I.H. $23: 243$. - Var. giganteum, Hort., is a stronger-growing form of the species, with larger fls.

63. Aphrodite, Reichb. f. Pseudobulbs 6-12 in. tall : lvs. linear-lanceolate : fls. 2 in. across, often in pairs sepals whitish; petals similarly colored; midlobe of labellum large, yellowish, with 2 maroon blotches at base. Burma.

FF. Pseudobulbs not conspicuously nodose. G. Lip yellow at base.

64. gratiosíssimum, Reichb. f. Pseudobulbs slender at base, thickened above, swollen at the nodes: lvs. lanceolate : fls. in 2's or 3's, from the leafless stem, about 2 in. across; sepals and petals white, tipped with pale crimson-purple ; labellum white, blotched with crimson-purple at the apex and marked with yellow on the disk. Burma.

65. crystallinum, Reichb. $\mathrm{f}$. Stems about $1 \mathrm{ft}$. long, slender, striated, nearly pendulous: lvs. narrow: fls. in pairs or solitary; sepals and petals white, with amethyst purple apices; labellum yellow, with an amethyst blotch on front, margin whitisb. Burma. B.M. 6319.

66. crepidàtum, Lindl. Stems $1 \mathrm{ft}$. long, slender, striated: lvs. linear-lanceolate: fls. 2 or 3 in a group, about 1 in. across, white, tinted with lilac ; labellum yellow, with a white border. Assam. B.M. 4993.-Var. roseum, Hort., occurs in catalogues.

67. Bénsoniæ, Reichb. f. Pseudobulbs cylindric: lvs. linear: fls, $2 \frac{1}{2}$ in. across, in 2's or 3 's, white, disk of labellum orange-yellow, with 2 maroon spots at base. British Burma. B.M. 5679. I.H. 35:47.-Var. màjus, Hort., is a larger-fld. form.

$$
\text { GG. Lip not yellow at base. }
$$

68. supérbum, Reichb. f. (D. macrophýllum, Hort.). Stems stout, pendent: lvs. ovate: sepals lanceolate petals ovate-lanceolate, delicate rose-mauve; labellum of same color, with deep crimson-purple throat. Philip. pine Isls. B.M. 3970. - Var. anosmum, Hort. Fls. scentless or nearly so, mostly solitary ; sepals and petals shorter, not undulate. J.H. III. 28:275 (var. Houttoni). Var. giganteum, Hort. Fls. larger.

69. lituiflorum, Lindl. Stems about $2 \mathrm{ft}$. long, greyish: lvs. linear: tls. in pairs or sometimes 4 or more in each group, amethyst-purple ; sepals oblong-lanceolate; petals ovate-oblong; labellum funnel or trumpet-shaped, deep maroon, anterior portion white. Burma. B.M. 6050.-Var. Freèmanii, Hort. Labellum with a pale yel low zone, sepals and petals deeper colored than in the type. Very similar in habit to Dendrobium nobile, but more slender.

70. MacCárthiæ, Thwaites. Fls. bell-shaped, rosy mauve and white; sepals and petals only slightly spreading; labellum pale maure, striped and blotched with purple, a maroon spot on the disk: racemes pendulous. India. B.M. 4886 .

71. transpàrens, Wall. Pseudobulbs slender: lvs. linear-lanceolate: fls. $11 / 2$ in. across, in 2 's and 3 's; sepals white, tinted with pale-maure; petals similarly colored; labellum white with manve spots, tinted with mauve at the apex. India. B.M. 4663.

EEE. Labellum cucullate, wholly or in part, pale sulfur yellow.

72. primulinum, Lindl. Stems drooping, slender, about $1 \mathrm{ft}$. long, greyish: sepals and petals about equal, pink-lilac; labellum yellow with deep crimson margin. Nepal. B.M. 5003 (as D. nobile, var.).-Var. gigantéum, Hort. Pseudobulbs longer and more slender: fls. much larger.

73. Pierárdi, Roxb. Stems long, slender, pendulous: lvs. ovate-lanceolate : sepals and petals pink-lilac; la bellum yellow, marked with deep crimson at base Burma. B.M. 2584. Gn. 55, p. 405.-Var. latifolium, Hort., is very similar to this.

74. cretàceum, Lindl. Stems about $1 \mathrm{ft}$. long: lvs. oblong-lanceolate : fls. solitary, whitish, disk of labellum yellowish, with crimson marking, margin fringed. Khasia Hills.

Hybrids : $D$. Ainsworthii $=\mathrm{D}$, heterocarpum $\times \mathrm{D}$. nobile (see No 42$)-D$ Dominianum $=\mathrm{D}$ nobile $\times \mathrm{D}$ Linawianum $-D$. Oassiope $=$ D. Japonicum $\times$ D. nobile, var. albiflorum. - D. splen didissimum $=\mathrm{D}$. aureum $\times$ nobile. - Var. grandiflorum $=\mathrm{D}$. aureum $\times$ nobile.

D. Johannis, Reichb. $f$., and $D$. robustum are not in cult. in the United States, but have appeared in trade catalogues.

OAKes Ames.

DENDROCÁlamUs. Consult Bamboo.

\section{DENDROCHILUM. Compare Platyclinis.}

DENDROMECON (Greek dendron,tree; mecon, poppy). The only genus of Papaverdcea known to have woody stems. California. Probably only one species. D. rígidum, Benth. Dry, rocky hills of the Coast Range, mainly in the south: $3-10 \mathrm{ft}$. high : stems up to 1 in. thick: bark whitish : branches stiff, erect: lvs. linear-lanceolate, not cut, coriaceous, reticulately veined, rery acute and mucronate : fls. bright vellow, 1-3 in. in diam., on pedicels $1-4$ in. long: capsules linear, nerved, $11 / 2-21 /$ in. long; seeds black, almost globular. Hardy in some parts of England. Propagated from seeds, that take very long to germinate. B.M. 5134. F.S. 14:1411. Gn. 50:1087. J.H. III. 29:92.-D. Hárfordii, Kell., and D. fléxile, Greene, from Santa Cruz and Santa Rosa Islands, are now considered as forms of above, varying mainly in the habit, more drooping and graceful, and in the much larger, ovate, more glaucous leaves. These different forms occur also in the mountains near Santa Barbara. Considerable variation in size of flowers appears to depend mostly upon the conditions where plants are growing. Outdoor shrubs.

F. Franceschi.

DENDROPANAX (Greek, tree Panax). Aralidcea. A genus of about 20 trees and shrubs from tropical America aud Asia, also China and Japan. D. Japonicus, Seem., may be obtained from dealers in Japanese plants. The leaves have been compared to F'atsia Japonica, but are smaller and mostly 3-lobed. The floral parts are in 5's. Berry globose. 
DENDROPHŸLAX (Greek, growing on a tree). Orchidacere, tribe Vándece. Epiphytes: sepals and petals spreading, labellum 3-lobed, lateral lobes small, angular, middle one with spreading lobes; spur long, filiform: column short; pollinia 2. Near Phalænopsis. The following are introduced into American horticulture:

Lindenii, Reichb.f. Scape leafless, bearing a single white flower: sepals and petals lanceolate; divisions of midlobe of labellum lanceolate: capsule smooth. On Oreodoxa Regia, and live oaks, S. Florida.

funàlis, Hort. (EEcoclades fundlis, Lindl. Angracum fundle, Lindl.). Leafless, roots numerous, fleshy: peduncles 2 -fld.: fls. white; sepals and petals oblong-lanceolate; labellum 3 -lobed, with a long horn. Mts. of Jamaica.

OAKEs AMEs.

DENNSTÉDTIA (a personal name). Polypodidcece. A genus of hardy or greenhouse ferns of wide distribution, often referred to Dicksonia but belonging to a different family from the antarctic or southern hemisphere tree ferns of the latter genus. Indusium inferior cup-shaped. For culture, see Dicksonia

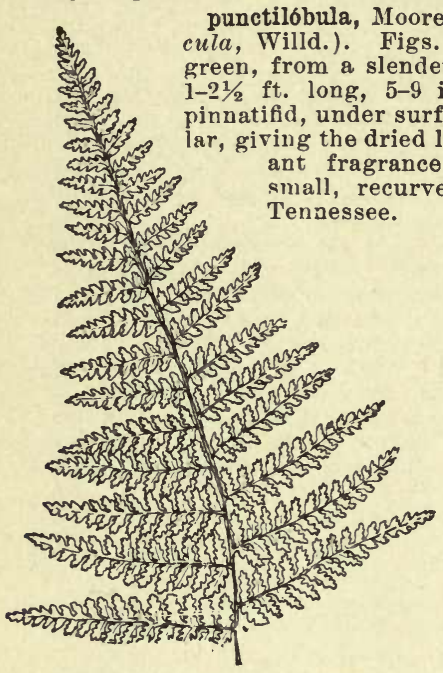

692. Tip of leaf of Dennstædia punctilobula.

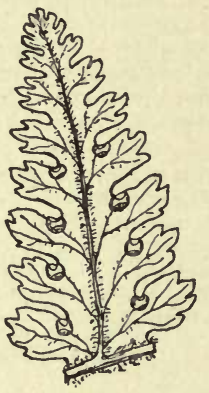

693. Fruiting lobe of Dennstædtia punctilobula.
Smithii, Moore. Lrs, thick, the under surface almost woolly, glandular, tripinnate; lower pinnæ 9-12 in. long, 3-4 in. Wicle; sori $2-8$ to each segment. Philippines.

dissécta, from the West Indies, often 6-7 ft. high, with broad (2-4 ft.) lvs. is sometimes seen in cultivation, and is well worth a place in the trade.

\section{M. UNDERWOOD.}

DENTARIA (Latin, dens, tooth ; referring to the toothed rootstocks). Cruciferce. Toothwort. Dealers in native plants sometimes cultivate a few of these hardy herbaceous perennials, which have pleasant tasting rootstocks, 2 or 3 lvs., mostly with 3 leaflets, and corymbs or racemes of large white or purplish fls. in spring. The European and eastern American species are readily told from Cardamine by habit and many obvious differences, but the western American of the two genera converge so that some botanists have merged Dentaria into Cardamine. (See E. L. Greene, Pittonia, 3:117-124.) The genus contains no arctic or alpine forms. About 9 species are cultivated in Old World rockeries. They are of easy culture in light, rich soil and moist, shady positions. Usually prop. by division, as seeds are not abundant.

\section{A. Rootstock not tuberous.}

diphýlla, Michx. PEPPER-Root. Rootstock several in. long, often branched, strongly toothed at the many nodes: stem-lvs. 2, similar to the root-lvs., close together; leaflets 3 , ovate or oblong-ovate, coarsely cre- nate, the teeth abruptly acute: petals white inside, pale purple or pinkish outside. Nova Scotia to S. C., u r st to Minn. and Ky. B.M. 1465.- Rootstocks 5-10 in. long, crisp, tasting like water-cress. Pretty spring flower.

\section{AA. Rootstock tuberous.}

B. Lvs. 3-parted, but not into distinct leaflets.

c. Tubers usually not jointed or prominently tubercled.

laciniàta, Mubl. Tubers deep-seated: stem-lvs. 2 or 3 , with lateral segments often 2-lobed, all broadly oblong to linear, more or less sharply toothel: petals pale rose to white. Quebec to Minn., south to Fla, and La.

$$
\text { cc. Tubers with joints about } 1 \text { in. long. }
$$

macrocárpa, Nutt.' (C. gemmàta, Greene). Lvs. 1-3, palmately or pinnately 3-5-parted or divided, segments linear to oblong, entire : fls. purple or rose. N. Calif. to B. C.

$$
\text { Bв. Lvs. cut into } 3 \text { distinct leaflets. }
$$

\section{c. Leaflets linear, entire.}

tenélla, Pursh. Tubers small, irregular: stem-lvs. 1 or 2, nearly sessile, sometimes bulbiferous: leaflets linear-oblong or linear, obtuse, entire: petals rose. Washingtou.

cc. Leaflets not linear or entire.

Califórnica, Nutt. Tubers mostly small: stem $1 / 2-2 \mathrm{ft}$. high : lvs. very variable; stem-lvs. $2-4$, mostly shortpetiolate, and above the middle of the stem, with 3-5 leaflets, rarely simple or lobed; leaflets mostly shortpetiolulate, ovate to lanceolate or linear, entire or toothed: petals white or rose. Mts. of Calif. and Ore.

máxima, Nutt. Tubers near the surface jointed, strongly tubercled : stem-lvs. 2 or 3 , usually alteruate; leaflets ovate or oblong-ovate, coarsely toothed and somewhat cleft or lobed. Vt. to western N. Y. and Penna.

W. M.

\section{DEODAR. Cedrus Deodara.}

DEPARIA (Greek, depas, a beaker or chalice; referring to the form of the involucre). A small genus of Hawaiiau and South Americun ferns related to Dennstædtia, rarely seen in cultivation in America. The sori are marginal and usually on stalked projections from the margin of the leaf. $\quad$ L. M. UNDERWOOD.

DERRIS (Greek, a leather covering). Legumindsa. A genus of tropical, tall, woody climbers, one of which is cult. in S. Calif. About 35 species, mostly Asian. Lvs. alternate; lfts. opposite, the odd one distant; stipules none: fls. violet, purple or white, never yellow.

scándens, Benth. Climbing: lfts. 9-13, 11/2-2 in. long, oblong, obtuse, muticous or retuse, glabrous or minutely pilose beneath: racemes 4-6 in. long, unbranched: fls. purple: pod long, lanceolate acute at both ends, narrowly winged at the base; ovules 6-8. S. Asia and Indian Archipelago.- It has been offered in this country, but has not been successfully cultivated. The above description is made from specimens contributed by Dr. Franceschi, Santa Barbara, Calif.

DESCHÁMPSIA (after Deschamps, a French botanist). Perennial grasses with small, shining spikelets, like Trisetum and Aira. The plants are usually stouter and the spikelets longer than in Aira, from which it differs in the prolongation of the rachilla. Lvs. flat or convolute: spikelets 2- (rarely 3-) fld., in terminal, usually spreading panicles : awn slender, twisted below. Species about 20 , inhabiting cold and temperate regions, a few occurring in the high mountains of the tropics. About 8 species are found in N. America.

cæspitòsa, Beauv. (Aira caspitosa, Linn.). TUFTED HaIR-Grass. Hassock-Grass. A native perennial having a tendency to form tufts or tussocks. Panicle pyramidal or oblong, 2 in.long ; rays slender, bearing spikelets above the middle ; awn variable in length.Abundant in the Rocky Mt. region, where the tufts help to bind the spongy soil and prevent land-slides. In England it is sometimes used by the farmers to make door mats. Also used for ornament. 
flexuòsa, Trin. (Aira flexuòsa, Linn.). Wood HaIrGrass. A slender, perennial grass, 1-2 ft. high, with numerous very fine root-lvs., and a delicate capillary panicle. It grows in tufts like the above, and cau be distinguished by the much longer and twisted awn. N. Amer., Eu. - Valuable for woorlland pastures, as it will grow well in the shade. Also used for ornament.

\section{P. B. KeNNedy.}

DESIGN. The "design-work" of florists refers to formal arrangement of material as opposed to informal arrangement of cut-flowers. Funeral designs are perhaps the commonest. Dried grasses and ererlasting flowers are used in funeral designs. The term design is burrowed from the language of art, and can also be applied to formal styles of bedding as opposed to the informal border. Design work is less popular in America than in parts of the Old World, the distinguishing feature of our florlculture being the general taste for cut-flowers and for their free arrangement. Many pictures of designs may be seen in the florists' trade papers.

\section{DESMAZERIA. See Demazeria}

DESMODIOM (Greek, a brind or chain; referring to the jointed pods). By some called Meibomia. Legumindsce. TICK Trefoil. Mlostly herbs, of 150 or more species, in temperate aud warm regions of America, Asia, Africa and Australia. Lrs. pinnate, with 3-5 (rarely 1) leaflets: fls. small and papilionaceous, in terminal or axillary racemes in summer, mostly purple: pod flat, deeply lobed or jointed, the joints often breaking apart and adhering to clothing and to animals by means of small hooked hairs. Fig. 694. A number of species are native to N. America, and are sometimes grown in the hardy border, where they thrive under ordinary conditions. One hothouse species, D. gyrans, is sometimes cult. for its odd moring leaflets. $D$. penduliflorum and $D$. Juponicum will be found under Lespedeza. Several of the native species are worthy of cult., but are practically unknown in the trade. The following hare been offered by collectors : Canadense, DC.; cuspidatum, Hook.; Dillenii, Darl.; Marilandicum, Boott; nudiflorum, DC. ; paniculatum, DC. ; pauciflorum, DC.; sessiliflorum, Torr. \& Gray. The Florida

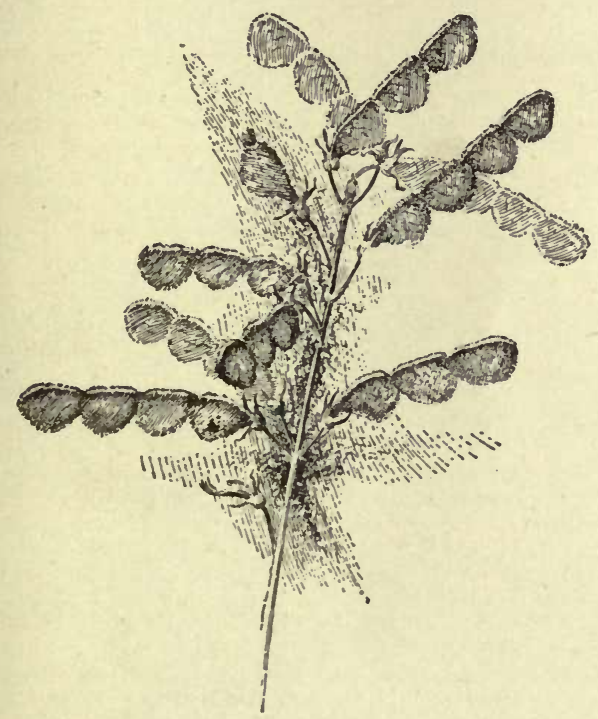

694. Loments or pods of Desmodium Canadense.

Beggar-weed is Desmodium tortuosum, DC., of the W. Indies. It is coming into prominence in the south as a forage plant (see Farmers' Bull. 102, U. S. Dept. of Agric.). gỳrans, DC. Telegraph Plant. From 2-3 ft. high, with 3 oblong or elliptic leaflets, the small lateral ones (which are almost linear) moving in various directions when the temperature is congenial, and especially in the sunshine: fls. purple or violet, in a many fld. panicle. S. Asia. Grown occasionally as a curiosity, particularly in botanical collections. See Darwin's Power of Movement in Plants, and various botanical treatises, for fuller accounts.

Desmodium gyrans is of tolerably easy culture. It requires stove temperature, aud, although a perennial, it is best treated as an annual. 'Thu best method of propagation is by seeds. These should be sown in February in a light, sandy soil, in 4-in. pots, and placed in a warm, close atmosphere, where they will soon germinate. The seedlings should be potted singly into small pots as soon as large enough to handle, and be grown on as rapidly as possible, using a mixture of good, flbrous loam and leaf soil in about equal proportions. By mid. summer they will be bushy plants, and, though not showy, they will be rery interesting.

\section{H. B. and Edward J. Cannisg.}

DEÙTZIA (named by Thunberg in honor of his friend and patron, Johann van der Deutz). Saxifragdcen. Very ornamental shrubs with showy white or blush fls. appearing in spring or early summer. Lrs. deciduous, opposite, petioled, serrate, usually with rough stellate pubescence : fls. in racemes or corymbs, white, sometimes purplish, epigynous; calyx-teeth 5; petals 5; stamens 10 , rarely more, shorter than the petals; filaments usually winged and toothed at the apex : capsule 3-5celled, with numerous minute seeds. About 15 species in E.Asia and Himalayas and 1 in Mexico. D. parviflor $a$ and D. Lemoinei are the hardiest, but $D$. scabra. Sieboldiana and gracilis are also hardy north in somewhat sheltered positions or with sligbt protection, while most of the others are more tender and can not be grown safely north of New York. The Deutzias thrive in almost any well drained soil, and are well adapted for borders of shrubberies. Potterl plants forced with a temperature not exceeding $50^{\circ}$ develop into beautiful specimens for the decoration of greenhouses and conservatories, es pecially $D$. Lemoinei, $D$. gracilis and discolor. The same plants cannot be forced again. Prop. readily by greenwood and hardwood cuttings, also by seeds sown in pans or boxes in spring.

A. Fls. in racemes or panicles: petals valvate in the bud.

B. Longer filaments narroued toward the apex, without teeth.

Sieboldiàna, Maxim. (D. scabra, Sieb. \& Zucc.). Low shrub, to $2 \mathrm{ft}$.: lvs. short-petioled, the pair below the panicle sessile, ovate or ovate-elliptic, rounded or cordate at the base, rough and rugose above, stellate-pubescent beneath, light green, 1-2 in. long: panicles erect, loose, 2-3 in. long: fls. white, rather small, with spreading petals; calyx lobes persistent. June. Japan. S.Z. 7. -Graceful low shrub, but less showy than the two following species.

BB. All filaments with 2 large teeth below the anthers.

scabra, Thunb. Shrub, to $6 \mathrm{ft}$. : lvs. all petioled, ovate to orate-lanceolate, rounded at the base, crenate-dentate, with rough pubescence on both sides, dull green, 1-3 in. long: panicles erect, 2-4 in. long: fls. white or blushed, with erect petals: calyx lobes deciduous. June, July. Japan, China. S.Z. 6. B.M. 3838. B.R.20:1718. S.B.F.G II. 4 :393. A.G. 18: 356. Var. angustifolia, Voss. Branches reddish brown: lvs. ovate-lanceolate, rougher. Var. crenàta, Voss (D. crendta, Sieb. \& Zucc.). Branches brown: lrs. ovate or oblong-ovate, less rough. This var is less common in cultivation than the former. Var. marmorata, Hort. Lws. spotted with yellowish white. Var. plèna, Maxim. With double fls. R.H. 1867:70. F.S. $17: 1799 ; 18: 1850$. I.H. $11: 389$ - Cult. in different forms as Candidissima, with nure white double fls. (A.F. 6 :263. J.H. III. 34:153. G.C. II. 18:173) ; Pride of Rochester, with very large white double fls.; Purpurea Plena, double outside purplish ; Watereri, with large double fls., tinged rose. 


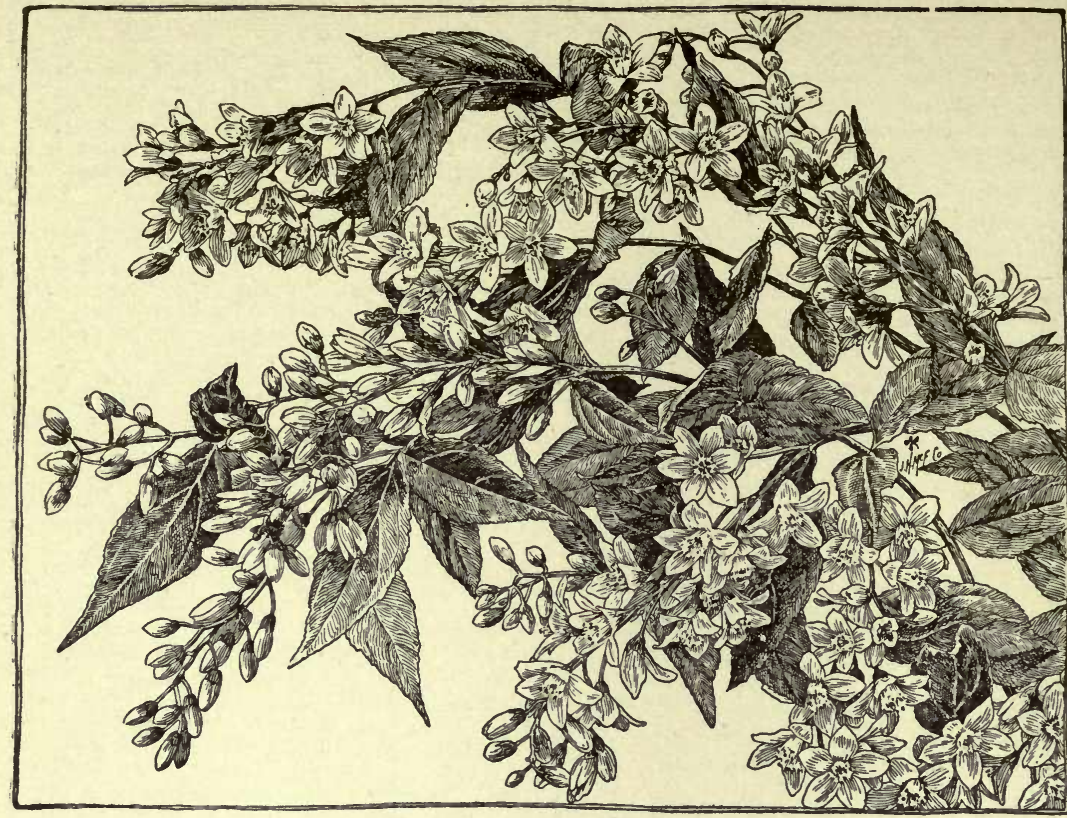

695. Deutzia gracilis $(\times 1 / 2)$.

lvs. ovate or lanceolate, long acuminate: fls. larger; all filaments toothed. Himalayas. $-D$. dentàta, Hort. $=D$. scabra. $-D$. Fór. tunei, Hort. (D. scabraX Sieboldiana). Lvs. ovateoblong: fls. large, pure white: filaments partly indistinctly toothed. Usually a variety of $\mathrm{D}$. Usually a variety of $D$. scabra is mitis, Hort. =D.scabra, var. crenata. - D. ròsea, Hort. (D.gracilis rosea, Lemoine). Hybrid between D. discolor purpurascens and D. gra. cilis, with campanulate blush fls. in panicles. Of the same parentage as are var. campanulata and var. venusta, with white, and var. grandiflora with large blushed fls. Thesevars. are described by Lemoine as forms of D. gracilis, except var. grandiflora, which he has under $D$. discolor $-D$. stamínea, B. Br. Shrub, to $3 \mathrm{ft}$.: lvs. ovate or ovatelanceolate, with whitish stellate pubescence beneath: corymbs many-fld.: fls. white, fragrant ; filaments with large teeth. Himalayss. Var. Brunoniana, Hook. $f$. \& Thoms. Lvs. less densely pubescent: fls. larger. B.R. 26:5 (as D. corymbosa). $-D$. Setchuénsis,Franch. Shrub: lvs. ovate-lanceolate, bright

grácilis, Sieb. \& Zucc. Fig. 695. Shrub, to $3 \mathrm{ft.,} \mathrm{with}$ slender, often arching branches: ivs. oblong-lanceolate, acuminate, sharply serrate, with sparse stellate hairs above, nearly glabrous beneath, bright green, 1-2 in. long: fls. pure white, in racemes; petals erect or somewhat spreading, oblong; stamens much shorter than the petals; calyx-teeth persistent. May, June. Japan. S.Z.8. P.F.G. 2, p. 7. F.S.6:611. R.H. 1891, p.203. There are vars. with yellow and with variegated lvs.; see, also, D. rosea (Suppl. list).

$$
\text { AA. Fls. in corymbs. }
$$

díscolor, Hemsl. Shrub, to $7 \mathrm{ft}$. : lvs. oblong-lanceolate, denticulate, dark green above, much paler beneath, coated with stellate hairs, sparingly above, densely beneath: corymbs loose, 10-20 fld.: fls. white, with spreading petals, valvate in the bud; filaments with large teeth. China. Var. purpuráscens, Franch. Three-4 ft. : Ivs. ovate, less stellate-hairy, 1-2 in. long : corymbs rather few-fld.: petals pinkish outside; calyx red, with large teeth. June. China. R.H. 1895:64. G.F. 7:287. G.C. III. $26: 45$.

Lemoinei, Hort. (D. grácilis $\times$ parvifldra). Fig. 696. Spreading shrub, to $3 \mathrm{ft}$.: lvs. elliptic-lanceolate, finely serrate with appressed teeth, with sparse stellate hairs above, nearly glabrous beneath, $1 \frac{1}{2}-3$ in. long: fls. in large corymbs or broad panicles, pure white; petals broadly ovate, spreading, partially valvate and partially imbricate in the bud; flaments with large teeth. G.F. 9:285. A.F. 11:457. Gt. 44, p. 567 and 46, p. 383. Gng. 4:135. J.H. III. $34: 77$. G.C. III. $18: 389$. Gn. 48, p. 317 . -A very desirable shrub, more vigorous and with showier fls. than $D$. gracilis. Excellent for forcing.

parviflora, Bunge. Shrub, to $6 \mathrm{ft}$., with erect branches : 1vs. ovate or oblong-ovate, finely serrate, with stellate hairs on both sides, often grayish green beneath, 2-3 in. long: fls. in many-fld. corymbs; petals roundish obovate, spreading, imbricate in the bud; longer filaments without teeth. June. N. China, Mongolia. G.F. 1:365. Gt. $11: 370 ; 43$, p. 65 and 46 , p. 382 . R.H. 1892 , p. 223 . G.C. III. $14: 153$.

D. angustifòlia, Dipp. $=$ D. Lemoinei. $-D$. Brunoniàna, R. Br. =D. staminea var. - D. corymbiflòra, Lem. Shrub, to $4 \mathrm{ft}$.: lvs. ovate-lanceolate, denticulate, pubescent beneath : corymbs many-fld.: petals spreading. June, July. China. R.H. 1897, p. 466 (as D. corymbosa) and 1898, p. 402. G.C. III. 24:267. A.F. 14:166. Ging. 7:2.-D. corymbòsa, R. Br. Allied to D. parviflora: green above, whitish beneath, with appressed stellate hairs : corymbs few-fld.; filaments toothed, half as long as
China. $-D$. Wátsoniand Wéllsi, Hort. $=\mathrm{D}$. scabra vars.

\section{DEVIL-IN-A-BUSH. Nigella.}

ALFRED REHDER.

DEWBERRY. The Dewberry is one of the most recent acquisitions among garden fruits. As a cultivated fruit, it is American, and the rarieties are forms of native species. It is distinguished from the blackberry chiefly by its low, trailing habit, its method of propagating by tips instead of suckers, and its few-flowered cymose clusters. Four distinct species are found in cultivation. (1) The northern Dewberry (Rubus villosus, Ait., until

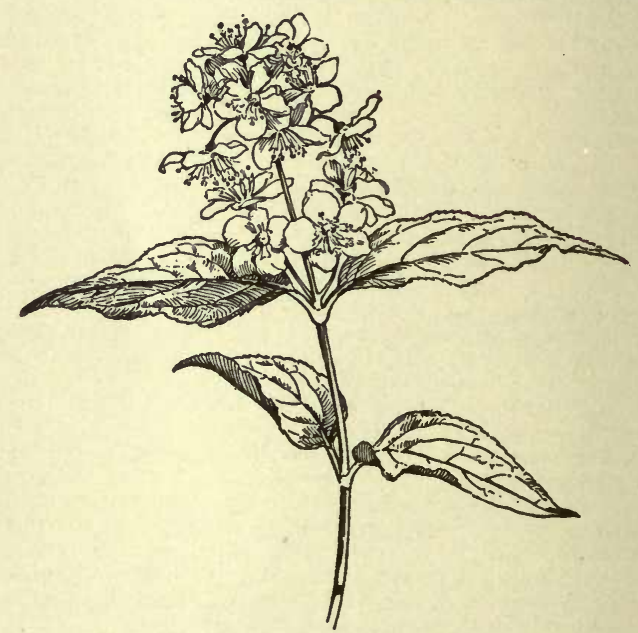

696. Deutzia Lemoinei $(\times 1 / 3)$.

lately known as $R$. Canadensis). In this species the leaflets are thin and deciduous, the stems sparsely and lightly prickly, and the flower-stalk slightly fuzzy but not glandular. A well marked sub-type has been set off from this species, comprising the Lucretia Dewberry 
(var. roribaccus, Bailey), which is a stronger plant, with wedge-ovate, jagged leaflets, long flower stalks, large flowers and leaf-like sepals. Figs. 697, 698. (2)

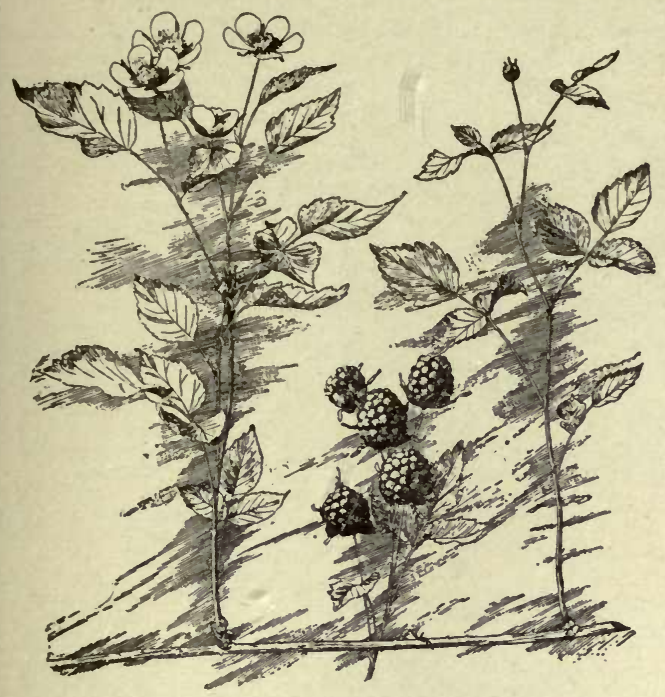

697. Lucretia Dewberry $\left(X^{1 / 4}\right)$.

The Bartel type ( $R$. invisus, Bailey), with stout, stiff stems, straight, reflexed prickles, large leaflets with simple teeth, and having the unopened buds surmounted by a tip formed by the sepals which clasp around it. (3) The southern Dewberry ( $R$.trivialis, Michx.). This has round, shrubby, trailing stems, bearing strongly recurved or reflexed prickles, glandular-tipped hairs and bristles. The leaves are evergreen, leathery and smooth, with numerous stout, recurved or reflexed prickles on the veins and petioles as well as on the flower-stems. It is represented in cultivation by the Manatee and a few others. (4) The western Dewberry (R. vitifolius, Cham. \& Schlecht.). This has round, woody stems, usually weak and trailing but sometimes upright, the fruiting branches numerous, armed with slender prickles, often rendering the smaller parts densely setose. It includes the Skagit Chief and others. Still another species, better known as the cut-leaved blackberry, has been long in eultivation, chiefly for ornament. Its stems are armed with strong, recurved prickles and its leaves are much parted and divided.

The culture of the Dewberry is much the same as that of the blackberry, except in the matter of training, thongh it is thought to thrive better on light and sandy soils than the blackberry. No summer pruning of the canes is needed, although the old canes may be removed as soon as done fruiting. Various methods of training are employed, the object of all being to keep the bearing canes off the ground, so that they will not interfere with cultivation and the fruit wil be kept clean. For this purpose the single stake and the wire trellis methods are best known. Tying the canes to stakes (Fig. 699) is perhaps the best method. The fruiting canes are tied to the stake or trellis in spring, being shortened to from 3 to 5 feet in length. The young canes are allowed to grow upon the ground at will, or at most are turned in the direction of the row if they interfere with cultivation. They remain in this position during winter, where they can be very conveniently protected, and take their place upon the trellis or stakes the following summer.

The Dewberries have proved successful and profitable with some and a failure with others. Different varieties should be planted together to insure proper fecundation of the blossoms. Their chief value lies in their season of ripening, which is in advance of the blackberries. Lueretia and Bartel are the most important varieties.

For history and botany, see Bailey, Evolution of Our
Native Fruits; for culture, see Card's Busb-Fruits, and Cornell Bulletins 34 and 117. Consult Blackberry, Loganberry and Rubus.

Fred W. Card.

DIACRIOM (through and point; the stems are surrounded by sheaths). Orchiddeece, tribe L'pidéndrece. Four tropical Amer. epiphytes, closely allied to Epidendrum, with which they have been included. Differs from that genus in the fact that the column and lip are not united. Fls. showy, in loose racemes: lvs. few, sheathing: pseuclobulbs slender. Culture of Epidendrum and Cattleya.

bicornùtum, Benth. (Epidéndrum bicornùtum, Hook.). Pseudlobulbs 1-2 ft. long, hollow, bearing dry sheaths: IFs. short and leathery: raceme slender, 3-12-fld.: the fls. white, with small crimson spots on the 3-lobed lip, fragrant. B.M. 3332 . G.C. III. 16:337. J.H. III. 33:29. -A hand some orchid, requiring high temperature.

D. bidentàtum, Hemsl. (Exidéndrum bidentàtum, Lindl.), of Mexico, has been listed in trade eatalogues, but it is practieally unknown to cult., and is probably not now in the Amer. trade.

L. H. B.

\section{DIAMOND FLOWER. See Ionopsidium.}

DIANELLA (diminutive of Diana). Lilidcea. Tender perennial fibrous-rooted plants, with hard, linear, sheathing, grass-like lvs., often 2-3 ft. long, large, loose panicles of blue fls, on delicate, pendent pedicels, and great numbers of pretty blue berries, which remain attractive for several weeks, and are the chief charm of the plant. There are about a dozen species of worldwide distribution. They perhaps suceed best in the open border of a cool greenhouse. Prop. by divisions, or by seeds sown in spring in mild heat. A few plants have lately been inported, but the species are not advertised. Latest monograph by J. G. Baker, in Journ. Linn. Soc. 14:574 (1875).

\section{A. Stems entirely wanting.}

B. Anthers 1 line long.

Tasmánica, Hook. Height 4-5 ft.: lvs. numerous, in a rosette, broadly ensiform, $2-4 \mathrm{ft}$. long, $3 / 4-1$ in. wide, margined with snall reddish brown spines, that cut the hand if the leaves are carelessly grasped : panicle very lax, surpassing the lvs. 1-2 ft., with as many as $60 \mathrm{fls}$.: fls. pale blue, nodding, $1 / 2-3 / 4$ in. across, segments finally refexed. Tasmania and Australia. B.M. 5551.

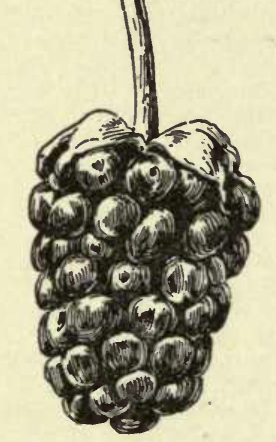
Natural size.
698. Lucretia Dewberry.

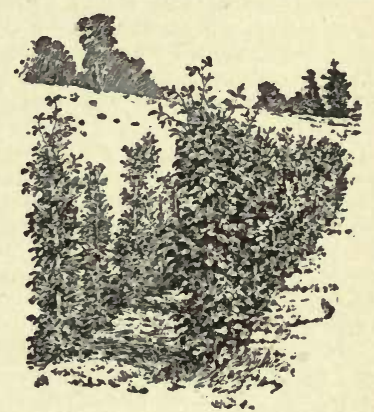

699. Training Dewberry to stakes.
BB. Anthers $1 \frac{1}{2}$ lines long.

o. Veins of the outer perianth-segments rather distant.

làvis, R. Br. Lvs. 1-11/2 ft. long, 6-9 lines wide, less leathery and paler than in $D$. corrulea and at first slightly glaucous: panicle deltoid, the branches more compound than in $D$. revoluta: outer segments of the perianth with 5 distant veins, inner ones densely 3-veined in the middle third. Eastern temperate parts of Australia. B.R. $9: 751$. L.B.C. $12: 1136$. 


\section{oc. Veins of the perianth-segments crowded into a central space.}

revolùta, R. Br. Height 2-3 ft.: lvs. in a rosette, 1$11 / 2 \mathrm{ft}$. long, 3-4 lines wide, dark green, purplish at the base and margin, not spiny at the margin: panicle branches short, ascending : fls. later than $D$. carulea. W. and E. Australia in temperate parts. Tasmania. B.R. 9:734 and 13:1120.

\section{AA. Stems present but short.}

cærùlea, Sims. Subshrubby, with a short stem in age, branching: lvs. about 6 , clustered at the ends of branches, 9-12 in. long, 6-9 lines wide, dark green, rough on the back and margin : outer perianth-segments with 5 distant veins, inner ones with 3 closer veins. Eastern temperate Australia. B.M. 505.

ensifolia, Red. Caulescent herb, 3-6 ft. high, the lvs. never in a rosette, numerous, hard, linear, 1-2 ft. long. 9-12 lines wide, lighter colored on the keel and margin: fls. blue or greenish white. Trop. Asia, China, Australia, Hawaiian Islands. B.M. 1404.

W. M.

DIÁNTHUS (Greek for Jove's flower). Caryophyllacece. Pink. About 200 species of Old World small herbs, many of them prized for their rich and showy flowers. Nearly all of them are perennials; they form tufts and have grass-like lvs., and jointed stems with terminal fls. and opposite lvs. From kindred genera Dianthus is distinguished by the sepal-like bracts at the base of a cylindrical calyx (cf. Figs. 366,367 ); petals without a crown; styles 2 . They are temperate-region plants. The flowers are usually pink or red, but in garden forms white and purple are frequent colors. Most of the cult. species are hardy in the north and are easy of culture. The perennial species are excellent border plants. The chief care required in their cultivation is to see that the grass does not run them out. Best results in flowering are obtained usually from 2year-old seedling plants. Two weedy species, $D$. prolifer, Linn., and $D$. Armeria, Linn., are naturalized in the eastern states. Monogr. by F. N. Williams, Journ. Linn. Soc. 29 (1891-3).

L. H. B.

Dianthus is essentially a Europeau genus, there being but one species found native on this continent (D.alpinus, found in high northern regions and in Europe), though others are escapes from gardens, such as $D$. deltoides and $D$. barbatus. Among the gems of the genus are various pretty little alpine tufterl sorts as $D$. neglectus, D. glacialis and D. alpinus, all of which are of dwarf, close habit, not exceeding 3 in. in height and having very iarge single flowers of brightest colors. These are suited only for rock gardening, as on level ground they often become smothered with weeds or swamped with soil after a heavy rain storm, and to these two causes are attributable the failures to cultivate them. Dianthuses like a warm soil, and one that will not become too wet at any time, especially in winter, where the perennial kinds are grown, as they are often killed not so much from cold as from too much ice round them. Snow is the best possible protection, but ice is the reverse.

All Dianthuses are readily propagated from seeds sown in rich soil, but the double kinds are reproduced from cuttings alone to be sure to have them true, and in the fall months cuttings are easily rooted if taken with a "heel" or a part of the old stem adhering to the base of the shoot; so that to make cuttings it is best to strip them off rather than to make them with a knife. It will be found also that, if cuttings made from plants growing in the open ground do not root readily but seem to dry up in the cutting bench, if the plants to be in creased are carefully lifted and potted, placed in a temperature of say $50^{\circ}$ until young growth shows signs of starting, every cutting taken off at this stage will root easily. The transition from outdoors to the propagating house should not be too abrupt. Another method of propagation is by layering, and with the garden Pinks, or forms of $D$. plumarius, it is the easiest and surest. After hot weather is past stir the soil round the parent plant, take the branches that have a portion of bare stem, make an incision half way through and along the stem for an inch, and peg this down in the soil without breaking the shoot off (Fig. 370). Roots will be formed and good strong plants be the result before winter. The layering method is specially suitable to $\mathrm{such}$ species as $D$. plumarius, $D$. Caryophyllus and double forms of others, such as Sweet William. E. O. ORPET.

Index: alpinus, 11 ; atrorubens, 2 ; barbatus, 5 ; capitatus, 3 ; Carthusianorum, 2; Caryophyllus, 8 ; Chinensis,

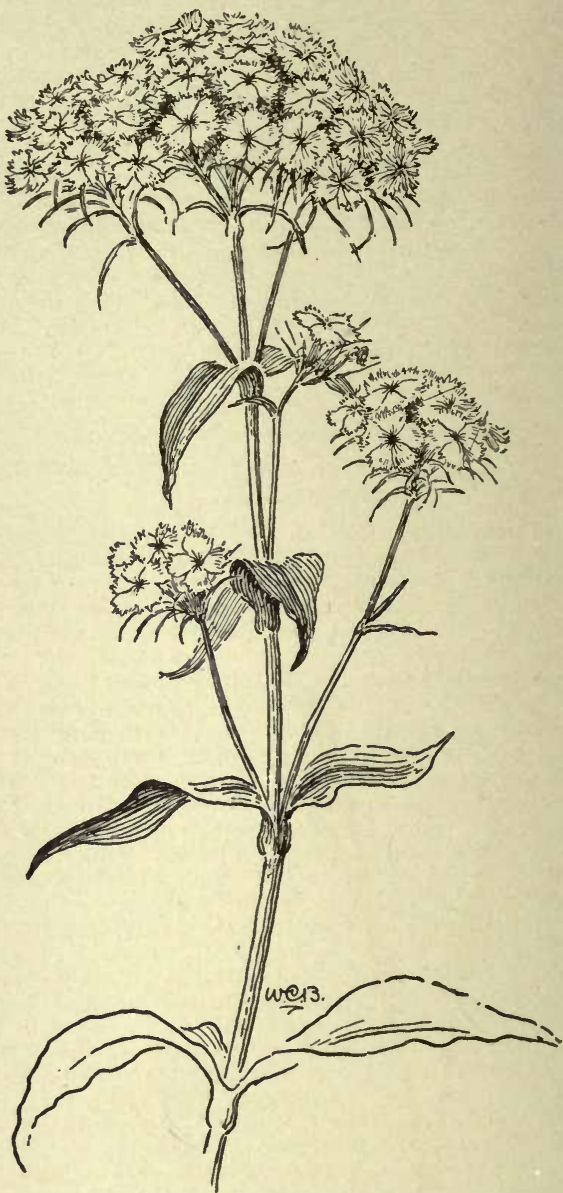

700. Sweet William-Dianthus barbatus $\left(\times \frac{1}{2}\right)$.

13: Cincinnatus, 13; cinnabarinus, 1 ; cruentus, 4 ; del toides, 10 ; dentosus, 13; diadematus, 13; glacialis, 12 ; Heddewigi, 13 ; hybridus, 13 ; imperialis, 13 ; laciniatus, 13; latifolius, 14 ; macrosepalus, 13 ; plumarius, 6 ; punctatus, 8 ; semperflorens, 13 ; Sinensis, 13; superbus, 7 ; sylvestris, 9; viscordalis, sub 14.

A. Flowers in dense cymes or in heads, the cluster often subtended by involucre-like lvs.

B. Petals not bearing hairs or barbs : bracts dry.

1. cinnabarinus, Sprun. A ft. high, woody at base, perennial, blooming in Aug. and Sept.: lvs. linear, sharp-pointed and rigid : petals fiery red above, paler beneath, glandular: stamens included. Greece.-Handsome little species; useful for hardy border or rockery.

BB. Petals with hairs or barbs on the lower part of the blade.

2. Carthusianorum, Linn. (D. atrórubens, Willd.). Hardy perennial or biennial, glabrous, scarcely glaucous, 12-18 in. high, the stem angled: lvs. short, linear and pointed, without prominent nerves when fresh : fls. in a dense, 6-20-fld, head, in shades of red, the petals sharply but not deeply toothed, the cluster subtended 
by very narrow or even awl-like lvs. Denmark to Portugal and Egypt. B.M. 1775, 2039. - Very variable. Little known in Amer. gardens.

3. capitatus, Balb. Much like the last: plant glaucous, conspicuously pubescent, taller: petals purple-spotted. Siberia, Servia.

4. cruéntus, Griseb. Cespitose, glaucous, glabrous : stem 1-2 ft., terete, forking: lvs. linear or lance-linear, sharp acuminate: fls. deep blood-red, small, numerous in a contracted cyme; petals red-hairy towards the base. July. Greece.

5. barbàtus, Linn. Sweet Willias. Fig. 700. Perennial, but readily grown from seed, and flowering well the second year, glabrous, the stems 4-angled, 10-18 in. high: lvs. broad and flut or conduplicate, 5-nerved: fls. several to many in a round-topperl, dense cyme, in many colors, the petals not hairy. Russia to China and S. to the Pyrenees. B.M.207.-The Sweet William is one of the oldest garden flowers. It is sure to be found in the old-fashioned gardens. The cult. forms run into many colors. Sometimes found along roarisides as an escape. There are double-fld. forms. R.H. 1894, p. 277.

$$
\text { AA. Flovers solitary, or in 2's or 3's. }
$$

B. Calyx-bracts short and broad, appressed.

$$
\text { c. Petals fimbriate. }
$$

6. plumàrius, Linn. Common Grass or GaRDEN PINK. Scotch Pink. Pheasant's Exe Pink. Low, tufty, $1 \mathrm{ft}$., blooming in spring and early summer, very fragrant: lvs. narrow and short, blue-glancous : fls. medium size, pink, purplish and white, MI $1 / 4)$ the blade of the petal fifth its depth; calyx cylindrical, with short, broadtopped mucronate bracts. Austria, Siberia. - A universal favorite. Hardy. Much used in old -fashioned gardens as edging for beds. There are doublefld. forms.

7. supérbus, Linn. Fig. 701. Taller, the stems forking, less tufted, later-fld., broader-lvd.; calyx longer: petals lilac, dissected below the middle. Norway to Japan and Spain. Variable. B.M. 297. - A handsome species, growing 16-24 in., fragrant. Perennial.

cc. Petals only dentate (except in some garden forms).

8. Caryophýllus, Liun. CARnation. Clove Pink. PicoTEE. Grenadine. Figs. 366-8, 370-5. Plate IV. Cespitose, glabrous, 1-3 ft, the stems bard or almost woody below, the nodes or joints conspicuous: Ivs. long-linear, very glaucous: fls. on long stems, particularly in American cult.; calyx - bracts very broad, abruptly pointed : Vars. solitary, large, very variuble in size, form and color, but originully pale lilac, fragrant. B.M. 39 (Bizarre Carnation) 1622 (var. imbricatus); 2744 (Picotees). - Generally supposed to be native to the Mediterranean region, but

Williams gives its geograph-
701. Dianthus superbus. (X1/2.) ical limits as "north and west Normandy" and "south and east Punjab" (northwestern Hindoostan). Long cultivated. In Europe it is largely grown as an outdoor Pink, but in this country it is chiefly known as the greenhouse Carnation. The American forcing type is distinguished by very long stems and a continuous blooming habit. Garden varieties of 1). Caryophyllus are numberless, and they often pass under Latinized names (D.punctatus, Hort., is one of these names). For studies in the history and evolution of the Carnation, see Bailey, Surviral of the Unlike, Fssay 28. See Carnation.

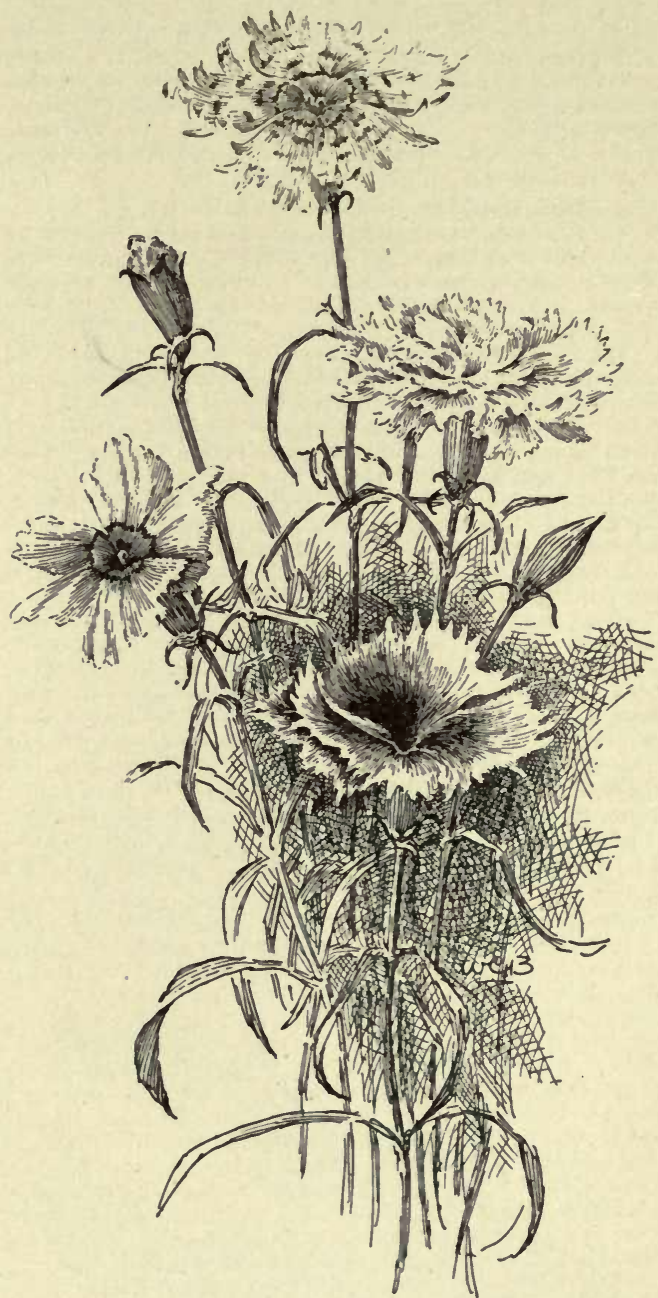

702. Dianthus Chinensis $(X 1 / 8)$.

9. sylvéstris, Wulf (D. virgineus, Hort.). Slender, $1 \mathrm{ft}$. high, the stem angular compressed and bearing $1-3$ odorless fls.: lvs. tufted, linear and sharp-pointed, scabrous on the margins : fls. rather small, red, the petals obovate and shallow-toothed. Eu. B.M. 1740.Pretty perennial border plant.

BB. Calyx-bracts half the length of the calyx, mostly narrow-pointed: lv's. short and spreading, the radical ones obtuse or nearly $s o$.

10. deltoldes, Linn. MaIden Pixk. Tufted, 6-10 in., blooming in spring and early summer, creeping: stems ascending, forking, with solitary fls. on the branchlets: stem lvs, an inch long, sliarp-pointed: fls. small (1/2-3/4 in. across), the petals toothed, deep red with a crimson eye, the petals bearing an inverted $V$-shaped pocket at their base (whence the name deltoides). Scotland to Norway and Japan.-One of the prettiest border Pinks, making neat mats of foliage and bearing profusely of the little bright fls. There is a white-fld. variety. 
11. alpinus, Linn. Very dwarf, the 1-fld. stems rarely reaching more than 3-4 in. high, more or less prostrate: foliage dark shining green: fl. 1 in. or more across, deep rose or purplish and crimson spotted, a darker ring around the eye. Russia to Greece and Swiss Alps. B.M. 1205 . Gn. $26: 455 ; 47$, p. $292 ; 45$, p. 53. - One of the choicest of alpine and rockwork plants.

BвB. Calyx-bracts leafy and spreading.

12. glacialis, Hænke. Three to $4 \mathrm{in}$. high, the stems tufted and usually 1-fld.: lvs. green, narrow-linear and pointed, somewhat serrulate: fls. small and odorless, red-purple; the petals toothed. Mts. of S. Eu. G.C. II. 21:809. - A pretty species, but difficult to establish. Grown among alpine plants.

13. Chinénsis, Linn. (D. Sinénsis, Hort.). Fig. 702. Perennial, cespitose, glabrous, more or less creeping at base: stem forking, angled and more or less grooved, pubescent: lvs. broad and nearly flat or slightly troughshaped, 3-5-nerved: fls. large, solitary or more or less clustered, pink or lilac; the petals (at least in the wild) barbed or hairy towards the base; calyx-bracts 4 , in some cult. vars. short. - China and Japan; but recent authorities consider a European Pink to be but a form of it, und thereby extend its range west to Portugal. The Amoor Pink ( $D$. dentosus, Fisch.) is a form known as var. macrosépalus, Franch.: it is a hardy border plant, $1 \mathrm{ft}$. high, with bright red fls. and a spot at base of each petal. $D$. semperflorens, Hort., is a hardy perennial form, 12-18 in., with silvery foliage and deep pink, redeyed, fragrant fls. $D$. Chinensis has given rise to a beautiful and variable race of garden Pinks, var. Héddewigi, Regel (D. Héddewigi, Hort.). 'These are" extensively grown from seeds, and are practically annuals, although plants may survive the winter and give a feeble bloom in the spring in mild climates. The flowers are scarcely odorous. They are single and double, of many vivid colors; and many of the garden forms have bizarre markings. In some forms, var. laciniatus, Regel (D. lacinidtus, Hort.), the petals are slashed and cut. D. imperialis, Hort., is a name applied to a strain with strong habit and rather tall growth, mostly double. C. diadematus, Hort., is another garden strain. D. Cincinnatus, Lem., is a red form with shredded petals. I.H. 11:388. D. hybridus, Hort., is

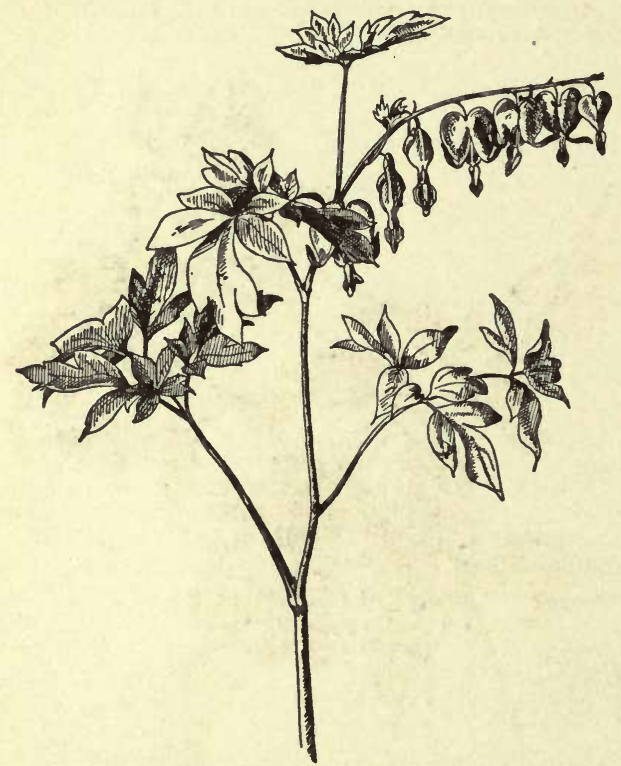

703. Dicentra spectabilis-Bleeding Heart $(X 1 / 4)$.

another set. This name (D. hybridus) is also applied to a dentosus-like form, which some regard as a hybrid of dentosus and some other species. For portraits of garden Pinks, see B.M. 5536; F.S. 11:1150; 12:1288-9;
13:1380-1. Gn. 49:1051. The garden Pinks are of easy culture. Seeds may be sown in the open where the plants are to stand, but better results are obtained, at least in the north, if plants are started in the house.

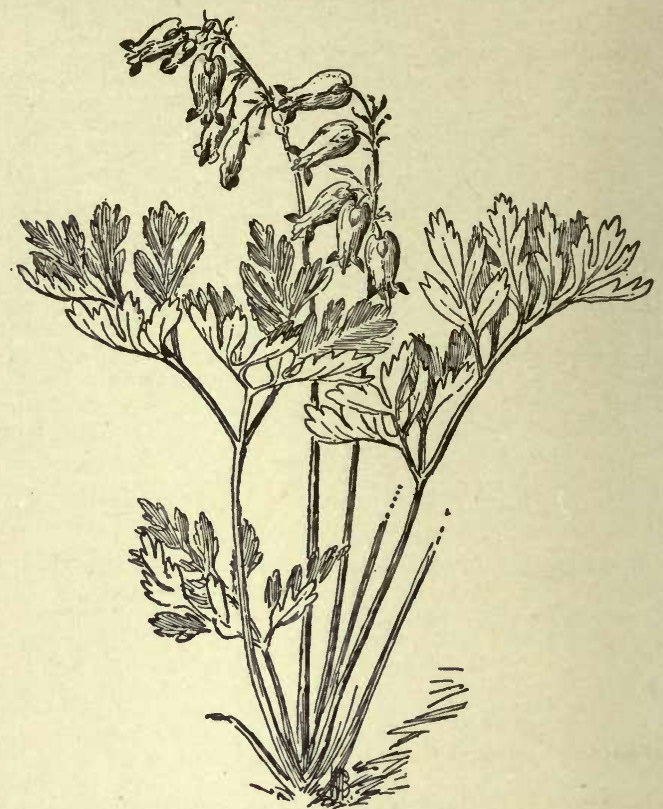

704. Dicentra formosa $(\times 1 / 3)$.

Plants bloom after the first fall frosts. They grow 10$16 \mathrm{in.} \mathrm{high,} \mathrm{and} \mathrm{should} \mathrm{be} \mathrm{planted} \mathrm{6-8} \mathrm{in.} \mathrm{apart.} \mathrm{They}$ are very valuable for borders and flower gardens.

14. latifolius, Hort. Perennial, 6-12 in. high, of doubtful origin, but in habit intermediate between $D$. Chinensis and $D$. barbatus. Fls. large, double, in close clusters or even heads: lvs. oblong-lanceolate. - A good border plant.

D. viscordalis is a name which once was advertised by Manning, but is not now in the trade. The seed was obtained from an English firm. It is probably a garden form of some old species.

L. H. B.

DICENTRA (Greek, dis, kentron, two-spurred, but originally misprinted Diclytra, and then supposed to be Dielytra). Fumaridcea. A genus of charming hardy perennial plants with much cut foliage, and rose, white or yellow fls. of interesting structure. The Squirrel Corn and Dutchman's Breeches are two of our daintiest native springtime flowers, and the Bleeding Heart is one of the choicest memories of old-fashioned gardens: it is also the most widely cultivated of all the plants of this delightful order. Though long known to herbaria, plants of Bleeding Heart were not introduced to western cultivation from Japan until the late forties. Robert Fortune saw it on the Island of Chusan, where he also got Diervilla rosea and the epoch-making "Chusan Daisy," the parent of pompon Chrysanthemums. The first live plants seen in England flowered in May, 1847. It rapidly spread into every garden in the land, and is now rich in home associations. It is an altogether lovely plant. There are about 15 species of Dicentra, mostly N. American. Sepals 2, scale-like : petals united into a 2 -spurred or heart-shaped nectariferous corolla: stamens diadelphous.

Dicentras are easily cultivated in borders and wild gardens. Two kinds can be readily secured from the woods in the E. Try to reproduce the natural conditions, especially the degree of shade, They like a rich, light soil. Prop. by dividing crowns or roots. It is a singular fact that the forcing of Bleeding Hearts, though practically unknown in America, is said to be commoner in England than outdoor culture. According to Nicholson, the forc- 
3-4 in. wide, with a short, sharp, rather abrupt point: stem unbranched, robust, spotted: raceme short, densely thyrsoid: sepals white or greeuish. Gt. 1868:593. F.S. 16:1711. - Its chief beauty is the mosaic appearance of the foliage, due to numberless short, transverse, whitish lines, which do not pass by the longitudinal veins of the leaf. The under side of the lvs. is a rich purplish color. Var. gigantè, Hort., is cult. abroad.

Var. undàta (D. undata, C. Koch \& Linden). Foliage without any mosaic appearance, the variegation being entirely longitudinal. Each parallel vein lies in the midldle of a long, whitish band extending the full length of the leaf. F.S. 17:1763. - Clarke refers D. undata to $D$. mosaica, but horticulturally they are very distinct.

Sièbertii, Hort. A little known plant with white midrib and margins.

D. acaùlis, Cogn. Stemless: lvs. in a rosette, almost sessile, narrowly oblong, wavy, acutish, short-cuneate at the base, sparsely pilose on both sides: panicles terminal, sessile, much shorter than the lvs. Braz. I.H. 41:19. Handsomely variegated with countless short, longitudinal lines. $-D$. angustifolia, Lind. \& Rod. Stem purple, spotted green: lvs, oblong-lanceolate, sessile, glabrous, roundish at the base, ucute, about 6 in. late, sessile, glabrous, roundish at the base, ucute, about 6 in. long, 2 in. wide at the middle, purple below, marked above with cophthálmos, Hook., differs from all here described in having radical inflorescence, its fls. lying flat on the ground. Lvs. e]liptic, acuminate, green on both sides: fls. blue, with a white eye; stamens 6. Braz. B.M. 4733.-D. oxypétala, Hook.. is instantly recognized by its acute petals, which are purple. Lvs. green on both sides. Braz. B.M. 2721.-D. picta, Lodd., has green on both sides. Braz. B.M. 2721.-D. picta, Lodd., has is told from all others here described by the irregular blotches is told from all others here described by the irregular blotches
of purple on the upper side of the lvs. The purple is the same color as that on the under surface. Braz.? B.M. 4760. L.B.C. $17: 1667,-D$. Saundersi, Hook., differs from all others here described in the extreme density of its head-like inflorescence. Lvs. green on both sides, lanceolate: sepals white, tinged blue. Braz. B.M. 6165 .

W. M.

DICHROA (Greek, dis, two, and chros, color). Includes Adamia. Saxifragdcece. This genus contains a rare greenhouse shrub in habit resembling a $\mathrm{Hy}$ drangea, with violet-blue fls, in a pyramidal panicle a foot across, and handsome blue berries, instead of the capsular fruit of Hydrangea. Lvs. persistent, alternate, stalked, widest at middle, tapering both ways, serrate: panicles terminal, many-fld.: fls. blue, lilac, or violet; petals 5 or 6 , valvate; styles $3-5$, club-shaped. The genus has only 2 species, the commoner and more variable one, $D$. febrifuga, which is glabrous, being found in the Himalayas, Malaya, and China, while D. pubescens is native to Malaya only.

febrifùga, Lour. (Addmia versícolor, Hort.). Later writers also include Addmia cydnea, Wall., which Lindley distinguished by its smaller lvs. and fls., 5 petals, and 10 stamens, while $A$. versicolor had 7 , or sometimes 6 petals, and 20 stamens. Plants are still cultivated abroad under the name of $A$. cyanea, but it cannot be stated here how distinct they are for horticultural purposes. A. versicolor, P.M. 16:322. A. cy. anea, B.M. 3046.

W. M.

DICKSONIA (named for James Dickson, an English botanist, 1738-1822). Cyathedcece. Tree ferns with a distinctly 2-valved inferior indusium, the outer valve formed by the apex of the leaf segment. A small genus, mostly of the southern hemisphere. For $D$. pilosiuscula, punctilobula and Smithii, see Dennstodtia.

Dicksonias are amongst the most important tree ferns, both for their beauty and because of their relative hardiness. In their native countries some of them are occasionally weighted with snow, and $D$, antarctica has to endure frosts. They can be grown in coolhouses, and should be tried southward outdoors in sheltered places. Their trunks are more fibrous than those of most tree ferns, and hence more retentive of moisture, so that they need less care. A good trunk produces $30-40$ fronds a vear, and retains them until the next set is matured, unless the trees suffer for moisture in winter. Although they rest in winter, the fronds soon shrivel up if the trunks are allowed to get too dry. Dicksonias should have their trunks thoroughly watered twice a day during the growing season. These waterings should be gradually decreased until winter, when the trunks should be kept merely moist all the time. Only in the hottest summer days is slight shade needed. It is a pity to grow tree ferns in pots, but if this must be done several principles should be observed. The lapse of a single day's watering will often cause serious damage. As a rule, the pots should be of the smallest size consistent with the size of the trunk. Three or four inches of soil all round the trunks is euough. The above points are taken from Schneider's Book of Choice Ferns, as tree ferns are little grown in America.

antárctica, Labill. Scales of the short leaf-stems dense, dark purplish brown: lvs. 5-6 ft. long, the central pinnæ 12-18 in. long: segments oblong, the sterile incised. Australia and Tasmania. G.C. III. 9:81. - Trunk sometimes $30-35 \mathrm{ft}$. high. A very useful decorative plant.

squarròsa, Swz. Scales of the short leaf-stem fibrillose, light colored: lvs. 3-4 ft. long, the pinnæ 9-15 in. long; segments lanceolate, the sterile toothed, the ribs scabrous. New Zealand and Chatham Island.

\section{M. UNDERWOOD and W. M.}

DICLYTRA. This ancient typographical error for Dielytra seems to be immortal. See Dicentra.

DICTÁMNOS (old Greek name, supposed to indicate foliage like the ash: hence Fraxinella, diminutive of the Latin Fraxinus, au ash). Rutdcece. Gas Plant. Burning Bush. Fraxinella. Dittany. This genus includes an old garden favorite which has a strong smell of lemon, and will sometimes give a flash of light on sultry summer evenings when a lighted match is held near the flowers. It is also one of the most permanent and beautiful features of the hardy herbaceous border. Instances are known in which it has outlived father, son and graudson in the same spot. The genus has only 2 species, and is distinguished from allied genera (none of which have garden value) by the 5 unequal petals,

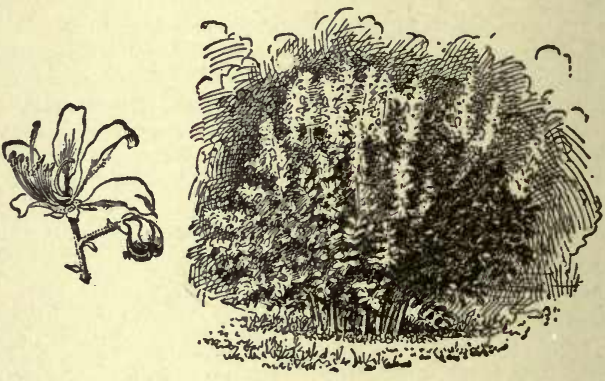

707. The Gas Plant-Dictamnus albus.

10 declined stamens, and short stipe, on which the ovary is raised.

The Gas Plant makes a sturdy, bold, upright growth, and a clump 3 feet high and as much in thickness makes a brave sight when in flower. A strong, rather heavy soil, moderately rich, is best for these plants. They are not fastidious as to situation, succeeding as well in partial shade as when fully exposed to the sun, and drought will not effect them when once fairly established. Old, strong clumps are good subjects as isolated specimens on a lawn, and a large patch, planted in the border, is not only effective while in full flower, but the dark, persistent foliage is ornamental throughout the season. It is not advisable to disturb the plants very often, as they improve with age, producing taller flower-stems and more of them as they grow older. They are excellent for cutting, especially the white variety. Prop. with difficulty by division, but easily by seeds, which are sown in the open ground in fall as soon as ripe, and covered an inch or so. They will germinate the next spring, and, when two years old, the seedlings may be removed to their permanent positions, where they will flower the following year. 
álbus, Linn. (D. Fraxinélla, Pers.). Fig. 707. A vig. orous, symmetrical, hardy herb, with glossy, leathery foliage surmounted by long, showy terminal racemes of good-sized, fragrant fls. Lrs. alternate, odd-pinuate; lfts. ovate, serrulate, dotted with oil glands: fls. white. En., N. Asia. Gn. 35:701. A.F. 5: 328. Gng. 5: 321. Var. rubra, Hort., has rosy purple fls., the reins deeper colored. Var. gigantéus, Hort. (D. giganteus, Hort.), was recently introduced. J. B. KELLER and W. M.

DICTYOGRÁMMA (Greek, netted lines). Polypodidcece. A genus of a few Japanese and Pacific Island ferns, with naked sori, which follow the course of the reticulated veins. The species are sometimes referred to Gymnogramma. Strong-growing indoor fern, useful for specimen plants.

Japónica, Fée. Lvs. simply pinnate or bipinnate at the base, $1 \frac{1}{2}-2 \mathrm{ft}$. high, the piunæ $6-12 \mathrm{in}$. long and an inch wide; sori extending from the midrib to the edge. Japan and Formosa. Also known as Gymnogramma Japonica. An interesting fern of rather strong growth, and very distinct in appearance. Grows best in a moderate temperature - for example, $55-60^{\circ}$ - and requires an open and well-drained scil of peaty character.

$$
\text { L. M. UNDERWOOD and W. H. TAPLIN. }
$$

DICTYOSPÉRMA (Greek, netted seed). Palmdcea, tribe A rècea. This genus of Areca-like palms contains a few species of considerable commercial importauce, the young plants being used chiefly for house and table decoration. Slender spineless palms, with a ringed trunk: Ivs. equally pinnatisect; segments linear-lanceolate, acuminate or bifid, the apical ones confluent; margins thickened, recurved at the base; midrib and nerres prominent, sparsely clothed with persistent scales beneath, or naked; rachis and petiole slender, scaly, 3-sided, furrowed, sheath elongaterl, entire: spadix on a short glabrous or tomentose peduncle, the branches erect or spreading and flexuose, the lower ones with membranaceous bracts at the base: spathes 2 , complete, dorsally compressed, papery, the lower one 2-crested; flower-bearing areas much depressed: bracts and bractlets scaly: pistillate fls. rather large, white or vellowish: fr. scaly, small, olive-shaped or subglobose. Species 2 or 3. Indian Archipelago.

JARED G. SMith.

Dictyosperma is a genus of medium-sized palms of slender habit, and having pinnute leaves. At least two species of Dictyosperma (rubra and alba) have been included among commercial palms for some years past, though not grown in such quantities as the popular Kentias, Arecas and Latanias. D. aurea is also occasionally seen in commercial collections.

The cultivation of these palms does not present any great difficulties, similar conditions to those required by Chrysalidocarpus lutescens answering well. These conditions may be briefly summarized as follows: A soil consisting of well rotted sod, to which bas been added about one-sixth, in bulk, of good stable manure, firm potting, and an abuudance of water both at the root and overhead, a night temperature during the winter of 60 to $65^{\circ} \mathrm{F}$., and moderate shade on the glass from March 1 to November 1. This treatment applies especially to young stock, and may be modified somewhat with old and well established specimens, the latter enduring a slightly lower temperature without injury, providing they are not overwatered. Dictyospermas are rather susceptible to the attacks of some insects, notably red spider and various scale insects, and, if allowed to become very dry, are liable to lose their lower leaves, the most satisfactory species being $D$. rubra. Projagation by seeds, which germinate in 6 to 8 weeks, when sown in a warm greenhouse.

W. H. TAPLIN.

álba, Wendl. \& Drude (A rèca álba, Bory. Ptychospérma álba, Scheff.). Distinguished by the whitish petioles and the whitish green veins of the lvs. Caudex 40-50 ft. high, 8-9 in. in diam., dilated at the base: lrs. 8-12 ft. long; petiole 6-18 in. long, grooved down the face; segments $2 \frac{1}{2}-3$ ft. long, $2-3$ in. wide, 7 -nerved; veins and margins green or reddish: branches of the spadix $6-18$ in. long, erect or slightly reflexed, zigzag when young. aùrea, Wendl. \& Drude (Arèca aùrea. Hort.). Dis. tinguished by the yellow or orange petioles and veins of young plants. Caudex about $30 \mathrm{ft}$. high, smaller and more slender than the preceding: $1 \mathrm{vs} .4-8 \mathrm{ft}$. long; vetiole 8 in. long; segments $1 \frac{1}{2}-2 \mathrm{ft}$. long, 1 in. wide; secondary reins scarcely visible: branches of the spadix rigidly erect, 9-11 in. long.

furfuràcea, Wendl. \& Drude (Avèca furfurd̀cea, Hort.). Like D. rubra, but the petiole and leaf-sheath of the young plant tomentose.

rùbra, Wendl. \& Drude (A rèca rùbra, Hort.). Re. sembling $D$, alba, but the Irs. of the young plants darker green, the primary veins and margins dark red, the redness disappearing very much in adult plants: branches of the spadix longer and more reflexed.

JARED G. SMITH.

DICYRTA is a gesneraceous genus closely allied to Achimenes, but with smaller fls, and different anthers. It has 2 species, both from Guatemala. D. candida is cult. abroad as Achimenes candida.

\section{DIDIscus. See Trachymene.}

DIDYMOCHLENA (Greek, twin cloak; alluding to the indusium). Polypodidcexe. A small genus of greenhouse ferns of rather coarse foliage. Indusium elliptical, emarginate at the base, attached along a central vein, free all round the margin.

lunulata, Dess. (D. trunculata, Hort.). Lvs. clustered from an erect caudex, bipinnate, 3-6 ft. long ; pinnules almost quadrangular $3 / 4-1$ in. broad, entire or slightly sinuate, each bearing $2-6$ sori. Cuba to Brazil; the same or an allied species in Madagascar and Malaya. $-D . l u$. nulata is a very attractive fern while in a small state, but its articulated pinnules are a drawback as a com mercial species, rendering it of little value for house decoration.

L. M. UNDERWOOD and W. H. TAPLIN.

The following points are condensed from Schneider's admirable work, The Book of Choice Ferns: D. lunulata is one of the most distinct ferns in cultivation. It looks like a tree maidenhair, but the stems, instead of being black and slender, are thick and fleshy and the leaves are fleshier than any Adiantum. In cult. the trunk is only a few inches high, but the fronds are 4-6 ft. long and densely covered with long, brown, chaffy scales. The metallic color of its young fronds is a fine feature. This is a warmhouse fern, and may be used for subtropical bedding. It has a bad trick of dropping its pinnules if allowed to get too dry at the root, but soon rallies under liberal treatment.

DIDYMOSPERMA (Greek, double-seeded). Palmacece, tribe $A$ rècea. Low or erect palms with slender trunks. Leaves terminal, unequally pinnatisect, silvery-scaly below ; segments opposite, alternate, solitary, or the lower ones in groups, cuneate at the base; obovate-oblong or oblanceolate, sinuate-lobed and erose, the terminal one cuneate; margins recurved at the base; midnerve distinct, nerves flabellate; sheath short, fibrous: spadices with a short, thick peduncle and thick branches: spathes numerous, sheathing the spadix: fls. rather large: fr, ovoid or oblong. Species 6. India and Malay Archipelago.

porphyrocárpon, Wendl. \& Drude (Wallichia porphyrocárpa, Mart.). Stems reedy, 3-6 ft.: lvs. 5-8 ft. long; leaflets 9-15 in. long, distant, narrowly oblong, long cuneate, blunt, or sinuately 2-3-lobed, truncate, denticulate, glaucous beneath. Java.

Didymosperma is a genus of East Indian palms of moderate growth, containing possibly 8 species, most of which are stemless or else forming but a short trunk, the pinnate leaves rising from a mass of coarse brownish fibers that surround the base of the plant. The leaflets are of irregular shape, bearing some resemblance to those of Carrota, and the plants frequently throw up suckers from the base. The members of this genus are not very common in cultivation. The species that is most frequently seen is the plant known to the trade as D. caryotoides, an attractive warmhouse palm that has also appeared under the synonym Harinu caryotoides, 
and has lately been referred to Wallichia, which see. While young, at least, the Didymospermas enjoy a warm house and moist atmosphere with shading from full sunshine, though we are told that one species, $D$. oblongifolia (or Wallichia), is frequently found in Sikkim at an elevation of 3,000 feet above the sea. Prop. usually by seeds; occasionally by suckers, which are kept rather close for a time after their removal from the parent plant.

JARED G. SMith and W. H. TAPLIN.

DIEFFENBACCHA (Dieffenbach, a German botanist). $A$ roidece. Low, shrubby perennials: stems rather thick, inclined or creeping at the base, then erect, with a leafy top: petioles half cylindrical, sheathed to above the middle, long, cylindrical at the apex; blade oblong, with a thick midrib at the base; veins very numerous, the first and second parallel, ascending, curving upwards at their ends: peduncle shorter than the lvs. Differs from Aglaonema in floral characters. Central and South America. Perhaps a dozen species. Engler (in DC. Monogr. Phaner. vol.2) recognizes 6 species, wilh many varieties. Dieffenbachias are popular hothouse plants, being grown for their handsome and striking foliage.

For Dieffenbachias, similar rooting material to that mentioned for Anthuriums, combined with a high and moist atmosphere, will produce a very healthy and luxuriant growth of foliage, especially after the plants have made their first few leaves in ordinary light potting soil. Unless it be the very large-leaved kinds, like triumphans, nobilis and Baumanni, three or four plants may be placed together in large pots, keeping the balls near the surface in potting. Jenmani, Shuttleworthiana, Leopoldii and eburnea are all well suited for massing together in large pots. When above a certain height, varying in different species, the plants come to have fewer leaves, and those that remain are small; they should then be topped, retaining a considerable piece of the stem, and placed in the sand bed, where they will throw out thick roots in a week or two. The remaining part of the stems should then be cut up into pieces 2 or 3 inches long, dried for a day or so, and then put into boxes of sand, where, if kept warm

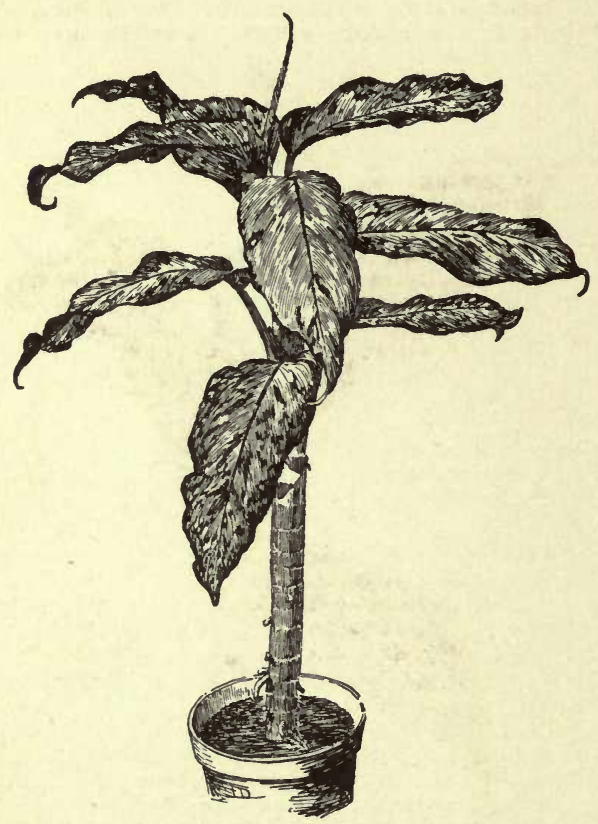

708. Dieffenbachia picta, var. Bausei.

and only slightly moist, every piece will send out a shoot, and from the base of this shoot roots will be produced. These can be potted up as soon as roots have formed. pícta, Schott. Blade oblong, or oblong-elliptical, or oblong-lanceolate, $2 \frac{1}{2}-4$ times longer than wide, rounded or acute at the base, gradually narrowing to the long acuminate-cuspidate apex, green, with numerous irregular oblong or linear spots between the veins; veins 15-20 on each side, ascending. L.B.C. $7: 608$.

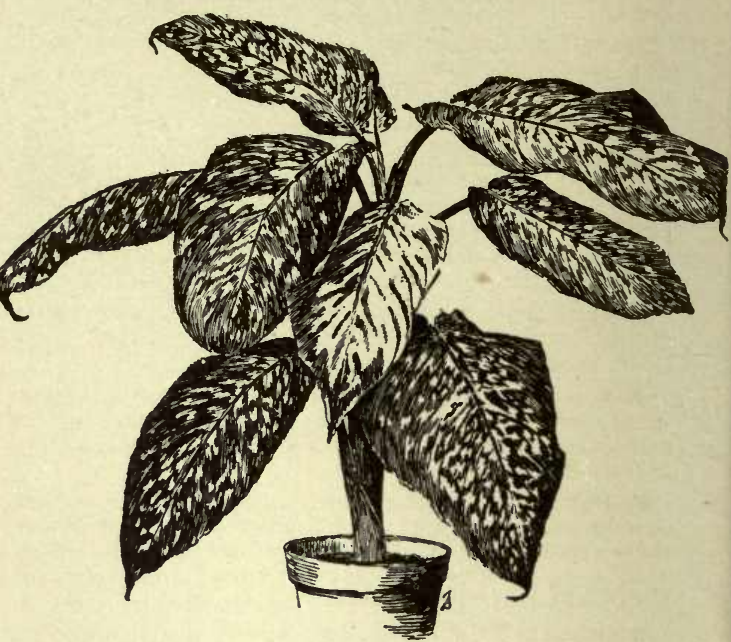

709. Dieffenbachia Seguine, var. nobilis.

Var. Baùsei, Engl. (D. Baùsei, Regel). Fig.708. Blade nearly or completely yellowish green, with obscurely green-spotted margins and scattered white spots. I.H. $26: 338$.

Var. Shuttleworthiàna, Engl. (D. Shuttleworthidna, Bull). Blade pale green along the midrib.

Seguine, Schott. Lvs. green, with white, more or less confluent stripes and spots, ohlong or ovate oblong, rounded or slightly cordate or subacute at the base, narrowed toward the apex, short cuspidate; primary veins 9-15, the lower spreading, the upper remote and ascending. Lowe 14 (as var. maculata). W. Indies.Called "Dumb Plant" because those who chew it sometimes lose the power of speech for several days.

Var. Barraquiniàna, Engl. (D. Barraquinidna,Versch. \& Lem. C. gigantèa, Versch.). Petioles and midribs almost entirely white; blade with scattered white spots. I.H. $11: 387 ; 13: 470,471$.

Var. nobilis, Engl. (D. nobile, Hort. ). Fig. 709. Blade elliptical, acute, dull green with dirty green spots. Brazil.

Var. lituràta, Engl. (D. Lèopoldii, Bull. D. Wallisi, Lind.). Blade dark green, with a rather broad, yellowish green, ragged-margined stripe along the midrib; spathe glaucous. I.H. 17:11. S.H. 1, p. 455.

Var. irroràta, Engl. (D. irrorata, Schott. D. Bà̀manni, Hort.). Isvs. large and bright green, blotched and sprinkled with white. Brazil.

The above are the recognized type species. The following are in the Amer. trade. Probably some or all of them belong to the foregoing species:

Chélsoni, Bull. Lvs. deep, satiny green, the middle gray-feathered, and the blade also blotched yellow-green. Colombia.

Córsii, Hort. See D. Parlatorei.

ebúrnea, Hort. Compact : lvs. light green, freely spotted with white, the stems reddish and white-ribbed. Brazil.

illústris, Hort. See D. late-maculata.

imperator, Hort. Lrs. 16-18 in. in length, 5-6 in. wide, olive-green, fantastically blotched, marbled and spotted with pale yellow and white. Colombia.

insignis, Hort. Lvs. dark green, with irregular, angular blotches of pale yellowish green, 6 or more in. wide. Colombia. 
late-maculàta, Lind. \& André (D, illuistris, Hort.). Lvs. glaucous-green, profusely white-barred and whitespotted. Brazil. I.H. 23:234.

Jénmani, Veitch. Lvs. rich, bright, glossy green, relieved by a milk-white band at every lateral nerve, and by a few white spots interspersed between the bands. Guiana.

magnifica, Lind. \& Rod. Lvs. ovate-acuminate, large, dark green, blotched and spotted with white along the veins. Venezuela. I.H. $30: 482$. S.H. 2, p. 383 .

marmòrea, Hort. See Parlatorei.

Parlatòrei, Lind. \& André, var. marmòrea, André (D. memoria and mormora and Corsii, Hort.). Los. long-oblong, acuminate, the midrib white and the blades blotched white, the green deep and lustrous. Colombia. I.H. 24:291. - Engler refers this plant to the genus Philodendron. *

Regina, Bull. Lvs. oblong-elliptical, greenish white, mottled and blotched with alternate light and green tints. S. Amer.

Réx, Hort. Compact: Irs, oblong-lanceolate, the two sides not equal, deep green, but the white angular blotehes and midrib occripying more space than the green. S. Amer.

spléndens, Bull. Stem faintly mottled with dark and light green: Ivs. have a thick ivory white midrib, and the ground color is of a deep, rich, velvety bottle green, with a resplendent, lustrous surface, freely marked with whitish striate blotches. Colombia.

triúmphans, Bull. Lvs. dark green, ovate-lanceolate and acuminate, a ft. long, irregularly marked with angular yellowish blotches. Colombia.

JARED G. SMITH and G. W. Oliver.

\section{DIELYTRA. See Dicentra.}

DIERVILLA (after Dierville, a French surgeon, who took D. Lonicera to Europe early in the eighteenth century). Caprifolidcece. WeIGela. Shrubs of spreading habit, with more or less arching branches, and, especially the Asiatic species, with very showy fls. from pure white to dark crimson, appearing late in spring. Lvs. opposite, petioled, serrate : fls. in 1 to several-fld. axillary cymes, often panicled at the end of the branches, yellowish white, pink or crimson, epigynous ; calyx 5 parted; corolla tubular or campanulate, 5 -lobed, sometimes slightly 2-lipped; stamens 5 : fr. a slender, 2 celled capsule, with numerous minute seeds. About 10 species in $\mathrm{E}$. Asia and $\mathrm{N}$. Amer. They thrive in any common humid garden soil, the Amer. species preferring moist and partly shaded positions. The Asiatic species require protection north during the winter, or sheltered positions. Prop. readily by greenwood cuttings or hardwood cuttings; the Amer. species usually by suckers and by seeds sown in spring.

Index of species (some of the names in italies were described under Weigela): amabilis, 3 ; arborea, 4 ; urborescens, 6; Canadensis, 1; Coraeensis, 4; floribunda, 6 ; florida, 3 ; grandiflora, 4 ; Groenewegeni, 7 ; hortensis. 5; hybrida, 7; Japonica, 5; Lonicera, 1; Mid. dendorflana, 8 ; multiflora, 6 ; rosea, 3 ; sessilifolia, 2 ; Steltzneri, 7; trifida, 1; Van Houttei, 7 .

A. Fls. yellow, slightly 2-lipped, small, 1/2-3/4 in. long. I iervilla proper.

1. Lonicèra, Mill. (D. trifida, Mœnch. D. Canadénsis, Willd.). Shrub, to $3 \mathrm{ft}$ : : branchlets nearly terete, glabrous: lvs. distinctly petioled, ovate-oblong, acuminate, serrate, nearly glabrous, finely ciliate, $3-4$ in. long: cymes usually 3 -fld.; limb nearly equal to the tube. June, July. Newfoundland to Saskatschewan, south to Ky. and N. C. B.M. 1796. D. 44.

2. sessilifdlia, Buckl. Shrub, to $5 \mathrm{ft}$.: branchlets quadrangular : lvs. nearly sessile, ovate-lanceolate, serrate, nearly glabrous, of firmer texture, $3-6$ in. long: cymes 3-7-fld., often crowded into dense, terminal panicles: limb shorter than the tube. June, July. Carol. and Tenn. G.C. III. 22:14. - Hardy in Canada.
AA. Fls. showy, white, pink or crimson, rarely yellowish.

B. Anthers not connected with each other. (Weigela.) C. Calyx lobes lanceolate, connate at the base, often to the middle: stigma a-lobed: seeds wingless.

3. florida, Sieb. \& Zucc. (Weigèla ròsea, Lindl. W. amábilis, Hort.). Shrub, to $6 \mathrm{ft}$ : : branchlets with 2 hairy stripes : lvs. short-petioled, elliptic or ovate-oblong, serrate, glabrous above except at the midrib, tomentose on the veins beneath: calyx nearly glabrous: ovary slightly hairy: fls. $1-3$, pale or deep rose, $1 \frac{1 / 4}{\mathrm{in}}$. long; corolla broadly funnel-shaped, abruptly narrowed below the middle. May, June. N. China. B.M. 4396. F.S.3:211. B.H. 1:577. -This is one of the most cultivated species, very free-flowering and rather hardy. Var. álba. Fls. white, changing to light pink. R.H. $1861: 331$. Var. cándida. Fls. pure white. Var. Isoline. Fls. white or slightly pink outside, with yellowish spot in throat. F.S. 14:1445. Var. Kosteriàna variegàta. Dwarf: lvs. bordered yellow : fls. deep rose. Var. sieboldi alba-marginata. Lvs. bordered white: fls. rose. Var. nàna variegata. Dwarf. Lvs. variegated with white: fls. nearly white.

cc. Calyx lobes linear, divided to the base: seeds winged: stigma capitate.

D. Plant nearly glabrous.

4. grandiflora, Sieb. \& Zucc. (D. Coraeénsis, DC. D. amábilis, Carr.). Shrub, 5-10 ft.: lvs, rather large, obovate or elliptic, abruptly acuminate, crenately serrate, sparingly hairy on the veins beneath and on the petioles : fls. in 1-3-fld., peduncled cymes; corolla broadly funnel form, abruptly narrowed below the middle, changing from whitish or pale pink to carmine. May, June. Jap. S.Z. 31. F.S. 8:855. -Vigorously growing shrub, with large lvs. and fls., but less free-flowering, and the type not common in cultivation. Var. arborea, Hort. ( $W$. arbdrea grandifldra, Hort.). Fls. yellowish white, changing to pale rose; of vigorous. growth.

DD. Plant more or less pubescent : corolla finely pubescent outside.

5. Japónica, DC. Shrub, to $6 \mathrm{ft}$.: Ivs. oblong-obovate. or elliptic, acuminate-serrate, sparingly pubescent.

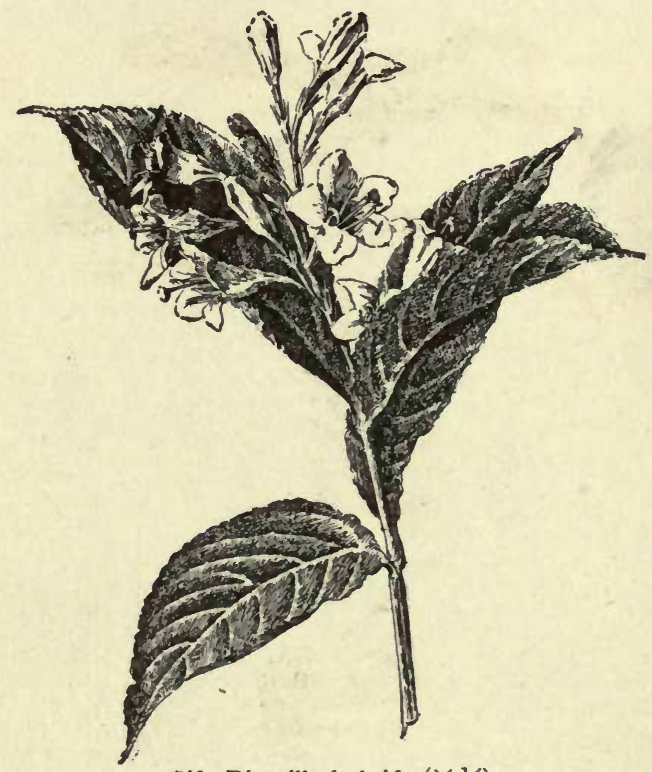

710. Diervilla hybrida $(\times 1 / 8)$.

above, tomentose beneath: fls. usually in 3-fld., sheripeduncled cymes, often crowded at the end of short branchlets; corolla broadly funnel form, narrowed below the middle, whitish at first, changing to carmine; style 
somewhat exserted. May, June. Jap., China. G.F. 9:405. - Var. horténsis, Rehder (D. horténsis, Sieb. \& Zuce.). Lvs. nearly glabrous above, densely grayish tomentose beneath: cymes usually rather long-peduncled: fls. white or carmine. S.Z.29, 30. More tender and slower-growing than the type. Offsprings of this variety are the following: Var. gratissima. Fls. light pink. Var. nívea. Pure white fls. Var. Looymánsi aurea, with yellow lvs.: of slow growth.

6. floribúnda, Sieb. \& Zucc. (D. multifldra, Lemaire). Shrub, to $8 \mathrm{ft}$.: lvs. oblong-ovate or elliptic, acuminate, serrate, sparingly pubescent above, more densely beneath: fls. 1-3, usually sessile, mostly crowded at the end of short branchlets; corolla rather gradually narrowing toward the base, brownish crimson in the bud, changing to dark or bright crimson; lobes about 5 times shorter than the tube; style exserted. May, June. Jap. S.Z. 32. I.H. 10:383. - Vigorously growing shrub, with rather small but abundant fls. Var. grandiflora, Hort. ( $W$. arboréscens, Hort.). Fls. rather large, brownish crimson. Var. Lavállei, Hort. Fls. bright, deep crimson, smaller. Var. Lowei, Hort. Fls. dull, purplish crimson, small. Var, versic61or, Rehder (D. versícolor Sieb. \& Zucc.). Fls. greenish white at first, changing to crimson. S.Z. 33 .

7. hybrida, Hort (Fig. 710), may be used as a collective name for the different hybrids between $D$. florida, floribunda, Japonica and grandiflora, which are now more commonly cultivated than the typical species. Some of the best and most distinct are the following: $A$. Carrière, rose-carmine, changing to red, with yellow spot in throat; Congo, of vigorous growth, with abundant large, purplish crimson fls.; Conquete, very large, deep pink fls. - the largest fls. of all varieties; Desboisi, fls. deep rose, abundant; $\boldsymbol{E}$. André, fls. very dark, brownish purple; Eva Rathke, fls. deep carmine-red, erect, very free-flowering, R.B. 19:126; Groenewegeni, fls. red outside, whitish within, somewhat striped with yellowish red; Gustav Mallet, fls. light pink, bordered white; Mad. Coutourier, yellowish white, changing to pink; Mad. Lemoine, white, with delicate blush, changing to pink: Mad. Tellier, large white fls., with delicate blush; Othello, fls. carmine, brownish outside; $P$. Duchartre, fls. deep amaranth, very dark, free Pécheur fils, fls. violet-red, abundant; Van Houttei, fls. carmine, F.S. 14:1447; Steltzneri, fls. dark red, abundant.

BB. Anthers connected with each other. (Calyptrostigma.)

8. Middendorffiàna, Carr. Shrub, to $3 \mathrm{ft}$.: lvs. shortpetioled, ovate-oblong or oblong-lanceolate, serrate glabrous at length: fls. in 2-3-fld. axillary and terminal clusters; corolla campanulate, funnel form, yellowish white, spotted orange or purplish inside; calyx-teeth partially connate. May, June. E. Siber., N. China, Jap. Gt. $6: 183$. R.H. $1854: 261$. F.S. $11: 1137$. I.H. $4: 115$ G.C. III. $7: 581$.

D. arborea, Hort $=\mathrm{D}$, floribunda $-D$, paucifldra, Carr. D. florida. $-D$. proecox, Lemoine. Allied to D. florida. Fls. large, pink, with yellow in throat; early and free-flowering. Jap. Gt. 46:1441.-D. rivulàris, Gattinger. Allied to D. sessilifolia. Lvs. and branchlets pubescent: fls. in large, terminal panicles. Georgia.

Alfred ReHDER.

\section{DIÈTES. See Morcea}

DIGITALIS (Latin, digitus, a finger; referring to the shape of the flowers). Scrophularidcece. FoxGLOVE. A fine genus, numbering several species and some hybrids of hardy or half-hardy herbaceous plants, famous for their long racemes of inflated flowers, which suggest spires or towers of bells. They are old-fashioned and dignified, elean of growth and wholesome company in the choicest garden. The strong, vertical lines of their flower-stalks, rising from rich and luxuriant masses of cauline leaves, give always an appearance of strength to the rambling outlines of the usual herbaceous border. The genus is a very distinct one, its nearest ally being Isoplexis, which contains a few greenhouse plants rarely cultivated. About 18 species, natives of Europe and middle and western Asia. The flowers are companulate or ventricose, 4-5-lobed; calyx 5-parted: seed pod ovate, 2-valved; seeds numerous. For a week or two the Fox- gloves usually dominate the whole border. The commonest species in cultivation is $D$. purpurea, which is one of the commonest English wild flowers. The name "Foxglove" is so inappropriate that much ingenious speculation has been aroused, but its origin is lost in antiquity. The word "fox" is often said to be a corruption of "folk," meaning the "little folk" or fairies. Unfortunately, etymologists discredit this pretty suggestion. In the drug stores, several preparations of $D$. purpurea are sold. They are diuretic, sedative, narcotic. For medicinal purposes, the leaves of the second year's growth are used.

Foxgloves are of the easiest culture. The common species and hybrids can be grown as biennials from seed. The perennial species are propagated by seeds or by division. J. B. Keller says: "A light, well enriched soil, not too dry, suits them admirably. They succeed in partial shade or in open places."

A. Middle lobe of the lower lip longer than the others.

$$
\text { B. F'ls. rusty red. }
$$

ferrugínea, Linn. (D. aùrea, Lindl.). Biennial, 4-6 ft. high : stems densely leafy : lvs. glabrous or ciliate : racemes long, dense: fls, rusty yellow, reticulate. marked, downy outside ; lower lip of corolla ovate, entire, bearded. July: S. Eu. B.M. 1828.

BB. Fls. gray or creamy yellow.

landta, Ehrh. Perennial, 2-3 ft. high : lvs. oblong, ciliate: fls. rather small, $1-1 \frac{1}{2}$ in. long, grayish or creamy yellow, sometimes whitish or purplish, downy, in a dense, many-fld. raceme, with bracts shorter than the fls. July, Aug. Danube river and Greece. B.M. 1159 (poor figure).-A fine species.

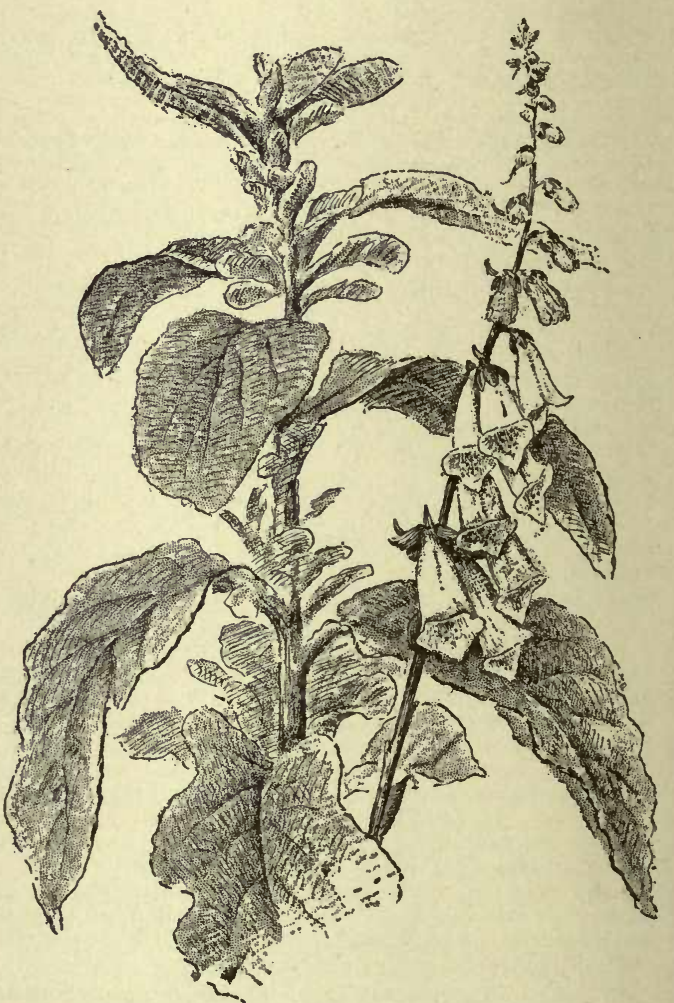

711. Digitalis purpurea, var. gloxiniæflora.

Sibírica, Lindl. Has the habit of D. ambigua, with fls. like those of $D$. lanata. Lrs. downy, ovate-lanceolate: fls. ventricose, villose; calyx segments linear, villose. Siberia. - This is a rare trade name, and it is doubtful if this little known plant is really in cultivation. 
BвB. Fls. purplish.

Thápsi, Linn. Plant much like D. purpurea. Perennial, 2-4 ft. high: lvs. oblong, rugose, decurrent: fls. purple, throat paler, marked with red dots. June-Sept. Spain.

AA. Middle lobe of the lower lip shorter or hardly longer than the others.

\section{B. Fls. yellowish.}

ambigua, Murr. (D. grandifldra, Lam. D. ochrolèuca, Jacq.।. Perennial, 2-3 ft. high: lvs. ovatelanceolate, toothed, sessile, downy below: fls. large, 2 in. long, yellowish, marked witl brown; lower bracts about as long as the fls. Eu., W. Asia. B.R. $1: 64$.

BВ. Fls. white to purple, seldom yellowish.

purpùrea, Linn. ( D. tomentosa, Link. \& Hoffmgg.). Common Foxglove. The species most commonly cultivated. Mostly biennial, but sometimes perennial. Height 2-3 ft.: lvs. rugose, some what downy: fls. large, 2 in. long, ranging from purple to white and more or less spotted, rather obscurely lobed. Gn. 34: 676. Var. gloxiniæflora, Hort. (D. gloxinioides, Carr. D. gloxiniaflora, Hort.). Figs. 711, 712. Of more robust habit, longer racemes, larger fls., which open wider, nearly always strongly spotted, though a subvariety, gloxiniofldra álba, is offered. D. alba and punctata of the seed trade are presumably white and spotted varieties. $D$. alba, Schrank $=D$. purpurea.

D. laciniàta, Lindl. Perennial, $2 \mathrm{ft}$. high: lvs. lanceolate, jagged: fls. yellow, downy, with ovate, bearded segments; bracts much shorter than the pedicels. Spain. B.R.14:1201-D. laevigàta, Waldst. \& Kit. Perennial, 2-3 ft. high: lvs, linear-lanceogata, Walical ones obovate-lanceolate: fls. seattered, glabrous, yellow. Danube and Greece. - D. Mariana. Boiss. Lvs. radical, very downy, ovate-oblong: fls. rose; corolla bearded. Spain.D. monstròsa, Hort. An interesting abnormal form of D. pur. purea. P.G. 4:151. Monstrosities are common in this genus.D purpuráscens, Roth. Biennial: fls, yellow or sometimes purplish. pale inside, spotted at the mouth; lower lobe of corolla short. En. F. A. WAUGH.

\section{DILIVARIA. See Acanthus.}

DILL (A nèthum gravèolens, Linn.), an annual or biennial plant of the Umbellifero. Native of $\mathrm{S}$. Eu. the seeds of which are used as a seasoning, as seeds of Caraway and Coriander are. It is of the easiest culture from seeds. It should have a warm position. The plant grows 2-3 ft. high: the Ivs. are cut into thread-like divisions: the stem is very smooth: the fls. are small and yellowish, the little petals falling early. It is a hardy plant. The foliage is sometimes used in flavoring, and medicinal preparations are made from the plant. The seeds are very flat and bitter-flavored.

DILLENIA (named by Linnæus for J. J. Dillenius, botanist and professor at Oxford). Dillenidcea. A ge. nus of handsome East Indian trees, thought by some to be as showy as a magnolia. One species is cult. in $\mathrm{S}$. Fla, and $S$. Calif., but it takes too much room and flowers too rarely for northern conservatories. It has gorgeous white fls. fully $9 \mathrm{in}$. across. Tall tropical trees from Asia, Indian Archipelago and Australia. Lvs. large, with pronounced pinnate, parallel venation: fls. white or yellow, lateral, solitary or clustered. D. Indica is said to bethe showiest of the whole order, being attractive in foliage, flower and fruit. Dillenias may be grown in light, sandy loam. Prop. readily by seeds, but with difficulty from cuttings.

Indica, Linn. (D. specidsa, Thunb.). Trunk stout, not bigh: branches numerous, spreading, then ascending: lvs. confined to the ends of branches, on short, broad, channelled sheathing petioles, the blade 6-12 in. long, oblong or oblong-lanceolate, acuminate, narrowed at the base, strongly serrate: sepals 5, thick, fleshy, enlarging and inclosing the fr.; petals obovate, white; stamens very numerous, forming a lirge yellow globe erowned by the white, slender, spreading rays of the stigma: fr. edible, acid, the size of an apple, many celled and many oruled. Trop. Asia. B.M. 5016 (B.M. $449=$ Hibbertia volubilis).

W. M.

DIMORPHÁNTHUS. Included in Aralia.

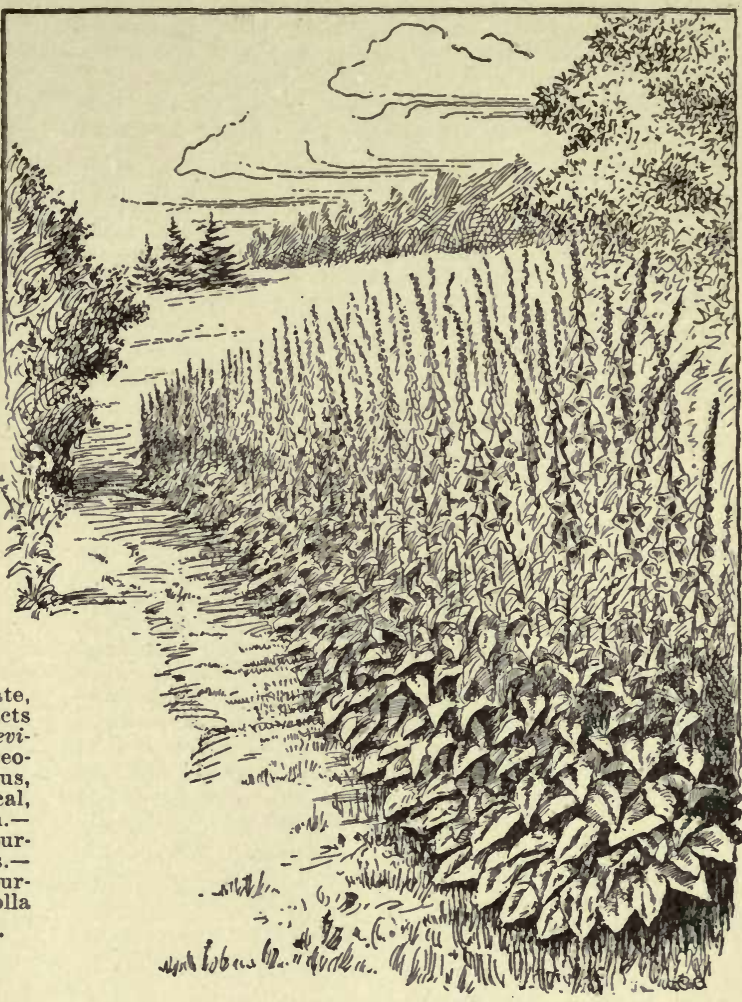

712. Border of Foxgloves.

DIMORPHOTHECA (Greek, two-formed receptacle; the disk florets of two kinds). Composita. A charming genus of plants from the Cape of Good Hope which is almost totally neglected here, largely because the climatic conditions of that womlerful region are not gen. erally understood. This genus contains about 20 species, some of which riral the Paris Daisy and others vie with Cinerarias. Annual or perennial herbs, or even somewhat shrubby: lvs alternate or radical, entire, toothed, or incised, often narrow : heads long-peduncle? rays yellow, orange, purple or white: disk fls. same colors except white. The genus is closely allied to $\mathrm{Ca}$ lendula, but has straight instead of incurved seeds. The fls. are usually said to close up, like those of Gazania, unless they have sunlight. Their backs have as great a variety of coloring as their faces. The fls, are often 3 in. across, and their long, slender rays ( 20 or more) give a distinct and charming effect A dozen kinds are grown abroad, representing a wide rauge of colors and foliage. They are wintered in coolhouses and flowered in spring, or else transplanted to the open, where they flower freely during summer. The shrubby kind, D. Ecklonis, has been grown at Kew as a summer bedding plant, flowering from July to frost, and was a surprising success as a coolhouse plant, making a much branched plant $3 \mathrm{ft}$. high, and flowering freely all spring. Monograph by Harvey and Sonder, Flora Capensis 3:417 (1864-65). Sometimes called Cape Marigolds.

ánnua, Less. (Caléndula pluvialis, Linn.). This is the only white-fld. annual kind and the only species sold in America at present. Erect or diffuse, simple or branched, rough with jointed and gland-tipped hairs (seen with a small lens): lvs. narrowly oblong or obovate-oblong, tapering to the base, with a few distant 
teeth, pilose, the uppermost smaller and narrower: peduncles terminal, nodding in fr.: fls. white above, purple or discolored beneath. Var. liguldsa, Voss (Calén. dula Póngei, Hort.), is a double form-the heads full of rays - with heads white on upper side and yellow or violet beneath.

Seven species have been pictured under various names in the Botanical Magazine-all perennials, and worth importation.

D. aurantìaca, DC. Lvs. slender, entire: fls. yellow. B.M 408. - D. Bárberice, Haw. Perennial: fls. purple above, paler beD. chrysanthemifòlia, DC. Lvs. cut like a Chrysanthemum: fls. yellow, reverse reddish. B.M. 2218, -D. cuneàta, DC. Lvs strongly cut: fls. scarlet-orange. B.M. 1343,-D. Ecklonis, DC. Differs from all in its shrubby stem and branches, and is perhaps the most promising of all. Fls. white, violet-blue, and strongly veined on the back. the disk azure-blue. B.M. 7535. D nudicaìlis, var grammifolia, Harv, \& Sond. Fls, white, with a purple ring at the base, and orange-brown on the back, with a purple ring at the base, and orange-brown on the back,
the disk purple. B.M. 5252.-D. Tragus, DC. Lvs. narrower than in D. Ecklonis, linear: fls. white, veined purple, the rays narrower at the base, reverse orange purplish, the disk purplish. B.M. 1981

W. M.

DIOCLEA (after Diocles Carytius, said to be second only to Hippocrates among the ancients for his knowledge of plants). Leguminosae. About 16 species of tender shrubby twiners, mostly tropical American, with delicate trifoliolate leaves and blue, violet, scarlet or white fls., sometimes nearly an inch long, and borne in clusters which have been roughly compared to Wistaria. Calyx bell-shaped, 4-cut, 2 lobes shorter and narrower, standard wider than long: ovary nearly sessile; pod wide, the upper suture thickened or 2-winged. The following species is cult. in $\mathrm{S}$. Calif., where it has a moderate growth, shining foliage, and clusters of 10 or more large fis. of a splendid scarlet.

glycinoides, DC., from Rio de la Plata basin, is probably the only species grown in European gardens and in California. Fls. 1 in. long, bright scarlet, in racemes, somewhat like Wistaria: will stand some cold. Propagated by seeds, cuttings, or suckers, freely produced on grown up plants. (Syn. Camptosema rubicundum, Hook. \& Arn.)

F. Franceschi and W. M.

\section{DION. See Dioon.}

DION EAA (an unusual name for Venus). Droserdcece. VENUS' FLY-TRAP. This insectivorous plant is olle of the wonders of the vegetable kingdom. See Fig. 713. It closes its trap with remarkable quickness. The plant grows wild only in the sandy savannas of North Carolina. It is a perennial herb, the lvs. all radical and in a rosette, the spatulate portion being regarded as petiole, and the trap as the blade: fls. good sized, white, in a bracted corymb, borne on a leafless scape. It is allied to the sundews, other famous insectivorous plants which are also cultivated, but has about 15 stamens, a columinar style, and seeds at the base of the pod. Many famous naturalists have studied and written about this plant, and it has a large special literature. At times it is sold widely throughout the north, often at high prices, but the plants are soon "worked to death." It is difficult to keep it more than a year in the north, but it ought to be furnished in large quantities at low rates, so that all the school children may see it. It is mostly grown in conservatories associated with botanical institutions.

"It is seldom that this wonderful little plant is seen in a good state of cultivation any length of time after removal from its native haunts. Its cultivation in a greenhouse is usually atnative haunts. Its cultivation in a greenhouse is usually attended with more or less difficulty, owing to unsuitable condi-
tions, such as too much dry air, shade or unfriendly soil. It tions, such as too much dry air, shade or unfriendly soil. It When the plants can be secured and transplanted with considerable of the soil in which they grow attached to the bulblike root-stalks, they are quite easily dealt with, and may be kept in a healthy growing state for years. I find a round hang. ing earthenware receptacle most useful to grow them in; the bottom is carefully drained, first with large pieces of broken pots, then smaller pieces, and the upper layer is quite fine. Some chopped fibrous peat is placed above this, when the plants are built in, with live sphagnum moss used to fill the spaces between the clumps. Arranged in this way, it is hardly possible to give them too much water, and they revel in abundant sup. plies. If kept in the sun the leaves take on a reddish tinge, but when grown in the shade they are always green. Flowers will develop about the middle of June, but they should be nipped off as they make their appearance, for they are apt to weaken the plant.

"The Dionæa has been grown successfully in a dwelling house by a very different method. The plants were in a wide, shallow dish, without any drainage, and simply placed, not too

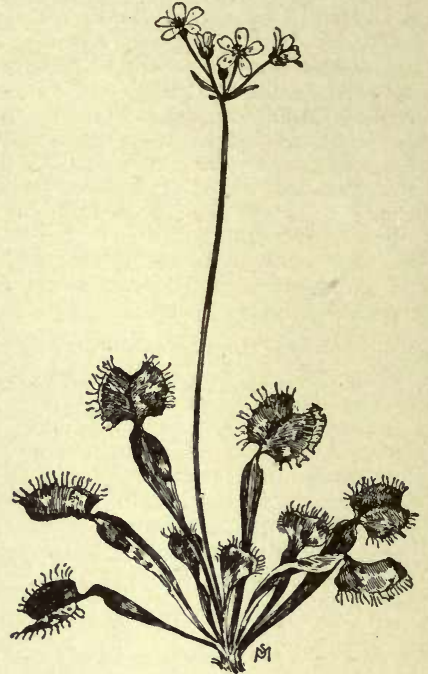

713. The Venus' Fly-trap-Dionæa muscipula ( $X 1 / 4)$.

firmly, in loose live sphagnum moss, with a glass covering. Water was given every other day by filling the space above the plants until the dish was filled, and then it was poured off. In this way the potting material never became sour. From the luxuriant condition in which these plants remained for years, I am inclined to think this was a close imitation of the condi. tions under which they thrive in a wild state. Some yezrs ago, owing to Professor Asa Gray's endeavor to have the Govern. ment purchase a strip of land on which this plant grows, there existed a widespread idea that it was gradually becoming extinct. There seems to be little likelihood of this calamity, however, as Dionæa is found abundantly in some places all the way from Wilmington to Fayetteville, in North Carolina. Its permanency is all the more assured seeing that the plants thrive Oliver, in Garden and Forest, 10:237 (1897).

muscipula, Ellis. Fig. 713. Described above. B.M. 785. F.S. $3: 280$. Mn. 1:69. - The genus has only one species.

W. M.

DIOON (Greek, two and egg; each scale covers two ovules and the seeds are in pairs). Cycaddceoe. Handsome foliage plants suitable for warm or temperate palm houses. This once powerful order is now nearly extinct, and the few remaining species are of the greatest scientific interest and also decorative value, $D$. edule has a flat, rigid frond which is more easily kept free from scale insects than Cycas revoluta, the commonest species of the order in cultivation. A specimen at Kew had a trunk 3-4 ft. high and 8-10 in. thick, the crown spreading 8-10 ft. and containing 50 fronds, each 4-5 ft. long and 6-9 in. wide. Both sexes make cones frequently, the male cone being 9-12 in. long and the female 7-12 in. The seeds, which are about the size of Spanish chestnuts, are eaten by the Mexicans. Many Cycads yield arrowroot. This genus is said to be the closest to the fossil forms of any living representative of the order. The genus has the cones and twin seeds of Zamia and Encephalartus, with the flat, woolly scales of Cycas, but without the marginal seeds and loose inflorescence of the latter. Prop. by seeds. Culture same as Cycas.

édule, Lindl. Lvs, pilose when young, finally glabrous, 3-5 ft. long, pinnatifid, rigid, narrowly lanceolate segments, about 100 on each side, linear-lanceolate, sharppointed, widest at the base, rachis flat above, convex beneath: male cones cylindrical, female cones ovoid. Mex. B. M. 6184. Gn. 55, p. 365. Gt. 48, p. 157. Var. 
lanuginosum, Hort., is a very woolly kind. Gt. 48, pp. $154,155 .-$ A variable species. D. tomentòsum, once sold by Pitcher and Manda, was probably woollier than the type. D. spinuldsum, Dyer, differs mainly in having the segments margined with small sharp points. Mex. A.F. $7: 461$.

W. M.

DIOSCORĖA (Dióscorides, tke Greek naturalist). Dioscoredcece. The type genus of a small family (of about 8 genera) allied to Liliaceæ. It contains upwards of 150 widely dispersed and confused species, most of them native to tropical regions. Stems herbaceous and twining or long-procumbent, usually from a large tuberous root, and sometimes bearing tubers in the axils. Lvs. broad, ribbed and netted-veined, petiolate, alternate or opposite, sometimes compound. Diøecious. Fls. small; calyx 6 -parted, anthers 6 ; styles 3 , ovary 3 -loculed and calyx adherent to it. Fr. a 3-winged capsule. Seeds winged. The great subterranean tubers of some species are eaten in the manner of potatoes. For an inquiry into the prehistoric cultivation of Dioscoreas in America, see Gray \& Trumbull, Amer. Journ. Sci. 25:250.

A. Stems strongly winged.

alàta, Linn. Fig. 714, Stem t-winged or angular: lvs. opposite, cordate-oblong or cordate-ovate, with a deep, basal sinus, glabrous, devoid of pellucid dots, 7 . nerved (sometimes 9-nerved), with the outer pair united: staminate spikes compound, special ones whorled, short, flexuose : pistillate spikes simple : fls. distant, anthers subglobose, about as long as the fllament: capsule leathery, elliptical. India and the S. Sea Islands. - Widely cult. in the tropies under many vernacular names. Tubers reach a length of 6-8 ft., and sometimes weigh $100 \mathrm{lbs}$; edible. The roots continue to yrow for years. Variable.

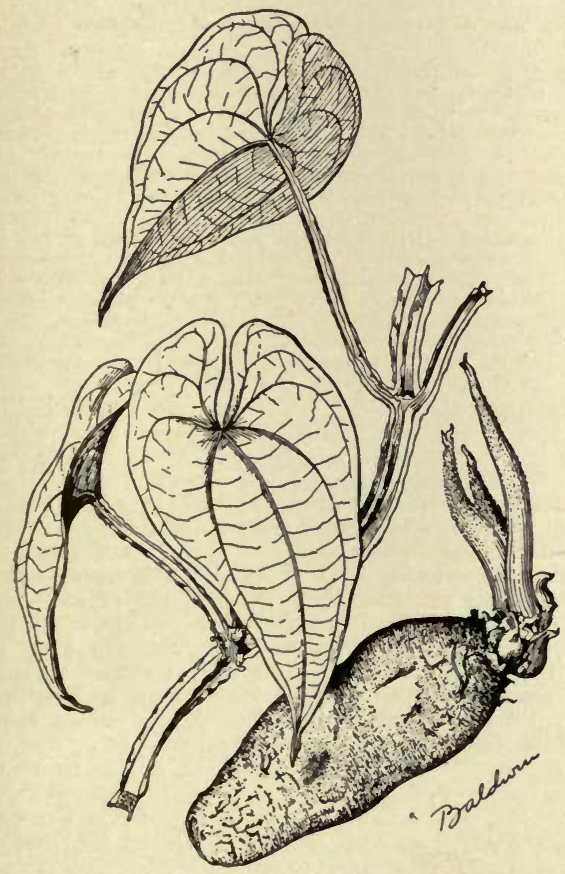

714. Dioscorea alata.

Showing foliage $(\times 1 / 2)$ and a small tuber.

AA. Stems terete (cylindrical).

B. Lvs. plain green.

divaricàta, Blanco. (D. Batátas, Decne.). YАM. CHInese Yam. Chinese Potato. Cinnamon Vine. Very tall climbing $(10-30 \mathrm{ft}$.), the lvs. 7-9 ribbed, cordate-ovate and shining, short-petioled, bearing small clusters of cinnamon-scented white fls. in the axils: root tubers deep in the ground, 2-3 ft. long, usually larger at the lower end. Philippines. F.S. 10:971. R.H. 1854, p. $247,451-2 .-T h i s$ is often grown in the tropies for its edible tubers, which, however, are difficult to dig. In this country the word Yam is commonly applied to a tribe of sweet potatoes (see Sweet Potato). The Yam is hardy. The root will remain in the ground over winter in New York, and send up handsome tall, twining shoots in the spring. The plant bears little tubers in the leaf-axils, and these are usually planted to produce the Cinnamon Vine; but it is not until the second year that plants grown from these tubercles produce the large or full grown Yams. A form with short and potatolike tubers is D. Decaisnedna, Carr. (R.H. 1865:110).

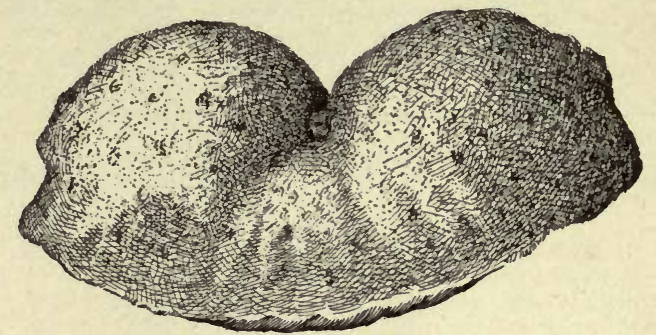

715. Air Potato-Arial tuber of Dioscorea bulbifera $\left(X \frac{1}{4}\right)$.

bulbifera, Linn. Air Potato. Fig. 715. Tall-climbing: lvs. alternate, cordate-ovate and cuspidate, 7-9-nerved, the stalks longer than the blade: fls. in long, lax, drooping, axillary racemes. Tropical Asia. G.C. II. 18:49.Somewhat cult. S. as an oddity and for the very large angular axillary tubers (which vary greatly in size and shape.) These tubers sometimes weigh several pounds. They are palatable and potato-like in flavor. The root tubers are usually small or even none.

villosa, Linn. Stems slender, from knotted rootstocks : lvs. cordate-ovate, cuspidate-attenuate, 9-11-r i b be d, somewhat pubescent or downy beneath, alternate, oppo. site or whorled: fls. greenish, the staminate in drooping panicles, the pistillate in drooping, simple racemes: capsules very strongly winged.-Common in thickets from N. Eng. to Fla. Perennial. Twining 8-10 or even $15 \mathrm{ft}$. Offered in the trade as a hardy border and arbor plant.

BB. Lvs. variously marked and colored, at least beneath.

díscolor, Hort. Lvs. large, cordate-ovate, cuspidate, with several shades of green, white-banded along the midrib and purplish beneath: fls. greenish and inconspicuous: root tuberous. S. Amer. Lowe 54.-Useful for the conservatory. Suggestive of Cissus discolor.

multícolor, Lind. \& André. Probably only a form of the last: lvs. variously marked and blotched and veined with silvery white, red, green and salmon. S. Amer. I.H. 18:53. - Very decorative glasshouse plant.

Other species are cult. in the Gulf region. One, with 2 winged stem and 3-lobed lvs. (the "Yampie"), is perhaps $D$. triloba, Linn. One with prickly cylindrical stems and opposite oblong-ovate lvs. may be D. nummulària, Lam.

D. sativa, Linn., was fornded upon a number of tropical culD. sativa, Linn., was fornded upon a number of tropical cul-
tivated species, and the nume should be dropped.-For Japanese cultivated species, see Georgeson, A.G. 13:80, with illustrations. L. H. B.

DIOSMA (Greek, divine odor). Rutdcea. Small, tender, heath-like shrubs from southwestern Africa. Of the 228 species described, barely a dozen now remain in this genus, the rest being mostly referred to allied genera, especially Adenandra, Agathosma and Barosma. Lvs. alternate or opposite, linear-acute, channeled, serrulate or sometimes ciliate, glandular dotted: fls. white or reddish, terminal, subsolitary or corymbose, pedicellate ; calyx 5-parted; hypogynous disk, 5-sinuate, 5plaited; petals 5; style short; stigma capitate. Latest monograph in Flora Capensis, vol. 1 (1859-60). W. M.

Diosma ericoides is more or less well known in America, and is put to various uses in floral decorations, in spray, or branchlets cut to the required length, and stuck in formal designs as a setting for other flow- 
ers in the same manner and for the same purpose as Stevia is used, to give that necessary grace and artistic effect to the whole. This species, like most of the genus, has an agreeable aromatic fragrance in the foliage. It is a strong grower, loose and heath-like in habit and

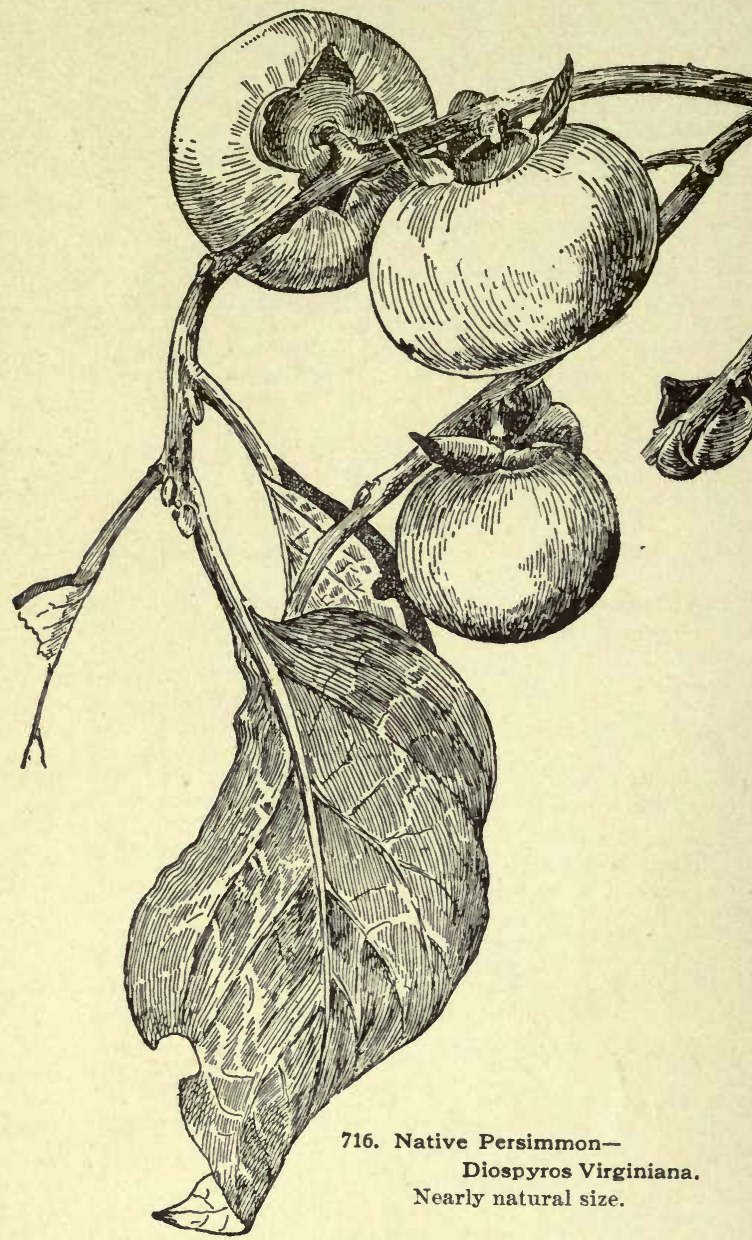

foliage, as the specific name indicates; flowers white and small, one or more on the points of tiny branchlets. While Diosmas undoubtedly do best in soil suitable for heaths, that is, soil composed largely of fibrous peat, they are not nearly so exacting in their requirements in this respect, and can be grown in good fibrous loam and leaf-mold in equal parts, with considerable clean, sharp sand added thereto.

The plants should be eut back rather severely after flowering to keep them low and bushy; this refers more particularly to the above species, other members of the genus being of more compact growth and needing very little corrective cutting to keep them in shape. Diosma capitata (now Ardouinia capitata) is a fine ex-' ample of the latter class, and is a much better one than $D$. ericoides for exhibition and show purposes; flowers pinkish lilac, in corymbs of many flowers. The propagation of Diosmas by cuttings is similar to that of heaths, but much easier with the same amount of care. The best material for cuttings is young wood, when not too soft or too hard.

Kenneth Finlayson.

The Diosma capitata referred to above was described by Linnæus, but is now referred to Ardouinia capitata, Brongn., which belongs in a different order (Brunidcea) and eren in a different subclass of the Dicotyledons. It is a heath-like shrub 2-3 ft. high, with erect branches, and somewhat whorled, mostly clustered branches: lvs. spirally arranged,stalkless, overlapping, linear,3-angled, roughish, with 2 grooves beneath: fls. crimson (according to Flora Capensis), crowded into oblong, spike-like, terminal heads. Generic characters are calyx adhering to the ovary, 5-cleft, segments large, overlapping: petals with a long, 2-keeled claw, and a spreading, roundish limb: stamens included: ovary half inferior,3-celled, cells 2-ovuled. style 3 -angled, with 3 small, papilla-like stigmas. This plant

is not advertised for sale in America.

ericoides, Linn. Much-branched: branches and twigs quite glabrous: lvs, alternate, crowded, recurved-spreading, oblong, obtuse, keeled, pointless, glabrous : fls: terminal, 2-3 together, with very short pedicels; calyx lobes ovate, obtuse; petals elliptic-oblong, obtuse. B.M. 2332 under this name is in realty $D . v i l$ garis, var. longifolia.

$D$. fràgrans, Sims. $=$ Adenandra fragrans, $-D$, vulgàris, Schlecht, has narrower lvs, than D ericoides, and they are acute: branchlets minutely pubescent: lvs. scattered, rarely apposite, linear, convex-carinate, subulate-acuminate. There are 5 well-marked botanical varieties.

DIOSPỲROS (Dios, Jore's, pyros, grain; alluding to its edible fruit). Ebendcece. PERsimmon. EBony. Trees or shrubs, with alternate, rarely opposite, entire lvs., deciduous or persistent, without stipules: fls, dicecious or polygamous in few or many-fld., axillary cymes, the pistillate often solitary, yellowish or whitish; caly and corolla 3-7-, usually 4-lobed ; stamens usually 8-16, included: fr. a large, juicy berry, 1-10-seeded, bearing usually the enlarged calyx at the base; seed flat, rather large. About 180 species in the tropies, few in colder climates. The few cultivated species are ornamental trees, with handsome, lustrous foliage, rarely attacked by insects and with decorative and edible fr. The only species which is tolerably hardy north is $D$. Virginiana, while $D$. Kaki, much cultivated in Japan for its large, edible fruits, is hardy only in the southern states. Most species have valuable hard and close-grained wood, and that of some tropical species is known as ebony. They thrive in almost any soil, but require, in cooler climates, sheltered and sunny positions. Prop. by seeds and by cuttings of half-ripened wood or layers; the tropical species by cuttings of mature wood in spring, with bottom heat; the fruit-bearing varieties are usually grafted or budded on seedling stock of $D$. Virginiana. See Persimmon.

Virginiàna, Linn. CoMmon Persimmon. Fig. 716. Tree, to $50 \mathrm{ft}$., rarely to $100 \mathrm{ft}$., with round-topped liead and spreading, often pendulous branches: Ivs. ovate or elliptic, acuminate, shining above, glabrous at length or pubescent beneath, 3-6 in. long: fls. short-stalked, greenish yellow, staminate in 3 's, $1 / 8$ in. long, with 16 stamens; pistillate solitary, larger, with 4 2-lobed styles, connate at the base: fr. globose or obovate, plum-like, with the enlarged calyx at the base, $1-1 \frac{1}{2}$ in. in diam., pale orange, often with red cheek, edible, varying in size, color and flavor. June. Conn. to Fla., west to Kans. and Tex. S.S. 6:252, 253. G.F. 8:265. Mn. $4: 21$.

Lòtus, Linn. Round-headed tree, to $40 \mathrm{ft}$.: Ivs. elliptic or oblong, acuminate, pubescent, often glabrous above at length, 3-5 in. long: fls. reddish white, staminate in 3 's, with 16 stamens, pistillate solitary: fr. black when ripe, globular, $1 / 2-3 / 4$ in. in diam., edible. June. W. Asia to China. A.G. $12: 460$

Káki, Linn. f. KAKI. Fig. 717. Tree, to $40 \mathrm{ft}$., with round head: lvs.ovate-elliptic, oblong-ovate or obovate, acuminate, subcoriaceous, glabrous and shining above, sparingly hairy or glabrous beneath, 3-7 in. long : fls. yellowish white, staminate with $16-24$ stamens, pistillate to $3 / 4$ in. long; styles divided to the base, pubescent: fr. large, $1 \frac{1}{2}-3$ in. across, very variable in shape and size, mostly resembling a tomato. June. Jap.. China. R.H. 1870 , pp. 412,413 ; 1872, pp. 254,255 (as D. Rox- 
burghi).-Var. costàta, Mast. Fr. large, depressed, globalar, orange-red, with 4 furrows. R.H. 1870:410. G.C. II. 4 :777; III. $9: 171 ; 13: 51$. Gn. 49, p. 171. Var. Mazéli, Mouillef. Fr. orange-yellow, with 8 furrows. R.H. 1874:70. Other varieties are figured in R.H. 1872 , p. $254 ; 1878: 470 ; 1887 ; 348 ; 1888: 60$, and A.G. $12: 331-8,459-62$. A very desirable and beautiful fruitbearing tree for the southern states, where a number of different varieties introduced from Jap. are cultivated, but the hardier varieties from the north of Jap. and China, which are likely to be hardy north to New England, seem hitherto not to have been introduced. Fig. 715 is from Georgeson's articles in A.G. 1891.

\section{AA. Lis. small, obtuse or emarginate: corolla and} calyx 5-lobed.

Texàna, Scheele (D. Mexicìna, Scheele MS.). Small tree, intricately branched, rarely to $40 \mathrm{ft}$. : lvs. cuneate, oblong or obovate, pubescent below, 1-2 in. long: fls. with the lvs., pubescent, on branches of the previous year, staminate with 16 stamens, pistillate with $4 \mathrm{pu}$ bescent styles, connate at the base: fr. black, $9 / 4-1$ in. in diam. Spring. Tex., N.Mex. S.S. 6:254.

D. Ebènum, Koenig. Tree, to $50 \mathrm{ft}$.: lvs. elliptic-oblong, bluntly acuminate, glabrous: fls, white, staminate, in short ra cemes. E. Ind., Ceylon. For cult, in hothouses or tropical climates. This species is said to yield the best ebony.

ALFRED REHDER.

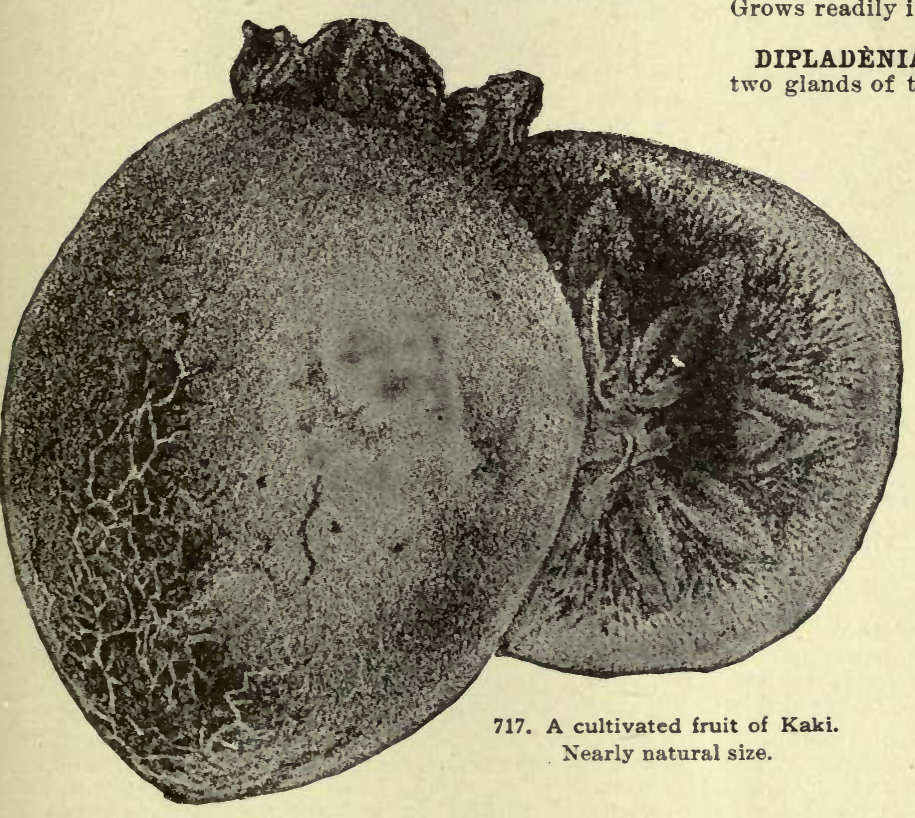

AA. Outer periunth-segments longer than the inner and tailed.

filamentòsum, Medic. (D. viride, Møuch). Lrs. 5-6, fleshy-herbaceous, narrowly linear, glabrous, $1 \mathrm{ft}$. long, 11/2-3 lines wide near the base: scape 1-2 ft. high: raceme loose, $6-15$-fld : bracts linear-acuminate, 4-6 lines long: perianth green, 12-15 lines long, outer segnuents 4-6 lines longer thau the inner: capsule sessile. S. Afr. W. M.

DIPHYLLEIA (Greek, double leaf). Berberidacece. UMBRELLA LEAF. An interesting hardy perennial herb. with thick, creeping, jointed, knotty rootstocks, sending up each either a huge peltate, cut-lobed, umbrellalike, radical leaf on a stout'stalk, or a flowering stem bearing two similar (but smaller and more 2-cleft) alternate lvs., which are peltate near one margin, and a terminal cyme of white fls.: sepals 6 , fugacious: petals and stamens 6 : ovules 5 or 6 : berries globose, fewseeded. This is one of many genera having only 2 species, one of which is found in N. E. North America, the other in Japan. There is a wonderful similarity between the floras of these 2 regions, and few areas have produced so many plants esteemed in culiivation.

cymòsa, Michx. Root-lvs. 1-2 ft. across, 2-cleft, each division 5-7-lobed; lobes toothed: berries blue. May. Wet or springy places in Alleghanies from Va. south. B.M. 1666. - Int. into general trade by H. P. Kelsey. Grows readily in dry soil under cultivation, kut is d warf.
DIPCADI (meaning uncertain). Lilidcea. Tender bulbous plants of minor importance, allied to Galtonia, with radical, thickish, narrowly linear lvs. and loose racemes of odd-colored fls, on leafless scapes. About 20 species in southern Europe, tropical and south Africa and India. During the winter, their resting time, the bulbs should be kept dry. A compost of light, sandy loam and leaf-mold has been recommended. Latest monograph in Latin, 1871, by J. G. Baker, in Journ. Linn. Soc. 11:395: the South African species in English by Baker, in Flora Capensis, vol. 6 (1896-7).

A. All perianth-segments equally long. (Tricharis.)

serótinum, Medic. Lvs. 5-6, fleshy-herbaceous, glabrous, narrowly linear, 6-12 in. long, 2-3 lines wide near the base, channeled on the face: scape 4-12 in. long: raceme loose, 4-12-fld.: bracts lanceolate, 4-6 lines long, longer than the pedicels: perianth greenish brown, 5-6 lines long: ovary sessile or subsessile. S. Eu., N. Afr. B.M. 859 .
(Greek, double gland, referring to the ovary, which distinguish this genus from Echites). A pocynacea. A charming genus of coolhouse twiners, mostly from Brazil, with large, showy more or less funnel-shaped fls, having a remarkable range of color, rarely white or dark red, but especially rich in rosy shades and with throats often brilliantly colored with yellow. The buds, too, are charming. The genus is fully as interesting as Allamanda, which belongs to another tribe of the same order. Other allied genera of great garden interest are Echites, Ontadenia, Mandevilla and Urechites. Some species are naturally erect bushes, at least when young, and many can be trained to the bush form. The group is a most tempting one to the hybridizer. An all-yellowflowered kind is desirable. Many names appear in European catalogues, but they are badly mixed, as the genus. greatly needs a complete botanical revision. Very many pictures are found in the European horticultural periodicals. Several prizes for American seedlings have been taken at Boston, by Geo. MeWilliam, Whitinsville, Mass., who has given a full account of his cultural methods in Gardening, 5:18 (1896).

W. M.

Although Dipladenias are natives of the tropics, they grow at high altitudes, and it is a mistake to keep them in close, steaming hothouses, as many gardeners do in the Old World. The writer has kept them in a house whose temperature was never above $50^{\circ} \mathrm{F}$, and frequently went down to $40^{\circ}$ on winter nights. Cuttings. should be rooted in winter, and the young plants planted outdoors during the summer, being careful not to bury the crowns deep in the soil. They can endure 5 degrees of frost without losing their foliage, but even after 7 degrees of frost and complete loss of foliage, the plants have been lifted, brought into the greenhouse, and flowered with success. A good specimen will have $50-80$ open fls. at one time. Tufts of fern root are excellent for potting soil, with some sharp sand added. A fine specimen may be grown in a pan $2 \mathrm{ft}$. across and 9 in. deep. Plants never need shading. In late fall, as the nights get cooler, the water supply may be gradually reduced until the middle of November, when water is. 
used sparingly until it is desired to start the plants into fresh growth. For points concerning training and pruniug, consult Gn. 5:18.

Geo. McWilliam.

Few tropical plants excel the Dipladenias as greenhouse twining plants, their handsome sprays of flowers being produced in profusion from May to November, when well grown. The usual method of propagation is by 1- or 2-jointed cuttings of the well ripened growths inserted in sand with brisk bottom heat, when they will usually root very readily. Seeds are not often produced in this genus, though occasionally well grown plants will produce seeds, which should be sown as soon as ripe, in pans of light, peaty soil, with a goodly proportion of silver sand mixed with it, and the pans placed in a warm, moist atmosphere. If given good attention the seedlings will flower the first year. Dipladenias thrive best when potted in fern or kalmia root fiber only. The potting should be attended to in early spring, just before active growth commiences. Care must be taken not to injure their tuberous roots, as this will result in weakening very materially the vitality of the plants. Great care must also be exercised in watering until the plants are in active growth, when they will require an abundance of water at the roots; they are also greatly benefited by an occasional watering of clear liquid cow- or sheep-manure water. Frequent spraying of the foliage will also be necessary to keep down the attacks of insects. Dipladenias do best when grown in full sunlight, the roof of an unshaded greenhouse being well suited to them. The pots should be covered with some nonconducting material, however, such as sphagnum moss, to prevent injury to the roots by the heat of the sun. As soon as the season of blossoming is past, the plants should be cut back, and allowed to rest by gradually withholding the water, keeping them during the winter almost dry in a temp. of 55 . EDwARD J. CANNING.

The following kinds sold in America are presumably horticultural varieties which have been insufficiently described:

D. amábilis. Lvs. short-stalked, oblong, acute: fls. rosy crimson, 4-5 in. across; corolla lobes very round and stiff. See Gn. 51, p. 227. Said to be a hybrid of D. crassinoda and D. splendens $-D$ Brearleyàna Lvs, oblong, acute, dark green: fls. dens. $-D$. Brearleyana. Lvs, oblong, acute, dark green: fls. pink at first, changing to rich erimson, very large. Gn. 51, p.
$226 .-D$. eximia. A recent hybrid. $-D$. hyेbrida. Lvs. large, stout, bright green: fls. flaming crimson red.-D. insignis. Stout growing; foliage strong; fls, rosy purple.

\section{A. Fls. dark purple.}

atropurpùrea, DC. Glabrous, lvs. ovate, acute: racemes axillary, 2-fld.: peduncles a little longer than the lvs.; pedicels twisted, bracted; calyx lobes lanceolateacuminate, a little shorter than the pedicel, and a third as long as the cylindrical part of the corolla; corolla tube funnel-shaped above the middle; lobes triangular, wavy, spreading, shorter than the dilated part of the tube. Brazil. B.R. 29:27. Gn. 44:937. I.H. 42:33. Gt. 43 , p. 548. - Lvs. about 2 in. long, acute at the very base: petiole $1 / 2$ in. long; corolla dark purple inside and out; tube 2 in. long. None of the pictures cited above show the fleshy, spreading, scale-like stipules nearly as long as the petioles which De Candolle says are characteristic of the subgenus Micradenia. F.S. $1: 33$ is said to be $D$. atroviolacea of the subgenus Eudipladenia, in which the stipules are absent or else small and erect. The plate shows a strongly ribbed corolla-tube and lvs. cordate at the base.

\section{AA. Fls, white: throat yellow inside.}

Boliviénsis, Hook. Glabrous : stems slender: lvs. petioled, 2-3 1/2 in. long, oblong, acuminate, acute at base, bright green and glossy above, pale beneath; stipules none: racemes axillary, $3-4$-fld.: peduncles much shorter than the lvs., about as long as petioles and pedicels: bracts minute at the base of the twisted pedicels: calyx lobes ovate, acuminate, 3 lines long: corolla almost salver-shaped, tube and throat slender and cylindrical, the former $1 / 2$ in. long, the latter twice as long and half as broad again: limb $1 \frac{1}{2}$ in. across; lobes broadly ovate, more acuminate than in $D$. atropurpurea. Bolivis. B.M. 5783. Gn, 44:922. Gng. 7:342.
AAA. Fls. rose: throat deep rose or purple within, whitish outside.

spléndens, DC. Fig. 718. Stem glabrous: lvs. sub. sessile, elliptic-acuminate, cordate at the base, wavy, pubescent, especially beneath, veins elevated, numerous: racemes axillary, longer than the lvs., 4-6-fld.: calyx lobes red-tipped, awl-shaped, as long as the cylindrical part of the corolla tube, which is half the length of the funnel-shaped portion: lobes of the limb rotund, subacute, almost as long as the tube. Brazil. Lvs. 4-8 in. long, $1 \frac{1}{2}-3$ in. wide, pedicels $1 / 2-1$ in. long: corolla tube $1 \frac{1}{2}$ in. long, white outside, lobes rosy, throat deeper, almost purple. Brazil. B.M. 3976. F.S. 1:34 shows a yellow throated form. Var. profùsa, Rod. ( $D$. profúsa, Hort.), has larger and brighter rosy fls., lined with yellow inside, the outside of the tube rosy except

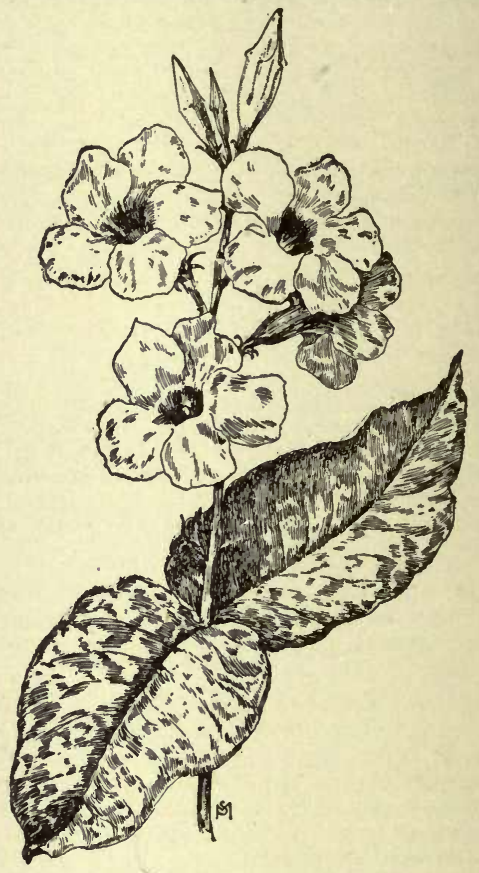

718. Dipladenia splendens $(\times 1 / 2)$.

at the base, which is yellow. I.H. 30:491. - Int. by B. S. Williams. D. amábilis, Hort., is said to be a hybrid of $D$. crassinoda and $D$. splendens. I.H. 27:396, shows a 12-fld. raceme with exceptionally bright red fls.

AAAA. Fls. salmon-colored: throat yellow inside and out.

urophylla, Hook. Named for the long, narrow apex of the leaf. Glabrous, erect bush, not a vine : branches numerous, swollen at the joints: lvs. ovate-oblong, obtuse at the base, suddenly narrowed at the apex into a narrow point $3 / 4$ in. long; peduncles long, drooping, flexuose: racemes axillary, 4-6-fid.: calyx segments awlshaped: corolla dull yellow outside, deeper and brighter yellow within; tube cylindrical in lower third, then swelling into an almost bell-shaped throat; lobes of the limb salmon inclined to purple. acute. Brazil. B.M. 4414. P.M. $16: 66$. F.S. 5:425.

D. crassindda, DC, Glabrous: stem much branched, with many nodes. lys lanceolate, acute or almost acuminate, acute at the base, shining and leathery on both sides: racemes axillary, about 6-fld.: calyx lobes lanceolate, acuminate, a little shorter than the cylindrical part of the corolla tube, 2 or 3 times shorter than the pedicel; corolla tube bell-shaped above the middle; lobes obovate-orbicular. The above is the orieinal description by $\mathrm{De}$ Candolle, who adds that the lvs, are 3-31/2in. long, $3 / 4-1$ in. wide, petiole 2-3 lines long: stipules interpetiolar, with 4 short cuspidate teeth. The plant pietured in B.R. 30:64 with 4 short cuspidate teeth. The plant pictured in B.R. 30:64 and stellate-lobed stipules. Later authorities refer B.R. 30:64 
to D. Martiana. F.S. 22:2310 may be the same plant as B.R. $30: 64$, but with variable lvs and stipules. The plant was prized for its delicate colors, being white at first, then shot with soft rose like a flame tulip, and finally a deep rose. Only one Hlower in a raceme was open at a time, and each lasted 8 or 9 days, throat orange inside. D. crassinoda is said to be a parent, with D). splendens, of D. amabilis. (Gn. 44, p. 141.) D. Hárrisi, Hook.=Odontadenia speciosa. - D). illústris, DC. Gla. brous or pubescent: lvs, oblong or rotund, obtuse or nearly acute, rounded or subcordate at the base, many nerved; stipules none; petiole short: racemes terminal, 4-8-fld.: fls. rosy, th roat yellow inside, purple at the mouth: corolla tube cylindrical to the middle then funnelshaped limb 3-31/2 in across, lobes rosy, orbicular-orate, obtuse Brazil. F. S. 3:256. Var. glàbra. rosy, orbicular-ovate, obtuse. Brazil. F.S. $3: 256$. Var. glabra, Mls. with throat yellow inside, and outside at the base has smaller lvs. than D. illustris, and no circle of purple at the mouth of the fl. Grn. 51:1111.

W. M.

DIPLARRHENA (Greek, two anthers; the third being imperfect). Iridacece. Only 2 species of tender plants from Australia and Tasmania. They belong to the same subtribe with our native Blue-eyed Grass, Sisyrinchium. Rhizomes short: stems terminul, erect, simple or somewhat branched: lvs. in a tuft, narrow, rigid, acuminate, equitant: spathe terminal, rigid, acuminate: fls. whitish; perianth without any tube cver the ovary; segments unequal, inner ones shorter, connivent: upper stamen imperfect. This plant is advertised in the American edition of a Dutch bulb dealer's catalogue.

Moræa, Labill. Stems 11/2-2 ft. long, with a single terminal cluster, and several sheathing bracts: lvs, 6-8 in a tuft, $1-1 \frac{1}{2} \mathrm{ft}$. long, $1 / 4-1 / 2$ in. wide: spathes cylindrical, 2-3 fld., 2 in. long.

DIPLÀZIUM (Greek, doubled). Polypodiàcea. A genus of ruther large, coarse ferns allied to Asplenium, but with the indusia often double, extending to both sides of some of the veins, which are unconnected. Eighty or more species are found, mostly in the warmer portions of the world. For culture, see Ferns.

\section{A. Lvs. simple: low plants.}

lánceum, Thunb. Lrs, 6-9 in. long, 3/4-1 in. wide, narrowed upward and downward, the margin mostly entire: sori reaching nearer to the edge than the midrib. India, China, Japan.

\section{AA. Lvs. pinnate, with the pinnoe deeply lobed: rootstock} not rising to form a trunk.

arbòreum, Willd. Lvs, 12-18 in. long, 6-8 in. wide, with a distinct auricle or lobe at the base. The habit is not arboreous, as originally supposed, and as the name would indicate; quite near the next, but less deeply cut. West Indies and Venezuela.

Shépherdi, Spreng. (Asplènium Shépherdi, Spreng.). Lvs. 12-18 in. long, 6-9 in. broad, deeply lobed, the lobes at the base sometimes reaching down to the rachis, somewhat toothed and often $1 / 4$ in. broad; sori long-linear. Cuba and Mexico to Brazil.

\section{AAA. Lis. bipinnate: trunk somewhat} arborescent.

latifolium, Moore (Asplènium latifòlium, Don). Caudex erect, somewhat arborescent: lvs. 3-4 ft. long, 12-18 in. wide, with about 12 pinnæ on either side. India, China and the Philippines.

L. M. UNDERWOOD.

DIPLOTHEMIOM (Greek, double sheathed). Pal mdcece, tribe Cocoinea. Spineless palms, low or stemless, or often with ringed, stout, solitary or fascicled trunks. Lvs. terminal, pinnatisect; segments crowded, lanceolate or ensiform, acuminate, glaucous or silvery beneath, margins recurved at the base, midnerve prominent : rachis 2-faced, strongly laterally compressed; petiole concave above: sheath fibrous, open: spadices erect, long or short-peduncled, strict, thickish: spathes 2 , the lower coriaceous, the upper cymbiform, beaked, ventrally dehiscent: bracts short, coriaceous: fls, rather large, cream colored or yellow: fr. oroid or obovoid, small. Species 5. Brazil.

Diplothemium is a small genus of very handsome palms. In size the members of this genus seem to rary as much as those included in the Cocos group. D. mariti- mum, which is found along the coast of Brazil, is but 10 feet in height when fully developed. This genus is without spines, the leaves being pinnate, very dark green on the upper side and usually covered with white tomentum on the under side, the pinnæ being clustered along the midrib in most instances. In a very young plant of this genus the ultimate character is not at all appurent from the fact that the seedling plants have undivided or simple leaves, this characteristic frequently obtaining in the case of $D$. caudescens until the plant is strong enough to produce leaves 4 or 5 feet long. A warm greenhouse, rich soil and a plentiful supply of water are among the chief requisites for the successful culture of Diplothemiums. D. caudescens is the best known of the genus, and where space may be had for its free development it is one of the handsomest palms in cultivation.

caudéscens, Mart. (Ceróxylon níveum, Hort.). Wax Palm. Stem 12-20 ft. high, 10-12 in. thick, remotely ringed, often swollen at the middle: lvs. 9-12 $\mathrm{ft}$., short petioled; segments 70-90 on each side, ensiform. densely waxy white below, the middle ones 24-28 in. long, 13/ in. wide, the upper and lower ones shorter und narrower, all obtuse at the apex. Brazil. R.H. 1876, p. 235.

JARED G. SMith and W. H. TAPLIN.

DIPSACUS (to thirst, from the Greek: the bases of the connate lvs. in some species hold water). Dipsdcen. Teasel. Perhaps 15 species of tall, stout biennial or

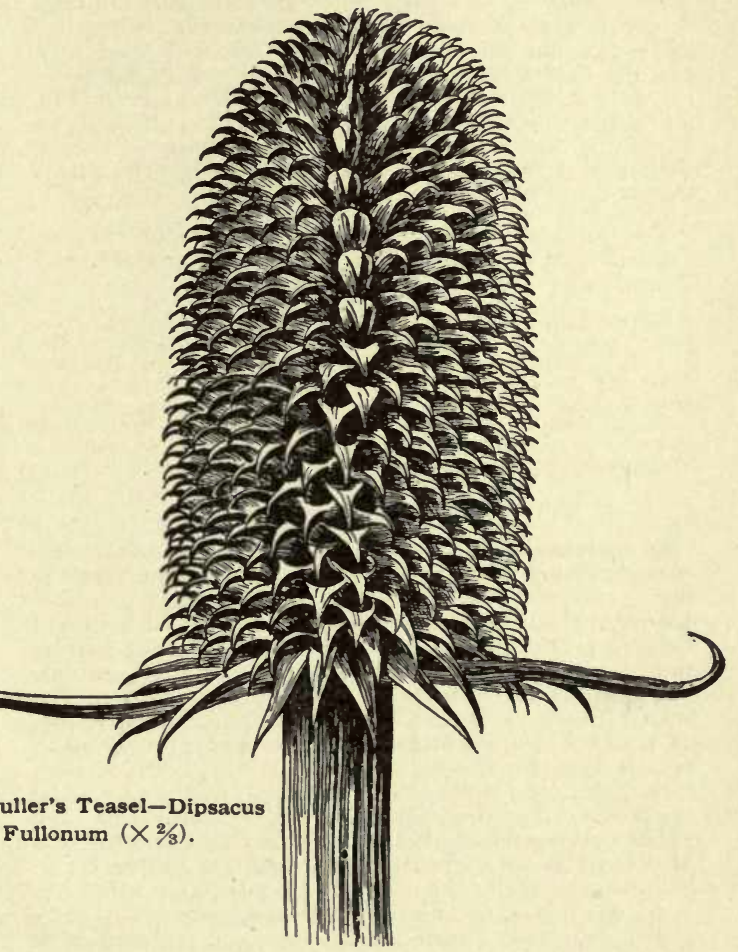

perennial herbs of the Old World. The fls. are small and in dense heads, like those of compositous plants, but the anthers are not anited (or syngenesious) as they are in the Compositæ. One species, D. sylvéstris, Mill., is an introduced weed along roadsides in the northeastern states and Ohio valley. It is biennial, the stem arising the second year and reaching a beight of 5 or $6 \mathrm{ft}$. It is said to be a good bee plant. The Fuller's Teasel, D. Fullonum, Linn. (Fig. 719), is probably derived from the former, and differs from it chiefly in the very strong and hooked floral scales. These scales give the head its value for the teasing or raising the nap on woolen cloth, for which no machinery is soefficient. This plant is grown commercially in a limited area in central New York.

L. H. B. 
DfRCA (Greek, from dirke, a fountain; referring to the plant as growing in moist places!. Thymelacdcece. Two species of North American shrubs, with tough, fibrous bark, alternate, thin, short, entire, petiolate, deciduous lvs., apetalous perfect fls. in peduncled fascicles of the previous season's growth, the branches developing subsequently from the same nodes : calyx corolla-like, yellowish, campanulate, undulately obscurely 4-toothed, bearing twice as many exserted stamens as its lobes (usually 8): ovary nearly sessile, free, 1-loculed, with a single hanging ovule; style exserted, filiform: fr. berrylike, oval-oblong. Hardy deciduous branching shrubs, often with the habit of miniature trees. Bark of inter laced, strong fibers, and branches so tough and flexible that they may be bent into hoops and thongs without breaking. So used by the Indians and early settlers. The Leatherwood is not one of the showiest of hardy shrubs, but its small, yellowish flowers are abundant enough to make it attractive, and it deserves cultivation especially for the earliness of its bloom in spring. It is of slow growth, and, when planted singly, makes a compact miniature tree; planted in masses or under shade it assumes a straggling habit. It thrives in any moist loam. Prop. by seeds, which are abundant and germinate rearlily: also by layers.

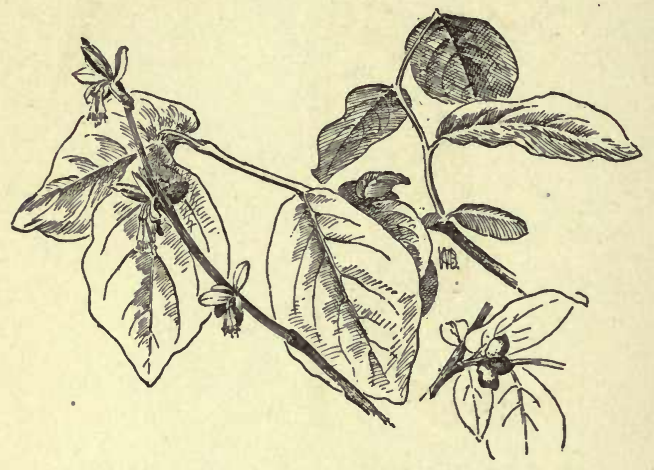

720. Leatherwood-Dirca palustris $(\times 1 / 3)$.

palústris, Linn. Leatherwood. Moosewood. Fig. 720. A shrub, 2-6 ft. high, with numerous branches having scars which make them appear as if jointed, at the beginning of each annual growth, and with yellowbrown glabrous twigs: lvs. oval or obovate, with obtuse apex, 2-3 in. long, green and smooth above, whitish and downy below, becoming smooth, the base of the petiole covering buds of the next season: fls. yellowish, abundant enough to be attractive, nearly sessile, $1 / 4 \mathrm{in}$. long, falling as the lvs. expand: fr. hidden by the abundant foliage, egg-or top-shaped, $1 / 3$ in. long, reddish or pale green. Woods and thickets, mostly in wet soil N. and S. B.R. 4 : 292.-Common.

D. occidentalis, A. Gray. A similar species found on the Pacific coast, differs mainly in the deeper calyx-lobes, lower insertion of the stamens, sessile flowers, and white involucre. Not in the trade, but worthy of cult.
A. PHELPS WrMAN.

DisA (origin of name unknown). Orchiddcece, tribe Ophrydea. One hundred or more terrestrial orchids, mostly S. African, of which several are known to fanciers, but only one of which is in the Amer. trade. Sepals free, spreading, upper one galeate, produced in a horn or spur at the base; petals inconspicuous, small, adnate to the base of the column. The species described below is undoubtedly one of the most beautiful of known orchids, but as yet difficult to manage under artificial conditions.

grandiflòra, Linn. FLower of THE GoDs. Rootstock tuberous: stems $1 \mathrm{ft}$. or more high, unbranched: lvs. dark green: fls. several; upper sepal hood-like or galeate, 3 in. long, rose-color, with branching crimson veins; lateral sepals slightly shorter, brilliant carmine-red; petals and labellum orange, inconspicuous. S. Afr. B.M. 4073. G.C. II. 18:521; III. 9: 365. OAKES AMES.
William Watson, in Garden and Forest $9: 284$, says of Disa: "They all require cool-greenhouse treatment, plenty of water, an open, peaty soil and shade from direct sunshine. As soon as the plants have flowered, they are shaken out of the soil, the suckers taken off, and potted singly in small pots and watered liberally. In November they are again potted into 3 -inch pots, in which they remain until they flower. They make a display of flowers for about two months." In G.F. 7:324, Watson writes of D. Kewense: "This is a beautiful hybrid, which is as easily grown as any orchid I know of, and multiplies itself by means of offsets with all the prodigality of Couch Grass. Many connoisseurs declare it is the best of all Disas. *** D. Veitchii is a noble plant, and almost as free as $D$. Kewense. I would recommend all growers of orchids to procure both and propagate them as rapidly as possible. *** The Kew plants are in 4-inch pots, and each bears a spike 18 inches high with from 10 to 20 flowers, each 2 inches across." For portrait of D. Kewense, see G.C. III. 18:273.

DISANTHUS (Greek, dis, twice, and anthos, flower the fls. being in 2-fld. heads). Hamamelidacea. Shrub, with alternate, deciduons, entire, long-petioled lvs.: fls. similar to those of Hamamelis, but borne in pairs on erect axillary peduncles and connate back to back: capsule 2-celled, with several seeds in each cell. The only species, D. cercidifolius, Maxim., is a shrub, with slender branches, $8-10 \mathrm{ft}$. high: lvs, roundish-ovate, palmately nerred, 3-4 in. long: fls. dark purple, in October. G.F. $6: 215$. Hardy ornamental shrub of elegant habit, with distinct, handsome foliage, turning to a beautiful claretred or red and orange in fall. Prop. by seeds, germinating very slowly, and by layers; probably also by grafting on Hamamelis.

ALFRED REHDER.

DISEASES of plants are of many classes. The word disease as applied to plants is commonly associated with those manifestations which are the result of seriously disturbed nutrition, rather than with mere attacks of devouring insects. We might classify diseases, for horticultural purposes, as those due to parasitic fungi (or fungous diseases), those due to bacteria or germs, those due to nematodes or eel worms,. and those which are associated with disturbed or imperfect nutrition. To these four classes we shall now give our attention:

Fungous Diseases are those that are due to the invasion of tissue by fungi (see F'ungus). All crop plants are more or less subject to the attack of these insidious foes, and the havoc they bring is rarely fully appreciated.

The chief lines of treatment with plants subject to injury from fungi are, first, to reduce the number of spores to a minimum, and, secondly, to surround the plants with conditions unfavorable for their development and yet not to interfere with the growth of the plant itself. Fungi as a rule are fond of moisture and, therefore, dry weather is an ally of the cultirator, while a season with high humidity and a large rainfall is associated with an abundance of plant diseases. So long, therefore, as the weather is without man's control there will be an uncertain quantity in the problem of plant healthfulness.

The growing season for crop plants is practically the same as that for fungi, and during the winter inactivity prevails for both host and parasite. In other words, there are several months of the year when the fungi are either inactive in the host plant or lying dormant outside of it, ready to begin their destructive work. When the plant is a perennial, the fungus may liveover winter in its tissue, as is well illustrated in the black-knot, Plowrightia morbosa, of the plum and cherry. The swellings upon the twigs increase from year to year until the stem is girdleu or otherwise destroyed. The fungus is perennial, and every knot, unless the branch is dead, is the direct starting point for new growth. Along with this fact is the equally important one that in the hard, black crust of the excrescence there are innumerable spherical pits in which countless spores pass the winter, and are ready to spread the disease to new, healthy twigs as the knot breaks up and fresh growth starts in the tree in spring. In the light of the above facts there are many reasons for destroying the knots upon a plum or 
cherry tree. The limbs affected are practically worthless, and by destroyiug them the disease is kept from spreading further in the branch and the forming spores are destroyed before they have an opportunity of getting a foothold elsewhere.

It the horticulturist understands the methods of growth anil propagation of a destructive fungus, he is better able to take the step that may lead to the eradication of

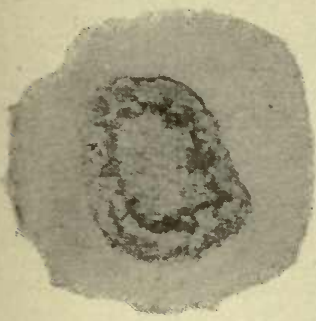

721 Colony of apple-scab. Natural size. the pest. Let another example be taken, namely, the appleleaf rust, which in some parts of the country is a serious menace to the orchardist. It is recognized as yellow blotches upon the foliage, followed by groups of deep cups in the under half of the leaf tissue, where orange-colored spores are produced in great abundance. The life cycle of this fungus, Gymnosporan. gium macropus, involves two hosts; that is, it lives in one stage upon the common red cedar and in the next it infest

the apple tree. Upon the cedar the fungus, forms galls of a chocolate color half an inch or more in diameter, which during the spring rains become swollen aud have a gelatinous exterior. In this jelly the spores are produced that find their way to the apple tree and there form, after vegetating for a few days, the destructive rust. It is seen that in a case like this the most important thing is to destroy the cedar-galls, for in them the fungus passes the winter; and this can be done set a high value upon their cedar trees, the end may be accomplished by removing the cedar trees that stand at all near the infested orcbard.

But there are many destructive fungi that pass their whole life upon the same plant, and the method mentioned for the apple rust would not obtain. In many such cases the use of fungicides has proved ef fective. The apple-scab (Fig. 721), due to a fungus (Fusicla. dium dendriticum), is a yood case in point. It infests both the leaf and the fruit, causing irregular blotches upon

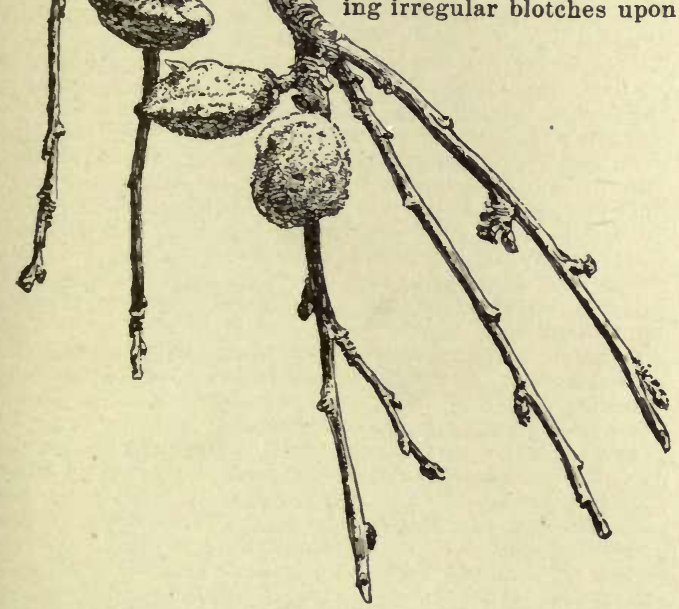

722. Peaches of last year's crop still hanging on the tree, attacked by monilia $(\times 1 / 2)$.

The branch is dead from the effects of the fungus.

both, and frequently destroying the crop. Many experiments have demonstruted that this scab-producing fungus can be kept down by the use of the Bordeaux mixture and various other similar substances. The fun. gus thrives below the skin of the fruit and the epidermis of the leaf, producing spores in abundance upon the surface. The fungicide, when left in a thin film upon the susceptible surface, prevents the germination of the spores and the extrance of the fungus. It likewise may kill the spores in the places where they ure formed and before they have been transplanted to another part of the plant. The fungicide cannot act as a cure in the sense of replacing the diseased, by healthy tissue, but may, by destroying the spores, so prevent the spread that the healthy parts may predominate. In the case of foliage, the spraying is chiefly preventive, and should be particularly directed to the younger leaves, the older ones, with the fungus already established in them, in time falling away. With the ordinary fruits there is no

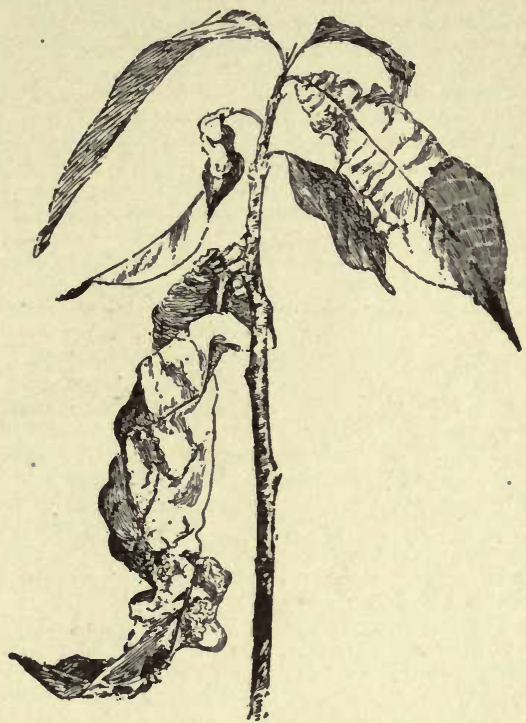

723. Effects of the leaf-curl fungus on peach foliage $(\times 1 / 2)$.

such succession, and the aim is to have each apple or pear coated with the fungicide.

As a rule a fungus that attacks the fruit also infests the leaves, and may likewise thrive in the stems. From this it is gathered that the spray should be very thoroughly applied to all parts of the plant, in order that the foliage may be kept in vigor and make the required food sub. stances for the growth of the fruit, and the latter saved from decay due to direct attack of the fungous germs. But this is not enough. From what has been remarked concerning the hibernation of fungi, it goes without long argument that much can be done by thorough sanitation in the orchard and fruit garden when the crop is off and the plants are at rest. In short, the foliage of a blighter orchard or vineyard is too important to be overlooked in considering the subject of fungous diseases. The pear leaves, for example, may be infested with the leaf-spot, Entomosporium maculatum, and spraying may have kept them from falling prematurely and a good crop saved thereby, but the old leaves, as they drop in autumn, are more or less infested with the disease, and, as far as possible, should be destroyed before the winds have scat. tered them. In the same way the black-rot of the grape (Lostadia Bidwellii) may be carried over in the foliage and the mummy berries that are left upon the vines. Here, again, the spray pumps can.be largely supplemented by vicking, pruning and burning. In the winter care of vineyards we can take a lesson from the grape growers of Europe, where much care is taken to clean up after every crop. They do not stop with the gather. ing of the refuse, but spray the leafless rines in winter, and the trel ises as well, with Bordeaux or plain solution of cupric sulfate. The subject of remedies for fungous diseases would be slighted were not emphatic words used in this connection. It is folly to delay the 
use of remedial measures until after the fungi are in evidence. With many quick-acting diseases it is then too late, and in fact with some the spray pump, when the trees are in full leaf and fruit, is of secondary importance. The fruit-rot or gray mold (Monilia fructigena) of the cherry, plum and peach is of this type. To eradicate this pest, it is not enough to wait until the disease is in the trees, for then, if the weather is warm and moist, the crop is destroyed. Here, again, the work of prevention should begin the winter before; by destroying all mummy fruit (Fig. 722) and blighted branches the disease is attacked at its weakest point.

Another point in this connection that must be kept in mind is the general health of the plant. Every tree or shrub should be well nourished and come to its appointed task in good health. This means the best form of the plant for the purposes intended, obtained by the use of the pruning knife or other means. Fungi do not lore the sunsuine half as well as the shade, and an open-topped tree needs less spraying than one with the branches crowded. This will also obviate in some measure another point of weakness, namely, overloading. A peach tree attempting to carry a double complement of fruit will breed more decayed fruit and foliage than many that are not overloaded. Thinning, in other words, is often as essential to healthfulness as spraying, and a congenial soil and situation are more important than either. Naturally, the question of remedies for fungous diseases comes in only after all the conditions for the best growth of the plants have been' met.

The number of fungi injurious to the horticulturist is large, and space permits of the mention of but a few under the several crops. Apples: Aside from the rust and scab used abore for general illustration, there are the ripe-rot (Gloosporium fructigenum); powdery mildew (Podosphora Oxyacantho), and the fire-blight ( $B a$ cillus amylovorus). The first of the three grows also upon the grape, and the fire-blight attacks the pear and the quince, upon the former being a serious enemy. In this fire-blight we have a bacterial disease in plants, that resides during the winter in the twigs, and is conveyed to flowers by insects which gather on the ooze of cracked, blighted stems in spring. All such diseased branches should have been previously removed. Quinces: The black-rot (Spharopsis malorum) and rust (Rostelia aurantiaca, are often destructive. Plums, in addition to the black-knot, have leaf-blight (CylindrosporiumPadi), while the cherry has the "shothole" fungus (Septoria cerasina). Peaches are sometimes much afflicted with the leaf-curl (Exoascus deformans, Fig. 723), and the scab or "gray back" (Cladospo-

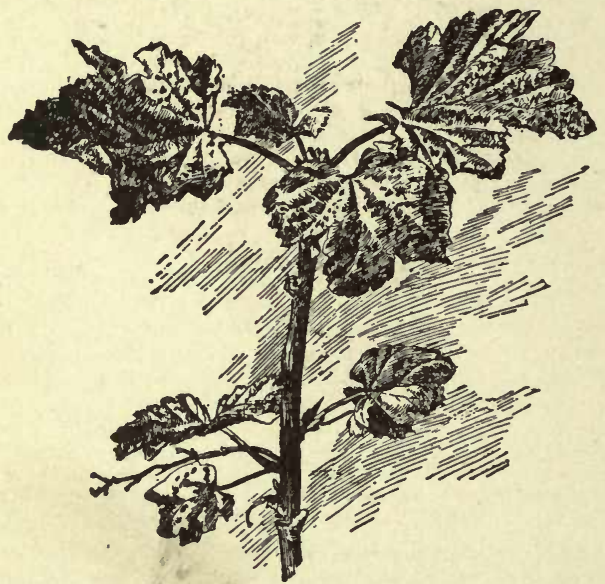

724. Currant foliage attacked by the leaf-spot fungus $(X 1 / 2)$.

rium carpophilum). The most obscure disease of the peach is the "yellows," a name given to a contagious disorder that manifests itself in a premature ripening of the fruit, which takes on an unnatural spotting of red or purple, with the flesh streaked and the taste insipid.
The affected trees produce tufts of small branches upon the older branches, with slender leaves, known as "Pennyroyal sprouts" or "willow shoots." Trees with these "bushes" are fit subjects for the burn heap.

Of the small fruits, the grape leads in the number of fungi, the black-rot and ripe-rot previously inentioned being among the chief, while the anthracnose (Sphace-

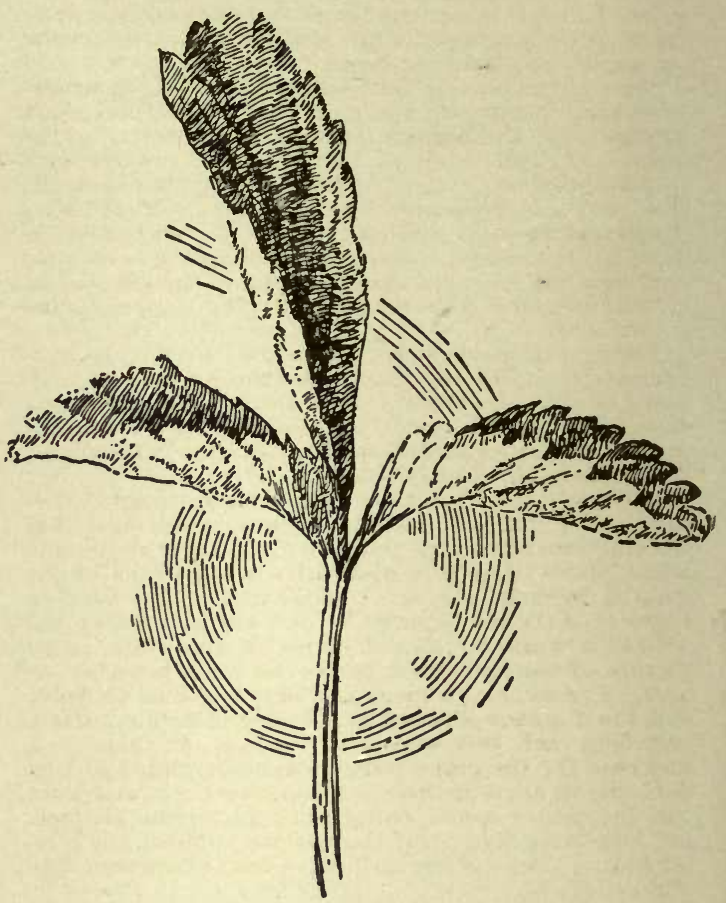

725. Strawberry leaf rolled up from the attack of the leaf-blight. Natural size.

loma ampelinum) and downy mildew (Plasmopara viticola) are quite destructive. Blackberries and raspberrise suffer from similar diseases, the leading ones being the rust (Puccinia Peckiana), requiring the destruction, root and branch, of the infested plants, and the anthracnose (Gloesporium venetum), amenable to spraying. Currants and gooseberries are similarly akin, and have nearly the same fungi, as leaf-spot (Septoria Ribis, Fig. 724) and anthracnose (Gloesporium Ribis), in addition to which the gooseberry is badly troubled with a mildew (Sphoerotheca Mors-Uvo), that may be kept off by sulfide of potassium, one ounce to two gallons of water, as a spray. Strawberries have the leaf-blight (Sphorella Fragarice, Fig. 725) as the leading fungous trouble, and this sometimes requires heroic treatment, even to the burning over of the bed in autumn to destroy the infested leaves and the germs they contain.

Annual Plants. In the previous discussion, perennial crop plants only have been considered. With the annuals the treatment is in large part the same, except that there are no live plants in winter to be considered, no stems and branches to be cleansed, and there is the very important difference that it is possible to grow the annuals upon new ground each season. While it is impossible to move the vineyard or fruit garden, it should be the rule not to grow an annual upon the same piece of soil continuously. In one sense the grower can move away from bis troubles by practicing a judicious rotation of crops. However, the truck grower and the gardener in a small way should not trust entirely to this itinerancy, but instead should place the spraying machine upon the same footing as the plow or planter as a necessary implement; and as insects compete with fungi for the possession of his crops he should spray for both, and usually this can be done at the same time. The 
spraying of crops like potatoes, beans, egg-plants and celery, can be done with great rapidity with the cart machines.

With the annual crops the idea of eleaning up and burning the rubbish should be enforcell as thoroughly as with the tree crops. The burn heap is a successful ally of the spray punp, and with the rotation suggested, growers of vegetables and vegetsble fruits should hope to be exempt from serious fungous attacks, except when the weather is unusually favorable for the excessive development of blights und rots.

Some of the leading fungous enemies upon the vegetable fruit plants are the anthracnose (Colletotrichum Lagenarium) and bacteriosis (Bacillus Phaseoli) of the bean, both beld in check by Bordeaux; the leaf-spot (Ascochyta Pisi) and mildew (Erysiphe Martii) of the pea; leaf-spot (Septoria Lycopersici), biack-rot (Macrosporium Tomato) and bacteriosis (Bacillus Solancearum) of the tomato; leaf-spot (Phyllosticta hortorum) and stem-rot (Nectria Ipomaea) of the egg-plant; and anthracnose (Colletotrichum Lagenarium) of melons and cucumbers.

Among vegetables strictly so-called, there is the leafblight (Cercospora $A$ pii) and bacteriosis of celery; mildew (Peronospora effusa) of spinach; smut (Urocystis Cepula) of onions; rust (Puccinia Asparagi) of asparagus; club-root (Palsmodiophora Brassica) of cabbage, and mildew (Bremia Lactuca) of lettuce.

The root crops hare their subterranean fungous enemies, and for these a soil treatment is necessary. For the club-root of turnips and cabbage, named above, and allied plants, lime is a preventive when added to the soil, 35 bushels per acre; while the scab (Oospora scabies) of the round potato is checked by soaking the seed in a weak solution of corrosive sublimate, or by flowers of sulfur added to the soil, 300 pounds per acre. The same treatment is effective for onion smut and the fungous diseases of the sweet potato. Use a new fleld each year whenever possible. In short, feed and care for the crops well, so that the plants will be perfectly at home in the place assigned them, and then use fungicides as an enlightened judgment dictates, not forgetting to destroy the autumn rubbish, the winter hiding places of the insidious germs of disease. See Fungicide.

Bacterial Diseases. - There is much damage done to higher plants by infesting bacteria. These low organisms may flourish in leaf, stem or root, and with some crops they are widespread and destructive. One of the most prominent of the bacterial diseases is the fire-blight of the pear, apple and quince, due to the Bacillus amylovorus, the germs of which multiply in the nectar of the blooms with great rapidity, and are carried from one flower to another by insects, and in this way an orchard may become infected. From the blossoms the disease extends downward into the branches or runs in from lateral fruit-spurs and girdles the limbs. The blight also enters through the tips of growing branches, as in the nursery when plants are too young to bear flowers. This is "twig-blight," as distinguished from "flower-blight," while a third form is a "body-blight," where the germs attack the main stem of the tree through the buds that may be found there. Warm, moist weather, with frequent showers, favor the spread of the disease, and with opposite conditions the germs may die out, even when in the cambium and protected by the bark. The germs, when they live over winter in the branch, may reach the surface as ooze from the blighted parts in spring and be carried by insects to the flower and other buds. As yet there is nothing better for a remedy than the removal of the blighted twigs, cntting well below where the dead adjoins the living bark. Trees highly fertilized with nitrogenous manures are especially subject to blight and, therefore, over-stimulation with manure is to be avoided, and upon very rich soil an orchard may do better in sod.

The above is a fair type of the bacterial diseases of ligneous plants. Among the many upon herbs, there is one that is very destructive to tomatoes, the Bacillus solanacearum, which is recognized by a sudden wilting of the foliage, followed by a yellow or brown color. Here, again, the germs are transmitted by insects as Colorado and flea beetles. One of the chief preventive measures, therefore, is to protect the tomatoes by insec ticides, and when any plant is diseased it should be de stroyed. Other plants allied to the tomato, as potato, egg-plant, petunias and the common weeds, as Jamestown weed, nightshade and ground cherry, are affected with the same disease; and, therefore, clean culture is demanded, and also a wille rotation of crops upon soil liable to bear infected plants.

A similar bacterial disease is met with in sweet corn, due to Pseudomonas Steu'arti; while other species attack sorghum and a long list of field and garden crops, particularly the roots like beet, carrot, turnip and similar plants, as the bean, onion and celery. Sprays do not seem to materially check these diseases, and the chief means of combating them are through soil sanitation and a judicious rotation.

NeMATODEs. - There are many troubles experienced by plants that are due to animals. None of these are more abundant and destructive than the nematodes, namely, microscopic worms, that infest various parts of plants, but the roots in particular, when they cause enlargements known as root-galls. As the conditions of continued warmth and moisture favor these eel worms, they are more frequently found in destructive numbers in the plant house. Roses are particularly subject to nematodes, which upon their roots cause a multitude of small swellings. The same is true of violets, with which they have been very serious at times. Cucumber tomato, eyclamen, coleus (see Fig. 518, p. 351), and other plants are likewise attacked.

It is thought that lime added to the soil has been beneficial, but the most effective method of exterminating these pests is by heating the soil by steam up to at least $180^{\circ}-212^{\circ} \mathrm{F}$. for one hour or more before being used in the pots or benches. The nematodes are killed by freezing, and probably on this account the number of these worms in fleld crops is kept within bounds at the north, while they are a menace to fleld crops at the south. In greenhouse work, take care that no soil is used which has not been thoroughly frozen since it bore a crop of indoor stuff.

IMPERFECT NUTRITION. - There are doubtless many ills of plants due directly to lack of proper physical conditions. Some are orerfed, others are starved, some are

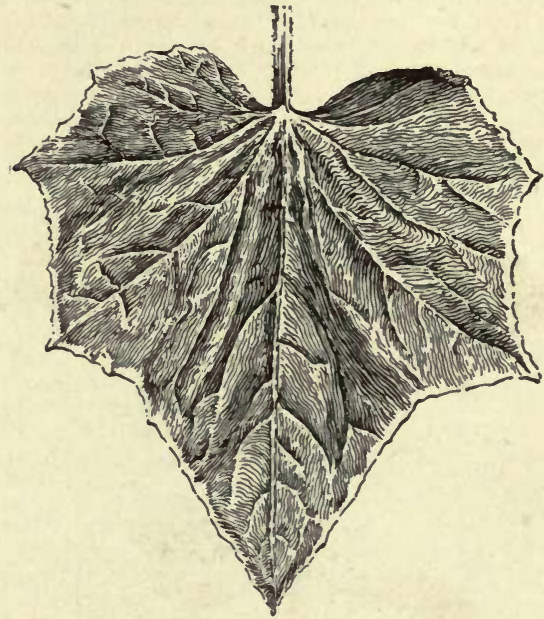

726. Disease of Cucumber leaf $(\times 1 / 2)$.

The dying margin indicates that the trouble is dne to some interference with the food supply.

drowned, and many perish from protracted thirst. Aside from all this, plants will sicken eren when the ordinary conditions seem satisfactory. For some reason not easily assigned, a change will come over the plant, the activities of growth are checked or cease, and the plant dies and without any cause that falls under the previous heads. Some physiological defect is charged with the cause, and various terms have been used to conceal the manifest ignorance. The "yellows" of the peach seems 
to be one of this class, and is as interesting co the vegetable pathologist as it is destructive to the orchardist. The latest view of this particular form of disorder is that of the uuorganized ferment, which by causing certain chemical changes in the substances of the cells brings about the peculiar and well marked malady of the "yellows." If we start with the premise that there is a certain small amount of chemical ferment in all plants, it is only necessary to have this increased to get the results in question; and how to prevent this augmentation is the practical point at issue. This ferment in actire form might be communicated from one plant to another by budding or grafting, and, instead of introducing liv. ing germs, it is a transmission of a germless ferment like diastase, that is found in seeds, and does its appointed work as a solvent, in the period of germination.

There are other disorders that are called "Edema," ol a dropsical form of disease. The tomato is subject to this, and pelargoniums likewise. Tumors are formed, or the leaves bear translucent dots along the veins. This trouble is most apt to appear with greenhouse plants in early spring, and may be favored by lack of sunshine, especially if the warm soil is wet and root action is excessive. The remedy lies in furnishing, so far as

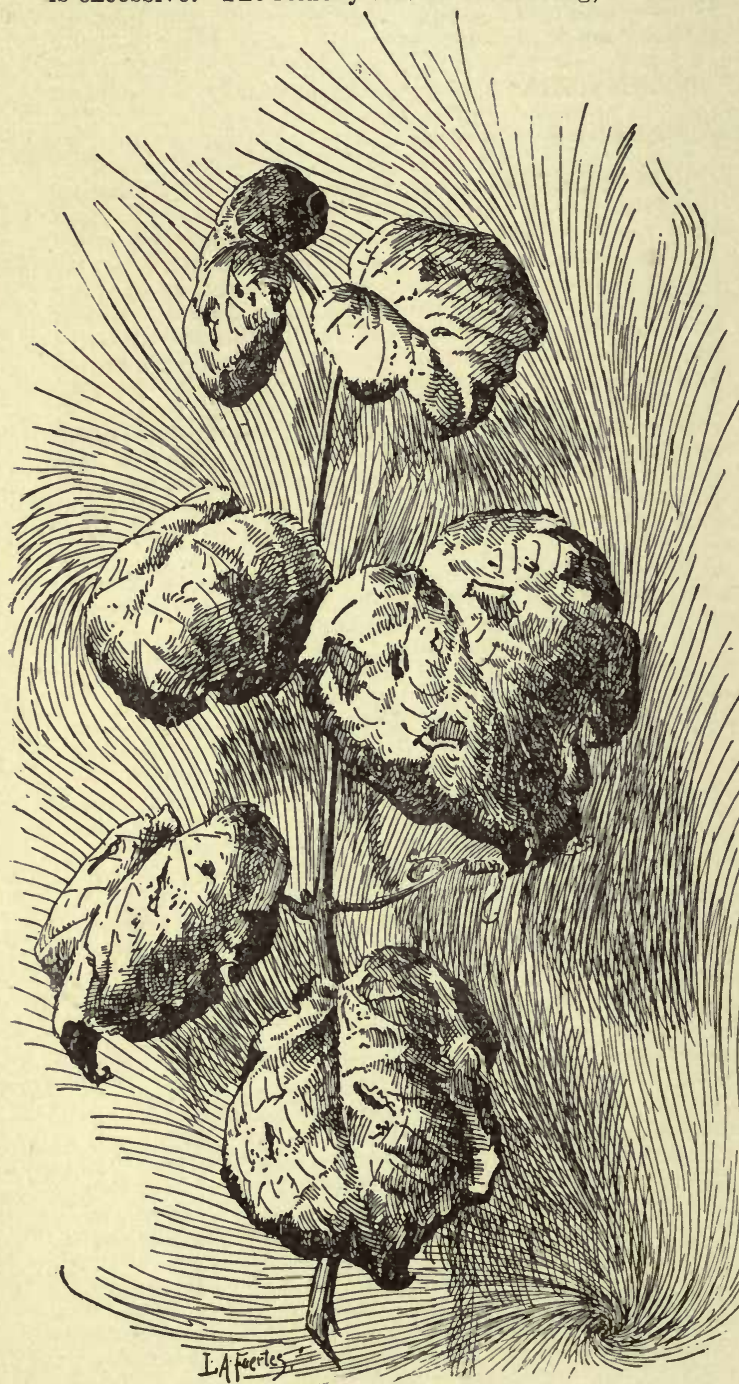

727. A blight of grapes due to some constitutional disorder. Notice that the leaves die first at the edges $(X 1 / 2)$. possible, the conditions opposite to thcse above named.

In general, it may be said that diseases which are due to germs or to malnutrition show the disorder more or less generally spread over the plant, rather than confined to local areas. For example, if the foliage shows a general wilting, it is evident that the trouble lies farther back than the leaves themselves. If one leaf begins to die all around the edge (as in Fig. 726), it is indication that the trouble is a cutting off of food supply in the entire leaf; the trouble may be near the base of the leaf, or farther back. After a time, the leaf becomes dry and brittle, and the winds break it. In Fig. 727 it is evident that the trouble is in the whole branch.

\section{DISHCLOTH GOURD. See Luffa.} BYroN D. HALSTED.

DISPÒRUM (Greek, double pored). Lilidceœ. Perennial herbs with the appearance of our much-loved eastern Bellwort or Uvularia, but distinguished by an indehiscent berry, while Uvularia has a capsule that splits down the back of each cell. In 1879, Bentham and Hooker proposed to include Prosartes in this genus. The American species of Prosartes are said by S. Watson to differ from the Asian ones in having their ovules hung from the top of the cell instead of ascending from the base, but in one American species, D. trachycarpa, they are fixed on the sides, as they are also in one Himalayan species. The habit of all is said to be alike. Latest monograph of both genera by Baker in Journ. Linn. Soc. $14: 586,588(1875)$; of the American species of Prosartes by S. Watson, in Proc. Am. surd. 14:270 (1879).

These plants have been little tried in the eastern states, and are probably not hardy without some winter covering.

A. Lvs, rarely cordate at base: stigma 3-cleft.

B. Perianth very broad and unequally rounded at the base.

Ménziesii, Nicholson (P. Ménziesii, Don). More or less woolly-pubescent: stem 2-3 ft. long, forking, arching above: lvs. ovate to ovate-lanceolate, narrowly acuminate or the lowest acute, sessile, $2-3$ in. long, often resin-dotted: fls. 1-3, greenish, from the topmost axils, nodding, 7-9 lines long; pedicels puberulous; perianth segments nearly erect, acute, 6-11 lines long; stamens a third shorter; anthers included, 11/2-2 times shorter than the filaments: berry $3-6$ seeded: cells $1-2$-seeded: fr. oblong-obovate, narrowed to a short beak. Calif. to B. C.

BB. Perianth narrou and more wedge-shaped at the base.

lanuginòsum, Nicholson. Woolly-pubescent: lvs. oblong-lanceolate, narrowly acuminate: perianth-segments greenish, linear-lanceolate, acuminate, spreading, 6 or 7 lines long, stamens a third shorter; style and narrow ovary glabrous : capsule oblong-ovate, obtusish or with a very short, stout beak, glabrous ; cells 1-2-seeded. W. N. Y. to Ga. and Tenn. B.M. 1490. - Int. by H. P. Kelsey.

trachycárpum, Hook. \& Jack. ( $P$. trachycárpa, Wats.). More or less pubescent: stem 1-11/2 ft. high, forking, with foliage on the upper half: lvs. ovate to oblong-lanceolate, acute or rarely acuminate, $2-4$ in. long: pedicels pilose; perianth-segments whitish, slightly spreading, more narrowly oblanceolate than in $D$. Menziesii, acute, 4-6 lines long, about as long as the stamens: berry many-seeded; cells 2-6-seeded: fr. broadly obovate, obtuse, rather deeply lobed, papillose. Saskatchewan to N. Idaho, Utah and Colo.

$$
\text { AA. Lvs. mostly cordate-clasping. }
$$

Oregànum ( $P$. Oregana, S. Wats.). More or less woolly-pubescent: lvs. ovate to oblong-lanceolate, long acuminate: perianth segments spreading, acute, narrowed below, very distinctly net-reined, 5-7 lines long, as long as or shorter than the stamens: fr. ovate, acutish, somewhat pubescent; cells 1-2-seeded. Oreg. and Idaho to B. C.

The following kinds are cult. abroad: D. Hodkeri, Nicholson (P. lanuginosa, var. Hookeri, Baker). Before D. Oreganum in the key. More or less rough-pubescent, with short, usually spreading hairs: lvs, ovate or sometimes oblong: perianth rather broad at the base: fr obovate, obtuse; cells usually 2 seeded. Calif. Baker regards this as a more robust form of 
D. lanuginosum, less puberulous, with lvs. wider, more deeply cordate at the base, and clasping the branches. $-D$. Leschenaul tianum, D. Don, differs from the others here described by hav ing white fls. India, Ceylon. B.M. 6935.-D. púllum, Salisb. Readily told from American forms by its brown or purplish green fls. India, Java, China. B.M. 916. W. $\mathrm{M}$.

DfgTICHLIS (Greek, tworanked). Graminece. SALTGrass. MarSh SPIKe-Grass. D. spicdta, Greene, is an upright, wiry grass, 10-20 in. high, with strong, extensively creeping rootstocks. A Salt-grass found on the coast of both continents, and thrives even in ground heavily crusted with alkali and other salts. Prospectors and miners consider its presence a sure sign of water near the surface. Good grass for binding loose sands or soils subject to wash. Not cult.

\section{P. B. KeNNEDY.}

DISTÝLIUM:(Greek, two styles). Hamameliddcece. An oriental genus of two species of evergreen trees, one of which has variegated foliage, and is used for hedges in China and Japan. The genus is very unlike our Witch Hazel, as it has no petals, a superior ovary and 2-8 stamens. Lvs. alternate, thick, leathery, ovate or oblong lanceolate, entire: fls. small, polygamous. Seeds and young plants of D. racemdsum, Sieb. \& Zucc., may be obtained through dealers in Japanese plants.

DITTANY is an old English word which in England often means Dictamnus albus, a plant of the rue family. The name is supposed to be derived from Mt. Dicte, in Crete, where the ancient Dittany grew. The Cretan Dittany is supposed to be Origanum Dictamnus, a plant of the mint family, and of the same genus with the wild marjoram. The plant commonly aalled Dittany in the eastern U. S. is Cunila Mariana, Linn. (C. origanoides, Britton), another mint. It has been used as substitute for tea, and is a gentle aromatic stimulant. All these plants yield an oil used as a mild tonic.

DOCK. A name applied to various species of Rumex (of the Polygondcea). The commonest species-grow ing in flelds and yards - are the Curled or Narrow-leaved Dock ( $R$. crispus, Linn.), and the Bitter or Broad-leaved

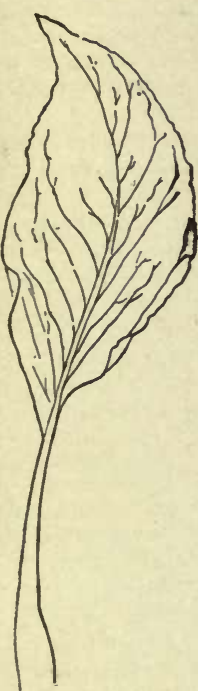

728.

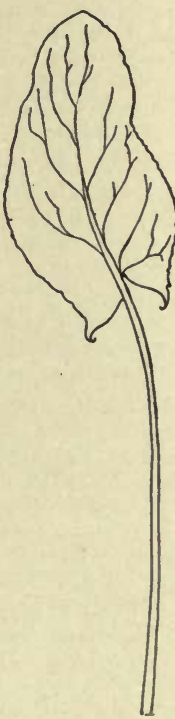

729.

Belleville Dock.
Spinage Dock.

Dock ( $R$. obtusifolius, Linn.). These are introduced from the Old World. Several species are native.

Various species of Docks and Sorrels have long been cultivated as pot-herbs. Some of them are very desirable additions to the garden because they yield a pleasant food very early in spring, and, once planted, they remain for years. The Spinage Dock and the Large
Belleville are amongst the best kinds. The former (Fig. 728) is the better of the two, perhaps, and it has the advantage of being a week or 10 days earlier. The crisp leaves (blade $1 \mathrm{ft}$. long) appear early in April, when there is nothing green to be had in the open, and they can be cut continuously for a montl or more. This Dock is the Herb Patience (Rumex Putientia, Linn.). It has long been an inhabitant of gardens, and it has sparingly run wild in some parts of this country. It is a native of Europe. The Belleville (Fig. 729) is also a European plant, and is really a Sorrel (Rumex Acetosa, Linn.). It has also become spontaneous in some of the eastern portions of the country. It has thinner, lighter green and longer-stalked leaves than the Spinage Dock, with spear-like lobes at the base. The leaves are very sour, and will probably not prove to be so generally agreeable as those of the Spinage Dock ; but they are later, and afford a succession. In some countries this Sorrel yields oxalic acid sufficient for commercial purposes. The round-leared or true French Sorrel (Rumex scutatus, Linn.) would probably be preferable to most persons. All these Docks are hardy perennials, and are very acceptable plants to those who are fond of early "greens." Some, at least, of the cultivated Docks can be procured of American seedsmen.

L. H. B.

DOCKMACKIE. Viburnum acerifolium.

DODDER. See Cuscuta.

DODECATHEON (Greek, twelve gods). Primulacece. Shooting STAR. AMERICAN Cowslip. Hardy herbaceous plants, with flowers that are never forgotten after the flrst sight. Shooting Star is a capital name. The flowers have been compared to a diminutive cyclamen, for they are pendulous and seem to be full of motion (see Fig. 730). The stamens in D. Meadia and all eastern species come to a sharp point and seem to be shooting ahead, while the petals stream behind like the tail of a comet. The fis. represent every shade from pure white, through lilac and rose, to purple, and they all have a yellow circle in the middle, $i$. e, at the mouth of the corolla. Dodecatheon is a most puzzling genus to systematic botanists. It is found from Maine to Texas and from the Atlantic to the Pacific; and along the Pucific slope, from the islands of Lower California to those of Behring straits. In this vast region, it varies immensely. It is also found in Asia, especially northeastward. This wonderful distribution and variability is all the more remarkable if, as Gray believed, it is all one species, because monotypic genera are considered, as a rule, to be comparatively inflexible or invariable. Dodecatheon belongs to the same order with Primula and Cyclamen, but in a different tribe from the latter, while its reflexed corolla lobes dis tinguish it from the 10 other genera of its own tribe. For the honor of American horticulture, it is a pity that the improvement of these charming American plants should have been left to English and French horticulturists. An important ers in their amelioration was probably begun with the introduction of the $D$. Jeffrey $i$ from the Rocky Mts., first pictured about 1866, which was stronger-growing than the common or Atlantic type, with longer and erect lvs. (not crowded in a flat rosette), and with larger fls. and more of them. The improvement of the Shooting Stars is very recent. Twenty-six horticultural varieties are giren in 1897 in R.H., p. 380. The best kinds are robust in habit, with 12-16 large fls., the main colors being white, lilac, rose, violet, and deep purplish red, with many delicate intermediate shades. After the fls, are gone the pedicels become erect. Some species have all their parts in 4's. The best picture of the most advanced types is R.H. 1898: 552. For other pictures, see B.M. 12 Gn. 10:41 and 24:414. Gng. 5:295. Mn. 4:65.

Of their culture, J: B. Keller says: "All they require is an open, well drained soil, not too dry, and moderately rich, and a shady or partially shady position. In a sunry border the fls, are of short duration. The rockery with a northern or eastern aspect suits them to a dot. They are prop. by division of the crowns, or by seeds, the latter method being rather slow." J. W. Manning advises a cool spot in rich loam. The lvs. disappear 
after flowering and do not appear again until the next spring. Shooting Stars are said to be easily forced. The best varieties at present are obtained from Europe.

The genus Dodecatheon is much confused : that is, it is differently understood by different authors. In the Synoptical Flora, 1878, Gray accepted but one species, $D$. Meadia, and referred all the known forms to

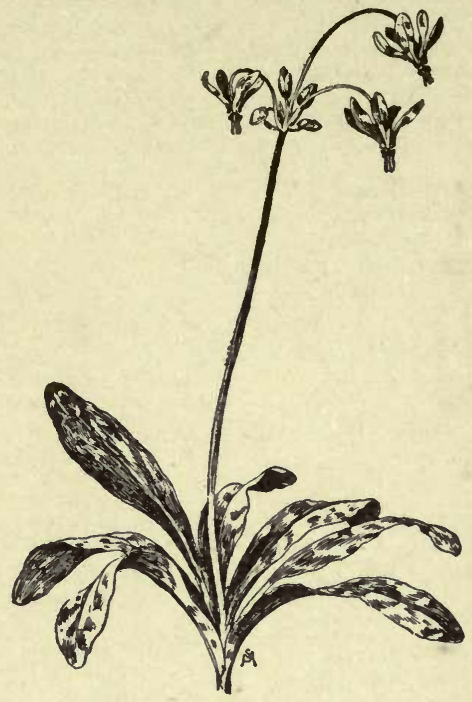

730. Shooting Star-Dodecatheon pauciflorum $\left(X^{1 / 4}\right)$.

six varieties of it. Later (Botanical Gazette $11: 231$ ) he revised his view of the genus, and recognized five species. A synopsis of this latter view is here given, and it is followed by a conspectus of the latest view of the genus by Professor Greene. Various garden names are not accounted for in either sketch, nor is it possible to refer them to their proper places without studying the plants themselves; and these forms are Old World productions, and are not known to be in the American trade.

A. Anthers on evident filaments, the latter being inserted at the very orifice of the short corolla-tube and distinctly monadelphous: lvs. with taperina base.

B. Capsule acute, opening at the apex by valves.

Meadia, Linn. Common or EASTERN Shooting StaR. Roots fibrous : lvs. 3-9 in. long, crowded on a thickish crown, spatulate oblong or oblanceolate, entire or nearly so, sometimes repand obtuse, below tapering into more or less of a margined petiole: scape 9-24 in. high: fls. few to many in an umbel. Penna. south and west. $-D$. integrifolium, Michx. (B.M. 3622) is regarded by Gray as probably synonymous, but in European horticulture it seems to be loosely used to distinguish an entire-lvd. from a dentate form.

BB. Capsule obtuse, opening at or from the apex by valves.

Jéffreyi, Moore. Large : lvs. from narrowly or elongated to obovate-spatulate: capsule oblong or eylindrical, usually much surpassing the calyx. Pacific coast. F.S. 16:1662, which represents a strong plant with erect root-lvs. $1 \mathrm{ft}$. long, and purplish red fls. twice as large as any cultivated before $1865-7$. The name is sometimes spelled Jeffrayi and Jeffreyanum. To this species, Gray provisionally referred his vars. alpinum and frigidum. The former appears to be the D. alpinum, Hort.

ellípticum, Nutt. (D. Mèadia, var. brevifòlium, Grav). Distinguished by its globular or short-ovoid eapsule, barely equaling or slightly surpassing the calyx; also by the short and blunt anthers: Irs. short, obovate or oval, with cuneate base. Cal. and north.
BBB. Capsule obtuse, thin, more or less cylindricai, surpassing the calyx, dehiscent by a circum. scission of the apex.

Héndersoni, Gray. About a foot high: lvs. small, obo vate: fls. like those of $D$. ellipticum. Idaho to Calif. and north.

AA. Anthers seemingly sessile, the very short filaments inserted below the orifice of the corolla.

frígidum, Cham. \& Schlecht. (D. Mèadia, var. frígidum, Gray). Lvs. obovate to oblong, very obtuse, mostly entire : calyx-lobes longer than the tube : capsule oblong. Behring straits to Rockies and Sierras. B.M. 5871 .

Var. dentàtum, Gray (D. dentatum, Hook. D. Mèadia, var. latílobum, Gray). Larger: lvs, with blade 1-4 in. long, oval or ovate to oblong, repand or sparingly dentate, abruptly contracted into long winged petioles. Utah, west and north.

Following are mostly Old World horticultural forms: D. Lemóinei, Hort. Said to be a hybrid between D. integrifolium and $D$. Jeffreyi, and intermediate in character. $-D$. Lemoinei, var. robustum, is like D. integrifolium, but more robust and erect, with larger fls., which are purplish rose, circled with white.-D. máximum, Hort. Fls. rose. $-D$. Meadia, var. elegans, Hort. Lus. wider and shorter: scape shorter: fls. more numerous, dark colored.-D. Méadia, var, gigantèum. more numerous, dark colored.- D. Meadia, var. giganteum, Hort. Much larger than the type in all its parts: lvs. paler: fls.
a little earlier. There is a white-fld. variety of it. $-D$. Meadia. a little earlier. There is a white-fld. variety of it. $-D$. Meadia.
var. spléndidum, Hort. Fls. 4-10, crimson, with a yellow circle, $-D$. tetrándrum, Suksdorf, has the general aspect of D. Jeffreyi, but the lvs. are ampler and relatively broader. Roots, as in D. Jeff reyi, are abundant, fleshy-fibrous, persistent: roots, lvs, and scapes form a short vertical crown: whole plant glabrous : corolla purplish, with a yellow ring near the base; segments and stamens usually only 4: capsule circumseissile very near the apex. Mountains, apparently throughout eastvery near the apex. Mountains, apparently throughout east ern Washington and Oregon. Quite distinct from D. Jeff reyi, though it is the nearest ally of that species: but it belongs to another tract of country. Fully described by E. L. Greene in F. H. Horsford in 1809 .

W. M.

ANother View of Dodecatheon. - The species fal into two well-marked groups : lowland species, which flower in winter and rest during the long, dry summer; and subalpine species, which rest in winter and flower in the subalpine spring of July and August. Species of the lowland group propagate by bulblets formed on the crown of the root. In the following notes, only some of the leading species of different regions are taken up. They are not all in commerce.

A. Lvs., roots and scapes from a short, vertical croun.

B. Anthers long, sharp, convergent; capsules valvately opening from the top.

Mèadia, Linn. Lvs. oblanceolate or spatulate-oblong, 6-9 in. long, toothed more or less irregularly, of a light green: fls. from deep lilac-purple to pinkish. Ranges from Maine to perhaps Texas, east of the mountains.The Allegheny mountain plant is entire-leaved, and is the D. integrifolium of Michx.

crenatum, Raf. Stouter, and of more fleshy texture than the last; foliage deep green, crenate rather than dentate: fls. more numerous in the umbels, equally $\mathrm{va}$ riable in color. Inhabits either low prairies or moist woodland borders of the upper Mississippi prairie region.

cordatum, Raf. Very light green, thin foliage, each leaf made up of broad, subcordate, crenate blade and distinct though broad petiole twice the length of the blade: fls. very few in the umbel, pale pink or white, but with very dark purple ring at base. Cult. at Philadelphia early in the nineteenth century, and named and described by Rafinesque, the habitat not then known, but it is now known to inhabit the limestone region of southern Illinois and adjacent Missouri, along with a few other equally rare and local plants. A most distinct species by its foliage.

BB. Anthers obtuse, forming a column (not convergent).

C. Capsules opening valvately: alpine species, or at least subalpine, blooming in summer, resting in winter.

pauciflorum, Greene. Fig. 730. Variable in size, 6-18 in. high, but slender: hairs oblanceolate, entire, suberect, 
3-5 in. long: fls. often few in the umbel, sometimes many, half the size of those of $D$. Meadia, usually deep purple: filaments long, united into a slender tube ; column of blunt anthers relatively short. Exclusively of the Rocky mountain region and subalpine.

alpinum, Greene. Smaller than the last, but with fls. twice as large and always with parts in 4's; filaments very short, wholly disconnected: lvs. narrowly oblanceolate or almost linear: corolla of a rich, dark pur. ple. Peculiar to the high Sierra Nevada and Cascades.

Jeffreyi, Moore. Lvs. oblanceolate, erect, entire, mucronate, 5-10 in. long: scape 1-11/2 ft. high : fls. 4-merous; pedicels and calyx hairy and glandular: segments of the large corolla dark purple; stamens disconnected, dark purple: capsule not exceeding the calyx. High Sierra Nevada and Cascades.

cc. Capsules circumscissile at top, this part falling off as a lid. Californian lowland, winter-blooming species, with broad, depressed lvs. except in $D$. Clevelandi.

Héndersoni, Gray. Lvs. obovoid, very obtuse, entire, depressed, thick and glossy: scapes 8-12 in. high: segments of corolla rose-purple, the base dark maroon encircled by a band of yellow: capsule oblong, twice the length of the calyx. Calif. to Brit. Columbia.

cruciatum, Greene. Foliage as in the last: scapes taller, more slender, few-fld.; parts of fl. in 4's; corolla of a darker purple; anthers more elongated ; capsule longer. Coast Range of Calif.

patulum, Greene. Lvs. as in the foregoing, nearly, but stout scapes only 3-7 in. high : umbel very manyfld.: corolla large, with pale cream-colored segments, sometimes purplish tinged: tube of a dark, velvety maroon-purple: anthers very short and broad, of a deep blue-purple: capsule subglobose, hardly surpassing the calyx. Plains of the interior of middle Calif.

These three species have, among other peculiarities, that of propagating by their roots. Each root, after flowering time, thickens and shortens, detaches itself from the ground and forms a bud at the end, thus becoming a new plant.

Clèvelandi, Greene. Lvs. more elongated, not depressed: scape tall and stout; umbel very many-fld.; corolla usually rose-purple, with yellow base and some dark velvety spots next the stamens, these very short and broad, purple. Dry hills of southern Calif.-Most beautiful species; winter-blooming like the foregoing, but not propagating by root-metamorphosis.

AA. Lvs. and scapes from a horizontal rootstock, this rooting from beneath. F'ar northwestern species.

dentàtum, Hooker. Pale green, white-fld. species, with broad, subcordate lvs. as in $D$. cordatum of the southeastern states, but anthers blunt: lrs. coarsely dentate, but the horizontal rootstock must, as well as the blunt stamens, prevent its being confused with $D$. cordatum. Washington and Brit. Columbia.-Apparently rare.

frigidum, Cham. \& Schlecht., is a similarly rhizomatous species, but with purple fls., from the shores of Behring sea. Is not in cult., nor likely to be.

viviparum, Greene, is a very large and handsome, purple-fld. species; subalpine on Mt. Rainier. In the axils of the lvs., along the thick rootstock, bulblets are produced, by which it propagates. Its capsule opens by a lid, as in many far-western species. E. L. Greene.

DODON A A (from the Greek name of a famous oracle of Jupiter). Sapindacece. About 50 species of trees and shrubs, widely scattered, but especially abundant in Australia. Lvs. alternate, without stipules, simple or abruptly pinnate, inconspicuous, solitary, or in racemes, corymbs or panicles. Reasoner Bros., Oneco, Fla, introduced D. remotiflor a and D. divia, Switch Sorrel, from Australia, in 1889. These names are not found in Index Kewensis.

DOGBANE is A pocynum.

DOG'S-TAIL GRASS. Eleusine Indica.
DOGTOOTH VIOLET. See Erythronium.

DOGWOOD. Cornus, especially Cornus Mas.

DoLICHOS (old Greek name). Leguminòsa. Differs from Phaseolus in technical characters: keel of the corolla narrow and bent inwards at a right angle, but not distinctly coiled; style bearded under the stigma, which is terminal; stipules small. Tropical twining beans of perhaps 40-50 species, of which a few forms are in cult. in this country. D. Japonicus, a most worthy ornamental vine, will be found under Pueraria. For the

Velvet or Banana Bean, D. multiflorus, see Mucuna. For $D$. unguiculatus, see Vigna.

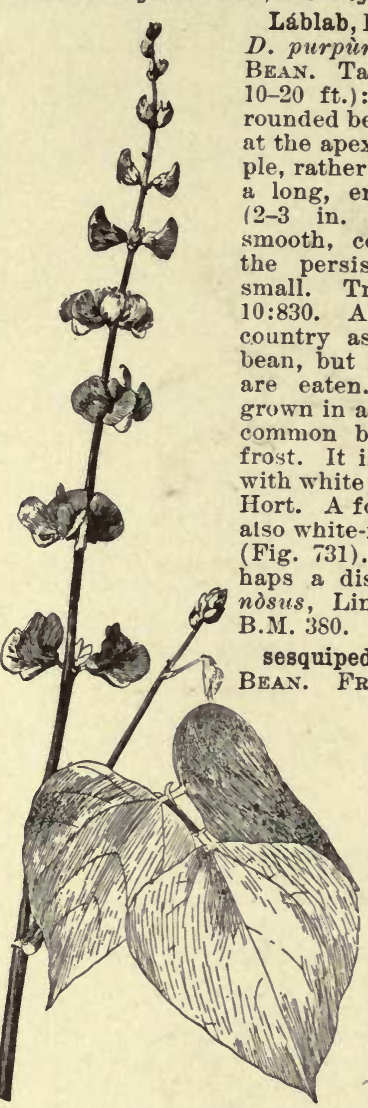

731. Dolichos Lablab (form giganteus). ( $\times 1 / 3$.

den esculent, the green other beans.
DÓMBEYA (after Joseph Dombey, (1742-1793), French botanist and companion of Ruiz and Pavon in Peru and Chile). Sterculiacece. About 24 species of shrubs or small trees of minor importance from Africa or Madagascar: lvs. often cordate, palmately nerved: fls. rosy or white, numerous, in loose axillary or terminal cymes or crowded into dense heads; calyx 5-parted, persistent; petals 5 ; stamens $15-20,5$ sterile, the rest shorter: ovary 3-5-celled.

Natalénsis, Sond. Distinguished by its cordate, acute lvs. and the narrowly awl-shaped leaflets of the involucre. Lvs. long, petioled, somewhat angular, toothed, with minute stellate pubescence, 5-7-ribbed: umbels 4-8-fld. Natal. - Cult. in S. Fla. and north under glass. "Very rapid growing, foliage poplar-like: fls. pure white, large, sweet-scented; a very good winter blooming plant."-Franceschi. 
D. acutángula, Cav. Height9 ft.: lvs. glabrous, heart-shaped, long-acuminate, serrate, deeply 3-5-lobed or cleft: fls. few, large, pink, in compact, forking corymbs. Mauritius. B. M. 2905 shows a form with entire lvs. $-D$. Búrgessice, Gerrard. Lvs. pubescent, cordate, but with 2 deep, wide cuts, and 2 shallow ones besides the basal one: fls, numerous, large, white, rosy at center and along veins; petals rounded. S. Africa. B.M. 5487. $-D$. Mástersii. Hook. Shrub, 4-5 ft. high: lvs. velvety, heartshaped, serrate: fls, fragrant, white, with thinner veins of rose than in D. Burgessiz; petals acute. Trop. Afr. B.M. 5639.D. viburniflòra, Boj., has very numerous white fls. with nar. rower petals than any here described: lvs, cordate, 3 -lobed, the cuts not as wide as in D. Burgessiæ. Comoro. B.M. 4568.

DOdDIA (after Samuel Doody). Polypodidcece. A small genus of greenhoüse ferns from Ceylon, Malaya and New Zealand. Sori curved, placed in one or more rows between the midribs and the margins of the pinnæ.

\section{A. Lvs. pinnatifid.}

áspera, $\mathrm{R}$. Br. Lvs. 6-18 in. long, 2-4 in. wide, pinnatifid, the lower pinnæ gradually becoming smaller: sori in 1 or 2 rows. Australia. Crested varieties occur in cultivation.

\section{AA. Lvs. pinnate in the lower half.}

mèdia, R. Br. Lvs. 12-18 in. long, with pinnæ 1-2 in. long, the lower ones gradually smaller. Australia and New Zealand. D. Kunthidna, Gaud., from the Hawaiian Islands, has close central pinnæ. D. supérba, Hort., is a larger garden form.

cauddata, R. Br. Lvs. 6-12 in. long, with pinnæ about an inch long, the spore-bearing ones shorter; apex often terminating in a long point. Australia and New Zealand. L. M. UNDERWOOD.

According to Schneider's Book of Choice Ferns, all Doodias, except $D$. blerhnoides, are of dwarf habit, and are useful for fern-cases and for edgings of window boxes, especially for northern aspects, where flowering plants do not prosper. Cool and intermediate temperatures are best. They are excellent for forming an undergrowth in cool houses, as they are seldom infested with insects, endure fumigation, and do not care whether their taller neighbors are syringed or not. Schneider recommends 3 parts of peat and one of silver sand. Loam does not help, but a little chopped sphagnum does. They are very sensitive to stagnant water, and do not like full exposure to sunlight. Always prop. by spores, but division is possible.

In the American Florist 12:142, "A.H." writes: " $n$. aspera and its crested variety are most useful, but they can hardly be recommended as market ferns. They require similar treatment to the Blechnums, and are seen at their best in a 4-inch pot. The young fronds have a very bright tint, which livens up the more somber hue of the older fronds. They lose the bright tint much more quickly when allowed to get too dry. Being of slender growth, care should be taken not to over-pot. They like, plenty of leaf-mold and peat in the compost, and good drainage."

\section{DOOR-WEED. Polygonum aviculare.}

DORÓNICUM (Latinized Arabic name). Compositoe. LEOPARD's BANE. Hardy herbaceous plants, 1-2 ft. high, with yellow flowers, mostly one on a stem and 2-3 in. across, borne high above the basal crown of foliage, from April to June. From 10-24 species, natives of Europe and temperate Asia. Stems little branched or not at all: lvs. alternate, radical ones long-stalked, stemlvs. distant, often clasping the stem. The genus is allied to Arnica, and distinguished by the alternate Irs. and by the style. The plants are of easy culture in rich loam. The flowers are numerous and good for cutting. Doronicums have been strongly recommended for forcing.

A. Root-lvs. not notched at the, base, ovate.

plantagíneum, Linn. Glabrous, but woolly at the neck, with long, silky hairs: root-lvs. ovate or oval, wavytoothed: stem-lvs. nearly entire, the lower ones narrowed into a petiole and not eared, the upper ones sessile, oblong, acuminate. Sandy woods of Eu. Rhizome tuberous, roundish, or creeping obliquely. Stalk of the root-lvs. about 3 in. long. Typically about $2 \mathrm{ft}$. high. G.C. III.
17:229. Var. excélsum, Hort. (D. excélsum, Hort. D. "Harpur Crewe," Hort.), is more robust, grows about $5 \mathrm{ft}$. high and is probably more cult. than any other kind of Doronicum. Fls. sometimes 4 in. across. Gn. 47 , p. 269 , and $28: 518$. G.C. 11. $20: 297$.

Clùsii, Tausch. Lvs. ovate or oblong; stem-lvs. half clasping, with distant teeth or many small ones. One subvariety has long, silky hairs on its lvs., while another has none. Swiss and Austrian Alps. - "Soft, downy foliage," J. W. Manning. "Grows 2 ft. high,". Woolson. "Larger and later fls. than D. Caucasicum," Ellwanger and Barry.

AA. Root-lvs. notched at the base, heart-shaped.

B. Root tuberous.

Pardaliánches, Linn. Hairy: lvs. toothed; lower stemlvs. eared at the base of the stalk, sub-ovate, upper ones spatulate-cordate, highest ones cordate-clasping, acute. Woods of lower mts. of Eu.-While all species are typjcally 1-fld., any of them may have now and then more than $1 \mathrm{fl}$. on a stem, and this species particularly may have $1-5 \mathrm{fls}$.

\section{Bв. Root not tuberous.}

Caucásicum, Bieb. Glabrous except as noted above: lvs. crenate-dentate, lower stem-lvs. eared at the base of the stalk, the blade subcordate, highest ones cordate to half-clasping. Shady woods of Caucasus, Sicily, etc. B.M. 3143, which shows stems with $1 \mathrm{fl}$. and $1 \mathrm{lf}$. -Fls. 2 in. across.

Austriacum,Jacq. A trifle hairy: lvs. minutely toothed, lower stem-lvs. spatulate-ovate, abruptly narrowed at the base, half-clasping, highest ones cordate-clasping, lanceolate. Subalpine woods, Eu.

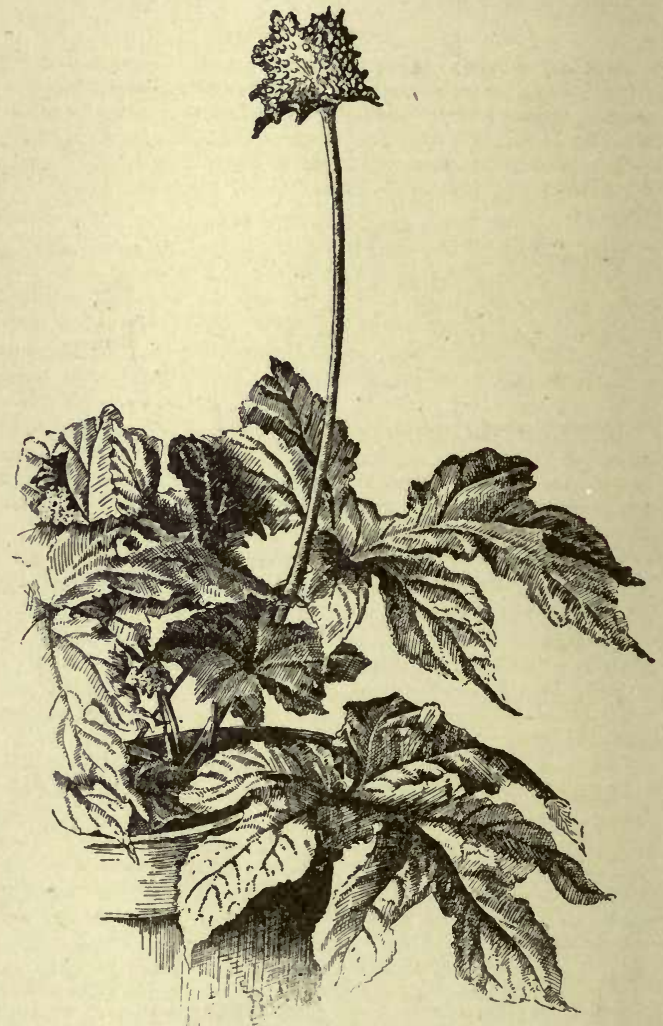

732. Dorstenia Contrajerva $(X 1 / 4)$.

DORSTENIA (an early German botanist, Theodor Dorsten). Urticdcece (or Mordcece). Between 40 and 50 tropical herbs, remarkable for the dilated receptacle 
in which the unisexual fls. are borne. The plants are not in the Amer. trade, but they are often grown in botanical establishments to illustrate morphology. The fig is a hollow receptacle; the Dorstenia bears a flattened or cup-like receptacle, and is an intermediate stage between the fig and other plants. One of the common species is $D$. Contrajerva, Linn. (Fig. 732), which is native to trop. Amer. Both staminate and pistillate fis. are without perianth; stamens 1 or 2 : ovary 1-loculed; stigma 2 -lobed. Dorstenias are easily grown in warm, shady glasshouses.

L. H. B.

DORYANTHES (Greek, spear-flower; the flowering stem 8-25 ft. high, crowned by a spike of fls. $3 \mathrm{ft}$. high). A marylliddcea. A genus of 4 species of gigantic desert plants from Australia, with 100 or more lvs. $6 \mathrm{ft}$. long when full grown. Franceschi, Santa Barbara, Calif., writes, "They are impressive plants for large conserva. tories, or for open ground in the South, where they will stand slight frosts." They belong to the same family with the Century Plants, and are the only ones in the tribe outside of America. The roots are fibrous and clustered. The orules and seeds, though inserted in two series, are so placed above one another as to form one row in each cell. The lrs. have a curious brown tubular tip, which is especially long in D. Palmeri. Franceschi says, "D. Guilfoylei and $D$. Larkini, recently described from Queensland, are yet to be introduced to this country." A plant of D. Palmeri remained at Kew 16 years before flowering. Plants of Doryanthes are prop. by suckers, which are produced only after flowering. The process is very slow. The young plants must be repotted for several years until they have attained a large size. They are said to do best in a compost of loam and leafmold in equal parts.

\section{A. Lvs, not ribbed.}

excélsa, Correa. Lrs. sword-shaped, smooth, entire, with a very narrow cartilaginous margin, lower ones reourved, others erect: scape clothed with lanceolate lvs., whioh sheath the stem at their base: fls. in a globular head, deep crimson or maroon inside and out. B.M. 1685. R.H. 1865 , pp. 466,471 ; 1891 , p.548. G.C. II. $11: 339$.

\section{AA. Lvs. slightly ribbed.}

Pálmeri, W. Hill. Even more gigantic than D.excelsa, lvs. longer and broader, and a longer brown point: fls. in a thyrsoid panicle, bright scarlet outside, whitish within. B.M. 6665. F.S. 20:2097. R.H. 1891:548. G.C. II. 17: 409. - "This has been flowering and fruiting sereral times in southern California."-Franceschi.

DORYOPTERIS (Greek, lance-fern). Polypodidcece. A genus of small sagittate or pedate greenhouse ferns, with continuous marginal sori and copiously anas. tomosing veins. Sometimes joined to Pteris, which see for culture. Not to be confused with Dryopteris.

palmata, J. Sm. Lvs.4-9 in. each way, with 5 or more triangular lobes or the fertile still more divided; ribs black. West Indies to Brazil.

nobilis, J. Sm. Larger: lvs. sometimes $1 \mathrm{ft}$. long, pedately bipinnatifid; ribs chestnut. South Brazil.

D. decipiens, with lvs. resembling a geranium leaf, 3-6 in. each way, is sometimes caltivated, as is $D$. decora, with more divided lvs. Both are natives of the Hawailan Islands.

\section{M. UNDERWOOD.}

DOSSINIA (E. P. Dossin, Belgian botanist, 1777-1852). Orchiddcece. A genus of 2 species of terrestrial orchids, allied to Anoetochilus, but lacking the bearded fringe on the lower part of the labellum. The species described below may possibly be cult. by a few amateurs who are skilled in the cultivation of dwarf warmhouse foliage plants.

D. marmoràta, C. Morr. (Anoectochilus Lowei, Hort.). Lvs. golden-veined or marbled, 4-5 in. long, elliptic: scape pubescent 10 in. high: spike 5 in. long, with many white, pubescent fis. Java. F.S. 4:370. - There is a stronger-growing var., with foliage better colored.

DOUGLASIA (after David Douglas, the tireless Scotch botanist, who explored California. Oregon and British Columbia in 1823 and 1829 , introduced many splendid plants to cultiration, and perished in the Hawaiian
Islands, at the age of 34 , by falling into a pitfall made for wild animals). Primuldcea. Five species of tiny primrose-like plants, one of which has yellow fls, and dwells in the mountains of middle Europe; the rest bare rosy purple fls. and are found in the Rocky mountains and the shores of the Arctic ocean. The genus is closely allied to Androsace and Primula, but in those two genera all the lvs. conie from the root, while Douglasia has branches, though very short ones, which are densely clothed with lrs. Douglasia has a corolla-tube longer than the calyx, and the capsule is 1-2-seeded. Androsace has a corolla tube as long as or shorter than the calyx, and its capsule may have few or many seeds. Primula is usually long-tubed, always many-seeded. The secret in the culture of alpine plants is a steady supply of moisture. "Like all the hardy Primulaceæ,"writes J. B. Keller, "Douglasia requires half shade and a certain amount of moisture during the hot summer months. Frequent and copious waterings must be administered. A light mulch will assist in keeping the ground from drying out too fast. A winter protection of evergreen boughs is indispensable. The plants are prop. by division or by seed." Some of the American species can be obtained of foreign dealers.

Vitaliàna, Benth. and Hook. (A rètia Vitalidna, Willd. Gregdria Vitalidna, Duby). Height 2 in.: stems numerous, prostrate, somewhat woody: branches denuded of lvs. at the base, but at the tips clothed with overlapping, linear, entire, pilose lvs.: fls. nearly stalkless, solitary, yellow, rather large; corolla tube 2 or 3 times longer than the calyx. not dilated at the throat, the lobes ovate. lanceolate, obtuse. Alps, Pyrenees.

\section{DOUGLAS SPRUCE. Pseudotsuga Douglasii.}

DOWNING, ANDREW JACKSON (Plate II), the first great landscape gardener of America, was burn at Newburg, N. Y., Oct. 30,1815 , and perished by drowning July 28,1852 , at the early age of 37 . As a boy, he was quiet, sensitive, and much alone with himself and nature. The Catskills, the Hudson, and his father's nursery had much to do with his development. His "Treatise on the Theory and Practice of Landscape Gardening," published 1841, when he was but 26 years old, is, in many respects, a unique production. It was the first, and is to-day one of the best American books on the subject, and has exerted a greater influence upon American horticulture, it is said, than any other volume. "Cottage Residences,"1841, also had great popularity. In 1845 appeared simultaneously in London and New York the flrst ediuion of "Fruits and Fruit Trees of America," and in 1846 he founded, at Albany, "The Horticulturist," which he edited from his home at Newburg until his untimely death. His edi. torials in this excellent periodical (now represented in succession by American Gardening) were republished after his death, with a letter to his friends by Frederika Bremer, and a memoir by George William Curtis, under the title of "Rural Essays." It was not until 1850 that he had an opportunity to visit the great estates of Eng. land, and to see with his own eyes the landscape gariening of Europe. On his return in 1851, he was engaged to lay out the grounds near the Capitol, White House, and Smithsonian Institution at Washington. On July 28 , 1852. he left Newburg on the steamer Henry Clay for New York. The Clay took fire near Yonkers, while it was racing, and Downing's life was lost in an attempt to save others. It would be difficult to overestimate the influence of Downing. He created American landscape gardening. His only predecessor, André Parmentier, is little known, and his infuence was not of a national character. Downing's quickening influence affected country life in its every aspect. He stood for the simple, natural, and permanent as opposed to the intricate, artificial, and ephemeral. He was the first great American practitioner of what is known in polite and technical literature as the English or natural school of landscape gardening in distinction from all artificial schools, as the ltalian and Dutch. Downing's pupils are many, and his spirit still lives. He gave inspiration to F'rederick Law Olmsted. our next great genius in landscape gardening, who, by his early work in Central Park, New York, aroused that popular enthusiasm which has culminated in the American idea of great municipal park sys. 
tems, as opposed to the earlier Old World idea of exclusive pleasure grounds and private parks. Downing's books have had large sales, and have gone through many editions. His intellectual successor in his purely pomological work was his brother Charles, whose modest labors in the revision of the Fruits and Fruit Trees of America have brought him little popular fame, but much sincere admiration from students. Most horticultural writings are, in reality, only records of progress; they do not create progress. Few of our horticultural books are epoch-making. Downing's writings, however, started a great popular movement in America toward beautiful homes and home grounds. By many persons, Andrew Jackson Downing is considered the greatest single figure in the history of American horticulture, and one of the few persons who can be said to have had real genius. An appreciation of Downing's personality will be found in Frederika Bremer's "Homes of the New World." (See Douningia, for the genus of plants named after him.)

W. M.

DOWNING, CHARLES (Plate II), distinguished pomologist and elder brother of Andrew Jackson Downing, the landscape gardener, was born at Newburg. N. Y. July 9,1802 . He was educated at the local academy, and from the age of 13 to 18 worked part of the time in his father's nursery. At the age of 20 he started in the nursery business on his own account. From 1834 to 1839 his brother Andrew was a partner in this business. About 1850, he sold out his nursery business and devoted himself to the study of varieties of fruits, on which subject he was the leading authority until his death. The Fruits and Fruit Trees of America is the monumental American work on varieties of fruits. The book was projected by Andrew, but the great bulk of the work was done by Charles in continuing and revising it. His test orchard contained trees and grafts of $1,800 \mathrm{va}-$ rieties of apples, 1,000 pears, and other fruits in proportion. In 1869 a city street was put through it. Charles Downing was very modest and retiring. He would never make a public speech, but he wrote many pomological articles over the signature "C. D." All his work is marked by conscientious accuracy. He was married, but, like his brother, had no children. He died Jan. 18, 1885 .

W. M.

DOWNINGIA (after Andrew Jackson Downing, of whom a sketch is given above). Lobelidcece. Three species of annual herbs, 2 from western America, 1 from Chile, much branched, diffuse, with pretty and characteristic fls. Lvs, alternate, entire, passing above into bracts : fls. blue or violet, marked with yellow and white; corolla 2-lipped, the upper lobes much narrower than the 3 lower ones; tube of stamens free from the corolla: seeds numerous, small, oblong to spindle-shaped. This genus has no near allies of much garden value. It is still known to the trade as Clintonia. David Douglas (see Douglasia) named it after DeWitt Clinton in 1829 , but in 1818 a genus of the lily family had been named after the celebrated Governor of New York and projector of the Erie canal.

In 1836 Lindley wrote, in the Botanical Register, of $C$. pulchella: "I figure this little plant more for the sake of recording its existence than from any expectation that it will ever become an object of horticultural interest, for since $C$. elegans, a far hardier and more cultivable plant, has disappeared, there can be little hope that this, beautiful as it is, will be preserved." Nevertheless, pulchella is still cultivated, while elegans is unknown to the American trade. In Lindley's time, pulchella was grown in a flower pot and treated as a tender plant. Nowadays it is considered perfectly hardy, the seed being sown in the open ground. The credit of simplifying the culture of this plant is given to Haage \& Schmidt, Erfurt, Germany, who have fixed varieties that are chiefly blue and chiefly violet, though in cach case the 3 lower lobes of the corolla have a 3-lobed spot of white in the middle, and a 3-lobed spot of yellow at the base. The plants grow about 6 in. high, and have been recommended for edgings. For culture, see Annuals.

A. F'ls. large, with a 3-lobed spot of yellow: lvs.obtuse, narrou.

pulchélla, Torr. (Clintònia pulchélla, Lindl.). The lower lip more dilated and more deeply 3-lobed. The 2 divisions of the upper lip ovate-lanceolate or oblong and strongly diverging. Calif. B.R. 22: 1909. R.H. 1861: 171 . R.H. 1895 , p. 19, shows its straggling habit as a pot-plant. Many of the branches fall below the top of the pot.

AA. F'ls. half as large as the above, and no yellow spot: lvs. acute, broader.

élegans, Torr. (C.élegans, Doug.). Lvs. ovate to lanceolate; the broad lip moderately 3 -lobed; the 2 divisions of the smaller lip lanceolate, parallel; lower lip with a white, but no yellow spot. Calif. B.R. 15: 1241 .

DRABA (Greek, acrid, from the taste of the lvs.). Cruciferce. Whitlow Grass. One of the most important groups of spring-flowering plants for the alpine garden. It is a large and widely scattered genus of tufted, hardy herbs, with stellate hairs: lvs. often in a rosette, mostly uncut: scapes or stems leafy or not: racemes short or long : fls. without bracts, small, white, yellow, rosy or purple.

Drabas are very pretty, dwarf, compact alpine plants, with small but numerous fls.; admirably adapted for the rockery or front part of a sunny border. They require a sunny position and an open soil. It is important that they be well matured by the autumn sun. The plant forms a dense little rosette of lvs., and has a neat appearance at all times. In spring, Drabas are thickly covered with their little fls., and when planted in masses are decidedly effective. Prop. chiefly by division; also by seed, which may be sown in the fall if desired.

Cult. by J. B. KeLLer.

Of the species described below, only the first, second, fourth and sixth are advertised in Amer. at present. The rest are worth introduction, and can be procured abroad under their names or synonyms.

$$
\text { A. Flowers yellow. }
$$

B. Lvs, rigid, keeled, ciliate.

$$
\text { c. Scape not hairy. }
$$

D. Style as long as the pod is wide.

aizoldes, Linn. About 2-3 in. high : lvs. lanceolatelinear: stamens nearly as long as the petals. March. Eu. B.M. 170.

DD. Style half as long as the pod is wide.

Aizoon, Wahl. About 3 in. high : lvs. linear. April. Europe.

cC. Scape hairy (villous or pubescent).

D. Pod lanceolate, bristly.

cuspidàta, Bieb. Lvs. linear : style a little shorter than the pod. Asia Minor.

DD. Pod oval, pubescent.

Olýmpica, Sibth. (D. brunicefolia, Stev.). About 4 in. high: lvs. linear, a trifle keeled: petals twice as long as the calyx and stamens: style very short. June. Greece, Orient.

Bв. Lvs. not rigid or keeled.

$$
\text { c. Scape not hairy. }
$$

híspida, Willd. (D. tridentàta, DC.). About 3 in. high : lvs. obovate, narrowed into a long petiole, obscurely 3-toothed at the apex, somewhat bristly: pods oblong, not hairy. Scotland, Caucasus.

cc. Scape more or less hairy.

D. Hairs long, soft and slender, i.e., pilose.

alpina, Linn. Lvs. lanceolate, flat: pods oblong: style very short. April. Arctic regions.

DD. Hairs short, soft and downy, i.e., pubescent.

aùrea, Vahl. Doubtfully perennial or biennial: lvs. ovate-lanceolate, entire or remotely serrate: pods oblong-lanceolate. Arctic regions. B.M. 2934.

$$
\text { AA. Flowers white. }
$$

B. Plants biennial or annual.

cinerea, Adams. Lvs. oblong-linear: pods oblong, pubescent, shorter than the pedicel. Early spring. Siberia. - Closely related to D. ronfusa, but has a looser, weaker, less leafy stem, the stem-1vs. 5-6, scattered, entire. 
BB. Plants perennial.

\section{c. Leaves rigid.}

Máwii, Hook. Forming low, densely tufted, bright green patches: stem much branched, densely clothed with spreading, rosulate lvs.: lrs. linear-oblong, obtuse, bristly, with a prominent nidrib below: scape very short, woolly, 2-4-fld., very short-pedicelled: petals thrice as large as the sepals, obcordate, white: pods ellipsoid, compressed. Spain. B.M. 6186.

$$
\text { cc. Lvs, not rigid. }
$$

Fladnizénsis, Wulf (D. nivdlis, DC. D. Lappónica, Willd.). Lvs, oblong-linear to lanceolate, ciliate: pods elliptic-oblong to ovate-lanceolate, not hairy. Arctic regions.-According to De Candolle, these three names were distinct species.

\section{AAA. Fls. rose or purple.}

Pyrendica, Linn. Height 2-3 in.: lvs. inversely wedge shaped, 3-lobed at apex: fls, white at first, changing to rosy pink. May. Pyrenees. B.M. 713.-Said to be easily prop. by cuttings.

violàcea, DC. Lvs. obovate-oblong, obtuse, equally woolly on both sides: seapes leafy: petals obovate, dark purple. Andes of Equador at elevations of 13,000 15,000 ft. B.M. 5650 .

W. M.

DRACENA (female dragon; the dried juice supposed to resemble dragon's blood). Lilideece. A genus of tropical plants of which but few are in cultivation. They are all woody, often arborescent, with sword-shaped or broad lvs., mostly crowded at the summit of the stem: fls. clustered in panicles or heads, greenish white or yellowish; perianth salver-form or companulate; lobes spreading; stamens 6: fr. a 3-celled berry. Differs from Cordyline in having larger fls., and solitary instead of many ovules in each cell of the ovary. All ornamental stove plants, frequently with variegated lvs. See Baker, Journ. Linn. Soc., vol. 14, for a monograph of the genus. Dracana Draco, of the Canaries, is the Dragon Tree. It reaches a height of $30-60 \mathrm{ft}$., branching when of great age. The Dragon Tree of Teneriffe, famous for centuries, is $70 \mathrm{ft}$. high, and one of the oldest of known trees.

Some American trade names not referable to species are: alba-marginata, argenteo-striata, DeSmetiana, Elizabethia, Frederica, Hendersoni, imperator, $\mathrm{Sal}$ monea, Alexandria, recurva, spectabilis. See Cordyline for other names not found in this article; also for culture. D. Nova-Caledonica is probably Cordyline NeoCaledonica, Linden, with bronze lvs.

The following is a key to the cultivated species of both Dracæna and Cordyline, based upon the lvs.:

A. Lvs. long and sword-shaped, sessile.

B. Glaucous beneath, $2-5$ in. wide. C. indivisa. BB. Both faces similar, narrower.

c. Of mature plants quite narrow (6-15 lines broad). C. stricta.

cc. Of mature plants broader (1-2 in.)

D. Margins green.

Glaucous green, costate, $1 \frac{1}{2}-2 \mathrm{ft}$ by 15-21 lines. D. Draco.

Green, costate, undulate below,

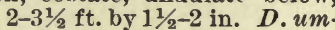
braculifera.

Green, costa obscure, 3-4 ft. by 13-18 lines. C. australis.

DD. Margins white-pellucid. D. Hook eriana.

AA. Lvs. oblanceolate, broadly petioled or sessile.

B. $3-4$ in. by $1 \frac{1}{2}-2$ in., opposite or whorled. $D$. Godseffiana.

BB, 12-15 in. by 18-21 lines, alternate. C. rubra. BBB. $1 \frac{1}{2}-3 \mathrm{ft}$. by $2 \frac{1}{2}-4$ in., alternate. $D$. fragrans. AAA. LVs, ovate, lanceolate, or elliptical, petioles narrow.

Lvs. $4-8$ in. by $2-2 \frac{1}{2}$ in., oblong-falcate, green. C. Haageana.

Lvs. 7-8 in. by 4-5 in., oblong, white-spotted. D. Goldieana.

Lvs. $7-10$ in. by $1 / 2-1 \frac{1}{2}$ in., lanceolate, whitemargined. D. Sanderiana.

Lvs. 10-18 in. by $1-3 \frac{1}{2}$ in., elliptical. C. terminalis.

The following Dracænas are in the American trade:
Boerhavii, 1; Draco, 1; fragrans, 4 ; Godseffiana, 7; Goldieana, 5; Hookeriana, 3; Knerkii, 4; latifolia, 3; Lindeni, 4; Massangeana, 4 ; Rothiana, 4; Sanderiana, 6; umbraculifera, 2 .

1. Dràco, Linn. Dragon Tree. Arborescent $(60 \mathrm{ft}$. high), branched : lvs. very numerous, crowded, swordshaped, erect or the outer recurved (11/2-2 ft. x 15-21 in.), scarcely narrowed below, long-attenuate at the apex, glaucous-green: pedicels 3-6 lines long: bracts minute, lanceolate: perianth 4 lines long, greenish; filaments flat : berries orange. Canary Isl. B.M. 4571. R.H. 1869 , p. $416 ; 1880$, p. 196 . G.C. II. $14: 749$. - Fine for conservatory. D. Boerhavii, Tenore, is a garden form, with elongated lvs. all recurved.

2. umbraculifera, Jacq. Arborescent (3-10 ft. high), simple : Ivs. very numerous, crowded, sword-shaped $\left(2-3 \frac{1}{2} \mathrm{ft} . \times 1 \frac{1}{2}-2\right.$ in. $)$, outer recurved, all green and shining, attenuate at the apex, scarcely narrowed toward the conspicuously undulate base, costa distinct on both faces: pedicels 4-6 in. long: bracts minute, deltold: perianth large, 2 in. long, white, tinged with red; filaments filiform. Mauritius. L.B.C. $3: 289$.

3. Hookeriàna, Koch. Trunk 3-6 ft. high, sometimes branched : lvs. numerous, densely clustered, swordshaped $\left(2-21 / 2 \mathrm{ft} . \times 1 \frac{1}{2}-2\right.$ in.), outer reflexed, all long attenuate at the apex, scarcely narrowed below, margin white-pellucid, lower face concave, indistinctly costate beneath: bracts $1 \frac{1}{2}-3$ in. long, white: pedicels $3-4$ in. long; perianth greenish, 12-15 in. long; filaments filiform: berries orange. Cape Good Hope. D. latifolia, Regel, is a horticultural variety, with $1 \nabla s .3-31 / 2$ in. wide. G.C. 20:305 (var. latifòlia). B.M. 4279 as Cordyline Rumphii.

4. fràgrans, Ker-Gawl. (Aletris fràgrans, Linn. Sansevièra fràgrans, Jacq.). Arborescent (20 ft. high or more), sometimes branched: lvs. (11/2-3 ft. $\times 2 \frac{1}{2}-4$ in.) sessile, oblanceolate, lax and spreading or recurved, flaccid, green and shining, acute, indistinctly costate : bracts minute, scarious, deltoid: pedicels $1-1 \frac{1}{2}$ in. long:

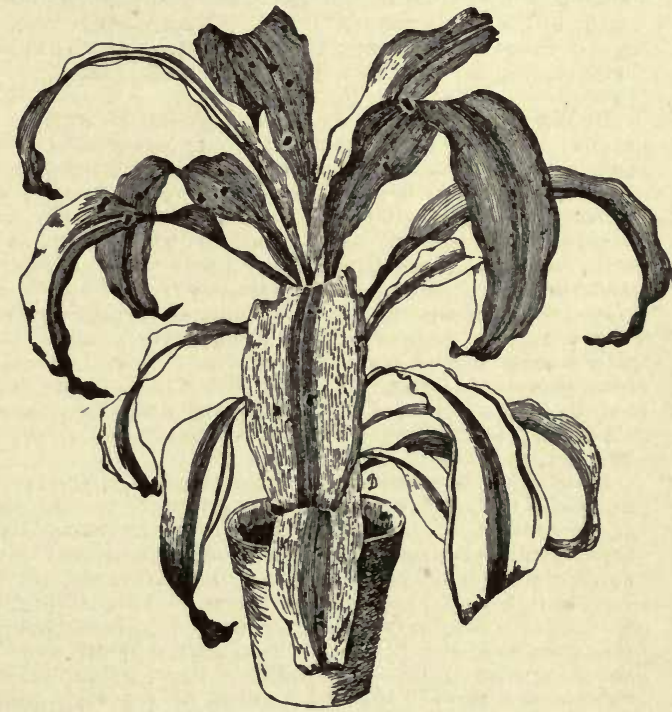

733. Draczena fragrans, var, Lindeni.

fls. glomerate; perianth 6-8 in. long, yellow : berry orange-red. Guinea. B.M. 1081. A.G. 18:389. F.R, $4: 189$. - Much used for greenhouse and table decoration. D. Knérkii, Hort. Form with glossy light green, less pendulous lvs. D. Rothiana, Hort. A garden form. I.H. 43, p. 97. R.H. 1877 , p. 68 . Var. Líndeni, Hort. (D. Lindeni, Hort.). Fig. 733. Lvs, recurved, traversed from base to apex by creamy white bands. Very decorative. I.H. 27:384. F.R. 4:191. Var. Massangeana, Hort. $(D$. Massangedna, Hort.). A broad, yellow stripe along the center of the leaf throughout its entire length. F.R. $4: 193$. 
5. Goldieàna, Hort. Trunk simple, slender: lvs. distant, spreading, thick-oblong (7-8 in. $x 4-5$ in.), cuspidately pointed, base broadly rounded or cordate, glossy green, conspicuously white-spotted and banded, young lvs. often tinged with red; petioles erect (2-3 in. long), deeply grooved: fls. unknown (?). W. Trop. Afr. B.M. 6630. R.H. 1878 , p. 15 . I.H. $25: 300 ; 42$, p. 257 . G.C. II. 17:49. - A fine foliage plant.

6. Sanderiàna, Hort. (D. thaloides, var. variegdta, Hort. ?. Slender: lvs, distant, alternate, spreading or recurved ( $7-10$ in. $x \frac{1}{2}-1 \frac{1}{2}$ in.), narrowly lanceolate, acuminate, on rather broad petioles (1-3 in. long), glossygreen, broadly margined with white. Congo. A.F. 8: 1281 ; $11: 235$. I.H. $40: 175$. G.C. III. $13: 445$. - Int. by Sander \& Co. in 1893.

7. Godseffiana, Hort. Woody, but very slender, rather diffuse: lvs. at many nodes small, erect, scale-like and lanceolate, the others opposite or in whorls of 3 , oblong or obovate, spreading, cuspidate, sessile ( $3-4$ in. $\times 1 \frac{1}{2}-2$ in.), firm, green, with copious white spots: raceme short-peduncled; bracts small : fr. globular, greenish yellow or red, nearly 1 in. in diam. Congo. G.C. III. $21: 347$. Gn. 50, p. 276; 51:1115, and p. 299. A.F. 13:1340. F.E. 10, supp. 2:12. Gng. 6:294. -Int. by Sander \& Co. Fine for decorative purposes.

D. arbòrea, Link. Lvs. green, sword-shaped, dense, sessile. Gt. 46, p. 226 and 1438.-D. Broomfieldi, Hort. J.H. III. 33:541. G.C. III. $20: 667 ; 23: 249$. - D. concinna, Kunth. Lvs. oblanceolate, green, purple on the margin, green-petioled. Gt. 441:1864. -D. cylindrica, Hook. Lvs. linear-laneeolate or obovate-lanceolate, bright green, spreading. B.M. 5846.-D. elliptica, Thunb. Lvs. spreading, petioled, thickish, elliptic-lanceolate, glossy, acute, longitudinally striate. B.M. 4787 and G.C. II. 17:261 (var, maculata) -D Eeckhanti, Hort. F 4 G.1899-D ensi

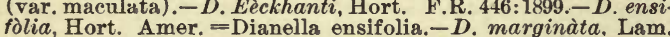
folia, Hort. Amer, = Dianella ensifolia. - D. marginata. Lam.
Lvs. sword-shaped, dense, spreading, green margined and veined with red.-D. marmoràta, Hort. B.M. 7078.-D. phry nioides, Hook. Lvs, petioled, mostly oval, acuminate, coriaceous, spotted with yellowish white, pale beneath. B.M. 5352 -D. refléxa Lam Lvs. lanceolate or sword-shaped acute, con tracte into a petiole. D. Saposchnfkovi Regl. shaped, crowded,green. Gt. 705.-D. Smithii, Baker. Lvs. large, narrowly sword-shaped, crowded bright green. B.M. 6169 .

$$
\text { K. M. WIEGAND. }
$$

Dracænas should be divided into two sections or types for practical purposes:

(1) The Tropical type: This includes the colored foliage sorts and the garden hybrids, all of which can be propagated from both root and stem-cuttings or joints. All of them require a stove or warmhouse temperature, and must be grown quick, and never allowed to get potbound until they are as large as required; then they can be allowed to get pot-bound, and with liquid or other stimulant and plenty of light will color well.

(2) The Cordyline or Subtropical or Australian type: This embraces the kinds known to gardeners as aus. tralis, indivisa, lineata, sanguinea, aurea-striata, Doucetiana, umbraculifera, Rumphii. Nearly all of these are propagated from seeds, and require a cooler temperature.

Following are some popular current Dracænas: Sanderiana makes not only a perfect center plant for table jardinieres with small ferns and selaginellas, but it also makes a fine large decorative plant by putting from 35 in a 4-5 in. pot, and letting them get fairly well potbound until each plant throws up shoots from the base; then repot, and one will have a fine, large specimen in a short time. Godseffiana is a valuable plant for a hanging basket, easily propagated from top shoots. Other popular kinds are: Norwoodiensis, albo-marginata, terminalis alba, Gladstonei (one of the most brilliantly colored of the broad-leaved type), Guilfoylei, Anerleyensis, Scottii, hybrida, metallica, ferrea, De-Smet iana, Victoria-Regina, Sanderiana, Godseffiana, gracilis. H. A. SIEBRECHT.

DRACOCEPHALUM (Greek, dragon's head, from the wide-open mouths of the flowers). Labidtce. This genus contains a few hardy herbaceous perennial plants of the mint family, of easy culture and of minor importance. The whorls of fls. are distant or crowded into spikes or heads, the colors blue or some shade of purple. The genus has altogether about 30 species, from Europe, especially the Mediterranean region; also A sia outside the tropics. All the species described below are erect, but some others are diffuse : uppermost lvs. like the lower ones or reduced to bracts. Very closely allied to Nepeta. Sandy loam, moderately rich, and a ruther moist, partially shaded situation will suit these plants best. In a sunny, dry border they are never very showy; the fls. are of short duration, and are seldom at their best except in very moist seasons. Prop. by division or seeds.

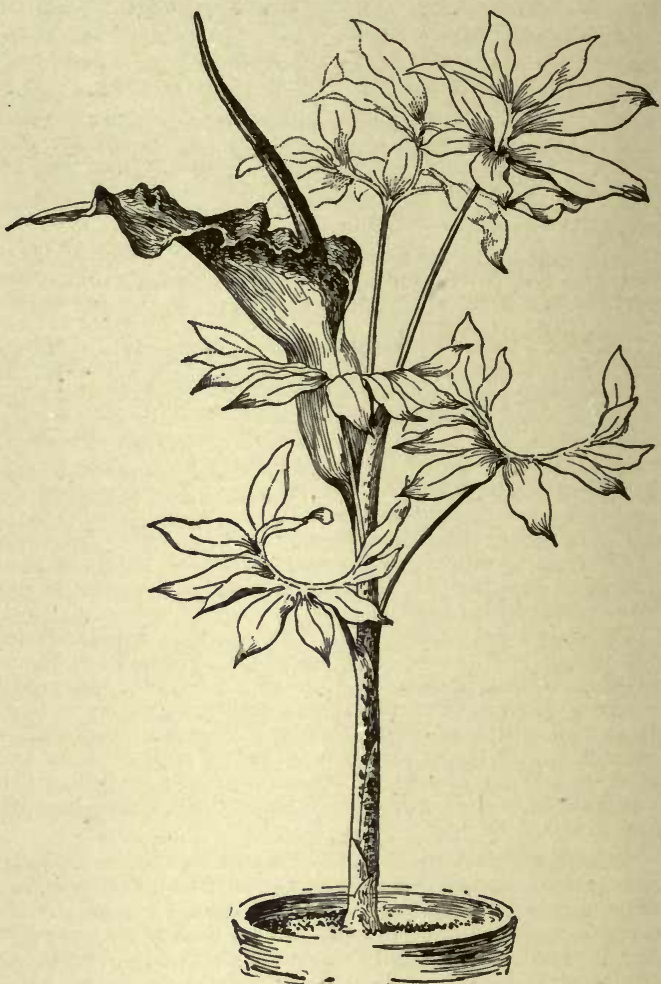

734. Dracunculus vulgaris $(\times 1 / 6)$.

A. Lvs. entire, not cut in any way.

Ruyschiànum, Linn. Stems slightly pubescent: lvs. linear-lanceolate, glabrous: bracts ovate-lanceolate, entire; whorls in somewhat interrupted spikes: fls. 1 in. long, purplish blue or purple; anthers villous. Siberia. Var. Japonicum, Hort., has white fls. shaded with blue, and is a distinct improvement. G.C. II. 12:167.-According to Vilmorin, this species has been sold as $D$. Altaiense (see D. grandiflorum).

\section{AA. Lvs. deeply 3-5-cleft.}

Austriacum, Linn., has the habit of the above, and belongs to the same subgenus Ruyschiana, but the lvs. are divided and more distinctly revolute at the margin. About $1-1 \frac{1}{2} \mathrm{ft}$. high : fls. blue, $1 \frac{1}{2} \mathrm{in}$. long and more. July, Aug. Eu., Caucasus.

AAA. Lvs. cut only at the margin, mostly crenate.

B. Whorls crowded together into spikes or heads.

c. Color of fls. blue: lvs. not wrinkled.

grandiflòrum, Linn. (D. Altaiénse, Laxm., but plants in trade under this name are said to be D.Ruyschiana). About $1 \mathrm{ft}$. high. Root-Ivs. long-stalked, oblong, notches at base: stem-lvs, few, short-stalked, ovate, not notched at base, the uppermost still more rounded: whorls in spikes 2-3 in. long, the lowest whorl usually at some distance: fls. 2 in. long. June, July. Siberia. B.M. 1009. P.M. 13:51.

cc. Color of fls. purple: lvs, wrinkled.

speciòsum, Benth. Allied to $D$. grandiflorum, but stem pubescent instead of pilose above, root-lvs. more 
broadly heart-shaped, and all lis. pubescent beneath instead of nearly glabrous: fls. purplish to deep purple. June, July. Himalayas. B.M. 6281.

\section{B. Whorls distant, in long racemes.}

$$
\text { c. Flowers erect. }
$$

Moldávicum, Linn. Lvs. larceolate, inciso-crenate, the floral ones narrower and saw-toothed at the base. Eu., N. Asia.

Rùprechtii, Regel. Lvs, ovate-lanceolate, variously incised and toothed: fls. rosy purple or lilac, about 1 in. long, in axillary clusters. Turkestan. Gt. 1018.

$$
\text { cc. Fls. somewhat nodding. }
$$

nùtans, Linn. Lvs. ovate, crenate, the floral ones oblong-lanceolate and more nearly entire: fls. blue. MayJuly. N. Asia. Mn. 4:137. B.R. 10:841.-Var. alpina, Hort., is commoner.

D. Virginianum, Linn. See Physostegia - D. Canadense of Bridgeman's Catalogue is a misprint for $\mathrm{D}$. Canariense $=\mathrm{Ce}$ dronella triphylla.

J. B. KELLER and W. M.

DRACUNCULUS (Latin, a little dragon). Aracea. This genus contains the r,lant pictured in Fig. 734 . It has uncanny, dragon-flngered lvs. and a terrifying odor when in flower. Its tubers are sold by bulb dealers under the name of Arum Dracunculus. The latest monographer of this order (Engler, in DC. Mon. Phan., vol. 2,1879 ) puts this plant into the genus Dracunculus because the ovules are attached to the base of the ovary, while in Arum they are attached to the side. The lvs. of the true Arums are always arrow-shaped, while in Dracunculus they are sometimes eut into finger-like lobes. For culture, see A rum.

There are only 2 species. The common one is an entertaining, not to say exciting, plant. When it flowered in the forcing-houses at Cornell University, innocent visitors thought there must be a dead rat under the floor. It is well worth growing for the experience, though its stench is not quite as bad as that of a Helicosideros, sold as Arum crinitum, which makes any house unbearable in which it flowers. Nearly all Arums are illsmelling.

vulgàris, Schott. Fig. 734. Sheath of lvs. livid, spot ted : stalks green : blades with 10 fingers projecting from a bow-shaped base: tube of spathe streaked with purple except at the bottom: spathe purple all over and much darker along the wavy border. Mediterranean regions.

W. M.

DRAGON PLANTS. The Dragon Arum, Dragon Root or Green Dragon, is the native Ariscema Dracontium. The Dragon Plant of Europe is Dracunculus vulgaris. The Dragon's Head is not an Aroid, but a Dracocephalum, a genns of mints. False Dragon's Head is Physostegia. The Dragon's Blood of commerce is a dark red,
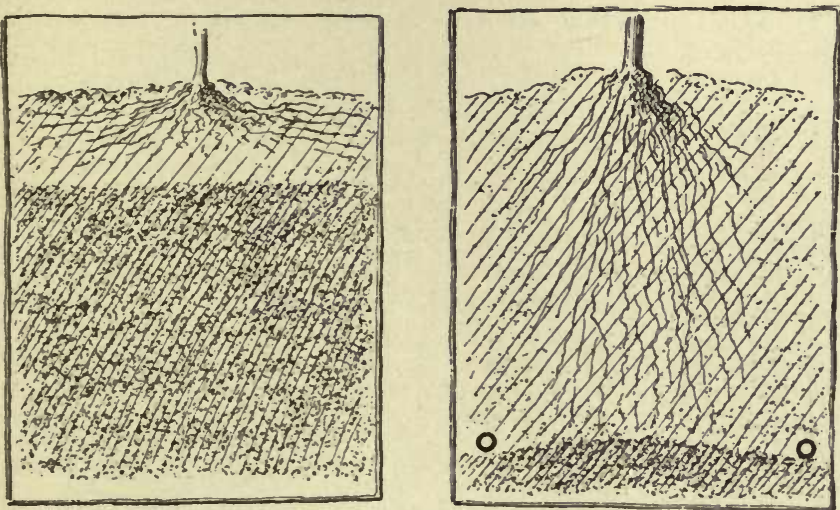

735. Diagrams showing the effect of lowering the water-table by means of under-draining.

On the undrained soil, the roots do not penetrate deep; and when droughts come, the plants suffer. astringent, resinous secretion of the fruits of a palm Damonorops 1)raco. Other kinds of Dragon's Blood are produced by Dracuna Draco and Ecastaphyllum Monetaria. "Sticks," "reeds," "tears" and "lumps" of Dragon's Blood are known to commerce. The resin is used in coloring varnishes, dyeing horn in imitation of tortoise shell, and $n$ the composition of tooth-powders and various tinctures.

DRAINAGE. Underground or sub-drains serve to relieve the land of free water, which is harmful to most plants if left to stagnate in the surface soil or subsoil. They serre not only to dry the land in early spring, but indirectly to warm it, for if the water is removed the sun's heat warms the soil instead of cooling it by evaporating

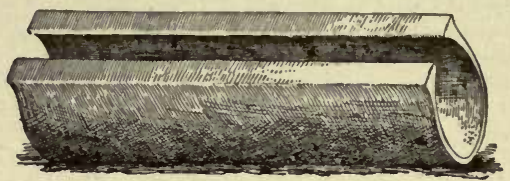

736. Old-fashioned drain tile.

the surplus water. Tenacious lands devoted to gardening and small fruits are made more productive, warmer and earlier by sub-drainage. Drains promote nitrification, assist in liberating mineral plant-food and cheapen tillage. They serve not only to remove deleterious stagnant water, but they promote aëration as well, and this hastens beneficial ehemical changes in the soil. Drainage promotes the vigor, healthfulness and fruitfulness of plants. Tenacious soils are made more friable by drains, thereby giving easier access to plant roots, while the percolation through the soil of rainwater, which carries some plant-food, is hastened. Rainwater in the spring is warmer than the soil; in midsummer it is cooler than the soil: therefore, percolation of rainwater warms the soil in the spring and cools it in extremely hot weather. Drains serve not only to relieve land of free water, but they impart to it power to hold additional available moisture, which materially benefits plants during droughts.

Drainage is of two kinds, surface and sub-drainage.

On land on which large outlays of money are to be expended, as in horticultural plantations, it is of the utmost importance that the soil be freed to considerable depths from stagnant water. Trees, many shrubs, and even some garden crops send their roots deeper into the subsoil than most of the cereals, hence they require a greater depth of drained feeding ground. In horticulture the planting may often precede the harvest by 5 to 10 years, while with many farm crops the harvest follows the planting in a fow months. If the grain raiser loses one crop, an annual, by planting on wet land, the loss is not great, but if the orchardist loses 15 to 20 years of labor by planting on undrained lands, before the mistake is discovered, the losses are serious. Some lands require little more than to be relieved from surplus surface water in early spring. This may be accomplished by forming ridges and open furrows as far asunder as the rows of trees are to be placed. But it is only rarely that surface drainage fully prevents serious damage from surplus moisture. Surface drainage may be considered a cheap way of temporarily alleviating undesirable conditions. It does not always eradicate them. Fig. 735 illustrates how sub-drainage low ers the water-table (or the area of stand ing water), and thereby ameliorates the soil.

Sub-drainage consists in placing conduits of tile or other material in the ground at depths varying from $21 / 2-4$ feet, and at such distances apart as will serve to relieve the subsoil of deleterious stagnant water. When suitable stones are at hand they are sometimes used instead of tile for forming drainage conduits. If such use is made of them, the drains should be somewhat deeper than tile drains, since the stones which form the drain occupy 
nearly a foot of the depth of the ditch and are more likely to become obstructed, especially if placed near the surface, than are tile drains. The throats or openings of stone drains are irregular in size, while those of tile drains are smooth and uniform in size, and are, therefore, most desirable. Years ago, various flat-bottomed tiles (Fig. 736) were used, but the only style in general use at present is the cylindrical unglazed tile shown in Fig. 737.

In some sections drains are placed 200 to 300 feet apart, and serve their purpose well. In others they should not be placed farther apart than from 20 to 30 feet. Whereever the subsoil is composed of tenacious, fine clay, through which the water moves upwards or downwards with difficulty, the narrower intervals are necessary. In some instances the surplus water in the subsoil is under pressure by reason of water which finds its way into it from higher levels, and if this is not removed, the water has a constant tendency to rise to the surface. In many such cases drains placed at wide intervals may serve to relieve the pressure and drain the land. Since sub-drains are designed to be permanent, are expensive to construct and difficult to repair, the principles of drainage should be well understood, and the work should be undertaken only after a most careful inspection of the land and after the fundamental principles of the subject have been mastered.

Mains and sub-mains should be avoided so far as possible, since they greatly increase cost, tend to become obstructed, and are often unnecessary. The three long mains in Fig. 738 are not drains, strictly speaking,

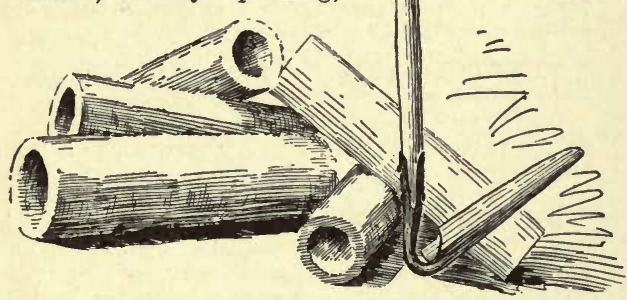

737. Common cylindrical drain-tile; and a scoop for preparing the bed for the tile.

since the land may be as fully drained without them, as shown in Fig. 739; therefore, they only serve to conduct the water of the drains proper. Tiles of 3 to 4 and 5 inches diameter should be used when the drains are infrequent and the flow of water considerable. Smaller ones, 2 to 3 inches in diameter, will suffice when the intervals between the drains are narrow. Drains should have as uniform a fall as possible, and no abrupt lateral curves or sharp angles should occur as are seen in many places in Fig. 738. If the drain has a rapid fall in its upper reaches, as is often the case, and but slight fall in the lower, a silt basin should be constructed at the point at which the rapid changes into the slight fall, if obstructing silt is present. All drains which may be necessary should be placed before the planting occurs. Orchard lands may be drained in the spring, fallowed in the summer, and planted in the fall or the following spring. Drains placed at frequent intervals because of the tenacity of the soil should be comparatively shallow, for if placed deep or at wide intervals, the water will be too long reaching them. If drains are placed at wide intervals they should be at least $3 \frac{1}{2}$ feet deep to be most efficient. If the parallel system is adopted (Fig. 739), there may be more outlets to construct and maintain than is desirable; if so, the system might be modified by constructing a sub-main, one side of which will serve also

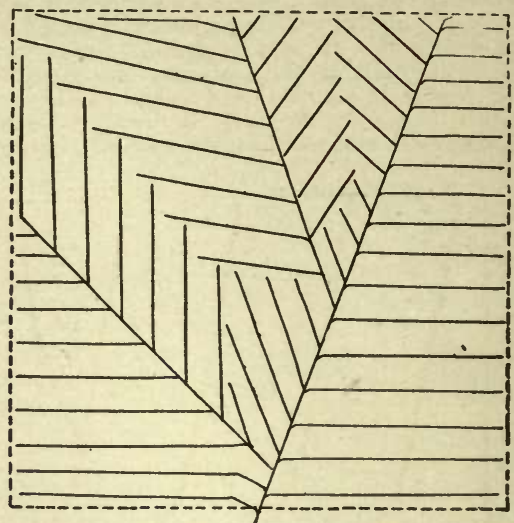

738. Improper method of draining a field.

as a drain, and but one outlet will be required (Fig. 740). Drains through which water runs for the greater part of the year are likely to become obstructed by roots, if water-loving trees, such as the willow, soft maple and elm, are allowed to grow near them. If floating silt is present the joints of the tiles should be protected for two-thirds of their upper circumferences by a narrow strip of tarred building paper, or collars should be used. Stone drains should receive a liberal covering of straw before they are filled.

I. P. ROBERTS.

DREER, HENRY A. Seedsman, and founder of one of the oldest American horticultural establishments; was born in Philadelphia, Aug. 24, 1818, and died there Dec. 22,1873 , at the age of fifty-five. His parents were Frederick Dreer, of Hanover, and Fredericka Augusta Nolthenius, of Grossakenheim, Germany. They were married in America. The Nolthenius family emigrated to the United States in the last decade of the eighteenth century, and were closely connected with the Lutheran Church. Henry. A. Dreer's education was largely in German, and obtained in Philadelphia. He was fond of gathering seeds and plants in the country, and would bring them home to cultivate. He was trained in his father's business, that of a cabinet-maker. In 1838, at the solicitation of a friend, he began as a florist in a small way, near Front and Chester Sts. About 1870 he removed to Seventh and Chestnut. In 1869 he enjoyed a 5 months' trip to Europe, where he met business correspondents of 30 years' standing. He was married June 22, 1847, to Mary Leavenworth, of Reading, Pa.,

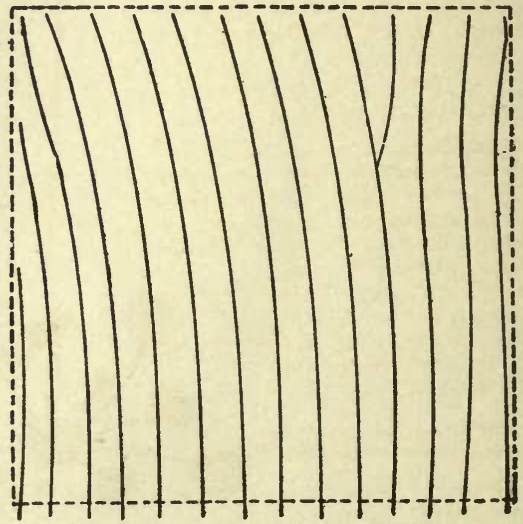

739. Best method of draining a field. 
and had six children. Of the two sons, one died in infancy, and the other, William F. Dreer, conducts, at 714 Chestnut street, the business which is incorporated in the name of his father. Henry A. Dreer died of a nervous affection of the heart. He was of modest temperament and frail constitution, and confined himself to business rather closely. He was liberal in public matters, but always kept out of political life. He compiled several small works in connection with the business, and wrote frequently for the Weekly Saturday Evening Post, of Philadelphia, and for Godey's Ladies' Magazine.

W. M.

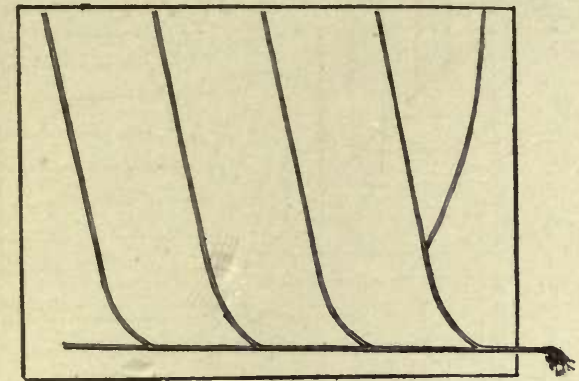

740. Showing how the drains may be gathered into one when there is only one place at which an outlet can be secured.

DROPWORT. Spircea Filipendula; also Potentilla Filipendula.

DRÓSERA (Greek, dew; referring to the dew-like drops on the glandular leaves). Droserdcea. SunDEw. DEw Plant. A very interesting group of insectivorous plants. About 100 species scattered throughout the world, except the Pacific islands, and most common in Australia outside the tropics. Perennial bog herbs with basal lvs. clothed with glandular hairs, which secrete a fluid that holds insects fast. Foliage and inflorescence differ widely. The 3 species described below may be obtained through dealers in native plants. For culture, see Darlingtonia.

\section{A. Lus. thread-like, with no distinct stalk: petals} purple.

filiformis, Rafin. Lrs. 6-15 in. long, glandular-pubescent throughout, at the very base woolly with brown hairs: racemes 1 -sided, 10-30-fld.: fls. 4-12 lines broad. July-Sep. Wet sand near the coast. Mass. to Fla.

\section{AA. Lv's, with an oblong blade: petals white.}

longifolia, Linn: Lvs. long.petioled; blade $8-15$ lines long, 1 1/2-2 lines wide, the petiole glabrous. Summer. Bogs, northern and arctic regions.

AAA. Lvs. with a blade that is wider than long: petals white. rotundifolia, Linn. Fig. 741. Lvs. with a blade 3-6 lines long, glandular above, petiole $1 / 2-2$ in. long, pubescent but not glandular : racemes 4-12-fld.: fis. about 2 lines broad, opening in sunshine. July, Aug. Bogs, L ab rador to Alaska, south to Fla. and Ala., and in the Sierra $\mathrm{Ne}$ vada to Calif.

Other Droseras are to be expected in finecollections, and some of them are more showy than those mentioned above. Some of the best are as follows: $D$. bi. nata, Labill., of Austral. and N. Zeal., with lvs. deeply parted into 2 long, linear lobes. Prop. by root-cuttings. B.M $308^{\circ}-D$ Capénsis, Linn of S. Afr. has linear or strap-shape leaf-blades as long as the petiole, Afr. has linear or strap-shape leaf-blades as long as the petiole, and large $(1$ in. in diam.), rosy red fls. Prop. by root-cuttings. G.M. $6583,-D$ dichótoma, Hort. $=$ D. binata. $-D$. linearis, erect petioles, and purple fls.-D. spathulàta, Labill., Austral. N. Zeal., has short, oblong-spatulate lvs. in a rosette, narrowed into short petioles, and purplish fis. G.C.1881, 16:852

\author{
W. M.
}

DRUPE. A fleshy fruit containing a single seed with a bony covering or "stone," as a plum. Fig. 742. A Drupe resembles an akene in being 1-sided, and not splitting, but an akene is dry instead of pulpy or fleshy. The most important drupaceous or stone fruits are peaches, plums, apricots, cherries and raspberries. Each of the fleshy parts of a raspberry is a drupelet.

DR $\mathbf{I} \mathbf{A}$ (Greek, woodnymph). Rosdcea. A genus of 2 or 3 species of dwarf, hardy, tufted, evergreen, somewhat shrubby plants with oblong lvs. half an inch long, recurved at the margins, shining above, snowy white beneath, and large white or yellow fls. borne singly on slender scapes: calyx glandular-hairy : petals 8-9, broadly ohovate: stamens many. The genus is close to Geum, but the species of Geum are herbs with deeply cut foliage. J. W. Manning recommends a soil well furnished with peat.

Dryas octopetala requires a well drained, porous soil, a sunny but not dry position. It is well to shade the foliage from bright sun during the winter months with evergreen branches to prevent the foliage from having a scorched appearance. A capital plant for the rockery. Prop. by cuttings, division, or by seed.

octopétala, Linn. Lvs. oblong, deeply and regularly crenate, downy beneath: scapes $2-3$ in. long: fls. white: seeds with a feathered awn orer 1 in. long. North temperate and arctic regions.

J. B. KELLER.

DRYMOGLOSSUM. A genus of small ferns from Japan, with wide creeping rootstalks, and small, entire leaves: sori resembling those of Polypodium. None are advertised in America. Three or four kinds are cult. abroad.

L. M. UNDERWOOD.

DRYMOPHLC̀US (Greek words meaning oak and smooth inner bark). Palmacece, tribe Arècece. This genus contains a tropical palm, with very distinct wedgeshaped leaflets and ornamental scarlet fruits, borne every year. It flowers when only a few feet high, and is suitable for pot culture. Spineless palm, with slender, medium caudex: lvs. terminal, equally pinnatisect, the segments cuneate-oblong or linear, broadly oblique, submembranaceous, 3 - to many-nerved, the margins recurved at the base: rachis scaly, 3 -sided: sheath long: spadix with a short peduncle and slender branches : spathes 2 or many, the lower one 2-crested. Species 12. Australasia and the Pacific islands.

The chances are that most of the plants now known to the American trade as $D$. olivaformis are really $D$. $a p$. pendiculata. The true $D$. olivaformis is said to have been offered by a few dealers as Ptychosperma Rumphii. D. appendiculata was described and figured by William Watson, in Garden and Forest, erroneously as D. olive formis, as explained in B.M. 7202. He adds, "Like all the palms of this section of the order, Drymophlœus requires a tropical moist house with abundance of water at all times." The plant figured was about 14 years old, $3 \mathrm{ft}$. high, with lvs. about $3 \mathrm{ft}$. long. The plant takes about six months to mature its fruits.

appendiculàta, Scheff. (A rèca grácilis, Griseke, not Roxb, or Thou.). Leaflets wedge-shaped, raggedly cut, serrate. Moluccas, New Guinea. B.M. 7202. G.F.4:331.

D. olivaformis, Mart., has narrower leaflets than the above, and the fruit half immersed in the greatly enlarged perianth.

JARED G. SMITH and W. M. 
DRYNARIA (Greek, oak-like). Polypodidcece. A genus of 10 or more East Indian ferns, with round naked sori, allied to Polypodium, but with a fine net-work of veins, with free included veinlets, and with either a separate oak-like leaf or with the lower portion of the spur-bearing leaf deeply pinnatifid like an oak leaf. $D$. quercifolia, with two sorts of lvs., the spore-bearing 2-3 ft. long, is the commonest species. D. rigídula, Sw. (D. diversifòlia, R. Br.), a similar but larger species from the same region, also appeared at one time in the American trade, but the species are seldom seen in cultivation in this country. D. musafòlia is occasionally seen in fine collections, where it is grown for its striking, simple foliage, which reminds one of the Bird's Nest Fern (Thamnopteris). It is really a Polypodium, which see for description.

\section{M. UNDERWOOD.}

DRYÓPTERIS (Greek, oak-fern). Polypodidcea. WOOD FERN. A widely distributed genus of handsome ferns with dissected foliage and bearing round sori covered with heart-shaped or reniform indusia, which are fixed at the center or along the sinus. The veins are either wholly free or the lowest united. A considerable number of our common wood ferns belong to this genus. The species have been variously known under the names Lastrea, Aspidium, and Nephrodium. Other species sometimes referred to under this genus may be found under Polystichum. For D. acrostichoides, see Polystichum; for D. decurrens, see Sagenia. In North America, known mostly as Aspidiums. For culture, see Ferns. Not the same as Doryopteris.

\section{A. Veins entirely free.}

B. Pinnce lobed less than one-third to midrib.

hirtipes, Kuntze (Nephrddium hirtipes, Hook.). Lvs. 2-3 ft. long, 8-16 in. broad, on stalks clothed with dense black scales; pinnæ with broad, blunt lobes, the lower ones not reduced in size : sori medial on the lobes. India.

BB. Pinno cleft nearly to midrib, or lvs. bipinnate or tripinnatifid.

c. Texture thin, membranous; veins simple or once forked.

D. Lower pinnce gradually reduced to mere lobes.

Noveboracénsis, Gray (Aspídium Noveboracénse, Sw.). Lvs. somewhat clustered from ereeping rootstocks, pale green, 1-2 ft. long, tapering both ways from the middle. Canada to N. C. and Ark.

Físcheri, Mett (Lastrèa opd̀ca, Mett). Lvs. 6-8 in long, 2-3 in. wide, bipinnatifid, cut into close, entire lobes, the lowest much reduced; surfaces smooth. Braz.

DD. Lower pinnce scarcely smaller than those above. E. Veins forked.

Thelypteris, Gray (Aspidium Thelypteris, Sw.). MARSH FERN. LVs. scattered on wide creeping black rootstocks, 1-2 ft. long; margins of the spore-bearing pinnæ often strongly convolute: sori $10-12$ to each segment. Canada to Fla. and Tex.

\section{EE. Veins simple.}

simulàta, Dav. Lvs. scattered from a creeping rootstock, 8-20 in. long, 2-7 in. wide, with $12-20$ pairs of lanceolate pinnæ: sori rather large, somewhat distant, 4-10 to each segment. Native in N. Y. and N. Eng., where it is often confused with $D$. Thelypteris. G.F. 9:485.

pàtens, Kuntze. Lvs. clustered at the end of a thick rootstock, 2-3 ft. long, 4-10 in. wide, soft-hairy beneath ; pinnæ cut three-fourths to the midrib, the basa segments usually longer. Fla. to Tex. and Trop. Amer. A.G. $20: 25$.

CC Texture firm or subcoriaceous; veins 2-4 times forked.

D. Lvs. bipinnatifid or nearly bipinnate: indusia large, mostly flat.

cristàta, Gray (Aspidium cristatum, Sw.). Lvs. 1-2 ft. iong, with short, triangular pinnæ $2-3$ in. long, which are much wider at base. Var. Clintoniàna is larger, with pinnm 4-6 in. long, and with the sori rather near the midvein. Canada to Ark.; also in N. Eu. Hybrids are described with $D$. marginalis. G.F. 9:445.

Goldieàna, Gray (Aspidium Goldieànum, Sw.). Lvs. growing in large crowns, 2-4 ft. long, 12-18 in. wide, the pinnæ broadest at the middle: indusia very large. Canada to $\mathrm{Ky} .-$ One of our largest and most stately native species.

DD. Lvs. mostly bipinnate: indusia convex, rather firm.

Filix-más, Schott (Aspídium Fìlix-más, Sw.). MALE FerN. Lrs. growing in crowns, 1-3 ft.long, sori near the midvein. Used as a vermifuge, as is also the next species. N. Eu., Canada and Colo.

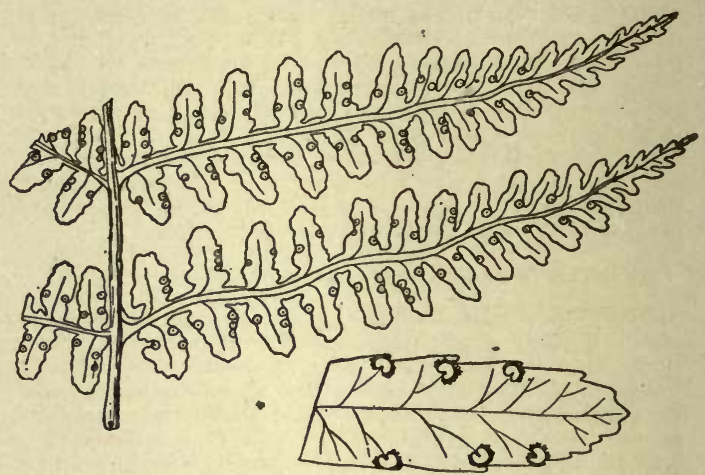

743. Dryopteris marginalis.

marginàlis, Gray (Aspídium margindle, Sw.). Fig. 743. Lvs. 6 in. to $2 \mathrm{ft}$. long, growing in crowns, mostly in rocky places: sori close to the margin. Canada and southward.-One of our commonest ferns.

DDD. Lvs. mostly tripinnatifid; segments spinulosetoothed: indusia shriveling at maturity.

E. Leaf-stalks naked, polished.

viridéscens, Kuntze. Lvs. 18-24 in. long, on stalks two-thirds as long; lower pinnæ largest: sori near the midribs. Japan.

\section{EE. Leaf-stalks scaly.}

spinulòsa, Kuntze (Aspidium spinutòsum, Sw.). Lvs. ovate-lanceolate, with a few pale, deciduous scales at the base : indusia smooth, without marginal glands. Var. intermèdia, Underw., has more persistent scales, with a brown center, and the margins of the indusia with stalked glands. One of our commonest wood ferns in the northern states. - Var. dilatata, Underw., has similar scales to the last and tripinnate lvs. In woods, from Canada to Ore.; also in Europe.

Bodttii, Underw. (Aspídium Bodttii, Tuckm.). Lvs. elongate-lanceolate, with broadly oblong pinnules : in dusia minutely glandular. Canada, N. Y. and N. Eng.

DDDD. Lvs. ample, 4-5-pinnatifid.

effùsa, Kuntze. Lvs. 3-4 ft.long, $2 \mathrm{ft}$. or more wide, with polished stems and short, creeping rootstocks : sori abundant, scattered, often without indusia. Cuba to Brazil.

dissécta, Kuntze (Lastrèa membranifôlia, Hort.). Lvs. 1-5 ft. long, 1-3 ft. wide, membranous, decompound segments broad and blunt; surfaces nearly naked: sori near the margin, abundant. India and Madagascar to Australia.

AA. Veins not entirely free, the lower veinlets of adjoin. ing segments united.

Otària, Kuntze (Lastrèa aristata, Hort.). Lvs. $1 \mathrm{ft}$. long, with a long terminal pinnæ an inch or more wide, with lanceolate lobes, and 6-12 similar lateral pinnæ; texture thin; surfaces naked; veins united half way from the midrib to the edge. Ceylon to the Philippines. - Good for table ferneries, but slow of growth. 
móllis, Kuntze. Lrs. 1-2 ft. long, 8-12 in. wide, bipinnatifi, the pinnæ cut into blunt lobes; lower pinnæ distant from the others and somewhat shorter; surfaces tinely villose. Trop. regions of both hemispheres. Probably several species are confused under this name.

Philippinénsis, Baker. Lvs. 2-3 ft. long, 12-18 in. wide, bipinnatifi, smooth, with a naked rachis; lower pinn scarcely smaller: sori midway from midrib to margin, with firm, smooth indusia. Philippines.

DUCHÈSNEA. See Fragaria.

L. M. UNDERWOOD.

\section{DUCK-WEED. Lemna.}

DUCKWHEAT. Some years ago, as the story goes, a man in New England shot a wild duck, and in the crop found strange seeds. These seeds were planted, and the flour from the grain was found to make good pancakes. He increased his stock to hundreds of bushels. The grain was offered by seedsmen as Duckwheat. It seems not to have had great popularity, and for the past 2 or 3 years it evidently has not appeared in catalogues. It turns out that this grain is the India wheat or Tartarian buckwheat, $\boldsymbol{H}^{\prime} \mathrm{c}$ gopyrum Tataricum, an Asian grain, which has been known in this country for some time. It is earlier than buckwheat, but is very similar to it. See Buckwheat and Fagopyrum.

\section{DODAIM MELON. See Cucumis.}

L. H. B.

DUFOUR, JOHN JAMES. A Swiss vigneron, who was at the head of a colony to grow the wine grape in Kentucky, and the author of "Vine Dresser's Guide," published in Cincinnati in 1826. The Kentucky experiment failed, and the colony then settled in southern Indiana, on the banks of the Ohio river; and this settlement is now the city of Vevay. Here Dufour died in 1827. This Indiana experiment brought out the merits of the Alexander grape, a native, and thereby did much to establish an American viticulture. For detailed account of the Dufours and their associates, and the results of their work, see Bailey, Evolution of our Native Fruits.

DUGUETIA (probably made from a personal name). Anondcea. A dozen South American trees differing from Anona in technical characters, particularly in the imbricated petals, which are wide-spreading in flower (in Anona the petals are valvate). D. longifolia, Baill. (Andna longifólia, Aubl.), is a small tree: lvs. oblongacuminate, mucronate and smooth : fls. axillary and stalked, the 2 series of petals much alike; inflorescence lateral; outer stamens sterile and petaloid: fr. ovateglobose, dotted and reticulated, nearly smooth, fleshcolored. Guiana and Peru. Recently introduced into southern Florida as a fruit-plant, but very little known. L. H. B.

DULfCHIUM (old Latin name). Cyperdcea. One perennial species (D. Spathaceum, Pers.), in eastern N. Amer. Grass-like, with terete leafy culms, 2-3 ft. tall: grows in ponds and swales. Has been offered by collectors as a bog plant.

DURÁNTA (after Castor Durantes, physician and botanist, died 1590). Verbenacece. About 10 species of tropical American shrubs, of which 2 kinds are cultivated outdoors in Florida and California, and in a few northern greenhouses. The best known kind has long racemes of blue, 5 -lobed fls., followed by yellow berries which remain all winter. It is said to be used for ornamental hedges in warm regions. Shrubs, glabrous or woolly, often armed with axillary spines: lvs. opposite or in whorls, entire or toothed: racemes long and terminal or short and axillary: fls. small, short-pedicelled in the axis of a small bract; corolla limb of 5 spreading oblique or equal lobes; stamens 4 , didynamous.

A. Stems without prickles.

Plumièri, Jacq. Golden Dew Drop. Shrub, 6-15 ft. high: branches ash-colored, villous: lvs. opposite, elliptic, acute, entire or obtusely and unequally saw-toothed above the middle: fls. pale blue or lilac, with 2 purple streaks down the middle of the 2 smaller and narrower lobes. The above description is from B.R. $3: 244$, where it is said that another plant was cultivated which had long lanceolate lvs., with deep, close saw-teeth and green branches. There is a white-fld. variety.
AA. Stems with a few prickles or spines.

Ellisia, Jacq. This is at least horticulturally distinct from the above by reason of the lighter color of its fls. but it has been lately referred to $D$. Plumieri. B.M. 1759 shows the lower half of each lobe white, and a few short spines on the stem. It adds, "two kinds [of Duranta], one with thorns and one constantly without, are *** cultivated. The lvs. of the smooth are larger and more coarsely serrated, and the branches more rounded than in the prickly Duranta." W. M.

DUSTY MILLER. Lychnis coronaria; also species of Centaurea and Senecio.

\section{DUTCHMAN'S BREECHES. Dicentra Cucullaria.}

\section{DUTCHMAN'S PIPE is Aristolochia.}

\section{DUVAUA, A synonym of Schinus.}

DỲCKIA (after Prince Salm-Dyck, German botanist, and author of a great work on succulent plants). Bromeliaceas. About 57 species of succulent plants from South America, somewhat resembling century plants, but with smaller spines, as a rule, and flowering regularly. They are usually stemless, and the lvs. form dense rosettes. For culture, see Agave. They are rarely cultivated in Florida and California, and in a few northern collections. The following have showy yellow fls. Latest monograph in Latin by C. Mez in DC. Monogr. Phan. vol. 9 (1896).

\section{A. Inflorescence amply branched or panicled.}

altíssima, Lindl. Lvs. spiny at the margin : floral bracts small, all manifestly shorter than the fls. Braz. Baker's plant of this name is really 1 . encholirioides, $\mathrm{Mez}$, which is distinguished by the fllaments. Beyond the tube they are free in the tree $D$. altissima, while in Baker's plant they are grown together about a twelfth of an inch. The sepals are obtuse in Lindley's plant, but acute in Mez's.

A.1. Inflorescence not branched, a raceme or spike.

B. F's. with scarcely any pedicel; filcments forming a tube.

rariflòra, Schult. Lvs. with small spines on the margin, shorter than in $D$. altissima: sepals not emarginate at the apex: upper sheaths of the scape shorter than the internodes. Braz. B.M. 3449. B.R. 21:1782.

BB. Fls. with a short but conspicuous pedicel; filaments not forming a tube all the way.

c. Fls. loosely disposed, erect.

gemellària, Morr. This is the plant which Baker calls D. sulphurea, not Koch's plant.

cC. Fls. more densely disposed, spreading.

sulphùrea, C. Koch, not Baker. Lvs. with small spines at the margin: sheaths of the scape longer than the internodes, the higher ones entire: bracts lanceolate, the lowest conspicuously longer than the pedicelled fis.: blades of the petals wide and longer than the stamena. Brazil.

W. M

\section{DYER'S WEED. Reseda Luteola.}

DÝPSIS (obscure name). Palmàcea, tribe Arècece. Purhaps half a dozen species of Madagascar palms that have been poorly described and are little known. They are all small, unarmed palms, with reed-like stems. Lvs. terminal, entire, bifld at the apex or pinnatisect; segments split at the apex or irregularly toothed, the apical ones confluent: sheath short: spadices long, loosely fld.: fruit small, oblong or ovoid, straight or curved, oblique at the base.

No species of Dypsis are common in cultivation, as they possess but little beauty. They are among the easiest and quickest to germinate. All of them require a stove temperature. ID. Madagascariénsis, Nicholson, is also known as Areca Madagascariénsis, Mart. D. pinnatifròns, Mart. (A. gracilis, Thou.), is one of several plants that have been known as A reca gracilis. It is a pretty palm, now grown in large quantities by some dealers.

JARED G. SMITH and $G, W$. Oliver. 



\section{The Rural Science Series}

EACH BOOK IS THE WORK OF A COMPETENT SPECIALIST, UNDER THE EDITORIAL SUPERVISION OF

PROFESSOR L. H. BAILEY, of Cornell University

The following volumes are now ready:

THE SOIL. By F. H. KING, of the University of Wisconsin. 303 pp. 75 ets.

THE SPRAYING OF PLANTS. By E. G. Lodeman, late of Cornell University. 399 pp. \$1.

MILK AND ITS PRODUCTS. By H. H. Wing, of Cornell Univ. 311 pp. \$1. THE FERTILITY OF THE LAND. By I. P. RoBeRts, of Cornell University. $421 \mathrm{pp} . \$ 1.25$.

THE PRINCIPLES OF FRUIT-GROWING. By L. H. BaIley. 516 pp. \$1.25. BUSH-FrUits. By F. W. CARD, R. I. Agric. College. 537 pp. $\$ 1.50$.

FERTIlizers. By E. B. Voorhees, N. J. Exp. Sta. and Rutgers College. 335 pp. $\$ 1$.

THE PRINCIPLES OF AGRICULTURE. By L. H. BAiley. 300 pp. $\$ 1.25$.

IRRIGATION AND DRAINAGE. By F. H. KING, of the University of Wisconsin. 502 pp. $\$ 1.50$.

THE FARMSTEAD. By I. P. Roberts, of Cornell University. 350 pp. \$1.25.

RURAL WEAlth AND Welfare. By George T. Fairchild, Ex-President of the Agricultural College of Kansas. 381 pp. $\$ 1.25$.

PRINCIPLES OF VEgetABle-GARDENing. By L. H. BaIlet. 458 pp. $\$ 1.25$.

FEEDING OF ANIMALS. By W. H. JoRdan, of New York State Experiment Station. $\$ 1.25$ net.

FARM POULTRY. By G. C. Watson, of Pennsylvania State College. \$1.25 net.

So long as the demand warrants, new volumes will be added to the RURAL SCIENCE SERIES. Definite arrangements have been completed for the following:

Physiology of Plants. By J. C. Arthur, Purdue University.

Plant Pathology. By B. T. Galloway and associates, of U. S. Dept. of Agr.

The Pome Fruits (Apples, Pears, Quinces). By L. H. Bailey.

The Care of Stock. By N. S. Mayo, Kansas State Agriculture College.

The Principles of Stock-Breeding. By W. H. Brewer, Ph.D., Yale University.

"The 'Rural Science Series,' representing the truly scientific spirit which now pervades our leading schools of agriculture, is an attempt to popularize fundamental agricultural laws, and at the same time to inculeate practical lessons in the art of tilling the soil."-Review of Reviews.

\section{The Macmillan Company}




\section{The Garden-Craft Series WRITTEN BY}

\section{PROFESSOR L. H. BAILEY}

Of Cornell University, Editor of the Cyclopedia of American Horticulture

PRACTICAL handbooks for the horticulturist, explaining and illustrating in detail the various important methods. They may be called manuals of practice, and, although nearly all are written by Professor BaILEY, of Cornell University, they include the opinions and methods of successful specialists in many ines. The fact should be emphasized that the Garden-Craft Manuals are summaries of principles and of the best practice in the leading American horticulture methods.

The volumes are compact, uniform, and are illustrated as the subject demands. They are of convenient shape for the pocket, and are bound in flexible green cloth.

THE HORTICULTURIST'S RULE BOOK. By L. H. BAILEY 312 pp. 75 ets. THE NURSERY-BOOK. By L. H. BAILEY. 365 pp. \$1.

PLANT-BREEDING. By L. H. BAILEY. 293 pp. $\$ 1$.

THE FORCING-BOOK. By L. H. BaILEy. 266 pp. \$1.

GARDEN-MAKING. By L. H. BaILey. 417 pp. $\$ 1$.

THE PRUNING-BOOK. By L. H. BaILey. 545 pp. \$1.50.

THE PRACTICAL GaRdEN-BOOK. By C. E. Hunn and L. H. Batlet. 250 pp. $\$ 1$.

\section{Other Works by Professor Bailey}

THE CYCLOPEDIA OF AMERICAN HORTICULTURE. 4 vols. Sold by subscription. $\$ 20$ net.

THE EVOLUTION OF OUR NATIVE FRUITS. 472 pp. $\$ 2$.

THE SURVIVAL OF THE UNLIKE. $515 \mathrm{pp} . \$ 2$.

LESSONS WITH PLANTS. $491 \mathrm{pp}$. $\$ 1.10$ net.

FIRST LESSONS WITH PLANTS. 117 pp. 40 ets. net.

BOTANY: AN ElEMENTARY TEXT FOR Schools. 372 pp. $\$ 1.10$ net.

\section{The MaCMillan COMPANY}

NEW YORK

CHICAGO

BOSTON

SAN FRANCISCO 

6)18

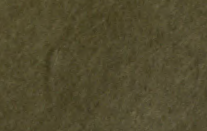

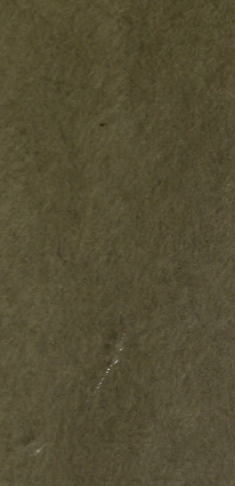


THIS BOOK IS DUE ON THE LAST DATE STAMPED BELOW

AN INITIAL FINE OF 25 CENTS

WILL BE ASSESSED FOR FAILURE TO RETURN THIS BOOK ON THE DATE DUE. THE PENALTY WIILL INCRÉASE TO 50 CENTS ON THE FOURTH DAY AND, TO $\$ 1.00$ ON THE SEVENTH DAY OVERDUE.

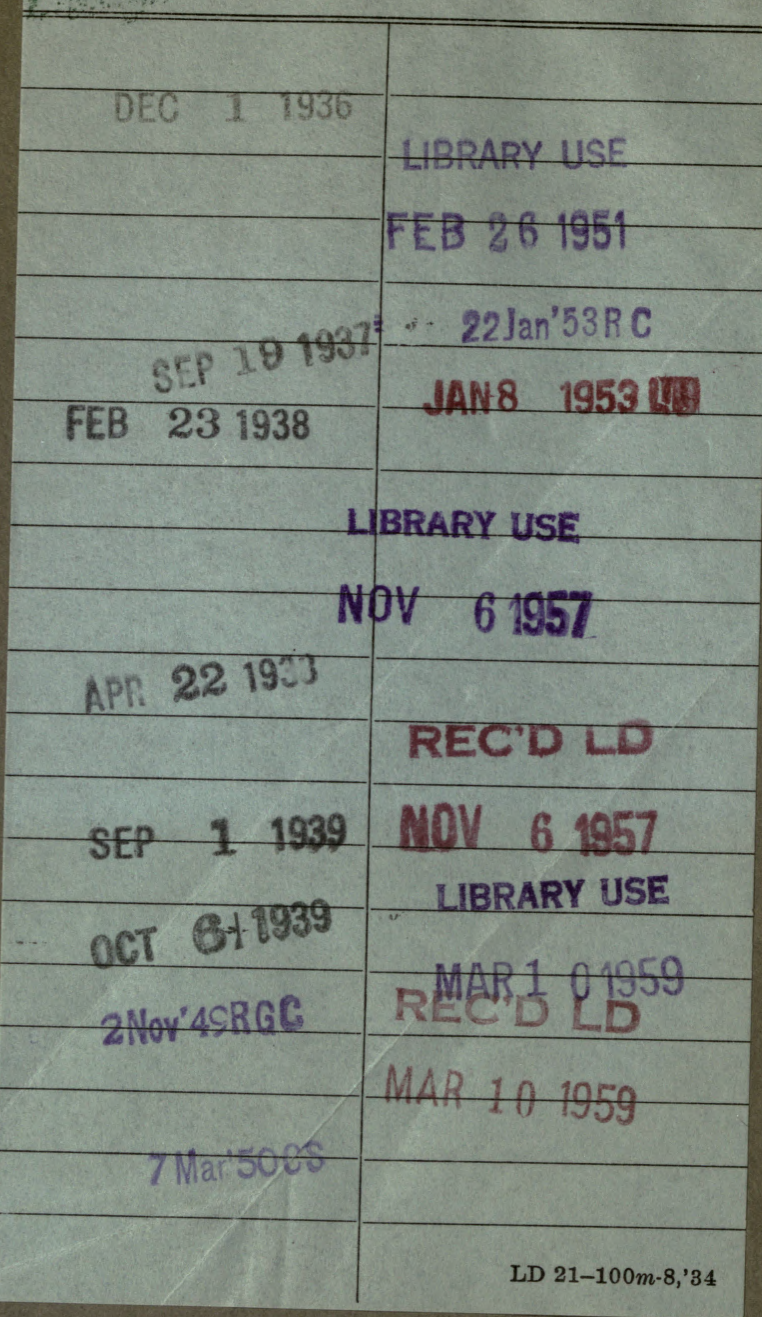


YE 19048

205617

SB 45

BL

UNIVERSITY OF CALIFORNIA LIBRARY 
